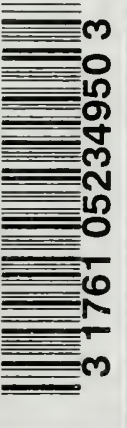


$\ddot{i}$ 
WOSIIUTE 



SOCIETAS PRO FAUNA ET FLORA FENNICA

FLORA FENNICA I

\section{DIE}

\section{LAUBNOOSE FENNOSKANDIAS}

BEARBEITET

VoN

V. F. BROTHERUS

MIT 118 FIGUREN

Gedruckt mit slaatlicher Unterstützung

HELSINGFORS 1923

BERLIN

R. Friedländer \& Sohn NW. 6. liarlstrasse 11.
IIELSINGFORS

Akademische Buchhandlung.
LONDON

Wheldon \& Wesley Ltd.

2. 3 \& 4, Arthur Street New Oxford Street, IVC 2. 
$\frac{621000}{20,0.55}$

QR
544
S2B7

DAS DRUCKPAPIER LIEFERTE DIE A.-G, KYMMENE A.B. (KUUSANKOSKI, FINNIAND)

H EL S I N G F R S 1923

DRUCKERLI DER FINNISCIEN LIIERATUR-GESELLSCHAFT 


\section{VORWORT.}

Ende 1917 erhielt ich von der Societas pro Fauna et Flora Fennica den Auftrag, ein Handbuch der Laubmoose ron Fennoskandia mit besonderer Berücksichtigung ilurer Verbreitung in Finnland auszuarbeiten. Da ich durch zahlreiche Exkursionen seit jungen Jahren mit unserer Moosflora vertraut bin, nahm ich den Auftrag mit Freude entgegen. Ein solches Handbuch schien vonnöten, weil fast 50 Jahre verflossen waren, seitdem die zehnte Auflage von C. J. H a r t m a n s Handbok i Skandinaviens Flora veröffentlicht wurde, und lanach kein diesem entsprechendes Werk publiziert worken ist. Die Aufgabe nahm indes viel mehr Zeit in Anspruch, als ich berechnet hatte, dies hauptsächlich, weil ich mich ihr nicht ungeteilt widmen konnte. In Lauf der Jahre stiegen die Druckkosten in so hohem Grade, dass, als das Manuskript schliesslich druckfertig vorlag, diese eine solche Höhe erreicht hatten, dass sich die Societas pro Fauna et Flora Fennica ausserstand sah, sie zu bestreiten. Der Vorstand der Gesellschaft wandte sich daher mit einem Gesuch um eine Subvention für die Deckung der Druckkosten an die Regierung. Mit tiefstem Danke ist zu erwähnen, dass der Reichstag in weitblickender Schätzung wissenschaftlichen Forschens die Subvention auf Antrag der Regierung bewilligte.

Was die Angaben iiber die Verbreitung der Arten inmerhalh des naturgeschichtlichen Gebietes Finnlands betrifft, sind sie so vollständig, wie sie unser diesbezügliches Wissen zur Zeit erlaubt. So habe ich das Material, welches das Botanische Museum und meine eigene Sammlung bieten, voll ausgenutzt, woneben mir die Herren Doktoren H. B u c h, E. Hä y rén und H. Lin ḑberg ihre Sammlungen zur Verfügung gestellt haben. Vielen Dank bin ich ferner den Herren Forstmeister E. a f $\mathrm{H}$ ä $\mathrm{llström,} \mathrm{Lehrer} \mathrm{Pastor} \mathrm{O.} \mathrm{K} \mathrm{y} \mathrm{g} \mathrm{k} \mathrm{y} \mathrm{e} \mathrm{n,} \mathrm{cand.} \mathrm{phil.} \mathrm{M.} \mathrm{J.} \mathrm{K} \mathrm{o} \mathrm{t} \mathrm{i-}$ l a i ne n und stud. phil. H. Ro i va in e in schuldig für die umfassenden und wertvollen Aufschlüsse, die ich von ihnen erhalten labe. Ausserdem habe ich die in rlem folgenden Literaturverzeichnis angeführten Arbeiten kritisch benutzt. Was dagegen die entsprechenden Angaben für Skandinavien anbelangt, ist eine gewisse Ungleichmässigkeit nicht zu vermeiden gewesen, inden erschöpfende Angaben nur innerhalb derjenigen Familien geliefert werden konnten, die in den Werken von 1. H a ge $n^{1}$ und $H \mathrm{j}$. M ö 11 e $\mathrm{r}^{2}$ behandelt sind. Andere Angaben hat'mir freundlichst Herr Lektor $\mathrm{H}$ j. II ölle $\mathrm{r}$ gemacht, wofür ich ihm auch hier meinen herzlichen Dank aussprechen möchte.

In bezug auf das System bin ich Ma x F l e i s c ll e $\mathrm{r}$ gefolgt, dessen eingehende Studien auf diesem Gebiete einen so befruchtenden Einfluss ausgeübt haben

1 I. Hagen: Forarbeider tid en norsk lormosflora. I-XX. (I). K. X. Tid, Selkk. skrift. $1907-1914)$.

$2 \mathrm{H} \mathrm{j}$. Möller: Lömossornas utbredning i sverige. (Arkis för Botanik Bd, 10, 12, $15-18$ ). 
und dessen Resultate wohl an besten den Ansprüchen gerecht werden, die man in unserer Zeit an ein phylogenetisches System stellen darf.

Die Figuren, fast alles Originale, sind von Herrn $\mathrm{J}$ o s e p h $\mathrm{Pohl}$ in Berlin gezeiclnet. Fïr die grosse Mühe, die er auf sie verwendet, und für das ausgezeichnete Geschick, mit dem er seine Aufgabe gelöst hat, erlaube ich mir ihm meinen aufrichtigen Dank auszusprechen.

Helsingfors, im September 1923.

V. F. BROTHERUS. 


\section{VERZEICHNIS DER DIE LAUBMOOSFLORA FINNLANDS BERÜCKSICHTIGENDEN SCHRIFTEN.}

A s p e li n, E. F. och Th u r é n, A.: Bidrag till Tavastehus-traktens flora (Notis. Sällsk. F. Fl. Fenn. Förh. VII. ny ser. IV. 1867).

B a c k m a n, A. L.: Floran i Lappajärvi jänte omnäjd (Acta Soc. F. Fl. Femm. 32, No. 3. 1909).

B o m a n s s o n, J. O.: Alands mossor (Acta Soc. F. Fl. Fenn. XVIlI. No. 4. 1900).

$\mathrm{B}$ o m a $\mathrm{n}$ s s o n, J. O. et B r o $\mathrm{th}$ e r u s, V. F.: Herbarium Musei Fennici. Editio secunda. II. Musci. Helsingfors 1894 .

B o n s d o rff, E. J. W.: Öfversigt af Gustaf Adolfs sockens flora (Notis. Sällsk. F. Fl. Fenn. Förl. VII. ny ser. IV. 1867).

B r o the rus, V. F.: Anteckningar till Norra Tavastlands Flora (Notis. Sällsk. F. Fl. Fenu. Förh. XIII. ny ser. X. 1872).

B rot he rıs, V. F. et Sa ela n, Th.: Musci Lapponiae kolä̈nsis (Acta Soc. F. Fl. Fenn. V'I. N:o. 4. 1890).

B u ch, H.: Cber einige im finnischen Florengebiete seltene oder wenig bekannte Leber- und Laubmoose (Meddel. Soc. F. Fl. Fenn. 35. 1909).

E lf ving, F.: Anteckningar om regetationen kring floden Svir (Medclel. Soc. F. Fl. Fenn. II. 1878).

H u lt, R.: Mossfloran i trakterna mellan Aavasaksa och Pallastunturit (Acta Soc. F. Fl. Fenn. III. No. 1. 1886).

H u lt, R.: Växtgeografiska anteckningar frán den finska Lappmarkens skogsregioner (Acta Soc. F. Fl. XVI. No. 2. 1900).

L i n k o l a, K.: Lisätietoja Ḱnopion pitäjän kasvistosta (Acta Soc. F. Fl. Fenn. 39. No. 5. 1914).

N e r va n d e r, J. H. E.: Bidrag till Finlands bryologi. Akad. avh. Helsingfors 1859.

X or r li n, J. P.: Bidrag till sydöstra Tavastlands flora (Notis. F. Fl. Fenn. Förh. XI. ny ser. VIII. 1871).

Norrlin, J. P.: Öfversigt af Torneá (Muonio) och angränsande delars af Kiemi Lappmarker mossor och lafvar (Ibid. XIII. ny ser. X. 1871-7t).

N orr lin, J. P.: Några anteckningar till mellersta Finlands (n. Y. Tavastlands) flora (Ibid. XIII. ny ser. X. 1871-7t).

N y l a n d e r, IV:: Conspectus Florae Helsingforsiensis (Notis. Sällsk. F. Fl. Fenn. Förh. I. 1848).

Nylan de r, W.: Collectanea in Floram Karelicam (Ibid. II. 1850).

N y l a n d e r, W.: Collectanea in Floram Karelicam, continuatio (Ibid. II. 1851).

N y l a n d e r, W.: Additamentum ad Conspectum Florae Helsingforsiensis (Ibid. II. 1851). 
VI Verzeichnis der die Laubmoosflora Finnlands berücksichtigenden Schriften.

X v l a $n$ d e r, W. och $S$ a e I a n, T h.: Herbarium Musei Fennici. Helsingfors 1859. R a n c ke n. H.: Bryologiska meddelanden I-II (Acta Soc. F. Fl. Fenn. 38, No. 4. $1911)$.

Se li n, G.: Fut bidrag till nordvestra Nylands flora (Notis. Sällsk. F. Fl. Fenn. V1. ny ser. III. 1861).

Si m m i ng, Th.: Förteckning över die under en år 1859 företagen botanisk resa i Satakunta och Södra Österbotten observerarle Ormbunkar, Mossor och Characeer (Notis. Sällsk. F. Fl. Fenn. Förh. VI. ny ser. III. 1861).

IV a i n i o. E. A.: Florula Tavastiae orientalis (Meddel. Soc. F. Fl. Fenn. III. 1878).

Le t t e r m a n, A. J. och B r a n d e r, A. E.: Bidrag till sydvestra Finlands flora (Notis. Sälsk. F. Fl. Fenn. VII. ny ser. IV. 1867). 


\section{ABKÜRZUNGEN.}

$$
\text { F. = Finnland. }
$$

Al. = Alandia

Ab. = Regio aboënsis.

N. = Nylandia.

Ka. = Karelia australis.

Ik. = Isthmus karelicus.

St. = Satakunta.

Ta. = Tavastia australis.

Sa. = Savonia australis.

Kl. = Karelia ladogensis.

hol. = Karelia olonetsensis.

oa. = Ostrobothnia australis.

Tb. = Tavastia borealis.

Sb. = Savonia borealis.

$K b . \quad=$ Karelia borealis.

Kon. = Karelia onegensis.

Om. = Ostrobothnia media.

Ok. $=$ Ostrobothnia kajanensis.

Kpom. = Karelia pomorica.

ob. = Ostrobothnia borealis.

K. = Kunsamo.

Kk. = Karelia keretina

Lkem. = Lapponia kemensis.

Le. = Lapponia enontekiensis.

Li. = Lapponia inarensis.

Lim. = Lapponia imandrensis.

Lt. = Lapponia tuloniensis.

Lmur. = Lapponia murmanica.
$L p . \quad=$ Lapponia ponojensis
$L v . \quad=$ Lapponia varsugensis.

S. = schweden.

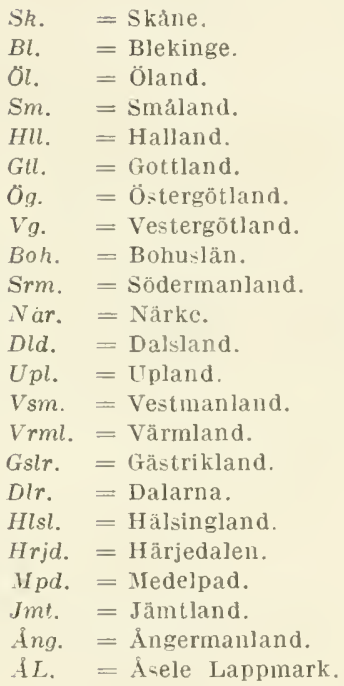

Vb. = Västerbotten.

Ly L. - Lycksele Lappinark.

Nb. = Norrbotten.

PL. = Pite Lappmark.

TL. = Torne Lappmark.

LiL. = Lule Lappmark.

Lpm. = Lappinarken.

N. = Norwegen.

Sm. - Smaalenenes Aint.

A. = Akerhus

Bu. = Buskeruds "

$J L$. = Jarlsberg 11. Larviks Amt.

$\mathrm{Br} . \quad=$ Bratsberg

Ne. = Nedenes "

LM. $=$ Lister und Mandals

St. = Stavanger $r$ "

$\mathrm{SB}$. = Sondre Bergenhus ;

NB. = Nordre $"$ "

R. = Romsda!s \#

H. = Kristians \#

H. = Hedemarkens \#

ST. = Sondre Trondhjems

NT. = Nordre " n

No. = Nordlands

Tr. = Tromse "

F. = Finnmarkens " cpp. = copiosissime.

cop. = copiose.

fq. = frequenter. -t. fq. = sat frequenter.

pass. $=$ passim. r. $=$ raro.

rr. $=$ rarissinie.
Ant. $=\mathrm{J}$. Anttila

Arrh, = C. J. Arrhenius.

Asp. $\quad$ E. F. Aspelin.

Backm. = 4. L. Backman.

H. Backm. = H. Backman.

Bergr.

Bergr.

Björkenb.

Blom

Boldt

Bomans.

Bonsd.

Brand.

Brenn.

IV. Brenn.
$=$ C.G.Björkenheim.

$=\mathrm{E}$. VV. Blom.

$=$ Ch. E. V. Boldt.

$=$ J. O. Bomansson.

$=$ E.J.W.Bonsdorff.

= A. E. Brander.

= M.M.W. Brenner.

$=$ IV. M. Brenner.
$=$ I. O. Bergroth.
Broth.

$=\mathrm{V} \cdot \mathrm{F} \cdot$ Brotherus.

A. H. Broth. = A. H. Brotherus.

Buch

$=$ H. R. V. Buch.

A. H. Caj.

A. I. Caj.

Carl.

Cederer.

H. Coll.

Colland.

Coll.

Dahlb.

Ekl.

Ekm.

Elfv.
= A. H. Cajander.

= A. K. Cajander.

. . Carlenius, Font.

$=$ C. Cedercreutz. Fridtz

$=$ Hertta Collall. Furuhj.

$=$ P. R. Collander. Grottb.

$=$ o. Collin.

Graeflé

$=$ R. R. Dahlberg. Grot.

$=0$. Eklund. Günth.

= B. E. Ekman. Helaak.

- F. E. WV. Elfving. Herl.
- Naema Eifring.

$=$ J.A. Fastberg.

$=$ N. I. Fellman.

Walborg v. Fieandt.

$=$ J. A. Flinck

$=$ C. IV. Fontell.

$=$ R. Fridtz.

$=$ J. E. Furuhjelm.

$=\mathrm{H}$. R. Gottberg.

$=$ H. A. Graeflé.

$=\mathrm{G}$. Grotenfelt.

=A. Günther.

=A. Helaakoski.

$=$ R. Herlin 


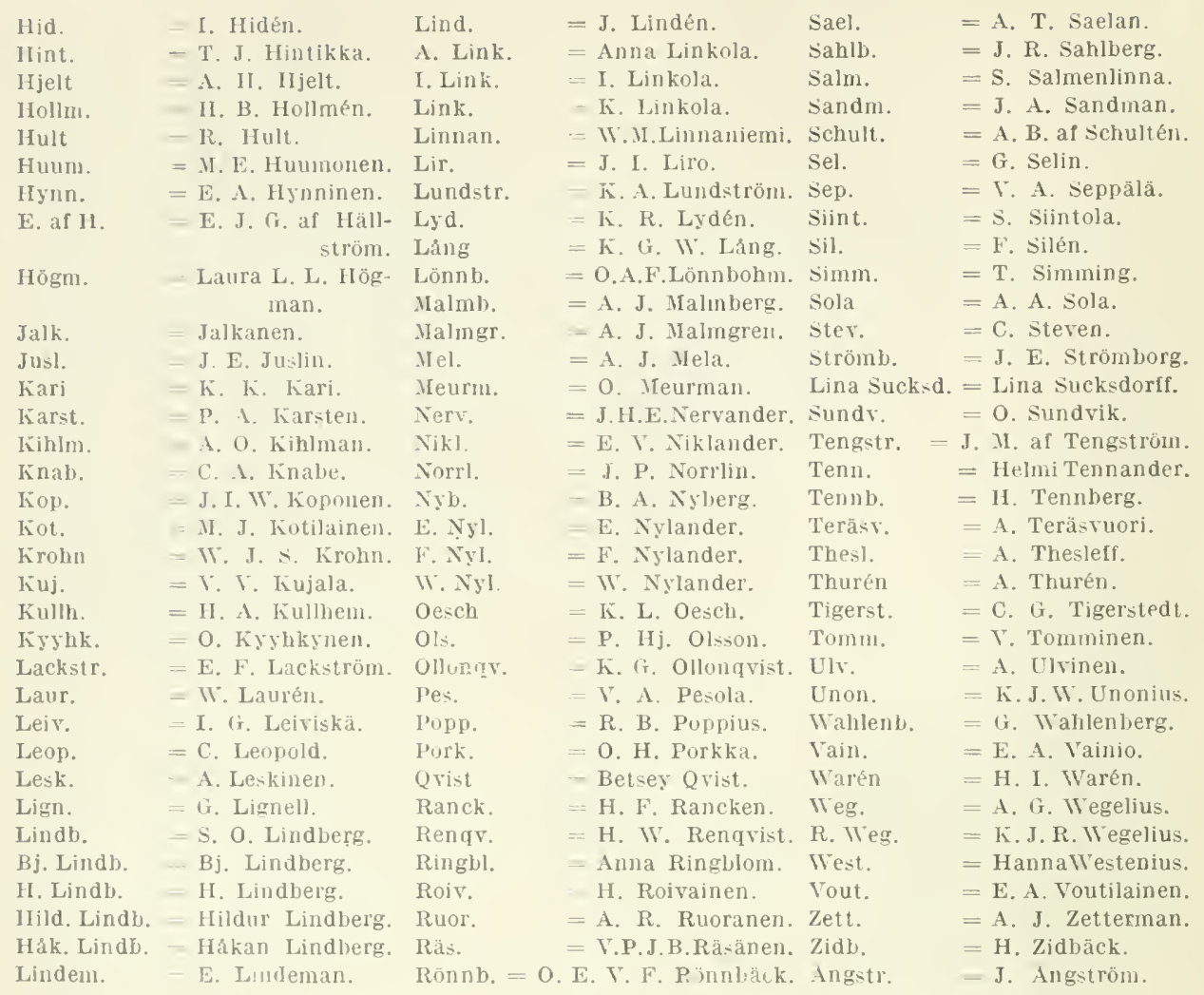




\section{DER AUFBAU DER LAUBMOOSE.}

Bei der Keimung der Moosspore entwickelt sich ein meist fädiges, grünes, reich verzweigtes und meist flüchtiges Geflecht, das p r i mä r e P r o t o n e ma (Vorkeim), an dem die Geschlechtsgeneration (Gametophyt) in Form rou Ixnospen angelegt wird (S. 195, Fig. 36). Ein ähnliches Protonema kann sich sekundär aus fast jeder anderen Zelle der lebenden Mloospflanze entwickeln.

Die $\mathrm{R}$ h i zo i d e n sind mehrzellige verzweigte, hyaline oder braune Haare mit schiefen Querwänden, die teils auf dem Protonema und teils \pm reichlich auf dem Stengel, seltener auf den Blättern sich entwickeln.

Der $\mathrm{S}$ t e $\mathrm{n} \mathrm{g}$ el ist bald kurz, bald \pm verlängert, niederliegend bis aufrecht, seltener luängend oder flutend, im Querschnitt rundlich, elliptisch oder kantig. Das Gewebe ist selten homogen, sondern meist nach innen weitlumig und parenchymatisch, oft mit einem aus selır engen und zartwandigen Prosenchymzellen gebildetem Zentralstrange versehen, am Lmfang liegen eine oder mehrere Schichten gefärbter, stark verdickter, meist prosenchymatischer Mantelzellen mit \pm engen Lumen (S. 475, Fig. 90 B). Die Zweighilung beruht entweder auf Endrerzweigung, wenn sie in fortwachsendem Sprossscheitel stattfindet, oder auf interkalarer Sprossbildung, wemu sie entfernt vom Scheitel an älteren Stammteilen eintritt.

Die $B$ lät t e r sind sitzend und fast stets quer inseriert, meist einschichtig, mit oder ohne Rippe. Von diesen gibt es: 1. Ni e d e r b lä t t e r, kleine oder schuppenartige Blättchen an Ausläufern, Stolonen oder unterirdischen Stengelteilen; 2. L a u b b l ät t e r, die als Stengel- und Astblätter unterschieden werden; 3. H ïllblät ter (Perigoni a l- und Perichätialblät t e r), welche die Geschlechtsorgane einschliessen. Die P a r a p h y l l e n sind Zellfäden oder unregelmässig geteilte, blattähnliche Bildungen an der Oberfläclıe des Stengels. Die Blattzellen sind parenchymatiseh oder prosenchymatisch. Die Parenchymzellen sind isodiametrisch, wenig länger als breit oder bei grösserer Streckung an den Enden quer abgestutzt. Die Prosenchymzellen sind gestreckt und an beiden Enden zugespitzt. Die Blattrippe ist ein \pm breiter Strang, der die Mlitte der Lamina durchzieht oder nur am Gruncle kurz angedentet ist. Sie setzt sich entweder aus gleichartigen bis fast gleichartigen, meist mehrschichtigen Zellen (homogene Rippe) oder aus ungleichartigen Zellen (heterogene Rippe) zusammen. Bei der homogenen Rippe unterscheidet man Aussenzellen (ventrale und dorsale) und Innenzellen. Bei der heterogenen Rippe findet sich eine Reihe medianer, selten ventraler, sehr grosser, leerer oder stärkeführender, aneinanderschliessender Parenchymzelten (Deuter) und bald beiderseits, bald nur unterseits Stereidenbänder (S. 62, Fig. 12). Zuweilen kommen auch kleine Gruppen enger, dünnwandiger, auf der Rückenseite der Deuter oder hier zwischen je zwei Deutern eingebetteter Zellen (Begleiter) vor. 
Die sexu a lorgan e sitzen gruppenweise zusammen in blütenähnlichen Gebilden an der Spitze der Hauptachsen oder am Ende kleiner Seitenzweiglein, in (ler Regel mit gegliederten Haartildungen (Paraphysen) und umgeben von den Hiillblättern. Die Antheridien sind knrz gestielte, ei-bis keulenförmige Schläuche mit einschichtiger Wandung und im reifen Zustande mit Spermatozoiden erfültt. Die Arehezonien sind flaschenförmige, den Stempeln der Phanerogamen ähnliche Zellkörper mit massivem Fuss, fruchtknotenartigem Bauche, griffelartigem Halse und narbenähnlichen Schliess-oder Deckelzellen. Im Bauchteile wird die zu befruchtende Eizelle eingesehlossen. Nich der Verteilung der Geschlechter (Blütenstand) unterscheidet man:

A. Synözisch: Antheridien und Archegonien nebeneinander in derselben Hülle ( $\breve{c})$.

B. Parözisc lı: Antheridien und Arehegonien an derselben Sprossachse, doch getremnt dureh besondere Hüllblätter $\left(\mp / \mathcal{C}^{7}\right)$.

c. \u $\mathrm{t}$ ö z is c h: $\sigma^{7}$ Blüten und fö̈ten auf derselben Pflanze, aber an verschiedenen Sprossachsen $(z+c)$.

D. Heteröziseh: 2 oder 3 der vorigen Blütenstände treten bei derselben Art $\left(\breve{q}+\sigma^{\pi}\right.$ oder $\left.\breve{q}+\sigma=q\right)$ auf.

E. D i ̈̈zisch: \ Blüten und of Blüten sind auf verschiedene Individuen verteilt $\left(+-\gamma^{7}\right)$.

F. Polyözise h: Dieselbe Art hald autözisch, bald diözisch (우 $\pm \sigma)$.

Infolge der Befruchtung entwickelt sich die Eizelle zur ungeschlechtlichen Generation ( $\mathrm{S}$ porophyt, S porogon). Das Sporogon besteht aus drei wesentlich verschiedenen Teilen: der Seta, der Kapsel und der Haube. Die Seta ist ein eng zylindrischer, kurzer oder verlängerter Gewebekörper, anatomisch wie der Stengel aufgebaut. Beim Austrocknen :erflacht sie sich meist bandartig und dreht sich seilartig um ihre Achse, häufig ober- uncl unterwärts in entgegengesetzter Richtung. Der Fuss der Seta ist der untere, abwärts konisch verschmälerte, selten angeschwollene Teil derseben, womit das Sporogon in das Stengelgewehe eingekittet ist, ohme mit demselben zu verwachsen. Das Scheidehen (Vaginula) ist das meist zylindrische Gewebe, welches den Fuss und oft noch die Basis der Seta wollartig umgiht. Zuweilen wird die Seta über das Scheidehen noch von einem hellen, tutenlörmigen Röhr(hen (Ochrea) ungeben. Die typische Kapsel zeigt, wemn noch nicht ausgereift, im (n!ersehnitt durch die Nitte folgende konzentrische Ringe: die Kapselwand, cineu ilohi- oder Interzellularraum, den äusseren Sporensack, die sporenbildencle Schicht (das A r c l e s p o r), den inneren Sporensack, welcher den zentralen Teil, die Columella unschliesst. Bei den meisten Arten liegt der imnere Sporensack der Columella dicht an. Von diesen Schichten bithet die Columella den inneren Sporensack und das Archesporimm das En dothecium und die ïhrigen das $A \mathrm{mp}$ p i t he e i um. Äusserlich sind an der Kapsel von unten nach olsen Hals, Ansatz, Crme, Ring und Deckel zu unterscheiden. Der Hals hesteht aus einem massiven, lockeren, parenchymatischen Schwammgewebe, in dem häufig Spaltöfnungen liegen. Entweder geht er allmählich in die Urne über oder er wird durch eine linschnïrung von derselben abgetrennt. Der Ansatz (H y pophy-

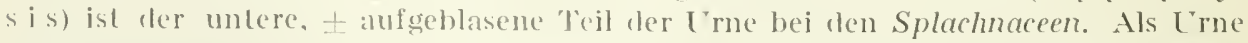
hezeiclnet man den mittleren Teil der Kapsel, in dem die Sporen ausgebildet werden. Der Deckel ist der rings unsehriehene Teil der Kapsel, welcher zur Zeit der Sporenreile sich ablöst. Der Ring ist eine zwischen Trnenrand und Deckel liesende gürtelförnige Zone, von einen oder mehreren Stockwerken leerer, nach innen diunnandiger \%ellen gohildet. Jie kapselwand ist meistens zwei- oder mehrschichtig: die äussere Lage differenziert sich \%u einer kutikularisierten Epidermis (lixuthecium). Dic atussen t verlickten Epidermiszellen schliessen sich 
dicht zusammen und sind an der Umenmündung in wenigen oder mehreren Reihen enger und oft quer breiter. Die Spaltöfnumgen finden sich meistens in Halsteil oder in der Hypophysis, seltener höher hinauf und sind entweder oberflächlich (S. 215, Fig. 43 B) oder eingesenkt (Fig. 13 E). Der Mundbesatz odler das l' e r i$\mathrm{s}$ t o m an dem inneren Urnenrand oder unterlalb desselben kommt bei den meisten Laubmoosen vor und ist einfach oder doppelt, selten in melireren Kreisen geordnet. Bei dem doppelten Peristom wird der äussere líreis Exostom, der innere Endos $t$ o m genannt. Wenn das Peristom einfach ist, ist es fast stets als Exostom ausgebildet. Das Exostom besteht aus 4, 8, 16, 32 oder 64 Peristomzähmen, die entweder voneinander frei oder \pm weit hinauf miteinander verbunden sind. Die Zähne der Georgiaceen werden aus dem den Deckel ausfüllenden Gewebe gebildet, das sich gegen die Sporenreife hin kreuzweise in 4 zahnartige, dreiseitig-pyramidale Klappen spaltet, deren beide äussere Schichten dickwandig sind und die ungegliederten Zähne bilden. Bei den Polytrichaceen bestehen die 32 orler 6.1 Zähne aus hufeisenförmig aufwärtsgebogenen Schenkeln, die aus Bündeln schmaler, verdickter, faserähnlicher Zellen zusammengesetzt sind. Bei den iibrigen sind die Zähne gegliedert, und an der Bildung eines Zahnes beteiligen sich am häufigsten drei Zellreihen, nach dereu Lage zwei Reihen zu unterscheiden sind: 1. H a p l ole pi d e a e, jeder Zahn besteht aus einer Reihe von Aussenplatten und einer doppelten Reihe von Innenplatten: 2. Diplole pi d e a e, Aussenschicht der Zähne aus zwei Reihen, Innenschicht aus einer Reilue von Membranplatten zusammengesetzt. Die Ausserschicht ist oft dunkler gefärbt als die immere, glatt oder papillös, zuweilen verschiedenartig gestrichelt. Ist die Innenschicht breiter als die äussere, so tritt sie beiderseits als Saum hervor. Als Lamellen bezeichnet man die nach imnen \pm stark vortretenden Querleisten der Zähne und als Querglieder oder Querbalken die nach aussen vortretenden Artikulationen. Beide können auch seitlich über die Ränder der Zähne vorspringen. Das imnere Peristom ist fast immer weit zarter als das äussere, bald von gleicher Länge, selten länger, häufig kürzer, zuweilen rudimentär. Wenn am besten entwickelt, spaltet sich die Grundhaut in verschiedenartig ausgebildete Fortsätze und Wimpern (S. 225, Fig. 47). Die ersteren liegen zwischen je zwei Peristomzähnen und die letzteren hinter diesen. Die einzelligen $\mathrm{S}$ p o r e n sind meist rundlich oder tetraëdrisch, seltener ovoidisch, oder nierenförmig, glatt, warzig oder papillös, selten igelstachelig oder netzförmigg gefeldert. Die $\mathrm{H}$ a u be ist das häutige Gebille, welches die jugendliche, häufig auch noch die reife Kapsel gänzlich oder teilweise bedeckt. Sie ist entweder halbseitig und schief aufsitzend oder regelmässig und aufrecht. Im ersten Fall ist sie meist einseitig tief gesehlitzt und heisst dann kappenförmig (S. 61, Fig. 11). Die regelmässige Haube ist kegelförmig (S. 212, Fig. $42 \mathrm{E}$ ), mützenförmig (S. 370, Fig. 66 E und G), glockenförmig (S. 162, Fig. 31 A) oder blasenförmig.

Die vegetative Vermehrung, durch welche sich aus verschiedenen Teilen des Gametophyten neue Pflanzen bilıen, ist hei den Laubmoosen eine selur ergiebige und tritt in grosser Mannigfaltigkeit auf. 


\section{ÜBERSICHT DES SYSTEMS.}

Unterklasse ANDREAEALES.

Familie Andreaeaceae. S. 1.

Unterklasse BRYALES.

I. Reihengruppe ELBRYINALES.

1. Reihe FISSIDENTALES.

Fan:ilie Fissidentaceae .... S. 16

2. Reihe DICRANALES.

1. Unterreihe DICRANINEAE.

Familie Archidiaceae ...... S. 25

Ditrichaceae......... S. 26

Seligeraceae ......... S. 38

Dicranaceae ......... S. 45

2. Unterreihe LEUCOBRYINEAE.

Familie Leucobryaceae ...... S. 108

3. Reihe POTTIALES.

Familie Encalyptaceae ...... S. 158

4. Reihe GRIMMIALES.

Familie Grimmiaceac...... S. 165

5. Reihe FUNARIALES.

1. Unterreihe FUNARIINEAE.

Familie Disceliaceae ......... S. 195

Ephemeraccae ...... S. 196

Funariaceae........ S. 198

2. Unterreihe SPLACININEAE.

Familie Ocdipodiaceae ...... S. 24.4

Splachnaceae ...... S. 205

6. Reihe SCHISTOSTEGALES.

Familie Schistostegaceac ... S. 218

7. Reihe TE'TRAPHIDALES.

Familie Georgiaceae
8. Reihe EUBRYALES.

1. Unterreihe BRYINEAE.

Familie Bryaceae ${ }^{1}$

Iniaceae

2. Unterreihe BARTRAMINEAE.

Familie Aulacomniaceae ... S. 3i Meeseaceae ......... S. 3

Catoscopiaceae...... S. 3

Bartramiaceae ...... S. 3 .

3. Unterreihe TIMMINEAE.

Familie Timmiaceae

S. 36

9. Reihe ISOBRYALES.

1. Unterreihe ORTHOTRICHI-

NEAE.

Fanilie Ptychomitriaceac .. S. 36 Orthotrichaceae .... S. 36

2. Unterreihe FONTINALINEAE.

Familie Fontinalaceae ...... S. 39

Climaciaceae

S. 40

3. Unterreihe LEUCODONTI-

NEAE.

Familie Hedwigiaceae ...... S. 40 Leucodontaceae ... S. 40

1. Unterreihe NECKERINEAE.

Familie Neckeraceae........ S. 40 : Lembophyllaceae .. S. 41:

10. Reihe HOOKERIALES.

Familie Hookeriaceae

S. 42

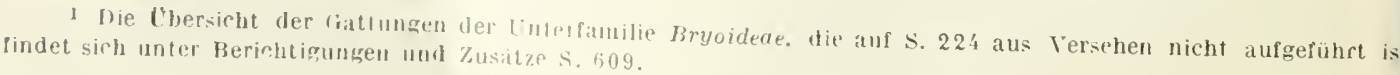


11. Reihe HYPNOBRYALES.

Hypnaceae

S. 559

1. Unterreihe LESKEINEAE.

Familie Leskeaceae......... S. 122

Thuidiaceae S. 133

Pseudoleskeaceae. S. 143 Amblystegiaceae.... S. 119

Brachytheciaceat. S. 502

Fabroniaceae.

S. 537

2. 'Unterreihe HYPNINEAE.

Familie Entodontaceae .... S. 539

Plagiotheciaceae.... S. 516

Sematophyllacere.. S. 558
II. Reihengruppe BLXBAUMIINALES.

12. Reihe BUXBAUMIAI.ES.

Familie Buxbaumiaceae ....... S. 581

13. Reihe DIPHYSCIALES.

Familie Diphysciaceae ......... S. S 586

III. Reihengruppe POL Y TR ICIINALES.

14. Reihe POLITRICHALES.

Familie Polytrichaceae

S. 587 



\section{ANDREAEALES.}

Sporogon sich grösstenteils innerhalb des Archegon:ums entwickelnd, das letztere jedoch schon vor der Sporenreile abgesprengt und den liapselscheitel als flüchtige Haube bedeckend, schliesslich durch das sich oberwärts streckende Pseudopodium emporgehoben; Sporensack das obere Encle der Columella überdachènd und der Kapselwandung anliegend. Sporenaussaat durch $4-8$, \pm weit herabreichende I.ängsrisse.

Einzige Familie:

\section{A N D R E A E A C E A E.}

Rotbraune bis schwarze, starre, rasenbildende Felsmoose, doch nicht auf lialk. Stengel ohne Zentralstrang, mit dickwandigem, getüpfelten Grundgewebe und gelben, engen Mantelzellen, wiederholt gabelteilig, nur am Grunde mit Rhizoiden, mehrreihig und meist dicht beblättert. Untere Blätter klein, ab"allend, obere grösser, trocken meist anliegend bis \pm einseitswendig; Rippe, wenn vorhanden, aus fast gleichartigen Zellen gebildet: Zellen klein, oben rundlich-6seitig, meist stark verdickt, am Blattgrunde mehr quadratisch oder verlängert rektangulär und buchtig, meist, besonders im oberen Blatteile und an der Aussenfläche papillös. Autözisch, selten diözisch; beiderlei Blüte knospenförmig, gipfelständig. durch nachträgliche Sprossung pseudolateral; $\sigma$ Blüte häufig mit langen, gebräunten, oft oben bandartig verbreiterten Paraphysen. Pseudopodium anfangs weich und weiss, später verhärtet und gebräunt. Kapsel meist länglich-eiförmig, braunrot bis schwarz, Scheitel und Basis lichter gefärbt; Spaltölfnungen fehlend: Zellen rektangulär, dickwandig. Haube kegel-mützenförmig, meist nur den Scheitel deckend, zart, weisslich oder gebräunt, gelappt. Sporen gross, zuweilen in derselben Kapsel ungleich gross. Sporenreile im Frülıjahr oder im Frühling.

\section{ANDREAEA.}

Ehrh. in Hann. Nag. 1781, p. 1601.

A. Blätter olnne Rippe.

$$
\text { íbersicht der Arten. }
$$

a. Blätter am Rande der Basis gezähnelt .................. 8. A. alpinø.

b. Blätter ganzrandig.

«. Stengel locker beblättert. Blätter aus eiförmiger Basis allmählich lang zugespitzt: Zellen oberwärts 10 $14 \mu$, rings verdickt, mit grossen Papillen .......... 3. 1. sparsifolia.

$\beta$. Stengel dicht beblättert. Blätter am loreitesten unter ler Blattmitte. 
I. Kräftige Pfl. Blätter aus eiförmiger Basis lanzettlich zugespitzt; Zellen oberwärts $15-18 \mu$, mit grossen Papillen

\author{
2. A. papillosa.
}

II. Weniger kräftige Pfl. Blätter länglich-eiförmig bis eilanzettlich; Zellen oberwärts $10-14$, in den Ecken stark verdickt. mit grossen Papillen. 1. A. petrophila.

III. Sehr schlanke Pfl. Blätter länglich-eiförmig oder eilanzettlich; Zellen oberwärts rings fast gleichmässig verdickt, $7-9$ ", schwach papillös ...... 4. A. alpestris.

$\gamma$. Blätter am breitesten an oder oberhalb der Blattmitte: Zellen oberwärts schwach papillös bis glatt.

I. Stengel sehr locker beblättert. Blätter hohl, breit verkehrt-eiförmig, kurz zugespitzt, mit breit gerundeter Spitze, bis $1,3 \mathrm{~mm}$ lang und bis $0,5.5 \mathrm{~mm}$ breit; Zellen oberwärts rings wenig verdickt ...... 5. A. Hartmanii.

II. Blätter dichter gestel!t. kürzer und schmäler als bei der vorigen Art, mit etwas schmälerer und bisweiJen rinnenförmiger Spitze; Zellen oberwärts etwas stärker verdickt und deutlich getüpfelt ........... 7. A. Thedenii.

III. Stengel dicht beblättert. Blätter breit verkehrteiförmig, über der Basis etwas verengt und in eine meist kürze und stumpfe Spitze verschmälert: Zellen oberwärts sehr stark verdickt und getüpfelt. 6. A. obovata.

B. Blätter mit Rippe.

a. Blattzellen uicht papillös. Perichätialblätter differenziert.

«. Blattrippe auslaufend. Innere Perichätialblätter ohne Rippe.

I. Blätter aus eiförmiger Basis pfrienenförmig; Rippe sehr kräftig, 4-6schichtig.

1. Perichätium sehr lang und schmal. Innere Perichätialblätter allmählich zu einer ziemlich kurzen Spitze verschmalert ................... 9. A. crassinervia.

2. Perichätium kürzer als bei der vorige? Art. Innere Peric’ütialblätter verkehrt-eilänglich, abgerundet uder mit winzigem Spitzchen, oben gekerbt und aussen mit grossen Papillen

10. A. Huntii.

II. Blätter aus schmal elliptischer Basis pfriemenförnig; Rippe schmal, 2-3schichtig ............ 13. A. Blyttii.

$\because$ Blattrippe meist vor oder mit der Blattspitze aufhörend.

1. Blätter aus ovaler Basis rasch pfriemenförmig. Innere Pcrichätialblätter meist mit vollständiger

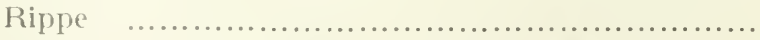

Il. Blätter lineallanzettlich, allmühlich versehmälert.

Innere Pcrichätialblätter ohne Rippe ............. 12. A. frigida.

b. Blattzełlen beiderseits mit je einer spitzen Papille über dem Lumen 14. A. nivalis.

Un tergal l. I. Euandreaea Lindb. Musc. scand. p. 31 (1879). perichätialblitter schr gross, scheidenförmig und zusammengewickelt.

S c e t. I. Enerviae Cairl. in Schwed. Siidpol-Exp. 1901/03, 1V: 8, p. 51 (1908). Blätter ohne Rippe. 
1. Andreaea petrophila Ehrh. Hann. Mag. 1778, p. 1601.

Pfl. in oft ausgedehnten, leicht zerfallenden, bräunlichgrünen oder braunroten bis schwärzlichen Połstern oder Rasen. Stengel 1-2 cm, selten lıölıer. Blätter trocken anliegend, feucht aufrecht-abstehend, hohl, länglich-eiförmig bis eilanzettlich, schief zugespitzt, meist stumpflich, bis $1 \mathrm{~mm}$ lang und bis $0.15 \mathrm{~mm}$ breit; Zellen oberwärts rundlich-mehreckig, $10-14 \mu$, in den Ecken stark verdickt und dicht getüpfelt, auf der Rückseite mit grossen, stumpfen, hyalinen Papillen, am Blattgrunde mit linearem Lumen. Innere Perichätialblätter stumpf. - Fig. 1 A-B.

Durch das ganze Gebiet bis in die alpine Region häufig.

Eur., Kaukasus, Lral, Japan, Nord-Amerika, Fuegia, Tasmanien, New Zealand.

var. rupestris (Hedw.) Wallr. Fl. germ. crypt. I. p. 192 (1831). [A. rupestris Hedw. Sp. musc. p. 47, t. 3, f. 2 (1801). - A. petrophila v. homomalla Schimp. Syn. p. $661-(1860)$.]
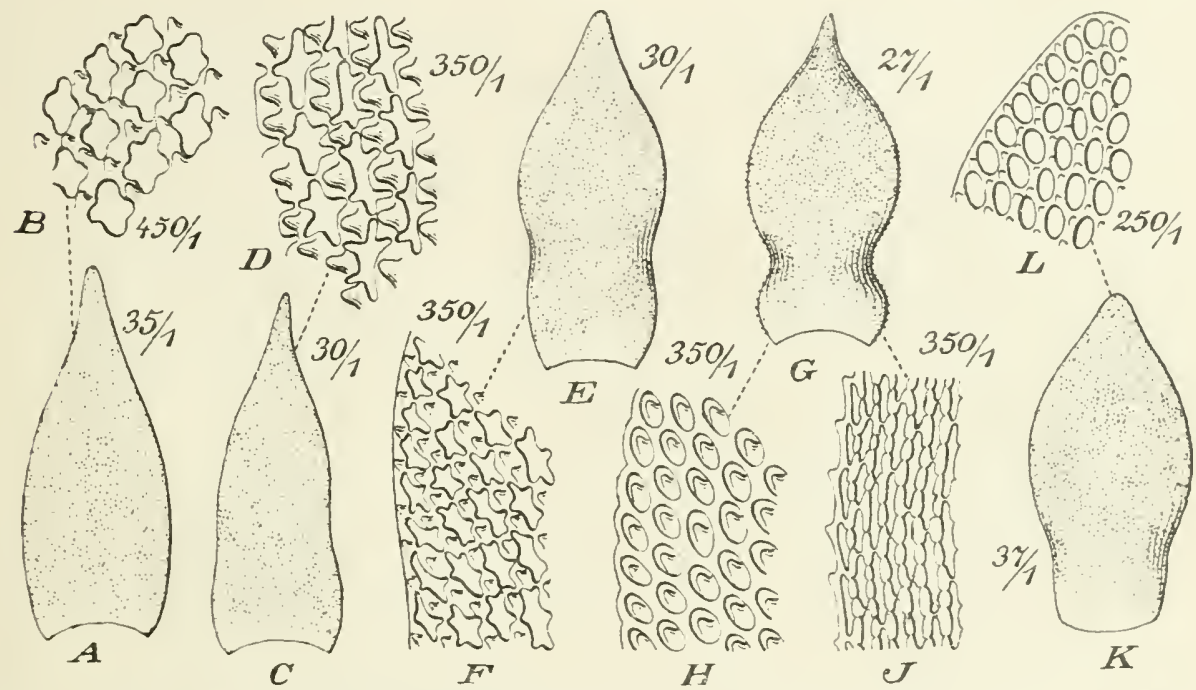

Fig. 1. Stengelb. A-B Andreaea petrophila Ehrh. - C-D A. papillosa Lindh.. - E-F A. alpestris

(Thed.). - G-I A. alpina (L.). - K-L A. oborata Thed.

Blätter auch leucht einseitswendig bis sichelförmig.

F. Ab. Kakskerta, Harjattula (Buch). - N. Borgå (Sael.). - Ta. Kuhmoinen. Harmoin (Norrl.). Hartola (Bonsd.). - Kl. Kurkijoki, Haavikko (Jusl.). - ok. Kajana (Broth.).

Europa.

2. Andreaea papillosa Lindb. in Öfv. K. Vet.-Ak. Förh. Årg. 23, p. 577 (1866).

Kräftige Pfl. in oft ausgedehnten, dunkel- bis schwärzlichbraunen, polsterförmigen Rasen. Stengel bis $4 \mathrm{~cm}$, selten höher. Blätter trocken anliegend oder aufrecht-abstehend, feucht \pm abstehend, aus eiförmigem Grunde allmählich lanzettlich zugespitzt, bis $1,3 \mathrm{~mm}$ lang und bis $0,45 \mathrm{~mm}$ breit; Zellen oberwärts rundlich-mehreckig, 15-18 $\mu$, stark verdickt, auf der Rückseite mit grossen, stumpfen Papillen, am Blattgrunde mit linearem Lumen. Innere Perichätialblätter mit kurzer Spitze. - Fig. 1 C--D.

S. $P L$. Tjidtjakk. LuL. Sarekgebiet.

Arkt. Zone von Spitzbergen bis Behringstrasse.

3. Andreaea sparsifolia Zett. Mon. Andr. p. 32 (1855). [Andreaea petrophila * A. sparsifolia Linclb. Musc. scand. p. 31 (1879).]

Pfl. in lockeren bis dichten, braunen bis bräunlichgrïnen Rasen. Stengel $2-3 \mathrm{~cm}$, locker beblättert. Blätter anliegend und einseitswendig. feucht aufrecht- 
abstehend bis einseitswendig, aus eiformiger Basis almählich lang zugespitzt, bis $1,2 \mathrm{~mm}$ lang und bis $0,3 \mathrm{~mm}$ breit: Zellen oberwärts rundlich, rings verdickt, 10 11 ", auf der Rückseite mit grossen, hyalinen Papillen, am Blattgrunde mit linearem Lumen. Innere Perichätialblätter allmählich zugespitzt, mit gekerbten Rändern.

S. Hrjd. Helagsfället. PL. Peljekaisie. LuL. Sarekgebiet.

N. Br. Gaustafjeld. K. Jotunfjeldene; Irariestuen: Ronderne. Yo. Saltdalen. Nurdgrenze bei etwal $6 \pi=n \cdot B r$.

Zentralalpen.

4. Andreaea alpestris (Thed.) Schimp. Bryol. eur. VI. t. 626 (1855). [Andreaea petrophila var. alpestris Thed. in Nya Bot. Notis. 1849, p. 79. f. 1547. - A. petrophila * A. alpestris Iindb. Muse. scand. p. 31 (1879).]

Selır schlanke Pfl. in breiten und kissenförmigen, schwarzroten bis tiefschwarzen, zuweilen glänzenden Rasen. Stengel bis $4 \mathrm{~cm}$. Blätter trocken rỉcht anliegend, feucht aljstehend, kleiner und breiter als bei A. pelrophila, länglicheiförmig oder schief eilanzettlich, stumpf: Zellen oberwärts rundlich-mehreckig bis queroval, 7 -9 :", rings fast gleichmässig verdickt, nicht getüpfelt, auf der Rückseite schwach papillös, am Grunde meist mit rektangulärem, bisweilen beinahe quadratischem Lumen. Innere Perichätialblätter stumpf. - Fig. $1 \mathrm{E}-\mathrm{F}$.

An etwas feuchten bis periodisch überrieselten Felsen.

F. Ka. Wihorg. Pälli (Buch). - sa. Kangasniemi (Lackstr.), - K. Kuusamn. Nuorunen (Nyb.); zw. Marttila und Vattula (Broth.); Paanajärvi. Kiekhivaara (B.). - Le. Kilpisjärvi, Leutsuvaara (Norrl.).

Li. Sodankylit. Raututunturi. Palotunturi und Lupukkapää in der alp. Reg. (Hult); Inari, Pietarlautosnaivi und Peldoaivi in der alp. Reg. (H.); Ltsjoki. Heikura am Tenojoki (H.). - Lim. Nuotjärvi (Hollm.); Hibinä, in der alp. Reg. (Broth.); Ljaro-tschorr (Kihlm.): Lujavr-urt. Vavnbed (K.). - Lt. Oslseile des Pasvikflusses gegenüler Buris Gleb (Fridtz): Subovi (Broth.), - Lmur. Semjostrov (Broth.). - Lp. Orlor (Kihlni.).

S. Hrjd. Imt. Snasahögen. LyL.. PL. und LuL. all mehreren Fundorten.

N. Ve. sidetersdalen. St. Ryfylke. ST. Norefjeld. No.-F. an mehreren Fundorten.

Europa.. Nord-Ameriki. Nordgrenze auf Gronland.

5. Andreaea Martmanii Thed. in Nya Bot. Notis. 1849, p. 78.

Pfi. in lockeren, oft ausgedehnten und mit Gletschersand durchsetzten, leicht zerfallenden, weichen, bräunlichgrünen bis bramen Rasen. Stengel bis 6 und $10 \mathrm{~cm}$, locker bel,ättert. Blätter trocken und feucht wenig abstehend, hohl, breit verkehrt-eiförmig. kurz zugespitzt, mit breit gerundeter Spitze, bis $1,3 \mathrm{~mm}$ lang und bis $0,55 \mathrm{~mm}$ brit: Zellen oberwärts rundlich oder rundlich quadratiseh. $12-$ 16 ", rings wenig vedicki, nicht getüpfelt, glatt, am Blattgrunde nit ziemlich weitem l.umen. Innere Perichätialblätter stumpf.

An Felsen, Blöcken und Steinen der Wasserläufe in der alpinen Region.

S. Hrjd. und Imt. PL. Tjidıjakk. LuL. Sarekgebiet. 1. $\mathrm{Br}$.

N. Br. Gaustafjeld, h. Jotunheim; Dorre; Ronderne. No. Alstahaug. Nondgrenze bei $66^{\circ} 23^{\circ}$

6. Andreaea obovata Thed, in Nya Bot. Notis. p. 78, t. 1, f. 27-36 (1849).

Kriätige Pfl. in oft ausgedehnten, kissenförmigen, oben dunkel-, innen rotbraunen Rasen. Stengel ㅁ- 1 cm. Blätter trocken dachziegelig anfiegend, feucht aufrecht-abstehenr, verkehrt-eiförnig und in eine meist mur kurze und stumpfe Spitze verschmälert, ïber der Basis etwas verengt, bis $1,2 \mathrm{~mm}$ lang und bis 0.15 $11 m$ breit: Zellen sehr stark verelickt und dicht getüj)felt, oberwärts rundlich-mehreckig oder oval, 10-12 " Blatgrunde mit linearem Lunen. - Fig. 1 G-I.

An feuchten Felsen, besonders in und neben alpinen Bächen.

F. Lik. hirakkatunturi, in der alpinen:Region (SiLll.. Broth.). L Lem. Ounastunturi (Norrl.).Le. Kilpisjarvi, Malla bis in die alpine Region (Kot.). - Li. Sodinḳ̣ä, Palotunturi, Pyhätunturi und Lupukkapaä bis in die alpine Reginn (Hult); Inari. Verkkojärvi und Kuarvekod; (Sil.); Peldoivi, in

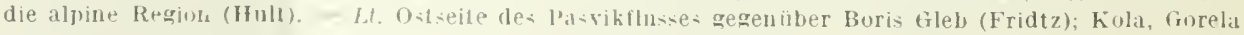
(Broth.). 
S. An mehreren Fundorten in Hrjd., Jmt.. LyL., PL. und LuL.

N. Ne. Saetersdalen. St. Ryfylke. NB. Sogn. ST. Norefjeld. NT. Dovre; Ronderne; stu rialen. No.-F. an mehreren Fundorien.

Spitzbergen, Grönland, Sibirien.

7. Andreaea Thedenii Bryol. eur. fasc. $52 / 54$ Mon. p. 20, t. 8(18.55). [Andreaea Hartmanii var. Thedenii Lindb. Muse. scand. p. 31 (1879).]

Pfl. in dichten, braunen Rasen. Stengel bis $5 \mathrm{~cm}$, dicht beblättert. Blätter trocken dachziegelig, feucht abstehend, kürzer und schmäler als bei A. Hartmanii, mit etwas schmälerer und bisweilen rimnenförmiger Spitze; Zellen oberwärts etwas stärker verdickt, deutlich getüpfelt, auf der Rückseite schwach papillös-höckerig, am Blattgrunde mit engem Lumen. Innere Perichätialblätter stumpf.

An Steinen und Felsen der Gebirgsbäche.

S. Jmt. Snasahögen.

N. $K$. Ronderne. ST. Dovre; Norefjeld. No.-F, an einzelnen Fundorten. Nondgrenze bei $\sigma_{0}^{\circ}$ $29^{\circ} \mathrm{n} . \mathrm{Br}$.

var. obtusifolia (Th. Jens.) Hag. Musc. Vorv. bor. p. 351 (1901). (A. obtusifolia Th. Jens. in Vid. Medd. nat.-hist. For. 1858 p. 55.)

Stattliche, weiche Pfl. in schwellenden Rasen. Stengel gedunsen beblättert. Blätter mit breiterer, stumpfer Spitze.

N. ST. Snehätten. No. Salıdalen. F. Karasjok.

8. Andreaea alpina (L.) Sm. Fl. brit. 1179 excl. Syn. nomull. et Eingl. Bot. t. $1278(1804)$.

Pfl. in lockeren bis dichten, leicht zerfallenden, schwarzroten, mattglänzenden Rasen. Stengel $2-5 \mathrm{~cm}$. Blätter trocken dachziegelig, feucht aufrecht-abstehend, aus eiförniger, kleingezähnter Basis verkehrt eispatelförmig und kurz zugespitzt, über der Basis etwas verengt, bis etwa $1.2 \mathrm{~mm}$ lang und bis etwa $0,55 \mathrm{~mm}$ breit; Zellen stark verdickt. nicht getüpfelt und glatt, oben rundlich-mehreckig, etwa 7 ". nach der Mitte zu mehr oval, mit etwas buchtigem, am Grunde mit sehr engem, linearem Lumen. Innere Perichätialblätter plötzlich in eine kurze Spitze verschmälert. —' Fig. $1 \mathrm{G}-1$.

An feuchten Felsen und an Steinen in Bächen.

N. Ve. Saetersdalen pass. St. Ryfylke. NB. Sogn; Oster.e. R. rom Meeresniveau bis in die alpine Region sehr häufig und zuweilen massenhaft. No. Alstahaug. Nordgrenze bei etwa $65^{\circ} 57^{\prime} \mathrm{n}$. Br.

Schottland, Wales, Irland.

S e c t. II. Nerviae Card. 1. c. p. 55.

Blätter mit Rippe.

9. Andreaea crassinervia Bruch in Denkschr. Akad. Münch. 1828, p. 279, t. 10.

Pfl. in dichten, oft ausgedehnten, schwarzen, etwas glämzenden Rasen. Stengel 1,5-2 cm. Blätter meist einseitswendig, aus eifömiger Basis rasch pfrienenförmig, etwa $0,9 \mathrm{~mm}$ lang und 0,22 $\mathrm{mm}$ breit; Rippe kräftig, den oberen Pfriementeil ganz ausfüllend und mamillös; Zellen gleichmässig und stark verdickt, nicht getiipfelt, glatt, rundlich-quadratisch, im llittel $10 \mu$, am Blattgrunde nächst der Rippe rektangulär. Perichätium sehr lang und schmal. Innere Perichätialblätter allmählich zu einer ziemlich kurzen Spitze verschmälert: Rippe fehłend. -Fig. $2 A-C$.

An periodisch berieselten Felsplatten.

F. At. Hammarland, Finström, Geta und Sund an einzeInen, saltrik an mehreren Fundorten (Bom.). - Ab. Abo, Hirvensalo, Jänismaa (Buch). Pargas, Gunnarsnäs (Elfv.). Kimito (Flinck); Tjuda Stormossen (Ranck.). Angelniemi (Buch). Bromarf. Norrstrand und Prästgàdsbärget (Sundr.). Lojo, Lesaari (Lindb.). Vichtis, Palajärvi (Broth.). - N. Kyrkslätt, Humaljärri (Buch); Esbo ( Käri); Ka.berget (Buch). Helsingfors (Lindb.). Helsinge, Viiks Ladugird (Norrl.); Aggelby (Bucli). Hogland (Lindb.). Ka. Tehkalahti, Hylksaari (Krohn). - Ta. Padasjoki, Nyystölä (Tain.). Forpilahti, Paljakko, Rappukallio (V.). - Kl. Jaakkima, Puutsalo (Norrl.). - Tb. Viitasaari, Kohiseva und Pinjärvi (Broth.). Ok. Kajana, Huuhkankallio (B.). - Lt. Kola, Lukinskaja Pahta (B.). - Lmur. Teribjerka (B.); Bjelousiha am Voronjeflusse (B.). 
S. Ög., När., Vrml, und Ing. an einzelnen oder wenigen Fundorten.

N. Sm. st. f(1. A. Kristiania. JL. Sandefjord. Ne. Saetersdalen. St. Ryfylke. Pyrenäen, Zentralalpen, Nord-Amerika. Nordgrenze auf Grönland.

10. Andreaea Huntii Limpr. l.aubm. I. p. 145 (1885). (A. Rothii * Huntii Joerg. in Berg. Nus. Aarb. 1894/95 No. XIII. p. 13.)

Pfl. in dichten, schwarzen, glanzlosen bis schwach glänzenden Rasen. Stengel bis 3 cm. Blätter sichelförnig-einseitswendig, aus kurzer, breit eiförmiger, hohler Basis allmählich lang pfriemenförmig, bis $1,9 \mathrm{~mm}$ lang und bis $0,38 \mathrm{~mm}$ breit: Rippe sehr kräftig, nur den oberen Pfriementeil ganz ausfüllend; Zellen rundlich-quadratisch, glatt, im Nittel etwa 8 ", am Blattgrunde nächst der Rippe rektangulär. Inmere Perichätialblätter verkehrt-eilänglich, oben abgerundet ofler mit winzigem Spitzchen, gekerbt, aussen mit grossen Papillen: Rippe fehlent.

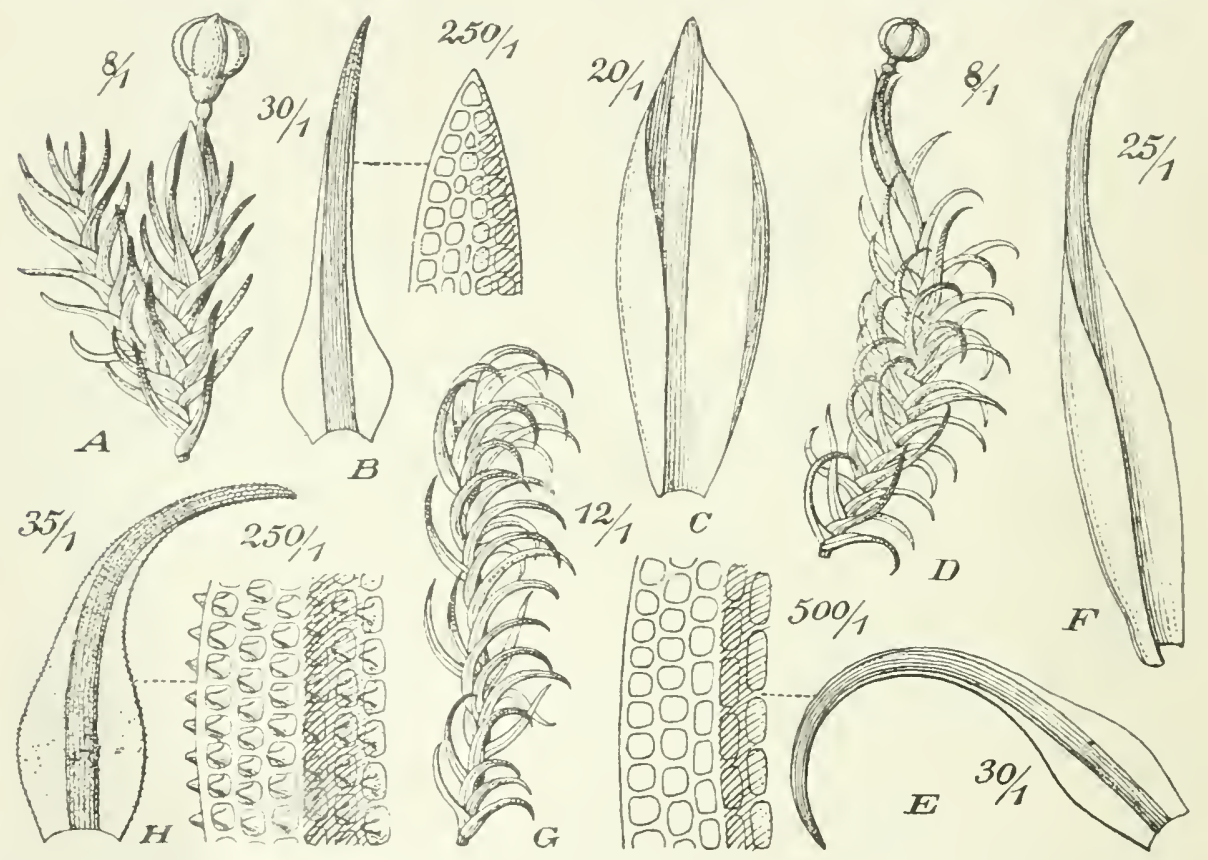

Fig. 2. A-C. Andreaea crassinervia Bruch. A Fruchtende Pfl. (8/1); B Stengelb. 30/1); C Perichätialb. (20/1). - D-F. A. Blyttii Schimp. D Fruchtende Pfl. (8/1): E Stengelb. (30/1); F Perichātialb. (25/1). - (i-H. H. nivalis Hook. G sterile Pfl. (12/1); H Stengelb. (35/1).

An feuchten Felsen.

N. Sm. Borge. (rlemminge und Onw., $J L$. Sandefjord. Ne. Saetersdalen. St. Ryfylke, Frafjord cop. SB. Bergen st. fq. R. Romsdalen. Veblungsnaes; Bud. Stemshesten; Kristiansund. No. Alstahaug. Schottland, England. Deutschland.

11. Andreaea Rothii Web. et Mohr Bot. Taschenb. 386, t. 11, f. 7-9 (1807). [Andreaea rupestris Roth Neue Beitr. I. ]. 234 (1802).]

Pfl. in dichten, rötlichbraunen bis schwärzlichen, glanzlosen Rasen. Stengel lis $1,5 \mathrm{~cm}$. Blätter meist einseitswentig, aus eiförmigem Grunde rasch breit linealisch-p friemenförmig, spitz, etwa $1,5 \mathrm{~mm}$ lang uncl $0,4 \mathrm{~mm}$ breit: Rippe allmählich verschmälert, ntir dlie Spitze des pfriemenförmigen Teiles ausfüllent; Zellen gleichmässig verdickt, nicht getüplelt, glatt, rundlich-quadratisch und queroval, $8-10$ ", oberwärts wenigstens an Rande doppelsehichtig. am Blattgrunde nïchst der Rippe rektangulär. Innere Perichätialluätter rasch zu einer mässig langen Pfriemenspitze versehmïlert. 
An trockenen, etwas schattigen Felsen.

F. Al. Eckerö, Hamıarland, Lemtand, Finström, Geta und Kökar an einzelnen, sumd an meh. reren und saltrik an rielen Fundorten (Bom.). - Ab. Bronarf. Norrstrand (sundr.). Lojo. Jalassaari. Ivars (H. Lindb.). - N. Kyrkslätt, Vitträsk (Sundv.).

S. Sh., Bl., Hll., Boh., sm, VG. Dl., srm. und $\mathrm{rm}$. meist - r. Auclı aus $\mathrm{V} b$. und $L$. angegeben.

N. sm. fqq. A. Kristiania, JL. Tјum, fqq. Ne. saetersdalen $\mathrm{f} q$. St. Ekersind fq. R., pass. K. Jotunfjeldene bis $1,400 \mathrm{~m}$. No. Alstahaug.

Europa, Nord-Amerika.

12. Andreaea frigida Hueb. Hep. germ. p. 305 (1834).

Kräftige Pfl. in ausgedelınten, rötlichen bis kupferfarbenen, auch schwarzen, meist glänzendem Rasen. Stengel $2-5 \mathrm{~cm}$. Blätter aufrecht bis einseitswendig. aus lanzettlichen Grunde allmählich verschmälert, bis $1,8 \mathrm{~mm}$ lang und $0,5 \mathrm{~mm}$ breit: Rippe kräftig, rötlich, allmählich verschmälert, in die scharfe Spitze eintretend oder kurz vor der stumpflichen Spitze endend; Zellen gleichmïssig verdickt, nicht getüpfelt, glatt, rundlich-quadratisch, etwa $10 \mu$, zweischichtig, am Blattgrunde einschichtig und nächst der Rippe rektangulär. Äussere Perichätialblätter zusammengewickelt, rasch in einc breite, zungenförmige Spitze verschmälert, die inneren schmäler, lanzettlich zugespitzt, rippenlos.

An feuchten Felsen und an Felsen und Steinen in Bächen

N. Ne. Saetersdalen. st. Lyse, Kjelkesharet. st. Norefjeld.

Pyrenäen, Alpenkette.

13. Andreaea Blyttii Bryol. eur. fasc. 52/54 Mon. p. 25. t. 13 (1855).

Diözisch. Schlanke Pfl. in dichten, oft ausgedehnten, rotbraunen bis schwärzlichen, schwach glänzenden, kissenförmigen Rasen. Stengel bis $1-1,5 \mathrm{~cm}$. Blätter meist \pm einseitswendig, lanzettlich rasch pfriemenförmig verschmälert, etwa 1,2 $\mathrm{mm}$ lang und $0,3 \mathrm{~mm}$ breit; Rippe kräftig, fast den ganzen Pfriementeil einnehmend und austretend; Zellen gleichmässig verdickt, nicht getüpfelt, glatt. oben rundlich-quadratisch, $8-10 \mu$, abwärts quadratisch und rektangulär. Perichätium sehr schmal und lang. Innere Perichätialblätter schmäler und kürzer als die äusseren, kurz zugespitzt, rippenlos. - Fig. $2 \mathrm{D}-\mathrm{F}$.

An Steinen, besonders schicferigen, fast nur in unmittelbarer Nähe der Gletscher und Schneefelder.

S. Hrjd., Jmt., LyL., PL. und LuL. an einzelnen Fundorten.

N. Br., Ne., NB., R., K., ST. - Tr., im Hochgebirge rerbreitet.

spitzbergen, arkt. Nord-Amerika.

Un t e r g a t t. II. Chasmocalyx Lindb. Musc. scand. p. 30 (1879).

Perichätialblätter von den Laubblätter wenig verschieden.

14. Andreaea nivalis Hook. in Trans. Linn. Soc. X. p. 395, t. 31, f. 4 (1811).

Diözisch; $C^{\top}$ Pfl. in eigenen Rasen. Pfl. in ziemlich dichten, weit ausgedehnten, braungrünen oder rotbraunen bis schwarzen Rasen. Stengel aufsteigend oder selten bis $10 \mathrm{~cm}$, ziemlich dicht beblättert. Blätter einseitswendig bis sichelförmig, aus \pm deutlich geöhrtem Grunde lanzettlich, allnählich und scharf zugespitzt, meist etwa 1,2 mm lang und $0,3 \mathrm{~mm}$ breit; Rippe gleichbreit, mit der Blattspitze endend, rötlich; Zellen überall zienlich gleichgross, nicht verdickt, quadratisch, kurz rektangulär und querrektangulär, 9-10 ", beiderseits mit je einer spitzen Papille über dem Lumen. - Fig. $2 \mathrm{G}-\mathrm{H}$.

An Steinen der von den Gletschern und Schneeleldern herabfliessenden Bäche.

S. Hrjd., Jmt. und LuL. an wenigen Fundorlen.

N. Br., Ne.. St., $S B$. - K., $S T$. - No in Hochgebirgest. fq.. in F. r. Nordgrenze bei $70^{2}: 25^{\prime} n$. BI, Schottland, Pyrenäen, Alpenkette, British Columbia, Washington. Oregou.

var. fuscescens Hook. l. c.

Rasen bräunlich. Blätter stark sichelförmiç.

S. Jmt. Sylarna.

N. ST, Norefjeld.

Verbr. wie bei der Hauptart. 


\section{BRYALES.}

Sporogon (excl. Archidiaceae) schon frühzeitig das Archegonium absprengend und dessen oberer Teil sich als Haube entwickelnd. Seta (exel. Archidiaceae) vorhanden. Sporensack in der Regel von der Columella durchsetzt und von einem Luftraum umgeben. Sporenaussaat durch einen sich ablösenclen Deckel, selten durch unregelmässiges Bersten oder durch Fäulnis der Kapselwandung.

$$
\text { İbersicht der Reilnengruppen. }
$$

A. Kapsel multilateral. Peristom im Deckelamphithecium in 2-3 konzentrischen Zellagen aus verdickten Wandteilen der Zellmembranen enstehend, selten aus hohlen, ganzen Zellen gebildet. Beide Peri itome (excl. Georgiaceae) derselben Gewebeschicht angehörig ........................

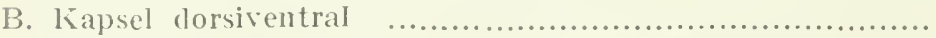

C. Peristom in zahlreichen, konzentrischen Zellagen aus ganzen, schiefgegliederten Zellen gebildet

I. Eubryinales

II. Buxbaumiinales. III·Polytrichinales

\section{Reihengruppe EUBRYINALES.}

Kapsel multilatimal. Columella sehr selten fehlend. Peristom im Deckelamphithecium in 2-3 konzentrischen Zellagen aus verdickten Wandteilen der Zellmembranen entstehend, selten aus hohlen, ganzen Zellen gebildet, sehr selten bei der Zalnnteilung das Innere des Deckelgewebes mitgerissen. Exostom und Enclostom derselben Gewebeschicht angehörig.

Ir ünstlicher $\mathrm{Schl}$ üs sel zur Bestimmung der Enbryinales.

A. Kapsel ohne Andeutung eines Deckels.

a. Kapsel lange von der sehr zarten Haube umhüllt, diese zuletzt unregelmässig gesprengt. Sporen 100-200 " ... Archidiaceae. S. 25.

b. Haube an der Spitze der Kiapsel.

«. Blïtter lanzetllich-pfriemenförmig; Rippe breit und flach, den P'friementeil ausfüllend; Zellen verlängertrechteckig, glatt.

I. Haube kappenförmig, etwa die halbe Krapsel

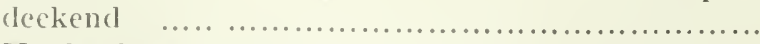

II. Haube kegel-mützenförmig, gelappt und nur den Scheitel deckend

5. Pleuridium.

4. Sporledera. 
§. Blätter kurz bis lanzettlich zugespitzt; Rippe am Grunde oft erlöschend, zuweilen fehlend; Zełlen glatt.

I. Protonema ausdauernd, grïn. Schopfblätter schmal lineallanzettlich; 7ellen locker, oberwärts rhomboidisch bis rhombisch. Haube klein, kegelmüitzenförmig

II. Protonema nicht auslauernd. Schopfblätter schmal lanzettlich: Zellen verlängert-rektangulär.

Haube kappenförmig ........................... 11. Pseudephemerum.

III. Protonema ausdauerud, grün, später bräunlich. Schopfblätter schmal linealisch, zugespitzt; Rippe sehr kräftig, als Stachelspitze austretend; Zellen in der Mehrzahl verlängert rhomboidisch-6seitig. Haube kappenförmig 63. Ephemerum.

276. Ephemerum recurvifolium.

$\because$. Schoplb]ätter lanzettlich bis fast spatelförmig; Rippe dünn, vor der Blattspitze auflı̈rend; Zellen sehr weitlichtig, glatt. Haube klein, kegel-mützenförnig, gelappt 61. Physcomilrella.

ઈ. Pfl. knospenförmig. Schopfblätter breit eiförmig, mit zurückgekrïmmter, ausgeschweift-gezähnelter Spitze; Zellen oberwärts rhombisch bis rhomboidisch-6seitig, glatt, nach unten verlängert rechteckig. Haube klein, kegel-mützenförmig ............

๕. Blattzellen oberwärts quadratisch bis mehrechig, meist warzig-papillös, nach unten verlängert rechteckig, glatt

49. Acaulon.

B. Kapsel eingesenkt, fast kugelig, mit stumpfem, durch Druck sich ablösendem Deckel. Haube klein, kegel-kappenfömig Schopfblätter trocken gekräuselt, schmal lanzettlich, mit aufrechten oder eingebogenen Ränclern: Rippe liräftig: Zellen oberwärts quadratisch, papillös, nach unten verlängert-rechteckig und 6seitig, hyalin.

36. Astomum.

C. Kapsel dick oval, kurzhalsig, mit meist kurz stumpf und schief geschmäbeltem, nicht abfallenden Deckel. Peristomzïhne in der Anlage vorhanden. Schopfblätter länglichlanzettlich bis spatelförmig, mit oberwärts umgebogenen Rändern; Rippe kräftig, als Stachel oder Haar austretend; Zellen oberwärts unregelmässig quadratisch odler mehreckig, glatt oder papillös, am Gruncle verlängert rektangulär, hyalin

50. Phascum.

51 I. Mildeplla.

D. Kapsel mit sich von selbst ablösendem Deckel.

a. Sterile Stengel zweizeilig beblättert, mit longitudinal inserierten, am Grunde seitlich verschmelzenden, Blättern,

fertile an der Spitze mehrreihig beblättert

Schistostegaceae. S. 218.

b. Alle Stengel zweizeilig beblättert.

«. Blätter scheidig-kahnförmig, mit Dorsalflügel ......... Fissidenlaceae. S. 16.

$\beta$. Blätter aus halbscheidiger Basis rasch pfriemenförmig verschmälert

9. Dis!ichium.

c. Stengel drei- bis mehrreihig beblättert.

«. Peristom fehlend.

1. $\Varangle$ Blïte gipfelständig an Hauptsprossen. 
1. Blüte pfriemenförmig zugespitzt; Zellen glatt.

* Glänzende Pfl. Blattzellen oberwärts sclimal, länglich und rektangulär. Kapsel eingesenkt. 54. Blindia caespiticia.

** Glanzlose. kleinste Pfl. Blattzellen oberwärts quadratisch. Kapsel emporgehoben ........t5. Seligera Doniana.

2. Blätter lanzettlieh-linealiseh bis linealisch Zellen oberwärts klein, rundlich-quadratisch, meist papillös, unten rektangulär.

* Kapsel gerippt.

$\dagger$ Kapsel entleert unter der Mündung stark erweitert

21. Amphidium.

$\dagger \dagger$ Kapsel entleert engmünclig

99. Zygodon.

** Kapsel nicht gerippt.

$\dagger$ Urnenmündung nach der Entdeckelung noch längere Zeit geschlossen

37. Hymenostomum.

†† Urnenmündung durch die Entdeckelung geöffnet.

Deckel mit der anhängenden Columella abfallend

41. Hymenostylium. Columella bei der Entdeckelung in der Urne zurückbleibend 39. Gymnostomumu.

3. Obere Blätter hohl, länglich und länglich-lanzettlich, rasch in ein Haar verschmälert: Zellen oberwärts klein, rundlich-quadratisch, glatt, am Blattgrunde verlängert rechteckig ..........250. Grimmia anodon.

4. Blätter oberwärts hreit: Rippe als Stachelspitze oder Haar austretend: Lellen oberwärts rundlich-4-6scitig, ziemlich locker, meist warzigpapillös, am Blattgrunde verlängert-rechteckig.

* Rippe oberwärts mit ventralen Längslamellen. 53. Pterygoneurum.

** Rippe ohne Längslamellen 51). Pollia ex p.

5. Blätter oberwärts breit: Zellen oberwärts selır locken chlncopliyllarm, glatt.

* Blatter mit abgerundeter Spitze. Seta sehr kurz. Kapsel mit sehr langem, schwammigem llalse. Haube klein, kegelig-zylindrisch, einerseiis gespalten

** Blätter zugespitzt. Seta verlängert. Kapsel mit kurzem Halse. Haube mützenförmig, drei- bis mehrspaltig.

† Haube bis gegen die Mitte der Urne herabreichencl

Oedipodiaceae. S.2(14.

† Haube unter den Hals herabreichend, 4-kantig 66. Pyramidula.

6. Blätter zungen- ocler spatelförnig Zellen oberwärts klein, chloroplyyllreich, dicht warzig.

Haube sehr gross, zylindriselı-glockenförmig ... 59. Encalypta exp.

II. Alle Blüte aul seitenständigen Kurztrieben. Seta verlängert

35. Anoectanginm.

III. + Blüte aufangs gipfelständig, später durch subflorale Sprosse scheinbar seitenständig oder in einer Gabchng. Blattrippe fehleno

Hedwigiaceae. S. 103. 
$\beta$. f Blüte gipfelständig. Inneres Peristom fehlend.

I. Innere Zellen der Blattrippe grün.

1. An Sphagnum crinnernde Pfl. Äussere Schichten der Blattrippe sehr weitlichtig, hyalin, mit grossen, rundlichen Perforationen ...............eucobryaceae.S.108.

2. An Dicranum erinnernde Pfl. Äussere Schichten der Blattrippe weitlichtig, hyalin, ohne Perforationen

II. Blattrippe ohne grüne Zellen.

1. Aussenschicht der Peristomzähne aus ciner Reihe, Innenschicht aus zwei Reihen Membranplatten gebildet.

* Grünes Protonema ausdauernd. Blattrippe fehlend ..................................... Disce'iaceue. S. 195.

** Protonema nicht ausclauernd. Blattrippe einfach.

$\uparrow$ Peristomzähne meist \pm weit lherab $2(3)$ schenkelig und gestreift ................... Dicranaceae. S. 45.

$\dagger \dagger$ Peristomzähne ungestreift.

$\times$ Peristomzähne gesondert.

\$ Peristomzähne breit, ungeteilt, nicht durchbrochen, glatt ................. Seligeraceae. S. 38.

$\S \S$ Peristomzähne mcist breit, durchlöchert oder \pm weit limab in 2 (3) Schenkel geteilt, papillös .............. Grimmiacear.S. 165.

$\times \times$ Peristom mit \pm entwickelter Basilarmembran.

$\S$ Blätter lanzettlich bis lanzettlichpfriemenförmig; Zellen klein, quadratisch bis rektangulär, glatt. Peristomzähne bis zum Grunde in zwei lange, fadenförmige, aufrechte Schenkel geteilt. Haube kappenförmig ... Ditrichaceae. S. 26.

\$§ Blätter lanzettlich bis lanzettlichlinealisch; Zellen oberwärts klein, rundlich bis quadratisch, meist warzig papillös. Peristomzähne bis zum Grunde in zwei meist lange und fadenförmige, oft nach rechts ansteigende bis spiralig gewundene Schenkel geteilt. Haube kappenförmig .......... Trichostomoidece. S.

$\$ \S \S$ Blätter längich-eiförmig bis spatelförmig: Zellen oberwärts 1-6seitig. im Mittel etwa $20, u$, meist warzigpapillös, am Grunde verlängert und hyalin. Peristomzähne bald flach, längs durchbrochen oder oberwärts 2-3spaltig, bald bis zum Grunde in zwei meist lange und fadenförmige, spiralig gewundene Schenkel geteilt. Haube kappenförmig ............... 
oberwärts klein, rundlich-quadratisch, glatt, am Grunde linealisch. PeristomLähne bis zum Grunde in zwei lange, aufrechte, fadenförmige Schenkel geteilt. Haube mützenförmig, gelappt, lis zur kilpselmitte reichend ........ 97. Ptychomitrium.

$\gamma \cdot$ - Blüte gipfelständig anf kurzen Ästchen. Inneres Peristom fehlend. Peristom mit niedriger Basilarmembran. Peristomzähne unregelmässig in 2-3 lange, fadenförmige, am Grunde durch Querleisten verbundene Schenkel geteilt

57. Cinclidotus.

$\delta$. Blüte gipfelständig an Hauptsprossen. Peristom einfach oder doppeit. Haube sehr gross, zylindrischglockenförmig, ungefaltet, nackt 59. Encalypta.

\&. Fruchtsprosse kurz, gegen den Grund dles Stengel oder der Jahressprosse. Ausseres Peristom fehlend. 75. Mielichhoferia.

$\therefore$ - Blüte gipfelständig, an Hauptsprossen. Peristom meist doppelt. Aussenschicht der Peristomzähne aus zwei Reihen, Imneuschicht aus einer Reihe Membranplatten gebildet.

I. Blattzellen klein, quadratisch und kurz rektangulär, glatt. Kapsel horizontal, sehr klein, aus sehr kurzem Halse eikugelig. Inneres Peristom fehlend. Haube kappenförmig

y(1. Catoscopium.

II. Blattzellen oberwärts klein, rundlieh-cquadratisch, (hlorophyllreich. meist papillös. Kapsel aufrecht, bimfömig l,is zylindrisch. Haube kegel-glockenförnig, faltig. Inmeres Peristom wemn vorhanden, ohne Grundhaut

Orthotrichoideat. S. 369.

III. l3latLzellen oberwärts parenchymatisch, sehr locker und dümmwandig, chlorophyllarm, glatt.

1. Kaps^l aufrecht. Spaltöffnungen zahlreich, zweiz.hig. Peristomzähne paarig oder doppelparig verbunden. Inneres Peristom fehlend. Haube klein, kappen- oder kegelförmig Splachnaceae.S.205.

2. Kapsel aufrecht oder geneigt; Spaltöffnungen zahlreich, einzellig. Peristomzähne nicht paarig verbunden. Inneres Peristom, wenn vorlanden, ohne Grundhant. Haube gross, aufgeblasen kappenförmig, lang geschnäbelt ..............

IV. Inneres Peristom mit einer \pm weit vortretenden. lielfaltigen Grumdhaut und mit den Peristomzälnnen alwwechselnden, gekielten fortsätzen.

1. Iusseres Peristom kürzer als das innere.

* Kapsel langhalsig. Fortsätze des inneren Peristoms voneinander frei.

† Blattzellen locker, dümmwanclig, rhombisch6seitig.

Seca bis $15 \mathrm{~mm}$. Kapsel mit dem ?angen

Halse keulenförmig

$\times \times$ Seta $2-1$ coll. Kapsel alls langem

Halse längich-lsirnförmig

78. Piagiobryum.

87. Amblyodon. 
$\dagger \dagger$ Blattzellen eng, quadratisch und kurz rektangulär. Kapsel aus langem Halse gebogen keulig-birnförmig 88. Meesea.

** Blattzellen locker, mehreckig. Kapsel kugelig-oval bis länglich, kurz- und dickhalsig. Fortsätze des inneren Peristoms oberwärts zu einem Kuppeldach verbunden 8.). Cinclidium.

2. Beide Peristome gleichlang.

* Kapsel nicht längsstreifig.

$†$ Blätter sparig-zurückgekrümmt; Zellen olerwärts rundlich-6seitig, klein, beiderseits mamillös. Kapsel aus aufrechtem, kurzem Halse länglich-eiförmig, mässig gekrümmt 89. Paludella.

$\dagger \dagger$ Blätler \pm abstehend: Zellen glatt.

$\times$ Blüte mit fatlenförmigen l'araphysen. Blattzellen oberwärts prosenchymatisch, rhombisch- oder rhomboidisch6seitig bis linealisch. Spaltöffnungen (excl. Mniobryum) oberflächlich ......... Bryaceae. S. 222.

$x \times c^{r}$ Blïte mit keulenförmigen Paraphysen. Blattzellen oberwärts locker, parenchymatisch, 6seitig. Spaltöffnungen eingesenkt Mniaceae. S. 320.

** liapsel trocken gerippt.

† Kapsel fast kugelig, olne Hals. Fortsätze hald nach der Entdeckelung in zwei diver gente Schenkel gespalten .................Bartraniaceae.S.34?.

$\dagger \dagger$ liapsel aus kurzem Halse eilänglich bis zylindrisch. Fortsätze klaffend ........... Anlacomniaceae. S.

††† Kapsel aus kurzem Halse oval bis länglicheiförnig. Inneres Peristom mit hoher, schwach kielfaltiger Grundhaut und 64 farlenförmigen, kuotig gegliederten, hier und da anastomosierenden fortsätzen ...... Timmiaceac. s. 361.

r. Sporogone auf sehr verkürzten Seitenästchen. Peristom meist doppelt. Aussenschicht der Peristomzähne aus zwei Reihen, Innenschicht aus einer Reihe Membramplatten gebildet.

1. Zellen des Stengel locker, alle gleichgross orler nach aussen etwas enger, doch nicht verdickt.

1. Liräftige, ölglänzende Pfl. Blattzellen sehr locker, breit rhombisch-6seitig, glatt, in den Blattflügeln nicht differenziert

115. Hookeria.

2. Schlanke, glanzlose Pfl. Blattzellen locker, oben oval-länglich. am Blattgrunde in Schrägreihen rhomboidisch und die Randreihen quadratisch 148. Helicodontium.

11. Mantelzellen des Stengel verdickt. \pm englumig.

1. Blattzellen klein, in der Mehrzahl rundlichmehr-eckig, meist papillös.

* Laubblätter gleichförmig. Kalpsel meist aufrecht und regelmässig 
** Laubbiatter zweigestaltig. Kapsel geneigt bis horizontal, besonders trocken und entdeckelt \pm gekrümmt

Thuidiaceae. S. 133 .

2. 13lattzellen rhomboidisch-6seitig, mit deutlichen, auf dem Blattrücken mit grossen Papillen besetzten Eckverdickungen, in den Blattecken quadratisch

152.Plerygynandrum.

3. Blattzellen in der Mehrzahl prosenchymatisch, nicht papillös.

* Inneres Peristom ohne Grundhaut: Fortsätze fadenförmig, meist längs durch Querbalken gitterartig verbunden, selten frei und mit rangen Anhängseln. Wassermoose ......Fontinalaceae.S. 393.

** Hatutstengel kriechend, stoloniform. Sekundare Stengel verlängert und rund beblättert. Zellen gegen die Ränder des Blattgrundes in vielen Schrägreihen quadratisch und rundlich. auch querbreiter und rhomboidisch.

† Blätter eilanzettlich, mehrmals längsfaltig, am Rücken glatt.

Sekundäre Stengel einfach oder zerstreut beästet. Blätte ohne Rippe ... 109. Leucodon. Sekundäre Stengel fiederästig. Blattrippe einfach, vor der Blattspitze endend 108. Antitrichia.

$\dagger \dagger$ Sekundäre Stengel büschelig bis baumartig verzweigt: Äste und Ästchen kätzchenartig. Blïtter breit eiförmig, scharf zugespitzt, ungefaltet, an Rijcken etwas rauh; Rippe kurz, doppelt oder gegabelt 110. Pterogonium.

$\dagger+\dagger$ Hauptstengel kriechend, stoloniform. Sekundäre Stengel verlängert, verflacht beblättert, gefiedert. Seitenständige Blätter unsymmetrisch, zungenförmig, häufig querrollig. in den blattecken sehr klein und чuadraliseh

Neckeroideae.S. 410.

$++\dagger+$ Stengal kriechend oder niederliegend, unregelmässig oder dicht gefiedert. Blätter hohl, ungefaltet; Rippe fehlend oder ange(leutet: 13lattflügelzellen locker, quadratisch, eine gut begrenzte Gruppe bildend. Grundhaut des immeren Peristoms nicht oder kaum vortretend.

Âste drehrund beblättert. Blätter lanzettlich und scharf zugespitzt ...........

$\times \times$ Stengel und Xste verflacht beblättert.
Seitenständige Blätter selır hohl, stumpf

$\times$ Stengel und Aste verflacht beblättert.
Seitenständige Blätter selır hohl, stumpf

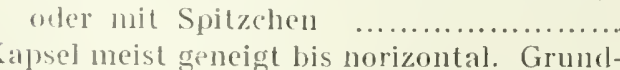
150. Platygyrium. 151. Entodon.

$f+t+$ Lapsel meist geneigt bis norizontal. Grumd-
haut des immeren Peristoms weit vort retend $\times$ l'aupstengel kriechend, z. T. stoloniform. Sekmudäre Stengel oberwärts biischelig und baumartig verzweigt. 
Blätter sehr hohl, ungefaltet, ei- oder länglich-cilörmig: Rippe einfach; Blattflügelzellen klein, quadratisch, eine gut begrenzte, ausgehöhlte Gruppe bildend. 111. Isolhecium.

$\times \times$ Stengel unregelmässig beästet bis \pm deutlich fiederästig.

Blätter symmetrisch; Rippe einfach; Blattliügelzellen differenziert.

$\mathrm{x}$ Stengel niemals unterbrochen stoloniform. Kapsel verlängert ellipsoidisch bis zylindriseh, gekrümmt. Peristomzähne gegen die Spitze oft treppenartig gezähnt. Deckel aus gewölbter Basis kurz kegelig, mit Spitzchen oder Warze ............ Amblystegiaceac. S. 149.

xx Stengel oft unterbrochen stolonilorm. Kapsel meist kurz, eiförnıig oder länglich und hochrückig, selten aufrecht und regelnässig. $\mathrm{Pe}$ ristomzähne nicht treppenartig gezähnt. Deckel kegelig, stumpflich oder gespitzt, oft lang gesehnäbelt. Brachytheciaceac.S.5012.

xxx Stengel niemals unterbrochen stoloniform. Blattflügelzellen klein, quadratisch, gelb- und dickwandig, eine nicht ausgehöhlte, loch an den Rändern sich hinaulziehende Gruppe hildend. Kapsel hochrückig, last zylindriseh. Deckel gewölbt kegelig, kurz und schief geschnäbelt

162. Rhytidium.

$\S \S$ Blattrippe doppelt oder fehlend.

$\mathrm{x}$ Stengel meist mit Stolonen; Äste meist verflacht beblättert. Seitenständige Blätter schief inseriert, zweizeilig abstehend, meist unsymmetrisch; Blattflügelzellen nicht oder nur wenig differenziert. Kapsel länglich bis zylindrisch. Deckel kegelig bis geschnäbelt ............ Plagiotheciaceac. S. 516.

xx Stengel stets ohne Stolonen. Blätter bald quer inseriert und symmetrisch, bald etwas schief inseriert und \pm unsymmetrisch: Blattflügelzellen differenziert. Kapsel länglich bis zylindrisch, \pm hochrückig. Deckel meist kegelig ...... Hypnacere. S. 559.

xxx Stengel stets ohne Stolonen. Blätter quer inseriert, symmetrisch: Blattflügelzellen meist nicht differenziert. Kapsel dick eiförmig oder oval bis länglich, nicht gekrïmmt. 
Deckel meist kegelig, selten gesehnäbelt Hylocomiaceae.S.575.

$+\uparrow+\uparrow+\dagger$ Hauptstengel rhizomartig. Sekundäre Stengel meist aufrecht. im unteren Teile mit schuppenartigen Niederblätter, oberwärts - baumartig verzweigt. Blattrippe einfach, meist unter der Blattspitze aufhörend. Laminazellen prosenchymatisch, in den Blattflügeln differenziert. Kapsel aufrecht, länglich-zylindrisch. Grundhaut des inneren Peristons sehr niedrig: Fortsätze schmal, längs leiterförmig klaffend; Wimpern fehlend

115. Climacium.

$\times \times$ Laminazellen oberwärts 1 undlich $4-$ 6seitig, in den Blattilügeln nicht differenziert. Kapsel geneigt bis horizontal, länglich-eiförmig, etwas hochrückig. Grundhaut des immeren peristoms sehr hoch: Fortsätze klaffend: Wimpern vollständig. mit Anhängseln

113. Thamnium.

$v$ Blüte gipfelständig an Hauptsprossen. Kapsel aufrecht, regelmässig, oval bis zylindrisch. Peristom einfach. aus dem ganzen inneren, kegelartigen Deckelgewebe hervorgehend. 4 dreiseitig-pyramidale Zellenzähne bildend

Georgiaceae. S. 219.

\section{Reihe FISSIDENTA LES.}

Längenwachstun mittelst zweiseitiger scheitelzelle. Blätter zweizeilig mit einem Dorsalflïgel und meist mit Rippe: Zelien meist parenchymatiseh. Peristom einfach; Zähne 16. meist 2schenkelig: Dorsalschicht dümner, mit Querleisten, meist grubig-längsstreifig.

\section{F I S S I E N T A C E A E.}

Gesellig wachscinde oder rasenbildende Pflanzen von farnwedelartiger Tracht. Stengel im Querschnitt oval, meist mit Zentralstrang. \pm dieht beblättert, einfach oder verzweigt, meist nur an Grunde mit Rhizoiden. Blätter genau zweizeilig. halbstengelumfassend, scheidig-kahnförmig, mit ungleich ausgebildeten Laminahälften, die kleinere nach der Spitze zu in der Fläche der grösseren endend; die oberen am Rücken der Rippe mit einem der grösseren Laminahälfte fast gleichen Auswuchs, Dorsalflügel genannt, der oberhałb des Scheidenteils mit der grösseren Laminahälfte den sogenannten Fortsatz bildet und welcher bei den unteren Blättern fehlt: Rippe \pm kräftig, mit basalen Deutern, 2- Stereidengruppen und grossen Innenzellen: Zellen fast gleichmässig. bei den europäischen Arten klein. rundlich1-6seitig. meist chloroplyyllreich und glatt. Perichätialblätter nicht oder wenig (lifferenziert. Blüte knospenlörmig, olne oder mit spärlichen, fadenförmigen Paraplaysen; Hüllblätter der Blïte ohne Dorsallügel. Seta meist verlängert. aufrecht, glatt. Kapsel kurzhalsig. aufrecht und regelmässig oder geneigt und \pm symmetrisch, trocken und entleert glatt: Spaltöffnungen oberflächlich, spärlich, am Kapselgrunde, selten iehlend. King differenziert, dem Deckelrande anhaftend. Peristomzähne rot, oherwärts hleich, am Grunde verschmolzen. meist bis zur Nitte und tiefer herab in 22 (3) priemenförmige Schenkel geteilt, aussen meist 
grubig-längsstreifig, mit dichtgestellten, \pm vorspringenden Querleisten, innen mit stark entwickelten Lamellen. Deckel kegelig bis geschnäbelt. Haube meist kegeloder kappenförmig, selten kegel-mützenförmig und mehrlappig. Sporen klein his mittelgross.

\section{FISSIDENS.}

Hedw. Fund. II. p. 91 (1782).

¿́bersicht der Arten.

A. Blätter mit engen Prosenchymzellen gesäumt.

a. Blätter wulstig gesäunt.

r. Polyözisch: Blüten zahlreich ....................21. F. Mildeanus.

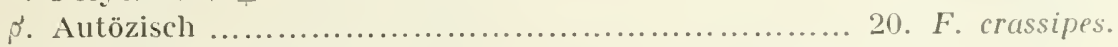

b. Blattsaum einschichtig und schmal bis z. T. fehlend.

«. Kapsel aufrecht bis schwach geneigt, regelmässig oder

fast regelmässig.

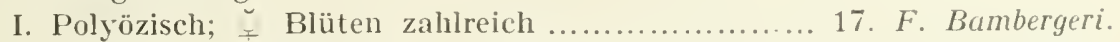

II. Autözisch; ç Blüten klein, gestielt, in den Achseln der Blätter ........................................16. F. bryoides.

III. Parözisch; Antheridien nackt in den Blattachseln. 16. F. bryoides var. gymnandrus.

IV. Diözisch.

1. Deckel fast von U'rneıiänge .................... 15. F. minutulus.

2. Deckel von halber Lirnenlänge ............. 16. F. bryoides var. viridulus.

ґ. Kaapsel geneigt bis horizontal, hoclırückig, entdeckelt gekrümmt.

I. Diözisch; c Pfl. beblättert ....................... 18. F. incurvus.

II. Rhizautözisch; $`$ Pfl. knospenförnig, der ₹ Pll. am Grunde anhängend

19. F. Haraldi.

B. Blätter ungesäumt. Fortsatz kürzer oder wenig länger als der Scheidenteil.

a. Sehr kleine Pfl. Blätter am Rande gekerbt

22. F. Bloxami.

b. Mehr odler weniger kräftige Pfl.

«. Beiderlei Blüten gịfelständig. Blätter am Rande gekerbt

23. F.osmundioides.

$\beta$. Blüten achselständig.

1. - grundständig. Blätter klein kerbig-gezähnelt. 24. F. taxifolius.

II. - Blüten aus oder oberhalb der Mitte des Jahrestricbes.

1. Blätter oberwärts = scharf und ungleich gesägt; Zellen am Rande in wenigen Reilien \pm stark verdickt, einen lichter- oder gelblich-gefärbten Saum bildend.

* Laminazellen $7-9$ ", dümmwandig ..........26. F. cristalus.

** Laminazellen $15-22 \mu$, dickwandig ........... 25. F. adiantoides.

2. Blätter mit schwach gekerbten, an der Spitze spärlich und undeutlich gezähnten Rändern ... 27. F. polyphyllus.

C. Flutende Wassermoose. Fortsatz 2-3mai so lang als der Scheidenteil 28. F. julianus. 
I n t e r g a t t. l. Eufissidens Mitt. Muse, austr. ant. p. 58! (1869). Stengel mit Zentralstrang. Fortsatz etwa von der Länge des scheidigen Teiles. Seta verlängert, meist giplelständig. Kapsel mit Spaltöfnungen. Periston vollständig. Haube meist einseitig aufgeschlit\%. - No. 15- 27.

Se e t. 1. Bryoidium C. Müll. Gen. musc. p. 56 (1901): emend. Broth. in Engl.-Prantl Bryal. p. 353 (1901). Kleine, meist freudig grüne Erdmoose, selten Felsbewohner. Blätter weich, überall gesäumt: Saun einsehichtig. Peristomzähne mit spiralig verdickten Schenkehn. - No. I.j-19.

15. Fissidens minutulus Sull. in Mlem. Amer. Acad. n. Ser. 111. p. 58, t. 3 (18.18). [Schistoplyyllum pusillum Lindb. Musc. scand. p. 13 (1879). Sch. minululum Lindb. Medal. Soc. Faun. Fl. Fenn. 14. Heft. p. 70 (1887).]

Diözisch: p pfl. meist beblättert, kleiner als die + Pfl., mit ungesäumten Blïtlern. Sehr kleine, grüne, gesellig und herdenweise wachsende Pfl. Stengel 13. selten bis $5 \mathrm{~mm}$. Blätter meist 3-5paarig, trocken einseitswendig, obere schmal lanzettlich, scharf zugespitzt, bis $1 \mathrm{~mm}$ lang: Dorsalflügel vollständig, allmählich versclunälert: Rippe vor der Blattspitze aufhörend: Zellen 8-12 4 ; Saum 1 reihig, ziemlich weit vor der Blattspitze aufhörend, im Scheidenteil 3- כreihig. Seta 2 - 1 mm, gelblich oder blassrot. Kapsel aufrecht oder etwas geneigt, regelmässig, eiförmig bis länglich, trocken und entdeckelt unter der llündung eingeschnürt. Deckel fast von Urnenlänge.

Felsbewohner, besonders an Sandsteinen und Kalkfelsen.

F. Al. Saltrik, Kvarnbo, auf sandstein in Bächlein spärlich (Bom.).

S. sk. Bosjö kloster. $\mathrm{rg}$. Kinnekulle.

N. A. Kristiania. , $L$. Drammen. Bu. Eker. Lillel,y. Br. Brevik, Ringerike, Buruil.

England. Nord-Amerika.

16. Fissidens bryoides (L.) Helw. Fund. 11. p. 91 (1782). |Hypnum bryoides L. Sp. pl. Il. p. 1123 (1753).]

Autözisch: ॠ Blüten achselständig, kurz gestielt. Schlanke Pfl. in meist dichten, llachen Rasen. Stengel meist niedergebogen, bis $1 \mathrm{~cm}$. Blätter bis 12paarig, trocken einseitswendig, obere länglich-zungenlörmig, schnell zugespitzt, meist mit Stachelspitze, bis $2 \mathrm{~mm}$ lang; Dorsalflügel vollständig, allmählich verschmälert; Rippe in der Stachelspitze aufgelöst oder kurz austretend; Zellen 7-12 "“; Saum 2-3reilig, im Sclieidenteil breiter, vollstindig oder kurz vor der Blattspitze aufhörend. Seta bis $12 \mathrm{~mm}$ lang. rot. Kapsel aufrecht, regelmässig, eiförmig bis länglich, trocken mnd enfieche! unter der Iündung verengt. Deckel von halber Urnenlänge. Sporenreile im Herbst.

Auf nackter Erde, an Weg- und Grabenrändern.

F. H. Sall vik. in der Nahe des Pfarhauses. - K. Kiusamo. Paanajarvi, Kuoppaoja (Broth.).

S. sk., sm., Ög. und Boil. an mehreren und När, itn wenigen Fundorten. - Dld. Rostock. - Ang. Tăsjö.

N. Sm. Flemunge und Onsi, JL. Sanderjord, $R$. Geiranger und Bud. SB. Bergen. NT. Nedre stjirdalen an mehreren Fundorten. - - Vo., $T r$. und $F$, an einzelnen Fundorten. Nordgrenze bei $70^{\circ} 25 \cdot \mathrm{n}$. Br.

Europa, kankasuc, Irimalaya. Sibirien, Nord-Anerika.

var. viridulus (Sw.). |Dicronum viridnlum Mlusc. suec. p. 8t, t. 2, 1. 3 (1799). Fissidens viridnlus Wahleub. F1. lapp. p. 334 (1812). Schislophyllum incurvum * Sch. viridulum Lindb. Musce. scand. p. 13 (1879). Fissidens bryoides var. Hedvigii Limpr. Laul)m. I. i). 129 (1887).I

Diözisch; ‘ Pfl. klein, knospenförmig im IRlizoidenlilze oder länger. Blätter 4 -8paarig, bis $1,4 \mathrm{vmm}$ lang; Saum schwächer. - Fig. $3 \mathrm{~A}-\mathrm{B}$.

An ähnlichen Standorten wie die Hauptart, besonders auf toniger Erde.

F. 1 . Siltvik, an viclen Fundorten (Bom.). Sund. Kastelholm und Vestra kyrksundet (B.). Ab. Abo (kars1., Lund:lr., Lifv.). Pikkis, Bacarla (\%etl.). Lojo, hiviniemi (Lindb.); Lylyis (E. af II.). Vichtis (W. Nyl.). - N. Helsingfors an mehreren Fundorten (Lindb.). Helsinge, Malm (Broth.). Sibbo, 
Löparö (Buch). Elimäki, Mustila (Tigerst.). - Ta. Asikkala, Kailas und Laitiala sl. f(f. (Norrl.). - Sa. Taipalsaari (Simm.). Ruokolahti, Imatra (Kullh.). - Kl. Sorlavala. Tulolansaari (I1. Backm.); Kirjavalahti, Kotomäki (Lindb.). - Tb. Jyväskyla (Broth.); Lohikoski (Vain.). - Sb. Maaninka, Tuovilanlahti. Haatala, an mehreren Fundorten (Roiv.). - Kb. Tohmajärvi, Hicumaki (Broth.). - Kon. Kentjärvi (Simu.). Tiudie (Kullh.). - Ok. Kajana (Lacksır.). Sotkamo, Naapurinviari (L.). - Kpom. Paadana (Sahlb.). - K. Kuusamo, Kitkajoki (Brolı.). Merenoja (B.).

var. gymnandrus (Bus.) Ruth. in Hedwigia 1870, p. 178. (Fissidens gymnandrus Bus. Musc. Nearl. exs. Fase. IV. No. 77 et Annuar. Soc. bot. Neerl.)

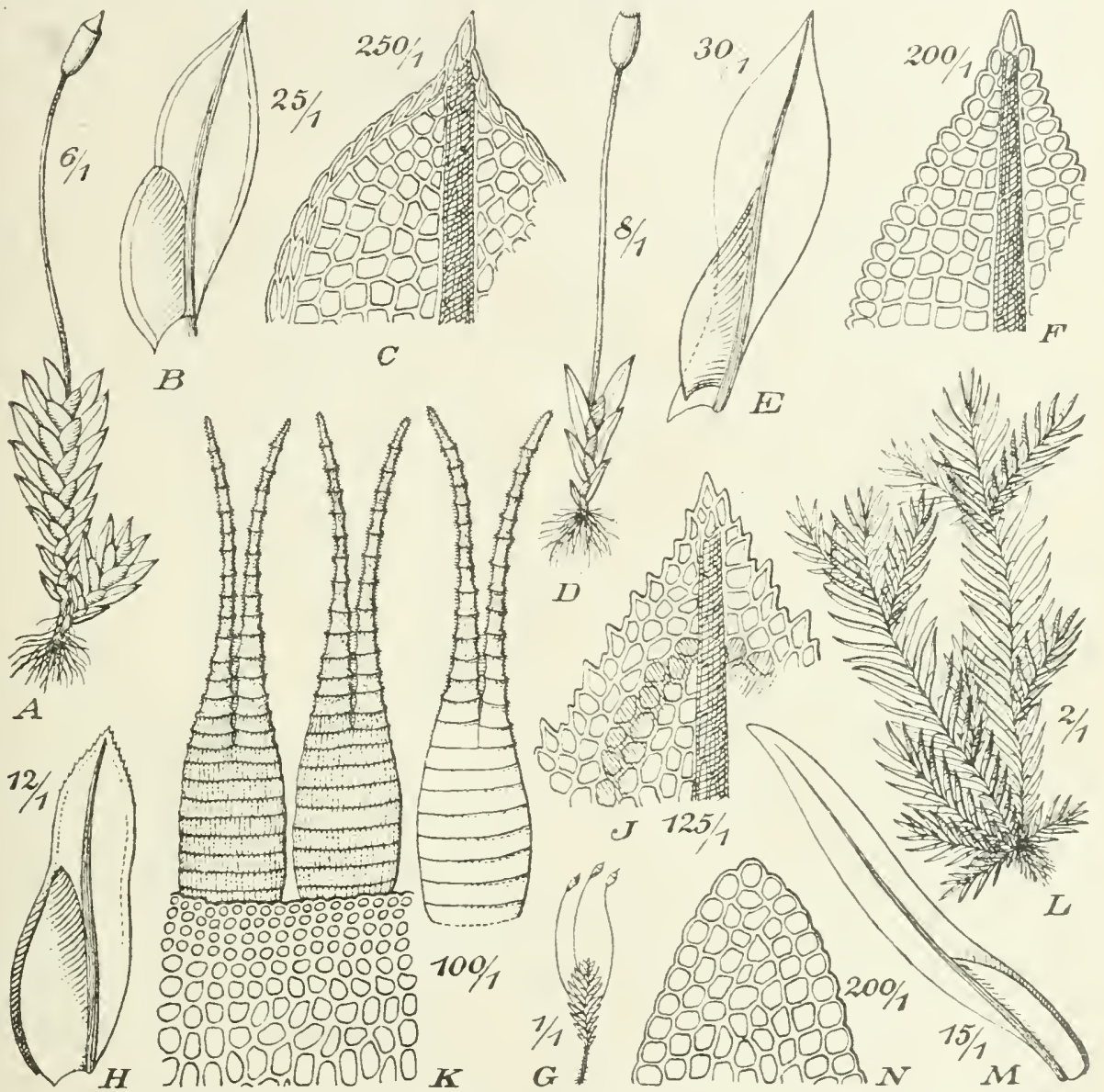

Fig. 3 A-B Fissidens bryoides var. viridulus (Sw.). A Fruchtende Pfl. (6/I); B Stengelb. (25 I); C - D F. Bloxami Wils. C Fruchtende Pfl. (8/1); D Stengelh. (30/1). - E-G F. adiantoides (L.). E Fruchtende Pfl. (1/); F. Stengelb. (12/1); G Peristom $(100 / 1)$.

Parözisch; Antheridien 1-2 nackt in mittleren und oberen Blattachseln,

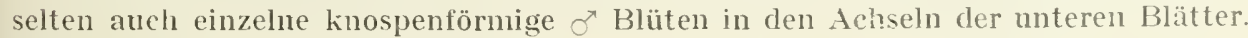
Grösse und Tracht der Hauptart.

Auf Steinen und Holz in der Nähe der Wehre und Wasserfülle, selten auch in Felsritzen.

F. Al. Liby, in einer Felsritze (Bom.). - $I k$. Uusikirkko, Kaukjärvi, Tommila (H, Lindb.).

N. Bu. Hunefos, Ringerike. Heen.

Europa, Japan, Nord-Amerika.

17. Fissidens Bambergeri Schimp. in litt.; Mild. in Botan. Ztg. 1864, Beil. p. 12. 
Polyözisclı; $\subsetneq$ Blüten gipfelständig, zuweilen ausserhalb der Hïllblätter nackte Archegonien, einzeln oder in Gruppen mit Antheridien, selten Sprosse mit cr Blüten aus älteren Stammesteileı. Gesellig oder in kleinen, lockeren, grünen, später gelbgrüneı Räschen wachsende Pfl. Stengel 2-3 mm, niedergebogen. Blätter 4-12paarig, niedergebogen, zungen-lanzettförmig, meist plötzlich kurz zugespitzt, mit Stachelspitze, bis $1.6 \mathrm{~mm}$ lang; Dorsalflügel der oberen Blätter nicht vollständig: Rippe vor der Stachelspitze verschwindend bis vollständig: Zellen in der Mehrzahl 7-9 " Scheidenteil 1-5reihig. Seta bis $1,5 \mathrm{~mm}$, rötlichgelb. Kapsel aufrecht regelmässig, oval, trocken und entdeckelt unter der Mündung stark verengt. . Deckel von mehr als halber Ưrnenlänge.

N. A. Kritiania, Allergodt, in tonigem Acker. Bu. Ringerike, Heen.

Tirol.

18. Fissidens incurvus Stark. Mser. in Web. et Molnr Bot. Taschenb. p. 161 (1807). [Schislophyllum incurvum Lindb. Musc. scand. p. 13 (1879).]

Diözisch; c Pfl. beblättert, entweder an Gruncle der rasen eingesprengt. Kleine Pfl. in lockeren, flachen, grimen Rasen. Stengel niedergebogen, bis 5 mm. Blätter bis 10paarig, einseitswendig, obere schmal lanzettlich-zungenförmig, rasch zugespitzt, an der Spitze meist gezähnelt, bis $1 \mathrm{~mm}$ lang: Dorsaliflügel vollständig, allmählich verschmälert; Rippe vor der Blattspitze aufhörend bis kurz austretend; Zellen 8--10 $\mu$; Saum 1--2reihig, vor der Blattspitze aufhörend, im Scheidenteil verbreitert. Seta bis $7 \mathrm{~mm}$, rötlichgelb. Kápsel geneigt bis horizontal, hochrückig, oval bis länglich, entdeckelt gekrümmıt und schiefmündig, unter der Mündung nicht verengt. Deckel etwa von halber Urnenlänge. Sporenreife in Herbst.

S. Sm. und Vär. an mehreren Fundortun. Boh. Gustafsberg.

N. In den Ungebungen von Kristiania fq.

Europa, Iadeira, Nord-Afrika, Kaukasus, Nord-Asien, Nord-Amerika.

19. Fissidens Haraldi (Lindb.) Limpr. Laubm. III. p. 670 (1901). (Schislophyllum Haraldi lindb. in Bot. Notis. 1887, p. 40.)

Rhizautüzisch: " Pfl. knospenförmig, der Pfl. an der Basis anhängend. Kleine, herdenweise wachsende, weiche, braungrüne Pfl. Stengel niedergebogen, bis j $\mathrm{mm}$. B]ätter bis 10paarig, einseitswendig, obere schmal lanzettlich-zungenförmig, rasch zugesjitzt, bis 1 mm lang, an der Spitze meist gezähnelt; Dorsalflügel vollständig, alimählı h̀ verschmälert: Rippe zarter als bei der vorigen Art, vor der Blattspitze auflörend his kurz austretend; Zellen etwa 15 " ; Saum sehr zart, weit vor der Blaltspitze aufhörend. Seta bis $7 \mathrm{~cm}$, rötlichgelb. Kapsel geneigt, hochrückig, oval bis länglich, cntdeckelt gekrümmt und schiefmündig, unter der Iündung \pm verengt. Deckel von halber Urnenlänge.

F. Ab. Lojo, Antila, sol hem, auf feuchter, nackter, toniger Erde (H. und S. O. Lindb.).

S e c t. I I. Pachylomidium C. Müll. in Flora 1897, p. 327 et Gell. musc. p. 60 (1901).

Mehr oder weniger kräftige, kalkliebende Wassermoose. Blätter überall gesäumt; Saum wulstig, zwei- bis mehrschichtig. Peristomzähne mit spiralig verdickten Schenkeln.

20. Fissidens crassipes Wils. Mscr. in Bryol. eur. fasc. 42, t. suppl. 1 (1849).

Meist diözisclı; $\Upsilon^{\top}$ Pll. beblätlert. Ziemlich kräftige l’fl. in lockeren, dunkelgrünen Rasen. Stengel anfrecht, $1-2 \mathrm{~cm}$. Blätter vielpaarig, obere lanzettlich, 士 lang zugespitzt, his 2.,3 mm lang; Dorsalflügel vollständig, am Grunde sehr schmal und ungesäimut: Rippe vor der Blattspilze auflörend; Zellen 10-12 " ; Saum kräftig, im Alter gebräunt, in Scheidenteil nach unten verbreitert, vor der Blattspitze crlöschent. Seta 5-10 mm, rötlich. Kåpsel aufrecht oder ein wenig 
geneigt, regelmässig, länglich-eiförmig, trocken und entleckelt unter der Mündung eingeschnürt. Deckel von mehr als halber Urnenlänge. Sporenreife im Herbst.

An von Wasser bespülten Steinen.

F. Ta. Padasjoki, Osola (Vain.). Luhanka, Kotkalahti (V.). Korpilahti. Rutalahti (V.).

S. Sk. an mehreren Fundorten.

Vittel- und Süd-Europa, Algịer.

21. Fissidens Mildeanus Schimp. in litt.; Mild. in Bot. Zeit. 1862, p. 159.

Polyözisch; $\breve{q}$. $\mathcal{C}^{\top}$ und $q$ auf derselhen Pfl. Ziemlich kräftige Pfl. in niedergedrückten, schmutzig grünen, später bräunlichen Rasen. Stengel aulsteigend, bis $3 \mathrm{~cm}$. Blätter vielpaarig. ziemlich gleichgross, elliptisch-lanzettlich, scharf zugespitzl, bis $3 \mathrm{~mm}$ lang; Dorsalflügel abwärts verschmälert, in 2 Reihen die Insertion erreichend; Rippe dick, vor der Blattspitze endend; Zellen 10-18 "; Saum wulstig, bis 1-6reihig, zwei- und mehrschichtig, vor der schwach gezälınten Spitze aufhörend, im Alter bräunlich. Seta 7-10 mm, rot. Kapsel aulrecht oder schwach geneigt, regelmässig oder schwach gekrümmt, verkchrt-eiförmig, entdeckelt oval, bräunlich. Deckel von mehr als halber Lrnenlänge. - Vegetative Vermehrung durch kugelige, an der Spitze von braunen Rhizoiden gelegene Zellen und durch keulenförmige, mehrzellige, in den Achseln der oberen Blätter gelegene und von paraphysenartigen Haaren umgebene Brutkörper.

N. JL., Sande, an Steinen im Bache.

West- und Zentral-Europa.

S e c t. I I I. Aloma C. Miill. Gen. musc. p. 61 (1901); emend. Broth. in Engl.Prantl Bryal. p. 357 (1901).

Blätter weich, ungesäumt, durch hervortretende Zellen \pm deutlich gekerbt. Peristomzähne mit spiralig verdickten Schenkeln.

22. Fissidens Bloxamii Wils. in Lond. Journ. Bot. p. 19 5, t. 9. [Fissidens exilis Hedw. Sp. musc. p. 152 ex. p. Schistophyllum exile Lindl). Musc. scand. p. 13 (1879). Sch. Bloxami Lindb. in Meddel. Soe. Faum. Fl. Fenn. 14. Heft. p. 71 (1887).]

Diözisch; $r^{7}$ Pfl. sehr winzig, knospenförmig, am Grunde der f Pfl. oder isoliert im Rhizoidengeflecht. Sehr kleine, herdenweise wachsende, grüne oder gelbgrüne Pfl. Stengel $1-2 \mathrm{~mm}$, einfach und niedergebogen. Blätter 3 -1paarig, die unteren sehr klein, das oberste Paar viel grösser, und trocken abwärts gebogen, lineal-lanzettlich, bis $1,2 \mathrm{~mm}$ lang, durch vortretende Zellecken kerbig-gezähnelt; Dorsalflügel nach unten verschmälert und oberhalb der Blattbasis aufhörend; Rippe kurz vor oder mit der Blattspitze endend; Zellen unregelmässig mehreckig, 12-18 ", glatt, am Grunde rektangulär. Seta 3-5 mm. bleich bis rötlich. Kapsel sehr klein, aufrecht und regelmässig, länglich-eiförmig trocken und entdeckelt unter der Mündung eingeschnürt. Sporenreife zeitig im Frülıjahr. - Fig. 3 C-D.

Auf schattigen, tonigen Eroblössen an Grabenböschungen, in Schluchten und Höhlungen.

F. Al. Saltvik, Kvarnbo, am Bache reichl. (Bom.); Lillaker, Liby und Hullly (B.). Sund, Tosarby (B.). - Ab. Lojo, Kiviniemi (H. und S. O. Lindb.); Lylyis (E. af H.): Hevonsaari (H. Lindb.). - N. Heìsingfors, Fredriksberg (Buch). Helsinge, Gumtäkt (Lindb.); Backas (Ranck.). Elimäki, Mustila (Buch). - St. Hämeenkyrö, Kyröskoski (Simm.). - Ta. Kalvula (Knab.). Sääksmäki, Hunna (Nerv.).

S. Sk., Sm., Öl., Boh., Srm., Upl. und Ism. an einzelnen oder wenigen Fundorten.

N. A. Kristiania. Sm. Glemminge.

Europa.

S e c t. I V. Serridium C. Müll. Gen. musc. p. 67 (1901).

Mittelgrosse bis sehr kräftige, starre Pfl. Blätter ungesäumt, oberwärts meist gesägt. Peristomzähne mit knotig verdickten Schenkeln. - No. 23-27.

23. Fissidens osmundoides (Sw.) Hedw. Sp. musc. p. 153, t. 40, f. 7-11 (1801). [Dicranum osmundoides Sw. in Act. Holm. 1795, p. 240. Schistophyllum osmundoides Lindb. Musc. scand. p. 13 (1879).] 
Diözisch: - Pfl. schlanker. Schlanke Pfl. in dichten, meist lebhaft bis dunkelgrünen Rasen. Stengel aufrecht, $1-3 \mathrm{~cm}$, selten höher. Blätter vielpaarig, trocken einseitswendig, eilanzettlich bis fast zungenförmig, stumpflich, mit Stachelspitze, etwa 1,7 mm lang, durch vortretende Zellecken kerbig-gezähnelt; Dorsalflügel an Grunde plötzlich verengt und abgerundet; Rippe vor der Blattspitze aufhörend; Zellen 15-20 " a, am Grunde rektangulär. Seta 7-12 mm, rot. Kapsel aufrecht oder wenig geneigt, regelmässig, verkelırt-eiförmig, (lerblıäutig, rotbraun, trocken und entleert mnter der erweiterten IIündung eingeschnïrt. Haube kegel-mützenförmig, mehrlappig, wenig unter den Deckel reichend. Sporenreife im Herbst.

Auf feuchter, torfiger Erde und in Sümpfen, an Bach- und Seenfern, auf feuchter Erde am Fusse der Felsen und in erderfiillten Felsspalten. Nordgrenze auf Spitzbergen.

F. Al. Eckerö. Jomala, Geta und sund an einzelner, Saltvik an mehreren Fundorten (Bom.). Ab. Nidendal (Arrh.). Pargas, Lindberg (Elfv.). Karislojo (sundr.); Täsväri (Broth.). Lujo, Kirchdorf und Lylyis (Lindb.): Kalkkisari (E. af H.). Pusula, Käkölä (Broth.). - N. Kyrksłatt (Nyb.). Esbo. Lângträsk (Ranck.). Helsingfors (II. Ny̧l.). Hogland (Lindb.). 一 Ka. Sippola, Ruotila, Pitkäkoski (Kuj.). Wiborg. Juustila (Buch); Lalo, Soskuanjoki (B.). Antrea. Hatula (Lindb.), - Ik. Muoli, Perkjärvi (H. Lindb.). - St. Mynamäki (A. K. Caj.). Ulfsbỵ (Nerr.). - Ta. Hattula. Nilzattula (Ranck.). Im südöstl. Teile pass. (Norrl.). Fartola (Bonsd.). Luhanka und Kurpilahti pass. (Vain.). - Sa. Willmanstrand (Buch). Fangasniemi (Lachstr.). Nyslott (Carl.). - hl. Kurkijoki, Oraska (Jusl.). Valamo (Jusl.). Sortavala (simm.); Kirjavalahti (Norrl.). Suistamo, Leppäsỹä (Pes.): Jänisjärvi ([3rotlı.). Impilahti. Pullinvuori (Broth.). Pälkjärvi. Kuhilasvaara und Pilkäniemi (B.). - Kol. Salmi, Pallivaara (Pes.). Vusnessenje (Elfv.). - Ua. Närpes. Benvik (Nerr.). - Tb. Virrat, Torisera (Brolh.). Jỵväskylä, Haapakoski (B.). Laukaa (B.). Viitanari (B.). Kinnula, Kirchdorf. savijärvi (Roiv.); Kivijärvi, Muhola (R.). Pihtipudas, Kolimajärvi (R.); Heinola, Lieson puro (R.); Elämäisjarvi (R.): lluurasjärvi, Kotalahti (R.). - Sb. Kuopio pass. (Link.). Kaavi, Siikajàrvi (Kot.). Nilsiä, Louttemen und Konttimäki (K.). Maaninka und Pielavesi pass. (Ruir.). - kb. Pielisjärvi, Koli (Linn.). - Kon. Pirttiniemi (Kullı.). Käppäselkä (Simn.). Perguba (Sel.). - Ok. Kajana (Lackstr.). Sotkamo. Hepolahti (Kỵhk.). PuoJanka (Lackstr.). - Kp. Suondali (Bergr.). - Ol. Simo (H. Lindb.). Pudasjarvi (Nyb.), 一 K. Kuusamo, an vielen Fundurten (Broth., E. af H.). - Lkem. Kittilä, nördl. vom Kirchdorf (Ifult): Pallastunturit, in der Fichtenreg. (H.); Muonioniska (Norrl.). Kuolajärvi, Sallatunturi (E. al M.); Kotala und Jungoivi (Linn.). - Le. Pättikio und Kilpiskoski (Norrl.); Kilpisjö, vi, Malla und Saana (Kot.). - Li. Inari und Utsjoki, in der Nadelwalılreg. pass.. in der Birkenreg. st. r. (Hubt). 一 Lim. Kandalaks (Broth.). Umpjok. Kitschakoski (Kihlm.). Ifibinä (Broth.): Partom-tschor, in der wheren alp. Reg. (Kihlın.). - Ll. Nonkijok, Lasschjäsr (Roir.). subori (Broth.). - Lmur. Teriberka (Broth.). — Lp. Lumbossk (Brenn.). Panfelorka (Br.). Ponoj ( $\mathrm{Br}$.).

S. $\therefore i k-L$.

N. sm. $-F$.

Europa. Sibirien, nuitl. Nord-Amerika.

21. Fissidens taxifolicis (L.) Hedw. Fund. 11. p. 91 (1782). |Hypnum taxifolium L. Sp. pl. II. p. 1122 (1753). Schistophyllum taxifolium La Pyl. in Desv. Journ. Bot. 1813, p. 60, t. 35, f. 10.]

Diözisch, selten autözisch mit grundständigen \& Blüten. Weniger schlanke Pfl. in lockeren bis dichten, flachen, dunkel- oder bläulichgrünen Rasen. Stengel bis $2 \mathrm{~cm}$, rom Grunde aus büschelästig, mit meist niedergedrückten Ästen. Blätter vielpaarig, trocken einseitswendig, länglich, rasch zugespitzt, durch die austretende Rippe stachelspitzig. bis $1,8 \mathrm{~mm}$ lang, durch vortretende Zellecken kerbiggesägt; Dorsalflügel am Grunde plötzlich verengt und etwas herablaufend; Zellen $9-151$, am Rande meist lichler gefärbt. Seta aus dem Stengelgrunde, $1-1,5 \mathrm{~cm}$, rötlich. Kapsel geneigl bis horizontal, länglich, etwas gebogen, sehr dickwandig, rötlichbraun, trocken und enllecrt unter der erweiterten Münchung deutlich eingeschnürt. Sporenreife im Spätherbst.

Auf sandig-tonigen und lełnnig-kalkigen Er(lblössen an Ablüngen und Grabenränderı.

F. Al. Saltvik, an vielen Fundorten (Bum.). Sund, aum Bache zw. Björby und dem Pfarrhause (B.). - Ab. Reso, Luonnonmaa (Högm.). Kustö (Lundstr.). Lojo, Ǩiviniemi und Ojamo (Lindb.).

S. Sk. und Sm. an inehreren, Og., lg., Nä. und $\boldsymbol{l l l}$. an wenigen Fundorlen.

N. sm., A., Bu. und $N T$. an wenigen Fundorten.

Europa, Kaukasus, Persien, Japan, Nord-Amerika. 
25. Fissidens adiantoides (L.) Hedw. Fund. II. 1).91 (1782). [Hypnum adianthoides L. Sp. pl. II. p. 1123 (1753). Schislophyllum adiantoides N. mse. in Brid. Bryol. univ. [I. p. 703 (1827).]

Diözisch, selten antözisch; beiderlei Blüten fast stets achselständig. Kŕäftige Pfl. in lockeren oder dichten, grünen, in Alter braungrünen, abwärts rotlïzigen Rasen. Stengel anfrecht, bis $10 \mathrm{~cm}$, selten höher, einfach orler reich verzweigt. Blätter vielpaarig, trocken einseitswendig, breit lanzettlich, alluählich oder rasch zugespitzt, bis $3 \mathrm{~mm}$ lang, rings dureh vorspringende Zellen klein gezühnt, an der Spitze scharf und ungleich gesägt; Dorsalllügel an Grunde oft wellig, meist plützlich verengt und etwas herablaufend; Rippe vol oder mit der Blattspitze aulhörenı; Zellen 15-22 $\mu$, an Rande bäufig 2-t Reihen stärker verdickt und lichter gefärbt. Seta aus der Mitte des Jahrestriebes, $1-2,5 \mathrm{~cm}$, rot. Kapsel geneigt, länglicheiförmig, etwas gebogen, braun, sehr dickwandig, troeken und entleert unter der erweiterten Mündung deutlich eingeschnürt. Sporenreife in Spätherbst. - Vegetative Vermehrung dureh am Grunde wurzelnde, sich leicht ablösende İste. Fig. $3 \mathrm{E}-\mathrm{G}$.

Auf Sumpf- und Moorwiesen, feuchter Erde, an Bach- und Seeufern, in Sehluchten und an feuchten Felsen, an Steinen in Bächen und Stromschmellen.

F. Al. St. fg. (Bom.). - Ab. Kurpu, Bemby (Elfr.). Sbo (Zett.). Nadendal (Elfr.). Reso (A. H. Caj.). Pargas, Skräbböle und Taras (Elfr.). Mynämäki (A. K. Caj.). Karislojo. Karkali und Tesjärvi (Sundv.); Punjarvi (E. af H.); Tammisto (E. af H.). Lojo, an vielen Fundorten (Lindb., E. af H., Sundv.). Vichtis, liauppilanvuori (Làg), - V. Ekenäs (Häyr.): Trärminne (H.). Ingả, Verkhohm (V. Brenn.). Sjundea (Sundr.). Esbo, Krarnbäck, Bemböle (s.). Helsingfors (Lindb.). Helsinge, Backas (Ranck.). Sibbo, Löparö (Bucl). Borgí (Sael.). Pernit, Sarfsalö, Horşök (Tennh.). Elimäki (Tigerst.). - Lia. Sippola, Ruotila (Kuj.). Wiborg. Lalo, Soskuanjoki (Bucls). Kirru, Sairala (Lindb.). - Ih. Rautus, Raasuli (H. Lindl.). - St. Pirkkala (Simm.). Kankaanpää, Päivike (Nerr.). - Ta. Hattula, Yli-Savijärvi und Nihattula (Ranck.). Kalvola (Knab.). Im südöstl. Teile pass._-st. r. (Norrl.). Hartola (Bonsd.). Luhanka und Kiorpilahti st. r. - pass. (Vain.). - Sa. Willmanstrand (Buch). Taipalsaari (Simnı.). Kangasniemi (Lackstr.). - Kl. Käkisalmi (Tommı). Kurkijoki, Ohtjärvi (Lind.). Kirjavalahti (WI. Nyl., Norrl.). Impilahti, Vípula (H. Backm.). Ruskeala (Link.). Soanlahti, Jokihaara (L.). Suistamo, Jalovaara (L.). Pälkjärvi, Annoniemi (H. Backm.). - Kiol. Salmi, Leppälä (Pes.). — Tb. Jyväskyla (Broth.). Pihtipudas, Kolimajärvi, Ahrenberg (Roiv.): Kianalamäki, Tussavainen (R.). - Sb. Lejpävirta (Lundstr.). Heinävesi, Palokki, Kultaniemi (Kot.). Kuopio, an wenigen Fundorten (Link., Kyylik.). Kaavi, Siikajärvi, Likosaari (Kot.). Nilsiä, Loutteisenpuro und Rahasenmäki (Kyyhk.); Loutteinen (Kot.). - Kb. Juuka, Juuanvaara (Kot.). Pielisjärvi, Koli (Linnan.). - Kol. Suojärvi (Norrl.). Jalguba (Kullh.). Kivatsch (Sel.). Santali (Sel.). Pirttinjemi (Simm.). - Om. Lappajärvi, Isoniemi, Nenlaniemi (Backm.). - Ok. Kajana (Lackstr.). Paltamo. Melalahti, Äijökallio (L.). Ristijärri (L.). Kpom. Suontelejoki (Bergr.). - ob. Iudasjärvi, Askanjoki (Nyb.). Ylitornio, Mlekojärvi (Hult); Laarasnäs (H.). - h. Kuusamo, an vielen Fundorten (Kiarst.. Broth., E. af H.). - ki. Kinjäscha (Sel.). Lkem. Kunlajärvi, Perävaara, Petserioja (E. af 11.). - Li. Inari, Vaskojoki, auf steinen in den strontschnellen (Ifult). - Lim. Porjaguba (SeI.).

S. $S k,-L$.

N. Sm. -F. Nordgrenze bei $70^{\circ} \mathrm{n}, \mathrm{Br}$.

Europa, Algier, Nord-Amerika.

26. Fissidens cristatus Wils. in Kew Journ. Bot. 1X. p. 29-1 (1857). [Fissidens decipiens De Not. in Piceone Elench. musch. lig. No. 181 (1863). - Schistophyllum decipiens Lin(lb. Muse. seand. p. 13 (1879).]

Diözisch, selten autöziseh, beiderlei Blïten last stets achselständig. Ziemlich schlanke, seltener \pm kräftige Pfl. in meist dichten, grünen, im Alter braungrünen. abwärts rotfilzigen Rasen. Stengel aufrecht, bis $3 \mathrm{~cm}$, selten höher, einfach oder verzweigt. Blätter vielpaarig, trocken einseitswendig, lanzettlich, allmählich oder rasch zugespitzt, schmäler als bei ter vorigen Art, bis $4 \mathrm{~mm}$ lang, tiefer herab scharf und ungleieh gesägt; Dorsalflügel und Rippe wie bei ter vorigen Art: Zellen der $7-9$ ", am Rande 3-4 Reihen stark verdickt und lichter gefärbt. Seta meist nur 1 cm. Kapsel kleiner. Sporen $12-15 \mu$. Vegetative Vermehrung wie bei der vorigen Art.

An trockenen Kalkfelsen und in deren Spalten, jedoch auch auf kalkärmerem Gestein und auf kalkhaltigem Erdboden. 
F. Al. Lemland. Forrby (Bom.). Saltrik, an vielen Fundorten (B.). - Ab. Karislojo, Karkali Lindb.). - .. Inga. Orslandel. Persholm (V. Brenn.). Hogland (Lindh.).

S. Sm.. Oi!.. Gil., Boh.. Ind.. Irm.

N. sm. Onso. L.M. Nederes. St. Rṛfylke.

Europa, Kaukasus. Himalaya. Java. Ost-Asien.

27. Fissidens polyphyllus Wils. Mser.: Bryol. eur. fasc. $46 / 47$ Suppl. t. 3 (1851).

Diözisch: beiderlei Blüten achselständig. Sehr kräftige Pfl. in lockeren oder dichten. grünen bis gelb- oder bräunlichgrünen Rasen. Stengel meist niederliegend ocler hängend. bis 15 cu. zuweilen noch länger, abwärts rotfilzig. Blätter vielpaarig. flach bis einscitswendig. sclımal und verlängert lanzettlich-zungenförmig, stumpflich, bis 5-b mm lang. mit schwach gekerbten, oft au der Spitze spärlich und undeutlicls gezälnnten Rändern; Dorsalflügel an Gruncle abgerundet; Rippe kräftị̣, dicht vor der Blattspitze aufhörend: Zellen 1 -6eckig, rings verdickt, in ler Mitte etwa 16 " und am Rande in mehreren Reilhen nur etwa $9 \mu$, am Grunde $20-26$ "

An feuchten Felsen.

N. $\therefore$. Flekkefjord.

Wales, Irland. Pyrenden.

L n t e rgat t. I I. Octcdiceras (Brid. Sp. Musc. 1. p. 162: 1806 als Gattung) Mitt. Musc. austr. am. p. 581 (1869).

Flutende. schlaffe $\mathrm{M}^{\mathrm{a}}$ assermoose. Stengel fadendüm, ohne Zentralstrang, reich büschelästig: Ïste an Grunde mit Rhizoiden und sich leicht ablösend. Blätter ungesäumst: Fortsatz 2-3mal so lang als der scheidige Teil. Fruchtast verlängert. Sporogon mit kurzer. fleischiger Seta. bei der Reife über dem Scheidchen abbrechend. Kapsel sehr klein. regelmässig. ohne Spaltöffnungen. Haube kegelförmig. kïrzer als der Deckel.

28. Fissidens Julianus (Sar.) Schimp. in Flora 1838, P. I. p. 271. [Fontinalis Juliana Sar. Bot. etrusc. III. p. 107 (1818). Octodiceras Juiianum Mlont. Ann. sc. nat. 1837, p. 246. t. 4. Schistophyllum Julianum Lindb. Nusc. scand. p. $13(1579)$.

Autōzisch: alle Blïten achselständig. Dunkelgrüne Pfl. Stengel bis $8 \mathrm{~cm}$, selten länger. Blätter locker gestellt. am Grunde schuppenförmig, die übrigen verlängert linealisclu. stumpflich. ganzrandig. bis 3-1 mın lang; Dorsalflügel die Blattbasis nicht erreichend: Rippe dünn. ziemlich weit vor der Blattspitze aufhörend: Zellen in der Blattnitte $15-30$ " . an der Rippe weiter und kurz rektangulär. nach den Rändern kleiner. Peristomzähne gelbrot, breit, nach oben nicht verschmälert. an der breitgestutzten Spitze unregelmässig durchbrochen und gespalten. grob papillös.

An Steinen und Baumwurzeln im Wasser.

F. Ik. Kivennapa. an Ǔfer zw. Afanati und Kĩukkala, allerlei anfgeworfenen Pflanzenresten beisemischt $(H$. Lindb.).

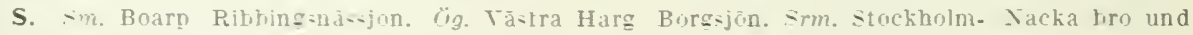
siderbysjo. L"pl. stamsjön.

Europa. Tord-Afrika. Nird-Amerika.

\section{Reibe DICRANALES.}

Längenwachstum wie bei allen folgenden Reihen mit dreiseitiger Scheitelzelle Blätter (excl. Distichium) mehrzeilig. verlängert bis pfriemenförmig, mit Rippe: Zellen nicht papillös. Sporogone meist gipfelständig. Peristom wie bei Reihe I. 


\section{Unterreihe DICRANINEAE.}

Blätter einschichtig.

\section{A R C H I D I A C E A E.}

Kleine Erdmoose. Tracht von Pleuridium. Stengel schopfig beblättert. mit Zentralstrang, lockerem Grundgewebe und engen, dickwandigen Mantelzellen. Blätter meist schmal eilanzettlich bis lanzettlich-pfriemenförmig; Rippe ohne Begleiter, mit einzelnen medianen Deutern und spärlichen ventralen Stereiden; Zellen fast überall verlängert-prosenchymatiseh. Seta fehlend. Kapsel kugelig, durch einen angeschwollenen Fuss in das Scheidchen eingesenkt, von der sehr zarten, zuletzt unregelmässig gesprengten Haube umhüllt; Zellen des Exotheciums mehreckig, dünnwandig; Spaltöffnungen fehlend. Columella fehlend. Sporensack anfänglich durch einen glockenförmigen Luftraum von der Kapselwand getrennt, später resorbiert. Sporen sehr gross. Sporenaussaat durch unregelmässiges Bersten oder "durch Fäulnis der Kapselwandung.

Enzige Gattung:
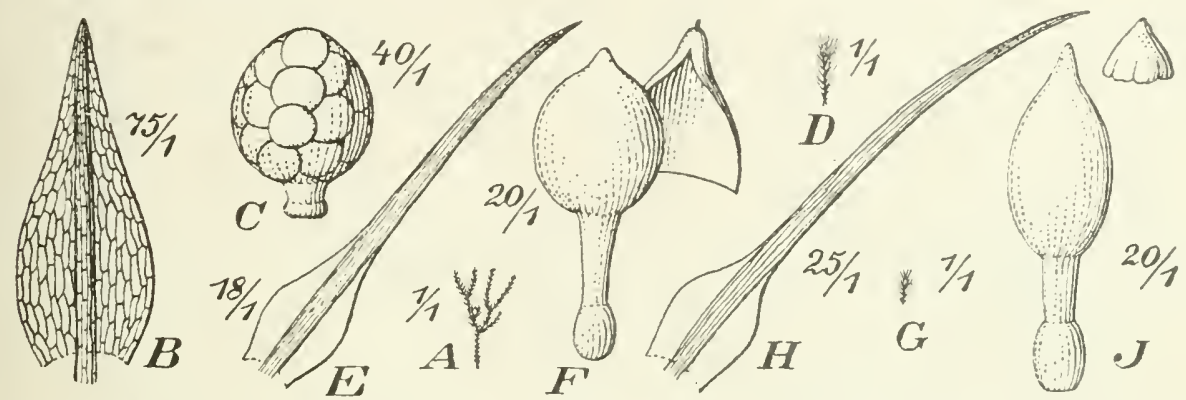

Fig. 4 A-C Archidium phascoides Brid. A Fruchtende Pfl. (1 1); B Stammb. (75 1); C Kapsel (40/1). - D-F Pleuridium alternifolium (Kanlf.) D Fruchtende Pfl. (1 1); E Perichätialb. (18 1); F Kapsel

(20/1. - $\mathrm{G}$ - I Sporledera palustris (Bryol. eur.) G Fruchtende Pfl. (1/1): H Perichätialt. (25'1); I Kapse! (20:1).

\section{ARCHIDIUM.}

Brid. Bryol. univ. I. p. 717 (1826).

29. Archidium alternifolium (Dicks.) Schimp. Syn. p. 28 (1860). [Phascum alternifolium Dicks. Pl. crypt. fasc. 1. p. 1, t. 1, f. 2 (1785). -- Archidium phascoides Brid. Bryol. univ. I. p. 747 (1826).]

Parözisch. Pfl. meist in dichten, flachen, grünen Rasen. Fertile Pfl. meist nur wenige $\mathrm{mm}$, später nicht selten längere, fertile oder bis etwa $15 \mathrm{~mm}$ lange, flagellenartige Sprosse bildend, letztere nierlerliegend, später Rhizoiden und fertile Sprosse bildend. Schopfblätter aufrecht-abstehend oder schwach einseitswendig, lanzettlich-pfriemenförmig, bis $2,5 \mathrm{~mm}$ lang, flachrandig und an der Spitze gezähnt; Rippe austretend. Sporogone blassgelblich, zarthäutig. Sporen unregelmässig polyedrisch, zuletzt gerundet. zw. 100 und 200 " schwankend, blassgelblich, fast glatt. Sporenreife vom Spätherbst bis zum Frühjahr. - Fig. I A -C.

Auf tonig-sandigem Boden in Ausstichen, ausgetrockneten Teichen und an niedrigen Ufern.

F. Al. Lemland, Norrby, am Meeresufer (Broth.). Saltvik, Svallhälla, am Meeresufer (B.).

S. Sk. und Sm. an mehreren Fundorten. Boh. in der Lmgegend von Kungalven. T'g. Venersborg und Lidköping.

N. Sm. an mehreren Fundorten. JL. Sandefjord.

Europa, Nord-Amerika. 


\section{I T R I C H A C E A E.}

Mehr oder weniger schlanke, meist rasenbildende Erd- und Felsmoose. Stengel aufrecht, meist mit gut begrenztem Zentralstrang, mit lockerem, meist getüpfeltem Grundgewelse und dickwandigen. engeren Mantelzellen, dicht beb]ättert, meist nur am Gruncle mit Rhizoiden. Blätter (excl. Distichium) mehrreihig, aus breiterem Grunde lanzettlich bis lang pfriemenförmig; Rippe meist krättig, heterogen. mit meist medianen (excl. Distichium) Deutern. mit wenigen ventralen Stereiden, mit Begleitern und einem starken, dorsalen Stereidenbande; Zellen klein, meist quadratisch oder rektangulär, glatt, am Grunde \pm verlängert und durchscheinend, ohne differenzierte Blattflügelzellen. Blüte gipfelständig, knospcnförmig, mit fadenförmigen, in der $\neq$ Blïte oft fehlenden Paraphysen. Seta meist verlängert. aufrecht, trocken mnten rechts, oben links gedreht. Kapsel meist aufrecht, regelmässig oder symmetrisch, meist glatt, kurzhalsig, selten ohne Hals; Zellen des Exotheciums dünnwandig, unregelmässig (excl. Pleuridium und Sporledera), in cler Mehrzahl = verlängert + -6seitig: Spaltöffnungen oberflächlich. Deckel meist differenziert, kegelförmig, selten kurz geschnäbelt Ring differenziert, mcist 2-3reihig und sich abrollend. Peristomzähne 16, mit \pm deutlicher Grundhaut und meist bis zum Grunde in zwei lange, pfriemenlörmige, oft durch die Querleisten miteinander zusammenhängende. gegliederte und meist papillöse Schenkel geteilt. Haube (excl. Sporledera) kappenförmig.

$$
\text { L bersichl der Gat tungen. }
$$

A. Kapsel eingesenkt, ohne Hals. Deckel nicht differenziert.

a. Spaltöfnungen nur am Grunde der Urne. Haube kappenförmig

5. Pleuridium.

b. Spaltöffnungen üher den mittleren Teil der Urne ver-

streut. Haube mützenförmig-gelappt .................... 4. Sporledera.

B. Kapsel emporgehoben, mit kurzem Halse. Deckel differenziert, abfallend.

a. Stammquerschnitt oval. Blätter zweizeilig ............ 9. Distichium.

b. Stammquerschnitt rundlich 3-5kantig. Blätter mehrreihig.

«. Blattzellen oberwärts rundlich-quadratisch.

l. Diöziseh. liapsel geneigt bis horizontal, symmetrisch, mit Längsrippen und trocken gefurcht, kropfig. rötlichbraun, glänzend ........................ S. Cerctodon

II. Autözisch. Kapsel aufrecht, regelmässig, trocken undeutlich gefurcht, lichtbraun

7. Saelania.

$\beta$. Blattzellen oberwärts verlängert

6. Ditrichum.

\section{DITRICHOIDEAE.}

Blätter mclırreihig. (excl. Ditrichum lenuifolium) lanzettlich bis lanzettlichpfriemenförmig; Zellen auch oberwärts verlängert. Kapsel (excl. Ditrichum pallidum) glatt. Peristomzähne bis zum Grunde in zwei fadenförmige, papillöse Schcnkel geteilt.

\section{SPORLEDERA.}

Hanı). in Limnaca 1837. p. 279.

Parözisch. Ḱleine, grünc odler gelbgrüne P'fl. in lockeren bis gedrängten Rasen, auch herdenweise. Stengel ohne Zentralstrang, meist sehr niedrig, schopfig be- 
blättert, einfach oder ästig. Blätter trocken I verbogen bis straff, feucht aufrecht-abstehend, die oberen viel grösser, aus eiförmiger bis länglich-eiförmiger Basis rasch lang rinnig-pfriemenförmig. bis 2,1 mm lang, mit aufrechten, oberwärts gesägten Rändern: Rippe breit und flach, die Plriemenspitze ausfüllend, gegen die Spitze am Rücken durch Zähnchen rauh; Zellen rektangulär. Seta etwa von der Länge des Scheidchens. Kapsel eiförmig, ohne Hals. stumpfspitzig, meist mit der Seta abfallend; Zellen des Exotheciums rundlich-mehreckig: Spaltolfnungen im mittleren Teile zerstreut. Haube kegel-mützenförnig, mehrlappig, nur den Scheitel deckend. Sporen 2t-30 $\mu$, zuletzt röt ichbraun, feinwarzig. Sporenreife im Mai und Juni.

30. Sporledera palustris (Bruch et Schimp.) Hamp. in litt.: (. Müll. Syn. I. p. 19 (18.8). [Phascum palustre Bruch et Schimp. in Mém. Soc. Mus. Strasb. II. p. 2, t. A (1835).]

An Grabenwänden, besonders auf torfigem Boden. - S. Fig. I G-I.

S. šk. Höör. Sm. Elmhult.

Europa, Nord-Amerika.

\section{PLEURIDIUM.}

Brid. Mant. Muse. p. 10 (1819).

Tracht von Sporledera, in 'ockeren oder dichten, grïnen oder gelblich- bis bräunlichgrünen Rasen. Stengel mit Zentralstrang, einfach oder ästig. schopfig beblättert. Obere Blätter viel länger, rinnig-pfriemenförmig zugespitzt, flachrandig; Rippe breit und flach. die Pfriemenspitze ausfüllend, oberwärts am Rücken durch Zähnchen rauh: Zellen rektangulär. Seta etwa von der Länge des Scheidchens. Kapsel eiförmig, ohne Hals, stumpfspitzig, von der Seta sich ablösend mit einem Loch, aus dem die Sporen entleert werden: Zellen des Exotheciums rundlich-mehreckig; Spaltöffnungen vereinzelt am Grunde der Urne. Hauhe kappenförmig, etwa die halbe liapsel deckend.

\section{Ĺbersicht der. Arten.}

A. Autözisch. Schopfblätter aus eiförmiger oder länglich-eiförmiger Basis raseh lang pfriemenförmig ..................31. Pl. alternifolium.

B. Parözisch. Schopfblätter aus lanzettlicher Basis allmählich pfriemenförmig zugespitzt

32. Pl. subulatum.

31. Pleuridium alternifolium (Dicks.) Rabenh. Deutschl. Krrypt. II. 3, p. 79 (1848). [Phascum alternifolium Dicks. Crypt. fasc. I. p. 2, t. 1, f. 2 (1785).]

Autözisch. Einjährige Pfl. einfach, zwei- und dreijährige mit Innovationen und kleinblättrigen, sterilen, bis $1 \mathrm{~cm}$ langen Sprossen. Schopfblätter oft einseitswendig, aus eiförmiger oder länglich-eiförmiger Basis rasch in eine lange. undeutlich gezälnnelte Pfrieme auslaufend, bis $3 \mathrm{~mm}$ lang: Rippe gut begrenzt. Kapsel dick eiförmig, gelbrötlich. Sporen 24-35 ", oekergelb, dicht grobwarzig. Sporenreife im Mai und Juni. - Fig. 4 D - F.

Auf feuchten Äckern, in Ausstichen, an Graben- und Wegrändern.

F. Al. An einzelnen Fundorten in Finstrim (Arrh.) und sund (Bcm.. Elfv.). in saltvik zerstreut (Bom.). - Ab. Pargas, Bjōrkö (Elfr.). Reso (A. H. Caj.). Lujo, Lỵlỵis (E. af H.); Ǩiviniemi (Lindb.). - St. Karkku (Hjelı). - Ta. Hollola. Hersala (Norrl.). Asikkala. ZW. Kamppila und Reivilä (Norrl.).Kl. Sortarala, Kirjavalahti, Kotomäki (Nurrl.).

S. Sk.-HIsI.

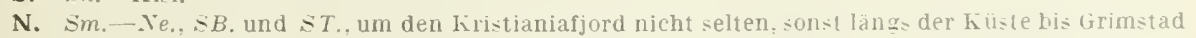
hier und da, mm Bergen und Trondhjem. Nur in niedriger Lage. Jordgrenze bei $63^{\circ} 27^{\prime} \mathrm{n}$. Br.

Europa, Kaukasus, Yord-Amerika. 
32. Pleuridium subulatum (Huds.) Rabenh. 1. c. [Phascum subulatum Huds. Fl. angl. p. 397 (1762).]

Parözisch. Stengel meist einfach, selten unter der Spitze sprossend. Schopfblätter feucht steif aufrecht-abstehend, selten einseitswendig, aus verlängertlanzettlicher Basis allmählich pfriemenförmig, oberwärts gezähnt, bis $2,6 \mathrm{~mm}$ lang: Rippe durch subkostale zweischichtige Laminazellen scheinbar verbreitert und undeutlich begrenzt. Ka apsel rundlich-eiförmig, glänzend gelbbräunlich. Sporen $18-23$. selten $25-28$ ", ockergelb, warzig. Sporenreife im Iai und Juni.

In Gräben, an Abhängen und auf feuchten Äckern.

F. Al. Saltrik, Krarnlo (Bom.). - Ab. Kustö (Lundsir.).

S. Bl.. G̈l.. sm.. Ög. $\mathrm{rg}$. und Srm. an einzelnen Fundorten.

N. Sm.. Br..SB. und VB. an einzelnen Fundorten. Nordgrenze hei $60^{\circ} 24^{\circ} \mathrm{n}$. Br.

Europa. Algier. Ost-China, Nord-Amerika.

\section{DITRICHUM.}

Timm Fl. megap. No. 777 (1788).

Seta verlängert. Kapsel eilänglich bis zylindrisch. Spaltöffnungen am kurzen Halse. Peristom rorhanden. Deckel differenziert, abfallend.

Übersicht der Arten.

A. Blätter aus halbscheidiger Basis fast plötzlich in eine lange, sparrig abstehende, trocken gekräuselte Pfrieme verschmälert

38. D. tenuifolium.

B. Blätter aus breiterer, nicht scheidiger Basis allmählich verschmälert, anliegend oder aufrecht-abstehend bis einseitswendig.

a. Diözisch. Seta rot. nur oben gelblich. Katpsel glatt.

(s. Blattränder oberwärts schmal umgebogen.

1. Perichätialblätter hochscheidig, oberhalb cler Mitte rasch pfriemenförmig. stumpf

34. D. vaginans.

II. Perichätialblätter aus fast halbscheidigem Grunde allmählich pfriemenförmig, spitz

36. D. tortile.

§. Blätter flachandig.

I. Hochrasige. verfilzte, kalkliebende Felsmoose. Blattzellen sehr unregelmässig, im Pfriementeil parenchymatisch

35. D. flexicaule.

II. Niedrige, nicht verfilzte Erdmoose. Blattzellen viel regelmässiger, im Pfriementeil gestreckt ...... 33. D. homomallum.

b. Autözisch. Seta strohgelb. Trockene Kapsel breit gerippt

37. D. pallidum.

Ln t e rg a t. I. Euditrichum Lindb. Muse. scand. p. 26 (1879).

Blätter aus breiterer, nicht scheidiger Basis allmählich verschmälert, anliegend oder aufrecht-abstehend bis einseitswendig.

33. Ditrichum homomallum (Hedw.) Hamp. in Flora 1867, p. 182. [Didymodon homomallus Hedw. Sp. musc. p. 105, t. 23. f. $1-7$ (1801)].

Diözisch. Meist lockerrasige, grüne oder gelbgrüne, schwach seidenglänzende Pfl. Stengel 5-10 mm, einfach oder gabelteilig und büschelästig. Blätter aufrechtabstehend, oberwärts meist einseitswendig, aus eilänglicher Basis allmählich lang rinnig-pfriemenförmig. 2.5-1.5 mm lang, flach- und ganzrandig oder gegen die Spitze kleingezälnnelt: Rippe breit. undeutlich begrenzt, den oberen Pfriementeil 
ausfüllend; Zellen der einschichtigen Lamina unten fast linear, oberwärts rektangulär. Perichätialblätter aus scheidigem Grunde plötzlich sehr lang plriemenförmig. Seta $1-2,5 \mathrm{~cm}$, rot, oberwärts gelblich. Kapsel eilänglich und länglich-elliptisch, engmündig, oft etwas gekrümmt. rötlichbraun, glatt. Peristomzälne schwach links gewunden, gelbbräunlich, fein papillös. Sporenreife im Herbst.

Auf nacktem, sandigem Boden, besonders an Wegrändern, Gräben und Ausstichen.

F. Al. Saltvik und Jomala selten (Bom.). -- Ab. Kustö (Lundstr.), Karuna (Elfv.). Finby (Broth.). Karislojo (E. af H.). - N. Kyrkslätt, stenkulla (Kullh.). Esbo (Härr.). - ha. Vehkalahti (E. W. Blom). - Ik. Valkjärvi, Lamminpāã (H. Lindb.). Muola, Perkjärvi (H. L.). - Tb. Jỵrä:kỵlä (Broth.). - $k$. Kuusamo, Pernu und Korojoki (B.): zw. Mrarttila und Vattula (B.): zw. Juuma und Pääsköskallio (B.); zw. Juuma und Paanajärvi (B.); Kapustaraara (E. af H.): Akanlahti, Keskikone (E. af H.). - Lkem. Kolari, Jokijalka (Hult); Kesankitunturi (H.); Kittilä, Kirchdorf (H.). Kuolajärvi, Kirchdorf und II antyvaara (E. af H.). - Le. Leutsuraara (Norrl.). - Lt. Rotsvaara (Roiv.).

S. $S k,-L$.

N. In allen Ämtern mit Ausnahme ron $F$. und ziemlich gleichmässig verbreitet, nur in L.M. und in Gudbrandsdalen, wie es scheint, selten. Steig̣t bis $800-850 \mathrm{~m}$ hinauf. Nordgrenze bei $69^{\circ} 40^{\prime} \mathrm{n}$. Br. Europa, Nord-Amerika.

34. Ditrichum vaginans (Sull.) Hamp. in Flora 1867. p. 182. [Trichostomum vaginans Sull. Musc. Alleghan. No. 176 (18-16).]

Diözisch. Meist dichtrasige, grüne oder gelbgrüne, etwas glänzende Pfl. Stengel bis $1 \mathrm{~cm}$, selten höher, mit sehr dünnen, aufrechten Sprossen. Blätter trocken angepresst, feucht straff aufrecht, aus eilänglichem, hohlem Gruncle allmällich scluarf zugespitzt, gegen die Spitze fast röhrig, ganzrandig oder gegen die Spitze unmerklich gezähnelt, bis 1,2 $\mathrm{mm}$ lang, mit oberwärts auf eine Strecke schmal umgebogenen Rändern: Rippe deutlicls begrenzt, bis zur Spitze fast gleichbreit und mit der Blattspitze endend; mit meist basalen Deutern; Lanina einschichtig, oberwärts die Randreihe zweischichtig: Zellen oberwärts rektangulär, mit wenigen quadratischen gemischt. Perichätialblätter hochscheidig, oberhalb der Mitte rasch pfriemenförmig, stumpf. Seta $1-2 \mathrm{~cm}$, unten rötlich, oben gelblich. Kapsel länglich-zylindrisch bis zylindrisch, lichthraun, glatt. Peristomzähne aufrecht, gelb, schwach papillös. Sporenreife im Spätherbst.

Auf nacktem. sandigem Boden, besonders an Wegrändern, Ausstichen und Flussufern.

S. LuL. sarekgebiet, hàlaktjảkko in der Weidenreg.

N. Aus den meisten İmtern von sm. bis $N T$. bekannt. ülerall jedoch selten und nur his etwa $600 \mathrm{~m}$ hinaufsteigend. Nordgrenze bei $63^{\circ} 27^{\prime} \mathrm{n}$. Br.

Europa, Nord-Amerika,

var. zonatum (Brid.) Hag. in D. L. N. Vid. Selsk. Skrift. 1910, No. 1, p. 49 (1910). [Weisia zonata Brid. Bryol. univ I. p. 36.1 (1826). - Ditrichum homomallum var. zonatum Lindb. IIuse. seand. p. 26 (1879). — D. zonatum Limpr. Laubm. I. p. $495(1887)$.]

Selır dichtrasige, oben glänzend goldgrüne, unten absatzweise grüne. gelbbraune und dunkelbraune Pfl. Stengel bis $3 \mathrm{~cm}$. Sporogone unbekannt.

Auf spärlichem Humus kieselreicher Felsen und in deren Spasten und Ritzen.

F. Al. Sund. Tranvik (Bom.). - h. Kuusamo, Arentojoki (Broth., E. af H.). - Lhem. Tă!ivaara, in der Fichtenregion (Norrl.). Pyhätunturi (Vain.).

S. LuL. Sarekgeb., Pelloreppe in der Birken region.

N. $B u_{0}, Y_{e}, K_{0}-S T$. an einzelnen Fundorten und meist bei $1100-1500 \mathrm{~m}$.

Pyrenäen und Zentral-Europa, besonders in der Alpenketle.

35. Ditrichum flexicaule (Schleich.) Hamp. in Flora 1867, p. 182. [Didymodon flexicaulis Schleich. Pl. crypt. helv. Cent. 4, No. 9 (1807).]

Diözisch. Dichtrasige, gelblich- bis bräunlichgrüne, innen dicht rostrot verfilzte, etwas glänzende Pfl. Stengel bis $10 \mathrm{~cm}$, gabeteilig und büschelästig. Blätter aufrecht-abstehend oder eiuseitswendig, trocken aufrecht und unregelmässig 
verbogen, aus lanzettlichem Grunde sehr langrinnig pfriemenförmig, bis $4 \mathrm{~mm}$ lang, flachrandig, an der Spitze gesägt: Rippe breit, die Blattspitze ausfüllend und in eine glatte oder gezähnte. kurze Granne austretend: Zellen in Pfriementeile zweischichtig, überall sehr dickwandig, mit bei den fertilen Sprossen oberwärts sehr unregelmässigem Lumen, bei den sterilen Sprossen regehmässiger, oberwärts fast nur rundlich und oval. Perichätialblätter bis zur Mlitte scheidig. Seta $1.5-2.5 \mathrm{~cm}$, rot, oberwärts gelblich. Kapsel eilänglich, gerade oder schwach ge-

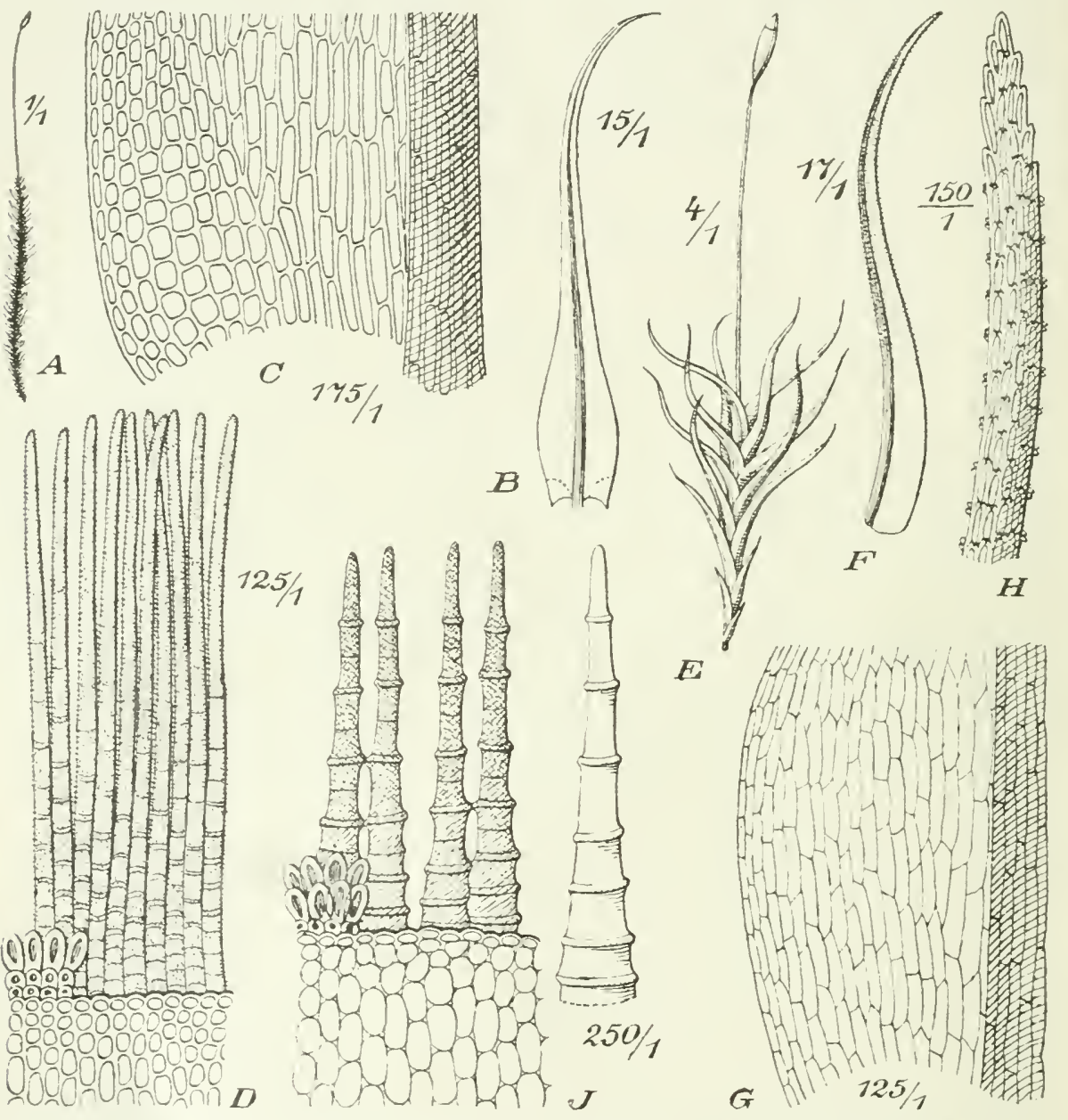

Fig. 5. 1- D. Ditrichum flexicaule (schleich.) A Fruchtende Pfl, (1 1): B stammb. (15 1); C Blattbasis (175 1); П Peristom (125 1). - E-I. Distichium montanum (Lam.) E Fruchtende Pfl. (4/1): F stammb. (1; 1) (; seheidenteil $(125,1):$ H. Pfriementeil $(150$ 1): I Peristom (250/1).

krümmt, rotbraun, glatt. Peristomzähne aufrecht, am Grunde rotbraun, oberwärts hyalin. dicht und fein-stachelig papillös. Sporenreife im Juni. - Fig. $5 \mathrm{~A}-\mathrm{D}$.

Auf kalkhaltigem Gestein aller Art und auf kalkhaltigem Erdboden, seltener an kalkfreien lielsen. Norlgrenze auf Spitzbergen.

F. Al.st. fg. (Bom.). - Ab. Pargas (Elfr.). Kimito (Uls.). Finby (Broth.). Tenala. Skogby (Hak. Lindb.). Karislojo (Sundr.): Maila (E. af H.); Karkali (Broth.). Lojo, Kiviniemi (Lindb.): storön (Hult, 


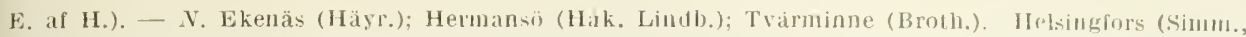
Lindb.). Helsinge, Vetterkulla, Kalkholmen (Ranck.). Sibho, Loflari (Broth.). Elinäki (Tigetst). Ka. Vehkalałti, Konnusjärvi (Kuj.). Wihorg, Lalo, Soskuanjoki (Buch). Il. Pylajjïri, Malmis (II Lindb.). - Ta. Korpilahti, Vaarunvoori (Vain.). — Sa. Wilmanstrand (Bush). Nyshott (Carl.). Kl. Sortavala, Kirjavalahti (Norrl.); Liskelï (Pes.). Impilahti (Broth.). Ruskealal (Lindi,.). Sulstano, Leppäsyrjä (Pé.). Pälkjärvi. Korkeanient (Broth.); kivinieni (Kog.). _ şb. Kưpio an molıreren Findorten (Link.). Kaavi. im Kalk- unł serpentingeb. f(L. (Ko1.). Nilsiä, Kuuslalıt, Jaakonlampi (Kyyhk. und kot.). Maaninkal, Sibinjarvi (kyylik.). - kb. Junka. in kalk- und serpentingel, frl. (Kot.). Tohnajärvi, IIidenvaąa (Broth.); Kemie (Oesch). - Kon. Snojärvi, Valpakylai, Alehsinsaari und Pöponsaari (Link.). Jalguba und Valkeamäki (Simm.). Perttinieni (Norri.). - (mm. Alajäri, Vestrabacka, Huosianmankallio und Moskrallkallio cop. (Backm.). - Ok. Paltamo, Melalahti. Viilonkatlio (Lackstr.); Norsiniemi. Hyyrylänmäk, Likulampi und Reetinniemi (Kyyhk.). Sotkanı, Ketrinsaari, Hepolahti, Talvialra. Aarrenniemi, Hankipuro und Kohrorinsaari (Kyylik.). Punlanka (fackstr., Kyyhk.). Suomusialmi, Kirchdorf (Vain.); Kallininen (Kyhk.). - K. Kuusano, an vielen Fundorten (Xy1., Sahlb., Broth., E. af H.). - Lkem. Kittili, Kirehdorf, llanaoja und Naalaoja (liult). Olostun turi (Norrl.). -- Le. Kilpisjärvi, Saana (Norrl.), Kitji-llalla, Malla, Saana und Gunjarvankka (Kot.). Li. Inari, Vastusjärvi. Juppura und Pitkävuono in der Nadelwaldregion (Hult); Peldoivi in der Birkenregion (H.). - Lim. Kandalaks, Tsehun und Hibini (Broth.). - Lt. Ruokojayr. Rotsvara und Rjetenjäyr (Roiv.). Vaidoguha und Pummanki (Broth.). Kildin (B.). - Lnur. Bjelousiha am Voronjellusse. Rinds, Semjostrovak und Litsa (Broth.). - Lp. Halo-Gorodetskaja (Broth.): Katsclikova (Brenn.); Orlor. Grubnoj (Kihlm.); Ponoj (siahlb.). - Lv. Pogorela 7.w. Pjatitsa und Balija (Broth.).

S. Sh.- - L.

N. In allen Ämtern unt Ausnahme von V.u. und in allen Höhenlagen verbreitet. in Lofoten und auf weiten Flächen ron s rlandet und llestlandet jeduch fehlend.

Europa, Kanaren, Algier, Kaukasıs, Zentral-A-ien, Silnirien, Nord-Amerika.

36. Ditrichum tortile (Schrad.) Lindb. IIusc. scand. p. 26 (1879). [Trichostomum tortile Schrad. Samml. Krypt. Gew. No. 19 (1796).]

Diözisch. Herdenweise oder in lockeren, leicht zerfallenden, schmulzig grünen, glanzlosen Rasen wachsende Pfl. Stengel bis $10 \mathrm{~mm}$, meist einfach. Blätter trocken meist anliegend und wenig verbogen, feucht aufrecht-abstehend oder cinseitswendig, lanzettlich-pfriemenförmig, die oberen 1,7-2 $\mathrm{mm}$ lang, mit oberhalb des Grundes bis gegen die schwach gezähnte Spitze leicht ungebogenen Rändern; Rippe nach oben allmählich dümmer, kurz austretend: Zellen einschichtig, nur gegen die Spitze oft die Randreihe zweischichtig, oberwärts rektangulär, vereinzelte quadratisch. Perichätialblätter aus fast lıalbscheidigem Grunde allmählich pfriemenförmig. Seta $8-\mathbf{1 5} \mathrm{mm}$, rot. Kapsel schmal zylindrisch, gerade oder schwach gekrümmt, lichtbraun, glatt. Peristomzähne schräg nach rechts aufsteigend, schmutzig rotbraun, lein papillös. Sporenreife im Herbst.

In feuchten Sandausstichen, an Weg-, Graben- und Bachrïndern.

F. Al. Prästgården und Krarnbo (Bom.). Finström, fodby (B.). — Ab. Lojo, Lojobacke (Lindb.). - N. Kyrkiätt (Nyb.). Litti, Perhenjemi (Buch). Hogland, Kiiskinkylä (Lindb.). - lk. Valkjärvi, Lamminpää (H. Lindb.).

var. pusillum (Hedw.) Lindb. Musc. scand. p. 26 (1879). [Trichostomum pusillum Hedw. Descr. 1. p. 74, t. 28, f. 2, 1, 9, 10 (1787). - Ditrichum pusillum Timm. Fl. megap. No. 777 (1788).]

Stengel bis 5 mm. Blätter kürzer zugespitzt, stumpflich: Rippe vor der Blattspitze aufhörend; Zellen oberwärts quadratisch. Perichätialblätter höher scheidig, mit kürzerer Pfriementeile. Seta bis $1 \mathrm{~cm}$. Kapsel ovoidisch und länglich, gerade.

F. Al. Saltvik, an mehreren Fundorten (Bom.). Sund, Gesterby (B.). - Ab. Pargas, Kanellstrand (Elfv.). Karislojo, Karkkali (Sundv.). Lojo. Storön, Pietilä (E. af H.). - X. Helsingfors (W. Nyl. Lindb.): Elimäki (Tigerst.). - Ka. Sippold. Ruotila (kuj.). - Ik. Sakkola, Kirkkojoki (H. Lindb.). Mluola, Perkjärvi (H. Lindb.). - St. Ikaalinen (Sundr.). - Ta. A sikkala, st. fq. (Norrl.). Luhanka, Hlietala (Vain.). Korpilahti, Putkilahti, Sutoinen (V.). - Sa. Willmanstrand. Koivulanmäki (Buch); Lapfee, Pajarila und Kiiala (B.). Nyclott (Carl.). Kangauniemi (Lackstr.). - Kl. Uukuniemi (Simm.). Soanlahti, Knirinvaara (Broth.). - hol. Salni (WW. Nyl.). Gorki (Elfv.). - Tb. Jyväskylä (Broth.). Viitasaari, Limattalan jnki (B.). Pihtipudas, Heinnlankyla (Roiv.). - $\$ b$. Maaninka, an mehreren Fundorten (Roiv.). - Kb. Lieksa, Kirchdorf (Tain.). - Kon. Korpiselkä, Ägläjärvi (Kullh.). - Om. Lappajärvi, Vartiasaari (Backm.). - oh. Kajana (Lackstr.). - ob. Zw. Aavasaksa und Turtula st. f(1. (Hult). K. Kuusano: Haataja (Broth.): Kirelidorf (B.). - Lkem. Käkesuanto und Vuontisjarvi (Norrl.). - 
Le. Karesuanto und Hetta (Nojrl.). - Li. Inari. Toivonieni1, Karasjoensuu und Parsji in der Nadelwaldregion (Hult); Mlandojäyri in der Birkenregion (H.). - Lmur. Varsinsk (Brulh.). — Lp. Ponoj (Sahlb.).

S. $\quad \therefore k .-L$.

N. sm.-Ye., $s B .-T r$. In 1)stlandet nicht sellen und stellenweise, wie es scheint. häufig, im grössten Teile von s rlandet fehlend, in Wesllandet und in den inneren Amlern sehr selten. Meist in niedriger Lage, steigt jedech lis 750 in hinauf. Nordgrenze bei $69^{\circ} 40^{\prime} \mathrm{n}$. Br.

Europa. Algier. Liaukasus, Himalaya, Nord-Amerika.

37. Ditrichum pallidum (Schreb.) Hamp. in Flora 1867, p. 182. [Bryum pallidum Schreb. Spic. Fl. Lips. p. 80. No. 1039 (1771).]

Autözisch; Blüten in den Achseln der Schopfblätter. Rasenbildende, lichtgrüne oder gelbliche Pfl. Stengel etwa $5 \mathrm{~mm}$, meist einfach. Blätter aufrechtabstehend oder einseitswendig, trocken steif und etwas verbogen, die oberen grösser, aus eiförmiger Basis sehr lang und fein rinnig-pfriemenförmig, $4-5$ mm lang, flachrandig. rings an der austretenden Rippe und an den Rändlern des Pfriementeiles entfernt gesägt: Rippe sehr breit, undeutlich begrenzt; Zellen nächst der Rippe in mehreren Reihen und im Pfriementeile bis zum Rande zweischichtig, am Blattgrunde der oberen Blätter erweitert, länglich 4-6seitig, sehr dünnwandig, gelblich, oberwärts verlängert, linear, undurchsichtig. Perichätialblätter aus halbscheidiger, etwas längerer und breiterer Basis allmählich pfriemenförmig. Seta 2-1 cm, strohgell). Kapsel länglich-eiförmig. gerade oder schwach gekrümmt, eng- und schiefmündig, lichtbraun, mit 4 dunkleren, breiten, an der trockenen Urnenwand als Rippen hervortretenden Längsstreifen.

Peristomzähne aufrecht, rot, dicht und feinstachelig papillös. Sporen $14-$ 18 " , braun, warzig.

Sporenreife im Hai und Juni.

S. Srm. Stockholun, LTrikidal. Tob. Hedell.

Europa, liaukasus. Ost-Asien, Nord-Amerikil.

Un tergat t. I l. Trichodon (Schimp.) Lindb. Musc. scand. p. 27 (1879). [Trichodon Schimp. Coroll. p. 36 (1856) als Gattung.]

Diözisch. Blätter aus halbscheidiger Basis fast plötzlich in eine lange, sparrig abstehende, trocken gekräuselte Pfrieme verschmälert.

38. Ditrichum tenuifolium (Schrad.) Lindb. Mlusc. scand. p. 27 (1879). [Trichostomum tenuifolium Schrad. Journ. Bot. II. P. I. p. 58 (1799). - Trichostomum cylindricum Hedw. Sp. muse. p. 107, t. 24, f. T-13 (1801). - Trichodon cylindricus Schimp. Coroll. p. 36 (1856).]

Diözisch. Hcrinwcice wachsende oder lockerrasige, grüne oder gelbgrüne Pfl. Stengel 5-10 $\mathrm{mm}$, einfach orler wenig verästelt. Blätter aus halbscheidiger Basis fast plötzlich in eine lange, sparrig abstehende, trocken gekräuselte, rinnige, flachrandige, gezähnte Pfrieme verschmälert, bis etwa $3 \mathrm{~mm}$ lang; Rippe den oberen "Pfriementeil ausfullend, unterseits clurch die mamillös vortretenden oberen Zellecken rauh; Zcllen einschichtig, im Scheidenteile linear, an der Insertion gelb, im Pfriementeile rektangulär. Perichätialblätter wenig verschieden. Seta 1 $2.5 \mathrm{~cm}$, sehr dünn, strohgelb, am Grunde rötlich. Kapsel schmal zylindrisch und etwas gekrümmt, rötlichbraun, glatt. Peristomzähne aufrecht, gelbrot, fein papillös. Sporenreife im Juni und Juli. - Fig. \& E-F.

Auf nackter, meist trockener, sandiger oder tonig-sandiger bis toniger Erde an Wegrändern, Grabenwänden, Bach- und Flussufern, in Ausstichen.

F. Al. Mariehann (Bom.). Saltvik, an wenigen Fundorten (B.). — Ab. Pargas, Skräbböle und Kapellstrand (Elfv.). Karislojo, Pellonkỵlä (1I. Lindb.); Niemi (E. af H.). Lojo, Isosaari, Pietilä (Lindh.); Lakspojo (Sundr.). - X. Helsiıgfors (Lindb.). Borgá, Sundo (Sael.). — Ik. Valkjärvi, Pasuri (HI. Lindb.). Py̧äjärvi, sallițaranta (H. L.). - St. Orivesi (Broth.). - Ta. Hollola. Hersala (Vain.). Asikkala (Norrl.). Korpilahti, Raianlahti und Pulkilahli (Vain.). - Sa. Lappee, Kansola (Buch). Willmanstraud (B.). Nyslott (Carl.). — Kil. Kurkijoki, Oraska und Sarioja (Jusl.). Jaakkima (Sundr.). Valamo (W. Nyl.). Sortavala, Kirjavalahti (Broth.); Puutsalo (Norrl.). Ruskeala (W. Nyl.). - Kol. Mjatusora (Elfr.). - Tb. Petäjäresi, Räsälä und Piesala (Ruor.). Jỵräskỵlä (Brolh.). Uurainen (Broth.). 
Konginkangas (E. af H.). Viitasaari, Liimattalanjoki (Broth.). Kinnula, Häăhäjärvi R(oir.). Pihtipudas, Heinolankylä, Liesonlampi (Roiv.); Alvejärvi, Kotalahti (Roiv.). 一 Sb. Joroinen (II. Lindb.). Kaavi, Siikajärvi, Huosiaisniemi (Kot.). Nilsiä, Palosaari (Kyyhk.). Maaninka, Tuovilanlảhti (Lundstr.). Pöljä, Uuhimäki (Kỵhk.). - Kb. Joensuu, Niinivaara (Linnan.). - Koh. Suojärvi, Mökkö (Norrl.). Porajärvi (Sahlb.). Gorskij Pogost (Simm.). - Ok. Kajana (Lackstr.). Paltano, Ilyyrylänmäki (L.). Suom ussalmi (L.). - Ob. Rovaniemi. Tervo (Hult). - K. Pudasjärvi, Häyrynen (Broth.). Kunsamo, Kirchdorf (B.); zw. Marttila und Vattula (B.). Paanajärvi (Sil.); zw. Paanajărvi und Sovajärvi (E. af H.). - Lkem. Ifuonio, Ylikylä und Muonioniska (Norrl.). Kuolajärvi, Kirchdorf (E. af H.). - Le. Kilpisjärvi (Norrl.). - Lt. Kóla (Broth.). - Lmur. Am Rindaflusse (Broth.). — Lp. Ponoj (Brenn.).

S. I rml.-L., an einzelnen Fundorten in $S m$., $O g$. und $N a r$.

N. Sm.-Ne., St.-F., am reichlichsten in den inneren Amtern und nördlicher, jedoch nirgends häufig. in Sorlandet und Westlandet fehlend. Neist im Os-Gebiet und in der subalp. Rcgion, kaum weit über die Baumgrenze hinaufsteigend.

Europa, Sibirien, Nord-Amerika.

var. oblongus (Lindb.) Hag. in D. K. N. Vid. Selsk. Skrift. 1910. No. 1, p. 51. [Trichodon oblongus Lindb. in Öfv. V. Ak. Förh. 1863, p. 226. - Ditrichum oblongum Kindb. Skand. Bladm.-fl. p. 91 (1903).]

Kapsel länglich, etwas hochrückig.

N. K. -ST. und No.-F. an einzelnen oder wenigen Fundorten.

Spitzbergen.

\section{CERATODONTOIDEAE.}

Blätter mehrreihig, lanzettlich; Zellen oberwärts quadratisch. Káapsel trocken \pm deutlich gefurcht. Peristomzähne bis zum Grunde in zwei fadenförmige, papillöse Schenkel geteilt.

\section{SAELANIA.}

Lindb. Utkast etc. p. 35 (1878).

Autözisch; $c^{*}$ Blüten gipfelständig an \pm verlängerten Sprossen. Perichätialblätter länger, sonst kaum differenziert. Kapsel aufrecht, gerade, trocken undeutlich gefurcht. Peristomzähne aulrecht, mit niedrigem Hohlzylinder. Deckel aus kegeliger Basis kurz geschnäbelt.

Einzige Art:

39. Saelania caesia (Vill.) Lindb. 1. c. [Bryum caesium Vill. Pl. Dauph. III. p. 879 (1789). - Trichosiomum glaucescens Hedw. Descr. III. p. 91, t. 37 B (1792).

- Ditrichum glaucescens Hamp. in Flora 1867, p. 182.]

Lockerrasige, gelblichgrüne und durch einen weissbläulichen Anflug blaugrün erscheinende Pfl. Stengel bis 2, selten bis $3 \mathrm{~cm}$, gleichloch gabelästig. nur am Grunde mit Rhizoiden. Lntere Blätter selır klein, die oberen abstehend, schopfig zusammengedrängt, lanzettlich bis aus lanzettlicher Basis linealisch, bis 3 mm lang, mit aufrechten oder schmal umgebogenen und entfernt stumpf gesägten Rändern; Rippe fast stielrund, mit der Blattspitze endend oder kurz austretend; Zellen am Blattgrunde kurz rektangulär. Perichätialblätter länger, sonst kaum differenziert. Seta $5-10 \mathrm{~mm}$, rötlich. Kapsel eilänglich-eiförmig, fast zylindrisch, lichtbraun. Peristomzähne trocken gerade, tiefrot. Sporen $15-20 \mu$, braun, papillös. Sporenreife im Juni und Juli. - Fig. $6 \mathrm{~A}$-E.

Auf humusreicher oder sandiger Erde an Wegrändern, in Gräben, Höhlungen und erderfültten Felsspalten besonders kalkhaltiger Gesteine. Nordgrenze auf Spitzbergen.

F. Al. Jomala und Finström an vereinzelten und Saltvik an mehreren Fundorten (Bom.). - Ab. Pargas (Elfv.). Uskela, Linnanmäki (Lindb.). Bromarf (Sundv.). Karislojo, an mebreren Fundorten (Broth., E. af H.. Sundv.). Lojo, Ojamo (Lindb.); Huhtsaari (Sundv.); Lylyis (E. af H.). Vichtis (TW. Nyl.). - N. Helsingfors, Stansvik (Ranck.); Tusby, Sarvikallio (Broth.). Esbo, Kilo (Sola); Lảngträsk, Dalsvik (Ranck.). Kotka (Roiv.). - Ka. Vehkalahti (Blom.) Wiborg, Juustila (Buch). Antrea (Lindb.). 
- St. Ikaalinen. Nygurd (Sundr.). - To. Im südöstlichen Teile pass.—st. fq. (Norrl.). Hattula, Hakola (Fihlm.); Yli Savijărvi (Panck.). Luhanka, Likolahti (Vain.). Korpilahti, Vaarunruori (Link.). - Sa. Kangasniemi (Lackstr.). Willmanstrand (Buch). Nyslott (Carl.). — hl. Kurkijoki. Oraska (Jusl.). Valamo (J.). Jaakkima (F. Ny.). Sortavala (Linnan.): Kirjavalahti fq. (Norrl.). Impilabti, Sumeria (Pes.); Majatsaari (Lång). Ruskeala (Lindb.). Suistamo, Pollampi (Link.). Soanlahti, Korpikallio und Vehkavırori (Broth.). Pälkjārvi (Broth., Link,). - Kol. Salmi. Leppālä (Pes.). — Oa. Nārpes, Yttermark, Vargbărget (E. af H.). - Tb. Virrat, Toriseva (Broth.). Jỵuäskylä (B.); Haapakoski (Link.). Konginkangas (Broth.). - Sb. Kuopio, an mehreren Fundorten (Link.. Roiv.). Kaavi, im Kalk- und Serpentingeb. st. fq. (Kot.). Nilsiä. Loutteinen (Kyyhk.). Iaaninka, an mehreren Fundorten (Kyyk. und Roiv.). - Kb. Juuka. im Kalk-und Serpentingeb. st. fq. (Kot.). - Kon. Suojärvi. Varpakylä (Kop.).

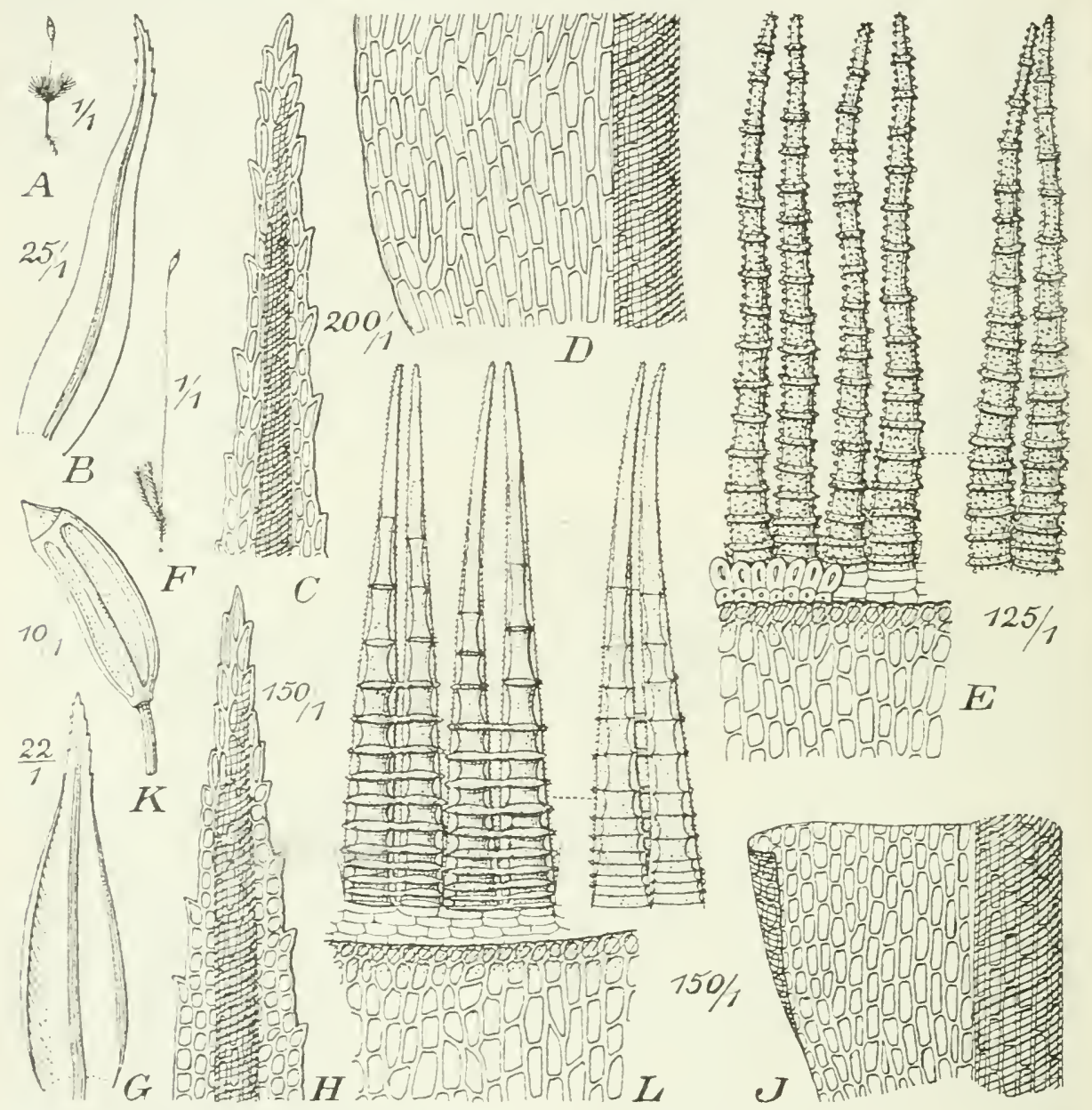

Fig, 6 A-E Saelania caesia (Vill.). A Eruchtende Pfl. (1 1); B Stammb. (25/1): C Blattspitze (200/1); I Blattbasis $(200,1)$; E Peristom (125.1). - F-L Ceratodon purpurens (L.) F Fruchten de Pfl. (1,1); (i) Stammb. (22/1): H. Blattspitze (150 1): I Blattbasis $(150,1)$; K Kapsel im trockenen Zustande $(10,1)$ : L Peristom $(15 \curvearrowleft 1)$.

Pertinjenni (Kullh.). Jänkäjärvi (Norrl.). - ok. Kajana (Lackstr.). Paltamo. an mehreren Fundorten (Lackstr.. Kyyhk.). Sotkamo. Jornazjarvi und Hustinjoki, Sahinkallio (Kyyhk.). Suomussalmi, an einigen Fundorten (Kyyhk.), - Ob. Rovaniesni, Lohiniva (Hult). - $K$. Kuusamo, an vielen Fundorten (Broth., E. af H.). - Lkem. Kuulajārvi, Palovaara (E. af H.). - Le. In der Wildregion pass. (Norrl.). Kilpisjärvi, in der alpinen Region (Norrl., Kot.). - Lim. Kandalaks (Sahlb.. Broth.). Tschun und Hibinä (Broth.). - Lt. Rotsvaara (Roiv.). Kitofka (Fellm.). Pummanki (Broth.). — Lp. Ponoj (Broth.). Lr. Tschapoma (Broth.). 
S. Vrml.-L. Ög., Srm. und När. an wenigen Fundorten.

N. In allen Amtern mit Ausnahme von st, jedoch nur im Binnenland st. fq., an meisten im OsGebiete und in der subalpinen Region, hier und da die Baumgrenze üherschreitend und bis 1.700 $\mathrm{m}$ hinaufsteigend.

Europa, Kaukasus, Kaschmir, Turkestan. Silirien. Ost-Asjen. süd-Afrika. Niw Zealand.

\section{S. CERATODON.}

Brid. Bryol. univ. J. p. 480 (1826).

Diözisch; Ơ Blüten dick kopfförmig. Innere Perichätialblätter längs scheidig zusammengewickelt, fast plötzlich zugespitzt, das innerste oft stumpf und oberwärts ausgerandet. Kapsel symmetrisch, mit Längsrippen, trocken gefurcht und mit \pm deutlichem, kropfigem Halse. Peristomzähne trocken oben eingerollt, mit weit vortretendem Hohlzylinder und unterwärts durch Querbalken verbundenen Schenkeln. Deckel kegelförmig.

40. Ceratodon purpureus (L.) Briel. Bryol. univ. I. p. 180 (1826). [Mnium purpureum L. Sp. pl. II. p. 1575 (1753).]

Neist grüne, zuweilen gelbgrüne oder rötliche bis rotbraune Pfl. in oft ausgedehnten, 士 dichten Rasen. Stengel meist 2-3 cm, steril oft viel höher, gabelteilig oder büschclästig. Blätter trocken anliegend, verbogen und etwas gedreht, feucht aufrecht-abstehend, gekielt, aus länglicher Basis lanzettlich, zugespitzt. mit weit hinauf zurückgerollten, an der Spitze meist \pm gezähnten Rändern; Rippe mit oder vor der Blattspitze endend bis kurz austretend. Seta $1-3 \mathrm{cn}$, glänzend rot. Kapsel geneigt bis horizontal, länglich, mit deutlich kropfigem Halse, glänzend rötlichbraun, trocken und entdeckelt abwärts gebogen und gekrümmt. Peristomzähne purpurn, \pm breit gelbgesäumt. Sporen 12-14", gelb, glatt. Sporenreife in Juni und Juli. - Fig. $6 \mathrm{~F}$ - L.

Auf nicht zu nassem Erdboden jeder Art, wie sterilstem Erdboden, trockensten, erdbedcckten Felsen und Blöcken, auf Mauern und Dächern, auf faulendem Holze und Bäumen, auch auf zerstörten animalischen Resten, durch das ganze Gebict bis in die alpine Region und auch dort fruchtend. Sehr gemein und formenreich.

In allen Teilen der Welt, auch in der tropischen Zone verbreitet.

var. flavisetus Limpr. Laubm. I. p. 487 (1887). [C. pur]. var. xanthopus Sull. Muse. bor. am. 2. ed. p. 29; Lesq. et Jam. Man. p. 92 (1884) nach H a g e n.]

Blätter lang zugespitzt. Seta dümmer, rötlichgelb. liapsel fast zylindrisch.

N. Nach H a gen bis Bod. zerstreut.

Steiernark, Tirol, Nord-Amerika.

var. obtusifolius Limpr. 1. c.

Tiefrasig. Blattrippe meist vor der stumpflichen Blattspitze verschwindend.

N. Nach 11 a gen in den dpinen und arkti-chen Gegenden beobachtet.

Steiermark.

* Ceratodon conicus (Hamp.) Dix. Handlb. Brit. Moss. p. 68 (1896). [Trichostomum conicum Hamp. Mser. in C. Müll. Syn. I. p. 575 (1849). - Ceratodon conicus Lindb. Musc. scand. p. 37 (1879).]

Blätter breit eilanzettlich, mit bis zur Spitze zurückgerollten Rändern; Rippe kräftig, als langer Endstachel austretend. Kapsel klein, eiförmig-clliptisch, weniger deutlich gerippt, nicht oder undeutlich kropfig, trocken und entleckelt kaum verändert. Peristomzähne nicht oder sehr schmal gesäumt.

F. Al. An einzelnen Fundorten in Eckerö, Lemland und Vådö, an mehreren in Saltrik (Bom.). Ab. Pargas, Söderby (Elfv.).

S. Öl., Gll. und $\ddot{g} g$. AIvastra.

N. Nach $\mathrm{H}$ a g e n hier und da, wenigstens im Waldgebiete.

* Ceratodon dimorphus (Philib.) (Ceratodon dimorphus Philib. in Rev. Bryol. $1-88$, p. 28). 
Selnr scllanke Pfl. in lockeren, grünen Rasen. Stengel bis 7 mm, fadenförmig, kätzchenartig beblättert. Blätter der sterilen Pfl. gleichgross, trocken dachziegelig anliegend, feucht aufrecht-abstehend, eiförmig, stumpf, begrannt, bis $0,5 \mathrm{~mm}$ lang, llach- und ganzrandig: Rippe kurz austretend; alle Zellen quadratisch, gleichgross und diumwandig. Seta bis $6 \mathrm{~mm}$, rötlich. Kapsel klein, trocken glatt oder undeutlich gestreift. Peristomzälnne ungesäunt.

N. An einzelnen Fundorten in Ve.. K. und $H$. , an mehreren in $S T$., meist in den Umgebungen von Dovrefjeld und dort meist in den oberen Tejlen der subalpinen Region.

Schweiz.

\section{DISTICHIEAE.}

Stengel im Querschnitt oval, mit ungetïpfeltem Grundgewebe. Blätter lanzettlich-pfriemenförmig. Kapsel glatt. Peristomzähne flach, \pm deutlieh gekreuztschrägstreifig, nicht papillös.

\section{DISTICHIUM}

Bryol. eur. fase. 29/30 (1846).

Stengel brïchig, gahelteilig. Blätter zweizeilig, aus halbscheidiger Basis 士 rasch in eine $\perp$ abstehende, rimnige und flachrandige Pfrieme versehmälert; Rippe breit, im unteren Pfriementeile dureh die zweischichtigen, sehmalen Laminastreifen verbreitert, im oberen stielrund und an Rïeken \pm rauh; Zellen des Seheidenteils glatt und sehr durchsichtig, verlängert-6seitig oder rektangulär bis linear, oberwärts sehr unregelmässig, rhombisch und dreieckig, im Pfriementeile quadratisch, durch gepaarte Mamillen \pm rauh. Perichälialblätter hochscheidig. Seta rot. Deckel kegelig. kurz.

\section{Übersieht der Arten.}

A. Kapsel aufrecht. Sporen 17-20"

41. D. montanum.

B. Kapsel geneigt bis horizontal. Sporen $30-40 \mu$.

a. Kapsel eiförmig. Peristom normal 42. D. inclinatum.

b. Kapsel zylindri: ch, gekrümmt. Peristom aus 8 ziemlich weit voneinander entfernten Bündeln gebildet

43. D. Hagenii.

41. Distichium montanum (Lam.) Hag. in D. K. N. Vid. Selsk. Skrift. 1910. No. 1, p. 61. [Bryum montanum Lam. Fl. franc. I. ]) 18 (1778). - Mnium capillaceum Sw. in Nov. Act. Soc. Ups. IV. p. 211 (1781). - Distichium capillaceum Bryol. eur. fasc. 29,30 , p. 1, t. I (1846). - Swartzia monlana Lindb. Muse. seand. p. 26 (1879).]

Autözisch oder parözisch, selten synözisch. Dichtrasige, grüne oder gelbgrüne, clurch die weisslichen Blattseheiden seidenglänzende, weit hinauf wurzelfilzige Pfl. Stengel $2-8 \mathrm{~cm}$, selten höler. Blätter im Pfriementeile sehr rauh, an der äussersten Spitze gezïhnelt. Seta $5-20 \mathrm{~mm}$. Kapsel aufrecht, seltener etwas geneigt, regehnässig und gerade oder schwach gekrümmt, eilänglich bis fast zylindrisch, lichtbraun, entdeckelt glänzend kastanienbraun. Peristomzähne 16, sehmal, gelbrot, meist bis zur Basis gespalten, die beiden Schenkel oft ungleich ausgebildet, hier und da verbunden. Sporen 17-20 " gelbliehbraun, warzig. Sporenreife im Juli. - S. Fig. 5 F-I.

Auf Kalk und kalkhaltigen Gesteinen, seltener auf kalkfreien Felsen, auf Sand- oder Torfboden. Nordgrenze auf Spitzbergen. 
F. Al. An einzelnen oder wenigen Fundorten in Fekerö (Arrh.), Finstrum (Nerv.), Lenıland, Jomala, Sund, Saltvik und Geta (Bom.). - Ab. Korpo (Ekl.). Pargas, Simunby (Arrh.). Kimito, Brändboda (Ohls.). Finby, an mehreren Fundorten (EIfv., Broth.). Vehmo, Susivuori (tzuor.). Karislojo, Puujärvi (Broth.). Lojo, an vielen Fundorten (Lindb., Hult, H. Lindb., E. af H., Sundv.). - X.. Sjundeả (Sundv.). Esbo, Sandudd (Broth.). Lovisa (Arrh.). Iitti, Perheniemi (Tigerst.). - Ka. Wiborg (W. Nyl.); Soskuanjoki (Bu(li). - St. Eurajoki (Simm.). - Ta. Säiksmäki, Linnastonvuori (Kihlm.). Lamni, Evo (Sil.). Hollola, Vaania und Sarva (Norrl.). Asikkala, zw. Kalkkis und Rauvala (N.). Luhanka, Sikolahti (Vain.). Korpilahti,: Vaurunvuori (Link.). - Sa. Nyslott (Carl.). — Kl. Valamo (IV. Nyl.). Sortavala, an mehreren Fundorten (Linnan., Popp., Link., Pes.); Kirjavalahti fq. (Norrl.); Paksunieni (Kop.). Ruskeala (W. Nyl.). Suistamo, Leppäsyrjä (Pes.); Jalonvaara, Riuttavuorı und Hyypinkallio (Link.). Pälkjärvi, Ullavankallio und Kiviniemi (Kop.); Korkeaniemi (E. af 11.). — Kot. Salmi, Leppälä Kallioniemi (Link.). - - sb. Kuopio, an mehreren Fundorten (Link., Roiv.). Kaavi und Juuka, in Kalkund Serpentingeb. fq. (Kot.). Nilsiä, Loutteinen und Kuuslahti, Jaakonlanpi (Kyyhk, und Kot.). $K b$. Tohmajärvi: Hiidenvaara (Broth.); Simosenvaara (Oesch). Polvijärvi, Kirelidorf (Kot.). Juuka, im Kalk- und Serpentingeb. fq. (Kot.). - Kon. Jalguba (Sahlı.). Valkeanäki, Tiudie und Kenijärvi (Norrl.). - Om. Alajärvi, Vesterbacka, Huosianmaankallio (Backm.). - Ok. Paltano, Mieslahti und Hyyrylänmäki, Likolampi (Kyybk.); Melalahti, Viilonkallio (Lachstr.). Sotkamo, Natula; Aarrennieıni und Kohvorinsaari (Kyybk.). Puolanka (Lackstr.); Salminen und Rytiaho, Vuorijärvi (Kyyhk.). Suomussalmi, Kallioinen und Kiannankylä, Katiskalampi (Kyyhk.). - hpom. Loukkovaara und Hukkakallio (Bergr.). - K. Kuusamo, an vielen Fundorten (Nyb., Sil., Broth., E. af H.). - Kk. Keret, Sonostrow (Sahlb.). - Lkem. Kolari, Ylläsjoki, Naalanja und Saivio (Hult). Kittilä (H.). Kuolajärvi. Kutsarjoki (E. af H.); Ulumapaljakka, in der alpinen Region (E. af H.). - Le. An einigen Fundorten in der Kiefernregion (Norrl.); in der Birken- und alpinen Region his Kiıpisjärvi st. f(I. (N.). - Li. Inari, an mehrereı Fundorten in der Nadelwaldregion (Hult); Kodossuannonjää in der Birkenregion (A. Arrh.). Utsjoki, an mehreren Fundorten in der Birkenregion (Sil., Hult, Ranek.). - Lim. Kandalaks (F. Nyl.); Lmpjaur, Unpnischk (Kihm.); Umba (K.). - Ll. Kola, Karaulnaja Pahta (Broth.); Tsipnavolok und Punmanki (B.). - Lmur. Teribjerka (Broth.). - Lp. Katsclikova (Sel.); Kitofka (Fellm.); Orlov (Kihlm.).

S. $S k .-L$.

N. In allen Amtern som Meeresniveau his 1,400 m hinaufsteigend.

In allen Weltteilen, in trop. und subtrop. Gegenden jedoch nur im Gebirge.

42. Distichium inclinatum (Ehrh.) Bryol. eur. 1asc. 29/30, p. 5, t. 2 (1816). [Swartzia inclinata Ehrh. in Hedw. Descr. II. p. 74, t. 27 (1789).]

Bliiten wie bei der vorigen Art. Dichtrasige, dumkel- bis braungrüne, weniger glänzende Pll. Stengel 1-2 cm, selten höher, nur am Grunde mässig mit Rhizoiden. Blätter wie bei der vorigen Art, nur die Rippe kräftiger und die Pfrieme weniger rauh. Seta $1-2 \mathrm{~cm}$. Kapsel geneigt bis horizontal, eiförmig bis länglich. meist etwas hochrückig, entleert glänzend kastanienbraun. Peristomzähne breit lanzettlich, blutrot, zuweilen paarweise verschmolzen, meist vielfach unregelmässig durchbrochen. Sporen $30-45 \mu$, gelblichbraun, warzig. Sporenreife im Juli.

Auf kalkhaltiger Erde, oft an See- oder Meeresufer, in feuchten Spalten der Kalk- und Schielerfelsen, ansnahmsweise auf Torfboden und kalkfreien Gestein. Nordgrenze auf Spitzbergen.

F. Al. An einzelnen Fundorten in Eckerö, Lemland, Jomala und Finstrüm, an mehreren in Saltvik (Bom.). - N. Lovisa (Arrh.). - Kon. Perttiniemi (Simm.). - Ob. Simo (H. Lindb.). - K. Kuusamo, Paanajärvi, Kuoppaoja (Broth.). - Lt. Kola (Karst.). - Lmur. Harlov (Broth.). - Lp. Malo Gorodetskaja (B.). Hapajov und Orlov (Kihln.).

S. Sk., Öl., Ög., Vg., Boh., Srm., Upl., Gstr., Hrjd., Jmt., Ang. und L., meist nur an einzelnen oder wenigen Fundorlen.

N. Sm., A., JL., SB., R.-F., in "Istlandet, Surlandet und Westlandet jedoch nur auf den Inselu oder in der Nähe des Ufers. Steigt bis 1,400 $\mathrm{m}$ hinauf.

Europa, Kaukasus, Nord- und Zentral-Asien, Nord-Amerika.

43. Distichium Hagenii Ryan Nscr.; Philib. in Rev. bryol. 1896, p. 36.

Parözisch und synözisch. Locker- oder dichtrasige, hraungrüne, glanzlose Pfl. Stengel bis $1 \mathrm{~cm}$, \pm filzig. Blätter bis $3 \mathrm{~mm}$, mit kräftiger, wenig rauher und fast die ganze Pfrieme ausfüllender Rippe. Seta etwa $1,5 \mathrm{~cm}$. Kapsel geneigt bis hori zontal, länglich-zylindrisch, symmetrisch, entdeckelt lederbraun und schwach glänzend. Peristonıähne aus 8 ziemlich weit voneinander entfernten Bïndehn gebilclet; Aussenschicht fast ungestreift, meist in $3-5$ unregelmässige Schenkel gespalten, ohne entsprechende Teilung der Innenschicht. Sporen bräunlich, 20$35 \mu$, schwach warzig. 
S. Gstr.. Hille. am lehmigen Ifeeresufer bei Edskorojning.

N. F. Kislrand. Mellanalus, an einem begrenzten Platze auf Qricksand in grosster Menge.

Noraja Zemlja. arkt. Sibirien. arkt. Ford-Amerika.

\section{S E L I G ERACEA E.}

Schlanke, oft zwergige fielsmoose. Stengel aufrecht, mit armzelligen Zentralstrange. dicht und mehrreihig beblättert. nur am Grunde mit Rhizoiden. meist einfach. Blätter am Gruncte klein. oberwïrts aus hohler, breiter Basis I lang pfriemenförmig. flach- und meist ganzrandig: Rippe homogen, unten flach, oberwärts stielrund und meist den Pfriementeil ausfüllend: Zellen rundlich-quadratisch und kurz rektangulär bis linealisch. glatt. am Grunde verlängert rektangulär bis linealisch. Blïte knospenförmig, ohne oder mit spärlichen, kurzen Paraphỹsen. Kapsel meist emporgehoben, anfrecht und regehnässig, nit dem dicken Halse meist rundlich-birnförmig, trocken und entrleckelt meist weitmündig und glatt; Spaltöffnungen (excl. Blindia caespilicia) vorhanden, oberflächlich im Halsteil. Ring (excl. Brachyodontium) nicht differenziert. Peristom meist vorhanden; Peristomzähne 16, lanzettlich oder breit gestutzt, meist mit anssen vortretenden Querbalken und schwach entwickelter Innenschicht. Deckel geschnäbelt.

\section{íbersicht der Gat $\mathrm{t}$ ungen.}

A. Kapsel trocken nit mehreren Längsfalten. Ring sich ablösend. Haube müitzenförmig. lappig 10. Brachyodontium.

B. Kapsel glatt. Ring nicht differenziert. Haube kappenförmig.

a. Sehr kleine Pfl. Blattflügelzellen nicht differenziert ... 11. Seligera.

b. Rasen höher. Blattflïgelzellen differenziert .......... 12. Blindia.

\section{BRACHYODONTIUM}

Bruch in Herb.: Fürnr. in Flora 1827, Il. Beil. I. p. 37.

Autözisch: वै Blüten später am Fuss des Fruchtsprosses. Zwergige, gruppenweise wachsende, gelbgrine. glänzende Pfl. Stengel $1 \mathrm{~mm}$, mit kurzen Innovationen. BIätter trocken verbogen, aus ovaler oder länglicher Basis rasch lang borstenförmị̣, bis $1.5 \mathrm{~mm}$ lang: Zellen oberwärts quadratisch, abwärts verlängert rektangulär bis rhomboidisch, an Grunde hỵalin, in den Blattflügeln nicht differenziert. Perichätialblätter nicht ditlerenziert. Seta aufrecht, $2-3 \mathrm{~mm}$, strohgelb. Kapsel länglich, dünnhäutig, lichtbraun, bis unter die Mitte mit 3-4 zellreihigen. unregelmässigen Streifen und schmäleren Zwischenfeldern, trocken mit mehreren Längsfalten; Zellen des Exotheciums verlängert, in den Streifungen mit verdickten Längswänden. Ring 2 (3) reihig, sich ablösend. Peristom die Ringzellen nicht iiberragend, bleich und zart, beiderseits papillös; Peristonıähne breit, gestutzt. zuweilen hier und da durchlöchert oder in unregelmässige Läppchen gespalten. Sporen 10 ", gell. glatt. Deckel gerade geschnäbelt. Haube mützenförmig, lang und schmal. Jlappig. Wenig unter den Deckel herabreichend. Sporenreife im Herbst. - Fig. 7.1-1).

Einzige Art:

14. Brachyodontium trichodes (Web. fil.) Bruch in Herb.: Fürnr. in Flora 1827 , II. Beil. I. p. 3i. [Gymurostomm trichodes Web. fil. in Web. et Mohr Ind. musc. pl. crypt. 3 (1803).]

An leuchten, beschatteten Felsen. 


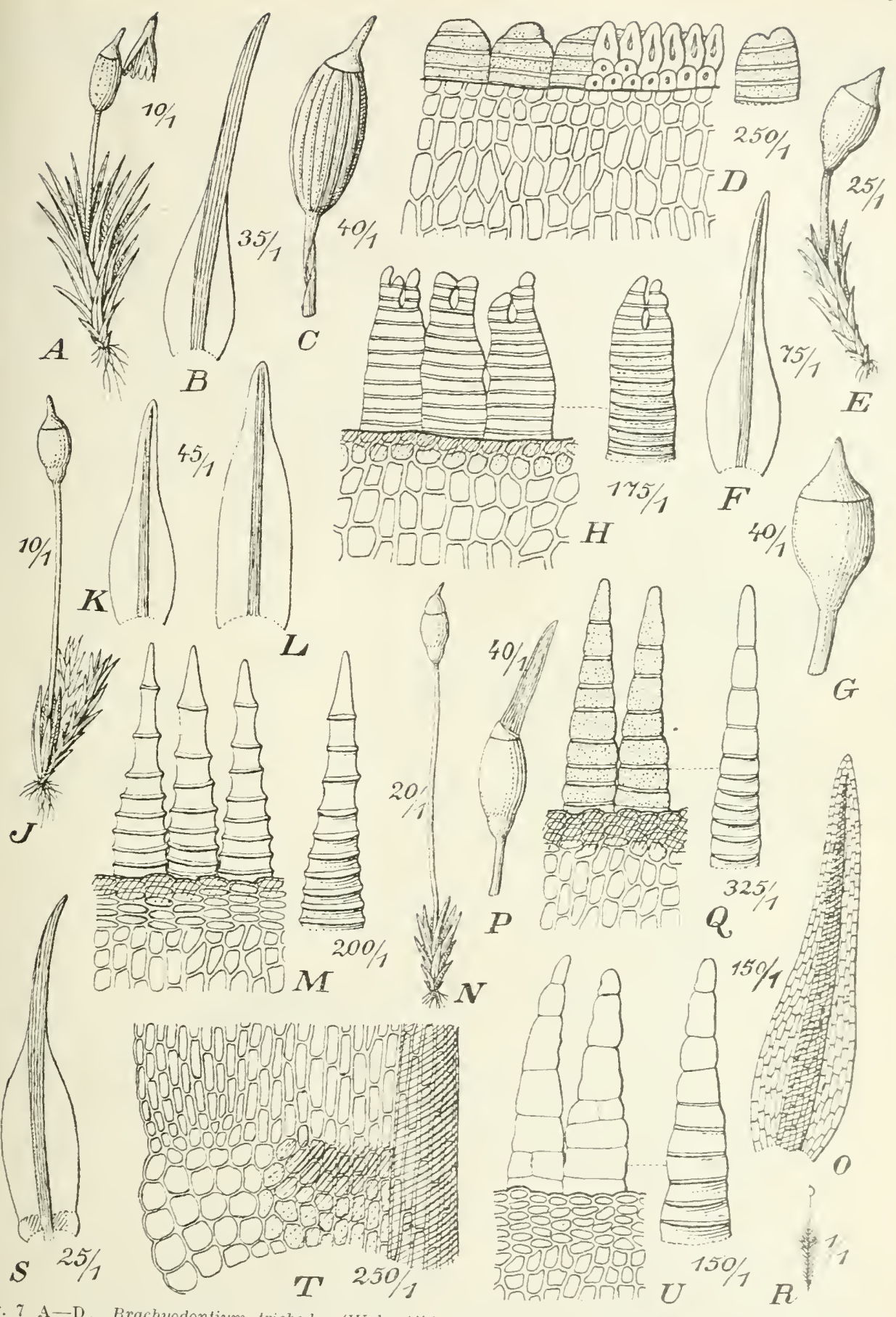

Fig. 7 A-D. Brachyodontium trichodes (Web. til.). A. Fruchtende Pfl. (10 1); B. Stammb. (35 1) E. Fruchtende PII. $(25$ Tustande $(40 / 1)$; D. Peristom $(2501)$. - E-H. Seligera tristichioides Kind diversifolia Lindb. $(200 / 1)-N-Q$. S. brevifolia Lindb. (10/1); K. Stammb. (45 1); L. Inneres Pb: $(45,1)$ : H. Peristom Haube (10/1); Q. Peristom Pfl. (1/1); S. Stengelb (25/1) T B 
N. Auf Gneis, Granit, Schiefer und Kalksandstein von den oberen Teilen des Waldgürtels bis in die Schneegrenze hinaufsteigend, bisher nur von einzelnen oder wenigen Fundorten in $B u_{.}, S t$., $S B$., $N B$. und $R$. bekannt.

West- und Zentral-Europa, Nord-Amerika.

\section{SELIGERA}

Bryol. eur. fase. $33 / 36$ (1846).

Autözisch, selten synözisch; ح Blüten (excl. S. diversifolia) grundständig. Meist zwergige, herdenweise wachsende oder rasenbildende Pfl. Stengel einfach oder aus dem Grunde sprossend. Blätter aufrecht bis aufrecht-abstehend; Zellen am Blattgrunde rektangulär oder rhomboidisch, in den Blattflügeln nicht differenziert. Perichätialblätter (excl. S. diversifolia) den oberen Laubblätter ähnlich, am Grunde meist halbscheidig. Kapsel emporgeholen, rundlich-birnförmig. Peristomzähne glatt, trocken zurückgeschlagen, selten fehlend. Deckel schief geschnäbelt. Haube kappenförmig, 士 weit unter den Deckel reichend, bei S. brevifolia fast zylindrisch, nur den Deckelschnabel mmhüllend. Sporen (excl. S. tristicha) klein, $10-14$ oder $18-21 \mu$, glatt oder fast glatt.

\section{ïbersicht der Arten.}

A. Ohne Peristom

45. S. Doniana.

B Mit Peristom.

a. Blattflügelzellen nicht differenziert.

๙. Zellen des Exotheciums dünnwandig, geschlängelt. Columella vortretend, lange hleibend .............. 51. S. tristichoides.

§. Zellen des Exotheciums dickwandig, mit geraden

Wänden. Columella bald sich ablösend.

I. Zellen des Exotheciums unregelmässig.

1. Blattzellen rektangulär

46. S. pusilla.

2. Obere Blattzellen quadratisch

48. S. calcarea.

II. Zellen des Exotheciums regelmässig.

1. Rippe vor der Blattspitze aufhörend. Haube fast zylindrisch, den Deckelschnabel umhüllend. 47. S. brevifolia.

2. Rippe vilständig bis austretend. Haube kappenförmig.

* Perichätialblätter hochscheidig, płötzlich in eine abgerundete Spitze verschmälert. Seta gerade

50. S. diversifolia.

** Perichätialblätter wenig differenziert. Seta anfangs herabgebogen

49. S. setacea.

b. Blattflügelzellen differenziert.

«. Kapsel emporgehoben

52. S. polaris.

$\beta$. Kapsel fast eingesenkt

53. S. subimmersa.

Unte r g a t t. I. Euseligera Lindlb. Musc. scand. p. 25 (1879). Blattflïgelzellen nicht differenziert.

45. Seligera Doniana (Sm.) C. Müll. Syn. I. p. 420 (1848). [Gymnostomum Donianum Sm. Engl. Bot. XXII. No. 1582 (1806).]

Synözisch. Zwergige, gesellig wachsende, oliven- oder gelblichgrüne Pfl. Stengel $1 \mathrm{~mm}$. Blätter aus eilänglicher, kleingesägter Basis rasch linealisch-plricmenförmig, bis 1,3 mm lang; Rippe gleiclıbreit, den Pfriementeil ausfüllend; Zellen oberwärts quadratisch. Seta bis $2 \mathrm{~mm}$, aufrecht, bleich. Kapsel verkehrt ei- 
birnförınig bis fast kugelig, bleich olivengrün, trocken und entleert verkürzt und weitmündig, im Alter dunkelbraun; Zellen des Exotheciums dickwandig, unregelmässig, mehreckig. Peristom fehlend. Sporenreife im Juli.

In Höhlungen und Schluchten, an liebsten an Kalkfelsen und kalkhaltigen Schiefern, seltener auf Sandstein, Gnejs und Granit.

F. Kl. Ruskeala, in IIarmorbruche (Simm., Norrl.). Pälkjärvi, Korkeaniemi (Broth.). — Sb. Kaavi, Siikajärvi, Huosiaisniemi (Kot.). - K. Kuusamo, Oulankajoki (Broth.).

S. Öl., Gll. und $\ddot{g}$. an einzelnen, $\mathbf{V g}$. und $\mathrm{Hrjd}$, an wenigen Fundorten.

N. A., Bu., Br., $S B$. N $B ., K, K_{\text {. }} N T$. pass., No. bis Andoen fq. Tr. Bardo. Steigt bis in die Birkenregion hinauf, an einzelnen Fundorten die Baumgrenze auch übersteigend. Nordgrenze lee $69^{\circ} 20^{\prime}$ n. Br.

Europa, Sibirien, Nord-Amerika.

var. pygmaea Hag. in D. K. N. Vid. Selsk. Skrift. 1910, No. 1 (1910).

Blätter kurz zugespitzt.

N. No. Dverluerg. Prestdalen, $150 \mathrm{~m}$.

46. Seligera pusilla (Ehrl.) Bryol. eur. fase. 33/36 Mon. p. 4. 1. 1 (1846). [Swartzia pusilla Ehrh. Hann. Mag. 1780/82.]

Zwergige, fast rasenbildende, freudig grüne, seidenglänzende $\mathrm{Pfl}$. Stengel etwa $1 \mathrm{~mm}$. Blätter steif aufrecht oder schwach einseitswendig, aus lanzettlicher Basis allmählich sehr schmal und scharf pfrienenförnig, bis $2 \mathrm{~mm}$ lang, mit deutlich ausgeschweift gezähnten Rändern; Pippe zart, mit oder vor der Blattspitze aufhörend; Zellen überall rektangulär. Seta bis 3 mm, aurrecht, bleich. Kapsel breit verkehrt ej-birnförmig, trocken und ent deckelt weitmündig, gebräunt; Zellen des Exotheciums dickwandig, unregelmässig, mehreckig. Peristomzähne etwa $10 \mu$ lang.

An beschatteten, feuchten Felsen, lesonders auf Kalk.

S. Vg. Kinnekulle.

N. Bu. Norderhov, Bure.

Europa. Kaukasus, Sibirien, Nord-Amerika.

var. acutifolia (Lindb.) Schimp. Syn. 2. ed., II. p. 125 (1876). [S. aculifolia Lindb. in Hartm. Skand. Fl. 9. ed. I1. p. 75 (186t).]

Blätter rasch lang und sehr schmal pfriemenförmig; Rippe auslaufend.

S. Gtl. an wenigen Fundorten.

N. L.M. Kristiansand. R. Sande. Brejviken,

England, Italien.

47. Seligera brevifolia (Lindb.) lindb. in K. Sv. Vet.-Ak. Handl. XXVIII. No. 10, p. 84 (1890). [Seligera pusilla var. brevifolia Lindb. in Öfv. K. Vet.-Ak. Förh. XXI. p. 187 (1864)]:

Zwergige, gesellig wachsende, grüne Pll. Stengel kaum bis mm. Blätter steif aufrecht, aus eiförmiger Basis almäblich kurz zugespitzt, bis $0,9 \mathrm{~mm}$ lang, fast ganzrandig; Rippe zart, vor ler Blattspitze auflörend; Zellen olserwärts quadratisch. Seta etwa $1,3 \mathrm{~mm}$, aufrecht. grünlichgelb. Kapsel oval, gelblich, trocken und entleert weitmündig: Zellen des Exotheciuns rektangulär, dickwandig. Peristomzähne zugespitzt, bis $0,18 \mathrm{~mm}$ lang. trocken fast spiralig zurïckgerollt. Haube fast zylindrisch, den Deckelschmabel umhüllend. Sporenreife im Juli. Fig. $7 \times-\mathrm{O}$.

F. K. Kuusamo, Paanajärsi. Kuoppaoja, auf Talkschjefer (Broth.)

N. An meisten auf Schiefer, selten auf Kalk, bisher nur an einzelnen oder wenigen Fundorten in SB., NB., K., ST., NT. und . No. beobachtet.

Silnweiz, sibirien.

48. Seligera calcarea (Dicks.) Bryol. eur. fase. 33336 Mlon. 1. 1, t. 1 (18+6). [Bryum calcareum Dicks. Pl. crypt. fasc. II. p. 3, t. 11, f. 1-5 (1801). - Seligera crassinervis Lindb. in Meddel. Soc. Fauna \& Fl. Fenn. 11. Heft, p. 72 (1887).]

Dicht gesellige, schmutzig- oder olivengrüne, starre Pfl. Stengel kaum bis 1 mm. Blätter aus eilänglicher Basis rasch in einen kurzen, schmal linealischen 
Pfriementeil verschmälert, bis 1,3 mm lang; Rippe unten zart, oberwärts kräftig, den oberen Pfriementeil ausfüllend; Zellen oberwärts quadratisch. Seta etwa 1,2 $\mathrm{mm}$, aufreclıt, gelb bis bräunliclıgelb. Kapsel verkehrt ei-birnförmig, entleert gebräunt; Zellen des Exotheciums dickwandig, unregehmässig, mehreckig.

An senkrechten Kalk- und Kreidefelsen.

S. Öl. Borgholm. ウ̈g. Omberg. Vg. Billingen (S. crassinertis).

Europa.

49. Seligera setacea (Wulf.) Lindb. in Öfr. Vet.-Ak. Förh. XX. p. 413 (1863). [Bryum paludosum L. Sp. p]. ed. 1, p. 1119 (1753). — Bryum setaceum Wulf. in Jacq. Misc. II. p. 96 (1781). - Grimmia recurvata Hedw. Descr. 1. p. 102, t. 38 (1787). - Seligera recurvata Bryol. eur. fasc. 33/36 Mon. p. 6, t. 3 (1846). - S. paludosa Hag. in D. K. N. Vid. Selsk. Skrift. 1910. No. 1, p. 92.1

Herdenweise wachsende oder breitrasige, dunkelgrïne Pfl. Stengel bis $5 \mathrm{~mm}$, gleichförmig beblättert. Blätter aus ei- oder länglich-lanzettlicher Basis allmählich lang pfriemenförmig. bis 1,5 mm lang; Rippe gleichbreit, den oberen Pfriementeil ausfüllend: Zellen oberwärts rektangulär bis fast quadratisch. Seta $3-4 \mathrm{~mm}$, anfangs herabgebogen, später sich aufrichtend, strohgelb. Kapsel oval oder länglich, rötlichbraun, entleert lichtbraun; Zellen des Exotheciums unregelmässig, verlängert, locker, mit geraden Wänden.

Am liebsten an Sandsteinfelsen und schwach kalkhaltigen Gesteinen, nicht selten grosse Flächen bedeckend. selten auf Kalk. Sporenreife im Sommer.

F. Konn. S’ojärvi (Norrl.). Valkeamāki (Simm.). Mundjärvi (Norrl.). - Kpom. Hukkakallio (Bergr.). - K. Kuusamo, Aventojoki, Ristikallio (E. af H.): Merenoja (Broth.); Riihijoki (F. Nyl.); Selkăjoki (Nyb.); Paanajärvi. Kuoppaoja (Broth.).

S. An einzelne. oder waigen Fundorten in Sh. Vg., Dld.. V'sm., Dlr. und LuL.

N. A. $-B r .$, S!., SB.. K.. H. - NT. t verbreitet und stellenweise st. fq., No, und $F$. r. Am reichlichiten in niefriger Lage und im Waldgebiete. sehr selten iiber die Baumgrenze hinaufsteigend. Nordgrenze bei $69^{\circ} 54^{\prime} \mathrm{n}$. Br.

Europa, Kaukasus. Nord-Amerika.

var. pumila Lindb. in Öfv. K. Vet.-Ak. Förh. 1864, No. 3 excl. syn. [S. recurvata var. pumila Hartm. Sk. Fl. 9 ed. II. p. 100 (186.1)].

In allen Teilen kleiner. Stengel mit zahlreichen Sprossen. Blätter weit kürzer; Rippe zarter. Seta aufrecht.

F. Kl. R likeala (F. Nyl.): Tırrinınylly (Broth.). - K. Kuusamo, IIāntyjoki (Vain.). Kuolajārvi, sipanlampi (Roir.); Sovajärvi, Ruokojärri (R.).

S. LuL. Krikkjokk. Njammats.

N. A. Aker, Riristinuia und Baerum an einzelnen Fundorten.

Schweiz, Steiermark, Nord-Amerika.

50. Seligera diversifolia Lindb. in Öfv. K. Vet.-Ak. Förh. XVIHI. p. 281 (1861).

Blüten in der Nähe der ₹ Blüten, dick knospenförmig, mit zahlreichen Hüllblättern. Herdenweise wachsende oder breitrasige, dunkelgrüne oder olivengrüne Pfl. 'Stengel bis $1 \mathrm{~cm}$. Untere Blätter klein, obere rasch grösser, lanzettlich, zugespitzt oder stumpl', bis $0,8 \mathrm{~mm}$ lang; Rippe gleichbreit, in der Spitze aufgelöst: Zellen oberwärts rektangulär bis fast quadratisch. Perichätialbłätter hochscheidig. plötzlich in eine abgerundete Spitze verschmälert, innere ohne versclmmälerten Teil. Seta 3-4 mm, strohfarben, geschlängelt. Kapsel oval oder länglich, gelblich, entdeckelt lichtbraun; Zellen des Exotheciums wie bei der vorigen Art. Fig. $7 \mathrm{I}-\mathrm{I}$.

An Kalkfelsen.

F. Kl. Rlikeala (F. Nyl.). - Ok. Paltain , Melalahti, Viilonkallio (Lackitr.).

S. I'sm. siala.

N. Bu. an wenigell Fundorten.

var, brevifolia (Zett.) Lindb. et Arn. in K. Sv. Vet.-Ak. Handl. XXVIII. No. 10 , p. $8.3(1890)$. [Setigeria recurvata var. brevifolia Zett. mss.: A. Blytt in Kr. 
Vid. Selsk. Skr. 1871, p. 138; nom. nud. - S. erecta Phil. in Rev. bryol. 1879, p. 67. - S. paludosa var. brevifolia Hag. in D. K. N. Vid. Selsk. Skrift. 1!10, No. 1. p. 97. - S. arctica Kaur. mss.; Jorg. in Kr. Vid. Selsk. Forh. 18!4, No. 8, p. 68 ut syn.].

Innere Perichätialblätter den Schopfblättern ähnlich.

Auf kalkhaltigen Schieferfelsen.

$\mathbf{N}$. An mehreren Fundorten in $Y_{0}$., an einzelnen oder wenigen in $Y B . K \ldots>T$. und $T r$.

Sibirien.

fo. obliquula (Lindb.) Hag. I. c. p. 98. [Seligeria obliqunla Lindb. in Medrlel. Soc. F. Fl. Fenn. XIV. p. 72 (1887).]

Kapsel oft einseitig bauchig, am Grunde abgerundet.

N. $s T$. Opdal, Vaarsien.

51. Seligera tristichoides Kindb. Sp. Eur. and X.-Am. Bryin I1. p. 213(1897). [Seligera patula var. tristichoides Hag. in D. K. N. Vid. Selsk. Skrift. 1910, No. 1. p. $98(1910)$.]

Gesellige, sattgrüne, starre PfI. Stengel bis 1,5 mul. Bläter dreireihig, obere aufrecht-abstehend, rasch grösser, aus schmal elliptischer Basis linealisch, stumpf. bis $0,45 \mathrm{~mm}$ lang, oberwärts leicht ausgefressen; Rippe mit der zweischichtigen Blattspitze verschmelzend: Zellen oberwärts quadratisch. Seta etwa 1,5 $111 \mathrm{~m}$. int Bogen gekrümmt, gelbbräunlich. Kapsel fast kugelig, gelbbraun, nach der Entdeckelung halbkugelig, mit vorragender Columella, trocken bepustelt; Zellen des Exotheciums dickwandig, sehr unregelmässig, mehreckig. Sporen $18-21 \mu$. Sporenreife im Juli und August. - Fig. $7 \mathrm{E}-\mathrm{H}$.

Auf Dolomit und kalkhaltigen Schieferfelsen.

F. K. Kuusamo, Paanajärvi (Vain.).

N. Am häufig;ten in No. be:onders in Ve;ien. Ranez und Salten, an einzelnen frundorten in $J L$. $B r$, und $K$.

Pyrenäen, Kaukasus, Nord-Amerika.

var. patula (Lindb.). [Seligeria trifaria var. patula Lindb. in Öfr. K. Vet.Ak. Förh. XXI. p. 187 (1864). - S. patula Hag. in Kgl. Yorsk. Vid. Selsk. Skrift. 1910, No. 1, p. 98 (1910).]

Blätter zu einem längeren, schwach zurückgebogenen Pfriementeil verschmälert.

S. Gll. Thorzborgen.

N. Mit der Hauptart, jedoch spärlich.

Un $\mathrm{t}$ e $\mathrm{rg}$ a $\mathrm{t}$. I I. Blindiadelphus Lindb. 1. c. Kapsel mit Peristom. Blattflügelzellen differenziert.

52. Seligera polaris Berggr. in K. Sr. Vet.-Ak. HandI. XIII. No. 7, p. 41 (1875). [Blindia polaris Hag. in D. K. N. Vid. Selsk. Skrift. 1910, No. 1, p. 99 (1910).]

Rasen schmutzig gelbbräunliclı bis schwarz. Stengel bis $1 \mathrm{~cm}$. Blätter aus breit ovaler Basis lanzettlich zugespitzt, stumpflich, bis $1,5 \mathrm{~mm}$ lang: Rippe nach oben breiter; Zellen oberwärts quadratisch, am Blattgrunde rektangulär, nicht verdickt, in den Blattecken quadratisch, hyalin oder gebräunt. Perichätialblätter grösser, aus scheidigeın Grunde lanzettlich. Seta etwa $3 \mathrm{~mm}$, dick, etwas gekrümmt, braungelb. Kapsel entdeckelt kugelig, trocken und entleert kreiselförmig, unter der Mündung eingeschnürt, braungelb. Peristomzähne ungeteilt, 12-15gliederig. rötlich. Sporenreife im Juli.

S. TL. Abisko.

N. $F$. Talvik.

Spitzbergen. arkt. Nord-Amerika.

53. Seligera subimmersa Lindb. Musc. scand. p. 25 (1879). [Blindia subinmersa Hag. in D. K. N. Vid. Selsk. Skrift. 1910, No. 1, p. $84(1910)$.

Räschen schwärzlich, dicht kissenförmig. Stengel $1 \mathrm{~cm}$ und darüber. Blätter trocken geschlängelt, oben eingekrümmt, aus lanzettlicher oder länglicher Basis 
allmählich pfriemenförmig, stumpflich, bis $1,3 \mathrm{~mm}$ lang; Rippe oberwärts allmällich breiter. Zellen verdickt, oberwärts quadratiseh, am Blattgrunde rektangulär, in den Blattecken quadratisch. Perichätialblätter zusammengewiekelt, plötzlich pfriemenförmig und die Urnenmündung erreichend. Seta bis $1.5 \mathrm{~mm}$. Kapsel elliptisch.

Peristomzähne ungeteilt, 10gliederig, purpurn.

F. K. Kuusamo, Kitkajoki (Sil.).

\section{BLINDIA.}

Bryol. eur. fasc. $33 / 36$ (1846).

Schlanke Pfl. in \pm dichten, glänzenden Rasen. Stengel gabelig geteilt. Blätter aufrecht-abstehend bis einseitswendig; Blattflügelzellen differenziert. Perichätialblätter differenziert Kapsel kurz birnförmig bis fast kugelig, derbhäutig; Zellen des Exotheciums unregelmässig, rundlich 3-6eckig, dickwandig. Peristomzähne, wenn vorhanden, breit lanzettlich, rotbraun, glatt, entfernt gegliedert, ohne aussen vortretende Querbaiken. Deckel sehief geschnäbelt. Ilaube kappenförmig. Sporen bis $18 \mu$, gelb, fast g]att.

\section{Übersiclit der Arten.}

A. Autözisch. Ohne Peristom 54. B. caespiticia.

B. Diözisch. Mit Peristom 55. B. acuta.

54. Blindia caespiticia (Sehwacgr.) C. Müll. Deutsehl. Moose p. 214 (1853). [Anoectangium caespiticium Sehwaegr. in Web. et Mohr Taschenb. p. 77 (1807). - Stylostegium caespiticium Bryol. eur. fase. 33/36, p. 3, t. 1 (1846).]

Autözisch: of Blüten gestielt unterm Perichätium. Bräunlichgrüne Pfl. in kleinen, dichten Rasen. Stengel $0,5-4 \mathrm{~cm}$. Blätter aus länglieher Basis allmählich pfriemenförmig, bis $2 \mathrm{~mm}$ lang; Rippe den Pfriementeil ausfüllend: Zellen linealisch, verdickt, am Grunde in melıreren Reihen braun, in den \pm deutlich ausgehöhlten Blattflügeln quadratisch. Perichätialblätter viel grösser, hochscheidig, in eine kürzere Pfrieme vershmälert. Seta sehr kurz, gelb. Kapsel eingesenkt, zuletzt oft seitlich hervortretend, fast kugelig, entdeckelt hallikugelig, entleert kreiselförmig, gelıräunt, ohne Spaltöfnungen. Peristom fehlend. Deckel kurz gesehnäbelt, zuletzt mit der anlaftenden Columella abfallend. Haube nur so lang wie der Deckel.

An schattigen oder nassen Schieferfelsen.

S. IIrjd. und LuL. an wenigen Fundorten.

N. $S B$. $K$. $S T$, und $T r$, an wenigen oder einzelnen Fundorten in den obersten Teilen des Waldgetietes und in der alpinen Region.

Europa im Hochgebirge.

55. Blindia acuta (Huds.) Bryol. eur. fasc. 33/36 Mon. p. 3, t. 1 (1846). [Bryum acutum Huds. F]. angl. 2. ed. ]) I8.1 (1778). - Weisia acuta Hedw. Descr. III. p. 85 , t. 35 (1792).]

Diözisclı und zweirasig. Grüne odler gelblich- bis braungrüne, unten schwärzliche Pfl. in meist dichten, oft ausgedehnten Rasen. Stengel $1-8 \mathrm{~cm}$, selten höher. Blätter aus länglicher Basis pfriemenförnig, stumpflich, bis 2 mm lang: Rippe den Pfriementeil ausfüllend; Zellen linealisch, verdickt, am Grunde in mehreren Reihen braun, in slen \pm deutlich ausgehöhlten Blattflügeln erweitert, quadratisch, gel)räunt. Perichätialblätter aus hochscheidigem Gruncle plötzlich pfriemenförmig. Seta $5-8 \mathrm{~mm}$, zuweilen etwas geschlängelt, rot. Kapsel kurz birnförmig, braun. 
Peristomzälne liier und da durchbrochen, bisweilen an der Spitze gespalten. Haube bis gegen die Urnenmitte reichend. - Fig. $7 \mathrm{R}-\mathrm{U}$.

An feuchten und ïberrieselten Gesteinen jeder Art.

F. Ab. Nảdendal (Elfr.). Pargas, Toijois (Colland.). Kimito. Norrlángvik (Ohli.). Lojn, Storon, Tamsaari (H. Lindb.). - Ka. Wiborg. Soskuanjoki und zw. Räihä und Pilli (Buch). - Ta. Ilollola. Jalkaranta (Vain.). Padasjoki, Arakoski und Vimaila (Norrl.). Kuhmoinen, Harmon( Norrl.). Luhanka, Onkisalo, Jänissaari (Vain.). Korpilahti. Rappakallio (V.). - Kl. Kurkijoki, Taskinen (Jusl.). Jaakkima. Ramola (Sundr.). Valamo (Norrl.). Sortavala, Kirjavalahti (Norrl.). — Tb. Pihlajavesi (Norrl.). Jyväskylä, Kanavuori (Tain.). Konginkangas (B.). Viitasaari, Niinilahti (Broth.). — S゙b. Kuopio, an mehreren Fundorten (Link., Roiv.). Maaninka, Korkeakoski (Broth.): Haalala, IIaukkavuori (Roiv.). - Om. Alajärvi, Ojajärvi (Backm.). - Ok. Kajana (Lackstr.). - Ou. Ylitornio, Kaarasnås (Hult). - K. Kuusamo. Korojoki (Broth., E. af H.); Hyväniemi (Broth.); Kitkanuiemi (E. af Il.); Kitkajoki (Broth.); Oulankajoki und Rissijoki (E. af H.); Paanajärvi (Broth.); Sovinkëngäs (B.). Le. An mehreren Fundorten in der Nadelwaldregion, in den oberen.Teilen der Birkenregion und der alpinen Region st. fq. (Norrl.). - Li. Inari, Luirojärvi, Väylä und_Jihmosuanto (Vishojoki) in der Nadelwaldregion (Hult); Kodossuannanpää (Kihlm.) und Peldoivi (Hult) in der Birkenregion; Lupukkapäa in der alpinen Region (H.). Utsjoki, Jalgelvedja, Kvadniljokka und Outakoski (Ranck.). - Lim. Tschun (Broth.). Hibinä, an mehreren Fundorten (Broth.. Kihlm.); Umpjok, Kangaskoski (Kihlm.). - Lt. Zw. Kossijäyr und Ruokojäyr (Roir.); Kallajäyr und Lavshjäyr (R.); Saariselkä, Jaurujoki (R.). Kildin (Broth.). - Lmur. Teribjerka (Broth.). - Lp. Orlov (Kihlm.).

S. Š. und Sin, an mehreren, Ög., $\mathrm{Vg} .$, Boh. und $\mathrm{När}$. an einzelnen oder wenigen Fundorten; Did.. Vrml.-L.

N. In allen Ãmtern sı. fq., am häufigsten im Os-Gełiete und in der subalpinen Region, kommt doch auch in niedriger Lage und bis 1,600 m vor. Nordgrenze auf spitzbergen.

Europa, Kaukasus, Zentral-Asien, Nord-Amerika.

\section{I C R A N A C E A E.}

Meist ausdauernde und rasenbildende Pfl. Stengel (excl. Amphidium und Rhabdoweisia) mit Zentralstrang und meist getüpfeltem Grundgewebe, dicht beblättert, einfach oder gabelig geteilt. Blätter mehrreihig, aus meist halbscheidiger Basis \pm verlängert lanzettlich, oft pfriemen- bis borstenförmig zugespitzt: Rippe meist heterogen und dann meist mit medianen Deutern und meist ohne Begleiter; Zellen am Blattgrunde gestreckt, oft mit differenzierten Blattflügelzellen, oberwärts kürzer bis rundlich-quadratisch. Blüte mit fadenförmigen Paraphysen, ơ Blüte meist knospenförmig. Seta verlängert, glatt. Kapsel meist geneigt und symmetrisch, seltener aufrecht und regelmässig; Spaltöffnungen oberflächlich oder fehlend. Peristomzähne 16, rot, oberwärts bleich, am Grunde meist zu einem Hohlzylinder verbunden, trocken (excl. Arctoa) aufrecht, mit einwärts gebogenen Spitzen, meist $t$ tief herab pfriemlich 2 (3)schenkelig, inmen mit Querleisten. Deckel aus kegeliger Basis \pm lang und schief geschnäbelt. Haube gross, kappenförmig, nackt.

\section{Übersielit der Unterfamilie n.}

A. Blattrippe ohne chlorophyllhaltige Zellen.

a. Hals von Urnenlänge oder länger, mit Schwammparenchym und vielen Spaltöfnungen I. Tremalodontoideae.

b. Kapsel mit kurzem oder undeutlichem Halse.

«. Peristomzälne ungeteilt, glatt, ungestreift oder abwärts querstreifig und oberwärts mit schräg sich kreuzenden Linien, zuweilen felılend

IV. Rhabdoweisioideae.

¡. Peristomzähne meist 2 (3)schenkelig und längsstreifig oder oberwärts schrägstreifig, mit papillösen Schenkeln.

I. Blätter von der Rippe bis gegen die Ränder all- 
mählich dünner. Spaltöffnungen (excl. Dicranella secunda) fehlend

III. Campylopodioideae.

II. Blätter an den Rändern kaum dünner als bei der Rippe. Spaltöffnungen vorhanden.

1. Blattflügelzellen und Perichätialblätter nicht

2. Blattflügelzellen \pm deutlich differenziert. Perichätialblätter scheidig ...................... V. Dicranoideae.

B. Innenschicht der Blattrippe reich an Chlorophyll V1. Paraleucobryoidecie.

\section{TREMATODONTOIDEAE.}

Meist autözisch; ح Blüte knospenförmig später am Grunde des verlängerten Fruchtsprosses. Blätter an den Rändern nicht dïnner als bei der Rippe. Perichätialblätter differenziert. Kapsel durch den langen, engen Hałs keulenförmig; Halsgewebe schwammig; Spaltöffnungen zahłreich.

\section{TREMATODON}

Michx. Fl. amer. bor. II. p. 289 (1803).

Niedrige, glanzlose, rasenbildende oder dicht gesellige Erd- und Moorbewohner. Stengel aufrecht, mit grossem Zentralstrang und nicht getüpfeltem Grundgewebe, nur am Grunde mit Rhizoiden. Blattrippe ziemlich breit, mit oder vor der Blattspitze aufhörend: Zellen glatt, in verbreitertem Blatteil verlängert rektangulär und 6seitig, gegen die Ränder enger, fast einen Saum bildend, in den Blattflügeln nicht differenziert. Seta autrecht. Peristom vorluanden.

\section{L bersicht der Arten.}

A. Blätter aus anliegender, breiterer Basis plötzlich lanzettlich-pfriemenförmig. Kapselhals fast kropfig von der Seta abgesetzt 56. T. elongatus.

B. Blätter eilanzettlich. Kapselhals allmähiich in die Seta verengt 57. T. brevicollis.

56. T. elongatus (Stroem) Hag. in Kgl. Norsk. Vicl. Selsk. Skrift. 1915 No. 1 , p. 178. [Bryum elongatum Stroem in Skrift. Nat. Hist. Selsk. 1. 2, p. 34, t. 11, no. 4 (1791). - Dicranum ambigunm Hedw. Stirp. crypt. IlI. p. 87 (1792). - Trematodon ambiguus Brid. Musc. rec. Suppl. IV. p. 52 (1819).]

Meist autözisch, zuweilen diözisch, wobei und Pfl. in demselben Rasen. Pfl. in lockeren, zuweilen ausgedehnten, grimen Rasen. Stengel bis $1 \mathrm{~cm}$, selten höher. Blätter aus aufrechter, dicht anliegender, eiförmiger bis länglich-ovaler Basis plötzlich lang lanzettlich-pfriemenförm g und feucht \pm abstehend bis einseitswendig, an der Spitze klein gezähnt, flachrandig, bis 4 mm lang; Rippe mit Stereiden, den Pfriementeil ausfüllend. Perichätialblätter aus länglichem, lockerzelligem Grunde liürzer pfriemenförmig. Seta $0,5-3 \mathrm{~cm}$, gelb. Kapsel gelb- bis braunrot; Hals gebogen, länger als die längliche Urne, fast kropfig von der Seta abgesetzt; Zellen des Exotheciums stark verdickt, am Rücken verlängert, eng prosenchymatisch, unterseits kürzer und weiter. Ring 3reihig, sich ablösend. Peristomzähne rotbraun, bis gegen die Basis in 2 ungleiche, fadenförmige, zuweilen 
durch Querleisten verbundene Schenkel gespalten; Innenschicht papillös. Sporen 25-30 $\mu$, kugel-tetraedrisch, gelb, warzig. Sporenreife im August. - Fig. 8 A - D.

Auf nacktem, sandigem, sandig-tonigem oder torfigem, feuchtem Boden, gern an den Wänden von Wiesen- und Torfgräben, in Ausstichen und an ausgetrockneten Seeufern.

F. Al. Geta, Olofsnäs (Bom.). Saltrik, an mehreren Fundorten (Bom.). - Ab. Abo. Ispois (Elfv.). Karuna (E.). Bromarf, Sandö, Sänkmossen (Sundv.). Uskela (Nikl.). Lojo, Skräddarla (Lindl).): Paloniemi (E. af 11.), - N. Ekenäs, Tvärminne (Ranck.). Esło, Grankulla (Ranck.). Helsingfors (Lindb.). Lovisa (Elfv.). Elimäki (Tigerst.). - Ik. Valkjärvi. Pasuri und Pähkinämäki (H. Lindb.). - Ta. Lamni, Evo (Nurrl.). Hollola, Uskila (N.). Asikkala, an mehreren Fundorten (N.). Sysmä. Konkkunitty (Blom). - Sa. Lapyee, Pajarila (Buch). Lappeenranta, Armila (P.). Kangasniemi, Py]ränälă (Lackstr.). Kl. Uukuniemi (simm.). - Oa. Korsnäs, Töjby (Ranck.). - Tb., Pihtipudas (Roiv.). Sb. Juuka, Petrovaara (Kot.). Maaninka, Varpasmaa, Hiikmäki (Roiv.). - Kb. Kitee (H. Backmanl). - K. Kuusamo, zw. Mlartıila und Yattula (Broth.): Ylikitkajärvi, Jäkäläiren (B.); Yasaraperä. Akanlahıi. Kuorikkilampi und Leveälampi (E. af H) - Lim. Kandalak; (F. Nyl.). Tschmn (Salllh.). Hiłinä (F. Nyl.).
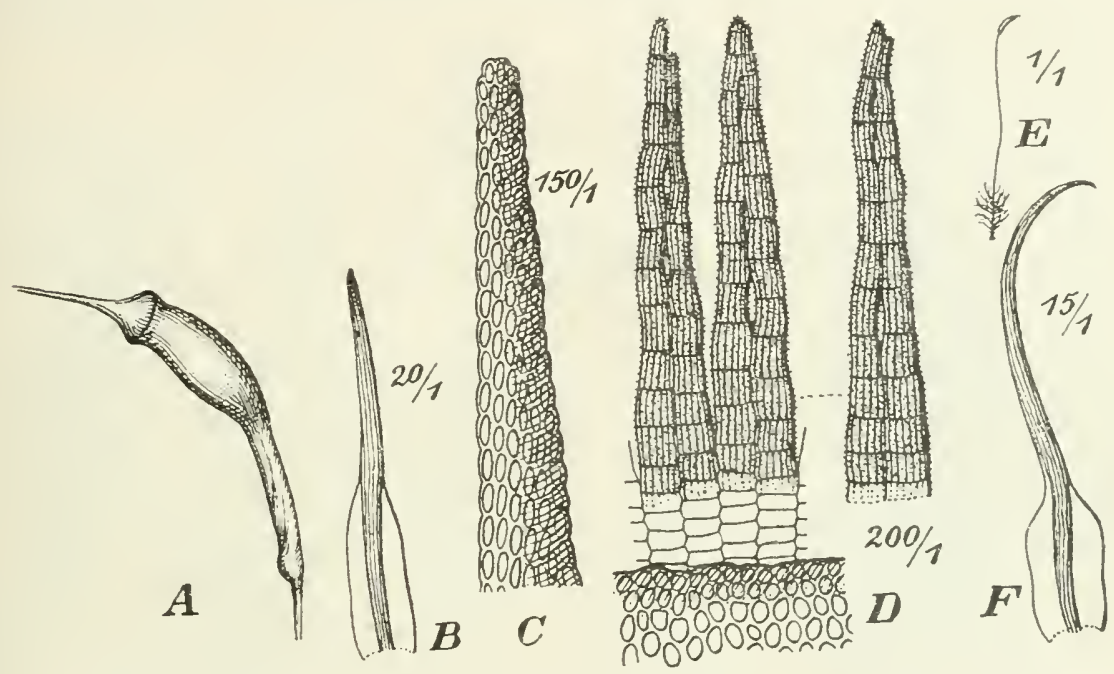

Fig. 8. A-D Tremalodon elongalus (Stroem). A Fruchlende Pfl. (1) 1 B Slamnl. (20 1); C Blattspilze (15,1): I Feristom (201) 1). - E-F Ditrichum lenuifolium (Schrad.) E Fruchtende Pfl. (1/1); F.Stammb. (15:1).

S. Sk.-Hlsl.: Boh.: Ang., PL. und I.uL. r.

N. In Hstlindet fq., in den südwestl. und westl. Küstengegenden rr., im ülrigen Lande bis sa!ten pass. Steigt \pm weit $\mathrm{im}$ Waldgebiete hinauf, nur auswahmsweice die Baumgres.ze überschreitend. Europa, Nord-Amerika.

57. Trematodon brevicollis Hornsch. in Flora 1819, I. p. 88.

Autözisch. Niedrige Pfl. in kleinen Räschen. Stengel bis $t$ mm. Blätter dachziegelig anliegend, hohl, die unteren kleiner und locker gestellt, länglich und zugespitzt, die oberen gehäuft, grösser, breit eiförmig, rasch in eine kurze, lanzettliche Spitze verschmälert, flach- und ganzrandig, bis $1,3 \mathrm{~mm}$ lang; Rippe ohne Stereiden, mit der Spitze endend; Zellen oberwärts polygonal bis rhomboidisch. Seta 4-6 mm, gelb. Kapsel zuletzt gebräunt; Hals vou Lrnenlänge, wenig gekrümmt, allmählich in die Seta verengt; Zellen des Exotheciums lockerer als bei der vorigen Art. Ring 2reihig, teils stückweise mit dem Deckel sich ablösend, teils zurückbleibend. Peristom tief inseriert; Peristomzähne purpurn, lanzettlich. ungeteilt, oft längs der Mitte von rundlichen Löchern durchbrochen; Innenschicht glatt. Sporen 45-60 $\mu$, rund und oval, rostfarben, warzig. Haube am Grunde mehrlappig. Sporenreife im August. 
Auf trockenem, humusreichem oder sandigem Boden und in Felsspalten, besonders auf Schiefer, meist in der alpinen Region.

F. Le. Westlich rom Kilpisjärvi (Sahlb.).

N. K. Vaage. ST. Dorre. No. Mo. Tr. Bard, und Nordrejsen.

Alpenkette von der Schweiz bis Steiermark, Zentral-Asien, Grönland.

\section{I. ANISOTHECIOIDEAE.}

Meist diözisch, selten autözisch oder synözisch. Stengel nur am Grunde mit Rhizoiden. Blätter an den Rändern kaum dünner als bei der Rippe. Blattflügelzellen und Perichätialblätter nicht differenziert. Spaltöfnungen vorhanden. Peristomzähne 2 -3schenklig.

\section{Übersicht de r Gat tungen.}

A. Deckel nicht differenziert

14. Pseudephemerum.

B. Deckel differenziert, sich ablösend.
a. Or Blüte fast scheibenförmig. Blätter schuppenartig anliegend
16. Aongstroemia.
b. $\subsetneq$ Blüite knospenförmig. Blätter \pm abstehend
15. Anisothecium.

14. Pseudephemerum (Lindb.) Hag. in D. K. N. Vid. Selsk. Skrift. 1910 No. 1, p. 45. [Pleuridium A. Pseudephemerum Lindb. in Öfv. K-Vet.-Ak. Förh. XXI. p. 583 (1864).]

Synözisch. Kleine, weiche, glanzlose Pfl. Blätter schmal lanzettlich und allmählich lang zugespitzt; Rippe zart, vor der Blattspitze aufhörend: Zellen locker, dünnwandig, verlängert rektangulär. Seta etwa von der Länge des Scheidchens. Kapsel klein, oval, mit geradem oder schiefem Spitzchen, zuletzt unregelmässig zerreissend; Zellen des Exotheciums unregelmässig 6seitig und dünnwandig.

58. Pseudephemerum axillare (Dicks.) Hag. 1. c. [Phascum axillare Dicks. Pl. crypt. fasc. I. p. 2, t. 1, f. 3 (1785). - Ph. nitidum Hedw. Descr. I. p. 92, t. 34 (1787). - Pleuridium nitidum Rabenh. Deutschl. Kryptfl. II. 3, p. 79 (1848).]

Pfl. grün oder gelbgrün. Stengel bis $5 \mathrm{~mm}$, einfach oder mit einem subfloralen Spross. Blätter aufrecht-abstehend bis schwach einseitswendig, trocken stark verbogen, bis $2 \mathrm{~mm}$ lang, flachrandig, an der Spitze \pm gezähnt. Kapsel licht-bis rotbraun. Sporen etwa 25 ", ockerfarben, warzig. Sporenreife vom Juli bis zum Herbst. - Fig. $4 \mathrm{~A}-\mathrm{C}$.

Auf feuchtem Ton- und Schlammboden, an Grabenwänden, in Ausstichen, an Teichrändern und am Boden ausgetrockneter Wasseransammlungen und Sümpfe.

F. Al. Saltrik, an mehreren Fundorten (Bom.). Sund. Kastelholm und Gesterby tjenan (B.). Föglö, Degerby (B.). - Ab. Abo, Ispoí (Elf r.): Lounasmaa (Brand.); Bagarla (Zett.). Kakskerta, Kaivoinen (Coll.). Uskela (Nikl.). Karislojo (Sundy.): Lohjantaipale (E. af H.). Lojo, Lylyis (E. af H.). N. Kyrkslätt, Vitträsk (Sundr.). Esbo, Kilo (Buch). Helsingfors, an mehreren Fuidorten (Lindb.). Helsinge, Aggelby (II. Nyl.). - Ka. Antrea, Kirchdorf (Buch). - Oa. Vasa (Broth.).

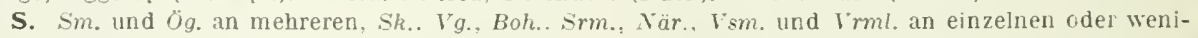
gen Fundorten.

N. In der Ebene an der Küste bis s.ndhordland, jedoch nur am Kristianiafjord st. fq.. in Ne.. L.M. und $S$ B. rr. Nordgrenze bei $59^{\circ} 46^{\circ} \mathrm{n}$. Br.

Europa, Algier.

\section{ANISOTHECIUM}

Mitt. in Journ. Linn. Soc. Bot. XII. p. 39 (1869).

Diözisch, selten autözisch. Blätter bald aus scheidiger Basis länglich lanzettlich oder plötzlich lanzettlich-pfriemenförmig, beiderfalls sparrig-abstehend, bald 
schmal lanzettlich oder lanzettlich-pfriemenförmig und dann aufrecht-alsstehend bis einseitswendig; Rippe (excl. A. vaginale) an Grunde seharf begrenzt. Seta rot. Kapsel meist symmetriseh, dickwandig und glatt; Zellen des Exotheciums parenchymatisch, verdickt, mit geraden Wänden. Peristomzähne lang, bis gegen die Mitte 2schenklig, dick, purpurn, oberwärts meist dieht papillös. Sporen 12-18 $\mu$, gelblich oder grüm, glatt oder zart papillös.

\section{Übersieht der Arten.}

A. Blätter aus seheidiger Basis sparrig-abstehend bis zurückgebogen.

a. Blätter aus ovaler Basis länglich-lanzettlich, breitspitzig: Rippe vor der Blattspitze aufhörend .........6. 61. A. squarrosum.

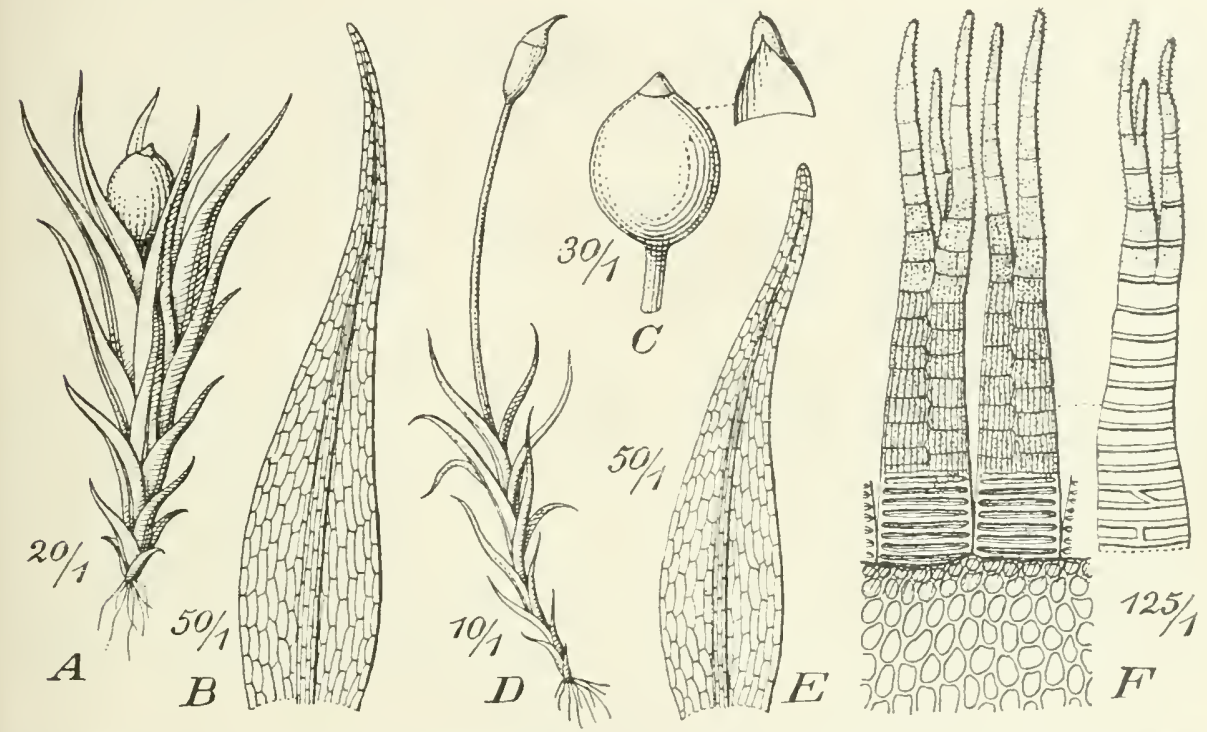

Fig. 9. 1-C. Pseudoephemerum axillare (Dicks.). A Frurhtende PlI. (20 1): B Stamm b. (50 1); C Kapsel (30 1); D-F Anisothecium rufescens (Dicks.). D Fruchtende Pf1. (10 1): E stammb. (50) 1): F Peristom (125 1).

b. Blätter plötzlieh lanzettlich-pfriemenförmig: Rippe vollständig bis austretend.

«. Kapsel aufrecht, regelmässig

61. A. vaginale.

P. Kapsel geneigt, symmetrisch.

I. Kapsel glatt: alle Zellen des Exotheciums gleich verdickt

62. A. crispum.

II. Kapsel trocken gefurcht; Zellen der Streifen mit stark verdickten Längswändlen ....................63. A. Grevilleanum.

B. Blätter schmal lanzettlich oder lanzettlich-pfriemenförmig, aufrecht-abstehend his einseitswendig.

a. Blätter mit zurückgebogenen Rändern..... 65. A. rubrum.

b. Blätter flachrandig.

I. Kapsel aufrecht und regelmässig 59. A. rufescens.

II. Kapsel hochrüekig und etwas gekrummt 60. A. humile. 
59. Anisothecium rufescens (Dicks.) Lindb. Ltkast p. 33 (1878). [Bryum rufescens Dicks. Pl. crypt. fasc. JII. p. 6, t. 8, f. 1 (1795). - Dicranella rufescens Schimp. Coroll. p. 13 (1855).]

Diözisch. Herdenweise wachsende, kaum rasenbildende, sehr schlanke, rötliche Pfl. Stengel meist nur einige $\mathrm{mm}$, selten bis $1 \mathrm{~cm}$, einfach. Blätter trocken straff, feucht aufrecht-abstehend oder einseitswendig, schmal lanzettlich, bis 1,5 mm lang, flachrandig, oberwärts gesägt: Rippe dünn, mit oder kurz vor der Blattspitze versclıwindend; Zellen verlängert rektangulär, dünnwandig. Seta $3-5 \mathrm{~mm}$. Kapsel klein, aufrecht, meist regelmässig, verkehrt-eiförmig oder oval, rotbraun, glatt, trocken und entdeckelt weitmündig, schwach längsfaltig. Ring nicht differenziert. Sporenreife im Spätherbst und ersten Frülnling. - Fig. 9 D--F.

Auf feuchtem, tonigem oder sandig-tonigem Boden an Grabenböschungen, in Ausstichen und auf $\ddot{\text { cckern. }}$

F. Al. Saltrik, an mehreren Fundorten (Bum.). - Ab. Lemo (Elrr.). Finnby (Bruth.). Lrijo, Ojamo (Lindb.). - X. Esboo, zw. Gräsa und Mlankans (Broth.); Kilo (Häyr.). Helsinge, Alberga (Buch). Helsingfors (Lindb.). Sibbo, Husō (Buch). - lk. Uusikirkko, Vammelsuu (H. Lindb.). - Ta. Ko:ki, Zw. Hankala und Hyvāneula (Norrl.). Asikkala. zw. Kurhila und Reivilā (Sil.). Korpilahti, Rutalahti (Vain.). - Sa. Lappee- Pajarila (Buch). - Kol. Mandroga (Elfv.). - Tb. Jỵrãskylä (Broth.). - Gk. Kajana (Lackstr.). Paltamo, Takaranta (L.). - Ob. Tornjonjoki (Graeflé). - Lim. Lmpjok, Kangaskoski (Kihlm.).

S. Sm. an mehreren, Sk., Yg., När., Lld.. Lpl., Gstr., Ang. und V b. an einzelnen Fundorten.

N. Sm.-No. pass. bis $\pm \mathbf{r}$, in $B r ., L M ., K$. und $H$. fehlend. Meist an niedrig gelegenen Standorten. Steigt bis $550 \mathrm{~m}$ hinauf. Nordgrenze lei $67^{\circ} 20^{\prime} \mathrm{n} . \mathrm{Br}$.

Europa, Kaukasus, Japan, Nord-Amerika.

60. Anisothecium humile (Ruth.) Iindl). [Dicranella humilis Ruth. in Hedwigia 1873, p. 147.]

Diözisch. Vereinzelt, herdenweise oder in kleinen, lockeren Häufchen wachsende, sehr schlanke Pfl. Stengel $5-7 \mathrm{~mm}$, einfach, rötlich. Blätter bleichgrün, trocken verbogen bis kraus, feucht oberwärts sichelförmig-einseitswendig, schmal lineal-lanzettlich, bis $1,14 \mathrm{~mm}$ lang, flachrandig und weit herab ausgeschweiftgezähnelt: Rippe mit oder vor der Blattspitze aufhörend bis austretend; Zellen kurz- bis verlängert-rektangulär, dünnwandig. Seta $5-15 \mathrm{~mm}$. Kapsel sehr klein. geneigt bis fast horizontal, hochrückig und etwas gekrümmt, gelbbräunlich, trocken und entdeckelt deutlich gefurcht und unter der Mündung eingeschnürt. Ring differenziert, sich stückweise ablösend. Sporenreife im Herbst.

An gleichen Standorten wie die vorige Art.

F. Al. Saltvik, an wenigen $\mathrm{fundorten} \mathrm{(Bom.).} \mathrm{Sund,} \mathrm{Gesterby} \mathrm{(B.).} \mathrm{-} \mathrm{Ab.} \mathrm{Karislojo,} \mathrm{Niemi} \mathrm{(E.}$ af H.). Lojo, Lylyis (E. af H.). - Ih. Uusikirkko, Rajajoki (H. Lindb.). — St. Pirkkala (Simm.). Sa. Lappee, Kiiala, Pajarila und Hanhijärvi (Buch). Iappeenranta, Komulanmäki (B.). - Ta. Kor lahti, Rutalahti (Vain.). - Tt- Pihtipudas, Heinolankylä (Roir.). Sb. Joroinen, Järvikylä (H. Lindb.). Maaninka, Hökōnen (Kyykk.); Haatala, Parola (Roiv.). - Ok. Kajana (Lackstr.). Paltamo (L.). Sot kamo (L.).

S. Ang. Helgerum.

N. A. an mehreren, sm. und Bu. an wenigen. No. und $\mathrm{Tr}$. an einzelnen Fundorten. Nurdgrenze liei $69^{\circ} 51^{\prime} \mathrm{n}$. Br.

Östl. Teile von Nord-Deutschland. Salzburg. Steiermark, Ost-Russland, Silirien.

61. Anisothecium squarrosum (Stark.) Lindlb. Ltkast p. 33 (1878). [Dicranum squarrosum Stark. in Schrad. Journ. Bot. I1. p. 435 (1801). - Bryum palustre Dicks. Pl. crypt. fasc. 1Y. p. 11 (1801). - Dicranella squarrosa Schimp. Syn. p. 71 (1860). - Anisothecium palustre Hag. in D. K. N. Vid. Selsk. Skrift. 1914, No. I. p. $35(1915)$.]

Diözisch; Antheridien in den Achseln der Hüllblätter. Kräftige, weiche Pfl. in schwellenden, gelb- oder freudig grünen, abwärts schwärzlichen, leicht zerfallenden Rasen. Stengel 2-20 cm. Blätter schlaff, trocken zusammenschrumpfend, feucht aus herablaufender, scheidiger Basis sparrig zurückgebogen, länglich-lanzettlich, stumpf, bis 3,5 mm lang, flach- und ganzrandig, nur an der abgerundeten 
Spitze gekerbt: Rippe dünn, vor der Blattspitze aufhörend; Zellen dïmnwandig, locker, länglich-6seitig, abwärts verlängert. Seta $1-1,5 \mathrm{~cm}$, dick. Kapsel geneigt, buckelig-eiförmig, rotbraun, glatt. Ring nicht differenziert. Sporenreife im Frühling.

In kalten Quellen, Bächen und Versumpfungen. Selten fruchtend.

F. Al. Saltvik, Orrdalsklint (Nerv.). - Le. Kilpisjärvi (Nurrl.). - Li. Sodankylä, an mehreren Fundorten in der Nadelwaldregion (Huit). Inari, saariselkä (H.). Ltsjoki, in der Birkenregiun st. fq. (II.); Lupakkapää und Ailigas, in der alpinen Region (H.). - Lim. Kandalaks (F. Nyl., Broth.). Hibinä (Brotlı., Kihlm.) Lmpjavr (Kihlm.), - Lt. Pummanki (Broth.). Kildin (F. Nyl.), - Lmur. Giavrilova (Broth.). Zw. Varsinsk und Jenjavr (B.). Zw. Kolmjavr und Nisanjanl (Kihlm.). - Lp. Orlow (Kihlm.). Punoj (sahlb.).

S. Sm. an mehreren, $\mathrm{V} g .$, Boh., $\mathrm{Vg}$. und Lh. an einzelnen oder wenigen Fundorten. Dlr.. I/rjd., $J m t$. und $L$.

N. In allen Amlern mit Ausnahme von $L . M$. in den kü-tengegenden von (1:t-. S r- und Westandet r... im Innern \pm fq., an reichlichsten in der subalpinen Region. Nordgrenze hei elwa 71 n. Br. Sleigl selten bis in die aipine Region hinauf.

Europa, Kaukasus, Nord-Auerika.

62. Anisothecium crispum (Schreb.) Lindb. Utkast p. 33 (1878). [Bryum crispum Schreb. Spic. Fl. Lips. p. 79 (1771). - Dicranum Schreberi Sw. Musc. suec. p. 37 et 88, t. 2, f. 6 (1799). — Dicranella Schreberi Schimp. Coroll. p. 13 (1855).]

Diözisch. Weniger schlanke, herdenweise wachsende oder lockerrasige, grüne oder gelbgrüne Pfl. Stengel bis $1 \mathrm{~cm}$, steril bis $2-3 \mathrm{~cm}$. Blätter trocken verbogen bis kraus, feucht aus halbscheidiger, ovaler Basis sparrig-abstehend, rasch schmal lanzettlich-pfriemenförmig, etwa $2 \mathrm{~mm}$ lang, flach- und ganzrandig oder oberwärts spärlich gesägt; Rippe dümn, in der Blattspitze aufhörend; Zellen dünnwandig, oberwärts kurz rektangulär, abwärts allmählich verlängert. Seta $5-10$ mm. Kapsel geneigt, hochrückig eiförmig bis eilänglich, braun, glatt, trocken und entdeckelt weitmündig und gekrümmt. Ring nicht differenziert. Sporenreife im Spätherbst und ersten Frühling.

Auf feuchtem Ton- und Lehmboden in Ausstichen, an Grabenböschungen, Bach- und Flussufern und auf Äckern.

F. Al. Mariehamn, Eckerö, Jomala und Gela, an einzelnen Fundorten (Bom.). Saltvik, an vielen Fundorten (B.). - Ab. Pargas, Lindberg (Elfr.). - N. Kyrkslätt (Sundv.). Esbo, Kilo (Hăyr.). Helsingfors (Lindb.). Helsinge, Degerö (Buch), - Ta. Korpilahti. Tianen und Rutalahti (Vain.). - Sa. Lappee, Askola (Buch). - Tb. Kinnula, Häähkäjärvi (Roiv.). Pihtipudas, Heinola (R.). — Sb. Kuopı, an wenigen Fundorten (Link.). Maaninka, Haatala. an mehreren Fundorten (Roiv.); Varpasmaa (R.). Pöljä, an einigen Fundorten (Kyyhk.). - Ok. Kajana (Lackstr.). Paltamo, Melalahti, Viilonkallin (L.). Hahtola (Kyyhk.). - Ob. Kiiminki (Sahlb.). - K. Kuusamo, Ilaataja, auf Schiefer (Broth.); zw. Rukatunturi und Pyhävaara (B.); Kuusinkijoki (E. af H.): zw. Paanajärvi und Sovajārvi (E. af H.). - Lkem. Kuolajärvi, Sallatunturi (Roiv.). - Ll. Sascheika, am Kolaflusse (Brolh.); Kola (B.).

S. Ög., Vg., Boh., Srm., Tär., Dld., Gstr. und Jml. an einzelnen oder wenigen, sm.. I pl.. $11 \mathrm{pd}$. und Ang. an mehreren Fundorien. LuL. Sarekgebiet.

N. In allen Ảmtern mit Ausnahme von st., NB., $R$. und $V_{0} .$. an häufigsten beiderseits des Kilixtianiafjords, anderwärts + selten, an der Küstenstrecke zw. Skiensfjord und Lofoten fast fellend. Meis $t$ uur in niedriger Lage.

Europa, Kaukasus, Sibirien, Kamtschatkil. Nord-Amerika, New Zealand.

var. lentum (Wils.) Möll. Fört. Skand. växt. 2. Moss. p. 16 (1907). [Dicranella lenta Wils. mscr.; Braith. in Journ. Bot. 1871, p. 289. - D. Schreberi v. lenta Limpr. Laubm. I. p. 318 (1886). - D. Schreberi var. elala Schimp. Syn. 2. ed. p. 72 (1876). - Anisothecium crispum var. elata Hag. in Kgl. Norsk. Vid. Selsk. Skrift. 1911. No. 1, p. 38 (1915).]

Dichtrasige, \pm kräftige Pfl. Stengel bis $4 \mathrm{~cm}$. Blätter kürzer und breiter, allmählich verschmälert, weit herab ungleichmässig grob gesägt; Rippe vor der Blattspitze aufhörend; Zellen locker. Sporogone sehr selten.

S. Vg., Gstr. und Ang. an einzelnen, Mpd. an mehreren Fundorten.

N. Sm., JL., SB., H., NT. und $T r$, an wenigen Fundorten.

Europa. 
63. Anisothecium Grevilleanum (Bryol. eur.) Lindb. Utkast p. 33 (1878). [Dicranum Grevilleanum Bryol. eur. fasc. 37/10, p. 19, t. 7 (1817). - Dicranella Grevilleana Schimp. Coroll. p. 13 (1855).]

Autözisch in den ersten Entwickelungsphasen auf grundständigen Ästen, später durch Zerstörung der Verbindung diözisch Schlanke, dichtrasige, gelbgrüne Pfl. Stengel 5-10 mm, selten höher. Blätter trocken verbogen bis gekräuselt, feucht aus verkehrt-eilänglichem, am Rande welligem Scheidenteile plötzlich in einen sparrig-abstehenden, langen, verbogenen Pfriementeil verschmälert, bis 2.5 $\mathrm{mm}$ lang, flach- und ganzrandig oder mit einzelnen Zähnen an der Spitze: Rippe dünn, die Spitze des Pfriementeils ausfüllend: Zellen eng, oberwärts rektangulär, im Scheidenteil fast linear. Seta bis $1 \mathrm{~cm}$. Kapsel geneigt, hochrückig verkehrt-eiförmig bis oval, rotbraun, schwach kropfig, am Rücken mit dunkleren, rippenartigen Längsstreifen, trocken und entrleckelt gefurcht. Ring nicht differenziert. Sporenreife im ersten Frühling.

Auf feuchter, toniger Erde in Ausstichen und an Bach- und Flussufern, auch auf torfigem und sandigem Boden.

F. Al. Saltrik. Kvarnbo (Bom.). - Ta. Lammi, Evo (Sil.). Kuski. zw. Hankala mnd Hyväneula (Xorrl.). Asikkala. Lrajärvi (Norrl.). - ok. Pallamo. Melalahti (Brolb.). - Lkem. Kolari, Jokijalka (Hult). Sodankỵlä. Kalkkivaara (Vain.). - Lt. Srednij (Broth.): Pummanki (B.). - Lmur. Olenji (Kar-l.).

S. Upl., Vsm., Gstr., Myd.. Jml, und LyL, an einzelnen, Hrjd. und Ang. an mehreren Fundorten. LuL. Sarekgebiet.

N. A., Bu.. NB.. K...\$T.-F., ïberhaupt selten. nördlicher jedoch hāufiger und dort auch an der Kïste. Meistens im Waldgebiele, stejg jedoch hin und wieder auch üher die Baumgrenze hinauf. Nordgrenze auf Spitzbergen.

Europa, Kaukasus. Sibirien, Nord-Amerika.

64. Anisothecium vaginale (Dicks.) Loesk. Studien p. 88 (1910). |Dicranum crispum Ehrh. Msc. Hedw. Descr. 1I. p. 91, t. 33 (1789). - Bryum vaginale Dicks. P1. crypt. fasc. 111. p. 8 (1793). - Dicranella crispa Schimp. Coroll. p. 13 (1855).]

Autözisch in den ersten Entwickelungsphasen auf grundständigen Ẍsten. später durch Zerstörung der Verbindung diözisch. Weniger schlanke. lockerrasige, grüne oder gelbgrüne Pfl. Stengel 5-10 mm. Blätter aus länglichem Scheidenteile plötzlich in eine geschłängelte, sparrig-abstehende, flachrandige, an der Spitze gezähnte Pfrieme verschmälert, bis 1,86 mm lang: Rippe dünn, am Grunde nicht scharf begrenzt; Zellen eng linealisch, im Scheirlenteile lockerer. Seta $1-1,5 \mathrm{~cm}$. Kapsel aufrecht, rege!nässig. oval, gelbbräunlich, mit rippenartigen, dunkleren Lïngsstreifen, trocken deutlich gefurcht, entdeckelt weitmündig und last kreiselförmig. Ring stückweise sich ablösent. Sporenreife im ersten Frühling. Fig. $9 \mathrm{~A}-\mathrm{D}$.

Auf trockener oder etwas feuchter, sandiger oder toniger Erde an Weg- und Grabenrändern und in Ausstichen.

F. Al. An einzelnen Fundorten in Lemland, Jomala. Sund und Vatrdö und an mehreren in sallvik (Bom.). - Ab. Abo. Runsala (Brand.). - Finbỵ (Broth.). - N. Kyrkslatt (Sol.). Helsingfors (Lindb.). Helsinge, Backas (Ranck.). Elimäki (Tigerst.). - Ka. Wiborg (stev.). Antrea (Lindb.). - Ik. Muola. Perkjärvi (H. Lindl).). - Sl. Bjöneborg (Häyr.). Karkku (Meumn.). Pirkkala (Simm.). Ikaalinen (Sundr.). Ta. Tammerfors (Sul.). Tarastehus (Coll.). Im sïdöstl. Teile pass. (Norrl.). Korpilahti, Sutonen (Vain.). — sa. Willıanstrand (Buch). Lappee, Pajarila (B.). - Kol. Salmi, Íäsnäselkä (Pes.). Suoju (Lir. und A. K. Caj.). - (ra. Näıpes, Ytlermark (E. af H.). Replol, Kvarken (Simm.). Vasa (Broth.). Isokyrö, Orisberg (Ranck.). - Tb. Virrat. (Simm.). Jyväłkylä (Broth.). Laıkaa (Link.). Konginkangas (E. af II.). Pihtipudas, an mehreren Fundorten (Roiv.). - Sb. Joroinen. Järikyä (1I. Lindb.). Kuopio, kiukimäki und Savilahti (Link.). Nilsiä, Kirchdorf (Kyyhk.). Maaninka und Pielavesi. an mehreren Fundorten (Kyyhk., Roiv.). - On. Tiudie (Sinum.). - Om. Lappajärvi. wahrscheinlich nicht selten (Backm.). - Ok. Kajana (Lackslr.). Pallamo (L.). Solkamu, an mehreren Fundorten (Kyyk.). SuoIn usialmi, Pietari (Vain.). - Kpom. Luvajärvi(Vain.). Kem (F. Nyl.). - Ob. Yuhos (Brenn.). Lleabors (II. Nyl.). Kiminki (Nyl.). Haukipudas (Brenn.). Ii (B.). Simo (B.), Kemi (B.), Tornio (Sael.). Zw. Aavasaksa und Turtola fq. (Hull). - K. Kiusamo, Posio (E. af II.); Ukonvaara (Nyls.); Valajankoski (Nyb.); zw. Patanajarvi und Sovajärvi (E. af II.). - Lkem. Zw. Kolari und Pallastunturil fq. (Hult). 
Kuolajärsi, an mehreren Fundorten (E. af H.). - Le. An mehreren Fundorten in der Nadelwaldregion und bei Peerakoski in der Birkenregion (Norrl.). - Li. Inari, Toivoniemi und Parsji in der Nadelwaldregion und Koadnilnjarga in der Birkenregion (Hult). - Lim. Kandalaks (Sahlb., Broth.). - Lt. Kola. (Fellm., Broth.). - Lmur. Olenji (Fellm.); Teribjerka, all Voronjeflusse und Rinda (Brotlı.). - L $\rho$. Katschkova (Broth.); Ponoj (Sahlb., Brolh.).

S. Sk. - L.

N. In allen Ảmtern mil Ausnahme vou $\ell . M$, am häufigsten im Bimenland und in $F$, an der siidkïste und in den Küistengegenden sehr selten. Nordgrenze auf spilzbergen.

Enropa, Sibirien, Nord-Amerika.

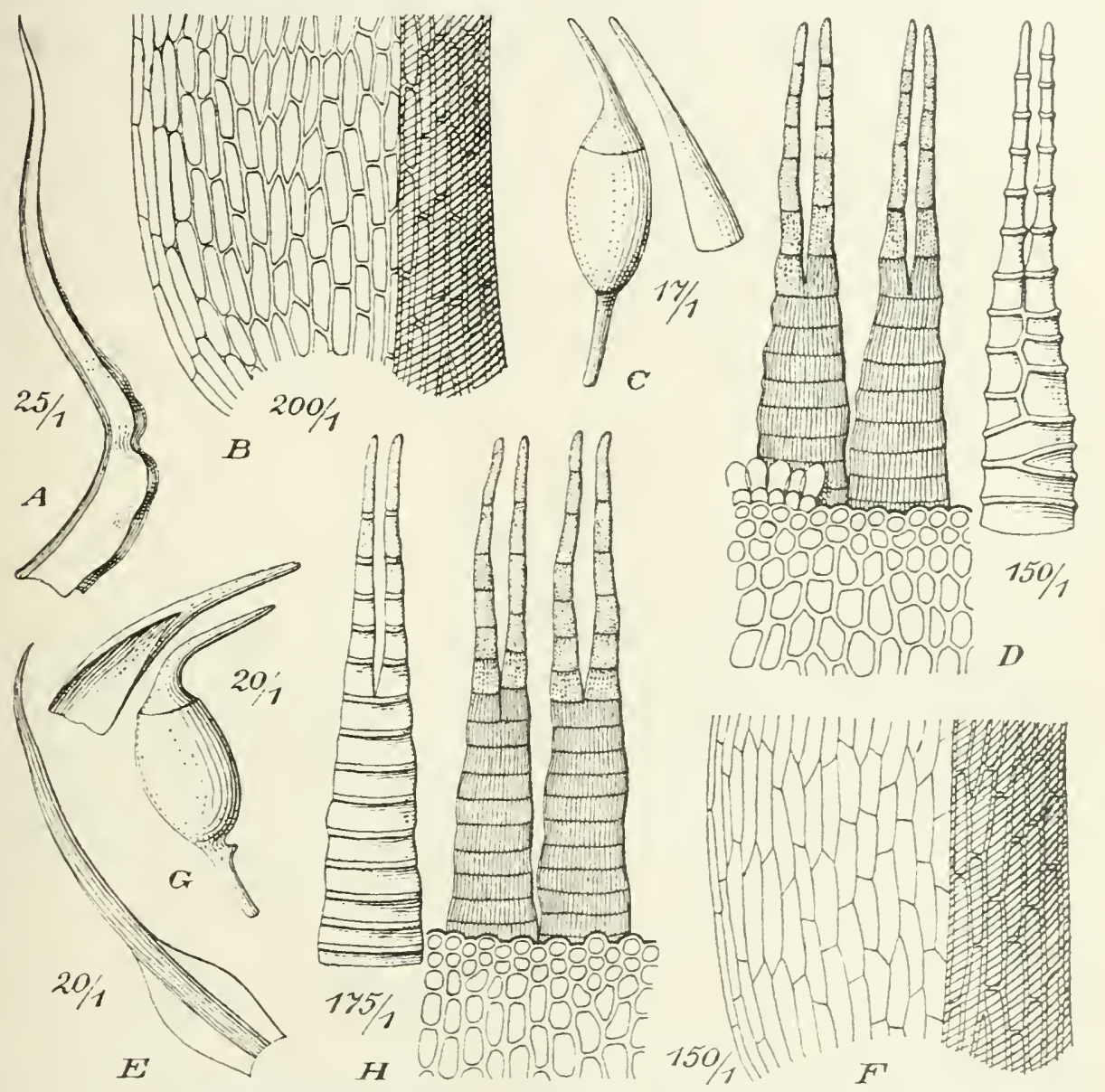

Fig. 9 A-D. Anisothecium roginale (Dicks.) A stengelb. (25 1): B Blaltbasis (260 1); C Kapsel (17 1); D Peristom (150/1). - E-H Dicranella cerviculata (Hedw.) E Stengelb. (21) 1): F Blattbasis (1501); (i Kapsel (20 1): H Peristom (175 1).

65. Anisothecium rubrum (Huds.) Lindb. Uthast p. 33 (1878). [Bryum rubrum Huds. Fl. angl. p. 413 (1762). - Dicranum varium Hedw. Deser. II. p. 93, t. $3+$ (1789). - Dicranella varia Schimp. Coroll. p. 13 (1855).]

Diözisch. Pfl. in dichten, grünen oder gelbgrünen Rasen. Stengel 0,5-2 cm. Blätter trocken straff, feucht aufrecht-abstehend oder einseitswendig, aus schma eilanzettlicher Basis ziemlich rasch in eine Pfrieme verschmälert, bis 1,6 $\mathrm{mm}$ lang, mit umgebogenen, oben schwach gezähnelten, zweischichtigen Rändern: Rippe ziemlich kräftig, mit der Blattspitze endend bis kurz austretend; Zellen eng rek- 
tangulär. dünnwandig Seta $5-10 \mathrm{~mm}$. Kapsel geneigt, hochrückig, rotbraun, glatt, trocken und entleert gekrïmmt und unter der Mündung etwas eingeschnürt. Ring nicht differenziert. Deckel von halber Urnenlänge. Sporenreife im ersten Frïlling.

Auf feuchten, sandig-tonigen und kalkigen Erdblössen, an Weg- und Grabenrändern, in Ausstichen und auf Äckern.

F. Al. Mariehamn (Bom.). Saltvik st. fq. (Bom.). Sund, Bomarsund (Nerv.). - Ab. ibo, Hirvisalo (Arrh.). Pargas, Piukala (Elfv.); Malm (Ruor.). - N. sjundeå, Myrans (Nerv.). Helsinge, Backas u. Degerö (Buch). Helsingfors (Popp.). - St. Pirkkala (Simm.). - Ta. Asikkala, an mehreren Fundorten (Norrl.). Korpilahti. Putkilahti (Vain.). - Tb. Pihtipudas, Heinolankylā (Roiv.). — Sb. Maaninka, Haatala, Parola (Roir.). - Kol. Vosnessenje (Elfv.). - Kon. Tiudie (Simm.). - K. Kuusamo, Paanajärri, Kuoppaoja (Broth.). - Lt. Suhovi (Fellm.). - Lv. Tsehapoma, in Felsritzen (Broth.).

S. $S k .-L$.

N. Sm.-Ye., K. - F., stellenweise \pm fq., fehlt an der Südküste und in We:tlandet, selten in Tr. und $F$. Meist in niedriger Lage, steigt jedoch stellenweise bis in die Kiefern region, selten bis in die Birkenregion hinauf. Nordgrenze auf Spitzbergen.

Europa, Nord-Afrika, Kaukasus, West-Asien, Himalaya, Sibirien, Nord-Amerika.

var. callistomum (Dicks.) Braithw. [Bryum callistomum Dicks. Fasc. pl. crypt. III. p. 5 , t. 7 , f. $10(1793)$.]

Seta kürzer. Kapsel kleiner, aufrecht, weitmündig. Deckel kegelig, von Urnenlänge.

N. Nach H a gen hier und da vereinzelt unter der Stammform.

Europa.

\section{AONGSTROEMIA}

Bryol. eur. fasc. 33/36 Mon. t. 1 (1846).

Diözisch; Blüte scheibenförmig, mit zahlreichen, grossen Antheridien. Blätter stumpf, schuppenartig anliegend bis aus \pm scheidiger Basis pfriemenförmig, flach- und meist ganzrandig; Rippe flach, aufwärts etwas dicker, mit 2 basalen Deutern, einer kleinen Begleitergruppe und wenigen Stereiden. Seta rot. Kapsel aufrecht, selten schwach geneigt, regelmässig. glatt; Zellen des Exotheciums dickwandig, umregelmässig, parenchymatisch. Ring nicht differenziert. Peristomzähne ungeteilt oder bis zur Mitte 2schenklig, linienförmig gestrichelt, tiefrot, oben gelb; Aussenschicht dick, mit breiten Querleisten.

66 Aongstroemia longipes (Sommerf.) Bryol. eur. 1. c. p. 3. [Weisia longipes Somm.erf. Suppl. ad Wahlenb. Fl. lapp. p. 52, t. 1, f. 1-10 (1826).]

Sehr schlanke, gesellige, bleichgrïne, schwach glänzende Erdmoose. Stengel bis $1 \mathrm{~cm}$, einfach oder mit vereinzelten kätzchenartigen, subfloralen Sprossen. Blätter schuppenartig anliegend, kurz eilanzettlich, stumpf, bis $1 \mathrm{~mm}$ lang, Schopfblätter aus scheidiger Basis verschmälert, bis 1,5 $\mathrm{mm}$ lang und zuweilen an der Spitze schwach gezähnelt; Rippe vor der Blattspitze aufhörend; Zellen oberwärts verlängert 6 seitig und verlängert rhomboidisch, unten länglich rektangulär. Seta 4-12 111n. Kapsel klein, oval, kastanienbraun, entdeckelt gestutzt. Sporen etwa $14 \mu$, olivengrün, glatt. Sporenreife im ersten Frühling. — S. 78, Fig. 16 F-K.

Am meisten auf feuchtem Sande an Bach- und Flussufern und auf sandigen Flussinseln, seltener auf feuchtem Ton und an Wegrändern.

F. Ko. Antrea, Kuparsaari, Mustasaari (Lind.). - Ta. Renko (Coll.). Asikkala, Vesijärvi, Kuivaharju (Norrl.). - $a$. Willmanstrand, Askola (Buch). - Sb. Kiavi, Lomomäki (Kot.). - K. Kuusamo, Haataja (Broth.).

S. Vg. Rangsdala. Irjd. an mehreren Fundorten. Jmt. Duvid.

N. $k$. $k$, hier und da, in der subalpinen Region zuweilen reichlich, nördlicher auch in niedriger Lage. Nordgrenze bei $70^{\circ} 11$, Br.!

Bayern und Zentral-Aipen, Nord-Amerika. 
var. sericea Ilag. Musc. Norv. bor. p. 369 (1901).

Pfl. in einigen mm hohen, weichen, tiefgrünen, seidenglänzencten Rasen. Steril. N. No. In den ätssersten Teilen des Saltenfjords.

\section{CAMPYLOPODOIDEAE.}

Diözisch, selten autözisch. Blätter llachrandig, von der Rippe gegen die Rändern allmählich dünner; Blattflügelzellen (excl. Dicranella) differenziert. Perichätialblätter differenziert. Spaltöffnungen (excl. Dicranella secunda) fehlend.

\section{Übersicht der Gat tungen.}

A. Autözisch. Seta aufrecht. Haube länger als die Kapsel. 19. Melzlerella.

B. Diözisclı. Haube kürzer als die Kapsel.

a. Zellen des Blattgrundes eng, gestreckt, in den Blattecken nicht differenziert. Seta aufrecht ............... 17. Dicranella.

b. Zellen des Blattgrundes locker, in den Blattecken differenziert. Seta anfangs bogig-herabgekrümmt.

«. Peristomzähne bis zum Grunde geteilt

18. Dicranodontium.

§. Peristomzähne fast zur Mitte 2schenklig

20. Campylopus.

\section{DICRANELLA}

Schimp. Coroll. p. 13 (1855); Mitt. Musc. austr.-amer. p. 39 (1869).

Diözisch; đ̛ Pfl. kleiner. Schlanke Erdmoose. Stengel aufrecht, nur am Grunde mit Rhizoiden. Blätter aufrecht-abstehend bis einseitig-sichelförnig, bald aus halbscheidiger Basis rasch pfriemenförmig, bald nicht scheidig, allmählich lanzettlich-pfriemenförmig; Rippe (excl. D. heteromalla) am Grunde verbreitert; Zellen des Blattgrundes gestreckt, in den Blattecken nicht differenziert. Perichätialblätter meist wenig verschieden Seta aufrecht. Kapsel geneigt, symmetrisch, trocken \pm deutlich gefurcht; Zellen des Exotheciums in der Mehrzahl verlängert prosenchymatisch, mit \pm deutlich gewundenen Längswänden. Peristomzähne bis zur Mitte 2schenklig, gelbbraun bis braunrot. Sporen meist $12-18 \mu$ und meist gelblich und glatt.

\section{Üb e rsicht der Arten.}

A. Blätter aus breiten, halbscheidigem Grunde rasch pfrieinenförmig.

a. Seta gelb. Kapse’ kropfig 68. D. cerviculata.

b. Seta rot. Kapsel ohne Kropf 67. D. secunda.

B. Blätter nicht scheidig, vom Grunde allmälılich lang pfriemenförmig. Seta gelb. Kapsel ohne Kropl

69. D. heteromalla.

67. Dicranella secunda (Sw.) Lindb. Musc. scand. p. 26 (1879). [Dicranum secundum Sw. in Vet. Ak. Handl. 1795, p. 241. - D. subulatum Hedw. Sp. musc. p. 128 , t. 34 , f. $1-5$ (1801). - Dicranella subulata Schimp. Coroll. p. 13 (1855).]

Lockerrasige, grüne oder gelbgrüne, etwas glänzende Pfl. Stengel $0,5-2 \mathrm{~cm}$. Blätter meist schwach einseitig-sichelförmig, aus fast halbscheidiger Basis plötzlich verlängert rinnig-pfriemenförmig, fast ganzrandig, bis $3 \mathrm{~mm}$ lang; Rippe austretend, glatt; Zellen eng prosenchymatisch. Seta 5-15 mm, rot. Kapsel hochrückig-eiförmig, gelb- bis rotbraun, trocken gerippt und weitıündig; Spaltöff- 
nungen vorhanden. Ring differenziert, sich abrollend. Sporenreife im Spätherbst und im ersten Frühling.

Auf trockener oder etwas feuchter, sandiger oder toniger Erde an Weg- und Grabenrändern und in Ausstichen.

F. Al. Hammarland, Torp (Ohlsson). Sund, Kulla und Tosarby (Bom.). Saltrik, an mehreren Fundorten (B.). - Ab. Pargas, Norrby (Elfr.). St. Karins, Littoinen (E.). Lemo, Alalemu (E.). Karislojø (E. af H.). Lojo, Gunnars (Lindb.). - X. Helsingfors (Lindb.). Helsinge, Backas (Ranck.). - Ik. Uusikirkko, Ongimojoki (H. Lindb.). Rautus, Viisjoki (H. L.). - St. Pori (Häyr.). Nakkila (Simm.). sa. Lappee. Askola und Pajarila (Buch). - Kl. Impilahti (W. Nyl.). - Kol. (rorki (Elfv.). Petru-avodsk (Kullh.). - Tb. Petäjävesi (Ruor.). Konginkangas (E. af H.). Viitasaari (Broth.). Kinnula. Olhavainen (Roiv.). Pihtipudas, nicht selten (R.). - Sb. Fuopio (Link., Roir.). Muururesi. Paloniemi (Kyyhk.). Iaaninka, an mehreren Fundorten (Kyyhk., Roiv.). - Kb. Lieksa. Kirchdorf (Vain.). - Kon. Polovina (Simm.). - Om. Vindala, Koskela und Kotakangas (Backm.). Lappajārsi, Harju (B.). - Ok. Kajana (Lacksstr.). Paltamo (L.). Kümnoniemi (E. af H.). - Kpom. Uhtua (Tain.). Moinanvaara (Bergr.). - ob. Lleaborg (W. Nyl.). Rovaniemi (Brenn.). Zw. Aavasaksa und Turtola fq. (Hult), - K. Kuusamo, an mehreren Fundorten (Sil., Broth., E. af H.). - Lkem. Kolari. Pallastunturit fq. (Hult). Kuolajärvi, Kirchdorf (E. af H.); Măntyraara (E. af H.); Kotala (E. af H.). I.e. Hetta, Naimakka und Peerakoski (Norrl.); Nalla (Kot.). - Li. Inari, Iluddusjärvi und Kaamasjoki in der Nadelwaldregion (Hult); Seidraara (Sil.). Utsjoki, Mielitsjokka in der Birkenregion (Kihlm.): Nuovusjokka und Yläjalve (Ranck.). - Lt. Luttojoki, Kellokoski (Roiv.). Kola (F. Nyl., Broth.). Subrivi (Fellm.). - Lmur. Aul Voronjeflusse (Broth.). Rinda und Varsinsk (B.). - Lp. Lumborskj und Ponoi Brenn.); Orlor: Gubnoi (Kihlm.). - Lr. Tschapolna (Broth.): Tschavanga (Brenn.).

S. $S k,-L$.

N. In allen Āmtern mit Aurnahme ron $L . Y$. und meistens fq.. nur im Küstengebiete ron sm. und in den südwestl. Teilen seltener bis fehlend. Kommt hauptsächlich im Os- und Waldgelsiete ror. steigl jedoch bis in die alpine Region hinauf. Tordgrenze auf spilzhergen.

Europa, Sibirien, Amur. Nord-Amerika.

var. curvata (Hedw.) Hag. in D K. N. Vid. Selsk. Skrift. 1914, No. 1, p. 50 (1915). [Dicranum curvalum Hedw. Sp. musc. p. 132, t. 31, f. 7-12 (1801). Dicranella curvata Schimp. Coroll. p. 13 (18.5.5).]

Kapsel aufrecht, fast regelmässig.

N. An einzelnen vder wenigen Fundorten in A.-JL., Ne., K. und $F$.

Zentral-Europa, Jord-Anerika.

68. Dicranella cerviculata (Hedw.) Schimp. Coroll. p. 13 (18.55). [Dicranum cerviculatum Hedw. Descr. III. p. 89, t. $3 \overline{7}$ A (1792).]

Pfl. in dichten, oft ausgedehnten, grünen oder gelbgrünen bis gelben, fast glanzlosen Rasen. Stengel meist $0,5-2 \mathrm{~cm}$. Blätter trocken verbogen und fast kraus, feucht aufrecht-abstehend bis \pm deutlich einseitswendig, aus halbscheidiger Basis ziemlich $r$ sch in eine lange, rinnig-hohle, an der Spitze kleingezähnelte oder ganzrandige Pfrieme verschmälert, bis 2 mm lang; Rippe oberwärts die Pfriemenspitze ausfüllend, glatt; Zellen verlängert 6eckig und rektangulär, gegen die Ränder des Scheidenteils enger. Seta $1-1,5 \mathrm{~cm}$, strohgelb. Kapsel dick eiförmig. kropfig, gelb- bis rotbraun, trocken und entleert \pm deutlich längsrippig. Ring bleibend. Sporenreife im Spätherbst und im ersten Frühling. - S. Fig. 9 E-H.

Auf feuchtem, sandig-tonigem und tonigem Boden und besonders in Torfausstichen, oft deren senkrechte Wände bekleidend, seltener an feuchten Felsen.

F. Al. Finström. riodbỳ (Bonn.). Sund, Gesterby tjenan und Tjurnäs trâsk (B.). Saltvik. an melıreren Fundorten (B.). - Ab. St. Karins. Reso. Bromarf, Tellala. Karislojo. Lojo. - N. Hangö. Ekenäs. Snappertuna. Kyrkılätt. Eslon. Helsingfors. Borgá. Perna. - Ka. Sippola. Wiborg. Jääski. 1k. Iuola. Rautu. Sakkola, - Ni. Eura. Nakkila. Honkajoki. Ikaalinen. - Ta. Kangasala. Im -lidätl. Teile st. fq. (Norrl.). sysuli. Hartola. Luhanka, - sa. Lappee. Kangasniemi. Nỵlott. Ki. Valamo. Impilahti. Suistamo. - Kol. Petrosavodsk, - ia. Solv. Vasa, Replot. Isokyrŏ. - Tb. Jy̌văskylä (Vain.). Pihtipudas, Korpiskylä, Sormulanmäki (Roiv.). - Sib. Knopin. Kaavi. Maaninki. Pielavesi. Iisalmi. - $\hbar b$. Tohmajärvi. - om. Lappajärvi. Säresniemi. - Ok. Kajana. Paltamo. Suskamo. Suomussami. - ob. Oulu. Simo. Tervola. Zw. Aavasaksa und Turtola fq. (HuIt). - K. Kunsamo. - Lkem. Zw. Kolari und Pallastunturit fq. (Hult). Le. In del Waldregion liı. (Norrl.). Li. In der Nadelwaldregion f f., in der Birkenregion pass. (Hult). - Lt. Kola. Sascheika. Vaidugulin. - Lmur. Voroninsk. Varsinsk. - Lp. svjätoinos. Triostruva. Ponoj.

S. $S k,-L$. 
N. In allen Antern und meist fq.. wie es scheint, jedoch seltener in der Elıene des siidwestl. und selten oberhalb der Baumgrenze. Nordgrenze bei $70^{\circ} 25^{\prime} \mathrm{n}$. Pr.

Europa, Sibirien, Kamtschatka, Nord-Amerika.

var. pusilla (Hedw.) Schimp. I. c. [Dicranum pusillum Hedw. Descr. 11. p. 81). t. 29 , f. $13(1789)$.]

Pfl. wenige mm! Blätter aufrecht-abstehend, lanzettlich, etwa 1 mm lang. Kapsel sehr klein, schwach kropfig.

69. Dicranella heteromalla (Dill., L.) Schimp. 1. c. [Bryum heteromallum 1)ill. Hist. musc. p. 375 , t. 47 , f. 37 (1711).]

Pfl. in \pm dichten, oft ausgedehnten, grünen oder gelbgrünen, glänzendle!n Rasen. Stengel 1-2 cm, seltener höher. Obere Blätter einseitig-sichelförmig. aus lanzettlicher, oben oft gezälnter Basis almühlich lang rimnig-pfriemenförmig, an der Spitze oder weit herab gesägt, bis $3 \mathrm{~mm}$ lang; Rippe am Grunde gut begrenzt, den oberen Pfriementeil ausfüllend und unterseits fein gesägt; Zellen eng rektangulär und 6eckig. Perichätialblätter aus hochscheidiger Basis pfriemenförmig. Seta $1-2 \mathrm{~cm}$, gelb. Kapsel verkehrt-eiförmig, gelbrot, glänzend, mit breiten, dunkleren Streifen, schiefmündig und entdeckelt unterseits unterhall, der Mündung eingeschnürt. Ring bleibend. Sporenreife im ersten Frühling.

Auf feuchtem, sandigem und tonigem Boden in Ausstichen und an Grabenrändern, auf Kieselgestein, selten auf kalkhaltigem Boclen.

F. Al. Eckerö (H. Lindb.). Jomala, Önningby (Bom.). Finström, Godby (B.). Sund. an weniqen Fundorten (B., Elfv.). Saltvik, an mehreren Fundorten (B.). - Ab. Korpo, Stromma (Elfv.). Pargas. liunnarsnās (E.). Finby (Broth.). Uskela (Nikl.). Tenald, Skogby (Hák. Lindł.). Karisłojo, Kourjoki (Hult). Lojo, Lylyis (E. af H.); Ojamo (Lindb.). - N. Kyrkalătı (Nyb., Brolh.). Esho, (iräsa (Broth.): Kilo (Häyr.). Helsingfors (Liıdb.). Helsinge, Degerö (Buch), Boxbacka (Link.); Backas (Ranck.); Dickursby (Colland.). Borgi, Sundö (Sael.). Elimäki (Tigerst.). Hogland (Lindlı.). - Ik. Metsäpirtti. Viisjoki (H. Lindb.). Sakkola, Taipale (Vain.). Pṣhäjărvi, Sortanlahti (H. Lindb.). — st. Jäınijärvi (Herl.). - Ta. Sääksmäki, Limojoki (Kihlm.). Lammi, Evo (Norrl.). Koski, Valkjärvi (N.). Asikkala, zw. Kaitas und Laitiala (N.): Loukas (Sil.). Hartola (Bonsd.). - Sa. Lappee, Kiiala (Buch). Kangasniemi (Lackstr.). - Kol. $1 \mathrm{~m}$ südl. Teile pass.-st. fq. (Elfr.). - Oa. Replot, Vallgrund (Broth.). - Tb. Konginkangas (E. af H.). 一 On. Klimskij mona-til (Simm.). Drorez (Sahlb.). - Ll. Silscheikal an Kulaflusse (Broth.).

S. $s k$. Gstr. und $D l r$.

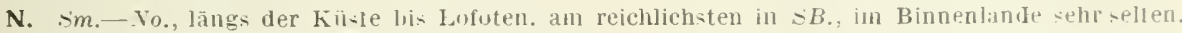
Europd, Kaukasus, Japan. Amur, Nord-Amerika.

var. sericea (Schimp.) H. Müll. in Verh. bot. Ver. Brandenh. VIII. p. 65 (1866). [Dicranodontium sericeum Schim]. Bryol. eur. Suppl. 1. Il. t. 2 (1864).]

Pfl. in dichten, bis 3 cm hohen, seidenglänzenden Rasen. Blätter aufrecht bis schwach einseitswendig, stark und weit herab gezähnt.

Auf kieselgestein.

F. Al. Saltrik, an wenigen Fundorten (Bum.). Kökar, Karlby (B.).

N. In Sorlandet.

Europa.

var. interrupta (Hedw) Bryol. eur. l. c.

Pfl. in selır dichten, $3-4,5 \mathrm{~cm}$ hohen Rasen. Stengel unterbrochen beblättert. Neist steril.

Auf Kieselgestein.

N. Vach $\mathbf{H}$ a ge $n$ rerbreilet wie die Himptart.

Europa, Nord-Amerika.

\section{DICRANODONTIUM}

Bryol, eur. fasc. 41 (18+7).

Diözisch; $\sim$ Pfl. meist in besonderen Rasen. Stengel aufrecht. Blätter aus verbreiterter, lanzettlicher Basis lang pfriemenförmig, oberwärts röhrig-hohl; Rippe breit und flach, den Pfriementeil ausfüllend, mit von 2 Stereidenbändern 
eingeschlossenen Deutern: Zellen des Pfriementeils eng rektangulär, innere Zellen des Blattgrundes rektangulär und verłängert 6seitig, äussere verengt, einen 士 breiten Saum bildend, Blattflügelzellen die Rippe erreiehend, meist aufgeblasen, hyalin orler bräunlich und hinfällig. Perichätialblätter scheidig, rasch lang pfriemenförmig. Seta anfangs bogig herabgekrümmt, später aufrecht und geschlängelt. Kapsel regelmässig, länglich-oval bis elliptisch, glatt; Zellen des Exotheciums in der Mehrzahl \pm verlängert rektangulär. Ring nicht differenziert. Peristomzähne bis gegen die Basis in 2 fadenförmige Schenkel gespalten. Sporen 10-18 "

\section{itbersieht der Arten.}

A. Blätter nur oberwärts gesägt; Rippe nicht scharf begrenzt;

Zellen ohne Tüpfel

70. D. denudatum.

B. Blattrippe scharf begrenzt; Zellen z. T. getüpfelt.

a. Innere Basalzellen nach oben scharf abgesetzt ....... 72. D. circinatum.

b. Innere Basalzellen in die Zellen der Pfrieme allmählich übergehend.

«. Blätter his gegen den Grund gesägt ............. 71. D. asperulum.

ॐ. Blätter ganzrandig ............................... 73. D. subfalcatum.

70. Dicranodontium denudatum (Brid.) Hag. in D. K. N. Virl. Selsk. Skrift. 1914 No. 1, p. 55. [Dicranum denudatum Bric. Muse. ree. Suppl. I. p. 18+ (1806).

Didymodon longirostrum Stark in Web. et Mohr Bot. Tasehenb. 1. 155 (1807).

Dicranodontium longirostre Bryol. eur. Monogr. p. 2 (1818). - Didymodon denudatus Lindb. Muse. scand. p. 25 (1879).]

Ziemlich schlanke Pfl. in \pm dichten, oft ausgedehnten, grünen oder gelblichgrünen, glänzenden Rasen. Stengel 2-10 cm, zumeist aus den Blattbasen rostoder rotfilzig, durch streckenweise abfallende Blätter scheinbar unterbrochen beblättert. Festsitzende Blätter meist \pm einseitswendig, aus verbreitertem, länglieh-eiförmigem bis lanzettlichem Grunde lang pfriemenförmig, röhrig-hohl, in der oberen Hälfte kleingezähnt, bis $7 \mathrm{~mm}$ lang: Rippe etwa 1/3 der Blattbasis, nicht scharf begrenzt, am Rüeken kleingezähnt: innere Basalzellen ohne Tüpfel, verlängert rektangulär. gegen clie Ränder enger, in den Blattflügeln hyalin und

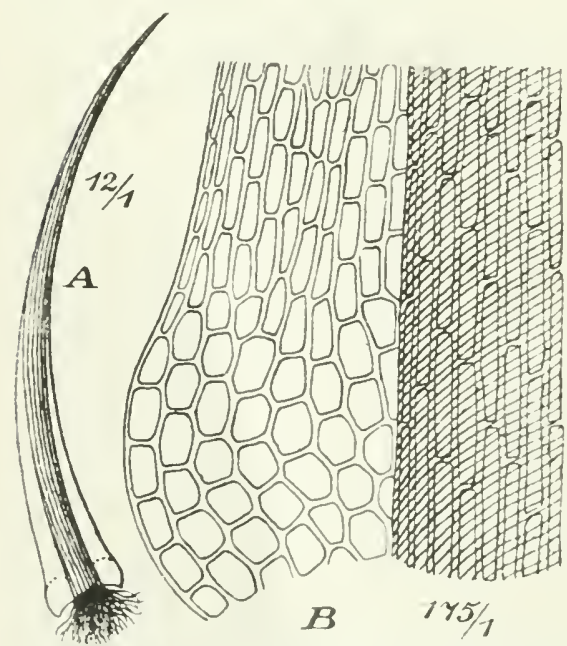

I"ig. 10. A-B Dicranodontium denudatum

(Brid.) Hag. A Stammb. (12/1); B Blat tbasis $(175 / 1)$. hinfällig. Abfällige Blätter schmäler, ganzrandig, oberwärts mit kürzeren Zellen. Seta $1 \mathrm{~cm}$, gelb. Kapsel länglich, licht gelbbräunlich. Peristom gelb, nicht papillös. Haube olne Wimpern. Sporenreife im Spätherbst und Frühling. - Vegetative Vermelırung durch die abfälligen Blätter. - Fig. 10.

An modernden Stämmen, auf torfigem Waldboden und auf dünner Humusdecke beschatteter, kalkfreier Felsen.

F. ‥ Helsinge, Backa; auf Granitspärl. (Buch).

S. sk. an wenigen, sm. an mehreren, Ög. und Intd, an einzelnen Fundorten.

N. Bu., Br.-K., st. und No., ann häufigsten alı der Küste bis Yo., in $\mathrm{S} B$. und $N B$. fqq., hier und da auch uach den inneren Teilen; vordringend. Meist in den niederen Teilen, stellenweise bis $900 \mathrm{~m}$ hinaufsteigend. Nordgrenze bei $67^{\circ} 40^{\prime}$ I. Br.

Europa, Kaukasus, sibirien, Japan, Nord-Amerika.

var. alpinum (Schimp.) Hag. in D. K. N. Virl. Selsk. Skrift. 1914, No. 1, p. 56 (1915). [Campylopus alpinus Schimp. Bryol. 
eur. Suppl. Mon. p. 2 (1861).

Dicranodontium longirostre var. alpinum Mild.

in Bot. Zeit. 1870 , p. 414.]

Tracht von Campylopus flexuosus. Stengel meist stark rotfiligig. Blätter fast anliegend, steifer, nicht abfallend, nur an der auslaufenden Rippe sclıwach gesägt, in den deutlich ausgehöhlten Blattflügeln meist rötlich.

Auf Torf und torfigem Boden.

N. Nach H a gen fast ausschliesslich in Westlandet.

schottland, Wales, Zentral-Europa.

71. Dicranodontium asperulum Wils. in Lew Journ. Bot. 1857, 1). 296 p. p. [Dicranum asperulum Mitt. Muse. Ind. or. p. 22 (1859). - Dicranodontium aristatum Schimp. Syn. p. 695 (1860). - Didymodon aristatus Lindb. Musc. scand. p. 25 (1879). - Campylopus asperulus Kindb. Laubm. Schw. und Norw. p. 88 (1883).]

Ziemlich schlanke Pfl. in dichten und sehr weichen, gelbgrünen bis grünen, schwach glänzenden oder glänzenden Rasen. Stengel $3-10 \mathrm{~cm}$, brüchig, nur aus den Blattachseln spärlich weissfilzig. Blätter aufrecht-abstehend, steif, brüchig, aus ovaler bis verkehrt eilänglicher Basis rasch lang borstenförmig, rinnig-hohı, bis gegen den Grund gesägt und die Unterseite des Borstenteils durch spitz mamillöse Zellen sehr rauh, bis $5 \mathrm{~mm}$ lang; Rippe scharf begrenzt, etwa 1/3 der Blattbasis; innere Basalzellen getüpfelt, locker und leer, scharf von dem Blattsaume abgegrenzt und allmählich in die Zellen der Pfrieme übergehend. Sporogone bei der Hauptform unbekannt.

An stark beschatteten, kalkfreien Felsen in feuchten, engen Schluchten und an nassen Flächen.

N. In den äusseren Küstengegenden zw. stavanger und Aalesund, am reichlichsten in $S B$. und NB. Nordgrenze bei $62^{\circ} 30^{\prime} \mathrm{n} . \mathrm{Br}$.

Schottland. Zentral-Europa, Sikkim, Yunnan, Alaska.

var. falcatum Mild. in Bot. Zeit. 1870 , p. 114.

Dunkelgrüne Pfl. Blätter sichelförmig-einseitswendig, weniger weit herab gesägt. Kapsel oval, kastanienhraun. Haube ohne Wimpern. Sporenreife im Spätherbst.

N. Bergen, Ejdsvaag und Ytre Hardanger.

Nord-Böhmen, Stejermark.

72. Dicranodontium circinatum (Wils.) Schimp. Syı. 2. ed. p. 100 (1876). [Dicranum circinatum Wils. Bryol. brit. p. 76 (1855).]

Ziemlich kräftige Pfl. in lockeren, dunkelgrünen, glanzlosen Rasen. Stengel bis $10 \mathrm{~cm}$, spärlich rotfilzig. Blätter einseitswendig und kreisförmig zurückgehrümmt, aus halbscheidiger, eilänglicher Basis rasch sehr lang rinnig-pfriemenförmig, weit herab mehrreihig fein gesägt, bis $7 \mathrm{~mm}$ lang; Rippe scharf begrenzt, etwa $1 / 3$ der Blattbasis; innere Basalzellen getüpfelt, locker und leer, nach oben scharf abgegrenzt, in den Blattecken nicht blasig erweitert. Innere Perichätialblätter im unteren Drittel scheidig. Seta bis $1 \mathrm{~cm}$, zuletzt rötlichbraun. KapseI elliptisch, engmündig, entleert rotbräunlich. Peristom gelbrot, oberwärts dicht papillös. Haube spärlich bewimpert.

An beschatteten, feuchten oder nassen, kalkfreien Felsen und Blöcken.

N. Im Küstengebiete zw. Lister u. Nordfjosd zerstreut, an einzelnen Fundorten massenhaft, ülerall nur steril. Nordgrenze bei $61^{\circ} 53^{\prime} \mathrm{n}$. Br.

Schottland, Zentral-Europa.

73. Dicranodontium subfalcatum (Limpr.) Loesk. et Osterw. in Bauer Musc. eur. exs. 729. [Dicranodontium circinatum var. subfalcatum Limpr. Laubm. I. p. 411 (1887).]

Ziemlich kräftige Pfl. in sehr dichten, ausgedehnten, grünen, grünlichgelben oder bräunlichgrünen bis rötlichen, glänzenden Rasen. Stengel bis $7 \mathrm{~cm}$, meist \pm rotfilzig. Blätter schwach sichelförmig-einseitswendig bis fast aufrecht, aus 
lanzettlicher Basis allmählich lang rinnig-pfriemenförmig, ganzrandig, bis $7 \mathrm{~mm}$ lang; Rippe scharf begrenzt, etwa $1 / 3$ der Blattbasis; innere Basalzellen nach oben allmählich in die Zellen der Pfrieme übergehend, in den Blattecken nicht blasig erweitert. Innere Perichätialblätter bis zur Mitte scheidig. Seten meist 2 in jedem Perichätium, bis $7 \mathrm{~mm}$. Kapsel wie bei der vorigen Art.

An kalkfreien Felsen.

N. An einzelnen Fundorten in $S t$. und $s B$. Steril.

Schweiz, Tirol.

\section{METZERELLA}

(Limpr. Laubm. I. p. 411 ut synon.: 1887) Hag. in D. K. N. Vid. Selsk. Skrift. 1914, No. 1, p. 62 (1915). [Metzleria Schimp. Msc. (1868); Mild. Bryol. siles. p. 75 $(1869)$.

Autözisch; ` Blüte dick knospenförmig, gestielt; Hüllblätter eilänglich, mit Rippe. Schlanke Pfl. in dichten, grünen, etwas glänzenden Rasen. Stengel aufrecht, bis $2 \mathrm{~cm}$, am Grunde rot-oder weissfilzig. Blätter aufrecht-abstehend, obere schwach einseitswendig, trocken gewunden, aus länglich-lanzettlicher, fast scheidiger Basis allmählich in eine tast röhrig-hohle, nur an der Spitze etwas gezähnte l’frieme auslaufend, bis $3.5 \mathrm{~mm}$ lang: Rippe sehr Jreit und flach, den Pfriementeil ausfüllend, an der Basis 2schichtig, aufwärts mit zahlreichen medianen und basalen Deutern und 2 geschlossenen oder in zahlreiche Zellgruppen aufgelösten Stereidenbändern: Zellen am Blattgrunde 10-12reihig, einschichtig, rektangulär his verlängert melıreckig, dünnwandig, nicht getüpfelt, nach dem Rande enger, in den Blattecken einsehichtig. wenig entwickelt, hinfällig. Perichätialblätter deutlich gesäumt, am Grunde scheidig, sonst kaum versehieden. Seta aufrecht. 5--15 mm, gelb. Kapsel aufrecht, regelmässig, meist länglich-elliptisch, (lerbhäutig, dunkelbraun, zuletzt schwärzlich, glatt, trocken und entleert unter der llündung etwas verengt: Zellen des Exotheciums unregelmässig. 3-6eckig, rektangulär und verlängert, gewunden, mit stark verdickten Längswänden. Ring fehlencl. Peristomzähne bis fast zur Basis 2-3teilig, an der Basis gellhraun und lïngsstreifig, aufwärts hleich und dicht papillös, undeutlich gegliedert, ohne vortretende Querhalken. Sporen 20-24, ", goldbräunlich, feinwarzig. Deckel ron Kapsellänge, glattraiılig. I Iaube etwas aufgeblasen, an Grunde sich verengernd und das obere Ende der Seta umfassend. ganzrandig. - Fig. 11.

Einzige Art:

7. Metzlerella alpina (Schimp.) Hag. 1. c. p. 63. [Mel-leria alpina Schimp. Msc.: Mild. 1. c.]

Auf fenchtem Moorboden an schattigen Felsabhängen.

N. $\therefore$. An wenigen Fundorten, 50-600 m. SB. Fuse, Tjernakslen, $400 \mathrm{~m}$. Nordgrenze bei 6.1 $100^{\prime} 11, \mathrm{Br}$.

schweiz, Tirsl. steiermark.

\section{CAMPYLOPUS}

Bricl. Mlant. p. 71 (1819).

Diözisch. Stengel aulrecht. Blätter trocken meist angedrückt, feucht aulrecht oder aufrecht-abstehend, aus lanzettlicher, oft geöhrter Basis \pm lang pfricmenförmig, oberwärts rinnig- his röhrig-hohl; Rippe sehr breit und flach, meist den ganzen Pfriementeil ausfïllend und zuweilen als hyalines Haar austretend. meist am Rücken gefurcht oder mit Längslamellen, in der Anlage 3schichtig. Aussenzellen der Bauchseite (excl. C. brevipilus und C. Kaalaasii) weit, meist 
dünnwandig und leer, Zellen der anderen Schichten bald zicmlich gleichförmig, mässig verdickt und chlorophyllös, bald die Mittelschicht gross und leer, jedoch verdickt und die alternierenden Zellen der Dorsalschicht durch kleine Stereidengruppen ersetzt: Laminazellen weit herab klein, parenchymatisch, sehr seiten getüpfelt, am tiefsten Blattgrunde locker, zartwandig, leer und hyalin, in den Blattflügeln oft aufgeblasen und meist braun oder rot gefärbt. Perichätialblätter wenig verschieden. Seta anfangs bogig-herabgekrümmt, später aufrecht und geschlängeit. Kapsel oval oder ellipsoidisch, meist regelmässig, trocken längsrippig. Ring differenziert, sich ablösend. Peristomzähne bis zur Mitte 2schenklig. Haube meist gewimpert.
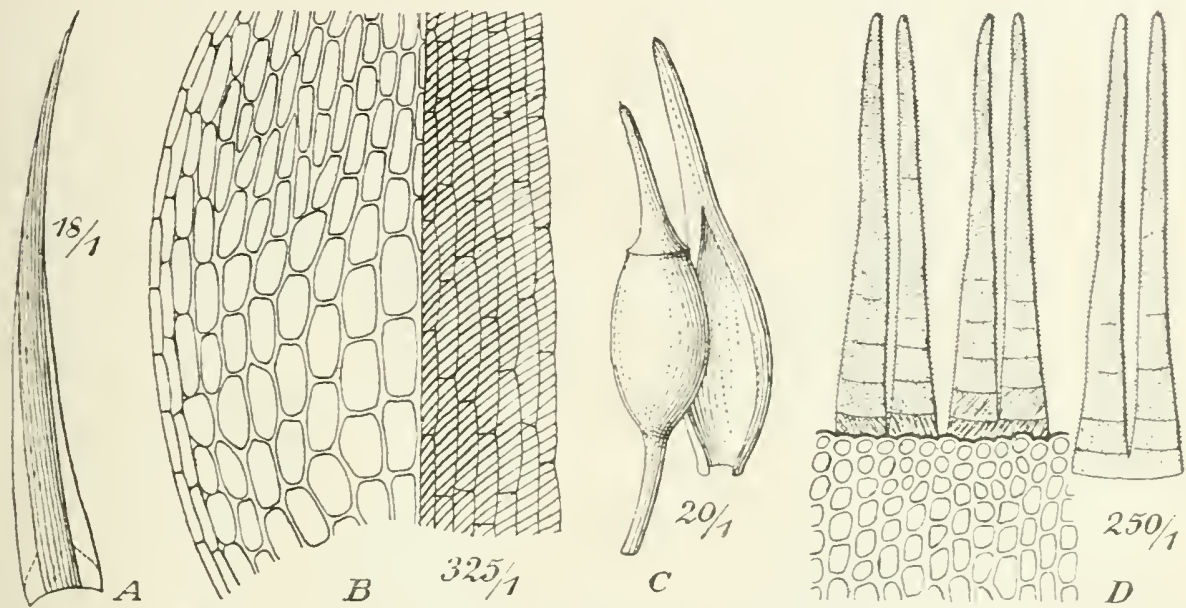

Fig. 11. A-D Wetzlerella alpina (Schimp.). A stammb. (15 1): B Blattlasis (325/1); C Kapsel (20 1): D Peristom (1.25 1$)$.

Ĺbersicht der Arten.

A. Blattrippe olne Stereiden.

a. Blätter mit grüner Spitze, am Rücken gefurcht, in den Ecken geöhrt: Zellen der Wittelschicht der Rippe im Querschnitt zugespitzt

77. C. Schwarzii.

b. Blätter nicht geöhrt; Zellen der Ilittelschicht der Rippe im Querschnitt rundlich-cuadratisch, kleiner als bei der vorigen Art.

«. Stengel längs dicht rostfilzig. Blätter mit grüner Spitze. am Rücken nicht gefurcht ................

$\hat{A}$. Stengel ohne Filz. Blätter hyalinspitzig, am Rücken gefurcht

75. C. Schimperi.

76. C. subulatus.

B. Blattrippe mit Stereiden.

a. Stereiden nur an der Rückenseite.

u. Laminazellen bis zur Spitze fortgeführt.

I. Zellen der Blattbasis sehr zart, mit verdickten, getüpfelten Querwänden

78. C. fragilis.

1I. Zellen des Blattgrundes kleiner als bei der vorigen

Art, nicht getüpfelt

80. C. flexuosus.

$\beta$. Blattrippe die obere Pfrieme ausfüllend.

I. Blätter mit Haar

79. C. atrovirens. 
II. Blätter ohne Haar

81. C. piriformis.

b. Stereiden auch an der Bauchseite.

«. Blätter nicht geöhrt; Zellen oberwärts rhomboidisch und etwas geschlängelt

$\beta$. Blätter geöhrt; Zellen oberwärts fast rektangulär, nicht geschlängelt 82. C. brevipilus. 83. C. Kaalaasii.

S e c t. I. Pseudocampylopus Limpr. Laubm. I. p. 381 (1886).

Blattrippe ohne Stereiden; Aussenzellen der Bauchseite weit, dünnwandig und leer, übrige Schichten aus ziemlich gleichförmigen, chlorophyllösen und mässig verdickten Zellen gebildet. - Fig. $12 \mathrm{~A}$.
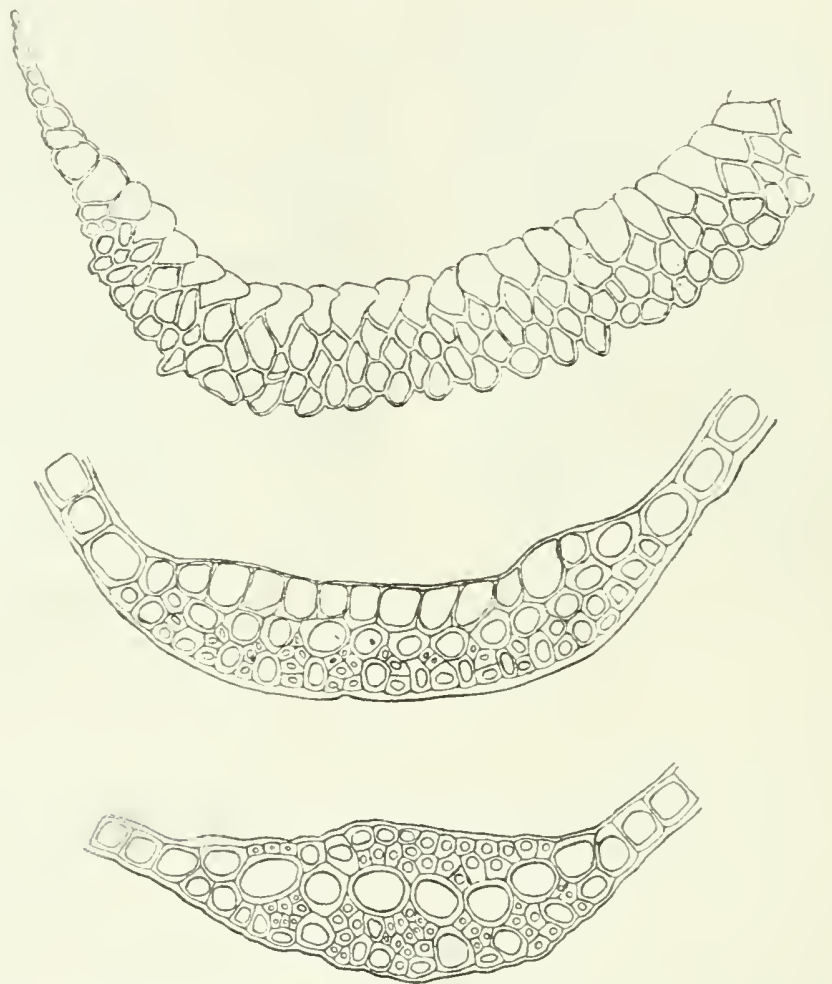

Fig. 12. Blattquerschnitte. A Campylopus schwarzii Schimn. (4011), - B C. fleruosus (L.) (400'1). C. C. urevipilus Bryol, eur. (400/1). (Nach I. impricht).

75. Campylopus Schimperi Mild. in Bot. Zeit. 1864 Beil. p. 13.

Schlanke Pfl. in sehr dichten, grünen und gelblichgrünen, bis zu den neven Tricben dicht rostfilzigen, etwas glänzenden Rasen. Stengel $1-3 \mathrm{~cm}$, selten höher. Blätter trocken angepresst, fencht aufrecht-abstehend, röhrig-hohl, aus nicht oder kaum geöhrtem Grunde allmählich pfriemenförmig, etwa $3,6 \mathrm{~mm}$ lang, an der grünen Spitze wenig gesägt; Rippe $2 / 3-3 / 4$ der Blattbasis, die obere Hälfte des Pfriementeils ausfüllend, am Rücken glatt, Zellen der Mittelschicht im Querschnitt rundlich-quadratisch; Zellen der Lamina schmal rhomboidisch bis elliptisch, am Rande bis hoch hinauf schmal lineal und hyalin, und an der Rippe rektangulär, in den Blattflügeln etwas erweitert, zart, wasserhell bis schwach rötlich. Kapsel eiförmig, gestreift. Sporen $21-21 \mu$. 
An feuchten Felsen und steinigen Abhängen.

N. In Westlandet von Ryfylke bis Romsdalen zerstreut und längs der Küute bis Nordrejsen. s'T. Opdal und Roan. Yom Meerufer bis etwa $1,400 \mathrm{~m}$ hinaufsteigend. Nordgrenze bei $69^{\circ} 47^{\prime} \mathrm{n}$. Br. Schottland, Zentral-Europa, Pyrenäen, Kaukasus, arkt. Nord-Amerika.

76. Campylopus subulatus Schimp. in litt. ad Mild.; Mild. in Bot. Zeit. 1862, p. 460 p. p. [Campylopus brevifolius Schimp. Bryol. eur. supp]. fasc. 1/2, t. 2 (1864).

- Orlhopus brcvifolius Wulfsb. in Kgl. Vid. Selsk. Skrift. 1875, p. 351.]

Schlanke Pfl. in flachen, leicht zerfallenden, gelbgrünen bis grünen, glänzenden Rasen. Stengel $1-1,5 \mathrm{~cm}$, ohne Rlizoidenfilz. Blätter trocken angepresst, feucht aufrecht, röhrig-hohl, nicht oder kaum geöhrt, aus etwas schmälerem Grunrle lanzettlicl und lang zugespitzt, bis $3,6 \mathrm{~mm}$ lang, an der Spitze wasserhell und \pm deutlich gezälnnt; Rippe $2 / 3$ der Blattbasis, am Rücken vielfurchig, Zellen der Mittelschicht im Querschnitt rundlich-quadratisch; Zellen der Lamina sehr klein, in der Mehrzahl quadratisch, am Blattgrunde zart und wasserhell, innere locker rektangulär, am Rande weit hinauf verlängert rektangulär und lineal, in den Blattflügeln wenig erweitert, sehr zart, wasserhell und hinfällig. Seta etwa $1 \mathrm{~cm}$, gerade. Kapsel eng elliptisch, glatt. Haube mit Wimpern. Sporen $11-13 \mu$.

An kalkfreien Felsen, auf sandigem Boden und zw. Steinen.

F. Lp. Rusiniha zw. Orlov und Ponoj, an erdbedeckten Felsen spärl. (Broth.).

N. Nur in Westlandet. zw. Stavanger und Aalesund; in Hardanger und Hordaland nicht selten. nördlicher und südlicher zerstreut, überall nur an der Küste. Nordgrenze bei $62^{\circ} 31^{\prime} \mathrm{n}$. Br.

West- und Zentral-Europa.

77. Campylopus Schwarzii Schimp. Bryol. eur. Suppl. fasc. 1/2, t. 1 (1864). Kräftige Pfl. in ziemlich dichten, meist gelb- bis bräunlichgrünen, zuweilen lebhaft grünen, innen braunen Rasen. Stengel bis $8 \mathrm{~cm}$, mit spärlichen, weisslichen und rötlichen Rhizoiden am Grunde der Blätter. Blätter aufrecht-abstehend bis schwach einseitswendig, rinnig-hohl, aus geöhrtem, lanzettlichem Grunde lang und fein pfriemenlörmig, etwa $6 \mathrm{~mm}$ lang, an der äussersten Spitze spärlich gezähnt: Rippe etwa $2 / 3$ der Blattbasis, den Pfriementeil ausfüllend, am Rücken vielfurchig, Zellen der Mittelschicht im Querschnitt zugespitzt; Zellen der Lamina klein, quadratisch bis kurz rektangulär, am Blattgrunde hart und wasserhell, innere locker, am Rande weit hinauf hyalin und lineal, in den Blattflügeln erweitert, zart und hyalin oder rötlich bis violett. Sporogone unbekannt.

An kalkfreien, ziemlich trockenen oder feuchten Felsen, auf steinigen Triften und besonders torfigem Erdboden.

N. Nur in Westlandet zw. Flekkefjord und Molde; in SB. und NB. in den äusseren Küstengegenden fqq., dringt jedoch auch stellenweise in den Fjorden und im Binnenlande bis $450 \mathrm{~m}$ ein. Nordgrenze bei $62^{\circ} 45^{\prime} \mathrm{n}$. $\mathrm{Br}$.

Schottland, Irland, Zentral-Europa.

var. falcatus Breidl. in Limpr. Laubm. l. p. 38.4 (1886).

Blätter sichelförmig-einseitswendig.

N. Ohne Fundortsangabe ( $\mathrm{H}$ a g e $\mathrm{n}$ ).

Steiermark.

var. albescens Limpr. mss.; Hag. in D. K. N. Vid. Selsk. Skrift. 1914, No. 1, p. 69 (1915).

Pfl. in lockeren, weisslich-gelblichen bis gelbgrünen Rasen.

N. $S B$. K vinnherred, Hattebergfossen.

S e c t. I I. Campylopus sens. strict. Limpr. l. c. p. 387.

Blattrippe auf der Rückenseite mit Stereidengruppen. - Fig. 12 B.

78. Campylopus fragilis (Dicks.) Bryol. eur. fasc. 41, p. 4, t. 2 (1818).

Ziemlich kräftige Pll. in grünen oder gelbgrünen, innen weisslichen, durch rotbraunen Rhizoidenfilz \pm verwebten Rasen. Stengel aufrecht, $1-3 \mathrm{~cm}$. Blätter trocken angepresst, feucht aufrecht-abstehend, aus nicht geöhrter, länglicheiförmiger und weisser Basis lanzettlich-pfriemenförnig, rinnig-lıohl, an ter Spitze 
gesägt, bis 5,5 mm lang; Rippe $1 / 2-1 / 3$ der Blattbreite, am Rücken gefurcht; Zellen der Lamina in 1-2 Reihen fast bis zur Spitze fortgeführt, im Pfriementeil klein, rhombisch und rhomboidiscl, im oberen Teil des Blattgrundes erweitert, rektangulär und quadratisch, mit stark verdickten, eintüpfligen Querwänden, weiter unten verlängert-6seitig und rektangulär, locker, wasserhell und sehr dünnwandig, gegen die Ränder viel enger, in den Blattflügeln nicht differenziert. Kapsel regelmässig. länglich-elliptisch. Sporenreife im Frühjahr. - Vegetative Vermehrung reichlich durch kleine schmal lineal-lanzettliche, trocken stark gekräuselte, leicht abfallende Brutblätter an gipfelständigen, büschelförmig verzweigten. dielıt gedrängten Brutsprossen.

An kalkfreien Felsen und in deren Spalten, seltener auf Torboden und mageren, sandigen Erdabhängen.

S. $s k$, an wenigen und Boh. an mehreren Fundorten.

N. Nur in Westlandet, ron Kristiansand bis .Iolde st. fiq. Nordgrente bei $62^{\circ} 40^{\prime} \mathrm{n}, \mathrm{Br}$.

Europa.

var. densus (Schleich.) Schimp. in litt.; Limpr. Laubm. I. p. 395 (1877). [Dicranum densum Schleich. Exs. et Cat. 1807. - Campylopus densus Bryol. eur. lasc. 11. p. 6, t. $5(1848)]$.

Pli. in diehten Rasen. Stengel $1 \mathrm{~cm}$ und höher. Stengel mehrmals geteilt, mit langen, pinselförmigen Sprossen. Brutblätter fehlend.

N. Im oben genannten (ieliele nach $H$ a $g$ en hier und da.

Eurupia.

79. Campylopus atrovirens De Not. Syll. musc. p. 221 (1838).

Kräftige Pfl. in dichten. oft breit kissenförmigen. oben dunkel- oder gelblichbis bräunlichgrïnen und glänzenden, innen gebräunten bis schwärzlichen Rasen. Stengel aufrecht oder aufsteigend, $2-3 \mathrm{~cm}$, mit weitzelliger Aussenrinde und spärlichen Rhizoiden. Blätter aufrecht-abstchend, oft leicht gekrümmt, die ohersten bisweilen sichelförmig, brïchig, röhrig-hohl, aus stark geöhrter. lanzeltlicher Basis sehr lang und fein borstenförnig und in ein rauhes, hyalines, langes Haar auslaulend, bis $6 \mathrm{~mm}$ lang: Rippe ${ }^{1}{ }_{2}$ der Blattbasis, am Rücken vielfurchig: Zellen der Lamina stark verdickt, in den Blattflügeln blasig erweitert, meist 2schichtig, trüb purpurn oder gebräunt, über diesen rektangulär und quadratisch, darüber selief leckig, am Rande lineal, einen sehr schmalen Sam bildend, die ïbrigen verlängert rhomboidich und schmal elliptisch, schwach wurmförmig.

An feuchten, bisweilen iberrieselten, kalkfreien Felsen und auf feuchter Ercle, meist auf Torfboden, seltener in Mooren. Sehr selten fruchtend.

S. Tg. Jurdallet.

N. Am reichlichsten in $\|$ esllandet. besonder in $\$ B$. und $X B$.. in s rlandel fas... nördlicher sparlicher. Nordgrenze in $\mathrm{XT}$., hei $65^{\circ} 6^{\prime} \mathrm{n} . \mathrm{Br}$.

(ipusirilannien. Pỵenäen. Schweiz, Ober-italien.

so. Campylopus flexuosus (L.) Brid. Mant. p. 71 (1819). [Bryum flexuosum L. Sp. pl. $1118(17.53)$.]

Ziemlich schlanke Pfl. in dichten. grünen bis gelb- odler bräunlichgrünen, etwas glänzenden Rasen. Stengel aufreeht, $1-4 \mathrm{~cm}$, sclten löher, längs rostfilzig. Blätter aufrecht-abstehend oder \pm einseitswendig, aus geöhrter, lanzettlicher Basis allıählich linealisch-pfriemenförmig, $3-5 \mathrm{~mm}$ lang, röhrig-hohl, an der Spitze gezälnt: Rippe etwa ${ }^{1 / 2}$ der Blattbasis, nur gegen die Spitze hin an Rücken gefurcht; mit den ventralen \%ellen in der llehrzahl durch radiale Teilung verdoppelt: zellen der Lamina in 1-2 Reihen bis zur Spitze fortgeführt, im Pfriementeil oberwärts klein, rlombisch und rlomboidisch, abwärts quadratisch und kurz rektangulär, locker und wasserhell, an den Rändern viel enger, in den Blattflügeln sehr gross und aulgeblasen. Kapsel länglich-zylindrisch, meist symmetrisch und etwas gekrümmt. Sporenreife im Hochsommer. - Vegetative Vermehrung durch Bruchknospen an gipfelständigen, oft büschelästigen Brutsprossen. 
Auf Torf, torfigem Waldbolen und erdbedeckten, schattigen, kalkfreien Felsen.

S. Sk. und Boh. an wenigen, $\mathrm{V} g$. und Lld. an einzelnen Fundorten.

N. An der häste zw. Lindentes und stal, seltener in L.M. und St., fqq. in SB., fr. in NB. Ostlicher nur in vereinzellen Fundorten in R.. ST. und NT.

Grossbritannien. Zentral-Europa, Nord-Amerika.

var. mícans (Wulfsb.) lHag. in D. K. N. Vił. Selsk. Skrift. 1914, No. 1, p. 76 (1915). (C. micans Wulfsb. in Clnistian. Vid.-Selsk. Forlı. 1876, p. 349).

Stengel etwa 7 cm. Blattrippe mit fast allen ventralen Zellen durch radiale Teilung verdoppelt; vertikale Wänden der Blattflügelzellen und der nächsten Basalzellen mit in den Zwischenräumen gelegenen, kammförmigen Erhebungen.

In Felswänden des westl. Norwegens bei Einingevik.

81. Campylopus piriformis (Schultz) Bricl. Bryol. univ. I. p. 471 (1826). [Dicranum pyriforme Seluttz Suppl. Fl. starg. p. 73 (1819). - Campylopus turfaceus Bryol, eur. fasc. 11 Mon. p. 1, t. 3 (1818).]
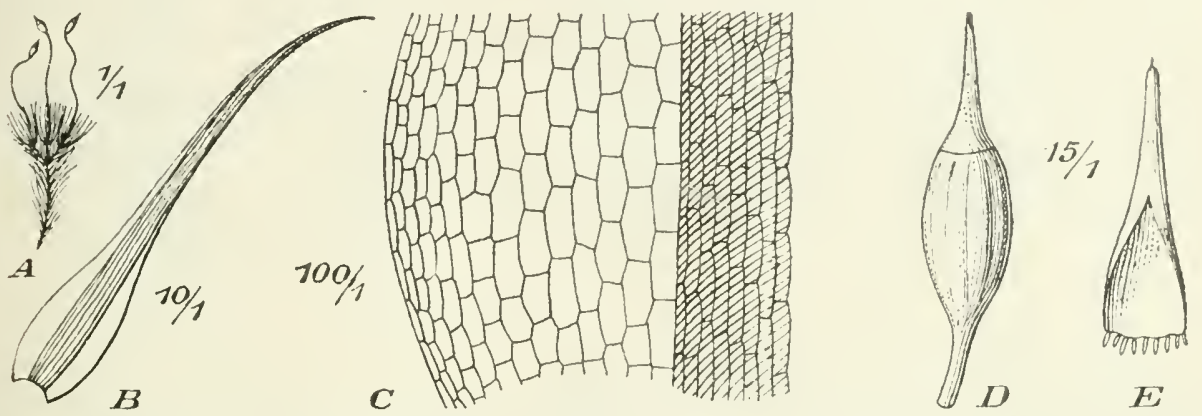

Fig. 13. Campylopus piriformis (schultz). I Frurbtende Pfl. (1/1); B stanmb. (10/1): C Blattlasis (100/!); D Kapsel (15/1); E Haule (15/1).

Schlanke Pfl. in lockeren bis dichten, grïnen oder gelbgrimen Rasen. Stengel 2 I cm, selten höher, kaum oder \pm rotfilzig. Blätter meist steif aufrecht oder aufrecht-abstehend, rimnig-hohl, aus länglich-eilörmiger Basis raseh lang borstenförnig, in der Spitze gezälnt, 3-5 $111 \mathrm{~m}$ lang; Rippe etwa $1 / 2$ cler Blattbasis, den Borstenteil ausfüllend, kaum gefurcht, mit sehr lockeren ventralen \%ellen; Zellen der Lamina im unteren Teil der l’frieme meist schmal rektangulär, nach unten alluählich erweitert, rektangulär und 6seitig, hyalin, am Rande eng, in den Blattflügeln kaum differenziert. Kapsel regehnässig, länglich-elliptisch. -.. Vegelative Vermehrung dureh kleine, gipfelständige Bruchknospen, deren Blätter narh dent Abfall der linospe sich voneinander trennen. - Fig. 13.

Aul bewaldetem Torfboden.

S. Sk. und öl. r.

N. An wenigen Fundorten in sim., an einzelnen in st. und $N B$.

Europa.

Sect. III. Palinocraspis Lindb. Muse. seand. p. 25 (1879).

Blattrippe ober- und unterseits mit Stereitlen. - Fig. 12 C.

82. Campylopus brevipilus Bryol, eur. fase. 41, p. 7 , t. $4(1847)$.

Ziemlich schlanke PfI. in dichten, flachen, ausgedehnten, gelbgrünen bis goldbräunlichen, glänzenden Rasen. Stengel $1-2$ cm, selten höher, nur am Grunde mit Rhizoiden. Blätter gegen die Spitze der Jahrestriebe plötzlich grösser unt sehr gedrängt, steif, trocken angepresst, aus nicht oder kaum geöhrter, enger Baris verlängert lanzettlich, allmählich pfriemenförmig, bis 3,5 mm lang, mit kurzer, rauher, hyaliner Haarspitze, oberwärts rölırig; Rippe $1 / 2-1 / 3$ (ler Blattbasis, ober- 
wärts am Rücken gefurcht; Zellen oberwärts verlängert rhomboidisch und schmal elliptisch, etwas geschlängelt, abwärts locker, rektangulär und quadratisch, wasserhell und dünnwandig, gegen den Rändern allmählich schmäler, in den Blattflügeln gross, braun oder wasserhell. Innere Blätter der $ᄋ$ Blüte allmählich in eine Pfricmenspitze verschmälert.

Auf feuchtem und torfigem Heidelande, zuweilen auch auf dem Winde exponierten Plätzen.

N. Nur in Westlandet zw. Jaederen und Fosen in den ăusseren Küstengegenden und ziemlich -elten. Nordgrenze bei $63^{\circ} 52^{\prime}$ в. $\mathrm{Br}$.

WTest-Europa, Algier. p. 55.

83. Campylopus Kaalaasii Hag. in D. K. N. Virl. Selsk. Skrift. 1910, Noo. 7.

Zicmlich kräftige Pfl. in sehr dichten, grünen, imnen bräunlichen, glänzenden Rasen. Stengel $4-7 \mathrm{~cm}$, aufrecht oder aufsteigend, am Gipfel gekrümmt, abwärts mit schwarzrotem Rhizoidenfilz. Blätter trocken geschlängelt, feucht \pm zurückgebogen, aus stark geöhrter Basis schmal eilanzettlich, lang linealisch-pfriemenförmig, bis $7 \mathrm{~mm}$ lang, oberwärts dicht gezähnelt, an der äussersten Spitze spärlich gezähnt, längs rinnig-hohl: Rippe etwa $3 / 5$ der Blattbasis, lang austretend, am Rücken nicht gefurcht; Zellen oberwärts rektangulär bis rhomboidlisch und lincar, abwärts locker, fast quadratisch. Innere Blätter der $\Varangle$ Blüte rasch in eine lange Pfriemenspitze verschmälert. Sporogone unbekannt.

N. R. Valderøen unweit Aalesund, an einer grasigen. feuchten stelle des Meeresufers.

\section{RHABDOWEISIOIDEAE.}

Meist autözisch; ơ Blüte knospenförmig, gestielt, in der Nähe der \& Blütc. Stengel ohne Zentralstrang. Blätter nicht dünner an den Rändern als bei cler Rippe. Kapsel aufrecht, regelmässig, trocken mit \& Längsrippen, entdeckelt weitmündig. Spaltöffnungen vorhanden. Peristomzähne ungeteilt, glatt, ungestreift oder abwärts querstreifig und oberwärts mit schräg sich kreuzenden Linien, zuweilen fehlend.

\section{Übersicht der Gattungen.}

A. Zellen der Lamina papillös. Peristom fehlend ............ 21. Amphidiumi.

B. Zellen der Lamina glati. Pcristom vorhanden

22. Rhabdoweisia.

\section{AMPHIDIUM}

Schimp. in Bryol. eur. Consp. (1855).

Felsmoose. Schlanke Pft. in oft sehr ausgedehnten, polsterförmigen Rasen. Stengel 3eckig, ohne Zentralstrang, bis zur Spitze mässig mit Rhizoiden besetzt. Blätter \pm abstehend, trocken verbogen oder kraus, länglich- oder lineal-lanzettlich, ganzrandig, oberhalt der Basis bis gegen dic Blattmitte umgerollt; Rippe mit der Blattspitze aufhörend: Zellen oberwärts rundlich-cuadratisch, chlorophyllreich, 8-10 ", mässig verdickt, beiderseits mit zahlreichen Papillen, gegen den Grund allmählich verlängert, rektangulär, dünnwandig bis wasserhell. Seta kurz. gelbgrün, nach oben dicker, trocken links gedreht. Kapsel aufrecht, birnförmig. rotbraun mit grünem Halse, trocken und entlecrt tief längsfaltig und wegen der stark erweiterten Mündung urnenförnig; Zellen des Exotheciums verlängert reklangulär, in den Längsrippen etwas breiter und stärker verdickt, un die Mündung in einigen Reihen querbreiter. Ring nicht differenziert. Peristom fehlend. Sporen $10-12 \mu$, braun, glatt. 
Üb e rsicht de $\mathrm{r}$ A r t e n.

A. Autözisch. Blätter trocken kraus. Seta von der Kapsellänge

B. Diözisch. Blätter trocken verbogen. Seta doppelt so lang wie die Kapsel

84. A. lapponicum. wie 85. A. Mougeotii.

84. Amphidium lapponicum (Hedw.) Schimp. in Bryol. eur. Consp. Vol. III. p. 3 (1855). [Gymnostomum lapponicum Hedw. Descr. III. p. 10, t. 5 A (1792). Anictangium lapponicum Hedw. Sp. musc. p. 10 (1801).]

Autözisch. Rasen dicht, $1-5 \mathrm{~cm}$, dunkel- bis bräunlichgrün, unten braun bis schwärzlich. Blätter länglich- oder lineal-lanzettlich, flachrandig, bis $2 \mathrm{~mm}$ lang, trocken gedreht und kraus. Perichätialblätter hochscheidig, kurz zugespitzt.
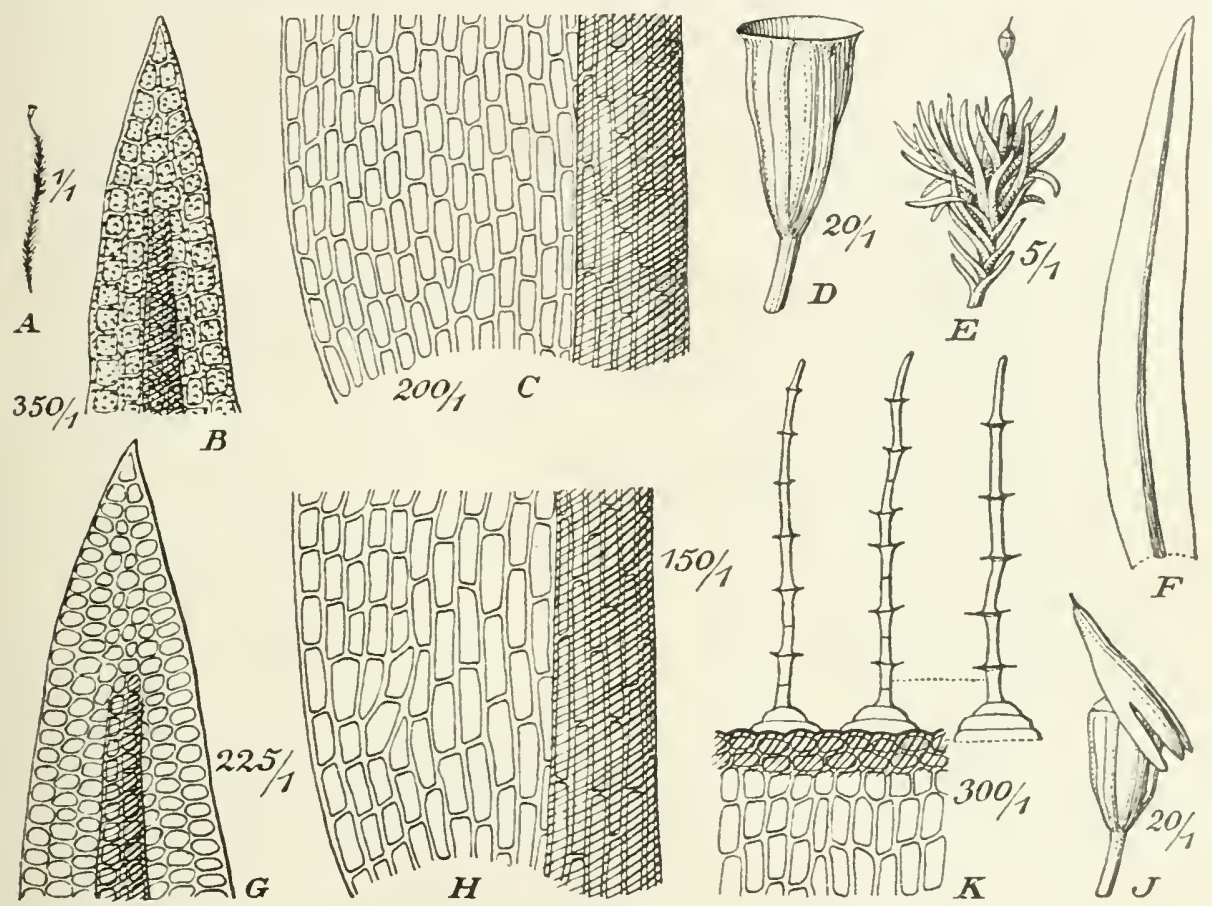

Fig. 14 A-D. D. Amphidium lapponicum (Hedw.) Schimp. A Fruchtende Pfl. (1/1); B Blattspitze (350/1); C Blattbasis (200/1); D Entleerte Kapsel im trockenen Zustande (20/1). - E-K. Rhabdoweisia striata (Schrad.) Kindb. E Fruchtende Pfl. (5/1); F Stengelb. (25/1); G Blattspitze (225.1); H Blattbasis (150/1); I Kapsel mit Haube im trockenen Zustande (20/1); $\mathrm{K}$ Peristomzähne (300'1).

Seta von der Kapsellänge. Deckelschnabel meist kürzer als der Radius. Sporenreife im Mai und Juni. - Fig. $14 \mathrm{~A}-\mathrm{D}$.

In Spalten kalkfreier und kalkärmerer Gesteine, stets reichlich fruchtend.

F. Al. Saltvik, Harald sby (Nerv.); Liby (Bom.). Geta, an wenigen Fundorten (Arrh., Bom., Hult). Ab. Pargas, Tervsund (Elfv.). Finby (Broth.). Karislojo, Mustasaari und Karkali (E. af H.); Tăsväri (Broth.). Uskela, Pahkavuori (Häyr.). Lojo, Skraatila und Mustasaari (E. af H.). Vichtis, Haapkylä (Broth.); Olkkala (Láng). 一 N. Nurmijārvi (Temb.). Tusby, Sarvikallio (Broth.). Perna (liäyr.). Elimäki (Tigerst.). Orimattila, Tekemäjärvi (Link.). Sibbo (Ekm.). Hogland, Haukkavuori (Lindb.). Ka. Sippola, Ruotila (Kujala). Vehkalahti (Blom). Wiborg, Juustila (Buch); Soskuanjoki (B.). Antrea (Lind.). - St. Eıra (Rönnb.). Karkku, Pirunvuori (Hjelt). Pirkkala (Simm.). Ikaalinen (Nerv.). Runvesi, Helvetinjärvi (Broth.). - Ta. Janakkala (Elfv.). Hattula, Nihattula (Ranck.). Im sïdostl. Teile st. fq. (Norrl.). Hartola (Bonsd.). Luhanka und liorpilahti st. fq. (Vain.). _ sa. Valkeala (Sundr.). 
Kangasniemi (Lackstr.). Taipalsaari (Sael.). Willmanstrand (Buch). 一 Kl. Jaakkima, Romola (Sundv.). Kurkijoki. an mehreren Fundorten (Jusl.). Valamo (Malmb.). Sortavala (Pes.); Kirjavalahti (Lindb.). Impilahti, Pullintuori (Brolh.); Kitelă (Link.). Ruskeala (W. Nyl.): Tirrinmylly und Hämekoski (Broth.). Pálkjārvi, an mehreren fundorten (Backın., Broth.). - Kol. Saluni, an mehreren Fundorten (Link. Pes.). Vo:nessenje und śchtjeliki (Elfv.). - Ox. Nirpes, Yttermark. Vargbărget (L. af H.). - Tb. Virrat, Toriseva (Broth.). Pihlajave; (Norrl.). Petäjävesi. Palavavuori (Ruor.). Jyväskylä, Ristikivenkallio und Lajanvuori (Link.). Laukaa, Vihtjärvi (Broth.). Konginkangas (Broth.). Viitasaari. Niinilahti (Broth.). Kinnula. Olhavainen (Roiv.). Pihtipnda:. Rikkavuori (R.). - Sb. Virtasalmi, IIontola (Kyyhk.). Kuotio pass. (Link.). Kaavi st. fq. (Kot.). Jukka, Halivaara [q. (Kot.). Maaninka und Pielaresi an mehreren Fundorlen (Kyyhk., Roiv.). - Kb. Tohmajärvi, Hiienmäki und Niirala (Broth.); Kemie (O;ch). Pieliajärvi. Rulivuori (Linnan.). - Kon. Tiudie (Kullh.). Pirttiniemi (Simm.). Jänkäjärvi (Narrl.). - Ok. Kajana (Lackstr.). Paltamn, Melatahti, Ellinlampi (Kyyhk.). Sotkamo, Vuorisilari (Ky̧hk.); Naapurinvaara (Broth.). Puolanka. Hepoköngäs (Kyyhk.). Suomussalıni, an mehreren Fundorten (Kyyhk.). - Ob. Muhos, Leppänjemi (Huum.). Pudasjärvi (Nyb.). Rovaniemi (Hult). Aavasaksa (Bıch). - $K$. Pudasjärvi. Pirrivaara (Broth.). Kuusamo, Korojoki, Iivaara und KallioperänVaara (Broth.); Vasaraperã, Ruoppijärvi (E. af H.); Valajankoski, IIantykoski und Urovaara (Nył.). - Lkem. Zw. Kolari und Pallastunturi an mehreren Fundorten (Hult). Kemijärvi, Pyhätunturi (Häyr.); Kitinen (Broth.). Kuolajărvi; Sallatunturi (E. af H.); Te:ınönjoki(Linnan.). - Le. In der Nadelwaldregion pass. (Norrl.); Kilpisjärvi (N.); Malla und Saana fq. (Kot.). - Li. In der Nadel wald-und Birkenregion st. fq. (Hutt). - Lim. Kandalaks und Hibinä (Brołh.). Unnba und Unpjok (Kihlm.). Sascheika (Fellm.). Lt. Rotsvara und Pomjatkivaara (Ruiv.). Srednij und Abramova Pahta am Kolabusen (Broth.). Imur. Teribjerka und Varsinsk (Broth.). - Lp. Panfelovka (Brenn.). Orlov, Gubnoi (Kihlm.).

S. Sm. V Ig. und Ög. r., Srm., Vir., Dld, und Vrml.—L.

N. In allen Imtern. jedoch mil verschiedener Frequenz, am reichlichiten in dersubalpinen Region. Nordgrenze aul spitzbergen. Steigl bis $1,300-1,350 \mathrm{~m}$ hinaul.

Europa, Kaukasus, Himalaya, Zentral-Asien, Tiehuktieh. Halbins.: Nord-Amerika.

85. Amphidium Mougeotii (Bryol. eur.) Schimp. 1. c. [Zygodon Mougeolii Bryol, eur. fasc. 4, p. 7. t. 1 (1839).]

Diözisch. Rasen lockerer, 2-10 cm, lebhaft bis gelblichgrün, unten rostrot. Blätter lineal-lanzettlich, schmal zugespitzt, mit am Gruncle schmal umgerollten Rändern, his 3 mm lang, trocken einwärts gekrümmt. Perichätialblätter viel länger und schmäler als bei der vorigen Art, aus halbscheidigem Grunde lanzettlichpfriemenförmig. Seta doppelt so lang wie die Kapsel. Deckelschnabel länger als der Radius.

In Spalten beschatteter, kalkfreier und kalkärmerer Felsen. ausnahmsweise anf Kalk. Sehr selten fruchtend.

F. Al. Eekerö (Arrh.). Lemland. Lambile (Oalison). Finström und saltvik, an einigen Fundorten (Bom.). - 1b. Nagu, Klockarbärget (Ellø.). Teרala, (Gesterby (Häyr.). Uskeła, Linnamäki (Lindb.). Karislojo. Fiarkkali (Brot: Lojo, an vielen findorten (Lindb.. Jusl., Sundv.). Vichtis. Hietainen (Broth.); Olkkala (E. al 11.). - N. liogland (Lilldb.). Elimiki (Tigerst.). Orimattila, Tekenäjärvi (Link.). Sımmarnäs, Kalliojärvi (A. Link.). - Ka. Virolalıti (Blom). WViborg. Juustila (Buch). Jäaski und Antrea (Pork.). Räisälä, sirlahti (Lind.). - Ta. Ja’akkala (Ettv.). Linmi, Evo (Norrl.). Hollola. Enonsaari (Vain.). Asikkala. Kissakation (Broth.). Koppilahti, Vaarunvuori (Link.). - Sa. Willmanstrand (Buch).

Kl. Jaakina (Sundy.). Sortavala. Kirjavalahti (Lindb.). Impilahti. Majalsaari (Popp.); Sumeria, Raukkívuoret (Pes.); Pullinvuori (Broth.). Ruskeala (W. Nyl.). - Oa. Övermark, Valshärget (E. al H.). - Tb. Viitasaari, Etelävuori (Broth.). 一 Kon. Pirttiniemi (Norrl.). 一 Om. Alajärvi, Käärmekallio (Backm.). - K. Kuusimo. Kiorojoki und Aventojoki (Broth.); Kitkajoki, Jyrävä (B.); Kallioperänvaara und Onlankajoki (B.): Mn+talampi (B.); Sovanköngäs (B.). — Lkem. Kienijärvi, Pyhătunturi (IIuun). Kätkesuanto (Norrl.). - Le. Kireilaıto 'und Lo lliuvara (Norrl.); Kilpisjärvi, Malla, Saana und Megapahta (Kot.). - Li. Sudankylä, Sakatinpahta (Hult). Iniri, Seidvaara (Sil.). Utsjoki, Kenischkoski (Hult). - Lim. Kandalaks (Broth.); Porjeguba (Sel.); Hihinä (Broth.). - Ll. Kola, Karaulnaja Pahta und Al,ranovaja Palıta (Broth.). - Lmur. Teriherka (Broth.): zw. Varsinsk und Jenjarr (B.). Lp. Maloje Breojannoje und Katschkova (Kihtın.). - Lx. Tichapoma (Broth.).

S. $S k,-l$.

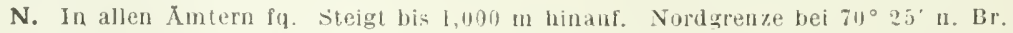

Europa, Kaukasus, Nord-Amerika.

var. caespitosum (Mitt.) Hag. in D. K. N. Vid. Selsk. Skrift. 1!)1.4, No. 1, p. 16 (1915). [Didymodon caespitosus Mitt. in .Joum. Limm. Soc. VIII. p. 18 (1864).] Blätter aus aufrecht-ahstehendem Grunde abstehend bis zurückgekrümmt, mit entfernt gesägten Rändern. Steril.

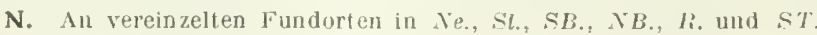

Westl. Teile von Nord-Anerika. 


\title{
22. RHABDOWEISIA
}

\author{
Bryol. eur. fasc. $33 / 36$ (1846).
}

Autözisch. Schlanke, I dichtrasige Pfl. Stengel aufrecht, ohne \%entralstrang und mit sehr lockerem, diinnwandigem Grundgewebe, abwärts mit Rhizoiden. Blätter trocken gekräuselt, feucht verbogen-abstehend, kielig-hohl, lineal-lanzettlich, flachrandig oder in der Blattmitte einerseits umgebogen; Rippe kräftig, meist vor der Blattspitze aufhörend, glatt; Zellen rundlich-quadratisch bis 6seitig und queroval, chlorophỵllreich, glatt, am Grunde rektangulär und hyalin. Perichätialblätter kaum differenziert. Seta 2-l mm, strohgelb. Kapsel klein, eiförmig, gelb- oder rötlichbraun; Zellen des Exotheciums rektangulär. Ring nicht differenziert. Peristomzähne dünn, gelblichrot. Deckel lang und fein geschnäbelt. Spıren 12-18 $\mu$, bräunlich, feinwarzig. Sporenreife im Sommer.

\section{[ै bersicht der Arten.}

A. Peristomzähne fadenlörmig, ungestreift ............... 86. Rh. striata.

B. Peristomzähne aus breit lanzettlichem Grunde linealischpfriemenförmig, gestreift ......................... 87. Rh. crispata.

86. Rhabdoweisia striata (Schrad.) Kindb. Eur. and N.-Am. Bryin. p. 211 (1897). Grimmia striata Sehrad. Bot. Journ. II. p. 57 (1799). - Weisia fugax Hedw. Sp. muse. p. 64, t. 13, 1. 5-10 (1801). - Rhabdoweisia fugax Bryol. eur. fasc. 33/36, tab. 41 (1846). - Oncophorus striatus Lindb. Musc. scand. p. 27 (1879).]

Rasen dicht und oft ausgedehnt, meist reingrün. Stengel meist nur bis $1 \mathrm{~cm}$, selten höher. Blätter schmal lineal-lanzettlich, allmählich zugespitzt, ganzrandig, bis $2,3 \mathrm{~mm}$ lang; Zellen $6-8 \mu$. Peristomzähne fadenförmig, ungestreift, leicht abbrechend. - Fig. $14 \mathrm{E}-\mathrm{K}$.

In schattigen Spalten kalkfreier und kalkärmerer. selten kalkreicher Felsen.

F. Al. Saltvik. Boxö und Tengsöda (Bom.). - Ab. Angelniemi, Karviais (Buch). Karislojo, Täsväri (Lindb.). - N. Hogland (Lindb.). - sa. Kangasnienii, Suomäki (Lackstr.). - sb. Nilsiä, Pisa, Pirun luola (Kol.). - ok. Kajana (Broth.). - Lkem. Ifuonioniska (Norrl.) Kätkesuanto (N.). Kemijårvi, Pyhätunturi (Vain.). - Le. Pietsovaara und Kilpisjärvi (Sahlb.). - Li. Tirro und Veitsjinnjarga (Hult); Pyttelvaara (H.). - Lt. Kola, Karaulnaja Pahta (Broth.).

S. $s k ., S m$. und Boh. an mehreren, Ög., $V g$. und srm. an wenigen Fundorten.

N. In allen Aintern, am reichlichsten in $S B,, Y B, \quad F$. und No. Meist in niedriger Lage, in den wheren! Teilen des Waldgebietes seltener und sehr selten oberhalb der Baumgrenze. Nordgrenze bei $70^{\circ} 25^{\prime} \mathrm{n} . \mathrm{Br}$.

Europa, Japan, Nord-Amerika.

87. Rhabdoweisia crispata (Dicks.) Kindb. 1. c. [Bryum crisputum Dicks. Pl. erypt. Fasc. III. p. 3, t. 7, f. 4 (1793). Weisia denticulata Brid. Sp. muse. I. p. 108 (1806). - Rhabdoweisia denticulata Bryol. eur. fase. 33/36, t. 12 (1846). Oncophorus crispatus Lindb. IIusc. seand. p. 27 (1879).]

Etwas kräftiger als die vorige Art. Räschen locker, dunkelgrïn, schwach glänzend. Stengel 1-2 cm, selten höher. Blätter breiter. kürzer zugespitzt, oben durch vortretende Zellen fein gesägt; Zellen in der Nähe der Rippe 8-10 $\mu$. Peristomzähne aus breit lanzettlichem Grunde linealisch-pfriemenförmig. abwärts querstreifig, oberwärts mit schräg sich kreuzenden Linien.

In schattigen Spalten kalkfreier Felsen.

F. Al. Geta. Djuprikskyrka (Bom.). Saltvik. Berdtby Khloddherg (B.).

S. Sk. und $V_{g}$. an mehreren, Sm., Ög., Boh., Lld. und Dlr. an einzelnen Fundorlen. - LuL. Njam. mats.

N. In allen Amtern mit Ausnahme von $K$. $H$. und $T r$, an der Westküite bis $R$. und besonders in $S B$. fqq., in Surlandet zerstreut, im Binnenlande selten. Neist in niedriger Lage, kaum über die Baumarenze hinaufsteigend. Nordgrenze bei $70^{\circ} \mathrm{n}$. Br.

Europa, Nord-Amerika. 


\section{DICRANOIDEAE.}

Autözisclı, pseudautözisch oder diözisclı. Blätter an den Rändern kaum dünner als bei der Rippe; Blattflügelzellen \pm dentlich differenziert. Perichätialblätter scheidig. Kapsel mit sehr kurzem Halse; Spaltöffungen vorhanden. Peristomzähne meist 2 -3schenklig.

\section{Übersieht de r Gat $\mathrm{t}$ ungen.}

A. Pseudautöziseh oder diözisch. An die Blattflügelzellen angrenzende Basalzellen locker, hyalin und leer. Kapsel (excl. Crassidicranum) symmetriseh ................... 32. Dicranum.

B. Alle innerhalb der Gruppe der Blattflügelzellen gelegenen Basalzellen gleichartig, gestreckt.

a. Diözisch; Blüte köpfehenförmig. Kapsel zylindrisch, meist glatt 31. Oithodicranum.

b. Autözisch, selten diözisch.

a. ๆ Blüte knospenförmig.

I. Kapsel trocken glatt.

1. Blattzellen glatt.

* Kapsel aufrecht, regelmässig ..............27. Dicranoweisia.

** Kapsel geneigt bis horizontal, hochrückig ... 28. Oncophorus.

2. Blattzellen beiderseits manillös.

* Kapsel aufrecht, regelmässig ..............26. Oreoveisia.

** Diözisch. Kapsel geneigt his horizontal, hochrückig .... 25. Dichodontium.

II. Kapsel trocken gestreilt.

1. Peristomzähne ungeteilt

23. Cnestrum.

2. Peristomzähne 2schenkelig

24. Cynodontium.

ß. Ci Blüte köpfehenförmig.

I. Kapsel regelmässig, verkehrt-eiförmig, trocken und entleert weitmündig, gestreift, mit strahlig ausgebreitetem Peristom

29. Arcloa.

II. Kapsel symmetrisch

30. Kiaeria.

\section{CNESTRUM}

Hag. in D. K. X. Viıl. Selsk. Skrift. 191t, No. 1, p. 23.

Autözisch. Stengel dreikantig, etwas verfilzt. Blätter aus länglicher Basis lanzettlich oder lineallanzettlich, zugespitzt, durch die zapfenartig vorspringenden Zellwäncle wie gesägt; Zellen oberwärts quadratisch, beiderseits mit kegeligmamillös aufgetriebenen freien Wänden, am Grunde verlängert rektangulär, in den Blattliugeln nicht differenziert. Perichätialblätter kaum bis zur Mitte schei(lig. Kapsel klein, regelmässig mit Rippen. Ring nicht differenziert. Peristomzühne ungeteilt, hier und da durchbrochen, nicht papillös, unten längs-, oben schrägstreifig. Deckel kurz geschnäbelt.

Einzige Art:

88. Cnestrum Schisti (Wahlenb.) llag. I. c. p. 21. [Weisia Schisti Wahlenb. 1*l. lapp. p. 325 (1812). - Cynodontiun Schisti Lindb. in Öfr. Vet.-Ak. Förh. XXI. 1). 230 (1864). - Oncophorus brenipes I.indl,. in Meddel. Soc. F. Fl. Fenn. I. p. 111 (1876). - O. Schisti Lindlb. Musc. scancl. p. 27 (1879). - Cynodontiella Schisti Bryln in Nyt Mag. I. Natur. XXXlI. p. $[16$ (1892).] 
Pfl. in \pm diclıten, gelbgrünen, polsterförmigen Rasen. Stengel bis $2 \mathrm{~cm}$, selten höher. Blätter aufrecht-abstehend, trocken gekräuselt, bis $1,8 \mathrm{~mm}$ lang, mit zurückgeschlagenen Rändern; Rippe meist vor der Blattspitze aufhörend, am Rücken rauh; Zellen oberwärts $7-9 \mu$, am Rande und an der Rippe zweischichtig. Seta 2-3 mm, gelblich. Kapsel dick oval, dickhalsig, rötlichbraun, mit dunkleren Rippen, trocken und entleert weitmündig; Zellen des Exotheciums locker, läng-

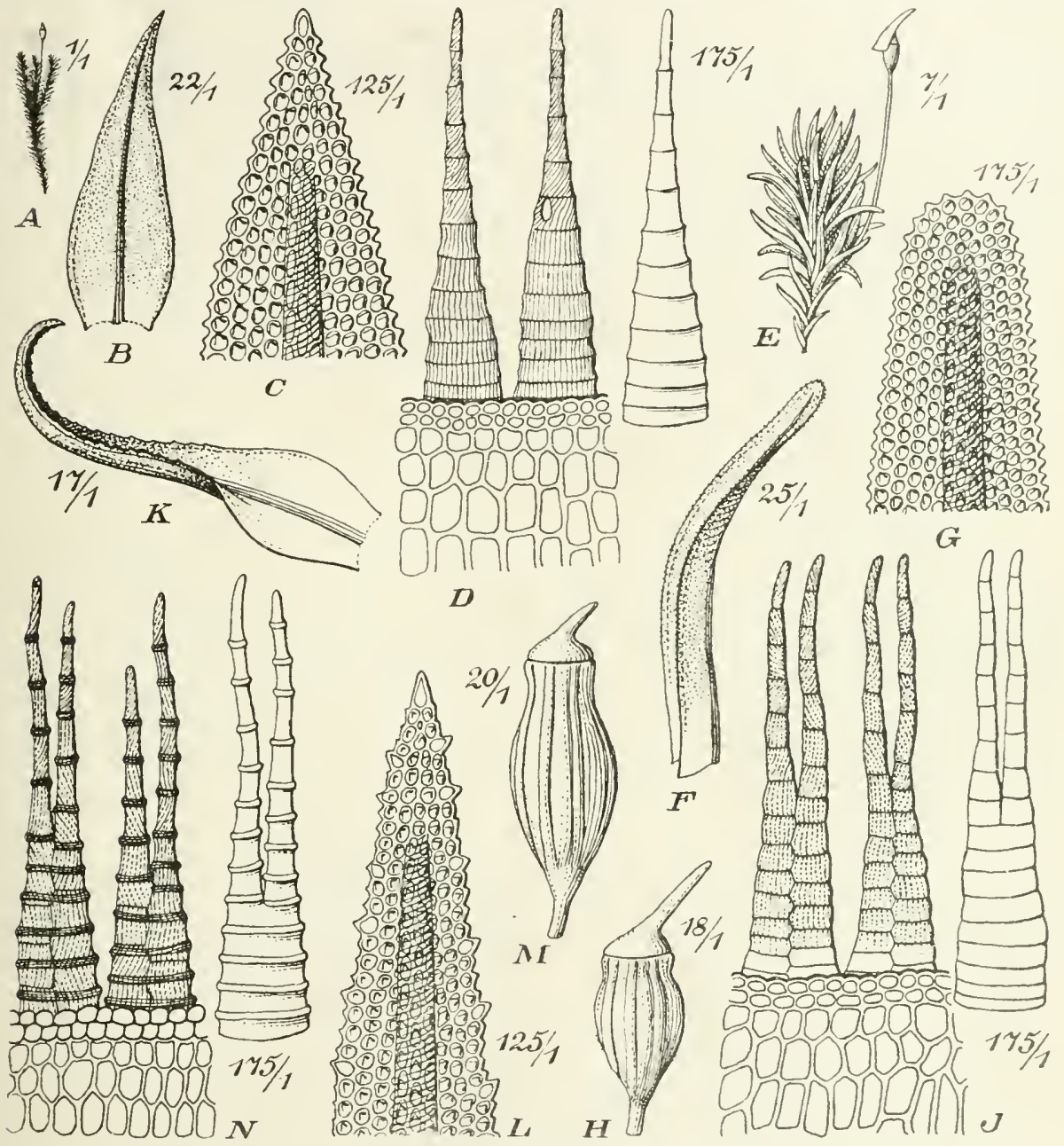

Fig. 15. A-D Cnestrum schisti (Wahlenb.) A Fruchtende Pfl. (1/1): B Stammb. (22/1); C Blattspitze (125/1); D Peristom (125/1). - E-I Cynodontium alpestre (Wahlenb.) E Fruchtende Pfl. (7/1); F Stanmb. (25/1): G Blattspitze (175/1). - K $-\mathbf{N}$ C. tenellum (Schimp.) K Stammb. (17/1) L Blattspitze (125/1). if Kapsel im trockenen Zustande (20/1); N Peristom (125/1).

lich-6seitig, dünnwandig, um die Mündung kleiner. Sporen 10-15 ", feinwarzig. Sporenreife im Frühling. - Fig. $15 \mathrm{~A}-\mathrm{D}$.

In erderfüllten, besonnten Spalten kalkfreier Felsen, überall fruchtend. Nordgrenze in Ellesmere Land bei $78^{\circ} 45^{\prime} \mathrm{n}$. Br.

F. Ab. Nádendal (Arrh.). Pargas, Terfsund und zw. Uepo und Bläsnäs (Elfr.). Uskela, Koskis und Linnamäki (Lindb.). Karislojo, Täsväri (Broth.); Teesjärvi (E. af H.). Lojn. Skraatila (Lindb.); 
Iaila (Hult); Lylyis (E. af H.). Vichtis. Olkkala (Broth.); Vanhala (Hult). - V. Pernà (Häyr.). OriInattila. Tekemäjärvi (Link.). - St. Pirkkala (Simm.). Ruovesi, Hollon horho (Broth.). 一 Ta. Tavastehus (Graefl., Asp.). Säāksmäki, Hakala (Kihlm.). Lammi. Evo (Norrl.). Im südöstl. Teile st. fq. (Norrl.). Hartola (Bonsd.). Luhanka und Korpilahti pass.-st. fq. (Vain.). - Sa. Willmanstrand (Buch). Taipalsaari (Simm.). Kangasniemi, Suomäki (Lackstr.). Nyslott'(Carl.). - K!. Uukuniemi (Simm.). Kurkijoki (Jusl.). Valamo, Puutsalo (Lindlı.). Sortavala. Kirjavalahti st. fq. (Norrl.); Kotomäki (Norrl.). Impilahti, Pullinvuori (Broth.). Soanlahti (H. Backman); Korpikallio (Broth.). - Kol. Vosnessenjo (Elfv.). - Tb. Virrat, Toriseva (Broth.). Petäjävesi, Palavavuori (Ruor.). Jyväskylä, Kanavuori (Link.) Laukaa, Vihtajärvi (Broth.). Viitasaari, Eteläruori (B.). - Sb. Kuopio. Puijo und Neulanäki. Vuorilampi (Roir.). Kaavi, Siikajārvi, Mustikkamäki (Kol.). Nilsiä, Kirchdorf, Loutteinen (Kot.). Maaninka, Tuovilanlahti, an nehreren Fundorten und Haatala, Haukkavuori (Roiv.). - Kb. Tohmajărvi Hiidenvaara (Broth.); Niirala, Rääkkäruori (B.): Simosenvaara (Oesch), Pielisjärvi, kolivuori (Linnan.). - Kon. Kohtsalmi und Valkearnäki (Simm.). Jalguba (Sahlb.). Kendjärvi, Pirttiniemi und Jänkäjärr (Norrl.). - Ok. Kajana, Jauhokallio (Lackstr.). Sotkamo, Vaapurinvaara (L.). Kuhmoniemi. Portinlouhikko (E. af H.). - Ob. Rovaniemi, Lohiniva (Hult). - K. Kuusamo, an mehreren Fundorten (sil. Broth.). - Lkem. Manaoja, Akäilompolo und Savio zw. Kolari und Pallastunturit (Hult). Kuolajärri. Jutsanjoki (E. af H.). - Le. Karesuanto (Norrl.). - Li. Pyttelvaara und Kenischkoski (HuIt). - Lim. Kandalaks (Broth.); Porjaguha (Sel.). - Lmur. Jokonsk (Broth.). - Lp. Ponoj (B.).

S. Sm., Hlsl. und Jmt. an inehreren, Ög.. Srm., När.. Irsm.. Hrjd., Mpd., Ang. und LuL. an ein. zelnen oder wenigen Fundorten.

N. Sm.-Bu., Br., K., ST., No.-F..nur im Binnenlande. Meist in der subalpinen Region und oberlalb der Baumgrenze bis elwa $1.000 \mathrm{~m}$. Fordgrenze bei $70^{\circ} \mathrm{n} . \mathrm{Br}$

\section{CYNODONTIUM}

(Bryol. eur.) Schimp. Bryol. eur. Coroll. (185.5).

Autözisch; o` Blüte unterhalb des Perichätiums oder in einer Gabelung, (excl. C. alpestre) zweiblättrig und ungestielt. Schlanke bis ziemlich kräftige, weiche. Jocker- bis dichtrasige, unten durch Rhizoidenfilz verwebte, glanzlose Pfl. Blätter trocken gedreht und gekräuselt, lanzettlich oder lanzettlich-linealisch, I lang zugespitzt, mit meist in der Blattmitte umgebogenen Rändern; Rippe kräftig, vor oder mit der Blattspitze aufhörend, mit zwei Stereidenbändern; Zellen oberwärts klein, rundlich-quadratiseh, zuweilen querbreiter, meist \pm manillös, am Rande doppelschichtig, unten verlängert rektangulär, an den Ecken kürzer und breiter. Kapsel aufrecht oder schwach geneigt, regelmässig oder \pm hochrückig. trocken meist längsrippig und gefurcht Zellen des Exotheciums länglich, an den Streifen mit stark verdickten Längswänden, um die Mündung einige Reihen klein, rundlich oder quadratisch-6seitig. Peristomzähne rot, oben beich, (exel. C. Bruntoni und C. strumiferum) unsymmetrisch, gegen die ventrale Seite allmälılich kürzer und zusammen einen etwas schiefen Kegel bildend.

\section{Übersicht der Arten.}

A. Blätter etwa $1 \mathrm{~mm}$ lang, mit abgerundeter Spitze

13. Blätter 3-5 mm lang, zugespitzt.

a. Peristomzähne klein bis rudimentär.

b. Peristom normal ausgebildet.

«. Blätter mit aufrechten Rändern.

1. Kaj)sel länglich bis fast zylindrisch............. 95. C. suecicum.

II. Kapsel dick, verkelırt-eiförmig .................... 94. C. hyperboreum.

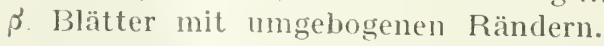

I. Seta feucht schwanenhalsartig herabgebogen ..... 92. C. yrucilescens.

II. Seta gerade.

1. King b'eibend.

* Perigonialblätter plötzlich zugespitzt. Blätter mamillös 93. C. fallax. 
** Perigonialblätler mit abgerundeter Spitze.

Blätter glatt

91. C. tenellum.

2. Ring sich ablösend.

* Kapselhals ohne Kropf ..................... 96. C. polycarpum,

** Kapselhals mit Kropf ..................... 97. C. slrumiferum.

Se c t. I. Cynodontia alpestria Hag. in D. K. N. Vid. Selsk. Skrift. 1911, No. 1, p. 91 (1915).

Ring einreihig, vom Deckel bedeckt. Deckel am Rande glatt.

89. Cynodontium alpestre (Wahlenb.) Lindb. [Dicranum alpestre Wahlenb. Fl. lapp. p. 339 (excl. var. $\beta$ ) tab. 21 (1812). - Oncophorus obtusalus Lindb. in Meddel. Soc. Faun. Fenn. Förh. III. p. 192 (1878). - Oncophorus alpestris Lindb. Musc. scand. p. 27 (1879).]

$C^{7}$ Blüte gestielt, 4-jblättrig. Schlanke, dichtrasige, grüne Pfl. Stengel his $1,5 \mathrm{~cm}$. Blätter trocken kraus, feucht aufrecht-abstehend, schmal lanzettlich lincalisch, mit abgerundeter Spitze, bis 1,3 $\mathrm{mm}$ lang, mit in der Nitte umgerollten, weit herab durch vortretende Zellen gezähnelten Rändern; Rippe vor der Blattspitze aufhörend, am Rücken mamillös; Zellen beiclerseits kegelig-mamillös. Peri(Chätialblätter längs scheidig, stumpflich. Seta etwa $5 \mathrm{~mm}$, gelb. Kapsel aufrecht, klein, regelmässig, dick oval, gestreift, trocken gefurcht, gelbrötlich. Ring einreihig, vom Deckel bedeckt. Peristomzähne nicht papillös. Deckel am Rande glatt. Sporen $17-20$, , bräunlich, feinwarzig. Sporenreife im Vorsommer.

Fig. $15 \mathrm{E}-1$.

Auf schattigen. erdbedeckten Felsen und Blöcken wie auch in deren Ritzen und Schluchten.

F. Sa. Kangasniemi (Broth.). - K. Kuusdulo, Kitkajoki (Sil.); Kallioperänvara, Kiekkivaara und Iäntyvaara (Broth.). - Lkem. Yllastunturi, Sairio (Hult). Kätkesuanto (Norrl.). - Le. Karesuantu, Pahtavaara und Hetta (Norrł.): Kilpisjärvi, Saana (Kot.). - Li. Ltsjoki, an einigen Fundorten (Ranek.) - l.t. Kola am Tulomaflusse (Karst.) und Karaulnaja Pahta (Broth.). - Lmur. Am Voronjeflusse und an Harkovkaflusse (Broth.). - Lp. Triostrova (F. Nyl.).

S. IuL. Sarekgehiet. in der oberen Birkenreginn ljis in die Weidenregion hinauf.

N. Ne.. h. $\rightarrow$ ST., Tr. und F., in Binnenlande zerstreut. Meist in den oberen Teilen des Waldgrhietes und $\mathrm{im}$ Hochgebirge bis $1.700 \mathrm{~m}$, seltener in niedriger Lage.

Grönland.

S e c t. II. Cynodontia tenella Hag. 1. c. p. 91.

Ring bleibend oder nur. angedentet. Deckel am Rande gatt.

90. Cynodontium Bruntoni (Sm.) Bryol. eur. fase. 33/36 t. 1 (1846). [Dicrunum Bruntonii Sm. Engl. Bot. t. 2509 (1812). - Oncophorus Bruntoni Lindb. Musc. scand. p. 27 (1879).]

Perigonialblätter stumpflich zugespitzt. Ziemlich kräftige, grüne oder gelbgriine Pfl. Stengel 1-4 cm. Blätter trocken kraus, feucht abstehend, die oberen viel länger und schopfig-zusammengedrängt, verlängert lanzettlich, lang zugespitzt, bis $3 \mathrm{~mm}$ lang, mit \pm weit hinauf zurückgerollten, gegen die Spitze entlernt gezähnten Rändern; Rippe fast vollständig, oberwärts am Rücken ctwas rauh; Zellen oberwärts mamillenartig sich vorwölbend. Innere Perichätialblätter halbscheidig, kurz zugespitzt. Seta $5-10 \mathrm{~mm}$, strohgelb. Kapsel aufrecht und regelmässig, länglich-oval, zuweilen etwas geneigt und gekrümmt, blassbräunlich. schwach längsrippig, trocken und entleert nicht gefurcht. Ring bleibend. Peristomzähne klein, unregelmässig. schräg- und längsstreifig, nicht papillös. meist bis zur Basis gespalten, mit ausgefressenen, hie und da verbundenen, selten freien Sehenkeln, selten rudimentär. Deckel am Raulle glatt. Sporen 17-20 " warzig. Sporenreife im Vorsommer.

Auf schattigem, kieselhaltigem Gestein.

F. Al. Jounala, Kasberg (Bom.). Sund, Vestra kyrksmndet (Elfr.). saltvik, Toböle lräsk (Bom.).

V. Hogland, Iläkipäällys (Lindb.). 
S. Sk., Sm. und $L l d$. an mehreren, Bl., Ög., $V g$. und Boh. an einzelnen oder wenigen Fundorten.

N. An der Kïste zw. der schwedische Grenze und Trondhjemsfjord. Steigt nur bis etwa $120 \mathrm{~m}$ linauf. Nordgrenze bei $63^{\circ} 2 \%^{\circ} \mathrm{n}$. Br.

Europa.

91. Cynodontium tenellum (Bryol. eur.) Limpr. in Krypt.-fl. Schles. I. p. 125 (1877). [Dicrannm torquescens Bruch in sched. Un. itin. 1828 nomen nudum. - Dicranum gracilescens $\gamma$ tenellum Bryol. eur. fasc. 37/40, p. 13, l. 1 (1846) p. p. - Oncophorus nigricans Kindb. in Bot. Not. 1882, p. 146. - Cynodontium torquescens Limpr. Laubm. I. p. 288 (1886). - Oncophorus torquescens Arn. et Jens. in Bih. K. Sv. Vet.-Ak. Handl. No. 10, p. 53 (1896).]

Perigonialblätter mit abgerundeter Spitze. Ziemlich schlanke, grüne oder gellggrüne Pfl. Stengel 1-5 cm. Blätter trocken kraus, feucht bogig-abstehend, verlängert lanzettlich, lang zugespitzt, bis $3 \mathrm{~mm}$ lang, mit in cler Mitte zurückgerollten, oberwärts gezähnten Rändern: Rippe fast vollständig, oberwärts am Rücken etwas rauh: Zellen meist völlig glatt. Perichätialblätter halbscheidig. Seta 5-10 mm, rötlichgelb. Kíapsel aufrecht, fast regelmässig, länglich-oval, schmal gestreift, trocken und entdeckelt gefurcht, unter der erweiterten Mündung nach der Mitte hin verengt, schliesslich blassbraun. Ring bleibend. Peristomzähne oben fein papillös. Sporen $15-20 \mu$, bräunlich, fein papillös. Deckel am Rande glatt oder fast glatt. Sporenreife im Hochsommer. - S. Fig. $15 \mathrm{~K}-\mathrm{X}$.

Auf trockenen, kalkfreien bis \pm kalkhaltigen Felsen.

F. Al. Eckerö. Jomala. Lemland. Finström. (ieta. Sund. Saltvik. - Ab. Abo (Arrh.). Pargas, Pitö (Elf Y.). Karislojo, Karkaji (E. af H.). Lojo, an mehreren Fundorten (Lindb., Hult, E. af H.). N. Helsingfors (Lindb.). Tusby (Broth.). Sibbo, Gesterby (Ranck.); Löparö (Sundv.). Borgá (Sael.). Etimäki (Buch). Hogland (Lindb.). - Ka. Wiborg, Iso Pelti (Buch). Antrea, Liikala (Lind.). Kirvu. Sairola (L.), - St. Pirkkala (Simm.). Hämeenkyrö, Petasenvuori (Sula). Ruovesi (Simm.). - Ta. Janakkala (Eifv.). Lammi, Evo (Norrt.). Hollola (N.). Asikkala (N.). Hartola (Bonsd.). Luhanka und Korpilahti st. fq. (Vain.). - Sa. Valkeala (Sundv.). Willmanstrand (Buch). Taipalsaari (Simm.). - Kl. Kurkijoki. Haavikko (Jusl.). Jaakkima (JusI.). Sortavala (Linnan.): Kirjavalahti (Norrl.); Lákela (Pes.). Ruskeala, Tirrin mylly (Broth.). Soanlahti, Korpikallio (Broth.). - Oa. Kristinestad (Nerr.). Tb. Petäjävesi (Ruor.). Laukaa (Broth., E. af 11.). Karstula, Ruotsila (B.). V'iitasaari (Broth.). - Sb. Heinävesi (Kot.). Kuopio, pass. (Link.). IIuuruvesi, an mehreren Fundorten (Kyyhk.). Nitsiä. Loutteinen (Kot.). Maaninka (Kyyhk.). Pielavesi (Roiv.). - Kb. Juuka. Polvijärvi, Juuanvaara (Kot.). Kon. Käpselkä, Valkeamäki, Tiudie und Niinisaari (Simm.). Perguła (Kullh.). Vojatsch (Sahı.). Om. Alajärvi. Kultavıori (Backın.). Vindala. Koskela, Kirkkokallio (B.); Pyhäruori und Rappukattiu (B.). - Ok. Kajana (Lackstr.). Pattamo (Lackstr., Kyyhk.). Sotkamo, Vuokatti (Broth.); Ketrinsaari (Kyyhk.). Kuhmoniemi ( $\mathrm{F}$ af H.). Ristijärvi (Lackstr.). Puolanka (L.). Suomussalmi (Lackstr.). Kpom. Loukkuvara (Bempr.). henı (F. Nyl.), - ob. Rovaniemi, Pöyhövaara (Bremn.). Zw. Aavasaksa und Turtola fq. (Hult). - K. Pudasjärvi, Iso Syöte (Broth.). Kuusamo fq. (Nyb., Broth., E. af H.). - kk. Kivakkatunturi (Broth.). - Lkem. Zw. Kolari und Pallastunturit fq. (Hult). Kemijärvi, I’ylıä1 unturi (Huum.). Kuolajärvi (Limau., E. af H.). - Li. In der Nadelwald- und Birkenregion wahrschein?tich fq. (Hult). Pyhätunturi und Tuarpunoivi in der alpinen Region (H1.). - Lim. Porjaguba (Sel.). Umba (Kihlm.). Hibinä (Kihlm.). - Lt. Rolsvaara und Pomjatkivaara (Roiv.). Kola, Lukinskaja, Karaulnaja und Abramova Pahta (Brolh.). Srednij am Kolabusen (B.). - Lmur. Teribjerka und Rinda (Broth.). J.p. l'anfelovka (Brenn.). Orlov (Kihlm.).

S. Nach Arnell besonders in den nordlicheren Teilen sehr verloreilet.

N. Mit Ausnalme der Kïisle zw. Lister und Romsdalen, wo sie fehlt, in allen Ämternst. f(ן. sowohl in niedriger Lage als im Waldgebiete. Steigt, wenngleich seftener, über die Bamgrenze hillauf. Europa, Kankasus, Nord-Amerika.

92. Cynodontium gracilescens (Web. et Mohr) Schimp. Bryol. eur. Coroll. 1. 12 (1855). [Dicranum gracilescens Web. et Mohr Bot. Taschenb. p. 467 (1807). Campylopus cirratus Brid. Bryol. univ. I. p. 179 (1826). -... Oncophorus gracilescens Lindb. Muse. scand. p. 27 (1879) et O. cirratus Lindb. I. c.]

Perigonialblätter plötzlich stachelspitzig. Ziemlich kräftige, meist lockerrasige, gelbliche oder gelblichgrïne Pli. Stengel bis $5 \mathrm{~cm}$. Blätter trocken eingekrïmmt und gedreht, feucht aufrecht-abstehend, breit lanzettlich-linealisch, meist stumpflich, his $3 \mathrm{~mm}$ lang, mit in der Mitte ungebogenen, gegen die Spitze gezähnten Rändern; Rippe vor der Blattspitze aufhörend, am Rücken dicht mamil- 
lös; Zellen oberwärts beiderseits mamillös-igelstachelig. Perichätialblätter längs scheidig zusammengewickelt, abgerundet oder stachelspilzig. Seta $5-12 \mathrm{~mm}$, schwanenhalsartig herabgebogen, trocken geschlängelt-aulrecht, strohlarben. Kapsel aufrecht ocker etwas geneigt, meist hochrückig, selten last regelmässig, länglich-oval, deutlich gerippt, trocken gefurcht, zuletzt braun. Ring heibend, durch 2 Reihen kleinerer Zellen angedeutet. Peristonzähne oben papillös. Deckel am Rande glatt. Sporen 17-20 $\mu$, braun, fein, warzig. Sporenreife im Hochsommer.

Auf etwas feuchten oder trockenen Felsen, hesonders aul Schiefer.

S. Sm. und Boh. an mehreren Fundorten. TL. Abisko.

N. Dovrefjeld und umgebende Gegenden, seltener auf Filefjeld. hauptsächlich im oberen 11 aldgebiete und in der alpinen Region. Nordgrenze bei $62^{\circ} 50^{\prime} \mathrm{n}$. Br.

Europa, besonders in der Alpenketle.

93. Cynodontium fallax Limpr. Laubm. I. p. 287 (1886). [Dicranum alpestre $\beta$ majus Wahlenb. Fl. lapp. p. 309 (1812). - Oncophorus fallax Mlöll. Fört. Skand. växt. 2. Mlossor p. 18 (1907).]

Perigonialblätter allmählich zugespitzt oder plötzlich zu einem Spitzchen zusammengezogen. Kräftige, freudig grüne und gelbgrüne Pfl. Stengel 1-3, zuweilen bis $5 \mathrm{~cm}$. Blätter trocken kraus, feucht verbogen-abstehend und zuwcilen einseitswendig, lanzettlich-linealisch, lang zugespitzt, bis $5 \mathrm{~mm}$ lang, mit im unteren und mittleren Teile zurückgeschlagenen, oben schwach gezähnten Rändern: Rippe n11it und vor der Blattspitze aufhörend, am Rücken oberwärts mamillös und schwach gezähnt; Zellen oberwärts meist nur an vler Innenfläche spitz mamillös. Perichätialblätter halbscheidig, lang zugespitzt. Seta bis $8 \mathrm{~mm}$, gelb, zuletzt rötlichbraun. Kapsel aufrecht oder wenig geneigt, oval und eilänglich, undeutlich gestreift, trocken und entleert schwach gefurcht. Ring bleibend, aus einer Reilıe querrektangulärer Zellen gebildet. Peristomzähne oben papillös. Deckel am Rande glatt. Sporen 18-24 $\mu$, gelbbräunlich, leinwarzig. Sporenreife im Sommer.

An schattigen, feuchten lielsen, gern in der Nähe von Wasserfällen.

N. In Ovre Telemarken und Sogn weniger selten, sonst nur von wenigen Fundorten in $S B ., N B$. $\boldsymbol{R}$. und $\boldsymbol{K}$. bekannt. Kommt meist in den niederen und mittleren Teilen des Waldgebietes vor. Fordgrenze bei $62^{\circ} 33^{\prime}$ n. $\mathrm{Br}$.

Zentral-Eurupa.

S e c t. I I I. Cynodontia polycarpa Hag. l. c. p. 91.

Ring 2-3reihig, sich abrollend. Deckel am Rande gekerbt.

94. Cynodontium hyperboreum (Bryol. eur.) Hag. in Kgl. Norsk. Vid. Selsk. Skrift. 1914, No. 1, p. 98. [Arctoa hyperborea Bryol. eur. Iasc. $33 / 36$ p. 5, t. 2 (1816). - Dicranum hyperboreum C. Müll. Syn. I. p. 372 (18.18).]

Perigonialblätter rasch lanzettlich zugespitzt. Ziemlich kräftige, bräunlichgrüne, abwärts braune oder schwärzlichbraune, schwach glänzende Pfl. Stengel I-5 cm. Blätter trocken geschlängelt, feucht abstehend, aus lanzettlichem Grunde allmählich pfriemenförmig, bis $5 \mathrm{~mm}$ lang, mit aufrechten, oberwärts kleingezähnten Rändern; Rippe kurz austretend, oberwärts oft am Rücken schwach gesägt; Zellen glatt, in den Blattecken locker, bräunlichgelb, die Rippe nicht erreichend. Perichätiallılätter halbscheidig. Seta bis $5 \mathrm{~mm}$, rötlichgelb. Kapsel aufrecht, verkehrt-ciförmig, gestreift, trocken und entdeckelt weitmündlig, braun. Ring dreireihig, sich ablösend. Peristomzähne oben papillös; Aussenschicht dick: Innenschicht dïnn, ohne Lamellen. Deckel am Rande kerbig. Sporen 25-30 $\mu$, braun, warzig. Sporenreife im August.

An nackten, steilen, trockenen oder periodisch überrieselten, harten, kalkfreien Felsen.

S. LuL. Sarekgebiet.

N. An einzelnen oder wenigen Fundorten in Ne., $N^{*} B ., K . . H_{.}, N_{o}$. und $T r$., an meltrerell auf Dorrefjeld. Kommt nur in den obersten Teilen des Waldgebietes und in der alpinen Region vor. Nordgrenze hei $69^{\circ} 5 l^{\prime}$ n. Br.

Grónland. 
95. Cynodontium suecicum (Arn. et Jens.) Hag. Musc. Norv. bor. p. 9 (1899). (Oncophorus succicus Arn. et Jens. in Res. bryol. 1895 p. 75 c. icon.)

Perigonialblätter rasch lanzettlich zugespitzt. Ziemlich schlanke, grüne oder gelblich- his bräunlichgrüne. schwach glänzende Pfl. Stengel $1,5-5 \mathrm{~cm}$. Blätter trocken geschlängelt und gedreht, feucht abstehend, selten einseitswendig, aus lanzettlichem Grunde allmählich pfriemenförmig, bis 3,5, zuweilen bis $1 \mathrm{~mm}$ lang, mit aufrechten. oberwärts schwach und stumpf gezähnten Rändern; Rippe kurz austretend. oberwärts oft am Rücken schwach gesägt; Zellen glatt, in den Blattecken locker, bräunliclıgelb, die Rippe nicht erreichend. Perichätialblätter lialbscheidig. Seta 1-2 cm, rötlich. oben gelblich. Kapsel fast aufrecht, länglich bis last zylindrisch, schwach gekrümmt, schmal gestreift, trocken und enteleckelt gefurcht, mit erweiterter IIündung, schliesslich blassbrann. Ring 1-3reilig, sich ablösend. Peristomzähne oben papillös. Deckel am Rande kerbig. Sporen $19-23 \mu$. schmutzig gelb, fast glatt. Sporenreife im Juni.

An kalkfreien Gesteinen.

F. Al. Finström, Grelsby (Bom.). - X. Pellinge, Alskär (Broth.). - Tb. Viitasaari, Koliatiurumi (Broll..). - K. Kuusamo, Oulankajohi, Mustosenraara (Broth.).

S. Imt. Östersund. Ing. Tásjö.

N. In allen Äintern mit Ausnahme ron sm.. L.M., st. und $s T$., am reichlichsten in Ostlandet, in den inneren Teilen von sorlandet pass. und anderwärts - selten. Steigt bis über dre Waldgrenze linauf. Nordgrenze bei $69^{\circ} 40^{\prime} \mathrm{n}$. Br.

var. Limprichtianum (Greb.) Hag. 1. c. p. 101. [Cynodontium Limprichtiunum Greb. in Hedwigia XXXVI. p. 103 (1897).]

Zellen der oberen Blatthälfte mamillös.

N. $T r$. Trondenes. Lillehornet, $150 \mathrm{n}$.

Deutschland.

var. arcticum Hag. l. c. p. 101.

Pfl. in sehr dichten Rasen. Blätter kürzer. Seta kürzer. Kapsel viel kleiner. kaum gestreift.

N. Tr. Karlso, Renoen.

96. Cynodontium polycarpum (Ehrl.) Schimp. Bryol. eur. Coroll. 12 (1855) excl. var. $\beta$. [Dicranum polycarpon Ehrh. Pl. erypt. exs. No. 84 (1786). - Oncophorus polycarpus Brid. Bryol. univ. I. p. 397 (1826).]

Perigonialblätter spitz. Ziemlich kräftige, griine oder gelbgrüne Pfl. Stengel $1-3$, selten bis 5 cr.s. Blätter trocken kraus, feucht abstehend, verlängert lanzettlich. lang zugespitzt, bis $5 \mathrm{~mm}$ lang. mit in der Nitte zurückgerollten, oberwärts gezähnten Rändern; Rippe fast vollständig, oberwärts am Rücken etwas rauh; Zellen oberwärts beiderseits schwach mamillös. Perichätialblätter halbscheidig. Seta etwa $1 \mathrm{~cm}$. gelb. Kapsel aufrecht, fast regelnässig. länglich-oval, schmal gestreift, trocken und enteleckelt gefurcht, schliesslich blassbraun. Ring 3reihig. sich ablösend. Peristomzähne oben papillös. Deckel am Rande kerbig. Sporen 20-24 $\mu$. dunkelbraun, warzig. Sporenreife im Hochsommer.

An kalkfreien Gesteinen.

F. Al. Eckerö (H. Lindb.). Hammarland, Strömma (Hull). Sund, Iángstekı, Kaslelholnı. Tjurnäs, Björly, Bomarsund und Prästö (Bom.). Saltvik. Kvarnbo (Bom.); Kuggsund (Ranck.). Gela, Djupvikskyrka (Elfr.); Danö. Rankaskär (Bonı.). Kökar, Hamno (Bom.). Brändö, Hullłärga, Trollstuga (Bom.). - - 1b. Pargas. L epo und Terfsund (Elfv.). Finbỵ, Tesvārr (Sundr.). Bromarf, Norrutrand (sundr.). Lojo, Maila (J1sl.). - Y. Helsingfors. Mlejlans (Lindb.). Hogland (Lindb.). — Tb. K゙(1nginkangas (Broth.). - Om. Alajarri, Kultaruori und Livijoki, Kirkkokallio (Backm.).

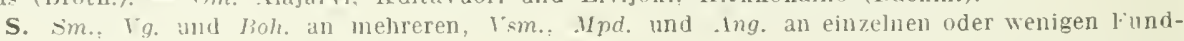
i)'

N. In allen Imlern mit Ausnahme von . Vo. und Tr., an der Küslespärlicher als im Binnenlande, nirgends jedoch häufig, am meisten in den niederen Lagen. sleigt jedoch wenngleich'selten uber die Baumgren\%e hinanf. Vurdgrenze lei $70^{\circ} \mathrm{n}$. Br.

Europa. Kauka-lı. Nord-Amerika. 
var. laxirete Dix. Stud. Handb. Brit. Moss. p. 73) (1896). [C. polycurpum var. laevifoliun Hag.]

Blätter länger und breiter, ganzrandig; 'Zellen mehr regelnässig quadratisch, doppelt grösser, glatt. Kapsel zylindrisch, mit längerem Halse, trocken sehr lang und sehmal.

F. 1l. Gela. Dánö (Bom.).

N. Sm., II.., Br.-P., sT.-Tr., fast ausschliesslich an der Küste. Steigt bis $5-600$ m binaut. Schottland.

97. Cynodontium strumiferum (Ehrlı.) De Not. Epil. p. 280 (1869). [Dicranum strumiferum Elirh. Pl. crypt. No. 84 (1786). - Oncophorus strumifer Brid. Bryol. univ. I. p. 395 (1826). - Gongronia strumifera Hag. in D. K. N. Viı. Se!sk. Skrift. 1914, No. 1, p. 86 (1915).]

Perigonialblätter stumpflich zugespitzt. Ziemlich kräftige, weiche, lockerrasige, gelbgrïne Pll. Stengel aufrecht, $2-4$, selten his 5 cm, aus clen unteren Blattachseln braunfilzig. Blätter trocken etwas gekräuselt, feucht aufrecht-al-stehend, gekielt, eilanzettlich, kurz pfriemenförmig zugespitzt, 3-5 $\mathrm{mm}$ lang, Init vom Grunde bis weit über die Nitte hinauf umgerollten, oberwärts gesägten Rändern; Rippe vor der Blattspitze aufhörend, mit zwei Stereidenbändern; am Rücken glatt oder oberwärts rauh; Zellen oberwärts klein, quadratisch und querrektangulär, oberseits mamillös, am Rande doppelschichtig, unten verlängert rektangulär, in den Błattecken locker, 6seitig oder kurz rektangulär. Perichätialblätter am Grunde scheidig. Seta etwa $1.5 \mathrm{~cm}$, geracle, zuletzt rötlich. Kapsel geneigt, hochrückig, länglich bis eilänglich, gelbbraun, mit von der Seta kropfig abgesetztem Halse, mit schmalen Streifen, trocken und entleert gefurcht; Ring 2-3reihig, sich ablösend. Peristom symmetrisch, rot, oben bleich und papillös. Deckel am Rande unregelmässig kerbig. Sporen $18-24 \mu$, rostfarben, feinwarzig. sporenreife im Hochsommer.

Auf trockenen kalkfreien Felsen und Blöcken.

F. Al. st. fq. (Bom.). - Ab. ibo. Reso. Tösala. Nystad. Uskela. Karislojo. Lojo. Viehtis.

N. Kyrkslätt. Esbo. Helsinge. Tusly. Silbbo. Borgi. Elimäki. - Ka. Ky ymmene. Sippola. Vehkalahti. Nuijamaa. Antrea, - Ik. Muola. Pyhäjärvi. - St. Eura. Pirkkala. Ikaalinen. Oriresi. Ruovesi. - Ta. Jokioinen. Hattula. Kalvola. Tyrväntö. Hollola. Lammi. Asikkaliz. Padasjoki. Kulhmoinen. Luhanka. Korpilahti. - Sa. Valkeala. Lappresi. Ruokolahti. Puumala. Kangasniemi. Rantasalmi. - Kl. Kükijoki. Valamo. Sortavala. Soanlahti. Pälkjärvi. - Oa. Kaskö. Vasa. Isokyrö. - Tb. Virrat. Laukaa. Kivijärvi. - Sb. Kuopio fq. (Link.). Kaavi. Maaninka. Pielavesi. Iisalıni. Kb. Joensul. - Kon. Ninisaari. Suosaari. Vojatsch. - Om. Alajärvi. Lappajärvi. Jakobstad. famla Karleby. Kalajoki. - Ok. Kajana. Paltamo. Sotkamo. - Ob. Lleảhorg. Haukipudas. Simo. Rovaniemi. Aavasaksa. Turtola (Hult). - K. Pudasjärvi. Pirivaara (Broth.). Kuusamo, Autinkängäs und Korojoki (Broth.); Ruoppijärvi (B.); Kitkajoki und Oulankajoki (B.); Ukonvaara (Nyb.). - Lkem. Kittilä-Pallastunturit (Hult). Kuolajärvi, Särkitunturi (I.innan.). - Le. Zw. Songanmuolka und Palojoki, in der' Kiefernregion (N.); Kilpisjärvi, Saivovaara, in der alpinen Region (Kot.). - I.i. Inari. an vielen Fundorten in der Nadelwal(tregion (Hulı): Peldojäyr und Saariselkä, Akanhärkäkuru in der Birkenregion (H.); Saariselkä, Vuomapää, in der alpinen Region (H.). - Lim. Kandalaks (Broth.).' Porjaguha (Sel.). - Lt. An mehreren Fundorten inı sïdl. Teile (Roir.).

S. $S k,-L$.

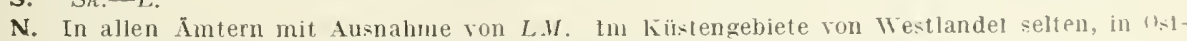
landet, oplandene und Sorlandet fı., nörllicher pass. Am häufigsten in niedriger Lage und im Waldgebiete, steigt jedoch hier und da ïber die Baumgrenze hinauf. Nordgrenze bei $70^{\circ} \mathrm{n}$. $\mathrm{Br}$.

- Europa, Kaukasus, Sibirien, Amur, Nord-Amerika.

\section{DICHODONTIUM}

Schimp. Bryol. eur. Coroll. p. 12 (1855).

Diözisch. Stengel dreikantig, am Grunde mit Rhizoiden. Blätter aus fast scheidiger, breiter Basis lanzettlich, flachrandig und \pm weit herab gesägt; Rippe kräftig, mil einer Begleitergruppe, ror der Blattspitze aufhörend, am Rücken 
mamillös; Zellen oberwärts beiderseits mamillös, auch am Blattgrunde in mehr 'ren Randreihen quadratisch. Perichätialblätter nicht differenziert. Kapsel symnetrisch, derbhäutig, glatt; Zellen des Exotheciums unterseits quadratisch, mit stark verdickten Längswänden. Ring nicht differenziert. Peristomzähne bis unter die Iitte 2-3schenklig, tiefrot, oberwärts papillös.

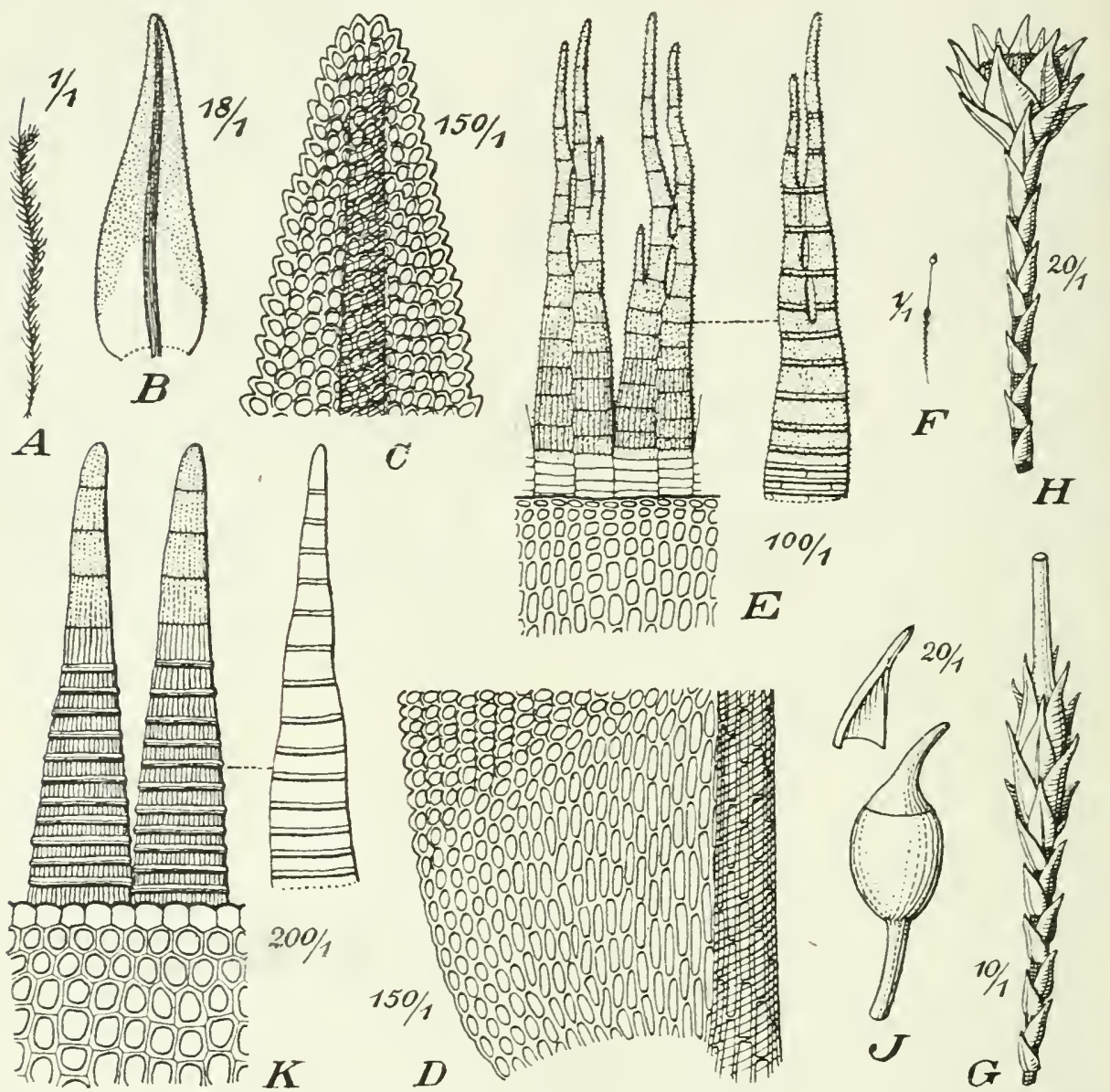

Fig. 16. A-E Dichodontium pellucidum (L.) A Fruchtende Pfl. (1/1); B Stammb. (18/1); C Blattspitze (150/1); D Blattbasis (150/1); E Peristom (100/1). - F- K Aongstroemia longipes (Sommerf.) F Fruchtende Pfl. (1/1); G Stämmchen (10/1); H. Oౌ Pfl. (20/1); I Kapsel (20/1); K Peristom (200/1).

Übersicht der Arten.

A. Blätter kurz zugespitzt, \pm stumpf, nur gegen die Spitze gesägt. Kapsel geneigt bis horizontal, hochrückig-eiförmig. Deckel von halber bis ganzer Urnenlänge ................. 98. D. pellucidum.

B. Blätter länger und scharf zugespitzt, mit bis gegen die Mitte scharf gesägten Rändern. Kapsel aufrecht, fast regelmässig. Deckel länger als die Urne ................... 99. D. flavescens.

98. Dichodontium pellucidum (L.) Schimp. 1. c. [Bryum pellucidum L. Sp. pl. II. p. $1118(1753)$ p. p.]. 
Lockerrasige, weiche, dunkel- oder gelbgrüne Pfl. Stengel bis 4 cm, seltener höher. Blätter trocken anliegend und gedreht bis gekräuselt, feucht sparrig-abstehend, kurz zugespitzt, bis $2 \mathrm{~mm}$ lang, gegen die Spitze gesigt. Seta etwa 1 cm. gelb. Kapsel geneigt bis horizontal, hochrückig-eilörmig, gelb- bis dunkelbraun. Deckel von halber bis ganzer Urnenlänge. Sporen 12-18 $\mu$, gelb), glatt oder fein papillös. Sporenreife in Frühling. -- Vegetative Vermelırung durch kugelige lis keulen- und walzenförmige, aul fadenfömigen, verzweigten Trägern in den Blattachsehn stehende, bräunliche Brutk. - Fig. $16 \mathrm{~A}$-E.

Auf Felsen und Blöcken längs der Wasșerläufe, gern auf Kalk, und auf dom durchfeuchteten Kiese der Ufer. Nordgrenze auf Beeren Eiland.

F. Al. Sund, Löfö und Kyrksundet (Bom.). Saltvik, Brändbolstad (Broth.). — Kl. Sortavalıl, hirjavalahti, Variskallio (Norrl.). - Kon. Jalguba (Kullh.). - Ok. Suomussalmi, Kirehdorf (Vain.). Ob. Rovaniemi, Jeltaus ( $\mathrm{Hult}$ ). - $K$. Kuusano. Autinköngäs (Broth.); an mehreren Fundorten am Kitkajoki, Oulankajołi, Kuusinkijoki lind selkäjoki (Broth.. E. af H.); Paanajärvi (Sil.). - Lkem. Kemijärvi. Kitinen (Broth.). - Le. Peerakoski in der Birkenregion (Norrl.): zw. Maunu und Kelottijärvi (Norrl.); Kilpisjärvi, Malia und Saana (Kot.). - Li. Sodankylä, Vajukoski (Hult). Inari, Sammelinköngäs in der Nadelwaldregion (H.): Kodossuamonpää in der Birkenregion (H.). Itsjoki, Koadniljokka (Ranck.). - Lt. Kildin (Broth.); Vaidoguba (B.). - Lmur. Bjelousiha am Voronjeflusse. Rinda. Semjostrovsk und Litsa (Brotb.). - Lp. Ialo Gorodetskaja (Broth.); Katschkova (Brenn.); (iubnoi bej Orlov (hilhm.): Ponoj (Sahlb.). - Lx. Babja zw. Pjalitsa und Babja (Broth.). - C'berall nur steril.

S. Sk., sm. und $\ddot{O g}$. an mehreren, $\mathrm{V} g ., B \circ h ., D l d .$, Ilr., Mpd.. Jmt., LyL. und LuL. an einzelnen vier wenigen Fundorten.

N. In allen Antern nit Ausnahme von $L M$., jedoch mit wechselnder Frequenz, am reichlichsten in der subalpinen Region. Steigt bis über die Baumgrenze hinauf.

Europa, Kaukasus, Nord-Amerika.

var. fagimontanum (Brid.) Schimp. l. c. [Dicranum pellucidum var. fagimontanum Brid. Sp. musc. I. p. 192 (1806).]

Blätter mehr aufrecht, kürzer, stumpf, kaum gezähnt. Seta etwa $5 \mathrm{~mm}$. Kapsel kleiner, fast aufrecht.

N. Nach $\mathrm{H}$ a ge $\mathrm{n}$, ohne Fundortsangabe.

Zentral-Europa, Schottland.

var. strictum Braithw. Brit. Mossfl. I. p. 300 (1887).

Pfl. in clichten, hohen Rasen. Stengel steif, locker beblättert. Blätter sehr kurz, rasch schmal zungenförmig zugespitzt, stumpf, ganzrandig.

N. Nach H a gen, ohne Fundortsangabe.

Schottland.

var. compactum Schimp. mss.; Dix. et James Stud. Handb. p. 76 (1896).

Sehr schlanke Pfl. in sehr dichten, abwärts rotbraunen Rasen. Blätter kurz und schmal.

N. Nach I a gen, ohne Fundortsangabe.

Schottland, Wales.

var. Mildei Limpr. Laubm. I. p. 300 (1886).

Pfl. äusserst zart, fadenförmig.

F. Kl. Sortavala, Kirjavalahti (Simm.).

Zentral-Europa.

99. Dichodontium flavescens (Dicks.) Lindb. in Botan. Notis. 1878, p. 113. [Dicranum flavescens Turn. Musc. hib. p. 70 (1804).]

Mit der vorigen Art sehr nahe verwandt. Lockerrasige gelbgrüne Pfl. Stengel bis 7 und $10 \mathrm{~cm}$. Blätter bis $3,3 \mathrm{~mm}$ lang, scharf zugespitzt, mit bis gegen die Mitte scharf gesägten Rändern; Zellen schwach mamillös. Kapsel aufrecht, fast regelmässig, länglich bis fast zylindrisch. Deckel lang und dünn geschnäbelt.

F. Kon. Petrosavodsk (Norrl.). Steril.

S. $\ddot{g}$. Omberg.

Zentral-Europa, England, Schottland, Nord-Amerika. 


\section{OREOWEISIA}

De Not. Epil. p. 489 (1869).

Stengel dreikantig. I weit hinauf mit papillösem Rhizoidenfilz. Blätter lineallanzettlich, bis hreit eilanzettlich oder zungenförmig, gegen die Spitze säge zähnig; Rippe kräftig, vor der Blattspitze aufhörend, olserwärts an Rücken rauh: Zellen oberwärts klein. quadratisch und rundlich-6seitig, beiderseits mamillös, auch am Rande cles Blattgruncles verlängert rechteckig. Perichätialblätter wenig verschieden. Liapscl aufrecht, länglich, glatt, regelmässig, zuweilen schwach geneigt und gekrümmt. Ring blcibend. Peristomzähne lanzettlich-pfriemenförmig, ungeteilt, rötlichbraun. schwach gestreilt, kaum papillös. 1)eckel kurz geschnäbelt.

100. Oreoweisia serrulata (Funck) 1)e Not. 1. c. [Weisia scrrulata Funck in Bricl. Bryol. univ. I. p. 804 (1826).]

Antözisch. Dichtrasige, weiche, gelblich-olivengrüne Pfl. Stengel bis j cm. Blätter aus anliegender Basis abstehend, trocken gedreht, breit eilanzettlich oder lineallanzettlich, kurz gespitzt oder stumpf, bis 2,6 mm lang, mit aufrechten oder um die Blattmitte einerseits umgerollten, welligen Rändern. Sporogone olt zu 2 in derselben Hülle. Seta etwa 5 mm, gelb, später braun. Kapsel braun; Zellen des Exotheciums dickwandig, unregelmässig, in der Mehrzahl rektangulär. Sporen $20-24 \mu$, rötlichbraun. warzig. Sporenreife im Sommer.

N. NH. Ardal, Irdalstungen, $10 \mathrm{~m}$ ii. d. II.

Alpenkette ron der schwein. his steiermark. Nord-Amerika.

\section{DICRANOWEISIA}

lin(l). in Öfvers. K. Vet.-Ak. Förh. 1864. p. 230.

Autözisclı. Pfl. in \pm dicht polsterförmigen Rasen. Stengel kreisrund, meist nur am Grunde mit Rhizoiden. Blätter trocken meist kraus, aus herablaufenden, länglichem Grunde lanzettlich bis pfriemenförmig, ganzrandig; Rippe meist kurz. vor der Blattspitze aufhörend; Zellen oberwiirts klein, rundlich-quadratisch, glatt oder schwach papillös, am Grunde vicl lockerer. rektangulär oder länglich-6seitig. mit \pm deutlich differenzierten Blattflügelzellen. Innere Perichätialblätter his oder fast bis zur Spitze scheidenartig zusammengewickelt, meist stumpf. Kapsel aufrecht, regelmässig, gla!t, zuletzt runzelig, entfleckelt an der Mündung wenig verengt; Zellen des Exotheciums locker, runcllich-6seitig, dünnwandig, um die IIündung in mehreren Reihen kleiner. Peristomzähne tief unterhalb der Urnenmündung inseriert, schmal lanzettlich, mit nach aussen vorspringenden ()uerbalken, ungeteilt oder mit zweispaltiger Spitze, gelbrot bis purpurn, papillös bis fist glatt. Deckel lang geschnäbelt.

$$
\text { Úbersich der Arten. }
$$

A. Blätter mit zurïckgebogenen Rändlern: Blattflügelzellen kaum dlifferenziert ................................... 101. D. cirratu.

B. Blätter flachrandig; Blattflügelzellen deutlich differenziert. 102. D. crispula.

101. Dicranoweisia cirrata (L.) Linclb. 1. c. [.Mnium cirratum L. Spl. pl. 1111 (1753). - Weisia cirrata Hedw. Sp. musc. p. 69 (1801)].

Dunkel- bis gelbgrüne, dichtrasige Pfl. Stengel bis $2 \mathrm{~cm}$. Blätter feucht aulrecht-abstehend, aus länglichem Grunde lanzcttlich, bis 2,5 $\mathrm{mm}$ lang, mit längs (ler Mitte schmal umgebogenen Rändern; Zellen glatt, oberwärts etwa $10 \mu$, in den Blattflügeln kaum differenziert. Seta bis $10 \mathrm{~mm}$, bleichgelb. Kapsel längliclıeiförmig bis zylindrisch, gelbbräunlich. Ring differenziert, sich ablösend. Peristom- 
zähne ungestreift, schwach papillös. Sporen 12-18 $\mu$, gelb, warzig. Sporenreife im Frühling. - Vegetative Vermehrung durch brotförmige bis länglich-zylindrische, zuletzt gelbbräunliche, chlorophyllreiche, kurz gestielte, auf der Rückseite des B. nahe über seiner Insertion auftretende Brutkörper.

An kalkfreien Felsen und Bammstïmmen.

F. Al. An einzelnen oder wenigen Fundorten in Eckerö, Sund und Kökar, an mehreren in Saltvik und Geta (Bom.).

S. Sk. an vielen, $\mathrm{Sm}$. an mehreren, Srm. und Dld. an einzelnen Fundorten.

N. Sm.-IL., LM. und St., hauptsächlich in den Umgebungen des Kristianiafjords.

Europa, Algier, Kaukasus, Kaschmir, Zentral-Asien, Nord-Amerika.

102. Dicranoweisia crispula (Hedw.) Lindb. I. c. [Weisia crispula Hedw. Sp. muse. p. 68 , t. 12 , f. $1-6$ (1801).]

Gelbgrüne oder dunkel- bis schwärzlichgrüne, weniger dichtrasige Pfl. Stengel bis 2 , selten bis 4-6 cm. Blätter feucht geschlängelt und abstehend, seltener einseitig-sichelförmig, aus eilänglichem Grunde allmählich lang rinnig-pfriemenförmig,
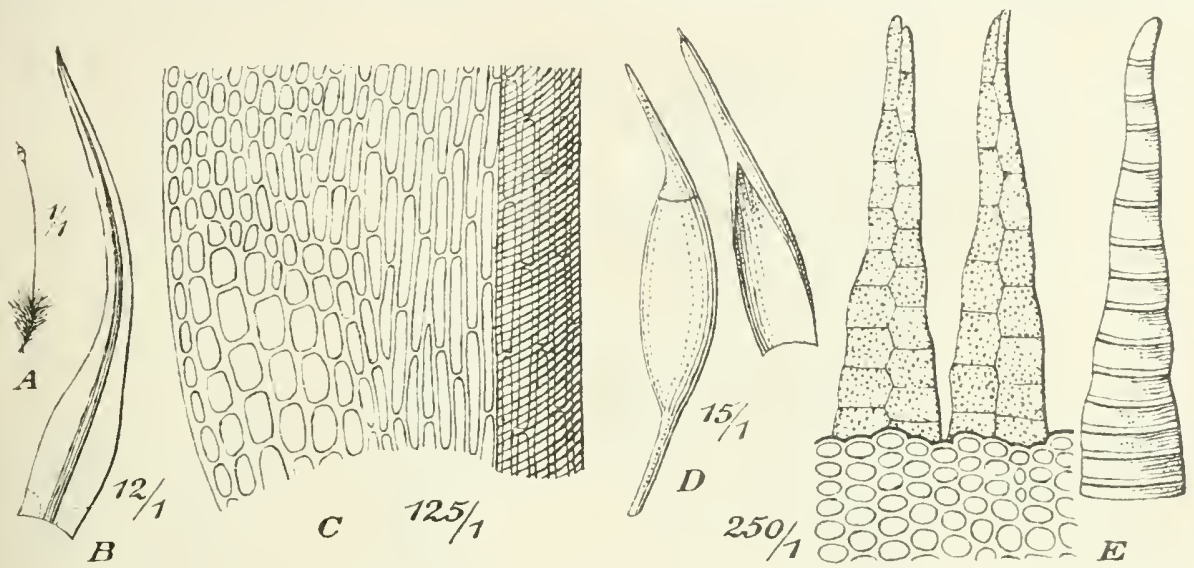

Fig. 17. Dicranoweisia crispula (Hedw.). A Fruchtende Pfl. (1/1); B Stammh. (12/1); C Blattbasis (125/1); D Kapsel (15/1); E Peristom (250/1).

bis 3,5 mm lang, mit aufrechten Rändern; Zellen oberwärts kleiner als bei der vorigen Art, schwach papillös, in den Blattfü̈geln locker 1-6seitig, scharf von den sehr engen und dickwandigen, verlängert rektangulären inneren Zellen des Blattgrundes abgegrenzt. Seta bis $12 \mathrm{~mm}$, zuletzt rötlich. Kapsel länglich und lichtbraun, später eilänglich und rötlichbraun. Ring nicht differenziert. Peristomzähne längsstreifig papillös. Sporen 10-15 mm, gelb, glatt. Sporenreife im Mai und Juni. -- Fig. 17.

Auf kalkfreien und \pm kalkhaltigen Felsen, erratischen Blöcken und Steinen, in der alpinen Region nicht selten auch auf Erdbocken, fast überall fruchtend. Nordgrenze auf Spitzbergen.

F. Al. Sund und Saltvik, an einzelnen Fundorten (Bom.). - N. Iitti, Mustaniemi (Blich). - $h a$. Antrea, Liikola (Lind.). - Ik. Pyhäjärvi, Sortaulahti (H. Lindb.). — St. Nakkila (Simm.). Pirkkala, Pyhäjärvi, Ollila reichl. (Broth.). Orivesi (Broth.). - Ta. Im südöstl. Teile ziemlich selten (Norrl.). Kuhmoinen, Pihlajakoski (Lesk.). Korpilahti, Päiräkııta (Häyr.). - Sa. Nyslott (Carl., H. Lindb.). - Fl. Kurkijoki, Haavikko (Jusl.). Valamo (WV. Nyl.). Sortavala, Kirjavalahti, an mehreren Fundorten (Norrl.). Impilahti (Broth.). Ruskeala (W. Nyl.); Jänisjärvi (Broth.); Tirrin mylly (B.). Pälkjärvi, Anonniemi (Broth.). - Ol. Tulemajärvi, Ruukki (Link.); Schtjeliki (Elfv.). Petrosarodsk (Kullh.). Oa. Isokyrö, Orisberg (Ranck.). - Tb. Jyväskylä, Koski (Buch). Viitasaari, Kinnula (Broth.). Pihtipudas und Kinnula, ziemlich selten (Roiv.). - Sb. Kuopio, Kasurila, Häntymäki (Kyykh.); Siikalahti (Kot.). Juuka, Halivaara, Halijoki (K.). Nilsiä, Kirchdorf, Loutteinen (Kot.). Piclavesi, Jylhä, Mustikkanjemi (Roiv.). - Kb. Polvijärvi, Paljakkavaara (Kot.); Sola, Solanjärvi(K.). Joensuu, Niniviaara 
(Linnan.). - Kon. Suojärvi, Tsoukunniemi (Koponen). Jalguba (Sahlb.). Perguba (Simm.). Zw. Lukina und Gorka (S.). - Om. Lappajärvi, an einigen Fundorten (Baclim.). Kalajoki (Tenn.). - Ok. Kajana (Lackstr.). Paltamo, Mieslahti (Kyyhk.). Sotkamo, an mehreren Fundorten (Broth., Kyyhk.). Ristijärvi (Lackstr.). Puolanka (I..). Hyrynsalmi. Kaistonjoki (Kyybk.). Suomussalmi, Kirchdorf, Ruottuspuro (K.). - Kipom. Knjäscha (Fellm.). - ob. Taala (Lackstr.). Haukipudas (Brenn.). Simo (Brenn., H. Lindb.). Kemi, Kallinkangas (H. Lindb.). Zw. Aavasaksa und Turtola st. fq. (Hult). - K. Kuusamo, an vielen Fundorten (Broth., E. af H.). - Kk. Susijārvi (Sahlb.). - Lkem. Zw. Kulari und Pallastunturit st. fq. (Hult). Ounastunturi (Sandm.). Kuolajärvi, Sallatunturi (Linnan., Broth.). - Le. Ain Iuonioflusse bis zur Birkenregion nicht selten (Norrl.). Kilpisjärvi, in der alpinen Region fq. (Kot.). - Li. Inari, in der Nadelwaldregion st. fq. und Peldojvi in der Birkenregion (Hult). Ltsjoki, in der Birkenregion st. fq., (H.). - In allen Prov. der Halbinsel Kola fq. (Broth.).

S. Srm., Dlr. - L.

N. In allen Imtern mit Ausnahme von JL. und L.V. und meist fq. Fehlt in der Ebene und an der Westküste. Steigt bis die Schneegrenze hinauf.

Europa, Asien, Nord-Ameriha.

var. compacta (Schleich.) Lindb. Nuse. scand. p. 25 (1879). [Grimmia compacta Schleich. Pl. Helv. exs. et Cat. (1807). - Dicranoweisia compacta Schimp. Syn. 2. ed. p. 53 (1876).]

Rasen dichter und niedriger. Blätter kürzer und derber, trocken einwärts gekrümmt; Zellen am Grunde kürzer und breiter. Seta bis $5 \mathrm{~mm}$.

Auf Erde und kalkfreien Gesteinen in der alpinen Region.

S. Hrjd. Helagsfjället. Jmt. Handöl-failet. LuL. Sarekgebiet.

N. An einzelnen Fundorten in $k$., $s T$., No. und $\mathrm{Tr}$.

Zentralzone der Alpen und arkt. Nord-Amerika.

\section{ONCOPHORUS}

Brid. Bryol, univ. I. p. 389 (1826).

Autözisch; Оフ Blüte scheinbar axillär, mit eiförmigen, kurz zugespitzten Hüllblätter. Yeist ziemlich kräftige, weiche, meist dichtrasige und gelblichgrüne, durch braunen Rhizoidenfilz \pm verwebte, glanzlose Pfl. Blätter trocken verbogen bis kraus, aus scheidigem Grunde \pm lang zugespitzt bis rinnig-pfriemenförmig; Rippe kräftig, in der Blattspitze endend oder austretend, mit zwei stark entwikkelten Stereidenbändern: Zellen des Scheidenteiles länglich-6seitig oder verlängert rektangulär, mit \pm gut entwickelten Blattflügelzellen: Zellen der Lamina klein, in der Nehrzahl rundli, h-quadratisch, glatt, an Rande doppelschichtig. Perichätialb]ätter aus hochscileidigen Grunde plötzlich pfriemenförmig. Seta bis 2 cm, gelblich, zuletzt meist rötlich. Kapsel geneigt bis horizontal, lichtbraun. hochrückig, kropfig, trocken und entdeckelt meist gekrümmt und schwach längslaltig. Ring bleibend. Sporen 20-24 "', gelbgrün, schwach papillös.

$$
\text { ¿̛̉ bersicht der Alten. }
$$

A. Blätter mit aufrechten Rändern ........................ 103. O. Wahlenbergii. B. Blätter mit in der Blattmitte umgebogenen Rändern ... 104. O. virens.

103. Oncophorus Wahlenbergii Brid. Bryol. univ. I. p. 400 (1824). [Cynodontium Wahlenbergii Hartm. Sk. Fl. 10, ed. p. 113 (1871).]

Hüllblätter der Cे Blüte fast flach und schmal. Blätter sparrig-abstehend, aus verkehrt-eiförmigem Grunde rasch sehr lang rinnig-pfriemenförmig, mit aufrechten, oberwärts gesägten Rändern; Blattflügelzellen wenig differenziert, einschichtig. Kapsel kürzer. Peristomzähne rotbraun. Sporenreife im Frühling. Fig. 18 E.

Auf nassen Felsen, auf feuchtem Boden, wie an Bach- und Flussufern, in sümpfen und auf morschen Stämmen. 
F. Al. Saltvik, Kvarnbo, Liby und Kuggböle (Bom.). Sund, Gesterby tjenan (13.). - _ 1b, Parga-, Loftsdal (Arrh.); Gunnarsnäs (Elfv.). Reso (A. H. Cajander). Lskela (Nikl.). Lojo, Torhola und IIako saari (Lindb.); Ojamo (H. Liıdb.). Vichtis, Ilokjärvi (Lảng). N. Lovisa (Arrh.). — Ka. Jääski, Láitila (Lind.). - Ik. Valkjärvi, Pasuri (H. Lindb.). Pyhäjärvi, Lohijoki (H. L.). - St. Ahlainen (Ollonqr.). - Ta. Koski, Putula (Leop.). Asikkala (Norrl.). Padasjoki (Vain.). IIartola (Bonsd.). Luhanka, an mehreren Fundorten (Vain.). — Sa. Valkeala (Sundv.). Ruıkolahti, Kirchdorf (Hult). - Kl. Lukunieni (Simm.). Sortavala (F. Nyl.); Kirjavalahti (Broth.). Ruskeala, Jänisjärvi (Backm.). Pälkjärvi, Pitkäniemi (Broth.). - Kol. Fabrika und Mandroga (Elfv.). - Oa. Vasa, Domarskar (Broth.). - Tb. Jyväskylă, Norola (Vain.); Korkeakoski (Lesk.). Laukaa (Broth.). Konginkangas (E. af I1.). - Sb. Ileiniivesi, Palokki, Kultaniemi (Kot.). Nilsiä, Loutteinen (Kyyhk.). Haaninka und Pielavesi an wenigen Fundorten (Lundstr., Kyyhk., Roiv.). Iisalmi, Peltosalmi (Sahlb.). 一 Kion. Kivatsch (Simm.). - Orn. Vindala, Pyhälahti (Backm.). - Ok. Paltano, Kives (Lackstr.). Sotkamo, Hepolehtu und Jormasjirvi. Suomussalıni (Lackstr.); Kiekinselkä (Kyyhk.). - Kpom. Keret (Brenn.); Sonostrova (Sahıb.). 'Tsehuja (Sahlb.). - Ob. Oulu (Huum.). Rovaniemi (Brenn.). Zw. Aavasaksa und Turtola fq. (Hult). - K. Kuusamo, an vielen Fundorten (Broth., E. af H.). - Lkem. Zw: Kolari und Pallastunturit fq. (Hult). Kuolajärvi, Sallatunturi (Broth., E. af H.). - Le. In allen Regionen st. fq. (Norrl.); fqq. (Kol.). - I.i. In del Nadelwaldregion fq., in der Birkenregion st. fq. (Hult). - Lim. Kandalaks und Tschun (Broth.). - Ll. Im sïdl. Teile st. fq.-fq. (Roiv.). Sascheika (Broth.); am Kolabusen (Felln.), — Lmur. kt. liq. (Broth.). - Lp. St. fq. (Broth.).

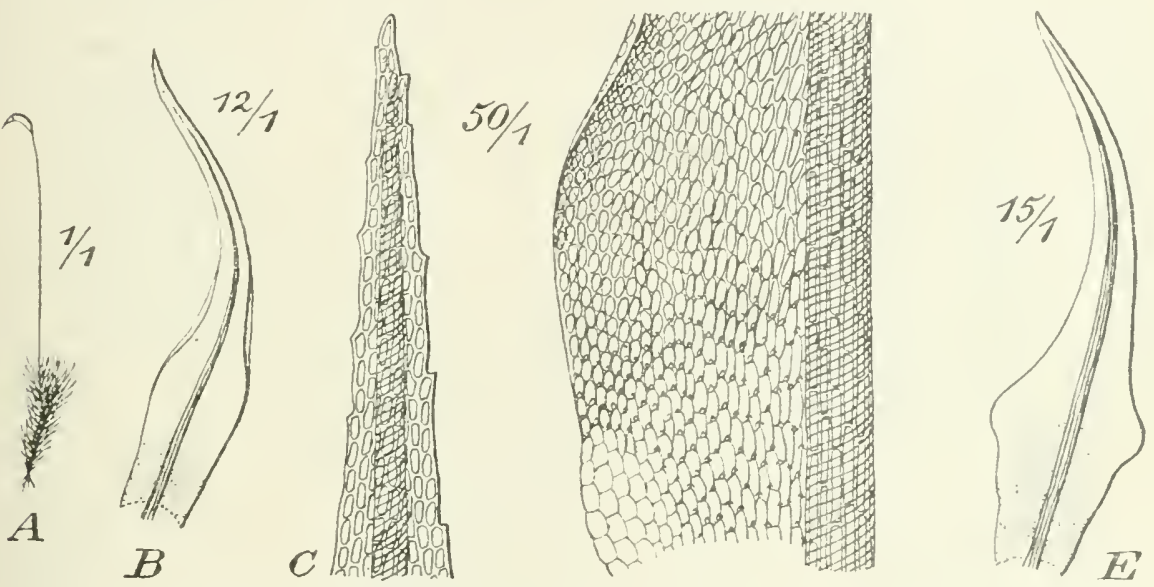

Fjg. 18. A-D Oncophorus virens (Hedw.) A Fruchtende Pfl. (1/1); B Stammb. (12/1); C Blattspitze (50/1); D Blattbasis 50/1). - E Stammb. von O. Wahlenbergii Brid. (15/1).

S. Sm., Upl. und Gstr. an mehreren. Srm., Vür., I'sm. und Hlal. an wenigen Fundorten. In den nordlichen Teilen bis in die alpine Region - verbreitet.

N. In allen Ämtern mit Ausnahme von L.M. und St., in O-i-bebiet und in der subalpinen Region nicht selten, im Süden in niederer Lage selten, in den äusseren $K$ üstengegenden $2 w$. Kristiansand und sindfjord fehlend. Steigt bis in die Weidenregion linauf.

Zentral-Europa, Nord- und Zentral-Asien, Nord-Amerika.

var. compactus (Funck) Bryol. eur. fasc. $37 / 40$ p. 15 (18t7). (Dicranum compactum Funck in sched.).

Pfl. in sehr niedrigen und dichten Räschen. Blätter ganzrandig. Seta kürzer. Kapsel kleiner.

Auf trockenen, offenen Plätzen, neist oberhalb der Baumgrenze.

N. No. Hatfjelddalen.

Tirol.

var. elongatus Hag. Musc. Norv. bor. p. 13 (1899).

Pfl. in lockeren, gelbgrünen Rasen. Stengel bis $6 \mathrm{~cm}$, kaum filzig. Blattrippe lang austretend.

An schattigen Standorten.

N. Vo. Saltdalen, Rognanfjeldet, $600 \mathrm{~m}$. F. Nessehy, Nyborg. 
var. gracilis (Broth.) Arn. et Jens. Moos. d. Sarekgeb. p. 181 (1907). [Oncophorus virens var. gracilis Broth. in Act. Soc. F. Fl. Fenn. VI. No. 4, p. 75 (1890).]

Pfl. in bis $7 \mathrm{~cm}$ hohen, sehr dichten, lebhaft grünen Rasen. Blätter kurz, aufrecht, ganzrandig. Seta kurz. Kapsel schmal.

Auf feuchtem Boden, an sandigen Flussufern und in Sümpfen.

F. Lt., am Kolaflusse (Broth.). - Lmur., Gavrilova und Varsinsk (B.).

S. Jml. Äreskutan. Ang. Edsele und Tåsjö. LuL., Sarekgeb., in der Weiden- und alpinen Region.

N. Nach 11 a ge $\mathrm{n}$ hier und da in der alpinen Region, seltener in der subalpinen Region.

var. minor Hag. l. c. p. 83.

In allen Teilen kleiner als der Typus. Rasen sehr dicht und niedrig. Blätter bis 1,7 mm lang; Zellen oberwärts etwas lockerer. Seta kurz. Kapsel kürzer.

N. No. Fauske, $400 \mathrm{~m}$.

104. Oncophorus virens (Sw.) Brid. Bryol. univ. I. p. 399 (1826). [Bryum virens Sw. in Act. Upsal. 1784, p. 241. - Dicranum virens Hedw. Descr. III. p. 77 (1792). - Cynodontium virens Schimp. Coroll. p. 12 (1856).]

Hüllblätter der Blüte sehr hohl, breit, kurz zugespitzt. Blätter aufrechtabstehend, aus eiförmiger bis eilänglicher Basis allmählich \pm lang pfriemenförmig zugespitzt, ganzrandig, mit in der Blattmitte umgcbogenen Rändern; Blattflügelzellen gut abgegrenzt, zweischichtig. Kapsel meist länglich. Peristomzälne dunkel purpurn. Sporenreife im Frühling. - Fig. $18 \mathrm{~A}-\mathrm{D}$.

An feuchten Plätzen, wie an Bächen, Quellen und nassen Felsen.

F. Al. Eckerō, Storby (Arrh.). Lemland, Jersö (Bom.). - Sb. Nilsiă, Palosaari (Kyyhk.). -- Ok. Paltamo, Korpinen (Kyyhk.). Suomussalmi, Portti (Kyyhk.). - Kpom. Suondali (Bergr.). Kem (F. Nyl.). - Ob. Simo (H. Lindb.). 一 $K$. Kuusamo, an vielen Fundorten (Nyb., Sil., Broth., E. af H.). Lkem. Kittilă (Hult); Levitunturi und Pyhăjärvi (H.). Kuolajärvi, Kutsanjoki und Enjanjoki. Huikuköngäs (F. af H.), - Le. In allen Regionen, jedoch viel seltener als O. Wahlenbergii (Norrl.); Kilpisjărvi (N.), Kitji-Malla, Malla und Saana (Kot.). - Li. Inari, an mehreren Fundorten in der Nadelwaldregion (Hult). Utsjoki, in der Birkenregion (H.). - Lim. Kandalaks (Sahlb., Broth.). Tschun (Broth.). Hibinä (Broth.); Naamuajw (Kihlm.). - Ll. Ruokojāyr und Pippojok im südl. Teile (Roiv.). Am Kolaflusse (Broth.). Tsipnavolok (B.). Kildin (B.). - Lmur. Am Olenkaflusse (Broth.). - Lp. Gorodetskaja und Malo Gorodetskaja (Broth.). Orlow (Kihlm.). Ponoj (Broth.). - Lv. Tschapona (Sahlb.). Tschavanga (Brenn.).

S. Sm., Ög., $Y g ., S r m ., U p l$. und Dlr. an wenigen Fundorten. In den nördlichen Teilen bis in die Weidenregion \pm verbreitet.

N. In allen Imtern mit Ausnahme von $S m$., $J L$. und $L . M_{\text {. }}$, am reichlichsten im Binnenlande und in Trondelagen, selten in niederer Lage. Steigt bis $1,300 \mathrm{~m}$ hinauf.

7entral-Euroja. No: und Zentral-Asien, Nord-Amerika.

var. serratus Bryol. eur. Coroll. p. 12, t. III ${ }^{1}$ (1855).

Pfl. in freudig grünen, lockeren Rasen. Blätter länger, sparrig abstehend, oben grob gesägt; Rippe sehr kräftig; Blattflügelzellen meist wenig oder nicht differenziert. Kapsel kürzer, zuletzt schwärzlich.

Am liebsten an zeitweise überrieselten, sandigen Bachufern und an Wasserfällen.

F. Ok. Kajana, Rehiänsaari (Broth.). - K. Kuusamo, Korojoki und Oulankajoki (Broth.). Paanajärvi, Măntyjoki (E. af H.); Selkäjoki (Nyb.). - Lkem. Kuolajărvi, Laskukuru (Broth.): in einem Bache am Kutsanjoki (E. af H.). - Li. Tenojoki, Sammelinköngäs, in der Kiefernregion (Hult). Utsjoki, in der Birkenregiou (H.). - Lim. Imandra (Fellm.), Tschun (Broth.). - Lmur. Gavrilova (Broth.).

N. Verbreitung wie bei der Hauptart.

Zentral-Europa, Kaschmir, Nord-Amerika.

\section{ARCTOA}

Bryol. eur. fasc. 33/36, p. 1, t. 1 (1816) emend. Hag. in D. K. N. Vid. Selsk. Skrift. 191.. No. 1 (1915).

Autözisch; OT Blüte köpfchenförmig, mit breit eilanzettlichen, spitzen oder stumpfen Hüllblätter. Pfl. in \pm glänzenden Rasen. Stengel aufrecht, mit spär- 
lichen Rhizoiden. Blätter aufrecht-abstehend oder sichelförmig-cinseitswendig, aus hohler Basis rasch \pm lang rinnig-borstenförmig; Rippe schmal, \pm lang austretend, mit einer Reihe medianer Deuter, olme Stereiden; Zellen eng, verlängert rektangulär, nicht getüpfelt, im Pfriementeil zweischichtig, zuweilen fast quadratisch, in den Blattecken mässig entwickelt, einschichtig. Perichätialblätter aus scheidiger Basis rasch lang rinnig-horstenförmig. Seta aufrecht, gelb. Kapsel klein, aufrecht, regelmässig, verkehrt-eiförmig oder geneigt, symmetrisch, länglich, schwach gebogen, rötlich, mit 8 unregelmässigen dunkleren Längsstreifen, trocken und entdeckelt unter der Mündung \pm stark eingeschnürt, längsfurchig. Ring dif-

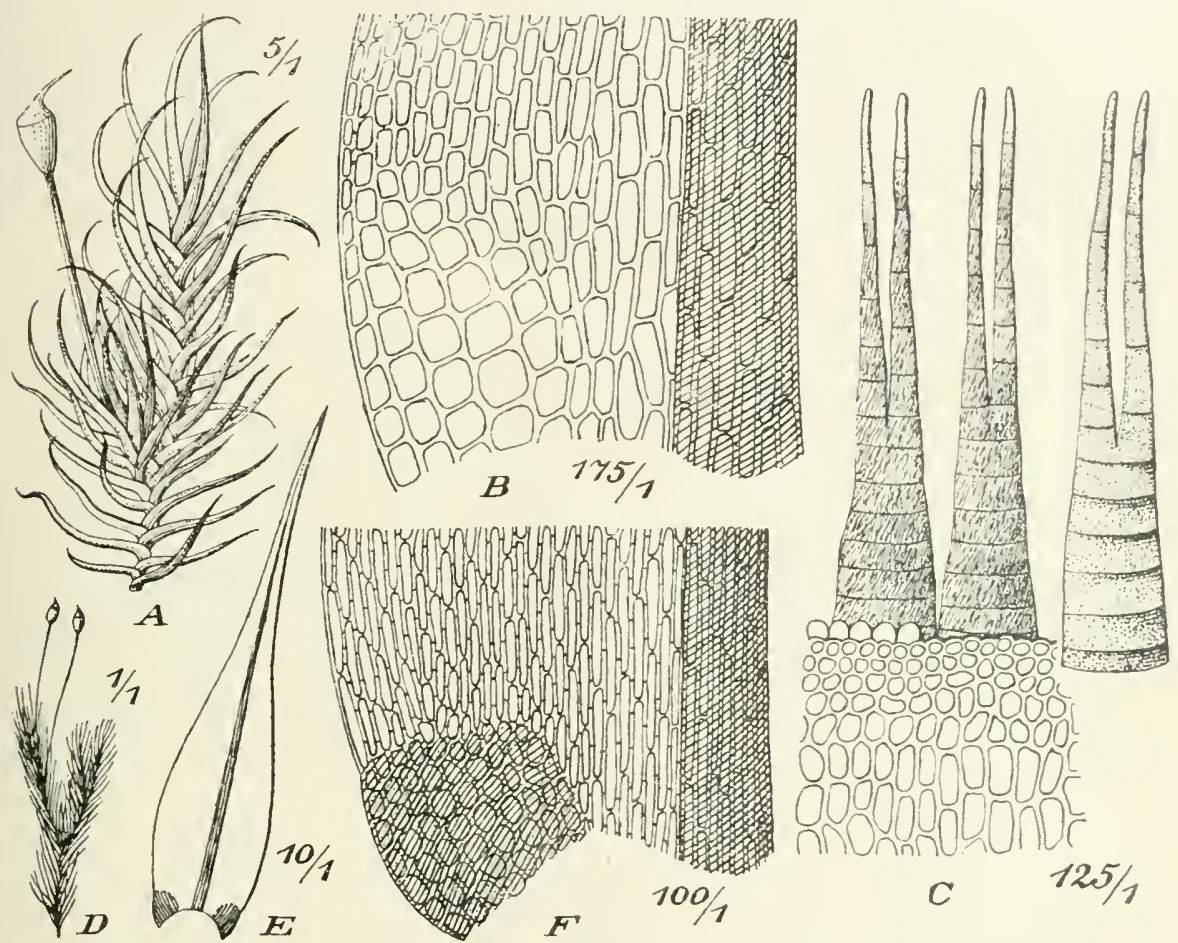

Fig. 19. A-C Arctoa fulvella (Dicks.) A Fruchtende Pfl. (5/1); B Blattbasis (175/1); C Peristom (125/1). - D-F Kiaeria arctica (Schimp.) D Fruchtende Pfl. (1/1); E Stammb. (10/1); F

Blattbasis $(100 / 1)$.

ferenziert; Zellen des Exotheciums unregelmässig, in der Melırzahl länglich, mit stark verdickten Längswänden, um die Mündung rot, rundlich 6eckig. Peristomzähne trocken oft strahlig ausgebreitet, purpurn, oberwärts gelb bis hyalin und papillös, flach, sehr lang, meist einfach und längs der Mitte unregelmässig durchbrochen, selten \pm tief ungleich 2schenkelig; Aussenschicht dick, mit an Grunde dicht gestellten Querbalken, linienförmig gestrichelt; Innenschicht sehr dïmn, olne Lamellen.

Üb ersicht der Arten.

A. Kapsel eingesenkt 106. A. Anderssonii.

B. Kapsel emporgehoben 105. A. fulvella. 
105. Arctoa fulvella (Dicks.) Bryol. enr. fasc. 33/36, p. 4, t. 1 (1846). [Bryum fulvellum Dicks. Crypt. pl. fasc. IV. p. 10, t. 11, f. 1 (1801). - Dicranum fulvellum Sm. Fl. Brit. III. p. 1209 (1804). — Blindia fulvella Kindb. Laubm. Schwed. und Norw. p. 95 (1883).]

Locker- bis dichtrasige Pfl. in oliven- bis braungrünen, oft ausgedehnten Rasen. Stengel bis $2 \mathrm{~cm}$, selten höher. Blätter aufreclit-abstehend und geschlängelt oder sichelförmig-einseitswendig, aus länglicher Basis rasch in einen langen, ganzrandigen oder an der Spitze kleingezähnten Pfriementeil verschmälert, bis $3.5 \mathrm{~mm}$ lang. Seta 2-4,5 mm lang. Ring sich ablösend. Sporen 14-17, auch $17-20 \mu$. Sporenreife im Juli. - Fig. $19 \mathrm{~A}$-C.

An kalkfreien bis \pm kalkhaltigen Felsen und Steinen, in den höheren Teilen der alpinen Region auf nackter Erde zw. Steinen. Nordgrenze auf Spitzbergen.

F. Kk. Kivakkatunturi, in der alpinen Region (Broth.). - Lkem. Y'llästunturi, in der alpinen Region (Hult). - Li. Peldoivi, in der alpinen Region (Hult). - Lim. Hibinä, in der alpinen Region (Angstr., Sahll)., Broth.).

S. Hrjd., Jmt., LyL. und $P L$. an einzelnen oder wenigen. LuL. an mehreren Fundorten.

N. Bu., Br., Ne., st.-F., fast ausschliesslich in der alpinen Region, am reichlichsten auf Filefjeld, Jotunfjeldene und Durrefjeld. Sleigt bis $2,300 \mathrm{~m}$ hinauf.

Japan. Nord-Amerika.

var. nana (Kern) Hag. in D. K. N. Vid. Selsk. Skrift. 1914. No. 1. p. 109 (1915). [Dicranum fulvellum var. nanun Kern in Jahresb. Schles. Ges. f. vaterl. Cult. L.XXXIX, zool.-bot. Sect. p. 8 (1912)].

Kleiner. Seta geschlängelt bis bogig herabgekrümmt.

N. Eine Hungerform an slark exponierten Standorten im Hochgebirge.

106. Arctoa Anderssonii Wich. in Flora 1859, t. VII. f. 3-8. [Dicranum Anderssonii Schimp. Syn. p. 689 (1860).]

Dichtrasige Pfl. in kleinen, gelb- oder braungrünen, polsterförmigen Räschen. Stengel bis $1 \mathrm{~cm}$. Blätter steif aufrecht-abstehend, aus breit eiförmiger Basis rasch pfriemenförmig oder lanzettlich-pfriemenförmig, ganzrandig oder an der Spitze kleingezihnt, bis 2,5 mm lang. Seta ca. $1 \mathrm{~mm}$. Ring bleibend. Sporen $25-33 \mathrm{~mm}$.

S. LuL. Njunyts: Sarekgebiet.

Faeroer, Island.

\section{KIAERIA}

Hag. in D. K. X. Yid. Selsk. Skrift. 1914, No. 1, p. 109 (1915).

Autözisch, selten polyözisch: ๙ Blüte köpfchenförmig. Stengel mit spärlichen Rhizoiden. Blätter aus hohlem, lanzettlichem Grunde rinnig- oder röhrigpfriemenlörmig; Rippe schmal, \pm lang austretend, (excl. $K$. falcata) mit einer Reihe medianer Deuter, (exel. K. glacialis) ohne Stereiden; Blattflügelzellen \pm gut differenziert, quadratisch, einschichtig und gebräunt; Zellen des Blattgrundes meist lineal-rektangulär. derbwandig, mit oder olne Tüpfel. Perichätialblätter \pm hoch scheirlig. Seta aufrecht. Kapsel geneigt, symmetrisch, meist kropfig. Peristomzähne bis zur Mitte oder tiefer herab 2schenklig. Sporen 12-18 $\mu$, fein gekörnelt. Sporenreife in Sommer.

\section{U' bersicht der Arten.}

A. Zellen des Exotheciums klein, verdickt. Ring nicht differenziert ................................................ 107. Kalcata.

B. Zellen des Exotheciums grösser, dünnwandig. Ring sich ablösend.

a. Blattrippe ohne Stereiden. 
a. Autözisch. Kapsel trocken und entcleckelt gefurcht. 108. K. Starkei.

$\beta$. Polyözisch. Kapsel trocken und entrleckelt glatt ... 109. K. Blyltii.

b. Blattrippe mit Stereiden ........................... 110. K. glacialis.

107. Kiaeria falcata (Hedw.) Hag. l. c. p. 112. [Dicranum falcalum Hedw. Sp. musc. p. 150 , t. 32 , fig. $1 / 7$ (1801).]

or Blüte unterm Perichätium, mit breit eiförmigen, plötzlich kurz und stumpflich zugespitzten Hüllb]ättern. Schlanke Pfl. in ziemlich dichten, grïnen bis loraunund schwarzgrünen, glänzenden Rasen. Stengel aufsteigend, 1-5 cm. Blätter sichelförnig-einseitswendig, trocken verbogen und hakenförmig, aus fast scheidigem Grunde fein pfriemenförmig, bis $3 \mathrm{~mm}$ lang, ganzrandig oder gegen die Spitze dicht und fein gezähnelt; Rippe aus homogenen Zellen gebildet; Zellen am Rande und oberwärts meist quadratisch, mit niedrigen, papillenartigen Auftreibungen, in den Blattflügeln weniger scharf differenziert. Innere Perichätialblätter plötzlich kurz pfriemenförmig. Seta 5--10 mm, rötlichgelb. Kapsel aus kropfigem Halse verkehrt-eiförmig, hochrückig, braun, glatt; Zellen des Exotheciums verdickt, in der Mehrzahl parenchymatisch. Ring nicht differenziert. Sporenreife im Juli.

Auf feuchten, kalkfreien, selten kalkhaltigen und auf von Schneewasser bewässertem Boden.

S. Hrjd. und in den Lappmarken, meist in der alpinen Region.

N. In allen Ãmtern mit Ausnahme von Sm., $A, J L ., I, M$, und $H$., am reichlichsten in Westlandet und meist in der alpinen Region bis zur Schneegrenze. Nordgrenze bei $70^{\circ} 25^{\prime} \mathrm{n}, \mathrm{Br}$.

Europa und Nord-Amerika im Hochgebirge.

108. Kiaeria Starkei (Web. et Mohr) Hag. 1. c. p. 114 p. p. [Dicranum Starkei Web. et Mohr Bot. Taschenb. p. 189 et 471 (1807).]

* Blüte unterm Perichätium, mit eiförmigen, zungenförmig zugespitzten Hüllblätter. Weniger schlanke Pfl. in lockeren, meist gelb- bis bräunlichgrünen, glänzenclen Rasen. Stenge] aufsteigend, meist 2-6 cm. Blätter meist sichelförmig-einseitswendig, aus lanzettlicher Basis lang pfriemenförmig, bis 4,5 mm lang, meist ganzrandig; Zellen oberwärts einschichtig, prosenchymatisch, glatt, in den Blattflügeln gross und gut differenziert. Perichätialblätter rasch pfriemenförmig zugespitzt. Seta $1-1,5 \mathrm{~cm}$, rötlich. Kapsel aus kropfigem Halse länglich bis zylindrisch, gekrümmt, mit schmalen, unregelmässigen Längsstreifen, später tief gefurcht; Zellen des Exotheciums dünnwandig, in Mehrzahl prosenchymatisch. Ring differenziert, sich ablösend. Sporenreife im Sommer.

Auf kalkfreien Felsen und Steinen, auch auf von Schneewasser bewässertem Botlen.

F. Lkem. Kuolajärvi, Sallatunturi (Roiv.). - Li. Ltsjoki, Paistunturit, Kuivis (Ranck.). - Lt. Saariselkä. Pirpojoki, in der alpinen Regiøn (Roir.). Pummanki und Tsipnarolok (Broth.). - Lmur. Gavrilova (Broth.). Zw. Varsinsk und Jenjavr (Broth.). - Lp. Ponoj (Brenn., Broth.).

S. Hrjd., an mehreren Fundorten. Jmt. snasahogen. PL. an mehreren und LuL. an vielen Fundorten.

N. In allen Ämtern mit Ausnalme von $s m$. und $L . M$. . fq.. meist in der subalpinen und alpinen Region. Steigt bis $1,950 \mathrm{~m}$ hinauf.

Europa. Kaukasus, Nord-Amerika.

var. glacialis (Zett.) Hag. in D. K. N. Vid. Selsk. Skrift. 1914. No. 1, p. 118 (1915). [Dicranum Slarkei var. glacialis Zett. in K. Sv. Vet.-Ak. Handl. XIII. No. 13, p. 13 (1876).]

Schlanke, niedrige, zuweilen schwärzliche Pfl.

Hungerform des Hochgebirges.

Pyrenäen.

109. Kiaeria Blyttii (Schimp.). [Dicranum Blyllii Schimp. in Bryol. eur. fasc. $37 / 40$, p. 26, t. 16 (1847). - Dicranum Schisti Lindb. in Act. Soc. scient. fenn. ×. p. 11 (1871). - Oncophorus Hambergii Jens. et Arn. Moos. d. Sarekgeb. nach 
Hagen. - Kiaeria Starkei var. Blyttii Hag. in D. K. N. Vid. Selsk. Skrift. 1914, No. 1, p. 118 (1915).]

Polyözisch; "O Blüte am Grunde des Fruchtsprosses oder endständig an den Sprossen von $\sigma^{\nearrow} \mathrm{Pfl}$. mit breit eiförmigen, zungenförmig zugespitzten Hüllblätter. Schlanke Pfl. in ziemlich dichten, weichen, dunkelgrünen bis schwärzlichen, am Grunde braunfilzigen, glanzlosen Rasen. Stengel aufrecht bis $5 \mathrm{~cm}$. Blätter trocken fast kraus, feucht hin und her gebogen oder schwach einseitswendig, aus lanzettlichem Grunde lang rinnig-pfriemenförmig, bis 3,5 $\mathrm{mm}$ lang, gegen die Spitze fein gezähnelt; Zellen oberwärts am Rande oder bis zur Rippe doppelschichtig quadratisch und kurz rektangulär, mit papillenartigen Auftreibungen, abwärts linealrektangulär, in den Blattflügeln gross und gut differenziert; Perichätialblätter rasch pfriemenförmig zugespitzt. Seta 1-1,5 cm, gelb, zuletzt schwarz. Kapsel aus undeutlich kropfigem Halse dick länglich, schwach gekrümmt, gelbbraun, rotmündig, glatt; Zellen des Exotheciums dünnwandig, in der Melnrzahl prosenchymatisch. Ring sich abrollend. Sporenreife im Juli.

Auf kalkfreien Felsen und Blöcken, oft grosse Flächen bedleckend, seltener auch auf Erdboden.

F. Al. Finström, Geta und Brändö an einzelnen, Saltrik an mehreren Fundorten (Bom.). - A $b$. Abo, Pargas, Kimito, Finby, Reso und Uskela an einzelnen, Lojo an mehreren Fundorten. - X. Ekenăs, Jussarô und skådō (Häyr.); Tvärminne, an mehreren Fundorten (Hãỵr., Ranck.). Kỉyrksaâtt (Nylb.). Esbo. Södrik (Link.); Gräsa, Toppelund (Broth.). Helsingfors, an mehreren Fundorten (Lindb.). Helsinge, Backas (Buch). Sibbo, Pōrtō (Tomm.); Lōparō (Broth.); Gesterby (Ranck.). Hogland (Lindb.). Ka. Kymmene (Ulv.). Vehkalahti, Ristniemi und Suurniemi (Krohn). Virolahti (Blom). Wiborg, Rãihã, Juustilanjärvi und Soskuanjoki (Buch). - St. Eurajoki (Simm.). Sastmola, Kalliojärvi (Ranck.). Ylöjärvi, Pengonpaljo (Sola). Pirkkala, Pỵaajärvi, Ollila (Broth.). Ruovesi, an mehreren Fundorten (Simnı., Broth.). - Ta. Kalvola (Ǩnab.). Kuhmoinen, Kotavuori (Norrl.). Luhanka, Keihäsniemi (Vain.). Korpilahti. an mehreren Fundorten (Norrl., Vain.). - Sa. Lappvesi, Karhusjärvi (Buch). Taipalsaari (Simm.). Kanganiemi. (Lackitr.). Nyslott (Carl.). - Kl. Kurkijoki, an mehreren Fundorten (Jusl.). Sortavala, Kirjavalahti (Norrl.). Pälkjārvi, Pitkäniemi (Broth.). — Kol. Salmi, Leppälā (Pes.). Petrosavodsk (Simm.). - Oa. Teura, Iso-Parra (Ranck.). Isokyrö, Orisuerg eRanck.). - Tb. Virrat, Toriseva (Broth.). Pihlajavesi (Norrl.). Jỵväskylā (Hāyr.). Lłukaa (Broth.). Kinnula, Saarenkylă, Mekkuvuori (Roiv.). - Sh. Kuopio, an mehreren Fundorten (Link.). Kaavi, siikajārvi, Kypäräisvuori (Kot.). Maaninka, Haatala, Haukkavuori (Roiv.); Pöljā, Kiemilāinen (Kyyhk.). Iisalmi (Sahlb.). - Kb. Polvijärvi, Paljakkavaara (Kot.). - Kon. Dianova gora (Kullh.). - Om. Vindala, Pyhävuori und Rappukallio (Backm.). - Ok. Kajana, Pỏllövaara (Lackstr.). - Kpom. Kolgora (Bergr.). Kem (B.). - Ob. Rovaniemi, Pọyliôyara (Brenn.). Tervōla (Brenn.). - K. Kuusamo, Pyhätunturi und Iivaara (Broth.); Ukonvaara (Nyb.); Kiekkivaara (Broth.). - Kke. Kivakkatunturi (Broth.). - Lhem. Yllästunturi, reg. alp. (Hult). Kemijārvi, Py̆łätunturi (Humm.). Küulajärvi, Sallatunturi (Limuan., Broth.); Sakantunturi (Linnan.). - Le. Leutsuvadrd, in dor Nadelwaldregion und Keimiotunturi. in der alpinen Region (Norrl.). - Li. Inari, Saariselkä, Iıpıkkapăä und Vuomapāā. in der alpinen Region (Hult). - Lim. Kandalaks (Broth.). Umpjok (Kihlm.). - Lt. Kola, Karaulnaja Pahta und Lukinskaja Pahta (Brolr.). Pummanki (B.). - Lmur. Teriberka. Favrilova, Olenka, Rinda. Semiostrovsk, Litsa und Jokonsk (Broth.). - Lp. Srjātoinos (Broth.). Punrjoj (B.).

S. Sm., Ög., Vg., Vpd. und Ing. an einzelnen, Boh.. Jmt. I'b. und i.uL. an mehreren Fundorten.

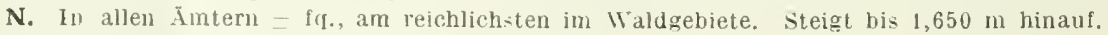
Grossbritannien, Zentral-Eurnpi. Nord-Amerika.

var. obtusula (Hag.). (Kiaeria Starkei var. obtusula Hag. 1. c. p. 117.) Blätter stumpflich, oberwärts 2-3schichtig.

N. A.-.Ve., St.-R., H., NT.-F.

var. laxiretis (Hag.). (Kiaeria Starkei var. laxiretis Hag. 1. c. p. 118.)

Zellen des Blattgrundes locker und zart, in den Blattflügeln ziemlich deutlich differenziert.

N. An einzelnen Fundoricu in $B r ., e_{.}, H$. und $s T$.

var. riparia (Lindb. fil.). [Oncophorus riparius Lindb. fil. Medd. Soc. Faun.

Fl. Fenn. XXIV. p. 28 (1900).]

Blätter kürzer, trocken straff; Blattflügelzellen nicht differenziert.

F. Ik. Valkjärvi. Pasuri, anf feuchtem, sandigem Ufer des Vuoksen (H. Lindb.).

N. K. Lom, Sletharn, 1,220 m; Dovre, Rejnheim, 1,770 m. 
110. Kiaeria glacialis (Berggr.) Hag. l. c. p. 125. [Dicranum Starkei var. molle Wils. Bryol. brit. p. 74. - D. molle Wils. 1. c. ut syn. - D. glaciale Berggr. in Act. Soc. Lund. 1865, Math. och Naturv. VII. p. 19 (19/5 1866 vel prius). D. arcticum Schimp. Bryol. eur. Suppl. fasc. III/14. p. 3 (1866).]

$c^{\top}$ Blüte unterm Perichätium, mit breit eiförmigen, kurz und stumpflich zugespitzten inmeren Hüllblätter. Mehr oder weniger kräftige Pfl. in lockeren bis dichten, starren, grünen oder bräunlichgrünen, etwas glänzenden Rasen. Stengel aufrecht, bis $11 \mathrm{~cm}$. Blätter meist aufrecht-abstehend, selten die obersten \pm cleutlich sichelförmig-einseitswendig, röhrig-hohl, aus läıglich-lanzettlichem Grunde allmählich pfriemenförmig, 4-6 mm lang, ganzrandig oder an der Spitze undeutlich gezähnelt; Rippe kurz austretend, mit meist zwei Stereidenbändern; Zellen langgestreckt, stark verdickt und getiipfelt, mit eng linearem Lumen, glatt, in den Blattflügeln zahlreiche, grosse und von den übrigen scharf abgegrenzte. Perichätialblätter breit abgerundet, mit langer Pfrieme. Seta 1,5 cm, rötlichge!b. Kapsel aus undeutlich kropfigem Halse länglich, etwas gekrümmt, längsstreifig, trocken gefurcht; Zellen des Exotheciums wenig verdickt, in der Mehrzahl prosenchymatisch. Ring differenziert, sich ablösend. Sporenreife im Juli und August. - Fig. 19 D-F.

An feuchten, erdbedeckten Felsen, in feuchten Niederungen, an sandigen Bach- und Flussufern, oft in ausgedehnten Rasen. Nordgrenze auf Spitzbergen.

F. Lkem. Sallatunturi (Linnan.). - Li. inari, Nattustunturit, Pyhätunturi, in der Nadelwaldregion (Hult); Saariselkä, Lupukkapää, in der alpinen Region (H.). - Lim. Tschun und Hibinä, in der alpinen Region (Broth.): Liaovo-tschorr (Kihlm.), - Lt. Pummanki (Broth.), zW. Subovi und Vaidoguba (B.). Vaidoguba und Kildin (B.). - Lmur. Teriberka, Gavrilova, Rinda, Litsa, zw. Varsinsk und Jenjavr (B.). - Lp. Zw. Ponoj und Orjow (B.). Orlov und Triostrova (Kihlm.).

S. Hrjd. Helagsfjället. Jmt, an mehreren Fundorten. LuL. Sarekgebiet.

N. In allen Åntern, init Ausnahme von Sm., $J L$, und $L M$., nicht selten von den oberen Teilen des Waldgebietes bis zur Schneegrenze, am reichlichsten in den Küstengegenden.

In der ganzen arkt. Zone, Schottland.

\section{ORTHODICRANUM}

Loesk. Studien p. 85 (1910). [Scytalina Hag. in D. K. N. Vid. Selsk. Skrift. 1914, No. 1, p. 129 (1915).]

Diözisch; ơ Pfl. kaum schlanker als die 우 Pfl.; ơ Blüte köpfchenförnnig, mit aus ovaler Basis allmählich zugespitzten inneren Hüllblättern. Mehr oder weniger schlanke Pfl. in dichten Rasen. Stengel aufrecht, rhizoidenfilzig. Blätter aus lanzettlichem Grunde allmählich rinnig- oder röhrig-pfriemenförmig; Rippe 1/3_1/ der Blattbasis, mit einer Reihe medianer Deuter und zwei Stereidenbändern; Blattflügelzellen gut differenziert, quadratisch, dickwandig, einschichtig und gebräunt; Zellen des Blattgrundes verlängert rektangulär, derbwandig, nicht oder schwach getüpfelt. Innere Perichätialblätter hoclıscheidig. Seta aufrecht, dünn, gelb. Kapsel aufrecht, regelmässig, länglich-zylindrisch, gelbgrün. dünnwandig, trocken zart gerippt; Zellen des Exotheciums unregelmässig rektangulär, mit etwas verbogenen WVänden. Ring differenziert, sich ablösend. Peristomzälne gelbrot, his zur Mitte orler etwas tiefer 2schenklig. Sporen $12-18 \mathrm{~mm}$, grün, \pm papillös.

$$
\text { Übersicht der Arten. }
$$

A. Stengel ohne Brutäste.
a. Blätter trocken sehr brüchig, steif
113. O. strictum.
b. Blätter trocken nicht brüchig, stark gekräuselt, weit herab gezähnt, am Rücken \pm mamillös 111. O. montanum. 
B. Stengel fast immer mit dünnen, kleinblättrigen Brutästen. Blätter trocken nicht brüchig, wenig kraus, oft \pm einseitswendig, nur gegen die Spitze schwach gesägt, am Rücken glatt

112. O. flagellare.

111. Orthodicranum montanum (Hedw.) Loesk. 1. c. [Dicranım montanum Hedw. Sp. musc. p. 143, t. 35, f. 8/13 (1801). - Scytalina montana Hag. 1. c..]

Schlanke Pfl. in clichten, sehr weichen, hell- bis gelbgrünen, glanzlosen, oft ausgedehnten, polsterförmigen Rasen. Stengel $0,5-5 \mathrm{~cm}$. Blätter trocken kraus, feucht aufrecht-abstehend, aus lanzettlichem Grunde allmällich rinnig-pfriemenförmig, bis $3 \mathrm{~mm}$ lang, mit weit herab kleingezähnten Rändern; Rippe mit der Spitze endend, oberwärts am Rücken schwach mamillös; Zellen oberwärts quadratisch und kurz rektangulär, regelmässig, unterseits \pm mamillös, abwärts verlängert rektangulär. Innere Perichätialblätter bis über die Mitte scheidig, plötzlich pfriemenförmig. Seta 1,5 cm. Sporenreife im Juli und August. - Vegetative Vermehrung durch kleine, lanzettliche, schmale, nur an der äussersten Spitze gezähnte, trocken stark gekräuselte, bald an vereinzelten, bald an zahlreichen, reich verzweigten uncl dann büschelförmig gehäuften. brüchigen, gipfelständigen Ästchen stehende Brutblätter.

An kalkfreien Felsen undi am Grunde alter Bäume, besonders Birken, am besten jedoch auf morschen Baumstrünkell, seltener auf humusreichem Waldboden.

F. Al. Finström. Geta. Saltrik. Föglö. - Ab. Korpo. Pargas. Kimito. Finby. Bromarf. Uskela. Karislojo. Lojo. Vichtis. - N. Ekenäs. Ingå. Kỵkslätt. Esbo. Helsinge. Borgả. Elimäki. Kotka. Hogland. - Ka. Tehkalahti. Wiborg. Antrea. - Ik. Uusikirkko. Muola. Metsäpirtti. Pyhäjärvi. St. Yläne. Ruovesi. - Ta. Kalvola, Sääksmäki. In südöstl. Teile pass. (Norrl.). Hartola. Luhanka und Korpilahti pass. (Tain.). - Sa. Lappee. Willmanstrand. Nyslott. Ruokolahti. Kangasniemi. Kl. Valamo. Sortavala. Pälkjärvi. - Kol.st. fq. (Elfr.). - Oa. Närpes. Vasa. Replot. - Tb. Jyväskylä-Vijtasaari st. fq. (Broth.). - Sb. Heinävesi. Kuopio. Kaavi. Maaninka pass.—st. fq. (Roiv.). Pielavesi. - Kb. Juuka. Joensuu. - Kon. Pirttiniemi. Klimskij monastir. Dianova gora. - Om. Vindala. - Ok. Kajana. Paltamo. Sotkamo. Puolanka. - Ob. Roraniemi, Pöylyönvaara (Brenn.). - K. Kuusamo, Ropojärvi (Broth.); Arentojoki (B.); Kithajoki und Merenoja (B.). — Iim. Umpnischk (Kihlm.). Tschunosero (Broth.). - Lt. Am Kolabusen (B.). - Lmur. Lovosersk und Voroninsk (Kihlm.). - Li. Tschapona (Brotls.).

S. Sk. - L.

N. In allen Ämtern, jedoch nur in den Gegenden um den Kristianiafjord und etwas westlicher, in Lttrondelagen und den inneren Teilen von Tr. fq.. am reichlichsten in der Ebene und in den unteren Lagen des Waltgeliete. Nordg:enze bei $70^{\circ} \mathrm{n}$. Br.

Europa, Kaukasus, Sibirien, Nord-Amerika.

var. pulvinatum (Pfeff.). [Dicranım monianum var. pulvinatum Pfeff. in $\mathrm{N}$. Denkschr. Schweiz. Ges. XXIV. No. 5, p. 21 (1871). - Scylalina montana var. pulvinata Hag. 1. c. p. 131.]

Sehr schlanke Pfl. in dichten, freudig grünen Polstern. Blätter kurz, lanzettlich, stark gekräuselt: Zellen locker, mit spärlichem Chlorophyll.

N. Im sirdl. Teile pass.

Schweiz.

var. flaccidum (Ryan et Hag.). [Dicranum montanum var. flaccidum Ryan et Hag. in D. K. N. Vid. Selsk. Skrift. 1896. No. 1, p. 82).]

Selır weiche l'fl. in leicht zerfallenden Rasen. Stengel verlängert. Blätter länger, an der Spitze brüchig.

N. sm. Vartejg, Bergsland, in dunklem Fichtenwald.

112. Orthodicranum flagellare (Hedw.) Loesk. I. c. [Dicranum flagellare Hedw. Deser. III. p. 1, t. 1, f. 1 (1792). - Scylalina flagellaris Hag. 1. c. p. 132.]

Weniger schlanke Pll. in dichten, oft ausgedehnten, grünen oder gelbgrünen, schwach glänzenden Rasen. Stengel 2-5 cm. Blätter meist schwach einseitswendig, trocken wenig kraus, aus lanzettlichem Grunde allmählich röhrig-pfriemen- 
förmig, bis $5 \mathrm{~mm}$ lang, mit gegen die Spitze gesägten Rändern: Rippe vor oder mit der Blattspitze aufhörend, oberwärts am Rücken gesägt; Zellen oberwärts in der Mehrzahl rektangulär und quadratisch, einzelne dreieckig und schief viereckig, abwärts verlängert rektangulär. Innere Perichätialblätter hochscheidig, an der abgestutzen, grob gezälınten Spitze kurz pfriemenförmig. Seta bis 2 cm. Sporen-

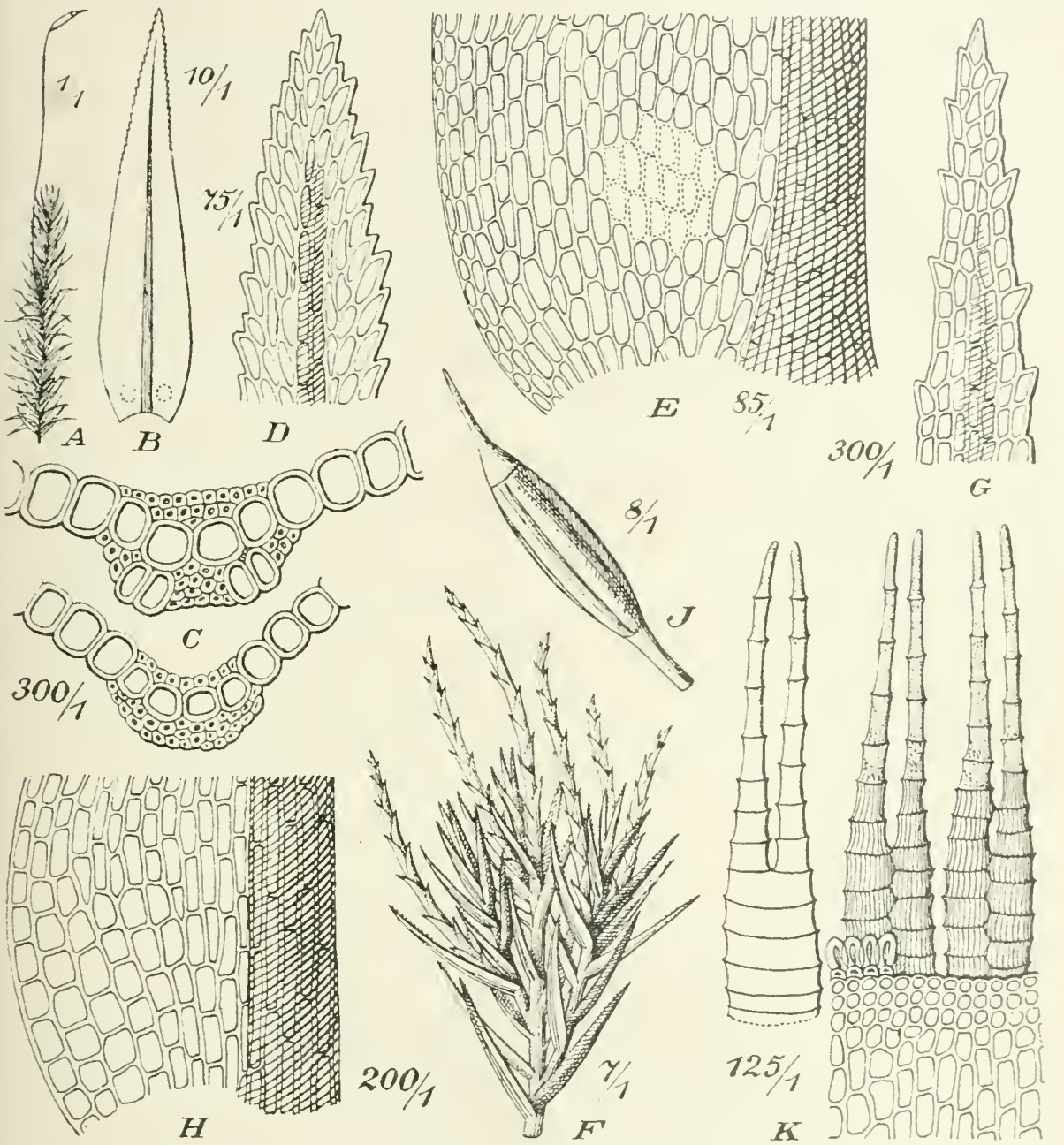

Fig. 20. A-E Dicranum Bonjeani De Not. A Fruchtende Pfl. (1/1): B Stammb. (10/1); C Blattquerschnitte $(300 / 1)$; I Blattspitze $(751)$; E Blattbasis (85 1). - F-I Orthodicranum flagellare (Hedw.) F stammstückchen mit Flagellen ( $/ 1 / 1)$; G Blattipitze $(300 / 1)$; H Blattbasis (2no 1): H Kapsel (8/1); I Peristom (125/1).

reife im Spätherbst. - Vegetative Vermehrung durch oft zallleiche, schlanke, kleinbeblätterte Bruchästchen in den oberen Blattachseln oder gipfelständig. - Fig. $20 \mathrm{~F}-\mathrm{I}$.

Auf modernden Stämmen in feuchten Wäldern und auf moorigem Waldboden.

F. Al. Eckerö, Lemland, Geta und Sund an einzelnen, Saltrik an mehreren Fundorten (Bom.). At. Korpo. Nagu. Pargas. Kakskerta. Nảdendal. Finbs. Bromarf. Karislojo. Lojo. Vichtis. - X. Ekenäs. Esbo. Helsingfors. Helsinge. Nurmijärvi. Pernå. Elimäki. Hogland, - Ka. Irmmene. Sippola. 
Wiborg. - Ik. Metsäpirtti. Muola. - St. Ylāne. Karkku. - Ta. Lammi, Evo fq. (Norri.). Im südōstl. Teile pass. (Norrl.). Hartola. Luhanka und Korpilahti st. fq. (Vain.). - Sa. Willmanstrand. Kangasniemi. - Kl. Sortavala. - Kol. fq. (Elfv.). - Tb. Virrat. Jyväskylä-Viitasaari st. fq. (Broth.). Kinnula und Pihtipudas (Roiv.). - Sb. Heināvesi. Kuopio. Nilsiā. Maaninka. - Kon. Kivatsch. - K. Kuusamo, Arentoioki (Broth.); zw. Virranniemi und Oijila (B.). 一 Li. Utsjoki, Yläjalve, am Gipfel des Kistu (Ranck.).

S. Sk.-Vrml., Dlr., Hlsl. und L.

N. A.-Ne., St., K., H. und NT. \pm r. und nur im Waldgebiete. Nordgrenze bei $64^{\circ} 30^{\prime} \mathrm{n} . \mathrm{Br}$. Europa, Kanaren, Kaukasus, Sibirien, Japan, Nord-Amerika.

113. Orthodicranum strictum (Schleich.) Culm. in Bull. Soc. Bot. France 1920, p. 201. [Dicranum strictum Schleich. Crypt. helv. Cent. III. No. 26 (1806).]

Schlanke Pfl. in dichten, grünen, später gelbgrünen ofler gelbbräunlichen, schwach glänzenden, polsterförmigen Rasen. Stengel $1-1 \mathrm{~cm}$, abwärts mässig braunfilzig. Blätter sehr brüchig, steif aufrecht-abstehend, aus lanzettlichem Grunde allmählich in eine rinnig-hohle, ganzranclige oder schwach gezähnte Pfrieme verschmälert, bis $7 \mathrm{~mm}$ lang; Rippe ohne Stereiden, etwa 1/5 der Blattbasis, lang austretend, glatt; Zellen oberwärts fast quadratisch, dann allmählich länger, am Blattgrunde verlängert rektangulär, dünnwandig. Innere Perichätialblätter hochscheidig, rasch pfriemenförmig zugespitzt. Seta $1,5--2 \mathrm{~cm}$, dünn, gelb. Kapsel aufrecht, eng zylindrisch, blass gelbgrün, dünnhäutig, trocken glatt; Zellen des Exotheciums rektangulär, wenig verdickt. Ring nicht differenziert. Peristomzähne ohne Längsstrichelung, oberwärts schräg gestreift. Sporenreife im Sommer. - Vegetative Vermehrung durch die oberen Teile der brüchigen Blätter.

Auf morschen Baumstümpfen und faulenden Stämmen oder am Grunde besonders von Nadelholzstämmen, ausnahmsweise auf Detritus von Glimmerschiefer.

F. Al. Eckerō, Koskär (H. Lindb.). - N. Borgả, Onas, Rävholmen (Broth.). - Ta. Lammi, Evo, mit Sporogonen (Sil.). - Sb. Maaninka, Tuovilanlahti, Korkeakoski (Broth.).

S. Gll. an wenigen Fundorten.

N. Ne.. H., VT.. No. $-F$. , nur im WValdgebiete und überall \pm r. Nordgrenze bei etwa $70^{\circ} 25^{\prime} \mathrm{n}$. Br. Europa, Nord-Amerika.

\section{DICRANUM}

Hedw. Fund. II. p. 41, t. 3, f. 11 et $42(1782)$ emend. Hag. in D. K. N. Vid. Selsk. Skrift. 1914, No. 1, p. 133 (1915).

Diözisch; ơ Pfl. meist sehr kurz, knospenförmig, einfach oder verzweigt, im Rhizoidenfilz unter dem Perichätium in Kolonien nistend (pseudautözisch), seltener von der Länge der 우 Pfl., jedoch meist schlanker; ơ Blüte köpfchenförmig, mit aus ovaler Basis allmählich 士 lang zugespitzten inneren Hüllblättern. Meist \pm kräftige, starre, locker- bis dichtrasige, \pm glänzende Pfl. Stengel aufrecht oder aufsteigend, rhizoidenfilzig. Blätter meist einseitig-sichelförmig, rinnig- bis röhrighohl, aus lanzettlichem Grunde \pm lang pfriemenlörmig; Rippe schmal, nur am Grunde durch beiderseits doppelschichtige Laminazellen scheinbar verbreitert; Blattflügelzellen gut differenziert, quadratisch, dickwandig, meist zwei- bis mehrschichtig und gebräunt; angrenzende Basalzellen von derselben Form, aber zartwandig und bald entfärbt, hyalin, später resorbiert; innere Zellen des Blattgrundes verlängert rektangulär bis linear, häufig getüpfelt. Innere Perichätialblätter hochscheidig. Seta aufrecht. Kapsel meist \pm geneigt und symmetrisch, oft etwas gebogen, glatt oder \pm deutlich gerippt, nicht kropfig. Peristomzïhne bis zur Mitte oder tiefer herab 2schenklig. 
Übersicht der Arten.

A. Blätter in der oberen Hälfte sehr brüchig.

a. Blätter trocken steif borstenförmig, einschichtig; Rippe

ohne Stereiden

119. D. fragilifolium.

b. Blätter trocken einwärts gebogen und gedreht, oberwärts

zweischichtig; Rippe mit Stereiden

116. D. viride.

B. Blätter nicht brüchig.

a. Blattzellen oberwärts parenchymatisch.

«. Blätter oberwärts zweischichtig

115. D. fulvum.

$\beta$. Blätter einschichtig; Zellen oberwärts \pm verdickt.

I. Blätter querwellig, stumpf, an der Spitze grobgesägt

129. D. Bergeri.

II. Blätter głatt, allmählicl zugespitzt.

1. Blätter an der Spitze kleingesägt; zartwandige

Zellen des Blattgrundes zahlreich ............ 120. D. Sendineri.

2. Blätter schmal, ganzrandig; Zellen der Lamina stark verdickt; zartwandige Zellen des Blattgrundes spärlich.

* Blattrippe bis $1 / 2-1 / 3$ der Blattbasis ....... 117. D. elongatum.

** Blattrippe $1 / 8-1 / 10$ der Blattbasis.............. 118. D. groenlandicum.

3. Blattzellen wenig verdickt.

* Blätter ganzrandig

114. D. Scottianum.

** Blätter oberwärts gesägt.

$\dagger$ Blätter querwellig, unterseits sehr rauh ... 130. D. spurium.

$\dagger \dagger$ Blätter glatt.

$\times$ Blattzellen oberwärts unregelmässig.

$\S$ Sehr kräftige Pfl. Blätter oberwärts am Rücken sehr rauh .............. 131. D. robustum.

$\S \S$ Weniger kräftige Pfl. Blattzellen oberwärts schwach mamillös bis glatt. x Blätter oberwärts röhrig-hohl. Kapsel zylindrisch.

Blätter oberwärts gesägt ........ 121. D. Mühlenbeckii.

Blätter ganzrandig bis undeutlich gezälnnt ...................

124. D. spadiceum.

xx Blätter rinnig-hohl. Kapsel kurz länglich-eiförmig, entdeckelt weitmündig
122. D. fuscescens
varr.

$\times \times$ Blattzellen oberwärts quadratisch ... 122. D. fuscescens.

b. Blattzellen oberwärts prosenchymatisch.

$\alpha$. Blätter stark querwellig, mit bis unter die Mitte herab scharf und grob gezähnten Rändern .......... 128. D. undulatum.

$\beta$. Blätter weniger stark querwellig bis glatt, weniger stark gezähnt bis ganzrandig.

I. Blattrippe schmal, vor der Blattspitze aufhörend.

1. Blätter oberwärts röhrig-hohl, ganzrandig ... 125. D. angustum.

2. Blätter oberwärts rinnig-hohl bis fast flach, breitspitzig und \pm scharf gesägt ............ 127. D. Bonjeani. 
II. Blattrippe kräftiger, vollständig bis austretend.

1. Blattrippe anfwärts mit gesägten Längslamellen. Seta einzeln ............................ 126. D. scoparium.

2. Blattrippe ohne Lamellen. Seten gehäuft ... 123. D. majus.

$\mathrm{U}^{\top} \mathrm{n}$ t e rgat t. I. Crassidicranum Limpr. Laubm. I. p. 370 (1886) ex p.; Hag. in D. K. N. Vid. Selsk. Skrift. 1914, No. 1, p. 138.

Kapsel aufrecht, zylindrisch. Sporensack gestielt, am Grunde von weitem Luftraum umgeben. Mit Vorperistom.

114. Dicranum Scottianum Turn. Musc. hibern. p. 75, t. 6, f. 1 (1804).

Diözisch; ح Pfl. in eigenen Räschen. Ziemlich kräftige Pfl, in ziemlich dichten, braungrünen, etwas glänzenden Rasen. Stengel $1-\bar{j} \mathrm{~cm}$, aufrecht oder aufsteigend. Blätter trocken mehrfach verbogen, feucht geschlängelt abstehend bis schwach sichelförmig einseitswendig. lanzettlich-pfriemenförmig, rinnig-hoh, ganzrandig, bis $6 \mathrm{~mm}$ lang: Rippe etwa $1 / 4$ der Blattbasis, austretend, glatt, zuweilen an der äussersten Spitze gezähnt; Zellen einschichtig, nur die Randreihe oberwärts 2schichtig, klein, quadratisch. streckenweise queroval, an Grunde rektangulär. Perichätialblätter bis zur Mitte scheidig, plötzlich rimnen-borstenförnig. Seta $2 \mathrm{~cm}$, gelb bis rötlichgelb. Kapsel meist schwach gekrümmt, engmündig, bleich gelbgrün, glatt; Zellen des Exotheciums rektangulär und verlängert. Ring differenziert, stückweise sich ablösend. Peristomzähne breit, fast ungeteilt, dann die Schenkel bis zur Basis unterbrochen zusammenhängend, gelbrot, ungestreift, mit vereinzelten groben Papillen. Sporen papillös.

Auf kalkfreien, \pm schattigen Felsen.

S Boh. Mrarstrand und Kon̈n.

N. Im äuseren Küstengebiete zw. Lindesnes und Sundfjord. Sporogone sehr selten. Nordgrenze bei $61^{\circ} 27^{\prime} \mathrm{n} . \mathrm{Br}$.

Dänemark, Frankreich. England. Irland.

115. Dicranum fulvum Hook. Milsc. exot. t. 149 (1820).

Diözisch; ơ Pll. in eigenen Räschen oder eingemischt. Ziemlich kräftige Pfl. in lockeren, weichen, braun- bis dunkelgrünen, glanzlosen Rasen. Stengel 2-5 cm, aufsteigend. Blätter schopfig zusammengedrängt, trocken krans, feucht geschlängelt abstehend, selten schwach sichelförmig einseitswendig, aus schmal lanzettlicher Basis lang pfriemenförmig, fast röhrig-lıoht, bis $5 \mathrm{~mm}$ lang, weit herab klein gesägt: Rippe etwa ${ }^{1 / 3}$ der Blattbasis, lang austretend, oberwärts am Rücken klein gesägt: Zellen oberwärts 2schichtig, klein, in der Mehrzahl quadratisch, mit papillösen Auftreibungen, an Grunde rektangulär. Perichätialblätter aus hochscheidiger, oben gezähnter Basis plötzlich lang pfriemenförmig. Seta $1-2 \mathrm{~cm}$, gelb, später gelbrötlich. Kapsel mit wenigen breiten Streifen, zuletzt kastanienbraun, trocken und entdeckelt faltig-gefurcht; Zellen des Exotheciums wie bei der vorigen Art, jedoch mit stark verdickten Längswänden. Ring siclı leicht ablösend. Zähne tief 2-3schenklig, purpurn, gestreift, beiderseits mit stark vortretenden Querleisten. Sporen glatt.

Auf beschatteten, kafkfreien Felsen.

S. S $k$. an vielen, $B l$, und $H l l$, an einzelnen und sm. an wenigen Fundorten.

N. Im Küstengebiete zw. .Handal und Yordfjord. Nordgrenze hei $61^{\circ} 50^{\circ} \mathrm{n}$. Br. Steril.

Zentral-Europa, Nord-Amerika.

116. Dicranum viride (Sull. et Lesq.) Lindb. in Hedwigia 1863 , p. 70. [Campylopus viridis Sull. et Lesq. Muse. bor. am. No. 72 (1856).]

Diözisch; ơ Pfl. unbekannt. Schlanke Pfl. in dichten, starren, grünen oder gelblichgrünen, fast glanzlosen, meist kleinen, polsterförmigen Räschen. Stengel $1-4 \mathrm{~cm}$. Blätter sehr brüchig, trocken anliegend, feucht steif aufrecht-abstehend, die obersten zuweilen schwach einseitswendig, aus lanzettlichem Grunde allnäh- 
lich rinnig-pfriemenförmig, etwa $5 \mathrm{~mm}$ lang, ganzrandig; Rippe etwa $1 / 4$ der BIattbasis, lang austretend, glatt; Zellen oberwärts 2schichtig, klein, quadratisch, dann kurz rektangulär, abwärts allmählich länger unıl dünnwandig. Innere Perichätialblätter hochscheidig, mit anfgesetzter, kurzer Pfrieme. Seta 2,5 cm, gelb. Kapsel klein, aufrecht, länglich und leicht gekrümmt, gelbbräunlich, glatt. - . Vegetative Vermehrung durch die oberen Teile der brüchigen Blätter.

Auf Laubholzstämmen (seltener Nadelhölzern) und auf kalkfreiem Gestein.

F. Ab. Lojo, Jalasiaari (Buldt). - Ih. Sakkola (Hid.) - To. Hollolit. Papinsaari (Norrl.).

S. Sk. Skärali.

N. An wenigen Fundorten in Ostlandet, Telemarken und Hardanger. Steril.

Zentral-Europa, Kaukasus, Nord-Amerika.

Un te rgat t. I I. Eudicranum Mitt. Musc. austr.-am. p. 62 (1869) emend.

Kapsel geneigt und symmetrisch, meist gekrümmt. Sporensack olıne Luftraum. Vorperistom fehlend.

S e c t. I. Dicrana elongata Hag. 1. c. ex p.

$\checkmark$ Pfl. sehr schlank, bald sehr kurz, jedoch nicht im Rhizoidenfilze nistend, bald \pm verlängert, zuweilen von der Länge der 오 PfI. Zartwandige Zellen des Blattgrundes spärlich, von den Blattliügelzellen nicht gut differenziert. Peristomzähne 2schenklig.

117. Dicranum elongatum Schleich. p. p. Pl. crypt. Helv. Cent. III. No. 27 (1806) et Catal. (1807).

Schlanke Pfl. in sehr dichten, gelblich- und bräunlichgrünen, glänzenden Rasen. Stengel bis $17 \mathrm{~cm}$, oft mit zahlreichen schlanken Sprossen, dicht rostfilzig. Blätter trocken angedriickt, feucht steif aufrecht-abstchend, die obersten zuweilen schwach einseitswendig, glatt, röhrig-hohl, aus schmal lanzettlichem Grunde allmählich in eine ganzrandige oder fast ganzrandige Pfrieme verschmälert, $3-3,5 \mathrm{~mm}$ lang und $0,4-0,5 \mathrm{~mm}$ breit; Rippe $1 / 4^{-1}{ }^{1 / 3}$ der Blattbasis, mit oder vor der Blattspitze aufhörend bis kurz austretend, glatt: Zellen am Grunde linear, mit sehr stark rerdickten und getüpfelten Längswänden, oberwärts parenchymatisch, rings sehr stark verdickt, mit rundlichem bis länglichem Lumen. Innere Perichätialblätter hochscheidig, mit langer Pfrieme an der breiten, fast gestutzten Spitze. Seta etwa $1,5 \mathrm{~cm}$, sehr dïrn, gelb, zuletzt rötlichgelb. Kapsel wenig geneigt, klein, oval und hochrückig, gelbgrün, dümnhäutig; gestreift, trocken und entleert gefurcht. lichtbraun, weitmïndig; Zellen des Exotheciums verlängert rektangulär. Ring differenziert, stückweise sich ablösend. Sporenreife im August.

Aut humusbedeckten, meist kalkfreien Felsen, an steinigen Abhängen und auf nackter, bald trockener, bald \pm feuchter Ercle.

F. S3. Nilsiä, Pisaruori (Link.). - Kpom. Kivioja (Bergr.). Tschuja (Sahlb.). - K. Kuusamo, an vielen Fundorten von Korojokj bis Paanajärvi (Sil. Vain., Brotls.. E. af H.). - Kk. Kivakkatunturi (Broth.). - Lkem. Kolari. Jouhisuannonvaara (Hult). Kiltilä, Pahtakallio (H.); Äkäskurkio, nördl. vom Yllästunturi (H.). Kuolajāıvi, Sallatunturi, in der alpinen Region (Linnan., E. af H.); Pỵäkuru ( nft Mascenvegetation bildend (Norrl.). Im Fjeldgebiete um Kilpisjärvi auch auf Heiden und trockenen Gipfeln fqq. (Kot.). - Li. Inari, in der Nadelwaldregion pass. (Hult); an einigen Fundorten in der Birkenregion (H.); Lupukkapää und Pietarlauttasoivi, in der alpinen Region (H.). Ll-joki, Ailigas (H.); Ilájalve, Kistushoski and Dalvados (Ranck.). - Lim. Tschun (Broth.). Lujaur-urt (Kihlm.). - Lt. Im südl. Teile an vielen Fundorten (Roiv.). - An der ganzen Kïste von Kola his Ponoj fq. (Broth.). Li. Tschavanga (Brenn.).

S. Vrml., Dlr.-L.

N. In allen Amtern init Ausnahme ron sm., A., JL. und $L . M$, meist iu den oberen Teilen des Waldgebietes und oberhalb der Baumgrenze. Steigt bis $1.880 \mathrm{~m}$ hinauf.

Europa, Sibirien, Nord-Amerika.

var. longifolium C. Jens. in Meddel. Grönl. III. p. 73 (1887).

Blätter länger, steif, brüchig, an der Spitze spärlich gezähnt; Rippe länger austretend. 
S. LuL., Sarekgebiet.

Grönland.

var. nitidum C. Jens. in Meddel. Grönl. XV. p. 412 (1898).

Blattbasis.

Blätter mit kürzerer und breiterer, \pm stumpfer Spitze; Rippe $1 / 8 \ldots 1 / 8$ der

S. LuL., sarekgebiet.

N. H a ge n. ohne nähere Angaben.

Grönland.

var. Sphagni (Wahlenb.) Th. Jens. [Dicranum Sphagni Wahlenb. Fl. lapp. p. 337 (1812).]

Blätter kürzer zugespitzt; Rippe $1 / 7{ }^{1} / 9$ der Blattbasis; Zellen rektangulär, Zellen rektangulär ınd getüpfelt.

N. H a ge n, ohne nāhere Angaben.

var. flagelliferum Th. Jens. in Vid. Medd. Nat. For. 1858, p. 55.

Tracht von Dicranum flagellare. B. gekräuselt. Stengel mit fadenförmigen, steifen, sehr brüchigen subfloralen Sprossen.

N. Gudbrandsdalen.

var. robustum C. Jens. l. c. III. p. 73.

Krräftiger als die Hauptart. Blätter lang pfriementörmig.

N. H a g e n, ohne nähere Angaben.

Grönland.

118. Dicranum groenlandicum Brid. Mant. musc. p. 68 (1819). [D. Lenuinerve Zett. in K. Sv. Vet.-Ak. Handl. Bd. 13. No. 13, p. 14 (1876).]

Schlanke bis ziemlich kräftige Pfl. in dichten, bräunliclıgrünen, glänzenden Rasen. Stengel 3-12 cm, braunfilzig. Blätter trocken angedrückt, feucht steif aufrecht-abstehenrl. glatt, röhrig-hohl, aus schmal länglichem Grunde in eine ganzrandige, stumpfe Pfrieme verschmälert, etwa $3 \mathrm{~mm}$ lang und $0,6-0,8 \mathrm{~mm}$ breit; Rippe $1 / 8-1 / 10$ der Blattbasis, weit vor der Blattspitze aufhörend; Zellen selır stark verdickt und getüpfelt, am Grunde lineal, oberwärts mit länglichem, an der Spitze mit fast rundlichem Lumen. Innere Perichätialblätter hochscheidig, oberhalb der Mitte gestutzt, plötzlich pfriemenförmig. Seta etwa $1.5 \mathrm{~cm}$, sehr dünn, gelb, zuletzt rötlichgelb. Kajsel klein, fast zylindrisch und hochrückig, trocken schwach gestreift; Zellen des Exotheciums mit stark verdickten Längswänden länglich und kurz rektangulär, einzelne quadratisch. Ring differenziert, sich ablösend. Sporenreife im Juli.

Auf leuchtem, besonders moorigem Boden, seltener auf erdbedeckten Felsen.

Lt. Arafjord und am Kolabusen (Broth.). - Lmur. Rinda, Semjostrovsk, Litsa und Varsinsk (B.). Lp. Orlov und Hapajor (Kihlm.).

N. In allen Āmtern mit Ausnahme ron Sm., A., JL., $L M$. und St., südlicher beiderseit, der Birkengrenze, bis etwa $1,600 \mathrm{~m}$, nördlicher auch in niedriger Lage, überall \pm selten.

Schottland und in der ganzen arktischen Zone, in Nord-Amerika bis $76^{\circ} 50^{\prime} \mathrm{n} . \mathrm{Br}$.

var. jotunicum Kaur. et Hag. in D. K. N. Vid. Selsk. Skrift. 1890, p. 4.

Pfl. in lockeren Rasen. Blätter länger, trocken aufrecht-abstehend.

N. $K$. Jotunfjeldene, Galdho.

119. Dicranum fragilifolium Lindb. Mscr., Schimp. Syn. p. 89 (1860).

Schlanke Pfl. in dichten, oft ausgedehnten, grünen oder gelbgrünen, schwach glänzenden Rasen. Stengel $1-13 \mathrm{~cm}$, dicht braunfilzig. Blätter sehr brüchig, steif aufrecht-abstehend, aus lanzettlichem Grunde allmählich in eine rinnig-hohle, ganzrandige Pfrieme verschmälert, bis $8 \mathrm{~mm}$ lang; Rippe ohne Stereiden, etwa $1 / 3$ der Blattbasis, austretend, glatt; Zellen oberwärts fast quadratisch, dann allmählich länger, am Blattgruncle verlängert rektangulär, dickwandig. \pm deutlich getüpfelt. Innere Perichätialblätter hochscheidig, mit langer, aufgesetzter Pfrieme. Seta bis $2 \mathrm{~cm}$, strohgelb bis rötlich. Kapsel eilänglich, hochrückig, mit farbigen Lïngsstreifen, trocken und entdeckelt gefurcht; Zellen des Exotheciums verlängert, 
mit verdickten Längswänden. Ring differenziert, stückweise sich ablösend. Sporenreife im Juli. - Vegetative Vermehrung durch die oberen Teile der brüchigen Blätter.

Auf morschen baumstrünken und faulenden Baumstämmen.

F. Tb. Pillajavesi, an mehreren Fundorten (Norrl.). Laukaa, Uurainen, Karstula, Sarajiarvi, Kunginkangas und Viitasaari an mehreren Fundorten (Broth.). Pihtipudas, an mehreren Fundorten (Broth., Roiv.). - Kon. Käpselkä (Simm.). Tiudie und Jänkäjärvi (Norrl.). Sulominskaja puslinja (Simm.). Telekina (Sahlh.). - Om. Vindali, Viitaniemi (Backm.). - ok, Kajana (Brolh.), - kpom. Salmivaara (Bergr.). - Ob. An mehreren Fundorten zw. Aarasaksa mo Turtola (Hult). - $K$. Kunsamo, an vielen fundorlen von Arentojoki bis Paanajärvi (Nyb., sil., Brollr.); Kulmakkapuro, aul Detrilus von Talkschiefer (E. af H.). - Kk. Pääjärvi (Hollm.). - Lkem. In der Fichtenregion an Muonioflusse it. fণ. (Norri.). Kuolajärvi, Alapeteri (Limnan.); Palovaara und Makiakuuvaara (E. af Il.). Socankylä (Blons): Kitinen (Broth.). - Le. In der Kiefernregion st. fq. (Norrl.). Kilpisjärvi, Megapahta und Saana, in der alpinen Region (Kol.). - Li. lıari. Kỵö (Vain.); Taakajoki und Muddusjärvi und Väylä (Hult); Jevjejoki (Kihlm.). Ltsjoki, Poakkuraari in der Birkenregion (IIult); Yläjalve (Ranck.). Lim. Kandalaks (F. Nr.): Lmpjok, Krivalseh und Kilsehakoski (Kihlm.) - Lt. Lultojoki, Lajakoski, Köngäs-Lounakoski an meirreren Fundorten und sunrsajok, Unsklompol (Roix.). Kola und Sascheika (Broth.). Nuortijaur (Holln.).

S. Mpd. Torp. Ang. Täsjö. LyL.. FL. und LuL.

N. Br., K.-ST, No.--F, ansschliesslich im Binnenlande. sleigl bis zou $m$ hinauf. Nurdgrenze bei elwa $70^{\circ}$ II. Br.

Silhirien, Nord-Amerika.

Unterscheidet sich im sterilen Zustande von dem in der Tracht sehr ähnlichen Orthodicranum sirictum durch breitere kippe und verdickte innere Basalzellen.

S e c t. II. Dicrana scoparia Hag. 1. c. p. 147.

Meist pseudautözisch. Zartwandige Zellen des Blattgrundes gut differenziert. zeitig durchsichtig und zusammenfallend. Peristomzähne 2 --3schenklig.

120. Dicranum Sendtneri Limpr. Laubm. I. p. 360 (1886). [D. Bergeri var. acuitifolium Lindb. et Arı. Musc. Asiae bor. II. p. 79 (1890).]

Ziemlich kräftige Pfl. in dichten, bräunlichgrünen, glanzlosen Rasen. Stengel bis $6 \mathrm{~cm}$. Blätter trocken angedrückt, mit verbogenen Spitzen, oft schwach einseitswendig, aus fast eilanzettlicher Basis allmällich lang rimnig-pfriemenförmig, bis $6 \mathrm{~mm}$ lang, oberwärts schwach gezähnt; Rippe kräftig, kurz austretend, schwach gezähnt; Zellen stark verdickt, am Grunde linear, oberwärts sehr unregelmässig. parenchymatisch, in den Blattecken zweischichtig. Innere Perichätialblätter hochscheidig; almuählich lang pfriemenförmig. Seta $2 \mathrm{~cm}$, trocken rechts gedreht. rötlichgelb. Kapsel fast aufrecht, regehmässig, zytindrisch, selten schwach gebogen, undentlich gestreift und trocken schwach gefurcht; Zellen des Exotheciums in der Mehrzahl rektangulär. Ring differenziert, stückweise sich ablösend. Sporenreife im August.

Auf Moorboden und an nassen Felsen, meist im Hochgebirge, auch auf Heiden und erdbedeckten Felsen.

F. K. Kuusamo, Juuma und Jỵäyä (Broth.); Paanajärri. Kiekkivara (B.). - Le. Killyisjärsi. Malla, Saana und Guonjarvanka (Kot.).

N. $B r_{.}, N_{2}, N_{B}, K-F_{\text {, }}$ ant reichlichsten in Jotunfjeldene und Dorrefjeld, meist in den oheren Teilen des Waldgebieles und anch in der alpinen Region bis $1.880 \mathrm{~m}$ hinauf leolbachtet.

Sehlesien, Schweiz, Frankreich, arkf. Nord-Amerika (Nordgrenze bei $76^{\circ} 30^{\circ}$ n. Br.).

121. Dicranum Mühlenbeckii Bryol. eur. fasc. $37 / 10$, t. 30 (1817).

Pseudautözisch. Kräftige Pfl. in dichten und breiten, gelbgrünen oder gebräunten, glanzlosen Rasen. Stengel aufrecht, 2-6 em, rosttilzig. Blätter fast gleichlang, trocken mit meist eingerollter Spitze, feucht aufrecht-abstehend, oberwärts röhrig-hohl, aus lanzettlichem Grunde linealisch-pfriemenförmig, bis über $6 \mathrm{~mm}$ lang, an der Spitze \pm gesägt; Rippe kräftig, 1/4-1/5 (ler Blattbasis. anstretend, oberwärts am Rücken rauh; Zellen oberwärts unregelmässig, recht- und schief-viereckige mit dreieekigen gemischt, mässig verdickt, am Grunde rektangulär und schwach getüpfelt. Innere Perichätialblätter hochscheidig. an der quergestutzten. 
entfernt stumpfgezähnten Spitze in einen gesägten, meist kurzen Pfriementeil verschmälert. Seta $2-2,5 \mathrm{~cm}$, diinn, gelb bis rötlichgelb. Kapsel aus aufrechter Basis geneigt, zylindrisch mo eingekrümmt, braun, mit glänzend rotbraunen Längsrippen. Ring differenziert, sich abłösend. Sporenreife im Juli und August. Auf trockenen, \pm kalkhaltigen Felsen und auf trockenem Erdboden.

N. A.. Bu.. VB., K. F. Fehlt in Westlandet und. sirlandet. in den inneren und nördlichen Teilen

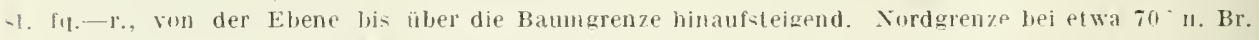
Zentral-Europa, Kaukath, Sibirien, Nort-Amerika.

var. brevifolium Lindl,. in Bot. Not. 1865. |D. brevifolium l.indb. Muse. scand p. 24 (187!).]

Weniger kräftige Pfl. Bläter trocken stark verbogen, kürzer und breiter zugespitzt. oberwärts rinnig-holıl.

F. Al. An einzelnen Fundorten in Eekerö und Lemland (Bont.). - Ab. Pargals. Parsby (Elfx.). Kimilo, Västlaks (Ols.). Kalislojo, Pellonkyla (E. af 11.): Karkkali (Lindb.). Lojo. an mehreren Fundorten (Lindb., H. Lindb., sundr.). - Ka. Wiborg, Räihä (Buch). - Ta. Tavastehus (firae?l.). Säāksmäki. Nikkilä (kihlnı.). Haıho, Ruokavuori (Brolh.). Asikkala. an nehreren Jindorten (Norrl., Broth., Vain.). Korpilahti (Nurl.): Pohjola (Vain.). - Sa. Willmanstrand (Buch). Lappee, Lauritsala. Huhlmarinvuori (Buch): Nieminen (B.); Karhujäri. Rasala (B.). 一 Kl. Kurkijoki. Ahtjäri (Jusl.). Valamo (Lindb.). Jaakkina, Pultalo (Norrl,), Sortavala. Kirjavalahti (Xorrl.). Impilabti (Broth. Pes.). Ruskeala (Pes.). Pälkjärri, Korkeaniemi (Brolh.). - Kol. sihtjeliki (EIfr.); Vusnessenje (E.). Da. Replot. Kvarken. Làppören (Broti.;. - Sb. Kuopio, Kurkinäki (Link.). Kaavi. Niinivaara. Loubilampi (Kinl.); Sikajärvi. Likosaari (K.); Losomäki und Soppilampi (k.). Waaninka. Haatala, Mäenpäankallio (Roir.). - hb. Polvijäri. Sala, Repovaara und Salansaari (Kol.). - Kon. Selki (Norrl.). Perltiniemi (N.). Repola, Tscholkka (Tain.). - Ok. Kajand (Lack-lr.). Iallano, Melalahli (Kyyhk.). Solkamo, Ketrinvara (K.). Kulmaniemi, Vieksi. Kellojărvi (K.). - Ob. Simu (Rá.). Yliturnio, KorpiVaara (Hult). Alkkulat (Norr!.). - K. Kuusamn, Ruoppijärvi (Broth.): zw. Rukatunluri und Kuon1ijäıi (B.); 2w. Rukatunluri und Pyhävara (B.): zw. Liikanen und sovanköngäs (B.). - lisem. Lolari,

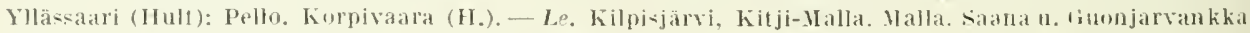
(Kol.). - Lim. Fedusejersk und Kandalaks (Eroll.). Tschunosero (B.). - l.t kiolil (B.). - Lmur. Jokonsk (B.). - L p. Ponoj (!..). - Lx. Roschutin (B.).

S. Öl., Gt!.. Srm.. Upl.. Gstr. und Jml.

N. Hie Verbreitung der var, breviolimm wird von 11 a ge $\Perp$ I. c. nichl besonders behandelt.

122. Dicranum fuscescens Turn. Musc. lib. p. 60, t. j, f. 1 (1804).

Mehr oder weniger kräftige Pfl. in lockeren oder dichten, dunkel-oder bräunlichgrüen, glanzlosen Rasen. Stengel aufrecht oder aufsteigend, 2-6 cm, \pm braunfilzig. Blätter flatterig abstehend oder \pm einseitswendig, trocken fast kraus, aus lanzettlichem oder länglich-lanzettlichem Grunde allmählich in eine lange, rimnig-hohle, oberwärs gesagte Pfrieme verschmälert, bis $6 \mathrm{~cm}$ lang: Rippe kräftig, $2 / 5-1 / 6$ des Blattgrundes, \pm lang austretend, oberwärts am Rücken, wie auch die L'nterseite der Lamina durch spitz-mamillöse Zellwände rauh; Zellen im oberen Teil der Pfrieme quadratisch, nach unten allmählich verlängert, wenig verdickt und nicht oder undeutlich getüpfelt. Innere Perichätialblätter von der Mitte rasch in einen gezähnten Pfriementeil versehmälert. Seta $1,5-2 \mathrm{~cm}$, dünn, gelb, zuletzt rötlich. Kapsel wenig geneigt, verkehrt länglich-eiförnig und gekrümmt, mit emporgehobenem Rücken, zuletzt gelbrot, derbhäutig, deutlich längsrippig. Ring differenziert, sich abrollend. Sporenreife im Herbst.

An beschatteten Felsen, auf Waldboden. verfaulten Baumstümpfen und modernden Baunstämmen in Wïldern und Erhebungen von Torfmooren.

F. Al. llammarland (II. Lindb.). (iela (Arrh.. Elfv.). Saitvik, an vielen Fundorten (Bom.). Sund (Bom.. Broth.). Vardo (Bom.). - Ab. kakskerta, kaivoinen (Colland.). Pargas, Lampis (Link). Bromarf, Norrstrand (sındr.). Lojo, Lohjanselkä und Ojanı (Lindb.). Vichtis, Palajärvi (Broth.). - Y. Helsingfors (Lindb.). Burga, Onas, Räłholuten (Broth.). Pernat. Sundo (Jusl.). Ilogland (Lindb.). - Oa. Vasa (Broth.). Reulot. Kiarken, Lappören (B.). - Tb. Aanekoski (Lesh.). - ok. Kajana (Lackstr.). Sotkamo, Vuokalli, Tolhovaitra (lisylik.). - hpem. Voivaara und Ontrosenvaara (Berer.). - (b). Alatornio. Hunalunto (Iäyr.). - K. Kuusamu. Nuorumen (Nyb.). - Ll. Tsipnavolok (Bruth.). - I.i. Inari, sompiojoki (lluls). - Lmur. Zw. Bjelonsiha und Gavrilesa an Voronjeflusse (Brolh.).

S. Sk. - J.. will der var. congestum u, der var. flexicaute. 
N. Nach $I$ a ge 11 mil der var. rongestum in ganzen crebiele fu. won der Elurne bis in die alpine Region.

Europa. Kaukasus, Sibirien, Japau, Nord-Amerika. Kommt auch aul spitabergen und im arki. Nord-Amerika vor.

var. falcifolium Braithw. Brit. Mossfl. p. 153 (1883).

Dunkelgrüne Pfl. Blätter sichelförmig-einseitswendig. kürzer und breiter zugespitzt, unterseits stark mamillös; Zellen weit herab ausgezeichnet quadratisch und querrektangulär.

F. Ai. Salt vik, Kuggsund, an bes(halteten Felsen (Brotlı.).

England, Nord-Deutschland.

var. angustifolium Arn. et Jens. Moos. Sarekgeh. p. 170 (1910).

Blätter schmäler, länger und schmäler zugespitzt, spärlich gesägt bis ganzranclig; Zellen des Pfriementeiles dickwandiger, in der Mehrzahl rektangulär.

S. LuL. Sarekgebiet.

var. tortum Arn. et Jens, in Bil. K. Sv. Vet.-Ak. Handl. Bol. 21. Afd. Ill. No. 10, p. 17 (1896).

Schlankere Pll. Blätter nicht einseitswendig, alstehend. trocken an ller Spitze gedreht.

S. Ing. Täjö, Tasjoedet iuf sumpfigem Boden.

var. congestum (Brid.) Husn. [Dicrannm congesfum Brid. Sp. musc. I. p. 176 $(1806)$.

Blätter breiter, kürzer zugespitzt, unterseits nicht orler schwach mamillös; Rippe $1 / 6$ - $1 / 9$ des Blattgrundes, nicht oder kurz auslaufend: Zellen oberwärts unregemässig, rektanguläre mit triangulären und rhombischen gemischt.

An ähnliclıen Standorten wie die Hauptart.

F. Al. Eekerö. Jomala, Geta. Sallvik. sund. Vardo. - Ab. Korpo. Pargas. Karuna. Kinito. Finby. Bromarf, Uskela. Lojo. Viehtis. - V. Ekenäs. Kyrksält. Esbo. Helsinge. Sihlıo. Borgit. - Ka. Sippola. Wihorg. - M. Kivennapa. Muola. Sakkola. Pyhäjärvi. - Sl. Björneborg. Eurajoki. Karkku. Pirkkala. Ruovesi. - Ta. Janakkalil, Lammi. In sïdösll. Teile st. fq. (Norrl.). Luhanka und Kor rijlahti st. ff. (Vain.). - ia. Willmanstrand. Kangasniemi. - Kl. Parikkala. Jaakkima. Valamo. Pälkjärvi. - Kol. st. fıl. (EIfr.). - Ha. Närpes. Vasa. Replol. - Tb. Virrat. Keuru. Petäjävesi. Jyväskylä. Laukia. Viitasaari. Pihtipudas. - Sh. Kuopir) st. f(1.-fq. (Link.). Nilsiä. Maaninki. Pielavesi. - Kb. Juuka. Joensuu. - Fon. Corka. Suopolıja. Käppäselkä. Dianova (iora. - Om. Vindala. ()k. Kajana. Pallano. Solkamo. Kuhmonieni. Puolanka. Suomussalmi. - Kpom. Rukajärvi. Särkijảrvi. Voivaara. Ken. - Ub. Pulasjärvi. Rovaniemi. Zw. Aavasaksa und Turlola fq. (Hult). - K. Kuusamo, an vielen Fundorten (Broth.). - kik. Kivakkatunturi. Soukelo. - L.hem. Zw. Kolari und Pallaslunturit fq. (Hult). In der Nadelwaldregion längs den Muonioflusse fqq. (Norrl.). - L . In der Birkenregion fq. und in der alpinen Region st. fq. (Norr..). -- Li. In allen Regionen fq. (Hult). - In allen Teilen der Halbinsel kiola fı. (Broth.).

var. flexicaule (Brid.) Wils. Bryol. brit. 1) 77 (1855). [Dicranum flexicrule Bricl. Bryol. univ. I. p. 121 (1826). - D. congestum var. flexicaule Bryol. eur. fasc. $37 / 40$, p. 36 . t. $29 \gamma(1817)$.]

Stengel bis über $20 \mathrm{~cm}$, bogig aufsteigend, locker beblättert, kaum filzig. Blätter sichelförmig-einseitswendig, oberwärts am Rande mnd am Rücken der Rippe gezähnt: Zellen oberwärts sehr unregelmässig. Seta $2.5-3,5 \mathrm{~cm}$. Kapsel trocken stark eingekrimmt und unter der Nündung eingeschnürt.

Am meisten an feuchten, schattigen Felsen.

F. A. Lemland, sund und Föglö an einzelnen, salt rik an mehreren Fundorten (Bom.). - Ab. Abu. IIirvensalo, Jänissaari (Buelı). Pargas, Kivija (Elfr.). Finby (Broth.). Bromarf, Prästbälget (Sundr.). Iskela, Linnamäki (Lindh.). Lojo, Lesaari (Lindb.); Torlıla (E. af H.). - X. Ekenäs, Hermansö (Hảk. Lindb.). Borgá, Pörtö und Lillpellinge (Brolh.). Hogland (Lindb.). - ha. Wihorg. Juustilanjärvi (Buch). - Ta. Hausjärvi, Hikiä (Huum.). - Kl. Kurkijoki (Jusl.). Valamo (W. Nyl.). - Kol. Salmi, Kãsnäselkä (Pes.). - ga. Vaca, Vassklot. (Brolh.). - Tb. Petäjävesi. Kellulanvuori (Ruor.). — Sb. Maaninka. Haatala, Haukkavuori (Roiv.). - Kb. Pielisjärvi, Kolivuori (Linnan.). - Om. Vindala, Viitaniemi und Rappukallio (Backın.). - Ok. Kajana (Lackstr.). - ob. Pudasjärvi (Brolh.). Simo (H. Lindb.). Rovaniemi, Pöyliövaara (Brenn.). Aavasaka ( $\mathrm{Nyb}$.). - K. Kuusamo. an vielen Fumdorlen (Nyb., Brolh.. F. af II.). - Lkem. Kiltilä, Ylläsjoki (Iủı). Kemijärvi (Huum.). Kuolajärvi. Sallatunturi (Linnan.). - Li. Inari, Tojvuieni (Hull). - Lim. Tichun (Broth.). - Ll. Tsipnavolok (B.). 
var. subspadiceum (Arn. et Jens.). [Dicranum congestum var. subspadicenm Arn. et Jens. Moos. Sarekgeb. p. 171 (1910).]

Blätter spitz, oberwärts \pm gezähnt; Zellen auch im unteren Pfriementeile getiipfelt.

S. LuL. sarekgebiet.

123. Dicranum majus Turn. Musc. lib. p. 59, t. $4(180-1)$.

Pseudantözisch und diöziscl, P Pfl. schlanker. Sehr krältige Pfl. in lockeren, grimen, zuweilen gelbgrünen, glänzenden Rasen. Stengel bis $10 \mathrm{~cm}$ und darüber, aufsteigend, mässig weiss- oder braunfilzig. Blätter sichelförmig-einseitswendig, glatt, aus breit lanzettlichem Grunde allmählich in eine lange, rinnig-hohle, oben scharf gesägte Pfrieme verschmälert, etwa $10 \mathrm{~mm}$ lang; Rippe etwa $1 / 9$ der Blattbasis, vollständig, mit einer Doppelreihe medianer Deuter, oberwärts stark gezähnt: Zcllen slark getüpfelt, sämtlich schmal und langgestreckt. in den Blattecken gelb oder hyalin, 3 - sschichtig. Innere Perichätialblätter hochscheidig. mit langer Pfrieme an der breit abgerundeten Spitze. Sporogone zu $1-\bar{j}$ aus demselben Perichätium. Seta 3-5 cm, dünn. gelb. Kapsel geneigt, verkehrt länglich-eiförmig, hochrïckig, grinlichgell, trocken glatt oder schwach längsrippig, entleert zuletzt dunkelbraun, gekrümmt und längsfaltig; Zellen des Exotheciums sehr unregelmässig, stark verdickt. Ring nicht differenziert. Sporenreife im August und September.

Auf tiefschattigem Wallboden.

F. Al. Hammarland. Finslröm. Geta. Lemland. Saltvik. Sund. Vảrdö, - Ab. Merimasku. Ábo. Pargas. Kimito. Finby, Bromarf. Karislojo, Lojo. Vichtis, - N. Ekenäs. Kyrkslätt. Esbo. Helsinge. Sibbo. Perna. Elimaki. Kotka. Hogland. - ka. Wiborg. - Ik. Kivennapa. MIuola. Metsäpirtı. Sakkola. Pyhājärvi. - St. Raumo. Ikaalinen. Oriresi. - Ta. Vanaja. Lammi. Hollola. Asikkala. Sysmä. Korpilahti. - Sa. Lappee. Nyslott. Kangasniemi. - Kl. Valamo. Pälkjärvi. Kol. Salmi. frorki. - Ou. Kaskö. Närpes. Replot. Vasa. - Tb. Virrat. Viilasaari. -- Sb. Kuopio. Kaavi. Nilsiä. Maaninka. Pielavesi. - $k b$. Joensuu. - Kon. Suojärvi. - Om. Lappajarvi. - Ok. Paltamo. - Kpom. Soroka. Kem. - Ob. Simo. - K. Pudasjärvi. Kuusamo. - Lkem. Kuolajarvi. - Le. An mehreren Fundorten in der Fichtenregion, in der Kiefernregion bei Hetta (Norrl.): Kilpisjärvi, Mlegapahta, in der subalpinen Region (Kot.). - Li. Sodankylă, an mehreren Fundorten in der Nadelwaldregion (Hult). - In allen Prov. der Halbiniel Fola, jedoch nur in der Nadelwaldregion fruclitend (Broth.).

S. Sk. - L L.

N. Im ganzen Gebiete fig., mit Ausnahme der südwesll. und westl. Küste, wo sie selten ist, am reichlichsten im Waldgebiete, seltener höher hinauf. Nordgrenze bei etwa $71^{\circ} \mathrm{n}$. Br.

Europa, Kauka`us, Sibirien, Nord-Amerika.

var. condensatum Hag. in D. K. N. Vidl. Selsk. Skrift. 1914, No. 1, p. 157 (1915).

Pfl. in dichten, seidenglänzenden Rasen. Stengel dicht beblättert. B. anfrecht-abstehend einseitswendig oder fast gerade, kürzer, undentlich gezähnt bis ganzranlig: Rippe am Rücken weniger gezähnt.

N. Nach Il age n in etwa: höheren Lagen verbreitet.

var. capnodes Hag. l. c. p. 161.

Pll. in lockeren, glänzenden, bräunlichgrauen, inncn russbranen Rasen.

N. $J L .$, st. SB.,NB. u. $R$. an einzelnen Fundorten.

124. Dicranum spadiceum Zetl. in K. Sv. Vet.-Ak. Handl. V. No. 10, p. 20 (1865). [D. negleclum Jur. Laubunfl. 1) 17 (1882). - D. majus var. spadiceum Hag. in D. K. N. Vid. Selsk. Skrift. 1911, No. 1. p. 158 (1915).]

Pseudautözisch. Kräftige Pfl. in dichten, oft ausgedehnten, gebriiunten, schwach glänzenden Rasen. Stengel aufrecht, wenige bis $10 \mathrm{~cm}$, mit spärlichem Rhizoiclenfilz. Blätter fast gleichlang, trocken etwas geschlängelt, feucht aufrechtabstehend, oberwärts röhrig-hohl, aus länglich-ciförnigem Grunde lanzettlichp) fricmenförmig, spitz oder stumpf, bis etwal $5 \mathrm{~mm}$ lang, ganzrandig bis oben undeulleh gezähnelt, nicht mamillös; Rippe $1 / 10^{-1 / 13}$ der Blattbasis, nicht oder nur kur\% austretend, am Rücken glatt; Zellen oberwärts unregelmässig, kurz rektangulär, fuadratisch und dreieckig, abwärts sclumal und verlängert, geschlängelt 
und stark getüpfelt. Innere Perichätialblätter in einc kurze Pfriemenspitze verschmälert. Kapsel wie bei D. Mïhlenbeckii.

Auî trockenem Borlen, besonders zw. Felstrïmmern.

F. Le. Kilpisjärvi, Sajvovaara (Kot.). - Lim. Hibinä, in der alpinen Region (Bruth.). - I.t. Tsipnavolok und Kildin (Broth.). - Lp. Ponoj (Bruth.).

S. LuL. Sarekgebiet.

N. An einzelnen oder wenigen Fundorten in siT., $T r$. und $F$.

Pyrenäen-Steiermark, Kaukasus. Zentral-Asien, Sibirienl. Nord-Amerika.

125. Dicranum angustum Lindb. in Meddel. Soc. Faun. Fl. fenn. 1881, p. 2.2.

Psendautözisch. Weniger kräftige Pll. in lockeren bis dichten, zuweilen ausgedehnten, grünen oder gelblichgrünen bis bräunlichen, glänzenden Rasen. Stengel bis $13 \mathrm{~cm}$, selten höher, bramfilzig. Blätter abstehend, glatt, röhrig-hohl, aus lanzettlichem Grunde allmählich in eine ganzrandige Plrieme verschmälert, bis $6 \mathrm{~mm}$ lang; Rippe etwa $1 / 10$ der Blattbasis, I weit unter der Blattspitze aufhörend, glatt; Zellen eng und gestreckt, nur die obersten kïrzer, dickwandig. Innere Perichätialblätter hochscheidig, mit langer Prrieme an (ler breit abgerundeten Spitze. Sporogone $1-3$ aus demselben Perichätium. Seta $2,5-3 \mathrm{~cm}$, sehr dünn, gelb. Kapsel geneigt, länglich, hochrïckig, gelbbräunlich, gestreift, trocken und entdeckelt braun und gefurcht; Zellen des Exotheciums rektangulär, mit verdickten Längswänden. Ring differenziert. sich abrollent. Sporenreife im August.

In Torfmooren und Versumpfungen der Fichtenwälder.

F. Kt. Suistamo, Jänisjärvi (Broth.). - Th. Saarijarvi (Broth.). Kinnula, Saarenkylä, Mekkojärvi (Roiv.). - Sb. Heinävesi, Papinniemi, Sammakkolalıti (Kot.). Juuka, Petrovaara (K.). - Kb. Juuka, Juuanvaara (k.). Lieksa, Koriseva (Vain.). - ok. Paltamo, Mattila (Ranck.). - Ob. Turtola (Hult). - K. Kuusano, Iivaara (Sil., Broth.); zw. Siikala und Oulankajoki (Broth.); zw. Sovajärvi und Korvasjärvi (B.); zw. Salmineı und Kesälahti (B.). Kuolajärvi, Sipanlampi (Roiv.), — Kk. Kivakkatunturi (Broth.). 一 Lkem. Kolari, Jokijalka (Hult). Kittilä, Levitunturi (H.); Palfastunturit (A. K. Caj.). Keimiotunturi (Norrl.). Kuolajärvi, Sallajoki (Linnan.). - Le. Palojoki (Norrl.). - Li. Inari, Kurittukoski, Tankajoki, Kopsusjärvi und Luirojärvi (Hult), - Ll. Luttojoki, Rajakoski (Roiv.): Lavschjäyrvaal (R.). Kola, am Tulomaflusse (Brnth.). - Lmur. Rinda (Broth.). Zw. Varsinsk und Jenjavr (B.).

S. Jml., Inq., Vh., PL. und LuL, an einzelnen oder wenigen Fundorten.

N. A., L.M., St., XR., H., No.-F. hier und da, am meisten in den oberen Teilen des Waldgel,ietes und etwas wherhalb der Baumgrenze. Nordgrenze bej $69^{\circ} \mathrm{n}$. Br.

Sibirien.

126. Dicranum scoparium (L.) Hedw. Fund. musc. II. p. 92. t. 8, f. 11,12 (1782). [Bryum scoparium L. Sp. pl. 1117 (1753).]

Pseudantözisch und diözisch, - Pfl. kleiner, in besonderen Rasen. Kräfitige Pfl. in lockeren, ausgedehnten, grünen oder gelblich- bis bräunlichgrïnen, glänzenden Rasen. Stengel bis $10 \mathrm{~cm}$ und höher, weisslich-, später braunfilzig. Blätter abstehend, die obersten schopfig zusammengedrängt, \pm sichelförmig-einseitswendig, glatt, aus lanzettlichem Grunde allmählich \pm lang in eine fast rinnighohle, oben scharf gesägte Pfrieme verschmälert, bis $8 \mathrm{~mm}$ lang; Rippe $1 / \pi^{-1 / 9}$ der Blattbasis, in der Spitze oder kurz vor derselben aufhörend, oberwärts mit meist 2, seltener mehreren, gesägten Lamellen; Zellen stark getïpfelt, unten lineal, oberwärts kïrzer, rhomboidisch-6seitig, in der Spitze oft rhombisch, in den Blattecken 2--3schichtig. Innere Perichätialblätter hochscheidig, plötzlich pfriemenförmig verschmälert. Sporogone einzeln. Seta $2-f \mathrm{~cm}$. unten rot, oben gelblich. Kapsel geneigt, zylindrisch, gekrimm, derbhäutig, brau, glatt; Zellen des Exotheciums mit stark verdickten Längswänden, obcrseits rektangulär und länglich. unterseits quadratisch und polygonal. Ring nicht differenziert. Sporenreife im Herbst.

In Nadel- und Laubwäldern auf der Erde und am Grunde der Stämme gemein, zuweilen Massenvegetation bildend, an Baumstrinken, gefallenen, frischen orler modernden Baumstämmen, wie auch auf Felsen. 
In allen Teilen von Fennoskandi: $f q q-f q .$, bis in die alpine Region hinaufsteigend, hipr aber srärlicher und steril.

Europa, Nord-Asiell. Kaukasıs. Kaschmir, Japan. Nord-Amerika.

var. orthophyllum Brid. Sp. musc. 1. p. 173 (1806).

Pfl. in sehr dichten, durch Rhizoidenfilz verwebten Rasen. Blätter steif aufrecht-anliegend oder einseitig steif bogig. bis 5 mm lang, oberwärts gesägt: Rippe mit gesägten Lamellen.

F. N. Ekenảs, Träminne (Broth.). Borg:t. Pellinge, Glusholm (Broth.). - ka. Kotka. Langinkoski (Roiv.). - Oa. Replot, Krarken. Lappören (Broth.). - Lt. Vaidoguba (B.). - Lp. Orlow (B.).

var. laticuspis Loesk. et Bauer in Bauer Musc. eur. exsicc. No. 109, c. (lescr.

Blätter trocken etwas einseitswendig, feucht allseits starr aufrecht und weit abstehend, ziemlich kurz und breit, wenig hohl bis flach, mit ziemlich breiter Spitze, oberwärts unregelmässig, meist stumpf sägezähnig: Rippe mit gesägten Lamellen: Zellen der Blattspitze selır unregelmässig. Seta gelb oder gelbgrïn.

F. Y. Sibbo. Löparö. aul beschatteten (iranithöcken (Broth.).

var. tectorum IH. Müll. Nestf. Laubm. No. 112.

Pfl. in dichten, ausgedehnten, leicht zerfallenden Rasen. Stengel mit spärlichem Rhizoidenfilz. Blätter aufreclit-abstehend, breit lanzettlich, ganzrandig orler nur in der äussersten Spitze gezähnt: Rippe am Rücken glatt.

Auf flachen Felsen, oft grosse Flächen bedeckend.

F. Al. sund (Broth.). - X. Ekenäs. Trärminne (Broth., Ranck.). - Ko. Anlsea (Pork.). - hl. Impilahti, Pullinvuori (Broth.). - Oa. Replot. Vallgrund (Broth.). Vasa, Korsör (Brolh.). - Th. Viitasaari, Kinnula (Broth.). L L. Tsipnavulok (Broth.). Kildin (B.).

var. alpestre Hüb. Musc. germ. p. 236 (183:3).

Pfl. in dichten, durch Rhizoidenfilz verwebten Rasen. Blätter anfrecht-anliegend. eilanzettlich, l,reitspitzig, ganzranrlig: Rippe am Rücken glatt. Seta sehr kurz.

Im Hochgelirge.

N. Obne nähere Angaben ( 11 a $q$ e $n$ ).

Sudeten, Pyrenäen, Altai.

var. recurvatum (Schultz) Brid. Sp. musc. I. p. 17:3 (1806). [Dicranum recurvatum Schultz Fl. starg. p. 265 (1806).]

Kräftige Pfl. in lockeren Rasen. Stengel stark rhizoidenfilzig, unterbrochen beblättert. Blätter schoplig gehäuft. sichelförmig. mit stark gesägten Rändern: Rippe mit gesägten I :imellen.

N. Ohne nähere ingaben ( $H$ a g e 11$)$.

Furopa.

var. paludosum Schimp. Syn. p. 90 (1860).

Kräftige, Inckerrasige Pfl. Blätter \pm bis sichelförmig-einseitswendig. z. T. querwellig. oberwärts gesägt; Rippe mit gesägten Lamellen. Auf versumpftem Waldboden.

F. Al. Saltvik. Langhergsöda (Bom.). - Th. Virral. Torisera (Brolh.). - Ok. Solkano. Nadpurinvaara (Brolh.). - K. Kulsamo. Paanajurvi. Nantyvara (Brolh.).

S. Inq. Tasji.

Europa, Japan. Nord-Anerikia.

var. turfosum llill. Bryol. siles. p. 71 (1869).

Pfl. in dichten Rasen. Blätter aufrecht-abstehend, ganzrandig; Rippe am Rücken glatt.

F. Oa. Replot, Vallgruna (Broth.), - L. Kuusauo, Slikitkajärvi (Broth.).

N. F. Maian, Havosund.

Europil.

var. integrifolium Lindb. in Öfr. K. Vet.-Ak. Förh. 1866, p. 5.55.

Kräiftige Pll. in hohen, lockeren, leicht zerhallenden, strohgelben bis braunoder grünlichgelben Rasen. Stengel mit spärlichem Rhizoidenfilz. Blätter steif. 
aufrecht-abstehend bis dachziegelig, oberwärts röhrig-hohl, nit stumpler bis abgerundeter, ganzrandiger Spitze; Rippe schmal, vor der Blattspitze aulhörend, glatt: Zellen oberwärts lang und schmal, geschlängelt, stark verdickt. Seta diinn, strohgelb.

An Felsen und in ziemlich trockenen Mooren.

F. Lmur. Rinda (Broth.).

S. LuL. Sarekgebiet in ter Birken- und in der Weidensenim.

spitzbergen. (irönland, arki. Silirien.

127. Dicranum Bonjeani De Not. in Lisa Elencho p. 29 (1837) et Syllab. Musc. p. 213 (1838). [D. palus/re Bryol. eur. fasc. 37/40, p. 39, t. 31 (18.17).]

Psendautözisch. Kräftige Pfl. in lockeren bis dichten, oft ausgedlehnten, grimen oder gelblich- bis bräunlichgrïnen, glänzenden Rasen. Stengel bis 10 und $15 \mathrm{~cm}$, dicht weisslich-, später biamfilzig. Blätter = abstehend, die obersten fast pinselartig aufrecht his sehwach sichelförmig, querwellig, aus lanzettlichem Grunde allmählich in eine rimnig-hohle, oben scharl gesägte Pfrieme verschmälert, $8-10 \mathrm{~mm}$ lang: Rippe $1 / u^{-1 / 13}$ der Blatthasis, weit unter der Blattspitze aufhörend; glatt odel oberwärts etwas ranh; Zellen bis in clie Spitze gestreckt, stark getiipfelt und derbwandig, in den Blattecken 2schichtig. Innere Perichätialblätter hochscheidig. plötzlich pfriementörmig verschmälert. Sporogone einzeln oder zu zweien aus demselben Perichätium. Seta 2-j cm, dïmn, gelb, Kapsel geneigt, zylindrisch, schwach gekrümmt, dünnhäutig, undentlich gestreift, lichtbraun: Zellen des Fxotheciums wie bei $D$. scoparium. Ring nicht differenziert. Sporenreife in Spätsommer. Fig. $20 \mathrm{~F}$-I.

Auf Sumpfwiesen und auf moorigem Boden.

F. Al. Eckerö. Finströn. Sund. Saltvik. - Ab. Pargis. Finly. Bromarf, Lojo, - Y, Eslon Helsinge. Borgi. Elimaki. Hogland. - Ka. Kymmene. Nujamaa. - Ik. Valkjärvi. sakkola. - St. L'lfsby. Orivesi. Ruovesi. - Ta. Vanaja. Lammi. Hollola. Asikkala. Kuhmoinen. Hartola. -- sa. Kangasniemi. - Kl. Kurkijoki. Valamo. Uukuniemi. Sortavala. Suislamo. Pälkjärvi. — Kol. Mandroga. Petrosarodsk. - Tb. Virrat. Laukaa-Viitasaari st. fr. (Brotlı.). - Sb. Kuopio. Kaavi. Nilsiä. Maaninka. Lisalmi. - $k b$. Joensum. - Kon. Ve!ikaja quba. Kivatsch. - Om. Lapuajäri. - Ok. Kajana. Pallamo. Sotkamo. Ristijärvi. Suonussalni. - Ob. Liminka. Kempele. Simo. - K. Kunsamo. Lhem. Iuonio, Kemiotunturi (Norrl.). Kuolajärvi, Pantatsilehto (E. af H.); Lampelan kylä (Roiv.). Le. Palojoki (Norrl.). - Li. In der Nadelwald- und Birkenregion st. f(T. (Hult). - Lim. Jokostrov (Broth.). - Lmur. Gavritova (B.).

S. Sh. - L.

N. In allen Amtern mit Ausnahme von $L . M .$, wie es scheint jedoch nicht häufig, an reichlichsten in Waldgebiete, auch oberhalb der Baumgrenze beobachtet.

Europa, Kankasus, Himalaya, Sibiripn, Nord-Amerika.

var. integrifolium Lindb. fil. in Bauer Musci eur. exsice. No. 94. (D. Bonjeani var. integrum Broth. Bryoth. Fenn. No. 309.)

Blätter etwa $5 \mathrm{~mm}$ lang, schmäler als bei der Haujtart, ganzrandig. Steril.

F. Oa. Närpes, Finnby, Slätmossen (Ranck.). Lapua, in sphagnummoor (H. Lindb.).

var. juniperifolium (Sendtn.) Braithw. Brit. Mlossfl. p. 149 (1883). (Dicranum juniperifolium Sendtn. in Flora 1840, 1. p. 59.)

Blätter etwa $5 \mathrm{~mm}$ lang, steifer und breiter als bei der Hauptart, nur an der Spitze querwellig.

N. Verbreitung wie bei der Hauptart (H a $g$ e n).

var. polycladum Bryol. eur. fase. $37 / 10$ (18t7).

Stengel mit schlanken, kätzchenförmigen, brïchigen Ästchen. Astblättel eilanzettlich, stumpflich, ganzrandig.

N. Fredrikssiad.

Europa.

var. anomalum (.. Jens. in litt.; Wamst. Laubm. p. 151 (1906).

Stengel bis $12 \mathrm{~cm}$, mit spärlichem Rhizoidenfilz. Blätler nicht oder zart wellig, ganzrandig, die unteren der Jahrestriebe sehr hoht, dicht anliegend, Jreit laing- 
lich-eiförmig, stumpfspitzig, lois $4 \mathrm{~mm}$ lang; Zellen gegen die Spitze unregelmässig rhombisch. Schopfblätter lanzettlich, bis 6 mm lang.

N. Ohne Fundorte (H a ge n).

กänemark,

var. rugifolium Bosw. in Hobk. Syn.

Blätter abstehend, etwas gekräuselt und gedreht, längs und oberwärts stark querwellig.

N. St. Haaland. IIalle.

England.

var. alatum Barn. in Bot. Zentralbl. 1890. No. 51.

Pfl. in dunkelgrünen, $4-6 \mathrm{~cm}$ hohen Rasen. Blätter lanzettlich, $1-1,5 \mathrm{~mm}$ lang, sehr scharf gesägt: Rippe mit 2-3 scharf gesägten Lamellen.

N. H. Nes, Helgrien.

Nord-Amerika.

128. Dicranum undulatum Ehrh. (iryt. No. 271 (1793). [Bryum rilgosum Hoffm. Deutschl. Fl. II. p. 39 (1796). - Dicranum rugosim Brid. Musc. rec. Suppl. I. p. 175 (1806).]

Pseudautözisch. Sehr kräftige Pfl. in lockeren. ausgedehnten, gelblich- bis bräunlichgrünen, etwas glänzenden Rasen. Stengel bis $12-15 \mathrm{~cm}$, braunfilzig. Blätter abstehend, die endständigen gedrängt und aufrecht oder schwach einseitswendig. alle stark querwellig und fast flach, breit lanzettlich, etwa $10 \mathrm{~mm}$ lang und $2 \mathrm{~mm}$ breit, mit bis unter die Mifte herab scharf grob gesägten, unten zurückgebogenen Ränclern: Rippe etwa $1 / 15$ der Blattbasis, vor der Blattspitze aufhörend, oberwärts mit 2-4 dornig gesägten Lamellen; Zellen langgestreckt, in den Blattecken 1-3schichtig. Innere Perichätialblätter hochscheidig, plötzlich lanzettlichpfriemenförmig. Sporogone 1-5 in dcmselben Perichätium. Seta 3-1 cm, dümn, geschlängelt, gelb. Kapsel gencigt, fast zylindrisch, gebogen, trocken stark gekrümmt und - leutlich gestreift. Ring nicht differenziert. Sporenreife im August und September.

Am meisten auf trockenem Waldboden. Heiden und erdbedeckten Felsen, oft massenhaft, zuweilen auclı in Monren.

F. In allen Prov. bis Lappland fq.-iqq. - Lkern. bis Pallastunturit fq. (Hult). Kuolajärvi, Sallatunturi. - Le. Karesuanto (Norrl.). - Li. Inari, Toivoniemi in der Nadelwaldregion und Tuarpumoivi in der Birkenregion (Hult). - L im. Kandalaks (Broth.).

S. $S k$. $-T^{-} b$, und $P$.

N. Sm. - sB..K. F. In ustlandet fq., in den sudwe-tl. Teilen r.. in Hordaland st. fq., in Binnenlande und nördlicher $\mathrm{r}$. Sleigt kaum bis über die Baumgrenze hinauf. Sordgrenze bej $70^{\circ} \mathrm{n}$. Br.

Europa, Kaukasu-, Himalaya, Sibirien, Nord-Amerika.

129. Dicranum Bergeri Bland. Nuse. frond. exs. III. No. 114 (1801). [D. intermedium Crome Samml. I1. No. 66 (1805). - D. Schraderi Web. et Mohr Bot. Taschenb. p. $177(1807)$.]

Pseudautözisch. Kräftige Pfı. in I dichten, grünen ofler gelbgrünen, etwas glänzenden Rasen. Stengel 3-15) cm, dicht braunfilzig. Blätter trocken anliegend, nit gelrehter Spitze. fencht aufrecht-abstehend, selten schwach einseitswendig, (puerwellig, kielig-hohl, breit lineal-lanzettlich. $5-8 \mathrm{~mm}$ lang, an der breiten, oft stumpflichen Spitze grob- und \pm weit herab kleingesägt; Rippe etwa $1 / 9$ der Blattbasis, vor der Blattspitze aufhörend. am Rücken glatt oder schwach rauh; Zellen oberwärts parenchymatisch, selır mmregelmässig, nach unten eng linealisch, in den Blattecken 2 -3schichtig. Innere Perichätialblätter hochscheidig, breit ausgerandet, mit aufgesetzter Pfrieme. Seta einzeln, 3- $\mathrm{cm}$, dünn, gelblich. Kapsel aufrecht bis etwas gencigt, länglich bis zylindrisch, schwach gekrimmt, gelbgrin, \pm deutlich gestreift, entleckelt bram und trocken gefurcht: Zellen des Exotheciums zicmlich regelnässig rektangulär. Ring differenzicrt, stückweise sich ablösend. Sporeureife im Spätsommer. 
Auf fenchtem Boden, hesonders in Torfmonren, und aul nassen lietsen.

F. In allen prov. fi., bis in die alpine Region hinaufsteigend.

S. $S k .-L$.

N. Sm.-Ne., St.-F. In ustlandet und in den inneren Teilen von sirlandet und llestlandet hier und da und an der Küste fast fehlend; im Binnenlande und nördicher st. Ir. Steigt bis in die Weidenregion hinauf. Nordgrenze bei $70^{\circ} \mathrm{n} . \mathrm{Br}$.

Europa, Sikkin, Sibirien, Nord-Amerika.

130. Dicranum spurium Herlw. in Timm Prodr. No. 781 (1788) et Hedw. Descr. II. p. 8\%, t. $30(1789)$.

Psendautözisch. IKräftige Pfl. in lockeren, oft ausgedehnten, leicht zerlallenden, grïnen oder gelblichgrïnen, etwas glänzenden Rasen. Stengel 2-6 cm, abwärts dicht rostfilzig, schopfig beblättert. Blätter trocken einwärtsgebogen mit gedrehter Spitze, fast kraus, feucht abstehend, querwellig, ans hohlem, eilänglichem Grunde rinnig-hohl, rasch lanzettlich zugespitzt, weit herab gesägt, unterseits durch Hamillen \pm rauh, bis $8 \mathrm{~mm}$ lang: Rippe $1 / 2-1 / 9$ der Blattbasis, vor der Blattspitze aufhörend, oberwärts raulı: Zellen in der oberen Blatthälfte klein und sehr unregelmässig, nach unten kurz rektangulär, am Blattgrunde verlängert linealisch, in den Blattecken 1-3schichtig. Innere Perichätialblätter hochscheidig, schwach ausgerandet, mit aufgesetzter Pfrieme. Seta einzeln, 2 $3 \mathrm{~cm}$, dünn, gell,. Kapsel geneigt, fast zylindriscl, gebogen. gelbgrün, gestreift. trocken gerippt. Ring differenziert, sich ablösend; Zellen des Exotheciums oberseits verlängert rektangulär, unterseits yuadratisch und polygonal. Sporenreile anfangs Juli.

Auf trockenem Boden in Kiefernwäldern und auf trockenen, kalkfreien Felsen und Blöcken.

F. Al. Eckerö, Hammarland. Mariehamn, lieta. Sund und Vardö an einzelnen. Saltvik an mehreren Fundorten (Bonr.). - Ab. Nudendal. Abo. Reso. Pargas. Kimitu. Finby. Bromarf. Karislojo. Lojo. - N. Ekenäs. Kyrkslätt. Esbo. Helsingfors. Helsinge. Sibbo. Borgi. Hogland. - Ka. K̇ymmene. Virolahti. Wiborg. - Ik. Kivennapa. Sakkola. Pyhajärvi. - st. Luvia. Loimijoki. Karkku. - Ta. Kalvola. An einzelnen Fundorten in Hollola, Asikkala, Padasjoki. Kummoinen, Luhanka und Korpilahti. - Sa. Willmanstrand. Ruokolahti. - Kl. Pälkjärvi. - Kol. pass. (Elfv.). Salmi. - Oa. Isokyrō. - Tb. Petäjävesi. Jyväskylä. Viitasaari. Kinnula. Pihtipudas. — Sb. Kuopio. Juuka. Nilsiä. Maaninka. Pielavesi. Rautavaara, - Kon. Perquba. - ok. Kajana. Paltamo. Kuhmoniemi. Puolanka. - Kpom. Kontokki (Vain.). - Ob. Oulujoki. Pudasjärvi. Aarasaksa. - K. Kuusamo. - Lkem. An mehreren Fundorten zw. Kolari und Pallastunturit, meist in den inneren Teilen. um Äkäslompolo st. fq. (Hult). Ounastunturi. Kuolajärvi. - Lt. Rotsvaara, imı südl. Teile (Roiv.).

S. Sk.-Ang., Hlr.. LyL. und PL.

N. Sm.-L.M., SB., R.-ST., Tr. und F. In den Kristianiafjord fø. und an einer Reihe ron Fundorten westlich davon bis Flekkefjord auftretend, anderwärts als selten zu bezeichnen. Nur im belıjete der Nadelwälder. Steigt bis $500 \mathrm{~m}$ hinauf. Nordgrenze bei $70^{\circ} \mathrm{n}$. Br.

Europa, sikkim, Sibirien, Nord-Amerika.

var. pseudo=elatum Tolf in Bih. K. Sr. Vet.-Ak. Handl. Bd. 16, Afd. Ill. No. 9, p. 65 (1891).

Kräftige Pfl. in weit ausgedehnten Rasen. Stengel bis $15 \mathrm{~cm}$, Schopfblätter einseitswendig, am Rücken sehr rauh. Innere Perichätialblätter gerippt. Sporogone meist zu 2 in demselben Perichätium.

S. Sm. Ingatory auf steinen und flachen Felsen.

131. Dicranum robustum Blytt in Bryol. eur. lasc. 37,10 Mon. p. 43 , t. 84 (1817). (D. elatum Lindb. in Hedwigia 1868, p. 15).

Pseudautözisch. Sehr kräftige Pfl, in lockeren, oft ausgedehnten, grïnen. glänzenden Rasen. Stengel bis $12 \mathrm{~cm}$, aufrecht oder aufsteigend, braunfilzig. Blätter trocken gekräuselt, feucht \pm sichelförmig-einseitswendig, die obersten fast pinselartig aufrecht, schwach sichelförmig, glatt, einzelne abwärts schwach querwellig, aus breit lanzettlichem Grunde rasch in eine lange, rinnig-hohle, am Rücken sehr rauhe, gesägte Pfrieme verschmälert, bis $12 \mathrm{~mm}$ lang und 1,7 $\mathrm{mm}$ breit; Rippe etwa $1 / 20$ (ler Blatlbreite, austretend, am Rücken oberwärts scharf 
gesägt: Zellen oberwärts parenchymatisch, sehr unregelmässig, am Blattgrunde lineal und getüptelt, in deı Blattecken 4-5schichtig. Innere Perichätialblätter hochscheidig. mit kurzer Pfrieme an der breit abgerundeten Spitze. Sporogone $1-3$ aus demselben Perichätium. Seta $3-5$ cm. strohfarben. Kapsel zylindrisch. gebogen. gestreift, im Alter braun und trocken gefureht: Zellen des Exotheciums verlängert. Ring differenziert, sich abrollend. Sporenreife im Sommer.

In trockenen Nadelwäldern, auf tlachen lelsen und selten auch auf trockenem Moorboden.

F. Al. Eckerö. Lemland, Sund und Vardö an einzelnen, Sallvik an mehreren Fundorten (Bom.). - Ab. Pargas. Gunnar:nās (Elfr.): Lampis (Link.). Finhỵ (Broth.). Bromarf. an mehreren Fundorten (Sundr.). Lojo. an wehreren Fundorten (Lindb.. Jusl.. H. Lindh.. sundr.). Vichtis. Palajārvi (Broth.). - Y. Kyrksătt. Obbnäs (Ju-l.); Skeppars und Böhle (Broth.). E:bu, Mirlenshy (Buch); Grãsa (Broth.). Helsingfors. Hegerö (Link.). Helsinge, Viks ladugird (Buch). Silher. Loparö (Sundr.). Hogland (Lindl).). - Ka. Sākkijärvi, Mellansaari (Link.). Wiborg. Isul Pälli (Bıch). — Ta. Padasjoki (Norrl. und sil.). Asikkala. Salu (Norrl.). - Sa. Willmansirand (Bueh). - Kl. Jaakkima (sundr.). Surtavala. Lảskelả (Norrl.). Suistamı. Loimalı (Brolh.). - Kol. Salmi. Käsuäselkā (Link. und Pes.). Tulemajäri, Kolalselkä (Link.). - Da. Vilsa. Vassklot (Broth.). Replot. Kirarken, Lappören (Broth.). - Tb. Konginkangas (E. af H.). Pihtipudas, an mehreren Fundorten (Rojv.). - - b. Kuopio. an. mehreren Fundorlen (Kol., Kyghk.. Link.). Kaavi. Siikajäri. Likosaari (Kot.). Juuka. Halivaard und Petrovaara, Iljanniemi (K.). Nilsiä. Kuuslahti. Jakkonlampi (Kyghk.). Maaninka. an mehreren Fundorten (Roir.).

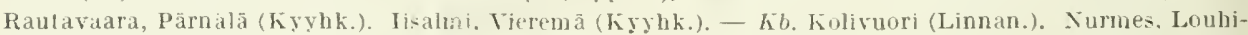
vaara (Vain.). - Kon. Suojärvi. Hautavaari (Link.): Näätoja (Kuj.). — Ok. Kajana (Lackstr.). Paltamo, an mehreren Fundorten (Lackstr., hy /hk.). solkamo, an mehreren Fundorten (Brolh., Kyyhk.). Kuhmoniemi (E. af H.). Puulanka. salminen, Vuurijărvi (Ky̧hk.). - ob. Simu (H. Lindb.). Zw. Aavasaksa und Turtola st. fq. (Hull). - K. Pudasjärvi fq. (Broth.;. Kuusamm. an vielen Fundorten (Nyb., Sil., Sahlb.. Broth.). - f.kem. Zw. Kölari und Pallactunturit -1. fọ. (Hult). Kemijärvi (Huum.). Kiuolajärvi, an mehreren Fu. korten (Linnan.. E. af H.). - Le. In der Waldregion bis Kilpisjārvi selten (Norrl.). - Li. In allen ficlonen ft.., in der aluinen Region von sndankyli jedoch nicht lieobachtet (Hult). Lim. In der Whisregion st. fq. (sahlb.. Broth.. Kihlm.). - Lt. Im südl. Trile nichl sellen (Roir.). Li. Tschapomá (Broth.).

S. Citl.. srm.. Vär., Lpl.. Ism.-Tb., IIrjd.. Jmt. und $L$.

N. Sm.-I.K.. B..K.-Tr. In den süd. Trilen weit rëbreilel und stellenweise fq.. nördlicher pass, und im Norden r. Steigt bis über die Baumgrenze hinauf. Nordgrenze bei $64^{3} 3 \hat{\prime}^{\prime} \mathrm{n}$. $\mathrm{Br}$.

var. alpinum Hag. in D. K. N. Vir. Selsk. Skrift. 1914. No. 1, p. 177 (1915).

Pfl. in niedrigen. sehr dichten Rasen. Blätter dichter gestellt, sichelförnigeinseitswendig. kürzer, anı Rücken weniger rauh.

N. Bu., Modum. Horlandsfjeldet. St. Opdal. Knudsho.

Der ron B lyt 1 dieser Art gegebene Name wurle von Lind berg geänlert, weiler scion litiher von Hooker fil. und Wilson an eine auf die siidliche Hemisphäre vorkommende Art vergeben war. Da indessen diese zu cler später von Dicranum abgetrennten Gattung Dicranoloma gehört, muss der von Blyt gegebene Name in Geltung bleiben.

\section{PARALEUCOBRYOIDEAE.}

Diözisch. Blattrippe sehr breit, mit medianen, chlorophyllhaltigen, oberund unterseits von weitlichtigen, dünnwandigen, hyalinen Zellen eingeschlossen. Blattflügelzellen differenziert. Innere Perichätialblätter hochscheidig. Peristomzähne 2schenkelig.

\section{:3. PARALEUCOBRYUM}

(Lind1,.) Lonesk. in Hedwigia XLVIl. p. 171 (1908).

Mehr oder weniger kräftige, meist weisslichgrüne, kaum odler abwärts nüssig filzige, glänzende Pfl. Blattrippe sehr breit, den Plriementeil ganz oder grösstenteils ausfüllend: Innensehicht clickwandig, getïpfelt, reich an Chlorophyll: alle 
Zellen der Aussenschichten weitlichtig. dünnwandig und hyalin oder diejenigen der Rückenfläche durch mehrere Längsreihen hervortretender Chlorophyllzellen unterbrochen: Zellen der l.amina verlängert rektangulär bis linealisch, getüpfelt, in den Blattecken gross, quadratisch, dickwandig und gebräunt. lnnere l’erichätialblätter hochscheidig. plätzlich kurz pfriemenförmig. Kassel aufrecht, regelmässig, länglich-zylindrisch, trocken glatt oder t deutlich längırippigs. Peristomzähne bis 7.1!r Mitte oder darunter 2schenkelig.

$$
\text { I"hersicht der irten. }
$$

A. Blätter in eine sehr lange und feine. I weit herab, neist doppelreihig kleingesägte l’frieme verschmälert.
a. Zellen der Lamina jederseits $10-1$ Jreihig
P. longifolium.

b. Zellen der Lamina jederseits 20-2.rreihig

P. Santeri.

B. Blätter mil kürzerer Pfrieme, nur an der stumpflichen Spitze undeutlich gezähnelt P. enerve.
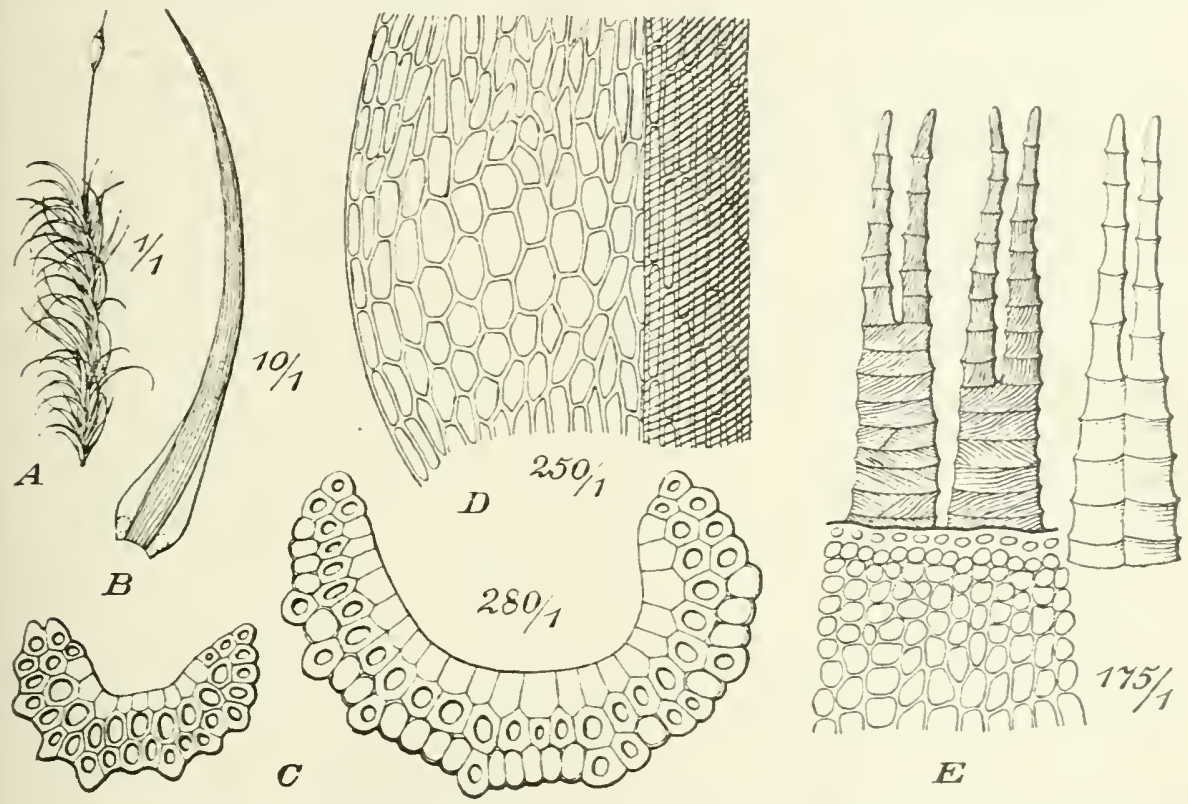

Fig. 21. Paraleucobryum longifolium (Ehrh.). A Fruchtende Pfl. (1 1): B stengelb. (1t) 1): C Blattquerschnitte $(2801)$ : D Blatthasis $(2501)$; E Peristom (175 1).

132. Paraleucobryum longifolium (Ehrh.) Loesk. 1. c. [Dicranum longifolium Ehrh. Dec. crypt. No. 114 (1786). - Hedw. Descr. III. p. 24, t. 9 (1792). - Campylopus longifolius Kindb. Laubm. Schwed. und Norw. p. 87 (1883).]

Locker- oder dichtrasige, weisslich-, gelblich- oder dunkelgrüne, kaum lilzige Pft. Stengel aufrecht bis aulsteigend, 2-5 $\mathrm{cm}$. selten höher. Blätter meist sichelförmig-einseitswendig, aus eilanzettlicher Basis allmählich in eine sehr lange und feine. röhrig-hohle Pfrieme verschmälert, etwa $8 \mathrm{~mm}$ lang, mit bis weit herab meist doppelreihig kleingesägten Rändern: Rippe wenigstens ${ }^{1}$ a der Blatthasis und den ganzen Pfriementeil ausfüllend, mit mehreren Längsreihen an Rücken hervortretender, oberwärts sich zahnartig vorwölbender grüner Zellen: Zellen der Lamini 10-15reihig. verlängert-rektangulär und 6seitig. Seta 1-2 cnn. gelblich. Kiapsel gelbgrün bis gelbhräunlich: Zellen des Exotheciums sehr unregelmässig. Ring 
nicht differenziert. Sporen ungleich gross, 18-24, mit 12 1 / " intermischt. Sporenreife im August. - Fig. 21.

Auf kalkfreien und kalkarmen Gesteinen und an Bäumen im Waldgebiete von Fennoskandia $\perp$ allgemein verbreitet, in den lappmarken seltener und sehr selten über die Baumgrenze hinaufsteigend. Nordgrenze bei $70^{\circ} 40^{\prime} \mathrm{n}$. Br.

Europa, Kaukasus, Sibirien. Japan. Nord-Amerika.

var. strictiforme (C. Jens. in Meddel. om Gronl. III. p. 73: 1887 als Dicranum). Pflanzen in dichten Rasen. Blätter kürzer. last aufrecht, weniger gesägt.

S. LuL. Sarekgebiet in der Birkenregion.

var. ditrichiforme (Arn. et Jens. in Bih. K. Sr. Vet.-Ak. Handl. Br. 21. Afd. III. No. 10, 1) 47: 1896 als Dicranum).

Schlankere Pfl. in dichten. flachen, gelbgrünen, seirlenglänzenden Rasen. Blätter kürzer, steif aufrecht, gesägt.

S. Ing. Tásiö, Jakobsscedbärget, an schaltigen Felsen.

133. Paraleucobryum Sauteri (Schimp.) Loesk. 1. c. [Dicrmum Sauteri Schimp. in Bryol. eur. lase. 37,41, p. 33. t. 21 (1847). Camplylopus Sauteri Kindb. Laubm. Schwed. und Norw. p. 87 (1883).]

Mit der vorigen Art sehr nahe verwandt. Rasen freudig grïn und seidenglänzend. Blätter mit nur gegen die Spitze kleingesägten Rändern: Rippe nur 1/4 1/5 der Blattbasis eimmehmend: Lamina löher vorgezogen. am Grmde 20-25 7ellreihen.

An Stälnmen und Baumwurzeln, selten an Felsen.

S. PL. Adolfiström.

Pyrenäen, Zentral-Europa. I†alien, haukasus.

134. Paraleucobryum enerve (Therl.) Locsk. ]. c. [Dicrunum enerve Thed. in Hartm. Skand. Fl. 5. ed. 1) 393 (1819). - D. albicans Bryol. enr. fase. 13. suppl. tab. 1 (1850). - Campylopus albicans Kindb. Laubm. Schwed. und Norw. p. 86 (188:3).]

Dichtrasige, weisslichgrüne, abwärts mässig lilzige Pfl. Stengel aufrecht, 3-10. seltener bis $15 \mathrm{~cm}$. Blätter steif aufrecht bis wenig sichellörnig, trocken starr, aus länglich-eiförmigen Gruncle allmählich lang rinnig-pfriemenförmig, etwa $6 \mathrm{~mm}$ lang. nur an der stumplichen Spitze undeutlich gezähnelt; Rippe glatt, mit leeren Aussenschichten, fast die ganze Lamina ausfüllend: Zellen der Lamina eng linealiseh, an Blattgrunde in wenigen Reihen. Innere Perichätialblätter mit oben gestutztem un: groh gezähntem Scheidenteil. Seta 1,5-2 cm, geblich, später rötlich. Kapsel bräunlich. inn Alter glänzend und glatt: Zellen des Exotheciums rcktangulär, mit stark verdickten Längswändlen. Ring 3reihig, sich ablösend.

Auf dem $=$ trockenen Boden des Hochgebirges. meist in der alpinen Region.

F. Lim. T-chun und IIbinä. in der Nähe des schnees, an letzteren Fundorte auch spärlich fruchtend (Brollh.).

S. Jmt. an mehreren Fundorten und in allen Lappmarken.

N. Ve. Sætersdalen. St. Ryfỵlke. Frafjord, bis zum Meeresufer herabsteigend. SB. Sogn, Jorddalen. K. Galdh und Lomseggen und im Gebirge zw. Langen und Rohjem. NT. stjudalen. Meraker, Fondfjeld. Dorre. No. an mehreren Fundorlen bis $1,300 \mathrm{~m}$.

Europa, Kaukasis, Sikkim. Tord-Amerika.

\section{Interreihe LEUCOBRYINEAE.}

Weissliche oder weissgrünliche Pflanzen. Biäter clrei- bis melnschichtig, aus Hyalin- und Chlorophyllzellen gebildet.

\section{E U C O B R Y A C EA E.}

Ausclauernde, \pm kräftige. rasenbildende. weissliche oder bläulich-weissgrünliche Pfl. Stengel gabelteilig, dicht beblättert, olne Rhizoiden, ohne Zentralstrang 
und mit wenig diflerenzierten Mantelzellen. Blätter melnreihig, röhrig-holı. Rippe fast die ganze Blattbreite einnehmend, drei- bis mehrschichtig und aus dimorphen Zellen zusammengesetzt; Innenschicht einreihig, aus grünen, kleinen, schlauchförmigen, untereinander verbundenen Zellen gebildel (Chlorocysten): dorsale wie ventrale Zellen ein-mehrsehichtig, gross, leer, hexaedrisch bis kubisch, dïnnwandig, nit grossen, rundlichen, ron einem Ring ungebenen Perforationen (Leucoeysten). Lamina einschichtig, aus 2-10reihigen, leeren Zellen (Hyalocysten) gebildet. Seta verlängert, gerade, glatt. Kapsel ohne Spaltölfnungen und ohne Luftraum.

\section{LEUCOBRYUM}

Hamp. in Flora 1837, p. 282.

Blätter aus holılem, I schmal eiförmigem Grunde allmälılich lanzettlich. ganzrandig. Perichätialblätter differenziert. Kapsel geneigt, trocken stark gekrümmt, aus kropfigem, kurzen Halse länglich, mit 8, trocken rippenartig vortretenden Längsstreifen. Peristom wie hei Dicranum. Deckel aus kegelförmiger Basis pfriemenförmig. Haube aufgeblasen kappenförmig. glatt. Sporen klein.

135. Leucobryum glaucum (L.) Schimp. Coroll. p. 19 (1855). [Bryum glaucum L. Sp. pl. II. p. 1118 (1753).]

Diöziselı; ơ Pfl. schlank, mit sternförmig ausgebreiteten Schopfblätten oder Zwergnuännchen im Blattfilze. Kräftige Pfl. in meist sehr dichten, oft ausgedehnten, polsterförmigen Rasen, aus älteren Blätter mit bleichem Filz. Stengel bis $10 \mathrm{~cm}$, selten höher. Blätter aufrecht-abstehend bis sehwach einseitswendig, bis $8 \mathrm{~mm}$ lang; Hyalocysten an Gruncle bis sreihig, am Rande eng und gestreckt, ei-

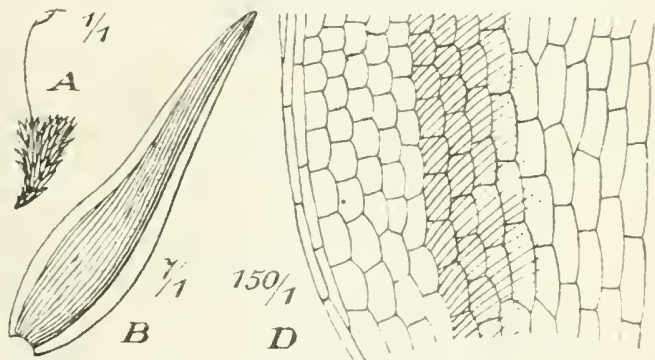
nen 3--treihigen Saum bildend,

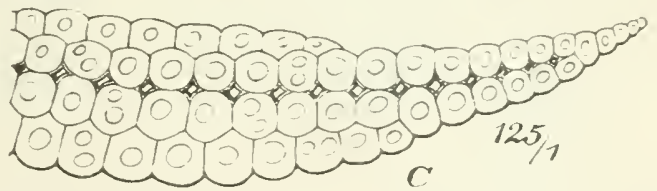

Fig. 22. Leucobryum glaucum A Fruchtende Pfl. (1 t): B Stamm]ı. ( 17 I); C Blattquerschnitt (125 1);

D) Blattbasis (1501). gegen die Spitze nur einreihig. Perichätialblïtler am Grunde selseidig, mit viel breiterer Lamina. Seta $1-1,5 \mathrm{~cm}$, rot. Kapsel rotbraun, glänzend. Fig. 22.

Auf feuchtem Torf- und Waldboden und auf Felsen. oft mit Sphagnum vergesellschaftet.

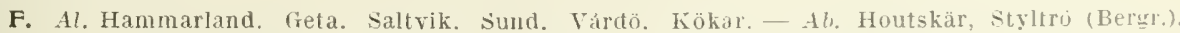
Korpo, Vatkas (Elfv.). Kakskerta, Kaivoinen (Collan.). Pargas, Gumnarsnäs (Elfv.); Bläsnäs (Pes.). Finby (Broth., Elfv.), Bromarf, nördl, von Norrstrand (Sundr.). - Y. Pojo, Lappvik (Elfr.). Ingit. Elisö (V. Brenn.); Höga bärget (Ranck..) Esbo, Kasberget und Marienslıy (Buch); Solbärga (Broth.). Helsingfors (A. H. Caj.). Hogland (Sael., Lindb.). - Ta. Hollola, Tirrisniaa (Norrl. und Sil.). - Kr Kymmene, Sunila (Kui.). Vehkalahti. Hylksaıri (Kruhn).

S. Sk. $-D l r$.

N. In den südlichen Amtern - allgemein verlreitet. nördlicher selten. steigl his stu In hinant. Nordgrenze bei $66^{\prime} \mathrm{l}^{\prime} \mathrm{n}$. Br.

Eurupa. Azoren, Kanaren. Madeira, Kaukasus, Japan. Jurd-Amerika. 


\section{Reihe POTTIA LES.}

Stengel meist aufrecht. Blätter mehrzeilig, einschichtig, mit Rippe; Zellen parenchymatisch, oft papillös. Sporogone meist gipfelständlig. Kapsel meist aufrecht und glatt. Peristom meist einfach: Dorsalschicht dicker als die Ventralschicht, meist papillös.

\section{P O T T I A C E A E.}

Meist kleine und mittelgrosse, selten kräftige, meist rasenbildende, seltener herdenweise wachsende Pfl. Stengel meist mit \%entralstrang, meist dicht beblättert, einfach his gabelig oder büschelig geteilt. Blätter mehrreihig, bald breit uncl von wechselnder Form, bald lanzettlich: Rippe meist kräftig und aus heterogenen Zellen gebildet, oft \pm lang austretend; Zellen oberwärts parenchymatisch, \pm chlorophyllreich und meist beiderseits warzig-papillös, am Blattgruncle oft rektangulär bis verlängert und durchscheinend bis wasserhell. Blüten mit fadenförmigen Paraphysen, c Blüten knospenförmig. Seta meist verlängert, glatt. Kapsel meist aufrecht und regelnü̈ssig, eilänglich bis zylindrisch, selten eiförmig odler kugelig, (excl. Cinclidoteue) mit oberflächlichen Spaltöffnungen am Kapselgrunde. Peristomzähne, wenn vorhanden. 16, einer niedrigen oder hohen Basilarmembran aufsitzend, bald kurz, längs durchbrochen oder oben 2--ispaltig, balı bis zur Basis in zwei fadenförmige aufrechte oder \pm gewundene Schenkel gespalten. Deckel meist kegelig geschnäbelt. Haube meist kappenförmigg.

Ĺbersicht der Lnterfamilien.

A. ${ }^{\top}$ und + Blüten auf achselständigen, am Grmnde wurzelnden Kurztrielen .................................... I. Pleuroweisioideae.

B. $f$ Blüten meist cladlogen. Kapsel olme Luftraum und ohne Spaltöffnungen ................................. III. Cinclidotoideae.

C. ₹lüten acrogen. Kapse] mit Luftramm nnd mit Spaltöffnungen.

a. Blätter meist schmal, oft lineal-lanzettlich: Zellen oberwärts klein

11. Trichostomoideae.

b. Blätter meisi breit, ei- bis spatelrörmig: Zellen oberwärts meist locker, unten verlängert his wasserhell ... W. Poltioideae.

\section{PLEUROWEISIOIDEAE.}

Diözisch; $\sim$ und - Blüten auf achselständigen, am Grunde wurzelnden Kurztrieben gipfelständig. mit knospenförmig zusammenschliessenden Hülbbättern;

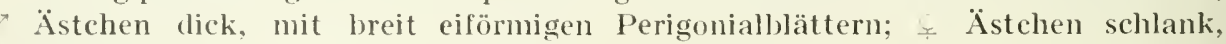
mit verlängerten inneren Perichätialblattern. Kapsel emporgehoben. Ring bleibend. Peristom fehlend. Deckel aus breiter basis sehr lang und schief geschnäbelt. Haule schmal kappenförmig.

\section{ANOECTANGIUM}

Schwaegr. Suppl. 1. T'. I. p. 33; emend. Bryol. eur. lasc. 29/30 (1816).

Mehr oder weniger schlanke Pll. in dichten. grünen bis gelbgrünen, weit hinauf wurzelhaarigen Rasen. Stengel dreikantig. Blätter ziemlich gleichgross, aufreclıtabstehend, gekielt, lineal-lanzcttlich, flach- und ganzrandig; Rippe mit basalen 
Deutern, meist mit oder vor der Blattspitze aulhörend und papillös; \%ellen klein, rundlich-c|uadratisch oder rundlich-6seitig, beiderseits dicht papillös, am I3latlgrunde rektangulär und glatt. Sporen klein.

136. Anoectangium compactum Schwaegr. Suppl. I. P. 1. p. 36, t. 11 (1811). [Gymnoslommm reslivim Hedw. Sp. musc. p. 32, t. 1I. (1801). - Plenrozygodon aestimus lindb. Musc. scand. p. 29 (1879).]

Sehr schlanke Pll. in sehr dichten, lebhaft grünen, innen rostbraunen Rasen. Stengel 2-7 cm. Blätter trocken anliegend und mit gedrehter Spitze cingekrümmt, spitz. bis 1,5 mm lang, fast mndurchsichtig. Seta $6-12 \mathrm{~mm}$, gelb. Kapsel länglich, dümnhäutig, lichtbraun, schwach glänzend: Zellen des lixotheciums dünnwandig, rektangulär. Sporen $1011 \mu$. brännlich, glatt.

An feuchten Schieferfelsen.

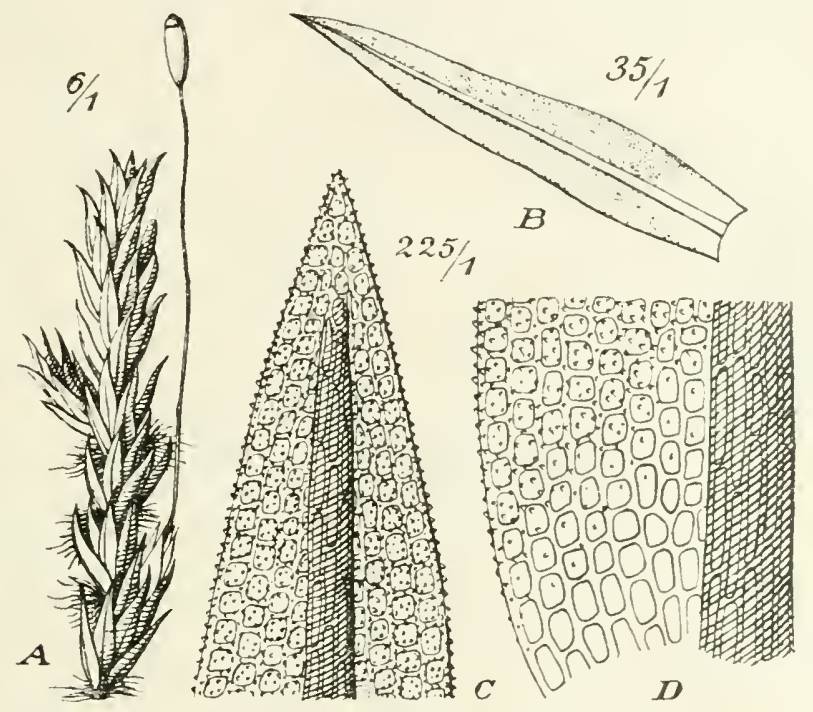

Fig. 22 bis. Anoectungium compactum Schwaegr. A Fruchtende Pfl. (6 1): B stengelb. 35 1); C Blattspitze (225 1); D Blattlasis (225/).

F. Le. Kilpisjärvi, Ma!la, Saana und saivovaara, in der alpinen Region (Kot.).

S Sm. an mehreren Fundorten. - Ög. Lemunda. Halbergel. - Hrjo. und Jmt. an einzelnen, LuL. und TI. an mehreren Fundorten.

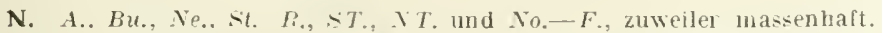

Europa, Kankasus, Kanaren. Jadeira, Kamerun, Cirönland, New Zealand.

\section{TRICHOSTOMOIDEAE.}

Blätter meist schmal, niemals in cler oberen Hälfte breiter; Rippe meist mit mehreren Dentern, ohme Begleiter und mit 2 Stereidenbändern; Zellen oberwärts klein.

$$
\text { ¿́leersicht der Gat } t \text { ung en. }
$$

A. Kapsel ohne oder mit differenz:ertem, bleibendem Deckel.

a. Kapsel fast kugelig, mit stumpf kegeligem Deckelchen. 37. Astomum.

b. Kapsel elliptisch, lang und schief geselinäbelt ......... Hymenost. rostellatum.

B. Deckel von selbst sich ablösend.

a. Blätter ganzrandig oder nur an der Spitze gezähnt. 
«. Peristum fehlend.

I. Urnenmündung nach der Enteleckelung durch ein Häutchen verschlossen

38. Hymenostomum.

II. Urnenmiindung durch die Entdeckelung geöfnet.

1. Deckel mit der anlüngenden Columella abfallend

2. Columella bei der Entdeckelung in der Urne zurückbleibend.

* Ring bleibend

** Ring sich abrollend

40. Gymnostomum.

41. Gyroweisia.

$\checkmark$ Peristom ausgebildet oder rudimentär.

1. Blätter oberlualb des weissglänzenden Basalteiles meist mit einigen Randzähnen

13. Eucladium.

I1. Blätter am Grunde ganzrandig.

1. Peristonzähne tief inseriert, ungeteilt. gegliedert, unregelmässig oder rudimentär

39. Weisia.

2. Peristom mit niedriger Grundhaut, an oder ein wenig unter der Lrnenmündung inseriert.

* Blätter mit aufrechten bis eingebogenen Rändern; Zellen am Blattgrunde verlängert rechteckig, gelblich oder hyalin.

$\uparrow$ Hyaline Zellen des Blattgrundes \pm weit hinauf als Randsaum fortgesetzt. Peristomzälnue bis zum Grunde in 2 fadenförmige, ein- oder mehrmal gewundene Schenkel gespalten

$\uparrow \uparrow$ Blätter ohne Randsaum. Peristomzähne aufrecht

** Blätter mit $\ddagger$ weit hinauf umgerollten Rändern.

$\uparrow$ Peristomzähne aufrecht

$\dagger+$ Peristomzähne steil nach rechts aufsteigend bis gewunden

b. Blätter mit bis unter die Mitte herab ungleich sägezähnigen Rändern.

«. Blätter scheidig: mehrere Randreihen des Scheidenteiles hyalin und fast linealisch, aufwärts als scharf begrenzter Randsaum sich verlierend ................

$\beta$. Blitter nicht scheidig; Randzellen am Blattgrunde nicht differenzicrt

46. Pleurochaete.

17. Leptodontium.

\section{ASTOMUM}

Hamp. in Flora $183 \overline{7}$, p. $28 . \overline{\text { p. p. }}$

Autözisch. Kleine Frdmoose in lockeren Räschen. Blätter schmal, kielighohl, ganzrandig; Rippe kräftig, glatt; \%ellen oberwärts klein, rundlich-quadratisch, beiderseits papillös, unten gestreckt-rektangulär und wasserlell. Seta sehr kurz. kiapsel eingesenkt. fast kugelig, mit meist rings umschrichenem, sehr kurzem. stumpf kegeligem. sich nicht ron sellsst ablösendem Deckelchen; Zellen des Exotheciums dünnwandig und rundlich-oder verlängert-melıreckig. Haube sehr klein. kegel-kappenförmig. 
137. Astomum crispum (Hedw.) Hamp. I. c. [Phascum crispum Hedw. Fund. musc. II. p. 85 (1782). - Systegium crispum Schimp. Syn. 1).3 (1860).]

Räschen grün oder gelbgrün. Stengel bis $5 \mathrm{~mm}$, oft büschelig geteilt. Untere Błätter sehr klein, obere viel grösser, schopfig gehäult, aus breit lanzettlicher, fast seheidiger Basis lanzettlich-linealisel, mit oberwärts eingebogenen Rändern, 2-3 mm lang; Rippe als Stachelspitze austretend. Deckel differenziert. Sporen 15-18, zuweilen bis $25 \mu$, braun, warzig. Sporenreife im Frülling. - lig. 2:3 A-lE.

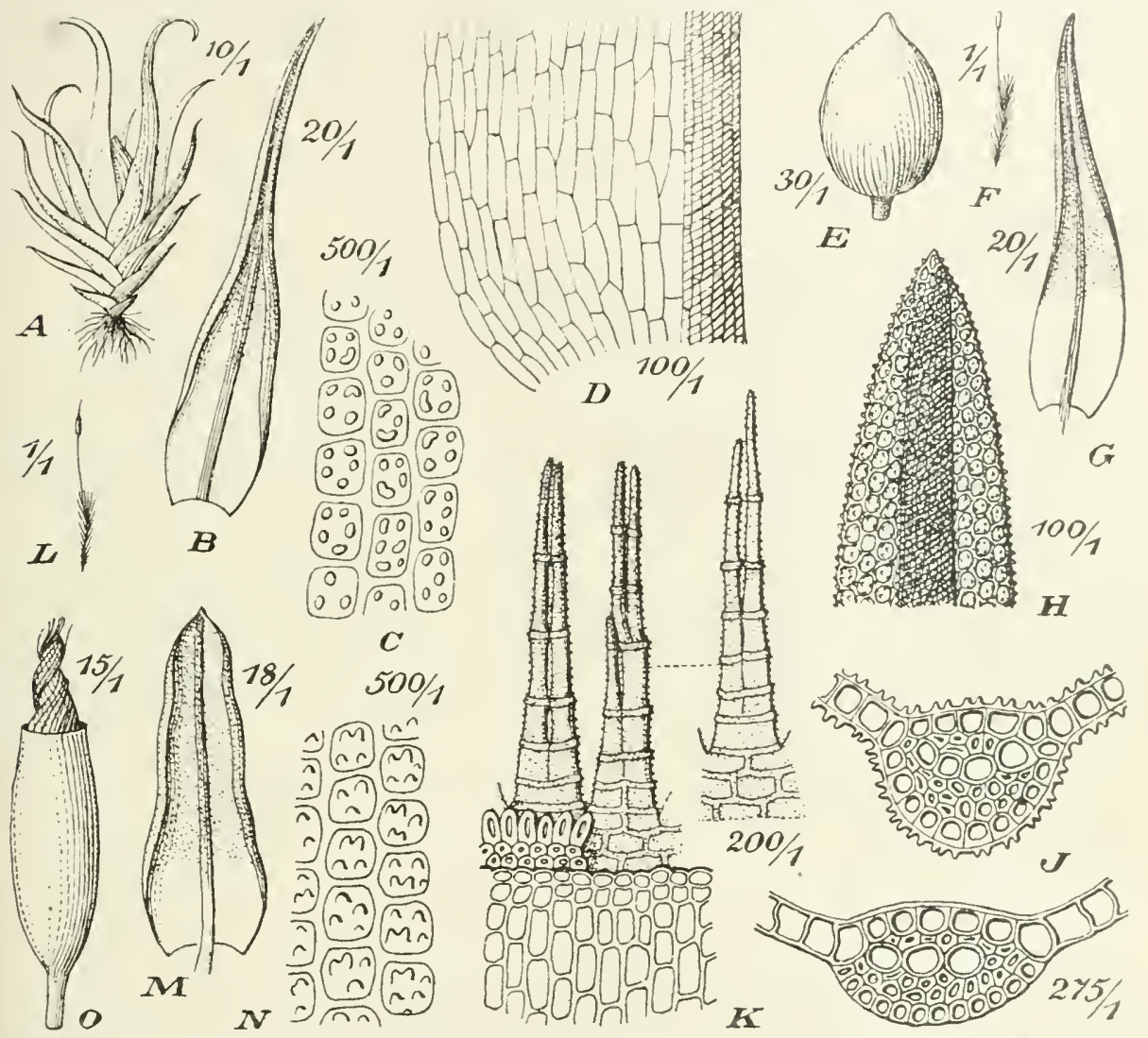

Fig. $23 \mathrm{~A}$-E. Astomum crispum (Hedw.) Hamp. A Fruchtende Pfl. (10/1); B Slammb. (20 1); C Blatt-

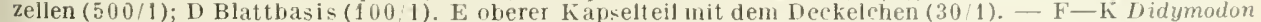
rubellus (Hoffm.) Bryol. eur. F Fruchlende Pfl. (1/1); f Stammb. (20 1); H Blattspilze (100 1); 1 Querschnitte durch die Blattrippe $(271 / 1)$; K Peristom $(2001)$. - I - O. Barbula unguiculata (Huds.) Hedw. L Fruchtende Pfl. (1/1); M Stammb. (18/1); N Zellen der Blattspitze (500 1); O Entdeckelte Kapsel (15/1). (G nach Li in p r c h t).

Auf etwas feuchten Brachfeldern, an Grabenrändern und auf Erdblössen der Wiesen, besonders an tonigen und mergelhaltigen Stellen.

F. Al. Saltvik, Ryssböle und Kvarnbo (Bom.).

S. Sk., Sm. und Upl, an mehreren, När., Vsm. und Gstr. an einzelnen Fundorten.

N. Kristiania.

Europa, Algier, Ägypten, Japan, Nord-Amerika.

\section{HYMENOSTOMUM}

R. Br. in Trans. Linn. Soc. XII. 2, p. 572 (1819).

Kleine, gesellige bis rasenbildende Pfl. Stengel cinfach oder gabel- bis büschelästig, am Grunde mit Rhizoiden. Obere Blätter grösser, schmal, trocken gekräu- 
selt, rimnig-hohl, ganzrandig; Rippe kräftig, als Stachelspitze austretend; Zellen oberwärts sehr klein, rundlich-quadratisch, beiderseits papillös, unten rektangulär, wasserhell oder durchscheinend. Perichätialblätter von den Schopfblätter wenig verschieden. Seta \pm verlängert, dünn, gelb. Kapsel aufrecht oder etwas geneigt, regelmässig oder gebuckelt, engmündig, trocken glatt. Ring nicht differenziert. Peristom fehlend. Urnenmündung nach der Entdeckelung durch ein von der verbreiterten Columella und der mehrsehichtigen Urnenwand gebildetes Häutchen versehlossen. Sporenaussaat durch eine später im Verschluss entstehende, kleine Öffnung. Deckel geschnäbelt. Haube kappenförmig, etwa die halbe Kapsel deckend.

\section{Übersieht der Arten.}

A. Sporogon zuletzt ausfallend. Deckel kaum von selbst sich ablösend

137. H. rostellatum.

B. Sporogon nicht alusfallend. Deckel sich ablösend.

a. Blätter feucht aufrecht-abstehend, mit oberwärts einge-

rollten Rändern. Deckel lang und schief geschnäbelt. 138. H.microstomum.

b. Blätter feucht fast sparrig-ahstehend, flachrandig.

Deekel kurz und gerade geschnäbelt ................ 139. H. squarrosum.

138. Hymenostomum rostellatum (13rid.) Schimp. Syn. 2 ed. p. 33 (1876). [Phascum rostellatum Brid. Mant. musc. p. 11 (1819). - Mollia rostellata Lindb. in Braithw. Brit. Mossfl. p. 233 (1885).]

Autözisch. Lockerrasige, schmutzig grüne Pfl. Stengel $1-2 \mathrm{~mm}$. Blätter aufrecht-abstehend, obere verlängert lineal-lanzettlich, bis $2,1 \mathrm{~mm}$ lang, mit aufrechten oder oben scliwach eingebogenen Rändern. Sporogone oft zu 2 in demselben Perichätium. Seta $0,5-1,5 \mathrm{~mm}$. Kapsel elliptisch, lang und schief geschnäbelt, olivengrün, später bräunlich, zuletzt nit der Seta abfallend; Zellen des Exotheciums rektangulär mit 6seitigen gemischt. Deckel durch eine Reihe kleinerer Zellen undeutlich gesondert, kaum von selbst sich ablösend. Sporen 17-22 ". gelbbräunlich, feinwarzig.

An feuchten Gräben, auf Erdblössen der Wiesen und auf grasigem Waldboden, besonders an tonigen Stellen.

S. $\quad U p l$. Knifsta.

N. sm. Glemming? und Onsn.

Zentral- und Wesi-Europa.

139. Hymenostomum microstomum (Hedw.) R. Br. l. c. [Gymnostomum microstomum Hedw. Descr. III. p. 71, t. 30 B (1792). - Nollia microstoma Lindb. Muse. scand. p. 22 (1879).]

Autözisch. Gesellige oder rasenbildende, grüne Pfl. Stengel 1-3, selten bis $5 \mathrm{~mm}$. Blätter aufrecht-abstehend, schmal lineal-lanzettlich, bis 1,86 $\mathrm{mm}$ lang, in der oberen lfälfte mit \pm stark eingerollten Rändern. Seta bis 3, selten bis $5 \mathrm{~mm}$. Kapsel eiförmig, elliptisch oder länglich-eiförmig, sehr engmündig, bräunlich; Zellen des Exotheciums unregelmässig, meist rundlich-6seitig. Deckel sich ablösend, lang und sehief geschnäbelt. Sporen 20-25, selten bis 28 ", dunkelbraun, warzig. Sporenreife im Frübling.

Auf Brachfeldern, Erdblössen, an Grabenrändern und an Waldwegen.

F. Al. Jomala, Mariehamn und Finström an einzelnen oder wenigen, Saltvik an mehreren Fundorten (Bom.). - A $b$. Lojo, Skratila und I.ylyis (E. af H.).

S. sk. -Gstr.

N. JL. Tjom". - NT. Stjordalen.

Europa, Algier, Tunis, Kaukasus.

1.10. Hymenostomum squarrosum Bryol. germ. I. p. 193, t. 12, f. 1 (1823). [Mollia sillarrosa lindb. Musc. scand. p. 22 (1879).] 
Autözisch und synözisch. Gesellige, grüne oder gelbgrüne P’fl. Stengel 3 $6 \mathrm{~mm}$. Blätter fast sparrig-abstehend, aus verbreiterter, fast scheidiger Basis verlängert schmal lineal-lanzettlich, bis $1,6 \mathrm{~mm}$ lang, mit aufrechten oder oben schwach eingebogenen Rändern. Seta bis $3 \mathrm{~mm}$, selten höher. Kapsel elliptisch bis länglichelliptisch, olivengrün, später bräunlich; Zellen des Exotheciums unregelmässig, meist länglich 4-6eckig. Deckel sich ablösend, kurz und gerade geschnäbelt. Sporen 15-25 $\mu$, braun und warzig. Sporenreife inı Frühjahr.

Auf feuchten Brachfeldern, in Ausstichen und an Grabenrändern, besonders auf sandig-tonigem Boden.

F. Al. Saltvik, Fremmanby und Hullby (Bom.).

S. Öl. Vickleby allvar. - Ög. Häradstorp.

N. Sm. Glemminge und Onsø.

Dänemark, England, Zentral- und West-Europa.

\section{WEISIA}

Hedw. Fund. muse. II. p. 79 (1782).

Kleine, rasenbildende Erdmoose. Tracht von Hymenostomum. Stengel einfach oder gabel- bis büschelästig. Obere Blätter grösser, schmal, feucht weit aufrecht-abstehend und verbogen, trocken gekräuselt, rinnig-hohl, ganzrandig; Rippe kräftig, als Stachelspitze austretend; Zellen oberwärts sehr klein, rundlich-quadratisch, beiderseits papillös, unten rektangulär und wasserhell. Perichätialblätter wenig verschieden. Seta \pm verlängert, dünn, gelblich. Kapsel aufrecht oder etwas geneigt, regelmässig oder schwach gebuckelt, eiförmig bis zylindrisch, trocken und entleert meist schwach längsfaltig; Zellen des Exotheciums dünnwandig, unregelmässig, rektangulär und mehreckig. Ring bleibend. Periston tief inseriert; Zähne papillös, unregelmässig, kurz und oft ruclimentär. Deckel lang und schief geschnäbelt. Haube kappen!örmig, etwa die halbe kapsel deckend.

Übersicht der $\mathrm{Arten}$.

A. Blätter mit oberwärts eingebogenen bis eingerollten Rändern.

a. Polyöziseh 142. W. Wimmeriana

b. Autözisch.

«. Blätter eilanzettlich, kurz zugespitzt, mit spiralig eingerollten Rändern .............................. 140. W. crispala.

$\beta$. Blätter aus breiterem Grunde schmal lineal-lanzettlich, mit eingebogenen Rändern .................. 141. W. viridula. B. Blätter mit aufrechten Rändern ........................ 143. W. rutilans.

141. Weisia crispata (Bryol. germ.) Jur. Laubm. Oesterr.-Ung. p. 11 (1882). [Hymenostomum crispatum Bryol. germ. I. p. 201, t. 12, f. 7 (1823). - Weisia gymnosiomoides Brid. Bryol. univ. I. p. 342 (1826). - Mollia viridula var. gymnostomoides Lindlb. Muse. seand. p. 21 (1879).]

Autözisch. Grüne, dichtrasige Pfl. Stengel bis $1 \mathrm{~cm}$. Blätter derb, trocken hakig eingekrümmt, verlängert eilanzettlich, kurz zugespitzt, bis 1,35 mm lang, oberwärts bis zur in Alter bramen Rippe spiralig eingerollten Rändern. Seta meist $2-3 \mathrm{~mm}$. Kapsel meist länglich-eiförmig oder elliptisch, oft geneigt und gebuckelt, sehr engmündig, meist glatt, bräunlich. Peristom rudimentär; Zähne bleich, stumpf, den Urnenrand nur wenig überragend. Sporen 15-17 ", braunrötlich, feinwarzig. Sporenreife im Frühling.

In Ritzen, besonders sonniger Kalkfelsen, auf Kalkschutt und kalkhaltigem Boden. 


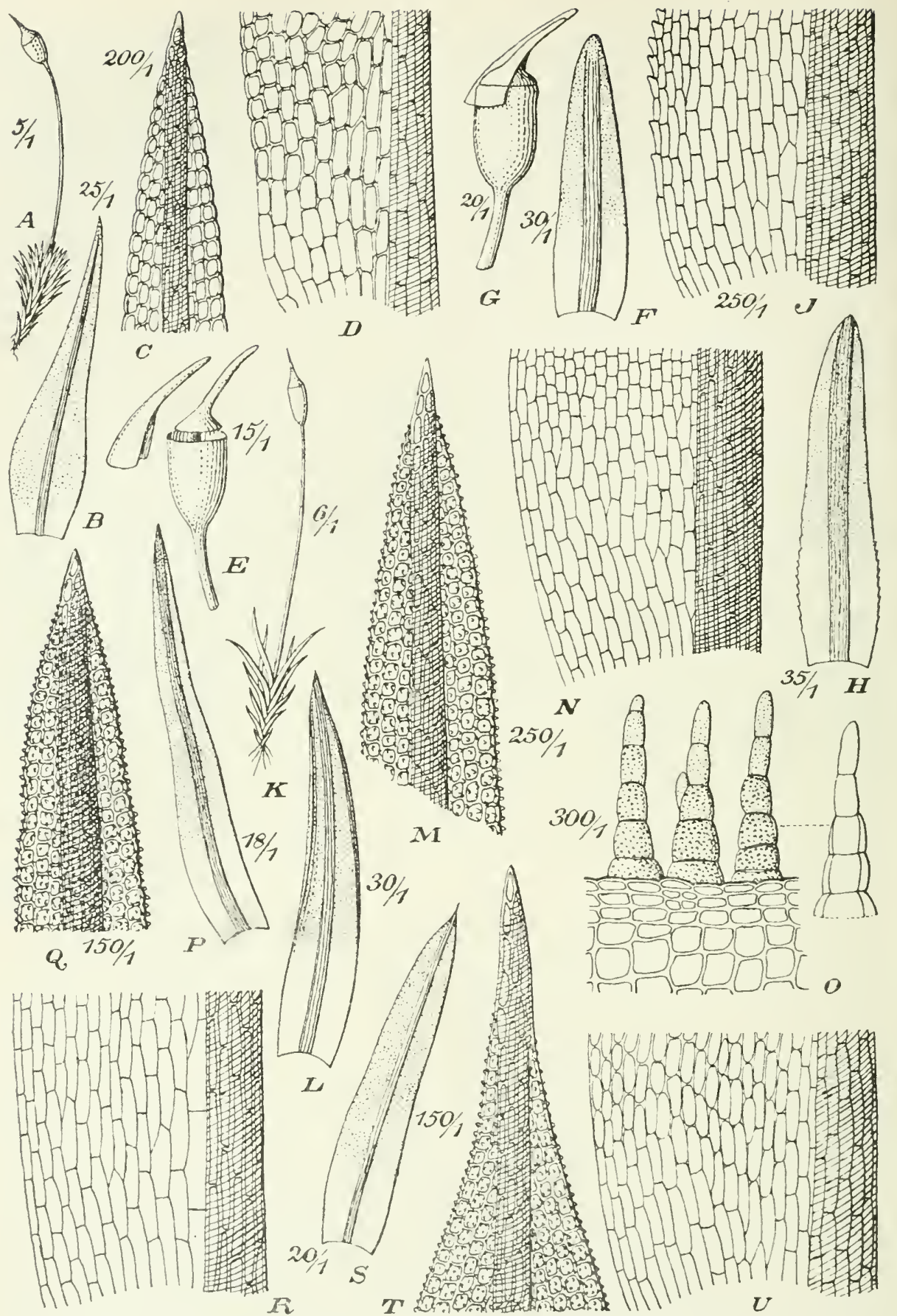

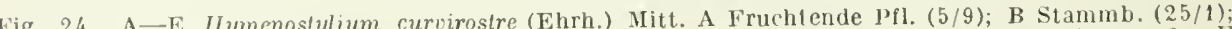
C Blattspitze (200/1). D Blatthasis $(200 / 1)$; E Kapsel $(20 / 1)$. - F-G Gunnostomum aeruginosum sul $\mathrm{F}$ S - Eucladium verticillatum (L); Bryol, eur. H Stammb ((35/1); Stammb. (30/1); G Kaps 1 Blattas A Blattspitze (250/2); (Bruch) brachydontium Bruch S Stammh. (20/1); T Blattspitie (150/1); U Blattbasis (150/1). 
F. Al, Finström, Bartsgårda (Bom.), Saltvik, an einigen funturten (B.).

N. Sm. Onso. - Br. Telemarken. - LM. Kristiansand. - it. Jaederen. N T. Stjurdalen.

Europa, Faukasus, Klein-Asien, Nord-Amerika.

142. Weisia viridula (L.) Hedw. Fund. Musc. II. p. 90 (1781). [Bryum viridulum L. Sp. pl. II. 1119 (1753). - Mollia viridula Lindb. Musc. seand. p. 21 (1879).]

Autözisch. Freudig grüne Pfl. in lockeren oder dichten Rasen. Stengel meist bis $5 \mathrm{~mm}$, seltener höher. Blätter aus breiterer Basis lineal-lanzettlich, bis 2 mn lang, mit oberwärts eingebogenen Rändern. Seta $3-7 \mathrm{~mm}$. Kapsel länglich-oval bis fast zylindriseh, licht- bis rötlichbraul. Peristomzälne lanzettlich, stumpl, gelbrot, mit deutlichen Querleisten. Sporen $12-18$ ", braun, warzig. Sporenreife im Frühling. - Fig. 21 K-O. stichen.

Auf nackter, feuchter Erde an Wald- und Wegrändern, in Gräben und Aus-

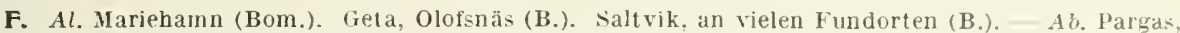
Björkö (Elfv.). Lojo, Holmarsjön. - N. Helsinge (Roiv.). - Ta. Asikkala, zw. Kalkkis und Rauvola (Norrl.). - Sb. Kaavi, Ninivaara, Lauttamäki u. Louhilammenkalliot (Kot.); Losomãki (K.). Kh. Juuka, Nunnanlahti (Kot.); Sola, Koposenvaara (K.); Saarijärvi, Mölö. Porttikallio coln. (K.).- ()k. Kuhmoniemi, Vieksi, Näätäniemi, Kellojärvi (Ky

S. Sk.-Gstr. und Dlr.-Jmt. Frösön. dalen.

N. $S m . \pm$ fq. A. fq. Bu. Ringerike. JL. Tjoma und Sandefjord, st. Jaderen. NT. Nedre sij. l-

In den meisten Teilen der gemässigten Zone verbreitet.

143. Weisia Wimmeriana (Sendtn.) Bryol. eur. l'ase. 33/36. Mon. p. 4, t. 1 (1846). [Gymnostomum Wimmerianum Sendtn. in Flora 1840, I. p. 50. - Mollia Wimmeri Lindb. Muse. scand. p. 21 (1879).]

Meist paröziselı, oft rein ơ und rein f Innovationen, seltener rein $₹$ Pll. Grüne Pfl. in lockeren oder dichten Rasen. Stengel meist bis $5 \mathrm{~mm}$. Blätter aus breiterer Basis lineal-lanzettlich, bis $2,4 \mathrm{~mm}$ lang, mit oberwärts stark eingebogenen Rändern. Seta 3-5 mm lang. Kapsel oval oter länglich, bräunlich. Peristomzähne sehr kurz, gestutzt, oft rudimentïr, selten fehlent. Siporen 17-20 ", braun, grosswarzig.

N. No. an wenigen Fundorten.

Pyrenäen, Zentral-Europa, Kaukasus, Kaschmir.

14. Weisia rutilans (Hedw.) Lindb. Bidr. moss. syn. No.65(1863). [Gymnosiomum rutilans Hedw. in litt.: Stark. in Schral. Journ. 1799, p. 217. - Weisia mucronata Bruch (in sehed. 1825): Bryol. eur. fasc. 33/36 Non. p. 7, t. I (1846). Mollia rutilans Lindb. in Braithw. Brit. Mossfl. p. 238 (1885)].

Autöziseh. Grüne Pfl. in ziemlich dichten Rasen. Stengel bis $5 \mathrm{~mm}$. 13lätter kürzer und breiter als bei $I^{\prime}$. viridula, mit aufrechten orler olserwärts schwach eingebogenen Rändern; Rippe als längere Stachelspitze austretend. Seta bis $5 \mathrm{~mm}$. Kapsel elliptisch oder länglich, rötlich, trocken kaum gefurcht. Peristomzähne gelb, unregelmässig gespalten oder durchbrochen, selten rudimentär. Sporen $20-26 \mu$, rötlichbraun, ziemlich grosswarzig.

N. sm. Gleminge u. Onso.

Eurnpa, Algier, Alessinien.

\section{GYMNOSTOMUM}

Hedw. Fund. Il. p. 87 (1787).

Diözisch; $0^{\star}$ Pfl. schlanker. Schlanke, dichtrasige, unten rostlarbenc Felsmoose. Stengel rund, mit armzelligem Zentralstrang, mässig nit Rhizoiden besetzt, wiederholt gabelig geteilt. Blätter trocken eingekrümmt uder verbogen anliegend, kielig-hohl, lanzettlich-linealisch bis schmal linealiseh, flach- und ganzrandig; Rippe mit oder vor der Blattspitze aulhörend, papillös; Zellen oberwärts klein, rundlich-quadratisch. beiderseits papillös, unten rektangulär, gelbwandig. 
Seta dünn, strohgelb. Kapsel oval oder länglich, lichtbrann, trocken glänzend und glatt; Zellen des Exotheciums rektangulär. Ring bleibend. Peristom felılend. Deckel schief geschnäbelt.

\section{$\mathrm{C}^{*}$ bersicht de $\mathrm{r}$ A r ten.}

A. Blätter lanzettlich-lincalisch: Rippe kräftig 145. G. aeruginosum. B. Blätter schmal linealisch; Rippe zart 146. G. calcareum.

145. Gymnostomum aeruginosum Sm. Fl. brit. 11I. p. 1163 (1801). [F. rupestre Schleich. Cat. p. 29 (1807). - - Trichoslomum aeruginosum Lindb. de Tort. p. 229 (1S6-1). - Mollia aeruginosa lindb. Musc. scand. p. 21 (1879).]

Rasen 1-3 cm, selten höher, oberwärts meist bräunlichgrün. Blätter feucht aufrecht-abstehend bis wenig zurückgebogen, lanzettlich-linealisch, kurz zugespitzt oder stumpflich, bis $1,5 \mathrm{~mm}$ lang; Rippe kräftig, mit oder vor der Blattspitze aufhörend. Perichätialblätter wenig verschieden. Seta $4-8 \mathrm{~mm}$. Sporen 10--14 " , gelb, gekörnelt. Sporenreife im Sommer. Fig. 24 F-G.

Auf Feisen, Kalk und kalkhaltige Gesteine bevorzugend.

F. Al. Sund und Sallvik, an einzelnen Fundorten (Bom.). - 1b. Lojo, Isosaari, Pietilä (Lindb.). Kl. Soltavala, Paksuniemi (Buch): Kirjaralalıti (Norrl.). Impilalti, Pullinvori (Broth.). Ruskeala (Lindł.). Pälkjärvi. Korkianiemi (Broth.). - હb. Kaavi, Siliajärvi. Huosiaisniemi (Kot.): Niinivaara (K.). Nikia, Kuuslahti. Jaakonlampi (Kot.). - Kb. Juuki. Sadrijärvi. Porttikallio (K.). - Kon. Valkeamäki, Tiudie (Norrl.). - K. Kuusamo. Kitkajuki, Jỵära (Broth.). Oulankajuki, Merenoja (B.); Oulankajoki, Kiutaköngäs (E. af H.): Purkuputaanköngä-(Roiv.): Paanajärvi. Kiekkivaara (Broth.). Le. Kilpisjärvi, Malla und Saana in der alpinen Region st. fq. (Kol.). - Li. Ltsjoki, Outakoski. Soavjebakte (Ranck.).

S. sm. an mehreren. Gll., Ög., Ig., Boh. Lld.. Ism., Llr., M.⿲., fmt., Il. und LuJ.. an einzelnen oder wenigen Fundorten.

N. sm.-F. Nordqrenze bei $70^{\circ} \mathrm{ll}, \mathrm{Br}$.

Europa. Kaukasus, Kanaren. Nord-Amerika.

146. Gymnostomum calcareum Brỵol. gerın. I. p. 153, t. 10, f. 15 (182:3). [Mollia calcarea Lindb. in Braithw. Brit. Mossfl. I. p. 239 (1885).]

Weit kleiner und zarter als dic vorige Art, in breiten und schredichten. oberwärts lebhaft grüneı Rasen. Stengel 1 mm bis $3 \mathrm{~cm}$. Blätter feucht zurückgebogen, obere schmal linealisch, stumpf oder kurz zugespitzt, bis $0,8 \mathrm{~mm}$ lang: Rippe viel schmäler als bei der vorigen Art, vor der Blattspitze aufhörend. Perichätialblätter mit fast scheidiger Busis. Seta $3-5 \mathrm{~mm}$. Sporen $8-10$ ", gelb, glatt.

Auf Kalk und kalkhaltigen Felsen.

F. Sb. Kaavi, Siikajärvi. Huosiaisniemi, auf Kalkdetritus (Roir.).

S. Gll.

Europa, Azoren, Nord-Afrika, liaukasus, Vorder-Asien, Himalaya, Sibirien, Noril-Anerika, Ecuador, Chile, Ost-Australien, Tasmanien, New Zealand.

\section{GYROWEISIA}

Sclimip. Syn. 2. ed. p. 38 (1876).

Diözisch. Kleine Felsmoose. Stengel rund, ohne Zentralstrang, nur an Grunde mit Rhizoiden, cinfach oder mit schlanken Innovationen. Blätter trocken verbogen, feucht \pm zurückgebogen, lineal-zungenförmig, mit meist abgerundeter Spitze, flach- und ganzrandig; Rippe schmal, homogen, vor der Blattspitze aufhörend; Zellen oberwärts klein, quadratisch, schwach papillös bis glatt. Perichätialblätter in der unteren Hälfte scheidig. Seta dünn, gelb. Kapsel länglich bis zylindrisch, bleich- bis lichtbräunlich; Zelleı des Exotheciums unregelmässig. Iänglich. Ring breit, vollständig oder stüekweise sich abrollend. Peristom rudineutär oder fehIend. Deckel kegelig oder aus kegeliger Basis gespitzt. 
1.17. Gyroweisia tenuis (Schrad.) Schimp. 1. c. [Gymnostomum tenue Schrad. Samml. I. No. 31 (1796). - Mollia tenuis Lindb. Musc. scand. p. 21 (1879).]

Weit- und \pm dichtrasige, grüne Pll. Stengel wenige mm, mit bis 5 mm langen Innovationen. Blätter meist mit abgerundeter Spitze, selten zugespitzt, bis $1 \mathrm{~mm}$ lang. Seta bis $7 \mathrm{~mm}$. Kapsel zuweilen etwas gekrimmt, dünnhäutig. Peristom fehlend. Sporen meist 8-10 " , gelb und glatt, selten bis 14 " und schwach gekörnelt.

S. Sk., $\partial t$. und Gtl. an einzelnen Fundurten.

Zentral-Europa. Gross-Britannien, Tunis, Nord-Amerika.

var. compacta Hag. Musc. Norr. bor. p. 3 (1901). Pf]. in sehr dichten u. reichlich verfilzten Rasen. St. etwa $1 \mathrm{~cm}$, reichlich verzweigt. - Vegetative Vermehrung durch im Rhizoidenfilze versteckte, keulenförmige, gestielte, braune Brutkörper.

N. No. Sialtdalen. Junkerdal*uren, lu!l m.

Thüringen.

\section{HYMENOSTYLIUM}

Bricl. Bryol. univ. II. p. 81 (1827) emend. Lindb. Trichost. p. 2:30 (1861).

Diözisch. Schlanke, dichtrasige Felsmonse. Stengel dreikantig, ohne Zentralstrang, mässig mit Rhizoiden besetzt, wiederliolt gabelig geteilt. Blätter kielighohl, lanzettlich, ganzrandig. Perichätialblätter wenig differenziert, am Grunde etwas scheidig. Seta verlängert, dünn. Kapsel meist verkehrt-eiförmig, trocken und entdeckelt weitmündig, glatt und glänzend: Zellen des Exotheciums parenchymatisch, unregelmässig. Ring nicht differenziert. Peristom fehlend. Deckel sehr lang und schief pfriemenförmig geschnäbelt, durch die sich streckende Columella wie ein Dach über die Urnemmündung und erst spät mit derselben abfallend. Sporen klein.

14. Hymenostylium curvirostre (Ehrh.) Lindb. 1. c. [Pottia curvirostris Ehrh. Beitr. I. p. 188 (1787). - Gymnostomum curvirostre Hedw. Descr. 1I. p. 68, t. 24 (1789). - Barbula curvirostris Lindb. Musc. scand. p. 22 (1879).]

Grüne oder gelbgrüne, abwärts bräunliche Pfl. in schwellenden, oft ausgedelınten Rasen. Stengel bis $12 \mathrm{~cm}$. Blätter trocken angedrückt, mit eingebogener Spitze, feucht aufrecht-abstehend, verlängert lanzettlich und lang zugespitzt, bis 1,3 mm lang, mit oft an einer Seite etwas zurückgebogenen Rändern: Rippe meist vor der Blattspitze aufhörend; Zellen dickwandig, oben rektangulär und rhomboidisch, mit einzelnen quadratischen und dreieckigen gemischt, glatt bis \pm papillös. Seta bis 1 cm, gelb, unten rötlich. Sporenreife im Sommer. - Fig. 24 A-E.

Auf Kalkfelsen und kalkhaltigen Gesteinen, massenhaft auf Tuff.

F. Al. Eckerö, Storby (Arrh.). - Sb. Kaavi, Niiniraara, Louhilampi (Kot.); Siikajärvi, Huosiaisnieni (K.). - K. Kuusamo, Kitkajoki, Pääsköskallio und Jyrãvā (Broth.); Oulankajoki, Merenoja (B.); Taivalköngäs und Kiutaköngās (Roiv.); Paanajärvi, Kiekkivaara (B.); Sovajoki, Kulmakkapuro (E. af H.). - Le. Kilpisjārvi, Malla und Saana (Kot.). - Lr. Tschapoma (Broth.).

S. Öl., Glt., Og., Boh., Dlr. an einzelnen, Jmt. an mehreren Fundorten. - LuL. Sarekgebiet.

N. sm. - F.. in den westl. Teilen sehr selten.

Spitzbergen, Europa, Algier, Kaukasus, Himalaya, Japan, Nord-Anerika.

var. commutatum (Mitt.) Hag. Musc. Norv. bor. p. 2 (1899). [H. commuta-

tum Mitt. Muse. Ind. or. p. 32 (1859)].

Blätter länger und schmäler; alle Zellen gestreckt, glatt.

F. Gtl.

N. Tr. Ibbestad.

England, Schweiz, Himalaya. Nord-Amerika.

var. scabrum Lindb. Musc. scand. p. 22 (1879). 
Stengel durch Papillen \pm rauh. Blätter kürzer und breiter, feucht zurückgekrümmt; Zellen oberwärts rundlich-quadratiseh, oft mit kurz rektangulären und quer rektangulären gemischt, beiderseits wie die Rippe mit zahlreichen Papillen.

F. Lu. Kilpisjärvi, Malla, in der alpinen Region (Kot.).

S. und $\mathbf{N}$. ohne Fundortsangaben.

Europa, Nord-Amerika.

\section{EUCLADIUM}

Bryol. eur. fasc. 33/36 (1846).

Diözisch. Schlanke Pfl. in dichten, meist von Kalktuff durchsetzten, oberwärts bläulichgrünen Rasen. Stengel aufrecht, $1-1 \mathrm{~cm}$, selten höher, olıne Zentralstrang, längs stellenweise mit \pm dicht gestellten Rhizoiden, brüchig, wiederholt gabelteilig bis büschelästig. Blätter trocken mit eingebogenen Spitzen oder gekräuselt, feucht aufrecht-abstehend, kielig-hohl, schmal lineal-lanzettlich, bis 2,6 $\mathrm{mm}$ lang, flachrandig, nur oberhalb des wasserhellen Blattgrundes mit einigen Randzähnen; Rippe kräftig, vollständig bis kurz austretend: Zellen oberwärts klein, quadratisch und kurz rektangulär, beiderseits papillös, am Blattgrunde verlängert-rektangulär, zartwanäig und wasserhell. Perichätialblätter kaum differenziert. Seta 1-2 cm, dünn, bleichgelb, später rötlich. Kapsel aufrecht, länglich bis zylindrisch, gelbbräunlich, glatt; Zellen des Exotheciums weitlichtig, ruudlich-melıreckig und verlängert rektangulär. Ring bleibend. Peristomzähne gelbrot, papillös schräg ansteigend, durchbrochen und durchlöchert oder bis gegen die Mitte unregelmässig 2 -3spaltig, mit sehr flachen, schiefen Querleisten. Sporen $10-14 \mu$, gelb, glatt. Deckel sehief pfriemenförmig geschnäbelt. Sporenreife in Sommer. - Fig. $21 \mathrm{H}-\mathrm{I}$.

Einzige Art:

149. Eucladium verticillatum (L.) Bryol. eur. fasc. 33/36, Monogr. p. 3, t. 1 (1846). [Bryum verticillatum L. Sp. ]). II. 1120 (1753). Mollia verticillata Lindb. Muse. scand. p. 21 (1879).]

An triefenden, 'Tuff bildenden Kalkfelsen und an nassen, stark kalkhaltigen Gesteinen.

S. Gtl., Öl. und $\ddot{g}$. an wenigen Fundorten.

Europa, Kanaren. Uadeira, Ugier. Tunis, Jugulen. Vurder-Asien. Kankasus. Kaschmir. Clima. Nord-Amerika.

\section{H. TRICHOSTOMUM}

Hedw. Fund. musc. II. p. 90 (1782).

Schlanke bis zicmlich kräftige Pfl. in meist dichten Rasen. Stengel aufrecht unten mit Rhizoiden, meist gabelig geteilt. Blätter trocken gekräuselt, obere grösser, meist lang und schmal, mit aufrechten oder cingebogenen, unversehrten Rändern; Rippe kräftig. vollständig bis kurz austretend, am Rücken glatt: Zellen oben klein und rundlich-c|uadratisch, beiderseits papillös, abwärts rektangulär und verlängert. Perichätialblätter wenig differenziert. Seta verlängert, dünn. Kapsel aufrecht, selten etwas geneigt, regelmässig, meist länglich-zylindrisch; Zellen des Exotheciums rektangulär. Peristom mit niedriger Basilarmembran: Zähne meist aufrecht uncl papillös, in der Nitte durchbrochen oder in 2 fadenförmige, freie oder durch Querleisten verbundene Schenkel gespalten, zuweilen rudimentär. Deckel kegelförmig und geschnäbelt: 7ellen oft steil nach rechts aufsteigend. Haube kappenförmig. 
Übersicht der Arten.

A. Blattbasis gelblich, mit mässig verdickten, rektangulären Zellen.

a. Blätter aus breiterem Grunde lanzettlich, zugespitzt. a. Blätter oberwärts rinnig oder nit eingebogenen Rändern und an der Spitze fast kappenförmig... 150. T. crispulum.

ß. Blätter obcrwärts flach oder mit aufrechten Rändern und an der Spitze nicht kappenförmig ....... 151. T. brachydontium.

b. Blätter länglich-zungenförmig, stumpf und flach ... 152. T. litorale. B. Blattbasis hyalin, mit \pm verlängerten Zellen ......... 149. T. cylindricum.

Un te rgat t. I. Oxystegus Lindb. de Tort. p. 213 (1864).

Zentralstrang armzellig, oft fehlend. Peristomzähne tief inseriert, ohne Basilarmembran, meist ungeteilt.

150. Trichostomum cylindricum (Bruch) C. Müll. Syn. I. p. 586 (1849). [Weisia cylindrica Bruch Mscr.; Brid. Bryol. univ. I. p. 806 (1826). - Weisia tenuirostris Hook. et Tayl. Musc. brit. 2. ed. p. 83, Suppl. t. 3 (1827). Didymodon cylindricus Bryol. eur. fasc. 29/30 Mon. p. 5, t. 5 (1816). - Mollia tenuirostris Lindb. Musc. seand. p. 21 (1879).]

Diözisch. Ziemlich schlanke, locker- bis dichtrasige, weiche, gelb- oder dunkelgrüne Pfl. Stengel bis 2, zuweilen bis $3-4 \mathrm{~cm}$. Schopfblätter rasch grösser. aus aufrechter, weisslicher Basis geschlängelt-abstehend, kielig-hohl, trocken sehr brüchig, schmal lanzettlich-linealisch, zugespitzt, bis $4 \mathrm{~mm}$, selten länger, mit flachen, schwach welligen, fein kerbigen, zuweilen an der Spitze spärlich gezähnten Rändern; Zellen am Blattgrunde verlängert-rektangulär, wasserhell, ohne Randsaun. Seta 1-1,5 em, gelb, unten rötlieh. Kapsel sclımal zylindrisch, hellbraun. trocken und entleert längsfurchig. Ring in einzelnen Zcllen sich ablösend. Peristomzähne aus breitem, gegenseitig verschmelzendem Grunde rasch schmal linealisch, ungeteilt und in der Mitte durchbrochen oder unregelnässig gespalten. fein papillös oder glatt. Sporen $10-14 \mu$, olivengrün, fast glatt. - Vegetative Vermehrung durch Bruchblätter. - Fig. $24 \mathrm{P}-\mathrm{R}$.

Auf feuchtem, schattigem Kieselgestein, gern an Steinen im Laubwalde. In Fennoskandia bisher nur steril.

F. Ab. Lojo, IIolmarsjön (Lindb.). - N. Sjundeá, svidja (Buch). Helsinge, Gammelstaden (Kuj.). Elimäki, llustila (Buch). Hogland (Lindb.). - Ka. Wibore, Mustajärvi (Buch). - Ik. Pyhajärvi. Polvalniemi (H. Lindb.). - Ta. Asikkala (Norrl.); Kopso (Häyr.). Hartola (Boned.). - Sa. Willmanstrand. Lauritsala. Huhtmarinvuori und am Wege nach Hanhijäri (Buch). Lappee, Rasala (B.). Nuijamaa. Pohjola (Brotb.). - Kl. Sortavala. Kirjavalahti (Lindb.). - Sb. Kaavi, Siikajärvi, Likolahti (Kont.) Maaninka. Korkeakoski (Roir.)

S. $S k$. und $S m$. an melireren, Boh. und $\boldsymbol{L}$ ld, an einzelnen Fundorten.

N. Sm., A., JL., St., R., $h$. und. .. an einzelnen oder wenigen Fundorten.

Europa, Nurd-Indien, Nord-Amerika.

Un terga t t. I I. Trichostomum sens. strict. Limpr. Laubn. I. p. 571 (1888).

Zentralstrang vielzellig und gut begrenzt. Periston mit niedriger Basilarmembran; Zähne meist fadenförmig 2schenklig.

151. Trichostomum crispulum Bruch in Flora 1829, P. II. p. 395, t. 1, f. 1. [Mollia crispula Lindb. Muse. scand. p. 21 (1879).]

Diözisch. Schlanke Pfl. in dichten, meist breit kissenförnigen, gelblich- bis bräunlichgrünen Rasen. Stengel bis $3 \mathrm{~cm}$. Blätter feucht aulreeht-abstehend. lanzettlich-linealisch, bis $3 \mathrm{~mm}$ lang, oberwärts rinnig-hohl oder mit eingebogenen Rändern und an der leicht eingekrümmten Spitze fast kappenförmig: Zellen am Blattgrunde verlängert-rektangulär, gelb und diekwandig. äussere oft wasserhell. Seta 7-15 $\mathrm{mm}$, rot, oben bleich. Kapsel länglich-elliptisch, braun, trocken 
und entleert runzelig-faltig. Ring bleibend. Peristomzähne purpurn, dicht papil-

lös. Sporen $12-17$ ", rostbraun, stark papillös.

An feuchten Kalkfelsen und Kalkmauern.

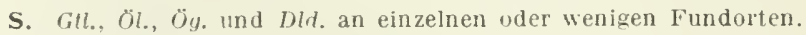

N. A. Kiristianiageb. - No. Bejeren.

Europa. Algier. Tunis, Kaukasus, Nord-Amerika.

152. Trichostomum brachydontium Bruch in Flora 1829, P. II. p. 393, t. 1 , f. 3. [Trichostomum mutabile Bruch Mser.; De Not. Syllab. p. 192 (1838). - Mollia brachydontia Lindb. Muse. scand. p. 21 (1879).]

Diözisch. Weniger schlanke Pfl. in lockeren, bis dichten, gelblich- bis bräunliclıgrünen Rasen. Stengel 1-2 cm. Blätter feucht geschlängelt-abstehend, schmal lanzettlich-linealisch, kurz zugespitzt, bis $3 \mathrm{~mm}$ lang, stachelspitzig, oberwärts flach oder mit aulrechten, gegen die gerade Spitze zuweilen schwach eingebogenen Rändern; Zellen am Blattgrunde verlängert-rektangulär, gelb- und dickwandig. Seta 1-1,2 cm. strohgelb. Kapsel eilänglich bis elliptisch, engmündig, rötlichbraun, trocken und entleert längsfaltig. Ring bleibend. Peristom gelbrot, glatt, olt unregelmässig ausgebildet oder rudimentär. Sporen $16-20 " \mu$, gelbbraun, stark warzig. - Fig. $24 \mathrm{~S}-\mathrm{U}$.

An etwas feuchten Kalkfelsen und auf kalkhaltigem Boden.

S. Gill. öı.

Europa, Kanaren, Madeira, Marokho, Algier, Kaukasus, Japan.

153. Trichostomum litorale Mitt. in Seem. Journ. Bot. 1868, p. 99, t. 77, f. 7/9. [Mollia litoralis Braithw. Brit. Mossfl. p. 214 (1885).]

Diözisch. Schlanke Pll. in dichten, grünen oder gelbgrünen Rasen. Stengel $1-f$ cm, selten höher. Blätter trocken anliegend, mit eingebogener Spitze, feucht his sparrig-abstehend, rinnig-hohl, linglich-zungenförmig, stumpf, bis $1,7 \mathrm{~mm}$ lang, stacheIspitzig. unterhalb der Blattmitte am Rande einerseits schwach umgebogen: Zellen am Blattgrunde länglichl-rektangulär. Seta etwa $3 \mathrm{~mm}$, strohgelb. Kapsel länglich, brämnlich. Ring bleibend. Peristom bleich, kurz.

N. SB. Bergen.

England, Normandie, Tirol, Ober-Italien.

\section{TORTELLA}

limpr. Laubm. I. p. 599 (1888) p. p.

Mehr oder weniger kräftige Pfl. in meist dichten Rasen und Polstern. Stengel aufrecht, mit \pm dichtem Rhizoidenfilz und gabelteilig. Blätter oben schopfig gehäuft, trocken meist sehr kraus, feucht aus weissglänzender Basis meist weit abstehend bis sparrig zurückgekrümmt, kielig-hohl, lineal-lanzettlich bis pfriemenförmig verschmälert, mit aufrechten, meist welligen, oberwärts eingebogenen, unversehrten Rändern; Rippe krältig, gegen die Spitze dünner, kurz austretend, am Rücken glatt und weissglänzend; Zellen oberwärts sehr klein, rundlich-mehreckig, beiderseits dicht warzig, am Blattgrunde plötzlich schmal rektangulär bis linealiseh, wasserhell, als Randsaum sich etwas höher hinaufziehend. Perichätialblätter wenig dilferenziert. Seta verlängert, rot, oben gelblich. Kapsel länglicheilörmig bis zylindrisch, gerade oder ein wenig gekrümmt, grünlichgelb bis gelbbräunlich: Zellen des Exotheciums verlängert rektangulär. Peristom mit niedriger Basilarmembran: Zähne rot, bis zum Grunde in 2 fadenförmige, papillöse, freie, links gewundene Schenkel gespalten. Sporen klein. Deckel schmal und verlängert kegelig. Haube kappenförmig. 
¿ bersich t der Arten.

A. Blätter trocken stark gekräuselt, nit warzigen, \& welligen Rändern.

a. Blätter almählich lang und schmal zugespitzt, oberwärts wenig hohl

15i:. T. Torluosa.

b. Blätter kurz und breit zugespitzt oder stumpflich, oberwärts rimig-hohl.

«. Peristomzähne 2 mal gewunden

151. T. inclinala.

б. Peristomzähne schwach gedreht

155. T. flavovirens:

B. Blätter steif aufrecht bis einwärts gekrümmt, mit meist abgebrochenen Spitzen.

a. Blätter mit warzigen, schwach welligen Ränderı ..... 156. T. nilidu.

b. Blätter mit glatten, nicht welligen Rändlerı .......... 157. T. fragilis.

154. Tortella tortuosa (L.) Limpr. Laubm. I. p. $60 t$ (1888). [Brymm lorluosum L. Sp. pl. 1. ed. I1. p. 1119 (1753). - Mollia lortuosa Schrank. Baier. FI. 11. p. 458 (1789), - Torlula lorluosa Ehrh. Beitr. Vil. p. 101, No. 204 (1792).]

Diözisch. Meist kräftige Pfl. in dichten, oft ausgedehnten, weichen, flachen oder polsterförmigen, grünen oder gelbgrünen Rasen. Stengel ohıe Zentralstrang. $2-5$, selten bis $10 \mathrm{~cm}$. Blätter trocken \pm brüchig, kielig-hohl, aus eiförmigem oder länglichem Grunde verlängert lanzettlich, allmählich scharf zugespitzt, 4$8 \mathrm{~mm}$ lang; Rippe als 1 -2zähnige Stachelspitze austretend. Seta $1-3 \mathrm{~cm}$. Ring nicht differenziert. Peristomzähne bis 3 mal gewunden. Sporenreife in Mai und Juni. - Fig. 25 A-D.

Auf Kalkgestein und Kalkboden, seltener auf Granit und Gneis.

F. Al. Eckerö, Jomala und Sund an einzelnen, Finström, Geta und Saltvik an mehreren Fund urten (Bom.). - Ab. Nådendal (Elfv.). Kimito, Bjōrkboda (Ols.). Finby (Broth.). Angelniemi. Kokkila (Buch). Halikko (Häyr.). Karislojo, an mehreren Fundorten (Broth., H. Lindb., E. af H., Sundv.). Lojo, an mehreren Fundorten (Lindb., E. af H., Sundv.). Vichtis, Olkkala (Broth.. E. af H.); Konjanvuori (E. af H.); Irjala (Hult). - N. Ekenäs (Häyr.); Trärminne (H.). Ingâ, Orslandet, Rörars (V. Brenn.). Sjundeá (Sundv.). Esbo, Sandudd (Broth.). Helsinge, Degerö (Lindb.); Vesterkulla. Kalkholmen (Ranck.). Tusby, Sarvikallio (Broth.). Hogland (Lindb.). - Ka. Wiborg, Soskuanjoki und Juustila (Buch). - Ik. Płhäjärvi, Mahois (H. Lindb.). — Ta. Hattula, Y'li-Savijärvi (Weg.); Nikkilā (Ranck.). Asikkala, Kärsālä (Norrl.). Padasjoki, Vieru (Vain.). Luhanka, Vahermäki (V.). Korpilahti. an mehreren Fundorten (V.). - Sa. Nyslott (Carl.). Kangasniemi (Lackstr.). - Kil. Kurkijoki (Jisl.). Valamo (Jusl.). Sortavala, in mehreren Fundorten (Norrl.). Impilahti, Pullinvuori (Broth.); Iajarsaari (Lång). Ruskeala (Broth.). Suistamo, Leppäsyrjä (Pes.); Jalonvaara (Link.). Pălkjărvi, Korkianiemi (Broth.); Linnunvaara (Pes.). - Kol. Salmi, Leppälä (Pes.). Tulemajärvi, Ruukki (Link.). Oa. Teuva, Pikku Poura (Ranck.). - Tb. Virral, Helvetinjärvi (Broth.). Viitasaari, harhuruori und Etelāvuori (B.). - Sb. Pieksämäki, Rummukka, Suurniemi (Kyyhk.). Kuopio, an vielen Fundorten (Link., Kot., Kyyhk.). Kaavi, Petkellahti (Kyyhk.); Losonmäki, Niinivaara und Siikajärvi, an mehreren Fundorten (Kot.). Juuka, Petrovaara, Saarijärvi, Sotisaari und Kasuriniemi (Kot.); Halivaara (K.). Nilsiä, Kuuslahti, Jaatonlampi (Kot.); Kirchdorf, Loutteinen (K.). Maaninka, Tuovilanlahti, Korkeakoski (Roiv.); Kurolanlahti, Vorlokso (R.). - Kb. Tohmajärvi, Hiidenvaara (Broth.): Kemie, Simosenvaara (Oesch). Juuka, Saarijärvi, Mölō (Kö.). - Kon. Suojärvi, Varpakylä (Link.). Jalguba (Simm.). Perguba (Sahlb.). Suuni, II undjärvi und Valkeamāki (Norrı.). - Om. Alajärri, Vesterbacka und Koskela. Kotakangas (Backm.). - Ok. Kajana (Broth.). Paltamo, an vielen Fundorten (Lackstr., Kyyhk.). Solkamo, an vielen Fundorten (Kyyhk.). Puolanka, an mehreren Fundorten (kyyhk.). suomussalni, Katiskalampi und Kallioinen (Kyyhk.). - Kp. Haukkakallio (Bergr.). - Ob. Alatornio, Kalkkimaa (Rảs.). - K. Kulisamo, an vielen Fundorten (Broth., E. af H.). - Lkem. Ikäsjoki, zw. Akäslompolo und Saivio (Hult). Kuolajärvi, Pyhäkuru (E, af H.): im südostl. Teil st. fq. (Roir.). - Le. Ruossotjărro (Wahlenb.). Kilpisjärvi, Malla und Saana in der alpinen Region (Kot.). - Lim. Kandalaks, Kreslovaja und Schelesnaja (Broth.). Porjaguba (Sel.). Hibinä (Broth.). - Lt. Pummanki (B.).

S. $S k .-L$.

N. $S m \cdot-F$.

Europa, Algier, Kaukasus, Persien, Zentral-Asien, Sibirien, China, Xord-Anerika.

155. Tortella inclinata (Hedw. fil.) Limpr. 1. c. p. 602. [Torlula inclinata Hedw. fil. in Web. et Mohr Beitr. I. p. 123, t. 5 (1805). - Mollia inclinala Lindi. in Braithw. Brit. Mossfl. p. 251 (1887).] 
Diözisch. Ziemlich kräftige Pfl. in flachen, oft ausgedehnten, gelb- oder bräunlichgrünen Rasen. Stengel ohne Zentralstrang bis $2 \mathrm{~cm}$. Blätter trocken nicht brüchig, aus etwas breiterem Grunde lanzettlich bis linealisch-lanzettlich, kurz und breit zugespitzt oder stumpflich, $2, \bar{j}-3 \mathrm{~mm}$ lang, mit oberwärts eingebogenen Rändlern: Rippe als ungezähnte Stachelspitze austretend. Seta $1-3 \mathrm{~cm}$. Ring nicht differenziert. Peristomzähne 2 mal gewunden.

Auf kalkhaltigem Boden.

S. Ol. an vielen Fundorten. Ög. Omberg. Dld. Rostock.

N. Sm. Hvaler. A. Kristiania. $B u$. Ringerike, $S B$. Sogn. No, an wenigen Fundorten.

Europa, Kaukasus.

156. Tortella flavovirens (Bruch) Broth. in Engl.-Prantl I 3. p. 397 (1902). [Trichoslomum flavovirens Bruch in Flora 1829, P. II. p. 104, t. 2, f. 7. - Mollia flavovirens Lindb. Muse. seand. p. 21 (1879).]

Diözisch. Weniger kräftige Pfl. in weichen, lockeren oder dichten, grünen oder gelblichgrünen, breiten Rasen. Stengel bis 1 , seltener bis $2 \mathrm{~cm}$. Blätter aus länglichem Grunde lanzettlich-linealiseh, kurz zugespitzt bis stumpflich, bis $4 \mathrm{~mm}$ lang, mit oberwärts eingebogenen Rändern; Rippe mit der Blattspitze endend oder als sehr kurze Stachelspitze austretend. Seta $1,5-2 \mathrm{~cm}$. Ring nicht differenziert. Peristomzähne schwach gedreht.

S. srm. Utö.

Auf sandigen, schatıigen Plätzen am Veeresufer in West- und sïd-Eusopa, Azoren, Flurida.

157. Tortella fragilis (Drumm.) Limpr. l. c. p. 606. [Didymodon fragilis Drumm. Muse. Amer. bor. I. No. 127 (1828). - Torlula fragilis Wils. in Hook. .Journ. Bot. J1l. p. 437 (1841). - Molla fragilis Lindb. Mlusc. scand. p. 21 (1879).]

Diözisch. Krältige Pfl. in dichten, starren, grünen bis gelblich- und bräunlichgrünen, polsterförmigen Rasen. Stengel ohne Zentralstrang, $2-6 \mathrm{~cm}$. Blätter kielig-hohl, trocken steif aufrecht-abstehend und wenig einwärts gekrümmt, sehr brüchig. olere länger, aus länglichem Grunde verlängert lanzettlich-pfriemenlörmig, bis $8 \mathrm{~mm}$ lang; Rippe oberwärts durch (loppelschichtige Zellreihen scheinhar verbreitert und als 3kantiger, ungezähnter Endstachel austretend. Seta 2 $3 \mathrm{~cm}$. Ring nicht differenziert. Peristomzähne 3 mal gewunden. Sporenreife im Juli und August. - Vegetative Vermehrung durch Blattfragmente.

Auf leuchtem Humus- und lloorgrund, in Felsritzen und auf flachen, erdhedeckten Felsen.

F. Al. Eckero (Arrh.). Jomala und Finström (Bom.), lieta und Lemland (Broth.), Brändö und Kökar an einzelnen, Saltrik an mehreren Fundorlen (Bom.). - Ab. Parga: (Arrh.), slorgård und Skrälhhöle (E!fv.). Karislojo, Karkali und Pellonkylä (E. af H.). Lojo, Kiriniemi (Lindb.); Lylyis und Pietilä (E. af J.); Seppälï (H. Lindb.). - N. Ekenäs, Hermansö (Hák. Lindb.). Ingh, Verkholm (V. Brenn.). - To. Hollola, Enonsaari (Vain.). Asikkala, l'ortlikallio (Brotlı.). Padasjoki, Arrakoski (Vain.). kl. Suistamo. Jäıisjārvi (Broth.). Pälkjärvi, Korkianienıi (B.). - Tb. Viitasaari, Eleläruori (B.). Sb. Kaavi, Sijkajärvi, Huosiainniemi und Likosaari (Kol.). Juuka. Petrovaara, Mäköniemi (Kot.). Kb. Juıka. Iıuanvaara (K.). - Kon. Suojärvi, Vappakylä, Pöpensaari (Link.). - (Jk. Kajana (Lackstr.). Kuhmoniemi, Vicksi, Kellojärvi (Kyyh.). Suouussalni, Kiannankỵlä (K.). - Ob. Simo (H. Lindb.). K. Kunsanto, llataja, Ruoppijärvj und Aventojoki (Broth.); Ylikithajärvi, Ingansaari (B.); Kitkajoki. Jyrãvă und Paanajärvi. Kiekkivaara (B.). Oulankajoki, Kiułakënqäs und Taivalkoski (Roiv.): Savinajoki(R.). Im südoیil. Teile von Kuolajärvi an melıreren Fundorten (Rnix.). - Lkem. Sodankylä: Kalkkivuori (Vain.). Kunlajarvi. Pyläkuru (E. af JI.). - Le. Leutsuvaara, in der alpinen Region (Norrl.). Kilpisjärvi, Malla und Saana (Kol.). - l.i. Inari, Jupfura (Hull); Peldoivi, in der Birkenregion (H.) Lim. Kandalaks, Krestovaja und Schelesnaja (Broth.). Hibina (Angstr., Broth.), - Lt. Punmanki, subovi und Tsipnavolok (Broll.). Kildin (B.). Lukin-kaja l'allta an kolabusen (B.). - Lmur. Teribjerka (Broth.). - L.p. Sapadnij navolok (Brolh.). Katsehkora und Ponoj (Brenn., Broth.). Orlov, lingulilıa (Kihlıı.). Lx. Tschapoma (Broll.).

S. Sh., Gtl., sm.. Öl. Ög., Vg., Ippl., Iml., LuL. an mehreren Fundorten. Stockholm. Ang. Tásjö. N. sim. - I.

Sibitzergen, liuropa, liaukasus, Himalaya. Zentral-Asien, sibjrien, China. Nord-Amerika.

158. Tortella nitida (Jindlb.) Brotl. in Engl.-Prant Bryal. p. 397 (1902). 
[Tortula nitida Lindb. De Tort. p. 252 (1861). - Trichoslomum nilidum Schinp). Syn. 2. ed. p. 179 (1876).]

Diözisch. Kräftige Plı. in dichten und kissenförmigen, olivengrünen, durch die stark vortretenden Blattrippen weisslich-glänzenden Rasen. Stengel his 2 em. Blätter trocken einwärtsgekrümmt, brüchig, mit schwach welligen, cingehogenen Rändern, feucht abstehend, lineal-lanzettlich, stumpflich, bis 5 mul lang; Ripj)e am Grunde durch roppelschichtige Zellreihen scheinbar verbreitert, kurz austretend; Randsaum von den grünen Zellen weniger scharf abgegrenzt. Seta $5-$ $8 \mathrm{~mm}$. Ring nicht dilferenziert. Basilarnembran nicht oder kaum vortretend; Peristomzähne rudimentär.

Auf Kalk und kalkhaltigen Felsen.

N. St. Mostero, Kvitings', auf Schiefer, 10-15 III ï. d. M. Steril.

An der Atlantischen Küste von den brittischen bis zu den kanarischen Küsten, längs den Küsteı des Mittelmeeres und an einzelnen Fundorten in Belgien, Steiermark und der sehwei\%. Auch aus NordAmerika angegeben.
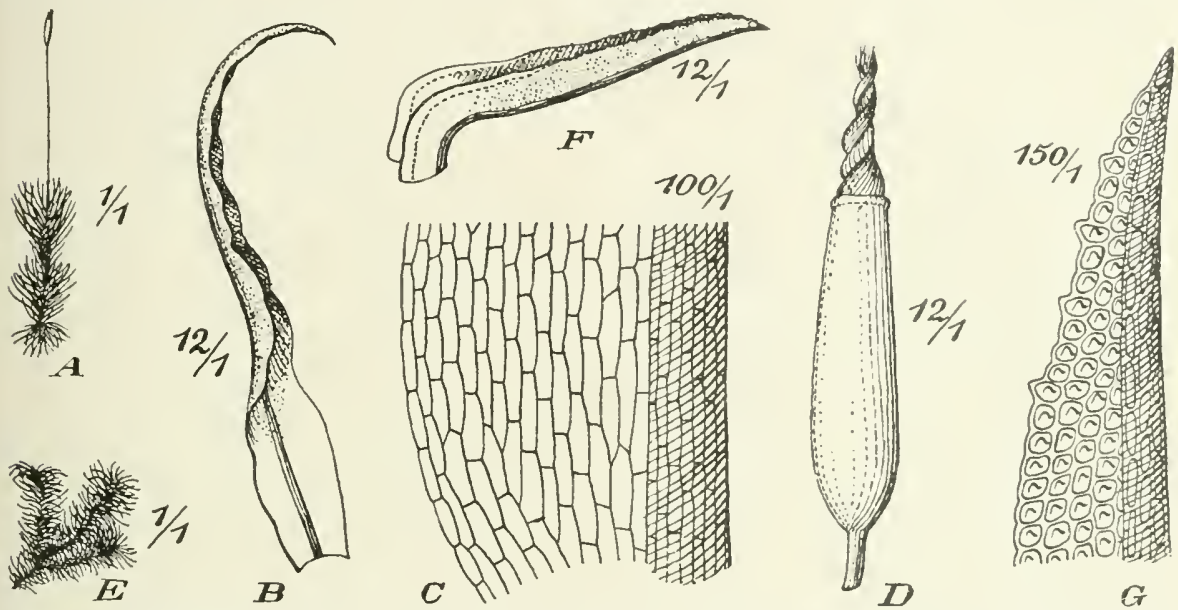

Fig. 25. A-D Tortella tortuosa (L.) Limpr. A Fruchtende Pfl. (1/1); B Stammb. (12/1); C Blattbasis (100/1); D Entdeckelte Kapsel (12/1). - E-G Pleurochaete squarrosa (Brid.) Lindb. E Sterile Pfl, (1/1); F stammb. (12/1); (i) Blattspitze $(150 / 1)$.

\section{PLEUROCHAETE}

\section{Liudb. De Tort. p. 253 (1864).}

Diözisch; beiderlei Btüten auf seitenständigen Kurztrieben. Ziemlich kräftigc Erdmoose in lockeren, grünen bis gelbgrünen Rasen. Stengel meist niederliegend und verbogen, seltener aufrecht, ohne Rhizoidenfilz, zuweilen mit zahlreichen Kurztrieben. Blätter oben schopfig gehäuft, trocken kraus, feucht sparrig-abstehend bis zurückgekrümmt, kielig-hohl, aus breiterer, scheidiger Basis verlängert-lanzettlich, mit aufrechten, welligen, bis unter die Mitte herab rleutlich und ungleich gesägten Rändern; Rippe kräftig, vollständig bis schr kurz austretend; Zellen oberwärts klein, rundlich-quadratisch, beiderseits dicht mit langspitzigen Warzen, im Mittelfelde des Blattgrundes verlängert-rektangulär, gelblichgrün, allmählich in die oberen Zellen übergehend, mehrere Randreihen des Scheidenteiles hyalin und fast linealisch, aufwärts als scharf begrenzter Randsaum sich verlierend. Innere Perichätialblätter aus scheidiger Basis pfriemenförmig zugespitzt. Seta bis $3 \mathrm{~cm}$, dünn, rot, oben gelblich. Kapsel eilänglich-zylindrisch, gerade oder elwas gekrümmt, rötlichbraun, glatt: Zellen des Exotheciums veriängert rektangulär. Ring wenig diffe- 
renziert, in einzelnen Zellen sich ablösend. Peristom wie bei Tortella, einmal gewunden. Sporen klein. Deckel sehmal und verlängert kegelig. Haube kappenförmig. - Fig. 25 E-G.

159. Pleurochaete squarrosa (Brid.) Lindb. ]. ๔. [Barbula squarrosa Brid. Bryol. univ. 1. p. 833 (1826). - Tortula squarrosa De Not. Specim. No. 29 et in Mem. Accad. Torin. XL. p. 321 (1838)].

S. Gll. Hoburgen.

Auf trockenem, sandig-kalkigem Boden in England, Frankreich. Zentral- und sud-Europa, Kauhạsus, Persien. Himalaỵa, Yünnan. Nord-Amerika.

\section{LEPTODONTIUM}

\section{Hamp. in Linnaea XX. p. 70 (18+7).}

Diözisch. Lockerrasige, weiche Pfl. Stengel ohne Zentralstrang. Blätter meist sparrig-zurückgebogen, kielig-hohl, breit länglich bis zungenförmig oder linealisch, lanzettlich zugespitzt, \pm weit hinab grob und ungleich sägezähnig; Rippe vor der Blattspitze aufhörend; Zellen rundlich + 6seitig, chlorophyllreich, meist beiderseits dicht papillös, am Blattgrunde verlängert, gelblich oder wasserhell. Perichätialblätter differenziert. Seta verlängert. Kapsel sehmal zylindrisch, \pm gekrümmt: Zellen des Exotheciums verlängert rektangulär. Ring differenziert. Peristom ohne Grundhaut. Peristomzähne aufrecht, meist kurz, bis zum Grunde in 2 fadenförmige, glatte bis fein papillöse Schenkel geteilt. Deckel verlängert kegelig. Haube kappenförmig.

160. Leptodontium norvegicum Kaal. in Nyt Mag. f. Naturv. Bd. 51, p. 161 (1913).

Pfl. in kleinen, grünen bis bläulichgrünen, innen braungrünen bis braunen Räschen. Stengel bis $1 \mathrm{~cm}$, aufrecht oder aufsteigend, mit reichlichen, teils dicken, fast einfachen grob papillösen, teils sehr feinen. reichlich verzweigten Rhizoiden. Obere Blätter abstehend und trocken schwach gekräuselt, lineal-anzettlich, dureh eine verlängerte, glatte Zelle stachelspitzig, bis $2,7 \mathrm{~mm}$ lang und $0,25 \mathrm{~mm}$ breit, mit aufrechten, bis unter die Mitte gesägten Rändern; Rippe oberwärts beiderseits gezähnt; Zellen oberwärts unregelmässig, 9-10 "u, an der Spitze kleiner, quadratiseh und rektangulär, beiderseits mamillös, am Blattgrunde verlängert rektangulär, hyalin, glatt. Blüten und Sporogone unbekannt.

N. Kristiansand, Sodal, an erdbedeckten Kalkfelsen spärlich.

Durch Blattform, oberwärts beiderseits gezähnte Rippe und mamillöse Zellen von allen früher bekannten Arten der Gattung verschieden. Wie vom Autor 1. c. hervorgehoben wird, ist es daher nicht ausgeschlossen, dass, wenn künftig Sporogone gefunden werden, diese Art sich als den Typus einer neuen Gattung erweisen wird.

\section{DIDYMODON}

Hedw. Descr. IlI. p. \& (1792).

Schlanke bis kräftige, rasenbildende Pfl. Stengel aufrecht, abwärts mit Rhizoiden, einfach oder büschelästig. Blätter feucht aufrecht-abstehend, kielig-hohl, meist aus breiterer Basis lanzettlich, nit ungerollten Rändern; Rippe kräftig, nach oben allmähtich verdünnt, am Rücken glatt; Zellen oben kilein, rundlichquadratisch, nach unten wenig verlängert und weiter oder länger und rektangulär. Perichätialblätter wenig differenziert. Seta verlängert, rot. Kapsel aufrecht, länglich-eiförmig bis zylindriseh, zuweilen schwach gekrïmmt, glatt; Zellen des Exotheciums kurz bis verlängert rechteckig. Peristom mit niedriger Basilar- 
membran, mit aussen und innen vorspringenden Querleisten; Zälne (excl. D. alpigenus) aufrecht, schmal, bald ungeteilt oder längs durchbrochen, bald in 2 fadenförnige Schenkel gespalten. Deckel kegelförmig und geschnälselt: \%cllen (excl. D. alpigenus) gerade verlaufend. Haube kappenförmis, flüchtig. Sporen klein.

Übersieht der Arten.

A. Zellen oberwärts dichtwarzig und trüb, am Blattgruncle fast immer rötlich, verlängert rektangulär, dünnwandig und durchscheinend.

a. Synözisch.

«. Blattspitze ganzrandig bis spärlich gezähnt. Deckelzellen gerade verlaufend ......................... 160. D. rubellus.

;. Blätter an der Spitze mit bräunlichen, scharlen Zähnen. Deckelzellen in Schrägreihen ............ 161. D. alpigena. b. Diözisch. Kräftiger als die vorigen .................. 162. D. ruber.

B. Zellen an Blattgrunde etwas erweitert, sonst von den übrigen wenig versehieden, nur an der Rippe in wenigen Reihen kurz, rektangulär.

a. Zellen der Blattmitte $6-9 \mu$....................... 163. D. luridus.

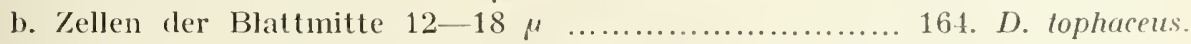

Un t e rgat t. I. Erythrophyllum (Lindb.) Limpr. Laubm. 1. p. 54.1 (1888). [Trichostomum Subg. Lindb. de Tort. p. 213 (1864).]

Zellen am Blattgrunde fast immer rötlich, verlängert rektangulär, dünnwandig und durchscheinend. Ring differenziert, in einzelnen Zellen sich oblösend.

161. Didymodon rubellus (Hoffm.) Bryol. eur. fase. 29/30 Mon. p. 3 exel. syn., t. 1 (1846). [Bryum rubellum Hoffm. Deutschl. Fl. II. p. 33 (1796). - Barbula rubella Mitt. in Journ. Linn. Soc. XII. p. 162 (1869)].

Synözisch, öfter auch parözisch. Schlanke Pfl. in lockeren oder dichten, dunkelgrünen bis rötlichbraunen, innen rostroten Rasen. Stengel $1-3 \mathrm{~cm}$. Blätter nach oben allmählich grösser, trocken gekräuselt, aus aufrechtem, halbscheidigenı Grunde lanzettlich, kurz zugespitzt, bis 3,5 mm lang, stachelspitzig, mit bis gegen die oft spärlich gezähnte Spitze zurückgerollten Rändern; Rippe mit oder vor der Blattspitze endend. Seta $1-1,5 \mathrm{~cm}$. Peristom blass- bis rötlichgelb, fein papillös: Zähne ungeteilt, \pm durehbrochen oder unregelmässig gespalten. Deckelzellen gerade verlaufend. Sporenreife im Sommer. - Fig. $23 \mathrm{E}-\mathrm{H}$.

An allerlei Felsen und Mauern, an schattigen Abhängen und auf nackter. besonders kalkhaltiger Erde.

F. Al. Eckerö, Hammarland. Jomala und Finström an einzelnen, Saltvik an mehreren Fundorten (Bom.). - Ab. Pargas, an mehreren Fundorten (Elfv.). Kimito. Illo (Ols.). Finby (Broth.). Angelniemi, Kokkila (Buch). Sagu, Träskby (B.). Lojo, an vielen Fundorten (Lindb., Hult, H. Liudt., E af H.). Pusula (Broth.). - N. Snappertuna, Raseborg (Häyr.). Sjundeá (Nerv.). Helsingfors (Lindt.). Helsinge, Kalkholmen (Ranck.); Sillböle und Degerö (Buch). — Ik. Sakkola, Makkara (FI. Lindb.). St. Pirkkata (Simm.). - Ta. Hattula, Yli Savujärvi (Ranck.). Palkäne, Onkkaała (Nerv.). Im südösll. Teile an mehreren Fundorten (Norrl.). Korpilahti. Vaurunvıori und Haukkavuori (Vain.). - Sa. Jäăski. Imatra (Buch). - Kl. Valamo (Jusl.). Sortavala, Kirjavalahti (Pes.), Impilahti, Pullinvuori (Broth.). Ruskeala (IV. Nyl.); Otrakkala (Link.). Pälkjärvi, Kuhilasvaara und Korkeaniemi (Broth.). - Oa. Sideby, sïdl. von Ömossan (Nerv.). - Sb. Kuopio, Siikalahti (Kot.). Kaavi, Siikaiärvi, Huosiaisniemi (K.) Losomäki (K.). Juuka, Halivaara (K.). Nilsiä, Kuuslahłi. Jaakonlanpi (K y̧hk.). Jaaninka, Tuovilanlahti, Arkkuvuori (Rojv.). - Kb. Juuka, Jutanvaara (Kot.). Polvijärvi, Kirchdorf (K.). - Kon. Valkeamäki und Pertnavolok (Simın.). - Ok. Paltamo, Metalahti (Kyyhk.). Solkamo, Närhiniemi (Kyyh.), Hepolehto und Kohvorinsaari (K.). Suomussalmi, Kallioinen (K.). - Kp. Kem (F. Nyl.). $-K$. Kuusamo, Aventojoki (E. af H.); Kitkajoki, Jyrävä (Broth.); Oulankajoki (B.); Paanajärvi, Kuoppaoja (B.); Sovajoki, Kulmakkapuro (E. af H.). - Lkem. Kittilä, Kirchdorf (Hult). - Le. Kilpisjārvi. Saana und Saivovaara, in der alpinen Region (Kot.). - Lt. Kildin (Brolh.). - Lmur. Teribjerka (Brolh.). - Lp. Ponoj (Sahlb., Broth.). Orlov (Kihlm.). - Lx. Tschapoma (Sahlb., Broth.). 
S $S k,-L$.

N. $S m,-F$.

Europa, Algier, Abessinien, Persien, Kaukasus, Zentral-, Nord- und Ost-Asien, Nord-Amerika, Tasmanien.

var. intermedius Limpr. Laubm. 1. p. 547 (1888).

Blätter an der breiten Spitze mit mehreren Sägezähnen.

N. Sm., No. und $F$. an wenigen Fundorten.

Deutschland.

var. pallens Ryan in D. K. N. Vid. Selsk. Skrift. 1896 No. 1.

'Blüten meist nicht synözisch; Antheridien teils in den Achseln der Schopfbätter, teils gipfelständig an kurzen Ästen. Peristomzähne bleich, kürzer.

N. Sm. Ostre Fredrikstad.

162. Didymodon alpigena V'ent. in Rev. bryol. 1879, p. 53. [Barbula alpigena M[ö]l. Förteckn. Skand. växt. 2. Moss. p. 21 (1907).]

Synözisch, öfter auch parözisch. Kräftiger als vorige Art. Stengel bis $4 \mathrm{~cm}$. Blätter trocken gekräuselt, aus halbscheidigem Grunde lanzettlich, bis 3,5 mm lang, an der breiten Spitze mit bräunlichen, scharfen Zähnen, am Rande nur bis zur Nitte zurückgerollt; Rippe kräftiger, mit der Blattspitze endend. Seta meist $2 \mathrm{~cm}$. Kapsel länger, zylindrisch. Deckelzellen schräg nach rechts gereilıt. Sporenreife im August und September.

In nassen Felsspalten und an Bachufern.

N. No. an wenigen Fundorten.

Alpengebiet, Kaschmir.

163. Didymodon ruber Jur. Mscr., Geh. in Rev. bryol. 1878, p. 28; Laubmfl. Oesterr.-Ung. p. 99 (1882). [Barbula rubra Möll. Förteckn. Skand. Växt. 2. Moss. p. 22 (1907).]

Diözisch und zweirasig. Kräftiger als vorige Art, lockerrasig, längs braunrot, an den Spitzen olivenbraun. Stengel bis $7 \mathrm{~cm}$. Blätter locker gestellt, trocken sehr kraus, aus halbseheidigem Grunde lanzettlich, allmählich oder plötzlich in eine feine, zuweilen gezähnte Spitze verschmälert, bis $5 \mathrm{~mm}$ lang, mit fast bis zur Spitze spiralig umgerollten Rändern; Rippe mit dem Spitzchen endend. Seta $1-1,5 \mathrm{~cm}$. Peristom weisslich, fein papillös; Zähne bis zur Basis in 2 gleichbreite, hier und da durch Querleisten verbundene Schenkel geteilt. Deckelzellen gerade verlaufend. Sporenreife im Sommer.

In feuchten Felsiklüften, besonders kalkhaltiger Gesteine.

N. Trondhjem. F, Alten.

Alpengebiet, Kaukiasus.

Un 1 e rga t t. I l. Didymodon sens. strict. Limpr. Laubm. 1. p. 549 (1888) p. p.

Diözisch. Blätter ganzrandig; Zellen am Blattgrunde etwas erweitert, sonst von den übrigen wenig verschieden, nur an der Rippe in wenigen Reihen kurz rektangulär. Ring nicht differenziert.

16 1. Didymodon luridus Hornsch. in L. Syst. veg. 16. ed. IV. P. I. p. 173 (1826). [Barbula lurida Lindb. Musc. scand. p. 22 (1879).]

Schlanke Pfl. in dichten, starren, oben dunkelgrünen bis bräunlichen, oft polsterförmigen Räschen. Stengel bis 1 , selten bis $2 \mathrm{~cm}$. Blätter trocken anliegend. breit eilanzettlich, spitz oder stumplich, bis etwa 1,6 $\mathrm{mm}$ lang, nit bis gegen die Spitze zurïkggerollten Rändern; Rippe mit oder kurz vor der Blattspitze endend: Zellen verdickt, rundlich-quadratisch und queroval, in der Blattmitte 6-9 :", glatt. Seta $1 \mathrm{~cm}$. Peristom bleicligelblich, zart, hinfällig, fein papillös bis fast glatt; /ähne ganz oder goteill, mit unregelmässig verbundenen Schenkel, oft rudimentär.

S. Gll. Hoburgen. Steril.

Europa. Algier, Tunis, Kaukasus, Persien, Nord-Amerika. 
165. Didymodon tophaceus (Brid.) Jur. Laubmfl. p. 100 (1882). |Bryum brévifolium Dicks. Pl. crypt. fasc. 1 I. p. 4 (1790). - Trichostomum tophaceum Briıl. Mant. p. 84 (1819). - Barbula brevifolia Lindb. Musc. scand. p. 22 (1879).]

Mehr oder weniger schlanke Pft. in lockeren oder dichten, oben olivengrünen bis braumen Rasen. Stengel $0,5-4$ cul, selten höher. Blätter trocken anliegend, aus eiförnigem oder eilänglichem Grunde lanzettlich, stumpflich bis stumpf al)gerundet, bis $2 \mathrm{~mm}$ lang, mit bis gegen die Spitze zurückgerollten Rändern; Rippe kurz vor der Blattspitze endend; Zellen unregelmässig, \pm verdickt und beiderseits warzig bis fast glatt, in der Blattmitte $12-18 \mu$. Seta bis $1,5 \mathrm{cn}$. Peristom bleichgelblich oder blassrötlich, hinfällig. papillös; Zähne ganz oder getcilt, mit unregelmässig verbundenen Schenkeln, oft rudimentär.

In alten, feuchten Mergel- und Tongruben, an kalkhaltigen, quelligen Abhängen, auf kalkhaltigen Sumpfwiesen nnd an nassen Kalklelsen.

F. Al. Finström, Färjsund (Bom.). Lemland, Nảtö und Jersö (B.). Saltvik, an vielen Fundorten (B.). ¿'berall nur auf kalkhaltigem Boden des Meeresufers.

S. Sk. und sm. an mehreren Fundorten; $O l$. und Gll.

N. JL. Skien. Rokstad.

Europa, Algier. Tunis, Sinaj, Vorder-Asien, Tiakasus, Tibet, Nord-Amerika.

\section{BARBULA}

Hedw. Fund. musc. 11. p. 92 p. p. (1782).

Diözisch. Schlanke bis ziemlich kräftige, rasenbilclende Pfl. Stengel aufrecht, meist nur am Grunde mit Rhizoiden, einfach oder gabelteilig bis büschelästig: Blätter kielig-hohl, meist eilanzettlich bis linealisch, mit \pm umgerollten, sclten flachen, meist ganzen Rändern: Rippe krältig, mit der Blattspitze endend oder austretend: Zellen sehr klein, meist rundlich-quadratisch. \pm verdickt und meist beiderseits papillös, am Blattgrunde ctwas weiter, quadratisch bis kurz rektangulär, selten wasserhell. Seta verlängert. Kapsel aufrecht, selten etwas geneigt. eilänglich bis zylindrisch, gerade oder schwach gekrümmt, braun, glatt; Zellen des Exotheciums meist kurz oder verlängert rechteckig. Peristom mit niedriger Basilarmembran; Zähne bis zum Grunde in 2 fadenförmige, papillösc, freie, links gewundene Schenkel gespaltcn. Deckel kegelförmig und geschnäbelt. Haube kappenförmig. Sporen klein, gelb oder gelbgrïn, glatt.

$$
\text { Utbersicht der Arten. }
$$

A. Blätter mit auch oberwärts sehr breit umgerollten Rändern.

a. Sehr schlanke Pfl. Blätter scharf zugespitzt; umgerollte Blattränder nicht oder nur in der Spitze die Rippe erreichend

175. B. Hornschuchiana.

b. Weniger schlanke Pfl. Blätter stumpflich und stachelspitzig; umgerollte Blattränder schon von der Blattmitte die Rippe erreichend 176. B. revolula.

B. Blätter mit oberwärts aufrechten ocler schmal umgerollten Rändern.

a. Rasen ohne Rhizoidenfilz. Perichätialblätter nicht oder wenig differenziert.

$\alpha$. Blätter breit- und stachelspitzig. mit bis ïber die Mitte zurückgerollten Rändern

$\beta$. Blätter allmählich zugespitzt. 
I. Blattrippe am Grunde am stärksten, nach oben allmählich schwächer werdend.

1. Blätter trocken locker anliegend; Zellen glatt.

* Rasen 1-2 cm. Rippe vollständig oder als Stachel austretend ......................... 165. B. gracilis.

** Rasen 3-6 cm: Rippe lang austretend ..... 166. B. icmadophila.

2. Blätter trocken bogig eingekrümmt; Zellen beiderseits warzig.

* Blätter mit bis gegen die Spitze zurückgerollten Rändern. Peristomzähne 2-3 mal gewunden

169. B. fallax.

** Blätler mit kaum bis zur Nitte sehr schmal umgebogenen Rändern. Peristomzähne steil ansteigend

170. B. spadicea.

II. Rippe rom Grunde bis über die Mitte gleichstark.

1. Schopfblätter meist grösser, trocken schneckenförmig eingerollt oder stark gekräuselt

167. B. cylindrica.

2. Schopfblätter kaum grösser, trocken weder schneckenförmig eingerollt noch gekräuselt.

* Blätter scharf zugespitzt; Rippe mit der Spitze endend: Zellen warzig.

+ Blätter feucht steif aufrecht-abstehend; Zellen wenig verdickt, am Grunde quadratisch und kurz rektangulär

168. B. vinealis.

$\uparrow+$ Blätter feucht mit der oberen Hälfte sparrig zurückgebogen; Zellen rings stark verlickt, mit rundlichem und querovalem lumen, nur am Grunde nächst der Rippe verlängert rektangulär.

$\times$ Mehr odler weniger schlanke Pll...... 171. B. reflexa. $\times \times$ Mehr oder weniger kräftige Pfl. der alpinen Regionen 172. B. rufa.

** Riple mit der stumpflichen Blattspitze verschmelzend oder als Stachel austretend; Zellen glatt, am Gruncle liurz bis verlängert rektangulär und durchscheinend.

$\dagger$ Dunkel- bis braungrüne Pfl.

$\uparrow \uparrow$ Blaugrüne Pfl.

173. B. rigidula.

174. B. glauca.

b. Rasen mit Rhizoidenfilz. Blätter flachrandig. Peristomblätter \pm hoch scheidig-röhrig zusammengewickelt.

«. Innere Perichätialblätter breit abgerundet ........ 178. B. convoluta.

ק. Innere Perichätialblätter lanzettlich-pfriemenförmig zugespitzt

179. B. paludosa.

Se c t. 1. Eubarbula Lindb. Musc. scand. p. 22 (1879) ex p.

Blätter trocken anliegend bis kraus, selten spiralig dem Stengel anliegend, meist zugespitzt. Innere Perichätialblätter wenig odler kaum differenziert.

166. Barbula gracilis (Schleich.) Schwaegr. Suppl. I. P. I. p. 125. t. $34(1811)$. [Torlula acula Brid. Sp. musc. p. 265 (1806). - Torlula gracilis Schleich. Cat. 1807.

- Barbula acuta Brid. Mant. p. 96 (1819).]

Schlanke Pfl. in lockeren oder dichten, dunkelgrïnen oder gebräunten Rasen. Stengel $1-2 \mathrm{~cm}$. Blätter trocken aufrecht anliegend, feucht zuletzt aufrechlbis fast sparrig-abstehend, aus eiförmiger Basis lanzettlich, plriemenförmig zuge- 
spitzt, bis 1,5 mm lang, mit meist nur bis zur Mitte schmal zurückgerullten lä̈ndern; Rippe oben allmählich dünner, in der Spitze endend oder als Stachel austretend, glatt; Zellen dickwandig und glatt, umregclmässig, runcllich-quadratisch bis mehreckig, mit dreieckig-ovalen untermischl, am Grunde quadratisch und bei der Rippe rektangulär. Seta $5-10 \mathrm{~mm}$ rol. Kaljsel länglich-eiförmigs, dunkêbraun. Ring bleibend. Peristomzähne unten rot, oben gelb, kalum einmal gewunden.

Auf sandig-lehmigem und tonigem Boden, auch atul fielsen.

F. Gtl. Vislıy. $L p l$. Vänge.

S. Sm. Skjelserg.

Europa, Algier, Tunis, Kaukasus, Nord-Imerika.

167. Barbula icmadophila Schimp. in Bryol. cur. fasc. 1:3, tab. suppl. 2 (1850). [Torlula icmadophila Lindb. (le Tort. p. 219-(1861).]

Sehr schlanke Pfl. in meist dichten, bräunlichgrünen und lraunen Rasen Stengel 3-6 cm. Blätter trocken straff anliegend, feucht zuletzt aulrecht-abstehend, aus eiförmiger Basis lanzettlich, pfrienenförmig zugespitzt, bis 1,6 mm lang, mit meist nur bis zur Mitte schmal zurückgerollten Rändern; Rippe oben allmällich dümner, lang austretend: Zellen wenig verdickt, glatt, regelmüissig. quadratisch, am Grunde nächst der Rippe kurz rektangulär. Seta kaum 1 cnt. Kapsel länger und etwas schmäler als bei $B$. grucilis. Ring leicht ablösbar. Peristomzähne fast 2 mal gewunden.

An Wasserfällen und feuchten Felsen

F. Kon. Tiudie (Nurrl.). - $\boldsymbol{k}$. Kuusamo, Paanajarvi, Palonient, auf Talkschiefer. - päıl. fruchtend (E. af H.).

N. NB. Sogn. R. Geiranger. Merok. K. Lom, Valders und Gudbrandsdalen, Ringeboe. St. Opdal.

Faer-Inseln, Auvergne, Westfalen, Alpengebiet.

168. Barbula cylindrica (Tayl.) Schimp. in Hedwigia 1873, p. 47. [Zygotrichia cylindrica Tayl. in Mack. Fl. hil.. II. p. 26 (1836). - Tortula cylindricr Lindb. in Bot. Not. 1865, p. 76.]

Weniger schlanke Pfl. in lockereh, grünen oder gelb- bis rotbrannen Rasen. Stengel bis $3 \mathrm{~cm}$. Blätter trocken stark gekräuselt, feucht flatterig ausgebreitet oder sparrig zurückgekrümmt, die obersten meist schopfig gehäuft, aus schmal eiförmigem bis länglichem Grunde lang pfriemenförmig, bis 3 mm lang. mit höchstens bis zur Mitte schmal umgebogenen Rändern; Rippe bis über die Blattmitte gleich dick, mit der Blattspitze endend; Zellen kaum oder wenig verdickt, beiderseits dicht warzig und sehr undurchsichtig, in der Mehrzabl quadratisch, an Grunde nächst der Rippe kurz rektangulär. Seta etwa $1,5 \mathrm{~cm}$, rotgelb. Ring 2--3rcihig. ohere Reihe sich stückweis ablösend. Peristomzälme weisslich oder blassrötlich, $2-3$ mal gewunden.

Auf sandigem und kalkhaltigem Boden an Grabenrändern und in Ansstichen. auch auf Steinen.

F. Al. Saltvik, an mehreren Fundorten (Bom.). Steril.

S. Sk., Öl, Gtl. und $O g$. an mehreren, Dld. an einzelnen Fundorten.

N. Bu. Ringerike, Skjærdalen, Tyristranden.

West-, Zentral- und Sud-Europa, Algier, Tunis, Kaukasus, Vorder-Asien, Persien, Nepal, Tünnan, Nord-Amerika.

169. Barbula vinealis Brid. Bryol. univ. I. p. 830 (1826). [B. cylindrica var. vinealis Lindb. Musc. scand. p. 22 (1879). - Tortula vinealis Spruc. in Hook. Journ. Bot. IV. p. 194 (1845).]

Schlanke Pfl. in ziemlich dichten, bräunlichgrünen bis rotbraunen Rasen. Stengel 1-2 cm, seltener höher, oberwärts gleiclımässig beblättert. Blätter trocken anliegend, nicht oder mässig einwärts gebogen, feucht aufrecht-abstehend, aus eiförmiger Basis lanzettlich, allmälılich pfriemenförmig zugespitzt, lis $1,5 \mathrm{~mm}$ lang, mit bis gegen die Spitze ungerollten Rändern; Rippe bis über die Mitte gleich- 
dick, mit der Blattspitze endend, beiderseits dicht papillös; Zellen kaum oder wenig verdickt, beiderseits warzig, in der Mehrzahl rundlich-quadratisch, gegen den Grund erweitert, kurz rektangulär und quadratisch. Seta $1-1,5 \mathrm{~cm}$, rot. Ring 2-3reihig, kleinzellig, obere Reihe sich stïckweise ablösend. Peristomzähne rötlichgelb, kaum einmal gewunden.

Auf sandigem und kalkhaltigem Boden.

S. Sk. und Gll.

N. $X T$. Stjordalen.

Verbreitung wie bei $B$. cylindrica.

170. Barbula fallax Hedw. Deser. I. p.62, t. 24 (1787). [Tortula fallax Schrad. Samml. krypt. Gew. I. n. 53 (1796).]

Mehr oder weniger schlanke Pfl. in lockeren oder dichten, gelb- oder schmutziggrünen, bräunlichen bis rotbraunen, oft ausgedehnten Rasen. Stengel $1-4 \mathrm{~cm}$. Blätter trocken eingebogen bis \pm kraus, feucht weit aufrecht- bis fast sparrigabstehend, aus eiförmiger Basis lanzettlich, allmählich in eine meist lange, scharfe Spitze verschmälert, bis $3 \mathrm{~mm}$ lang, mit bis gegen die Spitze zurückgerollten Rändern, am Grunde meist mit 1-2 Längsfalten; Rippe nach oben allmählich schwächer, in der Blattspitze endend. am Rücken \pm warzig: Zellen dickwandig und beiderseits warzig, selır unregeimässig mehreckig, mit 3-4eckigen untermischt, am Grunde ebenso odler kurz rektangulär und quadratisch. Innere Perichätialb]ätter scheidig, rasch in eine kurze Spitze verschmälert. Seta $1-2 \mathrm{~cm}$, rot. Ring bleibend. Peristomzähne blassrot, 2-3 mal gewunden. Sporenreife im Spätherbst.

Auf feuchter Errle, besonders auf tonigem und kalkigem Boden, an Mauern und kalkhaltigen Felsen.

F. Al. Eckerô (Linnan.). Jomala, an eirigen Fundorten (Bom.). Sund, Bomarsund (B.). Saltrik, an rielen Fundorten (B.). - Ab. Ábo (Lundstr.). Reso, Luonnonmaa (Högm.) Pargas, an mehreren Fundorten auf Kalk (Elfv., Broth., Link.). Sagu, Träskby (Buch), - N. Helsingfors (W. Nyl.). Helsinge, Degerö (Buch); Testerkulla, Kalkholmen (Ranck.). Sitbo, Löparö (Sundv.). Lovisa (Häyr.). Iitti, Perheniemi (Buch). - Ta. Tavastehus (Lindb.). Hollola, Hersala (Norrl.). Asikkala, Kaitas (N.). - Sa. Willmanstrand (Simm.). - Kil. Ruskeala (Lindb.). - Sb. Kuopio, Jynkkä (Link.). - Kon. Valkeamäki (Simm.). Tiudie (Kullh.). - Ok. Kajana (Lackstr.).

S. Sk. $M p d$, und Jml.

N. Sm. - F. Nordgrenze bei $70^{\circ}$ n. Br.

Europa, Algier, Tunis, Kaukasus, Sibirien, Nord-Amerika.

171. Barbula spadicea Mitt. in Journ. Bot. 1867, p. 326. [B. vaginans Lindb. in Medd. Soc. F. Fl. Fenn. p. 71 (1887). — Didymodon spadiceus Limpr. Laubm. I. p. 556 (1888).]

Ziemlich kräftige Pfl. in lockeren, schmutziggrünen bis rotbraunen Rasen. Stengel 3-- $7 \mathrm{~cm}$. Blätter trocken gewunden, feucht aufrecht-abstehend, aus eioder länglich-eiförmigem Grunde lanzettlich, allmählich zugespitzt, bis $3,5 \mathrm{~mm}$ lang, mit kaum oder bis zur Blattmitte umgerollten Rändern: Ripje rom Grunde allmählich verschmälert und mit der Blattspitze endend: Zellen rings stark verdickt, beiderseits warzig, rundlich-quadratisch, mit querovalen und dreieckigen gemischt, am Grunde etwas weiter, rundlich, einzelne oval bis länglich. Seta 1$1.5 \mathrm{~cm}$, purpurn. Ring nicht differenziert. Peristonzähne blassrot, steil nach rechts aufsteigend.

Auf erdbedecklen, feuchten Kalksteinen und Mauern und auf feuchtem. sandig-torfigem Bodlen.

s. $\Delta \eta$. Omberg.

N. Sm. Glemminge. $R$. an wenigen Fundorten,

Europa, liaukasus, Nord-Amerika.

172. Barbula reflexa (Brid.) Brid. Mant. musc. p. 93 (1819). [Tortula reflexa Brid. Sp. musc. I. p. 255 (1806). - Barbula recurvifolia Schimp. Coroll. suppl. (1856). - Tortula recurvifolia Berk. Handb. brit. moss. p. 258 (1863).] 
Mehr oder weniger schlanke Pfl. in lockeren, bräunlichen bis rotbraunen Rasen. Stengel 1-8 cm. Blätter scharf gekielt, trocken locker anliegend und etwas gedreht, feucht bogig-zurückgekrümmt, aus eiförmiger Basis lanzettlich und allmählich zugespitzt, bis $2 \mathrm{~mm}$ lang, mit bis gegen die Nitte nmgerollten Rändern, am Grunde meist mit einer Längsfalte; Rippe bis weit hinauf gleicholick, in der Blattspitze endend, beiderseits dicht warzig; Zellen stark verdickt und beiderseits warzig, fast regelmässig mehreckig, an Grunde nächst der Rijpe rektangulär. Seta etwa $1 \mathrm{~cm}$. rot. Peristomzälne nur einmal gewunden.

Auf feuchten, erdbedeckten Kalk- und kalkhaltigen Filsen und vauern wie auch aut kalkhaltigem Erdboden.

F. Al. Jomala und Finström an einzelnen, saltvik an mehreren Fundorten (Bom.). - X. Helsingfors, auf Urkalk (Lindb.). Sibbo, Kalkholmen (Buch). - K. Kuusamo, Paanajărvi: Kuopłranja (Broth.).

S. Sk., Öi., Gll., $\mathrm{lg}$. und Lld. an einzelnen oder wenigen Fundorten.

N. Kri-tiania.

Europa, Kaukasus: Sibirien, Nord-Amerika.

173. Barbula rufa (Lor.) Jur. Laubmfl. p. 113 (1882). [Didymorlon rufus Lor. in Rabenh. Bryoth. eur. No. 621 c. diagn. (1863).]

Mehr oder weniger kräftige Pll. in starren, lockeren oder dichten, dunkelbraunen oder braunroten Rasen. Stengel bis 5 und $10 \mathrm{~cm}$. Blätter trocken anliegend bis schwach gedreht, feucht bogig-zurückgekrümmt, aus eilanzettlicher Basis allmählich zugespitzt, bis $2,7 \mathrm{~mm}$ lang, mit bis gegen die Spitze zurückgerollten Rändern; Rippe ziemlich gleichbreit, rot, mit der Spitze endend, beiderseits rauh: Zellen rings stark und gleichmässig verdickt. mit rundlichem und querovalem Lumen, beiderseits lang papillös-mamillös, nur am Grunde nächst der Rippe verlängert-rektangulär. Sporogone umbekannt.

Auf kalkhaltigen Felsen.

N. No. an mehreren und $F$. an wenigen Fundorten. überall in unmiltell,arer xiahe des Ifeeres. Alpenkette in der hochalpinen Region, Zentral-Asien und Gronland.

174. Barbula rigidula (Hedw.) Mitt. in Journ. Bot. 1867, p. 326. [Didymodon rigidulus Hedw. Descr. III. t. 4 (1792). - Trichostomum rigidulum Bryol. eur. fasc. 18/20 Mlon. p. 10, t. 7 (1843). - Tortula rigidula Lindb. de Tort. p. 249 (1864).]

Mehr oder weniger schlanke Pfl. in meist dichten, dunkel- bis schmutziggrünen oder bräunlichen, polsterförmigen Rasen. Stengel $0.5-2 \mathrm{~cm}$, selten höher. Blätter trocken cinwärts gebogen und gedreht, feucht aufrecht-abstehend, dic oberen aus ei- oder länglich-eiförmigem Grunde lanzettlich, \pm lang und stumpflich zugespitzt, bis $2,3 \mathrm{~mm}$ lang, mit weit hinauf schmal umgerollten, oberwärts 2-3schichtigen Rändern; Rippe bis über die IIitte gleichstark, die stumpfliche Spitze ausfüllend, glatt bis \pm papillös; Zellen \pm verdickt. rundlich-quadratisch, meist glatt, nach unten allmählich weiter, quadratisch und rektangulär, am Grunde durchscheinend. Seta 5-12 mm, rot. Ring nicht differenziert. Peristomzähne schmutzig gelblich oder gelbrötlich, steil nach rechts aufsteigend. Sporenreife im Herbst. - Vegetative Vermehrung durch kugelige bis ei- oder scheibenförmige. ein- bis mehrzellige, braume Brutkörper an blattaclıselständigen, verzweigten Trägern.

Auf Kalk, kalkhaltigen Gesteinen und Mauern.

F Al. Saltvik und Sund, an einzelnen Fundorten (Bom.). - Ab. Korpu. Llö (Elfv.). Nidendal (E.). Pargas, an mehreren Fundørten (Elfv.). Lojo, Paavola (Hull). — Y. Ekenäs, Elgó (Brolh.). Snappertuna, Raseborg (Häyr.). Helsingfors (Lindb.). Helsinge, Vesterkulla, Kalkhulmen (Ranck.). - Ia. Wiborg (Vain.). - Sa. Willmanstrand (Buch). - Kl. Pälkjärri, Korkeaniemi (Broth., Link.). - Sb. Kaavi, Siikajārvi, Likosaari (Kot.). - Le. Ǐilpisjärvi, Saitoraara (Kot.).

S. Ör. und Sm. an mehreren, š., Ög., $1 \mathrm{~g}$. . Srm.. . $\mathrm{Tär}$. Trml.. Dlr. und LuL. an einzelnen oder wenigen Fundorten.

N. A., sm., Bu., $s$ B., R., K.. NT., No. und $F$.

Europa, Kaukasus, Sibirien. Nord-Anerika. 
var. valida (Limpr.). [Didymodon validus Limpr. Laubm. I. p. 557 (1888). Barbula valida Möll. Förteckn. Skand. växt. 2. Moss. p. 21 (1907).]

Kräftige Pfl, in dichten, leicht zerfallenden, trüb braungrünen, polsterförmigen Rasen. Stengel bis $5 \mathrm{~cm}$ und darüber. Blätter ziemlich gleichgross, trocken geschlängelt. feucht aufrecht-abstehend, aus eilänglichem Grunde allmählich linealisch verschmälert, etwa $3 \mathrm{~mm}$ lang, mit von oberhalb der Basis bis über die Blattmitte schmal umgebogenen Rändern; Rippe bis ïber die Mitte gleichstark, in eine stielrunde, kräftige Stachelspitze austretend, glatt; Zellen gebräunt, dickwandig und glatt, meist gleichgross, rundlicli-quadratisch, im Nittelfelde des Blattgrundes verlängert rektangulär und gegen die Ränder quadratisch. Sporogone unbekannt.

N. Hedalen.

Schweiz. Tirul, Kärnten.

175. Barbula glauca (Ryan) Möll. Förteckn. Skand. växt. 2. Mloss. p. 21 (1907). (Didymodon glaucus Ryan i Rev. bryol. 1901. p. 39).

Schlanke Pll. in ausgedehnten. leicht zerfallenden, weichen. trocken blaugrimen, immen gelblichen Rasen. Stengel bis $7 \mathrm{~mm}$. Blätter brïchig, trocken sehr liraus, feucht aufrecht-abstehend bis zurückgelogen, untere aus breiter Basis lanzettlich, llachrandig. obere viel grösser, aus schmal lanzettlicher Basis lanzettlich-linealisch, mit schmal umgebogenen, einschichtigen Rändern, bis 2,25 mm lang; Rippe ziemlich gleichstark, in eine Stachelspitze auslanfend: Zellen wenig verdickt, oberwärts quadratisch und querrektangulär, glatt, gegen die Basis qua(lratisch und kurz rektangulär, wasserhell. Sporogone unbekannt.

N. Auf dem Detritus kalkhaltiger schieferfelsen, welche des Lichtes und der Feuchtigkeil entlehren, an drei Orten in Gudbrandsdalen, $400-500 \mathrm{~m}$.

S e c t. I I. Helicopogon (Mitt. Muse. austr.-amer. p. 112: 1869) Lindb. Musc. scand. p. 22 (1879).

Bläter trocken meist spiralig dem Stengel anliegend, stumpf und stachelspitzig. Innere Perichätialblätter meist an Grunde scheidig, doch nicht vortretend.

176. Barbula unguiculata (Huds.) Hedw. Fund. musc. II. p. 92 (1782). [Bryum unguiculatum Huds. Fl. angl. [\%. 410 (1762). - Torlula unguiculata Roth Tent. fl. germ. II1. P. I. p. 206 (1800).]

Mehr oder weniger schlanke Pfl. in meist lockeren, grünen oder gelbgrünen Rasen. Stengel $0,5-3 \mathrm{~cm}$. Blätter trocken einwärts gebogen und gedreht, aus eiförmigen oder eilänglichem Grunde lanzettlicl. bis fast zungenförmig, stumpflich, bis 2.5 mm lang. nit bis über die Mitte zurückgerollten Rändern; Rippe nach oben allmählich schwächer, als Stachelspitze austretend, beiderseits dicht warzig: Zellen beiderseits dicht warzig, undurchsichtig, abwärts allmählich grösser, durchscheinend, quadratisch, rektangulär und verlängert 6seitig. Seta $1-1,5$ cm, rot. Ring nicht differenziert. Peristomzähne blass- bis purpurrot, $3-4$ mal gewunden. Sporenreile im Spätherbst.

Auf allerlei Bodenarten, an Weg- und Grabenrändern, in Ausstichen. auf latuern und besonders auf kalkhaltigen Felsen.

F. 1l. Eckerö, Jomala, Lemland und sund an einzelnen, saltvik an mehreren Fundorten (Bom.).

1b. Kuustö (Lundstr.). Sho (Karst.). Pargas, an mehreren Fundorten (Elfv.). Sagu, Träskbỵ (Buch). Jojo, Tytyri (Häyr.). Pusula (Broth.), - N. Pojo, Eckerö (Häyr.). Helsingfors (Lindb.). Lovisa (Häyr.). Iitti, Perheniemi (Buch). - Tu. Tammela, Mustiala (Karst.). Asikkala. Kaitas (Norrl.). - Sa. Lappee, Ihalais (Simm.). - Kl. Sortavala, Paksuniemi (Buch). - hb. Juensuu (Linnan.).

S. Sil.-Gsir., Dlr.; inq. Hernösand.

N. Sm. - No. Nordgrenze bei etwa $67 \cdot 20^{\circ} \mathrm{n}$. Br.

Europa. Nlgier, Twis: Kaukasus, Sibirien, Japan, Nord-Amerika.

177. Barbula Hornschuchiana Schultz Recens. in Nor. Act. Acad. Leopold. X I. ]). 217, t. 33, f. 25 (1823). [Torhula Hornschuchiana De Not. Syllab. p. 179(1838).] Sehr schlanke Pfl. in lockeren oder dichten, leicht zerfallenden, grünen oder brämnlichen Rasen. Stengel $5-15 \mathrm{~mm}$. Blätter trocken last spiralig eiuwärts 
gedreht, feucht aufrecht-abstehend, lanzettlich, scharl zuges]jitzt, bis 0,9 mm lang, mit stark umgerollten, nur oberwärts die Ripłe erreichenden Rändern; Rippe als Stachelspitze austretend, papillös; Zellen kaum verdickt, beiderseits papillös, sehr undurchsichtig, quadratisch und rundlich-melnreckig, am Grunde nächst der Rippe kurz rektangulär. Seta 5-12 mm. rot, oben gelb. Ring kleinzełlig, sich bald ablösend. Pcristomzälne bis 2 mal gewunden. Sporenreife im Mai.

Auf lehmig-sandigem und tonig-kalkigem Boden.

S. Sk., öl. und srm. an wenigen Fundorten.

N. Fredriksstad.

Europa, Algier.

178. Barbula revoluta (Schrad.) Brid. in Schrad. Journ. III. P’. 11. 1). 294 (1801). [Tortula revoluta Schrad. Syst. Samiml. krypt. Gew. I. No. 54 (1796).]

Schlanke Pfl. in dichten, oben grünen bis gelbgrünen und gclbbräunlichen. polsterförmigen Rasen. Stengel bis $1,5 \mathrm{~cm}$, selten höher. Blätter trocken einwärts gekrümmt, die oberen spiralig geilreht, feucht aufrecht-abstehend, lineallanzettlich, stumpflich oder kurz zugespitzt, bis $1,5 \mathrm{~mm}$ lang, mit breit von der Blattmitte oberwärts bis gegen die Rippe umgerollten Rändern: Rippe kräftig. in der Blattspitze endend, papillös; Zellen wenig verdickt, rundlich-quadratisch und queroval, beiderseits mit niedrigen Papillen, undurchsichtig, abwärts allmählich erweitert. quadratisch und kurz relitangulär, durchscheinend. Setá 1- $2 \mathrm{~cm}$, rot, oben gelb. Ring differenziert, sich ablösend. Peristomzähne kaum 2 mal gewunden. Sporenreife im Mai.

Auf steinigen Ǩalkhügehn und kalkhaltigen Felsen.

N. A. Asker.

Europa, Tunis, Persien.

* B. obtusula (Lindb.) Kindl). Eur. and $\mathrm{X}$. Amer. Bryin. p. 258 (1897). [B. obtusula Lindb. Musc. scand. p. 22 (1879).]

Blätter breiter, mit sehr dicker, als Spitzchen austretencler Rippe. Peristonzähne zarter, kaum gedreht.

S. Gtl.

S e c t. I I 1. Streblotrichum (Palis. Prodr. P. 27: 1805) Limpr. Laubm. I. p. 626 (1888).

Pcrichätialblätter I hoch scheidig-röhrig zusammengewickelt.

179. Barbula convoluta Hedw. Descr. 1. p. S6, t. 32 (1787). [Tortula convoluta Schirad. Spic. fl. germ. p. 66 (1794).]

Schlanke Pfl. in dichten, oben meist schön gelbgrinen, imen braunen, durch Rhizoidenfilz verwebten, flachen Rasen. Stengel 5-10 mm, selten höher. Blätter trocken einwärts gebogen und \pm deutlich um den Stengel gedreht, feucht aulrecht-abstehend, an cler Spitze der jungen Sprosse fast sternfömig ausgebreitet. lanzettlich bis lineal-lanzettlich, allmählich oder rasch zugespitzt, bis $1,7 \mathrm{~mm}$ lang. mit flachen oder gegen den Grund etwas umgerollten Rändern; Rippe ror oder mit der Blattspitze endend, beiderseits dicht pajillös: Zellen dinnwandig, beiderseits dicht papillös, rundlich-quadratisch und mehreckig, undurchsichtig, nach dem Grunde hin erweitert, quadratisch und verlängert rektangulär, gelblich durchscheinend. Innere Perichätialblätter des Scheidchen umfassend, oben breit abgerundet, mit oder ohne Spitzchen. Seta $0.5-2,5 \mathrm{~cm}$, strohgelh. Kápsel klein, rötlich- bis fast schwärzlich-braun. Ring 3-treihig, sich alorollend. Peristom braunrot, 3 mal gewunden. Sporenreife im Mai und Juni.

Auf allerlei diirrem und somnigem Boden, gern auf kalkhaltiger C'nterlage. auf erdbedeckten Mauern und auf Brandstätten.

F. $A l$. In fast allen Teilen beobachtet und nicht selten (Bom.). - $1 b$. Pargas, Lapplaks und soris (Elfv.). Kimito, Gammelby (Ols.). Finby, Pettu (Sundv.). Lojo, an mehreren Fundorten (Lindb. Hult, H. Lindb., E. af H.). — N. Snappertuna, Rasehorg (Häyr.). Helsingfors (W. Nỵl.). Helsinge, 
Backas (Sola); Vesterkulla, Kalkholmen (Ranck.). Sibbo, Löparö (Sundr.). Elimäki (Tigerst.). Orimattila, Rautanäki (Liık.). Lovisa (Arrh.). - Ka. Fredrikshamn (Lindb.). - Ik. Muola, Perkjärri (H. Lindb.). - Ta. Im siidöstl. Teil zerstreut (Norrl.). Korpilahti (Norrl.). - Sa. Willmanstrand (Simmı.). Rantasalmi (Westerl.), - Kl. Valamo (Jusl.). Sortavala (F. Nyl.); Kirjavalahti (Lindb.). Ruskeala, an mehreren Fundorten (Norrl., Broth., Link.). Suistamo, Leppäsyrjä (Pes.). Pälkjärvi, Annoniemi (Broth.). - Kol. Tulemajärvi, Ruukki (Link.). Vosnessenje (Elfr.). - Tb. Pihtipudas, Sydänmaa, Isoaho (Roiv.). - Sb. Kuopio, an vielen Fundorten (Link., Kot.). Kaavi, Siikajärvi, Likosaari (Kot.); Losomäki (K.); Petkellahti (Kyylı.). Juuka, Vesiraara (Kot.). Nilsiä, Kirchdorf, Lehtomäki (Kot.); Kuuslahti, Jaakonlampi (Kyylk.). Maaninka. Tuovilanlahti, Arkkuvuori (Roiv.). - Kb. Kuusjäri, Outokumpu (Kot.). Juuka, Juuanvaara (K.). - Kon. Suojärvi (Norrl.); Haukka (Link.); Varpukylä, P’öpönsaari (L.). Valkeamäki (Simm.). Tiudie (S.). - Om. Alajärvi, Vesterbacka (Backm.). - Ok. Kajaneborg (Lackstr.). Paltamo, Melalahti, Āijöıkallio (Kyyhk.). Puolanka (Lackstr.). - Ob. Ủleaborg (W. Nyl.). - Lhem. Kolari, IIanaoja (Hult). Kittilä, Kirchdorf (H.).

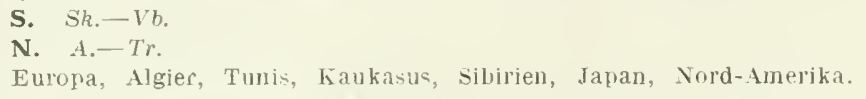

var. filiformis Hag. Muse. Norv. bor. p. 51 (1899).

Sehr schlanke Pfl. in sehr dichten Rasen. Stengel 2,5 cm, fadenförmig.

N. $F$. Nesseby.

180. Barbula paludosa Schleich. Cent. III. No. 23; Web. et Mohr Taschenb. p. 482 (1807). [Tortula paludosa Hook. et Grev. in Brewst. Edinh. Jouru. I. p. 301 $(1824)$.]

Weniger schlanke Pfl. in dichten und ausgedehnten, oben grïnen oder gelbgrünen. innen rostfarbenen, mässig durch Rhizoidenfilz verwebten Rasen. Stengel $1-10 \mathrm{~cm}$. Blätter trocken einwärts gebogen und schwach gedreht, feucht aufrechtabstehend, linealisch-lanzettlich. allmählich oder rasch zugespitzt, bis $2,5 \mathrm{~mm}$ lang, mit flachen, unten welligen. gegen die Spitze meist entfernt gezähnten Rän(lern; Rippe mit der Blattspitze endend oder kurz austretend, beiderseits \pm papillös; Zellen mässig verdiclit, beiderseits dicht papillös, quadratisch, unterhalb der Mitte allmählich rektangulär und gegen die Basis verlängert, gelblich und durchscheinend. Innere Perichätialblätter aus verlängert-scheidigem Grunde lanzettlich-pfriemenförmig, an der Spitze reichlicher gezähnt. Seta $5-10 \mathrm{~mm}$, rot, oben gelblich. Kapsel klein, schmal łänglich-eiförmig, braun. Ring nicht rlifferenziert. Peristomzälnne braunrot, 3 \& mal gewunden. - Vegetative Vermehrung durch grosse. ellipsoidische, rickellige Brutkörper an blattachselständigen, verzweigten Trägern.

An feuchten Felen mod Kalktulf.

N. Porsgrund.

Pyrenäen, Alpenketle. Nord-Ilalien, Algier

\section{POTTIOIDEAE.}

Blätter meist breil. ei- bis zungen- und spatellörmig: Rippe meist mit nur 2 medianen Deutern, mit Begleitern. dorsalem Stereidenbande mol weitlichtigen, oft 2reilhigen Bauchzellen, meist als Stachelspitze oder als Haar austretend; Zellen am Blattgrunde rektangulär bis verlängert, durchscheinend bis hyalin, oben Iocker.

$$
\text { I }^{4} \text { bersicht der Gat tungent. }
$$

A. Kapsel ohne Ancleutung eines Deckels.

a. Kapsel kugelrund, olne Spitzchen .................. 50. Acaulon.

b. Kapsel kiugelig bis eiförmig. mit Spitzehen ............ 51. Phascum.

B. Deckel differenziert, fast stets abfallend.

a. Obere Blatthälfte anf der Innenseite der Rippe mit besonderen Assimilationsorganen. 
«. Rippe mit 2-4 Längslamellen

54. Pterygoneurum.

j. Rippe mit einem Polster verzweigter Zellfäden ... 56. Aloina.

b. Blätter olne besondere Assimilationsorgane.

«. Deckel bleibend. Peristom vorhanden ............. 52 I. Mildeella.

$\beta$. Deckel abfallend.

I. Peristomzähne flach.

1. Peristomzäbne ungeteilt, durchbrochen bis unregelmässig getcilt, zuweilen fehlend.

* Knospenförmige, weissliche Pfl. Blätter löffelartig-hohl

53. Stegonia.

** Grüne bis bräunliche Pfl. Blätter kielig-hohl. 52. Pollia sens.

strict.

2. Peristomzähne bis gegen die Basis geteilt ... 55. Desmatodon.

II. Peristomzähne bis zum Grunde in 2 fadenförnige,

ein- bis mehrmals gewundene Schenkel geteilt... 57. Torlula.

\section{ACAULON}

C. Mü̈ll. in Bot. Ztg. 1847, p. 99 p. p.; Lindb. Musc. scand. p. 21 (1879).

Diözisch; or Pll. sehr klein, knospenförmig. entweder frei oder durch Rhizoiden mit dem Grunde der $f$ Pfl. verbunden. Winzige, knospenförmige, meist gebräunte und herdenweise wachsende Erdmoose. Stengel ohne Zentralstrang. am Grunde mit Rhizoiden, dicht beblättert, einfach. Untere Blätter klein, die oberen kielig-hohl, breit eiförmig, rasch zugespitzt; Rippe diin, vor der Blattspitze aufhörend bis austretend; Zellen oberwärts rhombisch bis rhomboidisch6seitig, glatt, unten verlängert rektangulär und hyalin. Kapsel tief in den Hüllblätter versteckt, kugelig, olne Andeutung eines Deckels; Zellen des Exotheciums weit, dünnwandig, parenchymatisch, unregelmässig. Haube sehr klein, kegelmützenförmig, nur den Scheitel deckend. Sporen gross.

Übersicht der Arten.

A. Sporen feinwarzig

B. Sporen fein igelstachelig

181. A. muticum.

182. A. mediterraneum.

181. Acaulon muticum (Schreb.) C. Müll. 1. c. [Phascum muticum Schrel). de Phasco obs. p. 8, t. 1, f. 11/12 (1770). - Sphaerangium muticum Schimp. Syı. p. $13(1860)$.]

Schopfblätter sehr hohl, aus sehr verengtem Grunde breit rundlich-eiförmig. rasch kurzspitzig, mit breit eingebogenen, an der Spitze zurïckgebogenen, ausgeschweift-gezähnten Rändern, bis 1,5 mm lang; Rippe kurz vor oder in der Spitze aufgelöst. Seta aufrecht. Kapsel glänzend braunrot. Sporen 30-35, zuweilen bis $45 \mu$, gelbbraun, feinwarzig. - Fig. $26 \mathrm{~A}-\mathrm{C}$.

Auf tonigem und kalkigem Boden, auf Brachäckern.

F. Al. Saltvik, an mehreren Fundorten (Bom.).

S. Sk.-Upl. Gstr. Gefle. När. Örebro.

N. Sm. an mehreren Fundorten. A. Kristiania.

Europa.!

var. minus (Hook. et Tayl.) Bryol. eur. (1849). [A. minus Jaeg. Musc. cleistocarp. p. 19 (1869).]

In allen Teilen kleiner. Schopfblätter bis 1,1 $\mathrm{mm}$ lang, ganzrandig, die liapsel kaum überragend. Sporen deutlich gekörnelt.

F. Ab. Lojo, Kiriniemi (Lindb.).

England, Frankreich, Algier. 
182. Acaulon mediterraneum Limpr. Laubm. I. p. 180 (1885).

Kleiner als die vorige Art. Blätter schmäler, mit an der Spitze flachen Rändern. Seta rudimentär. Kapsel rot. Sporen $20-28 \mu$, fein igelstachelig.

N. A. Kristiania, Allergodt, auf einem tonigen Acker.

Sardinien.

\section{PHASCUM}

Schreb. De Phasco Obs. (1770).

Winzige bis ziemlich kräftige Erdmoose. Stengel olme Zentralstrang, am Grunde mit Rhizoiden, dicht beblättert. Untere Blätter klein, obere ei- bis verlän-
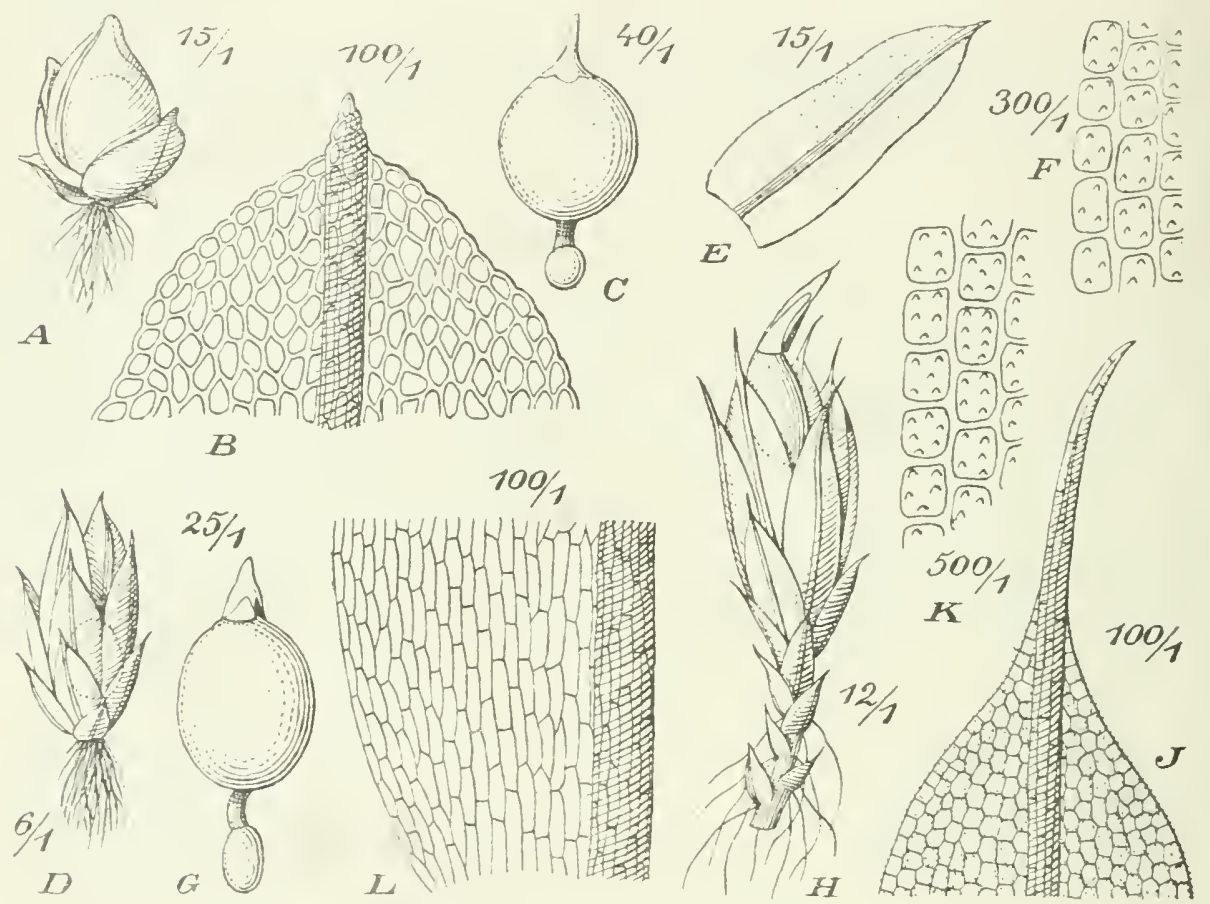

Fig. 26. A-C Acaulon muticum (Schreb.) C. Iüll. A Fruchtende Pfl. (15/1); B Blattspitze (100/1); C Kapsel mit Haube (40/1). - D-G Phascum acaulon L. D Fruchtende Pfl. (6/1); E Stammb. (15/1): F Zellen der Blattspitze (300/1): G Kapsel (25/1). - H-K Pottia bryoides (Dicks.) Limpr. H. Fruchtende Pfl. (12/1); I Blattspitze (100/1); K Zellen der Blattspitze (500,1): L Blatthasis (100/1).

gert-lanzettlich, ganzrandig; Rippe kräftig, austretend: Zellen oberwärts quadratisch oder 6seitig, meist beiderseits warzig-papillös. gegen den Blattgrund Jocker rektangulär, dünnwandig und chlorophyllarm. Sporogon eingesenkt, seitlich hervortretend oder etwas emporgehoben. Kapsel kugelig, eiförmig oder oval, meist stumpf gespitzt. meist ohne Andeutung eines Deckels: Zellen des Exotheciums dïnnwandig, meist rektangulär. Haube kappen-, seltener nü̈tzenförmig.

¿̇ bersicht der Arten.

A. Sehr kleine, bräunliche oder rotbräunliche Pfl.

a. Haube kegel-mützenförmig, nur den Scheitel bedeckend 
b. Haube kappenförmig, 士 weit herabreichend. Kajusel seitlich vortretend, nickend bis hängend .............. 186. Ph.curvicollum.

B. \pm kräftige Pfl.

a. Weniger kräftige, bräunliche Pfl. Blätter durch die austretende Rippe lang begrannt .....................

b. Kräftige, grüne Pfl. Blattrippe als mässig lange Stachelspitze austretend

185. Ph. piliferum.

183. Phascum Floerkeanum Web, et Mohr Bot. Taschenb. p. 70 el 151 (1807). [Microbryum Floerkeanum Schimp. Syn. p. 11 (1860).]

Parözisch; Antheridien schr klein, meist zu 2 in den Achseln der oheren Stammblätter. Äusserst kleine, bräunliche Pfl., vereinzelt oder truppweise, mit oft ausdauerndem Protonema, dem oft winzige $r$ Pfl. aufsitzen. Stengel einfach. Obere Blätter trocken \pm knospenförmig zusammenschliessend, ei- oder länglich-lanzettlich. zugespitzt, mit aufrechten oder oberwärts umgebogenen Rändern, bis 0,75 mm lang; Rippe nach oben kräftiger und als zurückgekrümmter Stachel austretend. Perichätialblätter grösser. Sporogone zuweilen zu 2-4 gehäuft, mit äusserst verkürzter Seta. Kapsel eikugelig, braun, mit geradem, stumpfem Spitzchen. Haube kegel-mützenförmig. nur den Scheitel (leckend. Sporen 18-25 ", bleichgelblich, glatt. Sporenreife im Spätherbst.

Auf feuchtem, nacktem. tonigem oder kalkhaltigem Boden.

F. Al. Saltvik, Haga, Bergön und an mehreren Fundorten um Krambo (Bom.).

S. Sk. Knästorp. När. Örehro. Lpl. an mehreren Fundorten.

Europa, Algier: Nord-Amerika.

184. Phascum acaulon L. Sp. p]. 1570 (1753). [Phascum cuspidatum Schrel). de Phasco Obs. p. $\$$, t. 1, f. 1/5 (1770).]

Autözisch; $\rightarrow$ Blüten klein, bei verzweigten Stämmchen in der Gabelung, bei einfachen in einer Blattachsel. Kriäftige, meist grüne Pfl,g gesellig oder in kleinen Räschen. Stengel 1,5--10 $\mathrm{mm}$, meist gabe]- und büschelästig. Obere Blätter trocken verbogen, breit länglich-eiförmig bis verlängert-lanzettlich, mit oberwärts zurückgebogenen Ränderı, bis 2,6 mm lang; Rippe ziemlich kräftig. als mässig lange Stachelspitze austretend: Zellen glatt oder \pm warzig-papillös. Seta sehr kurz, gerade oder schwach gekrümmt. Kapsel kugelig oder eiförmig, mit kurzem, stumpfem Spitzchen, mattbraun. Haube kappenförmig, his 1/2 der Urne reichend. Sporen 28-33 $\mu$, bräunlich, dichtwarzig. Sporenreife in Frühjalır. - Fig. $26 \mathrm{D}-\mathrm{G}$.

Auf Brachäckern und Erdblössen.

F. Al. fq. (Bom.). - Ab. Abo, Kuppis (Karst.. Elfv.). Pargas, Alön (Broth.). - N. Sjunded, Ir yran: (Nerv.). Helsingfors (Lindh.).

S. Sk.-Jmt. und ing.

N. sm., A. und $J L$.

Europa, Algier. Kankasus, Nord-Ameriki.

* Phascum papillosum (Lindb.) Lindb. Mlusc. scand. p. 24 (1879). [Ph. papillosum Linclb. 'Trichost. eur. p. 217 (1864). - Ph. cuspidalum var. papillosum Hartm. Sk. Fl. ed. 10, p. 119 (1871).]

Bläulichgrïne Pfl. Schopfblätter stumpflich, dlicht papillös. Haube dicht papillös.

S. stockholm, Danvikskrokar.

185. Phascum piliferum Schreb. de Phasco Obs. p. 8, t. 1, 1. 6/7 (1770). [Phascum cuspidalum $\beta$ piliferum Hook. et Tayl. Musc. brit. p. S. L. 5 (1818).]

Autözisch; Blüten klein, bei verzweigten Stämmchen in der Gabelung. bei einfachen unter dem Scheidchen. Ziemlich schlanke Pfl. in gedrängten, bräunlichen bis rotbraunen Räschen. Stengel nur wenige mm, meist büschelig verzweigt. Obere Blätter trocken verbogen. schmal länglich-lanzettlich, kurz zugespitzt bis 
abgerundet, mit zurückgebogenen Rändern, his $3 \mathrm{~mm}$ lang; Rippe kräftig, als langes, hỵalines oder gelbes Haar austretend; Zellen glatt odler warzig-papillös. Seta sehr kurz, gerade oder gekrümmt. Kapsel kugelig. mit sehr kurzem. stumpfem Spitzchen. glänzend braunrot. von oben sichtbar oder seitlich vortretend. Haube kegel-kappenförmig, die halbe Urne deckend. Sporen $24-28 \mu$, hellbraun, grobwarzig. Sporenreife im Frühling.

Auf Brachäckern und an sandig-lehmigen Abhängen.

F. Al. Saltrik, selten ( $\mathrm{B}$ ont.).

S. Nach Hartm. Sk, Fl. Sk. $-U p l$. und Nar.. sellenter als die voriqe Arl.

N. Bu. Honefos.

Europa. Alọier. Tord-Amerika.

186. Phascum curvicollum Ehrh. Mser.: Hedw. Deser. 1. p. 31, t. 11 (1787).

Parözisch: Antheridien zu 3-6 in den oberen Blattachseln. Selnr kleine, rotbräunliche, gesellige Pfl. Stengel $1-2 \mathrm{~mm}$, einfach oder geteilt. Obere Blätter schopfig gehäuft. verlängert lanzettlich, mit zurückgebogenen Rändern. bis $1,7 \mathrm{~mm}$ lang: Rippe als Stachelspitze austretend. Sporogone oft mehrere aus demselben Perichätium. Seta etwa ron der Kapsellänge. schwanenhalsartig gebogen. Kapsel klein, nickend oder hängend, oval, braun, mit schiefer Spitze. Haube kegel-kappenförmig. bis weit unter die Kapselmitte reichend. Sporen 23-25 ". bleichgelblich, glatt. Sporenreife im Frïhling.

S. Nach Kind herg ohne Angabe der Fundurle.

Europa.

\section{POTTIA}

Ehrh. Beitr. I. p. 17.j (1787).

Meist kleine. gesellige oder rasenbildende Erdmoose. Stengel nur am Grunde mit Rhizoiden, einfach oder wenig rerästelt. Blätter oberwärts meist schopfig gehäuft, kielig-hoh]. länglich-eiförmig bis lanzettlich-spatelförmig; Rippe abwärts schwächer, meist als Stachelspitze oder als Haar austretend: Zellen oberwärts 4-6eckig. meist beiderseits warzig oder papillös. am Grunde verlängert rektangulär, glatt und durchscheinend. Perichätialblätter nicht differenziert. Seta = verlängert. Kiapse] aufrecht, regelmässig. eiförmig bis zỹlindrisch, braun. glatt oder trocken längsstreifis: Zellen des Exotheciums \pm unregelmässig. in der Iehrzahl mehreckig und rektangular. Ring meist bleibend, selten nicht differenziert. Peristom fehlend, rudimentär oder mit niedriger Basilarmembran und aufrechten, längs durchbrochenen oder oberwärts 2-3spaltigen. papillösen Zähnen.

$$
\text { ithersicht der Arten. }
$$

A. Deckel bleibend

1si. P. bryoides.

B. Deckel abfallend.

a. Blätter flachrandig. Peristom tehlend. Sporen dicht warzig.

«. Polvözisch. Blätter bis $3.5 \mathrm{~mm}$ lang. oben gesägt. Deckel später von der Columella getragen ....... 194. P. Heimii.

ア. Autözisch. Blätter bis $1.7 \mathrm{~mm}$ lang, ganzrandig oder an der äussersten Spitze gezähnelt. Colmmella sjäiter nicht vortretend .......................... 190. P. Iruncatula.

b. Blätter mit bis zur Nitte und weiter hinauf = umgebogenen Rändern.

r. Deckel kurz stmmpfspitzig. Peristom fehlend. Sporen stachelwarzig 
$\beta$. Deckel lang und schief geschnäbelt. Peristom rudimentär. Sporen dicht und fein papillös ............. 191. P. intermedia.

$\gamma$. Peristom ausgebildet.

I. Deckel kurz kegelig.

1. Sporen mit grossen Pusteln .................. 189. P. Starkeuna.

2. Sporen fast stachelwarzig .................... 192. P. commutata.

II. Deckel lang und schief geschuäbelt. Sporen tein-

warzig

193. P. lancenlata.

L $n$ t e r g a t t. I. Mildeella (Limpr.) Broth. in Engl.-Prantl Bryal. p. 123 (1902). [Mildeella Limpr. Laubm. I. p. 191 (1885). - Mildea Warnst. Laubm. p. $82(1906)$.]

Kapsel mit bleibendem Deckelchen und deutlichem Peristom.

187. Pottia bryoides (Dicks.) Mitt. in Ann. nat. hist. 2. ser. VIII. p. 311 (1851). [Phascum bryoides Dicks. Fasc. pl. crypt. IV. ]. 3, t. 10, f. 3 (1801). Tortula bryoides Lindb. Musc. scand. p. 21 (1879). - Mildeelta bryoides Limpr. Laubm. I. p. 192 (1885).]

Autözisch: Blüten anfangs gipfelständig, später am Grunde des Fruchtsprosses. Dunkel- bis bräunlichgrïne PfI. in lockeren, oft ausgedehnten Rasen. Stengel ohne Zentralstrang, 2-10 mm. Obere Blätter eilänglich bis länglichlanzettlich und spatelförmig, kurz zugespitzt, bis $3 \mathrm{~mm}$ lang, mit ungebogenen, , an der Spitze zuweilen lein gezähnelten Rändern: Rippe als Stachel oder Haar austretend; obere Zellen papillös-warzig oder glatt. Seta bis $3 \mathrm{~mm}$, rötlích. Kapsel oval oder elliptisch, mit bleibendem, schief kegelförmigem Deckelchen, dessen Zellen steil nach rechts ansteigen. Peristomzähne fadenförmig, papillös, gelb, nach oben oft nur in Bruchstücken angedeutet, am Grunde gegenseitig verschmolzen. Sporen $25-35 \mu$, dunkelbramn, dichtwarzig. Sporenreife im Frühling. — Fig. $26 \mathrm{H}-\mathrm{K}$.

S. Sk., Ol., Gll., Srm. und Gstr. an einzelnen Fundorten.

Europa, Kaukasus, Nord-Amerika.

Un te rgat t. I I. Pottia sens. strict. Brotlı. in Engl.-Prantl Bryal. p. 423 $(1902)$

Kapsel mit abfallendem Dechel.

188. Pottia Davalliana (Sm.). [Gymnostomum Davallianum Sm. in Konig et Sims, Ann. Bot. I. p. 577 (1805). — G. rufescens Schultz Prodr. Fl. starg. p. 278 (1806). - G. minutulum Schleich. Cent. V. No. 8 Cat. (1807). - Pottia minutula Bryol. eur. 18/20 Mlon. p. 8. t. 3 (1843). - P. Starkiei var. gymnostoma Lindb. de Tort. p. 219 p. p. (186-1). - Tortula Starkei var. Davallii Lindb. Musc. scancl. p. 21 (1879). - P. rufescens Warnst. Laubm. p. 209 (1904).]

Parözisch. Gesellig, meist bräunlich oder rötlichbraun. Stengel wenige $\mathrm{mm}$. Blätter länglich-lanzettlich, bis $1.2 \mathrm{~mm}$ lang, mit über der Basis bis gegen die Spitze sehr schmal umgebogenen Rändern: Rippe \pm lang austretend; obere Zellen $t$ deutlich papillös bis fast glatt. Seta $2-5 \mathrm{~mm}$, gelb oder rötlichgelb. Kapsel gestutzt-eiförmig, entleert weitmiindig, trocken zart längsfaltig. Ring und Peristom fehlend. Deckel aus gewölbter Basis kurz und stumpf gespitzt. Sporen 25-36 ", rostfarben, dicht stachelwarzig. Sporenreife im Herbst.

Auf Erdblössen, Brachäckern und an Grabenrändern, besonders auf kalkhaltiger Unterlage.

F. Al. Jomala, Kirchdorf und Ytterby (Bom.). Saltvik, an wenigen Fundstellen (B.).

S. Sk. und $\ddot{g}$. an mehreren, Gtl., Srm., Upl. und Ang. an einzelnen Fundorten.

N. Sm. Glemminge und Ons". JL. Tj 'mo.

Europa, Algier, Tunis, Nord-Amerika.

189. Pottia Starkeana (Hedw.) C. Müll. Sym. I. p. 547 (1849). [Weisia Star- 
keana Hedw. Descr. III. p. 83, t. 34 B (1792), -- Tortula Starkei Lindb. Musc. scand. p. 21 (1879).]

Parözisch. Herdenweise und in kleinen, grünen Räschen. Stengel 1--2 mm. Obere Blätter aus etwas verschmälerter Basis ei- bis länglich-eilörmig, rasch zugespitzt, bis $1 \mathrm{~mm}$ lang, mit über der Basis bis gegen die Spitze zurückgerollten, unversehrten Rändern; Rippe kurz austretend, beiderseits, wie auch die mittleren Zellen \pm papillös. Seta $2-3 \mathrm{~mm}$, gelb oder gelbrötlich. Kapsel oval bis länglich, etwas glänzend, entdeckelt mit etwas verengter Mündung. Ring undentlich differenziert. Peristom weiss oder rötlichgelb; Zühne stimpf lanzettlich, dicht papillös, ganz oder durchbrochen. Deckel sehr kurz kegelig. Sporen $18-25$ ", gelblich, durch grosse Pusteln sehr uneben. Sporenreife zeitig im Frïhjahr.

Auf tonig-mergeligem und kalkigem Boden.

S. Gu., Srm. und $L p l$. an einzelnen Fundorten.

England, Irland, Zentral- und Süd-Europa, Kanaren. Algier. Syrien, Nord-Amerika.

190. Pottia truncatula (L.) Lindb. de Tort. p. 220 (1864). [Bryum truncafulum L. Sp. pl. p. 1119 (1753). — Gymnostomum Iruncatum Hedw. Descr. I. p. 13. t. 5, f. 5-14 (1787). - Pottia truncata Bruch in Herb.: Fürnr. in Flora Xil. P. II. Erg. p. 10 (1829). - Torlula truncatula Lindb. Muse. seand. p. 21 (1879).]

Autözisch; Blüten achselständig. Truppweise oder in kleinen, grünen Räschen. Stengel 1-4 mm. Obere Blätter länglich oder nach oben etwas verbreitert und fast spatelförmig, kurz zugespitzt, meist etwa 1.1.1, aber auch bis $1.70 \mathrm{~mm}$ lang, flach- und ganzrandig, zuweilen in der Blattmitte schmal umgebogen und an der äussersten Spitze gezähnelt; Rippe kurz austretend: obere Zellen mit vereinzelten, kleinen Papillen. Seta 3-6 mm, gelb oder gelblichrot. Kapsel kurz verkehrt-eiförmig, entdeckelt weitmündig. Peristom fehlend. Deckel flach gewölbt, schief geschnäbelt. Sporen 18-25, seltener lis $30 \mu$, gelbbräunlich, dichtwarzig. Sporenreife im Herbst.

Auf Erdblössen, Brachäckern und an Crabenrändern. besonders auf toniger Lnterlage.

F. Al. st. [q. (Bom.). - Ab. Aho (Elfr.). Reso, Llionnonmaa (Brand.). Kimito, Vreta (Ohls.). Ĺskela (Nikl.). Karislojo, Pellonkylä (H. Lindb.). Lojo, an mehreren Fundorten (H. Lindb., E. af H.). - N. Kyrkslätt (Sundv.). Eslo, Kilo (Buch). Helsinglors (Hult, E. al H.). Helsinge. Ággelby (II. Nyl.); Backas (Sola). Sibho, Gesterby (Ranck.). - Ka. Sippola. Ruotila (Kuj.). - Ik. Uusikirkko, Rajajoki (H. Lindb.). IIetsäpirtti, Tappari (H. L.). - St. Björneborg (Häyr.). Pirkkala (Simm.). Ikaalinen (Sundv.). - Ta. Vanaja Graefi. . Kalvola (Knab.). Im südösll. Teile auf Äckern โq. (Norrl.). Korpilahti, an mehreren Funuorten (Vain.). — So. Willmanstrand (Buch). — Tb. Jyväskylä und Laukaa (Broth.). - Sb. Maaninka. an mehreren Fundorten (Kyyhk., Roiv.). - Kb. Joensuu. Limnunniemi (Linnan.). - Kon. Kintes (Kulli.).

S. Sk. - Hlsl. und Dlr.- Ing. Härnösand.

N. $S m \cdot-S B$.

Europa, Kanaren. Algier, Vorder-A-ien, Sibirien. China. Japan. Nord-Imerika.

191. Pottia intermedia (Turn.) Fürnr. in Flora XII. P. II. Erg. p. 10 (1829). [Gymnostonum inlermedium Turn. Musc. hib. ]. 7, t. 1, f. a-c (1804). — Tortula intermediu Lindb. Musc. scand. p. 21 (1879).]

Autözisch; Blüten achselständig. Gesellig oder vereinzelt. seltener in kleinen. grünen Räschen. Stengel bis $5 \mathrm{~mm}$. Obere Blätter länglich-lanzettlich bis lanzettlich-spatelförmig, $1.7-3 \mathrm{~mm}$ lang, mit bis zur Mitte oder weiter hinauf schmal umgebogenen, unversehrten Rändern; Rippe \pm lang austretend; obere Zellen schwach warzig bis glatt. Seta bis $1 \mathrm{~cm}$, gelbrötlich. Kapsel länglich-eiförmig bis fast zylindrisch, entdeckelt nicht erweitert, trocken fein längsstreifig. Peristom auf eine bleiche, zart papillöse bis glatte Basilarmembran beschränkt. Deckel aus gewölbler Basis schief geschuäbelt. Sporen 25-30 $u$, braun, dicht und fein papillös. Sporenreife im Herbst.

An trockenen Orten, gern anf kalkhaltigem Boden. 
Pottia.

143
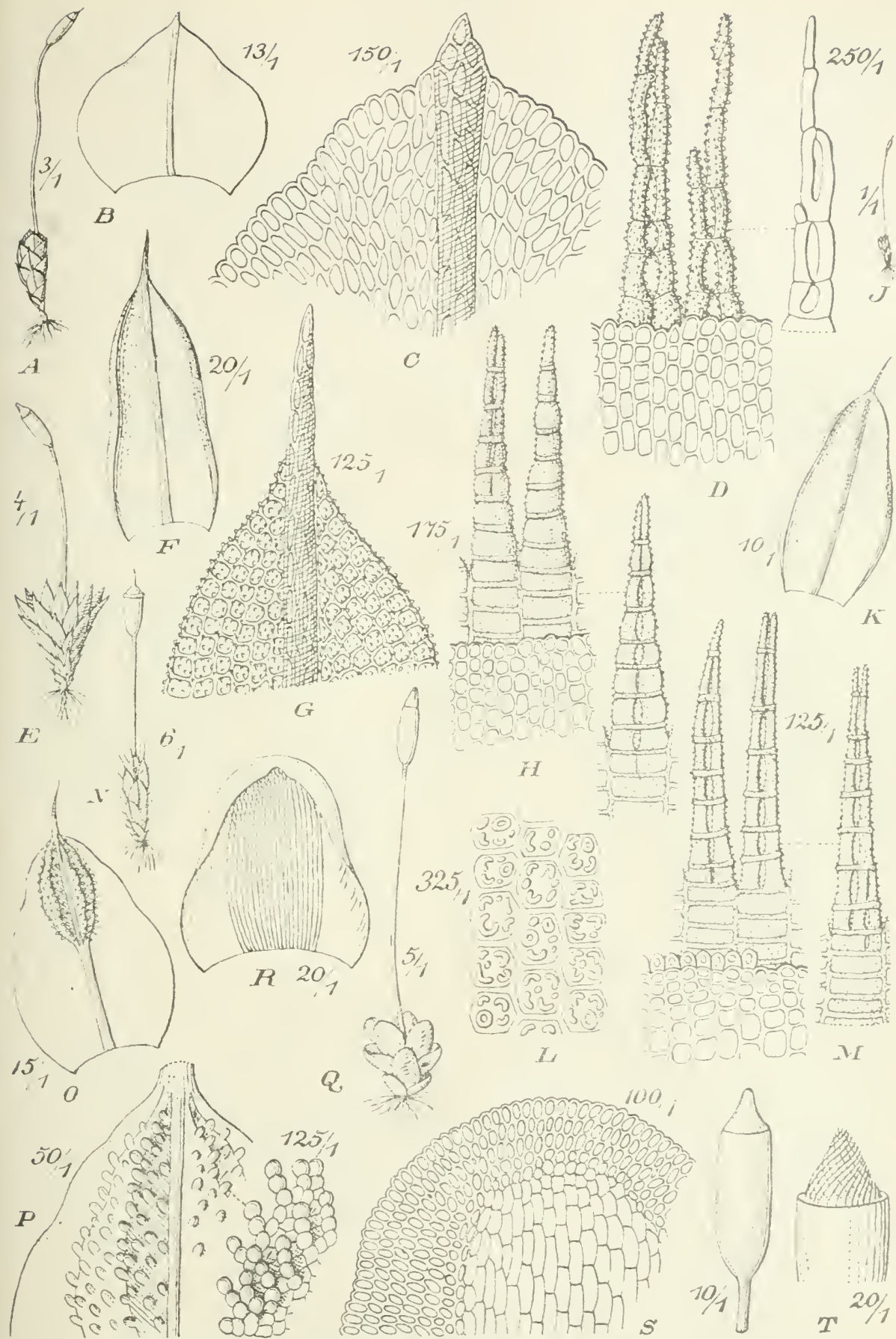

Fig. 28. A-D Stegonia latifolia (Schwaegr.) C. "Mrül." A Fruchtende Pfl. (3/1): B Stammb. (13/1) C Blattspitze (150/1); D Peristom (250/1) - E-H Potlia lanceolata (Hedw) C. Yïll. E Fruchtende Pfl (4/1); F Stammb. (20/1); G Blattspitze (125/1); H Peristom (175/1); - I-Ir Desmatodon latifolius (Hedw.) Bryol. eur. I Fruchtende Pfl. (1/1); $\mathrm{h}$ Stammb. (10/I); L Zellen aus dem oberen Blatteil (325 1); if Peristom (125/1). - N-P Pterygoneurum cavifolium (Ehrh.) Jur. N Fruchtende Pfl, (6/1); O Stammb (15/1); P Blattspitze $(50 / 1)$. - O - T Aloina brevirostris' (Hook et Grev.) Kindb. O Fruchtende Pf1. (5/1); R Stanmb. (20/1); S Blattspitze (100/1); T Bedeckelte u. entdeckelte Kapsel (101 $14.20 / 1)$. 
F. Al. Eckerö, Torp (H. Lindb.). Saltrik, an vielen Fundorten. - $\Lambda$. Helsingfors, botan. Garten (Lindb.).

S. Sm. an mehreren, Sk., C̈l., Irg., Srm., Vär., Upl., Irml. und Gsir. an einzelnen Fundorten.

N. Sm., A. und Bu.

Europa, Algier, Nord-Amerika.

192. Pottia commutata Limpr. Laubm. I. p. 537 (1888).

Parözisclı. Herdenweise wachsende, lichtgrüne Pfl. Stengel $1-2 \mathrm{~mm}$. Obere Blätter oval und länglich, kurz spitzig bis fast abgerundet, bis 1,35 $\mathrm{mm}$ lang, mit aufwärts schmal zurückgebogenen, unversehrten Rändern; Rippe sehr kurz austretend; obere Zellen dicht warzig-papillös. Seta $2-3 \mathrm{~mm}$, gelb, verbogen. Kapsel meist geneigt, oval bis länglich. gelblich, zuletzt lichtbräunlich, entdeckelt nicht erweitert, trocken schwach faltig. Ring nicht differenziert. Peristom blass gelblich, papillös, mit vortretender Basilarmembran; Zähne kurz und breit, gestutzt, zuweilen rudimentär. Sporen $20-24 \mu$, gelbbraun, fast stachelwarzig. Deckel stumpf kegelig, trocken gewölbt und dick genabelt.

N. Kristiania. Rambergo.

193. Pottia lanceolata (Hedw.) C. Müll. Syn. I. p. 548 (1849). [Leersia lanceolata Hedw. Descr. II. p. 66, t. 23 (1789). - Tortula lanceolata Lindb. Musc. scand. p. $21(1879)$.]

Autözisch; $\sim$ Blüten achselständig. Grüne Pfl. in lockeren oder dichteren Räschen. Stengel 3-6 mm. Obere Blätter ver]ängert-länglich oder aus spateliger Basis nach oben verbreitert und lanzettlich zugespitzt, bis $2.3 \mathrm{~mm}$ lang, mit bis gegen die oft schwach gezähnelte Spitze \pm deutlich zurückgebogenen Rändern; Rippe in eine gelbgrüne oder braune Granne austretend: Zellen oberwärts glatt oder schwach warzig. Seta 5-10 mm, rot. Kapsel länglich-eiförmig bis fast zylindrisch, entdeckelt an der Mündung etwas verengt, trocken längsrunzelig. Peristom gelbrot, seltener weiss, dicht papillös, mit vortretender Basilarmembran; Zähne schräg nach rechts aufsteigend, breit, meist längs durchbrochen, an der Spitze stumpf oder 2-3teilig. Deckel aus kegeliger Basis kurz bis länger schief geschnäbelt. Sporen $18-25 "$, gelblich bis gelbbraun, feinwarzig. Sporenreife im Frühling. - Fig. $28 \mathrm{E}-\mathrm{H}$.

An sonnigen Orten, gern auf kalkhaltigem Boden.

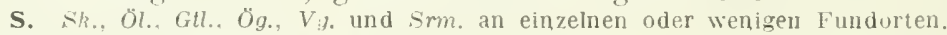

N. A. liristiania, Hovedoen.

Europa, Algier, Kaukasus, Vorder-Asien, Japan.

194. Pottia Heimii (Hedw.) Bryol. eur. fasc. 18/20, Iton. p. 12, t. 7 (1843). [Gymnostomum Heimii Hedw. Deser. I. p. 80, t. 30)(1787). - Tortula Heimii Mitt. in Journ. Linn. Soc. Bot. XII. p. 165 (1869).]

Polyözisch: Blïten gipfelständig. Mehr oder weniger kräftige Pfl. in meist dichten, grünen bis bräunlichen Rasen. Stengel 1-2 cm. Untere Blätter entfernt, breit lanzettlich, obere länglich-lanzettlich und länger zugespitzt, etwa $3,5 \mathrm{~mm}$ lang. mit flachen, oben gesägten Rändern: Rippe mit der Blattspitze endend oder als Stachelspitze austretend: obere Zellen beiderseits warzig-papillös oder l'ast glatt, an rlen Rändern bis gegen die Spitze hin oft durch 3-4 Reihen unregelmässiger, häufig rektangulärer Zellen fast gesäumt. Seta $5-15 \mathrm{~mm}$, gelb oder bräunlich. Kapsel länglich, gestutzt. Deckel flach gewölbt, schief geschnäbelt, noch längere Zeit von der sich streckenden Columella getragen. Sporen 25-37 " . l,raun, dicht warzig. Sporenreife in Sommer.

Auf salzhaltigem Boden, besonders an den Meeresküsten.

F. A!. Eckerö, Finströn, Lemland und sund an wenigen, Saltvik an melıreren Fundorten (Bom.).

Ab. Korpo, Utö (Elfv.). Pargas (A.H.Caj.). Bromarf, Brumholmen (Brotl.). - N. Ekenäs, Segelskär, (Iäyr.). Helsinge, Vesterkulla, Kalkholnen (Ranck.). - Ob. Kemi. Niemi (Brenn.). - Lp. Svjätojnos, sapadnij narolok (Brotlı.). Ponoj (Sahlb.).

S. Sh.-Vb., Öl., Hll. und Boh.-Upl. Upsala.

N. Sm. $-F$.

Europa, Nord-Amerika. 
var. obtusifolia (R. Br.) Hag. Musc. Norv. bor. p. 45 (1899). [Gymnostomum obtusifolium R. Br. Suppl. append. it. Parryan. p. 299 (1823). - Pottia Heimii var. arctica Lindb. in Öfr. K. Vet.-Ak. Förh. 1866, 1). 551. - P. Ryani Philib. in Rev. bryol. 1896, p. 28. - Didymodon Heimii * Ryani Kindb. Sp. Eur. and N.An. Bryin. II. p. 280 (1897).]

Blätter kurz. oben abgerundet. Kapsel zuletət trichterförmig. Deckel nicdriger.

N. F. Kistrand, Mellanalus auf ausgeglittenen, feuchten Quicksandmassen.

Spitzbergen, Tschuktschen-Hall,insel, arkt. Nord-Amerika.

\section{STEGONIA.}

Vent. in Rer. bryol. 1883, p. 96.

Kleine, knospenförmige, weissliche Pfl. Blätter knospenförmig zusammenschliessend, löffelartig-hohl, aus schmälerer Basis breit verkehrt-eirund, meist mit aufgesetztem Spitzchen: Rippe schwach; Zellen oberwärts in der Mehrzahl rhombisch und rhomboidisch, chlorophyllarm, derbwandig, glatt. Sporogone wie bei Poltia.

195. S. Iatifolia (Schwaegr.) Vent. I. c. [ Weisia latifolia Schwaegr. in Schult. Reise Grossglockn. t. IV. App. (1801). - Poltia latifolia C. Nïill. Syn. I. p. 549 (1849). - Pottia pilifera $\beta$ mutica Lindb. de Tort. p. 223 (1864). - Tortula bullata $\beta$ mutica Lindb. Musc. scand. p. 21 (1879).]

Autözisch; $\sigma^{x}$ Blüten gipfelständig, zuletzt am Fusse des Fruchtsprosses. Knospenförmige Pfl. in meist kleinen silbergrünen Räschen. Stengel meist nur bis $2 \mathrm{~mm}$. Blätter knospenförmig zusammenschliessend, löffelartig-hohl, aus schmälerer Basis breit verkehrt-eirund, meist mit aufgesetztem Spitzchen, bis etwa 1,5 mm lang, flachrandig, gegen die Spitze gezähnelt: Rippe schwach, vor und mit der Blattspitze aufhörend; Zellen oberwärts in der Mehrzahl rhombisch und rhomboidisch, chlorophyllarm, glatt und diunnhäutig. Seta $6-10 \mathrm{~mm}$, gelbrot. Kapsel ovoidisch bis fast zylindrisch, zuweilen schwach gekrümmt, zuletzt kastanienbraun und etwas glänzend. Peristomzähne bis zur Mitte 2-3spaltig oder ungeteilt und hie und da durchbrochen, gelbbraun, grob papillös. Deckel schief geschnäbelt. Sporen 30-40 $\mu$, rotbraun, papillös. Sporenreife im Hochsommer. Fig. $28 \mathrm{~A}-\mathrm{D}$.

Auf nacktem Humus und auf somigen, trocknen, erdbedeckten Absätzen der Kalk- und Schieferfelsen.

S. LyL. und LuL, an einzelnen Fundorten.

N. Dovre. No. Mo, Skjærstad und Ankenes. Tr. Nord-Reisen.

Europa, Kaukisus, Zentral-Asien, Sibirien, Nord-Amerika.

var. pilifera (Brid.). [Coscinodon pilifer Brid. Bryol. univ. I. p. 810 (1S26). Dicrunum bullatum Sommerf. Suppl. Fl. lapp. (1826). - Pottia latifolia var. pilifera C. Müll. Syn. I. p. 549 (1849). - P. pilifera Lindb. de Tort. p. 223 excl. var. $\beta$ (1864). - Tortula bullata Lindb. Musc. scand. p. 21 excl. var. $\beta$ (1879).]

Rippe aus der meist ausgerandeten Blattspitze als ein langes, wasserhelles, glattes Haar austretend.

S. Jmt. Snasahögen.

N. No. Skjaerstad, Salten und Helgeland. Tr. Nord-Reisen.

Verbreitung wie bei der Hauptart.

\section{PTERYGONEURUM}

Jur. Laubmfl. p. 95 (1882).

Autözisch. Kleine, rasenbildende, kalkholde Erdmoose. Stengel nur am Grunde mit Rhizoiden, meist einfach. Blätter nach oben grösser, schr hohl, breit 
eiförmig bis länglich-oval, flachrandig; Rippe abwärts schwächer, als Stachel vder wasserhelles Haar auslaufend, auf der Innenseite mit 2-4 chlorophyllreichen, zuweilen beiderseits Protonema entwickelnden Lamellen; Zellen oberwärts meist quadratisch, gegen die Spitze rhombisch, \pm deutlich kollenchymatisch verlickt, am Grunde rektangulär und wasserhell. Perichätialblätter nicht differenziert. Kapsel aufrecht, kugelig bis länglich-ciförmig, eingesenkt oder emporgehoben; Zellen des Exotheciums locker und dünnwandig. Ring nicht differenziert. Deckel geschnäbelt. Haube mützen- oder kappenförmig. Sporen gross.

196. P. pusillum (Hedw.). [Bryum pusillum Hedw. Fund. musc. It. p. 32 (1782). - Poltia cavifolia Ehrh. Beitr. I. p. 187 (1787). - Tortula pusilla Mitt. in Journ. Limn. Soc. Bot. Xi1. p. 165 (1869). - Aloina pusilla Kindb. Laubm. Schwed. und Norw. p. 137 (1883).]

Lichtgrüne Pfl. in oft ausgedehnten Rasen. Stengel bis $3 \mathrm{~mm}$. Obere Blätter knospenförmig zusarnmenschliessend, länglich-eiförmig oder verkehrt-eiförmig bis spatelförmig, bis $1,8 \mathrm{~mm}$ lang, ganzrandig; Rippe als Stachelspitze oder glattes Haar anslaufend; Zellen in der Blattmitte $12-15 \mu$, glatt. Seta 2--5 mm, gelbrötlich. Kapsel oval bis länglich-eiförmig, entdeckelt oben nicht erweitert, kastanienbraun, \pm glänzend und längsfaltig. Peristom fehlend. Deckel lang und schief geschnäbelt. Haube kappenförmig. Sporen $25-30 \mu$, braun, feinwarzig. Sporenreife im Frühjahr.

Auf trockenem Boden und auf Mauern.

S. Sh.-Upl.. Vstm. und Vrml. selten.

N. sm. und $B u$. an einzelnen Fundorten.

Europa, Algier, Kaukasus, Persien, Mesopotamien, Nord-Amerika.

var. incanum (Bryol. germ.). [Gymnostomum ovalum var. incanum Bryol. germ. I. p. 130 (1823). - Pottia cavifolia var. incana Bryol. eur. fasc. 18/20, p. 6 (1843). - Plerygonenrum cavifolim var. incanum .Jur. Laubmfl. p. 96 (1882).] Haar meist länger als das Blatt. Kapsel nicht iber die Haarspitzen vortretend.

S. Sk. und Gtt. r.

N. Liristiania.

Europa, Algier, Nord-Amerika.

\section{5.). DESMATODON}

Bricl. Mant. musc. p. 86 (1819).

Autözisch; $r$ Blüten am Grunde der $千$ Blüten oder in einer Gabelung. Ziemllich schlanke Pfl. in \pm dichten, weichen, grünen oder gelblichgrünen Rasen. Stengel aulrecht, reichlich mit Rhizoiden besetzt, einfach oder gabelteilig. Obere Blätter grösser, trocken zusammengefaltet und geclieht, feucht aufrecht-abstehend. kielig-hohl, von wechsehnder Form, scharf zugespitzt, meist ganzrandig; Rippe meist \pm lang austretend; Rippe und Lamina (excl. D. systylius) beiderseits (licht mit kleinen, hufeisenförmigen Papillen; Zellen \pm locker und cünnwandig, oberwärts meist rundlich 1 - 6 seitig, al,wärts rektangulär und verlängert-6seitig, wasserhell, glatt. Perichätialblätter nicht differenziert, nach innen kleiner. Seta verlängert, unten rötlich, oben gelblich. Kapsel (excl. D. cernuus) regelnuässig und länglich bis zylindrisch, braun, glatt; Zellen des Exotheciums rektangulär. Ring differenziert. Peristom mit etwas vortretender, getäfelter Ba:ilarmembran; Zähne bis gegen den Grund in 2-3 llache, fast fadenförmige, papillöse, freie oder verbunclene, steil nach rechts aufsteigende bis last eimmal gewundene Schenkel geteilt. Deckel aus kegeliger Basis kurz, dick und schief geschnäbelt; Zellen 上 schräg nach rechts gereiht. Haube kappenförmig. 
Übersicht der Arten.

A. Blätter ungesäunt. Kapsel aufrecht oller wenig geneigt.

a. Blätter oberwärts flachrandig; Zellen glatt ocler fast glatt

b. Blätter mit ungerollten Rändern; \%ellen papillös.

$\alpha$. Obere Blätter eilanzettlich; Zellen oberwärts $10-14 \mu, 199$. D). subereclus.

$\beta$. Obere Blätter länglich bis fast spatellörmig; Zellen oberwärts etwa $18 \mu$

197. D. latifolius.

B. Blätter gesäumt. Kapsel nickend bis hängend.

a. Kapsel nickend bis horizontal, eiförmig, hnchrückig. 200. I). cernuus.

b. Kapse] hängend, länglich, regelnässig ............... 201. D. Laureri.

197. Desmatodon latifolius (Herlw.) Bryol. eur. fasc. 18/20 .16n. p. 5, t. 1 (18.43). [Dicranum latifolium Hedw. Descr. I. p. 89, t. 33 (1787). Torlula latifolia Lindb. Muse. scand. p. 20 (1879).]

Stengel wenige $\mathrm{mm}$ bis $2 \mathrm{~cm}$, selten höher. Obere Blätter länglich bis fast spatelförmig, zugespitzt, bis 2 mm, mit umgerollten Rändern, (exel. var. mulicus) durch die austretende Rippe \pm lang begrannt: Zellen oberwärts etwa $18 \mu$. Seta 1-2 cm. Kapsel aufreeht, länglich-zylindrisch. Ring bleibend. Peristomzälne gelbrot, bis fast zum Grunde geteilt, fast in halbej Windung gecireht. Sporen $18-$ $24 \mu$, olivenfarben, warzig. Sporenreife im Sommer. - Fig. $28 \mathrm{I}$ M.

Auf entblösstem, sandigem oder humösem Boden, gern auf kalklualtiger ('nterlage.

F. Ob. Turtola, an einem Al,hange des liemiflusses (Kihlm.). - Lkem. Yllässaari, simu (Hult). Le. Ollisenvaara in der Nadelwaldregion (Wahlenb.). Kilpisjärvi, auf allen Fjelden st. fq. und reichl, in der alpinen Rcgion (Kot.). - Lim. Kandalaks (Broth.); Scheiesnaja (B.). Tschun (B.). Lujavr-urt, Vavnbjet, an der schneegrenze (KihIm.). - Lt. Kitovka (Fellm.). Tsipnavoiok und subovi (Broth.). Kildin (F. Nyl.). - Lmur. Gavrilova und Semjostrovsk (Broth.). - Lp. Orlov, Lesilschiha (Kihlm.). Triostrova (Brenn.). Ponof (Sahlb., Broth.).

S. Hrjd. und $.7 m$ t. an mehreren Fundorten. $-L$.

$\mathbf{N}$ A. Kristiania. - Bu. Norfjället. - ST. Dovre. - No.-F. durch die Baumregion und untere Alpenregion ziemlich verbreitet.

Spitzbergen, Europa im Gebirge, Kaukasus, Talysch, Zentral-Asien, Kamtsehatka, Nord-Amerika.

var. muticus Bricl. Sp. musc. I. p. 207 (1806).

Stengel meist 3-4 em. Blätter weicher und schlaffer, trocken stark gedreht, die oberen eilänglich und stumpf oder plötzlich in eine längere oder kürzere, schmale Spitze endend; Rippe schwächer, vor der Blattspitze auflı̈rend.

F. Lt. Pummanki (Broth.). - Lp. Svjätoinos (B.).

S. LuL. Sarekgebiet.

N. K. Lomsfjeldene und Jotunfjeldene.-No. und $T r$. an mehreren, $F$, an wenigen Fundorten. Steigt nach $\mathrm{H}$ a g e $n$ etwas höher in die alpine Region hinauf als die Hanptform.

Europa, Kaukasus, Himalaya, Nord-Amerika.

var. brevicaulis (Brid.) Sehimp. Syn. p. 157 (1860). [Desmalodon brevicaulis Brid. Mant. p. 87 exel. syn. (1819).]

Meist niedrige Pfl. Obere Blätter fast spatellörmig; Rippe als lange, geschlängelte Granne austretend. Kapsel etwas geneigt und schwach gekrümmt. Deckel kurze Zeit von der Columella getragen. Sporen etwas grösser als bei der Hauptform.

F. Lt. Kítofka (Fellm.).

S. LuL. Sarekgebiet.

N. No. und $F$, an wenigen Fundorten.

Europa.

198. Desmatodon systylius Bryol. eur. fase. 31, suppl. t. 1 (1846). [Torlula systylia I.indb. Musc. seand. p. 20 (1879).]

Stengel 1--2 mm. Obere Blätter breit länglich oder verkehrt-eilänglielı. scharf zugespitzt, bis $2 \mathrm{~mm}$ lang, mit nur gegen den Grund umgerollten. gegen clie 
Spitze etwas gezähnten Rändern: Rippe als lange, geschlängelte, gelbe Granne auslaufend, glatt: Zellen der oberen Blatthälfte oft in der Mehrzahl rhombisch und rhomboidisch, meist über $20 \mu$, glatt oder fast glatt. Seta $5-12 \mathrm{~mm}$. Kapsel zylindrisch. Ring in einzelnen Zellen sich ablösend. Peristomzähne blassgelb, steil nach rechts aufsteigend oder aufrecht, unregelmässig geteilt, durchbrochen oder in der Teilungslinie längs zusammenhängend. Deckel nach dem Abheben längere Zeit von der sich streckenden Columella getragen. Sporen 20-26, auch bis $32 \mu$, rötlichbraun, warzig. Sporenreife im Sommer.

Auf feuchtem Humus der alpinen Region.

S. Jmt. und LuL. an einzelnen Fundorten.

N. $K$. Filefjeld und fiaustafjeld. $K$. Dovre. $T r$. und $F$. an einzelnen Fundorten.

Europa, Alpenkette, Kaukasus, Zentral-Asien, Nord-Amerika.

199. Desmatodon suberectus (Drumm.) Limpr. Laubm. I. p. 651 (1888). [Tortula suberecta Drumm. Musc. am. bor. No. 145 (1828). - Desmatodon obliquus Bryol. eur. fasc. 18,20 Mon. p. 10, t. 7 (18t3).]

Stengel 2-10 mm. Blätter aus breit eiförmiger Basis lanzettlich, spitz, bis 2 mm lang, mit fast spiralig zurückgerollten, an der Spitze feingezähnten Rändern; Rippe lang auslaufend; Zellen oberwärts $10-14$ ". Seta $5-15 \mathrm{~mm}$. Kapsel aufrecht oder etwas geneigt, zylindrisch und meist schwach gekrümmt. Ring bleibend. Peristomzähne rötlichgelb, bis zum Grunde geteilt und eimmal gewunden. Sporen $18-24 \mu$. ockergelb, papillös. Sporenreife im Sommer.

Auf kalkhaltigem Humus der aJpinen Region.

N. $K$, und $H$, an einzelnen, No, $-F$, an wenigen Fundorten. NT. Dovre.

Europa. Alpenkette; Tschuktschen-Halbinsel, Nord-Amerika.

200. Desmatodon cernuus (Hüben.) Bryol. eur. fase. $18 / 20$ Mon. p. 8, t. 5 (1843). [Desmatodon cernuus Hüben. Musc. germ. p. 117 (1833). — Tortula cernua Lindb. Musc. scand. p. 20 (1879).]

Stengel olne Zentralstrang, wenige $\mathrm{mm}$ bis $2-3 \mathrm{~cm}$. Obere Blätter länglichlinealisch, scharf zugespitzt, bis $2 \mathrm{~mm}$ lang, mit wulstig gesäumten, bis über die Iitte umgerollten, in der Spitze kleingezähnten Rändern; Rippe in eine gezähnte Stachelspitze austretend, glatt: Zellen oberwärts mit zerstreuten Papillen, im Mittel $20 \mu$, am Rande 2-3schichtig, eng und verlängert. Seta 1-1,6 cm. Kapsel nickend bis horizontal, kurz eiförmig, hochrückig. Ring bleibend. Peristomzähne breit, aufrecht oder iast aufrecht, gelbrot, bis über die Mitte in $2-3$ freie oder hier und da zusammenhängende, meist ungleiche Schenkel geteilt. Sporen 30$37 \mu$, grïnlichbraun, feinwarzig. Sporenreife im Sommer.

An feuchten, kalkhaltigen Felsen.

S. Irsm. Sala. Jmt. Alreskutan.

N. $S T$., $T r$. und $F$. an einzelnen Fundorten.

Zentral-Europa von der Berg- bis in die Alpenregiun zerstreut, Zentral-A-ien, Nord-Amerika.

201. Desmatodon Laureri (Schultz) Bryol, eur. fasc. $18 / 20$ IIon. p. 9, t. 6 (1843). [Trichostomum Laureri Schultz in Flora 1827, P. I. p. 163. - Tortula Laureri Lindb. De Tort. p. 243 (1864).]

Stengel wenige $\mathrm{mm}$ bis $2 \mathrm{~cm}$. Obere Blätter länglich-linealisch, stumpflich oder rasch zugespitzt, bis 2,5 mm lang, mit wulstig gesäumten, umgerollten, gegen die schwach gezähnte Spitze flachen Ränderu: Rippe kurz austretend; Zellen oberwärts im Mittel $20 \mu$, an Rande 2schichtig, gelblich, linealisch und stärker verdickt. Seta S-12 mm, an der Spitze schwanenhalsartig gekrümmt. Kapsel hängend, länglich. Ring sich ablösend. Peristomzähne breit, gelbrot, bis fast zur Basis geteilt: Schenkel olerwärts hier und da verbunden, ${ }^{1 / 2}$ bis 1 mal gewunden. Sporen $35-18 \mu$, grünlichbraun his rostfarben, grosswarzig. Sporenreife im Sommer.

Auf Humus in der alpinen Region.

N. ST. Dovre.

Europa, Apen kette, Zentral-Asien, Yord-Amerika. 


\section{ALOINA}

Kindb. Laubm. Schwed. p. 136, excl. No. 5 (1883).

Starre, meist herdenweise wachsende, meist braune oder bräunlichgrune Errdmoose. Stengel sehr kurz, ohne Zentralstrang, am Grunde mit Rhizoiden, einfach. Blätter dick und fleischig, trocken meist \pm eingekrümmt, oberhalb der scheidigen und wasserhellen Basis mit breit eingebogenen Rändern, an der meist stumpfen Spitze kappenförmig: Rippe sehr breit und flach, oberwärts zwischen Rückenund Bauchzellen mit einem Stereidenbande und auf der Innenfläclıe mit gegliederten und dichotomisch verzweigten, grünen Zellfäden, deren Scheitelzelle stumpfspitzig und oben stark verdickt ist; Zellen chlorophyllarm, glatt, oberwärts quadratisch und querbreiter, stark verdickl, nach unten verlängert-rektangulär und wasserhell. Perichätialblätter grösser. Sporogon und Peristom wie bei Barbula. Sporen gelb, meist glatt.

\section{Ut bersicht der Arten.}

A. Polyözisch. Blätter trocken nicht eingekrümmt, so lang oder wenig länger als breit. Sporen $12-15 \mu \ldots \ldots \ldots \ldots .202$. A. brevirostris.

B. Diözisch. Blätter trocken sichelförmig eingelírümmt.

a. Peristom $0,70-0,85 \mathrm{~mm}$; basale Röhre über den Urnenrand ragend.

a. Ring schmal und lange bleibend. Peristomzähne nur 1 mal gewunden. Sporen $10-12 \mu$. Haube nur von Deckellänge

$\beta$. Ring breit, sich stïckweise zugleich mit dem Deckel ablösend. Peristomzähne bis 3 mal gewunden. Sporen $12-15 \mu$. Haube bis zur Lrmenmitte ..... 204. A. rigida.

b. Peristom $0,40-0,50 \mathrm{~mm}$; basale Röhre nicht über den Urnenrand ragend. Ring sclmal und lange bleibend. Peristomzähne kaum orler nur 1 mal gewunden. Sporen $18-25 \mu$. Haube his zur Urnenmitte................. 205. A. aloides.

202. Aloina brevirostris (Hook. et Grev.) Kindb. Laubm. Schwed. p. 137 (1883). [Tortula brevirostris Hook. et Grev. in Brewst. Edinb. Journ. I. p. 289 (1824).]

Polyözisch; કั Blüten und $\varsigma^{\nearrow}$ Pfl. L'ntere Blätter eirundlich, obere breit länglich, stumpf, bis 1,1 mm lang, trocken nicht eingekrümmt. Seta $10-15 \mathrm{~mm}$, rötlichbraun. Kapsel zylindrisch, lederbraun. Ring 2-3reihig. obere Reihe grosszellig und sich stückweise zugleich mit dem Deckel ablösend. Peristomzähne 1 mal gewunden, purpurn; basale Röhre über den Ring vortretend. Haube etwa die halbe Urne deckend. Sporenreife im Spätherbst. - Fig. 28 Q - T.

Auf etwas feuchtem Tonboden.

S. Sm. an mehreren, Ög.. När., Upl., Gstr. und Dlr. an einzelnen Fundorten.

N. A. Kristiania pass. Bu. Hunefos. ST. Trundhjem. NT. Nedre Stjordalen; Lurre, No. Budin. Spitzbergen, Dänemark, Schottland, Zentral-Europa selten, Sibirien, Nord-Amerika, überall selten.

203. Aloina ericaefolia (Neck.) Kindb. 1. c. p. 137. [Bryum ericaefolium Neck. in Act. Acad. Theod. pal. II. p. 451 (1770). - Barbula ambigua Bryol. eur. falsc. 13/15 Mon. p. 14, t. 2 (1842). - Tortula ambigua Aongstr. in Nor. Act. Soc. Upsal. XII, p. 377 (1844). — Tortula ericaefolia Lindb. IIusc. scand. p. 20 (1879).]

Diözisch. Pfl. herdenweise oder gedrängt und rasig. Blätter trocken bogig einwärts gekrümmt, feucht \pm abstehend bis fast sternförmig ausgebreitet. lineallanzettlich, mit $\perp$ hakig eingelogener, meist stumpfer Spitze, bis $3 \mathrm{~mm}$ lang. 
Seta $10-15 \mathrm{~mm}$, unten rot, oben gelblich. Kapsel zylindrisch, gerade oder schwach gekrünmt, trocken glänzend braunrot und unregelmässig fein gefurcht. Ring 1-2reihig, kleinzellig. lange bleibend. Peristomzähne 1 mal gewunden, hlassbis rosenrot: basale Röhre über die Urnemmündung ragend. Haube nur von Deckellänge. Sporenreife vom Herbst bis Frïhling.

Auf Ton- und Nergelboden.

N. Bu. Ringerike rr. Gudbrandsdalen rr. NT. Ovre stjurdalen.

Zentral-, West- und Siid-Europa, Nord-Afrika, Klein-Asien. Persien, Sibirien, Nord-Amerika.

204. Aloina rigida (Schultz) Kindh). 1. e. p. 137. [Barbula rigida Schultz Recens. in Nov. Act. Aead. Leopold XI. J. 196, t. 32, f. 1 (1823). - Tortula stellata Lindb. De Tort. p. 233 (1864).]

Diözisch. Pfl. herdenweise oder dichter gedrängt und fast rasig. Blätler trocken einwärts gekrimmt und zusammenneigend, feucht aus aufrechtem Gruncle abstehend, ohere länglich oder kurz zungenförmig, stumpf oder spitz, selten haarspitzig. bis $1,8 \mathrm{~mm}$ lang. Seta $10-15 \mathrm{~mm}$, rotbraun. Kíapsel eilänglich, sch!lank. gerade oder merklich gebuckelt, dunkelbraun. Ring 2-3reihig, obere Zellenreihe gross und sich stückweise ablösend. Peristomzähne 2-3 mal gewunden, rosenrot; basale Röhre ïber den Ring vorlretend. Haube bis zur Urnenmitte. Sporenreife von Juli bis zum Herbst.

Auf Tonbodien und auf erdbedeckten Mauern.

S. sim., Ig., När. und $U p l$. an einzelnen Fundorten.

N. A. Kristiania. Bu. an wenigen Fundorten. $N T$. Trundhjem.

Europa von der Ehene bis in die alpine Region verbreitet, Algier. Kaukasus, Zentral-Asien. NordAmerika.

205. Aloina aloides (Koch) Kindb. I. e. p. 136. [Trichostomum aloides lioch Iscr.: Schultz in Noy. Act. Acad. caes. Leop. XI. p. 197 (1823). - Tortula aloides Aongstr. in Nov. Act. Soc. Ups. XII. p. 377 (1844).]

Diözisch. Pfl. herdenweise oder gedrängt und rasig. Blätter trocken bogig eingekrümmt, feucht aufrecht-abstehend, obere lanzettlich, spitz oder stumpflich, bis 2,5 mm lang. Seta meist $15 \mathrm{~mm}$, rötlichgelb oder rot. Kapsel zylindrisch, schwach geneigt his horizontal, meist deutlich gebogen und schwach hochrückig, trocken schwach glänzend. Ring 1-2reihig, kleinzellig, lange bleibend. Peristomzähne nicht oder kaum 1 mal gewunden, blassrötlich; basale Röhre nicht über die Urnemmündlung ragninl. Haube bis zur Urnenmitte. Sporenreife vom Herbst lis zum Frühling.

Auf Tonboden.

S. ritl.

N. A. N. Fron. Bu. Ringerike. Gudbiandsdalen. K. Dovre.

Zentral-, West- und Süd-Europa. Kanaren, Algier, Sinai, Klein-Asien, Nord-Amerika.

\section{TORTULA}

Hedw. Fund. II. p. 92 (1782), Palis. Prodr. (1805).

Meist \pm kräftige Pfl. in lockeren Rasen oder dichten Polstern. Stengel aufrecht, abwärts mit Rhizoidenfilz. einfach oder gabelteilig. Blätter trocken niemals gekräuselt, meist gefaltet und gedreht, feucht \pm abstehend, gekielt, meist zungenund spatelförmig, alogerundet, selten kurz zugespitzt, mit meist \pm umgerollten und unversehrten Rändern; Rippe kräftig, meist als Endstachel oder hyalines Iaar austretend: Zellen oberwärts quadratisch und rundlich-6eckig, meist beiderseits warzig und chlorophyllreich, nach unten allmählich erweitert, rechteckig oder verlängert 6seilig, zartwandig und wasserhell. Perichätialblätter nicht differenziert. Seta verlängert. Kapsel aufrecht oder geneigt, regehnässig, länglich 
bis zylindrisch, gerade oder gekrümmt: Zellen des Exotheciums in dlor Mehrzahl rektangulär. Ring differenziert, meist lange bleibend. Peristom mit niedriger oder hoher, aussen durch vortretende Leisten gefelderter Basilarmembran; Zülnne bis zur Basis in 2 fadenförmige, freie, dicht papillöse, links gemundene Schenkel gespalten. Deckel schmal und t verlängert kegelig. stumpl. Sporen klein.

Übersicht der Arten.

A. Blätter mit rundlichen oder eiförmigen Brutkörpern.

a. Rippe in der Blattspitze endend .................... 210. T. Latifolia.

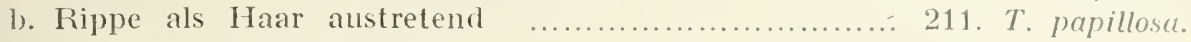

B. Blätter olıne Brutkörper.

a. Autözisch. Stets fruchtend.

$\alpha$. Schlanke Felsmoose. Rippe mit und vor der Blattspitze aufhörend oder als winzige Stachelspitze austretend. Peristomröhre sehr niedrig ..............206. T. obtusifolia.

$\beta$. Mehr oder weniger kräftige Erdmoose: Rippe als Stachel austretend. Peristomröhre weit hervorragend.

I. Blätter weit hinanf gelblich gesäunt: Zellen der Lamina warzig .................................... 213. T. subulula.

1I. Blätter ungesäumt: Zellen glatt ...................209. T.mucronifolia.

$\gamma$. Zienlich kräftige Felsmoose: Rippe als Haar austretend. Peristomröhre niedrig ................ 207. T. muralis.

b. Rippe als Haar austretend. Peristomröhre weit hervorragend.

$\alpha$. Autözisch. Blatthaar glatt oder fast glatt.

I. Felsmoos. Blätter mit bis zur Nitte schmal umgebogenen Rändern 212. T. alpina.

11. Baumbewohner. Blätter mit nur in der Mitte schwach umgebogenen Rändern

213. T. laevipila.

ß. Meist diözisch.

1. Blatthaar durch spitze, abstehende Zähne rauh. 1. Diözisch.

* Weniger kräftige Pfl. Blätter flachrandig oder mit am Grunde schmal umgebogenen Rändern; Rippe am Rücken fast glatt ..... 214. T. pulvinata.

** Ziemlich kräftige Pfl. Blätter mit in der unteren Hälfte umgerollten Rändern; Rippe am Rücken rauh

215. T. montana.

*** Weniger kräftige Pfl. Blätter mit bis über die Mitte schmal umgebogenen Rändern: Rippe am Rücken warzig, als rotbraunes Haar auslaufend 216. T. norvegica.

**** Iräftige Pfl. Blätter mit bis gegen die Spitze zurückgerollten Rändern: Rippe am Rücken rauh, als nur am Grunde gefärbtes Haar auslaufend .................................. 217. T. rurulis.

2. Polyözisch

218. T. princeps.

S e c t. I. Tortula sens. strict. Limpr. Laubm. I. p. 659 (1888). ragend.

Kleine Pfl. Tubus des Peristoms die Krapselmündung nicht oder wenig über- 
206. Tortula obtusifolia Schleich. Cat. p. 31 (1807).

Autözisch; junge Pfl. rein $c^{\top}$, ans tieferen Blattcyklen derselben die Fruchtsprossen. Schlanke Pfl. in sehr dichten, polsterförmigen, lebhaft grünen, innen bräunlichen Räschen. Stengel 5-15 mm. Blätter feucht aufrecht-abstehend, zungenförmig oder eizungenförmig, kurz zugespitzt oder stumpf, bis 1,5 mm lang, ungesäumt, mit über der Basis bis gegen die Spitze umgerollten Rändern; Rippe unten schwächer, vor und mit der Spitze endend oder als winzige Stachelspitze austretend, beiderseits papillös; Zellen der oberen Blatthälfte $8-10 \mu$. Seta 3,5$10 \mathrm{~mm}$, gelb, unten rötlich. Kapsel aufrecht, oval und eilänglich, zuletzt dunkelbraun. Peristom braunrot, kaum 1/2 mal gewunden.

N. ohne nähere Fundortsangabe (Bot. Notis. 1890, p. 157).

Bayern bis Steiermark und Galizien, Kaukasus, Turkestan, Nord-Amerika.

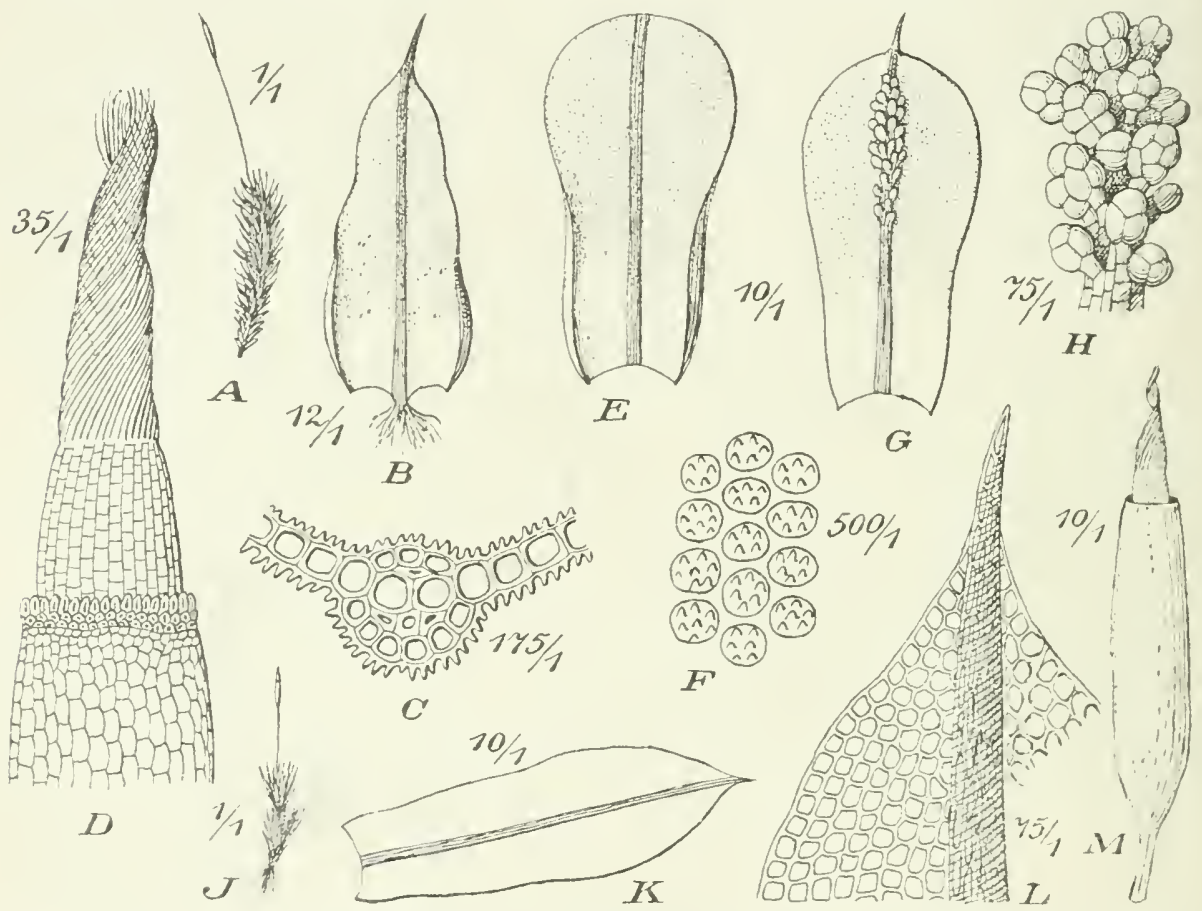

Fig. 29. A-D Torlula norregica (Web. fil.). A Fruchtende Pfl. (1/1); B Stammb. (12/1) C Qu erschnitt durch die Rippe (175/1); D Peristom (35/1). - E-F T. latifolia Bruch. E Stamml. (10/1); F Zellen der Blattspitze (5n0/1). - G-H T. pxpillosa Wils. G stammb. (10 1); H Blattrippe mit Bruth. (75 1); - I-II T. mucronifolia schwaer. I Fruchtende Pfl. (1) 1); K Stannb. (10 1): L Blattspitze (75'1): Il Entdekelte Kapsel ( $1 \cap 1)$ !

207. Tortula muralis (L.) Hedw. Fund. II. p. 92 (1782). [Bryum murale I.. Sp. pl. 1. ed. II. p. 1117 (1753).]

Autöziselı; or Blüten knospen- oder fast scheibenförmig, gipfelständig an einem Seitenspross am Fruchtstämmchen. Zienlich kräftige Pfl. in dichten, trocken grauschimmernden, feucht grünen oder bläulichgrünen Rasen oder Polstern. Stengel 5-15 mm, selten höher. Blätter feucht aufrecht-abstehend, obere längliclıbis verlängert-zungenförmig oder zungen-spatelförmig, stumpf, oft ausgerandet, selten kurz zugespitzl, 2 - $3 \mathrm{~mm}$ lang, ungesäumt, mit bis gegen die Spitze umgerollten Ränlern; Rippe selır kräftig, in ein langes, glattes, hyalines oder unterwärts gelbliches Haar ausłaufend, am Rücken dicht papillös: Zellen der oberen 
Blatthälfte $10-12 \mu$. Seta $1-2,5 \mathrm{~cm}$, unten rötlich, oben gelb. Kapsel aufrecht, länglich-eiförmig bis fast zylindrisch, zuletzt schwarzbraun. l'eristom gelb oder blassrötlich, ein- bis dreimal gewunden.

Auf alten Mauern und sonnigen Felsen.

F. Al. Lemland (Bom.). Saltvik, an mehreren Fundorten (Nerv., Bom.). - Ab. Kurpu. Lto (Elfv.). Nádendal (E.). Pargas, Ersby (E.). - Ta. Hollola, an der Kirchrnauer (Norrl.).

S. Sh. - Upl.

N. Sm., A., Bu, $J L ., K$, und $N T$. an wenigen Fundorten.

Zentral-, West- und sïd-Enropa gemein und auch in den anderen Weltteilen verbreitel.

Sect. I I. Zygotrichia (Brid. Bryol. univ. I. p. 520: 1826) Mitt. Musc. austr.-am. p. 145 (1869).

Niedrige Pflanzen. Blätter stachelspitzig. Tubus des Peristons hoch und getäfelt.

208. Tortula subulata (L.) Hedw. Fund. Il. p. 92 (1782). [Bryım subulalum L. Sp. pl. 1. ed. II. p. 1116 (1753).]

Autözisch; ơ Blüten am Grunde des Fruchtsprosses. Mehr oder weniger kräftige Pfl. in meist dichten, oft ausgedehnten, oben grünen Rasen. Stengel bis 1 , selten bis $2-3 \mathrm{~cm}$. Obere Blätter schopfig-gedrängt, feucht aufrecht-abstehend, rimnig-holıl, verkehrt-eilänglich bis verlängert-spatelförmig, stumpf oder zugespitzt. bis $6 \mathrm{~mm}$ lang, flachrandig oder einseitig bis über die Nitte schmal umgerollt, durch mehrere Reihen gestreckter Zellen gesäumt; Rippe als Stachelspitze austretend; Zellen der oberen Blatthällte 18-25 $\mu$, beiderseits mit \pm zahlreichen hufeisenförmigen Papillen. Seta $1-2,5 \mathrm{~cm}$, rot. Kapsel aufrecht, verlängert zylindrisch, schwach gekrümmt, dunkelbraun. Peristom $2 / 3-1 / 4$ rölırenförmig, rosenrot orler blassgelb; Zähne rot etwa $1 \frac{1}{2}$, selten bis 3 mal gewunden.

An beschatteten, erdigen Abhängen, Graben- und Wegrändern, erdbedeckten Mauern und Felsen.

F. Al. Finström, Åttböle (Bom.). Lemland, Norrbỵ (Broth.). Saltvik, an vieIen Fundorten (Boın.). Kökar (Bom.). - Ab. Pargas, Hyvilempi (Arrh.). Karislojo. Karkali (E. af H.). Lojo, Skraatila (E. af H.).

S. Sk.- l pl. und $\mathrm{V} \mathrm{rml}$. n. Br.

N. Sm. und A. pass. Bu., JL., SB., No. und $F$. an wenigen Fundorten. Nordgrenze bei $70^{\circ} 20^{\circ}$

var. bifrons Hag. in Nyt Mag. f. Naturv. Bd. 38, p. 323 (1900).

Blätter bis $3,3 \mathrm{~mm}$ lang, mit längs umgebogenen Rändern, dicht papillös. Kapsel eizylindrisch. Peristom $1 / 2$ röhrenförmig.

N. Nach H a ge $\mathrm{n}$, ohne näher angegebene Fundorte.

var. angustata (Wils.) Limpr. Laubm. 1. p. 671 (1888). [Torlula angustata Wils. Mser., Lindb. de Tort. p. 243 (1861)].

Blätter schmäler, schärfer zugespitzt, gegen die Spitze gezïhnt, sehr deutlich gesäumt; Rippe zarter.

S. ög. Omberg und Alvastra.

Europa, Nord-Amerika.

N. ohne nähere Fundorte ( $\mathrm{H}$ a $g$ e $n$ ).

209. Tortula mucronifolia Scliwaegr. Suppl. 1. P. I. p. 136, t. 34 (1811).

Autözisch, zuweilen auch ŏ Blüten; $\nwarrow^{\top}$ Blüten als kurz gestielte Knospen am Grunde der Sprossen oder in den Achseln der Schopfblätter sitzend. Weniger kräftige Pfl. in \pm lockeren, oben grünen Rasen. Stengel bis 1 , selten bis $2 \mathrm{~cm}$. Blätter feucht aufreeht-abstehend, weich und sehlaff, länglich-spatelförmig, zugespitzt, bis $4 \mathrm{~mm}$ lang, ungesäumt, mit nur gegen den Grund etwas umgebogenen Rändern; Rippe in eine längere Stachelspitze austretend, glatt: Zellen der oberen Blatthälfte $18-2 t \mu$, beiderseits glatt. Seta etwa $1 \mathrm{~cm}$, blutrot. Kapsel aufrecht, klein, eilänglich-zylindriseh, gerade oder schwach gekrümmt, schmutzigbraun. Peristom $1 / 3{ }^{1} / 2$ röhrenförmig; Zähne rosenrot, bis 2 mal gewanden. Fig. $29 \mathrm{~J}-\mathrm{MI}$. 
Auf Humus in Felsspalten und kleinen Höllungen.

F. K. Kuusamo, Paanajärvi. Ruskeakallio (Broth.), - Lp. Ponoj (Sahlb.).

S. Sm. risingsō. LuL. Krickjokk.

N. Gudbrandsdalen, Laurgaard. $Y B$, an mehreren Fundorten. $K$. Jotunfjeldene. ST. Durre und Trondhjem. No. an mehreren und $F$, an wenigen Fundorten.

Spitzbergen, Pyrenăen, Alpenkette, Kaukasus, Zentral- und Nord-Asien, Nord-Amerika.

S e c t. I I I. Syntrichia (Brid. Mant. musc. p. 97: 1819) Hartm. Sk. Fl. 10. ed. p. 88 (1871).

Grössere bis robuste Pflanzen. Stengel meist verlängert. Blätter meist behaart. Tubus des Peristoms hoch und getäfelt.

210. Tortula latifolia Bruch in litt. ad Hornsch.: Schultz Recens. Sep.-Abdr. p. 38 (1823). [Tortula mutica Lindb. Muse. seand. p. 20 (1879).]

Diözisch. Lrräftige Pfl. in lockeren, trocken schmutzig- bis schwärzlichgrünen Rasen. Stengel niedrig bis $2-3 \mathrm{~cm}$. Blätter sehr weich, obere rosettenartig gehäuft, feucht fast flach ausgebreitet, spatelförmig, breit abgerundet oder mit kurzer, stumpfer Spitze, bis $4 \mathrm{~mm}$ lang, mit in der unteren Hälfte deutlich zurückgerollten Rändern; Rippe in der Blattspitze endend, beiderseits feinwarzig; Zellen der oberen Blatthälfte $12-15 \mu$. Seta bis $1 \mathrm{~cm}$, rot. Kapsel aufrecht, schlank zylindrisch, gerade oder etwas gekrümmt, braun. Peristom mit bleicher basaler Röhre, $2 / 3$ der rosenroten, 1-2 mal gewundenen Zähne. - Vegetative Vermehrung durch sehr zahlreiche, meist aui der lnnenfläche der oberen Blatthälfte hervortretende, rundliche, 2 -4zellige Brutkörper. - Fig. $29 \mathrm{E}-\mathrm{F}$.

An Linden. Ulmen. Pappeln und Weidenstämmen, seltener an rom Wasser bespülten Steinen.

S. Sk, an mehreren Fundorten, Bl.

West- und Zentral-Europa. Nord-Amerika.

211. Tortula papillosa WVils. Mser.; Spruc. in Hook. Lond. Journ. IV. p. 193. [Tortula rotundifolia Hartm. Skand. Fl. 5. ed. p. 381 (1819).]

Diözisch. Ziemlich kräftige Pfl. in sehı lockeren. trocken dunkelgrünen, bräunlichen oder schwärzlichen Rasen. Stengel niedrig. höchstens bis $8 \mathrm{~mm}$. Blätter feucht sehr weich, aufrecht-abstehend, mit der oberen Hälfte schwach bogig zurückgekrümmt. breit spatelförmig. stumpf oder kurz zugespitzt, bis $4 \mathrm{~mm}$, mit nicht umgerollten, oberwärts \pm breit eingebogenen Rändern; Rippe als meist kurzes, fast glattes, oberwärts hyalines Haar auslaufend, am Rücken durch zahlreiche, lange Papillen rauh: Zellen rundlich-6seitig, in der Blattmitte 25-30 $\mu$, glatt oder aussen \pm papillös, nach unten quadratisch uncl kurz relitangulär, am Grunde nächst der Rippe wasserhell. Sporogone aus Europa unbekannt. - Vegetative Vermehrung durch zahlreiche, an der Ventralseite der Rippe oberwärts dicht gedrängte. rundliche oder mehr eiförmige, anfangs grüne, zuletzt braune. zwej- bis mehrzellige Brutkörper. - Fig. 29 G--H.

An freistehenden Laubbäumen.

S. Fik. uicht selten, Bl., Ty. und $B \circ h$. an einzelnen Fundorten.

N. Sm. Ons". LM. Kristiansand. St. Ryfylke.

IVest-. Zentral- und süd-Europa fa.. Nord-Anerika.

212. Tortula alpina (Bryol. eur.) Bruch: Breutel Musc. frond. exs. No. 163 (1813).

Autözisch: ơ Blüten axillär. gestielt. Ziemlich kräftige Pfl. in lockeren. weichen, polsterförmigen, bläulichgrünen, im Alter gescheckt rötlichbraunen, unten rostroten Rasen. Stengel $1-3 \mathrm{~cm}$. Blätter feucht aufrecht-abstehend, untere verkehrt-eilänglich, obere spatel-zungenförmig, kurz zugespitzt bis abgerundet, bis 3,5 mm lang, mit bis zur Mitte sehmal umgerollten Rändern; Rippe am Rüicken glatt, als glattes, kurzes, an der Spitze entfärbtes Haar austretend: Zellen der oberen Blatthälfte und am Rande oft bis gegen den Grund rundlich- 
quadratiseh und quadratisch. $10-15 \mu$, beiderseits dicht mit hufeisenförmigen Warzen. Seta 1-1,5 cm, gelb, unten rötlich, zuletzt längs rot. Kajpsel aufrecht, zylindriseh, meist etwas gekrümmt, grünlichgell, im Alter bräunlich. Peristom rot; röhrenförmiger 'Teil sehr niedrig: Zähne ein- bis fast zweimal gewunden.

An schattigen, kalkhaltigen Felsen.

S. Gll.

Zentral-Europa, Kaukaslls, N. W. Himalaya. Altai, China.

213. Tortula laevipila Brid. IIant. p. 98 (1819).

Autözisch; $0^{\top}$ Blüten in den Achseln der unteren Blätter. Ziemlich kräftige Pfl. in meist dichten, dunkelgrünen bis bräunlichen, innen rostroten, polsterförmigen Rasen. Stengel 1-2 cm, selten höher. Blätter feucht aufrecht-absteliend, mit der oberen Hälfte mässig zurückgebogen, länglich spatel- bis geigenförmig. breit abgerundet, zuweilen ausgerandet oder kurzspitzig, bis $3 \mathrm{~mm}$ lang, mit meist in der Blattmitte zurüekgeschlagenen Rändern; Rippe in ein langes, unten rotbraunes, fast glattes Haar auslaufend, am Rücken glatt; Zellen der oberen Blatthälfte $12-15 \mu$. Seta $5-15 \mathrm{~mm}$. Kapsel aufrecht, zylindrisch, gerade oder sanft gekrümmt, gelb- bis rotbraum. Periston mit weisslicher basaler Rölnre, $1 / 3-1 / 2$ so lang als die rosenroten, 2-3 mal gewundenen Zähme. - Vegetative Vermehrung durch sehr kleine, lanzettliche, grüne und dichtwarzige, in den Achseln der Gipfelblätter stehende Brutkörper.

An freistehenden Laubbäumen.

S. Sk. an mehreren Fundorten. Öl.

IVest-, Zentral- und Süd-Europa, Algier, Azoren. Kanaren. Nord-Amerika.

214. Tortula pulvinata (Jur.) Limpr. Laubm. I. p. 683 (1888). [Barbula pulvinata Jur. Verh. zool.-bot. Ges. Wien 1863. p. 501. — Barbula danica M. Lange. Tortula danica C. Hartm. Skand. F]. 12. ed. p. 88 (1871).]

Diözisch. Weniger kräftige Pfl. in lockeren oder dichten, oben oliven- bis schmutziggrünen, innen rostbraunen, polsterförmigen Rasen. Stengel $1-2 \mathrm{~cm}$. Blätter feucht aus aufrechter Basis mässig zurückgekrümmt, spatelförnig, an der breit abgerundeten Spitze ausgerandet, selten kurz zugespitzt, bis $3 \mathrm{~mm}$ lang, flachrandig oder mit am Grunde sehmal umgebogenen Rändern; Rippe sehr kräftig, in ein meist langes, \pm gezähntes Haar auslaufend, am Rücken fast glatt; Zellen der oberen Blatthälfte $12-15 \mu$. Seta $1-1,5 \mathrm{~cm}$, oberwärts gellorötlich. Kapsel aufrecht, zylindrisch, gerade oder sehwach gekrïmmt, braun. Peristom $1 / 2-1 / 3$ röhrenförmig. bleich; Zähne rosenrot, $1 / 2-1$ mal gewunden.

An alten Laubbäumen.

N. sm. Onso, steril.

Dänemark, Zentral-Eıropa. Nord-Italien.

215. Tortula montana (Nees) Lindb. Muse. scand. p. 20 (1879). [Syntrichia montana Nees in Flora 1819, P. I. p. 301. - Syntrichia intermedia Brid. Bryol. univ. I. p. j86 (1826). - Tortula intermedia Wils. Mser. (1861): Berk. Handb. brit. Moss. p. 251 (1863).]

Diözisch. Ziemlich kräftige Pfl. in rliehten, trocken grausehimmernden, feucht bräunlichgrünen, fest verwebten, polsterförmigen Rasen. Stengel ohne Zentralstrang, 1,5-3 cm. Blätter nach oben allmählich grösser und dichter gestellt, feucht aufrecht-abstehend oder nur die Spitze zurückgebogen, spatelförmig, breit abgerundet und meist herzförmig ausgerandet, bis $3 \mathrm{~mm}$ lang, mit in der unteren Hälfte umgerollten Rändern; Rippe in ein langes, gesägies, hyalines Haar auslaufend, am Rücken rauh: Zellen der oberen Blatthälfte $10-15 \mu$. Seta $1-1,5 \mathrm{~cm}$, rot. Kapsel aufrecht, zylindriseh, schwach gekrümmt, braun. Peristom $1 / 2-1 / 3$ röhrenförmig, bleich: Zähne rosenrot, $1 / 2-1$ mal gewunden.

An sonnigen Felsen, besonders auf Kalk. 
S. Sk. Benestad. Öl. und Gll.

N. Sm. Onsı. SB. Strandebarm. ST. Trondlijem. Steril.

Zentral-Europa, Kaukasus.

216. Tortula norvegica (Web. fil.) Lindb. in Öfvers. Vet.-Ak. Förh. XX. 1). 387 (1863). [Syntrichia norvegica Web. fil. in Web. et Mohr Archiv I. P. I. p. 130, No. 13, t. 5. f. 1 a-i (1804). - Barbula aciphylla Bryol. eur. fase. 13/15 Mlon. p. 42, t. 26 (18.12). - Tortula aciphylla Hartm. Skand. fl. 5 ed. p. 381 (18-19).]

Diözisch. Weniger kräftige Pfl. in lockeren, oft ausgedehnten, aus dem Schmutzig- oder Bläulichgrünen ins Braumrötliche übergehenden. immen rostfarbenen Rasen. Stengel meist aufsteigend, $2-7 \mathrm{~cm}$, selten bis $10 \mathrm{~cm}$. Blätter feucht aus anliegender Basis zurückgekrümmt abstehend. eilanzettlich, \pm zugespitzt, bis $3 \mathrm{~mm}$ lang. nit bis über die Blattmitte schmal umgebogenen Rändern: Rippe als rotbrame, ‡esägte Granne auslaufend, am Rücken warzig; Zellen der oberen Blatthälfte $12-15 \mu$. Seta etwa $1,5 \mathrm{~cm}$. Kapsel eiförmig und eilänglich. schwach gekriimmt. Peristom $1 / 2^{-1 / 3}$ röhrenförmig, bleich; Zähne gelb, 2 mal gewunflen.

Fig. $29 \mathrm{~A}-\mathrm{D}$.

Auf Felstrümmern aller Irt, besonclers auf Kalkgosteinen.

F. Le. Kilpisjärvi, Kitji-Malla, Malla, Saana und Gunjarvankka, in der alpinen Region (Kot.).

S. Dlr. Osmund-bārgę. Hrịd., PL. und $I u I$.

N. Ve saeterdalen. SB. Reldal. $K$. Jotun- und Lom-fjeldene. $S T$. Invre. No. an mehreren Fundorten. Tr. Flöjfjeld.

Beeren Island, Pyrenāen, Alpenkette, Kaukasus, Zentral-Asien. Sibirien, Nord-Amerika.

217. Tortula ruralis (L.) Ehrh. Pl. crypt. No. 184: Beitr. VHI. p. 1100 (1792). [Bryum rurale L. Sp. pl. 1. ed. II. p. 1116 (1753).]

Diözisch. Mehr oder weniger kräftige Pfl. in lockeren, oft ausgedehnten, trocken grauschimmernden, gelblichgrimen bis gebräunten Rasen. Stengel ohne Zentralstrang, bis 8 cm. Blätter feucht aus fast aufrechter, scheidiger Basis sparrig im Bogen zurückgekrümmt, seltener aufrecht-abstehend, obere grösser und schopfiggedrängt. verlängert-länglich, mit breit abgerundeter, $\perp$ deutlich ausgerandeter oder vorgezogener Spitze, bis $1 \mathrm{~mm}$ lang, mit bis gegen die Spitze ungerollten und am Grunde breit und gelb gesäumten Räudern; Rippe in ein meist langes, dornig-gesägtes. unten \pm gelbrotes Haar auslaufend, am Rücken = papillös; Zellen der oberen Blatthälfte $12-15 \mu$. Seta $1-2$ em. rot. Kapsel aufrecht, zylindrisch, gerade oder schwach gekrümmt, braun. Peristom ${ }^{1}-_{3}^{1}{ }_{3}$ röhrenförmig. bleich: Zähne roseurst, bis 2 mal gewunden.

Auf Sandfeldern, Manern, allerlei Felsen und am Grunde der Stämme.

F. Al. st. fq. (Bom.), - Ab. Tölsala. Kuusto. Ibo. s:t Karins. Pargas. Finby. Bromarf. Ha-

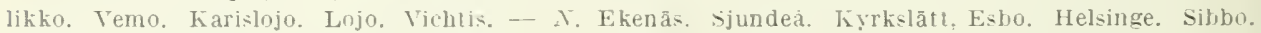
Borgá, - Ka. Antrea, - Ik. Kuolemajärvi. Valkeasari. Valkjärvi. Sakkola. - Nt. Pirkkala. - Ta. Vanaja. Hattula. Tỵränıó. Siăksıäki. Im südỏstl. Teile st. fq. (Norrl.). Luhanka, an mehreren Fundortell (Tain.). Kurpilahti, Tuarunvuori (V.). - Sa. Willmaustrand. Yyslott. - Kl. Kurkijoki. Valanu. Sortavala. Impilahti. Ruskeala. Suitlamo. Soanlahti, pälkjärvi. - Kol. Salmi, Mantshinsaari (Link.). Tulemajārri, Ruukki (L.). Tosnessenje (Elfv.). Yetrosavodsk (Kullh.). - Ca. Nărues, Ytlermark (E. al H.). Isokỵö, Orisberg (Ranek.). - Tb. Virrat, Toriseva (Broth.). Vitasaari, Kuliatinvuori (B.). Kinnula, Olhavainen (Roir.). Pihtipudas, Alrejärvi, Lusitalo(R.). - Sb. Joroinen, Lahnalalıti (11. Lindb.). Kuopio, an mehreren Fundurten (Link., Kot.). Kaavi und Junka im Kalk- und serpentingeb.st. f(I. (Kint.). Nilsiā. Kuus]alıti, Jaakonlampi (Kot.). Maaninka. Tuurilanlabti (Roir.). 一 Kon. sıojärri, Varpakylä (Link.). Pirttiniemi (simm.). — Om. Jakob-lad (Font.). ramlakirleby (Knab.). Brahestad (Broth.). - Oh. Kajana, an der Kïirche und Anmänkallio (KYyhk.). Paltamo, Melalahli (Lackstr.). Sothamo, Naapurinvaara (KỴlı.). - Ob. Lleảborg (Huum.). simn (Räঊ.). Rovaniemi. Valajankoski (Brenn.); Hepokallio (Hult); Turtola und Pello (H.). - K. Kuusamn, Rurpsijärvi (Bruth.); Rukalun¿uri (B.): Kitkajoki, J̣̣ärä (B.); Paanajärri, Ruskeakallio (B.). - Lkem. Kiulari (Hult). Kittilä. Kirchdorf (H.): Ākäsjoki, nördl. rom Rautujărvi (11.); Yllässaari (H.). Kuolajàrvi. Pỵähuru (E. af H.). Le. Pablavara, in der Kiefernregion (Norrl.); Pietsovaara und Leutsuvaara, an der Grenze zur alpinen Rogion (N.). Kilpisjärvi. Kitji-Malla, Ialla, Slana, Guonjarvankka und Saivovaara. in der alpinen Reÿion fil. (Kot.). - Li. Inari, Sakatinpahta (Hult). - Lim. Kandalaks (Karst.). Krestovaja und Schelésnaja (Broth.). sascheika (Karst.). Hibinā (Broth.). - Lt. Kola (liarst.): Abramnraja pahta und 
Karaulnaja Pahta am Kolabusen (Broth.). Tsipnavolok und Subovi (Broth.). Kildin (B.). - Lp. Ponoj (Broth.).
S. Sk. - L.

N. In allen Ämtern $\pm \mathrm{fq}$. und bis in die alpine Region hinaufsteigend.

Europa fq.-fqq. Spitzbergen, Vorder-, Zentra!- und Nord-Asien, Nord-Afrika, Nord-Amerika.

218. Tortula princeps De Not. Specim. de 'Tort. 1838.

Polyözisch. Kräftige Pfl. in dichten, trocken grauschimmernden, aus den Olivengrünen braumroten, innen rostroten Rasen. Stengel $2-4$ cnu. Blätter dicht gestellt, an den Sprossen schopfig gehäuft, feucht aufrecht-alsstehend, mit zurückgebogener Spitze, obere grösser, breit-länglich, zungen- und spatelförmig, meist kurz zugespitzt oder abgerundet stumpf, bis 4 mn lang, mit bis zur Mitte oder etwas höher schmaI umgebogenen Rändern; Rippe in ein langes, dicht gesägtes bis fast glattes, meist hyalines, seltener gelbbräunliches Haar auslaufend, am Rïcken t rauh; Zellen der oberen Blatthällte, $12-14 \mu$. Seta $1-3$ cu, rot. Kapsel
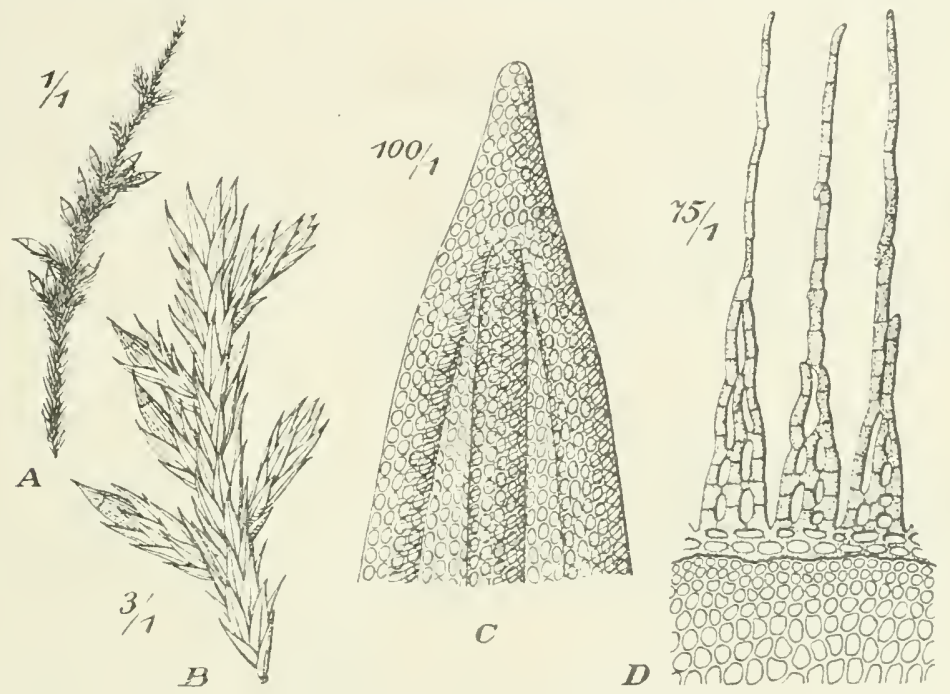

Fig. 30. Cinclidotus minor (L.) A Fruchtende Pfl. (1/1); B Dieselbe (3/1); C Blattspitze (100 1): D Peristom $(75 / 1)$.

anfrecht, zylindrisch, sanft gekrïmmt, kastanienbraun. Peristom $1 / 2$ röhrenförmig, blassrötlich; Zälıne rosenrot, 2 mal gewunden.

An erdbedeckten Mauern und Felsabhängen.

S. Öl. und Gtl.

N. SB. Strandebarm, Varaldsoen.

West- und Süd-Europa. Algier, Transkaspien, Nord-Amerika, New Zealand.

\section{CINCLIDOTOIDEAE}

Die Merkmale der Unterfamilie sind dem Gattungscharakter gleich.

\section{CINCLIDOTUS}

Palis. Prodr. p. 28 ex p. (1805).

Diözisch. Kräftige, meist flutencle Wassermoose. Stengel ohne Zentralstrang. verlängert, gabelig geteilt, unregelmässig kurzästig, am Grunde durch dicke, rotbraune Rhizoiden an die Unterlage befestigt. Blätter fleischig. lineal-lanzettlich. 
flach- und ganzrandig, wulstig gesäumt: Rippe sehr kräftig, als kurze Stachelspitze austretend, Zellen sehr klein und chlorophyllreich, auch am Grunde rundlich6seitig und quadratisch, glatt. Kapsel meist cladogen, länglich-oval, ohne Luftraum und ohne Spaltöffnungen. Ring nicht differenziert. Peristom mit niedriger Basilarmembran. Peristomzähne meist lang und unregelmässig in 2 -3 fadenförmige, am Grunde durch Querleisten rerbundene, gegliederte Schenkel gespalten, selten rudimentär. Deckel kegelförmig. Haube kegel-kappenförmig.

219. Cinclidotus minor (L.) Lindb. De Tort. p. 340 (1864). [Fontinalis minor L. Sp. pl. I. ed. 2, p. 1107 (1753). - Trichostomum fontinaloides Hedw. Deser. III. p. 36, t. 14 (1792). - Selra minor Lindb. Muse. scand. p. 23 (1879)].

Oliven- bis schwärzlichgrüne Pfl. in lockeren, büschelförmigen Rasen. Stengel sehr ästig, 4-10 cm, selten länger. Blätter trocken steif aufrecht oder eingebogen und gedreht, feucht aufrecht-abstehend, zuweilen einseitswendig, gekielt. aus herablaufendem, verschmälertem Grunde breit lineal-lanzettlich, scharf oder stumpflich zugespitzt, bis $5 \mathrm{~mm}$ lang, lurch 3-6 Zellschichten gesäumt. Perichätialblätter halbseheidig, länger zugespitzt. Kapsel eingesenkt, bram; Zellen đles Exotheeiums in de Mehrzahl rundlich 4-6eckig. Peristomzähne purpurn, in 2 -3 lange, fadenförmige, schräg nach rechts ansteigende, schwach papillöse Schenkel geteilt. Sporen $18-25 \mu$, olivengrün, warzig. Sporenreife im Sommer. - Fig. 30.

In fliessenden Gewässern an Steinen und Felsblöcken.

S. Sk. Skärali. Öl. Karlevi. Gll. Ög. Linköping.

N. Sm. Tune. ST. Opdal, Driva. Osterdalen, Aamot.

Europa, Algier, Kaukasus, Luristan. Wl est-Tibet, Nord-Anerika.

\section{E N C A L Y P T A C E A E.}

Autözisch (exel. Encalypla contorla); $\sigma^{x}$ Blüten knospenförmig kurz gestielt, in der Nähe der 우 Blüten, mit keulenförmigen, oben kurz gegliederten Paraphysen. Nehr oder weniger kräftige, meist dichtrasige und freudig grüne, immen rostfarbene. glanzlose Pfl. Stengel aufrecht, im Quersehnitt 3- oder jeckig, mit kleinem, abwärts oft fehlendem Zentralstrange, dieht beblättert, im unteren Teile mit Rhizoiden, gahelteilig und büschelästig. Blätter mehrreihig, trocken \pm einwärts gekrümmt, gedreht und kielig gefaltet, feucht aufrecht-abstehend, meist \pm zungenoder spatelförmig, gusuzrandig, oft haartragend; Rippe kräftig, am Rücken stark vortretend und \pm rauh, mit 2-3schichtigen medianen Dentern. einem mehrschichtigen dorsalen und schwachem ventralen Stereidenbande, ohne differenzierte Aussenzellen; Zellen einschichtig, in den oberen ${ }^{2 / 3}$ des Blattes chloroplyyllreich, fast regelmässig 6seitig und beiderseits dicht warzig, meist etwa $12-18 \mu$, im basalen Teile plötzlich viel grösser, rektangulär und rlıomboidisch-6seitig, hỹalin oder sehwach rötlich, mit dünnen Längs- und verdickten, bräunlichen Qucrwänden. gegen die Ränder enger, oft linealiseh. einen lıäufig gelblichen Saum bildend. Perichätialblätter meist wenig differenziert. Seta gerade, trocken gedreht, glatt. Kapsel emporgehoben, aufrecht, regelmässig, dünnhäutig, mit meist sehr kurzem Halse, glatt oder mit dunkelgelben Streifen; Zellen des Exotheciums fast gleichartig, gestreckt, dïnnwandig orler in den Streifen mit verdickten Längswänden. Spaltöfnungen oberfächlich, zalılreiclı, gross. Peristom bald cinfach und mit Vorperistom. bald doppelt, zuweilen fehlend. Sporen (exel. Encalypla contorta) gross, bis 50, selten bis $90 \mu$ und meist grobwarzig. 1)eekel mit langem, geradem Schnabel. Haube zylindiseh-glockenförmig, lang geschnälselt, die Kapsel völlig einhüllend und oft weit unter dieselbe herabreichend, erst mit dem Deckel abfallend, nackt und ungefaltet, dureh Namillen \pm ranlı.

Einzige Gattung: 


\section{ENCALYPTA}

Sehreb. Gen. pl. 11. p. 759, Ño. 1643 (1791).

$$
\text { Übersicht der. Arten. }
$$

A. Peristom fehlend.

a. Blätter \pm stumpf.

a. Scheidehen eiförnig. Seta links gedreht. Haube gefranst. Sporen 28-37 $\mu$, gelbbrämnlich, mit grossen, halbkugeligen Papillen ..................... 222. E. extinctoria.

$\beta$. Seheidchen zylindriseh. Seta rechts gedreht. Haube ganz oder unregelmässig kurzlappig. Sporen $25-$ $32 \mu$, rostfarben, mässig papillösi .................. 221. E. mutica.

b. Blätter allmählich scharf zugespitzt. Sporen $32-40 \mu$, rostgelb, papillös .................................. 220. E. alpina.

B. Peristom (excl. E. rhabdocarpa var.) vorhanden.

a. Autözisch. Peristom einfach; Zähne aussen ohne Längslinie.

«. Seta gell. Kapsel glatt. Haube gefranst. Sporen $30-10 \mu$, rotbraun .............................. 224. E. Laciniata.

$\beta$. Sela rot. Kapsel mit farbigen längsrippen. Haube anı Grunile selıwach gelappt. Sporen $37-50 \mu$, gelbbraun, mit grossen, pustelartigen Warzen ..... 223. E. rhabdocarpa.

b. Peristom doppelt; Zähne aussen mit Längslinie; inneres Peristom dem äusseren anhängend.

«. Antöziseh.

I. Kapsel glatt, mit in die Seta verschmälertem Halse.

1. Sporen $28-35 \mu$, braun und grobwarzig ..... 225. E. brevicollis.

2. Sporen 21-26 $\mu$, ockerfarben, feinwarzig ... 226. E. uffinis.

1I. Kapsel trocken spiralig gestreift. Sporen 20-

$27 \mu$, grün, fein papillös .................... 227. E. procera.

§. Diözisch. Sehr kräftige Pfl. Sporogone sehr selten. Sporen 9-12 $\mu$, gelb, glatt .................... 228. E. contorta.

220. Encalypta alpina Sm. Engl. Bot. XX. t. 1419 (1805). |Encalypta commutata Bryol. germ. II. P. I. p. 46, t. 15, f. 4 (1827). - Leersia alpina Lindb. Nusc. scand. p. 20 (1879)].

Weniger kräftige Pfl. in dichten, grünen oder gelbgrünen Rasen. Stengel 1-2 cm, selten höher. Blätter aus spateliger Basis länglich, allmälılich scharf zugespitzt, flachrandig, bis $4 \mathrm{~mm}$ lang: Rippe in eine steife, gelbe Granne austretend; Zellen der Lamina sehr klein, nur etwa $10 \mu$. Seta $1 \mathrm{~cm}$, rot. Kapsel zylindrisch, blassbräunlich, glatt. Ring 2 -3reihig, in einzelnen Zellen sich ablösend. Peristonı fehlend. Haube weit unter die Kapsei herabreichend, mit im Alter verschwindenden Fransen. Sporenreife im August.

In Felsspalten kalkhaltiger Gesteine und auf Kalk.

F. Le. Kilpisjärvi, Malla und Saana, in der alpinen Region (Kot.). - Lp. Katschkora (Brotl..). Rusiniha zíw. Orlov und Ponoj (B.).

S. Hrid.. Jmt., $P L$. und $T L$, an einzelnen oder wenigen, $L u L$. an mebreren Fundorten.

N. Br., SB., R.-ST., No. und Tr., am häufigsten in Dovrefjeld und Jotunfjeldene; in No. und Tr. von vielen Fundorten bekannt. Kommt meist in den oberen Teilen des Waldgebietes vor und ist. oberhalb der Baungrenze noch bei $1,800 \mathrm{~m}$ beobachtet.

Spitzbergen. Zentral-Europa im Hochgebirge, Zentral- und Nord-Asien, Nord-Amerlka.

221. Encalypta mutica Hag. Muse. Norv. bor. p. 91 (1899). 
Weniger kräftige Pfl. in dichten, oberwärts grünen Rasen. Stengel etwa $8 \mathrm{~mm}$. Blätter trocken deutlich querwellig, zungenförmig oder verkehrt-eilanzettlich, nit sehr stumpfer Spitze, flachrandig, bis 2,3 $\mathrm{mm}$ lang; Rippe weniger kräftig, ziemlich weit vor der Blattspitze authörend: Randzellen der Blattbasis kamm differenziert. Seta $5-8 \mathrm{~mm}$. links gedreht, braun. Scheidchen eiförmig. Kapsel zylindrisch, bräunlichgelb bis rostfarben, glatt. Ring bleibend. Peristom fehlend. Sporen 25-32 $\mu$, rostfarhen, papillös. Haube bis zum Kapselgrunde reichend, mit regelmässigen, bleibenden Fransen. Sporenreife im Juli und August.

Auf besonnten, humusbedeckten Schiefer- und Kalkfelsen.

N. Bu., K., ST., No. und $F$. - selten. Im Süden in den inneren subalpinen Gegenden, nördlicher auch am Meeresufer.

222. Encalypta extinctoria (L.) Sw. Disp. musc. Suec. p. 24 (1799). [Bryum extinctorium L. Sp. pl. 1. ed., IJ. 1) 1116 (1753). — Leersia extinctoria Leyss Fl. hal. No. 1052 a (1783). - Leersia vulgaris Hedw. Descr. I. p. 46, t. 18 (1787).

Encalypta vulgaris Hoffm. Deutschl. Fl. II. p. 27 (1795).]

Weniger kräftige Pfl. in meist kleinen. \pm dichten, meer- bis bräunlichgrünen, polsterförmigen Räschen. Stengel $0,5-1,5 \mathrm{~cm}$. Blätter eilänglich und länglichzungenförmig, stumpf oder kurz zugespitzt, zuweilen mit aufgesetztem Spitzchen, flachrandig, bis 2,5 mm lang: Rippe kräftig, kurz vor oder in der Blattspitze aufhörend; Randzellen der Blattbasis differenziert. Seta $5-10 \mathrm{~mm}$, rechts gedreht. Scheidchen zylindrisch. Kapsel zylindrisch, gelbgrünlich bis braunrötlich, glatt, trocken sehr zart gefurcht. Ring 2reihig, in einzelnen Zellen sich ablösend. Peristom fehlend. Sporen 28-35 $\mu$, gelbbräunlich, mit grossen, stumpfen Papillen. Haube bis zum Kapselgrunde orler etwas weiter reichend. ganzrandig oder unregeimässig lappig. Sporenreife im Juni.

Auf besonders kalkhaltigem Boden an Erdlehnen, in Ausstichen, auf erdbedeckten Mauern und in erdigen Felsritzen.

F. Al. Eckerö, Storby (Arrh.). Hammarland, Skarpnăto (Elfr.). Finström, Godby (Bum.). Saltvik, an vielen Fundorten (B.). - Ab. Pargas (Arrh.. Ruor.). Karislojo, Karkali (Sundr.). Lojo, Kirchdorf (Bj. Lindb.). Pusula (Brolh.). - N. Snappertuna, Raseborg (Häyr.). Helsingfors (W. Nyl.). Ka. Fotka (Roiv). - Ta. Asikkala, Viitaila (Norrl.). - Kl. Soanlahti, Korjikallio (Brotl.). - Ok. Sotkamo, Natula (Kyyluk.).

S. Sk.-Dld. und $D l r$.

N. Sm., Bu. und $J L$. an wenigen, A. an mehreren Fundorten. ¿Łberal] nus in niedriger Lage. Europa, Nord-Afrika, Kankasus, Vorder- und Zentral-Asien, Nord-Amerika.

223. Encalypta rhabdocarpa Schwaegr. Suppl. I. p. 56, t. 16 (1811). [Leersia rhabdocarpa Lindb. Musc. scand. p. 26 (1879).]

Weniger kräftige Pfl. in \pm dichten, oberwärts grünen Rasen. Stengel bis $3 \mathrm{~cm}$. Blätter verlängert lanzettlich oder länglich zungenförmig, stumpflich oder kurz zugespitzt, flachrandig, bis 2,5 mm lang: Rippe meist mit der Spitze endend oder als gelbliche Stachelspitze austretend, flachrandig; Zellen des Blattgrundes am Rande in bis 8 Reihen einen deutlichen, gelblichen Saum bildend. Seta $4-8$ mm, rot. Kapsel länglich-zylindrisch, gelbgrün bis rotbraun, trocken mit 8 braunroten Längsrippen und deutlich gefurcht. Ring in einzelnen Zellen sich ablösend. Peristom einfach, purpurn oder gelbrot, mit \pm ausgebildetem, nach der Entdeckelung sehr hinfälligem Vorperistom: Zähne lanzettlich, papillös. Sporen 40 $55 \mu$, gelbbräunlich, mit grossen, pustelartigen Warzen. Haube nur wenig unter den Hals reichend, am Grunde schwach gelappt. Sporenreife im Juli und August.

Fig. $31 \mathrm{~F}-\mathrm{G}$.

Auf hmmusbedeckten Schiefer- und Kalkfelsen und kalkhaltiger Erde.

F. Al. Eckerö. Storby (Arrh.). Jomala, Iöckelö (Buch). Saltvik, an wenigen Fundorten (Bom.). Brändö, Jurmo (B.). - X. Helsinge, Vesterkulla. Kalkholmen (Ranck.). Lovisa (Arrh.). - Kl. Sortavala, Kirjavalahti (Simm.). Suistamo, Jànisjärvi (II, Backm.). Ruskeala (Linab.). Pälkjärvi, Pirttiniemi (Broth.). - St. Kınpio, Jervassaln, IIautasiari (Link.). Kaavi, Siikajårvi, Huosiaisuiemi. Likn- 
saari und Kypärä (Kot.). Juukil, Halivaara (K.). - Kon. Valkeamäki (Simm.), Tiudie (F, Nyl.). Ok. Sotkamo, Naapurinvaara, Kohvorinsaari (Kyyhk.). Suomussalmi, Kiannankylä (K.). - $K$. Kuusamo, Jäkälävuoma (Broth.); Juuma (B.); Kitkajoki, Päăsköskallio (B.); Paanajărvi, Ruskeakallio (B.): Sovajoki, Kulmakkapuro (E. af H.); Savinajoki (Roiv.); Oulankajoki, Taivalköngäs (R.), - Lkem. Kolari, Manaoja und Naalaoja (Hult). Kittilä, Pahtakallio (H.); Ảkäsłompolo (H.). Sodankylă, Kalkkivuori (Vain.). Kuolajärvi, Pyhäkuru (E. af H.). - Le. Kilpisjärvi, Koltapahta (Norrl.); Kitji-Malla, Malla, Saana, Guonjarvanka und Saivovaara, in der alpinen Region cop. (Kot.). - Lt. Kola, Karaulnaja Pahta (Broth.). - Lp. Katschkova (Brenn.). Ponoj (Sahlb., Broth.). - Lv. Tschapoma (Broth.).

S. Öl., Gll., Ög., Vg., Boh., Mpd., Jmt., Ang. und TL, an einzelnen oder wenigen Fundorten,

N. Sm., $S B .-F$. Fellt in Surlandet und im Küstengeliete von Westlandet, in den inneren Teilen. besonders nördlicher allgemein verhreitet, am häufigsten in den mittleren und oberen Teilen des Waldgebietes. Steigt bis $1,400-1,500 \mathrm{~m}$ hinauf.

Spitzbergen, West- und Zentral-Europa, Kaukasus, Vorder-, Zentral- und Nord-Asien, NordAmerika.

var. leptodon (Bruch) Limpr. Laubm. II. p. 116 (1890). [E. leptodon Bruch mser., Bryol. eur. fasc. 4, p. 9 (1838). - Leersia rhabdocarpa y leptodon Lindl). Musc, scand. p. 26 (1879).]

13ippe mit der Blattspitze endend oder als Stachelspitze austretend. Kapse und Peristom wie bei var, arctica.

S. Gtl.

Alpenkette.

var. arctica (Lindb.) Hag. Musc. Norv. bor. p. 95 (1899). [Leersia rhabdocarpa var. arctica Lindb. Musc. scand. p. 20 (1879).]

Niedrige Pfl. Blätter kürzer; Rippe meist als langes Haar austretend. IKalpsel kïrzer, weniger deutlich gerippt. Peristomzähne unregelmässig. ohne oder mit ruclimentärem Vorperistom.

F. Lim. Kandalaks (F, Nyl.).

N. Br., SB., K. - F.

spitzbergen noch bei $80^{\circ} \mathrm{n}$. Br.

var. nuda Hag. in D. K. N. Yid. Selsk. Skrift. 1910, No. 1, p. $7 \pm(1910)$. [Leersia rhabdocarpa var. gymnostoma Lindl. et Arn. in K. Sv. Vet.-Ak. Handl. Bil. 23, No. 10, p. 63 (1890) nom. nud.]

Blätter mit Spitzchen. Peristom fehlend.

N. Bu., K.. $N T .-F_{0}$, an einzelnen oder wenigen Fundorten.

Sibirien.

var. spathulata (C. Müll.) Hag. 1. c. [E. spathulata C. Miill. Syn. 1. p.519 (18t9). Leersia spathulata Lindb. Musc. scand. p. 26 (1879).]

Blätter schmäler, länglich und spatelförmig, an der Spitze abgerundet, stumpf orler kurz zugespitzt: Rippe cler oberen Blätter als langes, gelles Haar austretend. Peristom fehlend.

S. Öl. und Dlr. an einzelnen Fundorten.

N. A., Bu., Br., SB., NB., K.-No, an einzelnen oder wenigen Fundorten.

Spanien, Tirol bis Siebenbürgen. ïberall selten.

221. Encalypta laciniata (Hedw.) Lincth. in Act. Soc. Se. Fenn. X. p. 269 (1872). [Leersia laciniata Hedw. Fund. II. p. 103, t. 1, f. 24 a (1782). - L. ciliata Hedw. Descr. 1. p. 49, t. 19 (1787). - Encalypta ciliata Hoffm. Dentschl. Fl. II. p. 27 (1795).]

Kräftige Pfl. in lockeren, weichen, oberwärts bläulichgrünen Rasen. Stengel bis $3 \mathrm{~cm}$. Blätter verlängert-zungenförmig, kurz zugespitzt, meist mit Stachelspitze, mit in der Mitte zurückgeschlagenen Rảndern, bis 6 mm lang: Rippe in oder kurz vor der Stachelspitze endend: Zellen des Blattgrundes am Pande einen undeutlichen Saum bildend. Seta 5-10 mm, strohgelb. Kapsel zylindrisch, glatt. gelblich, zuletzt rötlich. Ring nicht differenziert. Peristom einfach. rot. oft init hinfälligem Vorperistom; Zähne schmal lanzettlich, längsstreifig-papillös. Sporen $30-35 "$, rotbraun, mit siernförmiger Zeichnung. Haube unter die Kapsel herab- 
reichend, blass strohgelb, glänzend, mit langen, bleibenden Fransen. Sporenreife im Juli.

Auf beschatteten, kalkärmeren und kalkfreien Felsen und in deren erderfüllten Spalten, doch auch auf dem Boden. - Nordgrenze auf Spitzbergen.

F. Al. Saltvik, Ödkarby (Bom.). - Ab. Pikkis, Bagarla (Zett.). Kimito, Västanvik. Brändbodal (Ohls.). Uskela, Linnanäki (Lindb.). Karislojo (Sundr.); Karkali (E. af H.). Lojo, an mehreren Fundorten (Hult, E. af H.). - K. Elimäki, Mlustila (Buch). - Ka. Virolahti (Blom). - Ta. Vanaja (Thur.). Im südöstl. Teile pass. (Norrl.). Sysmä (Lnon.). Hartola (Bonsd.). Luhanka, Onkisalo, Sikolahti (Vain.). Korpilahti, Peuba, Vuarunvuori (V.). - Sa. Valkeala (Sundv.). Lemi (Buch). Taipalsaari (Simm.). Kangasniemi (Lackstr.). - Kl. Kurkijoki (Jus].). Valamo (II. Nyl.). Sortavala (Linn.); Kirjavalahti (Lindb.). Impilabti, Pullinvuori (Broth.). Ruskeala (W. Nyl.). Soanlahti, Korpikallio (Brotb.). Pälkjärvi, an mehreren Fundorten (B.). - Tb. Virrat. Toriseva (Broth.). Viilasaari, Karhunvuori und Etelivuori (B.). - Sb. Joroinen (Grot.). Kuopio, an einigen Fundorten (Link., Kot., Roir.). Kaavi, Siikajärvi, Huosiaisnieni und llustikkaraara (Kot.). -- Kb. Tohmajärvi, Hiidenvaara und hæ̣pärävaara
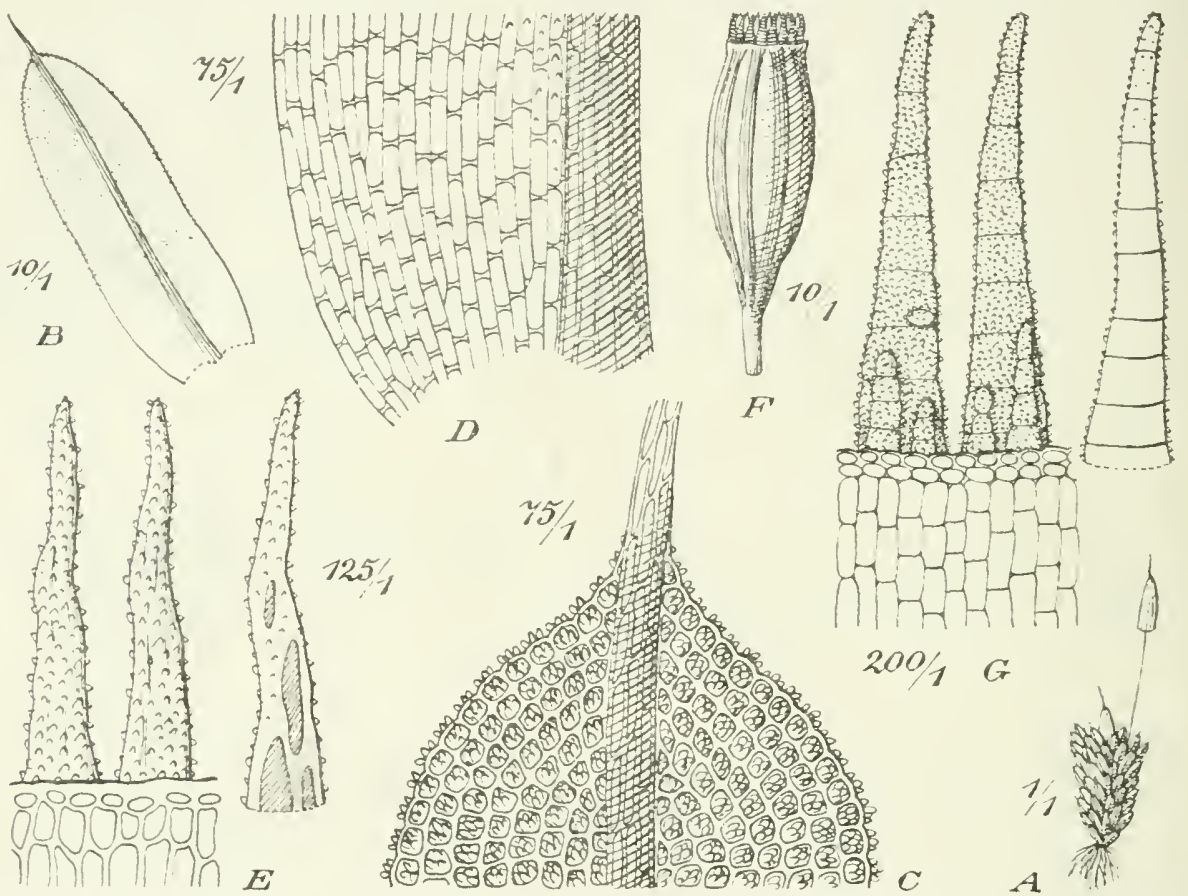

l*ig. 31. A-E. Encalypta brevicolla Bruch. A Fruchtende Pfl. (1/1); B Stammb. (14/1); C Blattspitze (75/1); D Blattbasis (75/1); E Peristom (125/1). - F-G. E. rhabdocarpa Schwaegr. F Entdeckelte Kapsel im trockenen Zu<tande (10 1); G Peristomzähne (200 1).

(Broth.); louhlola (H. Backm.). Fon. Pirttinieuni (Simm.). Jalguba (Sahlı.). - Ok, Sutkamo, Närlijniemi (Kyłhk.); Jormasjärvi, Kohvorinsaari (K.). - K. Kuusamo, Ruopłijärvi (Broth.); Kitkajoki (B.); Lammastuoma (B.). Urovaara (Nyb.); Paanajärri, Ruskeakallio (Sil.). - Lkem. Kittilä, Sairio. nördl. Von Yllästunturi (Hult); Pahtakallio (H.). — Lim. Porjaguba (Sel.). — Lt. Kola, Karaulnaja Pihta (Broth.). - I.p. Orlov. Lesitschicha (Kihlm.).

S. Sk. $-L$.

N. In allen Amtern mil. Ausnahne ron st. und fasl überall fig. Steigi von der Ebene bis 7.11J. Baumgrenze hinauf, selten noch höher.

Europa. Algier. Alesinien, Kaukasus, Himalaya, Nord- und Ost-Asien, Japan, Nord-Amerika.

225. Encalypta brevicollis Bruch in sclied.: Bryol. eur. fasc. 42/4-1 Ind. alph. et Suppl. ᄂ. 637 (18.55). [Leersia brevicollis lindl,. Musc. scand. p. 20 (1879).]

Ziemlich kräftige Pfl. in lockeren, weichen, oberwärts grünen Rasen. Stengel bis 2 cm, selten höher. Blätter breit zungenförmig, stumpflich oder kurz zugespitzt. 
behaart, flachandig, bis 3,5 mm lang: Rippe in ein \pm langes, am Grunde gellses, dann hyalines Haar auslaufend; Zellen am Blattgrunde einen \pm deutlichen Salum bildend. Seta $1-1,5 \mathrm{~cm}$, rötlich. Kapsel zylindrisch, glatt, gelblich, zuletzt rötlich. Ring bleibend. Peristom doppelt, bleich; Zähne schmal lanzettlich, dicht und grob papillös; inneres Peristom dem äusseren in Fetzen anluängend. Sporen $30-35 \mu$, braun, grosswarzig. Haube unter die Kapsel herabreichend, mit langen. bleibenden Fransen. Sporenreile in Mai. - Fig. 31 F-G.

Auf trockenen, humusbedeckten Felsabhängen und in crderfüllten fielsspaltcn, besonders von Schiefer und Granit.

F. Ab. Lujo, ohne nähere Fundorte (Boldt). - Гa. Korpilahti, Vuarunvuori (Lilk.). _. Sa. Sititaipale, Kuolimojärvi (Buch). - Kl. Valamo (IV. Nyl., Lindb.). Sortavala, Kirjavalahti (Sinm.). Tb. Virrat, Toriseva (Broth.). - Sb. Kuopio, Neulaniemi, Vuorilampi (Link.). Nilsiä, Kuuslahti, Jaakonlampi (Kyyhk.). - Kb. Nurmes, Hidenportti (Vain.). - Ok. Sotkano, Hyrkäs (Lackstr.). Suomussalmi, Kirchdorf, Jalonkallio (Kyylh.). - ob. Rovaniemi, Alajääskö (Hult). - K. liuusano, Ruoppijärvi (Broht.); Rukatunturi (B., E. af H.); Iiviara (B.); Aventojoki (E. af H.); Jäkälävtruna (Broth.); Merenoja (B.); Oulankajoki, Kallioperänvaara (B.); Kiutaköngäs (E. af H.); Taivalköngås (Rois.); Savinajoki (R.). - Lkem. Kittilä, Kenttäniemi und Savio, nördl. von Yllästunturi (Hult); Aakennusjoki und Pahtakallio (H.). Kuolajärvi, Kutsanjoki und Pyhäkuru (E. af H.). - Le. Pdhtavaara, in der kiefernregion (Norrl.). - Li. Inari, Sakatinpahta (Hult). - Lim. Kandalaks (Broth.). Trehın (13.). - LP. Ponoj (Sahlb.).

S. Upl. Upsala. Hrjd., Jmt. und $H L$, an einzelnen oder wenigen, LuL. an mehreren Fundorten.

N. A., Bu, Br., Ne., NB., K.-F.. hauptsächlich in den inneren Teilen, in den liustengegenden selten oder fehlend. Steigt von der Ebene bis über die Banmgrenze hinauf, am reichlichsten jedneh in der subalpinen Region vorkommend.

Nord-Amerika.

226. Encalypta affinis Hedw. fil. in Web. ef Mohr Beitr. z. Niturkunde I. p. 121, t. 4 (1805). [Encalypta apophysata Bryol. germ. I1. 1, 1. 19, t. 15. f. j (1827).

- Leersia affinis Lindb. Musc. scand. p. 20 (1879).]

Sehr kräftige Pfl. in dichten, oft ausgedehnten, bläulich- bis braungrinen Rasen. Stengel ohne Zentralstrang, $1-5 \mathrm{~cm}$, längs braunfilzig. Blätter schmal. verlängert zungenförmig, \pm stumpl oder kurz bis lanzettlich zugespilzt, mit bei den oberen Blätter in der Nitte etwas umgebogenen Rändern, bis $5 \mathrm{~mm}$ lang; Rippe weniger breit, in eine längere oder kürzere Stachelspitze auslaufencl: äussere Zellen des Blattgrundes nicht differenziert. Seta etwa $1 \mathrm{~cm}$, rot. Kapsel zylindrisch, gegen die Mündung verengt, glatt, blassgelb, später hell bräunlich, mit ziemlich langem, in die Seta verschmälertem, trocken faltigem und zuweilen von der Urne abgeschnïrtem Halse. Ring bleibend. Peristom doppelt; Zähne linealisch, an der Spitze meist geschlitzt, bleichrot, dicht papillös; inneres Peristom rudimentär, dem äusseren anhängend, hyalin oder gelblich. Sporen 21-26 $\mu$, ockerfarben, feinwarzig. Haube unter die Kapsel herabreichend, strohgelb, mit langen, hinfälligen Fransen. Sporenreife im Hochsommer.

Aul beschatteten, humusbedeckten, \pm kalkreichen Felsen und in deren Spalten.

F. Kl. Sortavala (W. Nyl.); Haukkariutta und Rauskunvuori (Linnan.). Ruskeala, im IIarmorbruche an mehreren Fundorten reichl. (Norrl.). - Sb. Kaavi, siikajärvi (Kot.). - Kb. Juuka, Polrijärvi, Juunvaara (K.). - lion. Valkeamäki (Simm.).-K. Kuusamo, Kitkajoki (Sil.); Jyrärä (Broth.); Urovaara (Nyb.); Pianajärvi, Ruskeakallio (Brotl.). — Lim. Kandalaks (Sahlb.). L.p. Ponoj (Broth.).

S. AL. Laxfjället. LuL. an mehreren Fundorten.

N. A., Bu., ST. und $F$. an wenigen Fundorten, in den Kalkggegenden von No. und $T r$. hâufiger. West- und Zentral-Europa, Kaukasus, Sibirien, Nord-Amerika.

227. Encalypta procerà Bruch in Denkschr. Ak. Nünch. p. 283, t. 11 (1828). [Leersia procera Lindb. Muse. scand. p. 19 (1879).]

Weniger kräftige Pfl. in bräunlichgrünen Rasen. Stengel $1-4 \mathrm{~cm}$. Blätter zungenförmig, stumpf, mit schmal umgebogenen Rändern, etwa \& mm lang; Rippe vor der Blattspitze endend. Seta $1-1,5 \mathrm{~cm}$. rot. Kapsel verlängert zylinclrisch. 
gelblich, trocken mit $\&$ geraden. rippenartigen Streifen. Ring 2reihig, sich abrollend. Peristom wie bei E. contorta. Sporen 20-27 $\mu$, grün, fein papillös. Haube weit unter den Hals herabreichend, bräunlich, an Grunde unregelmässig geschlitzt. Sporenreife im Juli. - Vegetative Vermehrung wie bei E. contorta.

Auf nackten oder humusbedeckten Sehiefer- und Kalkfelsen.

F. Kl. Ruskeala (Lindb.). - K. Kuusamo, Kitkajoki, Jyrävã (Broth.); Oulankajoki (Broth.); Paanajärvi, Kiekkivaara und Kuoppaoja (B.); Mänţjoki (Vain.). - Lkem. Pallastunturit, Pyhäkuru (Hult). - Lv. Tschapoma (Sahlb., Broth.).

S. Hrjd. und LuL. an einzelnen Fundorten.

N. K.—ST., No.-F.: überall selten und spärlich.

spitzbergen, Beeren Eiland, Sibirien, Nord-Amerika.

228. Encalypta contorta (Wulf.) Lindb. in Öfr. K. Vet.-Ak. Förh. No. 7 (1867). [Bryum contortum Wuli. in Jaeq. Collect. II. p. 236 (1788). - Encalypta streptocarpa Hedw. Sp. nuuse. p. 62, t. 10, I. 1015 (1801). - - Leersia contorta Lindb. Musc. scand. p. 19 (1879).]

Diözisch: $\sigma^{7}$ l'fl. schwächer. Sehr kräftige Pfl. in oft ausgedehnten, leicht zerfallenden, bläulich- bis bräunlichgrünen Rasen. Stengel 2-5 $\mathrm{cm}$. Blätter verlängert zungen- und fast spatelförmig und in der kurzen Spitze durch die eingełogenen Rändern fast kappenförmig, $1-8 \mathrm{~mm}$ lang; Rippe mit oder vor der Blattspitze endend. Seta $1-2$ cn. rot. Kapsel verlängert zylindriseh. gelblich oder gelbrötlich, trocken mit 8 spiralig links gewundenen, rippenartigen Streifen. Ring 2reihig, sich abrollend. Peristom doppelt: Peristomzähne fadenförmig, entfernt knotig gegliedert, rot, dicht papillös; inneres Peristom viel kürzer, dem äusseren anhängend, mit gelber, papillöser Basilarmembran und 16 oder 32 fadenförmigen, knotigen Wimpern. Sporen 9-12 $\mu$, gelblich, glatt. Haube weit unter den Hals herabreichend, bräunlich, am Grunde unregelmässig geschlitzt. Sporenreife im Sommer. - Vegetative Vermehrung durch auf rhizoidenartigen, achselständigen Trägern büschelig gedrängte. zylindrische, quergeteilte, gekrümmte, braune und papillöse Brutkörper.

An I $、$ alkfelsen, kalkhaltigen Gesteinen und auf Kalkboclen, selten auf Gneis.

F. Al. Eckerō, Storby, fert. (Bom.). Sund, Jusiböle bärg (B.). Brāndö, Jurmo, Harholmen (B.). Sottunga, Södö (B.). - Ab. Pargas, IIyrilempi (Elfr.); Piukala (Broth.); Finlỵ (Broth.). Angelniemi. Kokkila (Buch) Sag̣ı. Träskby (B.). Karislojo, Pellonkylä (E. af H.). Lojo, Maila (Hult); Torhola und Skraatila (E. af H.). Pusula (Broth.). - N. Snappertuna, Raseborg (Häyr.). Helsingfors (Lindb.); Degerö (Kullh.). Sibbo, Lönarö (Sundr.). Lorisa (Arrh.). - Ka. Wiborg (II. Nyl.). — Ta. Hattula, I’liSarijärvi (Ranck.). Lưrm inen, Kuohijoki (Leop.). Korpilalıti, Haukkavuori (Tain.); Pietilã (V.). Sa. Nyslott (Carl.). - Kl. Sortavala. Rauskunvuori (Linnan.): Kirjavalahti (Norrl.). Impilahti, Pullinvuori (Broth.). Ruskeala (Norrl.). Suistamo, Jalonvaara, Hyypinkallio (Link.). Pälkjäri, Korkeaniemi und Anoniemi (Broth.). - Kol. Tulemajoki, Ruukki (Link.). — Tb. Virrat, Toriseva (Broth.). Sb. Kuopio, an rielen Fundorten (Link.). Kaavi, Siikajärvi, Huosiaisniemi, an mehreren Fundorten (Kot.): Losomäki, Polvijärvi und Soppilampi (K.); Ninivaara. Louhilampi (K.). Juuka, Petroraara, Soticari und Kasurinniemi (Kot.). Nilsiă, Kirchdorf. Loutteinen c. fr. (Kryhk.); Kuuslahti, Jaakonlampi (Kot.). - Kb. Tohmajärri, Kemie, simosenvaara (Oe-ch). Polrijärsi. Kirchdorf (Kot.); Sala. Repovara und Kotosenvaara (K.). Juuka. Juuanvaara, im Umfang ron mehreren km² (Kót.); Nunnanlahti (K.). Kon. Suojärvi, Pöpönsaari (Kop.); Haukk- und Varpakylä (Link.). Jalguha (Kullh.). Valkeamäki (Simm.). Perguba (Sahlb.). - Om. Alajärri, Vesterbacka, Huosianmaankallio (Backm.). Ok. Kajana, Lelıtovaara (Kyyhk.). Paltamo, an mehreren Fundorten (Lackstr., Kyyhk.). Sotkamo, an mehreren Fundorten (K.). Kuhmoniemi, Kellojārvi (K.). Puolanka (Lackstr.); Tulijoki, Törmållmäki (Kyyhk.); Rällinmāki (K.). Suomussalmi, Kallioinen und Katiskalampi (K.). - Kpom. Hukkakallio (Bergi.). - K. Kuusamo, Haataja und Ruoppijārvi (Brotb.); Arentojoki, Rihtikallio (B.); Kitkajoki, an mehreren Fundorten (B.); Oulankajoki, Kallioperänvaara (B.), Tulilammenpuro (E. af H.); Ylerenoja, (Broth.); Pianajärvi, Ruskeakallio fert. (B.). - Lkem. Kittilä, Kirchdorf (Hult). Kuolajäı'vi, Kiimaselänoja (Roì.). — Le. Kilpisjärvi, Malla und Saana (Kotot.).

S. Sk.-Jmt. und Ang.-TL.

N. In allen Amtern nit Ansnalme von $R$, und iu den halkgegenden fq. Steigt run der Ebene bis zur Baumgrenze hinauf. Nordgrenze bei $70^{\circ} \mathrm{n}$. $\mathrm{Br}$.

Europa, Kaukasil, rilgit, Sibirien. Nord-Amerika. 


\section{Reihe GRIMTIA LES.}

Blätter meist lanzettlich, oft mit Haarspitze: Zellen der I,am na klein, meist parenchymatisch, oft mit gebuchteten Wänden. Sporogone acrocarp, selten cladocarp. Peristom einfach: Zähne 16, oben geteilt oder durchlöchert, selten 2 ;schenklig; dorsale Schicht meist dicker, mit Querbalken. Haube meist klein.

\section{G R I M M I A C E A E.}

Ausdauernde, polster- und rasenbildende Stein- und Felsmoose, selten Erdmoose. Stengel meist rund, mit lockerem, getüpfeitem Grundgewebe und oft dickwandigen, engeren Mantelzel en, dicht beblättert, gabel- und büschelästig, seltener mit verkürzten Seitenästen, meist nur am Grunde mit Rhizoiden. Blätter mehrreihig, sehr hygroskopisch, selten einseitswendig, meist lanzetlich und ganzrandig, oft haartragend. selten in der Spitze gezähnt Rippe wenigstens oben fast immer aus gleichartigen Zellen gebildet, abwärts oft mit meist ventralen Deutern: Zellen klein, mit glatten oder gebuchteten Scheidewänden, oben meist rundlich-quadratisch, gegen den Grund erweitert und durchsichtig, rektangulär bis verlängert, selten im ganzen Blatte linearisch. Blüten knospenlörmig, ohme ocler mit spärlichen Paraphysen; die ㅇ meist gipfelständig. Seta kurz bis \pm verlängert, gerade bis schwanenhalsartig, (excl. Rhacomitrium hyproides) glatt. Kapsel (excl. Gustrogrimmia regelmässig, kugelig bis zylindrisch; Spaltöffnungen am Grunde der Une oberflächlich, meist verkümmert und spärlich, bisweilen fehlend. Peristom meist vorhanden: Peristomzähme 16, meist bis zur Basis getrennt, ungestreift, meist papillös, flach, ungeteilt, unregelmässig durchbrochen oder bis zur Mitte und weiter herab 2-bis 4spaltig. Sporen meist klein. Deckel aus kegeliger oder gewölbter Basis stumpf oder geschnähelt. Haube meist klein, kegel-mützen- oder kappenförmig, glatt oder mit papillöser Spitze.

$$
\mathrm{L}^{\dagger} \text { bersicht der Gat } \mathrm{t} \text { ng e } 11 \text {. }
$$

A. Haube glockenförmig, faltig ....................... 6I. Coscinodon.

B. Haube mützen- oder kappenförmig.

a. Peristomzähne ungeteilt, durchbrochen oder an der Spitze gespalten, se ten fehlend ....................6.60. Grimmia.

b. Peristomzähne bis gegen die Basis farlenförmig zweischenklig

62. Rhacomilrium.

\section{GRIMMIA}

Ehrl. in Hedw. Fund. I1. p s9 (1782).

Stengel meist mit Zentralstrang, ohne verkürzte Seitenäste Blätter beim Anfeuchten sich meist pötzlich weit zurückbiegend, dann wierler aufrichtend und zuletzt aufrecht-ab tehend; Zellen meist g’att, oberwärts (exei. G. mollis) klein. rundlich-quadratisch und knotig-verdickt, an Grunde, wenigstens im Mittełfelde verlängert rektangulär und linealisch. Peristomzähne breit bis dlolchförmig. meist ungeteilt, zuweilen durchbrochen oder an der Spitze gespalten. Decliel stets kürzer als die Urne

$\mathrm{U}^{\dagger}$ bersicht der Arten.

A. Basalzellen, wenigstens die äusseren, mit den Querwänden viel dicker als die Längswände. 
a. Blattzellen oben dünmwandig, von der Mitte bis gegen die Basis lockerer, quadratisch und kurz rektangulär. 232. G alpestris.

b. Blätter länger zugespitzt; Zellen oberwärts verdickt, innere Basalzellen verlängert ........................ 233. G. montana.

B. Querwände der Basalzellen nicht dicker als die Längswände.

a. Kapsel eingesenkt, am Grunde einseitig-bauchig.

a Peristom fehlend ................................... 259 G. anodon.

ß. Peristom normal ausgebildet ....................... 260. G. ptagiopodia.

b. Kapsel eingesenkt. regelmässig Columella sich vom Kapselormule ablösend. meist mit dem Deckel abfallencl.

a. Peristom rudimentär

258. G flaccida.

$\beta$ Peristom norma ausgebilatet.

I. Blattzellen nicht buchtig. Sporen $16-20 \mu$.. 251. G. alpicola.

II. Blattzellen mit \pm buchtigen Wänden

1. Blätter schmal zungenförmig. Sporen etwa

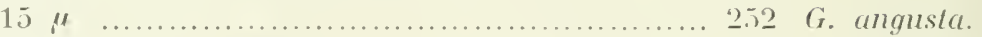

2. Blätter eilanzettlich.

* Blätter flachrandig.

$\dagger$ Blätter ïberall einschichtig. Sporen 11 $14 \mu$ ................ 253. G. sordida.

†† Blätter oberwärts zweischichtig. Sporen $8-10 \mu$ 2.5. G. atrofusca.

** Blätter mit umgerollten Rändern.

+ Küstenmoos. Rippe bikonvex, mit medianen Deutern. Sporen $20-21 \mu \quad \ldots . .257$. G. maritima.

$+\circ$ Rippe nur am Rücken konvex, aus gleichartigen Zellen gebildet.

$\times$ Obere Blattzellen $8-10 \mu$. Peristomzälne dunkel braumrot. Sporen $8-$ $10 " 1$ 256. G. «pocarpa.

$\times \times$ Obere Blattzellen $6-7 \mu$. Peristomzilhne sellorot. Sporen $8-10 \mu$..... 25. G. Gonferta.

c. Kapsel emporgehoben, regelmässig. Deckel von der Columella sich ablösend.

a. Blattfliigelzellen zart mol locker

261. G. atrata.

$\beta$. Blattflügelzellen nicht differenziert.

I. Blätter flachrandig.

1. Weiches Wassermoos. Blätter hohl, stumpflich; Zellen oberwärts $11-18 \mu \ldots \ldots \ldots \ldots . . .2$ 10. G. mollis.

2. Felsmoose. Blätter gekielt: Zellen oherwärts $7-9 \mu$.

* Rippe am Rücken nicht vortretend.

$\uparrow$ Blätter an der spitze stumpl und kappenförmig ................................... 22!). G. unicolor.

+ Blätter mit Haar.

$\times$ Basalzellen quadratisch ..............231. G. campestris.

$\times \times$ Basalzellen verlïngert ............... 230. G. commutata.

** Rippe am Rücken vortretend ............. 236. G. Doniana.

II. Blätter mit umgebogenen bis zurückgerollten Rändern. 
1. Blätter trocken spiralig anliegend.

* Blätter trocken gekräuselt .................2.50. C. Iorquala.

** Blätter trocken nieht gekräuselt.

† Blätter eng eilanzettlich. die oberen mit

langem Haar ........................... 238. G. funulis.

$\dagger+$ Blätter breit und stumpflich eilanzettlich, gipfelständige mit llaarspitzehen ....... 239. G. calvescens.

2. Blätter trocken nicht spiralig anliegend.

* Rippe am Rücken mit Längslamellen ..... 247. G. putens.

** Rippe ohne Lamellen.

$\dagger$ Basalzellen quadratisch ................ 219. G. anomala.

$\dagger \dagger$ Basalzelien verlängert.

$\times$ Gipfelblätter mit Brutkörpern .......2 218. G. IIartmanii.

$\times \times$ Brutkörper fehlencl.

$\S$ Kapsel glatt

$\mathrm{x}$ Rippe abwärls kräftig, rimnig-hohl. 23i, G. obalis.

xx Rippe schwächer. nicht rimnig-lohl.

$\square$ Diözisch. Seta gerade ........234. G. elongula.

$\square \square$ Autöziseh. Seta gekrimmt ... 237. G. apiculala.

$\S \S$ Kapsel längsrippig.

$\mathrm{x}$ Autözisch.

$\square$ Blätter plötzlich in ein langes

Haar versehmälert ............ 241. G. pulvinata.

Blätter allmählich in ein langes

Haar verschmälert ............ 215. G. decipiens. xx Diözisch.

[] Blätter oberwärts papillös ... 246. G. elatior.

$\square \square$ Blätter glatt.

$\bigcirc$ Blattliaar fast glatt ....... 242. G. Irichophylla.

$\bigcirc$ Blatthaar rauh.

$\triangle$ Blätter aus länglichem Grunde lanzettlich, trok-

ken aufrecht-anliegend. 241.G. Mühlenbeckii.

$\triangle \triangle$ Blätter schmal, aus lanzettlichem Grunde allmählich pfriemenförmig, trokken krans .............. 243. G. incurva.

Untergat t. 1. Litoneurum Hag. in D. K. X. Vid. Selsk. Skrilt. 1909, No. 5, p. 10 .

Diözisch. Blätter starr, trocken aufrecht anliegend, rimnig-hohl und flachrandig; Rippe am Rücken nicht vortretend. Scheidchen oval oder eiförmigs. Kapsel regelmässig, glatt. Deckel nicht mit der Columella verbunden. Haube unter den Deckel reichend.

229. Grimmia unicolor Hook, in Grev. Scott. Fl. Ill. t. 123 (1825). (Grimmia norvegica Bryhn in D. K. N. Vicl. Selsk. Skrift. 1889, No. 3).

Ziemlich schlanke Pfl. in schwarzgrünen bis bräunlichschwarzen, flachen. leicht zerfallenden Rasen Stengel 2-t $\mathrm{cm}$, aufsteigend. Blätter trocken locker anliegend und etwas eingebogen, aus länglichem oder verkehrt-eilänglichem. fast scheidigem Grunde lineal-lanzettlich, stumpf, fast kappenförmig, bis $2 \mathrm{~mm}$ lang. oherwärts 2-4schichtig und undurchsichtig; Zellen am Grunde gelblicli, nächst der Rippe oder in der ganzen Breite rektangulär. Seta $3-4 \mathrm{~mm}$, gerade, selten 


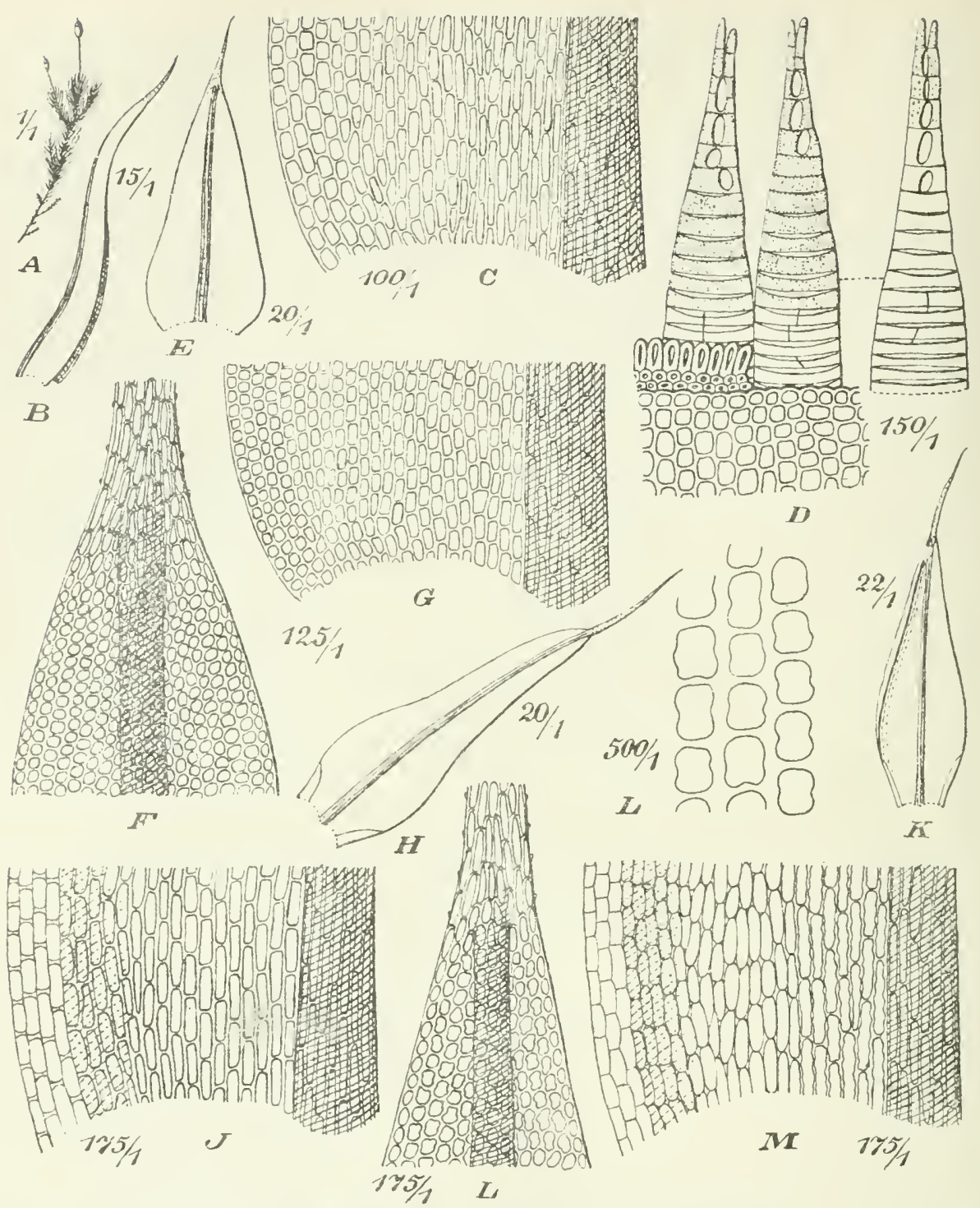

Fig. 32. A-I) Grimmia commutata Hül). A Fruchtende Pfl. (1/1); B Stammb. (15/1); C Blattbasis (100/1); D Peristomzähne (130/1). - E-G G. campestris Burch. E Stammb. (20/1); F Blattspitze (125/1); G Blaltbasis (125/1). - H-I G. montana Bryol. eur. Il Stammb. (20/1); I Blattbasis (175/1). - K- M G. funalis (Schwaegr.) Schimp. K Stammb. (22/1); L Blattspitze (175/1); M Blalthasis (175/1).

gekrümmt, gelb. Kapsel länglich, braun. Ring t-5reihig, sich ablösend. Haule mützenförmig-gelappt, schief, seltener kappenförmig. Sporenreife im Juni.

Auf meist feuchtem, ka kfreiem Kieselgestein.

F. Ab. Lojo, Paloniemi (Boldt). Vichtis, Olkkala, Kauppilanvuori und Konjanvuori (Broth.). Ta. Lammi, am Üfer von Pääjärvi (Vain.). Luhanka, Onkisalo und Judinsalo, Mäkelä (V.). - Kl. Kurkijoki (Jusl.). Jaakkima, Puutsalo (Lindb.). Impilahti, Pullinvuori (Broth.).

S. Sm. und Ang. an mehreren, När., Upl., Vrml., Mpd., Hrjd., PI. und LuL. an wenigen oder einzelnen Fundorten. 
N. In allen Åmtern mit Ausnahme von $L . M, N T$, und $F$, in den inneren und an der südwestl. Küste I selten, im äusieren Küitengebiet von WVestlandet felılend. In allen Hohenlagen, oberhalb des Baumgrenze jedoch selten.

Europa, Kaukasus, Nord-Amerika.

230. Grimmia commutata Hiib. Muscol. germ. p. 185 (1833).

Pfl. in dunkelgrünen bis schwärzlichen, schwach grauschimmernden, leicht zerfal enden Rasen. Stengel 2-4 cm, aufrecht odler aufsteigend. Blätter trocken locker anliegend, aus breit eiförmigem, halbscheidigem Grunde I rasch lanzetllich verschmälert, die oberen in ein mässig anges Haar verschmälert und ohne die Haarspitzen 2,5-3 $\mathrm{mm}$ lang, olserwärts 2schichtig und undurchsichtig: Zellen am Grunde nächst der Rippe verlängert rektangulär, gelblich gegen den Rand fast quadratisch und noch durchsichtiger bis wasserhell. Seta $3-4$ mm, gerade, rötlichgelb. Kapsel oval bis fast kugelig, rötlichbraun. Ring 3 -Ireihig, in einzelnen Zellen sich ablösend. Haube kappenförmig. Sporenreife in lirülnling. — Fig. $32 \mathrm{~A}-\mathrm{D}$.

Auf besonnten, kalkfreien oder kalkarmen Felsen und Blöckicn.

F. Al. Eckerö (Elfv.). Saltvik st. fq. (Bom.). - Ab. Korpo, Lånģvik (Ekl.). Nảdendal (Elfv.). Ảbo, Hirvensalo, Jänissaari (Buch). Pargas (Arrh.). Kimito, Brändboda (OIs.). Finby, Kiaukasalo; (Broth.). Uskela, Pahkavuori (Häyr.). Karisıjo, Täsväri und Karkkali (Broth.): Pipola (Sundv.). Loju,

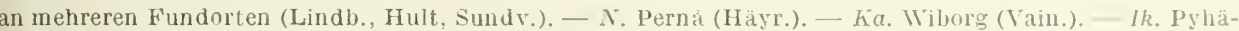
järvi, Jahois (H. Lindb.). - Ta. Hollola. Vesijärvi, Enonsaari (Norrl.); Kalliola (N.). Korpilahti, Vuarumvuori (Vain.). - Sa. Savitaipale, Kuuolimojärvi, Luotalahti (Buch), - Kil. Kurkijoki, Haavikkı (Jusl.). Valamo, besonders am Ufer fq. (IV. Nvl.). Sortavala, Liikolanmäki (Norrl.). Impilahti, Pullinvuori (Broth.). Soanlahti, Korpikallio (Broth.). - Oa. Sastmola (Malmgr.). — Tb. Viitasaari, Etelävuori (Broth.). - K. Kuusamo, Kitkajoki. Jỵävà (Broth.).

S. Sk.-Gslr.

N. In allen Ämtern mit Ausnahme von $R$., $T r$, und $F$, an der südwesıll. Küste rr. und in den äusseren Teilen von Westlandet fehlend. Neist in uiedriger Lage. Nordgrenze bei $67^{\circ} 17^{\prime} n$. Br.

Europa, Madeira, Nord-Afrika, Kaukasus, Vorder-Asien, Himalaya, Sibirien, Nord-Amerika.

231. Grimmia campestris Burch. Mser. in Hook. Musc. exot. 11. p. 9, t. 129 (1820). [Grimmia leucophaea Grev. in Wern. Trans. IV. p. 87, t. 6 (1822).]

Pfl. in unregelmässigen, flachen, oft ausgedehnten, sehr leicht zerfallenden, grauschwarzen Rasen. Stenge etwa $1 \mathrm{~cm}$, aufrecht, auf der L'nterlage fest haltend. Blätter trocken ocker anliegend und die B'atthaare an der Stengelspitze dicht pinselförnig zusammenschliessend, die oberen aus breit eiförmigem Grunde in der Nitte zu einer breiten, fast zungenförmigen Spitze verlängert und in ein langes, gezähntes Haar auslaufend, olıne die Haarspitzen 1--1, 1 mm lang, oberwärts 2-3schichtig und undurchsichtig; Zellen an Blattgrunde grösser. in den Blattecken quadratisch und queroval bis querrektangulär. Seta $1-2 \mathrm{~mm}$, gelblich. Kapsel oval bis länglich, rötlichbraun. Ring 3reihig, sich abrollend. Haube mützenförmig, gelappt. Sporenreife im Frülıling.

Auf besonnten, kalkfreien Felsen und Blöcken.

F. Ka. Wiborg (Tain.).

S. Sk., Ol., Sm. und $O g$. an mehreren Fundorten, $V g$., Srm., När., $U p l$.

N. An wenigen Fundorten in $S m$., JL. und $V B$. Nordgrenze bei etwa $61^{\circ} 2 u^{\prime} \mathrm{n} . \mathrm{Br}$.

Europa, Kanaren, Kapland, Kaukaıus, Persien. Twehitral, Khasia, Australien, Xord-. Imerika.

U 11 t e r g a t t. I I. Gümbelia (Hamp. in Bot. Ztg. 1846, p. 124 ex p.) Limpl.

Laubm. I. p. 777 (1889), emend. Hag. I. c. p. 14.

Blätter starr, oberwärts gekielt: Rippe am Rücken vortretend. Sclreidchen elliptisch oder eiförmig. Kapsel regelmässig, glatt. Deckel nicht mit der Columella verbunden. Haube unter den Deckel reichend.

S e c t. I. Grimmiae montanae Hag. I. c. p. 16.

Blätter trocken aufrecht-anliegend; Zellen glattwandig: Querwände cler Basalzellen, wenigstens am Rande, viel dicker als die Längswände.

232 Grimmia alpestris Schleich. Catal. 1807; Bryol. germ. II. 1. p. 139(1827); emend. Loesk. Laubm. eur. I. p. 100 (1913). 
Pfl. in feucht dunkel bläulichgrünen bis schwärzlichen. trocken kaum oder schwach grauschimmernden, leicht zerfallenden Polstern. Stengel $1-1, \bar{j}$ cm, aufrecht. Blätter flachrandig, die oberen viel grösser, aus länglicher Basis lanzettlieh, bis $2 \mathrm{~mm}$ lang, in ein meist kurzes Haar auslaufend, oberwärts meist zweischichtig, wie auch in Längslinien oder Streifen \pm weit herab; Zellen dünnwandig, an Blattgrunde kurz rektangulär bis quadratisch. Seta etwa 2,5 mm, bräunlichgelb. Kapsel länglich bis fast zylindrisch. Ring nicht differenziert. Deckel stumpl bis kurz geschnäbelt. Haube kappenförmig. Sporenreife im Mai.

An offenen, trockenen Felsen und Steinen, meist im Schiefergebirge und in den höheren Teilen des Waldgebietes.

var. mutica De Syll. No. 325 (1838). [Dryptodon caespiticius Brid. Bryol. univ. I. p. 200 (1826); Grimmia caespiticia Jur. Laubmfl. p. 172 (1882).]

Diözisch. Blätter kurz laazettlich, zu einer sehr kurzen Haarspitze vorgezogen, oberwärts tief dreifaltig. Kapsel aufrecht, braun. mit stupfem Deckel. spaltöffnungen spärlich.

N. $B r$. ITre Telemarken. $K$. Tang, Kramsklejven; Lom. Lomseggen.

Riesengebirge, Alpengebiel. Tatra, Pyrenänen. Kaukasus.

var. stomata Loesk. Laubm. Eur. I. 1) 104 (1913). Autözisch bis pselldo-diözisch. Blätter lanzettlich bis lang lanzettlich, länger haarspitzig. Kapsel meist geneigt; Spaltöffnungen vorhanden.

fo. sessitana (De Not.) Loesk. 1. c. [Grimmia sessitana De Not. in Erbar. critt. ital. Ser. II. No. 95; Epil. p. 704 (1869).]

Blätter einschichtig, unten an einer Seite oft umgeschlagen, olne Falten und Wülste. Kapsel gelblich bis bräunlich.

N. $B r . . N_{B} . K$. und $s T$, an reichlichsten in Jotunfjeldene und Dorrefjeld am Rande der (iletscher und Schneefelder. Nicht niedriger ais bei $900 \mathrm{~m}$ beobachtet.

Alpengebiet von Piemont bis Tatra, Kaukasus.

fo. subsulcata (Limpr.) Loesk. ]. c. p. 105 [Grimmia subsulcata Limpr. Laubm. 1. p. 757 (1889).]

Blätter kürzer lanzettlich, llachrandig, oberwärts zweischiehtig. mit Falten und Längswülsten. Kapsel bleichgelb.

F. Le. Naimakka, in der oberen Birkenregion (Norrl.). - Li. Inari. Iuddusjärvi (Sil.).

S. LuL. Sarekgebiel. orten.

N. $B u ., B r ., S B$. u. NB. an wenigen. $\hbar$. u. $\& T$. an vielen und $N o-F$. nur an einzelnen Fund-

Alpengebiet, Kaukasus. Alıai.

233. Grimmia montana Bryol. eur. fasc, 25/28, p. 26, t. 14 (1845).

Diözisch. Pfl. in feucht dunkelgrünen, trocken granschimmernden, nicht zerfallenden lolstern. Stengel 1-2 cm. aufrecht. Blätter flachrandig, die oberen viel grösser. aus länglicher Basis verlängert lanzettlich, bis etwa $2 \mathrm{~mm}$, in ein \pm langes, gezähntes Haar auslaufend, mit oberwärts zweischichtigen Rändern: Zellen oberwärts verdickt. wenig durchsichtig, in der Mitte kurz rektangulär, dann allmälılich länger, am Blattgrunde verlängert rektangulär, am Rande in mehreren Reihen kürzer. Wasserhell. Seta 2 mm, gelblich. Kapsel oval, rotbraun. Ring bleibend. Deckel schief geschnäbelt, bis $1 / 2$ der Crne. Haube kappenförmig. Sporeureife in Frühling.

Auf kalkfreien, besonnten orler beschatteten Felsen und Blöcken.

F. Al. sund, Gesterby tjenan (Bom.). - Ab. Finby, Kaukosalo (Brolh.). - Ka. Kutka, Langinkoski (Roir.). - - - Ruovesi, Kotavuori (Broth.). - Ta. Asikkala, Kaitas (Norrl.). L Le. Naimakka, iu der Birkenregion (Norll.): Pietsovaara und Folttapahta in der alpinen Region (N.). - Ll. Abramova Pahta am Kulabusen (Broth.).

S. Üg., Boh.. Srml. und Upl, an mehreren Fundorten.

N. In allen Ämtern mit Ausnahme von $S t, M$. und $F$, in $\|$ estlandet $r$.. am reichlichsten im $\|$ aldgebiete unterhall, der Baumgrenze. Nordgrenze hei $69^{\circ} 25^{\prime} \mathrm{n}$. Br.

Europa. Nord-Amerika. 
S e e t. 1 I. Grimmiae ovales Hag. I. c. p. 2 .

Blätter trocken aufrecht-anliegend; Zellen buchtig verdickt; Querwände der Basalzellen nicht dicker als die Längswände.

234. Grimmia elongata Kaulf. in Sturm Deutschl. Fl. 11. Heft. 15 c. icon. (181.5).

Diözisch. Pfl. in bräunlich- oder schwärzlichgrünen bis schwarzen, leicht zerfallenden, rasenartigen Polstern. Stengel $1, \overline{5}-3 \mathrm{~cm}$, selten höher, aufrecht. Blätter trocken straff anliegend, schmal lanzettlich oder aus länglichem Grunde lanzettlich, mit kurzer, wenig gezähnter Haarspitze oder ohne Haar und dam stumpflich bis kurz abgerundet, 1,2-1,8 mm, auf einer Seite umgerollt, in der Spitze doppelschichtig, am Rande 3schichtig und weiter herab 2schichtig: Zeilen am Grunde gelblich, glattwandig. verlängert rektangulär, gegen den Rand etwas kürzer und durchsichtiger, die übrigen stark buchtig verdickt. unterhalb der Blattmitte relitangulär. Seta bis 2 mm. gerade, gelblich. Kapsel elliptisch, hellbrann. Ring in einzelnen Zellen sich ablösend. Deckel stumpf-kegelig. Haube kappenmützenförmig, 2-5lappig. schief. Sporenreife in Sommer.

Auf nassen. kalkfreien Felsen.

F. Le. Pietsnvaara. in der alpinen Region (NorrI.). - Li. Saariselkä, sıkustomapäă und VuromaJää in der alpinen Reginn (Hult).

S. Hrja. und LuL. an mehreren Fundurten, Jmt.

N. Bu., Br., sB. $\rightarrow T$., Vo. und $T r$. am reichlichsten in Hochgelirge und dort unr selten unterhalh der Batmgrenze. Nordgrenze bei etwa $69^{\circ} 40^{\circ} \mathrm{n}$. Br

Europa. Kaukasus: Sikłinn. Lral, lirönland.

235. Grimmia ovalis (Hedw.) Lindb. Acl. soc. sc. fenn. X. p. 75 (1871). [Dicranum onale Hedw. Deser. III. p. 81, t. 34 A ex p. (1792).]

Autözisch, selten diözisch. Pfl. in rundlichen, gewölbten, gelblich- bis dunkelgrünen, trocken grauschimmernden Polstern. Stengel $1-2 \mathrm{~cm}$, aufrecht. Blätter trocken straff anliegend, aus schmal eiförmigem oder länglichem Grunde lanzettlich und in ein fein gezähntes Haar auslaufend, die oberen $2,5-3 \mathrm{~mm}$ und dic Haarspitzen bis etwa $0,5 \mathrm{~mm}$ lang, einseitig umgeschlagen, oberwärts doppelschichtig und hier an den Rändern dreischichtig: Zellen am Blattgrunde glattwandig, neben der Rippe gelblich, schmal lineal. Seta 2- $3 \mathrm{~mm}$, gerade, gellb. kapsel meist änglieh, braun. Ring sich stückweise ablösend. Deckel kurz und stumpf geschnäbelt. Haube kegel-mützenförmig. gelappt. Sporenreife im Sommer und Herbst.

Am meisten auf kalklreien, seltener auf \pm kalkhaltigen Felsen und Blöcken.

F. Ab. Gustafs, Eskola (Bergr.). Nadendal (Arrh.). Pargas, Pitá (Elfv.). Finby, Finnarf (E.). Karislojo, Puujärvi. Karkkali (Buch): Pipola (Sundr.); Lojo, an einigen Fundorlen (E. af H.. sundr.). I. Lovisa. Katton (Lindb.). - Ka. KYymene, Sunila (Kuj.). Wiborg, Monrepos (TW. Mryl.). - Ih. Juhannes, Vaahtola (H. Lindb.). -- Ta. Hollola. Siikaniemi (Tain.). Asikkala (Norrl.). Kuhmoinen (N.). Luhanka und Korpilahti, an mehreren Fundurten (Vain.). - Sa. Kianga-niemi, Suomäki (Lackstr.). Kl. Kurkijoki, Haarikkv(Jusl.). Jaakkima (Sundv.), Sortavala (Lindb.). Impilahti. Pullin ruori (Broth.). soanlahti. Kuhilanraara und Korpikallio (B.). Pälkjărvi, Annonniemi (B.). - Oa. Vasa (B.). - Tb. Virrat. Toriseva (B.). Tiitasaari. Koliatinvuori (B.). Pihtipudas. Elämäisjärri. Koiruharju (Roir.). $\therefore$. Kusupio. Neulaniemi, Vuorilampi (Link.). Mraaninka. Tuovilanlahti (Lundstr.. Roiv.). - Kh. Jnensuu. Linnunniemi (Limnan.). - Kon. Suojärri. IIaimalampi (Norrl.). Pirttiniemi (simm.). - Ok. Tiajana (Lackstr.). Paltamı, Melalanti (Broth.). suomussalmi. Kiannanniemi (Kigyhk.). - Ob. Ltajärri, Kurimo (Brenn.). Zw. Aarasaksa und Turtola st. fq. (Hult). - K. Puda-järvi. Piriraara und Iso Sröte (Broth.). huusamo, an vielen Fundorten (Nrb., Broth.). - kk. Kivakkatunturi (Broth.). Kieliak (Eahlb.). Lkem. Zw. Kolari und Pallastunturit st. fq. (Hult). Kiuolajärri, an einjgen Fundorten (E. af H.). - Lo. In allen Regionen $: t$. fq. (Norrl.). - Li. Inari und Ctsjoki, an einigen Fundorten in der Yadelwald- und Birkenregion (Vain.. Kihlm., Popp., Ranck.). - Lim. Kandalaks (Broth.). Tschun (Broth.). Hibinä (Sel., Broth.). - Ll. Rutsvaara (Roir.). Saariselkā, in der alpinen Region (R.). liola (Fellm.. Broth.). l.mur. Teribjerka und Varsinsk (Broth.). - Lp. Ponoj (Broth.).

S. Ög., Srml., Vär. und Upl. an einzelnen Fundorten. Hrjd.-L.

N. In allen Imtern fi. in der Ebene und im Waldgehiete. selten über die Baumgrenze steigend. Nordgrenze bei $7 \mathrm{I}^{\circ} \mathrm{n}$. Br.

Europa, d-ien. Nord-Amerika. 
var. affinis (Hornsch.) Hag. in D. K. N. Vid. Selsk. Skrift. 1909, No. 5, p. 26 (1909). (Grimmia affinis Hornsch. in Flora 1819, II. 1. p. 443).

Kräftiger. Blätter aus breiterer Basis lanzettlich, mit sehr langer Haarspitze. Kapselbasis nicht über die Hüllblätter emporgehoben.

N. Nach $\mathrm{H}$ a gen, ohne nähere Angabe.

Europa, Kaukasus, Nord-Amerika.

var. obliqua (Hornsch.) Hag. I. c. [Grimmia obliqua Hornsch. in Bryol. germ. II. 1 , p. 153 , t. 22 , f. 16 (1827).]

Kapsel über die Hüllblätter hervorragend, etwas geneigt, schwach hochrïckig, schiefmündig. Deckel schief geschnäbelt.

N. Nach $\mathbf{H}$ a gen kaum selten.

Europa.

var. cylindrica (Bryol, germ.) Hag. 1. c.

Sehr liäftige Pfl. Stengel $5 \mathrm{~cm}$. Blätter ohne oder mit kurzem Haare. Seta etwa 3 cm. Kapš̀el zylindrisch. Deckel etwas schief.

N. Nach $\mathbf{H}$ a gen, ohne nähere Angabe.

Europa.

var. heteracra Hag. 1. c. p. 27.

Blätter derselben Pfl. teils kurzhaarig. teils an der Spitze abgerundet und fast kappenförmig.

N. ST. Selbu, Rolset.

236. Grimmia Doniana Sm. Fl. brit. IIl. p. 1198 (1804).

Autözisch. Pfl. in ba'dl kleinen und kreisrunden, bald grösseren und dann meist ovalen, oliven- bis schwärzlichgrünen, grauschimmernden Rasen. Stengel $0, \bar{j}--2 \mathrm{~cm}$, aufrecht. Blätter trocken locker anliegend und etwas eingebogen, die oberen aus schmal länglichem Gruncle lineal-lanzettlich, bis etwa 2 mm und die schwach gezähnten Haarspitzen von halber bis ganzer Blattlänge, flachrandig und oberwärts an Rande 2-3schichtig; Zellen am Grunde glattwandig. verlängert rektangulär, gelblich, am Rande in mehreren Reihen entfärbt. Seta etwa 2 mm, ge b, gerade. Kapsel kleiı, oval, hell rötlichgelb. Ring in einzelnen Zellen sich ablösend. Deckel sehr kurz stumpfkegelig. Haube kegel-mützenförmig, gelappt. Sporenreife in Herbst.

Meist an Lrockenen, kalkfreien Steincn, Blöcken und Felsen.

F. K. Kulıamo, Il taara (Sil.). - Kk. Kirakkatunturi, in der alpinen Region (Broth.). - Le. Kilpisjärvi, Saana (Norrl.). - Lim. thibinä, in der alpinen Region (Sel., Broth.); am Passe zw. Vudjarr und Vunusu-Tum (Kihlnt.)

S. Hrjd., Jmt., LyL. und LuL., an wenigen Fundorten.

var. arenaria (Hamp.) Loesk. Laubm. Eur. I. p. 93 (191:3). [Grimmia arenaria Hamp. in Limnaea X. p. $40+(1836)$.]

Blätter mit längeren, stark gezähnten Haarspitzen. Seta $1-1,5 \mathrm{~mm}$. gekrïmmt. Kapsel seitlich hervortretend. Sporenreife im Juli.

S. Ab. Auf einer kleinen Insel in Ersian (Iilingst.). Karislojo, Karkkali (Broth.).

N. NB. Laerdal, Laerdalsoren $\left(61^{\circ} 6^{\prime 1}\right.$. Br. $)$.

Frankreich. Pyrenäen, Ober-Italien, Zentral-Europa. Iberall sehr selten.

237. Grimmia apiculata Fornsch. in Hopp. et Hornsch. Pl. select. Cent. 2, Dec. 5 (1818), Flora 181!, 1. p. 85 et Il. p. 413.

Autözisch. Pfl. in gelblichgrünen, innen schwillzlichen polstern. Stengel $1-1,5$ cm, aufrecht. Blätter trocken einwärts gebogen, aus verschmälertem Gruncle lanzettlich, allmählich in ein kurzes glattes odler schwach gezähntes Haar auslaufend, bis $1,5 \mathrm{~mm}$ und die Iaarspitzen bis $0.25 \mathrm{~mm}$ lang, am Rande einerseits bis gegen die Spilze, andererseits weniger hoch umgerollt, oberwärts und am Rande bis gegen die Basis zweischichtig; Zellen gelhgrün, am Grunde glatlwandig, rektangulär, gegen den Rand etwas kürzer und durchsichtiger, die übrigen stark buehtig 
verdickt, unterhalb der Blattmitte rektangulär. Seta his $2,4 \mathrm{~mm}$, blassgelb, heral)gebogen. Kapsel oval, gelblich. Ring 3-4reihig, sich abrollend. Deckel klein. gelbrot, kurz kegelförnig. Haube mützenförmig, ¿ Jlappig. Sporenreile in August.

Auf nassen, kalklreien Steinen und Felsen, fast ausschliesslich in der alpinen Region.

S. LuL. sarekgebiet, an der oberen Grenze der Birkenregion.

N. An einzelnen oder wenigen Fundorten in $N B, R, K_{.}, H$., S T. und $F$.

In den Hochalpen von der Schweiz bis zur Tatra.

S e c t. I I I. Grimmiae funales Hag. I. c. p. 30.

Blätfer trocken spiralig um den Stengel gedreht; Zellen \pm buclitig verdickt; Querwände der Basalzellen niclnt dicker als die Längswände.

238. Grimmia funalis (Schwaegr.) Schimp. Syn. p. 211 (1860). [Trichostomum funale Schwaegr. Suppl. I. P. I. p. 150, t. 37 (1811). - Grimmia spiralis Hook. et Tayl. in Drumm. Musc. Scot. II. No. 29.]

Diözisch. Pfl, in oft ausgedehnten, weichen, leicht zerfallenden, gelb ich- bis bläulichgrünen, oft grauschimmernden, imnen schwärzlichen, polsterförmigen Rasen. Stengel 1--3, selten bis $6 \mathrm{~cm}$, aufrecht, gleichmässig beblättert. J3ätter eng, eilanzettlich, zugespitzt, etwa $1,5 \mathrm{~mm}$ lang, die oberen in ein \pm langes, gezähntes Haar auslaufend, einerseits bis gegen die Spitze umgebogen, in der Spitze und oberwärts am Rande zweischichtig; Zellen stark verdickt, durchsichtig und 'gelblich, am Blatfgrunde mit eng linearem Lumen, nur die Randreihe verlängert rekfangulär, dünnwandig und fast wasserhell. Seta $1,5 \mathrm{~mm}$, herabgebogen, blassgelb. Kapsel klein, eiförmig, licłıbraun, rotmündig, trocken schwach srippig. Ring 3 - treihig, abfällig. Deckel kurz und stumpf kegelig. Haube mützenförmiggelappt. Sporenreife in Juli.

Auf trockenen, besomnten, seltener beschatteten und feuchten, kalkfreien oder efwas kalkhaltigen Felsen und Blöcken.

F. Le. Kỉlpisjärvi, Saana (Norrl.); Sairovaara (Kot.). - L im. Hibinä, in der alpinen Region (Broth.). Ljavo-tschor, an der Baumgrenze (Kihlm.).

S. Ang., Tásjö. Hrjd., Jmt., PL. und LuL. an mehreren Fundorten.

N. In allen Ämtern mit Ausnahme von Sm., $J L$. und $L . M$. in Dovrefjeld fq., anderwärts pas.. his $r$.. am reichlichsten in der subalpinen Region, seltener in der alpinen Region.

Europa, Kalıkasus, arkt. Amerika.

239. Grimmia calvescens Kindlb. in Christ. Vidl.-Selsk. Forh. 1888, No.6, p. 19. [Gymnostomum spirale Harfm. Skand. Fl. ed. 3, p. 265 (1828). - Grimmia funalis v. epilifera Zett. Rev. Grimm. Scand. p. 74 (1861). - G. imberbis Kindb. in Bot. Not. 1882, p. 186. - G. Ryani Limpr. mss.: Bryhn in N. Mag. f. Naturv. XXXIV. p. 73 (1892). - G. tortifolia * calvescens Kindb. Skand. Bladm.-fl. p. 110 (1903). - G. tortifolia * Ryani Kindb. 1. c.]

Diözisch. Sehr schlanke Pfl. in weichen, grünen oder bläulichgrünen, inmen schwärzlichen, polsterförmigen Räschen. Stengel 1-2 cm, aufrecht, gleichmässig beblättert. Blätter fast rinnig-hohl, aus breit eiförmigem Grunde kurz lanzettlich, stumpflich, etwa $1 \mathrm{~mm}$ lang, nur die gipfelständigen mit einer kurzen Haarspitze, flachrandig oder einerseits schwach umgebogen; Zellen wenig verdickt und kium buchtig, am Grunde kurz rektangulär, am Rande quadratisch. Sporogone wie bei Gr. funalis. Sporenreife im August.

Auf dem Winde stark exponierten Felsen von liartem Gestein.

F. Le. Kilpisjärvi, Koltapahta und Saana, in der aipinen Region (Norrl.). - Li. Ruoptuin raara (Vain.). - Lim. Imandra, Kurengi (Fellm.).

S. TL. Virijaur.

N. Bu, Br., SB. - ST, No., Tr, in den höheren Teilen des Waldgebietes paś.. auch bis in die alpine Region hinaufsteigend. Nordgrenze bei $69^{\circ} 30^{\prime} \mathrm{n}$. Br.

Europa, arkt. Amerika. 
Un $\mathrm{t}$ e rgat $\mathrm{t}$. I I I. Hydrogrimmia Hag. l. c. p. 35.

Blätter weich, fast kahnförmig-hohl; Rippe am Rücken vortretend. aus ungleichartigen Zellen gebildet: Zellen locker.

Scheidchen eng kegelig. Kapse] und Haube wie bei Gümbelia.

210. Grimmia mollis Bryol. eur. fase. 42, t. suppl. 1 (18+9).

Diözisch. Ziemlich kräftige, sehr weiche Pfl. in lockeren, von Ercle durchdrungenen, sattgrünen, leicht zerfallenden Rasen. Stengel meist $1,5-3$, seltener bis $6-8 \mathrm{~cm}$, aufrecht oder aufsteigend. Blätter trocken locker anliegend, feucht mässig abstehend, fast kahnförmig-hohl, aus schmälerem, etwas herablaufendem Grunde eilänglich bis länglich-lanzettlich. stumpf, häufig kappenförmig einwärtsgebogen, bis $3 \mathrm{~mm}$ lang und $1 \mathrm{~mm}$ breit, flachrandig, einschichtig; Rippe schmal, vor der Blattspitze aufhörend; Zellen wenig verdickt. nicht buchtig, quadratisch. oben etwa $14 \mu$, ain Grunde wenig grösser und z. T. kurz rektangulär. Seta 2-3 mm, gerade, gelb, aufwärts dicker. Kapsel länglich, gelblichbraun; Spaltöffnungen fehlend. Ring nicht differenziert. Deckel gewölbt, mit dickem Spitzchen. Haube kappenförmig, klein und flüchtig. Sporenreife im Juli.

Auf überrieselten, kalkfreien Felsen und Steinen, gern an und in Bächen, fast ausschliesslich in der alpinen Region.

F. Le. Kilpisjärvi, westlich vori Tuolihuippu (Kot.). - Lim. Hibinä, Ljavu-tschor (Kihlm.).

S. PL. Peljekaisse. LuL. Sarekgebiet. TL. Tornioträsk, Ripanes.

N. Br., SB., K. -ST., fast ausschliesslich im zentralen Hochgebirge, nirgends unter 1,200 in beobachtet.

Pyrenäen, Alpenkette von der schweiz bis zur Tatra. Kaukasus, Nord-Amerika.

lo. aquatica (Bryol. eur. pro var.) Loesk. Laubm. Eur. 1. p. 169 (1913).

Wasserform. Stengel bis $10 \mathrm{~cm}$.

F. Lim. Vunnunjok (Kihlm.).

N. K. Lom, Gialdhen, 1,500 111; Turre, Storhuen.

Verbreitung wie bei der Hauptart.

Un te rg. I V. Rhabdogrimmia Limpr. Laubm. 1. p. 759 (1889); emend. Hag. 1. c. p. 37.

Blätter starr, oberwärts gekielt, mit wenigstens einerseits umgerollten Rändern; Rippe am Rüicken vortretend. Scheidchen verlängert, sehr eng zylindrisch. Kapsel regelmässig, trocken längsrippig. Columella knäuelförmig, mit langem Anhängsel. Haube unter den Deckel reichend.

S e c t. I. Grimmiae trichophyllae Hag. l. c.

Blätter trocken nicht spiralig anliegend. Peristom normal ausgebildet.

241. Grimmia Mühlenbeckii Schimp. Syn. p. 212 (1860).

Diözisch. Pfl. in dunkel- bis schwärzlichgrünen, oft grauschimmernden, meist umregelmässigen, polsterförmigen Rasen. Stengel $1-2 \mathrm{~cm}$, aufrecht oder aufsteigend. Blätter trocken anliegend und schwach gedreht, aus eiförmigem oder eilänglichem Grunde lanzettlich, lang zugespitzt, 2 - 2,1 mm lang und in ein langes. gezähntes Haar auslaufend, einseitig \pm weit hinauf zurückgerollt, gegen die Spitze und weit herab in mehreren Randreilıen zweischichtig: Rippe kräftig, am Rücken kantig; Zellen clunkel, rundlich-quadratisch, buchtig-verdickt und glatt, nach unten beidlerseits der Rippe kurz rektangulär, am Grunde \pm verlängert rektangulär, glattwandig, nach den Rändern verkürzt. Seta $2-3 \mathrm{~mm}$, gelblich. Kapsel klein, oval, gelblich, später braun. Ring bleibend. Deckel rot, gerade oder etwas schief geschnäbelt. Haube kegel-mützenförmig. gelappt. - Vegetative Vermehrung durch melırzellige, unregelmässige, gebräunte, an langen und verzweigten Trägern am Blattgrunde entstehende Brutkörper. Sporenreife im Frühling.

Auf kalkfreien oder kalkarmen Felsen, Blöcken und Steinen.

F. Al. fq. (Bom.). - Ab. Korpo. Merimasku. Abo. Pargas. Finby. Angelnieni. Uskela. Kari-lojo. Sammatti, - N. Ekenäs. Kiyrkslătt. Esbo. Helsinge. Tusby. Sibbo. Borgå. Orimattila. Hogland. - Ka. Sippola. Säkkijärvi. Wiborg. Antrea. - Ik. Johannes. Muola. Valkjärvi. - St. Eura. 
Eurajoki. Sastmola. Pirkkala. Ikaalinen. Orivesi. Ruovesi. - Ta. Tammerfors. Vanaja. Haltula In südöstl. Teile fq. (Norrl.). Hartola. Luhanka und Korpilahti fq. (Vain.). - Sa. Lappee. Kangasniemi. Ruokolahti. Nyslott. - Kl. Kurkijoki. Jaakkima. Pälkjärvi. - hol. St. r. (Ellr.). Petrosarodsk. - Tb. Jyväskylä. Pihtipudas. - Sb. Järventaipale. Kuopio st. fq. (Link.). Kaavi. Nilsia. Maaninka und Pielaresi st. fq. (Roiv.). - Kb. Tohmajärvi. Juensuu. - Kon. Suojärvi. Kendjärvi. Jerguha. - Om. Alajärvi. Lappajärvi. Vimpeli. Merijärvi. - Ok. Kajana. Sotkamn. - Kip. I mana (Bergr.). - ()b. Ylitornio, Karhujupukka (Hult). - K. Kumsano, Sovajarvi (ILois.).

S. Sk.-Hlsl., ing. an mehreren Fundorten.

N. Sm.-Ne, SB., NB., K.-NT., in ust-und surlandet til., in den inneren Imtern nörlicher r. Steigt nur bis $500 \mathrm{~m}$ hinanf. Nordgrenze bei $63^{\circ} 27^{\prime} \prime 1 . \mathrm{Br}$.

Europa, Nord-Anerikil.

242. Grimmia trichophylla Grev. Fl. edin. p. $235(182-1)$.

Diözisch. Pfl. in lockeren, leicht zerfallenden, grünen oder gelbgrïnen l’olstem oder Rasen. Stengel $1-3 \mathrm{~cm}$, aufrecht oder aufsteigend. Blätter trocken gekrümmi und mässig gedreht, aus schmal eilänglicher Basis lanzettlich, lang und schmal zugespitzt, 2-2,5 mm lang, in ein kurzes, schwach gezähntes Haar auslaufend, einseitig \pm weit hinauf zurückgerollt, gegen die Spitze und weit herab in mehreren Randreihen zweischichtig; Zellen bis zum Grunde gelbgrün, oberwärts rundlichquadratisch, buchtig verdickt unc glatt, dann kurz rektangulär, an Grunde verlängert, hier am Rande einige Reihen glattwandig und gestreckt. Seta 3 j nnı, gelb. Kapsel oval bis länglich, gelblich, später braun. Ring stückweise sich ablösend. Deckel gelbrot, gerade oder etwas schiel geschnäbelt. Haube kegel-mützenlörmig, gelappt. - Vegetative Vermehrung wie bei Gr. Mühlenbeckii, die Träger der Brutkörper jedoch kurz. Sporenreife in Frühling.

Auf kalkfreien und kalkarmen Gesteinen.

S. Sh., Bl., Boh., Ög., Did.

N. Sm.-Bu., Ne.-R., sT., YT. pass.-1', nur in der Elene. Nordgrenze bei $63^{\circ} 28^{\prime}$ il. Br

Europa, Madeira, Algier, Klein-Asien, Australien, Nord-Amerika.

243. Grimmia incurva Sehwaegr. Suppl. P. I. p. 99 (1811). [Dicranum contortum Wahlenb. Fl. carp. p. 346, t. I (1S14). - Grimmia contorta Schimp. Sym. p. 209 (1860). - G. Hagenii Kaur. in Nyt Mag. for Naturv. Bd. 31, p. 217 (1888).]

Diözisch. Pfl. in dunkel- bis schwarzgrünen, auch schwarzen, flachgewölbten, kreisförmigen oder ovalen, etwas verwebten Polstern. Stengel $1-3 \mathrm{~cm}$, aufrecht. Blätter trocken verbogen und kraus, aus schmal länglichem Grunde lanzettlichpfriemenförmig, 3-5 mm lang, mit kurzer, brüchiger, gezähnter Haarspitze, flachrandig oder in der Nitte einerseits umgeschlagen, in der Spitze und oberwärts am Rande zweischichtig; Zellen dunkel bis fast undurchsichtig, stark buchtig verdickt, in der Blattmitte kurz rektangulär und oval, am Grunde lineal, schwach buchtig, am Rande glattwandig, kurz rektangulär. wasserlıell. Seta $2 \mathrm{~mm}$. herabgebogen. gelb. Kapsel länglich, bleich, später braun, trocken und entdeckelt nit Längsrunzeln. Ring 3--Ireihig, abfällig. Deckel stumpf kegelig, gelbrot. Haube nü̈tzenförmig-mehrlappig. Sporenreife im Juli.

An kalkfreien Felsen und Felstrümmern, gern in Klüften und Höhlungen, meist in der alpinen Region. Nordgrenze auf Spitzbergen.

F. Sa. Kangasniemi, Hitenmäki (Broth., Lacksir.). - h. Pudasjärvi, Iso syöte (Broth.). - Kk. Kivakkatunturi (Broth.). - Lkem. Saivio (Hult). - Le. Pantavaara, in der Nadelwaldregion, Nainakka. in der Birkenregion und Keiniotunturi, in der aly,inen Region (Norrl.). Kilpisjārvi. Malla, in der alpinen Region (Kot.). - Li. Inari, Peldoivi und Nattastunturit, Pyhätunturi (Hult). Saariselkä, Sokustomapää. Ukselmapää und Vuomapäả (H.). Utsjoki, Dalvados, bei Njiljokka (Ranck.). — Lim. Hibinā (Broth.): Ljavo-tschor (Kihlm.).

S. Hrjd. und Jmt, an mehreren Fundorten, LuL. Sarekgebiet.

N. Bu., Br., Ne.. SB., NB., K.,$S T$. . No. und Tr.. im Hochgebirge nicht selten und bis elwa $2.000 \mathrm{~m}$ hinaufsteigend, in No. und $\mathrm{Tr}$. $\mathrm{rr}$.

Europa, Kaukasus, Nord-Amerika.

244. Grimmia pulvinata (L.) Sm. Eng1. Bot. t. 1727 (1807). [Bryum pulvinatum L. Sp. pl. p. 1121 (1753).] 
Autözisch. Pfl. in gewölbten, weissgrau schimmernden, feucht bläulich grünlichen Polstern. Stengel 1-2 cm, aufrecht oder aufsteigend. Blätter trocken locker anliegend, dlie oberen verlängert länglich-lanzettlich, stumpf, bis $2,2 \mathrm{~mm}$ lang, plötzlich in ein langes, gesägtes Haar auslaufend, in der Spitze zweischichcig, mit \pm weit hinauf umgerollten Rändern: Zellen oberwärts rundlich-quacratisch, iı der Spitze dunkel, \pm knotig verdickt, dann allmällich grösser, quadratisch

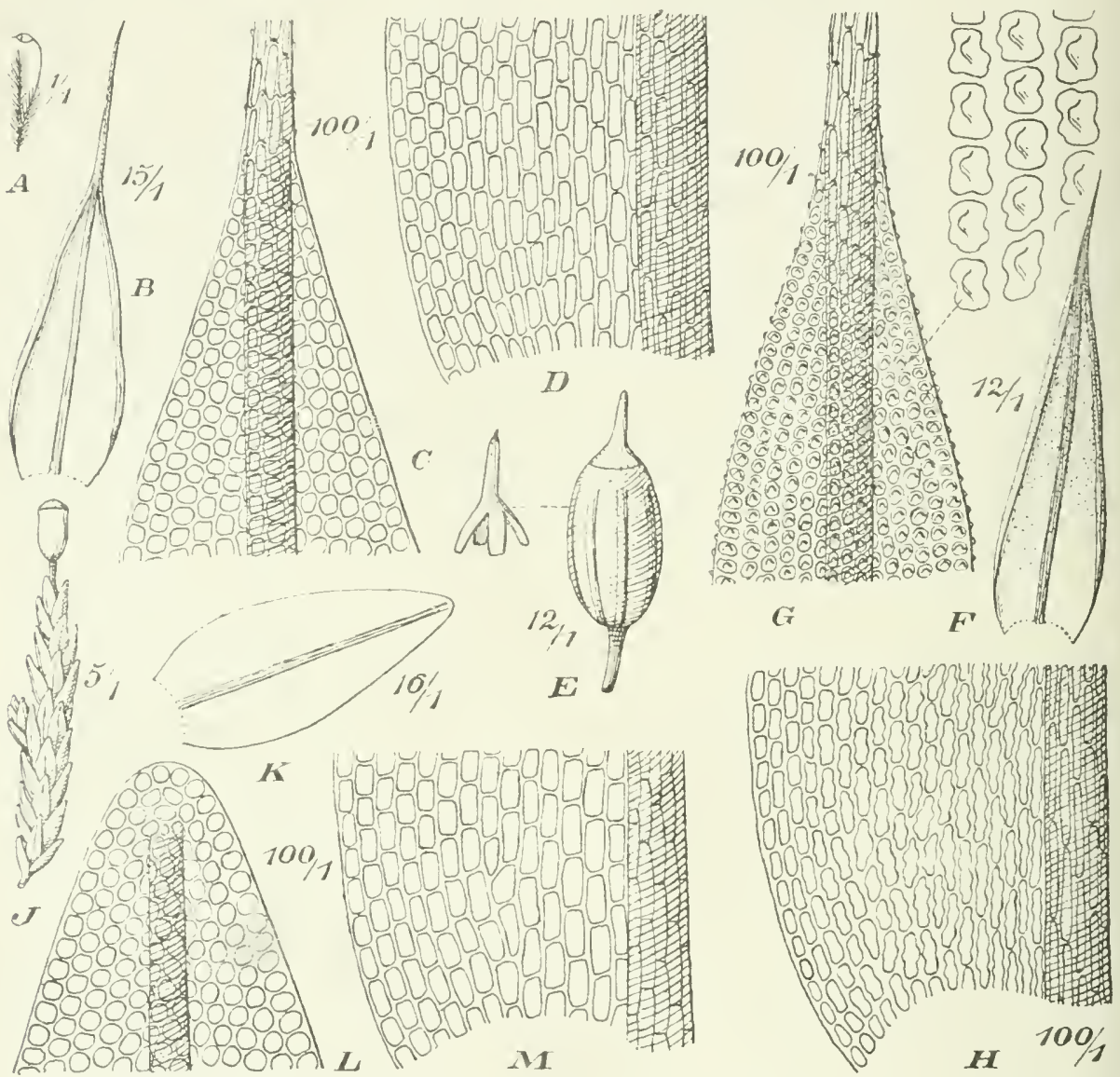

Fig. 33. A-E Grimmia pulvinata (L.) Sm. A Fruchtende Pfl. (1/1); B Stammb. (15/1); C Blattspitze (100/1); D Blattbasis (100/1); E Kapsel im trockenen Zustande mit Haube $(12 / 1)$. - F-H G. elatior Bryol. eur. F Stammb. (12/1); G Blattspitze (100/1); H Blattbasis (100/1). - I - I G. mollis Bryol. eur. I Fruchtende Pfl. (5/1); I Stammb. (16/1): L Blattspitze (100/1); M Blattbasis (100/1).

und kurz rektangulär, am Grunde nächst der Rippe verlängert rektangulär, glattwandig, gegen die Ränder kürzer bis quadratisch, wasserhell. Seta $2-4 \mathrm{~mm}$, blassgclb. Kapsel länglich-oval, zuletzt braun. Ring 3-4reihig, sich stückweise abrollend. Deckel rot, geschnäbelt. Hanbe schief kegel-miitzenförmig, gelappt. Sporenreife im Frühling. - Fig. 33 A-E.

An trockenen, besonnten Felsen, Blöcken aller Art und auf Manern.

F. Al. An einzelnen Fundorten in Eckerö, Jomala, Finström, Geta und Sund, an vielen in Saltvk (Bom.). - Ab. Lojo, Vohls (Tikk.).

S. Sk. $-U p l$.

N. Sm. $-J L ., N e,-N B$., ST., NT., an und in der Nähe der Kïste. Nordgrenze bei $63^{\circ} 28^{\prime} \mathrm{n}$. Br. Europa, Azoren. Nord-Afrika, Kaukasus, Vorder-Asien, Nord-Amerika, Australien. 
245. Grimmia decipiens (Schultz) Lindb. in Hartn. Skand. I 1. \&. ecl. p. 386 (1861). |Trichostomum decipiens Schultz Suppl. Fl. starg. p. 70 (1817). Dryplodon Schultzii Bricl. Bryol univ. I. p. 199 (1826). - Grimmia Schultzii Hüben. Muscol. germ. p. 195 ex p.; Wils. Bryol. brit. p. 157, t. 14 (1855).]

Autözisch. Kräftige Pfl. in lockeren und leicht zerfallenden, oft ausgedchnten, gelblich- bis braungrünen, grauschimmernden polsterförmigen Rasen. Stengel 2-3, zuweilen bis $5 \mathrm{~cm}$, aufsteigend. Blätter trocken anliegend, die oberen doppelt bis dreifach länger als die unteren, aus nicht herablaufender, länglicher Basis lang und schmal lanzettlich, bis etwa $4 \mathrm{~mm}$ lang und in ein langes, scharf gezähntes Haar auslaufend, mit bis weit über die Blattnitte stark ungerollten Rändern, in der oberen Blatthälfte und am Rande auch weiter herab zweischichtig; Rippe kräftig, am Rücken abgerundet; Zellen nicht papillös, oberhalb der Hitle rundlich-quadratisch, ziemlich, clurchsichtig, dann allnählich verlängert und wie oben buchtig verdickt, gegen den Blattgrund neben ter Rippe linear und an der Insertion fast glattwandig, gegen den Rand in mehreren Reilen quadiratisch und kurz rektangulär. Seta $3 \mathrm{~mm}$, gelblich. Kapsel eiförmig, bräunlich, entleert gelblich. Ring 3-4reihig, sich abrollend. Deckel rot, lang und gerade geschnähelt. Haube kegel-mützenförmig, mehrlappig. Sporenreife in Frühling.

An kalkfreien Felsen und Felsblöcken.

F. Al. An einzelnen Fundorten in Eckerö, Jomala, Finström. Lemland und sind, an vielen in Saltrik (Bom.). - Ta. A tikkala, Kaitas (Norrl.). Padasjoki (Sil.).

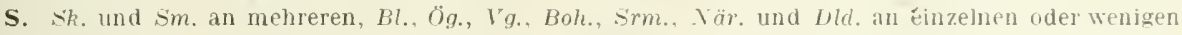
Fundorten.

N. Verbreitung etwa wie bei G. pultinata. Nordgrenze leei $63^{\circ} 27^{\prime} \mathrm{n}$. Br.

Europa, Algier'.

246. Grimmia elatior Bruch in Bryel. eur. 1ase. 25:28, p. 17, 1. 10 (1815).

Diözisch. Kräftige Pfl. in lockeren, oft ausgedehnten. leicht zerfallenden, dunkelgrünen, innen schwärzlichen, grauschimmernden Rasen. Stengel von mehreren bis 6 cm, selten höher, aufsteigend. Blätter ziemlich gleichgross, trocken anliegend, selten einseitswendig, aus eilänglichem. herablaufendem und längslaltigem Grunde verlängert lanzettlich, bis etwa $f \mathrm{~mm}$ lang und in ein meist langes, gezähntes Haar auslaufend, mit his weit über die Blattmilte stark mmgerollten Rändern. in der oberen Blatthälfte 2-3schichtig und am Rande 3-5schichtig; Rippe kräftig, am Rücken \pm kantig, zuweilen mit einer Längsfurche; Zellen bis zur Blattmitte und noch unter diese herab dunkel, rundlich-c[uadratisch, buchtig verdickt mit papillös vortretenden Wänden und dann neben der Rippe rasch langgestreckt, stark buchtig verdickt, getüpfelt und gefblich, am Rancle in mehreren Reihen länglich und rektangulär. Seta $2-3 \mathrm{~mm}$, gelblich. Kapsel oval, gelblich bis gelbbräunlich, rotmündig. Ring 3-4reihig, sich abrollend. Deckel kegelig geschnäbelt, rot. Haube kegel-mützenförmig, gelappt. Sporenreife im Frühling. - Fig. 33 F-H.

An trockenen, kalkfreien Felsen und Blöcken, meist an steilen, besonnten Wänden, seltener an nassen Felsen.

F. Al. Saltvik, an wenigen Fundorten (Bom.). - Y. Hogland, Haukkavaori (Lindb.). - $l k$. Prhäjarvi. Yahois (H. Lindb.). - Ta. Lammi. Evo (Norrl.); Pääjärvi (Vain.). Asikkala. Kopso. Portrikallio (Broth.). Kulmoinen, Lummene (Norrl.). - Sa. Anttola (Lackstr.). Kan@asniemi (Broth.). - Kl. Jaakkima, Puutsalo (Norrl.). Sortavala, Honkasalo (Link.); Mustasaari (Pes.); Liikolanmäki (Lindb.); Kirjavalahti (Lindb.). - Impilahti, Pullinvuori (Broth.). - Soanlahti, Liorpikallio (B.). - Le. Kilpisjărvi. Kilpiskoski (Norrl.); Saivovaara. in der alpinen Region reichl. (Kot.). - Lim. Kandalaks, Schelennaja (Sahll., Broth.).

S. Sm., Boh., Srm., Upl., Hlsl. und Ing. an mehreren, Ög.. I g.. Tar. und Trml. an weniqen oder einzelnen Fundorten.

N. In allen Ämtern mit Ausnahme von st. jedoch nur nu Kristiania, in Talders. Gudbrandsdalen und Opdal fir. Steigt von der Ebene lis in die alpine Region hinauf, oherhalh der Baungrenze viel seltener. Nordgrenze bei $70^{\circ} \mathrm{n}$. Br.

Europa, Kaukasus, sibirien, Alatau, Nord-Amerika. 
var. asperula (Geh.) Limpr. Laubm. I. p. 772 (1889). (Rhacomitrium asperulum Geh. in Flora 1879, No. 130).

Ausserst kräftige Pfl. in sehr dichten Rasen. Blätter trocken fast spiralig gedreht, oberwärts bis 3-4schichtig, mit kurzer Haarspitze und sehr dentlichen Papillen.

N. Nach $\mathrm{Hagen}$ in den oberen Teilen der Waldregion, meist auf in Flüssen geleqenen Blöcketh.

Sudeten, Tatra.

247. Grimmia patens (Dicks.) Bryol. eur. lasc. 25/26. p. 18, L. 10) bis (1815). [Bryum patens Dicks. Pl. crvpt. fasc. II. P. 6, t. 4, f. 8 (1790). - Rhacomitrium patens Hüb. Iluseol. germ. p. 198 (1833).]

Diözisch. Kräftige Pfl. in lockeren, flachen, leicht zerlallenden, freuclig grünen bis bräunlichen Rasen. Stengel olne Zentralstrang. 2-5. seltener bis $10 \mathrm{~cm}$ und darüber, aufsteigend, gleichmässig beblättert. Blätter trocken anliegend und schwach gedreht, aus schmal eiförnigem Gruncle lanzettlich, allmählich in eine haarlose, \pm deutlich gezühnelte, selten wasserhelle Spitze auslaufend, bis :3 mm lang oder etwas länger, mit weit herauf ungerollten Rändern, in der spitze und am Rancle anch weiter heral) zweischichtig: Rippe kräftig, am Rücken mit 2 -4 Längslamellen: ZeHen bis weit unter die blattmitte rundlich-quadratisch, verdiekt und stark buchtig, damn neben der Rippe rasch in lang lineare, buchtig verdickte, gelbliche übergehend, am Rande in einigen Reihen kurz rektangulär und quadratisch. Seta 3-5 mm. gelblich. Kapsel oval, brümulich, rotmündig. Ring 3reihig, sich ahrollend. Deckel gelbrot, gerade oder etwas schicf geschnäbelt. Haube mützenlörmig, gelappt. Sporenreife in lirühling.

An kalkfreien und kalkarmen, offenen ofler beschatteten Felsen, zuweilen Massenvegetation bildend.

F. Al. st. fq. (Bom.). - Ab. Kurpo. Haisby (Elfr.). Who (Elfr.). Pargat, Vepo (E.). Kimilo. fröjböle (Ols.). Lojo. Kirchdorf (Lindls.); Vaanila und rietilä (siunds.). - X. Ekenäs, Trärminnt (Broth.). Snappertuna (Häyr.). Kỵkslät (Kullh.); Hunaljärvi (Bueh). Helsingfors (Lindb.). Helsingِe Hoplaks (Lindh.); Viks ladugard (Buch). Hogland (Lindl,). - fa. Wiborg. Westlich ron Lieljärvi (Bucll). - Ta. Padasjoki (Vain.). Kuhmoinen, Kotavuori (Broth.). Luhanka. Judinsalo, Mäkelä (Vain.). sa. Wilmanstrand (Buch). - Kl. Sortavala, Kirjavalahli (Limdh.): Piisparuori (Popp.). Impilalti, Pullinvuori (Brolh.). Pälkjäri. Annoniemi und Pitkäniemi (Broth.). - Tb. Pihlajaresi. Komi (Norrl.). ok. Kajana, Lehtovara (Kiyhk.).

S. Sm., Hll., Boh.. Irml., Hlr. und Hsl.: Mpd. sindsvall: LuI., Sarekqeliel.

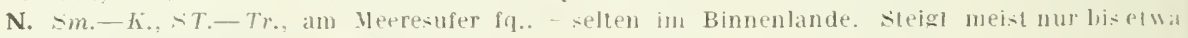
400 m hinauf. Noldorelte bei $69^{\circ}$ ito $\mathrm{n}$. Br.

Europa, Nord-Antrika.

248. Grimmia Hartmanii Schimp. Syn. p. 211 ( 1860$)$.

Diözisch. Pfl. in lockeren, oft ausgedehnten, eicht zerlallenden, grünen oder gelbbraumen Rasen. Stengel ohne Zentralstrang, 1-10 $\mathrm{cm}$, aufsteigend, gleicllmässig beblättert. Blätter locker anliegend und etwas verbugen, zuweilen einseitswendig, aus etwas herablaufendem, eilängliche in Grunde verlängert-lanzettich. lang zugespitzt, 3-1 mm lang, die oberen mit kurzer, gezähnter Haarspitze, einerseits bis gegen die Spitze ungerollt, oberwärts am Rande doppelschichtig: Rippe am Rücken fast lkantig: Zellen glatt, verdickt und getiipfelt, rundlich-quadratisch und ziemlich gleichgross, am Grunde nächst der Rippe in mehreren Reihen verlängert rektangulär. Sela 3-t mm, schwach gekrümmt. Kapsel länglich. bleichJ)raun, rotmündig, glatt. Ring nicht differenziert. Deckel kegelig geschnäbelt. elwas schief. Haube kappen-mützenförmig. I-jlappig. - Vegetative Vemelormg durch rundlich-wïrlellörmige, in Häufchen an der Spitze der Giplelblätter entstehende, vielzellige, zuletzt brammote Brutkörper.

An trockenen, beschalteten, kalklreien oder kalkarmen Folsenwänden und Blöcken.

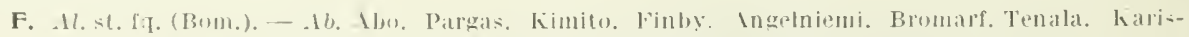

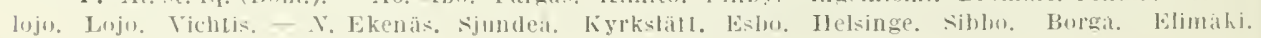




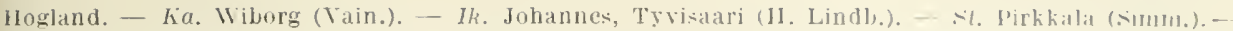
Ta. Lammi, Evo (Norrl.). Hollola und Asikkala st. r. (Norrl.). Padasjoki, Saksala (Vain.). Iifll, lallelidorf, Harjuruori (Buch). - sa. Lappee, Katukas (Buch). Savitapale. Ali-Saynatjarri (B.). - Ki. Kurhijoki (Jusl.).

S. Sk.-Gstr.. Upd., Norbyknöl.

N. In allen Amtern mil Ausnalme som $H$. und $F$.. von der Ebene bis zur Baumgrom\% linaulsteigend. Nordgrenze bei $69^{\circ} 40^{\circ} \mathrm{n}$. Br.

Europa. Kaukasus.

249. Grimmia anomala Hamp. Mser., Schimp. Syn. ed. 2, p. 270 (1876).

Diözisch. Pfl. in lockeren, leicht zerfallenden, dunkel- bis schwarzgrunen Rasen. Stengel mit Zentralstrang, 2 4 cul, aufsteigenel, gleiclunässig beblättert. Blätter ziemlich gleichgross, trocken locker dachziegelig, mit schwach gedrehter Spitze, lanzettlich, breit zugespitzt, bis 2,t mm lang, selten normal ausgeloildel und dann in eine kurze Haarspitze endend, meist mit der Spitze dureh reich iche Brutkörper verdeckt, nach dem Abfal'en derselben stumpl bis breil alogerundel mul durch den obersten, scheinbar grob gezähnten Teil der Blattrippe stachelspitzig. cinerseits stärker und bis gegen dic Spitze zurückgerollt, oberwärts an Rande in mehreren Reihen und oft die Blattspitze doppelschichtig Rippe an Rücken fast tkantig, papillös: Zellen mässig verdickt nicht getüpfelt, beiderseits papillös, rundlich-quadratisch und queroval, gegen den Blattgrund etwas ockerer. an der Rippe in wenigen Reihen kurz rektangular Seta 3 .j $11 m$, - gekrimunt. Kapsel länglich. Ring bleibend. Deckel lang und gerade geschnäbelt. IJaube mützenförmig. - Vegetative Vermehrung durch zahlreiche, aul kurzen Trägern blatlendständige, vielzcllige, kugelige, zuletzt braune Brutkörper.

An beschatteten, kalkfreien oder schwach kalkhaltigen Felsen. Blöcken und Steinen. Sehr selten fruchtend.

N. Ringerike und längs der Kü̈le ron Kristiansand bis yaaso und Kalasjok in F. Bisher nichl oberhall, der Baumgrenze beobachtet. Cordgrenze hei it $\mathrm{n}$. Br

Allgäu. Schweiz, Idaho in Nord-Amerika.

Se e t. I I. Torquatae Hag. in D. K. X. Vid. Selsk. Skrift. 1909, Xo, 5, p. 511.

Stengel dreikantig. Blätter trocken spiralig um den Stengel gedreht. Peristom schlecht entwickelt.

250. Grimmia torquata Hornsch. Mser.: Grev. Scot. crypt. fl. 1T. t. 199 (1826).

Diözisch. Pfl. in weichen, polsterlörnigen, oft ausgedehnten, leicht zerfallenden, grünen oder gelbgrünen, auch bläulichgrünen, innen braunen bis schwärzlichen Rasen. Stengel 1-i cm, aufrecht, gleichmässig beblättert. Blätter trocken meist etwas kraus, länglich-lanzettlich, zugespitzt, bis $1,5 \mathrm{~mm}$ lang, die obersten mit kurzer, glatter Haarspitze, flachrandig oder in der Mitte beiderseits schwach umgebogen, einschichtig, zuwcilen gegen die Spitze am Rande zweischichtig: Zellen stark verdickt, durchsichtig und gelblich, am Blattgrumle mit eng linearem Lumen nur die Randreile verlängert rektangulär, dïnnandig und fast wasserhell. Seta 3-i mm, gekrimmt. Kapsel länglich, im Ater zylindrisch. gefurcht und braun. Ring treilig, teils an Deckel, teils an der Mündung zurückbleibend. Deckel lang und gerade geschnähelt. Haube mützenförmig. - Vegetatire Vermehrung durch mehrzellige, gebräunte, rundliche, sich auf kurzen Trägern aus dem Rücken der Rippe entwickelnde Brutkörper.

An beschatteten, kalkfreien oder kalkarmen, steilen fielsenwänden. Sporngone sehr selten, bisher nur aus Norwegen und den westl. Teilen von Nord-Amerika hekannt. Nordgrenze auf Spitzbergen.

F. Ab. Pargac, Parsby und Vepo (Elfr.). Lojo, Marltila (Lindb.): Mustasari (E. af H.). - I Irtjärvi, Salmela (Ranek.). Elimäki, Iustila (Tigerst.). Hogland (Lindb.). — Kia. Wiborg Juustila (Buch). - St. Ruovesi, Koverojärvi und Helretinjärvi (Broth.). - Ta. Lammi. Ero (Norr.). Iitti. Kynmene, Eerola, Tähtivuori (Ranck.). Asikkala, Kydönsari und Lrajărvi (Norr..). Padajoki. Tirmala (Vain.). Kuhmoinen, an mehreren fundorten (Norrl.). Jämsä (Häyr.). Luhanka und kiorpilahıi. 
an mehreren Fundorten (Tain.). - Sa. Wiflmanslrand (Buch). Kangasniemi, Pyhämäki und Suomaki (Lackstr.). - Kl. Jurkijoki, Oraska und Taskinen (Jus.). Valamo (Jindh.). Jakkima, Ramola (Sundy.). Sortavala (II: Nyl.); Haavus, Haukkarinta (Link.): Kirjaralahti fq. (Norr..). Impilahti, Puflinvuori (Broth.); Majatsaari (Popp.). Ruskeala (Simm.). Suistamo. JaJovaara, Hỵpinkalljo (Link.). Pälkjärri, Könönen (Broth.). - Kol. Salmi, Leppälā (Pes.). - Tb. Virrat, Toriseva (Broth.). Pihlajavesi, Lehtimäki (Norrl.). J̣̣rä-ḳ̣lä, Ylistö (Siint.). Laukia. Vihtjärvi (Broth.). Kionginkangas (Broth.. E. af H.).

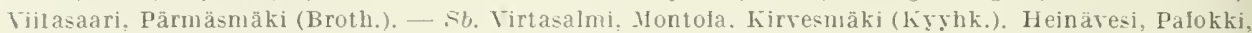
Kultaniemi (Kol.). Kuopio, an mehreven Fundorten (Link.. Kot.). Kaavi. Siikajärvi. Kypäräissuori (Kyyhk.). Jukka, Halivaara (Kot.). Maaninka. Haalala. Haukkavuori (Rniv.); Pöljä. Saarisenmäki (Kyyhk.). - Kb. Tohmajärvi, Hiienmäki (Brolh.); Kemie, Jalajanvaara (Oesch). Juuka, Larinsaari Telynvaara (Limnan.). - Gb. Rovaniemi, Hepokallo (Hul1). Aavasaksa (Buch). - K. Kuusamo, Autinköngäs (Brolh.); Kinrojoki (B.); Kotakatio (B.); Vasaraperä, Ruoppijärri (E. af H.); Kitkajoki, Jyrärä (Broth.); Oufankajoki. Kallioperänvara (B.); Paanajärri (Sif.); Mäntyraara (Broth.). - Kk. Kirakkalunturi (B.). - Lkem. Kittiä (Hult); Äkäskurkio und Savio, nördich rom Yliztunluri (H.). Kuolajärvi. Salıatunturi (E. af H.); Pỵäkuru (E. af H.). - Le. In der Nadefwafd-und Birkenregion zerstreut (Norrl.). Kilpisjärvi. Pietsovaard. Saana, Malla und saivovaara, in der alpinen Region (Norrl., Kot.). Li. Inari. Kultala fr. (HuJt); Kodossuannonpää, Peldoivi. Ailigas und Naanijärvi in der Birkenregion (H.); Saariselkä. Akonhärhäkuru in der Nadelwald- und Birkenregion (H.); Leviöraara und PytteIvaara in der Nadelwaldregion (H.); Ifuddusjärri (H.). Llsjoki. Patsjoki, Tsilsanjorga (Popp.); Yaajalve, auf Baktevarre und Kistuskaidde (Ranck.); Outakoski, auf Bodusvarre (R.); Nirvus. auf Nuovusvarre (R.). - Lim. Kandalaks. Kresturaja und Schefennaja. in der Nadelwaldregion (Sahfl., Broth.). Umlua (Ǩihim.). Tschun und Hibinä, in der alpinen Region (Broth.). - Lt. Saariselkä, Pippu-oja (Roir.): Rotsraara, Pomjatkivaar und Lamboraar (R.). Abramova Pahta, Karaninaja Pahta und Srednij am KolaJusen (Broth.). - Lmur. Teribjerka, Iíarlorka und Varinsk (Brollı.). - Lp. Katschkova und Ponoj (Broth.). Valnje Brerjannoje (Kihlm.).

S. Sm. und Boh. an mehreren. C̈g., V V., Vir. und Lld. an menigen Fundorten. Hlst.-L.

N. In allen Ämtern - fq., in der Ebene des siidöstlichen Teiles jedocist. r. Steigt lis 1,300 in hinauf. Europal, Nurd-Amerika.

L $n$ t e rg. V. Schistidium (Brid.) Schimp. Coroll. p. 4.) (1856). [Schistidium Brid. Mant. 1). 20 ex p. (1819); Bryol. eur. fasc. $25 / 28$ Mon. (1815).]

Autöziscls. Blätter starr, oberwärts meist gekielt, trocken nicht spiralig um den Stengel gedreht; Rippe am Rücken vortretend. Scheidchen sehr kurz und dick. Seta gerade, kiirzer als die Ḱapsel. Ḱapsel eingesenkt. regelmässig, glatt: Spaltöffnungen spärlich. funktionsos. selten fehlend. Ring meist nicht differenziert. Columella sicl rom Kapselgrunde alolösend und meist mit dem 1)eckel abfallend. Haube nicht den Dechelrand erreichend.

2.51 Grimmia alpicola Sw. Musc. suec. p. 27 et 81, t. 1. I. 1 (1799). [G. apocarpa v. alpicola Bryol. cur. fasc. 25.28, 1). 8 (1815).]

Weiche Pfl. in sehnutzig gellgriinen. fast kissentörmigen Rasen. Stengel bis $2 \mathrm{~cm}$ aufrecht isiätiei trocken locker an iegend, aus breit lanzettlicher Basis zu ciner breiten, meist abgerundeten Spitze verschmälert, bis 2,5 mm lang, mit \pm weit herauf ungebogenen, oberwäts doppelschichtigen Rändern: Rippe vor der Blattspitze aufhörend: Zellen glattwandig, oberwärts rundlich, abwärts quadratisch, am Gruncle neben der Rippe kurz rektangulir. Kapsel verkehrt-eiförmig. gelbloriunlich, entdeckelt weitmündig: Wand 5-6schichtig: Zellen des Exotheriums ziemlich mnegehmässig, um die Nïndung querbreiter, die ülrigen rundlichoval, mit stark verdickten Zellecken Sporen 16-20 ", gellogrim. Deckel tlachgewölbt. mil kurzem. schiefem Schnabel. Haube kegel-kappenlörmig. Sporenreife im Juni und Juli.

An Felsen und Steinen des fliessenden Wassers. Nordgrenze auf Spitzhergen.

F. Al. Saltrik, Jvarnbo (Bon.). - Kl. Sortavafa, Kirjaralahti (Lindh.). Suistamo, Loinafanjoki (Broth.). - Kol. Pelrosarodsk (Kulli.). - Ta. Luhanka. Tammijäri (Vain.). Jiorpilahti. Rutalahti (V.). - Tb. Jyräskłä, fiorkeakoski (Tain.). - Ob. Käiminki (Nyb.). Judasjärri (Nỷ).). Simo (H. Lindø.). Lkem. Kuolajărvi, Tenniönjoki (Linnan.). - Le. Kilpisjärvi. fı. (Kiot.). - Li. Palokoski (Huft). - Lim. Lujauri-urt, Siejljavr (Kihlm.). - Ll. Zw. Fandilatis und liula (Brenn.). Fola (Fellm.). Lmur. Lovosersk (Kihln.). - Lp. Ponoj (Brenn.).

S. Gstr., Ang., Irja., Jmt. und LuL.

N. An wenigen Fundorten in sm.. K., $I$. und $s T .$. meisl in der alpiuen Region.

Zentral-turuma, Sierri Kerada. Nord-Amerika. 
var. rivularis (Brid.). [Grimmia rivularis Bricl. in Schrarl. Bot. Journ. I. 2, p. 276 (1801). - G. apocarpa var. rivu aris Web. et Moln Taschenl,. p. 129 (1807).

Schistidium apocarpum $\gamma$ rimulare Bryol. eur. fase. 25/28, p. 7, t. + (181.5).]

Kräftige, meist flutende Pfl. in lockeren, satt-oder schwarzgrünen bis schwarzen Rasen. Stengel bis $10 \mathrm{~cm}$, büschelästig, abwärts entblättert. Blätter breit lanzettlieh, mit breit abgerundeter, meist kurz gezähnter Spitze und bis gegen lie Spitze zurückgerollten, weit herab wulstigen Rändern.

F. Ab. Ảbo, Hallis (Tengstr., Ellr.). Pusula, Pusulanjoki (Brotlı.). V'ichtis, Olkkala (Brothr.). X. Perni (Häyr.), - Ik. Uusikirkko, Ongimojoki (H. Lindl.). - St. Eurajuki (Karst.); T'uojoki (Bjorkenh.). Ikaalinen, Jämijoki, Jṿlli (Sundr.); im Flüssclien des Teejärvi (S.). Ta. Luhanka, Kurkoja (Vain.). Korpilahti, Rutalahti und Tyystjoki (V.). - hl. Kurkijoki (Jusl.). Jaakkima (Jusl.). Ruskeala (W. Nyl.). - Tb. Jyvä_kylä, Tourujoki (Broth.). Viitasaari. Limaltalanjuki (B.). Kinnıla und Pihtipudas, an mehreren Fundorten (Roiv.). - Sb. Kuopio, Rỵtky, Niinikuski (Link.). Nilsiä, kirchdorf, Myllypuro (Kot.). Maaninka und Pielavesi st. fq. (Roir.). - ok. Kajana (Lilckstr.). - ob. Alatornio (Brenn.). Ylitornio, Kaarasnäs (Hult), $-K$. Kuusamo, Autinköngäs (Broth.). Kitkajoki, Jyràä (B.); Käyläkoski (B.); So vanköngàs (B.). - Kk. ZW. Soukelo und Knjäscha (Sel.), - Lkem. Kuolajärvi, Tenniojoki (Linnan.). - Li. Inari, Sammelinköngäs (Hulı). - Lmur. Semjostrorsk (Broth.).

S. Ög. und $\mathrm{V} r \mathrm{rm}$. nach A d le r z. Weitere Litteraturangaben liegen nicht vor.

N. sm.-Br., sB., YB., $H .-Y T$. pass.-I., im äusseren Küstengebiete von Westlandet fehlend, Zentral-Europa, Nord-Amerika.

var. latifolia (Zett.) Hag. 1. c. p. 5ॅ. [Schistidium latifolium Zett. Rev. Grimm. p. 53 (1861). - Grimmia plalyphylla Mlitt. in Joum. Linn. Soc. 186+, p. 20. G. apocarpa var. platyphylla Lindb. in Meddel. Soc. Faum. Fl. Fenn. 13. IIeft, p. 253 (1886).]

Pfl. in weichen, schwellenden, grünen und schmutziggrünen Rasen. Blälter eiförmig bis länglich, stumpf bis abgerundet, mit stärker umgerollten, wulstigen Rändern.

Auf kalten, nassen Fundorten, meist im Hochgebirge.

N. $S B$., $K$., $S T$. und $T r$. Steigt bis 1,700 $\mathrm{m}$ hinaur.

Zentral-Europa, Yord- und Zentral-Asien, Nord-Aneriki.

252. Grimmia angusta (Hag.) Par. Ind. bryol. [Schistidium angustum Hag. Muse. Norv. bor. p. 57.(1899).]

Ziem ich schlanke, etwas starre Pfl. in bräunlichen bis schwarzen, last kissenförmigen Rasen. Stengel bis $2 \mathrm{~cm}$, aufrecht. B ätter trocken an iegend, aus schmal eiförmigem oder länglichem Gruncle allmällich schmal ineal odler schmal zungenförmig, stumpf bis abgerundet, etwa 3 nmm lang, einschichtig. flachrandig oder mit am Grunde umgebogenen Rändern Rippe ror der Blattspitze aufhörend; Zellen \pm deutlich buchtig verdickt. rundlich, abwärts quadratisch, am Grunde neben der Rippe kurz rektangulär Kapsel verkehrt-eiförmig, ge bbräunlich, entdeckelt weitmündig: Spa töffnungen fehlend Deckel flach-gewölbt, mit kurzem, schiefem Schnabel Haube kegel-kappenförmig. Sporenreife im Mai. - Fig. $34 \mathrm{G}-\mathrm{I}$.

Auf Kiesel- und Kalkgestein des fliessenden Massers.

F. Al. Saltvik, Krarnbo (Bom.). - Kl. Ruskeala (Broth.). - Sa. Lappee, Mikunsari (Buch). Tb. Jyväskylä. Korkeakoski (Vain.). - Kon. Vojatsch (Sel.). - Om. Lappajärvi, Yeulaniemi (Backni.). - Ob. Ii und simo (Brenn.). - K. Kuusamo, an mehreren Fundorten (E. at H.). - Lkem. Kittilä. Aakenusjoki (Hult). Kenijärvi, Kenijoki, zw. Pelkosenniemi und llartti (Brotlı.) liuelajarvi, Laskupuro (B.); Naruskajoki (E. af H.). - Le. Kilpi-järvi, Malla und Siana fq. (Kot.). - Li. Inari, Palokoski (Hult). Utsjoki, Yläjalve, Danssejokka (Ranck.). - Lim. Tschun (Broth.). - Lt. Am Kulabusen (Fellm.): am Kolafluse (Broth.); Subori (Fellm.), - Lmur. Bjelousilia am Voronjeflusse und (rilvrilova (Broth.), Voruninsk (Kihlın.). Rinda und Harlovka (Broth.), - Le. Tscliaranga (Brenn.).

S. LuL. Sarekgebiet.

N. In allen Äntern mit Ausnahme von sm., L.Y. und Sl. meist in der sulvalpinen Region, kummt. wenngleich - selten, aucl in der Ebene und in der alpinen Region vor. Nordgrenze bei etwa $70^{\circ} \mathrm{n}$. Br.

Estland. Tirol, Steiermark, Tatra.

253. Grimmia sordida (Hag.) Par. 1nd. Jryol. ed. 2, p. 287 (1904). [Schistidium sordidum Hag. in Nyt. Mag. Naturv. Bd. 38, p. 324 (1900).] 
Schlanke Pft. in schwärz ichbrannen, weichen, kissenförmigen Rasen. Stengel bis $2,5 \mathrm{~cm}$, aufrecht. Blätter trocken anliegend, hohl aus eiförmiger Basis oval, bis $1,5 \mathrm{~mm}$ lang. flachrandig und übera l einschichtig; Rippe vor der Blattspitze aufhörend: Zellen oberwärts rundlich und \pm knotig-verdickt, abwärts quadratisch. am Grunde neben der Rippe verlängert-rektangutär. Kapsel verkehrt-eiförmig. zuletzt braun, entheckelt weitminndig. Deckel flach gewölbt, kurz und schief geschnäbelt. Haube mützenförmig. Sporenreife im August.

N. Dovrefjeld. Finshö, an einer steilen. nur ron Regen- und schneewasser berieselten schieferwand. $1,300 \mathrm{~m}$.

25t. Grimmia atrofusca Schimp. Syn. 2. edl. p. 240 (1876). [Schislidium confer um var. oblusifolium Bryhn in N. Mag. f. Naturv. 1892.]

Schlanke Pfl in sehwarzen, innen brïunlich-schwarzen Polstern. Stengel bis etwa $2 \mathrm{~cm}$. aufrecht. Blätter trocken dachziegelig angedrückt, feucht aufrechtabstehend. eilanzettlich, stumpf ich. bis $1,5 \mathrm{~mm}$ lang. nur die gipfelständigen zuweilen hyalinspitzig oder in ein kurzes, rauhes Haar auslaufend, oberwärts und am Rande auch weiter herab doppelschichtig, Ilachrandig: Rippe vor der Blattspitze aufhörent: Zellen dickwandig, in cler oberen Blatthälfte rundlich, gegen den Blattgrund grösser. quadratisch, am Grunde neben der Rippe rektangulär. Perichätialbätter doppełt so gross, mit in der Mitte umgerollten Rändern. Kajısel klein, eizylindrisch, gelblich, entdechelt an der Mündung nicht erweitert. Peristomzähne meist wenig vortretend, breit gestutzt. Deckel flach gewölbt, geschnäbelt, gleichfarbig. Haube mützenförmig, gelappt.

N. K. Vang. Hermundstad und Shogstad.

Alpenkette ron der schweiz bis Steiermark.

255. Grimmia conferta Funek Moostaschenb. p. 18, t. 12 (1821). [Schistidium confertum Bryol. eur. fasc. $25 / 28$ Mon. p. 7 (18.5).]

Pfl. in sehr dichten, weichen, bräunlichen bis schwärzlichgrünen, leicht zerfallenden Polstern. Stengel $1-1.5$, selten bis $2 \mathrm{~cm}$, aufrecht. Blätter trocken dicht anliegencl, untere lanzettlich, stumpflich, obere eilanzettlich, doppelt so lang. etwa $2 \mathrm{~mm}$ und in ein bis etwa $0,5 \mathrm{~mm}$ langes, gezähntes Haar auslaufend, nit umgerollten. oberwärts doppelschichtigen Rändern; Rippe am Rücken glatı: 7ellen stark verdickt, oberwärts rundlich, $6-8 /$, abwärts quadratisch, am Grunde neben der Rippe kurz rektangulär. Kapsel oval und verkehrt-eiförmig. gelbgrün. Peristomzähne gelbrot. Deckel flach gewölbt, kurz geschnäbelt. Haube mützenförmig. gelappt. Siporenreife im Frühling.

An allerlei somigen Felsen.

F. Le. Kilpisjärvi. Milla, auf Dolomitfelsen in der alpinen Region (Kot.). - Lim. Fedoserk. in der Näle von Kandalaks, an steinen (Broth.).

S. Slorkholm, $\langle$ pl.

N. sm. -Bu., Ve., $\& B, \longrightarrow T$, und No.-F. Steigt bis $1,200 \mathrm{~m}$ linauf.

Europa, Kaukasus, Persien. Alessinien, Nord-Amerika.

var. Bryhnii (Hag.) Hag. in D. K. N. Vid. Selsk. Skrift. 1909, No. 5, p. 60 (1909). [Schistidium Bryhnii Hag. I. c. 1897. No. 2, p. 6 (1897).]

Haar der oberen Blättern herablaufend, fast von Laminalänge.

N. 1.-JI... Y. und.$T T$, an wenigen Fundorten, meist in der Ebene.

var. tenera (Zetf.) Hag. 1. c. [Grimmia tenera Zett. in K. Sr. Vet.-Ak. Handl. Xill. No. 1:3, p. $17(1876)$.]

Schr schlanke l'fl. in dichten, leicht zerfallenden Rasen.

N. Tr. und $F$. an wenigell Fundorlen.

256. Grimmia apocarpa (L.) Herlw. Descr. I. p. 10t, t. 39 (1787). [Bryum (upocarpum re 1.. Sp) pl. 1). 111.5 (1753). - Schislidium apocarpum Bryol. eur. fasc. 2.5/28 Ion. P. 7 (1815).। 
Pfl. in dichten, neist dunkel- bis olivengrünen, leicht zerfallenten kasen. Stengel etwa 1,j-2 cm, aufrecht. Blätter trocken loeker anliegend, aus eilörmiger Basis ziemlicl breit und kurz lanzettlich zugespitzt, bis 3 nm lang, die aberen in eine kurze oder längere, breite, gezähnte Haarspitze auslaufend, mit l,is zur Spitze ungerollten, doppelsehichtigen Rändern: Rippe am IRücken glatt: Zellen buehtig verdickt, oberwärts rundlich. $\$-10, "$, abwärts çuadratisch, am Grunde neben der Rippe kurz rektangulär. Kapsel eifömig bis verlängert-eilörmig, meist am Gruncie = deutlich symmetrisch, braun, trocken und entleert weitmündig: Wand tschichtig: Zellen des bxotheciums mässig verdickt, zienlieh regelmässig, in der Mehrzahl fast (fuadratisch. um die Mündung - i) Reihen querrektangulär und quadratisch. Peristomzälnme ticf bramrot, dicht papillös, zur Zcit der Sporenausstreutung unten ausgebreitet, über cler Vilte aufgerichtet und schwach gedreht. Deckel gewölbt, kurz und schief geschnäbelt. Haube nüitzen-orler fast kappenförmig. Sporenreife im Frülling.

An Felsen, BIöcken und Steinen aller Art in allen Teilen von Fennoskandia $=$ fq. Norlgrenze auf Spitzbergen.

Europa. Nord- und siud-Afrika. A*ien, Australien. Amerika.

var. gracilis (Schleich.) Web. et Mohr Taschenb. p. 131 (1807). |Grimmiagracilis Schleich. Crypt. helv. Cent. 3, No. 11 et Catal. Iso7. Schwaegr. Suppl. 1. sect. 1. p. 98, t. 20 (1811).]

Pfl. in lockeren, rotbraunen bis tiefschwarzen Rasen. Stengel bis 10 cm. niederliegend. Blätter meist einseitswendig, mit in der Spitze etwas gezähnten Rändern; Rippe am Rücken rauh: Zellen stark buchtig verdickt. Perichätium später seitlich gestellt. Perichätialblätter grösser und breiter.

An trockenen, meist beschatteten Orten übor Felsblöcken und an geneigten Felswänden aller Art, besonders auf Kalk und kalkhaltigen Gesteinen. Nordgrenze auf Spitzbergen.

F. Al. Finström, fodby, Färjsund (Bum.). Saltrik. an niehreren Fundorten. - Ab. Nadendal (Elfr.). Sbo. Pargas (Elfv.. Link.). Loju (Hult). Tichtis (Ling). - N. Ekenās. Trärminne (Broth.). Helsinge, Degerö (Lind\}.). Tusbỵ, Hỵinkäă (Ranck.). Pernả (Härr.). strōmfors. Tavastby (Ranck.). Hugland (Lindb.). - ha. Wiborg. Juustila. Răttijārvi und Soskuanjoki (Buch). Jāāski, Kārkkāilà (Lindb.). - Ta. sysmā (Lnon.). Korpilahti, Haukkaruori (Hạ̣r.). — sa. Willmanstrand (Buch). Lậpee. Hanhijärvi (B.). Kangasniemi (Lackstr.). - Kl. Jakkima. Puulsalo (Lindb.). Talamo (W. Nyl.). sijrtarala, Pellotsalo und Mustasaari (Pes.); Kirjavalahti (Link. und Pes.). Impilahti, Pullin ruori (Broth.): Viipula (Pes.): Vajat_aari (Popp.). - Kol. Salmi. Leppälä (Pes.). - Tb. Virrat, Toriseva (Broth.). Viitasaari (Broth.). - Sb. Kuopio fı. (Link.). Kaavi. Sikajärvi. Huo-iaisnieni (Kot, und Kyrhk.); Niinivalara, Louhilampi (Kot.). Maaninka, Tuotilanlahti (Roǐ.). - Kon. suojārvi. Varpakylä und Haukka (Link.). Tindie und Jalguba (Simm.). Perttiniemi (Kullh.). Dianovaja gora (Simm.). — Um. Lappajārri. Harju (Backm.). - ok. Paltamo. Melalahti (Lackstr.). Puolanka (Lack-lr.). Fast überall, wr) nur halk vorkonml (Kyyhk.). - Kp. Hukkakallio (Bergr.). - Ob. Haukipudas, Luukela (Brenn.). Alatornju. Kialkkimaa (Räs.). - K. Pudasjărvi. Pintamo (E. af H.). huusamo. Arentojoki (E. af H.): Lrotaara (Ny̧b.): Kilkajoki, Jyrärä (Broth.): Oulankajoki (B.): Paanajärrị (B.): Selkajoki (Nỵb.): Kuusinkijoki (E. af H.). - Lkem. Kuılajārvi. Palovaara und Kutsinkijoki (E. af H.). - Le. Kilpisjärvi. Leutsuraara (Norrl.): Malla (Kot.). — Lim. Kandalaks (Broth.). Lmba (Kihlm.). - Lp. Ponoj (Broth.).

S. sk.-L.. bis hoch in die Alpenregion hinauf.

N. In allen Ämtern mit Ausnahme ron $L M$. . wie es scheinl, häufiger als die Haptart.

Europa, Kaukasus, Himalaya. Zentral-Asien, Japan, Tord-Ameriki.

var. abrupticostata (Bryhn) Hag. I. c. p. 66. [Schislidium apocarpum var. abrupticostalum Bryhn Bryoph. It. pol. Norv. sec. p. 64 (1907).]

Blätter breit lanzettlich. stumpf: Rippe kräftig. weit ror ler Blattspitze aufhörend.

N. K. Lom. Galdhoen, $1,880 \mathrm{~m}$.

Kong Oscars Land.

257. Grimmia maritima Turn. Muscol. hib. p. 2\%. t. 3. 1. 2 (18(1). [Schistidium maritimum Bryol. eur. fasc. 2528 .Ion. p. 10 (1845).] 
Pfl. in dichten und starren, gelblich- bis schwarzgrünen Polstern. Stengel bis $2 \mathrm{~cm}$, selten höher, aufrecht. Blätter trocken eingekrimmt bis etwas gekräuselt. aus länglichem Gruncle lanzettlich verschmälert. bis $3 \mathrm{~mm}$ und melır lang, mit bis gegen die Spitze ungerollten, doppelschichtigen Rändern, oberwärts 23schichtig; Rippe oberwärts dicker und an Rücken rauh, mit der Blattspitze endend oder als papillöse Stachelspitze austretend, mit bis 10 medianen Deutern und 2 Stereidenbändern; Zellen glatt, verdickt. oberwärts rundlich-quadratisclı. gegen den Blattgrund noch derb und kurz rektangulär. Kapsel eiförmig bis fast kugelig. blass- bis rötlichbraun, entdeckelt weitmündig bis kreiselförmig; Decke] gewölbt. schief geschnäbelt. Haube kappenförmig. Sporenreife im Frühling.

Am meisten auf granitischen, weit seltener lialkfelsigen, im Bereich der Brandungszone ocker des Wasserstaubes liegenden Meeruferklippen.

F. Al. In den äusseren schären st. fq., in den inneren selten (Bom.). - - Ab. Brändö, Porsskär (Bergr.). Reso (Högm.). Kimito, an mehreren Fundorten (Ols.). Finby (Broth.). — N. Ekenäs (Häyr.); Hermansō (Hak. Lindb.); Hästō-Busō (Hạ̈r.): Trărminne, in den äusseren Schären fqq. und cup. (H.). Ingâ, in den äusieren schären (V. Brenn.). Kyrkslätt, Porkkala (Brotlı.). Helsingfors, Mjölö (Font.). Sibho, Pörtö (Broth.). Borga, Pellinge (B.). Hogland, Tytārsaari (Brenn.). - St. Björneborg, in den āusseren schāren st. cop. (Hạ̃̆.). Ahlainen, Ruohokari (H.). - Lt. Kola und Abramova Pahta am Fiolabusen (Broth.). - Lmur. und Lp. Längs der Küste des Ei-meeres von Teriberka bis Ponoj fq. (Brotlu.).

S. sk.-Boh., Ög., srm. und $L p l$. in den Schären.

N. An der hüste ron Sm. bis: Por-angerfjord fi.

Dănemark, Nord-Deutschland, Nord-Frankreich, Gross-Brilannien, Nord-Amerika.

var. pilifera Hag. in D. K. N. Vid. Selsk. Skrift. 1909, No. 5, p. 67 (1909). Blätter mit bis $0,5 \mathrm{~mm}$ langer Haarspitze.

N. Sm. - IL., Yo, und F.

258. Grimmia flaccida (De Not.) Lindb. Musc. scand. p. 30 (1879). [Anictangium flaccidum De Not. in Mem. Accad. Torin. 38, p. 254, sp. 85 (1836).]

Schlanke Pfl. in dichten, lileinen, grünen bis bräunlichen und schwärzlichen, durch die Haarspitzen graulichen Polstern. Stengel meist $5-10 \mathrm{~mm}$, aufrecht. Blätter trocken anliegend, feucht aufrecht-abstehend, die unteren eiförmig. mit vor der stumpfen Spitze aufhörender Rippe, die oberen grösser, eilanzettlich, bis $1.5 \mathrm{~mm}$ lang, mit vollständiger Rippe am Grunde schmäler und in eine am Grunde verbreiterte. kurze oder längere. gezähnte Haarspitze auslaufend, mit oberwärts 2-3schichtigen, flachen oder in der llitte schwach umgebogenen Rändern; Zellen dickwandig, in der oberen Blatthältte rundlich, gegen den Blattgrund grösser, quadratisch, am Grunte nehen der Rippe rektangulär. Perichätialblätter grösser. hervorragend, mit bis gegen lie Spitze breit zurückgeschlagenen Rändern. Kapsel fast kugelig, gelblichbraun, entdeckełt weitmündig. Spaltöffnungen verkümmert. Peristom rudimentär, kaum über den Urnenrand hervortretend. Deckel flach gewölbt, mit Warze. Haube liegel-mützenförmig. melırlappig. Sporenreife im Friilling.

Auf trockenen, besonnten, kalkfreien Felsen.

F. Ki. Impilahti. Pullinvuori (Broth.).

West- und Zentral-Europa, Algier. Kaukasus.

Un te r gat t. V l. Gastrogrimmia Sehimp. Coroll. p. 16. (1856).

Autözisch. Blätter starr: Rippe schmal. Scheidehen zylindriseh bis eikegelig, nicht gedreht. Kapsel cingesenkt, an Grunde einseitig-bauchig, glatt: Spaltöfnungen gross. Columella knätuelförmig zusammenschrumpfend.

259. Grimmia anodon Bryol. cur. fase. 25 28, p. 8. t. 1 (18.15).

Sehlanke l'fl, in sehr dichten, leicht zerfallenden, grausehimmernden Polstern. Stengel etwa $1 \mathrm{~cm}$, aufrecht. Blätter feucht aufrecht-abstehend, sehr hohl. trocken locker anliegend, untere eiformig und haarlos, nach oben allmähliel grösser, länglich und länglich-lanzett ich. stumpf, bis etwa $1,5 \mathrm{~mm}$ lang, die oberen in ein = langes, wenig gezïhntes llaar anslaufend, flachrandig. in der Spitze und am Rande 
gegen die Mitte doppelschichtig; Zellen glatt, oberwärts rundlich-quadratisch, kaum buchtig, in der Mitte quadratisch, am Grunde rektangulär, dïnnwandig, wenigstens in einigen Randreihen wasserhell. Perichätialblälter grösser und nit längerem Haare. Seta oben dicker und schwach gebogen, gelb. Kapsel fast kugelig, rötlichgelb, dünnhäutig, entleert weitmündig. Ring bleibend. Peristom fehlenıl. Deckel breit, flach gewölbt, stumpf genabelt, gleichfarbig. I Iaube kegel-niitzenförmig, gelappt. Sporenreife im Frülıling.

An trockenen, besomnten kilkfelsen oder kilkhaltigen fielsen.

F. K7. Soanlahti, Korpikallio (Broth.). - K. Kuusamo, Kitkajoki, Jyräria (Broth.).

S. Irjd. IIdtảkläppen und Ulfbärget. LyL. Laxfjället.

N. A., SB., NB., K.s $S T$. und $F$, an wenigen Fundorten, von der Ebene bis uber die Banmgrenze hinaufsteigend. Nordgrenze hei $70^{\circ} 10^{\prime} \mathrm{n}$. Br.

Europa, Algier, Forder- und Zentral-Asien, Nord-Amerika.

260. Grimmia plagiopodia Hedw. Sp. musc. p. 78, t. 15 (1801).

Schlanke Pfl. in braungrünen bis bräunlichen, leicht zerfallenden Rasen. Stengel 5-8 mm, aufrecht. Blätter dachziegelig, sehr hohl, breit eiförmig, bis $1 \mathrm{~mm}$ lang, die oberen in eine breite. gezähnte Haarspitze auslaufend, flachrandig, einschichtig; Zellen glatt, in der oberen Blatthälfte stark verdickt, rundlich, gegen den Blattgrund grösser, dïnnwandig, quadratisch und kurz rektangulär. Perichätialblätter grösser und mit längerem Haare. Seta gekrümmt, oben dicker, gelb . Kapsel dick oval, bleich bräunlich, ziemlich derbhäutig, entleert an der Mündung nicht erweitert. Ring bleibend. Peristom normal ausgebildet. Deckel llach gewölbt, stumpf genabelt, gelb. Haube kegel-mützenförmig, gelappt. Sporenreife im Frïhling.

N. F. Loppen und (1ksfjord, Insel Loppen, auf Quarzsanditein.

Europa, Kaukasus, Nord-Amerika.

Un tergat t. V I I. Streptocolea Hag. 1. e. p. 69.

Diözisch. Blätter starr, trocken einwärts gekrïmmt und gedreht; Rippe sehr kräftig, am Rücken vortretend; Blattflügelzellen differenziert, zart und locker. Scheidchen linlis gedreht. Columella fadenförmig, vortretend.

261. Grimmia atrata Mielichh. in Hopp. et Hornsch. Pl. erypt. sel. 1817 18: Hornsclı, in Flora 1819 , P. I. p. 85.

Ziemlich kräftige Pfl. in schwärzlichen bis schwarzen, oben gellolich- bis dunkelgrünen Rasen. Stengel $1-3$, selten bis 7 cm, aufrecht. Blätter feucht nicht sich zurückkrümmend, gekielt, lanzettlich, zugespitzt oder stumpflich bis an der Spitze schmal abgerundet, 2-2,j $\mathrm{mm}$ lang, einseitig umgeschlagen, oberwärts zweischichtig, am Rande in der Spitze dreischichtig, abwärts bis gegen die Basis zweischichtig; Zellen stark und buchtig verdickt, quariratisch, am Grunde nächst der Rippe rektangulär, glattwandig oder buchtig verdickt, in den Blattecken locker und zart, quadratisch oder rundlich-6seitig. Seta 2-4, anch bis 6-7 mm. gerade, gelb. Kapsel länglich bis fast zylindrisch, braum, später schwarz. glatt. Ring 4-5reihig, zuletzt in einzelne zellen zerfallend. Deckel kurz- und meist etwas schief geschmäbelt. Haube miitzen-kappenförmig, etwas schief. Sporenreile im Herbst.

N. SB., YB., ST., an wenigen Fundorten, 900-1,300 1n. Fordgrenze bei 62-24' n. Br.

Europa. Japan.

\section{COSCINODON}

Spreng. Einleit. i. (I. Stud. crypt. Gew. p. $281(180-1)$.

Schlanke Pfl. in polsterförmigen, \pm leicht zerfallenden Rasen. Stengel mit armzelligem Zentralstrange. Blätter fencht aufrecht-abstelzend, gekielt, flachund ganzrandig, die unteren haaros, die oberen grösser, mit = langem Haare: 

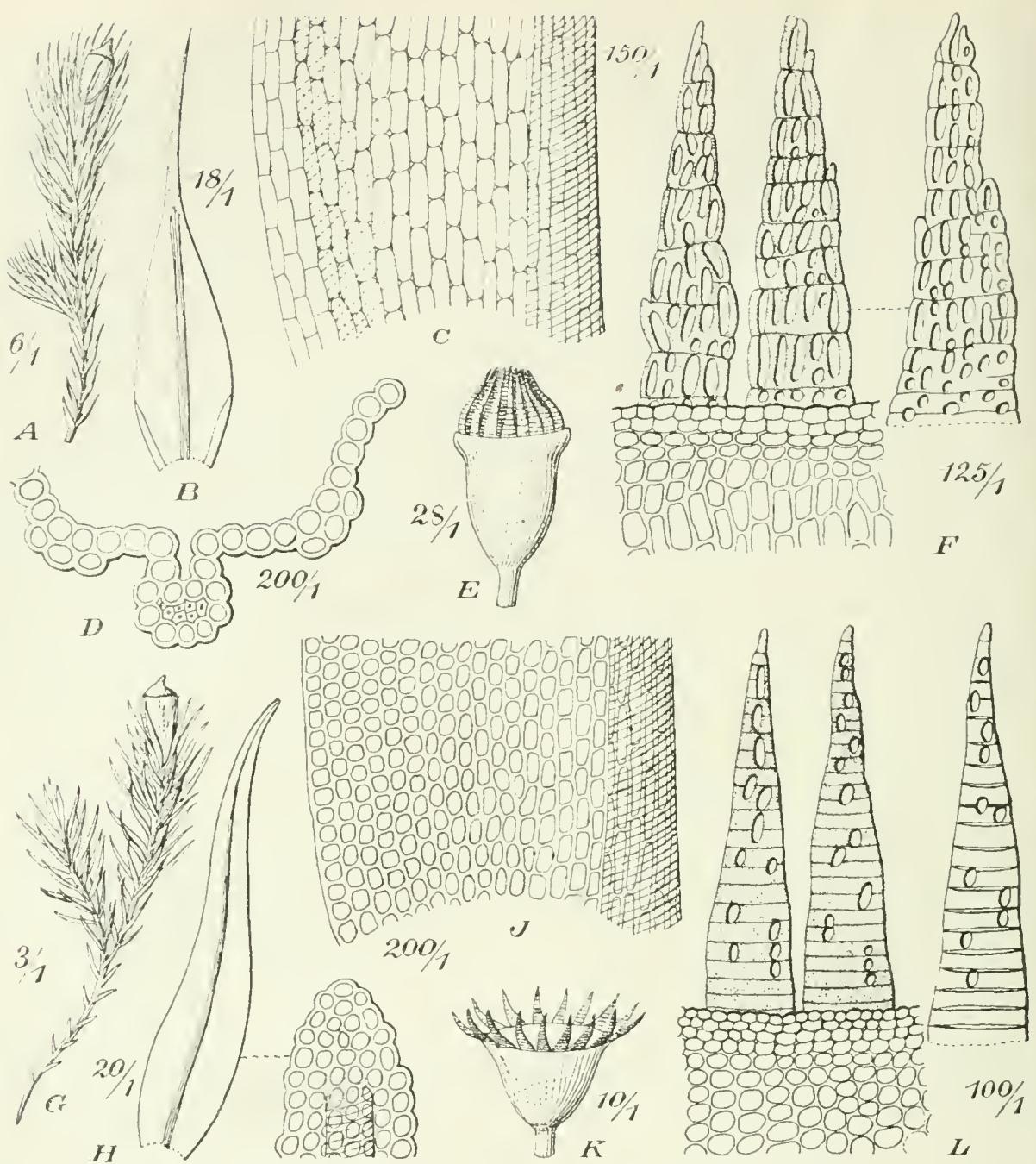

Fig. 34. 1-F Coscinodon cribrosus (Hedw.). A Fruchtende Pfl. (6/I); B Stanml,. (18 I): C Blattlasis (150/1); D Blattquerschnitt (200/1); E Entdeckelte Kapsel im trockenen Zustande (2. $/ 1$ ); F Peristom (125/1). - (i-L Grimmia angusta (Hag.). G Fruchtende Pfl. (3/1); H stammb. mil einzelnen Zellen der Blattspitze $(20 / 1)$; I Blatthasis (200/1); K Entelecelle Kitpsel im Irockenen Zustande (10/1); L Peristom ( 1001$)$.

Rippe am Rücken fast stielrund vortretend: Zellen nicht luchtig, glatt, oben rundlich-quadratisch, gegen den Grund lockerer, quadratisch und rektangulär. Perichäliabbätter breiter und länger. Kapsel aufrecht, \pm eingesenkt, verkehrtciförmig, glatt, entleckelt weitmündig. Ring nicht differenziert. Peristomzähne trocken zurückgeschlagen, lanzettlich, I sichartig durchbrochen gelblich bis rot. Deckel aus gewölbter Basis gerade geschuäbelt. Haule gross, weit glockenförmig. längsfaltig, nackt, am Grunde lappig zerschlitzt.

262. Coscinodon cribrosus (Hedw.) Sprue. in Ann. Mag. Nat. Hist. 2. ser. 111. p. 191 (1849). [Grimmia cribrosa Hedw. Descr. 111. p. 73, 1. 31 A (1792). Coscinodon pulvinalus spreng. 1. (. p. 281 und 37\%, t. 8, f. 7.5 (1804).] 
Diözisch: c" Pfl. meist den fertilen beigemischt Rasen blaugrün bis schwär\%lichgrün, grauschimmernd. Stengel bis 1 , selten his $2 \mathrm{~cm}$. Blätler kurz eilanzettlich, bis etwa $1,5 \mathrm{~mm}$ lang, beiderseits der Rippe oberwärts mit einer tielen Längsfalte, mit an den Faltungen 2-3schichtiger Lamina. Peristomzähne bis 0,55 mn lang. Sporen $\delta-13 \mu$, gelblich, gatt. Sporenreife im Frühling und Sonmer. S. Fig. $34 \mathrm{~A}-\mathrm{F}$.

An trockenen, kalkarmen bis kalklieien kieselgesteinen, seltener aul kalkhaltigeren Schicfern.

F. Ab. Karislojo, Täsväri (Broll.). - sia. Ohne Fundortsangabe (E. Nyl.). Kl. Valanr (ll. Vil.). - Li. Pyttelvaara (Hult). - L.l. Am kolabusen (F. Nyl.).

S. Jml. Straten. LuL. an mehreren Fundorten.

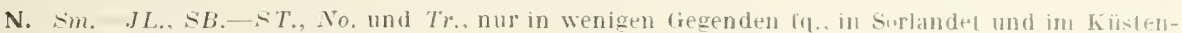
geliete ron Westlandet lirhlend.

Europat. Kaukasus. Nord-Amerika.

\section{RHACOMITRIUM}

Bricl. Nant. p. 78 (1819).

Diözisch; l’araphysen rosenkranzfömig. Mehr oder weniger kräftige Pfl. in meist ausgedehnten Rasen. Stengel ohne Zentralstrang, bald mit langen Sprossen, bald durch verkürzte Seitenäste fiederig beästet. Blätter meist überall cinschichtig Zellen \pm dickwandig und stark buchtig, am Grunde lang linearisch. mit sehr dickwandigen und stark geschlängelt buchtigen Längswänden, in den Blattecken rundlich l-6eckig, glattwandig, mehr durchsichtig bis hyalin. Seta (excl. Rh. sudeticnm) gerade und trocken meist rechts gedreht. Kapsel emporgehoben, aufrecht, eiförmig bis länglich-elliptisch und fast zylindrisch, engmündig, glatt. Ring breit, 2- Jre hig, sich abro lend. Vorperistom vorhanden. Peristomzähne am Grunde verbunden und meist bis zum Grunde in 2 fadenförmige, papillöse Schenkel gespalten, meist rot orler gelbrot. Deckel aus kegeligem Grunde pfriemenförmig, selten etwas schief. Haube lang, mützenförmig-gelappt, nicht gefaltet, wenigstens an der Spitze \pm raul.

L bersicht der Arten.

A. Blätter ohne Haar, stumpfspitzig.

a. Stengel gabelteilig und büschelästig, ohne verkürzte Seitenästchen.

a. Blattspitze breit und stumpf, meist gezähnt ..... 261. Rh. aciculare.

$\beta$. Blätter in eine verschmälerte, ganzrandige Spitze auslaufend.

1. Blätter flachrandig. Kapsel ciförmig bis eikuge-

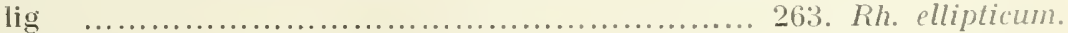

11 Blätter mit zurückgebogenen Rändern. Kapsel länglich bis fast zylindrisch 265. Rh. protensum.

b. Stengel mit verkürzten Seitenästchen.

a. Blattzellen oberwärts kurz 266. Rh. heterostichum

v. obtusum.

ß.. Alle Blattzellen gestreckt

269. Rh. fasciculare.

B. Blätter mit kurzem oder längerem Haar.

a. Stengel gabelteilig und büschelästig, ohne verkürzte Seitenästchen. Zellen bis zur Blattmitte herab quadratisch 267. Th. sudeticum.

b. Stengel mit rerkürzten Seitenästchen.

$\alpha$. Blatthaar nicht papillös. 
I Alle Blattzel en gestrecht

268. Rh. ramulosum.

II. Blattzellen oberwärts quadratisch 266. Rh. heterostichum.

$\beta$. Blatthaar papillös.

I. Blattzellen beiderseits dicht und grob papillös 271. Rh. canescens.

iI. Blattzellen glatt 270. Rh. hypnoides.

263. Rhacomitrium ellipticum (Turn.) Bryol. eur. fasc. 25/28, p. 5, t. 24 (IS45) [Dicranum ellipticum Turn. Musc. hib. p. 76 excl. syu. Dill. t. 6, T. 2 (1804). - Grimmia elliptica W. Arn. in Mem. Soc. hist. nat. Par. Il. p. 269 (1823).]

Weniger kräftige Pfl. in starren, braungrünen bis schwärzlichen Rasen. Stengel aufrecht bis aufsteigend, meist nur his $3 \mathrm{~cm}$. gleichhoch verästelt. Blätter trocken locker anliegend, feucht aufrecht, aus länglichem Grunde lineal-lanzettlich, stumpflich bis stumpf, bis $2,5 \mathrm{~mm}$ lang, flachrandig, oberwärts am Rande und in der Spitze doppelschichtig: Rippe kräftig, fast vol ständig; Zellen oberwärts rundlich-quadratisch, abwärts allmählich länger. Seta etwa $3 \mathrm{~mm}$, dick, gelblich. Kapsel oval, entleert fast kugelig, derbliäutig, rotbraun, zuletzt schwarz. Peristomzähne bis zur Mitte 2-3spaltig, brannrot, trocken strahlig ausgebreitet. Sporen $18-35 \mu$. Sporenreife im Mai.

N. Auf wenigstens periodisch nassen, kieselhaltigen Felsen der küste von Lindesnes bis IIolde $\left(62^{\circ} 39^{\prime} \mathrm{n} . \mathrm{Br}.\right)$ allgemein verbreitet.

Faeroer, Schotlland, Westküste von England und Irland, Japan.

264. Rhacomitrium aciculare (L.) Brid. Mant. p. 80 (1819). [Bryum aciculare L. Sp. pl. 1118 (17.53). - Grimmia acicularis (.. Müll. Syn. I. p. 801 (1819).]

Kräftige, starre Pll. in dunkel oliven-, satt- bis schwarzgrünen, nit Erde durchsetzten, eicht zerfallenden Rasen. Stengel meist aufrecht und 2,5-5 cm lang, zuweilen flutend und dann bis 10 cm, glcichhoch verästelt, stmmpf. B ätter trocken angepresst, beim Anfenchten sich nicht zurückkrümmend, aufrecht-abstehend ocler \pm einseitswendig. aus eiförmiger, schwach längsfaltiger Basis zungenförmig, an der breit abgesundeten Spitze \pm deutlich gezïhnt, 2 2,5 mm lang, in der unteren Hälfte beiderseits, aber meist ungleichmässig stark umgerollt; Rippe schmal, ziemlich weit vor der Blattspitze aufhörent, oben fast stielrund Zellen schwach papillös, oberwärts quadratisch und oval, in der Blattmitte rektangulär. Innere Perichätialblätter kürzer und breiter, fast scheidig, kurz zugespitzt. Seta j-10 mm, braunrötlich. Kapsel länglich bis fast zylindrisch, gelblich, zuletzt braunrot bis schwärzich. Sporenreife im Mai und Juni.

An kalkfreien, nassen oder zeitweise überrieselter Felsen und Blöcken, oft auch auf Steinen in Bächen und Flüsschen.

F. Al. Hammarland, Jomala, Finström, Geta und Lemland an einzelnen, Saltvik und sund an mehreren Fundorten (Bom.). - - Ib. Vemo, Rupikallio (Ruor.). Alo (Brand.). Lundo (Elrs.). Pargas, Kividja und Terfsund (Elfv.); Pyluänsuu (Link.). lsinitu, Fröjböle. Skinnarvik (Ols.). Finby (Broth.). Bromarf, an mehreren Fundorten (Sundv.). Lojo, an mehreren F'undorten (Hult, H. Lindb., E. af H.). Viehtis, Olkkala (E. af H.). - N. Ekenäs, Elgmo (Lindb.); Trollıöle (Häyr.). Sjundeal (Sundr.). Kìrkslätt, Obbnäs (Jusl.); Krarnby (Kullh.); Humaljärvi (Buch). Esbo, Linglrä‘k (Broll.). Helsingfors (Broth.). Helsinge, Dalsvik (Buch). Sibbo, Hita (Ekr.). Anjala (Sael.). Elimähi (Tiger-1.). Hugland (Lindb.). - Ka. sippola, Ruotila, Karjakoski (Kıj.). - St. Ikaalinen, Lavelahti (Herl.). - Ta. Lanmi. Evo (Norrl.). Asikkala, Viitala (N.). Padasjoki, Kaukela und Vimnaila (N.). Korpilaloti, Rutajoki (Vain.). - sa. Willmanstrand (Bu(h). Lappee, Kaukas und Mikousaari (B.); Rasila. Karbusjäri (B.). - Kl. Jaakkima, Puutsalo (Norrl.). Impilaliti, Sumeria (Pes.). Sujstamo, Loimalanjoki (Brolh.). Palkjärvi. Annoniemi und Pilkäniemi (B.). - Sb. Isuopio (Lackstr.). Laari. Luikolahti (Roiv.). - Kb. Ilomantsi, Kaltimo (IT. Nyl.). - Kon. Suojärvi, Anna (Kon.). - K. Kuusamo (F. Nyl.). - Li. L̈tsjoki Niuvus, Gissartschejave (Ranck.). - Lim. Umpjok, Liangaskoski (Kihlm.). - Ll. Jaurujoki (Roir.). - Lmur. Bjelousiha ans Vornjeflusse (Broth.). Rindil (B.).

S. Sk.-Illsl. I.uI. Sarekgebiet.

N. In allen Äutern, an reiehlidhsten in den Kiislongegenden. Sleigt nur sellen über die Batum. grenze hinauf. Nordgrenze lei il n. Br.

Europa, lladeira, Nord-Amerika. 
265. Rhacomitrium protensum A. Braun Msser., Hïben. Musc, germ. p. 211 (1833). [Grimmia aquatica C. Müll. Syn. 1. p. 800 excl. syn. (1819); Rhacomilrium aqualicum Lindb. Act. Soc. sc. fenn. X. p. 554 (1875).]

Ziemlich kräftige, weiche Pfl. in gelblich- bis bräunlichgrünen, locker zusammenhängenden, oft sehr ausgedelunten Rasen. Stengel $3-10 \mathrm{~cm}$, aus niederliegendem Grunde aufsteigend, gleichloch verästelt, fast spitz. Blätter trocken ange̊presst, beim Anfeuchten sich zurückkrümmend, dann aufrecht-abstehend, aus länglichem Grunde lineal-lanzettlich, stumpf, ganzrandig, $2,5-3 \mathrm{~mm}$ lang. am Grunde meist nur an einer Seite zurückgeschlagen; Rippe krältig, kurz vor der Blattspitze aufhörend; Zellen deutlich papillös, oberwärts rundlich-qquadratisch und kurz rektangulär, in der Blattmitte rektangulär. Innere Perichätialblätter kürzer, faltig-seheidig, kurz zugespitzt. Seta 4-8 $\mathrm{mm}$, gelb, unten rötlich, zuletzt längsbräunlich. Kapsel länglich bis last zylindrisch, lichtbraun. Sporenreife im Nai und Juni.

An fenchten oder ïberrieselten, kalkfreien Felsen, meist in der Nähe von W'asserläufen.

F. 11. Jomala, Geta und Lemland an einzelnen, Saltvik und Sund an mehreren Fundorten (Bom.). - Ab. Pargas, Terfsund (Elfv.). Finly (Broth.). Angelniemi, Karriais (Buch). Bromart, Norrstrand (Sundr.). Lojo, Yaanila und Pahasuu (Sundv.). Vichtis, Konjanvuori (Broth.). - N. Suappertuna Raseborg (Häyr.). Kỵrkslätı, Humajjärvi, Svartsjon (Ranck.). Esbo (Kar.); Kasherget (Buch); (irä<a (Broth.). Helsingfors, Fredriksberg (Buch).? Helsinge, Åggelby und Backas (B.). IIogland (Lindb.). ija. Öfvermark, Valsbärget (E. af H.).

S. Sk.-Hlsl.. Hrjd.

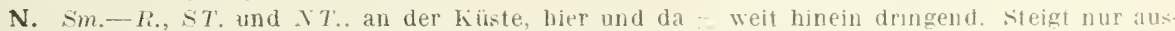
nahmsweise über $300 \mathrm{~m}$ hinauf. Nordgrenze bei $64^{\circ} 37^{\prime} \mathrm{n}$. Br.

Europa, Nord-Amerika, Kerguelen, New Zealand.

266. Rhacomitrium heterostichum (Hedw.) Brid. Mant. p. 7!) (1819). [Trichostomum heterostichum Hedw. Mser., Timm Fl. megap. p. 215 (1788). — Grimmiu heterosticha (. Müll. Syn. I. p. 807 excl. var. (18-19).]

Weniger kräftige $\mathrm{Pfl}$. in lockeren, \pm ausgedehnten, graugrünen bis weissgrauen Pasen. Stengel 2-6 cm, im L'nufang des Rasens niederliegend, in der Mitte aufrecht. unregelmässig ästig, mit \pm spärlichen verkürzten Ästen. Blätter trocken locker anliegend, beim Anfeucliten stark sich zurückliümmend, dann mit aufstrebender oder schwach zurückgebogener Spitze abstehend, selten einseitswendig, aus länglich-eiförmigem, etwas herablaufendem Grunde lanzettlich zugespitzt, in ein am Grunde breites, sclıwach gezähntes Haar auslaufend, etwa $2.5 \mathrm{~mm}$ lang, mit hoch hinauf umgerollten, einschichtigen Rändern; Rippe flach. schlecht begrenzt: Zellen nicht papillös, oben quadratisch oder kurz rektangulär, in der Blattmitte rektangulär. Innere Perichätialblätter kürzer und breiter, längs scheidig und faltig, zugespitzt. Seta $5-8 \mathrm{~mm}$, gelblich. am Grunde rotbräunlich. Kapsel zylindrisch bis fast keulenförmig, etwa $3 \mathrm{~mm}$ lang, mattbraun. Peristontzähne etwa $0,6 \mathrm{~mm}$ lang. Sporenreife im Nai. - Fig. $35 \mathrm{~A}-\mathrm{F}$

An kalkfreien Felsen und Blöcken, gern in trockenen und oflenen Lagen.

F. Al. fq. (Bom.). - Ab. Korpo, Strömma (Ekl.). Kustö, Isoky̆lä (Link.). Pargas, an mehreren Fundorten (Elfr., Link.). Kimito, Fröjböle (Ols.). Finbỵ (Brolh.). Angelnieni (Buch). Bromarf (Sundv.). Uskela, Anjala (Häyr.). Karislojo, Karkaji (Broth.). Lojo, Hiitis und Isosaari. Maila (Lindb.) Seppälä (Hult). - N. Ekenäs, Tvärminne (Broth.); Ekenäs (Häyr.). Esbo, Sandudd (Broth.); Luuk (Buch). Helsingfors (II: Nrl.). Helsinge, an mehreren Fundorten. Hogland (Lindb.). - Fa. Kotka Langinkoski (Roiv.). Kymmene, Sunila (Kuj.). Wiborg, westlich ron Lietjärii (Buch). - St. Pirkkala (Simm.). Sastmola und Tlöjärvi (Nerv.). - Ta. Jokioinen (Vain.). Lammi, Ero, Hakovari (Norrl.). Padasjoki, Kirchdorf (V.). — Sa. Wilmanstrand (Buch). Lappee, Rusala, KarhusjärYi (B.). Kangasniemi, Tuomarinvuori (Lackstr.). - Kl. Sortavala, Kirjavalahti, an einigen Fundorlen (Norr.). - Sb. Kuopio, an einigen Fundorten (Link.). - (om. Lappajärvi, Harju (Backin.).

S. $B l .-V r m l$.

N. Sm., A., JL.-R., ST.-Tr, nur im Küstengebiete. Nordgrenze hei $69^{\circ} 30^{\prime} \mathrm{n}$. B $3 \mathrm{r}^{\circ}$

Europa, China, Japan, Nord-Amerika. Tasmanien. 


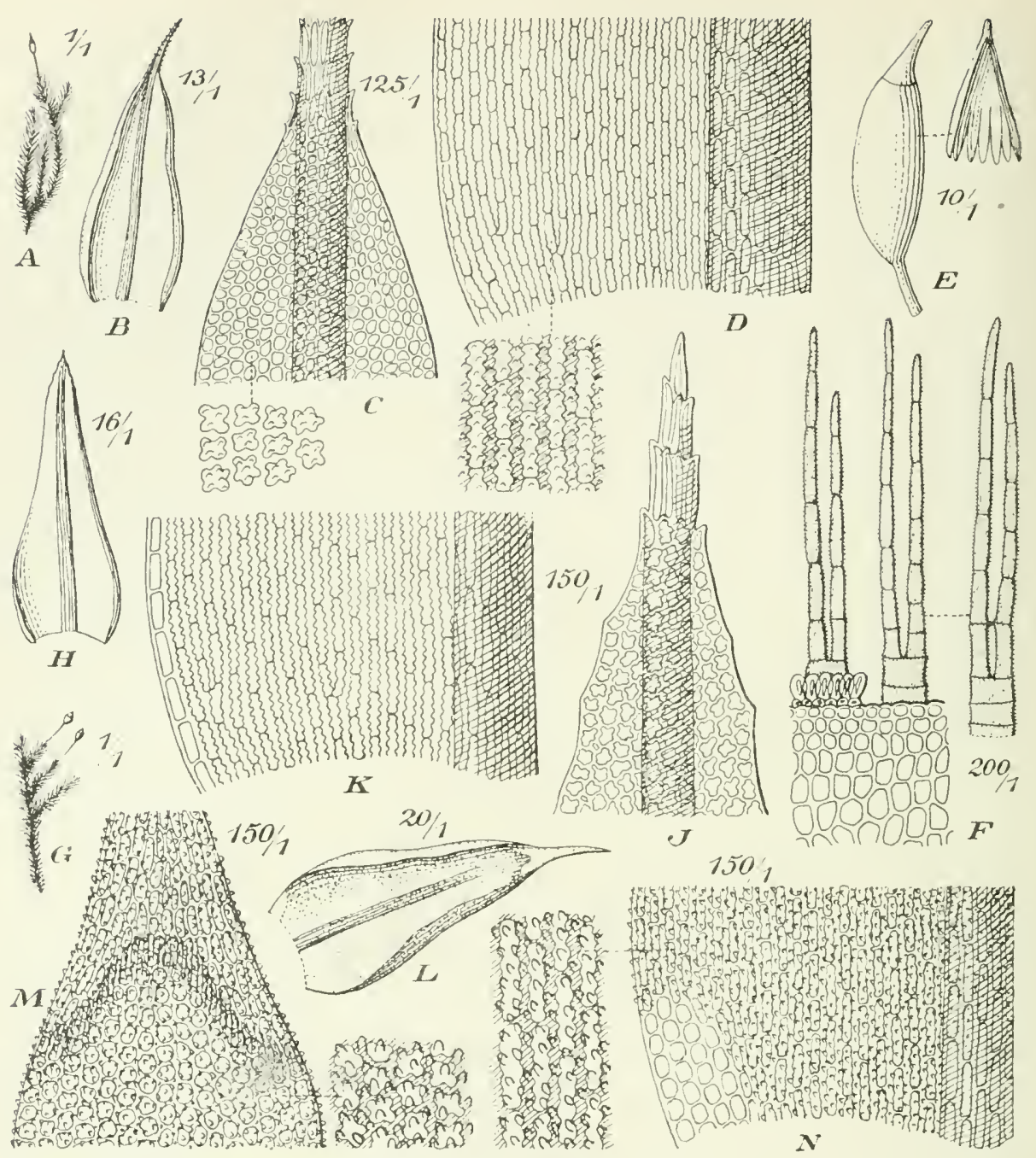

F'ig. 35. A-F. Rhacomitrium heterostichum lledw.). I Fruchtende Pfl. (1 I); B stengell, (13/): ( Blattspitze (125/1); D Blattbosis (125/1); E Kapsel ( ); F Peristom $(200,1)$. - 1i-K. Rh. sudeti-

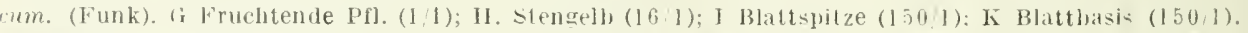
- L N. Rh. coneseens (Weis Tinm). L stengelb. (201); .I Blattspitze (1501); I Blatthasis (150,1).

* Rhacomitrium affine (Schleich.) Amann Fl. Hotss. Suiss. II. 1). 113 (1912). [Trichostomum affine Schleich. Pl. crypt. helv. 4. Cent. No. 18 (1805) el Cat. 1807.

T. alopecurum Schkuhr Deutschl. Ioos. p. 77, 1. 35 (1810). ․ Rhacomitrium alopecurtm Brid. Nant. p. 79 (1819). - R/h. helerostichum var. alopecurum Hüb. Muscol. germ. p. 208 (1833). - Grimmia affinis lindl). Muse. seandl. p. 20? (1879).]

Schlanke, fockerrasige, gelbgrïne his schwärzliche l'fl. Stengel niederliegencl his aufsteigend, meist 1 j cm, dureh zahlreiche Kuräste - deutlich fiederig. Blätter aus eiförmigem Grunde lang und schmal zugespilzt, kurzhaarig. oberwärts in 1--2 Reihen doppelschichtig: Rippe krälig. scharf begrenzt. Seta $1-6$ mm. Kapsel länglich-zylindriseh, derbhäutig und etwas glänzend: Zellen des 
Exotheciums liirzer als bei voriger Art. Peristomzähne elwa 0,3 mm lang. Sporenreife im Frühling.

An nassen, kalkfreien Felsen.

F. Al. Hammarland. Strönmal (HuIt). Jomala, Kasberg (Elfv.). Saltvik und sund. an wenigen Fundorten (Bon.). - Ab. Nadendal, Luonnonmaa (Elfs.). - K. Ekends, Trärminne (Ranck.). Eab). Kasbärgel (Buch): Sandudd (Broth.). Helsingfors, an mehreren Fundorten (Lindb.). Strönifors, Ö:lerby (Arrh.). Hogland (Lindb.). - Ta. Lammi (Norrl.). Luhanka, Onkisalo (Vain.). - sa. Kanga-nieni (Lackstr.). - Kl. Valamo (W. Nyi.). Sortavala, Kirjavalahti (Lindb.). - Kol. sichtjeliki und Fabriki (Elfv.). - Kon. Dianova gora (Simm.). - Db. Simo, Ruikku (Brenn.).

S. Sm. an mehreren Fundorten. Og., Boh. Sirm., Ypd., Ang.

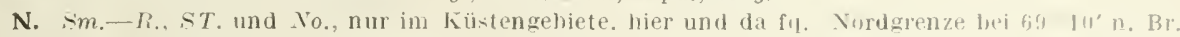
Europa, Nord-Amerilia.

var. obtusum (Sm.) Loesk. Laubm. Eur. p. 183 (1913). TTrichostomum oblustm Sn. Fl. brit. p. 1211 excl. syn. (1801). - Rhacomilrimm oblusum Brid. .1ant. p. 7!) (1819). - Grimmia oblusa Lindb. Muse. scand. p. 29 (1879).]

Schlanke Pfl. in grünen oder gelbgrünen, fast kissenförmigen Rasen. Stengel in der Mitte der Rasen aufrecht, unregelmässig verästelt, bald mehr lang-, balı mehr fieclerig kurzästig. Blätter trocken dachziegelig, aus länglich-eiförmigem Gruncle allmählich versehmälert, meist stumpf bis abgerundet, selten mit seln' kurzer Haarspitze. mit längs stark umgerollten, oberwärts doppelschichtigen Rändern: Rippe sehr kräftig, vollständig.

An trockenen, kalkfreien Felsen.

F. 11. Sultrik. Hulby (Bom.).

S. $\therefore$.. Boh.

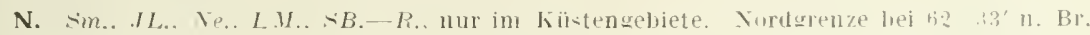

Euroja.

267. Rhacomitrium sudeticum (Funck) Bryol. eur. TTrichostonum sudelicum Funck Moostaschenb. p. 26, t. 18 (1820). - Gr:mmia microcarpa Lindb. in Aet. Soc. Scient. Fenn. X. p. 5.58 (1875).]

Weniger kräftige Pfl. in dunkel- bis schwarzgrünen, leicht zerlallenden Rasen. Stengel aus niederliegendem Grunde bogig aufsteigend, 2 bis 6 . selten bis $15 \mathrm{~cm}$. gleichhoch verästelt. Blätter aus länglich-lanzettlichem. Grunde allmählich lang zugespitzt, mit sehr kurzer, gesägter Haarspitze, 2,4-3 $\mathrm{mm}$ lang, am Grunde auf einer Seite zurïckgeschlagen, oberwärts am Rande in mehreren Reihen 2 (3)schichtig: Rippe krältig; Zellen (ler oberen Blatthälfte rundlich-quadratisch. Innere Perichätialblätter kurzscheidig, allmählich linealisch verschmälert. Seta 2 -3 mm, gebogen, trocken geschlängelt, gelblich. Kapsel oval, $1-1,5 \mathrm{~mm}$, Iichtbraun. Haube fast glatt. Sporenreife im Mai, in Hochgebirge in Sommer.

Fig 3is G.

An trockenen, gern offenen, kalkfreien Felsen und Blocken. Norlgrenze auf Beeren Eiland.

F. A. Geta, Lemiand und kökar an einzelnen. Saltwik an mehreren fundorten (Bum.). - Al. Pargas, Terfsund und (iunnarsnäs (Elfs.). Kimito, Markila (Oh]s.). Bromarl. Räkuby und Vors:tland

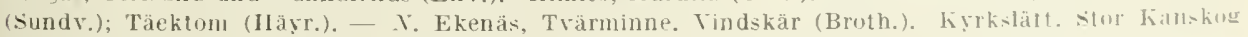
und Järsö (Broth.). Helsingfors, Fredrikslerg (Ranck.). Borga, Pörtö (Brolh.). Hogland (Lindh.). Ka. Wiłorg, wesll. von Lietjärvi (Buch). - Ta. Lammi. Jahkola (Norrl.). - Sa. Lappee. Kiankis und Miknnsari (Buch). - va. Replol, Vallgrund (Broth.). - K. Kuusano, Pỵllaraara (B.). Mh. Wivakh lunturi, in der alpinen Region (B.). - Le. Kilpisjäri, Halla und savvvaara. in der alpinen Regionl (Kot.). - Li. Inari. südt. Von Lupukkapaa, in der Vadelwaldregion (Hult): Akanhärkäkuru in des Birkenregion (H.); Sokuslamapä in der alpinen Region (H.), - Lim. Tschum, in der atpinen Region (Broth.). Lavotschor. in der alpinen Region (Kihln.). - Lmur. Teribjerka, Bjelnusina am voronjeflusse. Rinda lnd Harlorka (Broth.).

S. Am., sim., Irml., Hlsl., Wpd., Ang., IU.. Hrjd.. Jml. und PL.. an wenigen. LuL. an nehreren findorten. hinauf.

N. In allen Amtern und meist - fq.. am reichlichsten in der subalpinen Region. Steigt bis 1, xlu m

Europa, Kaukisus, Japan, Nord-Anerika. 
var. validius Jur. Laubmfl. p. 179 (1882).

Blätter haarlos oder nit kurzer. gezälnter Haarspitze: Rippe kräftiger: Zellen am Blattgrunde meist weniger buchtig.

N. Bu.. Br., Ye., sl.-\&T., No. und $F$.

In den Alpen ron der Schweiz bis Steiermark.

268. Rhacomitrium ramulosum (Lindl).) Hag. in D. K. N. Vid. Selsk. Skrift. 1909, No. 5. p. 85. [Dicranum microcarpum Schrad. Samml. I. No. 44 (1796). Grimmia microcarpa C. Müll. Sỹn. I. p. 804 ex p. (1849). - Grimmia ramulosa Lindb. Musc. scand. p. 29 (1879). - Rhacomilrium microcarpum (Schrad.) Brid. Mant p. 79 ex p. (1819): Brỵol. eur. fase. 2528, p. 10, t. 5 (1845).]

Ziemlich schlanke Pfl. in licht gelblichgrünen oder gelbgrauen, selten schwärzlichgrünen Rasen. Stengel an Rande des Rasens kriechend, in der Mitte aufstrebend, $2-5 \mathrm{~cm}$. büschelig geteilt, mit zahlrcichen, verkürzten Seitenästen. Blätter trocken locker und verbogen anliegend, beim Anfeuchten rasch sich sparrig zurückkrümmend, dam ziem ich weit abstehend, aus länglichem Grunde lanzettlich, in ein kirzes, am Gruncle verflachtes. gezähntes Haar auslaufend, mit bis gegen die Spitze umgerollten Rändern; Rippe flach, vollständig: Zellen gleichmässig hell gelblich durchscheinend, glatt, bis zur Blattspitze gestreckt. Innerc Perichätialblätter hochscheidig. rasch zugespitzt, mit verkürzter Rippe. Seta 3-5 mm, gelb, oft gekrümmt und trocken geschlängelt. Kapsel länglich bis zylindrisch, 1,5-2 $\mathrm{mm}$ lang, bleich gelblich, dann lichtbraun. Sporenreile im April und Mai.

An trockencn Felsen und Blöcken kieseliger, seltener $=$ kalkhaltiger Felsen in allen Teilen ron Fennoskanclia fq.-f(qq., zuweilen Iassenvegetation bildencl.

Europa, Nord-Amerika.

var. terrestre Hag. 1. c. p. 86.

Pfl. kräftiger, aufrecht, in kissenförmigen, dichten, leicht zerfallenden Rasen.

N. Auf Erdboden hier und da in den höchsten Fjelden

269. Rhacomitrium fasciculare (Schrad.) Bricl. Mant. 1). 80 (1819). [Bryum fasciculare Schrad. in Gmel. Syst. nat. 13. ed. II. P. 2, p) 1332 (1791). — Grimmiu fascicularis C. Miill. Syrl. I. p. 809 (1849).]

Weniger kräftige Pfl. in ausgedehnten, flachen, gelbgrünen. schmutziggrünen oder bräunlichen Rascn. Stengel am Rande les Rasens kriechend, oft schr verlängert. büschelig get.ilt. $t$ dicht mit knotigen Seitenästchen besetzt. Blätter trocken locker und mit gekrümmter Spitze anliegend, bcim Anfeuchten rasch sich sparrig zurückkrümmend, cłann nit auf- oder rückwärtsgebogenen Spitzen abstehend. seltener einscitswendig, aus länglichem und eilänglichem Grunde lanzettlich und allmählich in eine schmale, stumpfe Spitze vorgezogen. 3-3.5 mm lang. mit weit hinauf umgerollten Rändern: Rippe flach, weit vor der Blattspitze aufhörend; Zellen schwach papillös. stark buchtig und bis zur Blattspitze gestreckt. Innere Perichätialblätter kürzer und breiter, scheidig, an der kurzen Spitze meist kerbig gezähnt. Seta $1-10 \mathrm{~mm}$, rötlich, später gebräunt. Kapsel oval bis fast zylindrisch, braun, später schwärzlich. Haube fast überall rauh. Sporenreife im Früllling.

An nassen und überrieselten, kalkfreicn, selten kalkhaltigen Felsen. Nordgrenze auf Spitzbergen.

F. Al, nicht selten (Bom.). - Ab. Ab\%. Reso. Pargas. Kimito. Finby. Angelniemi. Bromarf Haliko. Karisinjo. Lojo. Vichtis. - N. Ekenäs. Ingi, Kyrkslä11. Esbo. Helsingfors. Helsinge. Hogland. - Ka. Vehkalahti. Antrea. - sl. Raumo. Pirkhala. - Ta. Kalvola. Im südöstl. Teile pass. (Norrl.). Hartola. Luhanka und Korpilahti an einigen Fundorten (Vain.). - Sa. Willmanstrand. Laypee. Taipalsaari. Kanga:niemi. Izuokolahti. - Kl. Kurkijoki. Valamo. Sortarala. Ǩirjaralahti nicht selten (Norrl.). - Kol. salmi, Leppälä. Pallivaara (Pes.)._ Oa. Närpes, Yiltermark, Vargbärget (Ranck.). Teuvd. Paljasuori (R.). Replot, Kvarken (Karst.), Vasa (Broth.). - Tb. Pihlajaresi (Norrl.). Laukaa. 
und Viitasaari pass. (Broth.). Pihtipudas. Heinolankylä, Jouhivuori (Roiv.); Sỹdanmaa, Rikkavuori (R.). - Sb. Heinăvesi, Palokki, an mehreren Fundorten (Kot.). Kuopio, an mehreren Fundorten (Link.). Kaavi, Losomäki (Kyyhk.). Juuka, Juuanvaara (Kot.). Maaninka, Kurolanlahti. Vorlokio (Iersi.); Pöljä. Lintuniemen kallio Kot.). - Kb. Tohmajärvi, Hidenvaara (Broth.). - rm. Vindala, Traprmkallio (Backm.). - ok. Kajana (Lackstr.). - ob. Rovaniemi, Alajäăkiö, Hepokallio (Hull), - h. Pıldasjärvi, Pirivaara (Broth.). Kuusamo, Iäntyvaara (B.). - Kh. Kivakkatunturi (Broth.). - I.kem. Pallastunturit (Norrl.). - Le. Välivaara und Leutsuvaara (Norrl.). - Li. In der Nadelwald-und Birkillregion st. fq. (Hult). Nattastunturit, Pyhätunturi, in der alpinen Region (H.). - Lim. Trchun und Ilibinä, in der alpinen Region (Broth.). - Lt. Jaurujoki (Roiv.). - Lmur. Teriberka und Rinda (Broth.). Lp. Ponoj (B.).

S. $S k .-L$.

N. In allen Amtern von der Ebene bis $1,500 \mathrm{~m} \pm$ gleichförmig verbreitet.

Europa, Japan, Nord-Amerika.

270. Rhacomitrium hypnoides (L.) Lindb. in Öfvers. Vet.-Ak. Förh. 1866, p. 552. |Bryun: hypnoides L. Sp. pl. p. 1119 excl. var. (1753). - Trichostomum lanuginosum Hedw. Descr. III. p. 3, t. 2 (1792). - Rhacomilrium lanuginosum Brid. Mant. p. 79 (1819). - Grimmia hypnoides Lindb. Musc. scand. p. 29 (1879).]

Krärtige Pfl. in grossen, schwellenden, graugrünen, trocken schr starren Rasen. Stengel bis 10 und $20 \mathrm{~cm}$, meist geschlängelt, bogig aufsteigend, mit zahlreichen, nach unten an Länge zunehmenden Kurzästen. Blätter trocken locker anliegend, mit verbogenen Spitzen, oft einseitswendig, beim Anfeuchten rasch sich zurückkrümmend, dann abstehend, aus herablaufendem, länglichení Gruncle lang lanzettlich zugespitzt und die hyalingesäumte, wimperig gezähnte und papillöse Spitze in ein langes, gewimpertes und grob papillöses Haar übergehend, $1-5 \mathrm{~mm}$ lang, mit am Grunde umgerollten Rändern; Rippe vollständig; Zellen beiderseits mit vorgewölbten Suturen, oben rektangulär und verlängert, hier am Rande kurz rektangulär und quadratisch. Inncre Perichätialblätter, um die Vitte plötzlich verschmälert, haarspitzig, die inmersten schmal lanzettlich, haarlos. Seta $3-\overline{7} \mathrm{~mm}$, gelblich, zuletzt schwärzlich, trocken oben links gedreht, raul. Kapsel eiförmig bis eilänglich, klein, braun. Sporenreife im April.

An trockenen, meist kalkfreien Felsen und Blöcken. oft Massenvegetation bildencl, seltener auf Sand- oder Torfboden.

F. Al. fqq. (Bom.). - Ab. Im K̈̈̈tengebiete fqq. Karisbojo, Tesjärr (sundr.). Lojo, Kaijola. Pumminmäki (Sundr.). - N. Im Küstengebiete fqq. Esbo, Kirchdorf (Ant.). Orimattila. Rautanäki, Kinnunmäki (Link.). Elimäki. Iustila (Buch). - Ka. Kymmene, sunila (Kuj.). Sikkijärvi, Pukalus (Krohn). Antrea (Pork.). - St. Eura (Rönnb.). Raumo (Simm.). - Ta. lialvola (hnab.). Im südöstl. Teile an mehreren Fundorten (Norrl.). Luhanka, an einigen Fundorten (Tain.): Korpilahti. Päiräkunta (T.). - Sa. Ruokolahti, Imatra (Buch). Lappee. Nieminen (B.). Kangasniemi (Lackstr.). - Kl. Kurkijoki (Jusl.). Sortavala, Kotiluoto und Pötsörara (Link.); Kirjaralahti (Forrl.). - Kol. Irjalusorat (Elfr.). - Oa. Verpes (Simm.). Teuva, Paljasvuori (Ranck.). - Tb. Pihlajavesi (Norrl.). Kar-tula (Broth.). - Sb. Kaavi, Sikajärvi, Likosaari (Kot.): Niinivaara, Louhimäki (K.). - Kb. Tohmajärvi. Värtsilä (H. Backm.). - Om. Alajärvi, Herralankallio (Backm.). Lappajärvi, Tarrola Vinninıuori (B.). - Ok. Paltamo, Jieslahti (Kyyhk.). Sotkamo, Kohrorinsaari (K.). - K. Pudasjärvi. Iso syöte, in der alpinen Region (Broth.). Kuusamo, Risitunturi (E. af H.). - Kk. Kivakkatunturi, in deralpinen Region (Broth.). - Lkem. Im Fjeldgebiete in der Fichtenregion und höher hinauf, jednch nicht reichlich (Hult). Ounastunturi (Sandm.). Kuolajärvi, Sallatunturi (E. af H.). - Le. Kilpisjärvi. Leulsıvaara reichl. (Norrl.); Malla und Saana, rejchl. in der alpinen Region (Kot.). - Li. Pälkemäjoki. Kodossuannonpää und Parsji in der Nadelwaldregion (Hult); in der Birkenregion st. fo. (H.); in der alpinen Region fq. (H.). - Lim. Hibinä, in der alpinen Region (Broth.). - Lt. Im südl. Teile fq. (Roir.). Kola (Broth.). - Lmur. An der ganzen Küste gemein und reichlich, zuweilen auch in Tersumpfungen rorkommend (Broth.).

S. $S k .-L$.

N. In allen Amtern fon der Ebene bis 2,000 m.

Europa, Madeira, St. Helena, Asien, Nord- und Siid-Amerika. Antarktis, Australien.

271. Rhacomitrium canescens (Timm) Brid. Mant. p. 78 (1819). [Trichostomum canescens Timm Fl. megap. prodr. p. 215 (1788). - Grimmia ericoides $\beta$ canescens Lindb. Musc. scand. p. 29 (1879).]

Ziemlich kräftige Pfl. in ausgedehnten, lockeren, zerfallenden, gell)- oder 
graugrünen, meist greisgrau schimmernden Rasen. Stengel meist aufrecht, am Rande der Rasen niederliegend, 2-10 cm, mit wenigen verkürzten Seitenästen. Blätter trocken locker anliegend, mit auf- und abwärts gebogenen Spitzen, beim Anfeuchten sich zurückkrümmend, dann fast sparrig abstehend, aus herablaufender, zweifaltiger, eiförmiger Basis schmal lanzettlich, zugespitzt, die entfärbte Spitze in ein papillöses und schwach gezähntes Haar \pm verlängert, mit bis zur Spitze stark umgerollten Rändern; Rippe schmal, flach, schlecht begrenzt, papillös; Zellen beiderseits auf dem Lumen dicht und grob papillös, oben quadratisch bis kurz rektangulär, in cler Blattmitte rektangulär. Innere Perichätialblätter scheidig, allmählich zugespitzt. Seta $1-2,5 \mathrm{~cm}$, gelblich, am Grunde rötlich, zuletzt schwärzlich, trocken links gedreht. Kapsel eikegelig, braun, mit farbigen Längsstreifen, trocken und entleert längsfaltig. Pcristomzälne sehr lang, mit fadenförmigen, knotig gegliederten Schenkeln. Haube fast überall rauh. Sporenreife im April und Mai. - Fig $35 \mathrm{~L}-\mathrm{N}$.

Auf feuchtem, sandigem Boden, besonders an Fluss- und Secufern, jedoch auch auf humusbedeckten Felsen. Nordgrenze auf Spitzbergen.

F. Ab. Aho (Arrh.). Reso, Luonnonmaa (Högm.). Pargas, Pitá (Elfv.). Kinito. Länıäs (Ols.). Finby, Kaukasalo (Broth.). Lojo, Lehmijärvi (Hult). — N. Ekenăs, Trärminne (Häyr.). Esbo, Sandudd (Broth.). Helsingfors (W: Nyl.). Helsinge, Malm (Sundv.): Vesterkulla, Kalkholmen (Ranck.). Strömfors, Tavastby (Ranck.). Elimäki (Tigerst.). - Ka. Kymmene, Sunila (Kuj.). Antrea (Lindb.). - Ik. Kivennapa, Rajajoki (Láng). Muola, Perkjärvi (H. Lindb.). Valkjärvi, Pasuri (L.). Sakkola, Ristniemi (L.). - Ta. Lammi, Evo (Norrl.). Koski, Hyväneula (N.). Asikkala, Kuivaharju und Enonsaari (N.). Luhanka und in den siidlicheren Teilen von Korpilahti zerstreut (Vain.). Hartola (Bonsd.). - hl. Kexlolm (Toum.). Kurkijoki, Migrilä (H. Lindb.). Sortavala, Kirjavalahti, an mehreren Fundorten (Norrl.). Ruskeala (Lindb.). Pälkjärvi, Annoniemi (Broth.). - Kol. Humbaritsa (Elfv.). - Oa. Vasa (Broth.). Tb. Jyväskylä (Link.). - Sb. Joroinen (H. Lindb.). Kuopio st. fq. (Link.). Kaavi. Huosiaisniemi (K.). Juuka, Petrovaara, Saarijärvi, Kasurinniemi (Kot.). Nilsiä, Kivikoski und Tarpinen (Kyyhk.). Pielavesi, Laukhala, Loivujoki (Roiv.). I Maaninka, Pöljä (Kyyhk.). Rautavaara, Riitomāki (K.). - Iib. Polvijärvi, Kirchdorf, Paljakkavaara (Kot.). - Ok. Kajana (Lachstr.). Sotkamo, Jormasjärvi, Kohvorinsaari (Kyyli.), Talvijoki. Kallola und Koirajärvi (K.). Suomussalmi, Salovaara (K.). - Ob. HaiJuoto (Brenn.). - Le. Am Cfer des Muonioflusses in der Nadelwaldregion (Norrl.). - Li. Tenojoki, in der Waldregion st. fq. (Hult). - Lim. Hibinā, in der alpinen Regicn (Broth.). - Ll. Maanselkä, Filsa und an Kolaflusse (B.). Tsipnavolok (B.). - Lmur. An den Flussufem von Voronje, Olenka, Rinda und Harlovka (Broth.).

S. $\leqslant k .-L$.

N. In allen Amtern von der Ebene bis 2,000 m gleichmässig verbreitet.

Europa, Madeira, Nord-Afrika. Ceylon, Sikkim, Sibirien, Janan, Nord-Amerika.

var. ericoides (Yeb.) Bryol. eur. fasc. 25/28 Mon. p. 12, t. 8, f. $\gamma$ (1845). [Hypnum canescens $\gamma$ cricoides Web. Spic. Fl. gott. p. 82 (1778). — Grimmia ericoides excl. var. canescens Lindb. Musc. scand. p. 29 (1879).]

Stengel verlängert, durch sehr zahlreiche, verkürzte Seitenäste fast fiederig. Auf trockenem, magerem Boden und auf dünn erdbedeckten Felsen.

F. Al. fq. (Bom.). - N. Borgá, Svartat (Fastb.). - Ka. Virolahti (Blom). Antrea, Korpilahti, (Lind.). - Ik. Sakkola, Ristniemi (H.lLindb.); Suvanto (H. L.). Pyhäjărvi, au Ladogaufer (Sahlb.). St. Eura (Rönnb.). - Ta. Sysuä (Lnon.). Hartola (Bonsd.). Luhanka. Judinsalo (Vain.). Korpilahti. Putkilahti (T.). - Sa. Valkeala (Sundr.). Willmanstrand (Buch). Kangasniemi (Lackstr.). Ruokolahti, Matikkala (Hult). Nyslott (Carl.). - Kl. Nurkijoki, Vätjkko (Jusl.). Valamo (W. Nyl.). Sortavala, kirjaralahti (Lind).). Impilahti, Sumeria, Raukkivuori (Pes.). - Kol. Petrosavodsk (Kullh.). - Oa. Vasa (Brotlı.). lsokyrö, Orisberg (Ranck.). - Tb. Laukaa, Karlvik (Link.). — sb. Pielavesi, Venetmāki (Roiv.). - Ob. Keni, Ajos (Räs.); Selkosaari (Buch). Tornio, Kallioluoto (Brenn.). - K. Kuusamo, Oulankajoki (Broth.). - Lt. Kola (Brenn.); an Kolaflusse (Broth.). Tsipnarolok (Broth.). - Lmur.

S. $s k .-L$.

N. In allen $\boldsymbol{X}$ mtern von der Ebene bis 2,000 $\mathrm{m}$ gleichmässig verbreitet. turopa, Kaukasus, Japan, Nord-Amerika. 


\section{Reihe FUNARIALES.}

Meist 1-2jährige Erdmoose. Stengel oft rosettenartig beblättert. Blattzellen locker, glatt. Sporogone acrocarp. Kapsel nie zylindrisch. Peristom einfach, doppelt oder feh end, ohne Vorperistom. Peristomzähne den Fortsätzen gegenübergestellt; letztere mit niedriger Grundhaut. Deckel nie geschnäbelt.

\section{Unterreihe FUNARIINEAE.}

Spaltöffunngen meist schildförmig (vergl. Fig. $39 \mathrm{G}$ ). Peristom oft doppelt; Zähne voneinander frei.

D I S C E L I C E A E.

Die Merkmale der Familie sind dem Gattungscharakter gleich.

\section{DISCELIUM}

Brid. Bryol. univ. I. p. 365 (1826).

Diözisch; ơ und $\sigma^{\star}$ Blüten auf demselben Protonema; o linospen kleiner und gedrungener, mit hochgelben, keuligen Paraphysen. Gesellig oder trupp- und herdenweise wachsende, einjährige, knospenförmige Pfl., mit bis zur Sporenreife bleibendem, grünem Protonema. Stengel etwa $1 \mathrm{~mm}$, einfach. Blättel. gedrängt, die inneren grösser länglich-lanzettlich, zuge spitzt, spitz oder stumpflich. flach- und ganzrandig; Rippe bald fehlend, bald vorhanden, von wechselnder Länge und Breite und aus zwei Schichten dïnnwandiger Zel-

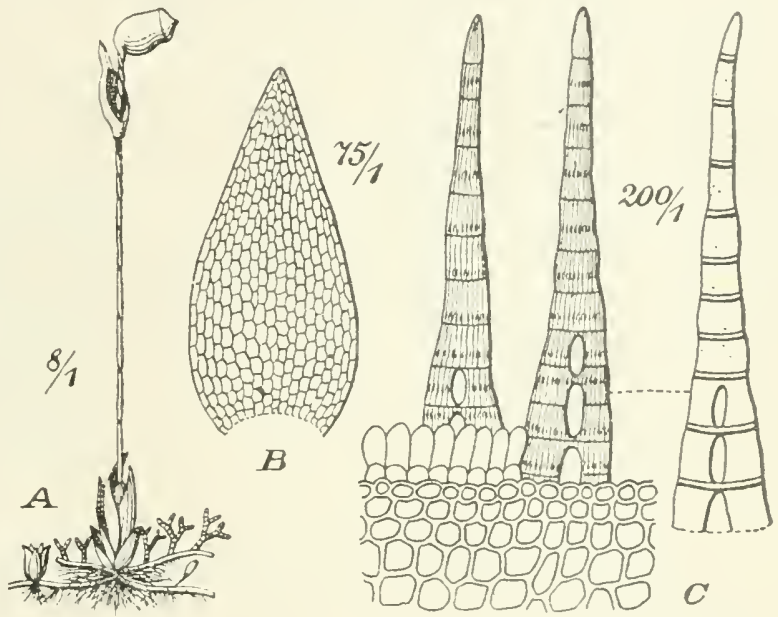
len gebildet; Laminazcllen locker 6seitig-rhomboidisch, unten verlängert, dünnwandig, mit spärlichem. Chlorophyll. Seta $5-20 \mathrm{~mm}$, steif, diim, purpurn oder rötlich, trocken vielmals rechts gedreht. Kapsel schief geneigt oder wagrecht bis herabgebogen, klein, gedrungen eirund bis fast kugelig, blass gelblich; weich, mit kurzem, scharf abwärts gebogenem, in die Seta verschmälertem Halse; Zellen des Exotheciums dinnwandig. unregelmässig t-6eckig rundlich und oval; Spaltöffnungen fehlend. Peristonzähne 16, gleichweit gestellt, lanzettlich, 8-9gliederig, meist rom Grunde bis gegen oder iiber die Mitte durchbrochen oder klaffend, rot; Aussenschicht längsstreifig; Innenschicht stärker entwickelt, mit breiten, vorspringenden Qucrbalken. Inneres Peristom als niedrige Grundhaut angedeutet. Sporensack rings ohne Luftraum direkt anliegend. Columella zurückschrumpfend. Sporen 20-24 i", rostbraun, fein papillös. Deckel gross, kegelig-gewölbt, stumpflich. Haube schmal, von der sich während der Entwickelung umbiegenden Kapsel seitlich durchbrochen und manschettenartig an der Seta herabgleitend. - Vegetative Vermehrung durch Wurzelknöllchen und ruhendes Protonema. Sporenreife im Winter. 


\section{Einzige Art:}

272. Discelium nudum (Dicks.) Brid. Bryol. univ. I. p. 366 (1826). [Bryum nudum Dicks. Pl. crypt. fasc. IV. p. 7, t. 10, f. 15 (1801).] - Fig. 36.

Auf feuchtem, nacktem 'Ton, gern an Ablaängen, Grabenwänden und Bachrändern.

F. Ab. Finby (Broth.). Angelniemi (Buch). - N. Helsingfors, an mehreren Fundorten in der Umgebung (Lindb.). Borgá, Kallola (Fastb.). - Ik. Sakkola, Suvanıo (H. Lindb.). Uusikirkko, Vammelsuu, Ongimojoki und Rajajoki (H. L.). Metsäpirtti, Viisjoki (fr. Lang). - St. Nakkila (Sinın.). U’lfsby (Karst.). - Ta. Säähsmäki, Limojoki (Kihlm.). Hollola, Kiurhila (Sil.); Kuivaharju (Norrl.). Korpilahti, Rutalahti, Tianen (Vain.). - Sa. Willmanstrand, Koirulanmäki (Buch), - Kl. Sortavali, Läskelă (Pes.). - Oa. Vasa (Broth.). - Tb. Jỵäskrylä. Tourujokj (Broth.). Konginkangas zw. dem Kirchdorf und Räihä (E. af H.). Pihtipudas, Kärräsjärvi (Broth.). — Sb. Sonkajärvi, Sukeva (Roir.) Maaninka, Haatala, Parola (Roiv.). - Om. Lappajärri, Kauhajärvi, Luomala (Backn.). - Ok. Kajana und Paltamo (Lackstr.). Sotkamo, Naapurinvaara (Broth.). - Ob. Mruhos (H. Lindb.). - Lkem. Folari, Väylänpäā (Hult). Juonionalusta und Muonioniska (Norrl.). Kíuolajärri, Salla, Peteri (E. af H.). - Lt. Kola (Broth.). - Lmur. Bjelousiha am Voronjeflusse (Brotls.).

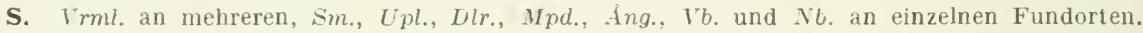

N. Sm., A., Bu. JL., SB., NB., H., ST., NT, und No. In der Ebene beiderseits der Kristianiafjord ziemlich häufig, sonst selten und in den Küstenämtern zwischen Bratsberg und Stavanger noch nicht beobachtet.

Europa, sibirien, Sachalin, Nord-Amerika.

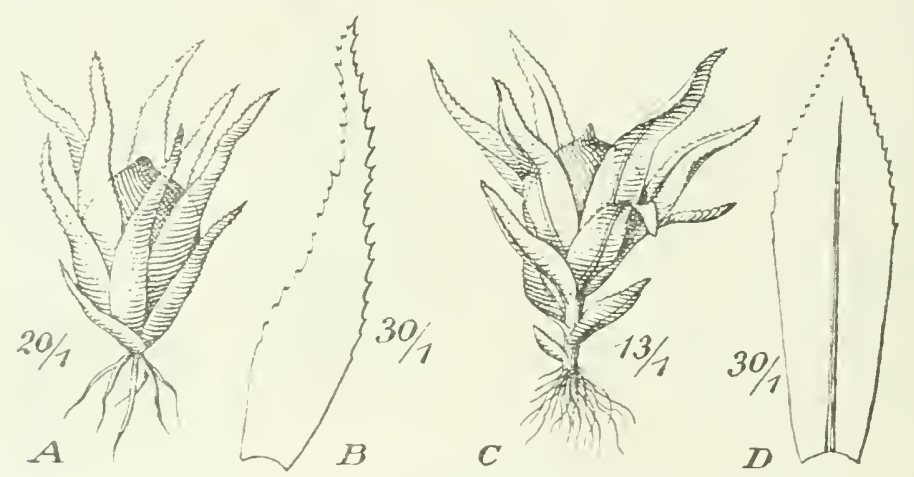

Fig. 37. A B Ephemerum serratum (schreb.). A Fruchtende Pfl. (20/1); B stengelb. (30 I). - C-D Physcomitrella matens (Hedw.). (C Fruchtende Pfl. $(13,1)$; D Stengelb. $(30,1)$.

\section{E P H E M E R C EA E.}

Meist diözisch: ơ Pfl. sehr winzig, knospenförmig, ohne oder mit fadenförmigen Paraphysen. Sehr kleine Pfl. mit reichlichem, ausdauerndem, ober- und unterirdisehem Protonema. Stengel sehr verkürzt, meist ohne Zentralstrang, armblättrig. L'ntere Blätter sehr klein, die oberen schmal und verlängert, \pm lang zugespitzt; Rippe meist schwach bis fehlend. Seta sehr kurz oder fehlend. Kapsel kugelig oder ellipsoidisch, ohne Hals: Spaltöffnungen, wenn vorhanden, oberflächlich. Deckel meist nicht differenziert. Columella meist zur Reifezeit innerhalb des Sporensackes resorbiert. Sporen meist sehr gross.

\section{EPHEMERUM}

Hamp. in Flora 1837, p. 285.

Kapsel mit stumpfem Spitzchen. Deckel nicht differenziert. Mit Spaltöffnungen. 
¿̇bersicht der Arten.

A. Blattrippe aus zwei Schichten dünnwandiger Zellen gebildet. Haube kegel-mützenförmig, nur den Scheitel der Kapsel deckend.

a. Sporen nackt, $50-70 \mu$, dicht und grosswarzig..... 273. E. serratum.

b. Sporen von einem hyalinem Schleier ungeben, fein papillös, kleiner als bei der vorigen Art

27.4. E. minutissimum.

B. Blattrippe kräftig, mehrschichtig. lang austretend.

a. Kapsel mit gerader, stumpfer Spitze. Haube breit kegelig, mehrlappig, nur den Scheitel der Kapsel deckend. 27j. E. sessile.

b. Kapsel schief geschnäbelt. Haube kappenförmig, bis zur Kapselmitte reichend

276. E. recurvifolium.

273. Ephemerum serratum (Schreb.) Hamp. in Flora 18:37, p. 285. [Phascum serratum Schreb. de Phasco Obs. p. 9, t. 2 (1770).]

Mleist gesellig wachsende Pfl. Blätter aufrecht-abstehend oder schwach einseitswendig, die oberen viel grösser, linealisch-lanzettlich, allmählich lang zugespitzt, rings unregelmässig mit groben, oft längeren und zurïckgebogenen Zälmen; Rippe aus zwei Schichten dünnwandiger Zellen gebildet; Zellen s:hr verlängert rhomboidisch, unten rektangulär. Seta sehr kurz und dick. Kapsel fast kugelig, mit kurzem, geradem Spitzchen, rotbraun, glänzend: Spaltöfnungen nur am Grunde. Sporen rund und nierenförmig, 50-70 ", bram, dicht und grosswarzig. Haube breit, kurz kegel-miitzenförmig, am Grunde gelappt, fast nur den Scheitel leckend. Sporen schmutzig gelbbraun. Sporenreife rom Spätherbst bis zum April.

Auf feuchten Ackern, in ausgetrockneten Teichen und Versumpfungen, in Torfgräben und an Grabenrändern.

F. Al. Saltvik, an vielen Fundorten (Bom.). Sund, Prästö und Kastelholm (Bom.).

S. Sk. an mehreren, Bl., Sm., Ög., Srm., Vär., Lpl., Irsm., Gstr. und Hlsl. an einzelnen oderwenigen Fundorten.

N. Sm. Glemminge u. Onso.

Europa, Nord-Amerika.

var. angustifolium Bryol. eur. I. Mon. p. 6. t. 1 (183i).

Blätter länger, linealisch, nur stumpf gezähnt. Kapsel kleiner, deutlich zugespitzt.

N. A. Aker, Kongshavn.

Europa, Nord-Amerika.

var. medium Hag. in D. K. X. Vicl. Selsk. Skrift. 1908, No. 9, p. 3-1 (1909). Sporen gelb.

N. A. Kristiania, Sm. und $J L$. an wenigen Fundorten.

274. Ephemerum minutissimum Lindb. in Notis. Sällsk. Faun. et Fl. fenn. förh. XIII. p. 411 (1874).

Viel kleiner als die vorige Art. Obere Blätter aufrecht-abstehend oder fast einseitswendig, schmal lanzettlich, etwa nur 10 Zellen breit, lang und geschlängelt zugespitzt, oberwärts unregelmässig und stumpf gesägt; Rippe aus zwei Schichten dünnwandiger Zellen gebildlet; Zellen verlängert. Kapsel kugel-eiförmig, mit kegeligen, geraden Spitzchen bleich kastanienbraun. Sporen kleiner als bei der vorigen Art, von einem hyalinen Schleier umgeben, gelb, fein papillös. Haube wie bei der vorigen Art. Sporenreife vom Spätherbst bis zum April.

N. An einzelnen Fundorten in $5 m$. . A. und $S T$.

England, Nord-Deutschland. Sardinien, Nord-Amerika.

275. Ephemerum sessile (Bruch et Schimp.) C. Müll. Syn. I. p. 33 (1848); Bryol. eur. t. 2 (1849). [Phascum sessile Bruch et Schimp. in Pollichia 1844, p. 49. - Ephemerum stenophyllum Schimp. Syn. 1 ed. p. 5 (1860).] 
Obere Blätter abstehend bis einseitswendig, steif, schmal lineal-lanzettlich, gegen die Spitze hin stumpf gesägt: Rippe kräftig, lang austretend; Zellen dickwandig und schmäler als bei den vorigen Arten. Seta fehlend. Kapsel dick oval, mit gerader, stumpfer Spitze Spaltöffnungen über die ganze Kapsel zerstreut. Sporen kugelig bis nierenförmig, $56-80 \mu$, dunke'-rostfarben, durch grosse Warzen wie netzig-gefeldert. Haube wie bei der vorigen Art. Sporenreife im Winter.

Auf tonigen Ackern. Wiesen und ausgetrockneten Versumpfungen.

F. Al. Sallvik, am Wege zw. Berdtby und Sonröda (Bom.).

S. srm. Österhaninge, Årsta.

Europa. Nord-Amerika.

276. Ephemerum recurvifolium (Dicks.) Boul. Muse. de l’Est p. 694 (1872). [Phascum recurvifolium Dicks. Pl crypt. fasc. IV. p. 1, t. 10, f. 2 (1801). - Ephemerella recurvifolia Schimp. Syn. p. 7 (1860).]

Obere Blätter trocken geschlängelt, feucht aufrecht-abstehend bis zurückgebogen, schmal linealisch, lang zugespitzt, oberwärts \pm ausgefressen-gezähnelt; Rippe sehr kräftig, als dicke Stachelspitze austretend: Zellen dickwandig, in der Mehrzahl verlängert rhomboidisch-6seitig. Seta sehr kurz und dick. Kapsel dick oval bis fast kugelig, mit schiefem. stumpfem Schnäbelchen: Spaltöffnungen sehr spärlich am tiefsten Kapselgrunde. Sporen kugelig bis nierenförmig, meist 35-45 ", bleichgelblich, fast glatt. Haube kappenförmig, fast bis zur Urmenmitte reichend. Sporenreife im Winter.

Auf nacktem, feuchtem Boden an Grabenwänden und auf Klecäckern.

F. Al. Saltrik. Krambo (Bom.).

S. $L_{p l}$. Uisala.

Zentral-Europa, England. Erankreich, Italien, überall selten.

\section{F U N A R I A C E A E.}

Herdenweise wachsende oder lockerrasige, niedrige, meist b.eichgrüne Erdmoose, die nur durch unterirdisches Protonema ausdauern können. Stengel rund, mit deutlichem Zentralstrange, lockerem Grundgewebe, wenig oder deutlich differenzierten Mantelzellen und dam oft mit dünnwandigen Epidermiszellen, einfach, mit ein oder zwei subfloralen Sprossen unter den zuerst erseheinenden ơ Blüten, nur am Grunde mit Rhizoiden. Bläţer nicht hygroskopisch, weich, trocken \pm verbogen und gedreht, ziemlich breit, die oberen grösser und rosettenartig gestellt; Rippe zart, selten austretend, mit zwe ventralen Deutern, einer kleinen, von einem unteren Stereidenbande umschlossenen Begleitergruppe und differenzierten Rückenzellen; Zellen sehr locker, parenchymatisch, quadratisch bis rechteckig und rhomboidisch6seitig, nach unten länglich-rektangulär. dlünnwandig, mit spärlichem Chlorophyll. Autözisch: $C^{\nearrow}$ Blüten seheibenförmig, an der Spitze des kurzlebigen Hauptsprosses, mit keulenförmigen Paraphỵsen. Kapsel aufrecht, kugel- bis birnförmig oder geneigt bis abwärts gebogen und dam meist schief birnförmig und gekrümmt; Spaltöfnungen zahlreich im Halsteile. Peristom fehlend odler rorhanden und dann einfach oder doppelt. Peristomzähne 16, schief nach rechts gerichtet, mit nach innen und seitlich stark vortretenden Querleisten. Fortsätze des immeren l'eristom den Zähnen entgegengestellt. Deckel meist flach gewölbt, sclten mit deutlicher Spitzc oder nicht differenziert.

\section{íbersicht der Gat tunge}

A. Deckel nicht dlifferenziert. Haube ganzrandig

B. Deckel differenziert. Haube meist gelappt.

a. Haube unter den Hals herabreichend, vierkantig..... 66. Pyramidula.

b. Haube höchstens die obere Hälfte der Kajsel deckend. 
«. Haube bis zum Grunde des Schnabels mützenförmig3-5lappig, flüchtig 6.5. Physcomitrium.

$\beta$. Haube aufgeblasen-kappenförmig, ganzrandig, lange bleibend

67. Funaria.

\section{PHYSCOMITRELLA}

Bryol. eur. fasc. 12 (1849).

Kleine Pfl. meist in lockeren, kłeinen, grünen bis gelbgrünen Häufchen. Stengel $2-5$, seltener bis $7 \mathrm{~mm}$, einfach oder gabel- und büschelästig. Obere Blätter abstehend, aus verschmälerten Grunde iiber der Mitte verbreitert und danı allmählich scharf zugespitzt, 1,3-2 $\mathrm{mm}$ lang, $0,25-0,70 \mathrm{~mm}$ breit, bis zur Mitte herab stumpfzähnig; Rippe vor der Blattspitze verschwindend. Seta sehr kurz. Kapsel kugelig, mit stumpfer, massiver Spitze, gelbbräunlich; Zellen des Exotheciums gross, quadratisch und rundlich-6seitig. Sporen 21-32 $\mu$, rostfarben, dicht stachelig. Haube kegelig-mützenförmig, nur den Scheitel deckend. Sporenreife im Spätsommer und Herbstanfang.

Einzige Art:

277. Physcomitrella patens (Hedw.) Bryol. eur. I. t. 3 (1849). [Phascum patens Hedw. Descr. I. p. 28, t. 10 (1787).] - Fig. 37 C-D.

Auf feuchten, tonigen Äckern und anf Schlamm an Teichen und Flüssen.

F. Al. Saltrik, an mehreren Fundorten (Bom.). sund. Kastelholm und Rosenlerg (Bom.). Ik. Rautus, Sumbula (H. Lindb.). - Sa. Willmanstrand, Kourulanmäki (Buch),

S. Bl.. Sk., Ög., När., Upl., Gstr. und Hlsl, an einzelnen oder wenigen Fundorlen.

N. A. Kristiania. Bu. Jueren. SB. Voss. NP. Sogn.

Europa, Sibirien, Nord-Amerika.

\section{PHYSCOMITRIUM}

(Brid.) Bruch et Schimp. in litt.: Fürnr. in Flora XIII. P. Il. Ergänz. p. 9 (1829).

Herdenweise wachsende oder lockerrasige, blassgrüne Pfl. Kapsel emporgehoben, aufrecht und regelmässig, fast kugelig oder dick birnförmig. Ring differenz ert. Peristom fehłend. Decke breit, flach gewölbt, mit kurzer oder längerer. zuweilen schnabe artiger Zitze. Haube lang und gerade geschnäbelt, die jugendliche Kapsel blasenförmig einhüllend, später mützenförmig. drei- bis mehrlappig, der Kapsel gerade aufsitzend, flüchtig.

\section{Übersicht der Arten.}

A. Kapsel nach der Entdeckelung tellerförmig bis halbkugelig; um die Urnenmündung 2-4 Reihen querbreiter und quadratischer Zellen ................................... 278. Ph. sphaericum.

B. Pfl. viel kräftiger. Kapsel nach der Entdeckelung becherförmig; mit vielen Reihen querbreiter Zellen um die nicht erweiterte Urnenmündung 279. Ph. pyriforme.

278. Physcomitrium sphaericum (Ludw.) Brid. Bryol. univ. II. p. 815 (1827). [Gymnostomum sphaericum Ludw. Mscr.: Schkur in D. Krypt. Gew. Il. 1). 26, t. 11 b (1810).]

Sehr schlanke Pfl. Stengel $1-3 \mathrm{~mm}$. Schopfblätter aus verschmälertem Grunde nach oben etwas verbreitert und dann stumpf oder stumpflich zugespitzt. etwa $2 \mathrm{~mm}$ lang und $0,5-0,6 \mathrm{~mm}$ breit, ungesäumt und ganzrandig oder oberwärts undeutlich gezähnt: Rippe vor der Blattspitze aufhörend. Seta $2-5$ mm. 
blassrötlich. Kapsel sehr klein, fast kugelig, mit sehr kurzem Halse, braun, entdeckelt sehr weitmündig, zuletzt fast schüsselförmig; Zellen des Exotheciums deutlich kollenchymatisch, am Mündungsrande 3-4 Reihen querbreiter und quadratisch. Ring 1--2reilig, kleinzellig, bald an der Mündung, bald am Deckelrande bleibend. Deckel mit sehr niedriger Zitze. Sporen 28-32 ", gelb, dicht stachelwarzig. Sporenreife im Spätsommer und Herbst.

Auf Schlamm an Teich- und Flussufern.

F. Ka. Antrea (Buch). - Ta. Asikkala (Sil.). - Sa. Willmanstrand, Kourulanmāki (Buch). kil. Kurkijoki (Broth.).

Ebene ron Zentral-Europa, England, Amur und Japan.

279. Physcomitrium pyriforme (L.) Brid. Bryol. univ. II. p. 815 (1827). [Bryum pyriforme L. Sp. p]. p. 1116 (1753). - Gymnostomum pyriforme Hedw. Fund. I1. p. 87 (1782).]

Ziemlich kräftige Pfl. Stengel bis 5 und $10 \mathrm{~mm}$. Schopfblätter aus deutlich verschmälertem, fast ohrartig vortretendem Grunde nach oben verbreitert und dann schne 1 in eine meist kurze, breite Spitze auslaufend oder bis unter dieselbe fast gleichbreit, $3-3,5 \mathrm{~mm}$ lang und $1,5-2 \mathrm{~mm}$ breit. ungesäumt oder in der unteren Hälfte \pm deutlich gesäumt und meist bis zur Mitte herab grobgesägt; Rippe vor der Blattspitze aufhörend. Seta $5-10 \mathrm{~mm}$, bleich, später rötlich. Kapsel kugelig-birnförmig, mit etwas aufgetriebenem Halse, zuerst gelblich und oben gebräunt, später ganz braun, entileckelt unter der Mündung etwas eingeschnürt und becherförmig; Zellen des Exotheciums mit verdickten Längs- und dümnen Querwänden, am Mündungsrande 8-15 Reilıen querbreiter mit verdickten Querwänden. Ring 2--3reihig, grosszellig. sich stückweisc ablösend. Deckel flach gewölbt, mit kurzer oder längerer, bis fast sclmabelartiger Zitze. Sporen 25-37 $\mu$, rostbraun, dicht stachelig. Sporenreife im Mai und Juni. - Fig. 38 E-G.

In feuchten Ausstichen und Gräben, an Fluss- und Teichufern und an Grabenrändern.

F. Al. Eckerö (H. Lindb.). Finström, Godby (Arrh.). Jomala, Dalkarby (Elfv.). Saltrik, Fremmanby, Kuggböle, Kvarnbo und Berdtby (Bom.). - Ab. Abo (Arrh.). Reso, Luonnonmaa (Hōgm.). N. Helsingfors (Bom.). - Ta. Tavastehus (Broth.). Vanaja, Hätilä (Thur.). - Kol. Mjätusova (Sahlb.).

S. Sk.-Mpd. Norbỵknöl.

N. Sm., A., Bu., JL., H.. NT.

Europa, Kaukasus, Alọier, Azoren. Kanaren.

\section{PYRAMIDULA}

Brid. Nlant. p. 20 (1819).

Kileine, einjährige Pfl. in lockeren, bleichgrünen Räschen. Stengel bis $2 \mathrm{~mm}$, einfach. Obere Blätter aufrecht und zu einer länglichen Knospe locker zusammenneigend, kielig-hohl, aus verschmälertem Grunde nach der Mitte verbreitert und dann lang und scharf zugespilzt, ganzrandig, $2-2,5 \mathrm{~mm}$ lang und $0,7-0,8$ mm breit: Rippe in der Pfriemenspitze endend. Seta $2-4 \mathrm{~mm}$, gerade, blassgelblich. Kapsel aufrecht, regelmässig, aus kurzem, dickem Halse oval bis fast kugelig, trocken und entleert deutlich tkantig, gelb oder bräunlichgelb: Zellen des Exotheciuns sehr locker und dünnwandig, um die Mündung einige Reihen querbreiter. Ring nicht differenziert. Peristom fehlend. Deckel klein, flach gewölbt, mit kurzer dicker Zitze. Haube bis nach der Entdeckelung bleibend, unter den Hals herabreichend, aus verengter l3asis nach oben blasig erweitert, 4kantig, mit kurzem, gebräuntem Schnalsel. Sporen 45-60 4 , rundlich oval bis nierenförnnig, gelb, glatt. Sporenreife zeitig im Frühling.

Einzige Art: 
280. Pyramidula tetragona (Brid.) Brid. Nant. musc. p. 20 (1819). [Gymnostomum tetragonum Brid. Muscol. rec. Suppl. I. p. 270 (1806).] - Fig. 38 A-D).

Auf feuchten Äckern, besonders auf İleefeldern.

F. Al. Saltvik, Kvarnbo und Liby (Bom.).

S. Sm., Srm., Upl., V'rml. und Dlr, an einzelnen Fundorten.

Europa, Nord-Amerika.

\section{FUNARIA}

Schreb. in L. Gen. pl. VIII. ed. II. p. 760 (1791); emend. Lindt. in Notis. Fauna \& FI. Fenn. Förh. XI. (1870).

Herdenweise wachsende bis rasenbildende, meist blassgrüne P\{l. Kapsel emporgehoben, aufrecht und regelmässig birnförmig oder schief birnförmig, hochrückig und dann aufrecht bis hängend. Deckel flach oder gewölbt, selten stumpl kegelig, ohne Zitze. Haube lange bleibenc, aufgeblasen kappenförmig, lang geschnäbelt, ganzrandig.
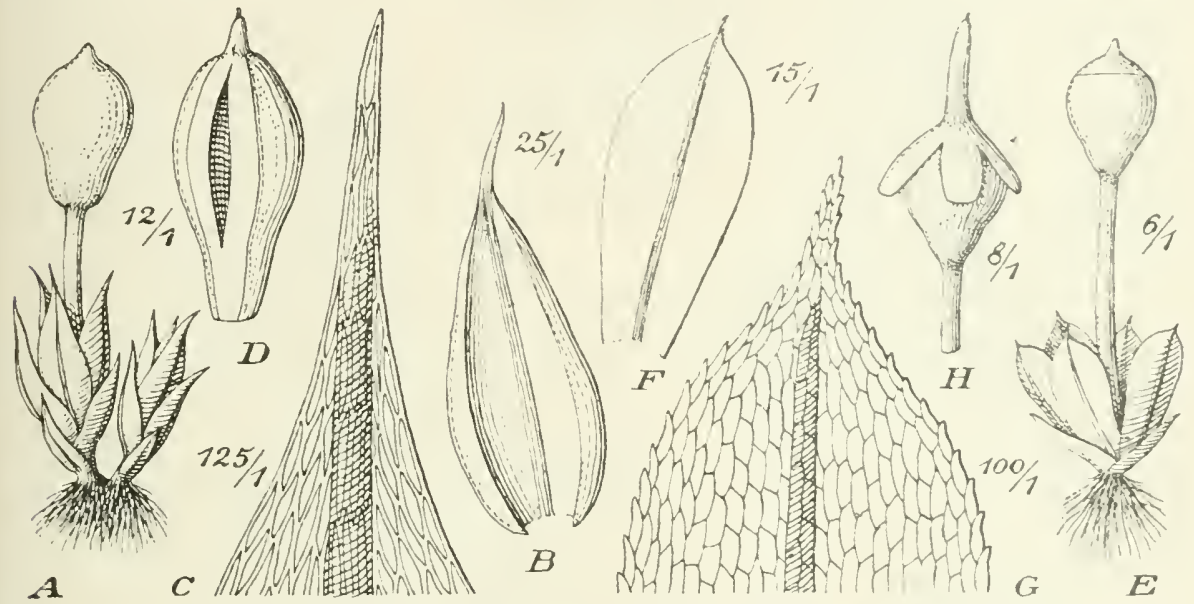

Fig. 38. A-D. Pyramidula tetragona (Brid.) Brid. A Fruchtende Pfl. (12 1): B Stammb. (25/1): C Blattspitze (125/1); D Haube (12/1). - E-G. Ihyscomilrium pyriforme (L.) Brid. E Fruchtende Pf1. (1/1): F Stammb. (15/1); G Blattspitze $(100 ; 1)$; G Kapsel mit Haube (8 1).

íbersicht der Arten.

A. Kapsel regelmässig birnförmig. Peristom ganz rudimentär.

a. Schopfblätter ungesäumt 282. F. fuscicularis.

b. Schopfblätter wulstig gelb gesäumt ................. 281. F. oblusa.

B. Kapsel schief birnförmig, hochrückig. Peristom doppelt.

a. Kapsel trocken stark längsrippig. Ring sich abrollend. 285. F. hygrometricu.

b. Kapsel trocken glatt. Ring fehlend.

«. Blätter oberwärts gesägt. Seta überall links geılreht. 28:3. F. culcarea.

$\beta$. Blätter ganzrandig oder oberwärts undeutlich stumpf gezähnt. Seta unten rechts, oben links gedreht

284. F. mediterranea.

Un t e rgatt. I. Entosthodon (Schwaegr. Suppl. II. P. I. fasc. 1, p. 14: 1823 als Gattung) Lindh. Musc. scand. p. 18 (1879).

Kleine Pll. Kapsel regelmässig oder fast regehnässig, glatt. Ring fehlend. Peristom einfach bis rudimentär oder fehlend. 
281. Funaria obtusa (Dicks.) Lindb. in Notis. Sällsk. Fauna et Fl. Fenn. Förh. XI. p. 65 (1870). [Bryım obtusum Dicks. Pl. erypt. fasc. II. p. 5, t. 4, f. 7 (1790). - Gymnostomum ericetorum Bals, et De Not. Pugill. No. 27 (1838). Entosthodon ericetorum Bryol. eur. fase. XI. p. 13, t. 3 (1841).]

Herdenweise wachsende, gelblichgrïne Pfl. Stengel 2--6 mm. Schopfblätter trocken schwach gedreht und aufrecht, feucht aufrecht-abstehend, aus deutlich verschmälerter Basis nach der Mitte verbreitert und allmählich zugespitzt, 22,5 $\mathrm{mm}$ lang und $0,4-0,5 \mathrm{~mm}$ breit, durch $1-3$ verdickte Zellreihen gelb gesäumt. kaum oder in der oberen Hälfte stumpfzähnig: Rippe meist mit dem Saume in ein Spitzchen verschmelzend. Seta gerade, $4-8 \mathrm{~mm}$, dünn, gelbrot, trocken links gedreht. Kapsel aufrecht, aus kurzem Halse kugelig-birnförmig, zur Reife purpurn, trocken nach der Entdeckelung unter der Mündung etwas verengt; Zellen des Exotheciums unregelmässig eng rektangulär, sehr dickwandig, un die Mündung bis 10 Reihen kleiner und querbreiter. Peristom ganz rudimentär. Deckel mit nach der Mitte in geraden Linien verlaufenden Zellen. Sporen 25-26 $\mu$, dunkel rotbraun. dichtwarzig. Sporenreife im Juni.

S. Boh. Kongälf.

N. $R$, an der Küste nicht selten.

Europa, Algier, Tunis.

var. Ahnfeltii (Fr.). [Gymnostomum Ahnfeltii Fr. Stirp. agr. femsj. p. 28 1825).]

Blätter steif aufrecht, locker dachziegelig, schmal verlängert lanzettlich, breiter gesäumt; Rippe fast austretend.

S. $S m$, und $V g$. an einzelnen Fundorten.

N. St. und $S B$, an wenigen Fundorten.

282. Funaria fascicularis (Dicks.) Schimp. Syn. p. 700,(1860). [Bryum fasciculare Dicks. Pl. crypt. fase. III. p. 3, t. 7, f. 5 (1793). — Entosthodon fascicutaris C. Müll. Syn. I. p. $120(18+8)$.]

Dicht gesellige oder lockerrasige grüne oder gelblichgrüne Pfl. Stengel bis $5 \mathrm{~mm}$. Schopfblätter trocken locker anliegend und etwas gedreht, feucht abstehend, breiter als bei der rorigen Art, sonst in der Form ähnlich, ungesäumt, bis zur Mitte oder weiter herab stumpfzähnig; Rippe ror oder mit der Blattspitze aufhörend. Seta gerade, $3-10 \mathrm{~mm}$, dünn, blassrötlich, trocken rechts gedreht. Kapsel aufrecht, aus kurzem Halse kugelig-birnförmig, zur Reife oberwärts oder einseitig lichtbraun, spater rutlichbraun, trocken nach der Entdeckelung unter der engen Mündung etwas eingeschnürt; Zellen des Exotheciums unregelmässig polygonal, etwas rerdickt, um die Mündung 3-4 Reihen kleiner und meist querbreiter. Peristom ganz rudimentär. Deckel mit in schwacher spiraliger Linksdrehung geordneten Zellen. Sporen 24-30 ", rostbraun, grobwarzig Sporenreife im Mai. - Fig. 39 A-E.

Auf Brach-, besonders Kleefeldern, an Graben- und Wegrändern.

F. Al. Saltvik, Kuggböle, Kvarnbo, Borgboda, Haraldsby und Rangsby (Bom.).

S. Sk, an wenigen Fundorten. Öl.

Europa, Algier.

Un t e rgat t. I I. Eufunaria Lindb. Muse. scand. p. 18 (1879).

Kỉleine oder grössere Pfl. Blätter ungesäumt. Kapsel geneigt bis hängend, schief birnförmig und hochrückig. Peristom doppelt, sehief nach rechts ansteigend: Peristomzähne lanzettlich-pfriemenförmig, an der Spitze zu einer Scheibe verbunden, rothraun, oberwïrts blassgelb, unten fein längsstreifig, oben papillös; inneres Peristom gelb oder orange, papillös, mit niedriger Grundhaut und lanzettlichen oder rudimentären, hinter den Zähnen stehenden Fortsätzen.

283. Funaria calcarea Wahlenb. in K. Vet.-Ak. Handl. XXV1I. p. 137, t. 4, f. 2 a-k (1806). [Funaria dentata Crome Samml. deutsch. Laubm. 2. Nachl. No. 12 c. diagn. (1806).] 
Kleine, herdenweise wachsende oder lockerrasige Pfl. Stengel l,is 5 mm. Schopfblätter aufrecht-abstehend, fast spatelfürmig, rasch in eine lange, feinc Spitze ausgezogen und in der oberen Hälfte stumpfzähnig, bis 2,j mm lang unl etwa $1 \mathrm{~mm}$ breit: Rippe vor der Blattspitze aufhörend. Seta 1-1,5 mm, gerarle, rötlich, trocken bis obenhin links gedreht. Kapsel geneigt, aus ziemlich langen, trocken faltigem Halse keulig-birnförmig, etwa $3 \mathrm{~mm}$ lang, trocken glatt uncl entdeckelt unter der Nündung eingeschnürt. Ring fehlend. Peristomzälnne mit seitlich etwas vortretenden Lamellen, ab und zu in der Mediane durchbrochen. Sponren 24-28 ", rostrot und grobwarzig. Sporenreife im Frühling.

S. Öl. und Gtl.

Europa, Kaukasus, Mesopotamien, Syrien, Nord-Afrika, Nord-Amerika.

284. Funaria mediterranea Lindb. in Öfr. K. Vet.-Ak. Förl. XX. p. $399(1863)$.

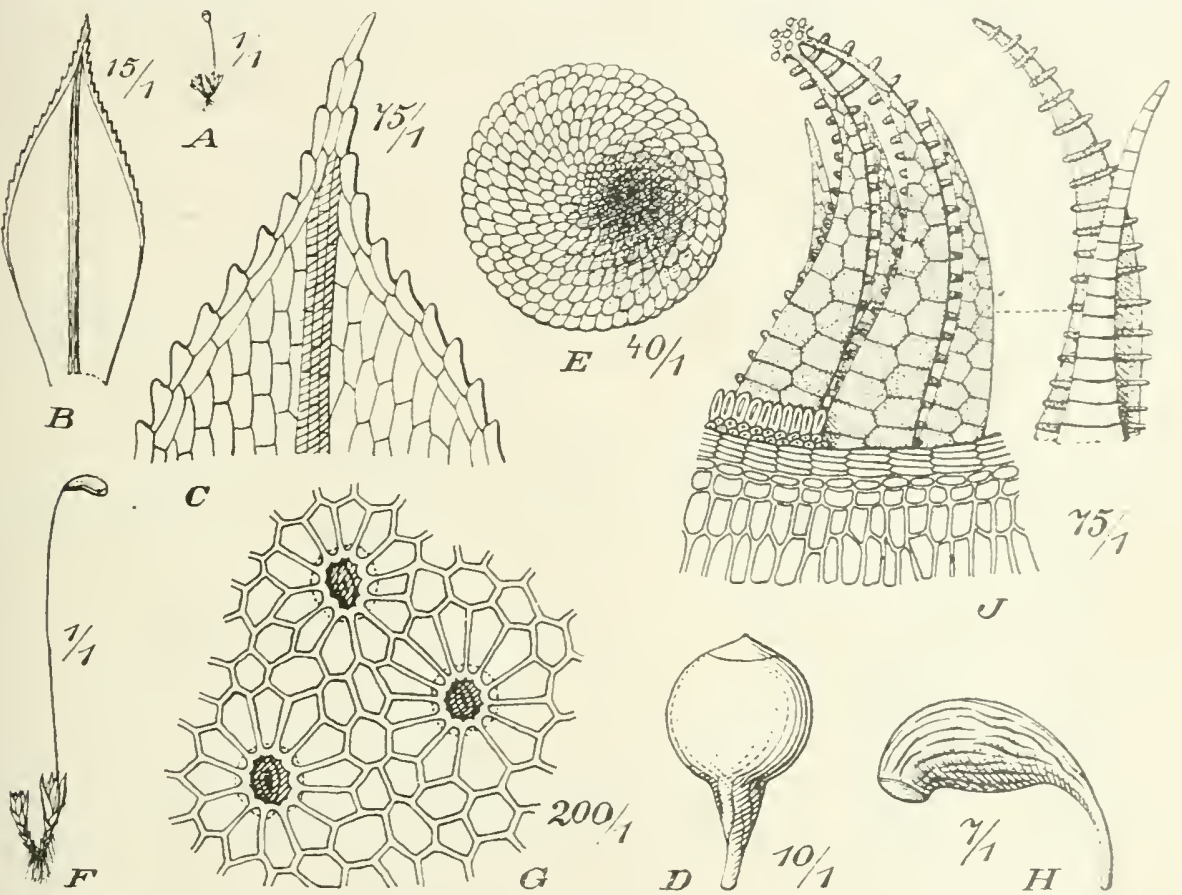

Fig. 39. A-E. Funaria fascicularis (Dicks.) Schimp. A Fruchtende Pfl. (1,1); B Stammb. (15 1): ( Blattspitze (15/1); D Kapsel im trockenen Zustande (10/1); E Deckel (40/1). - F-I. F. hyarometrica (L.) Sibth. F Fruchtende Pfl. (1/1); G Kapsel im trockenen Zustande (7/1); H Spaltöfnungen (200,1): I Peristom $(75 / 1)$,

Wuchs und Tracht wie bei der vorigen Art. Schopfblätter aufrecht-abstehend, fast spatelförmig, rasch in eine kürzere oder längere, hin- und hergebogene Pfriemenspitze ausgezogen, fast immer ganzrandig: Rippe vor der Blattspitze aufhörend. Seta bis $1 \mathrm{~cm}$, gerade, trocken unten links und oben rechts gedreht. Kapsel geneigt, aus etwas kürzerem, trocken zuletzt faltigem Halse geschwollen birnförmig, etwa $2 \mathrm{~mm}$ lang, trocken glatt, unter der Mündung wenig eingeschnirt. Ring fehlend. Peristomzähne nicht durchbrochen, ohne seitlich vortretende Lamellen. Sporen 18-25 $u$, rötlichgelb, fein gekörnelt. Sporenreife im Frülnling.

N. ST. Trondhjemsfjorden, Ladehammeren.

Europa, Kaukasus, Klein-Asien, Ägypten, Kalifornien.

285. Funaria hygrometrica (L.) Sibth. F]. Oxon. p. 288 (1794). [.Inium hygrometricum L. Sp. pl. II. p. 157 , (1763).] 
Kräftige, locker-oder dichtrasige Pfl. Stengel bis $3 \mathrm{~cm}$. Schopfblätter knospenförmig zusammensehliessend, hohl, länglich-eiförmig, kurz zugespitzt, bis 2,5 mm lang und etwa $1 \mathrm{~mm}$ breit, ganzrandig: Rippe in der Blattspitze versehwindend. Seta 2-6 cm, anfangs strohgelb und in Bogen herabgekrümmt, später gelbrot und aufrecht, trocken unten links, oben rechts gedreht. Kapsel horizontal oder hängend, geschwollen birnförmig, kleinmündig, zur Reife braun, trocken stark längsrippig. Ring 2reihig, spiralig sich abrollend. Peristomzähne nicht durchbrochen, mit seitlich weit vortretenden Lamellen. Sporen 15-18, auch bis $2 \overline{7}$ ", rostbraun, fein papillös. Fruchtreife im Sommer. - Fig. 39 F-I.

In Ausstichen und Gräben, an Wegrändern, llauern, auf Kohlenmeilern und an Branclstätten in Wäldern.

In bebauten Gegenden Fennoskandias - fq., auf kalkhaltjger Erde und an Branditäten oft cop. $L e$, und $L i$. spärl. bis in die Birkenregion. Lt. Suorsajok im südl. Teile (Roiv.). Kola (Karst.). Lmur. Bjelousiha am Yoronjeflusse (Broth.); zw. Varsinsk und Jenjarr (Brolh.). - Lp. Ponoj (Sahlb., Broth.). Kosmopolit.

var. nana C. Hartm. Sk. Fl. 9. ed. II. p. 12 (1864).

Schlanke Pfl. Seta $1-1,5 \mathrm{~cm}$. Kapsel sehr klein, undentlieh gerippt. Sporen etwa $15 \mu$, fast glatt.

F. Ik. Netsäpirtti, Koukkuniemi, auf sehr feinem Sande (Lång); Tuuskajoki (H. Lindb.).

S. Fundortsangaben feblen.

Zu var. nana neigende Formen.

F. Al. Saltvik, Rangsby und Ryssö (Bom.). - St. Ikaalinen (Sundv.). - Kon. Valkeamäki (Simm.); Tiudie (Sahlb.). - Ok. Kajana, Kajaneborg (Lackstr.). - Ob. Kiiminki (Sahlb.). Ii, Kauppila (Brenn.).

\section{Unterreihe SPLACHNINEAE.}

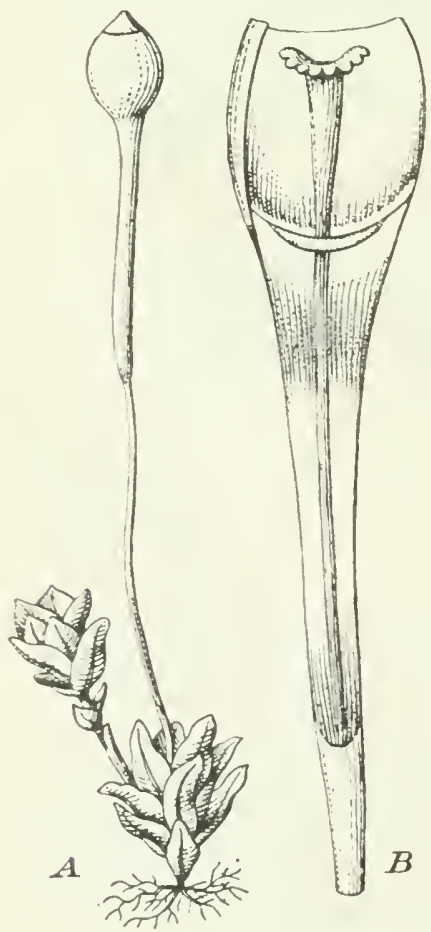

Fig. 40. Oedipodium Griffithianum; (Dicks.). A Fruchtende Pfl., vergr. B Lälgsichnitl durch die kapsel, vergr. (Nach Braithwa it p).

Spaltöffnungen von mehreren Zellen umgeben. Peristom seheinbar einfach, zu Paarzähnen verbunden.

\section{O E D I P O D I A C E A E.}

Synözisch uncl autözisch; Antheridien gross, länglich, mit keulenförmigen Paraphysen. Fleischige, weiche Pfl. in lockeren, sattgrünen, leicht aufgeweichten Rasen oder herdenweise. Stengel $1-2 \mathrm{~cm}$, olne Zentralstrang, aus lockeren, gleichartigen Zellen gebildet, am Grunde mit Rhizoiden, locker bebliattert, mit subfloralen Sprossen. Untere Blätter klein, entfernt, obere viel grösser, schopfig zusammengedrängt, aufrecht-abstehend, breit verkehrt eiförmigspatelig, abgerundet, flach- und oben ganzrandig, am Grunde mit langen, geschlängelten Cilien; Rippe sehr breit und flach, vor der Blattspitze auflıörend, am Rüßken stark vortretend, aus gleichförmigen, dünnwandigen Zellen gebildet; Zellen locker, dünnwandig, glatt, am Grunde rektangulär, die mittleren vieleckig-oval, die oberen vieleckigrundlich, am Randle kleiner, fast rektangulär bis quadratisch, glatt. Seta fast fehlend. Kapsel aufrecht, regelmässig, mit fast kugeliger Urne und sehr langem, schwammigen, bleichem, fast bis zur Vaginula mit sehr grossen Spaltöfnungen versehenem Halse. Ring und Peristom fehlend. Sporen mittelgross. Deckel hochgewölbt bis kurz- und stumpfkegelig. Haube klein, 
kegelig-zylindrisch, einerseits gespalten, glatt, flüchtig. -- Vegetative Vermehrung durch in Körbchen gebildeten und meist mit Antheridien zusammen stehenden Brutkörpern.

Einzige Gattung:

\section{OEDIPODIUM}

Schwaegr. Suppl. II. P. I. fase. 1. p. 15 (1823).

Einzige Art:

286. Oedipodium Griffithianum (Dicks.) Schwaegr.

Auf schattiger Humuserde, in Erdhöhlungen, feuchten Felsspalten und auf Baumwurzeln.

S. An einzelnen Fundorten in LuL., PL., LyL. und $N b$.

N. Am reichlichsten in Westlandet, kommt aber auch in den inneren Teilen, besonders im Fjeldgebiete vor und dringt weit über die Baumgrenze hinauf.

England, Schottland, Grönland, Alaska und Falkland.

\section{S P L A C H N A E A E.}

Autözisch oder diözisch, sehr selten pseudautözisch, zuweilen mit eingemischten Zwitterblättern; die or kopf- oder fast scheibenförmig, mit längeren, , keulenförmigen Paraphysen. Einjährige oder ausdauerncle, rasenbildende, mehr oder minder durch papillösen Rhizoidenfilz verwebte Sumpf- und Bergmoose, die vorzugsweise Humuserde und verwesende vegetabilische oder animalische Stoffe bewohnen. Stengel meist 5kantig, zart und weich, mit grossem Zentralstrange, lockerem Grundgewebe, ohne differenzierte Mantelzellen; mit subfloralen Sprossen und häufig mit Keulenhaaren in den oberen Blattachseln. Blätter meist nicht hygroskopisch, weich und schlaff, trocken \pm einschrumpfend, \pm breit und von wechselnder Form; Rippe meist vor der Blattspitze verschwindend, in der Pegel mit 2 ventralen Deutern, einer Begleitergruppe, einem unteren Stereidenbande und differenzierten Rückenzellen; Zellen sehr locker, parenchymatisch, rechteckig bis hexagonal, am Blattgrunde gestreckt, dünnwandig, glatt, olnne Tüpfe] und mit spärlichem Chlorophyll. Seta aufrecht, kürzer oder länger, zuweilen sehr lang. Kapsel aufrecht, regelmässig, bei unseren Gattungen langhalsig oder mit grosser, farbiger Hypophyse. Spaltöffnungen im Hals- oder im Hypophysenteile, zahlreich, gross, oberflächlich. Ring meist fehlend. Peristom einfach. Zähne 16 , flach, einzeln, paarig oder doppelpaarig verbunden, mehr oder minder hygroskopisch, fein punktiert, quergegliedert. Columella bleibend, an der Spitze meist verdickt, nach der Entleerung der Urne eingeschlossen oder hervorragend. Deekel meist gewölbt, zuweilen verlängert kegelförmig, selten nicht differenziert. Haube meist klein, kappen- oder kegelförmig.

Übersicht der Unterfamilien.
A. Kapsel ohne Hypophyse
I. Taylorioideac.
B. Kapsel mit Hypophyse
II. Splachnoideae.

Übersich t der Gat t u n g n.

A. Kapsel ohne Hypophyse. Haube bauclig-kegelig, am Grunde verengt 69. Tayloria.

B. Kapsel mit Hypophyse.

a. Hypophyse wenig dieker als die Urne.

«. Seta dick, gefärbt. Haube kappenförmig 70. Tetraplodon. 
ア. Seta zart, hyalin. Haube kegelig 71. Haplodon.

b. Hypophyse \pm aufgeblasen. Columella vortretend.

Peristomzähne gekammert

72. Splachnum.

\section{TAYLORIOIDEAE.}

\section{TAYLORIA}

Hook. in Journ. Sc. and Arts No. 3, p. 144 (1816); emend. Mitt.

Musc. Ind. or. p. 57 (1859).

Blätter nach oben allmälilich grösser und schopfig gehäuft. Kapsel in einem mehr oder minder verlängertem Halse allmählich herablaufend, entdeckelt meist verkürzt und querrunzelig oder unter der Mündung eingeschnürt: Zellen des Exotheciums meist querbreiter und mit stark verdickten Querwänden. Peristomzähne nicht gekammert. Columella an cler Spitze hutförmig verflacht und öfter nach der Entdeckelung der Urne vortretend. Deckel meist kegelig, selten halbkugelig. Haube bauchig-kegelig, am Grunde verengt und lappig.

\section{Übersicht der Arten.}

A. Peristomzähne nach der Entdeckelung ungeteilt.

a. Blätter stumpf bis abgerundet.

«. Peristomzähne gleichweit voneinander gestellt.

Sporen glatt

291. T. lingulata.

ค. Peristomzähne paarig genähert und durch Querglieder verbunden. Sporen papillös

290. T. Froelichiana.

b. Blätter scharf zugespitzt.

«. Stengelfilz ohne Brutkörper

287. T. tenuis.

ק. Stengelfilz mit Brutkörper

288. T. serrata.

B. Peristomzähne nach der Entdeckelung in der Längs-

linie sich trennend.

a. Blätter lang zugespitzt. Peristomzähne wenig oder

nicht rankenartig

b. Blätter stum! : mi! kurzem Spitzchen

289. T. acuminata.

Unt e rgatt. I. Eutayloria Lindb. Musc. scand. p. 19 (1879).

Autözisch; C Blüten kopfförmig. Blätter in eine scharfe Spitze verschmälert, oberwärts gesägt. Peristomzähne frei, sehr hygroskopisch, feucht nach innen gekrümmt und spiralig eingerollt, trocken zurückgeschlagen und der Urnenwand anliegend. Sporen $12-18 \mu$, glatt.

287. Tayloria tenuis (Dicks.) Schimp. Syn. 2. ed. p. 360 (1876). [Splachnum tenue Dicks. Pl. crypt. fasc. II. p. 2, t. 4, f. 2 (1790).]

Schlanke, lockerrasige, gelblichgrüne Pfl. Stengel bis $2,5 \mathrm{~cm}$. Blätter aus schmalem Grunde breit spatelförmig, kurz zugespitzt, bis 2,5 $\mathrm{mm}$ lang und 1,3 mm breit, nit abwärts zurückgeschlagenen, an der Spitze stumpf gesägten Rändern; Rippe vor der Blattspitze endend. Seta $1-3 \mathrm{~cm}$, dünn, schwach längsfurchig, tiefrot, im Alter von oben herab sich schwarz färbend. Kapsel klein, plötzlich in den engen und kürzeren Hals verschmälert, entdeckelt sehr verkürzt und weitmündig, zuletzt schwärzlichbraun. Columella gewöhnlich weit vorragend. Peristomzälne paarweise genähert, dunkel braunrot, trocken der Kapselwand dicht anliegend. Sporenreife im Juni. - Fig. 41 A-D.

Meist auf altem Dünger oder mit Tierexkrementen gemengter Erde, zuweilen auch auf humusreicher Erde und an morschen Baumstrünken. 
F. Al. Saltrik, Krarnbo, Andtböle, Kuggböle und Lafö (Bom.). Sund. Gesterty (Ranck.). Ab. Abo (Arrh.). Merimasku (Karst.). Pargas, Gunnarsnäs (F. E.). Karis]ojo, Tammicto (E. af H.).

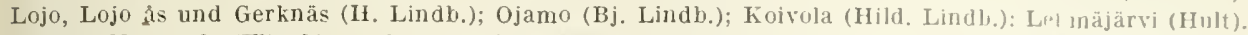
Vichtis, Nummela (Flinck). - N. Kyrkslätt (Nyb.). Esbo, Gräsa (Broth.). Helsingfor- (Buch). Sibbn, Husö (Buch). Lappträsk (Sael.). Elimäki, Mustila (Tigerst.). Orimattila, Nienıi, Anttila (Ringt)lorn). Ik. Pybäjärvi, Riiska (Lång). Sakkola, Taipale (H. Lindb.). — St. Birkhalia (Simm.). Ikalis, Nygård (Sundv.). Orihvesi, Juurakka (Broth.). - Ta. Vanaja. Aulanko (Unon.). Hausjärvi ((j;riff.). Hollola (Broth.). - Kl. Valamo (Malmb.). - Oa. Närpes. Ÿttermark, an vielen Fundorten und reichlich (E. af H.). Bötom, Pyhävuori (E. af H.). Kaskō (Nerv.). Kvarken, ziemlich gemein (Karst.). - Tb. Toirakka (E. af H.). Jonginkangas, Lekojärvi und Lassila (E. af H.). Petäjäves, Sajıentaus (Ruor.). Kivijärvi, Hilma (Broth.). - Sb. Iisalmi (Sahlb.). Jlaaninka, an mehreren Fundorten (Rojy.). Pielavesi, an mehreren Fundorten (Rojy.). Nilkiä, an mehreren Fundorten (Kłyhk.). Kuopio, Neulamäki (Roiv.). Jorois, Jārvikylä (H. Lindb.). - Kon. Suosaari (Simm.). - Om. Alajärvi, Kirchdorf (Backm.). - Ok. Kajana (Kyyhk.). Sotkamo, an mehreren Fundorten (Kyyh.). Suomusalmi (Lackstr.). Kpom. Suondali (Bergr.). - Ob. Turtola (Hult). - Ks. Kuusamo, Kitkaniemi, Alivenperäraara (E). af H.). Juuma (Broth.). - Lkem. Kolari (Hult). - Lim. Kandalaks (Broth.).
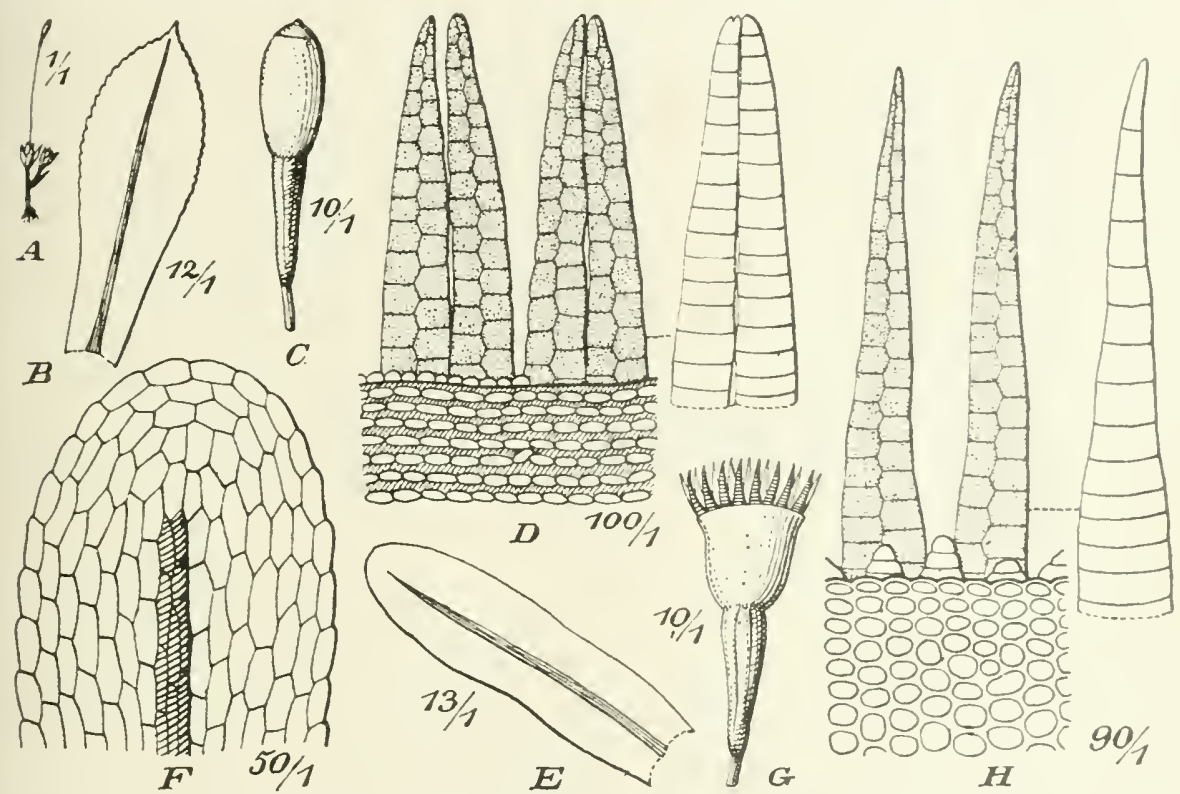

Fig. 41. A-D. Tayloria tenuis (Dicks.) Schimp. A Fruchtende Pfl. (1/1); B Stammb. (1: l); C Kiapcel im trockenen Zustande (10/1); D Peristomzähne (100 1). - E-H. T. lingulata (Dicks.) Lindb. E Stammb. (13/1); F Blatt'spitze (50/1); G Entdeckelte Kiapsel im trockenem Zustande (10 1); H Peristomzähne $(90,1)$.

S. Im ganzen Gebiete von $S m$, bis $N b$, zerstreut. Scheint in Bl., sk, Hll, und Boh. zu fehlenl. In L. nur von 2 Fundorten in $L u L$. bekannt.

N. Im ganzen Gebiete bis $70^{\circ} 45^{\prime}$ zerstreut, meist in der subalpinen, =elir selten in der alpinen Region.

Zentral-Europa, Gross-Britannien, nördl. Teile von Nord-Amerika.

288. Tayloria serrata (Hedw.) Bryol. eur. fasc. 23/24, p. 6, t. 1 (18tt): emend. Schimp. Syn. 2. ed. p. 359 (1876). [Splachnum serratum Hedw. Sp. nusc. p. 53, t. 8 (1801).]

Weniger schlanke, mässig lockerrasige, freudig grüne Pfl. Stengel bis 3 cm. Blätter verkehrt eilänglich bis verlängert spatelförmig, in ein zurückgehrümmtes Spitzchen verschmälert, bis $4 \mathrm{~mm}$ lang und $1,5 \mathrm{~mm}$ breit, mit abwärts zurückgeschlagenen, an der Spitze stumpf gesägten Rändern; Rippe vor der Blattspitze endend. Seta $1-3 \mathrm{~cm}$, dick, gelbrot, rund. Kapsel etwa 3 mm, oval, allnällich 
in den gleichlangen oder etwas längeren Hals verschmälert, nach der Entdeckelung nur wenig verkürzt, gelb, zuletzt schwärzlichbraun. Columella bald einschrumpfend. Peristomzähne paarweise genähert, dunkelbraun, trocken der Kapselwand locker anliegend. - Vegetative Vermehrung durch spindelförmige, goldgelbe, fast glatte, 6-izellige, rhizoidenbürtige Brutkörper.

S. Sm. Jönköping. Jmt. Klöfsjö.

var. flagellaris (Brid.) Bryol. eur. fasc. $23 / 21$ (1S+4), -- Splachnum flagellare Brid. Muscol. rec. Suppl. P. I. p. 145 (1806).

Äste sehr verlängert, oft rlie etwas geneigte Kapsel ïberragend.

N. Ne. Bykle. ornefjeld, $800 \mathrm{~m}$, auf Torfdächern. Ster.

Zentral-Europa und nördl. Teile ron Nord-Amerika.

289. Tayloria acuminata (Schleich.) Hornsch. in Flora VIIl. P. I. p. 78 (1826); Lindb. in Rer. bryol. 18st, p. 17. [Hookeria acuminala Schleich. in litt.; C. Nüill. Syn. I. p. 136 (18.48).]

Schlanke, lockerrasige, grüne Pfl. Stengel nur wenige mm. Blätter schlaff, locker anliegend oder abstehend, trocken verbogen, rhombisch-lanzettlich, lang zugespitzt, mit zurückgekrümmter Spitze, bis $2 \mathrm{~mm}$ lang und $0,85 \mathrm{~mm}$ breit, mit abwärts zurückgeschlagenen, an der Spitze gezähnten Rändern; Rippe in der Blattspitze aufhörend. Seta $1-1,5 \mathrm{~cm}$, dünn, rot. Kapsel meist nur $0,75 \mathrm{~mm}$, oval oder elłiptisch, trocken fast kugelig, plötzlich gegen den längeren, dünnen Hals abgeschnürt. nach der Entdeckelung wenig verkürzt, grünlichgelb, dam bleichbraun. Columella meist nur wenig vortretend. Peristomzähne etwa 0,16 mm lang, nach der Entdeckelung in der Teilungslinie sich trennend, trocken der kapsehwand anliegend, wenig oder nicht rankenartig. Deckel aus niedrig-kegeliger Basis plötzlich schief geschnäbelt. - Vegetative Vermehrung durch zahlreiche, keulenförmige oder ein wenig gekrümmte, an dem freien Ende abgerunrlete, deutlich papillöse, 2-3zellige, rhizoidenbïrtige Brutkörper. Sporenreife im August.

Auf feuchtor Erde und auf faulem Holze.

N. K. Gudbrandsdalen, an rereinzelten Fundorten in den unteren Teilen der subalpinen Region. ST. Durrefjeld, in der Region der Birken und Weiden.

Obere Berg- und Alpenregion ron Zentral-Europa, Zentral-Asien, Rochy MIts. ¿'berall sehr selten. var. brevifolia Hag. in Kgl. Norsk. Vid. Selsk. Skrift. 1910. No. 1, p. 11 (1910). Blätter breit ovał bis verkehrt-eiförmig, ziemlich rasch zugespitzt, bis $2 \mathrm{~mm}$ lang und $1 \mathrm{~mm}$ breit. I reckel gewöibt, mit WTarze oder kegeligem, stumpfem Spitzchen.

N. $S T$. Opdal, Kingsiold, $200 \mathrm{~m}$, auf einem Torfache spärlich.

290. Tayloria splachnoides (Schleich.) Hook. in Brande, Journ. Sc. Arts III. p. 14 (1816): Lindb. in Rer. bryol. 1884, p. 18. [Hookeria splachnoides Schleich. Cat. 1815; Schwaegr. Suppl. I. P. I1. p. 340, t. 100 (1S16).]

Kräftige, lockerrasige, freudig grüne, $1-2 \mathrm{~cm}$ lohe Pfl. Blätter fast steif, aufrecht, trocken angepresst und etwas runzelig-faltig, länglich-zungenförnnig, stumpf, mit kurzem, hohlem Spitzchen, bis $4 \mathrm{~mm}$ lang und $1.6 \mathrm{~mm}$ breit, mit abwärts zurückgeschlagenen, an der Spitze stumpf und grob gesägten Rändern; Rippe weit vor der Blattspitze endend. Seta $1-2,5 \mathrm{~cm}$, dick, gelbrot. Kapsel zuweilen ein wenig geneigt, länglich-zylindrisch, L'rne bis $4 \mathrm{~mm}$ lang, allmählich in den gleichlangen, verschmälerten Hals übergehend, entleert stark verkïrzt, lichtbraun. Columella weit vorragend. Peristomzähne bis $1 \mathrm{~mm}$ und darüber, nach der Entdeckelung in der Teilungslinie sich trennend, trocken zurückgeschlagen und rankenartig gewunden. Sporenreife im August.

Auf feuchter Humuserde, an steinigen Ablängen, Bachrändern und in Wäldern.

F. K. Kuısamo, Paanajärvi, Mäntyvaara, im Fichtenwalde (Broth.).

N. $B r ., K ., I I .$, St. und No., an vereillzelten Fundorten.

Obere Berg- und Alpenregion von Zentral-Eurona, nördl. Teile voll Nord-Amerika. 
Un te rgat t. I I. Cyrtodon (R. Br. in Parry I. Voyage p. 299: 1821) I.indb. Muse. scand. p. 19 (1879).

Aıtözisch, oft synözisch; ơ Blüten knospenlörmig. Blätter hohl, stumpl, meist ganzrandig, mit abwärts zurückgeschlagenen Rändern; Rippe vor der 13lattspilze aufhörend. Zähne des äusseren Peristoms wenig hygroskopisch, nie auswärts oder einwärts geschlagen, leucht kuppelartig zusammenneigend. Sporen gross, dicht- und feinwarzig.

291. Tayloria Froelichiana (Hedw.) Mitl.: Lindt. Muse. scandl. p. 19 (1879). [Splachnum Froelichianum Hedw. Deser. I11. 1). 99, t. 10 (1792). - Dissodon Froelichianus Grev. et W. Arn. in W. Arn. Disp. nseth. 1). 13 (1825).]

Ziemlich schlanke, herdenweise wachsende oder mässig dichtrasige, licht orler gelblichgrüne, glänzende Pfl. Stengel bis 3 , selten bis 5 cm, mit farst keulenförmigen lnnovationen. Blätter loeker anliegend, eilänglich bis fast zungenförmig, bis $2 \mathrm{~mm}$ lang und $1 \mathrm{~mm}$ breit. Seta $8-1+\mathrm{mm}$, diek, rot. Kapsel aulrecht oder etwas geneigt, breit oval, in dem gleiehlangen l fals herablaufend, bräunlich rotgelb, zuletzt rötlichbraun, trocken und entleert fast kugelig. Columella zurïckschrumpfend. Peristomzähme am Grunde anfänglich vereinigt. später paarig genïhert oder hier und da durch Querglieder verbunden, gell, Sporen 3,j- $42 \mu$, maun. Sporenreife im August.

Auf feuchtem Humus an steinigen Abhängen und in schaltigen Felsspalten. meist in der alpinen Region.

F. Lt. Bumandsfjord, in der Nähe des schmelzenden Schnees, reichlich aber nur sleril (Broth.).

S. TL.-PL., Jmt., Hrid.. auch dus Vrml. angegeben.

N. Dovrefjeld und Tromso Amt an melseren Fundorten, sonst nur selten. Nordgrenze $69^{\circ} 46^{\prime} \mathrm{n}$. Br. Hochgebirge von Zentral-Europa. Schottland, Kaukasus. Hintalaya, Gronland und Rocky Mft:

292. Tayloria lingulata (Dicks.) Lindlb. Nusc. scand. p. 19 (1879). [Splachnum lingulatum Dicks. Pl. crypt. fase. IV. p. I, t. 10, I. 6 (1801). - Dissodon splachnoides Grev. et W. Arn. in Mem. Wern. soc. V. p. 168 (1825).]

Ziemlich kräftige Pfl. in oft ausgedehnten und ziemlich dichten, oben lebhaft bis chnkel grünen, innen schwärzlichen Rasen. Stengel bis j cm, mehrmals gabelig oder büschelig geteilt. Blätter sehr locker anliegend, trocken etwas gedreht, verkehrt eilänglich und zungenförmig, selten in der Spitze stumpf gezähnt. lis $3 \mathrm{~mm}$ lang und $1,3 \mathrm{~mm}$ breit. Seta $1-5 \mathrm{~cm}$, llünn, rot. Kapsel aufrecht, selten etwas schief, aus gleichlangen oder wenig kürzerem Halse dick oval, entleert kugelig-kreiselförmig. Columella bald zurückschrumpfend. Vorperistom anwesend, aus 32 den Nündungsrand nur wenig überragenden, stumplen, braunen Platten gebildet. Peristomzähne gleichweit gestellt und am Grunde vereinigt, orange. Sporen 2.t 3.) $\mu$, grimlichgelb. Sporenreife im Juli und August.

Auf leuchter, humusreicher Erde an Bach-, Fluss- und Seeulern und in Nlooren, zuweilen auch an nassen Felsen und an Steinen in Bächen.

F. Ok. Pallamo, Melalahti (Kyyhk.). Ristijarvi, Mylypuro (Lackstr.), - $K$. Kusumo, an vielen Fundorten (Nyb.. sil., Brolh.. E. af H.). - Lkem. Kittilä. Aakenusjohì (Hult). sodankỵlä. Jouttenknski (Hult). Luolajärvi, an vielen Fundorten (E. af H.). - Le. Ziemlich gemein in der Birkenregion (Norrl.) und auch aus der Kieferregion bekannl (Wahlenb.). - Li. Inari, Kultala, an mehreren Fundorten bei Vaskojoki und Tanajoki; Kodossuannanpää (Kihlm.). Utsjoki, an einigen Fundorlen in der Birkenregion (Hult): Jalgelvalgi und Aittijoknjalbne (Ranck.). Suolaselkä (Vain.). - Lim. Kandalaks und Hibinä (Brolh.). Imandra (Angstr.). Seäptiroaivi (Lmnan.). - Lt. Tsipnavolok. Subovi und Vaidoguba (Broth.). - Lmur. Kildin und Gavrilova (Brolh.). - Lp. Ponoj (Broth.). Hapajow (Kihlm.).

S. TL.-Mrjd., seltener in den Küstenprovinzen und an vereinzelten Fundorleu in Gstr.. Dlr. und $\ddot{g} g$.

N. Ziemlich verbreitet, vom Meere bis über die Baumgrenze steigend. an häufigsten in der subalpinen Region. Nordgrenze bei $70^{\circ} 40^{\circ} \mathrm{n}$. Br.

sibirien und nördlichste Teile von Nord-Amerika. 


\section{TETRAPLODON}

Bryol. eur. fasc. 23/24 (18+4).

Autözisch: o Blüten koplförmig. Rasen dicht, mehr oder minder polsterartig. dureh Rhizoidenfiłz lest verwebt. Blätter fast gleichförmig, nur die Schoplblätter etwas grösser, in eine Pfriemenspitze verschmälert, hohl und flachrandig. Seta dick. Kapsel nach der Entdeckelung nicht verkïrzt; Urne klein, fast walzenförmig, lederartig; Hypophyse etwas dicker und auch länger als die Une, nach der Reife sich vergrössernd; Zellen des Exotheciums der Une in der Mehrzahı runcllich und gleichmässig verdickt oder mit stärker verdickten I.ängswänden, um die Münlung viele Reihen querbreiter. Zähne des äusseren Peristom rotgelb, zu I Doppelpaarzähnen, später zu \& Paarzälnnen tast bis zur Mitte verbunden, sehr hygroskopisch, feucht einwärts zusammenneigend, trocken zurückgeschlagen-anliegend. Columella nach der Entdeckelung zuriekschrumpfend. Sporen $\&-12 \mu$, blassgelb oder gelbgrün, glatt. Deckel stumpf kegelförmig. Haube klein, kegel-kappenförmig, einseitig geschlitzt.

\section{íbersicht der Arten.}

A. Blätter almählich in eine sehr lange Pfriemenspitze verschmälert, in der oberen Hällte entlernt gesägt. Seta

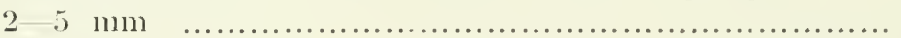

B. Blätter plötzlich in eine Pfriemenspitze versebmälert, ganzrandig. Seta länger.

a. Blätter sehr lohl; Rippe zart 295. T. urceolatus.

1). Blätter weniger hohl: Rippe kräftiger, ann Grunde durch zweischichtige subkostale zellen verbreitert

293. T. anguslatus.

293. Tetraplodon angustatus (L. lil.: Sw.) Bryol. eur. 1. c. Mon. 4, t. I. [Splarhnum angustalum (1. fil.) Sw. in Meth. nunsc. p. 33 (1781).]

Rasen gelhgrïn, $1-6$, selten his 11 cm hoch. Blätter aufrecht-abstebent, lïnglich-lanzettlich, almählich in eine sehr lange, gewundene Pfriemenspitze verschmälert, bis $5 \mathrm{~mm}$ lang und $1,5 \mathrm{~mm}$ breit, in der oberen Hälfte entfernt gesägt: Rippe in der I’friemenspitze erlöschend. Perichätialblätter ganzrandig, sehr lang, oberwärts fast gekräuselt, die inneren sehr schmal, ohne Rippe. Seta $2-5$ mm. rötlichgelb. Kapscl sur wonig ïber die Spitzen der Perichätialblätter vorragend; Urue oval bis zylindrisch, lichtbraun, nach der Entdeckelung rotbraun; Hypophyse fast doppelt so lang. anfangs verkehrt-kegelförmig und olivenfarben, nach der Entleckelung erweitert, vertängert birnförmig und gebräunt: Spaltöffnungen nur im oberen Teile der Hypopliyse. Sporenreife in Frühling.

Aul verwesenden tierischen Stoffen, nacktem Erdboden, Kiefernwnzeln und faulendem Holze in trockenen Kiefernwäldern, auf Heiden und an trockenen Felsen.

F. V. Lapplik (Linal sucksd.). - St. Eura (Rönb.). Birkkala, Linnantuori (Hjelt). Ruovesi, Ritonieni (Lindem.). - Ta. Vanaja (Tlurén). Lammi, Evois (Norrl.). Padasjoki, Sikomäkj (Norrl.). Korpilahti, Päiväkunla (Vain.). - Sa. Kangasniemi (Broth.). - Kl. Suistamo, Loimala, Songerjärvi (Broth.). - Kol. Suopohja und Lischma (Simm) Perguba (Kullh.). - Tb. Pihtipudas (Broth.). Viitasalari, I’iojärvi und Hakola, Kalliojärvi (Broth.). Konginkangas, Lassila und Leonmaa (E. af H.). Trıiviıki (E. af lI.). Jänkäjä!vi (Norrl.). Saarijärvi, Pyhähäkki (E. af H.). Kivijärvi, Kinnula, Hanhikangas (E. af Il.). - sib. Nilsä, Kirchdorl (Kyyhk.). Maaninka, Pöjä (Kyyhk.); Haafala, Mäenpäänkalliı (Roiv.). Luopio, liasurila (Korhonen); Ristavesi (Malmo.). - Kon. suojärvi (Kullh.). - Om. Pedersöre (Fontell). Lestijärvi, Kangasvieri (E. af H.). HaIso, an Wege nach Länlläpatti reichl. (E. af H.). Perho (E. af I1.), - Oh. Kajana (Broth., Kyyhk.). Sotkamo, Vuokatti (Broth.); Sapion kangas (Kyyhk.). kuhmonieni, an vie\}en Fundorten (L. af H.). Puolanka, Pyssyaara (Kyyhk.). - Kpom. Jyskjäri, lierovaara (Bergr.). Soroka und an Segflusse (Sahlb.). - ob. Vaala (Björklund). Pudasjärvi, Ii und Ranua, an vielen Fundorten (E. af H.). Rovaniemi, Tepojärvi und Lohiniva (Hull). Turtola, Koskenniemi (Hult). - K. Pudasjäri, Homevara (E. af H.); Iso-Syöle (Brotl.). Kuusano, an vielen Fundorten (Broth., E. af H1.). - Lkem. Kulari, Sieppijärvi (Hjelt) und Ylläsiaari (Hult). Sodankỵä, Sompio 
(Hult). Knolajäri, von vielen standorten (E. af H.). - Le. Ziemlieh gemein in der legrion der Nadplwä]der (Norrl.). - Li. Inari, Muddusjarvi (Silén); Muothataival, Toivoniemi, Vaylä mud ylijärviKaamas (Hult). Utsjoki (J. M. af Tengström), - Lim. Kandalaks und zwischen Intandril und kulit (Broth.). - Ll. In sudd. Teile seltener als T. bryoides (Roir.). Kola. Kitovka und t'sijllitoluk (l3roth.). - Lmar. Teribjerka und Garrilova (Broth.). - Lp. lomoj (13renu., Brotlı.).

S. TL.-Upl., I'sm., Trml., bis $700 \mathrm{~m}$. In Sidschwedten fehlend, in sin. und ön. nur vin vereinzelten Fundorten bekannt.

N. Hauptsächlich in den imeren Teilen rerbreitet. mit \%entrum aul dem Dovrefjeld, neist in del. subalpinen Region, nur selten über die Baungrenze steigend. Vordgrenze $70^{\circ} 40^{\prime} \mathrm{n}$. Br.

Obere Berg- und Alpenregion von Zentral-Europa, Nord-Italien und schothand und nordlichste Teile von Nord-Amerika.

var. flagellaris Hag. in Kgl. Norsk. Viel. Selsk. Skrift. 1910, No. 1. 1). 1.5 (1910). Äste sehlank, loeker beblättert.

N. $B r$. Gransherred, Bolkesjo. SB. Roldal, Roldalsfjeldet; iranrin.

var. pallidus Hig. 1. c.

Niedrige Pfl. Seta länger. Kapsel gelb; Hypophyse (2ng.

N. Br. Gransherred, Tirioset. K. Vang, Bergselven, $500 \mathrm{~m}$.

294. Tetraplodon bryoides (Zoeg.) Lindb. Musc. seand. p. 19 (1879). [Splachnum bryoides Zoeg. in Olafs, et Porels. Reis. Isl. 2, p. 12 (1772). S Splachnum mnioides (L. fil.) Sw. Meth. muse. p. 16 (1781). - Telraplodon mnioides Bryol. eur. lase. $23 / 24$, p. 5, t. $2(1841)$.]

Rasen gelbgrin odler grün, 1-6 em, selten höher. Blätter locker anliegend, trocken etwas gedreht, länglich-eilörmig, meist schnell in eine lange, geschlängelte Pfriemenspitze zusammengezogen, bis $5 \mathrm{~mm}$ lang und $1,5-2 \mathrm{~mm}$, ganzrandig. undeutlich gelblich gesïumt; Rippe am Grunde dureh zwejschichtige subkostale Zellen verbreitert, in Pfriementeile schwindend. Perichätialblätter mehr lanzettförmig, länger zugespitzt. Seta $0,5-3 \mathrm{~cm}$, anfangs rötlichgelb, später rot. Kapsel mehr oder minder weit vorragend; Urne zylindriseh, zuerst grünliehgelb, zur Reifezeit sehwarzrot; Hypophyse zuerst griun, verkehrt kegelig und sehmäler als die Urne, sృäter schwarzrot, verkelırt ei-kegelförmig, dieker und fast doppelt so lang wie diese; Spaltöfnungen über die ganze Hypophyse verteilt; Zellen des Exotheeiums um die Nündung rundlich. Sporenreife Juni-August. - Fig. I2 F-K.

Auf modernden Leichen kleincrer Tiere, seltener auf Exkrementen in trockenen Kiefernwäldern, auf Heiden, trockenen Felsen und erratisehen Blöcken.

F. Al. Saltvik, Kasberg, Kuggböle, Liby, Fremmanly und Orrdalsklint (Bom.). Sund, Gesterliy (Bom.). Mariehamn (Buch). Eckerö (H. Lindb.). - Ab. Abo (Arrh.). Pargas, Gunnarslläs (Elfv.). Sagu (A. H. Broth.). Bromarf (Sundr.). - N. Helsingfors, Tölö park (Lindb.). - Sl. Sastmola (Ranck.). Euraåminne (C. G. Bjôrkenheim). - Ta. Hollola (Norrl.). Asikkala (N.). Säähımăki (Kihlm.). Lammi, Evo (Sil.). Korpilahti (Vain.). - Sa. Kangasniemi (Broth.). - Kl. Impilahti (Broth.). Pälkjărri (B.). - Kol. Salmi (Pes.). - Oa. Öfvermark, Valsbärgel (E. af H.). Storkyrö (Ranck.). — Tb. Kivijärvi, Kinnula (E. af H.). Karstu]a (Broth.). Virrat, Toriseva (Brolh.). Konginkangas, Leonmaa (E. af H.). Viitasaari (Broth.). Pihtipudas (Broth.). — kb. Tohmajärvi (Hjelt). — Kon. Suopohja (simm.). Rugosa (W. Nyl.). Lentajärvi-Honkaniemi (Norrl.). Pirtliniemi (Simm.), — Om. Alajärvi, zw, Kaartunen und Pyhävuori (Backm.). Vindala, Pyhäruori (Backm.). Halso, Länttāpatti (E. af H.). Haapajärvi (H. Tennander). - Ok. Kajana (Lackstr.). Sotkamo (E. af H.). Kuhmoniemi, an mehreren Fundorten (E. af H.). Suomussalni, an mehreren Fundorten (Lackstr., Kyyhk.). - Ob. Taala (H. Bjôrklund). Ranua, Juntinlehto (E. af H.). Ijo und Pudasjärvi, an mehreren Fundorten (E. af H.). simo (Brenn.). Kemi (B.). Rovaniemi (B.). Aavasaksa-Turtola, an mehreren Fundorten (Hull). - K. Pudasjärvi und Kuusamo, an vielen Fundorten (Broth., E. af H.). - Lkem. Kolari-Pallastunturit, an mehreren Fundorten (Hult). Sodankỵä, Pokka (B. Stáhlberg). Kuolajärvi, an vielen Fundorten (E. af H.). - Le. Ziemlich gemem, besonders in der Birkenregion, und auch nicht selten in der alpinen Region (Norrl.). Li. Inari und Utsjoki, ziemlich selten in der Nadelwald- und Birkenregion (Hult). - Ll, auslr. p. - st. fq. (Roiv.). - Auf der ganzen Halbinsel hola sl. fq. (Broth.).

S. Am reichlichsten in Norrland und in den nördl. Provinzen Mittelschwedens, besonder's oberhalb der Baumgrenze, bis etwa $1,100 \mathrm{~m}$. In südschweden sehr selten und in mehreren Provinzen fehlend. jedoch noch in $\mathrm{S} k$. beobachtet.

N. In den inneren und nördl. Teilen zieml. gemein und noch bis etwa 1,860 $\mathrm{m}$ beollachtet, inl âusseren Küstengebiete ron Westlandet sehr selten.

Europa, Sikkim, Yunnan, Sibirien, Japan, Nord-Amerika, Neu-Gninea. 
var. Brewerianus (Hedw.) Braithw. Brit. moosll. 1) $112(1890)$. [Splachnum Breweriannm He(w. Descr. II. p. 105, t. is (1789).]

Lockerrasig. Iste schlank, verlängert, locker beblältert. Blätter abstehend, schmäler, breit lanzettlich, pfriemenförmig zugespitzt.

S. Mdp. Borgsjö, Ranklefven. Jmt. Ş̣lfjällen.

N. A. Baerum, Kolsåsen,

var. cavifolius (Schimp.) Möll. Bot. Nol. 1907. p. 1.13. [T. muioides var. cavifolius Schimp. Syn. p. 305 (1860).l

Pfl. in sehr dichten Rasen. Blätter dachziegelig, hohıl. Sela kurz. Spaltöfnungen in der oberen Hälfte der Hypopliyse.

F. Li. Utsjoki, Ontakoski, Soavjebakte und Aittijoknjalbme, Oainostschokka, am Gipfe] (Ranck.). Lm. Kildin (Karst.).

S. Lpmk. Ind Jmt. in der alpinen Region.

N. Dovrefjeld, sinehaetten u. s. w. in der alpinen Region.

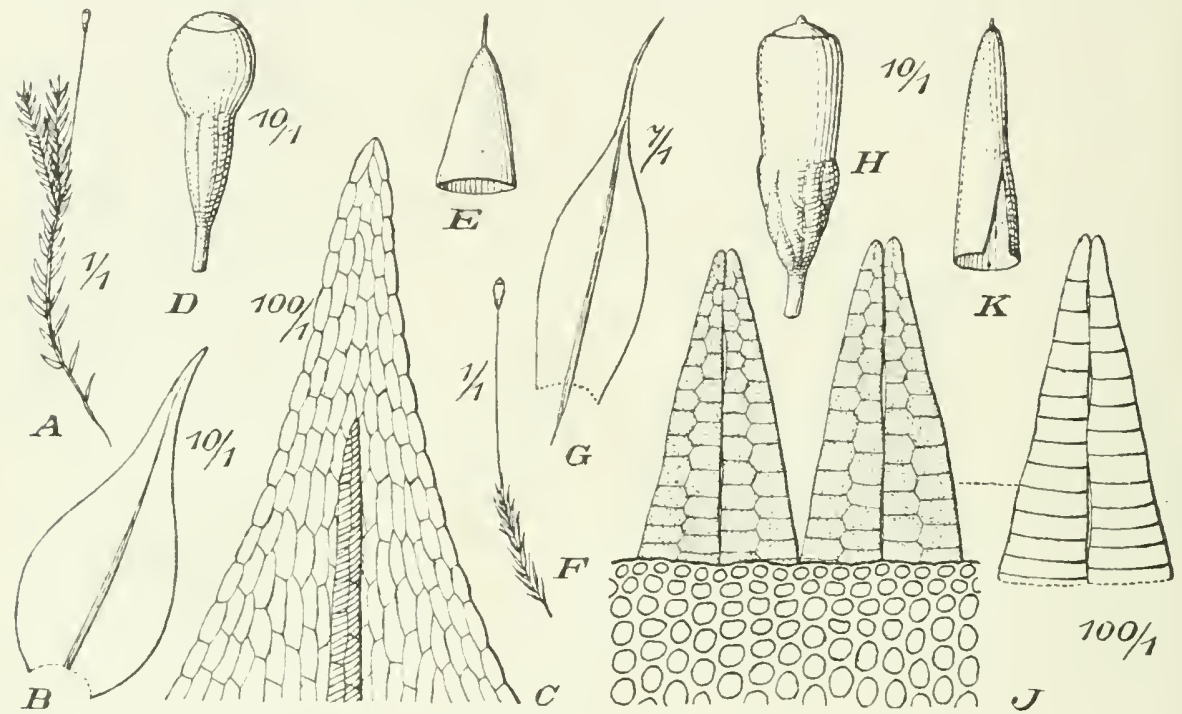

Fig. 42. A-E. Haplodon TTormskjoldii (Hornem.) R. Br. A Fruchtende Pfl. (1 1); B Stammb. (10/1): C Blattspitze (100/1); I Kunsel in trockenen Zustande (10/1); E Haube (vergr.). - F-K. Tetraplodon brynides (Zoeg.). F Fruchtende PfI. (1/1); G Stammb. (i/1); H Kafkel in trockenen Zustande (10/1); I Peristom $(100 / 1)$ : K Haube $(10 / 1)$.

var. paradoxus (R. Br.) Hag. in Kgil. Norsk. Virl. Selsk. Skrilt. 1910. No. 1. p. 17 (1910). [Splachnum paradoxum R. Br. Chlor. Melv. 1). Il (1823). - Telraplodon pallidus Hag. in Kigl. Norsk. Yid. Selsk. Skrift. 189\%;, 1\%. 75 (1893). — T. paradoxus Hag. in Nyt Mag. Naturv. 38, p. 332 (1900).]

Kapsel getb bis gelbrot, trocken und entleckelt unter der Nündung stark verengt. Hypoplusse enger als die Lrue; Spaltöfnungen in der oberen Hälfle: Zellen des Exotheciums un die Vinndung querbreiter.

Anf zersetztem kenntiertünger.

S. IIrjd. und Jml. an einzelnen Fundorten, TL. an mehreren und $\mathbf{I} u L$. an vielen Fundorten, in Sarekgebietest. fq. Am meisten in der Weidenregion, kommt jedoch auch in der Birken-und alpinen Region ror.

N. An mehreren Fundorten in $K$, stT. und $F$, seltener in $T r$. und an einzeluen Fundorten in $N B$, 11. und No.

Spitzbergen, Novaja Semlja, arkt. Sibirien und arkt. Nord-Amerika, meist kleislokarp.

295. Tetraplodon urceolatus Bryol. ell. fasc. 23/24 Moll. p. 7, t. :3 (1841). Rasen selır dichl polsterförmig, bis \& cm hoch, oben gellgrim, innen bleich- 
braun, bis zu den jungen Trieben selır dicht verwebt. Blätter geschwollen dachziegelig, fast löffelartig hohl, verkehrt-eilänglich, plötzlich in cine kürzere, šeschlängelte Pfriemenspitze verschmälert, ganzrandig, bis 2 mm lang und 0,9 mm breit; Rippe zart, am Grunde nicht verbreitert, vor der Pfriemenspitze schwindend. Seta 3-12 mm, sattgell). Kapsel vorragend; Urne kurz zylindrisch, rötlichbraun: Hypophyse von gleicher Länge, kurz birnförmig, grünlich, später wenig dicker, runzelig und rötlich schwarz; Spaltöfnungen über die ganze Hypophyyse verteilt.

N. SB. Ejdfjord; Hardangervidden, Kislenulen, I, 300 m, spärlich.

Alpen- und Hochalpenregion von Zentral-Europa. Kaukasus, Hinalaya. Thianschalı und Altai: arkt. Nord-Amerika.

\section{HAPLODON}

R. Br. Verm. Schrift. I. p. 412 .

Autözisch: $\sigma^{7}$ Sprosse sehr schlank, fast nackt, Blüten koplig-scheibenförnig. Schlanke Sumpfmoose in ziemlich dichten, lichtgrünen Rasen, mit trüb purpurrotem Rhizoidenfilz. Stengel $1-8$, selten bis $13 \mathrm{~cm}$, locker beblätert, unter dem Schopfe imnovierend. Blätter sehr weich, fast gleichförmig, nur die Schopfblätler etwas grösser, aufrecht-abstehend. breit oval, mehr oder minder lang zugespitzt. ganzrandig, bis $4 \mathrm{~mm}$ lang und $1,5 \mathrm{~mm}$ breit; Rippe vor der Blattspitze aufhörend. Seta 1-2 cm, sehr diumn, fast hyalin. Kapsel klein, braun; Lrne kulz oval; Hypophyse der Lrne gleich oder etwas dicker. Peristomzähne patarweise genähert, später gleichweit gestellt, leucht einwärts zusammenneigend, trocken zurückgeschlagen-anliegend. Columella nach der Entdeckelung zurückschrumpfend. Sporen $8-10 \mu$, gelbgrün, glatt. Deckel gewölbt. Haube kegelförmig, ganzranclig odler einerseits gespalten. Sporenreife im Juli.

Einzige Art:

296. Haplodon Wormskjoldii (Hornem.) R. Br. 1. c. [Splarhnum Wormskjoldii Hornem. in Fl. dan. X. fasc. 28. p. S. t. 1659 (1819). - Tetruplodon Wormskịoldii Lindl). Muse. scand. p. 19 (1879).] — Fig. 42 A-E.

Auf modernden Lemmingen und Tierexkrementen an sehr nassen Stellen, oft in tiefen Mooren.

F. Oa. Lappo, Särkimäneva (H. Lindb.). K. Kuusamo, Suolampi zwischen Kitkajărvi und Livojärvi massenhaft (E. af H.). - Le. Kilpisjärvi, Saana (Kot.) - Li. Inari, zwischenl syysjärvi und Kaamas und bei Väỵlä in der Nadelwaldregion (Hult); Veitsjiknjarga und Mandojäyrj in der Birkenregion (Hult). Utsjoki, Mierasjäyri (Hult); Dalvados, auf im Wasser liegendem Renntiergeweih (Ranck.). - Lim. Kandalaks (Sahlb.). - Lt. Ruokojäyr (Roir.); Kola und Tsipnavolok (Broth.). - Lmur. Olenji (Karst.); Teribjerka, Gavrilova, Semjostrovsk und Harlov (Broth.), - Lp. Ponoj (Sahlb., Broth.).

S. Bisher von mehreren Fundorten in $T L$. und Jmt, und von einzelnen in $L y L$. und Dlr. bekannt.

N. Sporadisch im Gebiete von $F$. bis st., weniger selten auf dem Dovrefjeld mit Umgebung, am haufigsten in den Fjelden in stjørdalen, Meraker und in den inneren Teilen ron Vimdalen.

Spitzluergen und arktische Teile von Asien und Nord-Amerika.

\section{SPLACHNUM}

L. Sp. pl. p. 1108 (17.53).

Autözisch oder diözisch; $\sigma^{T}$ Blüten kopfig-scheibenförmig, mit sternfürmig sich ausbreitenden Hüllblättern. Jehr odler minder kräftige, lockerrasige. glänzend saftgrüne oder gelbgrüne Pfl., am Grunde mit trüb purpurotem Rhizoidenlilz. Blätter nach oben allmählich grösser, Schopfblätter eine offene Rosette bildend, breit verkehrt-eiförmig, meist zugespitzt, flach- und meist ganzrandig: Rippe vor der Blattspitze aufhörend; Zellen sehr locker. Seta lang und dünn. Kapsel mit kleiner, walzenförmiger Urne; Hypophyse stets dicker als die Urme, zur Syorenreife sich vergrössernd und blasig aufgetrieben. Zellen des Exotheciums poly- 
gonal, olt kollenchymatisch: Zellen der Hypophyse weitlichtig, dünnwandig, mit zahlreichen Spaltöffnungen. Peristomzähne sehr hygroskopisch, feucht kuppelartig zusammenneigend, trocken zurückgeschlagen anliegend, fein punktiert, teilweise oder gänzlich zu 8 Paaren verbunden, am Grunde verschmolzen und aus 3 peristomzellschichten gebildet, von denen die dorsale und ventrale Schicht aus Zellplatten, die mittlere aus ganzen Zellen besteht, weshalb die Zähne innen gekammert sind. Columella sich streckend und mit dem fast hutförmigen Ende vorragend. Sporen $8-12 \mu$. gelb. glatt. Deckel gewölbt, fast fingerhutähnlich. Haube klein, kegelförmis.

\section{Ĺbersicht der Arten.}

A. Hypophyse rerkelırt-eilörmig, wenig dicker als die L'rne. schwarziol

B. Hypophyse aufgeblasen-birnfömig, mehrmals dicker als die Urne. fleischrot. zuletzt purpurn .................... 29s. S. ampullacenm.

(. Hypophyse aufgeblasen-kugelig, zuletzt schwarzrot ... 30.2. S. vasculosum.

I). Hypopliyse zuletzt schirmförmig.

a. Hypophyse gelb.

«. Seta oben schwärzlich-purpurı. L'rne bräunlichpurpurn; Hypophyse schirmförmig ausgebreitet.

bleicligelb

300. S. melanocatilon.

p. Seta oben rötlich. Lrue gelbbraun: Hypophyse sattgelb, halbkugelig,zuletzt sehirmförmig ausgebreitet. 299. S. luteum.

b. Hypollyse purpurn

301. S. rubrum.

S e c t. 1. Globovaria Hag. in D. K. X. Vid.-Selsk. Skrift. 1910, No. 1, p. 21.

Stengel mit echten Blattspuren. Hypoplı̣se kugelig-eiförmig; die die Spaltöffnungen umgebende Zellen nicht von den ïbrigen differenziert.

297. Splachnum pedunculatum (Huds.) Lindb. Musc. seand. p. 19 (1879). ['hascum pedunculalum Huds. Fl. Angl. II. p. 397 (1762). - Splachnum sphaericum (L. fil.) Sw. Meth. musc. p. 33. t. 1, f. 1 (1781).]

Autözisch oder diözisch. Stengel bis $3 \mathrm{~cm}$. Schopfblätter aus sehr schmalem Grunde sehr breit verkehrt-eiförmig, plötzlich in eine kïrzere oder längere Spitze verschmälert, bis $6 \mathrm{~mm}$ lang unc $2,5 \mathrm{~mm}$ breit, ganzrandig oder fast ganzrandig bis an der Spitze gesảgt. Seta $1-10$, selten bis $13 \mathrm{~cm}$, unten rötlich, gegen die Spitze gell, Lrne kurz, lichtrö́tlichbraun; Hypophyse wenig dicker als die Urne, kugelig-eiförmig bis kugelig. zuerst grïn, dann schwarzrot und glänzend. Peristomzähne dunkelgelb. Sporenreife im Juni und Juli. - Fig. 43 A-C.

Auf Rinclviehdünger, selten auf faulem Holze in feuchten Nadelwäldern, Sümplen und offenen Mooren.

F. Al. Eckerö, saltrik. Sund und Kumlinge, an wenigen Fundorten. - Ab. Abo (Tengstr.). Pargas, (imnarsıäs (Elfr.). Sagu (A. H. Brolh.). Iskela, Linnamäki (Lindb.). Karislojo. Vappula (Broth.). Lojo. Lohjanselkä (Lindb.): Pielnäs (Sundr.). - N. Kyrkslält (Nyb.). Esbo, Gräsa (Broth.). Sibbo. Löparö (Sundv.). Orimaltila. Niemi. Antlila (Link.). - Ik. PỴäjärvi, zw. Sortanlaks und Vernilsa (H. Lindb.). Melsajpirtti, salokylä (H. Lindb.). Sakkola (H. Lindb.). — Sl. Eura (Rönnb.). Karkku. sorvijarvi (Hjelı). Ikaalinen. Nygard (Sunds.). Birkkala (Simm.). — Sa. Valkeala, Tirvo (Sundr.). Kl. Sortavala. Rausku (Kul.). - Kol. Suloniemi (Kullh.). Petrosarodsk (Sablb.). Gorki (Elfv.). (10. Sideby (Karst.). Närpes. Benvik (Halll,.); Yltermark, von vielen Fundorten und reichl. (E. af II.). Bötum. Bölombarget (E. af H.). Replot (Simm.). kivarken (Karst., Brolh.). - Tb. Virrat (Brolli.). Pihlajavesi (Norrl.). Petäjäresi. IIongistonsuo und Pekkala (Ruor.). Lankaa und Saarijärvi (Broth.). konginkangas, Lekojärvi (E. af II.). Viitasaari. Säynällanipi und Pihlipudas (Brolh.). - Sb. Iisalmi, Peltosalmi (Sahlb.). Maaninka und Pielavesi, an melireren Fundorten (Roix.). Kuojio (Link.). - Kon. Sunjari, Varpakyla (liop). - Om. Alajärvi, Kirchdorf. Veslerbalcha- Poikhijoki und KaartunenPyhavuori (Backm.). Vindala, Pyhävuori und Pylıälahti (Backm.). Lappajäri, Kirchdorf und Kivikangas (Backm.); Leppälä-Jatlaniilty lq. (Backm.). - ok. Kajana (Lackelr.). Pallamo (Lacksir., 
liyhk.). Kuhmoniemi, an vielen fundurten (E. af II.). Suommsidlmi Lackstr., liyglik.). Kpom. Ondjärvi (Bergr.). Soroka (Sahlb.). - Ob. Simo (H. Lindb.). Pudasjarvi, Perakingas (F, af Il.). Rovatniemi (Hulı). Zw. Aarasaksa und Turtola st. fq. (Hul1). — K. Kuusimo, all vielen Fundorten (Nyb.. sil., Vain., Broth., E. af H.). - Lkem. Zw. Kulari und kiltiläsl. fq. (Iiult). Kunlajärvi, an vielen Furdorten (E. af H., Broth.). - Le. In der Nadelwald- und Birkenregron st. fa., in der unteren alp. Reg. zelstreut (Norrl.). - Li. Inari und Ul.johi, in der Nadelwald-und Birkenregion zerstreul (IIull), - Lm. Kandalaks (Broth.). Talvijoki (Linnan.). - Lt. Kola und Tsipnavolok (Brolh.). Im südl. Teile nichl selten (Roir.). - Lomur. Olenji (Karsl.). Teribjerka, (iavrilovi, Senjustrorsh und Ilarlor (Brollı.). Lp. Ponoj (Sahlb.. Brolh.. Env.).

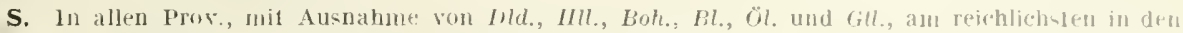
südl. Prov. v. Norland, auch über die Baungrenze steigend

N. In allen Antern und nur in den niedrigsten Teilen im siuden selfen. an reichlichsten in des sulalpinen Region, auch iiber die Baumgrenze steigend.

Zentral-Europa, Nord-1talien, (iross-Bribanien. Sibirien, nördl. Teile von Nord-Amerika.

S e c t. I I. Ampullaria (.. Müll. Syn. I. p. 14:3 (1819); emend. Hag. I. (.. p. 2.3

Stengel mit falschen Blattspuren. Hypophyse birnförmig: Spaltoffmungen umgebende Zellen verlängert, strahlenfürnigg geordnet.

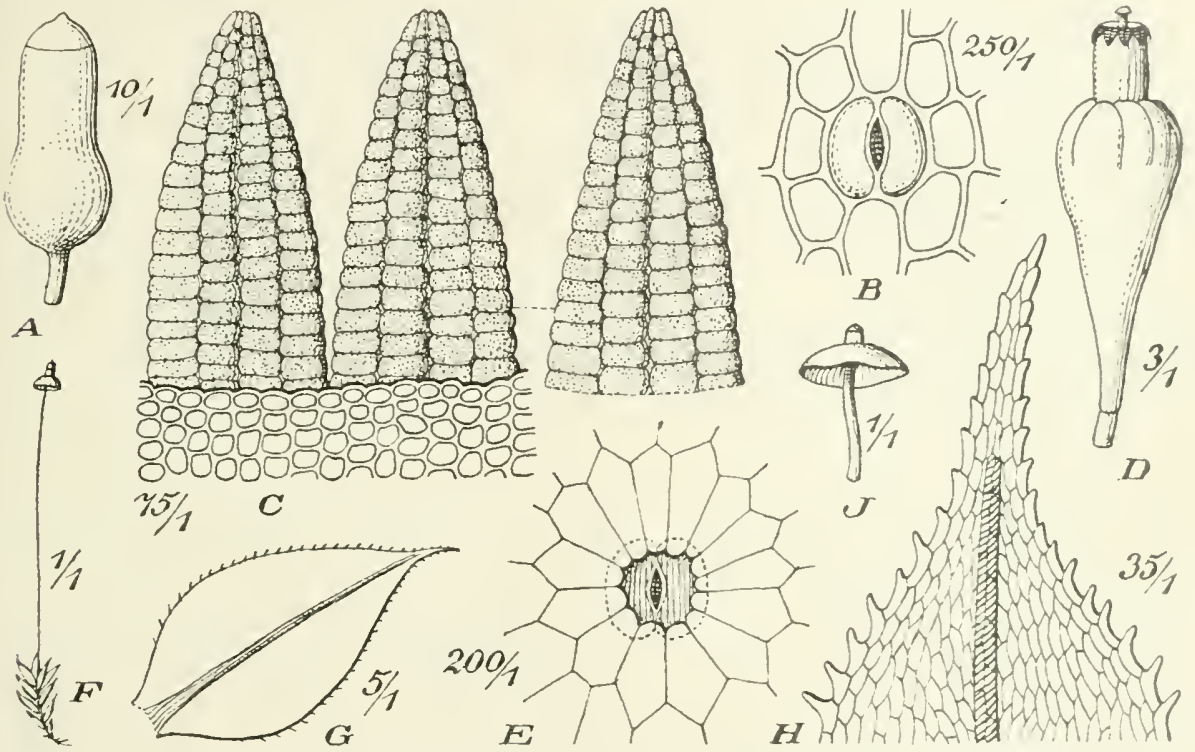

Fig. 43. A-C. Splachnum pedunculalum (Huds.) Lindb. A Kapsel (1(1/1): B Spaltötfnung (250), 1); (1) Perjatonzähne (75 1). - D-E. S. ampullaceum L. D Entdeckelte hapsel (3/1): E spaltüffnung (2u0/1). - F S. melanocaulon (Wahlenb.) Schwaegr. Frizchtende Pfl. (1 1). - G-I S. mbmu Iont. Stammblatt (5 1); H Blatlspitze (35 1); I Kapse] (1, 1).

\section{Splachnum ampullaceum L. Sp. pl. p. 1108 (17.53).}

Autözisch odler diözisch. Stengel $1-1 \mathrm{~cm}$. Schopfblätter aus verschmälcrter Basis nach oben verbreitert und dann in eine lange, meist grob und scharf gesägte Pfrieme auslaufend, bis $7 \mathrm{~mm}$ lang und $2 \mathrm{~mm}$ breit. Seta bis 5 , selten bis $10 \mathrm{~cm}$. unten sehr dïmn, nach oben stärker, anfangs gelblich, später rot. Urne länglich zylindrisch, gelb, dann rostfarben: Hypophyse viel dicker als die Urne, zur Reifezeit purpurviolett, aufgeblasen-birnförmig allmählich in die Seta versehmälert. Peristomzähne orange. Sporenreife in Juni und Juli. - Fig, 43 D-E.

Auf zersetztem Rindermist auf feuchten Weiden. Sümpfen und Torfmooren.

F. Al. Lemland (Broth.); Eckerö, Finstrom, Saltvik und sund nichl selten (Bom.). - Ab. Gustafs. Lypertö (Bergr.). Pargas, Alön (Elfv.). Uskela (Nikl.). Kinito. Kirchdnrf (Ols.). Bromarf (sundr.) Karislojo (Broth., Sundv.). Lojo, Lehmäjărí (Hult); Ojamo und Lylyis (E. af H.). Yichlis, Hiiskala (Flinch). - N. Trärminne (A. Sola). Kyrkslälı, Böle (Brolh.). Borga, Orrhỵ (sael.). Hogland (Lindb.). 
- Ik. Kivennapa (Malmb.). Valkjärvi, Vihtarisenjoki (H. Lindb.). Pyhäjärvi, Vernitsa (Lång); Lohijoki (H. Lindb.). - St. Eura (Ronnb.). Uifsby (Nerv.). Eurajoki, Vuojoki (Björkenh.). Karkku, sorvijärri (Hjelt). Pirkkala (Simm., A. Sola). Ikaalinen, Yygård (Sundv.). Siikais, Leppãjärvi (Ranck.). Ta. Hausjărvi, Herajoki. Asikkala und Hollola, an mehreren Fundorten (Norrl.). Padasjoki, Nyyclólä (Vain.). - Sa. Lappee, Askola (Buch). Ruokolaks, Utula (Hult). Kangasniemi (Lackstr.). - Kl. Kirjavalahti, Lakkalampi (G. Láng). Talamo (H. Backın.). - Kol. Nikola (E.). Gorka (Simm.). Gorskij pogost (Kullh.). Petrosarodsk (II. Nyl.). - Oa. Närpes, Benvik (R. Dahlberg); Yttermark (E. at H.). Kaskö (Lind.). Tasa (Broth.). Kvarken (Karst., W. Laurén). Bötum, Bötombārget (E. af H.). - Tb. Kivijārvi (Broth.). Pihlajavesi (Norrl.). Laukaa, Karlvik (Link.). Saarijärvi (Kihlm.). Konginkangas (Broth.); Lekojärvi (E. af H.). Viitasaari, Permasmäki (Broth.). Pihtipudas (Broth.). - Sb. Iisalmi. Peltosalmi (Sahlb.). Maaninka. Haatala, Veitswo (Roiv.); Varpasmaa, Hirvimäki (Roir.); Rautavaara, Riitamāki (Kyyhk.). Kuopio (Link., L. Korhonen). Joroinen. Keriniemi (Hint.). - Kon. Suojärvi, Tarpakylä (Kop.). Tiudie (Kullh.). Porajärvi (Norrl.). Suosaari (Simm.). - Om. Lappajärvi, Kirchdorf und Harju (Backm.). Tindala (Backm.). — Ok. Kajana, Sarvivaara (Lackstr.). Sothamo, Hanhilampi (Kyyhk.). Kuhmoniemi, an mehreren Fundorten (E. af H.). - Kp. Ondajärvi (Bergr.). Ob. Rovaniemi, Tervo (Hult). - K. Kuusamo (W. Nyl.); Pernu und Kiekkivaara (Broth.). - Lथ. Kusrăka (Malmb.).

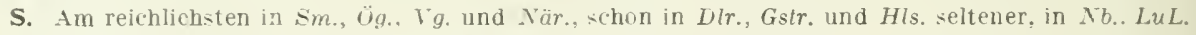
und TL. fehlend. Aus allen Prov. in südschweden bekannt. Nordgrenze $65^{\circ} 30^{\prime} \mathrm{n} . \mathrm{Br}$.

N. In allen Ämtern mit Ausnahme von $T r$. und $F$, auch in den Küstengegenden, jedoch nur in Ostlandet zieml. gemein. Nordgrenze $63^{\circ} 47^{\prime} \mathrm{n}$. Br.

Sect. I I I. Umbracularia C. Müll. Syn. I. p. 1 t6 (18 18$)$.

Stengel mit echten Blattspuren. Hypophyse halbkugelig oder zuletzt schirniförmig: Spaltöfnungen umgebende Zellen verlängert, strahlförnıig geor(hnet.

299. Splachnum luteum Ilontin Diss. Splachn. p. 8, No. 1 (1750).

Diözisch. Kräftige Pfl. Stengel his 3 cm. Schopfblätter aus kurz und schmal spateliger Basis oval, rasch lang zugespitzt, bis 5 mm lang, ganzrandig oder oberwärts klein gezähnt. Sela $5-11$, selten 11 cm, rot. [rrne kurz, rötlichbraun; Hypophyse hałbkugelig, zuletzt selirmförmig ausgebreitet, gelb. Peristomzähne gelb. Sporenreife Mai und Juni.

Auf Rindviehdïnger in feucliten Nadelwäldern, auf V'ersumplungen und offenen Mooren.

F. Ab. Gustafs, Lypertö (Bergr.); Lojo, Lylyis (E. F. af Hällström). - N. sjundeá, Myrans (Nerr.). - St. Eura (Rïnnb.). Sastmola, Kalliojärvensuu (Ranck.). Siikais, Leppäjärvi (Ranck.). Yläne (Sahlb.). Karkku, Sorvijärvi (Hjelt). Kuru (Hynn.). Pirkkala (Karst., Grönbl.). Ruovesi (Karst.). - Ta. Asikkala (Norrl.). - Oa. Närpes, Benvik (Dahlb.); Yttermark, von vielen Fundorten (E. af H.). Kaskö (Lind.). Kvarken, st. fq. (Karst.). Vasa (Lignell). Pörtom, Johannedal (Hjelt). Böton, Bötombärget (E. af H.). Oravais, Kimo (Laur.). - Tb. Virrat (Simm.). Karstula (Furuhj.). Krivijārvi (Broth.). Pihlajavesi (Norrl.). Saarijärvi, Tuutijarvi (Kihlm.). Konginkangas, Lekojärvi (E. af H.). Viitasaari, Lakomäki (Kihlın.). Pihtipudas (Brot...). - Sb. Iisalmi, Peltosalmi (Sahll.). Maaninka, an mehreren Fundorten (Roiv.). Pielavesi, an vielen Fundorten (Roiv.). Rautavara, Siera (Kyyhk.). Joroinen, Keriniemi (Hint.). - Kb. Juuka, Polvijärvi. Juuarvaara (Kot.). - Kon. Tiudie (Simm.). Porajărvi (Norrl.). Om. Soini, Uurimäki (Backm.). Alajārvi, zw. Vesterhacka und Poikhijärvi und zw. Kaartunen und Pyhāyuori (Backm.). Lapnajärvi, an mehreren Fundorten (Backm.). Vindala (Backm.). Haajajārvi, kirchdorf (Tenn.). - Ok. Kajana (Jalmgr.). Paltano (Lackstr., Lônnb., Kỹhk.). Sotkamo, Talvijoki ınd Natula (Kyyhk.). IIyrysalmi, Kivirinta (Kygh.). Kuhmoniemi. an vielen Fundorten (E. af H.). Suomnssalmi (Ky̧hk.. L. Oesch). - Kpom. Soroka (Sahlb.), Suondali, Ondojārvi. Nischnij Ig (Bergr.). Rukijärvi, Miinua (Link.). - ob. Oulujoki. Lylyjärvi (Huum.). Pudasjärvi, zw. Kariniemi und Koitijärvi (Nyb.). simo (H. Lindb., Räs.). Rovaniemi (Jernstr.). Aavasaksa-Turtola fq. (Hult). - K. Taivalkoski (V. Brenn.) und an mehreren Fundorten in Kuusamo (TV. Nyl., Broth., E. af H.). Kk. Soukelo (Sahlb.). Kinjäscha (Karst.). - Lkent. Kolari-Pallastunturit fq. (Hult). Kemijärvi (Hult). Sodankylä (Blom). Kuolajärvi (Linnan., E. af II., Broth.). - Le. In der Nadelwaldregion fq. und an einzelnen Fundorten in der Birkenregion (Norrl.). - Li. Inari, Väylä und Tirro (Hul1). - Lim. Kandalaks (Broth.). - Lt. austr. zw. Kusijäyr und Ruokojäyr (Roiv.).

S. Verbreitung etwa wie bei S, rubrum, jedoch viel reichlicher vertreten, weiter und höher in Gebirge vordringend olne ïber die Baumgrenze zu stejgen.

N. In gewissen Teile der inneren Amter ziemlich verbreitet, mit Zentren lesonders in $H$., in Namdalen, Ranen und Alten. Nordgrenze bei $70^{\circ} \mathrm{n}, \mathrm{Br}$.

Nord-Russland, Sibirien. ı̈̈rdl. Teilen von Nord-Amerika.

300). Splachnum melanocaulon (Wahlenb.) Schwategr. Suppl. II. P. II. fase. 1, p. 28, No. 2 (185i3). [Splachmm luleum var. melanocaulon Wahlenb. in Mag. Ges. Nat.-Fremde Berlin. V. 1). 294, No. 1 (1811).] 
Diözisch. Schlanke Pfl. Stengel bis 1 cm. Schopfblätter klein, aus kurz spalteliger Basis oval, rasch \pm lang zugespitzt, fast ganzrandig oder an der Spitze klein gezähnt. Seta 1-2 em, sehr dünn, schwärzlich. Urne verhältnismässig lang, trocken unter der Mündung stark verengt, dunkelbram: Hyjojlyvse klein, schirm förmig ausgebreitet, weisslichgelb. Zähne orange.

F. Lkem. Kätkesuanto (Norrl.).

S. LuL. Jockmock, Larve.

Sibirien, Kamtschatka, Rocky IIts.

301. Splachnum rubrum Montin Diss. Splachn. 1) 8, No. 1 (17.5(1).

Diözisch. Íräftige Pfl. Stengel bis $3 \mathrm{~cm}$. Schopfblätter aus kurz und schmal spateliger Basis oval, rasch lang zugespitzt, fast vom Grunde scharf gesägt. Seta 4-11, selten bis $14 \mathrm{~cm}$, rot. Urne kurz. rötlichbran; Hypophyse halbkugelig. im Durchschnitt bis $1 \mathrm{~cm}$. zuletzt dunkel purpurn. Zähme des äusseren Periston orange. Sporenreife im Mai.

Auf Rindviehdünger, am liebsten in feuchten Nadelwälflern, Jesonders in der Umgebung von Versumpfungen.

F. Ab. Nagu (Schult.). Sastmola, Kirehdorl (H. Cull.). Masku, Kankainen (I. Link.). Pargas, Gunnarsnās (Elfv.). Kimito, Pávalsby (Ols.). Bromarf (Sundv.). Lojo, an mehreren Fundorten. Tichtis. Nummela (Flinck). - N. Ekenäs, Elgmo (Lindb.). Esbo, aı mehreren Fundorten. Kyrkslătı. Siblo, Löparö (Sundv.). Orimattila, Niemi, Anttila (Ringbl.). Elimäki, Mustila (Tigerstedı). Pyıtis (s. Blomqvist). - Ka. Lunmäki, Pitkäpää, Mutinsuo (Ranck.). Wiborg, Lietjărvi und Mustajărvi (Buch). Ik. Kirennapa (Malmb.). Pyhājărvi, zw. Sortanlaks und Vernitsa (H. Lindb.). — st. Kaumo (Simm.). Ylāne (Sahlb.). Huittinen, Huhkola (Lỵd.). Karkku, Sorvijärvi (Hjelt). Ikaalinen (Śundv.). Laỵi, Hirvonsuo (Ranck.). Birkkala (Simm.). Orihvesi, Juurakka (Broth.). - Ta. Haltula, Mlierola und Ihalampi (Ranck.). Pălkäne, Uutana (Zidb.). Hausjärvi (Granf.). Lammi, Raivola (Leop.). Hollola, Taaveli (Vain.). Asikkala, Kaitas (Norrl.). Padasjoki, Tesijako (Norrl.). - Sa. Willnanstrand (Buch). Kol. Mjätusova (Elfv.). - Oa. Sideby (Karsı.). Nārpes, Ytlermark, an rielen Fundorten und mašenhaft (E. af H.); Benvik (Dahlb.). Bötom, Bōtombärget (E. af H.). Kvarken (Karst.). - Tb. Toivakká (E. af H.). Konginkangas, Lekojārvi (E. af H.). Rautalampi (Jalk.). - Sb. Joroilıen, Järvikylā (H. Lindı.). Kuopio (Lönnb.). Pielavesi, an mehreren Fundorten (Roiv.). Maaninka, an mehreren Fundorten ( $\mathrm{K} y \mathrm{l}$ lı. Roiv.). Nilsiä, Lehtomāki (Kỵhk.). Iisalmi (Sahlb.). - Kb. Liperi (N. Elfv.). Lieksa (Tout.). - Kon. Suosaari (Simm.). Tiudie (Sel.). - Om. Alajärvi, Kirchdorf und Kaarıunen-Pyhäruori (Backn.). Lappajărvi, Kirchdorf (B.); Savo, Leppālä-Latraniitty, gemein in den Versunpfungen (B.). - Ok. Kajana (Malmgr.). Ristijärvi (Lackstr.). Suomussalmi, saukko (Vain.). - Ob. Oulujoki. Lylyjảrs (Huun.). Pudasjärvi, zw. Kariniemi und Koitjaărri (Nyb.). Ylitornio (Sandm.). Turtola und Roraniemi. von mehreren Fundorten (Hult). - Kk. Soukelo (Sahlb.). - Lkem. Kolari und Ảkäslompolo (Hult). Lim. Kandalaks (Sahlb.).

S. Am' reichlichsten in einer von $\mathrm{Nb}$. durch $\mathrm{Vb}$. Ang., Hlsl., Gstr. und die südl. Teile von Dlr. Vsm. und V rml. sich erstreckenden Zone. Sonst nur sporadisch bis sm., in den westl. Küstenprovinzen fehlend.

N. Selten, nur in $K$. und $H$. etwas häufiger.

Nord-Russland, Sibirien. nōrdl. Teile von Nord-Amerika.

302. Splachnum vasculosum L. Sp. pl. 2. ed. p. 1572 (176:3); He(lw. I)escr. II. p. 41, t. $15(1789)$.

Diözisclı; $>$ Pfl. schlanker, oft in eigenen Rasen. Stengel 1-bo, selten bis 9 cm. Blätter hohl, die unteren fast kreisföming, die oberen aus schmaler Basis breit rundlich-eiförmig. stumpflich, bis 3,5 mm lang und 2,5 mm breit, ganzrandig oder dureh die stumpf vortretenden Zellecken etwas gezähnt. Seta 1-., selten bis 7 em, lichtrot, an (ler Insertion wenig verengt. Urme hurz zylindriscll, gelbbraun oder orange; Hypophyse bis $4 \mathrm{~mm}$ lang und 3 mm breit. anfangs sclumutziggrïn und eiförmig, später stark aufgeblasen, dreimal breiter als die Lrne, kugelig, schwarz-purpurn, oft am Grunde etwas eingedrückt. Peristomzälne onange. Sporenreife in IJai und Juni.

An cuelligen und sehr nassen Stellen, oft in tiefen Nooren.

F. Al. Eckerō (Arrh.). Sund, Gesterby (Bom.). Finströn, Altbōle Storträsk (B.). Saltrik. Langbergsöda und Toböle (B.). - Ab. Lojo, Ojamo (Lindh.); Lylyis (Lindb.). - Ik. Sakkula und Pyhajărri, an vereinzelten Fundorten (H. Lindb). Kexholm (Låıg). - Ta. Asikiala, Anianpelıo (Norrı.). - Oa. Nărpes, Yttermark, an vielen Fundorten (E. af H.). Krarken (Karst.). — Tb. Pihlajavesi (Norrl.). Konginkangas, Lekojărvi (E. af H.). — Sb. Nilsiä, Tiihola (Kð氵hk.). Rautavaara. an mehreren Fundorten 
(Kyyhk.). - Kub. Junka. Nunnanlahti (Kot.). - Om. Soini, Uurimäki (Backm.). Alajārvi, an vereinzelten Fundorten (B.). - Ok. Paltamo, Melalahti (Kyyhk.). Kuhmoniemi, an mehreren Fundorten (E. af H.). Puolanka, Pieni Kaitanen (Kyyhk.). Hyrynsalmi, Kiviranta und Tapaninvaara (K.). Suomussalmi (Lackstr., Kiyghk.). - K. Kuusamo, an mehreren Fundorten (Broth., E. af H.). - Lkem. Zieml. gemein in Kolari und Kittilä (Hult). Kuolajärvi, Sallajoki (E. af H.). — Le. Selten in der Kiefernregion (Norrl.). - Li. Inari, zerstreut in der Nadelwaldregion (Hult). Utsjoki, Heikura (Hult). - Lim. Kandalaks (Broth.). - Lt. Sonkijäyr und Kierkhijãyr (Roiv.). Kola (Karst.). Tsipnavolok und Vaidoguha (Broth.). - Lmur. Gavrilova, Semjostrovsk und Varsinsk (Broth.). - Lp. Ponoj (Broth.). Triostrova (Kihlm.).

S. In allen Prov. mit Ausnahme von Hll, und Boh., in Norden bis Karesuando in TL. Am reichlichsten in Mpd., Hrjd., Jmt. und Ảng. In mittl. und südl. Schweden sporadisch, meist in den inneren Teilen.

N. Aus allen Äutern nit Ausnahme von $J L$. und $L M$. bekannt. an den Küsten fehlend, in den ustl. Teilen = gemein.

Schottland. Spitzbergen, Sibirien. arkt. Nord-Amerika.

\section{Reihe SCHISTOSTEGIA LES.}

Protonema ausdauernd, Licht reflektierend, Stengel zweigestaltig. Sterile Stengel von der Mitte aufwärts mit längs inserierten, zweizeilig gestellten, herablaufenden, am Grunde miteinander verschmelzenden. lockerzelligen Blättern. Sporogone acrocarp. Peristom fehlend.

\section{S C H I S T O S T E G A C EA E.}

Sehr kleine, einjährige, herdenweise dem reichlichen, auch in seinen oberirdischen Teilen bleibenden Protonema aufsitzende oder lockerrasige, weiche Erdund Felsmoose. Sterile Stengel am Grunde nackt, von der Mitte aufwärts farnwedelartig mit längs inserierten, zweizeilig gestellten, herablaufenden, am Grunde miteinander verschmelzenden Blättern. Fertile Stengel nackt oder oberwärts wenig fiederig. an der Spitze mit sreihig gestelltein, schief und quer inserierten Blättern. Alle Blättel flach- und ganzrandig, zugespitzt; Rippe fehlend; Zellen prosenchymatisch, locker rhombisch. Diöziseh; ơ Blüten knospenförmig, ohne Paraphysen. Perichätialblätter nieht differenziert. Seta verlängert, glatt. Kapsel aufrecht, sehr klein. regelmässig. fast kugelig: Zellen des Exotheciums unregelmässig 6seitig. kollenchymatiseh. Spaltöffnungen fehlend. Ring und Peristom fehlend. Deckel klei: ind gewölbt. Haube sehr klein, kegelig, nur dem Deckel aufsitzend, ganz oiler einseitig gespalten, glatt, flüchtig. Sporen klein.

Einzige Gattung:

\section{7.). SCHISTOSTEGA}

Mohr Obs. bot. p. 26 (1803).

\section{Einzige Art:}

303. Schistostega osmundacea (Dicks.) Mohr 1. e. [Mnium osmundacem Dicks. Crypt. fasc. I. p. 3, t. 1, f. 4 (1785).]

Rasen oft sehr ausgedehnt, bläulichgrïn. Stengel aufrecht, bis $1 \mathrm{~cm}$, mit undeutlichem Zentralstrange, lockerem Grundgewebe, ohne differenzierte Mantelzełlen, einfach, nur am Grunde mit Rhizoiden. Die längs inserierten Blätter rhombiseh und rhombojdisch, die quer inserierten lanzeltlich. Seta 2-1 mm, zart, fast wasserhell. Kapsel bräunlich, enteleckelt verkïrzt. Sporen $8-10$ (", bleich gell)lichgrün, glatt. Sporenreife im Frühling. - Fig. 14.

Auf feuchter Erde in Höhlungen meist kalkfreier Felsen, auf Humus in Ercllöehern, unter überhängenden Rasendecken und oft aul der unteren Seite der erdbedeckten IVurzeln ungefallener Bänme, immer das Iicht fliehend. 
F. Al. Gela, Gröndal (Hult); Bolstahulı Kummelberg (Bom.). Saltvik, Orrdalsklint und Berdtby Kloddberg (B.). Sund, Gesterby (B.). Vårdö, Vargata (B.). - Ab. Nagu, Medvast (Tengstr.); Ernholm (Elfv.). Kakskerta, in der Nähe der Kirche (Colland.). Pargas, Gunnarsnäs (Arrh.). Karuna (A. H. Brolh.). Angelniemi, Karviais (Buch). Lojo, Vanhakỵlä (Hult). - N. Helsingfors, Fredriksberg (Iult). Helsiıge, Backas (Ranck.). Sibbo, Löparö (Hult). Borgå, Sundö (Sael.). Elimäki (Tigerst.). lk. Toubila (H. Lindb.). — Ta. Sääksmãki, Voipala (Nerr.). Lammi, Evo (Norrl.). Koski (N). Hollold, Papinsaari (N.). Pada-joki, Virmaila (N.). Hartola (Bon:d.) - sa. Willmanstrand, Dysterniemi (Buch.) - Kl. Suistamo, Jänisjärvi, Kukunvaara (H. Backm.). suanlahti, Remsinkorpi (Lång). - Kol. Salmi, Leppälï (Pes.). Nandroga (Elfv.). - Tb. Pihlajavesi (Norrl.). Konginkangas, Lekojärvi (E. af H.). Sb. Kuopio, Kotkankallio (Lackstr.). - Kon. Suopohja (Simm.). Mjadevoschij gora (S.). Kilimski nslruy (Kullh.). - Ob. Ylitornio, Kaarasnäs (Hult). - Kh. Päjärvi (A. I1. Brolh.).-I kem. Kuolajärvi. Naruskajoki, Paulatsilehto (E. af H.).

S. Sk., Sm. und Srm. an mehreren, Bl., Hll., Ög.. Vo., Vrml., Gstr., Dlr. Ang. und Vb. an einze]nen oder wenigen Furdo:ter.

N. A. $-B r . L M, S t .-N B, K-N_{0}$, an reich-

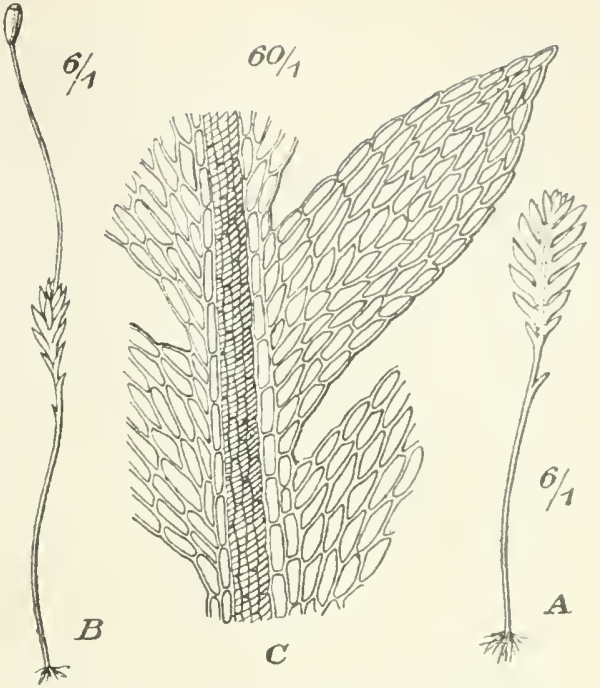

Fig. 44. Schistostega osmundarea (Dicks.). A sterile Pfl. (6/1); B Fruchtende Pfl. (6/1); \& Ster.gelstückchen $(601)$. lichsten in niederer Lage und in der Os-Region, steigt jedoch auch bis in die Birkenregion hinauf. Nordgrenze bei $66^{\circ} 17^{\prime} 11 . \mathrm{Br}$.

Europa, Amur, Nord-Amerika.

\section{Reihe TETRAPHIDIALES.}

Stengel mehrreihig beblättert, im Jugendstadium mit Protonemablättern und Dauerprotonema. Sporogone gipfelständig. Kapsel aufrecht, regelmässig. Peristom aus 1 (selten $3-6$ ) dreiseitigen Zellenzähnen gebildet, indem sich das ganze innere Deckelgewebe in meist 4 zahmartige Klappen teilt. Haube kegelförmig, längsfaltig, unten geschlitzt.

\section{G E O R G I A C E A E.}

Schlanke his sehr kleine, ausdanernde, rasenbildende oder in Herden wachsende Pll. An fadenförmigen Protonema entwickeln sich entweder blattartige Zellflächen oder reichverzweigte Protonemaäste, an denen die Knospen zu neuen Pll. angelegt werden. Stengel aufrecht, 3-5reihig beblättert. Blätter einschichtig; Zellen parenchymatisch, dickwandig, glatt. Autözisch; Blüten gipfelständig. knospenförmig, of Blüten mit faden-keulenförmigen, \& Blüten ohme Paraphysen. Perichätialblätter differenziert. Seta verlängert. Kapsel aulrecht und regelnässig, oval bis zylindrisch, glatt; Zellen des Exotheciums gestreckt, unregelmässig rektangulär, um die Mündung viele Reihen klein, quadratisch und querbreiter oder rundlich. Ring nicht differenziert. Peristomzähne 4, selten 3.5 oder 6, Areiseitig-pyramiılenförmig, jeder als ans einem Bünclel von Längsfasern gebildet. Columella nur bis zum Niveau der Unnemmündung reichend. Deckel kegelig. einschichtig, einseitig geschlitzt. Haube kegelförmig, längsfaltig. Sporen klcin. glall.

$$
\text { ¿ bersicht der Gat t ungen. }
$$

A. Stengel verlängert. Blattrippe kurz vor oder in der Spitze endend

B. Stengel sehr kurz. Blattrippe undeutlich 


\section{GEORGIA}

Ehrh. in Hann. Mag. 1780, p. 932.

Autözisch; o Blüten gipfelständig an grundständigen Sprossen. Pfl. in 士 diehten, flachen, weichen, hell- bis bräunlichgrünen, durch Rlizoidenfilz verwebten Rasen. Stengel verlängert, mit Zentralstrang, dickwandigem Grundgewebe und substereiden, meist zweischichtigen Mantelzellen: Sprosse grundstänlig. Untere Blätter entfernt gestellt, schuppenartig, ungerippt, obere raseh grösser und genähert, eilanzettlich, ganz- und flachrandig: Rippe homogen, vor und mit der Blattspitze endend; Zellen rundlich-6seitig, am Blattgrunde rektangulär. Perichätialblätter über die Selopfblätter vorragend, schmal lanzettlich. Kapsel zylindrisch; Spaltöfnungen und Luftraum fehlend. Haube etwa die halbe Urne deckend. an den Rippen der bräunlichen Spitze gezähnt und am Grunde unregelmässig geschlitzt. - Vegetative Vermehrung durch oft in eigenen Rasen auftre-
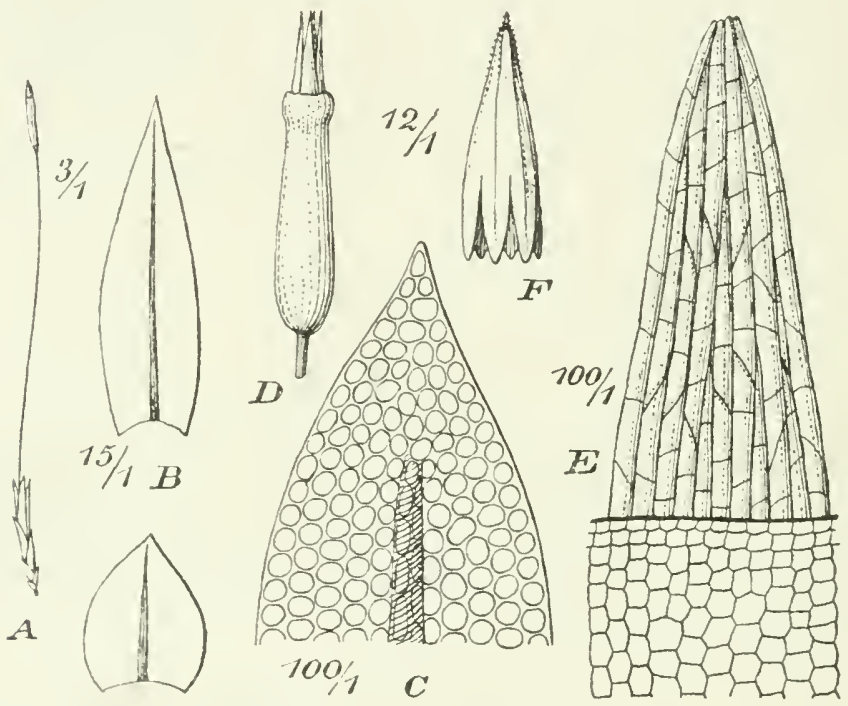

Fig. 45. Georgia pellucida (L.). A Fruchtende Pfl. (3/1);B slengelb. (15/1); C Blallspitze (100/1); D Entdeckelte Kapsel (12/1); E Peristomzahn (100/1); F Haube (12/1).

tende Pfl. und innerhalb s. s. Körbehen gebildete zartgestielte, linsenförmige Brutkörper.

304. Georgia pellucida (L.) Rabenh. Deutschl. Krỵpt. Fl. II. I'. 111. p. 2:31 (1818). [Mnium pellucidum L. Sp. p]. I1. ]. 1109 (1753). - Georgia Mnemosynum Ehrh. 1. c. - Tetraphis pellucida Hedw. Fund. muse. 11. p. 88. t. VI1. f. 32 (1782).]

Stengel bis $3 \mathrm{~cm}$, selten höher. Blätter bis $1,5 \mathrm{~mm}$ lang und bis $0.5 \mathrm{~mm}$ breit. Perichätialb]ätter bis üler $3 \mathrm{~mm}$ lang. Seta $1-1,5 \mathrm{~cm}$, zuweilen 2 aus demselben Perichätium, dïnn, strolıgelb, später rötlich, unten rechts. oben links gedreht, glatt. Kapsel l,is $2.7 \mathrm{~mm}$ lang, ı̈̈mmhäutig, grünlich, später braun, entleert schwach links gedreht. Sporenreile in Juni und Juli. - Fig. 45.

An verwesenden Baumstumpfen und Stämmen, besonders in schattigen. feuclsten Wäldern, auf feuchler, humusreicher Erde und herabhängenden Torlmassen der Felsen dureh das ganze Gel)iet bis in die alpine Region hinaufsteigend. Im Waldgebiete \pm lq., in der alpinen Region sclten. Nordgrenze hei $70^{\circ} 25^{\circ} \mathrm{n}$. Br.

L̇uropa, Kaukasus, Sibirien. Japan, Nord-Amerika. 


\section{TETRODONTIUM}

Schwaegr. Suppl. II. P. I. fasc. 2, p. 102 (1824).

Rhizautözisch. Sehr kleine, knospenförmige, gesellig und herlenweise wachsende Felsmoose. Stenge ohne Zentralstrang, armblätterig, einfach oder mit :3reihig beblätterten Seitensprossen. Blätter anliegend, nach oben allmählich grösser, hohl, eiförmig bis länglich, spitz, flachrandig, oberwärts zuweilen schwatch gezähnt; Rippe undeutlich bis fehlend; Zellen rektangulär bis verlängert, in tel Blattspitze länglich, oval oder rundlich. Perichätialblätter länger, hreit eiförmig. rasch mässig lang zugespitzt. Seta $+6 \mathrm{~mm}$, rötlichbraun, unten rechts, oben links gedreht. Kapsel oval oder länglich, etwa $1.2 \mathrm{~mm}$ lang, hellbraun, zuletzt schwärzlich: Spaltöffnungen spärlich. Haube die ganze Kapsel einlü̈llend, an den Rippen nicht gezähnt, einseitig gespalten und an Grunde mehrmals geschlitzt.

Einzige Art:

305. Tetrodontium Brownianum (1)icks.) Schwaegr. 1. c. 128. [Bryum Brownianum Dicks. Pl. crypt. fasc. IV. p. 7, t. 10, f. 16 (1801). - Georgia Browniana C. Miill. Syn. I. p. $1 \$ 1$ (1848). - Tetrodontium varium $\beta$ frondiferum l.indh, in Öfv. K. Vet.-Ak. Förh. XX. p. 414 (1863).]

Protonemablätter zahlreich, sehr lang. aus stielrundem Grunde schunal linealisch bis spatelförmig, spitz, oben zuweilen elchgeweihartig geteilt. Bchlïtlerte Seitensprosse fehlend oder spärlich und sehr kurz. Sporenreife im August.

An cler Decke kleiner Felshöhlen und an cler Unterseite übereinanter gelagerter Felsblöcke von kalkfreien oder kalkarmen Gesteinen.

F. Sb. Nilsiä, Piะavunri (Mela).

S. $\ddot{g} g ., \mathrm{V} g$. und $\mathrm{I} \mathrm{rml}$, an einzelnen oder wenigen Fundorten.

N. A., JL., St.-K. an einzelnen oder wenigen Fundorten, var, oratum häufiger und meist in regenreichen Gegenden. Kommt hauptsächlich bis in die sulbalpine Region vor, steigt jeduch auch weit iber die Baumgrenze hinauf. Nordgrenze bei $69^{\circ} 25^{\prime} \mathrm{n}$. Br.

Gross-Britannien, Pyrenäen, Zentral-Europa.

var. rigidum (Hedw.) Jur. Laubmfl. p. 222 (1882). [Tetraphis rigida Hedw. fil. Obs. I. P. 7, t. 2 (1802). - Tetrodontium varium a foliatum Lindb. in Öfv. K. gia Vet.-Ak. Förh. XX. p. $414(1863)$.]

Protonemablätter kürzer und breiter, spärlich oder fehlend. Stengel ohnc beblïtterte Seitensprosse.

N. A. $-B u$., St. $-\mathrm{V} B$.. K.

Zentral-Europa.

var. repandum (Funck) Limpr. in liryptil. v. Schles. I. p. 110 (1876). [Tetraphis repanda Funck in Sturm D. Fl. 11. Heft 17. c. icon. (1819). - Tetrodontium varium $\gamma$ flagelliferum Lindls. in Öfs. K. Vet.-Ak. Förh. XX. p. 414(1863). - GeorBrownii $\beta$ repanda Lindlb. in Notis. Sällsk. F. Fl. Fenn. IX. p. 153 (1867).]

Protonemablätter zahlreich, doch sehr klein. Stengel mit 3reihig beblätterten, aufrechten oder aufsteigenden, sich später niederlegenden und fertile Pfl. erzeugenden Seitensprossen.

S. LuL. Sirkasvare.

N. St.-No.

Zentral-Europa, Pyrenäen, Kaukasus. Nord-Ameriká.

\section{Reihe EUBRYA LES.}

Stengel mehrreihig beblättert. Sporogone gipfelständig. Kápsel meist geneigt bis hängend. Peristom meist doppelt und gut entwickelt, ohne Vorperistom. Peristomzähne 16, aussen mit Nittellinie und kaum vortretenden Querleisten. roneinander frei, meist mit Lamellen. Inneres Peristom mit \pm entwickelter Grundhaut, meist gekielten Fortsätzen und oft mit Wimpern. Haube kappenformig. 


\section{Unterreihe BRYINEAE.}

Blattzellen glatt. Kapsel weder gestreilt noch gefurcht.

\section{B R Y A C E A E.}

Ausrlauernde, meist rasenbildende Erd- und Felsmoose, ausnahmsweise an Stämmen oder faulendem Holz. Stengel mit Zentralstrang, lockerem, allmählich in die diekwandigen, engeren Mantelzellen übergehendem Grundgewebe, häufig mit subfloralen Sprossen, am Grunde oder längs mit meist warzigen Rhizoiden. Blätter meist nach oben altmählich grösser und gewöhnlich schopfig zusammengedrängt, meist zugespitzt: Rippe meist mit medianen Deutern, einer kleinen Begleitergruppe, einem dorsalen Stereidenbande und differenzierten Rückenzellen; Zellen oberwärts prosenchymatisch, am Grunde rektangulär bis quadratisch, mitunter überall eng linealisch. meist mit frühzeitig absorbiertem Chlorophyll. Blüten (excl. Mielichhoferia) gipfelständig, mit fadenförmigen Paraphysen. Innere Perichätialbläfter meist kleiner, sonst nicht versehieden. Seta \pm verlängert. Kapsel geneigt bis hängend, selten aufrecht, ei-, birn- bis keulenförmig. selten fast kugelig und nur der stets deutliche. meist in die Seta verschmälerte Hals trocken oft mit Runzeln und Falten; Spaltóffnungen meist oberfächlieh, stets im Halsteile. Ring meist differenziert und sich abrollend. Peristomzähne 16, meist dolchförmig. Inneres Peristom zart, mit einer meist kielfaltigen Grundhaut und meist gekielten, mit den Zähnen abwechselnden und durrhbrochenen Fortsätzen. Decke] gewölht bis kurz kegelig, mit Spitzchen oder mit Zitze, selten kurz geschnäbelt. Haube klein, flüchtig.

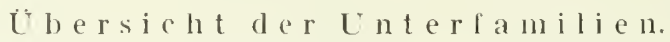

I. Blüten anf seitenständigen Kurztrieben gegen den Grund des Stengels oder der Jahressprosse. Ausseres Peristom fehlend

II. Blüten gipfelständig am Hauptspross. Peristom doppelt. Bryoideae.

\section{MIELICHHOFERIOIDEAE.}

Blïten auf seitenständigen Kurztrieben gegen den Grund des Stengels orler der Jahressprosse: $C^{\pi}$ Blüten dick knospenförmig. Schlanke Pfl. in dichten. gleich hohen. meist I gläizenden. weit hinauf durch Rhizoiden verwebten Rasen. Stengel aufrecht, ladenförmig, leicht brüchig, gleichmässig beblättert, mit zahlreichen, aufrechten Ästen. Blätter nicht herablaulend, trocken anliegend, eiförmig l,is lineal-lanzettlich, flachrandig, an der Spitze \pm gesägt; Zellen eng längsgestreckt, mr am Grunde etwas lockerer, kurz rektangulär bis quadratisch. Kapsel regelmässig, birnförmig, dünnhäutig. Äusseres Peristom fehlend. Inneres Peristom blassgelb, fein papillös, mit sehr niedriger Grundhaut und sehmalen, nicht durchbrochenen Fortsätzen; Wimpern meist fehlend.

Einzige Gattung:

\section{MIELICHHOFERIA}

Hornsch. in Bryol. germ. II. 2, p. 179 (1831).

i bersicht der Arten.

Blätter scharl zugespitzt; Rippe, kräftig: Zellen gelb- uncl dickwandig ................................................ 306. M. nilida.

Blätter stumpflich zugespitzt; Rippe zart; Zellen lockerer als bei der vorigen Art, liünnwandig..................... 307. M. elongala. 
306. Mielichhoferia nitida Hornsch. in Bryol, germ. 11. 2, 1). 18:3, t. 11, 1. 1 (1831). Weisia Wielichhoferiana Funck in Hopp. et Hornsch. (irypt. exs. (ient. I. Dec. II (1817). - Oreas Mielichhoferi Brid. Bryol. univ. I. p. 381 (1826): Lindl). Musc. seand. p. 18 excl. var. p (1879).]

Diözisch. Rasen an der Oberfläche rein grïn und glänzend oder olivenlarben bis glanzlos. imnen stets braun, mit warzigem, braunem Rhizoidenfilz. Stengel
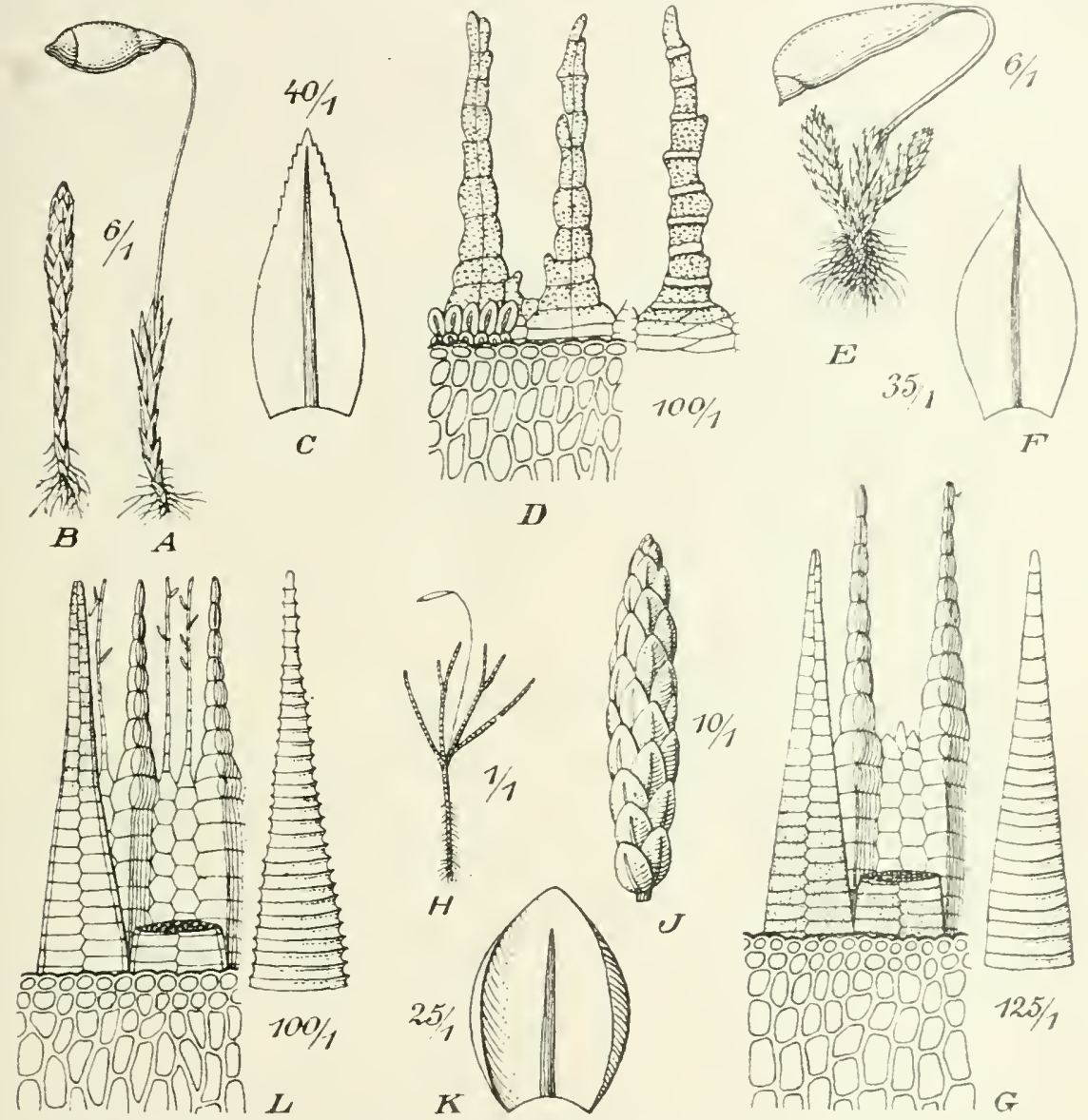

Fig. 46. A-D. Mielichoferia nitida Hornsch. A Fruchtspross (6 1); B steriler spross (6/1); C stengelb. ( $40 / 1)$; D Peristom (100/1). - E-G. Plagiobryum Zierii (Dicks.). E Fruchtende Pfl. (b 1); F stengelb. (35/1): fr Peristom (125/1). - H-L. Anomobryum filiforme (Dicks.). H Fruchtende Pfl. (1 1); I Slengel (10/1): K stengelb. (25.1); L Peristom (100/1).

5-30 $\mathrm{mm}$, kantig beblättert. Blätter feucht steif aufrecht, zuweilen am Sprossencle schwach einseitswendig, lanzettlich und lineal-lanzettlich, scharf zugespitzt. bis 1,8 mm lang: Rippe kräftig, mit der Blattspize, seltener vor derselhen aufhörend: Zellen gelb- und dickwandig, oben rhombisch-linealisch. Seta meist 10 $13 \mathrm{~mm}$, gleichdick, rötlich, nur an der Spitze gelb. Kapsel anfangs aufrecht, später schwach geneigt, mit dem gleichlangen Halse birnförmig, 3.5-1 mm lang, licht gelbgrün, zuletzt gelbrötlich: Zellen des Exotheciums in cler Mehrzah! quadratisch. Fortsätze des immeren Peristoms ohme seitlich vortretende Querleisten. Sporen 1.t-18 ", bräunlichgelb, gekörnelt. Sporenreife im August und September. Fig. 16 A-D. 
Auf zersetzten alaun-, eisen-oder kupferhaltigen Schieferfelsen und in deren Ritzen.

S. Ig. Hunneberg. LuL. Krirkjokk.

N. Gudbrandsdalen. Br. Gouslafjeld. SB. K. Dovre. Lomsfjeldene, Valders. No. $-F$. an einzelnen Fundorten.

Pỵrenāen. Zentralzone der Alpen, Kaukasus.

307. Mielichhoferia elongata (Hornseh.) Hornsch. 1. e. p. 186, t. 41, f. 2. [Weisia compacta Hopp, et Hornseh. Crypt. exs. Cent. I. Dee. II. (1817). - W. elongata Hornsch. in litt.; Hook. Musc. exot. II. t. 102 App. p. 7 (1820). - Oreas Mielichhoferi var. $\beta$ compacta Lindb. Musc. seand. p. 18 (1879).]

Diözisch. Rasen an der Oberfläche licht bläulichgrün, spangrün, seidenglänzend, innen bis zu den neuen Trieben schwärzlich, mit schmutzig-weisslichem. glattem Rhizoidenfilz. Stengel 3-10, selten his $15 \mathrm{~cm}$, kätzchenartig beblättert. Blätter fencht und trocken anliegend, ciförmig bis eilanzettlich, stumpflich zugespitzt, etwas hohl, meist nur $0,75 \mathrm{~mm}$ lang; Rippe zart, vor cter Blattspitze aufhörend; Zellen dïnnwandig, oben rhombisch und rhomboidisch. Seta bis $5 \mathrm{~mm}$, abwärts merklich verdünnt, oben im Bogen gekrïmmt, gelb, an Grunde braun. Kapsel horizontal oder herabgebogen. gedrungen birnförmig, mit trocken stark zusammenzogenem Halse, meist $2.4 \mathrm{~mm}$ lang. bleich olivenfarben, später bräunlich, zuletzt schwärzlich: Zellen des Exotheciums länglich und rektangulär. Fortsätze des inneren Peristoms mit seitlich vortretenden Querleisten. Sporen 18 24 ", bleichgelblich. glatt. Sporenreife im August und September.

An ähnlichen Standorten wie die vorige Art.

N. Dorre. Yo. Bodin.

Schottl.. Pצ̌ren., Aurergne, Zentralzone der Alpen.

\section{LEPTOBRYUM}

(Bryol. eur.) Wils. Bryol. hrit. p. 219 (185.5).

Weiche, stark seidenglänzende Pfl. Stengel einfach, nur am Grunde mit einzelnen Sprossen und Rhizoiden. Blätler nach oben viel länger, schmal pfriemenförmig, abstehend, trocken hin- und hergebogen: Rippe breit und flach; Zellen eng, fast ïberall linealiseh-6seitig. Kapsel nickend bis hängend, klein, regelmässig. aus langem Halse birnförnig. sehr dümnhäutig und stark glänzend: Sporensack klein. gestielt, die True auch zur Reifezeit nicht ausfüllend: Spaltöffnungen oberflïchlich. Ring differenziert. Peristom wie bei Eubryum.

308. Leptobryum pyriforme (L.) Wils. Bryol. brit. p. 219, t. 28 (18.5)). |Mnium pyriforme L. Sp. pl. p. 1112 (1753). - Bryum pyriforme Wegg Prim. Fl. Hols p. $29(1780)$.]

Synöziseh, seltener diözisch: Blïten fast kopfförmig, Paraphysen zahlreich, oben dicker, mit verlängerter, scharf zugespitzter Endzelle. Hüllblätter und Sehopfblätter mit achselständigen, 3-tzelligen, am Grunde roten Keulenhaaren. Lokker- bis dichtrasige, niedrige, selten bis 2-3 cm hohe, grüne oder getbliehgrüne Pfl. Blätter aus lanzettlicher Basis raseh verlängert pfriementörmig, rinnig-hohl, bis $5 \mathrm{~mm}$ lang und bis $0,1 \mathrm{~mm}$ breit, flach- und ganzrandig oder weit herab entfernt gesägt. Seta $1-3$, selten $1 \mathrm{~cm}$. duinn, gelbrot. Kapsel bis 2,5 $\mathrm{mm}$ lang und bis $1 \mathrm{~mm}$ dick, gelh- bis rotbraun; Zellen des Exotheciums sehr unregehmässig, dünnwandig. Ring schmal, sich abrollend. Peristomzähne blassgelb, bis $0.1 \mathrm{~mm}$ lang, nilt bis 25 Lamel en. Inneres l'eristom zart. hvalin: Fortsätze gefenstert; Wimpern mit langen Anhängseln. Deckel klein, hochgewölbt, mit Warze. Sporen klein, glatt oder fein papillös. Sporenreife im Juni und .Juli. -- Vegetative Vermehrung dureh Rhizoidenprotonema und Basal-. seltener Rhizoidensprosse. 
In Sandausstichen, an Weg- und Grabenrändern, auf feuchter, lıumöser uncl torfiger Erde, längs den Wasserläulen, an Brandstellen, in Fels- und Mauerritzen, auf Kalkdetritus.

F. Al. Hammarland, Skarpnâtö (Arrh.). Saltvik, an mehreren Fundorten (Bem.). - Ab. Kispo, Ifväslıy (Elfr.). Pargas (E.). Uskela (Nikl.). Karislojo (Sundv.). Kisko (Hult). Lojo (Lindl,). — X. Kyrksiätt (Nyb.). Esbo (Broth.). Helsingfors (Lindb.). Borgi (Sael.). - Ka. Wiborg (W. Nyl.). - Ih. Kirennapa (H. Lindb.). — St. Eura (Rönnb.). Björneborg (Nerv.). Hāmeenkyrö, Kyröshoski (NerY.).

Ta. Vanaja (Thur.). Hattula (Ranck.). Sääksmäki (Kihlm.). Tammerfors (Nerr.). lun südöstl. Teile pass. (Norrl.). Hartola (Bonsd.). Luhanka und Korpilahti pass. (Vain.). - sa. Willnanstrand (Buch). Ruokolahti (Hult). - ki. Hiitola (Fastb.); Kurkijoki (Jusl.); Valamo (J.); Unkuniemi (J.). Surtavala. Kirjavalahti (IW. Nyl.); Soanlahti, Korpikallio (Broth.). - Kol. Salmi (Pes.). Vosnessenje (EIfY.). Ua. Sidehy (Karst.). Lappfjärd, Ka askö und Närpes (Nerv.). — Th, si. fiq. (Broth.). — Sib). Joroinen, Järvikylä (II. Lindb.). Pieksämäki, Rummukka (Kyylık.). Kuopio, an mehreren Fundorten (Link.). Nilsiä, Timpinen (Kyslak.). Maaninka und Pielavesi pass. (Roir.). Iisalmi (Tonm.). - Kon. Suojärvi. Pöpön-
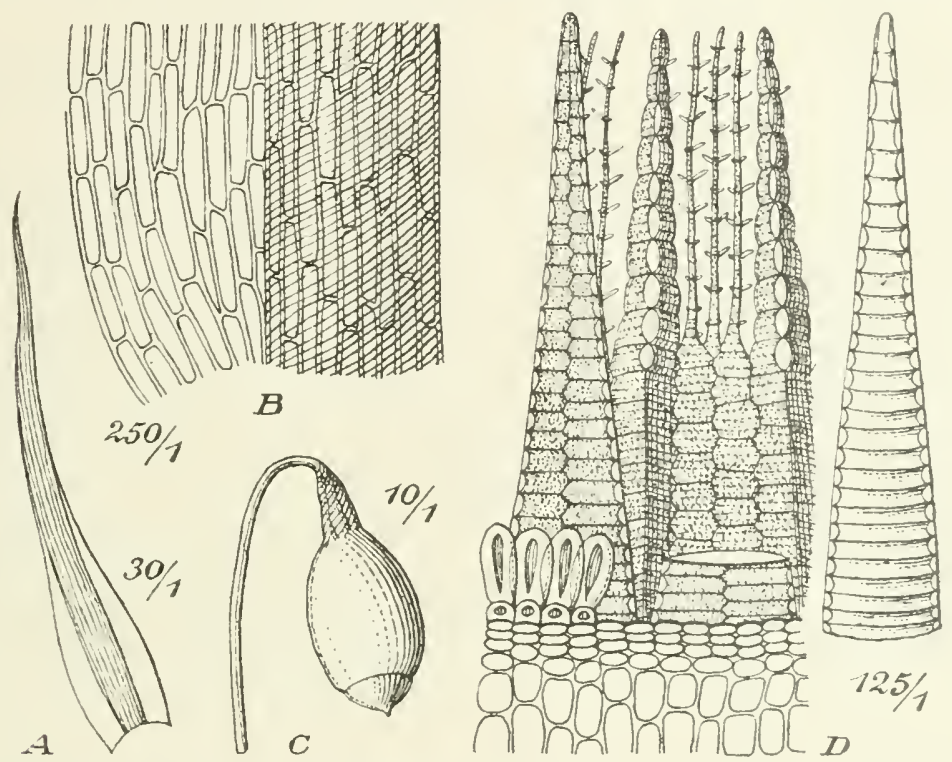

Fig. 47. Leptofrum pyriforme (L.). A Stengelb. (30/1); B Blattbasis (25) 1); C Kapsel in trochellem Zustande (10 1); D Peristom (1251).

sdari (Norrl.). Mundjärvi (N.). Gorka (Simm.). - Om. Alajärvi, Vesterbaeka, Huosiannaankallio und Moskvankallio (Backm.). - Ok. Kajana (Lackstr.). Paltamo, Norsinniemi und Reetinniemi (Kyyhk.) Sotkamo, Hanhipuro (K.). Puolanka, Rytiaho und Vuorijärvi (K.). Ristijäri (Laekstr.). Suomussalmi, Kaivosuo (Kyyhk.). — Kk. Pääjärvi (Hollm.). Knjāscha, Sonostror (Kahlb.). — Ob. Uleaborn (Brenn.). Kiiminki (Nyb.). Ii (Brenn.). Kiemi (B.). Alatornio (Häyr.); zw. Aavasaksa und Turtola fq (Hult), - Lkem. Kolari und Kittilä fণ."(Hı]t). - K. Pudasjärvi, Pärjänjoki (E. af H.). Kun-ano, Zw. Vattula und Narttila (Broth.); Pernu (B.); Vasiraperä. Akanlahti, Suolampi (E. af If.). - Le. In del Vadelwald- und Birkenregion bis Kilpisjärvi st. fq. (Yorrl.); Kilpisjärvi, silastupa, in der Birkenregion (Kot.). - Li. Inari, an mehreren Fundorten in der Nadelwaldregion (Hult). Utsjoki, Mandojäri, in der Birkenregion (H.). - Lim. Imandra (Fellm.). Lujauri-urt, suloaj (Kihlm.). - Li. Kiolil (Brolth.): Srednij am Kolabusen (B.). Jeretik, Tsipnarolok. Vaidoguba und Bumansfjord (B.). Kildiu (B.). Lmur. Bjelousiha an Voronjeflusse und Semjostrowsk (B.). Zw. Yarsinsk und Jenjavr (B.). Jokonsk (Fellm.). - Lv. Trehapoma (Broth.). Tscharanga (Brenn.).

S. $S k,-L$.

N. Sm. $-F$.

Europa, Kaukasus, Kaschmir, Pandschal, Nord-Asien, Japan, Nord-Amerika, Ecuador. Bra-ilien, Fuegia, Tasmanien, New Zealand. 


\title{
78. PLAGIOBRYUM
}

\author{
Lindb. in Öfr. K. Vet.-Ak. Förh. 1862, N:o 10.
}

Diözisch; c Blïten dick knospenförmig. Schlanke Pfl. in schwach glänzenden, weichen, unten durch Rhizoidenfilz verbundenen Rasen. Stengel \pm verlängert, fast gleichmässig beblättert, mit = kätzchenförmigen subfloralen Sprossen. Blätter etwas herablaufend, anliegend, eiförmig bis länglich-lanzettlich, ungesäumt, ganzrandig: Zellen selır locker und dünnwandig, mit spärlichem, inı Alter fehlendem Chlorophyll. Kapsel langhalsig-keulenförmig. gekrümmt, hochrückig, eng- und schicfmündig, trocken unter der llündung nicht verengt. Peristomzälnne schmal lanzettlich, ungesäumt. Inneres Peristom länger. gelblich: Fortsätze sehr schmal, ritzenförmig durchbrochen, mit nach innen vorspringenden Querleisten: Wimpern rudimentär. Deckel klein. gelbrot. Sporen 30-10 "* gelbhraun. papillös. Sporenreife im August und September.

$$
\text { Libersicht der Arten. }
$$

A. Rasen grünlich-silberweiss, innen weinrötlich. Blätter sehr hohl ..................................................309. P. Zierii.

B. Rasen mit Jraunrötlichem Anflug. Blätter mässig hohì. 310. P. demissum.

309. Plagiobryum Zierii Lindl). 1. c. [Bryum Zierii Dicks. Pl. crypt. fasc. 2, p. 8, t. 4, f. 10 (1790). — Zieria julacea Schimp. Coroll. p. 68 (1856).]

Rasen grünlich-silberweiss, innen weinrötlich. Stengel niedrig, sterile Sprosie selten bis $3-4 \mathrm{~cm}$. Blätter der sterilen Sprosse dachziegelig. sehr hohl, breit eiförmig, mit zurückgebogener, schmaler Spitze. bis $1 \mathrm{~mm}$ lang und $5 \mathrm{~mm}$ breit. flachrandig, oberwärts wasserhcll. Sclıopfblätter grösser und dichter gestellt, die oberen eilanzettlich, zugespitzt, mit am Grunde umgebogenen Rändern; Rippe vor und in der Blattspitze verschwindend. Seta $8-15 \mathrm{~mm}$, schwanenhalsartig gekrümmt, rötlich. Kiapsel horizontal oder geneigt, mit dem sehr langen Halse bis $4 \mathrm{~mm}$ lang. bräunlichgrïn. etwas glänzend, im Alter rötlichbraun, mit dunklerem Halse, entleert fast aufrecht. Peristomzähne wenig kürzer als das innere Peristom, in der unteren Hälfte gelbrot, oben gelblich, fein papillös, mit 20-25 Lamellen. Grundhaut des inneren Peristoms ${ }^{1 / 2}$ (er Peristomzähne. Deckel kegelig. scharf zugespitzt. - Fig. $46 \mathrm{E}-\mathrm{G}$.

In erderfüllten Spalten und Höhlungen feuchter und triefender Felsen, besonders auf Kalk und Schiefergesteinen. Nordgrenze auf Spitzbergen.

F. Le. Kilpisjärvi, Saana, in der alpinen Region (Kot.). - L.p. sijātonnos. Dolgaja guba (Broth.); Katschkova, Rusiniha und Ponoj (B.). - Lx. Tschapoma (B.).

S. Hrjd., Jmt., LuL. und $T L$. an mehreren, $P L$. und $L y L$. an einzelnen oder wenigen Fundorten. Ảng. Tảsjō.

N. Sm., NB., R. pass., ST., NT., No.-F. hāufig durch die ganze Baumregion, doch auch in ditHochgebirge hinaulsteigend.

Europa, Kaukasus, Zentral-Asien, Ost-China, Nord-Amerika.

310. Plagiobryum demissum (Hop]. et Hornsch.) Lindb. ]. c. [Meesea demissa Hopp. et Hornsch. in Flora 1819, I. p. 106. - Zieria demissa Schimp. Coroll. [). 69 (1856).]

Kleiner als die vorige Art. Rasen mit braunrötlichem Anflug, innen dicht rotfilzig. Stengel niedrig, sterile Sprosse höchstens bis $2 \mathrm{~cm}$. Blätter der sterilen Sprosse mässig hohl, locker anliegend, trocken etwas flatterig. cilanzettlich, in ein Spitzchen versehmälert, mit am Grunde umgebogenen Rändern. Schopfblätter aufrecht-abstehend, länglich-lanzettlich, dic innersten kleiner, in ein langes schmales Spitzchen verschmälert und mit längs schmal umgerollten Rändern: Rippe kräiftiger als bei der vorigen Art, in der Blattspitze endend. Seta bis $1 \mathrm{~cm}$, dick und slraff, gelbrot. Kapsel erst horizontal, dann mehr lierabgebogen, entleert 
aufstrebend, mit dem gleichlangen Halse bis $3 \mathrm{~mm}$ lang, gelblich hraun, zuletzt (lunkelbraun. Zähne des äusseren Peristoms viel kürzer als das innere, nur an Grunde gelbrot, oben hyalin, glatt, meist mit 12 Lamellen. Grundhant des inneren Peristoms niedrig; Fortsätze an der Spitze oft durch Quergliecler verbunden. Deckel flachgewö bt mit Spitzchen. Sporen zur Reifezcit noclı in Tetraden vereinigt.

Auf Humus und kalkarmer Erde an felsigen und steinigen Abhängen.

F. Lt. Kitorka (Fellm.). - Lp. Katsclikova (Brer.n.). Gorodetskaja (Broth.).

S. PL. Tjidtjakk.

N. Dovre. Jotunfjeldene. Filefjeld, No. an wenigen, Tr. $-F$. an einzelnen Fundorten.

schottland, Alpengebiet. Zentral-Asien, Rocky Its., Colorado, arkt. Aord-Amerika.

\section{ANOMOBRYUM}

\section{Anomobryum Schimp. Syn. 1. ed. p. 382 (1860).}

Diözisch; or Blüten knospenförmig. Schlanke Pfl. in meist bleich-oder gelbgrünen, glänzenden Rasen. Stengel fadenförmig, \pm verlängert, gleichmässig bcblättert, mit schlanken, \pm verlängerten subfloralen Sprossen. Biatter klein, nicht herablaufend, dachziegelig anliegend, ungesäumt, flachrandig; Rippe schwach entwickelt, mit 2-6 basalen Deutern, ohne Begleiter, differenzicrten Rückenzellen und homogen verdickten Füllzellen; Zel en der Lamina lang und schmal, ¿ verdickt, am Grunde lockerer. Kapsel derhhäutig, lichtlraun, in Alter hastanienbraun. Peristomzähne gelb, gesäumt, rasch in eine langc. hyaline Pfriemenspitze verschmälert, fein papillös. Inneres Peristom von gleichel Höhe; Fortsätze breit, gefenstert; Wimpern vollständig, zart, mit langen Auluängseln. Sporen 10-16 ", gelblich, glatt bis fast glatt.

\section{Übersicht de Arten.}

A. Stengel mit Brutknospen

312. A. concinnatum.

B. Stengel ohne Brutknospen.

a. Rasen loch. Blätter stumpf, ohne Spitzchen; Rippe kräftig, kurz vor der Blattspitze endend ........... 311. A. filiforme.

b. Rasen niedrig. Blätter zugespitzt oder mit zurückgebogenem Spitzchen: Rippe zart, weit vor der Blattspitze endend 313. A. juliforme.

311. Anomobryum filiforme (Dicks.; Lindb.) Husn. Muscol. gall. p. 222 (1888). [Bryum filiforme Dicks. Pl. crypt. fasc. IV. p. 16 excl. synon. (1801); Lindh. Notis-Sällsk. F. Fl. Fenn. Förh. XI I. p. 43 (1870). - B. julaceum Sm. Fl. brit. IlI. p. 1357, No. 13 ex p. (1804); Bryol. eur. fasc. $6 / 9$ p. 79, t. 40 (1839). - Anomobryum julaceum Schimp. Syn. p. 362 ex p. (1860).]

Rasen \pm dicht, unten durch Rhizoidenfilz nur locker verunden und mit Erde durchsetzt. Stengel 1-10 cm. Blätter sehr hohl, eilörmig und oval-länglich, stumpf, ohne Spitzchen, bis $1.2 \mathrm{~mm}$ lang und bis $0,7 \mathrm{~mm}$ breit, ganzrandig. zuweilen an der Spitze undeutlich, aber dicht gezähnt; Rippe krätig, kurz vor der Blattspitze endend, zuletzt rötlich; Zellen der oberen Blatthälfte verdickt, schmal rhomboidisch bis lineal, etwas geschlängelt, am Grunde locker und lïinwandig. Seta $2 \mathrm{~cm}$, dick, steif, rot. Kapsel \pm hängend, aus gleichlangem, verschmälertem Halse oval und schmal länglich, meist etwas gckrümmt, etwa $4 \mathrm{~mm}$ lang. trocken. unter der engen Iündung wenig eingeschnürt. Peristomzähne mit etwa 30 Lamellen in gleichweiten Abständen. Inneres Peristom zart, gelblich, oberwärts lyalin; Grundhaut von halber Zahnhölı. Deckel klein, glänzend rot. - Fig. $46 \mathrm{H}$ L.

Auf sandiger Erde, Humus und Kicselgestein an feuchten und nassen Stellen. gern an Wasserfällen und Bachufern. 
S. Jmt., LyL., PL. und LuL. an einzelnen oder wenigen Fundorten. steril.

N. Sm. Skjeberg und Tune. St. Ryfylke. SB. An mehreren Fundorten. NB. Sogn; Aalesund. K. Jotunheim. ST. Dovre; Maristuen. No. An mehreren Fundorten. Nordgrenze bei etwa $67^{\circ} \mathrm{n} . \mathrm{Br}$. Steril.

Europa, Kamerun, Ruvenzori, Abessinien, sïd-Amerika im Hochgebirge.

312. Anomobryum concinnatum (Sprue.) Lindb. in Öfv. K. Vet.-Ak. Förl. XVIII. p. 277, No. 65 (1861). [Bryum concinnalum Spruc. in Trans. bot. soe. Edinl. III. p. 155, No. $141(1819)$.]

Rasen ziemlich dicht. freudig- bis gelblichgrün, lebhaft seidenglänzend, innen braun und bis zu den neuen Trieben durch Wurzelfilz verwebt. Stengel $1-1 \mathrm{~cm}$. Blätter weniger hohl, eiförmig und eilanzettlich, zugespitzt oder mit kurzem, sehwach zurückgebogenem Spitzchen, bis $1,1 \mathrm{~mm}$ lang und etwa $0,5 \mathrm{~mm}$ breit, ganzrandig, selten an der Spitze undentlich gesägt; Rippe gelblich, vor und nit der Blattspitze endend: Zellen ziemlich gleichförmig, in den unteren Blätter nieht. in den oberen nur wenig verdickt, am Grunde etwas lockerer. Sporogone unbekannt. - Vegetative Vermehrung dureh achselständige, kurzgestielte, grünliche oder am Grunde gebräunte, einzelne oder gehäufte, von stumpfen Blättchen gekrönte Bulbillen.

Auf Humus und Errle an feuchten Felsen und an steinigen Abhängen.

S. Og. Omberg. Hrjd. Ulfbärget. Jmt. Handölsfallen LuL. Nammats.

N. Sm. Skjeberg. Hafslund; Tune, Borregalard und Grotet. Bu. Modum. Gravfossen; Ringerike, Krokkleven und Skjerdalen. IL. Holmestrand. Ne. Saetersdalen. K. Iomsfjeldene. ST. Dorte. NT. Stjordalen. No. Bodin und sorfolden.

Gross-Britannien, Pyrenäen, Kaukasus, Nord-Amerika. Nordyrenze in Ost-Grönland.

313. Anomobryum juliforme Solms-Laub. Tent. bryogeogr. Algarb. p. is (1868).

Rasen locker, gelbgrün, stark glänzend. Stengel etwa $1 \mathrm{~cm}$, an Grunde mit Rhizoiden. Blätter sehr hohl, verlängert eilörmig, zugespitzt oder mit zurückgebogenem Spitzchen, bis $0,9 \mathrm{~mm}$ lang und bis $0,3 \mathrm{~nm}$ breit. Schopfblätter grösser, eilanzettlich, lang zugespitzt, gegen die Spitze dicht und fein gesägt; Rippe zart, gelb]ich, weit vor, nur in den Schopfblätter mit der Blattspitze aufhörend; Zellen sehr dickwandig, lang und schmal, meist geschlängelt-linealisch, an Grunde loeker und dünnwandig. Seta $1-1,5 \mathrm{~cm}$, dünn, purpurn. Kapsel horizontal, geneigt oder aufsteigend. mit rlem gleichlangen Halse keulenförmig, etwa 2,5 mm lang, unter der weiten Mündung wenig verengt. Peristomzähne am Grunde orange, mit über 30 sehr dicht, nur am Grunde und an der Spitze locker gestellten Lamellen. Inneres Peristom straff, gelb; Grundliaut von $1 / 3$ Zalnhöhe. Deckel gross, gelbrot.

An erdbedeckten Anhängen.

N. SB. Aalesund, Iolde und Trsnes, store Godr. Steril.

Bretagne, Süd-Europa, Algier, Madeira.

\section{POHLIA}

Pohlia (Herlw.) Lindb. Muse. scand. p. 17 (1879) ex p.

Stengel meist einfach, oben dicht beblättert, in der Regel nur am Grunde mit einzelnen Sprossen und \pm reichlichen Rhizoiden. Obere Blätter der Fruchtsprossen meist verlängert und schopfig gehäuft, aufrecht-abstehend, meist lanzettlich bis lineal-lanzettlich, ungesäumt; Rippe weniger kräftig, selten austretend; \%ellen schmal rhomboidisch-6seitig bis linealisch, noeh unten etwas erweitert. Seta verlängert, an der Spitze hakig oder bogig gekrümmt. Kapsel geneigt bis nickend oder hängend, meist regelmässig; Spaltöflnungen oberflächlich. Peristom doppelt, beide von gleicher Länge. Peristomzähne am Grunde verschmolzen, lanzettlielı odler linealisch-pfriemenförmig, gehb, mit fein papillöser Dorsalfläche uncl hohen Lamellen. Inneres l'eristom frei; Grundhaut oft niedrig; Fortsätze lanzettlieh-pfriemenförmig; Wimpern, wenn vorhanden, ohne deutliche Anhängsel. 
I bersicht der Arten.

A. Diözisch. Kápsel aufreeht, regehuässig. Fortsätze und

Wimpern meist feh end, selten einzelne \pm entwickelt ... 31. P. crecta.

B. Fortsätze normal entwickelt.

a. Diözisch. Peristomzähne undurchsichtig, mit ausgeselnweiften Rändern

318. P. crassidens.

b. Peristomzähne durehsichtig, mit geraden Rändern.

a. Zellen des Exotheciums (exel. $P$. nutans und $P$. sphagnicola) mit geraden Wänden. Sterile Stengel ohne Brutknospen.

I. Parözisch, selten autöziseh.

1. Schopfblätter breit gespitzt bis stumpf; Zellen oberwärts 1: 3-4. Kapsel kurzhalsig. Wimpern kurz

323. P. cucullata.

2. Sehopfblätter allmählich zugespitzt: Zel en enger

* Blätter etwas glänzend: Zellen oberwärts 1: $5-6$.

† Grundhaut niedr g; Fortsätze schmal, ritzenförmig durchbrochen; Wimpern rudimentär oder fehlend.

$\times$ Hals von etwa halber Lrnenlänge ..... 315. P. polymorpha.

$\times \times$ Hals etwa von Umenlänge .......... 316. P. acuminata.

$\times \times \times$ Hals länger a's die Urne ............. 317. P. elongata.

$\dagger \dagger$ Zellen des Exotheciuns mit verbogenen Wänden. Grundhaut $1 / 3 \ldots 1 / 2$ der Zahnhöhe; Fortsätze lanzettlich-pfriemenförmig. gefenstert; Wimpern vollständig, knotig ... 321. P. nutans.

** Blätter gelbgrün, stark glänzend: Zellen oberwärts 1: $10-12$. Hals kürzer als die Urne. Grundhaut etwa $1 / 3$ der Zahnhöhe; Wimpern \pm entwickelt, knotig ..............

II Meist diöziseh, seltener parözisch oder synözisch. ter allmählich lang zugespitzt; Zellen oberwärts 1: 10-12. Hals von halber Urnenlänge. Grundhaut $1 / 4$ der Zahnhöhe; Fortsätze später klaffend; Wimpern vollständig, knotig

319. P. longicollis.

11. Paröziseh und polyöziseh. Neist purpurfarbene Pfl. Blattze len oberwärts etwa 1: 4. Peristom wie bei $P$. nutans

IV. Diözisch. C Blüten fast scheibenförmig. Tracht von $P$. nutans. Zellen des Exotheeiums mit verbogenen Wänden. Peristom wie bei $P$. nutans ... 322. P. sphagnicola.

ґ. Diöziseh. Zellen des Exotheciums mit rerbogenen Wänden. Grundhaut des imeren Peristoms $1 / 3-1 / 2$ der Zahnlänge; Wimpern vollständig.

I. or Bhïten fast seheibenförmig. Traeht von Leptobryum. Schopfblätter weit abstehend, trocken verbogen, sehr lang zugespitzt, mit weit herab scharf gesägten Rändern. Brutknospen fehlend. 333. P. lutescens. 
II. B Blüten knospenlörmig. Schopfblätter breit bis lanzettlich zugespitzt.

1. liräftige Pfl. Blätter der sterilen Sprosse abstehend, hohl, trocken locker anliegend, eiförmig, stumpf. Schopfblätter breit gespitzt: Zellen oben etwa 1: 4. Brutknospen fehlend ...

2. Schlanke Pfl. Blätter der sterilen Sprosse (excl. P. bulbifera) steif, aufrecht-abstehend, trocken anliegend, lanzettlich zugespitzt;Zellen enger.

* Kapsel sehr klein, aus dickem, kurzem Halse eikugelig, trocken und entdeckelt kreiselförmig, weitmïndig. Brutknospen fehlend. 332. P. pulchella.

** Kapsel grösser, aus \pm langen Halse oval, trocken und entrleckelt kaum verändert. Sterile Sprosse meist mit blattwinkelständigen Brutknospen.

$\dagger$ Brutknospen einzeln, seltener zu $2-3$.

$\times$ Brutkinospen einzeln, kugelig bis länglich-eiförmig, $\mathrm{m} \mathrm{t} 3-1$, selten $5-6$ aufrechten, spitzen Blättchen gekrönt. \$ Brutknospen zur Reife griun oder schwärzlich ........................... 327. P. gracilis.

$\S \S$ Brutknospen zur Reife rotbraun ... 331. P. annolina.

$\times \times$ Brutknospen einzeln, kugelig bis länglich-eiförmig, nit $3-4$ aufrechten. stumpfen Blättchen gekrönt, zur Reife purpurrot 326. P. commulata.

$x \times \times$ Blätter wenigstens feucht meist sparrig-abstehend. Brutknospen 1-3, kleiner, rund ich, oval orler verkehrt-eiförnig, mit $2-3$, selten $4-5$ stumpfen, kappenförmig hohlen, zusammenneigenfẹn Blättchen gekrönt, zur Reife gelb 330. P. bulbifera.

$\dagger \dagger$ Brutknospen büschelförmig gehäuft.

$\times$ Brutknospen länglich-oval oder sehmal Iänglich-keilförmig, mit $2-5$ deutlichen Blättchen gekrönt 329. P. grandiflora.

$\times \times$ Brutknospen langgestreckt, \pm spindelförmig, häufig gedreht und wurmförmig gekrümmt, mit meist nur 1-2 undentlichen, zuweilen fehlenden Blattspitzen gekrönt 328. P. proligera.

S e c t. I. Cacodon Lindb. in Rev. bryol. 1883, p. 7.

Diözisch. Kapsel aufrecht, regehmässig. Inneres Peristom \pm rudimentär 314. Pohlia erecta Lindl). 1. c. [Mielichhoferia erecta Kindb. Enum. p. 22. (1888).]

Herdenweise wachsende oder lockerrasige, dunkelgrïne, im Alter schwärzliche, gläızende Pfl. Stengel bis $1 \mathrm{~cm}$. Blätter fast aufrecht, trocken anliegend, weit und ziemlich breit herablaufend, lohl, ciförmig, spitz, bis $1,7 \mathrm{~mm}$ lang und his $0,4 \mathrm{~mm}$ breit, mit am Grunde umgebogenen, oberwärts entfernt kleingezähnten bis glatten Rändern: Rippe weit vor der Blattspitze aufhörend; Zellen zart, oben 
1: 1-6. Seta bis $8 \mathrm{~cm}$, rot. Kapsel aus fast gleichlangem Ialse wal, etwa $1,5 \mathrm{~mm}$ lang und etwa $0,8 \mathrm{~mm}$ dick, rotbraun, trocken und enteleckelt weitnsiundig, unter der Mündung kaum verengt. Peristomzähne $0,17 \mathrm{~mm}$ lang, fein papillös, mit etwa 16 Lamellen. Inneres Peristom gelblich; Grundhaul $1 / 3-1 / 4$ der Zahnlänge, unregelmässig zerschlitzt; Fortsätze und Wimpern meist fehlend, selten einzelne = cnlwickelt. Deckel gewölbt kegelig, stumpf. Sporen $18-20$ ", braun, papillös.

N. sT. Opdal, Vangsfjeld, am Skarbaecken.

S e c t. I I. Eupohlia Lindb. Husc. scand. p. 18 (1879).

Kapsel meist geneigt oder horizontal; Zellen des Exotheciums mit geraden. Wänden. Grundhaut des inneren Peristom meist niedrig; Fortsaitze vollständig, meist schmal; Wimpern meist rudimentär oder fehtend.

315. Pohlia polymorpha Hopp. et Hornsch. in Flora 1819, 1. p. 100. [Bryum polymorphum Bryol. eur. fase. $6 / 9$ Mon. p. 25, t. 8 (1839). - Webera polymorpha Schimp. Coroll. p. 65 (1856).]

Parözisch, zuweilen auch autözisch. Gruppenweise wachsende oder fockerbis dichtrasige, $0,5-3 \mathrm{~cm}$ hohe, grüne oder gelbgrüne, glanzlose Pll. Schopfblätter locker anliegend, länglich-lanzettlich, zugespitzt, bis $2 \mathrm{~mm}$ lang und bis 0,15 mm breit, mit schmal, oft einseitig umgerollten, in der Spitze gesägten Rändern: Rippe in oder vor der Blattspitze auflörend; Zellen nicht rerdickt, oben 1: 5- -6. Seta $0,5-2 \mathrm{~cm}$, rot, zuweilen stark gekrümmt. Kapsel geneigt bis hängend, aus dem Halse von etwa halber Umenlänge länglich-elliptisch bis oval, $2-3 \mathrm{~mm}$ lang, gelbbraun bis braun, kleimmündig, trocken und entdeckelt unter der Mündung = deutlich verengt. Peristomzähne $0,35 \mathrm{~mm}$ lang, gelbrot, meist \pm deutlich gestreift, grob papillös, mit meist 20-25 Lamellen. Inmeres Peristom gelb; Grundhaut $1 / 5$ der Zahnhöhe; Fortsätze schmal, dicht papillös, ritzenförmig durchbrochen; Wimpern fehlend. Deckel kegelig, meist stumpf. Sporen 20-24 $\mu$, rostfarben, papillös. Sporenreife im Juli ind August.

Auf Erdblössen, an steinigen Abhängen und in erderfüllten Felsritzen.

F. Le. Pietsovaara (Norrl.). - Li. Inari, Pyttelvaara, in der Nadelwaldregion (Kihlm.); Peldoivi, in der Birkenregion (Hult); Kultala (Vain.); Ruoptuinvaara (V.); Veskoniemi (V.).

S. Hrjd., Jmt., LyL. and $L u L$, an einzelnen oder wenigen Fundorten.

N. Ne. Saeterdalen. NB. sogn; Variestuen. $h$. Lomsfjeldene und Filefjeld. No. an mehreren, $T r$. und $F$, an einzelnen Fundorten.

Europa, Kankasus, Himalaya, Yunnan, Tschuktschen-Halbinsel, Kamtschatha, Nord-Amerika

var. affinis (Hopp. et Hornsch.) Möll. Förteckn. Sk. växt. 2. Moss. p. 32 (1907). [Pohlia affinis Hopp. et Hornsch. in Flora 1819, I. p. 97. - Webera polymorpha var. affinis Schimp. Coroll. p. 65 (1856).]

Kapsel schlank. Deckel scharf gespitzt.

N. Ne. Saetersdalen, Meienfjeld. F. Kistrand. Lemmivaara.

Europa.

var. brachycarpa (Hopp. et Hornsch.) Arn. et Jens. Moos. Sarekgeb. p. 160 (1907). [Pohlia brachycarpa Hopp. et Hornsch. in Flora 1819. I. p. 96. - Webera polymorpha var. brachycarpa Schimp. Coroll. p. 65 (1856).]

Niedrige Pll. Blätter kurz, knospenförmig zusammenschliessend; Rippe oft austretend. Seta selır kurz, meist stark gekrümmt. Kapsel nickend und hängend, kurz birnförmig.

S. LuL. Sarekgebiet, in der oberen Weidenregion.

Europa, Baltislan, Hudsonstrait.

316. Pohlia acuminata Hopp. et Hornsch. in Flora 1819, I. p. 94. [Bryum acuminatum Bryol. eur. fasc. 6/9 Mon. p. 21, t. 6 et 7 (1839). - Webera acuminata Schimp. Coroll. p. 61 (1856).]

Autözisch, auch mit vereinzelten $气$ Blüten. Tracht von $P$. elongata, jedoch kleiner. Herdenweise wachsende bis dichtrasige, niedrige bis $4 \mathrm{~cm}$ hohe, grüne oder gelbgrïne, etwas glänzende Pfl. Schopfblätter aufrecht, steif, lineal-lanzett- 
lich, spitz, bis 2,2 $\mathrm{mm}$ lang und $0,45 \mathrm{~mm}$ breit, mit längs schmal umgebogenen, in der Spitze gesägten Rändern; Rippe in oder vor der Blattspitze aufhörend bis kurz austretend; Zellen nicht verdickt, oben 1: $5-6$. Seta $0,5-2 \mathrm{~cm}$, rot, oben im weiten Bogen gekrümmt. Kapsel horizontal, seltener nickend, entleert fast aufrecht, aus gleichlangem Halse schlank keulenförmig, bis $4 \mathrm{~mm}$ lang und bis etwa $0,8 \mathrm{~mm}$ dick, bleichbraun, trocken unter der Mündung wenig verengt. Peristomzähne $0,36-0,4 \mathrm{~mm}$, gelbrot, oberwärts papillös, mit $22-27$ Lamellen. Inneres Peristom gelb; Grundhaut $1 / 5-1 / 4$ der Zahnhöhe; Fortsätze schmal, papillös, schmal ritzenförmig durchbrochen; Wimpern rudimentär oder fehlend. Deckel spitz kegelig oder mit Schnäbelchen, seltener stumpflich. Sporen $20-24 \mu$, rötlichbraun, feinwarzig. Sporenreife im Juli und August.

Auf Erdblössen, an steinigen Abhängen und in erderfüllten Felsritzen.

F. Li. IIuddusjärvi (Sil.).

S. Hrjd., Jmt. und PL. an einzelnen oder wenigen, $L u L$. an melrreren Fundorten.

N. Ne. Saeterdalen. NB. Sogn. K. Jotun- und Lomsfjeldene. ST. Dorre, NT. Stjordalen. No. und $T r$. an mehreren, $F$. an einzelnen Fundorten.

Europa, Kaukasus, Nord-Amerika. Nordgrenze auf Spitzbergen.

Mit der vorigen Art selır nahe verwandt. Nach den eingehenden Untersuchungen von $H$. Winter (Hedwigia XLIX. p. 300 u. f.) bleibt nur ein einziges, wie es scheint, konstantes Merkmal zur Unterscheidung von $P$. acuminala von $P$. polymorpha übrig: der Hals erscheint bei jener Art durchweg länger zu sein als bei dieser. Nach den Angaben von L i m p r i c.h t (Laubmfl. I. p. 236) hat indessen $P$. acuminata ebenso kurzhalsige als $P$. polymorpha langhalsige Varietäten. Frülier wurde als Hauptmerkmal für $P$. acuminala der autözische Blütenstand, auch mit verinzelten ŏ Blüten angegeben. Wie $\mathrm{W}^{\mathrm{i}} \mathrm{n} \mathrm{t} \mathrm{er}$ l. c. hervorhebt, kommt indessen bei norwegischen Exemplaren von $P$. polymorpha autözischer und liöchst wahrscheinlich synözischer Blütenstanrl vor. Nach diesen Befunden kann ein allgemein gültiger spefizischer Unterschied der beiden Arten nicht mehr aufrecht erhalten werden.

317. Pohlia elongata Hedw. Descr. I. p. 96, t. 36 (1787). [Bryum elongatum Dicks. Crypt. fasc. II. p. \& (1790). - Webera elongata Schwaegr. in L. Sp. pl. ed. 4, T. V. P. II. p. $48(1830)$.]

Parözisch. Herdenweise wachsende oder lockerrasige, wenige $\mathrm{mm}$ bis $2 \mathrm{~cm}$ hohe, grüne oder gelblichgrüne, kaum glänzende Pfl. Schopfblätter aufrechtabstehend, trocken verbogen, lineal-lanzettlich, fast pfriemenförmig zugespitzt. bis $5 \mathrm{~mm}$ lang und $0.4 \delta \mathrm{mm}$ breit, mit umgerollten, weit herab gesägten Rändern: Rippe meist kurz austretend; Zellen dickwandig, oben etwa 1: 5. Seta $1-4 \mathrm{~cm}$. rot. Kapsel geneigt oder horizontal, aus dem längeren Halse eizylindrisch, zuweilen etwas gebogen, zimtbraun, trocken und entdeckelt unter der Nündung etwas verengt. Peristomzähne bis $0,48 \mathrm{~mm}$ lang, warzig-papillös, mit bis 28 Lamellen. Inneres Peristom bleich, dicht papillös; Grundhaut 1/4 der Peristomzähne; Fortsätze oft mit ausgefressenen Rändern, nicht oder kaum durchbrochen; Wimpern kurz, oft rudimentär. Deckel kegelförmig, spitz oder kurz geschnäbelt. Sporen 20-25 $\mu$, rötlichbraun, fein papillös. Sporenreife in Juli und August.

Auf sandiger Erde an Wegrändern und Grabenwänden und auf kalkfreien Felsen.

F. Al. Saltvik, Ivarubo und Rangsby (Bom.).

S. Sk., Sm., Ög., Vg., Dlr., Hrjd., Ang. und LuL. an einzelnen Fundorten.

N. Ve. Saetersdalen. St. Frafjord und Ryfylke. SB. Bergen. NB. an melireren Fundorter. ST. 1)orre. No. und $F$. an wenigen Fundorten. Nordgrenze wahrscheinlich bei $70^{\circ} \mathrm{n}$. Br.

Europa, Algier, Afrikan. Hochgebirge, Kaukasus, Kaschmir, Himalaya, Yuman, Amur, Jaỹan, Nord-Anierika.

318. Pohlia crassidens Lindb. Rev. bryol. 1885, p. 5. IWebera trachydontea San. in Bot. Centralb]. XIlI. No. 7 (1883). - W. crassidens Kindb. Enum. 1). 22 (1888).] 
Diözisch. Pfl. in ziemlich dichten, bis 3 , selten bis $7 \mathrm{~cm}$ hohen, gollgrünen, lebhaft seidenglänzenden Rasen. Blätter aufrecht-abstehend, lineal-lanzettlich, schmal zugespitzt, bis $2,2 \mathrm{~mm}$ lang und bis $0,1 \mathrm{~mm}$ breit, nit längs breit ungebogenen, oberwärts entfernt gesägten Rändern: Rippe kräftig, kurz austretend; Zellen nicht verdickt oben 1: $10-12$. Seta bis $4,5 \mathrm{~cm}$, rot. Kapsel fast aufrecht bis schwach geneigt, etwas unregelmüssig, zuweilen schwach gekrümmt, eilinglich, etwa $5 \mathrm{~mm}$ lang und etwa $1,5 \mathrm{~mm}$ dick, auf der Rückenseite bräunlich, auf der Bauchseite grünlichgelb, trocken und entdeckelt unter der Mündung nielnt verengt. Peristomzähne $0,5 \mathrm{~mm}$ lang, schmal, mit ausgeschweiften Rändern, dicht und grob papillös, undurchsichtig, mit etwa 16, wenig vortretenden Lamellen. Inneres Peristom gelblich, dicht papillös: Grundhant niedrig; Fortsätze von der
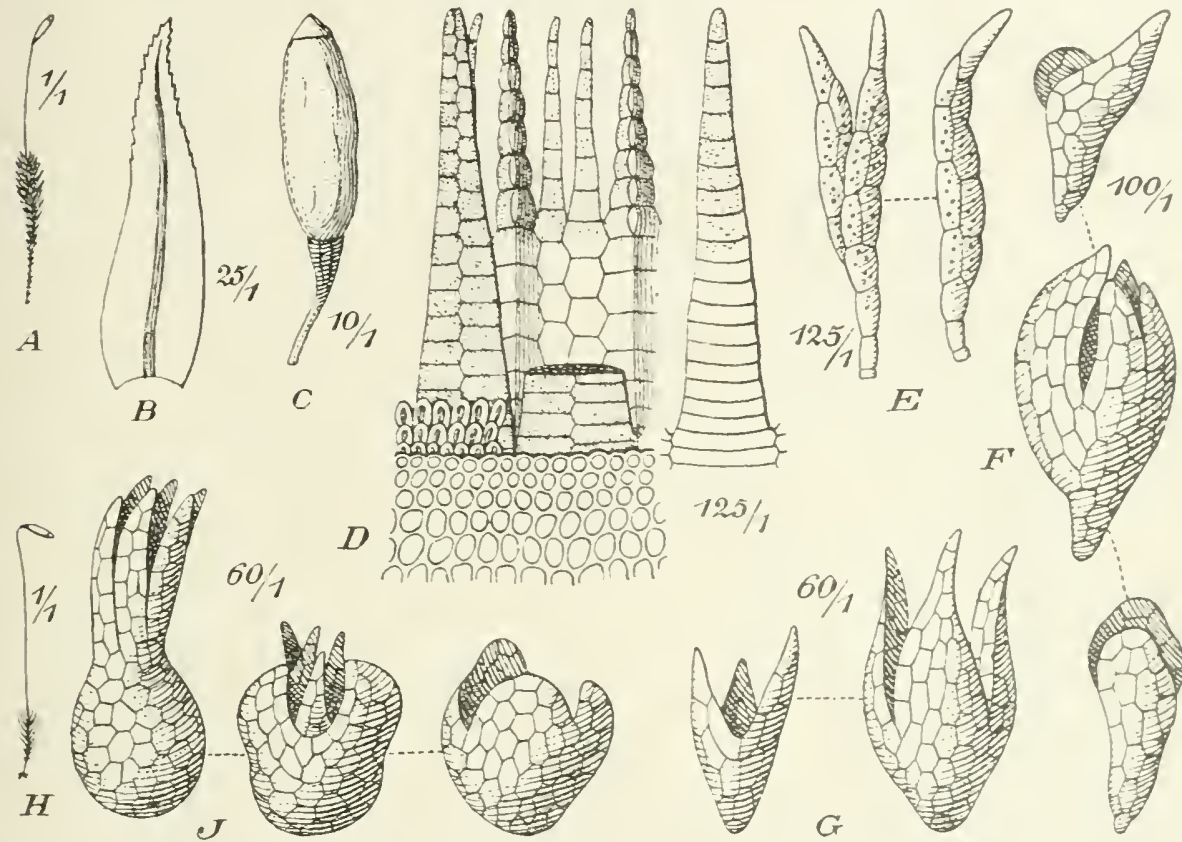

Fig. 47. A-D. Pohlia longicollis (Sw.). A Fruchtende Pfl. (1 1): B stengellı. (25,1): C Kapsel im trockenen Zustande (10 1): D Peristom (125 1). - Brutkorper von E. Pohlia proligera Lindb. 125 1, F P. bultifera Warnst. $100 / 1$, i P. grandiflora Lindb. fil. 60 1. - H-I. P. annotina (Leers). H Fluchtende Pfl. (1 1); I Brutk. (100,1).

Zahnlänge, schmal linealisch, kaum durchbrochen, mit ausgeschweiften Rändern: Wimpern rudimentär oder fehlend. Deckel gewölbt bis flach kegelig, mit Spitzchen. Sporen 18--20" ", braun, fein papillös. Sporenreife im Herbst und Frühling.

An steinigen Abhängen und in Felsritzen kalkfreien Gesteins.

F. Lkem. Yllästunturi (Hult), - Le. Välivaara, in der Fichtenregion (Norrl.). Kilpisjärri, Leutsuvaara. in der alpinen Region (N.); Saana, in der alpinen Region (Kot.). - Lim. Hibină (Sahlb.); Lujauriurt, Varnbjet (Kihlm.).

S. LuL. Sarekgebiet, am reichlichsten in Höhlen zwischen den die Alhänge der Alpenregion bedeckenden Felsentrümmern.

N. h. Lomsfjeldene. st. Dovre. Tr. Nordrejsen und Balsfjorden. F. Alten und Kistrand.

Arkt. Nord-Amerika.

319. Pohlia longicollis (Sw.) Lindb. Musc. scand. p. 18 (1879). [Bryum longicollum Sw. Musc. Suec. p. 49, 99, t. 6, f. 13 (1799). - Webera longicolla Hedw. Sp. muse. p. 169 , t. 41 , f. $1-5$ (1801.]

Parözisch. Pfl. in ziemlich dichten, oft ausgedehnten. 2-, cm hohen, gold- 
grünen, lebhaft seidenglänzenden Rasen. Blätter aufrecht-abstehend oder locker anliegend, lineal-lanzettlich, scharf zugespitzt, bis $4 \mathrm{~mm}$ lang und bis $0,55 \mathrm{~mm}$ breit, mit aufrechten, selten in der Mitte schmal umgebogenen, bis gegen die Mitte scharf gesägten Rändern: Rippe meist vor der Blattspitze aufhörend; Zellen nicht verdickt, oben 1: 10-12. Seta $1,5-3 \mathrm{~mm}$, gelbrot. Kapsel geneigt bis horizontal. mit dem plötzlich in die Scta abgesetzten und etwas kürzeren Halse länglichelliptisch und keulenförmig, 3-4 $\mathrm{mm}$ lang und $1-1.5 \mathrm{~mm}$ dick, gelblichbraun. trocken und entdeckelt unter der Mündung schwach verengt, entleert fast aulrecht. Peristomzähne $0,4 \mathrm{~mm}$ lang, grob papillös, mit bis 30 Lamellen. Inneres Peristom bleich, mit zerstreuten Papillen; Grundhaut $1 / 3$ der Peristomzähne: Fortsätze ritzenlörmig durchbrochen: Wimpern \pm entwickelt, knotig. Deckel kurz kegelig, spitz. Sporen 18-21 $\mu$, fein papillös. Sporenreife im Juli. - Fig. 47 A -D.

An steinigen Abhängen und in Felsritzen kalkfreien Gestcins.

F. Ok. Sotkamo, Naapurinvaara (Brolh.). - ob. Rovanieni, Valajankoski (NY\}.). Lohiniva (Hult). tavasaksa (Nỵb.). - K. Kuusamo, Oulankajoki, Kallioperänvaara (Broth.) und Kiutavaara (E. af H.). - Lkem. Kolari, Jouhisuannonvaara (Hult). Kitlilä, Rautujārri, nördlich vom Yilästunturi (Hult): Palhtakallio (H.). Sodankỵlă, Pỵhätunturi (Huum.). Kuolajărvi, Perāvaara, Palovaara, Pỵhäkuru und Tiutsanjoki (E. af H.); Tenniöjoki (Liman.). - Le. Kätkesuanto, in der Fichtenregion und an mehreren Fundorten in der Kiefernregion (Norrl.). Kilpisjārvi, in der alpinen Region (N.); Malla und Saana in der ałpinen Region (Kot.). Yähăkallio (Lind). … Li. Utsjoki, Ailịas (Ranck.): Yläjalve, Kistuskaidde (R.); Jalgelvalgi anı Tenojoki (R.). - Lim. Timba (Kinhm.); Umpjok, Aij-rarr (K.). - Lt. Kola (Karst.); Kula, Karaulnaja Pahta (Broth.).

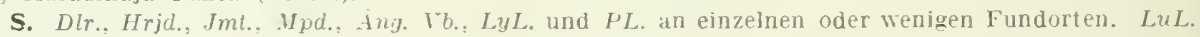
In der Waldregion fq.: sarekgebiet $r$.

N. st. Ryfylke. $T_{\text {. }}$ rr. K. Lomsfjeldene. H., ST.. Dorre. No. Hatfjelddalen an mehreren Fundorten; Skjaerstad. Tr. Bardo und Nordrejsen. F. Kistrand. Norgrenze etwas jenseits $70^{\circ} \mathrm{n}$. Br.

Europa, Kaukasus. Kaschmir. Kumaon, Japan, Nord-Amerika.

320. Pohlia cruda (L.) Lindl). Nusc. scand. p. 18 (1879). [Mnium crudum L. Sp. pl. p. 1576 (1753). - Bryum crudum Huds. Fl. angl. p. 491 (1778). — Webera cruda Bruch Mscr., Hüb. Muscol. germ. p. 125 (1833).]

Meist diözisch. seltener parözisch oder synözisch. Pfl. in lockeren. leicht zerfallenden, weichen, 2 ; cm, seltener höheren, meist blaugrünen, glänzenden Rasen. Schopfblätter abstehend und verbogen, lanzettlich, allmählich lang zugespitzt. 3-1 mm lang und etwa $0,6 \mathrm{~mm}$ breit, mit aufrechten, an der Spitze gesägten Rändern; Rippe unten rot, vor der Blattspitze aufhörend: Zellen dünnwandig, ïberall sehr lang und schmal, in der Blattmitte etwa 1: 10-12. Seta $2-1 \mathrm{~cm}$, oben meist schwanenhalsartis gebogen, rot. Kapsel geneigt oder horizontal, mit clem Halse von halber Urnenlänge länglich-zylindrisch bis fast keulenförmig, oft etwas hochrückig, bis $5,5 \mathrm{~mm}$ lang und bis $1,5 \mathrm{~mm}$ dick, gelblich, zuletzt rötlichbraun. trocken und entdeckelt unter der Mündung nicht oder \pm verengt. Peristomzähne bis $0.5 \mathrm{~mm}$ lang, an der Spitze grob papillös, mit bis 25 Lamellen. Inneres Peristom bleich. Grundhaut etwa $1 / 4$ der Peristomzähne: Fortsätze später klaffend; Wimpern vollständig, knotig. Deckel \pm gewölbt, meist mit Warze oder kegelig. Sporen meist $15-18 \mu$, selten grösser, rostgelb, papillös. Sporenreife im Juni.

Auf sandiger Erde an Wegrändern und Grabenwänden, in erderfüllten Spalten und Höhlungen der Felsen.

F. Al. Hammarland, Saltvik und Sund nicht selten (Bom.). - Ab. Töfsala. Reso. Finby. Bru-. marf. Uskela. Karislojo. Lojo. Vichtis. - V. Kyrkslätt. Esbo. Helsingfors. Helsinge. Tusby. Sibbo. Borgâ. Hogland. - Ka. Sakkijärvi. Virolahti. Rảisälä. - Ik. Kuolemajărvi. Lusikirkko. Muola. Sakkola. - St. Eura. Pirkkala. Ikaalinen. Orivesi. Ruovesi. - Ta. Vanaja. Hattula. Tỵrväntõ. Im südö.tl. Teile fq. (Norrl.). Sysmä. Harlola. Korpilahti und Luhanka fq. (Vain.). - Sa. Willmanslrand. Kangasniemi. - Kl. Kurkijoki. Sortavala. Impilahıi. Ruskeala. Soanlahti. Suistano. Pälkjări. hol. Petrusavodsk, - oa. Bötonn. Närpes. Isokỵö. — Tb. Jyväskỵlā-Pihtipudas fq. (Brotlı.). 一 sb. Kuopio fq. (Link.). Nilsiä. Maaninka und Pielavesi fq. (Roiv.). Iisalmi. - Kb. Tohmajärvi. Pielisjärvi. - Kon. Kenjärvi. Gorka. Dianovagora._-Om. Alajārvi, Vesterbacka, Huosianmaankallio (Backm_) Vindala, an wenigen Fundorten (B.). - Oh. Kajana. Ristijärvi. - Kpom. Vuiraara. Keret. - Ob. Muhos. simu. Kemi. Aavasaksa-Turtola st. fq. (Hult.). - K. Kuusamo. - Lkem. Kolari und Kittilä st. fq. 
(Hult). Kuolajärvi. - Le. Karesuanto (Norrl.); Kilpisjärvi, Mlalsit. Saana und saivivara fal. in der sul,alpinen und alpinen Region (Kot.). - Li. Inari, in der Nadelwaldregion s. M(J., in dor Birkenregion seltener (Hult). Utsjoki, Fjerramjokka (Ranck.). In Lim., Lt.. Lmur. und 'Lp. niclut selten, aber niei-t spärlich (Broth.).

S. $S h .-L$.

N. Sm. $-F$.

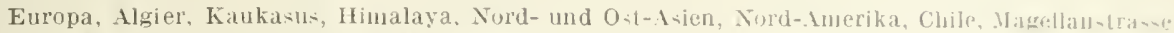
Kerguelen, Intarktis, Neu-Holland, New Zealand.

var. minor (Schimp.) Möll. Förteckn. Sk. växt. 2. Mossor, p). 32 (1907). [11 bera cruda var. ninor Schimp. Coroll. p. 6.) (1856). - Bryum (Webera) nitens IKindl, in Bot. Notis. 1882, p. 146.]

Diözisch. Schlanke, niedrige Pfl. Schopfln̈äter kiirzer, fast aufrecht. Kapsel läinglich-zylindrisch, fast aufrecht.

F. Lmur. Harlorka (Broth.). - Lp. Ponoj (Brenn.).

N. Kristiania, Dovre.

Europa, Nord-Amerika.

var. seriata Arn. et Jens. Moos. Sarekgeb. p). 160 (1907).

Blätter I scharf gekielt, deutlich Jreihig.

S. LuL. Sarekgebiet, in der Weidenregion spärlich.

var. alpina (Hag.) Möll. 1. c.

Pfl. in niedrigen Rasen. Kapsel nickend his hängend, kurz.

N. No. Skjerstad, Hankabakken, auf rerwittertem schiefer.

S e c t. I I 1. Lamprophyllum Lindb. Musc. scand. 1\% 17 (1879) ex p.

Kapsel nickend oder hängend: Zellen des Exotheciums (excl. P. culcullatu) mit verbogenen Vänden. Grundhaut des inneren Peristoms ${ }^{1}{ }_{3}{ }_{2}{ }_{2}$ der Zahnhöhe: Fortsätze meist lanzettlich-pfriemenförmig, gefenstert bis klaffend: IVimpern vollständig.

321. Pohlia nutans (Schreb.) Lindb. Musc. scand. p. 18 (1879). [Pryun mutans Schreb. Spic. p. 81, No. 1043 (1771). - Webera nutans Hedw. Descr. I. p. 9 , t. 4 (1787).]

Parözisch. Pfl. in lockeren bis dichten, oft ausgedehnten, 1-2, zuweiłen bis 4 cm hohen, grünen oder gelbgrünen, etwas glänzenden Rasen. Lntere Blätter kïrzer und breiter, eilanzettlich, ganzrandig. Schopfblätter gedrängt, aufrechtabstehend, lineal-lanzettlich, scharf zugespitzt, bis +t mm lang und meist nur (1,6 mm breit, mit bis über die Blattmitte schmal umgebogenen, an der Spitze gesägten Rändern; Rippe vor und mit der Blattspitze aufhörend, selten kurz austretend: Zellen oberwärts 1: 5-6. Seta meist 2-1 cm, rot. Kápsel nickend und hängend. aus dem kürzeren Halse länglich, meist etwa 3 mm lang, aus dem Gelblichen rötlichbraun, trocken und entdeckelt unter der Nündung verengt: Zellen des Exotheciums dünnwandig, in der Mehrzahl rektangulär. Peristomzähne bis 0.5) mm. gelb, mit bis 28 Lamellen. Inneres Peristom hyalin: Fortsätze gefenstert bis kilalfend; Wimpern knotig, mit vereinzelten, kurzen Anhängseln. Deckel breit gewölbt mit Spitzchen. "Sporen $18 \mathbf{2} 4$ ", gelbbraun.

Auf trockenem, sterilem Waldboden, in Ausstichen, auf Torf- und Heideland. an faulenden Wurzeln und Stämmen und auf erdbedeckten Felsen durch das ganze Gebiet bis in die alpine Region fqq. und meist reichlich fruchtend.

Europa, Kaukasus, Kaschnir, Sibirien, Japan, Nord-Amerika, Antarktis, Australien.

var. caespitosa (Hopp. et Hornsch.). [ITebera caespilosa Hopp. et Hornsch. in Flora 1819, p. 102 ex p. — Webera mutans var. caespilosa Hüben. Mluscol. germ. p. 129 (1833).]

Stengel verlängert, unter đler Spitze biischelästig. Schopfloläter etwas geschlängelt, länger, seharf gesägt. Kapsel horizontal, zỵlindrisch. Dechel zugespitzt.

S. Jmt. Areskutan.

N. Dovre, Kongsvold.

Europa in alpinen und subalpinen Lagen. 
var. bicolor (Hopp. et Hornsch.) Bomans. et Broth. Herb. Mus. Fenn. Il. Ilusci, p. 40 (1894). [Webera bicolor Hopp. et Hornsch. in Flora 1919, p. 102. II. nu ans var. $\gamma$ bicolor Hüben. Nuscol. germ. p. 429 (1833).]

Breit- und dichtrasige Pfl. Schopfblätter aufrecht, kürzer. Blätter der sterilen Sprosse eiförnig, zugespitzt, mit austretender Rippe. Seta $5-10 \mathrm{~mm}$, gekniet. liapsel nickend, dick, an der Rückenseite dunkler gefärbt.

F. Lkem. Kolari, Jokijalka (Hult). - Le. Mukkaraara (Norrl.). Karesuanto (N.). Kilpisjärvi (N.).

S. PL. Adolfström. Jmt. Areshutan, Sylarne und Täljstensfjället in der Weiden- und in der alpinen Region.

N. Dovre. $T r$. Nordrejsen, Skjervø. $F$. Hammerfest; Vardø; Vadso.

Europa, Kaschmir, Baltistan, Nord-Amerika (fo. pallescens).

var. pseudocucullata (Limpr.) Möll. Fört. Sk. Växt. 2. Moss. p. 32 (1907). [Webera nutans var. pseudocucullata Limpr. Laubm. 11. p. 250 (1891).]

Tracht von $P$. cucullata. Pfl. in glanzlosen Rasen. Stengel etwa $5 \mathrm{~mm}$, schopfig beblättert, mit entfernt beblätterten Stolonen. Schopfblätter lang und scharf zugespitzt, meist flacỉ- und ganzrandig, meist mit gedrehter Spitze; Rippe oberwärts am Rücken gesägt und als gezähnte Stachelspitze austretend; Zellen oberwärts 1: 3-4. Seta bis $2,5 \mathrm{~cm}$. Kapsel hängend, mit dem dicken, gleichlangen Halse verkehrt-eilänglich.

N. Dovre. Kiongsvold. Tr. Nordrejsen, Guolasjarre. F. Kistrand.

Riesengebirge.

var. angustirete H. Wint. in Hedwigia XLIX. p. 303 (1910).

Blattzellen äusserst schmal und lang, in der Blattmitte etwa $6-8 \mu$ breit und über $100 \mu$ lang. Steril.

N. Tr. Bodø, Løpsfjeld, unter Felsen in üppigen, glänzenden Vegetationen.

var. longiseta (Brid.) Bomans. et Broth. 1. c. [Bryum Webera longiseta Brid. Bryol. univ. I. p. 636 (1826), - Webera nutans var. longiscta Hüb. Muscol. germ. p. 430 (1833).]

Meist niedrige Pfl. Blätter steif, aufrecht-abstehend; Rippe oberwärts am Rücken gezälnnt und als Endstachel austretend. Seta bis $10 \mathrm{~cm}$. Kapsel nickend, liurz und dick, trocken unter der kleinen Mündung nicht eingeschnïrt.

In Versumpfungen an len Wänden der Torfgräben und Ausstiche wie auch an modernden Stubben.

F. Al. Saltrik, Ǩvarnuo (Bom.). Sund. Gesterby Ijenan (B.). - X. Esbo, Hagalund (Brotb.). Helsingfors (Lindb.) - Kl. Ruskeala, Hämekoski (Broth.). Suistamo (B.). - Oa. Vasa, Långviksträsk (Broth.). Replol, Vakören (B.). - Sb. Kuopio, Kurkimäki (Link.) - K. Kuusamo, Pernu (Broth.). suolampi (E. af H.). - Lhem. Kolari und Kittilä, an mehreren Fundorten (Hult), — Li. In der Waldregion fq. (H ). - Ll. Sascheika am Kolaflusise (Broth.). Uber die Terbreitung in $\mathbf{S}$. und N. liegen keine Literaturangaben ror.

Europa, Japan, Nord-Amerika.

var. strangulata (Nees) Möll. l. c. [Hebera strangulata Nees in Hüb. Muscol. germ. p. 428 (1833). - W. nutans var. strangulata Schimp. Coroll. p. 66 (1856).]

Blätter steif; Rippe vollständig bis kurz austretend, glatt. Seta meist etwa $4 \mathrm{~cm}$. Kapsel geneigt bis horizontal, lang und schmal, weich, trocken unter der erweiterten Mündung stark eingeschnürt.

N. SB. Bergen. No. Skjerstad.

Europa.

var. sphagnetorum (Schimp.) Möll. I. (. |Webera nutans var. sphagnelorum Schimp. Coroll. p. 66 (1856).]

Herdenweise oder in lockeren bis dichten Rasen. Stengel und Sprosse lang und dünm, entfernt beblättert. Blätter sehr lang und schmal: Rippe vollständig, glatt. Seta etwa j cm. Kapsel hängend, verkürzt, weich, gelblich, rlick- und kurzhalsig, oval, trocken unter der weiten Mündung nicht verengt.

In tiefen Waldsümpfen und Mooren.

F. Al. Sund, Tjurnäs trăsk und Gesterby ijenan (Bom.). Saltvik, strömma (B.). - N. Helsinglors (Lindb.). Lavansaari (Brenn.). 
S. Srm. Stuckholn. Dir., LuL. Siarekgebiet, nt der Birlienregion.

N. Dovre. Tr. Nordrejsen, Fladvold.

Eurupa, firönland.

var. turbinata (Bomans.) Möll. I. c. [Webera nu!ans Vär. Inrbinala Bomans. in Act. Soc. F. Fl. Fenn. XVIII. No. 4, p. 71 (190(0).

Blätter breiter: Zellen lockerer. Kapsel kïrzer, geneigt, selton hängend. Sinoren etwas grösser.

F. Al. Saltvik, Kugghöle (Bom.): Haga, Fredriksholm (B.).

322. Pohlia sphagnicola (Bryol. eur.) Lindl). et Arn. Musc. As. bor. 11. p. .), (1890). [Bryum sphagnicola Bryol. eur. fasc. 32, p. 6, t. sup])]. 7 (18.16).]

Diözisch: $\sigma^{7}$ Blüten durch die bis 4 mm langen, abstehenden Schoplbbäter fast seheibenförmig. Pfl. vereinzelt odler gesellig, selten in kleinen bis grösseren, oberwärts grünen oder gelbgrimen Rasen. Stengel 1-j, selten his 8 cm. Blätter aufrecht-abstehend, untere und mittlere entlernt gestellt, länglich eilanzettlich, kurz und scharf zugespitzt, bis 1,6 mm lang und bis $0.6 \mathrm{~mm}$ breit, flach- und meist ganzranclig; Rippe vor der Blattspitze aufhörend; Zellen oben 1: 3 - 1. Schopfblätter gelrängt, schmal lineal-lanzettlich, scharf zugespitzt, bis I nnm lang und (1,45 num breit, mit aufrechten ofler in der Blattmitte etwas umgebogenen, gegen die Spitze \pm (leutlich gesägten Rändern: Rippe fast vollstänrlig bis kurz austretend: Zellen oben 1: 1 6. Seta 2-4 cm, rot. Kapsel geneigt bis hangenu, aus kurzem Halse eng ei- ocler länglich-eiförmig, 2,j--3 mm lang und 1-- 1,j mun (lick, gell)grïn, später gelbloraun, trocken und entdeckelt unter der Mündung nicht verengt: Zellen des Exothcciums dickwandig, mit stärkerer Eckverdickung, unregelmässig. in der Melnzahl rumdlich-1-6eckig. Peristom wie bei $P$. nulans. Deckel gross kegelförmig oder gewölbt. Sporen $10-12 \mu$, blassgelb. fast glatt. Sporenreife im Juli und August.

In 'Torfsiintefen vereinzelt oder gesellig.

S. Sm. Ingatorp. $\mathrm{Vg}$. Billingen. Igelsjön und sköfde. LuL. Sarekgebiet. in der Buleturegiom.

N. Kristiania, Lysager.

Zentral-Europa, Sibirien, Nord-Amerika.

32:3. Pohlia cucullata (Schwaegr.) Bruch in Flora 1826, 1. p. 271. [Bryum ('ncul alum Schwaegr. Suppl. I. P. II. 1).94. t. 68 (1816). - Webera cucullala Schimp. coroll. p. 66 (1856).]

Parözisch. Pfl. in dichten, neist 1-2 cm, steril weit höheren, grünen. innen sehwärzlichen, glanzlosen oder schwach glänzenden Rasen. Stengel aufrecht oder aufsteigend. Blätter der längeren Sprosse \pm weit herablaufend, die unteren anliegend, sehr hohl, breit eiförmig und eilänglich, bis 1,5 mm lang und bis 1,2 $11 m$ breit, stumpflich, flach- und ganzrandig. Schopfblätter locker dachziegelig und eingebogen, verlängert lanzettlich, breit gespitzt bis stumpf, oft fast kappenförmig, bis 3,6 mm lang und bis $0,9 \mathrm{~mm}$ breit, mit aufrechten oder streckenweise etwas zurückgeschlagenen, an der Spitze muleutlich gezähnten Rändern: Rippe zuletzt schwärzlich, vor der Blattspitze endend; Zellen locker und sehr diunwandig. oben rhombisch und rhombisch 6seitig, 1: 3-1. Seta $1-3,5$ cm, brïunlich, oben gelblich. Kapsel hängend, aus dem dickem Halse von halber [rmenlänge länglichelliptisch, bis $1 \mathrm{~mm}$ lang und $1.5 \mathrm{~mm}$ dick, bräunlich, trocken mud entoleckelt unter der Mlündung nicht verengt, dümnhäutig; \%ellen des Exotheciums in der Mehrzahl rundlich-1-6eckig. Peristomzälne bis $0,4 \mathrm{~mm}$, gelb, mit bis 18 Lamellen. Inneres Peristom bleich; Grundhant sehr niedrig: Fortsätze schmal linealisch, ritzenförmig durchbrochen: Wimpern kurz, leicht hinfällig. Deckel klein, nierlrig gewölbt. mit Warze. Sporen 22-28 ", rotbraun, punktiert. Sporenreife im Juli bis September.

Auf feuchtem Boden, wie an Bachufern und an Stellen. wo der Schnee lange liegen bleibt.

F. Kk. Kivakkatunturi, in der alpinen Region (Broth.). - Lkem. Kittilä, Yllästunturi, in der alpinen Region (Hult). Kemijärvi, Pyhätunturi (Vain.). Sodankylä, Martinkylä(V.). - Le. Malla, Saana 
und Saivovaara (Kiot.). - Li. Inari. Jludıusjärvi (sil.): Kodossuannompää, in der Birkenregion (Kihlın.). Utsjoki, Ailigas (Ranck.): Daussejokka, Iläjalve (R.); Akkojokka (R.). — Lim. Tschun (Brotl.); Lujauriurt, Vambjet (Kihlm.). - Lt. Kola (Broth.) Subovi. Vaidoguba und Tsipnavolok (B.). - Lmur. Gavrilova, Rinda, Litsa und Varsinsk (Broth.). - Lp Ponoj (Broth.). - Lv. Tschapoma (Broth.).

S. Ang Hernösand. Hrjd., Jmt., PL., LuL. und TL. Steigt bis hoch $n$ die Weidenregion hinauf.

N. Kristiania. Bu. Norfjallet. Ve. Saetersdalen. St. Ryfylke SB. Ulvik; Maristuen. ST. Dorre. K. Lomsfjeldene H. No-F.

Europa. Baltistan, Tschnktschen-Halbinsel, Nord-Amerika. Nordgrenze in Spitzbergen und Grönlind.

var. contracta Perss. in Arkiv f. Bot. B(l. 14, No. 3, p. 38 (1916).

Kleine herdenweise wachsende, schwarzgrüne, glanzlose Pfl. Kapsel unter der Mündlung dentlich verengt. Deckel länglich-kegelig.

S. Jmt. Getryggen und Sylarna in der oberen Weidenregion.

N. Dorre, snehätten.

324. Pohlia rutilans (Schimp.) Lindb. Muse. seand. p. 18 (1879). [Bryum rulilans Schimp. in Bryol. eur. fasc. 32 Suppl. p. 5, t. 6 (1846). - B. Schimperi C. Iüll. Syn. I. p. 334 (1848). - Webera Schimperi Sehimp. Syn. 1. ed. p. 338 (1860).]

Parözisch und polyözisch. Pfl. in dichten, bis $5 \mathrm{~cm}$ hohen. meist purpurfarbenen, durch Rhizoidenfilz verwebten, glänzenden Rasen. Blätter aufrecht-abstehend, untere und mittlere entfernt gestellt, eilanzettlich, ganzrandig. Schoplblätter gedrängt. verlängert lanzettlich, scharf zugespitzt, bis 3 mm lang und bis $0,6 \mathrm{~mm}$ breit, mit bis über die Blattmitte schmal umgebogenen, an der Spitze gesägten Rändern: Rippe mit oder vor der Blattspitze aufhörend, selten kurz austretend: Zellen oberwärts ctwa 1: 4. Seta 1,5-2 cm, rot. Kapsel nickend und hängend. aus dem Halse etwa von halber L'rnenlänge eiförmig oder oval, bis $3 \mathrm{~mm}$ lang und etwa $1 \mathrm{~mm}$ dick, gelbbraun, trocken und entdeckelt unter der Mündung nicht verengt; Zellen des Exotheciums dimnwandig, unregelmässig, in der Mehrzahl rundlich-1-6eckig. Peristom kleiner als bei P. nutans. Deckel flach gewölbt, mit spitzchen. Sporen etwa $20 \mu$, gelbbraun, fast glatt.

In Alpensümpfen und auf Felsenabsätzen.

N. Kristiania. SB. K. Lomsfjeldene. $T r$. Malangen. $F$. Kistrand.

spitzbergen, arkt. Nord-Amerika.

325. Pohlia Ludwigii (Spreng.) Broth. in Act. Soc. Sc. Fenn. T. XIX. No. 12. 1) 27 (1892). [Bryum Ludwigii Spreng. Mscr.: Schwaegr. Suppl. I. 2, p. 95, t. 68 (1916). - Webera Ludwigii Schimp. Syn. 2. ed. p. 402 (1876). - Pohlia Weigelii 1.indb. Meddel. Soc. ? . Fl. Fenn. 13. Heft, p. 2.52 (1886).]

Diözisch: ơ Blüten diek knospenförmig. Pfl. in lockeren, ausgedehnten, schwellenden. weichen, lebhaft grünen, innen rötlichen, kaum glänzenden Rasen. Stengel aus niederliegendem Grunde aufrecht, bis 4, steril bis $10 \mathrm{~cm}$. Blätter weit herablaufend, hohl, trocken locker anliegend, feucht abstehend, untere locker gestellt, breit eiförmig, stumpf, ganzrandig, oberc allmählich grösser und dichter gestellt, ei- und länglich-lanzettlich, kurz und breit zugespitzt, bis 2,7 mm lang und $0,9 \mathrm{~mm}$ breit, mit schmal umgerollten, an der Spitze gezähnten Rändern: Rippe am Grunde rot und breit, vor der Blattspitze endend; Zellen locker und selı dïnnwandig, oben rhombiseh und rhombisch-6seitig, etwa 1: 4. Seta $1-2,5 \mathrm{~cm}$. geschlängelt, rötlich, oben gelblich. Kapsel nickend oder hängend, aus dickem, (-twas kürzerem Halse oval, zuletzt braum, trocken und ent deckelt unter der Mündung verengt: Zellen des Exotheciums in der Mehrzahl rundlich-4-6eckig. Peristomzälme bis $0,5 \mathrm{~mm}$, gelb, mit bis 30 Lamellen. Inneres Peristom hyalin; Grundhaut iiber $1 / 3$ der Peristomzälnne; liortsätze klaffend; Wimpern meist vollständig, schwach knotig. Deckel gewölbt, mit Zilze. Sporn 14-18 ", ockergelb, zart punktiert. sporenreife im August und September.

Auf leuchtem Boden und in kalten Bächen, wie an Bachufern und an Stellen. wo der Schnee lange liegen bleibt. 
F. Le. Ounatunturi und Kilpiskoski (Norrt.) - Li. Ltsjoki, Paistunturit. (Ranck.). Imur. Gavrilowa. Rinda, Lilsa, zw. Varsinsk und Jenjalv' (Broth.).

S. $\| r_{j} l_{l}$, Jmt. LuL. Sarekgelsiet.

N. Bu. Norefjeld. Ne. Saetersdalen 1,000-1,400 in fqu. und (opp., aued fruchtend. Br. Telemarksu, Hankelidfjeld. SB. Ulvik, Daasefjord; Bergen. NB. Hardanger, IJorruhei $900-1,000$ in cof: und reichtich fruchtend. $R$. an wenigen Fundorten 400 und $1,000 \mathrm{~m}$. K. Dovre; (ieiranger; Rondrur. S\%. Merat ker, Fondfjeld. NT. Stjordalen. No. an mehreren, $T r$. und $F$. an wenigen fundorten. Xridgrm\% lici i0 $25^{\prime} \mathrm{n} . \mathrm{Br}$.

Europa, Kaukasus, nördl. Teile von Nord-Amerika.

var. latifolia (Sehimp.) H. Wint. in Herlwigia XIJ . P. 304 (1910). [Webere Lndwigii var. latifolia Sehimp. Syn. 2. ed. I). 102 (1876).]

Pasen 5-10 cm. Blätter breiter, allmälnlich zugespit»t, mit lcicht ungebogenen, fast unversehrten Rändern. Nur steril.

N. Dovre. Tromso.

Pyrenäen, Ifont Blane.

326. Pohlia commutata (Schimp.) Lindb. MIusc. seancl. p. 17 (1879). [Heber( commulala Schimp. Syn. 2 ed. p. 103 (1876) excl. var. p.]

Diözisch: ơ Blïten dick knospenförmig. Pl'. in dichten, olt ausgeclehnten, starren, frendig- bis dunlielgrünen, imnen meist schwärzlichen, etwas glänzenrlen Rasen. Stengel aufrecht oder am Grunde niederliegend, bis 5 cm, steril weit lö̈ler. Blätter herablanfend, die der sterilen Sprosse trocken locker anliegend, l'eucht aufrecht-abstehend, länglich-lanzettlich, scharl zugespitzt, bis 1,j mm lang und 0,6 mm breit, mit hier und da schmal mmgebogenen, in der Spilzé schwach gesägten Rändern; Rippe vor der Blattspitze endend Zellen oben linealisch, 1: 1- 5. Schopfblätter allmällich grösser, aufrecht, länglich- und lincal-lanzettlich, scharl zugespitzt, etwa $2,2 \mathrm{~mm}$ lang und $0,5 \mathrm{~mm}$ breit, mit umgerollen, oberwärts deutlich gesägten Rändern; Rippe weit hinauf rot, am Grunde verbreitert, mit und ror der Blattspitze aufhörend; Zellen oben 1: 5-6. Perieluätialluätter mit scharfer Spitze. Seta $1-2$, selten bis $3 \mathrm{~cm}$, geschlängelt, rot. Kapsel geneigt bis hängencl. aus dem deutlich abgesetzten Halse von halber Urmenlänge oval, bis 2,7 mun lang und 1,5 mm dick, lichtbraun, trocken und enteleckelt unter der Miindung kaum verengt: Zellen des Exotheciums in der Mehrzahl rundlich-4-6eckig. Peristomzähne bis $0,5 \mathrm{~mm}$ lang, gelb, mit bis 25 Lamellen. Inneres Peristom gelblich: Grumdhaut etwa $1 / 3$ (ler Peristomzähne; Fortsätze klaffend; Wimperu vollständig, kaum knotig. Deckel kegelig, scharf gespitzt. Sporen 16-21 ", rostlarben, gekörnelt. Sporenreife in August. - Vegetative Vermehrung durch vereinzelte, blattwinkelständige, braumrote, von mehreren stumpfen Blättchen gekrönte Bulbillen. die sich häufig an der Mutterpflanze zu kurzen, leicht ablallenden Sprossen entwickeln. Bei den kompakten Formen aus höheren Lagen fehlen die l3rutkönper gäinzlich.

An feuchten Stellen, wie an Bachufern und an Stellen, wo der Schnee lange bleiben wird, auch in kalten Bächen, oft Massenvegetation bildend.

F. Lhem. Kittilä; Pyhätunturi, in der Fichtenregion (Hult); Yllästunturi. in der alpinen Region (H.). - Le. Kilpisjärvi, fq, in der Birken- und in der alpinen Region (Kol.). - Li. Sodankylä, Akinlhärkäkuru und Sokustamakuru, in der Birkenregion (Hult); Lupukkapää, in der alpinen Region (H.). Utsjoki, Ailigas (Ranck.). - Lim. Kandalaks (F. Nyl.); Tschun (Broth.); fibinä (Angstr.). - Ll. F'ummanki (Broth.).

S. Ảng. Tåsjö. Hrjd. und Jmt, an mehreren Fundorten. LuL. Sarekgehiet ron der Birkenregion bis in die höchsten Teile der alpinen Region eines der häuligsten und reichlichsten Ylouse

N. Ringerike. Sm. Glemminge. Bu. Hønefos. Ne. Saetersdalen. NB. Sogni, Aardill bis zum .leeresufer herabsteigend; Hardanger, Horruhei. $K$. Filefjeld. Dovre. Lomsljeldene. Ko.-F. an vielen Jinndorten.

Europa, Kaukasus, Altai, Nord-Anerika. Nordgrenze auf Spitzlergen.

var. filum (Schimp.) H. Wint. in Hedwigia XLIX. p. 304 (1910). [Bryum filum Schimp. Syn. 2. ed. p. 170 (1876). - Wcleta commulala var. filum IIusn. Museol. gall. p. 230 (1889).l 
Pfl. farlenförmig, $10-15 \mathrm{~cm}$ lang, in weichen, leicht zerfallenden, schmutziggrünen Rasen. Blätter klein, entfernt gestellt, hohl, eilanzettlich, zugespitzt oder stumpflich, flachrandig. Blüte und Sporogone unbekannt.

N. Dovre. F. Hammerfest.

Alpenkette.

327. Pohlia carinata (Boul.) Möll. Förteckn. Skand. växt. 2. Moss. p. 32 (1907). [Bryum carinalum Boul. Muscin. de la France I. p. 280 (1881). - Weber carinata Limpr. Laubm. II. p. 261 (1892).]

Diözisch: ơ Blüten köjfehenförmig. Pfl. in dichten, oft ausgedehnten, mattgrünen bis schwach glänzenden Rasen. Blätter \pm weit herablaufend, trocken locker anliegend, eilanzettlich, bald spitzer, bald kappenförmig zugespitzt, his last $1,5 \mathrm{~mm}$ lang und $0,5 \mathrm{~mm}$ breit, flachrandig, oben gekerbt; Rippe vor der Blattspitze endend, zuletzt rötlich: Zellen selır dünnwandig, oben 1: 3 - 1. Perichätialblätter lang linealisch-lanzettlich, ohne besonders scharfe Spitze. Sporogone etwa wie bei $P$. commulata.

Auf feuchlem Borlen und in kalten Bächen.

N. Dovre. NB. sogn, Aardal. ST. Opdal. Tr. Bodo. Steril.

Mont Blane. Velher Tauern.

328. Pohlia gracilis (Schleich.) Lindb. Musc. scand. p. 17 (1879). [Bryum gracile Schleich. Catal. 1V. (1821). - Webera gracilis De Not. Epil. p. 118 (1869).]

Diözisch: ๙ $\sigma^{7}$ Bl. dick knospenförmig. Pfl. gesellig oder in lockeren, meist reichlich fruchtenden, gelbgrünen, unten bräunlichen bis schwärzlichen, glänzenden Rasen. Stengel aufrecht oder am Grunde niederliegend, $1-2 \mathrm{~cm}$. Blätter kurz. herablaufend, steif, aufrecht, trocken angepresst, mit aufrechten oder nur hier und da schwach umgehogenen Rändern, untere sclımal eiförmig, ganzrandig. aulwärts allmählich grösser, lanzettlich, Schopfblätter verlängert lanzettlich, scharf zugespitzt, bis $1,5 \mathrm{~mm}$ lang und bis $0,1 \mathrm{~mm}$ breit, mit an der Spitze \pm deutlich gesägten Rändiern: Rippe zarter als bei $P$. commulala, mit oder vor der Blattspitze aufhörend: Zellen oben 1: $5-7$. Innere Perichätialblätter aus breiterem Grunde rasch linealisch, stumpf. Seta etwa $2 \mathrm{~cm}$, geschlängelt, rot. Kapsel hängend, mit dem Halse von L'rnenlänge geschwollen eiförmig, bis $2 \mathrm{~mm}$ lang und $1 \mathrm{~mm}$ dick, gelblich, zuletzt rötlich, trocken und entdeckelt unter der Nündung nicht verengt: Zellen des Exotheciums in der Mehrzahl rundlich-1-6eckig. Peristomzähne bis 0,1 mm lang, gelb, mit etwa 20 Lamellen. Inneres Peristom wie bei $P$. commulala. Deckel kegelig, mit oft verlangertem Spitzehen. Sporen $10-15 \mu$, ockergelb, fast glatt. Sporenreife im Juli und August. - Vegetative Vermehrung durch vereinzelte, blattwinkelständige, grüne oder schwärzliche Bulbillen.

Auf nassen, sandigen Bachufern nnd an Schammufern der Ströne.

F. Lim. Lujauri-urt, Suloaj (Kihlm.). - Lmur. An Voronjeflusse und am Hlarlovkaflusse (Broth.).

S. Hrjd. Helagstjället. Jmt. an mehreren Fundorten. PL. Peljekaisse. LuL. Krikkjokk-Njuonjes; sarekgebiel, in der Birkenregion fq. und cop., höher linauf weit spärlicher.

N. Ringerike r. Ne. Saetersdalen, in hoher Lage iqq. und cpp. NB. Hardanger, Buardal cpp. $K$. Norefjetd; Dovre; Jotun- und Lomsfjeldene. NT. Stjordalen. No. an vielen, $T r$. und $F$. an wenigen Fundorten.

Europa, Baltistan, Sibirien, Nord-Ameriki.

var. torrentium (Hag.) Arn. et lens. Moos. Sarekgeb. p. 156 (1907). [Webera lorrentium Hag. Musc. Norv. hor. ]) 110 (1900). - W. Payoli Limpr. Laubm. 11. p. 262 excl. syn. (1892).l

Pfl. etwas kräftiger in weichen und dichten, gelbgrünen, innen oft schwarzen Rasen. Stengel bis $6 \mathrm{~cm}$. Blätter kürzer und breiter, häufig stumpf; Zellen etwas lockerer. Brutknospen meist fehlend. Sporogone unbekannt.

An von kaltem und strömendem Wasser überschwemmten Felsen und Steinen.

S. LuL. Sarekgebiet in der Birkenregion.

N. $K$. Jotunfjeldene. No. an inehreren, $T r$. unl $F$. an wenigen oder einzelnen Fundorten. 
329. Pohlia proligera Lindb. in litt. 1887; Warnst. Lauhn. p. 125 (1906). [Webera proligera Kindb. Enum. Bryin. dovrens. Append. No. 309 (1888).]

Diözisch; ơ Blüten dick knospenförmig. PfI. herdenweise oder in lockeren, lunkel- bis weisslichgrünen, trocken glänzenden Rasen. Sterile Sprosse bis 2 cm, gleichmässig beblättert, fruchtende niediriger und schoplig beblättert. Blätter der sterilen Sprosse nicht herablaufend, lanzettlich, bis $1,5 \mathrm{~mm}$ lang und bis $0,45 \mathrm{~mm}$ breit, mit aufrechten, an der Spitze gesägten Rändern; Rippe vor der Blattspitze aufhörend; Zellen oben etwa 1: 9. Schopfblätter cler fruchtenden Sprosse schmal lanzettlich, allmählich zugespitzt, bis $3 \mathrm{~mm}$ lang und bis $0,5 \mathrm{~mm}$ breit, mit weit hinauf schmal umgebogenen, an der Spitze schwach gezähnten Rändern; Rippe bald vor oder mit der Blattspitze aufhörend, bald kurz austretend. Seta $2-2,5 \mathrm{~cm}$, rot. Kapsel geneigt, aus etwas kürzerem Halse oval, bis $2,5 \mathrm{~mm}$ lang und 1-1,5 $\mathrm{mm}$ dick, zur Reifezeit gelbbraun, trocken unr entdeckelt unter der Mündung nicht verengt. Peristomzähne etwa $0,45 \mathrm{~mm}$ lang, blassgelb, mit bis 25 Lamellen. Inneres Peristom gelblich; Fortsätze breit durchbrochen, später klaffend; Wimpern nicht knotig. Deckel klein, kegelig. Sporen $14-18 \mu$, gelt)braun, fein papillös. - Sporenreife im Juni und Juli. - Vegetative Vermehrung durch \pm spindelförmige, häufig gedrehte und wurmförmig gekrümmte, mit 1-2 fingerförmigen Blattspitzen gekrönte, in den Blattwiıkeln büsehelweise gehäufte, gelbbraune Bulbillen. - Fig. $47 \mathrm{E}$.

Auf sandiger und lehmig-sandiger Erde in Ausstichen, an schattigen Abhängen, Graben- und Wegrändern, in erderfüllten FeIsritzen.

F. Al. Saltvik, an einigen Fundorten (Bom.). Lemland, Järsö (Klingst). — Ab. Lojo, Ojamo (Lindb.). - N. Pojo, Ảminne (Broth.). - Ka. Wiborg. Lalo, Soskuanjoki (Buch). — Ta. Korpilahti, Vuarunvuori (Link.). - Sa. Willmanstrand, Dysterniemi (Buch). Lappee, an einigen Fundorten (B) Savitaipale, Kirchdorf (B.). - Kol. Salmi, Leppälä, Kallioniemi (Link.). - Tb. Jyväskylä, Tourujoki (Broth.). Laukaa, Hyypaaãnvori (E. af H.). Kinnula, Saarenkỵā, Taasila (Roir.). Pihtipudas, an mehreren, Fundorten (R.). — st. Kuopio st. fq. (Link.). Nilsiä, Kirchdorf (Kyyhk.). haavı. Losomäki (Kot.). Maaninka st. fq. (Kyyhk.). Pielaresi st. fq. (Roiv.). - kl. Ruskeala (H. Backm.). Suistamo (Brolh.). - Kon. Dianovagora (Simm.). - Ok. Paltamo, Melalahtı, Aijönkallio (Kłyhk.). suomussalmi, Alanne (Һ.). - Ob. Muhos (H. Lindb.). Uleåborg (Huum.). - K. Kuusamo, Oulankajoki, Pitkäkoski (Backm.). - Lkem. Kolari, Väylänpää (Hult). — Li. Utsjoki, Fjerramjokka und Daussejokka (Ranck.); Tenojoki, Onnela (R.). - Lt. Luttojoki (Roiv.). Kola (F. Nyl.); am holaflusse (Broth.). Lp. Ponoj (M. Br.).

S. Sm., Ög., Vg., När., Hls., Ipd., Jmt., Ang. und LuL. bis in die Weidenregion.

N. Sm., JL., Ne., R., K., NT., No.-F.

Zentral-Europa, arkt. Nord-Amerika.

330. Pohlia grandiflora Lindb. fil. in Meddel. Soc. Faun. Fl. Fenn. B(l. 25, p. 41 (1899). [Bryun annotinum Hedw. Fund. II. p. 94 (1782) et Sp. musc. p. 183, t. 43 (1801). - Webera annotina Bruch Mscr. in Schwaegr. Sp. muse. p. 52 (1830).]

Diözisch: ơ Blüten sehr dick. Pfl. herdenweise oder in lockeren, blass- odel gelbgrünen, glanzlosen Rasen. Sterile Sprosse bis 2 cm, gleichmässig beblättert. fruchtende niedriger und schopfig beblättert. Blätter der sterilcn Sprosse locker gestellt, trocken aufrecht-abstehend, aus weit herablaufendem Grunde lanzettlich, bis 1,5 mm lang und bis $0,5 \mathrm{~mm}$ breit, mit aufrechten an der Spitze gesägten Rändern; Rippe kräftig, vor der Blattspitze aufhörend: Zellen oben 1: 5 - 6. Schopfblätter der fruchtenden Sprosse gedrängt, schmal lanzettich, bis 2,5 mm lang und bis $0,45 \mathrm{~mm}$ breit, mit weit hinauf schmal umgebogenen, an der Spitze gezähngen Rändern; Rippe vollständig bis kurz austretelld. Seta $2-3$ cm, rot. Kapsel teneigt bis längend, aus dem Halse von halber Urnenlänge oval. bis 2,5 mm lang und bis 1 mm dick, zuletzt rotbraun, trocken unter der Münding verengt; Zellen des Exotheciums unregelmässig mehreckig. kollenchymatisch. Peristomzähne bis $0,4 \mathrm{~mm}$ lang, gelb, mit bis 30 Lamellen. Inneres Peristom geblich: Grundhaut bis $0,4 \mathrm{~mm}$ lang, gelh, mit bis 30 Lamellen. Inneres Peristom gelblich; Grundhaut $1 / 2$ der Peristomzähne; Fortsätze mit ovalen Öffnungen, später klaffend: IVim- 
pern knotig. Deckel kuppelartig gewölbt, mit Spitzchen. Sporen 16-18, selten bis $23 \mu$, gelbbraun, fein papillös. Sporenreife im August. - Vegetative Vermehrung durch kleine, länglichovale oder schmal länglich-keilförmige, mit 2-5 spitzen Blättchen gekrönte, auf kurzen Trägern in den Blattwinkeln steriler Sprossen büschelweise gehäufte, zur Reife gelbliche Bulbillen.

In feuchten Sandausstichen, an Graben- und Wegrändern, an Schlammufern und in Felsritzen.

F. Al. Saltvik, an vielen Fundorten (Bom.). - N. Ekenăs, Tvärminne (Häyr.). Helsingfors, Fredriksberg (Buch). Helsinge, Hoplaks (Popp.). - Ik. Valkjärvi, Vaalima, am Vuoksenufer (H. Lindb.). Sa. Willmanstrand, Armila (Buch). Lappee, Pajarila (B.). - Oa. Lappo (H. Lindb.). - Li. Utsjoki, Fjerramjokka (Ranck.). - Lt. Am Kolaflusse (Broth.).

S. $L U L$. Sarekgebiet, in der Birkerregion.

Zentral-Europa.

331. Pohlia bulbifera (Warnst. Warnst.) Laubm. p. 429 (1906). [Webera bulbifera Warnst. in Bot. Centralbl. Bd. 66, p. 230 (1896). - W. annotina $\beta$ tenuifolia Schimp. Syn. 2 ed., p. 401 (1876). - Webera tenuifolia Bryhn in Nyt Mag. Naturv. Bd. 40, H. 1, p. 34 (1902).]

Diözisch: c7 Blïten dick knospenförmig. Pfl. in lockeren, oft ausgedehnten, weichen, grünen, etwas glänzenden Rasen. Sterile Sprosse bis $2,5 \mathrm{~cm}$, gleichmässig beblättert, fruchtende niedriger und schopfig beblättert. Blätter der sterilen Sprosse trocken flatterig abstehend oder aufstrebend, feucht meist weit abgebogen, aus kaum herablaufendem Grunde lanzettlich, kurz zugespitzt, bis $1 \mathrm{~mm}$ lang und $0,43 \mathrm{~mm}$ breit, mit aufrechten, an der Spitze gesägten Rändern: Rippe meist vor der Blattspitze aufhörend; Zellen oben 1: $1-6$. Schopfblätter der fruchtenden Sprosse schmal lanzettlich, lang zugespitzt, bis $2,2 \mathrm{~mm}$ lang und bis $0,4 \mathrm{~mm}$ breit, mit oberwärts schmal umgebogenen, gesägten Rändern; Rippe vollständig. Seta 1-1,5 cm, rot. Kapsel hängend, länglich, etwa 2,5 $\mathrm{mm}$ lang und $1 \mathrm{~mm}$ dick; Zellen des Exotheciums unregelmässig 4-6eckig. Peristomzähne etwa $0,45 \mathrm{~mm}$ lang, bleichgelb, mit bis 30 Lamellen. Deckel kuppelartig gewölbt, mit Warze. Sporen wie bei $P$. annolina. Sporenreife im Juni. - Vegetative Vermehrung durch rundliche bis ovale, mit 2-3 (4-5) stumpfen, kappenförmig hohlen, zusammen, neigenden Blättchen gekrönte, zu $1-3$ in den Blattwinkeln steriler Sprossen stehende, zur Reife gelbe Bulbillen (Fig. $47 \mathrm{~F}$ ).

Auf feuchter, sandiger und toniger Frde an Seeufern, seltener auf Moorboden und an Felsen.

F. Al. Tengsöda (Bom.). - Ab. Lojo, Torhola (H. Lindb.). - X. Ekenăs, Trărminne (Ranck.). Esbo, Hagalund (Broth.). Helsingfors, Fredriksberg (Buch). - Ik. Sakkola. Suvanto (H. Lindb.). Ta. Luhanka, Onkisalo, Iso Vaukanvuori (Vain.). - Sa. Willmanstrand, Dysterniemi und Armila (Buch). Lappee. Kallionkoski (B.); Hanhijärvi, Lakeakallio (B.). Kangasniemi (Lackstr.). - Oa. Närpes, Öster-Yłtermark (Ranck.). - Tb. Virrat (Simm.). Laukaa, Seppälä (Hãyr.). Konginkangas, Limattalanjoki (Broth.). Pihtipudas, Heinolankylä, Likolampi (Roiv.). — Sb. Maaninka, Tuovilanlahti (Kyyhk.); Korkeakoski (Roí.). - Om. Lappajärvi, Sammakkosaari (Backm.). Vindala. Pyhälahti, Tiistelinsaari (G. R. Blom). - Ok. Sotkamo. Hepolaht (Kyyk.). - Ob. Lleaborg, Viita (Huum.). 一 K. Kuusamo, Posio (E. af H.); Vasaraperä, Akanlahti. Leveälampi und Kunrikkalampi (E. af H.); Alakitka, Kokkoniemi (E. af H.); Riisijoki. Riisiköngäs (E. af H.). Kapu-taraara cop. (E. af H.). - Lkem. Kuolajärvi, Sallatunturi (Roiv.). - Li, Kỵö (Vain.).

S. Vrm. Ang. Hernösand.

N. Ringerike fq. $J L$. Dönsberg. Ne. Saetersdalen. K. Valders, Nordre Aurdal. H. Romsdal. NT. Stjordalen.

Europa.

332. Pohlia annotina (Leers) Lindh. mscr.: Buch in Meddel. Soc. F. Fl. Fenn. Heft 32, p. 29 (1906). [Bryum annotinum Leers Fl. Herborn. (1775). - Bryum annotinum Roth Tent. F]. germ. III. P. 232 (1800). - Webera annotina Limpr. Laubm. 11. p. 266 (1892). - W. Rothii Correns in litt.; Limpr. fil. Laubm. III. p. $728(190: 3) \cdot]$

Diözisch; ç kopfförmig. Pfl. Irerdenweise oder in lockeren bis dichten, zu- 
weilen ausgedehnten, mattglänzenden Rasen. Sterile Sprosse his 22 ('m, gleichmässig, fruchtende niedriger und schopfig heblättert. Blätter ter sterilen Sprosse nicht herablaufend, lanzettlich, bis $1.5 \mathrm{~mm}$ lang und bis $11,4.5 \mathrm{~mm}$ breit, nit aufrechten, oberwärts gesägten Rändern: Rippe vor der Blattspitze anfhörcuı; Zellen oben 1: 8-9. Schopfbläter der fruchtenden Sprossen schmal lanzettlich, allmählich zugespitzt, bis $3 \mathrm{~mm}$ lang und $(0,5 \mathrm{~mm}$ breit, mit weit hinauf schmal umgebogenen, an der Spitze schwach gezïhnten Rändern; Rippe fast vollständig bis kurz austretend. Zellen oben 1: \& -9. Seta $2-2,5$ cm, rot. Kápsel geneigt, aus dem Hals von Urnenlänge oval, bis 2,5 mm lang und his 1.5 mm dick, zuletzt gelbbraun, trocken und entdeckelt unter der llündung nicht verengt: \%ellen des Exotheciums unregelmässig, quadratisch oder mehreckig. Peristom wie bei $P$. grandiflora, jedoch nur mit 2j Lamellen. Sporen etwa 18,4 , gelburam, fein japillös. Sporemeife im Sommer. - Vegetative Vermehrung durch kugelig- bis länglich-eiförmige, mit 3-I (5-6) aufrechten, spitzen Blättchen gekrönte, fast immer einzeln in ten Blattwinkeln steriler Sprossen stehende, zur Reife rutloraune Bulbillen (Fig. $47 \mathrm{H}-1$ ).

In feuchten Sandausstichen.

F. Al. Saltvik, Fremmanby und Lafsböle (Bom.). - Ab. Albo, Hirrensalu (Buch). - V. Helsingfors (Lindb.). - Ik. Kivennapa, Kuokkala (H. Lindb.). Pybäjäri, am LaduganIer (H. L.). - cia. Kangasniemi, Läsăkoski (Broth.). - Kl. Uukuniemi (Simm.). Ruskeala (S.). L Kiol. Fabrikil (Elı́. Tb. Pihtipudas, Heinolankylä, Jousivuori (Rois) — sb. Jorvinen, Peukkimäki (H. Linul).). Iaaninka, Korkeakoski (Roiv.). Pielavesi, Panka, Särkipuro (R.). - Kú. Lieksa (Tain.). - um. Pedersöre, I’äboda (Font.). - Ok. Kajana, Lehtovaara (Lackstr.). Sutkamo. Naajurinvaara (Broth.). - K. Küsamu, Haataja (Broth.); zw. Aikkila und Rukatunturi (B.); Marttila mnd zw. Marttila und Vattula (B.): Ja araperä, Akanlahti, Leveälampi (E. af H.): zw. Likanen und sovanköngäs (Broth.). -- Lkem. Käıkesuanlu (Norrl.). - Le. Tschappisjärvi (Kot.). - Li. Inari. Kaamasjuki (Hult). Ctsjoki, Ailigas (Ranck.): Teunjoki, Alaköngäs und Levojok (Ranck.). - Lim. Kandalaki (salıll.). Imandra (Fellm.). - Lt. Luttojoki (Roiv.). Kola (Broth.). - Lmur. Am Voronjefluse (Broth.); Rinda (B.). _ Lp. Ponoj (sahlb.).

S. Bl., Sm., Ög., Ig., Vär., Vrm., Gstr., Ipd.. Jmt. und Ang.

N. Ringerike pass., Sm. Iq., JL.. Ne., R. pass.. K., XT., No, und Tr.

Europa, sibirien, Nord-Amerika.

333. Pohlia pulchella (Hedw.) Lindlb. Muse. seand. p. 17 (1879). [Bryum pulchellum Hedw. Descr. II\}. p. 95, t. 38 B (1792). Webera pulchella Schimp). Coroll. p. 67 (1856) ex p.].

Diözisch; ơ Blüten dick knospenförmig: äussere Hüllblätter aufrecht, eilanzettlich, unmerklich gezähnt. Herdenweise wachsende oder lockerrasige, kaum über $1 \mathrm{~cm}$ hohe, grüne bis schmutziggrüne, etwas glänzende Pfl. Schopfblätter aufrecht, steif, länglich-lanzettlich, zugespitzt. bis $2 \mathrm{~mm}$ lang und bis $0.15 \mathrm{~mm}$ breit, mit schmal umgebogenen, nur an der Spitze schwach gezähnten Ränderı; Rippe am Rüicken glatt, vor orker mit der Blattspitze endend; Zellen mässig verdickt, gelbgrün, zuletzt (lunkel- bis fast sclnwarzgrün, oben $1: 6-7$. Seta $1-1, \overline{\text { s }}$ cm, an der Spitze dicker, rötlich. Kapsel hängend oder nickend, aus dicken, kurzem Halse eikugelig, bis $2 \mathrm{~mm}$ lang und bis $1,5 \mathrm{~mm}$ dick, dümnäutig. gelblich, zuletzt zimtbraun, trocken und entdeckelt kugelig-kreiselförmig. unter der weiten IIündung wenig verengt. Peristomzähne $0,36 \mathrm{~mm}$ lang, grünlichgelb. mit etwa 20 Lamellen. Inneres Peristom blassgelblich: Grundhaut ${ }^{1}{ }_{2}$ der Peristomzähne: Fortsätze kłaffend; Wimpern schwach knotig. Deckel gewölht-kegelig, spitz. Sporen 14-18 $\mu$, bräunlichgełb, fein punktiert. Sporenreife in Mai.

Auf feuchter, sandiger oder sandig-toniger Erde.

F. Al. Saltvik, Krarnbo und Rangsby (Bom.). - $-\mathbf{b}$. Abo, Runsala (Zett.). - N. Hangö (Häyr.). Ekenäs, Trärminne (H.). Helsingfors, Sörnäs (Lindb.) - ka. Wiborg (Qrist). - Ik. Sakkola, Kirkkujoki (H. Lindb.). - St. Nakkila (Simm.). Llfsby (Karst.). - Oa. Närpes, Yitermark (E. af H.). Lanpo (H. Lindb.). Vasa (Broth.). - Kb. Lieksa. Kirchdorl (Vain.). - Om. Jahobstad (B.). - Ok. Paltamo (Sil.). - Ob. Liminka (Huum.). Simo, Ruikka (Brenn.). Ylitomio. Tanhainen (Hult). - K. Kunsamo, Korojoki (Broth.): Autinköngās (B.); Kurtajoki. Koirukōngàs (E. af H.); Paanajārri (sil.). - Lkem. Kolari, Naalaoja (Hult). Kittilä, Iluonioniska, in der Fichtenregion (Norrl.); Palojuki, in der Kiefern- 
region (N.). Kuolajärvi, zw. Kelloselkä und Kirchdorf (Broth.); Sallatunturi (Roiv.); Pautatsilehto zw. Naruskajoki und Tenniojoki (E. af H.). - Le. Zw. Hetta und Vuontisjärvi in der Kiefernregion (N.). - . Li. Utsjoki, Fjerramjokka (Ranck.). - Lim. Kandalaks (Sahlb.). Umpjok, Hiekkasuvanto (Kihlm.). Lt. An der Vereinigung des Sonkijoki mit dem Luttojoki (Roiv.). - Lmur. Bjelousiba an Toronjeflusse (Broth.).

S. Sk., Bl., Sm., Ög., När., Gstr., Dlr., Mpd. und Jmt. an einzelnen, Äng. und V̈b. an mehreren Fundorten.

N. Sm., A.. JL., Br., K., Tr, und $F$. an einzelnen oder wenigen Fundorten. Nordgrenze bei $70^{\circ} 13^{\prime}$ n. $\mathrm{Br}$.

Estland.

334. Pohlia rubella (Philib.) Möll. Förteckn. Sk. växt. 2. Moss. p. 32 (1907). (Webera rubella Philib. in Rev. bryol. 1896, p. 85.)

Diözisch. Schlanke Pfl. in niedrigen, graugrünen, oft ausgedehnten Rasen. Untere Blätter nicht herablaufend, etwa shohl, eiförmig, abgestumpft oder kurz zugespitzt. Schopfluätter viel grösser, linealisch, bis $2 \mathrm{~mm}$ lang, flach- und ganzrandig: Rippe vor der Blattspitze aufhörend; Zellen oben 1: 5 . Seta $7-8 \mathrm{~mm}$, purpurn. Kapsel horizontal bis nickend, aus kurzem Halse verkehrt-eiförmig, zuweilen schwach gekrümmt, 1,25-1,50 mm lang und $0,60-0,70 \mathrm{~mm}$ dick, rlunkelrot, entleckelt weitmündig. Ring purpurrot, anhängend oder sich in einzelnen Zellen ablösend, glattrandig. Peristom wie bei $P$. pulchella. Deckel breit kegelig, meist stumpf. Sporen $15-17$ :

N. F. Kistrand, Lakselven.

Schweiz.

335. Pohlia lutescens (Limpr.) Möll. Förteckn. 2. Noss. p. 31 (1907). [IVebera lutescens Limpr. Laubm. I. p. 270 (1892).]

Diözisch; $\sigma^{7}$ IJlüten fast scheibenförmig; äussere Hüllblätter aus aufrechter, wenig breiterer Basis verlängert lineal-lanzettlich, abstehend bis ausgebreitet, scharf gesägt. Lockerrasige, meist $1 \mathrm{~cm}$ hohe, gelbliche oder bleichgrüne, etwas glänzende Pfl. Schopfblätter weit abstehend, trocken verbogen, lanzettlich-linealisch, lang zugespitzt, an der Spitze meist gedreht, bis $3,6 \mathrm{~mm}$ lang und bis 0,45 mm breit, mit nur in der Mitte schnal umgebogenen, weit herab gesägten Rändern; Rippe am Rücken der Spitze gezähnt und meist als gesägter Endstachel austretend; Zellen dünnwandig, hyalin, oben 1: 10-12. Seta 1,5-3 cm, im Bogen gekrümmt und trocken geschlängelt, an der Spitze nicht verdickt, rötlichgelb, oben strohgelb. Kapsel nickend, seltener hängend, mit dem alhmählich verschmälerten Halse von Lrnenlänge und däüber birnförmig, bis $3 \mathrm{~mm}$ lang und bis $1,5 \mathrm{~mm}$ dick, dünnhäutig, bleichgelb, zułetzt rötlichgelb, trocken und entdeckelt unter der weiten Münckung wenig verengt, entleert wenig verkürzt. Peristomzähne bis $0,4 \mathrm{~mm}$, gelb, mit bis 28 Lamellen. Inneres Peristom blassgelblich: Grundhaut $1 / 2$ der Peristomzähne: Fortsätze kJaffend; Wimpern kaum knotig. Deckel gewölbt, mit Spitzchen. Sporen 12-16 ", gelbgrün, fast glatt. Sporenreife im Mai.

S. Nach $\mathrm{H}$ a ge $\mathrm{n}$ befindet sich im Reichsmuseum ein wahrscheinlich aus Südschweden herrührendes Exemplar, leider ohne Fundortsangabe.

N. A. Eidsvold. Fagerli, an einem Grabenrande, etwa $150 \mathrm{~m}$.

Zentral-Europa, an vereinzelten Fundorten bis zur Ostseeküste.

\section{MNIOBRYUM}

(Schimp.) Limpr. Laubni. I1. p. 272 (1892).

Diözisch. Stengel und Blätter wie bei Pohılia, Zellen der Lamina jedoch meist Iockerer und dünnwandig. Kapsel aus kurzem Halse oval, trocken und entdeckelt verkürzt, weitmündig und $\leftrightarrows$ kreiselförmig: Zellen des Exotheciums dümmandig und in der Mehrzahl regelmässi: 6eckig, trocken mit stark verbogenen Wänden; Spaltöffnungen eingesenkt. Ring fthlend. Peristomzähne wie bei Pohlia. Grundhaut des inneren Peristonns 1/2 der Peristomzähne oder höher; Fortsätze klaffend; Wimpern vollständig und knotig. DeckeI hoch gewölbt, mit Spitze oder Warze. 
Übersieht der Arten.

A. Niedrige Pfl. in gelb- oder sehmutzig bräunlichgrünen bis rötlichen Rasen. Schopfblätter allmählich zugespitzt. Sporogone meist vorhanden.

a. Blätter mit längs stark umgebogenen Rändern. Seta dünn. «. Peristomzähne grünlichgelb 339. M. vexans. $\beta$. Peristomzähne braunrot

b. Blätter flachrandig oder mit sehmal umgebogenen Rändern. Seta dick 337. M. carneum.

B. Meist sterile Pfl. in weisslich-oder bläulichgrünen Rasen. Blätter kurz und breit gespitzt, flachrandig 336. M. albicans.

336. Mniobryum albicans (Wahlenb.) Limpr. Laubm. II. p. 277 (1892). [Bryum albicans Wahlenb. Mscr., Web. et Mohr Taschenb. p. 280 (1807). - Webera albicans Schimp. Coroll. p. 67 (1856). - Pohlia albicans Lindb. Musc. scand. p. 17 (1879).]

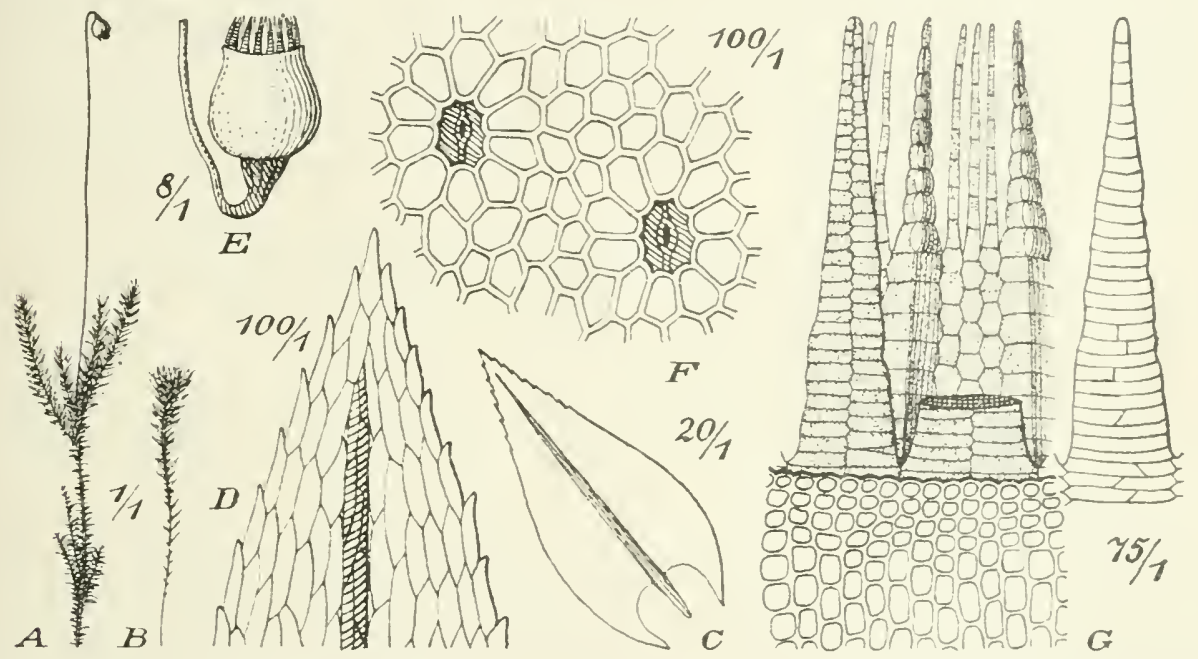

Fig. 48. Mniobr!num albicans (Wahlenb.). A Fruchtende Pfl. (1/1); B C Pfl. (1/1). C slengelb. (20/1) D Blattspitze (100/1); E Entdeckelte Kapsel im trockenen Zustande (8/1): F spalloffnungen (15(1): G Peristom $(75 / 1)$.

ơ Blüten fast scheibenförmig: äussere Hüllblätter aus hohler, aufrechter Basis breit lanzettlich und \pm sternförmig ausgebreitet. Pli. in meist lockeren, oft ausgedehnten, meist 2-3, steril zuweilen über $10 \mathrm{~cm}$ hohen, bläulich-weissgrünen, glanzlosen Rasen. Blätter etwas herablaufend. untere eiförmig, zugespitzt, die oberen länglich-lanzettlich, knrz und breit zugespitzt. bis $2 \mathrm{~mm}$ lang und bis $0,85 \mathrm{~mm}$ breit, mit aufrechten, oben gesägten Rändern: 12ippe am Grunde rot, vor der Blattspitze aufhörend: Zellen oben 1: 5-6, am Rande enger. Seta 2 -4 cm, dünn, gelbrot. Kapsel geneigt oder hängend, bis $2.5 \mathrm{~mm}$ lang und bis $1,2 \mathrm{~mm}$ dick, bläulichgrün, zuletzt rötlichbraun. Peristomzähne bis $0,5 \mathrm{~mm}$, clunkelgelb, später bram. mit über 30 Lamellen. Sporen $14-18 \mu$, gelbbraun, papillös. - Fig. 48.

In nassen, quelligen Sand- und Tonausstichen, an Bach- und Flussufern und auf quelligen Wiesen. 
F. Al. Mariehamn. Jomala und Geta an einzelnen, Saltvik an vielen Fundorten (Bom.). - Ab. Abo (Elfr.). Pargas, Piukala (E.). Lojo, Ojamo (Lindb.). - N. Helsinge, Gammelstaden (Broth.). Aggelby (Hāyr.). Iitti (Buch). - Ik. Valkjärri. Vaalima (H. Lindb.). - Kl. Sortavala, Paksuniemi (Buch). - Kol. Gorki (Elfr.). Petrosarodsk (Sahlb.). — Tb. Laukaa. Seppālā (Link.). - Sb. Nilsiä, Valkeiskỵlā (Kỵhk.). 一 Kb. Lieksa, Vieki (Vain.). - Ok. Ristijārri, Juurikka (Lackstr.). Hỵynsalmi, Kïchdorf (L.). - Ob. Uleâborg (Huum.). Kemi. Kirchdorf (Brenn.). Roraniemi, Alajāāsko (Hult). K. Pudasjārvi (Broth.). Kuusamo, zw. Pyhäraara und Rukatunturi (B.); zw. Liikanen und Soranköngäs (B.): Vasaraperä (E. af H.); Suininki. Măättälănvaara (E. af H.); IIäntyvaara (Nyb.); Paanajärvi (Sahlb.). - Lkem. Folari. Jouhisuanto (Hult). Juonio, Keimiotunturi, in der Nadelwaldregion (Norrl.); Muonioniska (Sahlb.). Kuolajärvi. Sallatuntıri (Roǐ.): zw. Jungoiła und Akanpşsy (Linnan.); Vuorijoki, Niemenköngās (Aschan). - Li. Sodankỵlă. au mehreren Fundorten in der Nadelwaldregion (Hult). Inari, an mehreren Fundorten in der Tadelwald- und Birkenregion (Sil., Hult). Utsjoki, an mehreren Fundorten in der Birkenregion und auf Ailiga: in der alpinen Region (Hult, Ranck.). - Lim. Seaptiroaivi und Kaitatunturi (Linnan.). Tschun (Sahlb.). — Lt. Sreduij am Kolabusen (Broth.). - Lmur. Jokonsk (Broth.). - Lp. Ponoj (Sahlb).

S. sk.. Öl. Sm.. Ög., Srm.. Var.. Upl.. Gstr. Dlr. Hlsl., Hrjd.. Jmt., Ang., LuL. und LuL.

N. Ringerike fq. Sm. an mehreren Fundorten. JL. Tjomø und Sandefjord. R. rr. K. Dovre; Lomseggen. ST. NT. Stjordalen fq. No.-F. an vielen Fundortell.

Europa, Algier, Kaukasus, Sibirien, Japan, Nord-Amerika. Anden. Chile, Falkłand, Kerguelen. Ost-Australien, New Zealand.

var. glaciale (Schleich.) Limpr. Laubm. II. p. 279 (1892). [Bryum glaciale Schleich. Catal. 1807: Brid. Bryol. univ. I. p. 852 (1826). - Webera albicans $\beta$ glacialis Schimp. Coroll. p. 67 (1856). - Pohlia albicans var. glacialis Möll. Förteckn. Sk. växt. 2. Moss. p. $32(1917)$.]

Kräftige Pfl. in ausgedehnten. bis 10 und mehr cm hohen, bläulichgrünen, trocken bräunlichgrünen Rasen. Blätter bis $3 \mathrm{~mm}$ lang und $1,5 \mathrm{~mm}$ breit. Seta 5 -6 $\mathrm{cm}$. Kapsel grösser.

In Gletscherbächen und kalten Quellen. Sporogone sehr selten.

F. Le. Kilpisjärri, zw. Kahperusraara und Vuopmekasjasr in der alpinen Region (Kot.). - Li. Ailigas in der alpinen Region (Hult). - Lmur. Semjostrorsk und Litsa (Broth.).

S. Hrjd. Helagsfjallet. Jmt. Skurdalshöjden. LuL. Sarekgebiet.

N. Ne. Saetersdalen in Hochgebirge fqq. und cpp. K. Dovre; Lomsfjeldene. F. Hammerfest. Europa, Kaukaะus, Himalą̧a, Tibet, Grônland.

337. Mniobryum carneum (L.) Limpr 1. c. p. 275. [Bryum carneum L. Sp. pl. 2. ed. p. 1587 (1763). — Webera carnea Schimp. Coroll. p. 67 (1856). — Pohlia carnea Lindb. Musc. scand. p. 17 (1879).]

$\sigma$ Blüten dick knospenförmig: Hüllblätter aus hohler Basis allmählich lang zugespitzt. Herdenweise wachsende oder lockerrasige, hellgrüne, später bräunliche, unten rötliche, haum slanzende Pfl. Stengel bis $2 \mathrm{~cm}$. Blätter etwas herablaufend, aufwärts allmählich grösser. lanzettlich. Schopfblätter lineal-lanzettlich, allmählich zugespitzt, bis $2,4-3 \mathrm{~mm}$ lang und bis $0,45-0,50 \mathrm{~mm}$ breit, mit weit hinauf schmal umgerollten, oben gesägten Rändern; Rippe vor der Blattspitze aufhörend Zellen oben 1: 5-6, an den Rändern in meist 2 Reihen enger. Seta $1-2 \mathrm{~cm}$, dick, gelbrötlich. Kapsel hängend, klein, bis $1,5 \mathrm{~mm}$ lang und $0,75 \mathrm{~mm}$ dick, fleischrot, später rötliclıbraun. Peristomzähne bis $0,45 \mathrm{~mm}$, dunkelgelb oder braunrot, mit bis 30 Lamellen. Sporen 14-18 ", gelblich, fast glatt.

Auf feuchtem tonigen und tonig-sandigen Boden, an Weg- und Grabenrändern, in Ausstichen und auf Brachäckern.

F. Al. Saltrik, an mehreren Fundorten (Bom.). - Ab. Lojo, Tytyri und Herosaari (H. Lindb.). Ta. Hollola, Laitiala (Norrl.).

S. Sk.. Öl., Gtl., Sm., Boh., Lpl. und Gstr. an einzelnen oder wenigen Fundorten.

N. Sm., Bu., $J L$. und $B r$. an einzelnen oder wenigen Fundorten.

Europa, Algier, Ägpten, Kaukasus, Y. W. Himalaya.

338. Mniobryum atropurpureum (Wahlenb.) Hag. Musc. Norv. bor. p. 114 (1901). [Bryum a ropurpureum Wahlenb. Mser. in Web. et Mohr Ind. Mus. pl. crypt. p. 4 (1803). - Pollia atropurpurea Lindb. fil. in Ac. Soc Faun. Fl. Fenn. XiI. No. 2, p. 14 (1899).]

Unterscheidet sich von dem nahe verwandten.$M$. carneum durch die eilan- 
zettlichen, am Rande stärker umgebogenen Blälter mit engerem (1: 8-10) Zellgewebe, durch die abgeflachten, vielreihigen Randzellen der Urnenmünrlung, durch den weiten Vorhof der Spaltöfnungen, durch die entfernteren lamellen der Peristomzähne und dureh das niedrigere, papillöse innere Peristomn.

Auf Schlammerde und feuchtem, lehnigem Boden.

F. Lt. Kola, an Tulomaflusse (Broth.). - Lp. Sapaduij navolok, unweit ron Svjatoino- (B.).

S. ing. Sollefteå.

N. ST. Trondhjem. NT. Stjardalen. No. Sorfolden. Tr. Nordrejsen, Venetraara; Bardo, Jerdne. varre; Tromsü.

Iünchen, Nord-Russland, Sibirien. Nord-Amerika.

339. Mniobryum vexans Limpr I. e. p. 273. [Poh'ia vexans Lindb. fil. in Act. Soc. Faun. Fl. Fenn. XIV. No. 2, p. 20 (1899).]

ơ Blüten dick knospenförmig: äussere Hüllblätter aufrecht, eilanzettlich. Herdenweise wachsende oder lockerrasige, grüne oder gelbgrüne, etwas glänzenıle Pfl. Stengel bis $1 \mathrm{~cm}$. Blätter herablaufend, eucht und trocken aufrecht und steif, aufwärts allmählich grösser, untere länglich-lanzettlich, die oberen schmal lanzettlich, allmählich zugespitzt, bis $2 \mathrm{~mm}$ lang und $0,45 \mathrm{~mm}$ breit, mit fast längs stark umgebogenen und weit herab gesägten Rändern; Rippe ziemlich kräftig, vor oder mit der Blattspitze aufhörend; \%ellen oben 1: $7-8$. Seta 1-1,5 cm, dünn. rot. Kapsel hängend oder nickend, mit dem kurzen, engen Halse knrz birnförmig. his $2,5 \mathrm{~mm}$ lang, gelbgrün, zuletzt rötlichbraun. Peristomzähne bis, $0,5 \mathrm{~mm}$ lang. grünlichgelb, mit etwa 30 Lamellen. Sporen $14-18$ u, blassgelblich, fast glatt. birge.

Auf sandig-lehmigen Erdblössen, in Ausstichen und an Wegrändern im Ge-

S. Dr., Hrjd. und Jml an einzelnen Fundorten.

N. Dovre und an einzelnen Fundorten in No.. Tr. und $F$.

Schweiz, Pinzgau, Salzburg, Steiermark.

\section{BRYUM}

Bryum Dill. Cat. Giss. p. 222 (1718) et Append. p. 85 (1719) emend. Schimp. Syn. (1860) et Limpr. Laubm. II. p. 280 (1892).

Stengel meist \pm verfilzt, mit meist kurzen und schopfig beblätterten subfloralen Sprossen. Untere Blätter meist entfernt gestellt, obere \pm schopfig gehäuft, aufrecht-abstehend, seltener anliegend, von wechselnder Form, meist gesäumt und mit \pm weit hinauf umgebogenen, gegen die Spitze oft gezähnten Rändern: Rippe meist kräftig und + lang austretend; Zellen ziemlich locker, meist rhombisch bis rhomboidisch-6seitig, am Blattgrunde quadratisch bis verlängert rektangulär. Seta verlängert, an der Spitze hakig oder bogig gekrïmmt. Kapsel meist hängend oder nickend, von wechselnder Form. Peristom doppelt, beide Peristome von gleicher Länge. Peristomzähne am Grunde verschmolzen, lanzettlich oder linealisch-pfriemenförmig, gelb oder orange, an der Spitze meist hyalin, mit meist fein papillöser Dorsalfläche und hohen Lamellen. Grundhaut des inneren Peristom hoch.

\section{L bersieht der Arten.}

A. Diözisch. Schlanke, meist weisslichgrüne bis silberweisse Pfl. Stengel nuit kätzchenförmigen Sprossen. Blätter niclıt herablaufend, löffelartig-lıohl, flachund ganzrandig, ungesäumt. Wimpern des inneren Peristoms vollständig, mit Anhängseln.

a. Kapsel kurz- und dickhalsig, regelmässig, dunkelrut bis schwärzlich. «. Blätter mit scharfer, verlängerter Spitze: Ripp` zart. 
bis zur Blattmitte oder bis zum Grunde der Spitze reichend

458. B. argenteum.

ß. Blätter kurz und stumpflich zugespitzt.

I. Kapsel mit abgerundetem Halse

455. B. Blindii.

II. Hals am Grunde verschmälert

b. Kapsel länglich-birnförmig, gelbbraun. Blätter scharf zugespitzt

456. B. oblongum.

454. B. Funckii.

B. Blätter kreisrund oder breitrund, mit eingebogenen Rändern. Sporogone unbekannt

457. B. veronense.

C. Diözisch. Weiche und schlanke Pfl. Blätter herablaufend, selır stumpf bis abgerundet, ungesäumt bis sehr schmal gesäumt; Rippe vor der Blattspitze aufhörend; Zellen sehr locker und dünnwandig.

a. Grüne Pfl. Stengel sehr locker beblättert. Blätter \pm hohl, flachrandig; Rippe dünn .........................379. B. cyclophyllum.

b. Pfl. oberwärts meist rötlich. Stengel dichter beblättert. Blätter sehr hohl, mit \pm weit hinauf schmal umgebogenen Rändern; Rippe ziemlich kräftig

378. B. obtusifolium.

D. Blätter meist sehr hohl und stumpf, nicht oder undeutlich gesäumt; Rippe vor oder mit der Blattspitze endend; Zellen locker. Kapsel (excl. B. teres) kurz und dicǩ.

a. Autözisch. Blätter etwas fleischig, mit am Grunde oder bis über die Mitte schmal umgebogenen Rändern. Kapsel bräunlich. Wimpern meist kurz bis fehlend .......381. B. calophyllum.

b. Autözisch. Stengel mit zahlreichen, verlängerten, sehr schlanken, entfernt beblätterten Sprossen. Untere Blätter breit oval, stumpf oder kurz zugespitzt, mit flachen oder am Grunde schwach umgebogenen Rändern. Kapsel walzenförmig, zuletzt weinrot

382. Bryum acutum.

c. Diözisch. Blätter flachrandig. Kapsel klein, fast kugelig, zur Reife rot. Wimpern fehlend ............... 340. B. Marratii.

d. Autözisch. Stengel mit steifen, oberwärts kätzchenartig beblätterten, leicht sich ablösenden subfloralen Sprossen. Blätter mit \pm weit hinauf umgerollten Rändern. Kapsel birnförmig, bleichbraun, trocken unter der weiten Mündung verengt. Wimpern mit langen Anhängseln

E. Schlanke, meist rötliche oder braune Pfl. Blätter herablaufend, zugespitzt, mit bis gegen die Spitze umgebogenen Rändern und ein- bis mehrreihigem, gefärbtem Saum; Rippe vollständig bis kurz austretend.

a. Diözisch.

«. Kapsel regelmässig, trocken unter der Urnenmünclung eingeschnürt

374. B. turbinatum.

ฬ. Krapsel meist unregelmässig, mit \pm emporgehobenem Rücken.

I. Stengel leicht brüchig, in den oberen Blattachseln mit hyalinen oder rötlichen Brutfäden. 364. B. rutilans.

II. Stengel nicht brüchig, ohne Brutfäden.

1. Wimpern meist vollständig, mit Anhängseln.

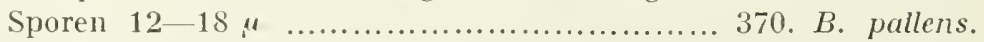

2. Wimpern rudimentär. Sporen $15-40 \mu$ in derselben Kapsel 
3. Kapsel fast regelın̈ssig. Wimpern oft sehr schwach entwicke]t. Blattzellen sehr locker. 372. B. finmarkicum.

4. Inneres Peristom anhängend; Wimpern rudimentär

b. Synautözisch. 371. B. purpureum.

«. Kapsel gekrümmt keulenförmig

$\not$. Kapsel fast regelmässig.

366. B. Lindbergii.

I. Seta bis $2,5 \mathrm{~cm}$. Wimpern oft rudimentär

367. B. amblystegium.

II. Seta $4-6 \mathrm{~cm}$. Wimpern mit Anhängseln

369. B. pycnodermum.

c. Seta bis $2 \mathrm{~cm}$. Kapsel fast regelmässig. Wimpern rudimentär oder fehlend.

a. Polyözisch. Peristomzälne aulacodont 363. B. opdalense.

§. Synözisch. Peristomzähne holodont 362. B. lepidum.

F. Diözisch. Schlanke Pfl. Blätter nicht herablaufend. Schopfblätter eilanzettlich, kurz zugespitzt, sehr schmal gesäumt; Rippe vollständig bis kurz austretend. Kajsel klein regelmässig ...................................365. B. alvarense.

G. Diözisch. Jehr oder weniger kräftige Pfl. Blätter hohl, stumpf oder kurz spitzig, dureh 3-5 Zellreihen gesäumt; Rippe kurz vor der Blattspitze aufhörend lis kurz austretend. Kapsel regehmässig.

a. Blätter rasch zugespitzt: Rippe ohne normal entwickelte Stereiden

376. B. turgens.

37.5. B. Schleicheri.

§. Blätter allmählich zugespitzt; Rippe nomal ........
ynözisch oder polyözisch. Blätter etwas herablaufend,

H. Synözisch oder polyözisch. Blätter etwas herablaufend,
zugespitzt, mit schwach umgebogenen, schmal gelbgesäumten Rändern; Basalzellen nicht gerötet. Peristomzähne sehr dick, bräunlichgelb; Dorsalschicht mit Querund Schrägstreifung: Fortsätze schmal, ritzenförmig durchbrochen; Wimpern rudimentär 380. B.purpurascens.

I. Autözisch. Schopfblätter aus verengtem, etwas herablaufendem Grunde länglich-lanzettlich, lang zugespitzt, mit gefärbtem Saum; Basalzellen nicht gerötet. Kapsel hochrïckig. Fortsätze breit. Wimpern rudimentär.

a. Rippe mit der Blattspitze endend oder kurz austretend. Kapsel mit dem gebogenen Halse keulig-birnförmig, klein und schiefmiindig. Deckel kurz kegelig ........
Rippe vor und mit der Blattspitze endend. Kapsel aus gebogenem, kurzem Halse eilänglich. Deckel flach gewölbt 361. B. campylocarpunr.

K. Autözisch. Blätter zugespitzt, mit gefärbtem Saum: Rippe kräftig, auslaufend; Basalzellen (excl. B. Moei) nicht gerötet. Kapsel hängend, regelmässig. Peristomzähne sattgelb oder gelbrot; untere Lamellen meist durch je 2-3 Zwischenwände verbunden. Fortsätze sehr schmal, ritzenförmig durchbrochen; Wimpern rudimentär bis fehlend (Warneiformia).

a. Blätter weit herablaufend, lang und schmal; Rippe lang auslaufend 341. B. Moei.

b. Blätter nicht herablaufend.

«. Lamellen ohne Zwischenwände.

I. Autözisch. Inneres Peristom normal entwickelt. 344. B. manillatum. 
II. Synözisch. Inneres Peristom rudimentär 315. B. mutilum. ґ. Untere Lamellen mit Zwischenwänden.

I. Dorsalplatten ohne Strichelung.

1. Kapsel fast birnförmig kugelig, trocken unter der Mündung verengt

343. B. warneum.

2. Kapsel länglich-birnförmig, trocken unter der Mündung nicht verengt

II. Dorsalplatten dicht quergestreift 346. B. Fridtzii.

L. Syıözisch oder polyözisch. Blätter zugespitzt, meist wulstig gesäumt; Rippe meist austretend; Basalzellen nicht gerötet. Kapsel oft \pm gebogen, dünnhäutig. Peristomzähne selten mit voneinander freien, meist mit gegen die Basis durch je eine oder mehrere Zwischenwände miteinander verbundenen Lamellen. Fortsätze selır schmal, ritzenförmig clurehbrochen; Wimpern kurz, ohne Anhängsel (Arcticiformia).

a. Lamellen durch je eine Zwischenwand mit einander verbunden

349. B. arcticum sens. lat.

b. Lamellen abwärts durch $2-3$ Zwischenwände mit einander verbunden.

a. Schopfblätter breiter als die halbe Länge, mit nur am Grunde umgebogenen Ränderı. Kapsel aus fast gleichlangem, engem Halse geschwollen verkehrt-eiförmig,

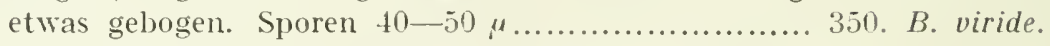

$\beta$. Schopfblätter n cht breiter als die halbe Länge. Kapsel mit nicht oder kaum gebogenem Halse.

I. Blätter mit am Grunde schmal ungebogenen Rändern, schwach gesäumt. Kapsel aus engem, fast gleichlangem Halse fast kugelig, glänzend. Sporen $28-32$ bis 36 " 351. B. micans.

II. Blätter mit längs \pm breit umgebogenen Rändern, stark gesäumt.

1. Schopfiliatter bis $3,2 \mathrm{~mm}$ lang. Kapsel aus kurzem, engem Halse fast kugelig. Sporen fast $40 \mu$. 352. B. inflatum.

2. Schopfblätter etwa $1,8 \mathrm{~mm}$ lang. Kapsel mit dem kurzen Halse eibirnförmig. Sporen 24-32 $\mu$..... 353. B.kongsvoldense.

3. Schopfblätter bis $3 \mathrm{~mm}$ lang. Kapsel mit dem verkehrt-kegeligen Halse von lialber Urnenlänge keulig-birnenförmig, glänzend. Sporen 28-32 $\mu$. 35. 1 B. Bornmülleri.

4. Heterözisch Kapsel mit schmalem Halse ke lenförmig, gekrümmt. Fortsätze wenig entwikkelt, sehr schmal, kaum durchbrochen ........ 355. B. camurum.

11. Blätter zugespitzt, mit umgebogenen, neist schmal oder undeutiich gesäumten Rändern: Rippe kräftig, meist 'ang auslaufend: Basalzellen rot. Kapsel meist hängend, regel mässig. Peristomzähıe gelb oder gelbrot; Lamellen der unteren Hälfte durch je 2-3 Zwischenwände verbunden a. Wimpern rudimentär bis fehlend (Anaglyphodon).

«. Synözisch oder polÿözisch. Kapsel lederbraun, später oft schwärzlich. Fortsätze gefenstert ......... 347. B. pendulum.

§. Autözisch. Kapsel kurz und dick. mit sehr kurzem 
und dickem Halse, blassgelblich. Fortsätze ritzen-

förmig durchbrochen 315. 13. confluens.

b. Wimpern völlig ausgebildet, mit Anlängscln ( $A r c^{\prime} O-$ bryum).

«. Autözisch 3.5.5. H. alandense.

§. Heterözisch.

I. Schopfblätter etwa $2 \mathrm{~mm}$ lang. schmal gesäumt.

Kapsel untér der erweiterten Iündung verengt. 356. B. dilatahum.

II. Schopfblätter etwa $3 \mathrm{~mm}$ lang, stark gesäumt.

Kapsel unter der Mündung nicht verengt ........ 357. B. dolomilicum.

$\gamma$. Polỹözisch. Schopfblätter etwa 2,5 mm lang, ziem-

lich breit, jedoch undeutlich gesäunt. Kapsel unter der Mündung nicht verengt ........................35. B. rhexodon.

N. Meist sỹözisch. Blätter zugespitzl, gesäumt, mit umgebogenen Rändern; Rippe kräftig, meist \pm lang austretend: Basalzellen rot. Inneres l’eristom dem äusseren nur locker anliegend oder frei: Wimpern (excl. B. proprium) ohne Anhängsel, kurz bis fehlend.

I. Peristomzähne mit schmalem, unten nicht gut begrenztem, rotem bis orangefarhenem Fundus (Inclinatiformia).

1. Rippe lang austretend. Peristomzähne fast immer aulacodont ausgebildet. Deckel flaclı gewölbt bis fast flach.

* Polyözisch.

$\uparrow$ Sporen 25-30 $\mu$, rostfarben, fein papillös. 383. P. archangelicum.

$\dagger$ Sporen etwa $30 \%$, gelblich, glatt ........ 384. B. Joergensenii.

** Autözisch. Sporen 30-33 ", schmutzig gelb, papillös ............................. 385. B. auloicum.

2. Peristomzähne holodont ausgebildet.

* Kapsel aus kurzem, deutlich abgesetztem Halse eiförmig oder länglich-eiförmig. gelb oder lichtbraun.

+ Meist autözisch, zuweilen auch ${ }^{7}$ Pfl. Blätter hohl, breit eiförmig, kurz und stumpf zugespitzt: Rippe vor der Blatt-

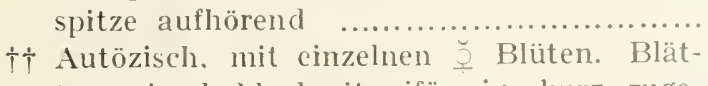
388. B. gilvum. ter sehr hohl, breit eiförmig. kurz zugespitzt, flachrandig: Rippe der oberen Blätter als etwas zurückgebogene. kurze Stachelspitze austretend .................390. B. Limprichtii. $+\dagger \dagger$ Synözisch.

$x$ Blätter ungesäumt oder schmal gesäumt:

Rippe meist mit der Blattspitze endend. 356. B. lacustre.

$\times \times$ Blätter mit 2-3reihigem. gelbem Saum:

Rippe als Stachel austretend ...........387. B. murmanicum.

Kapsel kurz birnförmig, rot .............. 389. B. globosum.

*** Schopfblätter mit = lang austretender Rippe. Kapsel grösser.

$\uparrow$ Kapsel geschwollen birnförmig. mit kurzem Hals 
$\dagger \uparrow$ Kapsel mit längerem Hals, meist 土 schmal birnförmig.

$\times$ Blätter nicht oder kaum herablaufend.

$\S$ Heterözisch; ŏ und grosse fast scheibenförmige $\sigma^{\succ}$ Blüten. Blätter bis $1,1 \mathrm{~mm}$ breit. Kapsel aus dem Halse von Urnenlänge oval oder verkehrteiförmig

$\S \S$ Autözisch. Blätter bis $0,7 \mathrm{~mm}$ breit. Kapsel mit dem Halse von etwa halber Urnenlänge keulenförmig

399. B. Bryhnii.

$\S \S$ Synözisch.

x Deckel kurz kegelig, mit Warze. Sporen $18-25 \mu$, feinwarzig.

Schopfblätter verlängert lanzettlich, 2,5-3,5 mm lang, mit breitem, gelblichem Saum ..... 395. B. inclinatum.

$\square \square$ Schopfblätter eiförmig oder aus eiförmiger Basis kurz lanzettlich, ungesäumt

394. B. boreum.

$\mathrm{xx}$ Seta sehr fein. Deckel scharf zu-

gespitzt. Sporen 15-21 $\mu$, glatt...396. B.trichopodium.

$\times \times$ Synözisch. Blätter deutlich herablau-

fend. Kapsel verlängert keulenförmig, rötlichbraun, breit gefenstert .......... 400. B. Hagenii.

$x \times \times$ Blätter lang herablaufend. Kapsel bräunlichgelb. Fortsätze mit langer, pfriemenförmiger Spitze.

§ynözisch. Fortsätze ohne Anhäng-

sel. Sporen $23-27 \mu \ldots \ldots \ldots \ldots \ldots . . . .$.
ş Synözisch. Fortsätze meist mit langen Anhängseln. Sporen 30-10 $\mu$. 392. B. proprium.

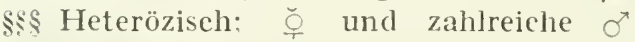
Blüten. Fortsätze sehr schmal. Sporen $20-26 \mu$ 393. B. litorale.

II. Peristomzähne nach unten durch eine Bogenlinie gut begrenzt, mit breitem, dickem, meist tief purpurfarbenem Fundus (Haematostoma).

1. Autözisch oder heterözisch.

* Blätter breit bis länglich-eiförmig; Rippe mit der Blattspitze endend bis kurz austretend. Kapsel aus deut.ich abgeset tem Halse rasch bauchig erweitert; Zellen des Exotheciums dünnwandig, an der Urnenmündung nur in wenigen Reihen differenziert. † Deckel gewölbt kegelig ......................

$\dagger \dagger$ Deckel sehr niedrig, ohne Warze.

401. B. maritimum. 402. B. Kaalaasii.

** Blätter länglich-lanzettlich Rippe kurz austretend. Kapsel mit dem fast gleich langen Halse birnförnig; Zellen des Exotheciums kleiner als bei den vorigen Arten, an der Urnenmündung in etwa 5 Reihen differenziert 
2. Synözisch.

* Peristomzähne abwärts querstreifig.

$\dagger$ Kiapsel gekrümmt

105 B. curvatum.

$\dagger \dagger$ liapsel fast kugelig 406. B. salinum.

** Peristomzähne ungestreift

$\dagger$ Schopfblätter herablaufend.

$\times$ Schopfblätter lang und schmal herablaufend. Kapsel trocken grubig ..... 415. B. foveolatum.

$x \times$ Schopfblätter weniger lang herablaufend. Kapsel trocken nicht grubig ... 413. B. stenodon.

$\dagger \dagger$ Schopfblätter nicht ocker kaum herablau-

fenct. Kapsel trocken nicht grubig.

$\times$ Fortsätze ritzenförmig bis elliptisch durchbrochen.

$\$$ Sporen $40-50 \mu$

404. B. longisetum.

\$s Sporen bis etwa $30 \mu$.

$\mathrm{x}$ Zellen des Exotheciums gross, quadratisch, dünnwandig .............407. B. subtumidum.

xx Zellen des Exotheciums kleiner, unregelmässig, verdickt.

$\square$ Schopfblätter 5 mal länger als breit 408. B. Lagerheimii.

$\square \square$ Schopfblätter kürzer.

O Blätter am Grunde ova'. Peristomzähne bis zur Mitte gleichbreit

409. B. retusum.

Blätter am Grunde eirund. Peristomzähne vom Grunde an verschmälert

$\triangle$ Blätter etwa $3 \mathrm{~mm}$ lang. Peristomzähne braungelb Dorsalplatten schmal rektangulär 411. B. lapponicum.

$\triangle \triangle$ Blätter etwa $2 \mathrm{~mm}$ lang. Peristomzähne hellgelb; Dorsalplatten breit rektangulär bis fast quadra tisch 412. B. aculealum.

$\times \times$ Fortsätze gefenstert.

\$ Blattsaum schwach bis fehlend.

$\mathrm{x}$ Blattzellen rhomboidisch. Zellen des Exotheciums stark buchtig. Fundus breit ........................

xx Blattzellen verlängert-6seitig. ZeIlen des Exotheciums nicht buchtig. Fundus schmal

416. B. fissum.

$\$$ Blattsaum mehrreihig.

x Deckel flachgewölbt, mit langer

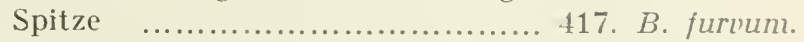

$\mathrm{xx}$ Deckel kurzspitzig oder warzig.

$\square$ Schopfblätter länglich-lanzettlich, kurz zugespitzt. Deckel klein, gewölbt, mit Zitze ... 419. B. haematostomum. 
Schopfblätter breit eiförmig bis eilanzettlich, zugespitzt. Decke] flach gewölbt, mit Zitze

418. B. Graefianum.

Blätter eilanzettlich, lang und schmal zugespitzt. Wimpern zuweilen vollständig, selten mit Anhängseln. Deckel kegelig ...

O. Kapsel regelmässig, mit dem verschmälerten Halse verlängert, braun. Peristomzähne gelb oder braungelb; Fundus rot. Wimpern vollständig, mit Anhängseln.

a. Diözisch.

«. Blätter \pm weit herablaufend, breit gesäumt.

I. Blätter weich, aus etwas herablaufender, verschmälerter Basis eilänglich und elliptisch-länglich, kurzspitzig oder stumpflich, an jüngeren Sprossen löffelartig-hohl, flachrandig .............

II. Blätter deutlich herablaufenrl, etwas starr, \pm hohl, eiförmig-oval, mit kurzer, \pm zurückgebogener Spitze, gipfelständige mit fast bis zur Spitze umgebogenen Rändern

420. B. neodamense.

III. Blätter etwas starr, lang und schmal herablaufend, obere länglich-lanzettlich, allmählich zugespitzt, mit bis gegen die Spitze umgerollten Rändern

414. B. humectum.

121. B. crispulum.

ß. Blätter nicht herablaufend, sehr schmal bis undeut-

lich gesäumt, mit stark umgerollten Rändern.

I. Kapsel schmal länglich. Deckel kegelig, mit scharfem Spitzchen

451. B. Jachii.

II. Deckel gross, gewölbt.

1. Kapsel aus kurzem Halse verlängert-länglich bis fast zylindrisch, gelbbraun

452. B. caespiticium.

2. Kapsel mit dem etwas aufgetriebenem Halse kurz birnförmig, rötlich-, zuletzt dunkelbraun. 453. B. badium.

๖. Heterözisch; ơ [̇] üten endständig auf eigenen Sprossen.

«. Kleine Pfl. Blätter fast geöhrt, mit schmal umgebogenen Rändern. Kapsel aus kurzem Halse dick eiformig bis fast kugelig, trocken unter der Mündung nicht verengt.

1. Blätter nicht oder undeutlich gesäumt; Blattflïgelzellen z. T. 6seitig

447. B. subrotundum.

II. Blattsaum 2-3reihig, Blattflügelzellen rundlichquadratisch, aufgeblasen

448. B. pumilum.

ß. Kräftige Pfl. Blätter breit gesäumt, mit längs umgerollten Rändern. Kapsel langhalsig, trocken unter der llündung verengt.

1. Blätter am Grunde rot. Fundus rötlichgelb. Wimpern vollständig .............................. 149. B. pallescens.

I1. Blätter am Grunde violett. Fundus braungelb. Peristomzähne schmäler, lang pfriemenförmig zugespitzt. Wimpern oft rudimentär .............. 450. B. Rosenbergiae.

c. Synözisch, selten polyözisch.

«. Blätter nicht herablaufend. 
1. Kkleine Pfl. Stengel mit kurzen sublloralen Sprossen. Blätter hohl, kurz und breit: Rippe dicht vor der Blattspitze aufhörend bis voliständig.

1. Blätter eiförmig, stumpf, mit zurückgebogenem Spitzchen, ungesäumt, flachrandig oder mit am Grunde umgebogenen Rändern ........ 126. B. bulbifolium.

2. Blätter kurz zugespitzt, flachrandig, undeutlich gesäumt

127. B. nigricans.

$\beta$. Schopfblätter \pm lang zugespitzt; Rippe als Stachel oder Granne austretend.

I. Blätter ungesäumt, längs stark umgerollt.

1. Rippe als kurze Stachelspitze austretend 128. B. Cuhlmannii.

2. Rippe als lange Granne austretend 129. B. polare.

II. Blätter 士 deutlich gesäumt.

1. Blätter flachrandig, meist zweireihig gesäumt; Rippe lang austretend. kapsel ockerfarben bis fast weiss.

* Deckel klein, kegelig mit Spitzchen 432. B. microstegium.

** Deckel breiter und niedriger, gewölbt mit Warze ..................................... 433.

B. angermannicunt

2. Blätter mit längs schmal umgelıgenen, 13reihig gesäumten Rändern. Deckel kegelig mit Spitzchen

431. B. sareliense.

3. Blätter längs \pm stark umgerollt.

* Blattsaum höchstens zweireihig, zuweilen undeutlich.

$\uparrow$ Peristomzähne holoclont.

$\times$ Rippe vollständig bis sehr kurz austretend. Kapsel lichtbraun 4.7. B. arctogaeum.

$x \times$ Rippe als Stachel austretend. Kapsel rötlichbraun, zuletzt dunkler bis schwärzlich 134. B. intermedium.

$\dagger \dagger$ Peristomzähne aulacodont.

$\times$ Kapsel kastanienbraun, zuletzt dunkler bis schwärzlich.

$\S$ Sporen $18-20 \mu$, fast glatt ........ 436. B. tardum.

$\$ \S$ Sporen 20-28 i", papillös ........... 43\%. B. clathratum.

$\times \times$ liapsel zuletzt lederbraun ........... 438. $B$. lut um.

** Blattsaum breiter, wenigstens ",-4reihig.

$\dagger$ Kapsel unter der Mündung eingeschnürt. $\times$ Seta steif.

$\S$ Blätter hald rotgefärbt 430. B. misandrum. $\S \S$ Blätter grün lis bräunlichgrün

$\mathrm{x}$ Kapsel aus engem Halse flötzlich dick eilörmig, bis $2,-1 \mathrm{~mm}$ lang. ent deckelt unter cler Mündung stark eingeschnürt 439. B. sysphinctum.

$\mathrm{xx}$ Kapsel aus fast gleichlangem Halse länglich, bis $3,3 \mathrm{~mm}$ lang, entdeckelt unter der Mündung weniger stark verengt 
$+\dagger$ Kapsel unter der Mündung nicht verengt. Heteröziscli. Rippe mässig lang austretend .

$x \times$ Synözisch. Rippe sehr lang austretend. \$ Deckel kegelig, stumpf. Sporen 23$27 \mu$, rötlichgelb 445. I. spissum.

$\$$ Decliel gewölbt kegelig, mit Spitzchen 443. B. aristatum.

$\beta$. Blätter etwas herablaufend.

I. Blätter kurz zugespitzt: Rippe als kurze Stachelspitze austretend; obere Zellen $15-30$ " breit ...

II. Rippe mit der Blattspitze verschwindend; obere Zellen 17-23 $\mu$ breit

III. Blätter lang zugespitzt: Rippe als kräftiger Stachel austretend

d. Autözisch, selten heterözisch. Lamellen der Peristom423. B. bimum. 424. B. castaneum. 441. B. affine. zälne durch 1-3 Zwischenwände verbunden oder unregelmässig zusanmenfliessend

425. B. sinuosum.

P. Diözisch. Schlanke Pfl. Blätter trocken anliegend, nicht herablaufend, allmählich zugespitzt, ungesäumt, mit längs umgerollten Rändern: Rippe als kräftige Stachelspitze oder Granne austretend. Kapsel hängend, aus dickem, trocken runzeligem Halse dick oval, blutrot, trocken schwarzrot. 459. B. bicolor.

Q. Mehr oder weniger schlanke Pfl. Blätter trocken anliegend, nicht herablaufend, allmählich zugespitzt; Rippe fast vollständig bis t lang austretend. Kapsel birnförmig bis länglich-kenlenförmig oder verlängert-zylindrisch (Erythrocarpa).

a. Autözisch. Blätter flachrandig, ungesäumt: Rippe

kräftig, kurz austretend ............................

460. B. Sauteri.

b. Diözisch. Blätter mit umgebogenen Rändern.

«. Blätter ungesäumt, ganzrandig oder mit entfernt gesägten Ründern.

I. Kapsel tiocken und entdeckelt mnter der Mündung kaum verengt.

1. Rippe als gesägte Grame austretend

463. B. excurrens.

2. Rippe kurz austretend 462. B. erythrocarpum

II. Kapscl trocken und entdeckelt unter ler weiten Mündung stark verengt 161. B. Klinggraeffii.

३. Blätter gesäumt, mit schmal umgehogenen Rändern; Rippe kurz austretend.

1. Blätter bis $3 \mathrm{~mm}$ lang, ganzrandig oder an der Spitze entfernt gezähnt. Kapsel bis $4 \mathrm{~mm}$ lang. 462. * B. rubens.

II. Blätter bis $2,7 \mathrm{~mm}$ lang, mit an der spitze scharf gesägten Rändern. Kapsel etwa 2,7 mm lang. 462.

R. Diözisch. Weniger schlanke Pfl. Blätter (excl. B. rivu* B. Bomanssonii. lare und $B$. riparium) nicht herablaufend, trocken dachziegelig, hohl, ungesäunt. Kapsel mit dem verschmälertem Halse verkehrt-ei- oder ei-länglich-birnförmig bis keulen-birnförmig (Alpinijormia).

a. Blätter nicht herablaufend.

«. Blätter stumpflich: Rippe vor der Blattrippe aufhörend; Zellen locker 464. B. Mühlenbeckii. 
$\beta$. Blätter zugespitzt: Zellen enger.

I. Rippe mit der Blattspitze endend 165. B. alpinum.

II. Rippe als Stachetspitze austretend 466. B. Mildeanum.

b. Blätter herablaufend.

a. Blätter mit aufrechten oder am Grunde schmal umgebogenen Rändern: Rippe vollständig bis kurz austretend: Blattsaum 2 : ireinig, Zellen im herablaufenden Teil verlängert rektangulär

168. B. riparium.

§. Blätter mit weit hinauf breit umgebogenen Rändern: Rippe in der Blattspitze versehwindend; Blattsaum 3-Ireihig: Zellen im herablaufenden Teil quadratiseh. 467. B. rivnlare.

S. Blätter weich, troeken anliegend, verbogen his spiralig um den Stengel gedreht, meist nicht herablaufend, aus versehmälertem Grunde verkehrt-eilänglich bis spatelförmig, in eine haarähnliche Spitze vorgezogen oder dureh die austretende Rippe begrannt, meist gesäumt und mit umgebogenen bis umgerollten Rändern. Kapsel mit dem verschmälerten Halse länglieh-zylindriseh bis länglieh-keulenförmig (Trichophylla).

a. Deekel kegelig.

r. Untere Blätter lang herablaufend. Deckel mit Spitzehen

$\beta$. Blätter nicht herablaufend. Deekel sehr stump ... 472. B. subrutilum.

b. Deckel gross, hoehgewölbt, mit Spitzehen.

a. Blätter bis $4 \mathrm{~mm}$ lang. in eine lange. haarähnliche Spitze vorgezogen, gesäumt, mit $\ldots$ weit hinauf sehmal umgebogenen Rändern: Rippe meist vor der Blattspitze aufhörend

471. B. capillare.

$\beta$. Blätter bis $2 \mathrm{~mm}$ lang, flachrandig oder mit nur am Grunde sehmal umgebogenen Rändern: Rippe als zurückgebogene Granne austretend ............ 469. B. elegans.

$\gamma$. Blätter deutlich herablaufend, ungesäumt, die oberen eilanzettlich. haarförmig zugespitzt, l,is $1,35 \mathrm{~mm}$ lang, mit \pm weit hinauf sehmal umgebogenen Rändern; Rippe mit der Blattspitze endend oder haarartig austretend 47. B. barbatum.

Un te rgat t. I. Ptychostomum (Hornsch. in Flora 1822, I. p. 64 als Gattung) Amann Fl. mouss. Suiss. p. 188 (1912).

Lametlen der Peristomzälne durch schräge Zwischenwände miteinander verbunden; Dorsalplatten (excl. B. Fridtzii) ohne Strichelung; Innenschicht in der Medianlinie weder gefurcht noch gelöchert (Zahntypus holodont: H a ge n).

S e c t. I. Euptychostomum Amann I. c. p. 189.

Inneres Peristom dem äusseren $\perp$ fest anklebend; Fortsätze meist linealiseh und ritzenförmig durehbrochen; Wimpern ohne Anhängsel. meist rudimentär bis fehlend.

1. Erythrodontia Kindb. Sp. Eur. and N.-Am. Bryin. p. 348 (1897).

Autöziseh. Blätter sehr hohl, länglich und länglieh-elliptisch, stumpf, flachrandig, fast ungesäumt; Rippe dümn, vor der Blattspitze endend; Basalzellen nicht gerötet. Kapsel hängend, klein, aus dünnem Halse fast kugelig, kleinmündig. Deckel lang gespitzt. Peristomzähne fast purpurn; untere Lamellen dureh je 2 oder 3 Zwisehenwände verbunden. Fortsätze schmal. nicht durehbrochen: Wimpern fehtend. 
340. Bryum Marratii Wils. in Bryol. Brit. Append (185.5).

Sehlanke Pfl. in lockeren, grünen. später bräunlichen Räschen. Stengel j-$10 \mathrm{~mm}$. sehr ästig, locker beblättert. Schopfblätter fast zu einer Rosette gehäuft, etwa 1,5 $2 \mathrm{~mm}$ lang und $0.7-1 \mathrm{~mm}$ breit: \%ellen locker und dickwandig, gegen den Rand etwas länger und enger. Seta $1,5-2,5 \mathrm{~cm}$. Kapsel bis $2 \mathrm{~mm}$ lang, rut, später dunkelbraun. Peristomzähne bis $0.40 \mathrm{~mm}$ lang, nit bis 25 Lamellen. Sporen 35-18 " gellogrün. Sporenreife Ende Juni und Juli. — Fig. 49 C-D.

Auf feuchter, griesig-toniger Ercle am Meeresufer, oft mit $B$. mamillatum. Selten fruchtend.

F. Al. Eckerö (H. Lindb.). Mariehamn (Bom.). Jomala. Ytremä- slätholmen (B.). Lemland, Nåtö (B.); Grillskär (Broth.). Fin-tröm an einišen und saltrik an mehreren Fundorten (Bom.).

S. Öl, Gtl.

N. sm. Onio. No. Bodo. F. Alcen. Borekop.

Pommern, Dänemark. Hulland, England, Faeroer.
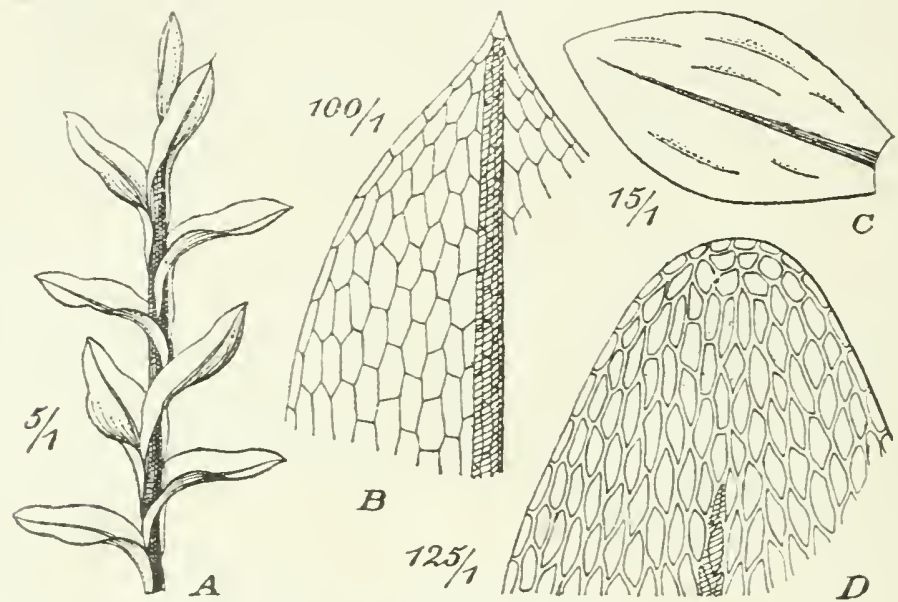

Fig. 49. A-B Bryum Duralii Woit. A stengelstückchen (5/1); B Blattspitze (100/1). - C- N B. Marratii Wils. C stengelb. (15/1): D Blattspitze (125/1).

2. Warneiformis Brnth. in Engl.-Prantl Bryales p. 567 (1903).

Meist autözisch. Blätter zugespitzt, gesäumt. mit \pm umgeloggenen Rändern: Rippe kräftig, auslaufend; Basalzellen (excl. B. Moei und B. confluens) nieht gerötet. Kapsel hängend, regelmässig. Peristomzälne rot- oder sattgelb: untere Lamellen meist durch je 2 oder 3 Zwischenwïnde verbunden. Deckel mit Warze oder Spitzehen.

311. Bryum Moei Sehimp. Syn. 2. ed. p. 117 (1876).

Autözisch. Ziemlich kräftige Pfl. in weichen, bleich gelbgrünen, innen schwach rötlichen Rasen. Stengel bis 2 cm, locker beblättert, mit spärlichen Rhizoiden. Blätter trocken locker anliegend, feucht aufrecht-abstehend, aus verengter und herah]aufender Basis verlängert linealisch, lang zugespitzt, etwa $3.5 \mathrm{~mm}$ lang und 0.9-1.2 mm breit, mit längs sehmal ungebogenen Rändern: Rippe am Grunde rot, in eine sehr lange, fast glatte Plrieme auslaufend; Zellen am Blattgrunde gerötet, am Rande gestreckt, einen 3reihigen, gelben Saum bildend. Seta 3,5 cm, dünn. rot. Kapsel nickend bis hängend. aus kurzem Halse lick eiförnnig, bis $4 \mathrm{~mm}$ lang. getbbräunlich, dünnhäutig. trocken unter der Mündung nicht verengt. Peristomzähne fast $0,40 \mathrm{~mm}$ lang, mit üher 20 entfornt gestellten Lamellen. Inneres Peristom hyalin; Wimpern zienlich ausgebildet. Sporen $30-35 \mu$, gelb, fast glatt.

N. coudbrandsdalen, Vadge. Bae-hrigda. Vo. Skjerstad, $300 \mathrm{~m}$, auf Frde. 
var. angustifolium (Kaur.) n. comb. [Bryum angustifolium Kaur. in Bot. Notis 1887 , p. 113; B. saltense Par. Ind. bryol. p. 212 (1891).]

Blätter mit nur unten umgebogenen, an der Spitze entfernt und grob gesägten Ränclern; Rippe anch am Grunde gelbgrün; Zellen am Blattgrunde nicht gerötet. Hals ron Lrnenlänge. Grundhaut orange, niedriger. Sporen 2.) -32 ", bräunlichgelb, feinwarzig.

N. No. Bodo; Nesne, Lökta. Tr. Tromsosundet, Tromsoen.

342. Bryum Brownii Bryol. eur. fasc. 32 Suppl. p. 3, No. 19, tab 4 exel. fig. $1+$ (1846). (B. stenocarpum Limpr. in Jahresb. d. Schles. Ges. 1884, p. 219). Antözisch. Ziemlich schlanke Pfl. in \pm dichten. blass- oder gelblichgrünen Rasen. Stengel bis $1 \mathrm{~cm}$, mit zahlreichen, oft rankenförmigen Sprossen. B'ätter beim Liegen im Wasser blau werdend. Schopfblätter aus kaum herablautender Basis lanzettlich und lang zugespitzt, bis $2.7 \mathrm{~mm}$ lang und bis $1,1 \mathrm{~mm}$ breit, mit bis zur Blattmitte umgebogenen, in der Spitze entfernt gezähnten Rändern; Rippe als kurze Granne austretend; Zellen locker, dünnwandig, oberwärts $35-50 \mu$ lang und 18-20 " breit, am Rande gestreckt, einen 2-3reihigen, \pm deutlichen, bräunlichgelben Saum bildend. Seta bis $5,5 \mathrm{~cm}$. Kapsel verlängert und länglich-birnförmig, bedeckelt bis $3,5 \mathrm{~mm}$ lang und bis $1,5 \mathrm{~mm}$ dick, gelbbräunlieh, trocken unter der Nündung nicht verengt. Peristomzähne bis $0,5-0,6 \mathrm{~mm}$ lang, mil sehr zahlreichen Lamellen. Inneres Peristom hochgelb: Wimpern bald rudimentär oder fehlend, bald vollständig, ohne Knnoten. Deckel breit, hoehgewölbt, mit Spitzchen. orange. Sporen 32-38 ", gelbgrün, feinwarzig. Sporenreife Mitte Juli.

In Sande der Flüsse, seltener am Meeresufer.

F. Al. Sund, Bomarsund, auf einem alten Kalkhäıfchen spärl. (Bom.). - Ll. Pummanki (Broth.). N. Disvre. Jotunfjeldene. No.-F, an mehreren Fundorten.

irrönland.

343. Bryum warneum Bland. Musc. exs. fase. 11. no. 18+ (1805).

Polyözisch. Ziemlich schlanke Pfl. in oft ausgedehnten, meist niedrigen, gelblich- bis bräunlichgrünen. innen durch Rhizoidenfilz verwebten Rasen. Stengel schopfig beblättert, \pm verzweigt, z. T. mit flagellenartig veriängerten Sprossen. Schopfblätter trocken hin- und hergebogen, aus wenig verschmälerter Basis rerlängert- bis eilanzettlich, bis $3 \mathrm{~mm}$ lang und $1 \mathrm{~mm}$ breit, mit schwach umgebogenen Rändern; Rippe als Stachel austretend; Zellen locker und dünnwandig, am Rande gestreckt, einen 2-3reihigen Saum bildend. Seta 3-6 cm, steif, rot. Kapsel hängend, mit dem deutlich abgesetzten Halse birnförmig, bis $4 \mathrm{~mm}$ lang und $1,5 \mathrm{~mm}$ lick, engmündig, gelbbräunlich. Peristomzähne bis $0,5 \mathrm{~mm}$ lang mit bis $30 \mathrm{La}-$ mellen. Inneres Peristom gelb; Wimpern rudimentär. Deckel klein, hoch kuppelartig gewölbt, mit Spitzchen. Sporen 40-50 "4, gelbgrïn, papillös.

Auf feuchten, sandigen Plätzen, gern an Fluss- und Seeufern.

S. Gll.

N. Sm. Hvaler und Glemminge. Dovre. No. Alstahaug. F. Kistrand.

Zentral-Europa, Nord-Frankreich, Gross-Britannien.

* B. oelandicum (Philib.) Amam Fl. mouss. Suiss. p. 190 (1912). (B. oclandicum Philib. in Rev. bryol. 1887, p. 9.)

Untere Dorsalplatten fast glatt; Lamellen meist voneinamder frei.

F. Al. Eckerõ, Lảngskär, am sandigen Meeresufer (H. Lindb.).

S. $\partial t$.

344. Bryum mamillatum Lindb. in Not. Sällsk. Faun. Fl. Fenn. Förh. 1X. p. 264 (1868).

Autözisch. Ziemlich kräftige Pfl. in dichten, grünen oder gelblichgrünen, durch Rhizoidenfilz verwebten Rasen. Stengel bis $5 \mathrm{~mm}$, dicht und selıpfig beblättert. mit kurzen, schopfig beblätterten subfloralen Sprossen. Schopfblätter trocken anliegend, feucht aufrecht-abstehend, oval, kurz zugespitzt, bis $3 \mathrm{~mm}$ lang und bis $1,5 \mathrm{~mm}$ breit, mit bis etwa zur Mitte schmal umgebogenen Ränderm: Rippe kräftig. 
Bryum.
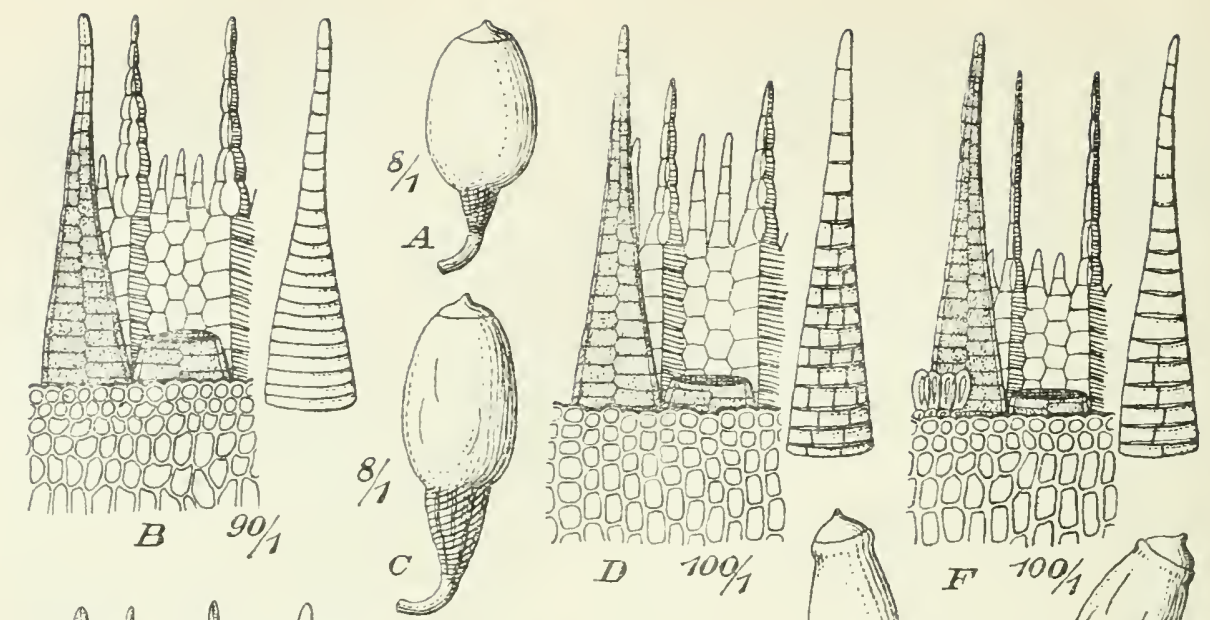

10000000000

1000000000
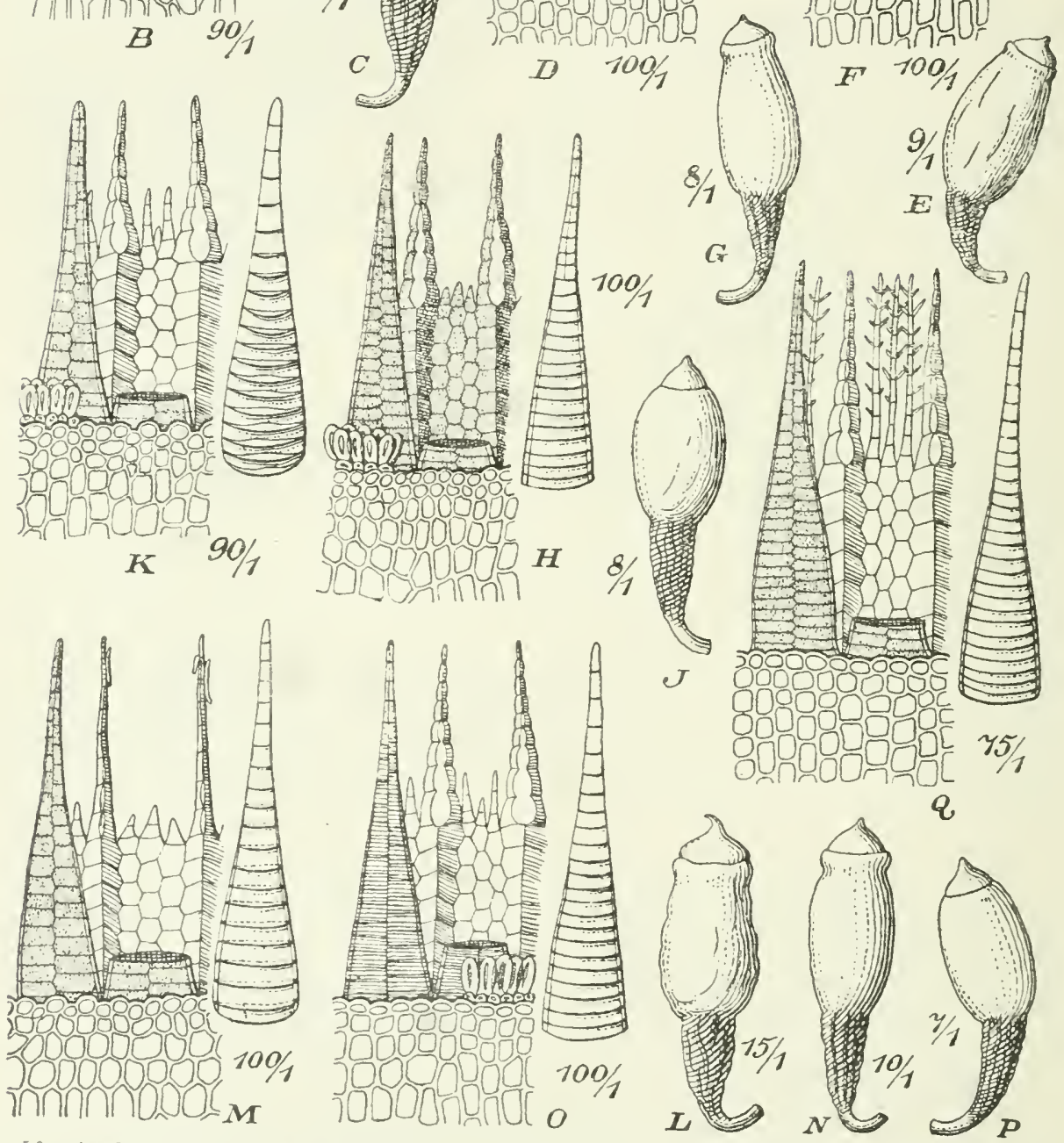

Fig. 50. A - B. Bryum mamillatum Lindh. A Kapsel (8 1), B Peristom (90 1) - C-D B pendulum (Itornsch.) C Kapsel (8 1): D Pคristom (ion 1). E-F. B. arcticum (R. Br.) E Kapsel (9 1); : lapponicum Kaur. I G-H. B. inclinatum (Sw.) G Kapsel (81); H Peristom (100/1). - I-K. $B$ II Peristom (100/1). Kapel $(8 / 1)$, K Peristom $(90-1)$ - L-M. B. acutum Lindb. 1. Kapsel (15 I): $\mathrm{P}-\mathrm{Q}$. B. pallens sw. P Kansel ( $7 / i) ; \mathrm{Q}$ Periston $(75 / 1)$. 
als kurzer Stachel austretend; Zellen locker und dümnwandig, am Rande cinen 2-3reihigen, gelblichen Saum bildend. Seta 2,5-4 cm, steif, rot. Kapscl hängend, aus dem kurzen, deutlich abgesetzten Halse dick oval, bis $3,5 \mathrm{~mm}$ lang und bis $2 \mathrm{~mm}$ dick, engmündig, gelbbräunlich. Peristomzähne bis $0,4511 n$ lang, mit bis 25, nur hier und da durch eine schräge Zwischenwand verbundenen Lamellen. Inneres Peristom frei. Wimpern \pm gut entwickelt. Deckel flach gewölbt, mit Spitzchen. Sporen 30-35 $\mu$, gelbgrün, papillös. Sporenreife im Juli. - Fig. 50. A-B.

F. Al. Eckerö, Torp (Bom.). Hammarland, Frebbenby (B.). Mariehamn (B.). Lemland, Nảtö (B.). Sund. Blixtören (B.). Jomala, Finström und Saltvik an mehreren Fundorten (B.).

S. Gtl. Srm. Dalarön.

Pommern, Schweiz.

345. Bryum mutilum Hag. Mlusc. Norv. bor. p. 124 (1901).

Synözisch. Pfl. in lockeren, etwa $2,5 \mathrm{~cm}$ hohen, lebhaft grünen, unten schwärzlich-grauen Rasen. Schopfblätter trocken locker anliegend, feucht abstehend, breit eiförmig. allnählich kurz zugespitzt, bis $3,3 \mathrm{~mm}$ lang und $1,5 \mathrm{~mm}$ breit, mit \pm weit hinauf umgebogenen Rändern; Rippe als Granne \pm lang austretend; Zellen oben etwa $50 \mu$ Iang und $27 \mu$ breit, am Rande gestreckt, einen 4-5reihigen Saum bildend. Seta 3-4 cm, gelbbraun. Kapsel nickend, mit dem Halse fast yon Urnenlänge birnförmig, 2,6 $\mathrm{mm}$ lang und 1,3 $\mathrm{mm}$ dick, braun, trocken runzelig, unter der Mündung nicht verengt. Peristomzähne gelb, mit gelbrotem Fundus, 0,35 mm lang, mit 16-1s Lamellen. Inneres Peristom rudimentär: Grundhaut zerstört; Fortsätze, wenn vorhanden, zu sehr kurzen Lappen reduziert. Deckel flach gewölbt, mit Spitzchen. Sporen $23-2 \bar{\imath} \mu$, grünlichgelb, fast glatt.

N. Tr. Tromsösundet, Tromsdalen.

346. Bryum Fridtzii Hag. Musc. Norv. bor. p. 21' (1901).

Autözisch. Ziemlich schlanke Pfl. in dichten, grünen, durch Rhizoidenfilz rerwebten Rasen. Stengel etwa $1,5 \mathrm{~cm}$, mit etwa $1 \mathrm{~cm}$ langen subfloralen Sprossen. Schopfblätter fast herzförmig-eilanzettlich, 2,3-2,6 mm lang und $0,7-0,9 \mathrm{~mm}$ breit, mit breit zurückgeschlagenen Rändern: Rippe ais Granne austretend; Zellen am Rande gestreckt, einen 4-5reihigen, gelben Saum bildend. Seta 2 cm, gelbbraun. Kapsel meist horizontal, aus kurzem Halse dick oval, 2,8 $\mathrm{mm}$ lang und $1,25 \mathrm{~mm}$ dick, braun. Peristomzähne etwa $0,4 \mathrm{~mm}$ lang, mit bis 20 Lamellen; Dorsalplatten fast quadratisch, sehr dicht quergestrichelt. Fortsätze sehr schmal, eng-rissig durchbrochen. Deckel flach gewölbt, scharf gespitzt. Sporen gelhgrün, $25-28 \mu$, fast glatt. Sporenreife Ende Juli.

N. No. Alstahaug, Alstenōen.

3. Anaglyphodon Philib. in Rev. bryol. 1900, p. 22.

Sỹnözisch, zuweilen autözisch, selten polyözisch. Blätter zugespitzt, am Rande meist \pm umgebogen, sehr schmal oder undeutlich gesäumt; Rippe kräftig, lang auslaufend; Basalzellen rot. Kapsel hängend, regelmässig. Peristomzähne orange oder gelb, trüb und undurchsichtig, Lamellen der unteren Hälfte durch je 2 oder 3 Zwischenwände verbunden; Fortsätze ziemlich breit, gefenstert; Wimpern rudimentär bis fehlend. Deckel klein und kleinspitzig.

347. Bryum pendulum (Hornsch.) Schimp. Coroll. p. 70 (1856). (Ptychostomum pendulum Hornsch. in Flora 1822, Syll. I. p. 64.)

Synözisch, б Pfl. in den Rasen eingesprengt. Ziemlich schlanke Pfl. in dichten, durch Rhizoidenfilz verwebten, gelblich- bis bräunlichgrünen Rasen. Stengel 0,5-1 cm, selten länger, dicht beblättert, mit meist schopfig beblätterten subfloralen Sprossen. Schopfblätter länglich-eiförnnig bis lanzettlich, kurz oder allmählich lang zugespitzt, $1,8-2.7 \mathrm{~mm}$ lang und $0.5-0,9 \mathrm{~mm}$ breit. mit bis gegen die häufig gezähnte Spitze umgerollten, schmal oder undentlich gesäumten Rändern: Rippe kräftig. als lange. gezähnnte Granne austretend: Seta 1,5-3 cm, rot. liapsel aus ctwas kïrzerem Halse eiförmig bis kugelig-eiförmig, bis $3 \mathrm{~mm}$ lang 
und bis $2 \mathrm{~mm}$ dick, engmündig, lederbraun, später oft schwärzlich. Peristomzähne bis $0.4 .5 \mathrm{~mm}$ lang. mit etwa 20 Lamellen. Deckel klein, gewölbt kegelig, mit scharfem Spitzchen. Sporen 24-35 ", gelb bis bräunlichgelb, fein gekörnelt. - Fig. $.00-\mathrm{D}$.

In feuchten Sandausstichen, auf kalkhaltigem Detritus, humusreicher Erde, an Mauern und in Felsenritzen.

F. Al. Eckerö, Storbỳ (Arrh.). Hariehamn, an mehreren Fundorten (Bom.). Jomala, Finström. Geta. Lemland und Sund an einzelnen oder wenigen und Saltvik an vielen Fundorten ( $A$.). - A $b$. Korpo Vidskär (Elfv.). Pargas, Simonby (E.). Finby (Broth.). Lojo, Kiviniemi und Pietnäs (Lindb.). - N. Snappertuna, Raseborg (Häyr.). Helsingfors (Lindh.). - Ka. Wiborg (W. Ny.). — Sa. Willmanstrand (Buch): Huhmarinvuori (B.). - Kil. Sortavala, Kirjavalahti, Varishallio und Liikolanmäki (Lindb.); Kolomäki (Norl.). - Kon. Tiudie (Simm.). Gorka (S.). - Om. Brahestad (Broth.). - Kpom. Kemi (F. Nyl.). - Kk. Knjäscha (F. Nyl.). - Le. Ylikylä, in der Fichtenregion (Norrl.). Kilpiskoski, in der Birkenregion (N.). - Li. Inari. Palokoski (Hult). - Lim. Kandalaks (Broth.). Hibinä, in der alpinen Region (B.). - Lt. Kildin (Broth.). Kola, Abramova Pahta und am Tulomaflusse (B.). Arafjord und Pummanki (B.). Kitorka (Fellm.). - Lmur. Garrilova, Olenka, Rinda, Semjostrovsk und Varsinsk (Broth.). Olenji (Karst.). - Lp. Katschkora und Orlor (Broth.). Ponoj (Sahlb.).

S. Sk., Öl., sm., Gtl., Ög., Vg., Boh., Šrm., Vrml., Dlr., Hrja.. Jmt., Âng. und LuL.

N. Sm. pass. A. Kristiania, JL. Tjomo. K. Jotunfjeldene, Lomseggen, Visdalen fqq.; Dovre. NT Stjurdalen. No.-F.

Europa, Kaukasus. Himalaya, Amur, Sachalin, Nord-Amerika, Nordgrenze auf s̈pitzbergen.

var. compactum (Hornsch.) Schimp. Coroll. p. 70 (1856). [Plychostomum compaclum Hornsch. in Flora Syll. I. p. 62 (1821).]

Autözisch, mit vereinzelten ŏ Blüten. Rasen sehr dicht. Blätter länger zugespitzt, 2reihig gesäumt. Kapsel trocken fast keulig-birnförmig. unter der Münlung nicht verengt. Peristomzähne kaum wellig-trüb. Sporen etwas grösser.

F. Lt. Kola und Subovi (Broth.). - Lmur. Kildin (Karst.). - Lp. Panfelovka (Brenn.).

N. No. und $F$. an wenigen Fundorten.

Alpenregion von Zentral-Europa. Ost-Grinland.

348. Bryum confiuens Joerg. in Christ. Vid. Selsk. Forh. 1894, No. 8, p. 101. (B. Kaurini Philib. in Rer. bryol. 1886, p. 21.)

Autözisch. Schopfblätter schmal lanzettlich, zugespitzt, etwa $2,5 \mathrm{~mm}$ lang und $0,65 \mathrm{~mm}$ breit, mit breit zurückgeschlagenen, breit gesäumten Rändern; Rippe auch in den Perichätialblättern und Hüllblättern als lange, fast glatte Granne austretend. Seta $\mathbf{1 , 5} \mathrm{cm}$. Kapsel aus sehr kurzem, von der Urne nicht abgesetztem Halse oval, 2,2 $\mathrm{mm}$ lang und 1,2 $\mathrm{mm}$ dick, sehr diunhäutig, blassgelblich. Peristom wie bei $B$. pendulum. Deckel fast flach, mit Spitzchen. Sporen 23-27, einzelne bis $32 \mu$.

N. ST. Opdal. No. Mo, Saltdalen und Skjerstad, 100-300 m. Tr. Tromsisundet, Tromsuen.

4. Arcticiformia Kindb. Sp. Eur. and Nortlam. Bryin. p. 3.19 (1897).

Synözisch oder polyözisch. Blätter zugespitzt, meist wulstig gesäumt und am Rande umgebogen; Rippe meist austretend: Basalzellen nicht gerötet. Kapsel oft etwas gebogen. dümhäutig. Peristomzähne selten mit voneinander freien, meist gegen die Basis durch je eine, meist mediane oder mehrere Zwischenwände miteinander verbundenen Lamellen. Fortsätze des inneren Peristoms sehr schmal, ritzenförmig durchbrochen: Wimpern kurz, ohme Anhängsel.

319. Bryum arcticum (R. Br.) Bryol, eur. fasc. 32, Suppl. I. p. 2. tab. 2 (1846). [Pohlia arctica R. Br. Suppl. App. ad iter Parryan. p. 197 (1821).]

Weiche Pfl. in lockeren, grünen oder gelbgrünen, im Alter geröteten Rasen. Stengel 2-5 mm, selten höher, einfach oder wenig ästig, nur am Grunde mit Rhizoiden. Schopfblätter trocken aufrecht und geschlängelt, feucht aufrecht-abstehend, eilänglich, zugespitzt, bis $2 \mathrm{~mm}$ lang und $0.75 \mathrm{~mm}$ breit, nit längs umgerollten Rändern: Rippe ziemlich kräftig, in einen kurzen Endstachel fortgesetzt: Zellen locker, dünnwandig, oberwärts $40-60$ " lang und 20-27 " breit, am Rande gestreckt, einen 2reihigen, gelben bis rostfarbenen Sam bildend. Seta 1-2 cm, dünngesthlängelt, rot. Kapsel horizontal bis hängend, mit dem gleichlangen Halse 
keulig-birnförmig, etwa $2.5 \mathrm{~mm}$ lang, meist etwas gebogen, mit emporgehobenem Rücken, dünnhäutig, trocken unter der Mündung nicht verengt, lecłergelb, im Alter lichtbraun. Peristomzähne $0,24-0,35 \mathrm{~mm}$ lang, unten (lunkelloraun; Fundus rötlich; untere Dorsalplatten fast qualratisch; Lamellen 13-15, auch bis $20-22$, dureh je eine mediane Zwischenwand miteinander verbunden. Grundhaut etwa $1 / 3$ der /ahnlänge: Fortsätze frei. Deckel niechrig, kegelig, trocken flacher, mit Spitzchen. Sporen 2t-35 ". gelbgrün, feinwarzig. Sporenreife im Juni und Juli. - Fig. 50 E-F.

Auf Humus und sandig-toniger oder torfiger Erde, an Felsen und in Felsenritzen.

F. At. Eckerö, Storhy (Arrlı.). Saltrik, an mehreren Fundorten (Bom.). - Ta. Korpilahti, Päiväkunta, Kupumäki (Hàyr.). - sb. Kávi, Losonäki (Kot.). Juuka, Pelrovara (K.). - K, Kunamo, Kitkajoki, Jyrävä (Brolh.); Oulankajoki, Kallioperänvaara (B.); Paanajärvi, Kiekkivatra und Kuoppaoja (B.). — Lkem. Kemijärvi, Kitinen (Broth.). - Le. Leutsuvaara, Mukkavuoma und Kilpiskoski in der Birkenregion (Norrl.); Malla, in der alpinen Region (Kot.). — Li. Utsjoki, Outakoski, Soavjebakte (Ranck.). - Lim. Kandalak`, Schelesnaja (Broth.). Lujauri-u’t, Vavn-łed, an der Baumgrenze (Kinlm.). - Lt. Kola und Kitovka (Karst.). Subovi (Broth.). - Lp. Triostrova (F. Nyl.). Fonoj (Brenu.). - Lr. Tschapoma (Broth.).

S. Tg. Lidköping. Stockholm, Sundsta. Gstr. Gefle. Hrjd. und Jmt. an mehreren Fundorten. PL. LuL. an mehreren Fundorten.

N. Br. Telemarken und Kongsberg. $\dot{K}$. Jotunfjeldene. Roshojen pass. Lomsfjeldene. Dovre. ST. Opdal. NT. Stjordalen. No.-F. ziemlich selten.

Eurona, Sibirien, Tschuktschen-Halbinsel. Nord-Amerika.

var. tomentosum Joerg. in Christ. Vid.-Selsk. Forh. 1894, No. 8, p. 76. [Bryum tomentosum Limpr. in litt.; Hag. Musc. Norv. bor. p. 208 (1901).]

Pfl. in dichten, durch reichlichen Rhizoidenfilz verwebten Rasen. Kapsel trocken unter der Iïndung verengt.

N. $\operatorname{Tr}$. Nordrejsen.

var. oxystegium (Hag.) H. Wint. in Hedwigia XIIX. p. 315 (1910). [Bryum oxystegium Hag. Muse. Norv. bor. p. 211 (1901).]

Deckel hoch kegelig, sehr spitz.

N. Dovre. $S T$. Opdal. Tr. Nordrejsen. F. Kistrand.

* Bruym arcuatum (Limpr.) Amann Fl. mouss. Suiss. I]. p. 195 (1912). [Bryum arcuatum Limpr. in 60. Jahresb. d. Schles. Ges. p. 237 (1883).]

Pfl. in sattgrünen, 2-3 $\mathrm{cm}$ hohen Rasen. Blätter bis 3,6 mm lang, sehr breit und wulstig gesäumt; Rippe grannenartig austretend. Kapsel mit dem fast gleichlangen Halse verlängert keulenförmig, gekrümmt, bis $4 \mathrm{~mm}$ lang. Untere Dorsalplatten der Peristomzähne schmal rektangulär.

N. ST. Opdal, an feuchten, beschatteten Fetsen. F. Kistrand. Smörstad, am Rande der Torfdecken längs dem Flusse; Nesseby.

Ost- und West-Grönland.

* Bryum callistomum (Philib.) Amann 1. c. (Bryum callistomum Plilib. in Rev. bryol. 1885, p. 76.)

Niedrige Pfl. Blätter aus verengter und herablaufender Basis elliptisch, lang zugespitzt, bis $3 \mathrm{~mm}$ lang, breit gesäumt: Rippe grannenartig austretend. Kapsel aus wenig kürzerem Halse schmal eilänglich, nicht gebogen. Unitere Dorsalplatten kurz rektangulär.

N. Dorre, Kongsvold.

* Bryum Kindbergii (Philib.) Amann 1. c. p. 193. (Bryum Findbergii Philib). in Rev. bryol. 1885, p. 83.)

Pfl. in grïnen, niedrigen Rasen. Schopfblätter aus verschmälerter Basis oval, zugespitzt, bis 2,5 $\mathrm{mm}$ lang, breit gesäumt: Rippe als Stachelspitze austretend. Kapsel aus fast gleichlangem Halse eng eilänglich, gerade und regelmässig. Peristomzähne nur hier und da durch eine Zwischenwand verbunden.

N. Dovre, Kongstold.

* Bryum helveticum (Philib.) Amann 1. c. p. 194. (Bryum helveticum Philib. in Rev. bryol. 1886, p. 83.) 
PfI. in niedrigen, dunkel weinroten Rasen. Schopfblätter etwas herablaufend, bis 3,25 $\mathrm{mm}$ lang, schmal. lang und fein zugespitzt, mässig breit gesäumt; Rippe kaum oder kurz austretend. Kapsel aus glcichlangem Halse länglich-birnförmig, stark gebogen. Peristomzähne mit voneinander freien Lamellen.

N. Dorre, Kongstold.

Schweiz.

350. Bryum viride Philib. in Rev. bryol. 1886, p. 25.

Sỵnözisch. Pfl. in niedrigen, sattgrünen Rasen. Schopfblätter aus enger Basis oral, kurz zugespitzt, bis 2,75 mm lang und breiter als die halbe Länge, schmal gesäumt, mit nur unten etwas umgebogenen Rändern; Rippe kurz austretend. Seta $1.75 \mathrm{~cm}$. Kapsel aus fast gleichlangem, engem Halse geschwollen verkehrt-eiförmig. etwas gebogen, matt gelbbram. Peristomzähne mit abwärts durch $2-3$ Zwischenwände verbundenen Lamellen. Sporen 40-50 $\mu$.

N. Dovre, Kongsvold.

351. Bryum micans Limpr. in 60. Jahresl). d. Schles. Ges. p. 236 (1883).

Sỹnözisch und vereinzelte Bliiten. Schlanke Pfł. in niedrigen, selten bis 1 cm lohen, schmutzig braungrünen, abwärts braunfilzigen Räschen. Schopfblätter aus mässig verengter Basis elliptisch bis lanzettlich, zugespitzt, bis $2 \mathrm{~mm}$ lang und $0,9 \mathrm{~mm}$ breit, mit am Grunde schmal umgebogenen Rändern; Rippe kurz austretend; Zellen am Rande gestreckt, einen zweireihigen, braungrünen Saum bildend. Seta $1-2.5 \mathrm{~cm}$, selten länger, braunrot. Kapsel fast hängend, aus engem, fast gleichlangem Halse fast kugelig, bis $3 \mathrm{~mm}$ lang und $1,4 \mathrm{~mm}$ dick, bleichbraun glänzend, trocken unter der Mündung nicht verengt.' Peristomzähne unten fast orange, bis $0,40 \mathrm{~mm}$ lang. mit etwa 20 Lamellen. Deckel sehr klein, stumpf kegelig, mit breiter Warze. Sporen $28-32$ bis $36 \mu$, ockergelb, kleinwarzig.

N. ST. Kongsvold; Opdal, Olmbärget. No. Skjaerstad. F. Kistrand.

Faerøer, Grönland.

var. liberum H. Wint. in Hedwigia XLIX. p. 322 (1910).

Lamellen der Peristomzähne ohne Zwischenwände.

N. ST. Kongstold.

352. Bryum inflatum Philib. in Rev. bryol. 1886, p. $\$ 1$.

Synözisch, mit vereinzelten $c^{7}$ Blüten. Pfl. in bis $1,5 \mathrm{~cm}$ hohen, gelbgrünen, innen rötlichbraunen Rasen. Schopfblätter weit herablaufend, lanzettlich, bis $3.2 \mathrm{~mm}$ lang und bis $1.5 \mathrm{~mm}$ breit. mit längs umgebogenen, wulstig 3reihig gesäunten Rändern; Rippe kurz austretend. Seta $2,5 \mathrm{~cm}$. Kapsel fast hängend, aus kurzem, engem Haise fast kugelig, 2,5 mm lang und 1,6 $\mathrm{mm}$ dick. Peristomzähne mit am Grunde durch 3, oberwärts durch 2 und 1 Zwischenwand verbundenen Lamellen. Deckel sehr klein, stmmpf kegelig, mit breiter Warze. Sporen fast 10 i".

N. Dorre. Tr. Tromsosundet, Tromscen.

353. Bryum kongsvoldense H. Wint. in Hedwigia XL1X. p. 320 (1910). Sýnözisch. Pfl. in sehr lockeren Rasen. Stengel $5-8 \mathrm{~mm}$. Schopfbłäter aus schmalem Grunde ei- bis elliptisch-lanzettlich, kurz zugespitzt, 1,8 mm lang und $0,8 \mathrm{~mm}$ breit, mit längs umgerollten. 2-3reihig gesäumten Rändern: Rippe als Stachel \pm lang austretend. Seta $1-1,5 \mathrm{~cm}$. Kapsel horizontal bis hängend, nit dem kurzen, kaum oder nicht gebogenen Halse eibirnförmig, 2,8 mm lang und $1.1 \mathrm{~mm}$ dick, hlassbraun, trocken unter der Mündung nicht oder kaum verengt. Peristomzähne tief gelbbraun; Lamellen 25 und mehr, dic oberen durch eine, die untersten durch 2-3 Zwischenwände verbunden. Deckel klein. schwach gewölbtkegelig mit Warze. Sporen 24-32 $\mu$, trocken bräunlichgelb, mit Stich ins Grüne.

N. Dorre, Kongsvold.

35-. Bryum Bornmülleri Ruth. mss., Hag. in Kigl. Norsk. Vid. Selsk. Skrift. 1908, No. 3, p. 10 (1908). 
Polyözisch: ₹ und $\sim^{-1}$ Blüten knospenförnig, bald atul verseliedenen, bald auf denselben Pfl. und dam ${ }^{\prime}$ Blïten in der Nähe der q oder mit dieser von den Schopfblätteri umgeschlossen. Pfl. in dichten, etwa $1 \mathrm{~cm}$ hohen, gelbgrimen Rasen. Stengel einfach oder mit knospenförmigen subfloralen Sprossen. Schopfblätter trocken aufrecht und geschlängelt, feucht aufrecht-abstehend, länglich-eiförnigg, mässig lang zugespitzt, bis $2,8 \mathrm{~mm}$ lang und $1 \mathrm{~mm}$ breit, die obersten bis $3 \mathrm{~mm}$ lang und $0,8 \mathrm{~mm}$ breit, länger zugespitzt, mit längs breit umgebogenen, an der Spilze gezähnten Rändern; Rippe austretend; Zellen oberwärts verlängert 6seitig, 66 - 80 " lang und 20" breit, am Rande gestreckt, einen ziemlich deutlichen, 3-Ireihigen, gelblichen Saum bildend. Seta $1,5-2,5 \mathrm{~cm}$, braunrot. Kapsel nickend bis hängend, mit dem verkehrt-kegeligen Halse von halber Urnenlänge keulig-bimentörnig, bis $2,9 \mathrm{~mm}$ lang und $1,45 \mathrm{~mm}$ dick, gelbbraun, glänzend, trocken unter der Mündung nicht verengt. Peristomzähne gelb, $0,4 \mathrm{~mm}$ lang, mit etwa 22 , abwärts durch 2-3, dann durch einzelne Zwischenwände verbundenen Lamellen. Inneres Peristom anklebend; Grundhaut sattgelb; Fortsätze ritzenförmig durchbrochen; Wimpern kurz oder länger, ohne Anhängsel. Deckel flach gewölbt, stumpf odler mit Spitzchen. Sporen 28-32", gelbbraun, fein papillös. Sporenreife im Juli.

N. Tr. Tromsö, Telegrafbugten, auf humöser, mit IIuschelschalen gemischter Erde am ileeresufer.

355. Bryum camurum Hag. in Kgl. Vid. Selsk. Skrift. 1908, No. 3, p. 16(1908).

Heterözisch $(\check{c}+\widetilde{c})$. Pfl. in dichten, etwa $1,5 \mathrm{~cm}$ hohen, lebhaft grünen. durch Rhizoidenfilz verwebten Rasen. Stengel mit kurzen, selopfig beblätterten oder längeren, schlaffen subfloralen Sprosscn. Vittlere Blätter breit eiförmig, $2,5 \mathrm{~mm}$ lang und bis $1,1 \mathrm{~mm}$ breit, rasch lanzettlich zugespitzt, mit längs breit zurückgeschlagenen bis spiralig umgerollten Rändern. Schoplblätter trocken anliegend und geschlängelt oder schwach gedreht, feucht aufrecht-abstehend, schmäler, ei- oder ovallanzettlich; Rippe als Granne austretend; Zellen oberwärts $40-45 \mu$ lang und 17-20 $\mu$ breit, am Rande gestreckt, einen 3reihigen Sam bildend. Seta $1 \mathrm{~cm}$, rot. Kapsel nickend bis hängend, mit schmalem Halse von kaum halber Urmenlänge keulenförmig, etwa 2,6 $\mathrm{mm}$ lang und $0,7+\mathrm{mm}$ dick. gekrümmt, gelbbraun bis braun, trocken unter der llündung kaum verengt. Peristomzähne gelb, 0,32 mm lang, mit etwa 19, am Grunde durch 2, dann durch einzelne, schräge Zwischenwände verbundenen Lamellen. Inneres Peristom fest anklebend, gelblich: Fortsätze wenig entwickelt, sehr schmal, kaum durchbrochen: Wimpern fehlend. Deckel kegelig. Sporen 23-30 $\mu$, grünlichgelb, fein papillös.

N. ST. Opdal, Håkår, auf humusbedecktem Grestein im Walde, $550 \mathrm{~m}$.

S e c t. I 1. Arctobryum Hag. Musc. Norv. bor., p. 222 (1901).

Heterözisch oder autözisch. Blätter zugespitzt, am Rande \pm umgebogen, gesäumt; Rippe kräftig, \pm lang austretend: Basalzellen rot. Kapsel regelmässig. Peristomzähne gelb oder orange, mit braunrotem oder purpurnem Fundus; Lamellen der unteren Hälfte durch je cine, selten 2-3 Zwischenwände verbunden; Fortsätze ziemlich breit, gefenstert. Wimpern völlig ausgebildet, mit Anlıängseln.

356. Bryum dilatatum Joerg. in Christian. Vid.-Selsk. Forl. 189\% No. 8, p. 102 .

Heteröziseh. Pfl. in sehr dichten, etwa $8 \mathrm{~mm}$ hohen, grünen Rasen. Schopfblätter eilanzettlich, etwa $2 \mathrm{~mm}$ lang und etwa $0,75 \mathrm{~mm}$ hreit, schmal gesäumt, mit umgerollten Rändern; Rippe kurz austretend. Seta 1,2-2 en. Kapsel nickend. etwa 2,5 mm lang und $0,8 \mathrm{~mm}$ dick, trocken unter der erweiterten Mündung deutlich verengt. Peristomzähne gelb, am Grunde gelbrot, etwa $0.40 \mathrm{~mm}$ lang. mit 16, in der unteren Hälfte durch mediane Schrägwände verbundenen Lamellen. Fortsätze klaffend; Wimpern z. T. voll entwickelt, mit langen Anhängseln. Deckel wenig gewölbt, mit breitem Spitzehen. Sporen 28-3.5 ", einzeln bis $1.5, "$, gelblichgrün. Sporenreife im Juli.

N. Tr. Tromso. 
357. Bryum dolomiticum Kaur. mscr.: Ryan in Hag. Musc. Norv. bor. p. 223 (1901).

Heterözisch. Tracht von B. affine und B. pendulum. Pfl. in sehr dichten, gelbgrünen, inmen bräunlichen, bis $2 \mathrm{~cm}$ hohen Rasen. Stengel mit $1-2$ schopfig beblätterten oder längeren, gleichmässig beblätterten subfloralen Sprossen. Schopfblätter verlängert lanzettlich, lang zugespitzt, etwa $3 \mathrm{~mm}$ lang und $0.9 \mathrm{~mm}$ breit, gelblich gesäumt, mit ungerollten Rändern: Rippe sehr kräftig, als lange Granne austretend; Zellen oben eng, 1: 3-4, am Rande eng und gestreckt, einen 3reihigen Saum bildend. Seta bis $2 \mathrm{~cm}$, oben in weitem Bogen gekrümmt. Kapsel horizontal bis nichend, aus engem Halse birnförmig, 3,6 $\mathrm{mm}$ lang und 1,2 mm dick, bleich grünlichgelb, später hellbraun, etwas glänzend, trocken unter der Münchng nicht verengt. Peristomzähne gelb bis fast gelbrot, bis $0,40 \mathrm{~mm}$ lang, mit $12-15$ welligen, in der unteren Hälfte durch mediane Sehrägwände verbundenen Lamellen; Fortsätze breit gefenstert: Wimpern sehr zart und hinfällig, meist mit Anhängseln. Deckel flach gewölbt, nit Spitzchen. Sporen 28-38 ", gellogrïn, lein gekörnelt.

N. F. Kistrand. Kolvik, an Dolomitielsen.

Mit $B$. dilatatum nahe verwandt, unterscheidet sich jedoch nach $\mathrm{H}$ a g e $n$ von dieser Art schon durch die viel grösseren, stark gesäumten Schopfblätter, durch die unter der Mündung nicht verengte Kapsel, durch die weiteren, sehr dünmwandigen und wenig verbogenen Żllen des Exotheciums, durch die über der Mitte stärker verschmälerten Peristomzähne und die weniger entwickelten Wimpern.

358. Bryum rhexodon Hag. in Kigl. Norsk. Vid. Selsk. Skrift. 1908. No. 3, 1). 30 (1908).

Polyözisch. Pfl. in dirlıten, bis $1 \mathrm{~cm}$ hohen, oben gelbgrünen Rasen. Stengel nit kurzen, knospenförmigen subfloralen Sprossen. Schopfblätter trocken anliegend, leucht aufrecht-abstehend, eilanzettlich, lang und schmal zugespitzt, etwa 2,5 mm lang und bis $0,68 \mathrm{~mm}$ breit. mit breit ungebogenen Rändern; Rippe als \pm lange Gramne austretend; Zellen oberwärts verlängert 6seitig und rhomboidisch, $-40-60$ " lang und $13 \mu$ breit, oberwärts am Rande gestreckt, einen ziemlich breiten, undeutlichen Saum bildend. Seta 2,5 em, gelblichrot. Kapsel hängend, troeken horizontal bis nickend, aus verkehrt-kegeligem Halse von etwa halber Urnenlänge dick oval. etwa $2,3 \mathrm{~mm}$ lang und $1,2 \mathrm{~mm}$ dick, gelblichbraun, trocken und entleert unter der Nündung nicht verengt. Peristomzälnne rötlichgelb, $0.34 \mathrm{~mm}$ lang, mit etwa 15 , abwärts durch zwei, dann durch einzelne Zwischenwände verbunderin Lamellen. Inneres Peristom leicht anklebend, blassgelblich: Fortsätze ritzenlörmig durchbrochen; Wimpern vollständig, knotig, zuweilen mit langen Anhängselı. Deckel unbekannt. Sporen 27-33 4 , gelbbraun.

N. K. Lom, Visdalen, in erderfullten Ritzen der Schieferfelsen, $700 \mathrm{~m}$.

359. Bryum alandense Bomans. in Act. Soc. F. Fl. Fenn. Xill1. No. 4, p. $73(1900)$.

Autözisch. Pfl. in dichten, bis 3 cm hohen, gelbgrïnen, innen braunen, abWärts schwärzlichen Rasen. Stengel mit etwa 1 cm langen, schlanken subfloralen Sprossen. Schopfblätter eilanzettlich, allmählich zugespitzt, schmal gesäumt, mit breit umgebogenen Rändern, bis :3 $11 m$ lang $u n d$ bis etwa 0,9 mm breit; Rippe lirältig, vollständig bis kurz austretend; Zellen oberwärts etwa 0,50 " lang und ctwa 18 " breit, an Gruncle rot. Scta $1-2 \mathrm{~cm}$. Kapsel hängend. aus kürzerem Halse oval bis kugelig-eifömig, etwa $2.25 \mathrm{~mm}$ lang und $1 \mathrm{~mm}$ dick, rotluraun, trocken unter der Mündung nicht verengt. Peristomzälne gelb, am Grunde purpurn, etwa $0.38 \mathrm{~mm}$ lang und $0,07 \mathrm{~mm}$ breit, nit etwa 15 Lamellen, die unteren durch 2 : Zwischenwände verbunden. Fortsätze ritzenförmig durchbrochen: Wimpern bisweilen mit Anhängseln. Decliel niedrig gewölbt, mit Spitzchen. Sporen 28-35 $\mu$, gelbgrün, papillös. Sporenreife in Juni.

F. Al. Mariehamn, $\eta$ kiesigem Meeresufer (Bom.). 
Un te rg a t t. I I. Bryotypus (Hag. Mluse. Norv. bor. p. 120: 1901) Amann Fl. mouss. Suisse p. 189 (1912).

Lamellen der Peristomzäline ohne Zwischenwände. Inneres Periston: frei.

Sect. I. Leucodontium Amann in Rer. bryol. 1893. p. 11.

Peristomzähne blassgelblich bis gelb: Fundus kaum verdickt, von gleicher Farbe. Zellen am Blattgrunde meist nicht gerötet.

360. Bryum cernuum (Sw.) Lindb. Musc. scand. p. 16 (187!). [Didymodon cernuus Sw. Jusc. snec. p. 28 et 85, tab. 1, fig. 2 (1799); Pohlia nliginosa Bruch Mscr. in Brid. Bryol. univ. I. p. 811 (1826): Bryum uliginosum Bryol, eur. fasc. 6/9, p. 18, tab. $4(1839)$.]

Autözisch. Ziemlich kräftige Pll. in meist lockeren, weiclıen, dłunkelgrünen bis gelbbräunlichen, niemals roten, an Grunde verfilzten Rasen. Stengel bis 2 cm, locker beblättert, ästig. Blätter trocken anliegend und etwas gedreht, feucht abstehend, aus nicht herablaufender, verschmälerter Basis elliptisch- oder länglichlanzettlich, allmählich \pm lang zugespitzt, an der Spitze entfernt und meist scharf gesägt, obere 3-4 mm lang und $0,7-0.8 m m$ breit: Rippe krältig. gelblich, im Alter bräunlich, vollständig oder kurz austretend: Zellen locker, dünnwandig, oberwärts $0,07-0,10 \mathrm{~mm}$ lang nnd 0,020 $\mathrm{mm}$ breit, am Rande gestreckt, dickwandig, einen 2 3reihigen, bräunlichgelben. fast wulstigen Saum bildend. Seta 3--5 cm, oben im Bogen gekrïmmt, rot. Kapsel horizontal bis hängend, gross, mit dem gebogenen Halse etwa von Umenlänge birnförmig bis kenlig-birnförmig, meist hochrückig, klein- und schiefmündig. gelblich, später braun, trocken unter der Mündung wenig rerengt. Peristomzähne fein papillös, $0,5 \mathrm{~mm}$ lang, rasch pfriemenförmig zugespitzt: Lamellen bis 25 nnd melnr. Inneres Peristom gelb, fein papillös: Fortsätze am Gruncle sehr breit, ritzenförmig durchbrochen, später klaffend; Wimpern rudimentär. Deckel klein, kurz kegelförmig. Sporen $24-30 \mu$, olivengrün bis gelbbräunlich, feinwarzig. Sporenreife im Juli.

In feuchten Ausstichen, an Grabenrändern, Bacll- und Seeufern.

F. Al. Eckerö, Storby (Bom.). Mariehamn (B.). Lemland, Hammarland und sund an einzelnen, Finström an wenigen und salt vik an mehreren Fundorten (B.). - Al. Pargas. Alön (Broth.). $-N$. Eke-

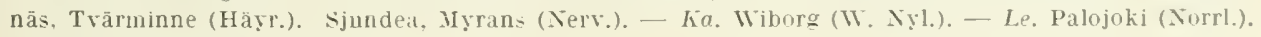
- Lx. Tschapoma (Sahlb.).

S. Sk., Gtl., sm., Ög. Vg.. Srm., Upl.

N. sm. Hralo und Oasø. $h$. Lomsfjeldene und Jotunsfjeldene pass. Dorre. No. Bodin, Bodo. Eurupa. Kaukasus. Pamir. Amur. Sachalin. Nord-Amerika. (1883).

361. Bryum campylocarpum Limpr. in 61. Jahresb. Schles. Ges. p. 218

Synautözisch ( $\curvearrowright$ Blüten neben der جִ am Achselscheitel, eine jede mit besonderen Hiillblättern). Mit der vorigen Art sehr nahe verwandt. Blätter locker gestellt. herablaufend, l,is $3,3 \mathrm{~mm}$ lang und 1,2 mm breit: Rippe bald vor oder mit rer Blattspitze endend. bald kurz austretend. Seta $2-3 \mathrm{~cm}$, dünn. Kapsel aus gebogenem, kurzem Halse eilänglich und hochrïckig, Peristomzähne bis $0.4 \mathrm{~mm}$ lang, allmählich zngespitzt. Fortsätze schmal, eng geschlitzt. Deckel flach gewölbt. Sporen $30-35 \mu$.

N. Dorre, hongsvold.

362. Bryum lepidum Hag. Musc. Norr. hor. p. 139 (1901).

Synözisch. Pfl. in dichten, weichen, bis 2 cm hohen, spärlich verwebten Rasen. Stengel mit 2-8 mm langen subfloralen Sprossen. Obere Blätter grösser und dichter gestellt, lang herablaufend, eiförmig bis eilanzettlich, bis $2,4 \mathrm{~mm}$ lang und 1-1,1 mm breit, mit \pm umgebogenen Rändern: Rippe austretend: Zellen mässig verdickt, oben 33-60 $\mu$ lang und 20-23" breit, am Rande gestreckt, einen 2-3reihigen, gelblichen Saun bildend. Seta etwa $2,5 \mathrm{~mm}$, am Grunde braunrot. Kaj)sel horizontal bis hängend, mit dem kurzen Halse birnförmig, gekrümmt, trocken unter der Mündung nicht verengt. Peristomzähne etwa $0.38 \mathrm{~mm}$. mit etwa 22 
Lamellen; Fortsätze linealisch, mit länglichen bis ovalen Öffnungen; Wimpern fehlend. Deckel kegelig. Sporen $2 t-31 \mu$, gelh, punktiert.

N. F. Ki-trand, Porsangerfjord auf sandiger Erde.

363. Bryum opdalense Limpr. in 60. Jahresh. d. Schles. Ges. p. 238 (1883). [B. Iromsoense Roth Eur. Laubm. II. p. 64 (1905).]

Synözisch mit einzelnen ₹־ Blüten. Herdenweise wachsende, bräunlichgrüne Pil. Stengel bis $1 \mathrm{~cm}$, mit 2-4, meist weinrötlichen subfloralen Sprossen. Schopfblätter herablaufend, hohl, breit elliptisch und eilänglich, kurz zugespitzt, 2 2,4 mm lang und $1-1,5 \mathrm{~mm}$ breit, mit abwärts umgebogenen Rändern; Rippe kräftig, kurz austretend; Zellen locker und rlünnwandig. oben $50-66 \mu$ lang und 27-33 $\mu$ breit, an Rande gestreckt, einen breiten, wulstigen Saum bildend. Seta 1.5-2 cm, dick, steif, purpurn. Kapsel hängend, mit dem Halse von halber Urnenlänge verkehrt-eilänglich, meist schwach gebogen, dümnhäutig, bleich gelbgrün, trocken unter der Mündung nicht verengt. Peristomzähne aulacodont, etwa 0,40 mm lang, mit 20-2! Lamellen; Fortsätze schmal, ritzenförmig durchbrochen; Wimpern rudimentär oder fehlend. Deckel flach gewölbt, mit Warze. Sporen 2.1-30 ", gelb, feinwarzig. Sporenreife im Juli und August.

N. ST. Opdal, auf sandigem Flussufer. F. Kistrand, Nesseby und Porsanger.

36 t. Bryum rutilans Brid. Bryol. univ. I. p. 68.1 (1826). [Bryum oeneum Blytt Mscr.. Bryol. eur. fase. 32 Suppl. p. 4, tab. 5 (1846).]

Schlanke Pfl. in dichten. wurzeltilzigen, olivenfarbenen und rötlichgrünen, im Alter fast kupferbraunen Rasen. Stengel bis $4 \mathrm{~cm}$, leicht brüchig, dicht beblättert, in den oberen Blattachseln mit hyalinen oder rötlichen, paraphysenartigen Haaren. Blätter trocken bogig eingekrümmt und etwas gedreht, an Grunde verengt und efwas herablaufend, untere klein, eiförmig und verkehrt-eiförmig, scharf zugespitzt, obere länglich- oder breit-lanzettlich, lang zugespitzt, ganzrandig, gesäunt, mit unten breit und oben schmal umgeschlagenen Rändern. $2-2,7 \mathrm{~mm}$ lang und 1,2 mm breit; Rippe kräftig, meist als Stachelspitze austretend: Zellen locker, dickwandig, obere $0,04-0,05 \mathrm{~mm}$ lang und $0,025 \mathrm{~mm}$ breit, am Rande gestreckt, einen 2 -3reihigen, doppelschichtigen, gelben oder rötlichen Saum bildend. Seta $1-2,5 \mathrm{~cm}$, rot. Kapsel hängend odler nickend, keulen-birnlörmig, etwas gekrümmt, dünnhäutig, rotbraun, mit dem Halse etwa $1 / 2$ der L'rne, trocken unter der Nündung nicht verengt. Peristomzähne etwa $0,40 \mathrm{~mm}$ lang. schmal lineallanzettlich, gelb, breit hyalin gesäumt, sehr fein papillös, mit 15-20 Lamellen. Inneres Periøom dem äusseren anhängend, gelb, papillös; Grundhaut sehr niedrig: Fortsätze schmal, geschlitzt; Wimpern breit und kurz, zuweilen gut entwickelt, sehr selten sogar mit Anhängseln. Deckel klein, gelb, gewölht, mit Warze. Sporen $20-2.5 \mu$. grïn, feinwarzig.

Auf feuchten Schiefer- und Kalkschieferfelsen.

F. h. Kuusamo, Oulankajoki (Broth.). - Le. Kilpisjärvi, Sairovaara (Kot.).

S. LuL. Sarekgebiet, in der Weiden- und alpinen Region.

N. Dorre. ST. Roraas. - No. und $F$. an wenigen Fundorten.

Spitzbergen, arkt. Nord-Amerika.

B. dubiosum Par. Suppl. Ind. p. 62 (1900) [B. zonatiforme KKindb. in Bot. Notis. 1 s.96 nec Par. Ind. p. 223 (1894)] aus Norwegen seheint nach von H a ge $n$ mitgeteilten Exemplaren von B. rutilans nicht spezifisch verschieden zu sein. Originalexemplare habe ich nicht erlangen können.

365. Bryum alvarense Arn. et Medelius in Botan. Notis. 1921, p. 27.

Diözisch. Pfl. in dichten, etwa 1 cm hohen, bräunlichen Rasen. Stengel mit schlanken, grünen subfloralen Sprossen. Schopfblätter nicht herablaufend, eilanzettlich, kurz zugespitzt, etwa $2 \mathrm{~mm}$ lang und $0,35 \mathrm{~mm}$ l)eit, gesäumt, mit flachen orler schmal umgebogenen Rändern: Rippe kräftig, schwarzrot, vollständig bis kurz austretend; Zellen oben 10 -50 " lang und 13 - $20 \mu$ breit, dickwandig, am 
Rande eng und gestreckt, einen selır schmalen, gelblichen Saum bildent. Seta 2-3 cm, braun. Kapsel klein, hängend, kurzlsalsig, verkehrt-eiförmig bis fast birnförmig, etwa 1,1 $\mathrm{mm}$ lang und $0,8 \mathrm{~mm}$ dick, regelmässig, braun, unter der Mündung schwach verengt. Peristomzähne gelb, mit etwa 18 Lamellen. Fortsätze ritzenförmig durchbrochen; Wimpern meist mit Anhängseln. Deckel gewölbt, mit Spitzchen. Sporen $13-16 \mu$, gelb, glatt. Sporenreile im Juni.

S. Öland, Stenåsa, Ebbelunda, auf Kalkboden.

366. Bryum Lindbergii Káar. in Bot. Notis. 1886, p. 129.

Synautözisch ( $\sigma^{\top}$ Blüten neben der am Achsenscheitel, eine jede mit besonderen Hüllblättern, erstere gewöhnlich auch terminal an einer Seitenachse). Herclenweise wachsende, schmutzig-grïne odler bräunliche Pfl. Stengel kaum $1 \mathrm{~cm}$, mit verlängerten Sprossen aus älteren Teilen. Blätter locker gestellt, wenig herablaufend, trocken geschlängelt, leucht aufrecht-abstelıend, obere grösser, aus enger Basis elliptisch, zugespitzt, ctwa 2,8 $\mathrm{mm}$ lang und bis 1,2 $\mathrm{mm}$ breit, mit \pm weit hinauf umgebogenen Rändern: Rippe kurz austretend; Zellen locker und dünnwandig, $50-70 \mu$ lang und $18-22 \mu$ breit. Seta bis $1,5 \mathrm{~cm}$, purpurn. Kapsel hängend, mit den gleichlangen, engen Halse gekrümmt-keulenförmig, gelblich, trocken unter der Mündung nicht verengt; Zellen um die Mündung in wenigen Reihen quadratisch. Peristomzähne gelb, 0, $45 \mathrm{~mm}$ lang, mit über 25 Lamellen. Inneres Peristom gelblich: Fortsätze klaffend; Wimpern zart, mit kurzen oder langen Anlängseln. Deckel gewölbt, mit Warze. Sporen $18-22 \mu$, bräunlichgelb, warzig. Sporenreife im September.

N. ST. Opdal, Vangefjeld bei Skarbäcken, 1,200 m. F. Nesseby, Bergebyelven, auf feuchter Erde. Schweiz.

367. Bryum amblystegium Ryan in Hag. Nuse. Norv. bor. p. 164 (1901). Synautözisch, bisweilen synözisch. Pfl. in lockeren, olivengrünen, in Alter schwärzlichen, mit Ercle durchsetzten, bis 2,5 cm hohen Rasen. Blätter herablaufend, abstehend, eiförmig bis länglich-lanzettlich, kurz zugespitzt, bis $1.75 \mathrm{~mm}$ lang und 0,87 mm breit. Schopfblätter aufrecht-abstehend, eiförmig. 2,5 mm lang und $1 \mathrm{~mm}$ breit, mit bis über die Nitte schmal umgebogenen Rändern: Rippe kräftig, kurz austretend; Zellen dïnnwandig, oben 33-60 " lang und 13-20 " breit. Seta bis 2,5 cm, rotbraun. Kapsel hängend, mit dem Halse von Urnenlänge verkehrt-eiförmig bis schmal birnförmig, 2-2,5 $\mathrm{mm}$ lang und 0,9-1 $\mathrm{mm}$ dick. lichtbraun, trocken unter der Mündung verengt; Zellen um die Mündung in wenigen Reihen quer rektangulär. Peristonzähne gelb, 0,38 mm lang. mit 20 Lamellen. Inneres Peristom gelblich bis orange; Fortsätze ritzenförmig durchbrochen; Wimpern meist rudimentär, zuweilen einzelne entwickelt, mit Anhängseln oder stückweise den Fortsätzen anhaftend. Deckel flach gewölbt, mit undeutlicher Warze. Sporen 22-27 $\mu$, gelbgrün, dicht feinwarzig. Sporenreife im Juli.

N. F. Nesseby, Abelsberg am Ufer.

Diese Art unterscheidet sich nach $\mathrm{H}$ age $\mathrm{n}$ von $B$. Lindbergii durch die rotgelben, an $B$. purpurascens erinnernden, subfloralen Sprosse, die kürzeren und weiteren Blattzellen, die an der Spitze hakenförmige Seta, die Farbe der Kapsel, die unter der Mündung verschmälerte Une, die Form des Deckels, das Kapselgewebe (bei dieser Art quer rektangulär, bei $B$. Lindbergii quadratisch) und durch die Farbe und Grösse der Sporen.

368. Bryum betulinum Kaur. in litt.; Joerg. in Christ. Vid. Selsk. Förh. 1894, p. 86.

Diese mir unbekannte Art ist nach $\mathrm{H}$ a g e $n$ mit $B$. amblystegium sehr nahe verwanıl, lässt siclı jedoch nach ihm folgendermassen von derselben unterscheiden. Sie ist synözisch; bei den Schopfblätter ist die Rippe länger austretend; das Zellgewebe der Kapsel ist weniger derb, mit unterhalb der Mündung entschieden 
abgeflachten Zellreihen; die Peristomzähne im unteren Teile fast gleichbreit und das innere Peristom liyalin, mit breiteren Fortsätzen.

N. F. Reisen, in einem Birkengehölz an der süd-eite de; Berges Jerta.

369. Bryum pycnodermum Limpr. in 61. Jainresb. Schles. Ges. p. 217 (I8\$4).

Synözisch, mit $\rightarrow$ Blüten untermiseht. Herdenweise wachsende, schmutziggrüne Pfl., mit weinrötlichen jungen Sprossen. Stengel bis $1,5 \mathrm{~cm}$, schwärzlielıbraun verfilzt, mit 1-2 dünnen subfloralen Sprossen. Blätter trocken locker anliegend, etwas verbogen, aus enger, etwas herablaufender Basis länglich-lanzettlich oder lanzettlich, lang zugespitzt, bis $3,3 \mathrm{~mm}$ lang und $1,5 \mathrm{~mm}$ breit, gesäumt, mit nur am Grunde etwas umgebogenen, an der Spitze gezähnten Rändern: Rippe kräftig, schwärzlich-rotbramn, in den Schopfblättern als gezähnter Stachel, in den Sprossblättern mit der Spitze endend oder kurz austretend; obere Zellen $50-70 \mu$ lang und 16-22:" breit. Sporogone zuweilen 2 aus demselben Schopte. Seta 1 - 6 cm, dünn und steif, braunrot. Kapsel hängend, aus engem, zuweilen schwach gebogenem Halse von ${ }^{2}, 3$ Urnenlänge eilänglich, fast 4 mm lang und $1,3 \mathrm{~mm}$ dick, im frischen Zustand fleischrot, wie tauig, trocken lerbhäutig, trocken und entdeckelt unter der Mündung wenig oder kaum verengt. Peristomzähne bis $0,45 \mathrm{~mm}$ lang, bräunlichgelb und etwas rötlich angehaucht, mit über 30 Lamellen. Inneres Peristom gelblich: Fortsätze geschlitzt bis klaffend; Wimpern mit Anhängseln. Deckel flach gewölbt, mit Warıe. Sporen 26-33 $\mu$, olivengrün, in Masse rostfarben, warzig.

N. ST. Opdal, in Sande des Drivafluses. No. Vessen, an mehreren stellen an skjervenelven; Bejeren, Vold.

370. Bryum pallens Sw. Muse. Suec. p. 47 et 98, tab. 4. fig. 12 (1799). (Bryum versifolium Bomans. in Rev. bryol. 1903. p. 88.)

Diozisch: r Pll. meist eingemischt. Schlanke Pfl. in lockeren bis ziemlich dichten, unten durch Rhizoidenfilz verwebten, weichen, schmutzig olivengrünen, bräunlichen bis weinroten Rasen. Stengel kurz, selten bis $3-4 \mathrm{~cm}$, ziemlich dicht beblättert. mit 1-3 subfloralen Sprossen. Blätter trocken locker anliegend und mässig gedreht, feucht aufrecht-abstehend, wenig holı, aus verschmälerter, herablaufender Basis nach der Mitte verbreitert und dann allmählich in eine kurze oder lange, scharfe Spitze fortgesetzt. bis $2.4 \mathrm{~mm}$ lang und bis $0,9 \mathrm{~mm}$ breit, mit bis gegen die Witte oder noch höher hinauf ungerollten Rändern; Rippe entweder mit der Blattspitze endend oder als scharfe Stachelspitze austretend: Zellen locker und dïnwandig, obere $40-60 "$ lang mol etwa $25 \mu$ breit, am Rande gestreckt, einen 1-3reilnigen, gelben oder bräunlichen Samm bildend. Seten oft ungleichlang, 1-t cm, braunrot. Kapsel nickend oder hängend, mit dem langen Halse verlängert birnförmig, meist etwas gebogen, mit emporgehobenem Rücken, zuweilen regelmässig, dünnwandig, blass- oder dunkelgelb, im Alter kastanienbraun, trocken unter der IÏndung nicht oder wenig verengt. Peristomzähne gelb, oben grob papillös, mit über 30 niedrigen Lamellen. Inneres Peristom gelb, schwer mit dem Sporensacke sich ablösend: Grundhaut etwa 1/2 der Zähne; Fortsätze schmal, eng oder weiter durchbrochen: Wimpern meist gut entwickelt, mit langen Anlı̈̈ngseln. Deckel von wechselncler Form, bald kegelförmig, bald gewölbt und mit sehr kurzem oder etwas längerem Spitzchen. Sporen meist $12-18 \mu$, selten grösser, gelb, fast glatt. - Fig. $51 \mathrm{C}-\mathrm{D}$.

An feucliten Stellen auf Sand- und Moorboden, besonders an Bach- und Flussuferu.

F. Al. Eckerö, Storby (Elfv.). Jomala, Ytlemäs und Y̌lterby (Bom.). Saltvik, an vielen Fundorlen (B.). - Ab. Korpo, Brunskär (Elfv.). Pargas (Arrh.). Abo (Brand.). Reso (Zetl.). Karislojo, Kourijoki (sundv.). Lojo, Lỵlỵis (E. af H.): Pietilä (E. af H.). - N. Ekenäs, Trärminne (Häy̆r.). Ingà (W. Brenn.). sjundeà (Nerv.). Esbo (Bruth.). Helingofors (Lindl).). Iilli (Buch). - Ik. Pyhäjärvi, Salitsaranta (H. Lindb.). - St. Hämeenkyrö, Kyröskoski (Merv.). Ikaalinen (Sundvo), - Ta. Vanaja (Thur.). Im südöstl. Teile s1. fq. (Norrl.). Luhankal und Korpilahtist. fq. (Vain.). - sa. Lappee (Buch). 
Kangasniemi (Lackstr.). - hl. Kurkijoki, Ohtjärvi (Jusl.). Valamo (Jus\}.). Uukuniemi (WV. Nyl.). Kol. Vosnessenje (Elfv.). Pelrosavodsk (Kullı.). - Oa. Replol (Simm.). Isokyrö, Orjsberg (Ranck.). Tb. Jyväskylä, Laukaa und Viitasaari s1. Iq. (Broth.). - S̈b. Kunpio, an mehreren Fundorlon (Jink.). Nilsiä, Pieni Tampinen (kyyhk.). Mamninka, Tuovilanlahti (Ruiv.): Pöljä, an melıeren Fundorten (ḱyylı.). Pielavesi, Jylhä (Roir.). Iisalmi (Sahlb.). - hb. Joensum (Linnan.). Lieksa (Vain.). - Kon. Suosaari (Simm.). Pirltiniemi (S.). - Om. Alajärvi, Kirehdorf (Backm.). Lappajärvi, IIarju (B.). Nirala und Ylivieska (Tenn.). - lk. Kajana (Lalckslr.). Ristijärvi (L.). Suomussalmi (L.). - Kpom. Vakanvaara (Bergr.). - Ob. Uleaborg (W. Nyl.). Isemi (Valmari). P’udasjärvi (Nyb.). Rovallemi (Hult). Ylitomio, Turtola und Pello fq. (Hulı). - Lkem. Lolari, Juurakkovaara (Norrl.). Kuolajärvi, Kolala (Limnan.). - Le. In der Waldregion bis Kilpisjärvi (Norrl.). - Li. Sodankylä, Kopsusjärvi, Luirojärvi und suomusjoki (Hull). Fiyrö (Vain.). - In den verschiedenen Teilen der Halbinsel fola $t$ fq. (Brolh.).

var. fallax (Mild.) Jur. Laubmll. p. 287 (1882). [Bryum fallax Mild. in Rabenh. Bryoth. eur. No. 242 c. diagn. (1859); Schimp. Syn. p. 691 (1860).]

Rasen gelblich- bis bräunlichgrün. Schopfblätter kaum herablaufend. Kapsel meist regelmässig, seltener etwas gekrümmt. Wimpern ohne Anhängsel.

S. var.

var. meeseoides (Kindb.). (Bryum meeseoides Kkindb. in Bull. Torr. Bot. Club 1889, p. 95.)

Mit $B$. pallens sehr nahe verwandt und von dieser Art wahrseheinlich nieht versehieden. Blattzellen ïberaus dünnwandig. Kapselform Meesea- oder Hypnum-artig, stark gebogen. Fortsätze des inmeren Peristoms mit kleinen, ovalen bis rundlichen Fenstern. Sonst wie bei $B$. pallens.

N. Telemarken, Bolkesjö.

Deutschland, Nord-Amerika.

371. Bryum purpureum Philib. in Rev. bryol. 1886, p. 24.

Diöziseh. Pfl. in dichten, roten, etwa 1,5 ('m hohen Rasen. Blätter oval-lanzettlich, liurz zugespitzt, bis $2.5 \mathrm{~mm}$ lang und $1 \mathrm{~mm}$ breit, mit längs breit umgebogenen Rändlern; Rippe kurz austretend; Zellen locker, an Rande eng und gestreckt, einen 2reihigen Saum bildend. Seta 2-3 cm. Kapsel aus ziemlich kurzen Halse eilänglich, etwas gekrümmt, blassgelb. Peristomzähne etwa $0,40 \mathrm{~mm}$ lang, gelb, mit etwa 27, unten hier und da durch eine Zwischenwand verbundenen Lamellen. Inneres Peristom anhängend; Fortsätze schmal, ritzenförmig durchbrochen: Wimpern rudimentär. Sporen 20-26 $\mu$, grün.

N. $\therefore T$. Opda\}, Omberget.

372. Bryum finmarkicum Kaur. in litt.; Jörgens. in Christian. Vid.-Selsk. Forls. 1894. No. 8, 1. 88. [Br. pallens var. brevisetum Lindb. et Arn. Musc. As. bor. II. p. $36(1890)$.]

Schlanke Pfl., truppweise oder in dichten, weichen, mässig verfilzten, kupferroten oder braunen und am Gipfel gelb- oder schmutziggrünen, meist $1-2 \mathrm{~cm}$ hohen Rasen. Stengel ziemlich dicht beblättert, mit schlanken, bis $1 \mathrm{~cm}$ langen subfloralen Sprossen. Blätter trocken locker anliegend, eingebogen und wenig gedreht, feucht abstehend, sehr hohl, aus wenig herablaufendem Grunde breit eiförmig oder rundlich-oval, knrz und scharf zugespitzt, bis $2 \mathrm{~mm}$ lang und etwa $1 \mathrm{~mm}$ breit, nit fast bis zur Spitze umgebogenen Rändern; Rippe in die Blattspitze eintretend bis kurz austretend; Zellen sehr locker und duinnwandig, oval6seitig, oberwärts $40-50 \mu$ lang und etwa 25 " breit, am Rande gestreckt, einen 1 -3reihigen, gelben oder bramen Saum bildend. Seta $1-2,5 \mathrm{~cm}$, braumrot. Kapsel nickend bis hängend, aus gleichlangem oder etwas längerem Halse birnförnig, fast regelmässig, 3-3,5 mm lang, im Alter lederbraun, trocken und entleert glänzend, unter der Mündung nicht verengt. Peristomzähne 0,4 mm lang, bleichgelb, oben grob papillös, mit 18-20 Lamellen. Inneres Peristom gelb; Grundhaut etwa 1/2 der Zähne; Fortsätze ritzenförmig durchbrochen; Wimpern bald sehr kurz, bald besser entwickelt, breit und meist olnne Anlıängsel. Sporen 20-25 ", selten grösser, gelbgrün, warzig. Deckel kegelig oder gewölbt kegelig, mit Warze. Sporenreife in August. 
An sandigen Flussufern und feuchten Felsen in Kalk- und Schiefergegenden.

N. No. und $F$. an mehreren Fundorten. Tr. Bardo, Rubben in der Birkenregion. Nach $\mathrm{H}$ a ge $\mathrm{n}$ auch sonst in den subalpinen Gegenden Norwegens verbreitet.

Unterseheidet sich nach $\mathrm{H}$ a g e n von $B$. pallens dureh ihre Farbe, ihre weit kleineren, mehr hohlen Blätter mit starker, in einen kurzen Stachel auslaufender Rippe, durch ihr aus weiteren, 6eckigen, turgiden Zellen bestehendes Blattgewebe und endlich durch die kleinere, regelmässige Kapsel mit oft sehr schwach entwickelten Wimpern.

var. lutescens (Bomans.). (Bryum lutescens Bomans. in Rev. bryol. 1897. p. 1.)

Rasen oberwärts gelblich. Blätter grösser, Rippe schwächer. Kapsel mit gebogenem Hals.

F. Al. Saltvik, Kariberg (Bom.).

373. Bryum versisporum Bomans. in Rev. bryol. 1896, p. 91.

Ziemlich schlanke Pfl. in \pm dichten, weichen, bräunlichgrünen, durch Rhizoidenfilz verwebten Rasen. Stengel $1-3 \mathrm{~cm}$, abwärts locker, oberwärts dicht und schopfig beblättert. mit schlanken, locker beblätterten subfloralen Sprossen. Blätter trocken locker anliegend und mässig gedreht, feucht aufrecht-abstehend, aus verschmälerter, herablaufender Basis nach der Mitte verbreitert und dann allmählich scharf zugespitzt, bis $3 \mathrm{~mm}$ lang und bis $1,1 \mathrm{~mm}$ breit, mit bis \pm weit hinauf schmal umgerollten Rändern; Rippe kurz austretend; Zellen am Rande gestreckt, einen 2-3reihigen, gelben oder bräunlichen Saum bildend. Seten oft ungleichlang, 2-1 cm, braunrot. Kapsel horizontal bis nickend, mit dem langen Halse verlängert birnförmig, 3-5 $\mathrm{mm}$ lang und bis $1,25 \mathrm{~mm}$ dick, regelmässig oder mit emporgehobenen Rücken, gelbbraun, im Alter dunkelbraun, trocken unter der Mündung nicht verengt. Peristomzähne bräunlichgelb, bis $0,4 \mathrm{~mm}$, mit etwa 30 Lamellen. Inneres Peristom gelb; Fortsätze schmal, ritzenförnig durchbrochen; Wimpern rudimentär. Deckel klein, gewölbt, mit Warze. Sporen in derselben Kapsel 15-40 $\mu$, bräunlichgelb, fein-papillös. Sporenreife im August und September.

An sandigen Grabenrändern und auf humusbedeckten Ǩalkfelsen.

F. Al. Eckerö, Storby (H. Lindb.). Jariehamn (Bom.). Jomala, Jomalaby (B.). Saltrik, Strömma und Fremmanl,y (B.). - Ab. Lojo, Mongola (H. Lindb.); Hermola (Sundr.).

S. Dlr. Buda, Östlojörka. Jmt. Handölsfallen. TL.

37. Bryum turbinatum (Hedw.) Schwaegr. Suppl. I. P. II. p. 109 (1816). [Mnium turbinatum Hedw. Deser. III. p. 22, tab. 8 (1792).]

Diözisch; ح Pfl. zarter und meist einfach, in besonderen Rasen oder eingemischt, mit fast scheibenförmigen Bliiten. Schlanke Pfl. in ziemlich dichten, ausgedehnten. weichen, schmutzig- oder gelblichgrïnen, oft rötlichbraunen, innen durch Rhizoidenfilz dicht verwebten Rasen. Fruchtende Stengel meist nur 1-2 cm, dicht beblättert, mit kurzen subfloralen Sprossen, steril 3-1 cm oder noch länger, \pm locker beblättert. Blätter trocken locker anliegend und etwas gedreht, feucht aufrecht-abstehend, untere und die der sterilen Sprossen kleiner, etwas herablaufend, eiförmig, zugespitzt, flach- und ganzrandig, schmal und undeutlich gesäunt, obere allmählich grösser und schopfförmig gehäuft, aus kaum verschmälerter, nicht odler wenig herablaufender Basis eilänglich-lanzettlich, scharf zugespitzt, mit 2-3reihigem Saume, flachranclig oder mit an Grunde selswach zurückgerollten Rändern, 2 - 2,2 $\mathrm{mm}$ lang und $0,8 \mathrm{~mm}$ breit; Rippe kräftig, in der Blattspitze aufhörend odler als kurze, glatte Granne fortgesetzt: Zellen locker, dünnwandig, obere 40-60 " lang und etwa $18 "$ breit. Seta $2-4$ cm, diunn, gelbrot, später braunrot. Kapsel hängend, regelnässig, aus kurzem odler längeren Halse dick birnförmig, 2-3 111 lang und 1-1.5 mm dick, dünnhäutig, gelblich oder braun. trocken unter der weiten Mündung stark eingeselniurt und dadureh 
fast kreisellörmig. Peristomzähne 0,5- 0,6 $\mathrm{mm}$ lang, ge blblich bis rötlichgelb, mit 25-30 lamellen. Inneres Peristom gelblich: Grundhaut l'ast $1 / 2$ der Zähne; Fortsätze schmal, ritzenfömig bis klaflend durehbrochen: Wimpern mit langen Anlı̈̈ngseln. Sporen $15-18 \mu$. gelbbräunlich, feinwarzig. Deckel kegelförnig odler gewölbt, mit Spitzchen oder Zitze. Sporenreile von Encle Mai bis Mitte Juni.

In leuchten Sandausstichen, in Ton- und Nergelgruben.

F. 11. Saltrik, an wenigen frundorten (Bom.). Sund, Kastelhohn (B.). - Ab. Pargals, Lindber (Elfv.). - Ta. Hartola (Bonsd.).

S. Sk. an meltreren Fundorten. Gll. Visby. Nar. Tysslinge.

N. Sm. Onsu. A. Kirstiania, St Ryfylke. $S B ., S T$., No. und $F$, an einzelnen Finndorten.

Europa, Kaukasus, Vordes- und Zentral-Asien, Nord-Amerika.

375. Bryum Schleicheri Sehwaegr. Suppl. I. P. II. p. 113, tab. 73 (1916).

Diözisch; $\Upsilon^{7}$ Pfl. in besonderen Rasen, mit fast scheibenförmigen Blüten. Mehn" oler weniger kräftige Pfl. in ausgedehnten, weichen, schwellenden, (hurch spärlichen Rhizoidenfilz locker zusammenhängenden, freudig- bis gelblichgrünen Rasen. Stengel :3-12 cm. hald locker, bald dicht, mitunter gedunsen belsättert. Blätter trocken locker anliegend, zuweilen etwas gedreht, feucht aufrecht-ahstehend, weit herablaufend, hohl, untere kleiner, ciförmig, kurz zugespitzt, dann allmählieh grösser, eilänglich, almühlich zugespitzt, lis $3,6 \mathrm{~mm}$ lang und $1.8 \mathrm{~mm}$ breit, mit flachen oder bis zur Mitte hinauf schwach zurückgerollten Rändern: Rippe ziemlich kräftig, in der Blattspitze aulgelöst odler als kurze, spärlich gezähnte Granne austretend: Zellen locker und dïnnwandig, obere 50-_90 $\mu$ lang und etwa 20 " breit, am Rande gestreckt, einen meist 3-5reihigen Sam bildend. Seta $2-6$ cm, rot. Kapsel hängend, nach Grösse und Form veränderlich, regelmässig, gelbbräunlich, entweder aus verlängertem Halse nach der Mitte bauchig erweitert und dann bis zur weiten vlïndung allmählich bedeutend verengt oder ausgezeichnet hirnförmig. Peristomzähne gelb, 0,60 --0,70 mm lang, mit 30 10 Lamellen. Inneres Peristom fast orange: Grundhaut $1 / 2$ (ler Zähne; Fortsätze rundlich und oval durchbrochen: Wimpern mit langen Anhängseln. Sporen 12-16 $\mu$. Dräunlichgelb, papillös. Deckel gross, spitz kegelförmig ader flach gewölbt und fein gespitzt.

An kalten Quellen.

N. F. Fistrand, oberhall, Russenirk neluen dent fylleelven, etwa to0 m.

Pyrenäet. Zentral-Europa, liaukasus, Hinalaya. Zentral-Asien. nöldl. mul westl. Teile von Nird-Amerika.

var. flaccifolium Hag. in Nyt llag. Naturs. Bd. 38, H. 4, p. 337 (1900).

Pli. in verfilzten, innen weinroten, oberwärts sattgrünen Rasen. Blätter entfernter gestellt, weicher, troeken abstehend und geschlängelt.

N. sT. Dovrefjeld, Finnshø, auf Steinen itu Bache Naerrabaekken. elwa 1,006 m.

376. Bryum turgens Hag, in Kgl. Norsk. Vid. Selsk. Skrift. 1897. No. 2. 1). 20.

Diözisch. Schlanke l'fl. in dichten, oft ausgedehnten, schwellenden, weichen, sattgrünen, inmen bräunlichen, durch Rhizoidenfilz verwebten Rasen. Stengel 6-10 em. ziemlich dicht und gleichmässig heblättert, einfach oder spärlich verzweigt. Blätter trocken \pm eingeschrumpft und \pm abstehend, fencht aufrecht, aus weit herablaufender Basis breit oval oder eiförmig, raseh klejnspitzig, bis $2,5 \mathrm{~mm}$ lang und bis $1.7 \mathrm{~mm}$ breit, mit längs sehmal umgebogenen Rändern; Rippe vor der Blattspitze aufhörend: Zellen locker und dïnnwantig, an Rande gestreckt, cinen 3-4roilhigen Saum bildend. Seta 2-3 cm, steif. bräunlich. Kápsel hängend, mit dem Halse fast von Urnenlänge birnförmig, bis $3,5 \mathrm{~mm}$ lang und bis $1,8 \mathrm{~mm}$ dick. gellibraun, trocken unter der Mündung wenig verengt. Peristomzähne $0,5 j-.$. 0.60 $\mathrm{mm}$ lang, gelblich, mit etwa 33 Lamellen. Inneres Peristom blass rötliehgell, fast glatt; Fortsätze gefenstert: Wimpern mit langen Anhängseln. Deckel niedrig, gewölbt-kegelig mit Warze. Sporen etwa $12 \mu$, gelblich, glatt. Sporenreife inl August. 
In Sümpfen der alpinen Region.

N. K. Ringebu, Pratestekampen, etwa 1,100 in. - ST. Dovre, Fimnshu und Knudsh:ı. $-F$. Tanen, sejda.

377. Bryum Duvalii Voit in Stum 1)utschl. Fl. 11. Heft 12, c. icon. (1811).

Diöziseh; $\overbrace{}^{7}$ Pl. fast immer in eigenen Räschen, mit dick knospen-scheibenförmigen Blüten. Schlanke Pfl. in lockeren, ausgedehnten, weichen, blassgrünen. meist weinrötlichen bis fast purpurroten, leicht zerfallenden Rasen. Stengel bis $10 \mathrm{~cm}$, nur am Grunde und aus den Achseln der unteren Blättern mit Rhizoiden. locker beblättert, einlach otler aus dem Schopf der Fruchtstengel mit sehr langen, schlanken, entfernt heblätterten Sprossen. Blätter trocken eingeschrumpft und hin- und hergebogen, feucht abstehend bis etwas zurückgebogen, aus etwas verschmälerter, sehr weit herablaulender Basis breit eiförmig bis breit eilanzettlieh. kurz zugespitzt, bis $2 \mathrm{~mm}$ lang und bis $1 \mathrm{~mm}$ breit. Schopfblätter grösser, flachund ganzrandig, nicht oder undeutlich gesämt: Rippe zart, kurz vor oder in der Blattspitze aufhörend; Zellen sehr locker und dïnnwandig, obere 40, an der Rippe bis $70 \mu$ lang und $20 "$ breit. Seta $2-6 \mathrm{~cm}$, dümn, meist geschlängelt, rot. Kapsel hängenı, mit dem fast gleich langen Halse verlängert birnförmig, bis $1 \mathrm{~mm}$ lang und bis $1.2 \mathrm{~mm}$ breit, regelnässig. dümnhäutig, gelbgrün oder bräunlich, trocken unter der weiten llüntlung eingeschnürt. Peristomzähne etwa $0,50 \mathrm{~mm}$ lang. blass- oder orangegelb, mit :30-36 Lamellen. Inneres Peristom blassgelblich: Grunthaut fast ${ }^{2} / 3$ der Zähne: Fortsätze fensterartig durchbrochen; Wimpern mit langen Anhängseln. Deckel gewöht, mit Zitze. Sporen 9-16 $\mu$, gelb, schwach papillös. Sporenreile im Juni und Juli. Fig. $49 \mathrm{~A}-\mathrm{B} . \mathrm{S}$.

Auf feuchtem Boden, besonders an quelligen stellen und an sumpligen Bachund Seeufern.

F. Ab. Kari-lojo, Hakos (E. af II.). Lojo, Ojanı (Lindb.). - Y. sjundeâ, X̧̣rans (Nerv.). Helsinge, Gammelstaden (Lindl.). Nurmijäri. Rihimäki (Häyr.). Iilti, Mustaniemi (Buch). IIogland (Lindb.). - Ka. sakkijärvi, Lahajärvi (Krohn). Virolahli, Muurola (Blom.). - Ik. Uusikirkko. Vammelcuu (H. Lindb.). Junia (Melil). Valkjärvi, Pasuri (H. Linlb.). Sakkola, Kurikka (H L.). Pyhäjäri

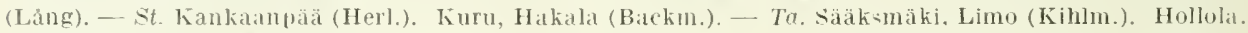
Tiirismaa (Norrl.). Asikkala (N.). Padasjoki. Vesijako (N.). Kuhmoinen, Isojärvi (Broth.). Luhanka,

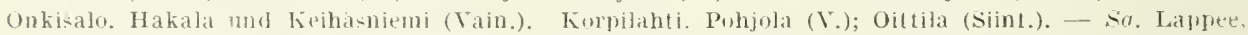
Paskalampi (Buch). Wilmanstrand (B.). kangasnieni (Lackstr.). 一 Kl. Kurkijoki (Jusl.). Parikkala (Sahlb.). Sortarala (F. Nyl.); Piisparuori (Kop.); Kirjaralahti (Norrl.). Suistamo, Jänisjärvi (Brolh.): Leppäsyrjä (Pes.). - Ko!. suojäri, Maimalanji (Norrl.): Kotajarvi (Link.). Gorki (Elfr.). - Tb. Virrat (Brolh.). Jyvăsỵlä (B i. Lauka (B.). Viliasaari (B.). - Sb. Kuopio, Alava und Suoru (Link.).

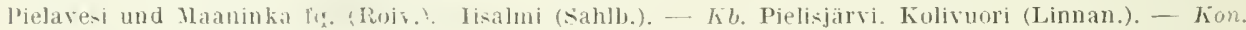
Kenljärvi (Simm.). ckor-ki pogoct (Kullh.). - ok. Kajana (Lackstr.). Pallano (L). Kuhmoniemi, Tiuronsuo (E. af H.). Rislijäri (L.), suomussalui (L.), - Kpom. IIoina (Bergr.). - K. Kunsamo, livaara (Broll.); zw. Rukalunluri und Pşäraara (B.); zw. Konttainen und Valtavaara (E. af H.). - Kk. Kivakkatuniuri (Broth.) - ob. Simo (Rä..). Rovaniemi. Terro (Hult); Apukka (Huum.). - Lhem. Killilĭ. Ylläsjoki (Hult); Muonio. Latitraara und Keimiolunturi (Norrl.) Kuolajärvi (Broth.): Peteri (Linnan.) Le Karesuanto (Norrl.). - L.i. Sodanky]ä, in der Vadelwa]dregin pass. (Hulı); Saariselkä, in derr Birkenregion (H.). Itojoki, llandojäyr, in der Birkenregion (H.); Nuovusjokka (Ranck.). L Lim. Kandalakis (Broth.). - Lt. suorsajnk in sïdwestl. Teile (Roir.). srednij an Kulabusen (Brolh.). Kildin (B.). subori, Tsipnavolok. Vaidoguba und Punnanki (B). - Lmur. Voroninsk (Kihln.). fiarrilova, Rinda und an IIarlorkillusese (Broth.).

S. sin. an mehreren, Ög., srm. und Yär. an wenigen Fundorten. Gslr. und Dlr.- $L$.

N. Gudbrandsdalen. Ne. Saetersdalen. $S B$. und $S T$. an einigen Fundorlen. R. r. K. Filefjeld und lomsfjeldene $V T$. Sijorditen Vo, $-F$. Nordgrenze bei $71^{\circ} 25^{\prime} \mathrm{n} . \mathrm{Br}$

Europal, Kaukisus, Kischmir, sibirien, Nord-Amerikit.

378. Bryum obtusifolium Lindl), in Öfvers. K. Š Vel.-Akad. Förh. 1866. 1.

Diöziseh, selten autözisch. Ziemlich schlanke Pfl. in weichen, weit ausgedehnten, leicht \%erfallenclen, oberwïts meist rötlichen Rasen. Stengel 2-7. selten bis $9 \mathrm{~cm}$, mit spärlichen Rhizoiden, locker beblättert, mit achselstäntigen, (lïnnen Sprossen. Bbatter weit herablaulend, trocken zusammengeschrumpft. 
leucht aulrecht-ahstehend, sehr hohl, oval, sehr stumpl, etwa 2,1 mm lang und $1,8 \mathrm{~mm}$ breit, mit bald flachen, hald am Grumcle oder bis gegen die Spitze schmal ungeschlagenen, unversehrten Rändern, ungesäumt bis mndeutlich gesäunt: Rippe zienlich kräftig, dicht vor der Blattspitze aufhörend; Zellen sehr locker, diünwandig, chlorophyllreich, in der Blattmitte $50-70 \mu$ lang und $20-30$ " Seta etwa 2,5 cm, dïmn, schön rot, glänzend. Kapsel nickend bis hängend, zicnlich klein, regelmässig, verkehrt-eiförmig, zuletzt kastanienbraun, unter der weiten Mündung nicht verengt. Peristomzähne blass gelblich, undeutlich papillös, mit sehr zahlreichen Lamellen. Grundhaut des inneren Peristoms 1/2 (ler Zähne, hyalin, glatt; Fortsätze zicmlich breit und breit gefenstert; Wimpern gut ausgebildet, mit kurzen Anhängseln. Deckel hochgewölbt, rotgelb, glänzend. Sporen 17 -20 " . bleichgruin, papillös.

An quelligen Stellen, anch auf feuchter Ere in den Sprüngen überrieselter Felsen in der alpinen Region.

S. LuL. sarekgebiet. steri.

N. Dovre. Lom:fjeldene. tialdhu. No. skjerstad. F. Karitjok Rastega ssi; Nessel,y, Bergelyelven. Steril.

spitzlergen, trönland, sibirien.

379. Bryum cyclophyllum (Schwaegr.) Bryol. eur. fase. 6/9, p. 63, No. 33. tab. 30 (1839). (Mnium cyclophyllum Schwaegr. Suppl. Il. P. II. J. 160, tab. 19 I (1827).]

Diözisch: $\mathrm{C}^{\mathrm{Pfl}}$. in eigenen Räschen. Schlanke, selı wejche Pll. in lockeren, oberwärts grimen, abwärts schwärzlichen Rasen. Fruchtende Stengel kurz, aus den Schople immovierend, aus dem Grunde mit verlängerten. bis 5 cm, selten noch längeren. zarten, schlaffen, selır locker und gleichmässig beblätterten Sprossen, am Gruncle und in den Blattachseln mit Rhizoiden. Blätter trocken stark wellig verbogen und gedreht, feucht abstehend, \pm holnl, aus sehr verengter, herablaufender Basis breit rundlich-oval bis fast zungenförmig, stumpf bis abgerundet, bis $1,5 \mathrm{~mm}$ lang und $0.9 \mathrm{~mm}$ breit, flach- und ganzrandig oder fast ganzrandig; Rippe dünn, vor der Blattspitze aulhörend; Zellen locker, dïnwandig, in der Blattmitte bis .50$60 \mu$ lang und 20 2.) $\mu$ breit, am Rande gestreckt, einen 1-3reihigen Sam bildend. Seta 1,j-3 cm, dünn, steil, rot. Kapsel lıängend, regelmässig, bis 2 mm lang und bis $0,9 \mathrm{~mm}$ dick mit dem dicken Halse kulz birnförnig, dünnhäutig, blassbräunlich, entdeckelt unter der weiten Mündung stark eingeschnürt. Peristomzähne 40-45 $\mu$ lang, blassgelb, papillös, mit 20. 25 Lamellen. Inneres Peristom blassgelblich: Grundhaut etwa $1 / 2$ (ler Zähne; Fortsätze breit, fensterartig durchbrochen, später klaffend; Wimpern mit langen Anhängseln. Deckel gross, hochgewölbt, mit Spitzchen. Sporen 10-14 a, gell), glatt. Sporenreife in] Juni. - Vegetative Vermehrung durch fast büschelförmig reichverzweigte, einzellreihige Brutfäilen in den oberen Blattachseh.

An schlammigen, moorigen Orten, in den Gräben der Torfmoore und in ausgetrockneten Teichen, selten fruchtend.

F. Al. Saltvik, an mehreren Fundorten (Bom.). - Ab. Pargas, Lampis (Link.). Uskela, Koskis (Lindb.). Lojo, Paloniemi (Buldt). - N. Ekenäs, Tvärminne. Norrgård (Broth.) und Lảngskär (Ranck.). IIelsingfors (Lindb.). Hogland, Ruokolahenjärvi (L.). - ka. Jiä:ki, Laitila (Lindl.). - Ik. Kexholm, Tenholahti (H. Lindb.). Muola, Kannilanjoki (II. L.). Valkjärvi, an Ufer des Sees Valkjärri (H. L.) Vuoksen, Vaalma (H L.) Sakkola, Kirkkojoki (H L.). - Ta. Haltjärvi (Granf). Lamm, Evo (Norrl.). Asikkala, Kurhila (N.). Padasjoki, Osoila (N.) - Sa. Savitaipałe, Säynijärvi (Buch). Kangasniemi (Lackstr.). - Kl. Suistamo, Loimala (Broth.) - oa. Tenva. Aystö, Luomanperänneva (Ranck.). Replot, Vallgrund, sandösund (Broth.). - Tb. Jyväskylä, Jy̧ä.joki (Broth.). — Sb Maaninka. Haatala, an mehreren Fundorten (Roiv.); Vianto (R.); Tuovilanlahti (R.). - Li. Kyrö (Vain.). - Lmur. Semjostrovsk (Broth). - Lp. Orlov: Goguliha (Kihlm.).

S. Sm an mehreren. Sk., Boh., Srm., När., Dlr., Hlsl. Ang. und $\mathrm{r}^{r} b$. an einzelnen oder wenigen Fundorten.

N. Sm., Bu, No. und $F$ an einzelnen Fundorten.

Europa, Sibirien, Nord-Amerika. 
S e e t. I I. Chroodontium Amamn I. c. p. 189.

Peristomzähne mit diekem, I lebhaft gefärbtem Funclus.

Subs e et. I. Eucladodium Amann l. $€$.

Wimpern ohne Anhängsel, wenig entwickelt bis rudimentär oder fehlend.

1. Purpurascentia Broth. in E.-P. I. ${ }^{3}$ p. 576 (1903).

Synözisch oder polyözisch $\left(\stackrel{+}{+}+\varsigma^{\top}\right)$. Blätter \pm herablaufend, zugespitzt, am Rande schwach umgebogen, schmal gelb gesäumt; Basalzellen nicht gerötet. Kapsel regelmässig. Peristomzähne sehr dick, sehr selten aulacodont ausgebildet. meist bräunlichgelb, mit orangefarbenem Fundus; Dorsalschicht (exel. B. purpurascens ex p.) mit Quer- und Schrägstreifung. Fortsätze des inneren Peristoms schmal, eng gesehlitzt.

380. Bryum purpurascens (R. Br.) Bryol. eur. fasc. 32, Suppl. p. 2, No. 48, tab. 3 (1846). [Pohlia purpurascens R. Br. in Suppl. App. ad iter Parryan. p. 197 (1824).]

Synözisch. Ziemlich schlanke Pfl. in lockeren, ausgedehnten, weiehen, schwach rötlichen Rasen. Stengel $1-2 \mathrm{~cm}$, unter der Spitze mit zahlreichen, schlanken, loeker beblätterten Sprossen. Blätter trocken locker anliegend, leucht aufrecht-abstehend, aus versehmälerter Basis oval- oder länglich-lanzettlich, \pm lang zugespitzt. 2$3 \mathrm{~mm}$ lang und etwa $1 \mathrm{~mm}$ breit, mit in der unteren Hällte umgebogenen Rändern; Rippe ziemlich kräftig, vor der Blattspitze aulhörend bis als kurze Stachelspitze austretend: Zellen dünnwandig. obere verlängert, 70 " lang, und 20 " breit, am Rande gestreckt, einen 1-2reihigen Saum bildend. Seta 1-; cm, ‘ünn, rot. Kapsel hängend, regelmässig, dünnwandig, aus gleichlangen Halse länglich, gelblich bis bleichbraun, trocken unter der Mündung etwas verengt. Zähne des äusseren Peristoms 0,40 mm lang, mit etwa 22 Lamellen. Inneres Peristom anhängend, gelblich, fein papillös; Grundhaut 1/3 der Zälıne: Fortsätze frei, geschlitzt; Wimpern unvolständig. Deckel mässig gross, flachgewölht, mit Spitzehen. Sporen $32-$ 36 " , gelbgrün, feinwarzig. Sporenreife im Juli und August. - Fig. $50 \mathrm{~N}$ - O.

Auf feuclitem, sandigem Boden, besonders im Sande der Flüsse inner- und ausserhalh der Ċbersehwemnungsgebicte, seltener auf feuchter Torferde und in Suimpfen.

F. $X$ Helsingfors, Fredriksberg (Lindb ). - Ih Valkjärvi. Pasuri, am Vunkien (H Lindb.). Pyhäjärvi. am Ladogaufer zw. Sortanlahti und Vernitsa und Salitsasanta (H. L.). - sl Björneborg, Ytterö (Häyr.). - Ob. Cleàlıorg, am Meeresufer (Huum.). Rovaniemi, Terro (Hult) - $k$. Kuusamo. zw. Martlila und Yattula (Broth.); s.glanin: zw. Kilkajärvi und Lixojärvi (E af H.): Leveälampi (E. af H.): Oulankajoki (Brotls.). - Lkem. Kittilä, Kirchdorf Hult) Levilunturi (H). - Le. Palojoki (Norrl.); Jeri.järvi (N.); zw. Hetta und Vuonit.järvi (N.). - Li. Sodankylä, an einzelnen Fundorten am Tankatjoki, Pälkemäjoki und Suomusjoki n der Nadelwaldregion (Hult). Inari. Krrö (Tain.). - Lim Inandra (Fellm.). - L. Am Kiolabusen (F. Nyl.); Kola, subovi und Vaidoguba (Brotl.). - Lmur. Am Voronjeflusse (B.) Rinda (B.) - Lp. Orlow, Gubnoi (Kilıhn.); an Bukorflusse (K.).

S. Dlr.. Hrjd.. Jmt., ing, PL. und LuL.

N. I Dovre Jotunfjeldene. Lomsfjeldene, $x T$. sljurdalen. Vo. und $F$, an melireren Fundorten. Arkt. Sibirien, Tord-Amerika, besonders in dell arklischen und hocharktischen Teilen.

* Bryum serotinum (Jin(l).) Amann Fl. mouss. Suiss. II. p. 2(12 (1912). [Bryum serotinum Lindl). Muse. scand. p. 17 (1879).]

Rasen gelbgrin. Blätter wie bei (ler Hauptart. Kapsel mit dem gleichlangen Hake birnförmig, braun, troeken unter ler Mündung nicht rerengt.

F. Helsingfors, Fredriksberg, auf fenchter sanderde (Lindb.).

S. Ang. Hernösand, auf steinigum Meeresuler.

* Bryum autumnale (I.mpr.) Amann 1. c. [Bryum aulumnale Limpr. in 60. Jahresb. (t. Schles. Ges. p. 239 (1883).]

laasen schmutzig grün, im Alter schwärzlich. Blätler hreiter und kürzer zugespilzt: 7ellen $27-33$ " breit.

N. ST. Ondill. skaret am sindigen l\%lusuler.

F. Tanen, Fielbma massenhaft. Nessebỵ. Berghyelven. 
* Bryum Lindgrenii (Schimp.) Amann 1. c. [Bryum Lindgrenii Schimp. Syn. ed. 2, p. 4 [2 (1876).]

Rasen bleichgrïn. Blätter wenig herablanfend, flachrandig. Sonst wic bei der Hauptart.

Auf sandiger oder torfiger Erde.

S. Weneru bei Lidköping

N. No., Tr. und $F$, an einzelnen Fundorten.

2. Calophylloidea Kindb. Sp. Eur. and Northam. Bryin. p. 3.19 (1897).

Autözisch ocler heterözisch. Bläller oval odler oval-länglich bis eilänglich, abgerundet bis kurz zugespitzt. lockerzellig: Basalzellen nicht bis schwach gerötet. Kapsel hängend, regelnässig, dick- und liurzlalsig. Peristom nahe der Mïndung inseriert: Peristomzähne last immer aulacodont ansgebildet, naclı unten alogerundet oder in der Medianlinie in eine kurze, rosenkranzförnige Zellenreihe herablaufend, mit tiefrotem oder braumrotem Fundus; Dorsalschicht ohne Strichelung.

381. Bryum calophyllum R. Br. Suppl. App. ad iter Parryan. p. 196 (1824).

Autözisch: $\Im^{T}$ Blüten an Fusse des Perichätiums. Ziemlich schlanke Pfl. in lockeren bis ziemlich dichten, olivenlarbenen, leicht zerfallenden Rasen, auch herdenweise. Stengel j-10 mm, mit spärlichen Rhizoiden und schlanken subfloralen Sprossen. Blätter etwas fleischig, selu hohł und stumpf, untere entfernt gestellt, etwas abstehend, rundlich oval, Schopfblätter grösser, lorker zusammenschliessend, aus verengtem Grunde oval-länglich, zu einer stumpfen Spitze verschmälert, bis $3 \mathrm{~mm}$ lang und $1.5 \mathrm{~mm}$ breit. mit am Grunde oder bis über die Yitte schmal umgehogenen, unversehrten Rändern: Pippe vor odler mit der Blattspitze endend: Zellen oberwärts 40-70 $\mu$ lang und 20-35 $\mu$ breit, am Rande gestreckt, einen einreihigen, gelbbräunlichen Saum bildend. Seta 2,5-3 cm, kräftig, steif, an Grunde gekniet, rot. Kapsel hängend, mit dem dicken, kurzen Halse verkehrt eilänglich, 2,5-3 $\mathrm{mm}$ lang und bis $1,5 \mathrm{~mm}$ dick, derbhäutig, bräunlich, trocken unter der llündung wenig verengt. Peristomzähne bis $0,40 \mathrm{~mm}$ : Aussensehicht schwach entwickelt, fast orange, fein papillös, mit kleinen, runden Perforationen längs ler geraden Längsłinie; Innenschicht stark entwickelt, blassgelb, an der Basis rot, mit einer Längsfurchmng in der Mittellinie und meist 25 Lamellen. Inneres Peristom gelb; Fortsätze breit, ritzenförmig durchbrochen; Wimpern kurz bis fehlend, selten völlig ansgebildet und hier und da mit Anhängsehn. Decliel klein, gewölbt, mit Warze. Sporen 33-12", bräunlich, fein papillös. Sporenreife im Juli.

Auf feuchtem Sandboden am Meeresufer, an salzigen Stellen im Binnenlande und an in Frühling überschwemmten Flussufern.

S. $V g$ Lidköping.

N. Dovre. ST. Trondhjem, Lerfossen. F. Kistrand an mehreren Fundorten.

Deutschland, fross-Britannien, Zentral-Asien. Sibirien, Tschuktschen-Hallinsel, Ford-Amerika Nordgrenze auf spitzbergen.

382. Bryum acutum Lindb. in Medı. Soc. Faum. Fl. Fenn. Dec. 1885: I indb. et Arn. Muse. As. bor. I1. p. 46 (1890).

Autözisch: ${ }^{\prime}$ Blïten an Fusse des Perichätimms. Sehlanke Pfl. in lockeren. oft ausgedehnten, gelbroten, im Alter schwärzlichen Rasen oder herdenweise. Stengel 1,5-3 cm, zum grössten Teil im Sande begraben, unten locker, oberwärts lichter beblättert, mit zahlreichen, verlängerten, sehr sehlanken, entfernt beblätterten Sprossen. Untere Blätter ans etwas verengter Basis breit oval, stumpf oder kurz zugespitzt, etwa 1,6 $\mathrm{mm}$ lang und $1,1+\mathrm{mm}$ breit, mit flachen oder an Grunde schwach zurïckgebogenen Rändern: Rippe dünn, vor oder mit der Blattspitze aufhörend; Zellen bis $0,06 \mathrm{~mm}$ lang und $0.02 \mathrm{~mm}$ breit, am Rande gestreckt, einen einreihigen Saum bildend. Schopfblätter grösser, eilanzettlich, zugespitzt, bis 2,5 mm lang und 1,3 mm breit, mit am Grunde umgebogenen Rändern; Rippe 
vollständig bis kurz austretend. Seta 2-j cul, dlüm und geschlängelt, rot. Kapsel lrängend, mit dem kuryen, wenig verengten Halse walzenförmig. 1,5-2,5 nm lang und 0,9-1.2 mu dick, rötlich, zuletzt weinrot, derbhäutig, trocken unter der Vündung wenig verengt. Peristomzähne bis $0,5 \mathrm{~mm}$ lang, mit breitem, gelhbraunem, abgerundetem Fundus mol etwa 15 Lamellen. Inneres Peristom den äusseren anlängen(l, gell), Jein papillös: Fortsätze ritzenförmig durchbrochen: Wimpern rudimentär. Deckel gewölbt, mit dicker. scharfer, oft sehiefer Spitze. Sporen 2.5 - $30 \mu$. Sporenreile im Juli und August. - Fig. $50 \mathrm{~L}-\mathrm{MI}$.

Aul l'euchten Sanclplätzen. besonders im Sande tler Flüsse.

F. Lt. Pummanki, an Flussufer massenhart.

N. No. Alstahaug und Bejeren. F. Kistrand.

Tord-Russland. Sibirien. Grönland. Nordgrenze bei etwa $70^{\circ} 30^{\prime}$.

* Bryum acutiforme (Limpr. et Ryan) Amann Fl. monss. Suiss. p. 202 (1!12). [Bryum aculiforme limpr. et Ryan in Hag. Ilusc. Norv. bor. p. 156 (1901).]

Kapsel aus dem Halse von Urnentänge plötzlich dicker und von der llitle gegen die Iründung verengt. Peristomzähne nit braunrotem, noch weiter abwärts breiterem Fundus und dichter gestellten Jamellen. Decke] niedrig und stumpfwarzig. Sporen lis 10 ". Sonst wie hei der Iauptart.

N. Yo. Bejeren. Vold. F kistrand bei smör-lad und lellanalus in dem früllings über-chwenumten sande des Fluses Lakselven

spilzlergen. sibirien. und Grönland.

* Bryum AxelzBlyttii (Kaur. in scheel.: Philib.) Amann l. c. (Bryum AxelBlyltii Philib. in Rev. bryol. 1889. p. 61.)

Sprosse kupferrot. Blüten gijfelständig auf einem tief geiegenen Seitenaste. Kapsel kurzhalsig. plötzlich dicker und von der Nitte gegen die Mündung verengt: Zellen ves Exotheciums enger, mit weniger verdickten, leicht verbogenen Wänden. Peristomzähne mit sehr schmalem, tiefrolem, in eine kurze, rosenkranzfömige Zellenreihe herablaufendem fundus und dichter gestellten Lamellen. Deckel hoch und spitz. Sonst wie bei $B$. aculum.

N. Dorre. $H$. Foldalen, an sandigen tTer des Mellung-bekken. No, und $F$. an einzelnen Fundorten.

3. Inclinatiformia Broth. in Engl-Prant] Brval. p. 569 (1903).

Blätter zugespitzt. am Rantle = umgehogen, gesäunt: Rippe kräftig, meist

lang austretend: Basalzellen rot. Kapsel regelmässig. Peristom nahe tler Mïn(lung inseriert: Jeristmmzähne (excl. Br. archangelicum) holodont, mit glatten Rändern und schmalem, unten nicht gut begrenztem, rotem bis orangefarbenem Fundus: Dorsalsehicht ohne Strichelung.

383. Bryum archangelicum Bryol. eur. lase. 32, p. 1. t. suppl. 1 (1846). [B. IJolmgrenii Lindll. Muse. scand. p. 17 (1879).]

Synözisch. auch ₹7, seltener 千 Blüten. Schlanke Pfl. in meisl lockeren, bleichgrïnen Rasen. Stengel nur (inige mm. schopfig beblättert. mit kurzen, schopfig heblätterten subfloralen Sprossen. Schopfblätter trocken locker anliegend, feucht aulrecht-abstehend, ei- oder länglich-lanzettlich. bis $1,9 \mathrm{~mm}$ lang und bis $0,6 \mathrm{~mm}$ hreit. mit flachen oder schmal umgebogenen Rändern: Rippe in eine lange und leine Granne auslaulend: Zellen an Rande gestreckt, einen 1-2reiligen, gelben Samm hildend. Seta $1-1, \bar{j}$ ('m. hraunrot. Kapsel nickend bis hängend, aus dem Halse von halber Unenlänge eiformig. elwa 2 mm lang und bis 1,2 mm elick. gelblich-ofler rötlichbraun, frocken und entleert unter der Mündung nieht verengt. l'eristomzähne aulacodont, gell), bis 0,3 mm lang, mit 10-12 Lamellen. Inneres Peristom getbilch: Forlsïtze schmal, ritzenlörnig durchbrochen: Wimpern meist lehlend oder rudimentär. I)eckel flach gewöbt, mit winziger Papjlle. Sporen 2.) $80 \mathrm{M}$. rostfarben, lein papillïs. Sporenreile im Juli. 


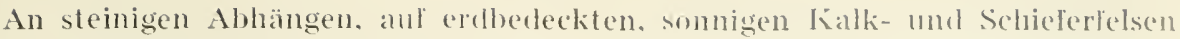
und in Felsenritzen.

F. Lkem. Kenijärvi, Kitinen (Broth.). - Li, ohue nahere Angabe (E. Nyl.). Utujuki. Jalgetvalgl. Budusvarre (Ranck.). - Lim. Hibina (Angatr.). Lt. Kola. Karaulnajal L'ahtil (Bmoll.). - I.mur. Ain Olenkaflusse (B.)

S. LuL. Nammats: sarekgebiet.

N. K. Dovre, Jotunfjeldene und Loureggen NT. Stjordalen. Tr. Tordrejsen.

Alpengebiet, arkt. Sibirien, Nord-Anerika.

384. Bryum Joergensenii Kaur. in Christian. Vidl. Setsk. Forh. 18!1, No. s. p. $82(1895)$.

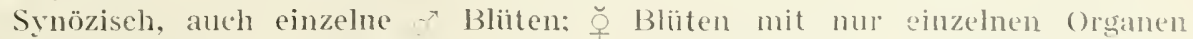
des eines Geschlechtes. Niedrige, locker-bis dichtrasige l'll. Schoplbuatter aus länglieh-eiförnnigem Grunde lanzettlich, bis 2 mm lang und $0 . \overline{6} 6$ mu breit. mit meist längs schmal umgebogenen Rändern: Rippe lang austretent: Zetlen oberwärts 40-50 $\mu$ lang und 12-14" breit, an Rancle gestreckt, einen 1-2reihigen, gelblichen Samm bildend. Seta bis $1,5 \mathrm{~cm}$, braunrot. Kapsel hämgend, mit dem Halse von halber Lrnenlänge dick hirnförmig, etwa $2 \mathrm{~mm}$ lang und $1 \mathrm{~mm}$ (lick. rötlichbraun, trocken unter der Mündung nicht verengt. Peristomzähne gell,. etwa 0.3 mm lang, mit 10-12 Lamellen, ohne Perforationen. Inneres Peristom gelblich: Fortsätze sehmal, ritzenförmig durchbrochen: Wimpern oft gut entwickelt. Deckel flach gewölbt, mit Warze. Sporen etwa $30 \mu$, gelblich, glatt. Sporenreife in der zweiten Hälfte Juli.

Hauptsächlich an Uferfelsen, gem an leicht verwittematen, = kalkhaltigen Gesteinen.

N. An mehreren Fundortes in $\mathrm{Yo}$., $T r$. und $F$.

385. Bryum autoicum Arn. in Rev, hryol. 1899, p. 22.

Autöziseh; $\rightarrow$ Blüten an kurzen, subfloralen Sprossen. Pli. herdenweise oder in niedrigen, lockeren Rasen. Stengel sehr kurz. Blätter trocken knospenlörnig anliegend, eiförmig, ziemlich lang zugespitzt. ungesäumt. nit zurïekgebogenen Ränclern: Rippe als Stachelspitze austretend: Zellen oberwärts mregehmässig rhomboidisch-6seitig, 35 t5 " lang und etwa $13 \mu$ breit. Seta etwa 1 rm, rot. oberwärts gelblich. Kapsel nickend bis hängend, mit dem Halse von etwa halber Crnenlänge dick birnförmig, $1,8 \mathrm{~mm}$ lang und $0,9 \mathrm{~mm}$ dick, gelb, dünnhäutig, trocken und entdeckelt unter der Mündung nicht verengt. Peristomzähne $0,26 \mathrm{~mm}$ lang, gelb, schmal gesäumt, mit etwa 12 Lamellen. Inneres Peristom dem äusseren leicht anhängend, schwach gelblich: Fortsätze schr schmal, ritzenförnig durchbrochen: Wimpern lehlent. Deckel klein, flach, mit winziger Warze. Sporen $30-33 \mu$, selnuutzig-gelb, papillös. Sporenreife im Angust.

N. No Salten, Junkersdalen, Baadfjeld.

386. Bryum lacustre Bland. Musc. exs. fase. III. No. 132 (1801).

Synözisch. Schlanke Pfl. in lockeren, lebhaft hellgrünen Rasen, atch herdenweise. Stengel $0,5-2,5 \mathrm{~cm}$, mit dicht beblätterten, fast kätzchenartigen. subfloralen Sprossen. Schopfbläter grösser, aus etwas versehmälerter Basis eiförmig und länglich-eiförmig bis last lanzettlich, kurz- und scharlspitzig, 1,5- 1.7 mm lang und $0,7-0,9 \mathrm{~mm}$ breit, mit ungerollten, ungesäumten oder sehmal gesäumten Rändern: Rippe meist mit der Blattspitze endend: Zellen oberwärts 36 - 0 " lang und $12-18$ " breit. Seta bis $4 \mathrm{~cm}$, selten länger, dün, rot. Kapsel nickend oder hängend, klein, aus kurzem Halse eiförmig oder länglich-eiförmig, $1,5-2,5 \mathrm{~mm}$ lang und bis $1 \mathrm{~mm}$ dick, dümnhäutig. gelb, entfleckelt lichtbraun, mit dunklerem, runzeligem Halse, trocken unter der Mündung nicht verengt. Peristomzähne hełlgelb, bis $0,40 \mathrm{~mm}$ lang; Lamellen 25 und mehr. Inneres Peristom getblich: Grunclhaut sehr niedrig; Fortsätze fensterartig durchbrochen. Deckel klein, kurz kegelig. Sporen $18-25 \mu$, grün oder gelbgrün, fein papillös. Sporenreife schon Mitte Mai, ron August bis Oktoher zum zweiten Mal. 
In feuchten Sandausstichen.

F. Al. Saltvik, an wengen Fundorten (Bom.). Sund. Bomarsund (B.). - Ab. Pargas, Ålön, Parıl)y gruva, massenhafl auf Iialkdetritus (Brotb.). - N. Helsingfors, Fredriksberg (Lindb.). - Ta. A ikkala. Lrajärvi (Norrl.). - Kl Uukuniemi (Simm.); Sortarala, Liikalanmäki (Lindb.) - Ob liemi Kallinkangas (Brenn.). - $K$ Ǩuusamo, Ilaataja (Bloth.): Ylikithajärví, Jäkäläinen (B.); zw. Virranniemi und Ojala (B.); zw. Martıila und Valtula (B.); Kecälahti (B.). - Lkem. Kolari, Huuki (Norrl.). Kittilä, Levitunturi (Hult). - Le. An wenigen Fundorten in der Kjefernregion (Norrl.); Vittanki in der Birkenregion (N.). - Lim Joknstrov (Broth.) — Lp Triostrova (Kihlm.). Ponoj (Sahlb.).

S. Sm.. $\mathrm{Vg}, B o h ., J m t$. und $\mathrm{V} b$ an wenigen Fundorten.

N. Sm. Onso. K. Lomseggen No.-F. an einzelnen Fundorten.

West- und Zentral-Europa, Sikkim. Amur. arkl. Nord-Amerika.

387. Bryum murmanicum Broth. in Act. Soc. Faun. Fl. Fenn. VI. No. 1. p. $58(1890)$.

Synözisch. Schlanke Pfl. in ziemlich lockeren, lebhaft grïnen, ahwäts schwärzlichen Rasen. Stengel bis 1 ('m, schopfig beblättert, mit bis 1,j cm langen, locker bebläterten subfloralen Sprossen. Schopfblätler trocken locker anliegend, feucht abstehend, ei-oder länglich-lanzettlich, kurz zugespitzt, bis 2,5 mm lang und bis 0,8 mm breit, mit umgerollten Rändern: Rippe als oft zurïckgebogener, \pm langer Stachel austrelend: Zellen an kande gestreckt, einen 2-3reihigen, gelben Sann bildend. Seta bis $3 \mathrm{~cm}$. düm, rot. Kapsel nickend. aus deutlich abgesclztem Halse von Lrmenlänge ]änglich, elwa $2 \mathrm{~mm}$ lang und $1 \mathrm{~mm}$ dick, dümnhäulig, lichtbraun, trocken unter der Münclung nicht verengt. Peristomzïhne hellgelb, ctwa 0,33 mm lang, mit 10 12 lanellen. Inneres Peristom gelblich: Grundhaut elwa 1/3 der Zähne; Fortsätze lensterartig durehbrochen. Beckel tlach, trocken oft konkar, mit scharfer Spitze. Sporen elma 25,4 , grim, fein papillös.

F. Lmur. Am sandigen $\mathrm{C}^{\mathrm{f}} \mathrm{er}$ des Flnses Harlofka (Brolh.).

388. Bryum gilvum Hag. Mluse. Norv. bor. p. 161 (1901).

Polyözisch; meist autözisch, zuweilen auch or Pfl. Herdenweise wachsende. in Sancle vergrabene, oben gelbe, abwärts schwärzliche Pll. Stengel 1,j c’m, schopfig beblättert, nit einzelnen subfloralen Sprossen. Blätter breit eiförnig, stumpl oder spitz, kurz zugespitzt. bis $0.91 \mathrm{~mm}$ lang und $0,72 \mathrm{~mm}$ breil, mit bis zur Mitte zurückgeschlagenen Rändern: Rippe krältig, vor der Blaltspitze aulhörend: Zellen dünnwandig. in der Blatunitte $5: 3-60 \mu$ lang und $2: 3 \mu$ breit. am Rande gestreckt, einen 1-2reihigen, undeutlichen Saum bildend. Sela $1-2$ cm, liraunschwarz, oben braunrot. Kapsel geneigt his hängend, aus deutlich abgesetzlem Halse von halber Truenlänge dick oval, bis 2,1 mm lang und etwa 1 mm dick, lichtluaun. trocken unter ler Mibidung aicht verengt. Peristomzähne dunkelbramngelb, bis (1,36 mm lang, mit 16 -20 Lamellen. Inneres Peristom gelb; Fortsätze lnear, mit elliptischen bis ovalen Ölfnungen; Wimpern kurz, gewöhnlich ohne Anh:ingsel.

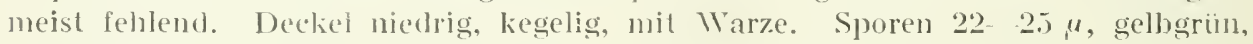
fast glatt.

N. F. Fistrand, Mellanalus reichlich anf den ausgelaufenen Quichsandursisen.

389. Bryum globosum Lintl). in Öfrers. K. Sv. Vet.-Akat. Förl. 1866. p. 5.15 .

Synäzisch. Schlanke l’ll. in festen, gelbgrimen, innen brännlichen läischen. Stengel 5-1.j mm, dicht beblältert, mit kurzen, schlanken, oberwärts last kätzchenartigen subfloralen sprossen. Blätter fast aulrecht, oval, scharl zugespitzt, bis 1,5 mm lang und 0,9 mun breit, mit bis ïber die Mitte zurückgebogenen Rändern: Rippe bei den unteren Blätern vor der Blaltspilze cndend, bei den oberen als kurze, efwas zuribligebogene spitze austrelend: \%ellen locker, dïnnwandig.

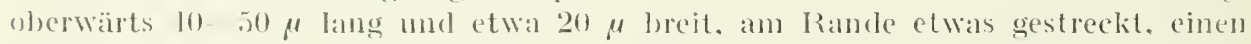
1 -greihigen Saum bililend. Seta i 15 mm, schr dïm, rot. hapsel hïngend, klein, kur\% und dick birnfömig, lilemümdig, dïmnläutig, rot, lrocken unter tler Jïnrlung nicht verengt, wegen les selu verengten Halses kugelig und etwas glän- 
zend. Peristomzähne hellgelb, bis $0,30 \mathrm{~mm}$ lang; Lamellen bis 16 . Imneres Peristom gelblich: Grundhaut sehr niedrig; fortsätze ritzenlörmig durchbrochen. Deckel klein, niedrig, mit 7itze. Sporen $18-20 \mu$, bräunlichgrün, lein warzig.

N. Tr. Nordrejsen, Javvreoaivve, auf nachter, aus Schieferdetritus gebildeter Erde in der Weidenregion, $69^{\circ} 32^{\prime} \mathrm{n}$. Br.

Arkt. Nord-Amerika, Spitzbergen, arkt. Sibirien

390. Bryum Limprichtii Kaur. in 130t. Notis. 1886 , p. 87.

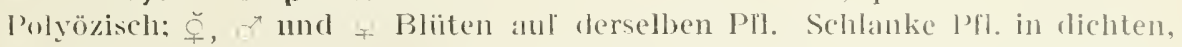
1-2 cm hohen. Ireudig grünen, innen bräunlichen und mit Schlannm durchsetzten Rasen. Fertile Sprosse kurz sehopfig beblättert, sterile verlängert und gleichmässig beblättert. Schoplblätter aufrecht, sehr hohl, breit aifömig, kurz zugespitzt, bis 1,2 mm lang und $0,9 \mathrm{~mm}$ breit, llach- und ganzrandig, ungesitumt; Riple in den unteren Blätter vor der Blattspitze endend, in den oberen als et was zurückgebogene Stachelspitze austretend; Zellen sehr dünnwandig. Seta 1 cm, rot. Kaj)sel nickend oder hängend, mit dem kurzen Halse verkehrt eilänglich oder dick birnförmig, etwa $2 \mathrm{~mm}$ lang und 1,2 $\mathrm{mm}$ dick, lichtbraun, trocken unter der Itündung nicht verengt. Peristomzähne bleichgelb, 0,35 mm lang, mit 15-18 Lamellen. Inneres Peristom gelblich: Fortsätze schmal, ritzenförmig durhbrochen: Wimpern lehlend. Deckel klein, flach, mit winziger Warze. Sporen 18 $22 \mu$, gelbgrïn. leinwarzig.

S. LuL. Sarekgebiel.

N. Dovra, Knudiho. an nasen Felsen, $1.600 \mathrm{~m}$. IT. Saetersdalen, lleienfjeld. F. Karasjok, Rastegaisse (Kaurin).

391. Bryum Lorentzii Schimp. Syn. ed. 2, p. 113 (1876).

Synözisch. Pfl. in dichten, gelblichgrünen, durch schwarzroten Rhizoidenfilz verwehten Rasen. Stengel kurz, mit längeren subfloralen Sprossen. Schopfblätter weit herablaulend, verlängert länglichlanzettlich, lang zugespitzt, bis $3 \mathrm{~mm}$ lang und his $1,6.5 \mathrm{~mm}$ breit, mit in der unteren Hälfte ungebogenen Rändern: Rippe als lange Stachelspitzo anstretend; Zellen an Rande gestreckt, einen 1-6reihigen Saum bildend. Seta 2-3 cm. Kapsel hängend, mit dem kïrzeren Halse verkehrt eilänglich, gelbbräunlich, trocken unter der Mïndung nicht oder kaum verengt. Peristomzähne oberhalb der llitte rasch pfriemenförmig, gell, etwa 0, 15 mm lang, mit etwa 22 Lamellen. Inneres Peristom an Gruncle anklebend: Fortsïtze lang pfriemenförmig. ritzenförmig durchbrochen bis breit klaffend: Wimpern rudimentär oder lehlenı. Sporen 2:3-27 $\mu$, rötlichgelb.

N. No Bodin, Bodimyren.

302. Bryum proprium Hag. Mluse. Norv. hor. p. 135 (1901).

Synözisch. Ziemlich sehlanke Pfl. in lockeren, grünen oder gelbgrünen, bald schwärzlichen Rasen. Stengel etwa 1 am, mit spärlichem Rhizoidenfilz, abwärts locker, oben dicht und schopfig beblätlert. Blätter \pm weit herahlanfend. Schoplblätter trocken anliegend und geschlängelt oder gedreht, aus eng ovaler Basis lanzettlich, allnählich lang zugespitzt, bis $3,2 \mathrm{~mm}$ lang und bis $0,7 \mathrm{~mm}$ breit, mit last his zur Spitze selmmal ungebogenen Ränclern: Rippe als Stachel austretend: Zellen der herablaulenden Blattecken eng rektangulär, an Rande gestreckt, einen etwa treihigen Saum bildend. Seta 2.5-3 cm, gelbrot. Kapsel niekend, selten horizontal oder hängend, mit dem etwas gekrummten Halse fast von Lrnenlänge verkehrt-kegelig, etwa 1,7 $\mathrm{mm}$ lang und 1,1 $\mathrm{mm}$ dick, bräunlichgelb, trocken und entdeckelt unter der Mündung nicht verengt. Peristomzähne gelb, nil gelbrotem Fundus, 0,35 mm lang, mit 16-18 Lamellen. Inneres Peristom frei, hyalin oder gelblich, last glatt; Grundhaut durchl,rochen; Fortsätze schmal, ritzentörmig bis eng elliptisch durchbrochen; Wimpern rudimentär ocłer lehlend. Decke] llach gewölst, mit Warze. Sporen 33-10 $\mu$, rostfarben, fein pajillös.

N. F. Kistrand, Borselven. 
Bryum proprium schliesst sich nach $\mathrm{H}$ age $\mathrm{g}$ vielleicht dem $B$. Lorentzii ann nächsten an. Es hat indessen in den rektangulären Zellen der herablaufenden Blattecken ein Nerkmal das den Inclinatiformia ganz. fremd, aher den $B$. pallentia, $B$. cyclophyllum und $B$. arcticum eigentümlich ist.

393. Bryum litorale Ryan et Hag. in Kgl. Norsk. Vid. Selsk. Slirift. 1s96, No. 1, p. 108 (1896).

Heterözisch: ఫ̆ und zalılreiche ${ }^{\prime}$ Blüten, letztere auf kurzen, knospenförmigen subfloralen Sprossen. Pll. in dichten, bis 3 cm hohen. spärlich verfilzten, oberwärts grimen Rasen. Schopfblätter lerablaufend, anfrecht-abstehend bis abstelend, liohl, eiförmig-oval, rasch in eine zurückgelogene Spitze verschmälert, bis t,s mm lang und $0.7 \mathrm{~mm}$ breit, undeutlich gesänmt, mit am Grunde zurückgebogenen Rändern: Rippe kräftig, als Granne austretend: Zellen oberwärts rhombisch6seitig. Seta etwa 1 cm. gellorot. Kapsel nickend bis hängend. mit dem Halse von Urnenlänge $2,25 \mathrm{~mm}$ lang und $0.65 \mathrm{~mm}$ dick, bräunlich, trocken und entdeckelt unter der Mündung nicht verengl. Peristonzähne blassgelb, 0,23 mm lang. mit etwa 16 Lamellen. Inneres Peristom frei, sehr zart, hyalin; Fortsätze seln schmal, last ladenförnig zugespitzt. undeutlich ritzenfömig flurchbrochen; Wimpern fehlend. Deckel klein. stumpf kegelig. Sporen 20-26 4 , braungelb, papillös. Sporenreile in Juni.

N. Sm Onsw, Store Marnet am Meeresufer und Foden in Fel.enritzen. F Maaso, Harosund. Nessehy, Bergeby, auf lraunem Tonschiefer.

391. Bryum boreum Hag. Musc. Norv. bor. p. 228 (1901):

Synözisch. Herdenweise oder einzeln wachsende pfl. Stengel •twa is mu, nit zahlreichen, kurzen, knospenförmigen subfloralen Sprossen. Schopfblätler nicht herablaulencl, aufrecht, trocken olıen stark geschlängelt, eiförmig oder aus eilörmiger Basis kurz lanzettlich, etwa 1,5 $\mathrm{mm}$ lang und $0,50,56 \mathrm{~mm}$ breit, ungesämmt, mit schmal umgebogenen Rändern: Rippe ziemlicli lang austretend; Zellen oben : 1 - 50 "lang und $14-20$ " breit. Setat $12 \mathrm{~mm}$. Kapsel fast hängend. birnförmig, etwa $1,7 \mathrm{~mm}$ lang mol $1 \mathrm{~mm}$ dick, gells, später braungelb. trocken unter der Mhindung nicht verengt. Peristomzälne $0,36 \mathrm{~mm}$ lang, braungelb, mit 14-16 niedrigen Lanellen. Fortsätze oval gefenstert: Wimpern rudinentär oder fehlend. Deckel niedrig, kegelig, stumpf ocker mit Warze. Sporen $18-20$ ", sehr lein punktiert. Sporenreife in August.

N. Tr. Maalselven, Vabrunen.

395. Bryum inclisatum (Sw.) Bryol. eur. fasc. 6/9, p. 17, t. 3 (1839). [Pohlia inclinata Sw. Inusc. Suec. p. 1.5 ot 96. i. V. fig. 11 (1799). Bryum lumidum Bomans, in Rev. loryol. 1899, p. 11.-- B. insulurnm Bomans. in Act. Soc. F. Fl. Fenn. ivlll. No. 1, p. $82(1900)$. B. Brotheri Bomans. in Rev. bryol. 1903, p. s6.1

Sỵözisch, selten polyörisch. Ziemlich schlanke Pfl. in dichten, gelblichgrünen, durch Rhizoidenfilz dicht verwebten Rasen. Stengel 0,5-2,5 cm, dicht und schopfig beblättert, mit kurzen subloralen Sprossen. Sehoplblätler trocken andiegend, feucht aulrecht-abstehend, verlängert lanzettlich, 2,5-3,5 mm lang und 10.9- $1 \mathrm{~mm}$ breit, mit bis zur Spitze umgerollten, oleerwärts meist spärliclu gezïhnten lämbern: Rippe als I lange, gezahnte Granne amstretend: \%ellen uberwäts etwa 50 lang und 12-15 " breit, am Rancle gestreckt, einen :" treinigen. gethlichen Saum bildend. Seta meist 2,j- : ('m, rot. Kapsel nickend oder hängend, aus ziemlich kurzem Halse eiförmigs, länglich oval his fast zylindriscle, 2,5--3 mm lang und elwa 1 mm dick, branm, trocken unter der Mündung etwas rerengt. l'eristonzähne gell), (0,30-0.36 $11 m$, mit 11 - 18 Lamellen. Inneres Peristom gelblich, papillös; Fortsätze unten hreit lenslerartig durchbrochen. Deckel kilein, flach his kurz kegelig mit Warze. Sporen $18-25 \mu$, gellogrün oder brämulichgedb. leinwarzig. Sporenreife im Sommer. - Fig. 50 G- lJ. S. 
In fenchten Sandausstichen und Gräben, an Wegrändern und aul erdbedeceten Felsen.

F. Al. Echerö, Storby, Marby und Tory (Bom.). Jomala, Kirchdorf, Inghy und Ylternäs (B.). Lemland, Nåtö (B.); Styrsö (Broth.). Saltvik an vielen Fundorten (Bonı.). - Ab. Kimito, Ganmelby (Olヶ.). Lojo, storön (Lindb.), - N. Ekenäs, Träminne (Ranck.). Ingå, Elisö) (WV. Bresn.). Helsingfurs: (Broth.). Sibbo, Brunskär (B.). Hogland (Lindb.). - St. Bjömelorg (Graeft.). Sastmola (Karst.). - Ta. Asikkala, Mustaniemi (Broth.). Sysmà (Thur.). - Kl. Valano (IV. Nyl.). - Oa. Vasa, in den Schären an mehreren Fundorten (Broth.). Rephot, Valsüren (B.). - Sb. Kaavi, Siikajärvi. Likncaari (Kont.). - Om. Alajärri, Ojajärvi (Backm.). Kalajoki, Kainunkari (Tenı.), - K. Kuusamo, zw. Marılila und Vattula (Broth.); Ylikitkajărvi, Tolva (B.); Kitkajoki. Jumna (B.); Paanajärvi (B.): Sovanköngäs (B.). - Lkem. Muonio (Sahlb.). - Le. Mukkavuoma in der Birkenregion (Norrl.). - Li. Inari, Sakatinpahta (I Uutt). - Lim. Fedosersk (Broth.). Kandalaks (Sahlb.). Lujatur-sijt (Kilılm.). - Lt, Srednij an Folahusen (Brolh.). Vaidoguba und zw. Vaidoguba und subovi (Brolh.). Kitovka (Fellin.). Lmur. An Olenkafluse (Broth.). Semjostmrsk und Rinda (B.). - Lp. Triostrova (Kihlm.). Ponoj (Brenn.). - Le. Tschapoma (Broth.).

S. Sk., Öl., Śm., Gll., Ög., När., Upl., Vrml., Gsir., Mpd., Jmt., Ang., LuL.

N. Sm., Bu, JL., NB., K., No., Tr., F.

Europa, Algier, Laukasus, Persien, Sibirien, Japan. Nord-Anerika.

var. stenotheca (Bom.). (Bryum stenotheca Bom. in Rev. bryol. 18919, 1). 10.)

Unterseheidet sich von der Hauptart nur durch etwas breiter gesüumte Blätter und schmätere Kapsel.

F. Al. Saltvik, Haga Norrholmen, am Meeresufer (Bom.). Eckerö. Högیkärsören, in Felsenrilzen (Ranck.). Kökar. Lindö, Yảtsharu und Karllyy (Ranck.).

var. rimosum Hag. Muse. Norv. loor. p. 1:30 (1901).

Kapsel kïrzer und bleicher. Fortsïtze des inneren l'eristom ritzenlommig durehbrochen.

Auf trockenen Lterwiesen zw. Gras in ausgedehnten, reichlich fruchtenden Rasell.

N. No. Saltdalen, zw. Hals und Rognan. Strfolden, Stromsnesset. Tr. Skjervn. Kristrand.

var. hyperboreum Joerg. in Christ. Vid.-Selsk. Forh. 189. I, p. 83.

Fortsätze klaffend. Sporen $25-30 \mu$.

N. $T r$. Nordrejsen. Shjervo, am Meeresufer.

396. Bryum trichopodium Hag. Mhse. Norv. bor. p. 131 (1901).

Svnözisch. Ziemlich kräftige Pfl. in dichten, durch Rhizoidenfilz verwebten, grünen odter gelbgrïnen Rasen. Stengel etwa $1.5 \mathrm{~cm}$, dicht und schopfig beblättert, mit liurzen subfloralen Sprossen. Schopflüäter trocken anliegend, feueht aufrecht-abstehend, eilanzettich, = lang zugespitzt. bis '..9 mm lang und $1 \mathrm{~mm}$ breit. mit längs und oberwärts schmal umgebogenen Rändern; Rippe austretend: Zellen am Rande gestreckt, einen mehrreihigen Sam bildend. Seta 2,5 cm. sehr cłün, rot. Kapsel nickenal bis fast hängend, feueht hängend, mit dem Halse ron halber Crnenlänge verkehrt-eilörmig, 1,8 $\mathrm{mm}$ lang und $0,8 \mathrm{~mm}$ diek, gelbbraun, trocken runzelig und unter der Mündung kaum verengt. Peristomzähne gell, $0.3 \mathrm{~mm}$ lang, mit etwa 16 Lamellen. Immeres Peristom fast frei, hyadin; Fortsätze gefenstert: Wimpern rudimentiir. Deekel aus flach gewölbter Basis scharf zugespitzt. Sporen 15-21 $\mu$, gelbgrïn, glatt.

N. F. an Meeresufer der Insel Loppen.

Von Bryum inclinatum durch kïrzer zugespitzte Blätter mit etwas grösseren Zellen, sehr dünne Seta, die Ausbildung der Peristome, durch den sehärfer zugespitzten Deckel und die kleineren, glatten, gelblichgrünen Sporen untersehieden.

397. Bryum Kaurinianum Warnst. in Hedwigia 1882, No. 2.

Synöziseh. Ziemlich schlanke Pfl. in dichten, grünen, im Alter schwärzlichen, dureh Rhizoidenfilz dicht verwebten Rasen. Stengel bis 1.5 cm. dicht und sehopfin beblättert, mit kurzen subfloralen Sprossen. Schopfb]ätter breit eilanzettlieh. zugespitzt, etwa $2,1 \mathrm{~mm}$ lang und etwa $1 \mathrm{~mm}$ breit, mit läng umgehogenen Rändern: Rippe als lange Grame austretend; Zellen dickwandig. an Rande gestreckt. cinen 2-3reihigen, bräunliehgellen Saum bildend. Seta 1-1.5 cm, rot. Kapsel 
nickend, nit dem kurzen, deutlich alogesetzten Halse birnförmig, bis :) mm lang und $1.5 \mathrm{~mm}$ dick, lichtbraun, trocken unter der llündung schwach verengt. Peristonzälne ans breiterer Basis allnählich verschmälert, bräunlichgelb, kaum bis $0,3 \mathrm{~mm}$ lang und $0,028 \mathrm{~mm}$ breit, mit etwa 1.5 Lamellen. Inneres Peristom anklebend, gelb; Fortsätze fast gefenstert; Wimpern kurz. Deckel klein, flach gewölbt. mit Warze. Sporen $3035 \mu$, grünlichgelb, feinwarzig.

F. Al. Saltvik, Haga, Yorrholmen am Ufer.

N. Nach Hagen im arktischen Nurwegen, hauptsächlich an den Fjord- und Meeresufern sowohl an grasigen Stellen als in erderfülten Felsenritzen. gern auf kalkhaltiger Unterlage sehr verhreitet. Dorre.

398. Bryum grandiflorum Arn. in Rev. bryol. 1899, p. 36.

Heterözisch: Pll. in - dichten, grünen oder gelbgrünen Rasen. Stengel j-1.5 mm, nit Rhizoidenfilz, dicht und schopfig beblättert, mit kurzen subfloralen Sprossen. Schopfblätter trocken locker anliegend, nicht gedreht, feucht aufrecht-abstehend, breit eilörmig, ziemlich lang zugespitzt, bis $2,5 \mathrm{~mm}$ lang und $1.1 \mathrm{~mm}$ breit. mit längs schmal umgebogenen Rändern: Rippe als . lange Grame austretend: \%ellen am Rande meist gestreckt, einen 1 -3reihigen, zuweilen undeutlichen Saum bilclend. Scta etwa 2 cm, gelblichrot. Kapse\} hängend, aus dem Halse von Lrnenlänge oval oder verkehrt-eiförmig, lis :3 $\mathrm{mm}$ lang und etwa $1 \mathrm{~mm}$ dick, lichtbram, trocken unter der Jiundung verengt. P'eristomzähne gelb. bis $0,40 \mathrm{~mm}$ lang, mit etwa 20 lamellen. Inneres Periston gelblich: Fortsätze schmal, ahwärts gefenstert, oberwärts ritzenförmig durchbrochen: Wimpern rulimentär. Deckel klein. hochgewölbt, mit Spitzchen. Sporen $24-27 \mu$, grün, spärlich papillös.

An Meeresufern.

F. Al. Sallvik, Hăga. Brăndskär (Bom.). Kökar. Karlby, Malsharu (Ranck.).

S. Gstr. am Meeresufer nicht selten

399. Bryum Bryhnii Hag. in Kgl. Xorsk. Vid. Selsk. Skrilt. 1908, No. ¿3, J. 13 (1908).

Antïzisch. Pll. in elichten lis sehr dichten, bis etwa 1 am hohen, grïnen oder bräunlichgrïnen, thrch reichlichen Rhizoidenfilz verwebten Rasen. Stengel mit kurzen, dicht gestellten, schopfig beblätterten subfloralen Sprossen. Schopfhlätter trocken anliegend, geschlängelt, feucht last anfrecht, eilörmig oder oval, allmählich mässig lang zugespitzt, ełwa 2 mu lang und his $0.7 \mathrm{~mm}$ breit, mit längs zurückgeschlagenen Rändern: Rippe kräftig. als mässig lange Granne austre-

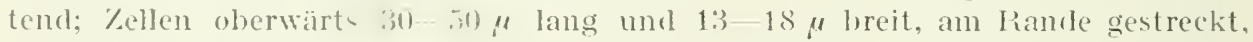
einen 1 jreihigen Sam bilkend. Seta 2 .3 cm, gelbbraun. Kapsel fast anfrecht, selten geneigt, keulenförmig, mit verkehrt-kegeligem Halse von etwa halber Uruenlänge. etwa $3.8 \mathrm{~mm}$ lang und $1.3 \mathrm{~mm}$ dick, gelbbräumlich, trocken unter der Ifün(lung nicht verengt. Peristomzähne hlassgell), etwa 0.5 mu lang, mit etwa 24 in der litte breit, jecloch nicht tiel eingedrückten Lamellen. Inneres Peristom frei. hyalin: Fortsätze mit fast runden Öfnumgen; Wimpern vollständig. knotig oder nit kmren Anhängseln. 1)eckel kegelig, mit Spitzchen. Sporen etwa 18 ". gelbgrim. fein papillös.

N. JL. Hof, Ejd-fos, in Felsenritzen am Lfer des Ekern.

400. Bryum Hagenii Limpr. Laubm. 11. p. 335 (18!)2). (Bryum leplocercis l'hilib. in Rev. bryol. 189.1, p. $86 . \quad$ B. contructum Bomans. in Rev. brvol. 18!9!, p. (9.)

Synözich. Yiemlich krältige Pfl. in dichten. oben grünen, am Gruncle durch Rhizoilenfil\% verwebten Rascn. Stengel 12 cm, schopfig beblättert, mit kmrzen subloralen sprossen. Blätter besonelers an den subfloralen sprossen dentlich herablaulend. Schopfblätler trocken locker und verbogen anliegend, feucht aulrecht-abstehend, lineal-lanzettlich, sehr lang und schmal zugespitzt, bis 1 mm lang und bis 1 mm breit, mit längs sehmal mmgehogenen Rändern; Riple als kräftige 
Granne lang austretend: Zellen am Rande gestreckt und verlickl. cinen :3-6reihigen, gellen Satm bildend. Sela 2,j-i cm. dünn, rot. Kapsel nickend bis last luängend. mit dem Halse von I'rnenlänge verlängert kenlenförnig. ?, ; ; mm lang und 1 mm dick, rötlichbraun, trucken unter der Mündung wenig rerengt.

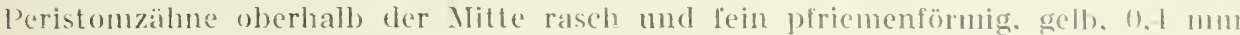
lang, mit etwa 1.j Lamellen. Inneres Peristom gelt) Fortsätze breit gefenstert: Wimpern rudimentär. Deckel klein. llachgewölst, mit Spitzclsen. Sporen 220-30) $\mu$. grün, leinwarzig. Sporenreife im August.

Auf griesiger und steiniger Frde am Meeresuler und in feuchten felsenritzen.

F. Al. Jomala, zw. Yuternäs und Mariehamn (Ranck.). Sallvik. Germundö, südernäs (Ranck.) Lafö (Bom.): Libỵ berg (B.). Kökar. Karlby (Ranck.). - N. Kyrkslält, Porkala. Träskön (Brotk.). Sibbo. Räsholmen (Broth.).

S. Ing. Säbrá, Vägnön.

N. Ne. Tromo, ST. Sognedalen. Praesthus, etwa $100 \mathrm{~m}$. Sim. Tune. No. Bondir. Bodunyren

t. Haematostoma Hag. Musc. Norr. bor. p. 141 (1901).

Blätter zugespitzt, meist gesäumt und mit - ungebogenen Rändern: Rippe kriftig. meist - lang austretend: Basalzellen rot. Peristom meist tief inseriert: Zähne sehr oft aulacodont ausgehildet, nath unten gewöhnlich dureh eine Bogenlinie begrenzt, mit breitem, dickem, tiefpurpurnem, nur selten gelbrotem Fundus.

101. Bryum maritimum Bomans. in Rev. bryol. 1897. 1. 1. [Bryum Arnellii Bontans. in Rev. bryol. 1901. p. i2. B. halophylum flag. in Mtuse. Nors. bor. p. $142(1901)$.

Autözisch. Pfl. in dichten, grünen ocier gelbgrünen, steril bis 2 'm hohen Raben. Stengel oft mit sehr schlanken, kurzen oder längeren, kïtzchenartig bebütterten, gipfel- oder seitenständigen Sprossen. Schoptbätter trocken anliesend, feucht aufrecht-abstehend, breit oder länglich-eiförmig, bis 's.) mm lang uncl bis 1.2 mm breit. mit längs ungebogenen Rändern: Rippe in der Blattspitze anthörend bis kurz austretend; \%ellen an Rande gestreckt, einen 2 -freihigen. gethlichen Saum bilkend. Blätter der larlenförmigen Sprosse sehr lrohl. tlachrandig, ungesäumt. Seta 1 2 cm, dümn, gelbrot. Kapsel hängend. aus deutlich abgesetztem Halse von etwa haller Lmenlänge oval. $1,5 \mathrm{~mm}$ lang und $1 \mathrm{~mm}$ dick. leclerbratn. trocken unter der llündung nicht verengt. Peristomzähne gelb, $(0, f(1)$ mm lang, mit etwa 20 Lamellen. Inneres Peristom gelblich: Fortsätze schmal. ritzenförnig durchbrochen: Wimpern rudimentär. Deckel gewölbt kegelig. stumpf oder mit Warze. Sporen 2:3 $27 \mu$, grün, fein papillös. Sporenreife im Juni.

F. Al. Eckerö, Torp, am Meeresufer (Bom.). - N. Sibbo, Löparo. din Meeresufer (Broth.).

S. Gstr. Hille, auf tongem Meeresufer. - Ing. Säbra, strinningen, auf lonigem Meere-uler.

N. F. lisistrand.

var. dioicum Arn. in Baner Bryoth. cur. n. 37.5.

Diözisch.

S. Gstr. Insel Halö, auf einem mit Humú bedeckten Felsen am Yfeeresufer.

102. Bryum Kaalaasii Hag. in Kgl. Norsk. Vid. Selsk. Skrift. 1!ns. No. ... p. 2.; (1908).

Heterözisch: šärliche ${ }^{9}$ Blüten. Pfl. in ziemlich dichten. etwa is mm holren, grimen oder gelbgrimen Rasen. Stengel mit kurzen, schopfig bebläterten subfloralen Sprossen. Schopfblitter trocken anliegend, feucht aulrecht-abstehend, eiförmig, kurz zugespitzt, undeutlich gesäumt, bis 2,2 mm lang und bis $0,64 \mathrm{~mm}$ breit, mit breit zurïckgeschlagenen Rändern: Rippe mit der Blattspitze endend: zellen zart. oberwärts rhomboidisch-6seitig, etwa in "lang und 18 " hreit. Seta 122-16 mm, brannrot, oben braungelb. Kapsel nickend bis hängend, aus verkehrt kegeligem Halse von halber Urnenlänge rasch bauchig erweitert. dann nicht oder wenig verengt, 1,75 mm lang und $1 \mathrm{~mm}$ dick, brümnlich. schwach glänzend. Peristomzähne braungelb, $0,4 \mathrm{~mm}$ lang. mit etwa 27 Lamellen. Inneres Peristom gell,lich; Fortsätze schmal Ianzettlich, oberwärts mit ovalen Öffnungen: Wimpern 
rudimentär. Deckel niedrig, legelig, selır stumpl. olme Warze. Sporen 2:3", ockerfarben, fein papillös.

N. K. Le:je, Lesjeskogen, Mölmen, auf schieferfelsen, $1,030 \mathrm{~m}$.

103. Bryum litorum Bomans. in Rev. bryol. 1898, p. 10.

Heterözisch: lichgrünen Rasen. Fertile Pll. nur wenige mm, dicht und schopfig beblättert. mit kurzen subfloralen Sprossen. Sterile Pll. bis $1.5 \mathrm{~cm}$ und gleichmässig beblättert. Schoptblätter trocken anliegend, fencht aufrecht-abstehend, länghich-lanzettlich, bis $2 \mathrm{~mm}$ lang und $0,8 \mathrm{~mm}$ breit, mit längs schmal umgelogenen Rändern: Rippe kurz austretenu: Zellen am Rande gestreckt, einen 1-2reihigen Sam bildend. Blätter der sterilen Pfl. nur etwa $0,95 \mathrm{~mm}$, flachrandig, fast ungesämmt. Seta 1,5 $2 \mathrm{~cm}$, gelbrot. Kapsel nickend, mit dem dentlich abgesetzten, fast gleichlangen Halse birnförmig, 2- 2.5 mm lang und etwa 1 mm dick, lederlıram, trucken und entdeckelt unter der Nündung nicht verengt. Peristomzähne gelb, bis 0,:3.) nmm lang. mit abwärts rektangulären Dorsalplatten und etwa 1 . L Lamellen. Fortsätze schmal, ritzenförmig durchbrochen; Wimpern rudimentär. 1)eckel klein. kegelig, mit Spitzchen. Sporen 25-28 $\mu$. gelbgrün, fein papillös.

F. Al. Saltik, Norrholmen, am Meeresufer (Bom.): Lemland, Nátö, am Meeresufer (Bom.). SImrogone sind nur selten vorhanden.

Pommern.

10-1. Bryum longisetum 13land. Muse exs. fase. V. No. 222 (1808).

Synözisch oder polyözisch. I'fl. in dichten, grünen bis bräunlichgrïnen, i 11, selten bis $20 \mathrm{~mm}$ hohen Rasen. Schoplblätter trocken fast aufrecht, feucht I weit abstehend, lanzettlich, allmählich lang zugespitzt, 1,6 2 mu lang und efwa $11,6 \mathrm{~mm}$ breit, mit fast bis zur Spitze umgerollten Ränlem: hippe als + lange Granne austretend: Zellen an liande gestreckt, einen 2-lreihigen, gelblichen Saum bildend. Seta $4-8$ cm, selten länger, dünn, rot. Kapsel meist hängend. trocken aun deutlich alogesetztem Halse von haber Lrmendänge dick oval, engmündig, etwa $3,5 \mathrm{~mm}$ lang, brann, trocken unter der Jündung nicht verengt. Peristomzähne gelb, bis $0,3+\mathrm{mm}$ lang, mit 10 - 12 Lamellen. Furtsätze sehr schmal. ritzenfömig durchbrochen, später klaffend: Wimpern rudimentär. Deckel klein. leicht abfällig, flach gewölbt, mit Spitzchen. Sporen in der Mehraahl $10-50$ at trüb bräumlich, warzig. Sporenreife im Juni und .Iuli.

Aul sumplwiesen. in Torfmoren und an Seeulern.

F. K. Kuusamo. Yli-Kitkajärvi, Tolva (Broth.): zw. Marttila und Vallula (B.).

S. Sk. Ignahero. Dlr. Rättvin Osjon; Boda.

N. $F$. Kistrand.

Zentral-Europra.

* Bryum labradorense (Philib.) . Amann Fi. mouss. Suiss. 11. p. 2099 (1912). (Bryum lubradorense Philib. in Rev. hryol. 1889, p. (61.)

Seta meist nur 3 cm. Kapsel kleiner. Deckel fast llach. Peristomähne dunkler. Fortsätze sehr eng durelsbrochen.

N. Dovre. Jotunfjeldene. $\& T$. Opdal.

Labrador.

10.). Bryum curvatum Kaur. el Arn. in Bot. Notis. 1897, p. 67.

Synozisch. Pft. in höheren, sehr lockeren oder niedrigeren und dichteren. blejchgrïnen Rasen. Stengel bis 1 cm, am Gruncle mit spärlichem Rhizoidenfilz. dicht und schoptig bebättert, hier und da mit etwa 1 cm langen, flagellenartigen isten. Schopllubatter trocken locker anliegend, leucht aufrecht-abstehend, eiförmig. kurz zugespitzt, 1, 5 2 $2 \mathrm{~mm}$ lang und bis $0,6 \mathrm{~mm}$ breit, mit fast bis zur spotze breit umgerollten Rändern; Rippe in der Spitze verschwindend oder - lang austretend: \%ellen am liande gestreckt, einen 2 Breihigen, getbliehen Samm bildend. Astbätter klein, aufrecht, llachrandis. undeutlich gesäumt; Rippe vor der blattspitze aulhörend. Seta :3- $1 \mathrm{~cm}$, rot. Kapsel nickend ofler hängend, schwach 
hochrückig, aus fast gleichlangem, gckrïmmtem Halse eilörmigh, :" 1 mm lamg und etwa $1,5 \mathrm{~mm}$ dick, gelblich, später rötlichbraun, trocken unter der Mündung schwach rerengt. Peristomzähne brangelb, etwa $0.3 \mathrm{~mm}$, (puerstreilig, nit efwa 2 -1 lamellen; fortsäte selmal, ritzenförmig durchbrochen, beckel liach gewöbt, mit Warze. Sporen :30 3:3" ", gelbgrim, papillös.

S. LuL. Virijaure.

N. Auf teuchter, sandiger Erde der Meeres- und Flussufer in F. nach H a ge n nicht selten, nach R y a n ausserdem auch im südhicheren Norwegen und zwar in Lesje auf den sandigen Ufern des Loraflusses beobachtet.

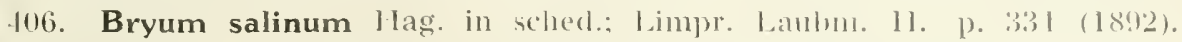
(Brymm malangense Kaur. et Arn. mse.: Arn. in Rev. loryol. 1898, p. 39 ex ]).).

Synözisch. Pfl. in dichten, oben grünen oder gelbgrimen, 1 - 1,is cm hohen Rasen. Schoplbbätter trocken anliegend, länglich-lanzettlich, scharl zugespitzt, etwa 2,1 $11 m$ lang und $0,78 \mathrm{~mm}$ breit, mit längs schmal umgerollten Rindern: l\{ippe als Grame austretend; \%ellen an Rande gestreckt, einen 3 Ireihigen. gelblichen Saum bildend. Seta $1-1,5$ cm, trüb purpurn. Kapsel meist nickend oder hängend, aus gleichlangem, deutlich abgesetztem Halse eikugelig, etwa $2 \mathrm{~mm}$ lang und $1 \mathrm{~mm}$ dick, braun. trocken unter der Mündung nicht rerengt. Peristomzähne gelb, bis $0,-1 \mathrm{~mm}$, abwärts querstreifig. mit etwa 15 Lamellen. Inneres Peristom anklebend, gelb; Fortsätze schmal, ritzenförmig durchbrochen: Wimpern von haller Höhe. Deckel klein, gewölht. mit langer, scharfer Spitze. Sporen 25-30 ", gell)grün, fein gekörnelt. Sporenreile Ende Juli.

An grasigen Ufern und auf der Erde der Felsenritzen in der ummittell)areis Nähe des Meeres.

F. Al. Finström, Gibböle, Gảsshär (Bom.).

S. Bl. Netraby. Boh. Orust.

N. Nach $\mathbf{H}$ a ge $n$ durch eine Reihe von Standorten, die sich der Kin:te entlang von $71^{\circ} n$. Br. bis zur Grenze gegen schweden erstrecken, hekannl.

Dänenark.

107. Bryum subtumidum Limpr. in litt.; Jörg. in Christ. Vid.-Selsk. Forh. 189.1, No. 8, p. 78.

Synözisch und polyözisch. Pfl. in dichten, oben grïnen, 1 - 2 cm hohen Rasen. Blätter trocken etwas gecheht, leucht aulrecht-abstehend, lanzettlich, lang zugespitzt, bis $3 \mathrm{~mm}$ lang und bis $0,9 \mathrm{~mm}$ breit, mit längs umgebogenen Rändern; Rippe als gelber Stachel austretend; Zellen am Rande gestreckt, einen 2- - Ireihigen, gelben Saum bildend. Seta $1-1,5 \mathrm{~cm}$, rot. Kapsel hängend, aus clem deutlich abgesetzten, gebogenen Halse von halber Lrnenlänge gedunsen-eiförnig. kJeinmündig, bis $2,5 \mathrm{~mm}$ lang und bis $1,5 \mathrm{~mm}$ dick, rotbraun, trocken unter der Mündung nicht verengt. Peristomzähne gell, $0,4 \mathrm{~mm}$ lang, mit abwärts rektangulären Dorsalplatten und etwa 16 Lamellen. Fortsätze mit ovalen und länglichen Fenstern: Wimpern sehr zart. Deckel klein. Sporen 2-1-28

N. Tr. skjervo am Meeresufer. Von dieser Art isl nach $\mathbf{H}$ a g e $\mathrm{n}$ B. scalariforme Jörg. l. c. 1. 79. Tr. Guola:javre, nicht spezifisch rerschieden.

408. Bryum Lagerheimii Joerg. 1. c. p. 77.

Synözisch. Pfl. in dichten, grünen, bis 1.5 cm hohen, dureh Rhizoidenfilz verwebten Rasen. Schopfblätter trocken anliegend, verlängert länglich, allmählich schmal zugespitzt, etwa $3 \mathrm{~mm}$ lang und bis $0,7 \mathrm{~mm}$ breit, mit schmal umgebogenen Rändern; Rippe als Grame austretend; Zellen am Rande gestreckt, einen etwa 2reihigen, gelblichen Saum bildend. Seta $1-2$ cm. bräunlichrot. Kiapsel nickend oder hängend, aus dem fast gleichlangen Halse eilänglich, 3-3.. m m lang und elwa $1 \mathrm{~mm}$ dick, bräunlich, trocken unter der Mïndung verengt. Peristomzähne gell, etwa $0,4 \mathrm{~mm}$ lang, mit etwa 27 Lamellen. Fortsätze schmal, ritzenförmig durchbrochen. Wimpern rudimentär oder fehlend. Deckel hoch gewöllt, mit Spitzchen. Sporen 25-30 $\mu$, gelbgrïn, feinwarzig.

N. $T r$. Skjerro. 
409. Bryum retusum Hag. in D. K. N. Vicl.-Selsk. Skrift. 1897. No. 2, p. 11.

Synözisch. Pft. in lockeren bis dichten. oberwärts grünen, abwärts schwärzlichen. bis $1 \mathrm{~cm}$ hohen Rasen. Schopfblätter trocken locker anliegend, leucht aufrecht-abstehend, länglich bis lanzettlich, schmal zugespitzt, $2,4-2,7 \mathrm{~mm}$ lang und etwa $1 \mathrm{~mm}$ breit, mit längs ungebogenen Rändern: Rippe meist vor der Blattspitze aufhören«; Zellen am Rande gestreckt, einen 2-3reihigen, gelblichen Samm Jildend. Seta $12-15 \mathrm{~mm}$, dünn, rot. Kapsel hängend, aus dem Halse von halber Urnenlänge eiförmig, etwa 2,75 $\mathrm{mm}$ lang und $1 \mathrm{~mm}$ dick. braun, trocken unter der Mündung nicht verengt. Peristomzähne gelb, schmal, bis $0.35 \mathrm{~mm}$ lang, mit fast quadratischen Dorsalfeldern: Ventralschicht mit welligen Rändern und etwa 12 Lamellen. Inneres Peristom nur an Grunde dem äusseren anhängend, gelblich; Fortsätze schmal, ritzenförmig durchbrochèn: Wimpern rudimentär. Deckel flach gewölbt. mit Spitzchen. Sporen in der Mehrzahl etwa $25 \mu$. gelbgriin. glatt. Sporenreife in der zweiten Hälfte des Juli.

Auf feuchter, mooriger Erde, an Fluss- und Fjordufern.

N. No. Bejeren. Tr. Nordrejsen: skjervo. F. an mehreren Fumdorlen.

Faeroer, Osi-Grönland.

410. Bryum orarium Bomans. in Rer. bryol. 1899. 1). 9. [B. bergöense Bomans. 1. c. p. 12; B. brechycarpum Bomans. in Act. Soc. Faun. Fl. Fenn. XVIII. No. 4, p. $77(1900)$.]

Synözisch. Pfl. in lockeren bis dichten, gelbgrimen. bis 1 cm hohen Rasen. Schopfblätter trocken anliegend, leucht aufrecht-abstchend, eilanzettlich, kurz. zugespitzt. bis 2,5 mm lang und bis etwa 1 mm breit, mit längs nmgebogenen Rändern: Rippe = lang austretend: Zellen am Rande in 1-3 Reilsen gestreckt, einen \pm deutlichen Saum bildend. Seta bis $1, j \mathrm{~cm}$, rot. Kapsel nickend bis hängend. mit dem fast gleichlangen, deutlich ahgesetzten Halse dick birnförmig, bis 2,j mm lang und bis $1,5 \mathrm{~mm}$ dick, kleimmündig, braur. Peristomzähne gelh, bis 0, $1 \mathrm{~mm}$ lang. mit etwa 15 Lamellen. Fortsäte schmal. elliptisch durchbrochen: Wimpern ruclimentär. Deckel klein, kegelig. mit Spitzchen. Sporen 20-25 "1. gelbgrïn, lein papillös.

Auf sandigem Meeresufer.

F. Al. Eckerö, Torp (Bom.). Jumala, Möckelö. (iloel (B.). Salırik, Bergö (B.).- Y. Ekenäs,

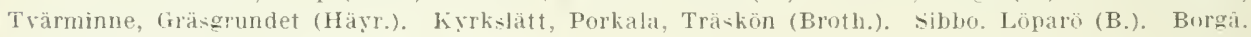
Pörtö, Răfholmen (B.): Pellinge, ölandet (B.).

S. Gstr. I gqü̈n (Arn.).

111. Bryum lapponicum Kaur. in Vid.-Selsk. Forh. 1894, No. 8. p. 76. [B. lingulanum Bomans. in Act. Soc. Faun. Fl. Fenn. Xilli. No. 4. p. 88 (19001).]

Synözisch. Pfl, in dichten, oben grünen. bis $4 \mathrm{~cm}$ hohen Rasen. Schopfb]ätter trocken anliegend, feucht \pm abstehend, ei- bis verlängert-lanzettlich, 3-.; num lang und bis $1, ; \mathrm{mm}$ breit, mit breit umgerollten Rändern: Rippe als lange Gramne austretend: Zellen olserwärts etwa 10 -50" lang und $18 \mu$ breit. am Rande gestreckt, einen 2-3reihigen Saum bildend. Seta 1,5-2.j. zuweilen bis t und .) cnı, rot. Kapsel hängend, aus gleichlangen Hałse elliptisch, bis $1 \mathrm{~mm}$ lang, braun, trocken unter der llïndung nicht verengt. Peristomzähne braungelb, etwa 0,38 mn lang, mit schmal rektangulären Dorsalplatten und 15-18 Lamellen; Fortsätze ritzenförmig durchbrochen; Wimpern rudimentär. Deckel gewölbt, mit Zitze. Sporen 20 25, anch bis $30-32 \mu$. gelbgrün. feinwarzig. Sporenreife im Juli. - S. 170. Fig. 50 l-K.

An leuchten, sandigen oder lelsigen Mceresküsten.

F, Al. st. fq. (Bon.). - Ab. Gustafs (Bergr.). Korpo, Brunskär (Elfv.). Pargas (Arrh.). Bromarf (Sundv., Broth.). - N. Hangö (Buch). Ekenäs, Trärninne, an melıreren Finndorlen (Broth.. Hä̀r., Ranck.). Ingal, Elisö (II, Brenn.), kyrksłatl, Porkala, Träskün (Brolh.). Esbo, Gräsa, solberga (B.). Sibbo, Löparo (B.). Borga, Pellinge (B.). — - Si. Luvia, Sübbskär (1layr.). - Da. Vasa. in den sehären st. fq. (Broli.). Replot, Vallgrund und Valsöarna (B.). - Lt. Am Kolaburen (Fellm.). - Lmur. semjostrorik, Tischniak (Brolh.). 
S. Boh.. BI.. Ög.. Srm., Gstr.. ing.

N. sm. Ilvaler und Glemminge. An der südöstichen kïste. Lille-Elvedalen. Lom. Nin, und Tr an wenigen. $F$, an mehreren lindorten.

112. Bryum aculeatum Joerg. in Christ. Vid.-Selsk. Forh. 189., p. 80.

Synözisch. Pfl. in lockeren, schmutziggrïnen, etwa 1 cm hohen Rasen. Schopfblätter trocken locker anliegend, länglich-lanzettlich, lang zugespitzt, etwa 2 mm lang und etwa 0,7 mm breit, mit längs breit ungerollten Rändern; Rippe als Granne austretend; Zellen am Rande gestreckt, einen mehrreihigen, gelblichen saum bildend. Seta 1,5-2 cm, rot. Kapsel hängend, aus dem leieht gekrïmmten Halse von halber Umenlänge oval, bis $2,8 \mathrm{~mm}$ lang und bis $08 \mathrm{~mm}$ dick, licht- bis rotbraun, trocken unter der Mïndung nicht verengt. Peristonzähne hellgell), $0,4 \mathrm{~mm}$ lang, mit etwa 15 Lamellen; Fundus schmäler als bei der vorigen Art. Fortsätze oberwïts sehr schmal, breit klaffend. Wimpern rudimentär. Deckel kegelig. Sporen 2. -30 $\mu$, gelbgrün, papillös. Sporenreife Ende Juli.

N. Tr. Nordrejsen, Reisenelven, auf feuchtem sandboden.

113. Bryum stenodon Hag. Musc. Norv. bor. p. 14.j (1901).

Synözisch. Pl. in dichten, oberwärts gelblichen, bis $1 \mathrm{~cm}$ hohen Rasen. Schopfblätter trocken dicht anliegend. feucht aufrecht-abstehend, aus last geöhrten, herablaufenclem Grunde oval oder eilanzettlich. rasch zugespitzt, etwa 1,8 mm lang und 0,67 mm breit, mit längs umgebogenen Rändern: Rippe kurz austretend: Zellen dickwandig, an Rande in melnreren Reilnen gestreckt, einen undeutlichen Samm bildend. Seta 1,3-2,5 cm, bräunliclngelis. Kapsel nickend, mit dem Halse von halber Urnenlänge fast keulenförmig, bis $3 \mathrm{~mm}$ lang und $1,4 \mathrm{~mm}$ dick, bramn, trocken unter der Nündung nicht verengt. Peristomzähne schmal, gleichmässig verengt, braungelh odler rötlichgelb, $0,32 \mathrm{~mm}$ lang, abwärts nit rektangulären Dorsalplatten, Lamellen etwa 16. Fortsätze abwärts elliptisch, oberwärts ritzenförmig durchbrochen; Wimpern $\neq$ entwickelt, sehr selten mit Anlüngseln. Deckel niedrig, kegelig. Sporen $24-36 \mu$, gelb, fast glatt.

N. No. skjerstad. Hankabakken, in erderfüllten Ritzen der schieferfelsen, $580 \mathrm{~m}$. Tr. Bardn. Lihammeren in der alpinen Region.

111. Bryum humectum Hag. in Kgl. Norsk. Vid. Selsk. Skrift. 1908, No. :3, p. $20(1908)$.

Synözisch. Pfl. mit Pohlia gracilis vermischt in ziemlich dichten, bis $1, \overline{5}$ cnl hohen Rasen. Stengel nur mit den gelbgrünen subfloralen Sprossen sich über den Erdboden erhebend. Schopfblätter trocken aufrecht-abstehend, feucht abstehend, eilanzettlich, allmählich schnnal zugespitzt, bis $3 \mathrm{~mm}$ lang und bis $0,85 \mathrm{~mm}$ breit, mit längs breit zurückgesehlagenen Rändern; Rippe als Granne austretend: Zellen oberwärts verlängert 6 seitig, 33-.57 $\mu$ lang und $13-20 \mu$ breit, an Rande schmäler, einen ziemlich breiten, undeutlich begrenzten Samm !ildend. Seta etwa $2,5 \mathrm{~cm}$, gelbrot, oben gelblich. Kapsel horizontal bis hängend, aus schmalem Halse von etwa halber Urnenlänge rasch eiförmig und allmählich verengt, 2,6 mm lang und $1 \mathrm{~mm}$ dick, kastanienbraun, trocken unter der Mündung kaum verengt. Peristomzähne braungelb, $0,14 \mathrm{~mm}$ lang, mit etwa 22, in der Vitte eingedrückten Lamellen. Inneres Peristom dem äusseren am Grunde anhängend, gelblich: Fortsätze breit gefenstert; Wimpern meist fehlend, znweilen vollständig, selten mit Anhängseln. Deckel kegelig. Sporen $23-27$ ", gelbbram, fein punktiert.

N. ST. Am Drivaflusse zw. Kongswold und Hjerkin, $900 \mathrm{n}$.

115. Bryum foveolatum Hag. in Nyt Mag. Naturv. Bd. 38. p. 333 (1901).

Synözisch. Pfl. in ziemlich lockeren, gelbgrünen, unten schwärzlichen, bis 3 cm hohen Rasen. Schopfblätter lang und schmal herablaufend, trocken anliegend, geschlängelt und zuweilen gedreht, feucht aufrecht-abstehend, ei- oder länglich-lanzettlich, bis $2,5 \mathrm{~mm}$ lang und etwa $0,8 \mathrm{~mm}$ breit, mit \pm weit hinauf schmal umgebogenen Rändern; Rippe austretend; Zellen am Rande in 1-2 Reilien ge- 
streckt, einen undeutlichen Samm bildend. Seta 1 cm, am Grunde rot, oberwärts bleich. Kapsel nickend bis hängend, ans dem Halse von halber Urnenlänge dick oval, 2, $4-2,9 \mathrm{~mm}$ lang und $1 \mathrm{~mm}$ dick, brann, trocken verschrumpft und grubig, unter der Mündung kaum verengt. Peristomzähne sattgelb, mit gelbrotem Fundus, $0.37 \mathrm{~mm}$ lang, mit abwärts rektangulären Dorsalplatten und $15-18$ Lamellen. Fortsätze breit elliptisch durchbrochen; Wimpern rudimentär. Deckel kegelig. stumpf. Sporen $18-26 \mu$, rotgelb, glatt.

N. F. Nesseby, Bergebyelven.

Ost-Grönland.

416. Bryum fissum Ruth. in Hedwigia XXXVI. p. 386 (1897).

Synözisch. Pfl. in dichten, grünen, 0,6-1,6 cm hohen Rasen. Schopfblätter trocken anliegend, feucht aufrecht-abstehend, ei- oder länglich-lanzettlich, kurz zugespitzt, bis $2.5 \mathrm{~mm}$ lang und bis $0,9 \mathrm{~mm}$ breit, mit längs schmal ungebogenen Rändern; Rippe kurz austretend; Zellen an Rande gestreckt, einen 2-3reihigen Saum bildend. Seta $1,5-2 \mathrm{~cm}$, rot. Kapsel hängend, mit dem gleichlangen Halse länglich birnförmig bis keulenförnig, bis 3,5 mm lang und etwa 1 mm dick, ledērbraun. trocken und entdeckelt unter der Iündung breit verengt. Peristomzähne gelb, bis $0,4 \mathrm{~mm}$ lang, mit breitem Fundus und $14-16$ Lamellen. Grundhaut des inneren Peristoms \pm tief geschlitzt; Fortsätze gefenstert; Wimpern etwa ${ }^{1 / 3}$ cler Fortsätze. Deckel gewölbt kegelig, mit Warze. Sporen 25-30 ", gelblichgrün fein papillös.

F. Al. Saltrik, am sandigen Ufer der Insel Gamsholn (Bom.); Sund, Högbolstad, am sandigen Heeresufer (Broth.).

Pommern.

417. Bryum furvum Hag. Iuse. Norv. bor. p. 151 (1901).

Synözisch. Pfl. in dichten, oberwärts gelbgrïnen, $5-15 \mathrm{~mm}$ hohen Rasen. Schopfblätter trocken anliegend, feucht aufrecht-abstehend, eilanzettlich, länger zugespitzt, bis $3 \mathrm{~mm}$ lang und $1,2 \mathrm{~mm}$ breit, mit längs umgebogenen Rändern: Rippe austretend; Zellen am Rande gestreckt und sehr verdickt, einen sehr breiten. gelblichen Saum bildend. Seta 1,2-1,8 cm, braun. Kapsel horizontal bis nickend. zuweilen hängend, aus dem Halse last von Urnenlänge dick oval oder eiförmig, $1,6-2,5 \mathrm{~mm}$ lang und $1 \mathrm{~mm}$ dick, braun, trocken unter der Nündung nicht verengt. Peristomzähne braun, mit braumpurpurnem Fundus, $0,34 \mathrm{~mm}$ lang und $0,075 \mathrm{~mm}$ breit, mit fast quadratischen Dorsalfeldern und 9-10 Lamellen. Fortsätze elliptisch durchbrochen; Wimpern rudimentär. Deckel llach gewölbt, mit scharfer Spitze. Sporen 25-3i $\mu$, griungelb, fast glatt.

N. R. Haram, Gamlemshoug, dicht an Mleesesufer auf feuebler, lorfiger Erde. Tr. Skjervo, an Fusse der Ufferfelsen. $F$. Loppen und Oskfjord.

118. Bryum Graefianum Schlieph, in Flora 1885, No. 19, t. 6.

Synözisch. Gesellig wachsente oder lockerrasige, schmutzig-grüne, im Alter schwärzliche bis $1 \mathrm{~cm}$ hohe Pfl. Schopfblatter trocken \pm dicht anliegend, breil eiförmig bis eilanzettlich, zugespitzt, bis $2,4 \mathrm{~mm}$ lang und $1 \mathrm{~mm}$ breit, mit schmal umgebogenen Rändern; Rippe als Granne \pm lang austretend; Zellen am Rande gestreckt, einen 2reihigen Saum bildend. Seta $1,5 \mathrm{~mm}$, rotbraun. Kapsel horizontal, mit dem kurzen, leicht gekrümmten Halse keulenförmig, kleinmündig. 2,5 nm lang und 1,5 mm dick, dunkelbraum, trocken unter der Mündung nicht verengt. Peristomzähne aus breiterer Basis allmählich verschmälert, bräunlichgelb, etwa $0,38 \mathrm{~mm}$ lang, mit abwärts schmal rektangulären Dorsalplatten uncl etwa 15 Lamellen. Inneres Peristom anklebend; Fortsätze gefenstert; Wimpern rudimentär. Deckel flach gewölbt, mit Zilze. Sporen 30-33 $\mu$, gelbgrün, fein gekörnelt.

N. Sm. IIvaler. Langnesholmen bei Vestera. ST. Kongsiold. Strinden. Muruviken. R. Bud. Sandvik. K. Loin, an mehreren Fundorten. No. Salten, R.d., Flatholmen. Mo, Bredikfjeldet. Tr. Nordrejsen, Sappen, an isbschüssigen Flussufer und Skjervo. F. Kistrand, Laxelven.

Schweiz. 
419. Bryum haematostomum Joerg. in Christ. Vicl.-Selsk. Forh. 1891, In. 8, p. 99.

Synözisch. Pfl. in dichten, gelblichen, etwa 1 cm hohen Rasen. Schopflbätter trocken anliegend, feucht aufrecht-abstehend, länglich-lanzettlich, kurz zugespitzt, bis $3,5 \mathrm{~mm}$ lang und bis $0,9 \mathrm{~mm}$ breit, mit längs schmal umgerollten Rändern; Rippe als Grame austretend; Zellen an Rande gestreckt, einen mehrreihigen Saum bildend. Seta 1,5-2 cm, bräunlichrot. Kapsel nickend odler hängend, aus dem Halse von Urnenlänge oval, bis $3,5 \mathrm{~mm}$ lang und bis $1,2 \mathrm{~mm}$ dick, lichtbraun, trocken und entdeckelt unter fler IIündung nicht verengt; Zellen des Exotheciums dickwandig. Peristomzähne gelh, etwa $0,4 \mathrm{~mm}$ lang, mit selumal rektangulären Dorsalplatten und etwa 15 Lamellen. Fortsätze gefenstert. Deckel klein, gewöll,t, mit Zitze. Sporen etwa $25 \mu$, gelbgrün, feinwarzig.

N. F. Altenfjord, Talvik, Jansnaes, auf Uferfelsen.

var. fennicum Broth. in Bryoth. 1enn. No. 141 (1911).

Blätter bis $4,5 \mathrm{~mm}$ lang und bis $1,5 \mathrm{~mm}$ breit. Seta bis $3 \mathrm{~cm}$. Kalpsel bis I $\mathrm{mm}$ lang und $1,5 \mathrm{~mm}$ dick, dunkelbraun.

F. N. Borgá, Pellinge.

S u b s e c t. I I. Eubryum Amann 1. c.

Wimpern vollständig, mit Anlıängseln.

j. Pseudotriquetra Amamn in Rev. bryol. 1893, p. 4.

Meist diözisch oder synözisch; $C$ Blüten köpfchen- bis last scheibenföruig. Stengel \pm verlängert bis sehr lang, mit \pm verlängerten, gleichmässig beblätterten subfloralen Sprossen. Blätter meist etwas bis weit herablaulencl, meist länglichoder cilanzettlich, zugespitzt, selten stumpf, gesäumt: Rippe meist in der Blattspitze aufgelöst bis \pm lang austretend; Zellen am Blattgrunde rot. Kapsel mit clem verschmälerten Halse verlängert keulenförmig bis verkehrt kegelförmig, regelmässig, braun. Peristomzähne gelb; Fundus rot.

420. Bryum neodamense Itzigs. in Flora 1841, 1. p. 360.

Diözisch. Ziemlich kräftige $\mathrm{Pfl}$, vereinzelt zwischen anderen Sumpfmoosen oder in lockeren bis dichten, grünen oder bräunlichgrünen, abwärts oft schwärzlichen, inmen durch braunen Wurzelfilz verwebten Rasen. Stengel 2-10 cm, bald dicht, bald locker beblättert. Blätter weich und etwas herablaufend, trocken wellig verbogen und gedreht, feucht aufrecht- bis sparrig-abstehend, an alten Stammteilen fast flach, nur in der oft eingebogenen Spitze zuweilen kappenförmig hohl, aus etwas verschmälerter Basis eilänglich und elliptisch-länglich, kurzspitzig oder stumpflich, bis $3 \mathrm{~mm}$ lang und etwa 1,2 $\mathrm{mm}$ breit, an jüngeren Sprossen löffelförmig-hohl und an der stumpfen Spitze kappenförnig, 1,86 mm lang und 0,7 mm breit, flach- und ganzrandig; Rippe weniger kräftig, kurz vor odler mit der Blattspitze endend, selten sehr kurz austretend: Zellen wenig verdickt, Iocker, in der Blattmitte $50-55$ " lang und bis $25 \mu$ breit, am Rande gestreckt, einen 3-6reihigen, gelblichen Saum bildend. Seta $3-4 \mathrm{~cm}$, rot. Kapsel hängend, regelmässig, $34 \mathrm{~mm}$, aus ziemlich langem Halse fast kegelförmig oder zylindrisch, braun, trocken unter der weiten Mündung eingeschniirt. Peristomzähne gelb, an der Insertion orange, bis $0,50 \mathrm{~mm}$ lang, etwa 30 Lamellen. Inmeres Peristom gelb, papillös; Grundhaut fast $1 / 2$ der Zähne; Fortsätze breit und breit gefenstert; Wimpern mit Anhängseln. Deckel ziemlich hoch gewölbt, mit Spitzchen. rot und glänzend. Sporen $12-16$ ", gelb, glatt.

In nassen Sandausstichen, auf feuchter Schlammerde und in kalkhaltigen Sümpfen.

F. Al. Eckerö, westlich ron Lảngskär (H. Lindb.). Saltvik, an mehreren Fundurlen (Bom.). - Ok. Kajana, Koivukoski (Lackstr.). Paltamo, Velalahti (Kyyhk.). Kuhmoniemi, Papinkallin cop. (K.). Suomussalmi, Kiannankylä (K.). - K. Kuusamo Näränkävaała (Vain.). - Li. Ltsjoki Ylïjalve am Ufer des Daussejokka (Ranck.). - Lp. Triostrova (kihlm.).

S. Ö. an mehreren, $N a ̈ r$, an wenigen Fundorten. Aing. Tasjö. Jmt. an mehreren Fundorten. 
N. A. Kristiania. Ne. Saetersdalen. K. Dorre. Jotun- und Lomsfjeldene. Tr. Nordrejsen.

Europa.

var. ovatum (Jur.) Lindb. et Arn. in K. Vet.-Ak. Handl. Bd. 23, No. 10, p. 34 (1890). [Bryum ovalum Jur. Laubmfl. p. 291 (1882).]

Pfl. schlanker und mehr gleichmässig beblättert, in meist dichten, bis $8-10$ cm hohen Rasen. Blätter sehr hohl, weiter herablaufend, breit oval und breit eiförmig, die obersten verkehrt eilänglich, zugespitzt, mit am Grunde schmal umgebogenen Rändern.

F. Ok. Paltamo, Mieslahli. Tolola, an Felsen reichlich (Kyykk.). Kuhmoniemi. Vieksi (K.). Suomusalmi, Kirchdorf (Vain.). - Lkem. Ounastunturi (Norrl.). - Le. Kilpiskoski (X.). - Lim. Hibinã. Ljaoro-tschor. am Bachufer (Kihlm.).

S. Hrjd. Helagsfjället. LuL. Sarekgebiet.

N. F. Karasjok, Rastegaisia; Nesselıy. Bergelyelven.

Europa, Sibirien.

121. Bryum crispulum Hamp. mss.: C. Müll. in D. II. Deutsch. Nordpolarf., Bil. II. p. 69 (1873).

Diözisch. Schlanke Pfl. in dichten bis sehr dichten, ziemlich starren, sattgrünen, abwärts bräunlichen, innen durch braunen Wurzelfilz verwebten Rasen. Stengel bis $7 \mathrm{~cm}$. I dicht beblättert. Blätter trocken dem Stengel dicht angedrückt bis locker anliegend, mit welligen Rändern, feucht aufrecht bis aufrechtabstehend, aus deutlich herablaufender Basis eiförmig-oval, mit kurzer, \pm zurückgebogener Spitze, 0,8-0,9 mm lang und 0,5-0,6 mm breit, \pm hohl, entfernt und stumpf gezälnelt, untere flachrandig, mit einreihigem Saume, gipłelständige mit fast bis zur Spitze umgebogenen, deutlicher gesäumten Rändern; Rippe ziemlich kräftig, mit der Spitze aufhörend; Zellen dickwandig, klein, obere 20-40 " lang und 20 " breit. Sporogone unbekannt.

An sumpfigen Stellen, am häufigsten in von Sclneewasser feuchten Mooswiesen, auch an nassen Felsen der alpinen Region.

F. Le. Kilpisjărri, Kitji-Malla. Malla und Saana (Kot.). - Lim. Hibiuā (Broth.) - Lp. Orlor (Kihlm.).

S. Hrjd. Helag:fjället. LuL. Sarekgebiet, in den höheren Lagen häufig und reichlich.

N. ST. Opdal, Nystuguho, $1,300 \mathrm{~m}$ und hoch oben am Sprenbaekken. Tr. Bardo, Rubben in der Birkenregion und Lihammeren in der alpinen Region. $F$. Nesseby, Bergeby.

Spitzbergen, Ost-GrönJand.

422. Bryum ventricosum 1)icks. Crypt. fasc. I. p. + (1785). [Mnium pseudotriquetrum Schwaegr. Suppl. I. P. II. p. 110 (1816) ex p. - B. quarnboense Bomans. in Rev. bryol. 1903, p. '1).]

Diözisch; Pl. heist in besonderen Rasen. Mehr oder weniger kräftige, starre Pfl. in lockeren oder dichten, oben dunkel- bis gelb- odler bräunlichgrünen, zuweilen rötlichen. durch Rhizoidenfilz verwebten Rasen. Stengel bis $12 \mathrm{~cm}$, \pm dicht beblättert. Blätter trocken wellig verbogen und etwas gedreht, feucht aufrecht- bis fast sparrig-abstehend, aufwärts allmählich grösser und dichter gestellt, lang und schmal herablaufend, untere breit lanzettlich, $1,-1-1,6 \mathrm{~mm}$ lang und 0,86-1 nun breit, obere länglich-lanzettlich, allmählich zugespitzt, $3 \rightarrow 1,5 \mathrm{~mm}$ lang und 1,4 mm breit, mit bis gegen die meist gesägte Spitze umgerollten Rändern; Rippe kräftig, in đer Spitze aufgelöst oder als kurzer, gezähnter Stachel austretend; Zellen mässig verdickt, am Rande gestreckt und verdickt, obere $30-40 \mu$ lang uncl $12-15 \mu$ breit, einen 3-5reihigen, gelblichen oder bräunlichen Saum bildend. Seta $2-6 \mathrm{~cm}$, rot. Kapsel nickend, seltener lıängend, aus ziemlich langem Halse fast kegelförmig oder zylindrisch, bis $5 \mathrm{~mm}$ lang, trocken \pm unter der Vündung verengt. Peristomzähne breit gesäumt, papillös: Lamellen 30-10. Inneres Peristom gell, papillös; Fortsätze breit gefenstert; Wimpern mit langen Anhängseln. Deckel gross, kegelförmig o(ler hoch gewölbt, mit Spilzehen. Sporen $10-$ $12 \mu$, zuweilen grösser, gelhgrïn oder gelb, fasl glatt oder dicht warzig. Sporenreife in Sommer. 
Auf feuchtem Boden, wie an Bachufern, auf sumpfigen Mooswiesen, in Sümpfen, auf feuchten und nassen Felsen, gern auf Kalk, in allen Teilen von Fennoskandia allgemein verbreitet bis in die Birkenregion, seltener in der alpinen Region.

var. gcacilescens Schimp. Coroll. p. 76 (1856).

Schlanke Pfl. Stengel bis $8 \mathrm{~cm}$, lockerer beblättert, unter dem Schopf mit mehreren kleinblätterigen Ästen. Blätter eiförmig, 1-1,25 mm lang unı $0,5 \mathrm{~mm}$ breit. Kapsel etwa $3,5 \mathrm{~mm}$ lang.

An quelligen Stellen und auf Sumpfwiesen.

F. K. Kuusamo, zw. Liikanen und Oulankajoki (Broth.). - Lkem. Kolari und Kittilă, ohne Angaben der Fundorte (HuIt). - Le. Häufiger als die Hauptart (Norrl.).

Europa, Sibirien, Tord-Amerika.

var. duvalioides Itzigs. in litt., Rab. D. Kryptfl. II. p. 214 (1848).

Lockerrasige Pfl. Blätter bleichgrün, breiter, weich und schlaff. Kapsel kürzer.

N. $S B$. Maristuen.

var. montanum Bom. in Act. Soc. Faun. Fl, Fenn. XVIII. No. 4, p. 92 (1900).

Pfl. in sehr dichten, bräunlichgrünen Rasen. Blätter trocken dachziegelig anliegend, kürzer zugespitzt, bis $1,5 \mathrm{~mm}$ lang und bis $0,6 \mathrm{~mm}$ breit. Kapsel bis 2,5 $\mathrm{mm}$ lang. Wimpern mit kurzen Anlängseln.

F. Al. Saltvik, Krarnbo, an Felsen (Bom.). Lemland, Norrby, an humusbedeckten F'elsen (Broth.).

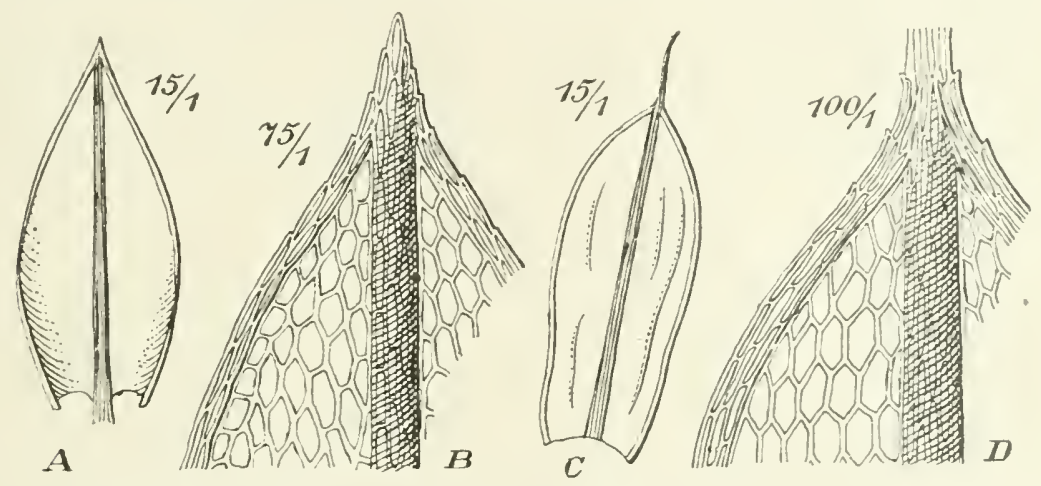

Fig. 51. A-B Bryum bimum schreb. A Stengelb. (15/1); B Blattspilze (75/1). - C-D B. capillare L. C Stengelb. (15/1); D Blattspitze (100/1).

var. compactum Bryol. eur. fasc. 6/9, p. 54 (1839).

Meist niedrige, sehr dichtrasige, stark verfilzte Pfl. Blätter starr, anliegend, breit eilanzettlich; Zellen sehr dickwandig. Seta oft nur $1 \mathrm{~cm}$. Kapsel kürzer, verkehrt-eiförmig.

N. A. Kristiania.

England. Alpengebiet, arkt. Sibirien.

var. arcticum Ryan in Hag. Nusc. Norv. bor. p. 205 (1901).

Seta diinn, geschlängelt. Wimpern knotig. Sporen $24 \mu$.

N. F. Kistrand.

423. Bryum bimum Schreb. Spic. fl. Lips. p. 83, No. 1047 (1771).

Synözisch, mit einzelnen $C^{7}$ Blüten. Ziemlich kräftige Pfl. in meist sehr dichten, durch Wurzelfilz verwebten, oben dunkel- bis bräunlichgrïnen, zuweilen braunrötlichen Rasen. Stengel 1-4, zuweilen bis 10 cul, dicht beblättert, $\perp$ ästig. Blätter wenig herablaufend, nach oben almählich grösser, Schopfblätter trocken anliegend, meist schwach gedreht, feucht aufrecht-abstehend, aus breitem Grunde verlängert lanzettlich, die äusseren kurz und breit zugespitzt, $3-3,5 \mathrm{~mm}$ lang und 1-1,3 $\mathrm{mm}$ breit, mit bis gegen die meist gesägte Spitze breit umgerollten Rändern; Rippe kräftig, als kurzer, gezähnter Endstachel austretend; Zellen derb- 
wandig, oberwïts $: 35-50 \mu$ lang und $15-30 \mu$ breit, am Rande gestreekt, einen 3-6reilngen, gelbbräunlichen Saum bildend. Seta $3-5$ cm, dünn, rot. Kapse] hängend, mit den kurzen Halse länglich-birnförmig und länglich-keulenförmig, 3,5-1 $\mathrm{mm}$ lang und $1-1,2 \mathrm{~mm}$ dick, derbhäutig, rotbraun, trocken unter der Mündung $\perp$ eingeschnürt. Peristomzähne bleiehgelb, $0,50-0,60 \mathrm{~mm}$, mit $20-$ 30 Lamellen. Inneres Peristom gelblich: Fortsätze fensterartig durchbrochen, später klaffend: Wimpern mit langen Anhängseln. Deckel gross, gewölbt-kegelig. mit scharfer oder zitzenförmiger Spitze. Sporen 10-15 ", gelb oder grünliehgelb. glatt. Sporenreile im Juni. - Fig. 51 A-B.

Auf Sumpfwiesen, in nassen Ausstichen und auf feuchten Felsen.

F. Al. Eckerö, Storby und Torp (Bom.). Sallvik, an vielen Fundorten (B.). - Ab. Inio (Bergr.). Pargas (Arrh.); Terfsund (Elfv.). Kimito, Pedersö (Ol..). Finby, Pettu (Sundv.). Sagu. Träskby (Buch). Karislojo, Karkali (S.). Lojo, Skräddarla (Lindb.): Kalkkisaari (Sundr.): Huuhtasaari (E. af H.). Vichtis (WV. Nyl.). - N. Helsingfors (Broth.). Borgá (Sael.). — St. Luvia, Sebbskär (Häyr.). Pirkkala (Simm.). Ikaalinen (Sundv.). - Ta. Hollola, Hersala (Norrl.). Asikiala (X.). Kulumoinen (N.). Hartola (Bonsd.). - Sa. Willmanstrand (Buch). Ruokolahti. Imatra (Nerv.). Kangasniemi (Lackstr.). Nyslott (Carl.). Kl. Jaakkima, Ramola (Sundr.). Talano (W. Nyl.). Sorlavala, Liikolanvuori (Lindb.); Kirjavalahti (Buch). Impilahti, Hunnukkalahti (Broth.). Ruskeala (II. Nyl.). Soanlahti, Korpikallio (Broth.). Pälkjärvi. Könönen (B.). - Kol. Ohne năhere Fundorte (Eltv.), - Sb. Kuopio, Siilinjärvi (Kyyhk.). Kaavi, Siikajärvi, Likosaari (Kot.). Nilsiä. Kunsiahti, Jakkonlammen kallio (Kł̣hk.). - Kb. Juuka, Polvijärvi, Juuanraara, Talkealampi (Kot.). Siaaninka, Tuovilanlahti (Roiv.). - Kon. Tiudie (W. Nyl.). Koselma und Jalguba (Simm.). - $(\mathrm{m}$. Alajärvi. Lirujärvi (Backm.). Lappajärvi. Isoniemi-Autio (B.). - Ok. Kajana, Ämmäkoski (Kyylhk.). Sotkamo, Talvivaara (K.). — Ob. Rovaniemi, Jaatilanlampi (Brenn.); Tervo (Hult). - K. Kuusamo, Haataja (Broth.); Ylikitkajärvi, Jäkäläinen und Tolva (B.); Marttila (B.); Virranniemi und Kesälahti (B.); Kitkajoki (B.). - Lkem. Sodankylä (Blom). - Le. An mehreren Fundorten bis Kilpisjārvi (Norrl.). - Lt. Srednij am Kolabusen (Brolh.). Kildin (B.). Tsipnavolok (B.).

S. $S k .-L$.

N. $S m \cdot-F$.

Europa, Kaukasus, Amur, Nord-Amerika.

424. Bryum castaneum Hag. in Kgl. Norsk. Vill. Selsk. Skrift. 1904. No. 1. p. $3(1904)$.

Synözisch. Pfl. in ziemlich dichten, bis 2 cm holen, schwärzlichen, nur ganz oben bräunlichgrünen Rasen. Stengel verfilzt, ziemlich locker beblättert, mit bis 8 mm langen subfloralen Sprossen. Blätter deutlich herablanfend, trocken aufrecht und geschlängelt, feucht abstehend bis schwach zurückgebogen, die oberen eilanzettlich. bis 3,2 mun lang und $0,8 \mathrm{~mm}$ breit, mit bis zur Mitte umgebogenen Rändern: Rippe vollstandig bis kurz austretend: Zellen oberwärts verlängert 6seitig, 35-56 $\mu$ lang und 17-23 " breit, am Rande gestreckt, einen 3-1reihigen. gelblichen Saum bildend. Seta etwa 3 en, kastanienbraun. Kapsel hängend, aus verkehrt-kegeligem Halse von etwa halber Urnenlänge dick oval, 2,2 mm lang und $0,8 \mathrm{~mm}$ dick, brann. Peristomzähne $0,6 \mathrm{~mm}$ lang. gelb, breit gesäumt, mit ausgeschweiften Rändern und etwa 25 Lamellen. Inneres Peristom blassgelblieh: Fortsäłze gefenstert: Wimpern vollständig, mit Anhängseln. Deckel gewölbt. mit Spitzelıen. Sporen $12-11 \mu$, grïnlichgelb, glatt.

Leipzig.

var. Bomanssonii Hag. 1. c. 1908. No. 3, p. 19) (1908).

Gametophyt wie die Hamptart. Peristomzähne an Rande nicht ausgeschweilt, mit oft durch Zwischenwände verbundenen Lamellen. lnneres Peristom sattgell). Sporen 18-22 " .

F. Al. Saltvik, llullby, in einem Graben (Bom.).

125. Bryum sinuosum Ryan in llag. Musc. Norv. hor. p. 225 (1901).

Autöziscl, selten heterözisch; Pll. in dichlen, bis 2 em hohen, grünen, innen tielbramen, Jurch Rhizoidenlilz verwebten Rasen. Stengel mit schopfig beblätterten subfloralen Sprossen. Schopflöäter trocken links gedreht, feucht aufrechtalstelınd, länglich-lanzcltich, schmal zugespitzt, bis 3,5 nm lang und $1, \bar{j} \mathrm{~mm}$ 
breit, mit breit zurückgeschlagenen Rändern; Rippe kräftig, áustretend; \%ellen oberwärts $40-70 \mu$ lang und $18 \mu$ breit, an Rande gestreckt, einen :3 1reihigen Saum bildend. Seta 2-3 cm, gelhbraum. Kapsel hängend, aus schmalem Halse von lualber [rnenlänge oval, 3-3,5 $\mathrm{mm}$ lang und $1-1,2 \mathrm{~mm}$ dick, rotbraun, trocken unter der Mïndung nicht verengt. Peristomzähne gelbrot, 0,42 mm lang. mit 15 wellig buchtigen, durch 1 -3 Querwände verbmulenen odler unregelmässig verschmelzenden Lamellen. Inneres Peristom frei, gellorot: Fortsätze mit grossen, ovalen bis länglichen Öflnungen; Wimpern mit langen und dicken Anhängseln. Deckel flach kegelig, mit Spitzchen. Sporen 28-33", gellgriin, papillös. Sporenreife im Juli.

N. F. Kistrand, Skovro, auf feuchter, toniger Kalkerde beim Fjorduter.

6. Caespitibryum Podp. in Beiheft. Bot. Centralbl. Bd. 12, p. 6 (1902) emend. Broth. in Engl.-Prantl Bryal. p. 528 (190-1).

Synözisch, autözisch oder diözisch; ₹ Blüten \pm dick knospenförmig. Blätter nicht herablaufend, trocken niemals spiralig um den Stengel gedreht, eiförmig oder eilanzettlich bis lanzettlich oder länglich-lanzettlich, mit meist gesäumten und umgerollten Rändern; Rippe meist heraustretend; Basalzellen gerötet. Kapsel regelmässig. Peristomzähne nahe der Mündung inseriert, gelb bis bräunlichgelb; Fundus orange bis rot.

426. Bryum bulbifolium Lindb. in sched., Norrl. in Bot. Not. 1873, No. 9: Not. Sällsk. Fauna et Fl. fenn. förh. Ny ser. X. p. 297 (1874).

Synözisch. Schlanke, herdenweise wachsende, gelbgrüne Pfl. Stengel bis $2 \mathrm{~mm}$, an Grunde mit Rhizoiden, sehr dicht und knospenförmig beblättert, mit kurzen, kätzenförmigen subfloralen Sprossen. Blätter hohl, eiförmig, stumpf. mit sehr kurzem und zurückgebogenem Spitzchen, bis $1 \mathrm{~mm}$ lang und $0,66 \mathrm{~mm}$ breit, ungesäumt, in der Spitze undeutlich gezähnt, mit nur am Grunde oder bis gegen die Blattmitte zurückgebogenen Rändem; Rippe vor der Blattspitze anfhörend; Zellen stark verdickt, $30-50$ " lang und 16-20 " breit. Seta bis $1 \mathrm{~cm}$. schwärzlichrot. Kapsel hängend, verkehrt kegelförmig, etwa $1,5 \mathrm{~mm}$ lang und $0,6 \mathrm{~mm}$ dick, derbhäutig, dunkel braumrot, trocken und entdeckelt unter der erweiterten Mündung wenig verengt. Peristomzähne am Grunde verbunden, 0,45 mm, trüb rötlichbraun, mit etwa 30 Lamellen. Inneres Peristom gelb; Fortsätze schmal gefenstert; Wimpern mit Anhängseln. Deckel gewölbt, mit Spitzchen. Sporen 16-18 $\mu$, bräunlich, fein papillös.

F. Le. Vittanki in der Kiefernregion, auf feuchtem, nacktem Sandboden am Ufer eines Bächlein: (Norrl.).

427. Bryum nigricans Kaur. mss.; Ryan in Hag. Musc. Norv. bor. p. 172(1901).

Synözisch. Herdenweise wachsende, im Sande vergrabene, schwärzliche Pfl. Stengel 1-1,5 cm, schopfig beblättert, mit steifen, etwa $5 \mathrm{~mm}$ langen, gleichmässig beblätterten, rötlichen bis grünen subfloralen Sprossen. Schopfblätter aufrecht, eilanzettlich, kurz zugespitzt, bis $2,2 \mathrm{~mm}$ lang und $0,9-1 \mathrm{~mm}$ breit, mit aufrechten oder am Grunde schwach zurückgebogenen Rändern; Rippe kräftig. vor oder mit der Blattspitze aufhörend; Zellen oberwärts 35-10 $\mu$ lang und 16$20 \mu$ breit, am Rande gestreckt, einen 1-2reihigen, undeutlichen Saum bildend. Seta etwa $2,5 \mathrm{~cm}$, braungelb. Kapsel hängend, aus deutlich abgesetztem Halse von halber Umenlänge oval, 2,5 $\mathrm{mm}$ lang und 1,25 $\mathrm{mm}$ dick, schwarz kastanienbraun, trocken unter der Mündung nicht verengt. Peristomzähne gelblich, bis zur Mitte lineal, 0,57 $\mathrm{mm}$ lang, mit etwa 32 Lamellen. Inneres Peristom hyalin: Grundhant sehr hoch; Fortsätze lanzettlich, mit breit eiförmigen Öffnungen; Wimpern mit sehr langen, dicken Anhängseln. Deckel gewölbt-kegelig, mit scharfem Spitzchen. Sporen $18-25 \mu$, gelbgrün, papillös. Sporenreife Ende Juli bis Anfang August.

N. F. Kislrand auf sandiger Erde. 
428. Bryum Culmannii Limpr. Laubm. 1I. p. 357 (1892).

Synözisch, mit einzelnen ơ Blüten. Pfl. in mässig dichten, lichtgrünen, nicht verfilzten, unten mit Schlamm durchsetzten, $2-4 \mathrm{~cm}$ hohen Rasen. Stengel farlenförmig, unter dem Schopfe mit schlanken, j 8 mm langen Sprossen. Bläter trocken anliegend und schwach links gedrelıt, fencht aufrecht, die unteren cilänglich, zugespitzt, bis 1,2 mm lang und bis $0,6 \mathrm{~mm}$ breit, mit nur an Grunde etwas umgebogenen Rändern; Schopfblätter knospenförmig zusanmenneigend, eiförmig, zngespitzt, bis 2,1 $\mathrm{mm}$ lang und bis $1 \mathrm{~mm}$ breit, ungesäumt orler sehr eng gelbgesäumt, mit stark umgerollten Rändern: Rippe als kurze Stachelspitze austretend; Zellen dünnwandig, 35-50 $\mu$ lang und $12-18 \mu$ breit. Seta bis 2,5 $\mathrm{cm}$, dünn. geschlängelt. Kapsel nickend oder hängend, aus dem kurzen, verschnälerten Halse länglich-zylindrisch, bis $3 \mathrm{~mm}$ lang, bleichbraun, trocken unter der Mündung stark eingeschnürt, entdeckelt weitmündig. Peristomzähne gelb, bis $0,6 \mathrm{~mm}$ lang, mit etwa 28 Lamellen. Inneres Peristom blassgelb; Fortsätze breit gefenstert; Wimpern mit sehr langen Anhängseln. Deckel kurz kegelig, nit Spitzchen. Sporen 15-19 ", gelbgrün, sehr fein gekörnelt.

N. K. Lom. No.-F. an einzelnen oder wenigen Fundorten.

Schweiz, Ost-Grönland.

429. Bryum polare Hag. in Meddel. Gronl. XV. p. 398 (1898).

Synözisch. Pfl. in niedrigen lockeren, gelblichgrünen Rasen. Schopflılätter trocken anliegend, aus ovaler oder eiförmiger Basis raseh lineallanzettlịch verschmälert, etwa 1,8 mm lang und 0,67 mm breit, ungesäumt, mit abwärts breit umgebogenen Rändern: Rippe kräftig, lang austretend; Zellen oberwärts etwa 35 " lang und $15 \mu$ breit. Seta $1,5-2 \mathrm{~cm}$. Kapsel hängend, nit dem Hals von Lrnenlänge eng elliptisch, etwa $2 \mathrm{~mm}$ lang und $0,54 \mathrm{~mm}$ dick, gelb, trocken unter der Mündung nicht verengt. Peristomzähne gelb, 0,34 mm lang, mit etwa 18 Lamellen. Fortsätze breit gefenstert; Wimpern mit langen Anhängseln. Deckel hoch kegelig. Sporen etwa $20 \mu$, rötlichgelb, papillös.

N. F. Talvik.

Grönland.

430. Bryum misandrum Hag. Huse. Norv. bor. p. 178 (1901).

Synözisch. Pfl, in dichten, 5-10 mm hohen, sattgrünen, unten braunschwarzen, durch Rhizoidenfilz verwebten Rasen. Stengel schopfig beblättert, mit knospenförmigen subfloralen Sprossen. Blätter bald rötlich, trocken anliegend, feucht aufrecht, obere elliptisch vder ciförmig-elliptisch, 1,9 mm lang und $0,6 \mathrm{~mm}$ breit, flachrandig, oberste breit eiförmig, plötzlich zugespitzt, mit sehmal umgebogenen Rändern; Rippe \pm lang austretend; Zellen oberwärts $50 \mu$ lang und $20 \mu$ breit, mässig' dickwandig, am Rande gestreckt, einen 3-4reihigen, gelblichen Saum bildend, in den Ecken der unteren Blätter selnmal rektangulär. Seta 2 cm, braun bis braunrot. Kapsel horizontal, selten nickend, mit dem kaum abgesetzten Halse elliptisch, 2,75 mm lang und $0,95 \mathrm{~mm}$ dick, braungelb, trocken unter der roten llündung verengt. Peristomzähne bleichbraun, lanzettlich, ziemlich breit gesäunt. 0,48 mm lang, mit etwa 24 Lamellen. Inneres Peristom hyalin; Fortsätze sehr breit, breit gefenstert bis klaffeñd; Wimpern mit langen, häufig gepaarten Anhängseln. 1)eckel kegelig, mit stumpfem Spitzchen. Sporen 16-20 $\mu$, grünlichgelb, papillös. Sporenreife im Juli.

N. No. Skjerstad, auf Erde in einer Felsenritze in der alpinen Region.

431. Bryum sarekense Arn. et Jens. in Moos. (l. Sarekgeb. 1). 150 (1910). |B. jemtlandicum H. Perss. in Ark. f. Bot. Bol. 14, No. 3, p. 32 (1916).]

Synözisch. Kleine, gesellige, grüne bis gelbgrüne, im Alter braune Pfl. Stengel 1-2 mm, mit kurzen, knospenförmigen sublloralen Sprossen. Sehopfblätter locker anliegend, hohl, breit eiförmig, raseh kurz und schmal zugespitzt, meist nit längs schmal umgebogenen Rändern; Rippe kräftig, \pm lang austretend: Zel- 
len oberwärts $40-50$ " lang und etwa 20 " breit, kaum verdickt, am Rande gestreckt, einen 1-3reihigen, \pm deutlichen Saum bildend. Seta $1-1,5 \mathrm{~cm}$, braun. Kapsel klein, horizontal bis hängend, aus dem Halse von halber Urnenlänge länglich-ellipsoidisch, gelbgrün bis braun, trocken unter der Mündung verengt. Peristomzähne lanzettlich, breit gesäumt, gelb, mit 23-26 lamellen. Inneres Peristom hyalin bis gelblich; Fortsätze breit, rundlich gefenstert; Wimpern mit langen Anhängsehn. Deckel kegelig, mit Spitzehen. Sporen 13-16 ", gelblichørün, glatt. Sporenreife im Juli.

S. LuL. Sarekgebiet, an erdbedeckten Felsen der Weidenregion. Jmt. Åre, Täljstensijället, auf zersetztem Talkschiefer.

432. Bryum microstegium Bryol. eur. fase. 32, Suppl. p. 7, t. 8 (1816).

Synözisch. Pfl. in sehr niedrigen. dichten, grünen Räschen. Stengel schopfig beblättert, mit knospenförmigen subfloralen Sprossen. Schopflbätter trocken fast dachziegelig, feucht aufrecht-abstehend, die äusseren eilanzettlich, die inneren grösser, länglich-lanzettlich, lang zugespitzt, etwa $2 \mathrm{~mm}$ lang und $0,6 \mathrm{~mm}$ breit, flachrandig; Rippe kräftig, lang austretend; Zellen dünnwandig, oben meist $70 \mu$ lang und $14 \mu$ breit, am Rande gestreckt, einen meist 2reihigen Saum bildend. Seta fast $3 \mathrm{~cm}$, purpurn. Kapsel nickend, mit dem Halse von halber Ĺmenlänge länglich-birnförmig, etwa $3 \mathrm{~mm}$ lang, kleinmündig, ockerfarben, dünnhäutig, trocken runzelig, unter der Mündung nicht verengt. Peristomzähne bleichgelb. kaum gesäumt, bis zur Mitte linealisch, etwa 0,4 mm lang, mit 20-22 Lamellen. Inneres Peristom fast hyalin; Fortsätze breit gefenstert; Wimpern bald mit, bald ohne Anhängsel, zuweilen rudimentär. Deckel klein, gewölbt-kegelig, mit Spitzchen. Sporen 20-24 $"$, gelb, gekörnelt. Sporenreife im Juli.

S. LyL. Stuorvare.

N. Dorre. Lon, Galdho.

433. Bryum angermanicum Arn. in Rev. bryol. 1898, p. 6.

Symözisch. Pfl. in lockeren, 2,5-3,5 cm hohen Rasen. Stengel etwa $5 \mathrm{~mm}$, schopfig belıättert, mit etwa $5 \mathrm{~mm}$ langen peitschenförmigen, subfloralen Sprossen. Schopfblätter trocken locker anliegend, eilanzettlich, allmählich \pm lang zugespitzt, bis $2 \mathrm{~mm}$ lang und bis $0,7 \mathrm{~mm}$ breit, mit meist schmal umgebogenen Rändlem; Rippe kräftig, \pm lang austretend; Zellen derbwandig, oben 35-50 " lang u. $18-20 \mu$ breit, am Rande gestreckt, einen etwa 3reihigen, gelben Saum bildend. Seta $2-3,5 \mathrm{~cm}$, unten kastanienbraun, oben gelb. Kapsel geneigt bis hängend, mit dem Halse von halber Urnenlänge keulig-birnförmig, etwa $3 \mathrm{~mm}$ lang und $0,9 \mathrm{~mm}$ dick, schmutziggelb bis fast weiss, trocken unter der Iündung nicht verengt. Peristonzähne gelb, breit gesäumt, vom Grunde an gleichmässig verschmälert, $0,4 \mathrm{~mm}$ lang, mit 25 Lamellen. Inneres Peristom fast hyalin; Fortsätze breit gefenstert; Wimpern meist rudimentär. Deckel flacl gewölbt, mit Warze. Sporen $17-23 \mu$, gelb, glatt. Sporenreife im August.

Auf trockenen Felsen.

S. Ang. Hernösand, Helletorp: Nora, Bole; Nordingra, Räfsö.

134. Bryum intermedium (Ludw.) Brid. Nant. muse. p. 120 (1819). [Mnium inlermedium Ludw. Moos. Cent. I. No. 81 (1802).]

Synöziseh. Ziemlich schlanke Pfl. in ausgedehnten, ziemlich dichten, grünen oder gelbgrünen, unten durch Rhizoidenfilz verwebten Rasen. Stengel bis $1-2$ ('m, mit kurzen, schopfig beblätterten Fruchtsprossen und schlanken. verlängerten sterilen Sprossen. Blätter \pm abstehend, trocken anliegend, obere breit länglichlanzettlich, bis 2,5 $\mathrm{mm}$ lang und bis $0,75 \mathrm{~mm}$ breit, mit bis gegen die Spitze ungerollten Rändern; Rippe kräftig, als kurzer oder längerer Endstachel austretend: Zellen oberwärts $35-50 \mu$ lang und 18-20 $\mu$ breit, am Rande gestreckt. einen 2-3reihigen Saum bildend. Seta 2-3 cm, rot. Kapsel horizontal und nickend, mit dem fast gleichlangen Halse länglich-birnförmig, bis $3 \mathrm{~mm}$ lang und bis $1,5 \mathrm{~mm}$ 
dick. mit etwas hervorgehobenem Rücken und schwach gebogen, derbhäutig, rötlichbraun, zuletzt dunkler bis schwärzlich, trocken unter der Iündung nicht orler wenig verengt. Peristomzähne gelb oder blassrötlich, $0,40-0,57 \mathrm{~mm}$, mit 25-30 Lamellen. Inneres Peristom blass gelblich; Fortsätze unten fensterartig, oben ritzenförmig durchbrochen, später klaffend: Wimpern knotig oder mit kurzen Anhängseln. Deckel kegelig, lange bleibend. Sporen $20-25$ " gelb oder olivengrün, fein papillös. Sporenreife rom Juni bis zum Herbst.

In feuchten, sandigen oder tonigen Ausstichen, an Iauern und auf Kalkdetritus.

F. Al. Eckerō, Överbঙ̣ (H. Lindb.). Mariehamn (Bom.). Jomala, Jomalaby (B.). Sund, Bomarsund (B.). Saltrik, an einigen Fundorten (B.). - Ab. Pargas Alōn, Simnnbș (Eifv.); Par-by (Broth.). Finby, Pettu (Sundr.). - Y. Helsingfors, Fredriksberg (Lindb.). - Ka. Wiborg (II. Nyl.) - Ga. Isokỵö. Orisberg (Ranck.). - Li. Inari. Outaknski, Par iji, am Flussufer (Hult). - Lx. Tschapona (Kihlm.). Tásjọ

S. öl., $\mathrm{Vg}$.. Srm. und $\mathrm{Upl}$. an wenigen. Tär. an mehreren Fundorten. Mpd. Norbyknöl. Ang.

N. Sm. pass. JL. Sandefjord und Tj"m". Bu. Hen. $h^{-}$. Dorre urd Lomsfjeldene. MT. Stjurdalen. No. an vielen. $T r$. und $F$, an mehreren Fundorten. Steigt nur selten über die Baumgrenze hinauf. Nordgrenze bei etwa $70^{\circ} 30^{\prime} \mathrm{n}$. Br.

Europa, Sibirien, Ford-Amerika.

var. subcylindricum Limpr. Laubm. II. p. 351 (182(1).

Seta bis 3-1 cm, oben hakenförmig. Kapsel hängend, schlank keulenförmig. nicht gekrümmt, bis $1 \mathrm{~mm}$ lang: Hals $1 / 2$ der Urne.

N. No. Ne:ne, Tomma; Mo.

Deutschland.

* Bryum fuscum (Lindb.) Bryhn in D. K. X̀. Vicl. Selsk. Skrift. 1892. p. 50 (1893). [Bryum fuscum Lindb. in Bot. Notis. 1884, p. 67. - B. intermedium var. fuscum Bryhn in Nyt Mag. Naturs. Bd. XXXII. p. 14 (1894).]

Synözisch. Ziemlich schlanke, herdeıweise wachsende, schmutziggrüne Pfl. Stengel bis $1 \mathrm{~cm}$. Blätter trocken anliegend, feucht aufrecht-abstehend. obere aus eiförmigem Grunde länglich-lanzettlich, lang zugespitzt, bis $3 \mathrm{~mm}$ lang und 1,2 $\mathrm{mm}$ breit, mit bis gegen die Spitze breit umgebogenen Rändern; Rippe kräftig. als kurze, gezähnte Granne austretend; Zellen oberwärts lang und schmal, $\overline{-}-8 \mu$ lang und $10-1+\mu$ breit, am Rande gestreckt, einen 2-3reihigen Saum bildend. Seta bis $4 \mathrm{~cm}$, braun. Kapsel horizontal oder geneigt, entleert meist schräg aufrecht, regelmässig. aus engem, gleichlangem Halse verlängert keulenförmig, 1-5 mm lang und 1,2 mm dick. derbhäutig, braum, trocken unter der Nündung etwas verengt. Peristnmzähne gelb, $0.55 \mathrm{~mm}$ lang, mit 25 stark entwickelten Lamellen. Inneres Peristom gelblich, fein papillös: Fortsätze fensterartig durchbrochen; Wimpern mit langen Anhängseln. Deckel kegelig. Sporen 20-22 $\mu$, gelbgrün, fein papillös. Sporenreife im Herbst.

In feuchten, sandigen Ausstichen.

F. N. Helsingfors. Fredriksberg (Lindb.). - ob. Kenni. an Meeresufer (Humm.). - K. Kuusamo, Martilia (Broth.).

N. Dovre. H. Romedal. ST. Foldalen. NT. Stjordalen. No. an mehreren Fundorten. Tr. Ibbestad, spandtinden. F. Kistrand.

135. Bryum clathratum Amam in Rev. bryol. 1889, p. 89.

Synözisch, mit einzehnen $c^{7}$ Blüten. Schlanke Pfl, in dichten, grünen, innen bräunlichen Rasen. Stengel bis $1 \mathrm{~cm}$, schopfig beblättert, mit bis $1 \mathrm{~cm}$ langen. schlanken subfloralen Sprossen. Schopfblätter trocken anliegend, feucht aufrechtabstehend, aus eiförmigem odler länglichem Grunde lanzettlich zugespitzt, bis 3 mm lang und etwa $1 \mathrm{~mm}$ breit, mit bis zur Spitze stark umgerollten Rändern; Rippe als Granne austretend; Zellen an Rande in mehreren Reihen gestreckt, einen \pm dentlichen Saum bilktend. Seta $1-1,5 \mathrm{~cm}$, diim, braunrot. Kapsel nickend, mit dem etwas kürzeren Halse länglich-keulenförmig, etwa $2 \mathrm{~mm}$ lang und $0,5-$ (1,75) $\mathrm{mm}$ dick, meist etwas gebogen, derbhäutig, kastanienhraun, trocken unter 
der Mündung nicht verengt. Peristomzähne blassgell, etwa $11,10 \mathrm{~mm}$ lang, meist mit einer deutlichen Längsfaltung und mit etwa 30 hohen Lamellen. Inneres Peristom gelb; Fortsätze breit klaffend: Wimpern mit langen Anhängseln. Deekel gross, flach gewölbt, mit Zitze. Sporen 20-28,", gelbgrün, papillös. Sporenreife im Herbst.

Auf magerer oder sandiger Erde, besonders im Flusssande.

F. Al. Saltvik. in einem sandigen Ausstich in der Nähe des Pfarrhause-(Bmn.).

N. Dorre. Jerkin. No. Skjerstad. F. Kistrand und Neseby an einiquen Fundorten. Nordgrenze bei $70^{\circ} 25^{\prime} \mathrm{n} . \mathrm{Br}$.

Schweiz.

436. Bryum tardum Bomans. in Rev. bryol. 1903, p. 87.

Synözisch, mit einzelnen or Blïten. Schlanke, gesellige oder lockerrasige. schmutziggrüne, abwärts braune Pfl. Stengel sehr kurz, dicht beblätert, mil knospenförmigen subfloralen Sprossen. Blätter trocken anliegend, leucht aufrechtabstehend, breit eilanzettlich, kurz zugespitzt, bis $1.9 \mathrm{~mm}$ lang und bis $0.8 \mathrm{~mm}$ breit, mit längss stark umgerollten Rändern; Rippe als Granne austretend; Zellen am Rande gestreckt, einen etwa 3reihigen, gelben Sam billend. Seta 1,5$2 \mathrm{~cm}$, dünn, rötlichbraun. Kapsel nickend, mit clem fast gleichlangen Halse dick keulenförmig, bis $2 \mathrm{~mm}$ lang und bis $1 \mathrm{~mm}$ dick, derbhäutig. kastanienbraun. trocken und entdeckelt unter der weiten Mïndung kaum verengt. Peristomzähne gelb, Jis $0,45 \mathrm{~mm}$ lang, mit Perforationen, deutlicher Längsfaltung und etwa 25 hohen Lamellen. Inneres Peristom gelb; Fortsätze breit klaffend: Wimpern mit langen Anhängseln. Deckel gross, flach gewölbt, mit Zitze. Sporen. $18-20 \mu$, gelb oder grünlichgelb, fast glatt. Sporenreife im September und Oktober.

F. Al. Saltvik, Hullby, in einem sandigen Ausstich (Bom.). Unterscheidet sich von B. clathralum durch kleinere Blätter mit dichterem Zellgewebe, weniger zahlreiche Lamellen und kleinere, glatte sporen.

437. Bryum arctogaeum Hag. Muse. Norv. bor. p. 230 (1901).

Synöziseh. Pfl. in ziemlich lockeren, kleinen, bis $1 \mathrm{~cm}$ hohen, sattgrünen, innen bräunlichen Räschen. Schopfblätter trocken anliegend und etwas gebogen, oval oder eiförmig, bis $1,5 \mathrm{~mm}$ lang und bis $0,8 \mathrm{~mm}$ breit, mit breit ungebogenen Rändern; Rippe vollständig bis sehr kurz austretend; Zellen am Rande gestreckt. einen gelblichen, 2-3reihigen Saum bildend. Seta etwa 1,5 cm, rotbraun. Kapsel horizontal bis nickend, mit dem kürzeren Halse keulenförmig, etwa 2 mm lang und $0,8 \mathrm{~mm}$ dick, bleichbraun, trocken unter der Mündung schwach verengt. Peristomzähne 0,43 mm lang, gelblich mit tiefrotem Fundus und etwa 28 Lamellen. Fortsätze gefenstert. Wimpern grob papillös, mit langen Anhängseln. Deckel kegelig-gewölbt, stumpf oder gewölbt, mit Warze. Sporen 17-20 ", gelblich, sehr fein punktiert. Sporenreife im August.

N. F. Vadsö, auf nackter, unfruchtbarer Erde.

Nach $H$ a g e n dürfte diese Art am nächsten mit $B$. intermedium verwandt sein, muss aber als davon spezifiseh versehieden betrachtet werden.

138. Bryum luteum Bomans. in Rev. bryol. 1903, p. 98.

Synözisch, mit einzelnen $c$ Blüten. Lockerrasige, lichtgrüne PfI. Stengel etwa $3 \mathrm{~mm}$, mit kurzen, schopfig Jeblätterten subfloralen Sprossen. Schopfblätter brejt eilanzettlich, schmal zugespitzt, bis $2,5 \mathrm{~mm}$ lang und $0.8 \mathrm{~mm}$ breit, mit längs: schmal umgebogenen Rändern: Rippe kurz austretend; Zellen am Rande gestreckt, einen 2-3reihigen, gelben Saum bildend. Seta bis $2 \mathrm{~cm}$. Kapsel nickend, mit kurzem Halse verkehrt eiförmig, etwa $2 \mathrm{~mm}$ lang und etwa $1 \mathrm{~mm}$ breit, zuletzt lederbraun, entdeckelt weitmündig, unter der Nündung kaum verengt. Peristomzähne gelb, etwa $0,40 \mathrm{~mm}$ lang, aulacoclont, mit etwa 20 Lanellen. Inneres Peristom gelb; Fortsätze breit gefenstert; Wimpern vollständig. mit I langen Anhängseln. Deckel niedrig, gewölbt kegelig, mit Spitzchen. Sporen $16-20 \mu$. gelbgrün, glatt. Sporenreife im Juni.

F. Al. Saltvik, in einem sandigen Austich in der Nähe des Pfarrhauses (Bom.). 
439. Bryum sysphinctum Limpr. Laubm. II. p. 352 (1892).

Synözisch, mit cinzelnen or Blïten. Schlanke Pfl. in goldgrünen, bis $1 \mathrm{~cm}$ hohen Rasen. Schopfblätter länglich-lanzettlich, zugespitzt, bis $2,4 \mathrm{~mm}$ lang und 0,86 mm breit, mit längs ungebogenen Rändern; Rippe kräftig, als Stachel austretend; Zellen oberwärts bis $70 \mu$ lang und $10-13 \mu$ breit, am Rande gestreckt, einen mehrreihigen Sam bildend. Seta 1-1,8 cm, dünn, rotbraun. Kapsel nikkend oder hängend, aus engem Halse von fast halber Urnenlänge plötzlich dick eiförmig, bis 2,4 $\mathrm{mm}$ lang und $1,0 \mathrm{~mm}$ dick, rotbraun bis blutrot, vor und nach der Entdeckelung unter der weiten Mündung stark eingeschnürt. Peristomzähne bis $0,48 \mathrm{~mm}$ lang, bleichgelb, mit 25-27 Lamellen. Fortsätze sehr breit gefenstert; Wimpern mit langen Anhängseln. Deckel glänzend, hoch gewölbt, mit Spitzchen, Sporen $16-20 \mu$, gelb, fast glatt. Sporenreife im August.

N. sT. Opdal, skaret, auf sandbänken an den Gebirgshächen.

410. Bryum cirratum Hopp. et Hornsch. in Flora 1919, I. p. 90. (Bryum subcirratum Bomans. in Rev. bryol. 1903, p. 85. - B. venustum Bomans. 1. c. p. 100.)

Synözisch, mit zahlreichen ơ Blüten. Ziemlich schlanke Pfl. in dichten, durch Wurzelfilz verwebten, oben grünen bis gelblichgrünen Rasen. Stengel bis 2 cm, selten noch länger, dicht und schopfig beblättert, oft mit schlanken, locker beblätterten subfloralen Sprossen. Schopfblätter trocken anliegend und etwas verbogen, feucht aufrecht-abstehend, aus breitem Grunde allmählich lang zugespitzt, bis etwa $3 \mathrm{~mm}$ lang und 0,6-0,9 $\mathrm{mm}$ breit, mit längs umgerollten Rändern; Rippe kräftig, als sehr lange, gezähnte Granne austretend: Zellen in verschmälerten Blatteile lang und schmal, etwa $70 \mu$ lang und 8 " breit, in der Blattmitte 12 16 " breit, am Rande gestreckt, einen mehrreihigen Saum bildend. Seta bis 4-; cm, dünn, rot. Kapsel nickend bis häıgend, aus fast gleichlangem Halse länglich, zuweilen verkelırt ei-birnförmig, bis $3,3 \mathrm{~mm}$ lang, trocken und entdeckelt unter cler Mündung verengt, braun und rötlichbramn. Peristomzähne bis $0,56 \mathrm{~mm}$ lang, gelblich, mit bis 36 Lamellen. Fortsätze des imneren Peristoms breit gefenstert: Wimpern mit langen Anhängseln. Deckel gross, gewölbt-kegelig, mit Spitzchen. Sporen 16-21 «, bräınlichgrün, fein papillös. Sporenreife im Sommer.

Auf feuchtem, sandigem Boden, auf Sumpfwiesen, auch an alten Mauern und in Felsritzen.

F. Al. Saltrik, in der Nähe des Pfarrhauses (Bom.) Sund, Bomarsund (B). - Ab. Pargas. Piukala (Elfv.). Finby, Kaukosalo Broth.). - N. Ekenäs, Tvärminne (Häyr.). Esbo, am Wege zwisehen Sandudd und Hagalund cop. (Wjuth.). Sibbo, Löparö, Tallholmen (B.). - Sa. Nyslott (Lackstr.). hl. Valamo (H. Baekm.). Sortavala, Mäkisalo (Link.). Impilahti, Pullinvuori (Broth.). Ruskeala (Buch). - Sb. Kaavi, Siikajärvi, Likosaari (Kot.). Pielavesi, Yijäkkö und Jylhä, Rovioranta (Roir.). Maaninka, Haatala, Savola (R.). - Om. Lappajärvi, Kärnä (Backm.). — Ok. Ristijärvi (Lackstr.). 一 Ob. Kemi, Laurila (Broth.). - K. Pudasjärvi, Iso Syöte (B.). Kuusamo, zw. Marttila und Vattula (B.); Y"liKitkajärvi (B.); Juuma und Kitkajoki (B.); Oulankajoki (B.); Paanajärvi. Selkäjoki (B.). - Lkem. Kulari, Jokijalka (Hult). - Le. Ylikylä und Vuontisjärvi in der Nadelwaldregion (Norrl.). Kilpisjärvi, Malla und Saana in der alpinen Region fq. (Kot.). - Li. Ivalojoki (Vain.). Utsjoki Parschi (Hult). Lim. Kandalaks Nivajoki (Broth.). Tschunosero (B.). Hibinä in der alpinen Region (B.). - Ll. Punuranki (B.). - Lmur. Gavrilova Rinda Harlovka und Litsa (B.). - Lp. Ponoj (Brenn.). Orlor Goguliha (kihlı.).

S. Gill. Yg. När.. Dlr., Hrjd., Imt., PL. und $L u L$. an einzelnen oder wenigen Fundorten.

N. Sm., Bu., $J L$, und $N e$, an einzelnen oder wenigen Fundorten. $K$. Dovre und Lomsfjeldene. No.-F. an einzelnen oder werigen Fundorten.

Europa, Kaukasus, Vorder-Asien, Baltistan, Kaschmir, Sibirien, Nord-Amerika.

* Bryum sulcatum Joerg. in Christ. Vicl.-Selsk. Skrift. 189-1, No. 8, ]). 86. Blätter schmal gesännt. Lapsel unter der Mündung verengt. Peristomzähne in der unteren Hälfte mit Längsfurchung und Perforationen.

N. No. Rejsenelven, Lyngmark, am sandigen Ufer.

111. Bryum affine (Bruch) Lindb. Musc. scand. D. 16 (1879). [Webera affinis Bruch in Bricl. Bryol. univ. I. p. 848 (1826). - Bryum cuspidatum Schimp. Syn. 2. ed. p. 430 (1876).] 
Synözisch. Ziemlich kräftige Pfl. in dichten, durch Wurzellil\% verwehten, oben grünen bis gelblichgrünen Rasen. Stengel bis 2 cm, dicht und schopfig beblättert, mit 4-6 mm langen subfloralen Sprossen. Blätter herablaufend, Schopfblätter trocken anliegend, meist selnwach gedreht, feucht aufrecht-abstehend, verlängert lanzettlich, lang zugespitzt, bis $3,8 \mathrm{~mm}$ lang uncl $0,9 \mathrm{~mm}$ breit, mit längs umgeschlagenen, unversehrten Rändlern: Rippe kräftig, als gezähnte Granne austretend; Zellen dünnwandig, oberwärts 10-50 " lang und 18 " breit, am Ranıle gestreckt, einen 2 -3reihigen, gelben Sam bildend. Seta 2-3 cm, rot. Kapsel übergeneigt bis fast hängend, aus langem Halse kur\% \%ylindriseh, 2,5-3 mm lang, lerbhäutig, trocken und entdeckelt unter der llündung wenig verengt. Zälnne (les äusseren Peristoms gell), l)is 0,6 mm lang, breit gesäumt, mit etwa 30 1,anellen. Fortsätze des inneren Peristoms breit gefenstert; Wimpern mil langen Anhängseln. Sporen 9-17 ", auch 15-20 ", gelb, glatt ofler sehr fein papillös. Deckel gross, gewölbt, mit Spitzchen.

Auf rersandeten Wiesen, an sandigen See- und Flussufern, in feuchten Sandansstichen, an Manern und in Felsritzen.

F. Al. Eckerö. Jomala, Finström. Brändö an einzelnen, saltvik an vielen Fundo·ten (Bum.. Ab. Korpo, Finnö und strömma (Ekl.). Pargas, Storgàrd und Skräbböle (Elfv.). Sagu, Träskbs (Buch). Lojo. Pietnäs (lindb.). - N. Ekenäs, Lappvik (Ranck.). Sıappertuna, Razeborg (IIäyr.). Eslıo, I1agalund (Broth.). Helsingfors (Lindb.). - Ko. Wiborg (II. Nyl.). - Ih. Pyhäjärvi, dun Ladoganier zw. surtan!ahti und Vernitsil (H. Lindb.). - St. Eura (Rönnb.). Piıkkala (Simun.). - Ta. Asikkala. Anianpelto (Broth.). Kalvola (Kinahe). Kangasala. Prinssivuori (Ranck.). Sysmä (Thur.). Hartola (Bonsa.)

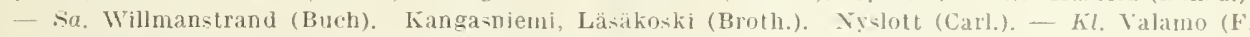
Nyl.). Sortavala (F. Nyl.). Ruskeala (W. Nyl.). Suaulahti, Korpikallio (Broth.). Pälkjärvi (Broth.). Kol. Petrosavodsk (W. Nyl.). - Oa. Isokyrö, Orisberg (Ranck.). - Tb. Viitasaarí (Broth.). - Sb. Juıka, Pelruvaara (Kot.). Maaninka, Pöljä, I uhimäki (Kyyhk.). - Kon. Tiudie (F. Nyl.). - Om. Gamla Karleby (Knabe). Ylivieska (Tenn.). Brahestad (Broll.). - Ok. Kajana (Lackstr.). O Ob. Kemi. Taivalkoski (Brenn.). - K. Kuusamo. Hatalaja und Marttila (Broth.); Juuma (Broth.). Soranköngäs (B.). - K'k. Knjächa (Fellm., Broth.). - Lkem. Muonioniska (Sahlh.). Kuolajärvi, Kurlajoki. Kioiruköngäs (E. af H.). - Le. Peerakoski und Palojoki (Norrl.). - Lim. Kandalaks (Brolh.). — Lt. Srednij am Kolalusen (Broth.). Tsipnavolok und Bumandijord (B.). - Lmur. Gavilova (Broth.). -.. Lp. Ponuj (Brenn.. Broth.). Triostrova (Brulh.).

S. Bl., Ø̈g., Vg., Upl., Vrml., Gstr., Dl... Ypd., Jml. und Ing.

N. Sm. frlemininge und Onsø. Bu, an wenigen Fundorten. JL. Tjomo. K. Lornsfeldene, Rø:hem. $X T$. Sijordalen. No. und Tr. an wenigen, $F$. an mehreren Fundorten.

Europa, Kaukasus, Ballistan. Kaschmir, Japan, Nord-Anerika.

var. urnigerum Arn. in Bot. Notis. 1897, p. 59.

Kapsel klein und kurz, unter der weiten Mliundung verengt: Hals kiirzer als die Erne.

S. Jmt. Täljstensbrottet. Ang. Hernön, am sindigen Ufer des Ösiön.

var. cylindricum Arn. 1. c.

Kapsel fast zylindrisch, unter der Mündnng eingeschnürt.

F. Al. Jomala, Grägerö (Ranck.). - N. Helsinge, Vesterkulla. Kalkholmen (R.).

S. Vg., Gstr., Dlr. und Ang.

N. ST. Opdal. Tr. Tromsø. F. an wenigen Fundorten.

* Bryum saxatile (Hag.) Amann Fl. mouss. Suiss. [1. p. 212 (1912). [Bryum suxalile Hag. Muse. Norv. bor. p. 170 (1901).]

Heterözisch ( und $\checkmark$ ). Pfl. in dichten, bis $1 \mathrm{~cm}$ hohen, grünen, innen braunen Rasen. Schopfblätter trocken geschlängelt und fast anliegend, kurz herablaufend. eiförmig, allmählich schmal zugespitzt, etwa 2 mm lang und 0.64 mm breit, mit bis über die Nitte zurückgeschlagenen Rändern; Rippe kurz austretend; Zellen sehr zartwandig, oben etwa 70 " lang und 2 " breit, am Rande gestreckt, einen 4 -jreihigen, gelben Saum bildend. Seta bis $3 \mathrm{~cm}$, gelbrot. Kapsel nickend, aus dem deutlich abgesetzten, fast gleichlangen Halse eiförmig, etwa 2,7 mm lang und bis $1 \mathrm{~mm}$ dick, braun, trocken und entdeckelt unter der weiten Miindung stark eingeschnürt. Peristomzähne gelb, 0,56 mm lang, mit etwa 25 Lamellen. Fort- 
sätze klaffend: Wimpern mit langen Anhängseln. Deckel kegelig oder gewōlbt. mit kleinem. stumpfem Spitzchen. Sporen 1j-17 ", gelb, entfernt papillös.

N. Yo. skjer-tad. Sandne: an feuchten Fel-er.

Unterscheidet sich nach $\mathrm{H}$ a ge $\mathrm{n}$ von der Hauptart durch die breiten Blätter, sehr dünnwandiges. lockeres Zellgewebe, wje auch durch die entfernt papillösen Sporen.

412. Bryum limosum Hag. Iusc. Norv. bor. p. 17.5 (1901).

Heterōzisch ( _ - ?). Rasen dicht, 2 cm hoch. schwärzlich, oberwärts grün, grōsstenteils in der Erde vergraben. Stengel schopfig beblättert, mit bis $5 \mathrm{~mm}$ langen. schopfig beblätterten subfloralen Sprossen. Schopfblätter trocken locker anliegend. etwas verłogen. feucht abstehend, aus verengter Basis oval oder ejfōrmig. kurz zugespitzt, $2,4 \mathrm{~mm}$ lang und $0,9-1.1 \mathrm{~mm}$ breit, mit fast bis zur Spitze schmal umgebogenen Rändern; Rippe als mässig lange Granne austretend; Zellen dünnwandig. oben $40-50$ " lang und $20 "$ breit, am Rande gestreckt, einen bis 5reihigen. braunen Saum bildend. Seta $2 \mathrm{~cm}$. gelbrot. Kapsel hängend, aus deutlich abgesetztem Halse fast ron halber Lrnenlänge plōtzlich dick oral, $1.4 \mathrm{~mm}$ lang und $1 \mathrm{~mm}$ dick, zimtbraun. trocken und entdeckelt weitmündig, unter der Iiündung nicht verengt. Peristomzähne gelbbraun, 0,16 mm lang, mit 18--20 niedrigen Lamellen. Inueres Peristom gelblich: Fortsätze gefenstert: Wimpern mit langen Anhängseln. Deckel gewölbt. mit Spitzchen. Sporen etwa $22 \mu$, grün. papillös.

N. Br. Telemarken, Gausta. F. Kistrand und sydraranger.

443. Bryum aristatum Hag. Musc. Norv. bor.,p. 183 (1901).

Sỹnözisch. Pfl. in dichten, bis $1 \mathrm{~cm}$ hohen, rötlichen. durch Rhizoidenfilz verwebten Rasen. Stengel mit sehr zahlreichen subfloralen Sprossen. Schopfblätter aufrecht. eilanzettlich. allmählich lang zugespitzt. $2.3 \mathrm{~mm}$ lang und etwa 1,6 mm breit. undeutlich gesäumt. mit schmal umgebngenen Rändern: Rippe als Gramne sehr lang austretend: Zellen zartwandig, oberwärts $50-60 \mu$ lang und 16-20 ": breit. Seta $2 \mathrm{~cm}$. dunkelbraun, oben braunrot. Kapsel meist hängend. aus deutlich abgesetztem Halse von halber Lrnenlänge eilänglich, etwa 2 mm lang und 1,1 mm dick, gelb, später lichtbraum, trocken unter der llündung nicht verengt. Peristomzähne gelb, ziemlich breit gesäumt, $0.4 \mathrm{~mm}$ lang, mit etwa 24 Lamellen. Inneres Peristom gelblich: Fortsätze breit gefenstert bis klaffend: Wimpern ohne oder mit kurzen Anhängseln. Deckel gewölbt-kegelig. mit Spitzchen. Sporen 19-22 $\mu$, grünlict bis 3raungelb. fast glatt. Sporenreife im August.

N. Tr. Ibbestad. Coarrrečukka, anf humōser Ĺnterlage.

14. Bryum flexisetum Lindb. et Arn. in K. Sr. Vet.-Ak. Handl. Bd. 23, o. 10, p. 44 (1890). (Bryum alandicum Bomans. in Rev. bryol. 1896, p. 90.)

Synözisch. Pfl. in lockeren, niedrigen. freudig- oder bräunlichgrünen, innen rötlichen Pasen. Schopfblätter eilanzettlich, meist lang zugespitzt, bis $2,5 \mathrm{~mm}$ lang und $0.7 \mathrm{~mm}$ breit, gesäumt, mit längs umgebogenen Rändern: Rippe kräftig, lang austretejd: Zellen oberwärts 30-40 " lang und etwa 15 " breit. am Rande gestreckt, einen etwa 3reihigen. gelben Saum bildend. Seta $1,5-3 \mathrm{~cm}$, dünn, = stark geschlängelt. rot. Kapsel geneigt bis hängend, mit dem Halse von halber Urnenlänge himenförmig, bis $2 \mathrm{~mm}$ lang und $1 \mathrm{~mm}$ dick, gelblich-, später rōtlichbraun. dünnhäutig, trocken unter der weiten Mündung verengt. Peristomzähne gelbrot, etwa $0.50 \mathrm{~mm}$ lang, mit 25-30 Lamellen. Fortsätze durchbrochen, mit wenigen ovalen Öffnungen; Wimpern vollständig. mit langen Anhängseln. Deckel hoch gewōlht, glänzend, mit Spitzchen. Sporen 20-2j ", gelbgrün, fein papillös. Sporenreife im Mai.

F. Al. Fin-trom, Emkarby und Ostanảker, an saudigen firabenränderri (Bom.).

Kurland. Sihirien.

Unterscheidet sich von der nächstverwandten $B$. cirratum schon durch die kurze, dicke Kapsel. 
41.). Bryum spissum Hag. in Kgl. Norsk. Vid. Selsk. Skrift. I908, No. :?, p. 35 (1908).

Synözisch. Pfl. in sehr dichten, etwa 1,5 cm hohen, flachen, gelbgrïnen Rasen. Stengel mit kurzen, knospenförmigen sul)lloralen Sprossen. Schopfl)]ätter trocken anliegend, feucht aufrecht-abstehend, länglich- oder eilanzettlich, his $2,1 \mathrm{~mm}$ lang und bis 0,77 mm breit, mit längs zurückgeschlagenen Rändern: Rippe als lange Granne austretend; Zellen oberwärts verlängert fiseitig, 10-62 $\mu$ lang und 13-17 $\mu$ breit, am Rande gestreckt und verdickt, einen 3-1reihigen, gelburaunen Saum bildend. Seta $1,5--2,5 \mathrm{~cm}$, rotbraun. Kapsel horizontal bis hängend, aus schmalem Halse von etwa halber Lrnenlänge dick eilörmig, meist etwa $2,2 \mathrm{~mm}$ lang und $1 \mathrm{~mm}$ dick, gelbbram, trocken und enteleckelt unter der Mindung nicht verengt. Peristomzähne blass gelbrot, $0,38 \mathrm{~mm}$ lang, mit etwa 20 [amellen. Inneres Peristom kaum anklebend, hyalin; Fortsätze gefenstert: Wimpern vollständig, mit langen Anlı̈ngseln. Deckel kegelig, mit Warze. Sporen 23-27 ", röllichgelb, fein papillös. Sporenreife im Juli.

N. Gudbrand:dalen, Nordre Fron. Lo: Sel, liringen. An schieferfelsen und in deren Ritzen.

446. Bryum teres lindb. in Öfvers. K. Sצ. Vet.-Ak. Förh. 1866 p. 545.

Autözisch. Schlanke Pfl. in lockieren, gelbgrünen, trocken glänzenden Rasen. Stengel niedrig, mit etwa $\&$ mm langen, steifen, unten entfernt und oberwärts kätzchenartig beblätterten, leicht sich ablösenden subfloralen Sprossen. Blätter aufrecht, sehr holl, breit eirund, stumpf, die oberen mit kleinem Spitzchen, etwa $1 \mathrm{~mm}$ lang und $0,9 \mathrm{~mm}$ breit, ungesäumt. untere flachrandig. Schopfblätter mit \pm weit hinauf umgerollten Rändern; Rippe sehr kräftig, vor der Blaltspitze aufhörend; Zellen oberwärts 24-35 " lang und 16-20 $\mu$ breit. Seta 1--1,5 cm, ziemlich dick, rotbraun. Kapsel hängend, mit dem Halse über $1 / 2$ der eilänglichen Urne, etwa $2 \mathrm{~mm}$ lang und $0,75 \mathrm{~mm}$ dick, bleichbraun, dümnwandig, trocken unter der weiten, wulstigen, glänzend roten Mündung verengt. Peristomzähne gelb, $0,15 \mathrm{~mm}$ lang, mit etwa 40 Lamellen. Inneres Peristom blass gelblich; Fortsätze breit gefenstert; Wimpern mit langen Anhängseln. Deckel klein, gewölbt, mit Warze, glänzend, purpurn. Sporen $18-20$ “, gelb, fein papillös.

S. LuL. Sarekgebiet, Ruopsok in der Weidenregion.

N. No. Skjerstad, auf nackter Erde, $750 \mathrm{~m}$.

Spitzbergen, arkt. Nord-Amerika.

417. Bryum subrotundum Brid. Bryol. univ. I. p. 673 (1826).

Autözisch. Schlanke, gesellig oder in unregelmässigen, meist von Erde bedeckten, kleinen, grünen, innen durch Rhizoidenfilz verwebten Rasen wachsende Pfl. Stengel meist nur wenige $11 m$, selten bis $2 \mathrm{~cm}$, mit zalılreichen knospenförmigen Ästen. Schopfblätter plötzlich viel grösser als die unteren, knospenförnig zusammenschliessend, äussere breit eiförmig, zugespitzt, stachelspitzig, innere eilänglich, lang zugespitzt, begrannt, die grössten 1,8-2 mm lang und $0,9-0,96 \mathrm{~mm}$ breit, mit nur am Grunde oder bis gegen die Spitze schmal umgebogenen Rändern; Rippe kräftig, als gezähnter Stachel oder als kurze Granne austretend; ZelIen oberwärts etwa $36 \mu$ lang und $18 \mu$ breit, am Rande gestreckt, einen undeutlichen Saum bildend, in den fast geöhrten Blattecken locker, quadratisch und 6seitig. Seta 1-2 cm, braunrot. Kapsel horizontal bis hängend, aus kurzem Halse dick eiförmig bis fast kugelig, 2 mm lang und 1 mm dick, dünnhäutig, lichtbraun, kleinmündig, unter der Mündung nicht verengt. Peristomzähne $0,40 \mathrm{~mm}$ lang. gelb, mit his 25 Lamellen. Inneres Peristom gelb, papillös; Fortsätze weit klaffend; Wimperı meist mit kurzen oder fehlenden Anhängseln. Deckel klein, gewölbt, mit Zitze, intensiv orange. Sporen $18-24 "$, gelbgrün, feinwarzig.

Auf Humus in Felsspalten und auf steinigem Boden in der alpinen Region.

S. Jmt. Åreskutan und Kölhaugen. LyL. Laxfjället. PL. Tjidtjakk.

N. Dorre. Vo. Mo und Skjerstad. Tr. Nordrejsen und Ibbestad. F. Nesseby. Nordgrenze bei $70^{\circ} 10^{\prime} \mathrm{n}$. Br. 
Alpensehiet. Himalaya, arht. Sibirien. Nord-Amerika.

var. clavatum Hag. Nusc. Norv. bor. p. 191 (1901).

liapsel keulenförmig, unter der Mündung eingeschnürt.

N. ST. Opdal. Olmberget und Vangsfjeldet. No. Skjerstad, mit der Hauptform; Hemnes, Gronfjeldet.

448. Bryum pumilum Ryan in Hag. Muse. Norv. hor. p. 191 (1901).

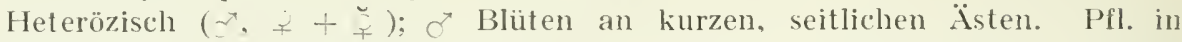
bis $8 \mathrm{~mm}$ hohen, sehr dichten, braungrünen, durch Rhizoidenfilz verwebten Rasen. Stengel schopfig beblättert, mit zahlreichen, meist knospenförmigen Sprossen. Sehopfblätter knospenförmig zusammenschliessend, länglich-lanzettlich, lang zugespitzt, bis fast $2 \mathrm{~mm}$ lang und bis $0.75 \mathrm{~mm}$ breit. mit bis gegen die Spitze breit umgeschlagenen Rändern: Rippe kräftig. als Granne austretend: Zellen dickwandig, oberwärts etwa $40 "$ lang und 18 " breit, deutlich kollenchymatiseh, in den geöhrten Blattecken aufgeblasen rundlich-quadratisch. niemals 6seitig, am Rande gestreckt und sehr dickwandig, einen 2-3reihigen, gelbhraunen Saum bildend. Seta 1,4 cm. braungell. Kapsel horizontal bis nickend, aus dem deutlich abgesetztem Halse von der Urmenlänge oval, bis 2,5 mm lang und $0,8 \mathrm{~mm}$ dick. bleich gelblichgrün. dïnnhäutig, trocken unter der Nündung nicht verengt. Peristomzähne $0,-12 \mathrm{~mm}$ lang, gelb, breit gesäumt, mit 15-20 Lamellen. Inneres Peristom braungelb: Fortsätze breit gelenstert: Wimpern flüchtig, lnotig, selten mit Anluängseln. Deckel kegelig. Sporen 16-22 ", gelblich, gekörnelt. Sporenreife im Juli.

N. F. Kistrand, in erderfütlten Ritzen der Dolomilfelsen bei Kolvik,

449. Bryum pallescens Schleich. Crypt. exs. Helv. No. 28; Schwaegr. Suppl. I. P. II. p. 107, tab. 75 (1816).

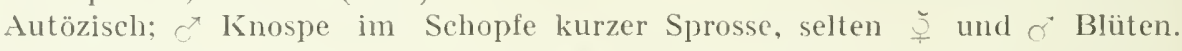
Ziemlich kräftige Pfl. in schwellenden, grïnen oder gelbgrünen, durch Rhizoidenfilz dicht verwebten Rasen. Stengel $1-3 \mathrm{~cm}$, zuweilen noch länger, dicht und schopfig beblättert, mit zahlreichen subfloralen Sprossen. Untere Blätter eiförmig, mit in der Spitze aufgelöster Rippe, Schopfblätter zahlreich und viel grösser, trocken gedreht, feucht abstehend, aus roter und fast geöhrter Basis eilanzettlich, lang zugespitzt, bis 3,2 $\mathrm{mm}$ lang und $0,7-1,1+1 \mathrm{~mm}$ breit, mit längs umgerollten Rändern; Rippe unten sehr kräftig, aufwärts stark verschmälert, als kurze oder längere glatte Granne austretend: Zellen oberwärts 35-50 " lang und 1.1-18" breit. am Rande gestreckt, emen 4-Jreihigen, gelblichen Saum bildend. Seta $1-3$ cm, geschlängelt, $r \div$ !rapsel geneigt oder horizontal bis hängend, nach Grösse und Form veränderlich, aus langem Halse nach der Mitte \pm bauchig und nach der weiten Mündung \pm verengt oder kurz keulig-birnförmig, zuletzt zimtbraun; Zellen dles Exotheciums unregelmässig, häufig rektangulär und mit verbogenen Wänden. Peristomzälne $0,50-0,60 \mathrm{~mm}$ lang, bleichgelb, mit etwa 30 Lamellen. Inneres Peristom gelblich bis weisslich: Grundluaut von halber Zahnhöhe; Fortsätze schmal, breit fensterartig durchbrochen; Wimpern vollständig, mit kurzen oder längeren Anhängseln. Deckel trocken meist am basalen L'mfange mit einem schmalen, ganz flachen Rande und dann entweder kegelig oder gewölbt und mit Zitze. Sporen 18-22 ", zwisehen dem Grünlichgelben und hell Ockerfarbenen spielend, warzig. Sporenreife im Juni und Juli.

An Felsenwänden und in Felsritzen, an Mauern und in sandigen Ausstichen.

F. Al. Eckerö (Bom.). Finström, Bartsgårda (Born.); frodby (Elfv.). Saltvik, an vielen Fundorten (Bom.). Sund. Kastelholm (B.). - Ab. Nảdendal (Arrh.). Kimito, Reku.(Ol..). Finby (Bruth.). Karislojo, Karkali (H. Lindl.); Torhola (E. at H.). Lojo, skräddarla (Lindb.). - N. Helsingfors (Lindb.). Itogland (Lindb.). - Ka. Wiborg (W. Nyl.). IIitola, Vavola (Lindb.). - Ta. An mehreren liundorten in südöstl. Teile (Norrl.). 一 Sa. Willniaıstrand (Buch). Kangasniemi (Larkstr.). — Kl. Kexholı (Tomin.). Kurkijoki. IIaavikho (Jusl.). Sortavala, Kirjaralaltti (Broth.). tmpilahti, Pultinvuori (B.) Ruskeata (Simm.). Palkjärvi, Kuhitasvaara (Broth.). - Kol. Vosnessenje und Sclıtjeliki (Elfv.). - Tb. Virrat, Toriseval (Broth.). - Sb. Kuopio, Neulanãki, Vuorilampi (Link.). Niliä, Kuuslihıti Jaakon- 
lampi (Kyyhk.). Maaninka, Tuorilanlahti (Lundstr.); Haatala (Roir.); Pöljā (Kyylık.). Iisalmi (Sahlb.). - Kon. Pirttiniemi (Simm.). Valkeamāki (S.). - Ob. Kemi, Laurila (Broth.). Aavasaksa (Buch). K. Kuusamo, Kitkajoki und Jyrärä (Broth.). Sovanköngảs (B.). 一 Lkem. Kittilă, Pahtakallio (Hult). - Lim. Kandalaks, Schelesnaja (Broth.). Porjaguba (Sel.). - Lt. Kola, Abramova Pahta und Karaulnaja Pahta (Broth.); Kildin (B.); Jeretik und Ara (B.). - Lmur. Rinda (Broth.). Semjostrotsk, Vicchniak (B.). - Lp. Ponoj (Brenn.). - Lv. Tschapoma (B.).

S. Sk.-Hlsl., Hrjd., Jmt., Ang., LyL. und LuL.

N. Sm. $-F$.

Europa, Kaukasus, Kaschmir, Sibirien, Amur, Kamtschatka, Nord-Amerika. Nordgrenze auf Spitzbergen.

var. boreale (Schwaegr.) Bryol. eur. fasc. 6/9, t. 22 (1839). [Bryum boreale Schwaegr. Suppl. I. P. II. p. 96, t. 69 (1816).]

Kräftiger. Stengel über $4 \mathrm{~cm}$ und mehr verzweigt. Blätter länger und schmäler, lang zugespitzt. Seta bis $4 \mathrm{~cm}$. Kapsel horizontal bis aufsteigend, verlängert, zur Reifezeit kastanienbraun.

Gern auf wassertriefenden Felsen. (B.).

F. Kk. Sonostrov pr. Keret (Sahlb.). - Lim. Kandalaks. Schelesnaja (Broth.). - Lv. Tschaponıa

S. Hrjd.-LuL.

N. Christiania. Lomfjeldene.

Europa.

var. contextum (Hopp. et Hornsch.) Bryol. eur. l. c. (Bryum contextum Hopp. et Hornsch. in Flora 1819, I. p. 91.)

Pfl. in sehr dichten. bis 5 und $6 \mathrm{~cm}$ hohen, durch Wurzelfilz verwebten Rasen. Blätter kleiner, kurz zugespitzt. Seta kürzer, oft kaum $1 \mathrm{~cm}$. Kapsel etwas geschwollen, trocken und entdeckelt unter der Mündung stärker eingeschnürt.

N. F. Nesseby, Mortensnes am Fjordufer.

Spitzbergen, Alpengebiet, Sibirien, Grönland.

var. Baenitzii (C. Müll.) Hag. Musc. Norฯ bor. p. 189 (1901). (Bryum Baenitzii C. Nlüll. in Flora 18s8, p. 417.)

Heterözisch $(\breve{g}+q)$. Blätter sehr weich, länger zugespitzt; Zellen sehr dünnwandig. Wimpern zerbrechlich.

N. No.. Tr. und $F$. an einzelnen Fundorten.

var. cylindricum Hag. I. c.

Heterözisch $(\breve{q}+\underset{+}{)})$; Blüten köpfchenförmig. Kapsel eng zylindrisch. etwa $6 \mathrm{~mm}$ lang und $1 \mathrm{~mm}$ dick. Wimpern meist nur knotig, ohne Anhängsel. $\mathbf{N}^{\cdot} \quad F$. Loppen und oksfjord.

450. Bryum Rosenbergiae Hag. in Ǩgl. Norsk. Vid. Selsk. Skrift. 1897, No. 2, p. 16 .

Autözisch, auch rein weiblich. Pfl. in dichten, 2 cm hohen, gelbgrünen. innen braunschwärzlichen Rasen. Schopfblätter trocken kraus gebogen, aus violetter und fast geöhrter Basis eilanzettlich, kurz zugespitzt, bis $3.2 \mathrm{~mm}$ lang und bis $1 \mathrm{~mm}$ breit, mit längs umgebogenen Rändern: Rippe als Granne austretend; Zellen oben etwa $70 "$ lang und 20 " breit, am Rande gestreckt und dickwandig, einen 4 -6reihigen, gelben Saum bildend. Seta $2,5-3,5 \mathrm{~cm}$, gelbrot, oben bleichgelb. Kapsel horizontal bis nickend, mit dem fast gleichlangen Halse elliptisch-zylindrisch, bis $2.6 \mathrm{~mm}$ lang und etwa $1 \mathrm{~mm}$ dick, gelblich bis ockergelb, trocken unter (ler Iü̈ndung verengt; Zellen des Exotheciums ziemlich regehmässig. in der Mehrzahl rektangulär. Peristomzähne gelb, mit bräungelbem Funclus, 0, 12 mm lang, schmal, lang pfriemenförmig zugespitzt, mit etwa 22 Lamellen. Grundhaut 1/3 der Peristomzähne; Fortsätze schmal, in eine lange. knotige Pfrieme verschmälert. unten gefenstert, in der Mitte ritzenförmig durchbrochen. Wimpern meist rudimentär, einzelne vollständig. mit langen Anhängseln. Deckel stumpf kegelig, mit kleiner Warze. Sporen 20-25 $\mu$, ockergelb, punktiert. Sporenreife im Juni.

N. Ne. Holt, Nes, an feuchten Granitfelsen. 
Lnterscheidet sich nach $\mathrm{H}$ age $\mathrm{n}$ von $B$. pallescens durch am Grunde violette Blätter, engere Kapsel, ziemlich regelmässige Zellen des Exotheciums, engere, breiter gesäumte, lang pfriemenförmig verschmälerte, am Grunde braungelbe Peristomzähne, niedrigere Grundhaut, schmälere und enger durchbrochene Fortsätze, meist rudimentäre Winpern, stumpf kegelige Deckel und grössere, ockergelbe Sporen.

451. Bryum Jackii C. Müll. in Bot. Ztg. 1864, p. 348.

Diözisch. Pfl. in sehr dichten, oben gelblichen Rasen. Stengel bis $3 \mathrm{~cm}$; fertile Sprossen kurz und schopfig beblättert, sterile lang und dünn, flagelliform. Blätter steif, nicht herablaufend, trocken etwas verbogen, feucht aufrecht-anliegend, eilanzettlich, zugespitzt, bis $2,4 \mathrm{~mm}$ lang und bis $0,9 \mathrm{~mm}$ breit, mit stark ungerollten Rändern: Rippe kräftig, als steife Granne austretend; Zellen bis gegen die Basis klein und dickwandig, oben rhombisch, 20-30 "lang und 10-12 $\mu$ breit, am Rande gestreckt, einen schmalen Saum bildend, gegen die Basis plötzlich weit lockerer und länger. Seta 1.5 -2 cm, rot. Kapsel hängend, aus langem Halse eng länglich, etwa $3 \mathrm{~mm}$ lang, braun, trocken unter der Nündung etwas verengt. Peristomzähne sattgelb, ungesäumt, $0,52 \mathrm{~mm}$ lang, mit über 30 Lamellen. Inneres Peristom gelb. Fortsätze gefenstert. Wimpern sehr zart, schwach knotig. Deckel kegelig, mit scharfem Spitzchen. Sporen etwa 18 ", gelblich, fein warzig.

N. ST. Opdal, Haakaar.

Kärntner Alpen.

Die Rasen der nur spärlich vertretenen norwegischen Exemplare sind niedrig und ohne die an clen Originalexemplaren auftretenden flagellenartigen Sprosse.

452. Bryum caespiticium L. Sp. pl. p. 1121 (1753).

Diözisch; $\checkmark$ Pfl. meist eigene Räschen bildend. Ziemlich kräftige Pfl. in meist sehr dichten, grau- oder gelbgrünen, durch Rhizoidenfilz verwebten, oft polsterförmigen Rasen. Stengel kurz oder bis $2-2,5 \mathrm{~cm}$, dicht beblättert, mit \pm zahlreichen subfloralen, schopfig beblätterten Sprossen. Schopfblätter viel grösser als die unteren Blätter, trocken anliegend, feucht aufrecht-abstehend, breit eilänglich-lanzettlich, allmählich lang zugespitzt. 1,5-2.9 $\mathrm{mm}$ lang und $0,8-1 \mathrm{~mm}$ breit, mit fast spiralig umgerollten Rändern: Rippe kräftig. als \pm lange Granne austretend; Zellen verlängert, wenig verdickt, in der Blattmitte $50-75 \mu$ lang und ca. 18 " breit, gegen die Ränder allmählich länger und enger, einen 2-3reihigen, 士 undeutlichen Sam bildind. Seta 2-4 cm, rot, steif. Kapsel nickend oder hängend, regelnuässig, derbwandig, aus kurzem oder längerem Halse dick oval und unter der weiten Mündung stark eingeschnürt, hell bis dunkel lederbraun. Peristonzähne bleich- bis dunkelgelb, breit gesäumt: Lamellen 25-28. Inneres Peristom gelblich; Fortsätze breit gefenstert oder klaffend; Wimpern mit sehr langen Anhängseln. Deckel gross, bald kegelförmig, bald gewölbt und mit Zitze, glänzend orange- oder blutrot. Sjoren 10-12 ", gelb, glatt. Sporenreife im Juni und Juli.

Auf magerer, besonders sandiger Erde, an Mauern und erdbedeckten Felsen.

F. Al. fq. (Bom.). - Ab. Abo. Piikkis. Reso. Pargas. Firby. Karislojo. Lojo. - r. Snappertuna. Kyrkslātt. Esbo. Helsingfors, - Ki. Virolahti. Antrea. - Ik. Pỵăjärvi. - St. fq. (Simm.). Ta. Vanaja. Hattula. Kalvola. Tammerfors. In sindöstl. Teile fq. (Norrl.). Hartola. Luhanka und Korpilahti f(. (Vain.). - Sa. Willmanstrand. Nyslott, - Kl. Valamo, Lukuniemi. Sortavala. Ruskeala. Pälkjärvi. - Kol. Petroärodsk. - Kon. Valkeamäki. Tiudie. - Oa. Vasa. - Sb. Joroinen. Kuopis. Kaavi, Jaaninka. Pielavesi. - Om. Alajärvi. Lappajärvi. Kalajoki. - Ok. Utajärvi. Sotkano. - Kpom. Suondali. - Ob. Oubr. hemi. - k. Kuusamo, Marttila.

S. Sh. $-L$.

N. Sm. $-F$., vom yeeresuler bis in die alpine Region auf:teigend, hier aber seltener. Nordgrenze l,ei $70^{\circ} 25^{\prime} \mathrm{n}$. Br.

Europa, Kaukasus, Vorder-A ien, West-Himalaya, Khasia, Sibirien, Japan, Nord-Amerika.

* Bryum Kunzei (Hornsch.) Amann Fl. mouss. Suiss. p. 231 (1912). (Bryum Kunzei Hornsch. in Flora 1819, 11. p. 90.) 
Diözisch. Schr schlanke Pfl. in dichten, grünen odler gelbgrünen, innen durch Rhizoidenfilz verwebten, fast polsterförmigen Rasen. Stengel bis I cm, unter der Spitze mit melıreren bis $1 \mathrm{~cm}$ langen, stielrunden Sprossen. Blätter der kätzenartigen Sprosse verkehrt eilänglich, kurz zugespitzt, etwa 0,75 nm lang und $0,45 \mathrm{~mm}$ breit, flachrandig; Rippe als zurückgebogener Stachel austretend. Schopfblätter eiförmig, kurz zugespitzt, bis 1,2 $\mathrm{mm}$ lang und $0,6 \mathrm{~mm}$ breit, mit nur am tiefsten Grunde schmal ungebogenen Rändern; Rippe als Granne austretend; Zellen äusserst dümnwandig, nicht getüpfelt, oben $30 \quad 40 \mu$ lang und $1-t-18 \mu$ breit, am Rande enger. Seta $1,5 \mathrm{~cm}$, braun. Kapsel hängend, aus fast gleichlangem Halse oval, 2,4-3 mm lang, braun, trocken und entrleckelt unter der Mündung eingeschnürt. Peristomzähne blassgelb, gesäumt, etwa $0,5 \mathrm{~mm}$ lang, mit etwa 26 Lamellen. Inneres Peristom blassgelblich; Fortsätze gefenstert; Wimpern zart, mit sehr langen Anhängseln. Deckel gross, gewölbt, mit Warze. Sporen 12-15 ", gelbgrün, glatt.

An Mauern und trockenen Felsen.

N. Ringerike, Tyristranden. Ve. Saetersdalen. NT. Stjurdalen.

Europa.

* Bryum comense (Schimp.) Amann 1. c. [Bryum comense Schimp. Syn. 2. ed. p. 144 (1876).]

Diözisch. Sehr schlanke Pfl. in \pm dichten, leicht zerfallenden, grünen, innen rötlichbraunen Räschen. Stengel etwa 5 mm, unter der Spitze mit mehreren, etwa 4 mm langen, stielrunden Sprossen. Blätter der kätzchenartigen Sprosse eilänglich, rasch zugespitzt, etwa $0,9 \mathrm{~mm}$ lang und $0,4 \mathrm{~mm}$ breit, flachrandig. Schopfblätter plötzlich viel grösser, trocken dachziegelig, eiförmig oder eilänglich, zugespitzt, bis $1,35 \mathrm{~mm}$ lang und $0,75 \mathrm{~mm}$ breit, ungesäumt, die innersten mit bis gegen die Spitze umgerollten Rändern; Rippe als kräftiger Stachel austretend; Zellen dickwandig und getüpfelt, in der Mehrzahl schmal rhombisch und rhomboidisch, oben $40-60 \mu$ lang und $10-14 \mu$ breit, am Rande enger. Seta 1,5-2 cm, braunrot. Kapsel fast hängend, aus gleichlangem Halse oval, etwa $2 \mathrm{~mm}$ lang und $0,75 \mathrm{~mm}$ dick, braun, trocken und entdeckelt unter der weiten llündung eingeschnürt. Peristomzähne gelb, bis 0,4 mm lang, breit gelblich gesäumt, mit 22-26 Lamellen. Inneres Peristom gelb; Fortsätze gefenstert; Wimpern zart, meist verkürzt. Deckel gross, halbkugelig, mit Warze. Sporen 10-12 "

F. Al. Saltvik, Boxö, an einer Felsenwand (Bom.); Krarnloo und Liby, auf Erdboden (B.). Kökar. Norrby und Ladö, auf schneckenerde (Ranck.).

S. Jmt. Handöl.

N. Sm. Tune, Grotet, an Steinen im Sollielven. Ne. Saetersdalen. NB. Sogn, Aurland, 900$950 \mathrm{~m} . K$. Vaage.

Pyrenäen, Schweiz, Italien.

var. brevimucronatum Bryhn in litt.; C. Jens. in Med(lel. Gronl. XV., p. 397 (1898).

Blätter mit oft zurückgebogenem Spitzchen.

N. Ringerike.

O:t-Grönland.

453. Bryum badium Bruch Mser. in Brid. Bryol. univ. I. p. 850 (1826). (Bryum caespiticium var. badium Brid. 1. c.)

Diözisch. Herdenweise oder in meist lockeren, bis $1 \mathrm{~cm}$ hohen, leicht zerfallenden, oft rot oder bräunlich überlaufenen Rasen. Fertile Stengel kurz, mit mehreren steifen, fast pinselförmigen Ästen. Blätter oberwärts almählich grösser, steif, trocken anliegend, feucht aufrecht, aus eiförmigem Grunde verlängert lanzettlich zugespitzt, bis $1,6 \mathrm{~mm}$ lang und bis $0,6 \mathrm{~mm}$ breit, mit flachen oder schmal umgebogenen Rändern; Rippe als lange, steife Granne austretend; Zellen locker und dünnwandig, in der Mitte $50-80 \mu$ lang und $9-12 \mu$ breit, am Rande enger, einen \pm deutlichen, schmalen Saum bildend. Seta $2-3 \mathrm{~cm}$, rot. Kapsel hängend, 
aus dem kurzen, meist aufgetriebenen, trocken runzeligen Halse fast zylindrisch, 2,5-3 $\mathrm{mm}$ lang und 1-1,2 $\mathrm{mm}$ dick, lebhaft rot bis rötlichbraun, zuletzt dunkelbraun, trocken und entdeckelt unter der weiten Mündung \pm verengt. Peristomzähne gelb, gesäumt, etwa $0,5 \mathrm{~mm}$ lang, mit bis 30 Lamellen. Imneres Peristom schön gelb; Fortsätze schmal, gefenstert; Wimpern mit langen Anhängseln. Deckel gross, spitz kegelförmig oder gewölbt, mit Zitze. Sporen 10-15 ", fast glatt. Sporenreife im Juni.

Auf feuchten Sand- und Schlammplätzen, in tonigen und kalkigen Ausstichen.

S. Gtl., Ög. Linköping. Jmt. an mehreren Fundorten.

N. Dorre.

Europa, Kaukasus.

454. Bryum Funckii Schwaegr. Suppl. I. P. II. p. 89, tab. 69 (1816).

Diözisch; ox Pfl. meist in besonderen Rasen. Schlanke Pfl. in lockeren oder mässig dichten, weisslichgrünen, trocken etwas glänzenden, innen rötlichen, unten

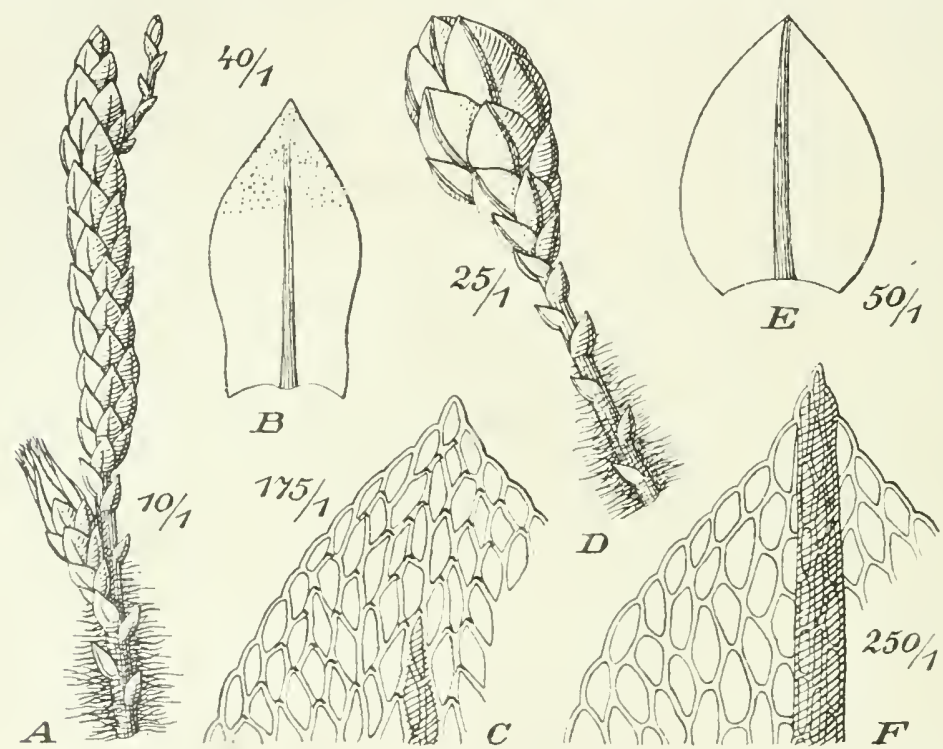

Fig. 52. A-C Bryum argentam L. A Sterile Pfl. (10/1); B Stengelb. (40/1); C Blattspitze (125/1). D-F B. Funckii Schwaegr. D Sterile Pfl. (25/1); E Stengelb. (50/1); F Blattspitze (250/1).

durch Rhizoidenfilz \pm zusammenhängenden, $1-2 \mathrm{~cm}$ hohen Rasen. Fertile Stengel kurz, unten entfernt und kleinblättrig, oben dicht schopfig beblättert, mit mehreren, bis 1 cm langen, kätzchenförmigen subfloralen Sprossen. Alle Blätter dachziegelig anliegencl. loffelartig hohl, eiförmig. kurz zugespitzl, ungesäumt, miltlere etwa $0,85 \mathrm{~mm}$ lang und $0,7 \mathrm{~mm}$ breit, endständige $1,2-1,5 \mathrm{~mm}$ lang $\mathrm{m}$ d bis etwa $1 \mathrm{~mm}$ breit; Rippe sehr kräftig, meist als liriftige Stachelspitze austretend; Zellen wenig verdickt, oberwärts 35-50 " Iang und 11 - 18 " breit, gegen die Ränder enger. Sela 2-3 cm. dünn, rot. Kapsel nickend oder hängend, aus verïägertem, almälnlich sich bis zur Lrme erweiterndem Hals fast kegelförmig, bis $3,6 \mathrm{~mm}$ lang und $1,5 \mathrm{~mm}$ dick, braun, trocken unter der weiten Mündmng \pm eingeschnürt. Peristomzälnne gelb, etwa $0,5 \mathrm{~mm}$ lang, fein papillös. mit 25-30 Lamellen. Inneres Peristom hyalin; Fortsälze weit fensterartig durchlorochen, später klalfend; Wimpern mit langen Anhängseln. Deckel gross, meist hoch spitzkegelig. Sporen 12-is $\mu$, gell, l'ein papillös. - Fig. $52 \mathrm{D}-\mathrm{F}$.

S. Sm. Jönköping. Gstr. Gefle.

Europa, Kaukasus, Sibirien. 
7. Argyrobryum C. Müll. Syn. I. p. 313 (1849).

Diözisch; or Blüten \pm knospenförmig. Schlanke bis sehr schlanke, meist rasenbildende PfI. Stengel dicht beblättert, mit kätzchenförmigen Sprossen. Blätter nicht herablaufend, dachziegelig anliegend, hohl, flach- und ganzrandig, ungesäumt; Pippe am Grunde mit basalen Deutern, ohne Begleiter. Kapsel dickhalsig, regelmässig, derbhäutig. Peristom unter der Mündung inseriert.

455. Bryum Blindii Bryol. eur. fasc. 32. Suppl. I. p. 11, tab. XII. (18-16).

Herdenweise wachsende oder kleine, mässig dichte Rasen bildende, bräunlich-oder weisslichgrüne, etwas glänzende Pfl. Stengel $4-10 \mathrm{~mm}$, bis zu den jungen Sprossen mit Rhizoiden, büschelästig. Untere Blätter breit eiförnig, kurz zugespitzt, obere eilänglich, kurz zugespitzt, bis $1,3 \mathrm{~mm}$ lang und $0,+\mathrm{mm}$ breit, Schopfblätter länglich-lanzettlich, $1.5 \mathrm{~mm}$ lang und $0,45 \mathrm{~mm}$ breit, nur die oberen und die Perichätialblätter mit schmal umgerollten Rändern; Rippe kräftig, mit oder kurz vor der Blattspitze aufhörend; Zellen gelbwandig und mässig rerdickt, oberwärts $40 "$ "lang und $12 "$ breit bis $60 \mu$ lang und $9 \mu$ breit. Seta $10-15 \mathrm{~mm}$, dïmn, steif purpurn. Kapsel hängend, meist der Seta angepresst, mit dem sehr dicken, am Grunde abgerundeten Halse ( $3 / 4$ (ler Urne) verkehrt-eiförmig oder birnförmig kugelig, 1,5-2,4 $\mathrm{mm}$ lang und $1-1,7 \mathrm{~mm}$ dick, kastanienbraun, im Alter schwarzbraun, trocken unter der Mündung nicht verengt. Peristomzälne gelb, papillös, 0,5-0,6 mm lang, mit gegen 30 Lamellen. Inneres Peristom gelb, papillös; Fortsätze fast gefenstert; Wimpern knotig oder mit Anhängseln. Deckel klein, hoch gewölbt, mit Zitze, rotbraun, stark glänzend. Sporen 12-16 $\mu$, gelb, fein papillös. sporenreife ins August.

Auf feinem Sande der Flussläufe.

N. ST. Opdal und Foldalen.

Riga, Alpengebiet, Rocky MIts.

456. Bryum oblongum Lindb. Neddel. Soc. Fauna et Fl. Fenn. 9. Heft, p. 127 (1883).

Herdenweise wachsende oder kleine, lockere Räschen bildende, blassgrüne Pll. Stengel 2-5 nm, vom Grunde bis zu den Schopfblätter mit Rhizoiden und mit steifen, fast fadenförmigen Sprossen. Untere Blätter aufrecht-abstehend. klein und schuppenförmig, breit eiförmig, stumpf, obere fast aufrecht, eilänglich, stumpflich, bis 1,2 mm lang und 0,40 $\mathrm{mm}$ breit; Rippe zart, vor der Blattspitze aufhörend: Zellen locker und dünnwandig, oberwärts $25-35$ " lang und $16-20 \mu$ breit. Seta 5-16 mm, geschlängelt, bräunlich-purpurn. Kapse] hängend, nicht der Seta angepresst, länglich, fast ellipsoidisch, bis $1,8 \mathrm{~mm}$ lang und bis $0,9 \mathrm{~mm}$ dick, mit allmählich verschmälertem, an der Basis abgerundetem Halse $(1 / 2$ der Urne), błutrot, später dunkler, etwas glänzend. Peristomzähne bräunlichgelb, papillös, 0,35 mm lang, mit meist 20 Lamellen. Inneres Peristom gelb, papillös; Fortsätze fast gefenstert; Wimpern mit Anhängseln. Deckel gewölbt, mit Spitzchen, rot, glänzend. Sporen 16-25 $\mu$, gelbgrün, fast glatt. Sporenreife im September.

In feuchten, tonigen oder sandig-tonigen Ausstichen und an Wegrändern.

F. N. Helsingfors, Fredriksberg (Lindb.). - Ob. Turtola, Pelio (Hult). - K. Kuusamo, zw. Marttila und Vattula (Broth.). - Le. Vittanki in der Birkenregion (Norrl.). - Lt. Kola (Broth.). Hellgum.

S. Srm., Vsm. und Dlr. an einzelnen Fundorten. IIpd. Torp, Ange. Jmt. Enafors. Ang. Selsjön, borg.

N. Bu. Honefos. K. Dovre. H. NT. Stjordalen. No. Nordrejsen. Tenetvaara; Shjerstad. F. NySilirien.

457. Bryum veronense De Not. Cronac. briol, ital. in Comm. II. No. 31 (1866). (Argyrobryum virescens Kindb. Laubm. Schwed, und Norw. p. 78 (1883). - Bryum claviger Kaur. in Bot. Notis. 1884, p. 3.) 
Rasen meist ausgedehnt, dlicht, lichtgrün und etwas glänzend. Stengel 1-2 cm, mit fast keulenförmigen Sprossen. Untere Blätter locker gestellt, obere gedrängt, fast halbkugelig-hohl, aus halb umfassender Basis kreisförmig oder breitrund, bis $0,9 \mathrm{~mm}$ lang und $1-1,1 \mathrm{~mm}$ breit, mit rings eingebogenen Rändern; Rippe zart, yor dem Blattrande endend; Zellen locker und dünnwandig. Sporogone unbekannt.

In nassem Sande cler Flussufer. an periodisch überschwemmten Stellen.

N. Ringerike. Heen. Bu. Honefos. Br. Telemarken, Borledalen. Ne. Saetersdalen. NB. Sogn, Aurland. K. Jotunfjeldene. Skogadalstren: Lom-fjeldene. R sheim. am Baerraflusse fq.

Bayern. schweiz. Nord-1talien an einzelnen Fundorlen, Ost-Grönland.

4.58. Bryum argenteum L. Sp. pl. p. 1120 (175.3).

Rasen meist ausgedehnt, dicht, feucht bläulichgrün, trocken silberweiss und glänzend. leicht zerfallend. Stengel bis 2 cm. selten länger, mit zahlreichen Sprossen. Blätter eiförmig, allmählich zugespitzt oder plötzlich in ein schmales, wasserhelles Spitzehen zusammengezogen, $0.5 \mathrm{~mm}$ lang und breit oder $0.7 \mathrm{~mm}$ lang und bis $0,6 \mathrm{~mm}$ breit, Schopfblätter der fertilen Pfl. grösser und allmählich zugespitzt, etwa $0.9 \mathrm{~mm}$ lang und $0,5 \mathrm{~mm}$ breit: Rippe zart, bis zur Blattmitte oder bis zum Grunde der Spitze reichend, in den Schopfblättern zuweilen bis in die Spitze fortgesetzt: Zellen in der Blattmitte 40-50 " lang und 14 " breit, im oberen Blattdrittel hyalin und verlängert. Seta $1-2 \mathrm{~cm}$, dïnn, rot. Kapsel hängend, aus kurzem, aufgetriebenem. am Grunde meist abgerundetem Halse länglich, 22,7 mm lang, trocken unter der Mündung verengt, dunkel-oder blutrot, im Alter schwärzlich. Peristomzälme gelt) bis blass weinrot, 40-4.5 "lang, ziemlich breit gesäumt, mit 20--25 Lamellen. Inneres Peristom gelblich, fein papillös; Fortsätze ritzenförmig durchbrochen: Wimpern mit langen Anhängseln. Deckel niedrig kegelförmig, glänzend. Sporen meist $10-15 " \mu$, gelb, glatt. - Vegetative Vermehrung dureh einzelne, in den Blattachseln stehende, meist kurzgestieite Brutknospen, sowie durch gipfelständige, sehr leicht abbrechende grosse Bruchknospen.

Auf magerer, nackter Erde, auf Dächern. steinernen Mauern und Felsen.

F. Al. sl. fr. (Bom.). - Ab. Abo (Brand.). salmola (Karst.). Pargas (Pes.). - N. Helsingfors fq. - Jh. Johannes (Popp.). IIetsāpirtti (H. Lindb.). - St. Björneborg (Graefl.). Loimaa (Malmgr.). Pirkkala (Simm.). - Ta. Vanaja (Graefl.). In südōsll. Teile pa... (Norrl.). - Sa. Lappee (Buch). Kangasniemi (Lackstr.). - kl. Sortavala (TT. Nyl.). - Kol. Petrosarodik (Kullh.). - Tb. Kinnula. Saarenkỵlä, Mekkoruori (Roir.). Pihtipuda. Heinolankylä (R.); Sydanmaa. Isoaho (R.). - Sb. Kuopio, an wenigen Fundorten (Link.). Mraninka. Haatala (Roir.): Pöljä (Krýhk.). Pielavesi. Lampaanmäki (Roir.). - Kb. Joensuu (Linnan) ). - Kon. Mednij gora (Simm.). — Om. Jakobstad (Font.). - Ok. Kajana (Lackstr.). Paltamo, Velalahti (ǐryhk.). Suomussalmi. Kiannankỵlā (Kyỵhk.). — Ob. Uleảborg. Pikistari (Huum.). Tornio (Graefl.). - Lhem. Kolari. Jokijalka (Hult). - Le. An mehreren Fundorten (meist auf Dächern) in der Nadelwald- und Birkenregion bis Vittanki (Norrl.). - Li. Inari. Toironiemi. Yandojāyri und an mehreren Fundorten am Tenojoki, meist auf Dächern (Hult). Utsjoki. Nurrus. auf Dächern (Ranck.). - Lim. Kandalaks (Broth.). Porjaguba (Sel.) - Lt. Suorsajok (Roir.). Kola, Abramova Pahta (Broth.). - Lmur. Semjostrorsk und Litsa (Broth.). — Lp. Orlor (Kihlm.). Ponoj (Broth.).

S. Sk. - L.

N. $\therefore m .-F$.

In allen Teilen der Welt in rerschiedenen Furinen bis spitzbergen und Antarklis rorkommend.

var. lanatum (Palis.) Bryol. eur. fasc. 6/9. p. 79, t. 11 (1839). [Mnium lanatum Palis. Prodr. p. $75(1805)$. $]$

Äste kurz und dick, entfärbt. Blätter silberweiss, lang zugespitzt oder die 13lattspitze in ein gesehlängeltes Haar fortgesetzt, zuletzt ohne Chlorophyll. Seta länger. Krapsel kürzer.

An trockenen, sonnigen Stellen.

S. $\therefore m$ an mehreren, srm und $T p l$. an einzelnen Fundorten.

In Europa und hauptsächlich in den warmeren Teilen der anderen Erdteile verbreitet.

8. Doliolidium C. Müll. in limnaea XXXIX. p. 388 (1875).

Diözisch: - Blüten dick knospenförmig. Blätter meist nicht herablaufend, trocken anliegend, feucht aufrecht-alstehend. lanzettlich bis ei-oder ovallanzett- 
lich, mit \pm zurückgerollten Rändern, ungesäumt: Rippe kräftig, meist als Stachel oder Granne austretend. Kapsel regelmässig, meist kurz und dick, mit am Grunde abgerundetem, trocken meist runzeligem Halse, reif meist blutrot bis schwarzrot. Peristomzähne gelb oder rötlich bis rot; Fundus orange bis rot.

459. Bryum bicolor Dicks. Crypt. fasc. IV. p. 16 (1801). [Bryum atropurpureum Bryol. eur. fase. 6/9, p. 73, tab. 37 (1839).]

Schlanke Pfl. in \pm dichten, zuweilen ausgedehnten, grünen, schwach glänzenden Rasen. Stengel 5-10 $\mathbf{~ m m}$, dicht beblättert, bis zu den schopfigen oder längeren. fast kätzchenartig beblätterten subfloralen Sprossen mit Rhizoiden. Blätter nicht herablaufend, lanzettlich oder eilanzettlich, zugespitzt, $0,7-1,2 \mathrm{~mm}$ lang und bis $0,5 \mathrm{~mm}$ breit. mit bis gegen die Spitze umgerollten Rändern; Rippe gelb, im Alter bräunlich, in den Schopfblätter als kräftiger Stachel austretend; Zellen oberwärts $35-50 \mu$ lang unr $12-16 \mu$ breit. Seta $1-1.5 \mathrm{~cm}$, rot. Kapsel hängend, aus kurzem, am Grunde meist abgerundetem Halse kurz zylindrisch bis oval, selten fast kugelförmig, bis $2 \mathrm{~mm}$ lang und bis $1 \mathrm{~mm}$ dick, unter der Mündung nicht oder wenig verengt. Peristomzähne $0,45-0,50 \mathrm{~mm}$ lang, gelb oder blassrötlich, mit etwa 30 Lamellen. Inneres Peristom blass gelblich; Fortsätze des inneren Peristoms breit, rasch zugespitzt, fensterartig durchbrochen; Wimpern vollständig, mit langen Anhängseln. Deckel gross, am Grunde oft etwas weiter als die Urnenmündung, hoch kegelförmig oder kuppelartig gewölbt mit Spitzchen, glänzend purpurrot. Sporen $8-10 \mu$, gelb, glatt. Sporenreife im Juni. Vegetative Vermehrung church eiförmige, achselständige, kleinblätterige Brutknospen. - Fig. $53 \mathrm{H}$-I.

F. Al. Jomala, Ytternăs (Bon.). Saltvik, Krarnbo (Bom.).

S. Sk. an mehreren. $S m$. und $O g$. an einzelnen Fundorten.

N. Sm. Glemminge.

Europa. Madeira, Kanaren. Algier, Sinai. Klein-Asien. Nord-Amerika, Australien.

* Bryum Arvenii (Arn.). (Bryum Arvenii Arn. in Botan. Notis. 1898, p. 61.)

Schopfblätter breiter, kürzer zugespitzt, mit schmal umgebogenen, zuweilen flachen Rändern. Astblätter holn, viel breiter als bei der Hauptart, rasch kurz zugespitzt, flach- und ganzrandig: Rippe vor der Blattspitze aufhörend.

S. Vg. Billingen, Ulunda, auf Kalkboden.

9. Erythrocarpa Kindb. Sp. Eur. and Northam. Bryin. p. 348 (1897).

IIeist diözisch; ح Blüten dick knospenförmig. Kleine, lockerrasige oder herdenweise wachsende Pfl. Blätter meist herablaufend, trocken locker anliegend. feucht aufrecht-abstehend, lanzettlich, mit \pm umgebogenen Rändern. gegen die Spitze meist etwas gezähnelt; Rippe weniger kräftig. als I langer Stachel austretend. Kapsel mit dem \pm langen, niemals aufgetriebenen Halse länglich-birnförmig bis länglich-keulenförmig, ledergelb bis blutrot oder schwarzrot. Peristomzähne gelb bis rötlich; Fundus orange bis rot.

460. Bryum Sauteri Bryol. eur. fase. 32 Suppl. p. 10, t. 10 (1S46).

Autözisch. Schlanke Pfl. in dichten, bräunlichen Räschen. Stengel etwa 5 mm, mit kurzen, schopfig beblätterten subfloralen Sprossen. Schopfblätter steif, trocken angedrückt, feucht aufrecht-abstehend, eilanzettlich und verlängert lanzettlich, bis $1.8 \mathrm{~mm}$ lang und bis $0,8 \mathrm{~mm}$ breit, flachrandig, ungesäumt; Rippe kräftig, kurz austretend; Zellen dünnwandig, oberwärts lang und schmal. Seta 1-2 cm, dünn, blutrot. Kapsel horizontal bis hängend, mit dem Halse von halber Urnenlänge schmal keulig-birnförmig, bis $3 \mathrm{~mm}$ lang und $1 \mathrm{~mm}$ dick, meist hochrückig, blutrot, trocken unter der Mündung verengt. Peristomzähne fast rötlichgelb, mit 24-30 Lamellen. Inneres Peristom sattgelb; Fortsätze schmal. fast fensterartig durchbrochen: Wimpern ohne oder mit sehr kurzen Anhängseln. Deckel kurz kegelig, kurz gespitzt, glänzend. Sporen 18-22 ", gelb. feinwarzig.

N. No. Ranen, Mo, an sandigen Wegrăndern.

In den Alpentälern von der Schweiz bis Steiermark und Färnten. 
161. Bryum Klinggraeffii Schimp. in v. Klinggr. Höhere Krypt. Preuss. p. 81 (1858).

Eine ler kleinsten Arten. Herdenweise oder in lockeren, leicht zerfallenden, lichtgrïnen Räschen. Stengel sehr niedrig, mit purpurroten, runden, vielzelligen Wurzelknöllchen. Blätter ziemlich steif, dle der Äste eiförmig und eilänglich, fast flachrandig, mit vor der Blattspitze endender Rippe. Schopfblätter aus breitem, rotem Grunde lanzettlich, bis $1 \mathrm{~mm}$ lang und $0,3 \mathrm{~mm}$ breit, ungesäumt, mit schmal zurückgebogenen Rändern; Rippe \pm lang austretend. Seta $1-2 \mathrm{~cm}$, dünn, rot. Kapsel hängend, kurzhalsig, 1-1,5 $\mathrm{mm}$ lang, blutrot, trocken unter der weiten Nlündung verengt, entleert kreiselförmig. Peristomzähne $0,4 \mathrm{~mm}$ lang, gelb, schmal gesäumt, mit bis 30 Lamellen. Inneres Peristom blass gelblich; Fortsätze unten meist klaffend, oben ritzenförmig durchbrochen; Wimpern nit langen Anluängseln. Deckel hoch gewölbt, mit scharfem Spitzchen. Sporen 9-11 ", gelb, fast glatt.

In feuchten Ausstichen; an Graben- und Wegrändern, Bach- und Seeufern.

F. Al. Saltrik, an mehreren Fundorten.

S. Sk.. Srm. und $U \mathrm{pl}$, an einzelnen Fundorten.

Europa.

462. Bryum erythrocarpum Schwaegr. Suppl. I. P. II. p. 100, t. 70 (1816). (Bryum pachydermum Bomans. in Rev. bryol. 1906, p. 60.)

Diözisch. Pfl, in lockeren, grünen oder gelbgrünen, zuweilen rötlichen oder bräumlichen Rasen. Stengel niedrig, oft im Sande versteckt, selten bîs $1 \mathrm{~cm}$, mit fast gleichmässig oder schopfig beblätterten subfloralen Sprossen. Blätter meist etwas schlaff und weich, trocken hin- nnd hergebogen, feucht abstehend, die unteren und die Blätter der sterilen Sprosse locker gestellt, herablaufend, lanzettlich, fast gesänmt, mit am Grunde zurückgeschlagenen Rändern, die obersten grösser und gehäuft, verlängert lanzettlich, lang zugespitzt, bis $2,7 \mathrm{~mm}$ lang und $0,5-$ $0,7 \mathrm{~mm}$ breit, mit umgerollten, nicht oder kaum gesäumten, gegen die Spitze entfernt gesägten Rändern; Rippe schmal, gelbgrün, zuletzt rötlich, in den Schopfblättern als kurzer, gezähnter Stachel austretend; Zellen dünnwandig, oberwärts $50-70$ " lang und 18-25" breit. Seten ron ungleicher Länge, im Mittel $2-3 \mathrm{~cm}$, purpurn. Kapsel hängend. mit dem etwas aufgeschwollenen Halse länglich-birnförmig. in der Grösse veränderlich, ledergell, bis blutrot, trocken und entdeckelt unter der Nündung wenig verengt. Peristomzähne etwa $0,50 \mathrm{~mm}$, rötlichgelb, mit bis 30 Lamellen. Inneres Peristom blass gelblich; Fortsätze gefenstert; Wimpern mit langen Anhängsehn. Deckel gross, hoch gewölbt, mit Spitzchen. Sporen $8-$ 12 ", gelb, glatt. Sporenreife im Juli. - Vegetative Vermehrung durch purpurrote, runde, vielzellige, im Wurzelfilze und in den unteren Blattwinkeln gelegene Brutkörper, selten durch an den sterilen Sprossen gelegene Brutknospen.

In Sand- und Torfausstichen, an Graben- und Wegrändern, an Bach- und Seeufern.

F. Al. Mariehamn (Bom.). Saltrik, an mehreren Fundorten (B.). Sund, Tranvik (B.). - Ab. Vehmo, Ristinkylä (Ruor.). Bromarf, Kovik (Sundv.). Lojo, Skrâddarla (Lindb.); Pietilä (E af H.). - N. Esbo, Ǩirchdolf, Kasberget (Gottb.). Helsingfors (Lindb.). Sibbo, Löparö (Broth.). Borgå, Sundö (Sael.): Storpellinge (Broth.). - Ik. Sakkola, Arustalampi (H. Lindb.). - Ta. Asikkala, Keltoniemi (Sil.). Ga. Vasa (Broth.). Lappo, Särkimäneva (Ranck.). - Kb. Lieksa, Nurmijārvi (Vain.). - K. Kuusamo. Kuorikilanıpi (E. af H.); Leveälampi (E. af H.).

S. Sk., Sm., Illl., Ög.. Vg., Srm., När., Upl., Vrml., Dlr., Hlsl. und Mpd.

N. Sm. an wenigen Fundorten. A. Kristiania, Bu. Ringerike nicht selten; Norefjeld bis $400 \mathrm{~m}$. Europa, Algier. Nord-Amerika.

* Bryum Bomanssoni (Lindb.) Amann Fl. mouss. Suiss. p. 238 (1912). [Bryum Bomanssonii Lindb. in Bot. Notis. 1884, p. 67 et in Meddel. Soc. Faun. Fl. Fem1. 13, p. 183 (1886).]

Stengel bis $4 \mathrm{~mm}$, mit $2-3 \mathrm{~mm}$ langen subfloralen Sprossen. Blätter lanzettlich-linealisch, an der Spitze scharf gesägt, bis $2.7 \mathrm{~mm}$ lang und bis $0,75 \mathrm{~mm}$ 
breit; Zellen am Rande sehr eng und verdickt, einen bräunlichen, 3--1reiligen Saum bildend. Seta bis $2 \mathrm{~cm}$. Liapsel verlängert-zylindrisch, etwa 2,7 mm lang, schwach gekrümmt. Deckel kurz kegelig. stumpflich. — Vegetative Vermehrung wie bei Br. erythrocarpum. - Fig. $53 \mathrm{~A}$ - C.

F. Al. Saltvik, an mehreren Fundorten (Bom.).

* Bryum rubens (Mlitt.) Podp. in Bot. Centralbl. Beiheft. Bd. XV. p. 186 (1903). (Bryum rubens Mitt. in Journ. Bot. 1856, p. 232.)

Stengel bis $1,5 \mathrm{~cm}$. Blätter eilanzettlich, bis $3 \mathrm{~mm}$ lang und $0,8 \mathrm{~mm}$ breit: Zellen an Rande gestreckt, einen 3-5reihigen. gelblichen Saum bildend. Seta bis $3 \mathrm{~cm}$. Kapsel verlängert-zylindrisch, bis 4 mm lang. Deckel gross, hoch gewölbt, lang zugespitzt. - Vegetative Vermelırung wie bei Br. erythrocarpum.

N. A. Kristiania, Hovik. Bu. Ringerike. Trristranden und Hovind. JL. Nrkirke.

England, Zentral-Europa.

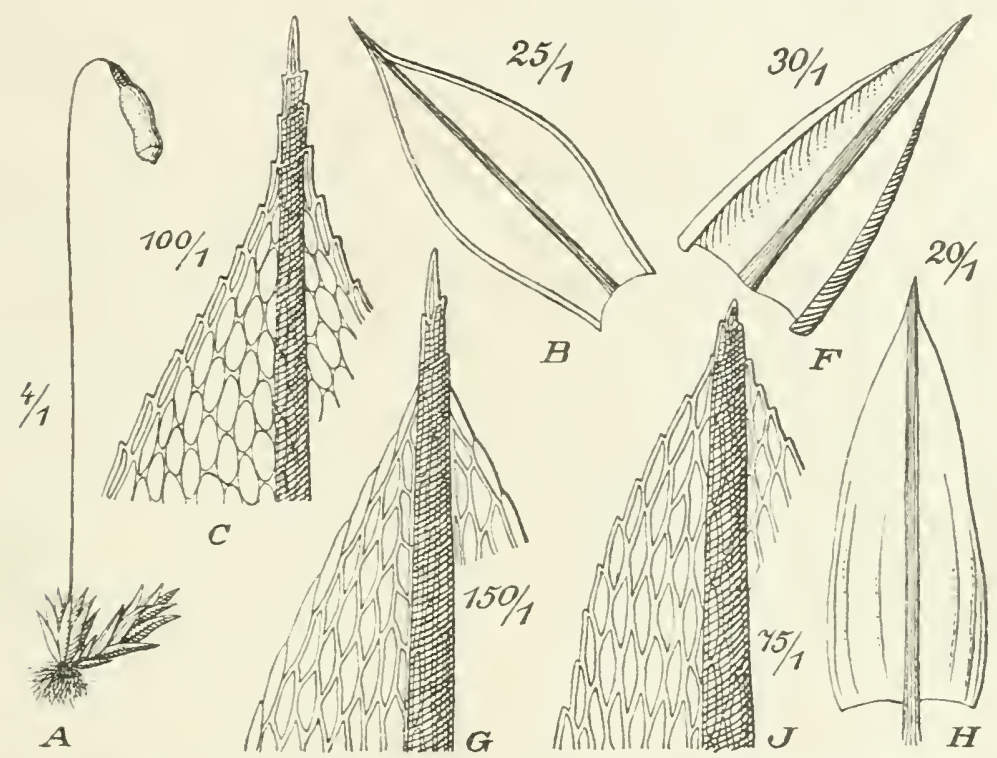

Figg. 53. A-C Bryum Bomanssonii Lindl). A Fruchtende Pfl. (4́/1): B stengelb. (25:1): C Blattspitze $(100 / 1)$. - F-G B. bicolor Dicks. F Stengelb. (30 1); G Blattspitze $(150 / 1)$. - H-I B. alpinum L. H stengelb. (20/1); I Blattspitze (75/1).

463. Bryum excurrens Lindb. in Meddel. Soc. Fauna et Fl. fenn. 13. Heft, p. 251 (1886) et Bot. Notis. 1886, p. 99.

Diözisch. Schlanke Pfl., herdenweise oder in lockeren, leieht zerfallenden, rötlichen bis kupferfarbenen Rasen. Stengel wenige Millimeter, längs wurzelfilzig, mit meist 2 subfloralen Sprossen. Blätter trocken anliegend, feucht aufrecht-abstelrend, eilanzettlich, lang zugespitzt, etwa $1,2 \mathrm{~mm}$ lang und $0,5 \mathrm{~mm}$ breit, ungesäumt, ganzrandig, mit bis oberhalb der Nitte oder längs zurückgebogenen Rändern; Rippe als gesägte Granne von 1/3 Laminalänge auslaufend; obere Blattzellen mässig verdickt, $50 \mu$ lang und $16 "$ breit bis $70 "$ lang und 12 " breit. Seta $1-1,5 \mathrm{~cm}$, purpurn. Kapsel fast horizontal bis hängend. mit dem gleichlangen, allmählich verschmälerten Halse birnförmig, etwa 2,1 mm lang nnd $1 \mathrm{~mm}$ dick, bleichrot, trocken und entdeckelt weitmüindig; Zellen des Exotheciums dickwandig. Peristomzähne etwa $0,38 \mathrm{~mm}$, gelb, an der Insertion orange. längs breit gesäumt, mit etwa 25 Lamellen. Inneres Peristom sattgelb; Fortsätze 
gefenstert; Wimpern mit Anhängsehn. Deckel gewölbt, mit Spitzehen, rot, glänzend. Sporen 10-14 $\mu$, gelbgrün, glatt. Sporenreife im Juli.

N. ST. Opdal, auf feuchtem Sande des Flusses Driva.

10. Alpiniformia Kindb. Sp. Eur. and Northam. Bryin. p. 348 (1897).

Diözisch; đ $^{7}$ Blüten knospenförmig. Blätter meist glänzend, nicht oder kaum herablaufend, trocken dachziegelig, fencht aufrecht-abstehend, länglich bis eioder länglich-lanzettlich, ungesäumt; Rippe \pm kräftig, vor der Blattspitze auflörend bis austretend. Kapsel regelmässig, rötlich oder rötlichgelb bis tiefrot. Peristonzähne gelb: Fundus orange bis rot.

46+. Bryum Mühlenbeckii Bryol. eur. fasc. 32 Suppl. p. 11, No. 58, tab. 13 (1846). [Bryum alpinum var. brevifolium Myr. Cor. Fl. ups. p. 68 (1833).]

Ziemlich schlanke Pfl. in ausgedehnten, dichten und schwellenden, dunkelbis olivengrünen oder bräunlichen, innen rötlich- bis schmutzigbraunen, glanzlosen Rasen. Stengel 2-1, selten bis $8 \mathrm{~cm}$, mehrmals geteilt und $=$ ästig, dicht beblättert, bis zu den neuen Trieben mit Rhizoiden. Blätter ziemlich weich, hohl, die unteren eiförmig, die oberen länglich. kurz zugespitzt, die obersten lanzettförmig, allmählich zugespitzt, bis $2,35 \mathrm{~mm}$ lang, und $1 \mathrm{~mm}$ breit, ganzrandig, mit zurückgeschlagenen Rändern; Rippe kräftig, rot, zuletzt schwarzrot, vor der Blattspitze aufhörend; Zellen locker. mässig rerdickt, oberwärts $40-50$ "lang und $18 \mu$ breit, in der Blattmitte bis $90 \mu$ lang und $20 \mu$ breit. Seta $1-2$ cm, trüb braunrot. Kapsel nickend oder hängend, mit dem verschmälerten Halse, verkehrt eibirnförmig, etwa $3 \mathrm{~mm}$ lang, derblıäutig, zuletzt dunkel rostbraun, trocken und entleert unter der llündung etwas verengt: Zellen des Exotheciums dickwandig, etwa $30 \mu$ breit. Peristomzähne $0,50 \mathrm{~mm}$ lang, gelb, nit $24-28$ Lamellen. Inneres Peristom gelblich: Fortsätze fensterartig durchbrochen; Wimpern mit langen Anlängseln. Sporen 14-1S ", grünlichgelb, fein papillös. Deckel hoch gewölbt, mit Spitzchen, glänzend, orange oder rot. Sporenreife im Juli und August.

An feuchten und nassen Stellen. besonders längs der Wasserlänfe, an flachen Felsen und auf steiniger Erde.

F. Al. Eckerö, Storby (Bom.). Lemland, Nảtö (B.) Geta, Rankoskär und Husklint (B.). Saltvik, an mehreren Fundorten (B.). Sund, Tosarby (B.). Vardö. Vargata (B.). Sottunga. Södö (B.). - A b. Naddendal (Elfr.). Albo, Littois (E.) Pargas, Lepo (E.). Lojo, Skräddarla (Lindb.); Paloniemi (Boldt). Vichtis. Olkkala, Kauppilanvuori (Broth.). - N. Hangö (Häyr.). Ekenäs, Trärminne (H.) Ky̌rkslätt, Porkiala, Träskö (Broth.). Esbo, Gräsa, Solberga (B.). Helsingfors (Lindb.); Ijölö (Buch). Helsinge, Tali (Broth.). Borgå, Haksalö : B.). Hogland (Lindb.). - Ka. Wiborg (Vain.). - St. Ikaalinen (Sundr.). Tammerfors (Nerv.). - Te. '́adasjoii, Arokoski (Vain.). Kuhmoinen (Norrl.). Luhanka, Judinsalo, Onkíalo (Vain.). - Kl. Vilamo (Lindb.). Sortavala (Norrl.): Kirjavalahti (X.). Impilahti, Pullinvuori (Broth.). Pälkjärvi. Pitkäniemi (B.). - Ok. Kajana (Broth.). - Kk. Kivakhatunturi (Broth.). - Lt. Taidoguba (Broth.).

S. Sm. und Aing. an mehreren, Vg., Ög.,Boh.. Srm., Upl., Vpd.. LyL., PL. und LuL. an einzelnen oder wenigen Fundorten.

N. A. Asker. Sm. an inelireren Fundorten. Bu. Ringerike, Tyristranden pass. JL. Tjømo fqq $B r$. Telemarken. Haukelifjeld. Ne. Saetersdalen fq. NB. Hardanger, Horahei. SB. Llvik st. fq. NB. Sogn; Filefjeld. R. viel seltener als B. alpinum. K. Dovre. Valders. Vang. Gudbrandsdalen. NT. Stjordalen fq. an Meeruferfelsen. No. Bodin; Srolvaer. Nordgrenze bei $68^{\prime} 13^{\prime} \mathrm{n}$. Br.

Europa. Katukasus. Nord-Amerika.

46.). Bryum alpinum Hucls. Fl. angl. p. 415 (1762): L. Mant. II. p. 309 (1767).

Mehr oder weniger kräftige Pfl. in oft ausgedehnten, polsterförmigen, aus dem Grünen und Gelbgrïnen bräunlich- bis purpurrot-gescheckten, inmen braunen, stark glänzenden Rasen. Stengel bis $6 \mathrm{~cm}$, ästig, dicht belblättert, mit spärlichen Rhizoiden. Blätter steif, kielig-hohl, länglich-lanzettlich, zugespitzt, bis $3 \mathrm{~mm}$ lang und $0,9 \mathrm{~mm}$ breit, ganzrandig oder in der Spitze deutlich gezälnnt, mit bis gegen die Spitze breit umgerollten ländern; Rippe kräftig, anfangs gelblich, später gebräunt oder braunrot, mit der Blattspitze endend; Zellen dickwandig, bis weit hinab schmal und verlängert, etwa $50-75$ " lang und 7 -10 " breit. Seta 
bis $2 \mathrm{~cm}$, rot. Kapsel nickend oder hängend, mit dem versehmälerten, geraden Halse eilänglich-birnförmig, bis 3,5 mm lang, derbhäutig, blutrot, zuletzt schwarzpurpurn, trocken und entdeckelt unter der Mündung wenig verengt: Zellen des Exotheciums äusserst dickwandig, meist $15 \mu$ breit. Peristomzähne etwa $0,5 \mathrm{~mm}$ lang, gelb, mit 22-25 Lamellen. Inneres Peristom gelb: Fortsätze ritzenförmig bis fensterartig durchbrochen: Wimpern mit Iangen Anhängseln. Sporen 12-15. seltener bis $18 \mu$, gelb, fein papillös. Deckel entweder spitz kegelförmig oder hoch gewölbt, mit Spitzchen, orange oder rot, glänzend. Sporenreife im Juli. - Vegetative Vermehrung durch achselständige, vereinzelt vorkommende Brutknospen. - Fig. $53 \mathrm{H}-\mathrm{I}$.

An nassen und flachen, kalkfreien Felsen, seltener in sandigen, feuchten Ausstichen.

F. Al. Echerö (Arrh., H. Lindb.). Finström, Godby (Bom.). Greta, Äppelö (Hult). Lemland, Vesterö und Norrby (Broth.). Saltvik, an mehreren Fundorten (Bom.). Föglö, Degerby (Elfv.). - Ab. Korpo (Elfv.). Nadendal (Elfv.). Karislojo, Karkali (Lindb.). Lojo, Skräddarla (Lindb.). - N. Ekenäs. Tvärminne, Lảngskär (Ranck.).

S. Sk.-Upl., läng; der Westkïste an vielen Fundorten. Trml., Mpd. und Hrjd. an einze!nen Fundorten.

N. A. Kristiania st. r. Sm. fq. Bu. Ringerike, Tyristranden. JL. Sandefjord st. fq. Tjomø fqr. Ne. Saetersdalen, im südlichen Teile fq. SB. Strandebarm et Yiker. R. Überall in dem Tieflande. besonders an der Küste, $500 \mathrm{~m}$ nicht ïbersteigend. $K$. Talders bei $700 \mathrm{~m}$. sonst nirgends in der alpinen Region oder fern von der Küste beobachtet. Lomsfjeldene, $550 \mathrm{~m}$. NT. Stjordalen, an Uferfelsen fq. No. Alstahoug. Nordgrenze bei $65^{2} 5 \tau^{\prime} \mathrm{n}$. Br.

Europa, Kaukasus, Kanaren, Madeira. Kamerun, Kilimandscharo. Mt. Elgon, Nord-Amerika.

466. Bryum Mildeanum Jur. in Verh. zool.-bot. Ges. Wien 1862, p. 967.

Schlanke Pfl. in ausgedehnten, oft polsterähnlichen, goldgrünen, innen bräunlichen, seidenglänzenden Rasen. Stengel $0,5-3 \mathrm{~cm}$, ästig, unten lockerer, oben dicht beblättert, spärłich wurzelhaarig. Blätter steif, kielig-hohl, breit länglichlanzettörmig, allmälılich zugespitzt, bis $2.5 \mathrm{~mm}$ lang und $0,70 \mathrm{~mm}$ breit, ganzrandig oder an der Spitze entfernt und klein gezähnt, mit längs umgerollten Rändern: Rippe weniger kräftig, gelbbräunlich, als kleine, gezähnte Stachelspitze kurz austretend; Zellen mässig verdickt, eng, 50-90 $\mu$ lang und $10 \mu$ breit. Seta 1,5-2,5 cm, gelbrot, am Grunde purpurn bis schwärzlichrot. Kapsel geneigt oder hängend, mit dem versehmälerten und etwas gekrümmten Halse keulen-birnförmig, 3,5 $\mathrm{mm}$ lang und 1,2 $\mathrm{mm}$ dick, dünnhäutig, rötlichgelb, zuletzt kastanienbraun, trocken und entdeckelt unter der Jündung nur sehr wenig verengt; Zellen des Exotheciums wenig verdickt, etwa $20 \mu$ breit. Peristomzähne etwa $0,54 \mathrm{~mm}$, gelb, an der Insertion rot, mit gegen 30 Lamellen. Inneres Peristom gelb; Fortsätze weit klaffend; Wimpern nit Anhängseln. Sporen $12-15 \mu$, grinlichgelb, gekörnelt. Deckel gewölbt, scharf gespitzt, orange bis rot, mässig glänzend. Sporen $12-15 \mu$, grünlichgelb, gekörnelt. Sporenreife im Juli und August. - Vegetative Vermehrung durch blattachselständige Brutknospen.

An feuchten und nassen Stellen anf Sand, Erde und Gestein.

F. Al. Eckerö, Torp (Bom.).

S. Ög., $\mathrm{Vg}$. und $\mathrm{N} \ddot{a}$. an einzelnen Fundorten.

N. A. Kristiania. Sm. Onso und Tune. Bu. Ringerike an mehreren Fundurten. Ve. Saeteridalen r. K. Valders, Bang und Vang. Dovre. Lomsfjeldene, Rosheim am Baevrafluse und Kraume. TB. Sogn, Laerdal. XT. Stjordalen, in niedriger Lage fq. und zuweilen cop. No. Alstahaug. Nordgrenze bei $65^{\circ} 5 \tau^{\prime}$ n. Br.

Europa, Kaukasus.

467. Bryum rivulare Arn. in Rev. bryol. 1898, p. 4: Bot. Notis. 1898, p. 53.

Pfl. in lockeren, bis $3 \mathrm{~cm}$ hohen, unten rötlichen, locker beblätterten, oben freudig grünen, schwach glänzenden Rasen. Stengel mit spärlichen Rhizoiden. Blätter lang herablaufend, aus verschmälerter Basis cilanzettlich, allmählich zugespitzt, bis $2 \mathrm{~mm}$ lang und $0,57 \mathrm{~mm}$ breit, mit weit hinauf breit umgebogenen Rändern: Rippe in der Blattspitze verselwwindend: Zellen am Blatlgrunde, auch im herab- 
laufender Teil quadratisch, oberwärts rektangulär bis verlängert 6 seitig, 3565 " lang und etwa 16 " breit, am Rande gestreckt, einen 3-4reihigen Saum bildend. Sporogone unbekannt.

An Bächen.

F. Ig. Bullingen.

N. $J L$. Sande, Hallerud.

468. Bryum riparium Hag. in Kigl. Norsk. Vid. Selsk. Skrift. 1908, No. 3, p. 33 (1908).

Pfl. in lockeren, etwa $3 \mathrm{~cm}$ hohen, gelblichgrünen, innen brämnlichen, schwach glänzenden Rasen. Stengel längs mit langen Rhizoiden aus den Blattachseln, einfach. Blätter fast gleichgross, trocken locker anliegend, feucht aufrecht-abstehend, hohl, \pm weit herablanfend, eilanzettlich, bis $1,7 \mathrm{~mm}$ lang und bis $0.45 \mathrm{~mm}$ breit, mit aufrechten oder am Grunde einerseits oder beiderseits schmal umgebogenen Rändern: Rippe vollständig bis kurz austretend: Zellen oberwärts verlängert 6seitig, 53-67 $\mu$ lang und $16 \mu$ breit, am Rande enger, einen ziemlich deutlichen, 23reihigen Saum bildend. Blüten und Sporogone unbekannt.

N. St. Lysefjord, am Ufer des Lyseelren.

11. Trichophora Kindb. Sp. Eur. and Northam. Bryin. p. 348 (1897).

Bliten dick knospenförmig. Stengel dicht und schopfig beblättert, mit schopfig beblätterten subfloralen Sprossen. Blätter meist. nicht herablaufend, verkehrt-eilänglich bis spatelförmig, zuweilen länglich oder verlängert länglich, selten eiförmig, in eine haarähnliche Spitze vorgezogen oder durch dié austretende Rippe begrannt, gesäumt: Basalzellen gerötet. Kapsel regelmässig, braun und rotbraun bis blutrot. Peristomzähne bräunlichgelb mit schr dicht gestellten Lamellen; Fundus orange bis rot, weniger deutlich begrenzt.

469. Bryum elegans Nees Mscr. in Brid. Bryol. univ. I. p. 849 (1826). [Bryum capillare var. cochlearifolium Brid. Bryol. univ. I. p. 666 (1826).]

Diözisch. Schlanke Pfl. in dichten und weichen, oben grünen, innen rötlichbraunen, durch Rhizoidenfilz fest verwebten Rasen. Stengel bis $1-5 \mathrm{~cm}$, mit zahlreichen, fast kätzchenförmigen Sprossen. Untere Stengelblätter und Astblätter löffelförmig-hohl, verkehrt-eirundlich, flachrandig, etwa $0.7-0,8 \mathrm{~mm}$ lang und 0,6 mm breit, ungesäumt bis sehr schmal gesäumt; Schopfblätter gedrängt und dachziegelig-anliegend, kielig-hohl, ans verschmälertem Grunde verkehrt-eilänglich, bis $2 \mathrm{~mm}$ lang und bis $1,3 \mathrm{~mm}$ breit, flachrandig oder mit nur am Grunde schmal zurückgebogenen, meist 2-3reihig gesäumten Rändern; Rippe vor der Blattspitze aufhörend bis als zurückgebogene Granne austretend; Zellen in der Blattmitte etwa $30-10 "$ lang und $18 " \mu$ breit. Seta $1-2 \mathrm{~cm}$, rot. Iiapsel horizontal oder nickend, mit dem fast gleichlangen Halse vertüngert länglich bis fast zylindrisch, etwa $2,5 \mathrm{~mm}$ lang, trocken unter der weiten Mündung \pm eingeschnürt, mit stark verengtem, vom bauchigen Urnengrunde deutlich abgesetztem Halse, lichtbraun. Peristomzälne etwa $0,5 \mathrm{~mm}$, gelb, mit 20-25 Lamellen. Inneres Peristom mit schmalen, ritzenförmig oder fast fensterartig durchbrochenen Fortsätzen; Wimpern mit kurzen, z. T. auch langen Anhängseln. Deckel gewölıt, mit winzigem Spitzchen. Sporen $11-15 \mu$, gelb, fast glatt. Sporenreife im Juli und August.

In feuchten Felsspalten, besonders kalkhaltiger Gesteine, seltener auf feuchtem Sandboden.

F. Ab. Uskela, Linnanäki (Lindb.). - Y. Ekenäs, Trärminne, Lảngnäs (Ranck.). Ingå, Elisö (T. Brenn.). Esbo, Sandudd (Broth.). Helsingfors (Lindb.). - Nurmijärvi (Tennb.). - ha. Kotka(Ulv.). - Ta. Asikkala (Norrl.). - Sa. Willmanstrand, Huhmarinruori (Buch). Ruokolahti, Imatra (Nerv.). - Oa. Vasa, Storstensbadan (Broth.). - Sb. Kuopio, Sikalahti (Kut.). Nilsiä. Kirchdorf (K.). Pielavesi. Venetmăki, Perälä (Roiv.). - Kb. Juuka, Juuanvaara (Kot.) Polvijārvi, Kirchdorf (K.). - Ok. Suonussalmi, Kirchdorf (Vain.). - Le. Kilpisjärvi, Ifalla (Kot.). - Lt. Kola, Abramova Pahta (Broth.). - Lmur. Gavrilora (B.). - Lp. Ponoj (Sahlb.). 
S. Bl., Öl., Sm., Gtl., Ög., Vg. När. Vrml., Vpd., Jml. und Ảng. LuL. Sarekgebiet bi.s in die Alpenregion hinaufsteigend.

N. $B u$. Ringerike st. fq. Ne. Saetersdalen. R. r. No. an mehreren Fundorten und zuweilen fq., bis mindestens $500 \mathrm{~m}$ hinaufsteigend. Tr. Tromsosundet, Flöjfjeldet. $F$. Karasjok, Rastegaissa.

Europa, Nord-Amerika.

var. Ferchelii (Funck) Breidl. Laubm. Steierm. p. 132 (1891). [Bryum capillare var. \& Fcrchelii Bryol, eur. fasc. 6/9, p. 60, t. 29 (1839).]

Schlanke Pfl, in dichten, oft mehrere cm hohen, zuweilen zonenartig gefärbten Rasen. Blätter anliegend, klein, sehr holı, verkehrt-eiförmig, plötzlich in ein gewundenes Spitzchen verschmälert, flachrandig, ungesäumt; Rippe weit vor der Blattspitze aufhörend. Seta kurz. Kapsel klein. Meist steril.

F. Al. Saltvik, Kvarnbo (Bom.). - N. Ekenäs, Tvärminne (Häyr.). Helingfors (Lindb.). — Sa. Imatra (Broth.). - Kl. Sortavala, Kirjavalahti (H. Backm.). Pälkjärvi, Könönen (Broth.). - Ok. Paltaino, Melalahti (Lackstr.). - K. Kuısamo, Ronkajärvi (Broth.).

N. NT. Nedre Stjordalen, Suttero, reichlich an Uferfelsen.

Europa, Nord-Amerika.

var. carinthiacum (Bryol. eur.) Breidl. l. c. p. 133. (Bryum capillare var. : carinthiacum Bryol. eur. 1. c.)

Blätter wenig hohl, aufrecht-abstehend, trocken oft etwas gedreht, breit verkelırt eiförmig, mit kurzem Spitzchen, flachrandig, ungesäumt oder mit undeutlichem, einreihigem Saum; Rippe vor der Blattspitze aufhörend. Meist steril.

F. Al. Saltvik an mehreren Fundorten. Ab. Pargas, Terfsund (Elfv.). Lojo, Storön (H. Lindb.). - N. Ekenäs, Tvärminne. Långskär (Ranck.). - Ta. Lammi (Norrl.). Tyrväntö. Joutsenjärvi (Broth.). Hartola (Bonsd.). Luhanka (Vain.). - Tb. Viitasaari (Broth.). — Ok. Suomussalmi, Kirchdorf (Vain.). - Lmur. Semjostrov (Broth.).

S. Bl., Sm., Ög., Gstr., Mpd. und ing.

N. No. Sorfolden. Tr. Javronive. $F$, an wenigen Fundorten.

Europa, Kaukasus, Sibirien.

var. norvegicum liaur. et Arn. in Bot. Notis. 1896, p. 107.

Blätter starr, trocken nicht gedreht, breit eiförmig, rundlich zugespitzt, mit Spitzchen und am Grunde umgebogenen, \pm deutlich gesäumten Rändern; Rippe kräftig, meist kurz austretend: Zellen derbwandig.

N. Tr. Bardo, Rubben, an Birken.

var. subelimbatum Joerg. in Berg. Mus. Aarl). 1894/95, No. XIII. p. 21.

Blätter rundlich verkehrt-eiförmig, fast ungesäumt.

N. JL. Sandefjord.

470. Bryum Stirtoni Schimp. Syn. ed. 2, p. 470 (1876).

Diözisch. Schlanke Pfl. in dichten, weichen, freudig grünen, immen bleichen, durch Rhizoidenfilz verwebten Rasen. Stengel $1-4 \mathrm{~cm}$, büschelästig. Blätter herablaufend, ganzrandig, ungesäumt, untere eiförmig, kurz zugespitzt, stumpflich, bis $1 \mathrm{~mm}$ lang und 0,6 $\mathrm{mm}$ breit, flachrandig, ungesäumt, mit vor der Blattspitze endender Rippe; oberwärts allmälılich grösser, eilanzettlich, bis $1,35 \mathrm{~mm}$ lang und bis $0,9 \mathrm{~mm}$ breit, allmälılich in eine fast haarförmige, zurückgebogene Spitze verlängert. Schopfblätter \pm weit hinauf mit schmal umgebogenen Rändern; Rippe mit der Blattspitze endend oder haarartig auslaufend: Zellen oben 40-50 " lang und 18 " breit. Seta bis $2 \mathrm{~cm}$, bleich rötliclibraun. Kapsel nickend bis fast lıängend, kurz birnförmig, 2,5 mm lang und $1 . t \mathrm{~mm}$ breit, bleich gelbbraun, trocken unter der Mündung verengt. Peristomzähne $0,5 \mathrm{~mm}$ lang, orangegelb, mit 30 Lamellen. Fortsätze breit gefenstert: Wimpern mit Anhängseln. Deckel halbkugeig, mit Spitzchen. Sporen 14-18 $/$, gelblich, glatt. - Vegetative Vermehrung wie bei $B$. capillare.

F. Al. Vårdö, Åggskär.

N. Sm. und $B u$, an mehreren Fundorten. Br. Tinn. Ve. Saetersdalen. Holt. ST. Trondhjem, Fagervik.

Schottland, Ost-Grönland.

471. Bryum capillare L. Sp. pl. p. 1586 No. 30 (1753).

Diözisch. Ziemlich schlanke, weiche Pfl. in lockeren bis dichten, grünen, 
innen rötlichbraunen, durch Rhizoidenfilz verwebten Rasen. Stengel 2-3 cm. Schopfblätter viel grösser als die unteren Blätter, trocken anliegend, meist spiralig um den Stengel gedreht, feucht \pm abstehend, aus kurzem oder verlängertem schmälerem Teile nach der Mitte oder im oberen Drittel verbreitert, zugespitzt, bis $4 \mathrm{~mm}$ lang und $1,14 \mathrm{~mm}$ breit und dann oft in eine \pm lange, haarähnliche, oft zurückgebogene Spitze vorgezogen. mit = weit hinauf schmal umgebogenen Rändern; Rippe nach oben schnell verdiinnt, meist vor der Haarspitze verschwindend, seltener auslaufend; Zellen sehr locker, dünnwandig, oberwärts $40-60$ " lang und 25-30 $\mu$ breit, am Rande gestreckt, dickwandig, einen 2-treihigen gelben oder bräunlichgelben Saum bildend. Seta 2-4 cm, rot. Kapsel horizontal oder nickend, selten hängend, aus kurzem oder längerem Halse länglich-keulenförmig bis fast zylindrisch, zuweilen schwach gekrümmt, bis $5 \mathrm{~mm}$ lang, braun und rötlichbraun, trocken unter der Mündung verengt. Peristomzähne $0,5-0,6 \mathrm{~mm}$, mit meist 25 Lamellen. Inneres Peristom gelblich, fein papillös; Fortsätze fensterartig durchbrochen; Wimpern mit langen Anhängseln. Deckel gross, gewölbt, mit Spitzchen, glänzend. Sporen 12-15, anch $10-18$ ", gelbgrün, feinwarzig. Sporenreife im Juni.

Auf Felsen, Steinen und Waldboden, an Mauern und am Grunde alter Baumstämme.

F. Al. st. fq. (Bom.). - Ab. Ispois (Buch). Kakskerta (B.). Uskela, Linnanäki (Lindb.). Lojo, an mehreren Fundorten (Lindb., H. Lindb., E. af H.). - N. Ingat, Bjurs (Bueh). Esbo, Sandudd (Broth.). Helsingfor (W. Nyl.). Helsinge. Aggelby (sol.). Sibbo. Husö (Ranck.). Perna (Häyr.). Hógland (Brenn.). - Ka. Kotka (Llv.). Jääski, Laitila (Lind.). - Ik. Murla. Perkjärvi (H. Lindh.). - Ta. Vanaja (Arrh.). Hattula. Yli-savijarvi (Ranck.). Sääsmäki, Rauttuniemi (Kihlm.). In südösll. Teile pass. (Norrl.). Luhanka und Kurpilahti pass. (Tain.). — Sa. Kangasniemi (Lackstr.). Nyslott (Carl.). _ Kl. Sortavala, Kirjavalahil (Norrl.). Impilahti, Kirehdorf (Pe:.). Ruskeala (Simm.). Suisımo. Saariselkä (Kot.). - Tb. Laukaa und Vitasaari st. fq. (Broth.). Kinnula, Muhola, Kotapuro (Roir.). Pihtipudas, Sormulanmäki (R.). — Sb. Kuopio, suovu (Link.); Kasurila, Mäntymăki (Kyyhk.). Nilsiä. Loulteinen und Haluna (K.). Maaninka, Pöjä (K.). Pielaresi fu. (Roir.). - Ok. Paltamo, Melalahti, Aijönkallio (Ky̧hk.). - Ob. Haukipudas, Luukela (Brenn.). - K. Kun:amo, Vasaraperä, Kumpu-aari (E. af H.). - Lim. Zw. Knjäscha und kandalaks (Broth.). -. Ll. liola, Abraınova Pahta (Broth.).

S. Sk.-Jint.

N. Sm. $-R$.

Europa, Azoren. Kanaren. Nord-Afrika. liakasus, Ka chmir, Zentral-Asien, Sibirien, Japan. Nord-Amerika.

var. flaccidum Bryol. eur. fasc. 69 , p. 61, t. 29) (1839).

Jfl. mit zahlreichen schlanken Sprossen. Blätter locker und flatterig, sehr weich, trocken fast ranhenartig gedreht. - Vegetative Vermehrung durch braune, warzige, zu dichten Büscheln vereinigte, stengelbürtige Brutfäden. Fast immer steril.

Auf Waldhoden und am Grunde alter Baumstämme.

F. Al. Finström, Mangelbroäng (Bom.). - Ab. Pusula, kärkölä (Broth.). - St. Björneborg (Häyr.). - $-S a$. Willmanstrand. Huhmarinvuori (Buch). - K. Kuusamo, Merenoja (Broth.). - Über dieVerbreitung die-er Varietät in S. und $N$. fehlen nähere Angahen.

Europa, Nord-Ameritia.

var. rosulatum Mitt. in Ann. Mag. Nat. Hist. 1851, p. 367. (Bryum elegans var. rosulalum Arn. in Bot. Notis. 1896, p. 108.)

Niedrige Pfl. mit reichlichen, achselständigen Brutfäden. Blätter klein, hohl, oft schopfig gehäuft, trocken gekräuselt, aus kurzer und enger herablaufender Basis breit oval, kurz haarförmig zugespitzt, flachrandig, ungesäumt oder einreihig gesäumt: Rippe wenig oberhalb der Blattmitte verschwindend.

S. Skara, an Baumstämmer.

England, Dänemark. West-Preussen. Steiermark.

172. Bryum subrutilum Limpr. in litt.: Hag. Muse. Norv. bor. p. 194(1901).

Diözisch. Pfl. in lockeren, freudig grünen Rasen. Stengel etwa $1 \mathrm{~cm}$, mit schopfig beblätterten subfloralen Sprossen. Schopfblätter der subfloralen Spros- 
se nicht herablaufend, trocken aufrecht und links gedreht, oval bis breit eiförmig, 2.2-2,4 mm lang und bis fast $1 \mathrm{~mm}$ breit, ziemlich rasch schmal zugespitzt, nit längs schmal umgebogenen Rändern; Rippe an Grunde kräftig, ziemlich lang austretend; Zellen oben etwa 40 " lang und 15 " breit, an Rande eng und gestreckt, einen 2-3reiligen Saum bildend. Seta $2 \mathrm{~cm}$. Kapsel geneigt, keulenförmig, etwa $4 \mathrm{~mm}$ lang und 1,3 mm dick, gelbrot, später dunkelbraun, trocken unter der Mündung etwas verengt. Peristomzähne $0,45 \mathrm{~mm}$ lang, mit bis 30 Lamellen. Fortsätze weit klaffend, an der Spitze mit Anluängseln; Wimpern mit langen Anhängseln. Deckel kegelig, niedrig, sehr stumpf. Sporen 16-20 " gelb.

N. No. Vessen, Dolstadaasen, an lialkfelien.

473. Bryum umbratum Hag. in Kigl. Norsk. Vid. Selsk. Shrift. 1908, No. 3, p. 37 (1908).

Diözisch. Pfl. in dichten, schwellenden, $3-1$ cm hohen, grünen, innen braunen Rasen. Stengel mit kurzen, schopfig beblätterten subfloralen Sprossen. Untere Blätter lang herablaufend, aus spateligem Grunde breit oval, ziemlich rasch zugespitzt. Schopfblätter weniger deutlich herablaufend, trocken geschlängelt, feucht abstehend, verlängert länglich, almühlich ziemlich kurz zugespitzt, etwa 2,4 num lang und $1 \mathrm{~mm}$ breit, mit längs zurückgeschlagenen Rändern; Rippe als Granne austretend: Zellen oberwärts rhombisch-6seitig, 40-60 $\mu$ lang und etwa $20 \mu$ breit, an Rande gestreckt, einen 2-3reihigen, gelblichen Sam bildend. Seta 2-3 cm, bleichrot. Kapsel horizontal bis nickend, mit dem verkehrt-kegeligen Halse von halber Urnenlänge keulenförmig, etwa $3,5 \mathrm{~mm}$ lang und $0,8 \mathrm{~mm}$ dick, gelblichrot bis braunrot, trocken und entdeckelt unter der Nündung stark eingeschmürt. Peristomzähne gelb, $0,6 \mathrm{~mm}$ lang, mit etwa 33 Lamellen. Inneres Peristom hyalin: Fortsätze breit gefenstert; Wimpern vollständig, mit entfernten, mässig langen Anhängseln. Deckel kegelig oder gewölỉ, mit Spitzchen. Sporen 13-15 ", gelbgrün, sehr fein punktiert. Sporenreife im August.

N. ST. Opdal. st. fq. auf Schieferfelsen, 520-650 m. Senjen, Hellandstand, in Felsritzen (Gabbro) etwa $200 \mathrm{~m}$.

\section{RHODOBRYUM}

\section{(Schimp.) Limpr. Laubm. II. p. 444 (1892).}

Diözisch; C’ Blüten scheibenförmig. Stattliche Pfl., in der Tracht an Mnium erinnernd, mit unterirdisehen Stolonen. Untere Blätter schuppenförmig; Schopfblätter vielmals grösser, feucht rosettenartig ausgebreitet, fast spatelförmig, mit gesägten Rändern: Rippe aus sehr breitem Grunde allmählich verschmälert, mit Begleiterstrang, dorsaler, sichelförmiger Stereidengruppe und sonst lockerzellig, ohne differenzierte Bauch- uncl Rückenzellen; Zellen locker. Sporogone zu $1-3$ in demselben Perichätium. Peristom wie bei Eubryum.

47. Rhodobryum roseum (Weis) Limpr. 1. c. p. 445. [Mnium serpyllifolium $\gamma$ proliferum L. Sp. pl. p. 1578 (1753). — M. roseum Weis Pl. crypt. Fl. Gotting. p. 157 (1770). - Bryum proliferum Sibth. Fl. Oxon. p. 292 (1794).]

Herdenweise wachsende oder lockerrasige, gelb- oder sattgrüne Pfl. Stengel bis $5 \mathrm{~cm}$, seltener höher, einfach, unter oder aus der Spitze sprossend, abwärts mit Rhizoidenfilz. Blätter bis gegen die Stammspitze schuppenförmig, entfernt gestellt, anliegend, eilanzeltlich, mit dünner Rippe. Schopfblätter trocken wellig und etwas gedreht, bis $10 \mathrm{~mm}$ lang und $3-4 \mathrm{~mm}$ breit, zugespitzt, mit \pm weit hinauf umgebogenen, oberwärts scharf gesägten Rändern: Rippe meist vor der Blattspitze aufhörend; Zellen in der Blattmitte $90-100 \mu$ lang und $35-10 \mu$ breit, an Rande enger, einen etwa 3reihigen, undeutlichen Saum bildend. Seta bis $5 \mathrm{~cm}$, steif, rot, oben gelbrötlich. Kapsel meist hängend, aus kurzem Halse länglichzylindrisch, bis $7 \mathrm{~mm}$ lang, zuletzt rotbraun, derbhäutig, trocken unter der Mün- 
dung nicht verengt; Zellen des Exotheciums rektangulär; Spaltöffnungen vorhanden. Ring breit, sich abrollend. Peristomzähne $0,9 \mathrm{~mm}$ lang, gelbrot, mit sehr zahlreichen Lamellen. Inneres Peristom gelb; Fortsätze gefenstert; Wimpern mit sehr langen Anhängseln. Deckel breit kegelig oder hochgewölbt, mit Spitzchen. Sporen 12-18 $\mu$, gelb, papillös. Sporenreife im Herbst. - Fig. 54.

In etwas feuchten Wäldern, an buschigen Plätzen, am Fusse von Felsen, auf schattigen, erdbedeckten Blöcken.

F. Al. fq. (Bom.). - Ab. Dragsfjärd. Kuustö. Abo. Reso. Kímito. Finbỵ. Nỵstad. Lskela. Karislojo. Lojo. - N. Esło. Helsingfors. Hogland. - Ka. Antrea. - Ik. Uusikirkko. Muola. Pỵājärri. - St. Eura. IIessukylä. Pirkkala, - Ta. Sääksmäki. Kalvola. Im südöstl. Teile pass. (Norrl.). Hartola. Korpilahti. Tianen, Vällyvuori (Vain.). - Sa Kangasniemi. Ruokolahti. - Kl. Valamo. Uukuniemi. Sortavala, liuhavuori (Linnan.); Kirjaralahti (Lindb.). - Kol. Petrosarodsk (Simm.). - Tb. Virrat, Helvetinportt (Broth.). Fonginkangas. Lekojärvi (E. af H.). - sb. Kuopio. Neulaniemi und

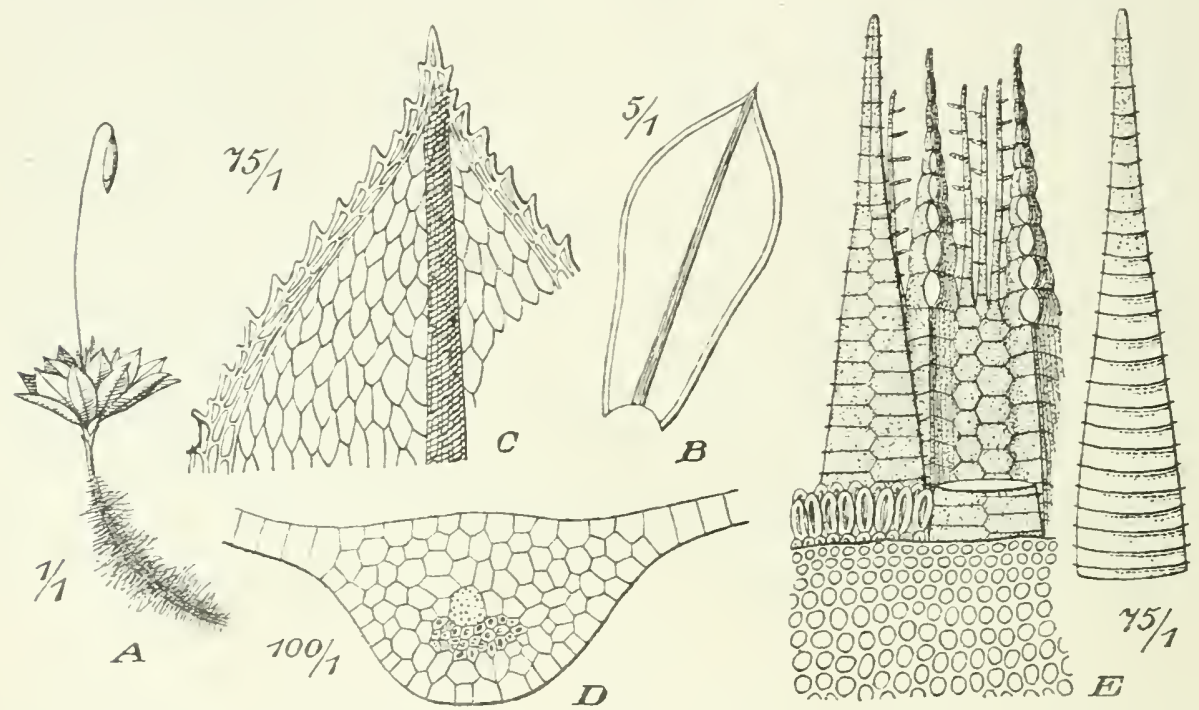

Fig. 54. Phodobryum roseum (Weis.). A Fruchtende Pfl. (1/1); B Stengelb. (5/1); C Blattspitze (75/1); D Blattquerschnitt (100/1); E Peristom (75/1). (D nach Lim p r c h t.)

Puijo (Link.). Kaavi, Huosiaisniemi cop. (Kot.). Maaninka, Tuovilanlahti (Lundstr.); Korkeakoski (Roiv.). - Kb. Joensuu, Niinivaara (Linnan.). - Kon. Tiudie (Kullh.). Kivatsch (Sel.). - Om. Evijärri, Pikku Kettusaari (Backm.). - Ok. Kajana (Lackstr.). - Kpom. Vaksuraara (Bergr.). - Ob. Rovaniemi, Mäntyjoki (Hult). - K. Kuusamo. Paanajärvi, Măntyvaara (Broth.). — Li. Sodankylā, Orariköngās, in der Nadelwaldregion (Hult). Inari, Tuarpomoiri, in der Birkenregion (H.). Utsjoki, Mandojäyr (H.). - Lim. Kandalaks. Schelesnaja (Broth.).

S. $S k,-L$.

N. Sm. - Tr. Nordgrenze lei $69^{\circ} 47^{\prime} \mathrm{n}$. Br.

Europa, kaukasus, Himalaya. Sihirien, Japan, O-t-China.

\section{N I A C E A E.}

Meist \pm kräftige, Schatten und dauernde Feuchtigkeit liebende Pfl. in oft ausgedehnten und lockeren Rasen. Stengel 5- bis mehreckig, mit grossem Zentralstrange, lockerem Grundgewebe und stark verdickten Mantelzellen, am Grunde bis weit hinaul mit meist papillösem Rhizoidenfilz, einfach oder mit meist reichlicher Sprossbildung, teils grundständig, mit aufrechten oder niedergebogenen Schösslingen, teils mit subfloralen Sprossen. Schopfblätter am grössten, rosettenartig gehäuft. Blätter nicht hygroskopisch. trocken meist eingeschrumpft, oft 
wellig verbogen und gedreht. meist breit eiförmig oder breit zungenlörmig und abgerundet oder zugespitzt, gesäumt und ganzrandig oder mit 1- 2 Reihen Zähne leselzt, selten ungesäumt; Rippe krältig. meist vor oder in der Blattspitze endend und anatomisch in 3 Typen ausgebildtet; Zellen meist rundlich-6eckig, glatt, an Grunde lockerer und verlängert. Blïten gipfelständig. § Blüten scheibenförmig. mit keulenförnigen Paraphysen: äussere Hüllbłätter am Grunde breit und hohl. oberwärts zurïekgebogen, die inneren viel kleiner, loekerzellig. 千 Blüten mit ladenförmigen Paraphysen. Perichätialblätter aufrecht, die äusseren lang uncl schmal, nach innen vieł kleiner und schmäler werdend, ungesäumt, gerippt. Seta verlängert, steif, glatt, oben meist kurz lakenförmig. Kapsel geneigt bis hängenı, regelmässig, elliptisch bis länglich, selten fast kugelig. mit kurzem, meist plötzlich in die Seta abgesetztem Halse, meist dünnhäutig, glatt; Zellen des Exotheciums locker, rundlich und verlängert mehreckig; Spaltöffnungen (exel. Mnimm Drummondii) eingesenkt und (excl. M. rostratım) auf den Hals beschränkt. Ring meist 2reihig und meist sich abrollend. Peristom doppelt, meist wie bei Eubryum ausgebildet. Deekel gewölbt bis sehief geschnäbelt. Haube kappenförmig, meisl bald schwindend. Sporen meist gross.

$$
\text { I'bersichl der Gat tungen. }
$$

A. Beide Peristome gleichlang ............................ 8.1. Mnium.

13. Äusseres Peristom kürzer, gestutzt .................... 8.5. Cinclidium.

\section{MNIUM}

(Dill. ex p.) L. emend.: Schimp. Bryol. eur. Consp. ad Vol. IV. (18.51).

Stengel häufig mit grundständigen, aufrechten oder niedergebogenen, danu an ler Spitze meist wurzelnden Schösslingen und ausserdem oft mit subfloralen Sprossen. Beide Peristome von gleicher Länge. Peristomzähne lang und kräftig. anı Grunde nicht verschmolzen, breit lanzettlich, \pm gesäumt, papillös, mit zickzackförmiger Längslinie, niedrigen Dorsalfeldern und zahlreichen, hier und dá 'lureh eine Zwisehenwand verbundenen Lamellen. Inneres Peristom meist gelbrot; Grundhaut von etwa halber Zahnhöhe, zuweilen durchlöchert; Fortsätze breit lanzettlich, meist plötzlich pfriemenförmig, breit gefenstert, zuletzt klaffend; Wimpern vollständig, knotig.

\section{íbersieht der Artell.}

A. Diözisch. Blätter beim Liegen im Wasser sich blaugrün färbend, zugespitzt; Rippe glatt. Deckel stumpf.

a. Blätter häufig unterbrochen und undeutlich gesäumt, ganzrandig oder mit kurzen, stumpfen Zähmen ........

b. Blätter rot gesäumt, bis zur Mitte herab streckenweise 1 -2reihig kurz und stumpf gezähnt 192. M. stellare.

Bätter beinı Liegen im Wasser unverändert.

a. Blätter zugespitzt, wulstig gesäumt, 2reilig gezälnnt. ๙. Deckel (excl. M. inclinalum) gesehnäbelt.

1. Diöziseh.

1. Blätter kaum oder kurz herablaufend: Rippe oberwärts ami Rücken gesägt: Zellen in der Blattmitte $14-20$,

* Deckel kurz und stumpf zugespitzt 177. 1. inclinatum. 
2. Blätter kaum oder äusserst schmal herablaufend; Rippe obcrwärts am Rücken meist glatt; Zellen in der Blattmitte $20-30 \mu$

1S0. M. riparium.

3. Blätter weit herablaufend.

* Obere Blätter eilanzettlich: Rippe oberwärts am Rücken gesägt: Zellen deutlich kollenchymatisch, in der Blattmitte 22-30 " .....479.1/.lycopodioides.

** Obere Blätter verkehrt-ciförmig, rasch scharf zugespitzt; Rippe oberwärts am Rücken meist glatt; Zellen nicht kollenchymatisch. 182. M. spinosum.

II. Synözisich 481. 11. marginalum. ß. Diözisch. Deckel hoch gewölbt, mit Warze ....... 475. M. hornum.

b. Blätter (excl. M. punctatum) durch einschichtigen, engen und dickwandigen Prosenchymzellen gesäumt, einreihig gesägt oder ganzrandig.

«. Synözisch.

I. Blätter kurz herablaufend, stumpf, mit Spitzchen, turch cinzellige, stumpfe Zähne gesägt. Deckel lang geschnäbclt

484. M. rostratum.

II. Blätter meist weit herablaufend, zugespitzt, scharf gesägt. Deckel hoch gewölbt, mit Spitzchen.

1. Sporogone einzeln 486. M. cuspidatum.

2. Sporogone meist gehäuft.

* und C. Sprosse meist aufrecht. Blätter firnisglänzend. Kapsel etwa $3 \mathrm{~mm}$ lang

485. M. Drummon-

** Sprosse heralogebogen. Blätter nicht glänzend. Kapsel etwa $5 \mathrm{~mm}$ lang.

$\dagger$ Seta rot, oberwärts gelb

$+\dagger$ Seta hyalin

dii.

ß. Diözisch. Deckel ungeschnäbelt.

I. Stengel mist nlit zahlreichen, bogig herabgekriimmten subfloralen Sprossen. Stammblätter weit herablaufend, zungenförmig, feucht querwellig

483. M. undulatum.

II. Stengel ohne subflorale Sprosse.

1. Sterile Sprosse bogig zur Ercle geneigt und an der Spitze meist Rhizoiden entwickelnd. Mittlere Stammblätter kurz herablatulend ...

2. Sterile Sprosse aufrecht.

* Stammblätter weit herablaufend, feucht mit hohler Aussenflächc

** Stammblätter nicht oder kaum herablaufend, feucht mit holler Innenfläche, ganzrandig oder oberwärts mit kurzen. stumpfen Zähnnen besetzt.

+ Blätter rundlich bis clliptisch, mit deutlich abgesetztem, 3 treihigem Samm; 7ellen rundlich- bis verlängert-6seitig ..... $+\dagger$ Blätter länglich-oval, mit 1-3reihigem,

487. M. medium. 4Ss. M. curvatulum.
190. M. Seligeri.

191. M. rugicum. 
nicht immer deutlich abgesetztem Saum:

Zellen rhombisch- bis rhomboidisch-6seitig. 496. W. cinclidioides.

$\gamma$. Obere Blätter verkehrt ei-spatelförmig, ganzrandig; Zellen weitlichtig. Deckel kegelig gespitzt bis schief geschnäbelt.

I. Diözisch. Blätter durch mehrschichtige Zellreihen wulstig gesäumt ................................ 195. . . punctatum.

II. Synözisch. Blätter durch rings oder wenigstens oberwärts einschichtige Zellreihen gesäumt ..... 494. M. pseudopunctatum.

$\delta$. Diözisch. Stengel schwarzbraun, mit 2zeilig gewendeten Blättern der sterilen Sprosse. Blätter oval, stumpf. mit Spitzchen, ganzrandig

193. M. hymenophylloides.
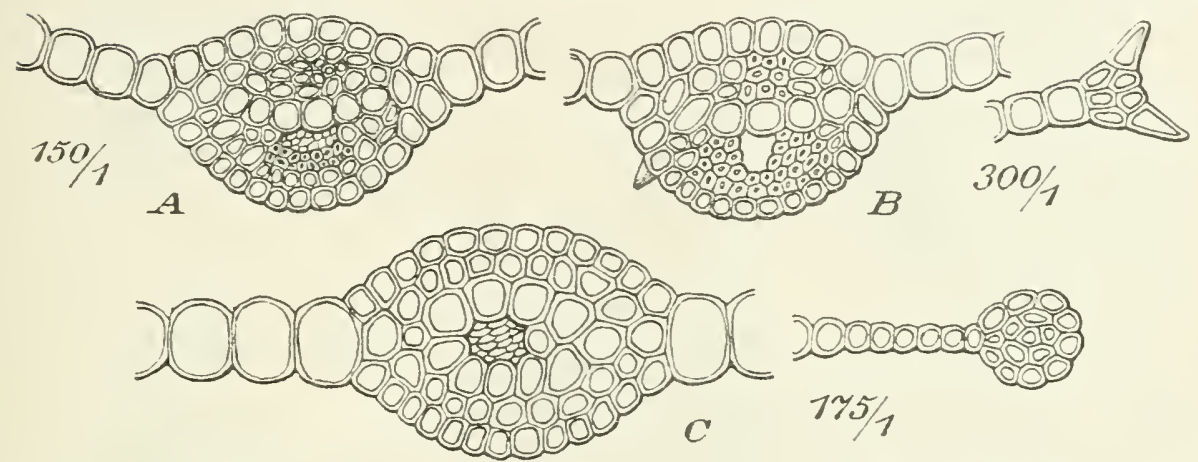

Fig. 55. Blattquerschnitte: A Inium cuspidatum (L. ex p., Schreb.) (150/1); B M. hornum L. (300/1): C M. punctatum L., Schreb. (175/1). (1891).

S e c t. I. Polla (Brid. ex p.) Mitt. in Trans. Linn. Soc. 2. Ser. Bot. III. p. 169

Blätter meist wulstig gesäumt und zweireihig gezähnt: Rippe mit einer Schicht medianer Deuter, einer lileinen, sternförmigen Begleitergruppe, das dorsale Stereidenband meist hufeisenförmig, das ventrale kleiner, zuweilen auf wenige Stereiden reduziert; Zellen nicht oder kaum getüpfelt. - Fig. 55 B.

475. Mnium hornum L. Sp. pl. 1. ed., II. p. 112 (1753). [Astrophytlum hornum Lindb. Musc. scand. p. 14 (1879).]

Diözisch. Pfl. in dichten, grünen, = weit hinauf verfilzten Rasen. Stengel aufrecht, bis $6 \mathrm{~cm}$, selten höher, einfach oder mit oben schwach gekrümmten, dicht beblätterten Seitensprossen. Blätter aufrecht-abstehend, aus etwas verschmälertem, wenig herablaufendem Grunde lanzettlich, aufwärts länger und dichter. bis $7 \mathrm{~mm}$ lang und etwa $1 \mathrm{~mm}$ breit, scharf zugespitzt, mit mehrschichtigem, = weit herab gesägtem, braunrotem Saume; Rippe vor der Blattspitze endend, obcrwärts am Rücken gezähnt: Zellen nicht kollenchymatisch, in der Blattmitte 22 $28 \mu$. Sporogone einzeln. Seta $2-5 \mathrm{~cm}$, rot, oben gelblich. Kapsel meist horizontal bis fast nickend, elliptisch bis länglich, 4-5 mm lang und bis 1,8 $\mathrm{mm}$ dick, grünlichgelb, zuletzt braun. Deckel kuppelartig gewölbt, mit spitzer Papille. Sporen $30-40 \mu$, gelbgrün, papillös. Sporenreife im Frühling. - Fig. $56 \mathrm{H}-\mathrm{M}$.

Auf feuchtem Waldboden, an Waldbächen, Quellen und an kieselreichen Felsen. 


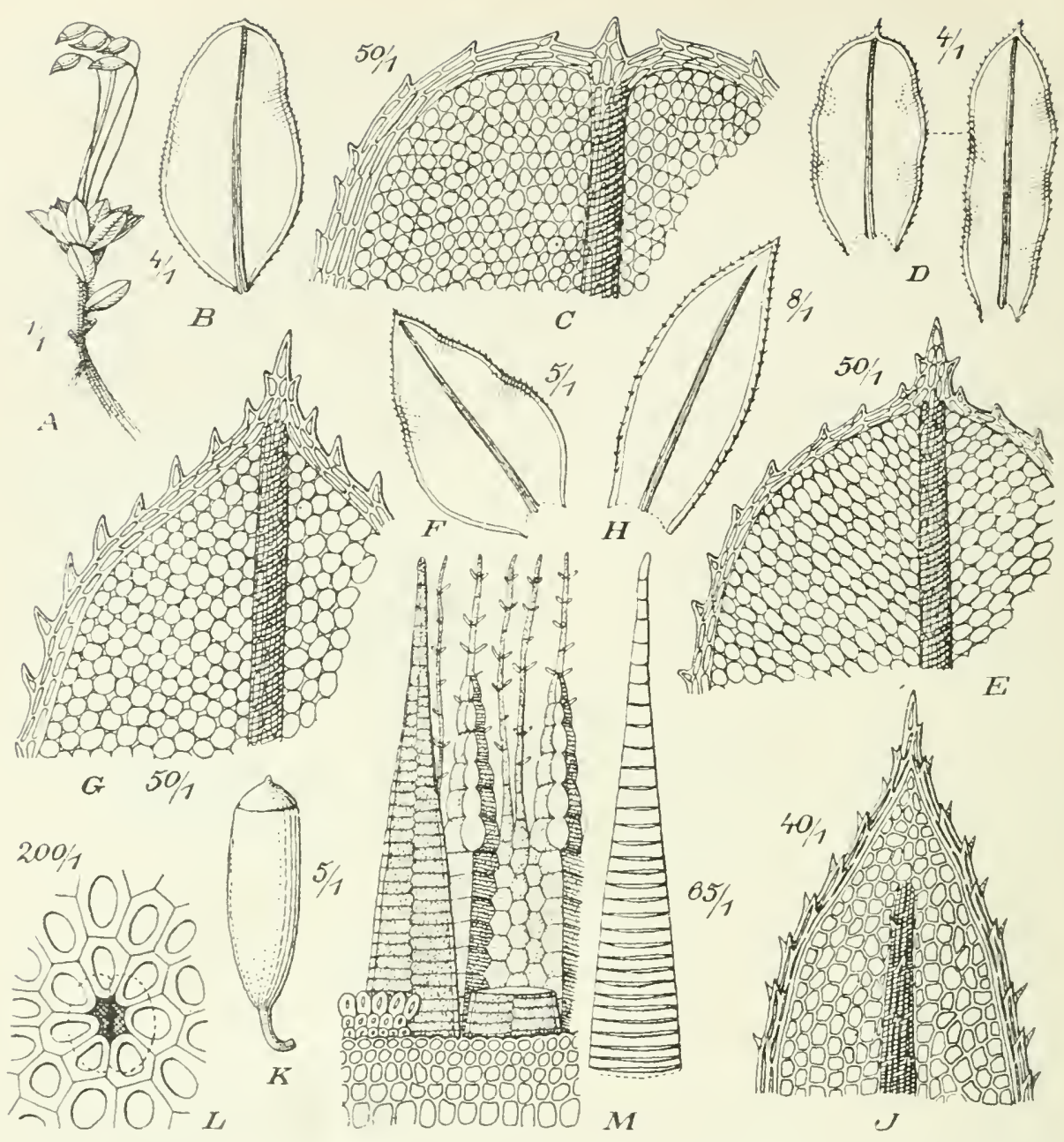

Fig. 5f. A 1 Mnium rostratum schzad. A Fruchtende Pfl. (1/1): B stengelb. (4/1); C Blattspitze (50/l). I) - E M. Seligeri Jur. D stengelh. (4,1): E Blattspitze $(50 ; 1)$. - F-G il. cuspidaium (L.ex p., Schreb.). F. Slengelb. (5 1): (i Blattspitze $(50 / 1)$. - H-MI M. hornum L. H Stengelb. (8/1); I Blattspitze (40/1); K Kapsel (5/1): L Spaltöffnung (150/1): M Peristom (65il).

F. Al. Xach Bo ml. Tq. und meist rejehlich fruchtend. - Ab. Korpo (Ekl.). Cillstafs, Eskola (Bererr.). Ibo (Brand.). Piikkis Harvarön (Zett.). Reso(A.H. Caj.). Pargas, an mehreren Fundorten (Elfv., Link.). Karuna (E.). Kimito, Fröjböle (Ols.). Finly (Broth.). Angehiemi (Buch). Bromarf (Broth.). Karislojo (Sundv., E. af H.). Lojo (lindb.). - K. Ekenäs (Broth.); Trärminne (B.). Ingà, Bjurs (Buch). Kyrkảatt, Obbnās (Ju=l.). Wsbo. Kirchdorf (Ranck.): Sandudd (Broth.). Helsingfors (Lindh.). Helsinge, Ijölö (Font.). Sibbo, Löparö (Sulldv.): Ciesterby (Linh.). Hogland (Lindb.). Tytärsari (Brenn.). Ka. Virolahti (Blom). - It. Muola, Perkjärvi (H. Lindl.). - St. Bjömeborg (Häyr.). Sastmola (Malıngr.). - Ta. Koski, Kellola (Vain.). Asikkala, Piskurinlahti (Norr.). — Sa. Valkeala (Sundr.). Runkolahti, Imatra (Buch). Kangasniemi (Lackstr.). - Kl. Surtavala. Kirjavalahti (W. Nyl.). - Kot. All inehreren Fundorten (Elfr.). - Oa. Vasa, kitperö (Broth.). - Kon. Valkeaühi (Simm.). - Ob. Rovaniemi, an mehreren Fundorten längs des Ounasjoki (Hult). - Lkem. Kittilä, Pahtakallio und am Aakenusjoki (Hult).

S. Sk. -Ifls. Jmt. Ing. Tảijö. 「'b. Skellefted.

N. $\$ m .-F$. Nordgrenze ein wenig jenseits des $\pi 1^{\circ} \mathrm{n} . \mathrm{Br}$.

Europa, Algier, Nord-Amerika. 
476. Mnium Blyttii Bryol. eur. fase. 31 Suppl. 1. 6, No. 20, t. 5 (1816). [Astrophyllum Blyllii Lindb. Nluse. seand. p. 1t (1879).]

Diözisch. Pfl. in dichten, lebhaft grünen, innen roten und dicht rotfilzigen, bis $8 \mathrm{~cm}$, selten höleren Rasen; grüne Blätter beim Liegen im Wasser sich blaugrün färbend. Stengel aufrecht, mit aufrechten Sprossen. Blätter aufrecht-abstehend, aus verschmälertem Grunde lierablaulend, nach oben allmählich grösser und dichter, untere oval, zugespitzt, ganzrandig, obere oval-länglich, zugespitzt, meist etwa $3 \mathrm{~nm}$ lang und 1,5 $\mathrm{mm}$ breit, gipfelständige spatelförmig, zugespitzt, elwa $4 \mathrm{~mm}$ lang und $1.2 \mathrm{~mm}$ breit, durch $1-2$ Reihen ein- und doppelschichtiger, verdickter Zellen rot gesämmt und bis zur IItte herab streckenweise ein- oder zweireihig kurz und stumpf gezähnt: Rippe vor und mit der Blattspitze endend, am Rücken glatt; Zellen undeutlich kollenchymatisch, in der Blattmitte $22-28 \mu$. Sporogone einzeln. Seta $2-2,5 \mathrm{~cm}$, blassrötlich. Kapsel horizontal oder nickend, verlängert-länglich, $3 \mathrm{~mm}$ lang und 1,3 $\mathrm{mm}$ dick, etwas gebogen, gelblich. 1)eckel hoch gewölbt, stumpf. Sporen $18-2+\mu$, schmutzig bräunlichgelb, fein papillös. Sporenreife im Juli und August.

Auf feuchtem Boden und an feuchten Kalk-und Schieferfelsen.

F. Le. Kilpisjärvi, Malla, Saana und ciumjarrankka, in der alpinen Region (Kot.). - L $p$. Sapadnij navolok in der Nähe von Svjäterinos (Broth.). Orlov, Rusiniha und Ponoj (B.).

S. Jmt. Handölsallen. Hrjd. St. Midtaklappen. LuL. an mehreren Fundorten in der Weidenund Alpenregion. TL.

N. Ne. Saetersdalen, 1,100-1,200 m. $S B$. K. Dovre. Gausdal, Lomseggen, 1,300 m. H. No.-F. an mehreren Fundorten in der Weiden- und Alpenregion.

Spitzbergen, Sibirien, arkt. Nord-Amerika.

477. Mnium inclinatum Lindb. in Not. Sällsk. Faun. Fl. Fenn. Förh. IX. p. 48 (1867). [Astrophyllum inclinatum Lindb. Musc. scand. p. 14 (1879).]

Diöziseh. Mit M. orthorrhynchum nahe verwandt. Schlanke Pfl. in blassgrünen Rasen. Stengel aufrecht, 2-3 cm. Blätter aufrecht-abstehencl. kaum herablaufend, obere länglich, stumpflich, bis $4 \mathrm{~mm}$ lang und bis etwa $1,3 \mathrm{~mm}$ breit, mit mehrschichtigem, bis zur Blattmitte herab gesägtem, rotem Saume; Rippe in der Blattspitze endend, oberwärts an Rücken gezähnt; Zellen undeutlich kollenchymatisch, in der Blattmitte 1t-18 $\mu$. Sporogone einzeln. Seta etwa $1,5 \mathrm{~cm}$, oben im flachen Bogen gekrümmt. Kapsel Hypnum-ähnlich, aufrecht bis geneigt, länglich-eiförmig, sehr dümmhäutig, rötlich, weitmïndig. Deckel aus niedrig-kegeliger Basis kurz und stumpf zugespitzt. Sporen bräunlich, glatt.

F. Le. Kilpisjärvi und am Kilpiskoski, in der Birkenregion (Norrl.). Steril.

S. PL. Käksa, auf feuchten, erdbedeckten Felsen in der alpinen Region.

478. Mnium orthorrhynchum Brid. Sp. musc. III. p. 45 (1817). [Aslrophyllum orthorrhynchum Lindb. Muse. scand. p. 14 (1879).]

Diözisch. Pfl. in dichten, grünen, später bräunlichen, innen roten und mässig verfilzten Rasen. Stengel aufrecht, $2-5$, selten bis $7 \mathrm{~cm}$, einfach oder mit wenigen aufrechten, oben mässig gekrümmten, dicht beblätterten Sprossen. Blätter aufrecht-abstehend, kurz herablaufend, mittlere eilänglich, obere aus verschmälertem Grunde länglich-lanzettlich, bis 4,5 mulang und bis etwa 1,3 min breit. mit mehrsehichtigem, bis zur Blattmitte herab gesägtem, rotem Saume; Rippe in der Blattspitze endend, oberwärts am Rücken gezähnt: Zellen nicht kollenchymatisch, in der Blattmitte $16-20 \mu$. Sporogone einzeln. Seta $1,5-2,5 \mathrm{~cm}$, rot, oben gelb. Kapsel horizontal bis fast nickend, länglich, bis $5 \mathrm{~nm}$ lang und $1,2 \mathrm{~mm}$ dick, gerade, grünlich, später braun. Deckel aus kegeliger Basis schief geschnäbelt. Sporen $24-32 \mu$, gelbgrün, warzig papillös.

Gern auf schiefrigem und kalkhaltigem Boden, in Wäldern und an Felsen.

F. Sb. Juuka, Halivaara, Haliruori (Ǩot.). - $h$. Kuusamo, Oulankajoki, Merenoja (Broth.); Paanajärvi, Kiekkivaara (B.). - Lkem. Kittilä, Kirchdorf (Hult). Kuolajärvi, Pşhäkuru (E. af H.). Le. Kilpiskoski(Norrl.). In Fjeldgebiete am Kilpisjärvi fq. in der subalpinen und alpinen Region(Kot.). 
Li. Utsjoki. Ailigas, in der alpinen Region (Hult). - Lim. Hibinä (Kilhlm.). - Lp. Orlov, Gubnoj (Kihlın.); Ponoj (Sahlb.).

S. Ög., $\mathrm{Yg}$., Dld., Dlr., Mpd., Ang. und $\mathrm{V} b$. an einzelnen oder wenigen, $\boldsymbol{H} r \mathrm{~d}$. und $J m t$. an inehreren Fundorten. In den Lappmarken $t$ verbreitet.

N. Kristiania nicht selten. Ringerike. Gudbrandsdalen. Vestfjorddalen. Ne. Saetersdalen. $K$. Dovre. Lomsfjeldene. NT. Stjørdalen. No.-F. an mehreren Fundorten.

Europa, Kaukasus, West-Himalaya, Zentral-Asien, Sibirien, Sachalin, Japan, Nord-Amerika. Nordgrenze auf spitzbergen.

479. Mnium lycopodioides (Hook.) Schwaegr. Suppl. II. P. II. fasc. 1, p. 24 , No. 1, t. 160 (1826). [Bryum lycopodioides Hook. Mscr., Spreng. in L. Syst. veg. XVI. ed., IV. P. I. p. 214, No. to (1827). — Astrophyllum lycopodioides Lindl). Musc. scand. p. 14 (1879).]

Diözisch. Pfl. in lockeren, dunkelgrünen, am Grunde rötlichen und verfilzten Rasen. Stengel aufrecht, bis $1 \mathrm{~cm}$, einfach, selten mit einzelnen, aufrechten, locker beblätterten Sprossen. Blätter locker gestellt, aufrecht-abstehend bis fast einseitswendig, breit und weit herablaufend, untere eiförmig, zugespitzt, fast ganzrandig. mittlere eilänglich, obere aus verschmälertem Grunde eilanzettlich, scharf zugespitzt, bis $5 \mathrm{~mm}$ lang und bis $1,5 \mathrm{~mm}$ breit, mit doppelschichtigem, fast bis zur Basis herab gesïgtem, rotbraunem Saume: Rippe in der Blattspitze endend, oberwärts am Rücken scharl gezïlnt: Zellen deutlich kollenchymatisch, in der Blattmitte $22-30 \mu$. Sporogone einzehı. Seta $2-3 \mathrm{~cm}$, blassrötlich. Kapsel horizontal bis fast nickend, verlängert länglich, etwa $6 \mathrm{~mm}$ lang und $1,25 \mathrm{~mm}$ dick, sanft gekrünmt, grüngelb, zuletzt braun. Deckel aus kegeliger Basis abwärts geschnäbelt. Sporen 16-2 $4 \mu$, bräunlichgelb, Warzig-papillös. Sporenreife im Juli und Juli.

An feuchten und steinigen Abhängen, an Bach- und Wegrändern, gern aul schiefrigem und kalkhaltigem Boden.

F. K. Kuusamo, Mäntyjoki (Vain.).

S. Ing. Tåsjö.

N. Kristiania, Ringerike. Dorre. Lomsfjeldene, Roshejm. sB. No.-F. an einzelnen Fundorten. Pyrenäen, Alpen, Hinalaya. Zentral-Asien.

180. Mnium riparium Nitt. in Journ. Proc. Linn. Soc. VIII. p. 30 in Obs. (1861). [Astrophyllum riparium Lindb. Minsc. scand. p. 14 (1879).]

Diözisch. Pfl. in lockeren, hellgrünen, beim Liegen im Wasser blaugrünen, imnen schmutzig rostfarbenen, am Grunde mässig filzigen Rasen. Stengel anfrecht, 2-3, selten bis $1 \mathrm{~cm}$, infach oder mit zahlreichen, aulrechten, etwas gekrümmten Sprossen. Blätter aufrecht-abstehend, kaum oder äusserst schmal herablaufend, nach oben allnählich grösser und dichter, untere rundlich-oval und ganzrandig, obere elliptiseh, kurz zugespitzt, bis $3,6 \mathrm{~mm}$ lang und 1,2 mm breit, mit melırschichtigem, bis mnter die Blattmitte gesägtem, blassrötlichem Samme: Rippe kurz vor oder in der Blattspitze endentl, am Rücken meist glatt: Zellen schwach kollenchymatisch, in ter Blattmitte 20-30 $\mu$. Sporogone zu 1 und 2. Seta 1$2 \mathrm{~cm}$, blassrötliclı. Kapsel geneigt bis fast hängend, länglich, $3-4 \mathrm{~mm}$ lang, gelhlich, später gebräunt. Deckel hoch gewölbt und schief geschnäbelt. Sporen 2.j$30 \mu$, schmutzig gelblich, fein papillös. Sporenreile im Mai.

An Bachufern. Waldrändern und beschatteten Erdabhängen.

S. Stockholn. Mpd. Norlỵkn̈̈l.

N. Ne. Saetersdalen r.

Gros-Britanien, Zentral-Europa, Kaaukasus, West-llimaliya, Sibirien.

181. Mnium marginatum (Dicks.) Palis. Prodr. P. 75 (1805). [Bryum marginatum Dicks. Pl. crypt. lasc. II. 1. 9, t. 5, f. 1 (1790). - Mnium serratum Schrad. in L. (Gmel.) Syst. nat. XIII. ed., II. P. II. p. 1330, No. 27 (1791). - Astrophyllum marginatum Linclb. Musc. scand. p. 11 (1879).]

Synözisch. Pll. in lockeren, grïnen, in Alter bräunlichen bis schwärzlichen, am Gruncle mässig filzigen Rasen. Stengel aufrecht. 2-3, selten 1 cm, einfach. 
seltener mit einzelnen aufrechten, locker beblätterten Sprossen. Blätter aufrechtalsstehend, von Blatt zu Blatt schmal herablaufend, nach oben allmählich grösser und dichter, untere oval und ganzrandig, obere länglich-elliptisch, kurz zugespitzt, bis $5 \mathrm{~mm}$ lang und bis $1,5 \mathrm{~mm}$ breit. mit mehrschichtigem, bis unter die Blattmitte herab gesägtem, blassrötlichem Saume; Rippe kurz vor oder in der Blattspitze endenct, am Rücken meist glatt; Zellen deutlich kollenchymatisch, in der Blattmitte 22-30 $\mu$. Sporogone einzeln. Seta $2-3 \mathrm{~cm}$, blassrötlich. Kapsel horizontal bis nickend, oval bis länglich, 4-5 mm lang und $1,5 \mathrm{~mm}$ dick, gelbgrünfich bis gelb, später gebräunt. Deckel hoch gewölbt und schief geschnäbelt. Sporen 25-30 $\mu$, schmutzig gelblich, fein papillös. Sporenreife im Mai und Juni.

An steinigen Waldabhängen, an Bachufern und in Felsspalten, besonders von kalkhaltigem Gestein.

F. Al. Saltvik, Lafö und lívarnbo (Bom.). Sund, Gesterby (B.). - Ab. Giustafs, Eskola (Bergr.). Loju (Boldt). - Kl. Ruskeala (Simm., Lindb.); Tirrin mylly (Buch). Pälkjärvi, Korkeaniemi (Broth.). Fol. Petrusivodsk ((iünth.). - śb. Nilsiä, Kirchdorf, Lehtomäki, an schattigen Felsen (Kot.). Juuka. Tatta (K.). - Kb. Juuka, Juuanvaara (Kot.). Tohmajärvi, Akkala (K.). — Kon. Jalguba (Simm.). Kohtsalmi (Kullh.). - K. Kuusamo, an vielen Fuudorten im östlichen Teile (Nyb.. Sil., Broth., E. af H.). - Le. Kilpisjärvi. Leutsuvaara (Norrl.); Saivovaara (Kot.). - Li. Utsjoki, Kenischkoski (Hult). Lim. Kandalaks, Schelesnaja (Broth.). - Lt. Kola, Karaulnaja Pahta (Broth.). - Lv. Tschapoma (Broth.).

S. Sk.-. Ang., init Ausnahme von Bl., HIl., Boh., Vrml., Hlst. und Ipd., meist jedoch nur an einzelnen oder wenigen Fundorten.

N. Kristiania fq. Sm. Onso. Bu. Ringerike st. fq. Ne. Saetersdalen rr. St. Ryfylke. SB. R.rr. K. Dorre. Lomsfjeldene. NT. Stjordalen $\mathrm{fq}$. Levangen. No. und $\mathrm{Tr}$. an mehreren Fundorten.

Europa, Kaukasus. Himalaya, Sibirien. Nord-Amerika.

482. Mnium spinosum (Voit) Sehwaegr. Suppl. I. P. II. p. 130, No. 10, t. 78 (1816). [Bryum spinosum Voit in Sturm Deutschl. Fl. II. Heft 11 (1810). - Astrophyllum spinosum Lindb. Musc. scand. p. 14 (1879).]

Diözisch. Pfl. in lockeren, oft ausgedehnten, grünen, am Grunde verfilzten Rasen. Stengel aufrecht, bis $6 \mathrm{~cm}$, selten höher, nach unten schwarzrot, weit hinauf mit entfernten, schuppigen Niederblätern besetzt, einfach, zuweilen mit herabgekrümmten subfloralen oder spärlichen grundständigen, aufrechten, an der Spitze etwas gebogenen, dicht beblätterten Sprossen. Blätter nach oben schnell grösser und schopfig gehäuft, abstehend bis zurückgebogen, aus verschmälertem, herablaufendem Gruncle verkehrt-eiförmig bis spatelförmig, 5-8 $\mathrm{mm}$ lang und bis $3,5 \mathrm{~mm}$ breit, kurz und scharf zugespitzt, mit mehrschichtigem, \pm weit herab dornig gesägtem, meist rötlichem Saume; Rippe in der Blattspitze endend, glatt orler am Rücken oberwärts mit vereinzelten Zähnchen; Zellen undeutlich kollenchymatisch, oberwärts am Rande 22-28 $\mu$, gegen die Rippe etwa 40 " lang und 22 " breit. Sporogone zu 2-7 gehäuft, selten einzeln. Seta $1,5-2,5 \mathrm{~cm}$, gelbrot. Kapsel nickend bis hängend, länglich, etwa $3 \mathrm{~mm}$ lang, gerade oder sanft gekrümmt, gelbgrün, später rötlichbraun. Deckel rötlichbraun, hoch gewölbt, kurz und dick geschnäbelt. Sporen $18-25 \mu$, gelblich, fast glatt. Sporenreife im Juli und August. orten.

Auf Humus in Nadelwäldern und auch anderwärts an beschatteten Stand-

F. Kl. Kirjavalahti (Kuj.). - Kon. Käpselkä (Simm.). - K. Kuusamo, Oulankajoki (Brotb.). Lkem. Kittilä, Aakenusjoki (HuJt). - Lim. Kandalaks. Schelesnaja (Broth.). - Lt. Srednij am Koldbusen (Broth.). Pummanki (B.). - Lp. Sapadnij navolok (Broth.). Rusiniha zW. Orloy und Ponoj (B.); Ponoj (B.).

S. Vg. Kinnekulle. Hrjd. und Jmt. an mehreren Fundorten. Ang. Tảsjö. LyL., PL. und LuL. an einzelnen oder wenigen Fundorten.

N. Kristiania st. r. Ringerike rr. Ne. Saetersdalen. $R$. Geiranger. Merok. h. Dovre. Lomsfjeldene. $\mathcal{N}_{T}$. Stjordalen. No. und Tr. st.r., bis in die Weidenregion hinaufsteigend. Nordgrenze bei $69^{\circ} 4 z^{\prime}$ n. Br.

Europa, Kaukasus, Zentral-Asien, Nord-Amerika.

S e c t. I I. Eumnium Mitt. 1. c. p. 166. [Mnium B. Serratae Limpr. Laubm. I1. p. 467 (1893).] 
Blattsaum einschichtig, einreihig gezähnt; Rippe mit einer stern- oder bandförmigen Begleitergruppe, einem unteren, meist sichelförmigen Stereidenbande, oberseits mehreren Schichten lockerer Zellen und unterseits 2 Schichten lockerer Rïckenzellen. - Fig. 55 A.

483. Mnium undulatum (L.) Weis. Pl. crypt. fl. Gotting. p. 158 (1770). [M. serpyllifolium $\delta$ undulatum L. Sp. pl. 1. ed., 11. p. 1113 (1753). - Astrophylium undulatum Lindb. Muse. scand. p. 13 (1879).]

Diözisch. Pfl. in sehr lockeren, oft ansgedehnten, dunkel- oder gelblichgrünen, bis $10 \mathrm{~cm}$ hohen, selten höheren Rasen. Stengel aufrecht. unter der Spitze meist mit zahlreichen, achselständigen, peitschenartig niedergebogenen đ̈sten und aus dem Grunde mit einzelnen. zuerst wagerechten, dann bogig aufsteigenden, anfangs stolonenartigen Sprossen. Blätter nach oben rasch grösser und diehter, breit und weit herablaufend, aufrecht-abstehend bis zurïckgekrümmt, in der oberen Hälfte querwellig, verlängert zungenförmig, abgerundet, mit Spitzchen, bis $15 \mathrm{~mm}$ lang und $2-3 \mathrm{~mm}$ breit, durch $3-5$ Reihen enger, verdickter Zellen gesäumt und rings durch 1-2zellige Zähne scharf gesägt: Rippe vor oder mit dem Spitzchen endend: Zellen deutlich kollenchymatisch, nicht oder undeutlich getüpfelt, äussere $12-25 "$, gegen die Rippe etwa 50 " lang und 25 " breit. Sporogone zu 2-10, selten einzeln. Scta 2-3 cm, rot, oben gelb. Kapsel horizontal bis hängend, länglich-eiförmig, $3,5-5 \mathrm{~mm}$ lang und bis $2 \mathrm{~mm}$ dick, gelbgrün. entleert blass orange, zuletzt braun. Deckel kuppelartig gewölbt, stunnpf oder mit Spitzchen. Sporen 18-30 $\mu$, gelblich, fein gekörneit. Sporenreife im Mai.

An fenchten Orten in Wäldern, gern an schattigen Quellen und Bachufern.

F. Al. Nach B o m. nicht selten, jedoch meist steril. - Ab. Iioryo, Finnö (Ekl.). Parga-, Lindberg (Elfv.). Kimito, Brändboda, Markbỵ (Ols.). Reso, Bagarla (Zett.). Karislojo, Karkali (E. af H.). Lojo, Ojamo (Lindb.). - N. Ekenäs (Häy̌r.); Vitsand (Broth.); Trärminne (Ranck.). Helsinge, Backas (Sola). Orimattila, Niemi (Link.). Iitti, Uranjärvi (Buch). — Ka. Säkkijärvi, Laihajärvi (Ranck.). Ik. Sakkkola, Kurikka (H. Lindl).). — Sl. Jämijärvi (Herl.). - Ta. Asikkala, Kārsälä, Paskalampi (Norrl. und sil.).

S. sik.-Hlsl.

N. Sm., A.. Bu.. JL., Br., Ye., SB., XB., R., NT. und No. Nordgrenze bei etwa $6 \tau^{\circ} 15^{\circ} \mathrm{ll}$. Br.

Europa, Aadeira. Kanaren, Azuren, Iarokko, Tunis, Algier, Kaukasus, Syrien, Sikkim. Japan.

484. Mnium rostratum Schrad. in L. (Gmel.) Syst. nat. 13. ed., 11. P. II. p. 1330. No. 28 (1791). [Astrophyllum rostralum Lindb. Mluse. scand. p. 13 (1879).]

Sv'nözisch. Pfl, in lockeren, sattgrünen, unten verfilzten Rasen. Stengel aufrecht, $23 \mathrm{~cm}$, an Grunde nit zahlreichen, sich bogig zur Erde neigenden, reichlich Rhizoiden entwickehnden, 2reihig und locker beblätterten, stolonenartigen Sprossen. Blätter kurz herablaufend, nach oben raseh grösser werdend und eine Rosette bildend, abstehend und etwas zurückgebogen, trocken stark wellig verbogen und gedreht, zurückgekrimmt und fast kraus, untere cirundlich, obere aus schmalem Grunde länglich-oval und zungen-spatelförmig, 3-5 mm lang und 2-3,5 $\mathrm{mm}$ breit, durch 3-5 Reihen enger, verdickter Zellen gesäumt und bis unter dic Nitte heral, mit einzelligen, anliegenden, stumpfen Zähnen besetzt; Rippe kurz vor oder mit dem Spitzchen endend: Zellen deutlich kollenehymatisch, schwach getüpfelt, rundlich-mehreckig. zicmlich gleichförmig, in der Blattmitte $25-30 \mu$, gegen die Ränder nur wenig enger. Blätter der Sprossen elliptisch, oval oder länglich, $3-5 \mathrm{~mm}$ lang und $2 \mathrm{~mm}$ dick, gelblich. Deckel ans kegelförnig gewölbter Basis lang-, zuweilen schief-geschnälselt. Sporen 18-28 “. gelbbräunlich, papillös. Sporenreife im Frühling. - Fig. 56 A-C.

An sehattigen Orten, gern an erdbedeckten kalkhaltigen Gesteinen.

F. Al. Saltvik, an mehreren Fundorten (Bom.). - Ab. Pargas, Blă:näs (Arrh.); Lindberg- gruva (Elfv.). Kinito, Jrajniemi (Ols.). Angelniemi. Kokkila (Buch). Karislojo, Karkali (IIult). Lojo, an mehreren Fundorten (Lindb.). - Ik. Py̧häjärvi, Lohijoki (II. Lindb.). - Ta. Hattula, Nikkilä (Weg. und Ranck.). - Sa. Willmanstrand (Buch). - Kl. Ruskeala (Lindb.). Soanlahti. Körpikallio (Broth.). 
Pälkjärvi, Korkeaniemi (B.). - Kb. Tohmajärvi, Akkala (Kot.). Kon. Valkeamaki (Simm.). - K. Fuusamo, Oulankajoki, Merenoja (Broth.); Sovajoki, Kulmakkapuro (E. af H.).

S. Sh.-Gstr. und Dlr.; Jmt. und Ang. an einzelnen Fundorten.

N. Sm., A., Bu., JL.. Br. und R. No. Sortolden. Tr. Nordreisen, Venetvadra. Nordgrenze luei $69^{\circ} 57^{\prime} \mathrm{n} . \mathrm{Br}$.

Durch die gemässigten und wärmeren Teilen der Erde weit verbreitet.

485. Mnium Drummondii Bruch et Schimp. in Hook. Lond. Journ. Bot. II. p. 669 (1843). [Astrophyllum Drummondii Lindb. Mluse. scand. p. 14 (1879).] Synözisch, selten auch or Pfl. Jfl. in \pm dichten, grïnen, fast firmisglänzenden, imnen verfilzten Rasen. Stengel aufrecht, 1,5- $-5,5$ cm, mit aufrechten, selten in Bogen niedergekrïmmien Sprossen. Blätter feucht und trocken aufrecht-abstehend, untere klein ,breit eiförmig und verkchrt-eiförmig, die übrigen allmählich grösser, aus enger, weit herablaufender Basis breit verkelırt-eiförmig, rasch zugespitzt, mit Spitzchen, bis 1,5 mm lang und $3 \mathrm{~mm}$ breit; äussere Schopfblätter verkehrt-eilänglich bis spatellörnig, innere allmählich schmäler, durch 2-4 Reihen verdickter Zellen gelb gesäumt und bis unter die Mitte herab mit langen, scharfen, meist einzelligen Zähnen besetzt; Rippe im Spitzchen aufgelöst; Zellen weder getüpfelt noch kollenchymatisch, eckig-rund, am Rande $30-35$ " , gegen clie Rippe $40-50 \mu$, reich an Chloroplasten. Sporogone zu $2-3$, selten einzeln. Seta 1,5$2.5 \mathrm{~cm}$, rot, oben gelblich. Kapsel hängend, oval bis länglich, $3 \mathrm{~mm}$ lang und 1,5 mm dick, gelblich, zuletzt braun. Deckel gewölbt, mit zuweilen schiefem Spitzchen. Sporen 16-21 $\mu$, gelblich, warzig-papillös. Sporenreife in Mai.

Auf feuchtem Boden und an schr morschen Stämmen in Wralcle.

F. Kl. Sortavala, Kirjavalahti, Lahentausta, an mehreren Fundorten (Norrl.); Louhivuoret (Lindb.). Pälkjärvi, Valkealampi (Broth.). - Kol. Petrosarodsk (Günth.).

Livland, Ober-Schlesien, Russland, Sibirien. Nord-Amerika.

486. Mnium cuspidatum (L. ex p., Schreb.) Leyss. Fl. Hal. p. 272 (1783). [.Mnium serpyllifolium $\beta$ cuspidalum L. Sp. pl. 1. ed., I]. p. 1113 (17.53). - Bryum cuspidatum Schreh. Spic. fl. Lips. p. 84 (1771). - Astrophyllum silvaticum Lindb. Musc. scancl. p. 11 (1879).]

Synözisch. Pfl. in lockeren, olt ausgedehnten, lebhaft grünen, unten verfilzten Rasen. Stengel aufrecht, bis I cm, einfach oder mit bogig aufstrebenclen, sich dann niederlegenden und an der Spitze wurzelnden, stolonenartigen Sprossen. Blätter aufrecht-abstehend und leicht zurückgebogen: mittlere aus versclımälerter, breit und weit herablaufender Basis verkehrt-eiförnig, stachelspitzig, 3$4 \mathrm{~mm}$ lang und $2 \mathrm{~mm}$ breit, nach oben allmählich länger und dichter; Schopfblätter verkehrt-eilänglich bis spatelförmig, $5-6$ mm lang und 1,5-2 mm breit: alle durch 3-5 Reilen verdickter Zellen gesäumt und etwa bis zur Mitte herab mit 1-2zelligen Zähmen besetzt; Rippe kurz vor oder im Spitzchen aufgelöst; Zellen fast gleichförmig, kollenchymatisch. nicht getüpfelt, in cler Blattmitte etwa $22-28 \mu$. Sporogone einzeln. Seta $1,5-2,5$ cm, gelbrötlich. Japsel horizontal bis hängend, dick oval, zuweilen etwas hochrückig, 2,5--3 mm lang und 2 mm click, gelblich oder grünlichgelb. Deckel hoch kuppelartig gewölbt und stumpfspitzig. Sporen 25-30 ", grünlichgelb, warzig. Sporenreife im Mai. - Fig. 56 F-G.

Auf schattigem, etwas feuchtem. Waldboden, auf Baumwurzeln, erdbedeckten Steinen und Felsen.

F. Al. Nach B o m. fq. - Ab. Nagu. ibo. Reso. Kunstö. Brontarf. Halikko. Lskela. Karisłojo. Lojo. - N. Helsingfors. Helsinge. Tusby. Borga. Kymmene. Hogland. - Ka. Tehkalahti. Firolahti. Wiborg. Antrea. - Ih. Muola. Sakkola, - St. Kjulu. Eura. Björneborg. Ylöjärvi. Pirkkala. - Ta. Vanaja. Hattula. Sääksmäki. Kalvola. Im sïdöstl. Teile f(q. (Norrl.). Luhanka. Korpilah1i. - Sa. Valkeala. Kangasniemi. Lappee. Ruokolahti. - Kl. Kexholm. Kurkijoki. Talamo. Sortarala. Suistano. Pälkjärvi. - Kol. Humbaritsa (Elfr.). Pefrosavodsk (Kullh.), - oa. Isokyrö, Orisherg (Ranck.). - Tb. Petäjäresi. Laukaa. Viitasaari. - Sb. Kuopio fq. (Link.). Pielavesi fq. (Roir.). Maaninka, im Westl. Teile fr. (Roiv.). - Kb. Tohmajärvi. Joensuu. - Kon. Pirttiniemi. Tiudie. Kendjärvi. - Om. Lappajärvi, zw. Hankijärvi und Kortesjärvi (Backm.). - Ok. Nach K y y k. wahrscheinlich st. fq. suomussalmi, Kylmölä (Vain.). - Ob. Liminka. Simo. - K. Kuusamo, Oulankajoki, Merenoja (Broth.). 
- Lkem. In Kolari und Kittilä fq.. jedoch ïberall spärlich (Hult). - Le. In allen Regionen bis zum Kilpisjärvi ( Korrl.). - Li. Inari. an inehreren Fundorten in der Nadelwaldregion (Hult). Ctsjoki, an einigen Fundorlen in der Birkenregion (H.). - Lt. Jaurujoki rr. (Roiv.).

S. $S k .-L$.

N. Sm.-F. Nordgrenze bei etwa $70^{\circ} 30^{\prime} 11 . \mathrm{Br}$.

Europa, Kaukasus, West-Himalaya. Nord-Asien. Japan, Nord-Amerika.

487. Mnium medium Bryol. eur. fasc. 5. p. 32, No. 11, t. 10 (1838). [Astrophyllum medium Lindb. Uuse. seand. p. 14 (1879).]

Sỹnözisch. Pfl. in lockeren, grünen Rasen. Stengel aufrecht, bis $10 \mathrm{~cm}$, dicht verfilzt, einlach oder mit einzelnen, herabgebogenen Sprossen. Blätter locker gestellt. nach oben rasch grösser und dichter, trocken \pm zurückgekrümmt und kraus, feuchf aufrecht-abstehend bis zurückgebogen und etwas wellig. untere und mittlere weit und breit herablaufend. rundlich-eiförmig, Schopfblätter aus verschmälertem, wenig herablaufendem Grunde länglich-oval, 6-10 $\mathrm{mm}$ lang und 3-j 1 m breit, mit stachelartigem Spitzchen, alle durch 3-5 Reihen verdickter Zellen gesäunt und rings mit 1-2zelligen Zähnen besetzt: Rippe kurz vor oder im Spitzchen aufgelöst: Zellen sehwach kollenchymatiseh und getüpfelt, oberwärts am Rande bis 3.5 " lang und 2.5 " breit, gegen die Rippe bis $80 \mu$ lang und bis $45 \mu$ breit. Sporogone $2-5$, selten einzeln. Seta $3-6 \mathrm{~cm}$, rot, oben gelb. Kapsel hängend, länglich, etwa $5 \mathrm{~mm}$ lang und $2 \mathrm{~mm}$ diek, bleich gelbgrün bis rötlich gelbbraun. Deckel kuppelartig gewölbt, mit Spitzchen. Sporen $18-25 \mu$, grünlichgelb, papillös. Sporenreife im Mai und Juni.

An quelligen und sumpfigen, schattigen Orten, an Gräben und Bächen, in TVäldern und Gebüischen.

F. Al. Finström. Tärnebolstad (Bom.). Saltvik, an wenigen Fundorten (B.). — Ab. Abo. Littoi: (Elỉr.). Ispois (Buch). Pargas. Bläsnäs(E.): Hyvilempi (Broth.). Finby (Broth.). Karislojo. Karkali (E. af H.). Lojo, Ojamo (Lindb.). - N. Inga, Kilkö (T. Brenn.). Esbo. Hagalund (Broth.). Helsingfors (Lindb.). Helsinge, Gammelstaden (Buch). Tusby. Saksa (Broth.). Borgả, Pellinge. Hasselön (Broth.). Lovisa, Kattön (Lindb.). strömfors (sael.). Elimäki (Tigerst.). - Ka. Antrea, Papinsaari (Lindb.). Ik. Lusikirkko. Vammelsuu (H. Lindh.). Sakkola. Lamppu (Hid.). - sit. Ulfsby (Hâyr.). Nakkila

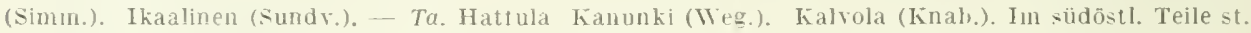
fq. (Norrl.). Hartola (Bonsd.). Korpilahti und Luhanka, an einigen Fundorten (Vain.). - Sa. Kangasniemi (Lackstr.). Millmanstrand (Buch). Lappee. Kausala (B.). Ruokolahti, Imatra (Broth.). - K'?. Valamo (II. Nyl.). Surtavala. Kirjavalahti fq̣. (Norrl.). - Kol. Humbaritsa (Elfy.). — Tb. Āännekoski (Lesk.). Laukaa (Broth.): Seppälā (Häyr.). Konginkangas (E. af H.). — Sb. Kuopio. an mehrercn Fundorten (Link., Kot.). Pielavesi. Säriä (Roir.). Maaninka, nicht selten (R.); Pöljā (Kyylhk.). 一 Kb. Juuka, Ahmovaara (Linnan.). Halivara (Kot.). - ok. Kajana (Lackstr.). Paltamo, Melalahti (Kyylik.). ob. Rovaniemi, an mehrercii Funde:ten (HuJt). - $\hbar$. Kuusamo. Oulankajoki. Merenoja (Brolh.). Lkem. Kittiă, Illästunturi (Hult). - Le. Karesuanto und Kelollijärvi (Norl.). - Li. Inari, Peldoivi. in der Birkenregion (Hult), [־tsoki. Outakoski, Soavjebakte (Ranck.). — Lim Htißinä (Sahlb.). - Lt. Kola, Karaulnaja Pahta (Broth.). — Lp. Rusiniha zw. Orlov und Ponoj (Broth.): Ponoj (Brenn.). Lx. Tschapoma (Broth.).

S. Sk., Ög., $V g .-V b$. und $L u L$.

N. Sm., A., Bu.: JL., Ne.. R., K., H., XT.. No. und F. Nordgrenze bei $70^{\circ} 15^{\prime} \mathrm{n} . \mathrm{Br}$.

Spitzbergen. Faeroer, Pyrenäen, Zentral-Europa, Kankasus, Himalaya, Sibirien, Japan. Nord. Amerika.

188. Mnium curvatulum (Lindb.) Limpr. Laubm. II. p. 476 (1893). [Astrophyllum curvalulum Lindb. in Bot. Centralbl. Bd. 6, p. 363 (1881).]

Vit $1 \%$. medium sehr nahe verwandt. Blätter kürzer, weniger herablaufend. Seta hyalin, trocken gelb, im Alter rot bis rotbraun. Kapsel blassgelblich, dünnhäutig, \pm glänzend; Zellen des Exotheciums selır dünnwandig. Sporen 27-35 $\mu$.

S. LuL. Njanmats.

N. Dovre. No, und $T r$, an wenigen Fundorten.

Sibirien, Grönland.

189. Mnium affine Bland. Musc. frond. exs. fasc. III. No. 133 (180.1). [Astrophyllum cuspidalum Lindb. Musc. scand. p. 13 (1879).]

Diözisch. Mninm medium sehr älnlich. Pfl. in lockeren, dunkelgrünen Rasen. Stengel aufrecht. bis i cm, selten höher, bis gegen den Gipfel hin verfilzt. mit zahl- 
reichen, bogig herabgekrünmten und wurzelnden, stolonenartigen Sprossen. Blätter nach oben schnell grösser und dichter, wenig herablaufend, abstehend, trocken zurückgekrümmt, mit zurückgeschlagenen, gekräuselten Laminahälften; untere rundlich und verkehrt-eiförmig, äussere Schopfblätter verkehrt-eiförnig bis zungenförmig, innere aus verschmälertem Grunde verkehrt-eilänglich bis elliptisclispatelförnig, rasch zugespitzt und stachelspitzig, $8-10 \mathrm{~mm}$ lang und $1-5 \mathrm{~mm}$ breit. durch 3-4 Reihen verdickter Zellen gesäumt und \pm weit herab nit 1-2zelligen Zähnen besetzt; Zellen in divergenten Schrägreilıen geordnet, kaum kollenchymatisch, deutlich getüpfelt, innere eckig länglich, in der Blattmitte $75-100 \mu$ lang und 37- $4 \mu$ breit, äussere eckig-rundlich, etwa $25 \mu$ oder eckig-oval, 37$50 "$ lang und 25-37 $\mu$ breit. Sporogone einzeln oder zu 2-5. Seta $2-4$, selten bis $5 \mathrm{~cm}$, rot, oben gelb. Kapsel hängend, länglich, $4-6 \mathrm{~mm}$ lang und $2-2.5 \mathrm{~mm}$ dick. gelbgrün, später gelbbraun. Deckel kuppelartig gewölbt, mit Warze. Sporen $18-25 \mu$, lichtgelb, feinwarzig. Sporenreife im Juni.

Auf feuchter Erde in Laub- und Nadelwäldern, auf erdbedeckten Felsen, an Bachufern, neben Quellen und in Sümpfen.

F. A?. Nach B o m. nicht selten. - - Ab. Pargas, storgard (Elfr.); Mustfinnträsk (Link.). Kustö. Isokylä (Link.). Angelniemi, Kokkila und Karviais (Buch). Sagu, Träskby (B.). Karuna (Ju-el.). Karislojo (Sundv.). Lojo. Ojamo und Kiviniemi (Lindb.); Kihilä (Hult). - Y. Esbo, Gräsa (Broth.). Helsingfors (Lindb.). Helsinge. Hoplaks (Popp.). Sibloo (Ekm.). Orimattila. Niemi, Tuomela (Link.). Hogland (Lindb.). - ka. Säkhijärvi, Suurkangas (Krohn): Laihojărvi (Ranck.). 一 Ik. Sakkola, Kurikka (H. Lindb.). Pṛhäjărvi, Sortanlalıti (H. L.). - St. Ruıvesi (Nimm.). - Ta. Hausjärvi (Granf.). Asikkala (Norr.). Kuhmoinen (Teräs.). Luhanka. Tientaali (Vain.). Korpilahti. Hankaruori (T.). Sa. Valkeala (sundr.). Runkolahti. Imatra (Broth.). - Kl. Parikkala (Sahll).). Sortarala, Kirjavalahti. Lahentausta (Norrl.). Ruskea'a (Lindb.). - Tb. Petäjäresi. Lepinmäki (Ruor.). Jyràskylä, Norola. Laurinniemi (Tain.). - Sb. Kuopio, an mehreren Fundorten (Link.). Nilsiä. Tiirinlahti (Kyyk.): Kuuslahti, Jaakonlampi (K.). Pielavesi. Kuusela (Roir.). Jaaninka. Tumvilanlahti (Lund-1r.); Haatala (Roir.). Iisalmi, Keli (Sahlb.). - Kb. Liek-a (Tain.). - Kon. Suisaari (Simm.). Supoha (S.). Mundjărvi (Norrl.). - Om. Evijārvi. Jouısen (Bachm.). - ob. Simo (Rãs.). Tllitornio. Kaaranäs (Hult). K. Kuu-amo. Aventojoki (Broth.): Kitkajoki (Sil.): Oulankajoki. Werenoja (Broth.). - Lhem. In Kolari und kittilä fq. (Hult): Olıstunturi (Norrl.). - Le. Viltanki. in der Birkentegion (Norll.). - Li. Inari. in der Sadelwaldregion $t$. fo. (Hult); Peldoivi. in der Birkenregion (H.). [tsjoki. an mehreren Fundorten (H.). - Lim. Lnupok. an den stromschnellen Kitschakoski und Krivalsch (Kihlm.). Kandalak: (Broth.). - Ll. Tripnavolok (Broth.): Kildin (B.). - Lmur. Rinda. Harlorik und Jokonsk (Broth.). L.p. Ponoj (Broth.).

S. $. k_{0}-T b$. L LyL. und $L u L$.

N. Sm, $-F$.

Europa, Kanaren. Madeira. Algier. Kauka-us. Sibirien, Japan, Nord-Amerika.

var. ciliare (Grev.) C. Miill. Syn. I. p. 159 (18t8). [Bryum ciliare Grev. in Ann. Lyc. N. hist. New-York I. p. 273 p. p. (1825). - Mnium ciliare Lindb. in Bot. Notis. 1878, p. 188. - Astrophyllum ciliare Lindb. Wusc. scand. p. 1t (1879).] Blätter am Rande mit 2-tzelligen Zähnen besetzt.

F. Al. Saltrik. Crermundö Södernäs, auf feuchtem Waldboden (Bım.): Lafö (B.). - Ab. Lojo. Ojann. an schattigen Ahhang im Fichlenwalde (Lindb.). - N. Helsingfor. Alphydden (Lindb.).

S. Dir. Leksand, auf schattigem Sandboden. Ög. T. Xy. Asen. am Efer des Tettern.

liakasns. Ford-Anerika.

var. integrifolium (Lindb.) Limpr. Laubm. II. I. 479 (1893). Mnium cuspidalum var. d integrifoliun Lindb. in Notis. Sällsk. Faun. Fl. Förh. IX. p. 65 (1868).] Pfl. kleiner, dicht beblättert. Blätter kürzer und breiter, ganzrandig oder fast ganzrandig. (Brenn.).

F. Ok. Suomusalnui. Kiannanniemi (Tain.). - $K$. Kunsamo. Pousu (T.). - Le. Tschavanga

N. F. an wenigen Fundorten.

Spitzbergen. Sibirien, Grönland.

190. Mnium Seligeri Jur. Mser., Mild. BryoI. siles. p. 227 (1869). [Astrophyllum Seligeri Lindb. Musc. scand. p. $\left.1 \frac{1}{2}(1879).\right]$

Diözisch. Mnium affine nächst verwandt. Pfl. in lockeren, lichtgrünen Rasen. Stengel aufrecht, bis $10 \mathrm{~cm}$, längs verfilzt, mit zahlreichen aufgerichteten. spä- 
ter häulig bogig abwärts gekrümmten, flagellenartig verlängerten und an der Spitze wurzelnden sterilen Sprossen. Blätter weit herablaufend, trocken stark gekräuselt und \pm zurückgekrümmt, feucht aufrecht-abstehend, hohl; mittlere rundlich-oval, bis $5 \mathrm{~mm}$ lang und $3,5 \mathrm{~mm}$ breit, obere aus verschmälertem Grunde zungenlörmig, \&-12 $\mathrm{mm}$ lang und $4-6 \mathrm{~mm}$ breit, sämtlich kurz gespitzt und durch 3-1 Reihen verdickter Zellen gesäumt, fast bis zur Basis herab mit meist kleinen, stumpfen Zähnen besetzt; Rippe in die Blattspitze eintretend; Zellen in divergenten Schrägreihen geordnet, schwach kollenchymatisch, \pm deutlich getüpfelt, kleiner als bei $M$. affine. Sporogone einzeln oder zu $2-4$. Seta $3-4 \mathrm{~cm}$, rot, oben gelb. Kapsel hängend, oval, bis $4 \mathrm{~mm}$ lang und $2 \mathrm{~mm}$ dick, gelbgrün, später braun. Deckel kuppelartig gewölbt, mit Warze. Sporen 25-30 $\mu$, grünlich, fein papillös. Sporenreife im Juni. - Fig. $56 \mathrm{D}-\mathrm{E}$.

Auf nassen, quelligen Sumpfwiesen und in Waldsümpfen.

F. Al. Nach Bom. st. fq. - Ab. Korpo (Ekl.). Pargas. Simonsby (Elfr.); sydmo (Link.). Karislojo, Niemi (Sundr.); Kourijoki (E. af H.). Lojo, Ojamo (Lindr.). — N. Ekenäs (Häyr.). Esbo. Gräsa (Broth.). Helsingfurs (Häyr.). Orimattila, Niemi. Tuomala (Link.). Hogland (Lindi.). - ha. Virolahti (Błom). Säkkijarvi (Krohn). - Ih. Valkjärvi, Pähkinämäki (H. Lindb.). Sakkola, Kurikka (H. L.). Pỵhäjärvi, Malois (H. L.): Riiska (Láng). - St. Eurajoki, Vuojoki (Björkenh.). Jämijärvi, Tervolahti (Herl.). Orisesi, Kivijärsi (Broth.). Kuru, Aukola (Backm.). - Ta. Hattula (Kihlu.). Asikikala, Cskila, Kikku (Norrl.). - Sa. Kangasniemi, Korteniemi (Lackstr.). Willmanstrand (Buch). - Kl. Sortasala, Ristijärvi (Liık.); Kirjavalahti, Anjala (R. Weg.). Impilahti, Valkiilampi (Link.). Rusheala (Buch); beim Marmorbruche (Link.). Suistimo, saariselkä (Kot.): Uıksujärvi und Jalovaara, (Link.). Pälkjärvi (Broth.). - Kon. Vojatsch (Sel.). - Oa. Närpes, Yttermark, Ormosskällan (E. áf H.). Isukyrö (H. Lindb.). - Tb. Jy̌äskyaă, Korkeakoski (Link.). - Sb. Kuopio, Leräinen (Link.). Nilsiä, Pisivuriri (Link.). Iraninka. Haatala (Roir.). - Kb. Tohmajärvi, Kemie (Link.). - Om. Soini, Hallapuro (Backm.). Alajärvi, Kirchdorf (B.); Veslerbacka, Huosianmaankallio (B.). Tindala, Kuskela (B.). Kalajoki, Kirclidorf (Tenn.). - ok. Paltamo, Melalahti (Lackstr.). Suomussalmi, Lehtovaara (Vain.). - Gb. Turtola (Hul1); Pello (H.). - K. Kuusamo. Korojoki (Broth.); Rukatunturi und Prhäraara (B.): Oulankajoki. Ierenoja (B.); Paanajärvi, Kiekkivaara (B.). - Lkem. Kolari, Simu (Hılt). - Le. Malla, iı der alpinen Region (Kot.). - Lt. Tsipnavolok (Broth.).

S. Sk. - V b., LyL. und $L u L$.

N. $s m .-F$.

Europa, Kaukasus, West-Himalaya .

191. Mnium rugicum Laur. in Flora 1827. p. 292. [Astrophyllum rugicum Kindb. Laubm. Schwed. und Norw. p. 61 (188:3).]

Diözisch. I/ninm Seligeri nächst verwandt. Pfl. in lockeren oder dichten und damn innen weit hinauf verfilzten, bis $12 \mathrm{~cm}$ hohen, licht-oder gelbgrimen, nach unten meist seliwarlicien Rasen. Stengel aufrecht, einfach oder mit aufrechten, entfernt beblätterten Sprossen. l3lätter entfernt. kaum oder sehr kurz herablaufend, alsstehend, etwas hohl, trocken wellig kraus, aus verengter Basis breit oval, etwa $4 \mathrm{~mm}$ lang und $3 \mathrm{~mm}$ breit: Schopfblätter dichter. zungenförmig, $5-8 \mathrm{~mm}$ lang $\mathrm{m}$ d $3-3,5 \mathrm{~mm}$ breit; Sprossblätter rundlich bis elliptisch, 3-4 mm lang und 3 nm breit; sämtlich breit abgerundet, mit Spitzchen und durch $3-4$ Reihen verdickter Zelben gesäumt, ganzrandig odler gegen die Spitze hin mit sehr kleinen, stumpfen Zähnchen besetzt: Rippe vor oder in der Blattspitze aufgelöst: Zellen in divergenten Schrägreihen geordnet, an der Rippe in der Blattmitte etwa $60-90 \mu$ lang und $37 "$ breit, nahe dem Rande $30 \mu$ lang und breit bis $50 \mu$ lang und 2.5-30 " hreit. Sporogone zu 1 und 2. Seta $1-6 \mathrm{~cm}$, sehr fein, trocken links gedreht, rot, oben gelb. Kapsel nickend orler hängend, oral, 3- $1 \mathrm{~mm}$ lang und $1,75 \mathrm{~mm}$ dick, grünlichgelh, später gelbl)äunlich. Deckel gewölbt, mit Warze. Sporen 20 - 30, auch $30-50 \mu$, schmutzig blassgelb, papillös. Sporenreife im Juni.

N. Inwre. $\therefore B$.

Dellschland. Sibirien.

Sect. I I I. Rhizomnium Nlitt. I. c. p. 167. [.Mnitum C. Integerrimae Limpr. latubn. II. p. $182(1893)$.]

Blätter ganzrandig, meist gesäumt. Rippe mit einer zentrierten Gruppe (Be- 
gleiter) kleiner, dïnnwandiger Zellen; Stereiden (excl. M. hymenophylloides) folilend. - Fig. 5i) (..

492. Mnium stellare Reich. Fl. moeno-franc. II. p. 12.), No. 763 (1778). [Astrophyllum stellare Lindb. Itusc. scand. p. 1 I (1879).]

Diözisch. Pll. in weichen, lockeren oder dichten, durch Rhizoidenfilz verwebten, dunkelgrimen Rasen. Stengel 2 6 , selten bis $8 \mathrm{~cm}$, locker beblättert, mit grundständigen, meist aufrechten Sprossen. Blätter herablaufend, trocken schwach wellig, eingebogen und etwas gedreht, feucht aufrecht-abstehend, bei längerem Liegen im Wasser sich meist blaugrün färbend, nach oben allmählich grösser, elliptisch- bis länglich-lanzettlich, scharf zugespitzt, bis $1 \mathrm{~mm}$ lang und $2 \mathrm{~mm}$ breit, ungesäumt oder häufig durch $1-2$ Reihen einschichtiger, verlängerter, engerer Randzellen unterbrochen. bisweilen bis zur llite und weiter herab mit kurzen. stumpfen Zähnen: Rippe dümn, weit vor der Blattspitze aufhörend; Zellen in der Blattmitte 25-30 $\mu$, schwach kollenchymatisch, nicht getïpfelt. Sporogone cinzeln. Scta 1,5-3,5 $\mathrm{cm}$, braunrötlich. Kapsel horizontal bis fast nickend, länglich bis verlängert länglich, $1-5 \mathrm{~mm}$ lang und $1-1,5 \mathrm{~mm}$ dick, zuweilen etwas gekrümmt, grün und gelogrün, zuletzt dunkelbräunlich. Deckel hoch kuppelartig gewölbt, stumpf. Sporen in ler Grösse sehr verändlerlich, 12 -32 ", gelbgrün, fein papillös. Sporenreife im Juni.

An feuchten, schattigen Orten, auf Waldboden, an Abhängen, Bachufern, in Erdhöhlen und erclerfüllten Felsritzen.

F. Al. Finström, (ieta, Lemland und Sund an wenigen. Saltvik an vielen Fundorten (Bom.). Ab. Lipre (Ekl.). A ho (Arrh.). Pargas, an mehreren Fundorten (Elfv., Broth., Link.). Finby (Broth.). Angelniemi (Buch). [skela, Linnamäki (Lindb.). Karislojo, Torhola (Sundr.). Lojo, an mehreren Fundurlen (Lindb., sundr., E. af H.). - . N. Ekenäs, Tvärminne (Häyr.). Heisinglors. Helsinge, Vesterkulla, Kalkholmen (Ranek.). Silbbo, Söderkulla (Lindh.). L Ka. Wiborg, Soskuanjoki (Buch). Antrea, Jaakonsaari (Lindh.). - Ih. Sakko]a. Mönkö (H. Jindl,.). Pyhäjärvi. Ivaskansaari (H. L.). - Ta. Im südä-tl. Teile zieml. selten (Norrl.). Ifartola (Bonsd.). Luhanka, Onkisalo und llakala (Vain.). Korpiłahti,

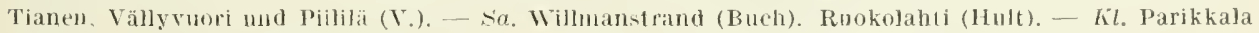
(sahlb.). Jaakkima (II. Nyl.). Sortavala, Rausku (Pes.); Kirjavalahti, Lahentausta st. fq. (Norrl.). Impilahli (Broth.). Ruskeala, Tirrin mylly (Bucls). Soaulahti, Koirinvaara und Kuldiasvara (Broth.). Pailkärvi, Annoniemi und Korkeaniemi (Broth.). - Kol. Mjätusova (Elfv.). Pel rosavodsk (Kullh.). Tb. Jyväskylä. Tuurujoki (Broth.); Norola und Laurimniemi (Vain). Viitasiari. Etelävuori (Broth.). Pihtipudas Ilaapauäki (Roiv.). - sb. Kuopio, an vielen Fundorten (Link., liot., Kyyhk.). Kaavi, siikajärvi, Huosiaieniemi (Kot.); Losomäki, Poskijärvi (K.). Nilsia, Kuuslahti, Jaakonlampi und Loutteinen (Kyyhk.). Maaninka. Pöljä (Kyy̧hk.); Tuovilanlahti (Lındstr.). — Kb. Tohmajärvi, Täåănäki und Kypäräsaari (H. Baekm.); Kypärävuori (Broth.). Juuka. Juunnsaari (Kol.). Polvijärvi, Kirehdorf (K.). - Kon. Valkeanäki (Simm.). Suopohja (S.). Pirtlinieni (S.). - Om. Alajärvi. Vesterlacka, Huotianmaankallio (Backm.). - $k$. Kuusamo, Iivaara (Broth.); Rukalunluri, frucht. (B.); Kitkaniemi,

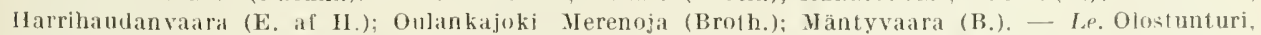
in der Nadelwaldregion (Norrl.). - Li. Inari, Sakatinpahta (Hult). Utsjoki. Mallejokkit, Kistuskaidde (Ranck.). - Lim. Kandalaks (Broth.). Empjok, Kitschakoski (Kihlsn.). Uurpavr. Kork-Juht und Tschuidi-vur (K.). - L.p. Ponoj (Bremn.).

S. Sk.-Ib. und $P L$. LuL. Sarekgebiet.

N. Sm.-JL., Ne.. SB.-K.. No.-F. Nordgrenze bei $70^{\circ} 25^{\prime} \mathrm{n} . \mathrm{Br}$.

Europa. Kaukdsus, West-Himalaya, Sibirien, Amurgebiet, Japan, Nord-Amerika.

193. Mnium hymenophylloides Hüben. Muscol. germ. p. 416 (1833). [Astrophyllum hymenophylloides Lindl). Musc. scand. p. 14 (1879).]

Diözisch. Pfl. in ziemlich dichten, lebhaft grünen, glänzenden, innen lichtbraunen und mässig verwebten Rasen. Stengel aufrecht, bis '3 cm, selten höher, dünn, schwarzbraun, brüchig, mit zweizeilig gewendeten Blättern der sterilen Sprosse. Blätter aufrecht-abstehend, trocken wenig verändert, etwas wellig, fest, etwas hohl, kam herablaufend, oval, stumpf, mit Spitzchen, $2,+1$ mm lang und $2 \mathrm{~mm}$ breit, die obersten aus verschmälertem Grunde elliptisch-spatelförmig, kurz zugespitzt, mit Spitzchen, etwa $3 \mathrm{~mm}$ lang und $1,5 \mathrm{~mm}$ breit, durch 2 Reihen einschichtiger, wenig verdickter Zellen gesäumt, ganzrandig; Rippe vor der Blattspitze endend, mit dorsalem, sichelförmigem Stereidenbande; Zellen deutlich kol- 
lenchymatisch, dicht getiipfelt, mit zahlreichen Chloroplasten, in der Blattmitte näclnst der Rippe etwa $50 \mu$ lang und $32 \mu$ breit, nahe dem Rande $22-32 \mu$. Seta $1,4 \mathrm{~cm}$. Kapsel nickend, länglich-zylindrisch, 3,2 mm lang und 1,3 mm dick, rötlichgelb. Deckel unbekannt. Sporen 13-19 $\mu$, fein papillös, braun.

Auf feuchter und nasser Erde in Felsspalten und Höhlungen ler Kalk- und Schiefergesteine.

F. hl. Sortavala, Kirjavalahti, Louhiyuoret (Lindb.); Variskallio (Norrl.). - Kon. Jalguba (Simm.). Valkeamäki (S.).-K. Kuusano. Juma. Lammasvuoma (Broth.); Kithajoki (Sil.); Oulankajoki. Kallioperänvaara (Broth.). Kiulaköngäs u. Taivalkoski (E. af H.); Paanajärvi. Mănţkoski (Nyb.) und Kuoppaoja (Broth.); Soranköngäs (B.): Sorajoki, Kulmakkapuro (E. af H.): Savinajoki (Roir.). - L. Kilpisjärri, Malla und Saana. in der alpinen Regionst. fq. (Kot.). - Li. Inari. Kultala Hult). Llsjoki, Lienischkoski (Hult); Ontakoski, Sodrjebakte (Ranck.). - Lp. Lumborski (Brenn.): Orlor, Gubnoj (kihlm.); Rusiniha, zw. Ponoj und Orloy (Broth.).

S. Mpd. Borgsjö. Randklöfven. Hrjd., Jmt. und L. im Fjeldgebiele. Bei Handöl:fallen in Jmt. ist cs Iferrn H. P e rsson gelungen, dat früher unbekannte sporogon zu enldecken.

N. Ringerike rr. Gudbrandsdalen. NB. Sogn. Aurland, $20 \mathrm{~m}$. R. Geiranger, llerok, $100 \mathrm{~m} . \mathrm{K}$. Iovre. Lomsfjeldene. ST. Trondhjem. XT. Stjordalen. No. $-F$. \pm fq., wie es scheint, jedoch nicht über die Baumgrenze hinaufsteigend. Nordgrenze bei $70^{\circ} \mathrm{n} . \mathrm{Br}$.

Alpengebiet, Sibirien. Nord-Amerika.

194. Mnium pseudopunctatum Bruch et Schimp. in Hook. Lond. Journ. Bot. 11. p. 669, No. 253 (18.13). [Mnium subglobosum Bryol. eur. fasc. 31 Suppl. p. 3, No. 16 (1816). - - Astrophyliam pseudopunclatum Iindb. Mlusc. scand. p. 13 $(1879) \cdot]$

Sỹnözisch. Pfl, in lockeren, dunkelgrünen, innen rötlichen Raśen. Stengel aufrecht, bis über $10 \mathrm{~cm}$, bis zur Spitze verfilzt, mit zahlreichen, aufrechten Sprossen. Blätter locker gestellt, kurz herablaufend, trocken wellig, feucht abstehend. rerkehrt-eilörmig, stumpf abgerundet bis ausgerandet, ohne Spitzchen, bis $5 \mathrm{~mm}$ lang und $3,5 \mathrm{~mm}$ breit. durch 1 - 2 Reilhen engerer, kaum verdickter, einschichtiger Zellen gesäumt. ganzrandig; Rippe vor der Blattspitze schwindend; Zellen undeutlich in divergenten Schrägreihen geordnet, in der Blattmitte nächst der Rippe $70-100 \mu$ lang und $50 "$ breit, nahe dem Rande 25-35 $\mu$. Sporogone zu 1 und 2. Seta bis $5 \mathrm{~cm}$, rot. Kapsel nickend, klein, kugelig-oval, $2 \mathrm{~mm}$ lang und 1,5 mm dick, grünlichgelb, zuletzt lichtbraun. Peristomzähne ohen längsstreifig papillös. Deckel kegelig gespitzt, fast geschnäbelt. Sporen 30-18 $\mu$, gelbgrün, warzig. Sporenreife im Frïhling.

An nassen und sumpfigen Stellen, neten Quellen und Bächen.

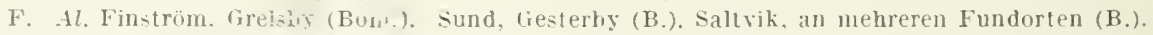
Ab. Pargas (Arrh., Elfr.). Karislojo (Sundr.). Lojo, Ojamo (Lindl.). - K. Kyrkslält. Humaljärvi (Ranck.). Ilelsingfors (Lindb.). Hogland (Lindb.). - Ka. Wiborg. südl. vom Lieljärvi (Buch). — $l k$. Pyhäjärvi (Lång): Riiska (H. Lindb.). - St. Jkaalinen (Sundr.). Kuru. Riullakorpi. Hakola (Backm.). - Ta. Hausjäri (Lund-tr.). Hollıla, Tirrisma (Norrl.). Luhanka, Onkisalo (Vain.). — Sa. Willmanstrand (Buch). - Kl. Parikiala (Sahll.). Sortavala. Kirjavalahti (Lang). - Tb. Peläjävesi, an einigen Fundorlen (Ruor.). Jỵäskyaa, Jỵiajoki (Brolh.). Laukaa (B.). Kinnula, II uhola, Kalajamäki (Roiv.). - Ṡb. Kuopio, Haminanlahti (Link.); Karhipuro (Kyyh.). Kaavi. Losomäki (Kot.): Kuuslahti, Jaakonlampi (K.). Junka. Petrovaari, Saarijärvi, sotisaari (K.). Nilsiä, Kirchdorf, Lehtomäki (K.). Pielavesi, Vaarıslalıti, Lokinmaki (Roir.); Jylha (R.). Maıninka, Püljä (Kyyłk.); Tuuvilanlahti (Roir.); horkeakoski (R.). - Om. Vindirla. nördl. vom I’yhävuori (Backm.). - Ok. Kajana (Lackstr.). Pallamo (L.). Kuhmoniemi (E. af H.). Suomussalni (Lackstr.). - Ob. Nach H ull zw. Aarasaksa und Turtola st. fr. - K. Kuusamo, an vielen Fundorten ( $F^{2}$ Nyl., Nib., Sil., Sahlb., Broth., E. af H.). - Lkem. Nach II ul t in Kolari und Kittiläst. frj. Sodankylä (Blom). Kuolajärvi (Linnan., E, af H.). - Le. Nach No r r l. nicht selten in der Nadelwaldregion. Kilpisjärvi f(j. (Kot.); .lalla, in der alpinen Region (K.). - Li. Sodankylā. in der Nadelwaldregion fq. (Hult). Inari und Ltsjoki, an mehreren Fundorten in der Nadelwald- und Birkenregion (II.). Tuorjumoivi. Peldoivi, kuarvekodds und Ailigas in der alpinen Region (II.). - Lim., Lt., Lmur.. L.p. und $L$ r. fq. (Broth.).

S. $\operatorname{sm} .-\mathrm{L}$.

N. Sm. rr. A. Kiristiania pass. Ne. Saetersdalen st. r. Gudbrandsdalen. VR. Sogn. K. Dorre. lomsfjeldene. II. NT. stjordalen. No.-F. pass., doch die Banmgrenze niclıt ülejsteigend. Nordgrenze lee $70^{\circ} 25^{\prime} \mathrm{u}$. Bi:

Gross-Iritanien, Zentral-Eurora. Sibirien, Nold-Amerika. 
195. Mnium punctatum (L., Schreb.) Hedw. Fund. 11. p. 91 (1782) et Sp. muse. p. 193 (1801). [.Mnium serpyllifolium u punctatum L. Sp. p]. 1. ed. II. p. 1113 (1753). - Astrophyllum punctatum Linılb. Musc. scand. p. 13 (1879).]

Diözisch. Pfl. in lockeren, dunkel- bis schwärzlichgrüncn, unten rötlichen Rasen. Stengel aufrecht, meist 2-5, selten $10 \mathrm{~cm}$ und clarüber, bis loch hinauf verfikt, mit zahlreichen, aufrechten Sprossen. Blätter nicht herablaufend, trocken wellig, fast kraus, feucht abstehend-zurückgebogen, untere entfernt gestellt, aus sehr engem Grunde fast kreisrund bis verkehrt-eirundlich, obere gchäuft, eine offene Rosette bildend, verkehrt ei-spatelförmig, $5-10 \mathrm{~mm}$ lang und $3-6 \mathrm{~mm}$ breit, abgerundet oder seicht ausgerandet, meist mit sehr kurzem Spitzchen, durch 2-4 verlängerte und stark verdickte, melırschichtige \%ellenreihen rötlichbraun

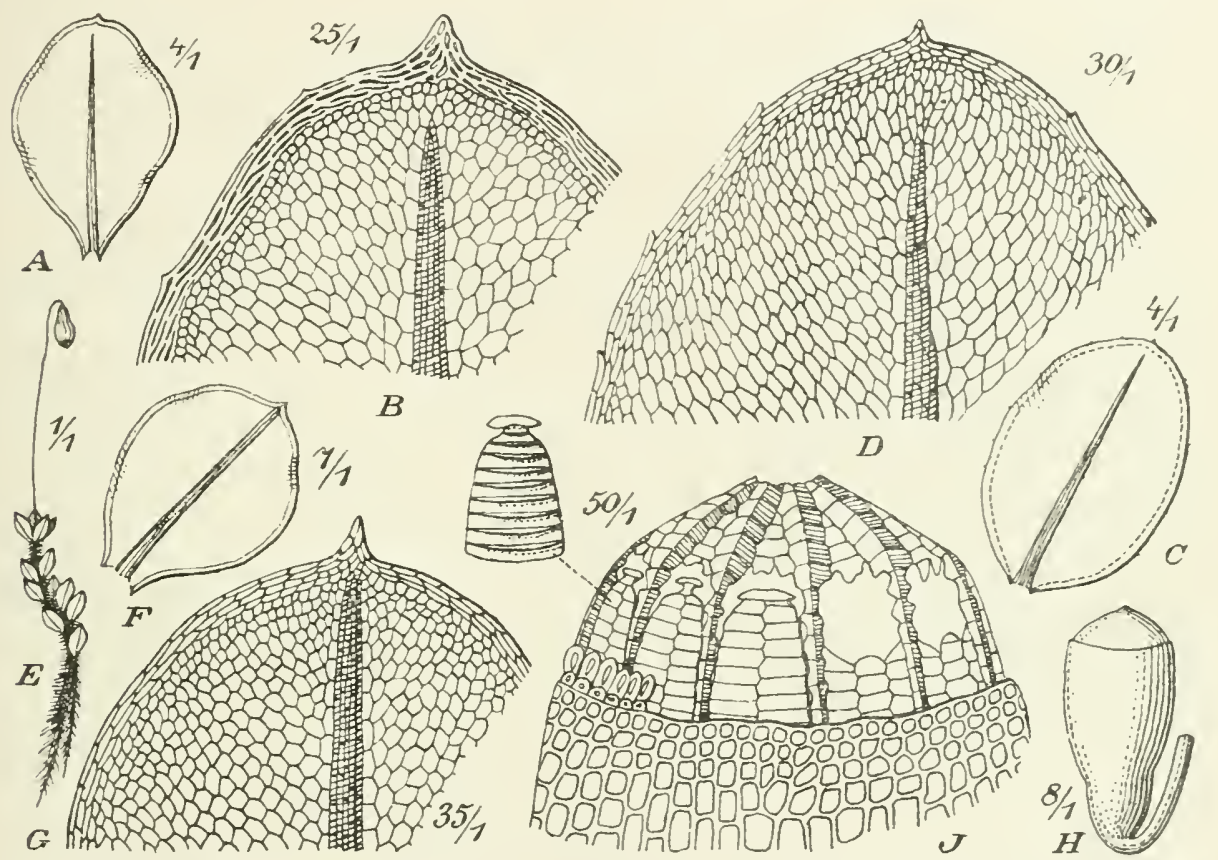

Fig. 57. A-B Mnium punctatum (L., Schreb.). A Stengelb. (4/1): B Blattspitze (25/1) - C-D M cinclidioides (Blytt). C stengelb. (4) 1); D Blattspitze $(30$ l). - E- K Cinclidium subrotundum Lindb. E Fruchtende Pfl. (1/1): I Stengelb. (7/1); H Blattspitze (35 1); I Kapsel im trockenen Zustande (8 1)K Peristom (50 1).

gesäumt, ganzrandig; Rippe im Blattspitzchen eintretend oder kurz vor demselben endend; Zellen in divergenten Schrägrcihen geordnet. schwach kollenchymatisch, nicht getüpfelt, in der Blattmitte nächst der Rippe 70-100 $\mu$ lang und $40-50 \mu$ breit, nahe dem Rande 40-50 " lang und $30 \mu$ breit. Sporogone meist einzeln, seltener zu 2. Seta 2-1 em, gelbrot. Kapsel liorizontal bis nickend, oval bis länglich, zuweilen schwach hochrückig und schiefmündig, 3-4,5 mm lang und $2 \mathrm{~mm}$ dick, gelbgrün, später blassgelb, zuletzt rötlichbraun. Deckel aus kurz kegeliger Basis schief geschnäbclt. Sporen $30-35 \mu$, bräunlichgelb, fein papillös. Sporenreife im Frülıling. - Fig. 57 A-B.

An Quellen, Bachrändern und nassen Stellen in Wäldern.

F. Al. st. f . (Bom.). - Ab. Iniö. Åbo. Reso. Sagu. Pargas. Kimito. Finby. Angelniemi. Lskela. Bromarf. Karislojo. Lojo. Vichtis. - N. Sjundeá, Kyrkslätt. Esbo. Helsinge. Borgå. - Fia. Kotka, Kymmene. Sākkijärvi. Vehkalahti. Antrea. Räisälä. - Ik. Muola. Metsãpirtti. - St. Eura. Norr- 
mark. - Ta. Hattula. Kalvold. In südöstl. Teilest. fq. (Norrl.). Sysmä. Hartola. Korpilanti. - sa. Ruokolahti. Kangasniemi. - Kl. Valano. Sortarala, Pā]kjārri. - Kö.st,fq. Nach Elfr. st. fq. Oa. Isokỵrō. - Tb. Sitarijārri. - sb. Kuopio fq. (Link.). Nilsiä, Tarpinen (Kyyhk.). Pielavesi fı. (Roir.). Jaaninka fq. (R.). Iisalmi. - hb. Pielisjärvi. Koli (Linnan.). - Kon. suojärvi. Joisseinvaara und Haukka (Link.). Klinskp̣ monastir (Simm.). Kivalsch (Kullh.). - Om. Alajärvi und Vindala. an wenigen Fundorten (Backm.). - ok. Kajana (Lackstr.). Paltamo, Melalahti (Kỵhk.). Hyrynsalmi. Isaiskonjohi (K.). Summussalmi. Lehlovara (Tain.). - Kpom. IIoina (Bergr.). - ob. Ruraniemi. an mehreren Fundorten lāngs des Ounasjoki (Hult).- - K. Liuusamo, fivaara (Broth.): Käỵlăkoski (B.). - Lkem. Kolari. Jouhisuanto und Ãkäslompolo (Hult). Kiltilä (Sandm.): Yllöstunturi und Pallastunturit (H.). Keiniolunturi (Norrl.). Mnonio (N.). Kuolajārvi. Sallatunturi (E. af H.). - Le. Karesuanto (Harın.): ZW. Maunu und Kelottijärvi in der Birkenregion (Norrl.). Kilpisjärvi, in der Birkenregion fq. (Kut.). Li. Sodankylă. an mehreren Fundorten in der Tadelwaldregion (Hult). Inari. Paloiri (Sil.): Akanhärkăkuru, in der Birkenregion (Hult): Peldoivi. in der a]pinen Region (H.). Ul.joki. IIandojäyri (H.): I]äjalve. Daussejokka (Ranck.).

S. Sk. $-L$.

N. Sm.-F. ron der Eluene lic über die Baumgrenze hinaufsteigend. Nurdgrenze bei $70^{\circ} 25^{\circ} 11 . \mathrm{Br}$. Europa. Kaukasu- Himalaya. Nord-Asien Japan. Nord-Allerikit.

var. elatum Schimp. Syzl. 1). 398 (1860).

Rasen dichter, his $10-15 \mathrm{~cm}$. Stengel verfilzt, ästig und diehter beblätert. Blätter in Alter rötlich. Ijis $8-10 \mathrm{~mm}$ lang und $6-7 \mathrm{~mm}$ breit, kurz zugespitzt. meist seicht ausgerandet und ohne Spitzchen. Sporogone einzeln.

In Sümpfen.

F. St. Orivesi. Kivijärvi (Broth.). - $K$. Kuusano, Merenoja (B.). - Le. Kilpisjärvi, Saana, in der subalpinen Region (Kot.). - Lim. Schelesnaja und Tschun (Broth.). — Lt. Tsipnavolok (B.). Lm. Olenji (Karst.). Semjostrorsk anı Harlorkaflusse (Broth.). - Lp. Ponoj und Triostrova (Karst.). N. No. skjerstad.

Alpengebiel, oft Iassenvegetation bildend, Nord-Amerikil.

496. Mnium cinclidioides (BIytt) Hüben. Museol. germ. p. 116(18:33). [Bryum cinclidioides Blytt Mser. olim, Lindgr. Musc. suec. exs. fasc. I. No. 11 (183.5). Astrophyllum cinclidioides Lindb. Musc seand. p. 13 (1879).]

Diözisch. PfI. in sehr lockeren, lebhaft grünen, glänzenden, meist $1015 \mathrm{~cm}$ oder noch höheren Rasen. Stengel aufreeht, schwarzbraun, längs zerstrent, mit Rhizoiden, meist einfach, häufig ohne Blüten. Blätter nicht herablaufencl, sehr schlaff, trocken sehr wellig und versehrumpft, feucht abstehend, aus meist abgerundetem Gruncle eiförmig oder oval und länglich, abgerundet, oft ausgerandet, ohme oder mit kurzem Spitzchen, bis $10 \mathrm{~mm}$ lang und $5-6 \mathrm{~mm}$ breit, durch 1 -3 Reihen einschichtiger, nicht verdickter Zellen \pm deutliclı gesäumt, selten mugesäumt, ganzrandig orlor entfernt kurz- und stumpfzähnig: Rippe vor cler Blattspitze endend: Zellen in sehı deutliehen Sehrägreihen, rhombisch bis rhomboidiseh. in der Blattmitte etwa $75-108, "$ lang und 30-33 $\mu$ breit, nicht kollenchymatiseh. reichlich, getüpfelt. Sporogone zu 1 und 2. Seta $5-8 \mathrm{em}$, diinn, rot. Kapsel hängend. oval. etwa $1 \mathrm{~mm}$ lang und 2 mm dick, gelbbramn. Deckel kuppelartig gewölbt, mit Spitzehen. Sporen 25-36 $\mu$, blassbräunlich. feimwarzig. Sporenreife im Juni. - Fig. is C : D.

Auf stmpfigen Wiesen und Miesemmooren, an quelligen Stellen, an Bachund Flussuferm und auf nassem Maldboden, in allen Teilen von Fennoskandia $\rfloor$ fq.. jedoch selten fruchtencl.

West- und Zentral-Europa, sibirien. Nord-Anerika.

\section{8.). CINCLIDIUM}

Sw. in Schrad. Bot. Journ. 1801. I'. I. I). 25.

Stengel mit zahlreichen subfloralen Sprossen. Blätter gesäumt, ganzranclig; Rippe mit einer Begleitergruppe und dorsalem Stereidenbande. Peristomzälne kiirzer, breit abgerundet oder gestutzt, am Grunde nicht versehmolzen, gelblieh, mit fast gerader I,ängslinie und weniger zahlreichen I.amellen. Inneres Peristom (lunkel- bis rötlichgelb, las äussere weit ïberragend: Grundhaut niedrig, zuweilen 
durchlöchert; Fortsätze schmal, oben zu einem am Scheitel durchlöcherten Kuppeldach verbunden; Wimpern fehłend. Deckel loch gewölbt bis halbkugelig, mit oder ohne Spitzchen.

$\mathrm{L}^{*}$ bersicht der Arten.

A. Synözisch. Blätter nicht herablaufend.

a. Schopfblätter spatelförmig, mit vorgezogener Spitze. Kapsel oval-länglich ............................... 497. C. stygium.

b. Schopfblätter aus sehr verengter Basis rundlich, ausgerandet oder abgerundet, mit zurǘckgebogenem, kurzem und breitem Spitzchen. Kapsel kugelig-oval ...... 498. C. subrotundum.

B. Diözisch.

a. Blätter etwas herablaufend, aus verschmälertem Grunde rundlich- und verkehrt-eiförmig ........................ 499. C. arcticum.

b. Blätter weit herablaufend, breit-eiförmig, stumpflich zugespitzt

500. C. hymenophyl-

lum.

497. Cinclidium stygium Sw. 1. c. p. 27.

Synözisch. Pfl. in lockeren oder dichten, bis $10 \mathrm{~cm}$ hohen und höheren, bis zu den Jahressprossen hinauf dureh Rhizoidenfilz verwebten, rotbraunen, unten schwärzlichen Rasen. Stengel aufrecht, einfach oder mit aufrechten, schlanken, locker beblätterten Ästen. Blätter bald locker stehend, bald gedrängt, trocken wellig und kraus, feucht aufrecht-abstenend, aus verschmälertem nicht herablaufendem Grunde rundlich und verkehrt-eiförmig, meist mit Spitzchen, obere ene armblättrige Rosette bildend, spatelförmig, mit vorgezogener Spitze, $5-5,5 \mathrm{~mm}$ lang und 3,5 $\mathrm{mm}$ breit, mit einschichtigem, 3--5reiligem, braunrotem Saume; Rippe kurz vor oder in der Blattspitze endend; Zellen in divergenten Schrägreihen geordnet, dicht getüpfelt, in der Blattmitte nahe der Rippe 80-116 "lang und $30 \mu$ breit, am Saume 50-60" lang und 20-30 " breit. Sporogone einzeln oder zu 2. Seta $3-6$, zuweilen bis $\delta \mathrm{cm}$, oben verdickt, gelbrot. Kapsel hängend, oval, 3-4 $\mathrm{mm}$ lang und 1,5-2 $\mathrm{mm}$ dick, bleich gelbgrün, pruinos angehaucht, entleert rostgelb. Sporen derselben Kapsel ungleich gross, 25-45, aber auch z. T. bis $64 \mu$, blassgelblich, fein papillös. Sporenreife im Juni und Juli.

In tiefen Sümpfen, besonders in Kalkgegenden.

F. Al. Eckerö, Storby (Bom.). Finström und Saltvik. an mehreren Fundorten (B.). - Ab. Pargas, Skräbböle (Elfv.). Kimito, Gảsterby (Ols.). Bromarf (Sundv.). Uskela (Nikl.). Lojo. Ojamo (Lindb.); Hermola (Hult); Pahasuo (E. af H.). — N. Ekenäs (Häyr.); Lappvik (Teräsv.). - Ka. Vehkalahti, Hunkeri (Krohn). - Ik. Valkjärvi, Pähkinämäki und Pasuri (H. Lindb.). — St. Orivesi, Kivijärvi (Broth.). - Ta. Hattula, Yli-Savijärvi (Weg. und Ranck.). Padasjoki, Nyystölä (Vain.). 一 Kl. Ruskeala (W. Nyl.). Suistamo, Uuksujärvi (Link.): Saariselkä (Kot.). - Kol. Salmi, Leppälä (Pes.). Petrosavodsk (Simm.). - Tb. Kinnula, Muholan kỵā, Katajamäki (Roir.). Pihtipudas, Harjula (Roiv.); Muurasjärvi, Likolampi (R.). - Sb. Kaavi, Losomāki, zw. Poskijärvi und Aittojärvi cpp. (Kot.); Niinivaara, Louhilampi (Kot.). Nilsiä, Kirehdorf (Kyyhk.); Kuuslahti, Jaakonlampi (Kot. und Kyylak.). Juuka, Petrovaara (Kot.): Vesivaara und Halivaara (K.). - Kb. Juuka. Juuanvaara fq. (Kot.). - Kon. Suojārvi (Norrl.). Selki und Iundjärvi (N.). Suisaari (Simm.). Tiudie (Sahlb.). — Om. Alajärvi, Poikkijoki (Backm.). - Ok. Kajana, Lehtovaara (Kyyhk.). Sotkamo, Vuokatti (K.). Hyrynsalmi, Kivirinta (K.). Suomussalmi (Lönnb.). - Kpom. Repola, Kiimovaara (Vain.). Siiterinvaara (Bergr.). - Ob. Oulun-Salo, Pahajärvi (Huum.). Simo. Kivalot (Räs.). - K. Kuusamo, an vielen Fundorten (F. Nyl.. Sil., Broth.). - Lkem. Kittilä fq. (Hult). Kuolajärvi, Vuorikylä, Nonnakkajänkä (E. af H.). - Le. Karesuanto und Vittanki (Norrl.). Kilpisjärvi, Malla, Saana und Megaspahta. in der subalpinen Region (Kot.). - Li. Inari, Tankajoki und Naptusjoki und an mehreren Fundorten lãngs des Vaskojoki und Tenojoki in der Nadelwaldregion (Hult). — Lim. Kandalaks (Sahlh.); Schelesnaja (Broth.). - Lt. Ruokojāyr (Roiv.). Kola (Broth.). Tsipnavolok und Vaidoguba (B.). - Lp. Orlov (Kihlm). Ponoj (Broth.).

S. Sk. - L.

N. Sm. rr. Kristiania pass. Ringerike pass. K. Dovre. Lomsfjeldene. H. ST. No.-F. ziemlich verbreitet, vom Meeresniveau bis in das Hochgebirge hinaufsteigend.

Europa, Nord-Amerika. 
498. Cinclidium subrotundum Lindb, in Notis. Sällsk. Faun. Fl. Fenn. IX. p. 72 (1867).

Synözisch. Pfl. in lockeren oder dichten, 3-5 cm hohen, bis zu den Jahressprossen hinauf durch Rhizoidenfilz verwebten, bleichgrünen, abwärts schwärzlichen Rasen. Stengel aufrecht, einfach oder mit niedergebogenen, am Ende verdümnten Sprossen. Blätter locker gestellt, trocken wellig, feucht abstehencl, aus kurzer, nicht herablaufender Basis rundlich, ausgerandet oder abgerundet, mit zurïckgebogenem, breitem Spitzchen, bis $4 \mathrm{~mm}$ lang und $3 \mathrm{~mm}$ breit, mit bis gegen die Blattmitte etwas umgebogenen Rändern, mit einschichtigem, 3-4reihigem, braunrotem Saume; Rippe im Spitzchen aufgelöst; Zellen in divergenten Schrägreihen geordnet, nicht getüpfelt, sonst wie bei C. stygium. Seta einzeln, $2-4 \mathrm{~cm}$, clünn, gelbrot. Kapsel hängend, klein, kugelig-oval, etwa 2,5 $\mathrm{mm}$ lang und $2 \mathrm{~mm}$ dick, blassgelb, entleert rötlichgelb. Sporen $40-45 \mu$, bräunlichgelb, fein papilIös. Sporenreife im Juli. - Fig. 57 E-K.

In Sümpfen.

F. Ok. Suomussalmi (Lönnb.). - Ob. Roraniemi, zw. Tolonen und Tepojärvi (Hult). - $K$. Kuusamo, Alakitka. Kokkoniemi (E. af H.). - Lkem. Kolari, Jokijalka (Hult). Sieppijärvi (Hjelt). Kittilā, an mehreren Fundorten (Hult). - Le. Kütanen und Karesuanto in der Kiefernregion (Norrl.); Vittanki in der Birkenregion (X.). - Li. Inari, Kaamajoki in der Nadelwaldregion (Sil.); in Sümpfen am Tankojoki und bei Toironiemi und Jibmosuano am Vaskojoki, wie auch an den Stromschnellen des Vaskojohi, sämtliche Fundorte in der Nadelwaldregion (Hult). Utsjohi, auf eine Mooswiese am Mandojäyri und am nassen Felsabhange Poarespaikhi in der Birkenregion (H.); Ailigas (Sil.). $\rightarrow$ Lim. Kandalahs (Broth.). - Li. Tsipnavolok und Vaidoguba (B.). - Lmur. Voroninsk (Kihlm.). Gavrilova, Olenka. St.mjostrovsk und Varsinsk (Broth.), - Lp. Orlov und Ponoj (Broth.).

S. Hrjd., LyL.. LuL. und TL. an einzelnen Fundorten. orten.

N. Ve. Saetersdalen, Meienfeld $1300 \mathrm{~m}$. K. Dorre. Lomsfjeldene, No. $F$. an wenigen ruald-

Sibirien, arkt. Nord-Amerika.

499. Cinclidium arcticum (Bryol. eur.) C. Müll. Syn. I. p.15.4 (1848). [Mnium arcticum Bryol. eur. fasc. 31 Suppl. 1. p. 1, t. 1 (18.16).]

Diözisch. Pfl. in dichten, bis $8 \mathrm{~cm}$ hohen, bis zu den Jahressprossen durch Rhizoidenfilz verwebten, blassgrünen, dann weinroten Rasen. Stengel aufrecht, einfach oder mit aufrechten, verlängerten, locker beblätterten Ästen. Blätter ziemlich locker gestellt, trocken wellig und kraus, feucht abstehend, aus verschmälertem, etwas herablaufendem Grunde rundlich- und verkehrt-eiförmig, meist mit Spitzchen, obere eine armblättrige Rosette bildend, 3.6-4,5 mm lang und 22,5 $\mathrm{mm}$ breit, mit in cier unieren Hälfte umgerollten Rändern, mit doppelschichtigem, 3reihigem, braunrotem Saume: Rippe mit der Blattspitze aufhörend; Zellen wie bei $C$. stygium. Sporogone einzeln. Seta $2-4 \mathrm{~cm}$, dünn, bräunlichgelb. KapseI hängend, aus ziemlich langem und engem Halse oval, etwa $3 \mathrm{~mm}$ lang und $2 \mathrm{~mm}$ dick, gelb. entleert bräunlich. Sporen wie bei C. stygium.

S. LUL.

N. Dovre. Tr. Bardo.

Beeren Eiland, arkt. Sibirien, arkı. Nord-Anerika.

jo0. Cinclidium hymenophyllum (Bryol. eur.) Lindb. in Notis. Sällsk. Faun. Fl. Fenn. 1X. p. 75 (1S67). [Mnium hymenophyllum Bryol. eur. fase. 31 Suppl. p. 5. t. 5 (1846).]

1)iözisch. Pfl. in dichten, $8-25 \mathrm{~cm}$ hohen, blaugrünen, innen rötlichen und łurch Rhizoidenfilz verwebten Rasen. Stengel aufrecht, dicht beblättert, geteilt, mit aufrechten Ästen. Blätter trocken anliegend, schwach wellig, feucht aufrechtabstehend, aus weit herablaufendem Grunde breit eiförmig, stumpflich zugespitzt, meist 2,4 $\mathrm{mm}$ lang und $1,8 \mathrm{~mm}$ breit, mit einschichtigem. 1-2-, streckenweise 3reihigem, nicht verschieden gefärbtem Saume: Rippe vor der Blattspitze endend: zellen nicht in divergenten Reihen geordnet, dicht getüpfelt, ziemlich regelnässig eckig-rund, 35-10 ", bis eckig oval, $50 \mu$ lang. Sporogone unbekannt. 
Auf feuchten bis nassen, erdbedeckten Felsen, in deren erderfüllten Spalten und am Fusse der Felsen.

F. Le. Kilpisjärvi, Malla und Saana, in der alpinen Region (Kot.).

S. Hrjd., PL., LuL. und TL.

N. Dovre. No.-F., höhere Lagen vorziehend und nur ausnahusweise bis $100 \mathrm{~m}$ hesalsteigend. spitzbergen, Sibirien, arkt. Nord-Amerika.

\section{Unterreihe BARTRAMIINEAE.}

Kapsel oft geneigt, bald aus langem Halse länglich-oder keulig-birnförmig, glatt, bald eilänglich bis zylindrisch oder kugelig und meist gestreift.

\section{A U L A C O M I A C E A E.}

Diözisch. Pfl. in lockeren bis dichten, durch glatten Rhizoidenfilz verwebten Rasen, meist an \pm feuchten Orten. Stengel Jeckig, mit Zentralstrang, lockerem Grundgewebe und mehrschichtigen, stereiden Mantelzellen, dicht beblättert. Blätter Sreihig, nach oben allmählich grösser, eilänglich, lanzettlich bis lineallanzettlich; Rippe vor der Blattspitze endend, mit medianen Deutern, einer kleinen Begleitergruppe, 2 Stereidenbändern und differenzierten Aussenzellen; Zellen klein, rundlich-mehreckig, meist stark kollenchymatisch und die Wandpfeiler scheinbar rissig oder grubig vertieft, beiderseits papillös, bis zur Basis fast gleichförmig oder hier verlängert, mehrschichtig und glatt. Sporogone einzeln. Seta aufrecht, \pm verlängert, dünn. Kapsel aus kurzem Halse eilänglich bis zylindrisch, derbhäutig, mit 8 dunkler gefärbten Streifen, trocken gerippt; Zellen des Exotheciums rektangulär, in den Streifen mit stark verdickten Längswänden, um die Mündung mehrere Reihen rings verdickter, roter Zcllen; Spaltöfnungen oberflächlich, im Halsteile. Ring differenziert, sich abrollend. Peristom doppelt und wie bei Bryum gebaut. Inneres Peristom frei, zart und hyalin; Grundhaut hoch; Fortsätze lanzettlich-pfriemenförmig, unterwärts klaffend: Wimpern vollständig, kaum knotig. Sporen klein.

Einzige Gattung:

\section{AULACOMNIUM}

Schwaegr. Suppl. III. I. fasc. 1, t. 215 (1827).

\section{L'bersicht der Arten.}

A. Zellen am Blattgrunde einschichtig, grün, von den nächst höheren nicht verschieden. के Blïten knospenförmig....501. A. androgynum.

B. Zellen am Blattgrunde zwei- und dreischichtig, im Alter gebräunt, etwas aufgeblasen. c7 Blüten scheibenförmig. Kräftigere Arten.

a. Blätter aufrecht-abstehend, an der scharfen Spitze gezähnt. Rasen filzig verwebt .......................... 502. A. palustre.

b. Blätter dachziegelig, kürzer und breiter, ganzrandig. Rasen leicht zerfallend.

«. Blätter länglich-lanzetllich, stumpflich ............. A. palustre var. $\beta$. ß. Blätter verkehrt-eilänglich, breit abgerunclet ..... 503. A. turgidum.

U n t e rga t t. I. Orthopyxis (Palis.) Jur. Laubmfl. p. 321 (1882).

c Blüten knospenförmig, mit faclenförmigen Paraphysen. Zellen am Blattgrunde einschichtig, grün, von den nächst höheren nicht verschieden. 
501. Aulacomnium androgynum (L.) Schwaegr. 1. c.. Mon. p. 2. №.1 (1827). [.Mnium androgynum L. Sp. pl. 1. ed., II. p. 1110, No. 4 (17.53).]

Pfl. in dichten, lebhaft oder gelbgrünen. $1-\bar{j}$ cm hohen, meist polsterförmigen Rasen. Stengel ohne differenzierte Aussenrinde, aufrecht, I verzweigt, meist mit 1-3 subtloralen Sprossen. Blätter trocken einwärts gebogen und links gedreht, feucht aufrecht-abstehend, gekielt, nicht herablaufend, eilanzettlich und lanzettlich, bis $1,5 \mathrm{~mm}$ lang und $0,45 \mathrm{~mm}$ breit. Schopfblätter gehäuft, lanzettlich und lineal-lanzettlich, bis $3 \mathrm{~mm}$ lang und $0,5 \mathrm{~mm}$ breit; sämtliche Blätter an der scharfen Spitze ausgefressen-gezähnt, mit einseitig meist stärker ungerollten Rändern; Zellen dicht papillös, auch am Blattgrunde einschichtig und bei den Astund unteren Stammblätter von den oberen nicht verschieden, bei den Schopfblättern in der unteren Hälfte rechteckig und glatt. Perichätialblätter lanzettlichpfriemenförmig, nach innen schmäler mit überall gestreckten und stark verdickten Zellen. Seta 1-2 cm. gelbrot. Kapsel aufrecht, später geneigt bis horizontal, länglich-zylindrisch, hochrüchig, 2,5-3 $\mathrm{mm}$ lang und $0,75 \mathrm{~mm}$ dick, rötlichbraun. Deckel stumpf kegelig bis fast gesclnäbelt. Sporen $8-12 "$, gelblich, fast glatt. Vegetative Vermehrung durch an blattlosen, verlängerten Trägern in ein kugeliges Köpfchen gehäufte, sehr kleine, gestielte Brutblätter.

An Baumstümpfen. Wurzeln und schattigen, kalkfreien Felsen.

F. Al. Eckerö. Jumala, Finström, Lemland, Föglö und Sund an einzelnen, Geta an mehreren und saltvik an vielen Fundorten (Bom.). - Ab. Korpo (Ekl.). Nagu (Tengstr.). Iniö. Norrby (Bergr.). Reso, Harvarön (Zett.); Luonnonmaa (Högm.). Karuna (Elfv.). Kimito (Ols.). Finby, Pettu (Sundv.). Angelniemi (Buch). Tenala (Jusl.). Bromarf (Sundv.). Karis. Fagervik (Lindb.). Uskela, Linnamäki (Lindb.). Karislojo, Pipola (E. af H.). Lojo, an mehreren Fundorten (Lindb., H. Lindb., Sundv.). N. Ekenäs (Hăyr.). Ingà, Barō (Sael.). Snapperıuna (Sundr.). Helsingfors (Lindb.). Sibbo, Löparö (Sundv.). Borgå, Sundö (Sael.). Kymmene (Ulv.). Hogland (Häyr.). - St. Eura (Rōnnb.). - Ta. Hollola, Enonsaari (Norrl.). Sysmā. Kanunivuori (Vain.). - Sa. Savitaipale, Ala-Säynätjärvi (Buch.).

S. Sk. - Hlsl.

N. $S m .-J L$.

Europa, Nord-Amerika.

Untergat t. I I. Gymnocybe (Fr.) Jur. 1. c. p. 322.

7) Blüten scheibenförnig, mit keulenförmigen Paraphysen. Zellen am Blattgrunde zwei- und dreischichtig, in Alter gebräunt, etwas aufgeblasen. Kräftigere Artell.

502. Aulacomnium palustre (L.) Schwaegr. Suppl. III. P.-I. fasc. I. Mon. p. 4, No. 2 (1827). T Tizium palustre L. Sp. pl. 1. ed., II. p. 1110, No. 3 (1753). - Gymnocybe palustris Fr. St. agr. femsj. p. 27 (1825). - Sphaerocephalus palustris Lindb. Musc. seand. p. 14 (1879).]

Pfl. in meist ausgedehnten, lockeren oder dichteren, bis 10 und $15 \mathrm{~cm}$ hohen, grïnen oder gelbgrïnen, schwammigen Rasen. Stengel mit lockerzelliger und diinmwandiger Aussenrinde. aufrecht oder aufsteigend. einfach oder gabelig bis büschelig verzweigt. Blätter trocken \pm gedreht, feucht aufrecht-abstehend, gekielt, aus halbumfassender, kurz herablaufender Basis lanzettlich, bis lineallanzettlich, meist 4-6 $\mathrm{mm}$ lang und $0,8-1 \mathrm{~mm}$ breit. mit meist gegen die Spitze zurückgerollten und an der meist scharfen Spitze ausgefressen- gezähnten Rändern: Zellen beiderseits mit je einer meist langen, hyalinen Papille, am Grunde wenige Reihen zwei- und dreischichtig. 4-6seitig, dünnwandig, dentlich aufgeblasen, slatt und im Alter gebräunt. Perichätialblätter länger und lang zugespitzt, die innersten kleiner, mit gestreckten und verdickten Zellen. Seta $3-5 \mathrm{~cm}$, gelbrot. Kapsel geneigt bis horizontal, länglich-eiförmig, hochrückig. 3,5-4 $\mathrm{mm}$ lang und 1-1,2 $\mathrm{mm}$ dick, gelblich- bis rötlichbraun. Deckel aus gewölbter Basis gerade oder schief geschnäbelt. Sporen $10-15 \mu$, gelb, glatt. Sporenreife im Juni. Vegetative Vermelırung durch an verlängerten, mit nach oben allmählich kleineren und entfernt gestellten, später abfallenden Blättern besetzten Trägern in ein kugeliges köpfchen gehäufte, kleine, dreieckige Brutblätter. - Fig. 58. 
Auf sumpfigen Wiesen, in Wald- und Torfsümplen, an nassen Felsen und überhaupt an feuchten Stellen durch das ganze Gebiet allgemein verbreitet, häufig Massenvegetation bildend und bis in die alpine Region hinaufsteigend.

Europa, West-, Zentral- und Nord-Asien, Nord-Amerika, Tasmanien.

var. imbricatum Bryol. eur. fase. 10, p. 9 (1841). [Sphaerocephalus palustris var. imbricatus Möll. Förteckn. Sk. växt. 2. Moss., p. 33 (1907).]

Tracht von A. lurgidum. Rasen locker, leicht zerfallend. Blätter dachziegelig, länglich-lanzettlich, stumpf, ganzrandig.

N. Slutemyr.

503. Aulacomnium turgidum (Wahlenb.) Schwaegr. Suppl. III. P. I. fasc. 1, Mon. p. 7, No. 3 (1827). [Mnium turgidum Wahlenb. Fl. lapp. p. 351, No. 619, t. 23 (1812). - Gymnocybe turgida Lindb. in Notis. Sällsk. Faun. Fl. Fenn. IX. p. 85 (1867). - Sphaerocephalus turgidus Lindb. Mlusc. scand. p. 14 (1879).]
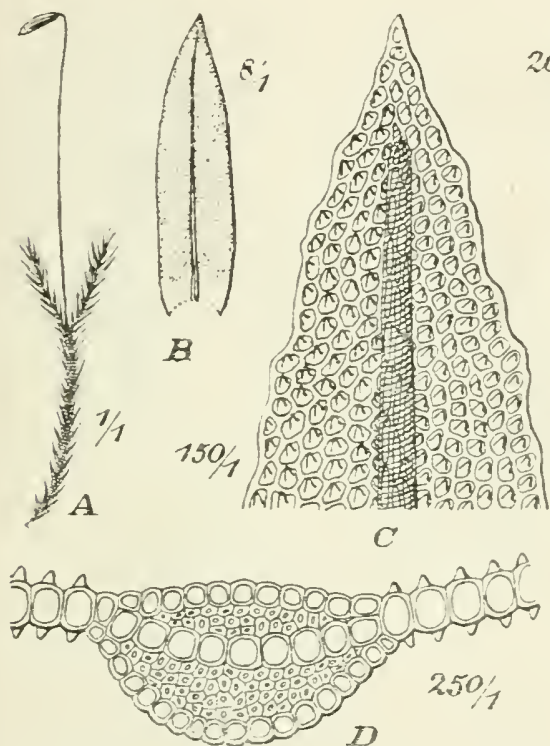

Fig. 58. Aulacomnium palustre (L.). A Fruchtende Pfl. (1,1); B stengelb. (8 1); C Blalt:pitze $(150,1)$; D Blattquerschnitt (250/1); E Kapsel im trockenen Zustande (8/1); F Spaftofinung (200/1); E Peristom $(75 / 1)$.

Pfl, in oft sehr ausgedehnten, leicht zerfallenden. gelblichgrünen, etwas glänzenden, inmen schmutzig gelblichbraunen Rasen. Stengel mit lockerzelliger und diunnwandiger Aussenrinde, bis $20 \mathrm{~cm}$, brüchig, mit kurzem. nicht vortretendem Rhizoidenfilz, unregelmässig ästig, kätzchenartig beblättert. Blätter dachziegelig, löffelartig-hohl, kaum herablaufend, verlängert verkehrt-eilänglich, breit abgerundet, meist etwa $3 \mathrm{~mm}$ lang und $1.5 \mathrm{~mm}$ breit, ganzrandig. mit bis zur Blattmitte spiralig zurückgerollten, an der Spitze eingebogenen Rändern; Rippe zart. weit vor der Blattspitze endend: Zellen in den Ecken sehr stark verdickt. un die Iitte des buchtig-sternfömigen Lumens beiderseits mit je ejner kurzen Papille. am Blattgrunde glatt, locker, 4-6seitig, zweischichtig, gelblichbräunlich, höher kurz rektangulär und grüı. Perichätialblätter länger. aufrecht-abstehend, länglich, stmmpflich. die immersten kleiner, lanzettlich, spitz. Seta $1,5-2,5$ cm. rot. oben gelblich. Kapsel geneigt, eilängliclı, gekrïmmt, bis $3,6 \mathrm{~mm}$ lang und $1.2 \mathrm{~mm}$ dick, gelblichbraun. Deckel kegelig, stumpf. Sporen $10-13 \mu$, gelblich, glatt. 
Auf feuchten, erdbedeckten Felsabsätzen, auf steinigen Abhängen und auf Erdboden, am reichlichsten in der alpinen Region und an der Küiste des Eismeeres. Sehr selten fruchtend.

F. Ok. Kajana, Suovalahdenkallio (Lackstr.). - Ob. Rovaniemi. Hepokallio (Hult). - K. Kuusamo, Korojoki (E. af H.); Ǩitkajoki (Sil.); Paanajärvi. Kiekkivaara (Broth.). - Le. Kílpisjärvi, Leutsuvaara (Norrl.); Malla. Saana und Guonjarrankka, in der alpinen Region (Kot.). - Li. Inari, Ivalo (Sil.); Prttelvaara (Hull). Ltsjoki, Mundjaur (Wahlenb.): an mehreren Fundorten in der Birkenregion (Hult); Yläjalve. Kistuskaidde (Ranck.). - Lim. Kandalaks, Schelesnaja (Brolh.); Tschun und Hibinä (B.); Lujauri-urt, Tschutsk-njun (Kihlm.). - Lt. Kivla. Karaulnaja Pahta (Broth.). - Lmur. Gavrilova, Rinda. Semjostrorsk, Tarsinsk und Jokonsk (Brolh.). - Lp. In der Küstenregion -t. fq. (B.).

S. IIrjd.-L.

N. R. Geiranger, Merok, ca, $60 \mathrm{~m}$. K. Dorte. Lom-fjeldene. No. $-F$. in der Weiden- und Alpenregion.

In der ganzen arktischen Zone allgemein rerbreitet. Faeroer, Alpengebiet, Sibirien, Japan, NordAmerika.

\section{ME E S E C E A E.}

Schlanke bis kräftige Moorpfl. in meist ausgedehnten und tiefen Rasen. Stengel aufrecht, mit Zentralstrang, lockerem Grundgewebe und (excl. Amblyodon) engen, dickwandigen Nantelzellen, dicht beblättert, in den oberen Blattachseln häufig mit Keulenhaaren, oft längs mit kurzem und meist warzigem Rhizoidenfilz. Blätter ziemlich gleichgross, meist aus aufrechter Basis \pm abstehend bis sparrig-zurückgebogen, ei- bis verlängert- und lineal-lanzettlich, ungésäumt: Rippe ohne Deuter und ohne Begleiter, mit meist gleichartigen, selten stereiden Innenzellen und zahlreichen Bauch- und Rückenzellen: Zellen (excl. Amblyodon) parenchymatisch, chlorophyllreich, weder getüpfelt noch kollenchymatisch, (exel. Paludella) glatt, am Blattgrunde verlängert rektangulär und 6seitig, zartwandig, oft hyalin. Blüten gipfelständig: - Büten fast scheibenförmig, mit keulenförmigen Paraphysen. Sporogone fast immer einzeln. Seta meist sehr lang und dünn, geschlängelt, rot. Kapsel nit emporgehobenem Rücken, aus aufrechtem Halse gekrümmt, kiein- und schiefnündig, glatt und dünnhäutig. trocken unter der Mlündung nicht verengt; Zellen des Exotheciums am Urnenrücken meist verlängert rektangulär, an der Bauclıseite eckig-rundlich und mehr verdickt: Spaltöffnungen im Halsteile, oberflächlich, zahlreich. Ring 1-2reihig, kleinzellig, stückweise sich ablösend. Peristom doppelt, ohne Vorperistom. Peristomzähne (excl. Paludella) viel kürzer als bas inneres Peristom. stumpf oder gestutzt und gegenseitig \pm verschmolzen. Inneres Peristom mit niedriger, den Peristomzähne anliängender, kielfaltiger Grundhaut und schmal linealischen Fortsätzen. Deckel klein. Haube klein, flüchtig, bauchig kegelförmig. am Grunde zu einer unversehrten oder zerfetzten Röhre verengt und einerseits tief geschlitzt. Sporen (excl. Paludella) sehr gross.

Übersicht der Gat tungen.

A. Blätter hakig zurückgekrümmt, bis zur nitte herab kleingesägt: Zellen oberwärts beidlerseits mamillös. Kapsel aus kurzem Halse länglich-eiförmig. Beide Peristome gleichlang

89. Paludella.

B. Blätter meist aufrecht-, selten sparrig-abstehend, ganzrandig oder an der Spitze kleingezälnnt: Zellen glatt. Kapsel aus langem Halse länglich- oder keulig-birnförmig. Iusseres Peristom viel kürzer als das immere.

a. Blattzellen locker, dünnwandig, oberwärts verlängertrhombisch und rhomboidisch-6seitig. Inneres Peristom ohne Wimpern und ohne Netzhant

87. Amblyodon. 
b. Zellen der Blattspitze klein, kurz rektangulär und quadratisch, derbwandig. Inneres Peristom mit rudimentären Wimpern und flüchtiger Netzhaut

88. Meesea.

\section{AMBLYODON}

Palis. Prodr. p. 35 (1805), emend. Bryol. eur. fasc. 10 (1841).

Einzige Art.

504. Amblyodon dealbatus (Dicks.) Palis. I. c. 1). 41. [Bryum dealbalum Dicks. Crypt. fasc. II. p. 8, t. 5, f. 3 (1790).]

Heterözisch, ơ, ₹ und Blüten auf derselben Pfl. Lockerrasige, niedrige, bleichgrüne Pfl. Stengel mit wenig differenzierten Mantelzellen, $1-1,5 \mathrm{~cm}$, meist
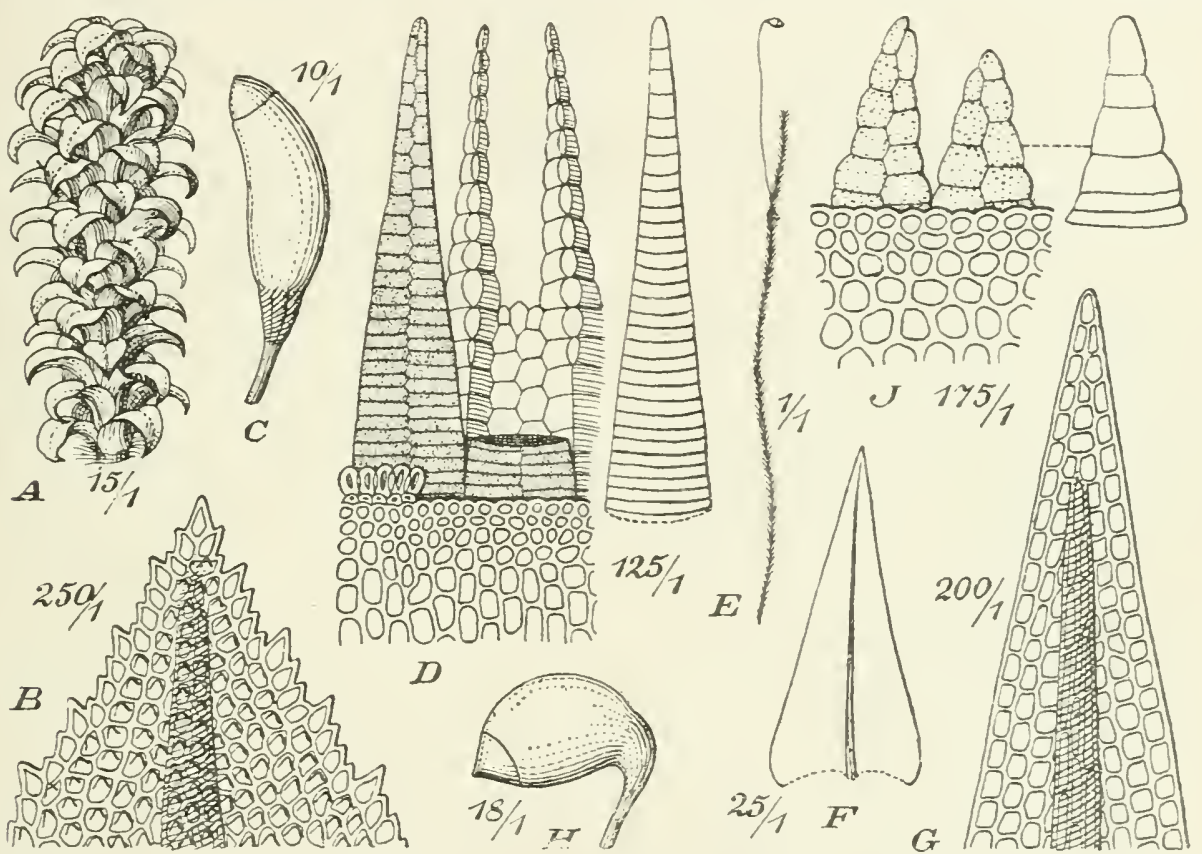

Fig. 59 A-D. Paludella squarrosa (L.). A Stengelstückchen (15/1); B Blattspitze (250/1); C Kapsel (10/1); D Peristom (125/1). - E-I. Catoscopium nigritum (H.). E Fruchtende Pfl. (1/1); F Stengelb. (25/1); G Blattspitze (200/1); H Kapsel (18/1); I Peristom (175/1).

nur am Grunde mit Rhizoiden, gabelig, seltener büschelig rerzweigt. Blätter schlaff, trocken etwas gedreht und zusammengeschrumpft, feucht aufrecht-abstehend, nicht herablaufend, untere verkehrt-eilänglich und elliptisch-lanzettlich. obere länglich- bis linealisch-lanzettlich, scharf zugespitzt, $3-3,5 \mathrm{~mm}$ lang und $1 \mathrm{~mm}$ breit oder bis $4 \mathrm{~mm}$ lang und $0,5 \mathrm{~mm}$ breit, flachrandig und in der oberen Blatthälfte $=$ gezähnt; Rippe gelblich, am Gruncle verbreitert, weit vor der Blattspitze aufhörend; Zellen sehr locker und dünnwandig, oberwärts verlängert-rhombisch- und rhomboidisch-6seitig. Perichätialblätter nicht verschieden. Seta 2$4 \mathrm{~cm}$. Kapsel aus ziemlich langem Halse länglich-birnförmig, etwas gekrümmt, 32-4 mm lang und 1-1,5 $\mathrm{mm}$ dick, gelblich-, zuletzt rotbraun. Peristomzähne $0.18-0.20 \mathrm{~mm}$ lang, blassgelb. stumpf, an der Basis verschmolzen. fein papillös, mit fast gerader, sehr zarter Mlittellinie und 12-14 Lamellen. Inneres Peristom blassgelb; Fortsätze schmal lanzettlich. fast doppelt so lang wie die Peristomzähne, 
ritzenförmig durchbrochen oder unten klaffend, oben z. T. mit Anhängseln; Wimpern fehlend. Deckel stumpfkegelig. Sporen 25-37, selten bis $45 \mu$, rostfarben, grobwarzig. Sporenreife im Juli. - Fig. 60 A-D.

Auf feuchtem Torf-, Sand- und Schlammboden in Ausstichen, an Grabenböschungen, Seeufern und nassen Felsen.

F. Al. Eckerö (Bom., H. Lindb.). Finstrôm, Östanåker (Ranck.). Sund, Kastelholm (Bom.). Saltvik, an mehreren Fundorten (B.). - Kon. Tiudie (Simm.).

S. Sk., Öi., Sm., Gtl., Ög., Vg., Srm., Upl., Gslr., Hrjd., Jmt. und L., meist nur an einzelnen oder wenigen Fundorten.

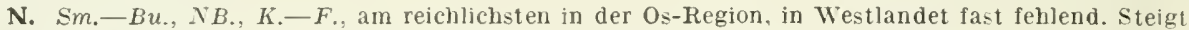
rom Meeresniveau bis in die Birkenregion hinauf. Nordgrenze bei $70^{\circ} \mathrm{n} . \mathrm{Br}$.

Europa, Kaukasus, Zeniral-Asien, Nord-Amerika.

\section{MEESEA}

Hedw. Fund. II. j. 97 (1782).

Meist tiefrasige Pfl. in grünen oder gelbgrünen, innen meist schwärzlichen, durch warzigen Rhizoidenfilz \pm verwebten Rasen. Blätter gleichgross oder nach oben allmälllich grösser, meist \pm herablaufend; Rippe kräftig, vor der Blattspitze aufhörend; Zellen oberwärts kleiì und dünnwandig, quadratisch und rektangulär, glatt. Perichätialblätter länger. Kapsel aus langem und engem Halse gekrünmt keulig-birnförmig. Peristomzähne kurz, zart, gestutzt, meist gegenseitig \pm verschmolzen. Pcristom gelb; Fortsätze 2-tmal so lang als die Peristomzähne, an der Spitze oft durch seitliche Anhängsel gegenseitig verbunden; Wimpern kurz oder rudimentär, ihre Fortsetzung in der nicht resorbierten, unverdickten, gemeinsamen Wand der inneren Peristomschicht als Reihen verdickter Knoten und Stäbchen vorhanden. Deckel kurz stumpfkegelig oder gewölbt mit dicker Waĩze.

$$
\text { Lbersicht der Arten. }
$$

A. Blätter flachrandig.

a. Diözisch. Blätter 3zeilig geordnet 506. M. triquetra.

b. Synözisch. Blätter 6-Sreihig geordnet ............. 505. M. longiseta. B. Blätter mit bis gegen die Spitze umgerollten Rändern ... 507. M. trichodes.

505. Meesea lorigiseta Hedw. Descr. I. p. 36, t. 21 et 32 (1787).

Synözisch. Rasen locker, his $10 \mathrm{~cm}$. Stengel fast einfach. Blätter 6 - Szeilig, herablaufend, aufrecht-abstehend, gekielt, aus länglich-ovalem Grunde lanzettlich, spitz oder stumpflich, lis $3 \mathrm{~mm}$ lang und 1,2 $\mathrm{mm}$ breit, flach- und ganzrandig oder gegen die Spitze uncieutlich gezähnelt; Schopfblätter etwa doppelt so lang, verlängert-lanzettlich; Zellen in der Mehrzahl kurz rektangulär, am Grunde verlängertrektangulär, an den Rändern deutlich enger und meist gestreckt. Seta bis $10 \mathrm{~cm}$. Kapsel 5-6 mm lang und bis $2 \mathrm{~mm}$ dick, gelbbräunlich, später rotbraun. Sporen 37- 5 "

In tiefen Sïmpfen und Torfmooren.

F. Al. Eckerö, Torp (H. Lindls.). Sund, Tjurnäs träsk (Bom.). - Ab. Uskela (Nikl.). - $1 k$. MIuola, Myräpääjarvi (11. Lindb.). Valkjarvi. Sasuri (H. L.). - Ta. Vanaja, Harviala (Ranck.). Koski, Kellolanlähde (Norrl.). Hollola. Hälvälä (X.). Asikkala. Paakkula und Koskuenlampi (N.). Luopioinen, Altoo (Leop.). Korgila]sti (Korrl.). Hartola (Bonsd.). - Kl. Parikkala, Törölampi (Sahlb.). Lukuniemi (simm.). Ruskeala (W. Nyl.). - hol. Jjälusova und fabrika (Elfr.). - Tt. Pihlajavesi, an mehreren Fundorten (Nurrl.). Jyräskylä. Haapakoski (Liro). Konginkangas (Broth.). - Sb. Iisalmi, Palojärvi (Sahlb.). - Kon. Kentjärri (Simm.). Jundjärvi (Norrl.). Suopohja (Külh.). Tiudie (Norrl.). - Ok. Kajana, Sarvivaara (Broth.). Paltamo, Jattila (Ranck.). Sotkamo, Natula und Haapala (Kyyhk.). Ob. Kemi, Kallinkangas (Brenn.). - K. Kuusamo, Ylikitkajärvi, Visolainen (Broth.): Vasaraperä, Akanlahti, Leveälampi (E. af H.). Hypiö (Nyb.); Kitkajäri (Sahlb.); Kallunkijärvi (S.). Kuolajärvi. Tuutiarri (Roir.), - Kk. Knjäscha (Karst.). - Lkem. Kittila, an mehreren Fundorten (Hult). IIuonio, in 
der Nadelwaldregion (Norrl.). Kuolajärvi, Pahto-aapa zw. Märkäjärvi und Kelloselkä (E. af H.). 一 Le. Karesuanto, in der Nadelwaldregion (Norrl.). - Li. Inari, Kaamasjoki (Sil.); Tankajoki (Hult); zw. Säytäjärvi und Syysjärvi (H.). Utsjoki, Patsjoki, Tsitsanjarga (Popp.). - Lmur. Njutskanjavr zw. Voroninsk und Porojavr (Kihlm.).

S. Ög. und $N a ̈ r$. an einzelnen Fundorten $-L$.

N. A., Bu., K.-ST., No.-F., meist nur an wenigen Fundorten und meist in niedriger Lage. Nordgrenze bei $70^{\circ} \mathrm{n}$. Br.

Zentral-Europa, Sibirien, Nord-Amerika.

506. Meesea triquetra (L.) Aongstr. in Nov. Act. Soc. Upsal. XII. p. 357 (1844). [Mnium triquetrum L. Sp. pl. 1. ed., p. 1114 (1753). - Meesea tristicha Bryol. eur. fasc. 10, Mon. p. 8, t. 4 (1841).]

Diözisch. Pfl, in lockeren bis ziemlich dichten, oft ausgedelnten Rasen. Sten gel bis $15 \mathrm{~cm}$, einfach oder mit 1-2 subfloralen Sprossen. Blätter 3zeilig, gleichgross, aus halb umfassendem, aufrechtem, herablaufendem, breit ovalem Grunde allmählich in eine schmale, gekielte Spitze auslaufend, trocken $\neq$ wellig verbogen, feucht mit der oberen Hälfte sparrig-abstehend und die Spitzen bogig aufstrebend, bis $3,5 \mathrm{~mm}$ lang und $1,5 \mathrm{~mm}$ breit, flach- und ganzrandig oder rings klein gezähnt; Rippe sehr kräftig, mit oder vor der Blattspitze aufhörend; Zellen oberwärts quadratisch und kurz rektangulär. Seta bis $10 \mathrm{~cm}$. Kapsel 5-6 mm lang und bis 2 mm dick, gelbbräunlich, später rotbraun. Sporen 30-44 $\mu$, gelbbraun, dicht papillös. Sporenreife im Juni und Juli.

In tiefen Sümpfen und Torfmooren.

F. Al. Finström, Attböle Storträsk (Bom.). - N. Esbo, Langträsk (Gottsb.). Tusby, Saksa (Broth.). — Ka. Säkkijärvi, Likavajärvi (Krohn). - Ik. Muola, Äyräpääjärvi (H. Lindb.). Valkjärvi, Mutajoki. Pasuri und Valkjärvi (H. L.). Pyhäjärvi, Lohijoki (H. L.). - St. Ikaalinen, Nygárd (Sundv.). Jämijärvi (Herl.). - Ta. Vanaja. Harviala (Ranck.). Hattula, Leteensuo (Sundv.). Lammi (Norrl.). Koski (N.). Hollola, Hälvälä (N.). Asikkala, Paakkola und Parinpelto (Norrl.). Padasjoki, Nyystölä (Vain.). Luhanka, Varma (V.). - Sa. Taipalsaari (Simm.). - Kl. Kurkijoki, Savioja (Jusl.). - Kol. Pass.-st. fq. (Elfv.). Petrosavodsk (W. Nyl.). - Oa. Korsnäs, Rutjilträsk (Ranck.). - Tb. Keuruu, Haapamáki (Kot.): Pihlajavesi (Norll.). Jyväskylä (Broth.). Laukaa, Aännetkoski (B.). Karstula (B.). Viitąaari, Säynätlampi (B.). Kinnula, Saarenkylä. Nekkojärvi (Roiv.). Pihtipudas, Sydänmaa, Harjula (R.); Muurasjärvi, Urpila (R.). - Sb. Virtasalmi, Montola, Pölkönjärvi (Kyyhk.). Kuopio, Jỵnkä (Kot.); Pietarinlanpi (Kyyhk.); Lehdonkylä, Kasurila (K.). Kaavi, Losomäki (Kyyhk.). Nilsiä, Kirchdorf. Syväri (Kyyhk. und Kot.); Kuuslalıti. Jaakonlampi (Kyyhk.); Loutteinen (K.); Valkeinen swo und Rahasenmäki (Kot.). Juuka, Halivaara (K.). Iaaninka, Pöljä, Mlikkojärvi und Riitaniitty (Kyyhk.). Rautavaara, Hlankamäki (K.). - Kb. Juuka, Juuanvaara (Kot.); Nunnanlahti (K.). - Kon. Suojärvi, Pöpönsilari (Norrl.). Selki (N.). Jalguba (Popp.). Tiudie (Angstr.). — Ok. Kajana (Lackstr.); Lehtovaara (Kyyhk.). Paltamo (Broth.). Sotkamo. Isoniitty und llustinjoki (K.). Kuhmoniemi, Kellojärvi und Kuivajärvi (Kyyhk.). Ristijärvj (Lackstr.). Suom lsalmi, Säynäjäjoki, Kivijärvi und Ulkupuro (Kyyhk.). - Kpom. Kontukki (Vain.). Siiterinvaara (Bergr.). — Ob. Simo (Räs.). Alatornio, Kalkivuori (R.). Rovaniemi (Hult). - K. Kuusamo, zw. Haataja und Oivanki (Bro\{h.); Riisijoki (E. af H.): Kitkajoki (Sil.); zw. Salminen und Kesälahti (Broth.). Kuolajärvi, im südöstl. Teile st. fq. (Roiv.). - Lkem. Kolari st. r. (Hult). Kittilä fণ. (H.). Kuolajärvi, Alapeteri, Ahma-aapa (Linnan.); Sallajoki (Broth.); Pahtoaapa und Renkkuma-aapa (E. af $\mathrm{H}$.); im zentralen Teile an mehreren Fundorten (Roix.). - Le. Kuttanen. Karesuanto und Yaunu in der Ǩiefernregion (Norrl.). - Li. Inari, Tankajoki. Kurtonkoski und Tenojoki, Sammelinköngäs, in der Nadelwaldregion (Hult): Tenojokj, Yliköngäs und Hamma:tunturit. in der Birkenregion (H.). - Lt. Kivijärvi, zw. Kinsijäyr und Ruokojäyr (Roiv.). Pippojok (R.). Tsipllarolok (Broth.). - Lp. Orlov (Kihlm.). - Le. Tschavanga (Brenn.).

S. sk., Sm., Ög., När.-L.

N. A., Bu, Br., Ne., SB., NB. $\mathrm{S} T$., No. und $F_{\text {., an }}$ reichlichsten in der -uhalpinen Region. Steigt bis $1,400 \mathrm{~m}$ hinauf.

Spitzbergen, West- und Zentral-Europa, Silirien, Nord-Amerika.

507. Meesea trichodes (L.) Spruc. in Ann. and Mag. Nat. Hist. II. Ser., III. p. 369 (1849). [Bryum trichodes L. Sp. pl. 1. edl., p. 1120 (1753). - Meesea uliginosa Hedw. Deser. I. p. 1, t. 1 et $2(1787)$.]

Polyözisch (autözisch und synözisch). Rasen dicht, $1-4 \mathrm{~cm}$, selten höher. Stengel büschelästig und gabelteilig. Blätter Szeilig, kaum herablanfend, nach oben allmählich grösser, aufrecht-abstehend, zuweilen einseitswendiğ, rinnig-hohl, olsere verlängert lanzettlich-linealisch, mit abgerundeter, selten scharfer Spitze, 
bis $2,5 \mathrm{~mm}$ lang und bis $0,44 \mathrm{~mm}$ breit, mit bis gegen die Spitze umgerollten, unversehrten Rändern; Zellen in der Mehrzahl verlängert rektangulär, mit quadratischen gemischt. Seta $1-8 \mathrm{~cm}$. Kapsel bis $3,5 \mathrm{~mm}$ lang und bis $1,25 \mathrm{~mm}$ dick, gelbbräunlich, später dunkelbraun. Sporen 37-45, seltener bis 56 ", gelbbräunlich, dieht leinwarzig. Sporenreife im Juni und Juli. - Fig. 60 E-K.

In Sümpfen und Torfmooren, auf nassen Felsen. an See- und Bachufern.

F. Al. Eckerö, Storby (Bom.). Saltvik, Andtböle. Ersberg (B.): Krarnbo, Sandvik (B.). - Ab. Pargas, Skräbböle (Elfr.). Kimito, Pörtsnä: (Ol↔.). - N. Helsinge. Vesterkulla, Kalwholmen (Ranck.). - Ik. Valkjärvi (W. Nyl.). - Ta. Korpilahti (Norrl.). - Kl. Ru.keala (Lindh.). - Kol. Fabrika und

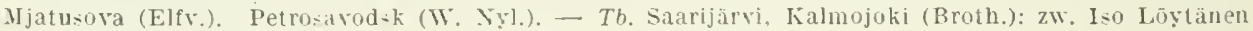

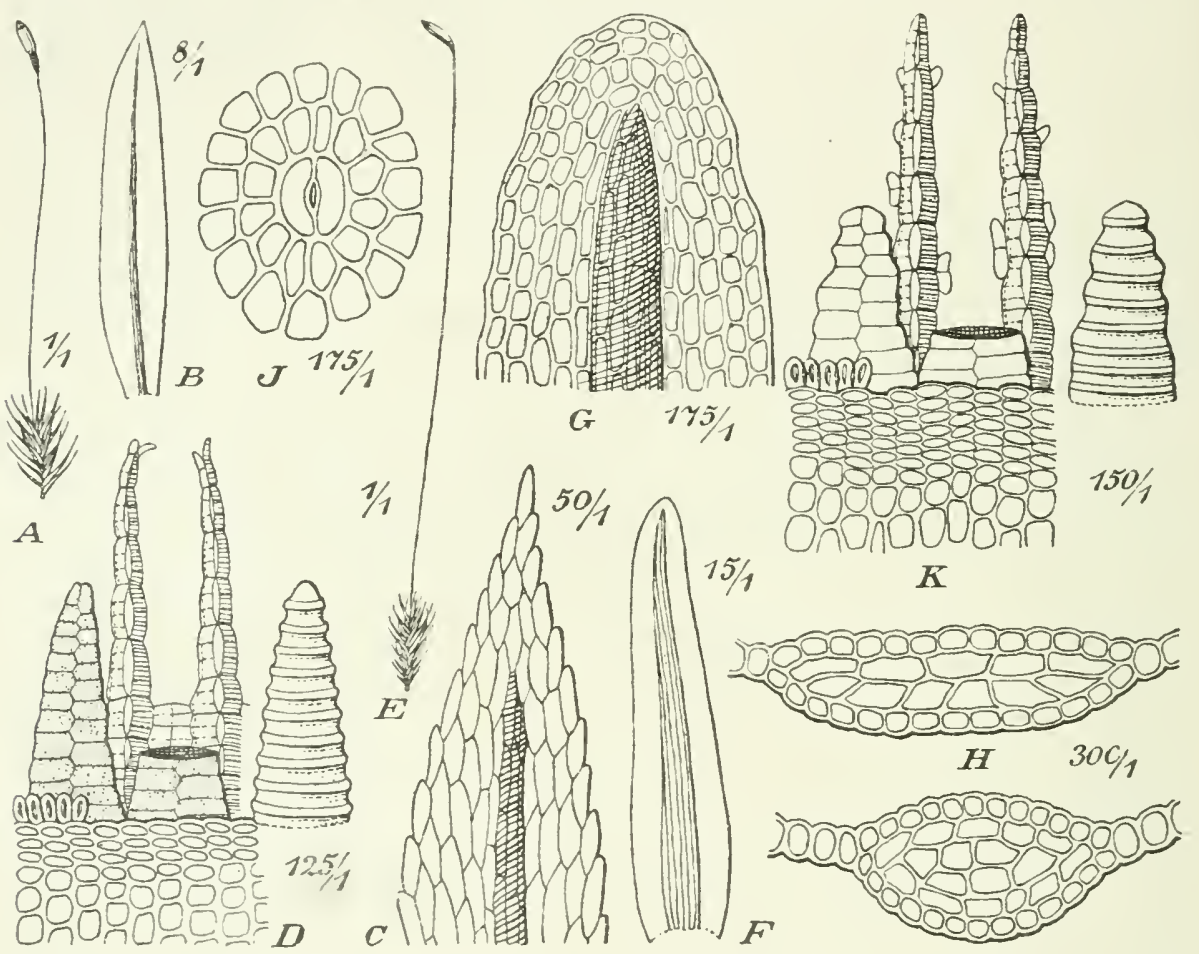

Fig. 60 A-D. Amblyodon dealbalus (Dicks.). A Fruchtende Pfl. (1/1): B Stengelb. (8/1): C Blat1spitze (50/1): D Peristom (125/2); - E-K. Meesea lrichodes (L.). E Fruchtende Pfl. (1/1); F Stengelb. (15/1): G Blattspitze (175/1); H Blattquerschnilte (300/1); I Spaltöfnungen (175/1); K Peristom $(150 / 1)$.

und Kalmarinjärvi (B.). Viita-aari, Saynatlampi (B.). — Sb. Joroinen. Pasula (H. Lindb.). Nilsiä. Küslahti, Jaakonlaupi (Kyyhk.). - Kon. Talkeamäki (Simm.). Tiudie (F. Nyl.). - Ok. Kajana, Lehtovaara (Lackstr.). Sotkamo. Hepolahti (Kyyhk.): Tipasky̨ă. Vunriniemi (K.). Puolanka. Törmänmáki und Leppälä (K.). Hỵrsnalmi. Kiviranta (K.). Suomusalmi. Pahalanpi und Koirnsuo (K.). - $O b$. Y'litornio, Karhujupukka (liult). Rovaniemi. Lohiniva und Alajäskö (H.). - $K$. Kuusamo, an vielen Fundorten (Broth. E. af H.). Kuolajärvi s. fq. (Roiv.). - Kk, Keret. Sonostrov (Sahlb.). - Lkem. Kittiläsr. fq. (Hult) Kinolajärvi, an mehreren Fundorten (E. af H.. Roiv.). - Le. Kilpisjärvi, an melıreren Fundorten in der Birkenregion (..orrl.): Malla, Saana und fuonjarvankka. selten in der Birkenregion (Kot.). - Li. Inari. Kyrö (Tain.): st. fq. in der Nadelwaldregion (Hul1); Kodossuannonpää in der Birkenregion (Arrh.). Utsjnki, Aligitjokka. Nurrus (Ranck.). - Lim. Kandalaks (Sahlb.). Uunjarr, Tschıidi-vun (Kihlın.). Sascheika (Karst.). Hibinä (Broth.). — Ll. Im südl. Teile pass. (Roir.). Kïldin (Broth.). - Lmur. Im Kïstengebiete nicht selten (Broth.). - Lp. Orlor (Broth.); İapajer und Triostrova (Kihlm.).

S. sm., Gll., Og., Dld., Lpl., Srml.-L. 
N. In allen Ämtern mit Ausnahme von Sm., JL., L.M. und $R .$. im Binnenlande und in den nordlichen Teilen $\pm \mathbf{f q}$.

Europa, Kaukasus, Himalaya. Zentral-Asien, Sibirien, Nord-Amerika.

var. minor (Brid.) Hag. in D. K. N. Vid. Selsk. Skrift. 1908, No. 9 (1909). [Meesea minor Brid. Bryol. univ. II. p. 62 (1827).]

Pfi. in sehr dichten, kamm $1 \mathrm{~cm}$ hohen Rasen. Blätter sehr dicht gestellt, steif, eilanzettlich bis lanzettlich-linealisch, stumpf oder spitz: Rippe sehr dick. Seta kaum $1 \mathrm{~cm}$. Kapsel kürzer und dicker. Eine Hungerform der alpinen Region.

P. Le. Kilpisjärvi (Norrl.). In allen Fjelden um den Kilpisjärvi, in der alpinen Region. - Lmur. Olenji (Karst.). - Lp. Ponoj (Brenn.. Salilb.).

S. Hrjd., Jmt., LuL. Sarekgehiet.

N. NB., R., K., H., ST., No.-F.

Europa im Hochgebirge. Nord-Amerika.

var. angustifolia (Bricl.) Hag. 1. c. p. 1:3. [Meesea angustifolia Brid. Bryol. univ. II. p. 62 (1827).]

Blätter abstehend, trocken mehr geschlängelt, aus ovaler Basis lanzettlichlinealisch, spitz, selten stumpf; Zellen der Blattmitte eng rektangulär.

N. Bu., Ne., SB.. K. $-F$., am reichlichsten in der subalpinen Region.

Alpengebiet.

\section{PALUDELLA}

Ehrh. in Phytophyll. VI. No. 69 (1788).

Einzige Art:

508. Paludella squarrosa (L.) Brid. Sp. musc. II1. p. 74 (1817). [Bryum squarrosum L. Sp. pl. 2. ed. p. 1585 (1763).]

Diözisch. Pfl. in dichten, ausgedehnten, lebhaft grünen und gelbgrünen, innen braunen bis schwärzlichen, längs durch glatten Rhizoidenfilz verwebten Rasen. Stengel bis 10 und $15 \mathrm{~cm}$, selten länger, meist einfach, durch ein oder zwei subflorale Sprosse sich verjüngernd. Blätter 5reihig, eilanzettlich, zugespitzt, bis $2 \mathrm{~mm}$ lang und $1 \mathrm{~mm}$ breit, aus aufrechter, herablaufender Basis hakig zurückgebogen, scharf gekielt, bis etwa zur Mitte herab durch mamillös vortretende Zellecken klein und unregelmässig gesägt und von hier bis gegen die Basis mit schmal zurückgerollten Ränclern: Rippe dünn, vor der Blattspitze auîhörend; Zellen in der oberen Blatthälfte rundlich-6seitig, etwa 12-16 $\mu$, last g]eichmäsșig rings verdickt, beiderseits durch Mamillen rauh. Schopfblätter und Perichätialblätter länger, aufrecht oder oberwärts hakig, lanzettlich, mit fast längs breit zurückgebogenen Rändern. Sporogone selten zu zweien. Seta $4-6 \mathrm{~cm}$. Káapsel aus kurzem Halse länglich-eiförmig, mässig gekrümmt, 3-4 mm lang und $1 \mathrm{~mm}$ dick, gell)lich-, zuletzt rötlichbraum. Beide Peristome gleichhoch, bis $0.50 \mathrm{~mm}$ lang. Peristomzähne lanzettlich, blassgelb, papillös, oberwärts längs- und teilweise unregelmässig gestrichelt, mit deutlicher Zickzacklinie und über 25 Lamellen. Inneres Peristom bleich; Fortsätze ganz oder ritzenförmig durchbrochen, an der Spitze meist mit Anhängseln: Wimpern fehlend. Deckel kuppelartig gewölbt, stumpf. Sporen $14-$ $20 \mu$, blassgelblich, papillös. Sporenreife im Juni und Juli. - Fig. 59 A-D.

In tiefen Mooren und Sümpfen und an quelligen Stellen.

F. Al. Eckerö. Storby (H. Lindb.). Finström und Saltrik, an wenigen Fundorten (Bom.). - A b. Pargas, Gunnarsnäs, Långholm (Elfr.). Bromarf (Sundr.). Uskeli (Nikl.). Karislojo, Hakos (E. af H.). Lojo, Ojamo (E. af H.). Lakspojo (Sundv.). - N. Elimäki (Tıgerst.). - Ka. Säkkijärvi, Pukalus (Krohn). Virolahti (Blom); Orslahti, Vehkalahdensıo (Ranck.). - Ik. Valkjärri, Pähkinämäki (H. Lindb.). Sakkola, Kurikka (H. L.). - St. Eura (Simm.). Ikaalinen, Nygåd (Sundv.). - Ta. Kalvola (Knab.). An einzelnen Fundorten in Lammi. Knski. Hollola, Asikkala und Padasjoki (Norrl.). Hartola (Bonsd.). Luhanka, Tientali, Kangasjärvi (Vain.). - Sa. Lappee (Buch). Kangasniemi (Lackstr.), - Kl, Kurkijoki, Migrilä (Jusl.). Ruskeala (W. Nỵ.). Suistamo, Leppäsỵrjä (Pe-.). - hol. Salmi Leppälä (Pe-.). Gorki (Elfr.). - Oa. Teura, Luova. Ukkoharjunneva (Ranck.). - Tb. Kieumu. Haapamäki (Kot.). Saarijärvi und Viitasaari, an mehreren Fundorten (Broth.). Pihtipudas, an mehreren Fundorten (Roir.). - Sb. Virtasalmi, Montola, Pölkönjärvi (Ky̧hk.). Kunpio, an wenigen Fundorten (Link., liygh.). 
Kaavi, in Ninivaara, Luikonlahti und Losomäki fq. (Kot.); Petkellahti (Kyyhk.). Nilsiä, Kirchdorf (Kiot.); Jaakonlampi, Loutteinen, Tarpinen und HaJuna (K.). Rautavaara, Yrttimäki (Kyyhk.). Pielavesi, Lampaanjärvi, Kukkaromäki, Mehtola (Roiv.). Maaninka, Pöjä (Kyyhk.). 一 Kb. Juuka, Ahmovaara (Linnan.); Juuanvaara fq. (Kot.); Nunnanlahti (K.). - Kon. Suojärvi (Norrl.); Mitrasenlahti (Kop.). Jalguba (Simm.). Suosaari (Kullh.). Tiudie (Sel.). Solominskaja pustinja (Simm.). Selki (Norrl.). - Om. Alajärvi, Vesterbacka (Backm.). - Ok. Kajana, Lehtovaara (Kyyhk.). Paltamo, an mehreren Fundorten im Kalkgebiete (K.). Sotkamo, Kirchdorf (K.); Hepolehto (K.); Tipaskylä, Vuoriniemi (K.); Tuokatti, Roti (K.). Hyrynsalmi, Kiviranta (K.). Puolanka und Suomussalmi, an mehreren Fundorten (K.). - Ob. Salo, Pahajärvi (Huum.). Uleåborg (W. Nyl.); Pyykösjärvi (Huum.). Simo (Brenn.). Zw. Aavasaksa und Turtola fq. (Hult). - K. Taivalkoski, Kostenjärvi (V. Brenn.). Kuusamo, zw. Haataja und Ronkalampi (Broth.). - Lkem. Kolari und Kittilä fq. (Hult). Küulajärvi, an vielen Fundorten (Linnan., E. af H.). - Le. In der Nadelwald- und Birkenregion fq. (Norrl.). Kilpisjārvi, in der Birkenregion nicht selten (Kot.). - Li. In der Nadelwald- und Birkenregion des ganzen Gebietes fq. (Hult). In allen Teilen der Halbinsel Kola st. fq. (Broth.).

S. Sk., Öl, Sm.-L.

N. Sm.-Ne., SB., YB., K., H.-F., am reichlichsten in der subalpinen und alpinen Region. Spitzbergen. Zentral- und Ost-Europa, Sibirien, Nord-Amerika.

fo. leptocarpa Hag. in D. K. 土. Selsk. Skrift. 1908, No. 9, p. 19 (1909).

Kapsel zylindrisch, gekrümmt, trocken $0.4 \mathrm{~mm}$ dick.

N. No. Bejeren, Solojen.

\section{A T OS COP I A CEAE.}

Sehr schlanke, wasserlicbende Pfl. in meist ausgedehnten, dichten und tiefen Rasen. Stengel fadendün, mit Zentralstrang, lockerem Grundgewébe und etwas kleineren, dickwandigen Mantelzellen, dicht beblättert, in den Blattachseln spärlich mit kurzen. hyalinen Keulenhaaren. Blätter mehrreihig, ziemlich gleichgross, aufrecht-abstehend, trocken einwärts gebogen, ovallanzettlich, scharf zugespitzt, ganzrandig; Rippe aus gleichartigen Zellen gebildet; Zellen klein, parenchymatisch, glatt. Diözisch: cr Blüten knospenförmig, mit fadenförmigen Paraphysen. Perichätialblätter differenziert. Seta verlängert, glatt. Kapsel geneigt his horizontal, sehr klein, aus schr kurzem, gekrümmtem, in die Seta verschmälertem Halse oval-kugelig, hochrückig, (lerbhäutig, glatt: Spaltöfnungen fehlend. Ring fehlend. Peristomzähne cingekrümmt, weich, lanzettlich, stumpf, blcich, mit unregelmässigen Rändern; dorsale Längslinie nicht immer die Spitze erreichend; Innenschicht sehr dünn, nur am Grunde mit einzelnen, niedrigen Lamellen. Inneres Peristom fehlend, zuweilen durch eine sehr niedrige Haut angedeutet. Deckel kurz kegelig, stumpf. Hailıe kappenförmig, klein. flüchtig. Sporen gross.

Einzige Gattung:

\section{CATOSCOPIUM}

Bricl. Bryol. univ. I. p. 368 (1826).

Einzige Art:

509. Catoscopium nigritum (Hedw.) Brid. 1.c. [ Weissia nigrita Hedw. Desc. 111. p. 97, 1. 39 (1792).]

Rasen oft bis $8-10 \mathrm{~cm}$, lebhaft grïn bis bräunlichgrün, innen rostbram bis schwärzlich. Stengel weit hinauf mit dichten, warzigem Rhizoidenfilz besetzt, mit subfloralen Sprossen. Blätter etwa $1 \mathrm{~mm}$ lang und $0.4 \mathrm{~mm}$ breit, mit schmal zurückgeschlagenen Rändern: Rippe in der Blattspitze schwindend; Zellen rektangulär, am Blattgrunde länger. in den Blattecken kurz. Perichätialblätter bis 3 mm lang, aus hoher, halJscheidiger Basis lanzettlich-pfriemenlörmig, flachrandig. Seta $8-15 \mathrm{~mm}$, jurpurn. Liapsel rötlichbraun, zuletzt glänzend schwarz, hart und spröıle: Zellen des lixotheciums am Rücken unregelmässig rektangulär, auf der Bauchseitc rundlich 1 - 6 seitig. Sporen 38 - 50 \%, bräunlich-gelbgrün, feinwarzig. Sporenreile im Sommer. - lïg. 59 E-I. 
Auf feuchtem, ton- und kalkhaltigem Boden, an und in Bächen und Quellen, in kalkhaltigen Sümpfen und an überrieselten Felsen der Kalk- und Schiefergegenden.

F. Al. Eckerö, Storby (Bom.); Torp (H. Lindb.). - $\sigma a$. Närné, Yttermark. Norra Kararamossen (Ranck.). - Sb. Juuka, Petrovaara, Mrakoniemi (Kot.). - Kb. Juuka. Juuan raara (Kot.).-- Kon. Tiudie (Simm.). Saoneschje, Podmosero (Norrl.). — Ok. Paltamo, Nelalahti, Horkanlampi (Lackstr., Kyyhk.): Leppikangas, Norsiniemi und Likolampi (Kyyhk.): Mieslahti, an 2 Fundorten (K.); Mattila (Ranck.). Sotkamo, Hanhilampi (K.); Kohrorinsaari (K.). Puolanka, Rällinmäki und Tuorijärvi (K.). Hyrynsalmi, Kiviranta (K.). Suomussalmi, Kallioisensuv und Kairosuo (K.). Meist reichl. und zuweilen massenhaft (K.). - Ob. Simo (H. Lindb.). Kiemi. Kallinkangas (Brenn.). - $K$. Kuusamo, an vielen Fundorten (Broth., E. af H.). Kuolajärvi, im südöstl. Teile an vielen Fundorten (Roir.). - $k$ k. Keret. sonostrov (Sahlb.). - Lkem. IIuonio (Hartm.); Kaunavaara und Iustavaara (Walılenl.). Kuolajärri, Kimaselänoja (Roiv.). - Le. Vittanki, in der Birkenregion (Norrl.). Kilpisjärvi, Malla und Saana. in der Birkenund in der alpinen Region (Kol.). - Ll. Tsipnarolok und Vaidoguba (Broth.), - Lp. Orlor (Kihlm.).

S. Öl., Gtl., Ög., Upl.. Irml.—TL.

N. Kristiania r. Ringerike rr. K. Dovre. Lomsfjeldene. VT. Stjordalen. No. -F., in den südlicheren Teilen rom Meeresnireau bis ins Hochgebirge ziemlich verbreitet.

Mropa, Sibirien. Nond-Amerika. Nordgrenze auf Spitzbergen.

\section{B A R T R A M I'A C E A E.}

Erd-, Fels- und Sumpfmoose in meist durch Rhizoidenfilz verwebten Rasen oder Polstern. Stengel aufrecht oder aufsteigend, meist rundlich 5-mehreckig, mit Zentralstrang, lockerem Grundgewebe, substereiden bis stereiden Mantelzellen und meist differenzierter, trocken kollabierter Aussenrinde, dicht beblättert und mit 1-2 oder quirlständigen subfloralen Sprossen. Blätter 5-8reihig. ziemlich gleichgross, nicht oder kaum herablaufend, lanzettlich bis pfriemenförmig zugespitzt, ungesäumt, oberwärts am Rande und oft am Rücken der Rippe gezähnt; Rippe meist kräftig und am Rücken stark vortretend, vor oder mit der Blattspitze aufhörend bis als gesägte Granne austretend, mit mehrzähligen medianen Deutern, einer armzelligen Begleitergruppe, meist nur dorsalem Stereidenbande und differenzierten Aussenzellen; Zellen oberwärts meist parenchymatisch und klein, dickwandig, ungetüpfelt, meist beiderseits mamillös. Blüten gipfelständig. Seta meist \pm verlängert, glatt. Kapsel meist kugelig, hochrückig, schiefnı̈̈ndig und ohne Hals, mit dunkleren, trocken als Rippen hervortretenden Längsstreifen; Zellen des Exotheciums am Urnenrïken meist verłängert, an der Bauchseite rundlich-mehreckig, um die Mündung kleiner und querbreiter; Spaltöffnungen oberflächlich, nur am Kapselgrunde. Ring meist nicht differenziert. Peristom meist doppelt: Peristomzähne lanzettlich, mit stark vortretenden Lamellen und oft oberwärts zwischengelagerten Verdickungen. Inneres Peristom meist etwas kürzer, kielfaltig, mit \pm weit vortretender Grundhaut und später in 2 divergente Schenkel geteilten Fortsätzen; Wimpern meist rudimentär oder fehlend. Deckel klein, meist flach kegelig. Haube klein, kappenförmig, glatt und flüchtig.

Übersich t der Gat t ungen.

A. Stengel 3eckig, mit lockerzelliger Aussenrinde. Blattzellen glatt

93. Plagiopus.

B. Stengel 5-mehreckig. Blattzellen mamillös.

a. Rasen dicht und fest, blaugrün. Blätter steif, trocken

dicht anliegend, deutlich 5zeilig. Deckel geschnäbelt. 92. Conostomum.

b. Blätter (excl. Philonotis seriata) nicht in Reihen ge-

ordnet. Deckel flach kegelig.

«. Stengel mit lockerzelliger Aussenrinde und quirlständigen subfloralen Sprossen. 
I. Blätter aufrecht-abstehend, ohne oder nur am Grunde mit Längsfalten; Zellen am Blattgrunde erweitert

95. Philonotis.

II. Blätter sparrig-abstehend, längsfaltig; Zellen auch am Blattgrunde linealisch

94. Breutelia.

ґ. Stengel mit kleinzelliger Aussenrinde und $1-2$ sub-

floralen Sprossen. Blätter ungefaltet

91. Bartramia.

\section{BARTRAMIA}

Bartramia Hedw. Descr. II. p. 111, t. 10 (1789).

Stengel mit kleinzelliger Aussenrinde, mit meist fein papillösem Filze und ohne quirlständige İste. Blätter aus schmal lanzettlicher, meist halbscheidiger, nicht faltiger Basis rasch oder allmählich linealisch-pfriemenförmig, oberwärts wenigstens am Rande zweischichtig und gesägt; Zellen oberwärts quadratisch und kurz rektangulär, abwärts verlängert rektangulär, im Scheidenteil linealisch, hỹalin und fast glatt. Perichätialblätter nicht differenziert. Seta aufrecht. Peristomzähne ohne zwischengelagerte Yerdickungen, papillös, gelb- oder rotbraun. Sporen meist $15-25 \mu$, grobwarzig. Sporenreife im Mai.

\section{Übersicht der Arten.}

A. Blätter trocken \pm eingebogen und geschlängelt bis gekräuselt.

a. Blätter meist einseitswendig. Seta scheinbar seitenständig, schwach gekrümmt, bis $5 \mathrm{~mm}$ lang .......... 510. B. norvegica.

b. Blätter aufrecht-abstehend bis abstehend. Seta $1-2$ cm, aufrecht ........................................ 511. B. pomiformis.

B. Blätter trocken steif aufrecht, aus glänzend weissem Grunde plötzlich borstig-pfriemenförmig 512. B. ithyphylla.

510. Bartramia norvegica (Gumn.) Lindb. in Öfv. Vet.-Ak. Förh. XX.p. 389 (1863). [Bryum norvegicum Gunn. Fl. norv. II. p. 138 (1772). - Webera Halleriana Hedw. Fund. II. p. 95 (1782). - Bartramia Halleriana Hedw. Descr. II. p. 111, t. $40(1789)$.]

Synözisch, mit von zwei kleinen Hüllblättern umschlossenen Antheridien. Pfl. in meist lockeren. Weichen, grünen, gelbgrünen bis bräunlichen Rasen. Stengel aufrecht oder aufsteigend, bis $10 \mathrm{~cm}$, selten höher, durch $1-2$ subflorale Sprosse sympodial oder gabelig verzweigt. Blätter meist einseitswendig, trocken geschlängelt und etwas verbogen, aus fast halbscheidiger, ovaler Basis rasch lang borstenförmig, bis $8-10 \mathrm{~mm}$ lang, mit über dem Scheidenteil umgerollten, weit hinab grob gesägten Rändern: Rippe oberwärts am Rücken gesägt und als gesägte Pfrieme lang austretend. Zellen ziemlich durchsichtig. Sporogone scheinbar seitenständig, einzeln oder zu 2 in demselben Perichätium. Seta $3-5 \mathrm{~mm}$, schwach gekrümmt. rot.

An schattigen, kalkfreien und kalkarmen Felsen.

F. Ab. Abo, Ispois (Zett.). Lojo, Isosaari, Askola (Lindb.); II ustasaari (Sundy.). - Ka. Wiborg, Soskuanjoki. Lalo (Bucl1). - St. Eurajoki (Simm.). - Ta. Lammi, Evo (Norrl.). Hollola. Tiirismaa. Pirunnesä (N.). Asikkala, Urajärvi (X.). Sysmä, Päijätsalo (Renqv.). - Sa. Ny̧slott (Carl.). - Kl. Sortavala, Pispavuori (Popu.): Kirjavalahti, Lahentaustenvuoret (Norrl.). Pälkjärvi, Korkeaniemi (Broth.). - Tb. Keuruu, Haapanäki. Jokijärvi (Kot.). - Sb. Kuopio, suovu, Kivimäki (Link.); Silinjärvi (Kyyhk.). Kaavi, Siikajärvi, Huosiaisniemi (Kyyhk.); Mustikkaraara (Kot.). Nilsiă, Kuuslahti, Jaakonlampi (Kyyhk.); Kirchdorf, Tahkomäki nHuutavan holma» (Kyylık. und Kot.); Pisavuori (Link.). Maaninka, Tuovilanlahti, Korkeakoskj (Roiv.); Kurolanlahti, Vorlokso (R.). - Kb. Tohmajärvi, Hidenvaara 
(Broth.). Kemie, Simosenvaara (Oesch), Pielisjärvi, Koli (Linnan.). Juuka, Juuanvaara (Kot. und Ranck.). - Kon. Jalguba (Simm.). - Ok. Paltamo, Melalahti, Ellinlampi (Kyyhk.). Sotkamo, Natula (Kyyhk.); Tipasoja, Vuorisaari und Närhiniemi (K.); Vunkatti (Broth.), Keima und Kivelà cp.-cpp. (K.). Puolanka, Hepoköngäs (K.). suomussalmi, Katiskalammenkallio (K.). - ob. Aavasaksa (Buch). - K. Kuusamo, Pyhäraara (Broth.). Oulankajoki, Merenoja und Mustosenvaara (B.). Paanajärvi (Sil.). Kiekkivaara (Broth.). Kuusinkijoki (E. af H.). - Kk. Kivakkatunturi (Sahlb.). - Lkem. Kittilä, Pallastunturit (Mel.). Kuolajärvi, Pyhãkuru und Peravaara (E. af H.). - Le. Kätkesuanto, Pahtarinne (Norrl.). - Lim. Paitsitunturi und Tupoaiva (Linnan.). - Lt. Kola, Karaulnaja Pahta (Broth.).

S. Sm., Ög., Vg., Boh., Nür., Dld., Ism., I'rml.-L.

N. Sm. r. A. Kristiania pass. Bu. Ringerike. Ne. Saetersdalen. P. r. NT. Stjordalen. Yo.

Europa, Kaukasus, Himalaya, Yunnan, Rocky IIts.

511. Bartramia pomiformis (L.) Hedw. Sp. musc. p. 164 (1801). [Bryum pomiforme L. Sp. pl. p. 1580 (1753). - Bartramia crispa var. pomiformis Lindb. Musc. scand. p. $15(1879)$.]

Synözisch, meist mit von zwei kleinen Hüllblättern umschlossenen Hüllblättern. Pfl. in meist lockeren, polsterförnigen, weichen, bläulich oder gelblichgrünen Rasen. Stengel aufrecht oder aufsteigend, 2-1 cm, selten liöher, oft wiederholt gabelteilig. Blätter aufrecht-abstehend bis abstehend, trocken mehrfach verbogen bis kraus, aus länglichem, kaum scheidigem Grunde allmällich lang borstenförnig, bis $5 \mathrm{~mm}$ lang, mit bis weit hinauf umgerollten und weit herab doppelzähnigen Rändern; Rippe oberwärts am Rücken gesägt und als gesägte Pfrieme austretend; Zellen ziemlich durchsichtig. Sporogone meist einzeln. Seta $1-2 \mathrm{~cm}$, aufrecht, rot.

Auf kalkfreier oder kalkarmer Erde und an schattigen, kalkfreien und kalkarmen Felsen.

F. Al. Geta, Hagö (Hult). Saltvik, Krarnbo und Fremmanby (Bom.). - Ab. Korpo. Strömmia (Ekl.). Pargas (Tengstr.). - N. Helsingfors (Lindb.). Hogland. Kutikallio (L.). - Ta. Pirkkala (Simm.). - Kl. Valamo (W. Nyl.). - Tb. Virrat. Helvetinjärvi (Broth.). - Kb. Pielicjärvi, Koli (Linnan.). Kon. Kivatsch (Kul!h.). - ob. Rovaniemi, Pöyliävaara (Brenn.). - K. Kuusamo, Pyhävaara, Kallioperänvaara und Iustosenvaara (Broth.). Nuorunen (Nyb.). - Lkem. Kuolajärvi. Särkitunturi (Linnan.). - Li. Patsjoki, Tsitsanjarga (Popp.). - Lim. Porjaguba (Sel.). - Lt. Kola, Karaulnaja Pahta (Broth.). - Lp. Ponoj (Brolh.): zw. Ponoj und Orlor (B.).

S. $s i k-L$.

N. Sm.-F.

var. crispa (Sw.) Bryol. eur. fasc. 12 Mon. p. 13 (18+2). [Bartramia crispa Sw. Musc. suec. p. $73(1799)$.]

liräftiger als die Hauptart. Rasen bis $10 \mathrm{~cm}$. Blätter trocken fast kraus, feucht weit abstehend, aus ovaler Basis rasch lanzettlich-pfriemenförmig, $6 \mathrm{~mm}$ lang und darüber. Kapsel die verlängerten jungen Sprosse nur wenig überragend.

An schattigen Felsen und in Felsenritzen, oft in mächtigen Polstern.

F. Al. st. fq. (Bom.). - Ab., X. und $h a .=$ fq. - Ik. Muola (H. Lindb.). - St., Ta.. Sa.. $k l$. f(I. - Kol. Salmi (Pes.). Vosne-senje und Schtjeliki (Elfv.). - Oa. Närpes, Yłtırmark, Vargbărget (E. af H.). Isokyrö. Orisberg (Ranck.). - Tb., sb. und $K b$. N fq. - Kon. Jänkäjărvi (Norrl.). Zw. Tschuiskoi und Kivatsch (Sel.). Pirttiniemi (Kullh.). - Om. Soini. L'urimāki (Backm.). Alajärvi, liăärmekallio (B.). Vindala, an einigen Fundorten (B.). - Ok. wenigstens pass. ( $K$ yyhk.). - Kpom. Loukkovaara (Bergr.). - Ob. Muhos (Huum.). Rovaniemi (Brenn.); Ieltaus, Ristikallio und Hepokallio (Hult). K. Kuusamo (W. Nyl.): Valajankoski (Nrb.). - Lkem. Kolari, Jouhisuannonvaara (Hult). Kittilä, Ảkāslompolo (H.). Pỷhātunturi (Huum.). Ounasıunturi (Sandm.). - Le. An einigen Fundorten in der Nadelwaldregion (Norrl.). Kilpisjärvi. in der Birkenregıon (X.). - Li. Inari. an einigen Fundorten in der Nadelwaldregion (Hult); liodossuannonpää und Veitsiknjarga, in der Birkenregion (H.). L'tsjoki, Kenischkoski (H.).-Lim. Puitsitunturi (Linnan.). - Lt. Im südwestl. Teile ar einigen Fundorten (Roir.).

S. Sk.-L., häufiger als die Hauptar1.

N. sm. $-F$., häufiger als die Hauptart. Nordgrenze bei $70^{\circ} 25^{\prime} \mathrm{n}$. Br.

Europa, Algier, Kaukasus, Himalaya, Amurgebiet, Kamtschatka. Japan. Nord-Amerika.

var. heteromalla (Brid.) C. Müll. Syn. I. p. 199 (1819). [Bartramia heteromalla Bricl. Bryol. univ. II. p. 42 (1827). - B. Normanni Holmgr. Mss. 1869 et Hartm.

Sk. Fl. 10. ed. p. 47 (1871).]

Blätter stark sichelförmig-einseitswendig.

N. F. Maalselvdalen,

Nord-Amerika. 
512. Bartramia ithyphylla Brid Muscol. rec. II. P. III. p. 132. t. 1, f. 6 (1803).

Synözisch. Pfl. in lockeren bis dichten, etwas starren, bläulich-oder gelblichgrünen Rasen. Stengel aufrecht, bis $4 \mathrm{~cm}$, mit 1-2 subfloralen Sprossen. Blätter aufrecht-abstehend, auch trocken steif, aus weissglänzendem, oben etwas breiterem Scheidenteile plötzlich in eine borstenförmige Pfrieme verschmälert, bis etwa $6 \mathrm{~mm}$ lang, mit aufrechten, in der Spitze scharf, abwärts kleingezähnten Rändern: Rippe fast den ganzen Pfriementeil ausfüllend, mamillös: Zellen auch oberwärts verlängert und schmal rektangulär, sehr undurchsichtig. Sporogone einzeln. Seta 1-2 cm, aufrecht, rot. Sporen 25-30 und $37 \mu$ - Fig. 61 G-K.

- Auf sandiger und lehmiger Erde, an Wegrändern und in Felsenritzen kalkarmer Gesteine.

F. Al. Eckerö, Marby (H. Lindb.). Finström (Arrh.). Saltrik und Sund an mehreren Fundorten (Bom.). Kōkar, Hamnö (B.). - Ab. Gustafs, Eskola (Bergr.). Kustö (Zett.). Ało (Arrh.). Reso (Högm.). Pargas. Bläsnăs (Elfv.). Kimito, Påvalsby (Ols.). Finby (Broth.). Halikko (Nikl.). Karislojo, Karkali (Hult); Tesjärvi und Pipola (Sundr.). Lojo, Kaijola (Sundv.); Skraatila (E. af H.). - N. Helsingfors (Lindb.). Sibbo. Ge.terby (Ranck.); Löparö (Snndr.). Elimäki (Tigerst.), Hogland (Sael.), — Káa. Virolahti (Blom). Wiborg. Juustila und Soskuanjoki (Buch). Antrea (Lindb.), - Ik. Kuolemajärvi (H. Lindł.). - St. Raumo (Nerv.). Eura (Rönnb.). Huittinen, Lauttaḳ̂lä (Ranck.). Ikaalinen (Sundr.). Hāmeen kỵrō, Kyrōskoski (Nerv.), - Ta. Vanaja (Graefl.). Sāāksmāki (Ǩ̉hlm.). Pirkkala (Siınm.). Im südöstl. Teile st. fq. (Norrl.). Hartola (Bonsd.). Luhanka und Korpilahti pass. (Vain.). — Sa. Taipalsaari (Simm.). Kangasniemi (Lackstr.). Ruokolahti (Hult). - Kl. Kurkijoki (Jusl.). Sortarala, Kirjavalahti (Norrl.). Ruskeala, Tirrinmỵlly (Brotb.). Suistamo (Pes.). Pälkjärvi. Kuhilasvaara (Broth.). - Kol. Schtjeliki (Elfv.). - Oa. Sideby, Ömossan (Nerv.). - Tb. Petäjāvesi, Olkkosruori (Ruor.). Jyrăskỵă (Broth.). Laukaa (Broth., E. af H.). Pihtipudas, Sormulanmāki und Syảảnmaa (Roiv.). Sb. Virtasalmi, MIontola, Kirvesmāki (Kyỵk.). İuopio, Puijo (Roir.); Haminalahti, Mustamähi (R.); Neulaniemi, Vuorilampi (R.). Nilsiä, Haluna und Tiirinlahti (Kryhk.). MIaaninka, Haatala, Haukka-

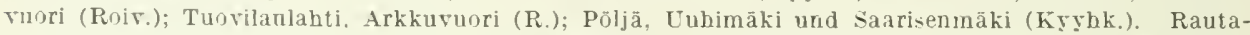
vaara, Riitamäki (K.). - Kon. Dianova gora (Kullh.). - Ok. Kajana (Lackstr.). Paltamo, Mrelalahti (L.). Sotkamo (L.); Hepolahti cop. (Krybk.); Mustinjoki, Sahinkallio und Sopenvaara (K.). - Ob. Utajärvi (Brenn.). Kemi, Pörhölā (Brenn.). Tornio (E. Nỵl.). Turtola, an mehreren Fundorten (Hult). K. Pudasjärvi, Iso-syōte (Broth.). Kuusamo, Korojoki und Rukatunturi (E. af H.). Nuorunen (Nyb.). Paanajārvi, Kiekkiraara (Broth.). - Lkem. Kittilä, Kalkbruch (H.); Ãkäslompolo, im Fjeldgebiete pałs. (H.). Kuolajärvi, Naruskajoki. Kuntsiköngās (E. af H.). Kutsanjoki (E. af H.). - Le. In der Nadelwald- und Birkenregion nicht selten (Norrl.). Kilpisjārvi. Yalla und Saivovaara. in der alpinen Region (Kot.). - Li. Sodankṛlä und Inari, an mebreren Fundorten in der Nadelwaldregion (Hult); Kodossuannonpãä und Ifuotkatunturit, in der Birkenregion (H.); Peldoiri, in der alpinen Region (H.). Utsjoki, an mehreren Fundorten in der Birkenregion (H.); Nuorgam und Yläjalve (Ranck.). - Lt. Rotsvaara, Sonkijăỵr und Pomja:kivaara im südwestl. Teil (Roir.). Kola und Karaulnaja Pahta (Broth.).

- Lmur. Semjostrovk, Ronionos, Sapadnij narolok und Jokonsk (B.). - Lp. Gubnoi (Kihlm.).

S. Sk.-L.

N. $S m .-F$.

Spitzbergen, Europa, Kaukasus, Kaschmir, Sibirien, Kamtschatka, Nord-Amerika.

var. strigosa Wahlenb. Fl. lapp. p. 362 (1812).

Blätter steif, straff anliegend, zerbrechlich.

S. Jml.-LuL. Sarekgebiet.

N. Ne. Saetersdalen, Støilkkar. 1,200 m. K. Dovre. No. Bardo.

Arkt. Nord-Amerika.

var. breviseta (Lindb.) Kindb. Arten d. Laubm. Schwed. und Norw. p. 153 ex p. (1883). [Bartramia breviseta Lindb. in Notis. Sällsk. F. Fl. Fenn. Förh. IX. [). 255 (1868).]

Kapsel eingesenkt oder \pm emporgehoben, zuweilen aufrecht und regelmässig. Peristomzähne sehr unregelmässig ausgebildet. teilweise der Innenwand des Deckels anhängend. Inneres Peristom stellenweise in Rudimenten vorhanden.

F. Lmur. Insel Kuvschin in der Năhe von Semjostrorsk. - Lp. Berdonos in der Năhe von Svjătoinos (A. H. Broth.).

N. F. Maaso. 


\section{CONOSTOMUM}

Sw. in Schrad. N. Journ. f. Bot. I. P. III. p. 26 (1806).

Pfl. in diclrten, durch glatten Filz fest verwebten, oben hlaugrünen, polsterförmigen Rasen. Stengel mit lockerzelliger Aussenrinde, brüchig, fast büschelig geteilt. Blätter steif, dicht anliegend, deutlich 5zeilig, gekielt, schmal lanzettlich, mit einschichtigen, nur gegen die Spitze schwach umgebogenen und gesägten Rändern; Zellen nur gegen die Blattspitze mamillös. Perichätialblätter zahlreich, länger, am Grunde halbscheidig, mit dümner Rippe. Seta verlängert, aufrecht. Kapsel gedunsen verkehrt-eiförmig. Ring bleibend. Peristom einfach. Peristomzähne bauchig-kegclig gegeneinander geneigt und an den Spitzen gitterartig verbunden. Deckel gerade oder schief geschnäbelt.

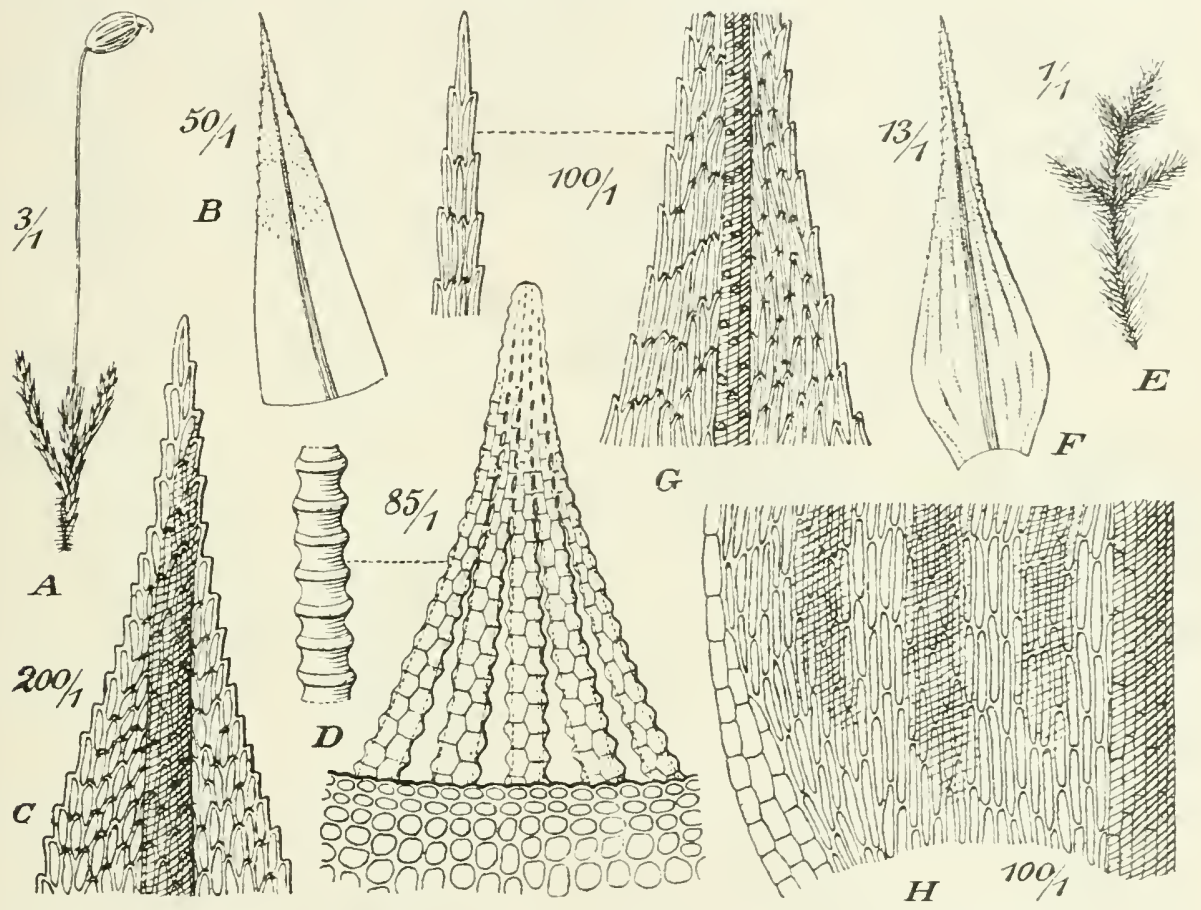

Fig. 61. A-D Conostomum tetragonum (Dicks.). A Fruchtende Pfl. (3/1); B Stengelb. (50/1); C Blattspitze (200/1); D Peristom (85/1). - E-H Breutelia chrysocoma (Dicks.). E Sterile Pfl. (1/1); F Stengelb. (13/1); G Blattspitze (100/1); H Blattbasis (100/1).

513. Conostomum tetragonum (Dicks.) Lindb. in Öfv. K. Vet.-Ak. Förh. 1863, p. 8. [Bryum tetragonum Dicks. Pl. crypt. fasc. II. p. 8, t. 4, f. 9 (1790). Conoslomum boreale Sw. in Schrat. N. Journ. f. Bot. I. P. III. p. 26 (1806).]

Diözisch; or Blüten fast scheibenförmig, mit keulenfömigen Paraphysen. Rasen bis 4, steril bis $10 \mathrm{~cm}$. Untere Blätter etwa $1 \mathrm{~mm}$ lang, aufwärts allmählich grösser, bis 1,5 cm: Rippe vor und mit der Blattspitze endend bis als Stachel austretend, am Rücken mamillös; Zellen derbwandig, oben rhomboidisch und verlängert rektangulär, am Blattgrunde lockerer, rötlichgelb. Perichätialblätter bis $3 \mathrm{~mm}$ lang: Zellen zart, oben fast linealisch. Seta $1-2 \mathrm{em}$, gelbrot. Kapsel gelblich und braun gescheckt, trocken und entleert braun. Peristomzälnne dunkelrot, glatt. Sporen $35-48 \mu$, viele ei- und nierenförmig, rostfarben, grosswarzig. Sporenreife im Juli. - Fig. 61 A-D. 
Auf steinigen Triften und verwitterten Felsen kieselreicher Gesteine.

F. Tb. Konginkangas (Broth.). - $K b$. Nurmes, Kirchdorf (Vain.). - Om. Kauhava, Vuorenmaa, Kukkuranvuori (Ranck.). Nykarleby, am Wege nach Kovjoki, etwa $2 \mathrm{~km}$ von der Stadt und im Walde NO von Matapall-mossen (Ranck.). - Ok. Kajana, Vimpelinvaara (Lackstr.). Paltamo, Mieslahti (Kyyhk.). - Ob. Turtola, Pello, Luppovaara (Hult). - K. Kuusamo, Korojoki (E. af H.). Pyhätunturi (Broth.). Vasaraperä, Akanlahti, Leveālampi (E. af H.). Ukonvaara (Broth.). Nuorunen (F. Nyl.). Oulankajoki, Mlustosenvaara (Broth.); Taivalköngäs (Roiv.). IIäntyraara (Broth.). — Kk. Kivakkatunturi (Broth.). Keret, Sonostrov (Sahlb.). - Lkem. Kittilā, im Fjeldgebietest. r. (Hult). Ounastunturi (Sandm.). Pỵătunturi (Hăyr.). Kuolajārvi, Sallatunturi (Linnan.. E. af H.). Tuntsajoki, Peurakōngās (E. af H.). - Le. Palojoki und Karesuanto, in der Kiefernregion und in der alpinen Region nicht selten (Norrl.). Kilpisjärvi, besonders in der alpinen Region fq. (Kot.). - Li. Sodankȳlā, Ukkola und Tankajoki in der Nadelwaldregion (Hult). Inari, Kultala und Muddusjărvi (H.); Tenọioki pass. (H.). In der Birkenregion von Hammastunturit nach Norden st. fr. (H.). Mluotkatunturit, in der alpinen Region fq. (H.); Tuorpumoivi und Lupukkapāä, in der alpinen Region (H.). L tsjoki, Ylājalve (Ranck.); Ontakoski, Soavjebakte (R.); Birkkoaive (R.). - Lim. Vainoaivi, in der alpinen Region (Linnan.). Nuortijaur (Holln.). Kandalaks (Broth.). - Ll. Im ganzen südwestl. Teile. jedoch spărl. (Roiv.). Kola (Karst.) Gorela und Srednij am Kolabusen (Broth.). Jeretik (B.). - Lmur. Voroninsk (Kihlm.). Teriberka. Gavrilova, Olenji und Johonsk (Broth.). Zw. Jenjavr und Varsinsk (Broth.). - Lp. Bolschaja Brevjannaja (Kihim.).

S. Vsm. und Hlsl. an einzelnen Fundorten. Irml.- $L$.

N. Sm.-F., ron der Birkenregion bis ins Hochgebirge, selten in niedrigeren Lagen.

Spitzbergen, Faerøer. Schottland, Pyrenäen, Hochgebirge von Zentral-Europa, Nord-Asien, nördI. Teile ron Nord-Amerika.

\section{PLAGIOPUS}

\section{Brid. Bryol. univ. I. p. 596, t. 5 (1826).}

Synözisch; Paraphysen sehr zahlreich, fadenförmig. Stengel 3eckig, mit lockerzelliger Aussenrinde, häufig durch subflorale Sprosse wiederholt gabelteilig, mit fast gleichhohen Ästen und stachelig-papillösem Filze. Blätter feucht allseits abstehend bis zurückgebogen, aus aufrechter, nicht scheidiger Basis schmal lanzettlich, allmählich lang zugespitzt, besonders oberwärts scharf gehielt, mit bis oberhalb der Blattmitte umgerollten, gegen die Spitze doppelschichtigen und mit scharfen Doppelzähnen besetzten, weiter hinab einfach gezähnelten Rändern: Zellen mit warzig-gestrichelter Cuticula. Perichätialblätter wenig differenziert. Seta verlängert, aufrecht. Peristomzähne rötlichbraun, glatt. Inneres Peristom bleichgelb.

514. Plagiopus Oederi (Gumn.) Limpr. Laubm. 11. p. 548 (1893). [Bryum Oederi Gunn. Fl. norv. No. 1005 (1772). - Bartramia Oederiana Sw. in Schrad. Bot. Journ. II. p. 181, t. 3 B, f. 5 (1800).]

Pfl. in \pm dichten, dunkel- oder brämnlichgrünen, bis $10 \mathrm{~cm}$ hohen, polsterförmigen Rasen. Blätter schwach gekräuselt, bis 4,5 mm lang; Rippe mit der Blattspitze endend; Zellen dickwandig, oberwärts quadratisch, gegen die Blattmitte rektangulär und am Blattgrund gestreckt. Seta $1-1,5 \mathrm{~cm}$, rot. Kapsel aufrecht, trocken etwas geneigt, später braun. Sporen $24-30 \mu$, in der Mehrzahl nierenförmig, dunkel rostrot, mit pustelartigen Warzen. Sporenreife von Mai bis August. - Fig. $62 \mathrm{~A}-\mathrm{F}$.

An etwas feuchten. beschatteten Kalkfelsen und \pm kalkhaltigen Gesteinen.

F. Al. Jomala, Ingby (Boin.). Salt vik, Harald:hy (B.). Sund. Jussböle (B.). - A h. Korpo, Finnö (Ekl.). Finhy, Kaukosalo (Broth.). Karisiojo, Tesjärvi und Karkali (Sundv.). Tammisaari (E. af H.). Lojo, an mehreren Fundorten (Lindb., Jusl., Hult, E. af H.). - Ka. Säkkijärvi, Risıniemi (Krohn). Wiborg (Vain.). - St. Ruovesi, Hollon horho (Broth.). - Ta. Asikkala, zw. Kalkkis und Rauvala (Norrl.). Paclasjoki. Arakoski (N.). Korpilahti, Paljakko (Vain.); Vaarunvuori (Link.). - Sa. Kangasniemi, Suomäki (Lackstr.). Nyslott (Carl.). - Kl. Kurkijoki (Jusl.). Valamo (Jusl.). Jaakkima, Ramola (Sundv.). Sortavala, Rausku und Neitsytriuttu (Link.); Kirjavalahti, Lahentaustenvuoret f(I. (Norrl.); Suosaaret (Popp.). Ruskeala, Tirrinmylly (Broth.). Soanlahti, Korpikallio (B.). Suistamo, Jalonvaara, Hyypinkallio (Link.): Leppiisyrjä, Säynävaara (L.). Pälkjārvi, Kulilasvaara (Broth.). - Kol. Salmi, Leppälā (Pes.). - Sb. Kuopio. Vanuvuori (Link.); Neulaniemi, Neulalanpi (L.); Silinjärvi (Kyyhk.). Kaavi, 
Siikajärvi, Huosiaisniemi (Kyyhk.); Niinivaara, Louhilampi (Kot.). Nilsiä, Kuuslahti, Jaakonlampi (li.). - Kb. Tohmajärvi, Hidenvaara (Broth.); Kennie, Simosenvaara (Oesch); Akkala (Kot.). Pielisjärvi, Koli (Linnan.). Juuka, Juuanvaara, an mehreren Fundorten (Kot.). - Kon. Kentjärvi (Norrl.). Jalguba (Kullh.). Kivatsch (Simm.). - Ok. Paltamo, Melalahti (Brenn.); Aijönkallio crp. (Lackstr.). Sotkamo, Natula (Kyyhk.); Rehjä, Aarreniemi (K.). - Kpom. Hukkakallio (Bergr.). - Ob. Aavasaksa (Buch). - K. Kuusamo, an vielen Fundorten, besonder im östl. Teile (Nyb., Sil., Bruth., E. af H., V. Brenn.). - Lkem. Kuolajärvi, Pyhäkuru (E. af H.). - Li. Lmba (Kihlm.). - Lt. Kola (Karst.); Karaulnaja Pahta (Broth.). - Lp. Rusiniha, zw. Orlov und Ponoj (Broth.). - Lv. Tschapoma (Brotls.).
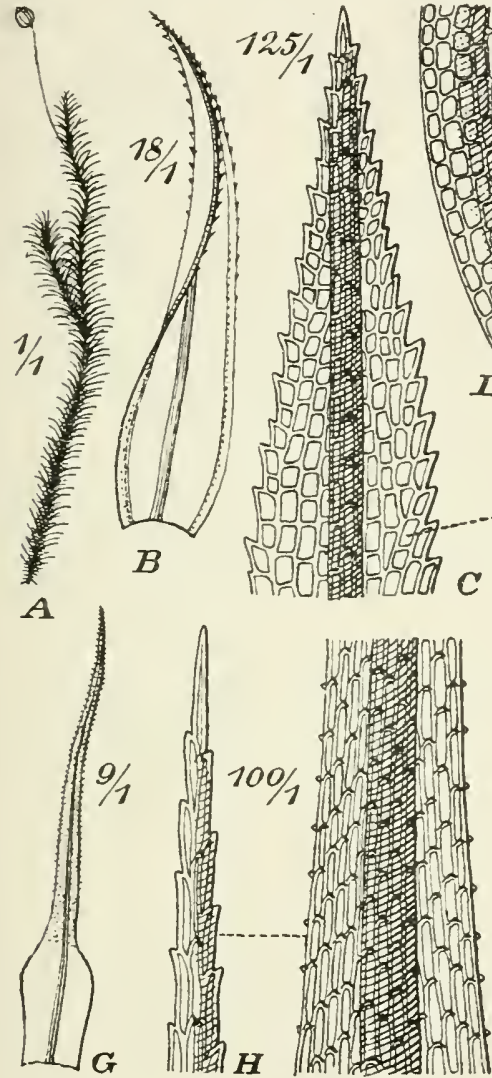
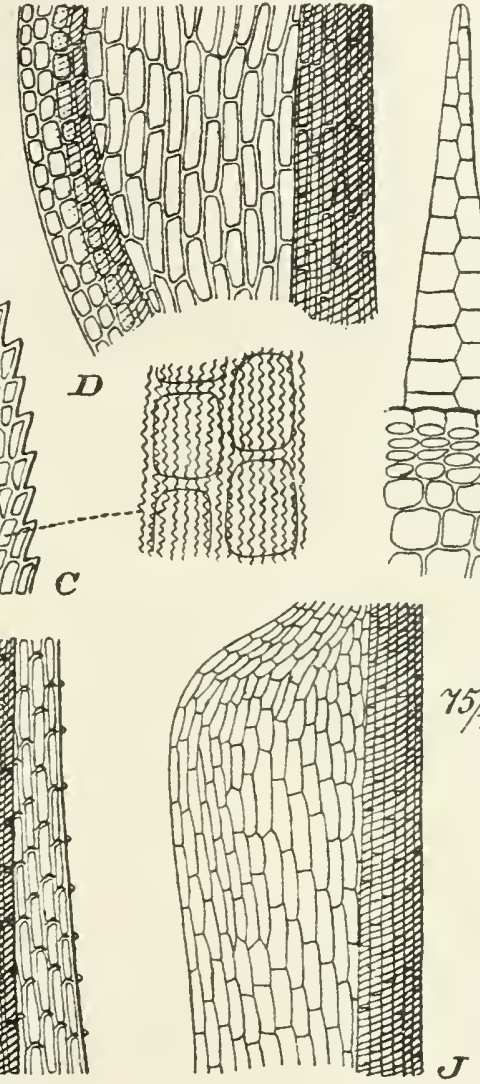
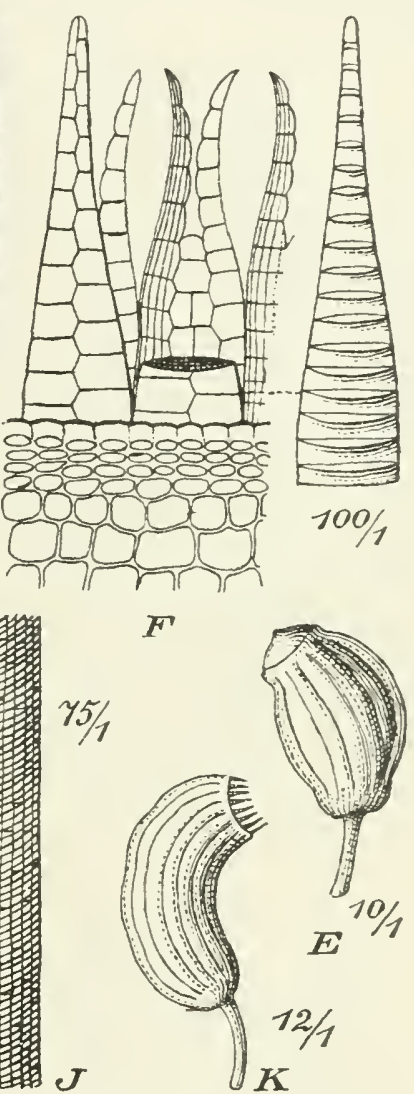

Fig. 62. A-F Plagiopus Oederi(Gunn.). A Fruchtende Pfl. (1/1); B Stengelb. (18/1); C Blattspitze (125/1); D Blattbasis (125/1); E Kapsel im trockenen Zustande (10/1); F Peristom (100/1). - G- K Bartramia ithyphylla Brid. G Stengelb. (9/1); H Blattspitze (100/1); I Blattbasis (75/1); K Entdeckelte Kapsel im trockenen Zustande (12/1).

S. $S k .-\mathrm{L}$.

N. Sm. $-F$.

Europa. Kaukasus, Himalaya, Zentral- und Nord-Asien, Japan, Nord-Ameriha.

var. condensatus (Brid.) Limpr. Laubnı. II. p. 550 (1893). [Bartramia Oederi var. condensata Brid. Sp. musc. III. p. 87 (1817).]

Schlanke Pfl. in niedrigen, sehr dichten und dicht verfilzten Rasen. Iste kïrzer. Blätter gedrängt, mehr aufrecht; Rippe austretend. Kapsel kleiner.

F. Le. Kilpisjärvi, Malla, Saana und Guonjarranka (Kot.).

N. No. Skjerstad. Tr. Ibbestad und Bardo.

Spitzbergen, Hochalpen von Europa, Zentral-Asien, Grönland. 


\title{
94. BREUTELIA
}

\author{
Schimp. Coroll. p. 85 (1856).
}

Diözisch; $\sigma^{7}$ Blüten dick scheibenförmig, mit sehr zahlreichen, fast keulenförmigen Paraphysen. Stengel mit lockerzelliger Aussenrinde, längs mit dichtem, rostrotem, fein papillösem Filze. Blätter \pm abstehend, meist mehrmals tief längsfaltig; Rippe schwach: Zellen meist gestreckt, am Rande der Blattbasis und in den Blattflügeln meist differenziert. Perichätialblätter etwas kleiner, aufrecht, glatt.

515. Breutelia chrysocoma (Dicks.) Lindb. in Öfr. Vet.-Akad. Förh. XX. p. 389 (1863). [Hypnum chrysocomum Dicks. Pl. crypt. fase. II. p. 12 (1790). Mnium arcuatum Dicks. 1. c. fasc. III. p. 2, t. 7, f. 3 (1793). - Breutelia arcuata Schimp. Coroll. p. 85 (1856).]

Kräftige Pfl. in meist lockeren und unregelmässigen, oben gelbgrünen, glänzenden Rasen. Stengel bis $15 \mathrm{~cm}$, geschlängelt-aufrecht oder niedergestreckt, längs unregelmässig beästet und mit quirlständigen, subfloralen Sprossen. Blätter aus verkehrt-eiförmigem, halbumfassendem Grunde sparrig-abstehend und verlängert lanzettlich, fein zugespitzt, etwa 3,5 mm lang, mit schmal umgebogenen, gesägten Rändern; Rippe mit der Blattspitze endend: Zellen linealisch, dickwandig, die untere Ecken hoch mamillös, am Rande des Blattgrundes in einigen Reihen locker, rektangulär, in den Blattecken quadratisch und mehreckig. Seta etwa $0,5 \mathrm{~cm}$, dick, meist schwanenhalsartig niedergebogen, rot. Kapsel eikugelig, schmutzig gelbrot. Peristomzähme gelbrot, mit hyalinen, grob papillösen Spitzen. Inneres Peristom sattgelb. Sporen 20-2S $\mu$, rund und nierenförmig, gelblicl, breitwarzig. Sporenreife im Juni. - Fig. 61 E-H.

An Felsen und auf Erde, gern an steilen und schattigen Abhängen, aber auch auf etwas feuchtem, flachem Heidelande. Sporogone sehr selten.

N. $R$. Im südlichen Teil nicht selten und seinerorts sogar massenhaft, im mittleren und nördlichen mehr sporadisch. Steigt wohi nirgends über $200 \mathrm{~m}$ empor. Nordgrenze bei $62^{\circ} 44^{\prime} \mathrm{n}$. Br.

Gross-Britannien, Faerøer, Westfalen, Pyrenäen. Schweiz, Korsika.

\section{PHILONOTIS}

\section{Philonotis Brid. Bryol. unir. II. p. 15 (1827).}

Meist diözisch, mit scheibenförmigen or Blüten, zahlreichen Antheridien und zahlreichen. keulenförmigen Paraphysen. Stengel mit lockerzelliger Aussenrinde, meist längs mit oft glattem Filze und oft quirlständiger Verzweigung. Blätter oft zweigestaltig, aufrecht-abstehend bis einseitswendig, gekielt, eilanzettlich, einschichtig, am Grunde oft faltig; Zellen schmal rektangulär, am Blattgrunde lockerer, rektangulär und 6seitig. Perichätialblätter kaum differenziert. Seta verlängert, aufrecht. Kapsel mit kurzem Halse. Sporen rundlich und nierenförmig, 20-28 $\mu$, feinwarzig. Sporenreife im Sommer.

Bei den meisten Philonotis-Arten sind die Blätter dimorph, indem die Blätter des $\sigma$ Sprosses gewöhnlich angedrückt und in ihrer Form von dem für jecle Art charakteristischen Typus verschieden, meistens kürzer und breiter sincl. Ebenso weichen die jüngeren Blätter an allen Sprossen recht stark von den älteren, voll ausgebildeten ab. Es ist daher angezeigt, sich vor allem an die tief unten am Stengel sitzenden Blätter zu halten. Form, Zellen. Ners und Rand der Blätter werden bei den meisten Arten in ungemein hohem Grade durch äussere Verhältnisse beeinflusst. Verschiedene Arten bringen also analoge Standortsformen hervor. So findet man bei den meisten Arten einerseits hygrophile Formen, teils formae adpressae, mit kurzen und breiten \pm baucligen und angedriickten Blättern, teils formae laxae, mit locker gestellten, aufrecht-abstehenden Blättern, glatten Blatträn- 
dern, dünnem Nerv und lockerem Zellgewebe fast ohne Mamillen, andererseits xerophile Formen mit lang ausgezogener Blattspitze, zurückgerollten Blatträndern und schmalen, stark mamillösen Blattzellen (formae aristatae); die letzteren bilden sich unter extremen Standortsverhältnissen zu verkrüppelten formae depauperatae aus.

\section{Übersicht der Arten.}

A. Zarte Pfl. Blätter schmal lanzettlich, lang zugespitzt, nicht faltig, mit flachen oder abwärts schmal umgebogenen, rings oder in der oberen Blatthälfte ziemlich scharf gesägten Rändern; Zellen kurz rektangulär, glatt oder in den oberen Ecken der oberen Blatthälfte mamillös vortretend ................................................. 516. Ph. capillaris.

B. Weniger schlanke bis kräftige Pfl. Blätter wenigstens am Rande mit einfachen und Doppelmamillen.

a. Innere Hüllblätter meist spitz. Blätter am Grunde schmal eiförmig, nicht faltig: Rippe schmal.

«. Blätter meist schwach sichelförmig, kurz zngespitzt, mit flachen oder am Grunde schmal umgebogenen, in der oberen Hälfte scharf gesägten Rändern; Rippe

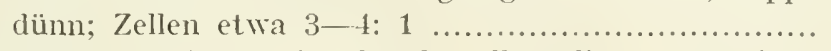

ß. Blätter aufrecht-abstehend, allmählich zugespitzt, mit längs umgerollten, durch einfache und Doppelmamillen gezähnten Rändlern; Rippe am Rücken vortretend: Zellen enger, mamillös ....................

517. Ph. caespitosa.

518. Ph. tomentella.

b. Blätter am Grunde faltig: Rippe kräftig.

$\alpha$. Innere Hüilblätter stumpf oder mit abgerundeter Spitze; Rippe undeutlich begrenzt. Blätter ziemlich kurz und breit.

I. Blätter nicht spiralig gereiht, oberwärts rasch verschmälert .....................................

1I. Blätter in spiralig geordneten Reilsen, sehr hohl, allmählich verschmälert: Rippe sehr kräftig, oben gekrümmt .........................................

p. Innere Hüllblätter lanzettlich zugespitzt: Rippe oberwärts gut begrenzt. Blätter lanzettlich, lang und schmal zugespitzt; Rippe kräftiger und Zellen weiter als bei Ph. fontana .............................. 521. Ph. calcarea.

516. Philonotis capillaris Lindb. in Hedwigia p. 40 (1867); emend. Dism. in Mém. Soc. nat. Sc. nat. et mathém. Cherb. XXXYI. p. 392 (1908). [Ph. fontana var. capillaris Lindb. Musc. scand. p. 15 (1879). - Ph. Arnellii Husn. Muse. gall. p. 268 (1890). - Ph. Ryani Philib. in Rev. bryol. 1894, p. 8. - Ph. media Bryhn in Kigl. N. Yid. Selsk. Skrift. No. 3, p. 39 (1899).]

Hüllblätter sparrig-abstehend, rasch schmal lanzettlich, lang zugespitzt; Rippe vollständig bis austretend. Sehr schlanke Pfl. in \pm dichten, grünen oder gelbgrünen Rasen. Stengel bis $2 \mathrm{~cm}$, selten höher. Blätter aufrecht-abstehend und schwach einseitswendig, schmal lanzettlich, lang zugespitzt, etwa $1 \mathrm{~mm}$ lang, nicht faltig, mit flachen oder abwärts schmal umgebogenen, rings oder in der oberen Blatthälfte ziemlich scharf gesägten Rändern; Rippe dünn, als lange, gezähnte Granne austretend; Zellen kurz rektangulär, oft in mit der Rippe parallelen Reihen. geordnet, glatt oder in den oberen Ecken der oberen Blatthälfte mamillös vortretend. Seta $1-1,5 \mathrm{~cm}$. - Fig. $63 \mathrm{~A}-\mathrm{B}$. 
An humusbedeckten, feuchten Felsen.

F. Al. Saltrik, Kuggböle (Bom.). Sund, Kyrkiundet (B.), - Ab. Lojo, Maikkala (H. Lindb.). N. Kyrkilät, Örerby (Ranch.). - Kl. Jaakkima, Puutsalo (Lindb.). Sortavala, Kirjaralahti, Kotoinäki (Lindb.).

S. Sm. Og. Boh. und $L^{*} p l$.

N. Sm. Bu. Tyristranden. Ne, Saetersdalen. Tr. Nordrejsen.

West- und Zentral-Europa selten, Nord-Amerika.

517. Philonotis caespitosa Wils. in sched. musc. brit. No. 287; Lor. Bryol. Notizb. p. 90 nom. nud. (1865): Mild, Bryol. sil. p. 241 (1869).

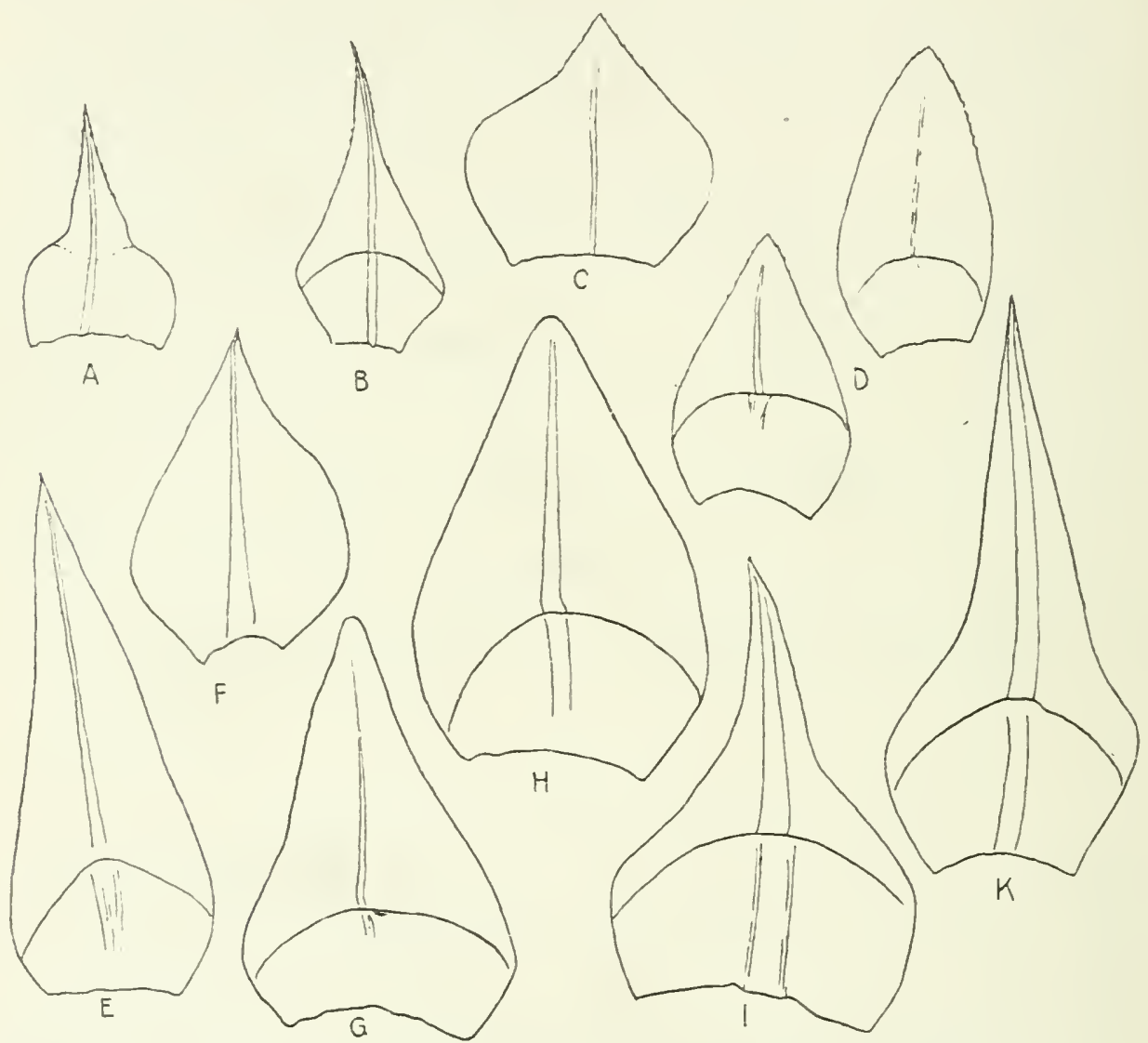

Fig. 63. Perichätialblätter. A-B. Philonotis capillaris Lindb. A äusseres (20/1); B inneres (20/1). C-D. Ph. caespitosa Wils. C äusseres (20/1); D inneres (20/1). - E Ph. tomentella Hol, inneres (20/1). F-G. Ph. fontana (L.). F äusseres (20/1); G inneres (20/1). - H Ph. seriata (Mitt.) inneres (20/1). I-K. Ph. calcarea Bryol. eur. I äusseres $(20 / 1) ; \mathrm{K}$ inneres $(20 / 1)$. (Nach $\mathrm{R}$ a $\mathrm{n}$ c $\mathrm{k}$ e $\mathrm{n}$.)

Hüllblätter aus aufrechtem, sehr verbreitertem Grunde \pm abstehend und rasch eiförmig-dreieckig. spitz, selten stumpf; Rippe dünn, meist vor der Blattspitze aufhörenı. Pfl. in lockeren bis dichten, meist gelbgrünen Rasen. Stengel bis $7 \mathrm{~cm}$, selten höher. Blälter meist schwach sichelförmig, eiförmig bis aus schmal eiförmigem Gruncle lanzettlich zugespitzt, bis 1,3 $\mathrm{mm}$ lang, nicht faltig. mit flachen oder am Grunde schmal umgebogenen, in der oberen Hälfte scharf gesägten, abwärts z. T. durch Doppelmamilen gezälınten Rändern: Rippe dünn, als kurze, gesägte Grame austretend; Zellen rektangulär, in der Blattmitte etwa 1: $3-1$, 
oben in den oberen Ecken, abwärts in den unteren Ecken mamillös vortretend. Seta etwa $5 \mathrm{~cm}$. - Fig. $63 \mathrm{C}$-D.

In feuchten Ton- und Sandausstichen, an Seeufern und anl Sumpfwiesen.

F. N. Abborfors (Arrh.). - Ik. Pşhăjärvi, Vernitsa (Lảng). - Kl. Kexholın (H. Lindb.).

S. Gtl. Dld. Upl. Vrml. und Mpd. an einzelnen Fundorten.

N. Ringerike st. fq. $J L$. Tjømø. Ne. Saetersdalen.

Europa, überall nur von wenigen Fundorten bekannt.

518. Philonotis tomentella Mol. in Lor. Moosst. p. 170 (1864); emend. Loesk. in Hedwigia XLVII, p. 203 (1906). (Philonotis anceps Bryhn in Bot. Notis, 1899, p. 253.)

Hüllblätter aus kurzer Basis aufrecht-abstelend, breit lanzettlich, lang und meist scharf zugespitzt; Rippe dünn, vollständig bis austretend. Pfl. schlanker als $P h$. fonlana, in dichten, grünen oder gelbgrünen Rasen. Stengel bis 6 und $10 \mathrm{~cm}$, selten höher. Blätter mit der oberen Hälfte aufrecht-abstehend bis zurückgebogen, nicht oder kaum faltig, oft dimorph, wechselweise bald ianzettlich, lang zugespitzt, etwa 1,2 $\mathrm{mm}$ lang, mit längs umgerollten, durch einfache und einzelne Doppelmamillen gezähnelten Rändern, schmaler, am Rücken vortretender, lang austretender Rippe und in der Blattmitte eng rektangulären (etwa 5: 1), stark mamillösen Zellen, bald kürzer, breiter und stumpf, flachrandig, mit vollständiger bis kurz austretender Rippe und weiteren, glatten oder fast glatten Zellen. Seta 1,5$2,5 \mathrm{~cm}$. - Fig. $63 \mathrm{E}$.

In Sümpfen, an Quellen, Bachufern und an trockenen bis nassen, besonders kalkhaltigen Felsen.

F. Al. Finström, Bartsgảrda und Mangelbro (Bom.). Salt vik, Liby bārg (B.). - Ab. Ảbo (Buch). Nảdendal (Elfv.). Pargas, Ersby, Văsterby (Salm.). Fiuby (Elfv.). Bromarf, Tallholmen (Sundv.). Karislojo, Karkkali (Hult, E. af H.); in der Nähe der Kirche (H. Lindb.). Lojo, Skraatila und Hiitis (Lindb.); Lylyis (E. af H.). Vichtis, Kourla (Hult). - N. Tvärminne (Teräsv.). Helsingfors, Vattenborgen (f. gemmiclada, Buch). - Ta. Hattula, Sattula, Yli-Savijärvi und Nihattula (Ranck.). - Sa. Lappee, Hanhijärvi und Kiiala (Buch). - Kl. Jaakkima, Puutsalo (Lindb.). Uukuniemi (Simm.). Sortavala, Liikolanmäki (Lindb.); Kirjavalahti (W. Nỵl.). - Tb. Korpilahti, Haukkavuori (Häyr.). Jyväskylä (Broth.). Viitasaari (B.). Pihtipudas, Heinolankylä, Ahrenberg (Roiv.); Kanalanmäki (R.); Sydänmaa, Antola (R.); Muurasjārvi, Urpila, Savijärvi (R.). - Sb. Kuopio, Vehmasmäki, Syränlampi (Link.): Neulaniemi, Vuorilampi (L.); Puijo (Kot.). Kaavi, Losomäki (Kyyhk.). Nilsiä, Loutteinen (K.). Maaninka, Pōljä, Pulaste (K.); Tuovilanlahti (Lundstr.); Arkkuvuori (Roir.). - Kb. Juuka, Juuanvaara (Kot.). 一 Ok. Kajana (Lackstr.). Sotkamo, Natula (Kyy̆h.). 一 Kp. Paadana (Sahlb.). — Ob. Rovaniemi, Alajääskö (Hult). - K. Kuusamo, Yli-Kitkajärvi, Jäāskelāinen (Broth.). Zw. Rukatunturi und Pyhäjärvi (B.). Paanajärvi, Kiekkivaara und Kuoppaoja (B.). - Kk. Kivakkatunturi (B.). - Lkem. Kuolajārvi, Sallantunturi (E. af H.); zw. Airistunturi und Jikkola (Linnan.); Enjanjoki, Huikuköngäs (E. af H.); Tuntsajoki, Kotikoski (E. af H.); Vuorijärvi, Pyhäkuru (H. Lindb.). - Le. Kilpisjărvi, Malla und Saana, in der alpinen Region (Kot.). - Li. Utsjoki, Soavjebakte und Bados, Goadniljokka (Ranck.). - Lim. Hibinä (Sahlb., Broth.). Tschun (Broth.). Umpjaur, Kuelkijaur (Kihlm.). - Lt. Kildin (Broth.). - Lmur. Rinda und Varsinsk (Broth.). - Lp. Orlov (Kihlın.); Rusiniha zw. Orlov und Ponoj (Broth.); Ponoj (Brenn.).

S. Vrml., Hrjd., Jmt. und LuL.

N. Ringerike. Dovre. No.-F.

Alpenregion von den bayerischen Alpen bis zur Tatra, Zentral-Asien, Nord-Amerika.

Philonotis borealis (Hag.) Limpr. (Norwegen, Lom, Galdho, auf von Schneewasser durchtränkter Erde bei $1,800 \mathrm{~m}$ ) ist nach L o e $\mathrm{ke}$ als das hochalpine Extrem der $P h$. tomentella zu betrachten.

519. Philonotis fontana (L.) Brid. Bryol. univ. II. p. 18 (1827). [Mnium fontanum L. Sp. pl. 2. ed. p. 1574 (1762).]

Hüllblätter aus kurzer, sehr breiter Basis \pm abstehend, eiförmig-dreieckig. die inneren stumpf bis abgerundet; Rippe sehr verbreitert, undeutlich begrenzt. vor der Blattspitze aufhörend. Pfl. in oft ausgedehnten, bläulieh- oder gelbgrünen Rasen. Stengel bis 10-12 cm, selten höher. Blätter aufrecht-abstehend bis sehwach einseitswendig, eilanzettlich, ziemlich rasch schmal und scharf zugespitzt, bis $2 \mathrm{~mm}$ lang, mit bis zur llitte und darüber, meist breit ungerollten, rings dureh 
einfache und Doppelmamillen gezähnelten Rändern; Rippe ziemlich kräftig, als kurze Granne austretend; Zellen eng rektangulär, in den unteren Ecken mamillös. Seta $3-5 \mathrm{~cm}$. - Fig. $63 \mathrm{~F}-\mathrm{G}$.

An Quellen, Gräben, Bächen, auf nassen Wiesen, in Sümpfen, Mooren und an nassen Felsen in allen Teilen von Fennoskandia bis in das Hochgebirge allgemein verbreitet.

Europa, Algier, Kanaren, Madeira, Abessinien, Kaukasus, Persien, Himalaya, Nord- und ZentralAsien, Nord-Amerika.

520. Philonotis seriata (Mitt.) Lindb. Musc. scand. p. 15 (1879); emend. Loesk. in Hedwigia XLVII. p. 210 (1906). [Bartramia seriata Mitt. Muse. Ind. or. p. 63 (1859).]

Hüllblätter aus kurzer, selır breiter Basis in eine abstehende, breit abgerundete, fast zungenförmige Spitze verschmälert; Rippe sehr verbreitert, undeutlich begrenzt, vor der Blattspitze aufhörend. Pfl. in lockeren bis dichten, grünen oder gelbgrünen bis bräunlichen, meist leicht zerfallenden Rasen. Stengel bis 6, selten bis $15 \mathrm{~cm}$. Blätter angedrückt, in spiralig geordneten Reihen, oft \pm deutlich sichelförmig, eilanzettlich, allmählich scharf zugespitzt, bis $2 \mathrm{~mm}$ lang, mit flachen oder abwärts schmal umgerollten, allermeist durch Doppelmamillen gezähnelten Rändern; Rippe sehr kräftig, nach unten verbreitert und meist rot, vollständig oder als kurze, gesägte Granne austretend, am Rücken stark mamillös: Zellen oberwärts eng rektangulär, in den unteren, oft auch in den oberen Ecken mamillös, am Grunde weiter, etwa 2: 1, kurz rektangulär und 6seitig, in der Vitte der Zellwände mamillös. Seta $3-4 \mathrm{~cm}$. - Fig. $63 \mathrm{H}$.

An quelligen Orten, an Bachrändern und in Bächen.

F. Ok. Kuhmoniemi, Honkavaara (E. af H.). Suomussalmi, Meriläissuo (Lackstr.). - Ob. Rovaniemi, Lohiniva und Alajääskö (Hult). - $k$. Pudasjärvi (Broth.). - Lkem. liuolajärvi, Tuntsajoki, Kotikoski (E. af H.). - Li. Sodankylä, Tankajoki, Kotaoja und Luirojärvi (Hult). Inari, Paloivi (Sil.); Kultala und IIuddusjärvi (Hult); Jevjejoki (KihIm.); Laanila (Räs.). Utsjoki, Rouvoivi, in der Birkenregion (K.); Ailigas, in der alpinen Region (Hult); Nurrusjokka (Ranck.); Tenojoki, Aittijoknjalbme, Valjasjokka (R.): Koadniljokka (R.). - Lim. Lujauri-urt, Sieitjäyr (Kihlm.). - Lt. Kildin (Broth.). Lmur. Garrilora (Broth.). Nisnosero (B.).

S. Ang. Nora. LuL. Sarekgebiet.

N. Ne. Saetersdalen, Neienfjeld. NB. Hardanger. R. r. K. Dorre, Lomsfjeldene, Jotunfjeldene und Ronderne. NT. Stjordalen, massenhaft längs kalten Bächen im Hochgebirge. No.-F.

Faeroer, Schottland, Frankreich. Zentral-Europa in der oberen Berg- und Alpenregion, Spanien. Italien. Baltistan, Himalaya, Frönland.

521. Philonotis, calcarea (Bryol. eur.) Schimp. Coroll. p. 86 (1856). [Bartramia calcarea Bryol. eur. fasc. 12 Mon. p. 19, t. 10 (1812).]

Hüllblätter aus kurzer, sehr breiter Basis aufrecht-abstehend bis fast horizontal, lanzettlich-zugespitzt; Rippe oberwärts gut begrenzt, kurz vor oder in der Blattspitze aufhörend bis kurz austretend. Pfl. kräftiger als Ph. fontana, in oft ausgedehnten, bläulich- oder gelbgrünen Rasen. Stengel bis $12 \mathrm{~cm}$, selten höher Blätter \pm einseitswendig bis sichelförmig, aus ejförmigem Grunde allmählich lang und schmal zugespitzt, bis $3 \mathrm{~mm}$ lang, selten länger, mit bis zur Mitte und larüber \pm deutlich umgerollten oder flachen, rings durch einfache und Doppelmamillen gezälnelten Rändern; Rippe sehr kräftig, \pm lang austretend; Zellen wie bei Ph. fontana, mit weniger vortretenden Mamillen. Seta $4-6 \mathrm{~cm}$, selten höher. - Fig. $63 \mathrm{I}-\mathrm{K}$.

In kalkhaltigen Quellen und Sümpfen.

F. Al. Eckerö, Storby (Arrh.). Geta, Dảnö (Hult). Saltrik, Färjsund, Ilullby und Germundo, Södernäs (Bom.).

S. Sk., Ol, Gtl., Ög. V'g.. När., Dlr. und Hrjd.

N. $B u$. Eder. $J L$. Tjoino. Ringerike fq. $N T$. Stjordalen. No. an mehreren Fundorten. Tr. Bardo. Nordgrenze bei $68^{\circ} 47^{\prime} \mathrm{n}$. Br.

Europa, Algier, Kaukasus, Luristan, Syrien, Himalaya, Zentral-Asien, Nord-Amerika. 
var. mollis (Vent.) Vent. in Vent. et Bott. Enum. crit. p. 24 (1884). (Philonotis mollis Vent. in Rev. bryol. 1882, p. 42.)

Rasen nicht verfilzt. Blätter locker gestellt, eilanzettlich, spitz, nicht gefurcht, gezähnt; Zellen fast glatt.

N Sm. Barkeryd.

S.. JL. Drammen. No. Skjerstad.

Tirol.

\section{Unterreiche TIMMIINEAE.}

Tracht von Polytrichum. Grundhaut des inneren Peristoms hoch, in 64 fadenförmige Wimpern aufgelöst.

\section{T I M M I A C E A E.}

Kräftige, starre, meist kalkholde Pfl. in lockeren oder dichtell, innen meist durch papillösen, braunen Rhizoidenfilz verwebten Rasen. Stengel dicht beblättert, im Querschnitt rund, mit grossem Zentralstrang, gegen die Sprossenlagen mit 2 und 3 gesonderten Zentralsträngen; Grundgewebe locker, allmählich in die ein- oder zweischichtigen Mantelzellen übergehend. Blätter Sreihig, fast gleichförmig, aus anliegendem, halbscheidigem Grunde lanzettlich bis verlängert lanzettlich, trocken oberwärts \pm röhrig-hohl, \pm weit herab grob gesägt: Rippe kräftig, mit der Blattspitze endend, mit medianen Deuterm. meist 2 Stereidenbändern und differenzierten Aussenzellen; Zellen klein. rundlich 4-6seitig, dünnwandig, auf der Blattinnenfläche mamillenartig vorgewölbt, im Scheidenteil hyalin oder gelb, verlängert rektangulär bis linealisch, gegen die Ränder enger. Autözisch oder diözisch; o Blüten der diözischen Arten knospen-scheibenförmig, mit fast keulenförmigen Paraphysen und aus der Mitte vegetativ weiter sprossend. Sporogone einzeln. Seta lang, aufrecht, rot. Kapsel regelmässig, aus kurzem Halse oval bis länglich-eiförmig, nicht oder undeutlich gestreift, trocken längsrippig; Spaltöffnungen oberflächlich, im Halsteile oft bis zur Lrmenmitte hinauf. Ring differenziert, meist sich abrollend. Peristom doppelt, ohne Vorperistom; beide Peristome von gleicher Länge. Peristomzähne breit lanzettlich, an Grunde verschmolzen, trocken von der Nitte knieförmig einwärts gebogen, in der unteren Hälfte gelb und (excl. T. anstriaca) querstreifig, in der oberen weisslich und papillös-längsstreifig. Inneres Peristom frei, gelblich; Grundhaut schwach kielfaltig, hoch, querstreifig; Fortsätze. 64, fadenförmig, knotig gegliedert, hier und da zu 2-4 anastomosierend oder an der Spitze rerschmolzen, aussen grob papillös, innen meist mit dornigen Anhängseln. Deckel fast halbkugelig, mit Spitzchen oder am Scheitel etwas vertieft, mit Warze. Haube kappenförmig. lang und sclmmal. Sporen klein, gelblich, fast glatt.

Einzige Gattung:

\section{TIMMIA}

Timmia Hedw. Descr. I. p. 83 (1787).

$\mathrm{L}^{*}$ bersicht der Arten.

A. Blätter oberwärts länger; Blattscheide gelblich, am Rücken papillös.

a. Blattrippe am Rücken oberwärts gezähnt: Zellen der Lamina etwa $8 \mu$ 522. T. comata. 
b. Blattrippe am Rücken oberwärts mamillös; Zellen der Lamina etwa $10 \mu$ 523. T. norvegica.

B. Blätter ziemlich gleichgross; Blattscheide am Rücken glatt.

a. Autözisch. Blattscheide wasserhell; Rippe am Rücken glatt 524. T. bavarica.

b. Diözisch. Blattscheide orange: Rippe am Rücken oberwärts gezähnt 525. T. austriaca.

522. Timmia comata Lindb. et Arn. in K. Sr. Vet.-Ak. Handl. Bd. 23, No 10, p. 24 (1890). [T. elegans Hag. in Nyt Mag. Naturv. Bd. 38, p. 338 (1900).]

Diözisch; ơ Blüten knospenförmig, aus der Mitte vegetativ weiter sprossend. Antheridienschlauch bis 3 mal länger als der Stiel. Pfl. in die Rasen anderer Moose eingesprengt, herdenweise oder in lockeren, grünen oder gelbgrünen Rasen. Stengel aufrecht, $1-3$, seltener $6-8 \mathrm{~cm}$, meist einfach. Blätter abstehend, trocken \pm bogig eingekrümmt, aus kurzem Scheidenteil allnı̈hlich schmal lanzettlich, bis $3.5 \mathrm{~mm}$ lang und $0,5 \mathrm{~mm}$ breit, von der \pm stumpflichen Spitze bis zur Blattmitte grob gesägt, abwärts kleiner gesägt bis glatt; Rippe am Rücken gegen die Spitze \pm deutlich gezähnt; Zellen der Lamina im Mittel $8 \mu$; Zellen des Scheidenteils gelb bis rotbraun, papillös. Schopfblätter an der Insertion leicht abbrechend, rasch viel länger und schmäler, linealisch, zugespitzt, olne Scheidenteil, bis 5,5 $\mathrm{mm}$ lang und $0.2 \mathrm{~mm}$ breit: Zellen an der Insertion äusserst zartwandig, hyalin. früh zerstört. $¥ \mathrm{Pfl}$. unbekannt.

In Spalten und Höhlungen beschatteter Dolomitfelsen und kalkhaltiger Schiefer.

F. $k$. Aventojoki, Ristikallio (E. af H.); Kuusinkijoki (E. af H.); Kuusamo, Oulankajoki (Broth.); Kiutaköngäs (E. af H.); Sovajoki. Kulmakkapuro (E. af H.); Paanajärvi (Broth.); Uäntyjoki (E. af H.); Savinajoki (Roiv.), - Lkem. Kuolajärvi, Kutsanjoki (E. af H.). - Lv. Tschapoma (Broth.).

S. $T L$, an wenigen Fundorten.

N. K., ST. und $F$, an wenigen. Yo. an mehreren Fundorten.

Sibirien.

523. Timmia norvegica Zett. in Öfr. Vet.-Ak. Förh. XIX. p. 364(1862).

Diözisch; $\sigma$ Blüten knospen-scheibenförmig, aus der Mitte vegetativ weiter sprossend; Antheridienstie] fast so lang wie der Schlauch. Pfl. in lockeren, bis $6 \mathrm{~cm}$ hohen, selten hölteren, gelblichgrünen, unten braunen Rasen. Stengel aufrecht, meist einfach. Blätter aufrecht-abstehend, trocken \pm eingekrümmt, gedreht und fast kraus, aus kurzem Scheidenteil allmählich lanzettlich, stumpflich zugespitzt, 6-10 mm lang und bis $1,25 \mathrm{~mm}$ breit, bis gegen die Mitte kurz gesägt, weiter herab undeutlich gesägt bis glatt; Rippe am Rücken oberwärts mamillös; Zellen der Lamina etwa $10 \mu$; Zellen des Scheidenteils gelblichbraun, papillös. Schopfblätter bis $10 \mathrm{~mm}$ lang und schmäler als die unteren, leicht abfallend; Zellen an der Insertion sehr zartwandig, hyalin, früh zerstört. Sporogone sehr selten und nur aus den österreichischen Alpen und Sibirien bekannt.

An erdbedeckten Schiefer- und Kalkfelsen.

S. Ir rjd., Jmt., $L y L$. und $P L$. an einzelnen oder wenigen, in $L u L$. und $T L$. an mehreren Fundorten.

N. SB.-ST., No.-F. Im südlichen Halbteile in den oberen Teilen der subalpinen Region und lis in die Weidenregion hinaufsteigend, in $N o,-F$. bis zum Meeresniveau hinabsteigend.

Spitzbergen, Schottland, Irland, Pyrenäen, Alpenzug bis Tatra, Kaukasus, arkt. Sibirien und NordAmerika.

524. Timmia bavarica Hessl. Comment. de Timmia p. 19, f. 3 (1822).

Autözisch; or Bliiten kurz gestielte, schlanke knospen neben der 우 Blüten. Pfl. in lockeren, bis $8 \mathrm{~cm}$ hohen, lebhaft grünen, innen gebräunten Rasen. Stengel aufrecht, gabelig oder büschelig verzweigt. Bläter fast gleichlang, abstehend lis zurïekgekrümmt, trocken bogig eingekrünmt bis kraus, meist etwa $8 \mathrm{~mm}$ lang und $1 \mathrm{~mm}$ breit, aus deutlichem Seheidenteil rasch verlängert lanzettlich, von dler stumpflichen Spitze bis zur Blattmitte grob gesägt, weiter herab undeutlich gesägt bis glatt; Rippe am Rücken glatt; Zellen der Lamina $7-8$ „1; Zellen 
des Scheidenteils hyalin, glatt. Seta $2-5 \mathrm{~cm}$. Kapsel horizontal und nickend, meist schwach gekrümmt, etwa $1 \mathrm{~mm}$ lang und 1,5 mm dick, grünlichbraun, im Alter braun; Zellen des Exotheciums unregelmässig, parenchymatisch, mit nicht welligen Rändern. Sporenreife im Juni und Juli.

Auf erdbedeckten Schiefer- und Kalkfelsen und in deren Schluchten und Höhlungen.

S. Ög., Tg., Mpd., Jmt., Ing., PL. und $L u L$. an einzelnen oder weniggen, Hrjd. und TL. an mehreren Fundorten.

N. A., Bu., SB. $-\mathrm{ST}$., No.-F., an reichlichsten in den oberen Teilen des Waldgebieles. Nordgrenze bei $70^{\circ} 25^{\prime} \mathrm{n}$. Br.

Europa, Algier, Kaukasus, Kazchmir. Zentral-Asien, Nord-Amerika.
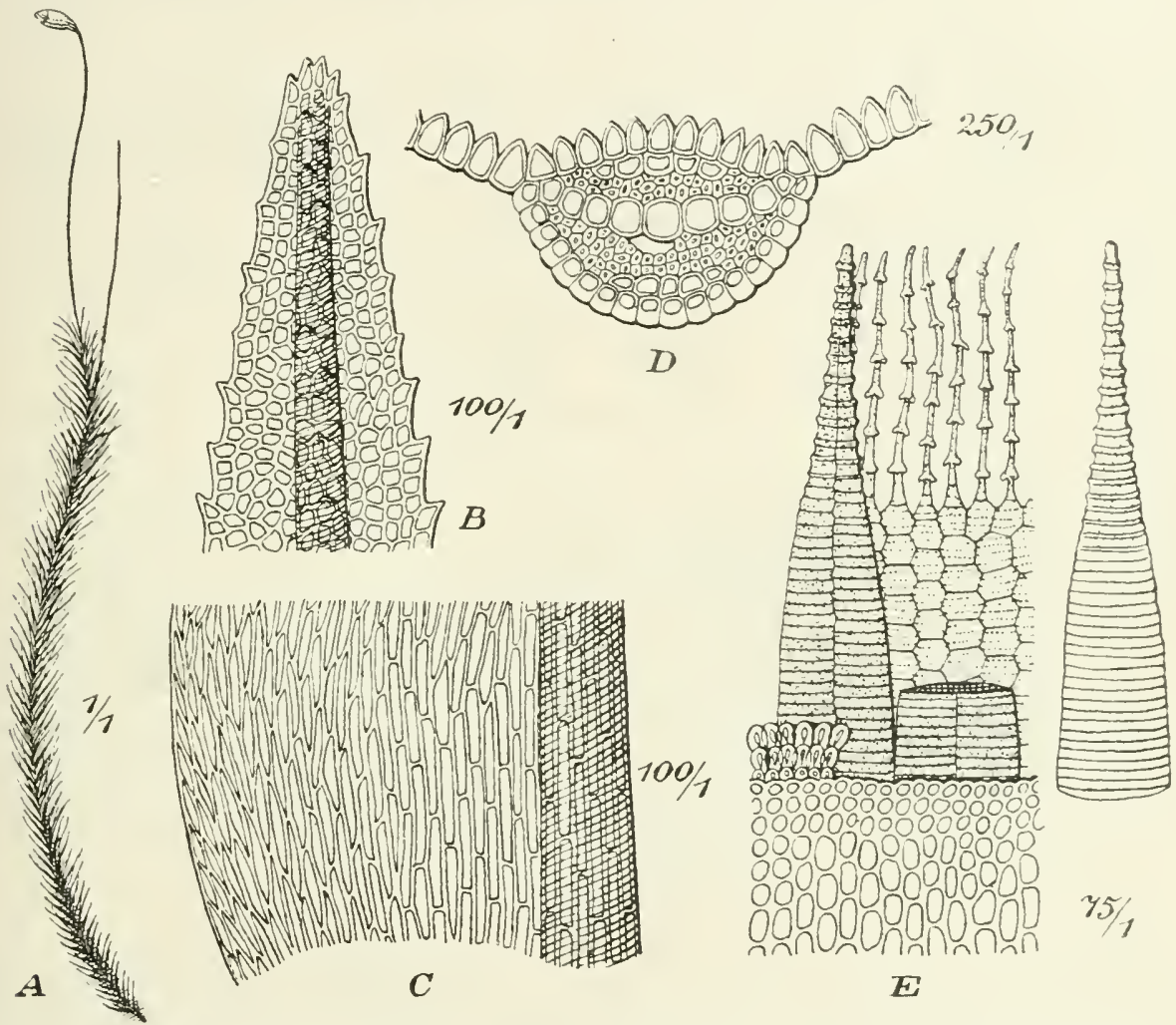

$\boldsymbol{E}$

Fig. 64. Timmia austriaca. Hedw. A Fruchtende Pfl. (1/1); B Blattspitze (100/1); C Blattbasis (100/1); D Blattquerschnitt (250/1): E Peristom (75/1).

525. Timmia austriaca Hedw. Sp. musc. p. 176, t. 42, f. $1-7$ (1801).

Diözisch; ơ Blüten knospen-scheibenförmig, aus der Nlitte vegetativ weiter sprossend; Antheridienschlauch 6-10 mal länger als der Stiel. Pfl. in ziemliclı dichten, bis 10 und $20 \mathrm{~cm}$ hohen, gelblichgrünen. innen rötlichbraunen Rasen. Stengel aufrecht oder aufsteigend, einfach odler gabelig verzweigt. Blätter fast gleichlang, aufrecht-abstehend, trocken fast anliegend oder bogig eingekrümmt und etwas gedreht, etwa $6-7 \mathrm{~mm}$ lang und etwa $1 \mathrm{~mm}$ breit, aus deutlichem Scheidenteil rasch verlängert lanzettlich, von der stumpflichen Spitze bis gegen die Mitte grobgesägt, weiter herab kleiner gesägt bis glatt; Rippe am Rücken gegen die Spitze gesägt; Zellen đer Lamina im Mittel $10 "$; Zellen des Scheidenteils orange. 
glatt. Seta bis $6 \mathrm{~cm}$. Kapsel horizontal, etwa 3,5 mm lang und 1,5 $\mathrm{mm}$ dick, rotbraun; Zellen des Exotheciums unregelmässig, parenchymatisch, mit stark welligen Rändern. Sporenreife im Juli.

Auf erdbedeckten Felsen und in deren Schluchten, auf trockner, sandiger Erde, oft in Höhlungen unter überhängenden Grasdecken und Baumwurzein, zuweilen auch auf Torfmooren.

F. Ab. Uskela, Linnamăki (Lindb.). Karislojo, Karkali (E. af H. und Sundr.). Lojo, Storōn, Pietilä (Lindb.); Seppälã (H. Lindb.). - Ta. Padasjoki, Virmaila (Norrl. und Sil.). - Kl. Kurkijokí (Jusl.). Valamo (W. Nyl.). Sortavala, Rauskunvuori (Linnan.); Kirjavalahti (Lindb.); Läskelä (Pes.); Pietrokallio (Oesch). Suistamo, Leppäsyrjä. Nykymäki (Pes.). Ruskeala (W. Nyl.). Pälkjärvi, Kuhilasvaara (H. Backm.). - Tb. Jyvāskylä, Haapakoski, Kanavuori (E. af H.). Laukaa, Hyyppäänvuori (E. af H.). - $\mathbf{S} b$. Kuopio, an mehreren Fundorten (Link., Kot.). Kaavi, Huosiaisniemi (Kot.). — Kb. Tohmajărvi, Kemie, Simosenvaara (Oesch); Akkala (Kot.). - Kon. Jalguba (Kullh.). - Om. Alajärvi, Vesterbacka, Huøsianmaankallio (Backm.). - Ob. Rovaniemi, Ounasjoki, an mehreren Fundorten (Hult). - K. Kuusamo, Arenlojoki (E. af H.); Oulankajoki, an vielen Fundorten (Broth., E. af H.); Kitkajoki (Sil.); Paanajärvi (F. Nyl.). - Lkem. Kolari, Naalaoja (Hult). Kuolajärvi, Kutsanjoki (E. af H.); Kuolajoki, zw. Ranta- und Nenäkevaara (E. af H.): Pỵhäkuru (E. af H.). - Le. Kilpisjärvi, Malla und Saana (Kot.). - Lim. Porjaguba (Sel.). Hibinä (Broth.). - Lt. Pummanki (Broth.). - Lp. sapadnij navolok (Broth.). Ponoj (B.). Rusiniha zw. Orlor und Ponoj (B.).

S. In allen Provinzen mit Ausnahme von sk., Bl.. Ol., Hll. und Boh., AL. und Nb. Region.

N. In allen Ämtern mit Ausnahme von sm., JL., L.M. und st., am reichlichsten in der subalpinen

spitzbergen, Europa, Himalaṛa, Yunnan, Sibirien, Nord-Amerika.

\section{Reihe ISOBRYALES.}

Peristom doppelt, oft scheinbar einfach oder fehlend, bisweilen mit Vorperistom. Dorsalschicht der Peristomzähne dicker: Ventralschicht meist mit Querleisten. Inneres Peristom unvollständig.

\section{Unterreihe ORTHOTRICHINEAE.}

Fels- und Baummoose. Blätter symmetrisch; Zellen rundlich, oft papillös. sporogone meist acrocarp. Haube meist gross, glocken-mützenförmig, oft behaart.

\section{P T Y C H O M I T I A C E A E.}

Ausdauernde, meist polsterförmig wachsende Felsmoose. Stengel aufrecht, mit Zentralstrang und lockerem, getüpfeltem Grundgewebe, dicht beblättert, am Grunde mit Rhizoiden, meist einfach. Blätter mehrreihig, verlängert, schmal, - lang zugespitzt, trocken geschlängelt, kraus oder schneckenlinig eingerollt; Rippe kräftig, mit medianen Deutern, ohne Begleiter und mit 2 Stereidenbändern; Zellen klein, rundlich-quadratisch bis kurz rektangulär, dickwandig glatt, am Blattgrunde linealisch oder quadratisch bis rechteckig. Autözisch: $\sigma^{\top}$ Blüten knospenförmig, kurz gestielt, mit kurzen Paraphysen. Kapsel emporgehoben, aufrecht, regelmässig, glatt. Deckel gerade geschnäbelt. Haube mützenförmig5 lappig oder glockig-mützenförmig, nackt.

\section{íbersicht der Gat tungen.}

A. Perichätialhlätter nicht differenziert 97. Plychomitrium.

B. Innere Perichätialblätter hochscheidlig zusammengewickelt. 98. Glyphomitrium. 


\section{PTYCHOMITRIUM}

(Bruch) Fürnr. in Flora 1829, II. Erg. p. 19.

Perichätialblätter nicht differenziert. Ring breit, sich abrollend. Peristonzähne voneinander frei, in zwei lange, fadenförmige, dicht papillöse Schenkel gespalten. Haube glockig-mützenförmig, bis zur Urnenmitte reichenrl, längsfaltig, anı Grunde zerschlitzt. Sporen klein.

526. Ptychomitrium polyphyllum (Dicks.) Fürnr. 1. c. [Bryum polyphyllum Dicks. Pl. crypt. fasc. III. p. 7 (1793). - Brachysteleum polyphyllum Hornselı. in Linnaea XV. p. 217 (1848). - Glyphomitrium polyphyllum Mlitt.. Lindb. Muse. scand. p. 29 (1879).]
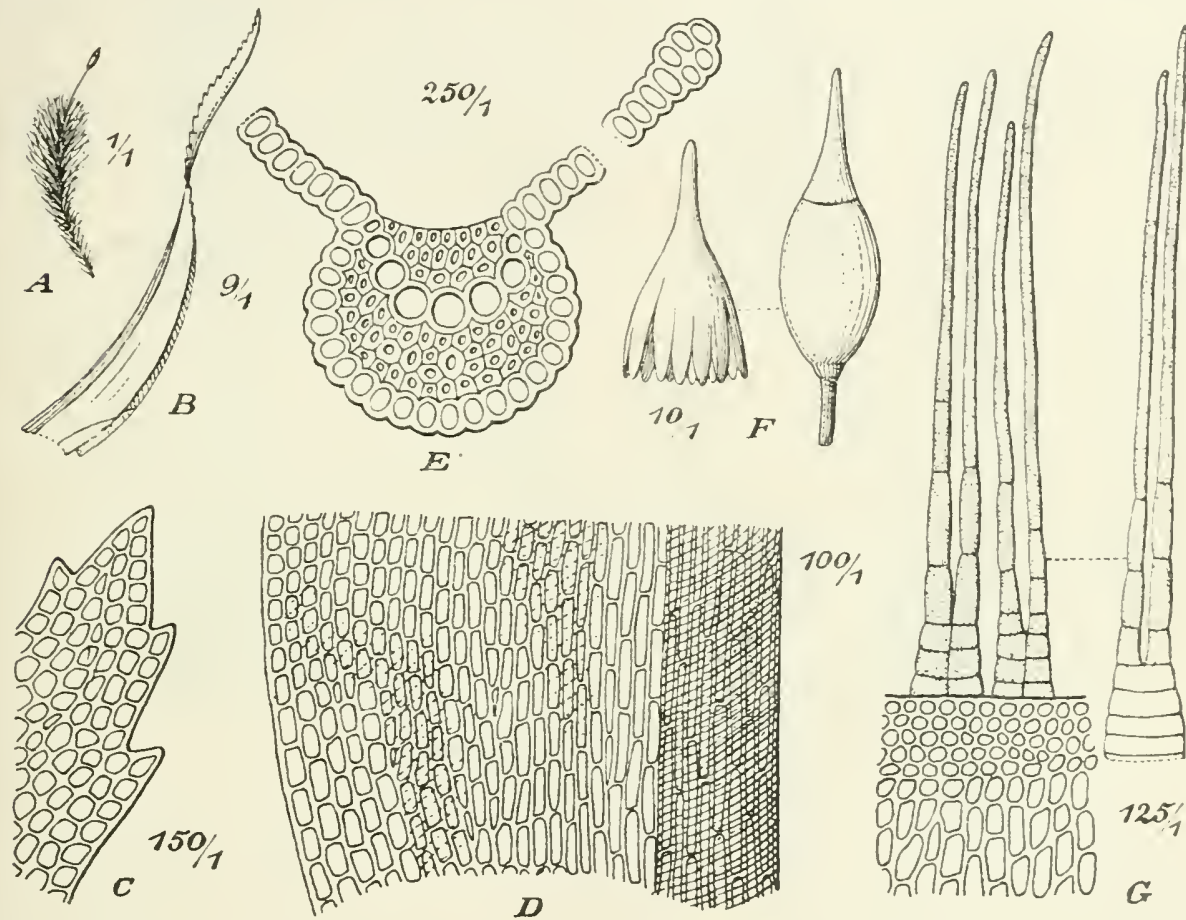

Fig. 65. Ptychomitrium polyphyllum (Dicks.). A Fruchtende Pfl. (1/1); B Stammb. (9/1); C Zellen der Blattspitze (150/I); D Blattbasis (I00/1); E Querschnitt der Blattrippe (250/t); F Kapsel und Haube (10/1): G Peristomzäne (125/1).

Kräftige Pfl. in ausgedehnten, dunkel- oder gelbgrünen, innen schwärzlichen Polstern. Stengel aufrecht oder aufsteigend, bis $5 \mathrm{~cm}$, aus länglich-eiförmiger. längsfaltiger Basis allmählich lineallanzettlich, bis $5 \mathrm{~mm}$ lang, mit unten zurückgeschlagenen, oben eingebogenen und grob gezähnten Rändern; Zellen am Blattgrunde eng linealisch, in den Blattecken mehrschichtig, rechteckig und 6seitig. gebräunt. Oft mehrere Sporogone aus einem Perichätium. Seta $5-15 \mathrm{~mm}$, unten rötlich, aufwärts gelb. Kapsel länglich-elliptisch. Sporen $9-12 \mu$, bräunlichgelb, glatt. Sporenreife im April. — Fig. 65.

S. Sk. Skäralid.

N. An trockenen, kalkfreien Felsen und Steinmauern der Küste von Lindesnes bis stat (620 ?' n. Br.) ziemlich allgemein verbreilet.

Färoer, Gross-Britannien, Dänemark, West- und süd-Deutschland, Schweiz, Tirol, Nord-Italien, Frankreich, Nord-Spanien, Madeira, Kanaren, Azoren. 


\section{GLYPHOMITRIUM}

Brid. Mant. p. $30(1819)$.

Innere Perichätialblätter hochscheidig zusammengewickelt, rasch in eine kurze Spitze verschmälert. Ring nicht differenziert. Peristomzähne breit lanzettlich, flach, mit Längslinie, paarweise genähert. Haube sehr gross, bis über die Kapsel herabgezogen, längsfaltig, am Grunde zerschlitzt. Sporen gross.

527. Glyphomitrium Daviesii (Dicks.) Bricl. 1. c. p. 31. [Bryum Daviesii Dicks. Pl. crypt. fasc. III. p. 3 (1793). - Aulacomitrium Daviesii Hag. in D.' K. N. Vid. Selsk. Skrift. 1907, No. 13, p. 96 (1908).]

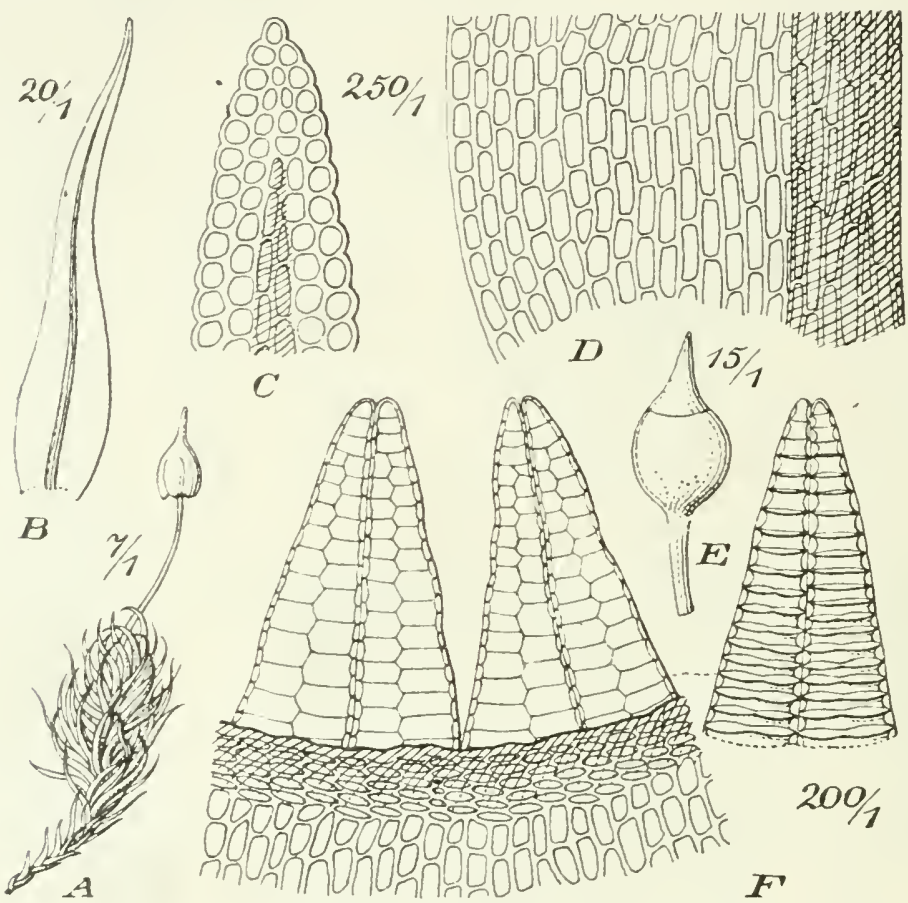

Fig. 66. Glyphomitrium Lar iesii(Dicks.) Brid. A Fruchtende Pfl, im trockenen Zustande (7/1); B Stammb. (20/1): C Zellen der Blattspitze (250/1); D Blattbasis (250/1); E Kap:el (15/1); F Peristomzähne (200/1).

Ziemlich schlanke Pfl. in kleinen, dichten, dunkel- oder bräunlichgrünen, polsterförmigen Rasen. Stengel aufrecht, bis $1,5 \mathrm{~cm}$. Blätter aus elliptischer Basis lineallanzettlich, zugespitzt, bis $1,7 \mathrm{~mm}$ lang, mit unversehrten, am Grunde schmal umgebogenen Rändern; Zellen am Blattgrunde verlängert rektangulär, gegen die Ränder kürzer und breiter. Seta $3-5 \mathrm{~mm}$, rötlichgelb. Kapsel fast kugelig. Peristomzähne ungeteilt anfangs zu 8 Paarzähnen verbunden, gelblichbis purpurrot, gesäumt. Sporen $30-40 \mu$, bräunlichgelb, warzig. - Fig. 66.

N. Auf kalkfreien Felsen und Blöcken an der Küste zwischen Ekersund und Aalesund $\left(62^{\circ} 31^{\prime}\right.$ n. Br.) selten.

Gross-Britannien, Färøer.

\section{O R T H O T R I C H A C E A E.}

Polsterförmig wachsende Rinden- und Felsmoose. Stengel meist aufrecht, ohne Zentralstrang, mit lockerem, getüpfeltem Grundgewebe und dickwandigen, engeren Mantelzellen, meist nur am Grunde mit Rhizo den, dicht beblättert, 
meist gabelteilig und büschelästig. Blätter mehrreihig, sehr hygroskopisch, beim Anfeuchten sich zurückkrümmend, dann \pm abstehend bis sparrig, meist gekielt, meist lanzettlich, meist zugespitzt, ganzrandig; Rippe aus gleichartigen Zellen gebildet, mit 2-4 basalen Deutern, vollständig oder vor der Blattspitze endend; Zellen oberwärts rundlich-quadratisch, dickwandig, beiderseits \pm papillös, am Grunde glatt, \pm verlängert und gegen die Ränder meist kürzer. Blüten knospenförmig, ohne oder mit kurzen Paraphysen; die $f$ gipfelständig. Perichätialblätter wenig oder kaum differenziert. Seta gerade, kurz bis \pm verlängert, glatt. Kapsel aufrecht, regelmässig, meist birnförmig, meist sstreifig und trocken und entleert gefurcht; Zellen der Kapselstreifen grösser, quadratisch und rektangulär, mit stark verdickten Längswänden, Zellen der Zwischenfelder schmäler, rektangulär bis verlängert, nur mässig verdickt; Spaltöffnungen oberflächlich oder eingesenkt. Ring bleibend. Peristom einfach oder doppelt, zuweilen mit Vorperistom, selten fehlend. Deckel gerade oder schief geschnäbelt. Haube entweder kappenförmig, nackt und ungefaltet oder kegel-glockenförmig, längsfaltig und oft behaart.

\section{Übersicht der Gat $\mathrm{tung}$ e $\mathrm{n}$.}

A. Haube kappenförmig, klein und flüchtig

99. Zygodon.

B. Haube kegel-glockenförmig, gross.

a. Innere Zellen des Blattgrundes von den Randzellen sehr verschieden, stark verdickt ...................... 100. C'lota.

b. Innere Zellen des Blattgrundes von den Randzellen nicht verschieden, wenig verdickt.

«. Blätter lanzettlich, zugespitzt, gekielt, mit umgebogenen bis umgerollten Rändern ................... 101. Orthotrichum.

$\beta$. Blätter eiförmig oder eilänglich, mit abgerundeter Spitze, löffelförmig-hohl, mit aufrechten bis eingebogeneı Rändern

102. Stroemia.

\section{ZYGODONTOIDEAE.}

Haube kappenförmig, nicht faltig, nackt, klein und flüchtig.

\section{ZYGODON}

Hook. et Tayl. Muscol. brit. p. 70, t. 3 (1818).

Blätter trocken anliegend bis fast kraus, feucht \pm abstehend, gekielt, etwas herablaufend, flachrandig; Rippe meist vor der Blattspitze aufhörend; Zellen fast im ganzen Blatte rundlich, \pm verdickt und klein. Kapsel emporgehohen, länglich, engmündig, trocken meist deutlich gestreift; Hals \pm lang, mit zahlreichen, oberflächlichen Spaltöffnungen. Peristom bei unseren Arten doppelt oder fehlend. Deckel schief geschnäbelt. Sporen klein.

$$
\text { Übersicht der Arten. }
$$

A. Brutkörper zur Reife braun ............................. 528. Z. viridissintus.

B. Brutkörper silberhell ................................... 529. Z. conoideus.

528. Zygodon viridissimus (Dicks.) Brown in Trans. Linn. Soc. XII. P. I. p. 575 (1819). [Bryum viridissimum Dicks. Pl. crypt fasc. IV. p. 9, t. 10, f. 18 (1801).] 
Diözisch. Schlanke Pfl. in freudig- bis gelblichgrünen, innen durch papillösen Rhizoidenfilz verwebten Räschen. Stengel bis $1 \mathrm{~cm}$, selten höher. Blätter feucht sparrig-zurückgebogen, länglich-lanzettlich, zugespitzt, oft mit hyaliner Endzelle, etwa 1,5 mm lang, ganzrandig: Rippe meist vor der Blattspitze aufhörend; Zellen entweder überall rundlich und dicht papillös oder am Grunde rektangulär bis quadratisch und glatt. Scta $3-7 \mathrm{~mm}$, dünn und gelb. Kapsel mit kurzem Halse. Peristom felnlend. - Vegetative Vermehrung durch blattachselständige, auf verzweigten Trägern büschelig gehäufte, zur Reife braune, meist 3-5zzellige, Brutkörper, deren grösste Breite an oder unterhalb der Mitte ist.

An Laubbäumen, seltener auf Fclsen. Selten fruchtend.

S. Sk. an vielen Fundorten, Bl., sm., Hil.. Boh. und Ig.

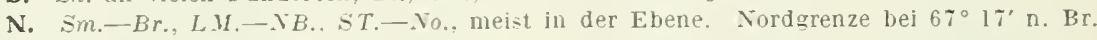

Europa, Algier, Kaukasus.

var. rupestris (Lindb.) Hartm. Sk. Fl. Moss. 9. ed. p. 52 (186-4). [Zygodon rupestris Lindb. Mlser. 1861; Mild. Bryol. sil. p. 16+(1869).]

Räschen dunkel- bis bräunlichgrün. Blätter mit längerer Stachelspitze.

Auf trockenen Felsen verschiedener Art.

F. Al. Jomala, Ingby̆bärg (Bom.). Finström und Geta an einigen Fundorten (B.). Lemland, Norby (B.). Sund an einigen und Saltvik an mehreren Fundorten (B.). Vardô, Vargata (B.). - Ab. Nadendal (Elfv.). Ábo. Kảludd (Bom.). Pargas. Björkō (Elfr.). Kimito. Strömma, sjölaks und Hiitis (Ols.). Finby, Tesrärr (Sundr.). Lojo, storö, Askola (Lindb.): Hiitis (L.). - N. Tenala, Gretarby (Hāyr.). Helsingfors. Stansrik (H. Lindb.). Borgà, Haksalö (Broth.). Hogland (Lindb.). Pצ̣hājärvi, Högfors, Āmmāmäki (Broth.). - Ta. Asikkala, Kopso. Porttikallio (Norrl.); Vesivehmas (N.). Padasjoki. Virmaila (N.): Arakoski (Vain.). - Tb. Viitasaari, Etelävuori (Broth.). - Ok. Kajana, Pirunpesä (Lackstr.). - K. Kuusamo, Kithajohi, Jỵrävã und Pääsķskallio (Broth.).

S. Sm.. Ög.. Boh., Srml., När., Dld., Gstr., Hlsl. und Ảng.

N. JL., Ne., L.M., SB. und NB.

Europa.

var. dentatus (Breidl. in litt. 1883 als Art) Limpr. Laubm. 1I. p. 12 (1890).

Räschen locker, grün oder bräunlich- bis schwärzlichgrün. Blätter kürzer und breiter, weniger scharf gespitzt, an der Spitze mit einigen groben Zähnen; Rippe vor der Blattspitze aufhörend; Zellen wenig verdickt. Sporogone unbekannt.

N. Br. Tinn. Sradde, an Ulmen, $200 \mathrm{~m}$.

Alpengebiet.

var. Stirtoni (Schimp.) Hag. in D. K. N. Vid. Selsk. Skrift. 1907, No. 13, p. 15 (1908). [Zygodon Stirtoni Schimp. Mser.: Stirton in Trans. Bot. Soc. Edinb. IX. p. 75 (1871). - Z. aristatus Lindb. in Act. Soc. Sc. Fenn. X. p. 542 (1875).]

Rippe kräftiger; als dicker Endstachel austretend. Brutkörper schmal ellipsoidisch, meist 6-7stöckig.

Auf trockenen Felsen.

F. At. Sund, Gesterby tjenan (Bom.). Saltrik, Krarnbo. Mörkdalsberg (B.).

S. Sk., Skäralid Gtl.

N. Sm., A. und $S B$, an wenigen Fundorten.

Gross-Britannien, Bretagne. Normandie.

529. Zygodon conoideus (Dicks.) Hook. et Tayl. Mluscol. brit. p. 71, t. 24 excl. syn. (1818). [Bryum conoideum Dicks. Pl. crypt. fasc. IV. p. 9, t. 11, f. 2 (1801).]

Diözisch. Kleiner als die vorige Art, mit glattem Rhizoidenfilz. Stengel nur wenige mm. Blätter feucht abstehend, kürzer. plötzlich zugespitzt: Zellen etwas grösser, stärker verdickt und mehr durchsichtig. Kapselhals fast so lang wie die Urne. Peristom doppelt; Peristomzähne anfangs paarweise verbunden, rötlichgelb, streifig; Fortsätze zu 8, fadenförmig, flüchtig. Brutkörper silberhell, 5-7 stöckig, am breitesten in oder oberhalb der Blattmitte.

An Baumstämmen.

F. Al. Sund, Bergö, gemischt mit Z. viridissimus var. rupestris (Bom. nach il a $1 \mathrm{t}$ a).

N. An der Küitte ron Ryfylke bis Xurdfjord $\left(61^{\circ} 37^{\prime} \mathrm{n}\right.$. Br. $)$, nur einmal mit sporogonen gefunden. 


\section{ORTHOTRICHOIDEAE.}

Haube glockenförnig ocler kegel-glockenförmig, oft die ganze Kapsel einhüllend, längsfaltig und an Grunde zerschlitzt, nackt oder + behaart.

\section{ULOTA}

Mohr Mser.; Brid. Mant. p. 112 (1819).

Autözisch (excl. L. phyllantha). Blätter trocken meist kraus, feucht abstehend bis sparrig, gekielt, meist aus breiterer, hohler Basis lanzettlich oder lineallanzettlich, überall einschichtig; Zellen stark verdickt, oberwärts mit kleinem, rundlichem Lumen und \pm dicht papillös bis glatt, am Grunde des Blattes beiderseits der Rippe eng linealisch, gelblich bis gelbrot, an den Rändern durch eine bis mehrere Reihen rektangulärer bis quadratischer, zartwandiger Zellen wasserhell gesäumt. Seta aufwärts dicker und in den Hals übergehend. Kapsel emporgehoben, (excl. $L$. Ludwigii) mit 8, trocken als Rippen vortretenden Längsstreifen: Spaltöffnungen oberflächlich, nur im Halsteile. Peristom meist doppelt und wie bei Orthotrichum gebaut: Peristomzähne trocken zurückgeschlagen. Haube meist überall mit langen. gelben, mehrzellreihigen Haaren dicht besetzt. Sporen mittelgross, meist braun und warzig.

\section{CHersicht der Arten.}

A. Steriles Küistemmoos mit blattendständigen Brulkörpern. 538. L'. phyllantha. B. Sporogone stets vorhanden. Brutkörper fehlend.

a. Blätter trocken steif und starr 530. L'. americana.

b. Blätter trocken I kraus.

«. Entdeckelte Kapsel trocken nur an der sehr verengten Iü̈ndung mit kurzen Streifen .............. 532. C'. Ludwigii.

$\beta$. Entdeckelte Kapsel trocken mit längs rortretenden Streifen.

I. Inneres Peristom fehlend 533. L'. Drummondii.

II. Peristom doppelt.

1. Felsmoos. Blätter mit dicht gestellten, zylindrischen Papillen................................ 531. $L$. curvifolia.

2. Rindenmoose. Blätter mit niedrigen Papillen bis glatt.

* Fortsätze 16, abwechselnd länger und kürzer. 536. $L$. intermedia.

** Fortsätze \$.

$\uparrow$ Sporen in Grösse und Form sehr ungleich, bis $35 \mu$. Kapsel trocken und entdeckelt schmal spindelförmig, gegen die Mündung allmählich verengt ......................... $534 . \tau$. Bruchii.

+ ti Sporen fast gleichgross und kleiner. Kapsel trocken und entdeckelt unter der erweiterten Mündung verengt.

$\times$ Bedeckelte Kapsel länglich-oval; Urne 1,5-2 mm lang. Sporen $16-18 \mu \ldots 57 . \quad$ L. ulophylla.

$\times \times$ Bedeckelte Kapsel oval: Lrme bis $1 \mathrm{~mm}$ lang. Sporen 20-28 " 535. U. crispula.

530. Ulota americana (Palis.) Mitt. in Journ. Linn. Soc. Bot. 1864, p. 26. [Orthotrichum americanum Palis. Prodr. p. 80 (1805). - O. Hutchinsiae Sm. Engl. But. t. 2523 (1813). - Llota Hutchinsiae Sm. Engl. Bot. 1. 2.223 (1813). — L'lota 


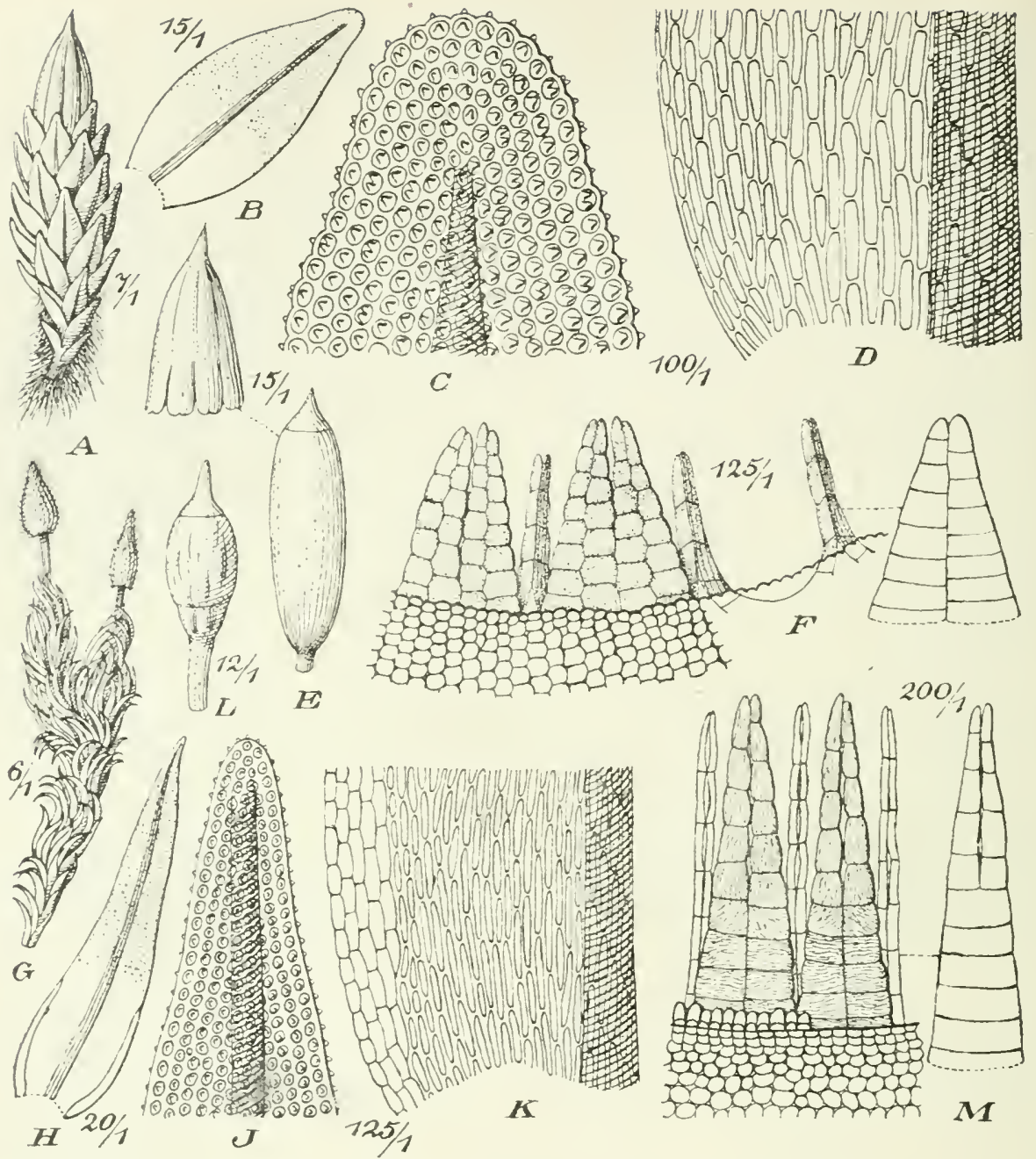

Fig. 66. A-F. Slroemia oblusifolia (Schrad.) Hag. A Fruchtende Pfl. (7/1); B Stammb. (15/1); C Blattspitze (100/1); D Blattbasis (100/1); E Kapsel mit Haube (15/1); F Peristom ( / ). - G-M. Ulota curcifolia (Wahlenb.) Brid. (F Fruchtende Pfl. im trockenen Zustande (6/1); H Stammb. (20/1); I Blattspitze (125/1): $\mathrm{K}$ Blattbasis (125/1); L Kapsel im trockenen Zustande (12/1); If Peristom (200/1).

Hutchinsiae Hanm. Mon. Orthotr. suee. p. 27 (1852). — Weisia americana Lindb. Muse. scand. p. 28 (1879).]

Ziemlich sehlanke Pfl. in leicht zerfallenden, grünen bis bräunlichen und schwärzlichen Rasen. Stengel aufrecht, etwa 1, selten bis 2 cn. Blätter trocken dicht anliegend, aus ovaler odler länglicher Basis lineallanzettlich, etwa $1.9 \mathrm{~mm}$ lang, mit am Grunde schwach ungerollten, glatten Rändern; Rippe vor der Blattspitze aufhörend. Seta $2-3 \mathrm{~mm}$, unten rot, oben gelb. Kapsel oval, entleert verlängert. Peristomzähne zu \& Paarzähnen verbunclen, oberwärts längsstreifig, an der Spitze gefenstert. Fortsätze etwas kürzer, zweizellreihig, fein papillös.

Aul kalkarmen und kalkärmeren Gesteinen, selten auf nahdiegenden Baumstämmen. Sporenreife im Juli und August. 
F. Al. Eckerö, Marby (Bom.); Överby (H. Lindb.). Hanmarland, škarpnátö (Arrh.). Finströn, Godby (Bom.). Saltvik, an wenigen Fundorten (B.). Sund, Lóvö (B.). Föglö, Jersö (Nerv.). - Ab. Kakskerta, Kaivoinen (Colland.). Ảbo (Lundstr.. Elfr.). Piikkis (Zett.). Pargas, Tervsund (Elfv.); Kridja (Link.). Kimito, Sjörik (Ols.). Finby, Finnarr (Broth.). Bromarf, Prästholmen, Bromholmen und Norrstrand (Sundr.). Uskela, Vuorenmäki (Hạ̈r.). Karislojo, Karkkali (H. Lindb.); Pipola (E. af H.). Lojo, Skraatila (Lindb.); Paloniemi (H. Lindb.); Hermola (H. L.): Jalasaari und Kulukasaari (H. L.). - . V. Kyrkslätt (Nyb., Sundr.). Helsingfors (TI. Ny̧.). Sibbo, Löparö (Sundr.). Borgå, Pellinge, Tirmo (Jusl.) und Suni (Broth.); Sundö (Sael.). Lorisa, Kattön (Lindb.). Elinäki, Mustila (Buch). Hogland (Lindb.). - Ka. Wriborg (Mela). Räisälä. Tuulankoskensaari (Lindb.). - Ik. Johannes, Vaahtola (H. Lindb.). st. Björneborg, Lỵttskär (Häyr.). Ikaalinen, Vehurarpe (Nerr.). - Ta. Vanaja (Häyr.). Lammi, Ronni (Leop.). Asikkala, Urajarri und Kärsälä (Norrl.): Salo und auf einem Inselchen des Vesijärvi (N.). Luhanka, Judinsalo (Vain.). Korpilahti, Piililä (V.). - Kil. Sortavala, Kirjavalahti, Piispanvuori (Popp.). — Oa. Bötom, Pyhärıori (E. af H.). - Tb. Pihtipudas, Elämäisjärri, Koiruharju (Roiv.). - Sb. Kuopio, humpusaari (Link.). Kaavi, Siikajärvi, Huosiaisnieni (Kỵhk.).

S. Sk. -Jmt.

N. Im Küstengebiete ron $\mathrm{Sm}$. bis No., hier und da auch im Binnenlande und zuweilen dort isoliert auftretend. Steigt bis $3-400 \mathrm{~m}$ hinauf. Nordgrenze bei $68^{\circ} 18^{\prime} \mathrm{n} . \mathrm{Br}$.

Europa, Japan, Nord-Amerika.

531. Ulota curvifolia (Wahlenb.) Brid. Bryol. univ. I. p. 302 (1826). [OrthoIrichum curvifolium Wahlenb. Fl. lapp. p. 365 (1812). — Weissia curvifolia Lind!). Musc. scand. p. 28 (1879).]

Ziemlich schlanke Pf]. in oft ausgeclehnten, flach polsterförmigen, gelblichgrünen bis bräunlichgelben, innen braunen bis schwärzlichen Rasen. Stengel kriechend, mit aufrechten, = verlängerten Ästen. Blätter trocken fast kraus, aus verkehrt-eiförmigem Grunde lineallanzettlich, kurz zugespitzt, bis 2 mm lang, mit in der Blattmitte schmal zurïckgeschlagenen Rändern: Rippe vor der Blattspitze aufhörend; Zellen beiderseits dicht mit zylindrischen Papillen. Seta bis $4 \mathrm{~mm}$. Kapsel klein, verkehrt-eiförm g, entleert oval. Peristomzähne zu $\&$ Paarzähnen verbunden, unten quer-, oben längsstreifig und unregelmässig gefenstert. Fortsätze wenig kürzer und ladenförmig. Sporenreife im Juni und Juli. — Fig. $66 \mathrm{G}-\mathrm{M}$.

Auf kalkfreien Felsen und Blöcken.

F. Al. Eckerö, Varby (Bom.). Finslröm, Godby (B.). Gëla und Saltrik an einigen Fundorten (B.). Sund, Iangstekta (B.). - Ab. Korpo (Elfr.). Abo (Zett.). Broniarf, Norrstrand (Sundr.). - N, Esbo, Luk (Buch). Helsingfors (Lindb.). Borgà, Haksalö (Broth.). - Ka. Säkkijärvi, Kaukiala (Kírohn). Wiborg, Juustila (Buch). — St. Karkku (Hjelt). — Ta. Im südōstl. Teile st. r.-pass. (Norr].). Hartola (Bonsd.). Luhanka pass. (Vain.). Jämsä (Häyr.). Kiorpilahti pass. (Vain.). - Sa. Taipalsaari (Simm.). Lappee (Buch). - Kl. Sortavala, Tumbanka (Link.); Kirjaralahti (Norrl., Broth.). Soanlahti, Korpikallio (Broth.). - Kol. Suojärvi, Kotajärvi (Link.). - Tb. Virrat, Helvetinjärri (Broth.). Pihlajavesi (Norr).). Petäjăresi. Mataraniemi (Ruor.). Laukaa, Vihtjärvi (Broth.); Seppälä. Linnasaari (Härr.). Karstu]a, Ruotila (B.). Viitasaari, Kalliojärri, Hakala und Kiohiseva (B.). - Sb. Heinävesi, Palokki, Kultaniemi (Kot.). Kuopio pass. (Link.). Kaavi, Siikajärvi, Mustikkamäki (Kot.). Nilsiä, Rahasenmäki (Kyyhh.). Maaninka, Tuovilanlahti, Arkkuvuori (Roiv.). Pielaresi, Vaaraslahti, Lokinmäki (R.). - Kb. Pieti.järvi, Koli (Linnan.). - Ok. Paltamo, Melajoki (Kyybk.). Sotkamo, Naapurinvaara (Brenn.). Suomussalmi, Saarnakallio und Jalonkallio (Kyyhk.). - Kpom. Kontokki (Tain.). - Ob. Aavasaksa (Nyb.). - K. Pudasjärvi, Pirrivaara (Broth.); Iinattijärvi, Hampusruori (E. af H.). Kuusamo, Ruoppijärvi (Broth.). Soidinselänne (E. af H.). Ukonvaara (Nyb.). Oulankajoki, Merenoja und Kallioperänvaara (Broth.). Paanajärvi (Sil.). - Kk. Susijärvi (Sablb.). Keret, Sonostrov (S.). - Lkem, Kolari und Kittilä fq. (Hult). Kemijārvi, Pỵhätunturi (Huım.). Kuolajärvi, Sallatunturi und Makiakuuvaara (E. af H.). - Le. In der Nadelwald-und Birkenregion nicht selten bis Kilpisjärvi (Norrl.). - Li. Inari, in der Waldregion st. fq. (Hult). L'tsjoki, Bodustarre (Ranck.); Yläjalve, Kistuskaidde (R.). 一 Lim. Kandalaks, Schelesnaja (Brolh.). Porjaguba (Sel.). Lmba (Fihlm.). Dichonostrov (Sahlb.). - Lt. Kola. Abramova Pahta und Srednij (Broth.). - Lmur. Varsinsk (B.).

S. Dld. - L.

N. A.-Ne., St. $-S T$. No.-F. In Westlandet selten und nur in den innersten Teilen der Fjorde und in den angrenzenden Tälern beobachtet. Steigt nur selten über die Baumgrenze hinauf. Nordgrenze bei $70^{\circ} 25^{\prime} \mathrm{n}$. Br.

Zentral-Europa in den Hochalpen r, Grönland, Ontario.

532. Ulota Ludwigii (Brid.) Brid. Mant. p. 112 (1819). [Orthotrichum Ludwigii Brid. Musc. rec. Suppl. II. p. 6 (1811). - Weissia coarctata Lindb. Muse. scand. p. 28 (1879).] 
Ziemlich schlanke Pfl. in flach polsterförmigen, grünen oder gelblichgrïnen bis bräunlichen Rasen. Stengel aus niederliegendem Grunde aufsteigend. Blätter trocken anliegend, etwas verbogen und wenig gedreht, aus eiförmigem Grunde schmal lanzettlich, allmählich zugespitzt, bis $3 \mathrm{~mm}$ lang, mit llachen oder abwärts schwach umgebogenen Rändern; Rippe mit oder kurz vor der Blattspitze aufhörend. Seta 4-7 mm, gelblich. Kapsel keulig-birnförmig, glatt und nur unter der stark verengten Mündung der enteleckelten Urne trocken kurz srippig. Peristomzähne dicht papillös, zu $\&$ Paarzähnen verbunden, kurz 4spaltig, später 16 Einzelzähne. Fortsätze fadenförmig, kurz und hinfällig oder rudimentär. Sporenreife im Herbst.

An den Stämmen der Waldbäume.

S. Sm., Boh.. Trml. und V rstm. an einzelnen Fundorten.

N. Sm.- Ve., St.-F., ST.-No. Steigl nul sellen uber 250 m hinauf.

Europa. Nord-Ameritia.

533. Ulota Drummondii (Hook. et Grev.) Brid. Bryol. univ. I. p. 299 (1826). [Orthotrichum Drummondii Hook. et Gres. Mser., Steud. Nomenel. crypt. p. 303 (1821). - O. subrepens Sommerf. Fl. lapp. p. 191, t. 1, f. 2 (1826). - Weisia Drummondii Lindb. Muse. scand. p. 28 (1879).]

Mehr oder weniger kräftige Pfl. in ausgedelınt polsterförmigen, grünen oder gelbgrimen bis lichtbrämlichen Rasen. Stengel kriechend, mit aufrechten Ästen. Blätter trocken anliegend und schwach gewunden, aus verkehrt-ciförmiger oder länglicher Basis lineallanzettlich, bis 3 mm lang, flachrandig oder nit am Grunde schwach umgebogenen und glatten Rändern; Rippe vor der Blattspitze auflıörend. Seta 3-5 mm, unten rötlich, oben gelb. Kapsel länglich oder keulenförmig, trocken und entleert spindelförmig. Peristom einfach, bald 16 dicht papillöse Einzelzälne. Sporenreife im Herbst.

An Waidbämmen, sehr selten auf Steinen.

F. Al. Saltrik, Anduböle (Nervo); Sonröda (Bom.).

S. Bl., Sm. Ög. $V g$., Dld. und $\mathrm{V} r m l$ an einzelnen oder wenigen Fundorlen.

N. In allen küstenamtern bis $T r$. sl. fq.., nicht nur in den Küstengegenden, sondern auch längs den Fjorden und Tälern weit linein dringend. Steigt bis $300 \mathrm{~m}$, selten tis 5-600 $\mathrm{m}$ hinauf. Nordgrenze bei $69^{\circ} 40^{\prime} \mathrm{n}$. $\mathrm{Br}$.

West- und Zentral-Europa, Japan, Nord-Amerika.

var. anceps Hag. in D. K. N. Vid. Selsk. Skrift. 1907, No. 1:3. p. 22 (1908).

Blätter trocken gekräuselt, aus verkehrt-eiförmigem Grunde rasch schmal lanzettlich.

N. Verbreitung wie bei der Hauptart.

534. Ulota Bruchii Hormsch. in Brid. Bryol. univ. I. p. 794 (1826). [Orthotrichum Bruchii Wils. Bryol. brit. p. 188, 1. 15 (1855). - Weissia Bruchii Lindb. Musc. seand. p. 28 (1879).]

Kräftige Pll. in ziemliel hoch gewölbten, freudig- l,is gelblichgrünen, innen gebräunten Polstern. Stengel anfsteigend. Blätter trocken mässig gekräuselt, aus verkehrt-eiförmigem Grunde schmal lanzettlich, scharf zugespitzt, bis I mm lang, mit in der Blattmitte hier und da zurückgeschlagenen Rändern; Rippe mit oder vor der Blattspitze aufhörend. Seta bis $5 \mathrm{~mm}$, gelb. Kapsel länglich-oval, trocken und entleert schmal spindelförmig, von der Mitte bis zur Mündung allmählich verengt. Peristomzähne zu \& Paarzähnen verbunden, dicht papillös, an aler Spitze gespalten. Sporen in Grösse und liorm sehr ungleich. Sporenreife im Juni und .uli.

An Stämmen und Ïsten von Waldbänmen verschiedener Art, selten auf Felsen und Steine ïbergehend.

S. Sk-Vstm. Mpd Norbyknöl.

N. In allen kïstenämlern bis Tr., in den kïstengegenden fqu und ron dort weit ins Binnenland dringend. Sleigt bis $250 \mathrm{~m}$, selten bis $400 \mathrm{~m}$ hinauf. Nordgrenze hei $69^{\circ} 40^{\prime} \mathrm{n}$. Br.

Europa, Nord-Amerikia. 
var. norvegica Grönv. Bi(lr. p. 22 (1885).

Blätter kïrzer; Zellen oberwärts kleiner. Fortsätze etwas breiter. Deckel mit sehr kurzer, stumpfer Spitze.

N. No Ranen.

var. marchica (Warnst.) Par. Lnel. bryol. V. p. 97 (1906). (Llola marchice Warnst. in Hedwigia 1889, p. 372.)

Kapsel engmündig, viel zarter gestreilt und gefaltet, nicht orler wenig in den Hals verschmälert. Deckel klein, kegelig verlängert.

N. $S B$. Aarstad, Haukeland, Li, $90 \mathrm{~m}$.

Brandenburg.

535. Ulota crispula Bruch in Bricl. Bryol. univ. 1. p. 792 (1826). [Orthotrichum crispulum Bryol. eur. fasc. 2/3, p. 23, t. 12 (1837). - Weisia crispula Lindl). in Act. soc. se. lenn. X. p. 12 (1875).]

Ziemlich schlanke PfI. in meist kleinen, grünen Polstern. Blätter trocken kraus, aus breit eiförmigem Grunde schmal lanzettlich, bis fast $3 \mathrm{~mm}$ lang, flachrandig oder mit in der Blattmitte leicht umgebogenen Rändern: Zellen oberwärts 10-12 $\mu$. Seta bis 2,5 $\mathrm{mm}$, gell,. Kapsel klein, oval, entleert gestutzt-urnenförmig, erst im Alter verlängert spindelförmig. Peristomzähme zu 8 Paarzähnen verbunclen, dicht papillös, gegen die Spitze hin stark durchbrochen und papillös gestreift. Fortsätze zu s, etwas kiürzer, häulig mit vereinzelten seitlichen Anhängsehn. Sporen fast gleichgross. Sporenreife im Mai und Juni.

An Walıbäumen, meist an Laubhölzern.

F. Al. Getil, Bastö (Bom.). Saltvik, an mehreren Fundorten (B.). Föglö, Gripö (Arrh.). - Ab. Korpo gârd (Elfv.). - N. Ekenäs, Trärminne, Björkskär (Broth.); Häıtö (A. H. Cai.) Jıะarö (Hä̀r.). Helsingfors, Mjölö (W. Nyl.). Borga. Sundö (Sael.). - Ik. Kivinapa, Mutajoki (H. Lindb.).

S. $\quad S k,-D l d$.

N. In allen Kü̈stenämtern bis No. steigt bis $250 \mathrm{~m}$ himauf. Nordgrenze bei $68^{\circ} 8^{\prime} \mathrm{n}$. Br.

Europa, Kaukasus, Japan. Nord-Amerikil.

536. Ulota intermedia Schimp. Syn. 2. e(l. p. 305 (1876).

Ziemlich kräftige Pfl. in kleinen, grimen Polstern. Stengel aufrecht. Blätter trocken kraus, aus breit eiförmigem oder verkehrt-eiförmigem Gruncle schmal lanzettlich, bis $3 \mathrm{~mm}$ lang, llachranclig oder mit in der Blattmitte leicht umgebogenen Rändern: Rippe mit oder vor der Blattspitze aufhörend: Zellen oberwärts $14-20 \mu$. Seta $1-5 \mathrm{~mm}$, gelb. Kapsel klein, oval, trocken und entleert fast urnenförmig, im Alter verlängert spindelförmig, unter der Mündung kaum verengt. Peristomzähne zu 8 Paarzähmen verbunclen, dicht papillös, an cler Spitze meist sehwach durchbrochen und oft kurz spaltig. Fortsaitze zu 8 oder 16 , letztere abwechsehnd länger und kürzer. Sporen in Grösse und Form sehr ungleich. Sporenreife im Juni und Juli.

An Waldbäumen. besonders Lanbhölzern.

F. Al. Saltvik, Sonröda, Haraldsby und Lingbergsöda.

S. Sk., Bl., Öl., Sm.. Tg., Boh., När. und Dld., meist nur an wenigen Fundorten.

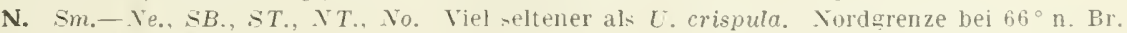
Europa, Nord-Amerika.

537. Ulota ulophylla (L.) Broth. in Engl.-Prantl Bryal. p. 173 (1902). [Weisia ulophylla Ehrh. Beitr. 1. p. 191 (1787). - Orthotrichum crispum Hedw. Muse. frond. II. p. 96 (1788). - Ulota crispa Bricl. Mant. p. 112 (1879).]

Ziemlich kräftige Pfl. in grünen oder gellgrinen, bis 2 cm hohen Polstern. Stengel aufrecht oder aufsteigend. Blätter trocken sehr kraus, aus breit eiförmigen. his verkehrt-eiförmigem Grunde schunal lanzettlich, bis 3,5 mm lang, meist flachrandig, zuweilen mit in der Blattmitte schwach umgebogenen Rändern: Zellen oberwärts $10-12 \mu$. Seta bis $5 \mathrm{~mm}$. gelb. Kapsel länglich-oval, trocken uncl entleert schlank spindelförmig und unter der Mündung meist verengt. Peristomzähne zu 8 Paarzähnen verbunden, dicht papillös, an der Spitze = durchbrochen. 
Fortsätze zu 8, etwas kürzer und mit vereinzelten seitlichen Anhängseln. Sporen fast gleichgross. - Sporenreife im Juni und Juli.

An Waldbämmen.

F. Al. Geta, Bastö (Bom.). Saltrik, Toböle (B.).

S. Sk.-IIls.

N. In Westlandet von Ryfylke bis Sondmor am meisten im äusseren Küstengebiete und von dort nur ausnahmsweise in die Fjorde dringend. Nordgrenze bei $62^{\circ} 13^{\prime} \mathrm{n} . \mathrm{Br}$.

Europa. Kanaren. Kaukasus, Amur, sachalin. Nord-Amerika, Tasmanięn.

538. Ulota phyllantha Brid. Mant. p. 113 (1819). [Orlholrichum jullandicum Brid. Bryol. unir. J. p. 296 (1826). - Weissia phyllanlha Lindb. Mlusc. seand. p. 28 $(1879)$.

Diözisch. Ziemlich krältige Pfl. in \pm ausgedebnten, braungrünen, kissenförmigen Rasen. Stengel kriechend, mit autrechten Ästen. Blätter bald aus breitem Grunde allmählich verschmälert und noch an cler Spitze verhältnismässig breit. balı aus schmälerem, verkelırt-eiförmigem Grunde rasch schmal lanzettliels oder lineallanzettlich, bis $3,5 \mathrm{~mm}$ lang. mit unten am Rancle umgerollten und schwach papillösen, an der Spitze undeutlich gezähnten Rändern: Rippe krältig, austretend, oft am Ende verdickt und ein Köpfchen selumal ellipsoidischer, dunkelbranner, meist 6gliediger Brutkörper tragend. Sporogone äusserst seften, bisher nur in Irland und in oregon, U. S. A., angetroffen.

Auf Felsen und Steinen wie auch an den Stämmen von Laubhölzern am Meeresufer, letztere olt fast bedeckend.

F. Al. Gela, Dånö, Rankoskär und (ieta bärg (Bom.). Lemland, Tistonholm und Lågskär (B.). Kökar. Vảrdö. Sottunga, Kumlinge und Brändö (Bom.). - Ab. Korpo, Ltö (Elfr.). Küimito, Vânö (Ols.). — N. Ekenäs. Tvärminne, Vindskär (Broth.). in den äusseren Schären pass._-st. fq. und zuweilen st. cop. (Häyr.). Ingil, Sadeln (W. Bremn.). Helsingfors, Torr Mjölö (Simm.). Borgă, Äggskär (Sael.).

S. Sk., Bl., Sm.. IHll., Ög. und Boh.

N. Von der südküste smaalenenes üler die llündung des Kristianiafjord längs sorlandet und der Westküste fast his zum Nordkap, ron der Westküste längs den Fjordufern weit hinein dringend. steigt bis $350 \mathrm{~m}$ hinauf. Nordgrenze lei $70^{\circ} 58^{\prime} \mathrm{n}$. Br.

Europa, Nord-Amerika, Fuegia.

\section{ORTHOTRICHUM}

Hedw. Deser. musc. II. p. 96 (1789).

Autöziseh (excl. O. Lyellii). Blätter trocken niemals kraus, feucht abstehend bis sparrig, gekielt, nut meist bis gegen die Spitze umgerollten Rändern; Rippe meist vor der Blattspitze aufhörend; die rundlichen Zellen meist \pm verdiekt und \pm papillös, selten glatt, meist $10-15 \mu$, selten grösser, am Blattgrunde liurz bis verlängert rektangulär und \pm durehscheinend, am Rande oft kürzer und grün, niemals einen wasserhellen Samm bildend. Seheidehen meist nackt oder wenig behaart. Kapsel nur selten enporgehoben. Peristom meist doppelt. Peristomzälnne fast immer zı \& Doppelzälmen verbunden, bleich orler gelblich: Fortsätze 8 odler 16, (excl. Ortholrichu striata) ladenlörmig. Sporen meist klein und meist braun und warzig.

i"bersicll der Arten.

A. Peristomzähne trocken anf recht bis sternfömig ausgebreitet.

a. Spaltöfinungen oberfläehlich 339. O. rupestre.

b. Spaltöfnungen eingesenkt ((). cupulat(t).

is. Seheidchen nackt octer fast nackit.

I. Kapsel birnförnig 5.5. O. nudum.

II. Kapsel clliptiseh bis eifömig. 1. Kapesel emporgehoben 510. O. anomalum. 
2. Kapsel eingesenkt bis z. T. emporgehoben.

* Zellen der Kapselstreifen 2-3reihig.

$\dagger$ Kapsel am Grunde abgerundet

511. O. cupulatum.

†† Kapsel alhmählich in die Seta verschmä-

lert

543. O. abbreviatum.

** Zellen der Kapselstreifen 1 -mehrreihig.

$\dagger$ Peristom einfach: Peristomzälne durchbrochen

511.0. Sardagnanum.

$+\uparrow$ Periston doppelt; Peristomzähne in der

Mittellinie mehrmals durchbrochen ..... it.). O. Limprichtii.

ґ. Scheidchen dichthaarig.

I. Kapsel trocken plötzlich in die Seta abgesetzt... 546. O. urnigerum.

II. Kapsel trocken allmählich in clie Seta versehmälert

517. O. Venturii.

B. Peristomzähne trocken zuriickgekrümmt oder der Unnenwand anliegend.

a. Spaltöffnungen oberflächlich.

«. Kapsel emporgehoben.

I. Peristomzälne fein papillös, trocken zurückgekrümmt $(O$. arctica).

1. Blattzellen sehr dünnwandig

553. O. mitigutum.

2. Blattzellen verdickt.

* Peristomzähne oberwärts gestrichelt

551. O. microble-

phare.

** Peristomzähne auch oberwärts papillös.

$\uparrow$ Peristomzähne weich, weisslich. Sporen gelb ocler grün

552. O. groenlandicum.

$\dagger \uparrow$ Peristomzähne starr, gelblich. Sporen rostfarben.

5.50. O. Blyttii.

II. Peristomzähne grob papillös, 1 rocken der Urnenwand anliegend (O. speciosa).

1. Fortsätze fehlend oder rudimentär

554. O. laevigatum.

2. Fortsätze von der Zahnlänge, papillös.

* Blattzellen mit dichten, kegelförmigen. spitzen Papillen

555. O. speciosum.

** Blattzellen mit zerstreuten, zylindrischen. abgerundeten Papillen

5.56. O. Killiasii.

$\beta$. Kapsel eingesenkt.

I. \& Paarzähne; Fortsätze zu 8 (O. affinia).

1. Peristomzähne ohne wurmförnige Linien ... 5 48 . O. affine.

2. Peristomzähne mit wurmförmigen Linien ..... 549. O. fastigiatum.

I1. Peristomzähne und Fortsätze zu 16 (O. striata).

1. Autözisel. Kapsel glatt ..................... 5.57. 0. striatum.

2. Diözisch. Kapsel gestreift ................. 5. 8. O. Lyellii.

b. Spaltöffnungen eingesenkt.

๙. Peristomzähne zu \& Paarzähnen verbunden (O. straminea).

I. Vorhof sehr eng.

1. Peristomzähne gelbrot, an der Spitze mit Lamellen 572. O. Rogeri.

2. Peristomzähme bleich, olme Lamellen. 
* Scheidchen und Haube behaart 570. o. Braunii.

** Scheidchen und Haube nackt 571. O. tenellum.

11. Vorhof \pm weit.

1. Scheidchen dicht behaart.

* Blätter dlureh längere Papillen fast igelstachelig. Peristomzälne oberwärts gestrichelt

565. O. alpestre.

** Blätter schwach papillös. Peristomzähne nicht gestrichelt.

† Blätter lang zugespitzt. Kapsel dick eiförmig, mit kurzen und schmalen Streifen. 567. O. patens.

$\div+$ Blätter kurz zugespitzt, oval, mit langen und breiten Streifen...

566. O. stramineum.

2. Scheidchen nackt oder sehr spärlich behaart.

* Blattzellen oberwärts sehr dlünnwandig.

† liapsel am Grunde abgerundet .......... 568. O. Schimperi.

†† Kapsel allmählich in lie Seta verschmälert 569. O. pumilum.

** Blattzellen oherwärts verdickt.

$\dagger$ Blätter stumpf.

Haube papillös. Peristomzähne oberwärts gestrichelt und unregelmässig durehbrochen

563. O. Arnellii.

Haube glatt. Peristomzähne weder ge-

strichelt noch durchbrochen.

x l3lätter flachrandig 559.O.microcarpum.

xx Blätter mit umgerollten Rändern ... 560. O. pallens. $\doteqdot \dagger$ Blätter spitz.

$\times$ Haube an der Spitze behaart ........ 564. O. Philiberti. Haube nackt oder mit einzelnen Haaren besetzt.

$\mathrm{x}$ Zellen des Blattgrundes verdickt. Peristomzähne ohne Lamellen

562. O. paradoxum.

$x x$ Zellen des Blattgrundes dünnwandig. Peristomzähne oberwïts mit Lamellen 561. O. pallidum.

$\beta$. Peristomzähne zu 16 , voneinancler frei.

I. Blätter lıaartragenı 575. O. diaphanum.

11. Blätter ohne Haar.

1. Kapsel emporgehoben 574. O. pulchellum.

2. Kapsel eingesenkt 573. O. leucomilrium.

S e c t. I. Brachytrichum (Rölıl) Limpr. Laubn. II. p. 38 (1890) emenıl. Hag. in D. K. N. Vid. Selsk. Skrift. 1907. No. 13, p. 37 (1908).

Peristomzähne trocken aufrecht bis sternförmig ausgebreitet, derb, durchsichtig, gestrichelt, seltener mässig mit groben Papillen, meist mit Vorperistom.

$\mathrm{S} u \mathrm{~b} \mathrm{~s}$ e c t. I. Orthotricha rupestria Hag. 1. c. p. 37.

Spaltöfnungen oberflächlich.

539. Orthotrichum rupestre Schleich. Crypt. helv. exs. Cent. III. No. 21 (1806). Catal. 1807. [Dorcadion rupestre lindb. Musc. scand. p. 29 (1879).]

Kräftige Pfl. in lockeren oder dichten, ausgebreiteten, leicht zerfallenden, dunkelgrünen oder gelıäunten Rasen. Stengel 2-t cm, aufrecht oder aufsteigend. Blätter aus länglicher basis lanzettlich, kurz und breit zugespitzt oder stumpf- 
lich, bis 4 mm lang. Kapsel eingesenkt oder z. T'. emporgehoben, oval, mit langem Halse, dünnhäutig, mit kurzen Längssitreıfen, trocken und entdeckelt etwas verlängert, aus breiter Basis urnenförmig, Iängsfaltig. Peristom doppell: Peristomzähne mässig mit groben Papillen; Fortsätze des inneren Peristoms zu 8, zweizellreilig, zart papillös. Haube gelbbraun, \pm dicht lrehart. Sporenreîe im Mai und Juni.

Auf kalkfreien und schwach kalkhaltigen Gesteinen, selten aul reinem kalk.

F. Al.st. fq. (Bom.). - Ab. Korpo (Ekl.). Nystad (Nyb.). Verinasku (Karst.). Nadendal (EltY.). Abo (Zett.). Pargas, Storgard (Elfv.); Simonby und Lampis (Link.). Kimito (Ols., Broth.). Finby, Finuars (Broth.). Tesvärr (Sundv.). Bromarf, Prästholmen (S.). Tenala, C'skela (Nikl.). Karislujo, Täsväri (H. Lindb.); Pipola (E. af H.). Lojo, an mehreren Fundorten (H. Lindb., E. af H.). - X. Ekenäs, Trärminne (Häyr.); Hăstö (H.); Ekenàs (H.). Ingả, Barö (Sael.). Snappertuna, Vàtar (Sundr.). Helsingfors (W. Nyl.). Sibbo. Löparö (Sundr.). Pärná (Häyr.). Hogland (Lindb.). - Ka. Antrea, Liikola (Lindb.). - St. Kumo (Halmgr.). Björneborg, Kahaluoto (Häyr.). Pirkkala (Simm.). - Ta. Im südöstl. Teile nicht selten (Norrl.). Korpilahti und Luhanka nicht selten (Vain.). -- sa. Taipalsaari (Simm.). Ruokolahti (Hult). Kanganniemi, Suomäki (Lackstr.). Anttola, Hirvensalo (L.). Nyslott. (Carl.). - Kl. Kurkijoki (Jusl.). Jaakkima (Sundv.). Sortavala, Neitsytriuttu (Link.); Palosaari (Pes.); Kirjavalahti, Kotomäki (Norrl.). Pälkjärvi, Kuhilasvaara (Broth.). - Kol. Schtjeliki (Elfv.). - Oa. Öfvermark. Valsbärget (E. af H.). - Tb. Jyväskylä (Link.). Laukaa, Vihtajärvi (Broth.). Viitasaari, Etelävuori (B.). 一 Sb. Heinävesi, Palokki, Kultaniemi (Kot.). Kuopio, an mehreren Fundorten (Link., Kot.). Kaavi, siikajärvi. Likosaari (Kot.). Nilsiä, Kuuslahti, Jaakonlampi (K.). Maaninka, Tuovilanlahti (Roiv.); Kurolanlahti, Vorlokso (R.). Pielavesi. Vaaraslahti, Lokinmiki (R.). - Kon. Pietsovaara (Norrl.). Pirttiniemi (Simm.). Käppäselkä (S.). - Ok. Kulmoniemi, Portin louhikko (E. af H.). Suomussalmi, Kirehdorf, Jalon kallio (Kyylh.) - Kpom. Repola, Koroppi (Vain.). - Ob. Rovaniemi, Hepokallio (Hult). - k. Kuusamo, Ronkajärvi (Broth.); Rukatun(uri (B.); Kithajoki (B.); Paanajärvi, Ruskeakaltio (Sil.). - Kk. Kivakkatunturi (Broth.). - Lkem. Killilä, Saivio. nördl. vom Ytlästunturi (Hult). - Le. Pietsovaara (Norrt.). - Li. Inari, Ruoptuinvara (Vain.); Pyttelvaara. Tirro und Kenischko:ki (Hult); IInddusjärvi (Sil.).

S. $S k .-L u L$. Sarekgebiet.

N. Von Lindesnes bis Varanger, von Bergen bis zur Ostgrenze eines der gemeinsten Woose und noch in der Weidenregion beobachtet. Längs der Kïste ron Sm. bis zum Trondlijenhusen auch auf Laubbäumen verschiedener Art. Nordgrenze bei $70^{\circ} 25^{\prime} \mathrm{n}$. Br.

Europa, Algier, Kaukasus, Himalaya, Nord-Amerika, New Zealand.

var. Sturmii Jur. Laubm. fl. p. 201 (1882). [Orthotrichum Sturmii Hornseh. in Flora 1818, p. 311. - Dorcadion rupestre $\beta$ Sturmii Lindb. Musc. scand. p. 29 (1879).]

Blattspitze und Blattränder weit herab zweischichtig. Kapsel rasch zum kurzen Halse zusammengezogen. Fortsätze sehr zart, oft fehlend.

F. Al. Echerö, Öfverby (H. Lindb.). Saltrik, Haraldsby (Arrh.). Sund, Tosarby (Bom.). - Ab. Abo, Katrinedal (Arrh.). - Sa. Taipalsaari (Sael.). - kl. Valamo (Lindb.). Jaakkima, Puntalo (L.). Sortavala (Simm.); Spaso (Lindb.); Kirjavalahıi (L.). - Kol. Petrosarod-k (Simm.). - K. Kuusamo. Urovaara und Nuorumen (Nyb.).

S. Sm.. Gll., Ög.. V'g., När.. Srml., Lpl., Hls., Mpd. und Ang.

N. Fast allschliesslich auf Uferfelsen längs der süd- und Westhilste bis kistiansund.

Europa, Algier, Kanaren, Kaukasus, Nord-Amerika

S u b s e c t. I I. Orthotricha cupulata Hag. 1. c. p. 12.

Spaltöfnungen eingesenkt.

540. Orthotrichum anomalum Hedw. in Timm Prodr. No. $73+$ (1788): Hedw. Descr. II. p. 102, t. 37 (1789). [Dorcadion unomalum Lindb. Mlusc. scancl. p. 28 (1879).]

Zienlich kräftige Pfl. in lockeren bis gedrängten, grünlichbraunen Rasen. Stengel bis $2 \mathrm{~cm}$, aufrecht. Blätter länglich-lanzettlich, kurz zugespitzt, his 3 mm lang. Seta $2-4 \mathrm{~mm}$. Kapsel emporgehoben, länglich bis zylindrisch, kurzhalsig. gelbbräunlich, mit 16, abwechselnd längeren ( $4-5$ zellreihigen) und kürzeren (2-Breihigen), im oberen Teile rötlichen Längsstreifen, trocken und entleert entweder unverändert oder über der IItte verengt und weitmündig. Peristom einfach, mit Vorperistom, letzteres \pm vortretend und meist gestrichelt: Peristomzähne oberwärts längs und schräg, unten meist quer gestrichelt, nicht oder \pm papillös. Haube gelbbräuntich, \pm behaart, selten fast nackt. Sporenreife im Mai und Juni. 
An freiliegenden Feldsteinen und besonnten Felsen allerlei Art, selten an Bäumen.

F. Al. Finström, Godby (Arrh.); Grelsby Mangelbro (Bom.). Saltrik, an mehreren Fundorten (B.). Sund, Rosenberg und Kastelholm (B.). - Ab. Nådendal (Elfv.). Pargas, Kapellstrand. Loftedal (Arrh.); Ersby (Elfv.). Angelniemi. Karviais (Buch). Karislojo, Karkali (Sundr.). Lojo, an mehreren Fundorten (Lindb.. Hult, H. Lindb.). - N. Ekenäs (Häyr.). Snappertuna, Rakeborg (Häyr.). Ingå, Norrstrand, Bålaskār (W. Brenn.). Tenala, Skogsby (H.). Helsingfor (IW. Nỹ.). Helsinge. Vesterkulla. Kalkholmen (Ranck.). - Kia. Wiloorg (W. Nyl.). - St. Pirkkala (Simm.). - Kl. Sortavala, Jäki-
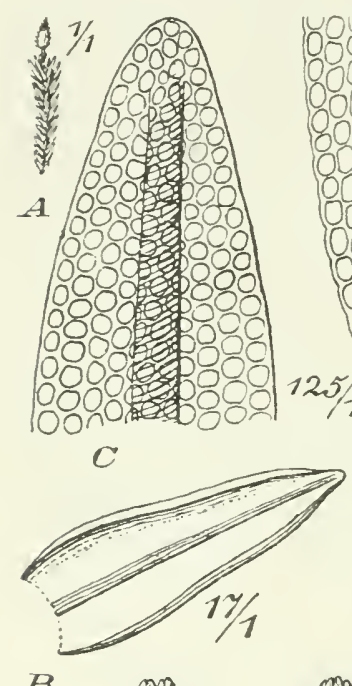

${ }_{B}$
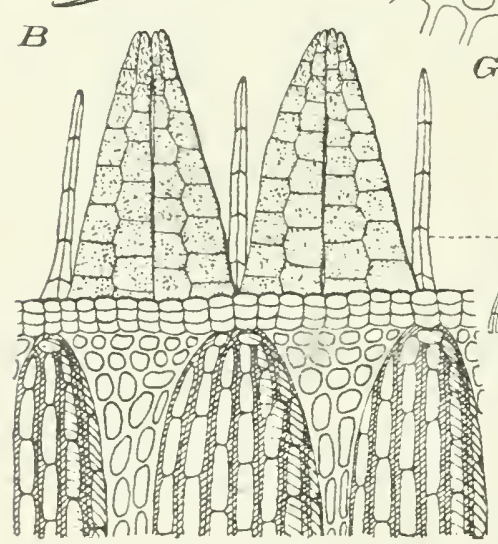
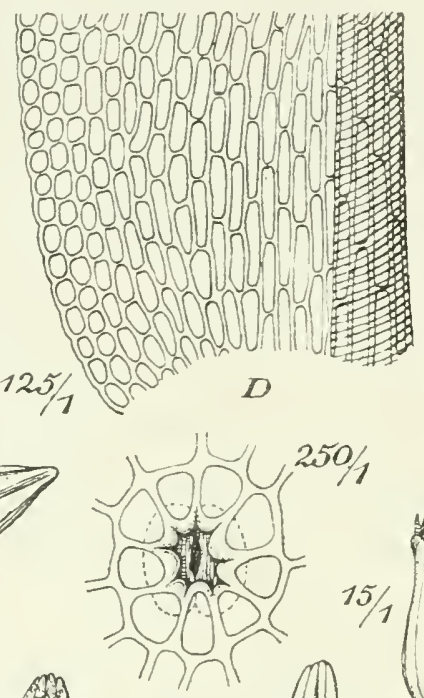

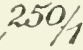

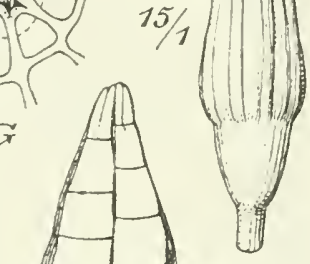

250
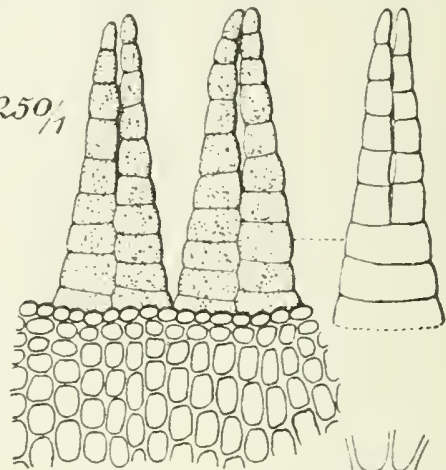

F
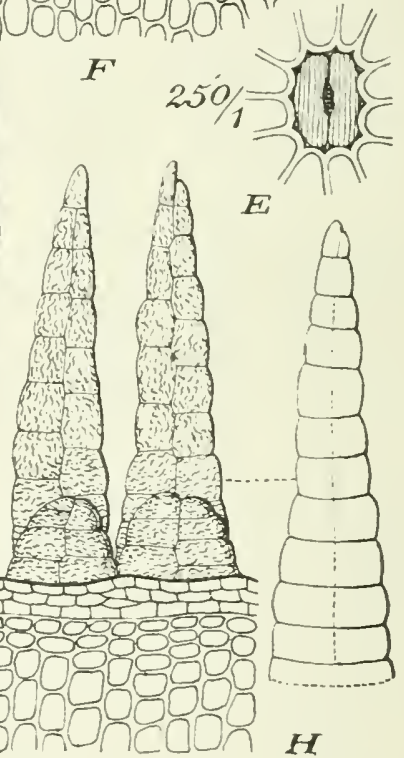

$175 / 1$

$\boldsymbol{K}$
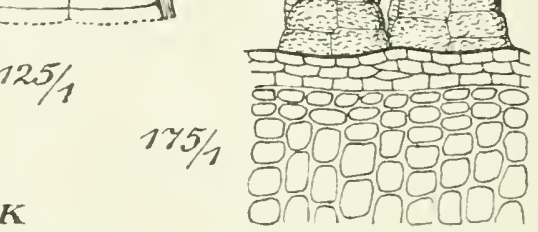

$H$

Fig. 57. A-F. Orthotrichum microblepharum Schimp. A Fu'uchlende Pfl. (1/1); B Stammb. (17/1): C Blattspitze (125/1): D Blattbasi (125/1); E spaltöfnung (250/1); F Peristom (250/1). - G-H. O. cupulatum Hoffn. (i spaltöfnung (250/1); H Perislom (175/1). - I-K. O. Arnellii Grönv. I Kapsed (15/1); $\mathrm{K}$ Peristom (125/1).

salo, Pallovuori (Link.). - Kon. Suojärvi, Varpakylä, Aleksinsaari (Link.). Valkeamäki und Tiudie (simm.). - K. Kuısanı) Kitkajoki. Jỵävä und Pääsöskallio (Broth.). Paanajärvi, Ruskeakallio (B.).

S. Sk. Mpd.

N. Sm. bis No.. mit versehiedener Frequenz, an haufigsten in don L mgelıungen des liristianiafjord, in L.M. und $I$, noch nicht beohachtet. Bei Trondlyjem noch nicht selten, nördlicher nur von wenigen Fundorten bekannt. Steigt bis $800-1,000 \mathrm{~m}$ hinauf. Nordgreuze bei $67^{\circ} 11 . \mathrm{Br}$.

Europa. Algier. West- und Zentral-Asien, Sitjirien, Nurd-Amerika.

var. montanum Vent. in Hedwigia XII. p. 8 (1873). [Dorcadion anomalum var. saxatile I.indl). Musc. scand. p. 28 (1879).] 
Peristom doppelt. Fortsätze zu 8 .

F. Al. Eckerö, Storby (H. Lindb.). Brändö, Jurmo, Harholmen (Bom.). - Ab. Pargas, Lividja (Zelt.). Karislojo, Karkkali (H. Lindb) - Kil. Valamo (Lindb.). - Kon. Tiudie (Kullh.).

S. Sk, Ol., Sm., Gll., Vg., Boh. und När.

N. Verbreitung etwa wie bei der Hauptart. jeduch nicht nördlicher als in NT. und nicht höles al: bei $250-300 \mathrm{~m}$ beobachtet.

Europa, Kaukasus, Klein-Asien.

5+1. Orthotrichum cupulatum Hoffm. Deutschl. Fl. 11. p. 26 (1796). [Dorcadion cupulatum Lindb. Musc. scand. p. 28 (1879).]

Ziemlich kräftige Pfl. in ziemlich dichten, schmutziggrünen oder braunen bis rotbraunen, kissenförmigen Rasen. Stengel bis $2 \mathrm{~cm}$, meist aufsteigend. Blätter länglich-lanzettlich, kurz zugespitzt. zuweilen stumpflich, bis $3 \mathrm{~mm}$ lang. Kapsel eingesenkt oder z. T. emporgehoben, aus kurzem, fast kugeligem Halse dick eiförmig, gelb, mit 16 abwechselnd längeren und kürzeren, 3-4zellreihigen Lïngsstreifen, trocken und entleert wejt urnenförmig. Peristom einfach, mit Vorperistom, letzteres \pm vortretend und gestrichelt oder glatt; Peristomzälme oberwärts längsstreifig, unten querstreifig. Haube weitglockig, gelbbräunlich. spärlich kurzhaarig oder nackt. Sporenreife im Mai und Juni. - Fig. $67 \mathrm{G}-\mathrm{H}$.

Auf lialk und kalkhaltigem Gestein.

F. Al. Saltvik, Fremmanby (Bom.). Sund, Jussböle (B.). Brändö, Harholmen (B.). - kll. Pälkjärvi, Korkeaniemi (Broth.). - Kon. Valkeamäki (Simm.).

S. Sk.-Lipl., $\mathrm{Irml}$. und $H l s$.

N. ST. Trondhjem, Ladehammeren. No. Bodin, Bodo.

Europa, Algier, West- und Zentral-Asien, Nord-Amerika.

542. Orthotrichum abbreviatum Grönv. Bidr. p. (1885). [Orthotrichum cupulatum var. luridum Hag. Musc. Norv. bor. p. 71 (1899).]

Weniger kräftige Pfl. in braungrünen, kissentörmigen Rasen. Stengel bis $1 \mathrm{~cm}$, aufrecht, mit dümnwandigem Grundgewebe und plötzlich verdickten, kollenchymatischen Mantelzellen. Blätter cilanzettlich, allmählich verschmälert, spitz oder stumpflich, bis $3 \mathrm{~mm}$ lang. Kapsel eingesenkt bis fast emporgehoben, mit dem langen $(2 / 3$ der Urnenlänge) Halse keulenförmig, gelblich, im Alter rotbram, mit 16 fast gleichlangen, 3-tzellreihigen Längsstreifen, trocken und entleert urnenförmig. Peristom einfach, ohne oder mit sehr niedrigem Vorperistom: Peristomzälne undeutlich gestrichelt, in der Mittellinie bis zum Grunde ritzenförmig durchbrochen und zuweilen zweispaltig. Deckelschnabel kürzer als der Radius des Deckels. Haube weisslich, an der Spitze gellbraun, dicht behaart.

An besomnten Kalk- und Kalkschieferfelsen.

N. K. Ringebu, Trosvik. No. An einzelnén Fundorten in Nesne, Saltdalen, Bodin, Ankener, Evenes und Dverberg. Tr. Troms.

543. Orthotrichum Sardagnanum V'ent. ill Rev. bryol. 1879, p. 56.

Ziemlich kräftige Pfl. in grünen bis gebräunten, kissenförmigen Rasen. Stengel 1-3 cm, aufrecht oder aufsteigend, mit sehr dickwandigem, kollenchymatischem Grundgewebe. Blätter länglich-lanzettlich, spitz, bis $3 \mathrm{~mm}$ lang. Kapsel eingesenkt, durch den verschmälerten ( $1 / 3$ der L'menlänge) Hals verkehrt-eilänglich, gelbbraun, mit 8 langen, 3-tzellreihigen und 8 kurzen oder undeutlichen. Längsstreifen, trocken und entleert urnenförmig und Srippig. Peristom einfach, mit niedrigem Vorperistom; Peristomzähme mit feinster wurmfömniger Schrägund Längsstreifung, nicht oder oberwärts undeutlich durchbrochen. Deckelschnabel so lang oder wenig länger als der Radius des Deckels. Haube gelblich, spärlich behaart.

N. A. Baerum, Snaroen Br. Ejdanger. Skjelsviken. Auf Tonschiefer und Kalkfelsen. Nordgrenze $59^{\circ} 53^{\prime}$ n. Br.

Schottland. Schweiz, Tirol, Dalmatien, Nord-Italien und Sizilien.

54. Orthotrichum Limprichtii Hag. in 1). K. X. Vid. Selsk. Skrift. 1897. No. 2, p. 10. [Orthotrichum perforatum Limpr. in 61 Jahresb. ¿l. schles. Ges. 1]. 214 
(188.1) nee C. Müll. in Bot. Centralbl. 1883, Bd. 16. p. 124 - o. cupulatum var. papillosum Grönv. in Örv. K. Vet.-Ak. Förh. 1889, No. 3, p. 174.]

Weniger kräftige Pfl, in kleinen, sehr dichten Räschen. Stengel bis $1 \mathrm{~cm}$, aufrecht. Blätter lanzetllich, kurz und meist stumpflich zugespitzt, bis $2,5 \mathrm{~mm}$ lang; Zellen am Blattgrunde in der ganzen Breite rektangulär bis verlängert und dünnwandig. Kapsel eingesenkt, oval, langhalsig, mit 16 gleichlangen, tzellreihigen Längsstreifen: auch feucht 16rippig, trocken und entleert urnenförmig. Peristom doppelt, mit sehr niedrigem Vorperistom: Peristomzähne in der Nitte mehrmals durchlöchert, dicht papillös, oberwärts undleutlich längsstreifig; Fortsätze 16, von der Zahnlänge, sehr lein fadenförmig, glatt, zweizellreihig und mit seitlichen, feinen Anhängen. Haube fast halbkugelig, gelblich, mässig ticht mit langen Haaren besetzt.

An offenen oder etwas beschatteten, trockenen oder feuchten Kalkfelsen und kalkhaltigen Schiefern.

N. Sm., A.. Bu., JL., Br., $k$. und $H_{\text {. }}$, an einzelnen oder wenigen Fundorten.

Tirol, steiermark, Kaukasus.

545. Orthotrichum nudum Dicks. Crypt. fasc. IV. P. 7, t. 10, f. 13 (1801).

Zienlich kräftige Pfl. in lockeren, weichen. griinen oder schmutziggrünen, polsterfömigen Rasen. Stengel $1-2 \mathrm{~cm}$, zuweilen flutend. Blätter breiter und weicher als bei $O$. cupulalum, stumpf, an Grunde beiderseits mit Längsfalte; Zellen bis zur Basis ziemlich gleichartig. Kapsel z. T. oder ganz emporgehoben, grösser und ticker als bei $O$. cupulatum, durch ten langen, schnell verschmälerten Hals birnförmig, gelblich, mit 16 abwechselnd längeren und kürzeren, tzellreihigen Streifen, trocken und entleert in der Umemmitte zusammengezogen. Peristom doppelt, mit die halbe Zahnhöhe erreichendem Vorperistom; Peristomzähne gesondert, ohne aussen vortretende Leisten. längsstreilig orler papillös-längsstreifig, nicht durehlöchert: Fortsätze zu 8 oder 16, kaum halb so lang wie die Zähne, oft rulimentär. Haube weitglockig, gelblich, nackt odler spärlich behaart.

An feuchten und nassen, zumeist kalkfreien Steinen und Felsen.

F. Hl. Kastelholm (Bom.). - kion. Valkeamäki (Simm.).

S. Gu. Visby.

Zentral- und West-Europa.

var. norvegicum Hag. in Kigl. Norsk. Virl. Selsk. Skrilt. 1907. No. 13, p. jt (1908).

Peristomzähne ungesticill, sehr dicht und fein papillös. Fortsätze $\$$, last von ter Zahnlänge, aus breiterem Grunde bald linealisch, bald sehr unregelmässig. zuweilen 16.

An nassen Kalkfelsen.

N. 1. Aker, Ialmoen; Baerum, Sandviken. Bu. Orre Eker, Lerberğhauğen. No. Alstahoug, Alstengen,

516. Orthotrichum urnigerum Myr. Corol]. fl. ups. p. 71 (18:36). [Dorcadion urnigerum Lindb. Muse. scancl. p. 28 (1879).]

Ziemlich kräftige Pfl. in lockeren bis dichten, grimen bis gelbbräunlichen, zuweilen bräunlichen oder schwärzlich grimen Rasen. Stengel bis 5 cm, niederliegend, in dichten Rasen anfrecht. Blätter aus eilänglichem Grunde lanzettlich, lang zugespitzt, bis 3,5 mm lang; Zellen fast bis zum Blattgrunde gleichgross. nur beiderseits an der Rippe ktrz rektangulär. Seheidchen dicht mit langen Haaren besetzt. Kapsel zur Hällte eingesenkt, dick eiförnig, mit kurzem, plötzlich in die Sela abgesetztem Ilalse, gelblich, im Alter braun, mit 8 längeren, sattgellen. Izellreihigen und 8 kürzeren, oft ganz fehlenden Längsstreifen, trocken und entleert kurz urnenförmig. Peristom toppelt, mil \pm entwickeltem, zuweilen fehlendem Vorperistom; Peristomzähne mit buchtigen Rändern, in fler unteren Hälfte grolo papillös, in der Mitte mit wurmförmigen Linien, gegen the Spitze längsstreifig, 
in der Mittellinie mehrmals durchbrochen: Fortsätze zu 16. gleichlang, längs der Iittellinie verdünnt. Haube weitglockig, strohfarben, mässig behaart. Sporenreife im Iai und Juni.

An beschatteten, kalkfreien oder kalkarmen Felsen.

F. Al. Finström, Wangelbro äng und Tärnebolstad (Bom.). Saltrik, Haraldsby (Arrh.); Lafö, Tuböle. Storriken (B.). - Le. Kilpisjärvi, Malla, spärl. (Kot.).

S. Sm.. Ö., Srml., Vstm.

N. A. bis ST., an einzelnen oder wenigen Fundorten, in $L M$., R. und $H$. noch nicht berbachtet. Steigt bis $680 \mathrm{~m}$, kaum über die Baumgrenze. Nordgrenze bei $62^{\circ} 35^{\prime} \mathrm{n}$. Br.

Schottland, Pyrenäen, Zentral-Europa, Nord-Amerika.

j.17. Orthotrichum Venturii De Not. Epil. 1). 305 (1869).

Ziemlich schlanke Pfl. in dichten, bräunlichen, kissenförmigen Rasen. Stengel bis $1,5 \mathrm{~cm}$, aufrecht. Blätter länglich-lanzeltlich, kurz zugespitzt, spitz oder stumpflich, bis 1,5 mm lang: Zellen fast bis zum Blattgrunde gleichgross. Schcidchen. dicht- und langhaarig. Kapsel wenig oder kaum emporgchoben, durch den langen, schnell verschmälerten Hals dick birnförmig, bleichgelb. bis zur Mitte mit 8 tzellreihigen Längsstreifen, trocken und entrleckelt weitmündig, mit 8 glänzend roten Rippen. Peristom doppelt. mit wenig entwickeltem Vorperistom: Peristomzähnc mit tief buchtigen Rändern, ohne Papillen, unten quer- und oben längsstreifig: Fortsätze zu 16, gleichlang. Haube glockig, gelbbräunlich, dicht- und langhaarig.

An Felsen. Steigt von $70-100$ bis $1,000 \mathrm{~m}$ hinaul.

N. $B u$. Hole, Skjerdalen $Y B$. Vik. K. Nordre Fron. Vistad i Kivikne. ST. Roros, hraernskaret. Tirol, Saroyen, Ober-Italien, Schweiz.

S e c t. I I. Euorthotrichum (Müll.-Hal.) Limpr. I. c. p. 53 emend. Hag. 1. c. p. 50 .

Peristomzähne weicher, trocken zurückgekrümmt oder der Urnenwand anliegend, dicht papillös, undurchsichtig. selten z. T. gestrichelt: Torperistom meist fehlend.

Su b se ct. 1. Orthotricha affinia llag. 1. c. p. 59.

Peristonzähne und Fortsätze des inneren Peristoms zu S. Kapsel röllig eingesenkt odler zur Hälfte emporgehoben; Spaltöffnumgen oberflächlich.

548. Orthotrichium affine Schrad. Spicil. fl. germ. p. 67 (179-4). [Dorcadion affine Lindb. Muse. scand. p. 28 (1879).]

Ziemlich kräftige Pfl. in lockeren, grünen oder gellgrünen Räschen. Stengel 2 -3 cm. Blätter aus länglichem Grunde verlängert lanzettlich, zugespitzt, bis $4 \mathrm{~mm}$ lang. Kapsel länglich-zylindrisch, mit in die Seta verschmälertem Halse. mit \& 2-3zellreihigen längsstreifen, trocken an der llündung etwas verengt, fein Srippig. Peristomzähne an der Spitze meist gefenstert und dreispitzig, dieht und fein papillös; Fortsütze fast von der Zahnlänge, schmal, papillös. Haube kegelig, nackt oder spärlich behaart. Sporenreile im Juni und Juli.

Auf Laubbäumen verschiedener Art, seltener an kalkfreien Steinen und Felsen.

F. Al. Jomala, Ramsholm (Bom.). Saltvik. Hagagảrd und Johannisberg (B.). Sund, in der Nähe des Pfarrhauses (B.). - Ab. Lojo, Kivinienni (H. Lindb.). - N. Ekenäs, Trärminne (H. Lindb.). Helsingfors (Lindb.). - st. Raumo (Karst.).

S. Sk. -Gstr. und Dlr.

N. Sm. bis R., ausschliesslich in den niedrig gelegenen Gegenden und nirgends $f_{q} .$. in $B r$. noch nicht beobachtet.

Europa, Nord-Afrika, Kaukasus, Nord-Amerika

5.19. Orthotrichum fastigiatum Bruch in Brid. Bryol. univ. I. p. 795 (1826). [Dorcadion affine var. fastigiatum Lindb. Musc. scand. p. 28 (1879).]

Weniger kräftig als die vorige Art m dichten, grünen oder gelbgrimen Räschen. Stengel bis $1 \mathrm{~cm}$. Blätter aus länglichem Gruncle lanzettlich, zngespitzt, bis $3 \mathrm{~mm}$ lang: Kapsel dick länglich-eiförmig, mit in die Seta verschmälertem Halse, mit 8 4-6zellreihigen Längsstreifen, trocken und entleert deutlich Srippig. Peristomzähne an der Spitze gefenstert und kreuzförmig, mit dichten wurmförmigen Linien: 
Fortsätze kürzer als die Zähne, kräftig, wurmförmig gezeichnet, zuweilen mit Anhängseln. Haube kegel-glockenförmig, nackt oder spärlich behaart. Sporenreife im Mai.

Auf Laubbäumen verschiedener Art.

F. Al. Hammarland, Skarpnátö (Arrh.). Geta, Östergeta (Elfr.). Saltvik, Johannisberg, Liby und Hagagảrd (Bom.). Sund, Kastelholm (B.). - Ab. Uskela (Häyr.), Lojo (H. Liıdb.). - N. Helsingfors (Lindb.).

S. Sk.—Ög., Vg., Boh., Hll., Srm., När. und Ång.

N. Sm. bis $N T$., ausschliesslich in niedrig gelegenen Gegenden und häufiger als $O$. affine. Nordgrenze bei $63^{\circ} 30^{\prime} \mathrm{n}$. Br.

Europa, Algier, Kaschmir, Nord-Amerika.

Sub sect. I I. Orthotricha arctica Vent. in Rev. bryol. 1880, p. 76.

Felsmoose. Kapsel oval, mit langem. in die Seta verschmälertem Halse. Peristomzähne tief inseriert, zu \& Paaren verbunden, fein papillös, trocken zurückgeschlagen-anliegend, oft mit Vorperistom. Fortsätze zu 8, flüchtig. kurz ocler rudimentär. Spaltöffnungen oberflächlich. Columella meist nicht zusammenschrumpfend. Haube \pm behaart. Sporen $20-27 \mu$.

550. Orthotrichum Blyttii Schimp. Bryol. eur. Suppl. I/1I. p. 3, t. 4 (1864). [Dorcadion Blyttii Lindb. Musc. seand. p. 29 (1879).]

Ziemlich kräftige Pfl. in dichten, starren, grünen oder bräunlichgrünen, leiclıt zerfallenden Rasen. Stengel $1-2 \mathrm{~cm}$. Blätter trocken dicht anliegend, aus verkehrt-eiförmiger Basis lineallanzettlich, kurzspitzig, etwa $2 \mathrm{~mm}$ lang; Zellen der oberen Hälfte verdickt, mit rundlichem Lumen, papillös, am Grunde quadratisch, nächst der Rippe kurz rektangulär. Innere Perichätialblätter eilanzettlich, allmählich zugespitzt, mit unterhalb der Spitze umgebogenen Rändern. Kapsel mit 8 langen. 3- tzellreihigen Streifen, trocken und ent leckelt oberwärts etwas verengt, srippig. Peristomzähne gelb ocler blass bräunlichgelb, am Grunde querstreifig, zuletzt sich voneinander \pm trennend. Sporen rostfarben, selten grün. Sporenreife im Juni.

S. Gstr.

N. An den Busen der Külste von No., Tr. und $F$, besonders auf kalkhaltigen Felsen, hier und dort masienhaft auftretend.

var. arcticum (Schimp.) Hag. Musc. Norv. bor. p. 83 (1899). [Orthotrichum arclicum Schimp. 1. c. p. 5, t. 5. - Dorcadion arcticum Lindb. 1. c. p. 29.]

Blätter breiter und stumpfer; Rippe zuletzt lebhaft braun. Innere Perichätialblätter breiter, kürzer zugespitzt, mit längs umgebogenen Rändern. Kapsel mit kïrzeren Streifen.

An offenen Küusten auf Steinen und Felsen allerlei Art.

F. Le. Knilpisjärvi, Sairovaara, in der alpinen Region (Kot.).- Lim. Kandalaks, Fedosejersk (Broth.). Porjaguba (Sel.). - Lt. Kola (Karst., Broth.); Arafjord (Broth.). - Lp. Orlor, froguliha und (Gubnoi (Kihlm.).

N. VB. bis F., zuweilen weit von der Küste in den Fjelden.

var. Sommerfeltii (Schimp.) Hag. 1. c. (Orthotrichum Sommerfellii Schimp. I. «. p. 6, t. 6. Dorcadion Sommerfellii Lindb. l. c.)

Blätter glatt, an der Spitze deutlich gekerbt.

N. Auf Schieferfelsen und Steinen an den Fjordufern entlang zw. dem 67. und 69. Breitengrad.

552. Orthotrichum groenlandicum Berggr. in K. Si. Vet.-Ak. Handl., Bd. 13. ํo. S, p. 23 (1875).

Kräftige Plı. in dichten, starren, lebhaft grïnen, leicht zerfallenden Rasen. Stengel bis $1,5 \mathrm{~cm}$. Blätter trocken dicht anliegend, breit eilanzettlich, stumpf, bis $2.8 \mathrm{~mm}$ lang; Zellen tler oberen Hälfte verdickt, mit rundlichem Lumen, in der Blattuitte etwa 17 , papillös, am Grunde guadratisch, näehst tler Rippe kurz. rektangulär. Innere Perichälialblätter wenig lifferenziert. Kapsel mit 8 langen, 2 - lzellreiluigen Streifen, trocken und entdeckell oberwärts etwas verengt, deutlich srippig. I'eristonzähme weisslich, am Grunde querstreifig, in der Mittellinie 
\pm rissig, zuletzt sich voneinander \pm tremnend. Sporen gelb, röllichgelb oder grün.

N. Bisher nur von einigen Fundorten in $T r$. und $F$. bekannt

Grönland.

553. Orthotrichum mitigatum lHag. Muse. Norv. bor. p. 86 (1899).

Ziemlich kräftige Pfl. in dichten, weichen, schwärzlichen oder oberwärts olivengrünen Rasen. Stengel etwa $1 \mathrm{~cm}$. Blätter trocken aufrecht-ahstchend, ejlanzettlich, rasch stumpfspitzig, bis $2,25 \mathrm{~mm}$ lang; Zellen sehr clünwandig, in der oberen Hälfte rundlich oder quadratisch, in der Blattmitte etwa $12 \mu$, chlorophyllreich, papillös, am Grunde quadratisch, nächst der Rippe kurz rektangulär. Innere Perichätialblätter länger und breiter. Kapsel dünnhäutig, mit langen - ]-5zellreihigen Streifen, trocken und entdeckelt oberwärts kaum verengt, deutlich 8riplpig. Peristomzähne gelb, am Grunde querstreifig, in der Vittellinie oberwärts rissig. Sporen braun.

N. F. Kistrand. an einer senkrechten Felsenwand nahe der Kirche sehr spärlich.

S u b s e c t. I I I. Orthotricha speciosa Hag. I. c. p. 6.

Kapsel emporgehoben: Spaltöffnungen oberflächlich. Peristomzähne zu 8 Paaren verbunden, grob papillös, trocken bogig zurückgekrümmt.

5.5. Orthotrichum laevigatum Zett. in Schimp. Syn. ed. 2. p. 309 (1876). [Dorcadion laevigatum Lindb. Musc. scand. p. 28 (1879).]

Kräftige Pfl, in lockeren, grünen oder gelb- bis bräunlichgrünen Raselı. Stengel $1-4 \mathrm{~cm}$, aufrecht oder anfsteigend. Blätter aus länglichem Grunde lineallanzettlich, kurz zugespitzt, his $3 \mathrm{~mm}$ lang: Zellen oberwirts beiderseits mit niedrigen, dichten, kegelförmigen Papillen. Kapsel klein, zylindrisch. dünnhäutig. glatt. Fortsätze des inneren Peristoms rudimentär oder fehlend. Haube kegel-glockenförmig, dicht behaart. Sporenreife im Juli.

Auf freiliegenden und schattigen Schieferfelsen der subalpinen Region. die Grenze der Birke kanm überschreitend.

N. NB. Aurland, Stejnbergdalen, $900 \mathrm{~m}$. Borgund. K. Lom, in der Nähe der Kirche; Rojsheim, $550-700 \mathrm{~m}$ : Visdalen. $650 \mathrm{~m}$.

Island, Nord-Amerika, Cascade ilts.

551. Orthotrichum microblephare Schimp. 1. c. p. 2, t. 3. [Docradion microblephare Lindb. Musc. scand. p. 28 (1879). - Orthotrichum brevinerve Lindb. in Notis. Sällsk. F. Fl. Fenn. XIII. (1873). - O. Pylaisii * microblephare Kindb. Sp. Eur. and X.-Am. Bryin. II. p. 302 (1897).]

Mit voriger Art nahe verwandt. Blattzellen weniger verdickt, schwach papillös bis fast glatt. Innere Perichätialblätter aus breit eiförmiger Basis kurz und breit zugespitzt, mit aufrechten oder oberhalb der Blattmitte schwach umgebogenen Rändern. Kapsel mit kurzen Längsstreifen, trocken undentlich gefurcht. Peristomzähne bleich, mit grösseren Papillen, oben mit wurmförmigen Linien. Sporen rostfarben, selten grün. Sporenreife im Juni. - Fig. 67 A F.

Auf exponierten Steinen und Felsen der Meeresküsten.

F. Al. Vårdö, Lảngskär und Ảggskär (Bom.). Brändö, Jurmo Harholnen (B.). — X. Ekenăs. Trärminne, Spikarna und Östra Vindskär (Häyr.). Sibbo, Löparö (Sael., Broth.). Lovisa, Kattön (Lindl.). - Om. Pedersöre, Bredskär (Backm.). - Le. Kilpisjärvi, Kilpiskoski (Norrl.). - Lim. Kandalaks (F. Nyl.). Sascheika (Karst.). - Lt. Kitovka und am Tulomafluse (Fellm.). - Lmur. Teribjerka (Broth.). Olenji (Karst.). - Lp. Ponoj (Brotl..).

S. Gstr, an mehreren Fundorten.

555. Orthotrichum speciosum Nees in Sturm Deutsch. Fl. fasc. 16 mit Abbild. (1819). [Dorcadion speciosum Lindb. Muse. seand. p. 28 (1879).]

Kräftige Pfl. in lockeren, grünen oder gelbgrünen Räschen. Stengel 2- $3 \mathrm{~cm}$. selten höher. Blätter breit lanzettlich, allmählich zugespitzt, bis $3-4 \mathrm{~mm}$ lang: Zellen oberwärts $18-20 \mu$, beiderseits mit niedrigen, dichten. kegelförmigen, spitzen Papillen. Kapsel zylindrisch, dümnhäutig, mit \& undeutlichen, tzellreihigen Längsstreifen,trocken und entleert schwach gefurcht oder glatt. Fortsätze 
zu 8, von der Zahnlänge oder wenig kürzer. kräftig. zweizellreihig, papillös, oft mit seitlichen Anhängen. Deckel mit schmalem, lichtrotem Saume. Haube kegelglockenförmig, gelb, dicht mit langen Haaren besetzt. Sporenreife im Juni und Juli.

Auf Laubbäumen verschiedener Art, seltener auf Steinen.

F. Al. fqq. (Bom.). - Ab. Korpo. Merimasku. Abo. St. Karins. Reso. Pargas. Kinito. Finby. Tenala. Bromarf. Lskela. Karislojo. Lojo. Tichtis. - N. Ekenäs. Snappertuna. Kỵrkslātt. Esbo. Helsingfors. Lovisa. Elimäki. Orimattita. - Ka. Sippola. Vehkalahıi. Miborg. Răisälä. - Ik. Muola. P̧̣hăjärvi. - St. Luvia. Björneborg. Pirkkala. - Ta. Jokioinen. Hausjärri. Vanaja. Kalvola. Sāāksmäki. Lempäälā. Im südöstl. Teile st. fq. Hartola. Luhanka, Judinsalo, Haukkaruori (Vain.). Korpilahti, Päiräkunta (Hāyr.). - Sa. Lappee. Kangasniemi (Lackstr.). - Kl. Sortavala. Kirjavalahti (Norrl.). Pälkjārvi. Annoniemi (Broth.). - Kol. fq. (Elfr.). - Oa. Närpes (Simm.). Vasa (Broth.). 一 Tb. Jỵä-kỵlä (Lesk.). Saarijärri, Kalıari und Taipale (Broth.). Viitasaari (B.). Pihtipudas, Sydänmaa, Antolan kallio (Roiv.). - Sb. Kiuopio st. fq. - nass. ? (Link.). Juuruve-i. Pelonniemi (Kyyhk.). Nilsiā, Kuuslahti, Jaakonlampi (Kyyhk. und Kot.). Maaninka, an mehreren Fundorten (Roix.): Pöljă. Luhimäki (Ǩỵhk.). - Ǩb. Tohmajărvi. Kemie, Jalajantaaara (Oesch). Nurmes, Hiidenportti (Tain.). - Kion. sıojārvi. Tarnakỵlä (Link.). Tiudie (Sel.). - Om. Alajärvi. Ojajärvi (Backın.). Lappajärvi st. fq. (B.). Jakobstad (Broth.). Gamlakarleby (Knab.). Pyhäjoki (Helaak.). 一 Ok. Kajana (Lack-tr.); Ảmmäkoski (Kyyhe.).

S. Sk.-Hrjd. und ing.

N. Sm.- Tr.

Europa. Algier. Kaukasus. Kaschmir. Amur, Nord-Ameriki.

var. elegans (Schwaegr.). [Orthotrichum elegans Schwager. in Frankl. Narrat. p. 756 (1823) ex Lindb. - O. speciosum * O. fuscum Lindl). in Notis. Sällsk. Fl. F. Fenn. XI. (1871). — Dorcadion elegans Lindb. Musc. scand. p. 28 (1879).]

Pfl. in allen Teilen kleiner. Kapsel glatt. Haube kürzer, fast glatt.

F. ‥ Helsingfors (Lindb.). - $h$. Kuusamo, Korojoki, an trockenen, feinen Zweigen ron Fichten in der Yăhe de: Was-ers (Broth.). Oulankajoki. Taivalkoski (Roiv.). - Lkem. Kittilä, Kirchdorf, an alten Birkenstämmen (Hult): Sodankỵlă. Kirchdorf (Vain.). - Le. Hetta - Vuontisjärvi und Kuttanen zwischen Palojärvi und Karesuanto, an zeitweise ïberschwemmten Birkenstämmen (Norrl.).

Rusiland, Sibirien. Ford-Amerika.

556. Orthotrichum Killiasii C. Müll. in Jahresb. (l. naturf. Ges. Graubindens 111. p. 160 (1858). [Doreadion Killiasii Lindl.. Muse. scand. p. 28 (1879).]

Weniger kräftige Pfl. in dichten, starren, schmutziggrünen Räschen. Stengel bis $2 \mathrm{~cm}$, aufrecht. Blätter schmal Janzettlich, stumpflich. bis $2.7 \mathrm{~mm}$ lang: Zellen oberwärts beiderseits mit zertreuten. langen. zylindrischen. an der Spitze abgerundeten Papillen. Kapsel zylindrisch, derbhäutig, olme Längsstreifen, trocken und entleert glatt. Fortsätze zu 8, von der Zahnlänge, breit, grob papillös, mit buchtigen Rändern. Deckei mit breitem, dunkelrotem Saume. Haube kegel-glockenförmig, bräunlich. spärlich mit langen Haaren besetzt. Sporenreife im Juli.

Auf Steinen und kleineren Blöcken.

N. In den Schiefergegenden ron Lom und Dovrefjeld, von $700 \mathrm{~m}$ bis über die Baumgrenze steigend. Alpenregion ron der Schweiz bis Kärnten. Kaukasus. Altai, Grönland.

var. transitoria Hag. in Kigl. Norsk. Vid. Selsk. Shrift. 1907. No. 13 (1908). Blätter zuweilen länger zugespitzt. Kapsel trocken und entleert längsfaltig. N. In den schiefergegenden von Lom und Dorrefjeld.

var. macroblephare (Schimp.) Lindb. in Öfvers. K. Sı. Vet.-Ak. Förh. 1866. 1. 549. [Orthotrichum macroblephare Schimp. Bryol. eur. Suppl., Orthotr. p. 7 (1S64).] Kapsel etwas dicker, elliptisch-zylindrisch. ent deckelt verkehrt oval-eiförmig. $\mathbf{N}$. In den Schiefergegenden ron Lom und Dovrefjeld.

Spitzbergen.

S u b s e e l. I V. Orthotricha striata Hag. 1. c. p. 70.

Kapsel nicht über die Hüllblätter emporgehoben; Spaltöfnungen oberflächlich. Peristomzähne 16. Fortsätze 16, von der Zahnlänge oder wenig kürzer, breit, grob papillös. mit lappig-buchtigen Rändern.

557. Orthotrichum striatum (L.) Schwaegr. Suppl. I. P. 11. p. 29, t. 54 (1816). [Bryum striatum L. S]. pl. 1115 (1753). Orthotrichum leiocarpum Bryol. eur. fasc. 3. p. 28, t. 15 (1837). - Dorcadion striatum Lindb. Musc. scand. p. 28 (1879).] 
Ziemlich kräftige Pfl. in kleinen, etwa $1 \mathrm{~cm}$ hohen ode̋r grossen, bis $3 \mathrm{~cm}$, selten höheren, lockeren, grünen oder gebräunten Räschen. Blätter aus cilänglichem Grunde lanzettlich, allmählich zugespitzt, bis $4 \mathrm{~mm}$ lang. Kapsel eingesenkt, eilänglich oder dick oval, kurzhalsig, glatt, trocken und entleert urnenförmig. Peristomzähne gẹlblich bis fast rötlichgelb. Haube weitglockig, mit wenigen liurzen oder zahlreicheren längeren Haaren besetzt. Sporenreile im Mai.

An Laubbäumen verschiedener Art.

F. Al. Saltrik, Liby (Bom.). Sund, Kastelholm (B.).

S. Sk., Sm., Gul., Hll., Vg., Boh.. När., Dld., Vrml., Gslr. und Mpd. Norbyknōl.

N. In den Küstengegenden ron Sm. bis Alten, in den südlicheren Teilen fqq., bis $300 \mathrm{~m}$ steigend und noch bei Trondhjem nicht selten, an mehreren Stellen nach innen dringend in den zentralen Teilen jedoch fehlend. Nordgrenze bei $70^{\circ} \mathrm{n}$. Br.

Europa, Algier, Kaukasus, Talysch, Kaschmir, Nord-Amerika.

558. Orthotrichium Lyellii Hook. et Tay1. Musc. 111t. p. 76, t. 22 (1818). [Dorcadion Lyellii Lindb. Musc. scand. p. 28 (1879).]

Diözisch; ‘ Pfl. schlanker. Krräftige Pfl. in lockeren, grünen oder gelbgrünen bis bräunlichen Rasen. Siengel $2-4 \mathrm{~cm}$, selten höher, aus niederliegendem Grunde aufsteigend. Blätter schmal lineallanzettlich, 3-4 $\mathrm{mm}$, flachrandig oder nur an Grunde etwas zurückgeschlagen. Perichätialblätter bis $6 \mathrm{~mm}$ lang. Kapsel dick und gross, nicht ganz über die Hüllblätter emporgehoben, länglich-oval, mit langem, in die Seta verschmälertem Halse, mit 8 , oben 4zellreihigen Längsstreifen, trocken und entleert srippig. Peristomzähne weisslich. Haube kegelförmig, spärlich oder reichlicher mit langen Haaren besetzt. Sporenreife im Juni und Juli. Vegetative Vermehrung durch blattbürtige und rhizoidenbürtige, rotbraune, einfache oder verschieden verzweigte, einzellreilige Brutfäden.

An Laubbäumen verschiedener Art.

S. Sk. st. fq., Bl., Öl., Sm. an mehreren Fundorten, Hll. ${ }^{q} q .$, Ol., Vg., Srml., Dld. und Vrml.

N. In den Küstengegenden von $\mathrm{Sm}$. bis $P$., nicht nur in den äusseren Teilen, sondern auch im Innern der Fjorde verbreitet, in Westlandet st. fq. und auf alten Bäumen oft massenhaft. Steigt bis $500 \mathrm{~m}$ hinauf. Nordgrenze bei $62^{\circ} 45^{\circ} \mathrm{n}$. Br.

Europa, Algier, Kaukasus, Nord-Amerika.

$\mathrm{S}$ u b s e c t. V. Orthotricha straminea Hag. 1. c. p. 73.

Peristomzähne zu 8 Paarzähnen verbunden. Spaltöffnungen eingesenkt.

559. Orthotrichum microcarpum De Not. in Erbar. critt. ital. fasc. 19/20 (1863) et in Epil. p. 306 (1869). [Orthotrichum obscurum Grönv. Bidr. p. 12 (1885) e Hag. 1. c. p. 73.]

Sehr kleine Pfl. in dichten, kissenförmigen, grünen, innen bräunlichen, durch Rhizoide verwebten Rasen. Stengel etwa $5 \mathrm{~mm}$, aufrecht. Blätter linealischzungenförmig, mit abgerundeter Spitze, bis $2 \mathrm{~mm}$ lang, flachrandig; Kapsel fast völlig eingesenkt, oval, mit etwas aufgeblasenem und in die Seta verschmälertem Halse, mit 8, oben 4-, in der Mitte 6zellreihigen Längsstreifen, trocken und entleert urnenförmig, Srippig und bräunlich: Spaltöffnungen mit sehr weitem Vorhof. Peristomzähne an der Spitze gefenstert, drei- oder einspitzig: Fortsätze zu 16, aus breitem Fusse fadenförmíg, abwechselnd länger und kürzer, letztere oft fehlend oder nur angedeutet. Haube glockig, gelblich, nackt.

An Laubbäumen.

N. Bu. Nedre Eker, Braaten. - ST. Trondhjem.

Nord-Italien, Kauka:us.

560. Orthotrichum pallens Bruch in Brid. Bryol. univ. I. p. 788 (1826); Bryol. eur. fasc. 2/3, p. 24, t. 13 (1837). [Dorcadion pallens Lindb. Musc. scand. p. 28 (1879).]

Schlanke Pfl. in kleinen, meist dichten, freudig- bis gelblichgriinen Räschen. Stengel bis $1 \mathrm{~cm}$, aufrecht. Blätter aus eilänglichem oder ovalem Grunde lanzettlich, mit breiter, kurzer, meist stumpflicher, zuweilen zungenförmiger Spitze, bis 
$3 \mathrm{~mm}$ lang; Kapsel zur Hälfte und mehr emporgehoben, eilänglich, mit in die Seta verschmälertem Halse, mit $\$$ \&-6zellreihigen Längsstreifen, trocken und entleert unter der Mündung mässig verengt; Spaltöffnungen mit sehr weitem Vorhof. Peristomzähne oben oft durchbrochen, aber selten gestrichelt; Fortsätze zu 16 , aus breitem Fusse fadenförmig, abwechselnd länger und kürzer, letztere oft rudimentär. Haube kegelförmig, gelb. scharf faltig, ohne Papillen und nackt. Sporenreife im Juni und Juli.

An Laubbäumen verschiedener Art, selten auch auf Wachholder.

F. Al. Eckerö, Storby (H. Lindb.). Finström. Grelsby und Tärnebolstad (Bom.). Geta. Dánö und Bastö (B.). Lemland, Nâtö (B.). Saltvik, Haga, Liby und Lafsböle (B.). Sund, Kastelholm und Jussböle (B.). - Ab. Abo, Katrinedal (Zett.). Lojo, Kiriniemi (Lindb.). - Ik. Valkjärvi, Pähkinämäki (H. Lindb.). - Ta. Hartola (Bonsd.). - Kl. Sortavala. Kirjaralahti (Lindb.).

S. Sk., oll. n. Br.

N. Sm. bis Ne., R, H., ST. und $N T$. Steigt nur loi= etwa $200 \mathrm{~m}$ hinauf. Nordgrenze bei $63^{\circ} 32^{\prime}$

Europa. Kaukasus, Nord-Amerika.

561. Orthotrichum pallidum Grönv. Bi(lr. 1). 15 (1885). [Orthotrichum pallens var. cuspidatum Grönv. Nya Bidr. p. 7 (1887).]

Schlanke Pll. in kleinen, dichten, gelblichgrünen Räschen. Stengel bis $1 \mathrm{~cm}$, aufrecht oder aufsteigend. Blätter aus eilänglichem Grunde lanzettlich, scharf zugespitzt, bis $2 \mathrm{~mm}$ lang. Kapseł zur Hälfte und mehr emporgehoben, eilänglich, mit in clie Seta verschmälerten Halse, mit 8 4-6zellreihigen, Längsstreifen, trocken und entleert unter der Mündung mässig verengt; Spaltöffnungen nit weitem Vorhof. Peristomzähne kürzer als bei den verwandten Arten, oben mit 1-3 deutlichen Querlamellen, überall selır fein paillös, in der Verbindungslinie oben mit einer listenförmigen, über die Spitze austretenden Erhebung: Fortsätze zu 16, hier und da mit Anlıängseln, abwechselnd länger und kürzer, letztere oft fehlend. Haube kegelförmig, gelb, scharf faltig, längs den Falten mit dentlichen Papillen, nackt oder mit einzelnen Haaren besetzt.

An Laubbämmen verschieclener Art. seltener auf Wachholder.

N. $B u$. bis Ne., SB. bis $T r$, besonders im Waldgebiete, im Kïstengebiete von Westlandet fehlend. Nordgrenze bei $69^{\circ} 40^{\prime} \mathrm{n}$. Br.

Sibirien, Nord-Amerika.

562. Orthotrichum paradoxum Grönv. in Öfv. K. Vet.-Ak. Förlı. 1889, No. 3. p. 179.

Ziemlich schlanhic Pll. in dichten, oft ziemlich ausgebreiteten, bräunlichen, nur am Gipfel grünen Rasen. Stengel bis $1 \mathrm{~cm}$, aufrecht. Blätter aus länglicher Basis lanzettlich, allmählich zugespitzt, bis $3 \mathrm{~mm}$ lang: Zellen oberwärts beiderseits dicht mit langen Papillen, am Grunde rektangulär und knotig verdickt, am Rande kürzer bis quadratisch. Kapsel zur Hälfte eingesenkt, längliclı, gelb, mit in die Seta verschmälertem Halse, mit 8 - -6zellreihigen Längsstreifen, trocken und entleert unter der Mündung wenig verengt. Peristomzähne nicht durchbrochen, olne Lamellen, zuweilen oberwärts selır undeutlich gestrichelt: Fortsätze zu 16, fadenförmig, fast von der Zahnlänge. Haube alhmählich verschmälert, trocken sehr verengt, gelb, scharf faltig, ohne Papillen und nackt.

An Wachholder und Weiden.

N. K. Vaage, Sorem, 1,020 m. ST. Opdal, Vang:fjeldet, $800 \mathrm{~m}$; Haakaar, $700 \mathrm{~m}$. Schweiz.

563. Orthotrichum Arnellii Grönv. Bidrag p. 15 (1885), Limpr. Laubm. II. p. 7.1 (1890). |Orthotrichum gevaliense Grönv. in Bot. Notis. 1884, p. 11. - O. boreale Grönv. Nya Bidr. p. 8 (1887).]

Ziemlich schlanke Pll. in kłeinen, dichten, grünen oder gelbgrïnen Räschen. Stengel bis $1 \mathrm{~cm}$, aufrecht. Blätter aus länglichem oder eiförmigen Grunde breit lanzettlich, stumpf bis abgermndet, bis 3 mm lang. Kapsel zur Hälfte vortretend, 
länglich, bleich, dünnhäutig, mit $\& 1-7$ zellreihigen Längsstreifen, mit etwas aufgeblasenem, in die Seta verschmälertem Halse, trocken und entlecrt unter der Nlündung etwas verengt, gelblich, im Alter rötlich. Peristomzähne in der Spitze zuweilen gefenstert, in der oberen Hällte mit warmfömigen Linien: Fortsätze zu S, krältig, wenig kürzer als die Zähne, glatt, zuweilen mit schwachen Anhängseln. Haube kegelig, gelblich, an den Falten mit spärlichen Papillen und nackt. Sporenreife im Juli. - Fig. 67 l- Is.

An Laubbäumen verschiedener Art und auf kalkfreien Steinen und Felsen.

F. Al. Jomala, Ramsholm (Bom.). Saltvik, Hagagard und Frarnbo (B.). Sund. an der Yrauer um die Kirche (B.). - N. Lovisa, Kattön (Lindb.). - Ik. Pyhäjärvi. Toubila (H. Lindb.). -. Oa. Tasa (Bruth.). Replot. Vallgrund (Kar:t.).

S. Gstr.. Ipd. Grapsjün. Ang. an mehreren Fundorten.

N. Bu., Br., Ne., LK., VB.. K., II. sT.. an einzelnen oder wenigen fundurten, be-onder: im Traldrebiete.

564. Orthotrichum Philiberti Vent. in Rev. bryol. 1878. p. 4.

Niedrige, sclnlanke Pfl. in kleinen, bräunlichgrünen Räschen. Stengel nur wenige mm. Blätter aus länglichem Grunde lanzetlich, rasch kurz- und hyalinspitzig, bis $2 \mathrm{~mm}$ lang. Kapsel zur Hälfte emporgehoben, aus kurzem, bauchigen Halse dick oval, mit 8 in der IIitte 5-6zellreihigen Längsstreifen. trocken und entdeckelt urnenförmig und 8rippig. Peristomzähne später in Einzelzähne gesondert. Fortsätze zu \&, etwas kürzer als die Zähne, ans breiter Basis pfriencnförmig. Haube glockenförmig, abwïrts nackt, ob?n dicht behaart.

N. An Bäumen an wenigen Fundorten $2 w^{\circ}$. Bergen und Nordfjord $\left(61^{\circ} 50^{\prime} \mathrm{n}, \mathrm{Br}\right.$.).

Provence, Sardinien.

565. Orthotrichum alpestre Hornsch. Mscr., Bryol. eur. fasc. 12, Suppl. I. t. 1 (18.19). [Dorcadion alpestre Lindb. Musc. scanct. p. 28 (1879).]

Ziemlich schlanke Pfl. in dichten bis lockeren. bläulich- bis braungrünen Räschen. Stengel his $2 \mathrm{~cm}$, aufrecht. Blatter aus herablanfendem, eilänglichem Grunde lanzettlich-linealisch, liurz zugespitzt, bis 3,5 mm lang; Rippe vollständig; Zellen oberwärts beiderseits dicht stachelig. Kapsel zur Hälfte odler ganz emporgehoben. Ume oval, durch den wenig kürzeren Hals allmählich verschmälert, bleichgelb, mit $\delta$ oben t-, in cler Mitte 6zellreihigen Längsstreifen, trocken und entdeckelt mnter der Mündung etwas verengt. Srippig, entleert später bräunlich und in der Mitte zusammengezogen. Peristomzähne in der unteren Hälfte fein papillös, in der oberen papillös-längsstreifig, in der Vittellinie geschlitzt, oben gefenstert oder 3-4spitzig: Fortsätze zu 8. aus breiter Basis fackenförmig, fast glatt, hier und da nit knotigen Anhängseln. Haube weisslichgelb, mässig langhaarig. Sporenreife im Juli.

Aul \pm beschatteten Felsen und Felsblöcken, besonders Schiefern und = kalkhaltigen Gesteinen, seltener an Baumstämmen.

F. Ka. Wiborg (W. Nyl.). - Ta. A-ikkala (Norrl.). - kl. Kurkijoki, Terrus (Jusl.). Valamo (W. Nyl.). Jaakkima. Puutsalo (Lindb.). Sortavala, Sraasu (Norrl.) Impilahti. Pullinvuori (Broth). Soanlahti, Korpilahti und Koirinvaara (B.). - Ta. Padasoki (Norli.). Hartola (Bonsd.). - Tb. Viitasaari, Koliatinvuori (Broth.). - Sb. Kaavi, Siikajärvi, Liko:aari (Kot.). Juıka. Petı́naara (K.). Nilsiä. Kuuslahti, Jaakonlampi (Krylak. und Kot.). Maaninka Tuorilanlahti (Lundstr.): Arkkuruori (Roir.). Kb. Tohmajärvi. Rääkkävuori (Broth.). - ob. Rovaniemi, Alajää-kö (Hult).. - K. Kunsamo, Rukajärvi (Broth.); Kỉtkajoki, Pää‘köskallio (B.); Juuma, Jäkälāruoma (B.): Paanajärvi, Ru^keakallio (B.). - Lkem. Im Fjeldgebiete st. fq. (Hulı). - Le. Pietsovaara (Norrl.). Kilpisjärvi, Guonjarrankika (Kont.). - Lim. Kandalaks, Fedosersk und Schelesnaja (Broth.). Tschun (B.). - Lt. Kola, Abramora Pahta (Brolh.). - Lp. Ponoj (Broth.).

S. Jmt. an mehreren Fundorten. Ang. Säbră. LyL. und PL.. I.uL. an mehreren Fundorten.

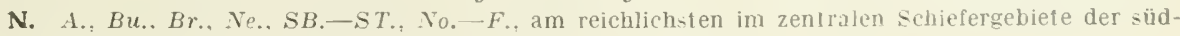
lichen Hälfte, in Ranen und Salten und be-onders in Waldgebiele.

Zentral-Europa. Pyrenäen, Kaschmir. Sibirien, Nord-Amerika.

566. Orthotrichum stramineum Hornsch. in Brid. Bryol. univ. I. p. 789 (1826): Bryol. eur. fasc. $2 / 3$ p. 23. t. 13 (1837). [Dorcadium stramineum Lindb. Musc. scand. p. 28 (1879).] 
Ziemlich schlanke Pfl. in kleinen, lockeren bis mässig dichten, grünen oder gelbgrünen Räschen. Stengel 1-2 cm. Blätter länglich-lanzettlich, kurz zugespitzt, bis $3 \mathrm{~mm}$ lang. Scheidchen kurz, eiförmig, dicht mit langen Haaren besetzt. Kapsel zur Hälfte, zuweilen ganz emporgehoben, oval oder länglich-eiförmig, gelb, derbhäutig, mit in die Seta verschmälertem Halse und mit 84 -6zellreihigen Längsstreifen, entdeckelt unter der Iündung eingeschnürt, entleert verlängert, braunrötlich. Peristomzähne nicht gestreift, an der Spitze meist \pm durchbrochen und dreispitzig; Fortsätze zu 16, aus breiter Basis fadenförmig, abwechselnd länger und liürzer, letztere zuweilen rudimentär. Haube glockig bis kegelförmig. strohgelb, mit spärlichen kurzen Haaren, selten nackt. Sporenreife im Juni und Juli.

An Laubbäumen allerlei Art, selten auf Steinen.

F. Al. Jomala, Fin-tröm. Lemland und sund an einzelnen, saltrik an vielen Fundorten (Bom.). Ab. Lojo, Kiviniemi (H. Lindb.). - N. Ekenäs, Elgmo (Lindb.). — Sb. Nilsiā, Kuułlahti, Jaakonlampi (Kiot.).

S. Sk. und Boh. an mehreren Fundorten, Öl.. Hll. Ög.. Vg.. Srml., När.. Dld. und Áng.

N. An der Kilste bis Trondhjem-fjord fq., läng=den Fjordufern und in ebeneren Gegenden nach dem Binnenlande bis 200 in dringend. Nordgrenze in Lofoten, bei $68^{\circ} 7^{\prime} \mathrm{n}$. Br.

Europa. Kaukisu=

var. defluens Vent. in Hedwigia 1873, p. 19.

Kapsel etwas hervortretend; Hats von Urnenlänge und bis zur Ochrea verschmälert, trocken verengt und von der Urne abgesetzt.

N. Nach $\mathrm{H}$ a gen fq. und etwa wie die Hauptart verbreitet.

Zentral-Europa, Spanien, Kaukasus.

567. Orthotrichum patens Bruch in Brid. Bryol. univ. I. p. 787 (1826).

Ziemlich schlanke Pfl. in meist kleinen, lockeren, grünen oder gelbgrünen Räschen. Stengel niedrig, selten bis 1,5 cm. Blätter schmal lanzettlich, lang und scharf zugespitzt, bis $3 \mathrm{~mm}$ lang; Scheidchen zylindrisch, dicht- und langhaarig. Kapsel eingesenkt oder zur Hälfte emporgelıoben, dick eiförmig, bleichgelb, dünnhäutig, mit $S$ kurzen, 2-tzellreihigen Längsstreifen, entleert urnenförmig, bauchig erweitert. Peristomzälne nicht gestreift und nicht durchbrochen; Fortsätze zu 8 , aus breiter Basis fadenförmig, etwas kürzer als die Zähne. Haube weit glockenförmig, gelb bis goldgelb, mässig kurzhaarig. Sporenreife im Mai.

An Laubbäumen verschiedener Art.

S. Sm., Gll., $\mathrm{rg}$. und Boh, an einzelnen Fundorten.

N. In der Ebene un den Kristianiafjord st. r.

Europa.

568. Orthotricham Schimperi Hamm. Mon. Orthotr. suec. p. 9 (1852). [Docradion Schimperi Lindb. Musc. scand. p. 28 (1879).]

Schlanke Pfl. in kleinen, gelb- oder schmutziggrünen Räschen. Stengel bis $1 \mathrm{~cm}$, aufrecht. Blätter lanzettlich-linealisch, kurz und breit zugespitzt, stumpflich oder mit Stachelspitzchen, bis 2,5 $\mathrm{mm}$ lang; Zellen sehr dünnwandig. Kapsel eingesenkt, aus kurzem, bauchigem Halse dick oval, mit 8 in der Mitte 5 -6zellreihigen Längsstreifen, trocken und entdeckelt urnenförmig und 8rippig. Peristomzähne weder gestreift noch durchbrochen, später in Einzelzähne gesondert; Fortsätze zu 8, etwas kürzer als die Zähne, aus breiter Basis pfriemenförmig. Haube glockenförmig, weisslichgelb, nackt. Sporenreife in Mai und Juni.

An Fejd-, Garten- und Alleebäumen.

S. Sk.- - Hlsl. und Jmt.

N. An der Küste ron Sim. bis Kristiansand, im $S B$ und $N B$ st. fq., ron der Kü̈te nach den ebenereu Gegenden des Binnenlande: bis $100 \mathrm{~m}$ dringend. Nordgrenze am südufer des Tromdhjemsfjords bei $63^{\circ} 31^{\prime}$ n. Br.

Eurola, Algier, Kaukasus, Semirjetschensk, Japan, Nord-Amerika.

569. Orthotrichum pumilum Sw. Disp. muse. suec. p. 42 et 92, t. 4 , f.9 (1799). [Dorcadion pumilum Lindb. Musc. scand. p. 28 (1879).]

Ziemlich schlanke Pfl. in kleinen, dunkelgrünen oder gelblichen Räschen. Stengel $5 \mathrm{~mm}$, selten bis $1 \mathrm{~cm}$, aufrecht. Blätter aus länglicher Basis Janzettlich, 
allmählich scharf zugespitzt, selten stumpflich, l,is 3 mm lang: Zellen sehr tünnwandig. Kapsel zur Hälfte oder mehr emporgehoben, länglich, nit allmählich in die Seta verschmälertem. Halse, mit $S$ in der Vitte meist 6zellreihigen Längsstreifen, trocken und entdeckelt scimal urmenförmig und srippig, zuletzt braun. Pcristomzähne weder gestreift noch durchbrochen; Fortsätze zu 8 , von der Zahnlänge oder kürzer, aus breiter Basis pfriemenförnisg. Hanbe kegel-glockenförmig. blassgelb, braun gespitzt, nackt. Sporenreife im Mai und Juni.

An Feld- und Alleebäumen.

F. Al. Jomala, Jomalahy (Bom.). Geta, Bolstaholm (B.). Saltwik und sund an wenigen Fundorten (B.). - Ab. Abo (Elfr.). - N. Ekenäs, Trärminne (Broth.). Ingá, Pả̧̊kär (TI. Brenn.). Sjundeả, Myrans (Lindb.). Helsingfors (L.).

S. Sk.-Mpd. Norbyknöl.

N. Verbreitung wie bei $O$. Schimperi. in Westlandel jedoch seltener.

Europa. Kanaren, Kaukasus.

570. Orthotrichum Braunii Bryol. eur. fasc, 2/3, p. 16, t. 7 (1837).

Ziemlich schlanke Pfl. in kleinen, mässig dichten, gelblichen bis olivengrünen Räschen. Stengel meist nur 5-8 mm. Blätter trocken dachziegelig, aus eilänglichem Grunde lineallanzettlich, kurz zugespitzt oder stumpflich, 1,8-2,7 mm lang. Scheidchen zylindrisch, mit zahlreichen, gelben Paraphysen. Kapsel eingesenkt oder wenig vortretend, oval, mit allmählich in die Seta verschmälertem Halse, mit 8 tzellreihigen, gelbroten Längsstreifen, trocken und entlecrt urnenförmig und 8rippig. Peristomzähne weder gestreift noch durchbrochen; Fortsätze zu 8, kürzer als die Zähne, aus breiter Basis pfriemenförmig. Haube klein, kegelglockenförmig, glänzend strohfarben, braun gespitzt, nackt.

N. JL. Holmestrand.

Zentral-Europa, an Laubbäunen, sehr selten auf Steinen.

571. Orthotrichum tenellum Bruch in Brid- Bryol. univ. I. p. 786 (1826). [Dorcadion tenellum Lindb. Musc. scand. p. 28 (1879).]

Ziemlich schlanke Pfl. in kleinen, lockeren, grünen oder gellogrünen Räschen. Stengel bis $1 \mathrm{~cm}$, aufrecht. Blätter aus eilänglichem Gruncle lanzettlich-zungenförmig, mit breiter, stumpfer Spitze, bis 2,4 mm lang. Kapsel his zur Hälfte oder länger emporgehoben, länglich-zylindrisch, mit langem, in die Seta verschmälertem Halse, mit 8 tzellreilhigen Längsstreifen, trocken und entleert in der Mitte verengt, 8rippig. Peristomzähne ungestreift, zweispaltig; Fortsätze zu 8, von der Zahnlänge oder wenig kürzer, fadenförmig, am Grunde zweizellreilhig. Haube kegelförmig, gelblich, braunspitzig, spärlich behaart. Sporenreife im Mai.

An Laubbäumen verschiedener Art.

S. Sk. an mehreren Fundorten und Git.

N. St. an wenigen Fundorten im südwestl. Teile. Nordgrenze bei $58^{2} 58^{\prime} \mathrm{n} . \mathrm{Br}$.

Europa, Nord-Amerika.

572. Orthotrichum Rogeri Brid. Sp. musc. II. p. 9 (1812).

Ziemlich schlanke Pfl. in selır lockeren, schmutzig dunkelgrünen Räschen. Stengel bis $1 \mathrm{~cm}$. Blätter locker gestellt, schlaff, trocken etwas gekräuselt, aus ovaler bis verkehrt eilänglicher Basis lanzettlich-zungenförmig, mit breit abgerundeter, meist etwas eingehogener Spitze, his 2,7 mm lang. Kapsel zur Hälite bis ganz eingesenkt, länglich, mit langem, in die Seta verschmälertem Halse, mit 8 oben 4-, abwärts 6- und 7zellreihigen rotbraunen Längsstreifen, trocken und entleert in der Mitte verengt, 8rippig, rotbraun. Peristomzähne rotgelb, weder gestreift noch durchbrochen, in der Spitze mit dunkler gefärbten, gut entwickelten Lamellen; Fortsätze zu 8, kürzer als die Zähne, längsstreifig. Sporen 18-26 $\mu$. Sporenreife im Juli. Haube nackt.

An Laubbäumen, besonders an Ebereschen, jedoch auch an Apfelbäumen, Pappeln, Linden und Flieder.

S. Sk. Börringe und Lund, öl. 
N. An der Küste zw. Kristiansand und Kristiansund fq.-fqq. und im süds. Teile der Westseite des Krislianiafjords. Nordgrenze bei $63^{\circ} \mathrm{n}, \mathrm{Br}$.

West- und Zeniral-Europa, Nord-Amerika.

Subsect. V I. Orthotricha pulchella Hag. 1. c. p. 90.

Ausseres Peristom sich sehr bald in 16 Einzelzähne auflösend, weder gestreift noch durchbrochen. Spaltöfnumgen eingesenkt.

573. Orthotrichum leucomitrium Bryol. eur. fasc. 2/3, p. 26, t. 15, sed non Bruch in Brid. Bryol. univ. 1. p. 790 (1826). [Orlhotrichum scanicum Grönv. Nya Bidr. p. 13 (1887).]

Ziemlich schlanke Pfl. in kleinen, lockeren, grünen bis gelbgrünliehen Räschen. Stengel bis $1 \mathrm{~cm}$. Blafter weich, aus ovaler Basis lanzettlich, mit breiter, meist etwas gezähnter Spitze, bis 2,7 mm lang. Kapsel ganz oder zur Hälfte eingesenkt, länglich, mit gleichlangem, in die Seta verschmälertem Halse mnd \& 2-3zellreilıigen Längsstreifen, trocken und entleert zylindrisch, Srippig. Peristomzälnne blassgelblich; Fortsätze zu 16, von der Zahnlänge oder wenig kürzer, oft mit Anhängseln. Haube glämzend, weisslich, nackt oder unter der gelbbräunliehen Spitze mit wenigen, kurzen Hataren.

An Feld- und Waldbäumen verschiedener Art.

S. Sh.

N. JL. Hedrum.

Zentral-Enropa, Italien.

571. Orthotrichum pulchellum Brunton in Engl. Bot. t. 1787 (1807). [Dorcadion pulchellum Lindb. Musc. seand. p. 28 (1879).]

Schlanke Pfl. in kleinen, lockeren, grünen oder gelbgrünen Räschen. Stengel $5-15 \mathrm{~mm}$. Blätter trocken etwas verbogen, aus schmal lanzettlicher Basis allmählich lang und fein zugespitzt, bis $3 \mathrm{~mm}$ lang. Kapsel emporgehoben, klein, länglich, mit in die Seta verschmälertem Halse, mit 8 meist 4zellreihigen Längsstreifen, entleert unter der Mündung verengt und 8rippig. Peristomzähne gelbrot; Fortsätze zu 16, von der Zahnlänge oder weniy kürzer, fadenförmig, zuweilen knotig oder mit vereinzelten Anhängseln. Sporenreife im Mai. Haube kegel-glockenförmig, gelblich, braunspitzig.

An Stämmen und Ästen von Bäumen und Sträuchern.

S. Sk. an mehreren Fundorten.

N. An der Westküste von Ekersund bis Trondhjem. Fordgrenze lee $63^{\circ} 25^{\prime} \mathrm{n}$. $\mathrm{Br}$.

Gross-Britannien, No:tkilste von Frankreich. nordweitl. Deutschland, bezonder an der Nordsee, Nord-Amerika.

575. Orthotrichum diaphanum (Gmel.) Sehrarl. Spic. Fl. germ. ए. 69 (1794.) [Bryum diaphanum Gmel. Syst. nat. II. 1335 (1791). - Dorcadion diaphanum Lindb. Muse. seand. p. $28(1879)$.]

Ziemlich schlanke Pfl. in kleinen. oft zusammenfliessenden, grïnen Räschen. Stengel bis 1 cm. Blätter schlaff, aus länglichem Grunde breit lanzettlich, kurz. zugespitzt, in ein kurzes odler längeres, hyalines Haar auslaufend, bis 2, ; $\mathrm{mm}$ lang; Zellen glatt oder oherwärts schwach papillös, diumwandig, rundlich-eckig, chlorophyllreich, 18-2:3 $\mu$, am Grunde kurz rektangulär, am Rande quadratisch. Kapsel ganz oder über die Hälfte eingesenkt, aus kurzem Halse länglich, undeutlich gestreift, entleert zylindriseh, zart Srippig. Peristomzähne weisslich, längsstreifigpapillös, zuweilen an der Spitze gespalten; Fortsätze zu 16, nur wenig kürzer als die Zähne, sehr dünn. dicht papillös. Haube kegel-glockenförmig. strohgelb bis bräunlich, nackt orler mit wenigen kurzen Haaren. Sporenreife im Frülıling. — Vegetative Vermehrung dureh blattbürtige, zur Reile braune, einzellreihige Brutkörper.

An alten Feldbäumen, wie auch auf Steinen.

S. Sk., Bl., Öl., Sm., Gll.. Ö.. Boh.. Erml., Xür. und İsm.

N. An beiden Seilen der Iründung des krislianiafjords und an der Küsle von Farsund bis Bergen, nirgend $=$ weil nach innen dringend. Nordgrenze bei $60^{\circ} 25^{\circ} \mathrm{n} . \mathrm{Br}$.

Zentral- und Sïd-Europa. Kanaren, Ilgier, Sibirien, Nord-Imerika. 


\section{STROEMIA}

Hag. in D. K. N. Vid. Selsk. Slirift. 1907. No. 13, 1. 92 (1908).

Diöziseh. Ziemlieh sehlanke Pfl. in dichten oder lockeren, leicht \%erfallenden, bläulich-oder gelblieh bis bräunlichgrünen Polstern oder Rasen; $r$ Pfl. schwächer. Stengel aufrecht, gabelig geteilt, zuweilen mit schlanken, kleinblättrigen, sterilen Sprossen. Blätter trocken dachziegelig, feucht abstelsenı, lölfellörnigg-hohl, eiförmig oder eilänglieh, mit abgerundeter Spitze, 2-3 mm lang; Rippe schwach, vor der Blattspitze aufhörend; Zellen überall einschichtig, am Blattgrunde glatt, beiderseits an der Rippe rektangulär, mit zuweilen schwach buehtigen Lüngswänden, am Rande in mehreren Reihen kürzer bis quadratisch. Seta sehr kurz. Kapsel von den grösseren Perichätialblättern umhüllt. Spaltöffnungen oberflächlich, etwa um die Urnemmitte. Haube klein, etwa die Hälfte der Ĺrne deckend, nackt oder unter der Spitze behart. - Vegetative Vermehrung durch blattbürtige, zur Reife braune, einfache oder verästelte, einzellreihige Brutkörper.

\section{Übersieht der Arten.}

A. Blätter mit anfrechten Rändern. Periston doppelt ...... 576. S. obtusifolia.

B. Blätter mit breit eingerollten Rändern. Peristom fehlend. 577. S. gymnostoma.

576. Stroemia obtusifolia (Schrad.) Hag. 1. e. p. 91. [Orthotrichum obtusifolium Sehrad. Krypt. Gew. No. 14 (1796). - Dorcadion obtusifolium Lindb. Muse. scand. p. $29(1879)$.!

Stengel bis $1,5 \mathrm{~cm}$. Blätter mit aufrechten oder in der Nitte schwach cingebogenen Rändern; Zellen oberwärts etwa $18 \mu$, beiderseits mit einer dieken Papille über deni Lumen. Kapsel länglich-oval, mit langem, allmählieh in die Seta verengtem Halse, trocken und entleert unter der Mündung eingeschnürt, mit 84 6zellreihigen, deutlichen Längsstreifen. Peristom doppelt, gelbrot; Peristomzähne anfangs zu 8 Doppelzähnen verbunden, später in Einzelzähne gesondert, dicht papillös, trocken zurückgeschlagen anliegend; Fortsätze des inneren Peristoms 8 . fadenförmig, etwas kürzer oder so lang wie die Zähne, zweizellreihig, oben papillös oder wurmförmig gestrichelt. Deckel mit sehr kurzem Spitzehen. Sporen 1.)-. $18 \mu$, gelbbraun, warzig. Sporenreife im IIai und Juni. - Fig. $66 \mathrm{~A}-\mathrm{F}$.

An Laubbäumen, besonders Espen.

F. Al., nicht selten (Bom.). - Ab. Abo, Katrinedal (Zett.). Reso, Luonnonmaa (Fieandt). Uskela, Kuskis (Lindb.). Lojo, an der Kirche (H. Lindb.); Kiviniemi, Gerknäs und Hakosaari (H. L.). Vichlis, Olkkala (E. af H.). - N. Ekenäs (Häyr.) Ingá, Stor-Ramsö (W. Brenn.). Kyrkslält (Sol., Ranck.). Helsingfors (Lindb.). Borgă, Sannäs (Broth.). Elimäki (Tigerst.). Orimattila, Pakia, Hilledal (Link.). Ka. Wiborg (W. Nyl.). Antrea. Papinsaari (Lindb.). - Ik. Kuolemajärvi IIuurila (H. Lindb.). Munla Perkjärvi (H. L.). Rautu. Sumbula (Lảng). - St. Llísby Koivisto (Häyr.). Björneborg (H.). Nurrmark, Södermark (H.). Ikaalinen. Nygård und Vaurila (Sundr.). - Ta. Tarastehus (Thur. Ranck.). Im südöstl. Teile pass. (Norrl.). Korpilahti pass. (Vain.). Luhanka, Kesäin (V.). _ sa. Kangasniemi (Lackstr.). - Kol. st. fq. (Elfv.). Petrosavodsk (Günth.). - Oa. Närpes, Benvik (Nerv.). - Tb. Jỹäskylä (Link.); Norola und Lauriniemi (Vain.). Saarijärvi, Kalmari (Broth.). Kinnula. Saarenkylä, Jekkovuori (Roiv.). Pihtipudas, IIuurasjärvi. Kojola (R.). - Sb. Joroinen. Örnevik (H. Lindb.). Kuopio, Vehmasıäki, Pirttimäki (Link.): Kasurila, Laukanranta (Kyylk.). Juuka. Halivaara (Kol.). Maaninka, rianto (Roir.). Pöljä, an einigen Fundorten (Krṿk.). Pielave-i. Laukkala (Roir.). - Kb. Tohmajärri, Kemie (Oesch). Joensuu (Linnan.). - Kon. Rogosa (W. Nyl.). Kentjärvi (Simm.). Tiudie (Sel.). Klimskij monastir (Simm.). Pirttiniemi (S.). - Om. Lappajärvi, Kirchdorf (Backm.) — Ok. Kajana, auf den Ruinen von Kajaneborg (Lackstr.). - Kpom. Luvajärvi (Tain.). — K. Kuusamo. Kitkajoki (Broth.). Näränkävaara (Vain.). ¿berall, wo alle Espen vorkommen. aluch fruchtend (E. af H.). 一 hik. sioukelo (Brenn.). - Lkem. Kuolajärvi, Naruskajoki, Politimaselkä (E. af H.). - Li. Patsjoki (Tain.). - Lim. Porjaguba (Sel).

S. $S k,-L$.

N. In den Lmgebungen des Kristianiafjords fqq., durch Osterdalen und lsudlirand-dalen nach Lom und durclı Eker nördl. von Ringerike vordringend, ferner in Telemarken und saetersdalen verbreitet, in Westlandet aber sehr zerstreut. Nördlicher bis $T r$, seltener. Nordgrenze bei $69^{\circ} 23^{\prime} \mathrm{n}$. Br.

Europa, Kaukasus, 1 . Himalaya, Sibirien, Nord-Amerika. 
577. Stroemia gymnostoma (Bruch) Hag. 1. c. p. 93. [Orthotrichum gymnostomum Bruch in Brid. Bryol. univ. I. p. 782 (1826).]

Stengel bis $3 \mathrm{~cm}$. Blätter mit breit eingerollten Rändern; Zellen oberwärts $10-14 \mu$, beiderseits mit ziemlich langen Papillen besetzt. Kapsel zylindrisch, mit kurzem, plötzlich zur Seta abgesetztem Halse, trocken und entleert unverändert, sehr zarthäutig, mit 83 -5zellreihigen, meist undeutlichen, zur Reifezeit

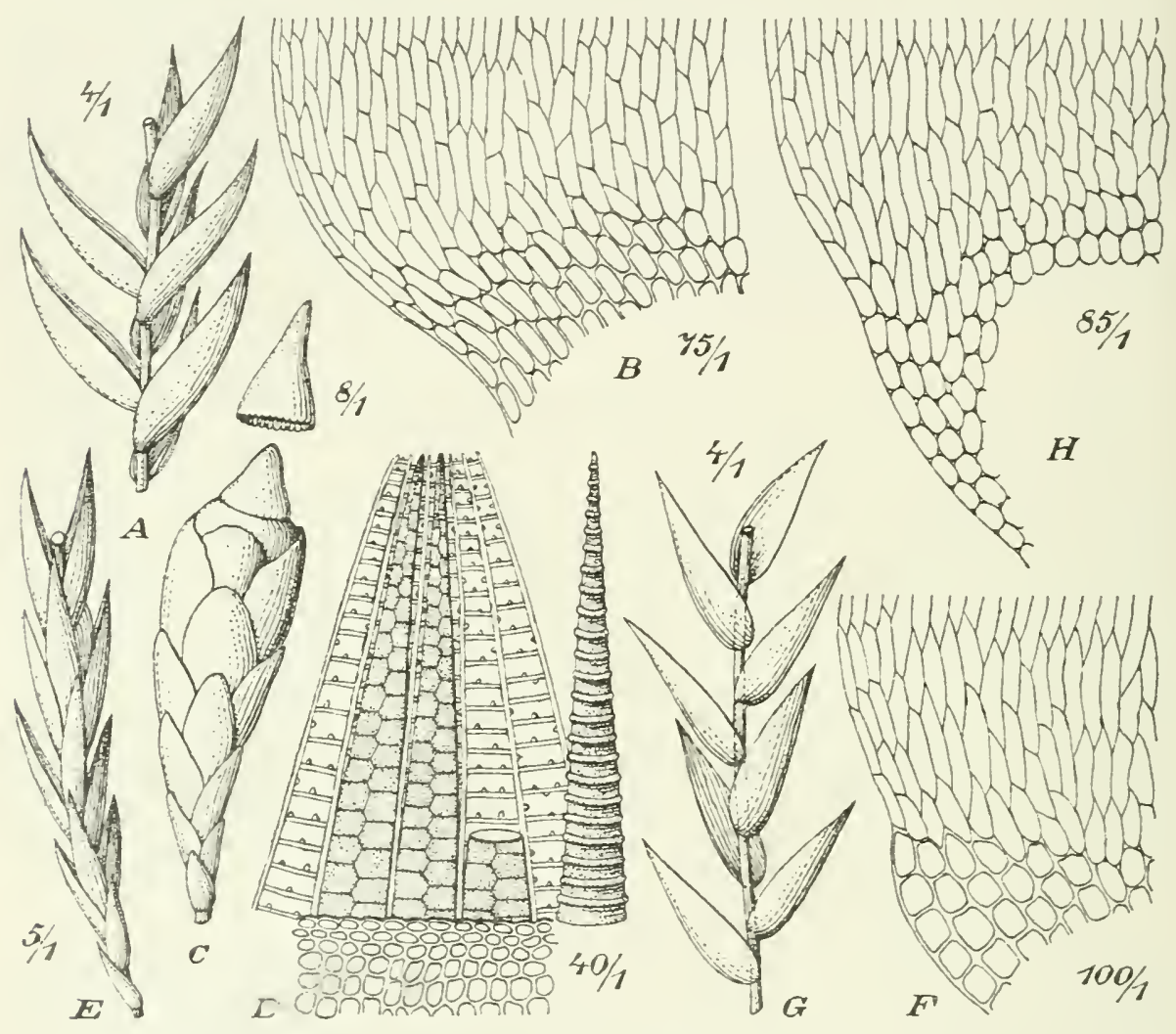

Fig. 68. A-D. Fontinalis antipyretica L. A Teil eines Laubsprosies (4/1); B Blattbasis (75/1); C Perichätialast mit Kapsel und Haube (8/1); D Peristom (40/1). - E-F. F. dalecarlica Schimp. E Teil eines Laubsprosses (5/1); F Blattba-is (i01/1). - r - H. F. hypnoides Hartm. G Teil eines Laubsprosses (4/1); $\mathrm{H}$ Blattbasis $(85 / 1)$. (A und $\mathrm{C}$ nach $\mathrm{L}$ i m $\mathrm{p}$ r i c h t.)

rötlichgelben Längsstreifen. Peristom fehlend. Deckel lang geschnäbelt. Sporen $18-25 \mu$, gelblich, warzig. Sporenreife im Frühling.

An alten Espen.

F. Al. Sund, Kastelholm (Bom.). - Ab. Ierimasku (Karst.). Finby (Broth.). Penar. Spurila (H. Lindb.). Lojo, an der Kirche (H. Lindb.); Gerknās und Hakosaari (H. L.). Sammatti (Sel.). - $N$. Ekenàs (Hāyr.). Karis, Fagervik (Lindb.). Helsinge, Sockenbacka (Buch). - ha. Wiborg (Vain.). Ik. Muola, Perkjärvi (H. Lindb.). - Kol. Humbaritsa (Elfr.).

S. Sk.-Gstr., Ang.

N. In den L'mgebungen de: Kristianiafjords st. fџ.; in allen Antern an der Süd- und Westküste selten und bis Salten vordringend, im Innern bis Ringerike. Nordgrenze bei $67^{\circ} 18^{\prime} \mathrm{n}$. Br.

Europa, Japan, Nord-Amerika. 


\section{Unterreihe FONTINALINEAE.}

Wasser- und Sumpfmoose. Blätter symmetrisch; Zellen linear, glatt. Sporogone meist acro- odler cladocarp. Haube klein, kegel-mützcnförnig oder kappenförmig, glatt.

\section{FO N T I N A A C E A E.}

Meist dunkel- und schwärzlichgrüne, flutende Wassermoose. Stengel verlängert bis sehr lang, dünn und fest, \pm reichlich verzweigt, nur am Grunde durch glatte Rhizoidenbüschel an überfluteten Baumwurzeln und Steinen befestigt; im Querschnitt rundlich 3-iseitig, ohne Zentralstrang, mit lockerem Grundgewebe und verdickten Mantelzellen. Blätter meist 3reihig, breit eiförmig bis lanzettlich-pfriemenförmig, flachrandig: Rippe einfach oder fehlend; Zellen meist verlängert prosencliymatisch, glatt, am Grunde lockerer und getüpfelt. Blüten meist diözisch und gipfelständig an kurzen Seitensprossen. Perichätialblätter differenziert. Kapsel eingesenkt oder emporgehoben, aufrecht, regelmässig, ohne Hals, ohne Luftraum und ohne Spaltöffnungen. Ring nicht differenziert. Peristom doppelt. Peristomzälne lanzettlich oder linealisch, ganz oder stellenweise durchlöchert bis klaffend, mit zahlreichen, niedrigen Lamellen. Inneres Peristom ohne Grundhaut; Fortsätze 16, fadenförmig, längs oder nur gegen die Spitze durch zahlreiche Querglieder zu einem kielfaltigen, oben offenen Gitterkegel verbunden, selten völlig frei und mit seitlichen Anhängseln. Sporen klein, oft in derselben Kapsel ungleich gross. Sporenreife im Sommer.

\section{FONTINALOIDEAE.}

Stengel meist reich und oft büschelig verzweigt. Blätter anliegend bis 士 allseits abstehend, eiförmig bis schmal lanzettlich; Rippe fehlend; Zellen der zuweilen ausgelı̈lılten Blattflügel erweitert, öfter aufgeblasen. Perichätialblätter gross, angepresst-dachziegelig, rundlich-spatelförmig, im Alter zerschlitzt. Kapsel fast völlig eingesenkt. Beide Peristome fast gleichlang. Deckel kegelig. Haube klein, kegel-mützenförmig.

\section{FONTINALIS.}

(Dill.) L. emend. Myr. in Act. Reg. Acad. Sc. Holm 1832.

C'bersicht der Arten.

A. Stengel dicht und feucht scharf dreieckig beblättert.

a. Synözisch. Stammblätter mit leichter, stumpfer Längs-

falte, zugespitzt, $4-4,8 \mathrm{~mm}$ lang und $1-1,8 \mathrm{~mm}$ breit. 580. F. Bryhnii.

b. Diözisch. Stammblätter scharf gekiełt bis nachenförmig.

«. Blätter mit gekrümmter Kiellinie.

I. Starre Pfl. Blätter scharf gekielt, $6-8 \mathrm{~mm}$ lang und 4-6 mm breit, kurzspitzig, in den Blattflügeln nicht ausgehöhlt ...........................578. F. antipyretica.

II. Weiche Pfl. Obere Blätter nachenförmig, 3-5 mm lang ùnd $1-1,5 \mathrm{~mm}$ breit, in den Blattflügeln wenig ausgehöhlt

582. F. gothica.

ґ. Blätter mit fast gerader Kiellinie, $3-4 \mathrm{~mm}$ lang und 1-2 $\mathrm{mm}$ breit, länger zugespitzt.

I. Blätter dicht gestellt, in den Blattflügeln $\perp$ deutlich ausgehöhlt 
II. Blätter entfernt gestellt, in den Blattflügeln nicht ausgehöhlt

B. Blätter dimorph, am Hauptstengel gekielt, an den Ästen rundrückig.

a. Astblätter $1-\mathbf{1 , 5} \mathrm{mm}$ breit

581. F. Kindbergii.

b. Astblätter etwa $0,5 \mathrm{~mm}$ breit

579. F. sparsifolia.

C. Stengel dicht beblättert. Blätter sehr hohl. rundrückigg. a. Stammblätter kurz und stumpflich zugespitzt, ganzrandig: Zellen 12-14 " breit

b. Stammblätter allmählich lang und schmal zugespitzt. a. Blätter deutlich dreireihig, ganzrandig: Zellen 12-

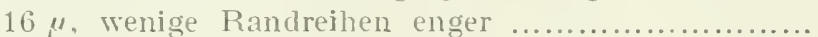

ॐ. Blätter nicht gereiht, ganzrandig oder mit einigen Zähnchen an der Spitze

582. F. gothicavar. dimorphophylla.

is t. F. squamosa.

586. F. seriate.

585. F. dalecurlica.

D. Stammblätter locker gestellt, sehr schlaff, fast flach, allmählich lang zugespitzt.

a. Parözisch. Blätter 2-3 nm breit

583. F. androgyna.

b. Diözisch. Blätter $1-1, \bar{j} 1 \mathrm{~mm}$ breit

5s7. F. hypnoides.

E. Stammblätter wenig hohl, schmal lanzettlich, verlängert linealisch-zugespitzt, an der Spitze lang röhrig-pfriemenförmig

588.F.dichelymoides.

S e c t. I. Tropidophyllae Card. in Jém. Soc. Nation. Sc. Nat.et Math. Cherb. XXVIII, p. 48 (1892).

Stammblätter kielig-zusammengefaltet.

578. Fontinalis antipyretica L. Sp. pl. p. 1571 (1753).

Kräftige Pfl. in gelb- bis dunkelgrünen orler bräunlichen, abwärts mcist schwärzlichen Rasen. Stengel bis 50 cm, selten länger, auch am Grunde beblättert, feucht scharf dreikantig beb]ättert: Äste aufrecht- bis fast sparrig abstehend. Blätter aufrecht-abstehend, scharf gekielt und zusammengefaltet, mit gekrümmter Kiellinie, breit eilanzettlich, zugespitzt, $5-8 \mathrm{~mm}$ lang, ganzrandig, mit am Grunde einerseits, seltener beiderseits zurückgeschlagenen Rändern: 7.ellen in den nicht ausgehöh]ten Blattfüsthin efwas grösser. rechtechig. Sporenreife im Juni und Juli. - Fig. $67 \mathrm{~A}-\mathrm{D}$.

In stehenden und fliessenden Gewässern an Steinen, Baumwurzeln und Holz.

F. Al. fqq. (Bom.). - Ab. Im sïdwe-11. Teile pass. (Zett. und Brand.). Finby. Angelniemi. Uskela.

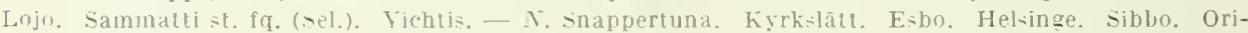
mattila. Hogland. - Ka. Kolka. - Ik. Kivennapa. Juola. Sakkola. - St. fq. (Simm.). - Ta. Vanaja. Hattula. Jokininen. Im - ïdóll. Teile fq. (Jorrl.). Iitli, Mustaniemi (Buch). Hartola, Luhanka und Kornilahtist. fq. (Vain.). - Sa. Ruokolahti. St. Michel. Nyslolt. Kangasniemi. - Kl. Kurkijoki. Valamo. Hiilola. Kexholm. Sorlavala. Impilahti. - Kol. Salmi. Im ösllichen Teile fq. (Elfr.). - Da. Isokỹō. — Tb.st. fq. (Broth.). - Sb. Kíuopio fq. (Link.). Maaninka und Pielaresi fq. (Roir.). - Kib. Pielisjârri. - Kon. Kivatsch. Tujatseh. Selki, - om. Soini. Alajärri, Tindala und Lappajărvi an einzelnen Fundorten (Backm.). Haapajarri. - Jk. Sl. fq.-pass. oft massenhaft (Kyyhk.). - Kpom. Toiraara und Ioina (Bergr.). - $r b$. Cleaborg. Simn. Vördl, von davasaksa an mehreren Fundorten (Hult). - $K$. Kuusamo Pudasjärif f. (Broth.). Kuusamo, Arentojoki, Kosojoki und Iatalaoja (B.): Akonlabti, Aikinlampi (E. af H.); Vazaraperä (E. af H.). - Lkem. Kolari und Kiltilä, an mehreren Fundorlen (Hull). Kuolajărvi. - Le. In der Nadelwa!d- und Birkenregion st. fq. (Norrl.). Kilpisjärri, Tschappisjärri (Kot.). Li. Etsjoki, Pihtioja (Ranch.). - Lim. Kandalaks (Sahlb.). Lmba (Sel.). Seidjarr (Kihlm.). - Lt. Kola (Karst.). - Lmur. (iavrilova (Broth.). - Le. Tschapoma (B.).

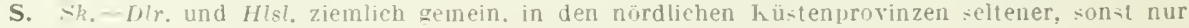
ron einzelnen Fundurten in $I, u L$. und $T L$. bekannt.

N. Fm. - F., im Vorden ziemlich selten. Wordgrenze hei $70^{\circ} 25^{\circ} \mathrm{n}, \mathrm{Br}$.

Europa. Algier, Tuni-, Kauka-us, sibirien, Surd-Amerika. 
var. alpestris Mild. Bryol. siles. p. 276 (1869).

Ziemlich kräftige, metallisci glänzende, grün, goldgell, und kupferrot gescheckte Pfl.; Aste stumpflicl. Blätter anliegend, breit, stumpl, kielig-nachenförmig, mit stark gekrümmter Killinie.

S. An wenigen Fundorten in $D l r$. und einzelnen in sim. und $L u L$.

Rie:en- und 1sergebirge, Fichtelgebirge. Zentral-Frankreich. Thesialien.

var. montana H. Müll. Westl. Laubm. No. 378: Verh. nat. Ver. Rheinl. 2.1. .lahrg. p. 138 (1867).

Weniger kräftige, bräunliche, schwach glänzende Pfl. Aste spitz. Bläter -kurz herablaufend, aufrecht-anliegend, bis $1 \mathrm{~mm}$ lang und $1,8 \mathrm{~mm}$ breit, oft in der Mittellinie gespalten.

IIcist in fliessenden Gewässern, meist in den Fjeldbächen.

F. Lmur. Kr rugloje guba (Broth.). Rindia (B.).

S. An inehreren Fundorten in Dlr. und .Imt.. an einzelnen in $1 \mathrm{~g}$., Dld.. Mrjd. und $T L$.

N. F. Kistrand.

IVestialen.

var. pseudoquamosa Card. Monogr. Font. p. 52 (1892).

Tracht von F. squamosa. Schlanke, weiche, etwas glänzende Pfl. Blätter oft in der Mittellinie bis zum Grunde gespalten.

S. An einzelnen Fundorten in sk., Bl. und Vrml.

Schweiz. Italien. Spanien.

var. livonica (G. Roth et r. Bock.) Moenkem. in litt.; Möll. in Ark. f. Bot. Brl. 17, No. 14, p. 35 (1922). [F. livonica Roth et r. Bock in Hedwigia Bd. XI IX. p. $221(1910)$.]

Flutend, mit entfernt gestellten, langen, weit abstehenden đ̈sten. Blätter weniger scharf gekielt, eher nur sehr hohl, fast ebenso breit wie lang.

In stehenden Gewässern. Scheint kalkliebencl zu sein.

S. s’k. Fjälkestad, Rảbelöf, Råbelōfsjön.

Lettland.

var. robusta Card. in Rev. 1,ryol. 1882, p. 88. [F. antipyrelica var. gigantea Lindlh. in Notis. Sällsk. Faun. Fl. Förh. Heft 9, p. 279 (1868).l

Sehr kräftige, gelbe oder gelbbraune, seltener grüne Pfl. Blattbreite ${ }^{2 / 3}{ }^{3} 4$ der Länge.

In stehenden Gewässern. Kalkliebend.

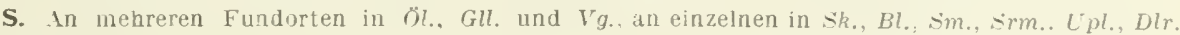
und Gstr.

Europa.

var. gracilis (Lindb.) Schimp. Syn. 2. ed. p. 552 (1876). [Fontinalis gracilis Linclb. in Notis. Sällsk. Faun. Fl. Fenn. IX. p. $27+$ (1868).]

Schlanke Pfl. in gelb- bis dunkelgrünen oder bräunlichen, schwach glänzenden Rasen. Stengel bis $40 \mathrm{~cm}$, am Gruncle entblösst, dichtästig; Äste und Ästchen parallel gestellt, dünn zugespitzt. Blätter aufrecht-abstehend, scharf kielig zusammengefaltet, meist in der fast geraden Kiellinie gespalten. eilanzettlich, stumpflich, :3-4 $\mathrm{mm}$ lang und $1-2 \mathrm{~mm}$ breit, flach- und fast ganzrandig. Peristomzähne mit feinen Papillen.

In \pm schnell fliessenden Gewässern.

F. Ab. Alo, Hallis (Elfr.). Karis. svartil (Ju-1.). Bjerno. Pojo gard (Printz). Pojo, Fiskils. Vichtis. Vanjoki (Hult). Pusula. Hauklampi (Broth.). - V. Helsinge. Talj (Broth.): Vanda (Lindb.). - Ka. Sippola. Saaremaa (Ranck.). - Ik. Valkjärvi, Valkoja (H. Lindb.). Pyaäjärvi, Riiłkajoki (H. L.). Ta. Lainmi, Evo (Norrl.). Korpilahti (N.); Tyytjoki (Tain.). - Kl. Sortavala, Kirjavalahti (Lindb.). Kol. Mjätusoxa und Fabrika (EIfr.). Petrosavodsk (Norrl.). - Oa. Isokyrö. Orisberg (Ranck.). - Tb. Korpilahti, Tyystijoki (Vain.). Jyväkyla, Korkeakoski (V.). Konginkangas (Broth.). - Sb. Kuopio, Vehmzsınäki. Laukaanjoki (Link.); Särkilahti (L.). Maaninka, Tuovilanlahtı (Lund-tr.). Kiuruvesi, Korpijoki (L.). - Kon. Suojärvi. Juurikoja (Kop.). - Kom. Alajärri. Hyllykangas, Mertaspuro (Backm.). Lappajärvi. Esse ả. Sirppikoski (B.). - Ok. Kuhınoinen. Pillojoki (E. ai H.). Suomu-salmi, Kiantojărri und Kieki (Kyyhk.). - Kpom. Tschirkkakemijoki, Hautaknski (Bergr.). - Ob. Ifuhys, Kylınälä, Muhosjoki (Ranck.). Ylitornio, Pessanlompolo (Hult). - K. Pudaijärri. Hirrasjokı (Nyb.). Kuu*amo, Akon- 
lahti, Siltinkijoki (E. af H.). - Lkem. Kolari, Jokijalka und Niesajoki (Hult); Rukasjoki (H.). Muonio, Ounastunturi (Norrl.). - Li. Sodankylả. Luirohaara, Vaula (Hult). Inari. Hammastunturit, Sammelinköngās, Onnila in der Nadelwaldregion (H.). Utsjoki, Nurvu*, Bissutzchuollanjokka (Ranck.); Outokoski, Luorreoja (R.). - Mandojäyri und Naamıjäyri, in der Birkenregion (H.). — Lr. T-charanga F. Nyl.).

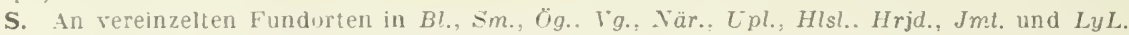

N. Bu. Torefjeld. Ve. Saeteridalen. H. Romedal. No.-F.

Zentral-Europa, Lra].

579. Fontinalis sparsifolia Limpr. Laubm. II. p. 659 (1894).

Sehr schlanke Pfl. Stengel zart, bis $30 \mathrm{~cm}$, bis weit hinauf schwärzlich und von Ästen und Blättern entblösst. Äste wenig zahlreich, fadenförmig und ziemlich kurz. Blätter entfernt gestellt, grün bis schwärzlich, weit herablaufend, mit fast gerader liellinie zusammengefaltet, lanzettlich-linealisch, scharf zugespitzt, in der Spitze gezähnt, $3-3,6 \mathrm{~mm}$ lang und 1,2-1,5 $\mathrm{mm}$ breit. nit unten einerseits schwach zurückgeschlagenen Rändern: Zellen in den nicht ausgehöhlten Blattflügeln etwas grösser, nicht aufgeblasen. Peristomzähne dicht und grob papillös. Sporenreife im Juni.

In fliessenden Gewässern.

S. Sk., Ög. und $\mathrm{rg}$. .. an wenigen Fundorterı.

N. K. Jotunfjeldene, Gjenderheim.

O:t-Preussen.

580. Fontinalis Bryhnii Limpr. in litt.; Hag. in Kgl. Norsk. Vid. Selsk. Skrift. 1908. No. 3, p. 40.

Synözisch. Pfl. in dunkel- bis schwärzlichgrünen oder bräunlichen Rasen. Stammquerschnitt rund; Stengel bis $25 \mathrm{~cm}$, auch am Grunde beblättert, feucht scharf dreikantig beblättert; Aste aufrecht. Blätter $\doteq$ bis weit abstehend, hohl, mit leichter, stumpfer Längsfalte, breit eilanzettlich, zugespitzt, $4-4,8 \mathrm{~mm}$ lang und $1-1,8 \mathrm{~mm}$ breit, flach- und ganzrandig. Sporogone unbekannt.

N. K. Valders, Sorven. an Steinen des Baevraflusses.

581. Fontinalis Kindbergii Ren, et Card. in Bot. Gaz. NV. p. 58 et t. IN A $(1890)$.

Kräftige, weiche, rostbräınliche, bisweilen gelbliche oder rötliche, oberwärts kupferfarbene und glänzende Pfl. Stengel meist mehr als $35 \mathrm{~cm}$, am Grunde meist entblättert, \pm fiederästig; Äste abstehend, federartig, bisweilen langspitzig. Blätter weit herablaufend, dimorph. Stammblätter aufrecht-abstehend oder locker anliegend, I deutlich gekielt vder nur gefaltet, mit fast gerader Kiellinie, breit eilanzettlich, allmählich lang zugespitzt, die oberen $5-7 \mathrm{~mm}$ lang und $2-3 \mathrm{~mm}$ breit, mit am Grunde einerseits zurückgeschlagenen Rändern: Zellen in den nicht ausgehöhlten Blattflïgeln erweitert, rektangulär und 6seitig. Astblätter schmal Ianzettlich, rundrückig, oben rinnig-hohl. Sporenreife im Juni und Juli.

Meist in stehenden Gewässern.

S. An einzelnen Fundorten in HHl., Gtl. und I'sm.

N. L.M. sogne, Mollen.

Ardennen, Rhön, Iänemark, Hamburg, West-Preussen, Schweiz, Istrien, Nord-Amerika.

582. Fontinalis gothica Card. et Arn. in Rev. bryol. 1891, p. 87.

Schlanke, gelblichgrüne, unten dlunkelgrïne Pfl. Stammquerschnitt rund; Stengel bis $30 \mathrm{~cm}$, geschlängelt, am Grunde entblösst; Äste zahlreich, verlängert, sehr locker und fast federig beblättert. Blätter anfrecht-abstehend bis abstehend, an den Sprossenden anliegend, hohl, mit leichter, stumpfer Längsfalte, untere und mittlere ei- oder länglich-lanzettlich, \pm stumpf, 3-5,5 mm lang und $1-1,5 \mathrm{~mm}$ breit, an den Sprossenden lanzettlich, bis $2,5 \mathrm{~mm}$ lang und bis $0,5 \mathrm{~mm}$ breit, flach- und ganzrandig oder an der Spitze undentlich gezähnt: Zellen in den wenig ausgehölıten Blattflügeln erweitert, hyalin bis gebräunt, eine gut begrenzte Gruppe bildend. द Bliten und Sporogone unbekannt. 
Meist in Seen, seltener in Bächen und Wassergräben.

F. Lmur. Semjostrov (Broth.).

S. Bl., Sm., Vg., Dld., $3 p$ d.. Hrjd. und $T L$. bisker nur von einzelnen oder wenigen Fundorten bekannt.

N. Ne. Ojestad, Rygene Fus: Holt, Ne.

Dänemark.

var. dimorphophylla Möll. in Ark. f. Bot. Brl. 17, No. 14, p. 4 (1922).

Pfl. steifer, dicht beblättert. Blätter weit abstehend, die unteren gekielt, die oberen flach bis schwach rinnig-hohl, etwa $1.3 \mathrm{~mm}$ lang und etwa 0,2.) mm breit.

S. LuL. Jokkmokk. Kitajaur, ritbäcken.

583. Fontinalis androgyna Ruth. in Hedwigia 1872. p. 166.

Parözisch. Ziemlich kräftige, bleichgrüne oder gelbliche Pfl. Stengel 10 $30 \mathrm{~cm}$, locker beblättert, ziemlich regelmässig gefiedert; Äste $\doteq$ abstehend, zugespitzt, mit blattachselständigen, hyalinen oder braunen Zellfäden. Blätter weit abstehend, wenig herablaufend, trocken fast flach, feucht rinnig-hohl, gegen die Spitze leicht gehielt, breit eilanzettlich, allmählich scharf oder stumpflich zugespitzt, 5-7 mm lang und 2-3 mm breit: Zellen dünnwandig, $15-20 \mu$ breit, wenige Randreihen etwas enger. in den nicht ausgehöhlten Blattflügehn stark erweitert, eine gut begrenzte Gruppe bildend: Astbłätter kürzer und schmäler.

S. öl. Tor:lunda, Treta. Steril.

Brandenburg, auf periodisch überschwemmten Wiesen unweit Bärwalde, steril. I-land, auch mit Sporogonen.

S e c t. I I. Lepidophyllae Card. 1. c. p. 80.

Blätter hohl, nicht gekielt.

584. Fontinalis squamosa L. Sp. pl. 2. ed. II. p. 1571 (1763).

Pfl. in tiefgrümen bis schwarzen, glänzenden Rasen. Stengel bis $40 \mathrm{~cm}$, am Grunde entblösst, büschelästig, mit anliegenden, drehrund beblätterten Ästen. Blätter anliegend, rinnig-hohl, wenig herablaufend, aus breiter Basis lanzettlich. stumpflich, 2,5- $4 \mathrm{~mm}$ lang und $0,7,5-2 \mathrm{~mm}$ breit, flach- und ganzrandig. Zellen 12-14 " breit. gegen die Ränder nicht verengt, in clen schwach ausgehöhlten Blattflügehn erweitert, oval, gebräunt, eine gut begrenzte Gruppe bildend. Kapsel rotbraun bis schwarzrot. Beide Peristome tiefrot, mit zerstreuten, groben Papillen. Deckel spitz kegelig, etwa $0,8 \mathrm{~mm}$, kastanienbraun. Sporenreife im Juli.

Meist in \pm schnell fliessenden Gewässern.

S. Sm.. Vg.. B эh., När., Dld., Hlsl.. Hrjd., Ip pd.. Jmt. und LuL., in den meisten Provinzen jedoch nur von einzelnen Fundorten bekannt.

N. Bu. Norefjeld. St. Egersund. Ryfrlke. SB. Vow. Bergen. Y'B. Sogn. $R$. an wenigen Fundorten. No. Lofoten. Yordgrenze bei $67^{\circ} 56^{\prime} \mathrm{n}, \mathrm{Br}$.

Europa, Algier.

585. Fontinalis dalecarlica Schimp. in Bryol. eur. fase. 31, Suppl. cum t. 1 (1846).

Tracht von F. squamosa, aber schlanker. Pfl. in dunkelgrünen bis bräunlichen, glanzlosen Rasen. Stengel bis $40 \mathrm{~cm}$, mit zahlreichen, langen. fadenförmigen. spitzen Ästen. Blätter locker dachziegelig, sehr hohl, lanzettlich, scharf zugespitzt. $2-3 \mathrm{~mm}$ lang und $0,5-0,7 \mathrm{~mm}$ breit, flach- und ganzrandig oder mit einigen Zähnchen in der Spitze: Zellen sehr eng, $5-7$ " enger, in den kaum ausgehöhlten Blattflügeln erweitert, länglich-6seitig, meist hyalin. Kapsel lederfarben. Peristomzähne gelbrot, glatt oder durch niedrige Warzen undeutlich gefeldert und schwach schrägstreifig. Inneres Peristom gelblich, glatt; Fortsätze nur an der Spitze gitterartig verbunden. Deckel kurz kegelig, stumpf, bis 0,6 nmm, gelbrot. Sporenreife im Juli und August.

In \pm schmell fliessenden Gewässern.

F. Ab. Bromarf (Sundv.). Karis (Hult). Uskela (Nikl.). Lojo. Veiby (H. Lindb.). Vichtis, Vanjoki (Hult). - N. Ky̆rkılätt, Kvarnby (Brenn.). Helsinge, Tali (Broth.). Hogland (Lindb.). - Ka. Sākkijārri, Alæoutila (Krohn). Wiborg, Soskuanjoki (Buch). - Ik. Kivennapa (Mela); Rajajoki (H. 
Lindb.). - st. Karkku (Hjelt). Pirkkala ( $\$$ mm.). Häneenkyrö, hyrönkoskı (Nerł.). Orive-i. Juurakka (Broth.). Sastmola. Turijoki (Ranck.). - Ta. Vanaja (Thur.). Kalvola (Knab.). Lammi, Evo st. fq. (Norrl.). Im südöstl. Teile st. r. (Norrl.). Kuhnoinen (Häyr.). Tammerfors (Nerv.). Kiorpilahti und Luhanka st. r.--pa-s. (Vain.). - Sa. Valkeala (Sundr.). Lappee. Kancola (Buch). Ruokolahti (Hult). Nyslott (Carl.). Pieksämäki (Lackilr.). Kangasniemi (L.). - Kl. Kurkijoki, Migrila (Jusl.). Hiitola (J.). Jaakimraara (J.). Sorravala. Kirjavalahti (Lindh.). Suanlahti. Hanuvaara (E. af H.). suistamo, 7w. Loimala und Thatsu (Broth.). - Kol. salmi. Kànäe kä und Leppälā (Pé.): Loimalanjoki (Link.).

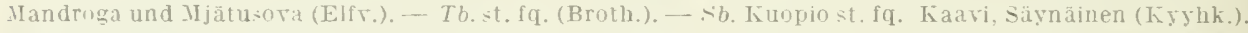
Vilsiä (Lund-tr.): Palonurmi (Kỵhk.). Juuka. Haliraara (Kot.). Maaninka und Pielare-i (Rjiv.). Ki aruve-i (Lund:tr.). - Kin. suojärri (hop.). Schuja (Simm.). - Om. Alajärvi. Lohijoki (Backm.).

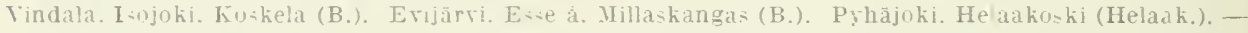
Oh. Kajana (Lack tr.). Sothamı. Rauramu (Brołh.): Tipasjoki und Orringinpuro (Kyyh.). Hyrynsalmi. Kaiskonjoki (Krrhk.). - Kpom. T.chikhakem! (Bergr.). - Ob. Cleaborg (WT. Nyl.). Ii. Ohtujohi (F. Vy. ). Simo (Ra-). Aara-aksa-Turiola fır. (Hult). - K. Purla-jări. an mehreren Fundorten (Broth.). Ǩuusamn. Arentojoki und Konrojoki (B.): Kảłảkı.ki (B.). - Lkem. Kolàri und Kittilă fıl. (Hult). Kuulajärvi, zw. Airistunturi und Mikkola (Limnan.). - Le. In der Vadelwald-und Birkenregion st. fq. (Korrl.). - Li. Inari. Saari-elkä. an mehreren Fundorien in der Salelwaldregirn (Hult). L'tsjuki, Nurru=, Juokkijokka. in der alpinen Region (Ranck.): in der Birkenrezion -t. fq. (IIult). - Hall,in-el Fola. in der Vadelwald- und Birkenregion pars. (Br th.)

S. In allen Provinzen. mit Au-nihme ton öl., Gll.. LyL. und PL.. am reichlich-ten in nōrdl. Teile ron svealand und im sildl. Teile von vorrland. steigt lik etwa ghil m hinauf.

N. Sm. $-F$. Nirdgrenze thei $i I^{\circ}$ n. Br.

Nord-Amerika.

Var. microphylla (Schimp.) Limpr. in litt.: Moll. in Ark. f. Bot. Bd. 17, No. 14. p. 62 (1922). [F. miernphylla Schimp. in lilinggr. Topogr. Fl. Westpreuss. p. 112 $(188(1) \cdot]$

Stengel schlaff. entfernt, bchlättert. Bläter klein, aufrecht bis abstehend, nur in den Sprosspitzen einander bedechend, schmal lanzettlich, lang zugespitzt, an der Spitze mehrzähnig, deutlich geöhrt. Zellen dünnwandig, länger als bei der Hauptart.

S. T'sm. Linde. All,ärken.

O-t- und We:t-Preu -en. Dānemark. Kianada.

586. Fontinalis seriata Lindb. in Soc. Fro Faun. et Fl. Fenn., 3 Dec. 1881; Bot. Notis, 1882, p. 26.

Schlanke Pfl. in weichen. schnutziggrünen. etwas glänzenden Raseil. Stengel bis $10-40 \mathrm{~cm}$. dicht beblättert: ̈̈ste zahlreich, parallel gestellt. Blätter ziemlich deutlich dreireihig, trocken locker anliegend. fcucht aufrecht-abstehend. wenig hohl, schmal lanzettlich, allmällich lang zugespitzt. bis 4 mm lang uncl bis $0,7.5 m m$ breit, flach- und ganziandig oder mit oben schwach eingerolltcn Rändern: Zellen $12-16$ " breit, in $6-8$ Randreihen enger, in den kaum ausgehöllten Blattflïgeln erweitert, rektangulär und 6seitig. Sporogone unbekannt.

In schnell fliessenden Gewässern.

S. Dir. Lindnäs und tresta. Asköfor:en.

N. II. Flommen. Elverum. Otta.

Lettland. tienf.

Scct. I I I. Malacophyllae Card. 1. c. p. as.

Blatter locker gestellt, sehr schlaff, fast flach.

587. Fontinalis hypnoides Hartm. Sk. Fl. ed. 4, p. 134 (1843).

Pf]. sehr schlaff und weich, hell- bis dunkelgrün. Stengel bis 20 cm. selten länger, locker beblätert, unregelmässig verästet: Iste zugespitzt. Stammbläter aufrecht bis aufrecht-abstehend, trocken \pm rerbogen und weiter ab-tehend, fast flach. lanzettlich, allmählich lang zugespitzt, $1-6 \mathrm{~mm}$ lang und $1-1,5 \mathrm{~mm}$ breit, flachrandig, an der Spitze mit einigen Zähnchen: Zellen locker, bis $25 \mu$ breit, in den nicht ausgehöhlten Blattflügeln sehr locker, rektangulär und länglich-6seitig, gebräunt. Astblätter schmäler, hohl, gegen das Sprossende dicht dachziegelig bis zusamnengewickelt. Sporenreife Ende Mai und Juıi.

Meist in stehenden Gewässer"? 


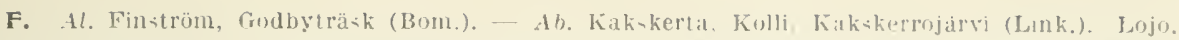
Maikkala (H. Lindb.), - N. Ekenä-, Tvärminne (Häyr.). Helinge. legerr. thanivik (Kihlm.). - Ik.

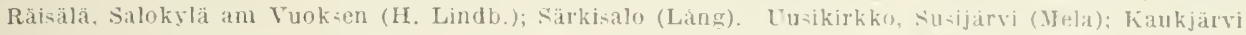

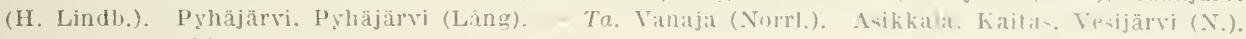
Liopioinen. Kukkainen (Broth.). Sysma, Kiio und Pajetalø (Renqv.). Śn. Siavilapale. Karhijärvj (Buch). 一 Tb. Viilasiari, Jiakelä und Piojärvi (Brolh.). Pihtipudas. suonkiviarv (J3.). Sob. Kumpio,

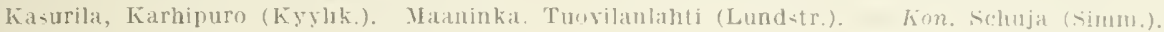

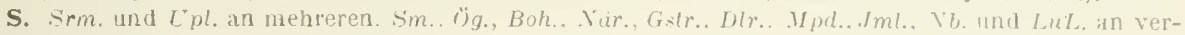
einzelten Fundorten.

Europia, Sibirien, Japan, Nord-Aneriki.

var. Adlerzii Card. in Adl. Bladmossll. p. 206 (1907).

Äste steif. Blätter starr, breiter zugespitzt, stumpf orler stumpllicls. zuweilen mit Spitzchen; Zellen enger als bei der Hauptart.

S. Vär. Iristbro. Svarti, in dem see stora Bjorken.

Sect. $1 \mathrm{~V}^{\mathrm{r}}$. Stenophyllae Card. 1. c. p. 122.

Blätter wenig lıolıl, schmal lanzetlich, verlängert linealisch-7ugespitzt, an (ler Spitze lang rölırig-pfriemenförmiğ.

58s. Fontinalis dichelymoides Lind. in Öfrers. Finsk. Vet. Soc. Förl. IlI. p. $76(1869)$.

Tracht von Dichelyma capillaceum. Gelbgrüne und etwas glänzende, oben goldglänzende Pfl. Stengel bis $20 \mathrm{em}$, locker, an den Sprossenden dieht und fast Areireihig beblättert, fast fiederig beästet; Aste verlängert, mit gespreizt abstehen(len Istchen. Blätter abstehend. oft einseitswendig. schmal lanzettlich, lang zugespitzt, meist stumpflieh, bis $4.5 \mathrm{~mm}$ lang und bis $0.6 \mathrm{~mm}$ breit, ganzrandig; Zellen 8-9 " breit, sehr verlängert, in den ausgenöllten Blattflügeln länglich ocler verlängert-1-6seitig. Sporogone unbekannt.

In stehenden Gewässern an Bauntwurzeln.

F. Ta. Lammi, Evo, Izo Talkjärvi (Lang). - Tb. Viita-rari. Pinjärvi (Broth.). Eb. Iiralmi nach sic hif f n e r. - Li. Sammelinköngäs (Huli).

S. Vg. Hunneherg.

Nord-Amerika, Minnezota.

\section{DICHELYMOIDEAE.}

Stengel meist entfernt und fast zweizeilig beästet. Blätter meist einseitigsichelfömig; Rippe einfach, lomogen: Blattflügelzellen nicht differenziert. Inere Perichätialblätter verlängert linealiseh-lanzettlich. Kajsel emporgehoben. Äusseres Peristom kürzer als das innere. Peristomzähne an den Artikulationen eingeschnürt. Deckel hoch und spitz kegelig. Haube kappenförmig, einerseits bis gegen die Spitze aufgeschlitzt, bis under die liapsel reichend, zuweilen an der Seta zurülekbleibend. Sporen kilein.

\section{DICHELYMA.}

Myr. in Act. Reg. Acad. Se. Holm. 1832.

¿́bersieht der $A r t e n$.

A. Rippe mit der Blattspitze endend oder kurz austretend. 589. D. falcatum.

B. Rippe lang auslaufend 590. D. capillaceum.

589. Dichelyma falcatum (Hedw.) Myr. 1. c. p. 271, t. 6. [Fontinalis falcata Hedw. Descr. III. p. 57, t. 24 (1792).]

Kräftige, stark glänzende, grün bis goldbräunliche, unten schwärzliche Pfl. Stengel bis $15 \mathrm{~cm}$, mit kräftigęn, meist im Bogen aufsteigenden und an der Spitze hakenförmigen Ästen. Blätter kielig-gefaltet, breit lanzettliclı-pfriemenförmig. bis 
$5 \mathrm{~mm}$ lang und bis $1,3 \mathrm{~mm}$ breit, gegen die Spitze gezähnt; Rippe mit der Blattspitze endend oder kurz austretend; Zellen eng linealisch. Innere Perichätialblätter bis zur Mitte der Seta reichend und diese rechts spiralig umwickelnd. Seta 5-15 $\mathrm{mm}$, rot. Kapsel länglich-oval, rostbraun. Peristomzähne warzig-papillös, gelbrot oder rotbraun. Fortsätze zu einen vollkommenen, rotbraunen Gitterkegel vereinigt. Sporenreife von August bis Oktober.

Auf Steinen in Bächen und an zeitweise bewässerten Wurzeln und Ästen.

F. Al. Eckerö (Arrh.). Saltvik und Sund, an wenigen Fundorten (Bom.). - Ab. Nadendal, Luonnonmaa (Högm.). St. Karins, Ispois (Elfr.). Uskela (Nikl.). Karislojo, Karkkali (Häyr.). Lojo. Vanhakylä (Hult). Piısula. Kärkölä (Bruth.). - N. Borgá, siggböle (Ant.): Tirmo (Ju<l.). Pernả, sarfsalo (Tennb.). Lovisa (Irll.). Strömfor-(Sael.). - Ka. Kymmene, Sunila (Kuj.). Virolahti (Blom). Jäaki,

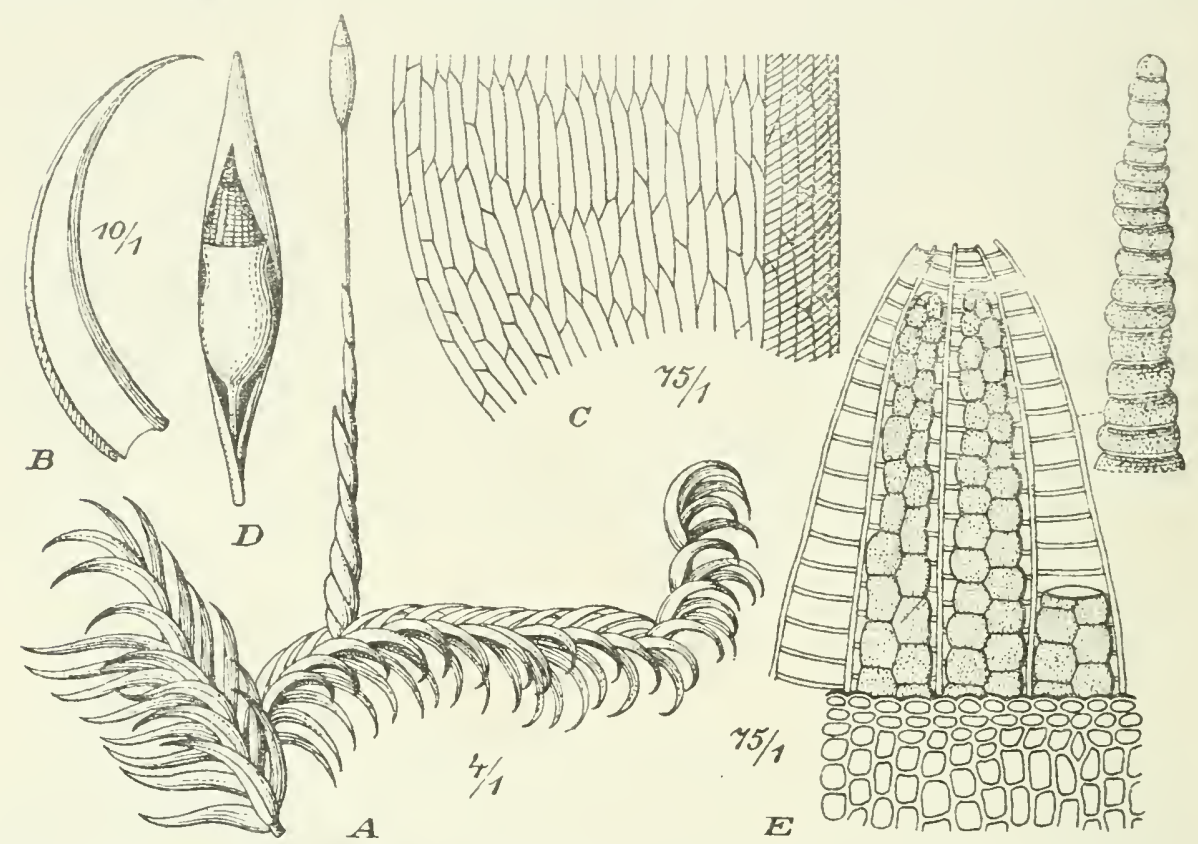

Fig. 69. Dichelyma falcalus (Hedw.). I Teil einer fruchtenden Pfl. (1/1); B Stammb. (10/1); C Blattba-is (75/1); D Entleerte Kapsel mit Haube (10/1); E Peristom (75/1). (A und D nach L i m p r c h t.)

Laitela (Lindb.). - Ik. Ǩivennapa, Rajajoki (Lâng). IIuola (Mel.); Perkjärvi (H. Lindb.). Pyhäjärvi, Lohijoki (H. Lindb.). — St. Eura (Rönnb.). Sastmola, Trorijoki (Ranck.). Pirkkala (Simm.). Hämeenkyrö, Kyrönkoski (Nerr.). Ruovesi (Simm.). 一 Ta. Im sïdöitl. Teile st. fu. (Norrl.). Kuhmoinen, Kopelankoski (Häyr.). Hartola (Bonzd.). Luhanka und Korpilahtifq. (Vain.). - Sa. Valkeala, Storön (Sundv.). Lemi, Tallinen (Buch). Lappee, Harajoki (B.). Ruokolahti, Immola (Hult). Kangasniemi (Lackstr.). Kl. Kurkijoki (Ju=l.). Kexholm (Tomm.). Sortavala (Linnan.); Kirjavalahti (Lindb.). Ruskeala (W. Nyl.). - Kol. Salmi, Leppälä (Link.). Im ätl. Teile an mehreren Fundorten (Elfv.). Petrosavodsk (Simm.). - Oa. Isokyrö, Orisberg (Ranck.). Storå (Nerv.). - Tb. Petäjävesi (Ruor.). Pihlajaresi (Norrl.). Jyväßkylä, Kojki (Buch). Ä̈nekokki (Lesk.). Laukia und Viitasaarist. fq. (Broth.). Pihtipudas, Alvejärvi, Kotapuro (Roiv.). - Sb. Kuopio pass. Kaavi, Petäjänäki und Losonäki (Kyylı.). Nilsiä, Tarpinen (k.). Maaninka und Pielnvesi pils.s. (Roiv.). lisalmi (Sahlb.). - Kb. Tohmajärvi (Broth.). - Kon. Kivatseh (Simm.). Vojatsch (Sel.). - Om. Alajärvi, Kirchdorf (Bitckm.); Myllykangas (B.). Lappajärvi, Sammakkosaari (B.). Nivala, Malisoki (Tenn.). - Ok Kajana (Lackstr.). Paltamo (Vest.). Sotkamn, Ruunepuro und II linjoki cop. (Kyyhk.). Puolanka (Lackstr.). Nach ky h ky n e im Gebiete wenigitens pass. - Kpom. Telekina (Sel.). Tschuja (Sahll.). - Ob. Kiininki (Nyb.). Ii, Paakkola (Brenn.). Ylitornio-Turtola f(1. (Hult). - K. Pudasjärvi (Nyb.). Kuusamo, an mehreren Fundorten (Broth., E. af H.). - Lkem. Kolaıi und Kittilä fq. (Hult). Kemijarvi, Pyhätunturi (Vain.). Sodankylä, östl. vom Ifaltiojoki (E. if H.). Kuolajärvi, Tenniönjoki (Linnan.). - Le. An mehreren Fundorten irn Waldgebiete (Norrl.). Kilpisjärvi st. fq. (N.). - Li. In der Nadelwaldregion st. fq. (Hult). Inari, Peldo- 
jäyri in der Birkenregion (H.). Utsjoki, Petsikkotunturi, in der Birkenregion (H.). - Lim. Kandalaks (Sahlb.). Umba (Sel.). Siejtjilvi und Lujauri-urt (Kihlm.). Sascheika (Karst.). - Lmur. Gavrilova (Broth.). Jokonsk (B.). - Lv. Pjalitsa (Brenu.).

S. In allen Provinzen, mit Ausnahme von öl. und Gll., am reichlichsten in den mittleren und nördlichen Teilen, in den südlichen selten. Steigt bis in die Weidenregion thinauf. Nordgrenze bei $68^{\circ} 3 b^{\circ}$ n. $\mathrm{Br}$.

N. Sm. an wenigen Fundorten. A. Kristiania pass. Bu. Ringerike r. $J L$. Sandefjord. Ne. Saetersdalen. SB. Voss. NB. Filefjeld. R. rr. K. Dovre. H. F. Kistrand und Tune. Nordgrenze bei $70^{\circ} 25^{\prime}$ il. Br.

Europa, Sibirien, Nord-Amerika.

var. amblystegioides Möll. in Ark. f. Bot. Bd. 17. No. 14, p. 16 (1922).

Stengel bis $25 \mathrm{~cm}$, spärlich beästet. Blätter entfernt gestellt, schwach einseitswendig. länger zugespitzt.

S. Vg. Sandhem, in dem See Grimstorpssjön. Steril.

590. Dichelyma capillaceum (Dicks.) Schimp. in Bryol. eur. fase. 31, Suppl. t. 1 (18.16). [Fontinalis capillacea Dieks. Crypt. 1ase. 2, p. 1 (1790).]

Schlanke, weniger glänzende, bleich- bis gelb- und bräunliclıgrüne, unten schwärzliche Pfl.. in der Tracht wie Drepanocladus fluitans. Stengel bis $10 \mathrm{~cm}$, mit abstehenden, an der Spitze gekrümmten Ästen. Blätter kielig gefaltet, sehmal lanzettlich-pfriemenförmig, bis $7 \mathrm{~mm}$ lang und $0,5 \mathrm{~mm}$ breii, mit klein gezähnelter Rändern; Rippe lang auslaufend; Zellen eng linealisch. Obere Perichätialblätter selır verlängert, die Kapsel überragend, spiralig reelıts gewickelt. Seta $3-4 \mathrm{~mm}$, rot. liapsel länglich-oval, schmutziggelb, nach der Entdeckelung seitlich hervortretend. Peristomzähne warzig-papillös, gelbrot. Fortsätze blassgelb, nur an der Spitze durch 2-3 Querleisten gitterartig verbunden. Sporenreife im September und Oktober.

An zeitweise in Wasser gelegenen Bamwurzeln und Ästen. Sehr selten fruchtend.

F. Ik. Muola, an der MEündung des Saaretjoki (H. Lindb.).

S. Sk.-Gstr., mit Ausnahme von Hll., Boh.. Öl., Gotll. und Ög. Überall st. r.

Dänemark, Deutschland, Frankreich und Schottland selten. Nord-Amerika.

\section{L I M A C I A C E A E.}

Stattliche, lockerrasige oder gesellig wachsende Erdmoose. itauptstengel rhizomartig, rhizoidenfilzig und mit den Resten der Niederblätter besetzt. Sekundäre Stengel meist aufrecht und baumartig verzweigt, stumpf dreikantig, mit Zentralstrang, lockerem Grundgewebe und mehrsehichtigen, verdickten Mantelzellen; Paraphyllien zahlreich in der Astregion, fadenförmig, gespreizt-vielästig. Blätter mehrreilig, zweigestaltig; der Hauptstengel und der untere Teil des sekundären Stengel mit schuppenförmigen, dicht anliegenden, entfärbten Niederblättern, der obere und die Äste mit grünen Laubblättern dicht besetzt. Alle Blätter \pm faltig; Rippe einfach, homogen; Zellen oberwärts schmal rhombisch, abwärts linealiseh, glatt, an der Insertion loekerer, getüpfelt, orange, in den Blattflügeln locker, hyalin, dünnwandig, eine gut begrenzte Gruppe bildend. Diözisch; Blüten an oberen Teil des sekundären Stengel nnd am Grunde der Äste. Perichätialast verlängert; Perichätialblätter aufrecht, die inneren hochscheidig. Seta verlängert, steif, rot, glatt. Spaltöffnungen oberflächlich. funktionslos. Periston doppelt, beide gleichlang. Haube kappenlöruig.

\section{CLIMACIUM}

Wreb. et Mohr Reise durch Schweden p. 96 (1804).

Kapsel aufrecht, regelmässig, meist länglich-zylindrisch, derbhäutig; Zellen (les Exotheciums dickwandig, unregelmässig rundlich-melnreckig. Ring nicht dif- 
ferenziert. Peristomzähne anı Grunde verschmolzen, lineallanzettlich, papillös braunrot, mit dicht gestellten, niedrigen Lamellen. Inneres Peristom gelbrot; Grundhaut niedrig, glatt; Fortsätze schmal, dicht papillös, leiterförmig klaffend, zuletzt zweiteilig; Wimpern fehlend. Deckel hoch spitzkegelig, durch die sich streckende Columella zuletzt emporgehoben. Haube die ganze Kapsel einhüllend, einseitig bis unter die Spitze geschlitzt, etwas gedreht und die Seta am Grunde les Halses umfassend.

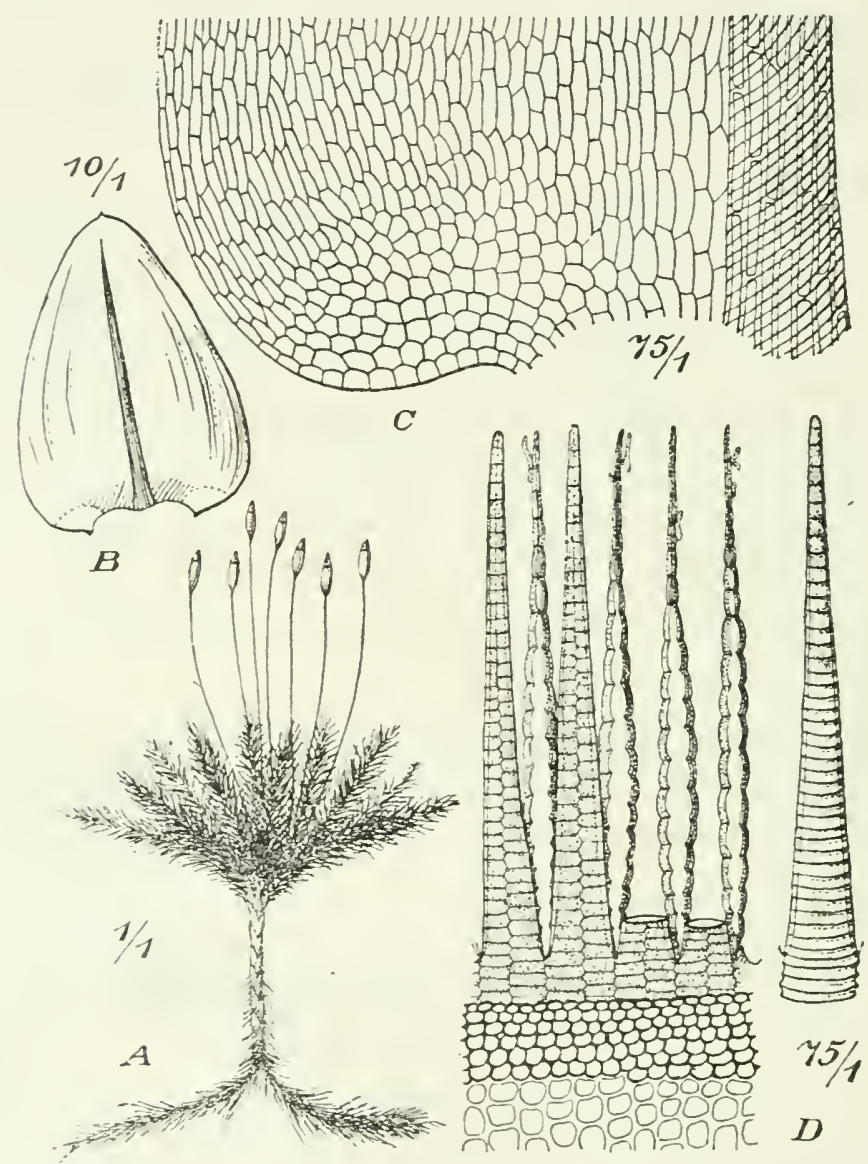

Fig. 70. Climxcium dentroides (L.). A Fruchtende Pfl. (1/1); B Stengelb. (10/1)C Blattbasis (75/1); D Peristoin $(75 / 1)$.

591. Climacium dendroides (L.) Web. et Mohr 1. c. |Hypnum dendroides L. Sp. pl. ed. 1, p. 1128 (1753).]

Pfl. grün bis bräunlichgrün oder gelblich, trocken von schwachem Seidenglanz. Sekundäre Stengel $5-12 \mathrm{~cm}$ oder noch höher. U'ntere Niederblätter entfernt gestellt, zarthäutig, aus sehr verengter Basis breit oval bis länglich-eiförmig, stumpf mit Spitzchen oder ausgerandet, bis $3 \mathrm{~mm}$ lang und bis $1.8 \mathrm{~mm}$ breit, ganzrandig, nach oben allmählich grösser und dichter, zuletzt den grünen Laubblätter ganz ähnlich. Astblätter aufrecht-abstehend, trocken dachziegelig, länglich-zungenförmig mit abgerundeten Blattecken, meist stumpfer bis abgerundeter Spitze und oben grob gesägten Rändern; Rippe am Gruncle stark verbreitert, kurz vor 
der Blattspitze enclent. Innere Perichätialblätter breit eiförmig, rasch fein zugespitzt. Seta $2-4 \mathrm{~cm}$. Kapse! bis $4 \mathrm{~mm}$ lang und bis $1 \mathrm{~mm}$ dick, rotbraun. Sporen 12-18, seltener bis $25 "$, gelb, foin gekörnelt. Sporenreife von August bis Oktober.

Auf versumpftem Waldboten, nassen Wiesen, in Gräben und Sümpfen, längs Bäehen und Flüssen und an niedrigen Seeufem im ganzen Gebiete fo. Steigt bis in die Weidenregion hinauf.

Europa, Kaukasus, Sibirien, Japan, Nord-Amerika.

\section{Unterreihe LEUCODONTINEAE.}

Fels- und Baummoose. Blätter symmetrisch, an den Blattecken mit runcllich verdickten Zellen. Sporogone meist pleurocarp.

\section{HE DW I G I A C E A E.}

Felsmoose in lockeren, starren, leicht zerfallenden Rasen. Stengel ohne Zentralstrang, mit lockerem, reichlich getüpfeltem Grundgewebe und englumigen Mantelzellen, unregelmässig beästet, dieht und gleichmässig beblättert. Blätter 8reilhig, absteliend, trocken dachziegelig, hohl, etwas herablaufend, breit eiförmig bis eílanzettlich; Rippe fehlend; Zellen klein, verdickt und getüpfelt, dicht papillös, quadratisch und kurz rektangulär, in Mittelfelde des Blattgrundes verlängert linear, gefärbt und durchscheinend. Blüten mit gelben, fadenförmigen Paraphysen. Perichätialblätter differenziert. Kapsel aufrecht, regelmässig, dickhalsig; Spaltöffnungen oberflächlich, am Kapselgrunde. Ring nicht differenziert. Peristom fehlend.

Üb e r sicht der Gat $t$ ung e n.

A. Blätter meist in ein \pm langes, papillöses Haar verschmälert; Zellen der Lamina mit zwei und mehrspitzigen Papillen Hedwigia.

B. Blätter ohne Haarspitze; Zellen der Lamina mit niedrigen, rundlichen Papillen Hedwigidium.

\section{HEDWIGIA}

Ehrh. Hann. Mag. 1781, No. 69, p. 109.

Autözisch; o Blüten kleine axilläre Knospen am Fruchtspross: † Blüten gipfelständig, später durch subflorale Sprosse scheinbar seitenständig oder in einer Gabelung. Stengel ohne Ausläufer. Blätter nicht längsfaltig, in ein gezähntes bis kurz gewimpertes, papillöses Haar verschmälert, mit längs ungerollten Rändern; Zellen im oberen Blatteil quadratisclı und kurz rektangulär, längs den Rändern und hier gegen die Basis bis zum Grunde in vielen Reihen quadratiseh, mit zwei- und mehrspitzigen Papillen, im Mittelfelde des Blatlgrundes gelbbräunlich. Perichätialblätter grösser, oberwärts mit längeren, geschlängelten, knotigen bis gezähnten Wimpern. Scheidchen kurz, dicht mit langen. gelben, z. T. zweizellreihigen Paraphysen. Seta sehr kurz. Kapsel verkehrt-eiförmig bis fast kugelig, dünnhäutig, glatt, bräunlich. Deckel breit, flachgewölbt. mit oder ohme Warze; Zellen des Exotheciums locker, unregelmässig mehreckig. Haube klein, kegelmützenförmig, flüchtig, nackt oder behaart.

Einzige Art: 
592. Hedwigia albicans (Web.) Lindb. Musc. scand. p. 40 (1879). [Fontinalis albicans Web. Spic. fl. gott. p. 38, No. 115 (1778). - Hedwigia ciliata Ehrh. Mscr., Hedw. Descr. I. p. 107, t. 40 (1787).]

Pll. in oft ausgedehnten, trocken bläulichgrünen bis weisslichen Rasen. Stengel aufrecht oder aufsteigend, 2-10 cm, meist nur am Grunde mit Rhizoiden. Blätter bis $2 \mathrm{~mm}$ lang und $0,86 \mathrm{~mm}$ breit. Perichätialblätter lanzettlich, bis $2,5 \mathrm{~mm}$ Jang und 0,6 $\mathrm{mm}$ breit. Sporen $20-25$ und $30 \mu$, gelblich, papillös. Sporenreife im Frühling. - Fig. $71 \mathrm{~A}-\mathrm{E}$.
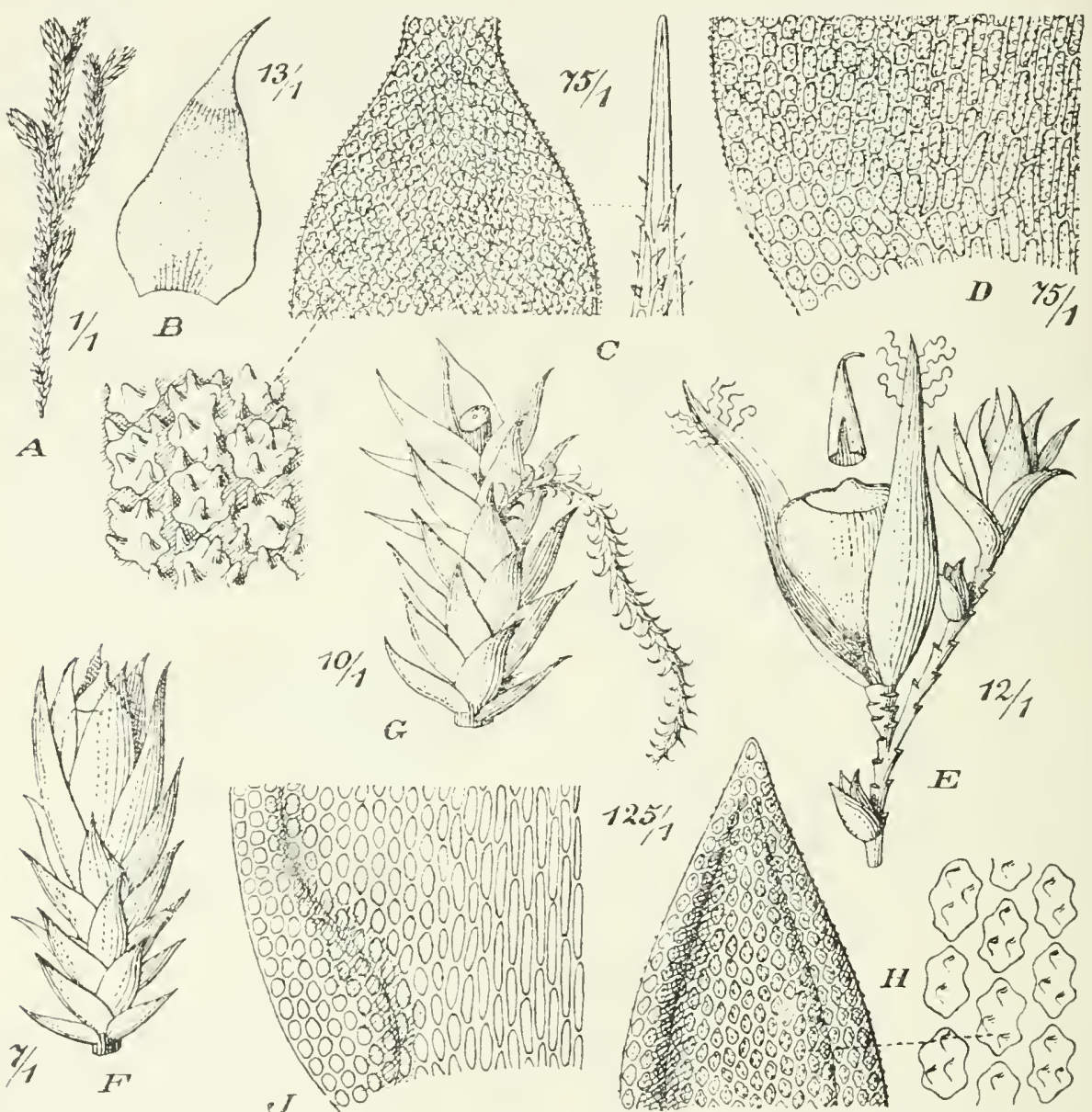

Fig. 71. A-E. Hedwigia albicans (Web.). A Fruchtende Pfl. (1/1); B Slengelb. (13/1); C Blattspitze (75/1); D Blattbasis (75/1); E Kapsel mil 2 Perielätialb. und $2 \gamma^{7}$ BI. (12/1). - F-I. Hedwigidium imbrae (Sm.). F Fruehtiprois (7/I); G slengelitück mit Stolonen (10/1); H Blattspitze (125/1); I Blattbasis $(125 / 1)$.

An trockenen Felsen, Blöcken und Steinen besonders harter Gebirgsarten, seltener aul Schiefer und katkhaltigem Gesteine.

F. Im grössten Teile des Lande; fq.-fqr., in Norden seltener. Le. Selten und spärlich in der Birkenregion (Norrl.). - Li, Sodankylä, Sakatinpahta (Hult). Inari, Pyttelvaara (H.), Utsjoki, Kenischkoski in (ter Nadelwaldregion und Parsij (Oulakoski) in der Birkenregion (H.). - Lim. Kandajaks (Broth.). Umba (Sel.). Tselnun, in der Nadelwaldregion (Broth.), - Lt. Kola, Mbramovija Pahta (B.).

S. $S h .-L$.

N. Sin.-F. Steigt kaum über die Baumgrenze hinauf, Nordgrenze bei $71^{\circ} \mathrm{n}$. Br.

Ko:mopolit. 
var. leucophaea Bryol. cur. fasc. 29/30, p. 5, t. II. $\beta 1$ (1846).

Äste verdickt. Blätter breiter, weit absteliend, bis zum dr:tten Teile herab wasserhell.

An trockenen und somnigen Orten.

var. viridis Bryol. eur. l. c. t. II. $\delta$.

Stengel zart. Blätter grün oder an der Spitze kaum entfärbt.

An schattigen Orten.

Beide Varietäten und zahlreiche Übergangsformen nicht selten.

\section{HEDWIGIDIUM}

Hedwigidium Bryol. eur. fasc. 29/30 (1s46).

Autözisch; beiderlei Blüten gipfelständig. Stengel mit absteigenden, kleinblättrigen, büschelig bewurzelten Ausläulern. Blätter trocken nicht längsfallig, ohne Haarspitze und mit längs stark umgerollten Rändern; Zellen des Blattgrundes wie bei Hedwigia, die oberen kleiner und schnı̈ler, unregelmässig rektangulär und elliptisch oder fast quadratisch, beiderseits mit niedrigen, rundlichen Papillen. Blätter der Ausläufer entfernt gestellt, viel kleiner, aus anliegender, breit ciförmiger Basis rasch zu einer sparrig zurückgekrümmten, sehr langen Spitze verschmälcrt. Perichätialbłätter schmäler, deutlich längsfaltig, länger zugespitzt. Scheidchen kurz, lang und gelbhaarig. Seta sehr kurz. Kapsel verkehrt-eiförmig, dünnhäutig, trocken und entleert tief runzelig-längsfaltig, bräunlich; Zellen des Exotheciums klein, quadratisch, rundlich-6seitig und rektangulär. Deckel aus gewölbter Basis schief kegelig zugespitzt. Haube schmal, kappenförnig, lappig eingeschnitten, nackt.

Einzige Art:

593. Hedwigidium imberbe (Sm.) Bryol. eur. 1. c. [Gymnostomum imberbe Sm. Engl. Bot. t. 2237.]

Pfl. in oft ausgedehnten, gelbbraunen, innen schwarzbraunen Rasen. Stengel niederliegend und aufsteigend, mit aufrechten, 2-4 cm langen, stumpfen ${ }^{7}$ Asten. Blätter bis $2 \mathrm{~mm}$ lang und $0,7 \mathrm{~mm}$ breit. Perichätialblätter bis $3 \mathrm{~mm}$ lang schmäler, länger zugespitzt, stärker längsfaltig. Sporen bis $30 \mu$, mit wurmförmigen IVarzen. - Fig. 71 F-I.

Auf trockenen, somnigen kalkfreien Felsen. Sporogone selten.

N. An der Küste zw. Lindesnes und Sogn pass., zuweilen Massenvegetation bildend. Selten fruchtend. Nordgrenze bei $60^{\circ} 52^{\prime} \mathrm{n}$. Br.

West-Europa, Kamerun, Ceylon, Tasmanien, Ost-Australien, New Zealand, Patagonien.

\section{LEUCOD O N T A C E A E.}

Meist \pm kräftige, starre, lockerrasige Baum- und Felsmoose. Hauptstengel stolonenartig, kriechend, lang und verzweigt, mit Rhizoiden. Sekundäre Stengel ohne oder mit rudimentärem Zentralstrang, lockerem Grundgewebe und mehrschichtigen, verdickten Mantelzellen, dicht und gleichmässig beblättert; Paraphyllien fehlend. Laubblätter vielreihig, aufrecht-abstehend bis cinseitswendig. trocken locker bis dicht anliegend, eiförmig oder eilanzettliclı; Zellen verdickt und meist glatt, wenigstens in der Mitte des Blattgrmndes prosenchymatisch und hier gegen die Ränder in zahlreichen schiefen Reilıen parenchymatisch. Diözisch; Blüten nur an sekundärem Stengel. Seta glatt. Kapsel aufrecht, regelmässig, länglich-eiförmig bis fast zylindrisch, glatt. Ring differenziert. Peristom wenigstens in der Anlage doppelt. Haube kappenförmig. 
Übersicht der Gattungen.
A. Blattrippe fehlend; Zellen glatt
159. Leucodon.
B. Blattrippe kurz, doppelt oder gegabelt; obere Zellecken gegen die Blattspitze papillenartig vortretend
160. Pterogoniutn.
C. Blattrippe einfach, vor der Blattspitze endend 158. Antitrichia.

\section{ANTITRICHIA}

Brid. Mant. musc. p. 136 (1819).

Sekundäre Stengel niedergestreckt oder hängend, einfach oder geteilt, unregeImässig fiederästig; Ästehen stumpf oder in rhizoidentragende Stolonen auswachsend. Laubblätter eilanzettlich: Rippe flach, vor der Blattspitze endend, homogen; Zellen eng wurmförmig. Perichätialblätter zahlreich, die inneren hochscheidig, plötzlich zugespitzt, ganzrandig. Kapsel dünnhäutig, mit engem Luftraum: Spaltöffnungen oberflächlich. Peristomzähnc lanzettlich-pfriemenförmig, nicht gekammert, gelblich, dicht gegliedert, ohne Lamellen. Inneres Peristom bleich, glatt: Grundhaut nicht vortretend; Fortsätze fadenförmig, etwa von der Länge der Peristomzähne.

594. Antitrichia curtipendula (L.) Brid. 1. c. [Hypnum curtipendulum L. Sp. pl. 2. ed. II. p. 1504 (1763).]

Kräftige Pfl. in oft ausgedehnten, gelblich- bis bräunlichgrünen, seidenglänzenden Rasen. Sekundäre Stengel bis $20 \mathrm{~cm}$. Stammblätter unregelmässig längsfaltig, aus kurz herablaufendem, herzeiförmigem Grunde allmählich lang und scharf zugespitzt, bis $3 \mathrm{~mm}$ lang und $1,2 \mathrm{~mm}$ breit, mit längs breit zurückgebogenen, an der meist schiefen Spitze kleingezähnten Ränderm; Rippe am Grunde mit mehreren schwächeren, kurzen Nebenrippen. Seta 5-12 mm, rot. Kapsel länglichoval, etwa $3 \mathrm{~mm}$ lang und $1 \mathrm{~mm}$ dick, rotbraun. Ring sich meist mit dem Deckel ablösend. Peristomzähne quer- und schräg gestrichelt, oben glatt. Deckel kegelig geschnäbelt. Sporen 25-35 $\mu$, gelbbraun, dicht- md feinwarzig. Sporenreife im April und Mai. - Fig. 72 A-D.

An Waldbäumen und an beschatteten Felsen und Blöcken aller Art.

F. Al. Eckerö, Torp (H. Lindb.). Finström, Godby (Arrh.). Saltvik, an mehreren Fundorten (Bom.). Vårdö, Vargata (B.). Kökar, Hamnö (B.). - Ab. Korpo, Vattkast (Ekl.). Kakskerta, Kairoinen (Colland.). Ảbo, Runsala (Brand.). Pargas, Kridja (Link.). Kimilo, Dahlsbruk (Häyr.). Finby. Finnary (Broth.). Bromarf śsundr.). Uskela. Linnamäki (Lindb.). Vemo, Ukkila, Heikolanruori (Ruor.). Karislojo, Karkalı (Sundr.). Lojo, an mehreren Fundorten (Lindb.. H. Lindb., Hult). Vichtis (VV. Nyl.); Irjala (Hult). - N. Hangö by (Ranck.). Ekenäs, Trärminne und Skedö (Häyr.); Gullö (Broth.). Ingå, Bjurs (Buch). Sibbo. Hitå (Ekm.); Löparö (Broth.). Borgá, Pellinge, Tullandet (Broth.). Mörskom (Tennb.). Elimāki (Tigerst.). Hogland (Lindb.). 一 Ka. Kotka, Mussalo (Uly.). Säkijärvi. Pukalus (Krohn). - St. Euraảninne (Simm.). Pirkkala, Pitkäniemi, Mlustalampi (Sola). - Ta. Asikkala (Norrl.). Luhanka, Onkisalo (Vain.). - Sa. Kangasniemi (Lackstr.). — Ki. Kurkijoki, Taskinen (Jusl.). Valamo (Norrl.). Sortavala, Kaarnesaari (Pes.). - Tb. Virral. Helvetinportti (Broth.). - Sb. Maaninka, Kurolanlahti, Torlokso (Roiv.)

S. In allen Provinzen von Götaland und srealand. In Norrland meist in den Küstenprovinzen bis Ang. Steigt nirgends über die Waldgrenze hinauf. Nordgrenze bei $63^{\circ} \mathrm{n} . \mathrm{Br}$.

N. In allen Ämtern mit Ausnahme von Tr. Häufig in den niedrigen Teilen ron sorlandet, längs Westlandet, in der L'mgegend von Trondhjem und in No. bis Salten. Sehr sellen im Binmenlande. Steigt bis $700 \mathrm{~m}$ hinauf. Nordgrenze bei Maaso $\left(71^{\circ} \mathrm{n} . \mathrm{Br}\right.$.).

Europa, Kankasu;, Madeira, Kanaren, Abessinien, Süd-Afrika, Nord-Amerika, Patagonien.

\section{LEUCODON}

Schwaegr. Suppl. I. P. II. P. 1 (1816).

Sekundäre Stengel zahlreich, aufrecht oder bogig aufsteigend, fast von gleicher Höhe, einfach oder zerstreut beästet. Laubblätter herzeilörmig: Rippe fehlend; Zellen stark verdickt, olerwärts kurz-, in der Mitte der unteren Hälfte verlängert- 


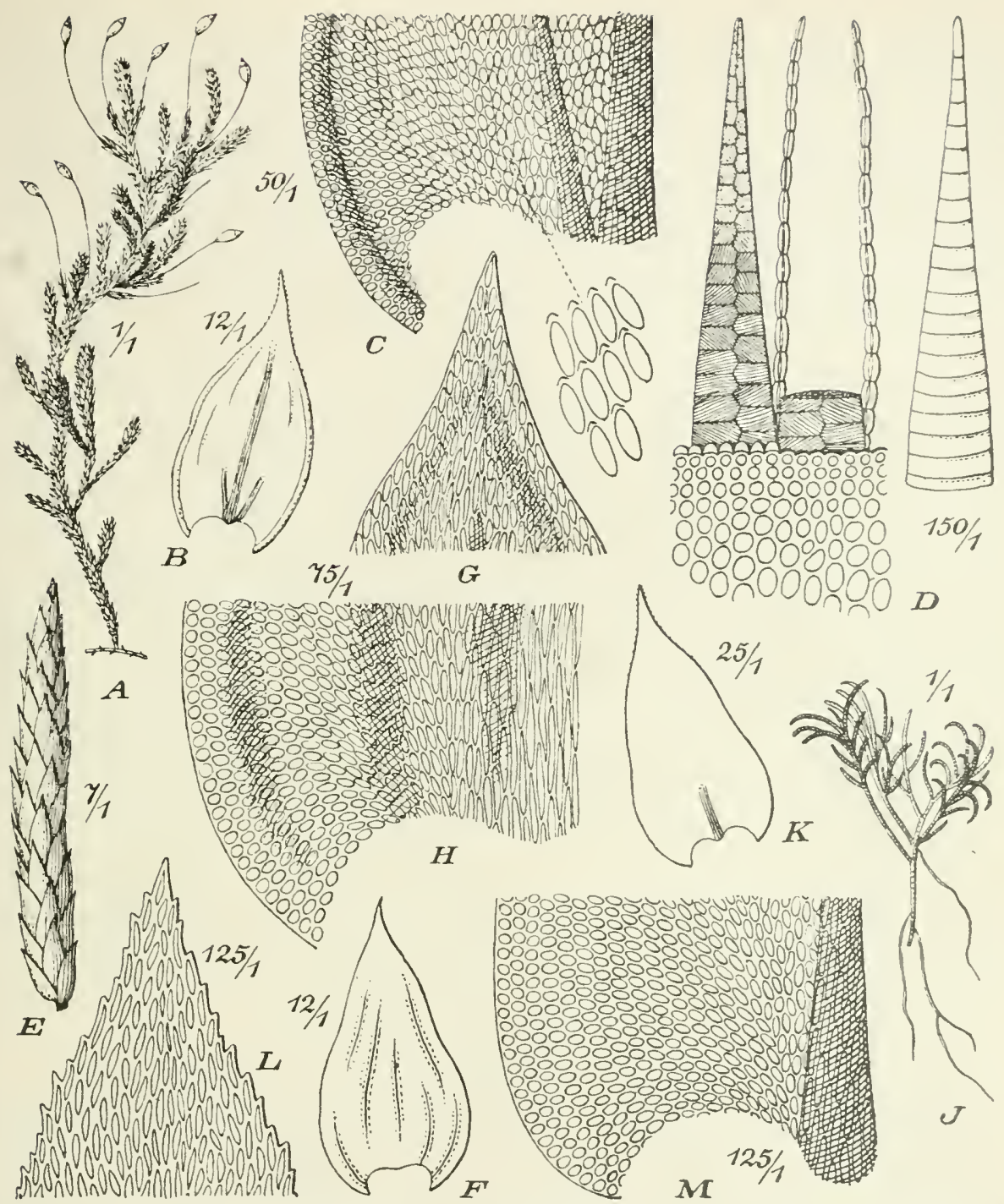

Fig. 72. A-D. Antitrichia curtipendula (L.). A Fruchtende Pfl. (1/1); B Stengelb. (12/1); C Blattbasis (50/1): D Peristom (150/1). - E-H. Leucodon sciuroides (L.). E Ast im trockenen Zustande (7/1); F Stengelb. (12/1); G Blattspitze (75/1); H Blattbasis (75/1). - I-M. Pterogonium ornithopodioides (Huds.). I Sterile Pfl. im trockenen Zustande (1/1); K Stengelb. (25/1); L Blattspitze (125/1); MI Blattbasis (125/1).

wurmförmig und hier gegen die Ränder rundlich- bis elliptisch-mehreckig. Innere Perichätialblätter scheidig, verlängert-lanzettlich; alle Zellen eng prosenchynatisch. Kapsel ohne Luftraum und ohne Spaltöffnungen. Peristomzähne lanzettlich, stumpf, durch eingelagerte ganze Zellen gekammert, gelblich-weiss, papillös. dicht geghiedert, meist durchbrochen oder oben gespalten. Inneres Peristom nur als Grundhaut ausgebildet. Deckeı kegelig. Haube kappenförnig, unter die Kapsef reichend und den oberen Teil der Seta umfassend, glatt. Sporen gross.

595. Leucodon sciuroides (L.) Schwaegr. 1. c. [Hypnum sciuroides L. Sp. pl. 2. ed. II. p. 1596 (1753). — Fissidens sciuroides Hedw. Sp. muse. p. 161 (1801).] 
Pfl. in oft ausgedehnten, grünen oder gelb- bis bräunlichgrünen, glanzlosen Rasen. Sekundäre Stengel bis $5 \mathrm{~cm}$, häufig mit achselständigen, seltener endständigen Stolonen. Blätter trocken dachziegelig, oft etwas einseitswendig, tief längsfaltig, kurz herablaufend, herzeiförmig, scharf zugespitzt, bis $2.5 \mathrm{~mm}$ lang und bis $1,25 \mathrm{~mm}$ breit, flach- und ganzrandig. Seta 8-10 $\mathrm{mm}$, gelbrot. Kapsel länglichwalzenförmig, mit verengter IIündung, etwa $3 \mathrm{~mm}$ lang und $1 \mathrm{~mm}$ dick, zuletzt rotbraun. Ring sich in einzelnen Zellen ablösend. Inneres Peristom nicht über den Lrmenrand vortretend. Sporen 25-40 $\mu$, gelbgrün, feinwarzig. Fruchtreife im Mai. - Vegetative Vermehrung durch Stolonen sowie durch häufig in den oberen Blattachseln auftretende Bruchästchen. - Fig. $72 \mathrm{E}-\mathrm{H}$.

An trockenen Felsen allerlei Art und an alten Baumstämmen. Sporogone sehr selten.

F. Al. Jomala, Ramsholm (Arrh.). Finstrōm, Grelsby, Bastö und Bartsgàrda (Bom.). Saltvik und Sund, an inehreren Fundorten (B.). - Ab. Kakskerta, Kaiboinen (Colland.). Abo (Zett.). Nảdendal (Elfr.). St. Karins. Ispois (Link.). Pargas, Kridja (Link.). Kimito, Páralsby (Ols.). Angelniemi, Kokkilansaari (Buch). Bromarf (Sundv.). Hallikko (Hāyr.). Usskela, Linnaniemi (Lindb.). Vemo. Heikola und Piilonen (Ruor.). Karislojo, Pellonkylä uud Karkali (Sundr.). Lojo, an mehreren Fundorten (Lindb., Hult, H. Lindb., E. af H.). Tichtis (IV. Nỵl.); Irjala (Hult). - T. Hangö (Ranek.). Ekenä-, Trärminne (Häyr.). Ingå. Barō (Sael.). Helsingfors (Lindb.). Helsinge. Degerō (Lindb.). Hogland (Lindb.). 一 Ka. Sākkijārvi, Pukalus (Krohn). Wiborg, Juustila (Buch). Rāisālā, Nāpinlahıi (Lindb.). - Ik. Valkeasaari (H. Lindb.). Pỵhäjärvi, Jahois (H. L.). - St. Pirkkala (Simm.). - Ta. Iitti, Harjuruori (Buch). Hollola, Laitiala. Lebmonienni und auf einigen Inselchen des Tezijārvi (Norrl.). Asikkala (Norrl.). Luhanka, Onkisalo (Vain.). Korpilahti, Paljakko und Haukkiruori (V.): Vuarunvuori (Link.); Päivakunta (Hāỵr.). - Sa. Savitaipale, Kuolimojārvi, Luotolahıi (Buch). Lappee. Nieminen (B.). Kanga-niemi, Korteniemi (Lackstr.). - Kl. Kurkijoki (Jusl.). Valamo (Norrl.). Jaakhima (Sundr.). Sortavala, Spaso (Lindb.); Rauskunvuori (Linnan.); Mäkisalo, Pekanvuori (L.); Ruskiiriutta (Link.); Karinesaari und Palosaari (Pes.): Tuoksjārvi (P.); Pōtsōraara (Kop.). Impilahti, Pullinvuori (Pé.); Sumeria (P.). - Kol. Salmi, Mantschinsaari (Link.). - Tb. Jỵäskȳā. Haapakozki, Kanavuni (Link.). Tiitasaari, Etelävuori (Broth.). - Sb. Kuopio, Haapalahti, Kourulampi (Link.). Kaari, Siikajārvi, Huosiaisniemi, Likosaari und Riihisaari (Kot.). Juuka, Petrovaara, Saarijärvi, Solísaari (Kot.). - Kib. Polvijärvi, Sola, Repovaara (Kot.): Salansaari (K.). - Kon. Suojărvi, Varpaḳlä, Aleksinsaari (Link.). Koselma (Simm.). Tiudie (Kullh.). Valkea!näki (Sahlb.). Pirttinieni (Simm.). - Ok. Sotkamo. Jormasjărvi. Ketrinsaari (Kỵhk.): Henolahti (K.); Kohrorinsaari, Kivelä (K.). - K. Kuusamo, Arentojoki, Ristikallio (E. af H ); Rukatunturi (Broth.); V'uosselijoki (E. af H.); Oulankajoki, Kallioperänvaara (Broth.): Kitkajoki, Pāäsköskallio (B.); Paanajārri (sil.): Ruskeakallio (Nỵb.). — Lkem. Saivio, nōrdlich rom Yllāstunturi (Hult). Kuolajärvi, an mehreren Fundorten (Roiv.). - Lim. Kandalaks. Schelesnaja (Broth.). Hibinä (Sel.); Ljavotschor (Kihlm.). - Lp. Ponoj (Broth.).

S. In allen Provinzen von Götaland und Srealand. In Norrland meist in den Kïstenprovinzen. Nirgends über die Baumgrenze hinaufsteigend. Nordgrenze bei $63^{\circ} \mathrm{n} . \mathrm{Br}$.

N. In allen Ämtern allgemeiı, verbreitet. Steigt meist nur bis zur Baumgrenze hinauf.

Europa, Algier, Kaukasus, Kurdistan, Kaschmir, Zentral-Asien, Sibirien. Nord-Anerika.

var. morensis (Schwaegr.) De Not. Syll. p. 79 (1838). [Leucodon morensis Schwaegr. Suppl. I. P. II. p. 2 (1816).]

Iräiftiger als die Hauptart. Sekundäre Stengel bis $10 \mathrm{~cm}$. Blätter trocken anliegend, kaum einseitswendig, stärker längsfurchig. 3,6 mm lang und 2 mm breit. Kapsel zylindrisch, meist etwas gekrümmt. Peristomzälnme dicht mit langen Papillen. Grundliaut des inneren Peristom vortretend.

F. Al. Brändö, Jurmo, Harholmen, an Kalkfelsen.

S. Boh. Lysekil. Srml. Ưtō.

N. Nach H a g e n am lleere-ufer und an der Küste ron der schwedischen Grenze bis Sogn. meist an Baumstämmen und nicht selter fruchtend.

Schottland, Schweiz, Mittelmeerlānder, Madeira. Kanaren.

\section{PTEROGONIUM}

Sw. Disp. syst. muse. frond. Suec. p. 26 (1799).

Weniger kräftige Pfl. Sekundäre Stengel aufsteigend, büschelig bis baumartig verzweigt, mit absteigenden Stolonen; Äste und Ästchen kätzchenartig, stumpf oder spitz, trocken stark herabgekrümmt. Laubblätter trocken dicht dach- 
ziegelig, feucht abstehend, nicht längsfaltig. sehr hohl, herablaufend, breit eiförmig, scharf zugespitzt, flachrandig, oberwärts scharf gesägt; Rippe doppeIt oder gegabelt, die Blattmitte kaum erreichend; Zellen ller Blattspitze rhombisch, mit papillenartig vortretenden oberen Zellecken, gegen den Blaltgrund allmählich verlängert und hier gegen die Ränder klein, quadratisch und querbreiter. Innere Perichätialblätter aus hochscheidigem Gruncle rasch lanzettlich-pfriemenförmig, ganzrandig. Kapsel mit Luftraum: Spaltölfnungen oberliachlich. Ring sicn abrollend. Peristomzähne lanzettlich, gelblich, papillös-querstreifig, oben papillös mit dicht gestellten, wenig entwickelten Lamellen. Inneres Peristom zart; Grundhaut niedrig, kielfaltig; Fortsätze kurz, pfriemlich; Wimpern fehlend. Deckel schmal kegelig. Haube $2 / 3$ der Urne bedeckend, spärlich behart.

596. Pterogonium ornithopodioides (IIuds.) Lindb. in Öfvers. Vet.-Ak. Förh. XX. p. 411 (1863). [Hypnum ornithopodioides Huds. Fl. angl. edl. 1, p. 130] (1762). - Hypnum gracile L. Nant. II. p. 310 (1771). - Pterogonium gracile Sw. Iusc. suec. p. 26 (1799).]

Pfl. in oft ausgedehnten, olivengrünen, trocken gelbrötlichen oder rötlichbraunen, glänzenden Pasen. Sekundäre Stengel bis $3 \mathrm{~cm}$. Laubblätter etwa 1,5 $\mathrm{mm}$ lang und $0,75 \mathrm{~mm}$ breit. Seta $1-1,5 \mathrm{~cm}$, rot. Kapsel länglich-zylindrisch, zuweilen leicht gekrümmt, bis $3 \mathrm{~mm}$ lang und $0,75 \mathrm{~mm}$ dick, gelbrot bis kastanienbraun. Sporen 14-20 $\mu$, dunkelbraun, grobwarzig. — Fig. $71 \mathrm{I}-\mathrm{M}$.

An trockenen, somnigen, kalkfreien Felsen, seltener am Grunde von Baumstämmen.

S. Hll. Tölö. $\mathrm{Vg}$. an wenigen und Boh an mehreren Fundorten.

N. Sm. Tune, Agnait und in Westlandet von Mandal bis Nordmore, am reichlichsten an der Küste längs den Fjordufern, ausnahmsweise auch länğ den Tälern nach innen dringend. Steigt bis $320 \mathrm{~m}$ hinaut. Nordgrenze bei $63^{\circ} \mathrm{n}$. Br.

Europa, Syrien, Kanaren, Madeira. Süd- und O=t-Afrika. Kalifornien.

\section{Unterreihe NECKERINEAE.}

Fels- und Baummoose. Sekundäre Stengel meist verflacht beblättert. Blätter meist unsymmetrisch und dimorph. Sporogone pleurocarp.

\section{N E C K E R A C E A E.}

Meist \pm kräftige Baum- und Felsmoose. Hauptstengel kriechend, durch Rhizoiden dem Substrat fest anhaftend, selten rhizomartig. Sekundäre Stengel aufrecht bis hängend, dicht und meist verflacht beblättert, meist \pm regelmässig einfach oder doppelt gefiedert. Stengelquerschnitt meist oval, ohne oder mit sehr kleinem Zentralstrang, lockerem Grundgewebe und mehrschichtigen, substereiden Mantelzellen. Blätter t-oder 8reihig, meist unsymmetrisch, oft zungenförmig und stumpf, mit oder ohne Spitzchen: Zellen meist glatt. Blüten knospenförmig, nur an den sekundären Sprossen. Perichätialast kurz, nie wurzelnd. Kapsel eingesenkt und ohne Spaltöffnungen oder emporgehoben und mit oberflächlichen Spaltöffnungen. Peristom doppelt. Peristomzähne schmal lanzettlich, mit niedrigen Lamellen oder Querleisten. Grundhaut meist niedrig; Fortsätze meist schmal inealisch; Wimpern selten vorhanden. Deckel kegelförmig bis geschnäbelt.

Übersicht der Unterfamilien.

A. Sekundäre Stengel verflacht, angedrückt, aufsteigend oder herabhängend. Blätter unsymmetrisch ..................

B. Sekundäre Stengel meist aufrecht und baumartig verzweigt. Blätter schwach unsymmetrisch

I. Neckeroideae.

II. Thamnioideae. 


\section{NECKEROIDEAE.}

Weiche, \pm glänzende Pfl. Stengel, verflacht beblättert, \pm deutlich fiederig beästet. Blätter scheinbar zweizeilig geordnet, unsymmetrisch; Rippe schwach.

$$
\text { Ú bersich t der Gat } \mathrm{t} \text { ung en. }
$$

A. Peristomzähne ungestreift. Grundhaut niedrig; Fortsätze schmal 111. Neckera.

B. Peristomzähne dicht querstreifig. Grundhaut weit vortretend; Fortsätze breit

\section{Homalia.}

\section{NECKERA}

Hedw. Fund. II. p. 93 (1782).

Hauptstengel oft mit Stolonen. Sekundäre Stengel meist hängend, einfach oder doppelt gefiedert. Blätter Sreihig, die bauch- und rückenständigen \pm anliegend und abwechselnd rechts und links geneigt, die seitenständigen \pm abstehend. Laubblätter aus kurz herablaufender Basis länglich-eiförmig bis zungenförmig, trocken häufig querwellig: Rippe bei unseren Arten fehlend oder kurz, zart und gegabelt; Zellen (exel. N. Besseri) eng prosenchymatisch, gegen die Spitze allmählich kïrzer mnd weiter, zuletzt rhombisch und rlomboidisch, in den Blattecken klein, quadratisch und mehreckig. Innere Perichätialblätter verlängert lanzettlich und scheidig. Scheidchen mit langen Haaren. Kapsel regehmässig. Ring nicht differenziert. Peristomzähne mit niedrigen ventralen Querleisten. Grundhaut nicht oder wenig vortretend: Fortsätze schmal linealisch, meist kurz und hinfällig: Wimpern fehlend. Deckel meist geschmäbelt. Haube kappenförmig.

$$
\text { Übersieht der Arten. }
$$

A. Blätter besonders trocken querwellig.

a. Autöziseh.

r. Äste gleichbreit, stumpf ........................ 597. N. pennata.

ఛ. Äste verschmälert ............................. $598 . \quad \mathrm{N}$. oligocarpa.

b. Diözisch.

«. Sehr kräftige Pfl. Äste fast nie flagelliform und ohne Brutästchen 600. N. crispa.

§. Pfl. viel schwächer. Äste stets z. T. flagelliform und mit Brutästchen 599. N. fontinaloides.

B. Blätter trocken nicht querwellig.

a. Blätter abgerundet, mit Spitzchen 602. N. complanata.

b. Blätter abgerundet, ohne Spitzchen 601. N. Besseri.

597. Neckera pennata (L.) Hedw. Deser. III. p. 17, t. 19 (1792). [Fontinalis pennata L. Sp. pl. 2. ed. II. p. 1371 (1763).]

Autöziseh. Pfl. in grau-, hell- bis gelblichgrimen, trocken \pm glänzenden Rasen. Sekundäre Stengel aufsteigend oder längend, $3-6$, selten bis $10 \mathrm{~cm}$, unregelmässig fiederästig; Äste abstehend, kurz und stumpf, selten flagellenartig verlängert oder mit kleinblättrigen Sprossen. Laubblätter länglieh eiförmig, almählich oder kurz zugespitzt, 2,5-3 $\mathrm{mm}$ lang und $1-1.5 \mathrm{~mm}$ breit, bis gegen die Mitte herab gezähnelt. Kapsel eingesenkt, ei- oder länglich-eiförmig, etwa 2 mm lang und $1 \mathrm{~mm}$ dick, bräunlich, später rotbraun. Peristomzähme glatt, an Grunde quer- und sehrägstreifig. Fortsätze rudlimentär. Deckel kurz und sehief geschnäbelt. Haube kaum melir als den Deckel bedeckenel. nackt. Sporen 15-25 $\mu$, blassgelb, \pm papiliös. Sporenreife im Herbst. 
An alten Waldbäumen, seltener an Felsen.

F. Al. Jumala, Ramsholm (Arrh.). Saltvik, Harald-loy (Bons.). Ab. [Pargas, Loftidal (Elfv.). Kimito, Skogsböle, Gästerby (Ols.). Halikko (Nikl.). Lojo, Ojano (H. Lindb.); Jalassairi (H. L.); Maila (Jusl.). Sammatti (Sel.). Vichtis, Ollimäki (Broth.). - N. Ingả, Kalkö (W. Brenn.). Kyrksı̈tt. Oblnäs (Jusl.). Esbo, Kasbärget (Buch). Helsinge, Hoplaki (.lalengr.); Gumtäkt (Norrl.). Bırga, Tirmu (Jusl.); Sundö (Sael.). - Ka. Sippola, Ruotila (Kuj.). - Ik. Kivennapa (Mela). Metsäpirtıj (II. Lindl,.). Pyhäjärvi, Riiska (Ling); Polvananniemi (H. Lindb.). - St. Ylänc, Kolva (Sahlh.). Hameenkyrö (Sỉnm.). - Ta. Asikkala (Norrl.). - Sa. Valkeala (Sundv.). Kangasniemi, Tuomarinvunri (Lackítl.). - hl. Valamo (Norrl.). Taakhima, Puutsalo (Lindb.). - Kol. Humbaritsa (Elfv.). - Oa. Närpes Benvik (Nerv.). 一 Kon. Kivatich (Simm.). Pirtliniemi (Norrl.). Dianova gora (Kullı.).

S. Bl., sm., Ög., Dld., När., Srml., Upl., Dlr., Gstr., IIls. und Ipd., meist nur ron wenigen Fundorten bekannt.

N. A., Bu. und $J L$., meist an der Weztseite des liristianiafjords und längs denn Drammenelv. grenze bei $60^{\circ} 9^{\prime} \mathrm{n}$. Br.

Europa, Kanaren, Kaukasus, Kaschmir, N. W. Himalaya, Sibirien, Amurgebiet, Japan, Iunnan, Nord-Amerika.

598. Neckera oligocarpa Bruch Mscr. in Hartm. Sk. Fl. ed. i), p. $338(18.19)$. [Neckera pennala var. tenera C. Nüll. Syn. II. p. 50 (1850).]

Autözisch. Pfl. in lebhaft grünen, im Alter blcichgrünen, trocken \pm glänzenden Rasen. Sekundäre Stengel aufsteigend oder hängend, bis $12 \mathrm{~cm}$, ziemlich regelmässig fiederästig, häufig mit kleinblättrigen Sprossen; Äste abstehend, verschmälert. Laubblätter eilänglich und zungenförmig, plötzlich kurz zugespitzt, etwa $1,3 \mathrm{~mm}$ lang und $0,45 \mathrm{~mm}$ breit, in der Spitze gezähnelt. Kapsel eingesenkt, oval, $1,5 \mathrm{~mm}$ lang und $0,75 \mathrm{~mm}$ dick, licht bräunlich, später rotbraun. Deckel kurz und schief geschnäbelt. Haube wenig unter den Deckel reichend, nackt. Sporenreife im Mai und Juni.

In Felsspalten und Höhlungen kalkfreier Gesteine.

F. Al. Finstrōm, rodby (Nerv.). Köhar, Idó (Bom.). Föglö. Juddö (B.). - Ab. Abo, Runsali. Huiskala (Bueh). St. Karins, Ispois (Link.). Uskela, Linnamäki (Lindb.). Lojo, Askola (H. Lindlı). Vichtis (WV. Nyl.). - N. Nurmijärvi (Tennb.). Elimähi (Tigerst.). Orimattila, Kalliojärvi (Link.). $K a$. Vehkalahti, Suurniemi (Krohn). Wiborg (Nerv.). Antrea, Papinsaari und Liikola (Lindb.). - $I k$. Rautu (Mela). Pyhäjärvi, Konnitsa (H. Lindb.). - Sl. Nystad (Nerv.). Yläne (Sahlb.). Eura (Pönnl.). Ruovesi (Norrl.). -- Ta. Kuhmoinen (Norrl.). Hartola (Bonsd.). Sysmä, Kammioraara. Korpilahti und Luhanka pass.-st. fq. (Vain.). - Sa. Valkeala (Sundr.). Willmanstrand (Buch). Lappee. Niemínen (B.). Ruokolahti. Imatra (Nerv.); Kouvola (Häyr.). Kangasniemi (Lackstr.). Nyslott (Cari.). Kl. Kurkijoki, Uhtjärvi (Jusl.). Valamo (Norrl.). Jaakhima (Juєl.). Sortavala, Kirjavalahtist. fq. (Norrl.). Ruskeala (W. Nyl.). Suistamo, Uuksujärvi, Roikonkoski und Saika (Link.). - Tb. Virrat (Simm.): Toriseva (Broth.). Petäjäresi, Mäntymäki (Ruor.). Jyväskylä, Haapakoski, Kanavuori (E. af H.). Toirakka (E. af H.) Laukaa (Broth). - Sb. Kuopio fq.-pass. (Link.). Kaavi und Nilsiä st. fq. - pass (Kot.). Maaninka pass. - st. r. (Roiv.). Pielavesi st. r. (R.). - Kb. Tohmajärvi, Akkala (Kot.). Korpiselkat. Eevanvaara (Link.). Polvijärvi und Juuka st. fq. (Kot.). Pielisjärvi, Koli (Linnan.). 一 Kon. Suojärvi. Huukka (Link.). Rogosa (W. Nyl.). Kentjärri (Norrl.). Pirttiniemi (Kullh.). Perguba (Sahlb.). Dialnova gora (Simm.). - Ok. Kajana (Brenn.). Sotkamo. Jormasjärvi, Ketrinsaari (Kyyhk.): Hepolehto (K.). Kuhmoniemi, Portinlouhikko und Iso Naurisvaara (E. af H.). Suomussalmi, Saarnakallio und Katiskalammenkallio (Ky̧̧h.). 一 Ob. Aavasaksa (Nyb.). - K. Pudasjärvi, Hampusvuori (E. af H.). Kuusamo, an mehreren Fundorten (Broth., E. af H.). - Lkem. Kolari und Kittilä fq. (Hult). Kuolajärvi. Peräraara st. cop. (E. af H.); Rantanenäkevaara (E. af H.). - Le. In allen Regionen, wenngleich seh. spärlich (Norrl.). - Li. Sodankylä, Sakatinpahta (Hult). Inari, Tirro (H.). [isjoki, Muddusjärvi (H.). - Lim. Kandalaks. Schelesnaja (Broth.). Porjaguba und Limba (Sel.). Tśchun und Hibinä (Broth.). Lt. Rotsvaar (Roiv.).

S. Yorrland. in allen Provinzen mit Zentrum in Hls., Mpd. und ing. Südlicher nur an wenigen Fundorten in Gstr. und an einem in Upl. weobachtet.

N. A., Bu.,Br.. Ne., R.-ST. und Tr. Nur in Schiefergebiete und dort meist im Binnenlande in der subalpinen Region, wo sie z. B. in Gudbrandsdaten und Dorre lıäufig ist. In niedriger Lage und in der alpinen Region setten.

Steiermark, Tirol, Sibirien, Nord-Amerika.

599. Neckera fontinaloides (Lam.) Lindb. Musc. scand. p. 40 (1879). [Hypnum fontinaloides Lam. Ene. méth. III. p. 164, sp. 12 (1789). - Neckera pumila Hedw. Descr. III. p. 49. t. 20 (1792).]

Diözisch. Pfl. in licht-, dunkel- oder gelbgrünen, etwas glänzenden Rasen. Sekundäre Stengel $3-10 \mathrm{~cm}$, unregelmässig bis regelnuässig fiederästig: Ïste kurz 
und stumpf oder aus kugeligen, blattachselständigen Knospen hervorgehend, dann flagellenartig, oft mit dünnen Brutästchen. Laubblätter länglich-eiförmig, kurz zugespitzt, bis $1,5 \mathrm{~mm}$ lang und bis $0,8 \mathrm{~mm}$ breit, mit weit hinauf beiderseits schmal zurückgebogenen, einerseits am Grunde eingebogenen, gegen die Spitze hin klein gesägten Rändern. Seta $3-5 \mathrm{~mm}$, gelblich. Kapsel etwas emporgehoben, eiförmig, bis $2 \mathrm{~mm}$ lang und etwa $1 \mathrm{~mm}$ dick, gelbbramn, zuletzt rotbraun. Peristomzähne glatt, gelblich, mit hỵalinen Rändern. Fortsätze fast die Zahnlänge erreichend, glatt. Deckel kurz und schief geschnäbelt. Haube bis zur Unienmitte reichend, nackt. Sporen 15-20 $\mu$, gelbbraun, papillös. Sporenreife im Frühling. - Vegetative Vermehrung durch zarte Brutästchen.

An Grunde von Baumstämmen und an trockenen, beschatteten Felsen und Blöcken.

S. Sk., Bl., sïdl. Sm. und südl. Hll. nicht selten; $T g$. und Dlr. an vereinzelten Fundorten: Hls. an mehreren und Hrjd. an wenigen Fundorten.

N. In Sorlandet beiderseits der Mündung des Kristianiafjords. St., SB. und NB. st. fq. und an einzelnen Fundorten in $R$. und No.

Europa. Kanaren.

var. Philippeana (Bryol. eur.) Lindb. Musc. seand. p. 40 (1879). [Neckera Philippeana Bryol. eur. fase. $44 / 45$, p. 11, t. 6 (1850).]

Blätter in eine lange. meist geschlängelte Haarspitze fortgesetzt.

S. sh. und an vereinzelten Fundorten in Hll., Sm. und Hls.

$\mathrm{H}$ a ge n, der wegen der grossen Veränderlichkeit der Blättern, sogar an demselben Individuum, diese Varietät nicht anerkennt, verteilt die extremen Formen der Hauptart wie folgt:

fo. olivacea Hag. in D. K. X. Vid. Selsk. Skrift. 1908, No. 9, p. 46 (1909).

Dunkelgrüne Pfl. Stengel kürzer. Blätter kürzer, mit beiderseits breit zurückgebogenen Rändern.

fo. pallescens Hag. l. c.

Gelbgrüne Pfl. Stengel länger. Blätter länger, mit sehr schmal oder undeutlich umgebogenen Rändern.

600. Neckera crispa (L.) Hedw. Fund. muse. II. p. 93, t. 12, f. 47 und 48 (1782). [Hypnum crispum L. Sp. pl. ed. 1, p. 1124 (1753).]

Diözisch. Stattliche Pfl. in oft ausgedehnten, grünen oder gelblichgrünen bis gebräunten, trocken meist lebhaft glänzenden Rasen. Sekundäre Stengel 3-$10 \mathrm{~cm}$, zuweilen bis $15 \mathrm{sm}$, selten noch länger, \pm regelmässig gefiedert: Äste stumpf oder allmählich zugespitzt. Laubblätter länglich-eiförmig bis fast zungenförmig, rasch zugespitzt, $3-4,5 \mathrm{~mm}$ lang und $1,5 \mathrm{~mm}$ breit, an der Spitze gesägt, trocken mit tiefen, halbkreisförmigen Querfalten. Seta $8-12 \mathrm{~mm}$, gelb oder gelbrötlich. Kapsel dick oval, bis $2,5 \mathrm{~mm}$ lang und bis $1,2 \mathrm{~mm}$ dick, gelb bis rotbraun. Peristomzähne quer- und sehrägstreifig, nach oben fein papillös. Fortsätze kürzer als die Zähne. Deckel lang geschnäbelt. Haube bis zur Urnenmitte oder nocl weiter reichend, spärlich behaart, später nackt. Sporen $15-23 \mu$, gelbbraun, dicht- und kleinwarzig. Sporenreife im April und Mai. - Fig. $72 \mathrm{E}-\mathrm{H}$.

An Baumstämmen, nördlicher ausschliesslich an trockenen, beschatteten Felsen versehiedener Art, am reichlichsten auf lialk.

F. Al. Finström, Tärnebolstad (Bom.). Geta, zw. der kirche und skinnerböle (Hult). Tàrdö, Vargata (Bom.). - Ab. Nagu, Klockarbärget (Elfv.). Kimito, Vikšedja (Ols.). Karislojo, Karkkali (H. Lindb.). Uskela, Linnamāki (Lindb.). Lojo, Gerknăs (Nerı.): 1sosaari, Lỵlỵis (E. af H.); Maila (H. Lindb.). - N. Karis (link.). Kyrksiät (Nyb.). Esbo (Cederer.). Borgá, Pellinge, Tullandet (Broth.). Elimäki (Tigerst.). Hogland (Lindi.). - Ka. Vehkalahti, Kannusjärvi (Kuj.). Virolahti (Blom). Wiborg, Monrepos (IV. Nyl.); Soskuanjoki (Buch). Antrea. Liikola (Lindb.). - Ih. Pyhäjärvi (Sahlb.); Konnitsa (H. Lindb.). - St. Björneborg. Lvitskär und nordöstlich ron der Nündung des kumo elv (Hạ̈̂r.). Hämeenkyö (Simm.). - Sa. Nyslot! (Carl.). - Kl. Sortavala, Kirjavalahti (Norrl.). Suistamo, Leppäsyrjä, Nykymäki (Pes.). Tohmajärvi, Akkala (Kot.). - Tb. Virrat, Helvetinportti (Broth.), Pihlajavesi (Norrl.). Laukaa, Vihtajärvi (Broth.). - Sb. Kuopio, Haminalahti. Justamāki (Link.). - Kb. Polvi- 
järvi, Repovaara (Kot.). Juuka, Juuąqaara (k.). - Kon. Lischınajäri (Norrl.). Valkeamáki (Simm.). - K. Kuusano, Kuusinkijoki (E. af H.).

S. In Südschweden nicht selten und oft fruchtend, nördlich vom Vänern, Hjälınaren und Mälaren seltener, in den Lappmarken fehlend. Nordgrenze bei etwa $63^{\circ} \mathrm{n} . \mathrm{Br}$.

N. Sm.-No., mit Ausnahme von 1 . und fast atsischliesslich in Küstengebiete; im siiden $+\mathrm{f} q$. Europa, Madeira, Kanaren, Kaukasus.

var. falcata Boul. Musc. de la France 11. p. 181 (1881).

Äste kürzer, an der Spitze hakig eingebogen, mit hohlen, sichelförmig-einseitswendigen, weniger querwelligen bis völlig glatten Blättern.

An trockenen, sonnigen Felsen.

S. Sh., Sm., Gtl., Ög., Vg., Boh., Srml, und Vsm. an einzelnen oder wenigen Fundorten. Europa.

601. Neckera Besseri (Lob.) Jur. in Verh. zool.-bot. Ges. Wien 1860, p. 368. [Omalia Besseri Lob. in Haiding. naturw. Abh. 1. p. 48 (1817).]

Diözisch. Schlanke Pfl. in grünen und gelblichgrünen, im Alter bleich bräunlichen, schwach glänzenden Rasen. Sekundäre Stengel $2-8 \mathrm{~cm}$, unregelmässig fiederästig; Äste und Paraphyllien wie bei $N$. complanata. Laubb]ätter länglicheiförmig und länglich-zungenförmig, stumpf oder abgerundet, $1-1,2 \mathrm{~mm}$ lang und bis $0,75 \mathrm{~mm}$ breit, ganzrandig oder an der Spitze undentlich gezähnt, glatt; Zellen weit hinab breit rhombisch, unten rhomboidisch und rektangulär. Ast- und Flagellenblätter kleiner, länglich, deutlich zugespitzt. Seta bis $8 \mathrm{~mm}$, bleich. Kapsel länglich-ciförmig, leicht gekrümmt, zuletzt rotbram. Peristom und Deckel wie bei N. complanala. Sporen 13--15 $\mu$, rostfarben, fein papillös. Sporogone sehr selten, im Norden noch nicht beobachtet.

An beschatteten Felsen und Blöcken verschiedener Art.

F. Ab. Angelniemi, Karviais (Buch). Vichtis. Haapkylä (Broth.). - N. Hogland (Lindb.). - Ta. Asikkala, zw. Kersala und Urajärvi (Norrl.). Luhanka, Onkisalo (Vain.), - Ka. Kotka, Mussalo (Ulv.). - Kl. Sortavala, Kirjavalahti (Norrl.). Impilahti, Pullinvuori (Broth.). Suistamo, Leppäsyrjä, Saariselkä (Pez.). Soanlahti, Kornikallio (Broth.). Pälkjärvi, Anoniemi (B.). - Sb. Kaavi, Siikajärvi, Likюsaari (Kot.). - Kb. Tohmajärvi, Akkala (Kot.).

S. An einzelnen Fundorten in Sim., Ög. und Vsm.

N. Sm.-JL., Ne., NB., K.. ST. und NT., am meisten nur in niedrigen Lagen. Nordgrenze bei $63^{\circ} 28^{\prime} \mathrm{n}$. Br.

Zentral- und Süd-Europa, Kaukasus, Persien.

var. rotundifolia (Hartm.) Mol. in sched. 1862; Limpr. Laubm. II. p. 71:3 (1895). [Neckera rotundifolia Hartm. Sk. Fl. ed. 5, p. 338 (1849).]

Fadenförmige Sprosse überaus zahlreich. Blätter der Hauptsprosse rundlich-oval, etwa $0,5 \mathrm{~mm}$ lang und $0,20 \mathrm{~mm}$ l)reit, ganzrandig: alle Zellen rund und oval. Sporogone umbekannt.

S. Vsm. Sala.

N. Sm. Onso.

Schweiz, Tirol, Kärnten.

602. Neckera complanata (L.) Hüb. Muscol. germ. p. 576 (1833). [Hypmum complanatum L. Sp. pl. ed. 2, p. 1588 (1763).]

Diözisch. Pfl. in grünen bis gelbgrünen, seidenglänzenden Rasen. Sekundäre Stengel 3-10 cm, selten länger, \pm regelmässig gefiedert: Äste bald vorherrschend stumpfspitzig, bald in der Mehrzahl flagellenartig verlängert und dann meist mit einzelnen Bruchästchen besetzt: Paraphyllien spärlich in der Nähe der Astbasen. meist lanzettlich. Laubblätter länglich und länglich-zungenförmig, abgerundet mit Spitzchen, 1,3-2 $\mathrm{mm}$ lang und bis $0.75 \mathrm{~mm}$ breit, an der Spitze klein gezähnelt. glatt. Seta 7-10 $\mathrm{mm}$, gell). Kapsel länglich-eiförmig. etwa 1,6 $1 \mathrm{~mm}$ lang und $0,7 \mathrm{~mm}$ dick, getblich bis rötlichbraun. Peristomzähne am Grunde undeutlich gestreift, glatt oder fein papillös. Fortsätze von etwa halber Zahnlänge. Deckel píriemenförmig geschnäbelt. Haube den Kapselgrund erreichend, mit vereinzelten Haaren orler nackt. Sporen $18-25 \mu$, grünlich, fein papillös. Sporenreife im Juni 
und Juli. Sporogone sehr selten. - Vegetative Vermelnrung durch an den flagellcnartigen Ästen gelegene, = zahlreiche, fadenförmige Brutästchen.

An beschatteten Felsen verschiedener Art und in deren Klüften, an Stämmen und Zweigen, besonders von Buchen. Selten fruchtend, in $F$. nur steril.

F. Al. Eckerō, Harbỵ (Bom.). Jomala. Österkalmar (B.). Geta und Sund an einigen und Saltrik an mehreren Fundorten (B.). - Ab. St. Karins. Ispois (Link.). Abo, Runsala (Brand.). Pargas, Kridja (Elfr.). Finby (Sundr.). Angelniemi. Kokhila (Buch). Karislojo, Puujārvi (Sundr.). Lojo, an mehreren Fundorten (Jusl., Hult, H. Lindb., E. af H.). Vichtis, Irjala (Hult). Mỵnāmāki (A. K. Caj.). - N. Ingá (Buch). Kirrkslătt (Ranck.). Sjundeả (Sundr.). Esbo (Hāỵr.). Helsingfors (Lindb.). Elimäki (Tígerst.). Hogland (Lindb.). - Ka. Kismmene, Sunila (Kuj.). Sippola, Ruotila (Kuj.). Wiborg, Juustila und Lictjäıri (Buch). Antrea, Jaakonsaari (Lindb.). - St. Björneborg (Häyrr.). Ulfsby (Karst.). Pirkkala Simm.). I kaalinen (Sundr.). - Ta. Vanaja (Buch). Im südôstl. Teile an mehreren Fundorten (Norrl.). Hartola (Bonsd.). Luhanka und Korpilahti pass. (Vain.). - Sa. Kangasniemi (Lackstr.). — Kil. Sortarala (W. Nỵl.); Kirjaralahti (Norrl.). Pālkjärvi. Korkeaniemi und Linnunvaara (Link.). - Kol. Salmi. Leppālā (Pes.). Vosnessenje (Elfy.). Petrosarodsk (Simm.). - Oa. Kristine:tad (Nerv.). Bōtom Prhävuori (E. af H.). - Tb. Virrat, Torisera (Broth.). Laukaa. Vihtajărvi (B.). - Sb. Virtasalmi, \rontola, Itāruori (Krỵk.). Kuopio, Yeulaniemi, Neulalampi (Link.), Lairo und Tairaanpankko (L.). Kaavi, Huosiaisniemi (Kỵhk.). Nilsiā, Kuuslahti, Jaakonlampi (K.). Maaninka, an mehreren Fundorten (Roiv.). Pielare:i, Vaara-lahti. Lokinmäki (R.). - Kb. Tohmajārvi, Kemie (Oeschı): Akkala (Kot.). Korpiselkă, Eevanvaara (Link.). Juuka, Juuanvaara (Kot.). Pielisjārvi, Koli (Linnan.). - Om. Alajārvi, Vesterbacka, Huosiaanmaankallio (Backm.). - Ok. Paltamo. Nelalahti, Viilonkallio (Lackstr.). Sotkamo, Jormasjārvi: Ketrinsaari (Kỵhk.). - Kpom. Kem (F. Jỵl.). - K. Kuusamo. IIāntyjoki (Nyb.); Paanajārri, Ruikeakallio (Broth.). Kitkajoki. Jyrärã (Broth.); Oulankajoki, Kallioperănvaara (B.). - Lkem. VIuonio, Rautujārvi, nördl. rom Yllāstuniuri (Hult). - Le. Kare-uanto und Kelottijārvi (Norrl.). Li. Inari, Peldoiri, in der Birkenregion (Hult).

S. In Südschweden bis Mălaren, Hjälmaren und Vänern st. fq., nördlicher st. r., in`den Kïıstenproxinzen bis Ang. LuL. Krikkjock, Niarre.

N. Sm.-K., ST.-Tr. Südlich rom Polarkreise fq., nōrdlich davon rr. Nordgrenze bej etwa $599^{\circ} 11 . \mathrm{Br}$

Europa, Algier, Kanaren, Kaukasus, Persien. Nord-Amerika.

var. longifolia Schimp. Coroll. p. 100 (1856).

Sekundäre Stengel verlängert, hängend, weniger ästig. Blätter verlängert. zungenförmig, allmählich zugespitzt.

N. Nach $\mathrm{H}$ a ge $\mathrm{n}$ in Südnorwegen rorkommend.

Zentral-Europa.

var. tenel!a Schimp. l. c.

Sehr zart und kriechend. Blätter doppelt kleiner, verkehrt eilanzettlich, kurzspitzig: Rippe fehlend; alle Zellen erweitert, rhombisch.

F. Al. Sund, Tranvik (Bom.).

S. Ög. Risinge. Mpd. Torp.

N. Sm.-Ne., $Y \dot{B} .-T Y$. nach $\mathrm{H}$ a ge n nicht selten.

Deutschland, England.

var. secunda Grav. in sehed. 1884: Limpr. Laubm. II. p. 711 (1895).

Blätter hohl, \pm einseitswendig gekrümmt.

An trockenen, sonnigen Felsen, meist auf Kalk.

S. Öl., Gtl., Ög. När., Srml., rstm., Hls.. Mpd. und Jmt., nach u ölle r wahrscheinlich nicht selten.

Zentral- und Ost-Europa.

\section{HOMALIA}

(Brid.) Bryol. eur. fase. 44, 45 Mon. (1850).

Hauptstengel mit zahlreichen Stolonen. Sehundäre Stengel aufstrebend, unregelmässig beästet: Aste selır flach und stumpf. Blätter zweireihig abstehend. trocken meist niedergebogen, wenig herablaufend, zungenförmig, glatt: Zellen oben rhombisch-, abwärts rhomboidisch-6seitig, unten eng linealisch, in den Blattecken klein, qquadratisch, mehreckig und kurz rektangulär. Innere Perichätialblätter scheidig. plötzlich in eine lanzettliche Spitze verschmälert. Seta verlängert. Kapsel aufrecht oder etwas geneigt. regelmässig orler symmetrisch, mit Spalt- 
öffnungen. Ring 2 (3)reihig. Peristomzälne gesäumt, gelb, (juerstreifig, mit normal entwickelten Lamellen. Inneres Peristom blassgetb, Grundhaut kielfaltig, weit vortretend; Fortsätze breit, gekielt, ritzenförmig durchbrochen; Wimpern von Zahnlänge oder rudimentär bis fehlend. Deckel schief geschnäbelt. Haube kappenförmig, nackt.

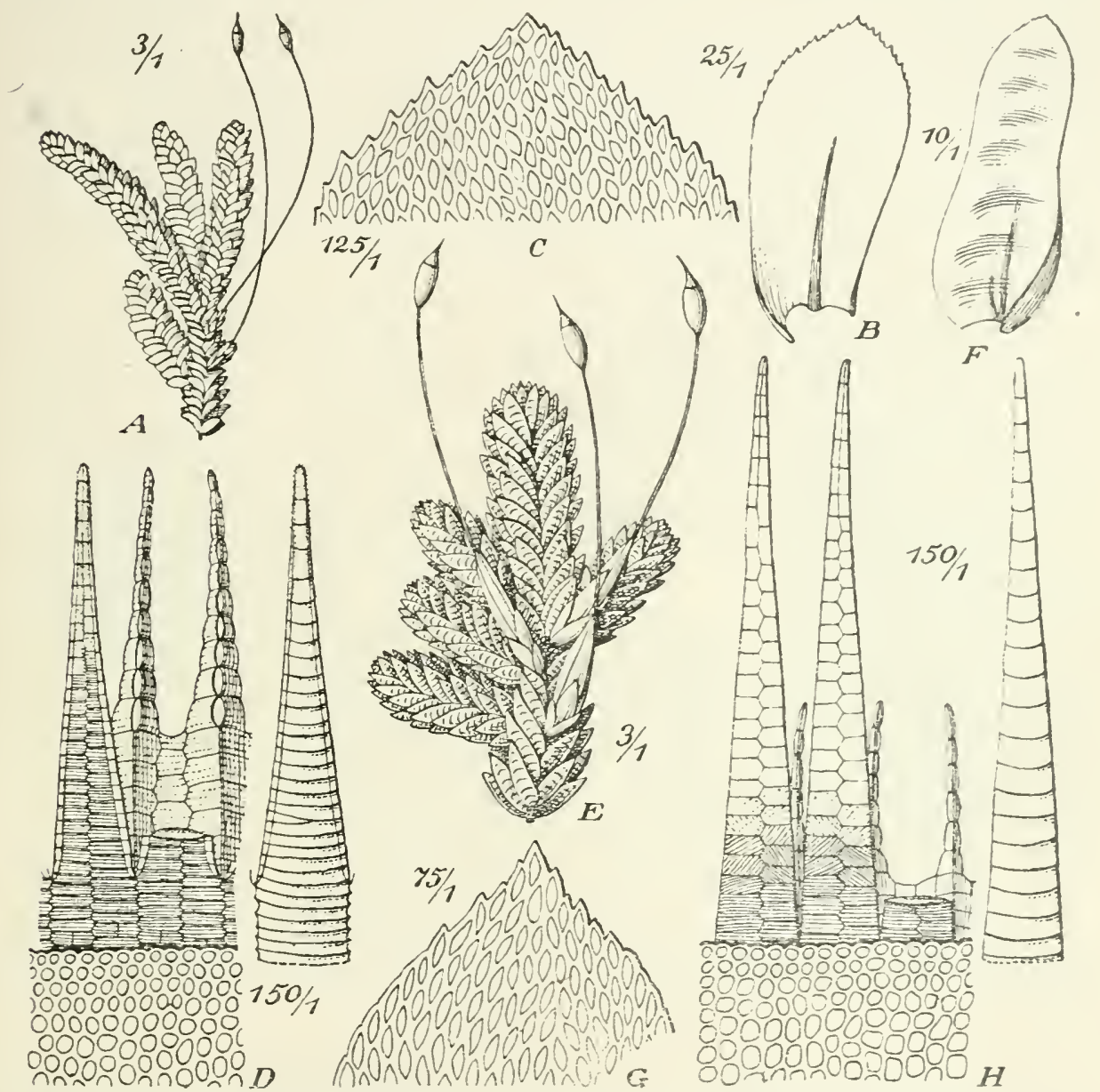

Fig. 22. A-D. Homalia trichomanoides (L.). A Fruchtende Pfl. (3 1): B Stengelb. (25/1): C Blattspitze (125/1); D Peristom (150/1). - E-H. Neckera crispa (L.). E Fruchtende Pfl. (3 1); F Stengelh. (10 1); G Blattspitze $(75 / 1) ;$ H Peristom (150/1).

603. Homalia trichomanoides (Schreb.) Bryol. eur. 1. c. p. 3, t. 1. [Hypnum trichomanoides Schreb. Spic. Fl. lips. p. 88, No. 1053 (1771). - Neckera trichomanoides Hartm. Sk. fl. ed. 5, p. 338 (1849).]

Autözisch. Pfl. in dichten, grünen oder gelblichgrünen. oft ausgedehnten, polsterförmigen Rasen. Laubblätter aus etwas verschmälerter Basis zungenmesserförmig, abgerundet und stumpf oder mit Spitzchen, bis $2 \mathrm{~mm}$ lang und $1 \mathrm{~mm}$ breit, in der oberen Hälfte ausgefressen-gezähnt; Rippe zart, etwa bis zur Blattmitte reichend, einfach, selten gegabelt oder fehlend. Seta $1-1,5 \mathrm{~cm}$, rot. Kapsel länglich, braunrot. Sporen $10-14 \mu$, blassgelb. glatt. Sporenreife im Spätherbst. - Fig. $72 \mathrm{~A}-\mathrm{D}$. 
Auf Baumwurzeln und am Grunde der Stämme, an Felsen und Blöcken verschiedener Art, seltener auf Erde.

F. Al. Jomala, Finström, Geta und Lemland an einzelnen, Saltrik und sund an mehreren Fundorten (Born.). Brändö. Jurmo (B.), - Ab. Abo, Runsala (Brand.). Nadendal, Luonnonmaa (Elfr.). St. Karins, Ispois (Aerh.). Kimito, Vreta (Ols.). Karis, Svartả (Jusl.). Uskela (Nikl.). Mynämäki (A. K. Caj.). Karislojo, Karkkali und Tesjärv (E. af H.). Sammatti st. fq. (Sel.) Lojo, an mehreren Fundorten (H Lindb.. E. af H., Sundv.). Vichtis, Irjala (Hult); Olkkala (Ling). - N. Ekenäs, Trärninne (Ranck.). Pojo, Fiskars (Hạ̈r.). Esbo, Kilo (Häỵr.). Helsinge, Degerö (Ranck.). Sibbo, Hita (Ekm.); Gesterby (Ranck.). Lovisa (Häyr.); Kattön (Lindb.). Hogland (L.). - Ka. Sippola, Ruotila (Kuj.). Wiborg (Jusl.). Antrea, Likkola (Lindb.). - Ik. Uusikirkko, Vammelsuu (H. Lindb.). Valkjărvi. Pảlkinämäki (H. L.). Šakkola (UTr.). Pyhäjärvi (Lảng), — St. Eura (Rönnb.). Ulfsby (Karst.). Björneborg. Torbonäs (Häyr.). Norrmark, Södermark (H.). Pirkkala (Simm.). - Ta. Hattula, Siankivenkorpi (Ranck.). Sääkimäki, Rauttuniemi (Kihlm.). Im südöstl. Teile pass. (Norrl.). Tamınerfors (Nerv.). Hartola (Bonsd.). Luhanka und Korpilahti pass. (Vain.). - Sa. Valkeala (Sundv.). Willmanstrand (Buch). Kangasniemi, Tuomarinvuori (Jackstr.). Nyslott (Carl.). - Kl. Kurkijoki, Haavikko (Jusl.). Valamo (Lindb.). Jaakkima, Ramola (Sundr.). Sortavala st. fq. (Norrl.). Impilahti, Ristisaari (Pes.). Ruskeala (W. Nyl.). Soanlahti, Koukkuhonka Louhunvaara (Link.). - Kol. Mjätusova (Elfv). Petrosarodsk (Kullh.). - Oa. Närpe: (Nerv.). - Tb. Jyväskylä (Broth.). Konginkangas, Leonmaa (E. af H.). - Sb. Virtasalmi, Montola, Itärnori (Kyylk.). Heinäresi, Palokki, Kultaniemi (Kot.). Kuopio pass. (Link.). Kaavi. an mehreren Fundorten (Kot.). Nilsiä. Kirchdorf, Lehtumảki (hot.); Jaakonlampi (Kyyhk.). Jaaninkil, Haatala. Haukkiruori (Roiv.); Pöljä. Lammasmäki und Soansuumäki (hyyhk.). - Kb. Tohmajärvi. Tattarinmäki (Kot.). Körpiselkä, Eevanvaara (Link.). Pielisjärv, Koli (Linnan.). - Kon. Salmi. Leppäla (Pé.). Tiudie (Norrl.). Kentjärvi (N.). Suunu (X.). - Om. Vindala, Pỵälahti (Backm.). - Ok. Paltamo, Melalahti, Viilonkallio (Lackstr.). Sotkamo. Vuokatti. Tolhovaara (Kyyhk.); Jormasjärvi, Ketrinsalari (K.); Hepolahti (K.). - Kpom. Ken (F. Nyl.). - Ob. Rovanieni. Hepokallio und Ristikallio (Hult). - Lkem. Kolari, Jouhisuanto (Hult). - Li. Sakatinpahta (H.).

S. In den süßlichen Teilen bis $N a r_{\text {. }}$, Srml. und $U p l$ st. fq., nördlicher viel seltener. Dringt in den Kirstenprovinzen bis. ing. Irinauf. Fehlt in Gll. und IIrjd. und ist nur von einzelnen Fundorten in Jml. und isL. bekannt.

N. In allen Ảntern mit Ausnalıme von $P$. und $F$. Nordgrenze bei etwa $69^{\circ} 30^{\circ} \mathrm{n} . \mathrm{Br}$. Europa, Kaukasus, Japan. Ost-China.

var. Jamesii (Schimp.) Holz. in Minn. Bot. St. 1898, p. 41. [Omalia Jamesii Schimp. Bryol. eur. Coroll. p. 100 (185̃).]

Schlanke Pfl. Perichätialblätter kürzer. Kapsel kleiner, aufrecht. Peristom und Deckel kürzer.

N. SB. und $N B$, an wenigen Fundorten. Scheint dort nur an Blöeken aufzutreten.

Nord-Amerika

\section{THAMNIOIDEAE.}

Mehr oder weniger starre, meist glanzlose Pfl. Stengel meist bäumchenartig, am Grunde nur mit Niscierblättern und unverzweigt. Blätter symmetrisch; Rippe kräftig.

\section{THAMNIUM}

Bryol. eur. fasc. 49/51 Mon. (1852).

Diözisch. Hauptstengel rhizomartig, mit Rhizoiden und Niederblättern. Sekundäre Stengel holzig. meist aufrecht oder aufsteigend, in der unteren Häifte meist astlos, mit Niederblättern besetzt und am Grunde oft Stolonen entwickelnd, in der oberen Hälfte durch fast zweizeilig gestellte Äste baumartig verzweigt. Niederblätter klein, häutig, dreieckig, mit Rippe und verlängerten Zellen, nach oben allmählich grösser und den Laubblätter ähnlich. Laubblätter grösser, von wechselnder Form, glatt. flachrandig, oberwärts fein bis grob gesägt: Zellen in der Mehrzahl parenchymatisch, glatt, am Blattgrunde verlängert, in den Blattecken nicht differenziert. Seta verlängert. Kapsel meist \pm deutlich hochrückig. Ring differenziert. P'eristomzähne am Grunde verschmolzen, gesäumt, querstreifig. mit dicht gestellten Lamellen. Grundhaut hoch, kielfaltig; Fortsätze breit, durchbrochen: Wimpern vollständig, knotig oder mit Anhängsehn. Deckel aus gewölbter Basis schief geschnäbelt. Haube kappenförmig. 
604. Thamnium alopecurum (L.) Bryol. eur. 1. c. p. 1, t. 1. |Hypnum alopecurum L. Sp. pl. 2. ed. p. 1594 (1763). - Porotrichum alopecurum Mitt. Mlusc. austr.amer. p. 467 (1869).]

Pfl. in lockeren, starren, dunkel- bis gelbgrünen, kanm oder mattglïnzenden Rasen. Sekundäre Stengel bis $10 \mathrm{~cm}$, selten höher. Äste teils kurz, stumpflich, teils lang, allmählich verdünnt und olt gekrümmt, einfach oder gefiedert. Laubblätter allseits aufrecht-abstehend, 'etwas hohl, länglich-eiförmig, kurz. zugespitzt. bis $2 \mathrm{~mm}$ lang und bis $1,1 \mathrm{~mm}$ breit, mit oben grob gesägten, abwärts kleingezähnten Rändern; Rippe sehr krậftig, kurz vor der Blattspitze endend, oberwärts am Rücken gezähnt; Zellen klein. in der Mehrzahl rundlich-melıreckig. am Blattgrunde nächst der Rippe kurz lineal. Perichätialblätter mit abgebogenen Spitzen, dir: inneren halbumfassend, rasch in eine lanzettliche, gesägte Spitzc versclnmälert. Scta $1-1,5 \mathrm{~cm}$, rot. Kapsel geneigt bis horizontal. länglich, bis $3,5 \mathrm{~mm}$ lang und

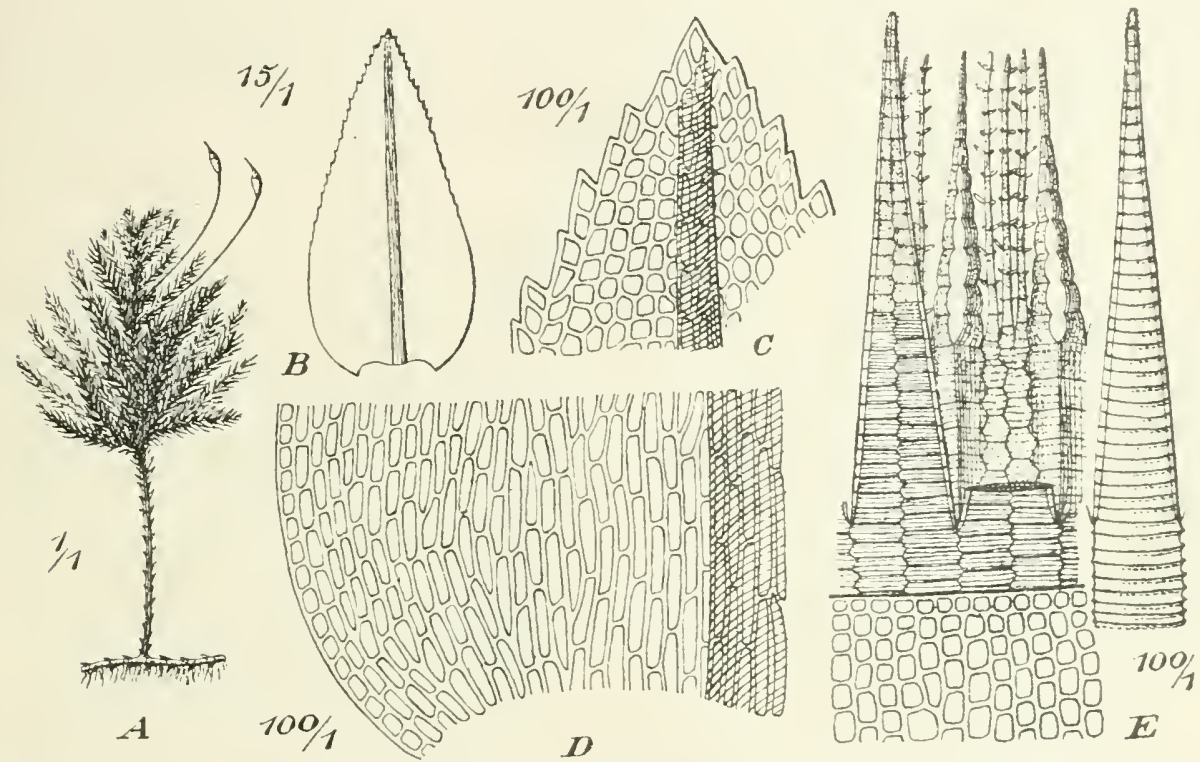

Fig. 73. Thamnium alopecurum (L.). A Fruchtende Pfl. (1 1): B stengelb. (15/1); C Blattspitze (100/1): D Blattbasis (100/1): E Peristom (100/1).

0,75 mm dick, braun. Peristomzälne gelb. Inneres Peristom bleichgelblich. Sporen $10-12 \mu$, grünlich oder gelblich, fast glatt. - Fig. 73 .

In schattenreichen Waldschluchten an Gesteinen verschiedener Art und in deren Klüften.

F. Al. Jomala, Ingbyberg (Bum.). Geta und sund an mehreren und salt vik an vielen Fundurten (B.). - Ab. Nagu. Klockarbärget (Elfv.). Kustö, Rövarholmsqrollen (Lundslr.). Angelniemi, Kokkila (Buch). Lojo, Torhola (H. Lindb.); Pietiłä und Lylyis (E. af H.).

S. Sk., Öl., Gll., Ög., Vg., Srml., När., Dld. und Hlsl.

N. Sm. pas.. A. Kristiania pass. $J L$. Tjoul st. fq. Sandefjord pass. Drammen. SB. pass. $、 B$. Sogn. ST. Trondhjem. No. Helgeland.

Europa, Madeira, Azoren, Kanaren, Algier, Tunis, Kaukasus, Persien.

var. smolandicum Tolf in Bilı. K. Sv. Tet.-Ak. Handl. Bd. 16. Afd. III. No 4, p. 95 (1891).

Sehr kräftige, schwellende, gelbgrüne, glïnzende Pfl.

An Steinen in Bächen.

S. Sm. an wenigen Fundorten. 


\section{E M B O P H Y L L A C E A E.}

Starre, meist lockerrasige, mattglänzende Baum- und Felsmoose. Hauptstengel kriechend, absatzweise stolonenartig und dann mit Viederblättern und Rhizoidenbüscheln besetzt. Sekundäre Sprosse einfach oder büschelig bis baumartig verzweigt, dicht beblättert, olne oder mit sehr spärlichen. blattförmigen Paraphyllien. Stammquerschnitt rundlich bis elliptisch; Zentralstrang klein und armzellig: Grundgewebe locker und rasch in die mehrschichtigen, stark verdickten Nantelzellen übergehend. Niederblätter klein. zart und rippenłos. Normale Laubblätter symmetrisch, selır hohl, nicht faltig. von wechselnder Form: Rippe bald doppelt oder fehlend, bald einfach, in der Blattmitte aufhörend: Zellen meist prosenchymatisch, in den meist ausgehöhlten Blattflügeln klein und rlickwandig, rundlich-mehreckig oder quadratisch. Diözisch oder pseudautözisch: beiderlei Blüten am sekundären Stengel und an Ästen. Seta verlängert, aufrecht, glatt. Kapsel glatt: Spaltölfunngen oberflächlich, spärlich in Halsteile. Peristom doppelt. beide gleichlang. Peristomzähne mit normal entwickelten Lamellen. Inneres Peristom mit weit vortretender Grundhaut und breiten Fortsätzen. Haube kappenförmig, nackt. Sporen klein.

\section{ISOTHECIUM}

Brid. Bryol. univ. II. p. 355.

Sekundäre Sprosse am Grunde öfter mit Stolonen, mit meist einseitig gerichteten, zugespitzten und oft gehrümmten Ẍsten. Laubblätter $\doteqdot$ lang zugespitzt; Rippe einfach, zuweilen gegabelt. Kapsel aufrecht oder geneigt, länglich bis fast zylindrisch, zuweilen leicht gekrümmt. Ring differenziert, sich ablösend. Peristomzähne an Grunde gegenseitig verschnulzen, gelb, mit clorsaler Querstrichelung.

A. Kapsel aufrecht.

$$
\text { Übersicht der Arten. }
$$

a. Meist kräftige Pfl. Stengelblätter eilänglich uncl verkehrt-eilänglich, kurz gespitzt. Deckel meist kurz und schief geschmäbelt

605. I. viviparum.

b. Weniger kräftige Pfl. Stengelblätter eiförnig, mit lan-

ger, borsten- bi: haarförmiger Spitze. Dechel kegelig. 606. I. tenuinerve.

B. Schlanke Pfl. Stengelbläıter aus herzeiförmigem Grunde

lanzettlich, lang zugespitzt. Kiapsel übergeneigt ..........607. I. myosuroides.

605. Isothecium viviparum (Neck.) Lindb. Musc. scand. p. 36 (1879). [Hypnum viviparum Neck. Delic. gall. lselg. II. p. 475, No. 20 (1768). - Hypnum myurum Poll. Hist. pl. Palat. III. p. 170, No. 1054 (1777). - Hypnum curvatum Sw. Disp. p. $6+$ (1799). - Leskea curvata Voit Hist. musc. Herbi]) p. 72 (1812). - Isothecium myurum Brid. Bryol. univ. II. p. 367 (1827).]

Meist kräftige Pf]. in ausgedehnten, bleich- oder dunkelgrünen bis gebräunten Rasen. Niederblätter anliegend, klein, fast halbkreisförmig, nit zurückgebogenem Spitzchen oder grösser, lanzettlich und lang zugespitzt. Stengelblätter aufrecht-abstehenł. trocken dachziegelig, länglich. länglich-eiförmig bis breit oval, kurz zugespitzt. bis 2.5 mm lang und bis 1 mm breit. mit eingebogenen, oben meist gesägten Rändern: Astbuätter wenig differenziert. Perichätialblätter locker anliegend, tie inneren allnählich zugespitzt. Sela $8-15$ mm, gerade, rot. Kapsel aufrecht, länglich-elliptisch, bis 2,5 mm lang und bis 1 mm dick, rotbraun. Winpern rudinentär. Deckel gewöllbt-kegelig, neist kurz und schief geschnäbelt. Sporen $12-15 \mu$, gelbbräunlich, fein papillös. Sporenreife im Frülaling. - Fig. 7.1. 
An beschatteten Felsenwänden und in Felsenklüften. auf Steinen und Blöcken, humosem Erdboden und Baumwurzeln.

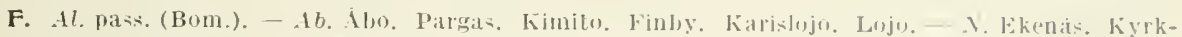
slätt. Helsingfors. Sibbo. Borgat. Elimäki. Hogland, - ka. Kotkit. Sipmola. Wiborg. Ih. Pyhäjärvi. - St. Eura minne. Sastmola. Pirkkala. Hämeenkyrö. - Ta. Vanaja, Haltulas. Kalvola. Lin südöstl. Teile st. fq. (Norrl.). Hartola. Korpilahti und Luhanka sl. fq. (Vain.). Gra. Lappee. Kangasniemi. - Kl. Valamo. Sorlavala. Impilahti. - hol. Salmi, Leppälä (Pé.). Nikola (Ellv.). - jo. ofvermark, Pikku Parra (Ranck.). - Tb. Virrat. Jyväskylä. Lakia. kinnula, - šb. Kiıpio, an wenligen Fundorten (Link.). Maaninka Haatala, Haukkavori (Roiv.); Poljä, Saarisennäki colo. (Kyyhk.). Kb. Pielisjärvi, Koli (Linnan.). - Kon. suojärvi, Haukka (Link.). Rogosa (II. Nyl.). J,íchnıa (Kullh.). -Om. Viudala, Pyhävuori (Backm.). - Ok. Kajana (Lack-1r.). Pallano, Melalahti. Xijonkillio (Kyylik.). Sotkamo. Vuokatti (Broth.); Tolhuraara und Sopenvara (kyyh.). - K. Kuncamo. kithajoki, Juuma (Broth.). - Lkem. Kittilä. Pahtakallio (Hult). L.p. Orlov, liulnoi (Kihlus.).

S. Sk- ing.

N. Sm.-No. Nordgrenze bei elwa fi $7^{\circ} 17^{\prime} \mathrm{n} . \mathrm{Br}$.

Europa. Algier, Kaukasus.

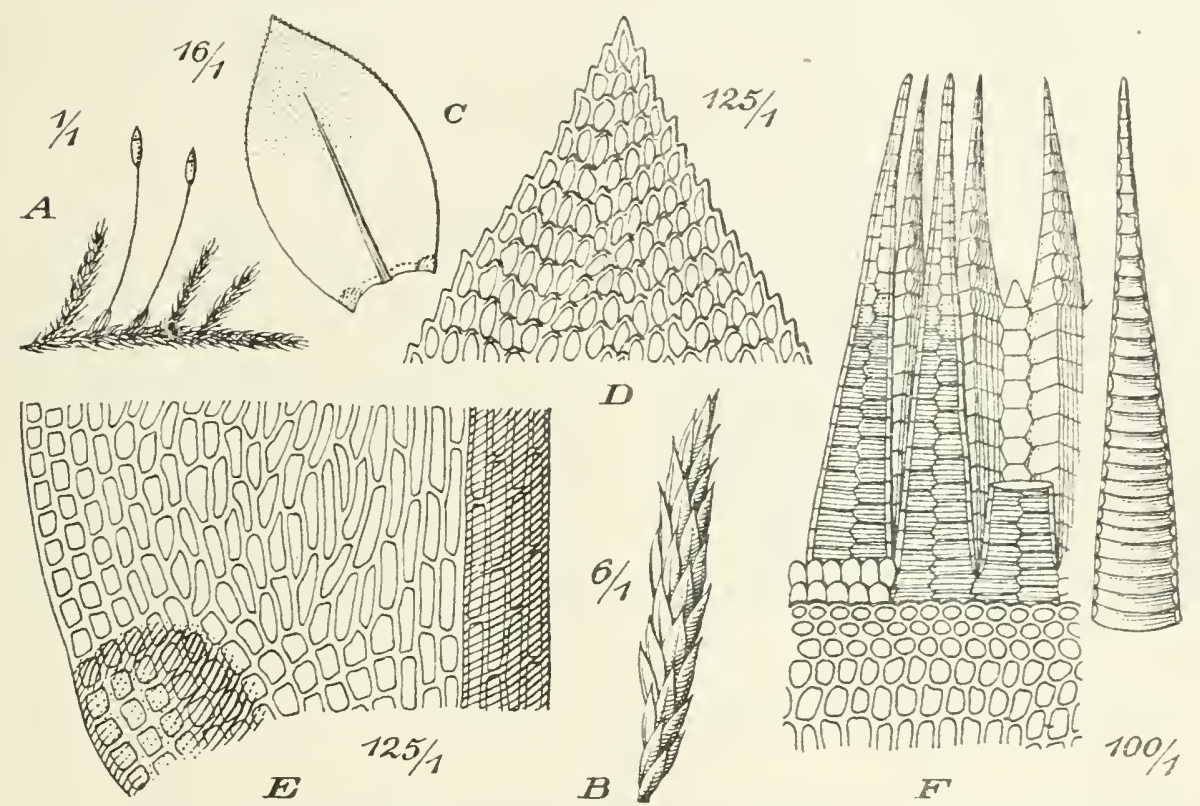

Fig. 74. Isotheciumviviparum (Neck.). A Fruchtende Pfl. (1/1); B Stammb. (16/1); C Blattspitze (1:25/1); D Blaltbasis (125/1); E Peristom (100/1).

var. robustum Bryol. eur. fasc. $46 / 47$ Mon. p. 5 (1851).

Sehr kräftige Pf1. Äste stengelartig, aufsteigend, unregelmässig und büschelästig, 4-6 cm; Ästchen kätzchenartig, sehr kurz gespitzt. Blätter sehr hoht. fast spatelförmig, etwa $2 \mathrm{~mm}$ lang und $1 \mathrm{~mm}$ breit.

S.

Europa.

606. Isothecium tenuinerve Kindb. Eur. and N.-Am. Bryin. p. 37 (1897). [Isolhecium myosuroides var. lenuinerve Kindb. in Braithw. Mossfl. III. p. 12.1 (1900).]

Mit der voriger Art nahe verwandt. Stengel- und Astblätter eiförmig. in einer langen, oft haarförmigen Spitze fortgesetzt. Deckel kegelig.

Auf Erdboden, Felsen und Steinen.

S. nach $\mathrm{K}$ in d b e rg ohne nähere Fundorte.

Kanada, England, Färoer. Island. 
Nach C. J e n s e $n$ ist diese Art auf den Färoern sehr gemein, auf Eroboden sogar masserhaft auftretend und in Grösse und Tracht sehr veränderlich, lässt sich aber immer durch die Blattform von den anderen Arten unterscheiden.

607. Isothecium myosuroides (L.) Brid. Bryol. univ. II. p. 369 (1827). [Hypnum myosuroides L. Sp. pl. p. 1130 (1753).]

Schlanke Pfl. in ausgedehnten, bleich- bis bräunlichgrünen Rasen. Äste und Ästchen oft peitschenartig verlängert. Niedterblätter aus rundlich-ovaler Basis plötzlich in einc lange, geschlängelte oder sparrig zurückgebogene Pfriemenspitze verschmälert. Stengelblätter aufrecht-abstehend, fast flach, aus eiförmigem Grunde allmählich lang pfriemenförmig. bis $1.8 \mathrm{~mm}$ lang und bis $0.6 \mathrm{~mm}$ breit, mit in der oberen Hälfte \pm scharf gesägten Rändern. Astblätter etwas hohl. lanzettlich. bis $1,3 \mathrm{~mm}$ lang und bis $0.1 \mathrm{~mm}$ breit, mit unten fein und oberwärts scharf gesägten Rändern. Innere Perichätialblätter aus halbscheidigem Grunde schnell in eine lange, sparrig zurückgebogene, gesägte Pfrieme verschmälert. Seta 1 $1,5 \mathrm{~cm}$, etwas gekrümmt, rot. Kapsel geneigt bis fast horizontal, oval bis länglich, regelmässig oder etwas hochrückig, rotbraun. Wimpern \pm ausgebildet. Deckel hoch kegelig bis kurz und schiel geschnäbelt. Sporen wie bei voriger Art. Sporenreife im Frühling.

An beschatteten Felsen und in Felsenkliiften.

F. Al. pass, (Botn.). - Ab. Nidendal, Kakskerta. Pargas. Kinito. Karislojo. Lojo. Vichtis. Sammalti. - X. Ekenäs. Ingd. Helsingfurs. Sibbo. Elimäki. Orimattila. Hogland. - Ka. Sippola. Virolahti. Antrea. - Ik. Pỵhäjärvi. - St. Enra. Björneborg. Lyıttskār (Hâyr.). Pirkhala. Ruovesi. Ta. Vanaja. Tammerfors. Im südōstl. Teilest. r. (Norrı.). Harıla. Korpilahti. Piilila und X̌orola (Vain.). Päivăkunta (Hāỵr). Luhanka, Onkisalo (V.). - Sa. Kangasniemi. TYslott. - Kl. hurkijoki. Valamo. Sorta rala. Suistamo. - Kol. Salmi. Leppälä (Pes.). - Oa. Öfvermark, Valıbärget (E. af H.). Bötom, Pỵăruori (E. af H.). - Tb. Virrat. Jỵäłkylā. Laukaa. Uurainen. Viitasaari. - Sb. Kuopio pass. (Link.). Maaninka. im we:11. Teile pass. (Roir.). Pielavesi, an mehreren Fundorten (R.). Raulaviara, Hankamāki (KY̧̧hk.). - Ǩ̉ Juuka, Saarijärvi, MIōlö (Kot.); Polvijārvi, Tahkoraara (K.). — Kon. Käpselkä und Dianora gora (Simm.). - Om. Soini, Uurimäki (Backm.). Vindala, Helamajanpuro und Metsäpelıo (B.). 一 Oh. Kajana (Lackstr.). Hyrynsalmi (L.). Suomussalmi. Lehtoraara (Vain.). - Ob. Rovaniemi, Pōỵliöraara (Brenn.); Hepokallio und Alajäăskö (Hu!1). Turtola, Pellojärvi (H.). - K. Kuusamo, Arentojoki. Riizikallio (E. af H.); Ukonvaara (Nyb.). - Lkem. Kolari. Jouhisuanto (Hult). Lkem. Kittilā. Pahtakallio (H.). IIuonio, Kätkesuanto, Pahtarinne (.rorrl.). Kuolajärvi, Perãvaara (E. af H.). - Lim. L'mpjok. Aij-varr (Kihlm.). - Lt. Rotsvaar (Roir.).

S. Sk.-.ing., LuL.

N. Sm.-Yo. Nordqrenze bei etwa $6 \tau^{\circ} 1 \tau^{\prime}$ n. Br.

Europa, Algier. Kanaren, Nord-Amerika.

\section{Rieihe HOOKERIALES.}

Stengel meist verflacht beblättert. Seitenständige Brätter meist unsymmetrisch, oft doppelripuig. Sporogone meist pleurocarp. Peristom doppelt. Peristomzähne meist mit Lamellen. Haube kegelig bis mützenförmig, oft gefranst.

\section{H O O KE R I A C E A E.}

Weiche, meist verflacht beblätterte Pfl. Stengelquerschnitt rundlich oder oval, mit schr lockerem, dïnnwandigem Grundgewebe; Zellen der peripherischen Lagen von gleicher Grössc oder etwas kleiner, (loch niemals stereid oder substereid. Blätter + -8reihig, von wechselnder Form, meist \pm unsymmetrisch, bald gleichartig und allseits \pm abstehend, bald ungleichartig. bauch- und rückcuständige dicht und schief anliegend, seitenständige \pm abstehend; Rippe aus homogenen \%ellen gebildet; \%ellen meist parenchymatisch, in den Blattecken nicht differenziert. Scheidchen dick, fleischig. meist nackt. Blüten stamm- und astständig. armblättrig, mit fadenförmigen Paraphy̌sen. Seta verlängert, aufrecht. Kapsel 
meist regehmässig: Zellen des Exotheciuns locker, kollenchymatisch; Spaltöffnungen oberflächlich, spärlich am Grunde des Halses. Peristom doppelt und heide gleichlang. Deckel aus kegeliger oder gewölbt-kegeliger Basis lein geschnäbelt. Haube kegel-mützenförmig. Sporen meist klein.

\section{HOOKERIA}

Sn. in Trans. Linn. Soc. 1X. p. 276 (1808).

Autözisch. Kräftige Pfl. in ausgedehnten, niedergedrückten, saftgrünen. trocken weisslichgrünen, ölglänzenden Rasen. Stengel niedergestreckt, verflacht, spärlich verzweigt, mit farblosen Rhizoiden: Zentralstrang armzellig, trübrot; Grundgewebe hyalin, mit siebplattenartigen Querwänden. Blätter 5reihig, bauchund rückenständige dicht und schief anliegend, seitenständige horizontal abstehend, etwas unsymmetrisch, eiförmig bis eilänglich und eilanzettlich, flach und ganzrandig; Rippe fehlend; Zellen sehr locker, dünnwandig, regelmässig, rliombischund rhomboidisch-6seitig, glatt, am Rande verlängert, einen einreilnigen. undeut-

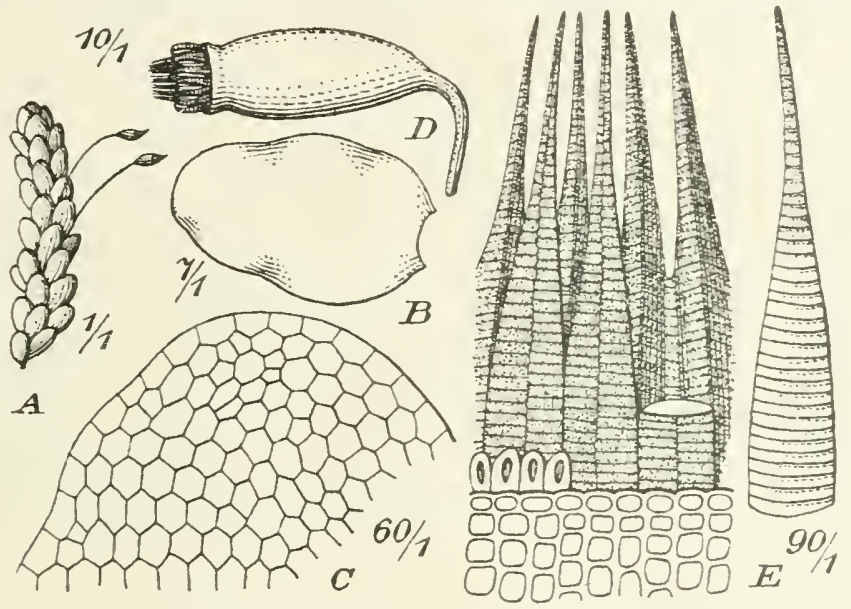

Fig. 75. Hookeria lucens (L.) A Fruchtende Pfl. (1/1); B Stengelb. (7/1); C Blatlspitze (60/1); D Kapsel (0,1); E Peristom (90/1).

lichen Saum bildend. Perichätialblätter klein, lanzettlich. Seta dick. glatt. Kapsel horizontal bis fast hängend, oval. kurzhalsig, dickhäutig. Ring grosszeilig, mit dem Deckel sich ablösend. Peristomzähne breit lanzettlich, allmählich zugespitzt, gelbrot, fein quergestrichelt, mit dicht gestellten, niedrigen Lamellen. Inneres Peristom gelblich, fein papillös; Grundhaut weit vortretend: Fortsätze gekielt, lanzettlich; Wimpern fehlend. Haube wenig länger als der Deckel, glatt, kurzlappig.

608. Hookeria lucens (L.) Sm. 1. c. [Hypnum lucens L. Sp. pl. ed. 1, p. 1124 (1753). — Pterogophyllum lucens Brid. Iant. musc. p. 1.9 (1819).]

Stengel 3-6 cm, selten lang. bels]ättert bis $1 \mathrm{~cm}$ breit. Lntere Blätter kleiner und fast kreisrund, die übrigen viel grösser, breit eiförmig. stumpf; Zellen 50 $60 \mu$ breit und $2-3 \mathrm{mal}$ so lang. Seta $1,2-2 \mathrm{~cm}$. gelbrot. Kapsel bis $2 \mathrm{~mm}$ lang und bis $1 \mathrm{~mm}$ dick, braun, zuletzt schwärzlich, trocken und entleckelt unter der IIündung etwas verengt. Sporen $7-10, "$, bräunlich, fein papillös. Sporenreife in März. - Fig. 75.

Auf feuchtem, quelligem, stark beschattetem Boden und an Bachufem, teils auf Humus, teils auf Wurzeln und morschem Holz, seltener auf Steinen. 
S. sk., sm. und Boh.. an vereinzelten oder wenigen Fundorten.

N. An der We;lküste keine Seltenheit. Nordgrenze bei $63^{\circ} \mathrm{n} . \mathrm{Br}$ Europa, IIadeira, Nord-Amerika.

\section{Reihe HYPNOBRYALES.}

Blätter meist symmetrisch. Sporogone pleurocarp. Kapsel emporgehoben. Peristom doppelt. Immeres Peristom meist in kielfaltige Grundhaut, Fortsätze und Wimpern gegliedert. Haube kappenförmig.

\section{Unterreihe LESKEINEAE.}

Stengel meist rund beblättert. Zellen der Lamina bald rundlich-parenchymatisch und meist papillös, bald prosenchymatisch und glatt, in den Blattflügehn meist nicht oder wenig differenziert; Rippe meist einfach.

\section{E S K E A C E A E.}

Locker-oder dichtrasige Baun- oder Felsmoose. Stengel mit lockerem Grundgewebe und englumigen Mantelzellen, meist kriechend und vielfach geteilt, mit glatten Rhizoiden, dicht und gleichmässig beblättert, zuweilen stolonenartig, mit kleinen und bleichen Niederblättern. Blätter mehrreihig, gleichförmig, \pm abstehend, trocken anliegend bis dachziegelig, zugespitzt oder stumpf; Rippe meist einfach, homogen, zuweilen doppelt oder gegabelt bis fehlend; Zellen klein, rundlich-mehreckig und quadratisch, in der Nähe der Rippe \pm weit hinauf länglich bis linealisch, glatt oder papillös. Blüten mit fadenförmigen l'araphysen. Perichätialblätter differenziert. Seta verlängert, gerade, glatt. Kapsel fast immer aufrecht und regelmässig, länglich-eiförmig bis fast zylindrisch: Spaltöffnungen oberflächlich im Halsteile oder fehlend. Ring meist differenziert. Peristomzähne lanzettlich, am Grunde meist verschmolzen, bald mit, bald ohne Lamellen. Grundhaut des inmeren Peristoms kielfaltig, \pm vortretend; Fortsätze und Wimpern ausgebildet bis fehlend. Deckel kegelförmig und oft kurz geschnäbelt. Haube kappenförmig, glatt.

Ĺbersie ht der Unterfamilien.

A. Blüten astständig. Hauptstengel stoloniform, kleinblätterig ..................................................... II.Anomodontoidecte.

B. Blüten stengelständig. Stengel nicht stoloniform.

a. Zellen der Lamina elliptisch bis rhomboidisch; Rippe kurz, einfach oder gabelig, auch doppelt oder fehlend. I. Thelioideae.

b. Zellen der Lamina rundlich: Rippe (excl. Leskeella tectorum) einfach, \pm ver]ängert

III. Leskeoidecte.

¿́bersiclut der Gat $\mathrm{t}$ ungen.

A. Hauptstengel stolonenartig: ${ }^{7}$ und $\Varangle$ Blüten nur am sekundären Stengel

168. Anomodon.

B. Hauptstengel normal.

a. Ilippe kräftig, einfach.

«. Rippe vor der Blattspitze endend; Zellen mit einer Papille über dem Lumen............................ 171. Leskea. 
३. Blattzellen glatt.

1. Blätter lang zugespitzt: Rippe im Pfriementeile endend; Zellen weniger stark verdickt ...... 17\%). Leskeella ner-

vosa.

2. Blätter kürzer zugespitzt: Rippe in cler Blattmitte endend: Zellen stark verdickt

16!. I'seudoleslieella.

b. Rippe kurz, gabelig oder doppelt bis lehlend.

(e. Blätter wenig hohl, ganzrandig ...................... 170. Leskeella tecto-

rulm.

p. Blätter löffelartig hohl, rings gezähnt bis gesägt ... 167. Myurella.

\section{THELIOIDEAE.}

Diözisch; \& Blüten stengelständig. Hauptstengel normal. Blätter holıl. trocken dachziegelig anliegend: Rippe kurz, einfach oder gabelig, auch undeutlich bis fehlend; Zellen elliptisch bis rhomboidisch: Spaltöfnungen normal entwickelt. Peristomzähne aufrecht, querstreifig, mit entwickelten Lamellen. Fortsätze von der Zahnlänge; Wimpern vollständig, etwas kiurzer als die Peristomzähne.

\section{MYURELLA}

\section{Bryol. eur. fase. 16,47 Mon. (1851).}

Schlanke Pfl. in lockeren oder dichten, trocken starren und brüchigen Rasen. Stengel aufrecht oder aufsteigend, absatzweise mit Büscheln von Rhizoiden, unregelmässig und büschelig verzweigt, ohne Paraphỳlien. Blätter löffelförmighohl, eirund; Rippe undeutlich bis fehlend; Zellen locker, wenig verlickt, unregelmässig, mehreckig und rhombisch, in den Blattecken quadratisch. Perichätialblätter aufrecht, derb, gefärbt, innere hochscheidig, oberwärts gesägt und in eine lange, oben einzellreihige Pfrieme verlängert. Kapsel aufrecht, entleert etwas geneigt, regelmässig, länglich. Deckel kegelig. stumpf oder spitz. Sporen $10-15$ „, ockerfarben oder licht bräunlich, fast glatt oder fein warzig.

\section{I bersicht der Arten.}
A. Blätter stumpf oder mit Spitzchen
610. M. julacea.
B. Blätter rasch lang zugespitzt
611. M. tenerrima.

610. Myurella julacea (Vill.) Bryol. eur. fasc. 46,47 Mon. p. 3. t. 1 (1851).

Pfl. in dichten, kissenförmigen, $2-3 \mathrm{~cm}$, selten bis $6 \mathrm{~cm}$ hohen, licht- bis blaugrünen, trocken weisslichgrïnen, schwach glänzenden Rasen. Stengel mit aufrechten, drehrunden, stumpfen Ästen. Blätter gedrängt, feucht und trocken dicht dachziegelig, stumpf, bis $0,45 \mathrm{~mm}$ lang und $0,30 \mathrm{~mm}$ breit, flachrandig. durch vorspringende Zellecken fein gezähnt: Rippe fehlend. selten kurz angedeutet, einfach oder geteilt; Zellen glatt, zuweilen durch verdickte Zellecken schwach papillös. Perichätialblätter aufrecht, derl), rotbraun, länglich-lanzettlich, scharl zugespitzt. Seta bis $1,5 \mathrm{~cm}$. Kapsel länglich, etwa $1,5 \mathrm{~mm}$ lang und $0.6 \mathrm{~mm}$ dick, gelbgrün, zuletzt lichtbraun, trocken und entdeckelt unter der llündung = verengt. Ring stückweise sich ablösend. Sporenreife Ende Juli und in der ersten Hälfte des Augusts. - Fig. 76.

Auf humusbedeckten Felsen und in Felsenspalten. besonders auf Kíalk und kalkhaltigen Gesteinen.

F. Al. Eckerö, Storby (Elfr.); Torp (H. Lindb.). Finström. an wenigen Fundorten (Bom.). (ieta, Snåckö (B.). Lemland, Järsö (B.). Sund, Ju<soöle (B.). Saltvik. an weniger Fundorten (B.). Brāndo. Jurmo, Harholmen (B.). - Ab. Pargas (Arrh.); Ersby (Elfv.): Simonby (Link.). Finhy. Kaukosaln und 
Forby (Broth. Karislojo, Karkkali (Sundv.). Lojo, an mehreren Fundorten (Lindb.. E. af H., sundv.). Vichtis (W. Nyl.). - N. Helsingfors (Lindb.). - Ta. Hollola. zw. Vaania und Uitto (Norri.). Asikkala, zw. Kalkkis und Raurala (X.). Korpilahti. Haukkavuori (Vain.) - Kl Valamo (Jusl.). Sortavala (F. Nyl.); Kirjavalahti. Variskallio (Norrl.): Iähisalo, Limanvuori (Popp.). Impilahti. Kirchdorf (Pes.). Suistamo, Leppäsyrjä, Säynönvaara (Pes.). Soanlahti, Korpikallio (Norrl.). - Sb. Kaavi. Siikajărvi, Likosaari (Kyghk. und Kot.); Huosiaisniemi (K. und K.); Tuohisaari und Riihisaari (Kot.): Niinivaara (K.). - Kb. Juuka, Juuanvaara (Kot.): Halivaara (K.). - Kon. Jalguba, Mundjärvi und Valkeamăki (Norrl.). - Ok. Puolanka. Salminen. Vuorijärri (Kyyk) - K. Kuusamo, an vielen Fundorten (Nyb., Sil.. Broth., E. af H.). - Lkem. Kuolajärvi, Kïimaselänoja (E. af H.); Vuorijärri, Pł̣häkuru (E. af H.). - Le. Keimiotunturi (Norrl.). Kilpisjärvi, Koltapahta und Leutsuraara (N.); Malia und Saivovaara, in der alpinen Region (Kot.). - Lt. Pummanki (Broth.). Kitovka (Fellm.). - Lp. Katschkova (Brenn.). Triostrova (Broth.). Ponoj (Brenn.). - Lv. Tichapoma (Broth.).

S. Sk.-TL. pass. im Binnenlande. an der Westküste rr. urd aus den Küstengegenden nördlich ron Gefle noch nicht bekannt.

N. In allen Provinzen mit Ausnahue von $L . M$., Sl. und $R$, in den Äntern bis SB. am reichlichsten im Binnenlande. nördlicher auch in den Küstengegenden I fq. Steigt wenigstens bis zur Baumgrenze hinaluf. - Jach $\mathrm{H} \mathrm{a} \mathrm{gen} \mathrm{sind} \mathrm{die} \mathrm{Blätter} \mathrm{am} \mathrm{Rücken} \mathrm{stets} \pm$ rauh.

Europa, Liaukasus, Kaschmir, Zentral-Asien. Sibirien, China, Nord-Amerika.
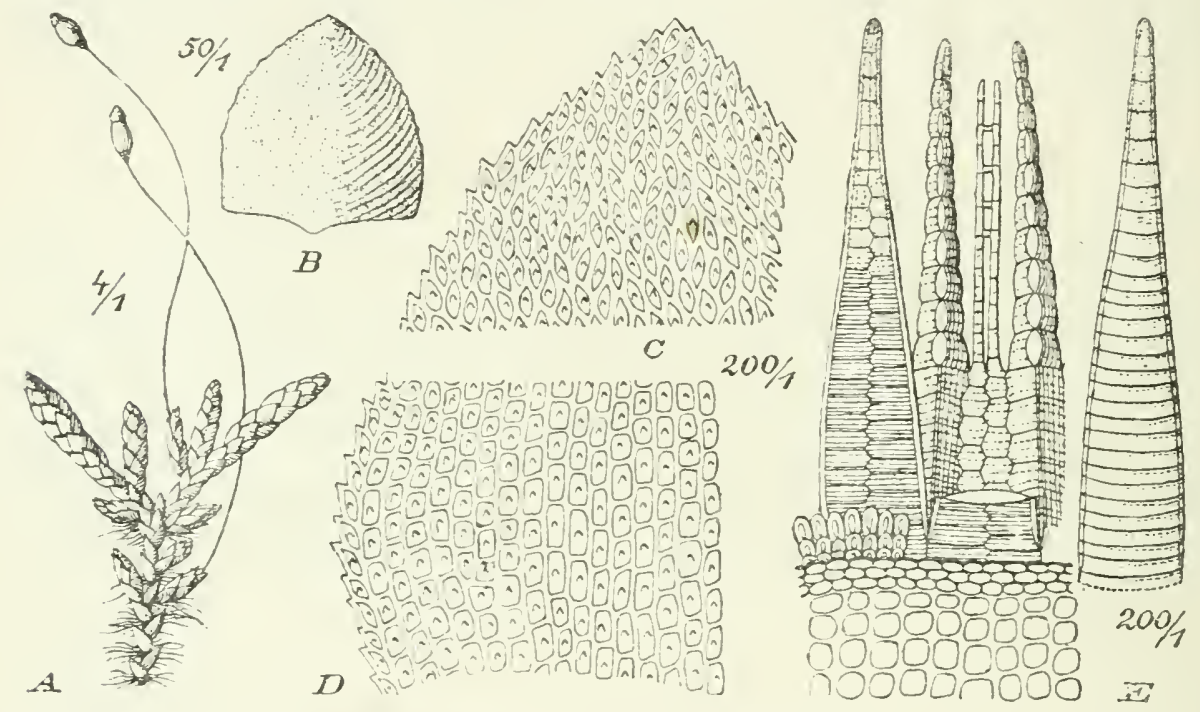

Fig. 76. Myurella julacea (Vili.j. A Fruchtende Pfl. (4/1); B Stengelb. (50/1); C Blattepitze (200/1); D Blattbasis (200/1); E Peristom (200/1).

var. scabrifolia Lindb. Musc. scand. p. 37 (1879).

Blätter mit deutlicher Spitze, besonders gegen die Basis stärker gezähnt; Zellen am Rücken deutlich papillös vortretend.

F. Ab. Lojo, Palonienti (Lindb.).

S. $O_{g .,}$ Vg., Srm., Hrjd., LuL. und $T L$, an einzelnen oder wenigen Fundorten.

var. gracilis Kindb. in Bils. K. Sv. Vet.-Ak. Handl. Bol. 7. No. 9. p. 8 (1883). Sehr schlanke Pll. in dichten Rasen. Obere Blätter mit winzigem Spitzchen.

S. Hrjd. Tämnäs, Ramundbärget.

N. $S T$. Knudho und sprenbaekken.

611. Myurella tenerrima (Brid.) Lindb. Musc. scand. p. 37 (1879). [Pterigynandrum (?) tenerrimum Brid. Nant. muse. p. 132 (1819). - Hypnum monilıforme var. apiculatum Sommerf. Suppl. Fl. lapp. (1826). — Isothecium apiculatum Hüb. Muscol. germ. p. 598 (1833). - Hypnum apiculatum Thed. in Hartm. Skand. Fl. ed. 5, p. 326 (1819). - Myurella apiculata Bryol. cur. fasc. 46/47, p. 4, t. 2 $(1851)$. 
Pfl. in lockeren, lebhaft grünen, glanzlosen Rasen. Stengel weniger dicht beblättert, dünnere Äste durch die entfernten Blätter perlschnurartig. I3lälter feucht und troeken aus abstehendem Grunde aufgerichtet bis eingebogen, bauchighabkugelig, rasch lang zugespitzt, mit aufrechten bis eingebrgenen, rings dureh vorspringende Zellecken gezähnten Rändern; Rippe fehlend oder undeutlich; Zellen dureh am Rücken vortretende Zellecken papillös. Perichätialblätter aulrecht, derb, gelbrot, die inneren hochscheidig, oberwärts gesägt unsl in eine lange, oben einzellreihige Pfrieme verlängert. Seta etwa $1 \mathrm{~cm}$. Kapsel länglich, etwa $1,2 \mathrm{~mm}$ lang und 0,6 mm dick, gelbgrün, zuletzt ockergelb, trocken uni enteleckelt unter der Nlündung kaum oder wenig verengt. Ring sich abrollend. Sporenreile im August.

Auf Humus an feuchten Felsen, besonders auf Schiefer und Kalk, in Erdhöhlungen und an herabhängenden Torfdecken.

F. K. Kuuzamo, Oulankajnki, Merenoja (Broth.); Kiutaköngäs und Tulilamminpuro (E. af II.). Paanajärvi. Kuoppaoja (Broth.). Sovajoki, Kulmakkapuro (E. af H.). Mustalampi (Broth.). - Le. Kilpisjärvi, Malla und Saana (Kot.). - Li. Utsjoki, Kenischkoski (Hult). - Lim. Hibinä, in der alpinen Region spärl. (Broth.). - Lp. Katschkova (B.). Rusiniha zw. Orlov und Ponoj (Broth.). Orlnv. (iubnoj (Kihlm.).

S. Dld. Bäcke. Hrjd., Jmt. und L. Steigt bis in die alpine Region hillauf.

N. In O:tlandet und Sorlandet fehlend, in We:tlandet an wenigen Fundurten in der alpinen Region. In Valders, Gudbrandsdalen, Jotunfjeldene und Lilleelvdalen haufiger. hie und da weit unter der Baumgrenze beobachtet. Nördlicher bis F. - fq.. zuweilen bis zum Yeeresufer heralısteigend.

Spitzlergen, schottland, Zentral-Europa, Sibirien. Grönland, Brit. Colunbia, Ltah.

\section{ANOMODONTOIDEAE.}

Diözisch; † Blüten astständlig. Hauptstengel weit kriechend, stoloniform. Zellen der Lamina rundlich-6seitig; Rippe einfach, meist vor der Blattspitze aufhörend.

\section{ANOMODON}

Hook. et Tayl. Muscol. brit. 1. ed. (181S).

Diöziselı; $\sigma$ und 우 Blïten nur am sekundären Stengel. Pfl. in lockeren bis dichten, trocken starren Rasen. Hauptstengel stolonenartig, mit kleinen, bleichen Niederblättern und Rhizoidenbüscheln. Sekundäre Stengel aufrecht bis aufsteigend, einfach, geteilt oder büschel- bis fiederästig. Blätter feucht weit abstehend bis sparrig, aus breit ei- oder länglich-eiförmigem Grunde zungenförmig, lanzettlich bis pfriemenförmig; Rippe meist vor der Blattspitze aufhörend: Zellen (cxcl. A. longifolius) dureh zahlreiche Papillen und Chloroplasten \pm undurehsichtig, nur am Blattgrunde nächst der Rippe glatt und durchscheinend. Grundhaut des inneren Peristoms kaum vortretend; Fortsätze fadenförmig: Wimpern rudinentär oder fehlend. Sporen klein.

$\mathrm{L}^{\dagger}$ bersieht der Arten.

A. Blätter clurchsichtig, allmählich lang zugespitzt; Zellen beiderseits nur mit je einer Papille 615. A. longifolius.

B. Blätter undurehsichtig; Zellen beiderseits dicht papillös.

a. Blätter aus breit herzeiförmigem Grunde mit abgerundeten, lang papillösen Blattohren plötzlich selmal zungenförmig 612. A. Rugelii.

b. Kräftige Pll. Blätter aus ei- oder eilanzettlicher Basis allmählich zungenförmig, stumpf, meist ganzrandig, mit einigen Querfalten 
c. Ziemlich schlanke Pfl. Blätter aus eiförmiger Basis lanzettlich-zungenförmig, mit stumpfem oder scharfem, meist gezälntem Spitzchen, ohne Querfalten 614. A. attenuatus.

Un t e rga t. I. Euanomodon Limpr. Laubm. II. p. 768 (1895) emend. Broth. in Engl.-Prantl Bryal. p. 987 (1907).

Blätter ganzrandig. Innere Perichätialblätter oberwärts den Laubblätter ähnlich. Kapsel ohne Spaltöffnungen und ohne Luftraum. Peristomzälnne ungestreift, grubig, \pm papillös, entfernt gegliedert und ohne Lamellen.

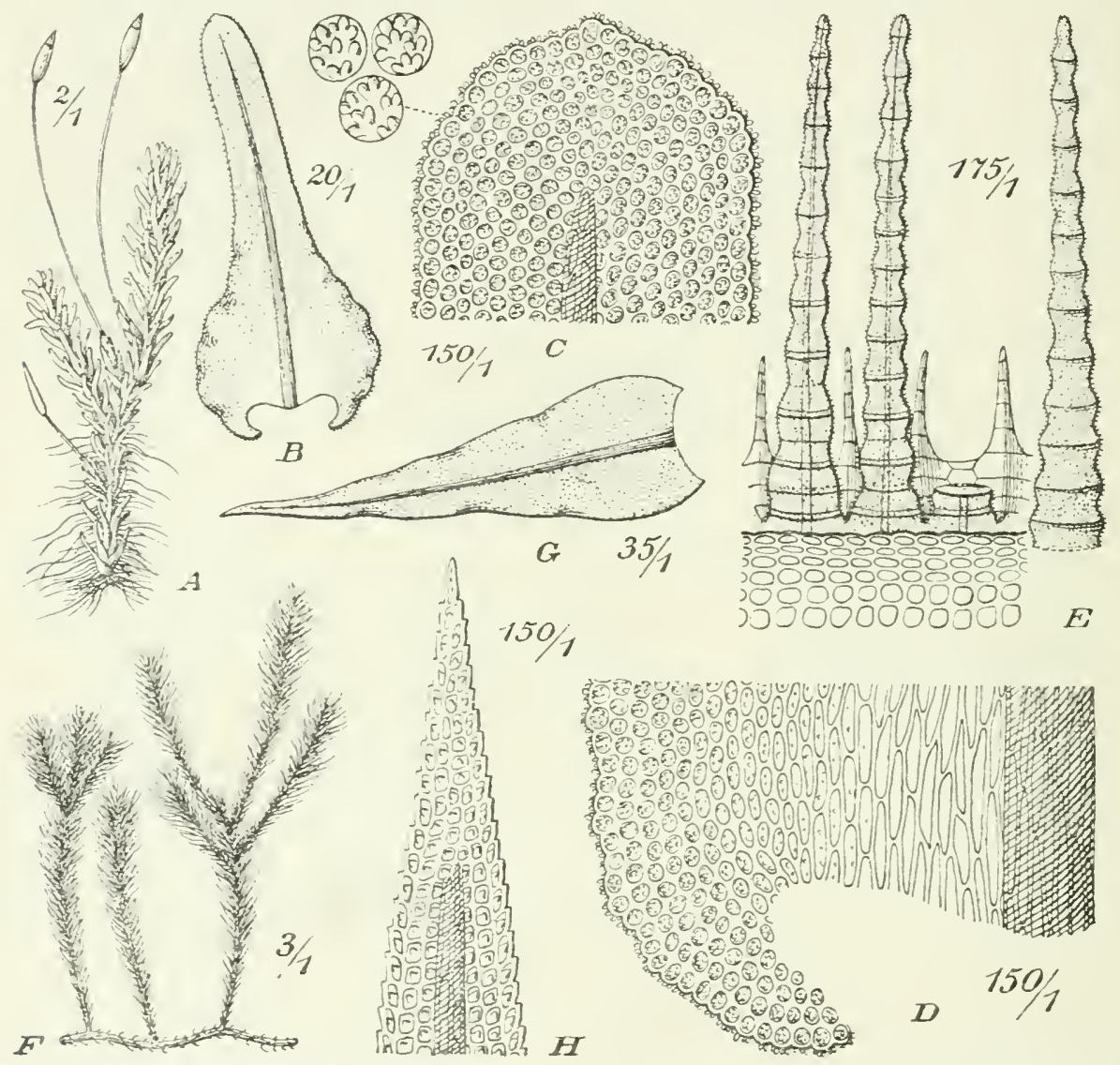

Fig. i7. Anomodon Rugelii (C. Miill.) Bryol. eur. A Fruchlende Pfl. (:/1): B stengelb. (20/1): C Blattspitze (150/1): D Blatlbasis (150/1): E Perislom (175/1). F-H. A. longifolius (Schleich.). F sterile Pfl. (3/1); (i stengelb. (35/1); H Blattspitze (150/1).

612. Anomodon Rugelii (C. Müll.) Kessl. in Amm. K. K. Naturh. Hofmus. Bd. XV. p. 21.1 (1900). [Hypnum Rugelii C. Müll. Syn. II. p. 473 (1851). - Anomodon apiculatus Bryol. eur. fasc. 44.45 Mon. p. b (1850), nom. nud.]

Weniger krätige Pfl. in ziemlich dichten, oft ausgedehnten, dunkel- bis schwarzgrünen Rasen. Blätter allseits abstehend, trocken verbogen und locker anliegend, aus breit herzeiförmigem, nicht herablaufendem Grunde mit abgerundeten, lang papillösen Blattohren plötzlich schmal zungenförmig, abgerundet, meist mit winzigem Spitzchen, bis $2 \mathrm{~mm}$ lang und $1 \mathrm{~mm}$ breit, abwärts schwach wellig, flach- und ganzrandig. Seta meist $8 \mathrm{~mm}$ lang, purpurn. Kapsel zylindrisch, $2.6 \mathrm{~mm}$ lang und $0.75 \mathrm{~mm}$ dick, glänzend braunrot, trocken längsfaltig. Ring 
sich stückweise ablösend. Peristomzähne an den Gelenken eingeschnürt, dlicht und fein papillös. Deckel schmal kegelig, mit Zitze. Sporenreife im Mai. - Fig. $77 \mathrm{~A}-\mathrm{E}$.

Auf beschatteten. besonders kalkfreien Blöcken. seltener auf Felsen und an alten Baumstämmen.

F. Ab. Vichti.. Haapkỵla (Broth.). - Ta. Asikkala, Kailas, Kisithallio (Norrl.). Ik. Sakkola, Loposenmäki (Hid.).

S. sm. Huskrarna und Hakarp. Ig. an mehreren Fundorten. Dld. Gunnarnas.

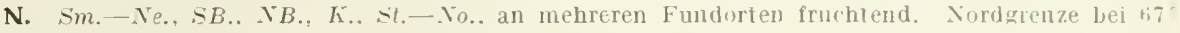
n. $\mathrm{Br}$.

Zentral-Europa. Pyrenäen, Italien, Kaukasus, Himalaya, Sibirien, O-t-Asien, Nurd-Amerika,

613. Anomodon viticulosus (L.) Hook. et Tayl. Mtuscol. brit. 1. ed., p. 79, t. 22 (1818). [Hypnum viticulosum L. Sp. pl. 1. ed.. p. 1127 (175.3).]

Kräftige Pfl. in lockeren, oft ausgedehnten, grïnen oder gelbgrünen Raser. Blätter + einseitswendig bis sichelförmig, feucht abstehend orler sparrig, aus nicht geöhrter, etwas herablaufender, eiförmiger oder eilanzettlicher Basis allnählich zu einer zungenförmigen, stumpfen Spitze verschmälert, $2-3 \mathrm{~mm}$ lang und 0.8 1 mm breit, mit einigen Querfalten, ganzrandig oder an der Spitze kleinzähnig. mit nur am Grunde zurïckgebogenen Rändern. Seta etwa $1,5 \mathrm{~mm}$, gelb. Kapsel länglich-eiförmig bis fast zylindrisch, bis $1 \mathrm{~mm}$ lang und $1 \mathrm{~mm}$ dick, glänzend hellbis rötlichbraun. Ring sich stückweise ablösend. Peristomzähne durch unregelmässige Verdickungen grubig. oberwärts schwach papillös. Deckel schmal kegelig. kurz geschnäbelt. Sporenreife in Frïhling.

Auf beschatteten. trockenen Felsen und Blöcken allerlei Art und an alten Bäumen.

F. Al. Finström, Bartigảda (Bom.). Saltvik, an mehreren Fundorten (B.). Brändö, Jurmo, Harholmen (B.). - Ab. St. Karins, Ispois (Arrh.). Pargas, Ersby (Elfv.); Kivida (Lint.). Kimito, Norrlangvik (Ols.). Finby, Finnary (Broth.); Falkberg. Kilöris (Elfv.). Angelıiemi. Karviais, Kinkkila (Buch). Karislojo, Puujärvi (Sundr.): Karkali (S.). Lojo, an mehreren Fundorten (Lindb.. Jusl., IIult, H. Lindb.). Sammatti (Sel.). - N. Ingà, Orslandet, Rörars (W. Brenn.). Sjunded (Sundr.). Kyrkiatt (Nyls.). Helsingfors, Degerö (Sundr.). Borgà, Pellinge, Tullandet (Broth.). - Ka. Wiborg. soskuanjoki (Buch). Räisälä, Ivaskazaari (Lind.). - St. Yläne, Kolva (Sahlb.). Kijulo (Ilalmgr.) Pirkkala (Sinnı). Ta. Hattula, Nikkilä (Ranch.). Kalvola (Häyr.). Iitti, Kirchdorf, Harjuruori (Buch). Im südöstl. Teile pass. (Norrl.). Korpilahti, Paljakko (Tain.). Luhanka, Onkisalo, Tammijärvi (V.); Oittila (Link.). - Sa. Lappee, Nieminen (Buch). Ruokolahti, Kouvola (Hull). Nyslott (Carl.). - Kl. Valamo (W. Nyl.). Sortavala (Lindb.); Rauskunruori (Limnan.): Pellonvuori (Link.): Kirjaralahti (Norrl.); Piisparuori (P)pp.). Impilahli, Ristisaari (Link.). Suistamo, Leppäsyrjä (Pe..): Jalonvaara, Riuttarıori (Link.). Saariselkä (Kot.). Ru^keala (WV. Kyl.). Pälkjärri, Kiviniemi (Kop.). - Kol. Schtjeliki (Elfr.). Petrusavodik (Simm.). - Tb. Virrą, Torisera (Bruth.). Viitasaari, Eteläruori (Broth.). - Sb. Virtasalmi, Montola, Itäruori (Krylh.). Kuspio. Kasurila, Mängmäki (Kot.): Siikalahti (K.). Kaavi, Siikajärvi, Huosiaisniemi (Kryhk.): Likosaari und Rihisaari (Kot.), Juuka, Petrovaara, Saarijärvi, Kasurinmäki (K.); Vesivaara. Kuuijärvi (K.). Nilsiä, Kuuslahti, Jaakonlahti, stellenweise cop._cpp. (Kyyhk. und Kot.). Maaninka, Tuovilanlahti, Arkkuviori (Roiv.). - Kb. Tohmajärvi, Piilovaara (Link.), Akkala (Kot.). Polvijärvi, Sola, Reporaara (Kot.). Pielisjärri, Koli (Linnan.). — Kon. Suojarri, Haukka (Link.). Pirttinieni (Simm.). Koselma (Kullh.). - ok. Paltamo, Melalahti (Lackstr.): Jieslahti (Kyyla.). Sotkamo, Natula (Kyyhk.); Jormaskylä, Kohrorinsaari (K.). - K. Kuusamo, Arentojoki (E. af H.); Jumma (Broth.); Paanajärri, Ruskeakallio (Nyb.). - Lkem. Kuolajärvi. Vuorijäri, Pỵäkuru (E. af H.).

S. In allen Provinzen ron Sk. bis Jmt. und Ang. meist $=$ fq. und meist in niedriger Lage. TL. Jukkasjärvi.

N. In allen Provinzen mit Ausnahme von $T r$. und $F$. Sleigt bis $650 \mathrm{~m}$ hinauf. Nordgrenze bei $67^{\circ} 18^{\prime} \mathrm{n} . \mathrm{Br}$.

Europa, Algier, Kaukasus, Himalaya, Sibirien, China. Nord-Amerika.

L n t e r g a t t. I I. Pseudanomodon Limpr. I. c. p. 77 .

Innere Perichätialblätter aus \pm scheidiger Basis allmählich lanzettlich-pfriemenförmig bis rasch lang pfriemenfömig: Zellen verängert. Kapsel mit spaltöffnungen und Luftramm. Peristomzähne gestreift.

614. Anomodon attenuatus (Sclıreb.) Hüb. Muscol. germ. p. 562 (1833). [Hypnum attenuatum Schreb. Fl. lips. p. 100 (17T1).] 
Ziemlich schlanke PfI. in lockeren bis dichten, grünen oder bräunlichgrünen Rasen. Sekundäre Stengel vielfach geteilt und büschelästig; Hauptäste stumpf undl meist eingekrümmt, durch dünne, oberwärts meist peitschenförmige Ästchen fast gefiedert. Blätter trocken anliegend oder schwach einseitswendig, feucht weit abstehend, aus etwas herablaufender, eiförmiger Basis lanzettlich-zungenförmig, mit stumpfem oder scharfem, gezähntem oder ganzrandigem Spitzchen, $1-2 \mathrm{~mm}$ lang und $0,45-1 \mathrm{~mm}$ breit, flachrandig. Seta $1-2 \mathrm{~cm}$, rot. Kápsel zylindrisch, dunkelbraun. Ring nicht differenziert. Peristomzähne unten quer, oben längs gestreift, mit niedrigen Lamellen. Deckel schmal kegelförmig, geschnäbelt. Sporenreife im März und April.

Auf beschatteten, trockenen Felsen allerlei Art und an alten Bäumen. Sporogone sehr selten.

F. Ab. Kimito. Pávalbby (Ol..) Uskela, Linnamäki (Lindb.). Karisłojo, Pipola (Sundv.). Lojo, an mehreren Fundorten (Lindb.. Hull. H. Lindb.. E. af H.). - N. Kyrkslätt (Nyb.). Helsinge, Gammelstaden (Broth.). Elimäki (Tigersı.). Orimallila, Järvenkylä (Link.). - Ka. Antrea, Papinsaari (Lindb.). - Ik. Sakkola, Makkara (H. Lindb.): Röykkylä und Loposenmäki (Hid.). - St. Kjulo (Malmgr.). Pirkkala (Simm.). Ikaalinen. Uroslahti (Sundv.). - Ta. Sääk-mäki, Rauttuniemi (Kihlm.). Im südöstl. Teile pass. (Norrl.). Hartola (Bonsd.). Korpilahti, Aittilä, Vaarunlampi (Link.). Luhanka, Onkisalo, Kesäin (Vain.). - Sa. Lappee, Hanhijärvi (Buch). Kaugasniemi, Tuomarinmäki (Lackstr.). Nysloti (Carl.). - Kl. Kurkijoki, Onaska (Jusl.) Sortavala, Kírjavalahti, Kolomăki (Norrl.). Ruskeala (Backm.). Suistamo, Jalonvaara, Riuttavuori (Link.). Pälkjärvi (Broth.). — Tb. Viitasaari, Eteläruori (Broth.). - Sb. Virtasalmi, Montola. Itävuori (Kyyhk.). Kuopio. Sikalahti (Kiot.). Nilsiä, Kuuslahti, Jaakonlampi cop. (Kyyhk.) - Kb Tohmajärvi, Akkala (Kot.). Pielisjärvi, Koli (Linnan.). - Kon. Koselma (Kullh.).

S. Sk.-Jml und Ang., in den meisten Provinzen pass., nördlicher seltener. Nordgrenze bei $63^{\circ}$ $? 0^{\prime}$ n. $\mathrm{Br}$

N. Sin-Ve., St. $-K$., ST., NT. Steigt bis $500 \mathrm{~m}$ hinauf. Nordgrenze bei $63^{\circ} 45^{\prime} \mathrm{n} . \mathrm{Br}$.

Europa, Kaukasus, Himalaya, Nord-Amerika.

var. immersus Ryan in Kgl. Norsk. Vicl. Selsk. Skrift. 1896 , No. 1, p. 125 (1896).

Blätter meist zweiseitig abstehend, zungenförmig, abgerundet, seltener kurzspitzig, mit liyaliner Endzelle: Zellen glatt oder undeutlich papillös.

S. Ög. Vreta kloster.

N. Sm. Tune, Grotet, Sollielven, an zeitweilig überfluteten, senkrechten Blockwänden.

615. Anomodon longifolius (Schleich.) Bruch in litt., Rabenh. Deutschl. krryptogamenfl. 1I. 3, p. 255 (1848). [Pterogonium longifolium Schleich. Catal. 1807 et Crypt. he]v. Cent. IV. No. 8.]

Schlanke Pfl. in lockeren, grünen, gelbgrünen bis gelbbräunlichen Rasen. Sekuncläre Stengel durch lange, häufig flagellenartig auslaufende Äste unregelmässig gefiedert. Blätter trocken anliegend, feucht \pm abstehend, zuweilen \pm einseitswendig, aus ciförmiger Basis lanzettlich, allmählich lang zugespitzt, 1,5$2,5 \mathrm{~mm}$ lang und $0,4-0,7 \mathrm{~mm}$ breit, flach- und ganzrandig oder mit hier und da schmal umgebogenen Rändern; Rippe mit oder vor der Blattspitze endend; Zellen bailerseits nur mit je einer stumplen Papille. Seta $5-10 \mathrm{~mm}$, gell. Kapsel zylindrisch, 1,5 - 2 mm lang und 0,6 mm dick. Ring nicht differenziert. Peristomzähne unten schräg, oben längs gestreift; Lamellen nicht entwickelt. Deckel schmal kegelförmig. - Fig. $77 \mathrm{~F}-\mathrm{H}$.

Auf beschatteten Felsen und Blöcken allerlei Art und an alten Bäumen. Sporogone sehr selten.

F. Al. Jomala, Ramsholm (Arrh.). Finström, Tärnebolstad (Bom.). Salıvik, Kivambo (K. A. Bom.): Boxo (Bom.). Brändö, Jurmo, Ifarholmen (B.). Kumlinge (Wahlm.). - Ab. Kakikerta (Buch). Nídendal (Elfv.). Sl. Karins (Arrh.). Pargas, Lindberg (Elfv.). Kimito, Västanvik, Tunnhamm (Ols). Karisbjo, Tesjäri (sundy,). Lojo, an mehreren Fundorten (H. Lindb., E. af H.). Vichtis (W. Nyl.). N. Snappertuni (Häyr.). Melzingfors, Degerö (Kihlm.) Borgí, Pellinge, suni (Broth.). Pernå (Tennb.). Hogland (Lindb.). - Ka. Vehkalahti (Krnhn). Suskuanjoki (Buch). - Ik. Sakkola, Tiurismäki, Orinniemi (H. Lindb.); Lupojenmäki (Hid.). - Tu. Ilattula, Nikkilä (Ranck.). Kalvola (Häyr.). Litti, Perheniemi (Buch). Hollola, Papinsauri Norrl.). Asikkala. Kaitas, Kissakallio (N.). Sysmä. Valittula 
(Link.). Hartola (Bonsd.). -. Sa. Nyslott (Car1.). - Kt. Kexholm (Tonm i. Kurkijoki (Jusl,). Valamo (W. Nyl.). Jaakkina (Sundv.); Puutsalo (Lindb.). Sortavala, Kauskunuori (l.innan.); Kirjavalahti (Lindb.). Ruskeala (L.). Suistamo, Leppäsyrä (Pes.); Saariselkä(Kot.). Päljärvi, Korkeaniemi (Link.), - Kol. Salmi, Leppälä (Link.). - Sb. Kuopio, Hapalahti, Kürulampi (Liık.); Siikalahti (Kot.). Kaavi. Siikajärvi, Kypäräissaari und Huosiaisnieni (Kyylı.); Losomaki (K.); Riihisaari (Kot.). Juuka, I'etruvaara, Saarijärvi, Sotisaari (Köt.). Nilsiä, Kirclıdorf, Lehtomäki (hyyhk, und kint.): Kunslalıti, Jalaknlampi cop. (K. und K.); Loutteisenkallio (Kyyh.). Naaninka, Tuovilanlalıti, Arkkuvuori (Roiv.). k̉b. Tohmajārvi, Piilovaara (Link.); Värtsilä, Juvansaari (L.); Akkala (liot.). Jinuka, Juuanvaara (Kot.). - Kon. Suojärvi, Haukka (Link.). Tiudie (F. Nỵl.). Pirttiniemi (Norrl.). Kuselna (Simm.). - Ok. Paltamo, Melalahıi (Lackstr.). Sotkamo, Jormaskylä, Ketrinsaari (Kyyhk.): Natula (K.). Plublanka, Rällinmäki (K.). - Ob. Nlatornio, Kalkkimaa (Räs.). - K. Kuusamo, Kitkajoki, Päakyskallio (Bruth.); Paanajärv, Mäntykoski (Nyb); Ruskeakallio (Nyb).

S. Sk.-Jmt. und Ang. pass, nördlicher sellener, in Mll, und Boh. fehlend. Ifeist nur in niedriger Lage.

N. In den Ungebungen des Kristianiafjords fqq und von dort lis nach Ringerike dringend. In Telemarken, Ne.-St. selten, in NB. nur in den innersten Teilen beobachtet. Fehlt in $R$. und $H$. In $K$. No. 士 selten, an der Südseite des Trondhjemsfjords jedoch st. fq. Steigt bis $680 \mathrm{~m}$ hinauf. Nordgrenze bei $69^{\circ} 10^{\prime} \mathrm{r}$. Br.

Europa, Kaukasus, Sibirien, Ussurigebiet

var. cavernarum Möll. in Ark. f. Bot. Bd. 15, No. 2, p. 35 (1917).

Sehr schlanke, lockerrasige Pfl. Stengel farlenförmig, einfach oder spärlich und muregelmässig beblättert. Stengelblätter entlernt gestcllt, 0,5-0,6 nm lang und $0.11-0,2 \mathrm{~mm}$ breit.

An schattigen Kalkfelsen.

S. Vg. Österplana När Ringkarleby.

\section{LESKEOIDEAE.}

Diözisch, selten autözisch; † Blüten stengelständig. Stengel normal, kriechend. Zellen der Lamina rundlich-6seitig; Rippe (excl. Pseudoleskeella tectorum) einfach, in der Blattmitte oder vor der Blattspitze endend.

\section{PSEUDOLESKEELLA}

(Kindb.) emend. Hag. in D. K. N. Vid. Selsk. Skrift. 1908. No. 9, p. 107 (1909).

Schlanke Pfl, in dicht verwebten, flachen, trocken starren und brüchigen, bram- oder olivengrïnen, seltener Trendiggrünen Rasen. Stengel niederliegend. im Unfange des Rasens kriechend, absatzweise mit Rhizoidenbüscheln, unregelmässig gefiedert. Blätter wenig hohl, aus herzeiförmiger Basis rasch schief lanzettlich; Rippe in der Blattmitte endend: Zellen klein, stark verdickt, glatt, in der Spitze und längs der Blattmitte oval und länglich, am Grunde gegen die Ränder in mehreren schiefen Reihen quadratisch und querbreiter. Perichätialblätter aufrecht, ausgebleicht, aus halbscheidiger Basis lang zugespitzt. Kapsel geneigt, länglich bis zylindrisch, gekrümnt. Deckel kegelig, kurz geschnäbelt. Sporen 12-16 ", olivenfarben, fast glatt.

616. Pseudoleskeella catenulata (Brid.) Kindb. Eur. and N.-Am. Bryin. p. 48 (1897). [Pterigynandrum catenulatum Brid. Muse, rec. II. P. I. p. 64, t. 5, f. 4 (1798). - Hypnum catenulatum Schwaegr. Suppl. I. P. II. p. 218 (1816). Pseudoleskea catenulata Bryol. eur. fasc. 19/51 Mon. p. 3. t. 2 (1852). - Leshea calenulata Mitt. in Journ. Linn. Soc. V'III. (1864).]

Blätter feucht aufrecht-abstehend, bis $0,65 \mathrm{~mm}$ lang und $0,12 \mathrm{~mm}$ breit, flachund ganzrandig. Seta $1--1.5 \mathrm{~cm}$, gelbbraun. Ring sich ablösend. - Fig. 78 A-C.

Auf trockenen Kalkfelsen und kalkhaltigen Gesteinen. Sporogone sehr selten.

F. Kl. Jaakhima (Sundv.). Sortavala. Kirjavalahti, Yariskallio (Norrl.). - Kol. Yosnessenje und Nikola (Elfv.). - Sb. Nilsiä. Kuuslahti, Jaakonlampi (Kyyhk.). - Kon. Jalgıba (Simm.). Santala (Kullh.). Pirttiniemi (Simm.) Dianova gora (Kullh). - Ok. Suomussalmi, Saarijāri (Kỵhk.). - $K$. Kuusamo, Paanajärvi. Ruskeakallio (Sil.). - Lkem. Kolari. Hukki (Norrl.). - Le. Kilpisjarvi, Leulsuvaara, in 
der alpinen Region (Norrl.). - Lt. Kola, Karaulnaja Pahta (Broth.). Pummanki (Broth.). - Lp. Orlov, rimbnoi (KihIm.). Ponoj (Broth.). - Lv. Tschapoma (B.).

S. In den kalkgehieten der südlichen und mittleren Provinzen nicht selten, stellenweise sogar st. fq.. nördlicher seltener. Nordgrenze in Jmt. bei $63^{\circ} 18^{\prime} \mathrm{n}$. Br.

N. In $A$, und $N o$. an vielen, in $B u . . B r$. und $S B$. an einzelnen oder wenigen Fundorten. Steigt bis $400 \mathrm{~m}$ hinauf. Nordgrenze bei $69^{\circ} 8^{\prime} \mathrm{n}$. Br

Europa, Syrien, Zentral-Asien, Sibirien.

\section{LESKEELLA}

(Limpr.) Loesk. Moosfl. (l. Harz. p. 255 (1903).

Diözisch; $c^{7}$ und Blïten nur am Hauptstengel. Stengel nicht stolonenartig, weit kriechend, absatzweise mit Rhizoidenbüscheln, dicht beblättert, längs dicht kurzästig. Blätter trocken dachziegelig. feucht aufrecht-abstehend bis \pm einseitswendig. aus etwas lıerablaufender, breit eiförmiger Basis $t$ raseh lang zugespitzt, ganzrandig: Zellen glatt, längs cler Blattmitte oval und länglich, am Blattgrunde nächst der Rippe rektangulär und getüpfelt, in den Blattecken quadratisch und querbreiter. Kapsel mit Spaltöfmungen. Ring stïckweise sich ablösend. Deckel kegelig, kurz und schief geschnäbelt.

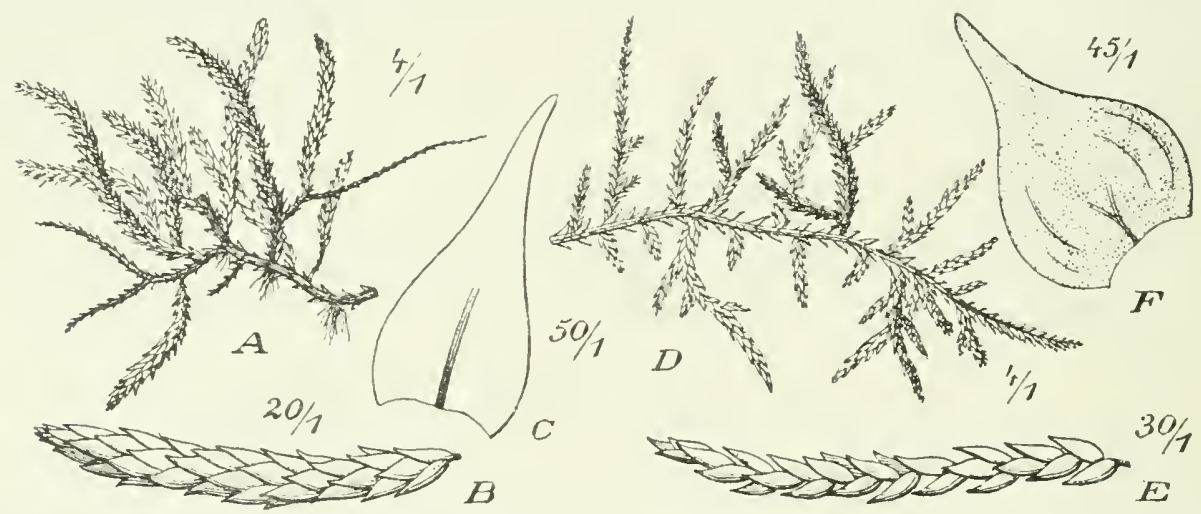

Fig. 78. A-C. Pseudoleskeella catenulala (Brid.). A Sterile Pfl. (4/1): B Astehen (20/1): C Stengell). (50/1). - D-F. Heterocladium papillosum (Lindb.). D sterile Pfl. (4/1): E Ästchen (30/1); F Stengelb. (45/1).

\section{[̈l,ersicht der Arten.}

A. Blattrippe kräftig, im Pfriementeile enclend 617. L. nervosa.

B. Blattrippe gabelig oder schwach bis fehlend 618. L. tectorum.

617. Leskeella nervosa (Schwaegr.) Loesk. 1. c. [Pterogonium nervosum Schwaegr. Suppl. I. P. I. p. 102, t. 28 (1811). - Leskea nervosa Myr. Coroll. Fl. Upsal. p. 52 (1834).]

Schlanke Pfl. in dichten, ausgedehnten, njedergedriickten, starren, meist dunkelgrünen oder bräunlichen Rasen. Stengel mit undeutlichem Zentralstrang und meist aufrechten, kurzen Ästen. Blätter aus herzeiförmiger Basis \pm rasch lanzettlich zugespitzt, bis $1,5 \mathrm{~mm}$ lang und $0,5 \mathrm{~mm}$ breit, mit abwärts sclumal zurückgeschlagenen Rändern; Rippe kräftig, im Pfriementeile endend: Zellen verdickt, rundlich-6seitig, längs der Blattmitte oval und länglich, am Blattgrunde nächst der Rippe rektangulär und getïplelt, in den Blattecken quadratisch und querbreiter. Innere Perichätialblätter aufrecht, aus halbscheidiger Basis plötzlich lang zugespitzt; Rippe zart; alle \%ellen verlängert. Seta etwa $10 \mathrm{~mm}$, purpurn. Kapsel aulreclit, länglich oder zylindriseh, bis $2.7 \mathrm{~mm}$ lang nnd $0,75 \mathrm{~mm}$ dick, 
zuletzt braun. Peristomzähne quer- und schrägstreifig, in ter spilze papillös, ohne entwickelte Lamellen. Fortsätze unregeluässig ausgelildet. Sporenreife im August und September. - Vegetative Vermehrung durch blattachselstindige Brutknospen oder büschelige Kurztriebe. - Fig. $79 \mathrm{~A}$ - C.

An Bammstämmen und Wurzeln. aul Felsen und Steinen allerlei Art.

F. Al Jomala, Finström, Geta, Lemland, sund und Brändö an einzelnen, Saltvik an melıreven Fundorten - Ab. St. Karins, Ispois (Buch). Reso, Lıotnonmaa (Höguı.). Karislojo. Pellonkylä (sundv.). Lojo, an mehreren Fundorten (Lindb., Hult, H. Lindb., E. af H.). X. Ekenti, Träminne (Terisy.).

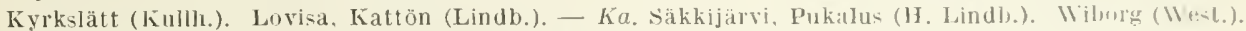
Jääski, Ahola (Lindb.). - Ik. Kuolemajärvi, Muurila (II. Lindb.). Valkjärvi, Veikkola (Il. L.). Sakkola, Makkara (H. L): Loposenmäki, Mönkï und Röykkyä (Hid.). P’̣läjärvi, Ivaskaısari (II. L.). St. Ulfsby (Nerv.). Björneborg, Torłonäs (Häyr.). Pirkkala (Simm.). IIämeenkyrö, Kyröskoski (Sindr.). — Ta. Vanaja, Järviöinen, Klemola (Buch). Kalvola, Iittala (Hạ̈r.). Sääkinäki (Kihlnı.). In sĭdiostl. Teile an inehreren Fundorlen, fq. und reichl, an Seeufern (Norrl.). Sysmï (Unon.). Kolpitahti, Veiju, Vuarunvuori und Haukkavuori (Vain.). Luhanka, Onkisalo (V). - Sa. Lappee, IIanlijärvi (Buch).

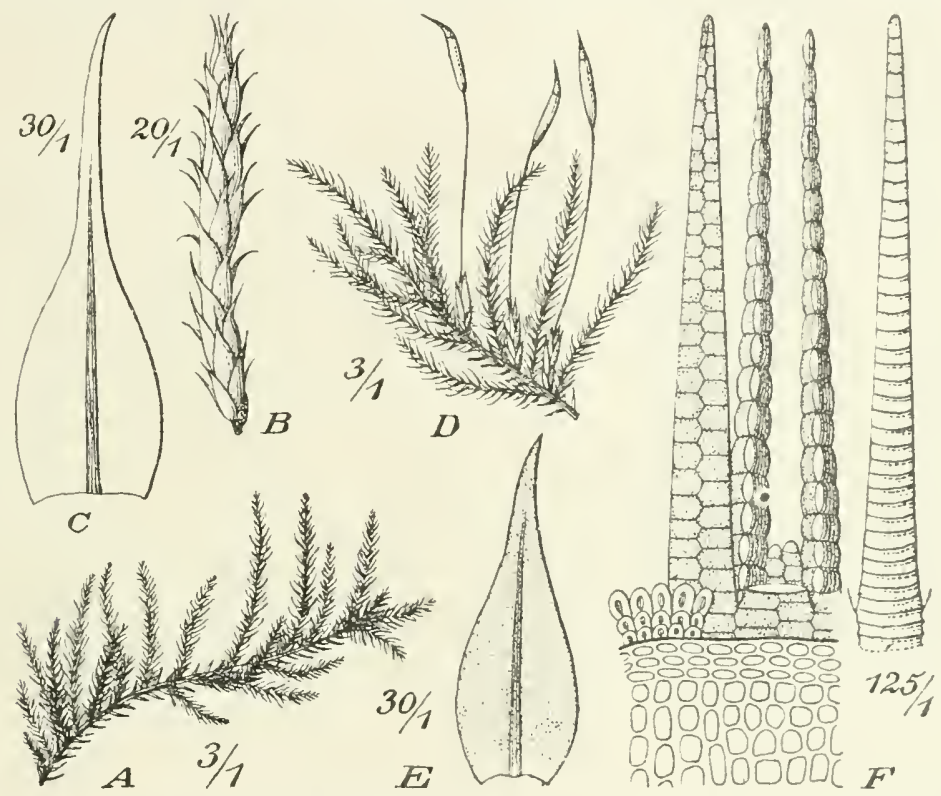

Fig. 79. A-C. Leskeella nervosa (Schwaegr.). A sterile Pfl. (3/1); B Ästchen (20/1): C stengelb. (30/1). - D-F. Leskea polycarpa Ehrh. D Fruchtende PfI. (3/1); E Stengelh. (30/1): F PerisLom (1:5/1).

Ruokolahti, Imatra (Sael.): Aitsaari (Hult). Nyslott (Carl.). - Kl. Kurkijoki, Tevuus (Jusl.). Valamo (W. Nyl.) Sortavala, Kirjavalahti st fq. (Norrl.). Impilahti, Sumeria (Pes.). Ruskeala (Broth.). Kol. Petrosavodsk (Kullh.). - - Sb. Kuopio, Puutosmäki, Likolammen talo, Kalkkisaari (Link.). Kaavi, Siikajärvi, Kypäräissaari (Kyyhk.); Huosiaisniemi (Kot.). Juuka, Halivaara (K.); Petrovaara. Saarijärvi, Sotisaari (K.) Nilsiä, Kuuslahti, Jaakonlampi (Kyyhk, und Kot.). Maaninka, Vianto (Rois.); Tuovilanlahti, Arkkuvıori cop. (R.); Haatala (R.). - Kb. Juuka, Polvijärvi, Sola. Pepovalara'(Kot.). Kon. Tiudie (Kullh.). Käpselkä (Simm.). Gorka (S.). Lnitsa (S.). Perguba (S.). — Om. Jakobstad (Font.). - Ok. Paltamo, Melalahti, an mehreren Fundorten, stellenweise cop. (Lackitr.. Kyyhk.). Puolanka (Lackstr.). - Ob. Haukipudas (Brenm.). Kemi (Brenn.). Rovaniemi, Alajääskö (Hult). Alatorno, Kalkkimaa (Rà.). Turtola, Pello (Norrl.). - K. Kuusamo, Kitkajoki, Jyrävä (Broth.). Paanajärvi (F. Nyl.). - Kk. Knjäsclıa (Karst.). - Lkem. Kolar, Manaoja (Hult). Kittilä, Kutunira und Rautujärvi (H.) Aakenusjoki (H.). - Le. Karesuarto (Yorr.). - Lim. Umba (Kilu!m.). Porjaguba (sel.). Fiandalaks, Sehelesnaja (Broth.). - Lt. Kula, Abramovaja Pabta (B.). - Lmur. Olenji (Karsı.). - Lp. Orlor. Rusiniha und Ponoj (Kihlnı.).

S. In den südlichsten und nördlichsten Teilen st. l., sonst pass. In allen Hohenlagen in der alpinen Region jedoch selten.

N. In allen Provinzen mit Ausnahme von L.Y., überall + fq., seltener in der alpinen Region. Steigt bis $1,300 \mathrm{~m}$ binaur.

Europa, Kaukasus, Kaschmir, Pendschab, Nord-Amerika. 
var. laxifolia (Lindb.) Hag. in Kgl. Norsk. Vicl. Selsk. Skrift. 1908, No. 9, p. 97 (1909). (Leskea nervosa var. laxifolia Lindl). in Bot. Notis. 1865, p. 75.)

Pfl. in sehr dichten Rasen. Stengel mit langen, unregelmässig verzweigten Ästen. Blätter kürzer zugespitzt, mit nur am Grunde schwach umgebogenen Rändern; Rippe ziemlich kräftig, im unteren Teile der Blattspitze versehwindend; Zellen doppelt grösser, mehr durchsichtig.

F. Le. Kilpiskoski (Norrl.).

S. Jmt., $P L . . L u L$. und $T L$. an einzelnen oder wenigen Fundorten.

N. Br.. K., H., $\Delta T ., N_{0}-F$.

var. rupestris (Bergr.) Möll. in Ark. f. Bot. B(l. 15, No. 2, p. 16 (1917). [Leskea rupestris Berggr. Bidr. Skand. Bryol. p. 9 (186i). - L. nervosa r rupestris Hartm. Sk. Fl. 10. e(l. 1I. p. 38 (1871).]

Pfl. in lockeren Rasen. Stengel mit langen, dïnnen Ästen. Blätter allmählich zugespitzt, mit kurzer Spitze, flachrandig, in der oberen Hälfte gekerbt; Rippe dïmn, meist etwa in der Mitte verschwindend; Zellen in der Blattmitte gestreckt.

An Felsenwänden und in dunklen Schluchten.

S. Ög., Hrjd., Jmt., Ang., LuL. und TL. an einzelnen Fundorten.

N. Dorre.

618. Leskeella tectorum (A. Braun) Hag. in Kgl. Norsk. Vid. Selsk. Skrift. 1908, No. 9, p. 93. [Pterogonium tectorum A. Braun in litt., Brid. Bryol. univ. II. p. 582 (1827). - Leskea tectorum Lindb. in Botan. Notis. 1864, No. 4.]

Mehr oder weniger schlanke Pfl. in dicht verwebten, meist kreisrunden, weichen, dunkel- bis bramgrünen Rasen. Stengel ohne Zentralstrang und kurzen, aufsteigenden okler dem Substrate angedrückten Ästen. Blätter sehr hohl, aus breit eiförmiger Basis plötzlich schmal und fast linealisch zugespitzt, bis $0,75 \mathrm{~mm}$ lang und bis $0.40 \mathrm{~mm}$ breit, mit am Grunde schwach umgebogenen Rändern; Rippe gabelig, vor der Blattmitte erlöschend oder schwach bis fehlend; Zellen dümnwandig, oben rundliclı- oder oval-6seitig bis kurz rhombisch, am Grunde quadratisch und kurz rektangulär und gegen die Rändler querbreiter. Innere Perichätialblätter aufrecht, langspitzig pfriemenförmig, die imnersten kürzer, an der breiten gestutzten Spitze sägezähnig. Seta $1,5 \mathrm{~cm}$, purpurn. Kapsel etwas geneigt, zylindrisch, $2.7 \mathrm{~mm}$ lang und $0,75 \mathrm{~mm}$ dick. rötlichbraun. Peristomzähne querstreifig, mit bis 25 hier und da dureh mediane Längsleisten verbundene Lamellen. Fortsätze von Zahnlänge, nicht durchbrochen, an den Gelenken eingeschnürt.

Auf trockenen Felsen, besonders Schiefer und Kalk, selten an Bäumen. Sporogone sehr selten.

F. Sb. Kaavi, Siikajärvi, Huo:ialsniemi und Likosaari (Kot.). Juuka, Petrovaara, Saarijärvi, Sotisaari (K.). - Ok. Suomussalmi, Saarijärvi (Kyyhk.). 一 K. Kunsamo, Kitkajoki, Pääskyskallio (Broth.). Oulankajoki. Kiutaköngäs und Taivalköngäs (Roir.). - Kuolajärvi, an mehreren Fundorten (R.). Lkem. Kittilä. Raulujärvi (Hult). - Le. Keloltijärvi, in der Birkenregion (Norrl.); Kilpisjärvi, Leutsuvaara und Saanavaara, in der alpinen Region (N.); Xalla, in der alpinen Region rr. (Kot.). - Lim. Kandalaks, Scheleinaja (Broth.).

S. Öl., Mpd., Hrjd., Jmt.. LuL. und $T L$. Sleigt bis in die Weidenregion, seltener bis in die alpine Region hinauf.

N. A., Bu.. sB., YB., K. $-F_{\text {., }}$ in den südlicheren Teilen nur im Binnenlande.

Europa. Sibirien. Nord-Amerika. Nordgrenze auf Spitzhergen.

\section{LESKEA}

Hedw. Fund. II. p. 93 (1782).

Autozisch. Mehr oder weniger schlanke Pfl. Stengel kriechend, mit lanzettlichen his pfriemenförnigen Paraphyllien, \pm deutlich fieclerästig, mit kurzen, aufrechten odter aufsteigenden Ästen. Blätter hohl, eilanzettlich, mit oft schiefer Spitze: Zellen dünnwandig, rundlich-mehreckig. beiderseits mit nur einer Papille über dem Lumen, in den Blattecken in mehreren Reihen quadratisch. Periehätial- 
blätter aufrecht, bleich, scheidig, allmählich zugespitzl: Zellen gestreckt, glatt. liapsel länglich bis zylindrisch. Ring dilterenziert, sich abrollend. Peristomzälnne gelb, quergestreift, mit zahlreichen Lamellen. Inneres Peristom gelb; Grundhaut etwas vortretend; Fortsätze gekielt, fast von Zalnnlänge; Wimpern rudimentär bis fehlend.

619. Leskea polycarpa Ehrh. Dec. erypt. No. 96 (1788).

Pfl. in weichen, lockeren bis dichten, dunkelgrünen Rasen. Bläter trocken anliegend, feucht weit aufrecht-abstehend, mit am Blattgrunde einer-oder beiderseits umgebogenen, glatten Rändern, bis etwa $1 \mathrm{~mm}$ lang und $(1,3-0,5 \mathrm{~m}$ m breit; Rippe kräftig, vor der Blattspitze aulhörend. Astblätter kleiner. Seta etwa 1 cm, gelb- oder dunkelrot. Kapsel aufrecht und regelmässig oder etwas geneigt und gekrümm, fast zylindrisch, dünnhäıtig, gelbgrün, später gebräunt, trocken und entrleckelt unter der Mündung verengt. Sporen $912 \mu$, gellılich, fein papillös. Sporenreife im Juli. - Fig. $80 \mathrm{D}-\mathrm{F}$.

An Stämmen und Wurzeln, auf Holzwerk und Steinen. besonders an Crewässern.

F. Al Sund, an wenıen Fundorten (Bnm). - Ab. Abo, Hallis (Elfy.). Vichtis, Olkkala (W. Nyl.). - V. Tusby, Sakisa (Broth.). Orimattila, Borga d (Link.). — Ta. Hattula, Saarela (Ranck.). - Kl. Pälkjärvi. Anoniemi (Broth.). - Tb. Jyväskylä (B.). — Sb. Maaninka, Haatala (Roiv.). Pielavesi, Sävia (Huu-k.). Iisalmi (Sahlb.). Kiuruvesi, Runni (Roiv.). - Kon. Unitsa (Simm.). - Kk. Iiava (Fellm.).

S. In den südichen und mittleren Provinzen zerstreut. nördlicher nur aus Gslr., Hls.. Mpd. und $J$ J hekannt. Nordgrenze bei $63^{\circ} 10^{\prime} \mathrm{n} \mathrm{Br}$.

N. En den Gegenden um den Kristianiafjord. in Ringerike, Hadeland und Land, in Telemarken und Elverum, in Gudbrandsdalen bis Lom. Steigt bis etwa $350 \mathrm{~m}$ hinauf. Nordgrenze bei $6 \mathbf{l}^{\circ} 40-50^{\prime} \mathrm{n}$. Br. Furopa, Kaukasus, Sibirien, Amur, Nord-Amerika.

var. paludosa (Hedw.) Schimp. Syn. p. 486 (1860). [Leskea paludosa Hedw. Deser. IV. p. 1, t. 1 (1793).]

Kräftiger als die Hauptart, mit langen Stengeln und Ästen. letztere meist stumpf und fiederig ausgebreitet. Kapsel zuletzt rotbraun.

Auf feucht liegenden oder periodisch bespiilten Steinen.

F. Ik. Kuolemajărvi, Pihkala (H. Lindb.).

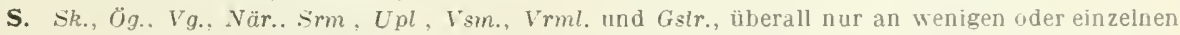
Furdorten.

N. Sm., $B u$, $J L_{\text {. }}, B r, K_{\text {. }}$, und $H$., an einzelnen oder wenigen Fundorten.

Europa, Amur-Gebiet, Nord-Amerika.

\section{T H U I D I A C E A E.}

Locker- oder dichtrasige, trocken starre, glanzlose Erd-, Baum- oder Felsmoose. Stengel ohne oder mit armzelligem Zentralstrang, lockerem Grundgewebe und verdickten Mantelzellen, meist weithin kriechend und $I$ geteilt, dicht beblättert, 1-3fach gefiedert, meist mit zahlreichen Paraphyllien. Blätter zweigestaltig. Stammblätter grösser, aus herablaufendem, herzförmigem Grunde rasch oder allmählich zugespitzt; Rippe (excl. Heterocladium) kräftig und lang. homogen: Zellen klein, (excl. Helodium) rundlich-mehreckig, papillös, in der Blattmitte bis zum Grunde oder nur hier verlängert. Astblätter kleiner, breit eiförnig ouler eilanzettlieh. Alle Blüten am Hauptstengel und an gleichwertigen Sprossen oder die $>$ Blüten z. T. astständig. Perichätialblätter differenziert, bleich. Seta verlängert, gerade. Kapsel geneigt bis horizontal, eiförmig, länglich-oval bis fast zylindrisch, trocken und entdeckelt \pm gekrümmt und unter der Mündung eingeschnürt; Spaltöffnungen oberflächlich. Ring differenziert. Peristomzähne lanzettlich, am Grunde verschmolzen, querstreifig. mit zahlreichen Lamellen. Inneres Peristom gleiehlang: Grundhaut hoch, kielfaltig: Fortsätze gekielt, ritzenförmig durchbrochen: Wimpern vollständig. Sporen klein. 
Ubersieht de r Gat ungen.

A. Stammblätter olne oder mit diinner, kurzer, einfacher oder doppelter Rippe ....................................

B. Stammblätter mit krältiger, in oder mit der Pfriemenspitze auflörender Rippe.

a. Blattzellen parenchymatisch f..................... 122. Thuidium,

b. Blattzellen prosenchymatisch ....................... 123. Helodium.

\section{HETEROCLADIUM}

Bryol. eur. fase. $49 / 51$ Ilon. (1852).

Diözisch. Stengel kriechend, fadendünn, stolonenartig verlängert, mit spärlichen, kurz pfriemenförmigen oder blattähnlichen Paraphyllien, durcls kleinblättrige, kurze Äste \pm unregelmässig gefiedert. Stammblätter aufrecht-abstehend bis sparrig zurückgebogen, flachrandig, nicht oder undeutlich gefurcht: Rippe dünn, kurz und meist doppelt, seltener etwas länger und einfach oder gegabelt, zuweilen undeutlich bis fehlend; Zellen längs der Blattmitte fast linealiseh, in der Spitze und gegen die Ränder kürzer, unregelmässig, beiderseits mit papillös vorgewölbten Zellecken. Seta $1-1,5 \mathrm{~cm}$, rot, glatt. Kapsel geneigt bis horizontal, klein, oval bis länglich, etwas hochrickig. derbhäutig, trocken und enteleckelt unter der llündung \pm verengt.

Íleersicht der Arten.

A. Blätter feucht allseits aufrecht-abstehend. hohl, ganzrandig: Papillen hallokugelig. Sehr schlanke Pfl. von Leskea-Tracht

621. H. papıllosum.

B. Weniger schlanke Pfl. Papillen klein, nicht halbkugelig.

a. Stammblätter sparrig, rasch lang zugespitzt. Astblät-

ter trocken dachziegelig .............................620.H.squarrosulum.

b. Stamm- und Astblätter abstehend-cinseitswendig, kurz zugespitzt.

«. Rippe vor der Blattmitte aufhörend, an Fnde oft gabelig ........................................... 622. H. heteropterum.

$\beta$. Rippe mit oder oberhall, der Blattmitte aufhörend, einfach

623. H. Wulfsbergii.

620. Heterocladium squarrosulum (Voit) Lindb. Musc. scand. p. 37 (1879). [IIypnum squarrosulum Voit in Sturm Deutschl. Fl. II. fasc. 11 mit Taf (1810). Hypnum dimorphum Brid. Sp. musc. I1. p. 119 (1812). - Heterocladium dimorphum Bryol. eur. fasc. $49 / 51$ Mon. p. 3, t. 1 (1852).]

Schlanke Pfl. in lockeren oder dichten, oft ausgedelnten. flachen, grünen, gelbgrünen bis bräunlichgelben Rasen. Stengel kriechend, fieder- und büschelästig: Äste kurz, stumpf, kätzchenartig. Stammblätter aus breit herzförmiger Basis rasch lang und fein zugespitzt und feucht mit der oberen Hälfte sparrig zurückgebogen, bis $0.9 \mathrm{~mm}$ lang und $0.6 \mathrm{~mm}$ breit, rings papillenartig gezälnt; Rippe kurz, doppelt bis undeutlich; Zellen dickwandig, in der Spitze und gegen die Ränder rhomboidisch, rhombisch, quadratisch und rundlich-mehreckig, mit niedrigen Papillen. Astblätter kleiner, leucht aufrecht abstehend bis sparrig, eiförmig, kurz zugespitzt. Innere I'erichätialblätter aus länglich-eiförmigem Gruncle in eine lange, sparrig zurückgebogene, lanzettlich-pf fiemenförmige Spitze auslaufend, bis 2,1 $\mathrm{mm}$ lang, gesägt, rippenlos. Kiapsel rotbraun. Deckel gewölbt kegelig, spitz oder stumpflich. Sporenreife von März bis Mai. - Fig. 80 . 
Auf schattigem, kieselreichem Gestein und kalkhalligem Schiefer, an Gruncle von Bäumen, besonders von Espen, an Bamwurzeln und auf lehmig-sandigem Bocken.

F. Al. Finströı, Godby (Arrh.); Grelsby (Bom.). Saltvik, Pfarrhatu=(B.). - Ab. Bromarf (Sundv.). Karislojo, Tesjärvi (E. af H.). Lojo, Lołıjanselkä und Skraatila (Lindb.); Isosaari, Pietilä (II. Lindb.). Vichtis, Olkkala, Konjanvuori (E. af H.). - v. Kyrkslätl. Humaljärvi (Ranck.). Helsingfors (Lindb.). Pernå (Häyr.). Elimäki (Tigerst.). Orimattila (Link.). - Ka. Sippola, Ruotila (Kuj.). Vehkalahti. Suoniemi (Krohn). Virolahti (Blom). Wiborg, Junstila und Soskuanjoki (Buch). Räisälä (Lindb.). - St. Eura (Rönnb.). - Ta. Im südöstl. Teile pass. (Norrl.). Harlola (Bonsd.). Korpilahti und Luhanká nas.. (Vain.). - Sa. Valkeala (Sundv.). Lappee, Rasala, Hypiänvuori (Buch). Savitaipale, Kuolimojärvi (B.). - Kl. Kurkijoki (Jusl.) Valamo (F Nyl.). Jaakkima (Jusl.); Ramola (Sundv.). Impilahti, Pitkäranta (Pes.). Sortavala, Pötsövaara (Pes.); Kirjavalahti (Norrl.); Paksuniemi (Buch). Suistamo, Uuksujärvi, Roikankoski (Link.); Leppäsyrjä (Pes.). - Kol. Schtjeliki (EIfv.). - Oa. Karijoki, Pyhävıori (E. af H.). Närpe;, Yttermark, Varghärget (E. af H.). Öfvermark, Valsbärget (E. af H.). - Tb. Virrat, Toriseva (Broth.). Petäjävesi, Palavavuori, Mäntymäki und Iataraniemi (Ruor.). Karstula, Saarijärvi und Viitasaari (Broth.). Pihtipudas, Sormulammäki (Roir.); Korpiskylä, Virkamāki (R.). — Sb. Pieksä-
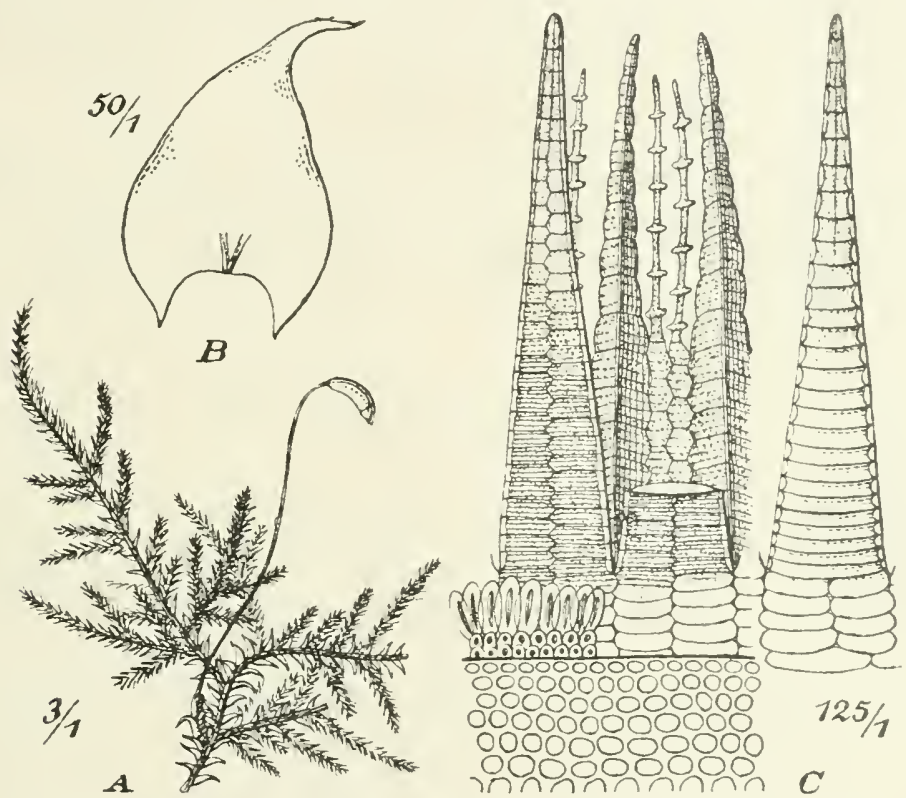

Fig. 80. Heterocladium squarrosulum (Voit). A Fruchtende Pfl. (3/1); B Stengelb. (50/1); C Peristonı $(125 / 1)$.

mäki, Rummukankylä, Suurniemi (Kyyhh.). Heinävesi, Palokki, Kultanienti und Tarislahti (Kol.). Kuopio, an vielen Fundorten (Link., Kyyhk., Kot.). Kaavi, Hoikanlampi (Kot.); Siikajärri: Likosaari, Huosiaisniemi und Rihisaari (K.). Juuka. Petrovaara (Kot.). Nilsiä, Kirchdorf, Loutleinen (Kot.); Haluna (Kyyhk.). Jaaninka, Haatala (Roiv.); Pöljä, Lammasmäki und Uuhimäki (Kyłhk.). Pielaresi, Jylhä (Roiv.). - Kb. Juuka, Nunnanlahti (Kot.); Saarijärvi, Porttikallio (K.). - Kon. Suojärti (Norrl.). Gorka (Simm.). - Om. Vindala, Pyhäruori (Backm.). - Ok. Kajana (Lackstr.). Solkamo, Yuokatti, Tolhovaara (Kyyhk.); Sopenvaara (K.). Kuhmoniemi. Kuivajărvi, Louhiniemen kallio (K.). Suornussalmi, Parvojārvi (K.). - K. Taivalkoski (W. Breın.). Kuusamo, Ruoppijärvi (Broth.); Pyhātunturi und Rukatunturi (B.). Iivaara (B.). - kik. Kivakkatunturi (B.).

S. Im Südschweden nur in den inneren Teilen und erst in Upl, auch an der Küste. Nördlicher in allen Provinzen mit Ausnahme ron A $L$., LyL. und $P L$. Steigt bis in die Birkenregion hinauf. Nordgrenze etwa bei $68^{\circ} \mathrm{n}$. Br.

N. In allen Provinzen mit Ausnalume von L.H., H. und NT., jedoch mil verschiedener Frequenz und an der Küste von Westlandet fehlend. Kommt an reichlichsten in der Os-Region und in der subalpinen Region vor, steigt jedoch auch bis in die alpine Region hinauf. Nordgrenze bei $70^{\circ} 40^{\prime} \mathrm{n}$. Br.

Europa, Kaukasus, Nord-Amerika. 
var. compactum (Mol.) Limpr. Laubn. II. p. 818 (1895). [Helerocladium dimorphum var. compactum Mol. in sched.; Pfeff. Bryogeogr. Stud. p. 71 (1869).]

Pfl. in niedrigen, dichten Rasen. Stengel mit kurzen. kïtzchenartigen Ästen.

S. LuL. Kvikkjokk, Kảbdesjaur.

N. Ne. Bykle, Vaering:dalen, $1,200 \mathrm{~m}$.

Bayern, Schweiz, Tirol 2-3000 m.

621. Heterocladium papillosum (Lindlb.) Lindb. Musc. scand. p. 37 (1879). (Leskea papillosa Lindb. in Bot. Notis. 1872, p. 135.)

Sehr schlanke Pfl. in lockeren bis dichten, flachen, grünen orler bräunlichgrünen Rasen. Stengel unregelmässig fiederästig: Äste kurz, (lrehrund, allmählich verdümnt, spärlich mit kurzen Ästchen. Stammblätler feucht allseits anfrechtabstehend, trocken locker anliegend, hohl, breit eiförmig. rasch lanzettlich und scharf zugespitzt, etwa $0.45 \mathrm{~mm}$ lang und $0.30 \mathrm{~mm}$ breit, ganzrandig; Zellen verdickt, in der Spitze und längs der Ränder oval 4-6seitig, in den Blattecken sclief quadratisch und rhomboidisch, am Blattrücken mit halbkugeligen Papillen. Astblätter den Stammblätter ähnlich, nur kleiner. Blätter der Ästehen sehr hohı, kurz zugespitzt, gezähnelt. 1’fl. unbekannt. - Fig. $78 \mathrm{D}-\mathrm{F}$.

Auf Felsen und Blöcken.

F. K. Pudasjärvi, Pi!rivaara (Broth.). Kuusamo, Näränkävaara (Vain.).-- Le. Zw. Palojoki und Karesuanto in der Kiefernregion (Norrl.). Pälikköko:ki in der Birkenregion (N.). Pietsovaara in der unteren alpinen Region (N.); Saivoraara (Kot.). - Li. Utsjoki, Mandojäyr in der Birkenregion (Hult). Lim. Hibinä, Tschuidi-run, an der Baumgrenze (Kihln.). Überall nur spärlich.

S. Vb. Nor:jö, Ku-for., PL. Arjeplog, Galtispoola. LuL. Krikkjokk, an wenigen Fundorten.

N. Tr. Nordreisen, Fossen.

Sibirien.

622. Heterocladium heteropterum (Bruch) Bryol. eur. fasc. 49/51 Moll. p. 4, t. 2 (1852). [Pterogonium heteropterum Bruch in litt.. Schwaegr. Suppl. III. P. I. t. 210 b (1827). - Hypmum heteropterum Spruc. in Ann. and Mag. nat. hist. 1849, p. 272.]

Schlanke Pfl. in dichten, grimen bis bräunlichgelben Rasen. Stengel niederliegend oder aufsteigend, fast regelmässig gefiedert, bis $2 \mathrm{~cm}$ lang. spitz, nicht selten flagellenartig. Blätter abstehend-einseitswendig. länglich-eiförmig, allmählich kurz zugespitzt, etwa $0,75 \mathrm{~mm}$ lang und $0,40 \mathrm{~mm}$ breit, rings papillenartig gezähnt; Rippe liurz, an Ende oft gabelig: Zellen in der Spitze und gegen die Ränder rhombisch und rbomboidisch, mehrere basale Randreihen quadratisch oder rundlich, mit niedrigen Papillen. Astblätter etwas kleiner, eilanzettlich, kurz zugespitzt. Innere Perichätiablätter fast aufrecht, verlängert lanzettlich, lang zugespitzt, gesägt, rippenlos. Kapsel olivenbräunlich. Deckel aus gewölbter Basis lang und schief geschmäbelt.

An beschatteten, feuchten Felswänden, in Kiülten und Höhlungen verschiedenartiger Gesteine. Sporogone bisher nur in England und in den Pyrenäen gefunden.

S. In sämtlichen Provinzen südschwedens mit Ansuahme rou ol. und Gtl.. jedoch überall ‡selter.

N. Im Küstengebiete von Sm. bis Lofoten, hier und da läng $₫$ den Fjordufern und den Tälern nach

dem Binnenlande dringend. Steiğt lis $300 \mathrm{~m}$, sellen höher hinauf. Nordgrenze bei $68^{\circ} 12^{\prime} \mathrm{n}$. Br.

Europa, Nord-Amerika.

var. flaccidum Bryol. eur. lase. 4951, p. 4, t. 2 (1852).

Stengel haarfein. Stammblätter entfernt gestellt, allseitswendig, länglichlanzettlich, etwa $0,45 \mathrm{~mm}$ lang und $0.36 \mathrm{~mm}$ breit.

An beschatteten, trockenen Felsen. besonders in Höhlungen.

S. sk. Hör. Sm. Korsbärga, skäftesfallshalan. rg. Y. Tunhem, Nygard. Halleberg. skytleklef.

N. Lu. Hitlero, zw. Flekkefjord und Flikke. St. Renneso. SB. Tysnes; Alversund.

Europa. Nord-Amerika.

623. Heterocladium Wulfsbergii Hag. in Kgl. N. Vid. Selsk. Skrift. 1908, No. 9, p. 74 (1909). 
Pfl. in dichten, ausgedehnten, gelbbraunen oder grünen his olivengrünen Rasen. Stengel kriechend, bis $10 \mathrm{~cm}$ lang, unregelmässig und entfernt beästet; Äste verlängert, kriechend, flagellenartig verlängert. Blälter abstehend-cinseitswendig, eiförmig, allmählich kurz zugespitzt, bis $0,8 \mathrm{~mm}$ lang und etwa $0,45 \mathrm{~mm}$ breit, mit rings papillenartig gezälnten Rändern; Rippe einfach, mit oder oberhalb der Blattmitte aufhörend: Zellen oberwärts ziemlich unregelmässig, rhomboidisch, oval und fast dreieckig, mit niedrigen Papillen. am Blattgrunde in mehreren Reihen quadratisch. Astblätter deutlich herablaufend, kleiner. - Pfl, unbekannt.

N. $\$ B$. Bergen, Blaamanden, an Felsen.

\section{THUIDIUM}

Bryol. eur. fase. 49/51 (1852).

Meist \pm kräftige Pll. in lockeren bis dichten Rasen. Stengel kriechend oder auf- und absteigend, absatzweise mit Rhizoidenbüschel, selten aufsteigend oder anfrecht, wenig geteilt, regelmässig ein- bis dreifach gefiedert, mit meist in der Ebene des Stengels ausgebreiteten Ästen: Paraphyllien sehr zahlreich, einfach oder gespreizt-ästig. Stammblätter längsfaltig, aus verengtem Grunde dreieckig- bis ei-herzförmig, meist lanzettlich bis lanzettlich-pfriemenförmig zugespitzt, an den meist \pm weit hinauf umgebogenen Rändern gezähnelt. Astblätter der ersten Ordnung oft noch den Stammblätter ähnlich, rlie der zweiten und dritten Ordnung viel kleiner, meist eilanzettlich, mit kürzerer, schwächerer Rippe. Seta rot, glatt. Deckel meist aus gewölbt kegeliger Basis schief geschnäbelt.

¿ bersicht der Arten.

A. Sehr schlanke Pfl. Paraphyllien kurz, in der Mehrzahl fadenförmig und einfach .................................624. Th. minulnlum.

B. Kräftige Pfl. Paraphyllien gespreizt-ästig.

a. Stengel dreifach gefiedert. Sämtliche Astblätter mit einspitziger Endzelle .............................. 628. Th. Lamariscifo-

liltm.

b. Stengel meist doppelt fïederästig. Astblätter zweiter Ordnung mit gestutzter, 2--Ispitziger Endzelle.

«. Rippe der Stammblätter am Grunde oder in der Nitte des Pfriementeils aufhörend. Zähnchen der Paraphyllien in der Mitte der Zellenwände.

I. Stammblätter lang und sehr fein zugespitzt. Perichätialblätter ohne Wimpern

627. Th. Philiberti.

II. Stammblätter kürzer und lanzettlich zugespitzt. Perichätialblätter am verbreiterten Teil mit Winpern

626. Th. delicalulum.

ß. Rippe der Stammblätter fast die ganze. meist zurüickgebogene, lanzettliche, kurze Spitze ausfüllend. Zühnchen der Paraphvilien an Ende der Zellen ........ 625. Th. recognilum.

c. Stengel fast aufrecht, einfach gefiedert. Astblätter mit spitzer oder schmal gestutzter Endzelle

629. Th. abietinum.

Un te rgat t. I. Thuidiella Schimp. in Besch. Prodr. bryol. mex. p. 91 (1871).

Autözisch. Schlanke bis sehr schlanke, weniger starre Pfl. Stengel kriechend, nicht stolonenartig verlängert, einfach oder doppelt gefiedert: Paraphyllien kurz, in der Nehrzahl fadenfömig und einfach. Stammblätter undeutlich gefurcht. Ast- 
blätter trocken eingekrümmt: Zeilen nicht verdickt, mit zahlreichen, niedrigen Papillen; Enclzelle gestutzt, zweispitzig. Seta dünn. Deckel lang und fein geschnäbelt.

624. Thuidium minutulum (Hedw.) Bryol. eur. fasc. 49/51 Mon. p. 5, t. 1 (1852). [Hypnum minutulum Hedw. Deser. IV. p. 90, t. 34 (1797).]

Sehr schlanke Pfl. in lockeren, flachen, dunkelgrünen Rasen. Stengel 1 $5 \mathrm{~cm}$. Stammblätter aus herzförmigem Grunde rasch lanzettlich zugespitzt, bis $0.5 \mathrm{~mm}$ lang und $0.35 \mathrm{~mm}$ breit, mit am Grunde zurückgebogenen, gekerbten Rändern: Rippe ziemlich kräftig, in der Pfriemenspitze endend. Astblätter eiförmig bis eilanzettlich, kurz zugespitzt; Rippe zart, weit vor der Blattspitze endend. Innere Perichätialblätter lanzettlich. lang zugespitzt, ganzrandig oder oberwärts gekerbt: Rippe kräftig, vor der Blattspitze endend. Seta etwa 1.5 em. Kapsel horizontal, klein, länglich, gekrümmt, dünnhäutig. braun.

In Laubwäldern auf Steinen, Baumwurzehn und am Grunde der Stämme.

F. Kol. Mljätusıva (Elfv.).

Zentral-Europa. Azoren, Nord-Amerika.

L n t e rgatt. I I. Euthuidium Lindb. Musc. seand. p. 31 (1879), emend. Broth. in Engl.-Prantl Bryal. p. 1014 (1908).

Diözisch. Kräftige Pfl. Stengel auf- und absteigend. oft stolonenartig verlängert, 2 -3fach fiederästig: Paraphyllien gespreizt-ästig. Blattrippe an der Basis verbreitert; Zellen \pm verdickt, rundlich-oval bis ]änglich-6seitig. Deckel weniger lang und dicker geschnäbe!t.

625. Thuidium recognitum (Hedw.) Lindb. in Not. Sällsk. Faun. Fl. Fenn. förh. XIII. p. 415, t. 1, f.9 (1874). [Hypnum recognitum Hedw. Descr. IV. fasc. 4, p. 92 , t. $35(1797)$.]

Dichtrasige, gelhgrume bis gellbraune Pfl. Stengel 5 $10 \mathrm{~cm}$, meist doppelt. selten einfach gefiedert: Äste bis $10 \mathrm{~mm}$ lang. Stammblätter aus breit herzförmiger Basis rasch in eine kurz lanzettliche, schiefe, meist zurückgekrümmte Spitze verschmälert, meist bis $0,8 \mathrm{~mm}$ lang und bis $0,6 \mathrm{~mm}$ breit, mit aufrechten oder sehr schmal umgebogenen, oberwärts gesägten Rändern; Rippe sehr kräftig, den Spitzenteil I ausfüllend: Zellen mässig bis stark verdickt, in der Mehrzahl länglich-mehreckig, in der Blattspitze und am Grunde nächst der Rippe verlängert. Fiederblätter eiförmig bis eilanzettlich, bis $0,4 \mathrm{~mm}$ lang und $0.3 \mathrm{~mm}$ breit. flachrandig, mit gestutzter, durch Papillen 2 -3spitziger Endzelle: Rippe schwach, weit ror der Blattspitze aufhörend: Zellen am Blatłücken durch je eine lange, nach vorwärts gebogene Papille auf der Wandmitte sehr rauh. Innere Perichätia'blätter breit lanzettlichpfriemenförmig. längsfaltig, oberwärts gesägt: Rippe selır kräftig, in der Pfrieme endend. Seta 2,5 cm. Kapsel fast aufrecht, zylindrisch, schlank, \pm gebogen, bis $4 \mathrm{~mm}$ lang und 0,6-0,7 $\mathrm{mm}$ dick, bramn. Deckel kurz geschnäbelt. Sporenreife im Sommer und Herbst. - Fig. 82 E.

Anf Waldboden und Wiesen, an Wegrändern, erdbedeckten Baumwurzeln, auf Felsen und Steinen verschicdener Art.

F. Al.sl. fq. (Bom.). - Ab. Korno (Ekl.). Lito (Arrh.). Reso (Zett.). Pargas, Piukala (Elfv.). Kimito (Ols.). Finby, Fōrbỵ (Brolh.). Bromarf, Framnäs (Elfv.). Karislojo (Sundr.); Niemi (E. af H.). Lojo, an mehreren Fundorten (Lindb., H. Lindb.). Sam!natti pass. (Sel.). Vichtis, Palajărvi (Broth.): Olkkala (Lảng). - N. Ekenäs, Elgö (Y. Brenn.). tạvkslätt. Gesterby (Kullh.): Yitträsk (Ranck.). Htelsingfors (Lindb.). Helsinge, lgggelby (Häyr.). Sibbo, Lōparö (Sundv.). Borgá. Haiko (Teräst.). - Ka. Antrea, Vatula (Lindl.). - Ik. Uusikirkko. Rajajoki (H. Lindb.). Muola, Pällilä (H. L.). Sakkola, Loposenmäki (IIid.). - śt. Eura (Rönnb.). Sastmola Nerv.). Pirkkala (Simm.). Hämeenkyrō, Kyröskoski (Nerv.). - Ta. Hattula. Letunsıo (Sundr.). lialrola (Linab.). Trrrāntö. Jionala (Broth.). Im südöstl. Tełle st. f(̨. (Norrl.). Kornilahıli und Luhanka sl. fq. (Vain.). — Sa. Mäntyharju. Toivola (Link.). Lappee, IIarajnki und Hanhijärvi (Buch). Ruokolahti, Inatra (Hult). Kangasniemi (Lackstr.). Nyslott (Carl.). - Ii. Kexholm (Tomm.). Kurkijoki (Jusl.). Jaakkima (Sundr.). Uukuniemi (Simm.). Sortavala, Kirjavalahti (Lindı.). Suistaun (Broth.); Leppäsy̨rjä, Säynăuvaara (Pes.). Ruskeala (Lindls.). Pälkjärvi. Anoniemi (Brotl.). hol. Salmi, Leppälä (Pes.). Ijätusova und Gorki (Elfv.). 
Petrosavodsk (Simm.). - Oa. Kristinestad (Nerv.). Isokyrö (Ranch.). - Tb. Jyvaskyla (Broth.). Viitasaari (B.). Kinnula, Japäjoki (Roir.). Pihtipudas, an mehreren Fundorten (R.). - Sb. Virtasalmi, Montola (Kyyhk.). Kuopio, an wenigen Fundorten (Lirk.). Kaavi, siikajarvi, Likolahti (Kot.); Losomäki, Poskijārvi (Ky̧̧hk.); Suojärvi, zw. Siikajärvi und Rautavara (K). Nilsiă, Kuuslanti, Jaakonlampi (K.). Maaninka, Haatala (Roir.): Pöljä, an mehreren Fundorten, zuweilen reichl. (Kyyhk.). Pielaresi, Otramäki (Roir.). Kiuruvesi, Rumni (Teräss.). — Kb. Tolnmajärvi, kemie (Oesch). Jıuka, Polvijärvi (Kot.). Pielisjärvi, Koli (Linnan.). - Kon. Suojärvi (Norrl.). Kivatsch (Simm.). Mundjärvi (Norrl.). - Om. Alajārvi, Kirchdorf (Backm.). Lappajärvi. Kirchdorf, an Wiesen fq. (B.). Kalajoki (Tenn.). - Ok. Iiajana (Lackstr., Kỵhk.). Paltamo, Hyyryanmäki (Lackstr.); Mclalabti. an mellreren Fundorten (Kyyhk.). Sotkamo, Hepolahti und sopenvara (K.). - ob. Haukipudas (Brenn.). - Lkem. Muonio (Norrl.). - Li. Inari, Kultala (Hult); Toironiemi (H.). Lim. Lmpjok, Kitchakoski (kihlm.).

S. In svealand und Götaland fq.. bisher jedoch nuch nicht in Boh. benlyachtet, in IIll. und Did. rr. In Forrland spärlicher und hauptsächlich in den Küstenprovinzen, his tif ${ }^{\circ} 15^{\prime} \mathrm{n}$. Br. Nordlicher nur von einzelnen Fundorten in $L u L$. und $T L$. bekannt. Nordgrenze bei $68^{\circ}: \mathfrak{\prime}^{\prime} \mathrm{n}$, Br.

N. An reichlichsten in den Gegenden um den Kristianiafjord und um den Dave, im Zwischengebiete fehlend und im Küstengebiete von Westlandet selten. Nordgrenze bei $66^{\circ} \mathrm{n}$. Br.

Europa, Kaukasus, Persien, Sibirien, Japan, Nord-Amerika.
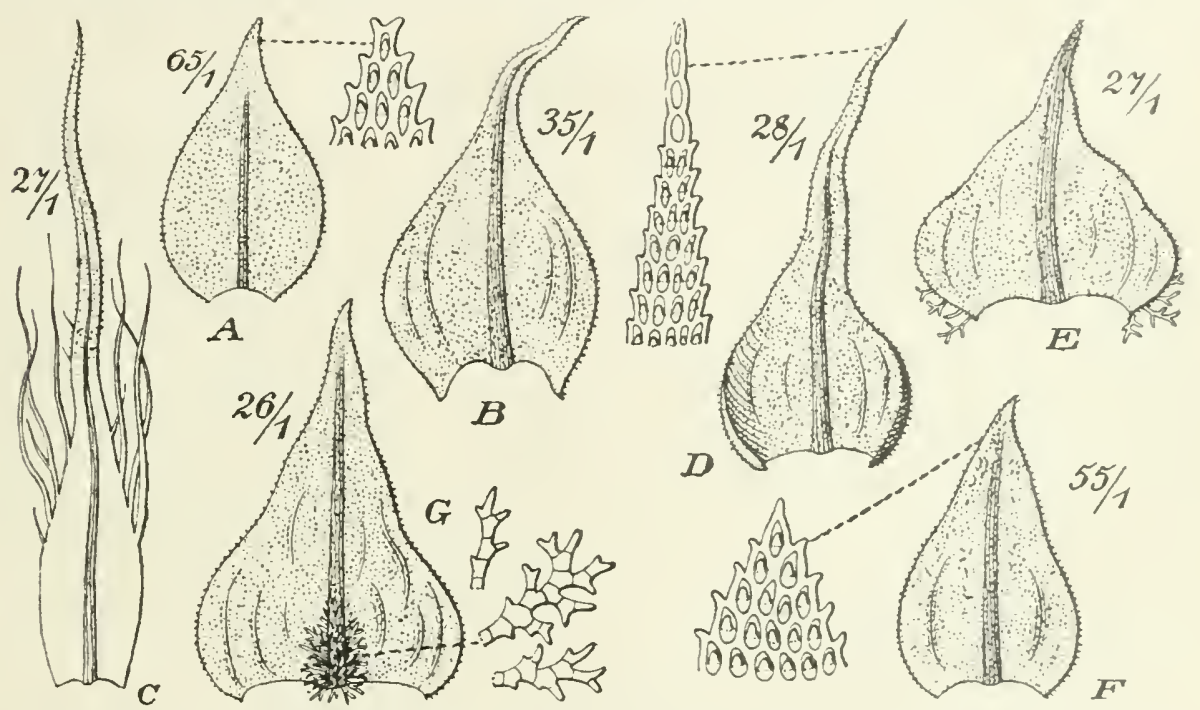

Fig. 81. A-C. Thuidium delicatulum (L., Hedw.). A Blatter der Aitchen ( $55 / 1$ ); B Stengelb. (35/1); C Perichätialb. (27/1). - D Stengelb. ron Th. Phii iberti Limpr. (28/1) — E stengelb. ron Th. recognitum (Hedw.) (27/1). - F-G. Th. tamariscifolium (Neck.). F Blätter der Āstchen (55/1): (i Stengelb. (26/1).

626. Thuidium delicatulum (L.) Mitt. in Journ. Linn. Soc. NII. p. 578 (1869). [Hypnum delicatulum L. Sp. pl. I. p. 1125 (17.53).]

Pfl. meist in schwellenden, locheren, grünen, gelbgrünen bis bräunlichen Rasen. Stengel 5-16 cm, doppelt gefiedert: Aste bis $10 \mathrm{~mm}$ lang. Stammbiitter herzförmig-dreieckig, mit kurz- bis länglich-]anzettlicher, scharfer oder stumpflicher Spitze, bis $0,9 \mathrm{~mm}$ und bis $0.8 \mathrm{~mm}$ breit, mit bis zum Grunde der Spitze \pm umgebogenen Rändern: Rippe kräftig, meist am Grunde der Spitze endend; Zellen mässig bis stark verdickt, klein, unregelmässig, in der Mehrzahl rundlich und oval, am Grunde nächst der Rippe kurz rektangulär. Astb]ätter eiförmig. zugespitzt, bis 0,6 mm lang und $0,3 \mathrm{~mm}$ breit. flachrandig, nit gestutzter, durc] Papillen 2-4spitziger Endzelle: Rippe schwach, weit vor der Blattspitze aufhörend: Zellen am Blattrücken mit je einer, nach vorwärts gebogene Papille auf der Wandmitte. Fiederblätter kaum halb so gross wie die Astblätter. Innere Perichätialblätter aus breit lanzettlicher Basis rasch in eine lange. handförmige, geschlän- 
gelte und gesägte Spitze verschmälert und an den oberen Rändern des breiteren Teiles mit langen Wimpern; Rippe sehr kräftig, in der Mitte der Pfrieme endend. Seta 1,5-2,5 mm. Kapsel geneigt bis horizontal, länglich-zylindrisch, gekrümmt, bis $\$ \mathrm{~mm}$ lang und bis $1,5 \mathrm{~mm}$ dick, rotbrann. Deckel dünn und schief geschnäbelt. Sporenreife im Spätherbst und Winter. - Fig. 81 A-C.

In feuchten Wäldern auf dem Boden, auf Steinen und modernden Stämmen, an Bächen, auf nassem Wiesen und am Grunde alter Stämme.

F. Al. Saltrik, an mehreren Fundorten (Bom.). - N. Hogland (Lindb.). - Ta. Padasjoki (Norrl.). - Kl. Sortavala, Paksuniemi (Buch).

S. Sk. und Sm. an vielen Fundorten sonst nur selten und nördlich vom Vänern und Mälaren nicht beobachtet.

N. In den Küstengegenden um den Kristianiafjord und von dort nach Ringerike vordringend, in Sorlandet selten in $S B$. st. fq. Steigt bis $200 \mathrm{~m}$ hinauf. Nordgrenze vei $62^{\circ} 25^{\prime} \mathrm{n}$. Br.

Europa, Kaukasus, Sibirien, Ost-Asien, Nurd-Amerika:

627. Thuidium Philiberti limpr. Laulm. II. p. 835 (1895). |Thuidium intermedium Philis. nec Mitt. in Rev. bryol. $1 \$ 93$, p. 33. - Th. pseudo-tamarisci Limpr. 1. c. p. 831. - Th. Philiberti var. pseudo-tamarisci Limpr. in litt.: Ryan et Hag. in D. K. N. Vid. Selsk. Skrift. 1896. No. 1, p. 127.]

Pfl. in lockeren, grünen bis gelbbräunlichen Rasen, in der Tracht wie Th. delicatulum. Stengel bis $12 \mathrm{~cm}$ und mehr, doppelt bis dreifach gefiedert; İste bis $10 \mathrm{~mm}$. Stammblätter herzeilanzettlich, allmählich oder fast plötzlich in eine meist lange, in 1-1 langgestreckte Einzelzellen auslaufende, pfriemenförmige Spitze verschmälert, bis 1,5 und $1,8 \mathrm{~mm}$ lang und bis $0,6 \mathrm{~mm}$ breit, mit in der unteren Hälfte umgeschlagenen Rändern; Rippe kräftig, vor oder in der Mitte des Pfriementeiles endend; Zellen mässig bis stark verdickt, unregelmässig in der Mehrzahl rundlich und oval, am Grunde nächst der Rippe kurz rektangulär. Astb]ätter eiförnig, allmählich zugespitzt, bis $0,6 \mathrm{~mm}$ lang und bis $0,4 \mathrm{~mm}$ breit, flachrandig, mit gestutzter, 2-3spitziger Endzelle: Rippe schwach, weit vor der Blattspitze aufhörend: Zellen an Blattrücken mit je einer nach vorwärts gebogenen Papille auf der Wandmitte. Fiederblätter kaum halb so gross als die Astblätter. Innere Perichätialblätter lanzettlich-pfriemenförmig und die Pfriemenspitze einzellreihig oder der Spitzenteil lang und schmal bandartig-pfriemenförmig, ohne Wimpern; Rippe in den Pfriementell eintretend. Seta $1,5-2,5 \mathrm{~cm}$. Kapsel geneigt, zylindrisch, gekrümmt, etwa $3 \mathrm{~mm}$ lang und $0.8 \mathrm{~mm}$ dick, rotbram. Deckel schief geschnäbelt. Sporenreife im Herbst und Winter. - Fig. 81 D.

Auf etwas feuchten Wiesen. an Wegrändern, in Wäldern und auf Felsen.

F. Al. Saltrik, an wenigen Fundoiten (Bom.). Sund, Fastelholn und Brännbolsta (Broth.). Ab. St. Karins, Ispois (Link.). Reso, Harvarö (Zett.). Pargas, Storgård (Elfv.); Lindberg (Broth.); Simonby (Link.). Sagu, Träskby (Häyr.). Karislojo (Sundv.). Lojo, an mehreren Fundorten (H. Lindb., sundr., E. af H.). Vichtis, Haapkyla (Brotb.). - N. Snappertuna, Raseborg (Häyr.). Tenala, Skogby (H. Lindb.). Sjunded (Sundr.). Kyrkslätt (Kullh., sundv.). Eslo. Kilo (sol.); Dalsvik (Ranck.). Helsinge, Viks Ladugård (E. af H.). Västerkulla, Kalkholmen (Ranck.). sibbo, Löparö (Sundv.). - Ka. Sippola, Ruotila (Kuj.). Säkkijärvi, Jokikylä (Krohn). Wiborg (IV. Nyl.); Julstila (Bucli). Antrea (Porkka). - Ik. Sakkola, Mönkij (H. Lindb.). Loposenmäki und Röỵkỵä (Hid.). - St. Kankaanpää (Sundr.). - Ta. Hattula (Sundv.). Iitti, Perheniemi (Buch). Tampere (Sol.). _- Sa. Willmanstrand (Buch). Lappee, Ihalais (B.). - Kl. Jaakkima, Ramola (Sundy.). Sortavala, Kirjavalahti (Lâng); Paksuniemi (Kuj.). Pälkjärvi, Korkeaniemi (Broth.). - Tb. Jyväkylä (Broth.). Pihtipudas, Kanalanmäki (Roiv.). - Sb Kuopio, Julkula (Link.); Siikalahti (Roiv.). Maaninka, Tuovilanlahti, Arkkuruori (Roiv.). - Kb. Tohmajärvi, Akkala und Tattarimäki (liot.). - Ok. Paltamo, Melalahti, Ellinlampi (Kyyhk.).

S. In den meisten Provinzen von srealand und Götaland st. fq., in Norrand nur aus Gstr. und von einzelnen oder wenigen Fundorten in $H l s$, .Jmt. und $\mathrm{T}^{\prime} b$. bekannt. Nordgrenze bei $65^{\circ} 56^{\prime} \mathrm{n}$. Br.

N. In den Küstengegenden seltener als $T h$. delicatulum, sonst reichlicher vertreten und weiter nach Norden dringend. Steigt bis $700 \mathrm{~m}$ hinauf. Jordgrenze bei $69^{\circ} 18^{\circ} \mathrm{1}$. $\mathrm{Br}$.

Europa, Nord-Ameriki.

628. Thuidium tamariscifolium (Neck.) Lindb. in Öfrers. Finsk. Vet.-Soc. Förh. X. p. 8, t. 1, 1. 7 (1868). [Hypnum iamariscifolium Neck. Meth. muse. p. 158 p. p. (1771). - Mypnum tamariscinmm Hedw. Sp. musc. p. 261 p. p. (1801). 
- Thuidinn tamariscinum Bryol. eur. fase. 49/51 Mon. I). 7, no. 22 1. 2 et ;3 (1852).]

Stattiche Pfl. in Jockeren, ausgeclehnten, dunkelgrïnen, gelblichen bis gebräunten Rasen. Stengel 10-20 cm und mehr, dreifach geliedert; Äste bis $15 \mathrm{~mm}$. Stammblätter aus breit dreieckigem Grunde rasch zu einer ziemlich langen, schnal lanzettlichen, meist zurïckgekrümmten Spitze verschmälert, etwa 1,2 mm lang und $0,8 \mathrm{~mm}$ breit, mit bis weit hinauf ungebogenen Rändern; Rippe sehr krältig, vor der Blattspitze endend; Zellen dickwandig, oval- bis länglich-melnreckig, in, der Spitze verlängert und an Grunde in der Nähe der Rippe rektangulär. Astblätter eiförmig, zugespitzt, etwa $0,7 \mathrm{~mm}$ lang und $0,5 \mathrm{~mm}$ breit, mit schwächerer und kürzerer Rippe und einspitziger Endzelle: Zellen am Blattrücken mit je xiner langen, nach vorwärts gebogencn Papille auf der Wandmitte. Fiederblätter kleiner. Perichätialblätter aus hreit länglich-eiförmigem Grunde rasch in cine lange, schunal bandförnige, gesägte Pfrieme verschmälert, an den oberen Rändern des breiteren Teiles zerschlitzt und in lange, hier und da gezälnte und verästelte Wimpern aulgelöst: Rippe kräftig, in die Pfrieme eintretend. Seta $3-4 \mathrm{~cm}$, selten länger. Kapsel gross, horizontal, zylindrisch, gekrümmt, bis $5 \mathrm{~mm}$ lang und bis $1,4 \mathrm{~mm}$ click, braunrot. Deckel lang und schief geschnäbelt. Sporenreife im Winter und Frühling. - Fig. $81 \mathrm{~F}$ - G.

ln fenchten, humusreichen Wälderı, an Waldbächen und quelligen Stellen, an Grunde alter Stämme.

F. Al. Eckerö (Elfv.). Jomala, Kasberg (Arrh.). Finstıöm, Grelsby (Bou.). Salıvik, an mehreren Fundorten (B.). Sund,-Gesterby und Tranvik (B.). - Ab. Ibs (Arrh.). St. Karins, Ispois (Link.). Reso, Harvarö (Zett.). Pargas, Storgård (Elf ı.). Bromarf, Håkandarv (Sundv.). Lujo, Ojamo (Lindb.). N. Ekenäs, Källviken (Häyr.). Snappertuna (11.). - St. Ikaalinen, Nygård (Sundv.). — Ta. Asikkala, Kärsälä, Paskurinlahti (Norrl.).

S. In allen Provinzen Südschwedens bis Vänern, Hjälmaren und Mälaren, in den meisten nicht selten. Nördlicher nur von wenigen Fundorten in Upl. und Gisir. sowie von einzelnen in $T^{\top} s m$. . Dlr. und Hls, bekannt. Steigt bis $150 \mathrm{~m}$ hinauf. Nordgrenze bei etwa $61^{\circ} \mathrm{n}$. Br.

N. Ausschliesslich in niedrig gelegenen Küstengegenden, um den Kristianiafjord st. fq., in Westund Sorlandet, Hordaland ausgenommen, selten. Nordgrenze bei $63^{\circ} 28^{\prime} \mathrm{n}$. $\mathrm{Br}$.

Europa, Azoren, Iadeira, Nord-Amerika.

Un te rgat t. I l. Abietinella (C. Miill.) Broth. in Engl.-Prantl Bryal. p. 1017 (1908). A Abietinella C. Nü̈ll. in Nuov. Giorn. Bot. ital. I11. p. 115 (1896).]

Stengel aufsteigend oder aufrecht, einfach gefiedert. Stammblätter herzeiförmig, kurz lanzettlich zugespitzt; Rippe am Grunde nicht verbreitert; Zellen in der Mehrzahl länglich, sehr stark verdickt und getüpfelt, auf der Wandmitte mit je einer vorwärts gerichtete Papille. Deckel kegelig zugespitzt.

629. Thuidium abietinum (L.) Bryol. eur. fasc. 19/51 Mon. 1).9, t. 5 (185\%). [Hypnum abietinum L. Sp. pl. p. 1126 (1753).]

Lockerrasige, gelbgrüne bis gebräunte Pfl. Stengel 5-12 'm, regelmässig geliedert; Äste bis $12 \mathrm{~mm}$ lang, nach der Spitze hin oft verdünnt. Stammblätter trocken dachziegelig anliegend, herzeiförmig, kurz lanzettlich zugespitzt, scharf oder stumpflich, bis $1,3 \mathrm{~mm}$ lang und bis $0,85 \mathrm{~mm}$ breit, nit an Grunde \pm umgebogenen, oberwärts gezähnelten Rändern; Rippe kräftig. vor der Blattspitze endend; Zellen in der Mebrzahl länglich, an Grunde nächst der Rippe rektangulär. Astblätter viel kleiner, eilanzettlich, mit schwächerer und küizerer Rippe und in der Mehrzahl rundlichen Zellen, mit spitzer oder schmal gestutzter Endizelle. Innere Perichätialblätter längsfaltig, lanzettlich, pfriemenförmig zugespitzt, mit hakenförmig zurückgekrümmter, gezähnter Spitze. Seta $1.5-3 \mathrm{~cm}$, gelbrot. Kapsel geneigt, zylindrisch, gekrümmt, bis $3 \mathrm{~mm}$ lang und 0,5 mm dick, braun. Sporenreife im Frühling.

An trockenen Orten anf sandigem und kalkhaltigen Boden, an sounigen. 
busehigen Abhängen, auf Heideland, in lichten Wäldern, auf alten Däehern, Felsen. Blöeken und Mauern, besonders auf Kalk. Sporogone sehr selten.

F. Al. Eckerö, Jomala, Finström, Saltvik und Sund nicht selten (Bont.). - Ab.-Ik. \pm fq. St.Liol I fq. - Oa. Närpes, Finby (E. af H.). Isokryoö. Orisberg. fruchtend (Ranck.). - Tb. Pihtipudas, Heinolankvlä (Roiv.). - Sb. Joroinen (H. Lindb.). Kuopio -1. fq. - pas... (Link.). Kaavi, Huosiaisniemi (Ḳ̌yhk.). Nilsiă, Kuuslahti, Jaakonlampi (K.). Maaninka, Tuorilanlahti, an Felsen cop. (Roiv.). Kon. Suojärvi (Link.). Kivatsch (Simm.). - Om. Lappajärvi, Kirchdorf (Backın.); Kărnä (B.). Kalajoki (Tenn.). - Ok. Kajana, Kajaneborg cop. (Kyyll..). Sotkamo, Talvivaara cop. (K.). Puolanka (Lackstr.); Salminen, Vuorijärvi (Ǩyyhk.), - Ob. Uleảborg (Huum.). Ii (Brenn.). Kemi, Kallinkangas (Rä̌) Ylitornio. Turtola und Pello (Hılı) Rovaniemi, Alajääskö und Tarkiaineı (H.). - K. Kuusamo, Uronkallio (Nyb.). Paanajärri, Ruskeakallio (Broth.). - Lkem. Kolari, Kirchdorf, an mehresen Fundorten und Naalaoja, im Kalkbruche cop. (Hult). Kittilä, Rautujärvi, nördl. rom Yllöstunturi, an Felsen

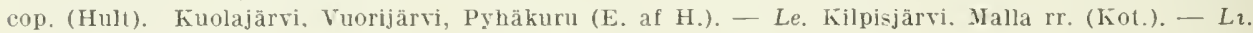
Inari, Jiundojāyr, in der Nadelwaldregion pass. (Hult). - Lim. Kandalaks (Broth.). Umba (Sel.). Lp. Ponoj (Broth.).

S. Sk.-TL., in den meisten Provinzen fq., in den Provinzen an der Westküste, wie es scheint, selten, ebenso in den Lappmarken. Steigt bis in die Birken- und Weidenregion hina'f. Nordgrenze bei $69^{\circ} \mathrm{n} . \mathrm{Br}$.

N. In allen Provinzen injt Ausnahme von Westlandet fq.-fqq., am reichlichsten in der Waldregion, jedoch auf gegen Süden exponierten Felsen bis $300 \mathrm{~m}$ oberkalb der Birkengrenze beobachtet.

Spitzbergen, Kaukasus, Kaschinir, Nord-, Zentral- und Ost-Asien. Nord-Amerika.
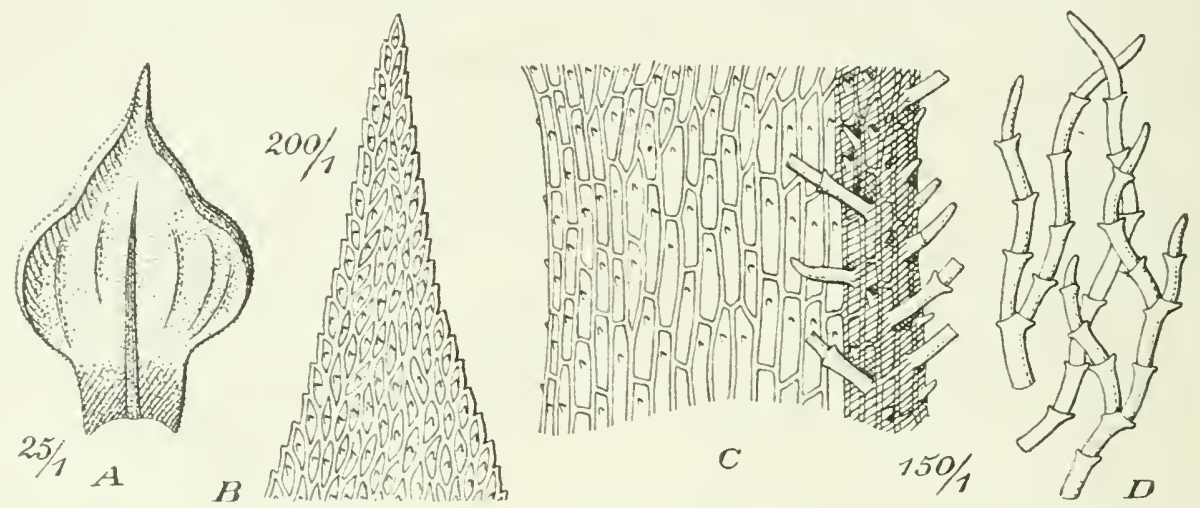

Fig. 82. Helodirm lanatum (Stroem). A Stengelb. (25/1); B Blattspitze (?00/1); C Blattbasi- (150/1); D Paraphyllien (I50/1).

\section{HELODIUM}

(Sull.) Warnst. Laubm. p. 692 (1905).

Mehr oder weniger kräftige, auch trocken weiche Sumpfmoose. Stengel aufrecht, wenig geteilt, dureh am Guncle mehrzellreilige, vielfach in lange, geschlängelte, einzellreihige Äste gespaltene Paraphyllien und durch Rhizoiden bis zum Gipfel fast zottig, filzig und regelmässig einfach gefiedert. Blätter gleichartig: Rippe weniger kräftig, weit vor der Blattspitze aufhörend: Zellen meist dünwandig. verlängert 6seitig bis fast linealisch, durehsichtig, am Grunde locker rektangulär. Astblätter kleiner: Endzelle einspitzig. Seta rot, glatt. Deckel gewölbt kegelförmig. spitz.

630. Helodium lanatum (Stroem) Broth. in Engl-Pranti Bryal. p. $101 \mathrm{~s}$ (1908). [Hypunm lanalum Stroem in Skrilt. Xaturhist.-Selsk. Bd. I. p. 36 (1796).

H. Blandowii Web. et Molnr Bot. Taschenls. 1807. p. 332. - Thuidimm Blandowii Bryol. eur. fase. 19/51, p. 10, t. 6 (1852). - Th. lanalum Hag. in D. K. N. Vid.Selsk. Skrift. 1897, No. 3, p. 119.l

Autözisch. Kräftige Pfl. in ausgedelnnten, tiefen, bleieh- ocler gelbgrünen bis gelbbrämulichen. trocken mattglänzenden Rascn. Stengel bis $15 \mathrm{~cm}$. dicht 
gefiedert; Äste bis $1,5 \mathrm{~cm}$, geschlängelt-abstehend, fast peitschenförnig zugespitzt, mit einer am Blattrücken scharf vortretenden. Haujtfalte. Stammblätter aus sehr verengtem. nicht herablaufendem Grunde plötzlich breit eilanzetlich. scharf zugespitzt, bis $1,3 \mathrm{~mm}$ lang und bis $0,90 \mathrm{~mm}$ breit mit bis weit herauf umgebogene», an der Spitze schwach gezähnten Rändern: Rippe dünn; \%ellen an Rücken mit je einer langen, dünnen, geraden oder schwach gekrümmten Papille anf der Wandmitte und in den oberen Ecken. Astblätter locker dachziegelig, etwa hall, so gross wie die Stammblätter. Innere Perichätialblätter längsfaltig, lanzetllich, lang und fein zugespitzt, in der flachen Spitze gezähnt: Rippe vor der Spitze endenrl. Seta 3-5 cm. Kapsel geneigt bis horizontal, zylindrisch, schwach gekrummt, bis $3 \mathrm{~mm}$ lang und $1 \mathrm{~mm}$ dick. braum. Sporenreife im Juni und Juli. - Fig. 82.

Auf sumpfigen und torfhaltigen Wiesen, in Mooren, an quelligen Orten, auf feuchtem Waldboden und an feuchten, morschen Stämmen.

F. Al. Finström (Arrh.). Saltvik, an mehreren Fundorten (Bom.). - Ab. Küstō. Åbo. Pargas. Kimito. Bronnarf. Karislojo, Lojo. Vichtis, - N. Ekenäs, Tvärminne. Ingå. Kyrkslätt. Esbo. Helsingfors. Nurmijärvi. Sibbo. Elimäki. Hogland. - Ka. Sippola. Vehkalahti. Săkhijärvi. Antrea. Ik. Mfuola. Valkjārri. Sakkola. Pỵhājărvi. - St. Eura. Eurajoki. Sastmola. - Ta. Yanaja. Kalrola. In südöstl. Teile st. ff. (Norrl.). Hartola. Korpilahti und Luhanka pass. (Vain.). - Sa Ruokolahli, Kanga:niemi, Nrslott. - Kl. Kurkijoki. Sortavala, Kirjavalahti, Ruıkeala, Pälkjärvi. - Kol. pass. (Elfr.), - Oa. Sideby. Lappfjärd. Närpes. Kaskö. Isokyrö. - Tb. Pihlajavesi. Äänekoski. Jyvāskylā. Viitasaari. Kinnula. Pihtipudas. - Sb. Kunpio, an wenigen Fundorter (Link.). Nuuruvesi. Kadvi, Luikonlahti (Kỏt.). Maaninka pass._st. fq., bei Pöljä an mehreren Fundorten cop.—cpp., zuweilen weite Flächen ohne Einmischung deckend (Kyyhk.). Pielavesi pass. -st. fq. (Roiv,), - Kob. Joensuu. - Kon. Suojärri. Suosaari. Selki. - Om. Soini. Vindala. - Ok. Paltamo-Suomussalmi st. fq.-pass. (Kyyk.). - Ob. Simo. Ii. Rovaniemi. Alalornio und Ylitornie fq. (Hult). - K. Kuusamo, Korojoki (Broth.). - Lkem. Kolari uud Kittilā fq. (Hult). Kuolajärvi, Sallajoki und Alapeteri (Linnan.). - Le. Im Waldgebiete bis Kilpisjärvi pass. (Norrl.), - Li. Inari, in der Nadelwaldregion st. fợ, in der Birkenregion pass. (Hult). - Lim. Fedosejersk und Kandalaks (Broth.), Porjaguloa (Sel.). - Lt. Kola (Broth.). - Lmur. Gavrilora (B.). Krugloje guba, zw. Litsa und Varsinsk (B.). - Lp. (Brenn.).

S. In Südschweden - selten und, wie e- scheint, nur in $U p l$. reichlicher vertreten, dagegen weder in den Provinzen der Westkïste noch in $\mathrm{Bl}$., Dld, und $\mathrm{V} g$. beobachtet. In Nordschweden pass. und aus fa-t allen Provinzen bekannt. Steigt bis in die Weidenregion hinauf. Nordgrenze bei $68^{\circ} 20^{\prime} 30^{\prime \prime} \mathrm{n}$. Br.

N. Iń allen Provinzen mit Ausnahme der Küstenprovinzen, kaum irgendwo jedoch fq. und ron der Ebene bis etwa $900 \mathrm{~m}$ hinaufsteigend. Nordgrenze bei $70^{\circ} 30^{\prime} \mathrm{n}$. Br.

Europa, Nord-A-ien, Nord-Amerika.

\section{PS E U D O LES K E A C E A E.}

Locker-oder dichtrasige Baum- oder Felsmoose. Stengel mit lockerem Grundgewebe und englumigen Iantelzellen, meist niedergestreckt und vielfach geteilt, mit glatten Rhizoiden. dicht und gleichmässig beblättert: Paraphyllien vorhanden. meist zahlreich. Blätter mehrreihig, gleichförmig, zugespitzt; Rippe einfach, vor der Blattspitze aufhörend bis austretend, homogen; Zellen meist parenchymatiscl. Neist diözisch; † Blüten stengelständig, mit farlenförmigen Paraphysen. Innere Perichätialblätter aufrecht, aus meist hochscheidigem Gruncle allmälnlich lang zugespitzt: Rippe zart. Seta verlängert. glatt. Spaltöffnungen rudimentär. Peristomzähne am Grunde verschmolzen und einer gelben, verdickten, leicht sich ablösenden Ringleiste aufsitzend. Deckel gewölbt kegelig. Haube kappenförmig. rechts gedreht, nackt. Sporen klein.

\section{ì bersicht der Gat $\mathrm{t}$ ug en.}

A. Kapsel aulrecht, regelmässig. Fortsätze des inneren Peristoms fadenförmig ...................................... 124. Lescuraea.

B. Kapsel meist geneigt bis horizontal. Fortsätze des inneren Peristoms lanzettlich.

a. Wimpern rudimentär oder fehlend

b. Wimpern gut entwickelt, knotig 


\section{LESCURAEA}

Bryol. eur. fasc. $46 / 49$ Mon. (1851).

Diözisch. Mehr oder weniger schlanke, weiche Pfl. in oft ausgedehnten, \pm glänzenden Rasen. Stengel durch aufrechte, kurze Äste unregelmässig fiederig, seltener büschelig verzweigt: Ẍste einfach, selten mit einzelnen Ästchen; Paraphỵllien sehr zahlreich, lanzettlich-pfriemen- odler fadenförmig. Blätter längsfaltig. aus lanzettlichem Grunde allmählich lang und fein zugespitzt; Zellen eng linealisch, meist mit papillenartig vortretenden Zellecken, in den Blattecken quadratisch und kurz rektangulär. Kapsel aulrecht, regelmässig. Ring nicht differenziert. Peristomzälne unten quer-, höher schräg- und vertikal-gestrichelt; ohne Lamellen. Grundhaut des inneren Peristons niedrig; Fortsätze fadenförmig, unregehmässig zweizellreihig, grösstenteils an der verlängerten Columella zurückbleibend; Wimpern fehlend. Deckel kegelig, kur\%, stumpf, gerade.

631. Lescuraea mutabilis (Brid.) Lindb. in Act. Soc. Sc. Fenn. X. p. 217 (1872). [Hypnum mutabile Brid. Musc. rec. Il. p. 170, t. 6, f. 1 (1801). - Pterogonium striatum Schwaegr. Suppl. 1. P. I. p. 103, t. 27 (1811). - Lescuraea striata Bryol. eur. fase. $46 / .17$ Mon. p. 2 (1851).]

var. saxicola (Bryol. eur.) Hag. in D. Kgl. Norsk. Vid. Selsk. Skrift. 1908, No. 9, 1). 53. [Lescuraea striata var. saxicola Bryol. eur. Mon. p. 3. t. 1, f. 12 et fs. (1851). - L. saxicola Mol. in Lor. Moosstud, p. 141 (1861): Mild. Bryol. siles. p. 288 (1869).]

Dicht- und flachrasige, gelbgrüne bis goldoräunliche, lebhaft glänzende Pfl. Aste oft bogig gekrümmt, meist am Endle hakenfömig. Stammblätter schmal herablaufend, meist einseitswendig, bis $1,3 \mathrm{~mm}$ lang und bis $0,5 \mathrm{~mm}$ breit, mit zwei Längsfalten und längs schmal umgelogener, glatten, zuweilen an cler Spitze entfernt und fein gezähnten Rändern; Rippe in der Blattspitze verschwindend. Astblätter wenig kleiner, meist einseitswendig, lanzettlich zugespitzt, an der Spitze deutlich gezähnt. Seta $5-7 \mathrm{~mm}$, rof. Kapsel oval bis länglich, rotbraun.

Auf kalkfreien und \pm kalkhaltigen Steinen und Felsentrümmern. Selten fruchitend.

F. Kb. Nurmes, Hiideuportti (Vain.). - Kon. Klimskij monastir (Simm.). Gorka (Norrl.). Povenet: (Kullh.). - Ok. Suomussalmi, Pystökoski (Lackstr.). - ob. Y'litornio, Kaarasnäs (Hull). - h. Kuusamo, Tavajärvi (Broth.); Paanajärvi, Mäntyvaara (B.). Selkäjoki und Niskakoski (B.). - Lkem. Kittilä, Kirchdorf (Hult). - Lt: An mehreren Fundorten in der Kiefen- und Birkenregion (Norrl.); Kilpi.järvi, Saana, in der alpinen Region (N., Kot.). - Li. Inari, Verkkojärvi und Seidvaara (Sil.); Kopsusjärvi und Luirojärvi (Hult). Kodoskorkia (Kihlm.); Palokoski (Hult). Utsjoki, Mandojäyr (H.). Lim. Kandalaks, Sehelesnaja (Brolh.). Tschunosero (B.). Hilinä (Sahlb.). - Lt. Kola (Karst.). Pummanki (Broth.). - Lmur. Rinda und Semjostrorsk (B.). - Lp. Jokonsk und Ponoj (B.).

S. Hrjd., Jmt., LuL. Sarekgebiet, st. fq. und st. cop., meist in der Birken- und Weidenregion. TL.

N. A., Br., Ne., SB., NB. und $K .-F$, am reichlichsten in der Birken- und Weidenregion, steigt. jedoch bis $1,300 \mathrm{~m}$ hinauf und kommt auch im Waldgebiete und sporadisch in der Os-Region ror.

Europa, durch die alpine und nivale Region des Alpengebietes, Kaukasus, sibjrien.

\section{PSEUDOLESKEA}

Bryol. eur. fasc. 49/51 (1852) cmend. Kindb.

biözisch. Kapsel $\neq$ geneigt und gekrümmt, selten aufrecht und regehmässig ocler hochrückig. Ring einreilıig, stüekweise sich ablöseme. Peristomzähne querstreifig, mit zahleichen, normalen limellen. Grundhaut des inneren Peristoms weit vortretend; Fortsätze lanzettlich-pfriemenförmig, gekielt. ritzenförmig durchbrochen: Wimpern rutlimentär oder lehlend. 
A. Blattzellen papillös.

Ubersicht der Arten.

a. Blattzellen beiderseits mit einer kegeligen, zentralen Papille 632. P. patens.

b. Blattzellen am Rücken dureh vortretende Zellecken papillös.

$\alpha$. Blätter fast flachrandig; Zellen oval bis rundlich. 633. P. filamentosa.

$\beta$. Blätter mit weit hinauf umgebogenen Rändern; Zellen \pm verlängert.

I. Blätter schwach einseitswendig: Zellen 1: 3-5. 635. P. decipiens.

If. Obere Blätter sichelförmig einseitswendig; Zcllen lockerer als bei der vorigen Art ................. 6.31. P. radicosa.

B. Blattzellen glatt.

a. Blätter aufrecht-abstehend, mit mehreren tiefen Längsfalten, alhmählich zugespitzt 638. P. plicuta.

b. Blätter fast sichelförmig einseitswendig, mit zwei Längsfalten, aus eiförmigem Grunde rasch zugespitzt.

«. Blätter mit breit umgebogenen Rändern; Zellen eng. 637. P. hyperboreu.

$\beta$. Blätter mit schmal umgebogenen Rändern: Zellen lockerer 636. P. Breidleri.

632. Pseudoleskea patens (Lindl].) Limpr. Laubm. I I. 1). 806 (1895). [Leskea(?) patens Lindb. in Soc. Faun. Fl. Fenn. 9. Okt. 1880. - Lesquerenxia patens Lindb. in Meddel. Soc. Faun. Fl. Fenn. 14. Helt p. 75 (1887).]

Pfl. in lockeren, dunkel- bis bräunlichgrünen, glanzlosen Rasen. Stengel durch kurze und stumpfliche, herabgebogene Äste und Ästchen unregelmässig gefiedert: Paraphyllien kurz pfriemenförmig oder lanzet!lich, einfach oder ästig. Blätter ziemfich locker gestellt, allseits abstehend, trocken locker anliegend, mit eingebogenen Spitzen, aus weit herablaufender, breit ovaler Basis schmal und scharf schief zugespitzt, bis $1,2 \mathrm{~mm}$ lang und $0,6 \mathrm{~mm}$ breit, zweifaltig und mit \pm weit hinauf schmal umgebogenen, oberwärts fein gesägten Rändern; Rippe vor der Blattspitze endend; Zellen klein, in der Mehrzahl rundlich-mehreckig. auf der Wandmitte beiderseits mit je einer spitzen Papille. am Blattgruncle quadratisch und nächst der Rippe einzelne kurz rektangulär. Seta $1-1,5 \mathrm{~cm}$, rot. Kapsel geneigt bis horizontal, oval-länglich, hochrückig, später sehwach gekrümmt, etwa $1,5 \mathrm{~mm}$ lang und $0,5 \mathrm{~mm}$ dick, rotbram. Sporenreife zeitig im Frülıling.

Auf Felsen und Steinen allerlei Art.

F. Ik. Uusikirkko, Vammelsuu, Ongimojoki (H. Lindb.).

S. $V g$. Alleberg. LuL. Sarekgebiet, in der Birkenregion.

N. Am reichlichsten im Waldgebiete der Küstengegenden, nicht nur in den äusseren Teilen, sonderı auch in den inneren, von diesen hie und da nach dem Binnenlande vordringend und dort meist oberhalb der Baungrenze auftretend. Nordgrenze bei etwa $70^{\circ} \mathrm{n}, \mathrm{Br}$.

Europa, Nord-Amerika.

633. Pseudoleskea filamentosa (Dicks.) Broth. in Lngl.-Prantl Bryal. p. 1001 (1908). [Hypnum filamentosum Dicks. Pl. crypt. fasc. I1. p. 11 excl. syn. (1790). Psendolestiea atrovirens Bryol. eur. fase. $49 / 51$ Mon. p. 2, t. 1 (1852). - Lesquereuxia filamentosa Lindb. Musc. scand. p. 36 (1879).]

Pfl. in lockeren bis dichten, oft ausgedelinten, licht-oder bräunlichgrünen. im Alter rostbraunen, glanzlosen Rasen. Stengel durcl ungleiclilange, stmmpfe. oft heral,gebogene Äste geliedert: Paraphyllien kurz pfriemenförmig oder lanzeltlich, einfach odler ästig. Blätter meist einseitswendig, aus breit eiförmiger Basis rasch kurz lanzettlich und schief gespitzt, bis $1,9 \mathrm{~mm}$ lang $u n(\mathrm{l}$ bis $0.75 \mathrm{~mm}$ breit, zweifaltig, mit \pm weit hinauf mmgebogenen, an der Spitze kleingezähnten Rändern: Rippe kräftig, oberwärts am Rücken gezähnelt: Zellen oval-1-6seitig, oberwärts 
länger, mit papillenartig vortretenden Zellecken, am Grunde in den Blattecken quadratisch. Seta bis $1,2 \mathrm{~cm}$, rot. Kapsel stark geneigt bis fast horizontal, ovallänglich, hochrückig bis zylindrisch und gekrümmt, rotbraun. Deckel gewölbt kegelig, stumpf. Sporenreife zeitig im Frühling. - Fig. 83.

Auf kalkfreien und \pm kalkhaltigen Gesteinen.

F. Al. Saltvik, an wenigen Fundorten (Bom.). - Ik. Kivennapa, Kirchdorf (H. Lindb.). $-T a$. Hollola. Hersala und Uskila (Norrl.). - Sa. Kangasniemi. Suntio (Lackstr.). - Kl. Kurkijoki, Haavikko (Jusl.). - Kol. Schtjeliki (Elfv.). - Oa. Kvarken (Simm.). - Tb. Kinnula, Kirchdorf, Koukoniemi (Roir.). Pihtipudas. Heinolan kylä, Kanalanmäki (R.). — Sb. Maaninka, Pöljä, Pulaste (Kyyhk.); Vianto (Roiv.). - Kb. Kontiolahti, Romppola (Linnan.). - Ok. Kajana (Lackstr.). Paltamo, Hyyrylänmảki (Lackstr.); Melalahti, an mehreren Fundorten (Lackstr., Kyyhk.). Ristijärvi (Lackstr.). Suomussalmi, Kiannanniemi (Kyyhk.). - Ob. Kiiminki (Broth.). - K. Kuusamo, Rukatunturi (Broth.); Paanajärvi, Ruskeakallio (Nyb.). - Le. NW. von Kilpisjärvi (Norrl.). Malla, Saana und Gumjarvanka
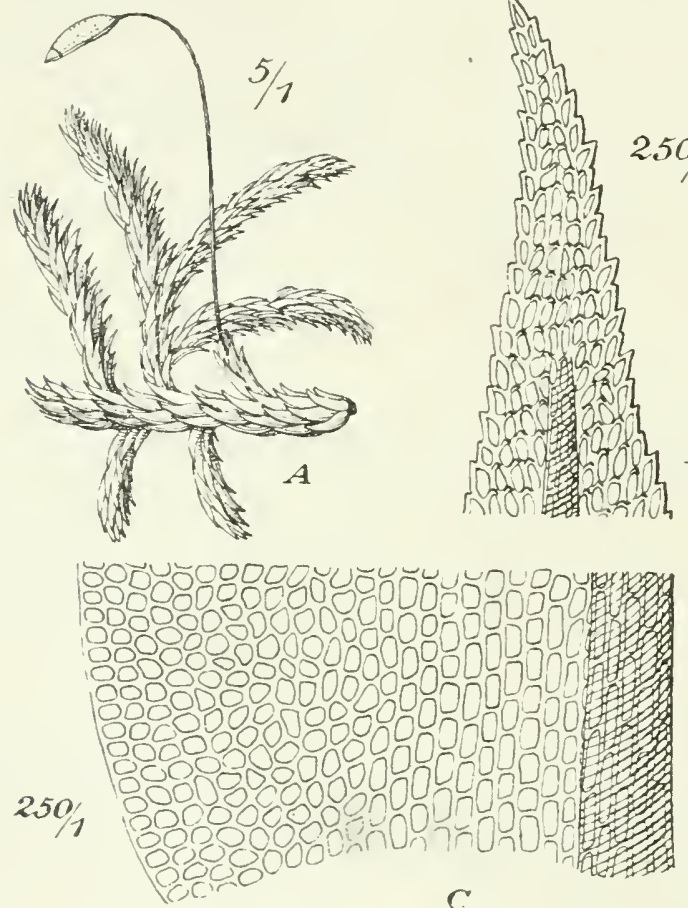
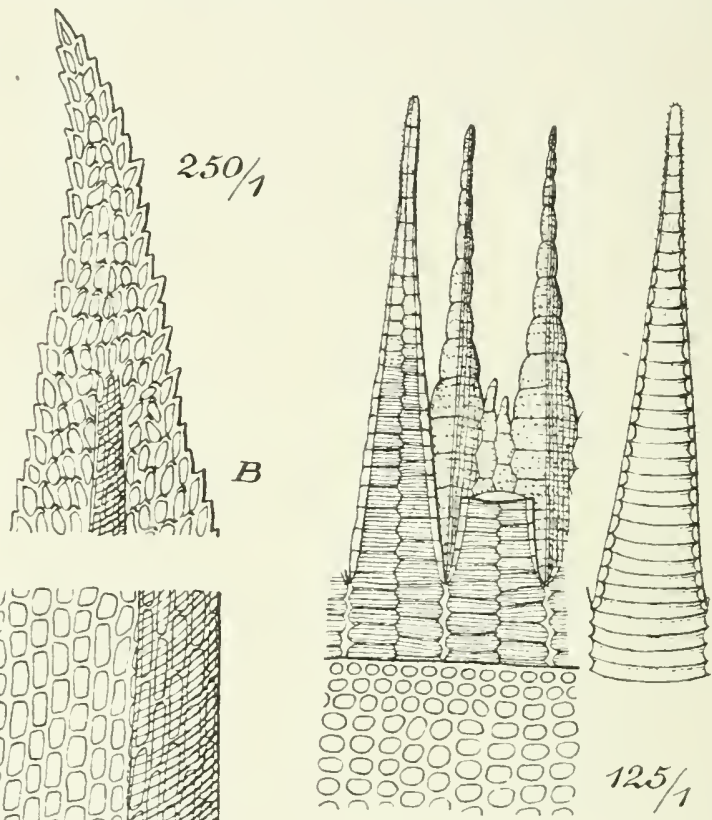

$D$

Fig. 83. Pseudoleskea filamentosa (Dick-). A Fruchtende Pfl. (5/1); B Blattspitze (250/1); C Blattbasis $(250 / 1)$; D Peristoin $(125 / 1)$.

in der alpinen Region (Kot.). - Li. Inari, Kopsusjärvi (Hult); Poakkuvarri (Kihlm.). - Lim. Kandalaks, Schelesnaja (Broth). Tschun (B.). - Lt. Srednij an Kolibusen (B.). Suborı, Vaidoguba und Pummanki (B.). Kildin (F Nyl.). - Lmur. Gavrilova, Rinda und Harlovka (Broth.) - Lp Orlov, Gubnoi (Kihlın.). Ponoj (Brenn.).

S. Sm., Upl., Jml. und Ang. LuL. Sarekgebiet, in der Birken- und Weidenregion.

N. In allen Antern mit Ansnahme von Sm., JL., Lm. und St., aul reichlichsien in der Birkenregion, steigt jedoch nicht selten über die Baumgrenze hinauf und kommt auch, wenngleich nur ausnahmsweise, in den oberen Teilen des Os-Gebietes vor.

Europa, Kaukasus, Kaschinir. NW.-Himalaya.

634. Pseudoleskea radicosa (Mitt.) Kinclb. et Mlac. Can. pl. VI. Musc. p. 181 (1892). [Hypnum radicosum IIt1. in Journ. Linn. Soc. VIll. p. 31 (1864). — Plychodium P/undineri Limpr. Laubur. II. p. 796 (189.5).]

Weniger kräftige Pfl. in dichten und meist flachen, hell- oder gelbgrünen, kaum glänzenden Rasen. Stengel kurz, mit dichtgestellten, kurzen, in Bogen auf- 
gerichteten, stumplen Ästen; Paraplyyllen kurz, farlen-bis pfrienenförmig und linealiselı. Stammbläter aufrecht-abstehend, troeken anliegend, meist etwas einseitswendig, aus wenig herablaufender, ovaler bis länglicher Basis allmählich in eine sehr lange und meist geschlängelte Pfrieme verschmälert, bis $1,5 \mathrm{~mm}$ lang und bis $0,5 \mathrm{~mm}$ breit, zweifaltig, mit schmal umgebogenen, glatten, selten in der Spitze undeutlich gezähnten Rändern; Rippe vor der Blattspitze endend, oberwärts verschmälert und am Rïcken gezähnelt; Zellen in der Mehrzahı rhombisch6seitig und rhomboidisch, oberwärts zuweilen mit papillenartig vortretenden \%ellecken, mehrere Querreihen des Blattgmudes lockerer, rechteckig, in den Blatiecken mehrere Reihen quadratisch. Astblätter schmäler, kïrzer zugespitzt, an der Spitze deutlich gezähnt. Seta $5-7 \mathrm{~cm}$, meist verbogen, rot. Kapsel aufrecht und regelmässig bis etwas geneigt und \pm hochrückig, oval, trocken und entdeckelt unter der erweiterten Mïndung stark eingeschnürt, rotbraun. Deckel aus gewölbter Basis kegelig, stumpf bis dick und schief geschnäbelt.

Auf kalkfreien und \pm kalkhaltigen Gesteinen.

S. LuL. Sarekgeliet, nicht selten und ziemlich reichlich bis hoch in die Weidenregion hinauf.

N. Verbreitung etwa wie lei der vorigen Art, nit welcher sie nicht selten an demselben Standorte und milunter in demselben Rasen eingemischt vorkomnt.

Alpengebiet, Nord-Amerika.

var. Holzingeri (Best.) Hag. in D. K. N. Vid. Selsk. Skrift. 1908, No. 9, p. 65 (1909). [Pseudoleshea denudata var. Holzingeri Best in Bull. Torr. Bot. Club XXVII. 1). $229(1900)$.]

Blätter breiter als bei cler Hauptart.

N. Im arktisehen Küstengebiete st. fq., seltener in der subalpinen und alpinen Region der südlicheren Teile.

Nord-Amerika.

var. jemtlandica (Kindlb.) Hag. I. e. [Pseudoleskea jemtlandica Kindb. Skand. Bladim.-fl. p. 27 (1903).]

Blätter schmal lanzettlich.

S. Jmt.

N. ST. Opdal.

635. Pseudoleskea decipiens (Limpr.) Kindb. in Nuov. giorn. bot. ital. 1896, p. 17. [Ptychodium decipiens Limpr. Laubm. IIl. p. 799 (1895).]

Schlanke Pfl. in dichten, fast kissenförmigen bis ausgedehnten, griinen, gelbgrünen oder goldbräunlichen, glänzenden Rasen; in cler Tracht der Lescurcea saxicola täuschend ähnlich. Stengel fast regelmässig gefiedert. mit kurzen. spitzen, zuweilen schwach gekrümmten Ästen; Paraphyllien sehr lang, meist linealischpfriemenförmig, oft kurzästig. Stammblätter aufrecht-abstehend, trocken anliegend und schwach einseitswendig, herablaufend, eiförmig, rasch schmal und schiel lanzettlich zugespitzt, pis $1,35 \mathrm{~mm}$ lang und bis $0.8 \mathrm{~mm}$ breit, liet zweilaltig, mit umgerollten, in der Spitze meist gezälnten Rändern: Rippe vor der Blattspitze endend, oberwärts am Rücken gezähnt: Zellen rhombisch-linealisch, oberwärts mit papillenartig vortretenden Zellecken, in den Blattecken kurz rektangulär und quadratisch. Seta 7-12 mm, rot. Kapsel fast aufrecht, kurz und dick oval, hochrückig, trocken und entdeckelt unter der Mündung nicht verengt, braunrot.

Anf Felsen und Steinen. Selten fruchtencl.

N. In zentralen Fjeldgebiele, besonders Jotunfjeldene und Dovrefjeldene, hauptsächlich in der alpinen Region, ferner an wenigen Fundorten in $T r$. und $F$.

Alpengebiele von Zentral-Europa.

636. Pseudoleskea Breidleri Kindh. Eur. and N.-Am. Bryin. p. 54 (1897). [Plychodium oligocladum Limpr. Laubm. III. p. S01 (1895). - Lescuraca Breidleri Arn. et C. Jens. Moos. Sarekgeb. p. 212 (1907).]

Kräftige Pfl. in flachen und lockeren, hell- und bleichgrünen, elwas glänzen- 
den Rasen. Stengel verlängert, fast astlos; Paraphyllien faden- und lanzettlichpiriemenförmig. Blätter fast sichelförmig-einseitswendig, aus herablaufender, eiförmiger Basis rasch lanzettlich, lang und zugespitzt, etwa 1,8 $\mathrm{mm}$ lang und bis $1 \mathrm{~mm}$ breit, heiderseits mit zwei Längsfalten und längs schmal umgerollten, glatten Rändern: Rippe vor der Blattspitze endend: Zellen kurz linealisch, glatt, am Blattgrunde nächst der Rippe rektangulär, in den Blatleeken quadratiseh. C Blüten und Sporogone unbekannt.

An grasigen Abhängen, auf erdbedeckten Sehielerblöcken und an Bachufern.

F. Le. Kilpisjärvi, Nialla (Kot.).

S. LuL. Sarek, an mehreren Fundorten in der Birken- und Weidenregion.

N. Ye., $S B$., NB.. ST.. No.-F.. an rereinzelten Fundorten in der alpinen Region.

Salzburg, British Columbia.

637. Pseudoleskea hyperborea (C. Miill.) Kindb. I. c. (Ptychodium hyperboreum C. Miill. in litt.)

Unterscheirlet sich von der vorigen Art durch stark sichelförmig einseitswendige Blätter mit breit umgebogenen Rändern und engen Zellen.

N. F. Kjelvik, Nordhap.

638. Pseudoleskea plicata (Schleich.) Kindb. 1. c. p. 51. [Hypmum plicatum Schleich. Cent. IV. No. 27 et Catal. 1815, Web. et Nohr Bot. Tasehenb. p. 36-1 adn. (1807). - Brachythecium plicatum Bryol. cur. fasc. 52/54 Mon. p. 21, 1. 21 (18.53). - Lesquereuxia plicata Lindb. Muse. scand. p. 36 (1879).]

Kräfige Pfl. in ausgedehnten, niedergedrückten bis schwellenden, gelb- bis dunkelgrünen, \pm glänzenden Rasen. Stengel durch dicke, fast kätzchenförmige, spitze, schwach gekrümmte Äste gefieclert: Paraphyllien sehr zahlreich uncl vielgestaltig. Stammblätter feucht allseits aufreeht-abstehend bis sehwach einseitswendig, trocken fast (lachziegelig, etwas herablaufend, eilanzettlich, lang zugespitzt, bis $3,5 \mathrm{~mm}$ lang und bis $1.5 \mathrm{~mm}$ breit, mit mehreren tiefen Längsfalten und breit umgerollten, glatten Rändern: Rippe oberwärts verdünnt, vor der Blattspitze endend; Zellen eng linealisch, glatt, am Blattgrunde stark verdickt und getüpfelt, in den Blattecken locker, quadratiseh und kurz rektangulär. Seta $1,5-2 \mathrm{~cm}$, rot. Kapsel geneigt his horizontal, länglich, schwach hochrückig, schwach gekrümmt. bis $3 \mathrm{~mm}$ lang und his $1.2 \mathrm{~mm}$ dick. braunrot. - Sporenreife im Frühling.

Auf Kalk und kalkhaltigen Gesteinen.

F. Lkem. Kolari, Huukki (Norrl.).

S. Jmt. und $L$.

N. $S B ., V B$. und $S T$, r einzelnen Fundorten, Vo.--F. nicht selten.

Europa, Kaıkasus.

\section{HAPLOCLADIUM}

(C. Müll.) C. Müll. in Nıov. Giorn. Bot. ital. 111 . p. 116 (1896).

Autözisch. Schlanke Pfl. in meist ausgedehnten und flachen, glanzlosen Rasen. Stengel mit armzelligem Zentralstrange. kriechend, gefiedert. Blätter aufrechtabstehend, wenig hohl. undeutlich oder kaum faltig, aus I breit eiförmiger Basis lanzettlich oder lanzettlich-pfriemenförmig zugespitzt, mit \pm deutlich umgebogenen Rändern; Rippe kräftig, bis in die Spitze verlängert, zuweilen austretend: Zellen oval bis länglich-6seitig, meist papillös, in den Blattecken quadratisch. Innere Perichätialblätter aufrecht, bleich, längsfaltig, lang und schmal zugespitzt. Kapsel geneigt, länglich-zylindrisch, trocken \pm bogig gekrümmt, ent deckelt .und entleert unter der Iüundung verengt.

639. Haplocladium microphyllum (Sw.) Brotlı. in E.-P. I. Bryales p. 1007 (1907). [Hypnum microphyllum Sw. Prodr. p. 112 (1788). - H. gracile Bruch et Sehimp. nom. nudl. in Lond. Journ. Bot. 1I. p. 668 (1813). - Thuidinm gracile Bryol. eur. fasc. 19/51 Mon. p. 5 (1852).] 
Rasen bleich gelbbräunlich. Stengel mit zahlreichen, fadenförmigen uns? gabelästigen Paraphysen, dieht gefiedert: Äste aufsteigent, teils etwa $2 \mathrm{~mm}$ lang, einfach, stumpf, teils bis $4 \mathrm{~mm}$. spitz. und durch Istchen gefiedert. Stengelblätter dreieckig-herzförmig, plötzlich schmal lanzettlich-pfriemenförmig, mit undentlich buchtig-gezähnelten, gegen die Basis zuweilen etwas ungerollten und in den Blattecken oft gewimperten Rändern: Rippe in der Spitze endend; \%ellen mit einer meist stumpflichen Papille über dem Lumen. Astblätter cilörmig, zugespitzt, scharf gesägt; Rippe dünner, vor der Blattspitze aufhörend: Zellen mit längeren Papillen. Seta 1,5-2 cm, rot. Kapsel diunnhäutig. bleichgelb.

An morschen und lebenden Stämmen, auf Fetsen und Frrlboden.

S. Stockholm, skarpneck, an erdıedeckten Baunwurzeln.

Nord-Russland, Sibirien, Nord-Amerika.

\section{A M B L Y S T E G I A C E A E.}

Locker- oder dichtrasige, teils kleinere Baum-. Ercl-oder Felsmoose, teils krätigere Sumpf- und Wassermonse. Stammquerschnitt rund oder rundlich mehreckig, ohne oder mit armzelligem Zentralstrange, lockerem Grundgewebe und verdickten, mehrsehichtigen llantelzellen. Stengel unregelmässig beästet bis 士 deutlich fiederästig, selten büschelartig verzweigt, ohne Stolonen: ̈̈ste rund beblättert. Blätter quẹr inseriert, symmetrisch; Rippe einfach, \pm verlängert, selten. doppelt. kurz oder fehlend: Zellen meist prosenchymatisch. glatt, sehr selten papillös oder papillös vortretend, in den Blattflügeln meist deutlich differenziert. Astblätter wenig versehieden, meist nur kỉiner, mit schwächerer Rippe. Blüte stengelständig, zuweilen auch astständig. Perichätialblätter differenziert, meist längsfaltig. Seta verlängert, aufrecht, glatt. Kapsel meist geneigt bis fast horizontal, länglieh bis zylintriseh; Spaltöffnungen oberflächlich im Halsteile. Peristom doppelt, beide von gleicher Länge. Peristomzähne lanzettlich-pfriemenförnig. anı Grunde meist versehmolzen, gegen die Spitze oft treppenartig gezähnt, meist querstreifig und mit gut entwiekielten Lamellen. Grundhaut des inneren Peristoms kielfaltig, weit vortretend: Fortsätze gekielt; Wimpern meist vollständig. Deckel aus gewölbter Basis kurz kegelig. mit Spitzchen oder Warze. Haube kappenförmig. glatt. Sporen klein.

Übersieht der Gattungen.

A. Rippe (excl. Cratoneurum subsulcatum) kräftig, fast vollständig bis austretend.

a. Paraphyllien zahlreich, polymorplı. Blätter tief längs-

faltig, meist einseitig-sichelförmig .................... 132. Cratoneurum.

b. Paraphyllien spärlich oder fehlend. Blätter ungefaltet. aufrecht-abstehend bis schwach einseitswendig ....... 131. Hygroamblyste-

B. Paraphytlien fehlend.

gium.

a. Blätter breit ei- oder herzförmig, in eine lange, sparrig abstehende bis zurückgebogene Pfriemenspitze verschmälert; Rippe bald einfach, dünn, etwa in der Blattmitte enclend. bald doppelt und sehr kurz oder fehlend; Zellen eng linealisch.

«. Autözisch

130. I. Campylophyllum.

ア. Diöziseh, selten polyözisch 130. II. Campyliadelphus. 
b. Autözisch. Blätter \pm weit bis sparrig-abstehend, herzei- oder eilanzettlich, $\rfloor$ lang zugespitzt; Rippe dünn, einfach, in oder über der Blattmitte verschwindend, selten länger; Zellen bald parenchymatisch-4seitig, bald prosenchymatisch-6seitig, selten linealisch

128. Amblystegium.

c. Autözisch. Blätter aufrecht-abstehend oder einseitig nach oben gerichtet, oval- oder länglich-lanzettlich, \pm lang zugespitzt; Rippe bald fehlend, bald kurz, dünn und doppelt oder einfach und etwas länger, zuweilen gegabelt; Zellen \pm eng prosenchymatisch

129. Homomallium.

d. Sehr schlanke Pfl. Blätter aufrecht-abstehend, lanzettlich bis lanzettlich-pfriemenförmig; Rippe fehlend oder sehr kurz und schwach; Zellen rhomboidisch oder länglich-6seitig

127. Amblystegiella.

e. Blattzellen verlängert linealisch, meist sehr eng.

$\alpha$. Blätter aufrecht-abstehend oder dachziegelig-anljegend, eilänglich bis eirund, abgerundet oder mit winzigem Spitzchen; Blattflïgelzellen locker und zahlreich.

I. Rippe einfach und fast vollständig

II. Rippe doppelt, kurz oder fehlend

135. Calliergon. 136. Acrocladium.

$\beta$. Blätter allseits abstehend oder einseitswendig bis dachziegelig, bald oval-lanzettlich und zugespitzt, bald breit eilörmig und stumpf bis abgerundet, zuweilen fast kreisrund; Rippe meist unglejeh zweischenkelig, kurz und schwach, selten ungeteilt und fast vollständig: Blattflügelzellen klein und spärlich. 137. Hygrohypnum.

$\gamma$. Blätter meist \pm einseitig-sichelförmig, ei- his fast dreieckig- oder herzförnig-lanzettlich, \pm lang zugespitzt; Rippe einfach, \pm verlängert

133. Drepanocladus ex p.

$\delta$. Blätter sehr hohl, die oberen oder alle \pm deutlich einseitswendig, eilänglich, kurz und stumpflich zugespitzt; Rippe doppelt, sehr schwach bis fehlend; Blattflügelzelle:; kleii und dickwandig, eine lileine Gruppe bildend

134. Scorpidium.

\section{AMBLYSTEGIELLA}

Loesk. Moosfl. d. Harz. p. 294 (1903).

Sehr zarte, flachrasige, glanzlose Pfl. Stengel ohne Zentralstrang, meist kriechend, unregelmässig beästet. Blätter \pm locker gestelit, feucht aufrecht-abstehend, zuwejlen schwach einseitswendig, wenig hohl, aus kaum oder kurz herablaufendem Grunde lanzettlich bis lanzettlich-pfriemenförmig, flach- und ganzrandig; Rippe fehlend oder sehr kur\% und schwach: Zellen rhomboidisch oder länglich6seitig, an der Basis etwas Iockerer, in den Blattecken quadratisch. Kapsel meist aufrecht und regelmässig oder schwach hochrückig, seltener geneigt und \pm gekrümmt.

$$
\text { (广) bersicht der Arten. }
$$

A. Diözisch. Innere Perichätialblätter rings dornig gezähnt. Kapsel aufrecht oder wenig geneigt, regelmässig .......641. A. Sprucei. 
B. Autözisch. Innere Perichätialblätter ganzrandig.

a. Kapsel fast aufrecht, regelmässig oder schwach hochrückig Blätter trocken anliegend

b. Kapsel geneigt bis horizontal, $t$ unregelmässig. Blätter trocken anliegend

c. Sporogone unbekannt. Blätter trocken sehach einseitswendig

6.10. A. subtilis.

6.12. A. confervoides. 642. bis A. alpicola.

640. Amblystegiella subtilis (Hedw.) Loesk. 1. c. p. 295. [Leskea sublilis Hedw. Deser. IV. p. 23, t. 9 (1793). - Amblyslegium sublile Bryol. eur. lasc. 55/56 Mon. p. t, t. 1 (1853).]

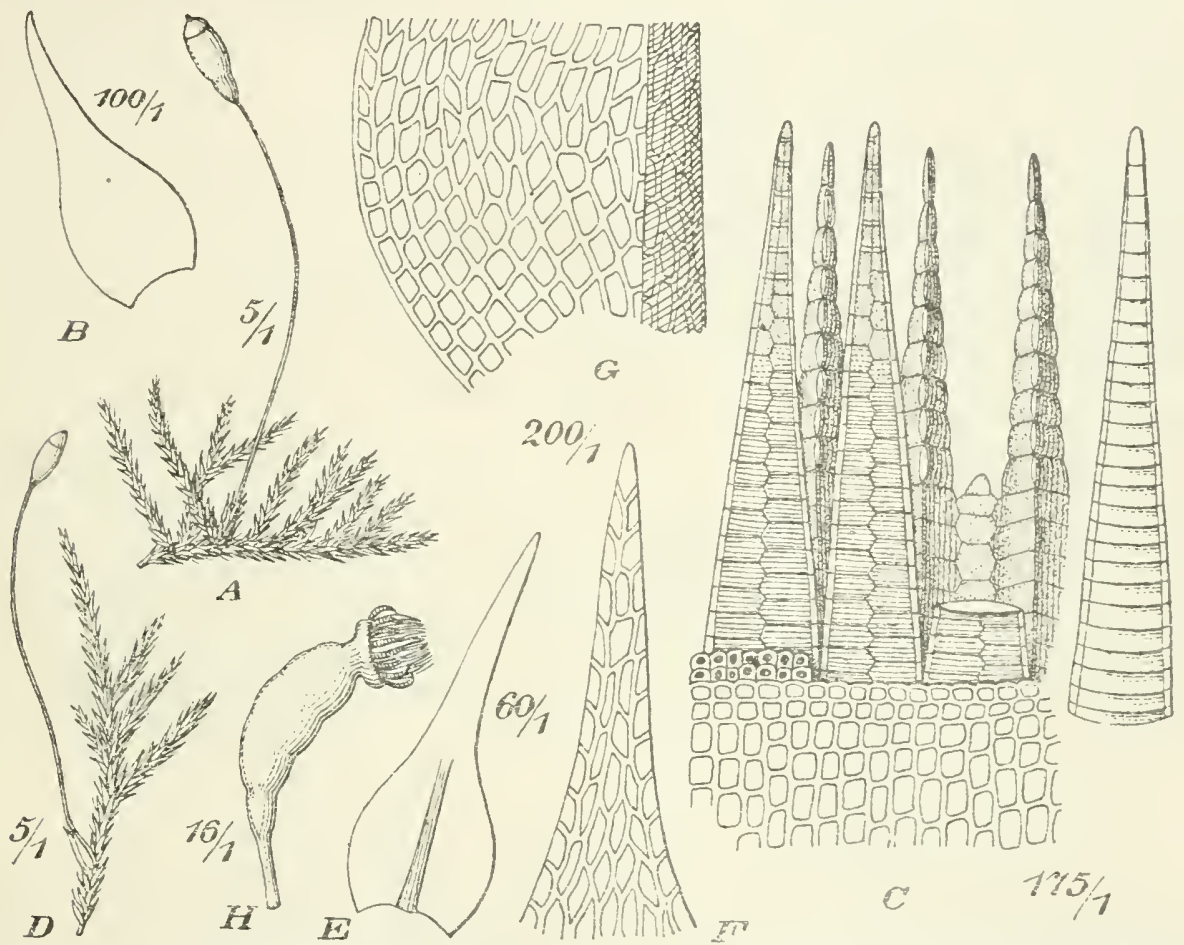

Fig. 84. A-C. Amblystegiella subtil is (Hedw.). A Fruchtende Pfl. (5/1): B stammb. (100/1); C. Peristom (175/1). - D-F. Amblystegium serpens (L.). D Teil einer Sprosse (5/1); E Stammb. (60/1); F Blattspitze $(200 / 1)$; G Blattbasis $(200 / \mathrm{I})$.

Autözisch. Pfl. in dichten, grünen bis gelbgrünen Rasen. Stengel durch Rhizoiden der Unterlage fest anhaftend, reichlich beästet, dicht beblättert. Biätter trocken anliegend, aus nicht herablaufender, schmal lanzettlicher Basis allmählich pfriemenförmig, bis $0.6 \mathrm{~mm}$ lang und $0,15 \mathrm{~mm}$ breit; Rippe fehlend oder sehr kurz und sehwach; Zellen 1: 3-5, in den Blattecken quadratisch und sich an den Rändern hinaufziehend. Innere Perichätialblätter meist raseh pfriemenförmig versehmälert, ganzrandig oder oberwärts gezähnelt: Rippe in oder iiber der Blattmitte endend. Seta $5-10 \mathrm{~mm}$, gelbrot. Kapsel fast aufrecht, regelmässig oder schwach hochrückig, zylindrisch-eiförmig, grïnlich. später gebräunt. Wimpern rudimentär oder fehlend. - Sporenreile im August und September. - Fig. $84 \mathrm{~A}$-C.

Am Grunde von Stämmen und an WTurzeln der Laubhölzer, selten an Steinen.

F. Al. Jomala, Finström, Lemland, Saltrik und Sund, an einzelnen Fundorten (Bon.). - Ab. St. Karins, Ispois (Elfv.). Pargas, Piukala (E.). Sagu, Träskby (Buch). Halikko (Nikl.). Lojo, Kivi- 
niemi (Lindb.); Maila (Jusl.); Torlola und Jalassaari (H. Lindb.). Vichtis, Irjala (H. Lindb.). $=$ N. Helsingtors, Brändö (Häyr.). Burgá. Sundö (Sael.). - Ik. Valkjärvi, Pähkinämäki (H. Lindb.). 一 Ta. Hollola, Papin-aari (Norrl.). Lorpilahti, Päiväkunta (Häyr.). Luhanka, Hauhanmäki (Vain.). - Sa. Ruokolahti, Imatra (Broth.). - Kl. Kurkijoki, Otsanlahti, Savioja (Jusl.). Sortavala, Liikolanmäli (Lindb.); Kirjavalahti (Simm.). Soanlahti (Lång). - Sb. Kuopio. aı wenigen Fundorten (Link.). Kaavi, Siikajärvi, Likosaari (Kot.). Maaninka, Tuovilanlahti (Roiv.); Haatala, Tuoınipuro (R.). -- Kb. Juuka, Juuanvaara (Kot.). - Om. Pyhäjärvi (K.).

S. Sk., Öl., Sm., Ög., Vg., Srm., Vär., Upl., Vsm., Vrml.. Gstr. und Hlsl.

N. Sm., A., JL., Br., Bu. und Nie.

Europa. Kaukasus, Kaschmir, Nord-Amerika.

641. Amblystegiella Sprucei (Bruch) Locsk. 1. c. [Leskea Sprucei Bruch in litt. ad Spruc. - Amblystegium Sprucei Bryol. eur. lasc. 55/56 Mon. p. 5, t. 1 (1853).]

Diözisch. Noch zarter als A. subtilis. Pfl. in bleichgrünen. oft ansgedehnten, spinnenwebartig lockeren Überzügen, flachen Rasen oder bis $3 \mathrm{~cm}$ tiefen Polstern.

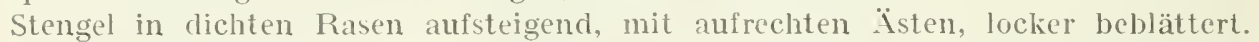
Blätter trocken anliegend, aus nicht herablaufender Basis schmal länglich-lanzettlich, lang zugespitzt, bis $0,33 \mathrm{~mm}$ lang und $0,075 \mathrm{~mm}$ breit; Rippe fehlend; Zellen arm an Chlorophyll, etwa 1: 1 oder 1: $6-8$, in den Blattecken wenige quadratisch. Astblätter unmerklich geschweift-gezähnt. Innere Perichätialblätter pfriemenförmig verschmälert, rings dornig gezähnt; Rippe fehlend. Seta etwa 5 mm, rot. Kapsel aufrecht oder wenig geneigt, regelmässig, verkehri-eilänglich, zuletzt rötlich, entleert fast kreiselförmig. Wimpern fehlend.

Auf beschatteten Kalk- und Schieferfelsen, gern in Spalten und Höhlungen. Selten fruchtend.

F. Al. Sckerö, Storby (H. Lindb.). Saltvik, an mehreren Fundorten (Bom.). Sund, Rosenberg (B.). Brändö, Harholmen und Hullberga (B.). - Ab. St. Karins, Ispois (Buch). Pargas, Storgård (Elfv.). Sagu, Träskby (Buch). Lojo, Kirchdorf (Lindb.); Storö (Hult). - Ǩl. Sortavàla, Kirjavalahti (Norrl.). Ruskeala (Lindb.). - Sb. Kuopio, Pitkälahti (Link.). Kaavi, Niinivaara, Louhilammen kallio (Kot.). Juuka, Petrovaara, Saarijärvi, Sotisaari (K.); Halivaaı (K.). - Kb. Polvijärvi, Kirchdorf (Kot.). Juuka, Nunnarlahti (K.). 一 Kon. Niinisaari (Simm.). Jänkäjärvi (Norrl.). Valkeamäki , N.). Pirttiniemi (Simm.). - Ok Puolanka, Rällinmäki (Kyslik.). Suomussalmi, Kiannankylä. Hoikanlampi (K.). - K. Kuusamo, Oulankajoki, Merenoja (Broth.); Tulilammenpuro und hiutakoßgàs (E. at H.). Sovajoki, Kul makkopuro (E. aî H ); Paanajärvi (B ). - Lkem. Nuonio, Saivio, nördl. vorn Yllästunturi (Hult). - L Lm. Kandalaks, Schelesnaja (Broth) - Lp. Orlov, Gubnoi (Kihlm.). Triostrova (Broth.). - Lv. Tschapoma (B.).

S. Sm.. Gtl., Ig., Dlr., Hrjd., Jml., LyL. und LuL. Sarekgebiet.

N. Sin., A. Ringerike. R., ST, No.-F.

Europa. Kaukasus, Sibirien, Tschuktschen-Halbinsel, Nord-Amerika.

612. Amblystegiellâ confervoides (Bricl.) Loesk. 1. c. [Hypnum confervoides Brid. Sp. musc. II. p. [.53 (1812). - Amblystegium confervoides Bryol. cur. fasc. 55/56 Mon. p. 6, t. 2 (1853). - Stereodon confervoides Lindb. Muse. scand. p. 38 (1879).]

Autözisch. Grösse vou A. Sprucei. Pfl. in spinnenwebartig lockeren Überzügen oder flachen, oft ausgedehnten. dunkelgrünen, im Alter bräunlichen bis schwärzlichen Rasen. Stengel durch Rhizoiden der Unterlage fest anheftend, locker beblättert, mit fast ficlerig verzweigten ïstchen. Blätter trocken anliegend, aus kurz herablaufender Basis eilanzettlich, pfriemenförmig zugespitzt, bis $0,45 \mathrm{~mm}$ lang und bis 0,12 $\mathrm{mm}$ breit; Rippe fehlend; Zellen etwa 1: 3, in den Blattecken wenige quadratisch. Innere Perichätialblätter allmählich pfriemenförmig zugespitzt, zuweilen an der Spitze unmerklich gezähnt; Rippe fehlend. Seta $5-8 \mathrm{~mm}$, rot. Kapsel geneigt bis horizontall, länglich-ciförmig, hochrückig, trocken und entleert eingekrümmt und unter der llündung verengt, bräunlich. Wimpern gut entwickelt.

An beschatteten Felsen und Steinen, besonders auf Kalk und Schiefer.

F. Kl. Sortavala, zw. Lakkalampi und Hali (Buch).

S. Vg., Jmt. und LyL.

N. Sm., A., Bu. Ringerike. Gudbrindsdalen. Ne. Saetersdalen, St., R., ST., NT. $-T r$. Nordgrenze bei $69^{\circ} \mathrm{n}$. Br.

Europa, Kaukasus, Nord-Amerika. 
642 bis. Amblystegiella alpicola (Lindb.). [Stereodon enervis Lindb. Musc. scand. p. 38 (1879). S. alpicola Lindl, in Medd. Soc. F. Fi. Fenn 1. . p. 151. (1883) nom. nud.: Arı. in K. Vet.-Ak. Handl. Bel. 2:3, No. 10, p. 15.3 (1890).]

Autözisch. Dichtrasige, freudiggrüne l’fl. Stengel niederliegend mit spärlichen Rhizoiden; Aste aufrecht, kurz, leicht abfallend, dicht beblättert. Blätter \pm deutlich einseitswendig, sehr hohl, eilanzettlich, lang und selur foin zugespitzt, bis $0,4 \mathrm{~mm}$ lang und bis $0,20 \mathrm{~mm}$ brent, abwärts entlernt und schwach gezähnelt; Rippe fehiend; Zellen etwa 1: 5, in den Blattecken wenige quadratiseh. Sporogone unbekannt.

In Felsritzen.

F. Le. Karesuanto und Leutsuvaara (Norrl.). - Lim. Kandalaks, schelesnaja (Broth.). Sibirien.

\section{AMBLYSTEGIUM}

Bryol. eur. fasc. 5i/56 (1853).

Autözisch. Kileine oder \pm krältige Pfl. in meist ausgedehnten und flachen, glanzlosen oder schwach glänzenden Rasen. Steıgel meist mit Zentralstrang, bald kriechend, bald aufsteigend bis aufrecht, unregehnässig beästet bis gefiedert. Blätter aufrecht-abstehend bis sparrig, wenig hohl, ungefaltet, meist liurz herablaufend, herzei- oder eilanzettlich. \pm lang zugespitzt; Rippe einfach, in oder über der Blattmitte anfhörend his gegen die Blattspitze fortgesetzt. Kapsel aus aufrechtem Halse geneigt, länglich bis zylindrisch, I gekrümmt, dünnhäutig, trocken und entleert minter der Mündung verengt, glatt.

A. Kleine PfI.

$$
\text { Übersicht der Arten. }
$$

a. Stengelblätter zweigestaltig: Rippe dünn, in der Blattmitte aufhörend; Zellen in der Blattmitte etwa 13 "

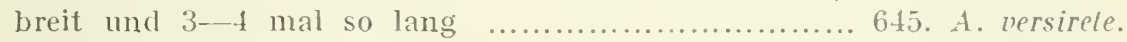

b. Stengelblätter gleichartig.

a. Rippe dünn, höchstens bis zum Grunde der Pfrieme reichend; Zelten in der Blattmitte $8-9 \mu$ breit und 2 - 4 mal so lang.

I. Stengelblätter meist aufrecht-abstehend, eilanzettlich. allmählich I lang zugespitzt.

1. Rippe $2-3 \mu$ breit .

643. A. serpens.

2. Rippe 5-6 " breit

643 bis. A saxicola.

11. Stengelblätler meist sparrig-abstehend, aus eiförmigem Grunde rasch sehr lang und fein zugespitzt

644. A. atronirens.

§. Stengelblätter weit abstehend: Rippe kräftiger, weit in die Pfrieme eintretend bis mit der Blattspitze endend, oben oft gekniet

647. A. varium.

$\gamma$. Stengel kriechend. Stammblatter weit abstehend, aus breit eitörmigem oder dreieckigem Grunde rasch pfriemenförmig; Rippe dünn, in oder über der Blattmitte endend; Zellen in der Blattmitte 9--10 i" breit

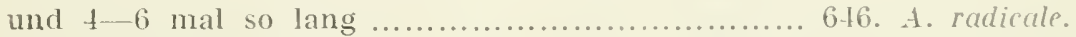

B. Mehr oder weniger krüftige Pfl. Stengel mit spärlichen Rhizoiden.

a. Stengebblätter bis etwa $1.5 \mathrm{~mm}$ lang: Zellen $8-10 \mu$ breit und +-6 , oberwärts bis 8 mal so lang 648. A.Irichopodium. 
b. Stengelblätter meist $3-3,5$ mm lang: Zellen $8-9 "$ "

breit und $8-12$ mal so lang 6.19. A. riparium.

Untergatt. I. Euamblystegium Broth. in E.-P. I. ${ }^{3}$ p. 1023 (1908). Stengel kriechend. Stengelblätter meist aufrecht-abstehend; Zellen meist derbwandig, teils parenchymatisch-4seitig, teils (besonders im oberen Blatteile) prosenchymatisch-6seitig, die mittleren $2-6$, selten $\$$ mal so lang wie breit.

643. Amblystegium serpens (L.) Bryol. eur. fase. 55/56 Mon. p. 9, t. 3 (1853). [Hypnum serpens L. Sp. pl. p. 1130 (1753).]

Pfl. in lockeren bis dichten, flachen, grünen bis gelbgrünen Rasen. Stengel locker beblättert. meist dicht beästet: Iste dïn, aufrecht, bis 7 und $10 \mathrm{~mm}$. Stammblätter aufrecht- bis völlig abstehend. eilanzettlich. allmählich \pm lang zugespitzt, flach- und ganzrandig oder undeutlich gezähnelt: Rippe dünm, höchstens bis zum Grunde der Pfrieme reichend: Zellen derbwandig, ]änglich-6seitig, etwa 9 a breit und $2-1$, in der Blattspitze bis 6 mal so lang, am Blattgrunde kurz rechteckig, in den Blattecken quadratisch. Astblätter gedrängt, schmäler: Rippe kürzer, selhr zart. Sporenreife im Mlai und Juni, im Herbst zum 2. Male. - Fig. 85 D-F.

Am Grunde der Stämme, auf Baumwrzeln und altem Holzwerk, auf Steinen, Felsen. Mauern und Torldächern. seltener auf Erde. - Fig. 84 D-F.

F. Al. fiq. (Bom) - $A b-I k$. - fq. - st. st. fq. (Simm.). - Ta. Kol. st. fq. $-T b . \pm \mathfrak{f q}$. (Broth.). - sb. Kuopio, an mehreren Fundorten (Link.). Kaavi, Siikajärti, Kypäräišaari (Kyyhk.); Likosaari (Kot.). Nilsia, Jaakunlampi. Kuuslahti (k.). Mlaaninka, an rielen Fundorten (Kyyhk., Rois.). - Kb. Lieksa (Tain.). Nurmes (V.). - Kon. Valkeamäki (Simm.). Tiudie (F. Ny̧l.). Kivatsch (Sel.). Solominskaja pustinja (Ǩlllh.), 一 Om. Nivala (Tenn.), 一 Ok. Kajana (Lackstr.). 一 Ob. Uleåborg (Huum.). Ii (Brenn.). Kèmi, Pörhölä (Brenn.). Alkhula (Norrl.). - K. Kuusamo, Välijärvi (Sil.). — Lkem. Ākåsjoki, nördl. ron Äkä-lompolo (Hult). - Le. Kilpiskoski (Norrl.). - Lim. Fedosejevsk und Kandalaks (Broth.). Sascheika (Karst.). - Lt. Kola (Broth.). Subori (B.). - Lmur. Semjostrovsk (B.). - I.p. Svjätoinos (B.). Dolgaja guba (B.). Ponoj (Brenn.) - Lr. Tichapoma (Sahlı.).

S. $S k$. - L .

N. Sm.-F. Nordgrenze bei $7 n^{2}: 9 \theta^{\prime} \mathrm{n}, \mathrm{Br}$.

Europa, Algier, Tunis, Kaukasus, Wesi-Himalaya, Ost-China, Nord-Amerika.

643 bis. Amblystegium saxicola Hans. in Bot. Tidskr. Bd. 25, p. 398 (1903).]

Pfl. in flachen etwas starren, dunkel- bis braungrünen Rasen. Stengel dicht fiederästig. Blätter aufrecht-abstehend. Stengelblätter aus breit eiförmigem Grunde lanzettlich, fein zugespitzt, bis $1,1 \mathrm{~mm}$ lang und bis $0,55 \mathrm{~mm}$ breit, ganzrandig oder am Grınde klein gezähnelt; Rippe kräftig, braungrün, dicht vor der Biattspitze aufiviend. in den Astblättern in oder etwas über die Blattmitte verschwindend: Zellen dickwandig. bräunlich, in der Blattmitte 1: 2-4, in der Spitze 1: 6, in den Blattecken guadratisch, querbreiter und unregelmässig, braungelb und getüpfelt, eine sehr grosse Gruppe bildend.

N. Trondhjem, lliviken. Vesteraalen, Andenes.

Dänemark.

644. Amblystegium atrovirens Hans. in Botan. Tidskr. Bd. 25, p. 101 (1903).

Pfl. in lockeren bis dichten. flachen. bräunlichgrünen Rasen. Stengel kriechend, dicht beblättert, mit reichlichen Rhizoiden, dicht beästet; Äste aufrecht, 5-10 $\mathrm{mm}$. Stengelblätter meist sparrig-abstehend, aus eiförmigem Grunde rasch sehr lang und fein zugespitzt, mit flachen, abwärts gezähnelten Rändern; Rippe dünn, in bis weit über der Blattmitte endend; Zellen ziemlich derbwandig, verlängert rhombisch, etwa $S \mu$ breit. in der Blattmitte $3-1$, in der Blattspitze $6-\&$ mal so lang, an der Insertion oval, dickwandig, gelb, in tlen Blattecken wenige rhombisch und quadratisch. Astblïter lanzettlich, haarförmig zugespitzt: Rippe kürzer und schwächer.

Am Grunde von Bäumen und auf deren Wurzeln, auf feuchtem Waldboden, auf Torfdächern und humusbedeckten Felsen. 
N. No. Bejeren, Arstadfossen. Tr. Trondenes, Bardo und Malangen. F. Loppen, Oksfjord, Kistrapd und sydvaranger.

Dänemark.

6.15. Amblystegium versirete Hag. Musc. Norv. bor. p. 311 (1901).

Pfl. in dichten, llachen, ausgedehnten, gelblichen Rasen. Stengel ohne Zentralstrang, kriechend, längs mit Rhizoiden, unregelmässig beästel. Stengelblätter trocken \pm abstehend und geschlängelt, feucht sichelförmig einseitswendig, die unteren aus eiförmigem Grunde alimählich verlängert lanzettlich, bis $1,3 \mathrm{~mm}$
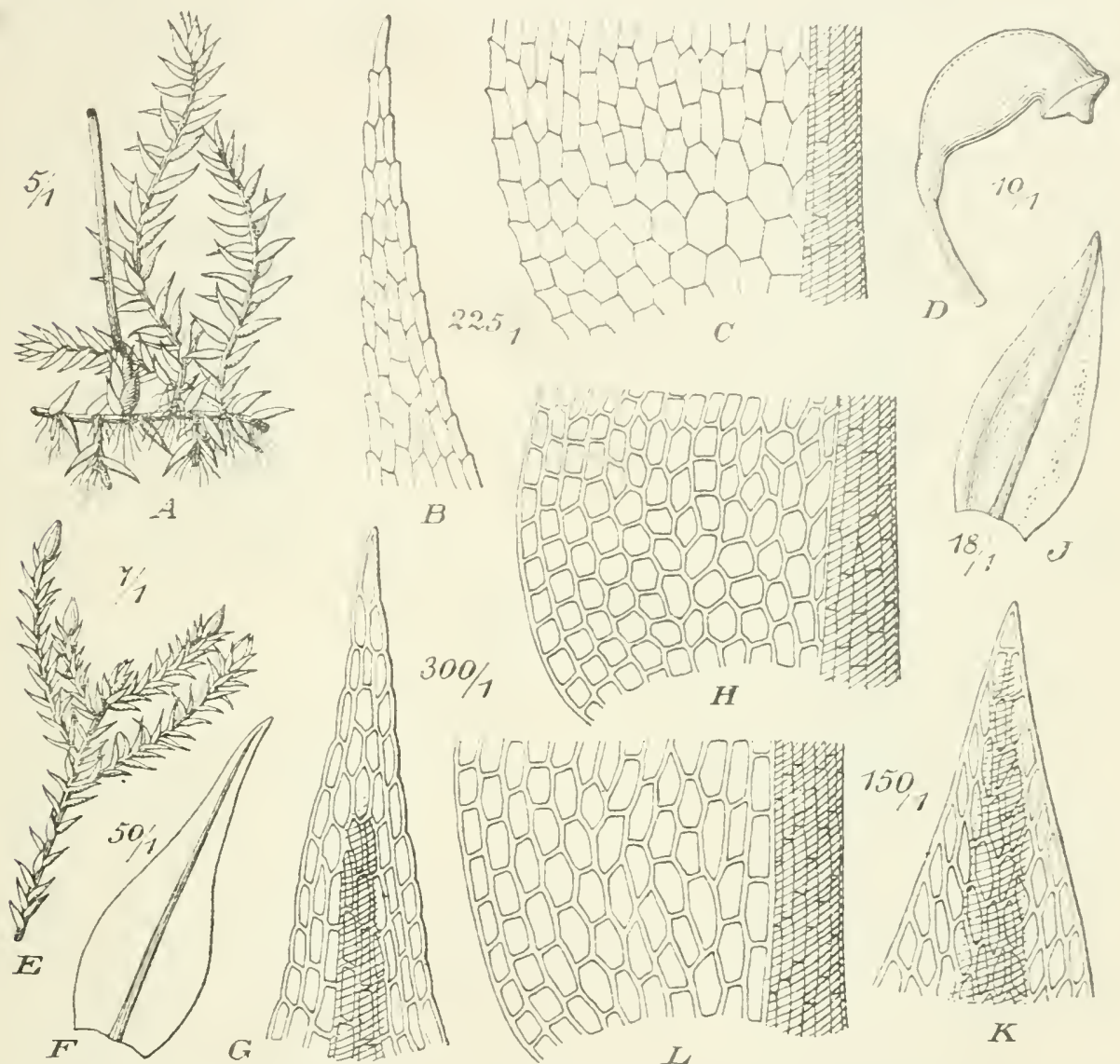

$B$
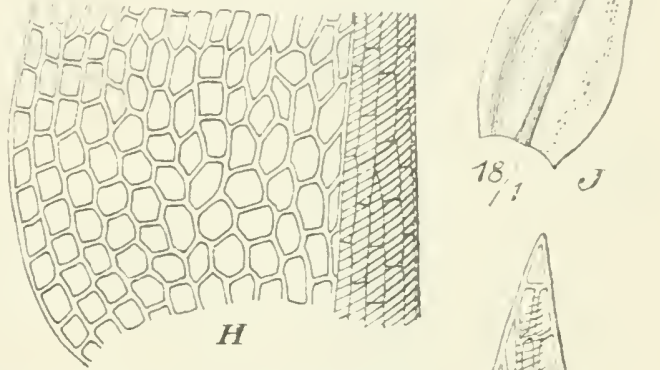

Fig. 85. A-D. Amblystegium radicale (Palis.). A Teil eines Sprosses (5/1); B Blattspitze (225/1); C Blattbasis (2:5/1); D Entdeckelte Kapsel in trockenem Zustande (10/1). - E-H. A. varium (Hedw.). E Teil eines Sprosses (7/1); F Stammb. (50/1): G Blattspitze (300/1): H Blattbasis (300 1). - I-L. Hygroamblystegium fluviatile (Sw). I Stammb. (18/1); K Blattipitze (150/1): L Blattbasis (150/1).

lang und bis $0.4 \mathrm{~mm}$ breit, flach- und ganzrandig: Rippe dün, in der Blattmitte aufhörend; Zellen dünnwandig. ohne Chlorophyll, in der Blattmitte verlängert-rhomboidisch, etwa $13 \mu$ breit und $3-t$ mal, in der Spitze 5 mal so lang, am Blattgrunde lockerer, rektangulär bis verlängert-6seitig. $2-3 \mathrm{mal}$ so lang wie breit, in den Blattecken wenige quadratisch. Obere Blätter aus eiförmigem Grunde kurz zugespitzt, etwa $0,5 \mathrm{~mm}$ lang und etwa $0.2 \mathrm{~mm}$ breit, am Grunde gezähnelt: Rippe vor oder in der Blattmitte aufhörend: Zellen mit Chlorophyll, am Blattgrunde kurz oval oder fast quadratisch, in den Blattecken in 2-3 Reihen quadra- 
tisch, in der Blattmitte rhomboidisch, etwa 3 mal so lang wie breit. Sporogone uubekannt.

N. F. Kistrand, an Steinel oder Felsen der Insel Juovre im Porsangerfjord.

Beansprucht nach $\mathrm{H}$ a g e $\mathrm{n}$ eine eigene Stelle nicht nur wegen der Stengelstruktur. sondern auch wegen der dimorphen Blätter, inclem die unteren sowohl in der Form als im Zellgewebe bedentend von den oberen abweichen; das Zellnetz ist für ein Amblystegium ungewöhnlich weitmasehig und dümnwandig.

616. Amblystegium radicale (Palis.) Mitt. in Journ. Linn. Soe. Bot. XII. p. 569 (1869). [Hypnum radicale Palis. Prodr. p. 68 (1805). - Amblysteginm Juratzkanum Schimp. Syn. p. 693 (1860). — * A. pachyrrhizon Lindb. Musc. scand. p. 32 (1879).]

Pll. in \pm dichten. hellgrünen. trocken weichen Rasen. Stengel entfernt beblättert, unregelmässig beästet; Äste aufrecht. bis 3 und $5 \mathrm{~mm}$ lang. Stengelblätter weit abstehend, aus fast herzförmiger Basis almählich lanzettlich-pfriemenförmig, flach- und ganzrandig oder abwärts \pm deutlich gezähnt; Rippe dünn, in oder über der Blattmitte endend; Zellen verlängert-6seitig, $9-10 \mu$ breit und in der Blattmitte 4-6 mal so lang, an Blattgrunde rektangulär, in den Blattecken wenige quadratisch. Astblätter weit abstehend, sehr schmal, lanzettlich; Rippe kürzer und schwächer. Sporenreile im Juni. - Fig. 85 A-D.

Auf nassem Humus, nassem, faulendem Holzwerk, an nassen Orten über Steinen und am Grunde von Erlen- und Weidenstämmon.

F. Al. Eekerö. Storby (Bom.). Lemland, Nátö (B.). Finström und Sund, an einigen Fundorten (Bom., Broth.). Saltvik, an vielen Fuṇdorten (Bom.). Vå̊dö (B.). - Ab. Pargas, Simonby (Elfv.). Karis, Svartả (Jusl.). Fimito, Tyrrändö (Flinck). Lojo, an inehreren Fundorten (Lindb.). $-N$. Helsingfors (L.). - Kl. Kurkijoki, Haavikko (Jusl.). Valano (Lindb.). Sortavala, Kirjavalahti (Broth.). Kol. Mjätusova (Elfv.).

S. Sk., Öl., Sm., Gtl., Ög., Boh., Srm., Upl., Hpd. und Áng.

N. Sm., Bu., JL. und No. an einzelnen Fundurten.

Enropa, Kaukasus, Nord-Amerika.

647. Amblystegium varium (1 Hedw.) Lindb. Musc. scind. p.32 (1879). [Leskea varia Hedw. Sp. muse. p. 216, t. 53, fig. 15 (1801).]

Pll. in lockeren bis dichten, flachen oder kissenförmigen, grünen bis gelboder bräunlichgrünen, trocken etwas starren Rasen. Stengel locker beblättert, mit reichlichen Rhizoiden: \pm dicht beästet; Äste aufrecht, meist kurz. Stengelblätter weit abstehenı, zuweilen einseitig nach obən gerichtet, aus herz- oder eiförmigem Grunde lanzettlich-pfriemenförmig, flach- und ganzrandig odler bis weit hinauf 土 deutlich gezälnelt; Rippe ziemlich kräftig, oben gekniet, weit in die Pfrieme eintretend bis mit cler Blattspitze endend; Zellen derbwandig, chlorophyllreich, länglich-6scitig. 9-12 $\mu$ breit und in der Blattmitte 2-4. in der Blattspitze etwa 5 mal so lang, abwärts in der Mehrzahl rektangulär. 10-1 14 breit und etwa 2 mal so lang, am Blattgrumde grösser, oval, gelbgrün, stark verlickt und getüpfelt. Astblätter gedrängt, schmäler und etwas kürzer. - Fig. 85 E-H.

An feuchten Orten auf Erde, 110l\%, an Stcinen, besonders in Erlenbrüchen.

F. Al. Jomala, Kirchdorf (Bom.). Saltvik und Sund an wenigen Fundorten (B.).

S. Og. an melireren Fundorten. Stockholm.

N. Sm. On $\div$ ø $J L$ Tjøins.

Europa, Madeira, Kaukasus, Persien, Silirien, Nord-Amerika.

Untergatt. 1 1. Leptodictyum Schimp. Syn. (1860).

Stengel oft aufsteigend bis aulrecht. Blätter häulig weit bis sparrig abstehend; Zellen meist dünnwandig, prosenchymatisch-6seitig, die mittleren i-s mal so lang wie breit oder linealisch und 10-15 mal so lang wie breit.

618. Amblystegium trichopodium (Schultz) I Iartm. Skand. Fl. 10. ed. 11. p. 19 (1871). [Hypnum Irichopodium Schultz lil. starg. p. 324 (1806). - H. lenuisetum Lindb. in Hartm. Skind. Fl. 9. ed. p.

(186.1).] 
Zicmlich schlanke Pfl. in lockeren, dunkel- bis gelbgrimen, trocken sehr weichen Rasen. Stengel kriechend bis anfsteigend, loeker beblättert, mit spärlichen Rhizoiden: Aste zerstreut, kurz ofler länger und aulsteigent. Stammblätler weit bis fast sparrig abstehend, schmal eilanzettlich, lang zugespilzt. liach- und ganzrandig bis undeutlieh gezähnelt, bis $1,5 \mathrm{~mm}$ lang unt bis $0.3 \mathrm{~m}$ m breil: Rippe dünn, mit oder kurz vor der Blattspitze aulhörend; Zellen 8-10 "l l) reit und 1-6, oberwärts his 8 mal so lang, am Blallgrunde erweitert und reklangulär, in den kaum ausgehöhlten Blattecken wenige quadratisch und kurz rektangulär. Asthlätter kürzer und schmäler. Sela (wa :) cm. Sporenreile inn Friblıling.

An feuchten und smmptigen Stellen aul Erde. gern zw. Schilf und Wur\%eln an Teich- und Seeufern.

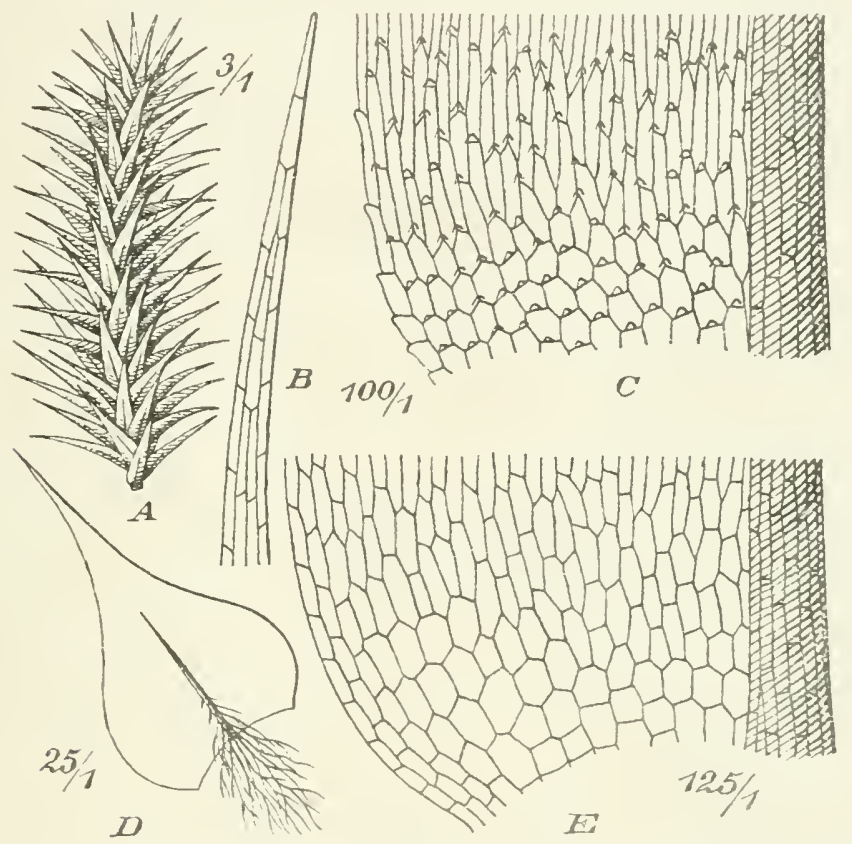

Fig. 86. A-C. Amblystegium riparium (L.). A Teil eines Sprosses (3/1); B Blattspitze (100,1): C Blattbasis $(100 / 1)$. - D-E. A.trichopodium var. Kochii (Bryol, eur.). D stengelb. (25/1); E Blattlasis (125/1)

S. Sk., Gtt. und När. an einzelnen Fundorten. Stockholn.

Deut:chland.

var. Kochii (Bryol. eur.) Lindb. in Act. Soc. Sc. Fenn. X. p. 275 (1872). [Amblystegium Kochii Bryol. eur. fasc. j., 6 Mon. p. 13, t. 6 (18.53).]

Stengelblätter aus breit eiförmigem oder dreieckigem Grunde rasch lanzettlich zugespitzt, bis $1.8 \mathrm{~mm}$ lang und bis $0,8 \mathrm{~mm}$ breit: Rippe in oder über der Blattmitte schwindend. Seta 3 -1, selten bis j cm. - Fig. 87 D-E.

F. Al. Finström, Godby (Bom.). Geta. Olofsnäs trāsk (B.). Saltvik, an einigen Fundorten (B.). - Ab. Kakskerta (Elfv.). Lojo, Ojamo (Lindb.). - N. Helsingfors (L.). - Ka. Wihorg, Kaislahti (W. Nyl.). - Ih. Sakkola, Järisevänieıni (H. Lindh.). - Ta. Hollola, Hälvälä und Papinzaari (Norrl.); Vesijärvi, an Seeufer (N.). Asikkala. Hokkola (N.). - Kt. Valanı (Jusl.). - Tb. Laukaa und Viitasaari (Broth.). - Sb. Nilsiä Kirchdorf (Kot.).

S. $\partial t$

N. Juveren. Kristiania.

Zentral-Europa, Amurgebiet, Nord-Anerika.

var. curvipes (Gïmb.). (Amblystegium curvipes Gümb. in Bryol. eur. 1. c. p. 14.) 
Stengeỉblätter bis $2 \mathrm{~mm}$ lang und $1 \mathrm{~mm}$ breit; Rippe dünner; Zellen lockerer und dïnnwandig.

F. Helsingfors (Lindb.).

Dänemark, Zentral-Europa, Kaukasus, Sibirien, Nord-Anerikit.

Nach den eingehenden Untersuchungen L o es $\mathrm{k}$ e's (vergl. Hechwigia LI. p. 286-298) ist Amblystegium hygrophilum Jur. keine selbständige Art, indem alle so benannten Exemplare gleichgerichtete Biomorphosen anderer Moose sind und zwar in erster Linie Kleinformen von A. riparium. A. Fochii und Campylium polygamum.

649. Amblystegium riparium (L.) Bryol. eur. fasc. 5556 Mon. p. 11, 1. 8 et 9 (1853). [Hypnum riparium L. Sp. pl. p. 1129 (1753).]

Iehr oder weniger liräftige Pfl. in lockeren. weichen, grünen oder gelbgrünen bis bräunlichgelben Rasen. Stengel I verlängert, niederliegend bis flutend, meist nur am Grunde mit Rhizoiden, zerstrent bis fiederig beästet. Stammblätter \pm weit abstehend, oft scheinbar zweizeilig bis einseitswendig, lanzettlich, \pm lang und fein zugespitzt, flach- und ganzrandig, meist $3-3,5 \mathrm{~mm}$ lang und etwa $1 \mathrm{~mm}$ breit; Rippe ziemlich krältig. meist $1 / 2$ bis $2 / 3$ (ler Lamina durchlaufend; Zellen $8-9 \mu$ breit und s-12 mal so lang. gegen den Blattgrund lockerer, rektangulär und 6seitig, in den Blattecken \pm deutlich differenziert. Astblätter kürzer und schmäler. Seta 1,5-3 cm. Sporenreife im Juni und Juli. - Fig. $86 \mathrm{~A}$-C.

An Steinen und Holzwerk, am Grunde der Stämme und auf Erde an feuchten und nassen Stellen, in Gräben. Tümpeln und Wasserläufen.

F. Al. pass. (Bom.). - Ab. Ibo (Brand.). Piikis (Zett.). Kimito, Tästanfjärd (Ols.). Lojo, Ojamo und Hermola (Hult), - N. Ekenäs (Häyr.); 'Trärminne (H.). Ingả. Esbo. Mankans (Broth.). Helsingfors (Lindb.). Helsinge. Sillböle (Broth.). - Ik. Valkjärvi, Valkoja (H. Lindb.). - St. Sastmola (Karst.). Hämeenkyrö: Kyröskoski (Nerv.). — Ta. Im südöst1. Teile pass. (Norrı.). Kiangasala, PaJonky]ä (Kar.). Korpilahti. Veijo (Vain.); Päiväkunta (İäyr.). - Sa. Kangasniemi (Lackstr.). Kiesảahti (F. Nyl.). Kl. Kurkijoki, Oraska (Jusl.). IIitola (J.). Valamu (WV. Nyl.). - Kol. In sivirgebiete fq. (Elfr.). Petrosayodsk (Simm.). - Oa. Kaskö (Nerv.). Närpes (Karst.). - Tb. Jyväskylà, Tourujoki (Broth.). Pihtipuda:, Heinolankylä, Kolimajäri (Roir.). - Sb. Kuopio, Lendonkylä, Kasurila. Karhipuro (Kyyhk.); Kolmisopenkylä. Autio (K.). Maaninka, Tuovilanlahti (Roiv.). Pielavesi, Jylhä (R.). - Kb. Kuusjärvi, Outokumpu (Kot.). Juuka, Kirchdorf (K.). - Kon. Suojärvi, Varpakylä (Kop.). Talkeamäki (Simm.). Velikaja guba und Suınu (Norrl.). - Ok. Solkamo, Talvivaara (Kyylık.); Jormasjärvi, Kohvorinsaari (K.). Kuhmoniemi, Aroniemi (K.). Puolanka, Latvajoki (Tennb.). Suomusialmi, Kiannankylä, Kuotluansalmi (K.). - Kpom. T-chuja (Sahlb.). - Ob. Rovaniemi, Norvajoki (Hult). Turtola, Paantajoki (H.). - K. Kuısamo, Kirchdorf (Nyb.); Käỵläkoski (Broth.); Syvälampi (E. af H.). 一Kk. Knjäscha (Sahlb.). - Lkem. Killilä, Xkäsjoki, nordl, vom Akäslompolo (Hult). Muonio (Norrl.). - Le. Kilpiskoski (N.). - Li. Inari, Toiresıemi (IIult). - Lim. Kandalak- (Salnlb.).

S. Sk.-IIlsl. I’b. skellefteá. LuL. Jokkmokik.

Europa, Iadeira, Kanaren. Algier, Tibet, Tonkin, Japan, Neu-Holland, Kerguelen.

var. longifolium (Schultz) Bryol. eur. I. c. p. 15, t. 9. [Hypnum longifolium Schultz Prodr. p. 33.), No. 938 (1806).]

Kräftiger als die Hauptart, flutend. Stengel bis 10 und $18 \mathrm{~cm}$. Blätter eilanzettlich, lang haarförmig zugespitzt, bis über $5 \mathrm{~mm}$ lang und bis 1,2 $\mathrm{mm}$ breit; Rippe kräftig, $3 / 4$ der Blattlänge.

F. Tb. Jyväskylä, lleinomenjoki (Broth.). - Lx. Tschapoma (B.).

Europa, Sibirien, Nord-Amerikit.

\section{HOMOMALLIUM}

(Schimp.) Loesk. in Hedwigia XLYI. p. 311 (1907).

Autözisch und polyözisch. Stengel mit armzelligem Zentralstrange, kriechend, durch Rhizoidenbüschel an Substrat haftend, geteilt und unregelmässig oder fast regelmässig gefiedert: Äste kurz: Psendoparaphyllien spärlich, nur in der Nähe der Astanlagen. Blätter \pm hohl, aus verengter, kaum herablaufender Basis ovalotler länglich-lanzettlich, pfriemenförnig zugespitzt: Rippe fehlend, kurz, dünn 
und doppelt oder einfach, etwas länger und zuweilen gegabelt: \%ellen eng prosenchymatisch, am Blattgrunde kürzer und etwas weiter, in den Blattecken zilllreiche quadratisch, klein, ehloroplyylteich, eine schmal dreicekige Gruppe bildend. Astblätter kleiner, sonst den Stammblättern ähnlich. Inuere Perichätiall,lätter ungefaltet. Kapsel länglich, + gekrümmt. Ring diflerenziert. Deckel gewïlbtkegelig, stumpl oder kuy geschnäbelt.

650. Homomallium incurvatum (Selirad.) Loesk 1. (.) [Hypnum incurvalum Schrad. Syst. Samml. 1. 1. 18 (1796). - Stereodon incurvalus Mitt. Linrlb. Musc. scand. p. 38 (1879).

Schlanke Pfl. in meist ausgedehnten, flachen, grinnen oder gelb- bis bräunlichgrïnen, trocken seidenglänzenden Rasen. Iste bis 5 mm und wie die Spitzen des Hauptsprosses an Ende schwach sichelförnig. Stammblätter locker gestellt, aufrecht-abstehend oder einseitig nach oben gerichtet, endständige fast sichelförmig, bis $1,2 \mathrm{~mm}$ lang und bis $0,4 \mathrm{~mm}$ breit, llach- und ganzrandig oder an der Spitze undentlich gesägt. Innere Perichätialblätter fast scheidig, rasch lang- und feinspitzig. Seta $1-2 \mathrm{~cm}$, rötlich. Kapsel bis $2,5 \mathrm{~mm}$ lang und bis 0,7 mun dick, rotbraun, trocken und entdeckelt stärker gekrümmt und unter der IIündung eingeschnürt. Sporenreife in Mai und Juni.

An beschatteten Steinen und Felsen verschiedener Art.

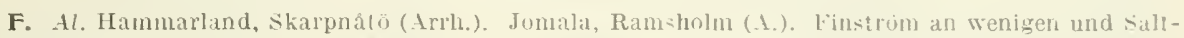
vik an mehreren Fundorten. - Ab. Ibo (Brand.). Pikkis (Zett.). Pargas, Lielak-(Elfr.). Kimito (Ol-). Finbỵ (Broth.). Karisiojo Karkhali (Sundr.). Lojo (Lindi., Sundr.). Vichlis (IT. Nyl.). - V. Likenäs, Elgmo (Lindb.). Helsingfors (L.). Hetsinge, Stansvik (Ranck.), - St. Hämeenkyrö (Simm., Sundv.). Ta. Im südöst]. Teile an mehreren Fundorlen, meist in den [ngebungen des Vesijärvi (Norrl.). Hartola (Bonsd.). Korpilahti, Haukhavuori (Vain.). - sa. st. Mlichel (Lackstr.). Kangasnieni (L.). - hil. Kurkijoki, Otsonlahti und Tervn. (Jusl.). Valamo (Lindls.). Sortavala. Kirjaralahti (L.): Paksunieni (Buch). Ruskeala (TV. Nyl.). - Tb. Jyväshylä, Tourujoki (Brut1.): Laurinniemi und Kanavuori (Vain.). Pihtipudas, Kanalanmäki (Roir.). - Sb. Kaavi, Poskijärvi, Losomäki (Kot.). Nilsiä, Kuułlahti, Jaakonlampi (K.). - Kon Valkeamäki und Pirttiniemi (Nimm) - Ok Sotkamo (Lackstr.); Jormasjärvi. Kohvorinsaari (kyph).

S. Sk.-Gstr. und Dlr.. Ang.

N. Sm. - Tr. Nordgrenze bei $68^{\circ} 47^{\prime} \mathrm{n} . \mathrm{Br}$.

Europa. Kaukasus, Kazchmir. Turkestan. Sibirien, Japan.

\section{CAMPYLIUM}

(Sull.) Bryhn in D. K. N. Vid. Selsk. Skrift. 1892, p. 219 (1893).

Meist \pm schlanke, rasenbildende, \pm glänzende Pfl. Stengel mit armzelligem Zentralstrang, bald kriechend, bald aufsteigend bis aufrecht, unregelmässig bis fiederig beästet oder büschelig verzweigt: Pseudoparaphyllien menst fehlend. Blätter aus etwas verengter, kurz herablaufender Basis breit ei- oder herzeiförmig und in eine lange, meist rinnig-hohle Pfriemenspitze verschmälert; Zellen eng linealisch, glatt, an den schwach ausgehöhlten Blattflügeh differenziert, meist gelbund dickwandig, klein, quadratisch. Innere Perichätialblätter scheidig. lanzettlich-pfriemenförmig, längsfaltig. Kapsel geneigt bis horizontal, fast zylindrisch, gekrümmt, dünnhäutig, trocken und entleert unter der Mündung verengt.

\section{$\mathrm{i}^{*}$ bersicht der Arten.}

A. Blattrippe sehr kurz und doppelt oder fehlend.

a. Blätter aus scheidiger Basis sparrig-zurückgekrummt, rings gesägt. Aıtözisch ........................... 651. C. Halleri.

๖. Blätter nicht scheidig. sparrig-abstehend, meist ganzrandig oder an Grunde fein gezähnelt. 
«. Autözisch. Ǩleine Pfl. Blattflügelzellen kaum dif-

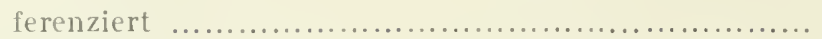

ß. Diözisch. Grössere Ptl. Blattlügelzellen stark er652. C. hispidulum. weitert.

I. Blätter aus verengter Basis ei-herzförmig, plötzlich schmal lanzettlich-pfriemenförmig

II. Blätter aus stark verengter Basis eilänglich-lanzettlich, alluählich lang zugespitzt

655. C. protensum. 656. C. stellatum.

B. Blattrippe einfach, in oder oberhalb der Blattmitte endend.

a. Diözisclı. Blattflügelzellen liaum differenziert.

«. Blätter eilanzettlich, lang zugespitzt: Rippe kräftig, fast vollständig 653. C. elodes.

३3. Blätter ei- oder dreieckig-herzförmiğ, lang und schmalspitzig: Rippe duinn, $1 / 2$ der Blattlänge

654. C. chrysophyllum.

b. Polyözisch. Blattflügelzellen differenziert, eine grosse, ausgehöhlte Gruppe bildend

657. C. polygamum.

S e c t. I. Campylophyllum (Schimp.) Broth. in E.-P. I². p. 1042 (1908). [Hypnum Sect. Campylophyllum Schimp. Syn. ed. 2, p. 721 (1876).]

Autözisch. Stengel kriechend. mit 亡 zahlreichen Rhizoiden; Pseudloparaphỵllien vorhanden. Blätter \pm sparrig-zurückgekrümmt; Rippe doppelt, selır kurz oder fehlend.

651. Campylium Halleri (Sw.) Lindb. Musc. scand. p. 38 (1879). [Hypnum Halleri Sw. Meth. musc. p. 34 (1781).]

Autözisch. Schlanke Pfl. in sehr dichten, flachen, oft ausgedehnten, grünen, gelblichen bis goldbräunlichen, glänzenden Rasen. Stengel kriechend, der Unterlage fest angeheftet, sehr dicht beästet; Äste kurz, aufrecht, im Umfange der Rasen ausgebreitet, stumpf. Blätter kaum herablaufend, sparrig-zurückgekrümmt, sehr hohl, breit eiförmig oder eirundlich, plötzlich in eine lanzettliche, rinnige Pfrieme verschmälert, Astblätter bis $0,75 \mathrm{~mm}$ lang und bis $0,40 \mathrm{~mm}$ breit: Rippe fehlend oder durch zwei kurze Streifen angedeutet: Zellen meist 1: 4-6. in den Blattflügeln quadraticch, gelbwandig. eine kleine, schwach gewölbte Gruppe bildend. Innere Perichätialblätter scheidig, längsfaltig, allmählich in eine lange, zurückgekrümmte und gesägt: Pfrieme verschmälert. Seta $1-1,5 \mathrm{~cm}$. Lapsel geneigt bis horizontal, länglich bis zyndndisch, bis $2,5 \mathrm{~mm}$ lang, leicht gekrümmt, anfangs bereift. später rotbraun. trocken und entdeckelt stärker eingekrummt und unter der Mündung verengt.

Aul Kalk und kalkhaltigem Gestein.

F. Kl. Sortavala. Kirjavalahti, Lahentausta (Norrl.). - Sb. Kaavi, Siikajärvi, Huosiaisniemi (Kot.). - K. Kuusamo, Juuma, Jäkäläruoma (Broth.): Oulankajoki, Jerenoja (B.). - Le. Kilpi.järvi, Malla (Kot.).

S. Og., Nir., I'sm. und Dlr. an einzelnen Fundorteı, Ilrjd. Jmt.. LyL. und PL.

N. A. Kristiania. Bu. Iker, Mjondalen. Ringerike. R. rr. NT. Stjordalen. No.-F. Nordgrenze bei $70^{\circ} 15^{\prime} \mathrm{n}$. Br.

West- und Zentral-Europa, West-Himalaya, nordl. Teile ron Nord-Amerika.

652. Campylium hispidulum (Brid.) Lindb. Muse. scand. p. 38 (1879). [Hypnum hispidulum Briel. Sp. musc. II. p. 198 (1812).I

Autözisch. Grösse und Tracht von Amblystegium serpens. Pfl. in locker verwebten, llachen, grünen oder gelbgrumen bis gelblichen, glanzlosen Rasen. Stengel kriechend, fast fiederig beästet. Stammblätler weit abstehend bis schwach zurückgebogen, zuweilen z. T. einseitswendig, aus verengter, kurz herablaulender, breit herzeilörmiger, hohler Basis rasch schmal lanzettlich-pfriemenförmig. bis $0,75 \mathrm{~mm}$ lang und bis $1,35 \mathrm{~mm}$ breit, rings fein gesägt: Rippe felslend oder doppelt 
und sehr kurz; Zellen der Lamina 1: j 6, in den schwach ausgehöhlten Blattllügeh quadratisch und kurz rektangulïr, eine kleine Gruppe bildend. Inure Perichätialblätter rasch pfriemenförnıig zugespitzt, undeutlich gesägt. Seta $1,5-$ $2 \mathrm{~cm}$. Kapsel bis $2 \mathrm{~mm}$ lang. Ring einreihig. Wimpern mit Anhängseln. Sporenreile in Juni und Jull.

Auf kalkhaltigem Boden und beschattetem, kalkhaltigem Gestein, am Grunde von Stämmen und moderndem Holz.

F. Al. Sund. Kyrksundet (Bom.). - Ab. Lojo, Ojamo (Lindb.). - Sl. Nakkila (Sinim.). - Tr. Hollola, Uskila (Norrl.). - Sa. Willmanstrand (Buch). - Kl. Valamo (Ju-1.). Surtavaliz, Kirjavilaht! (Lindb.). Ruskeala (L.). - Kb. Joensuu, Ninivaara (Liman.).

S. Sm. an mehreren Fund.rten. Gu., Ög., Boh. Ipd. und Aing.

N. Bu. Honefos und Tyristranden, Nakkerud. No. Hatfjelddalen und saltdalen.

Sibirien, Nord-Amerika.

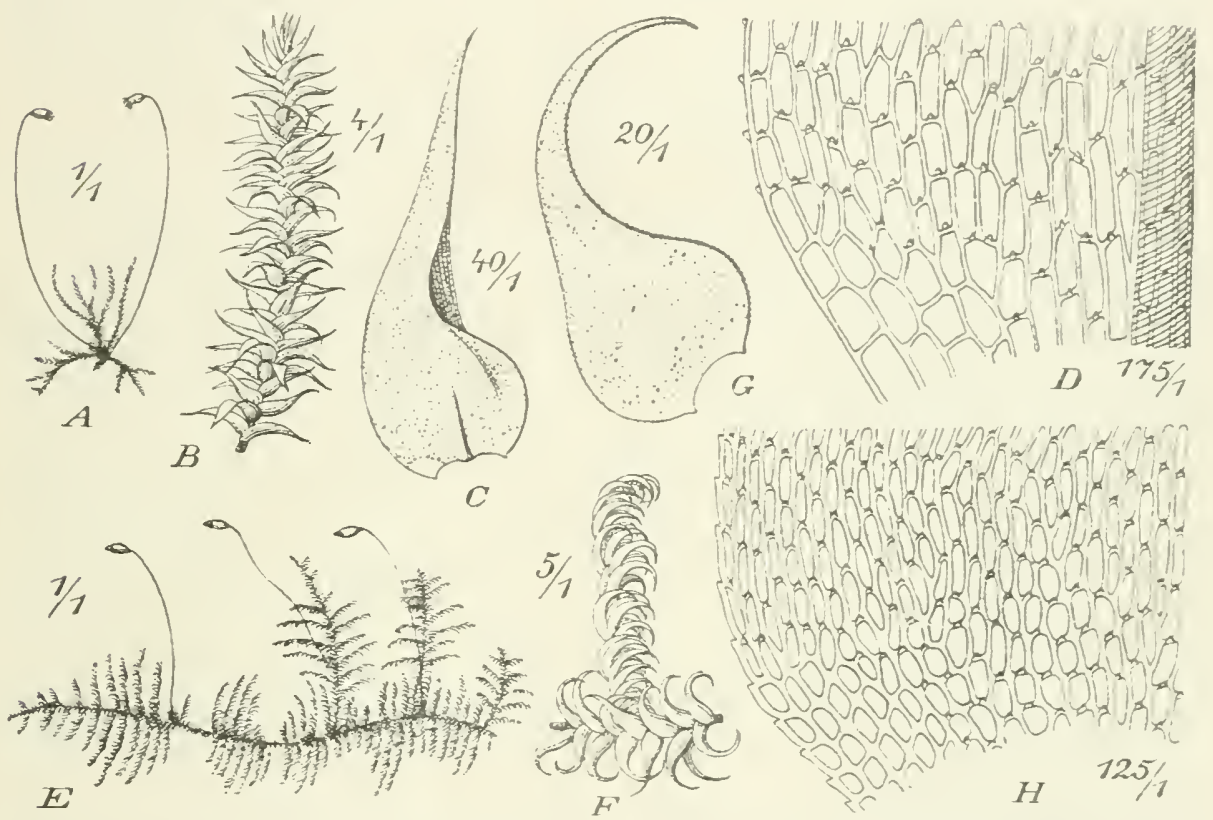

Fig. 87. A-D. Campylium hispidulum var. Sommerieltii (IIrr.). A Fruchtende Pil. (1/1): B Astchen $(4 / 1)$; C Astb. $(40 / 1)$; D Blattbasis $(175 / 1)$. - E-H. Ctenidium molluscum (Hedw.). E Eruchtende Pf). (1/1); F Astchen (5/1); ti Stengelb. (20/1); H Blattbasis (125/1).

var. Sommerfeltii (Myr.) Lindb. Musc. scand. p: 38 (1879). [Hypnum Sommerfeltii Myr. in K. Sv. Vet.-Ak. Àss, 1831, p. 328: Bryol. eur. fasc. 5T 61 Mon. p. 12, t. $2(18.54)$.

Blätter bis $1 \mathrm{~mm}$ lang und $0.5 \mathrm{~mm}$ breit, nur am Grunde entfernt und fein gezähnt. Wimpern knotig. - Fig. 87 A-D.

F. Al. Jomala, Österkalmar (Bom.). sund, hastelholm und Jusiböle (Bom.); Högbolstad (Broth.). Saltvik, an vielen Fundorten (Bom.). - A Ab. Abo (Elfr.). Piikis, Bagarla (Zett.). Pargas, Tara (Elfr.). Kimito (Ols.). Sagu, Träskby (Buch). Bromarf (Sundr.). Karis, srartá (Juil.). Lujo, an mehrerera Fundorten (Lindb., Jusl., H. Lindb.. E. af If.). sammatti (Sel.). — N. Tenala, skngly (H. Lindb.). sjundeả (Sundv.). Esbo, Gräsa (Broth.). Helsingfors (Lindb.). Sibbo. Hita (Ekm.). Hogland (Lindb.). - Ka. Wiborg (W. Nyl.). Antrea (Porkka). - Ik. Muola, Perkjärvi (H. Lindb.). Pyhajärri. Toubila (H. L.). - St. Ylöjärri (Sol.). Pirkkala (Simm.). Ikaalinen. Nygảrd (Sundr.). 一 Ta. Hattula. Nikikila (Ranck.). Inn südostl. Teile st. fє. (Yorrl.). Sysmă (Blom). Hartola (Bonsd.). Kiorpilahti und Lubanka st. fq. (Vain.). - Sa. Kangasnieni (Broth.). Willmanstrand (Buch). Lappee suuninen (B.). - Kl. Kurkijoki (Jusl.). Valano (Ju.l.). Parikkala (Sahlb.). Sortavala Kirjavalahti fq. (Norrl.). Ruskeala (Broth.). Soanlahti (H. Backm.). Palkjärvi an mehreren Fundorten (Brotb.). - Kol. Mjatuiova fq. 
(Elfv.). Gorki (E.). - Ga. Sideby (Karst.). - Tb. Jyväskylä Tourujoki (Link.); Haapakoski (Broth.). Karstula. Koruisenjäri (B.). Viitasairi, Korpisenjoki (B.). Kinnula. Olhavainen (Roiv.). Pihtipudas (R.). - Sb. Kuopio, an wenigen Fundurten (Link.). Kadvi. Huosiaisniemi (Kot.). Maaninka, Tuovilanlahti (Broth., Roiv.); Hannula, Riuttamäki (liỵhk.). Ii_almi, Palojārvi (Sahlı.). — Kb. Pielisjārvi, Koli (Linnan.). - Kon Klimskij monastir (Simm). - Om. Alajärvi und Vindala, an wenigen Fundorten (Backm.). - Ok. Kajana (Lackstr.). Paltamo, Takaranta (Broth.); Melalahti, Äijönkallio (Kyyhk.) - Kpom. Moina (Bergr.). - ob. Kemi, Lassila (Brenn.). Rovaniemi. Talajankoski (B.): Tervo (Hult) Koskenniemi und Täs̆ănpää (H.). - K. Kuusamo, Kitkajoki (Broth.). - Le. Im Waldgebiete bis Kilpisjärvi nicht selten (Norrl.). - Lim. Porjaguba (Sel.). Tschunosero (Broth.). - Lt. Ruoknjoki und Atselemjāyr im südlichen Teile (Roiv.). Kola, am Tulomaflusse (Broth.).

S. Sim., Boh.. Upl., Dlst., Irrmt. und Ipd.

N. sm., A., Bu., JL.. K., H. und $N T$.

Europa, Kaukasus, Kaschmir, Sibirien, Amurgebiet, Japan, China, Nord-Amerika.

var. stragulum (Hag.). [Hypnum stragulmm Hag. Musc. Norv. bor., p. 315 (1901). - Campylium stragulum Arn. et C. Jens. Moos. Sarekgeb. p. 215 (1907).]

Blätter bis $1,4 \mathrm{~mm}$ lang und $0,4 \mathrm{~mm}$ breit, meist rings gesägt; Zełlen der Lamina 1: 6-10. in den Blattecken nur wenige differenziert. Wimpern knotig.

S. Dlr.. Mpd.. Hrjd., Jmt., Ang. und LuL. an einzelnen Fundorten.

N. Ringerike, $s T$., Yo. und $F$. an einzelnen oder wenigen Fundorten.

Nord-Amerika.

Sect. I I. Campiadelphus (Lindb.) Broth. in F.-P. I. ${ }^{3}$ p. 10.12 (1908). [Amblystegium B. Campiadelphus Lindb. Musc. scand. p. 32 (1879).]

Stengel meist aufsteigend oder aufrecht, ohne oder mit spärlichen Rhizoiden, ohue Pseudoparaphyllien. Blätter vom Grunde sparrig-abstehend.

653. Campylium helodes (Spruc.) Broth. in Engl.-Prantl Bryal p. 1042 (190\$). [Hypnum helodes Spruc. in Lond. Journ. Bot. IV. p. 17.t (1845). - Amblysleginm helodes Lindb. in Hartm. Skand. Fl. 10. e(l. p. 3 (1871).]

Diözisch. Schlanke Pfl. in lockeren bis dichten, flachen oder tiefen, grïnen oder rötlich- und gelblichgrünen, nicht oder schwach glänzenden Rasen. Stengel umherschweifend oder aufrecht, mit spärlichen Rhizoiden, locker bis dicht beblättert. Stengelblätter bis fast sparrig abstehend, an den Sprossenden oft sichelförmig-einseitswendig, aus wenig herablaufender, verengter Basis eilanzettlich, pfriemenförmig zugespitzt, bis $1,5 \mathrm{~mm}$ lang und bis $0,5 \mathrm{~mm}$ breit, ganzrandig oder gegen tie Basis unmerklich gezähnt; Rippe ziemlich kräftig, weit in die Pfrieme eintretend; Zellen 1: 6-10 in den schwach ausgehöhlten Blattflügeln quadratisch und kurz rektangulär, stark verdickt und gelbwandig, von den immeren Basalzellen kaum verschieden.

Auf Sumpfwiesen, srn Carexbülten und modernde Pflanzenteile überziehend, auch an kalkhaltigen Seenfern.

F. Al. Eckerö (Elfr.). Finströı, (indby (Arrlı.). Saltvik. an mehreren Fundorten (Bom.). Sund, Jusibäle (B.). - Kl. Sortavala. Kirjavalahti (H. Backm.. Lindb.).

S. Sk.. Öl.. Sm.. Git., Ög., Vg., Ẍ̈̈r., Vsm., Gstr.. Dlr. und IIpd.

N. Sm. Hvaler und On=o. A. Kristiania. Ringerike r. JL. Tjomo. K. Dovre. NT. Stjordalen, Vikan. Gross-Britannien, Belgien. Zentral-Europa.

65. Campylium chrysophyllum (Bricl.) Bryhn in D. K. N. Vid. Selsk. Skrift. 1892, p. 61 (1893). [Hypmum chrysophyllum Brid. Musc. rec. II. P. II. p. 84, t. 2, f. 2 (1801). - Amblysleginm chrysophyllum De Not. Epil. 1 Is (1869).]

Diözisch. Schlanke Pfl. in lockeren oder dichten, oft ausgedehnten, gold- bis braungrünen Rasen. Stengel niederliegend bis aufsteigend, mit spärlichen Rhizoiden. Stammblätter kaum herablaufend, fast sparrig abstehend und \pm zurïekgebogen, aus etwas verengter, breit herzförmiger. fasi dreieckiger Basis schmal lanzettlich, lang zugespitzt, bis $1,5 \mathrm{~mm}$ lang tnd bis $0,15 \mathrm{~mm}$ breit, ganzrandig; Rippe dünn, bis über der lBlattmitte aufhörenof Zellen 1: 6-10 in den schwach ausgehöhlten Blattliügeln quadratisch und kurz rektangtü̈r, von den inneren Basalzellen kamm verschieden. Seta $2 \ldots 2,5 \mathrm{~cm}$. Kapsel bis $3,5 \mathrm{~mm}$ lang. Ring 3reihig. Deckel mit Spitzchen. 


\section{stänme.}

Auf kalkhaltigem Boden, kalkhaltigen Gestein und an Grunde alter Baun-

F. Al. Eckerö (Arrh.). Jomala, Ramsholın (Bom.). Finström, Barısgårda (B.). Salıvik, an nnebreren Fundorten (B.). Sund, Gesterby (B.). - Ab. Pargas, Storgard, Björkö und Tara (Elfv.). Sagu, Träskby (Buch). Karislojo, Tesjärvi (sundy.). Lojo, an mehreren Fundorlen (Lindb., II. Lindb.. F. af H., Sundv.). - N. Helsingfors (Lindb.). Ingà, Verkholın (W. Brenn.). Helsinge, Degeró (Buch). Lovisa (Häyr.). Hogland (Lindb.). - St. Ikaalinen, Nygârd (Sundv.). — Ta Hattıla. Y’li-Savijärvi (Ranck.). Hollola, Hersala (Norrl.). Asikkala, Laitiala (N.). Kuhmoinen, Kotavuori (Broth.). KorpiIahti, Pãiväkunta (Häyr.). - Kl. Sortavala, Kirjavalahti (Norrl.). Suistaıno, Loimala (Kuj.). Pälkjārvi, Pitkäniemi (Brolh.). - Oa. Replot, Vallgrund (B.). - Tb. Virral. Helvetinjärvi (B.). — Sb. Kaavi, Siikajärvi, Huosiaisniemi (Kot.). Juuka, Petrovaara, Saarijäri, Sotisaari (K.); Halivaara (II.). - Kon. Jalguba (Simm.). Koselma (S.). Pirttinieni (Kullh.). - Om. Alajärvi, Vesterbacka, Huosiannaankallio (Backm.). Vindala, Viitaniemi (B.). - K. Kuusamo, Marttila (Broth.); Kitkajoki, Jyrävä (B.); 2 W. Liikanen und sorajoki (B.); Paanajärvi, Kuoppanja (B.). - Lkern. Kolari, IIanaoja (HuIt).

S. Sk.-Gstr., Ang. und PL.

N. Sm. pass., A. liristiania, Ringerike. JL. Sandefjord. $K$. Lom. XT. Sijordalen. No.-F. Nordgrenze bei $70^{\circ} 15^{\prime} \mathrm{D}$. Br.

Europa, Kaukasus, West-Himalaya, sibirien, Japan, Nord-Amerika.

655. Campylium protensum (Bricl.) Kindb. Eur. and N. Amer. Bryin. I. p. 121 (1897). [Hypnum protensum Brid. Musc. rec. II. P. II. p. 85, t. 2, f. 3 (1801). -. Amblystegium protensum Lindb. Musc. scand. p. 32 (1879).]

Diözisch. Tracht von C. chrysophyllum. Pfl. in lockeren bis dichten, grünen oder gelbgrünen bis goldgelben Rasen. Stengel meist kriechend und mit Rhizoidenbüscheln an der Unterlage haftend, reichlich beästet. Stengetbätter deutlich heral,laufend. sparrig abstehend bis zurückgekrimml, aus verengter, breit herz-eilörmiger Basis plötzlich in eine lange, rinnige Pfrieme verschmälert, bis $2 \mathrm{~mm}$ lang und bis $0,9 \mathrm{~mm}$ breit, ganzrandig: Rippe fehlend, zuweilen einlach, selten bis zur Blattmitte reichend: Zellen wie bei C. stellatum. Seta $2-3$ cm. Kapsel bis 2,5 mm lang. Ring treihig. Deckel gespitzt.

Auf Kalk und kalkhaltigen Gesteinen und deren Detritus, sowie auf moderndem Hol\%.

F. Al. Saltrik. Krarnbo und Rangsby (Bom.): Liby (Broth.). Sund (Hull); Gesterly tjänan (Bom.) - Ab. Pargił. Lindberg und Skräbböle (Elfr.). Bromarf, Räkuby (Sundr.). Karislojo, Niemi (Sundr.). Lojo, an mehreren Fundorten (Lindb., Jusl, Hult, H. Lindb.). Pusula, am Kalkbruche und Kärkölä (Broth.). - N. Ekenäs, Trärminne (H. Lindb.). Sibbo, Hilà (Ekm.). Lovisa (Häyr.). - Ka. Wiborg. Kaislahti (W. Nyl.). Antrea, Oravankytö (Lindb.). — St. Pirkkala (Simm.). - Ta. Lammi, Evo (Norrl.). Hartola (Bon<d.). - Sa. Kangasniemi, Olıensalo (Lackitr.). - Kl. Kurkijoki (Jusl.). - Kol. Vosnessenje (Elfr.). Petrosavodik (Kullh.). - Tb. Keuru, Mänttă (Sael.). Jyräskylä (Broth.). Viitasaari (B.). Kinnula. Koukoniemi (Roiv.). Pihtipudas, sydänmaa, Isoaho (R.). - Sb. Kuopio, Puutosmäki, Kalkkisaari (Link.): Suovu, Paloisjoki (L.). Kilavi, Siikajärvi, Huosiaisnieni (Kyyhk. und Kot.); Rihisaari und Lo:omäkj (Kot.). Nilsiä, Niinivaara, Louhilampi (Kot.); Tahkomäki (Kyyhk.). Maaninka, Haatala, Tikkala (Roir.). Rautavara. Hankamäki cup. (Kyyhk,), - Kb. Tohmajärvi. Akkala (Kot.). Juuka. Juuanvaara (Kot.): Nunnanlahti (K.); im Kalk-und Serpentingebiete fq. (K.). Polvijārvi. Sola, Repovaara (h.). Pielisjärvi. Koli (Linnan.). - Kon. Kentjärvi und Jalguba (Simm.). Pirttiniemi (Kullh.). - Om. Alajärvi, an einigen Fundorten (Backı.). - Ok. Kajana (Lackstr.). Paltamo, Kives (Lackstr.); Melalahti (Kyylh.). Solkamo, Talvivaara (K.); Sarrenniemi und Natula (K.): Kohvorinsaari (K.). Puolanka, Tulijoki und Toriseva (K.). Suonussalmi, Kirchdorf (Tain.). - Ob. Rovaniemi, Tervo (Brenn.). Lkem. Kittilä. Kirchdorf (Hult). - Li. Inari, Toivoniemi und Kopiusjärvi (H.). - Lim. Tupujoki (Linnan.). - Lt. Pummanki (Brolh.).

S. Öl., Sm.

N. A Kristiania. Ringerike pass.

Europa, Kaukasus, West-Himalaya, Sibirien, Nord-Amerika.

656. Campylium stellatum (Schreb.) Bryhn in D. K. X. Vid. Selsk. Skrift. 1892 , p. 61 (1893). [Hypnum stellalum Schreb. Spicil. fl. lips. p. 92 (1771). - Amblystegium stellatum Lindb. Musc. scand. p. 32 (1879).]

Diözisch. Meist \pm kräftige Pfl. in \pm tiefen, grünen oder gelbgrünen bis goldgelben oder gebräunten Rasen. Stengel meist aufrecht oder aufsteigend, bis $10 \mathrm{~cm}$, selten höher, ohne oder mit spärlichen Rlizoiden. Stengelblätter kaum herablaufend, sparrig abstehend, aus verengter, abgerundeter Basis breit eilanzettlich, 
allmählich lang und fein zugespitzt, bis $3 \mathrm{~mm}$ lang und bis etwa $1 \mathrm{~mm}$ breit. ganzrandig: Rippe fehlend oder durch zwei dünne Streifen angedeutet; Zellen 1: 10-12, in den ausgehöhlten Blattflügeln locker, rektangulär und länglich-mehreckig, gelbbram oder hyalin, eine deutlich abgesetzte Gruppe bildend. Innere l’erichätialblätter aufrecht, pfriemenförmig zugespitzl, ganzrandig. Seta 2,5$3,5 \mathrm{~mm}$. Kapsel bis $4 \mathrm{~mm}$ lang. Ring 3reihig. Deckel gespitzt. Sporenreife im Jumi und Juli.

Auf sumpfigen Wiesen, an quelligen Orten, auf feuchter, mooriger Erde, an See und Bachufern und fenchten Felsen.

F. Al. fq. (Bom.). - Ab. Korpo, Jurno (Lkl.). Pargas (Arrh.); Terrsund und Lindberg (Elfv.). Kimito, Gesterby (Ol\%). Lojo, Alniala und Paavola (Jusl.); Hermola (Hult); Pietnäs (H. Lindb.); Ojamo (sundr.). - N. Bırgå (Sael.). Nurmijärrvi (Tennb.). Hogland (Lindb.). - Ka. Jäảski, Kärkkäilä (Lindb.). - Ik. Talkjärvi (H. Lindb.). - St. Ulfsby (Nerv.). Pirkkala (Simm.). — Ta. Kalvola (Knab.). In süd ö-tl. Teile pass. (Norl.). Korpilahti und Luhanka pass. (Tain.). - Sa. Nyslott (Carl.). - Kl. Valamo (TI. Nyl.). Ruskeala (Lindb.). Sortavala, Kirjavalahti (Broth.). Suistamo, saariselkä (Kö.). Pälkjärvi (Broth.). - Kol. IIjatusova (Elfv.). - Oa. Kaskö (Nerv.). - Tb. Laıkaa und Viitasaari pass. (Broth.). Kinnula und Pihtipudas pass. (Roiv.). - Sb. Kuppio pass. (Link.). Kaavi, an kalkhaltigen Orten fq. (Kot.). Nilsiä, Kuuslahti, Jaakonlampi (Kyyhk.); Loutleinen und Valkeinen (K.). Maaninka: Pöljă (Kyyhk.); Tuovilanlahti (Roiv.). Pielavesi, Laukkala und Jyllä (R.). Rautavaara, Honkamäki (Kỵhk.). - Kb. Juuka. im Fialk- und Serpentingebiete fq. (Kot.). Kiontiolahti. Romppala (Linnan.). Nurmes (Tain.). kion. Suojärvi, Mökkö (Norrl.). Suisaari und Kivatsch (Simm.). Valkeamäki und Tiudie (S.). - Om. Alajärvi, Vesterbacka und Kuparikallio (Backm.). - Ok. Kajana (Kyyhk.). Paltamo, Kives (Lackstr.). sotkamo, Aarreniemi und Tuoriniemi (Kyyhk.); Heinäjoki (K.). Ristijärvi (Lackstr.). Hyrynsalmi, Kiviranta (Kỵ̧h.). Puolanka, Törisevä und Leppälä (K.). Suomussalmi, Parvala, Kaivosuo und Hãmeenniva (K.). - ob. Kempele (Huun.). Rovaniemi und Ylitornio st. fq. (Hult). - K. Kuusamo, an vielen Fundorten (Nyb., Sahlb.. Broth., E. af H.). - Kk. Iiavanjoki (Broth.). Sonostrov und Kinjäscha (Sahlb) - Lkem. Kittilä fq. (Hult). Sodankylä (Blom). Kuolajärvi, zw. Airistunturi und Mikkola (Linnan.). Sallatunturi (E. af H.). Kutsanjoki (E. af H.). - Le. An mehreren Fundorten in der Nadelwald- und Birkenregion (Norrl.). Kilpisjärvi st. fq. bis in die alpine Region (Kot.). - Li. Fq., in der Nadelwaldregionst. Pq. in der Birkenregion und nicht selten in der alpinen Region (Hult). - L Lm. Kandalaks (Sahlb.). Umpjarr, Kopustjave und Pontschosero (Kihlm.). T'schunosero und Hibinü (Broth.). Lt. Tsipnavolok (Broth.). - Lmur. Teribjerka und Gavrilova (B.). - Lp. Orlov (Kihlm.). Rusiniha und Triostrova (Broth.). Ponoj (Brenn.).

S. Sk.-Vb., LuL.

N. $S m \cdot-F$.

spitzbergen, Europa, Kaukasus, Thian schan, Sibirien, Nord-Amerika.

657. Campylium polygamum (Bryol. eur.) Bryhn 1. c. p. 61. [Amblysteginm polygamum Bryol. eur. 55/56 Mon. p. 16. t. 10 (1853). - Hypnum polygamum Wils. Bryol. brit. p. 36.5 (185.5). - Amblystegium auriculatum Bryhn in Nyt Mag. Naturr. Bd. 40, Heft ‘, p. 9 (1902).]

Polyöziseh; Blüten oft zu 2-4 an sehr kurzem Astchen gehäuft, meist und ₹, seltener $\sigma^{7}$. Naeh Grösse und Tracht sehr veränderlich, bald C. stellatum, bald Amblystegium riparium gleichend. Rasen locker, grün oder gelbgrün bis goldbraun. Stengel \pm verlängert. niedergestreckt bis aufsteigend, streckenweise mit Rhizoidenbüscheln oder mit spärlichen Rhizoiden. Stengelblätter wenig herablaulend, aufrecht- bis weit abstehend, nicht zurüekgcbogen, aus sehr verengter Batsis breit lanzettlich, allnählich in eine lange, rinnig-hohle Pfrieme verschmälert, bis $3 \mathrm{~mm}$ lang und bis $0,9 \mathrm{~mm}$ breit, ganzrandig; Rippe dïn, meist einfach, 1/2_ $3 / 4$ des I3lattes durchlaulend; Zellen 1: $10-15$, ju deı stark ausgehöhlten Blattflügeln rektangulär und länglich-mehreckig, gelb oder hyalin, eine grosse, deutlich abgesetzte Gruppe bildend. Innere Perichätialblätter aufrecht, allmählich lang zugespitzt, ganzrandig. Seta $2-4 \mathrm{~cm}$. Kapsel bis $4 \mathrm{~mm}$ lang. Ring 3reihig. Deekel gespitzt. Sporenreife im Juli.

An feuchten. sandigen Orten, besonders am Meeresufer und auf sumpfigen Wiesen.

F. At.st. fq. (Bom.). - Ab. Pargas. Ontala und Skräbloōle (Elfv.). Kimito, Tjuda (Ols.). Finby (Broth.). Bromarf (Sundv.), - N. Ekenäs, Tvärminne (Broth.). Ingà, Skälö und Skeppö (WV. Brenn.). Esbo, Hagalund (Broth.). Helsingfors (Lindb.). Tusby, Saksa (Broth.). sibbo, Löparö (B.). Borgá, 
Tirmo (Jusl.). Lovisa, Kattön (Lindb.). - Ka. Fredrikslıann, Aspo (L.). - Sl. Ikaalinen, Uuraslahti (Sundv.) - Ta. Vanaja, Harviala (Häyr.). Lammi, Evo, Savijärvi (Norrl.). Hollola, Papinsaari (N.). Asikkala (N.). Padasjoki, an mehreren Fundorten (N.). Kuhmoinen, Koski (N.). Ifartola (Bonsd.). Korpilahti und Luhanka, an mehreren Fundorten (Vain.). - Sa. Taipalsaari (Simm.). Kangasniemi, Korteniemi (Lackstr). - Kl. Ruskeala, Marmorbruch (Norrl.). - Tb. Pihlajavesi (Vain.). Keuru, Mänttä (Sael.). Viitasaari (Broth.). - Sb. Pielavesi, Jylhä, Mustikkaniemi (Roiv.). - Om. Brahestad (Broth.). - Ok. Kajana (Broth.). - Kpom. Luvajärvi (Vain.). - K. Kuusamo (1. Nyl., Nyb.); YliKitkajärvi, Tolva (Broth.), - Lkem. Kolari, Jokijalka (Hult). Mruonio, Ylläsjoki (lIult). - Li. Inari, Kopsusjärvi u. Palokki (Hult); Vastusjärvi, Juppura (H.). Utsjoki, bis in die Birkenregion (H.). Lm. Kandalaks (Sahlb.) — Lt. Am Kolabusen nicht selten (Broth.). Tsipnavolok (B.). - Lmur. Olenka, Rinda u. Varsinsk (B.). - Lp. Katschkova (B.). Ponoj (Brenn.).

S. Sk., Bl., Öl., Gll., Ög., Srm., När., Dlr., Hrjd. u. Vb.

N. Sm. pass., JL Sandefjord. R. am Meeresufer. NT. Stjoldalen. No.-F.

Spitzbergen, Beeren Eiland, West- und Zentraleuropa, Sibirien, Japan, Nord-Amerika.

var. fallaciosum (Jur.) Mild. Bryol. siles. p. 316 (1869). [Hypnum fallaciosum Jur. in Verh. zool. bot. Ges. XI. p. 267 (1861). - Amblystegium polygamum * A. fallaciosum Lindb. Musc. scand. p. 32 (1879).]

Kräftiger als die Hauptart, mit meist sichelförmig-einseitswendigen Stengeluncl Astspitzen. Rippe sehr veränderlich, kürzer oder länger bis fehlend, meist ungleich 2schenkelig.

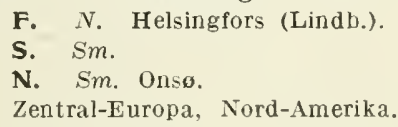

\section{HYGROAMBLYSTEGIUM}

Loesk. Moosfl. d. Harz. p. 298 (1903) ex p.

Autözisch. Stengel mit armzelligen Zentralstrange; Paraphyllien fehlend. Blätter aufrecht-abstehend oder schwach einseitswendig, ohne Längsfalten, nicht oder wenig herablaufend, ei- bis länglich-lanzettlieh; Rippe kräftig, kurz vor oder in der Blattspitze aufhörend, selten austretend; Zellen derbwandig, verlängert 6seitig, 1: 2-4, auch bis 1: 6. Sporogone wie bei Amblystegium.

Ư bersicht der Arten.

A. Blätter stumpflich

658. H. fluviatile.

B. Blätter langspitzig 659. H. irriguum.

658. Hygroamblystegium fluviatile (Sw.) Loesk. Moosfl. d. Harz., p. 299 (1903). [Hypnum fluviatile Sw. Disp. musc. suec. p. 63 (1799). - Amblystegium fluviatile Bryol. eur. fasc. 62/6+ Suppl. t. 1 (1855).]

Autözisch. Pfl. in feucht weichen, dunkel- bis schwarzgrünen oder gelbgrünen, meist flutenden Rasen. Stengel meist nur am Grunde mit Rhizoiden, zähe, in älteren Teilen entblösst, unregelmässig verästelt; Äste verlängert, einfach bis \pm verzweigt. Stengelblätter allseits abstehend, oft schwach einseitswendig, trocken dachziegelig, aus nicht herablaufendem, etwas verengtem Grunde ei- bis länglichlanzettlich, stumpflich, bis $2 \mathrm{~mm}$ lang und bis $0,75 \mathrm{~mm}$ breit, flach- und ganzrandig: Rippe fast stielrund, oberwärts nur wenig schwächer, dicht vor der Blattspitze aufgelöst; Zellen am Grunde rektangulär, in den nicht ausgehöhlten BlattflügeIn kaum differenziert. Perichätialblätter aufrecht, verlängert lanzettlich. stumpflich, ganzrandig; Rippe kräftig, in der Spitze aufgelöst. Seta 1,2-2 cm, rot. - Fig. 85 I-L.

In Bächen und Fliissen kalkfreier Gewässer, sowohl auf Steinen als auch auf Holzwerk. Sehr selten fruchtend.

F. Ab. Abo, Hallis (Elfv.). Vichtis, Niemenkylä (Hult). Pusula (Broth.). — N. Karis, Svartá (Jusl.). Esbo, Bemböle (Sundv.). Helsinge, Gammelstaden (Lindb.). Strōmfors, Abborfors (Arrh.). - 
Ka. Kotka, Langinkoski (Roir.). Rättijärvi (Buch), - Ik. Rautu, Koskitsanoja (H. Lindb.). Sakkula, Ojaniemi (Hid.). - Ta. Asikkala, Vesijärvi (Norrl.); Vääksy (Häyr.); Kajaan kallio und Kaitas (N.). Padasjoki, an mehreren Fundorten(N.). Kuhmoinen (N.). Tammerfors (Simm.). Hartola (Bonsd.). Korpilahti, Päiväkunta (Vain.). Luhanka, Tammijoki (V.). - Sa. Valkeala, Tirva (Sundv.). Kangasniemi (Lackstr.). - Kl. Kurkijoki (Jusl.). Jaakkima (Jusl.). Sortavala, Kirjavalahti (W. Nyl.). - Kol. Mjatusova (Elfv.). - Tb. Jyväskylä, Tourujoki (Brotlı.). Viitasaari, Ilınojoki (B.). — Sb. Nilsiä (Teräsv.). Iisalmi, Soinjoki (Sahlb.). - Kon. Kentjärvi (Simm.). Suopohja (Kullh.). Solomina (K.). Suunu (Norrl.). Pirtliniemi (S.). - Ok. Kajana (Lackstr.). Utajärvi, Myllyranta (L.). Suomussalmi, Ruuki (Kyyhk.). - Ob. Ylitornio, Kaarasnäs (Hult). - K. Kuusamo, Käyläkoski (Broth.); Oulankajoki, Merenoja (B.); Selkäjoki (B.).

S. Sh. $-\mathrm{Hsl}$.

N. Sm. Skjeberg. A. Kristiania pass. Bu. Ringerike st. r.

Europa, Nord-Amerika.

659. Hygroamblystegium irriguum (Wils.) Loesk. 1. с. [Hypnum irriguum Wils. Bryol. brit. p. 361, t. 25 (1855). - Amblystegium irriguum Bryol. eur. fasc. 62/64 Suppl. ad gen. Amblystegium (1855).]

Autözisch. Pfl. in flachen, trocken sehr starren, gell)- bis clunkel- und schwärzlichgrünen Rasen. Stengel hingestreckt, zähe, absatzweise mit Rhizoiclenbüscheln, \pm deutlich fiederästig; Äste meist aufrecht, gegen das Sprossendie kürzer werdencl. Stengelblätter abstehend bis einseitswendig, aus herablaufendem Grunde ei- bis länglich-lanzettlich, lang und fein zugespitzt, bis $1,5 \mathrm{~mm}$ lang und bis $0,5 \mathrm{~mm}$ breit, flach- und ganzrandig bis undeutlich gezähnt: Rippe kräftig, kurz vor oder mit der Blattspitze endend, zuweilen den oberen Pfriementeil ausfüllend; Zellen am Blattgrunde rektangulär, gelbbraun und dickwandig, in den ausgehöhlten Blattflügeln quadratisch. Innere Perichätialblätter aufrecht, lanzettlich, allmählich scharf zugespitzt, ganzrandig oder oberwärts uncleutlich gesägt; Rippe kräftig, vollständig. Seta $2-3 \mathrm{~cm}$, rot, oben gelblich.

Auf Steinen an nassen und sumpligen Orten.

F. Ab. Lojo, Isosaari. Askola, in tiefen Schluchten kalkhaltigen Gesteins (Lindb.).

S. Sk., Ög. und $U p l$. an einzelnen Fundorten.

N. Sm. Tune. JL. Tjomo. No. Sorfolden.

Europa, Kaukasus, Altai, Nord-Amerika.

\section{CRATONEURUM}

(Sull.) Roth in Hedwigia XXXVIII. Beibl. p. 6 (1899). [Hypnum Subg. Craloneurum Sull. Musc. and Hep. U. S. p. 73 (1856).]

Diözisch. Stengel ahne Zentralstrang; Paraphyllien zahlreich, vielgestaltig, ungeteilt. Blätter meist sicheliörmig und stark faltig, aus \pm weit herablaufender, verengter Basis eiförmig oder dreieckig-herzförmig und lanzettlich-pfriemenförmig zugespitzt; Rippe kräftig, vor der Blattspitze aufhörend bis austretend; Zellen in clen ausgehölılten Blattflügeln locker, hyalin oder gefärbt. Seta lang und kräftig.

A. Blattzellen glatt.

a. Blattzellen eng linealisch

660. C. glaucum.

b. Blattzellen kurz, rundlich-6seitig 661. C. filicinum.

B. Blattzellen papillös, rundlich-6seitig 662. C. decipiens.

660. Cratoneurum glaucum (Lam.). \Hypnum glaucum Lam. Fl. Franc. 1. p. 522 (1778). - H. commulalum Hedw. Descr. IV. p. 68, t. 26 (1797). - Amblyslegium glaucum Lindb. Musc. scand. p. 32 (1879). - Craloneurum commulatum Roth in Hedwigia XXXVIII. Beibl. p. 6 (1899); Moenkem. in Pasch. Süisswass.-Fl. Heft 1.1. p. 116 (1914).]

Pfl. in weichen, lockeren bis dichten, \pm tiefen, grünen oder gelbgrünen, innen oft ron Kalktuff durchsetzten Rasen. Stengel aufsteigend bis aufrecht, durch 
rotbraune, papillöse Rhizoiden filzig, locker beblättert, dicht kammartig gefiedert; Paraphyllien selır zahlreich und vielgestaltig. Stengelblätter sichelförmig, tief längsfaltig, aus herablaufender, enger Basis plötzlich breit dreieckig-herzförmig, rasch lanzettlich zugespitzt und rinnig hohl, bis $2 \mathrm{~mm}$ lang und bis $1 \mathrm{~mm}$ breit, flachrandig, weit herab fein gezähnt; Rippe vor der Blattspitze aufhörend; Zellen eng linealisch, 1: 6-10, am Grunde locker, in den ausgehöhlten Blattflügeln locker rektangulär bis verlängert. Astblätter gedrängt, sichelförmig, kleiner und schmäler, trocken an der Spitze gekräuselt. Innere Perichätialblätter aufrecht, längsfaltig, verḷängert lanzettlich, scharf zugespitzt. Seta $4-5 \mathrm{~cm}$, rot. Sporenreife im Mai und Juni.

F. Ok. Paltamo, Melalahti, Hahtola (Kyylik.).

S. Sk., Öl., Sm., Gll., Ög., Vg., Upl., Vsm., Dlr., Hrjd., Jmt., Ang., LyL. und l'L.

N. A. Kristiania, Ringerike. SB.,NB., R. r. H. NT. Stjordalen. No. und Tr. Nordgrenze bei $70^{\circ} 40^{\circ} \mathrm{n} . \mathrm{Br}$.

Europa, West- und Zentral-Asien, Japan, Nord-Amerika.

var. falcatum (Brid.) Moenkem. ]. c. p.118. [Hypnum falcatum Brid. Muscol. rec. III. p. 63, t. 1, f. 6 (1801). - Amblystegium glaucum * A. faleatum Lindb. Musc. scand. p. 33 (1879). — Cratoneurum falcatum Roth Eur. Laubm. 11, p. 534 (1905).]

Kräftiger als C. glaucum. Pfl. in etwas starren, lockeren, gelbbraunen Rasen. Stengel meist aus niederliegendem Grunde aufsteigend, ohne oder mit spärlichen Rhizoiden, dicht beblättert, unregehmässig beästet; Äste meist zweizeilig gestellt: Paraphyllien zahlreich. Stengelblätter sichelförmig, tief längsfaltig, aus kurz herablaufender, länglich-eiförmiger Basis allmählich lanzettliclı-pfriemenförnıig, bis 2,2 $\mathrm{mm}$ lang und etwa $0,9 \mathrm{~mm}$ breit, flachrandig, nur am Grunde undeutlich gezähnelt; Rippe vor der Blattspitze aufhörend; Zellen linealisch-wurmförmig, 1: 8-12, dickwandig und getüpfelt, am Blattgrunde locker, klein, stark verdickt, goldbraun, in den ausgehöhlten Blattflügeln wenig differenziert. Innere Perichätialblätter sehwach längsfaltig. Seta $2-3 \mathrm{~cm}$, rot.

In kalkhaltigen'Sümpfen, an Seeufern und an quelligen Stellen.

F. Al. Eckerö, Storby (Alrh.). Jomala, Ytterby (Bom.). Saltvik, an mehreren Fundorten (B.). Sund, Tjurnäs (B.). - Sb. Kaavi, Siikajärvi, Huosiaisnieni (Kot.). - Kon. Selki (Norrl.). - Ok. Paltamo, Melalahti, Horkanpuro cpp. (Lackstr.). Puolanka (L.); Salminen (Kyyhk.). Suomussalmi, Kiannankylä, Ulkupuro (Kyyhk.). - K. Kuusamo, zw. Rukatunturi und Pyhävaara (Broth.); Juuma (B.); zw. Liikanen und Oulankajoki (B.); Juurikkavaara (E. af H.). - Le. Kilpisjärvi (Norrl.); Malla und Saana fq. (Kot.). - Li. Utsjoki. Mandojäyri, in der Birkenregion (Kilhlm.); Bados, Koadniljokka (Ranck.). - $L \mathrm{~m}$. Kandalaks (Sahlb.). Hibinä, in der Nadelwaldregion (Broth.); Tuil-luht (Kihlm.). - Lt. Vaidoguba (Broth.).

S. Verbreitung wie bei der Hauptart.

N. Sm. Onsø. A. Kristiania. JL. Tjømø. Bu. Eker. Ringerike rr. Dovre. No.-F. Nordgrenze bei ca. $70^{\circ} \mathrm{n}$. Br.

Europa, Algier, Kaukasus, Persien, Pendschab, Turkestan, Nord-Amerika.

var. sulcatum (Schimp.). [Hypnum sulcatum Schimp. Syn. p. 699 (1860); emend. Syn. ecl. 2, p. 744 (1876). - Amblystegium glaucum $\gamma$ sulcatum Lindb. Musc. scand. p. 32 (1879). - Cratoneurum sulcatum Roth Eur. Laubm. II. p. 536 (1905).]

Pfl. in \pm dichten, etwas starren, gelbbräunlichen und bräunlichgrünen Rasen. Stengel bis $6 \mathrm{~cm}$, aus niederliegendem Grunde aufsteigend, ohne oder mit spärlichen Rhizoiden, unregelmässig gefiedert; Paraphyllien zahlreiclı. Stengelblätter stark sichelförmig, fast eingerollt, aus kurz herablaufender, breit eiförmiger Basis schmal lanzettlich, lang und fein zugespitzt, bis $1,5 \mathrm{~mm}$ lang und bis $0.7 \mathrm{~mm}$ breit, am Grunde faltig und sackartig ausgehöhlt, mit nur am Grunde schmal umgebogenen und gezähnelten Rändern; Rippe schmal, $1 / 4-1 / 2$ cher Blattlänge, zuweilen undeutlich; Zellen rhomboidisch-6eckig, 1: 3-5, am Blattgrunde oval, 4-6eckig. goldgelb, dickwandig, in den ausgehöhlten Blattflïgeln oberwärts quadratisch.

In feuchten Lagen an Felsen und deren Detritus, meist auf Kalk und kalkhaltigen Schiefern. 
S. $P L$.

N. Dovre, SB. Strandebarm.

Spitzbergen, Alpengebiet in der alpinen Region, Grönland, Alaska.

var. subsulcatum (Schimp.). [Hypnum subsulcatum Schimp. Syn. p. 698 (1860). - Amblystegium subsulcatum De Not. Epil. p. 152 (1869). - Hypnum sulcatum var. subsulcatum Schimp. Syn. 2. ed. p. 744 (1876). - Cratoneurum sulcalum var. subsulcalum Rotl. Eur. Laubm. II. p. 536 (1905).]

Pfl. in lockeren Rasen. Stengelblätter trocken \pm gekräuselt, schwächer gefurcht, länglich-lanzettlich, allmählich lang und feinspitzig; Rippe über die Blattmitte reichend, zuweilen gegabelt; Zellen oberwärts wurmförmig, 1: 8-12.

N. No.-F. bis oberhalb der Baumgrenze hinaufsteigend.

Alpengebiet.

var. irrigatum (Zett.) Moenkem. 1. c. p. 118. [Hypnum irrigalum Zett. in K. Sv. Vet.-Ak. Handl. V. No. 10, p. 48 (1865). - H. commutatum y fluctuans Bryol. eur. fasc. 57/61, Mon. p. 39, t. 26, f. r 1-3 (1854). - Amblystegium irrigatum Vent. et Bott. Enum. crit. p. 13 (1884). - Cratoneurum irrigatum Roth Eur. Laubm. II. p. 536 (1905).]

Kräftige Pfl. in starren, dunkel- bis schwarzgrünen, meist flutenden Rasen. Stengel bis $20 \mathrm{~cm}$, unregelmässig, oft büschelig beästet; Paraphyllien spärlich bis fehlend. Stengelblätter aufrecht-abstehend bis schwach sichelförmig, am Grunde undeutlich faltig, wenig herablaufend, eilanzettlich, allmählich zugespitzt, bis 2,5 $\mathrm{mm}$ lang und etwa $0,9 \mathrm{~mm}$ breit, flachrandig, nur am Grunde undeutlich gezähnelt; Rippe sehr kräftig, ziemlich gleichbreit, am Rücken stark vortretend, in "der Blattspitze mit der zweischichtigen, Lamina verschmolzen; Zellen eng linealisch, 1: 12-18, an Grunde locker, in den nicht ausgehöhlten Blattflügeln kaum differenziert.

An Steinen in fliessenden Gewässern der Schiefer- und Kalkgebiete.

F. K. Kuusamo, Kuusinkijoki, zw. Vuotunki und Paanajärvi (E. af H.). Le. Kilpisjärvi, Kitji-Malla (Kot.). 一 Li. Sodankylä, Luirojärvi in der Fichtenregion (Hult).

S. Jmt.

N. Dovre. NT. Stjørdalen. No. $-F$. an wenigen Fundorten. Nordgrenze bei ca. $70^{\circ} 10^{\circ} \mathrm{n}, \mathrm{Br}$. Europa, Kaukasus, Turkestan.

661. Cratoneurum filicinum (L.) Roth 1. c. [Hypnum filicinum L. Sp. pl. p. 1125 (1753). - Amblystegium filicinum De Not. Cronac. II. p. 25 (1867).]

Pfl. in meist dichten, oft ausgedehnten, grünen bis gelbgrünen oder bräunlichgelben Rasen. Stengel kriechend, aufsteigend oder aufrecht, oft \pm rotfilzig und meist unterbrochen gefiedert; Äste kurz, zweireihig abstehend; Paraphyllien meist zahlreich, vielgestaltig. Stammblätter \pm abstehend, nicht faltig oder schwach faltig, aus verengter, weit herablaufender Basis dreieckig-herzförmig, schmal lanzettlich zugespitzt, bis $1,5 \mathrm{~mm}$ lang und bis $1 \mathrm{~mm}$ breit, flachrandig, rings klein gesägt; Rippe kräftig, fast vollständig; Zellen in der Melırzahl 1: 2-4, in den stark ausgehöhlten Blattflïgeln sehr erweitert, aufgeblasen, hyalin oder gelb, eine grosse, scharf begrenzte, dic Rippe erreichende Gruppe bildend. Astblätter häufig einseitswendig bis sichelförmig, eilanzettlich; Rippe schwächer und kürzer. Perichätialblätter aufrecht, gelblich oder weisslich, längsfaltig, allmählich oder rasch pfriemenförmig, ganzrandig oder am Grunde der Pfrieme unregelnässig gezähnt. Seta $3-4 \mathrm{~cm}$, unten dunkel-, oben gelbrot. Kapsel braun, trocken eingekrümmt, entdeckelt unter der weiten Mündung eingeschnürt. Sporenreife im Mai und Juni. Fig. $88 \mathrm{~A}-\mathrm{C}$.

Auf nasser Erde, ïberrieselten, gern kalkhaltigen Felsen, faulendem Holz, in Sümpfen und an quelligen Orten.

F. Al. pass. (Bom.). - Ab. Korpo (Ekl.). Pargas (Aırh.); Bläsnås (Link.). Karislojo, Kourijoki (Sundv.). Lojo, Ojamo (E. af H.); Isosaari, Paavola und Pietilä (Hult). - N. Ekenäs Hermansö (H. Lindb.). Helsingfors (Lindb.). - Ta. Hollola Uskila (Norrl.). - Kl. Sortavala, Mäkisalo, Linnavuori 

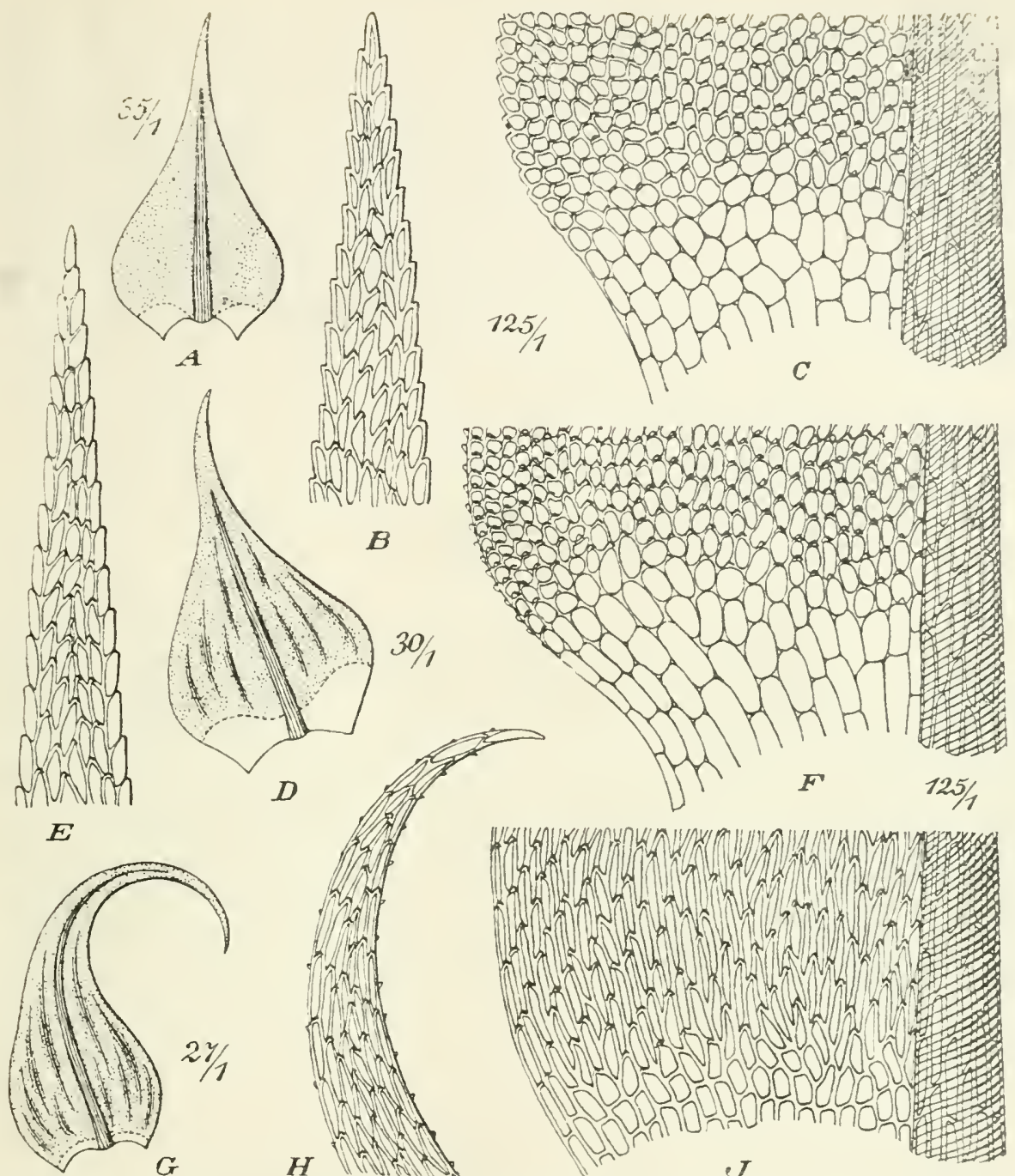

$D$

G
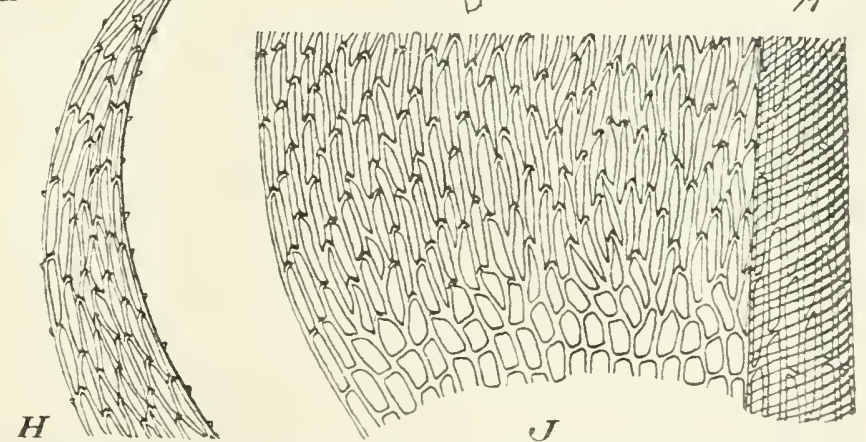

Fig. 88. A-C. Cratoneurum filicinum (L.). A Stengelb. (35/1); B Blattspitze (125/1); C Blattbasis (125/1). - D-F. C. decipiens (De Not.) D Stengelb. (30/1); E Blattspitze (125/1); F Blattbasis (125/1). - G-I. C. glaucum var.' falcatum (Brid.) G Stengelb. (27/1); H Blattspitze (125/1); I Blattbasis $(125 / 1)$.

(Lång); Harlu (Kuj.). - Kol. Petrosarodsk (Simm.). - Kon. Suopohja (Simm.). Kivatsch (Kullh.). Tiudie (Norrl.). Pirttiniemi (Sahlb.). - Ok. Paltamo, Melalahti, Ellinlampi (Kyyhk.). Suomussalmi, Kiannankylä, Ulkupuron suo (K.). - K. Kunsamo, an mehreren Fundorten (Broth., E. af H., Roiv.). - Lim. Inari, Kaamas (Hult), - Lmur. Rinda und Litsa (Broth.). — Lp Katschkova (Brenn.). - Lv.

Tschapoma (Sahlb., Broth.).

S. Sk.- Ang., LuL.

N. Sm. $-F$. vom Meeresniveau bis $\mathrm{zu} 800 \mathrm{~m}$.

Europa, Algier, West-, Nord- und Ost-Asien bis Japan und China, Nord-Amerika, New Zealand. Nordgrenze auf Spitzbergen.

var. fallax (Brıd.) Moenkem. in Pasch. Süsswasserfl. Bryophyta p. 119 (1911). [Hypnum fallax Brid. Muscol. rec. II. P. II. p. 66, t. 2, f. 1 (1801). - Amblyste- 
gium fallax Mild. Bryol. siles. p. 325 (1869). - Amblysteginm filicinum * fallax Lindb. Musc. scand. p. $32(1879)$.]

Pfl, in lockeren, sehr starren, dunkel- bis schwarzgrünen, meist flutenden Raseı. Stengel mit spärlichen Rhizoiden, meist regelmässig gefiedert; Äste steif aufrechi-abstehend, gegen die Stammspitze allmählich kürzer; Paraphyllien ziemlich spärlich. Ältere Blätter bis auf die Rippe zerstört. Stammblätter steif aufrecht, aus etwas herablaufendem Grunde breit lanzettlich, bis $1,8 \mathrm{~mm}$ lang und bis 0,6 mm breit, flach- und ganzrandig oder undeutlich gezähmelt; Rippe sehr kräftig und als Endstachel \pm lang austretend: Zellen oberwärts verlängert 6 seitig. 1: 1-6, am Blattgrum le länglich und verlängert rektangulär, in den schwach ausgehölnlten Blattflügeln erweitert, quadratisch und kurz rektangulär, gelb- und dickwandig. Astblätter wenig kleiner.

An Steinen in kalkreichen Quellen und Bächen.

S. Gtl. Visby.

N. NT. Stjordalen.

Europa, Algier, Kaukasus. Armenien, Turkestan. Sibirien, Nord-Amerika.

* Cratoneurum curvicaule (Jur.). [Hypnum curvicaule Jur, in Verh. zool.bot. Ges. Wien. XIV. p. 103 (1861). -- Amblystegium filicinum var. curvicaule Mol. Bayr. Laubm. p. 238 (1875). - A. filicinum * A. curvicanle Lindb. Musc. scand. p. $32(1879)$.]

Pfl. in dichten, gelbgrünen, goldgelben oder bräunlichen, zuweilen etwas glänzenden Rasen. Stengel niederliegend oder anfsteigend, geschlängelt, mit spärlichen Rhizoiden, unregeimässig fiederig. meist armästig. mit meist einseitswendigen und gekrummten Stamm- und Astspitzen: Aste meist kurz, einseitig oder zweizeilig abstehend; Paraphyllien spärlich, nur in der Nähe der Astanlagen. Stammblätter aufrecht-abstehend, trocken dachziegelig, herablaufend, eilanzettlich, \pm rasch zugespitzt, bis $1,2 \mathrm{~mm}$ lang und bis $0,6 \mathrm{~mm}$ breit, flachrandig, rings oder nur oberwärts klein gesägt; Rippe weniger kräftig, weit vor der Blattspitze aufhörend: Zellen eng rhombisch-linealisch, etwa 1: 6, in den schwach ausgehöhlten Blattflügelı erweitert. hyalin oder gebräunt. eine scharf begrenzte, die Rippe nicht erreichende Gruppe bildend. Astblätter einseitswendig mol schwach sichelförmig, lanzettlicì, zugespitzt.

Meist auf trocknerer Unterlage ais $H$. filicinum, auf steinigen und Triften kalkhaltigen Schiefern.

F. Lkem. Iuonio, Laitavaara, an einer Quelie in der Fichtenregion (Norrl.).

S. L., ohne nallere Aigabe cier Fundorte.

N. No, $-F$, an wenigen Fundorten.

spitzbergen, Beeren-Eiland, Schottland, Alpengebiet.

var. patulum (Hag.). [Hypnum curvicaule var, patulum Hag. Musc. Nors. bor. p. 327 (1901). — Ambilystegium curvicaule var. patulum Möll. Fört. Sk. växt. 2. Moss. p. 39 (1907).]

Blätter allseits abstehend, mit eingekrümmter Spitze oder hakenförmig einseitswendig.

N. No. Sorfolden und Ankenes. Tr. Ibbestad.

662. Cratoneurum decipiens (De Not.) Loesk. Moosfl. d. Harz. p. 311 (1903). |Thuidium decipiens De Not. Epil. p. 233 (1869). — Amblystegium ylaucum $\beta$ decipiens Lindb. Musc. scand. p. 32 (1879).]

Tracht von C. filicinum. Pll. in lockeren, oft ausgedehnten, dunkel- bis braungrünen Rasen. Stengel meist aufreclit, steif, his $10 \mathrm{~cm}$, oft durch rotbraune, papillöse Rhizoiden filzig, regelmässig gefiedert; Äste kurz, dünn, zweizeilig abstelıend; Paraphyllien sehr lang und sehr zahlreich. Stammblätter sparrig abstehend und verbogen, aus weit herablaufender und zusammengezogener, sackartig ausgehöhlter Basis breit dreieckig-herzförmis, rasch kurz- und schmalspitzig. oft breiter als 
lang, bis 1,2 $\mathrm{mm}$ lang und bis 1,35 mm breit, mit am Grunde zurückgeschlagenen, rings gesägten Rändern; Rippe vor der Blattspitze endend; Zellen fast parenchymatisch 1-6seitig, 1:3-5, mit meist nur je einer spitzen I'apille in der oberen Hälfte der Aussenwand, am Blattgrunde sehr locker, hyalin, dünnwandig, glatt, in den Blattflügeln verlängert rektangulär. Astblätter kleiner, meist sichellörmig, eiförmig, schmalspitzig. Inneres Peristom bleich, dicht anliegencl, längsfaltig, pfriemenförmig zugespitzt. Seta $3-4 \mathrm{~cm}$, rot. - Fig. 88.

An quelligen Stellen.

F. Sb. Juuka, Petrovaara, Mäkönieni (Kot.). - Ok. Paltamo, Ielalahti. an mehreren Fundurten (Lackstr., Kyyhk.). Puolanka, Salminen (Kyyhk.). Suomussalmi, Kiannankylä, Ulkupuro (k.). K. Kuu־amo, Iivara (Sil.); zw. Rukatunturi und Pyhäjärvi (Broth.); «W. Liikanen und Oulankajoki (B.); nördlich vom Juurikkavaara (E. af H.); Savinajoki (Roiv.), - Lkem. IIuonio, Keimiotunturi, in der Nadelwaldregion (Norrl.). - Le. Kilpisjärvi, in der alpinen Region (N.); Salana. in der Birkenregion (Kot.). - Li. Sodankylä, Matarakoski (Hult). Inari, Ivalo (Sil.). Lim. Kandalaks, Schelesnaja (Sahll,.). - Lt. Tsipnavolok und Vaidoguba (Broth.). - Lmur. Teribjerka und Rindil (B.).

S. Vg., Mpd., fing. u. LyL. an einzelnen oder wenigen Fundorten.

N. A. Kristiania, $J L$. Dranmen. $B r$. Skien, Ringerike, $R$. Geiranger und Merok. $H$. Lille Elvedal. ST. Dovre. NT. stjordalen. Yo. - F. an melıreren Fundorten, Nordgrenze bei $70^{\circ} 10^{\prime} n$. Br.

Europa, kaukasus: Canada.

\section{DREPANOCLADUS}

(C. Müll.) Roth in Hedwigia XXXVIII. Beibl. p. 6 (1899); Warnst. in Beibl. z. Bot. Centralbl. XIII. p. 397 (1903).

Meist \pm kräftige Sumpf- und Wassermoose in glänzenden, ausgedehnten, oft tiefen Rasen. Stengel ohne oder mit spärlichen Rhizoiden, meist unregelmässig oder regelmässig fiederästig, mit in der Regel sichelförmig gekrümmten Sprossenden; Pseudoparaphyllien nur in der Nähe der Astanlagen. Blätter meist \pm einseitig-sichelförmig oder hakig gekrümmt, \pm hohl, aus meist verengter und \pm herablaufender Basis ei- bis fast dreieckig- oder herzförmig-lanzettlich und kurz bis selır lang pfrienenförmig zugespitzt; Rippe einfach, \pm verlängert: Zellen meist verlängertlinealisch, glatt, in den meist \pm ausgehölıten Blattflügeln parenchynatisch, eine gut begrenzte Gruppe bildend, selten nicht differenziert. Perichätialblätter aufrecht, meist längsfaltig, sehr lang und schmal zugespitzt. Kapsel geneigt bis horizontal, zylindriseh, gekrümmt, trocken meist unter der Urnenmïndung verengt. Ring meist differenziert. Deckel gewölbt-kegelig, mit Spitzchen.

\section{$\dot{\mathrm{U}}^{\dagger}$ be rsicht de $\mathrm{r}$ A r tell.}

A. Diözisch. Stengel ohne Zentralstrang. Blätter stark längsfaltig; Blattflügelzellen nichi differenziert ..................664. D. vernicosus.

B. Stengel mit Zentralstrang. Blattflügelzellen differenziert.

a. Blattflügelzellen nur etwas erweitert, von den übrigen nicht scharf geschieden.

๔. Autözisch. Blätter tief längsfaltig, stark sichelförmig, mit sehr langer Pfriemenspitze und mit gesägten Rändern 663. D. uncinatus.

ß. Diözisch. Blätter sehr hohl, gross und breit, \pm deutlich längsfaltig, nur in der Spitze stumpf gezähnt ...........................................6 672. D.lycopodioides.

b. Blätter ungefaltet; Blattflügelzellen nur wenige, gross und hyalin, ein flaches Öhrchen bildend.

«. Diözisch. Pfl. meist bräunlich 666. D. intermedius.

$\beta$. Autözisch. Pfl. meist purpurn oder griin und purpurn gesclieckt 665. D. revolvens. 
c. Blätter ungefaltet; Blattflügelzellen gut differenziert, eine grosse, scharf abgesetzte Gruppe bildend.

«. Blätter ganzrandig. Perichätialblätter längsfaltig.

I. Rippe ziemlich dünn; Blattflügelzellen die Rippe oft erreichend ...................................

II. Rippe kräftig; Blattflügelzellen die Rippe nicht erreichend

670. D. aduncus.

671. D. Sendineri.

d. Blätter ungefaltet; Blattflügelzellen oval, sehr stark verdickt 669. D. badius.

$\beta$. Blätter \pm deutlich gesägt. Perichätialblätter ungefaltet.

I. Autözisch. Blätter oberwärts oft mit Initialen oder Rhizoiden; Rippe dünn, meist in und über der Blattmitte verschwindend

668. D. fluitans.

II. Diözisch. Blätter nur selten mit Initialen oder Rhizoiden: Rippe kräftig, weit in die'Blattspitze fortgesetzt bis austretend

667. D.exannulatus.

S e c t. I. Sanionia (Loesk.) Broth. in E.--P. 1³. p. 1033 (1908). [Sanionia Loesk. in Hedwigia XLVI. p. 309 ex p. (1907) als Gattung.]

Autözisch. Stengel mit lockerzelliger Aussenrinde; Pseudoparaphyllien vorhanden. Blätter meist kreisförmig eingebogen. tief mehrfaltig, entfernt und fein gesägt; Zellen sehr eng, einige der nicht ausgehöhlten Blattflügeln hyalin und dünnwandig. Innere Perichätialblätter tief längsfaltig, oberwärts scharf gesägt. Ring vorhanden.

663. Drepanocladus uncinatus (Hedw.) Warnst. in Beilh. z. Bot. Centralbl. XIII. p. 417 (1903). [Hypnum uncinatum Hedw. Descr. IV. p. 65, t. 25 (1797). H. aduncum L. Sp. pl. p. 1126 excl. syn. Dill. (1753). - Amblystegium uncinatum De Not. Cronaca II. p. 24 (1867). - A. aduncum Lindb. Musc. scand. p. 33 (1879).]

Autözisch. Pfl. in lockeren oder dichteren, meist gelblich- bis bräunlichgrünen Rasen. Stengel niederliegend oder aufsteigend. Stengelblätter aus breiter Basis lanzettlich, allmählich sehr lang pfriemenförmig, bis $5 \mathrm{~mm}$ lang; Rippe über der Mitte oder in der Blattspitze verschwindend; einige Zellen der Blattflügel etwas erweitert, fast 6seitig, dünnwandig und hyalin, oberwärts von mehreren kleinen, parenchymatischen Zellen umschlossen. Innere Perichätialblätter aufrecht, sehr lang haarförmig zugespitzt. Seta $2-3 \mathrm{~cm}$, rot. Sporenreife Mai bis Juli. - Fig. $89 \mathrm{~A}-\mathrm{C}$.

An Steinen mul Felsen (Kieselgestein), auf steiniger, feuchter Erde, auf Humus und Waldboden, auf altem Holze, an Stämmen, Ästen und Baumwurzelı durch das ganze Gebiet vom Meeresufer bis in die alpine Region fqq. und meist reichlich fruchtend. Sehr formenreich.

Spitzbergen, Europa, Kaukasus, Himalaya, Zentral-, Nord- und Ost-Asien, Nord-Amerika, Ecuador, Chile, Patagonia, Fuegia, Süd-Georgien, Kerguelen, Crozet-Inseln, Ost-Australien, New Zealand, Antarktis.

var. subjulacens (Bryol, eur.) Warnst. 1. c. p. 418. [Hypnum uncinatum var.

subjulaceum Bryol. eur. fase. $57 / 61$ Mon. p. 31, t. 20, f. \& 1 et 2 (1854). - *H. orthothecioides Lindb. in Öfr. K. Sv. Vet.-Ak. Förh. XXIII. p. 540 (1867). Amblystegium aduncum * A. orthothecioides Lindb. Musc. scand. p. 33 (1879).]

Sehr kräftige Pfl. Stengel einfach oder unregelmässig kurzästig, oberwärts mitunter in längere Äste geteilt. Kapsel aufrecht oder geneigt und schwach gekrümmt.

fo, orthophylla Warnst. I. c.

Stengelspitzen gerıde. Stengelblätter dicht und steif aufrecht anliegend.

Tracht von Orthothecium.

Spitzbergen. 
fo. subfalcata Warnst. l. c. wendig.

Stengelspitzen \pm gebogen. Stengelblätter hakig bis fast sichelförmig einseits-

F. N. Ekenäs, Tvärminne (Häyr.). - Oa. Vasa, an mehreren Fundorten in den Schären (Broth.). Replot, Vallgrund (B.). - Lim. Fedosejevsk und Kandalaks, am sandigen Meeresufer (B.). Hibinä, zw. Vudjäyr und Vunnun-Vum (Kihlm.). - Längs den Ufern des Eismeeres, auch an Steinen und Felsen Pq., zuweilen Massenregetation bildend (B.).

S. LuL. Kvikkjokk.

N. Tr. und $F$. auf trocknen Uferwiesen pass., auch in der alpinen Region beobachtet. Schweiz, Salzburg.
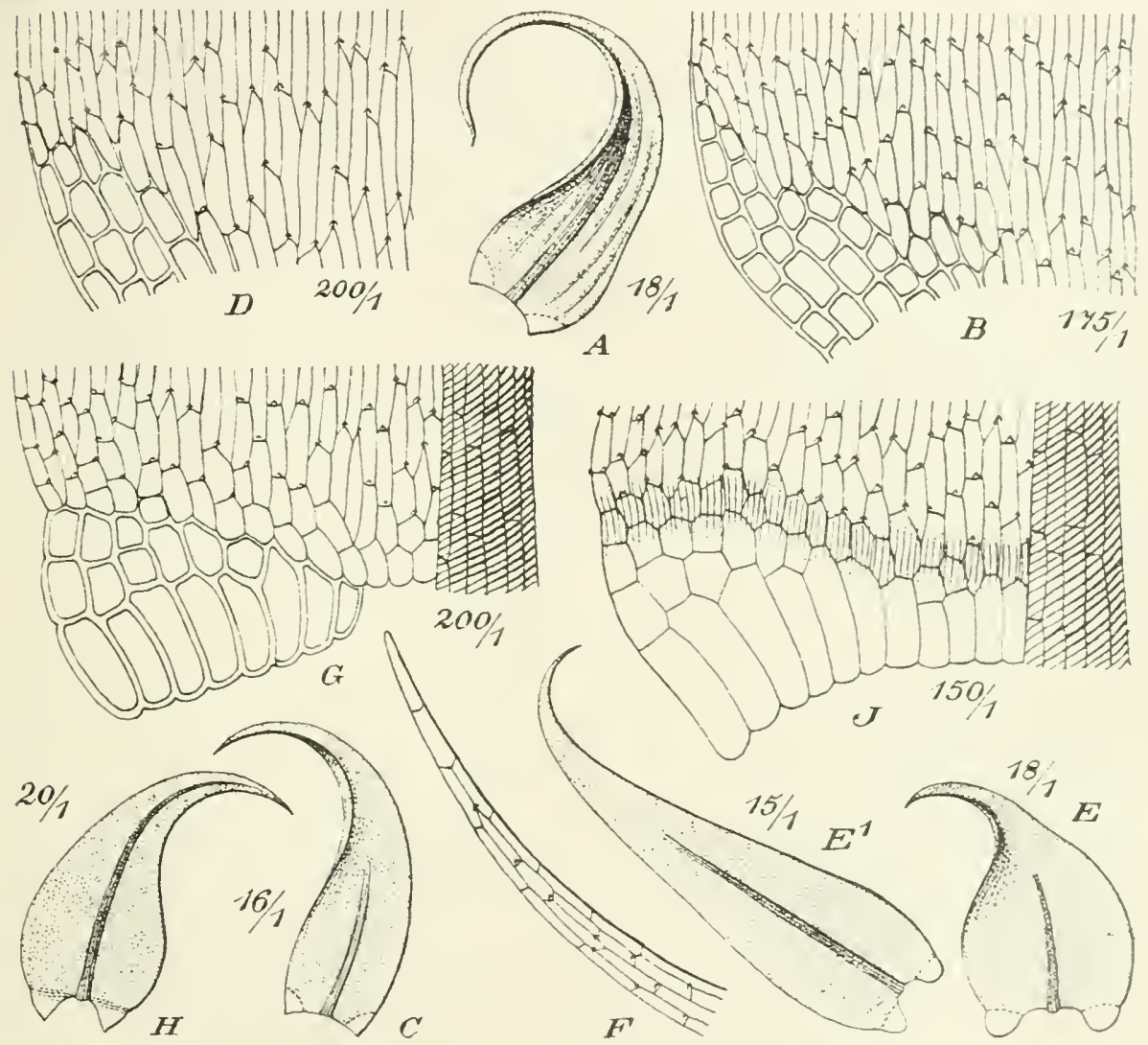

Fig. 89. A-B. Drepanocladus uncinatus (Hedw.). A Stammb. (18/1); B Blattbasis (175/1). - C - D D. fluitans (L.). C Stammb. (16/1); D Blattbasis (200/1). - E-G. D. aduncus var. polycarpus (Bland.). E Stammb. (18/1); F Blattspitze (200/1); G Blattbasis (200/1). - H-I. D. exannulatus (Günb.). H Stammb. (20/1); I Blattbasis (150/1).

var. abbreviatus (Bryol, eur.) Warnst. 1. c. p. 420. [Hypnum uncinatum var. $\gamma$ abbreviatum Bryol. eur. 1. c. f. $\beta 1$ et 2. - Amblystegium uncinatum v. abbreviatum Möll. Fört. Sk. växt. 2. Moss. p. 40 (1907).]

Stengel kürzer als bei der Hauptart, meist aufrecht und unregelmässig ästig. an der Spitze oft nur schwach sichelförmig gebogen. Stengelblätter sichelförmig gekrümmt, nur mit wenigen, schwachen Längsfalten.

N. nach Warnstorf.

Europa.

var. gracilescens (Bryol. eur.) Warnst. l. c. [Hypnum uncinatum var. graci- 
lescens Bryol. eur. 1. c. f. $\delta 1$ - Amblystegium uncinatum v. gracilescens Möll. Fört. Sk. växt. 2. Moss. p. $40(1907)$.]

Sehr zierliche Sumpfmoose. Stengel aufrecht, bis $10 \mathrm{~cm}$, fast regelmässig geficdert, an der Spitze \pm sichelförmig. Stengelblätter kürzer, weniger sichelförmig, ohne oder mit schwachen Längsfalten.

F. Lkem. Kolari (Hult). - Li. Inari (H.).

S. Mpd.

N. Dorre.

Spitzbergen, Alpenkette bis über die Baumgrenze, Sibirien, Grönland.

var. plumosum (Schimp.) Warnst. ]. c. p. 421. [Hypnum uncinat'ın var. $\varepsilon$ plumosum Schimp. Syn. p. 612 (1860). - Amblystegium uncinatum var. plumosum Möll. Fört. Sk. växt. 2. Moss. p. 40 (1907).]

Weniger schlanke Pfl. in flachen Rasen. Stengel niedergestreck , lang kriechend und der Unterlage oft durch reichliche Rhizoidenbüschel fest a geheftet, gefiedert. Stengelblätter hakenförmig, aus eiförmigem Grunde rasch sehr lang pfriemenförmig und geschlängelt bis fast kreisförmig, 3-4 mm lang. Kapsel zylindrisch, trocken eingekrümmt.

Auf den Himschnitten modernder Stämme und an beschatteten steinen nicht selten.

Europa.

var. plumulosum (Bryol. eur.) Warnst. ]. c. [Hypnum uncinatun, var. 5 plumulosum Bryol. eur. 1. c. $\gamma 1$ et 2. - Amblyslegium uncinatum var. olumulosum Arn. in K. Sv. Vet.-Ak. Handl. Bd. 23, No. 10, p. 118 (1890).]

Wuchs und Tracht wie bei der vorigen Var., nur in allen Teilen kleiner. Stengel dicht fiederästig und häufig durch Rhizoidenbüschel der Unterlage fest anhaftend. Stengelblätter weniger lang zugespitzt, fast kreisförmig gekrümmint, 2$3 \mathrm{~mm}$ lang. Seta kurz. Kapsel klein.

An Stämmen und Ästen der Nadelbüume, seltener als var. plumost.ım.

Europa, Sibirien.

S e c t. I I. Limprichtia (Loesk.) Brotlı. 1. c. (Limprichtia Loesk. l. c. p. 310 als Gattung.)

Pseudoparaphyllien fehłend. Blätter einseitig-sichelförmig, (excl. D. revolvens) ganzrandig; Zellen sehr eng. Innere Perichätialblätter längsfaltig, 'ganzrandig. Ring vorhanden.

664. Drepanocladus vernicosus (Lindb.) Warnst. l. c. p. 402 . [Hyt mnum vernicosum Lindb. in Hartm. Sk. Fl. 8. ed. p. 17 (1861). - Amblystegium v ernicosum Lindb. Musc. seaitd. p. 33 (1879).]

Diözisch. Pfl. in hell- bis gelbgrünen, zuweilen rötlichen oder bräunlicl ien, fïrnisglänzenden Rasen. Stengel ohne Zentralstrang und ohne Aussenrinde, ả ıfrecht, 8-15 cm, fast regelmässig gefiedert, meist mit stark eingekrümmter St engelspitze. Stengelblätter weder herablaufend noch geöhrt, mehrfaltig, eilanze.ttlich, in eine mässig lange, rinnige Spitze fortgesetzt, bis 2,5 $\mathrm{mm}$ lang, ganzrana'ig; Rippe über der Blattmitte verschwindend; Zellen sehr eng, am Blattgrunde 2-3 Querreihen gelbrot bis purpurn, in den Blattflügeln nicht differenziert. Irr. nere Perichätialblätter aufrecht, rasch fein zugespitzt, mit langer Rippe. Seta 4-5 cm, rot. Sporenreife im Mai und Juni. - Fig. 90 A-D.

In tiefen, kalkfreien Grïnlandsmooren. Selten fruchtend.

F. Al. Saltrik, Basstjena (Boin.). - Ab. Lojo (Lindb., Sundr.). - Ik, Muola, Āyräpāäjărvi (H. Lindb.). Valkjärvi, Pasuri und Păhkinäınăki (H. L.). Rautu, Toubila (H. L.). Pyahäärrvi (H. L.). St. Ikaalinen (Sundv.). - Ta. Tammela (Arrh.). Vanaja, Harviala (Hä̀rr.). Hattula. Pelkola, Kalakorpi (Veg.). In sïdöstlichen Teile an mehreren Fundorten, zuweilen massenhaft (Norrl.). Korpilahti, Peuha, Tianen, Raianlahti (Vain.). Luhanka: Avosalmi (T.). - Sa. Lappee, Kansola (Buch). Taipalsaari (Simm.). Kangasnieini (Lackstr.). Joroinen, Parala (II, Lindb.), - - Kl. Kurkijoki, Savioja (Jus..): Otsonlahti (J.); Tervus (J.) Soanlahti, K̈itjunsuo (Lång) - Kol. Im ganzen südlichen Gebiete (Elfv.). Petrosavodsk (Norrl.). - Oa. Närpes, Yltermark. Orrmosskällan (E. af H.). - Tb. Virrat (Simm.). Pihlaja- 
resi (Norrl.). Jỵäskylä (Broth.). Pihtipudas, an mehreren Fundorten (Roiv.). - Sob. Virtasalmi, Montola. Pölkönjärvi (Kyyhk.). Kuopio, an mehreren Fundorten (Link., Kịyh.). Kaavi, Losomaki (Kot.). Nilsiä, Kuuslahti, Jaakonlampi (K.). Maıninka, Pöljä, Lutinpıron suo (Kyyhk.). Rautavaara, Suojärvi (Kyyhk.). Iisalmi (Sahlb.). - Kb. Kuusjärvi, Outokmmpu (Kot.). Juukd, Jumanraara (K.). Kon. Kentjärvi (Simm.). Suopohja (Kulı.). Unitsa (Popp.). Valkeaniaki (Sahlh.). Selki (Norrl.).

S. Öl., Sm., Hll., Ög., Srm., När., Upl.. Gslr. und Vb.

N. A. r. Bu. Ringerike r. NT. stjordalen.

Europa, Sibirien, Nord-Amerika.

var. lapponicus (Norrl.). [Hypnum lycopodioides var. lapponicum Norrl. in Notis. Sällsk. F. Fl. Fenn. XIII. p. 293 (1873). — Amblyslegium vernicosum var. $\gamma$ lapponicum Lindb. Musc. scand. p. 33 (1879).]

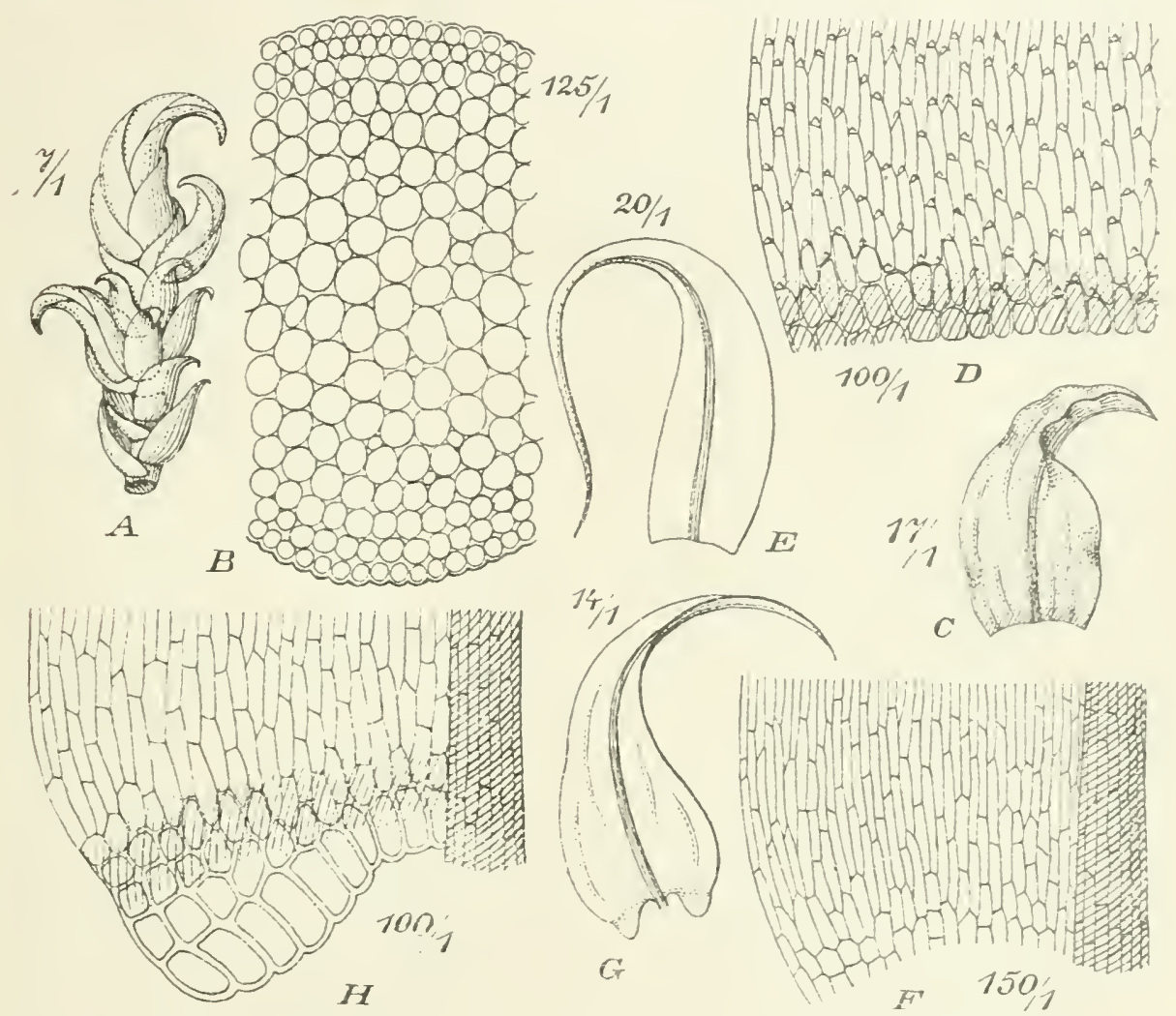

Fig. 9i). A-D. Drepanocladus vernicosus (Lindb.). A ripfelteil des St. (7/1); B Stammquerschnitt (125/1); C Stammb. (17/1); D Blattbasis $(100 / 1)$. - E-F. D. revolvens (Sw.). E Stammb. (20/1): Blattbasis $(150 / 1)$. - G-H. D. Sendtneri (Schimp.) rar. Wilsonii(Schimp.). G Stanmb. (14/1); G Blattbasis (t00/1).

Tracht von D. revolvens. Pfl. in braunen bis schwarzen Rasen.

F. Kl. Soanlahti, Kitjunsuo (Lång). - Ok. Kajana (Broth.).- Lkem. Kolari und Kittilă in sümpfen fq. (Hult). Muonioniska (Norrl.), - Le. Ounastunturi (N.). Karesuanto (N.).

var. major (Lindb.) Warnst. Laubm. p. 1020 (1906). [Amblystegium vernicosum var. $\beta$ majus Lindb. Musc. scand. p. 33 (1879).]

Kräftige Pfl. in gelbgrünen Rasen. Stengel sehr dicht beblättert, fast büschelig verästet. Stengelblätter sehr hohl, aus etwas verengter Basis breit rundłichoval, rasch pfriemenföruig zugespitzt, bis $3 \mathrm{~mm}$ lang.

F. Ik. Mruola, Kịyrölä (H. Lindb.). - Tb. Viitasaari (Broth.).

S. Stockholm. Dlr. Grỵcksbo. 
var. gigas (Lindb.) Warnst. Laubm. p. 1021 (1906). [Amblystegium vernicosum var. $\gamma$ gigas Lindb. Musc. scand. p. 33 (1879).]

Sehr kräftige, dunkel- bis schwarzbraune, meist flutende Pfl. Stengel bis $20 \mathrm{~cm}$, sehr dicht beblättert, einfach oder spärlich verästet. Stengelblätter sehr hohl, kaum oder schwach längsfaltig, aus verschmälerter Basis breit ovallanzettlich, kurz pfriemenförmig zugespitzt, $4-5 \mathrm{~mm}$ lang.

F. N. Pernå (Sael.). Lovisa (Arrh.). - Ik. Uusikirkko, Vammelsuo (H. Lindb.). Sakkola, Isosuo (H. L.). Pyhăjārvi, Kajarasuo (H. L.). - Ta. Hollola, Laitiala (Norrl.). Sāāksmāhi, Kasuri (Kihlm.). - Kl. Kurkijoki, Tervus (Jusl.). - Tb. Virrat (Simm.). Laukaa (Broth.). Pihtipudas, Elāmäjārvi (B.). - Sb. Iisalmi (Sahlb.). - Ok. Kajana (Lackstr.). Ristijārvi (L.). - Ob. Rovaniemi, Alakỵlā (Hult); Alajāāskō (H.). - Lkem. Kolari, Jokijalka (H.).

S. $M p d$.

665. Drepanocladus revolvens (Sw.) Warnst. 1. c. p. 402. [Hypnum revolvens Sw. Disp. musc. frond. suec. p. 101, t. 7, f. 14 (1799). - Amblystegium revolvens De Not. Epil. p. 140 (1869).]

Autözisch. Pfl. in meist purpurnen bis schwarzroten oder grün und purpurn gescheckten Rasen. Stengel mit Zentralstrang und lockerzelliger Aussenrinde, aus meist niederliegendem Grunde bis aufrecht, $5-10 \mathrm{~cm}$, unregelmässig bis büschelig verzweigt und wenig bis fast fiederästig. Stengelblätter kreisförmig eingekrümmt, ungefaltet, aus nicht herablaufender, eiförmiger Basis lanzettlich und lang pfriemenförmig zugespitzt, 3-5 $\mathrm{mm}$ lang, an der Spitze klein gesägt; Rippe dünn, zuletzt rot, über die Blattmitte reichend; Zellen sehr eng und sehr verłängert, in den Blattecken 1-4 locker, hyalin, eine winzige Gruppe bildend. Innere Perichätialblätter aufrecht, pfriemenförmig zugespitzt, ganzrandig oder in der Pfrieme \pm deutlich gesägt. Seta 2-4,5 $\mathrm{cm}$, rot. Sporenreife im Mai und Juni.

In Sümpfen und an nassen Stellen, zuweilen Massenvegetation bildend. Fig. $90 \mathbf{E}-\mathrm{F}$.

F. Al. pass. (Bom.) - Ab. Pargas (Arrh.). Lojo, Ojamo (Lindb.); Huuhtasaari (E. af H.); Paarola (Hult). Vichtis (W. Nỵl.). - Ka. Wiborg, Lalo, Soskuanjoki (Buch). Jảāski, Kārkkhãāã (Lindb.). Ik. Nuola, Āyräpāānjārvi (H. Lindb.). Valkjārvi (H. L.). Pyhājärri, zw. Sortanlahti und Vernitsa (H. L.). - St. Ikałìnen, Nygảrd (Sundv.). - Ta. Im südōstl. Teile pass. (Norrl.). — Sa. Lappee, Paskalampi (Buch). Kangasniemi (Lackstr.). - Kl. Kurkijoki, Ohtjārvi (Jusl.). Suistamo, Saariselkā (Kot.). - Kol. Gorki (Elfv.). - Tb. Keuruu, Haapamäki (Kot.). Jỵ̂ãskyłă (Broth.). Āännekoski (Lesk.). Kinnula, Saarenkylā, Mekkojărvi (Roir.); Olhavainen (R.). Pihtipudas pass. (R.). - Sb. Kuopio, Vehmasmāki, Syvãnlampi (Link.). Kaavi, Losomăki (Kot.); Niinivaara (K.); Luikonlahti (K.). Nilsiā, Kirchdorf, Pieni-Tarpinen (Kyyhk.); Loutteinen (K.). Rautavaara, Hankamāki (K) - Kb. Juuka, Ahmovaara (Linnan.); Juuanvåza (Kot.). Nurmes (Vain.). - Kon. Paaduna (Sahlb.). - Om. Alajărri, Vesterbacka (Backm.). - Ok. Kajana (Lackstr.). Sotkamo (L.); Hanhilammensuo (K.); Isoniitty (K.). Hyrynsalmi (Lackstr.); Kaiskonjoki (Kyyhk.); Kiriranta (K.). Suomussalmi, Kairosuo (K.); Katiskalamminsuo (K.). - Kpom. Lahnajoki (Bergr.). - K. Pudasjārvi (Nyb.). Kuusamo, Kirchdorf (Nyb.. Broth.); Kitkanniemi (E. af H.). - Ob. Turtola (Hult). - Lkem. Kolari und Kittilā fq. (H.). huolajärvi (Linnan., E. af H.). Muonio st. fq. und auch in der alpinen Region beobachtet (Norrl.). - Le. Kilpisjărvi Nalla und Saana in der Birkenregion (Kot.). - Li. In der Nadelwaldregion fqq. (Hult): in der Birkenregion pass.- - fq. (H.). - In den Provinzen der Halbinsel Kola fq. (Broth.).

S. Sk., Sm., Ög., När.. Vrm.—Vb.. L.

N. A. Kristiania st. fq., Sm. fq., Bu. Ringerike fq., JL. Tjømo. $R$ r. $K . N T$. Stjørdalen fq. No. $-F$. Europa, Nord-Asien, Nord-Amerika.

666. Drepanocladus intermedius (Lindb.) Warnst. 1. c. p. 402. [Hypnum intermedium Lindn. in Hartm. Sk. Fl. 9. ed. p. 17 (1864). - Amblystegium intermedium Lindb. Musc. scand. p. 33 (1879).]

Diözisch. Pfl, in gelbłichgrünen bis bräunlichen Rasen. Stengel mit Zentralstrang und lockerzelliger Aussenrinde, aufrecht, $8-15 \mathrm{~cm}$, unterbrochen gefiedert. Stengelblätter ungefaltet, aus nicht herablaufender, eilänglicher Basis lanzettlich bis lanzettlich-pfriemenförmig, etwa 2 mm lang, ganzrandig; Rippe dünm, über der Blattmittc aufhörend; Zellen sehr eng, in den Blattecken 2-4 erweitert, dünnwandig, eine winzige Gruppe bildend. Innere Perichätialblätter aufrecht, 
lang und fein zugespitzt, zartrippig. Seta $4-5 \mathrm{~cm}$, rötlich. Sporenreife im Mai und Juni.

In kalkhaltigen und kalkfreien Sümpfen und auf sumpfigen Wiesen, oft Massenvegetation bildend, aucli an nassen Felsen.

F. Al. fq. (Bom.). - Ab. Pargas, Skräbböle und Lindberg (EIfv.). Karislojo, Hattala (Sundv.). Lojo, an mehreren Fundorten (Lindb, Jusl., Sundy.). - N. Helsingfors (Lindb.) Esbo, Grăsa (Broth.). - lk. Valkjärvi (H. Lindb.). Sakkola (H. L.). Pyhäjärvi (Lång). - St. Sastmola (Karst.), - Ta. Kalvola (Knab.). Koski (Norrl.). Hollola (Vain.). - Sa. Willmanstrand (Buch). - Kl. Kurkijoki (Jusl.). Valamo (J.). Sortavala, Kirjavalahti (Norrl.). Ruskeala (Lindb.). Suistamo, Saariselkä (Kot.). - Kól. Mjätusova (Elfr.). Petrosavodsk (Norrl.). - Tb Keuruu, Haapamaăki (Kot.). Kinnula und Pihtipuda. r.-st. r (Roir ). - Sb. Virtasalmi, Pōlkōnjärvi (Kyyhk.) Heinäresi, Palokki, Kultaniemi (Kyyhk.). Kuopio, an mehreren Fundorten (Link., Kyyhk.). Kaavi und Juuka im Kalk- und Serpentingebiete fq. (Kot.). Nilsiä, Kuuslahti (Kot.); Loutteinen (Kyyhk.) Rautavaara, Hankamāki, Yrttimäki und Suojärvi (K.). 一 Kb. Tohmajārvi, Akkala (Kot.). Juuka, Juuanvaara (Kot.). Pielisjärvi, Koli (Linnan.). - Kon. Suosaari (Simm.). Selki (S.). - Om. Alajărvi, an mehreren Fundorten (Backm.) — Ok Kajana (Lackstr.). Paltamo (Lackstr.); Melalahti und Miesmäki (Kyyhk.). Sotkamo, an mehreren Fundorter (Lackstr., Kyyhk.). Kulmoniemi, Vieksi, Năătänniemi (Kyyhk.). Hyrynsalmi, Kivirantă (K). Puolanka, Tulijoki (K.). SuomussaImi, an mehreren Fundorten (K.). - K. Kuusamo, Jäkäläinen cop. (Broth.). - Lkem. Kolari, Teurajärvi (Hult). Kittilă fq. (H.). Muonio, Jenisjärvi und zw. Muonio und Olostunlúri (Norrl.) - Le. Vittanki in der Birkenregion (N.). Leutsuvaara in der alpinen Region (N.). Kilpisjārvi, Malla und Saana (Kot.). - Li. In der NadelwaIdregion fq., in der Birkenregion st. fq. (Hult). - Lim. Kandalaks (Broth.). Hibină (B.). - Lt. Im südl. Teile pass, (Roiv.). Jeretik, Tsinnavolok. Vaidoguba und Pummanki (Broth.). - Lmur. Zwischen Varsinsk und Jenjavr (B.). - Lp. Malo Gorodetskaja und Orlor (B).

S. $S k_{0}-L$.

N. Sm.-F. bis hoch in die alpine Region.

Europa, Nord-Amerika.

S e c t. I I I. Warnstorfia (Loesk.) Broth. 1. c. p. 1031. (Warnstorfia Loesk. l. c. p. 310 als Gattung.)

Stengel mit Zentralstrang und meist ohne Aussenrinde; Pseudoparaphyllien fehlend. Blätter ungefaltet, \pm gesägt; Zellen der Blattflügel differenziert, eine meist grosse und oft scharf begrenzte, gewölbte Gruppe bildend. Innere Perichätialblätter ungefaltet. Ring fehlend.

667. Drepanocladus exannulatus (Gümb.) Warnst. 1. c. p. 405. [Hypnum exannulatum (Gümb.) Bryol. eur. fasc. 57/61 p. 34, t. 33 (1854). - H. fluitans $\delta$ purpurascens Schimp. Syn. p. 609 (1860). - H. exannulatum $\beta$ purpurascens Mild. Bryol. siles. p. 349 (1869). - Amblystegium exannulatum De Not. Epil. p. 142 p. 92 (1879). - Hypnum fluitans var. exannulatum Ren. in Ném. Soc. d’Emul. Doubs p. 92 (1879). - H. purpurascens Limpr. Laubm. III. p. 418 (1898). Drepanocladus' purpurascens Loesk. Moosfl. Harz. p. 304 und 309 (1903).]

Diözisch. Tracht von $D$. fluitans. Meist etwas starre Pfl. in hell- oder gelbgrünen, bräunlichen oder oberwärts $z$. T. rötlich angehauchten bis tief roten Rasen. Stengel meist aufsteigend bis aufrecht, bis $10 \mathrm{~cm}$, seltener länger, regel- oder unregelmässig gefiedert. Stengelblätter meist sichelförmig-einseitswendig, aus herablaufendem, etwas verengtem Grunde breit ei- bis eilänglich-lanzettlich allmählich lang und fein zugespitzt, bis $3 \mathrm{~mm}$ lang, sehr selten mit Initialzellen und Rhizoidenbildung; Rippe kräftig, bis weit in die Blattspitze fortgesetzt, zuweilen grannenartig austretend; Zellen in den Blattflügeln aufgeblasen, bald dünnwandig und hyalin, bald dickwandig und braunrot, eine grosse, gewölbte, die Rippe nicht selten erreichende Gruppe bildend, seltener am Blattgrunde nur eine Reihe aufgeblasener Zellen. Innere Perichätialblätter aufrecht, hochscheidig, rasch zugespitzt, ganzrandig, mit dünner Rippe. Seta $3-5 \mathrm{~cm}$, rot. Sporenreife im Juni.

In Sümpfen, Gräben und Tümpeln durch das ganze Gebiet vom Meeresufer bis in die alpine Region fq.

var. pinnatus (Boul.). [Hypnum fluitans « pinnatum Boul. Musc. de la France p. 62 (1884). - Drepanocladus exannulatus A. Moenkem. in Pasch. Süsswass.-Fl. Heft 14, p. 142 (1914).] 
Blattzellen derb, eng und sehr lang.

fo. pratensis Moenkem. in Pasch. Süsswass.-Fl. Heft 14, p. 144 (1914).

Pfl. kräftig dunkel-gelbgrün, fast regelmässig gefiedert. Blätter stark sichelförmig einseitswendig, aus breitem Grunde lang zugespitzt, fast ganzrandig oder gesägt.

Die gewöhnliche Wiesenform.

subfo. submersa Moenkem. ]. c. [Hypnum exannulatum d serratum Mild. Bryol. sil. p. 349 (1869). - Drepanocladus serratus Warnst. Laubm. p. 1055 (1906).]

Pfl. untergetaucht, fusslang, meist reich verästet, dicht gefiedert. Blätter flatterig, sehr lang und schmal lanzettlich-pfriemenförmig, rings und in der Pfrieme stärker gesägt. Parallelform zu D. fluitans fo. submersa.

fo. orthophylla (Mild.) Moenkem. 1. c. [Hypnum exannulatum var. $\gamma$ orthophyllum Mild. Bryol. siles. p. 349 (1869). - Hypnum fluitans $\beta$ exannulatum b. acutum San. in Bih. K. Sv. Vet.-Ak. Handl. Bd. 10, No. 1, p. 12 (1885). — * Drepanocladus orthophyllus Warnst. Laubm. p. 995 (1906) ex p.]

Íräftige, starre, lockerrasige Pfl. Stengel meist wenig verästelt, mit spitzen und meist geraden Sprossenden, durch die anliegende Beblätterung fast drelırund. Stengelblätter aufrecht, gerade oder leicht gekrümmt, breit lanzettlich, weniger lang zugespitzt.

F. K. Kuusamo, Korojoki (Broth.); Jäkäläinen (B.). - Lkem. Kuolajärvi, Sallatunturi (Broth.. E. af H.). - Lmur. Litsa (Broth.).

S. Dir., Jmt. und Ang.

N. No

Europa, im Hochgebirge.

fo. procera (Ren. et Arn.) Moenkem. 1. c. [Hypnum fluitans var. procerum Ren. et Arn. in Husnot Muscol. Gall. p. 383 (1894). — * Drepanocladus pseudorufescens Warnst. in Beih. Bot. Centralbl. XIlI. p. 404 (1903) ex p. - Amblystegium fluitans $\gamma$ procerum Arn. et C. Jens. Moos. Sarekgeb. p. 198 (1907).]

Kräftige, starre, rotbraune bis tiefrote Pfl. Stengel dicht und regelmässig gefiedert. Blätter stark siclrelförmig: Rippe kräftig, bis in die Spitze fortgesetzt.

F. Lkem. Muonioniska (Norri.). Kuolajärvi, Sallanjoki, in tiefen Sümpfen (Broth.). - Le. Hetta (Norrl.); zw. Palojoki und Iruotkajärvi (N.). - Lmur. Semjostrovsk, in Tümpeln (B.).

S. Mpd. Torp. LuL. Sarekgebiet.

N. $K$. Valders.

fo. Rotae (De Not.) Moenkem. 1. c. [Amblystegium Rotae De Not. Cronac. II. p. 24 (1867). - Hyprium purpurascens var. $\gamma$ Rotae Limpr. Laubm. III. p. 120 (1898). - Drepanocladus Rotae Warnst. in Beih. Bot. Centralbl. Bd. XIII. Heft 4, p. 403 (1903). — * Amblystegium exannulatum \& Rotae Arn. et C. Jens. Moos. Sarekgeb. p. 198 (1907).]

Kräftige Pfl. in untergetauchten, schmutzig- und ranchbraunen bis dunkelpurpurnen Rasen. Stengel bis $30 \mathrm{~cm}$, streckenweise dicht gefiedert. Blätter der schwach sichelförmigen Stengel- und Astspitzen zusammengewickelt, aus gleichbreiter Basis lang linealisch pfriemenförmig, rings entfernt und fein gesägt; Rippe als lange Granne auslaufend.

F. Lmur. Varsilsk, in Tümpeln

S. Jmt. LuL. Sarekgebiet.

N. Ringerike rr. $K$. Valders.

Alpenkette von der Schweiz bis steiermark.

var. brachydictyus (Ren.) Moenkem. J. c. p. 143. [Hypnum fluitans exannulatum var. brachydictyon Ren. in Muscol. Gall. p. 385 (1894). — * Amblystegium exannulatum p brachydictyon Arn. et C. Jens. Moos. Sarekgeb. p. 198 (1907).]

Meist schlanke P[j. in gelblichgrünen bis rötlichen, weniger starren Rasen. B)ätter küirzer, meist \pm deutlich längsfaltig, schwach gezähnt; Zellen weit kürzer und breiter als bei var. pinnatus, am Blattgrunde kurz parenchymatisch. 
fo. orthophylla Moenkem. I. c. p. 1-15.

Blätter gerade, kürzer zugespitzt. Parallelform zu var. pinnulus fo. orthophylla.

F. Lmur. Gavrilova und Semjostrovsk (Broth.). Litsa, in der Nähe von schneebedeckten lilächen (B.).

S. Jmt., LuL. Sarekgebiet.

N. No. und $T r$, an einzelnen Fundorten.

fo. tundrae (Arn.) Moenkem. ]. c. [Amblystegium tundrae Arn. in K. Sv. Vet.Ak. Handl. Bd. 23, No. 10, p. 128 (1890). - Hypnum tundrae Joerg. in Christ. Vid.-Selsk. Forl. 1894, No. 8, p. 97.]

Tracht von Calliergon stramineum. Blätter kurz, stark faltig, mit stumpf abgerundeter, oft kappenförmig eingekrümmter Spitze.

N. Tr. Nordrejsen.

Sibirien.

668. Depranocladus fluitans (L.) Warnst. 1. c. p. 404. [Hypnum fluitans (Dill.) L. Fl. suec. 2. ed. p. 899 ex p. (1755). - Amblystegium fluitans De Not. Cronaca II. p. 24 (1867).]

Autözisch; o Blüten meist zahlreich. Pfl. in weichen, gelb- oder braungrünen Rasen. Stengel bis $20 \mathrm{~cm}$ und darüber, niederliegend, aufsteigend oder flutend, unregelnıässig oder fast fiederig beästet. Stengelblätter flatterig abstehend bis \pm einseitswendig gekrümmt, aus verengter, nicht oder kaum herablaufender Basis verlängert lanzettlich, meist mit langer Pfriemenspitze, an der Spitze \pm deutlich gesägt, bis $4 \mathrm{~mm}$ lang: Rippe dünn, meist in oder bald über der Blattmitte verschwinclend: Zellen sehr eng, in der Blattspitze sowie an den Seitenrändern mit weiteren, helleren, später zu langen, braunen Rhizoiden auswachsenden Rhizoideninitialen, in den Blattecken kurz rektangulär, eine kleine, zuweilen gewölbte Gruppe bildend. Innere Perichätialblätter aufrecht, hochscheidig, rasch schmal und mässig langspitzig, ganzrandig, mit undeutlicher Rippe. Seta 6-10 cm, rot. Sporenreife im Juni und Juli. - Fig. $91 \mathrm{C}-\mathrm{D}$.

In Sümpfen, Nooren, Gräben und Tümpeìn. Sehr formenreich.

var. amphibius (San.). [Hypnum fluitans d amphibius San. in Bot. Centralbl. 1880, Gratisbeil. No. 2, p. 3. - Amblystegium fluitans a amphibium Arn. et C. Jens. Moos. Sarekgeb. p. 198 (1907).]

Pfl. in mässig dichten, meist blassgrünen Rasen. Blätter locker gestellt, gerade bis sichelförmig; Rippe schwach, in oder über der Blattmitte endend: Blattflügelzellen erweitert, eine weniger scharf abgesetzte, nicht ausgehöhlte Gruppe bildend.

Durch das ganze Gebiet fq., im Norden jedoch, wie es scheint, seltener als D. exannulatus.

fo. brachycarpa (Lindb. fil.). [Hypnum fluitans var. brachycarpum Lindb. fil. in sched.; Warnst. in Beih. Bot. Centralbl. Xili. p. 426 (1903). - Drepanocladus fluilans var. brachycarpus Warnst. Laubm. p. 1038 (1907).]

Schlanke Pfl. in dichten, bis $5 \mathrm{~cm}$ hohen, gelblichen Rasen. Stengel aufrecht, dicht beblättert, unregelmässig verästet. Blätter schwach sichelförmig, lanzettlich zugespitzt, bis $1,1+\mathrm{mm}$ lang, ganzrandig oder an der Spitze gesägt; Rippe $1 / 3-1 / 2$ der Blattlänge, öfter gabelig. Kapsel aufrecht oder geneigt, kurz, hochrückig.

F. Ik. Sakkola, Suvanto, Hiekkaranta, am nassen, sandigen Ufer (H. Lindb.).

fo. pseudostraminea (C. Müll.) Noenkem. in Pasch. Süsswasser-Fl. Heft 14, p. 139 (1914). [Hypnum pseudostramineum C. Mitlì. in Bot. Zeit. 1855. p. 500. Amblysteginm fluitans * A. pseudostramineum Lindb. Mfusc. scand. p. 33 (1879). Drepanocladus fluitans var. pseudostramineus Warnst. Laubm. p. 1040 (1906).]

Rasen gelbgrün. Stengel meist aufrecht, bis $10 \mathrm{~cm}$, wenig oder mregelmässig beästet: Iste stumpflich, \pm zusammengewickelt. Blätter aufrecht-abstelıend, kurz zugespitzt, stumpflich, fast ganzrandig, $2-3 \mathrm{~mm}$ lang. 
S. När. Örebro.

N. Sm. Glemminge. Bu. Ringerike $r$.

Deutschland, Schweiz.

fo. elata (Ren. et Arn.) Moenkem. 1. c. [Hypnum fluitans var. elatum Ren. et Arn. in Husnot Muscol. Gall. p. 381 (1894).]

Kräftige, bis $25 \mathrm{~cm}$ lange, bräunlichgrüne Pfl. Stengel unregelmässig bis fiederig verästet. Blätter schwach sichelförmig, aus breiterer Basis länglich-lanzettlich, ziemlich kurz und breit zugespitzt, schwach gesägt; Rippe bis zur Mitte oder $3 / 4$ des Blattes fortgesetzt.

S. Mpd. Torp, in Sümpfen.

Erzgebirge.

fo. submersa (Schimp.) Moenkem. 1. c. [Hypnum fluitans var. $\beta$ submersum Schimp. Syn. p. 609 (1860). - Drepanocladus submersus Warnst. Laubm. p. 1050 $(1907) \cdot 1$

Untergetauchte bis schwimmende, oft sehr feine und zarte Pfl. Stengel bis $30 \mathrm{~cm}$, dünn und schlaff, fast einfach, seltener fiederästig. Blätter sehr lang und schlaff, gerade, weit herablaufend, rings gesägt; Blattflügelzellen wenig entwickelt. Seta sehr lang und dünn. - Parallelform zu D. exannulalus subfo. submersa.

In Torflachen, Torfgräben und Bächen.

var. falcatus (Bryol. eur.) Warnst. Laubm. p. 1042 (1907). [Hypnum fluitans var. $\gamma$ falcatum Bryol. eur. fase. $57 / 61$ Mon. p. 33, t. 22, f. $\gamma$ (1851). - Amblystegium fluitans $\beta$ falcatum Arn. et C. Jens. Moos. Sarekgeb. p. 198 (1907).]

Kräftige, gelbliche bis schwarzrötliche Pfl. Stengel dicht beästet: Blätter gedrängt, in der gewöhnlichen Form stark sichelförmig einseitswendig, aus breiterer Basis \pm lang zugespitzt, gesägt; Rippe kräftiger als bei var. amphibius; Blattflïgelzellen eine gut begrenzte, rundlich ausgehöhlte Gruppe bildend.

Verbreitung etwa wie bei var. amphibius.

fo. alpina (Schimp.) Moenkem. 1. c. p. 141. [Hypnum fluitans $\varepsilon$ alpinum Schimp. Syn. p. 609 (1860). - H. Schulzei Limpr. Laubm. III. p. 428 (1898). Drepanocladus fluitans var. alpinus Warnst. Laubm. p. 1043 (1906).]

Pfl. in dichten und weichen, schmutzig- bis braungrünen, rötlichen bis schwärzlichen oder gescheckten Rasen. Stengel bis über $12 \mathrm{~cm}$, schlaff, unregelmässig gefiedert; Äste dünn und langspitzig, gerade oder schwach gebogen. Stengelblätter kaum herablaufend, aus wenig verbreiterter Basis lanzettlich, meist sehr lang pfriemenförmig zugespitzt, an der Spitze deutlich gesägt: Rippe rötlieh bis rotbraun, weit in die Pfriene eintretend; Blattflügelzellen eine kleine. gelbfarbene, geöhrte Gruppe bildend.

In Torfmooren, Torfgräben und in Tümpeln.

F. K. Kuusamo, zw. Rukatunturi und Pyhājārrvi (Broth.). - Lmur. Litsa (Broth.).

N. Bu. Hønefos. Ringerike. No. und Tr. an mehreren Fundorten.

Riesengebirge, Brocken, Schweiz.

* Drepanocladus Berggrenii (C. Jens.) [Harpidium fluitans * H. Berggreni C. Jens. in Meddel. om Gronl. III. p. 6 (1887). — Amblystegium Berggrenii C. Jens. in Meddel. on Gron]. XV. p. 432 (1898). - Hypnum Berggrenii Hag. Musc. Norv. bor. p. $326(1901)$.]

Autözisch; ơ Blüten zahlreich. Schlanke Pfl. in gelblich- oder bräunlichgrünen Rasen. Stengel gesehlängelt-aufsteigend, spärlich und unregelmässig verzweigt. Blätter einseitswendig gekrümmt, aus eilänglichem Grunde allmählich zugespitzt, ganzrandig oder an der Spitze entfernt und undeutlich gesägt; Rippe kaum die Blattmitte erreichend, meist ungleich zweischenklig; Zellen eng, mässig verlängert, \pm dickwandig, in den Blattecken einige kurz rektangulär, \pm verdickt, gelbbraun. Innere Perichätialblätter aufrecht, hochscheidig, rasch \pm lang zugespitzt, ganzrandig: Rippe sehr kurz oder fehlend. Seta lang. Kapsel aufrecht oder geneigt. 
S. Jmt. Undersåker, Vällista, in der Weidenregion.

N. Tr. Ibbestad. F. Nesseby.

Grönland.

S e c t. I V. Pseudo=Drepanocladus Broth. in E.-P. I3. p. 1034 (1908).

Diözisch. Stengel mit Zentralstrang und olne Aussenrinde. Pseudoparaphyllien fehlend. Blätter ungefaltet, ganzrandig; Zellen sehr derbwandig. in den Blattecken oval, sehr stark verdickt. Innere Perichätialblätter ungefaltet. Ring differenziert. Peristomzähne ungestreift.

669. Drepanocladus badius (Hartm.) Roth Eur. Laubm. II. p. 569 (1905). [Hypnum badium Hartm. Sk. Fl. 5. ed. p. 332 (1849). - Amblystegium badium Lindb. Musc. scand. p. 33 (1879). - Calliergon badium Kindb. Eur. and N.-Am. Bryin. p. 82 (1897).]

Diözisch. Starre Pfl. in gelblichen oder rötlichbraunen bis schwärzlichen, firnisglänzenden Rasen. Stengel niederliegend bis aufrecht, wenig geteilt, mit wenigen Ästen. Blätter nicht herablaufend, sehr hohl, aus locker dachziegeliger Basis meist einseitswendig und schwach sichelförmig, breit eiförmig und allmählich kurz lanzettlich zugespitzt, bis $1,5 \mathrm{~mm}$ lang; Rippe etwa $3 / 4$ der Blattlänge durchlaufend, an der Spitze oft zweischenklig; Zellen geschlängelt-linealisch, derbwandig, bis zur Basis verlängert, an der Insertion kupferrot und oval, in den Blattecken sehr stark verdickt, eine kleine, schwach ausgehöhlte, beim Abziehen des
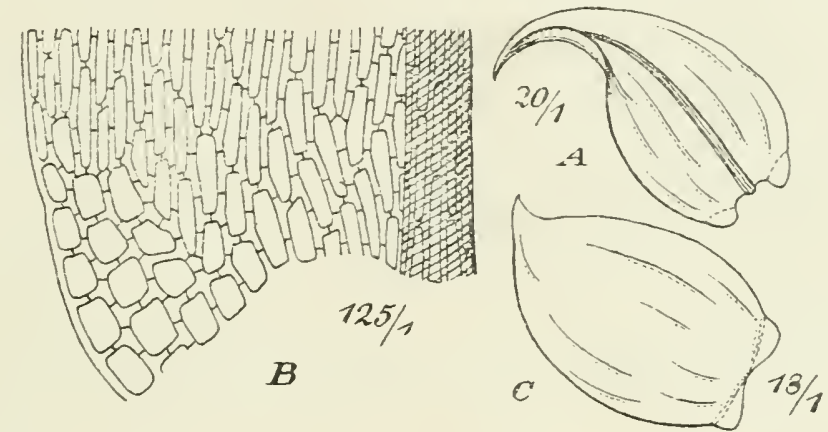

Fig. 92. A-B. Drepanocladus badius (Hartm.). A Stammb. (20/1); B Blattbasis (125/1). - C. Scorpidium scorpioides (Warnst.). Stammb. (18/1).

Blattes am Stengel zurückbleibende Gruppe bildend. Innere Perichätialblätter fast scheidig, rasch sclımalspitzig; Rippe kräftig, bis zur Blattmitte oder länger. Seta bis $3 \mathrm{~cm}$, dünn, gelblichbraun. Sporenreife im Juli. - Fig. 92 A-B.

In Sümpfen, seltener an feuchten Felsen.

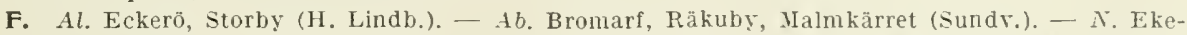
näs, Tvärminne (Elfv.). Nurmijärvi, Hyvinkää, Ridasjärvi (Ranck.). - Ka. Tehkalahtj, Kannusjärvi (Kuj.). - Kl. Suistamo, Saariselkä (Kot). Salmis, Pensaanjoki (A. K. Caj.). - Oa. Jurra (Malmgr.). - Tb. Pihlajavesi (Norrl.); Peltomäki (Kot.). Petäjävesi. Lautalamminmäki (Ruor.). Karstula, zw. Niihilampi und Runtsila (Broth.). Pihtipudas (Broth., Ruor). - Sb. Kaavi, Losomäki (Kyyk. et Kot.). Juuka, Petrovaara, Merelä (Kot.); Vesivaara und Halivaara (K.). - Kb. Tohmajărvi. Tikkala. Saarekesuo (Var.). Juuka, Juuanvaara (Kot.). Kontiolahti, Puso (Linnan.). Nurmes, Mujejärvi (Vain.) Kon. Selki (Norrl.). - Om. Soini. Niemelä. Lautakangas (Backm.). Lestijärvi. Ilola (Roiv.). - Ok. Kajana (Lackstr.). Paltamo, Mattila (Ranck.); Melalahti (Kỵhk.): Hyyryänmäki. Likolampi (K.). Sotkamo. Isosuo (K.); Vuoriniemi (K.). Kuhmoniemi, Portinlouhensuo (E. aỉ H.). Puolanka, Törmănmäki (Kyyhk.). Suomussalmi, Meriläissuo (Lackstr.): Ulkopuronsuo (Kyy̆hk.); Portti (K.); Porvalan suo (K.); Pahalammin suo (K.); Kaivosuo (K.). - Kpom. Kellovaara (Font.). - Ob. Kempele. Marjasuo (Huun.). - K. Iivaara (Broth.); Jäkäläinen (B.); Karitunturi, Karilammenpuro (E. af H.); Kirintojärvi (E.af H.); Kirintojoki (E. af H.); Merenoja (Broth.): Paanajärvi (B.). - Lkem. Kolari, Ylläsjoki (Hult): Teurajärvi (H.). Kittilä. zw. dem Kirchdorf und Levitunturi (H.). Kuolajärvi, Sallatunturi (E. af H.); Ionkalampi, Enjanniemi (E. af H.); Jungoiva (Linnan.). - Le. In der Nadelwaldregion st. fq. - $L i$. 
Im Waldgebiete fq., im Fjeldgebiete pass. (Hult). - In allen Provinzen der Halbinsel Kola st. fq. (Broth.).

S. Hlsl., Dlr., Hrjd., Jml.. Ing., $\mathrm{i} b$., Nb. und $L$.

N. Gudbrandsdalen, Ringebo. Ne. Saetersdalen. NB. Sogn. R. Aalesund; Romsdalen. ST. Dovre. No.-F. pass., bis in die alpine Region hinaufsteigend.

Spitzbergen, Grönland, Labrador.

S e c t. V. Drepanocladus sens. strict. (Loesk.) Broth. 1. c. p. 1034. (Drepanocladus Loesk. 1. c. p. 311 als Gattung.)

Diözisch. Stengel mit Zentralstrang und olme Aussenrinde. Blätter ganzrandig, sehr seiten durch vorspringende Zellecken undeutlich gezähnelt. Innere Perichätialblätter längsfaltig, ganzrandig.

670. Drepanocladus aduncus (Hedw.) Moenkem. l. c. p. 132. [Hурлиm aduncum (non L.) Hedw. Descr. IV. p. 62, t. 24 (1797). - Amblystegium Kneiffii Bryol. eur. fasc. 55/56 Mon. p. 17, t. 11 (1853).]

Diözisch. Weiche $\mathrm{Pfl}$. in griinen oder gelblichgrünen bis schmutzig braungrünen Rasen. Stengel wenige Zentimeter bis fusslang, niederliegend, aufsteigend oder flutend, unregelmässig ästig oder gefiedert. Stengelblätter weit herablaufend, ungefaltot, bald geschlängelt-abstehend, bald \pm deutlich sichelförmig-einseitswendig, verschieden gestaltig, bald ans breiter Basis breit eiförmig, rasch schmal lanzettlich zugespitzt, bald aus schmalem Grunde breit lanzettlich, allmählich und sehr lang zugespitzt; Rippe meist clünn, bis oder über die Blattmitte schwindend; Zellen oberwärts bald eng linealisch, bald kurz 6seitig, am Blattgrunde kürzer und weiter, in den Blattflügeln gut differenziert, oft bis zur Rippe reichend. Innere Perichätialblätter aufrecht, allmählich lang zugespitzt; Rippe dünn, unter der Blattspitze verschwindend. Seta $3-5 \mathrm{~cm}$, dïm, geschlängelt. Sporenreife im Mai und Juni. Sporogone sehr selten.

Europa, Algier, Kaukasus, Zentral- und Nord-Asien, Nord-Amerika, New Zealand.

Drepanocladus aduncus « typicus (Ren.) Moenkem. in Pasch. Süsswass.-Fl. Heft 14, p. 134 (1914). |Hypnum aduncum a typicum Ren. in Husn. Muscol. Gall. p. 368 (189-1).]

Stengel 5-10 cm, mit fiederigen, weitläufig gestellten Ästen. Stengelblätter sichelförmig, aus breiter Basis allmählich lang zugespitzt; Rippe bis in die Pfrieme eintretend: Zellen eng, sehr verlängert: Blattflügelzellen fast die Rippe erreichend.

F. Al. Mariehamn (Bom.). (ieta. Bolstaholm (B.). Saltvik, an mehreren Fundorten (B.). Sund, Bomarsund (B.). Kökar, Hamnö (B.). - Ab. Korpo, Brunskār (Elfv.). Pargas, Hy̌rilempi, Skräbbōle und Piukala (EIfv.). Lojo, Strron (Hult); sOL hem (Sundr.). Vichtis, Vanhala (Hult). $-N$. Helsingfoŕ (Lindb.). - Ik. Valkjärr, Päkikinämäki (H. Lindb.). — Ta. Im südöstl. Teile st. fq. (Norrl.). — Sa. Nyslott (Carl.). - Kl. Kurkijoki, Ovaska, Otranlahti (Jusl.). Valamo (J.). Ruskeala (Lindb.). Suistamo, Jänisjärvi (Broth.). - Kol. Iın ganzen südlichen Teile unter verschiedenen Formen und oft cop. (Elfv,). Petrosavodsk (Sahlb.). - Oa. Närpe:, Yttermark, Orrmosskāllan (E. af H.). Vasa (Broth.). Ta. Saarijärvi (Broth.). — Sb. Saarijārvi, Hiltulanlahti. Korsumäki (Link.). - Kon. Kendjärvi (Sinm.). Solominskaja pustinja (S.). Koselına (S.). - Ok. Suomussalmi, Kiannankylä (Kyyhk.). - Ob. Kiiminki (Nyh.). Sino (Brenn.). - K. Kuusamo, Kirchdorf (Broth.). - Lkem. Iuoniovaara, in der Fichtenregion (Norrl.).

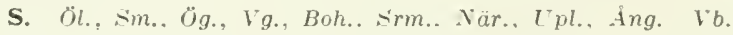

N. Sm. r., A. st. r., JL. Sandefjord, Bu. Ringerike, ST. Dovre, Tr. Mulangen und F. Kistrand.

val. polycarpus (Bland.) Warnst. l.aubm. ]) 1000 (1906). [Hypnum polycarpon Bland!. in sched., Voit in Sturm D. Fl. II. 14. Heft (1813). — H. aduncum

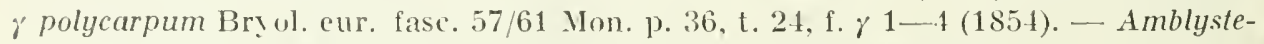
gium polycarpum Vent. et Bott. Enum. p. 11 (18S-1) ex p.]

Stengel etwas starr, $5-10 \mathrm{~cm}$, uregelmässig ästig. Stengelhlätter t einseitswandig, hreit eiförmig bis eilänglich, rasch schmal lanzettlich zugespitzt; Rippe $1 / 2-2 / 3$ der 13lattlänge; \%ellen weit kürzer und breiter als bei a typicus, in den Blattflügeln selır zalilreich, oft die Rippe erreichend. - Iig. n1 E-G.

F. Al. Siltvik, Ifaraldsby (Broth.). - Ab. Nadendal (Elfv.). Pargas, Piukala, Lindberg und Erslıy (E.). Karislojo, Jellonkylii (Sundv.). - N. Ekenäs, Tvärminne (Broth.). - Ka. Antrea (Lindb.). 一 St. Ikaalinen. Nygârd (Sundr). - Sa. Willmanstrand (Buch). Lappee, Ilclkiä (B.). - Kl. Ruskeala 
(Lindb.). - Oa. Vasa (Broth.). - Ok. Kajana (Lackstr.). Paltamo (L.); Melalabti, Ellinlampi (Kyyhk.). - Ob. Liminka, Tupas (Huum.). Simo (H. Lindb.). - Kk . Keret (Brenn.). - Lt. Subovi (Broth.). Tsipnavolok (B.). - Lmur. Semjostrovsk (B.). - Lv. Tschavanga (Brenn.).

S. Verbreitung etwa wie bei var. typicus.

N. Bu. an mehreren Fundorten, No.-F. an mehreren Fundorten. Nordgrenze bei $70^{\circ} 30^{\circ} \mathrm{n}$. Br.

671. Drepanocladus Sendtneri (Schimp.) Warmst. 1. c. p. 100. [Hypnum Sendtneri Schimp. Musc. eur. nov. fasc. III/1V. Hypnum p. 2, t. 2 (1866). - Amblystegium Sendtneri Lindb. Musc. scand. p. 33 (1879).]

Diözisch. Ziemlich kräftige Pll. in starren, gelbgrünen bis bräunlichen Rasen. Stengel bis $20 \mathrm{~cm}$ und darüber, niederliegend bis aufsteigend, unregelmässig odler weitläufig fiederästig. Blätter sehr kurz herablaufend. sichelförmig-einseitswendig, ungefaltet, eilanzettlich, alımällich in eine rimnige Spitze verschmälert, lois 2, 1 nm, selten bis $3 \mathrm{~mm}$ lang; Rippe kräftig, bis in die Spitze reichend; Zellen derb, eng linealisch, an der Insertion rektangulär, gelb- und dickwandig, getüpfelt, an den $\frac{1}{-}$ ausgehöhlten Blattlügeln fast quarlratisch, dickwandig, braungelb, eine kleine, gut begrenzte Gruppe bildend. Inncre Perichätialblätter aufrecht, verlängert lanzettlich, kurz und fein zugespitzt. Seta $3-4$ cm, dünn, rot.

In Moorsimpfen und kalkhaltigen Grimlandsmooren, sowie in Gräben und Wassertümpeln.

fo. vulgaris (San.) Moenkem. in Pasch. Süsswasser-Fl. Heft 14, p. 136 (1911). (Hypnum Sendtneri var. vulgare San. in Bot. Centralbl. 1880. Gratisbeil. No. II. p. 15.)

Stengel etwa $10-15 \mathrm{~cm}$. Stengelblätter stark sichelförmig, breit eilanzettlich, kurz zugespitzt.

F. Ab. Pargas, Lindberg, Kalkbruch (Elf r.). St. Karins. Littois (Trahlb.).—Ik. Pyhäjärvi, Lohijoki (H. Lindb.). - Sa. Ruokolahti, Utula (Hult). - Kol. Tosnessenje und Nikula (Elfv.). Petrosarodsk (Kullh.). - Sb. Lapinlahti, Mätäsjärvi (Lindem.). — Kon. Tiudie (Simın.). — Ob. Karlö (Brenn.).

S. Sk., Öl., Sm., Ög., Uipl. und Hrjd.

N. A. Fornebo.

Europa, Sibirien, Nord-Amerika.

fo. Wilsonii (Schimp.) Moenkem. 1. c. [Hypnum Sendtueri var. Wilsoni Schimp. Musc. eur. nov. fasc. III/IV. Hypnum p. 3, t. 3 (1866). - H. Wilsoni Schimp. in litt., Lor. Bryol. Notizb. p. 76 (1865). - Amblystegium Wilsoni Lindb. Musc. scand. p. $33(1879)$.

Pfl. schlaffer, $15-30 \mathrm{~cm}$, meist untergetaucht. Stengelblätter aus schmälerem Grunde schr lang, zuletzt fadenförmig; Rippe schwächer; Blattflügelzellen sehr locker und dünnwandig, eine grössere Gruppe bildend. - Fig. 90 G- H.

F. Ab. Pargas, Lindberg (Elfv.). - Ta. Padasjoki, Ansio (Norrl.). Hartola (Bonsd.). - Sa. Savitaipale, Ala-Säynätjärvi (Buch). - Kol. Im Waldgebiete pass. (Elfv.). — Sb. Nilsiä, Loutteinen (Kyyhk.). - Kb. Juuka, Saarijärvi, Iölö (Kot.). - Ok. Paltamo, Ielalahti, Horkanlampi (Kyyhk.). - Kpom. Luvajärvi (Vain.). Repola, Tscholktia (V.). - Ll. Pummanki (Broth.).

S. Öl., Sm., Ög., Vg., Boh., Srm., När., Upl. und Ism.

Europa, Sibirien, Nord-Amerika.

subfo. hamata (Schimp.) Moenkem. 1. c. [Hypnum aduncum \& hamatum Bryo]. eur. fasc. $57 / 61$, p. 36, t. 24, f. \& 1-3 (1854). - H. Wilsoni var. hamatum Ren. in Husu. Muscol. Gall. p. 376 (1894). — Amblystegium Wilsoni var. hamatum Lindb. Musc. scand. p. 33 (1879).]

Kräftige, starre Pfl. Stengel unregelmässig bis fast fiederig beästet. Stengelblätter starli sichelförmig.

F. Kl. Ruskeala (Lindb.).

Zentral-Europa.

fo. gigantea (Bryol. eur.) Moenkem. 1. c. [Hypnum aduncum $\vdots$ giganteum Bryol. eur. fasc. $57 / 61$ Mon. p. 36, t. $24^{2}$ (1851). - H. hamifolinm Schimp. Syn. 2. ed. p. 732 excl. syn. p. p. (1876). - Amblystegium Sendtneri var. hamifolium Bomans. et Broth. Herb. Mus. Femn. 2. ed. I1. p. 61 (1894). — Drepanocladus Sendtneri var. giganteus Warust. Laubm. p. 1015 (1906).] 
Sehr kräftige Pfl. in sehr tiefen Rasen. Stengel locker und meist regelmässig gefiedert. Stengelblätter gross, sehr lang und fein, einseitswendig, jedoch flatteriger als bei der vorigen Var.

In tiefen Gräben und Tümpeln.

F. Y Lovisa (Arrh.). - Ta. Korpilahti, Peuha, Kassaari und Pajulahti (Vain.). Luhanka, Keihăssaari (V.). - Kll. Ruskeala (Lindb.).

S. Öl. und Gll.

Europa, Nord-Amerika.

fo. capillifolia (Warnst. p. p.) Moenkem. 1. c. p. 137. [Hypnum capillifolium Wrarnst. in Bot. Zeit. 1877, p. 478 ex p. - Drepanocladus capillifolius Warnst. in Beih. Bot. Centralbl. XIII., p. 400 et 410 ex p. (1903). - Amblystegium Sendtneri var. capillifolium Arn. et C. Jens, in Tảk. Faun. o. Fl. 1. p. 29 (1915).]

Rippe stark verdickt, borstenförmig austretend.

F. Ik. Răisaalā, Salokỵlā, aıf nassen Wiesen am Vuoksen (H. Lindb.). - Sa. Lappee, Hanhijärvi (Buch). - ob. Uleaborg. Kiriniemi (Leir.).

S. Ög. Takern.

N. F. Kistrand, etwa $70^{\circ} \mathrm{n}, \mathrm{Br}$.

Zentral-Europa. Sibirien.

672. Drepanocladus lycopodioides (Schwaegr.) Warnst. 1. c. p. 401 et 413. [Hypnum lycopodioides Schwaegr. Suppl. I. 2, p. 300 (1816). — Amblystegium lycopodioides De Not. Cronaca II. p. 23 (1867).]

Diözisch. Sehr kräftige Pfl. in weichen, gelblich- bis bräunlichgrünen Rasen. Stengel bis $30 \mathrm{~cm}$, niederliegend, in einfache oder wenig verästelte Zweige geteilt. Stengelblätter wenig oder kaum herablaufend, \pm hakenförmig einseitswendig, \pm deutlich längsfaltig, breit cilänglich, kurz lanzettlich-pfriemenförmig zugespitzt, meist 3-4 mm, und bis 1,6 nm breit: Rippe vor der Blattspitze aufhörend; Zellen eng linealisch, am Grunde kürzer und stark getüpfelt, in den Blattecken schwach oder kaum erweitert, gebräunt, eine nicht scharf abgesetzte Gruppe bildend. Innere Perichätialblätter breit lanzettlich, lang zugespitzt, mit dünner Rippe. Seta 2 - 4 cm. gelbrot.

In kalkhaltigen Sümpfen. Selten fruchtend.

F. Al. Eckerö (Arrh.). Finström, Godby (A.). Geta, Björkholm (Hult). Lumparland, Tistronholm (Bom.), saltrik, an mehreren Fundorten (Bom., Elfr.). Sund, Tjurnäs (Bom.). Vảrdö, Gảsskär (B.). - Ab. Korpo (Juil.). Pargaș (Arrh.); Lindberg (Elfv.). Lojo, Seppälã (Hult). - Ta. Hollola, Laitiala (Norrl.). Lammi (Sil.). - Kon. Suojärvi, Varpakỵlă (Kop.). Valkeamăki (Simm.). Tiudie und Soutajärvi (Norrl.).

S. Sk, Ot., Sm., Gtl., Ör. Ig., Yär., Ism., Gstr. und Dlr.

N. Sm. Hvaler, Asmale. On:s Lyngholm.

Europa, sibirien, Grönland.

\section{SCORPIDIUM}

(Schimp.) Limpr. Laulın. III. p. 570 (1899).

Diözisch. Kräftige, glänzende Sumpf- und Wassermoose, ohne Rhizoiden. Stengel und Äste dicht und aufgeschwollen beblättert, mit verdickten und gekrümmten Astenden. Blätter sehr hohl, gedunsen dachziegelig, aufrecht bis sichelförmigeinseitswendig, breit ei- oder länglich-eiförmig bis eilanzettlich, ungefaltet, ganzrandig; Rippe kurz und doppelt, sehr schwach bis fehlend: Zellen eng prosenchymatisch, am Blattgrunde kürzer und weiter, stark verdickt und getüpfelt, in den etwas ausgehöhlten Blattecken oval und rektangulär bis mehreckig, bald dünıwandig und hyalin. bald dickwandig und gelb bis braun, eine selır kleine Gruppe bildend. Innere Perichätialblätter aufrecht, mehrfaltig. lanzettlich, ganzrandig, oln Rippe. Kapsel geneigt bis horizontal, länglich-zylindrisch, wenig gebogen. Sporensack in der jugendlichen Urne von einem doppeltem Luftraum umgeben. Ring differenziert. Deckel hoch kegelförmig, mit Spitzchen.

Einzige Art: 
673. Scorpidium scorpioides (L.) Limpr. 1. e. p. 571. [Hypnum scorpioides L. Sp. pl. p. 1127 (1753). — Amblystegium scorpioides Lindb. Muse. scand. p. 33 (1879). - Calliergon scorpioides Kindb. Eur. and N.-Am. Bryin. p. 82 (1896). Drepanocladus scorpioides WVarnst. Laubm. p. 1027 (1906).]

$\mathrm{Pfl}$, in lockeren, gelb- bis braungrünen, rot-bis schwarzlbraunen Rasen. Steıgel aufrecht oder nieclerliegend bis $30 \mathrm{~cm}$, einfach oder wenig geteilt, unregelmässig gefiedert. Blätter bis $3,5 \mathrm{~mm}$ lang und bis $2 \mathrm{~mm}$ breit. Seta $4-6 \mathrm{~cm}$, rot. Kapsel bis $4 \mathrm{~mm}$ lang, trocken und entcleckelt stark eingekrümmt, ylatt oder selnwach gefurcht, unter der Mündung \pm eingeschnïrt. Sporenreife im Jumi und Juli. Fig. $92 \mathrm{C}$.

In tiefen, besonders kalkhaltigen Wiesenmooren, zuwcilen völlig untergetaucht und schwimmend, auch in Tünpeln.

F. Al. Eckerö (Arrh.). Finström, Tjudö (Bom.). Geta. Gröndal (Hult). Siltvil. Lafsböle und Lángbergsöda (Bom.). Brändo, Jumo Harhomen (B.). - Ab. Korpo. Jurmo (Ekl.). Paruas, Lindberg (Elfv.) Bromarf (Sundv.). Karislojo (s.). Lojo, an mehreren Fundorlen (Lindl).. Hult. E. af H.). Sammatti (Sel.). Vichtis (IF. Nyl., Hult). - N. Ekenäs. LaIpvik (Teräsv.): Ekenäs (Hayc.). Pojo) (H.). Kỵkslätt (Broth.). Helsingfors (Lảng). - Ik. Valkjärvi. Tihtarisenjoki (H. Lindb.). Pylhäjärvi, Konnitsa (H. L.). - St. Björneborg (Häyr.). - Ta. Hattula, Letunsuo (Sundr.). Asikkala, an mel.reren Fundorten (Norrl.). Korpilahti. Rajanlahti (Vain.). Luhanka, Vanha Jutila (V.). - sa. Willuanstrand (Buch). Ruokolahti (Hult). Kangasniemi (Lackstr.). - Kol. Salmi (Pes.). Nikola (Elfr.). Oa. Kaskö (Nerr.). - Tb. Kinnula, Iruhola, Torniojärvi (Roir.). Pihtipudas, an mehreren Fundorten (R.). - sb. Kuopio, Suovu (Link.). Kaavi, im Kalk-und Serpentingebiete fq. (Kot.). Nilsiä. Kirchdorf (hot.); Loutteinen (k.); Kuuslahti. Taakonlampi (Kỵhk.). Màninka. Pöljänjärvi (K.). - kh. Juuka, JuuanVaara (Kot.); Nurmes (Tain.). - Kon. Suosaari (Kullh.). Tolvoja (Popp.). Tiudie (Sahlb.). Dianora gora (Kullh.). Selki (Nourl.). - Ok. Paltamo (Lackstr.). Kuhmoniemi. Lapinsalmi (Kyyh.). - hpom. Kellovaara und Lahnajoki (Bergr.). Repola. Tscholkka (Vain.). - Ob. Simu (Räs.): Iartimonjärvi, Kivalo (Brenn.). Rovaniemi, Koskenniemi (Hult): Tolonen und Alajääskö (H.). - K. Kuusamo, an vielen Fundorten (F. Nyl, Nyb., sil., Broth., E. af H.). - Lkem. Kiltilä st. f(I. (Hult). Muonio. in der Waldregion fq. (Yorrl.). Kuolajärvi, Hàräsjärvi, Vilkalampi (Roir.): Vuoriḳlä, Pet-erilampi (R.). Le. Kilpisjärvi, Saana, in der subalpinen Region (Kut.). - Li. Inari in der Nadelwaldregion fq.. in der Birkenregion pass. (Hult). - Lim. Kandalaks (Sahlb., Broth.). Sascheika (Karst.). - Lt. Subovi (Broth.); Tsipnavolok und Vaidoguba (B.). - Lmur. Voroninsk (Kihlm.). Gavrilova, Olenka. Semjoslrovik und Krugloje guba (Broth.). Zw. Tarsinsk und Jenjäyr (B.). - Lp. Or]ox (Kihlm.). — Lr. Tschavanga (Brenn.).

S. Sh. $-L$.

N. A. nicht selten. JL. Sindefjord rr.; Tjono. Ve. Saetersdalen. F. rr. No.-F an vielen Fundorten und in allen Höhenlagen

Europa, Tschuktschen-Halbinsel. nördl. Teile von Nord-Amerika. Nordgrenze bei $71^{\circ} \mathrm{n} . \mathrm{Br}^{\circ}$

\section{CALLIERGON}

(Sull.) Kindb. Eur. and N.-An. Bryin. p. 80 ex p. (1897); Sull. Musc. and Hep. U. S. p. $72(1856)$ als Subg.

Meist \pm kräftige Sumpf- und Wassermoose in meist lockeren, oft ausgedehnten Rasen, seltener vereinzelt zwisehen anderen Sumpfmoosen. Stengel olne Aussenrinde, einfach oder geteilt, unregelmässig verästelt oder \pm deutlich gefiedert, mit geraden, stumpflichen Spross- und Astenden: Pseudoparaphyllien nur in der Nähe der Astanlagen. Stammblätter aufrecht-abstehend oder dacliziegelig. selten schwach längsfaltig, eilänglich bis fast kreisrund, flach- und ganzrandig: Rippe kräftig, einfach, zuweilen an Ende ungleich gabelig: Zellen verlängert linealisch, glatt, häufig mit eingesprengten Rlizoideninitialen. an den Blattflügeln locker, aufgeblasen, dünnwandig, anfangs hyalin. eine grosse, \pm ausgehöhlte Gruppe bildend. Astblätter kleiner und sehmäler, oberwärts oft rölırig-hohl. Innere Perichätialblätter aufrecht, nicht längsfaltig. Kapsel geneigt bis horizontal, eiförnig bis länglich-zylindrisch, troeken \pm eingekrümmt. Deckel gewölbt-kegelig. 


$$
\text { I"bersicht der A r ter. }
$$

A. Blattfligelzelten zalılreich, locker, dünnwandig und hyalin.

a. Diözisch. Schlanke, fast einfache, drehrund beblätterte, strohfarbene Pfl. Blattfügelzellen eine schmale, dreieckige, ausgehöhlte, scharf abgegrenzte Gruppe bildend

677. C. stramineum.

b. Weniger schlanke bis kräftige, unregelmässig bis fiederig beästete $\mathrm{Pfl}$. Blätter \pm abstehend.

«. Blüte unbelannt. Stengel oberwärts weissfilzig.

Blätter aus herzförmiger Basis breit eiförmig ..... 679. C. solitarium.

$\beta$. Stengel niemals verfilzt, meist ohne Rhizoidlen.

I. Autözisch. Grüne Pfl. Rippe kurz vor der Blattspitze aufhörend: Biattflügelzellen eine kaum oder schwach ausgehöhlte. nicht scharf begrenzte Gruppe bildend

680. C. cordifolium.

II. Blattflügelzellen eine stark ausgehöhlte und scharf begrenzte Gruppe bildend.

1. Autözisch. Rippe fast ${ }^{3 / 4}$ der Blattlänge, zuweilen oben ungleich 2schenklig ...............681.C.Richardsonii.

2. Diözisch. Rippe bis unter die Blattspitze reichend.

* Stattliche, grüne bis bräunliche Pfl. Stengel meist \pm regelmässig fiederästig ....... 682. C. giganteum.

** Rote bis schwärzlich-rote oder rot und grün gescheckte Pfl. Stengel unregelmässig beästet

678. C.sarmentosum.

B. Diözisch. Blattflügelzellen gefärbt und dickwandig, ron den Basalzellen \pm deutlich verschieden.

a. Starre, schlanke, drehrund beblätterie Pfl. Blattspitze

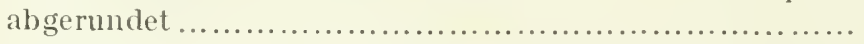

674. C. Irifarium.

b. Irräftige. weniger starre, durch die Beblätterung aufgeschwollen-kätzchenförmige Pfl. Blätter plötzlich kurz und feinspitzig

675. C. lurgescens.

S e c t. I. Pseudocalliergon (Limpr.). [Hypnum Subg. Calliergon sect. PseudoCalliergon Limpr. Laubm. III. p. 5.7 (1899). - Callierga trifaria C. Jens. in Bot. Notis. 1921, p. 30.]

Blattflügelzellen gefärbt und dickwandig, von den Basalzellen wenig verschieden: Laminazellen olme eingelagerte Rhizoideninitialen.

675. Calliergon turgescens (Th. Jens.) Kindb. Eur. and N.-Am. Bryin. p. S4 (1897). [Hypnum turgescens Th. Jens. Mser.; Schimp. Sym. p. 648 (1860). — Amblyslegium lurgescens Lindl. Muse. scand. p. 33 (1879). - Drepanocladus turgescens Broth. in E.-P. I². p. 1035 (1908).]

:" Diözisch. Kräftige Pfl. in weichen. schwellenden, goldgelblichen oder grünlichen bis bräunlichen Rasen, auch zwischen andere Sumpfmoose eingesprengt. Stengel 6-20 cm, niederliegend bis aufrecht, ohne Rhizoiden, durch die Beblätterung aufgeschwollen-kätzchenförmig, einfach oder büschelig geteilt, mit wenigen, am Grunde stoloniform entwickelten. stumpfen Isten. Stengelblätter nicht herablaufend, sehr hohl, aus abgerundeter, umfassender Basis breit länglich, stumpf, mit kurzer und feiner, zurückgekrümmter Spitze, bis $3,3 \mathrm{~mm}$ lang und bis $1,2 \mathrm{~mm}$ breit, durch die stark eingeschlagenen Ränder kappenförmig, ganzrandig; Rippe schwach, etwa $1 / 3$ der Blattlänge, einfach oder oben 2 -3schenklig; Tellen derb- 
wandig, in der Melurzahl etwa $9 \mu$ breit und $6-9$ mal so lang, an der Insertion stark verdickt und getïpfelt, in den Blattecken einige quadratisch und oxal. Innere Perichätialblätter aufrecht, etwas längsfaltig, aus scheidiger Basis breit lanzettlich, kurz zugespitzt oder stumpf.

In kalkhaltigen Versümpfungen und am Rande der Tümpel. Sporogone bisher nur aus Öland bekannt.

S. $V g ., \ddot{l}$., Gll., Irjd und $L u L$.

Spitzbergen, Beeren-Eiland, Zentral-Europa, Terski Alatau, arkt. Sibirien und arkt. Nord-Ameriki.

676. Calliergon trifarium (Web. et Mohr) Kindb. Eur. and N.-Am. Bryin. p. 85 (1897). - Hypnum trifarium Web. et Mohr Reis. in Scliwed. p. 177, t. 2. I. 2 a-d. (180-1). - Amblystegium trifarium De Not. Epil. p. 138 (1869).]

Diözisch. Pfl. schlank bis ziemlich kräftig, bald zwischen anderen Sumpfmoosen eingesprengt, bald geschlossene, grïne, braungelbe oder braungrüne, innen schwarzbraune, trocken starre und glänzende Rasen bildend. Stengel $10-30 \mathrm{~cm}$. gesclılängelt-aufrecht oder niederliegend, ohne Rhizoiden, astlos oder mit spärlichen, kurzen, keulig-walzenförmigen đ̈sten. Stammblätter dieht schuppenlörmig angedrückt, löflelartig-hohl, wenig herablaufend, breit oval bis rundlicli-eiförmig, mit abgerundeter, fein gekerbter, fast kappenförmiger Spitze, flach- und ganzrandig, nur an den Blattflügeln zurückgeschlagen, bis $2 \mathrm{~mm}$ lang und bis 1,5 mm breit; Rippe dünn, in und über der Blattmitte aufhörend, seltener cloppelt und kürzer; Zellen in der Blattmitte etwa $6 \mu$ breit und $6-12$ mal so lang, am Grunde erweitert, rektangulär und länglich-mehreckig, verdickt, gelb- bis l)raunwandig, in den Blattflügeln etwas weiter. Innere Perichätialblätter längsfaltig. verlängert lanzettlich, stumpflich. Seta $3-5 \mathrm{~cm}$, geschlängelt, rot. Ring $3-5-$ reihig, kleinzellig. Sporenreife im Juni und Juli. - Fig. 93 G-H

In tiefen, besonders kalkhaltigen Sïmpfen.

F. Al. Eckerö, Storby (H. Lindb.). Finström, Attuöle Storträsk (Bom.); Finströmsgảrd (B.). Sund, Tjurnäs (B.). - Ta. Hattula, Yli-Savijärri (A. Weg.). - Kil. Suistamo, Saariselkä (Kot.) - Kol. Petrosavodsk (Simm.). - Sb. Kaavi, Niinivaara, Lauttalampi (Kot.). Juuka, Petroraara, Merelä (K.). - Kb. Juuka, Juuanvaara fq. (Kot.). — Kon. Suojärvi, Pöpönsaari (Norrl.). Suosaari (Kullh.). - Ok. Paltamo, Melalahti (Kyyhk.). Sotkamo, Tipasoja, Vuorinienn (K.). Hyrynsalmi, Kiviranta (K.). Puolanka, Törmönmäki (K.). Suomussalmi, Kallioisen suo, Kaivosuo und Ulkopuron suo (K.). - ob. Ilitornio. Hallila (Hult). - K. Kuusamo, Oivanki, Ylimmäinen Sammallanpi (E. af H.). - Lkem. Kolari. Teurajärvi (Hult). Kittilä, Kirchdorf (H.); Levitunturi und Aakenustunturi (H.). - Le. Karesuanto (Norrl). Kilpisjärvi, Saana (Kot.). - Lim. Hibinä, an nassen Felsen in der alpinen Region (Broth.); Tuil-lukt, in der alpinen Region (Kihlm.). - Ll. Tsipnarolok (Broth.). - Lmur. Garrilova, Olenka, Semjostrovsk, Krugloje guba und Varsinsk (B.). - Lp. Orlov (Kihlm.).

S. Sm. an mehreren Fundorten, Ög., Boh., När., Upl, Vsm, Gstr, Hrgd, Jmt. und LuL.

N. A. Kristiania r. Ringerike rr. JL. Tjømø. Ne. Saetersdalen. K. Jotunfjeldene. Røshejm. No.-F. Färøer, Sehottland, Dänemark, Zentral-Europa, Sibirien, nördl. Teile ron Nord-Amerika.

Se ct. I I. Eucalliergon (Limpr.). [Hypnum Subg. Calliergon sect. EuCalliergon Limpr. Laubm. III. p. 547 (1899).]

Blattflügelzellen zahlreich, meist aufgeblasen, dünnwandig und hyalin: Laminazellen gegen die Blattspitze hin oder beiderseits der Rippe mit eingelagerten. am Blattrücken nicht selten zu Rhizoiden auswachsenden, oft geteilten und zu Gruppen vereinigten Initialen.

677. Calliergon stramineum (Dicks.) Kindb. 1. c. p. 81 [Hyprum stramineum Dicks. Pl. crypt. fasc. I1. p. 6, t. I. f. 9 (1790). - Amblystegium stramineum De Not. Epil. p. $173(1869)$.]

Diözisch. Schlanke Pfl. in weichen, lockeren bis dichten, gelbgrünen bis strohfarbenen, glänzenden Rasen. Stengel bis $20 \mathrm{~cm}$, meist aufrecht, ohme Rhizoiden, meist dicht beblättert, astlos oder mit zerstreuten, schlaffen Ästen. Stammblätter aufrecht-abstehend, trocken locker anliegend und zart längsfaltig, aus herablaufendem Grunde eilänglich-zungenförmig, mit abgerundeter, kappenförmiger Spitze, bis $2 \mathrm{~mm}$ lang und bis $0,9 \mathrm{~mm}$ breit; Rippe dünn, weit über der Blattmitte 
endend; Zellen in der Blattmitte et wa $6 \mu$ breit und $8-14$ mal so lang, an den ausgehöhlten Blattflügeln eine schmale, dreieckige, nicht scharf begrenzte Gruppe bildend. Innere Perichätialblätter fast scheidig, breit lanzettlich und kurz zugespitzt oder zungenförmig mit Spitzchen. Seta $4-8 \mathrm{~cm}$, dünn, rötlich. Ring nicht differenziert. Sporenreife im Mai und Juni. - Fig. $93 \mathrm{C}-$ F.

In Waldsümpfen, auf Sumpfwiesen und in Torfmooren im ganzen Gebiete \pm fq.

Spitzbergen, Europa, Sibirien, Nord-Amerika.

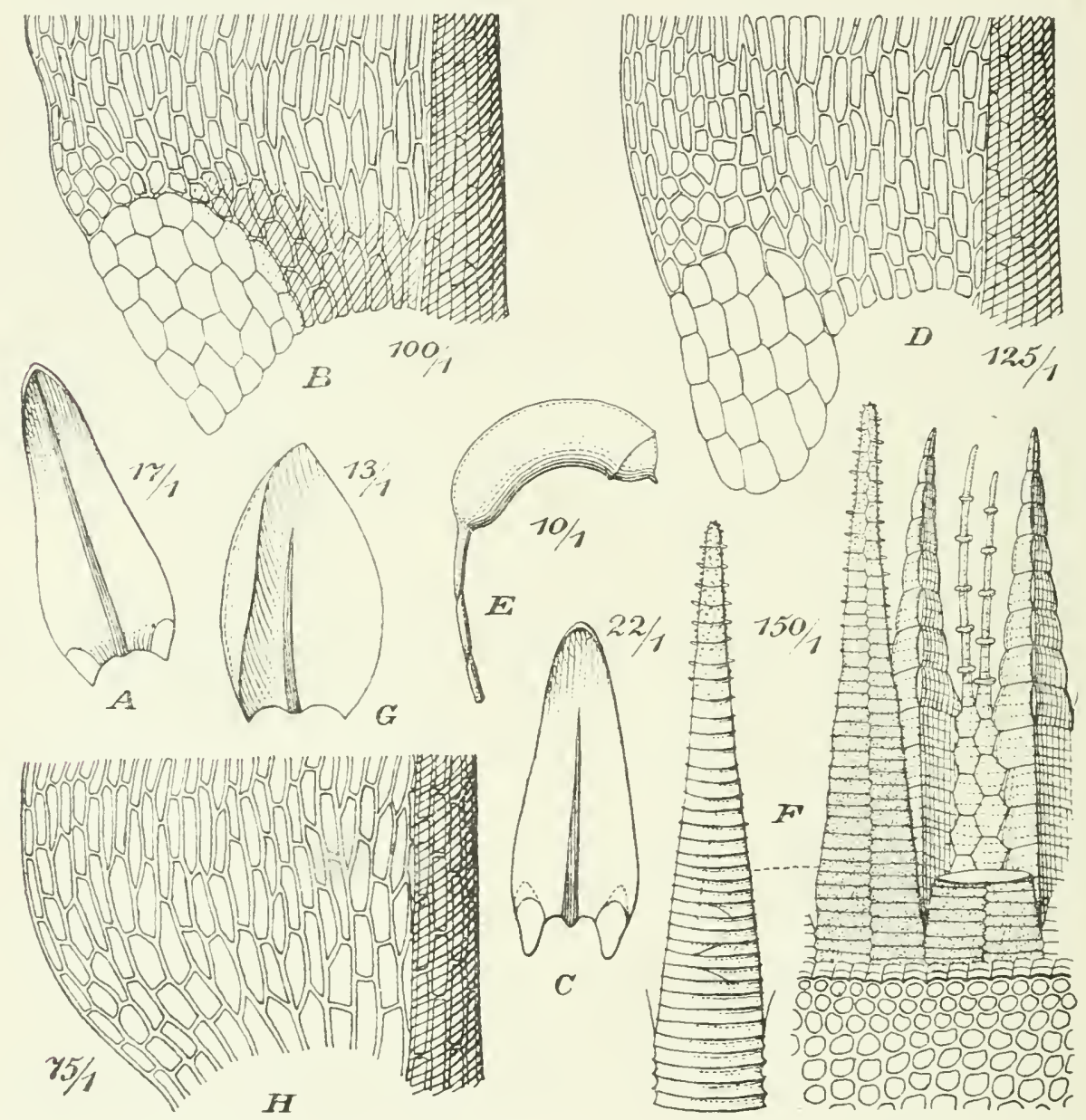

Fig. 93. A-B. Calliergon sarmentosum (Wahlenb.). A Stengelb. (17/1); B Blattbasis (100/1). - C-F. C. stramineum (Dicks.). C Stengelb. (22/1); D Blattbasis (125/t); E Kapsel (10/1); F Peristoul (150/1). G-H. C. trifarium (Web. et Monr). G Stengelb. (13/1); H Blattbasis (75/1).

var. nivale (Lor.). [Hypnum nivale Lor. Moosstud. p. 122, t. V. f. B. (1864). - Amblystegium stramineum var. nivale Vent. et Bott. Enum. p. 10 (1886).]

Rasen hingestreckt, verwebt, goligelb. Stengel geschlängelt, schlaff, z. T unregelmässig beästet; điste am Grunde kleinblätterig, aufwärts kätzchenförmig, an der Spitze hakenförmig gekrimmt. Stengelblätter oval-länglich.

N. K. Jotunfjeldene, Galdhø in der alpinen Region. Alpenkette in der hochalpinen Region. 
var. patens (Lindb.). [Amblysteginm straminenm $\beta$ patens Lindb. Ilusc. scand. p. 34 (1879).]

Kräftiger und starrer als die Hauplart. Stengelblätter abstehend bis horizontal, oberhalb der Basis breiter, an der Spitze tief kappenförmig; Rippe viel Jänger; Blattflügelzellen zahlreicher und grösser.

F. Helsingfors, in Torfgräben (Lindb.).

Deutschland, Schweiz.

678. Calliergon sarmentosum (Wahlenb.) Kindb. 1. c. p. 81. (Hypnum sarmentosum Wahlenb. Fl. lapp. p. 380 (1812). - Amblystegium sarmenlosum De Not. Epil. p. 136 (1869).]

Diözisch. Pfl. in oft ausgedehnten, weichen, tief- oder schwärzlichroten, oft rot gescheckten, stark glänzenden Rasen. Stengel bis $20 \mathrm{~cm}$, meist niederliegend, ohne Rhizoiden, dicht beblättert, unregelmässig beästel; Äste fast zweizeilig gestellt, von ungleicher Länge. Stengelblätter aufrecht-abstehenr, trocken locker eingebogen. herablaufend, sehr hohl, fast zungenförmig, nit oder ohne Spitzchen, bis 2,5 $\mathrm{mm}$ lang und bis $1 \mathrm{~mm}$ breit: Rippe kurz vor der Blattspitze aufhörend: Zellen in der Blattmitte etwa 6 a breit und 6-10 mal so lang, an den stark ausgehöhlten Blattflügeln eine scharf abgegrenzte Gruppe bildend. Perichätialblätter fast scheirlig, rasch zugespitzt, mit abgebogener Spitze. Seta 2,5$3,5 \mathrm{~cm}$, dünn, rot. Kapsel geneigt, länglich bis fast zylindrisch, etwa $2,4 \mathrm{~mm}$ lang und $1 \mathrm{~mm}$ dick, lederbraun. Ring fehlend. Sporenreife im Juni und Juli. - Fig. $93 \mathrm{~A}-\mathrm{B}$.

An nassen Felsen, in Bächen und Wassertümpeln, an quelligen Stellen und am reichlichsten in den Sümpfen, und dort im Norden zuweilen Massenvegetation bildend.

F. Al. Saltvik, Kuggböle und Kuggsund (Bom.). Sund. Östra Krrksundet (B.). - N. Snappertuna, Gebbesby (Var.). Kyrkslätt, Bobäck (Ranck.). Esijo, Bubäck (Kot.). Helsinufors (Lindb.). Hogland (L.). - Ka. Wiborg, Juustilanjärvi (Buch). - St. Ruovesi, zw. Koverojärvi und Helvetinjärvi (Broth.). -- Ta. Asikkala, Kuivaharju (Norrl.). Kuhmoinen, Isojärvi (Broth.). - Kl. Sortavala, Kirjavalahti (Lång). - Kol. Salmi (A. K. Caj.). - Tb. Karstula, zw. Nihilampi und Ruotsila (Broth.). Pihtipuda;, Sydänmaa, Kukkanen (Roiv.). - Sb. Juska. Vesivaara und Halivaara (Kót.). Nilsiä, huuslahti, Jaakonlampi (Kyyhk.). - Om. Vindala, Helamajanpuro - (Backm.) Ok. Kajana (Lackstr.). Paltamo, hives (L.). Sotkamo, Vuokatti (L.). Hyrysalmi, Kiviranta (Kyyhk.), Suomussalmi. Meriläissuo (Lackstr.); Ulkupuro und Kaivosuo (Kyyhk.). - Ob. Uleảborg, Marjasuo (Huum.). Simo (H. Lindb.). Rovaniemi, IIänty und Tervo (Hult). Turtola, Pullinki (H.). - K. Pudasjärvi (Nyb.); zw. Iso Syöte und Naamanka (Broth.). Kuusamo, Pyhäraara und Alakitka (E. af H.). Iivaara (Brolh.) Nuorunen (Nyb.). - Kk. Kiekkivaara (Brolh.). Knjäscha (Fellm.), - Lkem. Kolari. Sieppijärvi (Hult). Kittilä und im Fjeldgebiete st. fq. (Hult). Ounastunturi (Sandm.). Kuolajärvi, an vielen Fundorten (Linnan., E. af H.). - Le. In der Nadelwaldregion st. fq., in der Birken- und alpinen Region fq. (Norrl.), - Li. In Waldgebiete fqq., in der alpinen Region st. fq. (Hult). - In allen Teilen der Halbinsel Kola fq. (B roth.).

S. Dlr., Mpd., Ang., Hrjd.-L.

N. A. $-F$.

Spitzbergen, Färoer, Gross-Britannien, Alpengebiet, Thian-Schan, Sibirien, Tschuktschen-Halbinsel, nördl. Teile von Nord-Amerika, Fuegia, Süd-Georgien, New Zealand, Antarktis.

var. fallaciosum (Mild.). [Hypnum sarmentosum var. fallaciosum Mild. Bryol. siles. p. 369 (1869). - Amblystegium sarmentosum var. fallaciosum Möl. 1. c.]

Tracht von C. stramineum. Rasen gelbgrün. Stengel aufrecht, bis $10 \mathrm{~cm}$, dünn.

S. Hrjd.

N. K. Valders.

Riesengebirge.

var. fontinaloides (Berggr.). [Hypnum sarmentosum var. $\beta$ fontinaloides Berggr. in Hartm. Sk. Fl. 10. ed. p. $\downarrow$ (1871). - Amblyslegium sarmentosum var. fontinaloides Möll. l. c.]

Flutende, dunkelgrüne Pfl. mit dünnen, langen Ästen. Blätter länger als bei der Hauptart.

F. Lkem. Ounastunturi (Norrl.). - Le. Vittanki (N.).

N. K. Uovre. Valders. 
679. Calliergon solitarium (Hag.). (Hypnum solitarium Hag. in D. K. X. Vid. Selsk. Skrift. 1897, No. 2. p. 29.)

Stengel (Ast?) au; kriechendem Grunde aufsteigend, längs mit Rhizoiden und im aufsteigenden Teil weissfilzig. Blätter \pm abstehend, trocken dachziegelig anliegend, aus herzförmiger Basis breit eiförmig. mit abgerundeter Spitze und
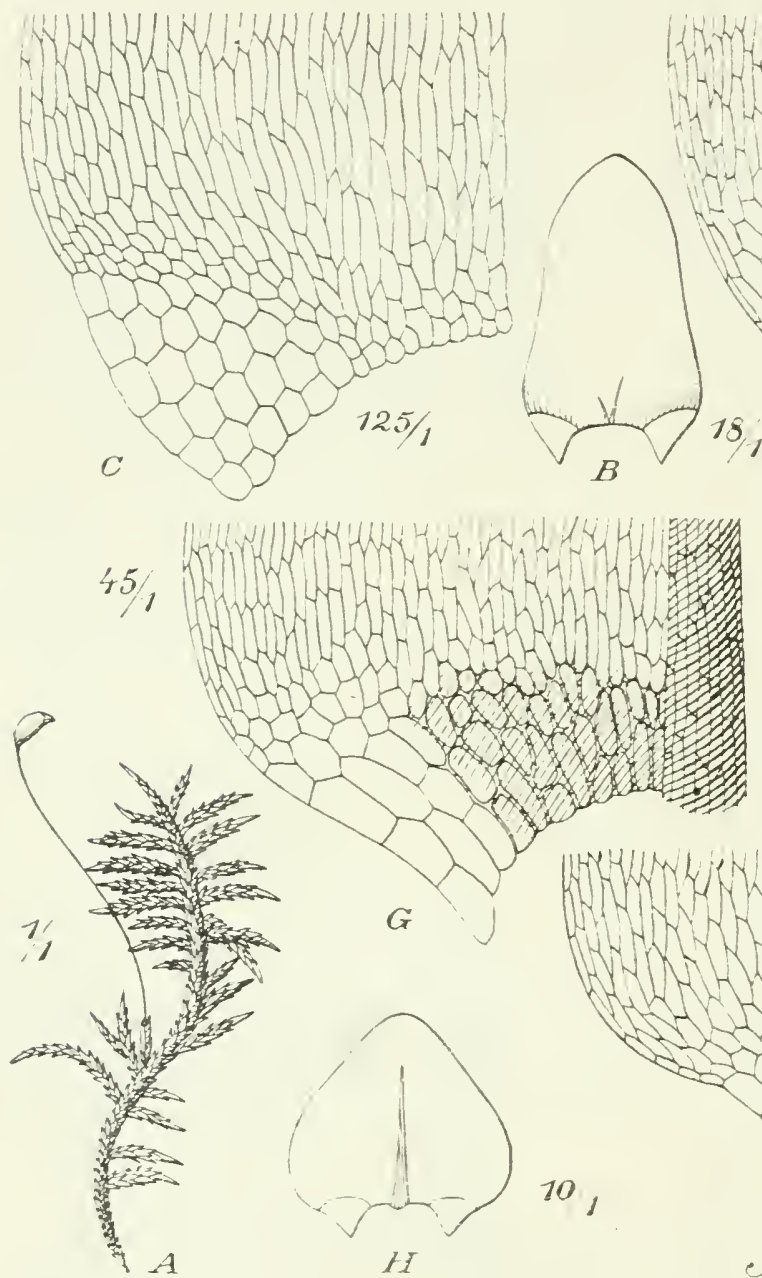

sist

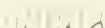

(1) 
Hedw. Deser. IV. p. 97, t. 37 (1797). - Amblystegium cordifolium De Xot. Epil. p. 136 (1869).]

Autözisch. Pfl. in oft ausgedelnten, weichen, grünen bis gellygrünen Rasen. Stengel bis $20 \mathrm{~cm}$, niedergestreckt oder aufsteigend bis aufrecht, meist weit hinauf mit kurzen Rhizoiden, astlos oder mit wenigen kurzen bis längeren Ästen. Stammblätter aufrecht- bis weit abstehend, wenig hohl, trocken meist mit eingebogenen Rändern und etwas gedreht, aus herablaufendem Grunde herz-cilänglich bis länglich-lanzettlich, nit abgerundeter Spitze, bis 3,5 mm lang und bis 1,6 $\mathrm{mm}$ breit: Rippe dünn, dicht vor der Blattspitze endend; Zellen in der Blattmitte 9-12 " breit und 8-12 mal so lang. gegen die Ränder allmählich enger, an den schwach ausgehöhlten Biattflügeln eine bis zur Rippe reichende, nicht scharf alsgesetzte Gruppe bifdend. Innere Perichätialblätter breit lanzettlich, last scheidig, lang und fein zugespitzt. Seta $5-9 \mathrm{~cm}$, rot. Kapsel horizontal, Kinglich-eiformig, bis $4,5 \mathrm{~mm}$ lang und bis $1,5 \mathrm{~mm}$ dick, gelbbräunlich. Ring nur angedeutet. Sporen reife im Mai und Juni. - Fig. 9-1 D-E.

An quelligen Waldstellen, in Wiesemmooren, Gräben und 'Tümpeln im ganzen Gebiete \pm fq.

Europa. Sibirien, Amurgebiet, Nord-Amerika, New Zealand.

var. angustifolium (Schimp.). [Hypnum cordifolium var. angustifolium Schimp.

Mscr. in Klinggr. Leber.- und Laubm. West- und Ostpreuss. p. 291 (1893).]

Tracht von C. stramineum. Stengel sehr dünn. Blätter viel schmäler als bei der Hauptart.

P. Ta. Jaala. Iso Ruhmasjärvi, in einem im Sommer ausgetrockneten Teiche (Buch), 一 Oa. Va-it. Korsör (Broth.).

Deutschland.

var. coloratum (Arn.). (Amblystegium cordifolium var. coloratum Arn. in Bot. Notis. 1894, p. 62.)

Tracht von C. Richardsonii. Gelbgrüne, abwärts rötlichbraune, glänzende Pfl. Blätter länger, locker gestellt, fast abstehend: Rippe oft rot: Zellen enger als bei der Hauptart.

S. Bl. und ing.

Dänemark, Russland.

var. lanato=caule (Bryhn). [Hypnum cordifolium var. lanato-caule Bryhn in Nyt. Mag. Naturv. Bd. 40, Heft 1, p. 22 (1902). - Amblysteginm cordifolium var. lanato-caule Möll. Fört. Sk. växt. 2. Moss. p. 41 (1907).]

Stengel mit Rhizoiden dicht besetzt. Blätter abstehend.

Auf nassem, zeitweise überschwemmtem Torfboden.

N. Ringerike, an mehreren Fundorten.

681. Calliergon Richardsonii (Mitt.) Kindb. 1. c. p. 80 . [Stereodon Richardsonii Mitt. in Linn. Proc.-Bot. VIII. p. 12 (1865). - Hypnum Richardsonii Lesq. et James Man. p. 404 (1884). — Amblystegium Richardsonii Lindb. in Arn. et Lindb. Musc. As. bor. II. p. 125 (1890).]

Autözisch. Pfl. in starren, grünen und gelbgrünen, innen bräunlichen und schwärzlichbraunen, glänzenden Rasen. Stengel bis $10 \mathrm{~cm}$, aufrecht, nur am Grunde mit Rhizoiden, astlos oder locker und unterbrochen gefiedert: Iste abstehend, kurz, scharf zugespitzt. Stengelblätter aufrecht-abstehend, trocken eingebogen, sehr hohl, aus kurz herablaufenden Grunde herz-eilänglich, mit abgerundeter Spitze, his $2.4 \mathrm{~mm}$ lang und bis $1,65 \mathrm{~mm}$ breit; Rippe schmal, zureilen ungleich zweischenklig, nur $1 / 2-3 / 4$ des Blattes durchlaufend: Zellen in der Blattmitte etwa 9 " breit und $8-10$ mal so lang, gegen die Räncter allmällich enger, an den Blattflügeln eine stark ausgehöhlte und scharf begrenzte Grupje bildend. Innere Perichätialblätter zusammengewickelt, lanzettlich und stumpflich zugespitzt. Seta etwa $6 \mathrm{~cm}$, rot. Ring fehlend. Sporenreife im Mai und Juni. - Fig. $94 \mathrm{H}-\mathrm{I}$. 
An sumpfigen und quelligen Stellen, zuweilen auch an trockneren Stellen und im Wasser.

F. 1l. Sund, Gesterby und Tjurnäs träsk (Lindb.). - Ab. Lojo, Ojamo (Lindb.). - Ka. Antrea, Kaskinen (Lindb.). - Ta. Hollola, Siikanjemi (Vain.). - Kl. Soanlahti, Korpikallio (Broth.). - Sb. Kuopio, Koivusaari. Höttälä (Kyyhk.); Toivala (K.); Pitkālahti (Humm.). Kaavi, Losomäki (Kyyhk.). Nilsiä. Kuuslahti, Jaakonlampi (K.). Maaninka, Kinnulanlahti, Lahteld (K.). — Kb. Juuka. Juuanvaara (Kot.). Lieksa. Tieki (Vain.). - Kon. Jalguba (Simm.), - Ok. Suomussalmi, an mehreren Fundorten zw. Salovaara und Saarijäri (Kyyh.). - Ob. Lleáborg (Hum.). - $k$. Kuusamo, zw. Oivanki und Haataja (Broth.); Jäkälainen, Hỵänjemi und Tolva, am Ufer des Y'ikitkajärvi (Broth.). - Lken. In Kolari und Kittilä =t. fq. (Hult). Inonio, Lompolanvooma (A. K. Caj.). Kuolajärvi. Alapeteri (Linnan.); zW. Airistunturi und Lampela (L.). - Li. Sodankỵă, Kopsusjārơi und Tankajoki (Hult). Inari. Vâỵả und sàytsjärvi (H.). - Lim. Kandalaks (Broth.). - Lt. Kola (B.). Tsipnarolok (B.). - Lmur. Semjostrov (B.).

S. Sm., ̈̈g.. Ig.. L̈pl.. Gstr., Dlr.. Hlsl.. Ipd.. Ang. und LuL.

N. Sm. Onso. Bu. Honefos. Ringerike, Tyristranden. JL. Tjomo. A. Kristiania. K. Dorre. Lomsund Jotunfjeldene. $\ T$. Stjordalen. No. $-F$.

Alpengebiet, Russland. Sibirien, Nord-Amerika.

var. fluitans (Bryhn). [Hypnum Richardsonii var. fluitans Bryhn in Nyt Mag. Naturv. Bd. 40, Heft 1. p. 23 (1902). - Amblystegium Richardsonii var. fluitans Möll. Fört. Sk. växt. 2. Moss. p. 41 (1907).]

Flutende, schwarzgrüne, abwärts schwärzliche Pfl. Stengel bis $40 \mathrm{~cm}$, mit zahlreichen. langen, abstehenden Ästen. Stengelblätter abstehend, etwa $4 \mathrm{~mm}$ lang und 2,5 $\mathrm{mm}$ breit.

N. Ringerike, an mehreren Fundorten in Torfgräben und Tümpeln.

var. robustum (Lindb. et Arn.). [Amblystegium Richardsonii var. robustum Lindb. et Arn. in K. Sr. Vet.-Ak. Handl. Bd. 23. No. 10, p. 126 (1890).]

Flutencle, sehr kräftige. grüne Pfl. Stengelblätter bis $40 \mathrm{~cm}$. Stengelblätter bis $6 \mathrm{~mm}$ lang und $4 \mathrm{~mm}$ breit.

S. L'pl., ing. Hernösand. TL.

N. Gudbrandsdalen. $T r$. Nordrejsen, Skruvtjern.

Russland, sibirien.

var. lanatum (Bryhn). [Hypnum Richardsonii var. lanatum Bryhn I. c. Amblystegium Richardsonii var. lanatum .Möll. 1. c.]

Stengel mit reisslichen, später brämulichen Rhizoiden. Stengelblätter 1$1,5 \mathrm{~mm}$ lang und 2-2,5 $\mathrm{mm}$ breit, an Riicken mit \pm zahlreichen Rhizoiden.

N. Ringerike, an mehreren Fundorten. JL. Tjomø. Gudbrandsdalen, Fron. F. Kistrand.

682. Calliergon giganteum (Schimp.) Kindb. 1. c. p. 80. [Hypnum giganteum Schimp. Syn. 1. ed. p. 6ł2 (1860). - Amblystegium giganteum De Not. Epil. p. 135 $(1869)$.]

Diözisch. Kräftige Pfl. in lockeren, starren und tiefen, oft nur mit den Spitzen aus dem Wasser hervorragenden, grünen bis gelblichen, unterwärts meist ockerfarbigen, \pm glänzenden Rasen. Stengel bis $30 \mathrm{~cm}$, selten noch länger, aufrecht, fast olne Rhizoiden, meist ziemlich regelmässig gefiedert, an der Spitze trocken steif und fast stechend; Iste abstehend. meist nur bis $1 \mathrm{~cm}$, dünn, spitz und federartig beblättert. Stammblätter $I$ abstehend, hohl, aus herablaufendem Grunde herz-eilänglich, kappenförmig und stumpf, bis 3 , $5 \mathrm{~mm}$ lang und $2 \mathrm{~mm}$ breit; Rippe I kräftig. kurz vor cler Blattspitze endend: Zellen in der Blattmitte etwa 7 " breit und bis 15 mal so lang, gegen die Ränder allmählich enger, an den stark ausgehöhlten Blattflïgeln eine scharf begrenzte Gruppe bildend. Äussere Perichätialblätter mit fast sparrig abgebogenen Spitzen, innere aufrecht, zusammengewickelt. lanzettlich und stumpflich. Seta $5-6 \mathrm{~cm}$, rot. Ring fehlend. Sporenreife im IIai und Juni. - Fig. $94 \mathrm{~F}-\mathrm{G}$.

In tiefen Gräben. Teichen und wasserreichen Sümpfen.

F. Al. pass. (Bom.). - Ab.-Ik. pass. St.-Kol. pass. Tb. Uurainen. Laukaa und Viitasaari, an wenigen Fundorten (Broth.). - Sb. Kuopio fq. (Link.). Nilsiä st. fq.-pass. (Kighk.). Maaninka und Pielavesi fq. (Roiv.). - kit. Polvijărvi, Juuanvaara (Kot.). - Kon. Suosaari und Kentjärvi (Simm.). - om. fq. (Backm.). - Ok. Kajana (Lackstr.). sotkamo, Isoniitty (Kyyhk.). Ristijärri (Lackstr.). 
Suomusalmi (Lackstr.); Kiannankylä, Katiskanlampi (Kyylı.). - Kpom. Moina (Bergt.). - K. Pudasjärvi (Nyb.). Kuusamo, Haataja (Broth.); Ylikitkajärvi, Visolainen (B.); zW. Liikanen und Oulinhajokj(B.); Kuusinkijoki und Kulmakkapuro (E. af II.). - Lkem. Kolari und Kîttilā pass. (Hult). Kúnolijarvi, an mehreren Fundorten (Linnan., E. af II.). - Le. In der Nadelwald- und Birkenregion f(q.. bestonders längs Muonio und Könkömäjoki (Norrl.). - Li. Sodankyla, Matarakuski und kiupsısjärvi (Hult). Inari. Tenojoki, Sammalinköngäs (H.). - Lim. Kandalaks (Brolh.). Zw. Yjaljavr und Pijjavr (Linnan.) Hibinä (Broth). - Lt. Ruokojäỵr (Roiv.); Ahvenlampi und Atselemjäỵr (Rroth.). Kola (Broth.). Kildin (B.). Pummanki (B.). - Lmur. Gavrilova und Semjostrorsk (B.). - Lp. Orlor (Kihln.). Triosiruva und Punoj (Broth.). Devjätoi (Sahlb.).
S. $S k \cdot-L$.
N. $S m \cdot-F$.
Spitzbergen, Europa, Sibirien, Nord-Amerikil.

\section{ACROCLADIUM}

Mitt. Musc. austr.-am. p. 22 (1869) ex p.

Kräftige, etwas starre, lockerrasige, glänzende Pfl. Stengel mit lockerzelliger Aussenrinde, meist aufrecht und ohme Rhizoiden. meist fast regelnissig gefiedert: Stengel- und Astenden durch zusammengewickelte Blätter zugespitzt und steif: Pseudoparaphyllien nur in der Nähe der Astanlagen. Stengelblatter aufrechtabstehend, ungefaltet, aus enger, herablaufender Basis breit eilänglich. stumpf. mit Spitzchen, ganzrandig; Rippe doppelt, kurz oder fehlend; Zellen sehr eng, geschlängelt-linealisch, gegen die Basis weiter und getüpfelt, in den stark ausgehöhlten Blattecken sehr locker, hyalin und dünnwandig, eine scharf begrenzte Gruppe bildend. Innere Perichätialblätter aufrecht. tief längsfaltig. Kapsel horizontal, länglich bis hochrückig-zylindrisch, trocken und entdeckelt stark eingekrümmt und gefurcht, sowie unter der weiten Mündung eingeschnürt. Deckel gewölbt-kegelig.

683. Acrocladium cuspidatum (L.) Lindb. Musc. scand. p. 39 (1879). [Hypnum cuspidatum L. Sp. pl. p. 1127 (1753). — Calliergon cuspidalum Kindb. Eur.and N.-Am. Bryin. p. 81 (1897).]

Diözisch. Rasen grün oder gelblich bis rotbraun. Stengel meist aufrecht. bis 15 cm. Stengelblätter bis 2,4 mm lang und 1,2 mm breit, mit gegen die Spitze \pm eingebogenen Rändern. Astblätter kleiner, eiförmig bis eilanzettlich. Innere Perichätialblätter breit lanzettlich, breit- und kurzspitzig, bis $6 \mathrm{~mm}$ lang. in der Spitze öfter gezähnelt. Seta $4-7 \mathrm{~cm}$, purpurrot. Sporenreife im Juni und Juli. Fig. $94 \mathrm{~A}-\mathrm{C}$.

In sauren Sümpfen und Gräben, auf feuchter Erde in Wiesen und längs Flussund Bachufern, zuweilen an feuchtem Holzwerk.

F. Al. Pq. (Bom.). - Ab.-Ik. St.-Kol. Oa. Närpes, Yltermark (E. af H.). Korsnās, Edsvik (Ranck.). - Tb. Jyväskylä (Broth.). Pihtipudas, Kanalanmāki (Roiv.); I Iuurasjärvi, Lrpila (R.). Sb. Kuopio pass. (Link.). Nilsiä, Kuuslahti, Jakkonlampi (Kyyhk.): Lehtomäki (K.). Maaninka, an mehreren Fundorten (Kyyhk., Roiv.). Pielavesi. Lampeenjärvi, Kukkaromäki (Roiv.). 一 Kb. Tohmajärvi. Akkala (Kot.). Pielisjärvi, Koli (Linnan.). - Kon. Suojärvi (Norrl.). Santala (Sel.). Talkeanłäki (Simm.). Pirttiniemi (S.). Klimskij monastir (S.). - Ok. Kajana (Kyyhk.). Paltamo. Mattila (Ranck.) - Ob. Pudasjärvi, Luukela (Brenn.). Simo (B.). - K. Kuusamo, Vasaraperä, Kokkolampi (E. af H.); Kuusinkijoki (E. af H.); Oulankajoki (Brolh.). - Lkem. Sieppijärri (Hjelt). 一 Lim. Lmpjok. Kangaskoski (Kihlm.). - Lmur. Teribjerka (Broth.). - Lp. Ponoj (Brenn.).

S. $S k .-L$.

N. Sm. - F. Nordgrenze bei $70^{\circ} 15^{\prime} \mathrm{n} . \mathrm{Br}$. Zealand.

Europa, Algier, Azoren, Kaukasus, Syrien. Sibirien, Lssurigebiel, Japan, Nord-Amerika, New

\section{HYGROHYPNUM}

Hygrohypnum Lindb. in Act. Soc. sc. fenn. X. p. 277 (1872); Loesk. Moosfl. d. Harz. p. 319 (1903).

Wasserliebende Pfl. Stengel niederliegend, meist olne oder mit spärlichen Rhizoiclen, im Alter oft von Blätter entblösst, \pm geteilt, entfernt und unregel- 
mässig beästet: Äste meist aufsteigend bis aufrecht; Pseudoparaphyllien nur in der Nähe der Astanlagen. Blätter allseits abstehend bis dachziegelig, oft einseitswendig, \pm hohl und herablaufend, bald kurz bis lanzettlich zugespitzt, bald breit eiförmig und stumpf bis abgerundet, zuweilen fast kreisrund, meist flach- und ganzrandig oder gezähnelt; Rippe meist ungleich zweischenklig, kurz und schwach, selten ungeteilt und fast vollständig; Zellen bis zur Blattbasis gleichartig, eng linealisch-wurmförmig, in den wenig oder nicht ausgehöhlten Blattflügeln meist erweitert, quadratisch oder rektangulär, hyalin oder gefärbt, eine kleine, oft gut abgesetzte Gruppe bildend. Innere Perichätialblätter aufrecht, verlängert. Kapsel meist oval bis länglich, hochrückig, trocken eingekrümmt und meist unter der Mündung verengt. Ring differenziert.

A. Autözisch.

Utbersicht der Arten.

a. Blätter abgerundet oder kurz und stumpflich gespitzt.

«. Blätter starr, fast sparrig; Rippe kräftig, einfach, $1 / 2-5 / 6$ des Blattes durehlaufend ................ 689. H. Smithii.

\%. Rippe (excl. H. rivulare) kurz zweischenklig.

I. Stengel kriechend, strcckenweise mit Rhizoidenbüscheln und kurzen, aufrechten Ästen. Blätter bis $0.75 \mathrm{~mm}$ lang, flachrandig ................. 690. H. viridulum.

II. Stengel niederliegend, ohne oder mit spärlichen Rhizoiden: Äste $1-5 \mathrm{~cm}$. Blätter $1,2-2 \mathrm{~mm}$ lang.

1. Blätter löffelartig-hohl, mit rings breit zurückgeschlagenen Rändern 691. H. cochlearifolium.

2. Blätter flachrandig.

* Blätter fest und straff, trocken locker dachziegelig; Rippe kräftig, bald ungleich zweischenklig, bis über die Mitte reichend, bald einfach und ror der Blattspitze endend: Blattflügel ausgehöhlt. gut begrenzt .........

** Stengel úberall beblättert. Blätter sehr weich; Blattflügel nicht ausgehöhlt.

† Blätter allseits aufrecht-abstehend. Spo-

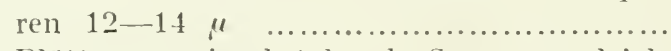

$+\dagger$ Blätter sparrig-abstehend. Sporen ungleich gross, bis $20 \mu$

693. H. molle.

692. H. rivulare.

Stengel im unteren Teile entblösst. Blätter trocken starr, abstehend, meist nach einer Seite gerichtet. Sporen 18--22 " ......... 695. H. dilatatum.

b. Blätter lanzettlich zugespitzt.

«. Blätter ganzrandig: Rippe einfach, über der Blattmitte endend

694. H. alpinum.

ß. Rippe zweischenklig, kurz.

I. Blätter weit herab gesägt; Blattflügel nicht ausgehöhlt 684. H. palustre.

II. Blätter nur an der Spitze gezähnelt: Blattflügel stark ausgehöhlt 68.5. H. montanum. 686. H. eugyrium. B. Diöziseh. 
a. Blätter lanzettlich zugespitzt: Rippe gabelig, in oder oberhalb der Blattmitte endend ... 687. H. ochraceum.

b. Blätter abgerundet oder mit stumpfem Spitzchen; Rippe dicht vor der Blattspitze endend 688. HI. polare.

684. Hygrohypnum palustre (Hucls.) Loesk. Moosfl. d. Harz. p. 319 (19033). [Hypnum palustre Huds. Fl. ang]. p. 429, No. 37 (1762); L. Sp. pl. 2. ed. p. 1593 (1763). - Amblystegium palustre Lindb. Musc. scand. p. 33 (1879).]

Autözisch. Pfl. in \pm flachen, meist ausgedehnten, grimen oder gelblich-bis bräunlichgrünen, trocken etwas glänzenden Rasen. Stengel streckenweise durch zahlreiche Rhizoidenbiischel der Unterlage angeheftet, mit \pm dicht gestellten, aufsteigenden Ästen. Blätter aufrecht-abstehend oder einseitswendig bis sichelförmig, hohl, aus verengter, wenig herablaufender Basis ei- bis länglich-eiförnig und kurz zugespitzt oder eilanzettlich, bis etwa $1.5 \mathrm{~mm}$ lang und bis $0,6 \mathrm{~mm}$ breit, ganzrandig, mit \pm eingebogenen Rändern: Rippe einfaclı und oberhalb der blattmitte aufhörend oder kürzer und gabelig; /ellen dünnwandig, 1: 6-11, in den ausgehöhlten Blattflïgeln quadratisch und kurz rektangulär, eine kleine, gut begrenzte Gruppe bildend. Innere Perichätialblätter allmählich zugespitzt, ganzrandig; Rippe lang. Seta $1,5-2 \mathrm{~cm}$. Kapsel länglich-zylindrisch, bis 2,5 mm lang, gelbbraun, trocken und entdeckelt unter der Mündung eingeschnürt. Ring nicht differenziert. Deckel kegelig, spitz oder stumpflich. Sporenreife im Sommer.

Auf nassen und periodisch ïberlhuteten Steinen, Felsen und Holzwerk längs der Bäche und Flüsse.

F. Al. Finström, Bartsgårda und Tärnebulstad (Bom.). - Ab. Karis, svartá (Jusl.). Lojo. Kirchdorf und Kiviniemi (Lindb.); Iaila (Hulı), - Kl. Sortavala. Kirjavalahti (Liudl..). Ruskeala (Lindlı.). — Tb. Viitasaari, Limattalanjoki (Broth.). - Kon. Koselma (Kullh.). - K. Kursamo. Sorajoki, Kulmakkapuro (E. af H.). Kuusinkijoki (E. af H.). Oulankajoki, Ylimmäinen Ansapuro (E. af H.). Selkäjoki (Broth.) IIäntyjoki (Vain.). - Lkem. Kolari, Sieppijärvi (Hjelt). Käittiä. Kirchdorf (Hult). Kuolajârvi, Kutia (F. Nyl.). - Le. Kilpisjärvi, Ialla (Kot.).

S. Sk.-Ang. und Hrjd., PL. und LuL.

N. $S m \cdot-F$.

Europa, Kaukasus, Kaschmir, Tibet, Turkestan, Sibirien, Nord-Amerika.

var. subsphaericarpum (Schleich.) Amann Fl. mouss. Suisse p. 357 (1912). [Hypnum subsphaericarpon Schleich. Cat. 1807; Cent. Pl. II. No. 46. - Hypnum palustre var. $\delta$ subsphaericarpon Bryol. eur. fasc. 55/56 Mon. p. 2. t. 2 f. $\delta$ (185.3). - Amblystegium palustre var. $\beta$ subsphaericarpon Lindb. Musc. scand. p. 3:; (1879).]

F. Kl. Sortavala, Kirjavalahti (Norrl.)

N. $S B$.

Europa, Kaukasus, Tibet, Turkestan.

var. laxum (Bryol. eur.) Amann l. c. [Hypnum palustre var. $\gamma$ laxum Bryol. eur. fasc. $55 / 56$ Mon. p. 2, t. 2, f. $\gamma$ (1853). - Amblystegium palustre var. laxum Möll. Fört. Sk. växt. 2. Moss. p. 41 (1907).]

Stengel schlank, grösstenteils von Blättern entblösst. Blätter entfernt gestellt, allseits abstehend, eilanzettlich, rasch zugespitzt.

N. $S m$.

Europa.

685. Hygrohypnum montanum (Wils.) Broth. in Engl.-Prantl Bryal. p. 1039 (1908). [Hypnum montanum Wi]s. Mser.; Janes in Proceed. Acad. Nat. sc. Philadelphia 1855, p. 447. - Amblystegium montanum Lindb. IJusc. scand. p. 33 (1879).]

Autözisch. Pfl. in schwellenden, ausgedehnten, weichen, gelblich- oder bräunlichgrünen, innen rötlichbraunen, schwach glänzenden bis glanzlosen Rasen. Sekundäre Äste aufrecht, bis zum Grunde dicht beblättert, meist büschelästig. Blätter meist sichelförmig einseitswendig, kurz herablaufend, hohl, aus eiförmiger oder oval-länglicher Basis kurz lanzettlich zugespitzt, etwa $0,75 \mathrm{~mm}$ lang und $0.30 \mathrm{~mm}$ breit, mit in der unteren Hälfte zurückgeschlagenen, von der Spitze weit herab 
scharf gesägten Rändern; Rippe ungleich zweischenklig, kurz, zuweilen fehlend; Zellen derbwandig, bis zur Basis eng linealisch, 1:6-8, in den nicht ausgehöhlten Blattflügeln wenige quadratisch und kurz rektangulär, klein. Innere Perichätialblätter kurz und scharf zugespitzt, weit herab scharf gesägt; Rippe einfach, dümn. Seta 1,5-2 cm. Kapsel kurz- und enghalsig, länglich, etwa $2 \mathrm{~mm}$ lang, gelbbraun, trocken und entdeckelt unter der Mündung verengt. Ring 3reihig. Deckel gewölbtkegelig, spitz.

N. A. Tordmarken. Ringerike r. Ne. Saetersdalen.

Japan, Nord-Amerika.

686. Hygrohypnum eugyrium (Bryol. eur.) Broth. 1. c. [Limnobium eugyrium Bryol. eur. fasc. 62/64 Mon. Limnobium Suppl. I. p. 1, t. 1 (1855). - Hypnum eugyrium Schimp. Syn. p. 639 (1860). - Amblystegium eugyrium Lindb. Musc. scand. p. 33 (1879).]

Autözisch. Pfı. in dichten. flachen, zuweilen ausgedehnten, weichen, freudig- und gelblich- oder bräunlichgrünen, glänzenden Rasen. Stengel mit deutlicher Aussenrinde, reichlich verzweigt; Äste niederliegend oder aufsteigend, kurz, \pm deutlich verflacht. Blätter herablaufend, länglich und breit länglich-lanzettlich, rasch schmalspitzig, etwa $1,4 \mathrm{~mm}$ lang und bis $0,6 \mathrm{~mm}$ breit, flachrandig und an der stumpflichen Spitze gezähnt, bauch- und rückenständige hohl, seitenständige sehr hohl und fast längs zusammengefaltet: Rippe fehlend oder angedeutet; Zellen 1: 6-10, am Blattgrunde dickwandig und getüpfelt, in den stark ausgehöhlten Blattflügeln quadratisch und kurz rektangulär, dickwandig und gelbbis rotbraun, eine gut begrenzte Gruppe bildend. Astblätter oft einseitswendig, verlängert lanzettlich. Innerc Perichätialblätter lang und fein zugespitzt, an der Spitze ausgefressen-gezähnt; Rippe einfach, dünır. Seta $1-1,5 \mathrm{~cm}$. Kapsel kurzhalsig, eilänglich, etwa $2 \mathrm{~mm}$ lang, gelbbraun, trocken und entdeckelt unter der Mündung wenig verengt. Ring 3reinig. Deckel gelbrot, hoch gewölbt, mit Warze.

S. Og. und Vär, an einzelnen Fundorten.

N. Sm. Tune.

Gross-Britannien, Baden, Schweiz, Nord-Amerika.

687. Hygrohypnum ochraceum (Turn.) Loesk. Moosfl. d. Harz. p. 321 (1903). [Hypnum ochraceum Turn. Mscr.; Wils. Bryol. brit. p. 400 (1855). - Amblystegium ochraceum Lindlb. Musc. scand. p. 33 (1879).]

Diözisch. Pfl, in dichten, ausgedehnten, schwellenden. weichen, grünen oder gelbgrünen, oft gelbbräunlich gescheckten Rasen. Stengel mit sehr lockerer Aussenrinde, in lange, aufsteigenile oder aufrechte, an der Spitzc gekrümmte Äste geteilt. Blätter einseitswendig bis sichelförmig, hohl, undeutlich längsfaltig. aus wenig herablaufendem, länglichem oder eiförmigem Gruncle lanzettlich zugespitzt, meist etwa $1.8 \mathrm{~mm}$ lang und $0.9 \mathrm{~mm}$ breit, flach- und ganzrandig oder an der meist stumpflichen Spitze undeuthch gezähnt: Rippe unten oder oben gabelig geteilt, in oder oberhalb der Blattmitte aufhörend; Zellen dünnwandig, 1: 8-14, in der Blattspitze kürzer, in den kaum ausgehöhlten Blattflügeh erweitert, dümnwandig, rektangulär, eine nicht gut abgesetzte Gruppe bildend. Innere Perichätialblätter lang zugespitzt, in cker Spitze schwach gesägt; Rippe einfach. Seta etwa $1.5 \mathrm{~cm}$. Kapsel aus trocken faltigem Halse länglich-eiförmig, bis $2.5 \mathrm{~mm}$ lang. getbbräunlich. Ring 3-treihig. Deckel gewölbt, mit Warze. Sporogone selten. - Fig. $95 \mathrm{~K}-\mathrm{L}$.

Auf überriesclten Stcinen, Felsen und Holzwerk, in Bächen und Stromschnellen.

F. Ab. Mbn. IIallis (Elfv.). Tenala, skoglyy (Hạ̈r.). - N. Pojo, Fiskars (Broth.). Tenala, Skogby (H. Lindb.). Helsinge, Gammelstaden (Lindb.); Tali (W. Nyl.). Sibho. Söderkulla (Ekm.). - Ka. Wiborg, Rättijäri, Soskuanjohi (Buch). Kirvu. Inkila (Lindb.), - Ik. Uusikirkio, Vammelsuu (H. Lindb.). Kivennapa, Rajajoki (H. L.). Sakkola. Suvanto, Hiekkaranta (H. L.). Pyhäjärvi, Lohijoki und Riirkonjoki (H, L.). - St. Euraaminne, Vuojoki (Björkenh.). Pirkkala (Simm.). Ikaalinen, Jämi- 
joki, Jyllikoski (Sundr.). - Ta. Vanaja, Kattis (Coll.). Kioski (Norrl.). IIollola, Uskila, Kiikka (Norrl.). Padasjoki, Kivistö (Vain.). Korpilahti (Norrl.). - Kil. Kiurkijoki, Sarioja und Otsanlahti (Jusl.). Jaakkima, Ihalanoja (W. Nyl.). Sortavala, Kirjavalahti (Norrl.). - Kol. Fabrika und Mandroga (Elfv.). Petrosavodsk (Simn.). - Oa. Lappfjärd (Karst.). — Tb. Petäjävesi, Kuitula (E. af H.). Jyväskylä. Norola (Vain.). Uurainen, Palsanoja und Lannejoki (Broth.). Eaukaa, Leppävesi (Häyr.). Karstula, Korpinenjoki (B.). Saarijärvi, Harju und Mahlu (B.). — Sb. Kuopio, Haminanlahti, Myllyjoki (Link.); Rytky, Niinikoski (L.). Nilsiä, Kirchdorf (Kyyhk,); Kuutava (K.). Kiuruvesi, Korpijoki (Lundstr.). Kb. Lieksa, Egypti (Vain.). - Kon. Suojärvi, Annantehdas (Kop.). Jänkäjärvi (Norrl.). Kivatsch (Simn.). 一 Om. Alajärvi, Lohijoki (Backm.). - Ok. Kajana (Lackstr.). Ristijärvi, Matarapuro (L.). SuomussaImi, Kiekkiselkä (Kyyhk.). - K Kom. Tschuja (Sahll.). — Ob. Uleảborg (Hunin.). Pudasjärvi (Nyb.). Rovaniemi (Hult). - K. Kuusamo, Autinköngäs (Broth.); Korojoki (Broth.); Kurtajoki, Koivuköngäs (E. af H.); Juuma (Broth.); Sovanköngäs (B.); Mäntykoski (Nyb.): - Lkem. Kolari und Kittila st. fí. (Hult). Pybätunturi (Häyr.). Kuolajärvi, Naruskajoki (K. af Il.); Latkukuru (Brotlı.). 一 Lee. An mehreren fundorten bis in die alpine Region (Norrl.). Kilpisjärvi f(f. (Kot.). - Li. Inari, in der ganzen Nadelwaldregion st. fq. (Hult). Sodankylä und Utsjoki, an mehreren Fundorten in der Birkenregion (H. Ranck.). - Lim. Tschun (Broth.). Lujauri-urt, Seidjavr und suloaj (Kihlm.). Partontschor (K.). Zw. Vudjult und Vunn-vun (K.). Kontiokoski (K.). - Lt. Kola (Broth.). Kildin (B.). Pumnanki (B.). - Lmur. Teribjerka und Jokonsk (B.). - Lp. Ponoj (Sithlb.). - Le. Pjalitsa (Kihlm.). Tschapouna (Broth.).

S. sk., Ög., Boh., Vsm.. Vrml., Dlr., Hrjd., Jmi., Ang. und $L$.

N. Sm.-F. in allen Höhenlagen vorkommend.

Spitzbergen, Europa, Kaukasus, Sibirien, Nord-Amerika.

var. uncinatum (Mild.) Amann Fl. mouss. Suisse, p. 361 (1912). [Hypnum ochraceum var. uncinatum Mild. Bryol. siles. p. 376 (1869). - Amblystegium ochraceum var. uncinatum Adlerz in Bot. Notis. 1883, p. 6.]

Stengel- und Astspitzen hakenförmig eingekrümmt. Blätter lot und grün gescheckt, sichelförmig-einseitswendig, länglich, lang zugespitzt, stumpflich, zuletzt zersclilitzt.

S. Hrịd. Helagsfjället. Jmt. Handölsfallen. LuL. Sarekgebiet.

N. Bu. Norefjeld. NB. Sogn, Stenbergdalen. $K$. Nordre Aurdal, Valders pass. Dovre. Tromso. Hanmerfest.

Europa.

var. flaccidum (Mild.) Amann 1. c. [Hypnum ochraceum var. $\gamma$ flaccidum Mild. 1. c. - Amblystegium ochraceum var. flaccidum Möll. Fört. Sk. växt. 2. Moss. p. 41 (1907).]

Stengel verlängert, locker beblättert. Blätter allseits abstehend, braun, breit lanzettlich lang zugespitzt, etwa $2,2 \mathrm{~mm}$ lang, mit langer Gabelrippe.

S. LuL. Sarekgebiet.

N. Gudbrandsdalen. Røsheim. Dovre, Nystuen.

Europa.

var. complanatum (Mild.) Amann 1.c. (Hypnum ochraceum var. $\delta$ complanatum Mild. 1. c. - Amblystegium ochraceum var. complanatum Möll. l. c.)

Pfl. sehr weich und saftig grün. Stengel lang. Blätter locker und fast zweizeilig gestellt, abstehend, breit lanzettlich, kürzer zugespitzt, zuletzt zerschlitzt; Rippe kräftig, am Gruncle oder oberwärts zweischenklig.

N. Bu. Honefos. K. Gudbrandsdalen, Lom.

Europa.

var. filiforme (Limpr.) Amann 1. c. [Hypnum ochraceum var. $\varepsilon$ filiforme Limpr. in Kryptfl. Schles. I. p. 63 (1876). - Amblystegium achraceum var. filiforne Möll. 1. c.]

Sehr lang flutend, fadenförmig. mit fast drehrund beblätterten, sehr dünnen, verlängerten Ästen. Blätter kurz zugespitzt, anliegend, an clen Sprossenden zu einer geraden Spitze zusammengewickelt.

S. LuL. Sarekgebiet.

N. K. Gudbrandsdalen. Lom. Dovre, Snehaetten.

Europa.

var. simplicinerve (Lindb.). [A mblystegium simplicinerve Lindb. in Act. Soc. F. Fl. Fenn. III. No. 1 (1886).] 
Schlanke Pfl. Stengel verlängert. Blätter schwach einseitswendig, länglichlanzettlich, stumpflich; Rippe bald einfach und bis $2 / 3$ der Blattlänge, bald oben gabelig geteilt.

F. Ob. Rovaniemi. Norrajoki und Tervo (Hult). - Lkem. Kolari, Lapinlahti (H.).

68s. Hygrohypnum polare (Lindb.) Broth. 1. c. p. 1041. [Hypnum polare Lindb. in Kgl. Vet.-Ak. Förh. XXIII. p. 540 (1866). - Amblystegium polare Lindb. Musc. scand. p. 33 (1879).]



Fig. 95. A-B. Hygrohypnum polare (Lindb.). A Stengelb. (15/1); B Blattbasis (90/1). - C-D. II. rixulare (Sw.). C stengelb. (18/1); D Blattbasis (125/1). - E-F. H. dilatatum (Wils.). E stengelb. (14/1); F Blattbasis (125/1). - G-I. H. Smithii (Sw.). G Stengelh. (25/1); II Blattspitze (150/1); I Blattlasis (150/1). - K-L. H. ochraceum (Turn.). K. Stengelb. (20/1); L Blattbasis (100/1)

Diözisch. Pfl. in lockeren bis dichten, ausgedehnten, weichen, goldgrünen, abwärts gebräunten, glänzenden Rasen. Stengel mit deutlicher Aussenrinde: Äste aufrecht, kätzchenförmig. Blätter trocken locker anliegend, feucht aufrecht-abstehend bis etwas einseitswendig, sehr hohl, aus enger, kurz herablaufender Basis länglich und breit eiförmig, abgerundet oder mit breitem und stumpfem, etwas zurüickgebogenem Spitzchen, bis $1,8 \mathrm{~mm}$ lang, flach- und ganzrandig oder an der Spitze gekerbt; Rippe einfach, dicht vor der Blattspitze endend: Zellen dünnwan- 
dig, 1: 5-8, in der Blattspitze parenchymatisch, 1-6eckig, in den nicht ausgehöhlten Blattflügeln quadratisch, eine llreieckige Gruppe bildend. Innere Perichätialblätter abgebrochen zugespitzt, an der Spitze gesägt. Sporogone unbekannt. - Fig. $95 \mathrm{~A}-\mathrm{B}$.

Auf nassen Felsen und an überrieselten Steinen.

F. Lmur. Harlovka (Broth.). - Lp. Dolgaja guba zw. Srjätoinos und Ponoj (B.).

S. LuL. Stora Sjöfallet. Sarekgebiet von der Birkenregion bis in die alpine Regirn. TL, an mehreren Fundorten.

N. SB. Voss, Vinje, epp. bei $300 \mathrm{~m}$. NB. Sogn, Naerodia, 50 m. K. Jotunfjeldene. Tr. Nordrejsen und Tromsø.

Spitzbergen, Beelen-Eiland, arkt. Sibirien, (irönland.

var. falcatum (Bryhn). [Hypnum polare var. falcatum Bryhn in Nyt IJag.

f. Naturv. Bd. 40, Heft 1, p. 24 (1902).]

Blätter deutlich sichelförmig einseitswendig.

N. ST. Opdal. $K$. Jotunfjeldene.

689. Hygrohypnum Smithii (Sw.) Broth. 1. c. p. 1039 (1908). [Leskea Smithii Sw. in Liljebl. Sv. Fl. 3. ed. p. $5+9$ (1816). - Hypnum arcticum Sommerf. in Wahlenb. Fl. lapp. p. 65, t. 2 (1826). - Amblystegium Smithii lindb. in Hartm. Sk. Fl. 10. ed. p. 6 (1871).]

Autözisch. Pfl. in lockeren, starren, dunkel- oder braungrünen, meist schwärzlichen Rasen. Blätter fast sparrig, aus enger, etwas herablaufender Basis breit eirund und fast kreisförmig, bis $1 \mathrm{~mm}$ lang und bis $1 \mathrm{~mm}$ breit, flach- und ganzrandig; Rippe kräftig, $1 / 2 \_5 / 6$ der Blattlänge; Zellen stumpf, $1: 4-6$, in der Blattspitze rundlich und oval, in einer Randreihe weit herab schief quadratisch, in den nicht ausgehöhlten Blattflügeln wenige kurz rektangulär. Innere Perichätialblätter lang und fein zugespitzt, abgerundet, ganzrandig; Rippe lang, einfach. Seta etwa $1 \mathrm{~cm}$. Kapsel verkehrt länglich-eifömig, bis 1,5 $\mathrm{mm}$ lang, kastanienbraun, trocken und entdeckelt unter der Mündung kaum oder wenig verengt. Ring 2reihig. Sporenreife in Sommer. - Fig. $95 \mathrm{G}-\mathrm{I}$.

Auf kalkfreiem Gestein in raseh fliessenden Bächen.

F. Le. Kilpisjärvi (Norrl.); Kitji-IIalla (Kot.), - L Li. Inari, Saariselkä, Lupukkapää. in der Nadelwaldregion (Hult); Naamijärvi, Sahalemkoski (H.); Rouvuaivi (Kihlm.). Kultala (Vain.).- - Lim. Haarakoski (Kihlm.). - Lt. Vaariselkä, Jaurıjok, Pippojok und Sonkijok im südl. Teile (Roiv.). IIırdnsern südl. von Kola (Brenn.). - Lp. Malo Gorodetskaja (Broth.).

S. Dlr., Hlsl., Mpd., Hrjd., Jmt., LyL., PL. und LuL.

N. A. Kristiania r. Gudbrandsdalen. Br. Gaustafjeld. Ne. Saetersdalen. st. Ryfylke. NB. Hardanger. K. Jotunfjeldene und Lomseggen. No.-F. Nordgrenze leei $70^{\circ} 40^{\prime} \mathrm{n} . \mathrm{Br}$.

Schottland, Alpenkette. Nord-Amerika.

690. Hygrohypnum viridulum (Hartm.) Broth. 1. c. p. 1039 (1908). [Hypnum viridulum Hartm. Sk. Fl. 5. ed. p. 524 (1849). — Limnobium norvegicum Bryol. enr. fasc. 55/56 Mon. p. 6, t. 3 (1853). - Hypnum norvegicum Schimp. Syn. p. 637 (1860). - Amblystegium viridulum Lindl). Muse. scand. p. 33 (1879).]

Autözisch. Schlanke Pfl. in lockeren bis dichten, weichen, dunkelgrünen, seltener gelbgrünen, wenig glänzenden Rasen. Stengel kriechend, mit kurzen, aufrechten, stumpfen Ästen. Blätter trocken locker anliegend, feucht allseits abstehend, etwas herablanfend, sehr hohl, breit eiförmig, mit kurzer, stumpflicher bis abgerundeter Spitze, bis $0,75 \mathrm{~mm}$ lang und bis $0,50 \mathrm{~mm}$ hreit, mit an Grunde \pm deutlich umgebogenen, glatten Rändern; Rippe ungleich zweischenklig, dünn und kurz; Zellen dünnwandig, 1: 5-6, in der Blattspitze kürzer, in den nicht ausgehöhlten Blattflïgeln kaum differenziert. Innere Perichätialblätter kurz zugespitzt, mit schmal umgebogenen, in der Spitze unmerklich gezähnten Rändem; Rippe einfach, dünn. Seta etwa $1 \mathrm{~cm}$. Kapsel kurz- und enghalsig, länglicl, etwa $2 \mathrm{~mm}$ lang, rötlichgelb, trocken und entdeckelt unter der Mündung verengt. Ring 2reihig. Deckel rot, kegelig, seharf gespitzt.

An feuchten Felsenwänden und an Steinen in Bächen. 
F. Le. Kilpisjärvi, im Bächlein, $3 \mathrm{~km}$ rom Tuolihuippu (Kot.). - Lim. Kandalaks, Schelesnaja (Broth.).

S. LuL. Sirkavare und Stora Sjöfallet. Sarekgebiet, Svirjajokk, an der oberen Grenze der Birkenregion.

N. Gudbrandsdalen, Dorre.

691. Hygrohypnum cochlearifolium (Vent.) Broth. 1. c. [Limnobium cochlearifolium Vent. in De Not. Erb. crittog. ital. II. Ser. Fasc. X. (1871). - Hypnum Goulardi Schimp. Syn. 2. ed. p. 778 (1876). - Amblystegium cochlearifolium Lindb. in Herb. Mus. Fenn. 2. ed. II. p. 66 (1894).]

Autözisch. Pfl. in sehr weichen, schwellenden, grünen, oft rötlich gescheckten Rasen. Äste lang, drehrund beblättert. Blätter aufrecht-abstehend, löffelartighohl, mit wenigen Längsfalten, aus enger, schmal herablaufender Basis breit eiförmig, abgerundet oder breit und stumpf zugespitzt, bis 1,2 mm lang und bis $0,85 \mathrm{~mm}$ breit, mit fast rings breit und leicht zurückgeschlagenen, glatten Rändern; Rippe 2-3schenklig, kurz, selten bis zur Blattmitte reichend; Zellen 1: 4-8, in der Blattspitze rhombisch und dort in einer Reihe rhomboidisch, in den kaum ausgehöhlten Blattflügeln wenige kurz rektangulär, im Alter gelbbraun. Innere Perichätialblätter lanzettlich zugespitzt, stumpflich, mit streckenweise zurückgeschlagenen, an der Spitze ausgeschweift-gezähnten Rändern. Sporogone wie bei $H$. Smithii.

Auf kalkfreiem Gestein in Bächen.

S. LuL. Sirkavaare. Sarekgebiet in der Weidenregion.

N. Ne. Filefjeld. H. Veslefjeld und Bleja. Dorre, Snehaetten. K. Jotunfjeldene und Lomseggen. Tr. Nordrejsen, Gakkovarre. F. Alten.

Pyrenãen, Alpenkette, Grönland.

692. Hygrohypnum rivulare (Sw.). [Hypnum rivulare Sw. in Vet.-Ak. Handl. 1795, p. 262. - H. alpestre Sw. Disp. Musc. Suec. p. 63 et p. 102, t. 6, f. 15 (1799). - Amblystegium rivulare Lindb. Musc. scand. p. 33 (1879). - Hygrohypnum alpestre Broth. 1. c.]

Autözisch. Pfl. in ziemlich dichten, weichen, leicht zerfallenden, gelblichen und rötlichen, abwärts braun-schwärzlichen, glänzenden Rasen. Äste dicht gestellt, aufrecht, stumpf und bis zur Basis kätzchenartig beblättert. Blätter sehr dicht gestellt, fest und straff, locker dachziegelig bis schwach einseitswendig, sehr hohl, etwas herablaufend, oval und breit länglich, bis 1,8 mm lang und bis $0,75 \mathrm{~mm}$ breit, flach- und ganzrandig oder an der kurzen bis längeren, oft schiefen Spitze undeutlich gesägt: Rippe kräftig, bald ungleich zweischenklig, bis über die Mitte reichend, bald einfach lisd vo: der Blattspitze endend; Zellen derbwandig 1: 812, in der Blattspitze 1: $3-1$, im basalen Mittelfelde gelbrot und getüpfelt, in den meist deutlich geöhrten Blattflügeln aufgeblasen, quadratisch und oval, gelbrot, eine ausgehöhlte Gruppe bildend. Innere Perichätialblätter allmählich zugespitzt. oberwärts sparrig abgebogen, ganzrandig, mit dünner Rippe. Seta $1-1,5$ cm. Ǩapsel aus engem Halse länglich, bis $2,2 \mathrm{~mm}$ lang, kastanienbraun, trocken und entdeckelt unter der Mündung eingeschnürt. Ring 2-3reihig. Deckel orange, abgerundet, mit oder ohne Warze. Sporenreife im Sommer.- - Fig. 95 C-D.

An Blöcken. Steinen und Holz längs den Wasserläufen.

F. Al. Saltvik, Långbergsöda, Kvarnsjöbãcken (Bom.). - Kb. Pielisjărvi, Koli (Linnan.). - Kon. Koikari (Norrl.). Pirttiniemi (Kullh.), - Ok. Paltamo, Melalahti. Āijönkallio (Lackstr.). Ristijārvi, Iyllypuro (L.). - K. Kuusamo, Korojoki und Arentojoki (Broth.); Iiraara (Sil.); Risijoki (E. af H.); Y’linmäinen Ansapıro, südl. ron Oulankajoki (E. af H.). Käylākoski (Broth.). Paanajärvi, Māntykoski (Xyb.); Mäntyvara (Broth.); Selkäjoki (B.). Yaaninkajoki. Kuntaikkiköngäs (E. af H.). - Lkem. Kuolajarvi, Sallatunturi, an mehreren Fundorten (E. af H., Broth.). - Le. Hãufiger als $H$. dilatatum bis in die Birkenregion (Norrl.). - Li. Sodankỵä, Niemselä und Saariselkä (Hulı). In der Birkenregion ron Inari und Utsjoki fq. (H.). - Lim. Tschun (Broth.). - Lt. Im Fjeldgebiete des siidlichen Teiles fqq. (Roiv.). Kola und an Tulomaflusse (B.). - Lmur. (ravrilova und Varsinsk (B.): zw. Varsinsk und Nisnosero (B.). - Lp. katschkova (B.). Hayajoy (Kihlm.). — Lr. Babja (Brenu.).

S. HIsl.-L. 
N. A. Kristiania r. Ringerike. Ne. Saetersdalen. SB. Voss, Tvinde und Vinje. Ulvik, NB. Filefjeld. Hardanger, Roldal. Sogn. K. Dovre. Jotunfjeldene. Lomseggen. NT. Stjordalen pass. No.-F. Spitzbergen, Beeren-Eiland, arkt. Sibirien, Grönland, Rocky IIts.

693. Hygrohypnum molle (Dicks.) Loesk. Moosfl. d. Harz. p. 320 (1903). [Hypnum molle Dicks. Pl. crypt. fasc. II. p. 11, t. 5, f. 8 ex p. (1790). - Amblystegium molle Lindb. Musc. scand. p. 33 excl. var. (1879).]

Autözisch. Pfl. in lockeren, auch trocken weichen, zerfallenden, schmutzig olivengrünen bis bräunlichen, wenig glänzenden Rasen. Stengel spärlich geteilt, überall beblättert; Äste fast kätzchenförmig, stumpf; Pseudoparaphyllien pfriemenförmig, in der Nähe der Astanlagen. Blätter wenig gedrängt, allseits aufrechtabstehend, hohl, schwach faltig, aus enger, herablaufender Basis breit oval-elliptisch, die obere Blatthälfte zu einer stumpflichen Spitze verschmälert, bis $1,8 \mathrm{~mm}$ lang und bis $0,9 \mathrm{~mm}$ breit, mit am Grunde etwas zurückgeschlagenen, an der Spitze schwach gezähnten Rändern; Rippe ungleich 2-3schenklig, kurz und schwach, selten die Blattmitte erreichend; Zellen 1: $5-8$, in der Blattspitze 1: $2-3$, an Blattgrunde gelbrot, in den nicht ausgehöhlten Blattflügeln quadratisch und kurz rektangulär, dickwandig und rektangulär. Innere Perichätialblätter lang zugespitzt, stumpflich, oberwärts zurückgebogen, mit streckenweise umgebogenen, weit herab gesägten Rändern; Rippe lang und dlünn. Seta etwa $8 \mathrm{~mm}$, gelbrot. Kapsel kurz- und enghalsig, oval, dünnhäutig, bis $2 \mathrm{~mm}$ lang, rötlichgelb, trocken und entdeckelt unter der Mündung verengt. Ring 3-4reihig. Deckel gelb, hoch gewölbt, mit gelbrotem Spitzchen. Sporenreife im Sommer.

Auf kalkfreien Steinen in kalten Bächen.

F. Lim. Hibinä, an Flusse Tuil-jok, in der oberen alpinen Region (Kihlm.); an den Quellen des Kukisjok (K.).

S. Jmt., LuL. Sarekgebiet.

N. $S m$. Tune. $B u$. Norefjeld. $K$. Ronderne $1,500 \mathrm{~m}$. Jotunfjeldene. $F$. Tanen.

Spitzbergen, Schottland, Alpengebiet, Nord-Amerika.

var. Schimperianum (Lor.) Amann Fl. mouss. Suisse p. 360 (1912). [Hypnum Schimperianum Lor. Moosstud. p. 123, t. 5, f. C (1864). — Amblystegium molle var. $\gamma$ Schimperi Lindb. Musc. scand. p. 33 (1879).]

Pfl. meist metallisch glänzend. Stengel verlängert. Blätter breiter; Rippe kräftig; Zellen am Blattgrunde bleichgrün, in den nicht ausgehöhlten Blattflügeln oval-6seitig und rektangulär.

F. Lim. Hibinä (F. Nyl.). - Lmur. Litsa (Broth.).

N. Ne. Saetersdalen. NB. Hardanger, Horrahei, 1,050 11. K. Dovre Snehaetten. ST. Alpengebiet.

694. Hygrohypnum alpinum (Schimp.) Loesk. in Hedwigia XLIrI. p. 194 (1904). [Hypnum alpinum Schimp. Syn. 2. ed. p. 777 (1876). - Amblysteginm molle var. alpinum Lindb. Muse. scand. p. 33 (1879).]

Autözisch. Pfl. in dichten, trocken weichen, zerfallenden, bleichgrünen odel gelblichgrünen, oft gelbrot gescheckten Rasen. Sekundäre Stengel und Äste dicht gestellt, aufrecht, bis zum Grunde dicht beblättert, stumpf. Blätter sparrig-ah)stehend, zuweilen nach einer Seite gerichtet, fast löffelartig-hohl, unregelnässig wellig-längsfaltig, fast kreisrund, sehr breit und stumpf zugespitzt, bis $1,4 \mathrm{~mm}$ lang und bis $1,2 \mathrm{~mm}$ breit, flachrandig, rings \pm deutlich gezähnt; Rippe undeutlich oder kurz zweischenklig; Zellen dünnwandig, 1: 6--10, in der Spitze in der Mehrzahl rhombisch, 1: 2—4, in den kaum ausgehöhlten Blattflügeln hoch rektangulär, dünnwandig; hyalin. Innere Perichätialblätter kurz und stumpflich zugespitzt und an der Spitze gezälmt. Seta $8-12 \mathrm{~mm}$. Kapsel kurz- und dickhalsig, geschwollen oval und kurz eiförmig, bis $2,4 \mathrm{~mm}$ lang, kastanienbraun, trocken und ent deckelt wenig verengt. Ring 2-3reihig. Deckel hochgewölbt, glänzend braunrot, mit dicker Warze. Sporenreife im Sommer.

Auf Steinen in Bächen, meist in der alpinen Region. 
F. Lim. Lujiır-urt Kiełk-uaj (Kihlın.). Hibinä (Sahlb.).

S. Hrjd. und Jmt.

N. $B u$. Norefjeld. Br. Telemarken, Haukelidfjeld. SB. Voss, Vinje und Trinde. NB. Sogn, Laerdal und Naerødal. K. Valders, Vang. Dovre. Loms-und Jotunfjeldene. NT. Stjordalen, Meraker. No. all mehreren Fundorten. Tr. Bardo. F. Alten. Nordgrenze bei etwa $70^{\circ} \mathrm{n} . \mathrm{Br}$.

Alpen kette.

695. Hygrohypnum dilatatum (Wils.) Loesk. Moosfl. d. Harz. p. 320. [Hypnum dilatatum Schimp. Syn. 2. ed. p. 776 (1876). - Amblystegium dilatatum Lindb. Muse. scand. p. 33 (1879).]

Autözisch. Pfl. in lockeren, trocken starren, freudig- oder gelblichgrünen, zuweilen goldig und braunrötlich gescheckten, \pm glänzenden Rasen. Stengel mehrmals geteilt, abwärts entblösst, gegen die Spitze aufsteigend, mit aufrechten, stumpfen Ästen. Blätter abstehend, meist nach einer Seite gerichtet, etwas herablaufend, wenig holıl, aus verengter Basis breit oval-elliptiseh bis fast kreisrund, stumpf oder mit Spitzchen, bis 2,1 $\mathrm{mm}$ lang und bis 1,4 $\mathrm{mm}$ breit, flach- und ganzrandig oder an der Spitze undeutlich gezähnt; Rippe dium, ungleich zweischenklig, selten bis zur Blattmitte reichend, sporadisch auch einfach; Zellen derbwandig, 1: $10-15$, gegen den Blattgrund bis 1: 20, in der stumpflichen Spitze 1: $2-4$, in den Blattflügeln oval- und länglich-mehreckig oder rektangulär, gelb- und dickwandig, eine sehwach ausgehöhlte, rundliche Gruppe bildend. Innere Perichätialblätter lanzettlich zugespitzt, mit aufrechter, fein gesägter Spitze, mit dünner Rippe. Seta 1,2-2 cm. Kapsel aus engem Halse länglich, bis $2 \mathrm{~mm}$ lang, kastanięubraun, trocken und entdeckelt unter der Mündung verengt. Ring 2 reihig. Deckel orange, hoch gewölbt, mit roter Papille. Sporenreife im Sommer. - Fig. 95 E-F.

Auf kalkfreiem Gestein in rasch fliessenden Bächen und Stromschnellen.

F. Al. Saltrik, Frarnsjöbäcken (Bonr.). - Ab. Vichtis, Haapkylä (W. Nyl.). - Ta. Lammi, Ero (Sil.). Hollola, Messilä (Norrl.). Asikkala, Viitaila (N. . Padasjoki, Virmaila (N.) Kivistö (Nerv.). Kuhmoinen, Uskila (Norrl.). Korpilahti, Rutajoki (Vain.). - Sa. Ruokolahti, Imatra (Hult). - Kl. Sortavala. Kïjavalahti (Norrl.). - Sb. Kuopio, Rytky, Ninikoski (Link.); Kasurila, Raikaansuo (Kyyhk.). Maaninka, Tuovilanlahti, Korkeakoski (Broth.). - Kb. Juuka, Juuanvaara (Kot.). 一 Kon. Jalguba (Kullh.). - Ok. Kajana (Lackstr.). Utajärvi, Vaala (L.). - Kpom. Tschuja (Sahlb.). - Ob. Muhos, Leppiniemi (Huum.). Uleåborg (T. Nyl.). - K. Kuusano, Korojoki (Broth.); Kitkajoki, Jyrävä (B.). - Lkem. Muonio, Yllastunturi (Hult), - Le. Jerisjärvi (Norrl.); zw. Kelottijärvi und Naimakka (N.). Kilpiskoski (N.); Kiłpisjärvi, Malla, Saana und Tuolihuippu in der subalpinen und alpinen Region (Kot.). - Li. Inari, an mehreren Fundorten am Tenojoki in der Nadelwaldregion (Hult); Saariselkä, Lumikurı (H.). Utsjoki, in der Birkenregion (H.). - Lim. Uinba (Sel.). Tschun (Brolh.). - Lt. Pummanki (B.). Kildin (F. Nyl.). - Lmur. Litsa und Bakalda (Broth.). - Lp. Malo Gorodetskaja und Triostrova (B.). Ponoj (Brenn.).

S. Boh., Srm.. Ism.. Dir., Irjd., Jmt.. Ang., LyL. und $L u L$.

N. Sm. Onso. A. Kristiania st. fq. $J L$. Sandefjord. Bu. Norefjeld. Ringerike. Ne. Saetersdalen. k. Jotunfjeldene und Lomsfjeldene fq. Vo, und $\mathrm{Tr}$. an mehreren Fundorten. $F$. Rastegaissa.

Europa, Kaukizus, Kaschmir, Turkestan, Sibirien, Nord-Amerika.

\section{B R A C H Y T H E C I C E A E.}

Pfl. in \pm glänzenden Rasen. Stammquerschnitt rund, mit Zentralstrang, lockerem Grundgewebe und mehrschichtigen, meist substereiden Mantelzellen. Stengel kriechend oder bogig niederliegend bis aufsteigend, oft unterbrochen stolonenartig, absatzweise mit Rhizoidenbüscheln, dicht und rund beblättert, durch einfache oder verästelte, ungleich lange Sprosse unregelmässig gefiedert; Paraphyllien meist fehlend. Laubblätter gleichförmig, von wechselnder Form, meist \pm lang zugespitzt, oft mit Längsfalten; Rippe meist homogen, einfach, meist vor der Blattspitze endend; Zellen prosenclsymatisch, glatt, gegen den Blattgrund meist lockerer und getüpfelt, an den oft ausgehöhlten Blattflügeln quadratisch bis länglich-mchreckig. Blüten stamm-, sclten zugleich astständig. Perichätialast kurz, meist mit Rhizoiden. Seta verlängert, aufrecht. 
Ü b e r s i cfh t d e r G a tit in n ge/n.

A. Kapsel aufrecht und regelmässig ... 138. Homalothecium.

B. Kapsel geneigt bis horizontal, unregelmässig.

a. Blätter mit mehreren tiefen Längsfalten. Deckel kege-

lig bis kurz und dick geschnäbelt

b. Blätter glatt oder mit seichten Längsfalten.

$\boldsymbol{\alpha}$. Deckel kegelig.

I. Stengel regelmässig gefiedert; Äste zweizeilig abstehend. Blätter breit eiförmig und eilänglich, an der abgerundeten Spitze mit zurückgebogenem Spitzchen 139. Camptothecium.

II. Stengel unregelmässig verzweigt bis unregelmässig fiederästig

141. Scleropodium. 140. Brachythecium.

$\beta$. Deckel lang geschnäbelt.

I. Diözisch.

1. Blätter sehr hohl, eiförmig bis länglich, \pm rasch oder plötzlich lanzettlich bis haarförmig zugespitzt; Rippe niemals als Dorn endend; Zellen eng, glatt ........................... 142. Cirriphyllum.

2. Blätter nicht oder weniger hohl, eiförmig bis dreieckig-herzförmig, kurz und breit bis allmählich länger zugespitzt; Rippe am Rücken oft als Dorn endend; Zellen eng, glatt ........ 143. Eurhynchium.

3. Blätter dreieckig-herzförmig, kurz zugespitzt; Zellen länglich-rhomboidisch oder länglich-6seitig. Astblätter am Rücken durch vortretende Zellecken etwas rauh

144. Bryhnia.

II. Autözisch.

1. Blätter eiförmig oder eilänglich; basale Zellen lockerer. Zellen des Exotheciums nicht kollenchymatisch

146. Rhynchostegium.

2. Blätter schmal lanzettlich; basale Zellen nicht erweitert. Zellen des Exotheciums kollenchymatisch 145. Rhynchostegiella.

\section{HOMALOTHECIUM}

Bryol. eur. fase. 46/47 Mon. (1851).

Diözisch. Stengel kriechend, durch glatte Rhizoidenbüschel an die Unterlage befestigt, durch dicht gestellte, meist kurze und aufrechte Äste gefiedert. Blätter nicht herablaufend, tief längsfaltig, lanzettlich, lang und fein zugespitzt. rings fein gesägt; Rippe am Rücken stark vortretend, vor oder mit der Blattspitze cndend; Zellen eng prosenchymatisch, glatt, am Blattgrunde kürzer und erweitert, in den Blattecken klein, quadratisch und mehreckig. Kapsel aufrecht, länglichellipsoidisch bis fast zylindrisch, engmündig. Peristomzähne oben papillös, mit wenig vortretenden Lamellen. Inneres Peristom viel kürzer; Grundhaut niedrig: Fortsätze schmal; Wimpern fehlend. Deckel kegelig oder geschnäbelt.

696. Homalothecium sericeum (L.) Bryol, eur. 1. c. p. 3. t. 1. [Hypnum sericeum L. Sp. pl. p. 1129 (1753).]

Pfl. in meist flachen und gelbgrünen, oft ausgedehnten, trocken seidenglänzenden Rasen. Äste trocken meist eingekrümmt. Blätter aufrecht-abstehend. zuweilen schwach einseitswendig, aus eiförmiger Basis lanzettlich-pfriemenförmig. 
bis $2,5 \mathrm{~mm}$ lang und bis $0,75 \mathrm{~mm}$ breit, mit flachen oder hier und da schmal umgebogenen Rändern; Rippe dünn, weit vor der Blattspitze aufhörend; Zellen linealisch, 1: 10-15, in den nicht ausgehöhlten Blattecken klein, quadratisch und mehreckig. Innere Perichätialblätter aufrecht, längsfaltig, allmählich lang und fein zugespitzt, etwa $4 \mathrm{~mm}$ lang, ganzrandig oder am Grunde der Pfrieme gezähnt. Seta 1,5-2 cm, rot, überall sehr rauh. Urne etwa $3 \mathrm{~mm}$ lang, gerade oder schwach gekrümmt, im Alter rostfarben. Peristomzähne dunkel- bis rötlichgelb, unten quer, oberwärts schräg- und längsgestrichelt. Deckel hochkegelig. Haube am Grunde mit aufrechten Härchen. Sporenreife in Frühling. - Fig. 96 A-D.

An Nauern und Felsen verschiedener Art und an alten Baumstämmen.
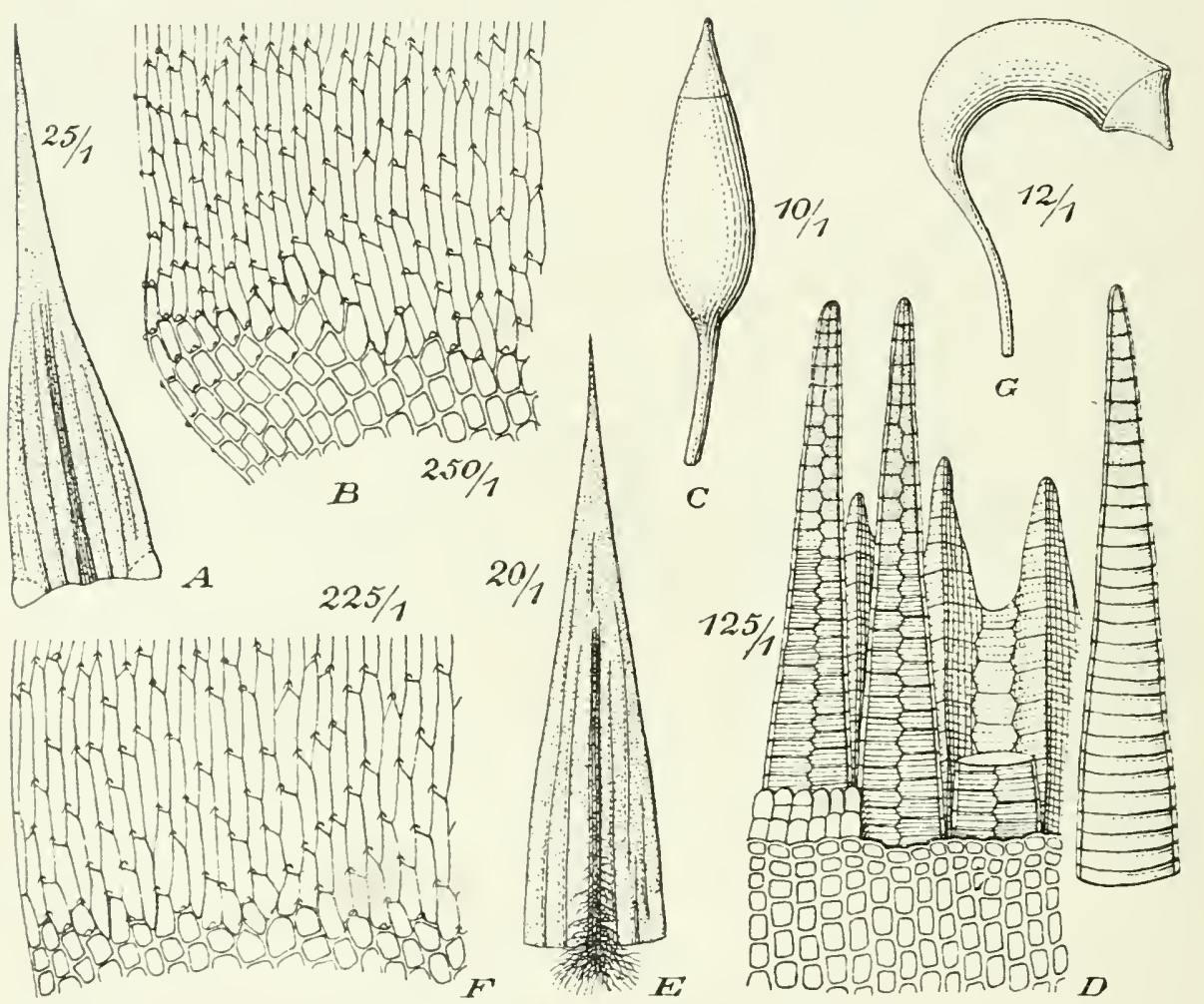

Fig. 96. A-D. Homalothecium sericeum (L.). A Stammb. (25/1): B Blattbasis (250/1); C Kapsel (10/1); 1) Peristom (125/1). - E-6. Camptothecium trichoides (Neck.). E Stammb. (20/1); F Blattbasis (225/1); ir Kapsel in trockenem Zustande (12/1).

F. Al. pass. (Bom.). - Ab. Ȧbo. Nảdendal. Pargas. Kimito. Angelniemi. Finby. Karislojo. Lojo. - N. Tenala. Ekenäs. Ingả. Helsingfors. Borgả. Pernả. - Ka. Kotka. Virolahti. Wiborg (Jusl.); Juustila (Buch). Antrea Hatula (Lind.). — Si. Björneborg, Lỵttskār (Häyr.). - Ta. Im südostl. Teile pass. (Norrl.). Hartola (Bonsd.). Korpilahti und Luhanka pass. (Vain.). - Sa. Lappee, Nieminen (Buch). Savitaipale, Ali-Särnătjărvi (B.). Taipalsaari (Simm.). Nyslott (Carl.). - Kl. Kurkijoki, Taskinen (Jusl.). Talamo (W. Nyl.). Sortavala Rauskunvuori (Linnan.). Pälkjărvi, Korkianieni (Broth.). - Oa. Bötom, Pyhävuori (E af H ). - Tb. Virral, Toriseva (Broth.). — Sb. Kuopio, Puijo (Kot.). Kaavi, Siikajärvi, Huosiainniemi und Likosaari cop. (Kyylı.). Nilsiă, Kuuslahti, Jaakonlampi (Kot.). Maaninka, Haatala, Haukkavuori (Rois.); Tuovilanlahti Arkkuvuori (R.); Kurilanlahti, Vorlokso (R.). Pielavesi, Kiukaismäki (R.): Vaaraslahti. Lokinmäki(R.). Rautavaara, Hankamäki (Kyyhk.). Iisalmi, Mustalaismäki (Roiv.). - Kb. Pielisjărvi, Koli (Linnan.). - Kon. Valkeamäki (Simm.). - h. Kuusamo, -Haataja, Ruoppijärvi (Broth.); Jumma Lammasvoma (B.).

S. Sh, - L. 
N. Sm.-F. Nordgrenze bei $70^{\circ} 20^{\prime} 11$. Br.

Europa, Algier. Tunis, Kanaren, Madeira, Kaukasus, Persien, Kurdistan, syrien, westl. Teile von Nord-Amerika.

\section{CAMPTOTHECIUM}

Bryol. eur. fasc. 46/47 Mon. (1853); emend. Schimp. Syn. (1860).

Stengei regelmässig oder unregelmässig fiederästig. Blätter tief längsfaltig, ei- oder länglich-lanzettlich, meist pfriemenförmig zugespitzt; Rippe \pm kräftig, vor der Blattspitze aufhörend, am Rücken nicht als Dorn vortretend; Zellen eng prosenchymatisch, am Blattgrunde kürzer und erweitert. Seta meist überall sehr raul. Kapsel geneigt bis horizontal, länglich-eiförmig bis länglich-zylinảrisclı, hochrückig, derbhäutig, trocken und entdeckelt meist schwach gekrümmt. Deckel schief kegelig bis kurz gesclnnäbelt.

Übersicht der Arten.

A. Stengel aufrecht, meist dicht filzig. Seta glatt 697. C. trichoides.

B. Stengel niederliegend, ohne Stengelfilz. Seta rauh.

a. Blätter verlängert lanzettlich, pfriemenförmig zugespitzt, mit an Grunde schmal umgebogenen Ränderı; Zellen 1: $10-15$

698. C. lutescens.

b. Blätter eilanzettlich, scharf zugespitzt, mit an Grunde breit umgebogenen Rändern; Zellen 1: 4-6 ......... 699. C. Geheebii.

S e e t. I. Tomentella Kindb. in Eur. and Northam. Bryin. I. p. 86 (1896). Stengel aufrecht, fast immer mit dichten, zumeist dem Rücken der Rippe (ler Stammblätter entspringendem Rhizoidenfilz. Seta glatt.

697. Camptothecium trichoides (Neck.). [Hypnum trichoides Neck. Gallobel. p. 483 (1768). - Hypnum nitens Schreb. Spic. p. 92 (1771). — Camptothecium nitens Schimp. Syn. p. 530 (1860).]

Diözisch. Pfl. in meist dichten, tiefen, gelbgrünen oder gold- bis bräunlichgrünen, trocken glänzenden Rasen. Stengel bis $10-15 \mathrm{~cm}$, bis zu den Jahressprossen hinauf mit braunem, glattem Rhizoidenfilze, mehrfach geteilt und durch zweizeilig gestellte, spitze Äste unregelmässig gefiedert. Blätter steif aufrechtabstehend, nicht herablaufend, verlängert lanzettlich, allmählich pfriemenförmig zugespitzt, bis $3-4 \mathrm{~mm}$ lang und etwa $0,75 \mathrm{~mm}$ breit, ganz- und meist flachrandig: Rippe rasch verdünnt, am Rücken vortretend, vor der Blattspitze auflı̈rend; Zellen sehr eng linealisch, etwa 1: $10-15$, glatt, am Blattgrunde verkürzt und erweitert, in den Blattflügeln niclıt differenziert. Innere Perichätialblätter allmählich pfriemenförmig zugespitzt, ganzrandig; Rippe gut entwickelt. Seta 3,5$5 \mathrm{~cm}$, rot. Kapsel länglich-zylindrisch, rotbraun. Deckel spitzkegelig. Sporenreife im Juni und Juli. - Fig. $96 \mathrm{E}-\mathrm{G}$.

Auf feuchten Wiesen, in Sümpfen und Mooren.

F. Al. Jomala (Elfv.). Finström an wenigen, Saltvik und Sund an einzelnell Fundorten (Bom.) - Ab. Pargas, Lindberg (Elfv.). Kimito, Skinnarvik (Ols.). Uskela (Nikl.). Karislojo, Kourijoki und Hakos (E. af H.). Lojo, Storön, Paavola (Hult) - N. Elimäki (Tigerst.). - Ik. Uusikirkko, Vammelsuu (H. Lindb.). Sakkola, Kirchdorf (H. L.). - St. Eurajoki (Nerr.). Viljakkala (Herl.). Orivesi (Broth.). - Ta. Vanaja (Thur.). Im südöstl. Teile st. r. (Norrl.) Hartola (Bonょd.). Korpilahti, Peuha (Vain.). Luhanka, Kangasjärvi, Sikalahti, Varma (V.). -- Sa. Willmanstrand (Bueh). - Kl. Kurkijoki, Migrilä und Savioja (Jusl.). Ruskeala (WV. Nyl.). - Kol. Im Svirgehiete pass. (Elfr.). Petrosavodsk (Sahlb.). - Oa. Närpes, Yttermark (E. af H.). - Tb. Keuru, Haapamäki (Roir.). Jyväskylä-Pihtipudas pass. (Broth.). - Sb. Kuopio, Vehmasmäki, Syvälampi (Link.). Kaavi, an mehreren Fundorten (Kot.). Juuka (K.). Nilsiā, Jaakon]ampi und Loutteinen (Kyyhk.). Maaninka, Pöljä, líunakkamäki, Ahvenlampi und Kokkosenlampi (K.). - Kb. Juuka, Juuanvaara (Kot.). - Kon. Tiudie (F. Nyl.). Suosaari (Kullh.). Om. A ajärvi, an einigen Fundorten (Backm.). - Ok. Kiijana (Lackstr.). Paltamo (L.). Sotkamo. 
Kuhmoniemi, Hỵrynsalmi und Suomussalmi pass.-st.r. (Kyyhk.). Ristijärvi und Puolanka (Lackstr.). - Ob. Oulujoki, Pyykösjärvi (Huum.). Simo und Rovaniemi (Brenn.). - K. Kuusamo, an vielen Fundorten (Broth., E. af H.). - Kk. Keret (Sahlb.). Zw. Kouda und Knjäscha (Broth.). — Lkem. Kolari und Kittilä, besonders in den nördl. Teilen fq. (Hult). Kuolajärvi (Linnan.). - Le. In der Nadelwaldund Birkenregion fq. und zuweileu Massenvegetation bildend (Norrl.). Kilpisjärvi, Malla und Saana, auch in der alpinen Region (Kot.). - Li. In der Nadelwald- und Birkenregion fq. (Hult). Im Waldgebiete der Halbinsel Kola st. fq., im Tundragebiete pass. (Broth.).

S. Sk.-L.

N. $S m \cdot-F$.

Spitzbergen, Beeren-Eiland, Europa, Nord-Asien, Nord-Amerika.

var. involutum Limpr. Laubm. III. p. 60 (1895).

Dichtrasige Pfl. Stengel reichlich beästet, mit spärlichen Rhizoiden. Blätter gegen die Spitze röhrig-hohl. Rippe $3 / 4$ der Blattlänge.

S. Hrjd. Ramansberg.

S e e t. I I. Eucamptothecium Broth. in Engl.-Prantl Bryal. p. 1139 (1908).

Stengel niederliegend bis aufsteigend, fast gänzlich ohne Rhizoidenfilz. Seta rauh.

698. Camptothecium lutescens (Huds.) Bryol. eur. fasc. 52/54 Mon. p. 6, l. 1 (1853). [Hypnum lutescens Huds. Fl. angl. p. 421 (1762).]

Diözisch, selten pseudautözisch, mit Zwergmännchen im Rhizoidenfilze der ₹ Pfl. Kräftige Pfl. in lockeren, oft ausgedehnten, grünen bis gelblichen, trocken glänzenden Rasen. Stengel mehrfach geteilt, unregelmässig fiederästig; Äste von ungleicher Länge, gerade und steif, meist spitz. Blätter steif aufrecht-abstehend, etwas herablaufend, verlängert lanzettlich, pfriemenförmig zugespitzt, bis $3 \mathrm{~mm}$ lang und bis $0,75 \mathrm{~mm}$ breit, ganzrandig oder oberwärts schwach gezähnelt, mit am Grunde schmal umgebogenen Rändern; Rippe ziemlich kräftig, rasch verdünnt, am Rücken vortretend, vor der Blattspitze aufhörend; Zellen sehr eng linealisch, etwa 1: $10-15$, glatt, am Blattgrunde verkürzt und erweitert, in den Blattflügeln nicht differenziert. Innere Perichätialblätter rasch in eine fast haarförmige Pfrieme verschmälert und am Grunde der Pfrieme mit einzelnen grossen Zähnen; Rippe undeutlich. Seta $1,5-2,5 \mathrm{~cm}$, rot. Kapsel länglich-eiförmig bis länglich-zylindrisch, braun. Deckel kegelig, schief und stumpflich geschnäbelt. Sporenreife im Mai und Juni.

An trockenen Standorten, besonders auf kalkhaltigem Erdboden, Mauern und \pm kalkhaltigen Felsen.

F. Al. st. fq. (Boln.). - Ab. Nådendal (Elfv.). - N. Snappertuna, Raseborg (Hult). Sjundeả, Pikkala (Nerv.). - St. Raunto (Ner:.). - Kol. Fabrika (Elfv.).

S. Sk. -Upl., Vrml.

N. Sm. st. fq. A. Kristiania st. r. JL. Tjomo und Sandefjord.

Europa, Kanaren, Kaukasus, Taurus, westl. Teile ron Nord-Amerika.

var. fallax (Philib.) Breidl. Laubm. Steierm. p. 178 (1891). [Homalothecium fallax Philib. Mscr., Schimp. Syn. 2. ed. p. 634 (1876).]

Kapsel aufrecht und fast regelmässig bis schwach geneigt und ein wenig gekrümmt.

N. Ringerike, sten und skjorvold.

süd-Frankreich, Tirol, Steiermark, Kärnten.

699. Camptothecium Geheebii (Mild.) Kindb. Eur. and N.-Am. Bryin. p. 94 (1897). (Brachythecium Geheebii Mild. in Botan. Ztg. 1869, p. 823.)

Diözisch. Weniger kräftige Pfl. in ausgedehnten, der Unterlage fest aufliegenden, grünen, trocken glänzenden Rasen. Stengel kriechend, mehrfach geteilt, dicht und ziemlich regelmässig gefiedert; Äste kurz, gerade, drehrund und spitz. Blätter herablaufend, trocken dicht dachziegelig, eilanzettlich, allmählich scharf zugespitzt, bis 2,7 $\mathrm{mm}$ lang, mit am Grunde breit umgebogenen, unversehrten Rändern; Rippe kräftig, vor der Blattspitze aufhörend; Zellen kurz linealisch. etwa 1: 4-6, glatt, am Blattgrunde kurz und erweitert, in den Blattflügeln nicht 
differenziert. Innere Perichätialblätter allnählich in eine lange Pfrieme verschmälert, ganzrandig. Seta $8-10 \mathrm{~mm}$, braunrot, zulctzt schwärzlich. Kapsel länglicheiförmig, braun, in Alter schwärzlich. Deckel schmal kegelig, fast geschnähelt. Sporenreife im Frülling.

Auf Gesteinstrümmern in schattigen IVäldern.

N. A. Kristiania. JL. Sandefjord. Ne. Saetersdalen. NB. Sngn, Mundalen.

Deutschland, Alpengebiet, Frankreich, Italien.

\section{BRACHYTHECIUM}

Bryol. eur. fasc. 52/54 Mon. (1853).

Stengel unregelmässig beästet bis unterbrochen fiederästig. Stengelblätter und Astblätter meist deutlich differeniziert. Stengelblätter aus eiförmiger oder dreieckig-herzförmiger Basis schmal lanzettlich, \pm lang, seltener kurz zugespitzt; Rippe dünn, meist etwa in der Blattmitte endend und am Rücken meist glatt: Zellen eng prosenchymatisch, glatt, am Blattgrunde kürzer und erweitert. Astblätter meist kürzer und schmäler; Rippe schwächer und meist kürzer. Kapsel geneigt bis horizontal, meist kurz eiförmig und hochrückig, selten länglich-zylindrisch, derbhäutig, trocken und entleert meist wenig verändert. Deckel gewölbtkegelig, spitz oder stumpf.

\section{Uं bersicht der A r ten.}

A. Meist \pm kräftige Pfl. Stengelblätter aufrecht-abstehend, längsfaltig, kaum oder wenig herablaufend, allmählich lang pfriemenförmig oder haarähnlich zugespitzt, flachund meist ganzrandig. Seta glatt.

a. Meist polyözisch. Stengel meist aufsteigend bis aufrecht, unregelmässig verzweigt 704. B. Mildeanum.

b. Autözisch.

$\alpha$. Stengel kriechend, fast fiederästig. Stengelblätter schlaff, in der oberen Hälfte klein gezähnt ....... 703. B. saiebrosun.

$\beta$. Kräftiger als die vorige Art. Stengel unregelmässig beästet. Stengelblätter steif aufrecht, ganzrandig, mit zahlreichen differenzierten Blattflügelzellen ....... 703. * B.turgidum.

c. Diözisch.

๙. Kräftige Pfl. Stengel mit spärlichen Rhizoiden, unregelmässig beästet. Siengelblätter haarförmig zugespitzt, mit der Haarspitze etwa so lang wie die

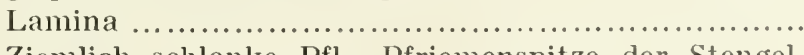

§. Ziemlich schlanke Pfl. Pfriemenspitze der Stengelblätter nur etwa $1 / 2$ der Lamina.

I. Stengel mit spärlichen Rhizoiden, meist unregelmässig beästet

701. B. albicans.

II. Stengel längs mit reichlichen, rötlichen Rhizoiden. fast regelmässig gefiedert. Stengelblätter oberwärts geschlängelt und oft knitterig-verbogen. .. 700. B. erythrorrhi-

$\approx O R$.

B. Autözisch. Tracht und Grösse von B. salebrosum. Seta nur in der oberen Hälfte etwas rauh 705. B. campestre.

C. Mehr oder weniger kräftige Pfl. Stengelblätter aufrechtabstehend, längsfaltig, \pm herablaufend, breit eiförmig, kurz und breitspitzig oder breit eilanzettlich, rasch und 
meist lurz pfriemenförmig, meist flachrandig und oberwärts feingesägt. Seta ïberall sehr rauh.

a. Autözisch. Stengelblätter kurz herablaufend, breit eilanzettlich, rasch und meist kurz pfriemenförmig zugespitzt $\ldots \ldots \ldots \ldots \ldots \ldots \ldots \ldots \ldots \ldots \ldots \ldots \ldots \ldots \ldots \ldots \ldots \ldots \ldots \ldots \ldots \ldots \ldots \ldots \ldots \ldots \ldots \ldots$
Diözisch Stengel mit schwach verdickten Mantelzellen. Stengelblätter weit und eng herablaufend, lang und fast haarförmig zugespitzt, fast ganzrandig; Zellen sehr eng... c. Diözisch.

a. Stengel mit substereiclen Mantelzellen. Stengelblätter mässig weit herablaufend, allmählich pfriemenförmig zugespitzt, mit abwärts breit, oberwärts schmal umgebogenen, nicht gezähnten Rändern; Zellen sehr eng, in den schwach ausgehöhlten Blattfluigeln quadratisch und kurz rektangulär, eine dreieckige, gut begrenzte Gruppe bildend

706. B. rutabulum.

709. B. coruscum.

$\beta$. Stengel mit kaum verdickten Mantelzellen. Stengelblätter kurz und eng herablaufend, \pm lang pfriemenförmig zugespitzt, flach- und ganzrandig ............

$\gamma$. Stengel mit substereiden Mantelzellen. Stengelblätter sehr hohl, weit herablaufend, mit meist kurzer, breiter und scharfer Spitze, fast rings fein gesägt; in den ausgehöhlten Blattflügeln zahlreiche, sehr lockere, fast hyaline und dünnwandige, eine gut begrenzte Gruppe bildende Zellen .....................

$\delta$. Stengel mit weitlichtigen Mantelzellen. Stengelblätter nicht faltig, weit und sehr breit herablaufend, rhomboidisch-dreieckig, rasch lang und scharf zugespitzt, ganzrandig, in den etwas ausgehöhlten Blattflügeln zahlreiche Zellen recht- und mehreckig ...

D. Autözisch. Weniger kräftige Pfl. Stengelblätter aufrechtabstehend bis dachziegelig, längsfaltig, schmal herablaufend, aus breit ei- bis herzfömiger Basis rasch lanzettlichpfriemenförmig, mit am Grunde breit umgebogenen Rändern. Seta überall sehr rauh.

a. Stengelblätter bis 2,4 $\mathrm{mm}$ lang; Zellen 1: 10-15. Wimpern mit Anhängseln 713. B. gèlidum.

b. Stengelblätter bis $1,8 \mathrm{~mm}$ lang; Zellen $1: 5-8$. Wim-

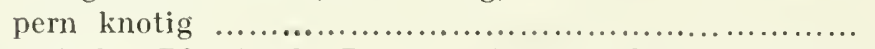
707. B. rivulare.

711. B. latifolium. 708. B. udum. 712. B. glaciale.

E. Autözisch. Pfl. (excl. B. curtum) \pm schlank. Stengelblätter meist sparrig abstehend, nicht faltig. Seta (excl. B. tromsoënse) überall rauh.

a. Stengelblätter weit herablaufend, dreieckig-herzförmig oder breit herz-eiförmig, lang pfriemenförmig verschmälert.

a. Seta oberwärts schwach rauh 717. B. tromsö̈nse.

p. Seta ïberall sehr rauh 716. B. reflexum.

b. Stengelblätter etwas herablaufend.

๔. Weniger schlanke, glänzende Pfl. Stengelblätter breit eilanzettlich, meist allmählich verschmälert. Seta durch niedrige Mamillen schwach rauh....... 714. B. curtum. 
$\beta$. Schlanke, kaum glänzende Pfl. Stengelblätter aus breit herzförmig-deltoidischer Basis rasch verschmälert. Seta durch grössere, dichter stehende Mamillen stärker raulı

715. B. Starkei.

F. Autözisch. Schlanke, seidenglänzende Pfl. Äste kurz, drehrund. Stengelblätter kurz herablaufend, sehr hohl, breit eiförmig, kurz lanzettlich zugespitzt, rings scharf gesägt. Seta glatt, zuweilen oberwärts mit zerstreuten, sehr niedrigen Mamillen

720. B. collinum.

G. Autözisch. Schlanke Pfl. Stengelblätter wenig oder kaum herablaufend, schmal eilanzettlich, lang und fein zugespitzt. Seta überall rauh.

a. Stengelblätter mit nur wenigen, kleinen, quadratischen Blattflügelzellen. Astblätter federartig abstehend bis einseitswendig ......................................... 718. B. velutinum.

b. Stengelblätter mit zahlreichen, quadratisehen und kurz rektangulären Blattflügelzellen. Astblätter allseits aufreclrt-abstehend

719.B.trachypodium.

H. Autözisch. Stengelblätter kaum herablaufend, rasch pfriemenförmig verschmälert. Seta nur oberwärts rauh.

a. Stengelblätter mit kräftiger, weit in die Blattspitze eintretender bis vollständiger Rippe

b. Stengelblätter mit dünner, vor oder in der Blattmitte aufhörender Rippe .................................... 722. B. plumosum.

Un te rgatt. I. Salebrosium Loesk. in Allg. Bot. Zeitschr. 1907, No. 1 und 2.

Meist \pm kräftige und weiche Pfl. Stengelblätter trocken anliegend, meist deutlich längsfaltig, aus verschmälertem, kaum oder wenig herablaufendem Grunde breit eilanzettlich, meist allmählich in eine lanzettliche bis pfriemenförmige oder haarähnliche Spitze verschmälert, an den meist nicht gezähnten Ränderı flach bis streckenweise schmal umgebogen; Rippe meist dünm, vor, in oder über der Blattmitte aufhörend: Zellen eng und verlängert. Seta (excl. B. campestre) glatt.

700. Brachythecium erythrorrhizon Bryol. eur. 1. c. p. 11, t. 13. [Hypnum erythrorrhizon C. Mülì. Mser., Hartm. Sk. Fl. ed. 9, p. 11 (1864).]

Diözisch. Tracht von B. salebrosum, doch schlanker. Pfl. in flachen, oft ausgedehnten, weichen, bleichgrünen Rasen. Stengel kriechend, reichlich mit rötlichen Rhizoiden, fast regelmässig gefiedert, mit niederliegenden, gekrümmten Ästen. Stengelblätter oberwärts gescluängelt und oft knitterig-verbogen, tief längstaltig. herablaufend, eilanzettlich, lang und scharf zugespitzt, bis $1,8 \mathrm{~mm}$ lang und bis $0,8 \mathrm{~mm}$ breit, ganzrandig; Rippe dünn, über der Blattmitte endend; Zellen 1: 5 - $\$$. auch bis 1: 10, in den Blattflügeln zahlreiche quadratisch und rektangulär. Astb)ätter sichelförmig-einseitswemdig, lanzettlich, an der Spitze gesägt. Perichätialb]ätter scheidlig, die inneren aufrecht, allmählich schmal lanzettlich-ptriemenförmig, ganzrandig. Seta $1-1,5 \mathrm{~cm}$. Kapsel geneigt, länglich, gekrümmt, braun.

Auf beschatteten Steinen, seltener am Grunde von Bäumen. Selten fruchtend.

F. Al. Saltvik, Kvarnbo und Hullby (Bom.). - Ab. Pargas, Gunnarsnäs (Elfv.). Karislojo, Niemi (E. af 11. und Sundv.). Lojo, Paloniemi (Lindb.). Pyhäjärvi, Högfors, Ämmämähi (Broth.). - N. Esbo. Lảngträsk (Broth.). Helsingfors (Lindb.). Tusby, Saksa (Broth.). Sibbo (Ekm.). Borgå, Ylike (Broth.). Orimattila, Järvensuo (Link.). - Ik. Kuolemajärvi, Hatjalahdenjärri (H. Lindb.). Mluola. Lehtokŗla (H. L.). Rautu, Sumbila (H. L.). Jetsäpirtti, Saarois (H. L.). Sakkola, Järiserãniemi (H. L.). — st. Ikaalinen (Herl.); Uuraslahti (Sundv.). Ruovesi, Koverojärvi (Broth.). - Ta. Hollola, Tiirismaa (Tain.) Lammi, Evo, Savijärvi (Lảng). Asikkala (Norrl.); Porttikalio (Broll.). Padasjoki (N.). Kulınoinen, Kirchdorf (Broth.). Sysmä (Thur.). Korpilahti und Luhanka st. fq. (Vain.). - Sa. Nuijamaa. Poljjola 
(Broth.). Willınanstrand (Buch). Ruokolahti, Imatra (B.). Nyslott (Carl.). Kangasniemi, Korteniemi (Lackstr.), - Kl. Kurkijoki, Ohtjärvi, Haavikko und Migrilä (Jusl.). Sortavala, Kirjavalahti (Norrl.). Impilahti, Pullinvuori (Broth.). Ruskeala (Lindb.); im Marmorbruche (Broth.). Soanlahti, Korpikallio und Vehkavuorj (B.). Pälkjärri, Pitkäniemi und Korkeaniemi (B.). - Oa. Vasa (Broth.). - Tb. Karstula, Hirvijärvi und Ruotsila (Broth.). Saarijärvi, Summasjoki (B.). Viitasaari, Karhuvuori und Koliatinvuori (B.). Pihtipudas, Kintturijärvi (B.). - Sb. Kuopio, an mehreren Fundorten (Link.). Kaavi, Luikonlahti (Kot.). Juuka (K.). Nilsiä, Kuuslahti, Jaakonlampi (Kyyhk.). Maaninka, Tuovilanlahti (Lackstr.). - Kb. Juuka, Juuanvaara (Kot.); Halivaara (K.). Kontiolahti, Rompala (Linnan.), - Kon. Koselma (Simm.). Kargostrov (Kullh.). Dianova gora und Perguba (K.). - Om. Alajärvi, Kirchdorf (Backm.). Lappajärvi, Kärnä, Pukkila (B.). 一 Ok. Kajana (Lackstr.). Paltamo, Melalahti (Broth.). Sotkamo, Naapurinvaara (B.). Puolanka (Lackstr.). Suomussalmi, Pietari (Vain.). - K. Kuusamo, Rukatunturi (Broth.); Kitkajoki (B.); Juuma (B.); Nuorunen (B.). Kuorikkilampi (E. af H.). - Kk. Kivakkatunturi (B.). Suma (Brenn.). - Lkem. Kolari, Hukki (Norrl.). Ounastunturi (Sandm.). Le. zw. Palojoki und Karesuanto (Norrl.). Kilpisjärvi, Malla, in der Birkenregion (Kot.).

S. Mpd., Ang., LyL. und $L u L$. an einzelnen Fundorten.

N. A. Kristiania. Ringerike, Tyristranden. $k$. Valder:

Tirol, Steiermark, Kărnten.

Var. Thedenii (Bryol. eur.) Lindb. Nusc. scand. p. 36 (1879). [Brachythecium Thedenii Bryol. eur. fasc. 52/5.1 Mon. p. 18, t. 17 (1853). - Hypnum albicans var. Thedenii Hartm. Sk. Fl. 9 ed. p. 11 (1864).]

Schlanke Pfl. Stengel regelmässig gefiedert. Blätter locker gestellt, meist einseitswendig-sichelförmig. Innere Perichätialblätter rasch in eine scharf gesägte, (loppelt so lange Pfrieme verschmälert. Kapsel horizontal, kurz, geschwolleneiförmig.

F. Ab. Ảbo, Runsala (Arrh.). - N. Helsinge, Gumtäkt (Lindb.). - Ta. Hollola, Tiirismaa (Norrl.). Sa. Kangasniemi (Lackstr.). Nyslott (Carl.). - Kl. Kurkijoki (Jusl.).

S. Sm., När., Gstr. und Dlr. all einzelnen Fundorten.

N. sm. r. Ringerike, Vesaetrud.

701. Brachythecium albicans (Neck.) Bryol. enr. 1. c. p. 19, t. 19. [Hypnum albicans Neck. Meth. musc. p. 180, No. 36 (1771).]

Diözisch. Pfl. in lockeren bis dichten, leicht zerfallenden, weisslichgrünen Rasen. Stengelblätter unregelmässig und schwach mehrfaltig, \pm herablaufend, eilanzettlich, pfriemenförmig zugespitzt, bis $2 \mathrm{~mm}$ lang und bis $1,14 \mathrm{~mm}$ breit, meist flach- und ganzrandig; Rippe dünn, in oder wenig über der Blattmitte endend; Zellen 1: $5-8$, auch bis 1: 10, in den nicht ausgehöhlten Blattflügeln zahlreiche quadratisch und rektangulär, sich am Rande ziemlich weit nach oben erstreckend. Astblätter dicht anliegend, lanzettlich bis länglich-lanzettlich, fast haarförmig zugespitzt, ganzrandig oder an der Spitze klein gesägt. Perichätialblätter scheidig, n eine lange zurickgehiummte Pfrieme verschmälert, am Grunde der Pfrieme eingeschnitten-gezähnt. Seta 1,2-2 cm. Kapsel geneigt bis horizontal, eiförmig, etwas hochrückig, leicht gekrümmt, rot- bis schwarzbraun. Sporenreife zeitig im Frühling.

An trockenen, sandigen und grasigen Stellen, an sonnigen Abhängen, auf Torfdächern, Manern und Steinen.

F. Al. st. fq. (Bom). - Ab. Abo. Pargas. Kinnito. Finby. Loju. - N. Ekenäs. Ingá. Esbo. Helsingfors. Helsinge. Sibbo. Elimäki. Hogland. - Ka. Tirolahti. - lk. Muola. - St. Eura. Pirkkala. - Ta. Vanaja. In südöstl. Teilest fq. (Norrl.). Hartola. Forpilahti und Luhanka, wahrscheinlich st. fq., jedoch spärl. und steril (Vain.). - Sa. Wilmanstrand. Ruokolahti. Anttola. Kangasniemi. Kl. Valano. Sortarala Ruskeala. - Oa Isojoki. Närpes. Isokyrö. Vasa. Replot. - Tb. Viitasaari.

Sb. Joroinen. Kuopiost. fq (Link.). Maaninka und Pielaresi st. fq. (Roiv.). - Om. Alajärvi. Gamla Karlehy. - Ok. Paltamo. Sotkamo. - Ob. Uleaborg. Pudasjärvi. Rovaniemi, Valajankoski (Brenn.). - K. Kuusano, Juuma (Broth.). - Lkem. Kolari, Kirchdorf (Hult); Manaoja (H.). - Li. Inari, Yäyä (11.). - Ll. Kola (Brenn.); srednij am Kolabusen (Broth.). Kitovka (Fellm.).

S. $S k-A n g$

N. $s m-F$. Nordgrenze bei $i l^{\circ} \mathrm{n} . \mathrm{Br}$.

Europa, Kaukasus, Nord-Amerika.

var. groenlandicum (C. Jens.). [Hypnum albicans var. groenlandicum C. Jens. in Meddel. Gronl. XV. p. 437 (1898).] 
Grösse von B. salebrosum. Blätter tief mehrfaltig, an den Ästen \pm deutlich einseitswendig, allmählich kurz zugespitzl, mit schmal umgebogenen, I weit herab entfernt und kleingezähnten Rändern

S. Jmt. LuL. Sarekgebiet, an feuchten Felsenabbängen in der alpinen Region. Grönland.

702. Brachythecium glareosum (Bruch) Bryol. eur. 1. c. p. 19, t. 18 (1853). [Hypnum glareosum Bruch in sched.; C. Müll. Syn. 11. p. 361 (1851).]

Diözisch. Tracht von B. salebrosum, doch kräftiger. Pfl. in lockeren bis diclıten, oft ausgedehnten, weichen, leicht zerfallenden, bleich- oder weisslichgrüncn Rasen. Stengel unregelmässig beästet: Äste meist aufrecht und gedunsen, bis $2,5 \mathrm{~cm}$, einfach, selten mit vereinzelten. Ästchen. Stengelblätter dicht dachziege-

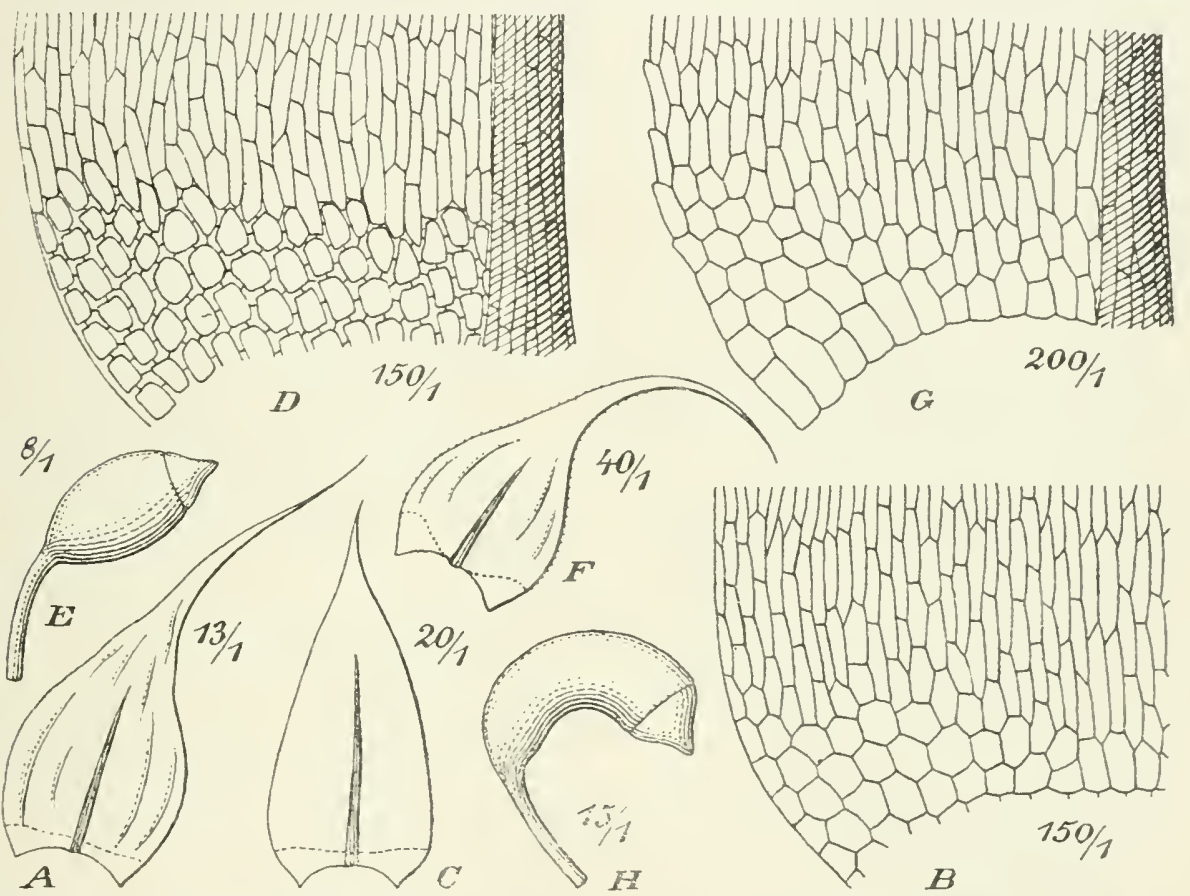

Fig. 97. A-B. Brachythecium glareosum (Bruch). A stengelb. (13/1); B Blattbasis (I50/1). - C E B. plumosum (Sw.). C Stengelb. (20/1); D Blattbasis (150/1); E Kapsel in trockenem Zustande (8,1). F-H. B. velutinum (L.). F Stengelb. (40/1); (i Blattbasis (200/I); Hi Kapselin trockenem Zustande (15/1).

lig, wenig herablaufend, eilanzettlich, allmählich lang haarförmig zugespitzt, bis $1 \mathrm{~mm}$ lang und $1,2 \mathrm{~mm}$ breit, unregelmässig tief längsfaltig, ganzrandig oder an der Spitze entfernt und klein gesägt; Rippe dünn, in oder über der Blattmitte endend: Zellen 1: 8-10, in den kaum ausgehöhlten Blattflügeln quadratisch und ver]ängert-mehreckig oder rektangulär. Astblätter zuweilen einseitswendig, schmäler und kürzer. Perichätialblätter aus scheidigem Grunde plötzlich in eine lange, geschlängelte oder zurückgekrümmte, haarförmige Pfrieme verschmälert, am Grunde der Pfrieme eingeschnitten oder gesägt. Seta 1,5-3 cm. Kapsel geneigt bis horizontal, eilänglich, etwas hochrückig, gekrümmt, dunkelbraun, derbhäutig. Sporenreife im Herbst. - Fig. $97 \mathrm{~A}$-B.

Auf steinigen und grasigen Plätzen, besonders auf mergel- und kalkhaltigem Boden, auch auf Kalk- und kalkhaltigen Felsen.

F. Al. Finström, Färjsund (Arrh.). Saltvik, an mehreren Fundorten (Bom.). — Ab. Korpo, Văsby 
(Elfy.). Pargas, Lapplaks (E.); Tala (Broth.). Lojo. Kiviniemi (Lindb.): Mongola (H. Lindb.); Hermola (H. L.). Pusula, Kalkbruch (Broth.). - N. Helsinge, Sillböle (B.). - Sa. Willmanslrand (Buch). Kl. Ruskeala, Marmorbruch (B.). - Sb. Kuopio, Jynkkä (Link.).

S. Öl., Sm., Gtl., Ög.. Vg., Boh., Srm., När., Upl., V'sm., Irjd.u. Jmt.

N. Sm. pass. A. Kristiania, $J L$. Sandefjord. Ne. Saetersdalen. $\lesssim B$. Ulvik. Gudbrandsdalen. Dorre. NT. Stjordalen. No.-F. Nordgrenze bei $70^{\circ} 30^{\prime}$ n. $\mathrm{Br}$.

Europa, Kaukasus, Sibirien.

703. Brachythecium salebrosum (Hoffm.) Bryol. eur. fase. 52/54 Mon. p. 16, t. 15 et 16 (1853). [Hypnum plumosum Huds. Fl. angl. 1. ed. p. 423, No. 18 (1762) ex Lindb. - H. salebrosum Hoffm. Deutschl. FI. II. p. 74 (1796).]

Autözisch. Mehr oder weniger kräftige Pfl. in flachen oder polsterförmigen, oft ausgedehnten, weichen, meist weisslich-oder gelbgrünen Rasen. Stengelblätter unregelmässig längsfaltig aus etwas herablaufender, ei- oder länglich-eiförmiger Basis verlängert lanzettlich, scharf zugespitzt, bis $3,4 \mathrm{~mm}$ lang und bis $1,14 \mathrm{~mm}$ breit, flach- und ganzrandig oder in der oberen Hälfte klein gezähnt; Rippe dünn, in oder über der Blattmitte verschwindend; Zellen meist 1: $8-10$, in den kaum ausgehöhlten Blattflügelı wenig differenziert. Astblätter oberwärts oft einseitswendig, lanzettlich, lang und oft schief zugespitzt, besonders oberwärts gesägt. Perichätialblätter scheidig, die inneren in eine lange, meist zurückgekrümmte Pfrieme verschmälert. Seta $1,5-2 \mathrm{~cm}$. Kapsel geneigt bis horizontal, länglich. hochrückig, \pm gekrümmt, rotbraun. Sporenreife im Spätherbst.

Am Grunde der Bäume, auf faulendem Holze, Waldboden und beschatteten Steinen und Felsen. Im Waldgebiete bis in die Lappmarken $\pm f q$. Stellenweise auch in der alpinen Region beobachtet, dort jedoch nur spärlich und steril.

Europa, Algier, Azoren, Kanaren, Kaukasus, Zentral- und Nord-Asien, Japan, Nord-Amerika.

*Brachythecium Rotaeanum (De Not.) Amamn Fl, mouss. Suisse II. p. 30-1 (1912). [Brachythecium salebrosum var. $\varepsilon$ cylindricum Bryol. eur. fasc. 52/54 Mon. p. 16, t. 16 , f. $\varepsilon(185 \%)$.]

Kapsel fast aufrecht, zylindrisch, schwach gebogen, in den Hals verschmälert, im Alter schwarzpurpurn und unter der Mündung verengt.

Schweiz, Ober-Italien.

var. cylindroides Limpr. Laubm. III. p. 71 (1896).

Tracht von B. laetum, jedoch in allen Teilen kleiner. Äste kürzer, nicht verflacht, am Ende nicht wurzelnd. Blätter mit einer- oder beiderseits fast bis zur Spitze schmal umgebogenen Rändern.

N. Kristiania.

Tirol, Siebenbürgen.

${ }^{*}$ Brachythecium turgidum (Hartm.) C. Hartm. Sk. Fl. II. Moss. p. 16 (1871). |Hypnum turgidum Hartm. Sk. Fl. 5. ed. p. 328 (1849). - H. plumosum * H. turgidum Lindb. Musc. scand. p. 36 (1879). - Brachythecium turgidum Findb. Enum. p. 294 (1888).]

Grösse und Tracht von B. glareosum. Pfl. in lockeren, weisslich-oder hellgrünen bis goldig angehauchten Rasen. Blätter feucht und trocken steif aufrecht, mehrfaltig, mit am Grunde und streckenweise auch oberwärts umgebogenen Rändern; Błattflügelzellen zahlreich, locker, in der Mehrzahl rektangulär.

Auf magerem Boden zwischen Gras und Steinen.

F. N. Helsingfors (Lindb.). - K. Kitkajoki, Jyrärä (Broth.). - Le. Vittanki (Norrl.): zwischen Kelottijärvi und Naimakka (X.): Kilpisjärvi, Malla in der alpinen Region (Kot.). - Lim. Hibinä, am Passe zw. Vunum vim und Vudjavr (Kihlm.). - Lt. Kildin (Broth.). Tsipnarolok (B.). - Lmur. Vornninsk (Kihlm.). Gavrilova (Broth.). - Lp. Orlor (Kihlm.). Ponoj (Brotl.). - Lv. Tschavanga (Brenn.).

S. Öl., Gll., IIrjd., Jmt., Ing., PL., LuL. und TL.

N. Ne. Saetersdalen, Neienfjeld. Hallingdalen, Gjeteryggen $1,200 \mathrm{~m}$. $K$. Galdhø. Ronderne. Dovre. NT. stjordalen. No.-.F.

spitzhergen, Schweiz, Tirol, Alatau, arktische Teile ron Asien und Nord-Amerika.

704. Brachythecium Mildeanum (Sehimp.) Schimp. in litt.; Mild. in Bot. \%eit. 1862, p. 153. [Hypnum Mildcanm Schimp. Syn. 1. ed. Addend. p. 694 (1860).] 
Polyözisch, seltener autözisch. Tracht von B. salebrosum. Pfl. in lockeren, ausgedehnten, grünen, bleich- und gelbgrünen bis gelbbräunlichen Rasen. Stengelblätter undeutlich längsfaltig, kurz herablaufend, eilanzettlich, allmählich scharf zugespitzt, etwa '2,7 mm lang und bis 1,3 mm breit. flach- und ganzrandig; Rippe dünn, in und über der Blattmitte endend; \%ellen 1: 8-15, in den \pm ausgehöhlten Blattflügeln zahlreiche quadratisch und rektangulär. Astblätter den Stengelblättern ähnlieh, nur kleiner und an der Spitze klein gezähnelt. Perichätialblätter scheidig, die inneren rasch in eine lange, zurückgekrümmte, ladenförmige Pfrieme verschmälert. Setal $2-3$, selten bis $5 \cdot \mathrm{cm}$, glatt. Kapsel geneigt bis horizontal, eilänglich, gekrümmt, kastanienbraun. Sporenreife im Spätherbst.

Auf feuchtem, besonders tonig-lehmigem Bodlen, auf sumpligen Wiesen, in Gräben und Sümpfen, selten am Grunde der Felsen.

F. Al. Saltvik, an mehreren Fundorten (Bom.). - Ab Pargas, Piukala (Elfv). Lojo, Kiriniemi (Lindb.); Tytyri (H. Lindb.). - N. Helsingfors (Lindb.). - Kol. Mjätusova (Elfv.). - Tb. Jyväskylä, Haapakoski (Lir.). Laukaa (Broth.).

S. Sk., Sm., Öl., Ög., När. und Upl.

N. Sm. Glemminge und Onso. A. Kristiania. JL. Tjøma fqq. Bu. Honefos. Ringerike. Dovre. No. Saltdalen und Ankenes.

Europa, Sibirien.

705. Brachythecium campestre (Bruch) Bryol. eur. 1. c. p. 12, t. 11. (Hypnum campestre Bruch in sched.)

Autözisch. Tracht von B. salebrosum. Pfl. in meist lockeren, oft ausgedehnten, weichen, grünen bis gelbgrünen Rasen. Stengelblätter aulrecht-abstehend, unregehmässig und schwach längsfaltig, kurz herablaulend, breit eilanzettlich, pfriemenförmig zugespitzt, bis $2 \mathrm{~mm}$ lang und $1 \mathrm{~mm}$ breit, flach-und ganzrandig ofler gegen die Spitze fein gesägt; Rippe dünn, in odler über der Blattmitte verschwindend; Zellen 1: 8-10, in den kaum ausgehöhlten Blattflügeln vom übrigen Gewebe nicht scharf abgesetzt. Astblätter uft einseitswendig, verlängert lanzettlich, oberwärts scharf gesägt. Perichätialblätter scheidig, die inneren rasch in eine lange, geschlängelt zurückgekrümmte Pfrieme verschmälert. Seta $1,5-2 \mathrm{~cm}$, oberwärts dureh entfernt gestellte Mamillen etwas rauh. Kapsel geneigt bis horizontal, länglich-eiförmig bis fast zylindrisch, 土 gekrümmt. Sporenreife zeitig im Frühling.

Auf lichtem Waldboden und Grasplätzen.

F. Al. Saltvik, Rang:by Bergmyra und Liby (Bom.). Sund, Kastelholm (B.). $-N$. Helsingfors (Lindb.).

S. Öl., Boh., Srm. und Upl.

N. Sm. st. r. Bu. Eker. Ringerike, Tyristranden. $J L$. Tjoms.

Pyrenāen, Zentral-Europa, Algier, Kaukasus, Kaschmir, Sibirien, Yord-Amerika.

Un t e rg. I I. Eubrachythecium Loesk. l. c.

Schlanke bis kräftige, \pm starre Pfl. Stengelblätter trocken oft \pm abstehend, kurz bis weit herablaufend. Seta (excl. B. tromsö̈nse) überall rauh.

S e e t. I. Rutabula Limpr. 1. c. p. 62.

Mehr oder weniger kräftige Pfl. Blätter weniger abstehend, bald mit, bald ohne Längsfalten, breit eiförmig, mit kurzer, breiter und scharfer Spitze oder breit eilanzettlich, rasch kurz pfriemenförmig zugespitzt.

706. Brachythecium rutabulum (L.) Bryol. eur. 1. c. p.11, t. 9 et 10. [Hypnum rutabulum L. Sp. pl. 1. ed. II. p. 1124 (1753).]

Autöziseh. Kräiftige Pfl, in lockeren bis dichten, grünen oder gelbgrünen. \pm glänzenden Rasen. Stengહl läufig stolonenartig verlängert, streckenweise dicht und unregelmässig beästet; Äste meist einfach, anfrecht und gerade, kurz oder verlängert, stumpf oder langspitzig. Stengelblätter abstelıend, hohl, unregelmässig und schwach längsfaltig, 士 herablaufend, breit eilanzettlich, scharf zugespitzt. bis $3 \mathrm{~mm}$ lang und bis $1,6 \mathrm{~mm}$ breit, mit aufrechten, bis weit hinab klein gesägten 
Rändern; Rippe dünn, in oder über der Blattmitte endend; Zellen 1: 8-10, selten bis 1: 15, an den schwach ausgehöhlten Blattflügeln erweitert, dünnwandig und hyalin, eine kleine Gruppe bildend. Astblätter den Stengelblättern ähnlich, nur meist schmäler. Innere Perichätialblätter aus hochscheidiger Basis plötzlich lang pfriemenförmig. Seta $2-2,5 \mathrm{~cm}$. Kapsel geneigt bis horizontal, länglich, etwas hochrückig und gekrümmt, rotbraun. Sporenreife im Spätherbst und zeitig im Frühling. - Fig. $98 \mathrm{~A}$-C.

An feuchten, grasigen Stellen, an Stämmen und Baumwurzeln, an beschatteten Felsen verschiedener Art.

F. Al. st. fq. (Bom.). - Ab. Pargas, Piukala (E]fv.). Kiınito, Fröjböle (Ols.). Finby (Broth.). Angelniemi (Buch). Bromarf, Norrstrand (Sundv.). Karislojo, Tammisaari (E. af H.). Lojo, an mehreren Fundorten (Lindb., H. Lindb.). Vichtis, Haapkylä (Broth.). Sammatti (Sel.). - N. Ekenäs, Trärminne (Broth.). Snappertuna, Raseborg (Häyr.). Ingá, Orılandet, Persholm (W. Brenn.). Kỵkslătt, Kolmpers (Broth.). Helsingfors (Lindb.). Helsinge, Ijö̈ö (W. Nyl.). Borgá. Pellinge Hasselö (Broth.). - Ka. Antrea, Likala (Lindb.). - Ik. Cusikirkko, Vammelsuu (H. Lindb.). Valkjärvi, Pähkinämäki

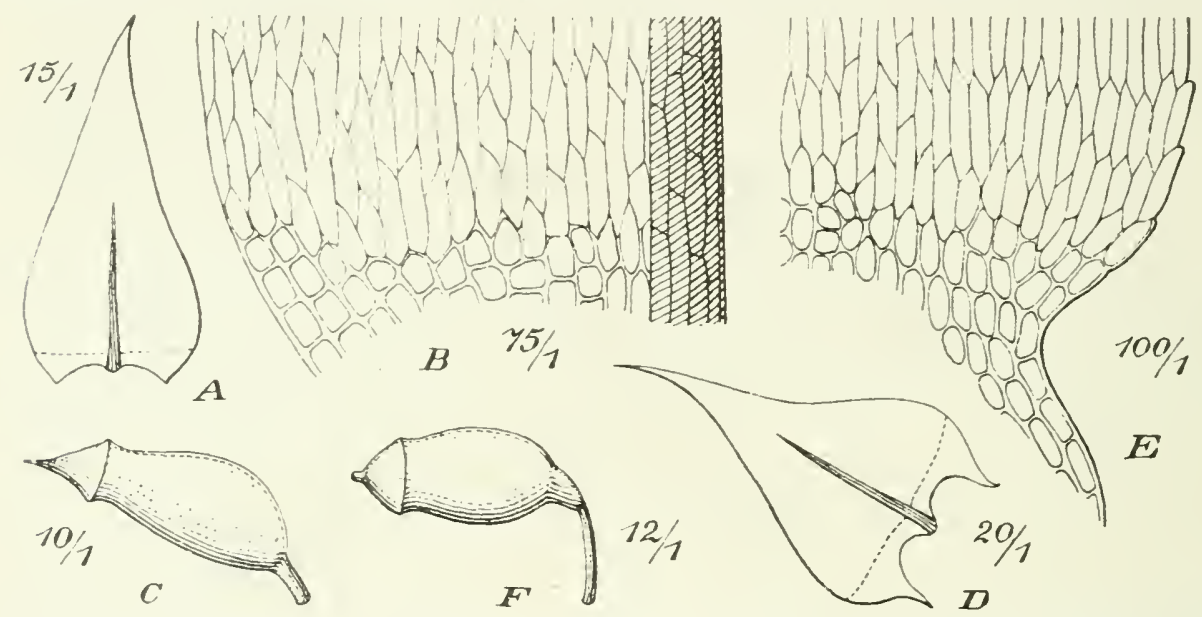

Fig. 98. A-C. Brachylhecium rulabulum (L.). A Stammb. (15/1); B Blattlasis (75/1); C Kapsel in trockenem Zustande (10/1). - I -F. B. curtum (Lindb.). I Stammb. (20/1); E Blattbasis (100/1); F[Kapse] in trockenem Zustande (12/1).

(H. L.). Sakkola (H. L.). Pynajarvi, Łohijoki (H. L.). - St. L'lfoby (Neri.). Pirkkala, Nokia (Broth.). Hămeenkyrö, Kyrőskoski (Simm.). - Ta. Iitti, Radansuu (Buch). Jaala. Pieni Kuhmasjärvi (B.). Im südöstl. Teile an mehreren Fundorten (Norrl.). Hartola, Vehkasalo (Bonsd.). Luhanka, Onkisalo. Hietala und Kesäin (Vain.). - Sa. Lappee, Sunuinen (Buch). Willnanstrand (B.). Nyslott (Carl.). - Kil. Kexholm (Tomm.). Kurkijoki, Ohtjărvi (Jusl.). Uukuniemi (Simm.). Impilahti (Broth.). Ruskeala (Kot.). Pālkjärvi, Korkeaniemi (Broth.). — Kol IIjătusova (Elfv.). - Tb. Virrat, Helvetinjärvi (Broth.). Pihtipudas, Heinolankylä, Taka]a (Roiv.). - Sb. Kaavi, Luikonlahti (Kot.). Nilsiä, Rahasenmäki (Kyyhk.). Maaninka, Pöljä, Pulaste (K.); Haatala, Parola (Roiv.); Tuovilanlahti, Korkeakoski (R.). Kb. Pielisjarvi, Koli (Linnan.). - Le. Kätkesuanto (Norrl.): zw. Palojoki und Karesuanto (N.). - Li. Inari. Ivalo (Sil.).

S. Sk.-Hlsl.

N. Sm. fq. A. Kristiania st. Iq. Ringerike. JL. Sandefjord fq. Tjonı fqq. Ne. Saetersdalen. R. K. Lom ieggen. NT. Stjordalen. No. an inelireren. $T r$. und $F$. an einzelnen Fundorten. Nordgrenze bei $70^{\circ} 5^{\prime} \mathrm{n}$. Br.

Europa, Algier, Kaukasus, Syrien, Persien, Himalaya. Sibirien, Japan, Nord-Amerika. Ecuador, Tasinanien, New Zealand.

var. flavescens Bryol. ellr. l. c. L. 10, f. y (1853).

Strohgelbe und bleichgrüne, weiche Pfl. Stengel und Äste sehr verlängert, schlaff. Blätter sehr breit eiförmig, kurz gespitzt.

S. $\check{g}$.

N. Sm. Onso.

Europa, Nord-Amerika. 
var. viviparum Bryhn in Nyt. Mag. Naturv. XXXII. p. 21 (1891).

In der Tracht die Mitte zwischen Drepanocladus fluitans und Calliergon turgescens haltend. Freudig grüne, weiche Pfl. Stengel wenig verästet; Äste lang und flatterig. Blätter hohl, plötzlich in ein kurzes Spitzchen verlängert, die unteren entfernt gestellt, breit lanzettlich, die oberen schoplig in eine leicht abbrechende Knospe gehäuft, eiförnig. Sporogone unbekannt.

N. $J L$. Tjøme, untergetaucht in stehenden Gewässern.

707. Brachythecium rivulare Bryol. cur. 1. c. p. 13, t. 12. [Hypnum rivulare Bruch in sched.; Wils. Bryol. brit. p. 316, t. 55 (1855).]

Diözisch. Pfl. in lockeren bis dichten, oft schwellenden, etwas starren, grünen bis gelbgrünen Rasen. Hauptstengel meist kriechend, von Blättern enthlösst. Sekundäre Sprosse sehr kräftig, aufrecht bis übergebogen, einfach, gefiectert oder oberwärts büschelig verzweigt und gegen das Ende oft flagellenartig verrlünt. Blätter der sekundären Sprosse aufrecht-abstehend, schr hohl, unregehmässig längsfaltig, weit herablaufend, eiförmig oder eiläuglich, mit meist kurzer und breiter, scharfer Spitze, bis 2,5 $\mathrm{mm}$ lang und bis 1,6 mum breit, mit aufrechten, fast rings entfernt und fein gesägten Rändern; Rippe am Grunde kräftig, rasch verdünnt und über der Blattmitte endend: Zellen 1: $\$-12$, in den ausgehölılten Blattflügeln zahlreiche sehr locker, fast hyalin und dïnnwandig, eine gut begrenzte Gruppe bildend. Blätter der Ästchen letzter Ordnung kleiner, eilanzettlich, allmählich zugespitzt. Innere Perichätialblätter aus der Nitte rasch pfriemenförmig und sparrig zurüickgebogen. Seta $2-2,5 \mathrm{~cm}$. Kapsel übergeneigt bis horizontal, eilänglich, etwas hochrückig, dunkelbram. Sporenreile im Spätherbst.

An feuchten und nassen Stellen in Wäldern, an Quellen und in Quellsümpfen, an Bachufern und Steinen in Bächen. Selten fruchtend.

F. Al. Eckerö (Arrh.). Finström. Grelslyy (Bom.). Saltvik, an mehreren Fundorten (B.). Sund, Jussböle und Kastelholm (B.). - Ab. Sagu, Sandö (Elfv.). Anselniemi, Kokkila (Buch). Karis, Svartâ (Jusl.). Karislojo, Saarenpää (Hult). Lojo, Ojamo und Kiviniemi (Lindb.); Maila (Hult). Jalassaari (H. Lindb.). - N. Nurmijärvi, Kupumäki (Buch). - Ka. Antrea, Hatula (Lindb.). - Ik. Uusikirkko, Vammelsuu (H. Lindb.). Sakkola, Kurikka (H. L.). Pyhäjārvi (Lảng). — St. Jämijărvi, Tervola (Herl.). - Ta. Iitti, Kirchdorf (Buch). Asikkala (Norrl.). Padasjoki (N.). Kuhmoinen, Isojärvi (Broth.). Korpjlahti, Haukkavuori (Vain.). - Sa. Lappee, Kiiala (Buch). Kangasniemi, Py̌lvönälă (Lackstr.). - Kil. Sortavala, Kirjavalahti (Norrl.). Impilahli (Broth.). Ruskeala (Kot.). Pälkjärvi, Anoniemi (B.). Kol. Vosnessenje (Elfv.). Petrosavodsk (Norrl.). - Tb. Jyväskylă, Tourujoki (Broth.). Lurainen, Palsanoja (B.). Laukaa, Porrinlampi (B.). Pihtipudas, tho (B.). - Sb. Kuopio, Veulamãki, Vuorilampi (Link.). Kaavi, Säynäinen (Kot.); Luikonlahti (K.). Nilsiä, Kuuslahti, Jakanlampi (Kot.). Maaninka; Haatala, Suursuo (Roiv.); Pöljä, Kivipuro (Kyyhk.). - Kb. Pielisjärvi, Koli (Linnan.). - Kon. Kivatsch (Kullh.). Tiudie (Norrl.). - Ok. Kajana (Lackstr.). Paltamo, an mehreren Fundurten (Lackstr., Ky yhk.). Ristijärvi (Lackstr.). Suomussalmi, Kiannankylä, Clkupuro (Kyyhk.). - 0 b. Kempele, Isonjilty (Huun.). 一 K. Pudasjärvi (Nyb.). Kuutamo. Oulankajoki, Merenoja (Broth.); Kuusinkijoki (E. af H.); Mänlỵjoki (Vain.). - Lkem. Kolari, Simu und Pudas (Hult). Muoniu, Ounastunturi (Sandm.); zw. Ylikylä und Kätkesuanto (Norrl.). Kuolajärvi, zw. Jongoiva und Akka (Linnan.); Tenniojoki (L.). - Le. Karesuanto in der Kiefernregion (Norrl.): 2w. Maunu und Kelotlijärvi in der Birkenregion (N.). Kilpisjärvi, Kilji-Malla. Saana und Guonjarvanka in der Birkenregion (Kol.). - Li. Sodankylä, Tankajoki und Pälkemäjoki (Hult); Suomusjoki und Vaula (H.). Inari, Iluddusjärvi und Verkojārvi (Sil.); Kultala und Verkontemi (Vain.); Laanila (Räs.). Utsjoki, Mandojāyri, in der Birkenregion (Hull). - Lim. Lujaur-urt, Seidjavr (Kihlm.). Hibinä, Vudjum und Kangaskoski (K.). Pontschosero (K.). Lmur Teribjerka (Broth.). - Lv. Tschapoma (B.).

S. $S k .-T L$.

N. Sm. A. Kristiania. Bu. Eker. Ringerike, nicht selten. JL. Sandefjord nass. Tjomo. Ne. Saetersdalen. Gudbrandidalen. NB. Sogn, $R$. ST. Dovre. NT. Stjordalen. No. und Tr. an mehreren, F. an wenigen Fundorten.

Beeren Eiland, Europa, Madeira, Kaukasus, Zentral- und Nord-Asien bis Japan. Nord-Amerika. Kerguelen.

var. longifolium Bryhn in Nyt Mag. Naturv. Bd. 40, H. I. p. 13 (1902). [Hypnum rivulare var. longifolium Möll. Fört. Sk. växt. 2. Moss. p. 13 (1907).]

In der Tracht die Mitte zwischen B. glareosum und $B$. turgidum lialtend. Sten- 
gelblätter länger und schmäler als bei der Hauptart, ganzrandig, allmählich in eine haarförmige Spitze verschmätert; Rippe dïnner. Sporogone unbekannt.

N. K. Valders, Fulsen, 1,100 m; Jotunfjeldene, Veslefjeld, 1,300 m.

708. Brachythecium coruscum Hag. in D. K. N. Vid. Selsk. Skrift. 1908, No. 3, p. 3 (1908).

Diözisch. Pfl. in lockeren, gelblichen oder gełbgrünen, seidenglänzenden Rasen. Stengel niederliegend, ohne oder mit spärlichen Rhizoiden, unregełmässig bis fast fiederig beästet. Stengelblätter dachziegelig anliegend, einseitswendig, tief mehrfaltig, herablaufend, aus eiförmiger Basis allmählich pfriemenförmig zugespitzt, etwa 2,4 $\mathrm{mm}$ lang und bis $1 \mathrm{~mm}$ breit, mit abwärts breit, oberwärts schmal ungebogenen, nicht gezähnten Rändern; Rippe allmählich verdünnt, weit vor der Pfrieme endend; Zellen etwa 1: 10, in den schwach ausgehöhlten Blattflügełn quadratisch und kurz rektangulär, eine dreieckige, gut begrenzte Gruppe bildend. Astblätter kürzer zugespitzt. q Pfl. unbekannt.

N. K. Gjendin, Vesleloittind, $1,400 \mathrm{~m}$.

Nach $H$ a ge $n$ mit $B$. rivulare, $B$. latifolium und $B$. Ryani verwandt, von allen diesen aber schon durch das dichte Zellgewebe unterschieden (Exemplare nicht geschen).

709. Brachythecium udum Hag. in D. K. N. Vid. Selsk. Skrift. 1908, No. 3, p. 4 (1908).

Diözisch. Pfl. in lockeren, gelbgrünen, glänzenden Rasen. Stengel niedergestreckt bis aufrecht, entfernt gefiedert bis einfach, mit kaum verdickten Mantelzellen; Äste aufrecht-abstehend, kurz und gerade. Stengelblälter aufrecht-abstehend, trocken aufrecht-abstehend bis anliegend, hohl, mehr faltig, kurz und schmal herablaufend, breit eilanzettlich, \pm lang pfriemenförmig zugespitzt, bis $2,6 \mathrm{~mm}$ lang und bis $1 \mathrm{~mm}$ breit, flach- und ganzrandig; Rippe rasch verdünnt, etwa in der Blattmitte endend; Zellen etwa 1: 10, in den etwas ausgehöhlten Blattflügeln kurz rektangulär. $>\mathrm{Pfl}$. und Sporogone unbekannt.

N. An nassen Stellen und in Bächen. bisher nur von einzelnen Fundorten in $K$. und ST., bei 1,0001,500 $\mathrm{m}$, bekannt. Tracht von $B$. rivulare und mit dieser am nächsten verwandt.

710. Brachythecium Ryani Kaur. in Bot. Notis. 1888, p. 177.

Diözisch und pseudautözisch; knospenförmige $\sigma$ Pfl. zuweilen im Wurzelfilze. Pfl. in lockeren, ausgedehnten, bleich- bis weisslichgrimen, etwas glänzenden Rasen. Stengel mit schwach verdickten Mantelzellen, niederliegend, unregelmässig gefiedert; Äste bis 1,5 cn', oft bogig geliümmt. Stengelblätter aufrecht-abstehend, trocken locker anliegend, mehrfaltig, aus lang und schmal herabłaufender, eilänglicher Basis rasch oder allmählich lang und fast haarförmig zugespitzt, bis $3 \mathrm{~mm}$ lang und bis $1 \mathrm{~mm}$ breit, mit flachen oder streckenweise schmal umgebogenen, sehr fein gesägten Rändern; Rippe rasch verdünnt, vor der Blattmitte endend; Zellen 1: $6-8$, in den nicht ausgehöhten Blattflügeh quadratisch und kurz rektangulär. Astblätter cilänglich, lang zugespitzt, oberwiirts scharf gesägt. Innere Perichätialblätter rasch in eine schr lange, haarförmige, nicht gezähnte Pfrieme verschmälert. Seta $1,5-2 \mathrm{~cm}$. Kapsel horizontal, fast zylindrisch, gekrümmt, dunketbraun.

N. Sm. On:o, auf begrastem Boden.

711. Brachythecium latifolium (lindb.) Philib. in Rev. bryol. 1890, p. 19. [Hypnum latifolium Lindb. Musc. scand. p. 35 (1879).]

Diözisch. Ziemlich schlanke Pfl. in lockeren und tiefen, weichen, grünen und gelbgrünen Rasen. Stengel niedergestreckt, in tiefen Rasen aufrecht, locker beblätlert, entfernt geliedert bis fast einfach; Ẍste gespreitzt-abstehend, gerade und scharf. Stengelhlätter abstehend, hohl, nicht faltig, lang und sehr breit herablaufend, rhomboidisch-dreieckig, rasch lang und scharf zugespitzt, bis 1,8 mm lang und bis $1,4 \mathrm{~mm}$ breit, mit am Grunde etwas zurückgeschlagenen, glatten 
Rändern; Rippe dïnn, meist unter (ler Blatlutlte endent: Zellen 1: j-10, in den etwas ausgehöhlten Blattflïgeln zahlreiche recht- uncl mehreckig. Astblätler eilänglich, scharf zugespitzt, oberwärts entlerut und scharl gesägt, bis 1,3 mn lang und bis $0,6 \mathrm{~mm}$ breit. Innere Perichälialbläller rasch in eine zurückgekrümmte Pfrieme verschmälert. Seta $1,2 \mathrm{~cm}$. Kapsel ïbergeneigt, eiförmig, hochrïckig, braun.

Auf humosem Boden unter Weidengebüsch, an Bachufern und in der Nähe des schmelzenden Schnees.

F. Lkem. Olo:tunturi, in der Fiehtenregion (Norrl.). - Le. Kilpisjärvi, Malla, in der alpinen Region (Kot.). - Lt. Pummanki (Broth.). - Lmur. Jokonsk (Broth.). Berdonos in der Nahe von Svjäloinos (B.).

S. LuL. Sarekgebiet, in der Birkenregion st. f(I. und cup.. nur aunnahm<weise in den unteren Teil der Weidenregion hinaufsteigend.

N. K. Snehaetten, 1,400 m. Ronderne. Lomsfjeldene und Jotunfjeldene. Tr. Nordrejsen. Alpengebiet, Sibirien.

712. Brachythecium glaciale Bryol. eur. 1. c. p. 11, 1. 8.

Pfl. in lockeren, weichen, llachen bis schwellenden, gelblich-bis braungrünen, glänzenden Rasen. Stengel kriechend, entfernt beästet; Äste j-8 mu, rundlich beblättert, gekrünmt, am Ende verdinnt und oft wurzelnd. Stengelblätter aulrecht-abstehend bis schwach einseitswendig, deutlich längsfaltig, schmal herablaufend, breit eiförmig, rasch und meist schief lanzetllich-plriemenförmig, bis $1,8 \mathrm{~mm}$ lang und bis $1,2 \mathrm{~mm}$ breit, mit an Grunde stark zurückgeschlagenen, rings entfernt und schwach gezähnten Rändern: Rippe rasch verdïnnt, in der Blattmitte oder vor der Pfrieme endend; 7ellen meist 1: 5-8, in den schwach ausgehöhlten Blattflügeln zalılreiche quadratisch und rektangulär. Astblälter meist schwach einseitswendig, eilanzettlich, allmählich zugespitzt, rings scharf gesägt, bis $1,5 \mathrm{~mm}$ lang und bis $0.6 \mathrm{~mm}$ breit. Perichätialblätter aufrecht, die inneren hochscheidig-zusammengewickelt, \pm rasch verschmälert. Seta $8-12 \mathrm{~mm}$, überal! sehr rauh, mit gestutzten und ausgerandeten Warzen. Kapsel horizontal, eiförmig, hochrückig, rotbraun, zuletzt schwärzlich, trocken und entleert unter der Mündung nicht oder kaum verengt. Sporenreife im Juli uni August.

Auf nackter. nasser Erde, in feuchten, grasbewachsenen Senlingen, in der Nähe des schmelzenden Schnees, an Bachufern und in Bächen, zuweilen auch an nassen Felsen.

F. Lkem. Kittilä, Yllästunturi, in der alpinen Region (Hult). Oundstunturi, in der alpinen Region (Norrl.) - Le Kilpisjärvi, Halla, in der alpinen Region (Kot.). - Lt. Pummanki (Broth.). - Lmur. Litsa (B.). - Lp. Malo Gorodetskaja (B.). Ponoj (B.).

S. LuL. Sarekgebiet, in der oberen Birkenregion md in der Weidenregion.

N. Br. Gaustafjeld. Ne. Saetersdalen, Meienfjeld SB. Ulvik. YB. Sogn, Stenbergdalen 1,200 m. Gjeiteryggen 1,400 m. K. Dovre. Jotunfjeldene und Lonsfjeldene. No.-F.

Beeren Eiland, Sehotlland, Pyrenäen, Alpenkefte. Tibet, Nord-Amerika.

var. dovrensz Limpr. Laubm. III. [) 112 (1896). [Hypnum glaciale var. dovrense Möll. Fört. Sk. växt. 2. Moss. p. 12 (1907).]

Viel kleiner als die Hauptart. Rasen schmutzig- bis dunkelgrïn, glanzlos. Äste drehrund, gegen das Ende verdünnt und oft wurzelnd. Stengelblätter weit herablaufent, nicht oder undeutlich faltig, meist so lang wie breit; Rippe kräftig. fast vollständig, oft mit einem seitlichen Schenkel: Zellen meist $1: 4-5$. Astblätter niemals einseitswendig. sehr hohl, kurz und oft stumpflich zugespitzt. rings schwach gezähnt. Seta am Grunde schwächer warzig. mit niedrigeren, nicht ausgerandeten Warzen. liapsel wenig geneigt, fast regelmässig. trocken und entleert unter der weiten llündung stark verengt.

N. Dovre, Knudshø, längs der Gletscherbäehe. I,300-1,600 m.

713. Brachythecium gelidum Bryhn in Bot. Notis. 1899, p. 256.

Autözisch. Pfl. in lockeren, ausgedehnten, bräunlich- bis gelblichgrünen, glänzenden Rasen. Stengel verlängert, kriechend, dicht beblättert, unregelmässig 
beästet; Äste kurz, niederliegend oder aufsteigend. Stengelblätter fast dachziegelig und einseitswendig, faltig, hohl, aus herablaufender, breit ei- bis herzförmiger Basis plötzlich lang lanzettlich-pfriemenförmig, bis 2,4 mm lang und bis 1,2 mm breit, mit am Grunde breit umgebogenen, klein gezähnten bis glatten Rändern; Rippe vor der Blattspitze aufhörend; Zellen 1: 10-15, in den schwach ausgehöhlten Blattflügeln zahlreiche quadratisch. Astblätter einseitswendig, aus herablaufendem, eiförmigem Grunde allmählich lanzettlich-pfriemenförmig, oberwärts scharf gesägt. Innere Perichätialblätter nicht faltig, rasch pfriemenförmig zugespitzt, ganzrandig; Rippe meist fehlend. Seta etwa $1 \mathrm{~cm}$, rot, überall sehr rauh. Kapsel geneigt bis nickend, eiförmig. hochrückig, rotbräunlich. Deckel kegelig, scharf geschnäbelt.

An Felsen in kalten Bächen und auf Erde an der Schneegrenze.

N. Ne. Røldal. Horrahei, 1,100 m. Saetersdalen, Ireienfjeld 1,200 m. K. Jotunfjeldene, 1,000 und $1,600 \mathrm{~m}$. Hollinerdalen, Hol, Gjeiteryggen, 1,400 m cop.

Sect. I I. Reflexa Limpr. I. c. 1). 62.

Schlanke bis ziemlich kräftige Pfl. Blätter sparrig abstehend, nicht faltig, dreieckig-herzförung bis breit eilanzettlich.

714. Brachythecium curtum (Lindb.) Lindb. in Meddel. Soc. F. Fl. Fenn. Heft. 5 (1879). [Hypnum curtum Lindb. Muse. scand. p. 35 (1879).]

Autözisch. Mit $B$. Starkei nahe verwandt. Pfl. in weniger starren, lockeren, oft ausgedehnten, grünen, glänzenden Rasen. Stengel verlängert, niedergestreckt, entfernt und ziemlich regelmässig gefiedert; Äste bis $2 \mathrm{~cm}$, zurückgekrümmt, verflacht, oft flagellenartig verdünnt und am Ende Rhizoiden entwiekehnd. Stengelblätter abstehend, zart und schlalf, etwas herablaufend, breit eilanzettlich, meist allmählich lang und schmal zugespitzt, bis $2.5 \mathrm{~mm}$ lang und bis $1,5 \mathrm{~mm}$ breit, mit am Grunde schmal ungebogenen, glatten oder an der Spitze entfernt gezähnten Rändern; Rippe dünn, vor oder mit der Blattmitte endend, zuweilen kurz und gegabelt; Zellen 1: 8-15. in den sclıwach ausgehöhlten Blattflügeln kurz rektangulär bis länglich-mehreckig. Astblätter fast zweizeilig abstehend, kürzer und schmäler, mit oft gedrehter Spitze: Rippe glatt. Innere Perichätialblätter wie bei $B$. Starkei. Seta bis $3 \mathrm{~cm}$, zerstreut mit sehr niedrigen Mamillen bis fast glatt. Kapsel horizontal, eiförmig bis länglich-eiförmig, hochrückig, trocken und entdeckelt meist stark eingekrümmt, rotbraun. Sporenreife im Herbst. - Fig. 98 D-F. F.

An Baumwurzeln, modernden Stänmen, Baumstümpfen und Steinen in feuchten, schattigen Wäldern.

F. Al, nicht selten (Bom.). - Ab. Reso. Luonnonmaa (Högm.). Pargas, Gunnarsnăs (E.); Simonsby (Broth.). Lojo, an mehreren Fundorten (Lindb., Hult, H. Lindb.). Kisko, Orijärvi (Hull). Sammatti (Sel.). - N. Ingå. Kälkö (W. Brent.) Kyrkslätt, Porkkala (Broth.). Esbo, Gräsa (B.). Helsingfors (Lindb). Borgå, Suni (Brolh.). Ilogland (Lindb.). - Ka. Kolka, Langinkoski (Roiv.). Antrea, Papinsaari (Lindb.). - Ik. In ola, Pällilă (H. Lindb.). Valkjärvi, Veikkola (H. L.). Sakkola, Järiseväniemi (H L.). - St. Ruovesi, lielvetinjärvi (Broth.). - Ta. Kalvola (Knab.). Im südöstl. Teile an mehreren Fundorten (Norrl). Sysmä (Unon.). Hartola (Bonsd.). Korpilahti, Piililä (Vain.). - Sa. Nuijamaa, Pohjola (Broth.) Ruokolahti, Maltarila (Hult). - Kl. Kurkijoki, an mehreren Fundorten (Jusl.). Valamo (W. Nyl.). - Oa. Vasa (Broth.). - Tb. Pihtipudas, Kanalanmäki und Haapamäki (Roiv.). Sb. Joroinen, Järvikylä (H. Lindb.). Kuopio, an mehreren Fundorten (Liık.). Maaninka pass.--st. fq. (Kyyhk.). Pielavesi, wahrscheinlich s1. fq. (Roiv.). - Kb. Nurmes (Vain.). - om. Vindala, Viilaniemi (Baekm.). Lappajärvi, Purola und Perälä (B.). - Ok. Kajana (Laekstr.). Paltamo, Kives (L.); Melalahti, Aijönkallio (Kyyhk.). Suomussalmi (Vain.). - Ob. Haıkipudas, Luukela (Brenn.). Ii, Karhu und Pihlajankari (B.). - K. Kuusamo, zw. Siikala und Oulankansuu (Broth.). Näränkä (Vain.). - Kkk. Kivakkatunturi (B.): zw. Kontajärvi und Ruva (Sel). - Lkem Kittilä, Pyhäjärvi im Fjeldgebiete (Hult); Y'llastunturi (H ). - Lim Umpjavr Tsehuidi-vum (KihlıI ). Marikkajärvi (K.). - Lt. Kola, Lukinskaja Pahtil (Brolh.).

S. Sk., Öl, Sm., Ogg., Vg., Nar., Upl., Vrm. Dlr., Mpd. und ing.

N. Sim. pass. A. Kristiania, $J L$. Tjøms und Sandefjord. Ringerike. Ne. Sueterdalen $S B$. ST. Europa, Kacchmir, Sibirien, Nord-Amerika. 
715. Brachythecium Starkei (Bricl.) Bryol. eur. 1. c. p. 10, t. 7 ex p.; Lindl). in Meddel. Soc. F. Fl. Fenn. Heft. 5 (1879). [Hypnum Starkei Brid. Muscol, rec. II. P. II. p. 107 (1801).]

Autözisch. Pfl. in starren, grünen bis gelbgrünen, matt glänzenden Rasen. Stengel verlängert, niedergestreckt, dicht und fast regelmässig fiederästig; Äste kurz, bogig gekrümmt, meist lang zugespitzt. Stengelblätter fast sparrig absteheno, etwas herablaufend, kaum faltig, breit herzörmig-deltoidisch, platzlich in eine lange, gedrehte Spitze verschmälert, etwa 1,6 mm lang und bis 1,2 $\mathrm{mm}$ breit, mit flachen, oberwärts schwach gezälnten Rändern; Rippe oberlıall, der Blattmitte endend, zuweilen fast vollständig; Zellen 1: $7-10$, in der Blattspitze nur 1: 4-5, in den stark ausgehöhlten Blatfiügeln zahlreiche quadratisch und melreckig, eine gut begrenzte Gruppe bildend. Astblätter dicht gestellt, abstehend, mit kurzer und breiter, gedrehter Spitze, rings scharf gesägt; Rippe vor der Blattspitze endend, meist am Rücken oberwärts gezähnt. Innere Perichätialblätter nicht faltig, rasch in eine abgebogene, zuweilen etwas gezähnte Spitze verschmälert; Rippe felılend. Seta 1-1,5 cm, rot bis sehwarzrot, überall durel hohe, dicht stehende Mamillen rauh. Kapsel horizontal, dick eiförmig, hochrïckig, gelbbraun. Sporenreife im Herbst.

Auf Waldboden, an Baumwurzehn, modernden Stämmen, Baumstümpfen und Steinen in feuchten, schattigen Wäldern.

F. Al. Hammarland, Hellesby (H. Lindb.). Saltvik, an vielen Fundurten (Bom.). - $A b$. Lojo, Paloniemi (Lindb.); Jalassaari (H. Lindb.). - N. Ifelsingfnrs (Lindb.). Borgá, Tirmo (Jusl.). Hogland (Lindb.). - Ik. Kiremnapa, Vehnais (H. Lindb.). Sakkola, Järiseräniemi (H. L.). - Sl. Björneborg. Kunnäs (Häyr.). Kuru, Aureejarrvi (Herl.). - Ta. Lamıni, Evo, Majakoski (Valle). Hartola (Bonsd.). Korpilahti, Vällyvuori (Vain.). - Sa. Villmanstrand (Buch). - Tb. Virrat, Helvetinportli (Broth.). Kb. Joensuu, Linnunniemi (Linnan.). 一 Kon. Klimskij ostrov (Kullh.), - Kopom. Suma (Brenn.). K. Puda-järvi, zw. Särkelä und Virkku (Broth.). Kuusamo, zw. Virrannieni und Juuma (B.); Nuorunen (B.); zw. Ke älaki und Salminen (B.). - Lkem. Kuolajärvi, südöstl. von Jungoiva (Linnan.). Muonio, Olo,tunturi, in der Waldregion (Norrl.). - Li. Inari, Mfuddusjärvi in der Nadelwaldrcgion (Hult); Tuorpumoivi in der Birkenregion (H.). - Lim. Kandalaks (Broth.). - Lt. Kola, Karaulnaja Pahta (B.). Lmur. Teribjerka, Varsinsk und Jokonsk (B.). - Lp. Ponoj (Sahılb.).

S. Sk., Bl., Öl., Sm., Ög., Vg., Srm., Vrml., Dlr., Hlsl., Ipd., Jml., Ang. und LuL.

N. Sm. JL. Tjomø und Sandefjord. Ringerike fq. Ve. Saetersdalen st. fq. YT. Stjordalen. Vo.$F$. pass., jedoch in der alpinen Region anscheinend selten. Nordgrenze bei $70^{\circ} 25^{\prime} \mathrm{n} . \mathrm{Br}$.

Europa, Kaukasis, Sibirien, Amurgebiet, Japan, Nord-Amerika.

var. complanatum Limpr. Laubm. III. p. 100 (1896). [Hypnum Starkei var. complanatum Möll. Fört. Sk. växt. 2. Moss. p. 42 (1907).]

Pfl. etwas grösser, gelblich, mit reichlichen Rhizoiden. Stengelblätter entfernt gestellt, etwa 1,8 $\mathrm{mm}$ lang und $0,9 \mathrm{~mm}$ breit; Zellen bis 1: 12 . Äste durch zweiseitswendige Blätter verflacht. Astblätter schwach sichelförmigs, abwärts gebogen; Zellen bis 1: 15; Rippe vollständig.

N. No. Bejeren und Ankenes.

Steiermark.

716. Brachythecium reflexum (Stark.) Bryol. eur. l. c. p. 8, t. 5. [Hypnum reflexum Stark. Mscr., Web. et Mohr Taschenb. p. 306 et 476 (1S07).]

Schlanke Pfl. in dichten, flachen, verworrenen, dunkel- oder gelbgrïnen, fast glanzlosen Rasen. Stengel kriechend, an den Spitzen stolonenartig und meist \pm regelmässig gefiedert; Äste $5-8 \mathrm{~mm}$, rundlich beblättert, spitz, aufrecht oder zweizeilig abstehend, meist bogig und trocken eingekrümmt. Stengelblätter abstehend, weit herablaufend, dreieckig-herzförmig, fast plötzlich in eine lange Pfriemenspitze verschmälert, bis $1,4 \mathrm{~mm}$ lang und bis $0,9 \mathrm{~mm}$ breit, rings entfernt und schwach gezähnt; Rippe dünn, weit in die Pfrieme eintretend; Zellen 1: 6-8, in den schwach ausgehöhlten Blattflügeln quadratisch, rektangulär und mehreckig, eine grosse Grupje bildend. Astblätter anliegend. mit etwas abstehender, zuweilen einseitswendiger Spitze, lanzettlich, allmählich zugespitzt, scharf gesägt. mit am 
Grunde schmal zurückgebogenen Rändern. Innere Perichätialblätter scheidig, über der Mitte in eine lange zurückgebogene Pfrieme verschmälert. Seta $1-1,5 \mathrm{~cm}$. Kapsel geneigt bis horizontal, eikugelig. etwas hochrïckig, rot- bis dunkelbraun. Sporenreife im Spätherbst.

Am Fusse der Stämme und an Wurzeln, modernden Stämmen, auf Steinen und auf dem Boden. Im ganzen Gebiete und noch in der Birkenregion pass. - st. fq. Steigt stellenweise bis in die alpine Region hinauf, dort jedoch nur spärlich und steril.

Europa, Kaukasus, Sibirien, Amurgebiet, Sachalin, Nord-Amerika.

717. Brachythecium tromsoënse Kaur. in Limpr. Laubm. III. p. 93 (1904). [Hypnum tromsoënse Kaur. et Arn. in Bih. Sr. Vet.-Ak. Handl. Bd. XXI. Afd. III. No. 10, p. 60 c. icon. (1896).]

Autözisch. Tracht von $B$. reflexum. Pfl. in sehr lockeren, gelblichgrünen, etwas glänzenden Rasen. Stengel stolonenartig verlängert, umhersehweifend oder bogig auf- und absteigend, locker beblättert, unregelmässig beästet; đ̈ste kurz, gekrümmt, oft flagellenartig versehmälert, mit Rhizoiden. Stengelblätter aufrecht-abstehend, hohl, nicht oder kaum faltig, sehr weit und schmal herablaufend, breit herz- bis länglich-eiförmig, rasch odler allmählich lang, fast haarförmig zugespitzt, bis $2.2 \mathrm{~mm}$ lang und bis $1 \mathrm{~mm}$ breit, mit nur am Grunde schwach umgebogenen, rings klein gezähnten Rändern: Rippe rasch verdünnt, $1 / 2 \mathrm{bis} 3 / 4$ des Blattes durchlaufend: Zellen 1: $4-6$, in den ausgehöhlten Blattflügeln sehr zahlreiche locker quadratisch, kurz rektangulär und mehreckig, eine gut begrenzte Gruppe bildend. Astblätter kleiner, eilanzettlich, oft mit halbgedrehter Spitze, deutlicher gesägt. Innere Perichätialblätter aufrecht, rasch pfriemenförmig zugespitzt, nicht faltig, an cler Spitze gezähnt; Rippe fehlend. Seta 1,5-2 cm, rot, oberwärts schwach rauh. Kapsel horizontal, eiförmig, hochrückig, lichtbraun. Sporenreife im Juni.

S. Ảng. Tåsjö, ān beschatteten Granitblöcken.

N. Tr. Tromsøen, im Birkenwalde.

Steiermark

L'n t e r g. I I I. Velutinium Loesk. I. c.

Sehlanke, \pm weiche Pfl. Blätter ohne oder mit undeutlichen Längsfalten, aus wenig oder kaum herablaufendem Grunde bald schmal eilanzettlich, allmählich in eine feine Spitze verschmälert, bald breit eiförmig, rasch lanzettlich zugespitzt: Rippe dünn, in (ne î̉ über der Blattmitte aufhörend. Seta meist rauh.

Sect. I. Velutina Broth. in Engl.-Prantl Bryal. p. 1145 (1908).

Astblätter aufrecht-abstehend bis einseitswendig. Stengelblätter meist schmal eilanzettlich, alhmählich in eine feine Spitze verschmälert.

718. Brachythecium velutinum (L.) Bryol. eur. 1. c. p. 5, t. 4. [Hypnum velutinum L. Sp. pl. p. 1129 (1753).]

Autözisch. Schlanke Pfl. in meist dichten und flachen, grïnen bis gellogrünen. \pm glänzenden Rasen. Stengel kriechend, unregelmässig fiederig; Äste kurz. meist aufgerichtet, zuweilen einwärts gebogen. Stengelblätter abstehend bis zurückgebogen, \pm deutlich sichelförmig, schmal eilanzettlich, allmählich lang und fein zugespitzt, bis $1.8 \mathrm{~mm}$ lang und $0.5 \mathrm{~mm}$ breit, flach- und fast ganzrandig; Rippe dünn, in octer über der Blattmitte aufhörend; Zellen 1: 8-15, in den kaum ausgehöhlten Blattflïgelı wenige klein, quadratisch und kurz rektangulär. Astblätter federartig abstehend bis einseitswendig, scharf gesägt. Innere Periehätialblätter in eine lange, gesägte Pfrieme versehmälert, die innersten zuweilen iiber der Mitte gestutzt, ausgefressen gezähnt und plötzlich pfriemenförmig zugespitzt. Seta 1-2 cm, rot, ïberall rauh. Kapsel geneigt bis horizontal, dick eiförmig, hochrückig, branmrot. Sporenreife im Frühling. - Fig. $97 \mathrm{~F}-\mathrm{H}$. 
An Stämmen, Wurzeln, auf morsehem Holze, Erde, Steinen und Felsen an beschatteten Standorten.

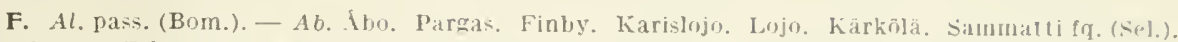
- N. Ekenās. Esbo. Helıingfors. Helsinge. Burgà. Hogland. - Ku. Intrea. - Ik. Kivenmapa. Valkjärvi. - St. Pirkkala. - Ta. Vanaja. Im sudö̈tl. Teile f(. (.Yorrl.). Hartola. Korpilahti und Luhanka pass. (Vain.). - Sa Ruokolahti. Yyłoll. - Kl. kinkijuki. Valamo. Parikkala. l'ukuniemi. Pálkjärvi. - Tb. Kar-tula und Viitasaari, an eirzelnen Fundorten (Broth.). _ ¿ :b. Kuopo Leväinen und Harjulanmäki (Link.). Niliaă, Kuuliahti. Jaakunlampi (Kyshk.). Maaninka, an mehreren Fundorten (Kyyhk., Roiv.). - Kb. Lieksa (Tain.). - Kon. Kivatsch (Simın.). - Om. Lappajarvi, Kauhajarvi, Nokuapuro (Backm.). - Ok. Paltamo, Melalahti (Broth.).

S. Sk.-L.

N. Sm. - F. Nordgrenze bei $70^{\circ} 15^{\prime} \mathrm{n}, \mathrm{Br}$.

Europa, Algier, Kaukasus, Persien, Kaschmir. Sibirien, Sachalin, Nord-Amerika.

719. Brachythecium trachypodium (Funck) Bryol. (ur. l. c. p. 7. t. 13. [Hypnum trachypodium Funek Mscr. in Brid. Bryol. univ. II. p. 766 (1827).]

Pfl. in dichten, fast schwellenden, verwebten, goldgrünen und blass rötlichgrünen, lebhaft seidenglänzenden Rasen. Stengel kriechend, mit reichlichen Phizoiden, an der Spitze fast stolonenartig verlängert, dicht beästet: Äste meist 5$7 \mathrm{~mm}$, aufreçt, steif, an der Spitze wenig verdïnnt. Stengelblätter allseits abstehend bis einseitswendig, schwach längsfaltig, kaum herablaufend, eilanzettlich, allmählich lang haarförmig zugespitzt, etwa $1,8 \mathrm{~mm}$ lang und bis $0.75 \mathrm{~mm}$ breit, flachrandig, rings entfernt und fein gesägt; Rippe über der Blattmitte endend; Zellen 1: 8-15, in clen Blattflügeln zahlreiche quadratisch und kurz rektangulär. Astblätter dichter gestellt, aufrecht-abstehend, schmäler, oberwärts seharf gesägt. Innere Perichätialblätter aufrecht. breit länglich, aus gestutzter uncl ausgefressen-gezähnter Spitze bandförmig zugespitzt. Seta etwa $1 \mathrm{~cm}$. Kapsel \pm geneigt, eilänglich, etwas hochrückig, etwas eingekrümmt, in ler Jugend zweifarbig, im Alter lederfarben, trocken unter der VÏ̈ndung stark verengt. Sporenreife im Juli.

Auf Felsen und in deren Krüften und Höhn̉ngen.

F. Le. Kilpisjärvi, Kilpiskoski (Norrl.). - Lim. Kandaiaks, schelesnaja, in der Fichtenregion (Broth.). Hibinii, in der alpinen Region (Salılb.). - Lt. Pummanki (Broth.). - Lp. Ponoj (B.).

S. LuL. Sarekgebiet, Pelloreppe in der alpinen Region.

N. K. Lom;fjeldene. Dorre. No. Saltdalen und Ankenes. Tr. Mordrej:en.

Spitzbergen, Alpenkette, Kaukasus.

Se ct. 1 1. Julacea Broth. 1. c. p. 1116.

Schlanke Pfl. Äste durch dachziegelige Bebłätterung drehrund. Stengelblätter sehr hohl, breit eiförmig. rasch lanzettlich zugespitzt.

720. Brachythecium collinum (Schleich.) Bryol. eur. 1. c. p. 15, t. 11. (Hypnum collinum Schleich. Cat. 1815.)

Schlanke Pfl, in dichten, meist kreisrunden, in der Yitte fast kissenförmigen. gelblichgrünen, seidenglänzenden Rasen. Stengel kriechend. teilweise stolonenartig, dicht beästet; Aste bis $4 \mathrm{~mm}$, aufrecht, drehrund, stumpf. Stengelblätter sehr hohl, vor den Rändern mit schwacher Falte, kurz herablaufend, breit eifōrmig. rasch kurz lanzettlich zugespitzt, bis $0.9 \mathrm{~mm}$ lang und bis $0,5+1 \mathrm{~mm}$ breit. rings scharf gesägt; Rippe dünn, in und vor der Blattmitte endend: Zellen 1: 4-5, in den nicht ausgehöhlten Blattflïgeln quadratisch. Astblätter kleiner, aufgeschwollen dachziegelig bis schwach einseitswendig. Innere Perichätialblätter kurz hochscheidig. an der abgerundeten, gesägt-gezähnten Spitze plötzlich in eine meist aufrechte, lanzettliche, gesägte Spitze verschmälert. Seta 6-12 mm. glatt. zuReilen oberwärts mit zerstrenten, sehr niedrigen Vamillen. Kapsel geneigt, eilänglich, geschwollen-hochrückig, bleich rostfarben. Sporenreife im September.

An Felsenabhängen. in deren Spalten und Klüften.

F. Le. Kilpisjärvi, Saana, in der alpinen Region (Kot.).

S. Jmt. LuL. an mehreren Fundorten.

N. K. Jotunfjeldene und Lom-fjeldene. Dovre. Tr. Nordrejsen.

Spitzbergen, Pyrenäen, Alpenkette bis Tatra, Kaukasus, Nord-Anerika. 
Unterg. I V. Cirriphyllopsis Broth. l. c. p. 1117.

Ziemlich schlanke bis kräftige Pfl. Blätter olne, selten mit einigen Längsfalten, aus kaum herablaufendem Grunde dreieckig herzförmig bis länglich-eiförmig, rasch lanzettlich-pfriemenförmig, ganzrandig oder oberwärts kleingesägt. Seta oberwärts rauh, selten glatt. Deckel spitz kegelig bis kurz und schief geschnäbelt.

721. Brachythecium populeum (Hedw.) Bryol. eur. 1. c. p. 3, t. 1 et 2. [Hypnum populeum Hedw. Sp. musc. p. 270, t. 70, f. 1-6 (1801). - Hypnum viride Lam. Enc.-Néth. bot. III. p. 181 (1789).]

Pfl. in dichten, flachen, oft ausgedehnten, grünen oder gelbgrünen Rasen. Stengel kriechend mit Rhizoidenbüscheln, an der Spitze oft stolonenartig, entfernt bis fast fiederigg beästet; Äste kurz, einfach, gegen das Ende verdünnt bis flagellenartig. Stengelblätter aufrecht-abstehend, meist ohne Längsfalten, aus etwas herablaufender, dreieckig-herzförmiger oder länglich-eiförmiger Basis lanzettlich-pfriemenförmig, bis 1,8 $\mathrm{mm}$ lang und bis $0,6 \mathrm{~mm}$ breit, flach- und ganzrandig; Rippe weit in die Blattspitze eintretend bis vollständig; Zellen meist 1: $6-\delta$, am Blattgrunde und in den nicht ausgehöhlten Blattflügeln quadratisch, kurz rektangulär und länglich-mehreckig. Astblätter kleiner, lanzettlich-pfriemenförmig und wenigstens oberwärts entfernt und fein gesägt. Innere Perichätialblätter scheidig, in eine lange, zurückgekrümmte Pfrieme verschmälert. Seta $1-1,5 \mathrm{~cm}$, oberwärts durch niedrige Mamillen rauh. Kapsel geneigt bis horizontal, dick eiförmig oder ellipsoidisch, hochrückig, kastanienbraum. Sporenreife im Frühling.

Anf Steinen und Felsen, seltener an Wurzeln.

F. Al.st. fq. - Ab.-Ik.st. fq. - St.-Kl.st. fq. - Kol. Petrosavodsk. - Oa. Lappfjärd. Kaskö. - Tb. Kinnula. Pihtipudas. - Sb. Kuopio. Nilsiä. Maaninka. Rautavaara. - Kb. Pielisjärvi. - Kon. Suojärvi. Pırttiniemi. Santala. - Om. Alajārvi, Herralankallio (Backm.). 一 Ok. Kajana (Kyyhk.). Paltamo, Melalahti, Aijönkallio (K.). Sotkimo, Natula (K.). Suomusialmi, Kirchdorf (Vain.). - K. Kuusamo, Käyläkoski (Broth.); Kitkajoki, Jyrava (B.). Oulankajoki, Merenoja (B.); Selkăjoki (B.).

S. Sk.-Hlsl.

N. Sm. -F. Nordgrenze bei $71^{\circ} \mathrm{n} . \mathrm{Br}$.

Europa, Kaukasus, Sibirien, Nord-Amerika.

722. Brachythecium plumosum (Sw.) Bryol. eur. 1. c. p. 4, t. 3. [Hypnum plumosum Sw. Disp. Iusc. suec. p. 66 (1799). - H. pseudoplumosum Brid. Musc. rec. II. 2, p. 108 (1801).]

Pfl. in meist dichten, goldgrünen, bräunlichgelben oder etwas gescheckten, trocken lebhaft glänzenden Rasen. Stengel kriechend, mit Rhizoidenbüscheln, an der Spitze oft stolon'thartig, ungleichmässig gefiedert. Stengelblätter aufrechtabstehend, oft einseitswendig, nicht oder deutlich längsfaltig, kurz herablaufend, aus breit eiförmiger Basis lanzettlich, feinspitzig, flach- und ganzrandig oder am Spitzchen klein gezähnt, bis 1,8 mm lang und bis $0,8 \mathrm{~mm}$ breit; Rippe dünn, meist in der Blattmitte enclend, zuweilen gegabelt; Zellen 1: 6-10, in den ausgehöhlten Blattflügeln quadratisch und mehreckig, am Blattgrunde kurz rektangulär. Astblätter lanzettlich, scharf zugespitzt, oberwärts deutlich gesägt. Perichätialblätter scheidig, die inneren aus der Mitte rasch lanzettlich und zurückgebogen. Seta 1-2 cm, oberwärts durch flache und breite Mamillen rauh. Kapsel \pm geneigt, dick oval, etwas hochrückig, kastanienbraun, im Alter schwärzlich. Sporenreife in Frühling. — Fig. $97 \mathrm{C}-\mathrm{E}$.

An nassen Felsen und Steinen, besonders in und neben Bächen und Flüssen.

F. Al. Saltvik, an vielen Fundorten (Bom.). - Ab. Pargas, Gunnarsuäs (Elfv.); Simonby (Broth.). Finby (Broth.). Ingelniemi (Buch). Uskela (Nikl.). Karisiojo (Broth.); Tesjärvi (E. af H.). Lojo, Askola (Lindb.); Storön, Pietili (H. Lindb.). Vichtis, Olkkala (Broth.). - N. Kyrkslätt (Nyb.). Esbo, Sandudd (Broth.). Helsingfors (Lindb.). Helsinge, Boxbacka (Buch). Tusby, Skavaböle (Broth.). Hogland (kindb.). - Ka. Antrea, Likola (Lindb.). - Ik. Pyhijärvi, Rantakylä (H. Lindb.). S.lkkola, Ojaniemi (Hid.). - St. Hämeenkyrö, Kyröskozki (Nerr.). Ruovę, I elvetinjärvi (Brotl.). — Ta. Vanaja (Thur.). Im sïdöstl. Teile pasi. (Norrl.). Hartola (Bunid.). Korpilahti und Luhanka st. fq. (Vain.). - Sa. Nuijamal, Pohjola (Broth.). Lippee, Muitila (Bacis). Willmanstrand (B.). Ruokolahti, Imatra (WV. Nyl.). 
Kangasniemi (Broth.). - Kl. Kürkijoki (Jusl.). Sortavala, Kirjavalalıti (Lindl,.); Polsonvara (IV. Nyl.). Impilahti, Pullinvuori (Broth.). Ruskeala, Köksölä (Link.). Suanlahli, Kuirinvaira (B.). Palkjärvi, Annonniemi und Pitkäniemi (B.). - Tb. Jyvaskylä, Tourujoki (B.); Koski (Buch). Karslula, Nihilampi (Broth.). Viitasaari, Siyuätlampi (B.). Kinuula und Pihtipudas, an mehreren Fundorten (Roiv.). —Sb. Kuopio, Vehma`mäki, Pirttimäki (Link.); Rytky, Ninikoski (L.); Laivo)(L.). Nilsiä, Kumılahti, Jaakonlaupi (Kyyhk). Mauninka, Tuovilaulahti, Korkeakoski (Broth.); Haatala, IJankkavuori (Roiv.). - Kon. Pirttiniemi (Simm.). - OR. Kajana (Lacketr.). Utajärvi, Vada (L.). Suommsialmi, Runtula (Vain.). - K. Kuusamo, Aulinköugäs (Broth.); Oulankijoki (B.); Paanajärvi, Kuop)łoja (B.); Sovanköngäs (B.); Mäntyjoki (Vain.). - Lkem. Kolari und Kittilä, an mehreren Fundorten (Hult). - Le. Huotkajärvi, Könkämä und Kilpiskoski (Norrl.). L Li. Sodankylä, Tankajoki, Kopsusjarvi und Lunrojärvi in der Nadelwaldregion (Hult). Inari, Väyli (11.). - Lim. Kandalaks, schelesnaja (Bruth.). Umpjok, Haarakoski (Kihlm.). Imandra (Brenn.). - Ll. Ponjalkivatr (Roiv.). - Lmur. Bjelonsiha (Broth.).

- Lv. Tscliavanga (Brenn.).

S. Sk. - ib., LuL.

N. A. $-\operatorname{Tr}$.

Spilzbergen. Europa, Madeira, Algier, Kaukasus, Asien, Nord-Amerika.
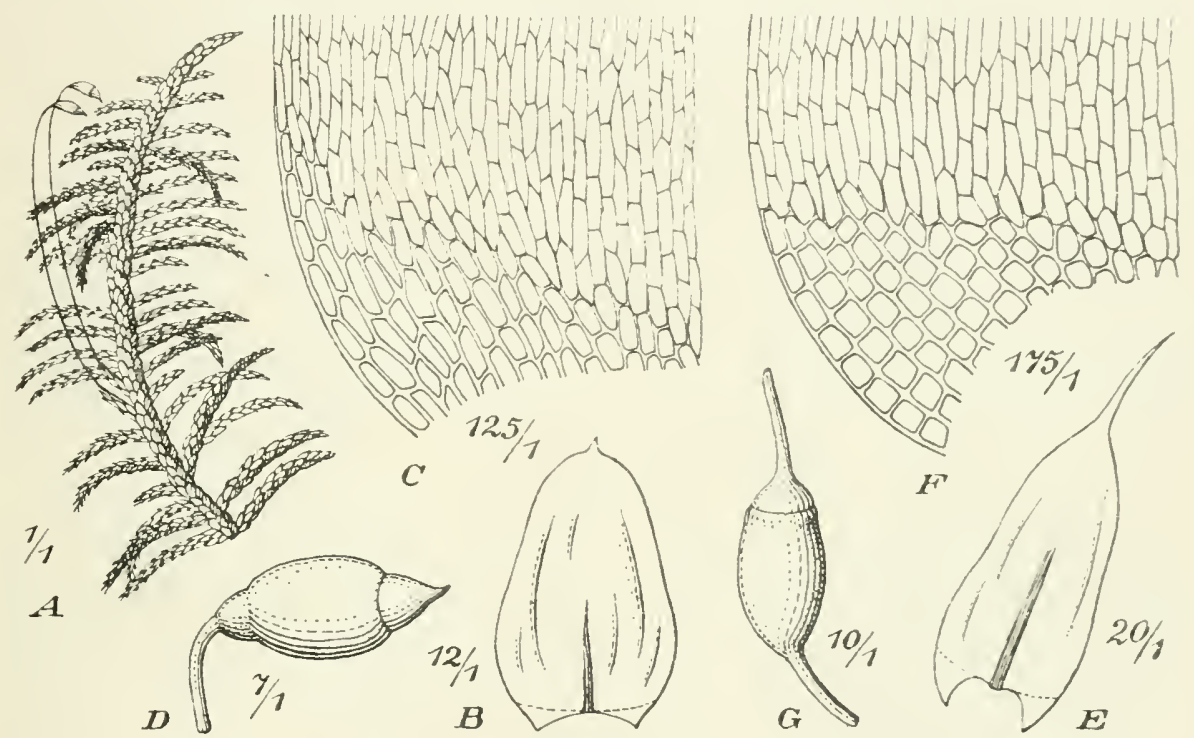

Fig. 99. A-D. Scleropodium purum (L.). A Fruchtende Pfl. (1/1); B Stengelb. (12/1); C Blattbasis (125/1); D Kapsel (7/1). - E-G. Cirriphyllum piliferum (Schreb.). E Stengelb. (20/1); F Blaltbasis (175/1); G Kapsel $(10 / 1)$.

\section{SCLEROPODIUM}

Bryol. eur. fasc. $45 / 46$ Mon. (1853).

Diözisch. Stengel ohne Stolonen. Stengelblätter sehr hohl, nicht oder \pm deutlich faltig, abgerundet, mit Spitzchen oder lanzettlich zugespitzt: Rippe einfach, 土 verlängert oder kurz und doppelt; Zellen sehr eng. glatt. Seta rauh, selten glatt. Kapsel geneigt bis horizontal, fast regelmässig oder schwach hochrückig. Deckel kegelig.

723. Scleropodium purum (L.) Limpr. Laubın. ill. p. 147 (1896). [Hypnum purum L. Sp. pl. 2. ed. p. 1594, No. 32 (1763).]

Tracht von Pleurozium Schreberi. Kräftige Pfl. in lockeren, ausgedehnten, grünen oder strohgelben, glänzenden Rasen. Stengel niedergestreckt bis aufsteigend, bis $10-15 \mathrm{~cm}$, ohne Rhizoiden, gedunsen-wurmförmig, stumpf. \pm regelmässig gefiedert; Äste zweizeilig abstehend, meist gegen die Spitze verdünnt. Stengelblätter $\perp$ deutlich faltig. locker dachziegelig, aus kaum herablaufender, etwas 
verengter Basis breit elliptisch bis eilänglich, an der abgerundeten Spitze mit gesägtem Spitzchen, bis $2,5 \mathrm{~mm}$ lang und bis $1,5 \mathrm{~mm}$ breit, mit am Grunde schmal ungebogenen. undeutlich gesägten Rändern; Rippe einfach, rasch verdünnt, bis zur Blattmitte reichend oder kürzer und doppelt; Zellen 1: $8-16$, in den ausgehöhlten Blattflügeln quadratisch und kurz rektangulär, eine kleine Gruppe bildend. Innere Perichätialb]ätter aufrecht, rasch lanzettlich zugespitzt, an der Spitze \pm deutlich gesägt. Seta $2,5-4.5 \mathrm{~cm}$, glatt. Kapsel meist horizontal, aus sehr kurzem Halse dick ellipsoidisch, bis $3,5 \mathrm{~mm}$ lang, gelbgrün bis gebräunt, trocken und entleert unter der Mündung verengt. Sporenreile im Winter. - Fig. 99 A-D.

Auf Waldboden. Selten fruchtend.

F. Al. Eckerö, Storby (Elfv.). Finström. Grelsby (Bom.). Sallvik, an vielen Fundorten (B.). N. Helsingfors, im botan. Garten (Lindb.).

S. Sk. $-U p l$.

N. Sm. nicht selten. $J L$. Tjømø. $R$. nur auf den Inseln am Meeresufer.

Europa, Algier, Madeira, Azoren, Kaukasus, Japan, Insel Miquelon (Nord-Amerika).

\section{CIRRIPHYLLUM}

Gront in Bull. Torr. Bot. Club XXV. p. 222 (1895) emend.

Loesk. et Fleisch. in Allg. Bot. Zeitschr. 1907.

Diözisch. Stengel (excl. C. piliferum) mit Stolonen. Stengelblätter meist sehr hohl, nicht oder schwach faltig, aus etwas verengter, kurz herablaufender Basis meist ei- bis länglich-eiförmig und rasch bis fast plötzlich in eine lanzettliche bis haarförmige Spitze fortgesetzt; Rippe \pm verlängert, niemals als Dorn endend. Seta raul. Kapsel geneigt bis horizontal, eiförmig bis länglich und etwas hochrüickig. Deckel lang und schief geschnäbelt.

\section{L $^{+}$bersicht der Arten.}

A. Blätter länglich-lanzettlich, allmählich schmal zugespitzt; Rippe zart, kurz vor der Blattspitze aufhörend .......... 724. C. filiforme.

B. Blätter eiläinglieh, rasch und kurz lanzettlich-pfriemenförmig: Rippe sehr kräftig, über der Blattmitte endend. ... 725.C.crassinervium.

C. Blätter plötzlich in eine anı Grunde röhrig-rimnige oder haarförmige Pfriemenspitze verschmälert.

a. Stengel gefiedert, whe Stolonen. Erdmoos 728. C. piliferum.

b. Stengel büschelästig, mit̀ Stolonen. Steinmoose.

«. Äste lang zugespitzt bis peitschenartig verlängert. Blätter aufrecht-abstehend 726. C. Vaucheri.

$\beta$. Äste kätzchenartig, kurz gespitzt. Blätter dachziegelig

\section{C. cirrosum.}

724. Cirriphyllum filiforme (Lam.) Broth. [Hypnum filiforme Lan. Fl. fr. I. p. 535 (1778). - H. velntinoides Bruch in sched. 1836. - Eurhynchium velutinoides Bryol. eur. fasc. 57/61 Mon. p. 12, t. 10 (1854). - Cirriphyllum velutinoides Loesk. et Fleisch. 1. c.]

Tracht von Brachythccium populeum. Pfl. in flachen. gelblichgrünen, später bräunlichgelben Rasen. Stengel kriechend, durch spärliche Rhizoidenbüschel der Unterlage angeheftet, dleht und fast regelmässig gefiedert; Äste kurz, aufsteigend, spit\%. Stengelblätter aufrecht-abstehend, trocken anfrecht, steif, weniger hohl, aus wenig herablanfendler, nicht verengter Basis länglich-lanzettlich, schmal zugespitzt, mit oft lalbgedrehter Spitze, bis $1,8 \mathrm{~mm}$ lang und bis $0,6 \mathrm{~mm}$ breit, mit nur an tiefsten Grunde schmal ungebogenen, klein gesägten Rändern; Rippe krüftig, gellygrün, allü̈hlich verdünnt, kurz vor der Blattspitze endend; 
Zellen 1: 6-9, in deı Blattlïgehn wenige quadratisch und rektangulär. Innere Perichätialblätter aus halbscheidiger Basis rasch in eine aufrecht-abstehende, lange Pfrieme versehmälert. Seta $8-12$ mm.

N. JL. Laurvig. Steril.

Zentral-Europa, Nord-Italien, Kaukasus, Perien.

725. Cirriphyllum crassinervium (Tayl.) Loesk. et Fleisch. I. c. [Hypnum crassinerve Tayl. in Mackay FI. hibern. II. p. 13 (1836). -.. Eurhynchium crassinervium Bryol. eur. fasc. 57/61 Mon. p. 11, t. 11 (1851). - Brachythecium sallense Hag. in N. Mag. f. Naturv. Bil. 38, p. 3399 (1900).]

Pfl. in dichten, sehwellenden, grünen oder gelly- bis weissliehgrünen Rasen. Stengel krieehend, absatzweise mit Rhizoidenbüscheln, dielıt beästet; Äste bis 1 und $1,5 \mathrm{~cm}$ lang. alufreeht, gerade oder etwas gelogen, feucht gedunsen, meist stumpflich. Stengelblätter aufrecht-abstehend, länglich-eilörnig, raseh und kurz. lanzettlich-pfriemenförmig, bis $2 \mathrm{~mm}$ lang und bis $1 \mathrm{~mm}$ breit, mit am Grunde sehmal umgebogenen, \pm deutlich gezähnten Rändern: Rippe sehr kräftig, oberwärts allmällieh verdünnt und über der Blattmitte endend; Zellen 1: $3-6$, an der Basis in mehreren Reihen weiter, in den Blattflügeln quadratisch, kurz rektangulär und mehreckig, grün, eine ziemlich grosse Gruppe bildend. Innere Periehätialblätter in eine lange, nicht sparrig zurückgebogene, ganzrandige oder schwach gezälnte Pfrieme verschmälert. Seta $7-15 \mathrm{~mm}$.

Auf beschatteten Gesteinen verschiedener Art. Sehr selten fruchtend.

S. Sk., Bl., Öl., Sm., Ög., Vg., Boh., meist nur an einzelnen oder wenigen Fundorten.

N. Sm. st. r. A. Kristianja r. $J L$. Tjømo und Sandefjord. Br. Skien.

Europa, Algier, Kaukasus.

726. Cirriphyllum Vaucheri (Sehimp.) Loesk. et Fleisch. 1. e. [Hypnum Vaucheri Sehimp. in sclied., Rabenh. in D. Kryptfl. II. 3, p. 294 (18.18). - Eurhynchinm Vancheri Bryol. eur. fasc. 5761 Mon. p. 15, t. 12 p. p. (185.1).]

Pfl. in oft ausgedehnten, flachen, hell- bis gelblichgrünen Rasen. Stengel kriechend, absatzweise mit Rhizoidenbüscheln und aufrechten oder aufsteigenden, bis $4 \mathrm{~cm}$ langen, oberwärts dicht büschelig verzweigten und übergeneigten, an der Spitze häufig sich niederbiegenden und stoloniform sich verlängernden Sprossen; Äste verdiumnt, oft peitschenartig verlängert und am Ende mit Rhizoiden. Stengelblätter aufrecht-abstehend, breit länglich-eiförmig, bis $2,7 \mathrm{~mm}$ lang und bis $1,5 \mathrm{~mm}$ breit, fast plötzlich schmal lanzettlich-pfriemenförmig, mit am Grunde schmal umgebogenen, fast glatten Rändern; Rippe zart, rasch verdünnt, wenig über der Blattmitte endend: Zellen 1: $8-10$, in den nieht ausgehöhlten Blattflügeln quadratisch und rektangulär. Innere Perichätialblätter aus oben buchtig gezähntem Scheidenteile rasch in eine geschlängelt-abstehende bis zurüekgehogene, bandartige Pfrieme versclmälert. Seta $1-2 \mathrm{~cm}$. Deekel kurz und dick geschnäbelt. Sporenreile im Frühling.

An besehatteten Kalkfelsen und Blëcken.

F. Ab. Lojo, Kiviniemi (Lindb.); Pitkäniemi (E. af H. und sundr.).

S. $O l$. und $r g$. an einzelnen Fundorten.

N. A. Lisistiania.

Zentral-Europa, Pyrenäen.

727. Cirriphyllum cirrosum (Schwaegr.) Grout 1. c. [Hypmum cirrosum Sehwaegr. in Schult. Reis. p. 365 (1804). - Brachylhecium cirrosum Schimp. Syn. p. 696 (1860). - Myurium (?) herjedalicum Schimp. 1. c. - Hypmum herjedalicum Hartnr. Sk. Fl. 9. ed. p. 9. - Brachylhecium herjedalicum Lindb. in Hartm. Sk. Fl. 10. ed. p. 14 (1871).]

Pfl. in matt silbergrünen oder bleich goldgriinen Rasen. Stengel kriechend, absatzweise mit Rhizoidenbüseheln und weit umherschweifenden Stolonen, streckenweise durch dichtgestellte, kurze. geschwollen-kätzchenartige und kurz gespitzte Äste gefiedert. Stengelblätter dachziegelig, länglich, bis $2,4 \mathrm{~mm}$ lang und bis 
$1,2 \mathrm{~mm}$ breit, an der abgerundeten Spitze in eine am Grunde röhrig-rinnige oder lıarförmige Pfriemenspitze verschmälert, mit obərwärts breit eingebogenen und \pm deutlich gezähnten Rändern: Rippe zart, rasch verdiinnt, in der Blattmitte endend. zuweilen nngleich 2-3schenklig; Zellen in der Blattmitte 1: 6-10, oberwärts kürzer, in den ausgehöhlten Blattflügeln quadratisch, kurz rektangulär und mehreckig, eine gut abgesetzte Gruppe bildend. Innere Perichätialblätter aus oben gezähntem Scheidenteil plötzlich in eine zurïckgekrümmte, gezähnte Pfriemenspitze verschmälert. Seta etwa $1.5 \mathrm{~cm}$.

Auf Erdboden und in Kliften, besonders von kalkhaltigen Felsen. Sporogone sehr selten.

F. Lp. Katsehkova (Broth.). Rusiniha zw. Orlov und Ponoj (Broth.). Ponoj (Sahlb.).

S. Hrjd. Stora Midtákläppen.

N. K. Dovre, Vang, Haufjeld. Tr. Nordrejen, Grind sfjeld. F. Kaafjord; Loppen; Oksfjord.

Spitzbergen, schottland, Alpengelsiet von den Pyrenäen bis zur Tatra.

728. Cirriphyllym piliferum (Schreb.) Grout 1. c. [Hypnum piliferum Schreb. Spic. p. 91, No. 1059 (1771). — Eurhynchium piliferum Bryol. eur. fasc. 57,61

Mon. p). 16, t. 13 (1854).]

Pfl. in lockeren, bleich- bis freudig-grïnen Rasen. Stengel sehr verlängert, niederliegend, unregelmässig geteilt, ohne Stolonen, durch aufrecht-abstehende, $1-2,5 \mathrm{~cm}$ lange, allmählich verdïnnte Äste fast regelmässig gefiedert. Stengelblätter aufrecht-abstehend, breit eilänglich, bis $2.5 \mathrm{~mm}$ lang und bis etwa $1 \mathrm{~mm}$ breit, plötzlich in eine lange, haarähnliche Pfrieme verschmälert, mit am Grunde schmal umgebogenen, klein gezähnten Rändlern; Rippe dïnn, in oder “über der Blattmitte aufhörend: Zellen 1: $8-10$, in den schwach ansgehöhlten Blattflïgeln rektangulär und mehreckig, fast hyalin, eine grosse. dreieckige Gruppe bildend. Innere Perichätialblätter aus anliegender Basis in eine lange, sparrig zurückgebogene, gesägte Pfrieme verschmälert. Seta $2-3 \mathrm{~cm}$. Sporenreife im Frühling. Fig. $99 \mathrm{E}-\mathrm{G}$.

Auf schattigen Grasplätzen, besonders mit toniger Unterlage.

F. Al. pass. (Bom.). - Ab Kimito, Brändboda (Ols.) Lojo, an mehreren Fundorten (H. Lindb.). - N. Ekenäs (Häyr.). Helsingfors (Lindb.). Sibbo. Söderkulla (Ekm.) Elimäki (Tigerst.). - Ik. Uusikirkko, Vammelsuu (H. Lindb.). Valkjärvi, Veikkola (H. L.). Sakkola. Loposenmäki (Hid.). - Ta. Kalvola (Knab.). Hollola, Messilä (Norrl.) Asikkala, an einigen Fundorten (N). — Sa. Willmanstrand (Buch). - Tb. Jyväskỵä, Tourujoki (Link.). — Sb. Maaninka, Pöljä (Kyyhk.).—K. Kuusamo, Mäntỵkoski (Nyb.). - Lim. Umpjok, Kitschakoski (Kihlm.).

S. Sk-Hlsl. Ang., V $b ., J m t$., LyL. und $T L$. an eiızelnen Fundorten.

N. Sm. fq. A. Kristiania ir. JL. Sandefjord und Tjomo fq. Ringerike fq. Ve. Saetersdalen. NT. stjordalen. No. und Tr. an wenigen Fundorten. Nordgrenze bei $69^{\circ} 47^{\prime} \mathrm{n}$. Br.

Europa, Kaukasus. Sibirien, Nord-Amerika.

\section{EURHYNCHIUM}

Bryol. eur. fase. $57 / 61$ Mon. (1854).

Stengel oft mit Stolonen. Blätter \pm weit herablaufend, wenig hohl, kurz und breit bis länger und feiner zugespitzt; Rippe einfach, 士 verlängert, an Rücken oft als Dorn endend; Zellen eng prosenchymatisch, am Blattgrunde kürzer, meist verdickt und getüpfelt. Seta meist glatt. Kapsel geneigt bis horizontal, \pm hochriickig, derbhäutig. Deckel aus kegeliger Basis lang und fein geschnäbelt.

\section{Übersiell der Arten.}

A. Blätter längsíaltig. Seta glatt.

a. Kleinere Pfl. Stengelbläter nicht sparrig abstehend, von den Astblättern auffällig verschieden ........... 733. E. strigosum.

b. Stengelblätter von den Astblättern wenig verschieden. 
. Kräftige Pfl. Stengelblätter sparrig abstehend, kur\% zugespitzt

ß. Ziemlich schlanke Pfl. Stengelblitter aufrecht-ab-

stehend, lanzettlich, langspitzig

734. E. striatulum.

B. Blätter ungefaltet. Seta warzig-rauh.

a. Stengelblätter zurückgekrümmt, breit herzförmig, plötzlich langspitzig, von den Astblättern auffällig verschieden 729. E. praelongum.

b. Stengelblätter \pm abstehend, von den Astblättern wenig verschieden.

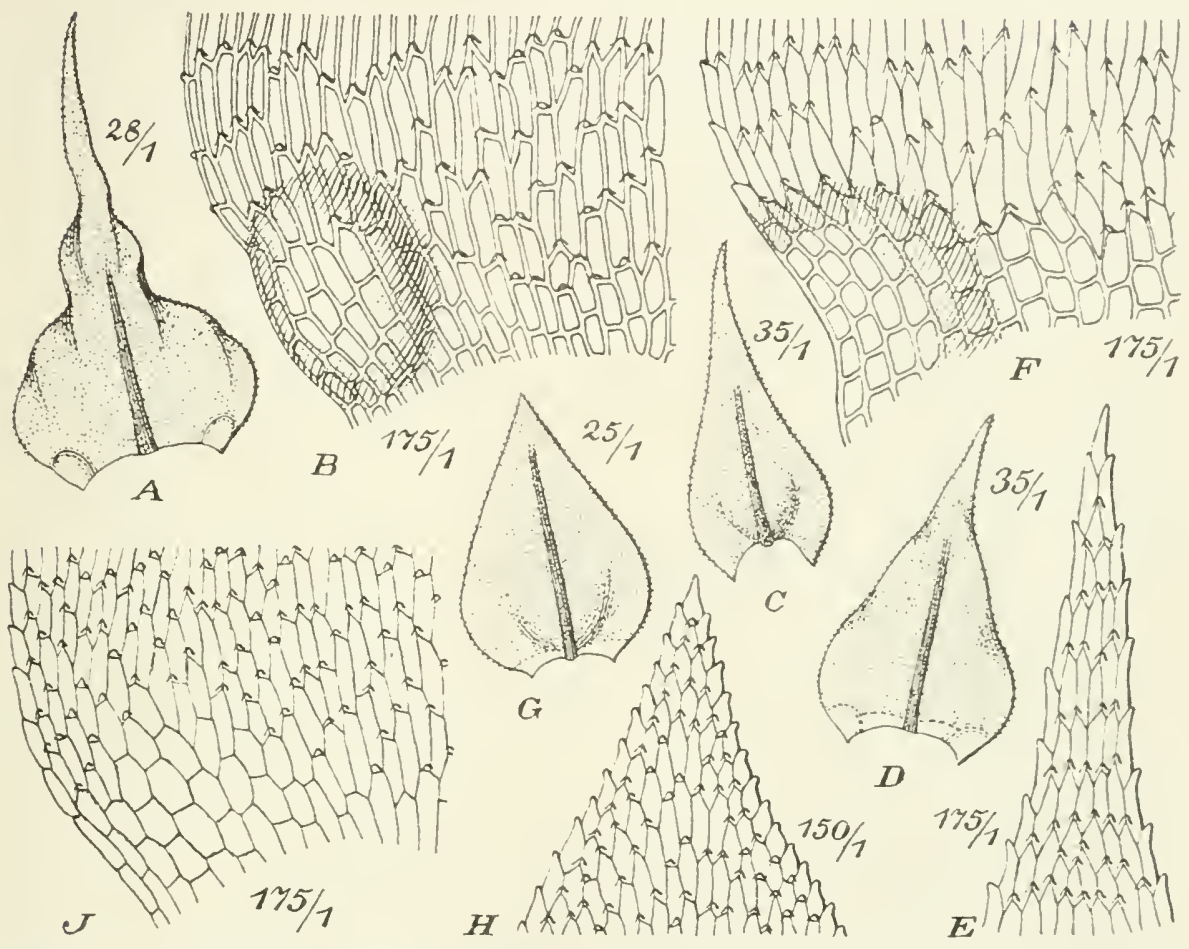

Fig. 101. A-C. Eurrhynchium praelongum (L.). A Stengelb. (28/1); B Blattbasis (175/1); C Astl). (35/1). - D-F. E. Swartzii (Turn.). I stengelb. (35/1); E Blattspitze (125/1); F Blattbasis (175/1). - G-I. E. hians (Hedw.). (i stengelb. (25/1); H Blattspitze (150/1); I Blattbasis (150/1).

«. Schlanke, sehr lockerrasige Pll. Blätter locker gestellt 730. E. hians.

ß. Ziemlich kräftige, dichtrasige und etwas starre Pfl. Blätter dicht gestellt.

I. Stengelblätter herzeiförmig, lang zugespitzt, an der Spitze nicht gedreht. Seta $15-25 \mathrm{~mm}$..... 731. E. Swarlzii.

II. Stengelblätter eilanzettlich, lang zugespitzt, an der Spitze halbgedreht. Seta kürzer

732. E. Schleicheri.

729. Eurhynchium praelongum (L.) Bryhu in D. K. N. Vid. Selsk. Skrift. 1892 , p. 219 (1893). [Hypnum praelongum L. Sp. pl. p. 1125 (1753). - H. Stokesii Turn. Nusc. hibern. p. 159, t. 15, f. 2 (1804). - Eurhynchium Stokesii Bryol. eur. fasc. $57 / 61$ Mon. p. 10 , t. 8 (1854).] 
Diözisch. Pfl. in ziemlich dichten, verworrenen, zuweilen ausgedehnten, grünen oder gelbgrünen, trocken starren. mattglänzenden Rasen. Stengel bis $10 \mathrm{~cm}$, niedergestreckt, mit spärlichen Rhizoidenbüscheln, absatzweise regelmässig einfach bis doppelt gefiedert: Aste zweizeilig gestellt, dünn und zugespitzt, nach oben allmählich kürzer werdend. Paraphyllien zahlreich. Stengelblätter weit herablaufend, sparrig zurïckgebogen, dreieckig-herzförmig, plötzlich zu einer am Grunde oft rinnigen Pfriemenspitze verschmälert, bis $1,1 \mathrm{~mm}$ lang und bis $1 \mathrm{~mm}$ breit, mit am Grunde etwas umgebogenen, rings gesägten Rändern; Rippe dünn, vor der Blattspitze aufhörend; Zellen 1: $5-8$, in den ausgehöhlten Blattflügeln zahlreiche erweitert, rektangulär und dünnwandig. Astblätter dichter gestellt, aufrechtabstehend, eilanzettlich, zugespitzt; Rippe am Rücken meist als Dorn endend. Innere Perichätialblätter halbscheidig, in eine lange, sparrig zurückgebogene, gesägte Pfrieme verschmälert. Seta $1,5-2,5 \mathrm{~cm}$; überall rauh. Kapsel horizontal bis nickend, fast regelmässig, dick oval, gelb- bis grünlichbraun, trocken und entdeckelt unter der Münclung wenig verengt. - Fig. $101 \mathrm{~A}-\mathrm{C}$.

In schattig-feuchten Wäldern, gern auf quelligem Grunde und in Felsenschluchten.

Sehr selten fruchtend.

F. Al. Geta, Westergeta bărg (Hult). Saltvik, Liby berg. (Bom.).

S. S々., Öl., Sm., Hll., Vg., Boh., Srm. und Gslr., meist nur an wenigen Fundorten.

N. Sm. Hvaler und On:o. JL. Tjorı fq. Sandefjurd. Ringerike fq. $R$. nicht selten. SB. NT. Stjordaler.

Europa. Tenerifa, IIadeira, Azoren, Algier, Tunis, Kaukasus, New Foundland und westl. Teile von Nord-Amerika.

730. Eurhynchium hians (Hedw.) Jaeg. et Sauerb. in Bericht. St. Gallen $1876 / 77$, p. 357 (1878). [Hypnum hians Hedw. Sp. musc. p. 272, t. 70, f. 11-14 (1801). - Eurhynchium praelongum Bryol. eur. fasc. 57/61 Mlon. p. 8, t. 6 excl. var. (1854). - Hypnum distans Lindb. Musc. scand. p. 34 (1879). - Eurhynchium distans Bryhn in D. K. N. Vid. Selsk. Skrift. 1892, p. 219 (1893).]

Schlanke Pfl. in flachen, oft ausgedelnten, grünen bis gelblichen, glanzlosen bis metallisch glänzenden Rasen. Stengel bis $15 \mathrm{~cm}$, niedergestreckt, z. T. stoloniform, unregelmässig, streckenweise auch fiederig beästet; İste bis etwa $1 \mathrm{~cm}$, stumpf oder spitz. Stengelblätter aufrecht-abstehend, kurz herablaufend, ei- oder herzeiförmig, kurz oder länger zugespitzt, bis $1 \mathrm{~mm}$ und bis $0,7 \mathrm{~mm}$ breit, mit nur an den Blattflügeln. sclımal umgebogenen, rings kleingesägten Rändern; Rippe meist über der Blattmite endend; Zellen 1: 6-8, in der Spitze locker und kurz und meist nur.1: 2-1, in den Blattflügeln rektangulär und quadratisch, eine kleine, ausgehöhIte Gruppe bildend. Astblätter entfernt gestellt und scheinbar zweizeilig abstehend oder gedrängter und allseits aufrecht-alstehend, eiförmig bis eilanzettlich, flachrandig, rings scharf gesägt. Sporenreife im Spätherbst. - Fig.101 G-I.

Auf feuchtem Garten- und Ackerland, besonders auf tonigem Boden, seltener an fanlenden Baumitümpfen und in Felsenritzen.

F. Al.st. fa. (Bom.). - Ab. Abo (Arrh.). Finby (Broth.). Bromarf, Bromholmen (Sundv.). Uskela (Lindb.). Lojo, Kiviniemi (Lindb.); Lakspojo (H. Lindb.). - N. Ekenäs (Häyr.). Snappertuna (H.). Helsingfurs (Lindb.). Helsinge, Backas (Sol.); Mejlins (Häyr.). Burgả, Haikko (Teräsr.). - Ik. Rautu, Leinikkilä (H. Lindb.). - St. Kankannpää, Kyrö (Sundv.). Häıneenkyrö, kyröskoski (S.). - Ta. Iitti, Radansıu (Buclı). Tavastehus (Coll.). Tyränlö, Lepaa (Teräsv.). Kóppilahti, Rutalahti (Vain.). Sa. Willmanstrand (Buch). Lappee, Kourulanmäki (B.). Savilaipale, Lovikanmäki (B.). - Kl. Kurkijuki (Jusl.). Tb. Jỵäskylä (Brulh.).

S. Sk. - I pd.

N. śm. fq. A. Kristiania fqq. Bu. Honefos. Ringerike fq. JL. Tjomo fqq. Sandefjord st. fq. Urammen. Br. Skien. St. Ryfylke. NT. Sijordalen.

Europa, Azoren, St. Helena, Algier, Kalıasus, Kurdistan, Sibirien, Japan, Nord-Amerika.

731. Eurhynchium Swartzii (Turı.) Curnow in Rab. Bryoth. eur. fasc. XI1. No. 593 (1862). [Hypnum Swartzii Turı. Mluscol. hilsern. p. 151, t. 1.1, f. 1 
(1804). - H. atrovirens (non Dicks.) Sw. Disp. p. 6.5 (1799). - H. praelongum var. atrovirens Brid. Sp. muse. II. p. 104 (1812). — Eurhynchium praelongum var. atrovirens Bryol. eur. fase. 57,61 Mon. p. 8, t. 7, f. 1/3 (1851).]

Diözisch. Tracht von E. hians, doch viel kräftiger. Pfl. in dunkel-, hellbis gelbgrünen und gelblichen, meist dichten, flachen, verworrenen, oft ausgedehnten, trocken starren, matt-bis metallisch-glänzenden Rasen. Stengel bis $15 \mathrm{~cm}$, niedergestreckt, häufig mit langen Stolonen, unregelmässig gefiedert; Äste zweizeilig, ungleich lang, bis 1,5 , selten bis $3 \mathrm{~cm}$, stumpf oder oberwärts verdünnt. Stengelblätter \pm weit abstehend, kurz herablaufend, herzeiförmig, raseh \pm lang zugespitzt, bis $1,4 \mathrm{~mm}$ lang und bis $1 \mathrm{~mm}$ breit, mit am Grunde schmal ungebogenen, rings klein gesägten Rändern; Rippe dünn bis kräftig, bis vor der Blattspitze endend; Zellen 1: $6-8$, in den ausgehöhlten Blattflïgelı rektangulär und quadratiseh, eine kleine Gruppe bildencl. Astblätter etwas hohl, eiförmig bis eilanzettlich, zugespitzt, an der Spitze nieht gedreht, rings scharf gesägt. Sporenreife in Spätherbst. - Fig. $101 \mathrm{D}-\mathrm{F}$.

In schattigen Wäldern über Steinen und Wurzeln. Selten fruchtend.

F. Al. Jomala, Ramsholm (Bom.). Finström, Tărnebolstad (B.). Sund, Lappböle (B.); Kastelholum (B). Saltvik, Johannesberg (B.): Kugghöle und Fremmanby (B.). Steril,

S. Sk.-Vrml.

N. Sm. nicht selten. A. Kristiania. Bu. Tỵistranden. JL. Tjomo fq. Sandefjord. Laurvig. R. r. $N^{*} T$. Stjordalen. No. Vefsen. Nordgrenze bei $65^{\circ} 5 \mathrm{f}^{\prime} \mathrm{n} . \mathrm{Br}$.

Europa, Madeira, Azoren, Algier, Kaukasus, Sibirien.

732. Eurhynchium Schleicheri (Hedw. fil.) Lor. Bryol. Notizb. p. 70 (1865). [Hypnum Schleicheri Hedw. fil. in Web. et Mohr Beitr. 1. p. 128, t. 7 (1805).]

Diözisch. Pfl. in meist dichten, dunkel- bis gelb- und bräunlichgrünen, trocken etwas starren, \pm glänzendén Rasen. Stengel bis $6 \mathrm{~cm}$, kriechend, unregelmässig oder am Ende fast büsehelig verzweigt, dieht gefiedert; Äste aufrecht, kur\%, stumpflich oder spitz; Paraphyllien fast fehlend. Stengelblätter dicht gestellt, abstehend, kaum herablaufend, eilanzettlich, \pm lang zugespitzt, bis $1,4 \mathrm{~mm}$ lang und bis $0,7 \mathrm{~mm}$ breit, mit am Grunde etwas ungebogenen, rings klein gesägten Rändern: Rippe dünn, über der Blattmitte endend; Zellen 1: 8--12, zuweilen noelı enger, in den schwach ausgehöhlten Blattflügeln klein, rektangulär und mehreckig, eine kleine Gruppe bildend. Astblätter ziemlich hohl, lanzettlich, zugespitzt, mit hall)gedrehter Spitze; Rippe am Rücken als Dorn endend. Innere Perichätialblätter halbseheidig, plötzlich in eine sehr lange, sparrig zurückgebogene, gesägte Pfrieme verschmälert. Seta bis etwa $1,5 \mathrm{~cm}$, überall rauh. Kapsel geneigt bis horizontal, hochrückig, dick oval, gelb- bis rotbraun, trocken und entcleckelt unter der Miindung wenig verengt.

S. Sk., Öl, Ög. und Srm. an einzelnen Fundorten

N. Sm. Ones.

Europa.

733. Eurhynchium strigosum (Hoffm.) Bryol. eur. 1.c. p. 2, t.1. [Hyplnum strigosum Hoftm. Deutseh. Fl. II. p. 76 (1796).]

Diözisch oder pseudautöziseh, mit knospenförmigen $\&$ Pflänzehen im Rhizoidenfilz der 우 Pfl. Pfl. in lockeren bis dichten, flachen, trocken etwas starren, grünen bis gelbgrünen, kaum oder mattglänzenden Rasen. Stengel kriechend, mit zahlreichen Rhizoidenbüseheln, absatzweise fiederig oder fast buischelig beästet; Äste meist kurz, aufrecht, einfach und an der Spitze verdünnt, seltener länger, mit vereinzelten Ästehen. Stengelblätter kaum herablaufend, aufrechtabstehend, aus verengter Basis eiherzförmig. allmählich fein zugespitzt, bis $1 \mathrm{~mm}$ lang und bis $0,5 \mathrm{~mm}$ breit, nieht oder undeutlich faltig, mit aufrechten, rings undeutlich oder klein gezähnten Rändern; Rippe zart, in oder über der Blattmitte endend; Zellen sehr eng, 1: 9-12, in den etwas ausgehöhlten Blattflügeln wenige klein, grün, quadratisch, kurz rektangulär und mehreckig. Astblätter abstehend, 
länglich-lanzettlich, kurz zugespitzt bis stumpflich, rings scharf gesägt. Innere Perichätialblätter halbscheidig, rasch in eine zurückgebogene, gesägte Pfrieme verschmälert. Seta $1-1.8 \mathrm{~cm}$, glatt. Kapsel aus kurzem, verengtem Halse eiförmig bis länglich und fast zylindrisch, rötlichbraun, trocken und entdeckelt eingekrümmt und unter der Mündung verengt. Sporenreife im Herbst. - Fig. $100 \mathrm{~A}-\mathrm{E}$.

Auf tonig-sandiger und humoser Erde, am Grunde der Baumstämme, auf Wurzeln und an Felsen.

F. Al. pass. (Bom.). - Ab. Pargas. Kimito. Lojo. Sammatti. - N. Ekenãs. Sjundeå. Kyrkslātt. Helsingfors. Helsinge. - Ka. Antrea. - Ik. Uusikirkko. Metsäpirtti. Pyhājärvi. - St. Eura. Yläne. Pirkkala. Hämeenkyrö. - Ta. Vanaja. Im südöstl. Teile pass.—st. fq. (Norrl.). Tammerfors. Hartola. Korpilahti und Luhanka st. fq. (Tain.). - Sa. Ruokolahti. Kangasniemi. Nyslott. - Kl. Kurki-
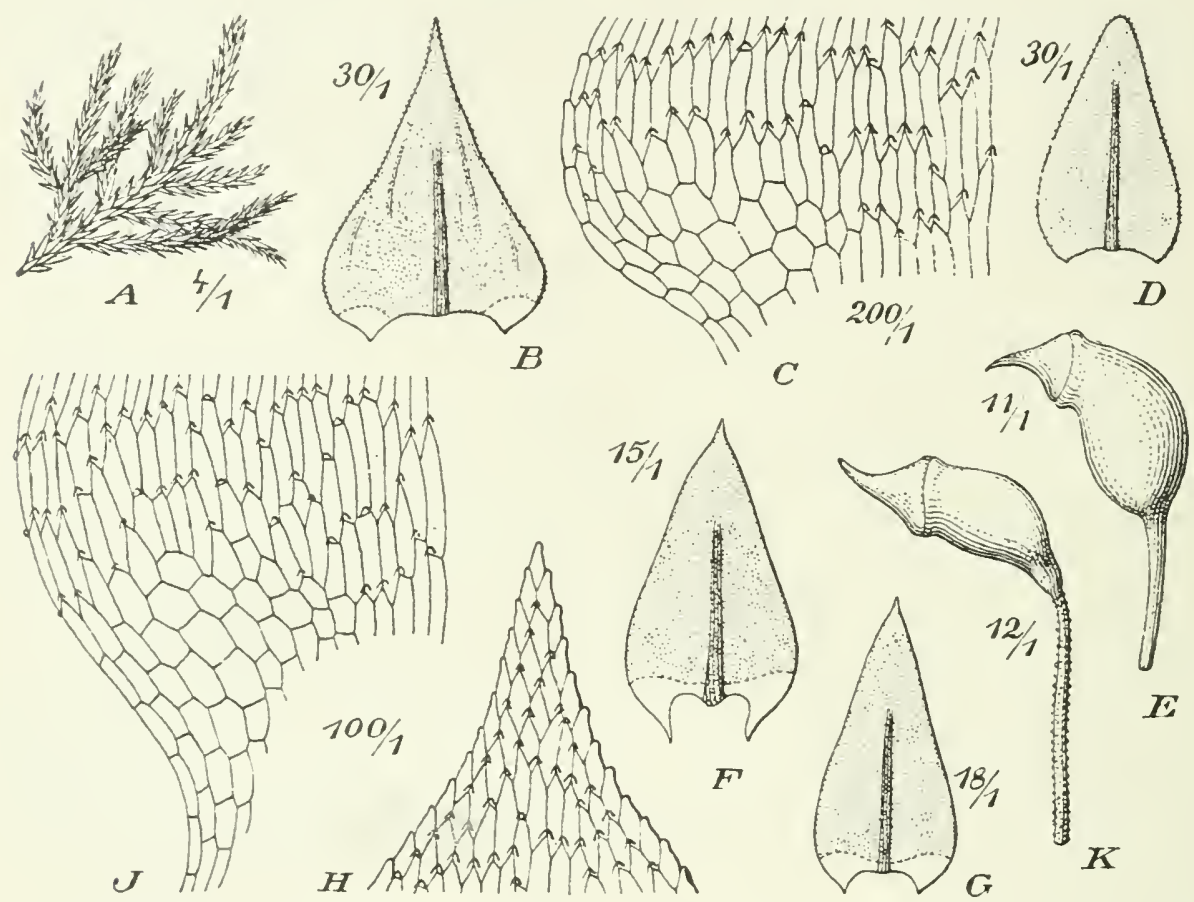
(1) 
suec. p. 703 (1826).

Eurhynchium strigosum $\beta$ imbricatum Bryol. cur. fasc. 57/61

Mon. p. 2, t. 1, f. $\beta$ (1854).l

Stengel kurz, dick und fast nackt, mit aufrechten, 3-i) mm langen, dicht dachziegelig rund beblätterten ïsten. Astblätter breit eiförnig, kurz zugespitzt, zuweilen stumpf.

An trockenen, somnigen Standorten.

F. Al. Salt vik, Kvarnbo und Kugghöle (Bom.). - Ab. Alho (Arrh.). Uskela (Lind\}.). Loju (Jusl.). - N. Helsinge, Dalsvik, im alten Kalkbruche (Buch). - Ta. Hollola, Hersala (Van.). Asikkala (Sil.). Viitaila, IIonkanmäki (Norrl.). Hartola (Bonsd.). Korpilahti, Itaukkavuorı (Vain.). Lıhauka, Juảinsalo (V.). - Sa. Taipalsaari (Simm.). Willmanstrand (Buch). - Kl Kurkijoki, Otsnnlahti (Jusl.). Valamo (J.). - Kol. Im Svirgebiele (EIfr.). - Sb. Kuopio, Hiltulanlahti (Link.). - Kon. Tiudie (Kullh.). Niinisaari (Simm). - Ok. Paltamo, Melalahti (Broth.). Sotkanı, Jorulajärvi, Kohyorinsaari (Kyyhk.). - K. Kuusano, Rukafunturi (Broth.): Kitkajoki, Pääsköskallio(B.), - Lkem. Kolari. Ianaoja (Huukki), im Kalkbruche (Norrl.); Naalaoja (Hult). - Le. Kilpisjärvi (Norrl.). — Lp. Ponoj (Broth.).

S. Verloreitung efwa wie liei der Hauptart.

N. Verbreitung etwa wie liei der Hauptill. Xordgrenze bei $6 y^{\circ} 32^{\prime} \mathrm{n}$. Br.

Europa. Algier sibirien, Nord-Amerika.

var, diversifolium (Schleich.) Mol. et Lol. in Flora 1867. [Hypmum diversifolium Schleich. in Herb. et Catal. $1807 \mathrm{ex} \mathrm{p.} \mathrm{-} \mathrm{Eurhynchinm} \mathrm{diversifolium} \mathrm{Bryol.}$ eur. fasc. $57 / 61$. Non. p. 4, t. 2 (1854). - Hypnum strigosum var. $\gamma$ diversifolium Lindb. Musc. scand. p. 34 (1879).]

Tracht und Grösse von E. strigosum var. praecox.

Stengelblätter aus sehr enger, herablaufender Basis dreieckig-lierzförmig, rasch und meist schief lang- und feinspitzig. Astblätter eiförmig, nit abgerundeter Spitze.

S. $P L$. Tjidtjakk.

N. K. Valders, Vang. Dovre. Yo.-F. an einzelnen oder wenigen Fundorten.

Spitzbergen, Pyrenäen, Alpengebiet, Kaukasus, Gronland, westliche Teile von Nord-Amerika.

734. Eurhynchium striatulum (Spruc.) Bryol. eur. fasc. 5761 Mlon. p. 5, t. 4 (1854). [Hypmum striatulum Spruc. Musc. Pyren. No. 12 (1847) et in Ann. and Mag. Nat. Hist. 18.49, p. 284.]

Diözisch. Tracht von Isolhecium myosuroides. PlI. in lockeren, trocken etwas starren, gelblich- oder brämulich- bis dunkelgrünen, schwach glänzenden Rasen. Stengel kriechend, mit Rhizoidenbüscheln, hier und da mit Stolonen. Sekundäre Sprosse niederliegend odler aufsteigend, büschelig oder dicht fiederig beästet; Äste gerade oder gekrümmt, oft nach einer Seite gewendet, \pm lang zugespitzt und ohne Rhizoiden. Stengelblätter aufrecht-abstehend, trocken locker anliegend, aus sehr verengter Basis dreieckig-herzförmig, rasch lanzettlich, lang zugespitzt, etwa 1,5 $\mathrm{mm}$ lang und $0,6 \mathrm{~mm}$ breit, beiderseits mit $1-2$ schwachen Längsfalten, mit nur am Grunde schmal umgebogenen, rings gesägten Rändern: Rippe kräftig, etwa $3 / 4$ der Blattlänge, zuweilen gegen die Spitze gezähnt; Zellen 1: 5, am Grunde mehrere Querreihen oval, dickwandig und getüpfelt, in den stark eingedrückten Blattflügeln zahlreiche klein, grün, oval und kurz rektangulär. Astblätter eilanzettlich, kurz zugespitzt, rings scharf gesägt. Innere Perichätialblätter hallscheidig, plötzlich lanzettlich-fadenförmig, gesägt. Seta 1-2 cm, glatt. Kapsel aus deutlichem Halse länglich, rötlichbraun, trocken schlank und unter der erweiterten Mündung verengt. Sporenreife im Frühling.

S. Öl. und Gtl.

Europa, Algier, Kaukasus.

735. Eurhynchium striatum (Schreb.) Schimp. Coroll. p. 119 (1856). [Hypnum striatum Schreb. Spicil. p. 91 No. 1058 (1771).]

Diözisch, selten pseudautözisch, mit knospenförmigen $\sigma^{r}$ Pflänzchen im Rhizoidenfilz der 오 Pfl. Kräftige Pfl. in lockeren, grünen, trocken etwas starren, glänzenden Rasen. Stengel bis $10-15 \mathrm{~cm}$, bogig niedergestreckt oder aufstrebend, mit Rhizoidenbüscheln, unregelmässig bis fast baumartig verzweigt; Äste stumpf 
oder gegen die Spitze verdünnt bis flagellenartig verlängert und dann zuweilen an der Spitze mit Rhizoiden. Stengelblätter sparrig-abstehend, aus verengter, etwas herablaufender Basis herz-eiförmig, kurz zugespitzt, bis etwa $2 \mathrm{~mm}$ lang und bis 1,5 mm breit, mit nur am Grunde schmal umgebogenen, rings gesägten Rändern: Rippe dünn, vor der Blattspitze endend; Zellen 1: 7-10, in der Blattspitze kürzer, in den ausgehöhlten Blattflügeln erweitert, rektangulär und länglichmehreckig, eine grosse Gruppe bildend. Innere Perichätialblätter halbseheidig, plötzlich in eine zurückgebogene, gesägte Pfrieme versehmälert. Seta $2-2,5$ cm, glatt. Kapsel aus deutlichem Halse länglich bis fast zylindrisch, kastanienbraun, trocken und entleert eingekrümmt. Sporenreife im Frühling.

Auf humosem Waldboden und am Grunde alter Stämme.

F. At. Jomala, Kasberg (Arrh.). Saltvik, an mehreren Fundorten (Bom.). Sund. Jussbōle (B.), - Ab. Pargas, Loftsdal (Elfr.). Kimito, Lappdal, Illo, Reku (Ols.). Lojo, Kı̀ilā (Hult). $-N$ Sjundeá (Nerr.). Kyrksıātt (Nyb.); Vitbāck (E. af H. und Sundr.) Helsingfors (Lindb ). Helsinge, Vanda (Sael.); Malm (Kot.). Borgå, Sundō (Jusl.); Haikko (Terāsv.). - Ik. Uusikirkko, Vammelsuu (H. Lindb.). Metsäpirtti, Tappari (H. L.). Pỵhäjärvi (Lång). - Ta. Hattula, Yli-Savijärvi (Ranck. und Weg.).

S. Sk. - Hlsl.

N. Sm. pass. A Kristiania fq. Bu. Hønefos und Haug. JL. Sandefjord fq., Holmestrand. Ne. Saetersdalen. SB. NB. Sogn: Svanø. ST. Levanger. No. Bronno und Alstahaug. Nordgrenze bei $65^{\circ}$ $57^{\prime} \mathrm{n}$. Br.

Europa. Algier, Kaukasus.

\section{BRYHNIA}

Kaur. in Bot. Notis. 1892 , p. 60.

Diözisch. Stengel ohne Stolonen. Stengelblätter weit lserablaufend, \pm holıl, unregelmässig längsfaltig, kurz oder länger zugespitzt: Rippe einfach, in oder über (ler Blattmitte endend; Zellen derbwandig, ehlorophyllreich, länglich-rhomboidisch oder länglich 6seitig, am Blattgrunde lockerer. Seta sehr rauh. Kapsel geneigt bis horizontal, hochrückig, derbhäutig. Deckel aus kegeliger Basis \pm deutlich kurz und rlick gesclınäbelt.

736. Bryhnia Novae Angliae (Sull. et Lesq.) Grout in Bull. Torr. Bot. Club Vol. 25, p. 229 (1898). [Hypnum Novae Angliae Sull. et Lesq. Musc. Bor. Am. 338 (1856). - Hypnum scabridum Lindb. in Bot. Notis. 1887, p. 41.]

Pfl. in lockeren, ausgedehnten, dunkelgrünen, glanzlosen Rasen. Stengel bis $10 \mathrm{~cm}$, niedergestrect: und bogig niederliegend, stellenweise mit Rhizoidenbüscheln, unterbrochen liederig beästet, in der Mitte der Rasen aufrechte und übergeneigte, bis $5 \mathrm{~cm}$ lange, oberwärts sich fast bäumchenartig verzweigende, später sich niederlegende Hauptsprosse: Äste bis $1 \mathrm{~cm}$ lang, abstehend bis niederwärts gebogen. Stengelblätter locker anliegend, sehr hohl, aus breit herablaufender Basis dreieckig-herzförmig, rasch kurz und meist schief zugespitzt, bis $1,4 \mathrm{~mm}$ lang und etwa ebenso breit, mit aufrechten, rings fein gesägten Rändern; Rippe grün, dünn; Zellen 1: $1-5$, am Rücken durch papillenartig vortretende Zellecken etwas rauh, in den kaum ausgehöhlten Blattflügeln zahlreiche kurz rektangulär. Innere Perichätialblätter länglich-eiförmig, rasch zu einer sparrig zurückgebogenen, gezähnten Pfrieme verschmälert. Seta $8-15 \mathrm{~mm}$. Kapsel hochrückig-oval, in die Seta verschmälert, bis $3 \mathrm{~mm}$ lang, kastanienbraun, trocken und entdeckelt unter der Mündung verengt. Sporenreife im Winter. - Fig. $100 \mathrm{~F}-\mathbf{K}$.

An Steinen in feuchten Laubwäldern, an sandigen Bachufern, am Fusse schattiger Felswände, auch in kalten Quellen und in Morästen ïber Ästen, Wurzeln und Laub.

N. Sm. an mehreren Fundorten. JL. Sandefjord, nicht selten. Tjomø. Kristiansand, Ravindalen. Japan, östliche Teile von Nord-Amerika. 


\section{RHYNCHOSTEGIELLA}

Limpr. Laubm. 111. p. 207 (1896).

Autözisch. Kleine Steinmoose. Stengel kriechend, unregelmässig beästet, ohne Stolonen. Stengel- und Astblätter nicht oder kaum differenziert, nicht oder kaum herablaufend, rinnig-hohl, ungefaltet, sehmal lanzettlich, flachrandig; Rippe einfach, \pm verlängert, am Rücken nicht als Dorn endend: Zellen eng prosenchymatisch, glatt, am Blattgruncle wenig verschieden, in den nicht ausgehöhlten Blattecken kaum differenziert. Seta S-förnig gekrümmt, meist rauh. Kapsel fast aufrecht bis horizontal, fast regelmässig; Zellen cles Exotheciums \pm kollenchymatisch verdickt. Deckel aus gewölbt kegeliger Basis lang und lein geschnäbelt.

\section{ìbersicht der Arten.}

A. Rippe vollständig oder fast vollständig.

a. Rasen rein- oder gelblichgrün, seidenglänzend. Blätter ganzrandig bis undeutlich gezähnelt; Zellen der Lamina 1: $10-15$. Seta glatt ....................... $7: 37 . R h$. algiriana.

b. Rasen (excl. Rh. curviseta) glanzlos.

«. Grïne Pfl. Blätter rings deutlich gezälnelt; Zellen der Lamina 1: $4-6$. Seta glatt .................. 7:38. Rh. compacta.

ß. Schmutzig- oder dunkelgrüne Pfl. Blätter stumpflich, ganzrandig oder gegen die Spitze entfernt gezähnelt; Zellen der Lamina 1: 3-5. Seta überall sehr rauh 740. Rh. Teesdalei.

B. Rasen grün bis gelblichgrün, etwas glänzend. Blätter ganzrandig oder an der Spitze undentlich gezähnelt: Rippe in oder vor der Blattspitze endend; Zellen der Lamina 1: 8-10. Seta überall rauh ...............................739. Rh. curviseta.

737. Rhynchostegiella algiriana (Brid.) Broth. in E.-P. I³. p. 1162 (1909). [Pterogynandrum algirianum Brid. Musc. rec. II. I. p. 65, t. 6, f. 7 (1798). - Hypnum lenellum Dicks. Pl. erypt. fase. IV. p. 16, t. 11, f. 12 (1801). - H. algirianum Bricl. Sp. musc. II. p. 162 (1812). - Rhynchostegium lenellum Bryol. eur. fasc. $49 / 51$ Mon. p. 5, t. 2 (1852).]

Pfl. in 士 dichten, flachen bis kissenförmigen, grünen oder gelbgrünen, trocken seidenglänzenden Rasen. Stengel mit spärlichen Rhizoiden, dicht mit aufrechten, bis $5 \mathrm{~mm}$ langen, federig beblätterten Ästen besetzt. Blätter aulrecht-abstehend, gegen die Stamm- und Astspitzen zuweilen einseitswendig schmal lanzettlichpfriemenförmig, bis $1,5 \mathrm{~mm}$ lang und bis $0.25 \mathrm{~mm}$ breit, ganzrandig bis undeutlich gezähnelt: Rippe dümn, meist weit in der Pfrieme erlöschend; Zellen 1: 10 15, am Blattgrunde wenige Reihen kurz rektangulär oder quadratisch. Innere Perichätialblätter aufrecht, zart, bleich, eilanzettlich. ganzrandig und ohne Rippe. Seta 6-12 mm, glatt. Kapsel aus kurzem Halse oval bis länglich, dünnhäutig, rötlichbraun, trocken und entdeckelt unter der erweiterten Mündung verengt: Zellen des Exotheciums dünnwandig, schwach kollenchỵatisch verdickt. Sporenreife im Frïhling. - Fig. $101 \mathrm{E}-\mathrm{I}$.

An Mauertrümmern und trockenen Felsen (Kalk und kalkhaltigen Gesteinen).

S. Öt., Gtl.. $O ̈ g$. und $V g$. an einzelnen oder wenigen Fundorten.

N. Sm. Onso. A. Kiristiania.

Europa, Madeira, Kaukasus, Sinai.

738. Rhynchostegiella compacta (C. Müll.) Loesk. Stud. p. 182 (1910). [Hypnum compactum C. Yü̈ll. Syn. II. p. 408 (1851). - Amblysteginm compactum Bryol. eur. fasc. 55/56, p. 11 in adnot. (1853). - Amblystegium salinum Bryhn in Nyt 
Mag. Naturv. Bd. 41, p. 47 (1903). - A. compactum var. salinum Moenkm. in litt.; Loesk. in Mag. Bot. Lap. 1911, p. 273.]

Grösse von A. serpens. Pfl. in sehr dichten, fast kissenförmigen, grünen Rasen. Stengel aufrecht oder aufsteigend, mit aufrechten Ästen. Stengelblätter aufrecht-abstehend, hohl, eilanzettlich, allmählich zugespitzt, bis $1 \mathrm{~mm}$ lang und bis $0,30 \mathrm{~mm}$ breit, flachrandig, rings deutlich gezähnelt: Rippe ziemlich dünn, vor der Blattspitze aufhörend: Zellen derbwandig, in der Blattmitte verlängert 6seitig, 1: 4-6, am Blattgrunde quadratisch und kurz rektangulär. Astblätter kürzer und schmäler. Seta $2 \mathrm{~cm}$, glatt. Kapsel aufrecht oder schwach geneigt, regelmässig oder fast regelmässig. trocken und entcleckelt unter der erweiterten Mündung etwas verengt: Zellen des Exotheciums derbwandig. Deckel kurz und bleich geschnäbelt. - Vegetative Vermehrung durch zylindrische, mehrzellige, papillöse, braune Brutkörper.

S. Gtl. Hoburg.

N. Sm., No $-F$. an wenigen Fundorten und nur am ILeeresufer.

England, Frankreich, Zentral-Europa, Nord-Amerika.

739. Rhynchostegiella curviseta (Brid.) Limpr. 1. c. p. 211. [Hypnum curvisetum Brid. Sp. muse. II. p. 111 (1812).]

Pfl. in weichen, dichten, flachen, freudig- bis gelblichgrünen, etwas glänzenden Rasen. Stengel auf kurze Strecken stoloniform, absatzweise mit langen, gelbroten Rhizoidenbüscheln, \pm regelmässig gefiedert: Äste bis $8 \mathrm{~mm}$, oft scheinbar zweizeilig beblättert. Stengelblätter aufrecht-abstehend, schmal eilanzettlich, scharf zugespitzt, bis 1,2 $\mathrm{mm}$ lang und bis $0,30 \mathrm{~mm}$ breit, ganzrandig oder an der Spitze undeutlich gezähnt; Rippe dünn, in oder wenig oberhalb der Blattmitte endend: Zellen dünnwandig. 1: $8-10$, am Blattgrunde rektangulär, in den Blattecken nicht quadratisch. Innere Perichätialblätter aufrecht, doppelt so lang wie das Scheidchen, breit eiförmig, lang und scharf zugespitzt, an der Spitze ausgeschweift gezähnt. Seta $5-8 \mathrm{~mm}$, geschlängelt, meist oben schwanenhalsartig gebogen, überall sehr rauh. Kapsel fast aufrecht bis horizontal, mit dem deutlichen Halse verkehrt-eilänglich, dünnhäutig, olivenfarben, im Alter bräunlich, trocken und entleert eingekrümmt, unter der Mündung verengt; Zellen des Exotheciums dünnwandig, stark kollenchymatisch. Deckel von Urnenlänge.

An beschatteten, feuchten Felsen.

N. Kristiania

West- und Süd-Europa, Madeira, Kanaren. Nord-Amerika,

740. Rhynchostegielia Teesdalei (Sm.) Limpr. 1. c. p. 217. [Hypnum Teesdalei Sm. Fl. brit. IIl. p. 1291 No. 20 (180-4).]

Pfl. in lockeren bis dichten, flachen, dunkel- bis schwarzgrünen, trocken starren und brüchigen, glanzlosen Rasen. Stengel mit spärlichen Rhizoidenbüscheln, locker beblättert, dicht mit bis $5 \mathrm{~mm}$ langen, spitzen Ästen. Stengelblätter weit abstehend bis zurückgebogen, eilanzettlich, bis $0,5 \mathrm{~mm}$ lang und etwa $0,15 \mathrm{~mm}$ breit, ganzrandig: Rippe zart. Astblätter derb und steif, aufrecht-abstehend, aus etwas schmälerer Basis länglich-lanzettlich und lanzettlich, mit stumpflicher Spitze, bis $0,75 \mathrm{~mm}$ lang und bis $0,25 \mathrm{~mm}$ breit, gegen die Spitze entfernt gezähnelt; Rippe dick, in der Blattspitze verflacht und erlöschend; Zellen derb, 1: $3-5$, in der äussersten Spitze länglich und kurz rhombisch, am tiefsten Blattgrunde rektangulär, in den Blattecken quadratisch. Innere Perichätialbłätter klein, aufrecht, lanzettlich, ganzrandig und ohne Rippe. Seta $5-8 \mathrm{~mm}$, überall sehr rauh. Kapsel verkehrt-ciförmig, derbhäutig, gelbbräunlich bis dunkelbraun, trocken und entdeckelt unter der erweiterten Miindung wenig verengt: Zellen des Exotheciums rings verdickt, stark kollenchymatisch.

An beschatteten, feuchten Steinen.

S. Gll, $O g$ und $\mathrm{Vg}$ an einzelnen Fundurten

Gross-Britannien, Frankreich, Italien, Algier, Kaukasus. 


\title{
146. RHYNCHOSTEGIUM
}

\author{
Bryol. eur. fasc. 19/51 Mon. ex p. (1852).
}

Autözisch. Stengel kriechend oder niedergestreckt, unregelmässig oder fierlerig beästet, meist ohme Stolonen. Stengelblätter und Astblätter nicht oder deutlich differenziert, nicht oder wenig herablaufend, \pm hohl, ungefaltet, meist \pm lang zugespitzt, mit nur an Grunde zurückgeschlagenen Rändern; Rippe cinfach, \pm verlängert, am Rücken nicht als Dorn endend; Zellen eng prosenchymatisch, glatt, am Blattgrunde küizer und weiter, in den schwach ausgehöhlten Blattflügeln kurz rektangulär und quadratisch. Seta aufrecht, glatt. Kapsel geneigt bis horizontal, schwach bis deutlich hochrückig; Zellen des Exotheciums nicht kollenchymatiscl. Deckel aus gewölbt kegeliger Basis lang und fein geschnäbelt.

\section{U bersicht der Arten.}

A. Lockerrasiges Erdmoos. Stengelblätter weit abstehend, pfriemenförmig zugespitzt 741. Rh. megapolitanum.

B. Dichtrasige Steinmoose.

a. Stengelblätter aufrecht-abstehend, wenig hohl, eiförmig,

\pm lang zugespitzt

712. Rh. confertum.

b. Stengelblätter dachziegelig, sehr hohl, länglich-oval, kurz zugespitzt oder abgerundet, mit Spitzchen, ganzrandig oder an der Spitze undeutlich gezähnt ....... 743. Rh. murale.

C. Starres Wassermoos auf Stein- oder Holzunterlage. Blätter kurz zugespitzt und rings gesägt

74. Rh. rusciforme.

741. Rhynchostegium megapolitanum (Bland.) Bryol. eur. 1. c. p. 8, t. 5. [Hypnum megapolitanum Bland. Muse. exs. III. No. 147 (1804).]

In der Tracht an Brachythecium curtum erinnernd. Pll. in lockeren, flachen, wenig zusammenhängenden, grünen bis gelbgrünen, matt glänzenden Rasen. Stengel bis $10 \mathrm{~cm}$, niedergestreckt und geschlängelt, mit spärlichen Rhizoidenbüscheln, locker beblättert, meist unregelmässig beästet; Äste von ungleicher Länge, $0,5-$ $3 \mathrm{~cm}$, schlaff, rundlich bis flach, zuweilen flagellenartig verlängert. Stengelblätter weit abstehend, fast flach, aus wenig herablaufender, enger Basis eiförmig oder länglich-eiförnig, rasch in eine häufig halbgedrehte Pfriemenspitze verschmälert, bis $2 \mathrm{~mm}$ lang und bis $1 \mathrm{~mm}$ breit, besonders oberwärts deutlich gezähnt; Rippe zart, fast $3 / 4$ des Blattes durchlaufend; Zellen 1: 8-12, am Blattgrunde lockerer, in den etwas ausgehölıten Blattflügeln zalılreiche quadratisch, kurz rektangulär und mehreckig. Innere Perichätialblätter scheidig, aus der Mitte rasch pfriemenförmig und zurückgebogell, ganzrandig oder schwach gezähnt. Seta $1,5-3 \mathrm{~cm}$. Kapsel oval bis zylindrisch, dünnhäutig, lederbraun, trocken und entdeckelt gekrümmt und unter der Mündung verengt.

An grasigen Plätzen.

S. Sk, und Öl. an einzelnen Fundorten.

Europa, Kanaren, Algier, Kaukasus, Syrien, Persien.

742. Rhynchostegium confertum (Dicks.) Bryol. eur. 1. c. p. 7, t. 4. [Hypnum confertum Dicks. Pl. crypt. fasc. IV. p. 17, t. 11, f. 1+ (1801).]

Pfl. in lockeren bis dichten, flachen, hell- oder dunkelgrünen, trocken \pm glänzenden Rasen. Stengel bis 3 oder $5 \mathrm{~cm}$, kriechend, mit zahlreichen Rhizoidenbüscheln, ziemlich locker beblättert, dicht und fast regelmässig fiederästig: Äste bis $1 \mathrm{~cm}$, ausgebreitet oder aufrecht, verflacht beblättert. Stengelblätter aufrechtabstehend, fast flach, aus verengter, nicht herablaufender Basis eiförmig, allmählich \pm lang zugespitzt, bis $1,5 \mathrm{~mm}$ lang und bis $0,6 \mathrm{~mm}$ breit, besonders oberwärts 
entfernt und klein gezähnt; Rippe zart, bis $3 / 4$ des Blattes durchlaufend; Zellen 1: 8-12, auch in der Blattspitze eng und verlängert, am Blattgrunde rektangulär, in den ausgehöh]ten Blattflügeln quadràtisch, kurz rektangulär und mehreckig. Innere Perichätialblätter aufrecht oder wenig zurückgebogen, scheidig, in eine lange, gesägte Pfrieme verschmälert. Seta $1-1,5 \mathrm{~cm}$. Kapsel aus kurzem, deutlichem Halse länglich, dünnhäutig, olivenfarben, später gelbbräunlich, trocken und entdeckelt gekrümmt und unter der Mündung stark verengt. Sporenreife im Winter.

An beschatteten, feuchten Steinen und Felsen allerlei Art.

N. Sm. Onsø. JL. Sandefjord. Ne. Holt.

Europa, Madeira, Azoren, Kanaren, Algier, Kaukasus, China.

743. Rhynchostegium murale (Neck.) Bryol. eur. 1. c. p. 10, t. 8. [Hypnum murale Neck. Del. Gallo-Belg. p. 479 (1768).]

Tracht von Rh. confertum. Pfl. in dichten, flachen bis polsterförmigen, dunkelbis gelbgrünen, zuweilen goldbräunlichen, glänzenden Rasen. Stengel $3-4 \mathrm{~cm}$, kriechend, mit zahlreichen Rhizoidenbüscheln, dicht beblättert und dicht beästet; Äste bis $7 \mathrm{~mm}$, aufrecht, dicht und rund beblättert, etwas geschwollen, stumpf oder spitz. Stengelblätter dachziegelig, sehr hohl, aus verengter, wenig herablaufender Basis länglich-oval, abgerundet, mit Spitzchen oder kurz zugespitzt, bis $1, t \mathrm{~mm}$ lang und bis $0,8 \mathrm{~mm}$ breit, ganzrandig oder an der Spitze undeutlich gezähnt: Rippe rasch verdünnt, in und über der Blattmitte endend; Zellen 1: 8-10, in der Blattspitze kürzer und breiter, am Blattgrunde in mehreren Reihen rektangulär und mehreckig. in den ausgehöhlten Blattflügeln locker, quadratisch, kurz rektangulär und mehreckig. Innere Perichätialblätter aufrecht oder oberwärts abgebogen, scheidig, in eine lange, meist ganzrandige Pfrieme verschmälert. Seta $1-2 \mathrm{~cm}$. Kapsel aus verengtem Halse länglich, derbhäutig, rotbraun, trocken und entdeckelt unter der Mündung \pm verengt.

An feuchten Felsen und Steinen.

N. Modum, Heggen. No. Fauskeejdet, am Fusse feuchter, schattiger Dolomitfelsen an mehreren Stellen in der Baumregion, oft reichlich, aber spärlich fruchtend. Nordgrenze bei $67^{\circ} 20^{\prime} \mathrm{n}$. Br.

Europa, Algier, Kaukasus, Syrien.

var. arcticum Hag. Musc. Norv. bor. p. 305 (1901).

Sehlanke, fast silberweisse, glänzende Pfl. Äste bis $1 \mathrm{~cm}$. Stengelbätter etwa $0,8 \mathrm{~mm}$ lang und $0,6 \mathrm{~mm}$ breit.

N. No. Skjerstad und sisfolden, bis $300 \mathrm{~m}$ hinaufsteigend.

744. Rhynchostegium rusciforme (Neck.) Bryol. eur. fasc. 19/51 Mon. p. 11, t. 9 (1852). [Hypnum rusciforme Neck. Del. Gallo-Belg. II. p. 481, No. 30 (1768). - H. ruscifolium Neck. in Act. acad. theod.-palat. II. p. 453 (1770).]

Kräftige Pfl. in lockeren bis dichten, starren. dunkel- oder gelbgrünen bis schwärzlichgrünen, glanzlosen oder etwas glänzenden Rasen. Stengel bis $10 \mathrm{~cm}$, selten länger, hingestreckt oder flutend, sehr zähe, nur am Grunde mit Rhizoiden, im unteren Teile entblösst, unregelmässig, oft büschelig verzweigt, zuweilen mit langen, bogig aufsteigenden, rund oder verflacht beblätterten Ästen. Stengelblätter aufrecht-abstehend, aus verengter Basis eiförmig bis länglich-oval, scharf oder stumpflich zugespitzt, bis $2,4 \mathrm{~mm}$ lang und bis $1 \mathrm{~mm}$ breit, mit aufrechten, rings gesägten Rändern; Rippe kräftig, nicht als Dorn endend, bis $3 / 4$ der Blattlänge; Zellen 1: 8-15, in der Blattspitze kürzer, am Blattgrunde zweischichtig, in den wenig ausgehöhlten Blattflïgeln kamm differenziert. Astblätter kleiner. Innere Perichätialblätter halbscheidig, in eine bogig abstehende, gesägte Pfriemenspitze verschmälert. Seta $7-15 \mathrm{~mm}$, glatt. Kapsel aus kurzem Halse hochrückig-eiförmig, lederbraun. Sporenreife im Herbst. - Fig. $102 \mathrm{~A}-\mathrm{D}$.

In fliessenden Gewässern an überrieselten Steinen und vom Wasser bespültem Mauer- und Holzwerk. 
F. Al. Jomala Kasherg (Nerv.) Ab Kimito, Kirehdurf (Ols.). Karis, Svartá (Jusl.). Karislojo, Särkijärvi (Sundv.). Vichtis, Palajärvi (Broth.); Olkkala (B.); Niemenkylä (Ifult). - St. Pirkkala, Nokia (Broth.). Hämeenkyrö, Kyröskoski (Nerv.). - Ta. Sääksnäki, Valkeakoski (Nerv.). Hollola, Mesailä (Norrl.). Kuhmoinen, Harmoin (X.). Tammerfors (Nerv.). - Tb. Jyväskyla. Tourujoki (Broth.). - Kon. Koselma (Simm.). - Ok. Ristijäri, Myllyjoki (Tennb.). - K. Kuusamo, Paanajärvi, Selkä-

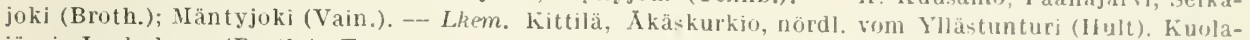
järvi, Laskukuru (Broth.). Tuntsanjoki, Enjanjoki (E. af H.): Enjanjoki, Sulahaara corv. (E. af H.).

S. Sk.-Gstr.

N. Sm. Onsø. A. Kristiania, nicht selten. Bu. Eker. Ringerike. JL. Sandefjord. R. rr NT stjordalen. No. Hatfjelddalen.

Europa, Kanaren, Algier, Sinai, Kaukasus, Luristan, Himalaya, Yunnan, Mandschurei, Japan, Nord-Amerika.

var. complanatum H. Schulz. in Kryptll. Schles. I. p. 86 (1876). [Hypnum rusciforme var. complanatum Tolf in Bih. K. Sv. Vet.-Ak. Handl. Bd. 16. Afd. IlI. No. 9, p. 87 (1891).]

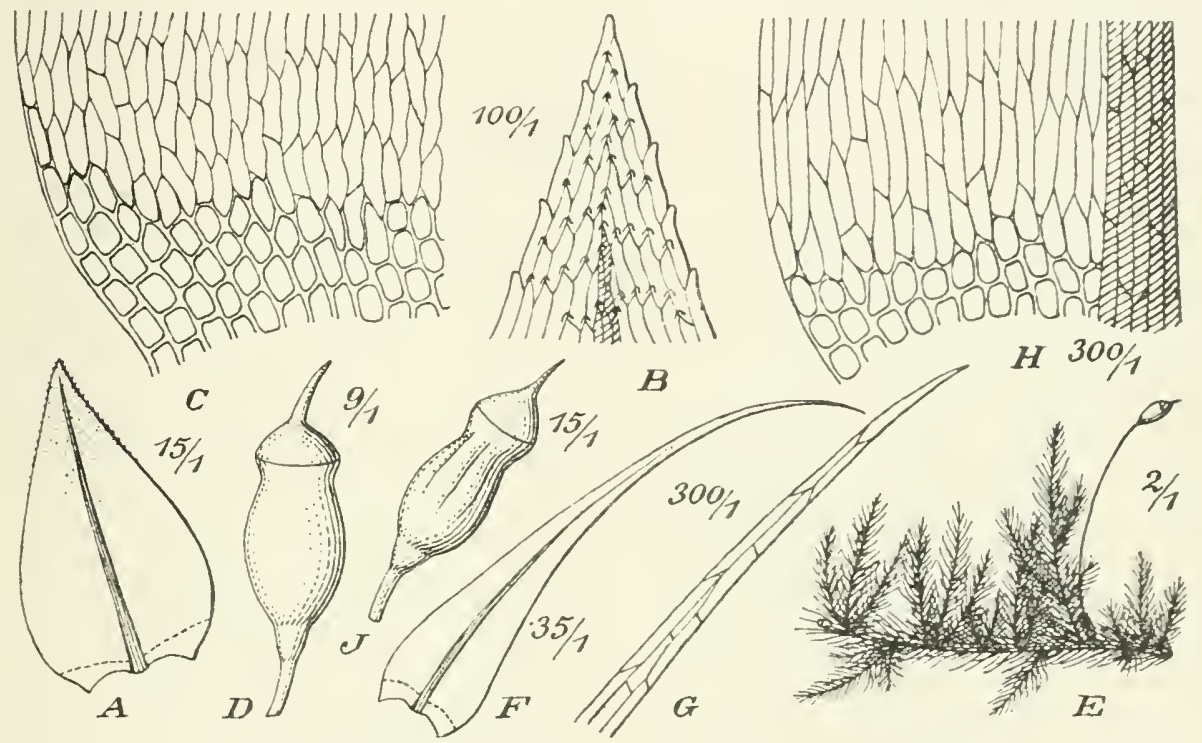

Fig. 102. A-D Rhynchostegium rusciforme (Neck). A Stammb. (15/1); B Blattspitze (100/1); C Blattbasis $(100 / 1)$; D Kapsel in trockenem Zustande (9/1). - - E-I. Rhynchostegiella algiriana (Brid.). E Fruchtende Pfl. (2/1); F Stammb. (35/1); G Blattspitze (300/1); H Blattlasis (300/1); I Kapsel in trockenem Zustande $(15 / 1)$.

Kräftige, grüne Pfl. Äste durch zweizeilig abstehende Beblätterung verflacht. Blätter flach, allmählich scharf zugespitzt.

S. Sm. Ankarsrum.

Europa.

var. lacustre Mos. in Öfr. K. Vet.-Ak. Förh. Bd. 27, p. 402 (1870). [Hypnum rusciforme var. lacustre Möl]. Fört. Sk. växt. 2. M[oss. p. 42 (1907).]

Kräftige, starre Pfl. Stengel bis $60 \mathrm{~cm}$, locker beblättert. Blätter weit abstehend bis zurückgekrümmt, eiförmig, kurz und scharf zugespitzt, mit nur am Grunde kleingesägten Rändern.

S. Srm. Stafsjön, in einer Tiefe ron wenigitens $2 \mathrm{~m}$ eine Fläche von etwa $3,000 \mathrm{~m}^{2}$ bedeckend.

\section{FABR O N I C E A E.}

Schlanke bis sehr schlanke, weiche, rasenbildende Banm-, selten Felsmoose. Stengel im Querschnitt rund, ohne Zentralstrang, aus gleichartigen, dünnwandigen oder wenig verdickten Zellen gebildet, kriechend, mehrteilig, mit aufrechten, dicht 
beblätterten Ästen; Paraphyllien fehlend. Blätter mehrreihig, eiförmig oder eilanzettlich, 士 lang zugespitzt, flachrandig; Rippe einfach, aus gleichartigen Zellen gebildet, selten fehlend; Zellen in der Mehrzahl prosenchymatisch, glatt, in den Blattecken quadratisch und querbreiter. Autözisch oder diözisch; O’ Blüten knospenförmig, mit spärlichen Paraphysen; 우 Blüten nur am Hauptstengel. Perichätialblätter differenziert. Seta verlängert, aufrecht, meist glatt. Kapsel aufrecht und regelmässig, oval bis fast zylindrisch, kurz- und dickhalsig: Spaltöffnungen oberflächlich im Halsteile. Haube kappenförmig. Sporen klein.

$$
\text { Übersicht der Gat tung en. }
$$

A. Diözisch. Blätter pfriemenförmig zugespitzt; Rippe fehlend. Inneres Peristom fehlend ........................ 147. Habrodon.

B. Autözisch. Blätter kurz zugespitzt; Rippe vorhanden. Peristom doppelt 118. Helicodontium.

\section{HABRODON}

Schimp. Syn. ed. 1, p. 505 (1860).

Diözisch. Pfl. in niedergedrüclten, bräunlichgrünen, glanzlosen Rasen. Stengel kriechend, mit spärlichen, gelbroten, glatten Rhizoiden; ̈̈ste kurz, selten mit einzelnen Ästchen. Blätter sparrig-abstehend, trocken anliegend bis dachziegelig, hohl, aus ovalem oder eiförmigem Grunde \pm lang pfriemenförmig, mit meist ausgefressen-gezähnelten Rändern; Rippe fehlend oder schwach angedeutet; Zellen verdickt, rhombisch, in der Mitte des Blattgrundes rhomboidisch bis verlängert und hier gegen die Ränder in schiefen Reihen, mehrere Randreihen quadratisch. Perichätialblätter aufrecht, nicht scheidig, die inneren verlängert, lang zugespitzt, ausgefressen-gezähnelt, alle Zellen verlängert. Seta $3-7 \mathrm{~mm}$, dünn, rot oder gelb. Kapsel oval-länglich, dünnhäutig, Lrocken längsfurchig. Ring mehrreihig, leicht sich abrollend. Inneres Peristom fehlend. Peristomzähne 16, gleichweit gestellt, linealisch, oft zweispitzig, ungesäumt, glatt; Dorsalschicht weisslich, querstreifig, entfernt gegliedert: Ventralschicht dicker, meist gelblich, mit genäherten Querbalken. Deckel kegelig, gerade und stumpflich. Sporen $10-14 \mu$, gelblichgrün bis bräunlich, fast glatt. - Vegetative Vermehrung durch elliptische, 4-5stöckige, stengelhijrige Brutkörper.

Einzige Art:

745. Habrodon perpusillus (De Not.) Lindb. in Öfr. K. Vet.-Ak. Förh. XX. p. 401 (1863). [Plerogonium perpusillum De Not. Spicil. p. 12, No. 22 (1837).]

An Baumstämmen.

N. St. Ryfylke. NB. Bergen, an Ulmen.

Gross-Britannien, Portugal, Süd-Frankreich, Italien, Dalmatien, Algier, Nord-Amerika.

\section{HELICODONTIUM}

Schwaegr. Suppl. III. P. II. p. 2 (1824).

Autözisch. Pfl. in dunkelgrünen, glanzlosen Rasen. Stengel kriechend, mit spärlichen, glatten Rhizoiden; Äste kurz und aufrecht, zuweilen länger und herabgekrünmit. Blätter abstehend, trocken anliegend, etwas herablaufend, hohl, kurz zugespitzt; Rippe vorhanden; Zellen nicht verdickt, rhombisch, gegen den Blattgrund allmählich länger und hier gegen die Ränder in schiefen Reihen, einige Randreihen quadratisch. Innere Perichätialblätter anliegend, scheidig, \pm lang zugespitzt. Kapsel dünnhäutig, trocken glatt. Peristom doppelt, beide gleichlang. Peristomzähne lanzettlich, gesäumt: Dorsalschicht gelblich, fein papillös, gestreift; 
Ventralschicht dicker, weisslich, glatt, mit diclit gestellten Querbalken. Inneres Peristom sattgelb bis gellorot, fein papillös; Grundhaut kielfaltig, \pm weit vortretend; Fortsätze schmal lanzettlich, gekielt.

746. Helicodontium pulvinatum (Wahlenb.) Linclb. Musc. scand. p. 37 (1879). [Leskea pulvinata Wahlenb. Fl. lapp. p. 369 (1812). - Myrinia pulvinala Schimp). Syn. p. 483 (1860).]

Pll. in dichten, fast kissenförmigen Rasen. Blätter eiförnig und eilanzettlich, schief und stumpflich zugespitzt bis stumpf, bis $0,75 \mathrm{~mm}$ lang und $0,10 \mathrm{~mm}$ breit, ganzrandig; Rippe zart, höchstens bis zur Blattmitte fortgesetzl. Innere Perichätialblätter allmählich lang und scharf zugespitzt, ganzrandig, alle Zellen verlängert. Seta $6-8$ mm, fleischfarben, trocken links gedrelıt. Kapsel länglich bis fast zylindrisch, bis $2 \mathrm{~mm}$ lang und bis $0,9 \mathrm{~mm}$ dick, bleiclıbraun, entleert zuweilen leicht gekrümınt, trocken glatt, unter der Münchung eingeschnürt. Ring nicht differen-

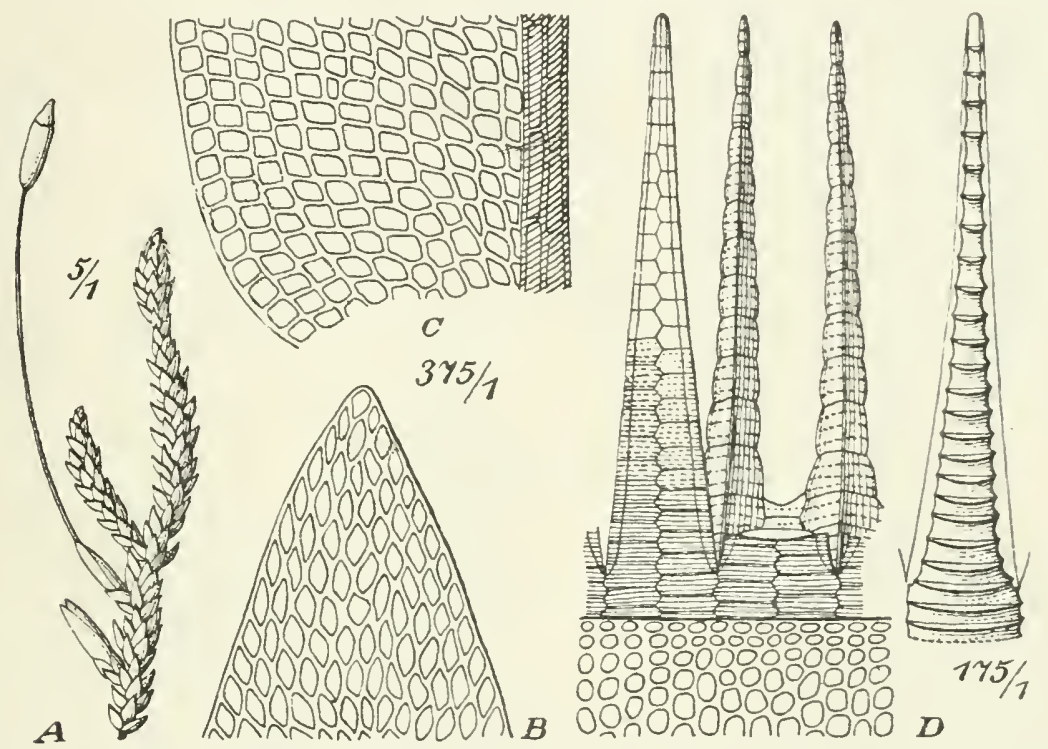

Fig. 103. Helicodontium pulvinatum (Wahlenb.). A Fruchtende Pfl. (5/1); B Blattspitze (375/1); C Blattbasis $(375 / 1)$; D Peristom $(175 / 1)$.

ziert. Wimpern fehlend. Deckel kegelig, stumpf. Sporen 12-18 “, rostbraun, warzig. Sporenreife in Mai und Juni. - Fig. 103.

An feuchten Orten am Grunde von Stämmen und an Zweigen, besonders von Weiden und Birken.

F. Ab. Uskela (Nikl.), - Ka Wiborg (11. Nyl.). - K. Kuusamo, Korojoki (Broth.). - Lkem. Kittilä, Kirchdorf (Hult); zw. Muonio und Ylikylä (Norrl.). - Li. Inari, Sompiojärvi, Pihtijoki und Riesto (Hult). Törmānen (Vain.).

S. Vrm. Karlstad.

N. Ringerike, an mehreren Fundorten. Sandefjord. Hadeland. Gudbrandsdalen. Ringeboe. Dorre. Gross-Britannien, Frankreich, Russland, Sibirien, Nord-Amerika.

\section{E N T OD O T A C E A E.}

Rasenbildende, \pm glänzende Baum- und Felsenmoose. Stengel im Querschnitt rund bis oval, ohme oder mit armzelligem Zentralstrang. mit hyalinem Grundgewebe und mehrschichtigen, verdickten Nantelzellen, kriechend oder niederliegend bis aufrecht, dicht und rund bis verflacht beblättert: Paraphyllien feh- 
lend. Blätter mehrreihig, zuweilen unsymmetrisch, von wechselnder Form; Rippe fehlend oder zart, aus homogenen Zellen gebildet, meist doppelt angedeutet; Zellen prosenchymatisch, rhomboidisch bis linealisch, glatt, selten papillös vortretend, in den Blattecken (excl. Orthothecium) differenziert. Blüten stengel- und astständig, mit fadenförmigen Paraphysen; ơ Bl. Bl. kiein, knospenförmig; f Bl. an sehr kurzen, meist wurzelnden Perichätialästen. Seta veriängert, glatt. Kapsel aufrecht, regelmässig, glatt; Spaltöffnungen oberflächlich, spärlich im Halsteil. Peristom doppelt. Grundhaut des inneren Peristoms niedrig; Fortsätze schmal; Wimpern rudimentär oder fehlend. Deckel aus kegeliger Basis \pm lang gesclmäbelt. Deckel aus kegeliger Basis \pm lang geschnäbelt. Haube kappenförmig.

\section{Üb e r s c h t d e r G a t t ungen.}

A. Blattflügelzellen nicht differenziert; Zellen der Lamina eng linealisch, geschlängelt, glatt

149. Orthothecium.

B. Blattflügelzellen differenziert.

a. Blattzellen glatt.

«. Blätter stumpf oder mit Spitzchen, am Grunde verengert, flachrandig oder mit nur am Grunde umgebogenen Rändern ................................. ॐ. Blätter lanzettlich zugespitzt, am Grunde nicht verengert, mit weit hinauf umgebogenen Rändern..... 150. Platygyrium.

b. Obere Blattzellen papillös vortretend .................. 152. Pterygynand-

rum.

\section{ORTHOTHECIUM}

Bryol. eur. fasc. 48 Mon. (1851).

Diözisch; beiderlej Blüten zahlreich, am Hauptstengel oder am Grunde sckunclärer Sprosse. Kalkliebende, meist alpine, seidenglänzende Felsmoose. Hauptstengel niederliegend, z. T. stoloniform, mit spärlichen Rhizoiden und meist verlängerten, einfachen oder unregelmässig verzweigten sekundären Sprossen. Blätter aufrecht-abstehend bis einseitswendig, nicht herablaufend, hohl, \pm lang zugespitzt, ganzrandig; Rippe sehr kurz und doppelt oder fehlend; Zellen eng linealisch, geschlängelt, meist getüpfelt. am Grunde kürzer und lockerer, in den Blattecken nicht differenziert, an der Insertion gelb oder gelbrot. Kapsel aufrecht oder schwach geneigt, regelmässig. Ring differenziert, sich ablösend. Peristomzähne lanzettlich-pfriemenförmig, flach, bleichgelb, gesäumt. querstreifig. Inneres Peristom gelblich, Grundhaut \pm weit vortretend: Fortsätze lanzettlich-pfriemenförnig. ritzenförmig durchbrochen. Sporen klein.

$$
\text { ¿'bersicht der Arten. }
$$

A. Kleinere Pfl. Blätter nicht oder schwach faltig.

a. Blätter lanzettlich-pfriemenförmig, flachrandig ....... 747. O. intricatum.

๖. Blätter eilanzettlich, mit kurzem Spitzchen und umgebogenen Rändern .................................... 7.18. O. strictum.

B. Grössere Pfl. Blätter tief längsfaltig.

a. Blätter allmählich lang pfriemenförmig .............. 750. 0. rufescens.

b. Blätter kurz gespitzt ........................... 749. O. chryseum.

747. Orthothecium intricatum (Hartm.) Bryol. eur. fasc. 48 Mon. p. 4, t. 2 et 3 (1851). [Leskea intricata Hartm. Sk. fl. ed. 5, p. 336 (18.19). - Leskea subrufa 
Wils. Bryol. brit. p. 33† (1856). - Stereodon subrujus Lindb. Musc, scancl. p. 38 (1879).]

Schlanke Pfl. in verwebt-lockeren, freudig- oder olivengrünen, selten rötlichen Rasen. Sekundäre Sprosse bis $4 \mathrm{~cm}$, bald kurz und aufrecht, bald verlängert und niederliegend, am Grunde mit absteigenden Stolonen. Blätter olıne Falten, meist etwas einseitswenrlig, lanzettlich-pfriemenförmig, bis $2 \mathrm{~mm}$ lang und $0,45 \mathrm{~mm}$ breit, flachrandig; Zellen der Blattmitte 1: 8-12. Innere Perichätialblätter eilanzettlich, an der fast gestutzten und gezähnten Spitze in eine geschlängelt-ab)stehende, lange Pfrieme verschmälert. Seta $1,5-2 \mathrm{~cm}$, rot. Kapsel eilänglich. gelbgrün, entleert weitmünclig, rotbraun. Peristomzähne olne entwickelte Lamellen. Wimpern fehlend. Deckel kegelig.

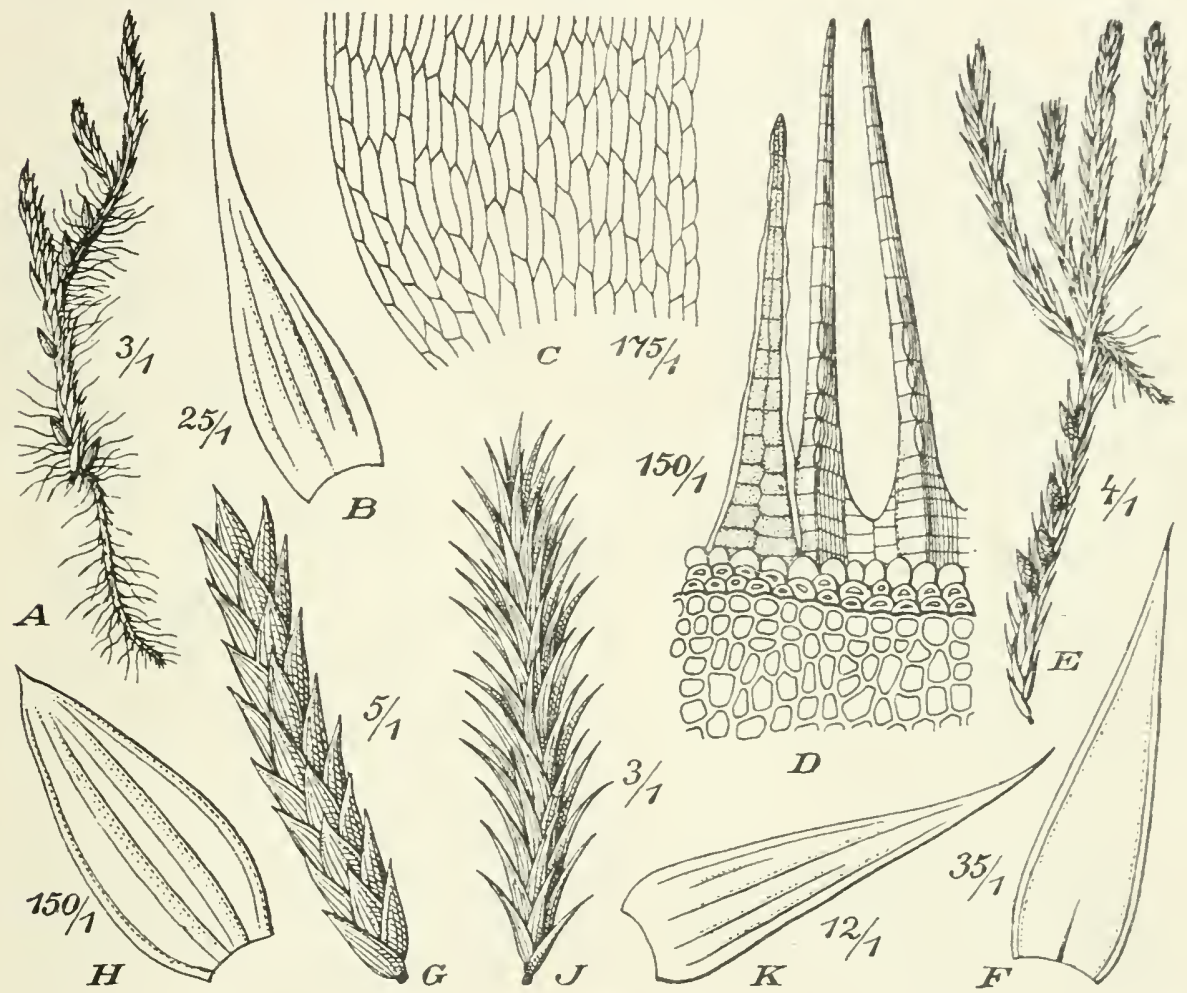

Fig. 104. A-C. Orthothecium intricatum (Hartm.). A Sterile Pfl. (3 1); B stengelb. (25/1); C Blatbasis (175/1). - D Peristom (150/1). - E-F. O. strictum Lor. E Sterile Pfl. (4/1); F Slengelb. (35,1). - GH. O. chryseum (Schwaegr.). G Stengelstückchen in trockenen Zustande (5 1); H Stengelb. (15/1). I-K. Orthothecium rufescens (Dicks.). I Stengelstïckchen im trockenen Zustande (3/1); K Stengelt. (12/I). (D nach L i m r i c ht.)

In erderfüllten Felsenspalten, in Klüften und an Absätzen, besonders kalkhaltiger Gesteine. Selir selten fruchtend.

S. Gul., Ög., Hrjd., Jmt. und LuL. an einzeInen oder wenigen Fundorten.

N. A. Kristiania r. Ringerike r. $\triangle B$. an mehreren Fundorten. $Y B$. Sugn, Aurland. $R$. an wenigen Fundorten. $K$. Jotunfjeldene. $N^{\top} T$. Stjordalen. $v_{0}-F$, nicht selten in der Baunregion, oberhalb der Baumgrenze weniger hăufig.

Europa, Kaukasus, Kaschmir und Pendschab, Rocky MIts.

748. Orthothecium strictum Lor. Moosstud. p. 122, t. 5 (1S64). [Stereodon rubellus Mitt. in Journ. Linn. Soc. VIII. p. 40 (1S64). - Orthothecium rubellum Kindb. Laubm. Schwed. und Norv. p. 46 (1883).] 
Schlanke Pil. in dichten, zuweilen ausgedehnten, goldgelben bis goldbräunlichen Rasen. Stengel aufrecht, bis $4 \mathrm{~cm}$. Blätter ohne Falten, aufrecht, eilanzettlicl, mit kurzem Spitzchen, bis $1,4 \mathrm{~mm}$ lang und bis $0,56 \mathrm{~mm}$ breit, mit bis zur Spitze umgebogenen Rändern: Zellen 1: 6, an der Spitze 1: 2-4. Sporogone unbekannt. - Fig. $104 \mathrm{E}-\mathrm{F}$.

In Felsspalten und auf humusbedeckten Felsen.

F. K. Kuu*amo. Merenoja (Broth.); Paanajärvi (B.); Kitkajoki. Lammasruoma (B.). - Le. Kilpisjărvi, Saana. in der alpinen Region (Kot.). - Lim. Hibinä (Broth.). - Lp. Katschkova (B.). Rusiniha zw, Ponoj und Orlor (B.).

S. Hrjd. Ramansberget. Jmt. Areskutan. LuL. Kaddepahta. Sarekgebiet.

N. Dovre. No, an mehreren, $T r$. und $F$. an wenigen Fundorter, bis in die untere alpine Region hinaufsteigend.

Franz Josephs Land. Spitzbergen, Beeren Eiland, Alpengebiet, Tibet, Turkestan, arkt. NordAmerika,

749. Orthothecium chryseum (Schwaegr.) Bryol. eur. 1. c. p. 3, t. 2. [Hypnum chryseum Schwaegr. in Schult. Reise auf d. Glockner lI. p. 364 (1804). Leskea chrysea Hartm. Sk. Fl. ed. 6, p. 365 (1854). — Stereodon chryseus Mitt. in Journ. Limn. Soc. VIII. p. 39 (1861).]

Weniger kräftige Pll. in oft ausgedehnten, leicht zcrfallenden, goldgrünen oder goldstrohfarbenen Rasen. Sckundäre Sprosse bis $10 \mathrm{~cm}$, aufrecht oder aufsteigend. Blätter tief 4faltig, aufrecht-abstehend, trocken dicht dachziegelig, ovallänglich, kurz zugespitzt oder mit einzellreihigem Spitzchen, bis $3,3 \mathrm{~mm}$ lang und bis $0.75 \mathrm{~mm}$ breit. mit rings umgerollten Rändern; Zellen der Blattmitte 1: 12-14. Innere Perichätialblätter scheidig, aus der Nitte der tief und spitz zweilappigen Spitze pfriemenförmig, oberwärts gezälnt. Seta $2,5-3 \mathrm{~cm}$, röllichgelb. Kapsel eilänglich, bleichbräunlich, trocken und entleert leicht gekrümmt und unter der erweiterten Iündung stark verengt. Peristomzähne mit gut entwickelten Lamellen. Wimpern gut entwickelt, nicht knotig. Deckel gewölbt, mit Spitzchen. Fig. $104 \mathrm{G}-\mathrm{H}$.

An feuchten Schiefer- und Kalkfelsen, zuweilen auch an mooriger Erde und an Bächen. Selten fruchtend.

F. K. Kuusamo, Paanajärri, Kuoppaoja (Tain.). - Le. Karesuanto und Hetta (Norrl.); Palojoki (N.); zw. Kilpisjärvi und Allipahta (N.); Malla, Megapahta und Saana (Kot.).

S. Hrjd., Jmt., PL. und $T L$. an einzelnen oder wenigen, $L u L$. an mehreren Fundorten, am reichlichsten in der alpinen Region.

N. Dorre. Lomseggen. No.-Tr., in allen Höhenlagen und ziemlich verbreitet. F. Kistrand.

Spitzbergen, Beeren Eilud, Alpengebiet, Tibet, arktische und westliche Teile von Nord-Amerika.

var. lapponicum (Sehimp.) Lindb. in Meddel. Soc. Fauna Fl. Fenn. 13. Heft, p. 254 (1886). [Brachythecium (?) lapponicum Schimp. Syn. p. 697 (1860). - Leskea lapponica Lindb. in Öfv. K. Vet.-Ak. Förl. 1866, p. 543. - Orthothecium lapponicum Hartm. Sk. Fl. 10. ed. p. 29 (1871). - Stereodon lapponicus Lindb. Musc. scand. p. 38 (1879).]

Schlanker als die Stammform. Blätter länglich-lanzettlich, rasch zu einem Spitzchen zusammengezogen, flachrandig.

S. PL. Tjidtjakk, in einem Schneebache.

750. Orthothecium rufescens (Dicks.) Bryol. eur. 1. c. p. 3, t. 1. [Hypnum rufescens I)icks. Pl. crypt. fase. III. p. 9, t. 8, f. 4 (1793). - Leskea rufescens Schwaegr. Suppl. I. P. II. p. 178, t. 86 (1816). - Stereodon rufescens Mitt. in Journ. Linn. Soc. VIII. p. 40 (1864).]

Kräftige Pfl. in oft ausgedehnten, schwellenden, rötlichen bis rostbraunen Rasen. Sekundäre Sprosse bis $8 \mathrm{~cm}$, niederliegend oder aufsteigend, selten aufrecht. Blätter tief mehrfaltig, aufrecht-abstehend bis einseitswendig, verlängert lanzettlich, allmählich lang und fein zugespitzt, bis $4,5 \mathrm{~mm}$ lang und bis $0,8 \mathrm{~mm}$ breit, mit fast spiralig umgerollten Rändern: Zellen 1: 15-20. Innere Perichätialblätter aus fast scheidiger Basis in eine geschlängelte Pfrieme verschmälert. Seta 
$2-3,5 \mathrm{~cm}$, rot. Kapsel verlängert länglich, gell)lıäunlich. I'eristomzähne olne entwickelte Lamellen. Wimpern rudimentär. Deckel kegelig, kurz und dick geschnäbelt. Sporenreife im August.

An nassen, meist beschatteten Kalkfelsen und kalkhaltigen Gesteinen.

F. K. Kuusamo, Kulmakkapuro zw. Paanajärvi und Sovajarvi (E. af II.).

S. Hrjd. Midtåkläpparne, LuL, an mehreren Fundurten.

N. Ringerike rr. A. Kristiania, $S B$, an mehreren l'undorten. R. Fraenen, Troldkirke. $K$. Dovre. $N T$. Stjordalen. Yo.-Tr. nicht selten, jedoch nur au wenigen Orten die Baungrenze übersteigend. F. Kistrand. Nordgrenze bei $70^{\circ} \mathrm{n} . \mathrm{Br}$.

Gross-Britannien, süddeutsche Berg- und Alpenland, Silirierı.

\section{PLATYGYRIUM}

Bryol. eur. fasc. $46+47$ Mon. (1851).

Diözisch. Stengel kriechend, durch meist kurze, kätzehenartige Äste unrege]mässig gefiedert. Astblätter feucht aufrecht-abstehend, holn, trocken dachziegelig, ei- bis länglich-lanzettlich, mit schmal zuruickgebogenen, glatten Rändern; Zellen eng linealisch. Kapsel länglich bis zylindriseh. King in einzelnen Zellen odler stïckweise sich ablösend. Peristomzälne dicht an der Iündung inseriert, dunkelgelb, breit gesäumt, dicht papillös, mit dicken ventralen Querleisten. Fortsätze schmal linealisch, gelb, ritzenförmig durehbrochen oder klaffend. Deckel aus kegeliger Basis kurz gesehnäbelt. Haube etwas gedreht, lis zum Halse herabreichend.

751. Platygyrium repens (Brid.) Bryol. cilr. fasc, $46+47$ Mon. p. 4, t. 1 (1851). [Hypnum palatinum Neck. in Act. Acad. Theod.-palat. II. p. 45.4 exc] syn., t. 1. f. 1 (1770). - Pterigynandrum repens Brid. Sp. musc. I. p. 131 (1806). - Entodon palatinus Lindb. Musc. scand. p. 39 (1879).]

Schlanke Pfl. in flachen, dichten, freudig grïnen, gold- bis braungrünen, trocken stark glänzenden Rasen. Äste meist aufrecht und stumpf, $3-5 \mathrm{~mm}$, seltener länger. Stengelblätter meist einseitig nach oben gerichtet, bis $1,2 \mathrm{~mm}$ lang und etwa $0,4 \mathrm{~mm}$ breit. Perichätialblätter lanzettlich, oberwärts schwach gezähnt. Seta $1-1,5 \mathrm{~cm}$, rot. Kapsel etwa $2-3 \mathrm{~mm}$ lang und bis $0,75 \mathrm{~mm}$ dick, gelbbräunlich, zuletzt rötlich. Sporen 12-15, selten bis $18 \mu$. gelbbräunlich. papillös. Sporenreife im Mai und Juni. - Vegetative Vermehrung durch kurze, meist sehr zahlreiche, gegen das Ende der Äste stehende Brutästehen.

Am Gruncle von alten Bäumen, seltener an Felsen.

F. Al. Jomala (Arrh.). Saltvik und Sund pass. (Bom.). - Ab. Abo, Runsala (Elfv.). Tskela, Linnamäki (Lindb.). Karislojo. Karkkali (Buch). Lojo, Kiviniemi und Pietilä (Lindb.): Kuulukainen (Sundv.). - N. Karis, Fagervik (Lindb.). Esbo, Grāsa (Broth.). Helsingfors (Lindb.). - Ka. Wiborg (Vain.). Antrea, Papinsaari (Lind.). Jāāski, Ahola (L.). - Ik. Valkjärøi, Pāhkināmāki (H. Lindb.). Konnitsajoki, an der Grenze zw. Pỵājärvi und Rãisalä (H.L.). Pyhäjärvi, Tiurinkỵlā (Lảng).-St. Y'lōjärvi, Pengonpohja (Sol.). - Ta. Tavastehus (Liadb.). In südôstl. Teile an mehreren Fundorten (Yorrl.). Słysmā, Ohrasaari (Renqr.). Hartola (Bonsd.). - Sa. Saritaipale, Kuulimojărvi, Luotolahti (Buch). - $k l$. Kurkijoki (Jusl.). Sortavala, Kirjavalahti (Lindb.). Soanlahti, Koirinvaara (Broth.). Pālkjärvi (B.). - Kol. Humbaritsa und Vosnessenje (Elfr.). - Tb. Jyväskỵlă, Tourujoki (Broth.). — Sb. Kuopio, Suuvu (Link.). Naauinka, Tuovilanlahti, Arkkuvuori (Roiv.); Pōljā, Kịipuro (Ky̧̧hk.). - Ko. Tohmajârvi, Niirala (Broth.). - Kon. Kentjärvi (Norll.). Koselma (Simm.). - Ok. Kajana (Broth.). - K. Pudasjàrvi, Pirrivaara (B.). - Lkem. Kittilă, Ākāslompolo (Hult).

S. Sm., Ög., Boh., V'g., När., Srm., Upl. Irml. und Hlsl.

N. Sm. r. A. Kristiania, nicht selten. Ringerike pass. JL. Sandefjord. Laurvig K. Lom. Ne. Saetersdalen.

Europa, Algier, Kaukasus, Persien, Sibirien, Nord-Amerika.

\section{ENTODON}

C. Müll. in Bot. Ztg. 1844, p. 740 .

Stengel niedergestreckt, selten aufsteigend oder aufrecht, zweizeilig beästet, meist \pm deutlich verflacht beblättert; Äste abstehend, einfach. Blätter sehr hohl, 
eilänglich bis eilanzettlich, stumpf oder mit Spitzchen, flachrandig oder mit nur an den Blattflügeln zurückgeschlagenen Rändern. Kapsel länglich bis zylindrisch. Peristomzähne ticf inseriert, nicht oder schmal gesäumt, oben gelb, rot, mit wenig entwickelten Lamellen; Fortsätze etwa halb so breit wie die Zähne.

752. Entodon orthocarpus (La Pyl.) Lindb. Musc. scand. p. 39 (1879). [Hypnum orthocarpum La Pyl. Mser. in Brid. Bryol. univ. II. p. 422 (1827). - Hypnum concinnum De Not. Mant. No. 18 (1835). — Entodon Montagnei C. Müll. in Linnaea XVIII. p. 708 (1844). — Hypnum Montagnei Hartm. Sk. Fl. 7. ed. p. 318 (1858). - Cylindrothecium concinnum Schimp. Syn. p. 515 (1860).]

Diözisch. Ziemlich kräftige, starre Pfl. in lockeren bis dichten, leicht zerfallenden, meist gelbgrünen bis goldbräunlichen Rasen. Stengel niederliegend b:s aufrecht, bis $10 \mathrm{~cm}$, selten länger, fast ohme Rhizoiden, dicht und regelmässig ge-

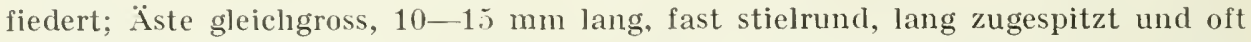
gekrümmt. Blätter aufrecht-abstehend, trocken dachziegelig, eiförmig bis eilänglich, stumpf, bis 2,5 mm lang und bis $1 \mathrm{~mm}$ breit, ganzrandig. Innere Perichätialblätter aufrecht, röhrig-scheidig, lang zugespitzt. Seta $1,5 \mathrm{~cm}$, rot. Kapsel zylindrisch, etwa $3 \mathrm{~mm}$ lang und $0,66 \mathrm{~mm}$ dick, braun. Ring bleibend. Peristomzähne unten querstreifig. in der Mitte schräg und senkrecht gestreift, oben fast glatt. Fortsätze ritzenförmig durchbrochen. Deckel kegelig. Sporen $14-17 \mu$, gelb, papillös.

Auf Kalkboden und an trockenen Schiefer- und Kalkfelsen. Sehr selten fruchtend.

S. Gtl., Vg. Upl. Uppsala. Steril.

N. A. Kristiania. NB. Aurland. R. Geiranger. ST. Levanger. Dovre. NT. Stjordalen. No. An wenigen Fundorten der Baumregion. Tr. Tromsasundet. Steril. Nordgrenze bei $69^{\circ} 40^{\prime} \mathrm{n}$. Br.

Europa, Kaukasus, Persien, Turkestan, Sibirien, Nord-Amerika.

\section{PTERYGYNANDRUM}

Hedw. Deser. IV. fasc. I (1793) emend. Bryol. eur. fasc. 4647 Mon. (1851).

Diözisch. Hauptstengel zum grössten Teil stolonenartig. Sekundäre Sprosse aufsteigend, am Grunde stoloniform, fieder- bis büschelästig, zuweilen auch einfach oder gabelteilig; Paraphyllien spärlich. Laubblälter fast aufrecht, trocken dachziegelig, sehr hohl, kurz herablaufend, aus etwas verengter Basis eiförmig. kurz und meist scharf zugespitzt, mit längs umgebogenen, in der oberen Hälfte fein gesägten Rändern; Rippe kurz, einfach, gabelig oder doppelt; Zellen rhomboidisch, mit deutlichen, auf dem Blattrücken mit fast zitzenförmigen Papillen besetzten Eckverdickungen. Liapsel zylindrisch. Ring sich mit dem Deckel zugleich ablösend. Peristomzähne am Grunde verschmolzen, bleich oder gelblich, glatt, am Grunde mit Quer- und Schrägstrichelung, ohne Lamellen. Inneres Peristom bleich: Grundhaut nicht vortretend; Fortsätze selır schmal, \pm entwickelt. Deckel aus kegeligem Grunde kurz und meisi schief geschnäbelt.

753. Pterygynandrum filiforme (Timm) Hedw. Descr. IV. p. 18, t. 7 (1793). [Hypnum filiforme Timm Prodr. fl. megap. No. 817 (1788). - Pterygynandrum decipiens * Pt. filiforme Lindb. Musc. scand. p. 37 (1879).]

Schlanke Pfl. in flachen, dichten, grünen oder gelbgrünen bis gebräunten Rasen. Sekundäre Sprosse nach einer Richtung aufsteigend, dann bogig niedergestreckt, flagelliform sich verlängernd, Rhizoiden entwickelnd und im Weiterwachsen in normale Stengel übergehend. Niederblätter klein, bleich, lanzettlich. Laubblätter bis $0,75 \mathrm{~mm}$ lang und $0,3 \mathrm{~mm}$ breit. Innere Perichätialblätter bleich, aufrecht, breit lanzettlich, allmählich zugespitzt, flach- und ganzrandig. Seta etwa $8 \mathrm{~mm}$, rot oder gelbrot. Kapsel etwa $2,5 \mathrm{~mm}$ lang und $0,75 \mathrm{~mm}$ dick, gelb- 
lich bis bräunlich. Fortsätze des inneren Peristoms kurz oder rudimentär. Sporen 12-18 $\mu$, rostfarben, fein papillös. Sporenreife im Juli und August. - - Fig. 105.

An Steinen, Blöcken und Felsen verschiedener Art, auch an Stänmen und Wurzeln der Bäume.

F. Al. pass. (Bom.). - Ab. St. Karins. Piikkis. Pargas, Uskela. Karislojo, Lojo, - N. Ekenăs. Kyrkslătt. Esbo. Helsinge. - Ka. Kymmene. Sippola. Valkeala. Säkkijārvi. Räisälä. - Ik. Kuolemajärvi. - St. Eura. Kuru. - Ta. Im südöstl. Teile st. fq. (Norrl.). Korpilahti und Luhanka st. fq.—(Vain.). - Sa. Valkeala. Ruokolahti. Puumala. Kangasnienni. Nyslott. - Kl. Kurkijoki. Valarno. Sortavala. Impilahti. Soanlahti. Pälkjärvi. - Kol. Schtjeliki (Elfv.). 一 Tb. fq. (Broth.). 一 Sb. Virtasalmi. Kuopio fq. (Link.). Maaninka und Pielavesi fq. (Roiv.). - Kb. Tohınajārvi. Pielisjārvi. - Kon. Käppäselkä. Dianova gora. - Ok. Kajana (Lackstr.). Sotkamo, Hepolahti und Talvivaara (Kyyhk.). - K. Kuusamo. Aulinköngảs (Broth.). - Le. In der Waldregion pass. bis Kilpisjārvi (Norrl.), - Li. Inarj, Sakatinpahta und Kultala (Hult); Hammastunturit, in der Birkenregion (H.). - Lim. Kandalaks, Schelesnaja (Broth.). Tschun (B.). - Lp. Orloy (Kilılm.). Poroj (Broth.).

S. $S k-L u L$., am reichlichsten in den mittleren und nördlichen Provinzen, selten in $S k$. und an der Westküste fast fehlend Steigt in $L$. bis $1,000 \mathrm{~m}$ hinauf.

N. Sm. $-F$.

- Europa, Algier, Kanaren, Kankasus, Japan. Nord-Amerika. Nordgrenze auf spitzbercen.



Fig. 105. Pterygunandrum filiforme. A Frucbtende Pfl. (3/1); B Stengelb. (50/t); C Blattspitze (3nu 1); D Blattbasis $(300 / 1)$; E Peristom $(300 / 1)$

var. decipiens (Web. et Mohr) Limpr. Laubm. II. p. 768 (1895). [Neckera decipiens Web. et Mohr Bot. Taschenb. p. 241 et 473 (1807). — Pterigynandrum heteropterum Brid. Bryol. univ. II. p. 176 (1827). - P. filiforme var. heteropterum Bryol. eur. fasc. $46 / 47$ Mon. p. 3 (1851). - P. filiforme var. crassius Hartm. Sk. Fl. ed. 9 (1864). - P. decipiens Lindb. Muse. scand. p. 36 (1879).]

Kräftige Pfl. in schwellenden Rasen. Äste meist stumpf, herabgekrümmt, rund oder einseitig beblättert. Blätter 1-1,2 $\mathrm{mm}$ lang und etwa $0,75 \mathrm{~mm}$ breit. Seta bis $2 \mathrm{~cm}$. Kapsel etwa $3,5 \mathrm{~mm}$ lang. Fortsätze des inmeren Peristoms meist von Zahnlänge.

F. Al. Geta (Arrh.). Finström, Bartsgarda (Bom.). Saltvik, Haraldsby (B.). - Ab. Abo, Runsala (Brand.). St. Karins. Ispois (Link.). Uskela, Linnamāki (Lindb.). Karislojo (Sundr.) Lojo, an inehreren Fundorten (Lindb., E. at H.). Vichtis (W. Nyl.). - Y. Helsingtors (Lindb.). Sibbc, Geiterby (Ranck.). - Ka. Kotka (Ulv.). Antrea, Liikola (Lindb.). - Ik. Sakkola (H. Lindb.). — st. Eura (Rönnb.). Karkku (Hjelt). Pirkkala (Simn.). — Ta. In südōstl. Teile pass. (Norrl.). Köorpilahti, Pāirākunta (Vain.). Sa. Valkeala (Sundv.). Lappee (Buch). Taipalsaari (Simm.). Kangasniemi (Lackstr.). - Kl. Valamo (Lindb.). Jaakkima, Puutsalo (L.). Sorlavala, Lāskelä (Pes.); Pölsōvaara (P.); Paastovuori (P.). Impi- 
lahti, K̈irchdorf (P.) - Kol Salmi. Leppälä (P.). - Tb. Jyväskylä (Broth.)._- Sb. Kuopio, an mehreren Fundorten (Link.). Nilsiä. Haluna (Kyyhk.): Kuuslahti. Jaakonlampi (K.). Maaninka, Pōljä, Uuhimāki (K.); Haatala, Haukkavuori (Roir.). Rautavaara, Suojärvi (Kỵhk.). - Kb. Tohmajārvi, Simc senvaara (Oesch). - Kon. Käpselkă (Simm.). - Om. Vindala, Viitaniemi (Backm.). Lappajārvi, Rāmākkōsaari und Kutsisaari (Backm.). - Ok. Paltamo, Melalahti, Aijönkallio (Kỵhk.). — Ob. Muhos, Lappiniemi (Huum.). Roraniemi (Hult). - Lkem. Kittilä, an mehreren Fundorten. meist im Fjeldgebiete (Hult). - Le. An mehreren Fundorten in der Waldregion bis Kilpisjārri (Norri.). Kilpisjärvi, Saivovaara (Kot.). - Li. Sodankylä, Sakatinpahta (Hult). Inari, Pỵttelvaara. Tirro, Heikura und Vãylä (H.). L'tsjoki. an mehreren Fundorten in der Nadelwald- und Birkenregion (H.). - Lim. Kandalaks (Broth.). Unba (Kihlm.). - Lt. Kola, Abramova Pahta und Karaulnaja Pahta (Broth.). - Lp. Orlov, (roguliha (Kihlm.). Ponoj (Broth.).

S. Verbreitung etwa wie bei der Hauptart.

N. Verbreitung wahrscheinlich etwa wie bei der Hauptart.

Europa, Algier, Pendschab, Kaschmir, Nord-Amerika.

var. cochlearifolium (Arn. et Jens.) Möll. in Ark. f. Bot. Bd. 15, No. 2, p. 92 (1917). [Pterigynandrum decipiens var. cochlearifolium Arn. et Jens. Moos. Sarekgeb. p. $213(1910)$.]

Pfl. fast schwarz, mit gelben Astspitzen. Blätter kürzer und stumpfer.

S. Öl. Resmo. LuL. Krikkjokk.

var. filescens Boul. Muse. de la France 1. p. 171 (188t).

Sehr schlanke Pfl. in sehr verflachten, schwach grünen oder blassgelblichen Rasen. Stengel und Äste sehr lang, der Unterlage angedrückt. Blätter länglich, allmählich zugespitzt .

In Felsenritzen.

S. Upl. Värmdö und Bondkyrka.

Togesen, Schweiz.

\section{P L A G I O T H E C I A E A E.}

Locker- oder dichtrasige, meist weiche und verflacht beblätterte, seidenglänzènde Pfl. Stengelquerschnitt eckig-rundlich bis elliptisch, ohne oder mit armzelligem Zentralstrange, lockerem Grundgewebe und \pm verdickten, mehrschichtigen. Mantelzellen. Stengel meist kriechend bis aufsteigend, meist dicht beblättert, zerstreut und unregelmässig beästet, allermeist mit bleichen, kleinblättrigen Stolonen; Äste den Hauptsprossen ähnlich; Paraphyllien fehlend. Blätter mehrreihig, gleichförmig, schief inseriert, bauch- und rückenständige anliegend und meist symmetrisch, seitenstäl dige zweizeilig abstehend und unsymmetrisch, aus verengter Basis eiförmig bis länglich-eiförmig, kurz oder \pm lang zugespitzt: Rippe kurz. meist doppelt oder ungleich zweischenkelig, zuweilen fehlend: Zellen prosenchymatisch, dünnwandig, glatt, gegen die Basis kürzer, weiter und meist getüpfelt, in den Blattecken meist nicht differenziert. Blüten stengel- und astständig. Perichätialblätter differenziert, ohne Falten. Seta verlängert, glatt. Kapsel aufrecht oder \pm geneigt, regelmässig oder symmetrisch, dünnhäutig; Spaltöffnungen oberflächlich. Ring differenziert, meist stückweise sich ablösend. Peristom doppelt. Peristomzähne meist querstreifig. Grundhaut des inneren Peristoms \pm vortretend; Fortsätze lanzettlich, gekielt. Deckel meist gewölbt kegelig und kurz gespitzt. Haube kappenförmig. Sporen klein.

\section{Übersicht der Gat tungen.}

A. Blätter \pm weit herablaufend; Zellen in den Blattflügeln erweitert, dünnwandig, meist hyalin .................... 154. Plagiothecium.

B. Blätter nicht oder kaum herablaufend; Zellen in den Blattflügeln klein, \pm verdickt, gelblich und hyalin oder nicht differenziert 


\section{ISOPTERYGIUM}

Mitt. Musc. austr.-amer. 1) 21 (1869).

Stengel mit 2-4schichtigen, engen und verdickten Mantelzellen, häufig stolonenartig unterbrochen. Laubblätter nicht oder kaum herablaufend; Zellen eng prosenchymatisch, in den Blattflügeln klein, \pm verdickt, gelblich und hyalin oder nicht differenziert.

¿́bersicht der Arten.

A. Diözisch. Selten fruchtend.

a. Blätter kurz bis etwas länger zugespitzt; Zellen 1: 610 , in den Blattflügeln differenziert, eine kleine Gruppe bildend 758. I. depressum.

b. Blätter allmählich lang und fein zugespitzt.

$\alpha$. Äste nicht flagellenartig verlängert. Blätter oberwärts fein gesägt; Zellen 1: $15-25$, in den Blattflïgeln nur wenige quadratisch und kurz rektangulär. Häufig mit Brutästchen ..................... 755. 1. elegans.

$\beta$. Äste häufig flagellenartig verlängert. Blätter ganzrandig; Zellen 1: $20-30$, in den Blattilügeln nicht differenziert. Ohne Brutästchen .................... 754. 1. Müllerianum.

B. Autözisch. Häufig fruchtend.

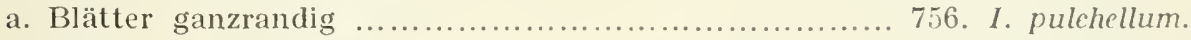

b. Blätter oberwärts gesägt.

«. Sprosse verflacht beblättert. Kapsel bis $2 \mathrm{~mm}$ lang, trocken schwach längsrippig .............. 757. 1. turfaceum.

§. Sprosse fast sparrig bis einseitswendig beblättert. Kapsel bis $3 \mathrm{~mm}$ lang, trocken glatt

759. I. repens.

S e c t. I. Euisopterygium Lindb. Musc. scand. p. 39 ex p. (1879).

Sprosse verflacht beblättert. Kapsel klein, oval bis länglich, nicht oder kaum gekrïmmt.

754. Isopterygium Müllerianum (Schimp.) Lindb. in Meddel. Soc. Faun. Fl. Fenn. 14. Heft, p. 77 (1887). [Plagiothecium Müllerianum Schimp. Syn. p. $584(1860)$.

Diözisch. Pfl. in lockeren, flachen, freudig grünen, stark glänzenden Rasen. Stengel mit sehr lockerer Aussenrinde, fast fiederästig; Äste niederliegend oder aufstrebend, ausgezeichnet verflacht und \pm locker beblättert, häufig flagellenartig verlängert. Laubblätter fast federig zweizeilig abstehend, holıl, lanzettliclı, allmählich lang und fein pfriemenförmig, bis $1,8 \mathrm{~mm}$ lang und $0,45 \mathrm{~mm}$ breit, ganzrandig; Rippe sehr kurz oder fehlend; Zellen sehr eng, 1: 20-30, in den Blattflügeln nicht differenziert. Innere Perichätialblätter länglich, allmälılich zu einer schwach gezälnten Pfrieme verschmälert. Seta $12-15 \mathrm{~mm}$. Kapsel fast aufrecht oder geneigt, verkehrt länglich-ciförmig, bis 2,3 $\mathrm{mm}$ lang, rötlichgelb, im Alter braun, trocken und entcleckelt unter der Mündung verengt. Deckel aus kegeliger Basis dick geschnäbelt. Sporenreife im Spätsommer.

An beschatteten, feuchten Felsen.

N. Br. Bamble, Herre. Telemarken. St. Lysefjord. SB.

Pyrenäen, Alpengebiet, Kaukasus, China, Nord-Amerika.

755. Isopterygium elegans (Hook.) Lindb. in Notis. Sällsk. Faun. Fl. Fenn. XIII. p. 416 (1874). [Hypnum elegans Hook. Musc. exot. I. t. 9 (1818).]

Diözisch. Tracht von $P l$. depressum. Pfl. in dichten, flachen, zuweilen ausgedehnten, grünen oder gelblichgrünen, lebhaft glänzenden Rasen. Blätter meist 
verflacht-zweizeilig, oft \pm deutlich, einseitswendig, seltener allseits aufrechtabstehend, länglich-lanzettlich, allmählich in eine lange, feine, schwach gesägte Spitze verschmälert, bis $1,6 \mathrm{~mm}$ lang und bis $0,45 \mathrm{~mm}$ breit; Rippe sehr kurz od . $\mathrm{r}$ fehlend; Zellen 1: 15-25, in den Blattflügeln nicht differenziert. Innere Perichätialblätter halbscheidig, rasch oder allmählich zu einer langen, geschlängelten, am Grunde gesägten Pfrieme verschmälert. Seta $12-20 \mathrm{~mm}$. Kapsel geneigt bis horizontal, länglich, etwa $2 \mathrm{~mm}$ lang, rötlichgelb, troeken und entleert fast aufrecht und unter der Mündung eingeschnürt. Deckel verlängert kegelig, stumpflich. Sporenreife im Frühjahr. - Vegetative Vermehrung durch zarte, entfernt beblätterte, blattachselständige, zu Büschelì vereinigte Brutästchen.

Am Fusse trockener, überschatteter Felsen und in humosen Klüften kieselreicher Gesteine. Sehr selten fruchtend.

F. Al, Mariehamn (Bom.) Geta, an mehreren Fundorten (B.). Saltvik und Sund, an vielen Fundorten (B.). Vảrdô und Kökar (B.). - Ab. Kakskerta (Colland.). Ábo (Arrh.); Hirvensalo (Buch); Vaarniemi (B.). St. Karins, Ispois (B.). Pargas, Vepo, Terfsund und Kridja (Elfv.). Bromarf, "Ön" (Sundv.). Lojo, Torhola und Ojamo (Sundv.). - N. Ingả, Bjurs (Buch). Kìrkssātt, Humaljārvi, Svartsjōn (Ranck ). Helsingfors (Lindb.). Tusby̧, Saksa (Broth.). Sibbo, Sōderkulla (Lindb.). Borgå, Storpellinge (Broth.). Hogland (Lindb.). - Ta. Yitti, Korpivuori (Buch). Hollola, Pirunpesã (Broth.). Padasjoki, Virmaila (Sil.). - Sa. Kangasniemi (Broth.). - Tb. Virrat, Helvetinportti (B.). Pihtipudas, Heinolankȳà, Jousivuori (Roiv.). - Sb. Kuopio, Tanovuori (Link.). Kaavi, Ninivaara, Louhilammenkallio (Kot.). - Kb. Tohmajärvi, Kypärävaara (Broth.). - Ok. Kajana, Aumanrinne (B.) Sotkamo, Naapurinvaara (B.). - Le. Välivaara, in der Fichtenregion (Norrl.).

S. Sk., Bl., Sm., Gll., Ög., Vg., Boh., När., Srm. Upl., Vrm. und Äng.

N. Sm. pass. A. Kristiania $r$. JL. Sandefjord st. fq. Laurvig. Ne. Saetersdalen. St. Rŷfylke. R, fq. im Tieflande. NT. Stjordalen. No. Saltdalen. Nordgrenze bei $66^{\circ} 50^{\prime} \mathrm{n} . \mathrm{Br}$.

Färøer, Gross-Britannien, Pyrenäen, Zentral-Europa, Nord-Amerika.

var. nanum (Jur.) Möll. Fört. Sk. växt. 2. Moss. p. 15 (1907). [Plagiothecium nanum Jur. in Bot. Zeit. 1864 Beibl. p. 16. - P. elegans var. $\gamma$ nanum Walth. et Mol. Laubm. Oberfrank. p. 183 (1868).]

Kleine, lockerrasige Pfl. Äste aufrecht, büschelig, sehr dünn und brüchig, oft flagellenartig verlängert. Blätter schmäler und spitzer, allseits aufrecht-abstehend, meist im oberen Teile der Äste schwach einseitswendig. Brutästchen weniger zahlreieh.

N. Ne. Saetersdalen, Ürdiken cpp.

Zentral-Europa.

756. Isopterygium pulchellum (Dicks.). [Hypnum pulchellum Dicks. Crypt. Fasc. II. p. 13, t. 5, f. 6 179(1). - Plagiothecium pulchellum Bryol. eur. fasc. 48, Mon. p. 9, t. 4 (1851). - P. nitidum var. $\beta$ suberectum Lindb. in Bot. Notis 1865, p. 145. - P. nitidulum var. $\beta$ pulchellum Lindb. in Hartm. Sk. Fl. 10. ed. II. p. 24 (1871). - Isopterygium nitidum var. $\beta$ pulchellum Lindb. Musc. scand. p. 39 (1879).]

Autözisch. Sehr schlanke Pfl. in kleinen, dichten, freudig grünen, glänzenden Räschen. Stengel kriechend, mit dicht gestellten, aufsteigenden bis aufrechten, undeutlich verflacht beblätterten, stumpfen Ästen. Blätter einseitswendig, bis sichelförmig, eilanzettlich, lang und fein pfriemenförmig zugespitzt, his $1 \mathrm{~mm}$ lang und bis $0,35 \mathrm{~mm}$ breit, ganzrandig; Rippe fehlend; Zellen 1: $10-15$, in den Blattflügeln nicht differenziert. Innere Perichätialblätter halbscheidig, mit am Grunde meist undeutlich gezähntem Pfriementeil. Seta $1-2 \mathrm{~cm}$. Kapsel fast aufrecht bis geneigt, fast regelmässig, länglich-zylindrisch, bis $2 \mathrm{~mm}$ lang, gelbbräunlich, im Alter braun, trocken und entdeckelt unter der weiten Mündung verengt. Ring 2reihig, lange beibend. Deckel kegelig, stumpf. Sporenreife im Sommer.

In erderfüllten Felsspalten, besonders auf Kalk und kalkhaltigen Gesteinen.

F. Lkem. Saivio, nördlich vom Yllästunturi (Hult). - Le. Peerakoski (Norrl.). - Lim. Umpjavr, Tschuidivum (Kinlm.). - Lp. Ponoj (Sahll).).

S. Vrml., Dlr. IIlsl, Mpd., Jml. und LuL. 
N. Sm. Onso. Ringerike, nicht sellen. Ne. Saetcrsdalen. SB. K. Lomseggen. Dovre NT. Stjordalen. No. $-F$. bis in die alpine Region.

Spitzbergen, West- und Zentral-Europa, Nord-Amerika.

var. nitidulum (WVahlenb.). [Leskea nitidula Wahlenb. in Web. et Mohr Ind. mus. pl. crypt. (1803). - Hypnum nitidulum Wahlenb. Fl. lapp. p. 370 (1812) excl. synon. - Plagiothecium nitidulum Bryol. eur. fasc. 48 Mon. p. 10, t. 5 (1851). - Pl. nitidum Lindb. in Bot. Notis. 1865, p. 115. - Isopterygium nitidum Lindb. in Notis. Sällsk. Fauna Fl. Fenn. XIII. p. 116 (1874).]

Etwas kräftiger als die Hauptart. Rasen oft ausgedehnt, stärker glänzend. Stengel oft in selır lange Stolonen übergehend; $\dddot{s}$ te verflacht beblättert. Blätter nicht einseitswendig, länger zugespitzt. Kapsel fast horizontal, im Alter rotloraun. Ring einreihig, mit dem Deckel sich ablösend. Deckel gewölbt-kegelig, mit dickem Spitzchen. - Fig. 105 A - C.
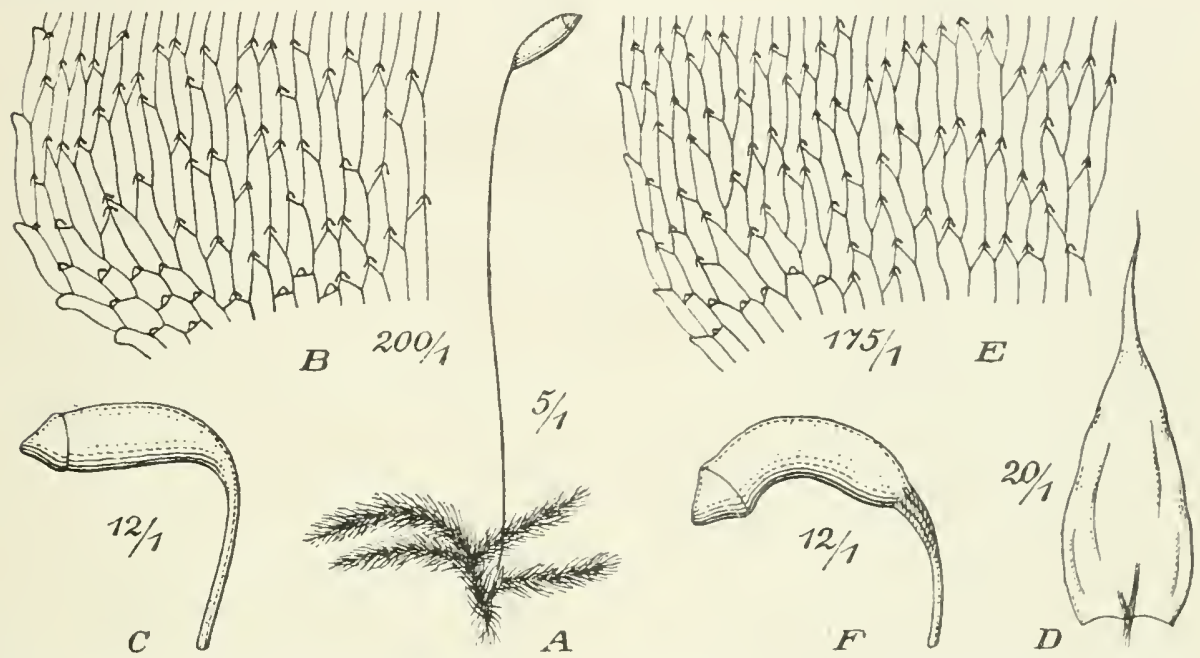

Fig. 106. A-C. Isopterygium pulchellum var, nitidulum (Wahtenb.). A Fruchtende PfI. (5/I); B Blatt(200/1); C Kapsel im trockenen Zustande (12/1). - D-F. I. repens (Poll.). D Stammb. (20/I); E Blattrasis (175/1); F Kapsel im trockenen Zustande (12/1).

In erderfüllten Felsspalten und auf modernden Stämmen.

F. Al. Eckerö (Arrh.); Torp (H. Lindb.). Finström und Saltrik, an mehreren Fundorten (Bom.). Geta, Vestergeta (B.). Hammarland, Hellesby (H. Lindb.). Sund, Prästö und Gesterby (Bom.). - Ab. Pargas, Piukala (Elfr.). Angelniemi (Buch). Bromarf, "Ön» (Sundv.). Uskela, Linnamäki (Lindb.). Karislojo, Karkkali (E. af H.); Tesjärvi (Sundv.). Lojo, Skraatila und Lylyis (E. af H.). Vichtis (WT. Nyl.). N. Helsinge, Degerö (Buch). Strömfor (Ströml).). Hogtand (Lindb.). - Ik. Pyhäjārvi, Rantakylä (H. Lindb.). - Ta. Hattula, Nikkilā und Yli-Savijärvi (Ranck.). Jaala, Pieni Ruhmasjārvi (Buch). Im südöstl. Teile pass. (Norrl.). Hartola (Bonsd.). Luhanka und Korpilahti pass. (Vain.), - Sa. Willmanstrand (Buch). Ruokolahti, Imatra (B.). Kangasniemi, Tuomarinvuori (Lackstr.). - Kl. Kurkijoki (Jusl.). Valamo (Norrl.). Sortavala, Kirjavalahti (Norrl.). Impilahti, Pullinruori (Broth.). Ruskeala (Backm.). Pälkjärvi, Anoniemi, Korkeaniemi und Kuhilasvaara (Broth.). - Kol. Im Svirgebiete pass. (Elfv.). Petrosavodsk (Kulth.). - Oa. Sideby (Karst.). - Tb. Virrat, Toriseva (Broth.). Jyväskylä, Lauriniemi (Tain.); Ristikivi. Vuoretsalo und Ylistō (Link.). Haapakoski, Kanavuori (E. af H.). Uurainen, Kuukkanen (Broth.). Konginkangas, Lennmaa (E. af H.). Viitasaari (Broth.). Kinnula, Olhavainen (Roiv.). Pihtipudas, Haapamäki (R.); Sydänmaa, Rikkavuori (R.). - Sh. Heinäresi, Palokki, Ǩultaniemi (Kot.). Kuopio. Neulaniemi, Neulaınäki (Link.); Vuorilampi (L.); Kasurila, Măntỵmäki (Kryhk.). Kaavi, Siikajãrvi, Intikkamäki (Kot.); Losomäki, Aittojārvi (K.); Niinivaara, Louhilampi (K.). IIaaninka, Tuovilanlahti und Haatala (Roiv.). Iisalmi, Iimåki (Sahlb.). - Kb. Juuka, Juuanvaara und Nunnanlahti (Kot.). Pielisjärvi, Koli (Linnan.). Lieksa, Kalliovaara (Vain.). - Kon. Jalguba (Simm.). Valkeamāki (S.). Tiudie (S.). Kăppäselkä (S.). Rogosa (W. Nỵl.). Pirttiniemi (Kullh.). - Ok. Kajana (Lackstr.). Paltamo, Melalahti, Aijōnkallio (Kyyhk.). Sotkamo, Naapurinvaara (Broth.); Talvivaara (Kyyhk.). Suomussalmi, Kirchdorf und Ahola (Vain.). - Ob. Rovaniemi. Meltaus (Hult). - $K$. Kuu- 
samo. an vielen Fundorten (F. Nyl., Broth., E. af H.). - Lkem. Kıttilä, Pahtakallio und Kujertunturi (Hult). Kemijärvi, Kitinen (Broth.). Kuolajärvi, Sallatunturi (E. af H.); Vuorijärvi, Pyhäkuru (E. af H.). - Le. In der Nadelwaldregion spärl. bis Kilpisjärvi (Norrl.); Kilpisjärvi, Malla und Saana in der alpinen Region (Kot.). - Li. Sodankylä, Săkätinpahta (Hult); Kalkkivuori (Vain.). Inari, Veskoniemi ( Vain.); Kultala und Toivoniemi (Hult); Pyttelvaara und Känssävaara (H.); Peldoivi und an mehreren Fundorten in den II uotkatunturit (H.); Kodossuannonpäă (Kihlm.). Utsjoki, Kenisjkoski und Veitsjinjarka (Hult): Soavjebakle, Outakoski (Ranck.). - Lim. Umba (Kihlm.). Umpjavr, Tschuidivum (K.). Kandalaks, schelesnaja (Broth.). Tschun (B.). Hibinä (Broth., Kihlm.). - Lt. Kola (Fellm., Brolh.). Zw. Tsipnayolok und Vaidoguba (Broth.). Pummanki (B.). - Lmur. Semjostrorsk. - Lp. Panfelovka (Brenn.). Ponoj (B.).

S. $S m,-L$.

N. A. $-F$.

Europa, Kaukasus, Kaschmir, Sibirien, Nord-Amerika.

757. Isopterygium turfaceum (Lindb.) Lindb. in Act. Soc. Sc. Fenn. IX. p. 278 (1872). [Hypnum turfaceum Lindb. in Fl. dan. Supp]. fasc. 2, p. 17, Suppl. p. 124 (1857). - Plagiothecium turfaceum Lindb. in Öfv. K. Vet.-Ak. Förlt. XIV. p. 124 (1857).]

Autözisch. Pfl. in lockeren, flachen, freudig grünen, lebhaft glänzenden Rasen: Stengel kriechend, mit dem Substrate anliegenden, ausgezeichnet verflachten, stumpfen oder \pm lang zugespitzten Ïsten. Seitenständige Blätter horizontal abstehend, ei- oder länglich-lanzettlich, pfriemenförmig zugespitzt, bis $1,5 \mathrm{~mm}$ lang und bis $0,54 \mathrm{~mm}$ breit, mit cberwärts scharf gesägten Ränclern; Rippe sehr kurz oder fehlend; Zellen 1: 12-15, in den Blattflügeln nicht differenziert. Innere Perichätialblätter halbscheidig und plötzlich in eine zurückgekrümmte,- scharf gesägte Pfrieme verschmälert. Seta $1,2-1,8 \mathrm{~mm}$. Kapsel geneigt, länglich-zylindrisch, etwas hochrückig, bis $2 \mathrm{~mm}$ lang, gelblich, später bräunlich, trocken schwach längsrippig und unter der Mündung verengt. Deckel gewölbt-kegelig, stumpf. Sporenreife im Juli.

Auf vermodernden Baumstümpfen und Stämmen, an Baumwurzeln und auf Torfboden.

F. Al. Eckerö, Torp (H. Lindb.). Hammarland, Hellesby (L.). Finström und Saltvik an mehreren Fundorten (Bom.). Sund, Prästō Gesterby (B.). - Ab. Kakskerta, Hylkilahti (Colland.). St. Karins, Gunnarsnäs (Arrh.). Pargas, Kvidja und Loftsdal (Elfv.). Finby (Broth.). Bromarf (Sundv.). Lojo, Paloniemi (Lindb.). Vichtis, Ollimāki (Broth.). - N. Ekenäs (Broth.). Kyrkslätt, Porkkala (B.). Esbo, Gräsa (B.). Helsingfors (Lindb.). Pernå, Kōpbacka (Arrh.). Lovisa (Buch). Nurmijārvi (Tennb.). Elimäki, Justila (B.). Hogland (Lindb.). - Ka. Wiborg (W. Nyl.) - Ik. Metsäpirtti, Saarois (H. Lindb.). Pyhäjärvi (Lảng). - St. Ikaalinen (Sundv.). Ruovesi, Helvetinjärvi (Broth.). — Ta. Lammi, Evo (Norrl., Backm.). Hol\}ola, Tiirısıłaa (N.). Asikkala, Urajărvi (N.). Harıola (Bonsd.). Luhanka. Keihāsniemi (Vain.). Korpilahti, Thàiunvuori (V.). - Sa. Ruokolahti, Kojolammi (Hult). Kangasniemi (Lackstr.). - Kl. Sortavala, Kirjavalahti (Lindb.). - Kol. Humbaritsa (Elfv.). - Tb. Pihlajavesi (Norrl.). Jyväskylä, Haapakoski (Broth.). Karstula, Koroisenjoki und Koroisenjärvi (B.). V'iitasaari. suojoki (B.). - Sb. Kuopio, Vehmasmäki (Link.). Maaninka, Tuovilanlahti, Korkeakoski (Broth.). Iisalmi, Palojārvi und Peltosalmi (Sahlb.). - Kon. Suopohja (Simm.). - Ok. Suomussalmi, Ruotula (Lackslr.). - Kpom. Keret, Sonostror (Sahlb.). Särkijārvi (Bergr.). — Lim. Umpjarr, Tschuidi-rum (Kihlm.). Tschunosero (Broth.). Hibinä (B.). - Lt. Kola (Fellm., Broth.).

S. Sm., Ög., Upl., Vsm., Vrml., Gstr. und Dlr.

N. Sm. 1. Ringerike r. No. Mo, F. Vardo. Nordgrenze bei $\tau 0^{\circ} 22^{\prime} \mathrm{n}$. Br.

Sibirien, Amurgebiet, Sachalin. Japan, Nord-Amerika.

758. Isopterygium depressum (Bruch) Nitt. in Journ. Linn. Soc. XII. p. 497 (1869). [Hypnum depressum Bruch in Flora 1824, p. 763. - Rhynchostegium depressum Bryol. eur. fasc. 49/51 Mon. p. 8, t. 6 (1852). - Plagiothecium depressum Dix. in Dix. et James Stud. Handb. p. 431 (1896).]

1)iözisch. Pfl. in sehr flachen und weichen, dunkel- bis gelbgrünen Rasen. Stengel durch Rhizoiden dicht am Substrat haftend und wie die kurzen, kriechenden Ästen ausgezeichnet verflacht beblättert. Blätter länglich-eiförmig, kurz bis etwas länger zugespitzt, zuweilen stumpflich, bis $1,3 \mathrm{~mm}$ lang und bis $0,5 \mathrm{~mm}$ breit, ganzrandig ocler oberwärts \pm deutlich gezähnt; Rippe sehr kurz oder fehlend; Zellen 1: 6-10, in den Blattflügeln quadratisch und kurz rektangulär, eine 
kleine Gruppe bildend. Innere Perichätialblätter halbscheidig, mit meist an Grunde eingeschnitten-gezähntem Pfriementeil. Seta 6-12 nm. Kapsel übergeneigt bis horizontal, länglich-eiförmig, etwas hochriickig, etwa $2 \mathrm{~mm}$ lang, bräunlich, trocken und entdeckelt unter der Mündung eingeschnürt. Deckel gelb, aus gewölbter Basis 士 lang geschnäbelt.

An feuchten und beschatteten Felsen und Steinen verschiedener Art.

F. Ab. Karislojo, am Bache des Kattelusjärvi (Boldt). Lojo, Lsosaari, Pietilă (Lindł.); Lylyí: (E. af H.); zw. Hermola und Maila (Boldt); Hittis (Lindb.); Torhola (H. Lindb.). Vichtis, Haapkylä (Broth.). - Ta. Asikkala, Kaitas (Broth.). Padasjoki, Virmaila und Arakoski (Norrl.). IIartola (Bonsd.). - Kl. Soanlahti, Korpikallio (Broth.). - Kol. Vosnessenje (Elfv.); Pirttiniemi (Simm.).

S. Sk., Öl, Sm., Ög., V $g ., S r m$. und $U p l$, an einzelnen Fiundorten.

N. A. Kristiania pass. Sm. r. Ne. Saetersdalen r. H. Stange. NT. Stjørdalen. Dovre. No. Alstahaug und Hemnes. Nordgrenze bei $66^{\circ} 10^{\prime} \mathrm{n}$. Br.

West- und Zentral-Europa, Kaukasus, Nord-Amerika.

S e c t. I I. Dolichotheca (Lindb. in Notis. Sällsk. F. Fl. Fenn. Förh. XIII. ny ser. X. p. 417: 1874) Lindb. Musc. scand. p. 39 (1879).

Blätter fast sparrig abstehend oder einseitswendig bis fast sichelförmig. Kapsel aus deutlichem Halse zylindrisch, im Bogen gekrümmt, trocken g]att.

759. Isopterygium repens (Poll.) Lindb. Musc. scand. p. 39 (1879). [Hypnum repens Poll. Hist. plant. Palat. III. p. 167, t. 1 (1777). - II. silesiacum Selig. in Palis. Prodr. p. 70 (1805). - Plagiothecium Seligeri Lindb. in Bot. Notis. 1865, p. 144. - Pl. repens Lindb. in Notis. Sällsk. Faun. Fl. Fenn. IX. p. 36 (1867). — Isopterygium silesiacum Warust. Laubnı. p. 807 (1905).]

Autözisch. Pfl. in lockeren bis dichten, zuweilen ausgedehnten, lebhaft bis bleichgrünen Rasen. Stengel niedergestreckt und umlierschweifend; $\ddot{s}$ ste bis 2 cm, bogig eingekrümmt, gegen das Ende \pm verdünnt und hier zuweilen mit Rhizoiden. Blätter aus aufrecht-abstehender, hohler Basis fast sparrig abstehend oder einseitswendig bis fast sichelförmig, ei- oder länglich-lanzettlich, allmählich lang und fein pfriemenförmig zugespitzt, bis $2 \mathrm{~mm}$ lang und $0,75 \mathrm{~mm}$ breit, oberwärts fein gesägt; Rippe sehr kurz oder fehlend; Zellen 1: 10-15, in den Blattflügeln quadratisch und kurz rektangulär, eine kleine Gruppe bildend. Innere Perichätialblätter locker scheidig, oberwärts gezähnt und rasch in eine \pm zurückgebogene, scharf gesägte Pfrieme verschmälert. Seta 1,5-2,5 cm. Kapsel geneigt bis horizontal, zylindrisch, regelmässig, gekrümmt, bis $3 \mathrm{~mm}$ lang, gelbbräunlich, trocken und entdeckelt unter der Mündung verengt. Deckel niedrig, stumpf kegelig. Sporenreife im Juni. - Fig. $106 \mathrm{D}-\mathrm{F}$.

An faulenden Stämmen und auf humusreichem Waldboden.

F. Al. Eckerö, Storby (Arrh.). Mariehamn (Bom.). Finström, Grelsby (B.). Saltvik, an mehreren Fundorten (B.). Sund, Högbolstad (Broth.). Föglö, Gripö (Arrh.). - Ab. St. Karins, Ispois (Elfr.). Reso, Harvarö (Zett.). Kimito, Grammelby (Ols.). Bromarf (Sundv.). Lojo, Ojamo (Lindb.); Huuhtasaari (H. Lindb.). - N. Ekenäs (Lindb.); Tvärminne (Högm.). kyrkslätt, Porkkala (Broth.). Esbo, Gräsa (B.). Helsingfors (Lindb.). Sibbo (Ekm.). Borgå (Jusl.); Pellinge, Suni (Broth.). Strömfors (Sael.). Hogland (Lindb.). - Ka. Wiborg (Vain.). - Ik. Uusikirkko, Muola, Metsäpirtti und Sakkola (H. Lindb.). — Ta. Hattula. Pelkola (Ranck,). Sysmä (Thur.). — Sa, Kangasniemi (Lackstr.). — Kl. Valamo (Ir. Nyl.). - Kol. Humbaritsa (Elîv.). - Oa. Lappijärd (Karst.). Kaskö (Nerv.).

S. Sk. $-\| p d$.

N. Sm.-NT.. No.-F, an einzelnen Fundorten. Nordgrenze bei $69^{\circ} 58^{\prime} \mathrm{n} . \mathrm{Br}$

Europa, Kaukasus, Kaschmir, Japan, Nord-Amerika.

\section{PLAGIOTHECIUM}

Bryol. eur. fasc. 18 Mon. (1851).

Stengel mit $1-2-$, selten melurschichtigen, wenig verengten und meist schwach verdickten Mantelzellen, häufig mit abwärts steigenden Siolonen. Laubblätter \pm weit herablaufend; Zellen in den Blattflügeln erweitert, dünnwandig und meist hyalin. 
Ĺbersicht der Arten.

A. Autözisch.

a. Sprossen undeutlich zweizeilig bis allseitig gleichförmig beblättert. Blätter symmetrisch bis schwach unsymmetrisch.

œ. Blätter sehr hohl, plötzlich haarförmig verlängert, ganzrandig

§. Blätter weniger hohl, allmählich in eine lange Pfriemenspitze verschmälert, rings kleingesägt

761. Pl. piliferum.

b. Sprossen verflacht beblättert. Seitenständige Blätter

762. Pl. striatellum. unsymmetrisch, ganzrandig oder an der Spitze klein gezähnt.

«. Blätter zweizeilig abstehend. Deckel trocken hochkegelig.

I. Blätter eilänglich, kurz und breit oder rasch schmal zugespitzt, mit aufrechten oder abwärts

sclimal umgebogenen Rändern

766.Pl.denticulatum.

II. Blätter eilanzettlich, mit weit hinauf schmal umgebogenen Rändern

768. Pl. Ruthei.

ґ. Blätter \pm bis fast sicheiförmig dem Boden zuge-

krümmt. Deckel trocken niedrig, mit dicker Zitze. 767. Pl.curvifolium.

B. Diözisch.

a. Kleine Pfl. Blätter aufrecht-abstehend, eilanzettlich,

lang und scharf zugespitzt .............................. 760. Pl. latebricola.
b. Kräftige Pfl. Blätter kürzer zugespitzt.

«. Blätter nicht querfaltig.

I. Sprossen wenig verflacht und mehr rundlich beblättert. Blätter sehr hohl, sämtlich fast symmetrisch; Zellen der Lamina 9-12 oder 10-15 $\mu$ breit und 1: $10-15$

763. Pl. Roeseanum.

II. Sprossen verflacht beblättert; seitenständige Blätter unsymmetrisch, wenig hohl; Zellen der Lamina $15-25 \mu$ breit und 1: $5-10$

764. Pl. silvaticum.

$\beta$. Blätter dachziegelig anliegend, querfaltig; Zellen eng und verlängert. Tracit von Neckera

769. Pl. undulatum.

C. Polyözisch; ơ Blüten zahlreich. Tracht von Pl. silvaticum

765. Pl.succulentum.

760. Plagiothecium latebricola (Wils.) Bryol. eur. fasc. 18, Mon. p. 6, t. 1 (1851). [Leskea latebricola Wils. Mscr. et Bryol. brit. p. 329, t. 54 (1855). - Hypnum latebricola Lindb. in Notis. Sällsk. Faun. Fl. Fenn. IX. p. 32 (1867).]

Diöziscls. Kleine Pfl. in dichten, grünen Rasen. Stengel aufsteigend; Äste 5-10 $\mathrm{mm}$, kaum verflacht; Stolonen fehlend. Blätter aufrecht-abstehend, eilanzettlich, lang und scharf zugespitzt, bis $1 \mathrm{~mm}$ lang und bis $0,45 \mathrm{~mm}$ breit, mit schwach cingebogenen, glatten Rändern; Rippe fehlend; Zellen sehr eng, 1: $8-15$, in den weit herablaufenden Blattflügeln sehr locker, rektangulär und quadratisch. Innere Perichätialblätter fast scheidig, allmählich sehr lang und fein zugespitzt. Seta 5-10 mm, rot. Kapsel aufrecht, sehr klein, regelmässig, länglich-oval, gelblich, im Alter braun, trocken und entleert weitmündig. Peristomzähne völlig gesondert, am Grunde quer und schräg gestrichelt und oberwärts längsstreifig, wciss bis gelblichweiss. Grundhaut niedrig; Fortsätze schmal; Wimpern fehlend. Deckel gross, geschwollen-kegelig, mit Spitzchen. Sporenreife im Herbst. - Vegetative 
Vermehrung durch blatt-, seltener stengelbürtige, zylindrisch-keulenförmige, grüne, meist 4zellige Brutkörper.

An schattigen, sumpfigen Orten, besonders in Erlensïmpfen, an Baumwurzeln, Farnstöcken und in den Höhlungen faulender Baumstïmpfe.

F. Al. Saltvik, an wenigen Fundorten, $-A b$ Lojo Ojamo (Lindb.). - N. Helsingfors (Lindb.). - Ta. Lammi, Evo (Norrl.). Hollola, Tiirismaa (N.).

S. Sk., Og., $V g$. und Boh. an einzelnen Fundorten,

N. Sm. Onsø. JL. Sandefjord, Laurvig. Dorre.

Gross-Britannien, Deutschland, Nord-Amerika.

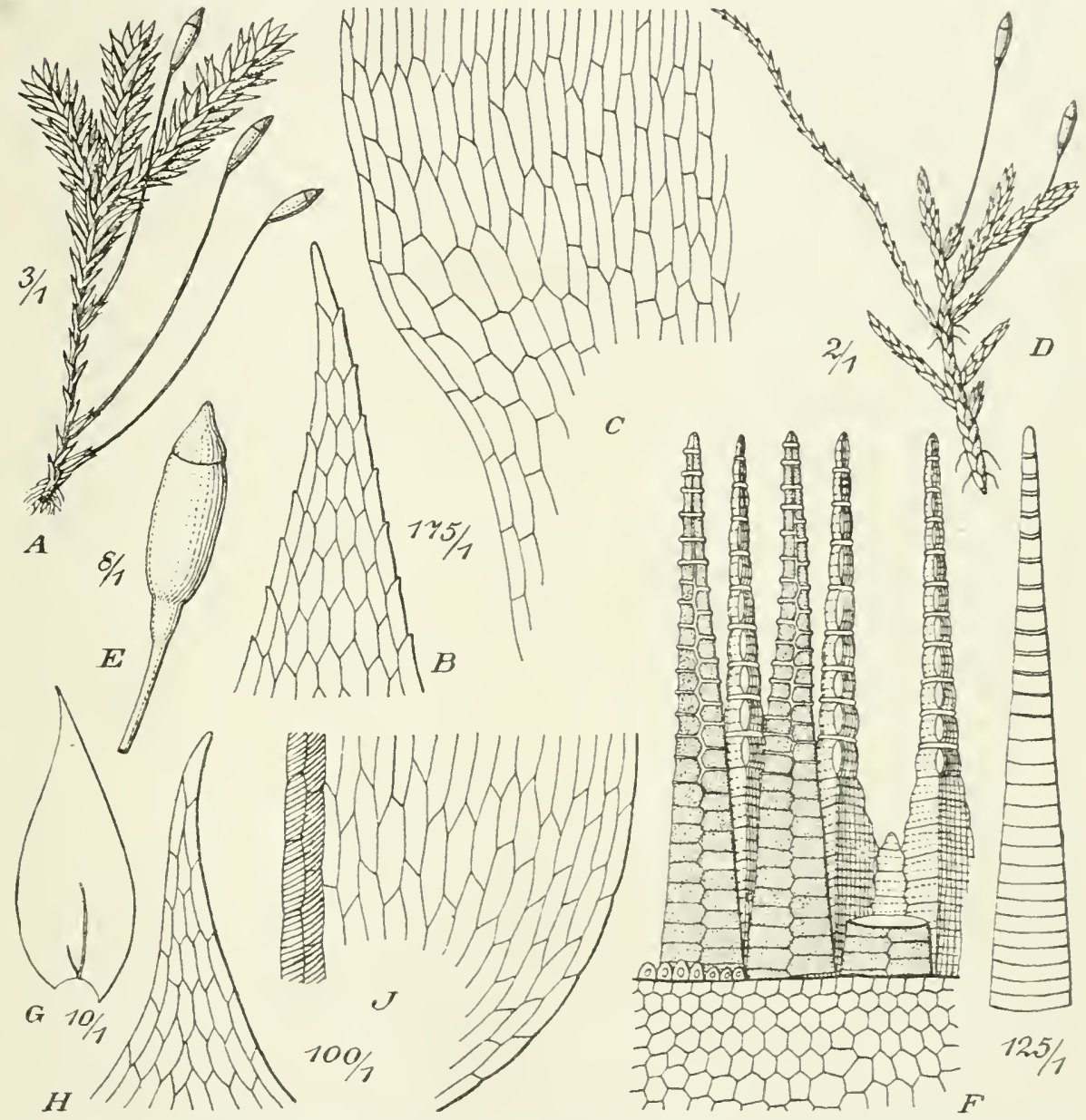

Fig. 107. A-C. Plagiothecium denticulatum (L.). A Fruchtende Pfl. (3/1); B Blattspitze (175/1): C Blattbasis (175/1). - D-F. P. piliferum (Sw.). D Teil eines Sprosses (2/1); E Kapsel (8/1); F Peristom (125/1) - G-I P silvaticum (Huds). G seitenständiges B. (10/1); H Blattspitze (100/1); I Blattbasis (100/1).

var. gernmascens Ryan et Hag. in D. K. N. Vid. Selsk. Skrift. 1896, Noo. 1, p. 135 .

Brutkörper unter der Blattspitze zahlreich, keulenförmig, 2-3zellig.

N. Sm. Onsø. $J L$. zwischen Larvik und Fredriksvaern. No. Saltdalen, Rognan. Nordgrenze bei $67^{\circ} 10^{\circ} \mathrm{n} . \mathrm{Br}$.

761. Plagiothecium piliferum (Sw.) Bryol. eur. I. c. p. S, t. 3. [Leskea pilifera Sw. Summ. Veg. Scand. p. 48 nom. nud., Hartm. Sk. FI. p. 419 (1820).] 
Autözisch. Schlanke Pfl, in weit ausgedehnten, grünen bis gelblichgrünen Rasen. Blätter weit und schmal herablaufend, wenig abstehend, sehr hohl, eiförmig und breit länglich, plötzlich in ein verbogenes Haar verlängert, mit weit hinauf schmal ungebogenen, glatten Rändern; Rippe sehr kurz und dünn; Zellen sehr eng, etwa 1: 10, in den Blattflügeln quadratisch und rektangulä. Innere Perichätialblätter fast scheidig, an der abgerundeten Spitze plötzlich in ein abgebogenes Haar verlängert. Seta $1-1,5 \mathrm{~cm}$, rot. Kapsel geneigt bis fast aufrecht, \pm regelmässig, länglich bis zylindrisch, runzelig-längsfaltig, gelbgrün, in Alter braun. Peristomzähne völlig gesondert, weisslich, ungestreift, gleichmässig fein papillös. Grundhaut selır niedrig; Fortsätze schmal, Wimpern fehlend. Deckel hochgewölbt. stumpfspitzig. Sporenreife im Sommer. - Fig. 107 D-F.

An trockenen, beschatteten Felsen und Blöcken verschiedener Art.

F. Al. Geta (Arrh.); Dånö (Bom.). Lemland, Norrbyudden (B.). Saltvik und Sund, an mehreren Fundorten (B.). Vảrdö, Vargata (B.). - Ab. Ảbo. Heikkilä (Tengstr.). Reso, Harrarōn (Zett.). Pargas, K vidja (Elfr.). Kiinito, Gästerby (Ols.). Finby (Broth.) Bromarf (Sundr.). Karislojo (Sundr.). Lojo, an mehreren Fundorten (Lindb. H. Lindb., E. af H.). Vichtis (Broth.). - X. Ekenăs, Tvārminne (Ranck.). Snappertuna, Köpböle (Häyr.). Ingå, Srartō (W. Brenn.). Kyrkslātt. Penttalö (Broth.). Esbo, Gräsa (B.). Helsingfors (Lindb.). Sibbo, Söderkulla (Lindb.). Borgả, Pellinge (Broth.). Elimäki (Tigerst.). Hogland (Lindb.). - Ka. Kymmene, Vakavuori (Kuj.). Kotka (Ulv.). Kirvu, Sairila (Lindb.). - St. Pirkkala (Simm.). - Ta. Tyrväntö, Joutsenjărvi (Broth.). Săäksmāki (Nerv.). Koski (Vain.). Im südöstl. Teile st. r.-pass. (Norrl.). Luhanka. Onkisalo, Hietala und Hakala (Vain.). Korpilahti, Haukkaviori (V.). - Sa. Valkeala (Sundv.). Kangasniemi, Suomāki (Lackstr.). — kl. Sortavala, Paassuruori (Pes.): Kirjavalahti (Norrl.); Tulolansaari (H. Backm.). 一 Oa. Vasa. Vassklot (Broth.), — Tb. Jyväskylä (Vain., Link.). Uurainen, Kuukkanen (Broth.). Viitasaari, Ninilahti und Karhuvuori (B.). - Sb. Kuopio, Kotkankallio (Lackstr.); Haminalahti, Neulaniemi (Link); Vuorilampi und Neulalampi (L ). Kaari. Hoikonlampi (Kot.). - Kon. Käppiselkă (Simm.). - Ok. Kajana (Lackstr.). - Ob. Aavasaksa (Nyb.). - K. Kuusamo, Iäntyvaara (Broth.). - Lkem. Kemijärvi, Pyhätunturi (Hāỵr.). Kittilä, Kenttāniemi (Hult). Iuonio, Kătkesuanto, Pahtarinne (Norrl.). - Li. Inari, Toironiemi und Pyttelvaara in der Nadelwaldregion (Hult). Utsjoki, Kenischkoski (11.). - Lim̄. Kandalaks, Schelesnaja (Broth.).

S. sim. - V b.. Jmt. und $P L$.

N. Sm. pass. A. Kristiania, nicht selten. Ringerike. JL. Sandefjord, nicht selten. Laurvig. Tjomø. Ne. Saetersdalen. NB. Sogn. R. r. NT. Stjordaten. No.-F. Nurdgrenze bei $70^{\circ} \mathrm{n} . \mathrm{Br}$.

Pyrenäen, Schweiz, Korsika, Apenninen, Sibirien, Nord-Amerika.

762. Plagiothecium striatellum (Brid) Lindb. in Bot. Notis. 1865, p. 144. [Leskea striatella Brid. Bryol. univ. II. p. 762 (1827). — Plagiothecium Mühlenbeckii Bryol. eur. fasc. 48 Mon. p. 11, t. 6 (1851).]

Autözisch. Pfl. in dichten, starren, flachen bis polsterförmigen, grünen oder gelblichen Rasen. Äste nicht verflacht, kurz, steif, an beiden Enden verdünnt. Blätter abstehend bis sparrig und einseitswendig, hohl, weit und schmal herablaufend, eilanzettlich, allmählich lang pfriemenförmig, bis $1,5 \mathrm{~mm}$ lang und bis $0,6 \mathrm{~mm}$ breit, flachrandig, rings entfernt und klein gesägt; Zellen sehr eng, 1: 6-9, in den Blattecken aufgeblasen, oval und länglich, hyalin oder gelblich, eine grosse, oberwärts durch meist quadratische Zellen begrenzte Gruppe bildend. Innere Perichätialblätter scheidig, rasch zu einer langen, geschlängelten und gezähnten Pfrieme verschmälert. Seta $1-2 \mathrm{~cm}$, rot. Kapsel fast aufrecht bis geneigt, langhalsig. schlank zylindrisch, etwas gekrümmt, trocken unregelmässig gefurcht und unter der Mündung etwas verengt, gelblich, später braun. Peristomzähne am Grunde querstreifig, oberwärts auch schräg- und längsstreifig.

Auf torfigem, feuchtem Boden, in erderfüllten Felsspalten, an Baumwurzeln und in Erdhöhlungen.

F. Al. Finström, Godby und Vandō (Bom.). Geta (Arrh.); Östergeta Kasbărg (Bom.). Saltrik. an mehreren Fundorten (B.). Sund, Jussböle und Gesterby (B.). Kỏkar. Vårdö und Brāndö (B.). Ab. Abo, Prästho men (Colland.); Hirvensalo, Jänissaari (Buch). Pargas, Tervsund und Kridja (Elfy.). Bromarf (Sundr.). Lojo, Palonienti (Lindb.). - N. Ekenās, Trärıninne, Elgö (Link.). Kyrkslātt, Skeppars (Broth.). Helsiugfors (Lindb.). Helsinge, Backas (Buch). Hogland (Lindb.). - Ta. Lammi, Evo (Norrl.). Hollola, Tiirismaa, Pirunpesā (Norrl.). Kuhnoinen, Sarvitaipale (N.). - Sb. Kuopio, Vehmasmäki. P’irttinäki (Link.). - kb. Lieksa, Kalliovaara (Vain.). 一 Ok. Sotkano, Naapurinvaara (Sil.); 
Vuohatti (Lackstr.). - Li. Inari. Kultala, in der Nadelwaldregion (Hult); Peldoivi, in der Birken region (H.) - Lim Kandalaks, Schelesnaja (Broth.). - Lmur. Teribjerka. (iavrilora und Harlovki (B.).

S. Sm., Boh.. När., Dtd. Cpl., Irjd., Jml., Ang. und LyL.

N. Sm. A. Krisiania pass. JL. Laurvig; Sandefjord fq.; Tjomo fqq. Ringerike rr. Ve. Satersdalen fq. St. SB. YB. R. fq. vom Meeresniveau bis in die alpine Region. Dovre. ST. IT. vitjordalen fqq. No.-F. Nordgrenze bei $7 \mathrm{l}^{\circ} \mathrm{n}$. Br.

Schottland, Pyrenäen. Zentral-Europa, Nord-Amerika.

763. Plagiothecium Roeseanum (Hamp.) Bryol. eur. fasc. 48, Mon. p. 15, t. 10 (1851). [Hypnum Roeseanum Hamp. Iscr. - Plagiolhecium silnalicum var. orthocladium Schimp. Coroll. 1) 115 (1856). - Pl. silvalicum var. Roesei Lindb. in Bot. Notis. 1865 p. 143.]

Diözisch. Kleiner als die vorige Art. Pfl. in meist lockeren und leicht zerfallenden, hell- bis gelbgrünen, oft ausgedehnten Rasen. Äste wenig verflacht bis fast kätzchenförmig. Blätter wenig herablaufend, aufrecht abstehend, meist symmetrisch und sehr hohl, eiförmig mit Spitzchen oder eilanzettlich, rasch feinspitzig, bis $2 \mathrm{~mm}$ lang und $1 \mathrm{~mm}$ breit, mit glatten und nur am Grunde schmal umgebogenen Rändern; Rippe doppelt oder gegabelt, nur bis ${ }^{1 / 3}{ }_{3}$ (ler Blattlänge: Zellen 9-12 oder 10-15 " breit, 1: 10-15, in den Blattflïgeln meist rektangulär. Seta $2-3$, selten bis $4 \mathrm{cn}$, rot. Kapsel aufrecht bis geneigt, regelmässig, länglich bis zylindrisch, gelbgrün, später lichtbraun, glatt oder schwach längsfurchig. Sporenreife im Juli und August. - Vegetative Vermehrung wie bei der vorigen Art.

Auf beschatteten, erdbedeckten Felsen, auf Baumwurzeln und in deren Hōhlungen und an schattigen Bachufern.

F. Al. Finström, Godby (Bom.). Sund und Saltvik, an wenigen Fundorten (Bom., Broth.). - A b. Korpo (Ekl.). St. Karins, Ispois (Link.). Bromarf (Sundv.). Lojo, an mehreren Fundorten (Lindb.). Pusula, Kärkōlä (Broth.). - X. Helsingfors (Lindb.). Helsinge, Backas (Ranck.). Tusby, Saksa (Broth.). - Ta. Asikkala, Kaitas (Broth.). Kulmoinen, Harnoin (Norrl.). - Sa. Kangasniemi. Suomäki (Bro!h.). - Kl. Sortavala, Kirjavalahti (Lindb.). Ruskeala, Marmorbruch (Broth.); Koirinvaara (B.). Pälkjārvi, Anoniemi (B.). - Tb. Pihtipudas. Surmulanmäki (Roiv.). - Sb. Kaavi, Losomäki, Poskijärvi (Kỵhk.). -Kb. Pielisjārvi, ǩoli (Linnan.). - Ok. Kajana, Suovalahdenkallio (Broth.). Paltamo, Melalahti, Aijönkallio (Kyybk.). - Lkem. Kuolajärvi, Särketunturi (Linnan.). - Le. Kilpisjärvi, Saivoraara (Kot.). - Li. Ruoptuinvaara (Vain.). - Li. Srednij am Kolabusen (Brolh.). Tsipnavolok (B.). - Lmur. Harlorka (B.). Tarsinsk (B.). Kljalnij (Brenn.). - Lp. Ponoj (B.).

S. Sm., Boh., När., Dld., Hrjd., Mpd. und LuL. Sarekgebiet.

N. Sm. pass. Ringerike, nicht selten. Ne. Saetersdalen. No. und $F$. an wenigen Fundorten.

Europa, Kaukasus, Japan, Nord-Amerika.

var. gracile Breidl. Laubm. Steiermı. p. 195 (1891). Schlanke Pfl. in weit ausgedehnten Rasen. St. und Äste meist aufrecht. B. eilanzettlich, allmälilich fein zugespitzt, etwa $1 \mathrm{~mm}$ iang und bis $0,4 \mathrm{~mm}$ breit. Brutkörper spärlich.

An beschatteten Felsen.

F. Ab. Pusula, Kärkōlä (Broth.). - v. Borgả, Pellinge. Hasselö (B.). - Ta. Hartola (Bonsd.). - Kb. Tohmajārvi, Tatta (kint.).

Zentral-Europa,

761. Plagiothecium silvaticum (Huds.) Bryol. eur. 1. c. p. 11, t. 11. [Hypnum silvaticum Huds. Fl. angl. p. 419 (1762).]

Diözisch. Lockerrasige, dunkelgrüne, trocken schwach glänzende oder glanzlose Pfl. Sämtliche Sprosse durch scheinbar zweizeilige Beblätterung sehr verflacht. Blätter 土 lang und schmal herablaufend, wenig oder deutlich hohl, seitliche weit abstehend und trocken oft etwas rückwärts gebogen, sämtlich eilänglich bis eilanzettlich, bis $3 \mathrm{~mm}$ lang und bis $1,4 \mathrm{~mm}$ breit, mit aufrechten oder abwärts schmal umgebogenen, glatten oder an der Spitze klein gezähnten Rändern: Rippe kräftig, gegabelt, vor oder in der Blattmitte endend; Zellen $15-25 \mu$ breit, 1: $5-10$, in den Blattflügeln meist rektangulär. Innere Perichätialblätter hochscheidig, an der meist abgerundeten Spitze fast plötzlich in eine kurze, lanzettliche Spitze verschmälert. Seta $2-3 \mathrm{~cm}$, selten bis $t \mathrm{~cm}$, rot. Kapsel geneigt bis fast horizontal, regelmässig oder etwas hochrückig, zylindrisch, gelbgrün, im Alter rotbraun, trocken und entdeckelt schwach gebogen, \pm deutlich längsfurchig und 
unter der Mündung verengt. Sporenreife im Juli und August. - Vegetative Vermehrung durch blattachselständige, auf büschelförmig verzweigten Trägern stehencle, 3 -6stöckige, zylindrische bis fast keulenförmige Brutkörper. - Fig. $107 \mathrm{G}-\mathrm{I}$.

Auf feuchtem oder torfigem Waldboden, an beschatteten, kieselreichen Felsen, in erderfüllten Felsenritzen und an Felsenabsätzen.

F. Al. Eckerö (Arrh.). Hammarland, Skarpnåtö (A.). Jomala, Kasberg (Bom.). Mlariehamn (B.). Finström, Godbฐ (B.). Geta, Hőckböle (Broth.). Saltrik, an vielen Fundorten (Bom.). Sund, an mehreren Fundorten (B.). Vảrdö (B.). - Ab. Korpo, Strömma (Ekl.). Gustafs, Eskola (Bergr.). Kustö (Nerv.). St. Karins, Ispois (Elfv.). Pargas, Terfsund (E.). Kimito (Ols.). Bromarf, Bromholmen (Sundv.). Lojo, an mehreren Fundorten (E. af H.). Vichtis, Kourla (W. Nyl.). - N. Ekenăs (Broth.). Kyrkslătt, Skeppars (B.). Esbo, Gräsa (Broth.). Helsingfors (Lindb.). Tusby, Sarvikallio (Broth.). Borgå, Tirmo (B.). Hogland (Lindb.). - Ka. Kotka, Mussalo (Uly.). Vehkalahti (Krohn). Antrea, Liikala (Lindb.). - Ik. Uusikirkko, Vammelsuu (H. Lindb.). Valkjärvi, Pähkinämäki (H. L.). Pyhājảrvi, Lohijoki (H. L.). - St. Ulfsby, Saaris (Häyr.). Ylöjärvi, Pengenpohja (Sol.). Pirkkala, Nakkila (Simm.). - Ta. Im südötl. Teile pass. (Norrl.). Hartola (Bonsd.). Korpilahti, an mehreren Fundorten (Vain.). Luhanka (V.). - Sa. Leini, Parkkala (Buch). Willmanstrand (B.). Lappee, Soininen (B.). Kangasniemi, Suomäki (Lackstr.). - Kl. Kurkijoki (Jusl.). Sortavala, Kirjavalahti (Lindb.); Pötsövaara (Buch). Impilahıi. Pullinvuori (Broth.). Ruskeala, Kolitsa (Link.). Pälkjärvi (Broth.). — Kol Mjảtusova (Elfv.). Tb. Kinnula und Pihtipudas (Roiv.). - Sb. Maaninka, Tuovilanlahti (Lundstr.); Haataja, Haukkaruori (Roiv.). - Kb. Kontiolahti, Romppala (Linnan.); Repola, Koroppi (Vain.). - Kon. Jalguba (Kullh.). Schungu (Norrl.). - Om. Lappajărvi, Haapaniemi (Backm.). - ob. Rovaniemi, Ileltaus und Ristikallio (Hult). - K. Kuusamo, Autinkōngäs (Broth.); zw. Karijärvi u. Karitunturi (E af H.). - Lkem. Kittilä. Kirchdorf (Hult). - Lim. Kandalaks, Schelesnaja (Broth.). Umpjok, Aij-varr (Kihlm.). Hibinā (Broth.). - Lt. Pummanki (B.). - Lmur. Litsa und Jokonsk (B ). - Lp. Orlov (Kihlnı.).

S. Sh. - Ang

N. $S m .-F$. Nordgrenze jenseits des $71^{\circ} \mathrm{n} . \mathrm{Br}$.

Europa, Madeira, Azoren, Kaukasus, Pendschab, Sibirien, Sachalin, Japan, Nord-Amerika.

765. Plagiothecium succulentum (Wils.) Lindb. in Bot. Notis. 1865, p. 143. [Hypnum succulentum Wils. Mscr. - H. denticulatum var. succulentum Wils. Bryol. brit. p. 407 (1854).]

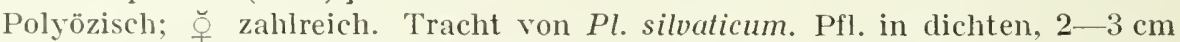
tiefen, licht- bis dunkelgrünen, trocken etwas glänzenden Rasen. Blätter schmal herablaufend, etwas hohl, länglich-eiförmig, rasch schmalspitzig, bis 2,4 mm lang und bis 1,2 m!n breit, mit bis über die Mitte schmal umgebogenen, glatten Rändern; Rippe meist kurz, ziemlich dünn und ungleichschenkelig; Zellen 12-18 $\mu$ breit, 1: $8-10$, in den Blattflïgeln quadratisch und rektangulär. Innere Perichätialblätter plötzlich kurz zugespitzt. Seta $1,5-2 \mathrm{~cm}$, zuweilen länger, rot. Káapsel geneigt, etwas hochrückig, fast zylindrisch, braun, trocken und ent deckelt etwas eingekrümmt, meist giatt ind unter der Mündung wenig verengt.

In nassen Erlenbrüchen an modernden Erlenstubben.

N. No.

West- und Zentral-Europa.

766. Plagiothecium denticulatum (L.) Bryol. eur. I. c. p. 12, t. 8. [Hypnum denticulatum L. Sp. pl. II. p. 1122 (1753).]

Autözisch. Kleiner als P. silvaticum. Pfl. in oft ausgedehnten, grünen oder gelbgrünen Rasen. Sämtliche Sprosse durch scheinbar zweizeilige Beblätterung selır verflacht und im Umrisse einer doppelten Säge ähnlich. Blätter weit und breit herablaufend, wenig hohl, eilänglich, rasch schmal zugespitzt oder mit Spitzchen, bis $2 \mathrm{~mm}$ lang und $0,7 \mathrm{~mm}$ breit, mit aufrechten oder abwärts schmal umgebogenen, glatten oder an der Spitze klein gezähnten Rändern; Rippe dümn und gegabelt; \%ellen $8-9 \mu$ breit, 1: 12-15, in den Blattflügeln zahlreiche rundlich-quadratisch, kurz relitangulär und mehreckig. Innere Perichätialblätter hochscheiclig, kurz und scharf zugespitzt. Seta $1,5-3 \mathrm{~cm}$, rot. Kapsel aufrecht bis \pm geneigt, länglich-zylindrisch, regelmässig oder schwach hochrückig, gelbbräunlich, trocken und entdeckelt gekrümmt, glatt, unter der Mündmng wenig verengt. Wimpern vollständig. Deckel hoch spitzkegelig oder aus gewölbt-kegelförmiger Basis kurz geschnäbelt. Sporenreife in Sommer. - Fig. 107 A-C. . 
Auf Hunusboden in sehattigen Wäldern, am Grunde der Stämme und deren Wurzeln, an Felsen und Blöcken versehiedener Art.

In allen Teilen von Fennoskandia \pm fq., in den nördlichsten Teilen und in deralpinen Region spărlich. Spitzbergen, Europa, Kaukasien, Himalaya, Sibirien, Sachalin, Japan, Nord-Amerika.

var. Donianum (Sm.) Lindb. in Notis. Sällsk. F. Fl. Fenn. IX. p .31 (1867). [Hypnum Donianum Sm. F]. brit. III. p. 1286 (180.)). - H. denticulatum y obtusifolium Turn. Musc. hib. p. 146, t. 12, f. 2 (1801). - H. obtusatum Wahlenb. Fl. lapp. p. 371 (1812). - Plagiothecium denticulatum $\beta$ obtusatum Hartm. Sk. Fl. 10. ed. II. p. 22 (1871).]

Blätter hohl, oval, mit abgerundeter oder stumpfer Spitze, zuweilen mit Lndspitzchen: Zellen locker.

S. Lpm.

N. Dovre, Snehaetten, in Schneebächen.

Irland, Sikkim, Nord-Anterika.

* Plagiothecium laetum (Bryol. eur.) Amann Fl. mouss. Suiss. I. p.174 (1912). [Plagiotherium laetum Bryol. eur. fase. 48 Mon. p. 7, t. 2. (1851). - Pl. denticulatum Lindb. var. $\gamma$ laelum Lindb. Musc. seand. p. 39 (1879).]

Kleiner als die Hauptart. Rasen stark glänzend. Aste aulsteigend bis aufrecht. Blätter kurz oder weiter schmal herablaufend, rasch oder alluählich fein zugespitzt, mit meist weit hinauf schmal umgebogenen Rândern \%ellen $6-8 \mu$ breit, 1: 18 -24. Kapsel klein, aufrecht bis schwach geneigt. Wimpern \pm vollständig bis fehlend.

An faulendem Holze und in Felsspalten.

F. K. Kuusamo, Pyhätunturi (Broth.). - Kk. Kivakkatunturi (B.). - Le. Kilpisjärvi, Leutsuvaara (Norrl.). - Lt. Kola, Karaulnaja Pahta (Broth.).

S. Jmt., Ang. und $L u$. an einzelnen Fundorten.

N. Ne. Saetersdalen. K. Dovre. No. Saltdalen. Tr. Nordrejsen. F. Kistrand.

Europa, Sibirien, Nord-Amerika.

767. Plagiothecium curvifolium Schlieph. in sehed. 1880; Limpr. Laubm. II1. p. 269 (1897).

Autözisch. Pfl, in lockeren bis dichten, flachen, zuweilen ausgedehnten, dunkel- oder bleichgrünen bis weisslichen, trocken stark glänzenden Rasen. Sämtliche Sprosse sehr verflacht. Blätter $\doteq$ bis fast sıchelförnig dem Boden zugekrümmt. unsymmetrisch, wenig hohl, a!ıs weit herablaufendem Grunde !ängiich-eiförmig. kurz. und scharf zugespitzt, bis $2 \mathrm{~mm}$ lang und bis $0,9 \mathrm{~mm}$ breit, flach- und ganzrandig; Rippe dïmn, kur $z$ und ungleichschenkelig, Zellen eng, 1: 12-18, in den Blattflügeln quadratisch und rektangulär. Innere Perichätialblätter hochscheirlig kurz und scharf zugespitzt. Seta $1, \overline{-}-2 \mathrm{~cm}$, rot. Kapsel klein, übergeneigt bis horizontal, schwach hochrïckıg, !änglich oder kurz zylindrisch, gelbbraun, trocken und entleckelt schwach gekrümmt, glatt, unter der llündung wenig verengt. Deckel trocken niedrıg, mit dicker, meist von einem feinen Spitzchen gekrönter Zitze, feucht gewölbt kurz kegelig.

Am Boden der Nadelwälder und am Grunde alter Stämmen.

F. Al. Sund, Gesterby (Broth.). - Ab. Pargas, Pyhänsuu (Link.). Finby (Broth.). - N. Tenala, Lapprik (Holmb.). Helsingfors (Lindb). - Oa. Vasa (Brot'o.). - Om. Jakobstad (B.). - Ok. Sotkamo, Vuokatt. (B.). - K. Kuusamo, zw. Sakkilänvuoma und Juuma (B.).

S. Ög., Boh., Vrml. und Mpd.

N. Ringerike pass. Trondhjem.

Zentral-Europa, Alaska.

768. Plagiothecium Ruthei Limpr. Laubm. Ill. p. 271 (1897).

Autözisch. Tracht von $\mathrm{Pl}$. silvaticum. PfI. in lockeren, oft ausgedelnten. grünen oder gelbgrünen, trocken glänzenden Rasen. Blätter weit und breit herablanfend, wenig hohl, die oberen meist etwas querwellig, eilanzettlich, bis 2,7 $\mathrm{mm}$ jang und bis $1.2 \mathrm{~mm}$ breit, mit weit hinauf sehmal umgebogenen. nur in der Spitze ge- 
zähnten Rändern; Rippe weniger kräftig, ungleichschenkelıg; Zellen ziemlich locker, 1: 8-12, in den Blattflügeln zahlreiche quadratisch, kurz rektangulär und mehreckig. Innere Perichätialblätter hochscheidig, kurz und scharf zugespitzt. Seta $2,5-4 \mathrm{~cm}$, rot. Kapsel übergeneigt bis horizontal, fast regelmässig oder etwas hochrückig, zylindrisch, gelbbram, trocken und entdeckelt stark eingekrümmt, \pm deutlich läingsfurchig und unter der Mündung verengt.

Auf Waldhoden, in Erlenbrüchen und an Seeufern.

F. V. Borgå, Storpellinge (Broth.). -- Sa. Kangasniemi, Korteniemi (Lackstr.). - Oa Kvevlaks (Karst ), - Oh Kajana (Lackstr.). - Ob. Rovaniemi, Valajankoski (Brenn.). - Lkem. Kem jārvi: Pyhätunturi (Vain.).

S. När., Vrml. und $M p d$.

N. Ringerike pass.

Zentral-Europa.

var. rupincola Limpr. Laubm. III. p. 273 (1897).

Dunkelgrüne, glänzencle Pfl. Blätter glatt.

An Felsen.

N. Sm. On:o.

Pyrenäen, Alpengebiet.

769. Plagiothecium undulatum (I.) Bryol. eur. 1. c. p. 17, t. 13. [Hypnum undulatum 1.. Sp. pl. II. p. $112.4(1753)$.]

Dï̈zisch. Stattliche Pfl. in oft ausgedehnten, grünen bis weisslichen, trocken mattglänzenden Rasen. Stengel mit mehrschichtigen Mantelzellen, bis $15 \mathrm{~cm}$, einfach odler meist spärlich beästet, ohne Stolonen. Blätter dachziegelig anliegend, hohl, querfaltig, aus verengtem, wenig herablaufendem Grunde breit ei- bis länglicheiförmig, rasch kurz zugespitzt, bis $5 \mathrm{~mm}$ lang und bis $3 \mathrm{~mm}$ breit, flachrandig und nur in der äussersten Spitze klein gezähnt; Rippe ungleich doppelt oder gegabelt; Zellen eng und verlängert, 1: 15-20, in den Blattflügeln wenige rektangulär. Innere Perichätialblätter hochscheidig, rasch in eine zürückgebogene, lanzettliche Spitze verschmälert. Seta $3, \overline{5}-5 \mathrm{~cm}$, rot. Kapsel geneigt bis horizontal, langhalsig, zylinchisch, bis $5 \mathrm{~mm}$ lang und etwa $1 \mathrm{~mm}$ dick, gelbbraun, trocken gekrïmmt, längsrppig und unter der Mündung eingeschnürt. Sporenreife im Juni und Juli.

Anf etwas feuclitem Waldloden, besonders in Nadelwäldern, am Fusse von Felsen, in K!üften und Hölllungen.

F. Al. Eckerö, Storby (II. Lirdb.). Mariehamn (Bom.). Geta, Djupvikskyrka (Arrh.). Saltvik und sund, an wenigen Fundorten (Bom.). Vảrdö, Vargata (B.) - N. Ekenās, Jusarō (Hāỵr)

S. Sh., Bl., Öl., Hll, Ogg., lg., Boh., När., Vrml. und Dld.

N. Sm. fq. A. Kristania r. JL. Sandefjord st. fq.: Tjomo fqq.; Laurvig. Ne. Saetersdalen $R$. Im Küstengebiete und in den mittleren Fjordgegenden fqq. ST. Levanger. NT. Stjorda'en fqq. No. Nordgrenze bei $68020^{\circ} \mathrm{n} \mathrm{Br}$.

West- und Zentral-Europa, Nord-Amerika

\section{SE M A T O P H Y LA C E A E.}

Locker-oder dichtrasige, \pm glänzende Pfl. Stengelquerschnitt rund bis oval, ohne Zentralstrang, lockerem Grundgewebe und \pm verdickten Mantelzellen. Stengel neist kriechend bis aufsteigend, rliclit beblättert, unregelmässig verzweigt, seltener fieder- oder büschelästig; Paraphyllien fehlend. Blätter mehreihig, symmetrisch und meist gleichartig, von wechselnder Form; Rippe doppelt, sehr kurz oder fehlend; Zellen prosenchymatisch, in der Blattecken in einer Reihe meist länglich, dünnwandig und aufgelılasen. Blüten stengel- und astständig; ơ Blüten knospenförmig; 우 Blüten an sehr kurzen, meist wurzelnden Perichätialästen. Perichätialblätter differenziert. Seta verlängert. Kapsel meist \pm geneigt bis hängend, meist oval bis länglich und \pm hochrückig, dümnhäutig, glatt; Zellen des Exotheciums \pm kollen- 
chymatisch verdickt; Spaltöflnungen oberfächlich. Ring nicht deutlich dilferenziert. Peristom wie bei Plagiotheciaceue. Deckel aus gewölhter oder kegelförmiger Basis meist nadelförmig geschnäbelt. Haube meist kappenförmig. Sporen meist klein.

\section{SEMATOPHYLLUM}

Mitt. in Journ. Linn. Soc 1865, p. 5.

Meist autözisch. Stengel lang kriechend. Blätter aufwärts abstehend, zuweilen aufwärts einseitswendig, ganzrandig: Rippe fehlend; Kellen glatt. Seta glatt, rot. Kapsel klein. Peristom oft auf niediriger Gewebeleiste inseriert.

770. Sematophyllum demissum (Wils.) Mitt. 1. c. [Hypnum demissum W'ils. in Engl. Bot. Suppl. t. 2740 et Wiis. Bryol. brit. p. 401, t. 59 (1855). - Rhynchoslegium dcmissum Bryol. eur. fase. $49 / 51$ Mon. 1) 4, t. 1 (1852). - Rhaphidostegium demissum De Not. Cronaca II. p. 31 (1867). - Plagiothecium demissum Dix. Stud. Handb. p. 439 (1896).]

Pfl. in flachen, dẹm Substrate fest anliegenden, gelblichgrünen bis rötlich goldgrünen, seidenglänzenden Rasen. Stengel unregelmässig getrilt, mit zahlreichen, kurzen, niedergebogenen, stumpflichen Ästchen. Stengel- und Astblätter ziemlich gleichförmig, hohl, länglich- oder elliptisch-lanzettlich, scharf zugespitzt, bis $1,4 \mathrm{~mm}$ lang und bis $0,45 \mathrm{~mm}$ breit, mit nur am Grunde ungebogenen Rändern: Zellen eng linealisch, etwas geschlängelt, an der Insertion kurz, dickwandig und stark getüpfelt, goldgelb, an den Blattecken wenige aufgeblasene, goldgelbe oder hyaline. Perichätialblätter aufrecht, verlängert länglich, scharf zugespitzt, mit bis gegen die Spitze ungebogenen, glatten Rändern. Seta $8-12$ mm, sehr dünn. Kapsel fast horizontal, fast regelmässig, läiglich, ledergelb, trocken und entdeckelt unter der erweiterten Nündung stark eingeschnürt. Sporenreife im Winter.

N. K. Valders. Amer:ka.

Schottland, Wales, Irland, Elsass, Lothringen, Vogesen, Schweiz, Ober-Italien, Japan, Nord-

\section{H Y P N A C E A E.}

Locker- oder dichtrasige, meist \pm glänzende Pfl. Stengelquerschnitt rund, selten oval, ohne oder mit angedeutetem Zentralstrang, mit lockerem Grundgewebe, nach aussen dichter bis substereid, selten mit Aussenrinde. Stengel kriechend, mit \pm reichlichen Rhizoiden, oft stoloniform und geteilt, mit \pm regelmässig gefiederten Ästen, selten aufsteigend und unregehmässig verzweigt; Paraphyllien meist fehlend. Blätter mehrreihig, meist symmetrisch, von wechselnder Form, jedoch immer zugespitzt; Rippe fehlend oder doppelt dün und kurz, aus homogenen Zellen gebildet; Zellen prosenchymatisch, glatt, zuweilen papillös vortretend, in den Blatteeken meist differenziert. Autözisch oder diözisch, selten polyözisch. Blüten meist stengelständig, mit fadenförmigen Paraphysen. Perichätialast wurzelnd. Perichätialblätter differenziert, oft längsfaltig. Seta verlängert, glatt. Kapsel meist geneigt bis horizontal; Hals wenig entwickelt; Spaltöffnungen oberflächlich, oft funktionslos. Ring meist differenziert. Peristom wie bei den Plagiotheciaceen. Deckel kegelig, zuweilen kurz geschnäbelt. Haube kappenförmig.

Übersicht der Gat $\mathrm{t}$ ungen.

A. Autözisch. Kapsel aufrecht, regelmässig ................. 156. Pylaisia.

B. Diözisch. Kapsel geneigt bis horizontal, meist \pm gekrünmt.

a. Pseudoparaphyllien spärlich oder fehlend. Stengelblätter gleichförmig. 
«. Stengelblätter sparrig-abstehend, weit herablaufend, breit deltoidisch-herzförmig, plötzlich schmal lanzettlich zugespitzt. Astblätter trocken dachziegelig, ovallanzettlich

161. Hyocomium.

$\beta$. Stengel- und Astblätter gleichförmig, sichelförmigeinseitswendig.

I. Tracht straussfederartig. Blätter tief mehrfaltig; Blattflïgelzellen nicht differenziert ............... 159. Ptilium.

II. Blätter nicht oder undeutlich längsfaltig; Blattfrügelzellen differenziert.

1. Stengel dicht kammartig gefiedert. Kapsel klein, eiförmig, hochrückig, trocken nicht gekrümmt 160. Ctenidium.

2. Kapsel länglich bis zylindrisch, \pm gekrümmt. 157. Hypnum.

b. Pseudoparaphyllien zahlreich. Stengelblätter zweigestaltig 158. Heterophyllium.

\section{PYLAISIA}

Bruch et Schimp. in Hook. Lond. Journ. Bot. II. p. 669 (1843).

Autözisch. Rinden- und Steinmoose. Stengel kriechend, durch zahlreiche Rhizoiden am Substrat haftend, unregelmässig oder fast fiederig kurzästig; Pseudoparaphyllien fehlend. Blätter gleichförmig, kaum herablaufend, hohl, glatt, lang und schmal zugespitzt, flach- und ganzrandig: Rippe fehlend oder schwach angedeutet; Zellen eng prosenchymatisch, glatt, am Blattgrunde kürzer und weiter, in den Blattflïgeln zahlreiche quadratisch und in einer sich hinaufstreckenden Reilie rhombisch und rhomboiclisch. Innere Perichätialblätter schwach längsfaltig, scheidig, rasch lanzettlich zugespitzt, oberwärts gezähnelt. Kapsel aufrecht, regelmässig, oval bis länglich-zylindrisch. Ring differenziert. Peristomzähne tief inseriert, mit bei der Entdeckelung abgerissenen Spitzen, gelblich, hyalin gesäumt, auf der Immenfläche mit dicken, nach inmen und meist auch seitlich vortretenden Querleisten. Grundhaut des inneren Peristoms niedrig; Wimpern rudimentär. Deckel kegelig bis kurz geschnäbelt.

\section{L bersiclnt der Arten.}

A. Inneres Peristom dem äusseren anlängend. Sporen 18 $22 \|$.............................................. 771. P. Schimperi. B. Inneres Peristom frei. Sporen 12-18 $\mu$................ 772. P. polyantha.

771. Pylaisia Schimperi Card. in Bull. l'Herb. Boiss. VII. p. 373 (1899). [Hypnum intricatum C. Müll. Syn. II. p. 338 (1850). — Pylaisia intricata Bryol. eur. fasc. $16 / 47$ Mon. p. 3 (1851).]

Grösse und Tracht von $P$. polyantha. Äste eingekrümmt. Blattflügelzellen zahlreich. Kapsel gedunsen. Ring ziemlich grosszellig, 2-3reihig. Peristomzähne am Grunde gegenseitig verschmolzen, breit gesäumt, querstreifig. Inneres Peristom dem äusseren anhängend, nach der Entdeckelung zweischenkelig und die Schenkel den Zähnen anhängend. Sporen 18-22 $\mu$, grün, gekörnelt.

An Baumstämmen.

F. Kol. Mjätusova am Svirflusse (Elfv.).

Sibirien, Nord-Amerika.

772. Pylaisia polyantiha (Schreb.) Bryol. eur. fasc. 16/47 Mon. p. 3, t. 1 (1851). [Hypnum polyanthos Schreb. Spicill. Fl. Lips. p. 97, No. 1070 (1771). - Stereodon polyanthos Mitt. Journ. Limn. Soc. VIII. p. 40 (1861).] 
Schlanke Pfl. in oft ausgedehnten, flachen bis gewölbten, dunkel-oder gell)grünen, trocken glänzenden Rasen. Aste meist aufrecht, oft etwas gekrümmt. Blätter aufrecht-abstehend, oft etwas einseitswendig, eilanzettlich, allmählich lang zugespitzt, bis $1,6 \mathrm{~mm}$ lang und bis $0,5 \mathrm{~mm}$ breit; Astblätter etwas kleiner. Seta $1-1,5 \mathrm{~cm}$, rot. Kapsel länglich-zylindrisch, bis 2,5 $\mathrm{mm}$ lang und bis $0,6 \mathrm{~mm}$ dick, rotbraun. Ring kłeinzellig, einreihig, in einzelnen Zellen sich ab]ösencl. Peristomzähne am Grunde nicht verschmolzen, schmal gesäunt, undeutlich querstreifig, innen mit nach oben allmählich stärker verdickten, zuletzt scheibenförmigen Querleisten. Inneres Peristom frei. Sporen $12-18 \mu$, grün oder bräunlich, gekörnelt oder dicht papillös. Sporenreife im Herbst. - Fig. 107.

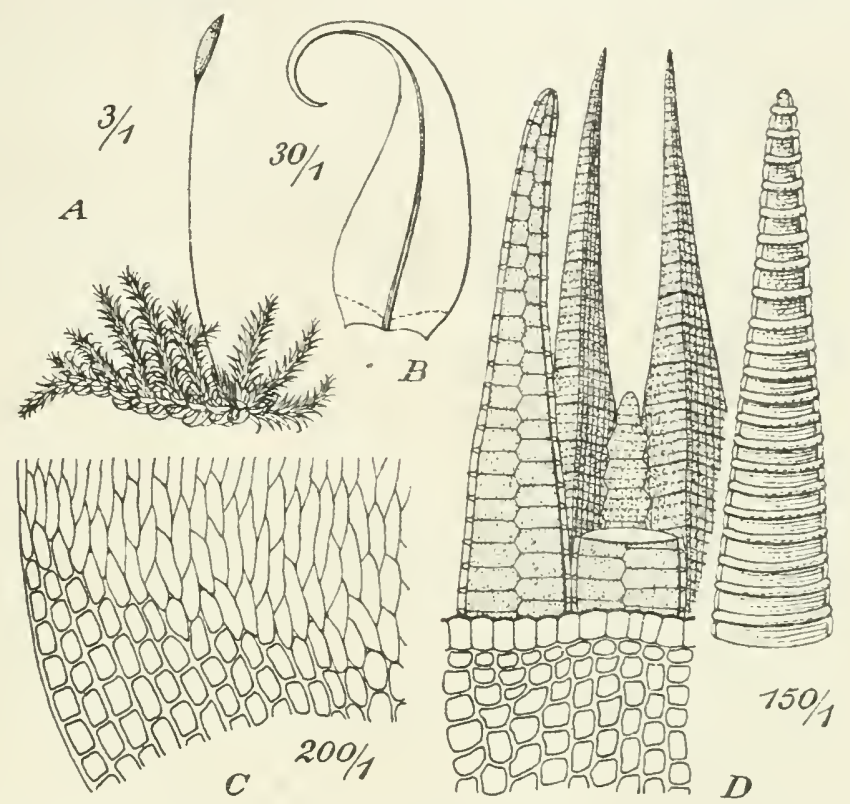

Fig. 107. Pylaisia polýantha (Schreb.). A Fruchtende Pfl. (3/1); B Stengelb. (30/1); C Blattbasis (200/1); D Peristom $(150 / 1)$.

An Baumstämmen und Wurzeln, auf altem Holzwerk, seltener auf Kieselgestein.

P. Al. pass. (Bom.), - Ab.-Ik. st. fq. - St. Eura. Björneborg. Norrmark. Karkku. Pirkkala. - Ta. st. fq. - Sa. Willmanstrand. Kangasniemi. Rantasami. - Kl. Kurkijoki. Jaakima. Sortavala. Ruskeala. - Kol. Im Svirgebiete fq. (Elfv.). Petrosavodsk. - Oa. Isokyrö, Orisberg (Ranck.). - Tb. Jyväskylä (Brolh.). Pihtipudas, Kanalanmäki (Roiv.); Muurasjärvi, Salmela (R.). - Sb. Joroinen, Järvikylä (H. Lindb.). Kuopio, an einigen Fundorten (Link.). Kaavi (Kŗ̧ȟk.). Maaninka, Tuovilanlahti, Niskala (Roiv.); Vianto (R.); Pöljā (Kyyhk.). - Kb. Joensuu (Linnan.). - Kon. Pirtlinieni (Simm.). - Om. Viıdala, Pyhälahti, Heinäaho (Backn.): Viitaniemi (B.). Lappajärvi, Ǩirchdorf (B.). - Ok. Kajana (Kyyhk.). Kuhmoniemi (K.). - Ob. Lleaborg, Hupisaaret (Huum.). Kemi, Kallinkangas (Räs.); Saarengrunni und Pörhölä (Brenn.). Yliturnio, Harrila (Hult). Turtola (H.), - Lkem. Kittild, Kirchdorf (H.). Zw. Muonio und Ylikylä (Norrl.). - Li. Inari, Tirro, in der Nadelwaldregion (Hult); Peldoivi, in der Birkenregion (H.). - Lim. Landalaks (F. Nyl.). - Lt. Lavschjăyr und Rjetemjäyr im südl. Teile (Roiv.).

S. $S k,-L$.

N. $S m,-F$. Nordgrenze bei $70^{\circ} \mathrm{n} . \mathrm{Br}$.

Europa, Algier, Kaukasus, Kaschmir, Sibirien, Japan, Nord-Amerika.

var. suecica (Bryol. eur.). [Thedenia suecica Bryol. eur. fasc. 19.51 Mon. p. 3. t. 1 (1852). - Stereodon suecicus Lindb. Musc. scand. p. 38 (1879). - Pylaisia polyantha var. paludosa Bryhn in Norsk Mag. Naturv. XXXII (1891).] 
Pfl. etwas k]einer. Blätter entfernt gestellt, weich, allseits abstehend, rasch kurz oder länger zugespitzt; Zellen rhombisch-linealisch. Seta etwa $7 \mathrm{~mm}$. Kapsel kleiner.

An Bäumen, auf faulendem Holze, auf Torfdächern und an Mauern.

S. Hrjd. Funnesdalsbārget, Hamrafjăllet und Malmagen. Mpd. Norbỵknöl.

N. Ringerike, an wenigen Fundorten. Saetersdalen. Telemarken. Hallingdalen. Gudbrandsdalen.

\section{HYPNUM}

(Dill., Hedw.) Fleisch, in Nova Guinea XII. Bot. 2, p. 122 (1914).

Pfl. auf verschiedenartiger Unterlage, doch nicht an nassen Orten. Stengel meist ohne oder mit spärlichen Rhizoiden und meist unregelmässig, seltener regelmåssig gefiedert: Sprossspitzen meist haken- oder sichelförmig gekrümmt; Pseudoparaphyllien nur in der Nähe der Astanlagen. Blätter meist zweizeilig einseitigsichelförmig, \pm hohl und (excl. H. revolutum) ohne Längsfalten, nicht oder wenig herablaufend; Rippe fehlend oder kurz und doppelt; Zellen eng prosenchymatisch, am Blattgrunde meist dickwandig und getüpfelt, in den Blattflügeln differenziert. Astblätter den Stammblättern ähnlich, nur kleiner. Perichätialblätter \pm deutlich längsfaltig, lang und feinspitzig. Kapsel länglich bis zylindrisch und \pm gekrümmt. Ring meist differenziert. Haube glatt.

\section{Übersicht der Arten.}

A. Autözisch.

a. Grüne bis gelbgrïne, \pm weiche, meist Rinden-Holzmoose. Deckel dünn geschnäbelt

773. H. pallescens.

b. Bräunlichgelbe oder braungrüne lis goldig gescheckte, trocken starre und brüchige Felsmoose. Deckel gewölbtkegelig, stumpf.

«. Blätter flach- und ganzrandig.

I. Sehr schlanke Pfl. ohne Stolonen. Innere Perichätialblätter kurz zugespitzt 776. H. Sauteri.

11. Weniger schlanke Pfl. mit Stolonen. Innere Perichätialblätter lang zugespitzt

774. H. fastigiatum.

ґ. Blätter von der Basis bis oberhalb der Mitte mit zurückgeschlagenen Rändern, ganzrandig oder undeutlich gesägt

775. H. recurvatum.

B. Diözisch.

a. Peripherische Nantelzellen in der Grösse von den angrenzenclen nicht verschieclen, mit meist stark verdickten Aussenwänden. Blattflügelzellen klein, 士 stark verdickt.

«. Blätter deutlich längsfaltig, mit bis zur Spitze breit umgerollten Rändern ...............................

$\beta$. Blätter ungefaltet, flachrandig oder mit nur am Grunde schmal umgebogenen Rändern.

I. Stengel fast regelmässig geficdert; Pseudoparaphyllien zahlreich, vielgestaltig. Blätter an der Spitze scharf gesägt, an der Insertionsstelle goldgell)

781. H. revolutum.

II. Pseudoparaphyllien spärlich oder fehlend. Blätter am Grunde nicht gefärbt.

1. Stengel unregelnässig und kurz beästet. Peri-

778. H. imponens. 
pherische Mantelzellen mit stark verdickten Aussenwänden. Blätter ganzrandig ......... 777. H. Bambergeri.

2. Stengel entfernt bis regelmässig gefiedert; peripherisehe IIantelzellen mit dünnen, trocken kollabierten Aussenwänden.

* Mit Stolonen. Blätter ganzrandig; Zellen der oberen Blatthälfte 1: $4-7$............... 779. II. Vaucheri.

** Olne Stolonen. Blätter ganzrandig oder oberwärts \pm gesägt; Zellen der oberen Blatthälfte 1: $10-15 .$. 780.H.cupressiforme.

b. Peripherische Mantelzellen lockerzellig, hyalin. Blätter flachrandig oder mit am Grunde \pm deutlich umgebogenen Rändern; Zellen am Blattgrunde meist nicht gefärbt, in clen Blattflügeln meist differenziert, aufgeblasen, dünnwandig und hyalin.

«. Schlanke Pfl. Blätter sichel- bis kreisförmig gekrümmt, lang pfriemenförmig zugespitzt. Innere Perichätialblätter \pm deutlich längsfaltig. liapsel scliwach gebogen.

I. Blattflügelzellen vereinzelt oder fehlend ........... 782. H.hamulosum.

II. Blattflïgelzellen zahlreich, eine ausgehöhlte, gut begrenzte Gruppe bildend .......................

ß. Kräftige Pfl. Blätter hakenförmig-einseitswendig, kurz und breit zugespitzt. Innere Perichätialblätter mit mehreren tiefen Längsfalten. Kapsel stark eingekrümmt, trocken sehwach gefurcht ................

C. Diözisch und pseudautözisch; o Zwergpfl. knospenförmig, wurzelnd, stengel- oder blattständig. Peripherisehe Mantelzellen locker und hyalin. Blätter zart und schlaff, fast flach, trocken oft querwellig, scheinbar zweizeilig, lang und schmal zugespitzt, an der Spitze gesägt, am Grunde wechselweise links und rechts eingeschlagen; von der Zellen in den flachen Blattflügeln wenige quadratiseh und rektangulär. 785. H. pratense.

773. Hypnum pallescens (Hedw.) Palis. Prodr. p. 67 (1805). [Leskea pallescens Hedw. Sp. muse. p. 219, t. 55, f. 1-6 (1801). - Hypnum reptile Rich. in Michx. Fl. bor.-amer. II. p. 315 (1803). - Stereodon pallescens Lindb. in Act. Soc. Se. Fenn. X. p. 257 (1872).]

Autözisch. Pfl. in dichten, flachen, oft ausgedehnten, grünen oder gelb- bis bräunlichgrünen, trocken matt glänzenden Rasen. Stengel kriechend, längs durch Rhizoidenbüschel an der Unterlage haftend, dicht und fast regelmässig gefiedert; Äste kurz, kätzehenartig, in der Rasenmitte aufreeht, gegen die Ränder ausgebreitet. Blätter sichelförmig-einseitswendig. Stammblätter aus kaum herablaufender, verengter Basis rundlich-eiförmig bis oval und plötzlich in eine feine Pfriemenspitze versclımälert, bis $1,2 \mathrm{~mm}$ lang und bis $0,6 \mathrm{~mm}$ breit, mit am Grunde zurückgeschlagenen, oberwärts \pm scharf gesägten Rändern; Zellen schwach papillenartig vortretend, in den nicht ausgehöhlten Blattflügeln zahlreiche klein, quadratisch und kurz rektangulär, mit Chlorophyll. Seta $1-2 \mathrm{~cm}$, rötlich. Kapsel aufrecht oder etwas geneigt, zylindrisch, bis $3 \mathrm{~mm}$ lang und $0,7 \mathrm{~mm}$ dick, gelbbräunlich, trocken und entleert gekrümmt und unter der Mündung verengt. Deckel bleichgelb, aus hochgewölbter Basis dünn geschnäbelt. Sporenreife im Spätsommer. - Fig. 108 A-C. 
Am Grunde ron Baumstämmen, an morschen Stämmen und auf Steinen.

F. Al. Jomala, Kasberg und Lördal (Bom.). Saltrik, an mekreren Fundorten (B.). - Ab. Âbo, Hallis (Elfv.). Kimito, Skogibōle (Ols.). Bromarf, an mehreren Fundorten (Sundv.). Lojo, an mehreren Fundorten (Lindb.. H. Lindb., Sundv, E. af H.). Sammatti (Sel.). Vichtis (IV. Nyl.). - N. Ekenäs (Broth.); Trārminne (H. Lindb.). Tenala (Jusl.). Sjundeå (Sundr.). Kỵrkslātt (Sundr.). Esbo, Gräsa und Sandudd (Broth.). Helsingfors (Lindb.). Helsinge, Halm (Sundr.). Pernả (Sael.). Hogland (Lindb.). — Ka. Wiborg (W. Nyl.). Jääski, Kārkkäālā (Lindb.). - Ik. Kivennapa und Muola (Mrel.). Valkjärvi (H. Lindb.). Rautu (Lảng). Metsäpirtti und Sakkola (H. Lindb.). Pyhäjärvi (Sahlb.). - St. Pirkkala (Simm.). Ikaalinen (Sundr.). - Ta. Tavastehus (Ranck.). Kalvola (Knab.). Kangasala (R.). Im südöstl. Teile st. fq. (Norrl.). Hartola (Bonsd.). Luhanka, an mehreren Fundorten (Vain.). - Sa. Nuijamaa, Pohjola (Broth.). Willmanstrand (Buch). Ruokolahti, Imatra (Broth.). Kangasniemi (Lackstr.). - Kl. Kexholm (Tomm.). Kurkijoki (Jusl.). Parikkala (Sahlb.). Uukuniemi (Simm.). Suistamo, Loimala (Broth.). Pälkjārri, Pitkäniemi und Korkeaniemi (B.). - Kol. Im ganzen Svirgebiete (Elfv.). Petrosarodik (Kullh.). - Tb. Jyväskylä, Tourujoki (Bruth.); Haapakoski (Lir.). Laukaa, Kuhankoski
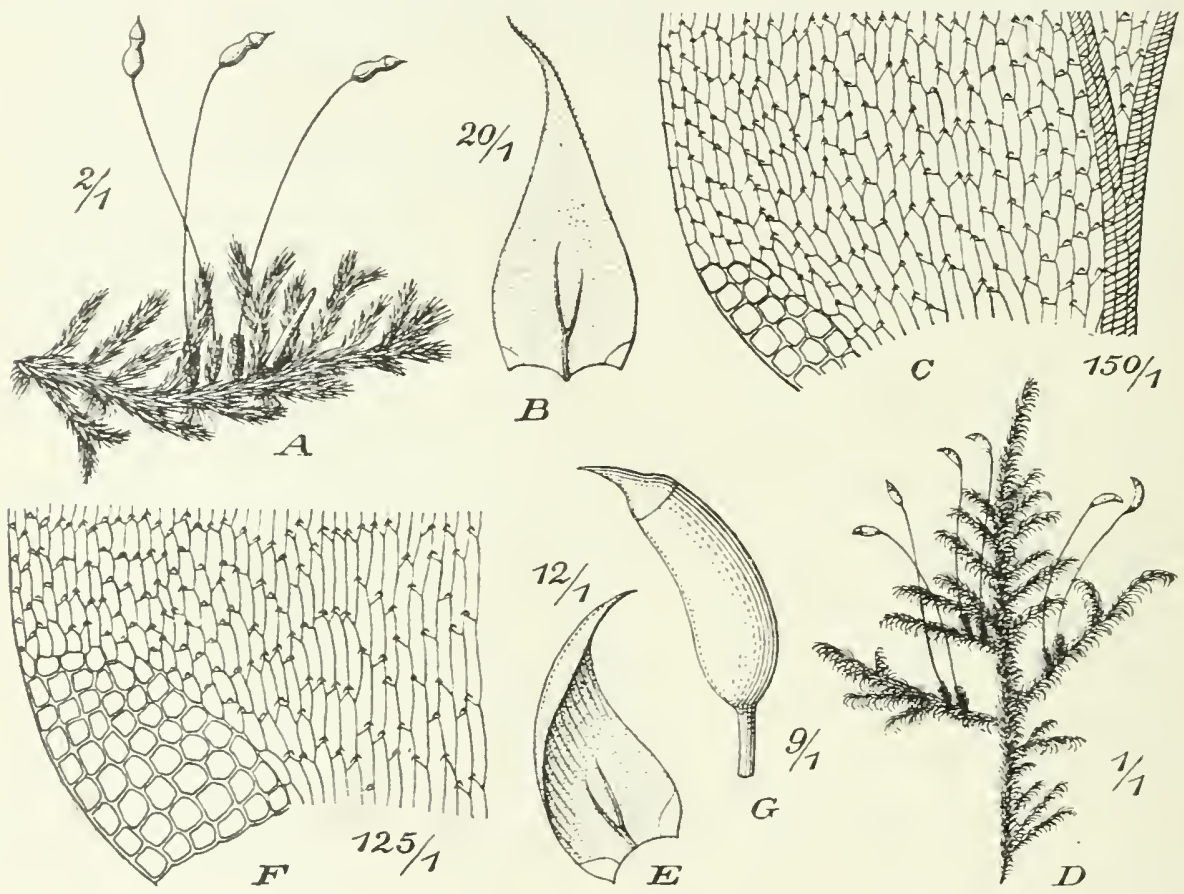

Fig. 108. A-C. Hypnum pallescens (Hedw.). A Fruchtende Pfl. (2/1); B Stengelb. (20/1); C Blattbasis (150/1). - D-G. H. cupressiforme L. D Fruchtende Pfl. (1!1): E Stengelb. (12/1): F Blattbasis (125/1); G Kapsel $(9 / 1)$.

(Broth.). - Sb. Leppävirta (L'ınd:tr.). Kuopio, an mehreren Fundorten (Link.). Nilsiä, Kuuslahti, Jaakonlampi (Kyyhk.): Keskisenmäki und Haluna (K.). Maaninka pass. (Kỵhk., Roiv.). Pielavesi, Rannankylä und Sãviā (Roir.). - Kb. Joensuu, Linnunniemi (Linnan.). - Kon. Jalguba und Kãppãselkā (Simm.). - Om. Jakolstad (Broth.). - Ok. Paltamo, Kives (Lackstr.); Takaranta (Broth.). Sotkamo (B.). - K. Kuusamo, Sarinajoki (Roir.).

S. Sm., Ög., Srm., Vär., Upl., Vsm., Vrml., Gstr., Dlr., Hlsl., Hrjd., Ảng. und Vb.

N. Sm. Onsø. A. Kristiania. Bu. Rirngerike. JL. Sandefjord. Br. Kongsberg. Ne. Saetersdalen. II. Gudbrandsdalen. Dovre

Europi, Kaukasus, Kaschmir, Sibirien, Sachalin, Nord-Amerika.

var. subjulaceum Schimp. Syn. p. 619 (1860). [Hypnum perichaetiale Bryol. eur. fasc. $57 / 61$ Mon. p. 18, t. 8 (1854). - Stereodon pallescens var. $\gamma$ perichaetialis Lindb. Musc. scand. p. 38 (1879).]

Blätter dicht gedrängt, genau dachziegelig, nur an den Astspitzen schwach cinseitswendig, kürzer zugespitzt, weniger deutlich gesägt. Pcrichätialblätter 
etwas länger, aus der Mitte abgebogen, die inneren scheidig-eingerollt und kaum faltig, mit umgebogenen Rändern.

F. Helsingfors (W. Nyl.).

N. Sm. r. A. Kristiania. Bu. Hønefors und skien.

*Hypnum protuberans (Brid.). [Hypmum Stereodon protuberans Brid. Bryol. univ. II. p. 612, No. 11 (1827). - H. palleseens 13ryol. eur. fasc. 57/61 Mon. p. 18, t. 7 (1854), - Stereodon palleseens var. protuberans Lindb. in Act. Soc. Sc. Fenn. X. p. $254(1872)$.

Autözisch. Schlanke Pfl. in dichten, flachen, weichen, bleich- oder gelbgrünen, seidenglänzenden Rasen. Stengel kriechend, längs durch Rhizoidenbiischel an der Unterlage haftend, \pm dicht gefiedert; đ̈ste kurz, aufrecht oder eingekrümmt. Blätter allseitswendig, schwach sichelförmig. Stammblätter aus etwas herablaufender, eiförmiger Basis schmal lanzettlich, allmählich pfriemenförmig, meist nur $1 \mathrm{~mm}$ lang und $0,35 \mathrm{~mm}$ breit, flachrandig, nur an der Spitze schwach gesägt; Zellen kaum papilienartig vortretend, in den uicht ausgehöhlteı Blattflügeln wenige quadratisch und wenigstens am Rande hyalin. Seta $6-12 \mathrm{~mm}$, rötlich. Kapsel fast aufrecht oder schwach geneigt, länglich, bis $2 \mathrm{~mm}$ lang und $0,5 \mathrm{~mm}$ dick, gelbbräunlich, kaum gekrümmt, trocken und entleert unter der Mündung nicht oder wenig verengt. Deckel gelbrot, aus gewölbter Basis dünn geschnäbelt. Sporenreife im Juni und Juli.

An Baumstämmen und Wurzeln.

S. Vrml. Filipstad.

N. $J L$. Sandefjord. $R$. Molde.

Europa.

774. Hypnum fastigiatum (Brid.) Hartm. Sk. FI. J. ed. p. 335 (1849). [Stereodon fastigiatus Brid. Bryol. univ. II. p. 620 (1827).]

Autözisch. Schlanke Pfl. in sehr dicht verwebten, trocken starren und brüchigen, weit ausgedehnten, flachen, seltener polsterförmigen, gelbgrünen und bräunlichen Rasen. Stengel kriechend, an der Spitze oft stolonenartig verlängert, oft reichlich büschelig verzweigt, unterbrochen dicht fiederästig, mit zahlreichen, langen, bleichen Stolonen; Äste kurz, fadenförmig, aufsteigend bis aufrecht, am Rande der Rasen ausgebreitet. Blätter stark sichelförmig. Stammblätter nicht herablaufend, eilanzettlich, lang zugespitzt, bis $0,9 \mathrm{~mm}$ lang und bis $0,3 \mathrm{~mm}$ breit, flach- und ganzrandig; Zellen $5 \mu$ breit, 1: 6-10, in den nicht ausgehöhlten Blattllügeln wenige quadratisch und hyalin. Innere Perichätialblätter lanzettlich, lang und fein zugespitzt. Seta etwa $1, \overline{c m}$, gelbrot. Kapsel etwas geneigt, länglich-zylindrisch, bis $2,5 \mathrm{~mm}$ lang und $0,7 \mathrm{~mm}$ dick, rostfarben, \pm gekrümmt, trocken und entleert unter der Mündung \pm verengt. Deckel gewölbt-kegelig, mit Spitzchen oder Warze.

Auf Kalkgestein und kalkhaltigen Schiefern.

F. Ab. Pargas, Storgård (Elfv.). Lojo (Boldt); SOL hem (Lindb.); Tytyri (L.); Hiitis (H. Lindb.); Hermola (Sundv.); Pietilä (E. af H.). - Kl. Sorlavala, Kirjavalahti (Norrl.). Ruskeala, Marmorbruch (Norrl.). Suistamo, Saariselkä (Kot.). - Sb. Juuka, Petrovaara, Saarijărvi, Kasurinniemi (Kol.); Iljanniemi (K.). - Kon. Valkeamäki (Sımm.). Perguba (Kullh.). - Om. Alajārvi, Vesterbacka, Hunsianmaankallio und Moskvankallio (Backm.). -- Ok. Paltamo, Hyyrỵlānmāki (Lackstr.). Sotkamo, Natula (Kyyhk.). Puolanka, Vuorikallio (Lackstr.); Rallinmäki (Kyyhk.). — Kipom. Hukkakallio (Bergr.) K. Kuusamo, Aventojoki (Broth.); zw. Virranniemi und Juuma (B.); Kitkajoki, Jỹrärã (B.); Juuma, Larnmasvuoma (B.): Oulankajoki, Merenoja (B.); Kiutakōngäs (E. af H.); Taivalköngăs (Roir.); Paanajärvi, Kuoppaoja (Broth.); zw. Liikanen und Sovanköngảs (B.). Kuolajärvi, an mebreren Fundorten (Roiv.). - Lkem. Kolari, Manaoja und Naalaoja (Hult). Kittilả, Kalkbruch (H.). - Le. Kilpisjärvi, Malla, in der alpinen Region (Kot.).

S. Ög. När., Irml., Dlr., Hrjd. und Jmt.

N. Bu. Eker. Pingerike, an mehreren Fundorten. No. knd 'Tr. Nordgrenze bei $69^{\circ} 40^{\prime} \mathrm{n} . \mathrm{Br}$. Alpengebiet, Nord-Amerika.

var. mitodes (Hag.) Hag. Musc. Norv. bor. p. 331 (1901). [Hypnum milodes Hag. in Nyt Mag. f. Naturv. Bd. 38, p. 340 (1900).] 
Polyözisch (autözisch $+\sigma^{x}$ Pfl.). Stengel fadenförmig, etwas entfernt fiederästig. Stengelblätter locker dachziegelig, schwach einseitswendig, aus eiförmiger Basis rasch in eine fast haarförmige Spitze verschmälert, rings entfernt und undeutlich gezähnelt.

N. No. Bejeren, Soløjen, an Kalkfelsen.

Schweiz.

775. Hypnum recurvatum (Lindb. et Arn.) Limpr. Laubn. III. p. 467 (1899). [Stereodon recurvatus Lindb. et Arn. in K. Sv. Vet.-Ak. Handl. Bd. 23, No. 10, p. $149(1890)$.]

Uit der vorigen Art sehr nahe verwandt. Blätter fast kreisförmig gekrümmt, aus enger Basis bald verbreitert, eiförmig, allmählich lang zugespitzt, mit bis oberhalb der Blattmitte deutlich umgebogenen Rändern; Zellen etwa $3,5, \mu$ breit, 1 : $10-15$.

An Kalk- und Schieferfelsen.

F. Kl. Jerovaara (H. Backm.). - Kon. Tiudie (Sahlb.). - Ok. Paltamo. Melalahti. Viilonkallio (Brenn.). - K. Kuusamo, Kitkajoki, Päāskōskallio (Broth.).

N. F. Kistrand, Lemmivaara.

Sibirien,

776. Hypnum Sauteri Bryol. eur. 1. c. p. 21, t. 10.

Autözisch. Tracht von $H$. fastigiatum, doch viel kleiner. Pfl. meist nur kleine, dünne, braungrüne bis goldig gescheckte Überzüge bildend. Stengel kriechend, längs durch Rhizoidenbüschel an der Unterlage haftend, ohne Stolonen, locker beblättert. gefiedert; Äste kurz, meist ausgebreitet. Stammblätter schwach sichelförmig, aus breit eirunder Basis plötzlich schmal lanzettlich-pfriemenförmig, etwa $0,5 \mathrm{~mm}$ lang und $0,27 \mathrm{~mm}$ breit, flach- und ganzrandig: von der Zellen in den nicht ausgehöhlten Blattflügeln wenige quadratisch und gelblich. Innere Perichätialblätter eilänglich, kurz zugespitzt. Seta bis $1 \mathrm{~cm}$. rötlich. Kapsel geneigt bis horizontal, länglich, bis 1,5 $\mathrm{mn}$ lang und $0,45 \mathrm{~mm}$ dick, ockerfarben, schwach gekrümmt, trocken und entleert unter der Mündung verengt. Deckel gewölbt-kegelig, stumpf.

An sonnigen oder beschatteten Kalkfelsen.

N. No. Vessen; Bejeren; Skjerstad. Nordgrenze bei $67^{\circ} 18^{\prime} \mathrm{n}, \mathrm{Br}$.

Alpengebiet.

777. Hypnum Bambergeri Schimp. Syn. Addend. p. 698 (1860). [Stereodon Bambergeri Lindb. Musc. scand. p. 38 (1879).]

Diözisch. Pfl. in starren, meist dichten und kissenförmigen, braungrün und goldbräunlich gescleckter, innen bleich rostfarbenen Rasen. Stengel aufrecht, büschelig geteilt, unregelmässig und kurz beästet, selten gefiedert, ohne Paraphyllien. Alle Blätter dicht gedrängt, hohl, ausgezeichnet zweizeilig-einseitswendig und meist aus aufrechter Basis kreisförmig gebogen. Stammblätter aus eiförmiger oder länglicher Basis allmällich lanzettlich und in eine lange, meist geschlängelte Pfrieme verschmälert, bis $2 \mathrm{~mm}$ lang und $0,75 \mathrm{~mm}$ breit, flach- und ganzrandig; Zellen \pm verdickt und getüpfelt, in der Insertion goldgelb und in den kaum geöhrten, etwas ausgehöhlten Blattflügelı quadratisch und rund oder oval und länglich, eine kleine Gruppe bildend. Innere Perichätialblätter an der gestutzten und grob gezähnten Spitze plötzlich in eine zurückgebogene, glatte Pfrieıne verlängert. Seta etwa $2 \mathrm{~cm}$, dünn und verbogen, rötlich. Kapsel aus fast aufrecliter Basis etwas gekrümmt, länglich-zylindrisch, bis 2,5 $111 \mathrm{~m}$ lang und 0,75 $\mathrm{mm}$ dick, bräunlich-olivenfarben. Deckel hochkegelig, stumpflich, gelbrot.

Auf erdbedeckten, feuchten Felsenabhängen und auf Alpenheiden.

P. Lo. Kilpisjārvi, IIalla und Saana, in der ailpinen Region (Kot.). — Lim. Hibinā, in der alpinen Region (Broth.).

S. Öl. PL. Tjidtjakk. Hrjd. Jml. Areskutan. Stora Midàtáklāppen. LuL. Sarekgebiet. $T L$.

N. Gudbrandjdalen. ST. Foldalen. K. Jolun- und Loinsfjeldene. Dovre. No. und Tr. in der Birken- und alpinen Region.

Spitzbergen, Alpenkette, arkt. Nord-Amerika 
var. condensatum (Schimp.) Limpr. Laubm. IlI. p. 475 (1899). [Iypnum condensatum Schimp. Syn. p. $698^{\circ}(1860)$. - H. flexuosum Berggr. Bot. Notis. 1872 p. 66. - Stereodon Bambergeri var. $\beta$ flexuosus Lindb. Musc. scand. p. 38 (1879).]

Blattzellen überall sehr stark verdickt und rosenkranzähnlich getüpfelt, am tiefsten Blattgrunde stark verdickt und gelbrot.

S. Hrjd.

N. K. Dovre, ST, Opdal. No. Bejeren. Tr. Tromsøsundet. Nordrejsen.

Allgäu, Schweiz.

778. Hypnum imponens Hedw. Sp. musc. p. 290, t. 77 (1801). [Stereodon imponens Brid. Bryol. univ. II. p. 618 (1827).]

Diözisch. Tracht von $H$. cupressiforme. Pfl. in flachen, oft ausgedelnten, grünen oder gelblich- bis bräunlichgrünen Rasen. Stengel meist hingestreckt, fast regelmässig gefiedert; Äste bis $12 \mathrm{~mm}$ lang; Pseudloparaphyllien ziemlich zahlreich, nach Form und Grösse sehr veränderlich. Stammblïtter hohl, aus breit eiförmiger Basis lanzettlich-pfriemenförmig, etwa $2 \mathrm{~mm}$ lang und $0,6 \mathrm{~mm}$ breit, mit am Grunde schmal umgebogenen, an der Spitze scharf gesägten Rändern; Zellen an den etwas ausgehöllten und schwach geöhrten Blattflügeln quadratisch und kurz rektangulär, eine gut begrenzte, rundliche, gelbliche bis braune Gruppe bildend. Seta $2-3 \mathrm{~cm}$, rot. Kapsel fast aufrecht, zylindrisch, wenig gekrümmt, etwa $3 \mathrm{~mm}$ lang und $1 \mathrm{~mm}$ dick, braun. Deckel gewölbt-kegelig, scharf zugespitzt. Sporenreife im Herbst.

An schattigen, kieselhaltigen Felsen und Felsenabsätzen.

F. Al. Jomala, Kasberg (Elfv.). Geta, Höckböle und Dånö (Bom.). Saltvik an mehreren und Sund an wenigen Fundorten (B.). - Ab. Kakskerta (Colland.). Åbo, Hirvensalo, Jänissaari (Buch); Vaarniemi (B.). Pargas, Gunnarsnäs (Elfr.). Kimito, Kobbel (Ol..). Lojo, an mehreren Fundorten (Lindb., Jusl., H. Lindb., Sundv.). Vichtis. Palajärvi (Broth.). -- N. Ingå, Svartō (W. Brenn.). Kyrkslātt, Obbnās (Jusl.); Humaljärvi (Ranck.). Helsingfors (Lindb.). Helsinge, Backas (Sol.). Sibbo, Sōderkulla (Lindb.). Hogland (L.). - Ka. Kotka, Langinkoski (Roiv.). Wiborg, Iso Pälli (Buch). Antrea, Liikola (Lindb.). - Ta. Janakkala, Hankaruori (Coll.); in der Nähe der Kirche (Elfv.). — Sa. Kangasniemi, Vehkasenvuori (Lackstr.); Suomảki, Torikkalanvuori (L.).

S. Sk., Sm.. Ög., I g., Srm., När., Vrml, und Vsm.

N. Sm. pass. A. Kristiania r. JL. Sandefjord rr. Br. Skien. Ne. Saetersdalen. Sl. Ryfylke. R. rr. NT. Stjørdalen. No. Bodin und Skjerstad. Nordgrenze bei etwa $67^{\circ} 17^{\prime} \mathrm{n} . \mathrm{Br}$.

Europa, Azoren, Himalaya, Japan, Nord-Amerika.

779. Hypnum Vaucheri Lesq. Cat. Mouss. suiss. p. 48 (1845). [Stereodon Vaucheri Lindb. Musc. scand. p. 38 (1879).]

Diözisch́. Tracht von H. cupressiforme. Pfl. in dichten kissenförmigen, gelbund braungrünen Rasen. Hauptstengel kriechend, mit langen, bleichen Stolonen und oft an der Spitze stolonenartig verlängert. Sekundäre Stengel aufreclit, fast büschelig geteilt und fast gefiedert, mit fast drehrunden, bis $1 \mathrm{~cm}$ langen Ästen. Blätter dicht gedrängt. dachziegelig, sichelförmig-einseitswendig. Stammblätter fast löffelartig-hohl, eiförmig oder länglich, rasch in einc verbogene Pfrieme verlängert, bis $1,6 \mathrm{~mm}$ lang und bis $0,75 \mathrm{~mm}$ breit, flach- und ganzrandig; Zellen in der oberen Blatthälfte etwa $7 \mu$ breit und $4-7$ mal so lang, in den weder geöhrten noch ausgehöhlten Blattflügeln klein und quadratisch, eine grosse, aufwärts gegen die Ränder sich verschmälernde Gruppe bildend. Sporogone nubekannt.

Auf Kalk und an kalkreichen Felsen.

F. K. Kuusamo, Paanajärvi, Ruskeakallio (Broth.).

S. Öl., Gtl., Vg., När., Srm., Jmt. und Vb. an einzelnen Fundorten.

N. Ringerike fq. Dovre. Trondhjem. NT. Stjørdalen. No.-F., stellenweise hãufig.

Beeren Eiland, Europa, Kaukasus, West-Himalaya, Zentral-Asien, Sibirien, Nord-Amerika. Nordgrenze in Ost-Grỏnland bei etwa $70^{\circ} \mathrm{n}$. Br.

780. Hypnum cupressiforme L. Sp. pl. p. 1126 (1753) p. p. [Stereodon cupressiformis Brid. Bryol. univ. II. p. 605 (1827).]

Diözisch. Pfl. in meist ausgedehnten, flachen oder fast kissenförmigen, bleicl]oder olivengrümen bis bräunlichen, trocken glänzenden Rasen. Stengel kriechend, 
zuwcilen aufsteigend bis fast aufrecht, unregelmässig geteilt, entfernt bis regelmässig gefiedert; Aste im Bogen aufgerichtet bis aufrecht oder zweizeilig-abstehend. Stammblätter zweireihig-einseitswendig, haken- oder sichelförmig, länglich-lanzettlich, allmäh]ich pfriemenförmig zugespitzt, bis 2,5 $\mathrm{mm}$ lang und $0,6 \mathrm{~mm}$ breit, mit aufrechten oder abwärts schmal umgebogenen, glatten oder oberwärts \pm gesägten Rändern; Zellen in den ausgehöhlten Blattflügeln stark verdickt, quadratisch und mehreckig, eine rundliche, bald hyaline, bald gelbe oder gebräunte, oberwärts von kleineren Zellen begrenzte Gruppe bildend. Seta 1,5-2, $5 \mathrm{~cm}$, rot. Kapsel fast aufrecht oder wenig geneigt, länglich-zylindrisch, bis $3,5 \mathrm{~mm}$ lang und $0,75 \mathrm{~mm}$ dick, leicht gekrümmt, braun, trocken und entleert unter der Mündung etwas verengt. Deckel ans gewölbter Basis lang spitzkegelig bis geschnäbelt. Sporenreife im Frühling. - Fig. $107 \mathrm{~A}-\mathrm{C}$.

Auf Steinen und Felsen aller Art wie auch an Baumstämmen, in deri südlichen und mittleren Teilen des Gebietes $\pm \mathrm{fq}$., nördlicher seltener, in den Lappmarken nur an einzelnen Fundorten beobachtet und die alpine Region nicht erreichend. Nordgrenze bei $70^{\circ} 40^{\prime} \mathrm{n}$. Br. Sehr formenreich.

Europa, Nord-Afrika, Azoren, Kanaren, Kaukasus, Zentral-Asien, Sibirien, Nord-Amerika, Ecuador, Fuegia, Süd- und Ost-Afrika, Neu-Holland, Tasmanien, New Zealand.

var. lacunosum Brid. Rec. I1. P. 2, p. 136 (1801). [H. cupressiforme var. $\eta$ elatum Bryol. eur. fasc. 57/61 Mon. p. 25, t. 15, f. $\eta 1-6,(1854)$ - Stereodon cupressiformis var. elatus Braithw. Brit. Mossfl. III. p. 161 (1902). — * Hypnum lacunosum Loesk. Moosfl. Harz. p. 315 (1903).]

Sehr kräftige Pfl. in meist lockeren, grünen, gebräunten bis goldbraumen Rasen. Stengel aufsteigend bis aufrecht, gedunsen beblättert, kurz und nie regelmässig fiederästig. Blätter sehr hohl, kaum bis deutlich einseitswendig, breit oval bis eilänglich, zuweilen bis unter die Spitze fast gleich breit und \pm plötzlich in eine kurze oder längere, rinnig-hohle, meist ganzrandige Pfriemenspitze verschmälert, bis $3 \mathrm{~mm}$ lang und $0,45 \mathrm{~mm}$ breit. Selten fruchtend.

Auf trockenem Kalkboden, in sandigen Kieferwäldern und auf feuchtem, lehmig-tonigem Heidelande.

F. Al. Lemland, Styrsö (Broth.).

S. Öl. und $B l$.

N. Sm. und Bu. No. Ankenes. Nordgrenze bei $70^{\circ} 10^{\prime} \mathrm{n} . \mathrm{Br}$.

Europa.

var. subjulaceum Mo]. Moosstud. Alg. Alp. p. 107 (1865). [Stereodon cupressiformis var. subjulaceus Arm. et C. Jens. in Bih. Sv. Vet.-Ak. Handl. Bd. XXI. Bd. III. No. 10 (1896).]

Schlanke Pfl. in 士 dichten, grünen oder gold- und rötlichbraun gescheckten Rasen. Stengel aufsteigend bis aufrecht, mit zahlreichen, kurzen, aufstrebenden, meist spitzen, fast kätzchenförmigen Ästen. Blätter ein- bis allseits aufrechtabstehend. Stengelblätter eilänglich, \pm rasch fein zugespitzt.

An Felsen.

S. Ång. Tåsjö.

N. Tr. Nordrejsen.

Allg ău, Sibirien.

var. longirostre Bryol. eur. fasc. 57/61 Mon. p. 25, t. 15, f. $\delta 1-5$ (1854). [Stereodon cupressiformis var. longirostris Braithw. Brit. Mossfl. III. p. 161 (1902).]

Schlanke Pfl. in lockeren, flachen, dunkelgrünen Rasen. Stengel unregelmässig gefiedert, mit zahlreichen Ästen und Ästchen. Stengelblätter leicht einseitswendig, ei- bis länglich-lanzettlich, rasch lang und fein zugespitzt. líapsel fast aufrecht, bogig gekrümmt. Deckel lang und dümn geschnäbelt.

N. Sm. Onso, an Stämmen.

Europa. 
var. filiforme Bricl. I. c. p. 138.

Schlanke Pfl. in flachen, herabhängenden Rasen. Stengel bis 12 cm, mit langen, fadenförmigen, fast parallel nach unten gerichteten \%weigen und Ästen. Blätter \pm deutlich einseitig haken- oder sichelförmig herabgekrümmt. Stengelblätter ei- oder länglich-eilanzettlich-pfriemenförmig. Seta kurz. líapsel klein. Deckel lang geschnäbelt.

An Baumstämmen, trockenen Blöcken und Felsen. Selten fruchtend.

F. In den suidlichen Teilen allgemein verbreitet. - ob. Rovanieni (Hult). Tornio (II.). Aavasaksa (Nyb.). - Le. Nainakka (Norrl.).

S. Wahrscheinlich, wenigitens in den südlichen Teilen, nicht selten.

N. Sm. fq. A., Ne. und ST.

Europa.

*Hypnum mamillatum (Brid.). [Hypmum cupressiforme var. mamillatum Brid. Musc. rec. II. P. 2. p. 137 (1801). — * Stereodon mamillatus Lindb. Mlusc. scand. p. 38 (1879). - S. cupressiformis var. mamillatus Braithw. Brit. Mossfl. III. p. 161 (1902).]

Schlanke Pll. in grïnen, meist flachen, oft ausgedehnten Rasen. Stengel oft stolonenartig verlängert, \pm regelmässig fiederästig. Blätter stark sichellörmig bis kreisförmig gekrümmt, flachrandig, oberwärts \pm deutlich gesägt. Seta 1,5$2 \mathrm{~cm}$. Kapsel aufrecht bis wenig geneigt, gerade oder schwach gekrümmt. Deckel fast halbkugelig gewölbt, mit stumpfem Spitzchen. Selten fruchtend.

An beschatteten Felsen und Bäumen.

F. Al. Geta und Sund an einzelnen, Saltvik an mehreren Fundorten (Bom.). Kumlinge, Ingersholm (Bergr.). - Ab. Åbo (Vain.). Finby (Broth.). Bromarf, "Ön» (Sundv.). Karis, Fagervik (Lindb.). Lojo, an mehreren Fundorten (Lindb., Hult, Sundv.). Vichtis (W. Nyl.). - N. Kyrkslätt (Jusl., Broth.). Esbo (Broth.). Helsingfors (Lindb.). - Ta. Hattula, Takajärvi (A. Weg.). - Oa. Isokyrö, Orisberg (Ranck.).

- Ok. Kajana (Lackstr.).

S. Sk.-Ang.

N. Uber die Verbreitung liegen keine Angahen vor.

Europa, Nord-Amerika.

*Hypnum ericetorum (Bryol. eur.) Loesk. Moosfl. Harz. p. 315 (1903). [Hypnum cupressiforme var. $\gamma$ ericelorum Bryol. eur. fasc. 57/61 Mon. p. 25, t. 15, f. $\gamma$ $1-4$ (1854).]

Tracht von $H$. imponens. Ziemlich kräftige Pfl. in meist bleichgrünen, trocken weichen Rasen. Stengel aufsteigend bis aufrecht, fast regelmässig gefiedert. Blätter sichelförmig gekrümmt, flachrandig, rings fein gesägt; Blattflügelzellen im herablaufenden Teile erweitert, rektangulär, dïnnwandig und meist hyalin. Seta $3-4 \mathrm{~cm}$. Kapsel geneigt bis horizontal, eilänglich, etwas hochrückig, \pm gekrümnt, derbhäutig, rotbraun. Deckel hoch, spitzkegelig.

Auf Heideland und in trockenen Kieferwäldern.

S. Sk. und $B l$.

Europa, Algier, Nord-Amerika.

*Hypnum resupinatum (Wils.). [Hypnum resupinatum Wils. Bryol. brit. p. 398 (1855). - H. cupressiforme var. resupinatum Schimp. Coroll. p. 133 (1856).]

Tracht von Pylaisia oder Homomallium incurvatum. Schlanke Pfl. Stengel kriechend, reichlich verzweigt; Zweige bald kurz und fieder- bis büschelästig, bald sehr verlängert und spärlich beästet bis einfach; Äste meist aufrecht, fadenförmig, gerade und spitz. Blätter dachziegelig oder schwach einseitswendig, flachund ganzrandig; Blattflügelzellen goldgelb oder gébräunt, eine schwach ausgehöhlte, an den Rändern sich hinaufziehende Gruppe bildend. Seta $1,5-2 \mathrm{~cm}$. Kapsel wenig geneigt, zylindrisch, gerade, dünnhäutig, bleichrötlich. Deckel lang und dünn geschnäbelt.

An Felsen, Blöcken, Baumstämmen u. auf trockener Erde. Selten fruchtend.

F. Al. Sund und Brändö an einzelnen, Saltvik an mehreren Fundorten (Bom.). $-\lambda$. Hogland (Lindb.). 
S. Sk. und $B l$.

N. Sm. Borge und Onsø. R. Kommt nur in den äussersten Küstenstrichen und zwar unmittelbar am Meeresgestade, jedoch häufig vor.

Grozi-Britannien, Holland, Schle;vig-Holstein, Dänemark, Frankreich, Pyrenäen, Azoren, New Foundland.

781. Hypnum revolutum (Mitt.) Lindb. in Hedwigia 1868, p. 108. [Stereodon revolutus Mitt. Musc. Ind. or. p. 97 (1859).]

Diözisch. Pfl. in dichten, flachen und oft ausgedehnten, bis kissenförmigen. bräunlichgrünen Rasen. Stengel niedergestreckt bis aufrecht, büschelig geteilt und gefiedert. Stammblätter \pm deutlich längsfaltig, aus eiförmiger oder länglicheiförmiger Basis lanzettlich-pfriemenförmig, bis $2 \mathrm{~mm}$ lang und bis $0,8 \mathrm{~mm}$ breit, mit bis gegen die Spitze zurückgerollten, glatten oder an der Spitze undeutlich gezähnten Ränderı: Zellen in den nicht ausgehöhlten Blattflügeln quadratisch, eine dreieckige Gruppe bildend.

Auf trockenen, meist \pm kalkhaltigen Felsen. Sporogone nur aus Turkestan bekannt.

F. Lo. Kilpisjoki in der Birkenregion (Norrl.); Kilpisjärvi, Malla, Guonjarvankka und Sairovaara. in der alpinen Region (Kot.). - Lim. Kandalaks, Schelesnaja (Broth.). Hibinā (B.). - Lt. Kola, Karaulnaja Pahta (B.). - Lp. Katschkova (B.). Ponoj (B.).

S. PL. Tjidtjakk. LuL. Sarekgebiet.

N. Gudbrandidalen. $K$. Dorre. Roshejm. No.-F.

P̧̧renāen, Alpengebiet, Kaukasus, West-Himalaya, Tibet, Turkestan, arkt. Nord-Amerika.

782. Hypnum hamulosum Bryol. eur. fasc. 57/61 Mon. p. 20, t. 10 (1854). [Stereodon hamulosus Lindb. in Act. Soc. Sc. Fenn. X. p. 255 (1872).]

Diözisch und pseudautözisch. Schlanke Pfl. in dichten, trocken starren, polsterförmigen, gelbgrünen oder gelben Rasen. Stengel mit lockerer, hyaliner Aussenrinde, aufsteigend bis aufrecht, büschelig verzweigt, fast regelmässig gefiedert. Stammblätter gedrängt, stark sichelförmig-einseitswendig, aus nicht herablaufender, wenig verengter Basis lanzettlich, allmählich lang pfriemenförmig, bis $1,5 \mathrm{~mm}$ lang und bis $0,5 \mathrm{~mm}$ breit, mit am Grunde etwas zurückgeschlagenen, an der Spitze zuweilen klein gesägten Rändern; Zellen in den Blattflügeln nicht differenziert, in den Blattecken $1-3$ oval und wasserhell. Seta $1,2-2 \mathrm{~cm}$, rot. Kapsel geneigt bis fast horizontal, länglich-zylindrisch, kaum gekrümmt, bis 2,3 $\mathrm{mm}$ lang und bis $0,6 \mathrm{~mm}$ dick, zuletzt rötlich. Deckel kegelig, stumpf. Sporenreife im Juli und August.

An feuchten oder etwas trockenen Schieferfelsen.

F. K. Kuusamo, Kitkajoki (Sil.). - Le. Kilpisjärvi, Malla, in der alpinen Region (Kot.). - Li. Utsjoki, Kenischkoski (Hult). - Lp. Rusiniha, zw. Ponoj und Orlor (Broth.).

S. Hrjd., Jmt., PL. und LuL.

N. A. Kristiania r. Bu. Eker, Mjondalen, $30 \mathrm{~m}$. Ringerike, nicht selten. Gudbrandsdalen. Ne. Saetersdalen. YB. Sogn. Hardanger, Kinservik. R. pass. bis $400 \mathrm{~m}$. K. Dovre. NT. Stjordalen fqq. No. an mehreren. $T r$. und $F$. an wenigen Fundorten.

Spitzbergen, Schottland, Irland, Alpenkette, nördl. Teile ron Nord-Amerika.

783. Hypnum callichroum (Brid.) Bryol. eur. 1. c. p. 27, t. 16. [Stereodon callichrous Brid. Bryol. univ. II. p. 631 (1827).]

Diözisch und pseudautözisch. Ziemlich schlanke Pfl. in sehr weichen, dichten, schwellenden oder kissenförmigen, grünen oder gelbgrünen Rasen. Stengel mit lockerer, hyaliner Aussenrinde, niedergestreckt oder aufsteigend, \pm regelmässig gefiedert. Stammblätter gedrängt, sichelförmig-einseitswendig bis kreisförmig. aus herablaufender, sehr verengter Basis gerundet eiförmig, rasch schmal lanzettlich-pfriemenförmig, bis $2 \mathrm{~mm}$ lang und bis $0,8 \mathrm{~mm}$ breit, flach- und ganzrandig; Zellen in den ausgehöhlten Blattfłügeln aufgeblasen und hyalin, eine gut begrenzte, meist kreisförmige Gruppe bildend. Seta 1,5-2 cm, rot. Kapsel geneigt bis horizontal, länglich-zylindrisch, schwach gekrümmt, etwa $4 \mathrm{~mm}$ lang und $0,8 \mathrm{~mm}$ dick, zuletzt bleich rustfarben. Deckel kegelig, mit dünnem Spitzchen. 
Auf \pm feuchtem Boden und erdbedeckten Felsenabsätzen und Steinen, zuweilen in ausgedehnten Rasen.

F. K. Kuusamo, Kitkajoki, Jäkälävuoma (Broth.); Oulankajoki, Kallioperänvaara (B.); Paanajärvi, Kuoppaoja (B.). - Lkem. Kuolajärvi, Särketunturi (Linnan.). - Le. Kilpisjärvi, Saivoviara (Kot.). - Li. Sodankylā, Sakatinpahta (Hult). Utsjoki, Kenischkoski (H.); Outakoski, Soarvjebakte, in der Birken region (Ranek.). - Lim. Umpjäyr, Tschuidi-vun (Kihlm.). Hibinä, Tiutlulıt (K.). - Li. Kola (Fellm.); Karaulnaja Pahta (Broth.). Kljatni (Brenn.). Vaidoguba (Broth.). - Lmur. riavrilova, Rinda, Semjostrovsk, Harlov, Olenka, Litsa und Jokonsk (Broth.). - Lp. Katschkova (Broth.). Orloy (Kihlm.). Zw. Orlov und Ponoj (Broth.). Ponoj (B.).

S. Jmt. und $L u L$.

N. Ne. Saetersdalen. St. Ryfylke, Suldal. R. st. fq. vom Ifeeresniveau bis in die alpine Regiun. $K$. Lomsfjeldene. $N T$. Stjordalen $f q \alpha$. No. und $T r$, an mehreren, $F$, an wenigen liundorten.

Spitzbergen, Gross-Britannien, Pyrenäen, Alpengebiet, Sibirien, arkt, Nord-Amerika.

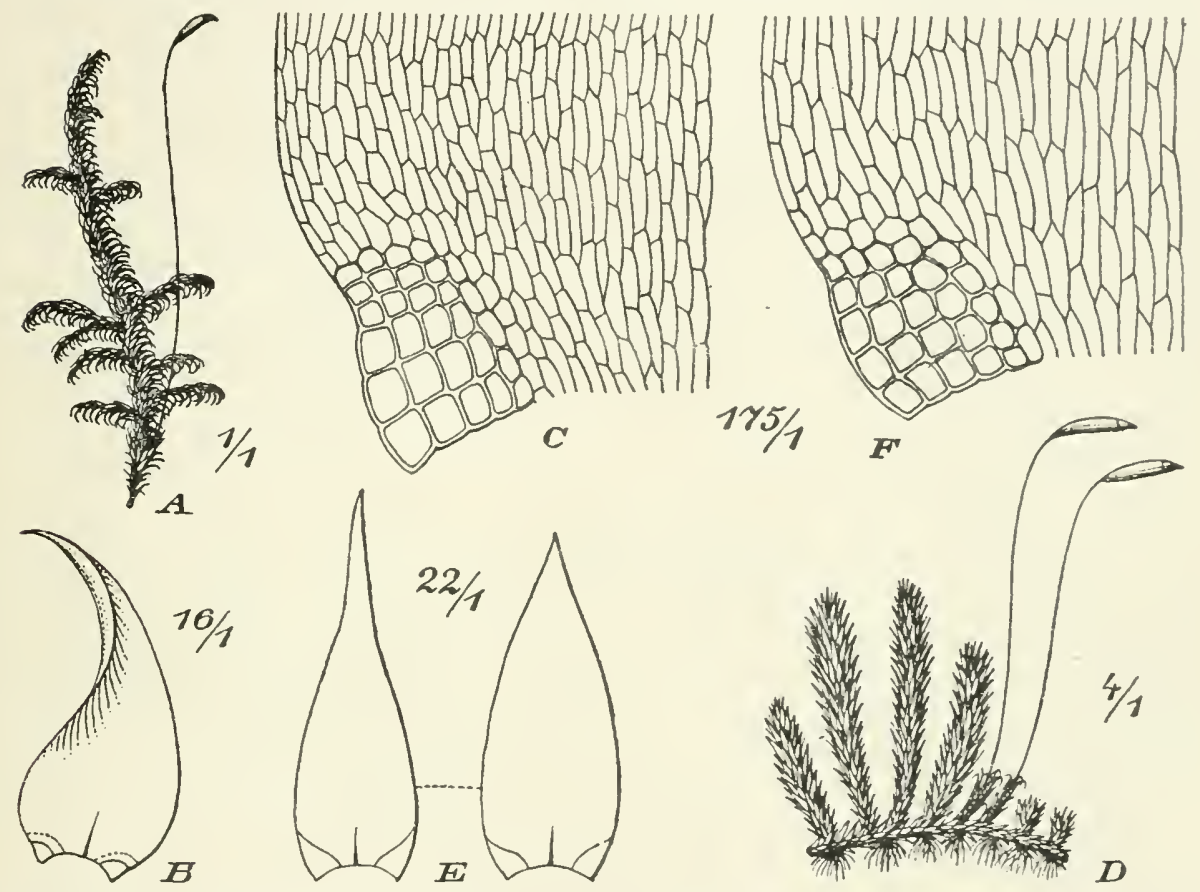

Fig. 109. A-C. Hypnum arcuatum Lindb. A Fruchtende Pf1. (1/1); B Stengelb. (16/1); C Blattbasis (175/1). - D-E. Heterophyllium Haldanianum (Grev.). D Fruchtende Pfl. (4/1); E Stengelb. (22 1); F Blattbasis $(175 / 1)$.

784. Hypnum arcuatum Lindb. in Öfv. K. Sr. Vet.-Ak. Förh. 1861, No. 8. p. 371. [Hypnum Lindbergii Mitt. in Seem. Journ. Bot. 1864. - Stereodon arcuatus Lindb. Musc. scand. p. 38 (1879).]

Diözisch. Kräftige Pfl, in lockeren, grüner, gelblichen bis gebräunten und goldgrünen, trocken weichen und glänzenden Rasen. Stengel niederliegend oder aufsteigend bis aufrecht, unregelmässig und entfernt beästet, mit hakig gekrümmten Stamm- und Astspitzen. Stammblätter zweizcilig, hakenförmig einseitswendig. flach- und ganzrandig oder an der äussersten Spitze gezähnt; rückenständige g!att. länglich-lanzettlich, kurz- und breitspitzig, etwa $2 \mathrm{~mm}$ lang und bis $0.7 \mathrm{~mm}$ breit. bauch- und seitenständige sehr hohl, längsfaltig, aus etwas verengter Basis eilanzettlich, ziemlich rasch in eine rinnige, scharfe Spitze verschmälert, bis $2,4 \mathrm{~mm}$ lang und bis 1,2 mm breit; Zellen in der Blattspitze meist rlomboidisch-6seitig. in clen ausgehöhlten Blattflügeln oval-mehreckig, aufgeblasen, meist hyalin, eine 
gut begrenzte Gruppe bilclend. Seta etwa $2 \mathrm{~cm}$, gelblich. Kapsel trocken schwach gefurcht, langhalsig, länglich-eiförmig bis fast zylindrisch, bis $3 \mathrm{~mm}$ lang und bis $1111 m$ lick, gelbbraun. Deckel gewölbt-spitzkegelig.

Auf etwas feuchter, besonders tonhaltiger Erde, längs Flüssen und Bächen, auf sumpfigen Wiesen, nassen Felsen und auf altem Holzwerk, in allen Teilen von Femnoskandia $\pm \mathrm{fq}$. Selten fruchtend. Nordgrenze bei $70^{\circ} 20^{4} \mathrm{n}$. Br.

Europa, Kaukasus, Sibirien, Amur, Japan, Nord-Amerika.

785. Hypnum pratense Ḱoch Mser. in Brid. Bryol. univ. II. p. 769 (1827). [Isopterygium pratense Lindb. Musc. seand. p. 39 (1879).]

Diözisch und pseudautözisch; Zwergmännchen sehr klein, knospenförmig, len Blättern angeheftet. Weniger kräftige, verflacht beblätterte Pfl. in lockeren, sehr weichen, bleichgrünen oder gelblichen, trocken glänzenden Rasen. Stengel schlaff, niederliegend oder aufsteigend bis aufrecht, unregelmässig oder büschelig beästet, mit schwach hakig gekrümmten Stengel- und Asíspitzen. Stammblätter scheinbar zweizeilig, wenig hohl, glatt oder trocken querwellig, eilanzettlich, \pm lang zugespitzt, bis $2 \mathrm{~mm}$ lang und bis $1 \mathrm{~mm}$ breit, ganzrandig oder an der äussersten Spitze gezähnelt, seitenständige kielig zusammengefaltet, mit niedergebogenen Spitzen: Zellen in den nicht ausgehöhlten Blattflügeln allmählich erweitert und am tiefsten wenige erweitert, doch nicht aufgeblasen, hyalin, quadratisch und rektangulär. Seta 2,5-4 $\mathrm{em}$, dünn, gelblich bis rot. Kapsel aus trocken faltigem Halse länglich-eiförmig bis zylindrisch, etwas hochrückig, bis $3 \mathrm{~mm}$ lang und $1 \mathrm{~mm}$ dick, gelblich bis gebräunt. Deckel gewölbt-spitzkegelig. Sporenreife in Frühling.

Auf sumpfigem Waldboden, sumpfigen Wiesen, feuchten Ausstichen, an Quellen und Seeufern.

F. Al. Saltvik, an mehreren Fundorten (Bom.). - Ab. Lojo, Ojamo (Lindb.). - N. Helsingfors (Lindb.). Helsinge. Vesterkulla. Kalkholmen (Tigerst.). Sibbo, Kalkholmen (Buch). - Ka. Wiborg (W. Nyl.). - Ik. Muola, Pällilä (H. Lindb.). - Ta. Sääksmäki, Rauttuniemi (Kihlm.). Asikkala, Kopso, Hokkala (Norrl.); Keltaniemi (Sil.). Padasjoki, Vesijako (Norrl.). - kl. Sortavala, Kirjavalahti, Louhivuorel (Lindb.). Ruskeala, Jänisjärvi (H. Backm.). Pälkjārvi, Pitkäniemi (Broth.). — Koi. Petrosarodsk (Kullh.). - Tb. Jyväskylä, Haapakoski (Broth.). - Sb. Nilsiä. Kuuslahti, Jaakonlampi (Kot.). - Kb. Lieksa (Vain.). - Kon. Klimskij monastir (Simm.). Kivatseh (Sel.). Irundjärvi (Norrl.). - Lim. Tschunoseru (Broth.). - Lt. Kildin (B.). - Lp. Orlov (Kiblm.) Ponoj (Brenn.).

S. Öl., Ög., Srm.. När.. Gstr., Hlsl., Mpd., Ang., PL. und LuL.

N. Sm.rr. A Kristiania r. Bu. Eker, Mjøndalen. Ringerike, an mehreren Fundorten. JL. Tjømø. $S B$. H. $\boldsymbol{R}$ medal. Lillehamuer. K. Dovre. Tr. u. $F$. an einzelnen Fundorten.

spitzlergen, Zentral-suropa, Japan, Nord-Amerika.

\section{HETEROPHYLLIUM}

(Schimp.) Kindl. Eur. and N.-Am. Bryin. p. 122 (1897).

Autözisch. Stengel meist niedergestreckt und streckenweise durch Rhizoidenbïschel am Substrat haftend, unregelmässig gefiedert; Äste ungleich lang, gerade: Pseudoparaphyllien vielgestaltig, nur in cher Nähe der Astanlagen. Blätter etwas hohl, aus verengter, wenig herablaufender Basis eilanzettlich oder lanzettlich, flach- und ganzrandig: Rippe fehlend oder selır kurz, doppelt oder zweischenkelig; Zellen eng prosenchymatisch, am Blattgruncle weiter, gelblich, dickwandig und getüpfelt, an den geöhrten und ausgehöhlten Blattflïgeln erweitert, quadratiseh und kurz rektangulär, hyalin oder gelb bis gebräunt. Stengelblätter zweigestaltig, in den mit Rhizoiden besetzten Teilen meist schräg nach oben gerichtet und unsymmetriseh, an anderen Teilen allseits aufrecht-abstehend und symmetrisch. Asthlätter allseits aufrecht-abstehend, lanzettlich. Perichätialblätter nicht längsfaltig. Kapsel zylindrisch. Ring undeutlich diflerenziert. Deckel hoch kegelig bis schief geschnäbelt. 
786. Heterophyllium Haldanianum (Grev.) Kindb). Eur. and N. Amer. Bryin. p. 122 (1897). [Hypnum Haldanianum Grev, in Ann. Lyc. New-York 1. p. 27j. t. 23 (1825). - Stereodon Haldanii Lindb. in Act. Soc. Sc. Fenn. X. p. 256 (1872).]

Pfl. in oft ausgedehnten, flachen, grünen oder gelblich- bis bräunlichgrünen, trocken glänzenden Rasen. Stengel wie auch Iste oft deutlich verflacht beblättert. Unsymmetrische Stammblätter bis $1, \pm \mathrm{mm}$ lang und $0,6 \mathrm{~mm}$ breit, symmetrische bis $2 \mathrm{~mm}$ lang und $0,9 \mathrm{~mm}$ breit. Innere Perichätialblätter scheidig, plötzlich in eine lange, zurückgekrümmte, ganzrandige Pfrieme verschmälert. Seta $1-2 \mathrm{~cm}$, rot. Kapsel fast aufrecht und gerade oller geneigt und sehwach gekrümmt. bis $3,5 \mathrm{~mm}$ lang und etwa $0,75 \mathrm{~mm}$ dick, rotbraun, trocken und ent deckelt unter der Mündung wenig verengt. Sporenreife im Frïlnling. - Fjg. 109 D-E.

Auf feuchtliegenden, faulenden Baumstämmen, zuweilen auch auf lehmigem oder tonigem Waldboden.

F. Ab. Halikko (A. Bergr.); Tytyri (Lindb.); Ojamo (H. Lindb.). - r. Helsingfors (Lindb.). Helsinge, Aggelby (Häyr.). Nurnijärvi (Broth.). - Ik. Uusikirkko, Vammelsuu und Rajajoki (H. Lindb.). - Ta. Vanaja (Arrh.). Lammi, Evo, an mehreren Fundorten (Norrl.). Lsikkala, Laitiala (N.); Kurhila (Sil.). Padasjoki, Nyystölá (Yain.). Kulınoinen, Isojärvi (Broth.). - Sa. Kangasniemi, Tuomarinvuori und Hämeensaari (Lackstr.). - Kl. Sortavala, Kirjavalahti (Kuj.). Pálkjärvi, Pitkäniemi (Broth.). Suistamo, Sulkiajoki (B.). - Kol. Humbaritsa und Vosnessenje (Elfr.). - Tb. Jyväskylä, Haapakoski (Broth.). Laukaa, Kantola (B.). Aannekoski (B.). Uurainen, Palsanoja (B.). Viitasaari, Hakola (B.). Kivijărvi, Hilma (B.). Pihtipudas, Aho (B.); Kanalanmäki (Roiv.). - Sb. Mataninka, Haatala, Parola (Roiv.). - Kb. Lieksa, Vieki (Vain.). - Kon. zw. Kondus und Tuulos (Sel.). - ok. Paltano, Kives und Teväsaari (Lackstr.). - Kpom. Suontelejoki (Bergr).

S. När. Mpd. und $V b$, an einzelnen Fundorten.

N. Sm. rr. A. Kristiania r. Ringerike rr. $J L$. Sandefjord. Tjømo. IT $T$. sijordalen.

Nord und Ost-Rusisland, Zentral Europa. Pyrenäen, Nord-Italien, Kankalsus. Kuschınir, Sibirien. Japan, Nord-Amerika.

\section{PTILIUNi}

(Sull.) De Not. Epil. p. 101 (1869).

Diözisch. Kräftige, etwas starre, lockerrasige Waldmoose von straussfederartiger Tracht. Stengel meist reihenweise aufgerichtet, meist ohne Rhizoiden, dicht wedelartig gefiedert: Pseudoparaphyllien nur in der Nähe der Astanlagen. Blätter kreisförmig-cinseitswendig, tief- und mehrfaltig, flachrandig, oberwärts fein gesägt; Rippe fehlend oder kurz und doppelt: Zellen eng linealisch, glatt, in den Blattecken wenige quadratisch und rektangulär. Perichätialblätter längsfaltig. Kapsel zylindrisch, glattwandig, trocken stark gekrümmt. Ring schmal. Deckel feucht kuppelartig gewölbt, mit Warze. Haube nackt.

Einzige Art:

787. Ptilium cristazcastrensis (L.) De Not. l. c. [Hypnum crista castrensis L. Sp. pl. p. 1125 (1753). - Stereodon crista-castrensis Mitt. in Linn. Proceed.Bot. VIII. p. 41 (1864).]

Rasen oft ausgedehnt, hell- bis gelbgrün oder gelblich, innen gebleicht. Stengel bis $20 \mathrm{~cm}$, mit sichelförmig gekrümmten Sprossspitzen; Äste bis $2 \mathrm{~cm}$, gegen die Stammspitze allmählich kürzer. Stammblätter aus kaum herablaufender Basis breit eilanzettlich-pfriemenförmig, bis $2,5 \mathrm{~mm}$ lang und bis $1,2 \mathrm{~mm}$ breit. Astblätter lanzettlich-pfriemenförmig, bis $1,8 \mathrm{~mm}$ lang und $0,4 \mathrm{~mm}$ breit. Perichätialb]ätter aufrecht, bleich, die imneren fast scheidenartig lanzettlich-pfriemenförmig, gegen die Spitze entfernt gesägt. Seta $4-5 \mathrm{~cm}$, rot. Kapsel bis $4 \mathrm{~mm}$ lang und bis $1,3 \mathrm{~mm}$ dick, rotbraun. Sporenreife im Herbst.

Auf etwas feuchtem Waldboden, besonders in Nadelwäldern, auch auf beschattete, erratische Blöcke und Baumstämme ïbergehend.

Im Nadelwaldgebiete fq., nur in den Lappmarken seltener, in der Birkenregion nur selten und steril.

Europa, Kaukasus, Sikkim, Nord-Asien bis Sachalin und Japan. Yunnan, Nord-Amerika. 


\section{CTENIDIUM}

(Schimp.) Mitt. Musc. austr.-am. p. 509 (1869).

Diözisch. Kalkliebende Fels- und Erdmoose. Stengel ohne oder mit spärlichen Rhizoiden, dicht und meist regelmässig kammartig gefiedert; Pseudoparaphyllien nur in der Nähe der Astanlagen. Blätter einseitig sichelförmig bis schnehkenförmig eingerollt, nicht oder undeutlich längsfaltig, flachrandig; Rippe fehlencl oder kurz und doppelt; Zellen eng linealisch, in den Blattflügeln differenziert. Perichätialblätter ohme Falten. IKapsel klein, eiförmig, hochrückig, trocken nicht gekrümmt. Ring breit. Deckel hochgewölbt, spitz kegelig. Haube spärlich behaart.

$$
\text { Übersicht der Arten. }
$$

A. Weiche Pfl. Blätter rings gesägt; Zellen oberwärts zahnartig vortretend ......................................... 782. C. molluscum.

B. Starre Pfl. Blätter ganzrandig: Zellen glatt ............ 783. C. procerrimum.

Un tergat t. I. Euctenidium Broth. in E.-P. I ${ }^{3}$. p. 1048 (1908).

Mehr oder minder schlanke und weiche Pfl. Stengel mit Rhizoiden. Blätter weit herablaufend, breit herzförmig, rasch zugespitzt, rings gesägt; Zellen meist papillös vortretend, am Blattgrunde nicht gefärbt.

788. Ctenidium molluscum (Hedw.) Mitt. I. c. [Hypnum molluscum Hedw. Descr. IV. p. 56, t. $22(1797)$.]

Pfl. in weichen, meist dicht verwebten, grünen oder gelblichen bis gebräunten, flachen oder polsterförmigen, trocken \pm glänzenden Rasen. Stengel bis $10 \mathrm{~cm}$; Aste bis $5 \mathrm{~mm}$, dünn, gegen die Stammspitze allmählich kürzer. Stammblätter aus herablaufender, herzeiförmiger Basis verlängert lanzettlich-pfriemenförmig, bis $2 \mathrm{~mm}$ lang und bis $0,9 \mathrm{~mm}$ breit, rings und besonders oberwärts scharf gesägt; Zellen beiderseits zahnartig vortretend, in den Blattecken zahlreiche quadratisch und rektangulär, dick- und gelbwandig. Innere Perichätialblätter aufrecht, länglich, rasch in eine lange, gesägte Pfriemenspitze verschmälert. Astblätter kleiner, lanzettlich, lang zugespitzt, stärker gesägt. Seta $1-2 \mathrm{~cm}$, rot. Kapsel $2-2,5 \mathrm{~mm}$ lang und bis $1 \mathrm{~nm}$ dick, kastanienbraun. Sporenreife im Sommer. - Fig. $88 \mathrm{E}-\mathrm{H}$.

An feuchten kalkfelsen und auf kalkhaltigem Boden.

F. Al. Eckerō, Storbỵ (Elfr.). Saltrik, Küuggsund und Färjsund (Bom.). - Ab. Karislojo, Karkkali (Sundr.). Lojo, an meireren Fundorten (Lindb.. Hult, Sundv.).

S. Sk., Öl., Sm., Gtl.. Ög., Vg., Boh.. Srm., När.. Dld., Upl. Vrml., Gstr. und Jmt.

N. A. Kristiania fq. Bu. Eker fq. Ringerike fq. $J L$. Sandefjord. Larvik. Ne. Saetersdalen. SB. . YB. Bergen. R. fq. YT . Stjørdalen fq. No. fq. Tr. und F. r. Nordgrenze bei $70^{\circ} 15^{\prime} \mathrm{n} . \mathrm{Br}$.

Europa, Algier, Kaukasus, Kamtschatka, Nord-Amerika.

var. procerum Bryhn in Nyt Mag. f. Naturv. XXXII. p. 26 (1891). [Hypnum subplumiferum Kindb. in Boll. Soc. bot. ital. 1896, p. 21. - H. molluscum var. $\beta$ subplumiferum Limpr. Laubm. III. p. 449 (1899). - Ctenidium molluscum var. $\beta$ subplumiferum Möll. Fört. Skand. växt. 2. Moss. p. 44 (1907).]

Pfl. kräftiger. Rasen dunkel- oder braungrün bis goldbräunlicl, oft rōtlich gescheckt. Blätter trocken geschlängelt, weniger rasch verschmälert, mit kleingesägten Rändern. Sporogone unbekannt.

S. $s m$. Barkeryd.

N. $J L$. Sande, an Baumwurzeln. der Bachufer. Br. Skien, an feuchten Kalkfelsen. St. Ryfylke, Frafjord. NB, Sogn, Balholmen.

Zentral-Europa.

var. condensatum (Schimp.) Braithw. Brit. Mossfl. III. (1902). [Hypnum molluscum var. condensatum Schimp. Syn. p. 632 (1860).]

Tracht von Brachythecium velutinum. Pfl. in dichten, weite Flächen überzichenden, verschiedenfarbigen Rasen. Untere Ficderäste etwa $10 \mathrm{~mm}$, nach oben 
rasch kleiner werdend; Stengel- und Astspitzen hakenförmig niedergelogen. Alle Blätter genau sichelförmig, oben meist querwellig, stark faltig.

N. Ne. Saetersdalen, Bygland uıd Bykle, an feuchten Bachufern.

Zentral-Europa.

Un t e r g a t t. I I. Pseudostereodon Broth. I. c.

Kräftige, starre Pfl. Stengel ohne Rhizoiden, dicht und meist regelnässig kammartig gefiedert. Blätter sichelförmig-einseitswendig, nur an Grunde undeutlich gezähnt; Zellen glatt, am Blattgrunde gefärbt.

789. Ctenidium procerrimum (Mol.) Broth. in Act. Soc. Sc. Fenn. XIX. No. 12, p. 125 (1892). [Hypnum procerrimum Mol. in Flora 1866, p. 158, De Not. Epil. p. 174 (1869).]

Kräftige, starre Pfl. in oft ausgedehnten, gold- und braungrünen, trocken glänzenden Rasen, nur die jungen Sprosse grün. Stengel bis $10 \mathrm{~cm}$; $\mathrm{Aste} \mathrm{bis}$ $15 \mathrm{~mm}$, gegen die Stammspitze allmählich kürzer. Stammblätter kurz herablaufend, aus herzförmiger Basis breit lanzettlich, allmählich in eine lange P'rieme verschmälert, bis $4 \mathrm{~mm}$ lang und bis $1,2 \mathrm{~mm}$ breit, ganzrandig: Zellen glatt, an der Insertion orange, in den abgerundeten Blattecken zahlreiche quadratisch. Astblätter kleiner, aus schmaler Basis lang und haarförmig zugespitzt. or Pfl. und Sporogone unbekannt.

Auf feuchten Felsen verschiedener Art.

N. Dovre. No. Alstahaug, Alstengen. Nordgrenze bei $66^{\circ} \mathrm{l}^{\prime} \mathrm{n}$. Br.

Alpenkette, Kaukasus, Zentral-Asien, arkt. Nord-Amerika bis $76^{\circ} 30^{\prime}$ n $\mathrm{Br}$.

\section{HYOCOMIUM}

Bryol. eur. fase. $45 / 46$ Mon. (1853).

Diözisch. Ziemlich kräftige, weiche, weit- und lockerrasige, freudiggrüne bis gelbliche, fast glanzlose Felsmoose. Stengel selır lang, niedergestreckt, hier und da mit Rhizoidenbüscheln, absatzweise regelmässig einfach bis doppelt gefiedert, streckenweise stolonenartig verlängert und umhersehweifend, dicht beblättert; Pseudoparaphyllien spärlich, lanzettlich, gesägt. Blätter zweigestaltig: Rippe sehr kurz und doppelt; Zellen eng linealisch bis geschlängelt, in den Blattflügeln differenziert. Seta sehr rauh. Kapsel geneigt, bis horizontal, länglich-oval, schwach hoshrückig. Deckel kegelig, spitz.

Einzige Art:

790. Hyocomium flagellare (Dicks.) Bryol. eur. J. c. Mon. p. 2, t. 1. [Hypnum flagellare Dicks. Pl. erypt. fase. II. p. 12 excl. syn. (1790).]

Stengelblätter fast sparrig-abstehend, weit herablaufend, hohl, schwach faltig, breit deltoidisch-herzförmig, plötzlich in eine schmal lanzettliche, zurückgebogene Pfrieme verschmälert, 1,5 $\mathrm{mm}$ lang und 1,3 $\mathrm{mm}$ breit, flachrandig, rings scharf gesägt; Blattflügelzellen zahlreich, oval- und länglich-4-6seitig, hyalin. Astblätter trocken locker dachziegelig, oval-1anzettlich, mit kurzer, gedrehter Spitze. Innere Perichätialblätter anliegend, länglich, mit ausgefressen-gezähnten Rändern, plötzlich in eine geschlängelt-abstehende, schwach gesägte Pfrieme verschmälert. Seta etwa $2 \mathrm{~cm}$, purpurn. Kapsel 3,5 $\mathrm{mm}$ lang und 1,8 mm dick, derbhäutig, braunrot. Ring sich ablösend.

An nassen und überrieselten, quarzhaltigen Felsen.

N. St. Ryfylke, Frafjord cpp. Steril.

West-Europa.

\section{H Y L O C O M I A C E A E.}

Kräftige, starre, lockerrasige, \pm glänzende, im Walde oft Massenvegetation bildende Pfl. Stammquerschnitt oval, ohne oder mit armzelligem Zentralstrange, 
lockerem Grundgewebe und mehrschichtigen, stereiden Mantelzellen. Stengel niedergestreckt bis aufrecht, ohne oder mit spärlichen Rhizoiden, dicht beblättert, einfach oder geteilt und unregelmässig bis fiederig beästet. Blätter mehrreihig, \pm hohl, von wechselnder Form; Rippe fehlend oder kurz und doppelt: Zellen eng linealisch, meist glatt, in den Blattecken meist nicht differenziert. Diözisch; 우 Blïten stammständlig, $\sigma^{\nearrow}$ Blüten meist astständig. Perichätialast kurz, meist ohne Rhizoiden. Perichätialblätter differenziert. Seta verlängert, aufrecht, glatt. Kapsel geneigt bis horizontal, meist \pm hochrückig, kurzhalsig, derbhäutig: Spaltöffnungen oberflächlich. Peristomzähne meist am Grunde nicht verschmolzen. Fortsätze des inneren Peristoms (excl. Rhytidium) gefenstert bis klaffend. Deckel kegelig bis kurz und schief gesclnäbelt. Haube kappenförmig, nackt. Sporen klein.

\section{$\mathrm{C}^{*}$ bersicht der Gat tungen.}

A. Paraphyllien fehlend.

a. Stengelblätter dachziegelig anliegend, abgerundet oder mit kurzer, stumpflicher Spitze ....................... 163. Pleurozium.

b. Stengelblätter \pm sparrig abstehend bis einseitswendig,

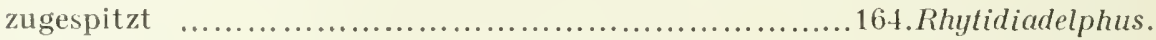

c. Stengelblätter aufgeschwollen dachziegelig und einseitig sichelförmig, lanzettlich-pfriemenförmig zugespitzt: Rippe einfach, dünn, etwa bis zur Blattmitte reichend; Blattflügelzellen zahlreich, weit lıinauf an den Rändern fortgesetzt 162. Rhytidium.

B. Paraphyllien sehr zahlreich, die Mantelschicht mit einem feinen Filz bedeckend 165. Hylocomium.

\section{RHYTIDIUM}

(Sull.) Kindb. Laubm. Schwed, und Norv. p. 15 (1882).

Stengel unregelmässig bis fiederig beästet; Pseudoparaphyllien spärlich und nur in der Nähe der Astanlagen. Blätter dlachziegelig und einseitswendig, dünnhäutig, längsfaltig und querrunzelig, aus wenig herablaufender Basis breit eilanzettlich-pfriemenförmig, an cier rinnigen Spitze I scharf gesägt; Rippe einfach. dümn, etwa bis zur Blattmitte reichend; Zellen eng lineal, besonders auf dem Blattrücken als zahnartige Mamillen vortretend, in den Blattflügeln klein, quadratisch, gells- und dickwandig, eine nicht ausgehöhlte, hoch an den Rändern sich hinaufziehende Gruppe bildend. Perichätialblätter aufrecht, längsfaltig, ohne Rippe. Ring 3reihig, sich ablösend. Peristomzähne am Grunde verschmolzen. Fortsätze des inneren Peristoms ritzenförmig durchbrochen. Deckel hochgewölbt kegelig, kurz und schief geschnäbelt.

Einzige Art:

791. Rhytidium rugosum (L.) Kindb. 1. c. [Hypnum rugosum Ehrh. Decad. No. 291 (1793). - Hylocomium rugosum De Not. Epil. p. 99 (1869).]

Pfl. in meist ausgedehnten, lockeren, wenig zusammemhängenden, gelblichen oder bräunlichgelben, selten grünen, trocken etwas glänzenden und starren Rasen. Stengel 5-12 cm; đ̈ste kurz und dick oder länger, allmählich zugespitzt und im Bogen herabgekrümmt. Stammblätter 3-5 mm lang und bis $1,5 \mathrm{~mm}$ breit, mit in der unteren Hälfte zurïckgeschlagenen Rändern. Perichätialblätter verlängert lanzettlich, pfriemenförmig zugespitzt und oberwärts gesägt bis ausgefressen gezähnt. Seta 2-5 cm, purpurn. Kapsel 3,5-4 mm lang und 1 mun dick, bräunlich, 
trocken und entleert bogig-eingekrümmt und unter der Mündung verengt. Sporogone sehr selten. - Fig. 110 .

Auf kalkhaltigem Detritus, an grasigen, trockenen Plätzen und an sonnigen steinigen und felsigen Abhängen.

F. Ta. Hollola, Sarva (Vain.). Asikkala, Kopso, Porttikallio (Norrl.). - Kl. Kurkijoki (Jusl.). Sortavala, Kuhavuori (Linnan.); Măkisalo (Kop.); Palosaari (Pes.); Haukhariutla (Link.); Pötsuvaara (Link.). Impilahti, Sumeria, Raukkijvuret (Pes.). Soanlahti, Jänisjärvi, Korkeanieni (Lâng); Korpikallio (Link.). Pălkjärvi, Korkeanieni (H. Backm.). — Kol. Tulemajărvi, Ruukki, Kỉlatselkă (Link.). - Kon. Valkeamäki (Simm.). Lischuajärvi (Norrl.); Sumu (N.). - Lkem. Kuolajärvi, Vuorijărvi, Pylıakuru (E. af H.); Niluntijärvi (Roiv.). - Le. Kilpisjärvi, an mehreren Fundorten in der alpinen Region (Norrl.); Saana, Grunjarvanka und Saivovaara (Kut.). - Kk. 2W. Knjäscha und Kandializks (Broth.). - Lim. Puitsitunturi (Linnan.). Kandalaks (Salub.); Schelesnaja (Broth.). Hibinä (Sel.). - Lp. Orloy (Kihlm.). Ponoj (Broth.).

S. $\check{O l} ., \ddot{O} g ., V g$. und Vrml. an einzelnen Fundurteu. Ing. und $H r j d .-L$.

N. A. - F. von der Ebene bis hoch in die alpine Region hinaufsteigend. Nurdgrenze bei $70^{\circ} \mathrm{n}$. Br. Europa, Kalukisus, Zentral-, Nord- und Ost-Asien, Japan, Nord-Amerika.
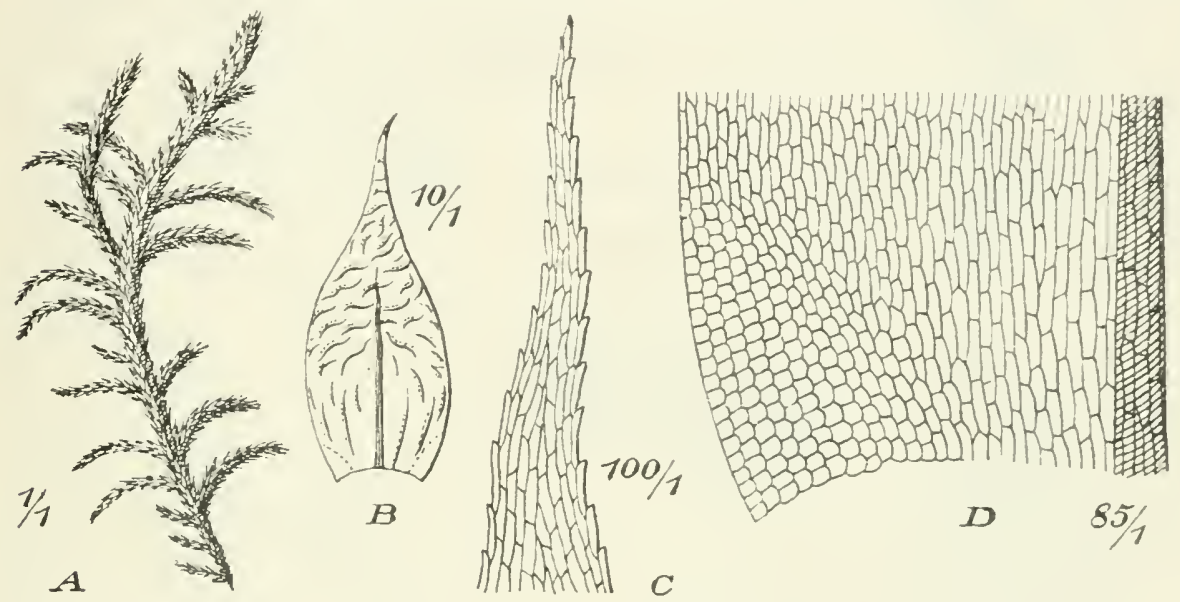

Fig. 110. Rhytidium rugosum(L.). A Sterile Pfl. (1/1); B Stengelb. (10/1); C Blatt-pitze (100/1); 1) Blattbasis $(85 / 1)$.

\section{PLEUROZIUM}

Mitt. Musc. austr.-amer. p. 5.37 (1869) ex p.

Stengel meist regelmåssig gefiedert: Paraphyllien fehlend; Pseudoparaphyllien nur in der Nähe der Astanlagen. Blätter dachziegelig. löffelartig-hohl, schwach längsfaltig, stumpf oder mit Spitzchen: Zellen glatt, am Grunde gelbbräunlich, in den Blattecken differenziert. Astb.ätter den Stammblätter ähnlich, nur kleiner. Innere Perichätialblätter aufrecht. Kapsel länglich. Ring nicht differenziert. Deckel gewölbt-kegelig.

Einzige Art:

792. Pleurozium Schreberi (Willd.) Mitt. l. c. [Hypnum parietinum L. Fl. suec. 2. ed. No. 1200 (1755) et Herb. ex p. - H. Schreberi Willd. Prodr. Fl. berol. p. 325, No. 955 (1787). - Hylocomium Schreberi De Not. Epil. p. 92 (1863). H. parietinum Lindb. in Act. Soc. Sc. Fenn. X. p. 251 (1572).]

Pfl. in ausgedehnten, grünen oder gell grünen, glänzenden Rasen. Stengel bis $15 \mathrm{~cm}$, aus niederlifgendem Grunte aufsteigend bis aufrecht, durch die Beblätterung rot durchscheinend; Äste oft lang zugespitzt und dam nicht selten an der Ende mit Rhizoiden. Stengelblätter aus kaum herablaufendem Grunde 
breit eiförmig bis eilänglich, abgerundet oder mit stumpflicher, etwas zurückgebogener, gekerbter oder gezähnelter Spitzehen, bis $2,4 \mathrm{~mm}$ lang $u n d$ bis $1,5 \mathrm{~mm}$ breit; Blattfügelzellen erweitert, dickwandig, eine kleine, ausgehöhlte, zuletzt goldbräunliche Gruppe bildend. Innere Perichätialblätter breit lanzettlich, scharf zugespitzt, ganzrandig. Seta $2-2,5 \mathrm{~cm}$, gelbrot oder rot. Kapsel regelmässig oder etwas hochrückig, etwa $3 \mathrm{~mm}$ lang und $1 \mathrm{~mm}$ dick, bram, trocken stärker gekrümmt und unter der Mündlung etwas verengt. Deckel gewölbt kegelig, stumpf. Sporenreife im Frühling. - Fig. $111 \mathrm{~A}-\mathrm{C}$.

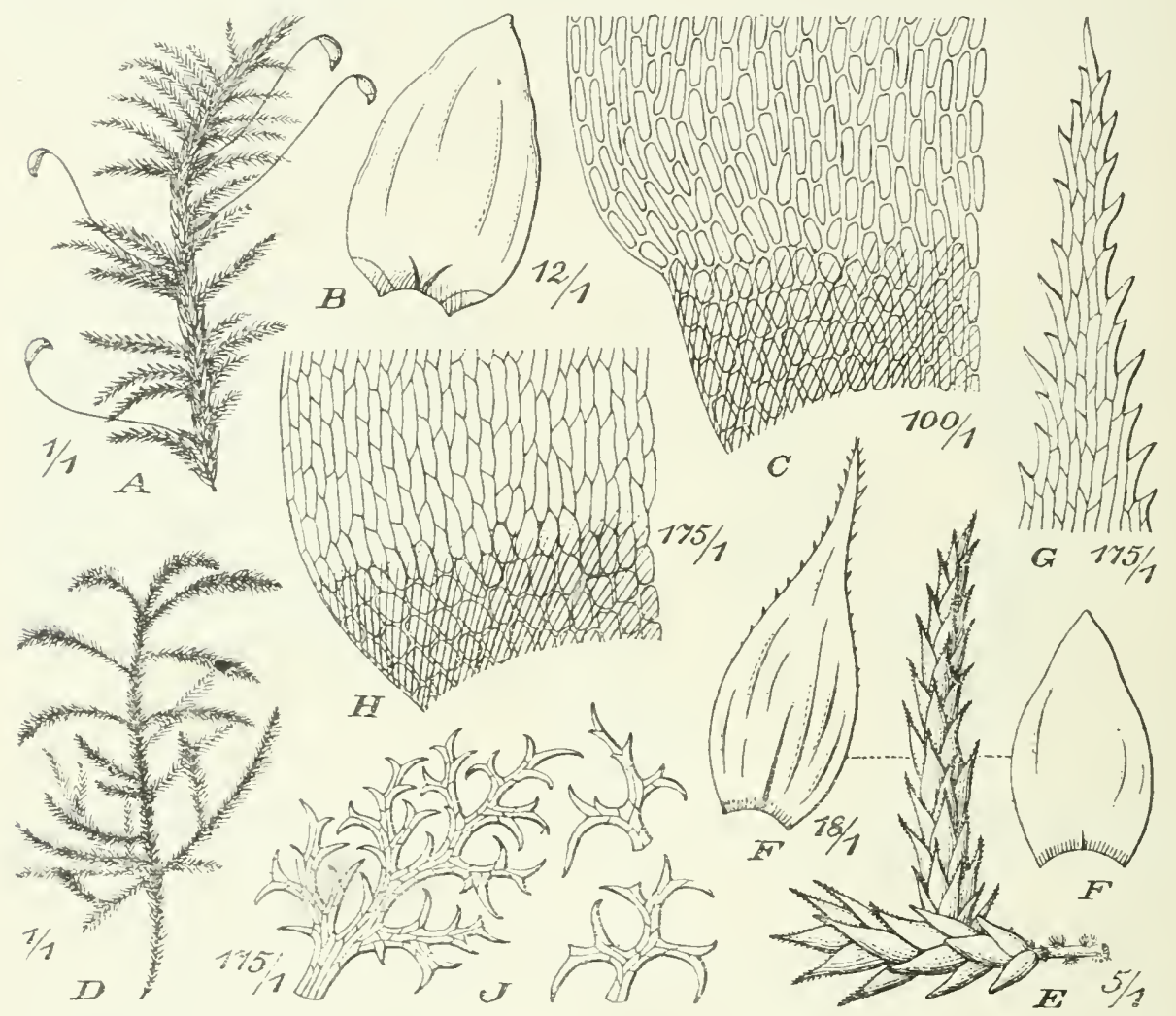

Fig. 111. A-C. Pleurozium Schreberi(Willd.). A Fruchtende Pf1. (1/1); B Stengelb. (12/1); C Btattbasis (100/1). - D-I. Hylocomium pyrenaicum (Spruc.). I) Sterile Pfl. (1/1); E Astchen (5/1); F Stengelb. (18/1); G Blattopitze (175/1); H Blattlasic (150/1): I Paraphyllien (175/1).

Auf Waldboden, Blöcken und Felsen, in trockneren Torfmooren durch Femnoskandia allgemein verbreitet und Massenvegetation hildend. Steigt bis in die alpine Region hinauf, dort jedoch meist spärlicher.

Spitzbergen, Europa, Kaukasus, Himalaya, Yunnan, Turkestan, Nord-Asien, Japan, Nord-Amerika, Nen-liranada, Ecuador.

var. secundum (Arn. et (.. Jens.). |Ilylocominm parietinum var. secunda Arn. et C. Jens. in Bih. K. Sv. Vel.-Ak. Handl. Bd. 21, Afd. Ill. No. 10, p, 62 (1896).]

Stengel an der Spitze hakenförmig gekrümmt. Obere Stengelblälter einseitswendig.

S. Ang. Tåsjö, Tåijöedet, in simpfen. 


\section{RHYTIDIADELPHUS}

(Lindb.) Warnst. Laubm. p. 8.12 (1906).

Stengel \pm deutlich gefiedert; Paraphyllien fehlend; Pseudoparaphyllien nur in der Nähe der Astanlagen. Stengelblätter (excl. Rh. loreus) allseits sparrig, bis zurückgebogen, \pm lang zugespitzt. Astblätter den Stengelblättern ähnlicli, nur kleiner. Perichätialblätter mit sparrig zurückgebogenen Spitzen. Kapsel aus sehr kurzem Halse dick oval, hochrückig. Ring differenziert. 1)eckel gewölbtkegelig, mit Spitzchen.

\section{itbersieht der Arten.}

A. Stammblätter sichelförmig-einseitswendig, aus eilörmiger Basis allmählich lanzettlich-pfriemenförmig; Zellen glatt. 793. Rh. loreus.

B. Stammblätler sparrig-abstehend, selten fast einseitig-siclnelförmig, breit herz-eiförmig, allmällich lanzettlich zugespitzt, am Rücken rauh 794. Rh. triquetrus.

C. Stammblätter sparrig zurïckgebogen, ans breit eiföruigem Grunde plötzlich lanzettlich-pfriemenförmig; zellen glatt.

a. Stengel entfernt beästet ......................... 795. Rh. squarrosns. b. Stengel deutlich_gefiedert ......................... $796 . R h$. calvescens.

793. Rhytidiadelphus loreus (L.) Warnst. 1. c. p. 922. [Hypmum loreun L. Sp. pl. p. 1593 (1753). - Hylocomium loreum Bryol. eur. fase. 4951. Mon. p. 7, t. $4(1852)$.]

Kräftige Pfl. in oft ausgedelnnten, unregelmässigen, grünen oder graugrünen Rasen. Stengel bis $20 \mathrm{~cm}$, niedergestreckt, mit aufsteigenden und meist hakenförmig gekrümmten Sprossenden, unregelmässig gefiedert. Stammblätter sparrigund sichelförmig-einseitswendig, aus tief längsfaltiger Basis allmählich lanzettlichpfriemenförmig, oberwärts scharf gesägt, 3,5-5 mm lang und bis $1,5 \mathrm{~mm}$ breit; Zellen glatt, in den Blattflïgeln nicht differenziert. Seta $2-4$ cm, purpurn. Sporenreile im Winter.

Auf Blöcken, Felsenalsätzen und Felsentrümmern in Wäldern.

F. Al. Eckerö, Enıkär (H. Lindb.). Jomala, Kasberg (Arrh.). Finström, Godby (A.). Geta (Bom.); Hagö (Hult). Saltvik, Borgo (Elfv.); Kugghöle (Bom.). Sund, Ge-terby (Broth.). Vảrdö, Vargata (Bom.). - Ab. Karisiojo, Laukjärvi (Boldt). - N. Ingá, srartö (W. Brenn.).

S. Sk. und Bl.-sirm. När. und Dld.

N. Sm. fqq. A. Kristiania pass. $J L$. Tjomo føq. Sandefjord fq. Ringerike rr. Ye. Saletersdalen fq. NT. Stjordalen fqq. No, uicht selten. Tr. an wenigen fundorten. F. Hammerfest. Nordgrenze bei $11^{\circ} 10^{\prime} \mathrm{n} . \mathrm{Br}$.

Europa, Nord-Amerika.

794. Rhytidiadelphus triquetrus (L.) Warnst. 1. c. p. 920. [Hypnum triquetrum L. Sp. pl. p. 1589 (1753). - Hylocomium Iriquelrum Bryol. eur. fasc. 49/51 p. 8 , t. $5(1852)$.]

Sehr kräftige Pfl. in oft ausgedehnten, grünen bis gelbgrünen Rasen. Stengel bis $15 \mathrm{~cm}$, anfsteigend bis aufrecht, gefiedert; Iste teils kurz und s'umpf, teils verlängert, allmählich verdünnt und zuweilen an der Spitze Rhizoiden entwikkelnd. Stengelblätter mehrfaltig, aus sehr enger, fast umfassender Basis breit herz-eiförmig, allmällich lanzettlich zugespitzt, oberwärts scharf gesägt. bis $5 \mathrm{~mm}$ lang und $3 \mathrm{~mm}$ breit: Zellen oberwärts an Blattrücken zahnartig vortretend, in den Blattflügeln nicht oder nur wenige differenziert. Seta $2-4$ cm, purpurn. Sporenreife im Winter. - Fig. 112 A-D.

Auf Waldhoden und beschatteten, felsigen Triften in den südl. und mittl. Teilen ron Fennoskandia f(1.-f(]ฯ., stellenweise Massenvegetation bildend, in den 
Lappmarken viel seltener. Steigt sehr selten bis in die alpine Region hinauf. Nordgrenze bei $70^{\circ}$ n. $\mathrm{Br}$.

Europa, Kaukasus, Zentral-, Nord- und Ost-Asien, Nord-Amerika.

795. Rhytidiadelphus squarrosus (L.) Warnst. 1. c. p. 918. [Hypnum squarrosum I. Sp. pl. p. 1693 (1753). - Hylocomium squarrosum Bryol. eur. fase. 49/51 Mon. p. 9, t. 6 (1852).]

Weniger kräftige Pfl. in oft sehr ausgedehnten, dunkel-, hell- bis gelbgrünen Rasen. Stengel bis $15 \mathrm{~cm}$, selten noch länger, niedergestreckt oder bogig aufsteigend, entfernt beästet; Äste teils kurz und stumpf, teils verlängert, allmählich verdünnt und zuweilen an der Spitze Rhizoiden entwickelnd. Stengelblätter trocken ohne
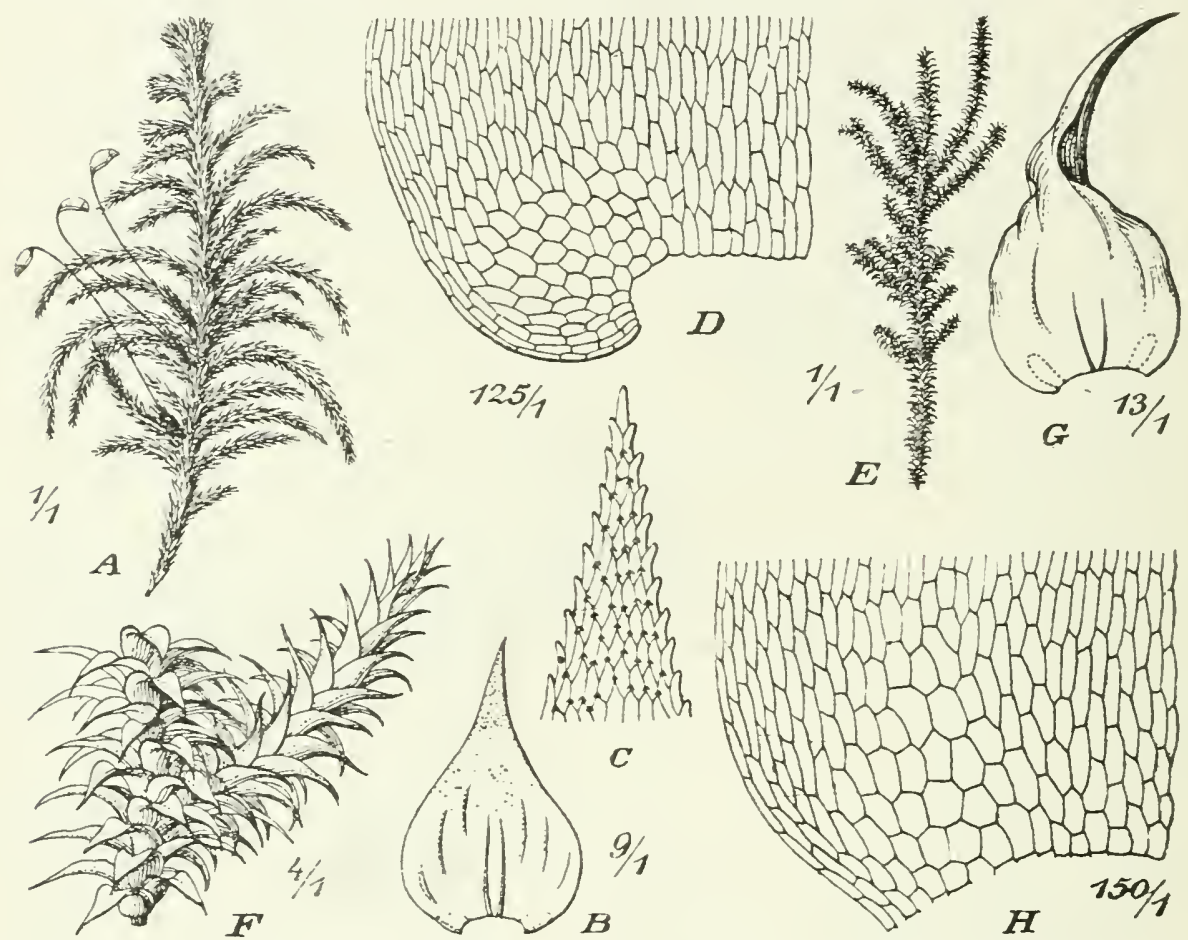

Fig. 112. A-D. Rhytidiadelphus triquetrus (L.). A Fruchtende Pfl. (1/1); B Stengelb. (9/1): C Blattspitze (125/1); D Blattbasis (125/1). - E-H Rh. squarrosus (L.). E Sterile Pfl. (1/1); F Astchen (4/1); (i) Stengelb. (13/1); H Blattbasis (150/1).

Falten, aus wenig verschmälerter, gelber Basis breit eiförmig, plötzlich in eine sparrig zurückgebogene, rinnig-hohle, lanzettlich-pfrienenförmige Spitze verschmälert, his $3,6 \mathrm{~mm}$ lang und $1,5 \mathrm{~mm}$ breit, fein gesägt; Zellen glatt, in den \pm deutlich ausgehöhlten Blattflügeln locker 6seitig, bräunlichgelb. Seta $2-3,5 \mathrm{~cm}$, purpurn. Sporenreife im Frülıjahr. - Fig. 112 E-H.

Auf feuchten, grasigen Plätzen in Gebüschen und Wäldern.

F. In den südl. und mittl. Teilen bis $O a$. und Kon. st. fq. - pa $=-O m$. st. fq. (Backm.). $-O k$. Kajana (Lackstr.). Paltamo, Melalahti (Kyyhk.); Miesmäki (K.). Sotkamo, Naapurinvaara (Broth.); Koirajärvi (Kyyhk.). - Kpom. Kem (Bergr.), 一 Ob. Oulujoki (Huum.). Hailuoto (Brelln.). Simo (Räs.). - K. Kuusamo, Korojoki, Autinköngäs (Broth.). - Lkem. Kolari, Pudas (Hult). - Le. Kilpisjārri, Kilpiskoski (Norrl.). - Li. Inari, hultala (Hult). - Lt. Kola (Broth.). Kildin (B.). Tsipnavolok (B.).

S. Sk.-L.

N. Sm. - F

Spitzbergen, Europa, Madeira, Azoren, Sibirien, Japan, Nord-Amerika. 
796. Rhytidiadelphus calvescens (Wils.) Broth. in Engl.-Prantl Bryal. p. 10.57 (1908). [Hypnum calvescens Wils. Bryol. brit. p. $387,11.65$ in obs. (185.5). - U. subpinnatum Lindb. in Hartm. Skand. Fl. ed. 9, I1. p. 1:3 (1861). Hylocomium subpinnatum lindb. in Hedwigia VI. p. 11 (1867). W. Calvescens Lindl). Musc. scand. p. 37 (1879). - H. squarrosum var. calvescens Hobk. Syn. Brit. Moss. 2 ed. (1884).]

Mit der vorigen Art selır nahe verwandt. l'fl. etwas krältiger und starrer. Stengel deutlich fiederästig. Stammb]ätter trocken am Gruncle meist deutlich faltig, an Grunde herz-eiförmig, kürzer zugespitzt. oberwärts schärfer gesägt. Astblätter nicht sparrig, trocken halbgedreht, breit eiformig. kurz zugespitzt.

Auf feuchten bis sümpfigen Plätzen in Gebüschen. Wäldern und an Bachufern.

F. Al. Finström, Godby (Arrh.). Salıvik und Sund, an wenigen Fundorten (Bom.). - Ab. U.kela, Linnamăki (Lindb.). Lojo, Lylyis (E. af H.): Vaanila und solhem (Sundr.). - N. Sjundeå (Sundr.). Helsingfors (Lång). Helsinge, Degerö (H. Lindb.). Siblon. Söderkulla (Ekın.). 13orgå, Suni (Broth.). Ik. Unsikirkko (H. Lindh.). - Sa. Willmanstrand (Buch). - Kit. Jatkkima. Ranola (sundr.). - Tb. Jyvāskỵä, Tourujoki (Bruth.). Laukad, zw. Tenniā und Iso Kunkkalen (B.); Porrasjoki (B.). Tiitasaari, Permasmäki (B.). - Sb. Kuopio, Sarkilahti (Link.); Telkkistenlahti (Kot.). Kaavi, Huosiaisniemi (Kot.); Sayneinen (K.). Ni]siä, Loutteinen (K.). Naaninka. Haatala, Hanhipuro (Rojv.); Tuovilanlahti Korkeakoski (Lundstr.). Pielavesi, Panka, Säripuro (Roiv.). - Kon. Tiudie (Simm.). - Ok. Kajana (Lackstr.). Paltamo, Tevä (L.). Kuhmoniemi (E. af H.)._K. Kuusamo, Oulankajoki (Broth.).- Lim. Kandalaks, Nirajoki (B.). Lujaur-urt, Kimahts-njun, an der Baumgrenze (Kihlun.). - Lt. Sascheika (Broth.). Pummanki (B.). - Lmur. Rindd (B.). Voroninsk, Varnjok (Kihln.).

S. Sm., Vg., Srm., Vär., Ism., Vrml., Gstr., Hlsl.. Mpd., Ang. und LuL

N. Sm. an mehreren Fundorten. A. Kristiania, niclit selter. Bu. Honefos. Ringerike rass. JL. Tjomø und Sandefjord. Ne. Saetersdalen. NT. Stjordalen. No.-F. r. Nordgrenze luei $70^{\circ}$ n. Br. Gross-Britannien, Zentral-Europa, Azoren, Sibirien, sachalin, Japan, Nurd-Auerika.

\section{HYLOCOMIUM}

Bryol. eur. fase. 4952 Mon. (1852).

Stengel mit stockartigem Aufbau, 1- bis 3fach geliedert: Paraphyllien vielteilig, die Mantelschieht mit einem feinen Filz bedeckend: Pseudoparaphylien in der Nähe der Astanlagen. Blätter dachziegelig his sparrig, meist zweigestaltig: Blattflügelzellen nicht differenziert. Perichätialblätter mit abgebogenen Pfriemenspitzen. Kapsel dick eiförmig oder länglich-oval. Ring (excl. H. umbratum) differenziert. Deckel gewölbt spitzkegelig bis kurz und schief geschnäbelt.

\section{Übersicht der Arten.}

A. Paraphyllien gross. Stengelblätter ohne abgerundete Basalecken.

a. Stengel ein- bis dreifach gefiedert; Paraphyllien unregelmässig in pfriemenförmige. gewundene, geschlängelte Äste geteilt. Stengelblätter dachziegelig anliegend, nicht herablaufend, schwach oder kaum längsfaltig, breit eilänglich, plötzlich \pm lang zugespitzt, kleingesägt....

b. Stengel einfach bis doppelt gefiedert: Paraphyllien geweihartig verzweigt und gezähnt. Stengelblätter albstehend, lang und schmal herablaufend, tief längsfaltig, breit herzförmig, allmählich lanzettlich zugespitzt, fast dornig gesägt 797. H. proliferum.

$\therefore$ Stengel einfach gefiedert; Aste dick wurmförmig, etwas zusammengedrückt; Paraphyllien reichlich verästet. Stengelblätter dachziegelig anliegend, nicht herablau- 
fend, tief längsfaltig, breit länglich-oval, plötzlich in

eine kurze, breite. grob gesägte Spitze verlängert 800. H. pyrenaicum.

B. Stengel unregelmässig und fast baumartig verzweigt und einfach bis doppelt gefiedert; Äste von ungleicher Länge, die längeren verdünnt, die kürzeren verdickt; Paraphyllien sehr kurz, vielästig. Stengelblätter sparrig. nicht herablaufend, mit den abgerundeten. basalen Ecken stengelunfassend. sclıwach längsfaltig, breit herzförmig, plötzlich

in eine lange, bandartige Spitze verschmälert, kleingesägt 799. $H$. brevirostre.

797. Hylocomium proliferum (L.) Lindb. in Act. Soc. Se. Fenn. X. p. 251 (1872). [Hypnum proliferum L. Sp. pl. p. 1125 (175:). - H. splendens Hedw. Sp. musc. p. 262. t. 67, f. $7-9$ (1801). - Hylocomiun splendens Bryol. eur. fasc. 19,51, p. 5. t. $1(18.52) .1$
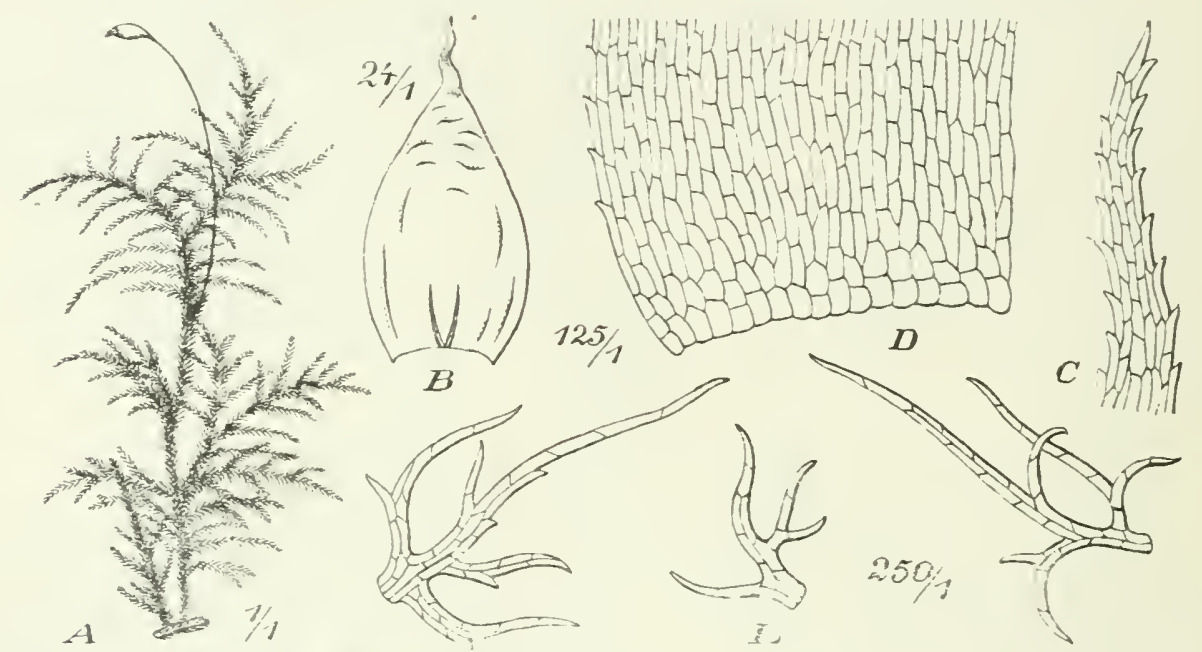

Fig. 113. Hylocomium proliferturn (L.). A Fruchtende Pfl. (1/1); B Stengelb. (2't/1); C Blattspitze (125/1); i) Bid'tbasis (125/1); E Paraphyllien (250/1).

Pfl. in meist ausgedehnten, grünen oder gelblichen, glänzenden Rasen. Stengel bis $20 \mathrm{~cm}$, bogig auf- und absteigend; Jahressprosse hogig gekrümmt, am Grunde astlos, oberwärts durch zweizeilig gestellte Äste und Ästchen regelmässig doppeltund dreifach gefiedert, mit dümnen und spitzen Fiedern: Paraphỵlien am Stengel und an den Ästen 1. Ordnung. in pfriemen-fadenförmige Äste geteilt. Stammblätter locker dachziegelig, schwach oder kaum längsfaltig. breit länglich-eiförmig, plötzlich in eine lange, geschlängelte Spitze verschmälert, bis $3 \mathrm{~mm}$ lang und $1,5 \mathrm{~mm}$ breit, klein gesägt: Zellen glatt oder hier und da zahnartig vortretend. Fiederblätter 1. Ordnung oval, plötzlich sehmalspitzig, 1,2 mm lang und 0,6 mm breit, scharf gesägt: Fiederblätter 2. Ordnung lïnglich, stumpflich zugespitzt, bis $0,6 \mathrm{~mm}$ lang und bis $0,24 \mathrm{~mm}$ breit, scharf gesägt. Innere Perichätialblätter lanzettlich-pfriemenförmig, ganzrandig. Seta $2-1 \mathrm{~cm}$, rot. Deckel hoch gewölbt und kurz geschnäbelt. Sporenreife im Frühling. — Fig. 113.

Auf Waldboden und felsigen Abhängen durch Fennoskandia allgemein verbreitet und Massenvegetation bildend. Steigt bis in die alpine Region hinauf, dort jedoch meist spärlicher.

Spitzbergen, Europa, Kanaren, Azoren, Algier, Tunis, Kaukasus, Zentral-.Asien, Sibirien, Japan, China, Nord-Amerika. 
798. Hylocomium umbratum (Ehrlı.) Bryol. eur. fasc. 19 .51 .1011. p. (4, t. 2 (1852). [Hypnum umbralum Ehrh. Pl. (rypt. No. 66 (1788).]

Pfl. in \pm ausgedehnten, dunkelgrünen bis bräunliclen, matt glänzendent Rasen. Stengel bis $20 \mathrm{~cm}$, niedergestreckt, unterbrochen und regelnässig buischelästig und einfach bis doppelt gefiedert: Jahressprosse und Fiederäste herał)gelogen; Äste stielrund und langspitzig; Paraphyllien an allen Achsen, vielgestaltig. geweihartig verzweigt und gezälnt. Stammblätter feucht abstehend, tief längsfaltig, aus verengter, schmal herablaufencter Basis breit herzförmig, rasch ofler allmählich lanzettlich zugespitzt, bis $2 \mathrm{~mm}$ lang und bis $1,5 \mathrm{~mm}$ hreit, unregelmässig und grob gesägt: Zellen glatt. Ficlerblätter 1. ()rdnung eiförnig, kurz zugespitzt, bis $0.9 \mathrm{~mm}$ lang und bis $0,6 \mathrm{~mm}$ breit, stärker gesägt. Perichätialblätter aus dem fast scheidigen, breiteren Teil rasch in eine dornig gezähnte l'frieme verschmälert. Seta $2-4 \mathrm{~cm}$, rot. Ring fehlend. Deckel hoch spitzkegelig. Sporenreife im Frühjahr.

Auf etwas feuchtem Waldboden, Baumwurzeln und beschatteten Steinen.

F. Al. Jomala, Kasberg (Arrh.). Geta, zw. Brändö und der Kirche (Hult). sund, Gesterby (Bruth.). Saltvik, an mehreren Fundorten (Bom.). - Ab. lrustafs, Eskola (Bergr.). Kurpo, Talkis (Elfv.). Lojo, Jalansaari (Hult). Vichtis, Palajärvi (Hult). - Y. Ekenäs. Tvärminne (Häyr.). Ingá, Barösund (Bıch). Kyrkslätt, Humaljärvi (Ranck.). Esbo, Gräsa (Broth.). Helsingfors (Lindł.). Peruá, IIärkàpãã (Sael.). Elimäki (Tigerst.). Hogland (Lindb.). - ka. Wiborg. Lietjärvi (Buch). - Jk. Muola, Lehukyla (H. Lindb.). Kivennapa, Vehmais (H. L.). - St. Eura (Rönnb.). Ikaalinen, Nygảrd (sundv.). - Ta. Ifo]lola, Tiirismaa (Vain.). - Sa. Nyslott (Carl.). - Kl. Vaimo (Jusl.). Jaakkima (Sundr.). Pälkjarvi, Valkealampi (Broth.). 一 Oa. Krarken, Lappören (Broth.). - Tb. Petäjäresi. Särkimäki (Ruur.). Sb. Tuusniemi, Seinäkallio (Mel.). Kuopio, Pujo (Link.); Neulamäki, Kolmisopenlampi (Roiv.); Vuorilampi (R.). Nilsiä, Pieni Tarpinen und Tahkomäki (Kyyhk.). Maaninka, Pöljä. saarisenmaki und Lintuniemi (K.); Uuhimäki (K.). Iisalmi, Kauppilanmaki (K.). - Ok. Kajana, Lehtıvaara (Lackstr.). Paltamo, Kivesvara (Kyyhk.); Jyhkyrinvaara cop. (K.). Sotkamo, Tuikatli (Lackil1.); lieima (kivhk.). - K. Pudasjārvi, Portinoja (Broth.); zw. Särkelä und Virkku (B.). Kuusamo, zw. Ruoppijārvi und Ronkalampi (B.). - Lim. Kandalaks, Schelesnaja (B.).

S. Sm.-Tb., Jmt. und PL.

N. Sm. - F. Fordgrenze bei $69^{\circ} 40^{\prime} \mathrm{n}, \mathrm{Br}$.

Europa, Kaukasus, Japan, Nord-Amerika.

799. Hylocomium brevirostre (Ehrh.) Bryol. eur. 1. c. p. 10, 1. 7 (18.52). [Hypnum brevirostrum Ehrh. Pl. crypt. Dec. IX. No. 7.5 (1788).]

Pfl. in ansgedehnten, schwellenden, grünen oder gelblichen, glänzenden Rasen. Stengel bis $20 \mathrm{~cm}$, niederliegend und bogig aufsteigend, unregelmässig und fast baumartig verzweigt, mit einfach bis doppelt gefiederten Jahressprossen: Äste ungleich lang, die längeren allmählich verdünnt, die kürzeren verlickt: Paraphyllien an allen Achsen, kurz und unregelmässig sparrig verästelt. Stammblätter sparrig abstehend, hohl, schwach längsfaltig, mit den abgerundeten basalen Ecken stengehmfassend, breit herzförmig, plötzlich in eine lange bandartige spitze verschmälert, bis $3 \mathrm{~mm}$ lang und bis $2 \mathrm{~mm}$ breit, rings gesägt; Zellen glatt. Fiederblätter 1. Ordnung aufrecht-abstehend, fast den Stammblättern ähnlich. Fiederblätter 2. Ordnung aus enger Basis lanzettlich, kleiner und stärker gesägt. Perichätialblätter aus fast scheidigem Basalteile plötzlich in eine lange, gesägte Pfrieme verschmälert. Seta $1,5-2,5$ cm, purpurn. Deckel kegelig. kurz und dick geschnäbelt. Sporenreife im Spätherbst.

Auf Waldboden, am Grunde alter Stämme und auf beschatteten Blöcken.

S. Sk., Ö., Sm., rg.: Srm. und ing.

N. St. Ryfylke, Frafjord. SB. Bergen. R. Gursko, Breivik cpp. Nordgrenze bei $62^{\circ} 1 l^{\prime} \mathrm{n}, \mathrm{Br}$. Europa, Algier, Tunis, Japañ. Nord-Amerika.

800. Hylocomium pyrenaicum (Spruc.) Lindb. Musc. seand. p. 37 (1879). [Hypnum pyrenaicum Sprue. Musc. pyren. No. $4(18+7)$ et in Annal. Nat. Hist. II. Ser. Vol. III. p. 129, t. 1 (1849). - H. Oakesii Sull. in Gray Man. Bot. L'. S. A. p. 673 (1848). - H. fimbriatum Hartm. Skand. Fl. 5. ed. p. 330 (1849). - Hylo- 
comium fimbriatum Bryol. eur. fase. 49/51, Mon. p. 7, t. 3 (1852). - H. Oakesii Schimp. Coroll. p. 139 (1856).]

Pfl. in lockeren, grünen oder gelbgrünen, glänzenden Rasen. Stengel bis $8 \mathrm{~cm}$, niederliegend, gefiedert; Äste gekrümmt. etwas verflacht. die längeren allmählich verdünnt; Paraphyllien sehr zahlreich. gross, vielästig, am Grunde gelbrot. Stengelblätter dachziegelig. sehr hohl, tief längsfaltig, die unteren fast kreisrund und oval, die übrigen aus verengter Basis länglich-oval, plötzlich in eine kurze, meist halbgedrehte Spitze fortgesetzt, bis $2,5 \mathrm{~mm}$ lang und bis $1,4 \mathrm{~mm}$ breit, mit am Grunde und streckenweise oberwärts zurückgeschlagenen, von der Mitte aufwärts grob gesägten Rändern: Zellen glatt. Astblätter kleiner. weniger hohl, kürzer zugespitzt. Imnere Perichätialblätter aus fast scheidigem Basalteile raseh in eine lange, gesägte Pfrieme versehmälert. Seta 1-2 cm, purpurn. Ring nicht differenziert. Peristomzähne am Grunde verschmolzen. Deckel kegelig, langspitzig. Sporenreife Spätherbst bis Frühling. - Fig. $111 \mathrm{D}-\mathrm{I}$.

Auf beschatteten Steinen oder auf dem Boden an steinigen und felsigen Abhängen.

F. Ab. Lojo (Boldt). - Ik. Valkjărri, Veikkola (H. Lindb.). Pỵhājārvi (H. L.). - St. Sorrmark (Karst.). - Ta. Hattula. Nikkilā und Oripelto (Ranck. und Weg.). Asikkala, Viitaila (Link.). - Sa. Nuijamaa, Pohjola (Broth.). Kangasniemi, Tuomarinruori (Lackslr.). — Kl. Kurkijoki, Ohtjärri (Jusl.). Jaakima, Ramola (Sundr.). Sortarala, Ristijārvi und Rausku (Kop.); Lakkalampi, Hali (Broth.); Kirjaralahti fq. (Norrl.); Hāmekoski (Brolh.). Impilahti (B.). Pālkjărvi, Valk̄ampi (B.). - Sb. Heināvesi, Palokki (Kot.). Kaavi. Huosiaisniemi und Sāỵneinen (K.). Juuka, Vesivaara (Kot.). Maaninka, Pöljā. Saarisenmāki (Kỵhk.). - Kb. Juuka. Polvijärvi. Juuanvaara (Kot.). - Ok. Kajana, an mehreren Fundorten (Lackstr., Kryhk.). Paltamo. Melalahti (Lackstr.). Sotkamo. Naapurinraara (Kyykk.). Puolanka. Iso Kaitanen (K.). Suomussalmi, Kiannankylā, Pahalamminpuro (K.). - $K$. Kuusamo, Arentojoki, Ristikallio (Broth.): Iivaara (Sil.); Māntyvaara (Broth.). - Kk. Kivakkatunturi (B.). Lkem. Kuolajārvi, Sallatunturi (B.). - Le. zw. Hetta und Vuontisjārvi. in der Kieferregion (Norrl.). Kilpiskoski, in der Birkenregion (. .); Kilpisjārvi, Yılla, in der alpinen Region (Kot.). - Lim. Kandalaks, Nirajoki und Schelesnaja (Broth.). Tschunosero und Tschun (B.). Hibinä (B.); Lujaur-urt, Straschna Paht, in der alpinen Region (Kihlm.); Naum-uajs, an der Baumgrenze (K.). Marikkojärvi (K.). - Lt. Tsipnavolok (Broth.). Subori (B.). - Linur. Varsinsk (B.). - Lp. zw. Orlor und Ponoj (B.). Ponoj (B.).

S. Upl., V'sm., Dlr., Hlsl., Hrjd., Mpd., Jmt., Ang., PL. und LuL.

N. A. F. Nordgrenze tei $70^{\circ}$ n. Br.

Europa, Kaukasus, Sibirien, Japan, Nord-Amerika.

\section{Reihengruppe BUXBAUMIINALES.}

Kapsel dorsiventral gebaut. Periston im Deckelamphithecium in $3-6$ konzentrischen Zellagen aus Wandteilen der Zellmembran entstehend; Endostom einer verschiedenen Gewebeschicht angehörig.

\section{Reihe BUXBAUMIALES.}

Einjährige Pfl. Gametophyt rudimentär, ohne Chlorophyll und zur Zeit der Sporenreife zerstört. ¿ und Geschlechtsstand nur ein eikugeliges Antheridium und meist nur ein Archegonium enthaltend. Äusseres Peristom zahnartig.

\section{B UX B A U M I A C A E.}

Kleine, cinzeln oder truppenweise, auf Erde oder faulem Holz wachsende, einjährige Pfl., mit ellorophyllreichem, oberirdischem Protonema. Stengel äusserst kurz, einfach, reichlich mit farblosen. dünnwandigen Rhizoiden. Blätter klein, bräunlich, breit eifömig und eilanzettlich, einschichtig: Rippe fehlend; Kellen locker, länglich-6seitig. dimnwandig, ohne Chlorophyll, am Blattrande zu langen Fäden auswachsend, die den später zum dicken, fleisehigen Scheidehen 
ungebildeten Stengel als dichtes Filzwerk einhïllen. J)iozisch. T Pfl, mikroskopisch, stammlos, dem grünen Protonema aufsitzend, aus einem muschelförmigen Hüllblatt und einem sehwanenhalsartig gestielten, völlig eingeschlossenen Antheridium bestehend. C Pfl. selır kurz, mit meist nur einem Archegonimu und ohne Paraphysen. Pericluätialblätter nicht differenziert, zur Zeit der Fruchtreife wie die übrigen Blätter zerstört. Seta dick, steif, rot, dichtwarzig. Kapsel mit deutlich differenzierter Ober- und Unterseite: Hals kurz, zylindrisch: Spaltöfnungen am tiefsten Grunde. Ring differenziert. Peristom doppelt. Ausseres Peristom 1-4 Zahnreihen mit Quergliederungen. Inneres Peristom eine gestutzt kegelförmige, weissliche, stark papillöse, enge Röhre, mit 32 Längsfalten. Deckel auírecht, klein, walzig-kegelförmig, stumpf. Haube fingerhutähnlich, nur den Deckel bedeckend, hinfällig, glatt. Sporensack gestielt, innen der bauchig-kegelförmigen Columella anliegend, aussen von einem grossen, von chloroplyylleichen Spannfäden durchgequerten Luftraum umgehen. Sporen sehr klein.

Einzige Gattung:

\section{BUХBAUMIA}

Hall. Enum. Stirp. Helv. I. p. 10 (1742).

S e c t. I. Eubuxbaumia Lindb. Muse. scand. p. 13 (1879).

Spaltöffnungen eingesenkt, einzellig. Ring sehr breit. Peristomzähne einreihig.

801. Buxbaumia aphylla L. Diss. Buxb. \& II. p. $10, \S$ VII. p. $15(1757)$.

Seta $1-2 \mathrm{~cm}$, grobwarzig. Kapsel schief ansteigend, später fast horizontal, zusammengedrückt eiförmig, bis $4 \mathrm{~mm}$ lang und bis $3,5 \mathrm{~mm}$ breit: Oberseite zur Fruchtreife lichtbraun und flach gewölbt, rings von einem wulstigen, roten Rande umgeben: Unterseite glänzend rotbraun, stark vorgewölbt; Aussenwand der Epidermis der Oberseite nach der Entdeckelung sich in Fetzen zurückrollend. Ring bis zur Mitte des inneren Peristoms verlängert, nach der Entdeckelung die Urnenmündung kronenartig umgebend. Deckel sich schwer ablösend. Sporenreife im Juni. - Fig. 114.

Auf sandigem oder tonig-sandigem Boden, be-

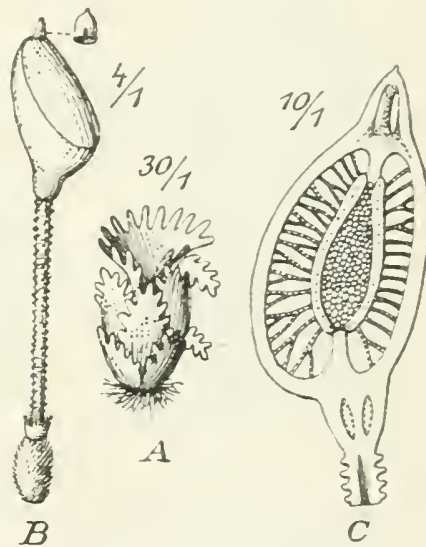

Fig. 114. Buxbaumia aphylla L. A Junges Pflānzchen $(30 / 1)$; B. Pflanze mit Haube (4/1); C. Kapsel im Lāngsschnitt $(10 / 1)$.

sonders in Ausstichen, Gruben und an Erdlehnen im trockenen Kiefernwald. Sporenreife im Frühling.

F. Al. Eckerö (H. Lindb.). Finstrôm. Gọoby (Arrh.). Saltvik, an mehreren Fundorlen (Bom.). - Ab. Pargas, Björkō (Elfr.); Blāsnäs (Lunditr.). Abo. Bagarla (Zesterm.). Kakskerıa (Colland.). Merimasku (Karst.). Kimilo, Södersundvik (Ols.). Karislojo. Tammisto (E. af H.). Lojo (Lindb., H. Lindb.). - N. Esbo, Kilo (Häyr.). Helsingfors, Mejlans (Lundb.). Helsinge, Boxbacka (Rauck.). Siblo, Gesterby und Husô (Ranck.); Sörik (Link.). Elimäki (Tigerst.). Orimattila. Virenojankoski (Anna Link.). Hogland, Liivalahenjärvi (Linab.). - Ka. Sippola. Ruotila (V. Kuj.). Vehkalahti (E. W. Blom). Wiborg, Liimatıa (Thesl.). Antrea (Lind.). Hiilola. Clavoja (Lind.). - Ik. Valkjärvi, Pasuri (H. Lindb.). Iuola, Pällilä (H. Lindb.). - St. Yläne (Sahlb.). Karkku (Hjelt). Punkaiaidun isosuo (Ranck.). - Ta. Im südöstl. Teile pass. (Norrl.). Padasjoki, Kirchdorf (Tain.). Hartola (Bonsd.). Sysmā (Ĺnon.). — Sa. Kangasniemi (Lackstr.). Jyslott (Carl.). - Kl. Luhuniemi (Simm.). Sortavala, Kirjaralahti (Norrl.). Oa. Sideby (harst.). - Tb. Petäjäresi (Ruor.). Jỵvăsḳlä (Siint.). Laukaa, Kivijărvi (Liro). - Sb. Joroinen, Jảrvikylä (H. Lindb.). Heinävesi, Papinniemi (Kot.). Kuopio. Sārkilahti (Link.): Sorsasalo und siikalahti (Kot.). Nilsiă, Keskisenmäki und Loutteinen (Kỵhk.) Maaninka Pyssymāki (Kyyhk.); Haatala (Roir.). - Kon. Kiratsch und Suopohja (Simm.). Jänkājārvi (Norrl.). - Um. Vindala, Viitaniemi (Backm.). - Ok. Kajana (Lackstr.). - Ot. Turtola (Huli). - h. Kuusamo (F. Nyl.). - Lkcm. 
Palojoki und zw. Palojoki und Muolkijärvi (Norrl.); Ounastunturi, in der alpinen Region (Norrl.). Li Inari, Peldoivi, in der Birkenregion (Hult) L'Ł.joki, Y̌läjalıve, Daussejokka (Ranck.).

S. Sh. - TL.. am reichlichsten in den zentralen Provinzen.

N. Sm. Onso. A. Klistiania pass. Ringerike r. JL. Sandefjord r. Ne. Saetersdalen r. $S B$. Ousedalen. K. Dovre. Tr. und F. r. Nordgrenze bei $70^{\circ} \mathrm{n}$. Br.

Eurupa, Sibirien, Amurgebiet, Nord-Anerika.

S e c t. I 1. Polyodon Schimp. Syn. p. 454 (1860).

Spaltöffnungen oberflächlich, zweizellig. Ring schmal. Äusseres Peristom aus 3-1 Zahnreihen gebildet; Peristomzähne bleichrot, stark papillös.

802. Buxbaumia viridis (Moug.) Brid. in Moug. et Nestl. Stirp. Crypt. Vog.Rhen. fase. 8, No. 724 (1823). [Buxbaumia aphylla $\beta$ viridis Moug. in DC. Fl. franc. 3. ed. V. p. 227 (1815). - B. indusiata Brid. Bryol. univ. I. p. 331 (1826) et II. p. 741, t. 2 Suppl. f. $1-8$ (1827).]

Seta j--10 mm, dicker, gelblichrot, kleinwarziger. Kapsel aufrecht, später schief ansteigend, bis $7 \mathrm{~mm}$ lang und $3.5 \mathrm{~mm}$ breit: beide Flächen fast gleichfarbig, entleert gelblich, ohne wulstigen Rand; Aussenwand der Epidermis der Oberseite schon beim Eintritt der Reife sich in Fetzen bis zur Grenze der Unterseite zurückrollend. Ring meist zweizellreihig und sich in einzelnen Zellen ablösend. Deckel sich leicht ablösencl. Sporenreife im Juni.

An morschen Baumst ̈̈mpfer, fauligem Holze und auf humusreichem Laubwallboden.

F. Al. Finström, Godby (Bom.). Sund, Geslerby (Bom.). Saltrik, an mehreren Fundorten (Bom.). - Ab. Kakskerta (Colland.). Merimasku (Karst.). Pargas (Arrh.).

S. Sk.-.Vb. Bisher noch nicht in Hll., Boh.. Dlr., Mpd. und Ang. leobachtel.

N. Sm. Onsø. A. Kristiania. Ringerike r. JL. Tjømø.

Europa, Kilukasus.

\section{Reihe DIPHYSCIALES.}

Mehrjährige Pfl. Blätter zweigestaltig, z. T. zweischichtig: Rippe vorhanden; Zellen parenchymatisch. Kapsel eingesenkt, schief eiförmig. Exostom sehr kurz, fast ringartig.

\section{I P H Y S C I A C E’A E.}

Ausdanernde, meist rasenbildende, dunkel- bis schwärzlichgrüne, zuletzt braune. glanzlose Pfl., deren Protonema spät verschwindet und schildförmige Assimilationsorgane trägt. Stengel aufrecht, ohne Zentralstrang und ohne Mantelzellen, dlicht und mehrreihig beblättert, am Grunde mit Rhizoiden. Stammblätter oberwärts 2(3)schichtig, zungenförmig bis verlängert spatelförmig, stumpf oder zugespitzt; Rippe kräftig, homogen, meist vor der Blattspitze endend; Zellen der Lamina klein, rundlich-1-6eckig, z. T. querbreiter, chlorophyllreich; Zellen des einschichtigen Blattgrundes locker, verlängert 4 -6eckig, mit stark verdickten Querwänden, glatt. Perichätialblätter viel grösser, aufrecht-anliegend, zart und fast läutig, glatt; Rippe kräftig, als lange Granne austretend. Seta sehr kurz, loleich. Fuss keulenförmig, mit dem Wandgewebe des Scheidchens durch schlauchartige Saugorgane verbunden. Kapsel dorsiventral gebaut, schief eikegelförmig: Spaltölfnungen oberliächlich, an tiefsten Kapselgrunde. Ring differenziert. Peristom doppelt. Iusseres Peristom ringförmig, einreihig: Peristomzähne 16, dreieekig, quergegliedert, \pm deutlich gesondert, hinfällig. Inneres Peristom eine weissliche, gestutzt kegelfömige, papillöse Röhre mit 16, mit den Peristomzähnen abwechselnden kielfalten. Deckel klein, spitz kegelförmig. Haube spitz kegelförmig. kaum den Deckel bedeckend, glatt. Sporensack gestielt, innen mit der Columella rerschmolzen, aussen von einem weiten, von langen, chlorophyllreichen Spannfäden darchquerten Luftraume umgegeben. Sporen klein.

Finzige Gattung: 


\section{DIPHYSCIUM}

Ehrh. Phytoph. X. X̃o. 99 (1788).

803. Diphyscium sessile (Schmid.) Lindh, in Öfr. K. Vet.-Ak. För rh. XX. p. 393 (1863). [Buxbaumia sessilis Schmid. Diss. Buxb. p. 26 (17.58). - B. foliosu Web. Spicil. p. 128 (1778). - Diphyscium foliosum Mohr Obs. bot. p. 31 (180:3). - Webera Diphyscium Ehrh. Beitr. 1. p. 189 (1787). — W. sessilis Lindl). I. (". p. 394.]

Diözisch; Blüten knospenförmig, mit fadenförmigen Paraphysen. Pfl. gesellig oder in dichten, flachen Rasen. Stengel nur wenige mm, einfach. Stammblätter trocken gedreht und gekräuselt, feucht aufrecht-alsstehend, his 3 mun lang und etwa $0,1 \mathrm{~mm}$ breit, flach- und ganzrandig oder undeutlich gekerbt; Zellen der Lamina beiderseits manillös. Perichätialblätter verlängert eiłanzettlich, bis $6 \mathrm{~mm}$ lang, an der Spitze wimperartig zerschlitzt. Kapsel his + $11 m$ lang und $1,5 \mathrm{~mm}$ dick, gelbgrün, zuletzt gelbbräunlich, weichhäutig: Zellen des Exotheciuns locker und dünwandig, unregelmässig 4-6seitig, an der Mündung einige Reihen kleiner und dickwandiger. Sporenreife rom Mai his Sept. - Fig. 115.

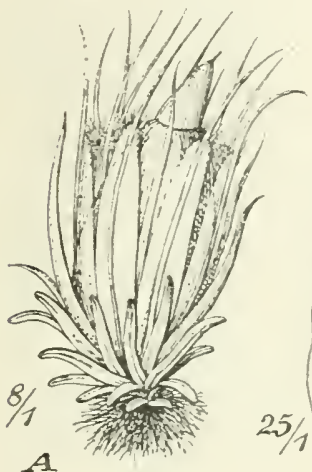

A

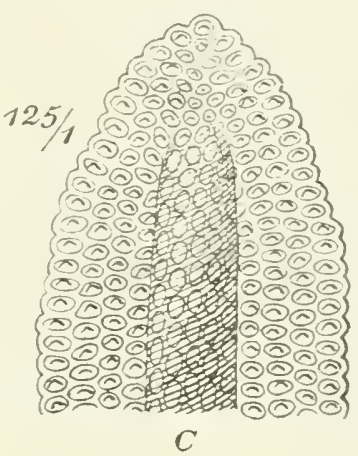

Fig. 115. Diphyscium sezsile (Schmid.). A Fruchtende Pfl. (8/1): B C̈nteres Stengelb. (25 1); C Blattspitze $(125 / 1)$; D Periston ( $15 / 1)$.

Auf tonig-sandigem Boden lichter Wätder, an Waldwegrändern, an Erdlehnen, auf Heideland, auf torfiger Erde an Felsabsätzen, zw. Steinen in Abhängen.

F. Kk. Kivakkatunturi, in der alpinen Region (Broth.). - Lim. Hillinä. in der alpinen Region (Broth.). - Li. Ltsjoki. Ailigas (Hult, Ranch.); Baktevarre (Ranck.). Čberall nur steril.

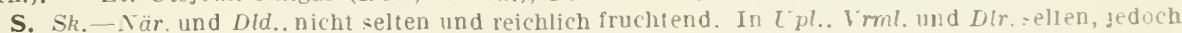
mit sporogonen. in Hrjd.-LuL. - selten und nur sieril.

N. Sm. nicht selten. Ringerike $r$. JL. Sandefjord pass. Ne. Sdelersdalen. \&B. NB. NT. Stjordalen. Yo. an mehreren Fundorten, auch fruchtend. Tr. und $F$. seltenl und nur steril. sleigt über die Baumgrenze hinauf. Nordgrenze bei $70^{\circ} \mathrm{n} . \mathrm{Br}$.

Europa. Madeira, Kaukasus, Yord-Amerika.

\section{Reihengruppe POLYTRICHINALES.}

Peristom in zah!reichen, konzentrischen Zellagen aus ganzen, schiefgegliederten Zellen gebildet.

\section{Reihe POLYTRICHALES.}

Kapsel multilateral. Peristomzähne aus hufeisenförmigen Faserzellen bestehend und an der Spitze durch ein Epiphragma verbunden. 


\section{P O L Y T R I C H A C E A E.}

Kleine bis sehr stattliche, \pm starre, truppweise orler in Rasen wachsende Errl- und Sumpfmoose mit blattlosem, meist dicht rhizoidenfilzigem Rhizom. Stengel aufrecht, einfach, gabel- oder büschelästig, rundlich 5-mehreckig, mit meist hochentwickeltem Zentralstrang, lockerem, \pm verdicktem Grundgewebe und mehrschichtigen, stark verdickten, gelben oder gelbroten Mantelzellen. Niederbłätter entfernt gestellt, meist anliegend, klein, schuppenförmig, bleich oder rot, mit dünner Rippe und ohne Lamellen. Laubblätter allmählich grösser und dichter gestellt, allermeist in Scheide und Spreite differenziert; Rippe kräftig, mit 2 Stereidenbändern, 2 Schichten 5-mehrzähliger Deuter, eingelagerten Zentralzellen, einschichtigen und dickwandigen Rückenzellen und meist zweischichtigen und dünnwandigen Bauchzellen mit aus den letzteren entspringenden, chlorophyllreichen Längslamellen; Zellen der Lamina parenchymatisch, meist klein, chlorophyllreich und meist glatt; Zellen der Blattscheide rektangulär, verlängert bis lineal, spärlich chlorophyllös bis hyalin. Diözisch, selten parözisch oder polyözisch. o Blüten knospen-becherförmig bis fast scheibenförmig, allermeist aus der Mitte sprossend; Hüllblätter zahlreich, verkehrt-herzeiförmig mit Spitzchen, oft rötlich: Antheridien und Paraphysen sehr zahlreich, letztere fadenförmig, oft mit oben flächenartig verbreiterten Zellfäden gemischt. ㅇ Blüten gipfelständig. Seta verlängert, oben oft bandartig verflacht. Kapsel von wechselnder Form. Peristom einfach, aus Bündeln bastfaserähnlicher Zellen bestehend, die sich aus einer \pm vortretenden, meist gefärbten Grundhaut hufeisenförmig zu 32 oder 64 zungenförmigen, ungegliederten Peristomzähnen vereinigen. Deckel aus kegeliger oder gewölbter Basis zugespitzt bis geschnäbelt. Haube kappenförmig, meist mit am Scheitel entspringenden, abwärts gerichteten, gegliederten, vielfach verästelten und verschlungenen, glatten Haaren bedeckt. Sporensack ein in sich zurücklaufender Schlauch, der (excl. Pogonatum nanum) frei aufgehängt ist und durch zahlreiche, grüne Spannfaden einerseits mit der L'rnenwand, andererseits mit der Columella verbunden ist. Columella oben scheibenförmig verbreitert, von den Spitzen der Peristonzähne getragen, glattrandig oder buchtig ausgezackt. Sporen klein.

\section{Chersicht der Gat tungen.}

A. Kapsel stielrund, ohne Spaltöfnungen.

a. Blätter nicht scheidig, wulstig gesäumt. Haube nackt. 168. Catharinaea.

๖. Blätter scheidig, ungesäumt. Haube filzig ......... 171. Pogonatum.

B. Kapsel mit Spaltöffnungen.

a. Kapsel nicht kantig. Haube nackt oder mit spärlichen, aufrechten Haaren.

«. Kapsel aufrecht, regelmässig. Haube mit spärlichen

Haaren ............................................... 169. Oligotrichum.

$\beta$. Kapsel geneigt, unregelmässig. Haube nackt....... 170. Psilopilum.

b. Kapsel meist kantig. Haube filzig .................. 172. Polytrichum.

\section{CATHARINAEA}

Ehrh. in Hann. Mag. 1780 p. 933 et in Beitr. I. p. 178 (1787).

Blätter am Grunde nicht scheiclenartig, gekielt, feucht t abstehend, trocken gedreht und gekräuselt, schmal und wulstig gesäumt, oberwärts grob gezähnt und allermeist am Rücken durch Schrägreihen von Zähnchen rauh: Rippe mit 
oder vor der Blattspitze aufhörend und mit wenigen, auf die Oberseite leschränkten, geraden, glatten, ganzrandigen Lamellen; Zellen rundlich-6seitig, dünwwandig, chlorophyllreich, gegen den Blattgrund rektangulär und ärmer an chlorophyll. Perichätialblätter nicht differenziert. Kapsel etwas geneigt, aus sehr kurzem Halse stielrund, meist schwach gekrümmt, derblı̈̈tig; Zellen des Exotheciums ohne Ausstülpungen, rektangulär, mit verdickten Längswänden; Spaltöfnungen fehlend. Peristomzähne 32, papillös, bleich, mit gelbroter Achse. Deckel kuppelartig gewölbt, lang und fein geschnäbelt. Haube glatt, nur an der Spitze rauh.

Übersicht der Arten.

A. Diöziseh. Blätter nicht oder kaum querwellig, am Rücken glatt oder mit vereinzelten Zähnchen, mittlere Laminazellen 18 - 30 ". Urne etwa $2 \mathrm{~mm}$, bräunlich............ 805. C. tenella.
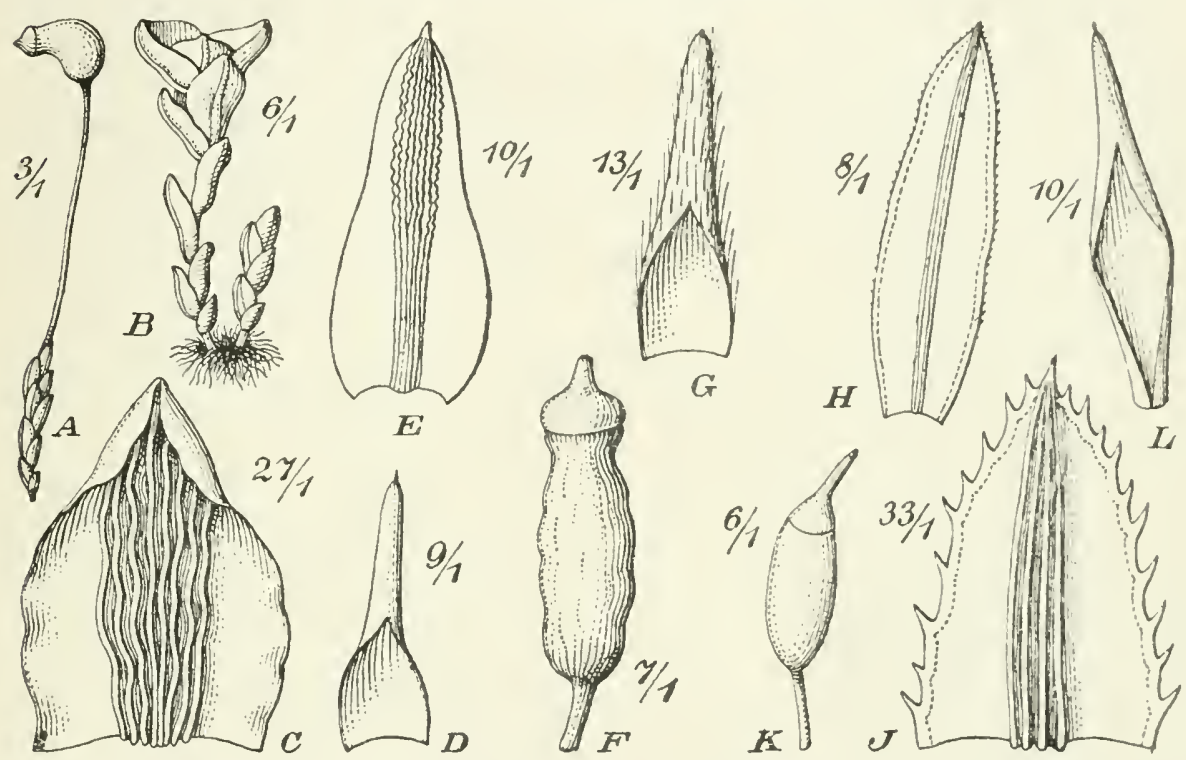

Fig. 116. A -D. Psilopilum laevigatum (Wahlenb.). A Fruchtende Pfl. (3/1); B $\subsetneq$ Pfl. (6/1); C Blattspitze (27/1); D Haube (9/1). - E-G. Oligotrichum incuroum (Huds.). E Stammb. (10/1); F Kapsel (7/1); G Haube (13/1). - H-I. Catharinaea tenella Röhl. H Stammb. (8/1): I Blattspitze $(33 / 1)$; K Kapsel (6/1); L Haube (10/1).

B. Diözisch. Blätter nicht oder kaum querwellig, an Rücken mit spärlichen Zähnehen; mittlere Laminazellen 9-15 " Urne etwa $4 \mathrm{~mm}$, kurz vor der Reife purpurrot........... 804. C. angus ata.

C. Blätter stark querwellig, am Rüeken durch Schrägreihen von Zähnehen rauh; mittlere Laminazellen 18-30 $\mu$.

a. Synantöziseh. Sporogone zu 2-6 aus demselhen Blattschopfe. Urne kurz vor der Reife purpurrot; Zellen des Exotheciums 1: $1-1,5$ 807.C.Haussknechtii.

b. Polyöziseh. Sporogone einzeln. Irne rotbraun; Zellen des Exotheciums 1: $2-1$ 806. C. undulata.

804. Catharinaea angustata Brid. Mant. muse. p. 204 (1819). [Atrichum anguslatum Bryol. eur. fase. 21/22, p. 9, t. 3 (184t).] 
Diözisch. Weniger kräftige Pfl. in lockeren, meist gelbgrünen bis bräunlichen Rasen. Stengel 1-2 cm, selten höher, meist einfach. Blätter nach oben grösser und gedrängter, kaum querwellig, schmal lineallanzettlich, stumpflich, bis $4,5 \mathrm{~mm}$ lang und etwa $0,6 \mathrm{~mm}$ breit, mit am Grunde zurückgebogenen, in der oberen Hälfte durch einfache und Doppelzähne dornig gesägten Rändern; Rippe mit $4-8$ meist 5-6zellreihigen Lamellen, am oberwärts am Rücken gezähnt; Zellen in der Blattmitte $9-15 \mu$. Sporogone einzeln. Seta $1-2 \mathrm{~cm}$ rot. Ume schlank zylindrisch, etwa I $\mathrm{mm}$ lang und etwa $0.5 \mathrm{~mm}$ dick, kurz vor der Reife purpurrot, später braun. Deckel von halber Urnenlänge. Sporenreife im März und April.

Auf fenchtem, tonig-sandigem Boden.

S. Bisher wur von einzelnen Fundorten in $s m$. und Boh. bekannt.

West-, Zentral- und Süd-Europa. Kaukasus, Japan, Xord-Amerika.

805. Catharinaea tenella Röhl in Annal. Wett. 111. p. 234(1814). [Atrichum lenellum Bryol. eur. fasc. 2122 IIon. p. 9, t. 4 (1844).]

Diözisch. Schlanke Pfl. in lockeren, dunkel oder bräunlichgrïnen Rasen. Stengel bis $2 \mathrm{~cm}$, selten höher, einfach oder büschelästig. Blätter nach oben rasch grösser, feucht kaum querwellig, am Rücken glatt oder mit einzelnen Zähnchen, länglich- und verlängert-lanzettlich, kurz zugespitzt, bis $4,5 \mathrm{~mm}$ lang und $1 \mathrm{~mm}$ breit, bis unter die Mitte herab durch einfache und Doppelzähne dornig gezähnt: Rippe mit 2-4 3-5zellreihigen Lamellen, am Rücken glatt oder oberwärts gezähnt: Zellen in der Blattmitte $18-30 \mu$. Sporogone cinzeln. Seta bis $2 \mathrm{~cm}$, gelblich, znletzt blass fleischfarben. Urne länglich-eiförmig bis kurz zylindrisch, bis $2 \mathrm{~mm}$ lang und $0,75 \mathrm{~mm}$ dick, bräunlich. Deckel etwa von Unnenlänge. Sporenreife im August und September. - Fig. $116 \mathrm{H}-\mathrm{L}$.

Auf feuclitem, sandigem oder tonig-sandigem Boden, an den Böschungen der Wiesengräben und Torfausstiche, an Wigrändern, Heideplätzen, meist an nackten Flecken.

F. Al. Saltvik und Geta, selten (Bom.). - Ab. Finbv (Broth.) Bromarf (Sundv.). Karislojo, Karkkali und Tammisto (E. af H.). Vichtis, Kourla (E. af H.). Lojo, Hiitis (Lindb.): Laxpojo (Sundr.). - N. Ekenäs, Trärminne (Ranck.). Esbo, Gräıa (Broth.). Helsingfors (Lindł.). Borgá, Haikku, Backas (Teräsv.). Hogland (Lindb.). - Ka. Antrea, Liikola (Lindb.). Sippola, Ruotila (Kuj.). - Ik. Pỵäjärvi (Sahlb.). Metsäpirtti, Igolkkaniemi (H. Lindb.). Muola, Perkjärvi (H. Lindb.). Lusikirkko, Vammelsuu (H. Lindb.). - St. Björneborg (Häyr.). Honkajoki, Paastokylä (Hjelt). - Ta. Tavastehus (Graeflé). Asikkala (Norrl.). Hartola (Bonsd.). Evsmä (Lnon.). - Ea. Lappvesi, Pajarila (Buch). Kangasniemi (Lackstr.). - Kl. Uukuniemi (Simm.). E’rkijoki, Migrilä (Jusl.). Ruskeala, Kaalano (Kuj.). Soanlahti, Koirinvaara (Broth.). Sortavala, Puiltatu (Lilil).). Valano (Kihlm.). - Kol. Ilandroga (Elfv.). Petrosavodsk (Kullh.). - Oa. Visa (Broth.). - Tb. Laukaa, Karlvik (Link.). Viitasaari (Brotl.). - Sb. Maaninka, Pöljä (Kyyhk.). Pielavéi, Jỵhä: Mäkelä (Roiv.). - Kb. Korniselkã. Āgläjärvi (Kullh.). - Kon. Gorskij Pogost (Simm.). - Om. Alajärvi, Kirchdorf (Backm.). - ok. Kajana (Lackstr.). Suomussalnii (Lackstr.). - Ob. Uleaborg (II. Nyl.). Rovaniemi. Tolonen und Alajääskö (Hult). Alkkula (Norrl.). - $K$. KuuSarno, Yli-Kitkajärvi (Broth.). - Lkem. Kittilä, Kirchdorf. Alakylä und Kaukonen (Hult). - Le. Nuonio (Norrl.). - Li. Inari, in der Nadelwaldregion zerstreut (Hult). Ltsjoki, Mandojäyr, in der Birkenregion (Hult). - Lt. Am Kolafhisie (Broth.)

S. In Mittel- und sudschweden zerstreut, in den Küstenprovinzen Noudschwedens spärlich, in den Lappmarken felnend. Bisher kaum höher als bis 460 m beobachtet. Nordgrenze vei $66^{\circ} 24^{\circ}$ n. $\mathrm{Br}$.

N. In We-tlandet felılend. im O-1- nnd Binnenlande zer-lreut lin zum Polarkreize, nirgends höher als bis $600-650$ m benlachtet.

West- und Zentral-Luropa.

806. Catharinaea undulata (1..) Weh. et Mohr Ind. musc. pl. erypt. (1803). [Bryum undulatum 1. Sp. p]. II. p. 117 (1753). - Atrichum undulatum Palis. Prodr. p. $72(1805)$.

l'olyözisch; \& Blüten aus der Mitte der o Bliiten sprossend, selten $\sigma^{7}$ Pfl. oder $>$ Jfl. Krätige I’fi. in lockeren. olt ausgeclehnten, dunlielgrüen Rasen. Stengel bis 8 cun, einlach ocker gabelteilig. Blätte- nach oben rasch grösser, feucht querwellig, verlängert lanzettlich bis sclmul zungenförmig, kurz zugespitzt, his 
$10 \mathrm{~mm}$ lang und bis $1,7.5 \mathrm{~mm}$ breit, bis unter die Nitte heral) durch einfache und Doppelzähne dornig gesägt; Rippe mit 1 - 8 3zellreihigen lannellen, am Rücken oberwärts dornig gezähnt: Zellen in cler Blattnitte $18-30 \mu$. Sporogone cinzcln. Seta $2-t$ em, rot. Urne zylindrisch, etwa $t$ mm lang und cetwa 1.75 mm dick, rotbraun; Zellen des Exotheciums 1: 2-t. Deckel fast von truenlänge. Sporenreife im Spätherbst und Winter.

Am liebsten auf feuchtem, tonigem Boclen lichter Lanbwilder, auf Humusund Torferde, kommt jedoch auch auf kiesiger Unterlage an Weg- und Gräbenrïndern und sogar auf erdbedeckten Felsen vor.

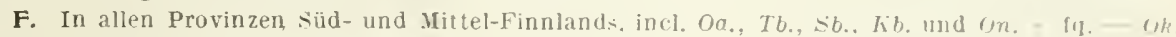
Kajana (Lackstr.). Suomussalmi (Kyyhk.). - Ob. Simo. Cleảborg. - K. Küsitu", an mehreren Fundorten (E. af H.). - Lkem. Kuolajärvi, hotala (Linnan.).

S. Im süd- und Mittel-schweden fa.. in den kilislenprovinzen Norrands ziemlich selten, in den Lappmarken selten und steril. Bisher kaum höher als bei etwa 500 m berbacltet. Norderenz bei $f_{1}{ }^{\circ}$ $55^{\prime} \mathrm{n}$. Br.

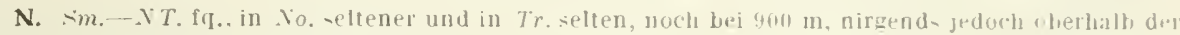
Baungrenze beokachtet. Nordgrenze lee fig० $11^{\prime} \mathrm{n}$. Br.

Europa, Madeira Azoren, Algier, Wesi-A-ien, Japan, China, Mord-Anerikd.

var. minor (Hedw.) Web. et Molur Bot. Taschenb. ]. 217 (1807). [I'olylrichum undulatum var. minus Hedw. Descr. p. 13, t. 17, f. 11, 1.5 (1787).]

Stengel niedrig. Blätter kürzer, kaun wellig, trocken gekränselt. Seta kürzer. Kapsel fast aufrecht, kürzer, last regelmässig.

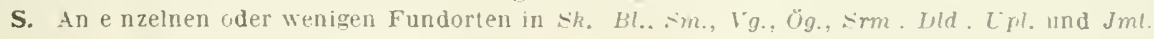

N. Nördlich bis Trondhjem hie und da heobachtet.

var. rivularis Brỵn in Kgl. Norsk. Vidl. Selsk. Skrift. 1899, No. 3. p. 13 (1896).

Stengel bis $15 \mathrm{~cm}$. lockier und abstehend beblättert. Blätter auf den Rücken fast glatt: Rippe mit nur 3- 1 Lamellen. Steril.

N. Ve. Saeterdalen, Ose, im Bache. H. Am Wasserfalle Laatefo:.

807. Catharinaea Haussknechtii (Jur. et Mild.) Broth. Eudud distr. Mouss. Canc. p. 4 (1884). [Atrichum Hanssknechtii Jur. et Milal. Verh. zonl-hot. Ges. Wien 1870, p. 598. - Catharinaea anomala Bryhn in Bot. Notis. 1886, p. 157).]

Synautözisch; zunächst dem Zentrum Antheridien und deren Hüllblätter, an der Peripherie Gruppen von Archegonien. Pfl. in lockeren, oft ausgeclehnten, grünen Rasen. Stengel bis 2.5 cm, einfach. Blätter nacl oben rasch grösser, feucht querwellig, linealisch-zungenförmig, Schopfblätter eilanzettlich und lanzettlich, zugespitzt, die innersten aufrecht, grösser, bis $9 \mathrm{~mm}$ lang, bis unter die Mitte herab durch einfache und Doppelzähne dornig gezähnt: Rippe mit $3-62$ - 3zellreihigen Lamellen, am Rücken oherwärts dornig gezähnt: Zellen in der Blattmitte 18 $30 \mu$. Sporogone zu 2-6 aus demselben Blattschopfe, selten einzeln. Seta 1$1.5 \mathrm{~cm}$, strohfarben odler rötlichgell. Irne zylindrisch. bis $3,5 \mathrm{~mm}$ lang und 0.7 mm dick, kurz vor der Reife purpurrot, zuletzt gelbbräunlich: Zellen des Exotheciums 1: 1-1,5. Deckel fast von Lrnenlänge. Sporenreife im Spätherbst.

Auf feuchtem, sandigem, sandig-tonigem oder humusreichem Boden, oft an Fluss- und Bachufern im Walde oder an schattigen Felsabsätzen.

F. Ik. Pỵäjärvi, Polvananiemi (H. Lindb.) und Riiska (f., Làng). - kl. Sortavala. Kirjavalalıli (Broth.).

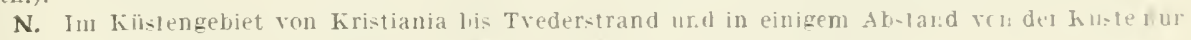
von der Umgebung de: Lrammenselv bis Honefos. Xurdgrenze bei $60^{\circ} 1 \omega^{\prime} \mathrm{n}$. Br.

England. Zentral- und Ost-Eurma. Kaukasus, Talysch. Sibirien Jalan. Nold-Anierika.

\section{OLIGOTRICHUM}

Lam. et De Cand. Fl. franc. 3. ed. II. p. 491 (1815).

Diözisch. Stengel einfach. Blätter am Grunde undeutlich scheiclenartig weder querwellig noch gesäumt. am Rücken glatt: Lamellenbildung auf die Rippe 
beschränkt; Rippe breit, als Stachelspitze austretend, am Rücken gegen die Spitze durch rudimentäre Lamellen kammartig gezähnt, Lamellen der Oberseite wellig, glatt, am Rande gekerbt; Zellen oben quadratisch und rundlich-6seitig, unten chlorophyllärmer und rektangulär; Perichätialblätter nicht differenziert. Kapsel aufrecht, eilänglich, kurz- und enghalsig, stielrund, gerade; Spaltöffnungen sehr gross, oberflächlich, 2- und tzellig: Zellen des Exotheciums ohne Ausstülpungen, 4-6seitig und rektangulär, dünnwandig. Peristomzähne 32, oft unregelmässig ausgebildet, bleich. Deckel leicht abfällig, aus gewölbt-kegeliger Basis zugespitzt bis kúrz geschnäbelt. Haube mit spärlichen, aufrechten Haaren.

808. Oligotrichum incurvum (Huds.) Lindb. in Hartm. Sk. Fl. 9. ed. II. p. 45 (186-1). [Bryum incurvum Huds. Fl. Angl. 2. ed. p. 479 (1778). - Catharinaea hercynica Ehrh. Beitr. I. p. 190 (1787). - Oligotrichum hercynicum Lam. et De Cand. Fl. frane. 3. ed. 11. p. 192 (1815).]

Pfl. in lockeren, leicht zerfallenden, schmutzig gelbgrünen, trocken rötlichbraunen Rasen. Stengel bis 2-3 cm, selten länger. Blätter trocken anliegend und hakig einwärts gekrümmt, oberwärts durch die eingebogenen Blattränder fast röhrig-hohl, aus fast scheidigem Grunde lineallanzettlich, bis $4,5 \mathrm{~mm}$ lang und etwa $1,5 \mathrm{~mm}$ breit, gegen die Spitze entfernt und klein gezähnt. Seta $1-3 \mathrm{~cm}$, gelbrötlich. Kapsel entleert nickeñd, bis 4 mm lang und $1,5 \mathrm{~mm}$ dick, bräunlich, trocken unregelmässig gefurcht und unter der Mündung verengt. Sporenreife im Juni unch Juli. - Fig. $116 \mathrm{E}-\mathrm{G}$.

Auf sandigem oder tonig-sandigem Boden, an Wegrändern, in Ausstichen. seltener auf Torfboden, meist in kleineren Rasen, an etwas fenchten Abhängen im Gebirge zuweilen in weit ausgedehnten Iatten.

F. St. Kuru, $\sim$ P Pll. anı Boden eines Grabens reichlich (Broth.). - Sb. Sonkajărvi, Sukeva, Ollins . o (Kot. et Roiv.). - ok. Sotkamo, Talvivaara (Kyyhk.). - $K$. Taivalkoski, zw. Kariniemi und Koitila (Broth.). Kuusamo, zw. Marttila und Vattula (Broth.); am Fusse des Rukatunturi (Broth.). Kapustavaara bei łäkelä, reichlich und sterile Pfl. bis $5 \mathrm{~cm}$ (E. af H.). - Lkem. Pallastunturit und Yllästunturi, oberhalb der Baumgrenze (Hult). Sodankỵlā, llartinkylä (Vain.). Ouna-tunturi (Norrl.) - Le. Kilpisjārvi, VIalia und Saana, in der alpinen Region fq. (Kot.). - Li. Inari. Tankajoki, in der Nadelwaldregion und Kodossuannonpāā (Hulı); Saariselkä, Sokustamakuru und Akanlıärkăkuru in der Birkenregion und Lupıkkapää in der alpinen Region (Hult): Peldoivi, am Gipfel (Hult). Utsjoki, Nuvvus, Ailigas (Ranck.). - L m. Hibinä (Ångstr.); Tschun (Broth.); Lujauri-urt, Vavnbjet (Kihlm.). - Lt. Zw. Kitsa una Kola und bei Kola (Broth.). Vaidoguba (Broth.). - Lmur. Kildin (F. Nyl.). Bjelousiha an Voronjeflusse Rinda, Semjostrovsk, Lilsa, und an mehreren Fundorten zw. Varsinsk und Jenjavr (Broth.).

S. Aus allen Provinzen in Nord-Schweden, $N b$, und $V b$. ausgenommen, bekannt, in den Küstenprovinzen selten, am reichliehsten in $J m t$. und Hrjd. bis in die alpine Region, in Dlr. und Dld. nicht selten; an einzelnen oder wenigen Fundorten in Hlsl., I'g. und Boh.

N. Aus allen Amtern und von der Küste bis zur Schneegrenze bekannt, jedoch nur in den inneren Teilen st. [q. Nordgrenze bei $70^{\circ} 40^{\prime} \mathrm{n}$. Br.

In den Gebirgen von West- und Zentral-Europa, Fäıøer, Grönland, Alaska.

var. brevifolium Hag. in D. K. N. Vid. Selsk. Skrift. 1913, No. 1, p. 26 (1914).

Niedrige Pfl. Blätter kürzer, meist breiter lanzettlich, kurz zugespitzt; dorsale Lamellen kleiner bis fehlend.

N. Verbreitung wie bei der Hauptart.

var. ambiguum Bryhn in D. K. N. Virl. Selsk. Skrift. 1899, No. 3, p. 44 (1899).

Kapsel \pm gekrümmt. Haube nackt oder mit einzehnen Haaren.

N. Ne. Sietersdalen, Bykle, 1,200-1,300 m.

var. molle Nym. in Bot. Notis. 1895, p. 13.

Weiche Pfl. Stengel bis $6 \mathrm{~cm}$, entfernt und abstehend beblättert. Blattränder nicht oder kaum eingebogen: Rippe schmäler.

N. St. Lyse zw. Stavanger und Bergen, aur feuchter Eıde. K. Valders, Hedalen, Nautskar, $1.000 \mathrm{~m}$, im Bache. Ne. Saetersaleri, an mehreren Fundorten in Bächen. 


\section{PSILOPILUM}

Brid. Bryol. univ. II. p. 95 (1827).

Diözisch. Stengel einfach. Blätter mit ziemlich langer, scheidliger Basis, hohl, weder querwellig noch gesäunt, am Rücken meist glatt; Lamellenbildung auf die Rippe beschränkt: Rippe breit, meist nur an der Oberseite lanellös, mit welligen, glatten Lamellen; Zellen quadratisch und rundlich-6seitig, am Blattgrunde chlorophyllärmer und rektangulär. Perichätialblätter länger, höher scheidig. Kapsel geneigt, \pm deutlich schief eiförmig, von den Seiten zusammengedrückt, engmündig; Zellen des Exotheciums ohne Ausstülpungen, dünnwandig; Spaltöffnungen sehr gross, oberflächlich, zweizellig, oft durch Fusion cinzellig. Peristomzälne 32, oft unregelmässig ausgebildet, bleich. Deckel kurz geschnäbelt. Haube nackt.

$\mathrm{L}^{*}$ bersicht der Arten.

A. Blätter ganzrandig; Lamellen 5-8, ganzrandig 804. Ps. cavifolium.

B. Blätter oberwärts kleingezähnt; Lamellen 8-11, am Rande grob und unregelmässig gezähnt

803. Ps. laevigatum.

809. Psilopilum laevigatum (Wahlenb.) Lindb. in Öfv. K. Vet.-Akarl. Förh. 1861, p. 190. [Polytrichum glabratum Wahlenb. nom. nud. in Web. et Mohr Ind. muse. (1803). - P. laevigalum Wahlenb. Fl. lapp. p. 349, t. XXII. (1812). Psilopilum arcticum Brid. Bryol. univ. II. p. 96 (1827). - Oligotrichum laevigalum Bryol. eur. fasc. $21 / 22$, Mon. p. 5, t. 6 (1844). - O.glabratum Lindb. Musc. scand. p. 12 (1879).]

Pfl. herdenweise oder in lockeren, leicht zerfallenden, grünen, später bräunlichen Rasen. Stengel bis 1,5 cm. Blätter trocken anliegend, verkehrt-eiförmig oder im oberen Teil elliptisch bis elliptisch-verlängert, mit stumpfer, fast kappenförmiger Spitze, bis etwa $3 \mathrm{~mm}$ lang und etwa $1 \mathrm{~mm}$ breit, mit oben breit eingebogenen, unregelnässig kleingezähnten Rändern: Rippe etwa $0,18 \mathrm{~mm}$ breit, vor der Blattspitze aufhörend, ohne oder fast ohne dorsales Stereidenband und mit 8-14 grob und unregelmässig gezähnten Lamellen; Zellen dünnwandig, an Rande in einigen Reihen enger und gestreckt. Perichätialblätter etwa $4,5 \mathrm{~mm}$ lang, hochscheidig, ziemlich rasch lineallanzettlich. Seta $1-1,5 \mathrm{~cm}$, dïnn, trocken geschlängelt, rötlich. Kapsel stark eingekrümmt, rostbraun, später schwarzloraun; Zellen des Exotheciums an der Rückenseite rektangulär (1:2 -3), an der Baucliseite kurz, z. T. querbreiter. Sporenreife in Sommer. - Fig. $116 \mathrm{~A}-\mathrm{D}$.

Am liebsten auf nackter, sandiger Erde an Fluss-, Bach- und Seeufern, zuweilen auch auf sandig-tonigem bis tonigem Erdboden.

F. K. Kuusamo, Hännilä (Nỵb.); Vasaraperä, Akanlahti, Kuorikkilampi, spārlich, und Leveălampi, an au:getrocknetem Seeboden cpp. (E. af H.). - Lkem. Juonio, Ylikylä (Norrl.). - Le. Kilpisjārvi, Saana, in der alpinen Region (Kot.).

S. Bisher nur von einzelnen Fundorten in $N^{*} b$. und $L u L$. und von wenigen in $T L$. bekannt.

N. No. Sorfolden. F. Bossekop.

Island, Spitzbergen, arkt. Sibirien, arkt. Nord-Amerika.

fo. nana Hag. in D. K. X. Vid. Selsk. Slirift. 1913, No. 1, p. 24 (1911).

In allen Teilen, besonders in Bezug auf die Kapsel kleiner.

N. F. Alten, Bossekop O-tfinmarken.

var. aloma Hag. l. c. p. 25.

Blätter zuweilen fast ganzrandig, nicht oder undeutlich gesäumt.

F. Lkem. Palojoki (Norrl.). - Lmur. Am Yoronjeflusse (Broth.).

810. Psilopilum cavifolium (Wils.) Hag. in The Bryologist 1916 p. 70. [Polytrichum cavifolium Wils. in Seem. Bot. Voy. Herold p. It (1852). - Catharinaea tschuctschica C. Müll. in Bot. Centralbl. Bd. 16, p. 93 (1883). — Psilopilum tschuctschicum Par. Ind. bryol. p. 1039 (1897).] 
Pfl. herdenweise oder in lockeren, lejcht zerfallenden, bräunlichen Rasen. Stengel bis $1,5 \mathrm{~cm}$. Blätter trocken anliegend oder oberwärts hakig einwärts gekrïmmt, verkehrt-eiförmig oder im oberen Teil elliptisch bis elljptisch-verlängert, bis etwa $3 \mathrm{~mm}$ lang und etwa $1 \mathrm{~mm}$ breit, mit oben breit eingebogenen, unversehrten Rändern; Rippe etwa $0,12 \mathrm{~mm}$ breit, mit kräftigem dorsalem Stereidenbande und 5- 8 ganzrandigen Lamellen; Zellen am Rande nicht differenziert. Perichätia]b]ätter etwa $3 \mathrm{~mm}$ lang, aus ovalem Grunde almuählich verschmälert, oberwärts breit lanzettlich. Seta $1-1,5 \mathrm{~cm}$, dünn, trocken geschlängelt, rötlich. Kapsel wenig gekrümmt und weniger engmündig, braun, später schwarzbraun: Zellen des Exotheciums an cler Rücken- und Bauchseite ziemlich gleichförmig, 1: 1-2.

An gleichen Standorten wie die vorige Art.

F. Li. Utzjoki, Jalvie (Kaurin); Fjerramjokka, Alaköngäs (Ranck.). - Lmur. Am Voronjeflusse (Broth.). - Lp. Triostrova (F Nyl.).

N. F. Polmak, Gollevarrebakte.

Island, Spitzhergen, arkt. Sibirien, arkt. Nord-Amerika.

var. anomalum Hag. 1. c.

Blätter trocken eingekrümmt, rotbraun, entfernt und ziemlich regelmässig gezähnt, an Rücken oberwärts mit halbkreisförmigen Lamellen; ventrale Lamellen schwach gezähnt: Zellen am Rande rhombisch, einen undeutlichen, zweirejhigen Saum bildend.

N. F. Polmak, Vanasgiedde.

Grönland

\section{POGONATUM}

\section{Palis. Prodr. p. $84(1805)$.}

Diözisch. Blätter starr, aufrecht-abstehend, trocken straff aufrecht oder eingekrümmt, am Grunde scheidig, ungesänmt, mit zweischichtiger, nur am Rande einschichtiger, glatter Lamina: Rippe fast vollständig bis als Stachelspitze austretend; Lamellen zahlreich, gerade verlaufend, auch den zweischichtigen Teil der Lamina bedeckend; Zellen rundlich-6seitig, am Rande quadratisch, im Scheidenteil rektangulär und meist hyalin. Perichätialblätter den nächsten Stammblättern ähnlich, nur höher hinauf scheidig. Kapsel stielrund, ohne Hals und ohne Spaltöffnungen: Zellen des Exotheciums häufig mamillenartig vorgewölbt, klein, rundlich-mehreckig und kurz rektangulär. Peristomzähne meist 32, rotbraun oder bleich. mit gelbreler oder roter Achse. Deckel gewölbt, kurz geschnäbelt. Haube filzig.

$$
\text { Ubersicht der Arten. }
$$

A. Obere Blätter stumplich und nur an der Spitze klein gezähnt .811. P.polytrichoides.

B. Obere Blätter scharf zugespitzt und bis zur Mitte oder weiter herab scharf gesägt.

a. Blattrippe nicht austretend; Zellen der Lamellen gleichgestaltet, dünnwandig und glatt .................. 812. P. nanum.

b. Blattrippe als Stachelspitze austretend: Randzellen der Lamellen grösser, stark verdickt und papillös.

a. Randzellen der lamellen kugelig, mit dreieckigem Hohlraume ...................................... 814. P. urnigerum.

p. Randzellen der Lamellen querbreiter, gestutzt, mit querrektangulärem Hohlraume ................... 813. P. capillare.

811. Pogonatum polytrichoides (L.) Brockm. Laubm. Mecklenb. p. 111 (1869). [Mnium polylrichoides L. Sp. pl. p. 1112 (1753). - Polylrichum subrolun- 
dum Huds. Fl. angl. p. $f(100$ (1762). - P. nanum Sehreb. Spicil. Fl. Lips. p. 7.1 (1771). - Pogonatum namum Palis. Prodr. P. 8.1 (1805). - I'. subrolundum L.indb. in Hartm. Sk. Fl. 9. ed. II. p. 1.1 (186.1).]

Herdenweise wachsende, lunkelgrune oder braune Pfl. Stengel bis 1 em, einfach. Blätter trocken eingekrümmt, aus halbscheiliger Basis rasch lanzettlich, his schmal zungenförmig, stumpflich, bis $1 \mathrm{~mm}$ lang und bis $0,9 \mathrm{~mm}$ breit, gegen die Spitze entfernt und klein gezähnt: Rippe nicht austretend, am Rüeken glatt; Lamellen :30-10, aus gleichgrossen, kugeligen, dïnwandigen, glatten Kellen gebildet. Seta $1-2,5$ cm, rot. Kapsel aufrecht oder geneigt. kugelig-urmenförmig,

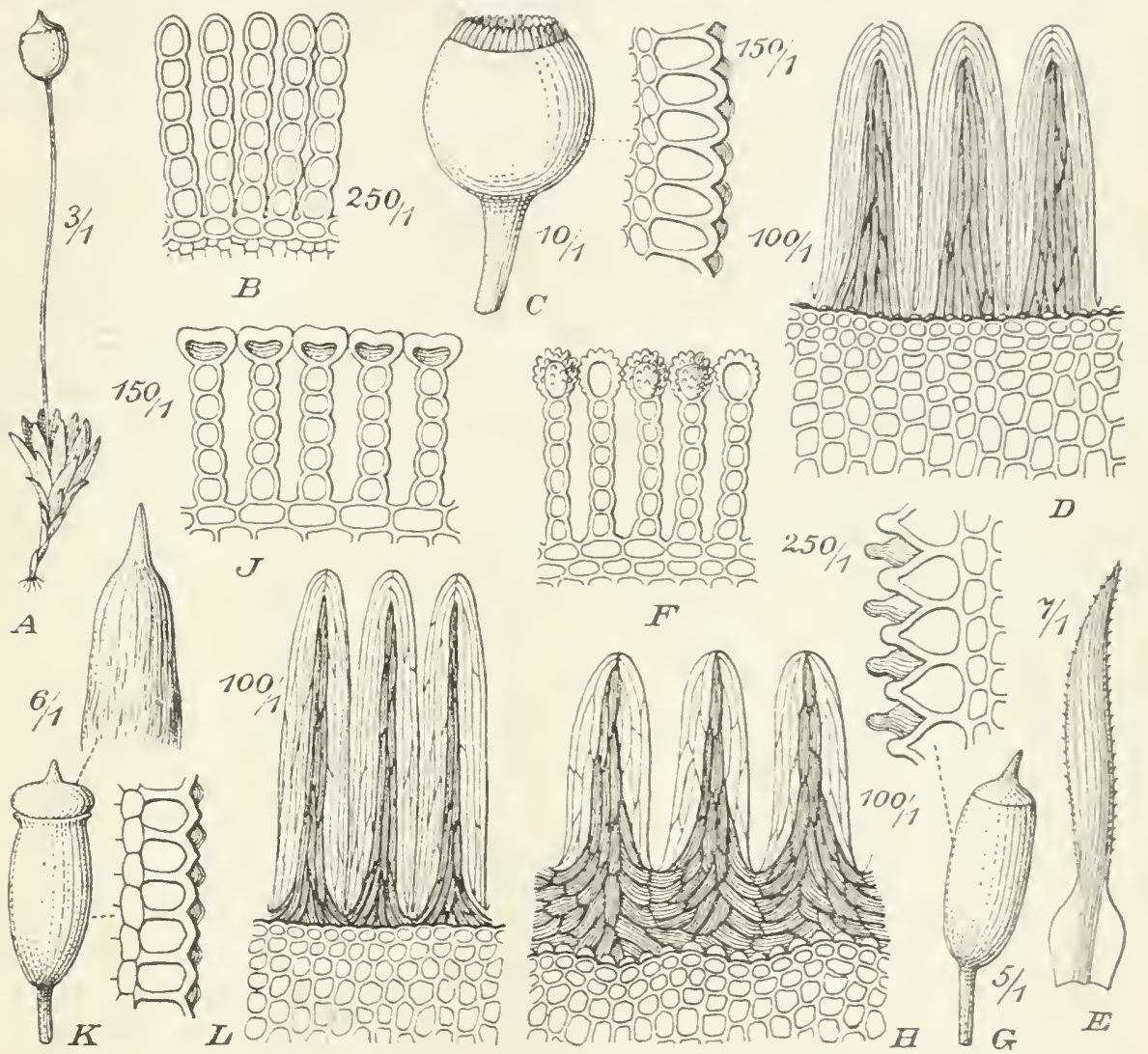

Fig. 117. A-D. Pogonatum polylrichoides (L.). A Fruchlende Pfl. (3/1): B Lamellen im Querschnitt (250/1); C KapseI (10/1); D Periston (100/1). - E-H. P. urnigerum (L.). E Stammb. (; 1); F Lamellen im Querschnitt (250/1); G Kapsel (5/1); H Periston (100/1). - I-L P. capillare (Michx.). I Lamellen in Querschnitt (150/1); K Kapsel mit Haube (6/1); I, Peristom (100/1).

etwa $2 \mathrm{~mm}$ lang und $1 \mathrm{~mm}$ dick, hräunlich, trocken und entdeckelt kreiselförmig, entleert unter der weiten Mündung \pm verengt. Sporenreife im Spätherbst. Entdeckelung im Februar und März. - Fig. $117 \mathrm{~A}-\mathrm{D}$.

Auf nacktem, sandigem, kiesigem oder tonigem Boden an Wegrändern, in Gräben, Gruben. Ausstichen und auf Heiden.

F. Al. Saltvik, an mehreren Fundorten (Bom.). - Ab. Lojo, Lojo backe (Bj. Lindb.); soLhem (H. Lindb.). - N. Helsingfors (Lindb.). Helsinge, Aggelby (Häsr.). Tusby, Lepola (O. Hjelt). - Ta. IIattula, Nihattula (Ranck.). Asikkala (Norrl.). - Sb. Niliä. Loutteinen (Kyyh.). 
S. In grössten Teil von Südschweden nicht setten. Nordgrenze in Gstr. bei $60^{\circ} 40^{\circ} \mathrm{n}$. Br.

N. Meist nur in den äuseren Küstengegenden, am häufigsten in Westlandet bis Aalesund und dort die Nordgrenze bei $62^{\circ} 30^{\prime} \mathrm{n}$. Br. erreichend.

Europa, Nord-Afrika, Madeira, Kanaren.

var. longisetum (Hamp.) Möll. in Ark. Bot. B(l. 16, No. 3, p. 43 (1919). [Pogonatum nanum var. longiselum Hamp. Mscr.; ryBol. eur. fasc. $21 / 22$, p. 5 , t. 7 , f. $\beta$ (184.). - Polytrichum subrolundum var. longiselum Lindb. in Notis. Sällsk. Faun. Fl. Fenn. IX. p. 143 (1868).]

Blätter länger, schmal lanzettlich. Seta etwa $5 \mathrm{~cm}$. Kapsel eizylindrisch.

S. An einzelnen Fundorten in Sk., Bl. und Sm.

An einzelnen Fundorten in Schleswig-Holstein, Sachsen, Rhöngebirge, Belgien und England.

812. Pogonatum nanum (Weis) Möll. 1. c. 1). 4. [Polytrichum nanum Weis Pl. crypt. fl. gott, p. 173 (1770). - P. mnioides Neck. Meth. musc. p. 123 (1771). P. aloides Hedw. Stirp. crypt. I. p. 37 (1787). — Pogonatum mnioides Hag. in D. K. N. Vid. Selsk. Skrift. 1913 No. 1, p. 30 (1914).]

Herdenweise wachsende oder rasenbildende, dunkelgrüne oder bräunliche Pfl. Stengel his $2 \mathrm{~cm}$, selten höher, einfach. Blätter trocken eingekrümmt, aus scheidiger, ovaler Basis rasch verlängert länzettlich, spitz, bis $7 \mathrm{~mm}$ lang und etwa $1 \mathrm{~mm}$ breit, bis zur Mitte orler weiter herab gesägt; Rippe nicht austretend, oben am Rücken gezähnt; Lamellen 10-60, aus gleichförnigen, glatten Zellen gebildet. Seta $1-3 \mathrm{~cm}$, rot. Krapsel aufrecht oder schwach geneigt, länglich-zylindrisch. dünnläutig, bis $3,5 \mathrm{~mm}$ lang und etwa $1 \mathrm{~mm}$ dick, grünlich, später gebräunt, trocken und entdeckelt runzelig, unter der kaum erweiterten Mündung schwach verengt. Sporenreife im Spätherbst, Entdeckelung im Februar und März.

Auf nacktem, sandigem, kiesigem oder tonigem Boden, an Wegrändern, in? Gräben, Ausstichen, Äckern und auf Hciden.

F. Al Saltvik, seltener als $P$. polytrichoides (Bom.). - Finby (Broth.). - Ab. Lojo, Mongola (H. Lindb.); Gerknäs (H. L.). - X. Helsinge, Fredriksberg (Buch). — Ta. Asikkala, an Wege zw. Kurhila und Lumila (Norrl.).

S. Im grössten Teil von Südichweden nicht selten und zel'streut noch in Dld., När. und Srm.; in den Provinzen nördlich rom Jälaren, Hjälmaren, Vänern und Vätlern sehr sellen. Nordgrenze bei $59^{\circ}$ n. $\mathrm{Br}$.

N. An der ganzen Küste von der schwedischen Grenze bis zum nördlichsten Teil von $N T$. und auch vor vielen Fundorten in den nach den inneren Teilen sich erstreckenden Tälern bekannt, bis $250-300$, selten $500 \mathrm{~m}$. Nordgrenze bei $64^{\circ} 30^{\circ} \mathrm{n}$. Br.

Europa, Nord-Afrilia, Madeira, Azoren, Kanaren, West-, Süd- und Ost-Asien.

var. minimum (Crome) Möll. 1. c. 1) 51. [Polytrichum minimum Crome Laubm.Samml. p. 48 (1803). - P. Dicksoni Turn. Muscol. hib. p. 90, t. 10, f. 2 (1804). P. nanum var. Dicksoni Lindb. Notis. Sällsk. Faun. Fl. Fenn. IX. p. 140 (1868). Pogonatum aloides var. minimum Limpr. Laubm. II. p. 608 (1893).]

Stengel etwa $5 \mathrm{~mm}$. Seta etwa $5 \mathrm{~mm}$. Kapsel fast oval. Haubenfilz unter (ler liapsel der Seta angepresst.

F. Al. Saltvik, an wenigen Fundorten.

S. Verbreitung etwa wie bei der Hauptart und zuweilen mit dieser vergesellschaftet. Nördlichster Fundort die Umgebung von stockholm.

N. Verbreitung etwa wie bej der Hauptart, jedoch seltener.

Europa.

813. Pogonatum capillare (Michx.) Brid. Bryol. univ. Il. p. 127 (1827). [Polylrichum capillare Michx. Fl, bor.-amer. II. p. 294 (1803). - P. capillare var. minus Wahtenl). Fl. lalpp., p. $3.18 \mathrm{ex} \mathrm{p.} \mathrm{(1812).} \mathrm{-} \mathrm{Pogonatum} \mathrm{longidens} \mathrm{Aongstr.}$ in Bot. Notis. 1852, p. 31. - Polytrichum Wahlenbergii Kindb. in Rev. Bryol 1894, p. 37. - Pogonatum dentatum (Menz.) Brid. var. minus (Wahlenb.) Hag. in D. K. N. Vid.-Selsk. Skrift. 1913, No. 1, p. 32 (1914).]

Herdenweise wachsende oder locker- bis clichtrasige, meist rötlichbraune I'fl. Stengel bis 2-4 cm, einfach, zuweilen gabelig oder büschelig geteilt. Blätter trocken anliegend, aus kurzscheidigem Grunde lineallanzettlich, zugespitzt, bis 
$4 \mathrm{~mm}$ lang und etwa $0,5 \mathrm{~mm}$ breit, meist fast bis zum Scheilenteile scharf gesägt; Rippe als braune Stachelspitze austretend; Lamellen lis -11, mit viel grösseren, gebräunten, querbreiteren, gestutzten, stark verdickten und papillösen Randzellen, mit querrektangulärem Hohlraume. Seta $1,5-3 \mathrm{~cm}$, hlassrötlich. Kapsel etwas geneigt, oval bis kurz zylindrisch, bis $3 \mathrm{~mm}$ lang $\mathrm{m}$ d bis $1,5 \mathrm{~mm}$ ljek, gell)bräunlich, trocken und entleert weitmündig. Haubenfilz nicht die ganze Kapsel einhüllend. Peristomzähne etwa $0,36 \mathrm{~mm}$ lang, mit kaum vortretender Grundhaut. Sporenreife wahrscheinlich im März und April. -- Fig. 117 I-L.

Am meisten auf nackten, sandigen oder kiesigen Flecken an Flussufern, stellenweise massenhaft, seltener auf Torfloden orler in erderfüllten Felsspalten.

F. Ob. Rovaniemi. Meltaus (Ifult). - K. Kunsamo, Mantytunturi (Vain.). - Le. Palojoki und Karesuanto (Norrl.). Hirvarvuopio (Lind). - Lkem. Sodankylä, Martinkylä (Vain.). - Li. Utsjoki, Jalve, Alaköngäs, an Wegrande (Ranck.). - Lv. Tschapoma (Broth.). - Lp. Ponoj (Brenn.).

S. Nb., Vb., Hrjd., Jmt. und alle Lappmarken, in Fjeldgetiete meist oberhalt) der Baumgrenze.

N. $F$. an vielen Fundorten, meist fruchtend. $K$., sT. und $N T$. in der alpinen Region, imuer steril (fo. compacta Hag.).

Island, Sibirien, Amurgebiet, Sachalin und nôrdl. Teile von Nord-Amerika.

81. Pogonatum urnigerum (L.) Palis. Prodr. p. 84 (1805). [Polytrichum urnigerum L. Sp. pl. II. p. 1109 (1753).]

Herdenweise wachsende oder lockerrasige, bläulichgrïne, später bräunliche Pfl. Stengel bis $5 \mathrm{~cm}$, selten höher, gabelig oder büschelig geteilt. Blätter trocken anliegend, aus kurzscheidigem, eiförmigem Grunde rasch lineallanzettlich, zugespitzt, bis $7 \mathrm{~mm}$ lang und etwa $0,5 \mathrm{~mm}$ breit, fast bis zum Scheidenteile scharf gesägt; Lamellen $40-50$, mit doppelt so grossen, kugeligen, stark verdickten und papillösen Randzellen, mit dreieckigem Hohlraume; Rippe als braune Stachelspitze austretend, am Rücken oberwärts gezähnt. Seta bis $5 \mathrm{~cm}$, unten rot, oberwärts blassrötlich. Kapsel aufrecht bis schwach geneigt, eilänglich bis zylindrisch, bis $4 \mathrm{~mm}$ lang und bis $1 \mathrm{~mm}$ dick. Peristomzähne etwa $0,2 \mathrm{~mm}$ lang, mit vortretender Grundhaut. Haubenfilz die ganze Kapsel einhüllend. Sporenreife vom Spätherbst bis April. - Fig. 117 E-H.

Auf nassem, feuchtem Sancle und sandig-tonigem Boden an Weg- und Grabenrändern, Flussabhängen, in Ausstichen und Gruben in allen Teilen von Fennoskandia fq., selten über die Baumgrenze hinaufsteigend.

Europa, Kanaren, Kaukasus, Persien, Nord- und Ost-Asien, Nord-Amerika.

var humile (Wahlenb.) Brid. Bryol. univ. II. p. 126 (1827). [Polytrichum urnigerum var. humile Wahlenb. Fl. lapp. p. 347 (1812).]

Stengel kurz, oft verästet. Blätter kurz und breit. Seta kurz. Kapsel kurz, fast eiförmig.

F. Lkem. Ounasjoki, Rijkinkoski, reichlich (Hult).

S. LyL., $P L$., LuL. ind $T L$., meist oberhalb der Baumgrenze.

N. Tr., F. und auch anderwärts in höheren Lagen.

var. subintegrifolium (Arn. et Jens.) Möll. in Ark. f. Bot. Bd. 16, No. 3, p. 69 (1919). [Polytrichum unrigerum var. subintegrifolium Arn. et Jens. Moos. Sarekgeb. p. 137 (1910).]

Pfl. in dichten, bis $5 \mathrm{~cm}$ hohen, dunkelbraunen Rasen. Blätter kürzer, anliegend, ganzrandig oder undeutlich gezähnt.

S. LuL., Sarekgebiet, an mehreren Fundorten in den Fjelden, auf ron Schneewasier nassem Boden. Steril.

\section{POLYTRICHUM}

Dill. Catal. pl. giss. p. 221 (1718) et Append. p. 85 (1719); L. Syst. nat. (1735).

Diözisch. Blätter starr, aufrecht-abstehend bis zurückgekrümmt, trocken anliegend, hochscheidig, ungesäunt, mit zweischichtiger, nur an Grunde einschichtiger, glatter Lanina; Rippe meist als gezähnte, rote Granne austretend; Lamellen 
zalllreich, gerade verlaufend, auch den zweischichtigen Teil der Lamina bedeckend; Zellen quadratisch und rundlich-mehreckig, oft querbreiter, im Scheidenteil verlängert rektangulär bis lineal, gegen die Ränder enger. Perichätialblätter den nächsten Stammblättern ähnlich oder \pm deutlich differenziert. Kapsel prismatisch 4-6kantig, selten stielrund, stets mit halbkugeligem oder scheibenförmigem Halse; Spaltöffnungen oberfläclılich, gross, zwischen Hals und Urne; Zellen des Exotheciums unregelmässig melnreckig. Peristonzähne meist 64. Deckel aus gewölbter oder kegeliger Basis kurz oder länger geschnäbelt. Haube filzig.

¿ bersicht der Arten.

A. Lamina mit breit eingebogenen, unversehrten oder gekerbten Rändern.

a. Blätter stumpflich. Kapsel 5-6kantig 822. P. sexangulare.

b. Blätter zugespitzt: Rippe grannenartig austretend.

«. Stengel einfach. Rippe als lange, gesägte, hyaline

Granne austretend

825. P. piliferum.

. Rippe als kurze Granne austretend.

I. Stengel $\perp$ weit hinauf mit gelblich-weisslichem Rhizoidenfilz bedeckt. Kapsel klein, kubisch ... \$24. P. strictum.

II. Stengel ohne oder an Grunde mit spärlichem Rhizoidenfilz. Kapsel länger als breit.

1. Untere Blätter mit Rhizoidenbüscheln. Zellen des Exotheciums mit je einem ritzenförmigen Tüpfel

823. P.juniperinum.

2. Lntere Blätter olne Rhizoirlen. Zellen des

Exotheciums mit je einem kreisrunden Tüpfel ... 826.P. hyperboreum.

B. Blätter mit flachen oder aufrechten, gesägten Rändern.

a. Lamellen mit nach oben verbreiterten, gestutzten bis ausgeraudeten Randzellen. Hals scheibenförmig, abgeschnürt. Zellen des Exotheciums getüpfelt.

. Blätter nur oberwärts entfernt und klein gezähnt ... 820. P. Jensenii.

$\beta$. Blätter bis oder fast bis zur Scheide herab scharf gesägt.

I. Lamellen mit zellen

821. P. commune.

II. Lamellen mit unregelmässigen, flachen bis schwach ausgerandeten Randzellen

819. P. Swartzii.

b. Blätter bis oder fast bis zur Scheide herab scharf gesägt; Lamellen (excl. $P$. decipiens) mit nicht nach oben verbreiterten Randzellen. Hals halbkugelig, nicht abgeschnürt; Zellen des Exotheciums nicht getüpfelt.

«. Blattzähne mehrzellig; Lamellen mit fein papillösen Randzellen. Kapse] nicht kantig ....................

$\beta$. Blattzähne einzellig: Lamellen mit glatten Randzellen. Kapsel kantig.

I. Lamellen mit nach oben verbreiterten, gestutzten

Randzellen

818. P. decipiens.

II. Lamellen mit ovalen Randzellen.

1. Zellen der Lamina oberwärts am Rande 23reihig, $12-15 \mu$. Kapsel länglich $\ldots . . . \ldots . .$. 6reihig, $18-23 \mu$. Kapsel dick eiförmig ...... \$16. P. gracile. 
S e c t. I. Polytricha alpina Hag. in I). K. N. Vid. Selsk. Skrift. 1913 No. 1, p. $11(1914)$.

Blätter mit aufrechten, scharf gesägten Rändern; \%ellen der Lamina den Pückenzellen der Rippe ähnlich. Hals von der Urne nicht abgeschnürt; Zellen des Exotheciums ohne 'Tüpfel. Peristomzähne olne Anhängscl.

815. Polytrichum alpinum L. Sp. pl. II. p. 1109 (1753). [Pogonatum alpinum Röhl in Ann. Wett. Ges. IlI. p. 226 (1812).]

Pfl. in lockeren, leicht zerfallenden, schmutzig-grünen, im Alter rötlichbraunen Rasen. Stengel bis $20 \mathrm{~cm}$, aufrecht oder aufsteigend, nur am Grunde mit Rhizoiden, unten schwarz und blattlos, oben büschelig, in gleichhohe $\ddot{A}$ ste geteilt. Blätter feucht abstehend bis zurückgebogen, lineallanzettlich, pfriemenförnig

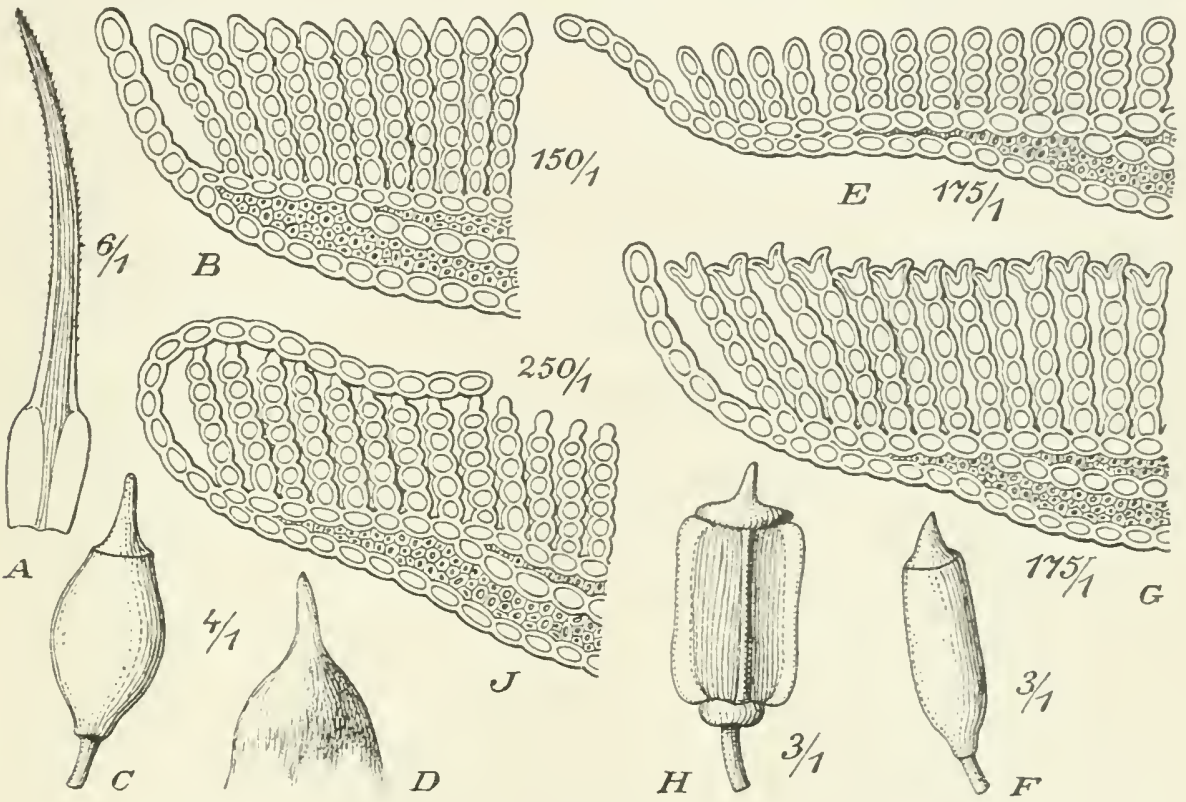

Fig. 118. A-D. Polytrichum alpinum L. A Stammb. (6/1); B Lamellenquerschnitt (150/1); C Kapsel (4/1); D Haube (4/1). - E-F. P. attenuatum IIenz. E Lamellenquerschnitt (175/1); F hapsel (3/1). G-H. P. commune L. G Lamellenquerschnitt (175/1); H Kapsel (3/1). - I Blattquerschnitt ron $P$. juniperinum Willd. (250/1).

zugespitzt, bis $10 \mathrm{~mm}$ lang und etwa $0,5 \mathrm{~mm}$ breit, bis zur Scheide scharf und grol, gesägt; Rippe oberwärts am Rücken gezähnt; Lamellen bis 40, mit grỏsseren. ciförmigen, stark verdickten, papillösen, bräunlichen Randzellen. Seta $3-5 \mathrm{~cm}$, rötlichgelb. Kapsel aufrecht oder geneigt, stielrund, meist länglich, schwach hochrückig und etwas gekrümmt, mit undeutlich differenziertem Halse, bis $4 \mathrm{~mm}$ lang und bis 2,5 mm dick, im Alter dunkelbraun bis schwärzlich. Peristomzähne unregelmässig. Deckel lang und schief geschnäbelt. Haubenfilz rotbraun, kürzer als die Urne. Sporenreife im Juli. - Fig. 118 A-D.

An steinigen und grasigen Plätzen, am liebsten mit sandiger oder kiesiger Unterlage, an erdbedeckten Felsen und Blöcken, zuweilen auch auf Torf.

F. Al. Eckerö, Saltvik, Sund und Kjkar, an einzelnen Fundorten (Bom.). - Ab. Korpo, Finnō (Ekl.). Ảbo und Pargas, Storgård (Elfv.); Tennās, Sattmarkerna (Link.). Merimasku (Karst.). Kimito, Vreta (Ols.). Lojo, Torhola. Pitkānperānlahti (Sundr.): Seppālā (Hult); Jalansaari (Buch), - X.. Lapptrāsk (Sael.). Elimāki (Tigerst.). Hogland. Lounatkorkia (Lindb.). - Ka. Wiborg, Soskuanjoki und Juustila (Buch). Antrea (Porkka). - Ik. Valkjārvi, Veikkola (H. Lindb.). — St. Eura (Simm.). Ruo- 
vesi, Koverojärvi (Brolh.). - Ta. Sāāksıäki, Limastenkylä (Kihlnı.). Ko-ki, Kalliojärvi (Norrl.). Asikkald (Sil.). - Sa. Willmanstrand (Buch). - Kl. Kurkijoki, Haavikko (Jusl.). Sortavala (Linn., Buch). Kirjavalahti (H. Backm., Norrl.). Ruskeala (WV. Nyl.). Soanlahti, Koirinvaara (Broth.). Pälkjärvi, Anoniemi (Broth.). Impilahti, Haukkavuori (Kop.). Valamo (H. Lindb.). - Kol. Salmi, Leppālā, Pallivaara (Pes.). - Oa. Vasa, Vassklot und Boskär (Broth.). - Tb. Virrat, Helvetinjärvi (Broth.). Uurainen, Kallinvuori und Kuukkanen (B.). Viitasaari, Tuosjoki (B.). - Sb. Heinävesi. Palokki, Kultalahti (Kot.). Kuopio, an mehreren Fundorten (Link.). Tuusniemi. Seinàvuori (Kot.). Muuruvesi, Pelonniemi, Virtasalıni und Montola (Kyyhk.). Kaavi, Sikajărvi, Likosaari (Kot.). Nilsiä, Kirchdorf und Jaakonlampi (K.). Maaninka, an mehreren Fundorten (Kyyhk., Roiv.) - Kb Lieksa (Vain.). Nurmes, Konnanlampi (V.). Om. Lappajärvi, Kirchdorf, Saveanjoki (Backm.). - Ok. Kajana (Lackstr.). Paltamo, Me!alahti (Kyyhk.). Sotkamo, Vuokatti (Lackstr.), Hepolehto und Mustinjoki, Sahinkallio (Kyyhk.). - Ob. Ii, Karhu (Brenn.). Alatornio, Kirchdorf (Brenn.); Aavasaksa (Buch). Rovaniemi, Tervo (Hult). - K. Kuusamo, Aventojoki und Korojoki (Broth.); Kuusinkijoki (E. af H.); UIäntyvaara (Broth.). - Kk. Kivakkatunturi (Broth.). - Lkem. Kolari, im Fjeldgebiete st. fq. (Hult). Kittilä, st. r. (Hult). Ounastunturit (Sandm.). Kuolaārvi, Sallatunturi (E. af H.). - Le. An vielen Fundorten reichlich, besonders in der Kiefernregion (Norrl.), in den Fjelden um den Kilpisjärvi fq. (Kot.). - Li. In den Waldregionen fq., in der alpinen Region pass. (Hult). In allen Provinzen der Halbinsel Kola verbreitet, seltener in der Wald- und alpinen Region, fq. im nördl. Küstengebiete (Broth.).

S. Südlich vom Dalälven $r$. und in mehreren Provinzen noch nicht beobachtet, nördlich davon nicht selten und besonders im Fjeldgebiete fq., am reichlichsten in der Höhe von $300-700 \mathrm{~m}$.

N. In allen Amtern + fq., nur an der ebenen Küste des Ost- und südlandes r.

Europa. Kaukasus, Nord- und Zentral-Asien, Japan, Nord-Amerika, Ost-Australien, Tasmanien, New Zealand, Antarktis.

var. voraginum Möll. in Ark. Bot. Bd. 17, No. 4, p. 9 (1921).

Stengel einfach, selten wenig geteilt. Blätter sehr locker gestellt, weit abstehend, schmal, trocken oft gedreht.

In lockeren, verworrenen Matten am Boden dunkler Höhlen und Spalten.

S. An einzelnen Fundorten in Dlr., Jmt., $P L$. und $L u L$.

var silvaticum (Menz.) Lindb. Musc. seand. p. 12 (1879). [Polytrichum silvaticum Menz. in Trans. Linn. Soc. IV. p. 83, t. 7, f. 6 (1798). - P. arcticum Sw. Disp. p. 77, 105, t. 8, f. $17 \mathrm{~g}, \mathrm{~h}(1799)$ - - I' alpinum v. arclicum Wahlenb. Fl. suec. p. $738(1826)$.]

Schlanke Pfi., einfach oder wenig geteilt. Kapsel länglich-zylindrisch, gekrümmt, weicher und bleicher.

F. Le. Karesuanto (Norrl.). - Lim. Kandalaks (Sahlb.).

S. In den Waldregionen, besonders in der Birkenregion des Fjeldgebietes, nur selten oberhalb der Baumgrenze beobachtet. Südgrenze bei $61^{\circ} 40^{\prime} \mathrm{n}$. Br.

N. Im Fjeldgebiete des Südlandes sehr selten, auf Dovrefjeld, wie es scheint, etwas allgemeiner bis 1,000 m, auf dem Dolomit in Salten fqq. und auch aus Kistrand in $F$. bekannt.

Hochgebirge von Zentrai-Europa, nördl. Teile von Nord-Amerika.

var. campanulatuma (Horısch.) Angstr. in Fr. Summ. veg. p. 90 (1816). [Polytrichum campanulatum Hornsch. in Nees Hor. phys. berol. p. 67, t. 13 (1820). P. brevifolium R. Br. in Parr. Voy. Suppl. p. 194 (1824). - P. alpinum * brevifolium Kindb. Sk. Bladmossfl. p. 82 (1903):]

Stengel selten bis 3 cm, oben büschelig-kurzästig. Blätter kürzer, dachziegelig anliegend, auf der Bauchseite gelbgrün, auf der Rückenseite kastanienbraun und glänzend. Seta bis $2 \mathrm{~cm}$. Kapsel aufrecht, klein, eikugelig.

S. Hrjd., Jmt., PL., LuL. und TL. selten und nur oberhalb der Baumgrenze, auf Heiden, oft auf nackten Flecken bis $12-1,300 \mathrm{~m}$.

N. In hōheren Lagen des Waldgebietes und etwas oberhalb der Baumgrenze nicht selten, an exponierten stellen der Westküste, wie es scheint, fq.

Verbreitung wie bei var silvaticum.

var. septentrionale (Sw.) Lindb. in Not. Sällsk. Faum. Fl. Fenn. IX. p. 131 (1868). [Polytrichum septentrionale Sw. in K. Vet. Ak. Handl. XVI. p. 270 (1795).] Niedrige Pfl. Stengel einfach, zuweilen oben kurzästig Blätter kurz, pfriemenförmig, zuweilen einseitswendig. Seta $1-1,5 \mathrm{~cm}$. Kapsel fast aufreeht, eikugelig.

Am meisten auf Fjel(theiden und dort am reichlichsten und oft deckend an Orten, wo der Schnee lange liegen bleibt oder die vom Schmelzwasser der Gletscher benetzt werden. 
F. Lkem. Yllästunturi (Hult). — Lim. Tsehun (Broth.). Lujauri-urt, an einigen Fundorten (kihlın.) - Lt. Pummanki und Subovi (Broth.). - Lmur. Gavrilova, Rinda, Litsil und Varsilsk (Broth.). - Lp. Ponoj (Sahlb.).

S. Im ganzen Fjeldgebiete, auch in der Birkenregion. Südgrenze bei $61^{\circ} 10^{\prime} \mathrm{n}$. Br.

N. Čberall im Fjeldgehiete, an meisten un die Baungrenze und - weit linauf in die alpine Region hinaufsteigend, kommt jedoch auch weit unten in llaldgelsiete vor.

Verbreitung wie bei var. silvaticum und anch auf den kămmen des Riesengebirges und des schlesisch-mährischen Gesenkes.

var. simplex Schimp. Syn. ed. 2, p. 539 (1876).

Pfl. mit Seta kaum $1 \mathrm{~cm}$, einfach. Blätter kurz, dachziegelig ankiegenrl, trocker leicht eingekrümmt. Kastanienbraun. Kapsel eiförmig bis eikugelig.

Auf nackten Flecken der höchsten Fjelde ron 1,000 m bis an die Vegetationsgrenze, fast immer fruchtend.

S. An einzelnen Fundorten in Jmt., PL., LuL. und TL.

N. An einzelnen Fundorten in $B u, B r ., N B$, No. und $F$, an mehreren in $K$. und $S T$.

Verbreitung wie bei var. silvaticum.

816. Polytrichum gracile Menz. in Trans. Linn. Soc. 1V. p. 73, t. 6, f. 3 (1798).

Pfl. in dichten, grünen bis gelbgrünen Rasen. Stengel bis $10 \mathrm{~cm}$, aufrecht, unten graufilzig, einfach. Blätter feucht weit abstehend und zurückgebogen, flachrinnig, lanzettlich, bis $7 \mathrm{~mm}$ lang und $1,5 \mathrm{~mm}$ breit, bis oberhalb der Scheide scharf gesägt; Rippe am Rücken oberwärts gezähnt; Lamellen etwa 10, mit fast gleichgrossen, ovalen und glatten Randzellen: Zellen der Lamina an Rande 4-6reihig, $18-23 \mu$. Seta $6-8 \mathrm{~cm}$, gelbrot. Kapsel aufrecht bis geneigt, zuletzt horizontal, dick eiförmig, schwach hochrückig, rundlich 5-6kantig, mit halbkugeligem Halse, Urne bis $4 \mathrm{~mm}$ lang und 2,5 $\mathrm{mm}$ dick, gelbgrün. Peristomzähne entweder 32 und gleichgross oder bis 64 und unregelmässig, auf kaum oder nicht vortretender Grundhaut. Deckel lang und schief geschnäbelt. Haubenfilz rost-oder schwarzbraun bis fast schwarz. Sporen $15-23 \mu$. Sporenreife im Juni und Juli.

Am reichlichsten in Torfmooren, moorigen Wiesen und Waldmoorsümpfen, in fast allen Teilen von Fennoskandia $\pm \mathrm{f}$ (., seltener in der Birkenregion und sehr selten oberhalb der Baumgrenze. Nordgrenze in $\mathrm{V}$. bei $70^{\circ} 25^{\prime} \mathrm{n}$. Br.

Europa, Kaukasus, Sibirien, Japan, nördl. Teile von Nord-Amerika, New Zealand.

var. anomalum (Mild.) Hag. in Kigl. Norsk. Vid. Selsk. Skrift. 1913, No. 1, p. 47 (1914). [Atrichum anomalum Mild. in Hedwigia 1869, p. 161. - Polytrichum gracile * anomalum Limpr. Krypt.-Fl. Schles. Bd. 1, p. 112 (1876).]

Stengel locker beblättert. Blätter dünner und breiter; Rippe am Rücken fast glatt; Lamellen etwa 24; Zellen etwa doppelt grösser und dünnwandig.

An sandigen und tonigen, zeitweise überschwemmten Fluss- und Seeufern.

F. Lmur. Voroninsk, Varıjog (Kihlm.).

S. An einzelnen Fundorten in Vsm., Dtr., Gstr., Hrjd., Jmt., Vb., PL. und an mehreren in $L u L$. und $T L$.

N. An einzelnen Fundorten in $S B ., H . . S T$., No, und Tr.

var, aquaticum Bryhn mss. in Hag. 1. c. p. 48.

Flutende Pfl. Stengel entfernt beblättert. Blätter schlaff, aus sehr kurzer Basis rasch zugespitzt, etwa $4 \mathrm{~mm}$ lang und $0,65 \mathrm{~mm}$ breit, ganzrandig oder an der Spitze undeutlich gezähnt; Lamellen spärlich und niedrig oder fehlend. Steril.

N. Bu. Modum, Snarumselven.

817. Polytrichum attenuatum Menz. 1. c. p. 72, t. 6, f. 2 (1798). [Polytrichum formosum Hedw. Sp. musc. p. 92 (1801).]

Pfl. in lockeren, sattgrünen Rasen. Stengel bis 10 und $15 \mathrm{~cm}$, aufrecht oder aufsteigend, am Grunde oder weiter graufilzig, meist einfach. Blätter feucht sparrig zurückgebogen, lanzettlich-pfriemenförmig, bis $14 \mathrm{~mm}$ lang und $1,5 \mathrm{~mm}$ breit. fast bis zur Scheide scharf gesägt; Rippe am Rücken oberwärts gezähnt; Lamellen bis 65 , ganzrandig. nit fast gleichgrossen, ovalen, dümnwandigen und glatten Randzellen; Zellen der Lamina an Rande 2-3reihig, $12-15 \mu$. Seta meist $6-8 \mathrm{~cm}$, 
rot, oberwärts gelb. Kapsel aufrecht, später geneigt bis horizontal, länglich, prismatisch stumpf 4 kantig, mit halbkugeligem Halse, Urne bis 5 , selten bis $9 \mathrm{~mm}$ lang und $2.5 \mathrm{~mm}$ dick, gelbgrün, später ledergelb. Peristomzähne 64, gleichgross, auf vortretender Grundhaut. Deckel gerade geschnäbelt. Haubenfilz rostbraun. Sporen 10-14 ". Sporenreife im Juli und August. - Fig. 118 E-F.

Auf schattigem Waldboden, besonders in Laubwäldern, an erdbedeckten Felsen, in Spalten und auf morschem Holze, seltener bis in die unteren Teile der subalpinen Region und nur sehr selten bis zur Baumgrenze hinaufsteigend.

F. Al. Eckerö, Finstrōm. Jomala und Sund an einzelnen, Saltrik an mehreren Fundorten (Bom.). Ab. Abo, Runsala (Arrh.). Parga;, an mehreren Fundorten (Elfv., Link.). Kimito, Grammelby (Ols.). Finbs (Broth.). Bromarf (Sundr.). Karislojo (Sundr.). Lojo, Paloniemi und Koivola (Lindb.): Vanhakṿä und Kihilä (Hult). - X. Ekenäs, Hermansō (H. Lindb.). Eşbo, Gräsa (Broth.). Helsingfors und Ľmgebuğn (Lindb.). Helsinge, Backas (Sol.). Sibbo, Sōderkulla (Lindb.); Lōparō (Broth.). Pellinge, Suni (Broth.). Borgả (Sael.). Perná, Sundö (Jusl.). Lovisa, Kattōn (Lindb.). - Káa. Wiborg (Vain.). Yehkalahti (V. Krohn). - Ik. Yuola. Perkjärri (H. Lindb.). Valkjärvi, Teikkola (H. L.). Uusikirkko. Vammelsuu (H. L.). Metsāpirtti. Saarois (G. Lång). - Ta. Tyrräntō, Joutsenjärvi (Broth.). Korpilahti, Pajusalmi (Vain.). - Sa. Kangasniemi (Lackstr.). - Kl. Küurkijoki, Yaatikkä (Jusi.). Pālkjārti, Pitkāniemi (Broth.). - Tb. Jỵrāskỵlă (Broth.). - Sb. Nilsiă, Kuuslahti, Jaakonlampi (Kỵ̣hk.). Naaninka. an mehreren Fundorten (Roir.). Pielaresi, Jỵlănginmāki (R.). - Om. Vindala, Pỵhāvuori (Backm.). - Ok. Sotkamo, Vuokatti (Lackstr.). - Ob. Aarasaksa (Buch).

S. In allen Provinzen Süd- und Mittel-Schwedens, mit Ausnahme von Boh. und Hrjd., ausserdem in Jmt.,.$p d$. und Ang., jedoch selten. Yordgrenze bei $62^{\circ} 5 ?^{\prime} \mathrm{n} . \mathrm{Br}$.

N. In allen Ämtern mit Ausnahme von $H$. und $F$, jedoch fast nur in den Küstengegenden. Nordgrenze bei $69^{\circ} 41^{\prime} \mathrm{n}$. Br.

Europa, Madeira, Algier, Srrien, Kaukasus, Japan, Nord-Amerika.

var. superbum (Sclrultz) Lindb). in Not. Sällsk. Faun. Fl. Fenn. förh. IX.p. 126 (1868). [Polytrichum superbum Sclultz in Syllog. Regensb. II. p. 152 (1828).]

Kräftiger als die Hauptart. Tracht von $P$. commune var. uliginosum.

N. Kristiania.

Deutschland.

var. pallidisetum (Funck) Möll. in Ark. f. Bot. Bd. 17. No. 4, p. 40 (1921).

Stengel kürzer. Blätter kürzer. fast aufrecht. Seta kürzer und dünner, oben strohfarben. Kapsel schlanker und länger, blass gelbgrün.

S. Jml. Frostriken, Jorm; Ankarede.

Europa, Japan, Nord-Amerika.

var. brachycaule $110 ̈ l l$. 1. c. p. 41.

Stengel $1-2 \mathrm{~cm}$. Blätter aufrecht-abstehend, etwa $1 / 2$ so lang wie bei der Hauptart, kurz zugespitzt. Seta 3-4 mal so lang wie der Stengel, rotbraun, nur an der Spitze gelb.

S. LyL. Tärna, Laisholmen. PL. Arjeploug, Verkenes.

818. Polytrichum decipiens Limpr. in 68 Jahresb. d. Schles. Ges. f. vaterl. Cultur 1890. II. p. 93.

Pfl. in lockeren, blaugrünen, zuletzt rotbraunen Rasen. Stengel bis $8 \mathrm{~cm}$, aufrecht, nicht filzig. Blätter feucht abstehend-zurückgebogen, lineallanzettlich, bis $12 \mathrm{~mm}$ lang und etwa $1 \mathrm{~mm}$ breit, bis oberhalb der Scheide grob gesägt; Rippe am Rücken oberwärts mit vereinzelten Zähnen; Lamellen bis 42 , undeutlich gekerbt, mit nach oben verbreiterten, gestutzten bis schwach ausgerandeten, glatten Randzellen; Zellen der Lamina am Rande 2-3reihig, 10-14 $\mu$. Seta $4-5 \mathrm{~cm}$, unten rot, oben strohfarben. Kapsel aufrecht, horizontal bis nickend, länglich, zuweilen schwach hochrückig, schwach 4-5kantig, mit halbkugeligem Halse, Urne etwa $3 \mathrm{~mm}$ lang und 1,5 $\mathrm{mm}$ dick, gelbgrün, später licht ledergelb. Peristomzähne 6.t, gleichgross, auf vortretender Grundhaut. Deckel fast von Urnenlänge. aus flach gewölbter Basis lang, dünn und schief geschnäbelt. Haubenfilz licht gelbbraun. Sporen $\$-\mathbf{1 0} \mu$. Sporenreife im Juli und August.

Auf schattigem, trockenem Waldboden und an Felsen und Blöcken im Walde.

P. Ta. Korpilahti, Pajusalıni (Vain.). - Ik. Sakkola, zW. Taipale und Järievānniemi (H. Lindb.). Pỵhăjảrvi, Toubila (H. L.). Metsăpirtti, Saarois (H. L.). t'berall im Fichtenwalde. 
S. Gstr. Torsảker, Korsinı.

N. An einzelnen Fundorten in A.. Bu., St., SB., K., II. und ST.

Schles.mähr. Gesenke, Riesengebirge, Thüringer- und Bömerwald, Brit. Colmubia.

S e c t. I 1. Polytricha communia IIag. 1. ('. p. 52.

Blätter mit aufrechten, gesägten Rändern; Zellen der Lamina den Rückenzellen der Rippe ähnlich. Hals scheibenförmig, von der Urne abgeschnüri; Zellen des Exotheciums mit grossen Tüpfeln. Pz. mit flügelartigen lıängsleisten.

819. Polytrichum Swartzii Hartm. Handb. Sk. Fl. 5. ed. p. 361 (1864).

Schlanke Pfl, in dichten, schr tiefen, grünen, innen dunkelbraunen bis schwärzlichen Rasen. Stengel aufrecht \pm weit linauf braun- oder graufilzig, locker beblättert, einfach oder gabelig, sclten büschelig geteilt. Blätter feucht \pm abstehend, trocken unregehmässig gedreht, aus hochscheidiger, weissglänzender Basis lineallanzettlich, pfriemenförmig zugespitzt, etwa $5 \mathrm{~mm}$ lang, fast bis zur Scheiıle herab fein gesägt: Rippe oberwärts am Rücken gezähnt; Lamellen etwa 40, mit nach oben verbreiterten, gestutzten bis \pm deutlich ausgerandeten, glatten orler fast glatten Randzellen: Zellen der Lamina am Rande 2-3reihig. Perichätialblätter hochscheidig, breit weisshäutig. Seta $5-8 \mathrm{~cm}$, rot. Kapsel zuletzt horizontal, eiförmig-kubisch, scharfkantig, Urne etwa $3 \mathrm{~mm}$ lang, zuletzt rotbraun. Peristonzähne 64, gleichgross. Deckel 1/2 der Urne, aus gewölbtkegeliger Basis dünn und gekrümmt geschnäbelt. Haubenfilz tief unter dic Lrne herabreichend, gelbbraun. Sporenreife Mitte Juli bis Mitte August.

Auf Sumpfwiesen, in Waldsümpfen, an See- und Bachufern und an Quellen.

F. Al. Eckerö, Engskär (H. Lindb.). Finström, Godby (H. L.). Saltvik, an mehreren Fundorten (Bom.). - Ab. Karuna, Smörvik (Elfv.). Karislojo, Piipola (Sundr.). Lojo, Paloniemi, Lylyis (E. af H.). 一 N. Ekenäs, Tvärminne, Storlandet (Ranck.). HelsingIors, Fredriksberg (Lindb.). Høgland (I. Lindb.). - Ih. Muola, Perkjärvi (H. Lindb.). Valkjärvi, Jauholampi und Valkoja (H. L.). Sakkola (H. L.). Pyhäjärvi, Yläjärvi (H. L.). - St. Kokemäenjoki, im Deltagebiet (Häyr.). - Ta. Luhanka, Judinsalo (Vain.). - Sa. Willmanstrand (Buch). Ruokolahti (Hult). - Oa. Vasa, Vassklot (Broth.). - Tb. Viitasaari, Korpinenjoki und Kohiseva (Broth.). - Sb. Joroinen, Järviky̧lā (H. Lindb.). Kuopio (Link.). Kaavi, Siikajärvi, Mustikkamäki (Kot.). Nilsiă, Kuuslahti, Jaakonlampi (Kot.). — Kib. Polvijärvi. Viinijärvi (Kot.). - Om. Lappajärvi, Pitkästön (Backm.). - K. Kuusano, Kitkajoki (Broth.): an mellreren Fundorten (E. af H.). - Lkem. Kittilä, Lohiniva (Hult). Muonio, Lompolonvuoma (A. K. Caj.). Kuolajärvi, Varpuaapa (E. af H.). Sallajoki (Linnan.).

S. Aus 16 Provinzen von $\mathrm{Sm}$. bis $T L$. bekannt, bisher jedoch meist nur ron einzclnen oder wenigen Fundorten.

N. H. Lilleelvedalen. Tronfjeldet.

Nord-Russland.

var. nigrescens (Warnst.) Hag. in D. K. N. Vid. Selsk. Skrift. 1913, p. $53(1914)$. [P. commune var. nigrescens Warnst. in Verh. Bot. Ver. Brandenb. Jahrg. 41, p. 6.5 (1899). - P. inconstans Hag. in Nyt Mag. Naturw. Bd. 38, p. 339 (1900).]

Blätter entfernt gesägt; Lamellen mit unregelmässigen Randzellen. Deckel flach. Haube schmutzig schwarz, am Grunde schmutzig braun.

F. Ab. Bromarf, Vetlaks, am Boden eines ausgetrockneten Teiches (Sundv.).

S. Nb. Karl Gustaf, auf einer Sumpfwiese. LuL. Jokknokk, St. Sjōfallet (Möll.). Krikikjokk, Rapadalen, Stuorra Skårkas (Jens. und Arn.).

N. An einzelnen Fundorten in A., H., ST. und $F$.

Brandenburg, Estland.

820. Polytrichum Jensenii Hag. in Meddel. om Grönland. Heft. 15, p. 14$\}$ (1898). [Polytrichum commune * cubicum var. integrifolium Lindb. in sched.; Brotlı. et SaeJ. in Act. Soc. Faun. Fl. Fenn. VI. No. 4, p. 44 (1890). - P. fragilifolium Lindb. fil. in Meddel. Soc. Faun. Fl. Fenn. Heft. 24, p. 28 (1900).]

Pfl. in ziemlich dichten, grünen, innen bräunlichen bis dunkelbraunen Rasen. Stengel aufrecht, $5-30 \mathrm{~cm}$, abwärts mit \pm reichlichem, graubraunem Rhizoidenfilz, dicht oder locker beblättert, einfach. Blätter mit oft leicht abfallender, abstehender bis etwas zurückgebogener Lamina, aus hochsclıeidiger, gelblichglänzender Basis lanzettlich, kurz zugespitzt, bis $11 \mathrm{~mm}$ lang, mit zuweilen eingebogenen, nur in 
der oberen Hälfte entfernt und kleingezälnnten Rändern; Rippe glatt; Lamellen bis etwa 40, 6-10reilig, mit nach oben verbreiterten, gestutzten bis ausgerandeten Randzellen; Zellen der Lamina am Rande etwa 2reihig. Perichätialblätter hochscheidig, breit weisshäutig. lang grannenförmig zugespitzt. Seta $4-5 \mathrm{~cm}$, rot. Kapsel aufrecht, fast kubisch bis prismatisch, rundlich 4-6kantig, etwa 3-4 mm lang und 2-2,5 $\mathrm{mm}$ dick, dunkelbraun. Peristomzälme 64, gleicligross. Deckel fast $1 / 2$ der Urne, aus flachgewölbter Basis schief und stumpf geschnäbelt. Haubenfilz unter die Urne herabreichend, schmutzig rotbraun. Sporenreife im Juli.

An Teichen, sandigen See- und Flussufern, auf feuchten Wiesen und in Torfmooren.

F. Ik. Talkjärvi, Vialima, am Seeufer massenhaft (H. Lindb.). Sakkola, Hiekkaranta, am sandigen Ufer (H. L.); Vuoksen, Rāihäranta (H. L.); Tiurinmäki (H. L.). - Oa. Närpes, Kjālaks, Uferwiese (H. Lindb.). - Lp. Ponoj, zw. Sphagna eingesprengt (Broth.).

S. An einzelnen Fundorten in $J m t$., $N b$.,$L u L$. und $T L$.

N. An einzelnen Fundorten in ST. und $F$.

Spitzbergen, frönland, Alaska, Wyoming.

var. diminutum Hag. in D. K. N. Vid. Selsk. Skrift. 1913, No. 1, p. 56 (1914).

In allen Teilen kleiner als die Hauptart. Blätter kürzer. Kapsel kubisch. N. $S T$. Opdal, am Wege nach Suehaetten.

821. Polytrichum commune \& L. Sp. pl. II. p. 1109 (1753).

Sehr kräftige Pfl. in lockeren, polsterförmigen, oft ausgedehnten, dunkelgrünen Rasen. Stengel aufrecht oder aufsteigend, bis $20-40 \mathrm{~cm}$, selten noch höher, nicht oder nur am Grunde schwach filzig, oft weit hinauf mit Niederblättern, meist einfach. Blätter abstehend-zurückgebogen, trocken mehr aufrecht, mit abstehenden Spitzen, aus hochscheidiger, gelber oder weisslicher, glänzender Basis lineallanzettlich, pfriemenförmig zugespitzt, bis $12 \mathrm{~mm}$ lang, bis zur Scheide herab scharf gesägt; Rippe als rotbraune, gesägte Granne austretend, am Rücken oberwärts gesägt: Lamellen bis 70, in der Regel 5-6reihig, mit nach oben verbreiterten, \pm ausgerandeten Randzellen; Zellen der Lamina an Rande etwa 2reihig. Innere Perichätialblätter bis zur langen Granne scheidig, breit weisshäutig. Seta 6-12 cm, selten länger, rot. Kapsel aufrecht, trocken und entleert horizontal, scharf 4-6kantig, bis $6 \mathrm{~mm}$ lang und bis $3,5 \mathrm{~mm}$ dick, zuletzt rotbraun. Peristomzähne 64 , gleichgross. Deckel flach gewölbt, mit kurzer, aufrechter Spitze. Haubenfilz unter die Kapsel rechend, rost- bis rotbraun. Sporenreife im Juli und August. - Fig. $118 \mathrm{G}-\mathrm{H}$.

Am reichlichsten in feuchten Wäldern, auf moorigen Wiesen, Torf- und Fichtenmooren, an Bachufern, Wegrändern und sandigen Gräben, oft Massenvegetation bildend, in allen Teilen von Fennoskandia bis in die Birkenregion fq.-fqq., in dem unteren Teil der alpinen Region selten und steril.

Europa, Madeira, Azoren, Kanaren, Kaukasus, Nord-Asien, Japan, Nord-Amerika, Brasilien, OstAustralien, Tasmanien, New Zealand.

var. uliginosum Hüb. Muscol. germ. p. 535 (1833).

Stengel sehr verlängert, bis fast $1 \mathrm{~m}$, etwas schlarf, locker beblättert. Blätter trocken weit abstehend, sichelförmig zurückgekrümmt und gedreht, länger und schmäler.

In tiefen Waldsümpfen und Torfmooren, hauptsächlich in der Ebene und dort oft weite Flächen deckend.

F. Die Verbreitung dieser hygrophilen Varietät ist bei uns noch nicht festgestellt. Exemplare liegen nur aus $A l$., $N$. und $O a$. vor.

S. Nach $M$ o l l e r st. fq. und von derselben Verbreitung wie dic Hauptart, jedoch nicht über die Baumgrenze steigend. In $L u L$. noch hei etwa $500 \mathrm{~m}$ beobachtet.

N. Nach II a gen bisher nur aus der südl. Hälfte bekannt. Europa. 
var. minus Weis Pl. crypt. gotting. 1). 171 ex p. (1770). [Polylrichum commune var. humile Sw. Adnot. bot. p. $1+1$ (1829). - P. commune * cubicum Lindls, in Notis. Sällsk. Faun. Fl. Fenı. IX. p. 117 (186s).]

Stengel kürzer und schlanker, dicht beblättert. 13lätter kürzer, trocken anliegend oder mit zurückgekrümuter Spitze: Spitze zuweilen hyalin: limellen mehr als 6, zuweilen bis 10rehig. Perichätialblätter den Schopfblättern ähnlich. an Rande häutig. Kapsel \pm aufrecht, klein, fast kubisch, mit weniger scharfen Kanten.

An trockneren Standorten, wie an Rändern von Sïmpfen, an zeitweise alusgetrockneten, flachen Vertiefungen und an Wegrändern.

F. Al. ziemlich selten (Bom.). - Ab. Uskela, Linnamāki (Lindb.). Bronarf (Sundv.), - N. Tvărminne, Björkskär (Ranch.). Ekenàs, Elugmo (Lindb.). Kyrkslält, Porkkala, Böhle und Mickelskär (Broth.), Helsingfors (Lindb.). - Da. Krarken (Broth.). - Om. Lapnajärvi, Hankijārvi anı ansgetruckneten Ufer cop. (Backm.). - Ob. Ii. Tannila (Brenn.). - Lkem. Sodankylä (Vain.); Kaareltwiki, auf einer Sumpfwiese reichlich (Hull).

S. Verbreitung nach yölle r wahrscheinlich wie bei der Hauptart, wenngleich viel seltener In $L u L$. noch in der Weidenregion bei etwa $900 \mathrm{~m}$.

N. An einzelnen oder wenigen Fundorten in śm., Ne., $x_{B} ., s T$. und $F$

Europa, Madeira, Azoren, Nord-Amerika.

var. perigoniale (Michx.) Bryol. eur. fase, $21 / 22$, p. 13, t. 17, f. $\beta$ (184.1). [Polytrichum perigoniale Michx. Fl. bor.-am. 2. ed. p. 293 (1803).]

Tracht voll $P$. juniperinum. Stengel bis $10 \mathrm{~cm}$. Blätter oft gegen das Sprossende gehäuft, trocken dachziegelig: Lamellen 6-8reihig, in fler Seitenansicht gerade verlaufend oder undeutlich ausgerandet. Perichätialblälter länger, breiter häutig und länger begrannt. Kapsel zuletzt horizontal, fast kubisch, dunkelbraun.

Am meisten in etwas feuchten Sandausstichen, an sandigen, ausgetrockneten Ufern, auf ausgetrockneten Sümpfen und Mooren, wie auclı an Wegrïndern und auf trockenen Wiesen.

F. Al Sallvik, an wenigen Fundorten (Bom.). - Ab. Abo (Buch). Merimasku (Karst.). - N. Kyvksıätı, Skjulet (Broth.). Helsingfors (Lindb.). - Kl. Pälkjärvi, Annonniemi (Brolh.). Suistamu, Songerjärvi (Broth.).

S. In fast allen Provinzen und nach II ölle r nicht sellen, auch oberhalb der Baumgrenze beobachtet.

N. Tach $\mathrm{H}$ agen viel allgenzeiner als die Hauplart.

Europa, Azoren, Nord-Amerika.

S e c t. I I I. Polytricha sexangularia Hag. 1. c. p. 63.

Blätter mit eingebogenen, unversehrten Rändern; Zellen der Lamina den Rückenzellen der Rippe ähnlich. Hals von der Urme nicht abgeschniirt; Zellen des Exotheciums mit Tüpfeln. Peristomzähne ohne Anhängsel.

822. Polytrichum sexangulare Flörk. in Hopp. Bot. Taschh. 1799, p. 126 et op. cit. 1800, p. 13 et 150 .

Pfl. in dichten, oft ausgedehnten, grünen, innen rostbraunen Rasen. Stengel aufsteigend, bis 6 cm, nur an Grunde mit Rhizoiden, einfach oder am Grunde geteilt. Blätter glänzend, aufrecht-abstehend und einwärtsgebogen bis einseitswendig, aus breit scheidiger Basis plötzlich verlängert-lanzettlich, kurz und stumpflich zugespitzt, bis $6 \mathrm{~mm}$ lang: Rippe vollständig bis sehr kurz austretend, am Rücken glatt: Lamellen bis $3 \overline{5}$, nicht gekerbt, mit grösseren, eiförmigen. stark verdickten, glatten Randzellen: Zellen der Lamina an den 2reihigen Rändern querrektangulär. Perichätialblätter länger, hochscheidig, die innersten kleiner und deren Lanina zu einer Stachelspitze reduziert. Seta $0,3-4.5 \mathrm{~cm}$, gelbrot. Kapsel aufrecht oder geneigt, eiförmig bis fast kubisch, stumpf $4-6$ kantig. etwa 3 mm lang, rötlichbraun, in Alter schwärzlich. Peristomzähne 64, regelmässig, auf holıer Grundhaut. Decker $1 / 2$ der Urne, kegelig, mit allmählich verdünntem Sthnabel. Haubenfilz kürzer als die Urne, rostbraun. Sporenreffe im Juli bis September. 
Am meisten auf feuchten, nackten Flecken der Fjeldheiden bis zur Schneegrenze, besonders an von Schnee lange bedeckten oder rom Schmelzwasser der Gletscher nassen Orten und da oft Matten von mehreren $m^{2}$ bildend, nur selten unterhalb der Baumgrenze beobachtet.

F. Li. Utsjoki, Paistunturit, Gamaoairve, an den Quellen des Akhojokka (Ranck.). Saariselkä, Vuennijäyr, Suorsapäā, in der Birkenregion, reichlich und fruchtend (Roiv.). - Lt. Pummanki und Tsipnarolok (Broth.). - Lmur. Garrilova und Semjostrovsk (Broth.).

S. Aus allen Lappmarken, Jmt., Hrjd. und Dlr. bekannt.

N. Aus allen Amtern mit Ausnahme von Sm., A., JL.. LM. urd Et bekannt.

Beeren Eiland, Riesengebirge, Tatra, gesamte Alpenkette, Pyrenäen. Kamtschatha. arkt. Amerika, Brilish Columbia, Rocky IIts, Oregon.

Se ct. I V. Polytricha juniperina Hag. 1. c. p. 65.

Blätter mit breit eingebogenen. unversehrten Rändern; Zellen der Lamina von den Rückenzellen der Rippe sehr verschieden. Kapsel scheibenförmig, von der L'rne abgeschnürt; Zellen des Exotheciums mit Tüpfeln. Peristomzähne mit flügelartigen Längsleisten.

\section{Polytrichum juniperinum Willd. Fl. herol. prodr. p. 305 (1787).}

Pll. in lockeren, meist ausgedehnten, bläulichgrünen Rasen. Stengel aufrecht, bis $10 \mathrm{~cm}$, meist nur das Rhizom filzig, meist einfach. Blätter fencht aufrechtabstehend, trocken anliegend, a!ıs scheidigem, gelbem Grunde lineallanzettlich, bis $10 \mathrm{~mm}$ lang; Rippe oberwärts am Rücken gezähnt: Lamellen bis 48, gekerbt, mit grösseren, fast flaschenförmigen, an der Spitze stark verdickten, glatten Randzellen: Zellen der Lamina querrektangulär. Innere Perichätialblätter breit weisshäutig, mit längerer Granne. Seta $2-6 \mathrm{~cm}$, rot. Kapsel aufrecht, zuletzt horizontal, thantig, bis $5 \mathrm{~mm}$ lang und $2,5 \mathrm{~mm}$ dick, braun. Peristomzähne 64, regelmässig. Deckel aus flachgewölbter Basis kurz und scharf gespitzt. Haubenfilz bis unter die Kapsel reichend, meist weisslichbraun. Sporenreife im Juni und Juli. - Fig. 118 I.

Auf \pm trockenem, sandigem, kiesigem oder steinigem Boden, auf trockenen, erdbedeckten Felsen, trockenen Wiesen und trockenem Waldboden in allen Teilen von Fennoskandia fqq., bis in die alpine Region hinaufsteigend und auch dort fruchtend.

Kosmopolit.

var. alpinum Schimp. Syn. p. 417 (1860).

Zwergig und dichrasig. Blätter kürzer, schopfig zusammengedrängt, trocken dicht anliegend. Perichätialblätter länger begrannt. Seta kurz. Kapsel klein, fast kubisch, gelbrot. Haube kürzer, oft schneeweiss.

Auf trockenen Fjeldheiden oberhalb der Baumgrenze.

S. An einzelnen oder werigen Fundorten in $A L .$. LyL., PL., LuL. und $T L$.

N. Nach $\mathrm{H}$ agen zerstreut, aber, wie es scheint, selten.

Sudeten, durch die ganze Alpenkette. Sierra Nevada. Nord-Amerika.

825. Polytrichum strictum Banks. Mscr., Menz. in Trans. Linn. Soc. IV. p. 77, t. 7, f. 1 (1798). [Polytrichum juniperinum * strictum Lindb. Musc. scand. p. $12(1879)$.]

Schlanke Pfl. in meist dichten, oft sehr tiefen und von Sphagna durchsetzten, blaugrünen Rasen. Stengel aufrecht, \pm weit hinauf dicht mit gelblichweissem Rhizoidenfily bedeckt, meist einfach. Blätter steif aufrecht-abstehend, trocken angepresst, aus scheidigem, gelbem Grunde rasch lanzettlich-pfriemenförmig, meist 5-7 mm lang; Rippe oberwärts am Rücken gesägt; Lamellen bis 30, gekerbt, mit grösseren, fast flaschenförmigen, an der Spitze nicht verdickten, glatten Randzellen; Zellen der Lamina querrektangulär. Innere Perichätialblätter breit weisshäutig, mit längerer Granne. Seta $3-8 \mathrm{~cm}$, sclten länger. Kapsel aufrecht, fast kubisch, bis 3 mm lang, gelbrot. Peristomzähne 64 , regelmässig, kürzer als bei 
der vorigen Art. Deckel flachgewölbt, mit kurzem Spitzchen. Haubenfilz lis unter die Kapsel reichend, gelbbraun. Sporenreife Ende Juni und Juli.

An reichlichsten in den trockneren Erhebungen der Torfmoore, bald in mächtigen Polstern, bald zw. Sphagna eingesprengt, auch auf mit Torferde bedeckten, \pm nassen Felsen und Mooswiesen, im grössten Teil ron Fennoskandia bis in die alpine Region $\mathrm{f}(\mathrm{q}$., in Süc-Schweden jedoch \pm selten.

Europa, Nord-Asien, nördı. Teile von Nord-Amerika, Antarktis.

var. alpestre (Hopp.) Rabenh. D. Kryptll. II. P. III. p. $2: 38$ (18.18). (I'olytrichum alpestre Hopp. 13ot. Taschenl). 1801, p. 198.)

Polster reichlich verfilzt, oft lichter als bei der Hauptart. Blätter sehr kurz. Seta sehr lang. Kapsel kleiner, fast genau kubisch, heller rot. Haubenfilz lichter, zuweilen schneeweiss.

Kommt fast ausschliesslich oberhalb der Baumgrenze und noch an der Grenze der Vegetation vor, an etwas trockneren Standorten als die Hanptart.

S. Nach AI öller keine Seltenheit im ganzen Fjeldgebiete, von Lir. bis $T L$.

N. Nach H a gen nicht selten und auch unter der Baumgrenze beobachtet.

Sudetenkämme und alpine Region der Alpenkette.

821. Polytrichum piliferum Schreb. Spic. fl. lips. p. 7.1 (1771). [I'olytrichum pilosum Neck. Meth. muse. p. 123 (1771).]

Pfl. in lockeren, bläulichgrünen, durch die Haarspitzen graugrünen Rasen. Stengel aufrecht, bis $3 \mathrm{~cm}$, selten höher, ohme Rhizoiden, einfach. Blätter aufrecht-abstehend, trocken dicht anliegend, aus breit scheidigem, gellblichem Grunde verlängert lanzettlich, bis $6 \mathrm{~mm}$ lang: Rippe als langes, weissliches, fein gesägtes Haar austretend, am Rücken glatt; Laməllen bis etwa 30, gekerls, mit grösseren, fast flaschenförmigen, an der Spitze nicht verdickten, glatten Randzellen: Zellen der Lamina querrektangulär. Perichätialblätter länger, zart, flachrandig, ohne Lamellen, länger behaart. Seta $2-3 \mathrm{~cm}$, unten rot, oben gelblich. Kapsel aufrecht, später geneigt bis horizontal, 4 kantig, etwa $3 \mathrm{~mm}$ lang und $1,5 \mathrm{~mm}$ dick, hellbraun. Peristomzälme 64, regelmässig. Deckel aus flach-kegeliger Basis kurz geschnähelt. Haubenfilz bis unter die Kapsel reichend, gebräunt. Sporenreife Ende Juni und Juli.

Auf sterilem Heideboden, an trockenen Felsen mit sehr dünner Humustecke. auf Brandstätten im Walde und auf Torfdächern in allen Teilen von Fennoskandia fqc., bis in die alpine Region steigend und auch dort fruchtend.

Kosmopolit.

var. fastigiatum (Lindb.) Par. Ind. bryol. p. 1005 (1897). [Polytrichum pilosum var. fastigiatum Lindb. Musc. seand. p. 12 (1879).]

Stengel bis $10 \mathrm{~cm}$, dicht und bammartig verästet. Blätter kürzer, kurz behaart.

F. Helsingfors, Degerö (Lindb.).

S. Vb. Burträsk, Kivarnuärget.

var. Hoppei (Hornseh.) Rab. D. Ḱrypt.-Fl. 3d. 2, Abt. I1l. p. 238 (1848). [Polytrichum Hoppei Hornsch. in Flora 1819, p. 106. - P. pilosum var. Hoppei Möll. in Ark. f. Bot. Bd. 17, No. 4, p. 102 (1921).]

Dichtrasig. Blätter auch feucht anliegend, kürzer, mit sehr langem Haar. Seta $1-1,5 \mathrm{~cm}$, dick. Kapsel aufrecht, fast kubisch, gelbrot.

Im Hochgebirge, oberhall der Baumgrenze.

S. Von mehreren Fundorten in $P L$., $L u L$. und $T L$., in einer Höhe von $800-1,300 \mathrm{~m}$ bekannt.

N. Ton einzelnen Fundorten bekannt.

Kämme des Riesengebirges, hochalpine Region der Alpenkette und Kaukasus.

826. Polytrichum hyperboreum R. Br. in Parry Voyage Suppl. p. 294 (182 1). [Polytrichum boreale Kindb. in Bih. K. Sv. Vet.-Ak. Handl. Bd. 7. No. 9, p. 32 ex p. (1883).]

Schlanke Pfl. in lockeren, olivengrünen bis braunen Rasen. Stengel aufrecht, bis $10 \mathrm{~cm}$, dünn, ohne Rhizoidenfilz, einfach oder büschelig geteilt. Blätter steif aufrecht-abstehend, trocken angepresst, aus scheidigem, gelblichem Grunde lan- 
zettlich, $5-7 \mathrm{~mm}$ lang: Rippe am Rücken glatt, als am Grunde braunes und am Rücken rauhes, oben hyalines, kurzes, gesägtes Haar austretend; Lamellen etwa 30. gekerbt, mit grösseren, fast flaschenförmigen, an der Spitze nicht verdickten, glatten Randzellen; Zellen der Lamina querrektangulär. Innere Perichätialblätter breit Weisshäutig, mit längerem Haar. Seta $2-3 \mathrm{~cm}$, rot. Kapsel aufrecht, später geneigt bis horizontal, fast kubisch, bis $3 \mathrm{~mm}$ lang, hellbraun. Peristomzähne 64 . regelmässig. Deckel flach gewölbt, kegelig zugespitzt. Sporemreife im Juli und August.

Am meisten auf trockenen Fjeldheiden bis zur Schneegrenze, zuweilen Massenvegetation bildend und auch in der Birkenregion beobachtet.

F. Lkem. Yllästunturi, oberhalb der Baumgrenze (Hult). Ounastunturit (Norrl.). - Le. Kilpisjărvi, Leutsuvaara (Norrl.); Maanselkä (Kot.). - Lim. Tschun, in der alpinen Region (Broth.).

S. Aus allen Lpmk. und au; den hōehsten Teilen von Jmt. und Hrjd. bekannt.

N. $S B, K ., H ., S T$. $T r$. und $F$. In Dovrefjeld und wahrscheinlich auch in den inneren Teilen von Tr. und $F$. st. fq.

Spitzbergen, Novaja semlja. arkt. Sibirien, arkt. Sord-Amerika. 


\section{BERICHTIGUNGEN UND ZUSÄTZE.}

S. 27, Zeile 16 von unten: Kaulf. statt Dicks. und Zeile 17 (Kaulf.) statt (Dicks.).

S. 33, Zeile 15 von oben: oblongum statt oblongus.

S. 36, Zeile 10 von oben: Distichioidene statt Distichene.

S. 60 , Zeile 9 von oben: Melzlerella statt Metzerella.

S. 170, Zeile 11 von oben: De Not. Syll. statt De Syll.

S. 196, Zeile 4 von unten: 63. Ephemerum statt Ephemerum.

S. 205, No. 286 Synonym: Bryum Griffithianum Dicks. Pl. crypt. Brit. fasc. IV. p. 8 (1801).

S. 210 vor Tetraplodon: 1I. Splachnoideae.

S. 224 vor Leptobryum:

\section{BRYOIDEAE.}

$\mathrm{I}^{*}$ bersicht der Gattungen.

A. Äusseres Peristom kürzer als clas innere 78. Plagiobryum.

B. Beide Peristome gleichlang.

a. Blattzellen eng, oberwärts verlängert-rhombisch bis lineal.

«. Stengel schopfig beblättert.

I. Blätter lang pfriemenförmig. Wimpern mit langen Anhängseln

77. Leptobryum.

II. Blätter lineal-lanzettlich. Wimpern ohme Anhängsel, oft rudimentär bis fehlend ............. 80. Pohlia.

ア. Stengel kätzchenförmig beblättert ................. 79. Anomobryum.

b. Blattzellen lockerer, oberwärts rhombisch und rhomboidisch bis 6 seitig.

«. Spaltöffnungen eingesenkt

\$1. Mniobryum.

ß. Spaltöffnungen oberflächlich

82. Bryum.

S. 248 ( ) bis: Blätter sehr weit herablaufend, kurz zugespitzt:

Rippe zart, kurz vor oder in der Blattspitze aufhörend:

Zellen sehr locker und dünnwandig

377. Bryum Duvalii.

S. 317. 470. Bryum barbatum Wils. mscr.; Hunt in Mem. lit. Phil. Soc. Manch.

3. Ser. Y. p. 238 (1872). [Bryum Stirtoni Schimp. Syn. eu. 2. p. t70 (1876).]

S. 382. 551. Orthotrichum microblephare Schimp. ist nach 5.0. O. Blyttii einzureihen.

S. 462. Zeile 21 von oben Campyliadelphus statt Campiadelphus.

S. 399. Zeile 18 von oben Lindh. statt Lind. 



\section{ALLGEMEINES NAMENREGISTER.}

Abietinella C. Müll. (Syn.) 441.

Abietinella Broth. (Unterg.) 441.

Acauion C. Müll. 9, 137.

mediterraneum Limpr. 137, 138.

minus Jaeg. (Syn.) 137.

muticum C. Müll. 137.

var. minus Bryol, eur. 137.

Acrocladium Mitt. $450,493$. cuspidatum Lindb. 493.

Aloina Kindb. 137, 149.

aloides Kindb. 149, 150.

brevirostris Kindb, 149.

ericaefolia Kindb. 149.

pusilla Kindb. (Syn.) 146 .

rigida Kindb. $149,150$.

Aloma C. Müll. (Sect.) 21.

Alpiniformia Kindb. (Gruppe) 314.

Amblyodon Palis. 12, 342, 343.

dealbatus Palis. 343.

Amblystegiaceae 15, 449.

Amblystegiella Loesk. 450.

alpicola Broth. 451, 453.

confervoides Loesk. 451, 452.

Sprucei Loesk. 450, 452.

subtilis Loesk. 451.

Amblystegium Bryol. eur. 450, 453. aduncum Lindb. (Syn.) 472.

*A. orthothecioides Lindb. (Syn.) 472. atrovirens Hag. 453, 454.

auriculatum Bryhn (Syn.) 464 .

badium Lindb. (Syn.) 481.

Berggrenii C. Jens. (Syn.) 480 .

chrysophyllum De Nol. (Syn.) 462.

cochlearifolium Lindb. (Syn.) 500.

compactum Bryol. eur. (Syn.) 533.

confervoides Bryol. eur. (Syn.) 452.

cordifolium De Not. (Syn.) 491.

var. coloratum Möll. (Syn.) 491.

lanato-caule Möll. (Syn.) 491.

curvicaule Dix. et James (Syn.) 470 .

var, patulum Möll. (Sуn.) 470.

curvines Gümb. (Syn.) 457.

dilatatum Lindb. (Syn.) 502 .

engyrium Lindb. (Syn.) 496.

exannulatum De Not. (Syn.) $47 \pi$.

var. brachydictyon Arn. et C. Jens. (Syn.) 478. Rotae Arn. et C. Jens. (Syn.) 478. fallax Mild. (Syn.) 470 .

filicinum De Not. (Syn.) 468 .

var. curvicaule Mol. (Syn.) 470

*A. curvicaule Lindb. (Syn.) 470 .

*A. fallax Lindb. (Syn.) 470 .

fluitans De Not. (Syn.) 479

var. proccrum Arn. et C. Jens. (Syn.) 478.

$\alpha$ amphibium Arn. et C. Jens. (Syn.) 479.

var. falcatum Arn. et C. Jens. (Syn.) 180

*A. exannulatum Arn. et Jens. (Syn.) 478.

var. brachydictyon Arn. et C. Jens. (Syn.) 478. Rotae Aru, et C. Jens. (Syn.) 478.

fluviatile Bryol. eur. (Syn.) 465.

giganteum Ile Not. (Syn.) 492.

glaucum Lindb. (Syn.) 466 .

var. decipiens Lindb. (Syn.) 470. sulcatum Lindb. (Syn.) 467 .

*A. falcatunı Lindb. (Syn.) 467 .

helodes Lindb. (Syn.) 462.

hygrophilum Jur, (Syn.) 458.

intermedium Lindb. (Syn.) 476 .

irrigatum Zett. (Syn.) 468 .

irriguum Bryol. eur. (Syn.) 466.

Juratzkanum Schimp. (Syn.) 456 .

Kneiffii Bryol. eur. (Syn.) 282.

Kochii Bryol. eur. (Syn.) 45i.

lycopodioides De Not. (Syn.) 484 .

molle Lindb. (Syn.) 501.

var. alpinum L ndb. (Syn.) 501 .

Schimperi Lindb. (Syn.) 501 .

montanum Lindb. (Syn.) 495.

ochraceum Lindb. (Syn.) 496.

var. complanatum Moll. (Syn.) 497.

filiforme Möll. (Syı.) 497.

flaccidum Möll. (Syn.) 497.

uncinatum Adlerz (Syn.) 497 .

palustre Lindb. (Syn.) $\$ 95$.

var. subsphaericarnon Lindb. (syn.) 495 . laxum Möll. (šnn.) 495.

polare Lindb. (Syn.) 498.

polycarpum Vent. et Bott. (Syn.) 48?.

polygamum Bryol. eur. (syn.) 464 .

*A. fallaciosum Lindb. (Syn.) 465 .

protensum Lindb. (Syn.) 463.

radicale Mitt. $453,456$.

*A, pachyrrhizon Lindb. (Syn.) 456 .

revolvens De Not. (Syn.) 476 . 
Richardiunii Lindb. et Arn. (Syn.) 491.

var. fluitans Möll. (syn.) 49?.

lanatum Yoll. (syn.) 492.

riparium Brjol. eur, 454, 458.

var. longifolium Bryol. eur. 458.

rivulare Lindb. (Syn.) 500.

Rotae De Not. (Syn.) 478 .

salinum Bryhn (Syn.) 533.

sarmentosum De Not. (Syı.) 489 .

var. fallaciosum Möll. (sỵn.) 489.

fontinaloides Möll. (syn.) 43 a.

saxicola Hans. 453, 45

scorpioides Lindb. (syn.) 485.

Sendtneri Lindb. (Syn.) $\mathbf{4} 83$.

var. capillifolium Arn, et C. Jens. (Syn.) 484. hamifolium Bom. et Broth. (syn.) 483.

serpens Bryul. eur. 453, 454.

simplicinerre Lindb. (Syn.) 497 .

smithii Lindb. (Syll.) 499.

Sprucei Bryol. eur. (syn.) 452.

stellatum Lindb. (Syn.) 463.

stramineum De Not. (Syn.) 487.

var. nivale Vent. et Bott. (Syn.) 488.

patens Lindb. (Sy̆ll.) 489.

subsulcatum De Xot. (Syn.) 468 .

subtile Bryol. eur. (Syn.) 451.

trichopodium Hartm. 453,456 .

rar. curvipes Broth. $45 \%$.

Kochij Lindb. $45 \%$.

trifarium De Not. (Syn.) $48 \%$.

turgescens Lindb. (syn.) 486 .

tundrae Arn. (Syn.) 479.

uncinatum De Not. (Syn.) \$72.

var. abbreviatum Möll. (Syn.) 473.

gracilescens Moll. (syn.) 474.

plumosum Yôll. (syn.) 474.

plumulosum Arn. (Syn.) 474.

rarium Lindb. 453,456 .

vernicosum Lindb. (Syn.) 474 .

var. gigas Lindb. (Syn.) 475 .

lapponicum Lindb. (Syn.) 45.

majus Lindb. (syll.: 475 .

versirete $\mathrm{Hag} .453,455$.

Wilsoni Lindb. (syn.) $\$ 8 \%$.

var. hamatum Lindb. (Syn.) 483.

viridulum Lindb. (syn.) 499.

Amphidium sichimp. 10, 66.

lapponicum schimp. 6i.

Mougeotii Schimp. 67, 68.

var. caespitosimm Mitı. 68.

Ampullaria C. Iüll. (sect.) 215.

Anaglyphodon Philib. (Subsect.) 261.

Andreaea Enrh. 1.

alpestris schimp. 2. 3.

alpina sin. 1, 5.

Blyttii Bryul. eur. 2, 7.

crasinervia Bruch 2, 5.

frigida Irueb. 2, 7 .

ILartmanii Thed. 2. 4.

var. Thedenii Lindb. (sisı.) 5.

If untii Limpr. 2, 5.

nivalis Hook, 2, 7 .

oborata Thed. 2, 4.

ubtusifulia Th. dens. (syn.) 5.

papillo:a Lindb. ?, 3. petrophila Ehrh. 2, 3.

sar. alpestris Thed. (Syn.) 4.

homomalla schimp. (Syn.) 3.

rupestris Wallr. 3.

*A. alpestris Lindb. (Sỹn.) 4.

*A. sparsifolia Lindb. (Syn.) 3 .

Rothii Web. et Mohr 2, 6.

*A. Huntii Joerg. (Syn.) 6.

lupestris Hedw. (Syn.) 3.

rupestris Roth. (Syil.) 6.

sparsifolia Zett. 1, 3.

Thedenii Bryol. eur. 2, 5 .

var. obtusifolia Hag. 5.

Andreaeaceae 1.

Andreaeales 1.

Ani tangium flaccidum De Not. (syn.) 184. lapponicum Hedw. (Syn.) 67.

An isothecio ideae 48 .

Anisothecium Mitt. 48.

crispum Lindb. 49, 51 .

var. elata Hag. (syn.) 51.

lentum Moll. 51.

Grevilleanum Lindb. 49, 52 .

humile Lindb. $49,50$.

palustre Hag. (Syn.) 50.

lubrum Lindls. 49. 53.

rar. callistomum Braithw. 54.

rufescens Lindb. $49,50$.

raginale Loesk. 49, 52.

Anoectangium schwaegr. 10, 110.

caespiticium schwaegr. (Syn.) 44 .

compactum Schwaegr. 111.

Anomobryum schimp. 227.

concinnatum Lindb. $22 \pi, 228$.

filiforme $\mathrm{Hu}=\mathrm{n}$. 227 .

julaceum Schimp. (Syn.) 227.

juliforme solıns-Laub. 227, 228.

Anomodon Hook. el Tayl. 422.

apiculatus Bryol. eur. (Syn.) 426.

attenuatus Hüb. 426, 427.

var. immersus Ryan 428.

longifolius Bruch 425, 428.

var. cavernarum 1löll. $4: 9$.

Rugelii Kessl. 4:5, 426.

viticulosus Hook, et Tayl. 425, 427.

Anomodonto ideae 42:, 4:5.

Antitrichia Brid. 14, 406 . curtipendula Brid. 14, 406 .

Aongstroemia Bryol. eur. 48, 54 . longipes Bryol. eur. 54. var. sericea Hag. 55.

Archidiaceae 8, 25.

Archidium Brid. 25. alternifolium schimp. 25. phascoides Brid. (sin.) 25.

Areticiformia Kindb. (Gruppe) $26:$.

Aretoa Bryol, eur. iij, 84.

Anderssonii Wich. 85. 86.

fulvella Bryol. eur. $85,86$.

var. nana Hag. 86.

hyperborea Bryol, eur. (syn.) 75.

Arctobryun Ilag. (sect.) 265.

Argyroloryum C. Müll. (truppe) $3 n 9$. virescen Kindb. (syn.) 309. 
Astomum Hamp. 9, 111, 112. crispum Hanp. 113.

Astrophyllum Blyttii Lindb. (Syn.) 325. ciliare Lindb. (Syn.) 331. cinclidioides Lindb. (Syn.) 336 . curvatulum Lindl). (Syn.) 330. cuspidatum Lindb. (Syn.) 330. Drummondii Lindb. (Syn.) 329. hornum Lindb. (syn.) 323.

hymenophylloides Lindb. (Syn.) 333. inclinatum Lindb. (Syn.) 325.

lycopodioides Lindb. (Syn.) 326 . marginatum Lindb. (Syn.) 326. medium Lindb. (Syn.) 330. orthorrhynchum Lindb. (Syn.) 325. pseudopunctatum Lindb. (Sy1.) 334. punctatum Lindb. (Syn.) 335 . riparium Lindb. (Syn.) 326. rostratum Lindb. (Syn.) 328. rugicum Kindb. (Syn.) 332. Seligeri Lindb. (Syn.) 331. silvaticum Lindb. (Syn.) 329. spinosum Lindb. (Syn.) 327. stellare Lindb. (Syn.) 333. undulatum Lindb. (syn.) 328.

Atrichum angustatum Bryol. eur. (Syn.) 589. anomalum MFild. (Syn.) 601 . Haussknechtii Jur, et Mild. (Syn.) 591. tenellum Bryol. eur. (syn.) 590. undulatum Palis. (Syn.) 590.

Aulacomitrium Daviesii Hag. (Sỵn.) 366.

Aulacomniaceae 13, 339.

Aulacomnium Schwaegr. 339. androgynum Schwaegr. 339,340 . palustre Schwaegr. $339,340$. var. imbricatum Bryol. eur. 339, 341. turgidum Schwaegr. 339, 341.

Barbula Hedw. 112, 129 aciphylla Bryol. eur. (Syn.) 156. acuta Brid. (Syn.) 130. alpigena \ōll. (Syn.) 128. ambigua Bryol. eur. (Syn.) 155. brevifolia Lindb. (Sy̧n.) 129. convoluta Hedw. 130, 135. var. filiformis $\mathrm{Hag} .136$. curvirostris Lindb. (syn.) 119. cylindrica schimp. 130. 131. var. vinealis Lindb. (syn.) 131. fallax Hedw. 130, 132. glauca Möll. 130, 134. gracilis Schwaegr. 130. Horuschuchiana schultz 129, 134. icmadophila Schimp. 130, 131. lurida Lindb. (Syn.) 128. obtusula Lindb. (Syn.) 135. paludosa Schleich. 130. 136. pulvinata Jur. (Syn.) 155. reflexa Brid. 130, 132. revoluta Brid. 1:9, 135. *B. obtusula Kindb. 135. rigida Schultz (Syn.) 150. rigidula Mitt. $130,133$. var. valida Broth. 13 '. rubella Mitt. (Sỵn.) $12 \pi$. rubra Möll. (Syn.) 1:8. rufa Jur. 130, 133.

madicra Vitt. 130, 13:

squarrosa Brid. (sรit.) 1:6.

unguiculatia Hedw. 129. 134.

vaginaus Lindb. (syu.) 1.2.

Talida Moll. (iyu.) 13\%

vineali- Brid. 130,131

Bartramia Hedw, 350 .

breviseta Lindb. (syn.) 352.

calcarea Bryol. eur. (syu.) 360 .

crispa Sw. (syil.) 351.

var. pomiformis Lindf. (syn.) 351

Halleriana Hedw. (Syn.) 350.

heteromalla Brid. (Syn.) 351.

ithyphylla Br,d. 350. 352 .

var. breviseta kindt). 352.

strigosa Wahlent). $35 \%$.

Normanni Holmgr. (Nyu.) 351.

norvegica Lindt. 350.

Oederiana sw. (Sin.) 354.

var. condensata Brid. (Syn.) 355.

pomiformis Hedw. 350, 351 .

var. crispa Bryol. eur. 351. heteromalla $C$. Mull. 351 .

Borlramiaceae 13, 349.

Bartrarnimeae 339. -eriata Mitt. (Syn. Sfilo.

Blindia Bryol. eur. 3x, 44 . acuta Bryol. eur. 4́. caespiticia C. Müll. 10, 44 . fulvella kindb. (syn.) sh. polaris Hag. (Syn.) 43 . subimmersa Hag. (Syı.) 43.

Blindiadelnhus Lindb. (Lntelg.) 43.

Brachydontium Bruch 38. trichodes Bruch 38.

Brachystelenm polyphyllum Hornsch. (syn.) 365 .

Brachytheciaceae 15, 502 .

Brachyihecium Bryol. eur. 503. $50 \%$. albicals Bryol. eur. 507. 510 var. groenlandicum Broth. 510. campestre Bryol. eur. 507, 513. cirro:um schimp. 525.

collinum Brỹol. eur. 509, 521. coruscum Hag. 508, 516. curtum Lindb. $508,518$. erythrorraizum Bryol. eur. 507, 509. var. Thedenii Lindb. 510. gelidum Bryhn 508. $51 \%$. glaciale Bryol. eur. 50s, $51 \%$. var. dovrense Limp1. 517. glarensum Bryol. eur. 507, 511. Geheebii Mrild. (syn.) 506. berjedalicun Lindl). 525 . Iapponicum Schimp. (syn.) 54?. tatifolium Philib. 508. 516. Hildeanum Schimp. 507, 512. plicatum Bryul. etr. (syn.) 4 \&8. plumo-um Bryol. eur. 509. 5:2. populeurn Bryol. eur 509. 5:2. rellexum Bryol. eur. 508. 519. rirulare Bryol. eur. 508. 515. var. longifolium Brybn 515 . rutabulum Bryol. eur. 508, 513. 
var. flarescens Bryol. eur. 514. viviparum Bryhn 515 .

Ryani Kaur. 508, 516.

saltense Hag. (Syn.) 525.

salebrosum Bryol. eur. 508, 512.

var. cylindricum Bryol. eur. (Syn.) 512. cylindroides Limpr. 512.

*B. Rotaeanum Amann 512.

*B. turgidum C. Hartm. 507, 512 .

Starkei Bryol. eur. 508, 519.

var. complanatum Limpr. 519.

Thedenii Bryol. eur. (Syn.) 510.

trachypodium Bryol. eur. 509, 521.

tromsoënse Kaur, 508, 520.

turgidum Kindb. (Syn.) 512.

udum Hag. 508, 516.

velutinum Bryol. eur. 509, 520.

Brachytrichum Limpr. (Sect.) 376.

Breutelia schimp. $350,356$.

arcuata Schimp. (Syn.) 356

chrysocoma Lindb. 356 .

Bryaceae 13, 222.

Bryhnia Kaur. 503, 532.

Novae Angliae Grout 532.

Bryotypus Hag. (Unterg.) 267.

Bryineae 222.

Bryoideae 222

Bryoidium C. Müll. (Sect.) l 8.

Bryum Dill., Schimp., Limpr. 247.

aciculare L. (Syn.) 188.

aculeatum Joerg. 253, 289.

acuminatum Bryol. eur. (Syn.) 231.

acutiforme Limpr. et Ryan (Sỵ.) 278.

acutum Lindb. 248, 277.

*B. acutiforme Amann 278.

*B. Axel-Blyttii Amann 278.

affine Lindb. 256, 300 .

var. cylindricum Arn. 301 urnigerum Arn. 301.

*B. saxatile Amann 276. alandense Bomans. $25 \mathrm{t}, 266$.

alandieum Bomans. (Syn.) 302.

albicans Wahlent. (Syn.) 245.

alpinum L. 257, 314.

var. brevifolium Myr. (Syn.) 314.

alvarense Arn. et Hedelius 249, 268 .

amblystegium Ryan 249, 269.

angermannicum Arn. 255, 297.

angustifolium kaur. (syn.) 259.

annotinum Hedw. (Syn.) 241.

annotinum Leers (Syn.) 242.

annotinum Roth (Syn.) 242.

apocarpum L. (\$rn.) 182.

archangelicum Bryol. eur. 251, 278.

arcticum Bryol. eur. 250, 262.

var. oxystegium H. Wint. 263. tomentosum Joerg. 263

*B. arcuatum Amanu 263.

*B. callistomum Amann 263

*B. helveticum Amann 263.

*B. Kindbergii Amann 263.

arctogaeum Hag. 255, 299.

arcuatum Limpr. (ivn.) 263.

argenteum L. 248, 310 .

var. lanatum Bryol, eur. 310. aristatum Hag. 256, 302.

Arnellii Bomans. (Syn.) 285.

Arvenii Arn. (Syn.) 311.

atropurpureum Bryol. eur. (Syn.) 311.

atropurpureum Wahlenb. (Syn.) 246.

autoicum Arn. 251, 279.

autumnale Limpr. (Syn.) 276.

Axel-Blyttii Philib. (Syn.) 278.

badium Bruch 254, 307.

Baenitzii C. Müll. (Syn.) 305.

bergoënse Bomans. (Sỵn.) 288.

betulinum Kaur. 269.

bicolor Dicks. 256, 311 ,

*B. Arvenii Broth. 311 .

bimum Schreb. 256, 293.

Blindii Bryol. eur. 248, 309 .

Bomanssonii Lindb. (Sỵn.) 313 .

boreale Schwaegr. (Syn.) 305 .

boreum Hag. 252, 282.

Bornmülleri Ruth. 250, 264.

brachycarpum Bomans. (Syn.) 288.

brevifolium Dicks. (Syn.) 129.

Brother. Bomans. (Syn.) 282.

Brownianum Dicks. (Syn.) 221.

Brownit Bryol. eur. 250, 259.

Bryhnii Hag. 252, 284.

bulbifolium Lindb. 255, 295.

caesium Vill. (Syn.) 33.

eaespiticium L. 254, 306 .

var. badium Brid. (Syn.) 307 .

* B. comense Amann 307.

var. brevimueronatum Bryhn 307.

*B. Kunzei Amann 306.

calcareum Dicks. (Syn.) 41.

callistomum Dicks. (Syn.) 54.

callistomum Philib. (Syn.) 263

calophyllum R. Br. 248, 277.

campylocarpum Limpr. 249, 267.

camurum Hag. 250, 265.

capillare L. 257,317 .

var, carinthiacum Bryol. eur. (Syn.) 317.

Ferchelii Bryol. eur. (Syn.) 317.

flaccidum Bryol. eur. 318.

rosulatum vitt. 318 .

carinatum Boul. (Syn.) 240.

carneum L. (Syn.) 246.

castaneum Hag. 256, 294.

var. Bomanssonii Hag. 294.

cernuum Lindb. 249, 267.

ciliare Grev. (Syn.) 331.

cinclidioides Blytt. (Syn.) 336.

cirratum Hopp. et Hornsch. 255, 300.

*sulcatum Joerg. 300 .

clathratum Amann 255, 298.

clariger Kaur. (Syn.) 309.

comense Schimp. (Syn.) 307 .

concinnatum spruc. (Syn.) 227.

confluens Joerg. 251, 262.

conoideum Dicks. (syn.) 368.

contextum Hopp. et Hornsch. (Syn.) 305.

contortum Wulf. (Syn.) 164.

contractum Bomans. (Syn.) 284.

crispatum Dicks. (Syn.) 69.

crispulum Hamp. 254, 292.

crispum schreb. (syn.) 51. 
crudum Huds. (Syn.) 234. cucullatum Schwaegr, (Syn.) 237. Culmannii Limpr. 255, 296. curvatum Kilur. et Arn. 253, 286. cuspidatum schimp. (Syn.) 300 . cuspidatum Schreb. (Syn.) 329. cyclophyllum Bryol. eur. 248, 275. Daviesii Dicks. (Syn.) 366. dealbatus Dicks. 343. diaphanum Gmel. (Syn.) 390. dilatatum Joerg. 251, 265 . dolomiticum Kaur. 251, 266. dubiosum Par. (Syn.) 268.

Duvalii Toit 274.

elegans Nees 257, 316.

var. carinthiacum Breidl. 317.

Ferchelii Breidl. 317.

norregicum Kaul. et Aln. 317 . rosulatum Arn. (Syn.) 318. subelimbatum Joerg. 317. elongatum Dicks. (Syn.) 232. elongatum Stroem (Syn.) 46 . ericaefolium Neck. (Syn.) 149. erythrocarpum Schwaegr. 256, 312. ${ }^{*}$ B. Bomanssonii Amann 312 .

*B. rubens Podp. 313 . excurrens Lindb. 256, 313 . extinctorium L. (Syn.) 160. fallax Mild. (Syn.) 271. fasciculare Dicks. (Syn.) 202. fasciculare Schrad. (Syr.) 192. filiforme Dicks. (Sỵn.) 227. filum Schimp. (syn.) 239. finmarkicum Kaur. 249, 271. var. Jutescens Broth. 272. fissum Ruth. 253. 290.

flexisetum Lindb. et Arn. 254, 302. flexuosum (L.) (Syn.) 64. foveolatum Hag. 253, 289. Fridtzii Hag. 250, 261. fulvellum Dicks. (Syn.) 86 . Funckii Schwaegr. 248, 308. furvum Hag. 253, 290. fuscum Lindb. (Syn.) 298. gilvum $\mathrm{Hag}$. 251, 280. glaciale Schleich. (Syn.) $2 \notin 6$. glaucum L. (Syn.) 109. globosum Lindb. 251, 280. gracile Schleich. (Syn.) 240. Graefianum Schlieph. 254, 290 . grandiflorum Arn. 252, 284. haematostomum Joerg. 253, 291. var. fennicum Broth. 291.

Hagenii Limpr. 252, 284. halophytum Bomans. (Syn.) 285. helveticum Philib. (Syn.) 263. heteromallum Dilt. : 7 . Holmgrenii Lindb. (Syll.) 278. humectum $\mathrm{Hag}$. 254, 289. hypnoides L. (Syn.) 193. inclinatum Bryol. eur. 252, 282. var. hyperboreum Joerg. 283. rimosum Hag. 283. stenotheca Broth. 283. incurvum Huds. (Syn.) 592. inflatum Plilıb). 250, 264. insularum Bornans. (syn.) 282. illternedium Brid. 255, 297. var. fuscuul Bryhn (syn.) 29x. sulicylindricun Limpr. 298.

*fuseum Bryln 298.

Jackii C. MÏ̈ll, 254, 306.

femtlandicun H. Perks. (syll.) 296;.

Joergensenii Kaur. 251, 279.

julaceum Sm. (Syn.) 227 .

Kaalaasii Ilag. 252, 285.

Kaurini Philil). (Syn.) 262.

Kaurinianum Warmst. 251, 283.

Ǩindbergii Philib. (Syn.) 263.

klinggraeffii Schimp. 25f, 312.

kongsvoldense H. Wint. 250, 264.

Kunzei Hornsch. (Syn.) 306.

tabradorense Philil,. (Syn.) 286.

lacustre Bland. 251, 279.

Lagerheimii Juerg. 253, 287. lapponicum Kaur. 253, 288. lepiduns Hag. 249, 267.

leptocercis Philib. (Syn.) 284.

limosum Hag. 256, 302.

Limprichtii Kaur. 251, 281.

Lindbergii Kaur. 249, 269.

Lindgrenii Schimp. (Syn.) $27 \%$.

lingulanum Bomans. (SyIl.) 288.

litorale Ryan 252, 282.

litorum Bomans. 252, 286.

longisetum Bland. 253, 286.

*]abradorense Amann 286.

Lorentzii schimp. 252, 281.

Ludwigii Spreng. (Syn.) 238.

lutescens Bomans. (Syn.) 272.

Juteum Bomans. 255, 299.

lycopodioides Hook. (Syn.) 326. mamillatum Lindb. 249, 259. marginatum Dicks. (Syn.) 326. maritimum Bomans. 252, 285.

var. dioicum Arn. 285.

liarratii Wils. 248, 258.

meeseoides Kindb. (syn.) 271.

micals Limpr. 250, 264.

var. liberum H. Wint 264 .

microstegium Bryol, eur. 255, 297.

Mildeanum Jur. 25\%, 315 .

misandrum Hag. 255, 296.

Ivei Schimp. 249. 258.

var. angustifolium Broth. 259

murale L (Syn.) 152.

murmanicum Broth. 251. 280. mutilum Hag. 250, 261.

Il uhlenbeckii Bryol. eur. 256, 314. neodamense Itzigs. 254, 291.

var. ovatum Lindb. et Arn. 29?.

nigricans Kaur. 255. 295.

nitens Kindb. (Syn.) 235.

nudum Dicks. (Eyn.) 196.

nutan- schreb. (syn.) 235.

oblongum Lindb. 248, 309.

obtusifolium Lindb. 248, 274.

obtusum Dicks. (Syn.) 20 ?.

Oederi Gunn. (Sỵn.) 354 .

oelandicum Philib. (Syn.) 259. 
veneum Blỵtt (syn.) 268. opdalense Limpr. 249, 268 . orarium Bomans. 253, 288. ovatum Jur. (Syn.) 292. oxystegium Hag. (syn.) 263. pallens sw. $248,270$.

var. brevisetum Lindb. et Arn. (Syn.) 271. fallax Jur. 271. meeseoides Broth. 271. pallescens Schleich 254, 304 .

var. Baenitzii Hag. 305 . boreale Bryol. eur. 305 . contextum Bryol. eur. 305. cylindricum Hag. 305. pallidum Schreb. (Syn.) 32. paludosum L. (Syn.) 42. palustre Dicks. (Syn.) 50. patens Dicks. (Syn.) 178. pellueidum L. (Syn.) 78 . pendulum Schimp. 250, 261. var. compactum Schimp. 262. polare Hag. 255, 296. polymorphum Bryol. eur. (Syn.) 231. polyphyllum Dicks. (Syn.) 365 . pomiforme L. (૬yn.) $35 \mathrm{I}$. proliferum Sibth. (Syn,) 319. proprium Hag. 252, 281. pulchellum Hedw. (Syn.) 243. pulvinatum L. (Syn.) 175. punnilum Ryall 254, 304. purpurascens Bryol, eur. 249, 276. *B. autumnale Amann 276. *B. Lindgrenii Amann 277. *B. serotinum Amann 276. purpureum Philıb. 249, 271. pusillum Hedw. (Sỵn.) 146. pycnodermum Limpr. 249, 270. pyriforme L. (Syu.) 200. pyriforme Wegg. (Syn.) 224. quarnboense Bum. (Syn.) 292. retusum Hag. 253, 288. rhexodon Hag. 25I, 266. riparium Hag. 257, 31 f. Rosenbergiae Hag. 254, 305. rubellum Hoffm. (Syn.) $12 \pi$. rubens IItt. (Syn.) 313. rubrum Huds. (Syn.) 53. rufescens Dicks. (Syn.) 50. rugosum Hoffm. (Syn.) 104. rurale L. (Syn.) 156.

rutilans Brid. 248, 268. rutilans Schimp. (Syn.) 238. salinum Hag. 253, 287. sarekense Arn, et C. Jens. 255, 296. Sauteri Bryol. eur, 256, 311. saxatile Hag. (Syn.) $30 \mathrm{I}$. Schimperi C. Mïll. (Syn.) 238. Schleicheri Schwaegr. 249, 273. var. flaccifolium IJag. 273. scoparium L. (Syn.) 10I. serotinum Lindb. (Syn.) 276. setaceum Wulf. (Syn.) 42 sinuosum IIag. 256, 294. sphagnicola Bryol. eur. (Sỵn.) 237. spinosum Voit (Syn.) 327. spissum Hag. 256, 303. squarrosum L. (Syn.) 347. stenocarpum Linipr. (Syn.) 259 . stenodon Hag. 253, 289. stenolheca Bomans. (Syn.) 283. striatum L. (Sym.) 384. subrotundum Brid. 254, 303. var. clavatum Hag. 304. subrutilum Limpr. 257, 318. subtumidum Limpr. 253, 287. subulatum L. (Syn.) 153. sysphinctum Limpr. 255, 300. tardum Bomans. 255, 299. teres Lindb. 248, 303. tetragonum Dicks. (Syn.) 353. tomentosum Limpr. (Syn.) 263. tortuosum L. (Syn.) 123. trichodes L. (Syn.) 345 . trichopodium Hag. 252, 283. truncatulum L. (Syn.) 142. tumidum Bomans. (Syn.) 282. turbinatum Schwaegr. 248, 272. turgens Hag. 249, 273. uliginosum Bryol. eur. (Syn.) 267. umbratum Hag. 257, 319. undulatum L. (Syn.) 590. unguiculatum Huds. (Syn.) 134. vaginale Dicks. (Syn.) 52. warneum Bland. 250, 259. *B. oelandicum Amann 259. ventricosum Dicks. 254, 292. var. areticum Ryan 293. compactum Bryol. eur. 293. duvalioides Iizigs. 293. gracilescens Schimp. 293. montanum Bomans. 293. veronense De Not 248, 309 . versifolium Bomans. (Syn.) 270. Versisporum Bomans. 248, 272. verticillatum L. (Syn.) 120 . virens Sw. (Syn.) 84. viride Philib. 250, 264. viridissimum Dicks. (Syn.) 367 . viridulum L. (Sÿn.) 11\%. Zierii Dicks. (Syn.) 226. zonatiforme kindb. 268.

Buxbaumia Hall. 585 . aphylla L. 585 . var. viridis Moug. (Syn.) 586. foliosa Web. (Syn.) $58 \pi$. indusiata Brid. (Syn.) 586. sessilis Schmid. (Syn.) 587. viridis Brid. 586 .

Buxbaumiaceae 584.

Buxbaumiales 584 .

Buxbaumiinales 8, 584.

Cacodon Lindb. (Sect.) 230.

Caespitibryum Podp. (Gruppe) 295. Callierga trifaria C. Jens. (Syn.) 486 . Calliergon Kindb. 450, 485 . badium Kindt. (Syn.) 481 . cordifolium Kindb. 486,490 . var. angustifolium Broth. 491 . coloratum Broth. 491. lanato-caule Broth. 491. 
cuspidatun lïindb. (Syn.) 493. giganteum Kindb. 486, 492.

Richardsonii Kindb. 486,491 .

var. fluitans Broth. 492 . lanatum Broth. 492. robustum Broth. 492.

sarmentosum Kindb. $486,489$.

var. fallaciosum Broth. 489. fontinaloides Broth. 489. scorpioides Kindb. (Syn.) 485 . solitarium Broth. 486,490 . stramineum Kindb. 486, 487. var. nivale Broth. 488 . patens Broth. 489 . trifarium Kindb. 486,487 . turgescens kindb. 486 .

Calophylloidea Kindb. (Gruppe) 277.

Campiadelphus Brotlı. (Sect.) 449 .

Camptothecium Bryol. eur. 503, 505. Geheebii Kindb. 505, 506. lutescens Bryol. eur. 505, 506. var. fallax Breidl. 506 . nitens Srhimp. (Syn.) 505. trichoides Broth. 505 . var. involutum Limpr. 506.

Campylium Bryhn 459 . chrysophyllum Bryhn 460 . Halleri Lindb. 459. helodes Broth. 460, 462. hispidulum Lindb. 460 . var. Sommerfeltii Lindb. 461. stragulum Broth. 462 . polygamum Bryhn 460, 464. var. fallaciosum Mild. 465. protensum Kindb. 460,463 . stellatum Bryhn 460,463 .

Campylophyllum Broth. (Sect.) 449, 460.

Campylophyllum schimp. (Syn.) 460 .

Campylopodioideae 46, 55.

Campylopus Brid. 55, 60.

Campylopus sens. strict. Limpr. (Sect.) 63. albicans Kindb. (Syn.) 108. alpinus Schinp. (Syn.) 58. asperulus Kindb. (Syn.) 59. atrovirens De Not. 61, 64. brevifolius Schimp. (Syn.) 63 . brevipilus Bryol, eur. 62, 65. cirratus Brid. (Syn.) 74. densus Bryol. eur. (Syn.) 64. flexuosus Brid. 61, 64. var. micans Hag. 65 . fragilis Bryol. eur. 61, 63. var. densus Schinup. 64. Kaalaasii Hag. 62, 66. longifolius Kindb. (Syn.) 107 . micans Wulfsb. (Syn.) 65 . piriformis Brid. 62, 65. Sauteri Kindb. (Syn.) 108. Schimperi Mild. 61, 62. Schwarzii Schimp. 61, 63. var. albescens Limpr. 63. falcatus Breidl. 63 .

subulatus Schimp. 61, 62 . turfaceus Bryol. eur. (Syn.) 65. viridis Sull, et Lesq. (Syn.) 94 .
Catharinatea Ehrh. 588.

mnomala Bryhn (syn.) 591.

angustata Brid. 589.

Hausknechtii Broth. 589,591 .

hercynica Ehrlı. (Syn.) 592.

tenella Röh] 589, 590.

tschuctschica C. Müll. (srn.) 593.

undulata Wels. et Mohr 589, 590.

var. minor Web. et Mohr 531 . rivularis Bryhn 591.

Catoscopiaceae 12, 348.

Catoscopium Brid. 12, 348. nigritun Brid. 348 .

Ceratodon Brid. 26, 35 .

conicus Liudb. (Syn.) 35.

dimorphus Philil, (Syn.) 35.

purpureus Brid. 35.

var. flavisetus Limpr. 35. obtusifolius Limpr. 35. xanthopus sull. 35.

${ }^{*}$ C. conicus Broth. 35.

*r. dimorphus Broth. 35.

Ceratodontoideae 33

Chroodontium Amann (Sect.) 276.

Cinclidium Sw. 85, 336 .

areticum C. II ̈̈ll. 337. 338.

hymenophyllum Lindl, $337,338$.

stygium Sw. 337 .

subrotundum Lindb. 337. 338.

Cinclidotoideae $110,157$.

Cinclidotus Palis. 12, 157. minor Lindb. 158.

Cirriphyllopis Broth. (Unterg.) 522.

Cirriphyllum cirrosum Grout 524, 525.

crassinervium Loesk, et Fleisch. 524, 525.

filiforme Broth. 524 .

piliferum Grout 503, 524.

Vaucheri Loesk, et Fleisch. 524, 525.

velutinoides Loesk, et Fleisch. (Syn.) 524.

Climaciaceae 401.

Climacium Web, et Mohr 16, 401. dendroides Web. et Mtohr 402.

Cnetrum Hag. 70 . Schisti Hag. 70.

Conostomum Sw. 349, 353. boreale Sw. (Syn.) 353. tetragonum Lindb. 353.

Coscinodon Spreng. 165, 185. cribrosus Spruc. 186.

pilifer Brid. (Syn.) 145. pulvinatus Spreng. (Syn.) 186.

Crassidicranum Limpr. (Unterg.) 94.

Cratoneurum Roth 449,466 . commutatum Roth (Syn.) 466 . var. fa]catum Moenkem. 467 . decipiens Loesk. 466.470. falcatum Roth (Syn.) 467 . filicinum Roth 466, 468 . var. fallax Moenkem. 469. *C. curvicaule Broth. 470 . var, patulum Broth. 470 . glaucum Broth. 466 .

var. Irrigatum Moenkem. 468 . subsulcatum Broth. 468. sulcatum Broth. 467. 
irrigatum Roth 468 .

sulcatum Roth 467 .

var. subsulcatum Roth 468 .

Ctenidium Mitt. 560, 574 .

molluscum Mitt. 574 .

var, condensatum Braithw. 574 . procerum Bryhn 574 . sulpplumiferum Möll. (Syn.) 574.

I)rocerrimum Broth. 275.

Cylindrothecium concinnum Schimp. (Syn.) 544 .

Cynodontia alpestria Hag. (Sect.) 73.

polycarpa Hag. (Sect.) 75.

tenella Hag. (Sect.) 73 .

Cynodontiella Schisti Bryhn (Syn.) 70 .

Cynodontium Schimp. 70, 72.

alpestre Lindb. 72, 73.

Bruntoni Bryol. eur. 72, 73.

fallax Limpr. 72, 75 .

gracilescens Schimp. 72, 74.

hyperboreum Hag. 72, 75.

Limprichtianum Greb) (Syn.) 76.

polycarpum Schimp. 72, 77.

var. laevifolium Hag. (Syn.) 77.

laxirete Dix. 77.

Schisti Lindb. (Syn.) 70.

strumiferum De Not. 73, 77.

suecicum Hag. 73, 76 .

var. areticum Hag. 76.

Limprichtianum Hag. 76.

tenellum Limpr. 73, 74.

Wahlenbergii Hartm. (Syn.) 82.

virens Schimp. (Syn.) 84.

Cyrlodon Lindb. (Unterg.) 209.

Cyrtodon R. Br. (Syn.) 209.

Desmatodon Brid. 137, 1/46.

brevicaulis Brid. (Syn.) 147.

cernuus Bryol. eur. 147, 148.

latifolius Bryol. eur. 147.

var. muticus Brid. 147.

brevicaulis Schimp. 147.

Laureri Bryol, eur. 147, 148.

obliquus Bryol. eur, (Syn.) 148.

suberectus Limpr. 147, 1 tis.

systylius Bryol. eir. 147.

Dichelyrua Mfyr. 399.

capillaceum Schimp. 399, 401.

faleatum Myr. 399.

var. amblystegioides Möll. 401.

Dichelymoideae 399.

Dichodontium schimp. 70, 77.

flavescens Lindb. 78, 79.

pellucidum sehimp. 78.

var. compactum schinp. 79.

figimontanum schinp. 79.

Mildei Limpr. 79.

strictum Braithw. 79.

Dicrana elongata IIag. (Sect.) 95. scoparia Hag. (Sect.) 97.

Licrunacede 11,-45.

Dicranales 24 .

Dicranella Schimp. 55.

cerviculata Schimp, 55, 56.

var. pusilla Schimp. 57.

crispa Schimp. (Sym.) 52.

curvala Schimp. (Syn.) 56.
Grevilleana Schimp. (Syn.) 52. heteromalla Schimp. 55, 57.

var. interrupta Bryol eur. 57. sericea H. Müll. 57.

humilis Ruth. (Syn.) 50 .

lenta Wils. (Syn.) 51.

rufescens Schimp. (Syn.) 50.

Schreberi Schimp. (Syn.) 51.

var. elata Schimp. (Syn.) 51

secunda Lindl). 55.

var. curvata Hag. 56.

squarrosa Schimp. (Syn.) 50.

subulata Schimp. (Syn.) 55.

varia Scluimp. (Syn.) 53 .

Dicranodontium Bryol. eur. 55, 57.

aristatum Schimp. (Syn.) 59 .

asperulum Wils. $58,59$.

var. falcatum Mild. 59.

circinatum Schimp. 58, 59.

var. subfalcatum Limpr. (Syn.) 59.

denudalum Hag. 58.

var. alpinum Hag. 58 .

longirostre Bryol. eur. (Syn.) 58.

var. alpinum Mild. (Syn.) 59.

sericeum Schimp. (Syn.) 57 .

subfalcatum Loesk, et Osterw. 58, 59.

Dicranoideae 46, 70 .

Dicranoweisia Lindb. 70,80 .

cirrata Lindb. 80.

compacta Schimp. (Syn.) 82.

crispula Lindb. 80.81.

var. compacta Lindb. 82 .

Dicranum Hedw. 70, 92.

albicans Bryol. eur. (Syn.) 108.

alpestre Wiahlenb. Syn.) 73.

var. majus Wahlenb. (Syn.) 75.

ambiguum Hedw. (Syn.) 46 .

Anderssonii Wich. (Syn.) 86.

angustum Lindt. 93, 101.

asperulum Mitt. (Syn.) 59.

areticum Schimp. (Syn.) 89.

Bergeri Bland. 93, 104.

var. acutifolium Lindb. et Arn. (Syn.) 97.

Blyttii Schimp. (Syn.) 87.

Bonjeani De Not. 93, 103.

var. alatum Barn. 104.

anomalum C. Jens. 103.

integrifolium Lindb. fil. 103.

integrum Broth. (Syn.) 103.

juniperifolium Braithw. 103.

polycladum Bryol, eur. 103.

rugifolium Bosw. 104.

brevifolium Lindb. (Syn.) 98.

Bruntomi Sm. (Syn.) 73.

bullatum Sommerf. (Syn.) 145.

cerviculatum Hedw. (Syn.) 56.

circinatum Wils. (Syn.) 59 .

compactum Funck (Syn.) 83.

congestum Brid. (Syn.) 99.

var. flexicaule Bryol. eur. (Syn.) 99. subspadiceum Arn. et C. Jens. (Syn.) 100 contortun Wahtenb. (Syn.) 175.

crispum Ehrh. (Syn.) 52.

curvatum Hedw. (Syn.) 56.

densum Schleich. (Syn.) 64. 
denudatum Blid. (Syn.) 58. elatum Lindb). (Syn.) 105. ellipticum Turn. (Syn.) 188. elongatum Schleich. 93, 95. var. flagelliferum Th. Jens. 96. longifolium Th. Jens. 95. nitidun C. Jens. 96. robusium C. Jens. 96. Sphagni Th. Jens. 96 . enerve Thed. (Syn.) 108. falcatum Hedw. (syn.) 87. flagellare Hedw. (Syn.) 90. flavescens Turn. (Syn.) 79. flexicaule Brid. (Syn.) 99. fragilifolium Lindb. 93, 96. fulvellum Sm. (Syn.) 86 . var. nanum kern (Syn.) 86. fulvum Hook. 93, 94 . fuscescens Turn. 93, 98.

var. angustifolium Arn. et C. Jens. 99. congestum Husı. 99. flexicaule Wils. 99. falcifolium Braithw. 99. subspadiceum Brotl., 100. tortum Arn. et C. Jens. 99. glaciale Berggr. (Syn.) 89. gracilescens Web. et Mohr (Syn.) 74. var. tenellum Bryol, eur (Syn.) 74. Grevilleanum Bryol. eur. (Syn.) 52. groenlandicum Brid. 93, 96. var. jotunicum Kaur, el Hag. 96. hyperboreum C. Müßl. (Syn.) 75. intermedium Crome (Syn,) 104. juniperifolium Sendtu. (Syn.) 103. Jalifolium Hedw. (Syn.) 147. longifolium Ehrh. (Syn.) 107. majus Turn. 93, 100 .

var. capnodes Hag. 100. condensatum Hag. 100. spadiceun Hag. (Syn.) 100. microcarpum Schrad. (Syn.) 192. molle Wils. (Syn.) 89. montanum Hedw. (Syn.) 90. var. flaccidum Ryan et Hag. (Syn.) 90. pulvinatum Pfeff. (Syn.) 90.

Mühlenbeckii Bryol. eur. 93, 97. var. brevifoliun Lindl). 98. neglectum Jur. (Syn.) 100. ovale Hedw. (Syn.) 171. pellucidum var. fagimontanum Brid. (Syn.) 79 . polycarpon Ehrh. (Syn.) 76. pusillum Hedw. (Syn.) 57. recurvatuu Schultz (Syn.) 102. robustum Blytt 93, 105. var. alpinum Hag. 106. rugosum Brid. (Syn.) 104. Sauteri Schimp. (Syn.) 108. Schisti Lindb. (Syn.) 87. Schraderi Web. et Mohr (Syn.) 104. Schreberi Sw. (Syn.) 51. scoparium Iledw, 94, 101. var. alpestre Hüb. 102 . integrifolium Lindb, 102. laticuspis Loesk, et Bauer 102. paludosum schimp. 102. recurvilum Brid. 102. lurfosim Mild. 102.

Scottiannm Turn. 93, 94. secundum siw. (sym.) 55. Sendueri Limpr. 93, 97. squarrosum stark (şn.) 50. Starkei Web. et Mohr (syn.) 87. var. glaciale Zell. (Syı.) 87. inolle W'ils. (Syn.) 89. strictum schleicls. (Syn.) 92. strumiferum Ehrh. (Syı.) 77. subulatum Hedw. (Syn.) 55. tenuinerve Zett. (syn.) 96. lorquescens Bruch (SyH.) 74. undulatum Ehrh. 104. varinm Hedw. (Syı.) 53. virens lledw. (Syı.) 84. viride Lindl). 93, 94.

Didymodon lledw. 112, 126. alpigena Vent. 127, 128. aristatus Lindl). (Syu.) 59. caespitosus Milt. (Syn.) 68. cernuus sw. (Syn.) 267. cylindricus Bryol. eur. (syn.) 121 denudatus Lindb. (Syn.) 58. flexicaulis Schleich. (Syn.) 29. fragilis Drumin. (Syn.) 124 . glaucus Ryan (Syn.) 134. Heimii *D. Ryani Kindb. (Syn.) 145. homomallus IIedw. (Syn.) 28. longirostrum Stark (Syn.) 58. luridus Hornsch. 127, 128. rigidulus Hedw. (Syn.) 133. rubellus Bryol. eur. 127, 128. var. intermedius Limpr. $1: 8$. pallens Ryan 128.

ruber Jur. 127, 128.

rufus Lor. (Syn.) 133.

spadiceus Limpr. (Syn.) 132.

lophaceus Jur. 127, 129.

validus Limpr. (Syrl.) 134.

Didymodon sens. stricl. Limpr. (Unterg.) 128.

Diphysciaceae 586 .

Diphysciales 586 .

Diphyscium Ehrh. 587. foliosum Mohr (Syn.) 587. sessile Lindl). 587 .

Disceliaceae 11, 195.

Discelium Brid. 195. nudum Brid. 196.

Dissodon Froelichianus Grev. et 11.-Arn. (Syn.) 209. splachnoides (irev. et W--Alı. (Syn.) 209.

$D$ istichioideae 36 .

Disíichium Bryol. eur. 9, 26, 36. capillaceum Bryol. eur (syn.) 36. Hagenii Ryan 36, 37. inclinatum Bryol. eur. 36, 37. montanum Hag. 36. 3i.

Ditrichaceae 11, 26 .

Ditrichoideae ?6

Ditrichum Timm 26, 28 flexicaule Hamp. 28. 29. glaucescens Hamp. (Syn.) 33. homomallum Hamp. 28. var. zonatum Lindb. (syn.) 29. 
oblongum Kindb. (syn.) 28, 32 . pallidum Hamp. 28, 32. pusillum Timm (Syn.) 31. tenuifoliun Lindb. 28, 32. var. oblongum Hag. 33. tortile Lindb. 28. 31 .

var. pusillum Lindb. 31 . vaginans Hamp. 28, 29. var. zonatum Hag. 29. zonatum Limpr. (Syn.) 29.

Dolicotheca Lindh. (Sect.) 551.

Doliolidium C. Müll. (Gruppe) $3 \mathbf{1 0 .}$

Dorcadion affine Lindb. (Syn.) 381 .

Far. fastigiatum Lindb. (Syn.) 381. alpestre Lindb. (Syn.) 387. anomalum Lindb. (Syn.) 377 . var. saxatile Lindb. (Syn.) 378 . arcticum Lindb. (Syn.) 382. cupulatum Lindb. (Syn.) 379. diaphanum Lindb. (Syn.) 390 . elegans Lindb. (Syn.) 384. Killiasii Lindb. (Syn.) 384 . laevigatum Lindb. (Syn.) 383. Lyallii Lindb. (Syn.) 385. inicroblephare Lindb. (Syn. 383. obtusifolium Lindb. (Syn.) 391. pallens Lindb. (Syn.) 385. pulchellum Lindb. (Syn.) 390. pumilum Lindb. (Syn.) 388. rupestre Lindb. (Syn.) 376. var. Sturmii Lindb. (Syn.) 377. Sommerfeltii Lindb. (Syn.) 382. speciosum Lindb. (Syn.) 383. stramineum Lindb. (Syn.) 387. striatum Lindb. (Syn.) 384 . tenellum Lindb. (Syn.) 389. urnigerun Lindb. (Syn.) 380 .

Drepanocladus Loe:k. 482 .

Drepanocladus Roth 450 . aduncus Moenkem. $472,482$. var. polycarpus Warnst. 482. badius Roth 472, 481 .

capillifolius Warnst. (syr.) 284 . exannulatus Moenkem. (Syn.) 477. exannulatus Warnst. $472,477$. var. brachydictyus Moenken. 478. fo. orthophylla Iloenkem. 479. tundrae Yoenkem. 479. var. pinnatus Broth. $47 \pi$. fo. pratensis Moenkem. 478. subfo. submersa Moenkem. 478. fo. orthophylla Hoenkem. 478. procera lloenkem. 478.

*D. orthophyllus Warnst. (Syn.) 478.

*D. pseudorufescens Marnst. (Syn.) 478.

fluitans Warnst. 472, 479.

var. alpinus Warnst. (Syn.) 480 . amphibius Broth. 479. brachycarpus Warnst. (Syn.) 479.

fo. brachycarpa Broth. $4 \pi 3$. pseudostraminea Moenkem. 479. var. pseudostramineus Warnst (Syn.) 479.

*D. Berggrenii Broth. 480 .

intermedius Warnst. $471,476$.

lycopodioides Warnst. 471, 484. purpurascens Loesk. (Syn.) 477. revolrens Warnst. $471,476$.

Rotae Warnst. (Syn.) 478. scorpioides Marnst. (Syn.) 485 . sendtneri Warnst. $472,483$. fo. capillifolia Mnenkem. 484. gigantea Moenkem. 483. var. giganteus Warnst. (Syn.) 483 . fo. Wilsonii Moenkem, 483 . subfo. hamata Moenkem. 483. fo. vulgaris Moenkem. 483. serratus Warnst. (Syn.) 478. submersus Warnst. (Syn.) 480 . turgescens Broth. (Syn.) 486. uncinatus Warnst. 471, 472. var. abbreviatus Warnst. 473 . gracilescens Warnst. 474 . plumosus Warnst. 474 . plumulosus Marnst. 474 . subjulaceus Warnst, 472. fo. orthophylla Warnst. 473. vernicosus Warnst. 471, 474 . var. gigas Warnst. 476 . Iapponicus Broth. 475. major Warnst. 475 .

Dryptodon caespiticins Brid. (syn.) 170. Schultzii Brid. (Syn.) 177.

Encalypta Schreb. 10, 12, 159. affinis Hedw. fil, 159, 163. alpina Sm. 159. apophysata Bryol. germ. (Syn.) 163. brevicollis Bruch 159, 162. ciliata Hoffm. (Syn.) 161. commutata Bryol. germ. (Syn.) 159. conterta Lindb. 159, 164. extinctoria Sw. 159, 160. laciniata Lindb. 159, 161. leptodon Bruch (Syn.) 161. mutica Hag. 159. procera Brucli 159, 163. rhabdocarpa schwaegr. 159, 160. var, arctica Hag. 161. Jeptodon Limpr. 161. nuda Hag. 161. spathulata Hag. 161 . spathulata C. Mïll. (Syn.) 161. streptocarpa Hedw. (Syn.) 164. vulgaris Hoffm. (Syn.) 160.

Encalyptaceae 158.

Entodon C. Müll. 14, 540. 543. Montagnei C. Müll. (Syn.) 544. orthocarpus Lindb. 544. palatinus Lindb. (syn.) 543.

Entodontaceae 539 .

Entosthodon Schwaegr. (Syn.) 201.

Entosthodon Lindb. (Lnterg.) 201. ericetorum Bryol. eur. (Syn.) :02. fascicularis C. Müll. (Syı.) ?02.

Ephemeraceae 196.

Ephemerella recurvifolia schimp. (Syn.) 198.

Ephemerum Hamp. 9, 196. minutissimun Lindb. 197. serratum Hamp. 197. var. anglistifolium Bryol. eur. 197. medium Hag. 197. 
recurvifolium Boul. 9, 197, 198. sessile C. MÏ̈ll. 197.

stenophyllum Schint). (Syn.) 197.

Erythrocarpa Kindb. (Gruppe) 311

Erythrodontia Kindb. (Subsect.) 257.

Erythrophyllum Limpr. (Unterg.) 127.

Euamblystegium Brolh. (Unterg.) 454.

Euanomodon Limpr. (Unlerg.) 426.

Eubarbula Lindb. (Sect.) 130.

Eubrachythecium Loesk. (Unterg.) 513.

Eubryales 221.

Eubryinales 8 .

Eubryum Amann (Subsect.) 291.

Eubuxbaumia Lindb. (secl.) 585.

Eucalliergon Broth. (Sect.) 487.

Eucamptothecium Broth. (Secl.) 506.

Eucladium Bryol, eur. 112, 120. verticillatum Bryol, eur. 120.

Eucladodium Amann (Subsect.) 276.

Euctenidium Broth. (Unterg.) 574.

Eudicranum Mitt. (Unterg.) 95.

Euditrichum Lindb. (Unterg.) 28.

Eufissidens Mitt. (Unterg.) 18.

Eufunaria Lindh. (Unterg.) ?0?.

Eumnium Mitt. (Sect.) 327.

Euorthotrichum Limpr. (Secl.) 381.

Eupohlia Lindb. (Secl.) 231.

Euptychostomum Amann (Scet.) 257.

Eurhynchium Bryol. eur. 503, 506.

crassinervium Bryol. eur. (Syn.) 525.

distans Bryhn (Syn.) 528.

diversifolium Bryol. (Syn.) 531 .

hians Jaeg. et Sauerb. 527, 528.

piliferum Bryol. eur. (Syn.) 526.

praelongum Bryhn 527.

praelongum Bryol, eur. (Syn.) 528.

var. atrovirens Bryol. eur. (Syn.) 529.

Schleicheri Lor. 527, 529.

Stokesii Bryol, eur. (Syn.) 527.

striatulum Bryol. eur. 527, 531.

striatum Schimp. 527,531 .

strigosum Bryol. eur. 526, 529.

var. diversifolium $\mathrm{Mol}$. et Lor. 531. imbricatum Bryol. eur. (Syn.) 531. praecox Limpr. 530.

Vaucheri Bryol. eur. (syn.) 525.

velutinoides Bryol. eur. (Syn.) 524.

Euthuidium Lindb. (Unterg.) 438.

Fabroniaceae 537.

Fissidens Hedw. 17.

adiantoides Hedw. 17, 23.

Bambergeri Schimp. 17, 19.

Bloxami Nils. 17, 21 .

bryoides Hedw. 17, 18.

var. gymnandrus Ruth. $17,19$.

Hedwigii Limpr. (Syn.) 18. viridulus Broth. 17, 18 .

crassipes Wils. 17, 20.

cristatus Wils. 17, 23.

decipiens De Not. (Syn.) :3.

exilis Hedw. ex p. (Syn.) 21.

gymnandrus Bus. (Syn.) 19.

Haraldi Limpr. 17, 20.

incurvus Stark 17, 20.

Julianus Schimp. 17, 24.
Mildeanus Selimp. 17, 21. minululus stull. 17, 18.

osinundoides Lledw. 17, 21.

polyphyllus Wils, 17, 24.

sciuroides lledw. (šn.) 407.

taxifoliu: 110 dw. 17. 22.

viridulus Walıleub. (syn.) 18.

Fissidentaceue $9,16$.

Fissidentales 16.

Fontinalaceae 14.393.

Fontinalineae 393.

Fonlinalis. L. 393.

albicans Wel. (SYu.) 404. androgyna Ruth. $394,397$. antipyretica L. 393,394

var. alpestris Nild. 395. gracilis Schimp. 393, 395. livonica Moenkemı. 395. monlana 1I. Müll. 395. pseudosquamosa Card. 395. robusta Card. 395.

Bryhnii Limpr. 393, 396.

capillacea Dicks. (Syn.) 401 .

dalecarlica Schimp. 394, 397.

var. nicrophylla Linıpr. 398.

dichelymoides Lindb. 394, 399.

falcata Hedw. (Syn.) 399.

gothica Card. et Arn. 393, 396.

var. dimorphophylla Möll. 394, 397.

hypnoides Hartm. 394, 398.

var. Adlerzii Card. 399.

Juliana Say. (Syn.) 24.

Kindbergii Ren. cl Casd. 394, 396.

livonica ( $\mathrm{x}$. Roth et $\mathrm{r}$. Bock. (Syn.) 395.

microphylla schimp. (Syı.) 398.

minor L. (Syn.) 158.

pennata L. (Syn.) 410 .

seriata Lindb. 394, 398.

sparsifolia Limpr. $394,396$.

squaniosa L. $394,397$.

Fontinaloidede 393.

Funaria Schreb. I2, 199, 201.

calcarea Wablenb. 201, 202.

dentata Crome (syn.) 202.

fascicularis schimp. 201, 202.

hygrometrica Sibth. 201, 203.

var. nana C. Hartm. 203.

mediterranea Lindb. 201, 203.

obtusa Lindl. 201, 202.

var, Ahnfeltii Broth. 202.

Funariaceae 198.

Funariales 195.

Funariineae 195.

Gastrogrinmia schimp. (Lnterg.) 184.

Georgia Elırh. 219, 220.

Browniana C. Müll. (Syn.) :? 1 .

var, repanda Lindb. (Syil.) 221.

Inemosynum Ehrb. (syn.) 229.

pellucida Rabenh. 220 .

Georgiaceae 16, 219.

Globovaria Hag. (Sect.) 214.

Glyphomitrium Brid. 364. 366.

I) aviesii Brid. 366 .

polyphyllum IItt. (SyH.) 365. 
Grimmia Ehrh. 165.

affinis Hornsch. (Syn.) 172. affinis Lindb. (Syn.) 190. alpestris Schleich. 166, 169. var, mutica De Not. 170. stomata Loesk. 170. fo. sessitana Loesk. 170. fo. subsulcata Loesk. 170. acicularis C. Müll. (Sỵn.) 188 . alpicola Sw. 166, 180 . var. Iatifolia Hag. 181. rivularis Broth. 181. angusta Hag. 166, 181. anodon Bryoì. eur. 10, 166, 184 . anomala Hamp. 167, 179. apiculata Hornsch. 167, 172. a pocarpa Hedw. 166, 182. var. abrupticostata Hag. 183. alpicola Bryol. eur. (SYn.) 180. gracilis Web. et Johr 183. platyphylla Lindb. (Syn.) 181. rivularis Web. et Mohr (Syn.) 181. arenaria Hamp. (Syn.) 172. atrata Nielichh. 166, 185. atrofusca Schimp. 166, 182. caespiticia Jur. (Syn.) 170. calvescens Kindb. 167, 173. campestris Burch. 166, 169. commutata Hüb. 166, 169. compacta Schleich. (Syn.) 82. conferta Funck 166, 182. var. Bryhnii Hag. 182. tenera Hag. 182. contorta Schimp. (Syn.) 175. cribrosa Hedw. (Syn.) 186. decipiens Lindb. $167,177$. Doniana Sm. 166, 172. var. arenaria Loesk. 172. elatior Bruch 167, 177. var. asperula Limpr. 178. elongata Kaulf. 167, 171. fascicularis C. Müll. (Syn.) 192. flaccida Lindb. 166, 184. funalis Schimp. 167, 173. var. epilifera Zett. (Sỵn.) 173. gracilis Schleich. (Syn.) 183. Hagenii Kaur. (Syn.) 175. Hartmanit Schimp. 167, 178. heterosticha C. Müll. (Syn.) 189. hypnoides Lindb. (Syn.) 193. imberbis Kindb. (Syn.) 173. incurva Schwaegr. 167, 175. leucophaea Grev. (Syn.) 169. maritima Turn. 166, 183. var. pilifera Hag. 184. montana Bryol. eur. $166,170$. microcarpat Lindb. (Syn.) 191. microcarpa C. Müll. (syn.) 192. mollis Bryol. eur. 166. 174 . fo. aquatica Loesk. 174. Mühlenbeckii Schimp. 167, 174. norvegica Bryhn (syn.) 167. ovalis Lindb. 167, 171 var. affinis llag. 172 . cylindrica IJag. 172. heteracra Hag. 172. obliqua Hag. 172. obliqua Hornsch. (Syn.) 172. obtusa Lindb. (Syn.) 191. patens Bryol. eur. 167, 178. plagiopodia Hedw. 166, 185. pulvinata Sm. 167, 175 . ramulosa Lindb. (Syn.) 192. recurvata Hedw. (Syn.) 42. rivularis Brid. (Syn.) 181. Ryani Limpr. (Syn.) 173. Schultzii Hüb. (Syn.) 177. sessitana De Not. (Syn.) 170. sordida Par. 166, 181. spiralis Hook. et Tayl. (Syn.) 173. striata Schrad. (Syn.) 69. subsulcata Limpr. (Syn.) 170. tenera Zett. (Syn.) 182. torquata Hornsch. 167, 179. tortifolia *G. calvescens Kindb. (Syn.) 173. *G. Ryani Kindb. (Syn.) 173. trichophylla Grev, 167, 175. unicolor Hook, 166, 167.

Grimmiaceae 11, 165. Grimmiae funales Hag. (Sect.) 173. montanae Hag. (Sect.) 169. ovales Hag. (Sect.) 171. torquatae Hag. (Sect.) 179. trichophyllae Hag. (Sect.) 174.

Gümbelia Hamp. (Unterg.) 169. Gymnocybe Jur. (Unterg.) 340 . Gymnocybe Fr. (Syn.) 340 . palustris Fr. (Syn.) 340 . turgida Lindb. (Syn.) 341.

Gymnostomum Hedw, 10, 112, 117. aeruginosum Sm. 118. aestivum Hedw. (Syn.) 111. Ahnfeltii Fr. (Syn.) 202. calcareum Bryol. germ. 118. curvirostre Hedw. (Syn.) 119. Davallianum Sm. (Syn.) 141 . Donianum Sm. (Syn.) 40 . ericetorum Bals. et De Not. (Syn.) 202. Heimii Hedw. (Syn.) 144 . inberbe Sm. (Syn.) 405. intermedium Turn. (Syn.) 142. lapponicuin Hedw. (Syn.) 67. microstomum Hedw. (Syn.) 114. minutulum Schleich. (Syn.) 141. ovatum var. incanum Bryol. eur. (Syn.) 146. pyiforme Hedw. (Syn.) 200. rufescens Schultz (Syn.) 141 . rupestre Schleich. (Syn.) 118 . rutilans Hedw. (Syn.) 117. sphaericum Ludw. (Syn.) 199. spirale Hartm. (Syn.) 173. tenue schrad. (Syn.) 119. tetragonum Brid. (Syn.) 201. trichodes Web. fil. (Syn.) 38. truncatum Hedw. (Syn.) 142. Wimmerianum Sendtn. (Syn.) 117 .

Gyroweisia Schimp. 112, 118. tenuis schimp. 119. var. compacta Hag. 119. 
Habrodon Schimp. 538. perpusillus Lindb. 58.

Haematostoma Hag. (Gruppe) 285.

Haplocladium C. IÏll. 443, 448. microphyllums Brothr. 448.

Haplodon R. Br. 213. Wormskjoldii R. Br. 213.

Harpidium fluitans *H. Berggrenii C. Jens. (Syn.)

Hedwigia Ehrlı. 403. albicans Lindb. 404.

var. leucophaea Bryol. eur. 405. viridis Bryol, eur. 405. ciliata Ehrh. (Syn.) 404.

Hedwigiaceae 10, 403.

Hedwigidium Bryol. eur. 405. adiantoides L. (Syn.) 23 . imberbe Bryol, eur. 405.

Helicodontium Schwaegr. 13, 538. pulvinatum Lindb. 539.

Helicopogon Lindb. (Sect.) 134.

Helodium IVarnst. 434, 442. lanatum Broth. 442.

Heterocladium Bryol. eur. 434. dimorphum Bryol. eur. (Syn.) 434. var. compactum Mol. (Syn.) 436 . heteropterum Bryol. eur. 434, 436. var. flaccidum Bryol. eur. 436 . papillosum Lindb. 43 ' 436 . squarrosulum Lindb. 434. var. compactum Limpr. 436. Wulfsbergii $\mathrm{Hag}$. 434, 436 .

Heterophyllium Kindb. 560, 572. Haldanianum Kindb. 562.

Homalia Bryol. eur. $410,414$. trichomanoides Bryol. eur. 415. var. Jamesii Holz. 416.

Homalotheciun Bryol. eur. 503. fallax Plitib. (Syn.) 506. sericeum Bryol. eur. 503.

Homomallium Loesk. $450,458$. incurvatum Loesk. 459.

Hookeria Sm. 13, 421 . acuminata Schleich. (Syn.) 208. lucens Sm. 421. splachnoides schleich. (Syn.) 208.

Hookeriaceae 420 .

Hookeriales 420 .

Hydrogrimmia Hag. (Unterg.) 174.

Hygroamblystegium Loesk. 449, 465 . fluviatile Loesk. 465. irriguum Loesk. 465, 466 .

Hygrohypnum Lindb. $450,493$. alpestre Broth. (Syn.) 500 . alpinum Loesk. 494, 501. cochlearifolium Broth. 494,500 . ditatatum Loesk. 494, 502. eugyrium Broth. 494, 496. molle Loesk. 494, 501. var. Schimperianun Amann 501. montanum Broth. 494, 495. ochraceum Loesk. 495, 496. var. complanatum Amann 497.

filiforme Amann 497. flaccidum Amann 497. simplicinerve Brotl. 497.

uncinatum Amann 497.

palustre Loesk. 494, 495.

var. laxum Amann 495.

subsphaericaryum Amanu 495.

polare Broth. 495, 498 .

var. fatcatum Broth. 498.

rivulare Broth. $\$ 94,500$.

Smithii Broth. $493,499$.

viridulum Broth. 493, 499.

IIylocomiaceae 16, 575 .

Hyloenmium Bryol. eur. 576, 581

brevirostre Bryol. elur. 582, 583.

calvescens Lindlo. (Syn.) $58 \mathrm{t}$.

fimbriatum Bryol. eur. (Syn.) 584.

loreum Bryol. eur. 579.

Oakesii Schimp. (Syn.) 584.

proliferum Lindb. 581, 582.

pyrenaicum Lindb. 582. 583.

rugosum ne Not. (Syn.) 576.

Schreberi Willd. (Syn.) 577.

splendens Bryol, eur. (Syn.) 582.

squarrosum Bryol. eur. 580.

var. calvescens Hobk. 581.

triquetrum Bryol. eur. (Syn.) 579.

Immbratum Bryol. eur. 581, 583.

Hynenostomum R. Br. 10, 112, 113. crispatum Bryol. germ. (Syn.) 115. microstomum R. Br. 114. rostellatum Schimp. 111, 114. squarrosum Bryot. germ. 114.

Hymenostylium Brid. 10, 112, 119. commutatum itt. (syil.) 119. curvirostre Lindb. 119.

var. commutatum Hag. 119. scabrum Lindb. 119.

Hyocomium Bryo1. eur. 560, 575. flagellare Bryol. eur. 575.

Hypnaceae 15, 559.

Hypnobryales 15, 422.

Hypnum H. Calliergon Limpr. (Sect.) 487. Pseudo-Calliergon Limpr. (Sect.) 486.

Hypnum Fleisch. 560, 562. abietinum L. (Syn.) 441 . aduncum L (Syn.) 472. aduncum Hedw. (Syn.) 48?. var. giganteum Bryol. eur. (SYn.) 483. hamatum Bryol. eur. (Syn.) 483. polycarpum Bryol. eur. (Syn.) 482. albicans Neck. (Syn.) 510. var. groenlandicum C. Jens. (syn.) 510. Thedenii Hartm. (Syn.) 510. algirianum Brid. (Sỵn.) 533 . 3lopecurum L. (Syn.) 417 . alpestre Sw. (Syn.) 500. a」pinum Schimp. (syn.) 501. apiculatum Thed. (sin.) 42'. areticum Sommerf. (s.n.) 499. arcuatum Lindb. 563, 571 . atrovirens Sw. (Syn.) 529. attenuatum schreb. (syn.) 4:7. badium Hartm. (syn.) 481 . Bambergeri schimp. 563, 566 . Far. condensatum Limpr. 567. Berggrenii Hag. (Syn.) 480 . 
Blandowii Web, et Mohr (Srll.) 442. brevirostrum Ehrh. (Syn.) 583. bryoides L. (Syn.) 18. callichroum Bryol. eur. 563, 570. calvescens Wits. (Syn.) 581. campestre Bruch (Syn.) 513. canescens var. ericoides Wel). (Syn.) 194. capillifolium Warnst.(Syn.) 484. canescens var. ericoides Web. (syn.) 194. capillifolium Warnst. (Gyn.) 484 . catenulatum schwaegr. (Syn.) 429. chryseum Schwaegr. (syn.) 542. chrysocomum Dicks. (syn.) 356. clirysophỵllum Brid. (Sỵn.) 462. cirrosum Schwaegr. (Syn.) 525. collinum schleich. (Syn.) 521. comnutalum Hedw. (Sy̆n.) 466. rar. fluctuans Bryol. eur. (Syn.) 468. compactum C. Müll. (Syn.) 533. complanatun L. (Syn.) 413. concinnum De Not. (Syn.) 544. confertum Dicks. (Syn.) 535. cordifolium Hedw. (Syn.) 490. var. angustifoljum Schimp. (Syn.) 490. lanato-caule Bryhn (Syn.) 491. crasinerve Taỵl. (syn.) 525. crispum L. (Syn.) 412 . crista castrensis L. (Syn.) 573 cupressiforme L 563, 567. var. elatum Bryol. eur. (Srn.) 565. ericetorum Bryol. eur. (Syn.) 569 filiforıne Brid. 569. lacunosum Brid. 568. longirostre Bryol. eur. 568. mamillatum Bryol, eur. (Syn.) 569. subjulaceım .10]. 568 .

*H. ericetorum Loesk. 569.

*H. lacunosurn Loesk. (SYn.) 568.

${ }^{*}$ H. mamillatum Broth. 569.

${ }^{*} \mathrm{H}$. resupinatum Broth. 569 . curtipendulum L. (Syn.) 406 . curtum Lindb. (Syn.) 518. curvatum Sw. (Syn.) 418. curvicaule Jur. (Syn.) 470. var. patulum Hag. (Syn.) \$7i. curvisetum Brid. (Ș̣n.) 53'. cuspidatum L. (șn.) 493 delicatulum L. (Syn.) 439. demissum IVils. (syn.) 559. dendroides L. (.yn.) 402 . denticulatum L. (syn.) 556. var. laetum Lindb. (Syn.) $55 \pi$ var. laetum Lindi). (SYn.) 557. obtusifolium 'Turn. (Syn.) 557 succulentum Wils. (Syn.) 556 depresium Bruch (syn.) 550. dilatatuu schimp. (syn.) 502 dimorphum Brid. (syn.) 434. distans Lindb. (Syu.) 528. diversifolium Schleich. (Syn.) 531. Donianum sin. (syu.) $55 \pi$. elegan: Hook. (Syn.) 547 . erythorrhizon C. Mäll. (Syn.) 509. eugyriun sihimp. (Sỵn.) $\$ 96$. exannulatuns Güınl. (syn.) 477. ral, orthophyllum Mild. (Syn.) 478. purpurascens Mild. (Syn.) 477. serratum Mild. (Syn.) 4i8.

falcatum Brid. (Syn.) 467 .

fallaciosum Jur. (Syn.) 465 .

fallax Brid. (Syn.) 469.

fastigiatum Hartm. 562, 565.

var. mitodes Hag. 565.

filamentosum Dicks. (Syn.) 445 .

filicinum L. (Srn.) 468.

filiforme Lam. (Syn.) 524.

filiforme Timm (Syn.) 544.

fimbriatum Hartm. (Syn.) 583.

flagellare Dicks. (Syn.) 575.

flexuo-um Berggr. (syn.) $56 \pi$.

fluitans L. (Syn.) 479.

rar. alpinum Schimp. (Sỹn.) 480 . amphibium San. (Syn.) 479. brachycarpum Lindb. fil. (Syn.) 479. elatum Ren. et Arn. (Syn.) 480. exannulatum Ren. (Syr.) 477. falcatum Bryol. eur. (Syn.) 480. procerum Ren. et Arn. (Sỵn.) 478. purpurascens Schimp. (Syn.) $47 \pi$. submersum Schimp. (Sỵn.) 480 .

fluviatile Sw. (Syn.) 465.

fontinaloides Lam. (Syn.) 411. glganteum Schimp. (Syn.) 492. glaciale C. Hartm.

var, dorrense Möll. (Syn.) 51 . glareosum Bruch (Syn.) 511. glaucum Lam. (Syn.) 466. Goulardi Schimp. (Syn.) 500. gracile Bruch et Schimp. (Syn.) 448. gracile L. (Syn.) 409.

Haldanianum Grev. (Syn.) 573.

Halleri Sw. (Syn.) 460.

hamifolium Schimp. "Syn.) 483.

hamulosum Bryol. eur. 563, 570. belodes spruc. (Syn.) 462 .

herjedalicum Hartın. (Syn.) 525. heteropterum spruc. (Sуn.) 436 . hians Hedw. (Syn.) 528. hispidulum Brid. (Syn.) 460 . imponens Hedw. 562, 567 . incurratum Schrad. (Syn.) 459 . intermedium Lindb. (syn.) 476. irrigatum Zett. (Syn.) 468 . irriguum Wils. (Syn.) 466 . lanatum Stroem (Syn.) 442. latebricola Lindb. (SYn.) 552. latifolium Lindb. (Syn.) 516. Lindbergii Mitt. (Sỵn.) 571. longifolium Schultz (Syn.) 458 . loreun L. (syn.) 579.

lucens L. (syn.) 421.

lutescens Huds. (Syn.) 506. lycopodioides Schwaegr. (Syn.) 484 . var. lapponicum Norrl. (Syn.) 475. megapolitanum Bland. (Syn.) 535. microphyllum Sw. (Syn.) 448 . Mitdeanum Schimp. (Sym.) 512. minutulun Hedw. (Syı.) 438. mitodes Ilag. (Sỵn.) 565. molle ricks. (Syn.) 501 . 
molluseum Hcdw. (syu.) 57 .

var. condensatum schimp. (sł̣n.) 57 4. subplumiferum Limur. (syn.) $5 \%$ í.

moniliforme var. apiculatun summerf. (syn.)

Montagnei IIartm. (Syn.) 541.

montanum Wils. (syn.) 495.

murale Neck. (syn.) 536.

mutabile Brid. (syn.) 44\%.

myosuroides L. (syn.) 4:0.

myurum Poll. (Syn.) 418.

nitens schrel. (syn.) 505.

nitidulum Wahlell). (Syn.) 549.

nivale Lor. (Syn.) 488.

norvegicum Schinp. (Ayn.) 499.

Novae Angliae sull. (syn.) 5.32.

Oakexii Sull. (syn.) 583.

oblusatum Wahlenb. (syn.) 557 .

whraceum Turn. (syn.) 496.

var. complanatum Mild. (Syn.) 49:

filiforme Limpr. (syn.) 497.

flaceidum Mild. (syn.) 497.

uncinatum Mild. (syn.) 197.

orthocarpum La Pyl. (syn.) 5\%.

jalatinum Neck. (Syn.) 543.

pallescens Bryol. eur. (syn.) 505 .

pillescens Palis. 562, 563.

var. subjulaceum schiınp. j6í.

*H. protuberans Broth. 565 .

flabustre Huds. (syn.) 495.

var. laxum Bryol. eur. (syn.) 495.

subsphaericarpon Bryol. eur. (syn.) 4?\$.

parietinum L. (Syn.) $57 \%$.

perichaetiale Bryol. eur. (syn.) 5 hi.

piliferum schrel. (Syn.) 526.

plicatum schleich. (syn.) 44s.

plumosum sw. (Syn.) 522.

plumosum Huds. (Syn.) 512.

*H. turgidum Lindb. (syn.) 51 ?.

polare Lindb. (Syn.) 498.

var. falcatum Bryhn (syn.) 499.

pulycarpon Bland. (Syn.) $4 \times 2$.

polygamum Wils. (Syn.) 464.

populeum Hedw. (Syn.) 522.

praecox Hedw. (Syn.) 530.

praelongum L. (syn.) 527.

praelongum var. atroviren- Brid. (Ș̣n.) 524.

pratense Foch 563,572 .

procerrimum Hol. (Syn.) 575.

proliferum L. (syn.) 582 .

protensum Brid. (Syn.) 463 .

pseudoplumosum Brid. (Syn.) 522.

pseudostramineum C. Müll. (Syn.) 179.

pulchellum Dicks. (Syn.) 548.

purpurascens Limpr. (Syn.) $47 \%$.

var. Rotae Limpr. (Syn.) 478.

purum L. (syn.) 523.

pyrenaicum spruc. (Syn.) 583.

radicale Palis. (Șn.) 456 .

radicosum Mitt. (Syn.) 446.

recognitum Hedw. (Syn.) 438.

recurvatum Limpr. 56?, 566 .

reflexum Stark (Syn.) 519.

repens Poll. (Syn.) 551.

reptile Rich. (syn.) 563. resupinatum ilis. (syn.) :sf?.

revilutun lindb. $56,2,570$.

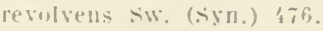

Richardsonii Lesq. et James (Syn.) 491.

var. fluitaus Bryhu (syn.) 491.

lanatum Bryln (syn.) 492.

riparium L. (iyn.) 458 .

rivulare Bruch (syn.) 515.

var. longifolium Möll. (syn.) 515.

rivulare sw. (syn.) 500.

lavespanum Hamp. (syn.) 555.

rufecens Dicks. (syn.) 542.

lugelii ( . Mull. (sym.) 426 .

rugosıl Ehrh. (syu.) 5รf.

ruscifolium Nerk. (Syn.) 536.

rusciforme Neck. (ș̣n.) 53ri.

var. complauatum Tolf (syu.) 537.

lacustre Möll. (syn.) 53\%.

rutalulum L. (syn.) 513.

salebrosum Hoffm. (Syn.) 512.

sarmentosum Wahlenb. (syn.) $48 \%$.

var. (allaciosun Mild. (syn.) 489.

fontinaloides Berggr. (syn.) $4 \times 9$.

Satuteri Bryol, eur. jof. 5 fi6.

scabridum Lindh. (syn.) 532.

$\therefore$ hleicheri Hedw. fil. (syn.) 5?9.

schreberi Willd. (syn.) 57.

schimperianum Lur. (syn.) 501.

schultzei Limpr. (syn.) 4811.

sciuruides L. (syn.) 40\%.

scorfioides L. (syn.) 485.

sendtneri schimp. (syn.) $4 \times 3$.

var. Wilsıni schimp. (syn.) 483. rulgare san. (Syn.) 4\$3.

sericeum 1. (syn.) 503.

serpens L. (syn.) 454 .

silesiacum selig. (syn.) 551.

silvaticum l1uds. (Syn.) 555.

solitarium Hag. (syn.) 490.

sommerfeltii Myr. (Syn.) 461 .

splendens Hedw. (Syn.) 382.

squarrosulum Voit (Syn.) 434.

-quarrosum L. (sฐn.) 580.

Starkei Brid. (Syn.) 519.

var. complanatum Yooll. (sỵn.) jl!?.

stellatum Schreb. (syn.) \{63.

stukesii Turn. (Syn.) 527.

stramineum Dicks. (Syn.) 487.

striatulum spruc. (Syn.) 531.

striatum Schreb. (Syn.) 531.

strigosum Holfm. (Syn.) 529.

var. disersifolium Lindb. (Syn.) 531.

praecox Wahlenb. (Syn.) 530.

subpinnatum Lindb. (Syn.) 581 .

subplumiferum hindt. (syn.) 574.

subsphaericarpon schleich. (Ayn.) 495.

succulentum Wils. (syn.) 556 .

sub-ulcatum schimp. (syn.) 468 .

sulcatum schimp. (Syn.) $46 \pi$.

var. subsulcatum Schimp. (syn.) 4 fis.

Swartzii Turn. (Syn.) 528.

tamariscifolium Neck. (Syn.) 440.

tilmariscinum Hedw. (syn.) \&io.

taxifolium L. (Sזn.) 22.

Teezdalei sm. (Fyn.) 534 . 
tenellum Dicks. (Syn.) 533. tenuisetum Lindb. (Syn.) 456. trachypodium Funck (Syn.) 521. trich oide: Neck. (Syn.) 505. trichomanoides L. (Syn.) 415. trichopodium Schultz (Sỹu.) 456 . trifirizm Web. el Muhr (Syn.) 4xi. triquetrum L. (Syn.) 579. tromsos̈use Kaur. et Arn. (Syn.) 5?0. tundrae Joerg. (Syn.) 479. turfaceum Lindb. (syn.) 550 . targescens Th. Jells. (Syu.) 486. turgidum Hartut. (syn.) 512. umbratum Ehrl. (Syn.) 583. uncinatum Hedw. (Syn.) 472. var, abbreviatum Bryol. eur. (Syn.) 4i3. gracilescens Bryol eur. (syn.) 474. plumosuin Schimp. (Syn.) 474 . plumulosum Bryol. eur. (Syn.) '47'. subjulaceum Bryol. eur. (Syn.) 472.

*H. orthothecioides Lindb. (Syn.) 472. undulatum L. (syn.) 558. Vaucheri Leiq. 563, 56\%. Vaucheri Schimp. (Syn.) 525. velutinoide: Bruch (Syn.) 524. velutinum L. (Syn.) 520 . vernicosum Lindb. (Syn.) 474 . Wilsoni Schimp. (Syn.) 483. var. hamatum Rell. (syn.) 483. viride Lam. (Syll. )522. viridulum Hartm. (Syn.) 499. viticulosum L. (Syn.) 427. viviparum Jeck. (Syn.) 418.

Inclinatiformia Broth. (Gruppe) 278. Isobryales 364 .

Isopterygium Mitt. 546, 547 . depressum Mitt. 547, 550. elegans Lindb. $54 \pi$. var. nanum Iöll. $54 \mathrm{~S}$. Iïllerianum Lindb. $5 \$ 7$. nitidum Lindb. (Sỵn.) 549. var. pulchellum Lindb. (Syn.) 548 pulchellum Broth. 5:7, $5 \%$. var. nitidulum Broth. 549. repens Lindb. 547. 551 . silesiacum Warnst. (Syn.) 551. turfaceum Lindh. 547, 550 .

Isothecium Brid. 15, 418 . apiculatum Hïb. (Syn.) 42't. myosuroides Brid. $418,420$. var. tenuinerve Kindb. (Syn.) 419. myurum Brid. (Syn.) 418. tenuinerve Kindb. $418,419$. viviparum Lindh. 418.

var. robustum Bryol. eur. 419.

Julacea Broth. (Sect.) 521.

Kiaeria Hag. $70,86$.

Blyttii Broth. 87.

var. laxiretis Broth. 88. obtusula Brotlı. 88 . riparia Brotlı. 88.

faleata Hag. 86,87 .

glacialis IIag. 87.

Starkei Irag. 87.

var. Blyllii Hag. (Ayu.) 88 . glacialis Hag. 87 .

laxiretis Hag. (Syn.) 88 . obtusula Hag. (Syn.) 88 .

Lamprophyllum Lindb. (Sect.) 235.

Leersia affinis Lindb. (Syn.) 163. alpina Lindl). (Syn.) 159. brevicollis Lindb. (Syn.) 162. ciliata Hedw. (Syn.) 161. extinctoria Leyss. (Syn.) 160. laciniata Hedw, (Syn.) 161. lanceolata Hedw. (Syn.) 144 . procera Lindh. (Syn.) 163. rhabdocarpa Lindb. (Syn.) 160. var, arctica Lindb. (SyH.) 161. gymnostoma Lindb. et Arn. (Syn.) 161. leptodon Lindb. (Syn.) 161 . spathulata Lindb. (Syn.) 161 . vulgaris Hedw. (syn.) 160 .

Lembophyllaceae 418

Lepidophyllae Card. (Secl.) 397.

Leptobryum Wils. 224. pyriforme Wils. 224.

Leptodictyum Schimp. (Unterg.) 456 .

I.eptodontium Hamp. 112, 126. norvegicum Kaal. 126.

Lescuraea Bryol. eur. 443, 444. Breidleri Arn. et C. Jens. (Syn.) 447. mutabilis Lindb. 444. var. saxicola Hag. 444. striata Bryol. eur. (Syu.) 444. var. saxicola Bryol. eur. (Syn.) 444.

Leskea Hedw. 432. catenulata Mitt. (Syn.) 429 . chrysea Hartm. (Syn.) 542 . curvata Vois (Syn.) 418. intricala Hartm. (Syn.) 540. lapponica Lindb. (Syn.) 542. latebricola Wils." (Syn.) 552. nerrosa Myr. (Syn.) 430. var. laxifolia Lindb. (Syn.) 432. rupestris Hartm. (Syn.) 432. nitidula Wahlenb. (Syn.) 549. pallescens Hedw. (Syn.) 563 . paludosa Hedw. (Syn.) 433. papillosa Lindb. (Syn.) 436 . patens Lindb. (Syn.) 445 . pilifera Sw. (Syn.) 553. polycarpa Ehrh. 433. var. paludosa Schimp. 433. pulvinata Wahlenb. (Syn.) 539. rufescens Schwaegr. (Syn.) 542. rupestris Berggr. (Syn.) 432. Sinithii sw. (Syn.) 499. Sprucei Bruch (Syn.) 452. striatella Brid. (Syn.) 554 subrufa Wils. (Syn.) 540. subtilis Iledw. (Syn.) 451 . tectorum Lindb. (Syn.) 432. varia Hedw. (Syn.) 456 .

Leskeaceae 13, 422.

Leskeella Loesh. 430 . nervosa Loesk. 430. var. laxifolia Hag. 432 . rupestris Möll. 43?. tectorum Hag. 432. 
Leskeineac 122.

Leskeoideae 422, 429.

Lesquereuxia filamentosa Lindb. (syn.) 445 . patens Linob. (syn.) 445. plicata Lindb. (Syn.) 448.

Leucobryaceae 11, 108.

Leucobryineae 108.

Leucobryum Hamp. 109. glaucum schinp. 109.

Lelleodon Schwalegr. 14. 406. morensis Schwaegr. (Syn.) 408. sciuroides sichwategr. 407. var. morensis De Nont. 408.

Leucodontaceae 405 .

Leucodont intae 403.

Leucodontium Amann (Sect.) 267.

Limnobium coehlearifolium Vent (Syn.) 500 . engyrium Bryol. eur. (Syn.) 496. norvegieum Bryol. eur. (Syn.) 499.

Limprichtia Loesk. (Syì.) 474.

Limprichtia Broth. (sect.) 474.

Litoneurum Hag. (Unterg.) 167.

Malacophyllą Card. (Sect.) 398.

Heesea Hedw. 13, 343, 344.

angustilolia Brid. (syn.) 3/7.

demissa Hopp. el Horusch. (Syn.) 2206 .

longiseta Hedw. 34t.

minor Brid. (Syn.) 347 .

trichodes spruc. 344.345.

var, angustilolia Hag. 347. minor Hag. 347.

triquetra Aongstr. 344,345 .

tristicha Bryol. eur. (Syn.) 345.

uliginosa Hedw. (Syn.) 345.

Meeseaceae 342.

Hetzlerella Hag. 55, 60. alpina Hag. 60.

Metzleria Schimp. (Syn.) 60.

Nicrobryum Floerkeanum Sehimp. (Syn.) 139.

Mielichhoferia Hornsch. 12, 222.

elongata Hornsch. 222, 224.

creeta Kindb. (Syn.) 230.

nitida Hornsch. 222, 223.

Miel ichhoferioideae 222.

Mildea Warnst. (Syn.) I't.

Mildeella Limpr. (Syn.) 141. bryoides Limpr. (Syn.) 141.

Mildeella Broth. (Unterg.) 9, 137, 141.

Mniaceae 13, 320.

Iniobryum Limpr. 244. albicans Limpr. 245.

var. glaciale Limpr. 246.

atropurpureum Hag. 245, 246.

carneum Limpr. 245, 246.

rexans Limpr. 245, 247.

Mnium L. 321.

affine Bland. 322,330 .

var, eiliare C. IÏ̈ll. 33 I.

integrifolium Limpr. 331.

androgynum L. (Syn.) 340 .

areticum Bryol, eur. (syn.) 338.

arcuatum Dieks. (Syn.) 356 .

Blyttii Bryol. eur. 322. 325.

capillaceum L. (Syn.) 36 .

ciliare Lindb. (Sin.) 331. cinclidioides II üb. 323,336 .

cirratum L. (Syn.) 86 .

erudum L. (Syn.) 234.

curvatulum Limpr. 322, 330.

cuspidatum Leyss. 322, 329.

eyclophyllum schwaegr. (Syı.) 275.

Drummondii Brurh et sichimp. 322, 324.

fontanum L. (Syn.) 359 .

hornum L, 322, 323 .

liygronietricum L. (syn.) 203.

hymenoplıylloides Ifül. $323,333$.

hymenophyllum 13ryol. eur. (syu.) $33 x$.

inclinatum Lindb. $322,325$.

intermedium Ludw. (Syn.) 297.

lanatum Pitis. (Syn.) 310.

Iycopodioides Schwaegr, 322, 326 .

marginatun palis. 322,326 .

medium Bryol, eur. 322, 330.

orthorrhynchum Brid. $322,325$.

osmundaceum Dicks. (Syn.) 218.

palustre L. (Syn.) 340.

pcllucidum L. (Syil.) 220.

pseudopun etatum Bruch et Schimp. (syn.) 323 , 334.

(1.eudotriquetrum Schwaegr. (Syn.) 29\%.

punctatum Hedw. 323, 3.35.

var. elatum schimp. 336.

furpureum L. (Sÿ.) 35.

pyriforme L. (syn.) 224.

riparium Mitt. 322, 326.

roseum Weis (syn.) 319

rostratum schrad. $322,328$.

rugicun Laur. $322,332$.

Seligeri Jud. 322,331 .

serpyllifolium L.

a punclatum L. (syn.) 335.

3 cuspidatum L. (syn.) 323.

$\gamma$ proliferum L. (Syn.) 319.

b) undulatum L. (Syn.) 328.

serratum Schrad. (Syn.) 326 .

spinosum Seliwaegr. 322, 327.

stellare Reich. 322, 333.

subglobosum Bryol. eur. (Syn.) 334.

triquetrum L. (Syn.) 345.

turbinatum Hedw. (Syn.) 272.

turgidum Wahlenb. (Syn.) 34 .

Mollia aeruginosa Lindb. (Syn.) 118.

brachydontia Lindb. (Syn.) 122.

calearea Lindb. (Syn.) Ils.

crispula Lindb. (Syn.) 121.

flavovirens Lindb. (Syn.) 124.

fragilis Lindb. (Syn.) 124.

inclinata Lindb. (Syn.) 123.

litoralis Braithw. (syn.) 122.

microstoma Lindb. (Syn.) 114.

rostellata Lindb. (Sy1).) 114.

rutilans Lindb. (sin.) 117.

squarrosa Lindb. (Sin.) 114.

tenuirostris Lindb. (Syn.) 121.

tenuis Lindb. (syn.) 119.

tortuosa sehrank (syn.) 123.

verticillata Lindb. (syn.) 1:0.

Wimmeri Lindb. (syn.) 117.

viridula Lindb. (Syn.) 117.

var. gymnostomoides Lindb. (syn.) 115. 
Myrinia pulvinata Schimp. (Syn.) 539.

Iuyrella Bryol. eur. 423.

apiculata Bryol. eur. (Syn.) 424.

julacea Bryol. eur. 423.

var. gracilis Kindb. 424.

scabrifolia Lindb. 424 .

tenerrima Lindb. 424.

Myurimm (?) herjedalicum Schimp. (Sym.) 525.

Neckeril Hedw, 410 .

Besseri Jur. 410, 113.

var. rotundifolia Mol. 413 .

complanata Hüb. 410, 413.

var. longifolia Schimp. 4 14.

secunda Grav. 414.

tenella schimp. 414 .

crispa Hedw. $410,412$.

var. falcata Boul. 413.

decipiens Web. el Mohr (Syn.) 545.

fontinaloides Lindb. $410,411$.

fo. olivacea Ilag. 412.

fo. pallescens Hag. 412 .

var. Philippeana Lindb. 412.

oligocarpa Bruch 410, 411 .

penuata Hedw. 410.

var. tenera C. Müll. 411.

pumila Hedw. (Syn.) 411.

rotundifolia IIartm. (syn.) 413 .

trichomanoides Harlm. (Syn.) 415 .

Necheraceae 409.

Neckerineae 409.

Neckeroideae 14, 409, 410.

Octodiceras Brid. (Syn.) 24.

Julianum Mont. (Sỵn.) 24.

Octodiceras Mitt. (Lnterg.) 2't.

Oedipodiaceae 10, 204 .

Oedipodium Schwaegr. 205.

Griffithianum Sehwaegr. 205.

Oligotrichum Lam. et De Cand. 588, 591.

glabratum Lindb. (syn.) 593 .

hercynicum Lam. et De Cand. (Syn.) 592.

incurvum Lindb. 592.

var. ambiguum Bryhn 59:

brevifolium Hag, 6i:2.

molle Nym. 59:.

Omalia Bezseri Lob. (Syn.) 413.

Jamesii Schimp. (syn.) 416 .

Oncophorus Brid. 70, 82.

alpeitris Lindb. (Syn.) 73.

brevipe: Lindl). (syn.) 70 .

Bruntoni Lindb. (Gyn.) 73.

cirratus Lindb. (Syn.) 74 .

erispatus Lindb. (syn.) 69.

fallax Möll. (Syn.) 75 .

gracilescens Lindb. (Syn.) 74.

Hambergii C. Jens. et Arn. (Syn.) 87.

nigricans kindb. (Syn.) 74 .

obtusatus Lindb. (syn.) 73.

polycarpus Brid. (Sym.) 76.

Schisti Lindb. (syn.) 70.

striatus Lindb. (syn.) 69.

suecicus Arn. et C. Jens. (Šn.) 76.

torquescens Arn. et C. Jens. (sym.) 74.

Wahlenbergii l3rid. 82.

var. compactus Bryol. eur. 83.

elongatus Hag. 83. gracilis Arn, et C. Jens. 84. minor Hag. 84.

virens Brid. 84.

var. gracilis Broth. (Syn.) 84.

serratus Bryol. eur. 84.

Oreoweisia De Not. 70, 80. serrulata De Not. 80.

Oreas Mielichhoferi Brid. (Syn.) 223. var. compacta Lindb. (Syn.) 224.

Orthodicranum Loesk. $70,89$.

flagellare Loesk. 90.

montanum Loesk. 89, 90.

var. flaccidum Broth. 90. pulvinatum Broth. 90.

strictum Culm. 89, 92.

Orthopus brevifolius Wulfsh. (Syn.) 63.

Orthopyxis Jur. (Unterg.) 339.

Orthothecium Bryol, eur. 540. chryseum Bryol. eur. 540, 542. var. lapponicum Lindb. 542. intricatum Bryol. eur. 540. lapponicum Hartm. (Syn.) 542. rubellum Kindb. (Syn.) 541. rufescens Bryol, eur. 540, 542. strictun Lor. $540,541$.

Orthotricha affinia Hag. (Sulısect.) 381 . aretica Vent. (Subsect.) 382. cupulata Hag. (Subsect.) 377. pulchella Hag. (Subsect.) 390 . rupestria Hag. (Subsect.) 376. speciosa Hag. (Subsect.) 383 . straininea Hag. (Subsect.) 385. striata Hag. (Subsect.) 384.

Orthotrichineae 364 .

Orthotrichoideae 12, 369.

Orthotrichum Hedw. 37t.

abbreviatum Grönv. 375, 379. affine Schrad. 375,381 . alpestre Hornsch. 375, 387 . americanum Palis (Syn.) 369 . anomalum Hedw. 374, $37 \%$. var. montanum Vent. 378. areticum Schimp. (Syn.) 382. Arnellii Grönv. $376,386$. Blyttii Schimp. $375,382$. var, areticum Hag. 382. Sominerfeltii Hag. 382 . boreale Grönv. (Syn.) 386. Braunii Bryol. 376, 389. brevinerve Lindb. (Syn.) 383 . Bruchii Wils. (Syn.) 372. crispulum Bryol. eur. (Syn.) 373. crispum Hedw. (Syn.) 373. cupulatum Hoffm. 375,379 . var. luridum Hag. (Syn.) 379. curvifolium Wahlenb. (Syn.) 371. diaplranum Schrad. 376, 390 . Drummondii Hook. et Grev. (Syı.) 372. elegans Schwaegr. (Syn.) 384. fastigiatum Bruclı. 375, 381. gevaliense Grönv. (Syn.) 386 . groenlandicum Berggr. 375, 382. gymnostomum Bruch. (Syn.) 392. Hutchinsiac Sin. (Syn.) 369. jutlandieum Brid. (Syn.) 374 . 
Killiasii C. IÏll, 375,384 .

var. macrobleghare Lindb. 384 .

transitoria $\mathrm{Hag} .384$.

laevigatum Zett. 375, 383 .

leiocarpum Bryol. eltr. (Syn.) 384.

leucomitrium Bryol, eur. 376, 390.

Limprichtii Hag. 375, 379.

Ludwigii Brid. (Syı.) 370.

Lyellii Hook, el Tayl. 375, 385.

macrollephare Schimp. (Syn.) 384.

microblephare Schimp. 375, 383.

microcarpum De Not. 376, 385.

mitigatum Hag. $375,383$.

nudum Dicks. 374, 380.

var. norvegicum Hag. 380.

obscurum Grönv. (Syn.) 385.

obtusifolium Schrad. (Syn.) 391.

pallens Bruch $376,385$.

var. cuspidatum (rönv. (syn.) 386.

pallidum Grönv. $376,386$.

patens Bruch. 376, 388.

paradoxum Grönv. 376, 386 .

perioratum Limpr. (Syn.) 379.

Philibertii Vent. $376,387$.

pulchellum Brunt. $376,390$.

pumilum Sw. 376,388 .

Pylaisii *microbleplare Kindb. (syı.) 383.

Rogeri Brid. 375, 389.

rupestre Schleich. $374,376$.

var. Sturmii Jur. 377 .

Sardagnanum Vent. $375,379$.

seanicum Grönv. (Syu.) $39 n$.

Schimperi Flamm. 376, 388.

Sommerfeltii Schimp. (Syn.) 382.

speciosum Nees $375,383$.

var. elegans Broth. 384.

*O. fuscum Lindb. (Syn.) 384.

stranineum Hornsch. $376,387$.

var. defluens Vent. 388.

striatum Schwaegr. 375, 38'.

Sturmii IIornsch. (Syn.) 377.

subrepens Sommerf. (Syn.) 372.

tenellum Bruch $376,389$.

urnigerum IIyr. 375, 380 .

Venturii De Not. 375, 381.

Oxystegus Lindh. (Unterg.) 121.

Paludella Ehrh. 13, 342.

squarrosa Brid. 342.

Paraleucobryoideae 46, 106.

Paraleucoliryum Loesk. 11, 106. enerve Loesk. 107, 108.

longilolium Lnesk. 107.

var. ditrichiforme Broth. 108. strictiforme Broth. $10 \mathrm{~s}$.

Sauteri Loesk. 107, 108.

Phascum Schreb. 9, 136, $\mathrm{t38}$. acaulon L. $\{39$.

*Ph. papillosum Lindb. 139.

alternifolium Dicks. (Syn.) 25. axillare Dicks. (Syn.) 46 .

bryoides Dicks. (Syn.) 141.

crispum Hedw. (Syn.) 1 t3.

curvicollum Ehrh. 139, 140.

cuspidatum Schreb. (Syn.) 139.

var. papillosum Hartm. (Syn.) 139. piliferum Honk. et Tayl. (svu,) 139.

Floerkeanum Weh. el Mohr 138, 13?.

inulicum selureb. (syn.) 137.

nitidum Hedw. (syn.) 48 .

paluslre Bruch et selump. (syn.) 27.

palens Hedw. (syn.) 199.

peduneulatum Huds. (Sym.) 21'.

piliferum Sclıreb. 139.

recurvifolium Dick:. (Syn.) 198

rostellalum Brid. (syn.) 114.

serratum schreb. (syn.) 197.

sessile Bruch el schimp. (syn.) 197.

suhulatum Huds. (syn.) 197.

Plitonotis Bridl. 350.356.

aneeps Bryhn (Sym.) 35 ?

Arnellii Huds. (Syn.) 357.

borealis Linpr. (Syn.) 359

caespitosa Wils. 357,358 .

calcarea schimp. 357360 .

var. mollis Vent. 361.

capillaris Lindb. 357

Iontana Brid. 357, 359.

var. eapillaris Lindl. (Syn.) 357 .

media Bryhn. (Syn.) 357.

mollis Vent. 361.

seriata Lindb. 357,360 .

tomentella Mol. 357,359 .

Physcomitrella Bryol. eur. ?, 198, ] 90. patens Bryol. eur. 199.

Physcomitrium Bruch et Sehimp, 10, 199. pyrifnrme Brid. 199, 200. sphaericum Brid. 199, 200.

Plagiobryum Lindb. 12, 226. demissum Lindh. 226.

Zierii Lindh 226 .

Plagiopus Brid. 349. 354.

Oederi Limpr. 35'.

var. condensalus Limjir. 355.

Plagiotheciaceae 15, 546.

Plagiothecium Bryol. eur. 546, 552. curvifulium Schliephl. 552, 557. demissum Dix. (Syn.) 559.

denticulatum Bryol. eur. 552, 556.

var. Donianum Lindb. 557.

oblusatum Hartm. (Syn.) 557

*Pl. laetum Amann 557.

depressum Dix. (Sỵu.) 550 .

elegans var. nanum Walth. (Syn.) 548 .

laetum Bryol. eur. (Syn.) 557.

lalehricola Bryol. eur. 552.

var. gemmascens Ryan el Hag. 553.

II ühlenbeckii Bryol. enr. (Syı.) 554.

Müllerianum schimp. (Syn.) 547.

nanum Jur. (Syn.) 548 .

nitidulnm Bryol. eur. (Syn.) 549.

var. pulchellum rindh. (Syn.) 548 .

nilidum Lindh. (Syn.) 549.

var. suberectum Lindb. (Syn.) 548 .

piliferum Bryol. eur. 552, 553.

pulchellum Bryol. eur. (Syn.) 548.

repens Lindh. (Syn.) 551.

Roeseanum Bryol. eur. 552, 555.

var. gracile Breidl. 555.

Ruthei Limpr, 552, 557.

var. rupincola Limpr. 558. 
Seligeri Lindb. (Syn.) 551 .

silvaticum Bryol. eur. 552, 555.

var, orthocladium Schimp. (Syn.) 555.

striatellum Lindb. 552, 554.

succulentum Lindb. 552, 556.

turfaceum Lindb. (Syn.) 550.

undulatum Bryol. eur. 552, 558.

Platygrimm Bryol. eur. 14, 543. repens Bryol. eur. 543.

Pleuridium Brid. 8, 26, 28. alternifolium Rabenh. 27. nitidum Rabenh. 48. subulatum Rabenh. 27, 28.

Pleurochaete Lindb. 112, 125. squarrosa Lindb. 126.

Pleuroweisioideae 110.

Pleurozium litt. 576, 577.

Schreberi Mitt. 577.

var. secundum Broth. 578 .

Pleurozygodon aestivus Lindb. (Sỵn.) 111.

Pogonatum Palis. 588, 594. aloides var. minimum Limpr. (Syn.) 596. alpinum Röhl (Syn.) 598. capillare Brid. 594, 596. dentatum var. minus Hag. (Syn.) 596. Jongidens Aongstr. (Syn.) 596. mnioides Hag. (Syn.) 596. nanum Mïll. 594, 595. var. minimum Möll. 596. nanum Palis. (Syn.) 594. var. longisetum liamp. 595. polytrichoides Brockm. 594. var. longisetum IIöll. 595. suhrotundum Lindb. (Syn.) 594. urnigerum Palis. 594, 597. var. humile Brid. 597. var. subintegrifolium Moll. 597.

Pohlia Lindb. 228. acuminata Hopp. et Fornsch. 229, 231. affinis Hopp. et Hornsch. (Syn.) 231. albicans Lindb. (Syn.) 245 .

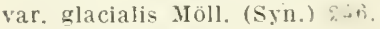
annotina Lindb. 230,212 . atropurpurea Lindb. fil. (syu.) 246. brichycarpa Hopp. et Hornsch. (Syn.) 231. bulbifera Warnst. 230. 242. carinata IIöll. 2 20. carnea Lindb. (Syr.) 246 cominutata Lindb. 230, 239. var. fllum H. Wint. 239. crassidens Lindb. 229, 232. cruda Lindb. 229. 234.

var. alpina 11 öll. 235. minor Möll. 235. seriata Arn. et C. Jens. 235.

cucullatil Bruch 229, 230 . var. contracta Persi. 238. elongata Hedw. 229, 23:. erecta Lindb. 229,230 . gracilis Lindb. $230,240$. var. torrentium Arn. et C. Jells, 240. grandiflora Lindb. fil. 230, 241. inclinata Sw. (Syn.) 28 . longicollis Lindb, 229, 233 . Ludwigii Broth. 230, 238. var. latifolia II. Wint. 239. lulescens Möll. 229, 244. nutaus Lindb. 229. 235 . var. angustirete H. Wint. 236 . bicolor Bomans, et Broth. 236. caespitosa Broth. 235. longiseta Bomans, et Broth. 236. pseudocucullata yöll. 236 . sphagnetorum Möll. 236. strangulata Möll. 236. turbinata Nöll. 237. polymorpha Hopp. et Hornsch. 229, 231.

proligera Lindb. $230,24 \mathrm{t}$. pulchella Lindb. $230,243$. purpurascens R. Br. (Syn.) 276. rubella IIoll. 244.

rutilans Lindb. 229, ?38.

sphagnicola Lindb. et Arn. 229, 237.

uliginosa Bruch (Syn.) 267.

Weigelii Lindb. (Syn.) 238.

vexans Lindb. fil. (Syn.) 247 .

Polla (Sect.) 323.

Polyodon Schimp. (Sect.) 586.

Polytrichaceae 587.

Polytrichales 587.

Polylrichinales 587.

Polytricha alpina $\mathrm{Hag}$. (Secl.) 598. communia Hag. (Sect.) 602. juniperina Hag. (Sect.) 605 . sexangularia $\mathrm{Hag}$. (Sect.) 605 .

Polytrichum Dill.; L. 588, 597. aloides Hedw. (Syn.) 596. alpestre Hopp. (Syn.) 606 . alpinum L. 598.

var, arcticum Wahlenb. (Syn.) 600. campanulatum Aongstr. 600. silvatium Lindb. 600. sinplex Schimp. 600. voraginum Moll. 600 .

*P. brevifolium kindb. (syn.) 600 . arcticum Sw. (Syn.) 600 . attenuatum Menz. 598, 601 . var. brachycaule Moll. 602. pallidicetum itöll. 60? superbum Lindb. 602 . foreale kindh. (Syn.) 607. brevifolium R. Br. (Syn.) 601 . campanulatum Hornseh. (Syn.) 60u. capillare Michx. (Syn.) 596. cavifolium Wils. (Sỵ.) 593. commune L. 598, 604.

var. Jumile Sw. (Syn.) 604. minus Weis 60 '. nigrezcens Warnst. (syn.) 6 t 3 . perigoniale Bryol. eur. 605. uliginosun Hüb. 60' .

*P. cubicum Lindb. (Syn.) 604. var. integrifolium Lindb. (Syıl.) 603. decipiens Limpr. 598, 602.

Dicksoni Turn. (Syn.) 596. formosum Hedw. (Syn.) 601 . fragilifolium Lindb. fil. (Syn.) 603. glabratum Wahlenb. (Syn.) 593. gracile Itenz. 598, 601. 
var. anomalum Mag. $60 \mathrm{I}$. aqualicum Bryhn 601.

*P. anomalum Limpr. (Syn.) 601.

Hoppei Horusch. (Syn.) 607.

hyperboreum R. Br. 598, 607.

Jensenii IIagr. 598, 603.

juniperinum Willd. 598, 605.

var. alpinum Schimp. 606.

*P. strictum Lindb. (Syn.) 606.

Jaevigatun Wahlenb. (Syn.) 593.

minimum Crome (Syn.) 596.

mnioides Neck. (Syn.) 595.

nanum Schreb. (Syn.) 59!.

nanum Weis (Syn.) 595.

var. Dicksoni Lindb). (Syn.) 596.

perigoniale Michx. (Syn.) 605 .

piliferum Sehreb. 598, 607.

var. fastigiatum Pir. 607.

Hoppei Ral. 607.

pilosum Neck. (Syn.) 607.

var. fastigiatum Lindb. (Syn.) 607.

Hoppei Yöll. (Syn.) 607.

septentrunale Sw. (Syn.) 600 .

sexangulare Flörk. 597, 605.

silvalicum Menz. (Syn.) 600 .

subrotundum Huds. (Syn.) 594.

var. longisetum Lindb. (Syn.) 595.

strictum Banks 598, 606.

var. alpestre Rab. 606 .

superbum Schultz (Syu) 60r.

Swartzii Hartm. 598, 602 .

var, nigrescens Hag. 603.

undulatum var. minus Hedw. (Syn.) 591.

urnigerum L. (Syn.) 597.

var. humile Wahlenb. (Sỵn. 597.

subintegrifolium Arn. el C. Jens. (syn.) 597.

Wahjenbergii Kindb. (Syn.) 596.

Porotrichum alopecurum Mitl. (Syn.) 417.

Pottia sens, strict. Broth. (Unterg.) 137, 141.

Pottia Ehrh. 10, 140.

bryoides llitt. 140, 141.

cavifolia Ehrh. (Syn.) 146.

vas. incana Bryol. eur. (Syn.) 146.

commutata Limpr. 141, 14\%.

curvirostris Ehrh. (Syll.) 119.

Davalliana Broth. 140, 141.

Heimii Bryol. eur. 140, 144.

var. arclica Lindb. (Syn.) 145. obtusifolia Hag. 145 .

intermedia Fürnr. 141, 142.

lanceolata C. Miill. I41, 144.

latifolia C. Müll. (Syil.) 145 .

var. pilifera C, Mïll. (Syn.) 1/45.

minutula Bryol. eur. (Syn.) 141.

pilifera Lindb. (Syn.) 145 .

var. mutica Lindb. (Syn.) 145.

rufescens Warnst. (Syn.) 141.

Ryani Philib. (Syn.) 145.

Starkeana C. Müll. (Syn.) 141.

Starkei var. gymnostomoides Lindb. (Syn.) 141 .

truncata Bruch (Syn.) 142.

Pottiaceae 110.

Polt iales 110.

Pottioideae $110,136$.
Psendoanoundon Limpr. (Inierg.) \$27.

Psemdncalliereon Brolt. (Sect.) 48 fi.

Pseudocaunglopus Limpr. (Sect.) fi2.

Pscudo-l)repanocladus Broth. (Srect.) 481.

Pseudeplemerum llate. $\mathbf{1 8}$.

axillate Ifag. 48.

Pseudoephemerum Lindb. (Interg.) (Sya.) 48.

Pseudoleskea Bryul. eur. 443, 144.

alrovirens Bryol. eur. (Syn.) 445.

Breidleri Kindb. 445, 147 .

decipiens Kindb. 445, 447.

denudata var. Holzingeri Bost (Syn.) 4f7.

filanentosa Lindl). 145 .

hyperborea Kindb. 445, 448.

jemtlandica Kindh. (Syn.) 447 .

patens Limpr. 445.

plicata Kindl. $445,448$.

radiensa Kindb. el Mac. 445, 446.

var. Ilolzingeri Hag. 447. jemulandica Hag. 447.

'seudnlesheaceae 443 .

Pseudoleskeella (Kindb.) Hag. 429. catenulata Kindb. 429.

Pseudostereodon Broth. (Unterg.) 575.

Pieudotriquetra Amann (Gruple) 291.

Psilopilum Brid. 588, 592.

arelicun Brid. (syn.) 593.

cavifolium llag. 593 .

var. anonalum Hag. 593.

laevigatum Lind\}. 593.

fo. nana Ilag. 593.

var. a]oma Hag. 593.

tschuetschicum C. Müll. (Syn.) 593.

Pterigynandrum catemulatum Brid. (Stn.) 429. helcroplerum Brid. (Syn.) 545.

repens Brid. (Syn.) 543.

tenerrimum Brid. (Syn.) 424 .

Plerogonium Sw. 14, 408.

gracile Sw. (Syn.) 409.

heternpterun Bruch (Sฐ̣n.) 436 .

Iongifolium schleich. (Syn.) 428 .

ornithopodioides Lindb. 409.

nervosum schwaegr. (Sym.) $\$ 30$

perpusillam De Not. (Syn. ) 538 .

striatum Schwaegr. (Syn.) 444 .

tectorum A. Br. (syn.) 432.

Pterogynandrum algirianum Brid. (Syu.) 533.

Plerygoneurum .Iur. 10, 137, 1:5.

cavifolium var, incanum Jur. (syn.) 146.

pusillum Broth. 1:6.

var. incinum Broth. 146.

['teryguhyl]um lucens Brid. (Syn.) 4:1.

Pterygynandrum Hedw. 14 540.544.

deripiens Lindt. (Syn.) 545 .

var, cochlearifolium Arı. ef C. Jens, (syn.) 546 .

*P. filiforme Lindl., (Syn.) 544 .

liliforne Hedw, 544 .

var. cochlearifolium Möl. 546. decipiens Limpr. 545.

filescens Boul. 546 . heteropterum Bryol. eur. (syn.) 545 .

Pliliuu De Not. 560. 573.

crisla-calstrensis De Not. 573 .

Plyohodum decipiens Limpr. (Sym.) $44 \pi$. hyperborem C. Müll. (syn.) 448. 
oligocladum Limpr. (Syn.) 447.

Pfundtneri Limpr. (Syn.) 446 .

Ptychomitriaceae 364.

Ptychomitrium Fürnr. 12, 364, 365. polyphyllum Fürnr. 365.

Ptychostomum Amaun (Cnterg.) 257.

Ptychostonum Iínrnsch. (Syn.) 257. compactum Hornsch. (Syn.) 262. pendulum Hornsch. (Syn.) 261.

Purpurascentia Broth. (fruppe) 276.

Pylaisia Schinm. 560 .

Pyramidula Brid. 10, 198, 200. tetragona Brid. 201.

Reflexa Limpr. (Sect.) 518.

Rhabdogrimmia Limpr. (Unterg.) 174.

Rhabdoweisia Bryol. ellr. 66, 69.

crispata Kindl. 69.

denticulata Bryol. eur. (Syn.) 69.

fugax Bryol. eur. (Syrl.) 69.

striata Kindb. 69.

Rhabdoweisioideae 45, 66 .

Rhacomitrium Brid. 165, $18 \%$. aciculare Brid. $187,188$.

*Rh. affine Amann 190. alopecurum Brid. (Syn.) 190. aquaticum Lindb. (Syn.) $18 \%$. asperulum Geh. (Syn.) 178. canescens Brid. 188, 193. var. ericoides Bryol. eur. 194. ellipticum Bryol. eur. 187, 189. fasciculare Brid. 187, 192. heterostichum Brid. 188, 189. var. alopecurum Hüb. (Syn.) 190. obtusum Loesk. 187, 191. hypnoides Lindb. 188, 193. lanuginosum Brid. (Syn.) 193. microcarpum Brid. (Syn.) 192. obtusum Brid. (Syn.).191. patens Hüb. (syn.) 178 . protensum 1. Braun 187, 189. sudeticum Bryol, eur. 187, 191. var. validius Jur. 192. ramułosum Hag. 188. 192. var. terrestre $\mathrm{Hag}$. 192.

Rhaphidostegium demissum Bryol. eur. (Syn.) 559.

Rhizomnium Mitt. (Sect.) 322.

Rhodobryum Limpr. 319. roseum Limpr. 31 .

Rhynchostegiella Limpr. 503, 533. algiriana Broth. 533 .

compacta Loesk. 533

curviseta Limpr. 533, 53 '́.

Teesdalei Limpr. 533, 534.

Rhynchostegium Bryol. eur. 503, 535. confertum Bryol. eur. 535. demissum Bryol. eur. (Syil.) 55!). depressum Bryol. enr. (Syı.) 550 . megapolitanum Bryol. eır. 535. murale Bryol. enr. 535, 536. var. arcticulı IIag. 536 . rusciforme Bryol, eur. 535, 536. var. complanatum H. Schultz, 537. lacustre Mos. 537. tenellum Bryol. eur. (Syı.) 533. Rhytidiadelphus Warnst. 576, 579. calvescens Broth. 579, 581 .

loreus Warnst. 579.

squarrosus Warnst. 579, 580 . triquetrus Warnst. 579.

Rhytidium Kindb. 15, 576. rugosum Kindb. 576.

Rutabula Limpr. (Sect.) 513.

Saelania Lindb. 26, 33. caesia Lindb. 33.

Salebrosium Loesk. (Unterg.) 500.

Sanionia Broth. (Sect.) 472.

Sanionia Loesk. (Syn.) 472.

Schistidium Brid. (Syn.) 180.

Sclristidium Schimp. (Unterg.) 180. angustum Hag. (Syn.) 191. apocarpum Bryol. eur. (Syn.) 18?. var. abrupticostatum Bryhn (Syn.) 183. rivulare Bryol. eur. (Syn.) 181. Brylnii Hag. (Syn.) 182. confertum Bryol. eur. (Syn.) 182. var. obtusifolium Brylin (Syn.) 182. latifolium Zett. (Syn.) 181. maritimum Bryol, eur. (Syn.) 183. sordidum Hag. (Syn.) 181.

Schistostega Mohr 218. osmundacea Mohr 218.

schistostegaceae 9. 218.

Sichistostegiales 218.

Schistophyllum adiantoides N. (Syn.) 23 . Bloxami Lindb. (Syn.) 21. decipiens Lindb. (Syn.) 23. exile Lindl). (Syn.) 21. Haraldi Lindb. (Syn.) 20. incurvum Lindb. (Syn.) 20 .

*Sch. virjdulum Lindb. (Syn.) 18. Juliaum Lindh. (Syn.) $: 4$. minutulum Lindb. (Syn.) 18. osmundoides Lindh. (Syu.) 21. pusillum Lindb. (Syn.) 18. taxifolium La Pyl. (Syn.) 2?.

seleropodium Bryol. eur. 503, 523. purum Limpr. 523.

scorpidium Limpr. 450, 484. scorpioides Limpr. 485.

Scytalina Hag. flagellaris Hag. (Syn.) 90. montana Hag. (Syri.) 90. var. pulvinata Hag. (Syn.) 90.

Seligera Bryol. eur. 38, 40. acutifolia Lindb. (Syn.) 41 . aretica liaur. (Sym.) 43. lirevifolia Lindb. $40,41$. calcarea Bryol. eur. 40, 41. crassinervis Lindb. (syn.) $\mathbf{1}$. diversifolia Lindb. 40, 42 . var. brevifolia Lindt. et Arn. 4:. fo. obliquula Hag. 43. Domiana C. Müll. 10, 40 . var. pygmaea Hag. 41. erecta I'hilib. (Syn.) 43. obliquula Lindb. (Syn.) 43. paludosa Hag. (Syn.) 42. var. brevifolia Hag. (Syn.) 43 . patula Hag. (Syn.) 43. var. tristichoides Hag. (Syn.) 43. 
polaris Berggr. 40, 43.

pusilla Bryol. eur. 40, 41.

var. acutifolia schimp. 41. brevifolia Lindb. (Syn.) /1. recurvata Bryol. eur. (Syn.) 42 . var. Lrevifolia Zett. (Syıl.) 42 . pumila Hartn. (syn.) 4?

setacea Lindb. 40, 42.

var. pumila Lindb. 42 .

trifaria var. patulat Lindb. (Syn.) 43.

tristichoides Kindb. 40, 43

var. patula Broth. 43.

Seligeracede 11, 38.

Sematophyllaceae 558 .

Sematophyllum Mill. 559. demissum Nitt. 559.

Sekra ininor Lindb. (Syn.) 158.

sphaerangium muticum sclimu. (syn.) 137.

Serridium (Sect.) 21.

Sphaerocephalus palustris Lindb. (Syn.) 340 . var. imbricatus Möll. (Syn.) 341.

turgidus Lindb. (syn.) 341.

Splachnaceae 12, 205.

Splachnineae 204.

splachnoideae 204 .

Splachnuın I. $206,213$.

ampullaceum ん. 214, 215.

angustatum Sw. (sym.) 210 .

Brewerianum Hedw. (Syn.) 212.

bryoides Zoeg. (syn.) 211.

flagellare Brid. (Syn.) 208.

Froelichiaumu Hedw. (Syn.) 209.

lingulatum Dicks. (Sỵ.) 209.

luteum Mont. 214, 216.

var, nelanocaulon Wahlenb. (Syn.) 216.

melanocaulon schwaegr. 214, 216.

mnioides Sw. (Syu.) 211.

paradoxum R. Br. (Syn.) 212.

pedunculatum Lindb. 214.

rubrum Mont. 214, 217.

serratum Hedw. (Syn.) 207.

sphaericum sw. (Syn.) 214.

tenue Dicks. (Syn.) 206.

vasculosum L. 214, 217.

Wormskjoldii Hornem. (Syn.) ₹13.

Sporledera Hamp. 26.

palustris Hamp. 27.

Stegonia Vent. 137, 145.

latifolia Vent. 145.

var. pilifera Broth. 145 .

Stenophyllae (Sect.) 399.

Stereodon alpicola Lindb. (Syn.) 453.

arcuatus Lindb. (Syn.) 571.

Bambergeri Lindh. (Syn.) 566 .

var. flexuosus Lindb. (Syn.) 567.

callichrous Brid. (Syn.) 570 .

chryseus Mitt. (Syn.) 542 .

confervoides Lindb. (Syn.) 452.

crista-castrensis Mitt. (Syn.) 573.

cupressiformis Brid. (Syn.) 567.

var. elatus Braithw. (Syn.) 568 . longirostris Braithw. (Syn.) 568. mamillatus Braithw. (Syn.) 569. subjulaceus Arn. et. C. Jens. (Syı.) 568. *s. mamillatus Lindl). (Syn.) 569. fastigialus Brid. (SyII.) 565 .

IIaldanii Lindl). (Syn.) 573.

Lamulosus J,indls. (syı.) 570.

imponens Brid. (Syu.) 567.

incurvatus Milt. (syn.) 459 .

litpunicus Lindb. (Syu.) 54?

pallescens Lindb. (syn.) 5 fi3.

val. perichatialis Lindls. (Sym.) 5riq. joluberans Lindb. (syas.) 565.5.

protuberans Brid. (syul.) 565.

recurratus Lindl), ef Arn. (Syu.) sfits,

revolutus Nitt. (Syu.) 570.

Richarolonii Mill. (Syı.) \$91.

rubellu; Mil.t. (syn.) 541.

rufescens Mitl. (syn.) 542 .

subrufus Jindl. (syn.) 541.

Vaucheri linab. (Syn.) 567.

Strelololrichum Limpr. (sect.) 135.

streptocolea Hag. (lYnterg.) I85.

Sirnemia Hag. 391.

gymnostoma Hag. 391, 392.

oblusifolia $\mathrm{Hag}$. 331

Stylosteginn caespiticium Bryol. elus. (Syn.) 44.

Swarlzia inclinata Ehrlı. (syı.) 37.

unontatua Lindl. (syn.) 36.

pusillia Ehrh. (syn.) dil.

Syntrichia inlermedia Brid. (Syn.) 155.

montana Nces (tiyn.) 155.

norvegica Web. fil, (Syı.) 156

Syutrichia Hartm. (Sect.) 154.

Systegium crispum Schimp. (Syn.) 113.

Tayloria Hook, 205, 206.

acuminata Hornsch. 206, 208.

var, brevifolia Hag. 208.

Froelichiana IItt. 206, 209.

lingulata Lindb. 206, 209.

serrata Bryol. eur. 206, 207.

var. flagellaris Bryol. eur. 208.

splachnoides Hook. 206, 208.

telluis schimp. 206.

Taylorioideae $205,206$.

Tetraplodon Bryol. eur. 205, 210.

angustatus Bryol. eur. 210.

var. flagellaris Hag. 211.

bryoides Lindl. $210,211$.

var. Brewerianus Braithw. 212. cavifolius Möll. 212. paradoxus Hag. 212.

mnioides Bryol. cur. (Sym.) 211.

var. cavifulius Schimp. (Syn.) 21?.

pallidus Hag. (SyH.) 212.

paradoxus Ilag. (Syn.) 212.

urceolatus Bryol. eur, 210, 21:

Wormskjoldii Lindb. (Syn.) 213.

Tetraphidiales 219.

Tetraphis pellucida Hedw. (syn.) \$20.

repanda Funck (Syn.) 221.

rigida Hedw. (Syn.) 221.

Tetrodontium Scwaegr. 219. 2:1.

Brownianum Schwaegr. 221.

var. $\alpha$ foliatum Lindb. (Syn.) 221,

$\beta$ frondiferum Lindb. (Syn.) 221.

¡ flagelliferum Lindb. (Syn.) ?21.

Thamnioideae 409.

Thamnium Bryol, eur. 16, 416. 
alopecurum Bryol. eur. 417. var. smolandium Tolf 417 .

Thel io ideae 422.

Thuidiaceue 14, 433.

Thuidiella schimp. (Unterg.) 437.

Thuidium Bryol. eur. 434, 437.

abietinum Bryol. eur. $437,441$.

Blandowii Bryol. eur. (Syn.) 442.

decipiens De Not. (Syn.) 470 .

delicatulum Mitt. 437, 439.

gracile Bryol. eur. (Syn.) 448 .

interınedium Philib. (Syn.) 4 40.

lanatum Hag. (Syn.) 442.

minutulum Bryol. eur. 437, 438 .

Pliliberti Limpr. 437,440 .

var. pseudo-tamarisci Limpr. (Syn.) 440.

recognitum Hedw. 437, 438.

tamariscifolium Lindb. 437.

tamariscinum Bryol, eur. (Syn.) 441 .

Timmia Hedv. 361.

austriaca Hedw. 362, 363.

bavarica Hessl 362.

comata Lindb. et Arn. 361, 362.

elegans Hag. (Syn.) 362.

norvegica Zett. 36?.

Timmiaceae 13,361 .

Timmiineae 361 .

Tomentella Kindb. (Sect.) 505 .

Tortella Limpr. 11:, 122.

flavovirens Broth. 123, 124.

fragilis Limpr. 123, 124.

inclinata Limpr. 123.

nitida Broth. 123, 124.

tortuosa Limpr. 1 23 .

Tortula Hedw. 137, 150.

aeiphylla Hartm. (Syn.) 156.

acuta Brid. (Syn.) 130.

aloides Aongstr. (Syn.) 150.

atpina Bruch 151, 154.

ambigua Aongitr. (Syn.) 149.

angustata Wils. (Syn.) 153.

brevirostris Hook, et Grev. 'sn.) 149.

bryoides Lindb. (Syn.) 141

bullata Lindb. (Syn.) 145.

cernua Lindb. (Syn.) 148.

convoluta Schrad. (Syn.) 135.

cylindrica Lindb. (Syn.) 131.

daniea C. Hartm. (Syn.) 155.

ericaefolia Lindb. (Syn.) 149.

fallax Schrad. (Syn.) 132.

fragilis Wils. (Syn.) 124.

gracilis Schleich. (Syn.) 130.

Heimii Mitt. (Syn.) 14 4.

IIornschuchiana De Not. (Syn.) 134.

icmadophila Kindl). (Syn.) 131.

inclinata Hedw. fil. (Syn.) 123.

intermedia Lindl. (Syn.) 14?.

intermedia Wils. (syn.) 155.

latevipila Brid. 151, 155.

lanceolata Lindb. (syn.) 144.

latifolia Bruclı, 151, 154.

latifolia lindb. (Syn.) 147 .

Laureri Lindl). (Syn.) 148.

montana Lindl). 151, 155.

Imucronifolia Schwaegr. 151, 153. muralis Hedw. 151, 152. mutica Lindb. (Syn.) 154. nitida Lindb. (Syn.) 125. obtusifolia sehleich. 151, 152. paludosa Hook. et Grev. (Syn.) 136. papillosa Wils. 151,154 . princeps De Not. 151, 157. pulvinata Limpr. 151, 155. pusilla Mit1. (șn.) 146. recurvifolia Berk. (Srn.) 132. reflexa Brid. (Syn.) 132. revoluta Schrad. (Syn.) 135. rigidula Lindb. (Syn.) 133. rotundifolia Hartm. (Syn.) 154. ruralis Ehrh. 151, 156. squarrosa De Not. (Syn.) taf. Starkei Lindb. (Syn.) 142 . var. Davallii Lindb. (Syn.) 141 . stellata Lindb. (Syn.) 150. suberecta Drumm. (Syn.) 148. subulata Hedw. 151, 153. var. angustata Limpr. 153. bifrons Hag. 153.

systylia Lindb. (Syn.) 147. tortuosa Ehrh. (Syn.) 123. truncatula Lindb. (Syn.) 14?. unguiculata Roth (Syn.) 134. vinealis spruc. (syn.) 131.

Tortula sens. strict. (Sect.) 151.

Trematodon Michx. 46. ambiguus Brid. (Syn.) 46. brevifolius Hornsch, 46, 47. elongatus $\mathrm{Hag} .46$.

Trematodontoideae 45,46 .

Trichodon Schimp. (Syn.) 32. cylindricus Schimp. (Syn.) 32. oblongus Lindb. (syn.) 33.

Trichodon Lindb. ([nterg.) 32. Trichophora Kindt. (Gruppe) 316. Trichostomoideae 11, 110, 111.

Trichostomum Hedw. 112, 120. aeruginosum Lindb. (Syn.) 118. affine schleich. (Syn.) 190. aloides Koch (Syn.) 150. alopecurum Schkuhr (Syn.) 190. brachydontium Bruch 121, 122. canescens Timm (Syn.) 193. conicum Hamp. (Syn.) 35. crispulum Bruch 121. cylindricum Hedw. (Syn.) 32. cylindricum C. Müll. 121. decipiens schultz (Syn.) 177. flavovirens Bruch (Syn.) 124. fontinaloides Hedw. (Syn.) 158. funale Schwaegr. (Syn.) 173. glaucescens IIedw. (Syn.) 33 . heterostichum Hedw. (Syn.) 189. lanuginosum Hedw. (syn.) 193. Laureri schultz (Syn.) 148. litorale Bruch 121, 122. unutabile Bruclı (Syn.) 122. nitidum schimp. (Syn.) 125. obtusum Sm. (Syn.) 191. pusillum lledw. (Syn.) 31. rigidulum Bryol. eur. (Syn.) 133. 
sudeticum Funck (Syn.) 131. tenuifoliom schrad. (sym.) 3:. Lophaceum Brill. (syil.) 124. tortile schud. (Syn.) 31. vaginans sull. (Syn.) 29.

Trichostommu sens. strict. (Unterg.) $1: 1$. Tropidophyllae Card. (Sect.) 39\%.

[']stit Mohr 369.

americana Mitt. 36 ?

Bruchii Hornsch. 369,372 .

valt. marehica Par. 373. norvegica ciriny. 373 . coarclala Lindb). (syul.) 37.

crispla Brid. (Syn.) 373

crispula Bruch 369. 373.

curvifolia Brid. $369,371$.

Jrunmondij Brid. $369,372$.

var, anceps Hag. 37 ?

Hutchinsiae Sm. (syu.) 369.

intermedia schimp. 369,373 .

Lıdwigii Brid. 369,370 .

marchica Warnst. (Syn.) 373.

phyllantha Brid. $369,374$.

ulophylla Broth. 369,373 .

L'mbracularia (Sect.) 216.

Warnejformia Broth. (Subsect.) 258 .

Warnstorfia Loesk. (Nyn.) 477.

Warnstorfia Broth. (Sect.) 47\%.

Webera acuminata Schimp. (Syn.) 231.

affinis Bruch (Syn.) $3 \bullet 0$.

allicans schimp. (syn.) 245.

var. glacialis Schimp. (syll.) 246.

annotina Bruch (Syn.) 2'1.

var. tenuitolia Schimp. (Syn.) 24?.

annotima Limpr. (Syı.) 242.

bicolor Hopn. et Hornsch. (Syn.) 236.

bulbifera Warnst. (syn.) :42.

caespitosa Hopp. et Hornsch. (Syn.) 235.

carinata Ljupr. (Syn.) : 40.

carnea Schimp, (Syn.) 246.

commutata Schinı. (Syll.) 239.

var. filun Husn. (syn.) 239.

crassidens findb. (Syn.) 23?.

cruda Bruch (Syn.) 234.

var. alpina Hag. (Słn.) 235.

ninor Schimp. (Syn.) 235

cucullata Schimp. (Syn.) 237

Diphyscimm Ehrl. (Syn.) 587.

pungata schwaegr. (Syn.) 23?.

gracilis De Not. (Syll.) 2:40.

Halleriana Hedw. (syn.) 350.

longicolla Hedw. (syn.) 233.

Jongiseta Brid. (Syn.) 236.

Ludwigii schimp. (Syn.) 238.

var. latifolia schimp. (Syn.) ?3?.

Jutescens Limpr. (Syn.) 24 '.

mutans Hedw. (syn.) 235.

var. bicolor Hüb. (syn.) 236.

caespitosa Hüb. (Syn.) 235 .

longiseta Hüb. (Syn.) ?36.

pseudocucullata Limpl. (Syn.) §36.

suhagnetorum schimp. (Syn.) 236.

strangulata schimp. (šn.) :3fi.
Lurbinata Boman- (syn.) 237.

Pagoli Limpte. (sym.) 2'y

polymorjha simu. (Syu.) 231.

val. affinis sebimp. (Syn.) 231.

brachycarpa sohimp. (syn.) 231.

proligeri kindb. (syn.) 241.

pulchella s'bimp. (sin.) 243.

Rothii Corr. (sim.) 24:2.

lubella l'tililu. (Syn.) 241.

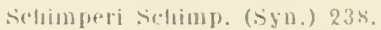

sp-ilis lindlo. (syu.) 587.

strangulata Nees (syn.) 236.

tenuilulia Bryhu (syn.) 242.

torrentium Hag. (syu.) 240.

traclyduntia San. (Syll.) 232.

Veisia Hedw. 112, 115.

acuta Hedw. (syn.) 44.

americana lindl). (syn.) 370 .

Bruchii I.indls. (syu.) 372.

cirrita Hedw. (SyH.) 80.

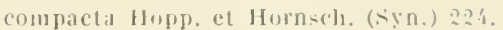

crispata Jur. (syn.) 115.

crispulat llcdw. (Syn.) 81 .

crispula Lindb. (Sỵi.) 373.

eurvifolia Lindl, (syn.) 371.

cylindrica Brucli (syul) 121.

denticulata Brid. (Syı.) 64.

Drmmonndii Lindb. (syn.) 372 .

elongata Hurnsch. (syn.) 224.

fugax Hedw, (syn.) 69.

gymnostomoides Brid. (syn.) 115.

littitolia schwaegr. (syn.) 145.

Inngipes sommerf. (Áyn.) 5's.

Mielichnoferiana l゙uıck (syn.) 223.

mucronata Bruch (Sỹn.) 11 .

nigrita Hedw. (syn.) 348.

phyllantha Lindb. (syn.) 374.

rutilans Lindb. 115, 11:

Schisti Wahlenb. (syu.) 70.

Starkealla Ifedw. (Syu.) 1:2.

sermlata Funck (syn.) 80).

tenuirostris Hook, et Tayl. (Syn.) 121.

ulophylla Ehrh. (Syn.) 373.

viridula Hedw. $115,117$.

zonata Brid. (Ayn.) 29.

Velutina Broth. (sect.) 5:0.

Velutinium Locsk. (Lnterg.) 520 .

Zieria demissa schimp. (.yn.) 226. julacea Schimp. (ะ.ıI.) 226.

Zygodon Hook. et Tayl. 10, 367.

aristatus lindb. (Nyn.) 368 .

convideus Hook. et Tayl. 367,3 fis.

dentalus Breidl. (syn.) 368 .

Mougeotii Bryol. eur. (Syn.) $6 \mathrm{~s}$.

rupestris Lindb. (Syn.) 368 .

Stirtoni sichimp. (Syn.) 368.

viridissimus Brown 367 .

var, dentatus Limpr. 368. rupestris Hartm. 368 . Stirtoni Hag. 368.

Zygodonto ideate $36 \%$.

Zygotrichia cylindrica Tayl. (syn.) 131.

Zygotrichia Mitt. (sect.) 153. 


$$
\text { . }
$$






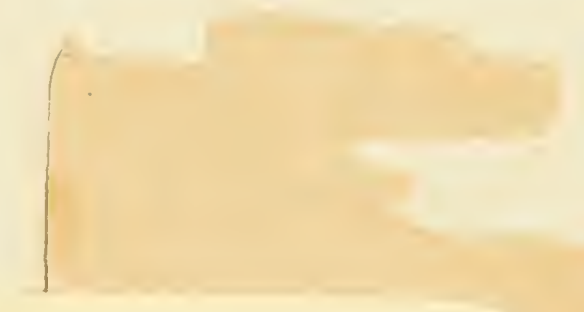

QK Brotherus, Viktor Ferdinand

544 Die laubnoose Fennoskandias S2B7

BioMed

\author{
PLEASE DO NOT REMOVE \\ CARDS OR SLIPS FROM THIS POCKET
}

UNIVERSITY OF TORONTO LIBRARY 


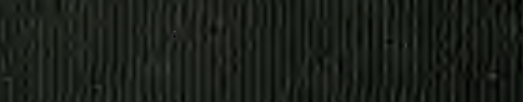

